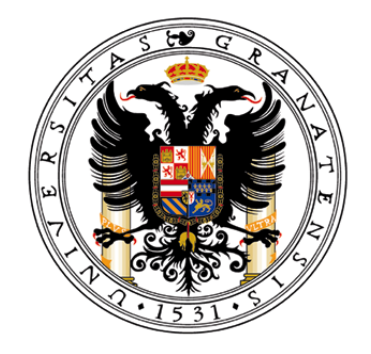

\title{
MÚSICA Y CEREMONIA EN LA ABADÍA DEL SACROMONTE DE GRANADA (SIGLOS XVII-XIX)
}

\author{
Tesis Doctoral \\ presentada para la obtención del Título de Doctor \\ Mención "Doctorado Europeo" \\ MERCEDES CASTILLO FERREIRA
}

Realizada bajo la dirección del Prof. Dr. EMILIO ROS-FÁBREGAS

VOLUMEN I: ESTUDIO

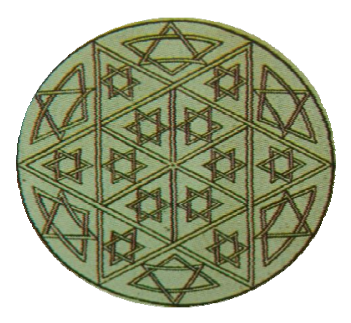

UNIVERSIDAD DE GRANADA

FACULTAD DE FILOSOFÍA Y LETRAS

DEPARTAMENTO DE HISTORIA DEL ARTE Y MÚSICA

PROGRAMA DE DOCTORADO EN HISTORIA Y CIENCIAS DE LA MÚSICA

GRANADA, 2009 
Editor: Editorial de la Universidad de Granada

Autor: Mercedes Castillo Ferreira

D.L.: GR 2316-2009

ISBN: 978-84-692-3124-1 
Ilustración de la portada:

Sello de Salomón utilizado por San Cecilio y San Tesiphón en los Libros Plúmbeos. Grabado para la Historia Eclesiástica de Justino Antolínez .

Francisco Heylan.

(C) 2009 por Mercedes Castillo Ferreira 
A mis padres.

A Iván. 



\section{Al Monte Santo de Granada}

Este monte de cruces coronado, cuya siempre dichosa excelsa cumbre espira luz y no vomita lumbre, Etna glorioso, Mongibel sagrado,

trofeo es dulcemente levantado, no ponderosa grave pesadumbre, para oprimir sacrílega costumbre de bando contra el cielo conjurado.

Gigantes miden sus ocultas faldas, que a los cielos hicieron fuerza: aquella que los cielos padecen fuerza santa.

Sus miembros cubre y sus reliquias sella la bien pasada tierra. Veneraldas con tiernos ojos, con devota planta.

Luis de Góngora y Argote

(1598) 



\section{ÍNDICE GENERAL}

\section{VOLUMEN I: ESTUDIO}

Agradecimientos $\mathrm{xxi}$

INTRODUCCIÓN 1

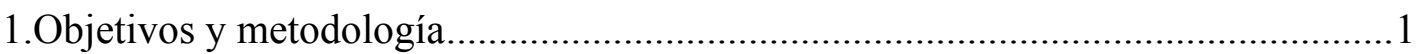

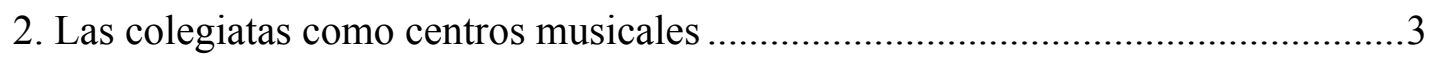

2.1. La Abadía del Sacromonte: ¿abadía o iglesia colegial? .................................. 3

2.2. Las iglesias colegiales como institución en España .....................................4

2.3. Las iglesias colegiales en Hispanoamérica..................................................16

2.4. La supresión de las colegiatas............................................................... 18

2.5. Estudios musicales sobre colegiatas: estado de la cuestión..........................20

3. La Abadía del Sacromonte en el contexto de las instituciones

eclesiásticas de Granada en la Edad Moderna .....................................................22

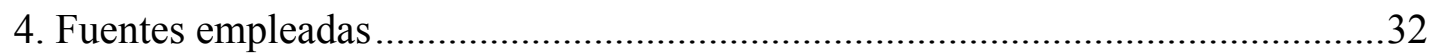

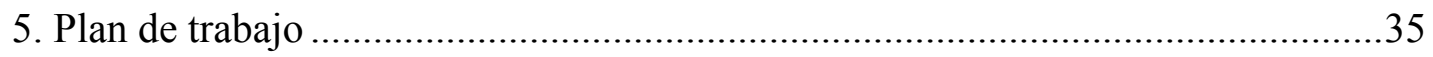

\section{CAPÍTULO I. LA FUNDACIÓN DE LA ABADÍA DEL SACROMONTE...}

1. Las reliquias que hay que custodiar: el motivo de la fundación.......................... 39

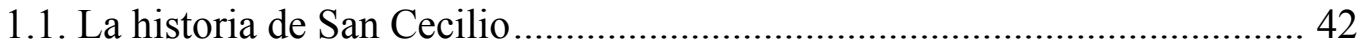

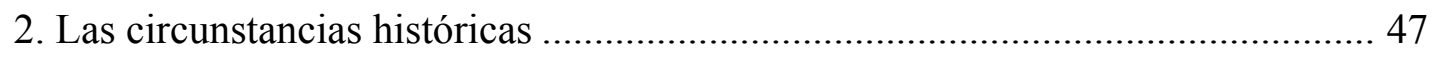

2.1. La situación granadina a inicios del siglo XVII ........................................ 47

2.2. La personalidad de Pedro de Castro: "segundo Ambrosio, otro Belarmino de la fe" ......................................................................... 48

2.3. Pedro de Castro reformador de Trento .................................................... 52

2.4. La perfección en el desarrollo del culto..................................................... 55

3. La Abadía, segundo Escorial: características de la fundación.............................. 57

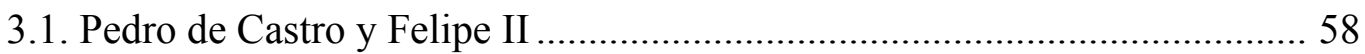

3.2. La Abadía y el Real Patronato: las características fundacionales................ 63

\section{CAPÍTULO II. LA ORGANIZACIÓN MUSICAL DE LA ABADÍA I:}

\section{FUENTES PARA SU ESTUDIO}

1. Las Constituciones del Sacromonte (1616 y 1647) y la música

2. Dos fundaciones tridentinas pero diferentes: la Abadía del Sacromonte y la Capilla del Corpus Christi de Valencia

3. Las Constituciones de la Colegiata

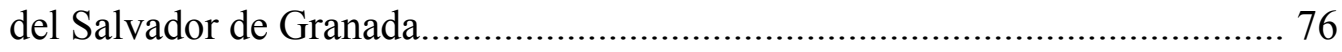

4. La redacción de la Consueta y su estructura...................................................... 79 
4.1. Fuentes para la redacción de la Consueta ............................................... 83

4.2. Consuetas comparadas: los casos abacial y catedralicio ........................... 85

4.3. El Caeremoniale Episcoporum como fuente para la Consueta .................. 92

CAPÍTULO III. LA ORGANIZACIÓN MUSICAL DE LA ABADÍA II: ORGANIZACIÓN DEL PERSONAL SEGÚN LA CONSUETA (1632) ...................99

1. Los oficios o cargos relacionados directamente con la música ................... 100

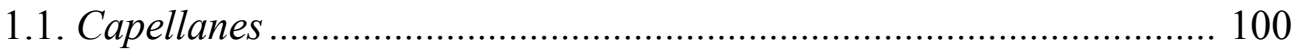

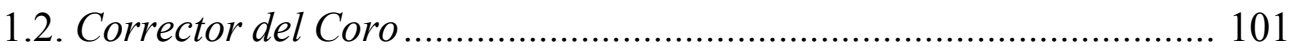

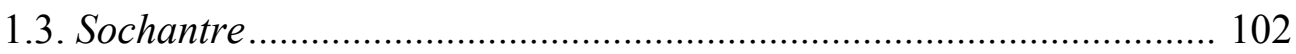

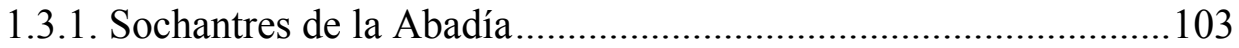

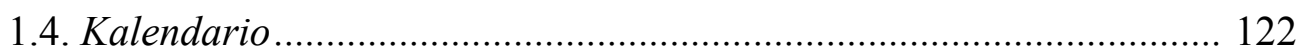

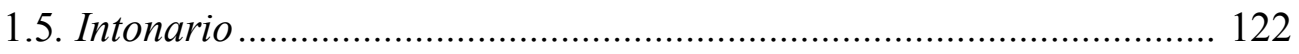

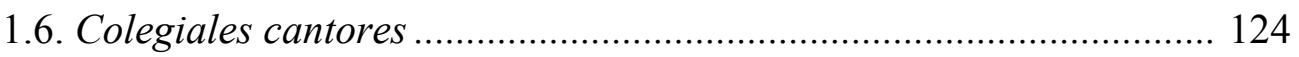

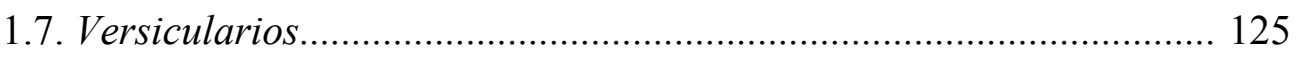

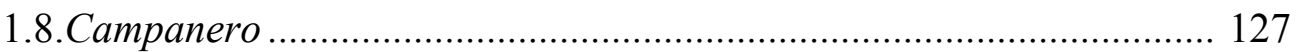

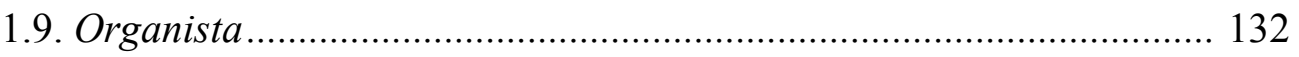

1.9.1. Organistas de la Abadía ............................................................. 135

2. Los oficios o cargos relacionados indirectamente con la música................ 150

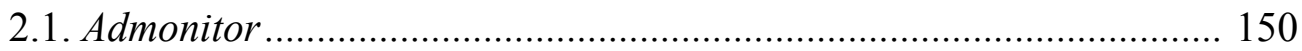

2.2. Apuntador y colector de misas ............................................................ 151

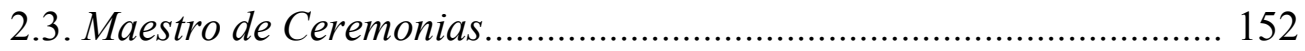

2.4. El presidente del coro ................................................................... 154

2.5. Visitadores o Zeladores .................................................................... 155

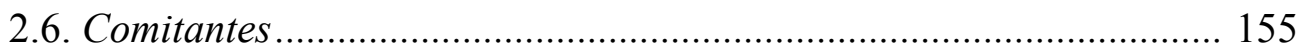

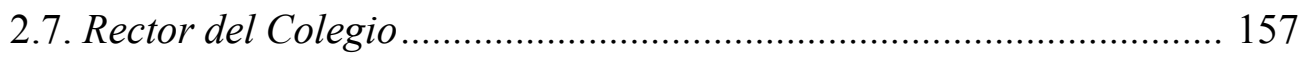

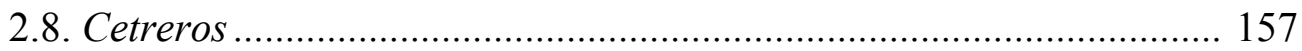

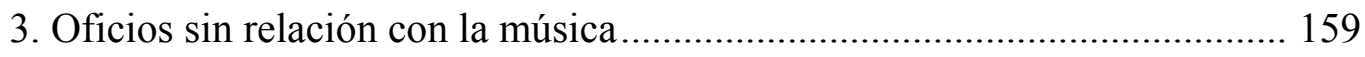

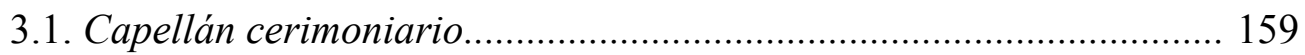

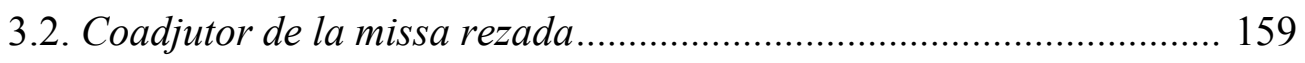

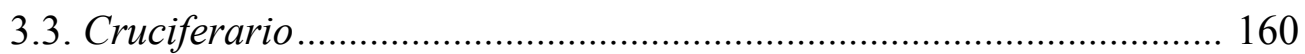

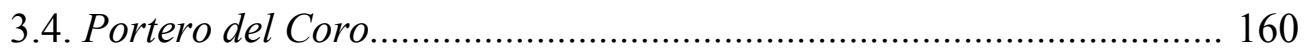

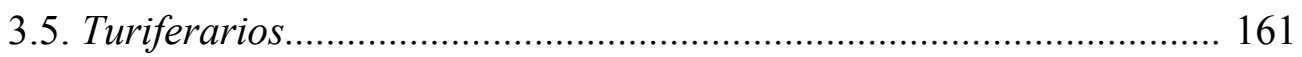

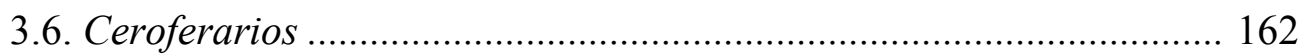

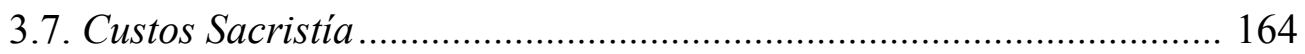

3.8. Flavelario y coadjutor de la misa de tercia ..................................... 165

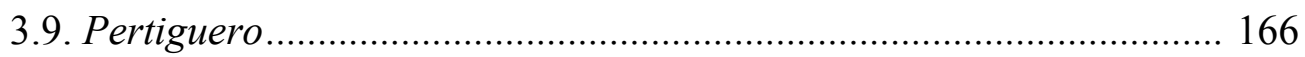

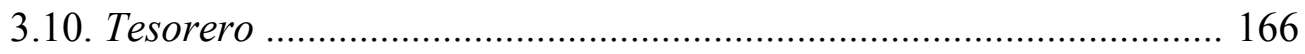

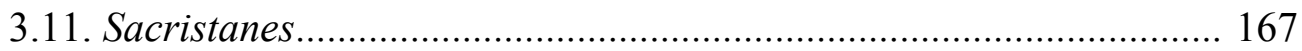

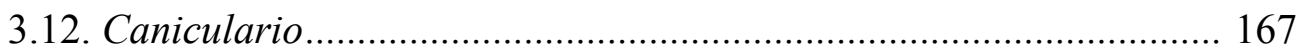


CAPÍTULO IV. MÚSICA Y CEREMONIAL I: LOS ESPACIOS CULTUALES. CONSIDERACIONES SOBRE LA MÚSICA EN LA ABADÍA

1. Los espacios cultuales de la Abadía: las Cuevas y la Iglesia

1.1. Las Santas Cuevas ........................................................................ 173

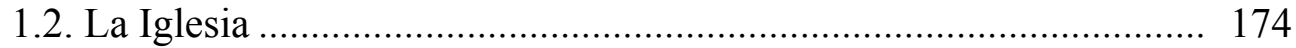

2. La música en las ceremonias de la Abadía ................................................. 181

2.1. Canto llano versus polifonía ............................................................ 181

2.2. Música instrumental versus música a cappella ................................ 189

3. La Música en el Colegio de San Dionisio Areopagita ..................................201

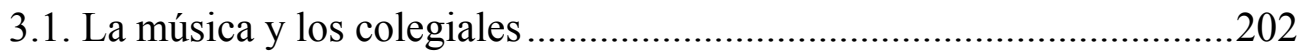

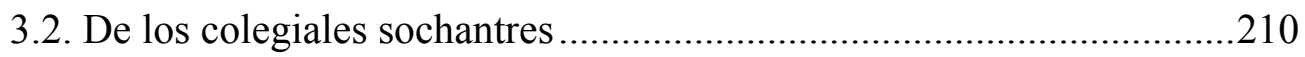

3.3. De las ceremonias propias del Colegio .............................................212

3.3.1. La Fiesta de Ntra. Sra. del Rosario .............................................212

3.3.2. San Dionisio Areopagita, Patrón del Colegio..............................213

3.4. La Loa a la Inmaculada de los Colegiales ...........................................215

\section{CAPÍTULO V. MÚSICA Y CEREMONIAL II: LAS CEREMONIAS DE LA} ABADÍA DEL SACROMONTE. DESCRIPCIÓN Y ESTUDIO CONTEXTUAL

1. Las ceremonias de la Misa Cantada ................................................................. 223

2. Las Vísperas Cantadas según la Consueta......................................................... 230

3. La Música en la Fiesta de San Cecilio, patrón de Granada............................. 239

3.1.Los orígenes de la fiesta de San Cecilio en 1600 ..................................... 239

3.1.1. La música durante la celebración del Sínodo para la calificación de las Reliquias ................................................ 239

3.1.2. Las fiestas por la aprobación de las reliquias.............................. 241

3.1.3. La fiesta en la Plaza de Bib-Rambla .......................................... 242

3.1.4. La primera misa en el Sacromonte......................................... 245

3.2. El establecimiento de la Fiesta y su celebración

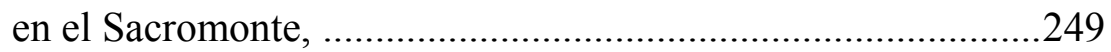

3.2.1. Las ceremonias el día de la Víspera de la Fiesta de San Cecilio ..............................................................251

3.2.2. El día de San Cecilio .................................................................254

3.3. La aprobación del rezo propio y su música, 1704 ................................. 255

3.3.1. Los villancicos que se hicieron con motivo de la aprobación

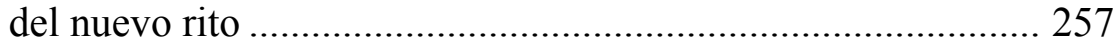

3.3.2. La Misa propia de San Cecilio 263

3.4. La liturgia para el San Cecilio medieval ................................................ 265

3.5. Otras músicas para San Cecilio: Catedral de Granada y Capilla Real ..... 267 
4. Las honras por el fundador y por sus padres …............................................... 269

4.1. La familia Vaca de Castro y su relación con el Sacromonte ..................... 269

4.2. Iconografía Musical en unos cuadros indianos......................................... 270

4.2.1. Prolegómenos de la Batalla de Chupas ...................................... 271

4.2.2. El desarrollo de la Batalla de Chupas ....................................... 277

4.2.3. La entrada triunfal a Cuzco ........................................................ 279

4.3. Las honras fúnebres de la Familia Vaca de Castro en el Sacromonte ...... 288

4.4. La muerte del Arzobispo Pedro de Castro ................................................ 289

4.5. Las honras fúnebres en la Consueta....................................................... 290

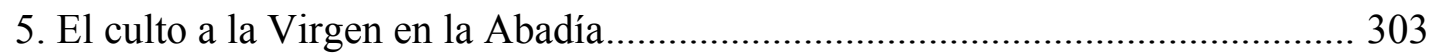

5.1. El culto a a Inmaculada Concepción en el siglo XVII ............................. 303

5.1.1. Dos fiestas a la Inmaculada: Granada 1615, Sevilla 1617......... 303

5.2. La Inmaculada Concepción en el Sacromonte........................................... 310

5.3. La estructura del rito de la Salve: .......................................................... 313

5.3.1. El ceremonial de la Salve de los Sábados .................................. 317

5.3.2. Las fuentes musicales para el rito de la Salve en la Abadía ...... 318

5.3.3. La significación de la Salve en la Abadía del Sacromonte ..... 319

\section{CAPÍTULO VI. LOS LIBROS DE CORO DE LA ABADÍA DEL SACROMONTE}

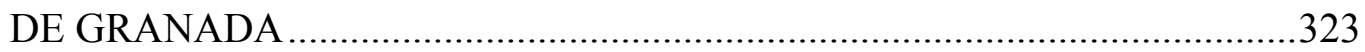

1. La formación de la librería coral de la Abadía del Sacromonte ......................... 323

1.1. Los cantorales copiados ex profeso para la Abadía ............................. 325

1.2. Los cantorales encargados por Bartolomé de Torres............................ 332

1.3. El "Cuaderno de la Salve" y otro oficio

de Francisco de Aguilar (1657) ............................................................. 333

1.4. Libros corales copiados en tiempos

del Abad José de Escalante (1662-1684)............................................ 333

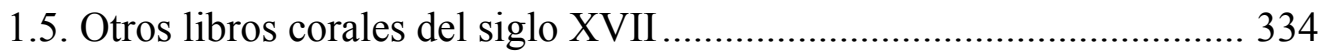

1.6. Los cantorales del siglo XVIII............................................................ 335

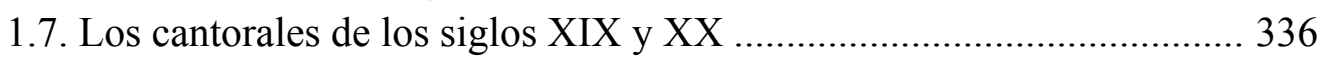

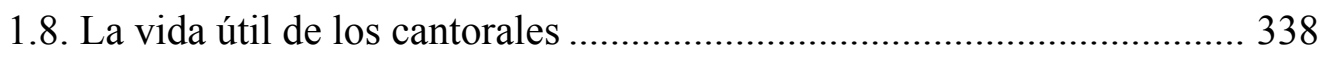

2. El repertorio de los cantorales de la Abadía ................................................. 342

2.1. Origen y filiación de los cantorales de la Abadía................................. 342

2.2. ¿Un himno universal con melodía hispana?: Ut queant laxis .............. 343

2.3. Una colección de kyries tropados....................................................... 347

2.4. El oficio de la Toma de Granada ...................................................... 355

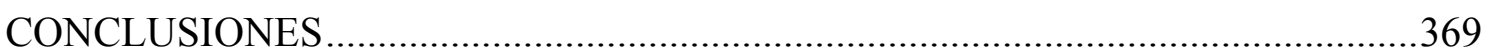


CATÁLOGO DE LOS LIBROS DE CANTO LLANO DE LA ABADÍA DEL SACROMONTE

BIBLIOGRAFÍA 513

\section{LISTA DE TABLAS}

Tabla 1. Iglesias colegiales en Andalucía 9

Tabla 2. Iglesias colegiales en España. 25

Tabla I.1: Abades del Sacromonte Fuente: Zótico Royo, Abades del Sacromonte

(Granada: Prieto, 1963)

Tabla II.1.: Horario y obligaciones de coro de un canónigo de la Abadía del

Sacromonte. Fuente: Constituciones de 1616, BN Ms. 6437.

Tabla II.2. Comparación de plantillas para el culto divino entre la Capilla del

Corpus Christi y la Abadía del Sacromonte .75

Tabla II.3. Índices de las Constituciones de las Iglesias Colegiales del Salvador (1596) y del Sacromonte (1647).

Tabla II.4. Índices de las Consuetas del Sacromonte (1632) y de la Catedral

de Granada (ca. 1678), con indicación de correspondencias entre ambas 87

Tabla II.5. Ceremoniales españoles impresos entre 1568 y 1600 ...............................93

Tabla II.6. Ceremoniales impresos en España 1600-1632 ............................................93

Tabla II.7. Índices de la Consueta de la Abadía del Sacromonte (1632) y del

Caeremoniale Episcoporum (1600)

Tabla III.1. Oficios o cargos del coro y la iglesia del Sacromonte y su relación con la música. Fuente: Consueta (1632) ............................................................... 100

Tabla III.2. Sochantres de la Abadía del Sacromonte (1613-1799) .............................121

Tabla III.3. Versos que cantan los colegiales cantores del coro y sus excepciones .......124

Tabla III.4. Campanas que se conservan en la Abadía del Sacromonte (Granada)

Fuente: Nieves Jiménez Díaz

Tabla III. 5. Campanas del Sacromonte y días que han de tocar. Fuente:

Consueta (1632)

Tabla III. 6. Horario de toques para el campanero del Sacromonte. Fuente:

Consueta (1632)

Tabla III.7. Presencia del organista en las ceremonias de la Abadía del Sacromonte.

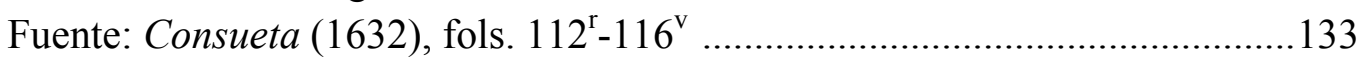

Tabla III.8. Organistas de la Abadía del Sacromonte (1613-1799) ...............................150

Tabla IV. 1. Fiestas para las que estaba estipulada la contratación de música en el

Sacromonte. Fuente: Consueta, 1632

Tabla IV.2. Ocasiones documentadas para las que se contrató música en el Sacromonte

(1600-1799).

Tabla IV.3. Asistencia de los colegiales al coro ("Choro para todos") según Praxis de 
Estudios (ca.1752)

Tabla IV.4. Colegiales que ejercieron como Sochantres en la Abadía del Sacromonte.

Fuentes: Actas Capitulares

Tabla V.1. Esquema de la hora de Vísperas según el Caeremoniale Romano y la

Consueta de la Abadía del Sacromonte

Tabla V.2. Resumen de la Fiesta de San Cecilio (día 31 de Enero, Fuente: Consueta,

1632

Tabla V.3. Resumen de la Fiesta de San Cecilio (día 1 de Febrero), Fuente: Consueta, 1632

Tabla V.4. Cuadro comparativo de los Ritos de San Cecilio, Fuentes:

Consueta (1632) e Impreso del Oficio y Misa de San Cecilio (1704). 263

Tabla V.5. Relación de las obras dedicadas a San Cecilio conservadas en la Catedral y en la Capilla Real de Granada. 268

Tabla V.6. Resumen del ceremonial de la Salve en la Abadía del Sacromonte. Fuente:

Consueta (1632), Libro IV, Capítulo 12, fol. $\left(307^{\mathrm{r}}-312^{\mathrm{r}}\right)$.....

Tabla V.5. Fuentes musicales para la reconstrucción del rito de la Salve en la Abadía

Tabla VI.1. Libros Corales copiados por Pedro Marañón

Tabla VI.2. Libros similares a los copiados por Pedro Marañón, pero con iluminaciones más toscas, ordenados según el repertorio contenido en ellos ..........................322

Tabla VI.3. Libros patrocinados por Bartolomé de Torres...........................................325

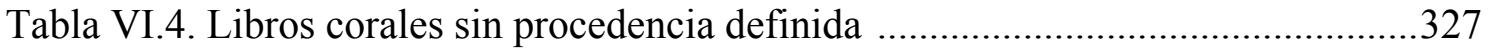

Tabla VI.5. Impresos conservados en la Abadía del siglo XVIII..................................328

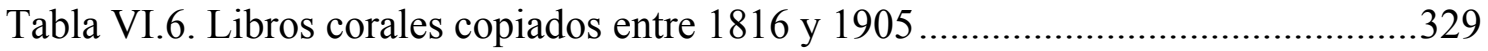

Tabla VI.7. Libros Impresos en el siglo XIX conservados en la Abadía ........................331

Tabla VI.8. Comparación contenido y rúbricas de las dos colecciones de Kyries (Abadía Cantoral LC IV y Officia ad Missas, 1544) ..........................354

Tabla C.1. Copistas de Cantorales del Sacromonte de Granada 386

\section{LISTA DE FIGURAS}

Figura 1. Colegiatas españolas en el siglo XVII .8

Figura 2. Iglesia Colegial de Guadalupe, Méjico. Grabado de

Francisco Silverio, 1787 Biblioteca Nacional de España, MV/26 18

Figura I.1. Felipe II como guerrero de la fe, Pedro Perret (1619) ..................................63

Figura I.2. Pedro de Castro como sabio de la Iglesia, Luengo (1740) ...........................63

Figura II.1. Consueta del Sacromonte (1621-1632) fol. 311 , con las rúbricas del Abad

Pedro de Ávila y los Canónigos Agustín Manrique y Francisco de Barahona....81

Figura II.2. Consueta del Sacromonte (1621-1632) fol. $312^{\mathrm{r}}$, con firmas y rúbricas

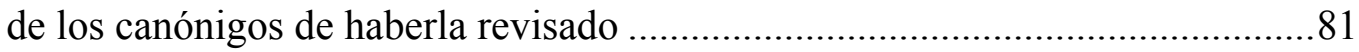

Figura IV.1. Horno de San Cecilio, Abadía del Sacromonte ......................................174 
Figura IV.2. Anónimo. Pintura de la primitiva fábrica de la Iglesia, (ca.1621)

Figura IV.3. Dibujo actual de la Fábrica de la Iglesia

Fuente: Turespaña-Subdirección

General de Promoción Exterior del Turismo.

Figura IV.4. Proyecto del Arquitecto Pedro Sánchez para la Abadía del Sacromonte (1614). Fuente: Gómez-Moreno Calera

Figura IV.5. Plano actual de la Iglesia y las Santas Cuevas.

Fuente: Margarita Martínez

Figura IV.6. Distribución de los asientos del Coro de la Iglesia Colegial de la Abadía del Sacromonte de Granada

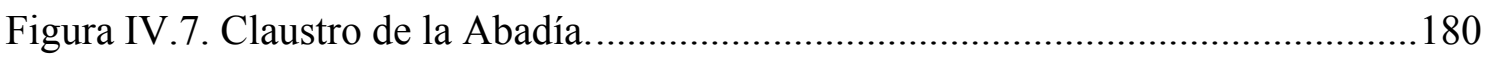

Figura IV.8. Portada de la Loa representada en el Sacromonte en 1767......................217

Figura V.1. Caeremoniale Episcoporum (Roma: Giannini et Mainardi, 1729) ............223

Figura V. 2. Caeremoniale Episcoporum (Roma: Giannini et Mainardi, 1729)...........229

Figura V.3. El Licenciado Vaca de Castro, Gobernador del Perú. Fuente: Antonio de Herrera, Historia general de los hechos de los Castellanos en las islas i tierra firme del mar oceano (Madrid: Imprenta Real, por Juan Flamenco, 1601-1615), vol. 4. 218

Figura V.4. Prolegómenos de la Batalla de Chupas. Óleo sobre lienzo. Abadía del Sacromonte, Sala Capitular

Figura V.5. Prolegómenos de la Batalla de Chupas. Detalle. Abadía del Sacromonte, Sala Capitular

Figura V.6. Thomas Styward, The Pathwaie to Martiall discipline (1581), p. 137.

Figura V.7. Thomas Styward, The Pathwaie to Martiall discipline (1581), detalle, p. 137.

Figura V.8. Arbeau, Orchesographie, pp. 9 y ss. Tabulature contenant toutes les diversités des battements du tambour (selección)

Figura V.9. Arbeau, Orchesographie, pp. 18 y ss.: "Tabulatura du Fifre, ou Arigot du troisieme ton".

Figura V.10. Anónimo, Desarrollo de la Batalla de Chupas. Abadía del Sacromonte, Sala Capitular 278

Figura V.11. Anónimo, Desarrollo de la Batalla de Chupas. Detalle. Abadía del Sacromonte, Sala capitular

Figura V.12. Anónimo, Entrada triunfal a Cuzco. Abadía del Sacromonte, Sala Capitular

Figura V.12. Anónimo, Entrada triunfal a Cuzco. Detalle, Abadía del Sacromonte, Sala Capitular

Figura V.14. Caeremoniale Episcoporum

(Roma: Giannini et Mainardi, 1729), p. 428

Figura V.15. Transcripción de la copla de Bernardo del Toro y Miguel Cid, Todo el mundo en general. Fuente: Impreso conservado en la Biblioteca Nacional de 
Madrid, Mss. 9.956, fol. 12. Transcripción: Mercedes Castillo 300

Figura V.16. Portada de la Relación del solemne juramento (Sevilla:

Francisco de Lyra, 1617)

Figura VI.1. Abadía de Sacromonte, LC VII. Introito de

la Vigilia de San Andrés, fol. $1^{\mathrm{v}}$. Foto: Javier Ruiz

Figura VI.2. Abadía de Sacromonte, LC VII. Introito de

la Vigilia de San Andrés, fol.1 ${ }^{\mathrm{v}}$. Detalle. Foto: Javier Ruiz

Figura VI.3. Abadía de Sacromonte, LC XVII.

Misas votivas de la Virgen, Foto: Javier Ruiz.

Figura VI.4. Abadía de Sacromonte, LC VIII. Inicial miniada con San Pedro en su Cátedra, fol. $1^{\mathrm{v}}$. Detalle. Foto: Javier Ruiz.

Figura VI.5. Detalle de la iluminación del Cantoral LC XIX, representando a un libro Plúmbeo

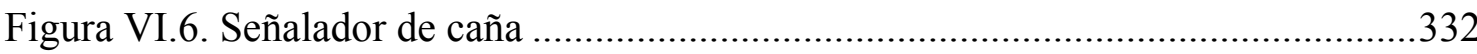

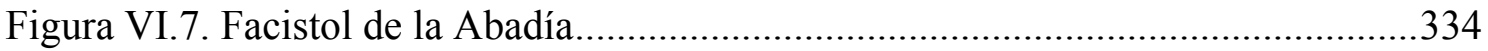

Figura VI.8. Himno Ut queant laxis para la festividad de San Juan Bautista. Fuente LC

I, fol. sin numerar, Abadía del Sacromonte.

Figura VI.9. Dos versiones del himno Ut queant laxis. Fuentes: Abadía, Cantoral LC I e Intonarium Toletanum (Alcalá: Brocar, 1515)

Figura VI.10. Himno Ut queant laxis, en un cantoral de la catedral de Augsburgo conservado en Copenhague

Figura VI.11. Antífona Magnificemus Dominus.

Abadía LC LXIII, fols. $1^{\mathrm{v}}-4^{\mathrm{v}}$.

Figura C.1. Detalle del Registro de los Libros de Coro del

Sacro-Monte, Abadía del Sacromonte de Granada

Figura C.2. Primera página del Índice General de los Libros

de Coro, s.s. de la Abadía del Sacromonte de Granada

\section{VOLUMEN II: APÉNDICES}

Introducción 1

\section{APÉNDICE 1. EDICIÓN DE LA CONSUETA (1632) DE LA ABADÍA DEL}

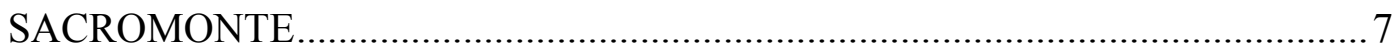

Libro I: Del Choro y cosas que en él y en la Iglesia se han de observar 14

Capítulo 1. Del choro y lo que se a de observar en el de la cortesía y policia. ...14 Capítulo 2. Quando y como se comienzan los oficios en el Choro y

quando están en pie, sentados, eregione y de rodillas 
Capítulo 3. Quando estan de rodillas, o en pié, sentados o

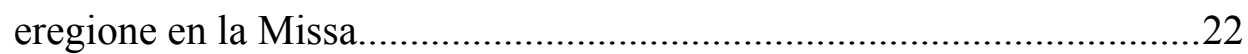

Capítulo 4. De la Prima y Kalendas y demas horas en tono ..................................24

Capítulo 5. Quando se dize el officio cantado o en tono .....................................27

Capítulo. 6. De la solemnidad de los oficios y capas pluviales...........................28

Capítulo 7. Quien entona en las horas y lo que ha de hazer el Hebdomadario............................................................................... 30

Capítulo 8. De los colores que usa la Iglesia y

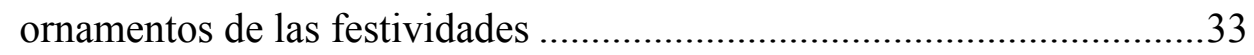

Capítulo 9. Del gasto y repartimiento de la cera y de las lámparas ......................35

Capítulo 10. Del hábito de los Prebendados y Ministros

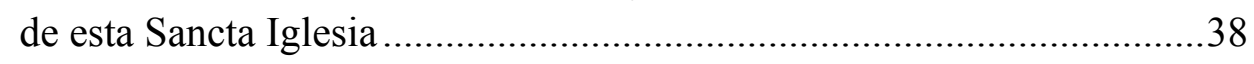

Capítulo 11. Quien celebra en el altar y haze officio en el choro.........................40

Capítulo 12. De la dignidad y orden de las fiestas que se celebran en este Sacro Monte y adorno de ellas......................................................43

Capítulo 13. De los Comisarios que nombra el Cabildo para las fiestas y de los fuegos.................................................................4

Capítulo 14. De los aniversarios que se celebran en esta

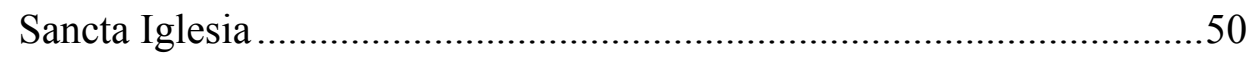

Capítulo 15. De los asientos de los Prelados, Cabildos y Señores en esta Iglesia y Choro ..........................................................54

Libro II: De los Officios de los Prebendados y Ministros de Esta Sancta Iglesia

Capítulo 1. Del Presidente del coro y licencias que ha de dar.............................55

Capítulo 2. Del apuntador y collector de Missas ..................................................58

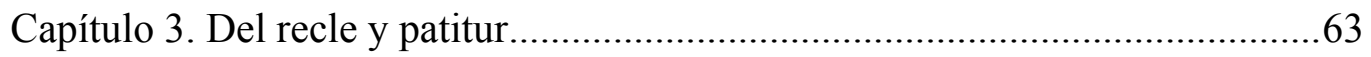

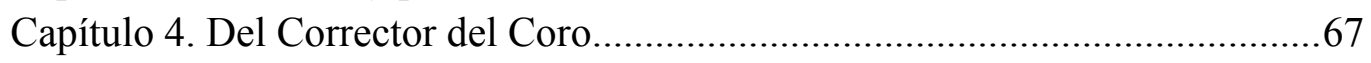

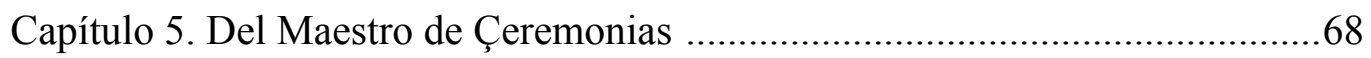

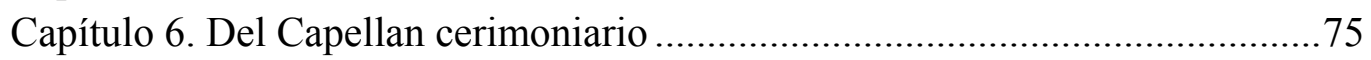

Capítulo 7. Del Rector en el Colegio y colegiales..............................................78

Capítulo 8. De los Visitadores o zeladores ......................................................... 81

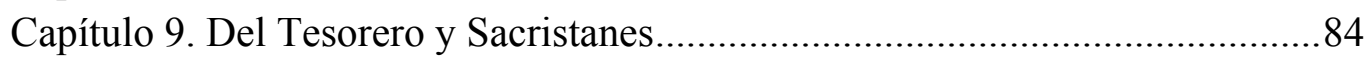

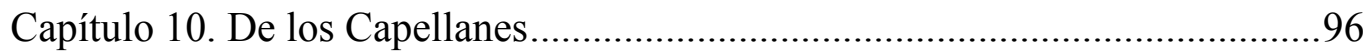

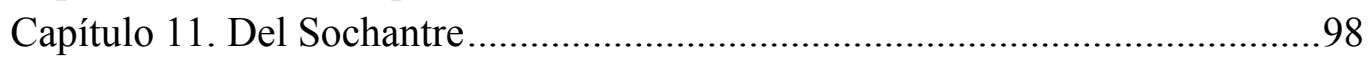

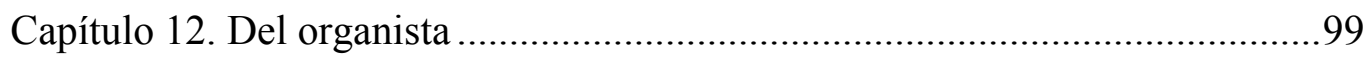

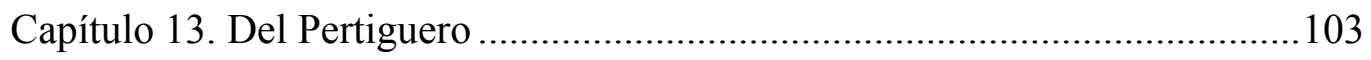

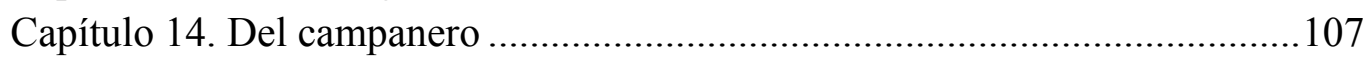

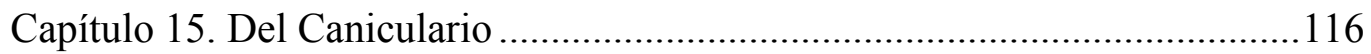

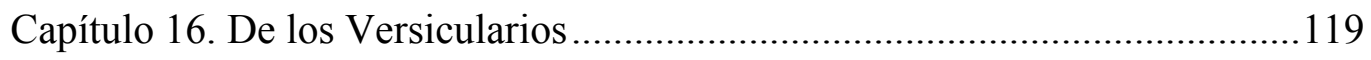

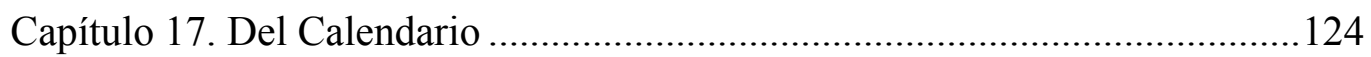




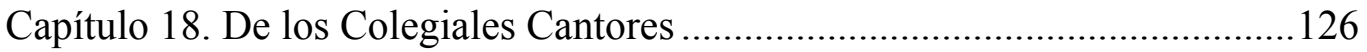

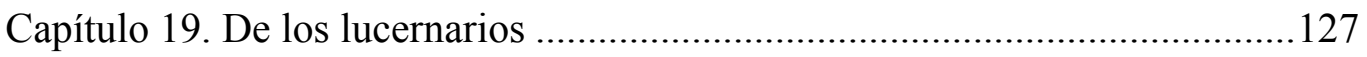

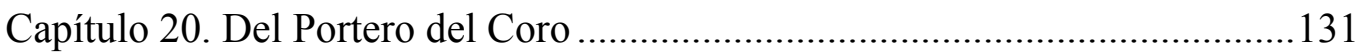

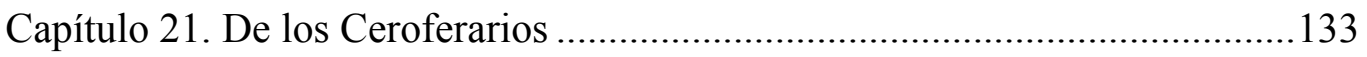

Capítulo 22. De los Turiferarios y modo de la turificación.................................147

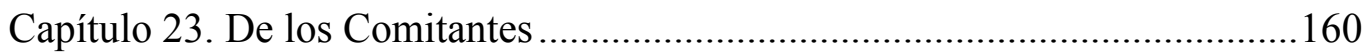

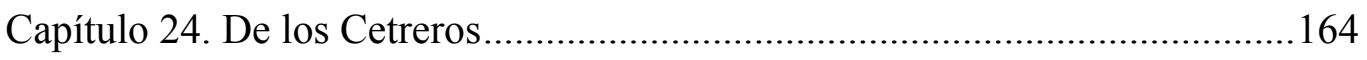

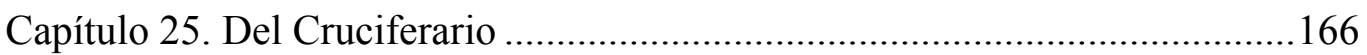

Capítulo 26. Del Flavelario y coadjutor de la Missa de Tercia .........................167

Capítulo 27. Del coadjutor de la Missa Rezada.................................................170

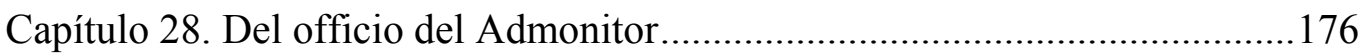

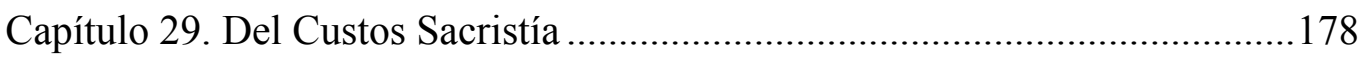

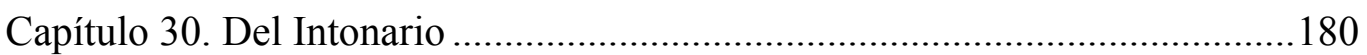

Capítulo 31. De la Tabla de los Oficios............................................................ 180

Libro III: Del modo con que se celebran los divinos oficios

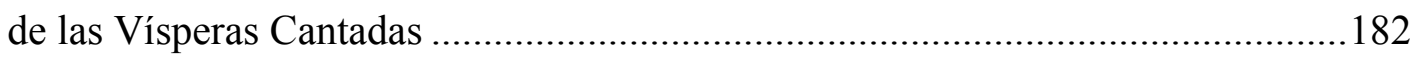

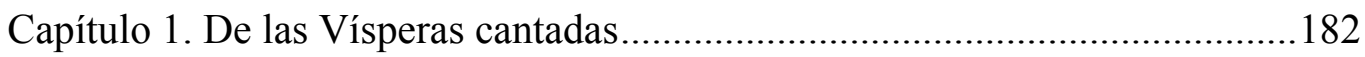

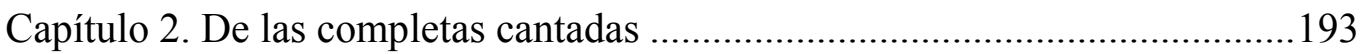

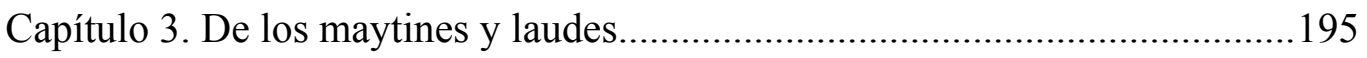

Capítulo 4. De la missa cantada y de los oficios de

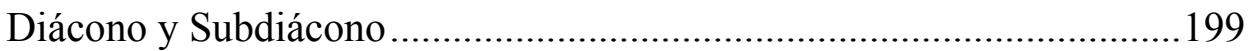

Capítulo 5. De los días que hay procesión y como se celebra ...........................221

Capítulo 6. De los días que hay sermón y de las ceremonias

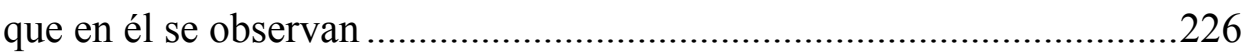

Capítulo 7. De los días que hay comunión general y de las ceremonias con que se hace y de la comunión particular ................228

Capítulo 8. Como se descubre y encierra el Sanctissimo Sacramento y en los jubileos de 40 horas ...........................................232

Capítulo 9. Como se renueva el Santísimo Sacramento y

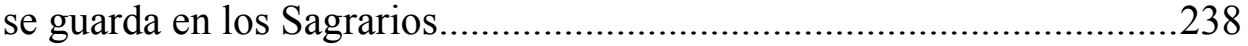

Capítulo 10. De la missa cantada sin Diáconos .................................................241

Capítulo 11. De la Missa de Nuestra Señora in Sabbatho .................................243

Capítulo 12. De las Salves de Nra. Señora en los sabados y en sus fiestas

Capítulo 13. De las rogativas y devociones que se hacen en las necesidades del bien público ....................................................249

Capítulo 14. De los oficios de difuntos y sus aniversarios ...............................252

Capítulo 15. De la Missa solemne de Réquiem ...............................................255

Capítulo 16. De la Missa rezada delante del Prelado ........................................258 


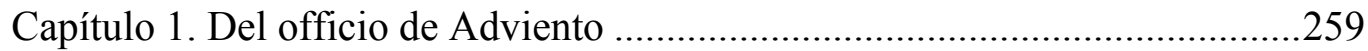

Capítulo 2. Del officio en la Vigilia de la Natividad ..........................................260

Capítulo 3. Del Officio en el día de la Natividad de

Ntro. Señor Jesucristo

Capítulo 4. Del Officio en el día de la Epifanía de Nuestro

Señor Jesucristo

Capítulo 5. Del officio y festividad en el día de Ntro.

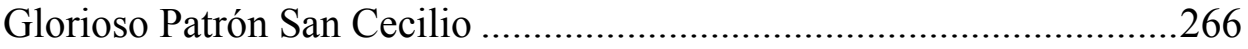

Capítulo 6. Del officio en el día de la purificación

Capítulo 7. Del officio en las fiestas de los Sagrados

Mártires de este Sacro Monte

Capítulo 8. Del oficio en el Miércoles de Ceniza y en el

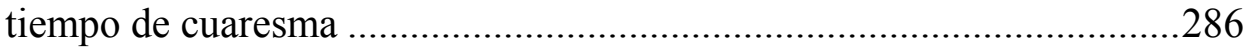

Capítulo 9. Del officio en la Dominica in Passione..........................................289

Capítulo 10. Del officio en el Domingo de Ramos ............................................293

Capítulo 11. De los maytines de Tinieblas de la quarta, quinta y sexta feria de Semana Sancta......................................2.298

Capítulo 12. Del officio del Jueves Sancto........................................................300

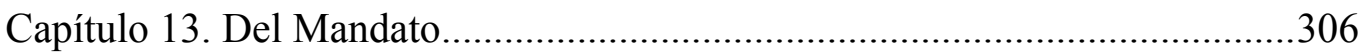

Capítulo 14. Del officio del Viernes Sancto ...........................................................309

Capítulo 15. Del officio del Sabado Sancto...........................................................318

Capítulo 16. Del officio en el dia de la Pasqua de Resurrección........................323

Capítulo 17. Del officio en el día de San Marcos,

Letanías Mayores y menores antes de la Ascensión................................327

Capítulo 18. Del officio en el día de la Ascensión del Señor .............................331

Capítulo 19. Del officio en la Vigilia y dia de Pentecostés ...............................332

Capítulo 20. Del officio en la Solemnidad de el Sanctissimo

Sacramento y en su Octava .......................................................................333

Capítulo 21. El officio de Nuestra Señora en el día de la Asumpción ...............339

Capítulo 22. Del officio en el Dia de la Conmemoración

de los Difuntos

Capítulo 23. Del officio en el Día de la Inmaculada

Concepción de Nuestra Señora

Capítulo 24. Del officio en el día de las honrras que

se hacen por el Illmo. Fundador y por sus padres

Capítulo 25. Del officio en la muerte y entierro de los

Prebendados y ministros de Sacro Monte

Capítulo 26. De las Sagradas Cuevas y cómo se han de enseñar 360

Capítulo 27. De las missiones y estilo que se tiene y ha de guardar en ellas 
Capítulo 28. Cómo se ha de renovar el Sanctissimo Sacramento en el altar del Sagrario todos los jueves.

Capítulo 29. El modo con el que se an de celebrar las missas y responsos cantados, por las ánimas del purgatorio, según las intención del Doctor don Pedro Dávila, Abbad de este Sacramento que las fundó y se admitió en Cabildo de 27 de septiembre de 1633, en la forma siguiente.

APÉNDICE 2. NOTICIAS DE INTERÉS MUSICAL CONTENIDAS EN LAS

ACTAS CAPITULARES DE LA ABADÍA

DEL SACROMONTE (1611-1799).

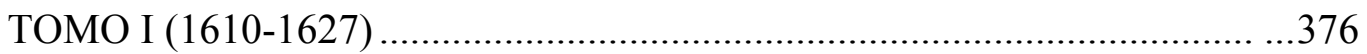

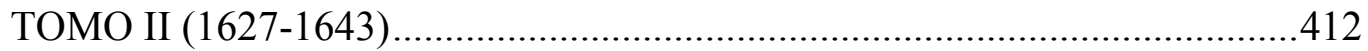

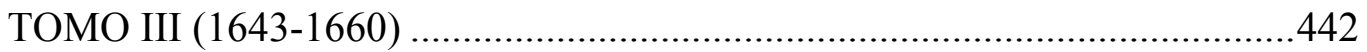

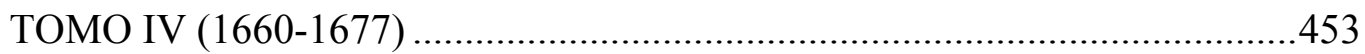

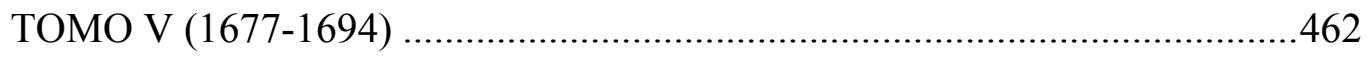

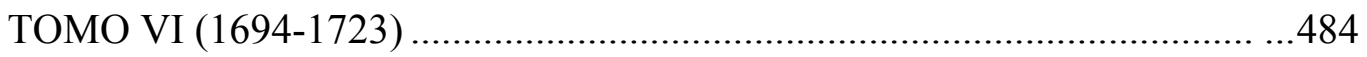

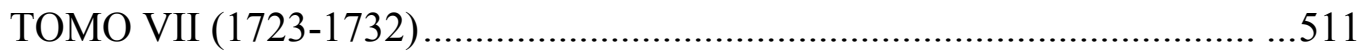

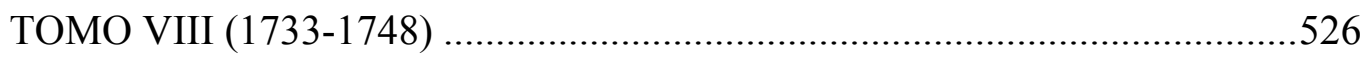

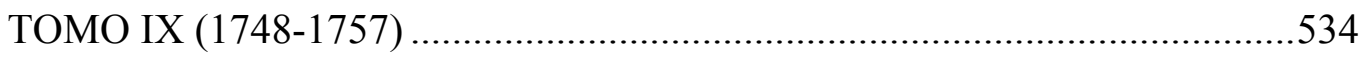

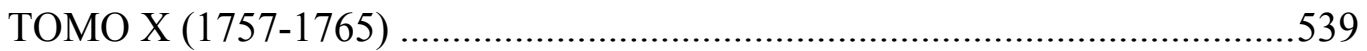

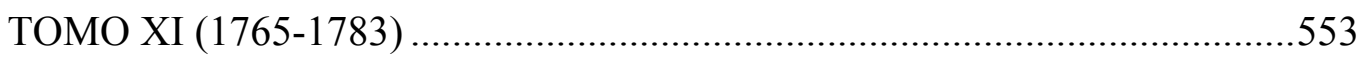

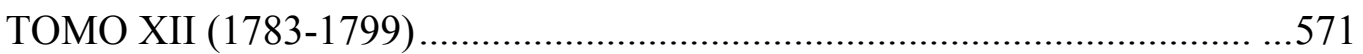

APÉNDICE 3. RECONSTRUCCIÓN DEL RITO DE LA SALVE SEGÚN LAS FUENTES CONSERVADAS EN LA ABADÍA DEL SACROMONTE ....... 591

APÉNDICE 4. EDICIÓN DE LA MISA PARA LA FIESTA DE

SAN CECILIO, PATRÓN DE GRANADA SEGÚN EL

CANTORAL LC XXII (olim 332, olim 32) DE LA

ABADÍA DEL SACROMONTE

APÉNDICE 5. EDICIÓN DEL OFICIO EXALTATIONIS

FIDEI (UN NUEVO OFICIO DE LA TOMA DE GRANADA HASTA

AHORA INÉDITO) SEGÚN EL CANTORAL 26,

FOLS. 101-107, DE LA CATEDRAL DE

SANTIAGO DE COMPOSTELA

APÉNDICE 6. DOCUMENTOS RELATIVOS A LA CELEBRACIÓN DE LA 


\section{APÉNDICE 7. EDICIÓN DE OBRAS POLIFÓNICAS DEDICADAS A} SAN CECILIO QUE SE ENCUENTRAN EN LOS ARCHIVOS DE LA CATEDRAL Y DE LA CAPILLA REAL DE GRANADA.

1. Anónimo. Hic nempe mundi gaudia. Himno a San Cecilio para doble coro y órgano (Fuente: ACG 236)

2. Antonio Caballero (¿1728?-1822). Iste Sanctus. Motete a 8 a San Cecilio, SSAT, SATB, órgano y acompañamiento (Fuente: ACRGr 559)

3. Celestino Vila de Forns (1830-1915)

Salve, Patrón de Granada. Himno a San Cecilio, a 3vv (STB), dos violines, clarinete y violón (Fuente: ACG 987) 649

Cecilio, pues en Granada. Gozos a San Cecilio, a 4vv. (SATB), dos violines, clarinete, contrabajo y órgano (Fuente: ACG 950).

Deus tuorum militum, canon de doble guía, a 4 vv (SATB) (Fuente: ACG 897/12). 



\section{Agradecimientos}

La elaboración de esta Tesis Doctoral ha sido posible gracias a la confluencia de diversas circunstancias y personas a las que estoy muy agradecida.

El inicio de este trabajo fue posible gracias a la amabilidad del Abad del Sacromonte de Granada, don Juan Sánchez Ocaña, que me brindó la oportunidad de visitar el Archivo y conocer la librería coral del Sacromonte, y siempre me facilitó mi labor. Al Cabildo de la Abadía del Sacromonte quiero agradecer su gentileza y disponibilidad, especialmente a Don Francisco y Don Federico con quienes tuve la oportunidad de charlar sobre el pasado, presente y futuro de la Institución. Mención especialísima merece el canónigo Don Vicente Redondo Toro, Archivero que fue del Sacromonte, con quien compartí no sólo momentos de estudio y conversación, sino también nuestra admiración por el pasado intelectual de la Abadía y las maravillosas puestas de sol sobre la Alhambra que pueden contemplarse desde la ventana del Archivo; su buen humor y su especial visión de la vida son un recuerdo imborrable. Su inesperada muerte ha impedido que viera concluido este trabajo en el que tantas ilusiones y expectativas había depositado. El Sacromonte ha perdido con él uno de sus defensores más críticos y eficaces.

De todas las personas que me han ayudado merece especial gratitud mi director de Tesis, el Dr. Emilio Ros-Fábregas, quién desde el primer momento mostró su entera disposición y atención a mi trabajo. Sus comentarios, sugerencias y palabras de aliento han sido el alma de este estudio. Su actitud de generosidad, honradez científica y su entusiasmo ante la enseñanza y la investigación serán siempre un ejemplo a seguir.

La Dra. María Gembero Ustárroz confió en mí cuando aún era alumna de Licenciatura de la Universidad de Granada para ser miembro del Grupo de Investigación "Mecenazgo musical en Andalucía y su proyección en América” que ella dirigía, dentro del cual comencé mi actividad investigadora. A ella también le agradezco sus sugerencias y cariño.

La Dra. Tess Knighton leyó parte de la primera redacción de esta Tesis durante mi estancia de investigación predoctoral como "Visiting Scholar"en la Facultad de Música de la Universidad de Cambridge. A ella debo agradecerle estimulantes 
sugerencias sobre el tema y posibles enfoques de trabajo, así como diversas recomendaciones bibliográficas. También por su dulzura y su generosidad durante y después de mi estancia allí le estaré eternamente agradecida.

En el complicado manejo de los enormes Libros de Coro del Sacromonte encontré versicularios modernos, sin cuya ayuda no podría haber examinado y catalogado dichos cantorales: mi gratitud a Javier Ruiz, algunas de cuyas fotos ilustran este trabajo, Julio Quijada, Iván Olmedo, Mercedes y Pablo García, Santi Alonso, Joaquín González, Víctor Castellón, Gloria Pérez, José Luis Carranza, Isabel Delgado, M Luisa Varo, Eduardo Contreras y Esther, Juan Carlos Carrillo, Martín Rey, José Ramón Cámara y Mercedes Ferreira.

A Germán Gan le debo no sólo su ayuda con los cantorales sino también sus sugerencias bibliográficas, algunas de las cuales llegó incluso a comprarme y regalarme; a sus palabras de aliento, comentarios y más de un tirón de orejas debo gran parte de esta Tesis. Gonzalo Roldán me brindó el uso privilegiado de su Biblioteca, y fue compañero de casa y estudio en la University Library de Cambridge, donde compartimos muchos momentos de descubrimientos bibliográficos. El profesor James Boyce de la Universidad de Fordham (E.E.U.U.) me facilitó su inventario de los Cantorales de la Catedral de Santiago de Compostela. Pilar Ramos me envió parte de sus trabajos en prensa, Juan Ruiz me proporcionó algunos de los suyos que han sido de gran utilidad y Eva Esteve me aportó diversas referencias sobre Consuetas. A todos ellos quiero corresponder su atención con estas palabras. Además quiero agradecer a mis colegas del Coro Tomás Luis de Victoria, en especial a su Director Pablo García Miranda todo el apoyo que me han brindado: Alejandro Borrego Pérez su asesoramiento en las traducciones del latín, a Eduardo Salas Romo sus sugerencias sobre bibliografía del teatro en España y a Margarita Martínez por su plano de la Iglesia y las Santas Cuevas que ilustra el Capítulo IV.

Mis compañeros del Departamento de Didáctica de la Expresión Musical, Plástica y Corporal de la Universidad de Jaén donde actualmente imparto clase me han acompañado durante este proceso. Isabel Ayala me brindó su ánimo y colaboración inestimable, especialmente durante nuestras visitas a la Biblioteca Nacional de España; $\mathrm{M}^{\mathrm{a}}$ Luisa Zagalaz, Catedrática y Directora del Departamento, me facilitó siempre que estaba en su mano diversas estancias de investigación al mismo tiempo que me ayudó a 
solicitar las ayudas correspondientes; Pedro Jiménez Cavallé puso a mi disposición sus trabajos de investigación. Dulcenombre Jiménez Cavallé, $\mathrm{M}^{\mathrm{a}}$ Paz López-Peláez, Victoriano Pérez y Marta Romero me han animado en esta última etapa. Virginia López y Javier Marín compartieron su biblioteca conmigo. Coral Morales me asesoró en todo lo referente al proceso de impresión y trámites burocráticos, Víctor Yanes me ayudó a reflexionar sobre el proceso creativo.

Durante la elaboración de esta Tesis he recibido diversas ayudas y becas. Obtuve dos Ayudas a Proyectos de Investigación Musical otorgadas por el Centro de Documentación Musical (CDMA) de la Junta de Andalucía que me permitieron realizar el vaciado de noticias musicales contenidas en las Actas de Cabildo y la Catalogación de los Libros de Coro; a los directores del CDMA, Esteban Valdivieso $\dagger$ y Reynaldo Fernández Manzano rindo mi sincero agradecimiento por el apoyo y ayuda facilitados en todo momento. La Junta de Andalucía me concedió una Ayuda de Movilidad para el Personal Docente e Investigador que posibilitó mi estancia en la Universidad de Cambridge como "Visiting Scholar" durante el periodo enero-abril de 2005.

También quiero agradecer la ayuda prestada por el personal de las Bibliotecas y Archivos en los que esta investigación se ha realizado, especialmente a los bibliotecarios de la Cambridge University Library, de la Biblioteca del Hospital Real y de la Biblioteca de Filosofía y Letras de la Universidad de Granada, con especial mención a Antonio Carmona, que solventó siempre todos los problemas de acceso a la documentacón con la máxima eficacia.

Mi familia y mis amigos han sido mi gran ayuda todos estos años. A ellos quiero reconocerles sus sacrificios y renuncias, especialmente a mis padres quienes han hecho todo lo posible para que este trabajo se materializara y a Iván que ha permanecido pacientemente a mi lado. Mi madre no sólo se ha encargado de animarme sino que también me ha ayudado a tomar las fotos de los cantorales. A mi padre y mi hermana Carmen les debo además la revisión de los textos de los apéndices. A mi hermano Rafa y a Sara Roberts les agradezco la revisión de los textos en inglés.

En último lugar quiero agradecer al profesor Dinko Fabris de la Università della Basilicata (Potenza, Italia) y al profesor Chris Collins de la University of Bangor (Reino Unido), que han avalado con sus informes la presentación de esta Tesis Doctoral con mención "Doctorado Europeo". 



\section{INTRODUCCIÓN}

\section{Objetivos y metodología}

Esta Tesis Doctoral estudia la actividad musical en la Abadía del Sacromonte de Granada desde su fundación en 1609 hasta principios del siglo XIX. Dedicaré especial atención a su organización y al papel desempeñado por la música en las ceremonias litúrgicas, donde el canto llano era el protagonista casi exclusivo. El estudio de las Constituciones (1616 y 1647), de la Consueta (1632) y de los 79 cantorales que todavía se conservan en el Sacromonte permite reconstruir con detalle muchas ceremonias, como la de la Salve, y la liturgia de festividades importantes como la de San Cecilio, patrón de Granada. Tradicionalmente las capillas musicales catedralicias y la polifonía que interpretaban han recibido mayor atención musicológica que la actividad musical en otras instituciones eclesiásticas como monasterios, parroquias, abadías e iglesias colegiales, especialmente si no contaban con capilla de música. Desde esta perspectiva, la Abadía del Sacromonte es una de esas instituciones "menores", ya que no disponía de capilla musical y sus únicos músicos de plantilla propiamente dichos eran el sochantre y el organista. Sin embargo, la ausencia de polifonía en la Abadía del Sacromonte no se debe a razones de índole económica o de rango eclesiástico, como pudiera parecer en un principio, sino al expreso deseo de su fundador Pedro de Castro, Arzobispo de Granada, cuya personalidad como reformador tridentino le llevó a querer emular la misma sobriedad musical que Felipe II estableció en la fundación de El Escorial. Desde esta perspectiva, la Abadía del Sacromonte emerge como una institución particularmente atractiva desde el punto de vista musical, ya que contrasta con el modelo catedralicio más conocido y ofrece una riqueza documental extraordinaria sobre el ceremonial litúrgico que acompañaba la interpretación del canto llano. Las circunstancias que rodearon la fundación del Sacromonte, a partir del descubrimiento de las supuestas reliquias de San Cecilio, y el espíritu contrarreformista que inspiró sus Constituciones contribuyen a enmarcar la actividad musical de esta emblemática institución granadina en la historia cultural de España en la Edad Moderna.

Al elegir como tema de investigación la actividad musical desarrollada en una institución eclesiàstica era ineludible utilizar la metodología empleada en estudios institucionales similares: lectura de actas capitulares, localización y estudio de los 
documentos fundacionales, catalogación de la música (en este caso la colección de cantorales de canto llano de la Abadía) y comentario biográfico de los músicos. Según Bryant y Quaranta "Los modelos de producción y consumo [musicales] se derivan de investigaciones realizadas en muchas instituciones de un mismo tipo (de modo que añadir una no puede más que confirmar, con o sin variaciones, estereotipos ya ampliamente delineados o establecer una excepción que confirma la regla general) y sobre todos los diversos tipos institucionales". ${ }^{1}$ Pero esta concepción debe matizarse, puesto que al menos entraña dos peligros: 1) el acomodar los datos obtenidos a una tipología y simplificar la descripción poniendo de manifiesto lo que es igual o lo que difiere con respecto a una tipología institucional, pero sin establecer aquello que realmente caracteriza a una institución en particular; y 2) presuponer en la institución una esencia, en cierto sentido, inamovible. La comparación entre las características específicas de la Abadía y las características de otras instituciones similares (que se ajustan más a la "norma") me ha servido para analizar hasta qué punto puede establecerse una tipología abadía/iglesia colegial y sus patrones de funcionamiento, poco estudiados desde la perspectiva musical. El estudio a fondo de las circunstancias que rodearon la fundación de la Abadía del Sacromonte, a su vez, ha sido fundamental para entender las mentalidades y la sociedad de la época en que se fundó.

En un primer momento, la escasez de evidencias musicales que habitualmente son consideradas más importantes (música polifónica, noticias sobre músicos relevantes) llegó a ser frustrante, pero este "defecto" del tema de estudio ha terminado convirtiéndose en su razón de ser. En esta Tesis Doctoral no aparecen grandes compositores ni obras maestras de la polifonía. Sin embargo, el hallazgo de la Consueta de la Abadía del Sacromonte me ha permitido concentrame en la vida diaria y el ceremonial litúrgico de una institución que - por lo que a la interpretación del canto llano se refiere- es modélica, y, en cierto sentido, representativa de la práctica musical habitual, especialmente en muchas instituciones que carecían de capilla de música. De una forma natural, a medida que transcurría mi investigación, el enfoque de esta Tesis

\footnotetext{
${ }^{1}$ David Bryant y Elena Quaranta, Produzione, circolazione e consumo. Consuetudine e quotidianità della poliphonia sacra nelle chiese monastiche e parrochiali dal tardo medioevo alla fine degli antichi regimi, Quaderni di Musica e Storia, 5 (Venecia: Fondazione Ugo e Olga Levi, 2006), p. 13: "I modelli di produzione vanno ricavati da ricerche condotte a tappeto su tante instituzioni di uno stesso tipo (al punto tal che aggiungerne una non può che confirmare-con o senza varianti- stereotipi già ampliamente delineati o fornire un'eccezione che comunque conferma la regola generale) e su tutti i diversi tipi istituzionali".
} 
también se ha ido tornando cada vez más interdisciplinario. La liturgia, la historia cultural, política y urbana, la iconografía, la literatura y por supuesto las disciplinas auxiliares de la musicología han contribuido a presentar la historia musical de la Abadía del Sacromonte como un paisaje. Parafraseando a John Lewis Gaddis, hay que hacer historia de tal manera que cualquiera que lea nuestro trabajo esté convencido de que esos distanciamientos con respecto a las dimensiones en las que vivimos actualmente nos proporcionen en realidad una información fiable acerca de cómo vivía la gente en el pasado. $^{2}$

\section{Las colegiatas como centros musicales}

\subsection{La Abadía del Sacromonte: ¿abadía o iglesia colegial?}

La Abadía del Sacromonte es una institución peculiar, pues su nombre no se corresponde con su verdadera naturaleza. Esta Abadía no es una "abadía” en la acepción común del término, ya que quienes en ella habitaban no pertenecían a una orden monástica. En los documentos fundacionales la palabra con la que se nombra a la institución es siempre el de Iglesia Colegial y nunca el de Abadía. ${ }^{3}$ El empleo de este vocablo, "abadía", para referirse al Sacromonte no aparece en documentos propios de la institución hasta el siglo XX. ${ }^{4}$

\footnotetext{
${ }^{2}$ John Lewis Gaddis, El paisaje de la Historia. Cómo los historiadores representan el pasado (Barcelona: Anagrama, 2004), p. 57. El libro de Gaddis ha resumido acertadamente las relaciones actuales entre historia y ciencia, poniendo de manifiesto cómo la teoría del caos y la complejidad son tan útiles al historiador como al científico. Según Gaddis, los historiadores hacen una abstracción de la realidad, no una representación literal, pero deben realizar esas man ipulaciones de manera que se puedan abordar las verificaciones existentes en las ciencias sociales, físicas y biológicas. Estamos a medio camino entre el arte y la ciencia, con la distinción de que los artistas no necesitan confirmar sus fuentes, los historiadores sí (pp. 38-39).

${ }^{3}$ Como ejemplo véase entre otros documentos fundacionales las Bulas de la Iglesia colegial del Sacromonte reproducidas en Diego Nicolás Heredia Barnuevo , Místico Ramillete (Granada: Archivum, 1998), p. 137: "Huismodi suplicationibus inclinati, novam Ecclesiam praedictam in Collegiatam Ecclesiam insignem (...) apostolica autoritate, et tenore praesentium perpetuo erigimus, et instituimus". También se habla en los mismos términos en: Gnomon seu gobernandi Abbati, et canonicis Sacri Montis Illipulitani praescripta Ab Yllustriss ${ }^{\circ}$ et Rss ${ }^{\circ}$ Domino D. Pedro De Castro et Quiñones Archiepiscopo Granatensi, et posteabis palensi, eius dem Ecclesiae Collegiatae Fundatori. Et ab Urbano VIII Pontifici Maximo Confirmata (Granada: Ex tipografia Regia apud Sanchez, 1647). Para un estudio sobre el término Abadía y sus implicaciones terminológicas, véase Antonio Linage Conde, "La Abadía (=Prelatura "nullius" territorial) de Alcalá la Real en la geografía y la historia de la Iglesia", en Abadía. I Jornadas de Historia en la Abadía de Alcalá la Real (Jaén: Diputación Provincial, 1997), pp. 181-202.
}

\footnotetext{
${ }^{4}$ Algunos de los documentos que comienzan a emplear esta denominación se encuentran en A.A.V.V., Granada 1899 (Granada: Albaida, 1995), pp.136-137 (edición facsímil de la de 1899).
} 
El empleo generalizado de la denominación "Abadía del Sacromonte" se debe en primer lugar a que la dignidad superior de las colegiatas en España se denominó con frecuencia abad, en lugar de deán o prior, de modo que parecía lógico que un abad gobernase una abadía. Sin embargo, esta confusión no se produjo en la Colegiata de Santa Fe ni en el resto de las colegiatas granadinas cuya dignidad superior era un abad. Sin duda la obligación de los canónigos del Sacromonte de residir en un edificio parecido a un monasterio y alejado del centro de Granada, con claustro, iglesia, biblioteca, refectorio y sus deberes de atención al culto, tan frecuentes como en una orden monástica, determinaron la adopción del término Abadía. ${ }^{5}$ Otro caso parecido es el de la Iglesia Colegial de Alcalá la Real en Jaén, que también fue conocida como abadía, con la salvedad de que aquí el abad sí tenía autoridad casi episcopal y gozaba de numerosas prebendas y prerrogativas sobre los territorios que gobernaba, mientras que la autoridad del Abad del Sacromonte se limitaba a su iglesia.

Desde el siglo XX y hasta la actualidad se emplea el término Abadía del Sacromonte, por lo que de aquí en adelante me referiré a ella como Abadía, aún sabiendo que se trata propiamente de una iglesia colegial. ${ }^{6}$

\subsection{Las iglesias colegiales como institución en España ${ }^{7}$}

No es el objeto de esta introducción el estudio exhaustivo de las iglesias colegiales en España. Es difícil establecer el número de iglesias colegiales, porque no existe un estudio histórico completo de esta institución en España. Las fuentes donde aparecen listados más completos datan del siglo XIX, época en la que muchas habían perdido esta categoría o se habían transformado en catedrales (como en el caso de

\footnotetext{
${ }^{5}$ En la voz "Colegiata" de la Enciclopedia universal ilustrada europeo-americana (Madrid : Espasa Calpe, D.L. 1958-), vol. XIV, pp. 17-18, [en adelante Enciclopedia Espasa-Calpe] se señala que "en España (los superiores de las colegiatas) llevan el título de Abad, que está poco conforme con la falta de carácter conventual de las modernas colegiatas, carácter que sólo se conserva en las de Roncesvalles, Covadonga y Sacromonte".

${ }^{6}$ Zótico Royo Campos, "Sacromonte", Diccionario de Historia Eclesiástica de España, editado por Aldea Vaquero (Madrid: Instituto Enrique Florez, Consejo Superior de Investigaciones Científicas, 19721975), vol. IV, p. 2337, denomina a la institución como "abadía y santuario".

${ }^{7}$ Para este apartado seguiré de cerca la voz "Colegiata" que aparece en la Enciclopedia Espasa-Calpe, vol. XIV, pp.17-18, concretando las características generales en el caso de las colegiatas españolas y andaluzas.
} 
Tudela). Las enumeraciones más exhaustivas son los censos que aparecen en la Historia eclesiástica de Españ $a^{8}$ en el Diccionario de Hacienda, ${ }^{9}$ y en el Diccionario geográfico-estadístico-histórico. ${ }^{10}$ Últimamente, algunos trabajos han llamado la atención sobre la laguna historiográfica que existe acerca de estas instituciones, a pesar de su importancia para el conocimiento de la sociedad y la economía españolas en la Edad Moderna. ${ }^{11}$

Dentro de las diversas instituciones eclesiásticas, las iglesias colegiales o colegiatas ocuparon un lugar singular en la historia de la Iglesia en España. A medio camino entre las iglesias catedrales y las iglesias conventuales guardaban con unas y otras algunas semejanzas: con ambas compartían su estructura capitular y una especial atención al culto. La principal diferencia con las catedrales es que las colegiatas carecen de cátedra episcopal fija, y con las conventuales que su cabildo es secular, no reglar.

Los motivos que llevaron a la creación de estas iglesias son diversos aunque siempre obedecen a una única consigna: el solemnizar el culto divino. En algunos casos se optaba por esta fórmula cuando ya había una catedral o estaba en una localidad próxima. Así ocurrió en Baza, cuya proximidad con Guadix, que tenía Catedral, hizo que se optara por esta fórmula. Para la erección de una iglesia colegial hacía falta la autorización del papa, que era otorgada por medio de bulas, aunque al principio y hasta el siglo XIV su fundación tan sólo dependía de la voluntad del obispo, como sucedió con la colegial de Úbeda, elevada a colegiata en 1259 por iniciativa de Don Pascual,

\footnotetext{
${ }^{8}$ Vicente de la Fuente, Historia eclesiástica de España (Madrid : Compañía de Impresores y Libreros del Reino, 1873-1875) vol. VI, pp. 470-471.

${ }^{9}$ José Canga Argüelles, Diccionario de hacienda (Madrid: Atlas, 1968).

${ }^{10}$ Pascual Madoz, Diccionario geográfico-estadístico-histórico (Valladolid: Ámbito, 1987).

${ }^{11}$ Una aproximación al censo, función y estructura de las iglesias colegiales puede encontrarse en: Víctor Heredia Flores, "Las Iglesias colegiales españolas y la Real Colegiata de Antequera" en La Real Colegiata de Antequera. Cinco siglos de Arte e Historia (1503-2003) (Antequera: Ayto. de Antequera y Archivo Histórico Municipal, 2004), pp. 53-102. Este trabajo resume el artículo "Colegiata", Enciclopedia Espasa-Calpe (sin citarlo) y otros trabajos anteriores. Su lista de colegiales es la más extensa, pero contiene ciertas imprecisiones en cuanto a lo que Andalucía concierne; no incluye la colegial de Arcos de la Frontera y cita como dos colegiales distintas de Granada la del Salvador y la de San Justo y Pastor, cuando en realidad son la misma. El cabildo de la Colegiata del Salvador de Granada, fundada en 1527, se trasladó a la que se conoció como Colegiata de San Justo y Pastor en 1771, quedando el templo del Salvador como parroquia ordinaria. También cita a la Iglesia de Huéscar como colegial y no lo era (agradezco a Victoriano Pérez Mancilla este dato).
} 
obispo de Jaén y con la Colegiata del Divino Salvador de Sevilla, fundada por el Arzobispo Don Remondo.

Como cualquier iglesia, las colegiatas también tenían una advocación concreta. La más frecuente en las colegiales andaluzas es a la Virgen (Santa María de los Reales Alcázares de Úbeda, Santa María de la Asunción de Alcalá la Real, Santa María de Baeza, Anunciación de Nuestra Señora de Baza, Santa María de la Encarnación de Santa Fe, Nuestra Señora de la Asunción de Ugíjar, Santa María la Mayor de Antequera, Santa María de la Asunción del Sacromonte ${ }^{12}$ o Nuestra Señora de la Encarnación de Motril), seguidas de tres al Salvador (Sevilla, Jerez de la Frontera y Granada) y otras tres a santos particulares (San Hipólito de Córdoba, San Pedro Apóstol de Arcos de la Frontera y Santiago en Castellar).

El mecenas que patrocinaba las obras adquiría ciertos derechos sobre el gobierno de la colegial, entre ellos el de presentación o nombramiento de los cargos y canongías. Dichas prerrogativas eran propias de lo que se conoce con el nombre de patronato, que podía ser particular, regio o libre, según fuera su fundador un noble, el rey, o careciera de patrón. ${ }^{13}$ De patronato particular fueron las colegiatas de Osuna, Olivares, Castellar, Sacromonte y Motril entre otras; de patronato regio las colegiatas de Jerez de la Frontera, Alcalá la Real, Córdoba, Baza, Santa Fe, Ugíjar y el Salvador de Granada. El caso del patronato libre no fue del todo efectivo en España, pues la monarquía obtuvo el patronato universal sobre las iglesias de su reino. Esto quiere decir que aunque los reyes no hubieran fundado la iglesia, les correspondía en último término la decisión sobre la aceptación de los cargos.

Para completar el personal que debía atender las necesidades de una colegiata se solía estipular la presencia de al menos un sochantre y un organista, como en el

\footnotetext{
${ }^{12}$ Y no Colegiata de San Cecilio como erróneamente la denomina Gallego y Burín en su Guía de Granada, véase Antonio Gállego y Burín, Granada, Guía artística e histórica de la ciudad (Granada: Editorial Don Quijote, 1982), p. 362.

${ }^{13}$ Utilizo el término "regio" para distinguir dos conceptos del Derecho: patronato real y Real Patronato (o Patronato Regio). El primero es el que hace referencia a la existencia efectiva de un patronato, mientras que el segundo tiene que ver con las prerrogativas que tiene el rey en cuanto a la presentación y nombramiento de cargos. Véase la voz "Patronato", Enciclopedia Espasa-Calpe, vol. XLII, pp. 886-905.
} 
Sacromonte, en Córdoba y Santa Fe. El resto de las colegiales andaluzas vieron completada su plantilla con una capilla de música. ${ }^{14}$

Siguiendo los decretos del Concilio de Trento algunas de estas iglesias, con la intención de aumentar el número de los asistentes al coro, creaban un seminario anejo a la Iglesia, cuyos colegiales tenían que cumplir obligaciones corales. Osuna contaba con una Universidad desde el siglo XVI, Baza fundó el seminario en 1603, y el Sacromonte tuvo otro colegio-seminario con grados universitarios.

Las iglesias colegiales, para incentivar la asistencia al coro, contaban con las distribuciones corales, gracias a las cuales se remuneraba directamente la participación en los servicios cantados. Las distribuciones corales tienen un origen anterior al siglo XIII, aunque el Concilio de Trento dispuso que tanto en las catedrales como en las colegiales que no tuviesen esta práctica o fueran pobres, los obispos habían de separar la tercera parte de los frutos y provechos de cada dignidad para destinarla a las distribuciones. Cada cabildo debía nombrar a un "puntador" o apuntador que anotara las faltas para controlar las retribuciones correspondientes. ${ }^{15}$

Las colegiatas podían ostentar diversos títulos como el de "Insigne" y "Magistral". La calificación de "Insigne" se otorgó a diversos centros desde el Concilio de Trento, dependiendo de si la iglesia colegial era muy antigua, de respetables tradiciones, tenía reliquias de mártires célebres, numeroso cabildo, abad o deán mitrado ó un espacioso templo. Urbano VIII reservó su concesión a la Santa Sede. ${ }^{16}$ La distinción de "Insigne" la obtuvieron al menos las colegiatas de Jerez de la Frontera, Castellar y Sacromonte. Para obtener el título de "Magistral" era necesario que al menos dos de las canongías fueran doctorales. En España tan sólo ostentan este título, la Abadía del Sacromonte y la Colegiata de Alcalá de Henares. En la Figura I.1. puede observarse un mapa con las colegiales españolas en los tiempos de la fundación de la Abadía del Sacromonte a principios del siglo XVII. La Tabla I.1. presenta resumida la información sobre las colegiatas en Andalucía. No se incluyen algunas iglesias que en

\footnotetext{
${ }^{14}$ Probablemente también en Ugíjar sólo se encontrara un sochantre y organista, pero no hemos podido localizar ningún documento fundacional o histórico que concrete las características de esa colegiata.

${ }^{15}$ Véase: Juan B. Ferreres, Instituciones Canónicas, 2 Tomos (Barcelona: Editorial Pontificia, 1934), Tomo I, pp. 304-306.

${ }^{16}$ Véase la voz "Colegiata", Enciclopedia Espasa-Calpe, Tomo I, p. 18
} 
algunas fuentes aparecen como colegiales, pero de las que no hemos podido encontrar confirmación documental como las de Alhama de Granada y Baena. ${ }^{17}$

Figura 1. Colegiatas españolas en el siglo XVII.

Fuente: elaboración propia sobre el mapa de Mansilla Reoyo. ${ }^{18}$

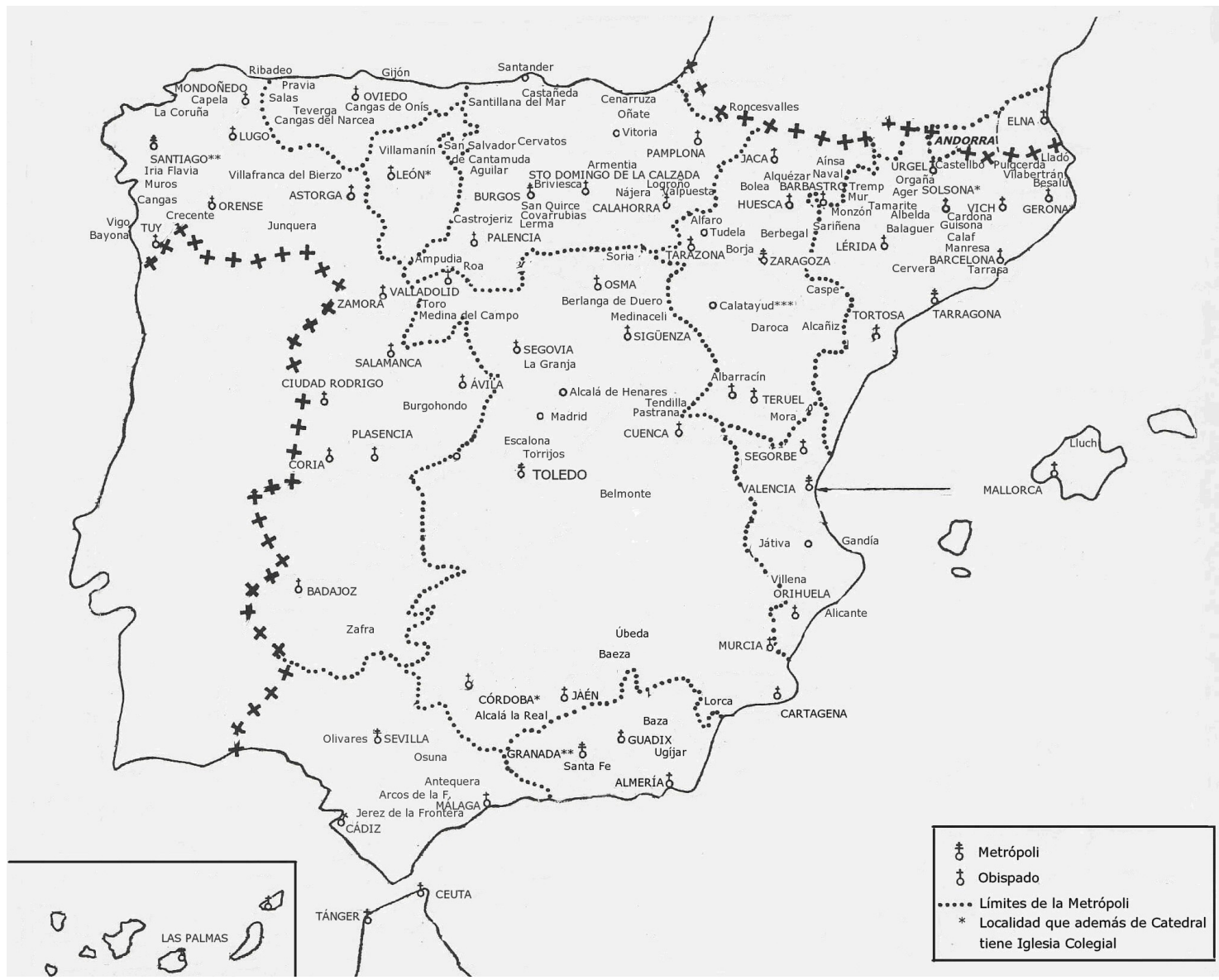

\footnotetext{
${ }^{17}$ Estas iglesias probablemente contaban con un cabildo, pero no tenían el título de colegiatas.

${ }^{18}$ Demetrio Mansilla Reoyo, "Panorama histórico-geográfico de la Iglesia española en los siglos XV y XVI" en Historia de la Iglesia en España, 5 vols., Ricardo García-Villoslada (dir.) (Madrid: Biblioteca de Autores Cristianos, 1979), vol. 3, Tomo 1, 1979, pp. 3-24.
} 


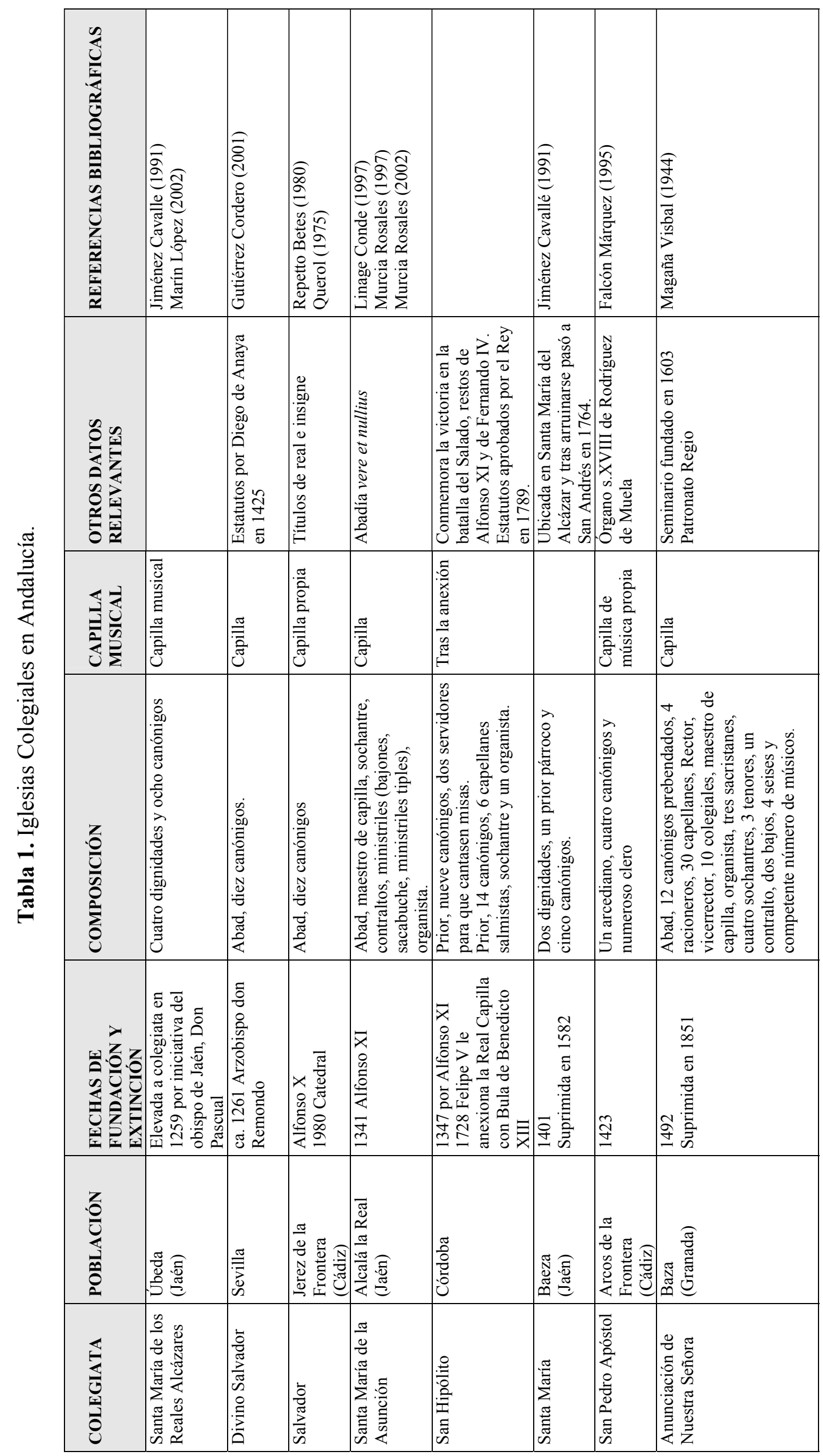




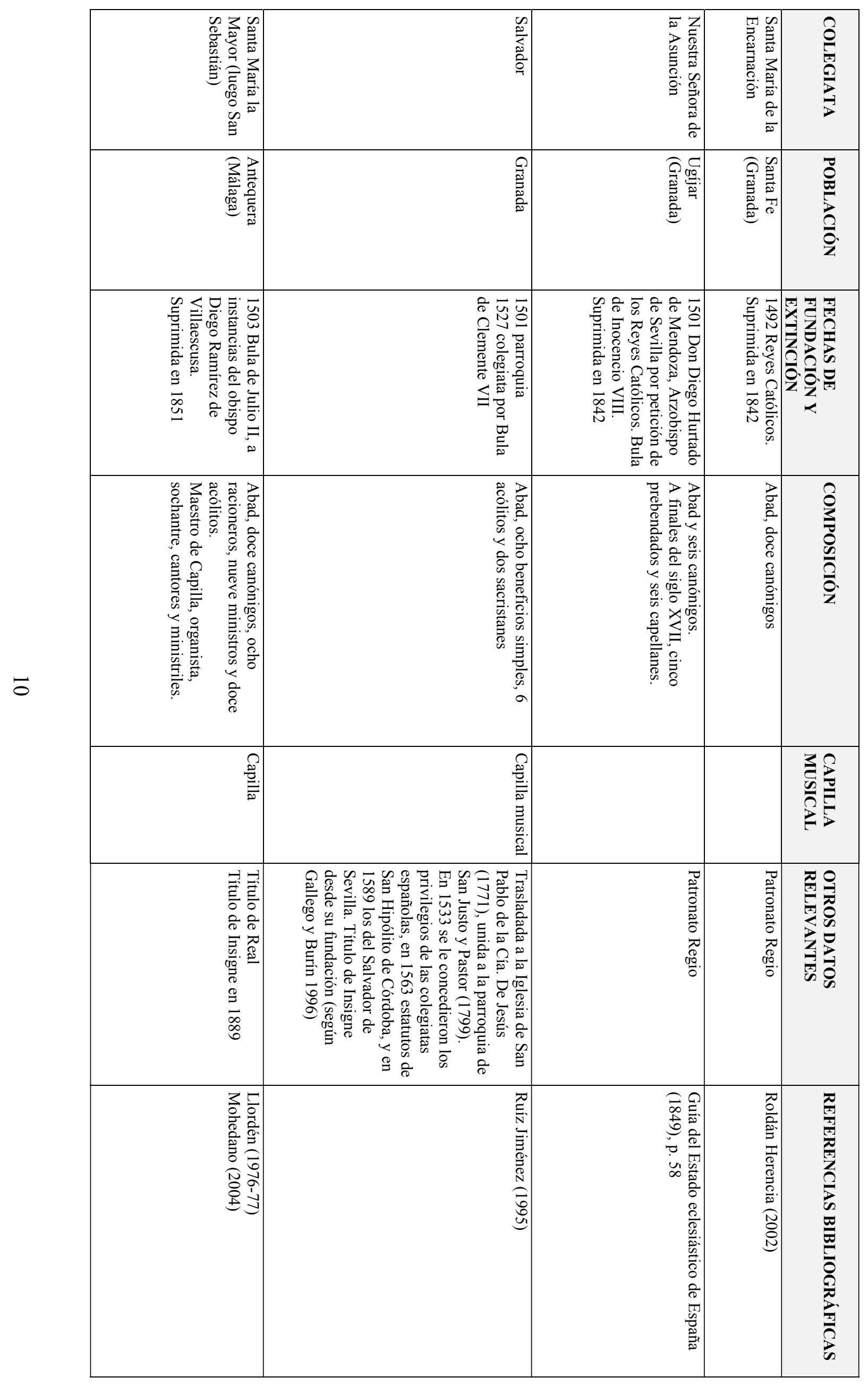




\begin{tabular}{|c|c|c|c|c|c|}
\hline 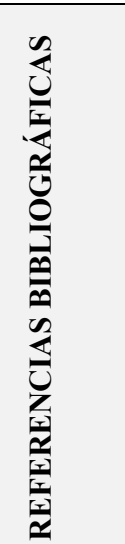 & 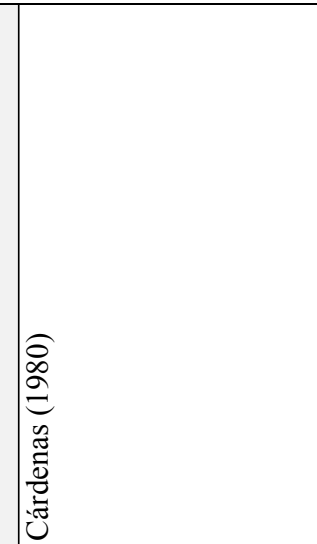 & 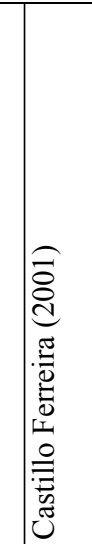 & 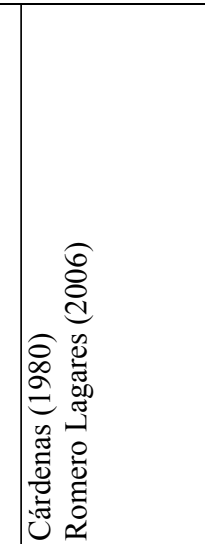 & 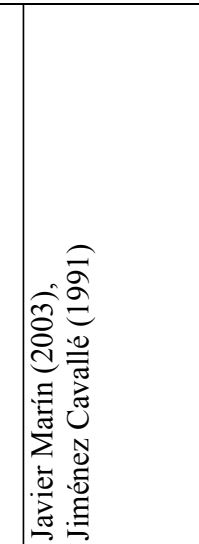 & \\
\hline 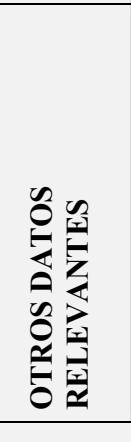 & 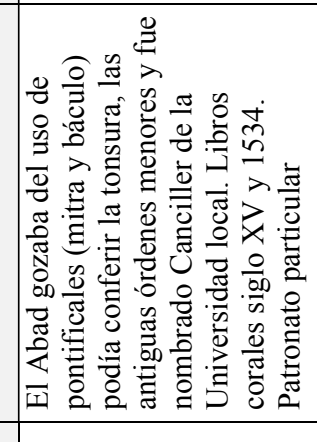 & & 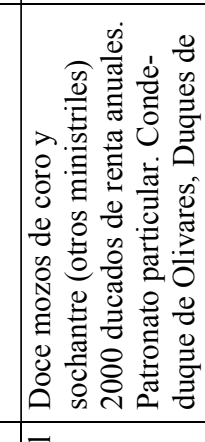 & 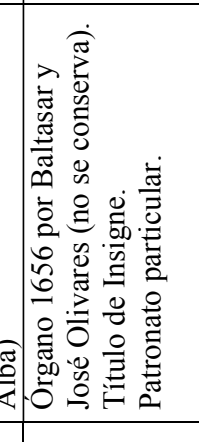 & 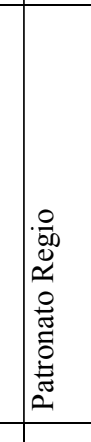 \\
\hline 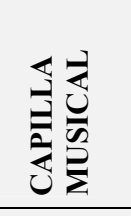 & & 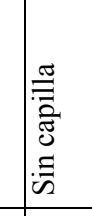 & 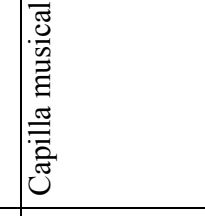 & 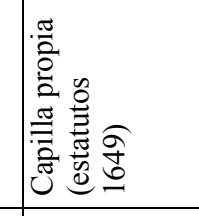 & \\
\hline $\begin{array}{l} \\
z \\
0 \\
0 \\
0 \\
0 \\
0 \\
0 \\
0\end{array}$ & 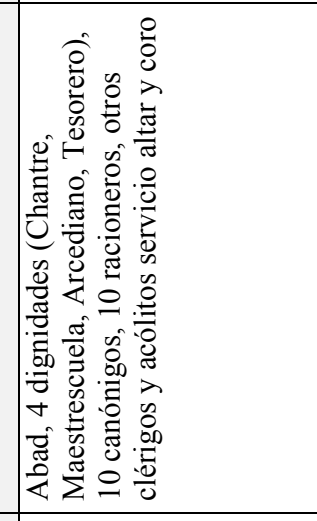 & 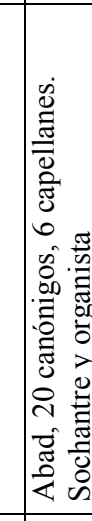 & 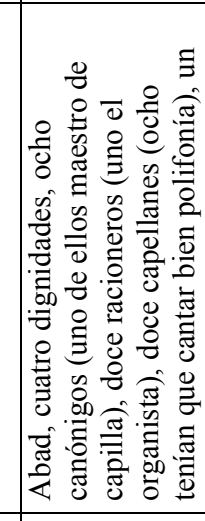 & 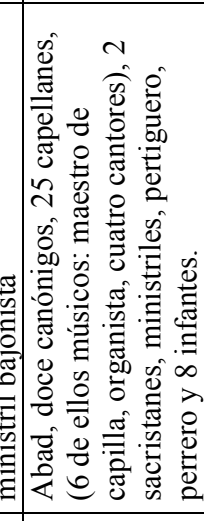 & 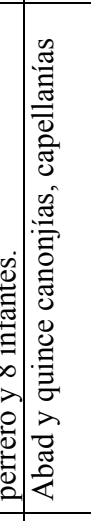 \\
\hline 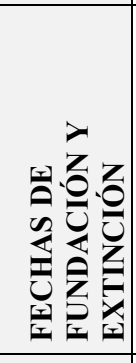 & 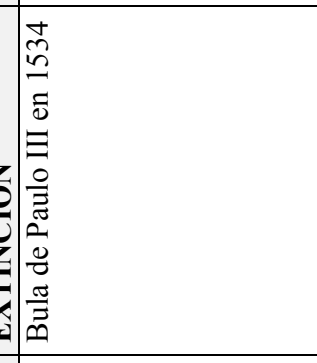 & 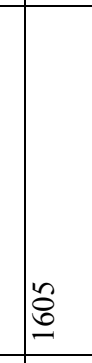 & 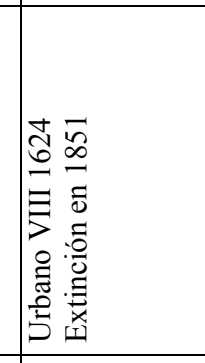 & 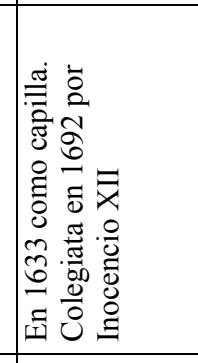 & 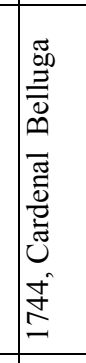 \\
\hline 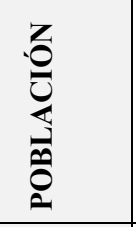 & 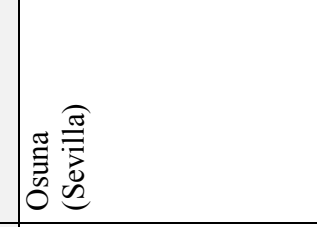 & 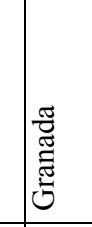 & 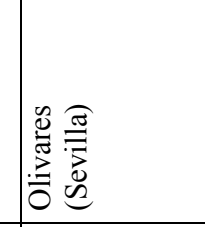 & 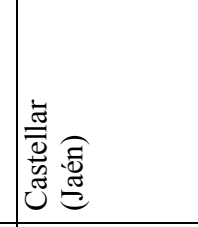 & 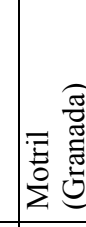 \\
\hline $\begin{array}{l}\mathbb{5} \\
0 \\
0 \\
0 \\
0 \\
0\end{array}$ & 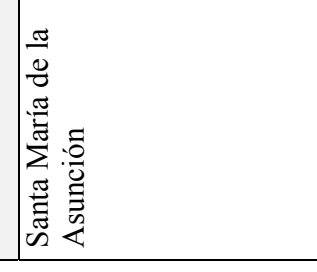 & 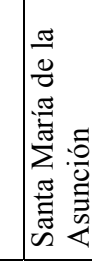 & 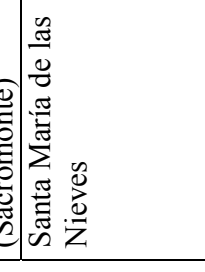 & 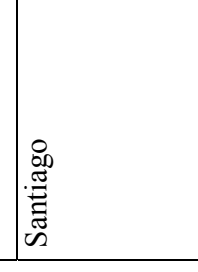 & 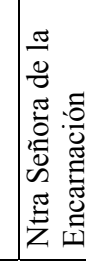 \\
\hline
\end{tabular}


De la Tabla 1 se pueden extraer diversas conclusiones que ayudan a clarificar la situación de la Abadía del Sacromonte en su contexto más inmediato. La mayoría de estas colegiales andaluzas son de fundación anterior a la del Sacromonte (excepto Olivares, Castellar y Motril), de lo que se desprende que en la época de la fundación de la Abadía, la erección de iglesias colegiales era algo excepcional y más raro que en el siglo XVI; un hecho lógico si atendemos a las razones por las que se fundaban. En Andalucía eran una manera rápida de evangelizar y controlar el territorio recién conquistado, que en muchas ocasiones quedaba directamente bajo el control de los reyes, pues eran ellos los patronos. Por otra parte, el siglo XVI fue una época económicamente próspera para las clases privilegiadas, sobre todo por la riqueza generada en las Indias. Esto facilitó no sólo la proliferación de fundaciones reales sino también nobiliares, ya que los nobles pretendían así alcanzar prestigio. Entre estas colegiatas auspiciadas por nobles se encuentran las de Osuna, Olivares y Castellar. Obispos y cardenales fundaron las colegiatas de Úbeda, Antequera y Sacromonte, mientras que las restantes fueron de patronato regio.

De las dieciocho colegiatas andaluzas, seis pertenecen a la actual provincia de Granada, lo que supone casi la mitad del total (Santa Fe, Baza, Ugíjar, Salvador, Sacromonte y Motril). ${ }^{19}$ Todas ellas son de creación anterior a la Abadía y por expreso deseo de los Reyes Católicos, salvo la Iglesia Colegial de Motril que es un siglo posterior al Sacromonte y curiosamente fue fundada por el Cardenal Belluga, muy relacionado con nuestra institución. ${ }^{20}$ Era de esperar que en un territorio recién cristianizado, los monarcas quisieran asegurarse el control religioso lo antes posible y más si éste estaba en cierta medida bajo su patronato. ${ }^{21}$

\footnotetext{
${ }^{19}$ En el siglo XVII pertenecían a diócesis distintas; Huéscar dependía de la archidiócesis de Toledo, Baza de la diócesis de Guadix y el resto de Granada.

${ }^{20}$ Luis Antonio de Belluga y Moncada (Motril, Granada 1662-Roma, Italia, 1743). "Canónigo de Zamora, posteriormente de Córdoba, obispo de Cartagena desde 1705 a 1724, fue nombrado cardenal en 1719. Desempeñó también los cargos de virrey y capitán general de Valencia y Murcia (1706). Durante la Guerra de Sucesión se caracterizó por su decidido apoyo a Felipe V (...). Se acreditó por su vasta cultura como uno de los prelados más ilustrados del siglo XVIII (...). Escribió numerosas obras y pasó sus últimos años en Roma, donde gozó de la estimación de los Pontífices", véase: Véase "Belluga y Moncada, Luis de”, A.A.V.V., Diccionario de Historia de España (Madrid: Revista de Occidente, 1973), Tomo I, p. 496.

${ }^{21}$ Para un estudio del Patronato de los Reyes Católicos sobre Granada, véase: W. Eugene Shiels, King and church. The rise and fall of the patronato real (Chicago: Loyola University Press, 1961), pp. 61 y ss.
} 
Entre las colegiales andaluzas, la Abadía del Sacromonte es la más rica en canongías (unas veinte estipuladas en la fundación, aunque rara vez estaban todas provistas), pero, por otra parte carece de racioneros. ${ }^{22}$ Una circunstancia llama poderosamente la atención: de todas las colegiatas andaluzas, tan sólo la del Sacromonte y la de Santa Fe (no sabemos nada de la de Ugíjar) carecían de capilla musical. En el caso de Santa Fe, cuya fundación data de 1492, no sabemos a ciencia cierta las razones por las que no existía una capilla musical. Para el Sacromonte las razones económicas no son determinantes, pero esta circunstancia será tratada en el siguiente capítulo.

La comparación con el resto de España es difícil de establecer, pero me centraré en algunas de las que tenían el título de insigne. Un documento de la Abadía nos muestra qué colegiatas eran más conocidas en la época. Cuando en la reunión del cabildo de julio de 1639 se decide escribir a las principales iglesias colegiales de España para que les comuniquen los privilegios de los que gozan con el fin de que la Abadía pueda solicitarlos a Roma, se dibuja un panorama bastante elocuente de las principales colegiatas españolas. Predominan por su proximidad las andaluzas, aunque también se menciona en general las de Aragón y Cataluña:

Item se propuso que esta Iglesia, conforme a sus Constituciones, tiene todos los privilegios que su Santidad ha concedido a todas las Iglesias Colegiales insignes de los Reinos de España. Que se hiciese diligencia para obtenerlos. Y a los señores Don Miguel de Ayllón y Don Rodrigo Cruçado se les encargó hiciesen esta diligencia en las Iglesias de San Salvador de Sevilla, Úbeda, Zafra, Baza, Villafranca, Aragón, Cataluña. Y a el señor Don Blasio de Santaella, de la de Antequera. Y al señor don Luis de Mendiçabal de las Iglesias de Osuna, Jerez y Olivares. ${ }^{23}$

Las iglesias insignes que se nombran específicamente en las actas no tenían todas el título de "Insigne"; Antequera ostentaba el título de Real y tuvo que esperar a 1889 para que León XIII en un Breve le concediera esta denominación a título

\footnotetext{
${ }^{22}$ Baza también tenía un cabildo con muchos miembros, lo que pudo ser en cierta medida una compensación por no haber restaurado en ella la diócesis primitiva con su catedral y haberla subordinado a Guadix.

${ }^{23}$ Abadía del Sacromonte, Actas Capitulares (desde ahora ASAC), Tomo II, junio de 1639 [206].
} 
honorífico. Del resto de las andaluzas tan sólo la Colegial de Jerez era Insigne. En Aragón, en ese momento, había al menos cuatro colegiatas con dicho título: la Colegiata de la Asunción de Nuestra Señora en Aínsa (Huesca) del siglo XI; la Iglesia Colegial de Santa María de Borja (Zaragoza), nombrada insigne por los papas Eugenio IV y Nicolás V en 1445 y 1449 respectivamente; y las Colegiatas de Santa María la Mayor y del Santo Sepulcro, ambas en Calatayud (Zaragoza) del siglo XII. En Cataluña, con la denominación de "Insigne", se encuentran la Colegiata de San Félix en Gerona, fundada en el siglo IV, y la Colegiata de Tremp (Lérida) del siglo XI. La que es nombrada en las Actas como Villafranca se corresponde con la Colegial de Villafranca del Bierzo (León), fundada en 1535 por Don Pedro de Toledo, Virrey de Nápoles. Todas ellas contaban con capilla de música, sochantre y organista. ${ }^{24}$ Incluso en Calatayud, dónde había dos iglesias colegiales, hay noticia de que cada una contaba con su propia capilla. De aquí se deduce que las principales colegiatas españolas contaban con capilla de música por lo que resulta más llamativa la carencia del Sacromonte, que se consideraba "igual" a estos centros.

Examinando otras colegiatas fundadas al mismo tiempo que la Abadía se observa que era común en ellas la creación de capillas de música. Al menos tres iglesias colegiales más fueron fundadas en España a principios del siglo XVII por nobles: la Colegiata de Lerma, la Colegiata de Zafra y la de Olivares.

La Iglesia Colegial de San Pedro de Lerma fue fundada por el valido de Felipe III, el Duque de Lerma, en 1603, fecha de la Bula de Clemente VIII. El Duque de Lerma apoyó a los canónigos del Sacromonte que fueron a Roma para obtener nuevas bulas y privilegios para la colegiata granadina; es de suponer que tanto el Duque como los canónigos conocían ambas instituciones. Estas dos colegiatas, cuyas bulas fueron otorgadas por Clemente VIII, difieren en la existencia de una capilla de música. En 1618 la Iglesia de Lerma estaba completamente terminada con la colocación del segundo órgano. ${ }^{25}$

\footnotetext{
${ }^{24}$ Sobre la colegial de Villafranca, véase J. A. Iglesias Arias y J. M. Voces Jolías, Villafranca del Bierzo (León: Ediciones Lancia, 1988).

${ }^{25}$ Douglas Karl Kirk, Churching the Shawms in Renaissance Spain: Lerma, Archivo de San Pedro Ms. Mus 1, (Montreal: Faculty of Music McGill University, 1993), p. 29; Bernardo J. García García, "Las fiestas de corte en los espacios del valido: la privanza del duque de Lerma" en María Luisa Lobato, Bernardo J. García García (Coords.), La fiesta cortesana en la época de los Austrias (Valladolid: Junta de Castilla y León, Consejería de Cultura y Turismo, 2003).
} 
La Iglesia colegial de Santa María de Zafra (Badajoz) fue fundada gracias al Virrey de Sicilia Lorenzo Suárez de Figueroa, III Conde de Feria, y su hijo Don Gómez, V Conde y I Duque de Feria, quienes en Roma consiguieron a tal fin una bula de Paulo $\mathrm{V}$ en $1609 .^{26}$ Es por lo tanto casi coetánea a la fundación del Sacromonte, y como ella, fue fundada por iniciativa particular y con el título de "Insigne". Tenía cuatro dignidades: abad mitrado, arcediano, cantor y tesorero; doce canonjías (una magistral y otra doctoral); 8 raciones y 8 capellanías de coro. El Duque nombraba al maestro de capilla, al sochantre, al organista y al bajonista, entre otro personal auxiliar. El cabildo nombraba a seis cantores, cuatro mozos de coro y al organista. ${ }^{27}$

La tercera de las colegiatas creadas en la época del Sacromonte es la Iglesia Colegial de Santa María de las Nieves en Olivares (Sevilla), patrocinada por el CondeDuque de Olivares, de la Casa de Alba. Las bulas de fundación de la Colegiata de Olivares datan de 1624 y designan la provisión de un abad, cuatro dignidades, ocho canónigos (uno de ellos maestro de capilla), doce racioneros (entre ellos el organista) y doce capellanes (de los que ocho tenían que cantar bien polifonía). ${ }^{28}$

Del análisis de estos tres casos puede deducirse que la ausencia de capilla musical en el Sacromonte no puede achacarse a un supuesto patrón estructural de las colegiatas de su época, más bien al contrario, pues la tónica parece ser la presencia de capilla musical. Aunque en Lerma, lugar que la Corte visitó en varias ocasiones, el prestigio que proporcionaba una capilla de música con ministriles era casi indispensable, por cuanto el Duque hacía ostentación de su poder, no es menos relevante la presencia de músicos en las otras colegiatas. Quizás una de las razones es el deseo de los impulsores de este tipo de centros de equipararse a las catedrales. No hay que olvidar la frecuencia con la que se sucedían en los siglos XVI, XVII y XVIII

\footnotetext{
${ }^{26}$ Para la genealogía de Lorenzo Suárez de Figueroa, véase Francisco Fernández de Bethencourt, Historia genealógica y heráldica de la Monarquía Española, Casa Real y Grandes de España (Madrid: Jaime Rates, 1907), vol. VI, p. 169.

${ }^{27}$ José Sarmiento Pérez, "Reforma beneficial en la Iglesia Colegial de Zafra (1770-1850)", Revista de estudios extremeños, 59/ 2 (2003), pp. 687-723.

${ }^{28}$ Inmacula Cárdenas, "La música en la colegiata de Olivares”, Anuario Musical, Vol. XXXVI (1981), pp. 91-129.
} 
los pleitos entre los cabildos por la preferencia en el orden en las procesiones y en el asiento en las ceremonias.

\subsection{Las iglesias colegiales en Hispanoamérica}

Dada la importancia y proliferación de colegiatas en España, resulta curioso que en Hispanoamérica se crearan sólo tres: una en Jamaica, ${ }^{29}$ otra en Santa Marta ${ }^{30}$ y la Iglesia colegial de Guadalupe en Méjico, de la que hay indicios que se creara a imitación de la del Sacromonte. Quizás la rápida expansión de las órdenes religiosas en Hispanoamérica, la falta de patronato privado, o incluso el temor por parte de los obispos a una posible interferencia en el gobierno de la diócesis hizo innecesario este tipo de instituciones. En España eran frecuentes los pleitos entre los cabildos de catedrales y colegiatas: sobre la repartición de los diezmos, el orden y la antigüedad de los canónigos en las procesiones, o la preferencia en tomar asiento en el coro. Esto unido al poder de las órdenes en Hispanoamérica, que contaban con obispos y arzobispos entre las filas de sus monjes, hacía que no les conviniese que este tipo de instituciones se establecieran y les restaran protagonismo.

La iglesia colegial de Guadalupe en Méjico se creó gracias a los 100.000 pesos que dejó al morir Andrés de Palencia en 1707, con la intención de fundar un convento de monjas o una colegial junto al famoso Santuario de Guadalupe. Felipe V se inclinó por esta última opción tras encargar al virrey Duque de Alburquerque que convocara a una junta al arzobispo Lanciego y Eguilaz y al capellán del Santuario que acordaron se instituyera un cabildo con un abad, cuatro canónigos y cuatro racioneros; véase Figura 2. El rey solicitó las bulas al papa pidiendo que la colegiata se llamara Real y obtuviera el título de Insigne, reservándose el privilegio de proponer a los beneficiados. La

\footnotetext{
${ }^{29}$ Francisco Morales Padrón, Jamaica española (Sevilla: Escuela de Estudios Hispanoamericanos,1952). En Jamaica, a instancias de Fernando el Católico, se fundó una abadía con abad mitrado que dependía directamente de la archidiócesis de Sevilla. En 1515 fue designado el primer Abad que no vivió en la isla, como sus sucesores, entre ellos Pedro Mártir de Anglería. En 1655 la abadía es suprimida con la invasión de los ingleses.

${ }^{30}$ Santa Marta en la actual Colombia fue transformada de Catedral en Colegiata entre los años 1562 a 1577 para recuperar luego su carácter catedralicio de nuevo. Véase Francisco Javier Hernáez, Colección de Bulas, Breves y otros documentos relativos a la Iglesia de América y Filipinas (Bruselas: Alfredo Vromant, 1879), p. 726.
} 
primera bula de erección se consiguió en $1725 .^{31}$ Dos años más tarde se escribió al cabildo del Sacromonte a instancias del agente del real patronato como queda reflejado en las Actas:

Propuso el señor Abad que a Don Joseph de Campo Redondo, canónigo de la Santa Iglesia se le había escrito por el agente del Real Patronato que había conseguido Bulas de su Santidad para la Fundación de una Iglesia Colegial en Mexico extramuros de la Ciudad en la Iglesia de Nuestra Señora de Guadalupe, y que había sido con condición de que había de ser dicha fundación según las Constituciones de este Sacromonte en cuya suposición, y [ilegible] Dicho Agente, que en este Sacromonte se había hecho impresión de ellas el año de $1647^{32}$, interesaba a dicho canónigo para que solicitase tres trasumptos impresos de dichas Constituciones para remitirlos a México, y oido y entendido lo referido, y que el señor Avilés dijo saberlo sobredicho por haber visto la Carta de dicho Agente, se acordó que se saquen de el Archivo los tres trasumptos impresos; y que se remitan a el señor Campo Redondo ${ }^{33}$

Dos años más tarde de este acta capitular, en 1729, se obtuvo la segunda bula y finalmente otra en 1746, concediéndose también su erección; el dinero disponible para su fundación ascendía a 527.832 pesos.

Con la excepción de la Colegial de Guadalupe, podemos concluir que la colegiata como centro de producción musical en la Edad Moderna es un fenómeno único y característico de la Península Ibérica en el mundo hispánico.

\footnotetext{
${ }^{31}$ Las noticias que se refieren a la Colegial de Guadalupe, exceptuando la noticia recogida en las Actas Capitulares del Sacromonte, están sacadas de A.A.V.V., "Guadalupe, Basílica de", Diccionario Porrúa, Historia, Biografía y Geografía de México, 6a ed. (México: Porrúa, 1995), p. 1565.

${ }^{32}$ La impresión a la que se hace referencia es la de: Gnomon seu gobernandi Abbati, et canonicis Sacri Montis Illipulitani praescripta Ab Yllustriss ${ }^{\circ}$ et Rss ${ }^{\circ}$ Domino D. Pedro De Castro et Quiñones Archiepiscopo Granatensi, et posteabis palensi, eius dem Ecclesiae Collegiatae Fundatori. Et ab Urbano VIII Pontifici Maximo Confirmata (Granada: Ex tipografia Regia apud Sanchez, 1647).

${ }^{33}$ A.S.A.C.VII, fol. $106^{\mathrm{v}}$ (28-VI-1727), [561].
} 
Figura 2. Iglesia Colegial de Guadalupe, Méjico. Grabado de Francisco Silverio, 1787. Biblioteca Nacional de España, MV/26.

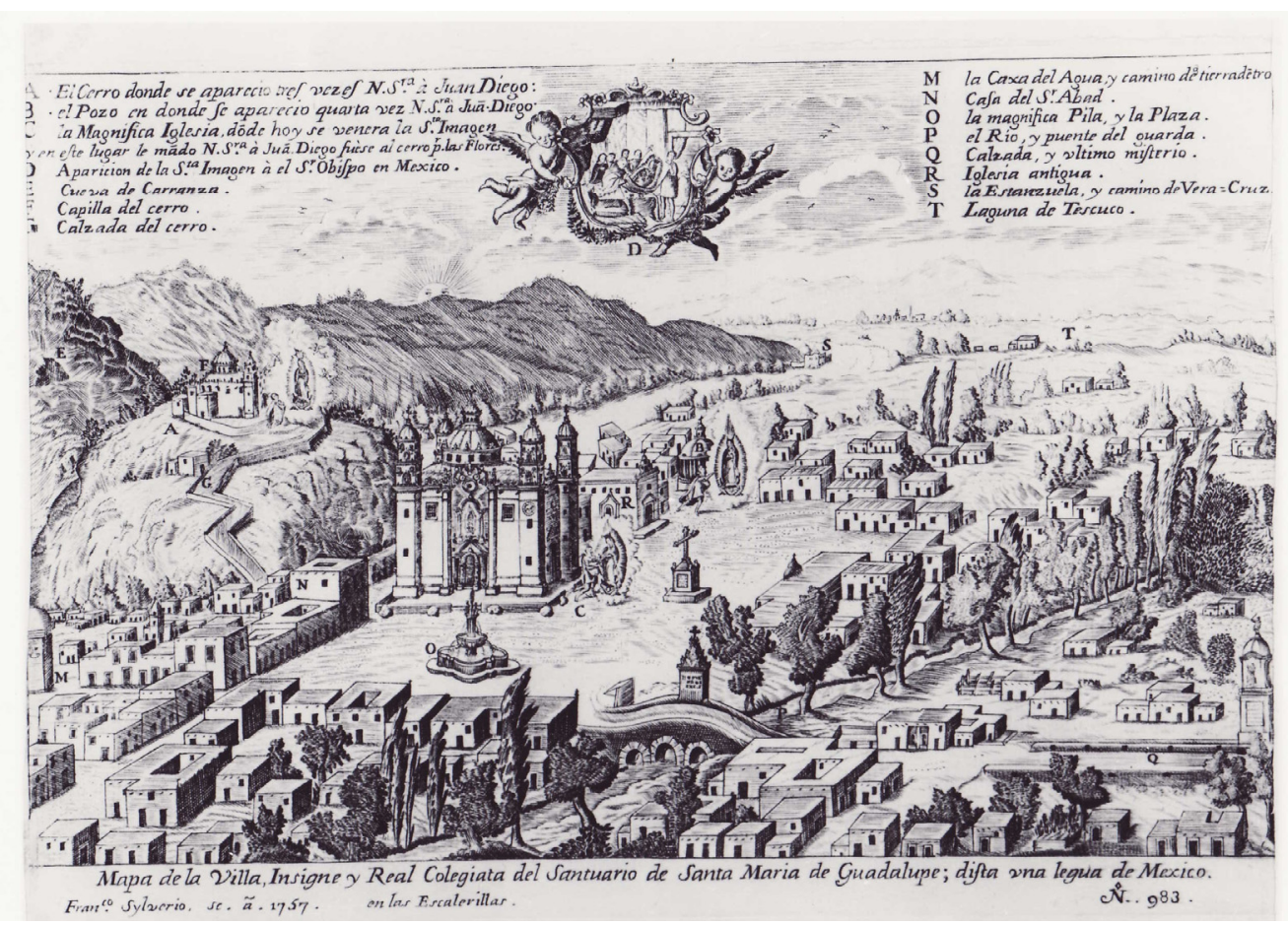

\subsection{La supresión de las colegiatas}

La situación económica de la Iglesia en el siglo XIX era como la del resto del país, bastante precaria. Dos importantes medidas administrativas minaron los bienes eclesiásticos: 1) la reforma tributaria de Martín de Garay (1817-1818); y 2) el decreto de 1820 que suprimió las comunidades de órdenes monacales, las de canónigos reglares, los conventos y colegios de órdenes militares, y todos los hospitalarios y demás del clero regular, aplicándose sus bienes al crédito público, o una contribución extraordinaria de treinta millones de reales. La desamortización propuesta por Mendizábal (1834) supuso la enajenación de las propiedades eclesiásticas. En 1841 se implantó una ley según la cual pasaban a manos del Estado todos los bienes del clero secular y a cambio se le concedía a la Iglesia treinta millones de reales para la dotación del culto y el clero. Pero esta medida no se hizo completamente efectiva, pues tras el triunfo de los moderados en 1843 se dispuso la suspensión de la venta de los bienes del clero. Finalmente, en el Concordato con la Santa Sede en 1851, aunque se prometía la 
devolución a la Iglesia de los bienes no enajenados, se obligaba a ésta a venderlos en subasta pública. Una de las consecuencias del Concordato fue la desaparición de un gran número de colegiatas en España. Aproximadamente se suprimieron dos tercios del total por escasez de las rentas, permaneciendo sólo las que eran capaces de mantenerse por ellas mismas y algunas otras cuyo prestigio o significación para la diócesis hacía desaconsejable su desaparición. ${ }^{34}$

La desamortización no afectó a la Abadía del Sacromonte. En primer lugar porque era autosuficiente y no necesitaba de las rentas del Estado para subsistir y además, porque contaba en la Corte con validos extraordinarios como Francisco de Saavedra, antiguo colegial de San Dionisio (adscrito a la Abadía) y ministro de Hacienda con Carlos IV, que ayudó a que las primeras medidas contra los bienes eclesiásticos no se aplicaran al Sacromonte. ${ }^{35}$ Otro excolegial, José María Velluti, oficial mayor del Ministerio de Hacienda, obtuvo por Real Orden que los bienes de Coro y Fábrica de la Abadía quedaran libres de cualquier contribución; y otra Real Orden, comunicada al Cabildo en 3 de enero de 1840, que declaraba no nacionales los bienes abaciales. ${ }^{36} \mathrm{Su}$ prestigio como institución de enseñanza de la que habían salido diversas personalidades del mundo de la política y la Iglesia también supuso un freno a la desaparición de la Colegiata, por existir el proyecto de convertir el Colegio de San Dionisio en Universidad Eclesiástica de Andalucía. En virtud de este proyecto académico la Abadía del Sacromonte quedó eximida de pagar tributos por el Concordato de 17 de Octubre de 1851, gracia que fue confirmada por Real Orden de 6 de septiembre de $1878 .^{37}$

\footnotetext{
${ }^{34}$ Véase "Desamortización" en A.A.V.V., Diccionario de Historia de España (Madrid: Revista de Occidente, 1973), Tomo I, pp. 1110-1113.

${ }^{35}$ A.S.A.C. VIII, fol. $441^{\mathrm{v}}$ (12-XI-1797), [839]. En este acta se da cuenta del ascenso de Saavedra y de las fiestas que hizo el Cabildo en su honor, haciendo una solemne procesión a las Cuevas y cantando un $T e$ Deum.

${ }^{36}$ Zótico Royo Campos, Abades del Sacromonte (Granada: Anel, 1964), pp. 217-218.

${ }^{37}$ Según Royo Campos, Abades del Sacromonte, pp. 213-233, la exención de pagar tributos también se debió a las gestiones del Abad Joaquín Venegas y Cabrera.
} 


\subsection{Los estudios musicales sobre las colegiatas: estado de la cuestión}

Las iglesias colegiales han sido consideradas como instituciones similares a las catedrales pero de menor importancia, de aquí que en su análisis se hayan seguido los modelos de estudio catedralicios.

De las colegiatas se ha estudiado, entre otros aspectos, la organización estructural de sus capillas musicales (los distintos cargos con sus obligaciones, rentas y en ocasiones nóminas de músicos con o sin datos biográficos) que se han revelado muy parecidas a las de las catedrales; se han recogido noticias de interés musical contenidas en las Actas de Cabildo y otras series documentales como libros de fábrica, libros becerros o libros de fundaciones y aniversarios. En otras ocasiones se ha primado la transcripción de obras musicales de sus archivos o se ha editado el inventario o catálogo de la música conservada. También se han estudiado las colegiatas a través del magisterio de uno de sus maestros de capilla, pasando la colegial a un segundo plano como institución-mecenas.

Todas estas aproximaciones historiográficas proceden de los estudios musicales de las catedrales, que como ha señalado Ros-Fábregas fue el punto de partida de la musicología española. Más que el estudio de una institución en sí, Ros-Fábregas argumenta que estos trabajos fueron un pretexto para obtener "datos biográficos, documentos, partituras o libros de coro con los que demostrar nuestro genio musical", en un momento en el que historiadores como Barbieri o Pedrell, se esforzaron por rebatir los estudios extranjeros en los que, o bien ni siquiera se mencionaba la existencia de una escuela española de música, o bien se le negaba la calidad y carácter propio. ${ }^{38}$ Además, este patrón historiográfico de corte positivista se olvidaba con frecuencia de "presentar el contexto histórico o estético en el que la actividad musical catedralicia tenía lugar". ${ }^{39}$ El caso de las colegiatas no es más prometedor. Pocas son las colegiatas que gozan de un estudio integral que nos permita visiones menos sesgadas de la institución. Sin menospreciar este tipo de trabajos, que de otro lado son muy útiles y necesarios, es preciso resituar la producción musical dentro de su contexto institucional, geográfico y temporal. Es difícil encontrar un estudio sobre colegiatas que añada datos

\footnotetext{
${ }^{38}$ Emilio Ros-Fábregas, "Historiografía de la música en las catedrales españolas: nacionalismo y positivismo en la investigación musicológica", CODEXXI, vol. I (1998), p. 71.

${ }^{39}$ Ros-Fábregas, "Historiografía de la música”, p.71.
} 
significativos sobre la reconstrucción del repertorio, el ceremonial o que establezca un análisis comparativo con otros centros, ya sean o no de su ámbito geográfico.

Las iglesias colegiales de Andalucía, que constituyen el contexto institucional más próximo a la Abadía del Sacromonte, han recibido atención en numerosos trabajos. La colegiata de Antequera fue la primera sobre la que se escribieron artículos acerca de sus maestros de capilla y organistas en dos trabajos de Andrés Llordén. ${ }^{40}$ El autor empleó en su trabajo las noticias facilitadas por las Actas Capitulares y señaló que ya había estudiado "este tema en la Catedral de Málaga", con lo que venía a corroborar la conexión entre el estudio de las colegiales y el de las catedrales. Últimamente se ha analizado la producción musical de uno de los maestros de capilla de Antequera en el siglo XVIII, José Zameza y Elejalde. ${ }^{41}$

De la colegial de Jerez se ha publicado un inventario de las obras conservadas en su archivo y una monografía de José Luis Repetto sobre la historia de la capilla de música. $^{42}$ Este estudio, que incluye biografías de sus músicos, tiene la virtud de presentar una valoración estética de la capilla musical y una buena contextualización histórica.

Las colegiatas de Osuna y Olivares, ambas de fundación nobiliaria, han sido estudiadas por Inmaculada Cárdenas en sendos artículos en los que presenta la historia de la fundación y sus patronos, los estatutos (cargos y salarios), los maestros de capilla, organistas y demás músicos, fiestas y un inventario de obras conservadas. ${ }^{43}$ De la de

\footnotetext{
${ }^{40}$ Andrés Llordén, "Notas históricas de los Maestros de Capilla en la Colegiata de Antequera", Anuario Musical, XXI-XXII (1976-1977), pp. 115-156; y "Maestros organistas de la Colegiata de Antequera", Anuario Musical, XXXIII-XXXV (1978-1980), pp. 51-79.

${ }^{41} \mathrm{M}^{\mathrm{a}}$ Teresa Díaz Mohedo, "La capilla de música de la iglesia colegial de Antequera en la segunda mitad del siglo XVIII. El magisterio de José Zameza y Elejalde", Tesis Doctoral, Universidad de Granada, 2003. Un resumen de esta tesis ha sido publicado por el Centro de Documentación Musical de Andalucía en colaboración con la Universidad de Granada; véase también de la misma autora, "La Iglesia Colegial de Antequera y su capilla de música en la segunda mitad del siglo XVIII", Revista de Musicología, 28/ 1 (2005), pp. 280-294.

${ }^{42}$ Miguel Querol, "El Archivo de música de la Colegial de Jerez de la Frontera", Anuario Musical, XXX (1975), pp. 167-180; y José Luis Repetto Betés, La capilla de música de la Colegial de Jerez (1550-1825) (Jerez de la Frontera: Centro de Estudios Históricos, 1980).

${ }^{43}$ Inmaculada Cárdenas, "La música en la colegiata de Olivares" Anuario Musical, XXXVI (1981), pp. 91-129; y de la misma autora "Música Barroca Andaluza en las Colegiatas de Osuna y Olivares", Tesis Doctoral inédita, Universidad de Sevilla, 1980.
} 
Olivares además existe un estudio sobre uno de sus maestros de capilla, Juan Valdivia, activo en el siglo XVIII, y el catálogo de las obras conservadas en su archivo. ${ }^{44}$

El único estudio sobre la colegial del Salvador de Sevilla fue el tema de la tesis doctoral de Rosario Cordero. Incluye un capítulo sobre ceremonial (en el que sólo hace afirmaciones generales sobre la clasificación de las fiestas y el calendario romano) y varios inventarios del antiguo archivo de música, lo que podría dar pie a futuros trabajos sobre reconstrucción del repertorio. ${ }^{45}$

Un breve pero muy interesante trabajo es el de Javier Marín sobre la Colegiata de Castellar (Jaén) en la época en la que Tomás Micieces II fue maestro de capilla. ${ }^{46}$ Marín analiza la institución comparándola con otras similares y trata de reconstruir el repertorio. Es un ejemplo de cómo se puede tratar la actividad musical de una institución en un momento determinado. Lógicamente, aquí la colegial ocupa un lugar secundario, ya que es la excusa para hablar de la producción musical de un compositor en una etapa de su carrera.

Entre todos los trabajos de las colegiatas andaluzas destaca el de Juan Ruiz sobre la colegiata del Salvador de Granada, en el que se estudia exhaustivamente el marco histórico, y la vida musical de la colegiata, tratando de reconstruir el repertorio y conocer los sochantres, organistas y músicos de la capilla, así como las interrelaciones con otros centros, haciendo un gran acopio de información. ${ }^{47}$

Del resto de España quedan muchas colegiatas sin estudiar, aunque existen diversos trabajos de interés. Se han publicado transcripciones de obras de músicos de Alquézar, ${ }^{48}$ Daroca $^{49}$ y Albarracín; ${ }^{50}$ así como catálogos e inventarios de los fondos

\footnotetext{
${ }^{44}$ Joaquín Romero Lagares, "Juan Pascual Valdivia, Maestro de Capilla de la Colegial de Olivares (17601811)", Tesis Doctoral, Universidad de Sevilla, 2004 y Romero Lagares, Catálogo del archivo de música de la antigua Colegial de Olivares (Madrid: Sociedad Española de Musicología, 2006).

${ }^{45}$ Rosario Cordero, "La Música en la Colegiata de San Salvador de Sevilla", Tesis doctoral, Universidad de Sevilla, 2001.

${ }^{46}$ Javier Marín López, "Música y patronazgo musical en Castellar (Jaén) en tiempos de Tomás Micieces II, 1679-1685”, Boletín del Instituto de Estudios Giennenses, 187 (2004), pp. 549-595.

${ }^{47}$ Juan Ruíz Jiménez, "La Colegiata del Salvador en el contexto musical de Granada", Tesis Doctoral, Universidad de Granada, 1995.

${ }^{48}$ Ignacio Nieto Miguel, Música para una Colegiata. Villancicos del siglo XVII en Alquézar (Valladolid: Glares Gestión Cultural, 2001).
} 
musicales de Roncesvalles; ${ }^{51}$ Calatayud $^{52}$ y Alfaro. ${ }^{53}$ También se han estudiado los instrumentos conservados en las colegiatas de Borja, ${ }^{54}$ Medinaceli, ${ }^{55}$ Lerma, ${ }^{56}$ Zenarruza $^{57}$ y Gandía, ${ }^{58}$ así como las actas de cabildo de Borja, ${ }^{59}$ y noticias musicales contenidas en las actas de Tudela. ${ }^{60}$ Las colegiatas de la provincia de Soria han sido objeto de una monografía en la que se reseñan algunos aspectos históricos y musicales de las colegiatas de Soria, Berlanga de Duero y Medinaceli. ${ }^{61}$

El estudio sobre la música en la colegiata de Manresa es el más reciente acerca de este tipo de instituciones en España: aunque aporta gran cantidad de datos para la reconstrucción histórica, uno de sus objetivos es que un número de partituras salgan a la

${ }^{49}$ Pedro Calahorra Martínez, Obras de los maestros de capilla de música de la Colegial de Daroca (Zaragoza) en los siglos XVI y XVII. Polifonía Aragonesa II (Zaragoza: Institución Fernando el Católico, 1985).

50 Jesús Muneta, Obras de los maestros de la capilla de música de la colegial de la Catedral de Albarracín (Teruel) siglos XVII y XVIII (Zaragoza: Institución Fernando el Católico, 1986).

${ }^{51} \mathrm{M}^{\mathrm{a}}$ Concepción Peñas García, Catálogo de los fondos musicales de la Real Colegiata de Rocensvalles (Pamplona: Gobierno de Navarra, 1995).

52 Antonio Ezquerro, "La Música en la Real Colegiata del Santo Sepulcro de Calatayud", Revista de Musicología, 22/2 (1999), pp. 11-52. Antonio Ezquerro y Joseph Pavía (eds.), Música de atril en la Colegiata de Santa María de Calatayud (Zaragoza: Institución Fernando el Católico, 2002). Josep Borrás y Antonio Ezquerro, "Chirimías en Calatayud”, Revista de Musicología, 22/2 (1999), pp. 53-85.

${ }^{53}$ Jorge Ruiz Preciado e Isabel Velázquez Pasquier, Catálogo del Archivo de Música de la Colegiata de San Miguel de Alfaro (Logroño: Instituto de Estudios Riojanos, 2007).

${ }^{54}$ Emilio Jiménez Aznar, "Los bajones de la colegial de Borja", Cuaderno de estudios borjanos, vol. 31$32, n^{\circ} 117$ (1994), pp. 227-254.

${ }^{55}$ Luís Magaz y José Ignacio Palacios Sanz, El órgano de la colegiata de Medinaceli (Soria). Historia y restauración (Valladolid: Asociación "Manuel Marín" de Amigos del Órgano, 1996).

${ }^{56}$ Alfonso de Vicente Delgado, El órgano en la Colegiata de Lerma (Valladolid: Junta de Castilla y León, Asociación "Manuel Marín" de Amigos del Órgano de Valladolid, 1996).

${ }^{57}$ J. M. Arrizabalaga, "El órgano histórico de la Iglesia de la Colegiata de Santa María de Zenarruza, Marquina (Vizcaya)", Nassarre, 7/ 2 (1991), pp. 9-32.

${ }^{58}$ Ferrán García, “Los órganos de la Colegiata de Gandía”, Cabanilles, 23 (1987), pp. 7-30.

${ }^{59}$ Emilio Jiménez Aznar, Actos del Cabildo de la Colegial y del Capítulo Parroquial de Santa María la Mayor de Borja (Zaragoza), 1546-1954 (Zaragoza: Institución Fernando el Católico, 1994).

${ }^{60}$ Dionisio Preciado, Noticias Musicales de la Catedral de Tudela (Navarra), entre los años 1516 y 1652 (Pamplona: Aranzadi, 1958).

${ }^{61}$ José Ignacio Palacios Sanz, La música en las Colegiatas de la Provincia de Soria (Soria: Diputación Provincial, 1997). 
luz para que puedan ser interpretadas. ${ }^{62}$ Para ello, además de presentar transcripciones de las partituras conservadas en el archivo de música de la colegial, su autora analiza las obras comparando sus técnicas compositivas con las de los grandes maestros de la tradición centroeuropea (Domenico Scarlatti, Pergolesi, Vivaldi, Bach, Haydn y Mozart entre otros). Esta idea resulta interesante para poner de manifiesto las diferencias y relaciones de la música española con la de otros países europeos, pero no ayuda a explicar el por qué de las peculiaridades estilísticas de la música en Manresa. Falta un análisis comparativo con otros músicos españoles de su tiempo, mucho más cercanos a los intereses y expectativas estéticas y por lo tanto más clarificadores a la hora de establecer la situación de los compositores de Manresa.

El estudio de Douglas Kirk sobre los manuscritos de música instrumental para ministriles que pertenecieron a la Iglesia Colegial de San Pedro resulta particularmente interesante; ${ }^{63}$ en este caso, la Colegiata fundada por el Duque de Lerma no es el objetivo del estudio, sino su música y usos musicales. ${ }^{64}$ Utilizando documentación conservada en la Colegial de Lerma (Burgos), Kirk compara su tradición ministril con otros centros en España. También reciben atención los inventarios y las concordancias con los manuscritos musicales que estudia, así como el papel de ese repertorio en la liturgia. De esta manera, estudiando un aspecto concreto (la música para ministriles), el autor consigue una visión muy iluminadora de lo que pudo ser la música no sólo en la Colegiata de Lerma, sino en otras iglesias españolas.

\footnotetext{
${ }^{62}$ Glòria Ballús Casóliva, "La Música a la collegiata basílica de Santa Maria de la Seu de Manresa: 17141808. Dades documentals per a la seva reconstrucció amb una aproximació al repertori litúrgic conservat", Tesis Doctoral, Universidad Autónoma de Barcelona, 2004, p. VII.

${ }^{63}$ Douglas Kirk, "Churching the Shawms in Renaissance Spain: Lerma, Archivo de San Pedro Ms. Mus. 1" Tesis Doctoral (McGill University, Montréal, 1993).

${ }^{64}$ Francisco Gómez de Sandoval (1553-1625) fue el famoso valido de Felipe III y es conocido como el Duque de Lerma; era descendiente de Fernando el Católico y de San Francisco de Borja. Con las rentas obtenidas por su aventajada posición, mandó construir en Lerma, un palacio e iglesia colegial. Consiguió el capelo cardenalicio lo que le libró de ser juzgado por corrupción.
} 


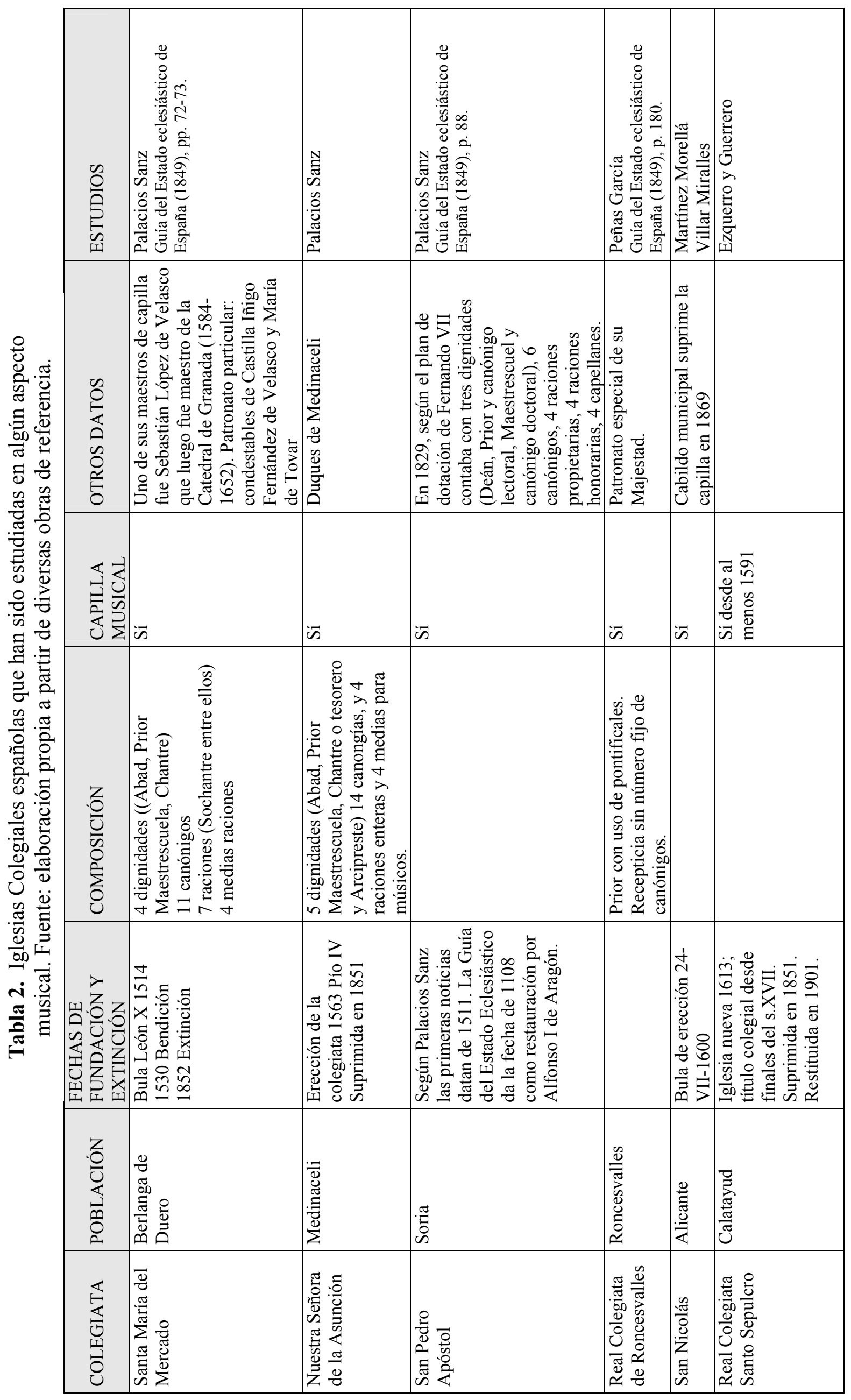




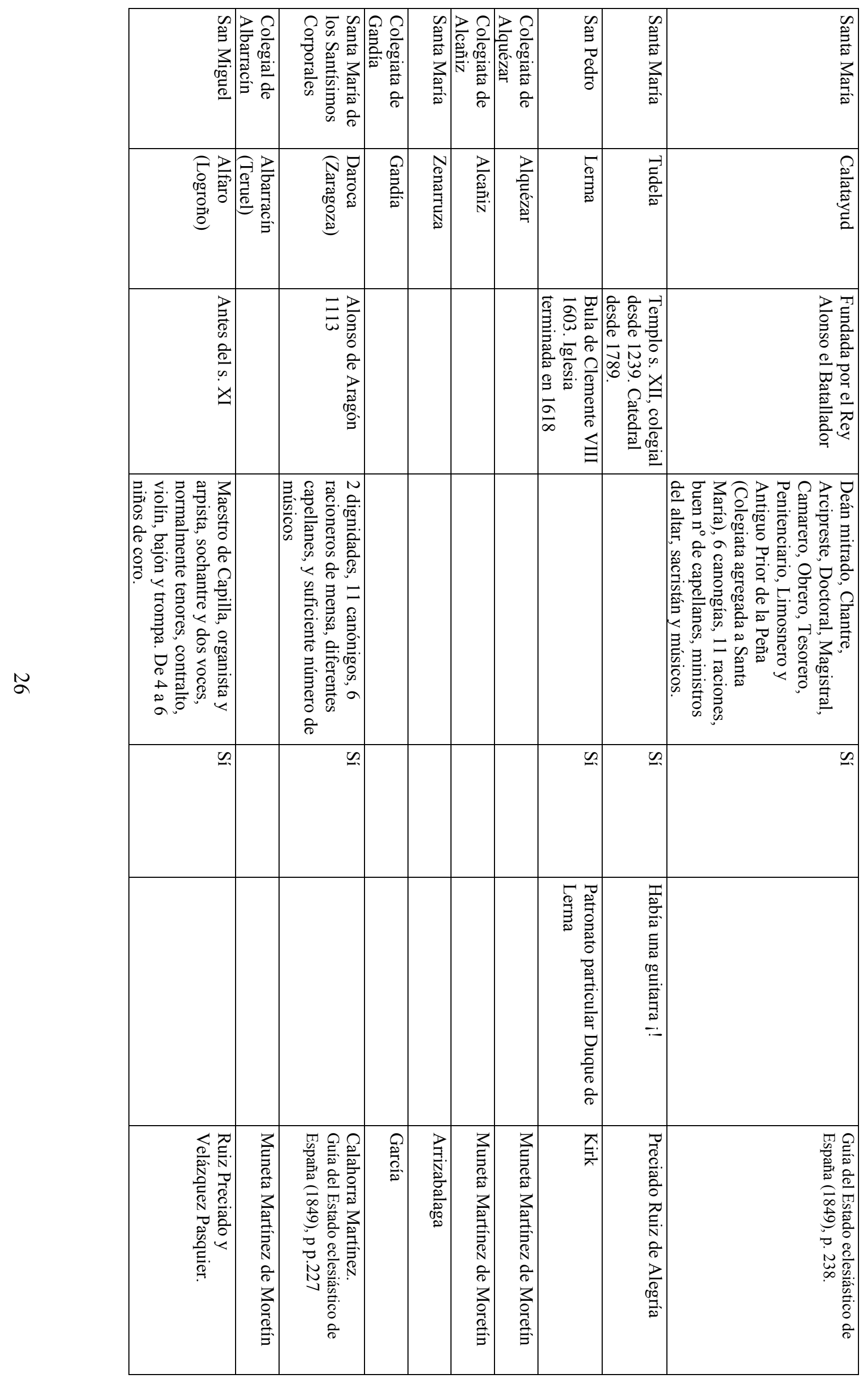




\section{La Abadía en el contexto de las instituciones eclesiásticas de Granada en la Edad Moderna}

Granada constituye un caso especial en el contexto de la Península Ibérica e incluso dentro del ámbito europeo, ya que al permanecer durante casi ocho siglos bajo el dominio musulmán, su conquista se convirtió en un hecho de trascendencia política y religiosa para toda Europa. Granada se trocó, en palabras de Orozco Pardo, en "Christianópolis", la ciudad cristiana ideal, una nueva Constantinopla en la que todas las órdenes religiosas querían estar presentes. ${ }^{65}$ Además los Reyes Católicos, gracias a la bula de Inocencio VIII, encontraron en las fundaciones religiosas una manera eficaz y rápida de controlar los territorios reconquistados.

Las nuevas autoridades cristianas de Granada se centraron en modificar el aspecto marcadamente musulmán de Granada, que aunque atrayente y fastuoso en la Alhambra, no dejaba de ser extraño a su cultura. ${ }^{66}$ El primer paso fue la transformación (y más tarde demolición) de las mezquitas en las primeras parroquias. Aunque este proceso de cristianización de los edificios y creación de una red eclesial sólida fue lenta, pues se tardó casi dos siglos, el resultado es que para la época de la fundación de la Abadía, había en Granada más de cincuenta instituciones religiosas entre parroquias, monasterios y conventos. Con la fundación de la Abadía en el siglo XVII y su papel en la reafirmación de la identidad y antigüedad cristiana de la ciudad podemos dar por culminado el proceso de "cristianización" de Granada. ${ }^{67}$ Esta concentración religiosa se tradujo además en una intensificación de las actividades musicales, bien dentro de la liturgia diaria de estas parroquias y conventos, bien por el resto de fiestas y actos religiosos que desarrollaron y en los que la música siempre jugó un papel fundamental.

La red musical granadina parece estar plenamente establecida para el siglo XVII, momento de la fundación de la Abadía, no sólo por los tres principales centros musicales hasta ahora más estudiados (Catedral, Capilla Real y Colegial del Salvador), sino también gracias a otros centros como San Jerónimo, de cuya Capilla Musical

\footnotetext{
${ }^{65}$ José Luís Orozco Pardo, Christianópolis (Granada: Universidad, 1988), pp. 2-27.

${ }^{66}$ Antonio Luis Cortés Peña y Bernard Vincent, Historia de Granada, La época Moderna: ss-XVI-XVII, Tomo III, (Granada: Editoria Don Quijote, 1986) p. 21.

${ }^{67}$ Sobre este aspecto se tratará más extensamente en el Capítulo I de este trabajo.
} 
únicamente sabemos el nombre de algunos músicos y su actividad de taller de copia de cantorales, al menos durante el siglo XVIII. ${ }^{68}$

De los estudios sobre la actividad musical granadina destacan los estudios sobre la Catedral de Granada. El emblemático trabajo de José López-Calo sobre la música en la Catedral de Granada en el siglo XVI inauguró una saga musicológica y sirvió como modelo de estudio institucional aún vigente hoy. ${ }^{69}$ Pilar Ramos estudió el magisterio de capilla en la catedral de Granada de Diego de Pontac. El mérito de su trabajo estriba en la visión amplia que Ramos adopta sobre la institución, mediante la que trata de reconstruir muchos aspectos de la vida musical en la Granada del XVII. ${ }^{70}$

Otra de las instituciones más importantes del panorama musical granadino fue la Capilla Real, fundada como enterramiento de los Reyes Católicos, y que ha sido sólo parcialmente estudiada desde el punto de vista musical. López-Calos elaboró un catálogo de sus fondos musicales al que añadió un documentario con noticias de interés musical y Ramos López estudió su estructura a través del análisis de sus Constituciones del siglo XVIII. ${ }^{71}$

\footnotetext{
${ }^{68}$ El blasón de María Manrique, viuda del "Gran Capitán" y fundadora del Monasterio de San Jerónimo, aparece junto con los de su hija y su yerno en uno de los manuscritos musicales más ricos de la época con todas las Misas de Jean Ockeghem (Ciudad del Vaticano, Biblioteca Apostolica Vaticana, MS

Chigi C VIII 234). Aunque las adiciones españolas a este manuscrito se hicieron en el Reino de Nápoles después de 1514, no sería extraño que, al volver a España (con o sin el "Chigi Codex"), María Manrique hubiera dotado al Monasterio de San Jerónimo de Granada de una capilla de música y libros que no ha sido posible documentar. Véase, Emilio Ros-Fábregas, "The Cardona and Fernández de Córdoba Coats of Arms in the Chigi Codex", Early Music History, 21 (2002), pp. 223-258.

69 José López-Calo, La música en la catedral de Granada en el siglo XVI, 2 vols. (Granada, Fundación Rodríguez Acosta, 1963). Véase del mismo autor el catálogo del archivo catedralicio, José López-Calo, Catálogo del archivo de música de la Catedral de Granada, 3 vols.(Granada,Centro de Documentación Musical de Andalucía, 1991).

${ }^{70}$ Pilar Ramos López, La música en la Catedral de Granada en la primera mitad del siglo XVII: Diego de Pontac, (Granada, Diputación Provincial de Granada, 1994) 2 vols.

${ }^{71}$ José López-Calo, Catálogo del archivo de música de la Capilla Real de Granada, Granada, Centro de Documentación Musical de Andalucía, 1993); Pilar Ramos López, "La música en la Capilla Real de Granada a través de las Constituciones de 1758", De musica hispana et aliis: Miscelánea en honor al Prof. Dr. José López-Calo, S.J., en su $65^{\circ}$ cumpleaños, vol. 1, pp. 669-690. Otros trabajos sobre la Capilla Real son: Germán Tejerizo Robles, Villancicos barrocos en la Capilla Real de Granada: 500 letrillas cantadas la noche de Navidad (1673 a 1830) 2 vols., (Sevilla: Andaluzas Unidas, 1989); Juan Ruiz Jiménez "Patronazgo musical en la Capilla Real de Granada durante el siglo XVI. 1.-Los músicos prebendados" Encomium musicae: Essays in memory of Robert J. Snow, pp. 341-363.

El catálogo de las obras de uno de sus maestros de capilla fue publicado por $\mathrm{M}^{\mathrm{a}}$ Angustias Ortiz Molina, Antonio Caballero: Incipits de sus obras (Sevilla: Centro de Documentación Musical de Andalucía, 2002).
} 
El tercer centro musical granadino fue la Iglesia Colegial del Salvador de Granada. Fundada por los Reyes Católicos en los primeros años después de la Toma de la Ciudad, pronto se convirtió en un centro de producción musical del que ya he hablado antes. Su capilla musical, conocida como los extravagantes dado su carácter itinerante, fue un eje fundamental para la actividad musical de la ciudad. ${ }^{72}$

Testimonio de la vida musical fuera de los centros de prestigio son entre otros la presencia de numerosos órganos en las parroquias e iglesias de los conventos y monasterios granadinos; de la intensa actividad en la construcción de órganos en la diócesis de Granada entre 1492 y 1625 da cuenta Ruiz Jiménez, quien señala la presencia de más de 39 órganos en las iglesias y conventos granadinos para finales del siglo XVI. ${ }^{73}$ Junto a ellos aparecen con frecuencia colecciones más o menos completas de cantorales necesarios para el servicio litúrgico diario; de algunas sólo queda la noticia histórica, como la del Monasterio de San Jerónimo, que fue la primera que Felipe II mandó copiar para El Escorial, pero que no siendo de su total agrado ordenó se donara al establecimiento que la orden tenía en Granada. ${ }^{74}$ Otras muchas iglesias y conventos conservan estos libros arrumbados en una habitación cercana al campanario, en el mejor de los casos. ${ }^{75}$

Otro índice que puede utilizarse para medir el grado de vida musical son las noticias que sobre pagos a músicos se encuentran en los libros de fábrica de muchas

\footnotetext{
72 Juan Ruiz Jiménez, La Colegiata del Salvador en el contexto musical de Granada, Tesis Doctoral, Universidad de Granada, 1995.

73 Juan Ruiz Jiménez, Organería en la diócesis de Granada, 1492-1625 (Granada: Diputación Provincial, 1995). Para un censo de los instrumentos conservados en la actualidad, véase Inmaculada Ferro Ríos Antonio Linares López, Catálogo de órganos de la provincia de Granada (Granada: Centro de Documentación Musical de Andalucía, 1997).

${ }^{74}$ Vicente Rabanal, Los cantorales del Escorial (Madrid: Imprenta del Monasterio del Escorial, 1947), p. 86.

75 Para este estudio intentamos sin éxito consultar la colección de Cantorales de la Iglesia de Santo Domingo, que pertenecería a la orden Dominica que tenía su sede en el Convento de Santa Cruz la Real, hoy convertido en Colegio Mayor Universitario y que se encuentra en una habitación cercana al coro de la Iglesia. Entre los estudios sobre otras colecciones de cantorales, si bien no desde el punto de vista musical, véase $\mathrm{M}^{\mathrm{a}}$ Angustias Álvarez del Castillo, La miniatura de los libros corales de la Catedral de Granada, Tesis Doctoral, Universidad de Granada, 1980. Gonzalo Roldán Herencia, La colección de cantorales de la Iglesia Colegial y Parroquial de Santa Fe, Trabajo de Investigación para la obtención del Diploma de Estudios Avanzados (DEA), Universidad de Granada, 2003.
} 
parroquias granadinas, como ha documentado Ruiz Jiménez. ${ }^{76}$ El problema suscitado para la visión de conjunto es, además de la dispersión de estas fuentes o la total desaparición de los archivos parroquiales, la propia idiosincrasia del hecho musical religioso que no era recogido como algo escrito (ni en referencias a él, ni a la propia música).

Las relaciones de fiestas religiosas son otro tipo de fuentes que junto con diversas imágenes dan fe de que con frecuencia no se tiene una visión amplia de la vida musical, pues la institución que se estudia, pocas veces se contextualiza en un ámbito más amplio. El calendario festivo anual incluía fiestas fijas, como la Toma de Granada o el Corpus y otras de carácter circunstancial, fruto de los nacimientos de miembros de la familia real, matrimonios reales, proclamaciones, visitas, conmemoraciones de victorias militares o canonizaciones de nuevos santos. Entre 1611 y 1789 conservamos la relación impresa de al menos 23 festejos relacionados con la familia real en Granada, y entre1619-1769 las relaciones de las celebraciones por la canonización o beatificación de 11 santos, en los que la música jugó un papel activo. ${ }^{77}$ En este estudio, prestaremos especial atención por su relación doctrinal con la Abadía, a las fiestas efectuadas en Granada y en gran parte de los territorios ibéricos, en defensa de la Inmaculada Concepción de la Virgen.

El estudio de la música en los conventos femeninos granadinos ha revelado una intensa actividad musical, que podemos hacer extensiva a los conventos masculinos. ${ }^{78}$ Aparte de la Capilla de Música de San Jerónimo, la música en los conventos y monasterios está demostrada por la presencia de diversos monjes o frailes que actuaban como sochantres $\mathrm{u}$ organistas en iglesias distintas a las de sus órdenes, como veremos en el caso de la Abadía. Algunas imágenes en las que aparecen monjes músicos

\footnotetext{
76 Juan Ruiz Jiménez, "Música y devoción en Granada (siglos XVI-XVIII): funcionamiento "extravagante" y tipología de plazas no asalariadas en las capillas musicales eclesiásticas de la ciudad", Anuario Musical, 52 (1997), pp. 39-76.

77 Reyes Escalera Pérez, La imagen de la sociedad barroca andaluza: estudio simbólico de las decoraciones efímeras en la fiesta altoandaluza. Siglos XVII y XVIII, (Málaga: Universidad de Málaga, 1994).

${ }^{78}$ Para un estudio sobre la música en los conventos granadinos, véase Julieta Vega García, La música en los conventos femeninos de clausura en Granada, (Granada: Editorial Universidad de Granada, 2005).
} 
testimonian esta realidad. ${ }^{79}$ A la actividad de los centros religiosos hay que sumar la de las cofradías y los gremios civiles, que alimentaron del mismo modo la vida musical de estos centros, ya fuera en las procesiones como en los aniversarios y sufragios por el alma de sus miembros y cuya actividad musical en Granada aún no ha recibido ninguna atención.

En este contexto, la Abadía es una institución sin la cual no podríamos entender la historia de la ciudad. ${ }^{80}$ Junto con la Catedral y la Capilla Real contó con un cabildo numeroso de cierto estatus intelectual. Como centro de formación de prestigio sobrepasó las fronteras locales y aunque aún no se ha hecho un estudio exhaustivo sobre el cursus vitae de sus individuos, muchos de los obispos, teólogos y personalidades de la época (como ministros y miembros de la Real Academia de la Historia) habían sido previamente colegiales o canónigos del Sacromonte.

Por todo lo anterior el estudio de instituciones como la Abadía, que a primera vista pueden resultar menos interesantes por la cantidad y calidad de sus fondos, es necesario para obtener esa visión de conjunto que ayude a comprender en su totalidad la música en la ciudad de Granada durante la Edad Moderna. Además, como señala Noel O’Regan "las instituciones musicales menos conocidas a menudo pueden contarnos más sobre el estado general de la situación que aquellas más excepcionales y famosas". ${ }^{81}$ Dicho de otra manera: "No basta una historiografía musical basada sobre todo en la

\footnotetext{
${ }^{79}$ Una de estas imágenes corresponde a un cuadro de gran formato que se encuentra en el crucero superior del Hospital Real (hoy Biblioteca General de la Universidad de Granada) en el que podemos ver un nutrido grupo de monjes en un coro, alrededor de un facistol, algunos cantando y otros tocando varios instrumentos.

${ }^{80}$ Sobre la música en la Abadía del Sacromonte, véase Mercedes Castillo Ferreira, La Música Litúrgica Monódica en la Abadía del Sacromonte de Granada, Trabajo para la obtención de la Suficiencia Investigadora, Universidad de Granada, 2001; Castillo Ferreira, "La Salve de Nuestra Señora en los Sábados y en sus fiestas (1632) en la Abadía del Sacromonte de Granada", Revista Española de Musicología, XVIII, 1 (2005), pp. 102-117; Castillo Ferreira, "Patronazgo musical indiano en Granada: la familia Cabeza de Vaca y la Abadía del Sacromonte en el siglo XVII”, María Gembero Ustárroz y Emilio Ros-Fábregas (Eds.) La Música y el Atlántico. Relaciones Musicales entre España y Latinoamérica (Granada: Universidad, 2008), pp. 69-88. Una primera versión del Catálogo de Libros de Coro de la Abadía del Sacromonte realizada por Mercedes Castillo fue premiada en la convocatoria de 2007 del Premio a la Investigación Musical "Manuel de Falla" de la Universidad de Granada, con el título "Los Libros de Canto Llano de la Abadía del Sacromonte de Granada".
}

${ }^{81}$ Noel O'Regan, Institucional Patronage in Post-Tridentine Rome. Music in Santissima Trinità dei Pellegrini (1550-1650) (Londres: Royal Music Association, 1995), p. 2: "Lesser known institutions can often tell us more about the normal state of affairs than can more exceptional and famous ones". 
actividad de los más importantes, de los mejores, o de los más bellos e innovadores (...) por el contrario, es necesario tener en cuenta también (...) la actividad de tantos otros, de los artesanos de la música, de la mayoría: o sea, de aquellos que constituyen la base, los fundamentos de la economía del arte musical." 82 En los próximos capítulos se analizará hasta qué punto la Abadía era una de esas instituciones peculiares o si por el contrario es representativa de la normalidad de aquellas menos conocidas.

\section{Fuentes empleadas.}

Para la elaboración de esta Tesis Doctoral, pese a la gran cantidad de documentación inédita conservada en el Archivo de la Abadía, sólo me fue permitido consultar las Actas Capitulares, algún libro de los acuerdos tomados por la Junta de Asistentes y el Ceremonial. Sin duda, otros documentos, como los Libros de Fábrica o los Expedientes de Limpieza de los capellanes y colegiales, habrían ayudado a completar la información sobre la vida abacial, o sobre la biografía de algún sochantre y organista. Éstos no estaban sometidos a la presentación de un expediente de limpieza si no ganaban una capellanía, por lo que el prescindir de estas series no parece haber sido especialmente relevante para el presente estudio. Del contenido del Archivo no existe ninguna descripción, a excepción del catálogo de manuscritos realizado por $\mathrm{M}^{\mathrm{a}}$ Carmen Calero Palacios. ${ }^{83}$ Los más de 25 volúmenes de las Actas Capitulares (más de 20.000 folios) documentan la historia de la Abadía desde su fundación hasta nuestros días, y constituyen la fuente más importante para la elaboración de este estudio. Hasta ahora no se había publicado ningún extracto de los acuerdos sobre música del Cabildo del Sacromonte, por lo que en el Apéndice 2 del segundo volumen de esta Tesis presento la transcripción de todas las noticias de interés musical aparecidas en las Actas desde 1609 a 1800 .

\footnotetext{
${ }^{82}$ David Bryant ed Elena Quaranta, Produzione, circolazione e consumo, p. 11: "non è suficiente una storiografia basata prevalentemente sulle attivittà dei "più grandi", dei "più importanti", dei "migliori", ovvero sul "più bello", sul "piú innovativo" (...) è necesario invece tenere conto anche (...) delle attività dei tanti altri, degli "artigiani" della música, della "maggioranza": ovvero di ciò che costituisce la base, le fondamenta dell'economia dell'arte musicale".

${ }^{83} \mathrm{M}^{\mathrm{a}}$ Carmen Calero-Palacios, La Abadía del Sacromonte de Granada. Catálogo de manuscritos (Granada: Universidad de Granada, 1999).
} 
Durante el período de elaboración de la Tesis he intentado consultar en diversas ocasiones el Archivo de la Catedral de Granada, pero no lo he logrado debido a diferentes circunstancias ajenas a mi voluntad. El Archivo catedralicio presumiblemente habría proporcionado información relevante sobre visitas pastorales a la Abadía. Sin embargo, dado que el Archivo Musical se encuentra microfilmado en el Centro de Documentación Musical de Andalucía (CDMA), cuyo permiso para la reproducción de materiales me fue facilitado por el ex archivero de la Catedral, Francisco Javier Martínez Medina, he podido localizar allí al menos obras polifónicas inéditas dedicadas a San Cecilio, patrón de Granada. Algunas noticias contenidas en las actas catedralicias relevantes para este estudio han sido transcritas por López-Calo y García de Leonardo. ${ }^{84}$ Otro de los archivos consultados ha sido el Archivo de la Capilla Real de Granada, que afortunadamente también está microfilmado en el CDMA; gracias a Esteban Valdivieso $(\dagger)$, Director que fue de este Centro de Documentación Musical, pude examinar las microfichas de los libros de canto llano relacionados con el culto a San Cecilio y de una obra dedicada al mismo. En el Apéndice 6 del segundo volumen de esta Tesis aparecen mis transcripciones de todas las obras polifónicas dedicadas a San Cecilio que se encuentran tanto en el Archivo de la Catedral como en el de la Capilla Real de Granada. En la misma Biblioteca del CDMA tuve acceso también a las microfichas de los libros de canto llano de la Catedral de Málaga.

La Biblioteca Universitaria (en el Hospital Real) de la Universidad de Granada es quizás la biblioteca de fondo antiguo más importante de la ciudad, y cuenta con documentación relevante sobre la historia de la ciudad desde el siglo XV al XIX; en ella he consultado documentos manuscritos e impresos (como sermones, letras de villancicos y relaciones de sucesos) relativos a la Abadía y a otras instituciones granadinas.

En el Archivo de la Real Chancillería de Granada se conserva una serie documental completa sobre la Abadía (en doce cajas) referida sobre todo al pleito de los Libros Plúmbeos y su historia; la documentación está fechada entre 1683 (fecha del Breve Papal con la Condena a los Libros Plúmbeos) y 1780. El examen detenido de estas cajas

\footnotetext{
${ }^{84}$ López-Calo, Catálogo del Archivo de Música de la Catedral de Granada, vol. III; y Ma Josefa Cuesta García de Leonardo, Fiesta y arquitectura efimera en la Granada del siglo XVIII (Granada: Diputación Provincial, 1995).
} 
no aportó ningún documento de interés musical, aunque sí fue útil para conocer las tribulaciones por las que pasó la Abadía durante un siglo.

Del Archivo Histórico Provincial de Granada he obtenido información relativa a la fiesta de San Cecilio, como el texto del Oficio de San Cecilio, conservado en un impreso romano de 1704 (fecha de la aprobación del nuevo rito), o el Decreto del Arzobispo de Granada Martín Carrillo y Alderete declarando festivo el día del patrón. Además, he consultado las disposiciones del Cabildo Municipal de Granada relacionadas con la celebración de dicha festividad.

La Biblioteca del Museo de los Tiros de Granada conserva un ejemplar impreso de la Consueta de la Catedral de Granada del siglo XIX y diferentes impresos de los siglos XVII y XVIII (como una Loa de los Colegiales del Sacromonte dedicada a la Inmaculada Concepción) que no se encuentran en otras bibliotecas. De los archivos granadinos también he consultado el Archivo de Protocolos Notariales de Granada. Desgraciadamente sufrió un incendio en el siglo XIX que destruyó gran parte de sus fondos, entre ellos probablemente los correspondientes a la escribanía de Antonio Ruiz de Prado, quien durante varias décadas llevó los asuntos del Sacromonte. ${ }^{85}$ He intentado localizar sin éxito el contrato que se firmó ante él por parte del Cabildo del Sacromonte y un grupo de músicos a principios del siglo XVII, pero la búsqueda ha sido infructuosa.

Se conservan importantes fondos documentales sobre Granada y la Abadía del Sacromonte en la Biblioteca Nacional de España en Madrid, como por ejemplo el Ms. 6437 que contiene diversa documentación inédita que debió de pertenecer al Archivo del Sacromonte o a algún canónigo; en este manuscrito se encuentran las Primeras Constituciones ( $\sin$ fecha, fol. 139r), así como otras versiones de las mismas fechadas en 1613, 1616 y 1623. De particular interés es la historia manuscrita inédita del Sacromonte escrita por Pedro Velarde de Ribera, un unicum que ha sido relativamente poco citado por los estudiosos del Sacromonte. Además, los fondos de la Biblioteca Nacional han sido de enorme interés para documentar festividades en el contexto español (como los utilizados al tratar del culto a la Virgen en el Capítulo V); el fondo de impresos litúrgicos (breviarios y misales) ha sido de gran ayuda para la redacción del Capítulo VI. En Madrid también he consultado el Archivo General de Palacio, donde he

\footnotetext{
${ }^{85}$ Cabe la posibilidad de que Ruiz de Prado se trasladara a otra ciudad y se llevara consigo los libros, que en esta época eran propiedad del notario, pero hasta el momento tampoco he localizado ninguna noticia al respecto.
} 
examinado documentación relativa a Miguel Rabaza, organista de la Abadía del Sacromonte y más tarde de la Real Capilla de Madrid.

En el Archivo de la Catedral de Santiago de Compostela pude consultar su rica colección de cantorales de canto llano; uno de ellos conserva un Oficio de la Toma de Granada hasta ahora inédito y que estudio en el Capítulo VI.

Durante mi estancia de investigación como "Visiting Scholar" en la Facultad de Música de la Universidad de Cambridge (Reino Unido) disfruté consultando los fondos de la University Library de esa Universidad y los de la British Library en Londres; la abundante documentación y bibliografía allí consultada ha enriquecido enormemente esta Tesis.

En Granada he consultado los fondos de las siguientes bibliotecas: Biblioteca de Andalucía; Biblioteca del Centro de Documentación Musical; Biblioteca Provincial; Biblioteca de la Facultad de Filosofía y Letras, de la Facultad de Bellas Artes y de la Facultad de Biblioteconomía y Documentación de la Universidad de Granada. En Sevilla visité la Biblioteca General de la Universidad de Sevilla y la de la Facultad de Filosofía y Letras. En Madrid, además de la Biblioteca Nacional, he consultado la Biblioteca de Palacio y la Biblioteca del Museo de América. En la era de las nuevas tecnologías de la información, me han resultado particularmente útiles la Biblioteca Virtual de Andalucía y la Biblioteca Virtual del Patrimonio Bibliográfico Español.

\section{Plan de Trabajo.}

Esta Tesis Doctoral consta de dos volúmenes: Volumen I: Estudio; y Volumen II: Apéndices documentales y edición musical. El primer volumen tiene seis capítulos y concluye con el Catálogo de los 79 cantorales de canto llano de la Abadía del Sacromonte.

El Capítulo I presenta las circunstancias socioculturales que rodearon la creación de la Abadía del Sacromonte y el papel de reformador tridentino que jugó su fundador Pedro de Castro, Arzobispo de Granada. Prestaré especial atención a la relación entre Felipe II y Pedro de Castro debido a las similitudes existentes entre sus fundaciones de El Escorial y el Sacromonte, respectivamente.

Los Capítulos II y III tratan de la organización musical del culto en la Abadía desde dos puntos de vista. El Capítulo II se centra en las Constituciones (1616 y 
1647) del Sacromonte para comparar las directrices sobre cuestiones musicales con las de otras constituciones de instituciones similares, como las de la Colegiata del Salvador de Granada y las del Colegio del Corpus Christi de Valencia, fundado por Juan de Ribera. El Capítulo III detalla, a partir de la Consueta (1632), las funciones de los diversos cargos u oficios del personal del Sacromonte y su relación con la música. Aquí presento también las noticias referentes a los sochantres y organistas del Sacromonte extraídas de las Actas Capitulares de 1607 a 1800.

Los Capítulos IV y $\mathrm{V}$ están dedicados a la música en el contexto de las ceremonias litúrgicas del Sacromonte. El Capítulo IV describe los espacios cultuales de la Abadía (la iglesia y las Cuevas), la preeminencia del canto llano sobre la polifonía y la música instrumental, y el papel desempeñado por los colegiales del Colegio de San Dionisio Areopagita contiguo a la iglesia. El Capítulo V estudia, además de la misa cantada y el Oficio de Vísperas, las ceremonias relacionadas con: 1) la Fiesta de San Cecilio, para la cual se creó en el siglo XVIII un oficio con canto gregoriano propio de la Abadía que he transcrito; 2) las honras fúnebres del fundador del Sacromonte y su familia, lo que permite adentrarnos en la intrahistoria de la Abadía; unos cuadros conservados en el Sacromonte relativos a las hazañas del padre del fundador, Cristóbal Cabeza de Vaca, Gobernador del Perú, contienen escenas musicales de interés; y 3) el culto a la Virgen en la Abadía en el contexto de la España de aquella época, especialmente en lo concerniente a la festividad de la Inmaculada Concepción y al rito de la Salve.

El Capítulo VI estudia la colección de Libros de Coro de canto llano de la Abadía. De la extensa biblioteca coral sacromontana he seleccionado algunos ejemplos para comentar el repertorio "hispano" interpretado: 1) una variante del conocido himno a San Juan Bautista Ut queant laxis; 2) una colección de Kyries tropados; y 3) el Oficio de la Toma de Granada, comparándolo con otro Oficio de la Toma hasta ahora inédito que he encontrado en la Catedral de Santiago de Compostela. Estas obras ofrecen la oportunidad de adentrarse en tradiciones locales de canto llano y buscar otros ejemplos fuera de la Abadía que están relacionados. Tras las Conclusiones y la Bibliografía, el primer volumen concluye con el Catálogo de los Libros de Coro de la Abadía del Sacromonte. 
El Volumen II contiene siete Apéndices con documentos y ediciones musicales. El Apéndice 1 presenta la transcripción completa de la Consueta (1632) del Sacromonte de Granada, un documento único especialmente rico en detalles respecto al papel de la música en el ceremonial de la Abadía. El Apéndice 2 contiene todas las noticias de interés musical que aparecen en las Actas Capitulares del Sacromonte desde 1607 a 1800. El Apéndice 3 es una reconstrucción detallada del rito de la Salve tal como se celebraba en la Abadía a partir de las propias fuentes tanto musicales como documentales del Sacromonte. El Apéndice 4 reconstruye la Misa para la Festividad de San Cecilio, patrón de Granada. El Apéndice 5 presenta la edición de un nuevo Oficio de la Toma de Granada (Exaltationis fidei), hasta ahora también inédito, que se encuentra en un cantoral de la Catedral de Santiago de Compostela. El Apéndice 6 reune la transcripción de varios documentos relacionados con la celebración de la Fiesta de San Cecilio. Por último, el Apéndice 7 reúne la edición de seis de las nueve obras polifónicas dedicadas a San Cecilio que aparecen en los archivos de la Catedral y de la Capilla Real de Granada pertenecientes a compositores como Antonio Caballero (1728?-1822), Celestino Vila de Forns (18301915); estas obras, que cubren un amplio espectro cronológico, contribuyen a completar el panorama musical de una fiesta tan emblemática para la ciudad como la de San Cecilio, patrón de Granada. 



\title{
CAPÍTULO I
}

\section{LA FUNDACIÓN DE LA ABADÍA DEL SACROMONTE DE GRANADA}

\begin{abstract}
Andando unos hombres buscando un Thesoro, medio quarto de legua desta ciudad de Granada, en la questa o monte alto de lo que llaman Valparayso, hallaron cavando por el mes de Março deste año de quinientos y noventa y cinco, una lamina de plomo, y leyendola dezia, que estava alli un cuerpo quemado de un sancto. Traxeronla a don Pedro de Castro y Quiñones, Arçobispo de la dicha ciudad. ${ }^{1}$
\end{abstract}

\section{Las reliquias que hay que custodiar: la excusa para la fundación.}

La Abadía del Sacromonte fue fundada en 1607 por don Pedro de Castro, Arzobispo de Granada, para custodiar las supuestas reliquias de unos santos mártires que habían aparecido en el monte de Valparaíso cercano a Granada en 1595. Estos hallazgos tuvieron lugar en un complejo clima sociocultural que esbozaré en este capítulo.

Las "invenciones", como se les denominó a estos hallazgos en la época, no fueron las primeras que salieron a la luz en Granada. Unos años antes, en 1588, con motivo de la ampliación de la Catedral, siendo Arzobispo de Granada don Juan Méndez de Salvatierra, se decidió derribar la torre llamada Turpiana, que además estaba en mal estado. En los cimientos de la torre apareció un cofre que contenía un trozo del supuesto pañuelo con el que la Virgen enjugó sus lágrimas, una tablita con la virgen María vestida de egipcia, un hueso y un pergamino escrito en latín, árabe, castellano y con letras griegas. Este pergamino contenía una profecía de San Juan sobre el fin del mundo, traído a Granada supuestamente por San Cecilio, quien a su vez lo había recibido de San Dionisio Areopagita en Atenas, y que finalmente guardó un diácono de Cecilio llamado Patricio. El Arzobispo Méndez de Salvatierra murió antes de tomar ninguna determinación sobre estos restos y el proceso de calificación para el que Sixto $\mathrm{V}$ había mandado un Breve, fue detenido por el nuevo arzobispo, Pedro de Castro en 1591. Los descubrimientos despertaron bastantes dudas entre los estudiosos, por lo que habrían caído en el olvido de

\footnotetext{
${ }^{1}$ Anónimo, Relación descubrimiento de las Reliquias ([Granada]: Impresso por Iuan Rene, 1595), p.1.
} 
no ser porque varios años más tarde, unos buscadores de tesoros descubrieron en el Monte de Valparaíso, extramuros de la ciudad, una mina abandonada, un horno de cal con restos humanos, láminas sepulcrales (entre las que supuestamente se encontraba la de San Cecilio, que según la tradición fue primer obispo de Granada) y los famosos Libros Plúmbeos. Estos curiosos objetos, formados por láminas circulares de plomo, estaban escritos en árabe con unos caracteres inventados para dar apariencia de mayor antigüedad. Su contenido es de carácter teológico, en una rara mezcla de conceptos cristianos e islámicos. Entre otras informaciones se narran la venida del apóstol Santiago a España y diversas profecías sobre la "nación árabe". 2

El hallazgo en el Monte de Valparaíso de Granada causó gran sorpresa, no sólo por la cantidad de los restos, sino por su naturaleza: eran las reliquias martiriales de varios de los varones apostólicos y sus discípulos que habrían acompañado a Santiago en la evangelización de España. La ciudad mostró su devoción desde el principio con procesiones, misas y exvotos. Pedro de Castro compró el terreno con su propia fortuna y mandó vigilar y excavar el resto de las cuevas. Para la salvaguarda de los restos mandó edificar una casa para los capellanes y tras el intento de algunas órdenes de hacer una fundación decidió emprenderla él mismo. Es complejo desde una perspectiva actual entender la trascendencia que para la sociedad granadina tuvo el hallazgo de los restos de San Cecilio y sus compañeros mártires y comprender la naturaleza excepcional de este

\footnotetext{
${ }^{2}$ La mayor parte de la historiografía sobre el Sacromonte está dedicada al estudio de los Libros Plúmbeos y su significación histórica. Dejando a un lado los libros laudatorios de los primeros tiempos, la historiografía crítica moderna comienza con el libro de José Godoy Alcántara, Historia crítica de los falsos cronicones (Madrid: Imprenta de Rivadeneyra, 1868) y Henry Charles Lea, Chapters from the Religious History of Spain (Nueva York: Burt Franklin, 1967 [Philadelphia, 1890]); en el siglo XX resurge el interés con las obras de: Darío Cabanelas, El morisco Alonso del Castillo (Granada: Patronato de la Alhambra, 1965); Carlos Alonso, Los Apócrifos del Sacromonte, (Valaldolid: Estudios Agustinianos, 1979); Ignacio Gómez de Liaño, Los juegos del Sacromonte (Madrid: Editora Nacional, 1975); Julio Caro Baroja, Las falsificaciones de la historia de España (Barcelona: Seix Barral,1986), Manuel Barrios Aguilera, Los falsos cronicones contra la historia (Granada: Universidad de Granada, 2005). También son significativos los trabajos de traducción de Hagerty, Los libros del Sacromonte (1980). Últimamente han aparecido dos números de la revista de estudios árabes Al-Qantara: XXXIII-2 (2002) pp. 343-543, y XXXIV-2 (2003), pp. 295-573, que posteriomente han sido editados en: Manuel Barrios Aguilera y Mercedes García Arenal (eds.), Los Plomos del Sacromonte, Invención y tesoro (2006). Sobre la apariencia de la escritura de los libros plúmbeos véase en este último volumen las páginas 59, 115-116. La investigación sobre los Libros Plúmbeos y el Sacromonte sigue en plena efervescencia como lo demuestra la publicación de otra colección de estudios: Manuel Barrios Aguilera y Mercedes García Arenal (eds.), ¿La historia inventada?Los libros plúmbeos y el legado sacromontano (Granada: Universidad de Granada y Legado Andalusí, 2008).
} 
hecho. Para ello debe tenerse en consideración que el interés por identificar los orígenes cristianos de la ciudad es una circunstancia que encontramos simultáneamente en otros lugares de España, sobre todo en aquellos que habían permanecido más tiempo bajo la dominación musulmana. En aquella época se multiplicaron los hallazgos de mártires cristianos por toda la Península Ibérica: Ávila había descubierto las reliquias de San Segundo en 1519, en Córdoba se encontraron las reliquias de Fausto, Januario y Marcial en 1577 y $1583^{3}$, y finalmente en Granada, las de San Cecilio y sus compañeros en 1595. Dicho fenómeno puede verse en un ámbito más amplio, el de la Europa católica posterior al Concilio de Trento donde la veneración de las reliquias cobró un protagonismo inusitado hasta la época, por cuanto se convirtieron en un símbolo de diferenciación ante los protestantes. Un significativo ejemplo es el del resurgir del culto a las catacumbas romanas popularizado por San Felipe Neri. ${ }^{4}$

No es de extrañar por tanto que en este clima de exaltación religiosa los hallazgos del Sacromonte tuvieran tanta repercusión en la sociedad granadina del seiscientos, que asistía a un complejo proceso de reafirmación de su identidad cristiana que culminaría con la expulsión de los moriscos. Aunque al principio las autoridades actuaron con cautela, los descubrimientos unos años más tarde del Monte de Valparaíso vinieron a legitimar las noticias de la Torre Turpiana y a aumentar la categoría de la ciudad con un sinfín de reliquias martiriales. De ser auténticos los hallazgos, Granada se habría convertido en un santuario de primer orden sólo comparable a Santiago o Jerusalén. ${ }^{5}$

En el resto de España no fueron menos conocidos los sucesos del Sacromonte, pues Felipe II, fanático de las reliquias, ordenó que se le mantuviera informado en todo momento

\footnotetext{
${ }^{3}$ Cesare Baronio (1537-1608) comenzó en 1588 a publicar su Martyrologium Romanum, cum Notationibus Caesaris Baronii (Roma: 1588) y las órdenes religiosas rivalizaron por la exaltación de sus mártires: a los jesuitas del Brasil (1570) y de la India (1583), siguieron los del Japón (1597), mayoritariamente franciscanos. Para una discusión sobre este asunto, véase Manuel Barrios Aguilera y Valeriano Sánchez Ramos, Martirios y mentalidades martiriales en la Alpujarra (Granada: Universidad de Granada, 2003), p.122.
}

${ }^{4}$ Simon Ditchfield, "Martyrs on the Move: Relics as vindicators of local diversity in the Tridentine Church", Martyrs and Martyrologies, Studies in Church History, vol. 30, ed. Diana Wood (Oxford: Blackwell Publishers, 1993), p. 287.

${ }^{5}$ Antonio Bonet Correa, "Entre la superchería y la fe. El Sacromonte de Granada", Andalucía monumental. Arquitectura y ciudad del Renacimiento al Barroco (Sevilla: Editoriales andaluzas unidas, 1986), pp. 33-52. 
del proceso, incluso hasta le fueron enviados algunos de los restos hallados. Las altas instancias eclesiásticas se interesaron por los nuevos santos y pronto surgieron gran cantidad de escritos y libelos en contra o a favor de la autenticidad de los restos del Sacromonte, como los alegatos del jesuita Ignacio de las Casas o los defensorios granadinos. ${ }^{6}$ Prueba de la popularidad que los Libros Plúmbeos y los sucesos del Sacromonte alcanzaron en su época es la alusión que Miguel de Cervantes hace en $E l$ Quijote. $^{7}$

\subsection{La historia de San Cecilio}

Con anterioridad a los descubrimientos de la Torre Turpiana, la única referencia a la devoción de San Cecilio en Granada es la parroquia bajo la advocación de este santo, erigida en 1501 sobre el solar de la antigua mezquita de la Antequeruela. ${ }^{8}$ A finales del siglo XVI se pensaba que éste era además el lugar donde la primitiva catedral mozárabe se había asentado.

San Cecilio, antes de las noticias que se daban en los Libros Plúmbeos hallados en las cavernas del Sacromonte, era conocido solamente por ser uno de los compañeros de San Torcuato. Esta tradición, nombrada en España como la leyenda de los varones apostólicos, es narrada en diversas fuentes medievales, algunas de las cuales eran de sobra populares en el siglo XVI. La leyenda narra cómo Torcuato, Tesifonte, Indalecio, Segundo, Eufrasio, Cecilio y Hesiquio habían sido ordenados obispos por San Pedro y San Pablo en Roma y envíados luego a evangelizar la Bética. Su primera parada tuvo lugar en Acci (Guadix), donde tras efectuar varios milagros, convirtieron a una noble pagana llamada Luparia. ${ }^{9}$

\footnotetext{
${ }^{6}$ Para un análisis y descripción exhaustiva de muchas de estas fuentes véase el volumen citado de Barrios y García Arenal, Los plomos del Sacromonte, especialmente pp. 51-79, 201-297, 481-521.

${ }^{7}$ Al final de la primera parte del Quijote (QI, 52) aparece una clara parodia: "una caja de plomo (...) se había hallado en los cimientos derrumbados de una antigua ermita que se renovaba; en la cual caja se habían hallado unos pergaminos (...)." Véase Emilio Sola "Cervantes y el Islam. Sin la luz de la fe", El Español en el Mundo:Anuario del Instituto Cervantes 2004, coord. por Paz Lorenzo (Barcelona: Plaza \& Janés, 2004), pp. 13-38.

${ }^{8}$ Francisco Javier Martínez Medina, San Cecilio y San Gregorio (Granada: Comares, 2002), p. 51.

${ }^{9}$ Señalo este nombre aquí, pues uno de los supuestos mártires encontrados en la Abadía se llamaba "Lupario", con lo que se ve claramente la fuente de inspiración de los falsificadores.
} 
Desde allí cada uno se dirigió a una ciudad distinta de la Bética y fundó una diócesis. Cecilio predicó su fe en Iliberris, conocida después como Elvira, a la sazón la antigua Granada. Entre los documentos más antiguos que narran dicha tradición se encuentran el Martirologio Lionés, el Oracional de Silos y la Misa del Sacramentarium de Toledo, que datan del siglo IX. Según Fábrega Grau, su origen sería incluso anterior, al tener como fuente un Pasionario cuya redacción primitiva debió tener lugar alrededor del siglo VIII. ${ }^{10}$ En estas fuentes el culto a San Cecilio es secundario, pues es San Torcuato el santo principal. De San Cecilio como primer obispo de la diócesis granadina existe también otro testimonio en el Códice Emilianense 992, conservado en el monasterio de El Escorial, en el que se recogen las sesiones del Concilio de Elvira (ca.300-324). ${ }^{11}$ En este códice aparece una lista con los obispos de la diócesis de Elvira, y el primero de ellos es Cecilio. Aunque la lista no puede considerarse completamente exacta pues hay diversas contradicciones en el orden de los obispos, podemos suponer que existía ya una tradición que situaba a Cecilio como el primer obispo de Granada. ${ }^{12}$ ¿Qué queda de la tradición de los varones apostólicos en el Cecilio descubierto a finales del siglo XVI? Sin duda, además del nombre y el de algunos compañeros, el hecho de que fuera el primer obispo de la antigua diócesis granadina, pues lo demás es todo una ficción. Así lo atestiguaron muchos de los que fueron críticos con las reliquias del Sacromonte, como Juan Bautista Pérez, Obispo de Segorbe. En un documento que iba a enviar bajo seudónimo ${ }^{13}$ al Arzobispo Castro en 1595, fecha de los primeros hallazgos, el Obispo de Segorbe demuestra un profundo conocimiento de la

\footnotetext{
${ }^{10}$ Para una enumeración exhaustiva de las fuentes sobre los varones apostólicos, véase Ángel Fábrega Grau, Pasionario Hispánico, Colección Monumenta Hispaniae Sacra, serie litúrgica vol.VI (Madrid-Barcelona: CSIC, 1953), pp. 125-130; y Zacarías García Villada, Historia Eclesiástica de España, vol.I, Primera parte (Madrid: Compañía Iberoamericana de Publicaciones, 1929), pp. 147-169.

${ }^{11}$ Aunque este códice fue copiado en el 962 parece reproducir las actas del Concilio de Elvira (ca. 300-320), véase Dictionnaire d'histoire et de géographe ecclésiastiques, Publié sous la direction de Alfred Baudrillart, Albert Vogt et Urbain Rouziés (París: Letouzey et Ané, 1912-), pp. 311-348; y Manuel Sotomayor y José Fernández Ubiña (coords.), El concilio de Elvira y su tiempo (Granada: Universidad, 2005).

${ }^{12}$ Martínez Medina, San Cecilio, p.163.

${ }^{13}$ El pseudónimo empleado por el Obispo de Segorbe fue el de Licenciado Valcárcel; véase Henry Charles Lea, Chapters from the Religious History of Spain, connected with the Inquisition (New York: Burt Franklin, 1967) [Philadelphia, 1890], p. 111.
} 
literatura hagiográfica medieval; entre otros documentos menciona, los martirologios antiguos de Beda, Usuardo y Adón, además de un "libro gótico de concilios de S. Millán de la Cogolla, que ahora están en S. Lorenzo el Real". ${ }^{14}$ El obispo de Segorbe argumenta que, al contrario de lo que decían los Libros Plúmbeos, estos santos no murieron en Granada (a excepción de Cecilio) ni eran discípulos de Santiago; que Tesifón no se llamó Abenatar (es decir, que no era de origen árabe) y que muchos de los nombres que aparecían en las láminas sepulcrales de estos mártires eran falsos. Sin embargo en el San Cecilio del siglo XVI concurren dos nuevas circunstancias que lo diferencian del varón apostólico de tradición medieval: su condición de árabe, lo que convertía a los moriscos en "cristianos viejos", y su categoría de mártir, que no aparece en ninguna de las fuentes de la leyenda de los varones apostólicos. Las voces contrarias a la autenticidad de las reliquias eran minoritarias y no fueron escuchadas por el Arzobispo. Entre ellas destacaron las críticas del gran polígrafo Benito Arias Montano o las del jesuita Ignacio de las Casas. ${ }^{15}$ En Granada se desató la euforia. Los granadinos no sólo habían visto la oportunidad de ratificar su origen cristiano, sino que además San Cecilio, según los hallazgos, había sido discípulo directo de Santiago. Como señala Peter Brown, el descubrimiento de una reliquia suponía para la sociedad que la encontraba un hecho que ponía de manifiesto la gracia de Dios, al mismo tiempo que anunciaba momentos de amnistía y traían el perdón al presente. En este sentido la reliquia no era más importante que el hecho del perdón de Dios, y el poder de la reliquia en la comunidad estribaba en la determinación de esa comunidad de creer que había sido juzgada por Dios y había merecido la presencia del santo. ${ }^{16}$ Por ello, desde el mismo momento del descubrimiento de las reliquias, la ciudad se hizo eco del carácter extraordinario del hecho. Innumerables procesiones, misas y otros actos se

\footnotetext{
${ }^{14}$ Esta carta del Obispo de Segorbe al arzobispo Castro la transcribe Jaime Villanueva, Viage literario por las Iglesias de España (Madrid: Imprenta Real, 1803-1852), tomo III, pp. 259-278. El "libro gótico" es el Códice Emilianense 992 referido en el párrafo anterior.

15 Sobre este particular, véase Rafael Benítez Sánchez-Blanco: "De Pablo a Saulo: traducción, crítica y denuncia de los libros plúmbeos por el P. Ignacio de las Casas, S.J.”, Al-Qantara, XXIII/2 (2002), pp. 404436.

${ }^{16}$ Peter Brown, The Cult of the Saints. Its rise and Function in Latin Christianity (Chicago: Chicago University, 1981), pp. 92-93.
} 
sucedieron sin descanso, se colocaron cruces en el camino del monte a modo de exvotos, e incluso se produjeron "milagros" entre aquellos que visitaban las cuevas. ${ }^{17}$ Como muestra del ambiente que se generó en los primeros meses de los descubrimientos, puede leerse el siguiente pasaje que recoge Diego de la Serna Cantoral en sus Vindicias Católicas. Aunque escribió esta obra en el siglo XVIII, la frescura y el detalle de su narración hace pensar que copió testimonios anteriores. A continuación extracto un pasaje en el que la música se hace presente como elemento indispensable para dar solemnidad a la procesión:

Lunes a primero de Mayo los Procuradores, Recetores, y solicitadores de la Chancillería, llevaron una Cruz muy adornada, y galana, para tomar con ella posesión, y señalar sitio, donde poner otra mas sumptuosa. Fueronla acompañando en gran numero los Oficiales de la Chancillería con hachas blancas, y los Conventos de San Agustin, y la Victoria, y Música de Cantores; y al passar por delante de la Audiencia Real, salieron unas compañías de Arcabuzeros que tomando toda la Plaza Nueva desde la boca del Zacatin hasta la calle de Darro, de un lado, y de otro de la procesión, arrodillados, hicieron salva de Arcabuzeria á la Cruz, y quando la procesión llegó cerca del Monte, dos docenas de personas, rica y curiosamente vestidos de sedas, y oros, y con máscaras, y hachas encendidas en las manos al son de harpas, y otros instrumentos, saliendola á recebir, danzaron muy bien. $^{18}$

O la procesión que narra Velarde de Rivera, por los niños cantores de la Capilla Real:

Asi mesmo se vido en esta ciudad, y en el Sancto Monte una procesión de niños, eclesiásticos y seises de la Sancta Iglesia y Real Capilla de Granada que luego que llegaron al Sancto Monte con su cruz y estandartes hicieron una muy regocijada y devota dança al son de sus chançonetas ministriles y cantores que les acompañaron, y a los que se hallaron aquel día en el Sancto Monte y vieron esto les pareció ser choro de

\footnotetext{
${ }^{17}$ El primer Abad del Sacromonte y provisor de Pedro de Castro, Justino Antolínez de Burgos, recoge varios de estos milagros en su Historia Eclesiástica de Granada, que quedó inédita hasta 1996.

${ }^{18}$ Diego de la Serna Cantoral, Vindicias catholicas granatenses: relacion breue de las reliquias que se hallaron en la ciudad de Granada en una torre antiquissima, y en las cauernas del Monte Illipulitano de Valparayso cerca de la ciudad, sacado del processo y aueriguaciones, q[ue] cerca dello se hizieron (Lyon: [s.n.], 1706), p. 45. De la Serna Cantoral enumera y describe muchas de las procesiones al Sacromonte que se llevaron a cabo para colocar una cruz como exvoto; en muchas de ellas está presente la música.
} 
celestial jerarchia de ángeles de gloria que con admirable favor hicieron compañía a los que están acá. ${ }^{19}$

Ya he comentado anteriormente que el Concilio de Trento desató un gran movimiento a favor de la devoción de los "vestigia" de los mártires de la época primitiva de la Iglesia, que puede ser interpretada como una reacción católica a la crítica protestante del culto de los santos y sus reliquias. Para el control de los asuntos derivados de esta práctica, se creó en 1588 la Sagrada Congregación de Ritos y Ceremonias. ${ }^{20}$ Desde el Concilio de Trento, la potestad para autentificar cualquier reliquia necesitaba al menos de la reunión de un Sínodo Provincial, hecho que significó todo un acontecimiento social, político y religioso en la Granada del seiscientos. ${ }^{21}$ Los cronistas e historiadores de la época recogen este suceso con descripciones pormenorizadas, donde la música ocupó un lugar destacado. $^{22}$ Estas ceremonias y algunas otras relacionadas con San Cecilio serán de especial relevancia y se discutirán en el Capítulo V.

Las reliquias fueron finalmente autentificadas en el Sínodo Provincial de 1600, pero los libros debían someterse al juicio de la Santa Sede, que terminó condenándolos como heréticos en 1682 mediante un Breve de Inocencio XI.

\footnotetext{
${ }^{19}$ Pedro Velarde de Rivera, Historia Eclesiástica del Monte Santo ciudad y Reyno de Granada dirigida a la magestad del Rey don Phelipe nuestro señor tercero de este nombre (BNE, Mss. 1583).

${ }^{20}$ Simon Ditchfield, "Martyrs on the move", p. 287.

${ }^{21}$ Unas décadas antes en Córdoba (1577 y 1583) se había efectuado un proceso de autentificación de las reliquias de San Marcial y Juvenal. El arzobispo Pedro de Castro mandó que se consultaran los procesos y sentencias que se hicieron en Córdoba antes de comenzar las reuniones del Sínodo provincial en Granada.

${ }^{22}$ Entre ellos destacan: Francisco Bermúdez de Pedraza, nacido en 1576, canónigo de la Catedral y cronista de la ciudad; Justino Antolinez; Alonso de Fonseca, Abad de Alcalá la Real, que ya había estado en la autentificación de las reliquias de los mártires de Córdoba; Prelados de Guadix; Sebastián Quintero, Obispo de Galipoli; Juan de Fonseca, Obispo de Guadix; Pedro Mallén de Rueda, oidor decano de la Real Chancillería en representación de Felipe II, doctor don Antonio Bonal, que perteneció después al Real Consejo; Baltasar de Lorenzana; Gregorio López Madera, Arzobispo de Santiago y Juan de San Clemente entre otros.
} 


\section{Las circunstancias históricas: el móvil de la fundación.}

Para entender la fundación de la Abadía del Sacromonte no sólo hay que mirar detenidamente los sucesos de la Torre Turpiana y la aparición de las reliquias en el Monte de Valparaíso, sino que también hay que atender a otro tipo de acontecimientos que sin duda debieron de influir en la creación de esta institución. A continuación analizaré las circunstancias sociopolíticas del momento marcadas por la expulsión de los moriscos españoles y la Contrarreforma católica; de otro la personalidad, formación, posición e influencia del Arzobispo Pedro de Castro.

\subsection{La situación granadina}

La Granada del seiscientos era una ciudad ávida por recuperar el protagonismo que había perdido durante el siglo anterior. De candidata potencial a capital del estado, panteón real y residencia de la corte en la era de Carlos V, la "nueva Constantinopla",23 en la que se habían fundado numerosas iglesias (muchas de patronato regio) y establecido casi todas las órdenes religiosas del momento, pasó a ser una ciudad en crisis, en la que sólo la Real Chancillería y la Universidad mantenían el añorado esplendor. Eclipsada por la riqueza de Sevilla que había prosperado con el comercio de Indias, Granada contaba además con "el problema morisco" de las Guerras de rebelión (1568-1570) que desembocarán en la expulsión definitiva de los moriscos no convertidos. ${ }^{24}$ No es de extrañar que en este clima, los descubrimientos tuviesen tanto éxito, pues eran una forma de devolver a los granadinos la primacía añorada; además la situación de los moriscos tuvo un claro papel como catalizador de la invención de las reliquias. Alonso del Castillo y Miguel de Luna, ambos

\footnotetext{
23 José Luís Orozco Pardo, Christianópolis: urbanismo y Contrarreforma en la Granada del seicientos (Granada: Diputación Provincial de Granada, 1985).

24 De la extensísima bibliografía sobre el problema morisco reseñamos algunos de los trabajos de los últimos años a los que el lector interesado podrá remitirse para obtener mayor información y fuentes bibliográficas actualizadas: Manuel Barrios Aguilera y Ángel Galán Sánchez (editores), La historia del Reino de Granada a debate, Viejos y nuevos temas, Perspectivas de Estudio (Málaga: Diputación de Málaga CEDMA, 2004); Manuel Barrios Aguilera y Valeriano Sánchez Ramos, Martirios y mentalidad martirial en las Alpujarras. De la rebelión morisca a las Actas de Ugíjar (Granada: Universidad, 2001); Rafael Benítez Sánchez-Blanco, "Estudio introductorio", Henry Charles Lea, Los moriscos españoles: su conversión y expulsión (Alicante: Universidad de Alicante, 2001), pp. 9-76.
} 
de origen morisco y traductores del Rey, han sido señalados por los estudiosos como creadores y/o transmisores de las falsificaciones. ${ }^{25}$ Según Cabanelas, al verse amenazada la comunidad morisca por el contrarreformismo y la situación política, intentó una especie de "sincretismo" de ambas religiones (la musulmana y la cristiana) para demostrar que "tras la crucifixión de Jesús, Dios habría preferido a los árabes y rechazado a los judíos, habiendo elegido también la lengua árabe como vehículo para la revelación final de su divina voluntad". ${ }^{26}$ De esta manera también se venía a acabar con el concepto de "cristiano viejo" por el que tantas diferencias de trato habían sufrido los moriscos conversos ya que los primeros cristianos de Granada habrían sido árabes.

El resultado fue contradictorio, como señala Barrios Aguilera, pues el montaje morisco "sirvió para fortalecer creencias católicas muy arraigadas, como la del inmaculismo, pero fue sobre todo, palanca del contrarreformismo en curso". ${ }^{27}$

\subsection{Pedro de Castro (1534-1623): segundo Ambrosio, otro Belarmino de la fe $\mathrm{e}^{28}$}

El arzobispo Pedro de Castro fue el principal artífice de la fundación de la Abadía del Sacromonte; sin su fortuna y su interés personal, los hallazgos del Sacromonte no habrían tenido tanta trascendencia. Como señala Barrios Aguilera, no existe una biografía

\footnotetext{
${ }^{25}$ No sabemos si los moriscos autores de las falsificaciones conocían de cerca a Felipe II y su obsesión por la figura del Rey Salomón, pero parece deducirse que sí. Curiosamente los hallazgos del Sacromonte hacen especial alusión a Salomón: un Libro Plúmbeo es el Libro de la Sabiduría de Salomón, y sigilos o sellos de Salomón aparecen por doquier (véase la ilustración de la portada) hasta tal punto que la estrella de seis puntas, símbolo de la sabiduría de Salomón llegó a convertirse en el escudo de la Abadía. Como señala Juan Rafael de la Cuadra Blanco, Simbología y génesis proyectiva: El Escorial y las fuentes históricas del Templo de Jerusalén, Tesis Doctoral (Universidad Politécnica de Madrid, 1994) la obsesión de Felipe II por la figura del Rey Salomón puede verse en los asuntos de las entradas reales, la intención de crear El Escorial según la planta del Templo de Salomón e incluso llamó a un perro suyo Salomón.

${ }^{26}$ Darío Cabanelas, El morisco Alonso del Castillo (Granada: Patronato de la Alambra, 1963), p. 227.

${ }^{27}$ Manuel Barrios Aguilera, "El Sacromonte de Granada y la religiosidad contrarreformista", La religiosidad popular y Almería: Actas de las III Jornadas, José Ruíz Fernández y Valeriano Sánchez Ramos (eds.)

(Almería: Instituto de Estudios Almerienses, 2004), pp. 15-37.

${ }^{28}$ Heredia Barnuevo, Mistico Ramillete, p.45.
} 
moderna de este arzobispo, por lo que para este apartado me basaré en este autor y en los datos que se encuentran en diversas fuentes que hablan del prelado. ${ }^{29}$

Pedro de Castro, también conocido como Pedro Vaca de Castro, nació en Roa (Burgos) en 1534 y fue el segundo hijo de Cristóbal Vaca de Castro, quién había sido gobernador del Perú, y de Magdalena de Quiñones, de la casa de los Condes de Luna. Don Pedro heredó el mayorazgo que su padre había fundado gracias a las ganancias obtenidas en América, ${ }^{30}$ de aquí que dispusiera de una fortuna considerable con la que pudo hacer frente a los gastos ocasionados con la construcción y puesta en funcionamiento de la Abadía del Sacromonte.

Pedro de Castro se educó en Valladolid ${ }^{31}$ y luego en Salamanca, en cuya Universidad estudió Filosofía, Hebreo, Griego y Derecho Civil y Canónico. En Salamanca tuvo como profesor a Francisco Sarmiento, que después sería obispo de Jaén y testamentario de Felipe II. Obtuvo su primera capellanía de altar en 1547, pero su carrera comenzó a partir de la defensa de su padre en la Corte, pues había sido acusado por pizarristas y almagristas de haberse quedado con dinero de las Indias perteneciente a la Corona. Su defensa logró la absolución y la restitución de su padre al Consejo de Indias. A partir de este momento, Pedro de Castro comenzó a recibir de Felipe II diversos nombramientos de importancia; en 1560 obtuvo el de Arcediano de Saldaña. Se ordenó sacerdote en 1561, al año siguiente fue nombrado Visitador de la Capilla Real de Granada y en 1563 visitador del Hospital Real, también en Granada; en esta ciudad permaneció dos años más en los que fue designado visitador del Colegio Real. El Rey lo nombró en 1566

\footnotetext{
${ }^{29}$ Manuel Barrios Aguilera, “Introducción” a Místico Ramillete [1741] de Nicolás Heredia Barnuevo (Granada: Universidad de Granada, 1998).

${ }^{30}$ En el Capítulo V comentaré las ceremonias de la Abadía relacionadas con las honras fúnebres de la familia Vaca de Castro.

31 Aunque lo asevera Heredia Barnuevo, Místico Ramillete, p.8, es poco probable que Pedro de Castro coincidiera con Pedro Fabro, pero sí que pudo asistir al Colegio de la Compañía que Pedro Fabro había fundado en Valladolid durante su segunda visita a España en 1545, cuando estuvo en la Corte. Pierre Fabro (1506-1546) fue uno de los compañeros de San Ignacio de Loyola, fundador de la Compañía de Jesús. Estuvo en España en dos ocasiones (la primera sólo un mes, en 1541) y la segunda en 1545. Véase, Charles E. O'Neill, S.I., Joaquín María Domínguez (directores), Diccionario histórico de la Compañia de Jesús: biográfico-temático (Madrid: Universidad Pontificia de Comillas ; Roma Institutum Historicum, 2001), pp. 1369-1370.
} 
Oidor de la Chancillería en Valladolid. En 1570 regresó a Granada como Oidor de la Chancillería de la que se convertiría en Presidente y Visitador en 1578; de esta presidencia pasó a la de la Chancillería de Valladolid en 1583. El Rey intentó que aceptara diversos arzobispados entre 1586-87 sin ningún éxito (Tarragona, Calahorra y Burgos), hasta que finalmente Pedro de Castro consintió asumir el de Granada en 1589, tomando posesión de su cargo en 1590. Los descubrimientos del Sacromonte y su proyecto fundacional le llevaron a aceptar el arzobispado de Sevilla en 1610, archidiócesis más rica que la de Granada, en la que residió hasta su muerte acaecida en 1623.

Pedro de Castro gozó de un extraordinario prestigio en su época y fue uno de los principales colaboradores de Felipe II en su idea de estado católico. Su formación fue muy completa y le permitió convertirse en un personaje influyente y bien relacionado. En Salamanca trabó relaciones con sus condiscípulos y maestros; allí pudo conocer entre otros a San Juan de Ribera con quien mantuvo correspondencia. ${ }^{32}$ Las fundaciones pías de ambos (el Colegio del Corpus Christi en Valencia y la Abadía del Sacromonte) guardan ciertas similitudes entre sí que se señalarán más adelante. Su privilegiada posición le llevó a mantener contacto con Santa Teresa de Jesús y San Juan de la Cruz. ${ }^{33}$ Santo Toribio de Mogroviejo le consultó si debía o no aceptar el arzobispado de Lima, a lo que el prelado contestó afirmativamente. Su puesto como presidente de la Chancillería (primero de la de Valladolid y luego de la de Granada) le harían mantener un trato especial con Felipe II, quien seguía muy de cerca la burocracia de estos organismos. También conoció a uno de los preceptores de este monarca, el humanista y escritor Juan Calvete de Estrella, quién escribiría por encargo de los Vaca de Castro el poema épico-laudatorio Vaccaeis sobre las

\footnotetext{
${ }^{32}$ Ramón Robres Lluch, San Juan de Ribera (Barcelona: J. Flors, 1960) p. 46, p. 79. Otros estudios sobre Juan de Ribera son Pascual Boronat y Borrachina, El beato Juan de Ribera y el Real Colegio del Corpus christi, estudio histórico (Valencia: Impr. de F. Vives y Mora, 1904) y Manuel Cubí, Vida del beato Juan de Ribera (Barcelona: Herederos de la Viuda Pia 1912).

${ }^{33}$ De San Juan de la Cruz se cuenta una curiosa anécdota, que yendo a visitarlo el santo por mandato de su superior, Don Pedro le dijo que era más necesario orando que visitando a las autoridades
} 
hazañas de Cristóbal Vaca de Castro en el Perú, y otro poema más breve dedicado a Pedro de Castro. $^{34}$

$\mathrm{Su}$ altura e inquietudes intelectuales se ven reflejadas en su biblioteca, que era tan numerosa y rica como las más importantes del siglo XVI. En ella los títulos jurídicopolíticos eran los más numerosos, seguidos de cerca por los de humanidades y los de teología. En total la biblioteca estaba compuesta por unos 837 volúmenes, una cantidad nada despreciable para la época. ${ }^{35}$ Entre sus lecturas debemos resaltar las obras fundamentales de santo Tomás de Aquino y de los escolásticos españoles contemporáneos además de Erasmo que como se verá, tendrán bastante influencia en las características del seminario tridentino que estableció junto a la Abadía.

La importancia de los autores que se refirieron a Pedro de Castro nos ayuda a comprender la verdadera relevancia de este personaje. Entre ellos encontramos a Thomás Sánchez, Diego Valdés, Padre Pineda, Mauro Castella Ferrer, Sancho Dávila, Fray Juan de la Puente, Bernardo de Alderete, Francisco Torreblanco Villalpanda y Gonzalo Céspedes de Meneses, historiador de Felipe IV. ${ }^{36}$

Todo no fueron halagos para Pedro de Castro; quizás su espíritu de reformador severo le hizo granjearse enemistades. Así lo señaló Diego Ortíz de Zúñiga en sus Anales Eclesiásticos, donde narra que el arzobispo en la archidiócesis sevillana

\footnotetext{
${ }^{34}$ Sobre el contenido de estos poemas trataré en el Capítulo V, donde además incluiré las pertinentes citas bibliográficas.

${ }^{35}$ José Antonio Ollero Pina, "La carrera, los libros y la obsesión del arzobispo D. Pedro de Castro y Quiñones (1534-1623)", De libros y bibliotecas: homenaje a Rocio Caracuel (coord.) por Sonsoles Celestino Angulo, (Sevilla: Universidad de Sevilla, 1995), p. 273.

${ }^{36}$ Véase la nómina completa de autores en la Sinopsis cronológica de Heredia Barnuevo, en su edición de 1741. La Sinopsis es una de las partes de la obra de Diego Nicolás de Heredia Barnuevo, Mystico ramillete historico, chronologyco, panegyrico, texido de las tres fragantes flores del nobilissimo antiguo origen, exemplarissima vida, y meritissima fama posthuma del Ambrosio de Granada ... el Illmo. y V.Sr. Don Pedro de Castro, Vaca y Quiñones ... Arzobispo de Granada, y Sevilla, y Fundador Magnifico de la Insigne Iglesia Colegial del Sacro Monte Illipulitano / dalo a la luz publica el doct. D. Diego Nicolas de Heredia Barnuevo...(Granada : en la Imprenta Real, 1741), pp. 124-126. El Místico Ramillete volvió a editarse en 1863 (de esta edición la Universidad de Granada editó un facsímil en 1998, eliminando algunas partes de la obra original (entre ellas parte de esta Sinopsis cronológica) que resultaban demasiado prolijas y redundantes pero que sí hemos utilizado para este estudio y que citaré como Sinopsis Cronológica. Siempre que cite el Místico Ramillete haré referencia al facsímil de 1998.
} 
comenzando a mostrar su rígido zelo, quería reformar estilos que tenia el tiempo tan arraigados, que era muy dificil arrancarlos, y mas de violencia y juntos, de que se fueron originando pesados disgustos, santísima sin duda su intención, pero acres y rigurosos, como lo era su natural heredado de su padre, los medios que le concitaban odios implacables. ${ }^{37}$

Uno de estos detractores fue el Abad Gordillo, quien dijo del Arzobispo que se había casado con la diócesis de Sevilla por su gran dote, y que de ella había tomado 450.000 ducados para llevarlos al Sacromonte, quitándoselos a los pobres de Sevilla. ${ }^{38}$

La crítica más obvia que se hizo al Arzobispo es el retrato que figura en el episcopologio sevillano que se encuentra en la Catedral hispalense, donde aparece representado con una enorme nariz aguileña y corva en lo que más parece una caricatura que un retrato realista.

\subsection{Pedro de Castro reformador de Trento}

Pedro de Castro conoció los decretos del Concilio de Trento no sólo por lo que concernía a su cargo, sino también a través del Sínodo Provincial que el Arzobispo Pedro Guerrero convocó en Granada en 1565 y al que el propio Castro asistió como vocal. ${ }^{39}$ Guerrero fue uno de los representantes españoles en el Concilio de Trento designado por Felipe II y estuvo encargado de la comisión para el estudio de los cánones y doctrinas del sacrificio de la misa. Como el resto de los legados españoles se preocupó también por la labor del obispo en la iglesia de la Contrarreforma. ${ }^{40}$

\footnotetext{
${ }^{37}$ Diego Ortíz de Zúñiga y Antonio María Espinosa y Carzel, Anales eclesiásticos y seculares de la muy noble y muy leal ciudad de Sevilla, Tomo IV, (Madrid: Imprenta Real, 1796), p. 225.

${ }^{38}$ Véase Carlos Ros, Los arzobispos de Sevilla, luces y sombras en la sede hispalense (Granada: Anel, 1986), p.171.

${ }^{39}$ El arzobispo Pedro Guerrero organizó dos sínodos provinciales: el primero de 1565, al que acudió Castro, véase: Ignacio Pérez de Heredia y Valle, El Concilio Provincial de Granada en 1565. Edición crítica del malogrado concilio del arzobispo Guerrero, (Roma: Iglesia Nacional Española, 1990); y el segundo en 1572 del que se publicaron las resoluciones en forma de Constituciones. Véase Constituciones Synodales del Arçobispado de Granada hechas por el señor Don Pedro Guerrero Arçobispo de la sancta Yglesia de Granada, en el sancto Sínodo que su señoría Reverendissima celebro a quatorze dias del mes de Octubre del año M.D.L.XXII (Granada: Hugo de Mena 1573). Guerrero cumplió con estas convocatorias las disposiciones de Trento, y siguió la estela de otras diócesis como la de Toledo (1568), Cuenca (1571) y Sigüenza (1571).

${ }^{40}$ Juan López Martín, La Iglesia en Almería y sus obispos (Almería: Instituto de Estudios Almerienses, Caja Rural de Almería y Unicaja, 1999), pp. 235-271. Entre los libros de la biblioteca de Castro figura el Cathecismus ex decreto Concilii Tridentini ad parochos, un Catecismo para los párrocos fruto del Concilio de
} 
Las Actas Carolinas de Carlos Borromeo probablemente sirvieron de fuente de inspiración para avivar el espíritu reformista de Castro. Estas actas eran disposiciones que Carlos Borromeo había formulado para el gobierno de su diócesis en Milán, siguiendo los decretos conciliares. Pedro de Castro citó este documento en su informe "ad limina" a Roma en 1596, en el que pretendía conseguir apoyo papal para el control arzobispal sobre las confesiones del clero regular y sobre la comprobación de la vocación de las niñas que entraban a los conventos. ${ }^{41} \mathrm{Al}$ seguir los ideales de Borromeo, Castro continuó la corriente reformista iniciada por otros obispos y arzobispos españoles como Ribera, Aliaga, Zapata y Quiroga entre otros. ${ }^{42}$

¿En qué aspectos actuó Pedro de Castro como reformador siguiendo las recomendaciones del concilio de Trento ${ }^{43}$ En primer lugar en el énfasis que durante toda su vida dio a las obras pías. Siendo presidente de la Chancillería en Granada impulsó la creación de un hospital para pobres; como arzobispo creó una casa de recogidas para las mujeres de mala vida en las que además de alojamiento y comida se les daba instrucción y catequesis. Para Pedro de Castro, el encontrar los restos del primer obispo de Granada debió suponer la culminación a sus esfuerzos como reformador tridentino. Además, al ordenar la confección del episcopologio granadino que aparece en la Historia Eclesiástica (1611) de Justino Antolínez, ilustrado en un grabado de Francisco Heylan, se presenta como un perfecto seguidor de Carlos Borromeo, quien había señalado en su tercer concilio provincial de Milán que el deber de todo obispo era el de recopilar los nombres, carácter y acciones pastorales de sus predecesores. ${ }^{44}$

Trento; véase Ollero Pina, "La carrera, los libros y la obsesión del arzobispo D. Pedro de Castro y Quiñones (1534-1623)”, pp. 265-276.

${ }^{41}$ A. D. Wright, "The Borromean Ideal and the Spanish church", San Carlo Borromeo, Catholic Reform and Ecclesiastical Politics in the Second Half of the Sixteenth Century, John M. Headley y John B. Tomaro, eds. (Washington: The Folger Shakespeare Library, 1988), p. 193.

${ }^{42}$ El trabajo de Juan de Ribera fue admirado por Borromeo, e incluso se ha sugerido el posible intercambio entre ellos de decretos; véase Wright, “The Borromean Ideal”, p. 188.

${ }^{43}$ Algunos de los siguientes aspectos referidos a Pedro de Castro están reseñados también en Wright "The Borromean Ideal" p.198-199.

${ }^{44}$ Simon Ditchfield, "Martyrs on the Move", p. 287. 
Otro aspecto en el que Castro emuló a Borromeo es en la fundación de un centro de peregrinaje en el Sacromonte, pues el italiano se había interesado por las montañas y santuarios del norte de Italia. También la labor misional fue muy importante durante su mandato, que se materializó más estrictamente en la exigencia a los canónigos de la Abadía de salir por los pueblos a catequizar tanto a los fieles como al clero. En este contexto misional, don Pedro llegó más lejos por la importancia que le dio a la formación de los sacerdotes, que era bastante deficiente en la época. ${ }^{45}$ De aquí que impulsara la creación de un seminario tridentino anejo a la Abadía del que hablaremos más adelante, para la instrucción de eclesiásticos. Uno de los hitos que más se conoce de su labor reformadora es la cruzada que emprendió contra las comedias. ${ }^{46} \mathrm{Al}$ igual que Borromeo, Castro se mostró especialmente severo con el teatro, hasta tal punto que en 1598 consiguió que el Rey prohibiese las comedias por medio de una Real Provisión que se hizo efectiva en todos los lugares del reino. ${ }^{47}$

La labor de Castro en Granada comenzó con la visita de su diócesis, de la que hemos de destacar el interés que mostró por la Iglesia colegial del Salvador, para cuyo gobierno otorgó Constituciones, ${ }^{48}$ y la reparación y construcción de diversas iglesias que se habían deteriorado por la dejadez y la guerra de los moriscos. Durante su mandato realizó tres de estas visitas, empleando tres años en la primera, cuatro en la segunda y dos en la última. Heredia Barnuevo describe el modo en el que se llevaban a cabo estas inspecciones a los territorios del arzobispado, señalando que el modo en que el Arzobispo las hacía "fue

\footnotetext{
${ }^{45}$ Para un estudio sobre las misiones sacromontanas, véase Manuel Barrios Aguilera, "Las misiones en la sociedad posrepobladora: las del Sacromonte de Granada", La historia del Reino de Granada a debate, viejos y nuevos temas. Perspectivas de estudio, Manuel Barrios Aguilera y Ángel Galán Sánchez, eds. (Málaga: Diputación, 2004), pp. 551-594.

${ }^{46}$ Puede leerse la provisión dada en mayo de 1598 en: Heredia Barnuevo, "Sinopsis Cronológica”, p. 14, al margen.

${ }^{47}$ Véase Emilio Cotarelo y Mori, Bibliografia de las Controversias sobre la licitud del teatro en España, edición facsímil, estudio preliminar e índices de José Luís Suárez García (Granada: Universidad de Granada, 1997), pp. 577-579. Borromeo también se mostró severo en este aspecto; véase Wright, "The Borromean Ideal", p. 197.

${ }^{48}$ Heredia Barnuevo, "Sinopsis Cronológica", p. 12.
} 
muy nuevo, y practicado por pocos". ${ }^{49}$ Castro cuidaba de la decencia y estado de las iglesias, interesándose sobre el desarrollo del culto y las ceremonias; por último, indagaba sobre el estado y virtudes de los párrocos y beneficiados. Reformó la Universidad y sus Colegios (San Miguel y Santa Catalina) dándoles también nuevas Constituciones y poniendo al día memorias y capellanías. Cuidó de que en los conventos se observase la clausura y que las niñas que entraran no fueran de corta edad y que hubieran sido anteriormente examinadas por el Provisor para que pudiera constatarse de que eran conscientes de su elección. Prohibió que se dijese misa en las casas particulares o que se confesase en casa a aquellos que no estaban enfermos. También creó un colegio de niñas nobles en el que eran educadas hasta la edad de casarse. Además de todos estos aspectos tuvo cuidado de las cofradías, a las que reprendió por sus gastos excesivos. Ordenó también que las parroquias cuidaran de sus pobres, invitando él mismo diariamente a trece necesitados a comer a su palacio. Destacó como defensor de la inmunidad eclesiástica, lo que le fue reconocido por Clemente VIII y Paulo V en sus breves. Barrios Aguilera señala su papel como "colaborador en la implantación de un catolicismo de estado", guardando fidelidad tanto a Felipe II como a Felipe III. ${ }^{50}$

\subsection{La perfección en el desarrollo del culto}

La preocupación por el detalle en las ceremonias y la devoción pública fue una constante en muchos de los obispos españoles. ${ }^{51}$ Igualmente, la atención preferente al culto, una de las disposiciones fundamentales de Trento, fue uno de los intereses primordiales del arzobispo Castro. Su principal biógrafo, Heredia Barnuevo, resalta constantemente esta circunstancia y le atribuye frases como "en yendo a decir misa, dure lo que durare", haciendo referencia a la solemnidad de la ceremonia y su correspondencia con el tiempo

\footnotetext{
${ }^{49}$ Heredia Barnuevo, "Sinopsis Cronológica", p. 34.

${ }^{50}$ Barrios Aguilera, Los falsos cronicones, p. 28.

${ }^{51}$ Wright, "The Borromean Ideal”, p. 197.
} 
empleado. ${ }^{52}$ En otro momento de la biografía, se narra el viaje de Castro a la Corte, justo después de poner los cimientos de la Iglesia del Sacromonte, para informar al Rey de sus pretensiones. En la Real Capilla celebró por petición del Rey el oficio, bendición de palmas y procesión del Domingo de Ramos del año 1606. Además el Domingo de Pascua de Resurrección celebró de Pontifical a petición del Rey que admiraba su cuidado y celo durante la celebración litúrgica

\begin{abstract}
y lo hizo con tanta autoridad, circunspección y gravedad, que admirados los católicos monarcas decían después: No celebra este Prelado como hombre, sino como Ángel. Esto dijeron aquellas piadosas Majestades, al ver aquella devoción en sus acciones, que captaba las atenciones e imprimía respeto. ¡Qué dirían si vieran el constante fervor y espiritual aliento con que celebró estos Oficios en los 33 años que en Granada y Sevilla fue Prelado! $!^{53}$
\end{abstract}

Más adelante Heredia describe el desarrollo de estos oficios y señala cómo Castro no perdía la compostura ni un solo instante a pesar de la duración del oficio por el canto de la Pasión

Y en la Pasión (que la solemnidad del canto la hace aquel día más dilatada) estaba en su silla en pie, y sin arrimarse al asiento, ni a los brazos ni a otra parte, parecía de bronce en lo exterior, más en la verdad la ternura interior le hacía inmoble. ${ }^{54}$

En su época Castro fue comparado con Borromeo por Francisco Vidon, su secretario

Fue tan vigilantísimo Prelado en ella, que todo lo que ay escrito del santo Cardenal Borromeo, se puede, y debe dezir de él, porque en su

\footnotetext{
${ }^{52}$ Heredia Barnuevo, Místico Ramillete, p. 29. Barnuevo relata cómo Castro rezaba los maitines al mismo tiempo que el coro de la Catedral, y si acababa antes el coro, llamaba al Sochantre para advertirle de "la pausa y devoción que era debida a la Majestad de Dios, que siempre estaba presente a los Oficios Divinos, y el compás que había de llevar según el rito del Santo de aquel día”, véase p. 30.

${ }^{53}$ Heredia Barnuevo, Místico Ramillete, p.134.

${ }^{54}$ Heredia Barnuevo, Místico Ramillete, p.135.
} 
tiempo estuvo el gobierno de su Arzobispado en el más alto punto de justificación, y estimación, que hasta allí se vió. ${ }^{55}$

El detalle con el que legisló la fundación del Sacromonte y los documentos que para su gobierno ideó reflejan en parte esta obsesión por el decoro cultual. La perfección de la Consueta, aunque no es obra suya directamente, obedece no obstante a su idea del culto. ${ }^{56}$

\section{La Abadía, segundo Escorial: características de la fundación.}

A pesar de las insistencias de diversas órdenes religiosas para hacerse cargo de la fundación del Sacromonte, ${ }^{57}$ el arzobispo Pedro de Castro decidió (movido por una supuesta aparición de la Virgen) erigir él mismo un santuario en $1607 .{ }^{58}$ Es difícil establecer en la distancia temporal los avatares de la fundación y las razones últimas que movieron a don Pedro a crear la Abadía y el Colegio. Una hipótesis es que un reformador tal, sintiera la necesidad de crear un orden de vida perfecto expresado en la rutina diaria de los canónigos seglares de la Abadía. Quizás la creación de una nueva orden religiosa suponía una empresa demasiado costosa, tanto en tiempo como en dinero, y escapaba a las pretensiones del Arzobispo. Por otra parte su relación con las órdenes religiosas tuvo una doble naturaleza: de un lado estuvo tentado de retirarse a la vida regular e incluso fue fructífera su relación con los jesuitas; de otro lado siempre cuidó de que las órdenes religiosas no tuvieran demasiados privilegios y controlaba férreamente el establecimiento de nuevas fundaciones en las diócesis que gobernó. Así, en Sevilla impidió la fundación de

\footnotetext{
${ }^{55}$ Heredia Barnuevo, "Sinopsis Cronológica", p. 80.

${ }^{56}$ Trataré de la Consueta, que se encuentra transcrita en el Apéndice 1, con más detenimiento en los Capítulos II y III.

${ }^{57}$ Heredia Barnuevo, Mistico Ramillete, pp. 52, 112, 122-23.

${ }^{58}$ Heredia Barnuevo, Místico Ramillete, p. 124.
} 
un convento por el que la Reina había intercedido, y fue capaz de decirle que sus asuntos eran criar a los hijos y bordar y que le dejara a él el gobierno de la Iglesia. ${ }^{59}$

La necesidad de dar culto a las reliquias fue la excusa perfecta para la creación además de un seminario para la formación de sacerdotes al estilo de Trento. Si no hubiera dispuesto de una gran fortuna personal (no sólo por las rentas que Felipe II le había ido asignando, sino también por heredar el mayorazgo que su padre había fundado con el dinero de Indias), no habría sido posible esta obra, pues la diócesis granadina no era muy rica. En el planteamiento de la fundación debieron influir además otras circunstancias que serán tratadas a continuación.

Dentro del clima social de la época estaban de moda las fundaciones particulares de la nobleza. Las intenciones de los nobles que erigieron colegiatas irían sin duda relacionadas con el prestigio que dichas obras les reportaban, tanto ante el rey como ante sus "súbditos". Así tenemos, como ya se ha señalado en la introducción, las fundaciones del Duque de Lerma en Lerma, la del Duque de Olivares en Olivares, o la del Virrey de Sicilia en Zafra. En otros casos esta voluntad está más acorde con una actitud marcadamente religiosa, como en el caso de Juan de Ribera (sobrino o tal vez hijo del Virrey de Nápoles) y su fundación del Colegio del Corpus Christi en Valencia, o del mismo Don Pedro de Castro, quien había intentado desde sus tiempos como Presidente de la Chancillería el ayudar a las fundaciones pías como la casa de recogidas y el hospital del maristán. Su obra en la abadía no carece de este espíritu de reforma social, por cuanto una de sus finalidades principales es la formación del clero. La fundación más insigne de aquella época y que en cierta medida se tomó como referencia es la magna fundación del momento: El Escorial de Felipe II.

\subsection{Pedro de Castro y Felipe II}

Barrios Aguilera ya apuntó que entre Pedro de Castro y Felipe II existía una "sintonía personal y afinidad política que necesitan revisión en una monografía". ${ }^{60}$ A falta

\footnotetext{
${ }^{59}$ Fray Pedro de San Cecilio, Anales de la orden de descalzos de nuestra señora de la Merced Redempción de Captivos Christianos Año 1669, Barcelona, por Fray Pedro de san Cecilio, Coronista general y Definidor por la Provincia de Andaluzía, de dicha orden, natural de Granada (Barcelona, 1669), Vol. 2, p. 960.
} 
de un estudio más detallado, es fundamental aclarar algunos de los términos de esta relación para que queden patentes las similitudes entre las fundaciones del Monasterio de El Escorial y de la Abadía del Sacromonte.

Felipe II y Pedro de Castro debieron conocerse en la Corte cuando el joven Castro defendía a su padre en el pleito que contra él se seguía por apropiamiento indebido de erarios reales como gobernador en Perú. Prueba de la valía y competencia de Castro son todos los cargos que Felipe II le fue asignando; los biógrafos de Pedro de Castro señalan que "el Monarca de España le consultaba en sus dificultades más arduas". ${ }^{61}$ Entre 1556 y 1560 Don Pedro estuvo en la Corte con su padre, que había sido restituido por el Rey en su plaza del Consejo Real, y durante esos años le fueron encomendados diversos asuntos por dicho Consejo. Por entonces Felipe II ya tenía la idea de construir su monasterio-palacio, pues en 1558 había comenzado a buscar el emplazamiento adecuado. No sabemos hasta qué punto Castro estaría al tanto de todos los asuntos de Felipe II, pero sin duda pudo conocer de primera mano las intenciones del monarca. Sus nombramientos en Granada le mantendrían alejado temporalmente de la Corte de España, hasta que en 1567 regresó a Valladolid para visitar a su padre. Mientras tanto el Rey siguió favoreciéndole con nuevos nombramientos, como por ejemplo el de Oidor de la Chancillería de Valladolid en 1570, o en 1578, Presidente de la Real Chancillería de Granada por una Real Cédula fechada y firmada por el Rey en El Escorial. En 1583 volvió a Valladolid para aceptar el cargo de Presidente de esta Chancillería. Durante los siguientes cinco años el Rey le ofreció diversos obispados, y todos los rechazó hasta que en 1590 tomó posesión del arzobispado de Granada quizás por temor a perder su influencia en la Corte viendo la vejez del monarca.

Es difícil establecer una clara filiación entre las fundaciones de El Escorial y el Sacromonte, pero un examen detenido de las intenciones de los fundadores y la esencia subyacente en el ambiente revelan más de un punto en común. En muchos sentidos Castro trata de emular al Rey en su fundación sacromontana, aunque las diferencias también son patentes. Las similitudes desde el punto de vista ideológico son evidentes, aunque por supuesto varía el resultado final, que sin duda viene condicionado por diversos factores,

\footnotetext{
${ }^{60}$ Barrios Aguilera, "Estudio Preliminar", Heredia Barnuevo, Místico Ramillete, p. XII, nota 6.

${ }^{61}$ Heredia Barnuevo, “Sinopsis Cronológica”, p. 5.
} 
entre ellos el económico. Sin duda el Rey y el Arzobispo eran personas afines. Su relación fue principalmente administrativa, pero está claro que Felipe II encontró en Pedro de Castro un fiel seguidor y súbdito, aunque no siempre sumiso. Garrido Atienza ${ }^{62}$ señala que cuando en 1591 el Rey pidió a Granada un tributo de ocho millones para los gastos de guerra, el gobierno municipal acordó un arbitrio sobre las carnes que incluía las consumidas por el clero. El Fiscal Eclesiástico pidió la revocación del impuesto, amenazando con la excomunión de los caballeros veinticuatro "por aver contravenido a la libertad Ecclesiastica, decretos de los Romanos Pontífices, y a la bula in cena Domini". ${ }^{63}$ Castro, contraviniendo al Rey y al Consejo, que censuraron su conducta, excomulgó a todos los que habían participado en el cobro del gravamen hasta que los bienes sustraídos fueron devueltos. $^{64}$

Entre los puntos que el Rey y el Arzobispo tuvieron en común debe señalarse, entro otros, la familiaridad de ambos con los decretos del Concilio de Trento. Felipe II ordenó que se cumplieran en España el 12 de agosto de $1564^{65}$ y Castro asistió al Sínodo granadino que fue convocado por el arzobispo Guerrero en 1565 para difundir las medidas acordadas en el Concilio.

Es preciso analizar las intenciones y objetivos de ambos fundadores. En el caso de Felipe II, Noone ${ }^{66}$ señala que los objetivos de la fundación de El Escorial son crear: 1) un "exvoto" (en acción de gracias por la victoria y mantenimiento de sus tierras; San Lorenzo de la Victoria); 2) un enterramiento de la familia real; y 3) un centro de propagación y diseminación de la fe católica después de Trento. La relación de El Escorial con Trento, ya

\footnotetext{
${ }^{62}$ Miguel Garrido Atienza, Las fiestas de la Toma (Granada: Archivum, 1998), p. 34.

${ }^{63}$ Garrido Atienza, Las fiestas, p. 35.

${ }^{64}$ Garrido Atienza, Las fiestas, pp. 36-37, narra otro enfrentamiento del prelado con el Cabildo de la ciudad, por la existencia de un banco para las funciones solemnes en la Catedral. Igualmente, el gobierno de la ciudad pidió su intercesión al Rey, y Castro, obviando las disposiciones de Felipe II, tuvo que recibir otra misiva del Monarca para acceder parcialmente a sus requerimientos.

${ }^{65}$ Primitivo Tineo, "La recepción de Trento en España (1565). Disposiciones sobre la actividad episcopal" Anuario de Historia de la Iglesia, 5 (1996), p. 241.

${ }^{66}$ Michael Noone, Music and musicians in the Escorial Liturgy under the Habsburgs 1563-1700 (Nueva York: University of Rochester Press, 1998), p. 22.
} 
vista en la época, es señalada por Noone, ${ }^{67}$ pues en este espíritu es un relicario, un hospital y un centro austero. Analizando los objetivos que impulsaron la creación de la Abadía se observa que algunos de ellos son comunes a El Escorial. Sirvió para enterramiento del Arzobispo y su familia, [aunque no para sus descendientes ya que no los tenía] y también fue un centro de propagación de la fe, pues estaba dedicado a la formación del clero y a las misiones.

Felipe II eligió a los monjes jerónimos para hacerse cargo del Escorial, mientras que Castro optó por una comunidad de canónigos seculares. ${ }^{68}$ Muchas órdenes religiosas quisieron establecerse en la Abadía (entre ellas la de los Premotacenses) pero quizás a Castro se le habría escapado el control de la obra si hubiera habido una jerarquía que no necesitara contar con él para tomar decisiones. A diferencia del Rey, Castro no habría tenido casi ninguna prerrogativa sobre la jerarquía de una orden religiosa, mientras que como Arzobispo y Patrón podría controlar mejor a los clérigos seculares.

Otro punto coincidente entre las dos instituciones es la austeridad con la que están planteadas, tanto en sus maneras, como en sus edificios (salvando las distancias). Herrera en El Escorial es el creador de un nuevo estilo, de formas limpias donde la arquitectura se articula en volúmenes cúbicos prescindiendo de la decoración profusa. En el caso de la Abadía la elección del jesuita Pedro Sánchez para continuar y reformar el proyecto de Ambrosio de Vico es una decisión consciente del Arzobispo que iba buscando entrar en la vanguardia arquitectónica con un edificio más monumental de cinco patios, iglesia amplia con escalinata y nártex. ${ }^{69}$ A diferencia de El Escorial, el proyecto de la Abadía quedó inconcluso con un único patio. Ambos templos están dedicados al culto de santos mártires de la Iglesia española primitiva: en El Escorial el santo elegido como advocación del templo es San Lorenzo, mártir español de la primera época, hecho que puede relacionarse con el resurgir del culto a los santos primitivos auspiciado por Trento; y en la Abadía,

\footnotetext{
${ }^{67}$ Noone, Music and musicians, p. 24.

${ }^{68}$ Noone, Music and musicians, p. 42, aunque el Rey no elegía, tenía que ser informado de la elección del Prior.

${ }^{69}$ Para un estudio sobre este arquitecto véase: Alfonso Rodríguez de Ceballos, "El arquitecto hermano Pedro Sánchez", Archivo español de arte, 43/169 (1970), pp. 51-81.
} 
aunque el templo está dedicado a la Asunción de la Virgen, se custodian las reliquias de los mártires granadinos.

El papel que el Rey y el Arzobispo asumieron como reformadores de Trento les hizo velar de una manera especial por el desarrollo del culto. Aunque Noone relaciona a Felipe II con Borromeo, la labor de algunos de los arzobispos españoles como Pedro de Castro y Juan de Ribera resulta más cercana al italiano. ${ }^{70}$ Noone señala cómo Felipe II se preocupó mucho por el ceremonial, ${ }^{71}$ y en la Abadía el celo de Castro se materializó en la Consueta elaborada por los primeros canónigos que él designó. Noone ${ }^{72}$ comenta las numerosas obligaciones que Felipe II instituyó para la celebración de los funerales y aniversarios de la familia real, y Castro también estipuló para la Abadía diversos aniversarios por sus padres, abuelo y hermano. Felipe II estableció un rígido horario conventual de oraciones y obligaciones, ${ }^{73}$ y no menos estricto es el que debía seguirse en la Abadía. $^{74}$

La prohibición de la polifonía que hizo Felipe II en El Escorial (que no fue total como analiza Noone) quedó también reflejada en las Consituciones de la Abadía donde se aclara que los servicios serán en canto llano, porque no corresponde con la veneración de este templo utilizar instrumentos (excepto el órgano). En El Escorial esta prohibición derivó en la creación de un nuevo estilo sobrio (el de Tafaya y Villanueva, entre otros), en el que predominaba la homofonía, siguiendo la norma del Concilio que primaba la claridad en el texto sobre el artificio de la música; ${ }^{75}$ en la Abadía la prohibición de la polifonía quedó reflejada en una marcada austeridad que enfatizaba el canto llano exclusivamente, renunciando a la creación de una capilla musical propiamente dicha.

\footnotetext{
${ }^{70}$ Noone, Music and musicians, p. 187.

${ }^{71}$ Noone, Music and musicians, p. 45.

${ }^{72}$ Noone, Music and musicians, p. 41.

${ }^{73}$ Noone, Music and musicians, p. 43.

${ }^{74}$ Véase el Capítulo III, Tabla III.1 con el horario de un canónigo de la Abadía.

${ }^{75}$ Michael Noone, Politics of austerity and musical style in Philip II's Escorial, (Armidale, N.S.W.: University of New England, [1990?]).
} 


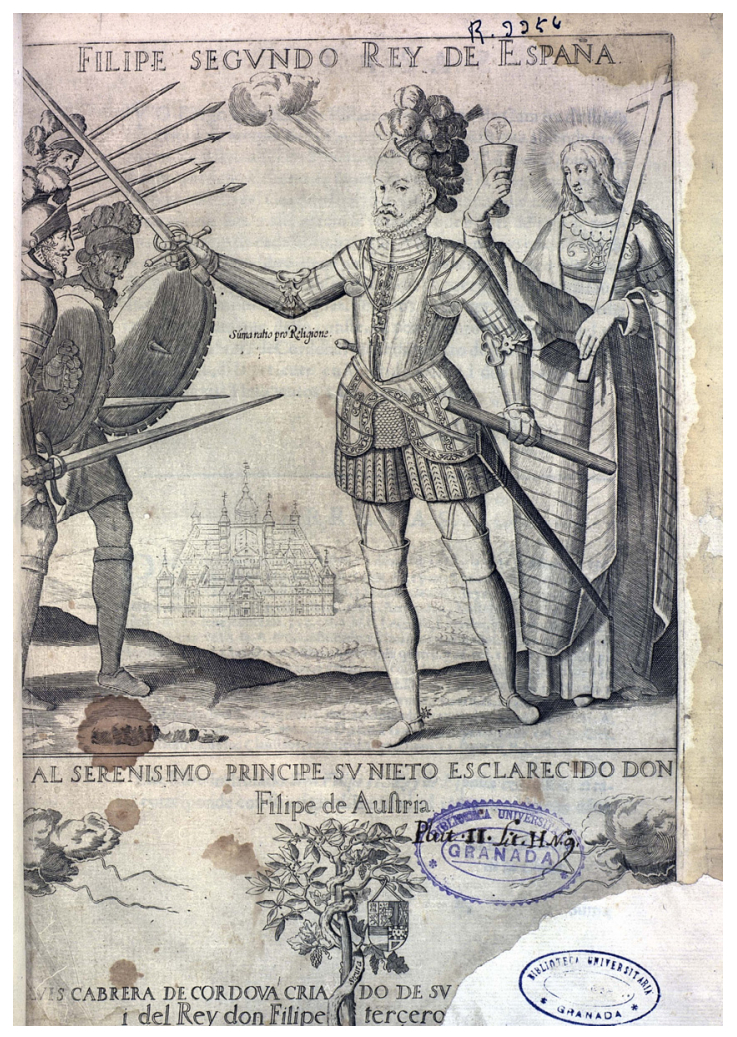

Figura I.1 Felipe II como guerrero de la fe, Pedro Perret (1619).

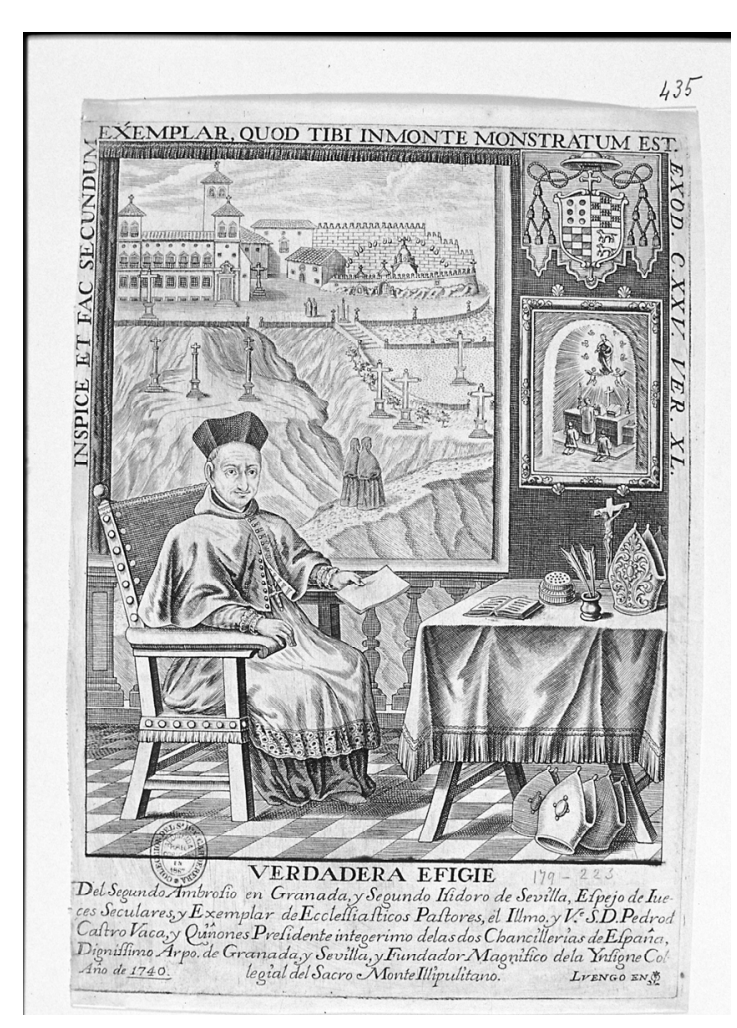

Figura I.2 Pedro de Castro como sabio de la Iglesia, Luengo (1740).

Las Figuras I.1 y I.2 muestran las imágenes de Felipe II y Pedro de Castro con sus respectivas fundaciones. Son grabados creados después de la muerte de ambos, para sus biografías oficiales, pero reflejan de manera significativa la influencia que aún ejercían sobre sus fundaciones. Felipe II, como guerrero defensor de la fe, y El Escorial al fondo, Pedro de Castro sentado en su silla arzobispal como "padre de la Iglesia", al lado de una ventana, a través de la cual se divisa su Abadía.

\subsection{La Abadía y el patronato real: las características fundacionales}

Pedro de Castro fundó la Iglesia Colegial del Sacromonte con cabildo secular de 20 canónigos, presidido por un Abad y estipuló la presencia de seis capellanes ad nutum amobiles (es decir, a voluntad y perpetuos) y varios ministros, entre los que se encontraban 
un sochantre para el gobierno del coro, un organista y otros ministros menores. Esta fundación, bajo la advocación de la Asunción de la Virgen María, pone de manifiesto la tendencia española contrarreformista de reafirmar el papel destacado de la Virgen en la Iglesia como mediadora entre el hombre y Dios, por contraposición a los reformistas que desdeñaron la figura de la Virgen. En este sentido hay que destacar el marcado carácter marianista de don Pedro de Castro, que como se tratará más adelante, fue fundamental en el impulso de la creencia de la Inmaculada Concepción en España. ${ }^{76}$ Además la Iglesia Colegial del Sacromonte obtuvo el título de "Insigne", sin duda por tener reliquias de mártires célebres (los varones apostólicos eran considerados los discípulos directos de Santiago) y por contar con un numeroso cabildo. La presencia de algunos canónigos del Sacromonte en Roma durante varios años, con motivo de la traducción de los Libros Plúmbeos, ayudó a la obtención de diversos privilegios directamente del Papa. ${ }^{77}$ Siguiendo los decretos del Concilio de Trento y con la intención de aumentar el número de los asistentes al coro, Pedro de Castro también fundó un seminario anejo a la iglesia del Sacromonte, cuyos colegiales tenían que cumplir obligaciones corales. Esta institución, denominada Colegio de San Dionisio Areopagita, obtuvo el reconocimiento de los grados académicos allí obtenidos por los estudiantes en todas las universidades del reino y se convirtió en un prestigioso centro de enseñanza del que trataré en el Capítulo IV.

Como se ha visto ya en la Introducción, todas las colegiatas granadinas anteriores a la fundación de la Abadía eran de patronato real. Esto quiere decir que fueron fundadas por reyes españoles que tenían ciertas obligaciones y derechos sobre estas instituciones: la corona aceptaba contribuir a todas las acciones religiosas, construcción y acomodación de iglesias y al mantenimiento del clero, y a cambio obtenía el derecho de presentación episcopal que el Papa garantizaría siempre que no existiera fraude. ${ }^{78}$ En España este patronato actuó en cierto sentido como configurador del Imperio, desde la Bula de Granada

\footnotetext{
${ }^{76}$ Véase el Capítulo V.

${ }^{77}$ Algunos canónigos recibieron en Roma el apoyo de los Cardenales Zapata y Borja y del Duque de Lerma, véase Zótico Royo Campos, Abades del Sacromonte (Granada: Anel, 1964), p. 34.

${ }^{78}$ W. Eugene Shields, The Rise and Fall of the Patronato Real (Chicago: Loyola University Press, 1963), Capítulo II.
} 
(Inocencio VIII en 1486 a los Reyes Católicos) con la que los Reyes asumían el derecho de presentación y la obligación de erigir iglesias para evangelizar en los territorios arrebatados a los musulmanes hasta las Bulas Alejandrinas que regulaban el patronato en las Indias, finalizando en el Universal por el que se ampliaban estos privilegios al resto de los territorios peninsulares. En el caso de la Abadía, al ser una fundación particular, obtuvo en 1624 de manos de Felipe IV la Cédula de Protección Real, que significaba que aunque el Rey no hubiera fundado dicha iglesia, habría de confirmar los cargos en ella elegidos a la vez que prestar auxilio a sus canónigos cuando éstos lo requirieran. A este socorro acudieron los canónigos con frecuencia para defender sus derechos. En 1652 se desató una pequeña polémica que sin duda debió causar malestar en el cabildo del Sacromonte, porque uno de sus canónigos envió un escrito al Rey por el que le atribuía los derechos de patronato sobre el Sacromonte, alegando que el terreno sobre el que estaba construido el complejo arquitectónico no era del arzobispo sino de la Corona. Esto motivó la publicación de una defensa por parte de otro canónigo, Blasio de Santaella, en la que sostenía que el verdadero fundador fue Castro, porque aunque no donó el suelo, éste no era de su Majestad al ser sagrado. ${ }^{79}$ Además, para ser patrón, según las bulas papales, había que dotar la iglesia, circunstancia que también hizo don Pedro. Castro sólo donó al Rey la protección y el honor de la aprobación de los nombramientos que efectuara el cabildo. Por bulas apostólicas reservó para sí, mientras vivió, el derecho de elegir y presentar todas las prebendas y demás ocupaciones (capellanes, colegiales y ministros), retuvo la libre y plena administración de los bienes de esa iglesia, para al final de sus días ceder ese derecho de elegir, nombrar y presentar en dichas prebendas al Abad y cabildo de dicha iglesia junto con la administración de los bienes. Por lo tanto, al Rey le correspondía aprobar el nombramiento que habrían hecho el Abad y el Cabildo.

\footnotetext{
${ }^{79}$ Véase MEMORIA Y DEFENSA JURIDICA POR LOS TITULOS DE FUNDADOR Y derecho de patronato de la Insigne Colegial Iglesia del Sacro Monte de Granada, devidos al Ilustrisimo y Reverendísimo señor Don Pedro de Castro y Quiñones, Arzobispo de Sevilla \& Contra la memoria que el maestro D. Alonso Ximenez Baltodano, Canonigo de dicha Iglesia, ofrece a el Real Consejo de la Cámara. Por el doctor d.Blasio Peynado de S.Ella, Canonigo de dicha S. Iglesia del Sacro Monte, y Catedrático de Prima de Teología de sus escuelas. En Granada, en la Imprenta Real, en casa de Baltasar de Bolívar, en la calle de Abenamar. Año de 1652.
} 
En otra ocasión los canónigos recurrieron a la intercesión del monarca para que revocara el Decreto de Inocencio XI de 1682 por el que se declaraban heréticos los libros plúmbeos. $^{80}$ La Corona intervino en diversos momentos, en especial debido a las desamortizaciones y la reforma de los estudios en el siglo XIX. ${ }^{81}$

La proximidad del cabildo del Sacromonte con la Corte fue una constante a través de los siglos, ya fuera por los canónigos o por los ex-colegiales. No en vano muchos canónigos y abades promocionaron a arzobispados en España y en las Indias (véase Tabla I.1), y algunos colegiales llegaron a ministros y miembros de la Corte. En la época a la que atañe este estudio, el Sacromonte fue visitado por Felipe IV y Felipe V, y después también por Alfonso XIII y las Infantas doña Isabel y Doña Paz de Borbón.

En resumen, podemos clasificar la Iglesia Colegial del Sacromonte como secular, ya que los clérigos de su cabildo no pertenecen a una orden religiosa, depende de la jurisdicción del obispo (no es exenta como la de Alcalá la Real), de patronato particular, aunque con protección regia, insigne (por guardar reliquias y tener numeroso cabildo) y magistral (por tener que ser al menos dos de sus canónigos doctores en teología).

Tabla I.1: Abades del Sacromonte. Fuente: Zótico Royo, Abades del Sacromonte (Granada: Prieto, 1963). Elaboración: Mercedes Castillo

\begin{tabular}{|c|c|c|}
\hline ABAD & AÑOS & \begin{tabular}{l|l|} 
CARGOS & OTRAS OBSERVACIONES \\
\end{tabular} \\
\hline Justino Antolínez de Burgos & $1609-1617$ & $\begin{array}{l}\text { Fue el segundo fundador de la Abadía. Obispo de Tortosa y mano } \\
\text { derecha del fundador Pedro de Castro. Autor de la Historia Eclesiástica } \\
\text { de Granada (1611) }\end{array}$ \\
\hline Pedro de Ávila y Herrera & $1617-1651$ & $\begin{array}{l}\text { Estuvo en Roma seis meses y con el apoyo del Duque de Lerma y el } \\
\text { Cardenal Borja consiguió diversos privilegios del Papa para el } \\
\text { Sacromonte. Autor de la Consueta. }\end{array}$ \\
\hline Rodrigo Cruzado Caballero & $1651-1657$ & 1649 estuvo en Roma. \\
\hline Bartolomé de Torres & $1657-1662$ & $\begin{array}{l}\text { Permaneció diez años en Roma. Fue nombrado por Felipe IV teólogo } \\
\text { para defender el dogma de la Inmaculada Concepción ante Urbano VIII. }\end{array}$ \\
\hline José de Escalante & $1662-1684$ & $\begin{array}{l}\text { Prohibió toda clase de juegos y diversiones, visitas a los cármenes o a } \\
\text { Granada sin su licencia. Rogativas por la guerra contra Portugal y } \\
\text { solemnes honras fúnebres por la muerte de Felipe IV. }\end{array}$ \\
\hline Juan de Jerez y Oñate & $1684-1685$ & Había sido canónigo con anterioridad. \\
\hline
\end{tabular}

\footnotetext{
${ }^{80}$ Royo Campos, Abades del Sacromonte, p. 80.

${ }^{81}$ Sobre las disposiciones relativas a impuestos y desamortizaciones véase la Introducción de este estudio. Sobre los decretos autorizando las reformas de los estudios, véase Zótico Royo Campos, El Insigne Colegio del Sacromonte y la Universidad de Granada (Granada: Editorial y librería Prieto, 1951) pp. 14, 20, 58-62.
} 


\begin{tabular}{|c|c|c|}
\hline Baltasar de la Peña y Avilés & $1685-1704$ & $\begin{array}{l}\text { Durante su mandato se aprobó el nuevo rezo a San Cecilio. Obispo de } \\
\text { Ávila. }\end{array}$ \\
\hline Tomás José de Montes & $1704-1715$ & $\begin{array}{l}\text { Desterrado por el Rey, Clemente XI lo nombró en una prebenda para la } \\
\text { Iglesia de San Juan de Letrán. Regresó a España como obispo de } \\
\text { Cartagena y Murcia. }\end{array}$ \\
\hline Baltasar Collado y Guerrero & $1715-1735$ & $\begin{array}{l}\text { Crea una clase de Canto Llano. Durante su mandato se extiende el rezo } \\
\text { de San Cecilio a todas las Iglesias de España. }\end{array}$ \\
\hline Hipólito Barbán de Castro & $1735-1743$ & $\begin{array}{l}\text { En } 1739 \text { pasó a la Corte a defender la hacienda del Sacromonte. Fue } \\
\text { nombrado por el rey Capellán Mayor de las Baronesas de Madrid. En } \\
1755 \text { Abad de la Iglesia Colegial de Lorca. }\end{array}$ \\
\hline Gaspar Salcedo y Quijano & $1743-1760$ & $\begin{array}{l}\text { Estudió en el Sacromonte y fue maestro de pajes en Pamplona y } \\
\text { arcipreste de Ibargoiti. Canónigo colegiata de Ugíjar, canónigo del } \\
\text { Sacromonte y Abad. En su mandato se coloca el órgano en la Iglesia. }\end{array}$ \\
\hline $\begin{array}{l}\text { Luís Francisco de Viana y } \\
\text { Bustos }\end{array}$ & $1761-1762$ & $\begin{array}{l}\text { Académico de la Real Academia de la Historia. Obtiene de Benedicto } \\
\text { XIV el jubileo para el día de San Cecilio. }\end{array}$ \\
\hline $\begin{array}{l}\text { Martín Vázquez Figueroa y } \\
\text { Peralta }\end{array}$ & $1762-1776$ & $\begin{array}{l}\text { Inquisidor general (puede leer libros prohibidos y permitir a los } \\
\text { capitulares que los lean). Renunció al cargo de Abad y murió allí doce } \\
\text { años después. }\end{array}$ \\
\hline Antonio López Chinchilla & 1776 & Murió antes de tomar posesión del cargo. \\
\hline Miguel Álvarez Cortés & $1777-1793$ & Nombrado en 1792 Obispo de Cartagena de Indias. \\
\hline Cayetano Marquez & $1793-1807$ & $\begin{array}{l}\text { Celebra el ascenso de un antiguo canónigo al Obispado de Buenos } \\
\text { Aires, de un ex-colegial a la diócesis de la Concepción de Chile, y de } \\
\text { otro a Secretario de Estado de Carlos III. }\end{array}$ \\
\hline Manuel Cueto y Ramírez & $1807-1829$ & $\begin{array}{l}\text { Renunció a la sede de Mérida de Yucatán. Obtiene la confirmación de } \\
\text { los privilegios de la Abadía y obtiene Real Orden por la que se declaran } \\
\text { exentos los bienes del Sacromonte. Reforma la Praxis de Estudios. Le } \\
\text { toca sufrir la invasión francesa. }\end{array}$ \\
\hline Cristóbal Muñoz de los Ríos & $1829-1835$ & $\begin{array}{l}\text { Había sido canónigo desde } 1815, \text { y con anterioridad colegial y capellán } \\
\text { del Sacromonte. }\end{array}$ \\
\hline Joaquín Venegas y Cabrera & $1836-1865$ & $\begin{array}{l}\text { Periodo muy inestable: 1) por las sucesivas desamortizaciones de las que } \\
\text { la Abadía se libró en parte, gracias al ex-colegial José } \mathrm{M}^{\mathrm{a}} \text { Velluti, oficial } \\
\text { mayor del Ministerio de Hacienda, 2) por el intento de supresión de la } \\
\text { colegiata. }\end{array}$ \\
\hline Ramón Antonio Bastante & 1865 & $\begin{array}{l}\text { Tan sólo pudo desempeñar su cargo un mes, debido a su repentina } \\
\text { muerte. }\end{array}$ \\
\hline Francisco Rico y Guzart & $1865-1871$ & $\begin{array}{l}\text { Reforma los estudios del Colegio de San Dionisio Areopagita. Solicitó y } \\
\text { obtuvo de la Santa Sede el traje coral de verano. }\end{array}$ \\
\hline José de Ramos López & $1885-1901$ & $\begin{array}{l}\text { Predicó en } 1862 \text { en la Capilla Real de Isabel II, quien mandó se } \\
\text { imprimiese el sermón a sus expensas. Académico de la Real Academia } \\
\text { de la Historia. León XII nombra a la Colegiata Magistral. Consiguió } \\
\text { nuevo traje coral, título de capellanes de honor de S.M. y la franquicia } \\
\text { postal. Órgano nuevo construido por la casa Roquers. Órgano para la } \\
\text { capilla. }\end{array}$ \\
\hline $\begin{array}{l}\text { Cristóbal González } \\
\text { Fernández }\end{array}$ & $1902-1912$ & Se enriqueció la biblioteca. En 1904 visitó la Abadía Alfonso XIII. \\
\hline $\begin{array}{l}\text { Francisco Sánchez y } \\
\text { Sánchez }\end{array}$ & $1912-1937$ & $\begin{array}{l}\text { Se enriqueció la biblioteca, iluminación eléctrica de la iglesia. Se } \\
\text { inaugura el museo. Celebra el tercer centenario del fallecimiento de don } \\
\text { Pedro de Castro. }\end{array}$ \\
\hline Jesús Mérida Pérez & $1939-1943$ & $\begin{array}{l}\text { Medalla de oro concedida por Pío X en Roma. Innumerables cargos: } \\
\text { desde Visitador de los Seminarios de España hasta Procurador en } \\
\text { Cortes. Siendo Abad, fue nombrado obispo de Astorga. }\end{array}$ \\
\hline José Gutiérrez Ramos & $1949-1953$ & $\begin{array}{l}\text { Las capellanías nutuales las convierte en colativas. Se instala una } \\
\text { comunidad de religiosas del Instituto de la Madre Rafols. }\end{array}$ \\
\hline Zótico Royo Campos & $1954-1971$ & Escribió diversas obras sobre la Historia del Sacromonte. \\
\hline Juan Sánchez Ocaña & $1998-$ & $\begin{array}{l}\text { Actual Abad del Sacromonte nombrado después de un periodo de } \\
\text { decadencia en el que no había Abad sino presidente del cabildo y/o } \\
\text { coordinador. Bajo su mandato se ha realizado el Plan Director para la } \\
\text { revitalización del Sacromonte. }\end{array}$ \\
\hline
\end{tabular}





\section{CAPÍTULO II \\ LA ORGANIZACIÓN MUSICAL DE LA ABADÍA I: FUENTES DOCUMENTALES PARA SU ESTUDIO}

En este capítulo analizaré las Constituciones de la Abadía del Sacromonte instituidas por Pedro de Castro en lo que respecta a su organización musical y las compararé con otras constituciones de su época, como las que Juan de Ribera otorgó para la Capilla del Corpus Christi de Valencia o las que el mismo Pedro de Castro ordenó para la Colegial del Salvador de Granada; también estudiaré la estructura y fuentes para la redacción de la Consueta de 1632 comparándola con otros ceremoniales.

\section{Las Constituciones del Sacromonte (1616 y 1647) y la música}

La concreción de la idea fundacional de Pedro de Castro se plasmó en las Constituciones. De este documento, que fue finalmente impreso en latín en 1647, se conservan diversas versiones anteriores manuscritas, tanto en el Archivo de la Abadía del Sacromonte como en la Biblioteca Nacional. ${ }^{1}$ De todas ellas nos detendremos en las de 1616 (Ms. 6437 de la Biblioteca Nacional) y en las impresas de $1647^{2}$ para estudiar cómo se define el papel de la música en la institución.

Las Constituciones que an (sic) de guardar el Abbad y cano/nigos de la Iglesia Collegial que fundamos en el Sacro/ Monte. Dadas año de 1616, constan de 68 puntos. El coro, según estas Constituciones, debía estar servido por 20 canónigos, unos 14 colegiales, 6 capellanes, de los que uno hacía de sochantre, y un organista que era elegido por el Abad y los canónigos. Exceptuando la mención a este último, no se nombra a ningún otro músico en estas Constituciones. Relacionados con el coro describen las Constituciones dos figuras: la de Maestro de Ceremonias y la de Capellán.

\footnotetext{
${ }^{1}$ Véase Carmen Calero Palacios, La abadía del Sacromonte de Granada. Catáologo de manuscritos (Granada: Universidad, 1999), p. 316, en la que enumera: Constituciones que deben guardar el abad, canónigos, capellanes y collegiales de nuestra Iglesia Collegial de la Asumpción de Nuestra Señora del Sacro Monte Illipulitano de Granada. 1618, mayo, 28. Sevilla; Constituciones del Sacromonte. 1620, noviembre, 8. Sacromonte; Constituciones. 1623, agosto, 6. Roma; Constituciones. 1625, enero, 18. En la Biblioteca Nacional, el Ms. 6437 contiene: Primeras Constituciones? s.f., fol. 139r; Constituciones (1613), fol. 145r; Constituciones (1616), fol. 167r; Constituciones (1623), fol. 186r.

${ }^{2}$ Gnomon seu gubernandi norma Abbati, et canonicis Sacri Montis Illipulitani praescripta ab Yllustriss ${ }^{\circ}$ et Rss ${ }^{o}$ Domino D. Petro de Castro et Quiñones (...). Granatae: ex Tipographia Regia: apud Balthassarem de Bolibar et Franciscum Sanchez, 1647. A partir de ahora [Constituciones, 1647].
} 
Del primero se señala que era un cargo elegido anualmente por el cabildo, que podía recaer tanto en un canónigo como en un capellán y todos debían obedecerlo en lo que mandara respecto a las ceremonias. Seis es el número de capellanes instituido en las Constituciones, que serán ad nutum amobiles, ${ }^{3}$ elegidos entre los colegiales o de fuera, según estimara el cabildo. Debían servir en el coro como los canónigos, sentándose después de ellos, en las sillas bajas y acudir "al façistor todas las vezes que se aya de cantar en el". ¿QQuiere decir esto que se hacía polifonía? Uno de los capellanes debía además desempeñar el cargo de sochantre, presidiendo el coro, para lo cual los canónigos según las Constituciones debían tener en cuenta para su elección "que sea sujeto capaz de desempeñar este oficio". 5

Las obligaciones de los canónigos respecto a la asistencia al coro estaban reguladas y eran muy similares a lo que estipularía posteriormente la Consueta (1632). Una síntesis del horario de los canónigos puede verse en la Tabla II.1. Para ganar las distribuciones corales tenían que asistir al menos a cuatro puntos, también ganaban si asistían a memorias y aniversarios o si poseían alguna capellanía fundada en la iglesia. A la lección de canto estaban obligados a asistir no sólo los canónigos, sino también los capellanes y colegiales

21. Abrá (sic) Lección de Canto todos los días que no oviere Vísperas cantadas ni rasura ni fuere asueto de los Collegiales, tendrá el Abad, o Presidente cuidado que acudan todos los canónigos, Capellanes, y Collegiales, excepto los que pareçiere estar legítimamente impedidos. La ora y orden será a disposición del Abad o Presidente y en particular hará ejercicio el semanero de los que oviere de cantar aquella semana, y los demás que ovieren de cantar algo en el choro, tendrán cuydado de averlo pasado y se les hará ejercicio dello.

Con el tiempo, la lección de canto sólo quedará para los colegiales. A este respecto es interesante que Castro viese la necesidad de que los canónigos, de cierta edad y formación, acudieran a la clase de canto.

\footnotetext{
${ }^{3}$ Capellanes perpetuos a voluntad.

${ }^{4}$ Constituciones (1616), fol. 177, $\$ 40$.

${ }^{5}$ Constituciones (1616), fol. $177^{\mathrm{v}}, \S 40$.
} 
Tabla II.1. Horario y obligaciones de coro de un canónigo de la Abadía del Sacromonte. Fuente: Constituciones de 1616, BN Ms. 6437.

\begin{tabular}{|c|c|c|c|c|}
\hline & Abril-Septiembre & \multicolumn{2}{|c|}{ Octubre-Principios de Cuaresma } & Cuaresma-Abril \\
\hline $\begin{array}{l}\text { Oración } \\
\text { mental }\end{array}$ & 5 a.m.-6 a.m. & \multicolumn{2}{|c|}{6 a.m.-7 a.m. } & 5.30 a.m.-6.30 a.m. \\
\hline Prima & \multicolumn{4}{|l|}{ En tono } \\
\hline $\begin{array}{l}\text { Después de } \\
\text { Prima }\end{array}$ & \multicolumn{4}{|c|}{$\begin{array}{l}\text { Misa rezada del día (Misa de prima) por el ánima de Cristóbal Vaca de Castro y por } \\
\text { las de nuestros difuntos }\end{array}$} \\
\hline Tercia & \multicolumn{4}{|c|}{ En tono } \\
\hline \multirow[t]{3}{*}{ Misa Mayor } & \multicolumn{2}{|l|}{ Resto del año } & \multicolumn{2}{|c|}{$1^{\circ}$ Octubre hasta Pascua de Resurrección } \\
\hline & \multicolumn{2}{|l|}{9 a.m. } & \multicolumn{2}{|l|}{10 a.m. } \\
\hline & \multicolumn{4}{|l|}{ En Canto Llano } \\
\hline $\begin{array}{l}\text { Responso } \\
\text { rezado }\end{array}$ & \multicolumn{4}{|l|}{ Después de la misa } \\
\hline \multirow[t]{2}{*}{ Comida } & \multicolumn{2}{|c|}{$\begin{array}{l}\text { Pascua de Resurrección hasta San } \\
\text { Miguel }\end{array}$} & \multicolumn{2}{|c|}{$1^{\circ}$ Octubre hasta Pascua de Resurrección } \\
\hline & \multicolumn{2}{|c|}{10 a.m. } & \multicolumn{2}{|l|}{11 a.m. } \\
\hline Sexta & \multicolumn{4}{|l|}{ En tono } \\
\hline Nona & \multicolumn{4}{|l|}{ En tono } \\
\hline \multirow{3}{*}{ Visperas } & \multicolumn{2}{|l|}{ Resto del año } & \multicolumn{2}{|c|}{$\begin{array}{l}1^{\mathrm{o}} \text { Octubre hasta } 1^{\mathrm{a}} \text { Domínica de } \\
\text { Cuaresma }\end{array}$} \\
\hline & \multicolumn{2}{|l|}{3 p.m. } & \multicolumn{2}{|c|}{2.30 p.m. } \\
\hline & \multicolumn{4}{|c|}{ En canto llano en las fiestas, y en tono el resto de los días } \\
\hline $\begin{array}{l}\text { Lección de } \\
\text { Canto }\end{array}$ & \multicolumn{4}{|c|}{ Después de Vísperas, siempre que las Vísperas no sean cantadas } \\
\hline \multirow[t]{2}{*}{ Cena } & \multicolumn{2}{|c|}{$\begin{array}{l}\text { Pascua de Resurrección hasta San } \\
\text { Miguel }\end{array}$} & \multicolumn{2}{|c|}{$1^{\circ}$ Octubre hasta Pascua de Resurrección } \\
\hline & \multicolumn{2}{|l|}{7 p.m. } & \multicolumn{2}{|l|}{9 p.m. } \\
\hline Completas & \multicolumn{4}{|l|}{ En tono } \\
\hline Maitines & \multicolumn{4}{|c|}{$\begin{array}{l}\text { Noche de la Natividad, Miércoles, Jueves, y Viernes Santo, Mañana de } \\
\text { Resurrección Cantados* }\end{array}$} \\
\hline
\end{tabular}

§Excepto los lunes y miércoles desde Pascua de Resurrección hasta finales de septiembre que habrá Conferencias Morales, el resto del año estas conferencias serán una hora antes de cenar.

${ }^{*}$ En los Maitines y Vísperas y Misas Mayores solemnes debe haber órgano. Además de todas estas obligaciones, todos los viernes del año que no sean fiesta, tendrán una hora de Conferencia Espiritual.

Las Constituciones de 1647 no varían mucho de las anteriores en lo que se refiere a la música. Constan de 31 títulos que están divididos a su vez en varios puntos. Son algo más extensas y detalladas que las de 1616, pero siguen estipulando casi el mismo número de miembros para la Abadía: 20 canónigos, 6 capellanes, 18 colegiales (cuatro más que en 1616) y menciona, además del sochantre y el organista, a otros ministros como el sacristán y el pertiguero, todos ellos con la obligación de residir en el Sacromonte. El sochantre no tiene por qué ser un capellán, ni si quiera debe ser 
eclesiástico, al igual que el organista. Si fueran de esta naturaleza, ganarían las distribuciones de la oración mental y las conferencias morales. Con respecto a la lección de canto, en estas Constituciones sólo son de obligada asistencia para los canónigos de aprobación y los capellanes y colegiales que no estén versados en el canto. Lo que si es más novedoso respecto a las Constituciones de 1616 es que dedica un pequeño apartado al Sochantre en el que se especifican sus obligaciones.

Erit etiam qui Succentoris officium exercere, quique cantus Chori Altares, et processionum, ac alias in dicta Collegiata Ecclesia modulationem, seu moderamen, et regimen habere, et in cantu lecciones, et exercitum ordinare, ut in titulo exercitorium expresum est, facere debeat, et stipendium sive salarium quod ei assignabitur percipiet, et si ex gremio capellanorum fuerit, ab obbligationibus aliorum Capellanorum a Capitulo, prout illi videbitur, et cum illo Conventum fuerit, relevari possit. ${ }^{6}$

En ningún apartado se prohíbe expresamente la polifonía, pero sí que se especifica que el servicio coral se desarrollará en canto llano al igual que lo dispuesto en las de $1616^{7}$

\section{Dos fundaciones tridentinas pero diferentes: la Abadía del Sacromonte y la Capilla del Corpus Christi de Valencia.}

Pedro de Castro y Juan de Ribera ${ }^{8}$ han sido comparados con frecuencia como reformadores tridentinos; ambos mantuvieron correspondencia. ${ }^{9}$ Al igual que Pedro de Castro, Ribera quiso plasmar su labor reformadora en la institución del Colegio y

\footnotetext{
${ }^{6}$ [Constituciones, 1647], Título XXII, V, fol. 51r.

${ }^{7}$ En este aspecto las Constituciones de 1647 son una traducción de las de 1616. [Constituciones, 1647], fol. 24: "Singulis veró diebus Missa major de officio diei in cantu plano a Kalendis Octobris usque ad diem Dominicam Resurrectionis decima hora, \& pro totius annis residuo hora nona". Constituciones (1616), fol. 168 $8^{\mathrm{r}}$ : "Dirán todos los días missa mayor del día en canto llano, desde primero de Octubre hasta Pascua de Resurrección a las diez y el resto del año a las nueve."

${ }^{8}$ Juan de Ribera (Sevilla 1532-Valencia 1611), nacido en Sevilla en una familia noble, fue obispo de Badajoz, arzobispo y virrey de Valencia y Patriarca de Antioquia. Fue uno de los defensores de la expulsión de los moriscos y fue nombrado beato en 1796 y santificado en 1960. Para una bibliografía sobre la vida de este Prelado; véase Capítulo II, nota 10 de este estudio.

${ }^{9}$ Algunas cartas de Juan de Ribera al arzobispo Castro se encuentran en el Archivo del Sacromonte; véase Zótico Royo Campos, El Insigne Colegio del Sacromonte y la Universidad de Granada (Granada: Editorial Prieto, 1951), p. 49.
} 
Capilla del Corpus Christi de Valencia. ${ }^{10}$ Zótico Royo Campos afirma que el Sacromonte y el Corpus Christi son "similares"; 11 sin embargo, aunque los dos fundadores citan en sus Constituciones al Concilio de Trento y su deseo de formar a jóvenes para llevar a cabo el servicio al culto divino, el resultado es sensiblemente diferente. Para empezar las tipologías de las instituciones son disímiles: el Corpus Christi nació como capilla particular aneja a un colegio-seminario, mientras que el Sacromonte era, como ya hemos señalado, una iglesia colegial. La diferencia que más llama la atención y que nos interesa para este estudio es la desigual consideración que la música recibe de los fundadores. Ribera afirma lo siguiente en sus Constituciones:

Que se digan y canten [los oficios] con toda atención, y de manera que se conozca que los que los cantan consideran que están delante de Dios nuestro Señor, hablando con la Suprema e infinita Magestad suya: y que asimismo muevan a los oyentes a la devoción y veneración de este Señor, y de su santo Templo ${ }^{12}$

Al contrario que Ribera, Castro no hace especial referencia a la utilidad de la música ni como manera de llegar a Dios, ni como medio para conmover al oyente. Ribera introduce comentarios muy específicos sobre la interpretación de la música, como el que recoge la necesidad de hacer la mediación en los versos al igual que hacen los monjes jerónimos, quizás en un intento por emular la orden que Felipe II había escogido para su fundación:

Que en todas las horas se haga mediación conocida en la metad de los versos, asi de los que se cantaren a canto llano, como de los que se cantares a canto de organo, imitando en esto a los Padres Religiosos del bienaventurado S. Hieronymo; y que los dias de fiesta sea mayor $(\ldots) .^{13}$

\footnotetext{
${ }^{10}$ Sobre Juan de Ribera y su fundación; véase Juan Jiménez, Vida del Beato Juan de Ribera (Valencia: Joseph de Orga, 1798); Manuel Pascual Boronat y Barrachina, El B. Juan de Ribera y el R. Colegio de Corpus Christi: Estudio histórico (Valencia: Impr. de F. Vives y Mora,1904); Anthony Wright, "San Juan de Ribera and Saint Charles Borromeo. The Counter-Reformation in Spain and Italy Compared", Miscellanea historiae pontificiae, viii, ed. Bernard Vogler (Bruselas y Lovaina: Universidad de Lovaina, 1987), pp. 221-8; Ramón Robres Lluch, San Juan de Ribera: Patriarca de Antioquía, Arzobispo, Virrey y Capitán General de Valencia (1532-1611): humanismo y eclosión mística (Valencia: Edicep, 2002).

${ }^{11}$ Royo Campos, El Insigne Colegio del Sacromonte, pp. 48-51.

${ }^{12}$ Constituciones de la Capilla del Colegio y Seminario de Corpus Christi (Valencia: Iuan Bautista Marçal, 1625), p. 5.

${ }^{13}$ Constituciones de la Capilla del Colegio y Seminario, p. 61.
} 
De otra parte Ribera estipula en su fundación la presencia de ministriles; en el Capítulo XXI, De los ministriles, se regula "que la Capilla tenga siempre asalariados un juego de ministriles, que sean en número de 6 o por lo menos $5 "{ }^{14}$ De ellos el bajón debe de tañer además todos los días que se diga el oficio en canto de órgano. ${ }^{15}$ Comparando la plantilla al servicio del culto divino de ambas instituciones puede verse que desde un primer momento Ribera tiene pensada la estructura típica para disfrutar de una capilla musical, mientras que Castro está interesado en cubrir sólo las necesidades para un coro de canto llano, pues no nombra ni a maestro de capilla ni a ministriles. La Tabla II.2 presenta las diferentes plantillas para el culto estipuladas en las dos fundaciones, si bien para completar la plantilla del Sacromonte no sólo he tenido en cuenta lo que dicen las Constituciones sino lo que determina la Consueta de 1632.

Un punto esencial en las disposiciones de Ribera es la convivencia de estilos (canto llano, fabordón, canto de órgano) que era habitual en la época pero que Castro reduce a uno, el canto llano. Quizás por los motivos que hemos señalado antes: su relación con El Escorial y una posible interpretación de Trento más estricta y radical, acorde con su personalidad austera.

\footnotetext{
${ }^{14}$ Constituciones de la Capilla del Colegio y Seminario, p. 27.

${ }^{15}$ Constituciones de la Capilla..., p. 28.
} 
Tabla II.2. Comparación de plantillas para el culto divino entre la Capilla del Corpus Christi y la Abadía del Sacromonte. Fuentes: Constituciones de

la Capilla del Colegio Seminario de Corpus Christi (Valencia, 1625);

Constituciones de la Abadía (Granada, 1647) y Consueta (1632) de la Abadía.

\begin{tabular}{|c|c|}
\hline Capilla del Corpus Christi & Abadía del Sacromonte \\
\hline Vicario de Coro & Sochantre \\
\hline Sacristán (de los colegiales sacerdotes) & Sacristán \\
\hline 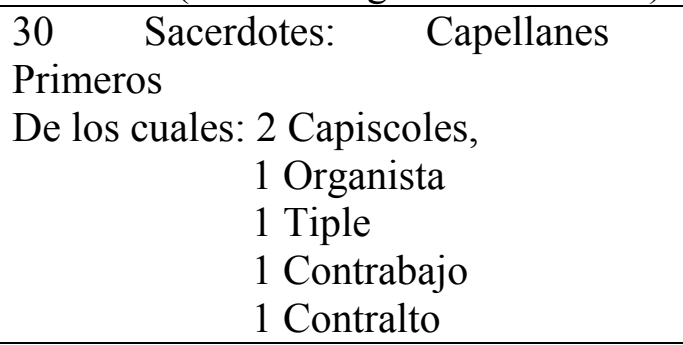 & 20 Canónigos \\
\hline 15 Capellanes Segundos & 6 Capellanes \\
\hline 1 Ayudante de Sacristán & \multirow{7}{*}{$\begin{array}{l}16 \text { Colegiales } \\
\text { (1 Custos Sacristía) } \\
\text { (2 Versicularios) } \\
\text { (2 Ceroferarios } \\
\text { (4-6 Cetreros) } \\
\text { (1 Cruciferario) } \\
(2 \text { Turiferarios) } \\
(1 \text { Intonario) }\end{array}$} \\
\hline 2 Mozos de Coro & \\
\hline 6 Infantes & \\
\hline 1 Asistente & \\
\hline 8 Acólitos & \\
\hline 4 Monazillos (sic) & \\
\hline 2 Incensadores & \\
\hline 1 Portero & 1 Pertiguero/1 Portero Coro \\
\hline 1 Campanero & 1 Campanero \\
\hline 1 Barrendero & 1 Caniculario \\
\hline 1 Maestro de Capilla & $\mathrm{NO}$ \\
\hline 1 Organista & 1 Organista \\
\hline $\begin{array}{l}\text { 6-5 Ministriles ( } 2 \text { tiples, } 2 \\
\text { contrabajos, } 1 \text { tenor y } 1 \text { contralto) }\end{array}$ & $\mathrm{NO}$ \\
\hline
\end{tabular}

Sorprende sin embargo que en la Abadía se permitieran las chanzonetas (aunque no en las Constituciones, sino en la Consueta, que ya no es obra directa de Castro) mientras que Ribera dedica un extenso párrafo a la condena de este género:

Item queremos y es nuestra voluntad, que en esta Capilla no se canten tonos profanos, ni se mezclen las canciones humanas con las divinas. Y assi de ninguna manera permitimos que se digan chançonetas: porque aliende que no se percibe lo que se dize, de ordinario es la composición poco grave, y las mas veces parecida a tonos profanos y deshonestos. Como nuestra intención sea que se pretenda alabar a Nuestro Señor con música modesta y devota y 
grave, por ser esto lo que agrada a su divina Magestad, y causa mayor devoción en las gentes. ${ }^{16}$

Las razones de la reprobación van en consonancia con las disposiciones trentinas, que criticaban la falta de inteligibilidad del texto. Además, su relación con lo profano nos habla de lo popularizante que debía ser este género en aquel momento, circunstancia que no nos extraña si acudimos a los textos de chançonetas que se conservan de la época en las que se incluyen personajes como labradores, esclavos y africanos con sus peculiaridades lingüísticas. En esta línea de repulsa a lo profano, Ribera comenta que los cantores deben tener una actitud de humildad en el servicio a Dios. ${ }^{17}$ Respecto a la prohibición de las representaciones en la Iglesia, Ribera dice: "Item prohibimos totalmente hazerle dança o representación alguna en esta Iglesia, aunque sea en la festividad del Santísimo Sacramento". Castro, aunque no lo prohibió expresamente en las Constituciones, luchó fervientemente contra las comedias y las representaciones; ${ }^{18}$ sin embargo, en muchas ocasiones se ejecutaron danzas en ceremonias que él ofició. ${ }^{19}$

\section{Las Constituciones de la Colegiata del Salvador de Granada:}

Pedro de Castro, siendo Arzobispo de Granada, dotó de Constituciones a la Iglesia Colegial del Salvador que, aunque fundada en 1501, carecía de ellas. En 1589, el cabildo de la colegiata del Salvador, había decidido adoptar las Consituciones de su homónima colegial de Sevilla, lo que suscitó una querella del fiscal eclesiástico de Granada porque eran contrarias a la erección de la Catedral de Granada. ${ }^{20}$ Finalmente, tras pedir una copia de la Consueta y Constituciones de la colegial de Baeza que sirvieron de base, se redactaron las Constituciones del Salvador, que fueron mandadas

\footnotetext{
${ }^{16}$ Constituciones Corpus Christi, p. 65.

${ }^{17}$ Constituciones Corpus Christi, p. 71.

${ }^{18}$ Cotarello y Mori o cualquier otra referencia. Habría que tener en cuenta lo que decía Pilar Ramos de que las mujeres se travestían en el teatro....

${ }^{19}$ Véase en el capítulo V la descripción de la misa celebrada en el Sacromonte cuando se finalizó el Sínodo que aprobó la autenticidad de las reliquias.

${ }^{20}$ Juan Ruiz, La Colegiata del Savador, pp. 42-43.
} 
cumplir por Pedro de Castro en $1596 .{ }^{21}$ Las Constituciones de la Colegial del Salvador nos interesan para contextualizar el entorno más cercano de la Abadía por varios motivos: 1) fueron dadas por Pedro de Castro, y por tanto el fundador del Sacromonte las conocía y pudo haberse inspirado en ellas para el diseño de las Constituciones de la Abadía $^{22}$; y 2) geográficamente la colegiata del Salvador es la más cercana al Sacromonte, pues se encunetra escasamente a $1 \mathrm{~km}$ de distancia. Ambas Constituciones externamente guardan pocos puntos en común, quizá porque las dos instituciones eran muy diferentes tanto por su tamaño como por sus funciones y objetivos. La colegiata del Salvador contaba con 1 Abad, 8 canónigos, 4 capellanes, 2 acólitos y 2 sacristanes, mientras que la Abadía tenía además del Abad, 20 canónigos, 6 capellanes, 2 sacristanes y otros ministros menores. El Salvador había sido una de las primeras fundaciones de los Reyes Católicos en Granada, pero era simplemente una iglesia con cabildo, mientras que el Sacromonte tenía anejo un colegio-seminario y servía de santuario para los libros plúmbeos y reliquias. Otra circunstancia que debió influir en la configuración de las Constituciones es que en el caso de la colegial del Salvador se trataba de dar carta de naturaleza a una realidad ya existente, mientras que las Constituciones abaciales fueron un documento que regulaba la creación de una fundación ex novo.

\footnotetext{
${ }^{21}$ Juan Ruiz, La Colegiata del Savador, p. 44: "Estas Constituciones de Baeza habían sido redactadas el 24 de octubre de 1572, con numerosas connotaciones al Concilio de Trento que acababa de finalizar en aquella fecha".

${ }^{22}$ Fueron redactadas por Justino Antolínez de Burgos, mano derecha del Arzobispo, quién luego llegó a ser primer Abad del Sacromonte.
} 
Tabla II.3. Índices de las Constituciones de las Iglesias Colegiales del Salvador (1596) y del Sacromonte (1647).

\begin{tabular}{|c|c|}
\hline Constituciones Abadía (1647) & Constituciones Colegiata del Salvador (1590) \\
\hline 1. De Fundatione Ecclesiae. & $\begin{array}{l}\text { 1. Del número de prebendados que hay en la iglesia } \\
\text { colegial de San Salvador y del lugar que cada uno tiene } \\
\text { en el coro y cabildo y en otras partes capitulares. }\end{array}$ \\
\hline 2. De Reliquiis, Libris, et Laminis Sacri Montis. & 2. De los días y horas en que se ha de hacer cabildo. \\
\hline 3. De approbatione. & $\begin{array}{l}\text { 3. Del oficio de las horas canónicas y de la referencia } \\
\text { con que se han de decir y del hábito honesto del coro. }\end{array}$ \\
\hline $\begin{array}{l}\text { 4. De Electione, et provissione Abbatis, } \\
\text { Canonicorum, Capellanorum, Collegialium, atque } \\
\text { aliorum Ministrorum dictae Ecclesiae. }\end{array}$ & 4. De las misas principales que ha de decir el abad. \\
\hline 5. De Residentia. & $\begin{array}{l}\text { 5. Del orden de repartir las semanas de prima y misa } \\
\text { mayor. }\end{array}$ \\
\hline 6. De Partitur infirmorum. & 6. Como se ganan y se reparten las capas. \\
\hline 7. De Exercitiis spiritualibus, et divinis officiis. & 7. Como se parten y ganan los maitines y misas. \\
\hline 8. De Distributionibus. & $\begin{array}{l}\text { 8. De las distribuciones que se ganan en los maitines y } \\
\text { las misas. }\end{array}$ \\
\hline 9. De abbate. & $\begin{array}{l}\text { 9. De los responsos de los lunes. Como se ganan y } \\
\text { parten. }\end{array}$ \\
\hline 10 .De Officiis Ecclesiae. & 10. De los derechos de los entierros y otros advenientes. \\
\hline 11. De Praesidente. & $\begin{array}{l}\text { 11. Del orden que ha de haber en pedir licencia para } \\
\text { salir del coro. }\end{array}$ \\
\hline 12. De Assistentibus. & 12. Del recle y cuando se ha de tomar. \\
\hline $\begin{array}{l}\text { 13. De Administratoribus, et administratione rei } \\
\text { familiaris. }\end{array}$ & $\begin{array}{l}\text { 13. De los que estando ausentes pueden ganar las } \\
\text { distribuciones cotidianas. }\end{array}$ \\
\hline 14. De Computatoribus. & $\begin{array}{l}\text { 14. De los entierros a los que sale el cabildo de esta } \\
\text { iglesia. }\end{array}$ \\
\hline 15. De Clavigeris, et Arca Depositi. & $\begin{array}{l}\text { 15. Del orden que se ha de guardar en el enterramiento } \\
\text { del abad y canónigos y otros ministros de la iglesia. }\end{array}$ \\
\hline 16. De Thesaurario, et Sacrista. & $\begin{array}{l}\text { 16. De la elección del puntador y de las cosas que tiene } \\
\text { obligación de hacer. }\end{array}$ \\
\hline 17. De Secretario Capituli. & $\begin{array}{l}\text { 17. De la dignidad del abad y de las cosas que por razón } \\
\text { de ella están a su cargo. }\end{array}$ \\
\hline 18. De Collectore, et Punctatore Collectoriae. & 18. Del oficio de cura. \\
\hline 19. De Domus Provisore, et Ministro. & 19. Del oficio de sochantre. \\
\hline 20. De Janitore, et Clausura. & 20. De los capellanes. \\
\hline 21. De Magistro Caeremoniarum, et Caeremonijs. & 21. Del oficio de sacristán. \\
\hline 22. De Capellanis, et sub Cantore. & 22. Del pertiguero y organista. \\
\hline 23. De Collegialibus. & 23. Del oficio de secretario del cabildo. \\
\hline 24. De Capitulo. & $\begin{array}{l}\text { 24. Del gobierno de los bienes de la iglesia y del } \\
\text { cabildo. }\end{array}$ \\
\hline 25. De Regimine Domus. & 25. Del oficio de contadores de la renta. \\
\hline 26. De Archivio. & 26. De los visitadores y arrendadores de la hacienda. \\
\hline 27. De Privilegiis. & 27. Del mayordomo de la renta del cabildo. \\
\hline $\begin{array}{l}\text { 28. De Vita, atque honestate Personarum Sacri } \\
\text { Montis. }\end{array}$ & 28. De los que dicen palabras injuriosas \\
\hline \multicolumn{2}{|l|}{ 29. De Paenis. } \\
\hline \multicolumn{2}{|l|}{ 30. De Curatione Infirmorum, et funeralibus. } \\
\hline 31. De Visitatione Sacri Montis. & \\
\hline 32. Titulus Finalis, De Juramento. & \\
\hline
\end{tabular}


Es curiosa la falta de intitucionalización del cargo de maestro de capilla en las Constituciones de ambas fundaciones, si bien es verdad que en el Sacromonte no existió este cargo, el Salvador sí que tuvo una capilla musical y por lo tanto resulta aún más llamativa esta ausencia en el texto.

Aspectos que se deducen del análisis de los índices y del contenido ulterior de las Constituciones ponen de manifiesto diversas cuestiones, como la mayor jerarquización y grado de detalle sacromontano. Por ejemplo, el punto 26 establece la necesidad de un Archivo en el que debían guardarse los expedientes personales, los libros de fábrica y cuentas del Sacromonte. Las costumbres de los habitantes del Sacromonte quedan reguladas por el punto 28 , y las penas que de su no cumplimiento se derivaran en el punto 29. El 30 es particularmente curioso porque habla de la “curación de los enfermos", es decir, de cuándo podían acudir a Granada para recibir asistencia médica, y los funerales que correspondían según la condición de cada uno. Del número de prebendas en ambas instituciones podemos deducir que el Sacromonte era más importante: 20 canónigos en la Abadía frente a 8 en el Salvador, 6 capellanes en lugar de 4, sin contar los 16 colegiales que también servían el culto en la Abadía. Sin embargo, el Salvador contó con una capilla de música bastante estable, que, si bien no estaba legislada en las Constituciones, fue parte viva de la institución hasta la fecha de su desamortización, mientras que el Sacromonte, como veremos, sólo ocasionalmente contrató a músicos.

\section{La redacción de la Consueta y su estructura}

Las Consuetas o Ceremoniales son documentos generados por las catedrales y otros centros eclesiásticos en los que se recogen reglas y normas por las que se rigen sus miembros y las ceremonias que se han de desarrollar en ellos. No son un documento cerrado, sino que van ampliándose con el paso del tiempo ante la aparición de nuevas necesidades susceptibles de ser reguladas. Con frecuencia estos libros se imprimían, pues así se facilitaba a todos los miembros de la Institución el acceso al documento, aunque muchas consuetas quedaban manuscritas como en el caso de la Consueta de la Abadía.

La Abadía del Sacromonte, como institución de la archidiócesis de Granada, tuvo una estrecha relación con la Catedral, especialmente porque el Arzobispo había 
sido su fundador. Por esto no es de extrañar que en un principio la Abadía se rigiese por la Consueta de la Catedral ${ }^{23}$

(...) se le pidió copia de la Consueta o libro de las Ceremonias por donde se rige y se usó del en esta Iglesia del Sacro Monte por algunos años celebrándose los oficios divinos conforme al estilo de la Iglesia catedral aunque mejoradas muchas ceremonias en el decoro puntualidad y perfeccion con que se hazian. ${ }^{24}$

Pero tras algunos años de estudio, el Cabildo observó que dicha Consueta no estaba ajustada al Ceremonial Romano y decidió la elaboración de una propia, en la que se solventasen los errores. Hay que considerar que el documento catedralicio que se tuvo por modelo debía ser el primer ceremonial de la Catedral (que había sido erigida en 1492), y por tanto era anterior a las disposiciones de Trento y a la reforma del Ceremonial Romano. Otra de las razones por las que se decidió hacer una nueva consueta es que la configuración espacial de ambas iglesias es diferente, por lo que muchas de las prácticas y movimientos no se adecuaban a la estructura de la Abadía.

La Consueta del Sacromonte que he consultado para este estudio es la más antigua de las que se conservan de la Abadía y probablemente sea la original, pues está rubricada en el anverso y reverso de casi todas sus hojas, ${ }^{25}$ por el Abad Pedro de Ávila y los dos canónigos, Francisco Barahona y Agustín Manrique, encargados de su redacción; este ejemplar no viene recogido en el Catálogo de manuscritos del Sacromonte, ${ }^{26}$ véanse las Figuras II.1 y II.2.

\footnotetext{
23 Para un estudio de la Consueta de la Catedral de Granada, véase José López-Calo, La música en la Catedral de Granada en el siglo XVI (Granada: Fundación Rodríguez Acosta, 1963); Pilar Ramos López, La Música en la Catedral de Granada en la primera mitad del siglo XVII: Diego de Pontac (Granada, Diputación, 1994); y Rafael Marín López, El Cabildo de la Catedral de Granada en el siglo XV (Granada, Universidad, 1998).

${ }^{24}$ Consueta, Prólogo.

${ }^{25}$ Hasta el Libro III, cap. 12, fol. $312^{\mathrm{r}}$.

${ }^{26} \mathrm{M}^{\mathrm{a}}$ del Carmen Calero Palacios, La Abadía del Sacromonte de Granada. Catálogo de Manuscritos (Granada: Universidad, 1999). La autora recoge una copia de la Consueta del s. XVIII, pero no da el asiento de la que aquí nos ocupa. He podido consultarla gracias a Don Vicente Redondo, Archivero y Bibliotecario de la Abadía: CONSUETA / DE esta Insigne Iglesia del / Sacromonte Illipulitano (1632). Véase la transcripción completa de la Consueta en el Apéndice 1 de este estudio.
} 
Figura II.1. Consueta del Sacromonte (1621-1632) fol. 311 $1^{\mathrm{v}}$, con las rúbricas del Abad Pedro de Ávila y los Canónigos Agustín Manrique y Francisco de Barahona.

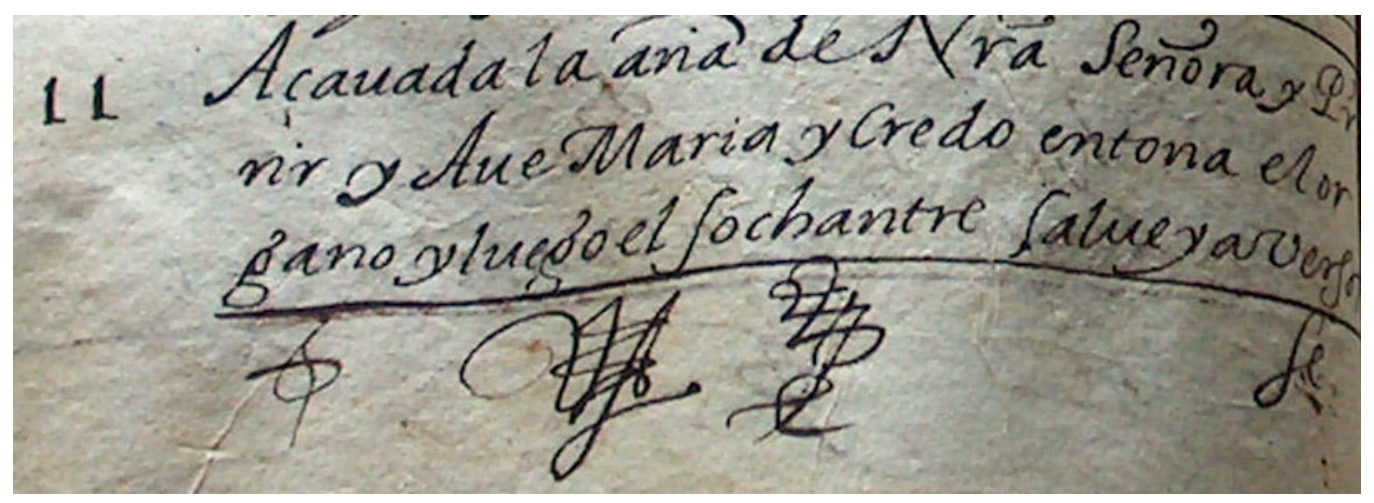

Figura II.2. Consueta del Sacromonte (1621-1632) fol. $312^{r}$, con firmas y rúbricas de los canónigos de haberla revisado.

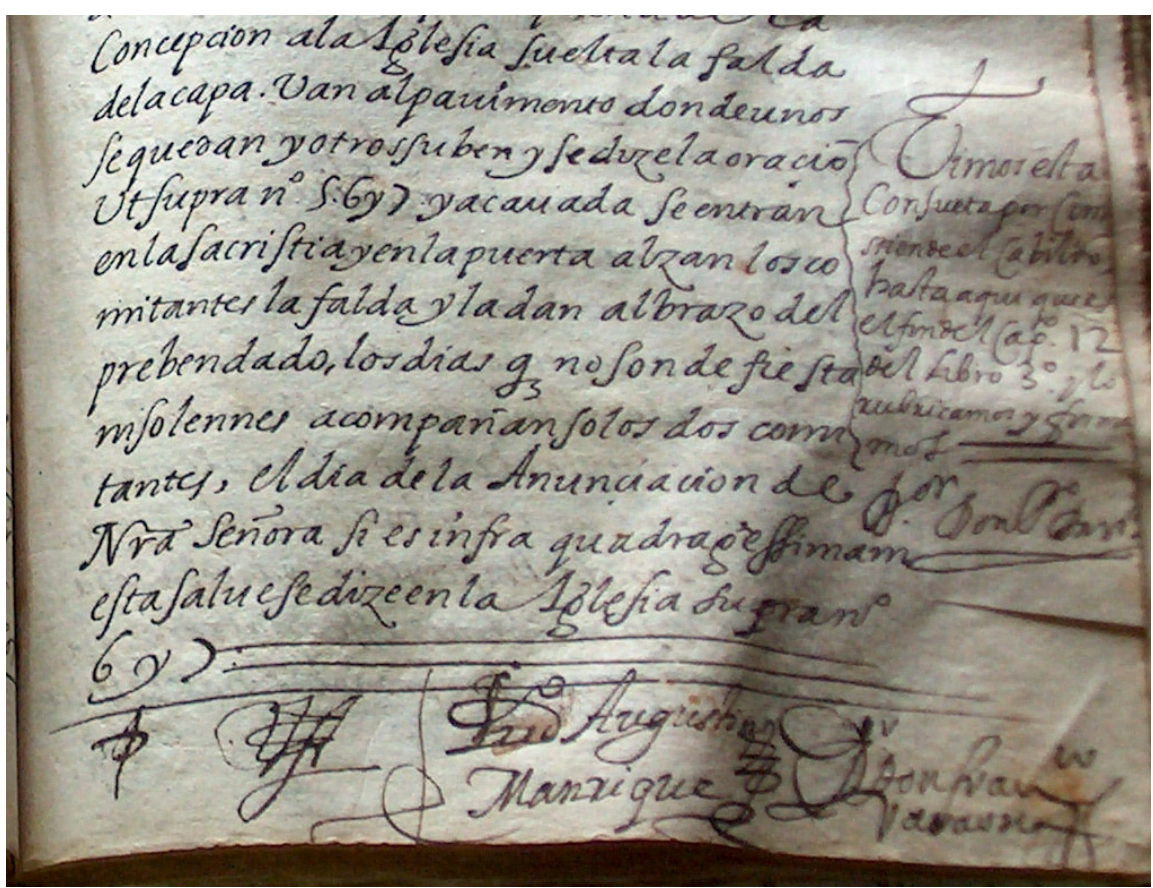


El Prólogo de la Consueta señala la historia de la redacción y sus autores. En 1621 comenzó la redacción de la Consueta el licenciado D. Bartolomé de Torres, ${ }^{27}$ y en 1625 retomaron el trabajo el licenciado D. Francisco de Barahona $^{28}$ y el Dr. D. Agustín Manrique. $^{29}$ Barahona iba anotando el desarrollo de las ceremonias y Agustín Manrique, junto con el Abad Pedro de Ávila, revisaban el trabajo, prestando atención a que fuera conforme al Ceremonial Romano y a las opiniones de los Maestros de Ceremonias del Sacromonte. Los dos comisarios, junto con el Abad, rubricaban lo que había pasado la aprobación. Esta etapa hizo que se concluyera hasta el capítulo 12 del libro III. Entre otras autoridades eclesiásticas que admiraron la perfección de la Consueta se encuentra el Cardenal Spínola que visitó la Abadía en $1627 .^{30}$ Tras leer lo que había sido redactado hasta ese momento, ordenó que se terminara en el plazo de seis meses, que por diversos avatares se convirtieron en seis años. No es de extrañar la prolijidad de la Consueta a la hora de describir las ceremonias, pues se elaboró durante un dilatado periodo de tiempo. Fue aprobada finalmente por el Cabildo del Sacromonte el 18 de Noviembre de 1633. Se mandó hacer dos copias; la original debía guardarse en el Archivo y es la Consueta rubricada que he utilizado para este estudio.

La Consueta se divide en cuatro libros: Libro I: Del Choro, y cosas que en el y en la Iglesia se an de observar; Libro II: De los Offiçios de los Prebendados y ministros de esta Sancta Iglesia; Libro III: Del Modo con que se celebran los divinos oficios; y Libro IIII: De las ceremonias particulares en los officios del tiempo. De las 500 hojas

\footnotetext{
${ }^{27}$ Bartolomé de Torres (Begel, Cádiz, 1585-Granada,1662) fue canónigo del Sacromonte desde los 25 años de edad y Abad entre 1657 y 1662. Felipe IV lo designó como teólogo ante Urbano VIII para defender el dogma de la Inmaculada Concepción y los descubrimientos del Sacromonte, por lo que permaneció 10 años en Roma. Fundó diversos aniversarios en el Sacromonte, entre los que destacan: la fiesta del Dulce Nombre de Jesús, Aparición del Arcángel San Miguel, San Bartolomé, la Nona de la Ascensión y la Vigilia y reponso para el día de su muerte cantado no en el coro sino en la iglesia; véase Royo Campos, Abades del Sacromonte, pp. 58-62.

${ }^{28}$ Francisco Barahona y Miranda († Génova, 1643) Teólogo que estuvo apunto de ser nombrado Cardenal por el Papa pero murió antes, véase Royo Campos, Abades, p. 48. Escribió un libro titulado "Sentencias de filósofos" que aparece listado en Bartolomé José Gallardo, Ensayo de una Biblioteca Española de libros raros y curiosos (Madrid: Rivadeneyra, 1866), vol. II, p. 13.

${ }^{29}$ Agustín Manrique murió a los 82 años en loor de santidad; véase Royo Campos, Abades, p. 20.

${ }^{30}$ El cardenal Agustín Spínola nació en Génova en 1597 y estudió en Alcalá de Henares y Salamanca. Fue nombrado arzobispo de Granada en 1627, y allí permaneció hasta 1630, año en el que fue destinado a Santiago de Compostela. Hijo del comandante Ambrosio Spínola, que logró la rendición de Breda, a él le dedicó Diego de Pontac su Missa Cardinalis Spinola; véase Ramos López, La Música en la Catedral de Granada, p. 201.
} 
en cuartilla manuscritas que contiene el ceremonial podemos decir que casi la mitad están relacionadas directa o indirectamente con la música, y es un documento esencial para conocer cómo se desarrollaba a diario la actividad musical en la Abadía. La vigencia de la Consueta y el grado de consecución de sus rúbricas son difíciles de establecer. En cuanto a la vigencia sabemos que se copió al menos dos veces más, una en el siglo $\mathrm{XVIII}^{31}$ y otra a principios del siglo $\mathrm{XX},{ }^{32}$ por lo que es de suponer que las consignas generales se mantendrían hasta entonces. Respecto al cumplimiento de todo lo estipulado en ella sólo puede aducirse que de un lado había muchos observadores que vigilaban su cumplimiento (maestro de ceremonias, celadores, corrector del coro, presidente, etc.) y de otro, que las ceremonias se trataban y estudiaban mensualmente en los cabildos y en lecciones impartidas a los colegiales y a los huéspedes de aprobación.

\subsection{Fuentes para la redacción de la Consueta}

Los redactores de la Consueta del Sacromonte contaban con la ayuda de las determinaciones tomadas en los cabildos de "ceremonias y loables costumbres" que tenían lugar mensualmente, normalmente el primer cabildo del mes, y además debían tener en cuenta otros documentos que servían para el gobierno de la archidiócesis. Una fuente directa es el Ceremonial Romano al que se alude en el Prólogo, que se publicó al menos en dos ocasiones después del Concilio de Trento: Caeremoniis Cardinalium et Episcoporum in eorum diæecesibus (Roma, 1564) y el Caeremoniale Episcoporum (1600), aunque debió ser el segundo el que alcanzó mayor difusión. ${ }^{33}$ La Consueta de la Catedral de Granada, que se siguió al principio también sirvió como modelo, hasta cierto punto, en la estructura general, aunque se modificaran sus rúbricas para adaptarse al Ceremonial Romano.

\footnotetext{
${ }^{31}$ Calero Palacios, Catálogo de manuscritos, p. 282.

${ }^{32}$ Esta copia se encuentra actualmente en el Archivo de la Abadía y tampoco está recogida en el Catálogo de Calero Palacios.

33 El Catálogo Colectivo del Patrimonio Bibliográfico Español incluye muchos más ejemplares de Caeremoniale Episcoporum de 1600.
} 
Otros documentos que regían la archidiócesis y que los redactores de la Consueta debieron conocer eran las Constituciones Synodales $^{34}$ y el Manuale Granatense. $^{35}$

Las Constituciones Synodales son el resultado de las disposiciones tomadas tras el sínodo de 1572 convocado en Granada por el arzobispo Pedro Guerrero a su vuelta de Trento, a dónde había acudido como parte de la legación española. Las Constituciones son un documento para el gobierno general de la diócesis, por lo que tratan sobre todo de cuestiones legales, de la vida y honestidad de los clérigos, de las parroquias o de la administración de los sacramentos, por lo que no es una fuente muy interesante para los redactores de la Consueta, más atentos al desarrollo de la liturgia. El Manuale Granatense, del cual se conservan varios ejemplares en la Abadía, era el manual de liturgia para los párrocos de la diócesis y se imprimió en 1625, siete años antes de la conclusión de la Consueta. ${ }^{36}$ El Manuale es parco en la descripción de ceremonias, pero sigue el nuevo rezado como indica el título, y obtuvo licencia del Prior y Convento de San Lorenzo el Real de Madrid que era quien tenía la exclusiva de la impresión de los libros litúrgicos reformados. Incluye además las fórmulas melódicas de algunos cantos por lo que se hará referencia a él más adelante.

El último documento con el que puede relacionarse directamente a la Consueta es el de las Constituciones del Sacromonte. Como se ha visto antes, la Consueta viene a ampliar algunos de los capítulos de éstas, sobre todo en lo que se refiere a los oficios. Tras un detenido estudios se puede concluir que dichos documentos son complementarios para comprender la estructura y la organización del culto en la Abadía, ya que las Constituciones suponen el marco legal en el que se fundamenta la Consueta. De hecho, para que los canónigos fuesen familiarizándose con las

\footnotetext{
${ }^{34}$ Constituciones Synodales del Arçobispado de Granada / hechas por ... Pedro Guerrero Arçobispo de la Sancta Yglesia de Granada, en el sancto Synodo que su Señoria Reverendissima celebro a quatorze dias del mes de Octubre del año M.D.LXXII (Granada: en casa de Hugo de Mena, 1573).

${ }^{35}$ Manuale granatense ad Rituale Romanum ut in plurimum reformatum / iussu ... Galcerandi Albanell, Granatensis Ecclesiae Archiepiscopi (Matriti : Apud D. Theresiam Iuntam, 1625).

${ }^{36}$ Ver en el Catálogo de este estudio el cantoral $\mathrm{N}^{\circ}$ LXXVIII.
} 
ceremonias de la Consueta y sus obligaciones, Pedro de Ávila, Abad entre 1617 y 1651 , mandó que se leyeran las Constituciones de la Abadía y la Consueta todos los jueves. ${ }^{37}$

\subsection{Consuetas comparadas: los casos abacial y catedralicio.}

Ya he señalado que al principio se tomó la Consueta de la Catedral como referencia para elaborar la del Sacromonte, pero se introdujeron no pocas variaciones en las ceremonias porque aquella no estaba ajustada al Ceremonial Romano. ¿Pero qué Consueta/s regían en la Catedral granadina? Antes de contestar esta pregunta es necesario hacer una aclaración bibliográfica sobre el documento catedralicio, pues es frecuentemente nombrado en muchos estudios sobre el Renacimiento y a menudo se producen ciertas confusiones. La más antigua se conserva manuscrita en dos redacciones: una es el borrador, que según López Calo fue escrito alrededor de 1514, y la otra es la definitiva, escrita en $1520 .^{38}$ De la Consueta granadina se hicieron al menos dos impresiones: una sin fechar, pero que puede datarse en el siglo XVII, que es la que utilizo para la redacción de este epígrafe y otra, del siglo XIX, pero que recoge una Consueta ligeramente diferente de la anterior y algo más antigua. ${ }^{39}$ La impresión más antigua de la Consueta de la Catedral de Granada lleva por título Las buenas e loables costumbres, y ceremonias que se guardan en la Santa Iglesia de Granada, y en el Coro de ella; es un impreso raro, del que se conserva un ejemplar en la Biblioteca Nacional. ${ }^{40}$ En esta copia no consta la fecha de edición ni el lugar, pero viene encuadernado con otro documento fechado en 1678 con el que comparte características tipográficas similares. El impreso consta de 76 folios agrupados en 62 capítulos. Si comparamos los índices de la Consueta de la Catedral de Granada y de la del Sacromonte observamos que la estructura de esta última en cuatro libros acota y organiza más el contenido. No sabemos si este modo de organización está basado en alguna otra

\footnotetext{
${ }^{37}$ Zótico Royo Campos, Abades del Sacromonte, p. 46.

38 José López-Calo, "Granada-Sevilla-Puebla de los Ángeles. Los comienzos del villancico barroco hispánico" ponencia del Seminario La música en las catedrales andaluzas y su proyección en América, Sevilla, Escuela de Estudios Hispanoamericanos, C.S.I.C., 27 de febrero de 2009 (en prensa).

39 Consueta de ceremonias y gobierno, de la Santa Iglesia Catedral Apostólica y Metropolitana, de la Ciudad de Granada (Granada: Nicolás Moreno,1819).

40 Madrid, Biblioteca Nacional, 2/69800(2): Las buenas e loables costumbres, y ceremonias que se guardan en la Santa Iglesia de Granada, y en el Coro de ella.
} 
consueta o es una característica peculiar de la sacromontana. Los capítulos de ambas consuetas se comparan en la Tabla, II.4. De la lectura atenta de la Tabla puede apreciarse capítulos con el mismo título (Ej: "Quando se dize el officio cantado o en tono" Sacromonte LI-Cap.5 y Catedral Cap. 9), otros cuya correspondencia se reparte entre varios capítulos (Ej.: los capítulos 2 y 3 del libro I del Sacromonte se reparten entre los capítulos 3, 4 y 5 de la Catedral) y algunos que no guardan relación alguna entre sí. En el apartado de los Oficios, la Consueta del Sacromonte describe un mayor número de ellos, mientras que la catedralicia no contempla, entre otros, los oficios de capellán cerimoniario, rector, visitadores, cruciferarios, flavelario e intonario.

Dos diferencias principales pueden señalarse entre ambas Consuetas: la primera es la extensión y grado de detalle que presenta la sacromontana, mucho mayor que la de la Catedral; la segunda es que la parte propia de descripción de ceremonias concretas es muy breve y parca en la catedralicia, mientras que por el contrario es uno de los aspectos más interesantes y atractivos de la Consueta sacromontana. Esta desigualdad en el apartado de las ceremonias hace que sea difícil establecer comparaciones entre la Catedral y la Abadía, pues no sabemos a ciencia cierta cómo se desarrollaba exactamente una ceremonia tan específica como la Salve en la Catedral, algo que sí aparece descrito con todo detalle en la Consueta de la Abadía. 


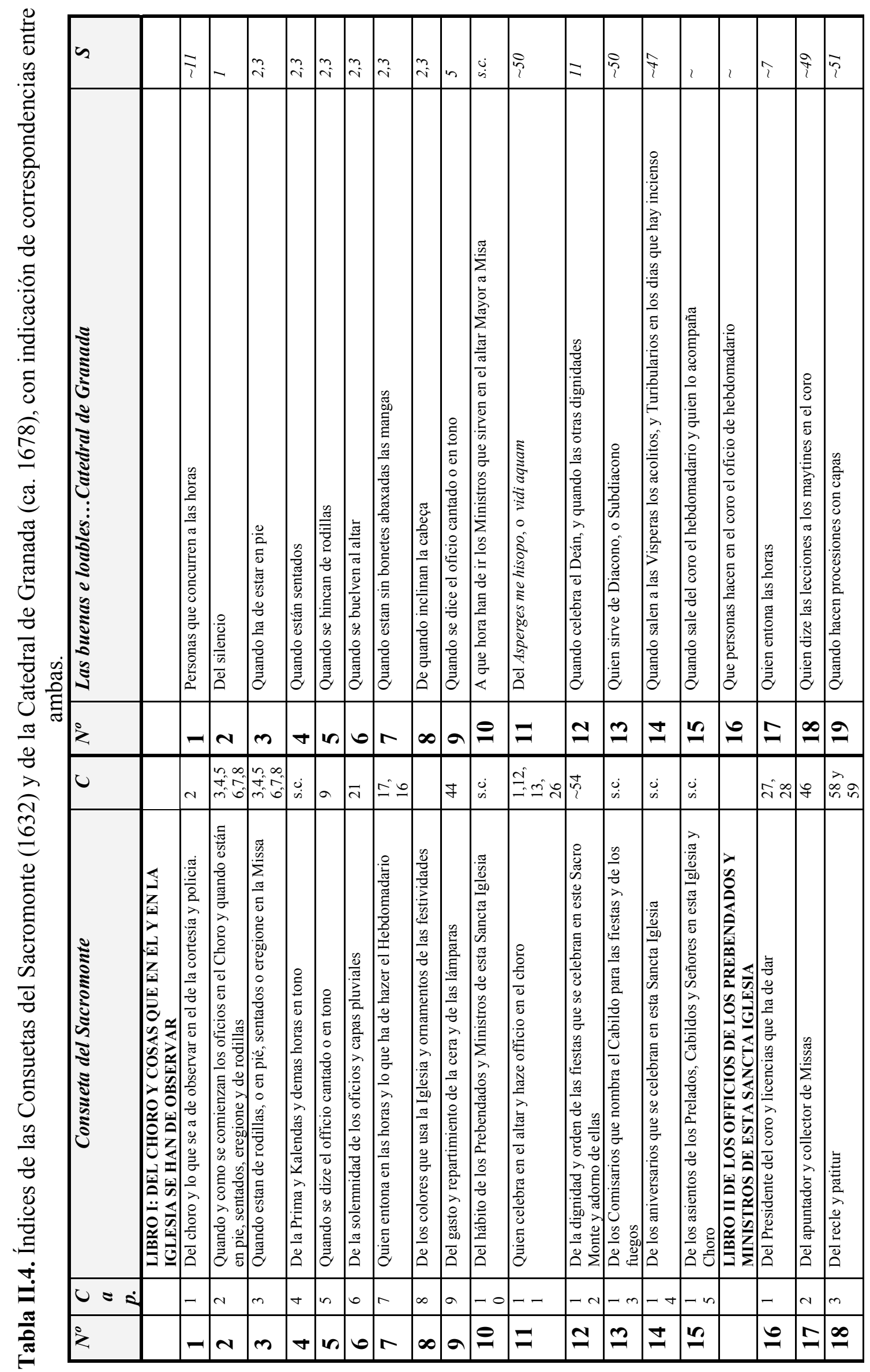


的

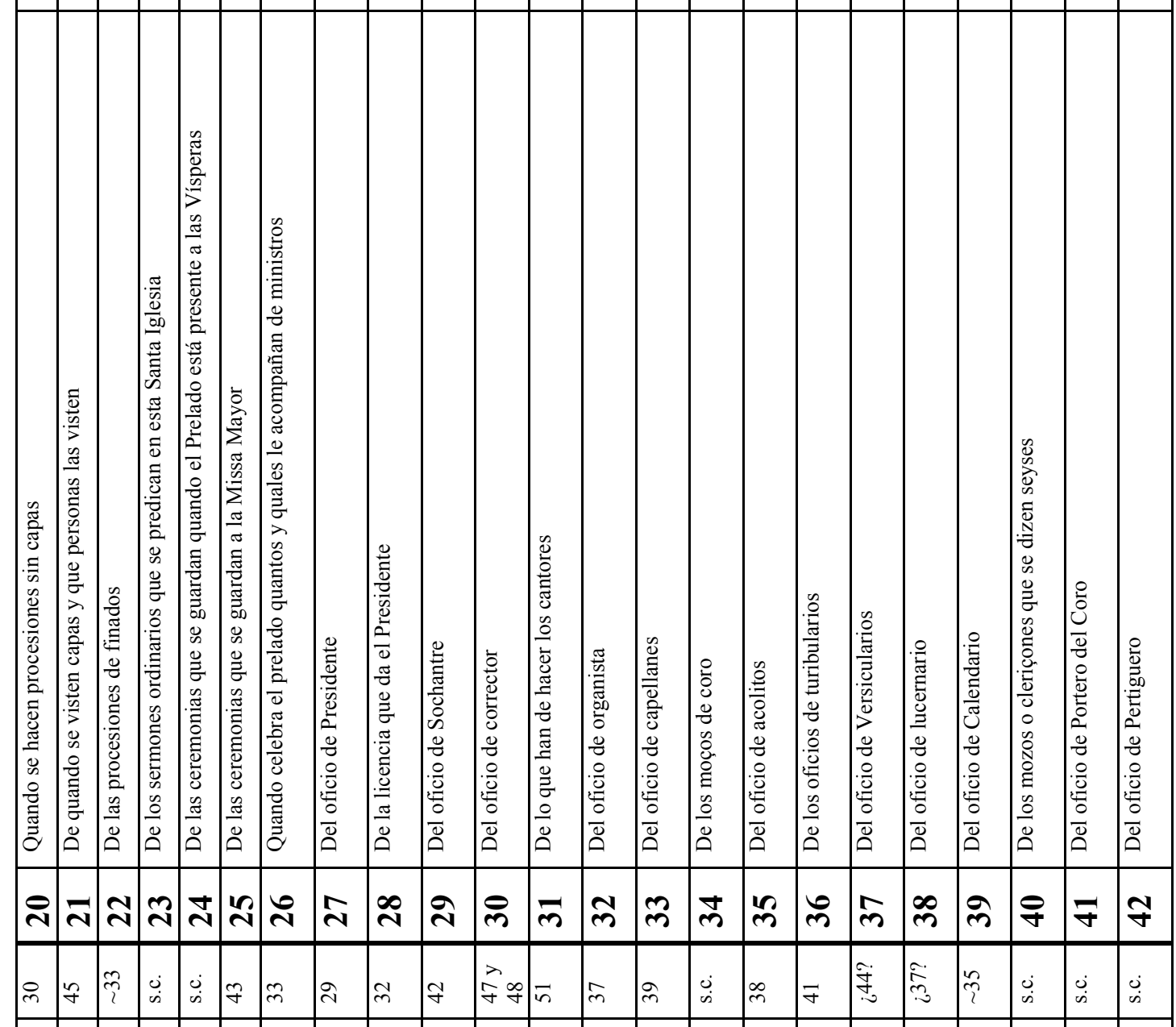




\begin{tabular}{|c|c|c|c|c|c|c|c|c|c|c|c|c|c|c|c|c|c|c|c|}
\hline$\stackrel{\Delta}{\sim}$ & $\begin{array}{l}a \\
\infty \\
\dot{m}\end{array}$ & $\curvearrowright$ & $\approx$ & থे & iे & & iे & m & \begin{tabular}{|l|}
$\dot{v}$ \\
$\dot{v}$
\end{tabular} & 势 & 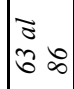 & $\mid \begin{array}{c}\vec{z} \\
\vec{b} \infty\end{array}$ & $\mid \begin{array}{ll}\approx & 0 \\
B & \infty\end{array}$ & $\begin{array}{l}\bar{\sigma} \\
\dot{0} \infty\end{array}$ & $\infty$ & $\infty$ & $\dot{\dot{s}}$ & î & $\dot{\dot{s}}$ \\
\hline 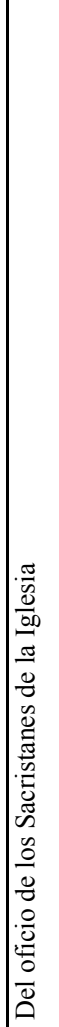 & 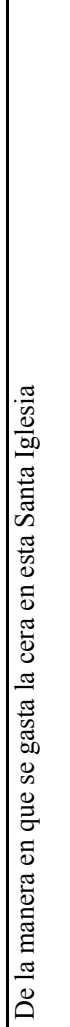 & 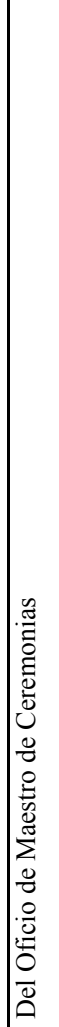 & 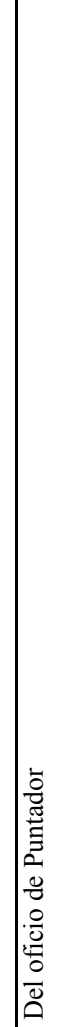 & 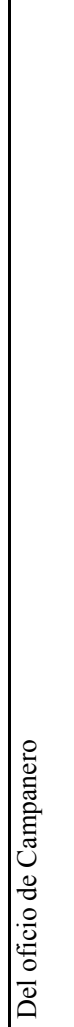 & 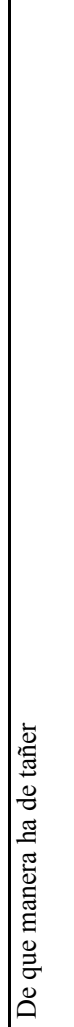 & 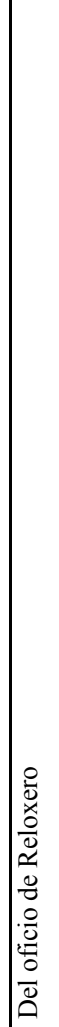 & 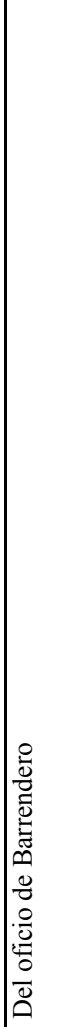 & 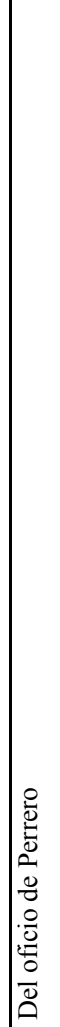 & 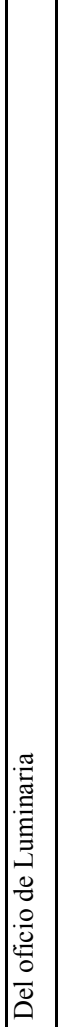 & 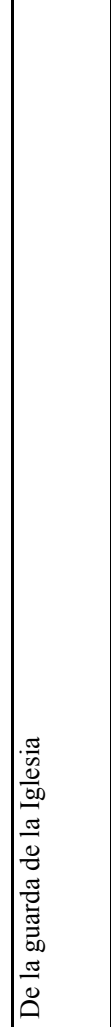 & 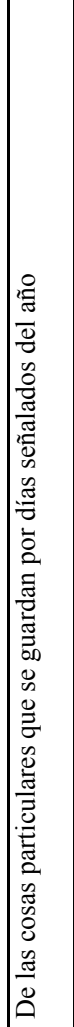 & 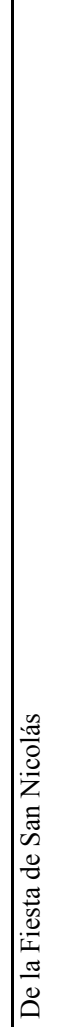 & 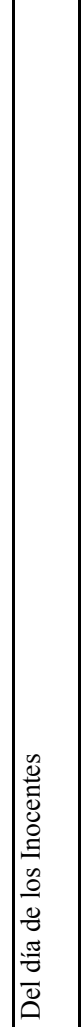 & 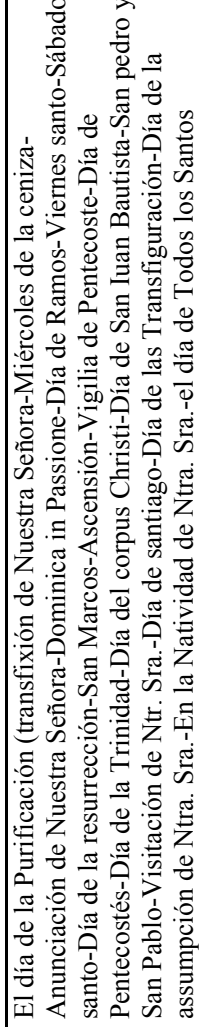 & $\frac{1}{2}$ & 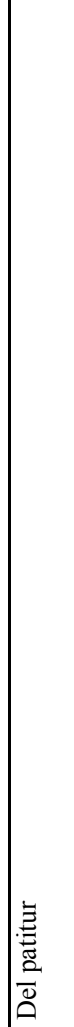 & 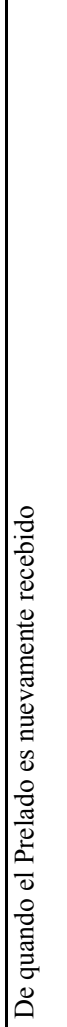 & 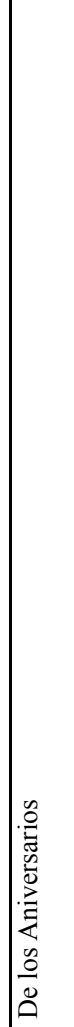 & 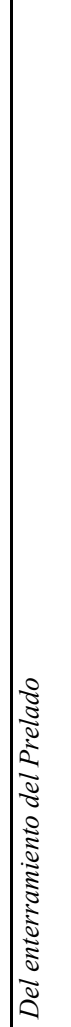 \\
\hline 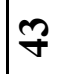 & $\exists$ & 18 & fo & $F$ & $\stackrel{\infty}{+}$ & qे & in & $\bar{n}$ & กิ & $n$ & 节 & $n$ & in & in & in & in & 8 & 6 & $\widetilde{\sigma}$ \\
\hline $\begin{array}{l}\dot{\omega} \\
\dot{\omega}\end{array}$ & $\begin{array}{l}\dot{b} \\
\dot{\omega}\end{array}$ & लिं & $\dot{\dot{s}}$ & $\dot{\dot{v}}$ & & A & $\begin{array}{l}\dot{b} \\
\dot{w}\end{array}$ & $\infty$ & 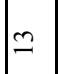 & $\vec{\theta} \vec{i}$ & $\approx$ & $\dot{\dot{s}}$ & $\begin{array}{l}\dot{b} \\
\dot{w}\end{array}$ & $\dot{\dot{\omega}}$ & $\approx$ & $\dot{v}$ & $\begin{array}{l}\dot{v} \\
\dot{v}\end{array}$ & $\begin{array}{l}\dot{v} \\
\dot{w}\end{array}$ & 金 \\
\hline 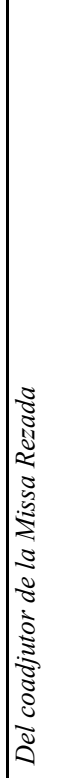 & 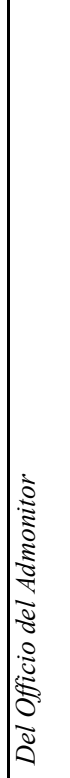 & 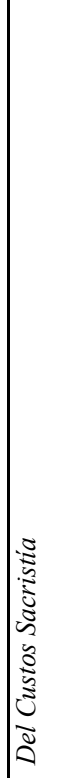 & 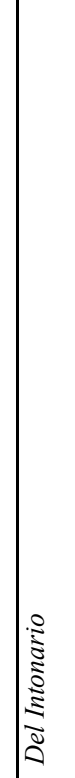 & 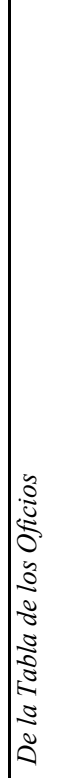 & 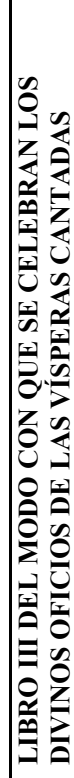 & 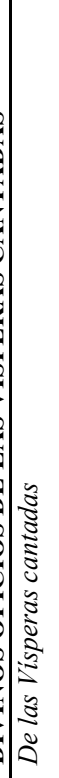 & 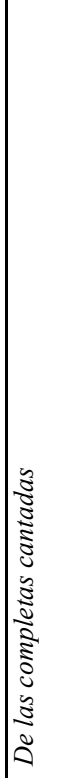 & 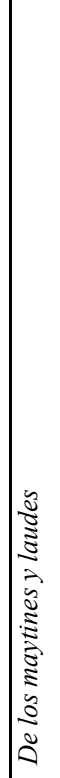 & 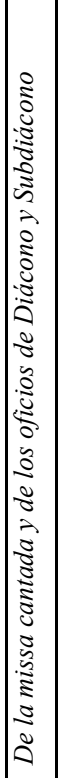 & 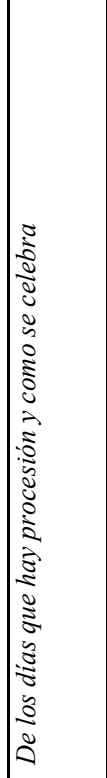 & 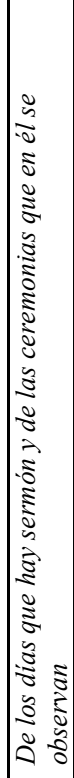 & 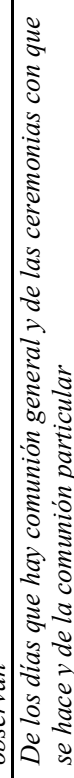 & 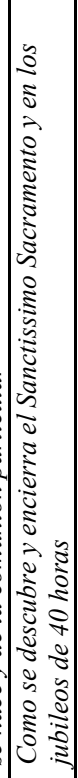 & 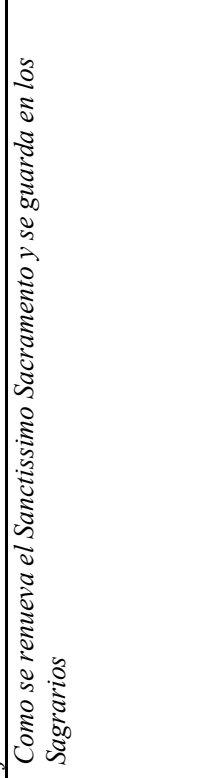 & 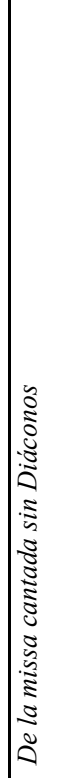 & 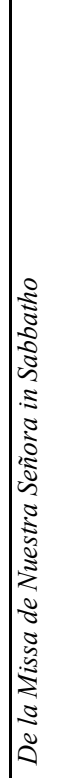 & 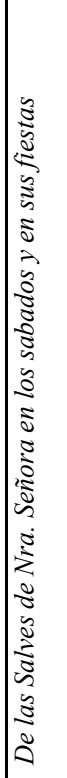 & 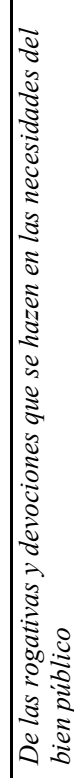 & 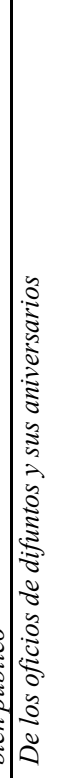 \\
\hline ar & $\sim \infty$ & No & mo & $m-$ & & - & $\sim$ & $m$ & $\nabla$ & in & 6 & $\curvearrowright$ & $\infty$ & a & -0 & $-1-$ & $-\sim$ & $-m$ & $-\infty$ \\
\hline F & $\mathscr{P}$ & $\nexists$ & 8 & \& & & F & $\underset{+}{\infty}$ & gे & in & $\bar{n}$ & $\tilde{n}$ & $\tilde{n}$ & 蓉 & $n$ & in & in & $\infty$ & in & 8 \\
\hline
\end{tabular}




\begin{tabular}{|c|c|c|c|c|c|c|c|c|c|c|c|c|c|c|c|c|c|c|c|c|c|c|}
\hline 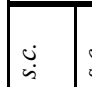 & ن & & $\dot{\breve{s}}$ & $\dot{\varphi g}$ & $|\dot{ن}|$ & $\dot{v} \dot{v}$ & & $\hat{s}$ & ti & in in & in & 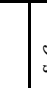 & & ti & $\dot{ن}:]$ & $i n$ & in & in & in & in & $i n$ & نे \\
\hline 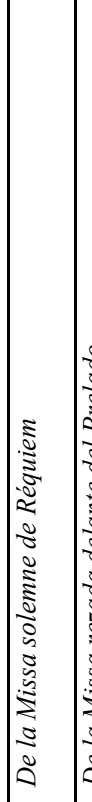 & 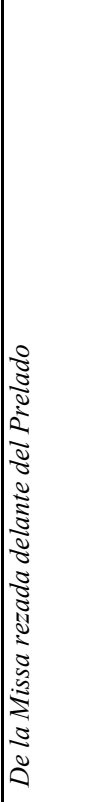 & 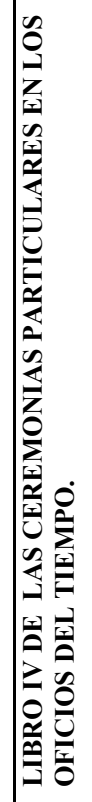 & 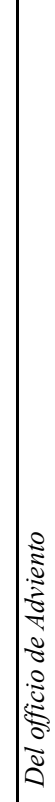 & 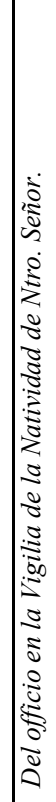 & 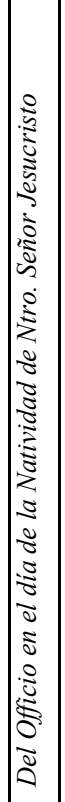 & 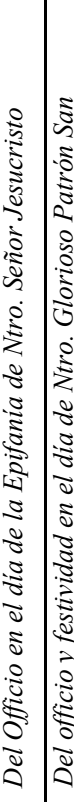 & 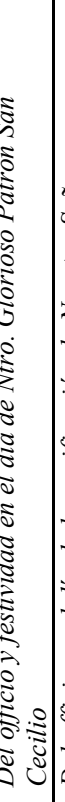 & 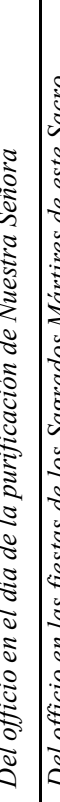 & & 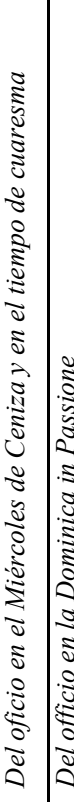 & 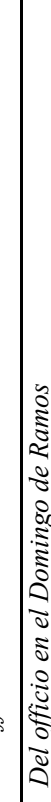 & & 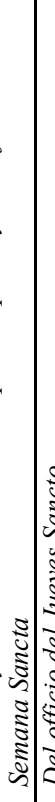 & & 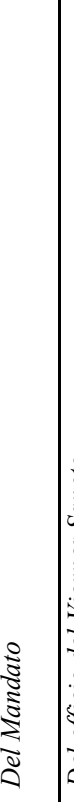 & 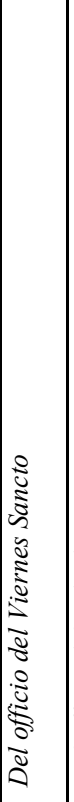 & 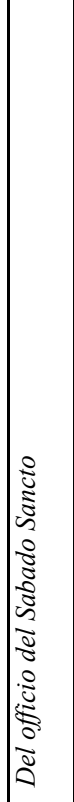 & 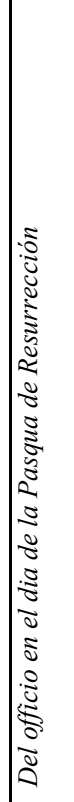 & 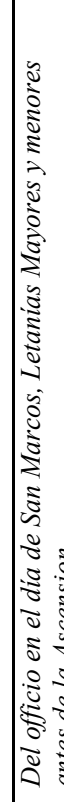 & 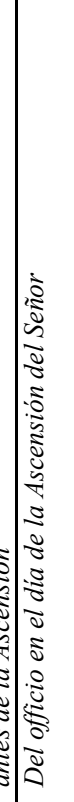 & 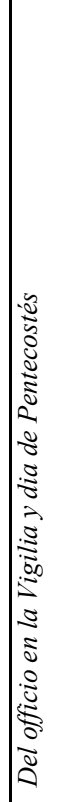 & 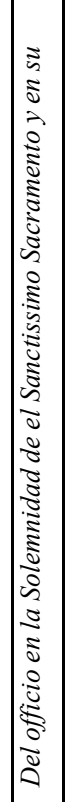 \\
\hline & $-\infty$ & & & $\gamma$ & n & $\begin{array}{lll}* \\
\end{array}$ & & & & $\infty$ & & & & $-\sim$ & $-m$ & -7 & $-i n$ & -6 & $1-0$ & $-\infty$ & -0 & v \\
\hline 6 & $\widetilde{\sigma}$ & & 6 & & & & & & & & & & & $\mathbb{I}$ & $\therefore$ & 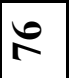 & $F$ & $\infty$ & 2 & $\infty$ & $\bar{\infty}$ & $\tilde{\infty}$ \\
\hline
\end{tabular}




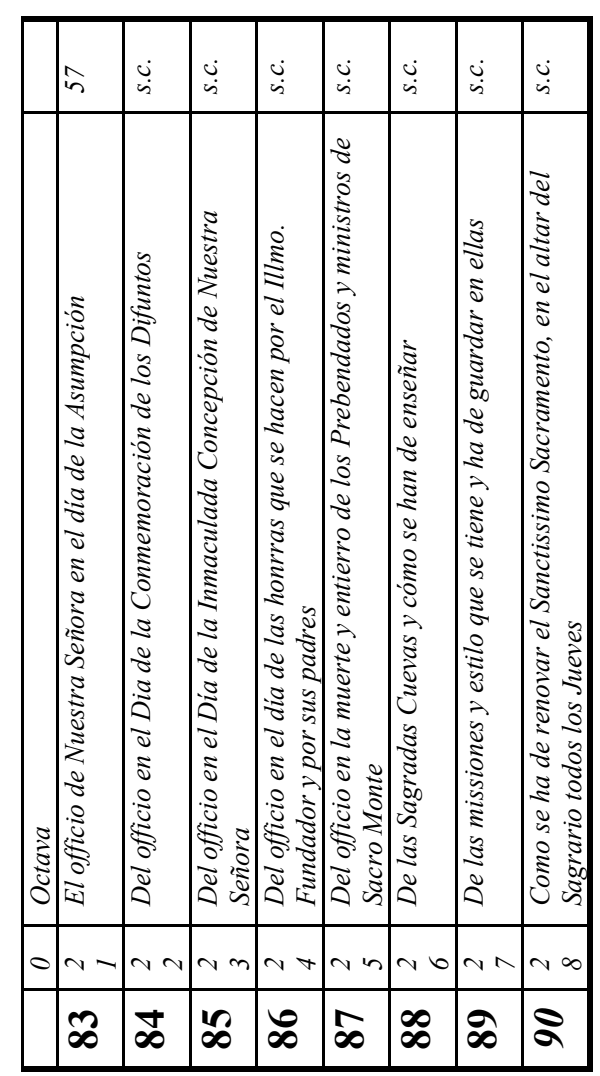




\section{3. $\quad$ El Caeremoniale Episcoporum como fuente para la Consueta.}

Con frecuencia se ha señalado la desigual acogida que la transformación que planteó Trento tuvo en las diferentes iglesias, llegándose a afirmar en ocasiones que la reforma no se llegó a hacer efectiva de manera completa en muchos casos. Dejando a un lado la posibilidad que la Bula de Pío V daba a las diócesis u órdenes religiosas de que continuaran con sus rezos si tenían una antigüedad de más de 200 años, el resto fue sometiéndose poco a poco, aunque el nivel de aceptación varió según la zona geográfica y la disposición y formación de sus mandatarios eclesiásticos. ${ }^{41}$ En el caso de la Abadía, una institución como ya se ha señalado de marcado carácter contrarreformista, no cabe la menor duda de que nació con las nuevas normas, y que no cupo en ella el rito antiguo. El ceremonial de la Abadía se creó con la intención de seguir el "nuevo rezo romano", es decir, el aprobado por Pío V en 1570 después de las disposiciones del Concilio de Trento. Por ello son particularmente interesantes las apreciaciones que sobre el desarrollo de las ceremonias y su relación con la música revelan las descripciones ceremoniales, pues nos ayudan a comprender el papel asignado a la música en la nueva liturgia a los ojos de los eclesiásticos.

Debería hacerse un estudio de la influencia del Caeremoniale romano en los ceremoniales españoles para comprender el grado de aceptación de las nuevas disposiciones en la Península y sus territorios de ultramar. Dos momentos principales pueden señalarse en la difusión del Rito romano: 1) La promulgación del nuevo Breviario en 1568 por la Bula "Quod a nobis postulat” y el Misal en 1570 con la Bula “Quo primum tempore” ambas de Pío V; y 2) la publicación en 1600 del Caeremoniale Episcoporum de Clemente VIII. Muchas de las órdenes religiosas comenzaron a imprimir sus ceremoniales adaptándose al nuevo rezado, gracias al privilegio que obtuvieron en $1577 .{ }^{42}$ En las siguientes tablas (II.5 y II.6) se presentan los principales

\footnotetext{
${ }^{41}$ En Granada, el rezo no podía contar en esa fecha doscientos años de antigüedad, por lo que en teoría debió someterse al nuevo rezado.

${ }^{42}$ Véase Fermín de los Reyes Gómez, "Los libros de nuevo rezado y la imprenta española en el siglo XVIII", Revista general de Información y Documentación, 9/1 (1999), p. 119: "Salvo las órdenes del Carmen, de la Cartuja, de San Benito, de San Bernardo (hasta 1577, en que se les da licencia para imprimir misales, breviarios y diurnales) y de Santo Domingo, todas debían utilizar en adelante los libros de Nuevo Rezado". El autor presenta un interesante estudio sobre los privilegios de impresión en España y el papel del Monasterio de San Lorenzo del Escorial en la distribución e impresión de este proyecto editorial. Interesante es también el trabajo de Vicente Bècares, "Aspectos de la producción y distribución del Nuevo Rezado", Tess Knighton e Ian Fenlon (eds.), Early musicprinting and publishing in the Iberian World (Kassel: Reichenberger, 2006), pp. 1-22.
} 
Ceremoniales de los que tenemos noticia que fueron impresos en España entre 1568

(fecha de la primera Bula de Pío V) y 1632 (fecha de fin de redacción de la Consueta Sacromontana). ${ }^{43}$

Tabla II.5. Ceremoniales españoles impresos entre 1568 y 1600.

\begin{tabular}{|l||}
\hline \multicolumn{1}{|c||}{ CEREMONIALES PÍO V, impresos en España } \\
\hline \hline Pedro Ruiz Alcoholado, Ceremonial romano para missas cantadas y rezadas: en el qual se ponen todas las rubricas \\
generales y particulares del Missal Romano, que diuulgo el Papa Pio V: con aduertencias y resoluciones de muchas \\
dudas ... : y al cabo se trata de lo tocante a los ministros y altar ... I todo nueuamente ordenado, facilitado y reuisto por \\
Pedro Ruyz Alcoholado sacerdote. \\
Alcalá de Henares: por los herederos de Iuan Gracian, a costa de Iuan de Montoya, 1589. \\
\hline $\begin{array}{l}\text { Ceremonial de los officios diuinos: ansi para el altar, como para el choro, y fuera del, segun el vso de la Sancta Iglesia } \\
\text { Romana / el qual compusieron ciertos Religiosos de la Orden de Sant Francisco. } \\
\text { Toledo: Pedro Rodriguez, 1591. }\end{array}$ \\
\hline
\end{tabular}

Tabla II.6. Ceremoniales impresos en España 1600-1632

\begin{tabular}{|c|}
\hline CEREMONIALES CLEMENTE VIII \\
\hline $\begin{array}{l}\text { Recopilacion del ceremonial de la Orden de ... S. Francisco para los frayles y monjas de ... Aragon, el qual se mandò } \\
\text { recopilar en el Capitulo Provincial celebrado en ... Çaragoça ... año de 1600: parte primera en que se trata de las } \\
\text { ceremonias del choro ... } \\
\text { Çaragoça: Angelo Tauano, } 1601 .\end{array}$ \\
\hline $\begin{array}{l}\text { Ceremonial Romano nueuamente reformado el qual la Beatitud del señor Papa Clemente VIII en toda la vniuersal } \\
\text { Yglesia manda guardar / compuesto por el padre Fray Iuan Zamora de la Orden del Seraphico Padre S. Francisco ... } \\
\text { Burgos: Iuan Baptista Varesio, } 1603 .\end{array}$ \\
\hline $\begin{array}{l}\text { Caeremoniale sacri ordinis Beatae Mariae de Mercede Redemptionis Captiuorum / auctore ... Fratre Francisco Andreu } \\
\text { Nuper aeditum et reformatum iuxta Breuiarium, \& Missale Romanum. } \\
\text { Valentiae: Petrum Patricium Mey ..., } 1614\end{array}$ \\
\hline $\begin{array}{l}\text { Ceremonial del officio divino: assi para el choro, como para el altar, según el uso, y orden de la santa Iglesia Romana y } \\
\text { conforme al missal, y Breviario, reformado por los sumos pontífices Pío V, y Gregorio XIII.../ recopilado por ciertos } \\
\text { padres del diffiuitorio de la Provincia de S. Iuan Baptista de los frayles Descalços de nuestro Padre S. Francisco. } \\
\text { Valencia: Juan Chrysostomo Garriz, } 1615 \text {. }\end{array}$ \\
\hline $\begin{array}{l}\text { Fray Eliseo de San Ildefonso, Manuale Diuinorum Officiorum Ordinis Fratrum Discalceatorum Beatae Mariae de } \\
\text { Monte-Carmeli, iuxta Missale, [et] Caeremoniale Romanum: iussu Clementis VIII ... nouissime recognita } \\
\text { Salmanticae: ex Typographia Antoniae Ramirez viduae, } 1616 .\end{array}$ \\
\hline $\begin{array}{l}\text { Ceremonial de la missa en el qual se ponen todas las rubricas generales ... / recopilado por Fray Juan de Alcocer de la } \\
\text { Orden de San Francisco de la Regular Observancia. } \\
\text { Lérida: Luys Manescal, } 1616 .\end{array}$ \\
\hline $\begin{array}{l}\text { Ceremonial de la missa: en el qual se ponen todas las rubricas generales y algunas particulares del Missal romano, que } \\
\text { diuulgo Pio Vy mando reconocer Clemente VIII ... I recopilado por Fray Iuan de Alcocer de la Orden de San Francisco. } \\
\text { Barcelona: Esteuan Liberos a costa de Iacinto Argimir, } 1623 .\end{array}$ \\
\hline $\begin{array}{l}\text { Ceremonial e instruccion de oficios de los religiosos descalços de } N . \text { Señora de la Merced, Redencion de Cantiuos : en } \\
\text { que se contiene lo tocante al rezado... segun el Breuiario y missal romano reformado por Clemente VIII y Ritual de } \\
\text { Paulo V, y assi mismo lo que pertenece a cada uno de los religiosos. } \\
\text { Rota: Andres Grande, } 1630 .\end{array}$ \\
\hline
\end{tabular}

\footnotetext{
${ }^{43}$ Estas Tablas se han confeccionado con los datos suministrados por el Catálogo Colectivo del Patrimonio Bibliográfico Español, en la web: http://www.mcu.es/bibliotecas/MC/CCPB/index.html (acceso el 29 de Septiembre de 2008).
} 
Cómo influyeron estos ceremoniales españoles y otros impresos fuera de España, en la formación de la Consueta es difícil de determinar, por eso la comparación la estableceremos con el "documento oficial" del que debían partir el resto: el Caeremoniale Episcoporum. ${ }^{44}$ Este Caeremonial (Ceremonial de los Obispos) fue publicado por orden de Clemente VIII en 1600, continuando una serie de libros creados para regular las ceremonias, como el Ordines Romani del siglo VII que recogía el ceremonial papal, o el De Coremoniis Cardinalium et Episcoporum in eorum dicecesibus del siglo XVI. El Caeremonial Episcoporum fue revisado y vuelto a publicar en 1650, en 1727 y 1729. En 1752 Benedicto XIV añadió una tercera parte en la que se especificaban las ceremonias que debían guardar los que ostentaban un cargo civil en los estados pontificios. ${ }^{45}$ Teniendo en cuenta que el Caeremoniale debía guardarse tanto en las catedrales como en las iglesias colegiales, no es de extrañar que se adoptara en el Sacromonte. Si comparamos los contenidos de la Consueta y el Caeremonial observamos una estrecha relación, sobre todo en el Libro II de este último que corresponde con los Libros III y IV de la Consueta. La diferencia principal deviene de la diferente especificidad de los destinatarios, ya que el Caeremonial va dirigido a todas las diócesis católicas, por lo que no se especifican ni ceremonias relacionadas con fiestas locales (San Cecilio, Mártires del Sacromonte), ni otras de contenido más específico, como las misas y oficios a la Virgen o el rito de la Salve. La Consueta, además de describir dichas ceremonias, hace hincapié en las ceremonias propias, como los aniversarios por el fundador y sus padres o la festividad de San Marcos. En la Tabla II.7. pueden compararse los dos índices (Consueta y Caeremoniale).

\footnotetext{
${ }^{44}$ En la Abadía también se conserva un ceremonial impreso en 1572 en Colonia, Sacrarum cerimoniarum siue rituum ecclesiasticorum sanctae romanae ecclesiae libri tres (Coloniae Agrippinae: apud haeredes Arnoldi Birckmanni, 1572).

${ }^{45}$ Augustin Joseph Schulte, “Cæremoniale Episcoporum”, The Catholic Encyclopedia ( New York: Robert Appleton Company, 1908); http://www.newadvent.org/cathen/03133a.htm (acceso el 18 de Septiembre de 2008).
} 
Tabla II.7. Índices de la Consueta de la Abadía del Sacromonte (1632) y del Caeremoniale Episcoporum (1600) con indicación de la correspondencia entre ambos.

\begin{tabular}{|c|c|}
\hline Consueta del Sacromonte & Caeremoniale Episcoporum \\
\hline \multicolumn{2}{|l|}{$\begin{array}{l}\text { LIBRO I: DEL CHORO Y COSAS QUE EN ÉL Y EN LA } \\
\text { IGLESIA SE HAN DE OBSERVAR }\end{array}$} \\
\hline Del choro y lo que se a de observar en el de la cortesía y policia. & s.c. \\
\hline $\begin{array}{l}\text { Quando y como se comienzan los oficios en el Choro y quando } \\
\text { están en pie, sentados, eregione y de rodillas }\end{array}$ & I-XVIII, I-XIX \\
\hline $\begin{array}{l}\text { Quando estan de rodillas, o en pié, sentados o eregione en la } \\
\text { Missa }\end{array}$ & $I-X V I I I, I-X I X$ \\
\hline De la Prima y Kalendas y demas horas en tono & s.c. \\
\hline Quando se dize el officio cantado o en tono & s.c. \\
\hline De la solemnidad de los oficios y capas pluviales & s.c. \\
\hline \multicolumn{2}{|l|}{ Quien entona en las horas y lo que ha de hazer el Hebdomadario } \\
\hline De los colores que usa la Iglesia y ornamentos de las festividades & $(I-X I I ; I-X I I I ; I-X I V)$ \\
\hline Del gasto y repartimiento de la cera y de las lámparas & s.c. \\
\hline Del hábito de los Prebendados y Ministros de esta Sancta Iglesia & $I-I, I-I I I I-X V$ \\
\hline Quien celebra en el altar y haze officio en el choro & s.c. \\
\hline $\begin{array}{l}\text { De la dignidad y orden de las fiestas que se celebran en este } \\
\text { Sacro Monte y adorno de ellas }\end{array}$ & $(I-X I I ; I-X I I I ; I-X I V)$ \\
\hline $\begin{array}{l}\text { De los Comisarios que nombra el Cabildo para las fiestas y de los } \\
\text { fuegos }\end{array}$ & s.c. \\
\hline De los aniversarios que se celebran en esta Sancta Iglesia & s.c. \\
\hline $\begin{array}{l}\text { De los asientos de los Prelados, Cabildos y Señores en esta } \\
\text { Iglesia y Choro }\end{array}$ & s.c. \\
\hline \multicolumn{2}{|l|}{$\begin{array}{l}\text { LIBRO II DE LOS OFFICIOS DE LOS PREBENDADOS Y } \\
\text { MINISTROS DE ESTA SANCTA IGLESIA }\end{array}$} \\
\hline Del Presidente del coro y licencias que ha de dar & s.c. \\
\hline Del apuntador y collector de Missas & s.c. \\
\hline Del recle y patitur & s.c. \\
\hline Del Corrector del Coro & s.c. \\
\hline Del Maestro de Çeremonias & I-V. De officio magistrorum caeremoniarum \\
\hline Del Capellan cerimoniario & s.c. \\
\hline Del Rector en el Colegio y colegiales & s.c. \\
\hline De los Visitadores o zeladores & s.c. \\
\hline Del Tesorero y Sacristanes & I-VI. De officio sacristae \\
\hline De los Capellanes & s.c. \\
\hline Del Sochantre & $I-X X V I I I$ \\
\hline Del Organista & $I-X X V I I I$ \\
\hline Del Pertiguero & s.c. \\
\hline Del campanero & s.c. \\
\hline Del Caniculario & s.c. \\
\hline De los Versicularios & $I-X I$ \\
\hline Del Calendario & s.c. \\
\hline De los Colegiales Cantores & s.c. \\
\hline De los lucernarios & s.c. \\
\hline Del Portero del Coro & s.c. \\
\hline De los Ceroferarios & s.c. \\
\hline De los Turiferarios y modo de la turificación & $I-X X I I I$ \\
\hline \multicolumn{2}{|l|}{ De los Comitantes } \\
\hline De los Cetreros & $I-X I$ \\
\hline Del Cruciferario & $I-X I$ \\
\hline Del Falvelario y coadjutor de la Missa de Tercia & s.c. \\
\hline Del coadjutor de la Missa Rezada & s.c. \\
\hline Del Officio del Admonitor & s.c \\
\hline Del Custos Sacristía & s.c. \\
\hline Del Intonario & s.c. \\
\hline De la Tabla de los Oficios & s.c. \\
\hline
\end{tabular}




\begin{tabular}{|c|c|}
\hline $\begin{array}{l}\text { LIBRO III DEL MODO CON QUE SE CELEBRAN LOS } \\
\text { DIVINOS OFICIOS DE LAS VÍSPERAS CANTADAS }\end{array}$ & \\
\hline De las completas cantadas & $I I-I V$ \\
\hline De los maytines y laudes & \begin{tabular}{l|l} 
& $I I-V ; I I-V I ; I I-V I I$ \\
\end{tabular} \\
\hline $\begin{array}{l}\text { De la missa cantada y de los oficios de Diácono y } \\
\text { Subdiácono }\end{array}$ & $I I-V I I I, I I-I X$ \\
\hline De los días que hay procesión y como se celebra & $I I-X X X I I$ \\
\hline $\begin{array}{l}\text { De los dias que hay sermón y de las ceremonias que en él se } \\
\text { observan }\end{array}$ & $I-X X I I$ \\
\hline $\begin{array}{l}\text { De los dias que hay comunión general y de las ceremonias } \\
\text { con } \\
\text { que se hace y de la comunión particular }\end{array}$ & s.c. \\
\hline $\begin{array}{l}\text { Como se descubre y encierra el Santísimo Sacramento y en } \\
\text { los jubileos de } 40 \text { horas }\end{array}$ & s.c. \\
\hline $\begin{array}{l}\text { Como se renueva el Sanctissimo Sacramento y se guarda en } \\
\text { los Sagrarios }\end{array}$ & s.c. \\
\hline De la missa cantada sin Diáconos & $I-X X I X, I-X X X$ \\
\hline De la Missa de Nuestra Señora in Sabbatho & s.c. \\
\hline De las Salves de Nra. Señora en los sabados y en sus fiestas & \begin{tabular}{l|l|} 
& S.c. \\
\end{tabular} \\
\hline $\begin{array}{l}\text { De las rogativas y devociones que se hazen en las } \\
\text { necesidades del bien público }\end{array}$ & s.c. \\
\hline De los oficios de difuntos y sus aniversarios & $I I-X$ \\
\hline De la Missa solemne de Réquiem & \begin{tabular}{l|l} 
& $I I-X I ; I I-X I I$ \\
\end{tabular} \\
\hline De la Missa rezada delante del Prelado & $I-X X I X ; I-X X X$ \\
\hline $\begin{array}{l}\text { LIBRO IV DE LAS CEREMONIAS PARTICULARES } \\
\text { EN LOS OFICIOS DEL TIEMPO. }\end{array}$ & \\
\hline Del officio del Adviento & $I I-X I I I$ \\
\hline Del officio en la Vigilia de la Natividad de Ntro. Señor. & $I I-X I V$ \\
\hline Del Officio en el día de la Epifanía & s.c. \\
\hline $\begin{array}{l}\text { Del officio y festividad en el día de Ntro. Glorioso Patrón San } \\
\text { Cecilio }\end{array}$ & s.c. \\
\hline Del Officio en el día de la Purificación de Nuestra Señora & $I I-X V I, I I-X V I I$ \\
\hline $\begin{array}{l}\text { Del officio en las fiestas de los Sagrados Mártires de este } \\
\text { Sacro Monte }\end{array}$ & s.c. \\
\hline $\begin{array}{l}\text { Del oficio en el Miércoles de Ceniza y en el tiempo de } \\
\text { cuaresma }\end{array}$ & $I I-X V I I I, I I-X I X$ \\
\hline Del officio en la Dominica in Passione & \\
\hline Del officio en el Domingo de Ramos & \begin{tabular}{l|l|}
$I I-X X I$ \\
\end{tabular} \\
\hline $\begin{array}{l}\text { De los maytines de Tinieblas de la quarta, quinta y sexta feria } \\
\text { de Semana Sancta }\end{array}$ & $I I-X X I I$ \\
\hline Del officio del Jueves Sancto & $I I-X X I I I$ \\
\hline Del Mandato & $I I-X X I V$ \\
\hline Del officio del Viernes Sancto & $I I-X X V, I I-X X V I$ \\
\hline Del officio del Sabado Sancto & $I I-X X V I I, I I-X X V I I I$ \\
\hline Del officio en el dia de la Pasqua de Resurrección & $I I-X X I X I I-X X X$ \\
\hline $\begin{array}{l}\text { Del officio en el día de San Marcos, Letanías Mayores y } \\
\text { menores antes de la Ascension }\end{array}$ & $I I-X X X I I$ \\
\hline Del officio en el día de la Ascensión del Señor & s.c. \\
\hline Del officio en la Vigilia y dia de Pentecostés & s.c. \\
\hline $\begin{array}{l}\text { Del officio en la Solemnidad de el Sanctissimo Sacramento y } \\
\text { en su Octava }\end{array}$ & $I I-X X X I I I$ \\
\hline El officio de Nuestra Señora en el día de la Asumpción & s.c. \\
\hline Del officio en el Dia de la Conmemoración de los Difuntos & s.c. \\
\hline $\begin{array}{l}\text { Del officio en el Día de la Inmaculada Concepción de } \\
\text { Nuestra Señora }\end{array}$ & s.c. \\
\hline $\begin{array}{l}\text { Del officio en el dia de las honrras que se hacen por el Illmo. } \\
\text { Fundador y por sus padres }\end{array}$ & s.c. \\
\hline $\begin{array}{l}\text { Del officio en la muerte y entierro de los Prebendados y } \\
\text { ministros de Sacro Monte }\end{array}$ & $I I-X X X V I, I I-X X X V I I, I I-X X X V I I I$ \\
\hline De las Sagradas Cuevas y cómo se han de enseñar & s.c. \\
\hline De las missiones y estilo que se tiene y ha de guardar en ellas & s.c. \\
\hline $\begin{array}{l}\text { Como se ha de renovar el Sanctissimo Sacramento, en el } \\
\text { altar del Sagrario todos los Jueves }\end{array}$ & s.c. \\
\hline
\end{tabular}


Si la apariencia externa de los índices muestra las concordancias entre los dos libros, una lectura atenta de algunos de sus capítulos revela una relación aún más estrecha. La Consueta sigue la mayor parte de las rúbricas del Caeremonial y en muchas ocasiones amplía y especifica los detalles. ${ }^{46}$

\footnotetext{
${ }^{46}$ Para comprobar las relaciones y novedades que la Consueta presenta respecto al Caeremonial presentaré la descripción de dos ceremonias en el Capítulo $\mathrm{V}$, prestando atención a las rúbricas que se refieren a la música o especifican acciones que la acompañan.
} 



\section{CAPÍTULO III \\ LA ORGANIZACIÓN MUSICAL DE LA ABADÍA II. ORGANIZACIÓN DEL PERSONAL SEGÚN LA CONSUETA (1632)}

En este Capítulo describiré las funciones de los cargos relacionados con el servicio del coro y la iglesia de la Abadía del Sacromonte, deteniéndome especialmente en las personas que ocuparon los puestos de sochantre y organista durante los siglos XVII y XVIII.

Los trabajos descritos por la Consueta de 1632 eran desempeñados por canónigos, colegiales, capellanes o por personal ajeno al ámbito eclesiástico (seglares contratados por el cabildo). ${ }^{1}$ Algunos de los cargos rotaban semanalmente y otros de manera anual. Los desempeñados por seglares solían ser oficios vitalicios o duraban hasta que la persona perdía la capacitación o decidía abandonar el empleo. Los cargos de los canónigos eran designados por votos en el día de la Traslación de Santiago (30 de diciembre). Los colegiales solían ser designados por el maestro de ceremonias o por el rector. Los oficios de sochantre $\mathrm{y}$ organista podían ser desempeñados por eclesiásticos (no canónigos) que normalmente ganaban además una capellanía. El organista también podía ser seglar, y aunque tenía la obligación de residir en el Sacromonte, en casos excepcionales podía tener casa propia fuera. ${ }^{2}$ A los cargos de sochantre y organista no se opositaba como en otros centros, sino que a los candidatos se les probaba durante un tiempo para comprobar su suficiencia, o se designaba a un expero, algún maestro de capilla de la Catedral o de la Capilla Real, para que juzgara su idoneidad. $^{3}$

En el funcionamiento del coro no todas las personas con una responsabilidad incidirán de la misma manera en la producción musical: unas tienen ocupaciones musicales (sochantre, organista), otras indirectamente influyen o controlan de alguna

\footnotetext{
${ }^{1}$ He omitido los cargos que no recoge la Consueta, como los de cocinero y barbero.

${ }^{2}$ Constituciones (1647) fol. $18^{\mathrm{r}}$ : "Sed casu quo Organista, aut aliquis famulus fuerit conjugatus, \& ob hanc aut aliam causam collegialiter, \& in dicto Sacro Monte residere non possint, extra illum de licentia Capituli possint mansionem habere."

${ }^{3}$ ASAC IV, fol. 319 (29-XI-1672), [302]: "Y por estar la Iglesia sin organista, y había el Señor Abad empezado a hacer algunas diligencias con el Racionero Garay Maestro de Capilla de la Santa Iglesia de Granada en orden a buscar y solicitar quien venga a ser organista a su satisfacción se dio comisión al señor Abad para que continue en la solicitación."
} 
manera el quehacer musical en la Abadía (presidente del coro, corrector del coro) y un tercer grupo no tiene participación en la música, pero interviene en la ceremonia (cruciferario, portero del coro). La Tabla III.1 presenta la lista de los oficios del coro y la iglesia desempeñados por el personal del Sacromonte.

Tabla III.1. Oficios o cargos del coro y la iglesia del Sacromonte y su relación con la música. Fuente: Consueta (1632).

\begin{tabular}{|c|c|c|c|}
\hline $\begin{array}{l}\text { Personal del } \\
\text { Sacromonte }\end{array}$ & $\begin{array}{l}\text { Relación directa con } \\
\text { la música: cargo }\end{array}$ & $\begin{array}{l}\text { Relación indirectacon la } \\
\text { música: cargo }\end{array}$ & $\begin{array}{c}\text { Cargos sin relación con } \\
\text { la música }\end{array}$ \\
\hline Presbíteros & $\begin{array}{l}\text { Capellanes } \\
\text { Corrector del Coro } \\
\text { Sochantre }\end{array}$ & $\begin{array}{l}\text { Admonitor } \\
\text { Apuntador y colector de } \\
\text { misas } \\
\text { Maestro de Ceremonias } \\
\text { Presidente del Coro } \\
\text { Visitadores o Celadores } \\
\text { Comitantes } \\
\text { Rector }\end{array}$ & $\begin{array}{l}\text { Capellán Ceremoniario } \\
\text { Coadjutor de la misa } \\
\text { rezada } \\
\text { Cruciferario } \\
\text { Portero del Coro }\end{array}$ \\
\hline Colegiales & $\begin{array}{l}\text { Kalendario } \\
\text { Colegiales Cantores } \\
\text { Intonario } \\
\text { Versicularios }\end{array}$ & Cetreros & $\begin{array}{l}\text { Acólitos } \\
\text { Ceroferarios } \\
\text { Custos Sacristía }\end{array}$ \\
\hline Seglares & $\begin{array}{l}\text { Campanero } \\
\text { Organista }\end{array}$ & & $\begin{array}{l}\text { Flavelario } \\
\text { Pertiguero } \\
\text { Tesorero y Sacristanes }\end{array}$ \\
\hline
\end{tabular}

\section{Los oficios o cargos relacionados directamente con la música.}

\subsection{Capellanes}

Según las Constituciones y como recuerda la Consueta, el Sacromonte podía tener hasta seis capellanes ad nutum amobiles que sepan cantar, entre quienes puede estar el sochantre y el capellán ceremoniario. Era raro que las seis capellanías 
estuviesen ocupadas, pues con frecuencia no se proveían por cuestiones económicas. Su papel en el coro era decisivo y por ello debían asistir a todas las horas, cantando delante del facistol grande, de pie y sin bonete. Debían desempeñar los oficios que el maestro de ceremonias les asignara como comitantes o cantores. ${ }^{4}$

\subsection{Corrector del Coro}

El corrector del coro debía supervisar que no se acentuaran mal las palabras y corregir los breviarios, misales, calendarios y todos aquellos libros que se utilizasen en el coro, tanto para las oraciones como para los cantos. Las razones que aduce la Consueta para justificar este cargo ponen de manifiesto el interés constante por la dignidad del culto divino

Es officio de mucha importancia, porque en el leer bien no solo está la decencia que se deve guardar hablando con Nr. Sr. sino también interviene la autoridad y reputación de el Cabildo de hombres doctos, y asi debe cuydar mucho de ello. ${ }^{5}$

Para asegurarse de que todo se decía bien, era su obligación que los encargados de las lecturas y las calendas le pasaran la dicción o el canto el día anterior. Además era el encargado de los libros de canto y de todos los que los utilizaban en su oficio

Es a cargo del Corrector del Coro los libros del Canto y todos los que sirven en el y así visita la librería para que estén vien tratados y puestos y que en el coro los suban y baxen en el facistol sin maltratarlos, y es superintendente de los Versicularios en esto y les advertirá como lo an de hazer y avisar al Retor de los descuydos para que les de las penitencias. ${ }^{6}$

En ausencia del corrector, este oficio era desempeñado por el canónigo que presidiera. En la Consueta de la Catedral el cargo no era anual, sino que correspondía al Maestrescuela ${ }^{7}$ y sus funciones son muy parecidas al corrector de la Abadía salvo que no tenía a su cargo el cuidado de los Libros del Coro.

\footnotetext{
${ }^{4}$ Para ver el posible papel de los capellanes como cantores de polifonía, véase Capítulo IV.

${ }^{5}$ Consueta, fol. $69^{\mathrm{v}}$.

${ }^{6}$ Consueta, fols. $70^{\mathrm{r}}-70^{\mathrm{v}}$.

${ }^{7}$ Las buenas e loables costumbres, fol. $20^{\mathrm{v}}$.
} 


\subsection{Sochantres}

El sochantre debía ser clérigo, aunque no estuviese ordenado y tener buena presencia, a la par que ser una persona virtuosa; de él dice la Consueta: "que sea diestro y sepa cumplir con su oficio". 8 Su lugar estaba en las sillas bajas del Coro junto a los Capellanes, sobre los que tenía precedencia en el orden. Entre sus obligaciones estaba el revisar que los versicularios hubieran llevado y señalado convenientemente todos los libros que debían utilizarse durante el servicio. Su cometido principal como sochantre era el de entonar, para lo cual debía situarse en medio del coro, con las mangas bajadas y $\sin$ bonete, dirigiéndose al coro o a la persona que convidaba a cantar en la denominada "preintonación". ${ }^{9}$ El sochantre era el director del coro, pues debía llevar el compás "conforme a la solemnidad del día"; la Consueta aclara que "para ajustarlo lo detiene o lo apresura, más nunca ni en ningún día vaya corrido y que siempre se haga la mediación, ni comience el coro verso hasta acabado el otro". También tenía que dar el tono a todo lo que se entonara ("dar el punto") y cuidar de que se hiciera correctamente, enmendando los errores y callando al que desentonara. En las procesiones el sochantre iba en medio cuidando del compás y el tono, y repartía los procesionarios a los que mejor cantaban. Si quería "cantar al órgano" podía hacerlo en las fiestas principales, siempre que advirtiera al presidente primero y recibiera licencia; podía cantar el cuarto psalmo y el Magnificat, y en la misa "algún motete al tiempo del alzar".

Otra de las obligaciones del sochantre era dar la lección de canto a los colegiales ${ }^{10} \mathrm{y}$ advertir a los músicos de las ceremonias que debían cumplir en el cantar

Que los menestriles no digan el primer verso del Gloria Patri, que no toquen el primer ni postrer verso del Himno, que todo esto lo dicen las voces, y en lo que cantaren por el facistol los lleve el compás. Adviérteles lo que pueden cantar al órgano. ${ }^{11}$

\footnotetext{
${ }^{8}$ Consueta, fols. $110^{\mathrm{r}}$ y ss.

${ }^{9}$ Sobre este término véase el Capítulo V de este estudio.

${ }^{10}$ Sobre este particular véase el epígrafe "La Música en el Colegio de San Dionisio Areopagita", en el Capítulo IV.

${ }^{11}$ Consueta, fol. $111^{\mathrm{v}}$.
} 
También debía comprobar la suficiencia para cantar al órgano de los que subían al Sacromonte, y comunicarlo al presidente para que no cantasen si no eran diestros. Por último la Consueta contempla la posibilidad de que los colegiales ejercieran de Sochantres provisionalmente si faltaba el Sochantre o estaba la plaza vacante. ${ }^{12}$

\subsubsection{Sochantres de la Abadía del Sacromonte}

A diferencia del cargo de organista, en el que algunos permanecieron en el Sacromonte varias décadas, hubo bastante inestabilidad en este oficio, quizás porque en un lugar dónde el canto llano era imprescindible, el sochantre tenía más trabajo en el gobierno del coro y más obligaciones que en cualquier otra iglesia; además del mayor peso en cantar, debía dar lección de canto semanal a los colegiales. Al igual que ocurría con los organistas, los sochantres eran sometidos a un periodo de prueba, y a veces a un examen, por racioneros de la Catedral o de la Capilla Real, o de los propios canónigos del Sacromonte para probar su valía. En alguna ocasión también se mandan poner edictos para buscar sochantre y acuden cantores de ciudades distantes como Toledo, Badajoz o Madrid. En la primera etapa, varios sochantres vinieron de Sevilla, quizás enviados a la Abadía por Castro o sus colaboradores. Otra etapa estuvo cubierta casi en su totalidad por colegiales, coincidiendo con un periodo de crisis económica de la Abadía.

\section{Gregorio Núñez (1613-1614) $)^{13}$}

Es el primer sochantre que ocupa este puesto en la Abadía, y fue llamado de Sevilla por Pedro de Ávila cuando aún era canónigo antes de ser Abad. El cabildo acordó que reunía las cualidades oportunas y se le dio de salario 500 reales al año, además de comida, médico, botica, barbero y lavandera. ${ }^{14}$ El 10 de Noviembre de 1614

\footnotetext{
${ }^{12}$ De los colegiales Sochantre se tratará en el epígrafe de "La Música en el Colegio de San Dionisio Areopagita", del Capítulo V.

${ }^{13}$ Después del nombre de cada sochante indicaré el periodo aproximado de servicio en el Sacromonte y/o las fechas primera y última en las que el nombre aparece en las Actas.

${ }^{14}$ ASAC I, fol. 63 ${ }^{\mathrm{r}}$ (18-VIII-1613), [15].
} 
se propuso que se le perpetuase el salario para que pudiera ordenarse, ${ }^{15}$ lo que efectivamente se otorgó en Diciembre de ese mismo año. ${ }^{16}$

Solicitó permiso para ordenarse en Málaga y presentarse a una ración en Toledo. $^{17}$

\section{Fernando de Zafra (1618)}

De Zafra sólo tenemos dos escuetas noticias por las que sabemos que era segundo sochantre ${ }^{18}$ y que pidió un aumento de sueldo. Un tal Fernando de Zafra solicitó ser organista de la Capilla Real en $1607 .{ }^{19}$

\section{Simón de Torres (1619)}

A este sochantre, que era vecino de Sevilla, ${ }^{20}$ lo despidieron por pelearse con un capellán. $^{21}$

\section{Juan Díaz de Rojas (1620)}

Las Actas lo presentan como licenciado, presbítero, vecino de Sevillla y capellán de coro de la Catedral de esa ciudad. Se le admitió por sochantre y se le concedió la capellanía de Vega. ${ }^{22}$ No sabemos cuándo dejó de servir en el Sacromonte, pero en noviembre de 1621 un clérigo contralto de Montilla pretendía la sochantría, pero no se le recibió, probablemente porque el colegial Juan del Villa estaba supliendo dicho oficio. $^{23}$

\footnotetext{
${ }^{15}$ ASAC I, fol. 93 ${ }^{\mathrm{r}}$ (10-XI-1614), [28].

${ }^{16}$ ASAC I, fol. 95 ${ }^{\mathrm{v}}$ (4-XII-1614), [29].

${ }^{17}$ ASAC I, fol. $121^{\mathrm{r}}$ (15-IX-1615), [35] y ASAC I, fol. 144 (9-XII-1616), [42].

${ }^{18}$ ASAC I, fol. $195^{\mathrm{r}}$ (28-VII-1618), [53].

${ }^{19}$ Ruiz Jiménez, Organería, p. 195.

${ }^{20}$ ASAC I, fol. $223^{\mathrm{r}}(27-\mathrm{V}-1619),[56]$.

${ }^{21}$ ASAC I, fol. 228v (9-VIII-1619), [58].

${ }^{22}$ ASAC I, fol. 249 (4-V-1620), [67].

${ }^{23}$ ASAC I, fol. 308 (9-XI-1621), [86].
} 


\section{Juan Villar de Vago (1621-1627)}

La primera noticia que hace alusión a este colegial se refiere a una ayuda de costa. $^{24}$ En 1625 se le reconocen sus privilegios de sentarse en la silla más antigua del coro de los capellanes y tener el título de sochantre "por su buena voz y por las demás partes que en él se conocen". ${ }^{25}$ En octubre de 1627 llevaba más de dos meses ausente y se decidió vacarle la capellanía de Luis de Vega. ${ }^{26}$ Algo después se escribió al Cardenal de Jaén para que Villar volviera porque estaba ordenado a título de colegio. ${ }^{27}$ Parece que no volvió porque dos meses más tarde se recibió a otro sochantre.

\section{Jacinto de los Ríos (1631)}

Según las Actas Capitulares de la Abadía había sido sochantre en la Iglesia del Salvador y el cabildo lo admitió por votación después de escucharlo. ${ }^{28} \mathrm{Se}$ le concedieron 600 maravedíes de salario al año, aunque unos meses después pidió aumento que se dejó en suspenso. ${ }^{29}$ En el cabildo siguiente se acordó darle la capellanía de Vega, ${ }^{30}$ y un año después pidió al cabildo que le diera ocho fanegas de trigo y doce de cebada para sembrar un cortijo. ${ }^{31}$ En 1630 se le adviertió que no debía faltar al coro sin licencia previa, y que de lo contrario le multarían. ${ }^{32}$ En ese mismo año se peleó con el organista y el cabildo decidió reprenderlo, al igual que en el cabildo siguiente, porque en la Lección de Canto no guardaba puntualidad ni enseñaba a los colegiales convenientemente. $^{33}$ Unos meses después se le reprochó cantar "con notable fuga y

\footnotetext{
${ }^{24}$ ASAC I, fol. 310 ${ }^{\mathrm{r}}$ (16-XI-1621), [87].

${ }^{25}$ ASAC I, fol. 446 ${ }^{\mathrm{r}}$ (17-III-1625), [98].

${ }^{26}$ ASAC II, fol. $6{ }^{\mathrm{r}}$ (25-X-1627), [118].

${ }^{27}$ ASAC II, fol. $8^{\mathrm{v}}$ (10-XI-1627), [119].

${ }^{28}$ ASAC II, fol. 12 ${ }^{v}$ (6-XII-1627), [121]. Ruiz Jiménez, La colegiata del Salvador, no menciona a este sochantre.

${ }^{29}$ ASAC II, fol. $35^{v}$ (3-VIII-1628), [122].

${ }^{30}$ ASAC II, fol. $36^{\mathrm{v}}$ (5-VIII-1628), [123]

${ }^{31}$ ASAC II, fol. $94^{\mathrm{r}}$ (2-X-1629), [125]. Un acta posterior refleja que es el Cortijo de Nicodemus el que tiene arrendado, véase: ASAC II, fol. 129 (19-VI-1630) [133].

${ }^{32}$ ASAC II, fol. 110 (4-II-1630), [130].

${ }^{33}$ ASAC II, fol. 145 (30-IX-1630) [139]; ASAC II, fol. 146 (2-X-1630) [140].
} 
velocidad algunas antífonas lo cual desdice de la gravedad de esta Iglesia” y en julio de ese mismo año de 1631 se discutió la conveniencia de despedirlo si continuaba faltando al coro y a dar la lección de canto. ${ }^{34}$ En agosto de 1633 ya no debía estar desempeñando su cargo, pues el Cabildo decidió poner edictos para la provisión del oficio de sochantre. ${ }^{35}$

\section{Licenciado Mora (1630-1634)}

Era colegial que ejerció el oficio de sochantre, como muchos otros colegiales. De ellos trataré en un epígrafe aparte en el Capítulo V.

\section{Licenciado Vela (1633-1639)}

En cabildo de 16 de octubre de 1633 aparece la referencia a un sochantre sin nombre, que debía de ser el licenciado Vela y que fue examinado por dos canónigos: Agustín Manrique y Francisco Hurtado Ossorio. Unos días después se determinó que fuera admitido con 600 reales de salario más los manuales y puntos de oración. ${ }^{36}$ Como sus antecesores, obtuvo la capellanía de Vega; ${ }^{37}$ y en 1637 se le reprendió: "Y al sochantre que ande con más cuidado en lo que toca a su oficio y salga de su silla para encomendar la antífonas y versículos a los colegiales y entonarles."38

\section{Francisco de Montoro (1639)}

Era Sochantre de la Iglesia de Guadix y tomó posesión de la sochantría del Sacromonte el 1 de febrero de 1639, con el mismo salario que tenía Vela. Al poco tiempo se decidió perpetuarle la renta de la capellanía para que pudiera ordenarse. ${ }^{39}$

\footnotetext{
${ }^{34}$ ASAC II, fol. 162 ${ }^{\mathrm{r}}$ (2-I-1631), [143]; ASAC II, fol. 182 (1-VII-1631), [147].

${ }^{35}$ ASAC II, fol. 278v (12-VIII-1633), [171].

${ }^{36}$ ASAC II, fol. 290 ${ }^{\mathrm{r}}(28-\mathrm{X}-1633)$, [175].

37 ASAC II, fol. 352 $2^{v}$ (30-XII-1635), [186].

${ }^{38}$ ASAC II, fol. 400 (2-XI-1637), [198].

${ }^{39}$ ASAC II, fol. 440 ${ }^{\mathrm{v}}$ (24-II-1639), [203]; ASAC II, fol. 441 ${ }^{\mathrm{r}}$ (25-II-1639), [204]; ASAC II, fol. 461 ${ }^{\mathrm{v}}$ (9XII-1639), [208]; ASAC II, fol. 462 ${ }^{\mathrm{r}}$ (11-XII-1639), [209].
} 


\section{Cosme Pinero o Piñero (1641)}

Fue admitido con 600 reales de salario en julio de 1641 y en octubre de ese mismo año fue despedido por no haber regresado en dos días. ${ }^{40}$

\section{Pedro de Raia (1641)}

Se recibió como sochantre en octubre de 1641 con el salario acostumbrado. No hay más noticias sobre él. ${ }^{41}$

\section{Licenciado Casas (1642)}

Este sochantre debió de interesar al Cabildo porque le propuso más dinero, cien ducados de renta, la capellanía de Vega, el uso de silla alta en el coro y el título de Maestro de Capilla, con la advertencia al cabildo de que cuando muriese el licenciado Casas, se volvería a la renta acostumbrada para los sochantres. ${ }^{42}$ Aún así no pudieron retenerlo mucho tiempo.

\section{Matías de Aranda (1642-1643)}

$\mathrm{Su}$ estancia en la Abadía tampoco fue muy larga; fue recibido en diciembre de 1642 con el salario acostumbrado de seiscientos reales y la capellanía de Vega. ${ }^{43}$ Dos meses después se trató si se debería despedirlo y se acordó que "no se despedida más que se sepa que si no está con gusto que el cabildo no disgustara de que se vaya y encargose de esto al Señor canónigo Aradillas". 44

Finalmente se acordó decirle que no faltase a las horas menores ni a Vísperas y él mismo decidió despedirse de la sochantría, tan sólo un año después de haberla aceptado. $^{45}$

\footnotetext{
${ }^{40}$ ASAC II, fol. i? (3-VII-1641) [215]; ASAC II, fol. 496 v (15-X-1641), [217].

${ }^{41}$ ASAC II, fol. 497 ${ }^{\mathrm{v}}$ (25-X-1641), [218].

${ }^{42}$ ASAC II, fol. 507 (31-III-1642), [219].

${ }^{43}$ ASAC II, fol. $523^{\mathrm{v}}$ (1-XII-1642), [221].

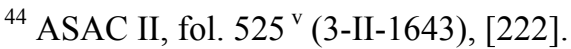

${ }^{45}$ ASAC III, fol. $5^{\mathrm{v}}$ (12-XII-1643), [223].
} 


\section{Miguel Antonio (1643)}

No sabemos si llegó a venir desde Sevilla a Granada, pues sólo tenemos la noticia de su posible venida. Parece que era amigo de un racionero de la Catedral de Granada y que se ofreció para servir en el Sacromonte. En 1645 se determinó se le diese por escrito el oficio al sochantre para que se ajustase a todo lo que debía, pero no se especifica el nombre del sochantre. ${ }^{47}$

\section{Jiménez, colegial (1647) ${ }^{48}$}

Jimñenez fue otro de los colegiales que desempeñaron el cargo de sochantre, y que solían aprovechar esta circunstancia para ordenarse a título de colegio y ganar también alguna capellanía de coro. ${ }^{49}$

\section{Francisco Martínez, colegial antiguo (1650-1653)}

Sirvió durante tres años en el Sacromonte hasta que el Cabildo lo despidió por sus continuas faltas en el comportamiento.

\section{Jiménez II, colegial (1656-1657)}

No creemos que se trate del mismo Jiménez colegial que había servido como sochantre en el Sacromonte entre 1647 y 1648. Entró a servir en Marzo de 1656 y al año siguiente ya no estaba. ${ }^{51}$

\section{Licenciado Español [Cosme Damián Español?] (1660-1661)}

\footnotetext{
${ }^{46}$ ASAC III, fol. $6{ }^{\mathrm{r}}$ (29-XII-1643), [224].

${ }^{47}$ ASAC III, fol. 30 (2-I-1645), [226].

${ }^{48}$ ASAC II, fol. 93 ${ }^{\mathrm{v}}$ (5-VII-1647), [231]

${ }^{49}$ ASAC III, fol. 80 (9-III-1647), [230]; ASAC II, fol. 93 v (5-VII-1647) [231]; ASAC III, fol. 132 r (2VI-1648) [236].

${ }^{50}$ ASAC III, fol. $196{ }^{\mathrm{r}}$ (26-VII-1650) [243]; ASAC III, fol. 370 r (28-XII-1653), [261].

${ }^{51}$ ASAC III, fol. 432v (22-III-1656) [266]; ASAC III, fol. (2-V-1657), [268].
} 
Aunque había escrito desde Jaén para ser sochantre en $1654,{ }^{52}$ fue recibido finalmente en junio de 1660 y desempeñó su oficio tan sólo un año o quizás menos, porque en julio de 1661 se recibió a Francisco Antonio de Aguilera “por promoción al de Plasencia por el licenciado Español". ${ }^{53}$ Es probable que se trate de Cosme Damián Español, tenor que está documentado en la Catedral de Jaén entre 1652 y $1653 .{ }^{54}$

\section{Francisco Antonio de Aguilera (1661-1676)}

Según las Actas, Aguilera había venido de Jaén a servir la sochantría y fue examinado por el organista Valenzuela y el canónigo Miguel Medina. ${ }^{55}$ Se le asignaron 600 maravedíes de salario más las distribuciones de capellanes y se le perpetuó la capellanía de Vega. ${ }^{56}$

Debía de ser un buen cantor, porque fue requerido por la Catedral de Córdoba en varias ocasiones, por lo que el Cabildo para retenerlo le ascendió el salario en 200 reales más y le concedió otra capellanía. ${ }^{57}$ En 1665 se determinó que se le dieran cartas al Sochantre para que lo ordenara el Obispo de Jaén. ${ }^{58}$ Entre 1665 y 1670 se insiste en la Lección de canto que el Sochantre debe dar a los colegiales, bien porque ellos no acudían o porque el Sochantre no la daba. ${ }^{59}$

\footnotetext{
52 ASAC III, fol. 378 ${ }^{\mathrm{r}}(28-\mathrm{V}-1654)$ [262].

${ }^{53}$ ASAC IV, fol. ¿? (11-VII-1661) [277].

54 Jiménez Cavallé, Documentario, pp.144-145, §2.204, §2.208, §2210. Según Cavallé en Jaén recibía 3000 reales de salario más 30 fanegas de trigo, lo que podría indicar que en el Sacromonte ganara igual o más con las distribuciones, la capellanía de Vega, más todos los emolumentos como la comida y la habitación.

${ }^{55}$ ASAC IV, fol. ¿? (11-VII-1661) [277].

${ }^{56}$ ASAC IV, fol. $69^{\mathrm{r}}$ (2-X-1663), [281]; ASAC IV, fol. $70 \mathrm{v}($ (¿-XI-1663) [282].

${ }^{57}$ ASAC IV, fol. $95^{\mathrm{r}}(10-\mathrm{I}-1665),[284]$.

${ }^{58}$ ASAC IV, fol. $110^{v}$ (1-X-1665), [287]. Un tal Francisco de Aguilera está documentado en la Catedral de Jaén en 1655 como músico "inútil”, pero el cabildo acuerda que asista al coro a "salmear el canto llano”; véase Jiménez Cavallé, Documentario musical, p. 148, § 2.260.

${ }^{59}$ ASAC IV, fol. 145 ${ }^{\mathrm{r}}$ (1-VII-1667), [291]; ASAC IV, fol. 185 ${ }^{\mathrm{r}}$ (1-IX-1668), [294]; ASAC IV, fol. 200 ${ }^{\mathrm{r}}$ (2-IV-1669), [296]; ASAC IV, fol. ¿? (2-I-1670), [297]; ASAC IV, fol. 245ำ (7-VIII-1670), [300]; ASAC IV, fol. $331^{\mathrm{v}}$ (4-XI-1673), [308]; ASAC IV, fol. 344 ${ }^{\mathrm{r}}$ (3-I-1674), [309].
} 
En dos ocasiones tan sólo reflejan las Actas una ayuda o un adelanto de salario. ${ }^{60}$ La última referencia es la concesión de una licencia por tres meses en Mayo de 1676, para que fuera a curarse por estar enfermo. ${ }^{61}$

\section{Juan del Castillo (1676-1680†)}

Hasta que Juan del Castillo fue nombrado sochantre, el maestro Rojas, que debía ser colegial, ejerció el cargo. ${ }^{62}$ Para su búsqueda se nombró a Garay, en ese momento racionero de la Catedral, y fue admitido como sochantre del Sacromonte con un salario de 1200 reales, dos censos de vino y seis reales para lavar la ropa todos los meses. ${ }^{63} \mathrm{El}$ nuevo sochantre pidió un testimonio de que para ser admitido en la plaza hizo examen ante Garay. ${ }^{64}$

En 1679 cayó enfermo y el Cabildo acordó enviarle a su casa una libra de carne y una hogaza diariamente y que se le adelantasen 200 reales de su salario. ${ }^{65}$ En 1679 solicitó al Cabildo un "vigolón" y se le denegó. ${ }^{66}$ En 1680 se menciona que ha fallecido y se determina se entierre en el Sacromonte

Item por haberse llevado Nuestro Señor a don J del Castillo, Sochantre de este Sacro Monte y haber muerto en su casa de enfermedad de dolor de costado, se trató de su entierro, y se determinó se trajese el cuerpo como así lo disponen las Constituciones y se enterrase en este Sacro Monte en la bóveda perteneciente donde se enterraban los colegiales. ${ }^{67}$

\footnotetext{
${ }^{60}$ ASAC IV, fol. ¿? (7-VI-1670), [299]; ASAC IV, fol. 322 v (21-I-1673), [304].

${ }^{61}$ ASAC IV, fol. $373^{\mathrm{r}}(23-\mathrm{VI}-1676)$, [313].

${ }^{62}$ ASAC IV, fol. $374^{\mathrm{V}}$ (1-VII-1676), [315].

${ }^{63}$ ASAC IV, fol. $375^{\mathrm{V}}$ (18-VII-1676), [316]; ASAC IV, fol. 376 r (10-VIII-1676), [317].

${ }^{64}$ ASAC IV, fol. $381^{\mathrm{V}}(1-\mathrm{X}-1676),[318]$.

${ }^{65}$ ASAC V, fol. 43 ${ }^{\mathrm{r}}$ (18-III-1679), [325].

${ }^{66}$ ASAC V, fol. $47^{\mathrm{r}}$ (19-V-1679), [327].

${ }^{67}$ ASAC V, fol. ¿? (30-IV-1680), [335].
} 


\section{Colegial Cecilio de la Torre (1680-1685)}

De nuevo se acude a un colegial para ocupar el puesto de sochantre ante la escasez de dinero, pues al colegial sólo se le perdonaban sus gastos y no tenían que librarse nuevas partidas. De aquí que el Cabildo le concediera al colegial Cecilio de la Torre una ayuda de 200 reales como ayuda de costa para comprar ropa ${ }^{68}$ y se le permita entrar a comer en el refectorio de los señores. ${ }^{69}$

El arzobispo obligó al Sacromonte a sustentarlo mientras ocupara el oficio de sochantre y no tuviera con qué mantenerse. ${ }^{70}$ En 1685 se decidió no darle una silla alta en el coro, aunque el arzobispo de Almería le había concedido una dignidad en su iglesia. También se le escribió al arzobispo agradeciéndole que lo hubiera ordenado. ${ }^{71}$ En ese mismo año se despidió de la sochantría, no sin antes solicitar una cantidad de dinero por haber suplido el oficio, pero el Cabildo se lo denegó alegando que le había pagado los gastos como colegial y muchas ayudas de costa. ${ }^{72}$

\section{Colegial Bartolomé Hervás (1685-1686)}

Su elección como sochantre suscitó cierta polémica puesto que era un colegial y había de instruirse más en el canto llano, pero de otra parte era un ahorro para los gastos de la fábrica. Se había presentado también un músico que había trabajado en la Catedral de Toledo y al que el canónigo Lucas de Bustamante creía más adecuado

Y en el punto tocante a la elección de Sochantre el señor Bustamante expresó su voto, y dijo que contradecía la elección hecha en el colegial don Bartolomé Hervás, y que su parecer era que se eligiese el pretendiente, que hay en esta casa que ha sido músico de la Santa Iglesia de Toledo; así porque era más decencia,

\footnotetext{
${ }^{68}$ ASAC V, fol. $86^{\mathrm{r}}$ (6-VII-1680), [336].

${ }^{69}$ ASAC V, fol. ¿? (3-XI-1683), [343].

70 ASAC V, fol. $178^{\text {r }}$ (1-XII-1683), [345].

${ }^{71}$ ASAC V, fol. $314^{\mathrm{r}}$ (2-I-1685), [350].

${ }^{72}$ ASAC V, fol. $236^{\mathrm{r}}$ (28-V-1685), [360].
} 
y lustre del Divino Culto, como porque no era ahorro alguno a la casa el elegir al colegial ${ }^{73}$

El canónigo Bustamante insistió hasta la fecha de su muerte en la necesidad de que el sochantre fuera alguien capaz de desempeñar su oficio con calidad y no valerse de colegiales a los que les faltaba el conocimiento necesario para dirigir el coro. Las razones que aducía en sus alegatos son muy interesantes, porque en Bustamante se ven aún los ideales de la fundación

\begin{abstract}
Así mismo propuso el sr Bustamante que el cabildo disconforme de proveer la Sochantría en sujeto científico y que pueda gobernar el coro con toda perfección, y dar a los colegiales lección de canto llano como es de costumbre antigua y loable de esta Santa casa en que se había mirado siempre con especial cuidado lo que pertenecía al culto divino y al mayor punto del coro el cual había descendido mucho porque el colegial que hacía el oficio de [240v] Sochantre con muchas faltas y se determinó por mayor parte que en este punto se conviniese lo determinado en el cabildo en el que se mandó proveer de oficio de Sochantre al colegial Bartolomé de Hervas y el sr Abad mandó expresar su voto que estaba pronto a dar parte para pedir buscar sochantre científico y de buena voz para que gobernase el coro y pudiese ser maestro de los que quisiesen aprender el canto llano. ${ }^{74}$
\end{abstract}

El canónigo Bustamante, viendo el poco caso que tenían sus palabras, volvió a exponer sus motivos, entre los que señalaba la mala administración de las rentas (por no separar la fábrica de la mesa capitular), que el nombrar a un colegial no suponía ahorro (por la pensión que se le perdonaba de 50 ducados al año podía venir un sochantre de fuera), y sobre todo porque no se atendía a la principal obligación del Sacromonte, que era el culto divino. Hay que tener en cuenta que la fecha en la que surgió esta polémica es crucial para la historia de la Abadía, justo después de que Inocencio XI condenara como heréticos los Libros Plúmbeos, marcando un periodo de decadencia que tan sólo se remontó unos años después. No es de extrañar que los canónigos, empeñados en recuperar el prestigio perdido, se dividieran ante el reparto de los bienes: unos insistiendo en el patrocinio y la impresión de obras que salvaguardaran al cabildo y

\footnotetext{
${ }^{73}$ ASAC V, fol. $229^{\mathrm{r}}(2-\mathrm{V}-1685)$, [357].

${ }^{74}$ ASAC V, fol. 240 ${ }^{\mathrm{r}}$ (3-VII-1685), [362].
} 
procurar una adecuada defensa en Roma y otros, como Bustamante, convencidos de que

Dios premiaría al cabildo siempre que se cumplieran las Constituciones

Y yo el infrascripto secretario (don Lucas de Bustamante) advertí el mucho tiempo que ha está grandemente minorada la solemnidad del culto divino y como por saltarse una grave Constitución que dispone haya un sujeto Sochantre que asista a las funciones pertenecientes a dicho culto divino y que sea su obligación enseñar el canto llano los colegiales para que puedan ayudar y obrar en el coro sin los accidentes que se experimentan se ofrecen y no hay de ellos quien sepa cosa alguna por razón de haber hecho Sochantre a un colegial que no sabe para sí ni para enseñar a los otros, y así pedía al cabildo buscase Sochantre digno de serlo y ejercer dichas obligaciones para que con toda puntualidad, decencia y experiencia se ejerza el divino culto como siempre se ejerció, y siendo como es el principal ministro y el total régimen del coro que deba la fábrica sustentar y para eso tiene en fábrica mil reales de renta, y así expresaba mi voto y requería al cabildo se hiciese, y separasen las haciendas de fábrica, patronatos y mesa, y así separadas se administrasen y se supiesen lo que cada una daba para que así se repartiese en sus ministerios y obligaciones coforme alcanzasen, siendo la primera obligación el culto divino y sus buenos y proporcionados ministros. Aquí expresó el sr Cuadrado en contra diciendo que se esté a lo hecho y determinado por el cabildo del dos de mayo del año pasado de 1685 en orden a lo del Sochantre, que entonces nombró el cabildo a dicho colegial por cuanto en este año ha servido bien este año pasado y va estudiando solfa, y sabe lo necesario y que está con resolución de dar lección de solfa a los colegiales con que se cumple la Constitución, y que no lleva salario, y que su comida es de colegio. Y yo dije que tenía que expresar sobre esto y es que las incoveniencias y faltas grandes que se han experimentado sin gobierno el coro y habiéndose advertido al pueblo muchos defectos e indecencias y sustentándole la casa a este colegial y perdonándole 50 ducados de pensión cada año, y que con otros tantos viniera a esta Iglesia otro cualquiera buen Sochantre como siempre los ha venido y que así se debe hacer con las circunstancias que ordenan las Constituciones en orden a este Ministerio que es el primero y principal de esta Iglesia y de su erección el culto divino y por tal primero lo ponen nuestras Contituciones en honra de Dios y de los Santos Mártires y al cumplimiento de tal tiene grandes rentas la fábrica y está obligada toda la hacienda. Y así pedía se cumpliesen las Constituciones en la conformidad que lo ordenan. (Al margen: Y juntamente que el cabildo del 2 de mayo del año pasado de 1685 está reclamado por mí y es nulo por no haberse citado al sr Cerda que estaba aunque enfermo dentro de este Sacro Monte)..$^{75}$

Probablemente, gracias a que el canónigo Bustamente ejercía como secretario, nos ha llegado su alegato, que él mismo trasladó a las Actas. Su muerte al año siguiente, privó al Sacromonte quizás de mejores sochantres. ${ }^{76}$

\footnotetext{
${ }^{75}$ ASAC V, fol. 275 v (1-VIII-1686), [373].

${ }^{76}$ ASAC V, fol. 300 v (27-III-1687), [380].
} 
Y por cuanto el licenciado Hervás colegial actual que es deste Sacromonte ha asistido a dicho ministerio de la sochantría más ha de un año que ha perdido la salud y parte del tiempo de sus estudios se determinó e hizo gracia este cabildo de la porción que pagan los colegiales en cada un año hasta que cumplan sus años de su asistencia al colegio. ${ }^{77}$

\section{Pedro de Castro y Pimentel (1686)}

Llegó con tan sólo 19 años a ser sochantre del Sacromonte, "de notable voz para sochantre y ciencia, y calidades para dicho ministerio, colegial que ha sido del Colegio Eclesiástico de la Iglesia catedral de Málaga”. Se le señalaron como salario mil maravedíes anuales y comida de señores, además de una capellanía para que pudiera ordenarse. ${ }^{78} \mathrm{Su}$ juventud y falta de educación hicieron que el cabildo lo despidiese tres meses después. ${ }^{79}$ Su expediente de Limpieza de Sangre figura en el Archivo de la Catedral de Málaga porque era un requisito para acceder a la sochantría de dicha Catedral en $1691 .^{80}$

\section{Francisco Palomino de León (1685-1704)}

Francisco Palomino de León ya había intentado ocupar la plaza de sochantre en 1685, pero en ese momento estaba servida por un colegial y se le dijo que estaba ocupada. Palomino, según las Actas, era sochantre de la Colegial de Úbeda, lo que sugiere que aspirar a la plaza del Sacromonte suponía un ascenso de categoría dentro del panorama de las colegiatas andaluzas. ${ }^{81}$ Fue examinado por Francisco Antonio Rico, racionero y organista de la Catedral de Granada, asignándosele 800 reales, ropa, vino, aniversarios y manuales para que pudiera ganar su distribución. ${ }^{82}$ Palomino estuvo

\footnotetext{
${ }^{77}$ ASAC V, fol. 282 v (27-IX-1686), [374].

${ }^{78}$ ASAC V, fol. 282 v (27-IX-1686), [374].

${ }^{79}$ ASAC V, fol. 289 v (2-XII-1686), [377].

${ }^{80}$ Málaga, Archivo Histórico de la Catedral, Legajo 54, pieza 18. "Ídem de D. Pedro de Castro Pimentel natural de Ubrique en el Obispado de Málaga, presentado a la Sochantría, año 1694”.

${ }^{81}$ ASAC V, fol. $113^{\mathrm{r}}(22-\mathrm{V}-1685)$, [359].

${ }^{82}$ ASAC V, fol. $297^{\mathrm{v}}$ (3-III-1687), [379].
} 
muchos años como sochantre del Sacromonte, pero debido a que se quedó casi ciego, hubo periodos en los que necesitó de una ayuda de sochantre, y se contrató al segundo sochantre de la Catedral de Granada. ${ }^{83}$ Varias actas señalan las advertencias que el cabildo le hacía respecto a no llevar la ceremonia y no hacer las pausas convenientes. ${ }^{84}$

\section{Alonso de Aguilar (1688 a 1689)}

No sabemos con exactitud el tiempo que sirvió de segundo sochantre, pues fue recibido en noviembre de 1688 como asistente al coro, y en enero del año siguiente solicitó ser admitido como sochantre, siendo aceptado por el cabildo como sochantre junto con Palomino, quitándole a éste parte de su salario. ${ }^{85}$ Parece que Aguilar fue el sochantre que en marzo de 1689 solicitó permiso para irse a una oposición a Toledo, después de lo cual ya no vuelve a aparecer en las Actas. ${ }^{86}$

\section{Joseph Garrido (1697)}

Joseph Garrido, de Alcalá la Real, fue admitido como sochantre en Enero de 1697 aunque seguía Francisco Palomino también con el cargo, con 700 reales de salario, alimentos, habitación y silla del coro, además de lavado de ropa ${ }^{87}$ No sabemos si se llegó a hace refectiva la posesión pues en marzo ya se busca a otro sochantre. ${ }^{88}$

\section{Francisco Zabalza (1697)}

Parece que Zabalza es el sochantre de Toledo que fue admitido con salario de 100 ducados, aniversarios, comida, asiento y habitación; se eligió como sochantre en 1697 frente a Agustín de Aranda que había venido de Málaga. ${ }^{89}$ En una ocasión se le

\footnotetext{
${ }^{83}$ ASAC V, fol. $474^{\mathrm{v}}$ (19-V-1690), [398].

${ }^{84}$ ASAC V, fol. $301^{\mathrm{r}}$ (2-IV-1687), [381] ; ASAC V, fol. 326 ${ }^{\mathrm{v}}$ (4-V-1688), [385].

${ }^{85}$ ASAC V, fol. 449 ${ }^{\mathrm{v}}$ (16-XI-1688), [389]; ASAC V, fol. 434 ${ }^{\mathrm{r}}$ (22-I-1689), [390].

${ }^{86}$ ASAC V, fol. 455 ${ }^{\mathrm{r}}$ (10-III-1689), [391].

${ }^{87}$ ASAC VI, fol. 83 ${ }^{\mathrm{r}}(19-\mathrm{I}-1697)$, [439].

${ }^{88}$ ASAC VI, fol. 85 ${ }^{\mathrm{r}}$ (16-III-1697), [441].

${ }^{89}$ ASAC VI, fol. 86 ${ }^{\mathrm{r}}$ (11-IV-1697), [442].
} 
multó debido a que faltó sin permirso quedándose a dormir en Granada; ${ }^{90}$ en otra acta de ese mismo año se advirtió a Palomino que supliera las enfermedades de Zabalza, del que ya no se vuelven a tener noticias. ${ }^{91}$

\section{Cristóbal de Ortega (1698)}

Este sochantre tenía que aprender "solfa", por lo que no sabemos cuáles fueron las razones que llevaron al Cabildo a admitirlo a prueba durante seis meses sin salario, ganando sólo la comida. ${ }^{92}$ Antes de los seis meses se le despidió porque no estudiaba "el canto llano y por su poca aplicación." 93

\section{Francisco Boteller (1699-1700)}

Sólo se conoce una petición de este sochantre en la que solicita 200 reales a cuenta de su salario para arreglar su habitación. ${ }^{94}$

\section{Joseph Perera (1700-1710)}

Venía de Almería y fue admitido en contra de la opinión del Abad porque según éste, al ser casado no era conveniente para el Sacromonte. ${ }^{95}$ Se le concedió una hogaza de pan más diaria y un aumento de 200 reales al año. ${ }^{96}$ Las siguientes referencias son para advertirle que imparta clase a los colegiales en el modo de cantar, ${ }^{97}$ y que tuviera

\footnotetext{
${ }^{90}$ ASAC VI, fol. $87^{\mathrm{v}}(10-\mathrm{VI}-1697)$, [445].

91 ASAC VI, fol. 90 (3-VIII-1697), [447].

${ }^{92}$ ASAC VI, fol. $102^{\mathrm{r}}$ (27-I-1698), [455].

${ }^{93}$ ASAC VI, fol. 109 $(1-\mathrm{V}-1698)$, [459].

${ }^{94}$ ASAC VI, fol. $127^{\mathrm{r}}$ (4-IV-1699), [463].

${ }^{95}$ ASAC VI, fol. $148{ }^{\mathrm{r}}$ (13-IX-1700), [469].

${ }^{96}$ ASAC VI, fol. $171^{\mathrm{r}}$ (23-III-1702), [475].

97 ASAC VI, fol. $239^{\mathrm{r}}$ (1-X-1705), [492].
} 
cuidado al designar a los que debían cantar los versículos, para que no fueran incompetentes. $^{98}$

Se despidió en mayo de 1710, volvió al mes siguiente, y abandonó definitivamente su puesto en octubre de ese mismo año. Cinco años después, en 1715 se examinó para ver si podía servir la plaza y se vió que "no estaba para servirla.",99

\section{Salvador de Santa Ana (1715)}

La primera referencia a Salvador de Santa Ana es para advertir del extraño comportamiento de este religioso agustino que inflingía penas físicas por su mano y castigos en sus confesiones, cosa que pareció escandalosa al Cabildo que decidió despedirlo de su cargo. ${ }^{100}$ Se le perdonó la falta, aunque poco después ya no servía la plaza pues se buscaba sochantre. ${ }^{101}$

\section{Juan de Berrotarán (1715-1718)}

Estuvo de suplente junto con el maestro Montes recibiendo de salario 30 reales cada mes; fue nombrado en la capellanía de Vega. ${ }^{102}$

\section{Alexandro de Montes (1715-1728) ${ }^{103}$}

Fue admitido en junio de 1715 como sochantre con un salario de 60 ducados, aniversarios y comida de señores con la condición de que había de ser examinado en

\footnotetext{
98 ASAC VI, fol. ¿? (1-IX-1709), [509].

${ }^{99}$ ASAC VI, fol. $326^{\mathrm{r}}$ (2-VI-1710), [511] ; ASAC VI, fol. $328^{\mathrm{v}}$ (2-X-1710), [513] ; ASAC VI, fol. $386^{\mathrm{r}}$ (2-IV-1715), [527]; ASAC VI, fol. ¿? (8-IV-1715), [528].

${ }^{100}$ ASAC VI, fol. 382 ${ }^{\mathrm{r}}$ (18-I-1715), [524].

${ }^{101}$ ASAC VI, fol. $385^{\text {v }}$ (7-II-1715), [525]; ASAC VI, fol. $385^{\text {v }}$ (18-III-1715), [526]; ASAC VI, fol. ¿? (8-IV-1715), [528].

${ }^{102}$ ASAC VI, fol. ¿? (8-IV-1715), [528]; ASAC VI, fol. 466 ${ }^{\mathrm{r}}$ (27-III-1718), [545].

${ }^{103}$ Un Alexandro de Montes casado con una tal Leonor María de Quesada aparece en la Diócesis de Granada en 1746; véase

http://www.familysearch.org/Eng/Search/IGI/individual_record.asp?recid=100266948596\&lds=1\&region $=15 \&$ regionfriendly $=$ Southwest + Europe $\&$ frompage $=99$ (consultada el 15-V-2008).
} 
diciembre. ${ }^{104} \mathrm{Al}$ año siguiente se le aumentó el salario en 20 ducados más y en 1717 pidió que se le perpetuara la renta para poder ordenarse. ${ }^{105}$ El Cabildo le reprendió por bajar sin licencia a Granada, ${ }^{106}$ aunque en general debía estar contento con sus servicios, pues le volvió a aumentar el salario en otros 20 ducados en 1720, con lo que recibiría 100 ducados de renta anuales. ${ }^{107}$

Un religioso tuvo que suplir sus ausencias, probablemente por enfermedad, ya que se le concedió más tarde una ayuda de costa por este motivo. ${ }^{108}$ Vendió unas fanegas de tierra al Sacromonte que eran suyas y de sus hermanos. ${ }^{109}$ Alexandro de Montes aceptó ser sochantre de la Capilla Real, por lo que el cabildo del Sacromonte acordó desligarse de la perpetuación de la renta al que estaba obligado. ${ }^{110}$ En la Capilla Real aún estaba activo el 11 de mayo de 1753, cuando a petición del cabildo elaboró informes sobre las voces de dos opositores a la capilla de música. ${ }^{111}$

\section{Diego Díez (1739-1760)}

Fue examinado por el sochantre de la Catedral de Granada, Antonio García y por un músico de la capilla de la Catedral, Joseph de Mena. ${ }^{112}$ Éstos elaboraron un informe señalando "ser la voz de dicho pretendiente de buena calidad, no fingida y quedaba en persona de que en teniendo más edad tendría más voz y que en cuanto a su suficiencia le juzgaban capaz para servir dicho empleo". ${ }^{113}$ Diego Díez era natural de Granada y sochantre de la Iglesia de la Colegial de Santa Fe. Después de 20 años de servicio en el

\footnotetext{
${ }^{104}$ ASAC VI, fol. $390^{\mathrm{r}}$ (3-VI-1715), [531].

105 ASAC VI, fol. $458^{\text {v }}$ (7-III-1717), [538].

${ }^{106}$ ASAC VI, fol. $457^{\mathrm{v}}$ (4-IX-1717), [540].

107 ASAC VI, fol. $494^{\mathrm{r}}$ (2-IV-1720), [547].

108 ASAC VI, fol. 508 ${ }^{\mathrm{r}}$ (4-V-1721), [550]; ASAC VI, fol. $511^{\mathrm{r}}$ (8-VIII-1721), [552].

${ }^{109}$ ASAC VII, fol. 67 r (10-XII-1725), [559].

${ }^{110}$ ASAC VII, fol. 151r (10-IX-1728), [566].

${ }^{111}$ López Calo, Catálogo del Archivo de Música de la Capilla Real de Granada, vol.II Apéndices Documentales, pp. 124 y 127; en 1750 hizo otro informe.

${ }^{112}$ ASAC VIII, fol. 223 r (1739)

${ }^{113}$ ASAC VIII, fol. 224 r (20-II-1739)
} 
Sacromonte solicitó un ayudante de sochantre, siendo nombrado Pedro Herrero, Sochantre de Baeza. ${ }^{114}$ Diego Díez murió y fue enterrado en el Sacromonte en $1760 .{ }^{115}$

\section{Fray Joseph Díez (1760-1763)}

Fray Joseph Díez era religioso mercedario y hermano del anterior sochantre, Díego Díez; parece que permaneció de primer Sochantre durante algún tiempo junto con Pedro de Herrero. ${ }^{116}$ Fue examinado por Joseph de Velasco, ${ }^{117}$ sochantre segundo de la Capilla Real, que prefirió a Díez sobre Herrero. Finalmente Herrero se fue a Madrid sin licencia, ${ }^{118}$ y vino a ayudar a Joseph Díez otro de sus hermanos, Francisco de Paula Díez.

\section{Francisco de Paula Díez (1772 a 1798) y Pedro de Torres ${ }^{119}(1766-1798)$}

Fueron los sochantres que más tiempo permanecieron estables en el Sacromonte como pareja de sochantres. Francisco de Paula ayudaba a su hermano en 1772 y permaneció como sochantre con Pedro de Torres hasta finales del siglo XVIII; era soltero e intentó no residir en el Sacromonte.

Pedro de Torres, originario de Málaga, donde era salmista en la Catedral, aparece en el Sacromonte en 1766 y permanece allí hasta finales de siglo. Trabajó en el arreglo de los libros de coro en diversas ocasiones. Intentó opositar a una plaza en Almería pero no la obtuvo. ${ }^{120}$ Estaba casado y tenía hijas como se desprende de un acta capitular en la que pide dinero para vestir a su mujer e hijas. ${ }^{121}$

\footnotetext{
${ }^{114}$ ASAC X, fol. ¿? ${ }^{\mathrm{v}}$ (6-VIII-1759)

${ }^{115}$ ASAC X, fol. $99^{\mathrm{v}}(15-\mathrm{IV}-1760)$.

${ }^{116}$ ASAC X, fol. $101^{\mathrm{v}}(28-\mathrm{IV}-1760)$

${ }^{117}$ Velasco fue sochantre en tiempos de Antonio Caballero; véase López Calo, Catálogo del Archivo de Música de la Capilla Real, pp. 165-166.

${ }^{118}$ ASAC X, fol. $128^{\mathrm{v}}(6-\mathrm{V}-1761)$.

${ }^{119}$ Un tal Pedro de Torres, Sochantre de Guadix, solicitó una plaza en Almería en 1769, pero regresó a su tierra con una ayuda de costa y una certificación de haberse examinado. Véase Juan López Martín et alii, Noticias y Catálogo de Música de la S. y A.I.C. de Almería (Granada: CDMA, 1997), p. 40.

${ }^{120}$ ASAC XI, fol. 102 ${ }^{\mathrm{r}}$ (16-I-1769), [692].

${ }^{121}$ ASAC XI, fol. ¿? (7-XI-1774), [721].
} 
La mayoría de las noticias que mencionan a estos dos sochantres son para pedir limosna, en dinero, en comida o en ropa. En 1798 por sus "crecidas edades" se decide jubilarlos y buscar a dos suplentes que puedan venir a residir en el Sacromonte para cumplir con sus obligaciones más cómodamente.

\section{Fray Juan Ribera de la Presentación (1798-¿?)}

En 1798 se recibió a Fray Juan Ribera de la Presentación, "Religioso presbítero agustino descalzo del convento de esta ciudad residente ahora en el de Sevilla" ${ }^{\text {"122 con }}$ informes del organista del Sacromonte, Luis de León en que daba cuenta de "la idoneidad, suficiencia, buena voz y arreglada conducta del susodicho.”

Diversos aspirantes acudieron a examinarse para obtener la plaza de sochantre en el Sacromonte. Este puesto debía de ser apetecible, por el prestigio del centro y por incluir el alojamiento y la comida en una época de hambruna. La capellanía aneja era otro emolumento a tener en cuenta, sobre todo para los eclesiásticos, pues eran los que podían ejercerla y ganar sus rentas. Entre los nombres de los pretendientes a sochantre que no fuerona admitidos podemos citar a los siguientes: Miguel Ambrosio de Vago, natural de Madrid, escribió una carta a la que se le respondió que no había necesidad de Sochantre; ${ }^{123}$ un pretendiente de Baza fue examinado y se llegó a pedir información (extrajudicial) de sus costumbres; ${ }^{124}$ M. de la Puente, de Antequera al que le dieron 50 reales de ayuda de costa "por haber venido a hacer la oposición a Sochantría y ser muy pobre"; ${ }^{125}$ Francisco Hernández Matheos; ${ }^{126}$ y un tal Francisco Antonio, de Cazorla. ${ }^{127}$

\footnotetext{
${ }^{122}$ ASAC XII, fol. ¿ $?^{\mathrm{r}}(1-\mathrm{VI}-1798)$, [843]

${ }^{123}$ ASAC V, fol. $479^{\mathrm{v}}$ (9-XII-1690), [402].

${ }^{124}$ ASAC VI, fol. ¿? (7-VIII-1694), [420].

${ }^{125}$ ASAC VI, fol. 74 ${ }^{\mathrm{r}}$ (12-XI-1696), [437].

${ }^{126}$ ASAC VI, fol. $97^{\text {v }}$ (14-XII-1697), [450].

${ }^{127}$ ASAC VI, fol. $102^{\mathrm{r}}$ (22-I-1698), [454].
} 
En una ocasión un de los pretendiente a sochantre era de la Catedral de Granada, pero no se admitió "por ser casado y no poder tener su habitación en el Sacromonte". ${ }^{128}$

Tabla III.2. Sochantres de la Abadía del Sacromonte (1613-1799).

\begin{tabular}{|c|c|c|}
\hline Sochantres & Fechas extremas en la Abadía & Procedencia- Destino \\
\hline Gregorio Núñez & 18-VIII-1613 a 4-XII-1614. & Sevilla - ¿Toledo? \\
\hline Fernando de Zafra & 28-VII-1618 & ¿? \\
\hline Simón de Torres & 27-V-1619 a 9-VIII-1619. & Sevilla - ¿? \\
\hline Juan Díaz de Rojas & $4-\mathrm{V}-1620$ & $\begin{array}{l}\text { Capellán de coro de la Catedral de } \\
\text { Sevillla - ¿? }\end{array}$ \\
\hline Juan Villar de Vago & 16-XI-1621 a 10-XI-1627. & Colegial del Sacromonte - ¿Jaén? \\
\hline Jacinto de los Ríos & 2-I-1631 a 1-VII-1631. & $\begin{array}{l}\text { Sochantre en la Iglesia del Salvador de } \\
\text { Granada - } ¿ ?\end{array}$ \\
\hline $\begin{array}{l}\text { Licenciado Francisco } \\
\text { de Mora }\end{array}$ & 2-III-1630 a 23-VI-1634. & ¿? \\
\hline Licenciado Vela & $16-X-1633$ a 2-XI-1637. & ¿? \\
\hline Francisco de Montoro & 1-II-1639 a 11-XII-1639. & ¿? \\
\hline Cosme Pinero o Piñero & 3-VII-1641 a 15-X-1641. & ¿? \\
\hline Pedro de Raia & $25-X-1641$ & ¿? \\
\hline Licenciado Casas & $31-$ III-1642 & ¿? \\
\hline Matías de Aranda & 1-XII-1642 a 12-XII-1643. & ¿? \\
\hline Miguel Antonio & $29-X I I-1643$ & Sevilla - ¿? \\
\hline Jiménez, colegial & 5 -VII-1647 & Colegial del Sacromonte - ¿? \\
\hline Francisco Martínez & 26-VII-1650 a 28-XII-1653. & Colegial del Sacromonte - ¿? \\
\hline Jiménez II, colegial & 22-III-1656 a 2-V-1657. & Colegial del Sacromonte - ¿? \\
\hline $\begin{array}{l}\text { Licenciado Español } \\
\text { ¿Cosme Damián } \\
\text { Español? }\end{array}$ & 1-VI-1660 a 11-VII-1661 & Catedral de Jaén - Plasencia \\
\hline $\begin{array}{l}\text { Fco. Antonio de } \\
\text { Aguilera }\end{array}$ & 11-VII-1661 a 23-V-1676 & Jaén - ¿? \\
\hline Juan del Castillo & 1-VII-1676 a 30-IV-1680† & ¿? - † Sacromonte \\
\hline Cecilio de la Torre & 6-VII-1680 a 28-V-1685. & Colegial del Sacromonte - ¿Almería? \\
\hline Bartolomé Hervás & $2-\mathrm{V}-1685$ a $27-\mathrm{IX}-1686$. & Colegial del Sacromonte - ¿? \\
\hline $\begin{array}{l}\text { Pedro de Castro y } \\
\text { Pimentel }\end{array}$ & 27-IX-1686 a 2-XII-1686. & $\begin{array}{l}\text { Colegial (Málaga) - Sochantre Catedral } \\
\text { de Málaga } 1694\end{array}$ \\
\hline Francisco Palomino & 22-V-1685 a 1-VII-1704. & Sochantre de la Colegial de Úbeda - ¿? \\
\hline Alonso de Aguilar & 16-XI-1688 a 10-III-1689. & ¿? - Permiso para oposición a Toledo. \\
\hline Joseph Garrido & ¿19-I-1697 a 16-III-1697? & Alcalá la Real - ¿? \\
\hline Francisco Zabalza & 11-IV-1697 a 3-VIII-1697. & ¿Toledo? - ¿? \\
\hline Cristóbal de Ortega & 27-I-1698 a 1-V-1698. & $i ?$ \\
\hline Francisco Boteller & 4-IV-1699 & ¿? \\
\hline Joseph Perera & 13-IX-1700 a 2-X-1710. & Almería - ¿? \\
\hline $\begin{array}{l}\text { Salvador de Santa Ana, } \\
\text { religioso agustino }\end{array}$ & 10-I-1715 a 18-III-1715. & ¿? \\
\hline Juan de Berrotarán & 8-IV-1715 a 27-III-1718. & ¿? \\
\hline Alexandro de Montes & 3-VI-1715 a 10-IX-1728. & $\begin{array}{l}\text { ¿? - Sochantre de la Capilla Real de } \\
\text { Granada (activo el 11-V-1753) }\end{array}$ \\
\hline
\end{tabular}

${ }^{128}$ ASAC VI, fol. $108^{\mathrm{r}}$ (5-IV-1698), [456] ; ASAC VI, fol. $108^{\mathrm{v}}$ (12-IV-1698), [457]. 


\begin{tabular}{|l|l|l|}
\hline Diego Díez & 20-II-1739 a 15-IV-1760. & $\begin{array}{l}\text { Sochantre de la Iglesia Colegial de } \\
\text { Santa Fe (Granada) - † Sacromonte }\end{array}$ \\
\hline Pedro de Herrero & 6-VIII-1759 a 6-V-1761. & Baeza - Madrid \\
\hline $\begin{array}{l}\text { Fray Joseph Díez, } \\
\text { religioso mercedario }\end{array}$ & 28-IV-1760 a 24-III-1763. & ¿? Jubilación en el Sacromonte. \\
\hline Pedro de Torres & $5-V-1766$ a 7-III-1798. & $\begin{array}{l}\text { Málaga, salmista en la Catedral - } \\
\text { Jubilación en el Sacromonte. }\end{array}$ \\
\hline Francisco de Paula Díez & ¿?-II-1772 a 1798. & Subilación en el Sacromonte. \\
\hline $\begin{array}{l}\text { Fray Juan Ribera de la } \\
\text { Presentación }\end{array}$ & $1-$ VI-1798 \\
\hline
\end{tabular}

\section{]}

\subsection{Kalendario}

Cada semana a la hora de Prima, un colegial que supiera entonar se encargaba de cantar las lecciones y de poner un facistol alto en medio del coro con el misal para que los prebendados diáconos pasaran la epístola y el evangelio que habían de cantarse al día siguiente; si faltaban los dos correctores avisaba al Presidente para que designara a otro Prebendado que ejerciese como tal. En algunas ocasiones más solemnes la kalenda no era cantada por el colegial, sino por otro prebendado o capellán. Los prebendados cantaban las kalendas de Navidad, San Cecilio, San Hiscio, San Mesitón, San Tesiphón y Santiago, los capellanes, las kalendas de la Dedición de Granada, de Resurrección y Dedicación de la Iglesia. La descripción de cómo se desarrollaba su acción es muy completa

Quando el que haze el offiçio dize la conclusion de la oraçion de príma el Kalendario por entre el coro de los colegiales y los asientos va al facistol alto donde está el martyrologio y haze genuflexión al altar auiendo hecho antes humiliaçión al que preside y respondido del coro Deo gratias entona la Kalenda que canta con mas pausa segun la solennidad del dia.

Pone mucho cuydado en la buena pronunciacion claridad y distinçion y pausas que de la apuntaçión en todo lo qual se â de esmerar como lo pide su ciencia y profesion.

Quando acaua haze genuflexión al altar y al coro venia como al prinçipio, se pone en su coro eregione ${ }^{129}$ al lado del facistol. ${ }^{130}$

\subsection{Intonario}

Este curioso oficio se ha confundido a veces con el que entona los versos o el comienzo de las antífonas en el coro, pero al menos en el contexto abacial hace alusión

\footnotetext{
${ }^{129}$ De pie.

${ }^{130}$ Consueta, fol. $143^{\mathrm{v}}$.
} 
a aquél que entona el órgano, es decir le infunde aire moviendo los fuelles. En una curiosa descripción, la Consueta subraya cómo el Intonario "a menester mucha adbertençia y cuydado en alzar, porque cualquiera falta que haga es causa de notable disonancia y desagrado". ${ }^{131}$ Debía avisar al organista cuándo había de acudir a tocar y estaba atento a todos los momentos en los que se debía de tocar

Antes de comenzar la missa o cualquiera offiçio en que aya organo â de yr y si no a llegado el organista le auise y con tiempo estan ambos en el organo no se aparta de la mesa de la escalera y está a punto en todas las ocasiones en que se a de tocar especialmente a los finales de las Epistolas y aunque hagan señal que çese el organo no a de dexar de alzar hasta que el organista dexe. ${ }^{132}$

De las advertencias que da la Consueta podemos deducir cuáles eran los problemas de este oficio y formular cuáles eran sus tres reglas fundamentales: 1) cuidado en el movimiento de "alzar" o levantar el mango del fuelle; 2) continuar moviendo (alzando) el fuelle hasta que el organista deje de tocar; 3) el movimiento no debe ser brusco evitando que se "topen los palos ni cadenas ni se rozen los cordeles ni dé golpes". 133

Además, el intonario tenía la obligación de ayudar al organista en la limpieza y aderezo del órgano

Esté en su ministerio sin sobrepelliz, alzará con blandura y destreza que no se topen los palos ni cadenas ni se rozen los cordeles ni de golpes, cuyda el organista de aderezarlos quando fuere menester y ayuda y asiste al organista quando limpia y adereza el organo. ${ }^{134}$

\footnotetext{
${ }^{131}$ Consueta, fol. $219^{\mathrm{r}}$.

${ }^{132}$ Consueta, fol. $219^{\mathrm{r}}$.

${ }^{133}$ Consueta, fol. $219^{\mathrm{r}}$.

${ }^{134}$ Consueta, fol. $219^{\mathrm{r}}$.
} 
Tabla III.3. Versos que cantan los colegiales cantores del coro y sus excepciones.

\begin{tabular}{|c|c|c|}
\hline Ceremonia y tiempo & Colegiales del coro & Capellanes \\
\hline Ferias & Responsorios y versos & --------------- \\
\hline Ferias Tiempo de Pascua & --------------- & Responsorios y versos \\
\hline Vigilias & Responsorios y versos & -------------- \\
\hline $\begin{array}{l}\text { Vigilias Navidad, Epifanía, } \\
\text { Ascensión, Pentecostés }\end{array}$ & --------------- & Responsorios y versos \\
\hline $\begin{array}{l}\text { Fiestas de } 1^{\text {a }} \text { Clase } \\
\text { Fiestas de Ntra. Sra. } \\
\text { Santos Sacromonte }\end{array}$ & -------------- & Responsorio y verso \\
\hline Vísperas & Benedicamus Domino en tono & --------------- \\
\hline Vísperas de $2^{\mathrm{a}}$ Clase & ------------ & Benedicamus Domino \\
\hline Misas $1^{\mathrm{a}}$ o $2^{\mathrm{a}}$ Clase & --------------- & $\begin{array}{l}\text { Verso del Introito } \\
\text { Gloria Patri } \\
\text { Incarnatus Est del Credo }\end{array}$ \\
\hline Misas & $\begin{array}{l}\text { Verso del Introito } \\
\text { Gloria Patri } \\
\text { Incarnatus Est del Credo }\end{array}$ & --------------- \\
\hline $\begin{array}{l}\text { Fiestas Cuaresma y Adviento, y } \\
\text { Vigilias de Santos }\end{array}$ & $\begin{array}{l}\text { Un colegial entona el } 1^{\text {er }} \text { Kyrie- } \\
\text { Coro el siguiente- } 2^{\circ} \text { colegial el } \\
\text { tercero }\end{array}$ & -------------- \\
\hline Salve cantada & $\begin{array}{l}\text { Verso Ora pro nobis Sancta Dei } \\
\text { Genitrix }\end{array}$ & -------------- \\
\hline $\begin{array}{l}\text { Conmemoraciones cantadas de } \\
\text { las Vísperas que no hay caperos }\end{array}$ & Versos & --------------- \\
\hline Estaciones de las procesiones & Versos & -------------- \\
\hline
\end{tabular}

\subsection{Colegiales cantores}

Dos colegiales eran elegidos cada semana para cantar las antífonas de las horas junto con los responsorios breves y los versos; en las horas menores los decían en tono en lugar de cantarlos. La Tabla III.6 recoge en qué ceremonia y tiempo cantaban los colegiales y cuándo lo hacían los capellanes. La Consueta les advierte de que "sean muy puntuales en salir a tiempo para dezir y coger el punto que les diese el Sochatre porque no desentonen". ${ }^{135}$ Además tenían a su cargo el avisar al sochantre qué días cantaban los versos los capellanes; de faltar estos últimos, los versos los "decían" los colegiales aunque fueran cantados, probablemente por continuar con la jerarquía fuertemente establecida en las funciones del coro.

${ }^{135}$ Consueta, fol. $147^{\mathrm{r}}$. 


\subsection{Versicularios}

Este oficio era rotativo: semanalmente dos colegiales eran señalados para cumplir con los cometidos que conllevaba el puesto. El más antiguo de los dos era el encargado de ver el breviario para saber "de quien se reza y haze el officio y dize la missa para prevenir los libros convenientes" y el más moderno debía limpiar el coro. Juntos tomaban los "libros grandes" y debían llevarlos entre los dos sobre los hombros. También era su función el registrar las oraciones y los salmos. Para la misa mayor debían llevar el libro de los Kyries y Gloria y "el de la misa apuntada", y si había profecías en la misa, ponían el facistol alto en medio del coro. La Consueta describe detalladamente todos los libros que debían preparar para cada ocasión, así como el momento preciso en el que debían quitarlos de los diferentes facistoles y cambiarlos por otros.

Para los maytines llevan los libros necesarios, ponen alfombras como para visperas mas el taburete del celebrante y facistol con su paño lo ponen en el hueco de la ventana hasta que se entona el Te Deum Laudamus que quitan el facistol alto que pusieron en el medio del coro para las lecciones y en su lugar ponen el pequeño y le ponen el breviario y traen el taburete y lo ponen donde ha de estar como en vísperas. ${ }^{136}$

Otra de las descripciones de la Consueta nos remite a que los versicularios utilizaban diversos instrumentos para señalar las hojas y los versos

Llevan asimismo los hierros para señalar las hojas, los punteros para apuntar el verso que se ha de decir, la vara del sochantre para que lleve el compás. ${ }^{137}$

Esta "vara" que tenía el Sochantre para marcar el compás corrobora que el canto llano se medía en el siglo XVII. ${ }^{138}$ Su lugar en el coro estaba siempre junto al facistol para que pudieran cumplir con su trabajo

\footnotetext{
${ }^{136}$ Consueta, fol. $139^{\mathrm{r}}$.

${ }^{137}$ Consueta, fol. $139^{\mathrm{v}}$.

${ }^{138}$ Sobre esta particularidad se hablará en el capítulo IV de este estudio.
} 
Asisten a los lados del facistol grande y nunca se apartan para cosa alguna excepto que si no ay otro Collegial en el coro el mas moderno sale a hazer la señal a la torre para que el campanero toque la plegaria o doble al Aniversario. ${ }^{139}$

La descripción de cómo debían pasar los folios de los cantorales es muy detallada y es quizás la más completa que tenemos de este desusado oficio.

Tienen las mangas baxas echadas sobre el brazo siniestro, estan con mucha atención los ojos en el libro para bolver las hojas con puntualidad y buelven las puntas altas primero para que se vea la dicción que se sigue, el versiculario de la mano derecha las buelve, el otro las recive y asienta de baxo del clabo para ygualarlas y allanarlas usan de la mano cubierta con las mangas del sobrepelliz porque no ensucien las hojas, quando las puntas altas estan caydas las levanta y igualan con los punteros, los quales tienen siempre en la mano diestra para apuntar el verso que se a de decir y cada uno apunta los versos de la plana que esta en su lado y todo lo que se ha de decir y lo que se ha de dexar de decir cubren con la manga de la sobrepelliz.

Y como suele por inadvertencia trocarlo el coro, los Versicularios han de prevenir y enmendar el hierro señalando con tiempo porque como los hierros que se hizieren en esto son mas notables asi deven estar con mas cuydado de que no se cometan. ${ }^{140}$

La Consueta incide en el cuidado que tiene que tener con los libros "en ninguna manera hurguen las hojas con los clavos para levantarlas ni hallar los registros porque las carcomen y rompen los hierros". ${ }^{141}$

Acavados los oficios van al aposento de los libros quitanse las sobrepellices porque con ellas nunca los an de llevar ni traer encierranlos y baxan sobre los hombros y los ponen en su lugar; de suerte que al ponerlo y baxarlos y mudarlos no los arrastren ni den golpes ni maltraten ni los dexen fuera del estante. ${ }^{142}$

Asimismo debían avisar "quando es menester aderezar los libros y no consienten que anden fuera del aposento que los traigan en otros usos". ${ }^{143}$

\footnotetext{
${ }^{139}$ Consueta, fol. $139^{\mathrm{r}}$.

${ }^{140}$ Consueta, fol. $140^{\mathrm{r}}$.

${ }^{141}$ Consueta, fol. $140^{\mathrm{r}}$.

${ }^{142}$ Consueta, fol. $140^{\mathrm{v}}$.

${ }^{143}$ Consueta, fol. $142^{\mathrm{r}}$.
} 
Su papel en las procesiones también aclara algún punto sobre el desarrollo de éstas, así además de repartir los procesionarios deben encargarse de trasladar el facistol de estación en estación "y registraran asimismo las antíphonas que se ubieren de decir". ${ }^{144}$ Los versicularios de la Catedral, a diferencia de los sacromontanos, debían entonar algunas veces, quizás de aquí el nombre de versicularios (versiculum).

\subsection{Campanero}

El campanero vivía en la torre, cuidaba del reloj y era el encargado de regular la vida de los canónigos y colegiales a través de sus toques de campana. La Consueta menciona varias campanas: la de la Asunción, la campana de San Cecilio, la Gorda y la campana de San Dionisio. En la actualidad no sabemos qué ha sido exactamente de éstas campanas. Algunas, como la de San Cecilio o la Asunción, parece que fueron refundidas a principios del siglo XX. Las Actas hablan de la refundición de las campanas por rotura en varias ocasiones.

Después propuso el señor Abad en atención a la quebracía tan irremediable que había padecido la campana de las Santas Cuevas, que era precisa su composición en fundición nueva, y resuelto por todos votos que se fundiese cuando los presentes ahogos y/grandes gastos lo permitiesen. Se dio comisión al señor Chinchilla tesorero, para que por su mano corra estas obras, y también para este caso quedo determinado para maestro de la referida fundición Joseph Lorenzo Corona, maestro de dicha ciudad bajo las premisas que ofrece el cabildo en memorial aquí presentado por cuyo tenor ha de otorgar la escritura que el dicho Corona ofrece. ${ }^{145}$

Joseph Lorenzo Corona era fundidor de Granada, por lo que se conservan campanas suyas en muchas iglesias de la ciudad y la provincia. ${ }^{146}$ Sin embargo, esta campana de Corona no ha podido ser identificada en la Abadía.

\footnotetext{
${ }^{144}$ Consueta, fol. $142^{\mathrm{r}}$.

${ }^{145}$ ASAC IX, fol. 105 ${ }^{\vee}$ (4-XI-1749), [626]. Otra referencia sobre fundición de campanas puede encontrarse en ASAC XI, fol. 70 ${ }^{\mathrm{r}}$ (8-I-1768), [686].

${ }^{146}$ Algunas de ellas en Íllora como puede verse en el siguiente enlace: http://www.bibliotecaspublicas.es/illora/imagenes/contenido14523 8.pdf , pp.5-6 (Consulta realizada el 28-5-2008).
} 
Anteriores a la redacción de la Consueta, se conservan dos campanas (una llamada de Santiago) y otra sin nombre, que bien pudiera ser una de las que se nombraban en la Consueta. En la actualidad se conservan las siguientes campanas según recoge Nieves Jiménez Díaz:

Tabla III.4. Campanas que se conservan en la Abadía del Sacromonte (Granada). Fuente: Nieves Jiménez Díaz. ${ }^{147}$

\begin{tabular}{|c|c|c|c|c|}
\hline Campana & Fundidor & Año & $\begin{array}{l}\text { Diámetro } \\
\text { cm }\end{array}$ & $\begin{array}{c}\text { Peso } \\
\text { Kg }\end{array}$ \\
\hline S. Jacobo & & 1613 & 101 & 597 \\
\hline Campana & & 1613 & 72 & 216 \\
\hline María & & 1660 & 57 & 107 \\
\hline $\begin{array}{l}\text { Sta. María de las } \\
\text { Angustias }\end{array}$ & CASARES, GERONIMO & 1854 & 67 & 174 \\
\hline $\begin{array}{l}\text { Sta. María de la } \\
\text { Asunción }\end{array}$ & $\begin{array}{l}\text { LÒPEZ ANTRÁS, JOSÉ } Y \text { DÍAZ } \\
\text { MURIEL, RICARDO }\end{array}$ & 1900 & 128 & 1214 \\
\hline $\begin{array}{l}\text { Campana del coro } \\
\text { (interior) }\end{array}$ & $\begin{array}{l}\text { LINARES ORTIZ, CONSTANTINO DE } \\
\text { (CARABANCHEL BAJO) }\end{array}$ & 1913 & 34 & 23 \\
\hline S. Cecilio & $\begin{array}{l}\text { MURUA, } \quad \text { HIJOS } \\
\text { (GASTEIZ/VITORIA) }\end{array}$ & 1919 & 87 & 381 \\
\hline Sacromonte & $\begin{array}{l}\text { LINARES ORTIZ, CONSTANTINO DE } \\
\text { (CARABANCHEL BAJO) }\end{array}$ & 1930 & 48 & 64 \\
\hline
\end{tabular}

Las fiestas debían anunciarse según su importancia con diferentes campanas y toques. La Tabla III.5 recoge los nombres de las campanas de la Abadía y las festividades en las que debían tocar. Los diferentes toques de los que habla la Consueta son "a vuelta", "a media vuelta", "a lengua" y "repique"; repicar está descrito de la siguiente forma:

\footnotetext{
${ }^{147} \mathrm{http}: / / 84.79 .33 .253 / \mathrm{php} /$ campanar.php?numer=1522 [7-6-2008]. Una ficha detallada de campana puede verse en http://84.79.33.253/php/campanes1.php?numer=1522 (Consulta realizada el 17-6-2008).
} 
El modo de repicar es, comienzan los esquilones y campana del relox a lengua como el espacio de un credo, luego entra la campana de St. Çeçilio y esquilon de San Dionisio juntamente a buelta entera como espacio de dos Credos, luego la Campana de la Asumpçión y despues de otros dos Credos la gorda y estas quatro campanas andan a buelo ni apriesa ni muy despaçio porque asi hazen musica.

Acavado el primer repique se quedan las que andan a buelo la campana arriba y la cabeza abaxo porque al segundo comienzan con mas presteza, al ultimo se quedan las campanas abaxo y las que andan a lengua no cesan hasta un rato despues de aver parado las otras. ${ }^{148}$

El sonido de las campanas regulaba el quehacer diario de canónigos, colegiales y demás ministros, por ello era fundamental atender a los distintos toques que variaban según la calidad de la fiesta o la época del año. En la Tabla III.6 puede verse el horario de toques principales del campanero. Los repiques eran sólo para señalar la misa mayor, la Víspera o los maitines, nunca para entrar en Vísperas o Completas. Además se tocaba no sólo para llamar a la iglesia, sino durante algunos momentos de las ceremonias, para lo que el campanero debía ser avisado desde el coro. Por ejemplo, en la Misa debía tocar al alzar o en las Vísperas tocaba la "plegaria" a la "expiración". Cuando estaba el Santísimo Sacramento manifestado, "al encerrar y desencerrar" se debía repicar con todas las campanas. Cuando moría alguien en el Sacromonte, el toque era diferente si el finado era un prebendado o un capellán, colegial, sacristán o pertiguero. En el primer supuesto se debían dar los "Clamores" con todas las campanas desde que expiraba y durante todo el día (excepto durante las horas y la misa) y más frecuente mientras se celebraba el entierro y oficio. Por los capellanes, colegiales, sacristanes y pertiguero tocaba todas las campanas excepto la gorda, tres clamores a la expiración y mientras se hacía el entierro y el oficio. También aparece el toque de la "matraca", un instrumento empleado en lugar de las campanas durante la Semana Santa como señal de duelo, sobre todo, durante el Triduo Sacro. ${ }^{149}$

\footnotetext{
${ }^{148}$ Consueta, fol. $125^{\mathrm{v}}$.

${ }^{149}$ Ramón Andrés, Diccionario de instrumentos musicales: de la antigüedad a J.S. Bach (Barcelona: Península, 2001) p. 234.
} 


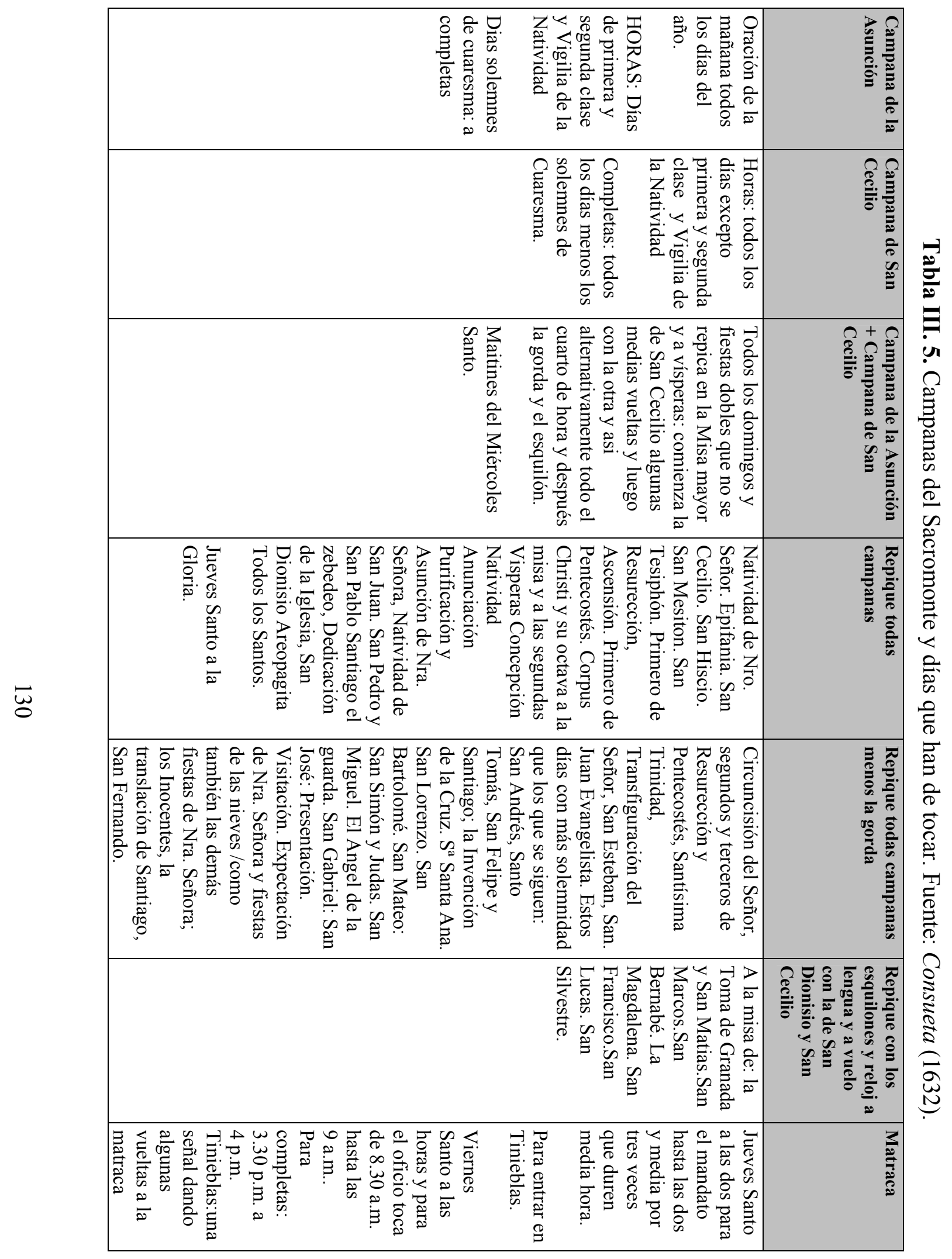




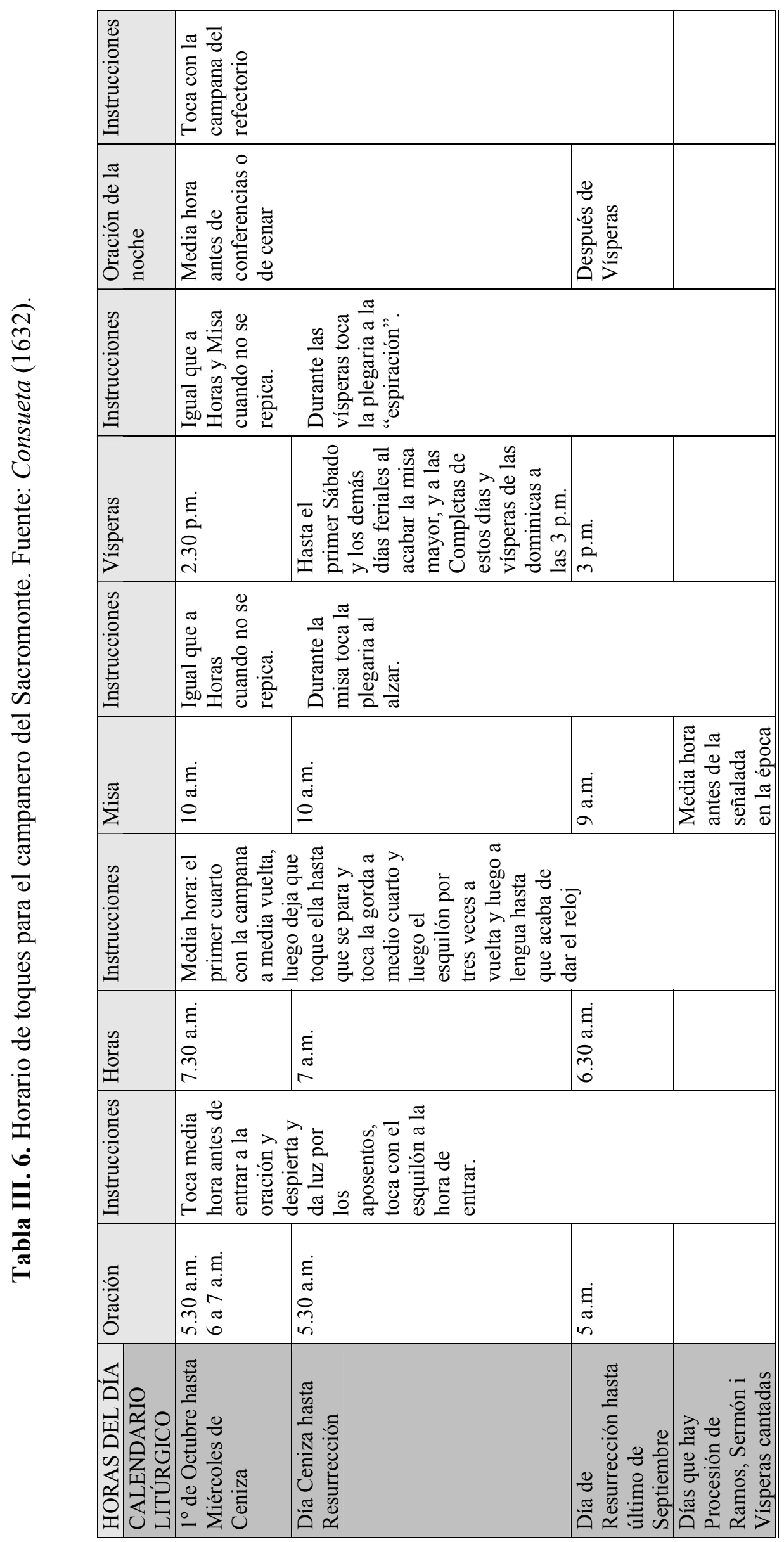




\subsection{Organista}

Las obligaciones del organista eran uno de los puntos comunes de muchos memoriales y consuetas, donde pueden encontrarse indicaciones sobre en qué fiestas debe tocar y en qué momento de la ceremonia. Rara vez se dan especificaciones técnicas, pero la Consueta del Sacromonte proporciona algunos datos que pueden darnos una visión más concreta del papel que jugaba el organista en cada ceremonia.

Como ya he señalado, el cargo del organista en la Abadía no era por oposición. La mayor parte de las veces, cuando se buscaba a un nuevo organista, se recibía durante un periodo de prueba, finalizado el cual el Cabildo decidía si continuaba o no. A veces, el Cabildo concedía ayudas de costa para el viaje de vuelta si el aspirante había venido de fuera y finalmente no era aceptado. Los candidatos solían enterarse por el boca a boca y las cartas que algunos canónigos enviaban a otros centros religiosos, habida cuenta de que tan sólo una vez se menciona en las Actas que se cuelguen edictos para cubrir una vacante y en esa ocasión fue para buscar sochantre. ${ }^{150}$ Los organistas no tenían por qué estar ordenados, pero debían preferentemente residir en el Sacromonte, con lo cual no podían estar casados. En algún caso excepcional, el organista es liberado de vivir en el Sacromonte o por tener familia que mantener o por estar casado, como el organista Jerónimo de Valenzuela, que sabemos tenía una hija. ${ }^{151}$

\footnotetext{
${ }^{150}$ ASAC II, fol. 278 (12-VIII-1633), [171]: "y en cuanto a la provisión del oficio de Sochantre se determinó por todos los votos que se pongan edictos ubicándose a los mismos señores Bartolomé de Torres y Gabriel de Ledesma la disposición de ellos y fijarlos a donde pareciere a ellos más conveniente".

${ }^{151}$ ASAC IV, fol. 324 (i?-IV-1673), [306].
} 
Tabla III.7. Presencia del organista en las ceremonias de la Abadía del Sacromonte. Fuente: Consueta (1632), fols. $112^{\mathrm{r}}-116^{\mathrm{v}}$.

\begin{tabular}{|c|c|c|c|}
\hline Ceremonia & Fiesta & Momento litúrgico & Toca \\
\hline \multirow[t]{8}{*}{ Misa } & \multirow[t]{8}{*}{$\begin{array}{l}\text { Dominicas } \\
\text { Fiestas Dobles } 1^{\mathrm{a}} \text { y } 2^{\mathrm{a}} \text { clase }\end{array}$} & $\begin{array}{l}\text { Kyrie } \\
\text { Gloria }\end{array}$ & Alternatim con el Coro \\
\hline & & $\begin{array}{l}\text { Gradual } \\
\text { Ofertorio }\end{array}$ & \\
\hline & & Sanctus & Alternatim \\
\hline & & Alzar & $\begin{array}{l}\text { Con más dulzura y } \\
\text { gravedad }\end{array}$ \\
\hline & & $\begin{array}{l}\text { Después Hosanna hasta } \\
\text { Pater noster }\end{array}$ & \\
\hline & & Agnus & Alternatim \\
\hline & & $\begin{array}{l}\text { Después de cantada antífona } \\
\text { comunicanda hasta } \\
\text { oraciones postcomunio }\end{array}$ & \\
\hline & & Deo Gratias & \begin{tabular}{|l|} 
Siempre, y el Sábado \\
Santo con el Coro
\end{tabular} \\
\hline \multirow[t]{3}{*}{ Visperas } & $\begin{array}{l}\text { Domínicas "Laetare" y } \\
\text { "Gaudete" }\end{array}$ & & \\
\hline & $1^{\mathrm{a}}{\mathrm{y} 2^{\mathrm{a}} \text { clase }}$ & $\begin{array}{l}\text { Toca a versos en el } 1^{\circ}, 3^{\circ} \text { y } \\
5^{\circ} \text { psalmo. } \\
\text { En el himno y Magnificat }\end{array}$ & $\begin{array}{l}\text { "con tal distinción y } \\
\text { advertencia que en las } \\
\text { fiestas más solemnes } \\
\text { toque con más pausa y } \\
\text { morosidad, más dulze y } \\
\text { gravemente" }\end{array}$ \\
\hline & $\begin{array}{l}\text { De los otros dobles y } \\
\text { dominicas }\end{array}$ & Himno y Magníficat a versos & $\begin{array}{l}\text { "de suerte que dé lugar } \\
\text { a la turificación del altar } \\
\text { y del choro" }\end{array}$ \\
\hline \multirow[t]{2}{*}{ Maitines } & $\begin{array}{l}\text { Solemnes de la Concepción, } \\
\text { Natividad de Nuestro Señor } \\
\text { Jesucristo }\end{array}$ & $\begin{array}{l}\text { Himno a versos } \\
\text { Psalmos a versos } \\
\text { (1.3.4.6.7.9.) } \\
\text { Te Deum a versos }\end{array}$ & \\
\hline & Resurrección & $\begin{array}{l}\text { Himno a versos } \\
\text { Psalmos 1.2.3. } \\
\text { Te Deum a versos }\end{array}$ & \\
\hline Laudes & & $\begin{array}{l}\text { Todos los psalmos, himno y } \\
\text { cántico y responde al Deo } \\
\text { gratias }\end{array}$ & \\
\hline \multirow[t]{3}{*}{ Completas } & $\begin{array}{l}\text { Cantadas cuando son } \\
\text { inmediatamente después de las } \\
\text { Vísperas }\end{array}$ & \multirow[t]{2}{*}{$\begin{array}{l}\text { Himno y cántico "Nunc } \\
\text { dimittis" a versos }\end{array}$} & \\
\hline & $\begin{array}{l}\text { Cantadas en días solemnes que } \\
\text { caen en feria de Cuaresma } \\
\text { cuando las vísperas se han } \\
\text { dicho ante prandium } \\
\text { (San Matías, San Gabriel, San } \\
\text { José) }\end{array}$ & & \\
\hline & $\begin{array}{l}\text { De San Hiscio, San Mesitón, } \\
\text { San Tesifón, Anunciación de } \\
\text { Nuestra Señora y Sábado } \\
\text { Santo }\end{array}$ & $\begin{array}{l}\text { Toca a todos los psalmos, } \\
\text { himnos y cánticos }\end{array}$ & $\begin{array}{l}\text { Con mucha solemnidad } \\
\text { como en vísperas de } 1^{\text {a }} \\
\text { clase }\end{array}$ \\
\hline $\begin{array}{l}\text { Prima } \\
\text { Tercia } \\
\text { Nona }\end{array}$ & $\begin{array}{l}\text { De la Vigilia de Natividad, del } \\
\text { Día de Pentecostés, de la } \\
\text { Ascensión. }\end{array}$ & $\begin{array}{l}\text { Toca el hymno y psalmo a } \\
\text { versos }\end{array}$ & \\
\hline
\end{tabular}


El organista tenía que acudir con mucha frecuencia al coro y tocar en todas las fiestas. No tocaba los días de los santos simples, excepto Santa María in Sabatho; las ferias, excepto en Feria V in Coena Domini y Sábado Santo a las misas; tampoco lo hacía en las Vigilias, excepto Navidad, Epifanía, Ascensión y Pentecostés; o en las Témporas, excepto en la Santísima Trinidad. La Tabla III.8. muestra el momento del día en el que tenía que tocar el organista según las festividades, el instante exacto dentro de cada una de ellas y las indicaciones sobre cómo debía tocar. Por ejemplo, en el momento del "alzar" el órgano debía tocar con más dulzura y gravedad. ${ }^{152}$

La Consueta proporciona otras especificaciones como que, salvo las excepciones indicadas en la tabla anterior, no debía tocar nunca el primer verso del himno o del salmo, ni el Gloria Patri del salmo ni de cántico para que se oyera cantado por las voces. Cuando tocaba alternatim debía dejar "en vacío un verso" y en los himnos Pange Lingua y Vexilla regis debía dejar que el coro dijera los versos "Tamtum ergo sacramentum" y "O crux ave spes unica", respectivamente, y en todos los himnos el último verso.

\section{Al tocar el Te Deum laudamus}

No toca el verso Te ergo quae sumus, el verso que toca el organo lo deven dezir todos los caperos en las horas que los ay en voz intelligible que no haga disonancia, mas si lo dize alguna voz al organo no es necesario. ${ }^{153}$

En el verso Te ergo quae sumus era costumbre arrodillarse, pero este párrafo de difícil interpretación parece hablar de la práctica polifónica, aunque una voz sola no puede hacer polifonía. Algo más abajo no queda duda de que la polifonía pudo estar presente en algún que otro momento en la Abadía, pues en las manifestaciones del Santísimo Sacramento se podía ordenar "otra cualquier musica de monacordio o violones y se canten algunos motetes al organo". El organista también debía tocar antes y después del verso Tantum ergo que cantaba el coro y mientras el celebrante mostraba al Santísimo Sacramento al pueblo hasta que se encerraba en el Sagrario. En las procesiones del Santísimo Sacramento (excepto en la del Jueves Santo) y en las de las

\footnotetext{
${ }^{152}$ Según Covarrubias, Tesoro de la lengua, p.81: "En el Santo Sacrificio de la Misa, [alzar] es mostrar el Sacerdote al pueblo la hostia y el cáliz consagrado. Tañer al alzar es a la plegaria, que a ese tiempo se hace una señal, a la cual todos los fieles donde quiera que están cuando la oyen, se hincan de rodillas y hacen oración".

${ }^{153}$ Consueta, fol. $114^{\mathrm{r}}$.
} 
Reliquias, el organista tocaba a versos el himno mientras la procesión estuviera en la Iglesia.

En las Salves el organista tocaba antes de la entonación del Sochantre y luego proseguía a versos. En los recibimientos de Prelado, Cardenal, Rey o Reina también debía tocar cuando éstos entraban a la Iglesia y no estaba permitido tocar en el recibimiento de ninguna otra persona secular por importante que fuera.

Podemos encontrar una alusión en las Actas a la interpretación al órgano de los versos, cuando se ordenó a los sochantres que hicieran las pausas necesarias en las mediaciones para que el organista pudiera tocar los versos

Para el aumento del culto divino, se mandó que los sochantres hiciesen la pausa conveniente para que el órganos toque los versos las veces que le pertenecen, tanto en las misas como en el oficio, siendo de más o menos duración según fuese la solemnidad del día. ${ }^{154}$

Otra de las obligaciones del organista era afinar y aderezar el órgano, sobre todo antes de las fiestas en que acudiera "gran concurso de gente", y cuidar de los “instrumentos músicos” que tenía a su cargo. Si obtenía alguna licencia debía buscar un sustituto al que él mismo debía pagar, pues la fábrica sólo le daría al organista la comida del día que supliera.

\subsubsection{Los organistas de la Abadía}

Gracias a las Actas Capitulares conocemos el nombre de muchos de los organistas que sirvieron en el Sacromonte. Algunos de ellos podemos encontrarlos en otros centros andaluces, uno, Miguel Rabaza pasó a servir a la Real Capilla de Madrid y llegó a ocupar el puesto de primer organista. Pero la mayoría de ellos eran músicos desconocidos que encontraron en el Sacromonte un centro de trabajo estable, quizás porque sus dotes no fueron excepcionales o porque en la Abadía se ofrecía una compensación económica suficiente, pues estaba incluía la habitación y comida.

\footnotetext{
${ }^{154}$ ASAC XI, fol. $400^{\mathrm{v}}$ (4-X-1779), [752].
} 


\section{Juan de Oñate ${ }^{155}(1612-1613)^{156}$}

Un Juan de Oñate aparece como seise en la Catedral de Jaén en $1568 .^{157}$ Probablemente es el mismo que opositó a las plazas de organistas de la Catedral de Jaén en 1594, que obtuvieron Pedro de Zafra y Sebastián de Oviedo. ${ }^{158}$ Juan de Oñate fue organista de la Santa Capilla de San Andrés en Jaén, desde al menos 1590 hasta $1602 .{ }^{159}$ Probablemente este Oñate, en ese momento organista de la ciudad de Jaén y de la parroquia de San Lorenzo, fue quien renovó el órgano de la Iglesia Colegial de Alcalá la Real en 1603. ${ }^{160}$ En 1604 llevó a la Capilla Real de Granada un realejo que había construido. ${ }^{161}$ Perdió la oposición a organista de la Catedral de Granada frente a Juan de Cisneros en 1606. ${ }^{162}$ En la Capilla Real se encargó de la afinación de los órganos hasta 1607, y después se trasladó a Loja como organista de la iglesia mayor; entre 1608 hasta abril de 1612 fue el organista de la Colegiata de Santa Fe. ${ }^{163}$ A la Abadía llegó en ese mismo año de 1612, recibiendo 9000 maravedíes de salario, habitación y comida con su hijo Hernando de Oñate, quien fue recibido como colegial "atento a que sabía cantadas y tenía las demás partes necesarias”. ${ }^{164}$ En mayo de 1613 ya no era organista, pues figura Francisco del Corral.

${ }^{155}$ Otro Juan de Oñate, que podría ser el padre de este Juan de Oñate, aparece como trompeta del Marqués de Mondéjar en 1545, y en 1560 en un contrato en que se comprometía a enseñar la trompeta, la vihuela y a danzar. Véase Juan Ruiz, La Colegiata del Salvador, vol. I, pp. 208-209.

${ }^{156}$ Después del nombre de cada organista indicaré el periodo aproximado de servicio en el Sacromonte.

${ }^{157}$ Pedro Jiménez Cavallé, "Los Seises de la Catedral de Jaén durante el siglo XVI", Boletín de Estudios Giennenses, CLIII (1994), p. 516.

158 Pedro Jiménez Cavallé, Documentario Musical de la Catedral de Jaén (Granada: Centro de Documentación de Andalucía, 1998), p.53.

${ }^{159}$ Pedro Jiménez Cavallé, La música en la catedral de Jaén (Jaén: Diputación provincial, 1991), p. 60.

${ }^{160}$ Domingo Murcia Rosales et alii., El patrimonio artístico de Alcalá la Real: Iglesia Mayor Abacial, (Alcalá la Real: Ayuntamiento de Alcalá la Real, 2002), p.41.

${ }^{161}$ Ruiz Jiménez, Organería, p. 34.

${ }^{162}$ Pilar Ramos, La música en la Catedral de Granada, p.165.

${ }^{163}$ Ruiz Jiménez, Organería, p.131, transcribe algunas actas de la Capilla Real referentes a Juan de Oñate por las que sabemos que era casado y su mujer estaba enferma, estuvo preso en la carcel y tenía un hijo contralto (pp. 193-195). Quizás enviudara y por eso pudo residir en el Sacromonte.

${ }^{164}$ ASAC I, fol. 50 v (10-IV-1612), [7]. 


\section{Francisco del Corral, Juan Baptista "organista" y Ju. de Villalar}

De estos tres organistas no he encontrado ninguna noticia fuera de la que aparece en el Tomo I (1613-1614) de las Actas del Sacromonte.

\begin{tabular}{|c|c|c|c|}
\hline Organista & $\begin{array}{c}\text { Fechas en la } \\
\text { Abadía }\end{array}$ & $\operatorname{Actas}$ & Observaciones \\
\hline Francisco del Corral & $\begin{array}{l}25-\mathrm{V}-1613 \text { antes } \\
\text { de } 2-\mathrm{IV}-1614\end{array}$ & Tomo I, fol. $62 \mathrm{r}$ & $\begin{array}{l}\text { Cobraba } 1000 \text { maravedíes } \\
\text { menos que su antecesor } \\
\text { (Oñate) y no dormía en el } \\
\text { Sacromonte. }\end{array}$ \\
\hline Juan Baptista ${ }^{165}$ & 1614 & $\begin{array}{l}\text { Tomo I, fols. } 74 \text { r, } \\
\text { 80v. }\end{array}$ & $\begin{array}{l}\text { Se indica si se le daría la } \\
\text { plaza de organista que } \\
\text { estaba sirviendo. }\end{array}$ \\
\hline $\begin{array}{l}\text { Ju. de Villalar o } \\
\text { Villalón }\end{array}$ & $1615-1617$ & $\begin{array}{l}\text { Tomo I, fols. } \\
118 \mathrm{v}, 143 \mathrm{v} .\end{array}$ & Vecino de Granada \\
\hline
\end{tabular}

\section{Ginés Valcés o Balces (1616-1617)}

Según Llordén, Ginés Valcés era diácono, natural de Málaga. Se presentó a unas oposiciones al cargo de organista de esa Catedral en 1613, y mientras ejercía de organista interino recibía 5 ducados al mes. La plaza la obtuvo finalmente Luis Páez de Malvenda, y por el tiempo que Valcés había servido en el órgano el cabildo malagueño le pagó 400 reales. ${ }^{166}$ La primera referencia a este organista en las Actas del Sacromonte es del 20 de diciembre de $1616 .^{167}$

\section{Joseph de Cea Hinojosa (1617-1618) ${ }^{168}$}

Joseph de Cea Hinojosa aparece como organista del Sacromonte entre 1616 y 1618. Según el documentario de la Capilla Real de Granada era capellán natural de Antequera y tomó posesión de la capellanía de organista el 9 de marzo de 1630,

\footnotetext{
${ }^{165}$ Podría ser el que cita Ramos, p.170 y Ruiz Jiménez como organero, pp. 47, 131-133.

${ }^{166}$ Andrés Llordén, "Notas históricas de los maestros organistas de la Catedral de Málaga”, Anuario Musical, 22 (1967), pp. 152-153.

${ }^{167}$ ASAC I, fol. 145 r (30-XII-1616), [43]; ASAC I, fol. 154 r (¿?-¿?-1617), [44]; ASAC I, fol. $155^{\vee}$ (23IV-1617), [45]; ASAC I, fol. 162 r (15-VIII-1617), [47].

${ }^{168}$ ASAC I, fol. $165^{\mathrm{v}}$ (10-X-1617), [49]; ASAC I, fol. ${ }^{\mathrm{v}}$ (26-IV-1618), [52].
} 
falleciendo el quince de noviembre de $1646 .{ }^{169}$ Ruíz Jiménez transcribe un informe suyo sobre la reparación del órgano de la Catedral de Granada. ${ }^{170}$

\section{Jerónimo de Valenzuela (1618-1672)}

Es el organista que más tiempo permaneció en el Sacromonte, 54 años, pues ya aparece en las Actas en 1618 y la murió hacia 1673. En 1630 pidió que se le diese su ración en Granada, donde quería irse a vivir pero parece que no se le concedió y se dispuso que "se le de su salario de trigo y coma en el refectorio el día que viniese a hacer su oficio" con lo que perdió el derecho a que le lavaran la ropa y lo curasen. ${ }^{171}$ Ese mismo año, tras una pelea con el sochantre Jacinto de los Ríos se despidió, aunque luego solicitó la readmisión que el cabildo concedió después de unos días de castigo con la condición de que:

con que viniese dentro de casa y que no salga sin licencia, y guarde el orden y constituciones de los capellanes en cuanto conviene a su estado de seglar, y en cuanto al salario el mismo que se tenía antes en manuales. ${ }^{172}$

Las actas recogen un incidente que Jerónimo de Valenzuela tuvo con Juan de Padilla, capellán del Sacromonte:

Propuso el señor Presidente que el licenciado Juan de Padilla capellán de esta Iglesia había usado una descompostura con Jerónimo de Valenzuela organista hasta darle de mojicones y hacerle sangre en la cabeza y lastimándole la mano con mucho escándalo de toda la casa, sobre el cual hecho por orden del señor Abad había estado recogido en su aposento desde el día que el caso sucedió, y habiéndose tratado en la Junta de la pena $(187 \mathrm{v})$ que se le ha de dar viene teniendo al cabildo a que tome en ello la resolución que más conviniere: y habiéndose conferido y considerado todas las circunstancias del caso por siete votos de ocho se determinó que al dicho licenciado Juan de Padilla en pena del exceso que cometió (por ser cosa nunca vista ni que se esperaba ver en esta casa) para satisfacer el

\footnotetext{
169 José López-Calo, Catálogo de Música de la Capilla Real de Granada, vol. II Apéndices documentales (Granada: Centro de Documentación Musical de Andalucía, 1994), p. 292; otras noticias aparecen en pp. 267-268.

${ }^{170}$ Juan Ruiz, Organería, pp. 147-148.

${ }^{171}$ ASAC II, fol. $131^{\mathrm{r}}$ (4-VII-1630), [134].

${ }^{172}$ ASAC II, fol. $147^{\mathrm{r}}(2-\mathrm{X}-1630),[140]$.
} 
escándalo y mal ejemplo, y por otras razones que en el cabildo se representaron, se le quite la capellanía y sea despedido del Sacro Monte, y que antes que se vaya se le dé una reprensión muy severa afeándole la acción que hizo y notificándole este auto del cabildo y que conforme a él se vaya luego a su casa. ${ }^{173}$

La mayoría de las noticias que aparecen sobre Valenzuela están referidas al salario, bien porque pide aumento, bien porque el cabildo se lo concede. ${ }^{174}$ El 22 de Marzo de 1667 fundó una memoria que el cabildo aceptó. ${ }^{175}$ Un acta de 1672 parece indicar que debió trasladarse a Sevilla sin permiso del Cabildo, que no quiso readmitirlo por ello, ${ }^{176}$ y en abril del año siguiente las Actas se refieren a él como "difunto"; por último, más de diez años después se indica se le paguen a su hija lo que se le debía a su padre. $^{177}$

\section{Juan de Riscos (1673-1715) $)^{178}$}

Casi con toda seguridad, este Juan de Riscos sea el Juan de Risco que figura como organista en la Iglesia Colegial del Salvador de Granada en 1672. ${ }^{179}$ El 1 de Junio de 1673 fue elegido organista del Sacromonte con 400 reales de salario y comida de colegio. Seis años después pidió una licencia para opositar a la plaza de órgano de la Catedral de Almería que no ganó y un mes después regresó al Sacromonte. Su hermano debía de ser también organista, pues en 1679 pidió licencia al Cabildo para tenerlo en su puesto, y probablemente se trate de Jacinto Risco. ${ }^{180}$ En 1680 recibió una multa por

\footnotetext{
${ }^{173}$ ASAC II, fol. $187^{\mathrm{r}}$ (31-VII-1631), [148].

${ }^{174}$ ASAC II, fol. 402 ${ }^{\mathrm{v}}$ (10-XII-1637) [199]; ASAC III, fol. 94 ${ }^{\mathrm{r}}$ (9-IX-1647), [232]; ASAC III, fol.153 ${ }^{\mathrm{v}}$ (4I-1649), [241].

${ }^{175}$ ASAC IV, fol. $142^{\mathrm{r}}$ (22-III-1667), [289].

${ }^{176}$ ASAC IV, fol. $319^{\mathrm{r}}$ (29-XI-1672), [302].

${ }^{177}$ ASAC V, fol. 204 ${ }^{\mathrm{r}}(7-\mathrm{X}-1684),[349]$.

${ }^{178}$ Puede que este Juan de Riscos fuera hijo o nieto del maestro de capilla que estuvo en Jaén entre 1598 y 1637, pertenecía a una familia de músicos, natural de Cabeza del Buey (Córdoba), y fue maestro de Capilla anteriormente de Antequera y de la Capilla Real de Granada desde donde pasó a Jaén para suceder a Francisco Ruiz. Véase, Jiménez Cavallé, La música en Jaén, p. 80.

${ }^{179}$ Ruiz Jiménez, La Colegiata del Salvador, vol. II, pp. 634-635.

${ }^{180}$ Ruiz Jiménez, La Colegiata del Salvador, p. 546, cree que Juan y Jacinto son la misma persona, pero probablemente sean hermanos, ya que sabemos por las actas del Sacromonte que Juan tenía un hermano
} 
pernoctar en Granada sin permiso. Este mismo año fue el encargado de juzgar a dos opositores a la plaza de organista de la Colegiata del Salvador. ${ }^{181}$ En 1681 pidió que se le igualara el salario al que había tenido Valenzuela, por tener madre viuda y hermanos; el Cabildo le concedió 6 fanegas de trigo y 200 reales de vino. En 1682 pidió testimonio de haber servido en el Sacromonte y en 1685 comenzó una de sus labores más relevantes para la Colegiata: hacerse responsable de las cuentas y de los bienes de la Abadía en La Calahorra. ${ }^{182}$ Por este motivo se ausentaba con frecuencia del Sacromonte teniendo el cabildo que buscar sustitutos. En 1686 se le otorgó una capellanía para que pudiera ordenarse, y dos años más tarde, en 1688, tuvo una pelea con el Abad. Por una referencia de 1690 sabemos que su madre y hermanas vivían en el Carmen de las Velas, aunque él vivió en el Carmen de los Naranjos, a los pies de la Abadía. $^{183}$

En 1690 Riscos quiso dejar la clavería de La Calahorra, pero el Cabildo lo persuadió y no lo hizo. Salvador de la Paz fue su suplente por enfermedad en 1697; en 1698 se nombró segundo organista a Atanasio de Alvons y unos días después renunció Riscos a su plaza. En 1699 presentó un memorial en el que pedía dinero por haber ajustado las cuentas, y en 1705 se menciona la fundación dedicada al rosario que había costeado. Su vinculación con el Sacromonte continuó durante unos años más, ya que en

organista. Jacinto, según las noticias del Salvador desempeñaría allí el cargo de organista al menos entre 1676 y 1677 , fecha en la que murió.

${ }^{181}$ Ruiz Jiménez, La Colegiata del Salvador, vol. I, p. 158. Fue precisamente la plaza que dejaba vacante Jacinto Risco la que Juan Riscos juzgó.

${ }^{182}$ La Abadía tenía muchas tierras en el pueblo de La Calahorra cercano a Guadix.

${ }^{183}$ Este Carmen de los Naranjos aún conserva el mismo nombre. Véase Juan de Echevarría, Paseos por Granada y sus contornos [1764] (Granada: Valenzuela, 1814), p. 224: “Gran. Ve V. ese 'Carmen? Esa hermosa espalera de Naranjos, le ha dado á ese Carmen el nombre. En él, ó porqué era suyo, ó porqué lo tomó arrendado, vivió un eclesiástico, llamado D. Juan de Riscos, este era el Organista del Sacro-Monte, y pasaba aquí una vida apacible. Como no tenia ocupación en todo el día, no paraba de meditar obras, una meditaba, hacer por aquella esquina inferior al puente de la Acequia, hizo que empezasen á mover la tierra, que estaba muy dura; una nube que sobrevino, fué causa de que ese barranco que baxa, casi desde S. Miguel el Alto, tomase una gran porción de agua, con la Violencia arrastró el pretil v Y de toda la esquina, que había hecho mover el dicho Organista, fue después á registrar el daño, y halló una esquina de una gran piedra descubierta, hizo descubrirla, y era un sepulcro al parecer de Gentiles, á ló menos por tal lo calificaron, la lápida que le cubría estaba con su lauda, pero como el Señor Organista no tenia gusto por la antigüedad, se sirvió de las cinco piedras que componían toda la máquina, las que hoy se hallan inclusas en el arranque del arco, que renovó un caballero Relator, también eclesiástico, que succedió en la posesión del Carmen, excepto la cubierta, que se partió en dos partes, que la una se extravió, y la otra estaba ahí seis ú ocho años ha, no habiendo quedado mas de medio renglón que decía VIX. A. XXX. Que dice:vixit/annos/triginta." 
1706 se volvió a mencionar como organista y le pidió que "subiese a residir su órgano". En 1707 solicitó permiso para hacer a su costa un altar a San Antonio. En 1709 estuvo preso en la cárcel eclesiástica, pues una mujer lo había acusado de "perder su honra". Debió de salir libre, habida cuenta de que en 1712 pidió la habitación de los libros como su cuarto, lo que se le concedió.

El 9 de mayo de 1715 Juan de Riscos falleció en la Abadía después de 43 años de vinculación con el Sacromonte. Fue enterrado en la bóveda de los capellanes al lado de la portería y se le dijo el oficio entero de difuntos.

\section{Atanasio de Alvons (1698)}

El paso por el Sacromonte de Atanasio de Alvons parece ser muy breve; en las Actas sólo aparecen tres referencias a este organista: su recibimiento el 15 de enero de 1698, su nombramiento como segundo organista el 18 de enero de 1698 y, diez años después, su solicitud de un testimonio de haber servido en el Sacromonte (11-V-1708).

\section{Thomás de Barragán (1699-1700)}

Thomás de Barragán fue uno de los sustitutos de Riscos mientras éste estaba desempeñando labores en La Calahorra. En 1699 se le asignó un salario de 200 reales con comida o 600 reales sin comida ${ }^{184}$ y un año después un aumento de salario de cien reales. ${ }^{185}$ En la Colegiata del Salvador estuvo como arpa y músico invitado entre 1714 y $1721^{186}$

\section{Laureano Gómez (1701-1706)}

El 29 de agosto de 1701 se admitió a Laureano Gómez como organista interino con 400 reales de salario, comida de colegio y cena de señores; un año después se le dan tres fanegas de trigo por "refinar el órgano y cantar la Semana Santa", pues también era tenor. En 1704 pidió llevarse la ración de carne cruda y el aceite, concediéndole que se

\footnotetext{
${ }^{184}$ ASAC VI, fol. 132v (3-VIII-1699), [464].

${ }^{185}$ ASAC VI, fol. $141^{\mathrm{v}}$ (4-IV-1700), [468].

${ }^{186}$ Ruiz Jiménez, La Colegiata del Salvador, vol. II, p. 421.
} 
llevase sólo la carne. ${ }^{187}$ Solicitó un aumento un poco después y el cabildo determinó avisar antes a Riscos por si iba a volver. ${ }^{188}$ Un año después pidió que se le perpetuase la renta del órgano para poder ordenarse, pero el Cabildo antes de decidirse preguntó a Riscos si iba a regresar o no. ${ }^{189}$ Riscos volvió y en 1706 Gómez solicitó se le diera un testimonio de haber asistido el órgano y de haber sido despedido por la vuelta de Riscos, lo que se le concedió. ${ }^{190}$

Después de haberse presentado a unas oposiciones de órgano a la Catedral de Granada, que no ganó, ${ }^{191}$ Laureano Gómez pasó a la Catedral de Almería como tenor en 1707, y como organista, parece que interino, a partir de 1710. A la muerte del organista de la Catedral de Almería, José Luís Delgado, ocupó la plaza en propiedad por 270 ducados y con la obligación de afinar el órgano y tocar el arpa. ${ }^{192}$

\section{Blas de Ledesma (1710-1722) $)^{193}$}

Blas de Ledesma fue otro de los organistas interinos que suplieron a Riscos. En 1710 solicitó la plaza de segundo organista, ${ }^{194}$ aunque esta primera noticia de Ledesma en las Actas sugiere que ya había estado sirviendo en el Sacromonte durante varios años. En 1712 era suplente ${ }^{195}$ y en 1714 , se le concedió la renta de un mes por haber

\footnotetext{
${ }^{187}$ ASAC VI, fol. 218 ${ }^{\mathrm{r}}$ (1-X-1704), [486].

${ }^{188}$ ASAC VI, fol. $234^{\mathrm{r}}$ (7-VII-1705), [489].

${ }^{189}$ ASAC VI, fol. 234 ${ }^{\mathrm{r}}$ (16-VII-1705), [490].

${ }^{190}$ ASAC VI, fol. $253^{\mathrm{r}}$ (12-VI-1706), [495].

${ }^{191}$ Ruiz Jiménez, La Colegiata del Salvador, vol. I, p. 170.

${ }^{192}$ Un hijo de Laureano Gómez entró como violinista y sustituto del órgano y otro como organista, quien finalmente sucedió a su padre a su muerte en 1755. Estas noticias están tomadas de Juan López Martín et alii, Noticias y catálogo de Música en el Archivo de la S. y A.I.C. de Almería (Granada: Centro de Documentación Musical de Andalucía, 1997), pp. 81-82.

${ }^{193}$ Hay un pintor granadino, discípulo de Sánchez Cotán, con el mismo nombre, que tal vez podría tratarse del abuelo de este oganista.

${ }^{194}$ ASAC VI, fol. 329 (1-IX-1710), [512].

${ }^{195}$ ASAC VI, fol. $353^{\mathrm{V}}$ (7-XI-1712), [518].
} 
suplido al propietario. ${ }^{196}$ Finalmente, tras la muerte de Riscos, obtuvo la plaza en propiedad con el mismo salario que había tenido aquél. ${ }^{197}$

Siguiendo la costumbre de sus antecesores, Ledesma también pidió que se le perpetuara la renta de organista para poder ordenarse, lo que el cabildo le concedió en $1715 .^{198}$

En 1721 aún ostentaba esta plaza, ${ }^{199}$ y en 1722 falleció en el Sacromonte.

Fue para determinar el funeral que se le debía hacer a don Blas de Ledesma, Presbítero organista que fue de esta Iglesia, se determinó se le dijese un Nocturno y Laudes el día antes de su entierro, y al siguiente día antes de horas se celebrase misa de cuerpo presente y se le diese inmediatamente sepultura. ${ }^{200}$

\section{Mathías de Barragán (1722-1732)}

Tal vez hijo o hermano de Thomás de Barragán, Mathías de Barragán fue nombrado organista en 1722 a la muerte de Blas de Ledesma con 872 reales de salario y seis fanegas de trigo. En 1727 se le concedió un aumento de salario para igualarlo al que tenía Blas de Ledesma con medio cahiz de trigo más. ${ }^{201}$ Cinco años más tarde tuvo un enfrentamiento con el Cabildo y se despidió por no querer tocas en las procesiones. Parece que se retractó, pues la esposa del Presidente de la Chancillería de Granada intercedió por él ante el Cabildo para que le volvieran a admitir. ${ }^{202}$ Ese mismo año de 1732 abandonó finalmente la plaza por encontrarse "accidentado". En 1737 era organista de la Capilla Real de Granada, para la que compuso los villancicos de

\footnotetext{
${ }^{196}$ ASAC VI, fol. 376r (6-VI-1714), [520].

${ }^{197}$ ASAC VI, fol. ¿? (20-V-1715), [530].

${ }^{198}$ ASAC VI, fol. 391 ${ }^{\mathrm{r}}(6-\mathrm{VIII}-1715)$

${ }^{199}$ ASAC VI, fol. $50^{\mathrm{r}}(20-\mathrm{III}-1721)$

${ }^{200}$ ASAC VI, fol. ¿? (11-IX-1722)

${ }^{201}$ ASAC VII, fol. $114^{\mathrm{v}}(13-\mathrm{IX}-1727)$

${ }^{202}$ Mathías de Barragán le daba clase de clave a sus dos hijas. ASAC VIII, fol. 301 ${ }^{\mathrm{r}}$ (10-VI-1732), [583].
} 
Navidad de $1737 .{ }^{203}$ Un año después se imprimieron unos villancicos a la Virgen de Gracia; éste es el último dato que se conoce de su actividad. ${ }^{204}$

\section{Miguel Rabaza (1732-1746) ${ }^{205}$}

Miguel Rabaza es sin duda el más atrayente y sugestivo de los organistas de la Abadía, tanto por su relación con la dinastía de los Rabassa, como por haber sido organista de la Real Capilla de la Corte en Madrid, donde falleció. Isusi afirma que es probable que fuera catalán, por la afición de los Rabassa catalanes al órgano, pero en mi opinión esta afirmación carece de fundamento. ${ }^{206}$ Es poco lógico que un músico catalán se estableciera en la Abadía, y es más probable que Miguel Rabaza estuviera relacionado con la rama sevillana de los Rabaza. También estuvo al servicio de la Duquesa de Medina Sidonia como maestro de clave. ${ }^{207}$ Los datos que tenemos de él en la Abadía son los siguientes:

En 1732 entró a servir en el Sacromonte como organista segundo y como organista primero cuando Barragán abandonó la plaza. ${ }^{208}$ Por un Acta de 1733 sabemos que tenía madre, tía y dos hermanas "pobres de solemnidad" al haber muerto el padre del organista por lo que el Cabildo acordó darles una limosna. ${ }^{209}$ Pidió se le aumentase

\footnotetext{
${ }^{203}$ López-Calo, Catálogo del Archivo de Música de la Capilla Real, p.120.

${ }^{204}$ Germán Tejerizo Robles, Villancicos Barrocos en la Capilla Real de Granada (Granada: Centro de Documentación Musical de Andalucía, 1989), p. 40. La referencia bibliográfica completa del impreso de las letras de estos villancicos, la encontramos en María José López-Huertas, Bibliografía de Impresos Granadinos de los siglos XVII y XVIII, tomo III, p. 1647. El nombre del compositor figura manuscrito en el ejemplar de la Biblioteca Nacional.

${ }^{205}$ Guy Bourligueux, "El violinista Pascual Juan Carriles, su familia y sus amigos", Anuario Musical, 42 (1987), pp. 216-217, se refiere a este organista como Miguel Martínez Rabaza, pero en ninguno de los documentos que he consultado aparece con este nombre. En ocasiones aparece como Ravaza en lugar de Rabaza.

${ }^{206}$ Rosa Isusi Fagoaga, "Los Rabassa: un linaje de músicos de origen catalán”, Revista Catalana de Musicología, II (2004), p. 84.

${ }^{207}$ Véase George Truett Hollis "El diablo vestido de fraile: some unpublished correspondence of Padre Soler", Music in Spain during the Eighteenth Century, ed. por Malcolm Boyd y Juan José Carreras (Cambridge: Cambridge University Press, 1998), p. 196.

${ }^{208}$ ASAC VIII, fol. $301^{\mathrm{r}}$ (10-VI-1732), [583] y ASAC VIII, fol. 308 ${ }^{\mathrm{r}}$ (24-VII-1732), [585].

${ }^{209}$ ASAC VIII, fol. $355^{\mathrm{r}}$ (13-IV-1733), [591].
} 
la licencia por estar en la Corte en Madrid solucionando algunos asuntos en 1746 en dos ocasiones. ${ }^{210}$ Después de estas referencias no es nombrado en las Actasde la Abadía.

Una obra de Miguel Rabaza se conserva en el Archivo de la Colegiata de Olivares. Se trata de una "cantada" dedicada a Juan Pascual Valdivia y Castilla en 1750, titulada Zéfalo aquel pastor, para tiple, violines y oboe firmada en $1732 .^{211}$

La documentación que se conserva en el Palacio Real sobre Rabaza, hasta donde me ha sido posible consultar, se refiere a sus nombramientos, y no existe un expediente personal como sí es el caso de muchos de los músicos de la Real Capilla. La primera noticia de Rabaza en la Real Capilla data de 1756, en el Reglamento o Planta de las voces e instrumentos que ha resuelto la Magestad del Señor Rey Don Fernando VI haya en su Real Capilla y de los goces anuales que se ha dignado a señalar a los músicos de ella, para desde primero del mes de mayo de 1756 adelante. $^{212}$ Según este documento, Rabaza era tercer organista tras José Nebra y Antonio Literes, y gozaba de una renta anual de 9.000 reales. Cuando a la muerte de José de Nebra, primer organista, ascendió a esa plaza Antonio Literes, se nombró a "Miguel Ravaza" segundo organista (7-III1768). ${ }^{213}$ Tan sólo unos meses después, a la muerte de Antonio Literes, Rabaza promocionó a primer organista, ${ }^{214}$ cargo que ostentó hasta su muerte el 5 de octubre de 1787 y en el que fue sucedido por José Lidón.

Casi veinte años como primer organista y más de treinta al servicio del Rey, harían de Rabaza una figura conocida que debía gozar de cierto prestigio. ${ }^{215}$ Isusi apunta que podría ser éste el Rabaza que menciona el Padre Soler en su Llave de la Modulación. ${ }^{216}$ Como persona de referencia y como autoridad, aparece mencionado en

\footnotetext{
${ }^{210}$ ASAC VIII, fol. 462 ${ }^{\mathrm{r}}$ (25-VII-1746), [617] y ASAC VIII, fol. 496 ${ }^{\mathrm{r}}$ (20-XII-1746), [620].

${ }^{211}$ Isusi Fagoaga, "Los Rabassa”, p. 92, y Romero Lagares, Catálogo del archivo, p. 98.

${ }^{212}$ Citado en Emilio Casares (ed.), Francisco Asenjo Barbieri. Documentos sobre música española y epistolario (Legado Barbieri) (Madrid: Fundación Banco Exterior, 1986) vol. 2, p.151, doc. 266.

${ }^{213}$ Madrid, Archivo General de Palacio, Organistas, Expediente de Antonio Literes doc. № 1.

${ }^{214}$ Madrid, Archivo General de Palacio, $\mathrm{n}^{\circ} 153$ fol. 95, 5-12-1768.

${ }^{215}$ Soriano Fuertes menciona a Rabaza como organista de la Real Capilla sin aportar ningún dato más; véase Mariano Soriano Fuertes, Historia de la Música Española desde la venida de los Fenicios hasta el año de 1850 (Madrid y Barcelona: Martín y Salazar/Narciso Ramírez, 1856), pp. 147-148.

${ }^{216}$ Isusi Fagoaga, "Los Rabassa”, p.85.
} 
un escrito del oboísta de la Real Capilla Manuel Cavaza, en que éste pedía la licencia para publicar una apología en favor de los músicos de la Real Capilla por el agravio que habían sufrido con la publicación del "Discurso 97" de la conocida gaceta madrileña El Censor, en 1786, en la que se ponía en duda la profesionalidad de los músicos de la Corte. ${ }^{217}$ Saldoni señala que murió en Madrid el 5 de octubre de $1787 .^{218}$

\section{Joseph del Águila (1746-1763)}

Joseph del Águila debió de ocupar el cargo de organista en 1746, pero después de haber servido durante 17 años, el cabildo decide despedirlo -al parecer por ser casado-, cuando por las Constituciones no figura que tuviera la obligación de ser soltero. Se decidió darle una limosna por un año mientras encontraba otro trabajo, al ser casado y tener obligaciones. ${ }^{219} \mathrm{El}$ organista puso un recurso para que el cabildo le restituyera en su empleo, pero los canónigos replicaron que era un criado doméstico, asalariado del Sacromonte, y que no tenía la plaza en propiedad, por lo que el Cabildo podía despedirle a voluntad. ${ }^{220}$

\section{Fray Francisco López}

En 1763 Fray Francisco López es aceptado junto con Fray Rodrigo de la Rosa O.P., por el despido de Joseph del Águila organista y Fray Joseph Díez, sochantre "por fundadas razones". Fray Francisco López era "agustino descalzo lego" y el secretario del cabildo lo definió, junto a Fray Rodrigo de la Rosa, como "sujetos de especial inteligencia y actitud para nuestro coro".221

\footnotetext{
${ }^{217}$ Nicolás Álvarez Solar-Quintes, "Nuevas noticias de músicos de Felipe II, de su época, y sobre impresión de música",Anuario Musical, 15 (1960), pp. 215-216.

${ }^{218}$ Baltasar Saldoni, Diccionario biográfico-bibliográfico de efemérides de músicos españoles (Madrid: Centro de Documentación Musical, 1986), p. 432.

${ }^{219}$ ASAC X, fol. 212 ${ }^{\mathrm{r}}$ (24-III-1763), [664]; en este cabildo se le despide y se acuerda darle la limosna señalada.

${ }^{220}$ ASAC X, fol. $226^{\mathrm{v}}$ (1-X-1763), [666].

${ }^{221}$ ASAC X, fol. $212^{\mathrm{r}}$ (24-III-1763), [664].
} 
En 1764 López reclamó que se le concediese la comida por entero, pero no tuvo éxito. $^{222}$ Debía ser muy jovén cuando entró al servicio de la Abadía, puesto que en 1777 pidió socorro para su madre y se le concedió la parte de ración de comida que se le había suspendido cuando entró a la plaza. ${ }^{223}$ Intentó anular su profesión religiosa en 1778, por lo cual estaba obligado a residir en el Sacromonte y obedecer al Abad mientras durase el pleito. ${ }^{224}$ Debió de hacerse efectiva la anulación, ya que en 1788 mencionó su bula de secularidades y que tenía que consignar 60 ducados "sobre el trabajo de su salario", lo que aceptó el Cabildo. ${ }^{225}$ El Cabildo tendría que tenerlo en buena consideración cuando le hizo un préstamo de 701 reales en $1790 ;{ }^{226}$ sin embargo no le dió ningún socorro en 1793, aduciendo que no había arreglado el órgano como decía. ${ }^{227}$ Ocupó el cuarto del caniculario en 1796 con la advertencia de que en adelante no diera a cabildo memoriales sobre ese asunto. ${ }^{228}$ No sabemos si sería esta situación la que desencadenaría que abandonara el Sacromonte, tal y como relata el Acta del mes siguiente y que transcribo a continuación por lo vivo de la narración.

Propuso el señor Abad que el día 15 del presente bajó por la tarde a la ciudad como había de costumbre nuestro organista don Francisco López, y dirigiéndose a casa de nuestro Sochantre don Pedro de Torres le entregó las llaves del órgano, para que las trajese al día siguiente asegurándole se ausentaba para no volver más, y que no le volvería a ver hasta el Valle de Josafat, diciéndole también con falsedad que de todo tenía ya noticia el señor abad y que en segundo, al amanecer del día siguiente había enviado por el ajuar de su cuarto, cuya llave entregó de su orden el conductor de la [?] a nuestro primer contador.

En vista de tan extraña despedida se acordó dar por vacante su plaza, y que poniendo el señor Abad un interino, examinemos a los pretendientes que ya empezaban a acudir y tratar de informar de sus respectivas habilidades y conductas, se hiciera en otro cabildo la elección de sucesión para dicha plaza, acordándose al mismo tiempo si este empleo se había de unir con el de

\footnotetext{
${ }^{222}$ ASAC X, fol. 255 v (16-III-1764), [669].

${ }^{223}$ ASAC XI, fol. $345^{\mathrm{r}}$ (11-XI-1777), [740].

${ }^{224}$ ASAC XI, fol. $36^{\mathrm{v}}$ (1-VI-1778), [745].

${ }^{225}$ ASAC XII, fol. ¿? (30-XII-1788), [791].

${ }^{226}$ ASAC XII, fol. 223v (10-IX-1790), [799].

${ }^{227}$ ASAC XII, fol. $314^{\mathrm{v}}$ (2-XII-1793), [812]

${ }^{228}$ ASAC XII, fol. $398^{\mathrm{v}}$ (12-V-1796), [827].
} 
contador que está vacante, y la renta que recibió en su pasado se le debería asignar. ${ }^{229}$

Las Actas de julio de 1796 se refieren a este organista como Francisco López, antes Fraile Francisco López de Loreto. ${ }^{230}$ Parece que optó a una plaza de organista suplente el 6 de noviembre de 1798 en la Colegial del Salvador, que no obtuvo. ${ }^{231}$

\section{Luis de Ledesma}

A Luis de Ledesma se le eligió por votos tras la renuncia voluntaria de Fray Francisco López,

Para servir la plaza vacante de organista, con la obligación también de afinar el órgano y servir en las horas compatibles con este oficio la plaza de contador tercero de nuestra contaduría. Asignándole de sueldo anual 3000 reales, comida diaria ordinaria cuanto a ración y propio o extraordinario de colegiales en los días que lo hiciera. ${ }^{232}$

No debió durar mucho en el cargo, puesto que a finales de ese mismo mes de julio de 1796 se nombró organista a Luís de León. Podría ser hijo o pariente de Blas de Ledesma, lo que explicaría el hecho de que se le eligiese por votos y sin necesidad de informe.

\section{Luis de León y Cisneros, Serafín Martín ó Serafín de Montijano}

Después del despido de Joseph del Águila, se decidió contratar en 1796 a dos organistas, uno que sirviera los días de fiesta y afinara el órgano (Luis de León y Cisneros) y otro, los de diario (Serafín Martín). Parece que Serafín Martín era la misma persona que Serafín de Montijano, quien se encargaba de la contaduría. ${ }^{233}$

\footnotetext{
${ }^{229}$ ASAC XII, fol. $400^{\text {v }}$ (18-VI-1796), [828].

${ }^{230}$ ASAC XII, fol. $401^{\mathrm{r}}$ (5-VII-1796), [829].

${ }^{231}$ Juan Ruiz, La colegiata del Salvador, vol. II, p. 483.

${ }^{232}$ ASAC XII, fol. 401 ${ }^{\mathrm{v}}$ (5-VII-1796), [829].

${ }^{233}$ ASAC XII, fol. 403 ${ }^{\mathrm{r}}$ (30-VII-1796), [830].
} 
Un acta capitular sin fecha señala la poca pericia de Serafín de Montijano, advirtiéndosele que en el plazo de cuatro meses debía intruirse "más de lo que estaba en los tonos y acompañamientos del órgano, de suerte que a fin de los cuatro meses pudiese tocarlo como debe, y apetece el cabildo y que así no lo hiciese se tratará de removerlo". ${ }^{234}$ En el acta siguiente a Serafín Martín se le permite pernoctar en Granada, a condición de que suba a instruirse en el órgano los domingos y festivos, lo que confirmaría que Serafín Martín era la misma persona que el inexperto Serafín de Montijano. $^{235}$

\section{Manuel de Torres}

El último organista del siglo XVIII en el Sacromonte fue Manuel de Torres, aunque su actividad se limitó a la de ser suplente en 1796.

Se leyó también otro memorial de don Manuel de Torres pidiendo alguna gratificación por el tiempo que había suplido las faltas del órgano, y acordó el cabildo se le diesen 150 reales. ${ }^{236}$

En la Tabla III.8. puede verse una relación con todos los organistas documentados en el Sacromonte (1613-1799) con indicación de su procedencia y destino cuando figura en las Actas Capitulares o en otras fuentes.

\footnotetext{
${ }^{234}$ ASAC XII, fol. ¿? (1-IX-1797), [838].

${ }^{235}$ ASAC XII, fol. 416 (10-I-1797), [834].

${ }^{236}$ ASAC XII, fol. 403 ${ }^{\mathrm{r}}$ (23-VIII-1796), [831]. En la Iglesia del Savador se nombró a un ayudante de sochantre el 6 de octubre de 1741, llamado Manuel de Torres pero parece poco probable que se trate del organista del mismo nombre que aparece cincuenta años más tarde en el Sacromonte. Véase Ruiz Jiménez, La Colegiata del Salvador, vol. II, p. 577.
} 
Tabla III.8. Organistas de la Abadía del Sacromonte (1613-1799).

\begin{tabular}{|c|c|c|}
\hline Organistas & $\begin{array}{l}\text { Fechas extremas en la } \\
\text { Abadía }\end{array}$ & Procedencia- Destino \\
\hline $\mathrm{J}$ [uan] de Oñate & $1612-1613$ & $\begin{array}{l}\text { Jaén-Loja-Colegiata de Santa Fe } \\
\text { (Granada)/ i? }\end{array}$ \\
\hline Francisco del Corral & 1613-1614 & ¿? \\
\hline $\begin{array}{l}\text { Juan Bautista o } \\
\text { Baptista }\end{array}$ & 1614 & ¿? \\
\hline $\mathrm{Ju}[\mathrm{an}]$ de Villalar & 1614 & ¿? \\
\hline Ginés Valcés o Balces & $1616-1617$ & Málaga-¿? \\
\hline $\begin{array}{l}\text { Joseph de Cea } \\
\text { Hinojosa }\end{array}$ & $1616-1618$ & $\begin{array}{l}\text { Antequera (Málaga)-Capilla } \\
\text { Real de Granada }\end{array}$ \\
\hline $\begin{array}{l}\text { Jerónimo de } \\
\text { Valenzuela }\end{array}$ & $1618-1672$ & ¿?-¿Sevilla? \\
\hline Juan de Riscos & $1673-1715$ & $\begin{array}{l}\text { Colegiata del Salvador } \\
\text { (Granada)-Sacromonte } \dagger\end{array}$ \\
\hline Atanasio de Alvons & 1698 & ¿? \\
\hline Thomás de Barragán & 1699 & $\begin{array}{l}\text { ¿?- Colegiata del Salvador } \\
\text { (Granada) }\end{array}$ \\
\hline Laureano Gómez & $1701-1706$ & ¿?-Catedral de Almería \\
\hline Blas de Ledesma & $1710-1722$ & ¿?-Sacromonte† \\
\hline Mathías de Barragán & $1722-1732$ & ¿?-Capilla Real de Granada \\
\hline Miguel Rabaza & $1732-1746$ & ¿?-Real Capilla de Madrid \\
\hline Joseph del Águila & $1746-1763$ & ¿? \\
\hline Fray Francisco López & $1763-1796$ & Agustino descalzo \\
\hline Luis de Ledesma & 1796 & ¿? \\
\hline $\begin{array}{l}\text { Luis de León y } \\
\text { Cisneros }\end{array}$ & 1796 & ¿? ¿? \\
\hline $\begin{array}{l}\text { Serafín Martín o } \\
\text { Serafín de Montijano }\end{array}$ & 1796 & ¿? \\
\hline Manuel de Torres & 1796 & ¿? \\
\hline
\end{tabular}

\section{Los oficios o cargos relacionados indirectamente con la música.}

\subsection{Admonitor}

El admonitor era el encargado de corregir a los colegiales en sus distintos oficios, siguiendo las Constituciones y la Consueta, y de elaborar semanalmente la tabla con los oficios de los colegiales. La supervivencia de un ceremonial tan complejo se debía a que había muchos observadores encargados de que el engranaje se moviera correctamente y el admonitor es uno de ellos. Entre sus funciones se encontraban el de suplir en las misas solemnes: 
Cuando faltare capellan ô Colegial ordenado que asista a las missas solennes con Diaconos y a las Visperas y offiçio cantado, el Admonitor suple asiste y acompaña de la misma manera que si fuera capellan y en tales casos usa de su bonete, y puesto acompaña y cuando asiste lo tiene en la mano. ${ }^{237}$

El admonitor también instruye en las ceremonias a los colegiales nuevos:

Quando reçiuen algun Colegial nuevo está a su cargo darle notiçia de las Constituçiones y costumbres del Collegio y comenzarlo a dirigir en las ceremonias y ante todo lo enseñará a ayudar a missa rezada y para esto le dará algunas lecçiones, lo lleuara a la sacristía E Iglesia quando estubiere çerrada y en el mismo altar con las cosas que sirven en la missa hara que se ensaie, crie en el, estima y reuerenzia de tan alto ministerio como ayudar a missa que los angeles se tubieran con servir en cualquiera ministerio del culto divino. ${ }^{238}$

Este último comentario sobre el ministerio del culto divino es un reflejo fiel del ideario de Pedro de Castro inspirado en la Contrarreforma y que se encuentra en el trasfondo de todos los capítulos de la Consueta.

\subsection{Apuntador y colector de misas}

El cometido del apuntador era controlar los libros de faltas y apuntar los errores, así como tomar nota de las asistencias a los aniversarios para repartir las distribuciones. El trabajo debía ser bastante arduo, pues en la Consueta de la Catedral, en lugar de ser anual, como el resto de los oficios electivos entre los canónigos, se rotaba cada cuatro meses.

Cada canónigo, capellán y colegial debía acudir a cuatro "puntos" diarios: oración mental, horas menores, misa de tercia, vísperas y completas. La manera en que se llevaban las faltas era en un cuadrado por persona y día en el que se reflejaban los cuatro puntos de oración y las faltas de asistencia y de lectura o canto cometidas. La Consueta describe la contabilidad de las faltas de la forma siguiente:

La falta que se apunta al que erró cantando o leyendo se pone con una $\mathrm{f}$ con un punto encima para que se conozca de que es y si fueran muchas aquel dia se vaian poniendo en la mesma casilla y forma. ${ }^{239}$

\footnotetext{
${ }^{237}$ Consueta, fols. $216^{\mathrm{r}}-216^{\mathrm{v}}$.

${ }^{238}$ Consueta, fol. $216^{\mathrm{v}}$.

${ }^{239}$ Consueta, fol. 59 .
} 
También se regulaba hasta qué momento se podía entrar al coro y no se consideraba falta. Por ejemplo, en la Salve, al que no hubiera entrado antes del verso "Ad te clamamus" debía anotársele una.

El apuntador debía tener en cuenta que los seis capellanes, en las memorias y aniversarios ganaban la parte de un canónigo, y que "el sochantre y organista siendo capellanes ganan los manuales de oración y conferencias y los otros asistiendo a ellos personalmente". ${ }^{240}$ En 1632 cada misa de encargo dicha por un canónigo costaba 66 maravedíes, más otros dos para el colector. ${ }^{241}$

\subsection{Maestro de Ceremonias}

El oficio anual de maestro de ceremonias le correspondía a un canónigo que se encargaba de supervisar el cumplimiento estricto de todo lo contenido en la Consueta, advirtiendo al presidente, corrector, tesorero y rector de lo que tenían que hacer respecto a las ceremonias. Por ello la Consueta dedica un capítulo bastante extenso a describir sus obligaciones, como responsable último en cuanto a la pulcritud en la ejecución de las ceremonias.

Como ya se ha descrito anteriormente, las ceremonias que se seguían en la Abadía estipuladas por la Consueta estaban basadas en el ceremonial romano:

En esta Consueta se guardan las [ceremonias] del ceremonial y misal Romano y algunas de las que por loable costumbre observa la Iglesia Catedral modificadas conforme al sitio y disposición de la Iglesia y coro de este Sacro Monte para que con mejor estilo y modo se puedan observar sin interrupción. ${ }^{242}$

\footnotetext{
${ }^{240}$ Consueta, fols. $61^{\mathrm{v}}-62^{\mathrm{r}}$.

${ }^{241}$ Según Bernardo Hernández, "Monedas y medidas" Francisco Rico, ed., Miguel de Cervantes, El Ingenioso Hidalgo Don Quijote de la Mancha, a principios del siglo XVII, 1 real equivalía a 34 maravedíes, con lo que en total cada misa costaría 2 reales.

Véase http://cvc.cervantes.es/obref/quijote/introduccion/apendice/hernandez.htm, (consultado el 5-52008).

${ }^{242}$ Consueta, fols. $71^{\mathrm{r}}-71^{\mathrm{v}}$.
} 
El primer cabildo de cada mes estaba dedicado a las ceremonias para que no se ejecutase ninguna contraria a la Consueta y por si era necesario añadir alguna que no figurara en ella

La ha de poner en un cuaderno y ejecutarla algun tiempo, y conforme sale la ejecución que no tenga incobinientes antes tenga decencia y hermosura lo referirá al Cabildo para que decrete se ponga en la Consueta. ${ }^{243}$

La Consueta no podía ser modificada si no era por medio de la aceptación del Cabildo, que debía votar el cambio en dos cabildos a los que debían asistir la mayoría de sus miembros.

Entre otras labores, el maestro de ceremonias cuidaba del silencio en la Sacristía, del orden general de la Iglesia cuando había gente y del buen estado de ornamentos y ropa, al tiempo que prevenía las fiestas avisando sobre lo que era necesario para cada una de ellas y preparaba la tabla de los oficios del coro.

Respecto a su implicación musical, estaba a su cargo repartir el canto de las lamentaciones a los cantores y prebendados siempre que fueran buenos cantores. Además determinaba quiénes cantaban los diferentes personajes en las Pasiones y supervisaba al campanero. Prevenía las antífonas, versos y oraciones que se cantaban durante las procesiones y todo aquello que se hubiera de cantar. Cuidaba de que los versicularios arreglaran y limpiaran el coro. Semanalmente tenía que impartir una hora de lección de ceremonias a los colegiales y al capellán cerimoniario:

\footnotetext{
Anima a los Collegiales que tomen con cuydado el aprender las ceremonias, que es cosa de tanta importancia como el culto divino con que se sirve la majestad de Dios y toda la autoridad de la Iglesia se ocupa en examinar y determinar las que se deven guardar. ${ }^{244}$
}

Cuando algún sacerdote quería decir alguna misa (ya fuera aspirante a un puesto en el Sacromonte o un forastero) debía cuidar y advertirles lo que no hacían conforme al rito del Sacromonte.

\footnotetext{
${ }^{243}$ Consueta, fol. $71^{\mathrm{v}}$.

${ }^{244}$ Consueta, fol. $77^{\mathrm{v}}$.
} 
El maestro de ceremonias era el encargado de fijar y organizar el protocolo en los recibimientos: cuántos salían a recibir, si era necesario cojín en el coro o sitial en la Iglesia, preparaba el hisopo si era un Prelado, avisaba al campanero y señalaba quiénes eran los que podían subir al altar a por la vela (grandes, oidores, alcaides de corte, hijosdalgo, fiscales...).

En cuanto a la música, debía tener cuidado con el compás y avisar a los versicularios y cantores las antífonas y los versos que debían cantar:

Tiene mucho cuidado que en el Coro se observe el compas que que pide la solemnidad del dia y que ninguno por su authoridad lo apresure ni detenga y avise al Presidente para que lo modere.

A los Versicularios avise las antiphonas que se an de decir y las que an de registrar por su orden a los cantores los versos para que con poca advertencia no los trueque y que todos los que ministran en el facistol sean muy diestros y prestos en bolver los Psalmos Hymnos y Antiphonas y todo lo demás para que el Sochantre y los otros a quien toca puedan entonar sin embarazo ni detención. ${ }^{245}$

\subsection{El presidente del coro}

La función de presidente del coro era desempeñada por el Abad o, en su defecto, por el canónigo situado a su izquierda en el coro, o el canónigo más antiguo. Tenía la obligación de llegar con antelación para comprobar que todo estaba a punto: desde la colocación y registro de los libros por parte de los versicularios hasta la limpieza de los asientos. Además, había de supervisar el cumplimiento de los deberes de todos los asistentes al coro, pudiendo multar a quien cometiese alguna falta, por lo que debía observar las ceremonias y cuidar del silencio en el coro.

En lo que a la música se refiere el presidente cuidaba de que se interpretase la música a un tempo acorde con la solemnidad de la festividad: "Tenga mucho cuidado en que se lleve el compás y pausa que pidiere la festividad y sea ante todo inclinado al compás moroso como conbiene a Coro de Prebendados ejemplares que tratan de oración y ninguno se entrometa en esto por su authoridad". ${ }^{246}$ Este cometido también estaba a cargo del maestro de ceremonias, quién a su vez debía comunicarle las variaciones del compás al Presidente.

\footnotetext{
${ }^{245}$ Consueta, fol. $79^{\mathrm{r}}$.

${ }^{246}$ Consueta, fol. $55^{\mathrm{v}}$.
} 
Quien cantaba o leía debía pronunciar el latín con corrección, pues si fallaba en algún acento o pausa, el presidente ordenaba que se le apuntase una falta, salvo si era por error de imprenta o escritura del libro, en cuyo caso se avisaba al Corrector del Coro para que enmendase el libro.

Otra de sus atribuciones era la concesión de permiso para salir o faltar del coro.

\subsection{Visitadores o Zeladores}

Los visitadores o zeladores eran prebendados que debían vigilar que todos los que estuvieran o visitaran el Sacromonte fueran "honestos" y guardaran "compostura". La Consueta insiste en el comportamiento entre diferentes sexos, que no debían hablar ni mirarse entre sí.

Desde el punto de vista sociológico la Consueta es un documento que refleja vívidamente la concepción que sobre la mujer se tenía desde la Iglesia y en general, en la sociedad del siglo XVII. La mujer es presentada como incitadora al pecado, su risa es mala; si aparecía tapada era un señuelo para establecer relaciones con el otro sexo. La Abadía era un mundo exclusivamente masculino y la mujer era vista como desequilibradora del orden. En este sentido, la mujer es casi equiparable a los bailes, la guitarra, la música instrumental, la comida y los juegos.

No aya bailes ni guitarras ni toquen instrumento alguno: que no aya mesas de fruta ni turrón ni consienten que ninguno venda ni pregone cosa alguna de comer por todo el Sacromonte excepto a los aguadores (...) Ni juegos de bolas ni bolos ni naipes (...) Vigilan que en las cuevas no entren juntos hombres ni mujeres. ${ }^{247}$

Esta visión peyorativa de la música instrumental volveremos a encontrarla en diversos documentos que comentaré en el Capítulo IV.

\subsection{Comitantes}

La función de los comitantes (comito, del latín acompañar) era servir de escolta al celebrante, en ocasiones cogiéndole la capa pluvial, en las vísperas, maitines y laudes cantadas "y siempre que se va y viene al coro en ceremonia" ${ }^{248}$ El número de

\footnotetext{
${ }^{247}$ Consueta, $89^{\mathrm{v}}-90^{\mathrm{r}}$.

${ }^{248}$ Consueta, $192^{\mathrm{v}}$.
} 
comitantes dependía de la solemnidad de la fiesta (cuatro para las fiestas de primera y segunda clase, el resto de los días dos). Los capellanes cumplían con esta función los días de la Circuncisión, Transfiguración, Concepción, Natividad y Anunciación de Nuestra Señora, San Hiscio, San Tesiphón, San Mesitón, San Dionisio Areopagita. E1 resto de las veces eran colegiales, sus gestos acompañaban la música, como en el siguiente momento que señala la Consueta:

Y quando el celebrante se levanta para entonar Deus in audiutorium le alzan el pluvial y quando se sienta lo buelven a poner como al principio. ${ }^{249}$

Esa coreografía de movimientos se hacía cada vez más sofisticada y complicada, como en el momento de la entonación de la última antífona y antes del Magnificat:

Quando se repite la ultima antífona van a la silla del celebrante y le alzan el pluvial quando se levanta a dezir la capitula y se quedan alli hasta que van a incensar y todas las vezes que se sentare y levantare, cuando entona la antífona del magnificat en entonando el magnificat se ponen las mangas de la sobrepelliz en los brazos y toma el antiguo el bonete y se van detrás de los cetreros y con todos hazen venia al coro y en saliendo da el comitante el bonete al celebrante, alzan la capa y al entrar en la Iglesia la sueltan y buelve el comitante a tomar el bonete y lo arrima al pecho. ${ }^{250}$

Al igual que los ceroferarios, los comitantes también debían ejecutar sus pasos de manera paralela y simultánea empleando ambos "el mismo compás":

y quando se levantan cada uno por su lado alzan el pluvial con la una mano la punta y con la otra un poco mas arriba y van y vienen con él dando los pasos con el mismo compas el rostro buelto al altar del mismo modo que lo lleva el celebrante hazen genuflexión con él. ${ }^{251}$

Otra de las funciones de los comitantes era quitarle al celebrante la capa canonical y ponerla en su asiento en el coro, movimiento que coincidía también con una acción musical:

\footnotetext{
${ }^{249}$ Consueta, $193^{\mathrm{v}}$.

${ }^{250}$ Consueta, $193^{v}$.

${ }^{251}$ Consueta, $194^{v}$.
} 
Y quando el coro o el organo dizen el octavo responsorio baxa el celebrante a decir la nona leccion, van a la silla quitanle la capa canonical si la trae y ponenla en su silla en el coro alto y ponen la estola y pluvial y un paso atrás a sus lados están en pie mientras dize la leccion. ${ }^{252}$

\subsection{Rector del Colegio}

La responsabilidad de rector del Colegio recaía siempre sobre un canónigo que era el que debía gobernar la vida y costumbres de los colegiales, controlar sus estudios y su intervención en las ceremonias, así como otros aspectos más específicos, como regular que frecuentaran los sacramentos y atendieran su higiene personal. El Rector debía tratar los asuntos sobre los colegiales con el Abad, el maestro de ceremonias y el tesorero. Era el responsable de que todos los días asistieran al coro el número de colegiales que el Cabildo tenía señalado según la ocasión.

En cuanto a su papel respecto a la música, el rector debía asistir alguna que otra vez tanto a las lecciones de canto y a las que sobre ceremonias daba el Maestro, para dar penitencia y para reprender a los colegiales que faltaren:

El Rector acudirá algunas vezes a la lección de canto para que estén con compostura y tengan cuydado de aprovechar e informarse de lo que allí pase, para que lo que fuere digno de remedio se pueda avisar y corregir. ${ }^{253}$

Cuida que se tenga la lección de canto dias y horas conforme a las Constituciones y que el ministro del Colegio avise a Sochantre y a los Capellanes Canonigos de aprobación y Semanero y si alguno faltare haga se avise al Abbad o Presidente. ${ }^{254}$

\subsection{Cetreros}

Los cetreros eran requeridos en las vísperas cantadas, los maitines y los laudes en los que hubiera capas pluviales o caperos, a los que ayudaban a vestirse en la Sacristía, y durante las procesiones en las que había estaciones. Podían ser cuatro o seis dependiendo del número de caperos. Como su nombre indica eran los portadores de los cetros sobre el hombro y los llevaban algo caídos hacia atrás. Este oficio era encomendado a los colegiales.

\footnotetext{
${ }^{252}$ Consueta, $195^{\vee}$.

${ }^{253}$ Consueta, fol. $87^{\mathrm{r}}$.

${ }^{254}$ Consueta, fol. $88^{\mathrm{r}}$.
} 
Los cetreros entregaban los cetros a los caperos en el Coro durante el canto de las antífonas.

Cuando llegan los caperos si es hora de comenzar Visperas danles los cetros y tomanles los bonetes los mas antiguos cetreros a los mas antiguos prebendados y siempre que dan o reciven los cetros hazen venia a los caperos.

Entonada la primera antiphona buelven los bonetes y toman los cetros con las manga de la sobrepelliz y con ellos estan siempre en pie bueltos al altar los del coro diestro tienen los çetros en la siniestra y los del siniestro en la diestra de suerte que siempre los cetros an de caer por la parte de adentro del coro. ${ }^{255}$

El intercambio de bonetes y cetros se sucedía en varios momentos, como durante el canto de la quinta antífona:

Cuando se repite la quinta antiphona dan los cetros y toman los bonetes, y si es doble que la antiphona del magnificat la dize entera entonandola buelven a dar los bonetes y toman los cetros al fin de la antiphona mas antiguos dan los çetros y toman los bonetes a los primeros caperos que van a entonar la Magnificat y después los otros dan los cetros y toman los bonetes y los doblan y ponen en sus asientos, y al magnificat se retiran y bueluen eregione las manos puestas como los demas Collegiales, mas si fuere dia de quatro comitantes y no ubiere capellanes los dos cetreros primeros acompañan al preste detrás de los ceroferarios, después del Gloria Patri dan los bonetes y toman los çetros por que se asientan los caperos quando se repite la antífona y al fin de ella bueluen a dar los cetros y al fin de las Visperas quando se parten de sus asientos, los caperos les dan los bonetes y toman los cetros y salen hazen genuflexión a los lados delante de los ceroferarios y acompañan como vinieron. ${ }^{256}$

Cuando los caperos cantaban en el facistol también recibían los cetros como refiere este pasaje de la Consueta:

Para los maytines [...]Salen los caperos más antiguos a dezir el ynuitatorio y al mismo tiempo los cetreros mas antiguos van por los cetros y con ellos se llegan al facistol grande quando se llegan los caperos donde todos quatro hazen genuflexión y le dan los cetros y en leuantandose cantan los caperos el ynuitatorio y los cetreros se estan â sus lados y en entonando el hymno toman los cetros y los lleuan a donde estan los otros y se bueluen a su lugar. ${ }^{257}$

\footnotetext{
${ }^{255}$ Consueta, fol. $198^{\mathrm{r}}$.

${ }^{256}$ Consueta, $198^{v}$.

${ }^{257}$ Consueta, $198^{v}$.
} 
La misma operación de dar y recibir los cetros antes y al final de las antífonas debían hacerla durante las procesiones.

La asociación entre cetro y celebrante que canta es curiosa, pues los cetros sólo eran llevados por los caperos cuando cantaban. El cetro, un símbolo de poder, revestía junto con el canto, a la persona de un aura de supremacía en el desarrollo del culto, lo que vuelve a poner de manifiesto la importancia de la palabra cantada en el rito y la diferenciación que de ella se hacía con la hablada. Es interesante observar que en la Consueta de la Catedral de Granada no se describe el oficio de cetrero.

\section{Oficios sin relación con la música.}

\subsection{Capellán cerimoniario}

El Abad nombraba a uno de los capellanes como Cerimoniario, que actuaba como coadjutor del maestro de ceremonias, por lo que debía conocer el "Ceremonial Romano reformado y la Consueta de la Iglesia". Asistía al celebrante todos los días en la Misa y en las Vísperas siempre que fueran cantadas. Para ello le alumbraba y registraba al mismo tiempo que controlaba que de la Sacristía se sacaba todo lo pertinente para la ceremonia. Supervisaba a los colegiales en su proceder durante las ceremonias. En las procesiones "anda por ellas ordenando al clero que proceda con compás y correspondencia". 258

\subsection{Coadjutor de la missa rezada}

Aunque el coadjutor sólo intervenía en las misas que no eran cantadas, varias cuestiones de su oficio deben ser comentadas. Es de nuevo un colegial el encargado de ayudar a la misa rezada asistiendo al sacerdote en ponerse y quitarse la capa o la sobrepelliz, coger las ampolletas con el vino y el agua, llevar el misal y encender las velas entre otras funciones.

Debía arrodillarse a la izquierda del sacerdote con las "manos puestas"259 y en las oraciones "le responde en el mismo tono y compas que lleva el sacerdote y aguarda a

\footnotetext{
${ }^{258}$ Consueta, fol. $82^{\mathrm{r}}$.

${ }^{259}$ Con las palmas hacia arriba y los brazos ligeramente elevados.
} 
que acabe de decir sin hollarle los finales". Claro que esta referencia no alude al tono y al compás del canto, sino a la cadencia y volumen de la recitación. La campanilla es el único instrumento del que se sirve el coadjutor para distinguir varios de los momentos más destacados de la ceremonia, durante el Sanctus y la adoración:

y trae la campanilla hincase de rodillas y en diçiendo Sanctus dá tres toques de dos golpes cada uno en buena proporcion, luego la pone en la peana en el suelo donde no estorbe [...]y quando se hinca de rodillas a adorar la hostia consagrada le tiende la casulla deçentemente con la siniestra y quando se leuanta el Sacerdote la alza y con la diestra da tres toques de â dos golpes con la campañilla, el primero quando se hinca el Sacerdote de rodillas, el segundo quando leuanta la hostia, el tercero quando la abaxa y lo mismo hara a la eleuacion del Caliz. ${ }^{260}$

\subsection{Cruciferario}

Un colegial era el encargado de desempeñar la función de cruciferario que consistía en llevar la cruz durante las procesiones e iba vestido con arneto, roquete y collar. La Consueta describe cómo ha de llevar y poner la cruz en las distintas procesiones, como por ejemplo en el Sábado Santo.

El Sabado Sancto lleva la Cruz quando se va a la vendiçión del nueuo fuego y a la buelta en llegando al pauimento la asienta en la grada junto al pulpito del Evangelio y quando el Diacono sube a cantar el Praeconio se pone frontero del pulpito y libro, en medio del lugar que suelen tener los ceroferarios, asienta la Cruz en el suelo que el Cruçifixo mire al Atril y libro del Diacono. Acabada la bendiçión la lleua a la Sacristía acompañandole los Çeroferarios. ${ }^{261}$

Mientras portaba la Cruz, el Cruciferario no debía hacer "humiliacion ni venia ni genuflexión a ninguna imagen ni altar ni cosa que se nombre”.

\subsection{Portero del Coro}

La Consueta no especifica si el portero del Coro debe ser un canónigo, un colegial o seglar. La prohibición de que cante nos hace pensar que debería ser un canónigo o colegial que estuviese instruido en el canto: "No cante ni diga nada en tono

\footnotetext{
${ }^{260}$ Consueta, fols. $210^{\mathrm{r}}-210^{\mathrm{v}}$

${ }^{261}$ Consueta, fols. $201^{\mathrm{r}}-201^{\mathrm{v}}$.
} 
aunque sea con el coro porque disuena en la Iglesia". Si acudían todos los colegiales al Coro, el portero se sentaba en un escabel en el hueco de la puerta y si faltaban colegiales se sentaba detrás del versiculario en el coro del apuntador. Su función era tener cuidado con la puerta y con los que venían a dar "recaudos", es decir avisos a los que estaban celebrando. No siempre podía comunicar el aviso.

No ha de entrar con recaudo en tiempo que se encomience hora ni quando se dize hymno, Capítula, preces, Cantico, oración. Gloria Patri: antiphona y oración de nuestra Señora y en la missa mientras estan de rodillas al Introito y alzar quando se dizen las oraciones evangelio Gloria rezada en el coro alto y Credo hasta el Homo factus est. ${ }^{262}$

Además avisaba al organista cuando debía dejar de tocar: "Tiene cuydado de avisar al organista que deje de tocar quando en el altar hiciere señal con la campanilla para que el celebrante entone el prefacio o Padre Nuestro" y avisar al campanero para que tocara o dejara de tocar "a todos los actos que ocurrieren y para convocar a los aniversarios". De esta manera, "Los sabados en la missa de nuestra Señora quando cantan la antífona post communio haze señal para que el campanero toque el ultimo signo para las horas menores". ${ }^{263}$

Y así continua la Consueta especificando en qué momento el Portero debe avisar al campanero para los diversos repiques. Si llegaba alguna persona forastera que quisiera asistir a Misa al Coro pedía licencia al Abad o Presidente y debía conducirlo al lugar que el Maestro de Ceremonias le indicara.

\subsection{Turiferarios}

Los turiferarios eran los portadores de los turíbulos (o incensarios) y el incienso, e iban vestidos como los ceroferarios con amitos, roquetes y collares. Esta función era desempeñada por colegiales y estaban presentes en todas las ceremonias con música: misas cantadas, vísperas cantadas de domingos y santos, procesiones y bendiciones, exceptuando los oficios de tinieblas.

\footnotetext{
${ }^{262}$ Consueta, fol. $152^{\mathrm{v}}$.

${ }^{263}$ Consueta, fol. $153^{\mathrm{r}}$.
} 
Sorprende una vez más la descripción minuciosa de este oficio: la colocación de los brazos, cómo han de sostener el turíbulo, cómo cada uno se coloca a un lado del altar y van alternándose en los movimientos, de suerte que cuando uno dirige el incensario hacia el altar el otro lo hace al lado contrario y viceversa. Deben realizar una coreografía de movimientos según la música, controlando el tiempo que deben tardar en hacerlos, casi como si de una danza se tratase.

Cuando se repite la quinta antífona salen y miden el tiempo de suerte que quando lleguen al pavimento se acabe en las gradas, hazen profunda en el pavimento genuflexión. Levantanse y allí se quedan en pie mientras dizen la capítula=si el hymno es veni creador spiritus o Ave maris Stella se hincan de rodilas allí mismo mientras se dize el primer verso levantanse y sin hazer genuflexión se van al altar: si el hymno es otro acabada la capítula hazen alli genuflexión y se van al altar y en medio el uno buelto el rostro al otro hazen genuflexión y despavilan de la manera que se dixo en el capitulo precedente de los ceroferarios $n^{\circ} 60$.

Mas el dia del Corpus y su octava miden el tiempo de salir de manera que quando en el coro se canta tantum ergo ellos se hinquen de rodillas en la ínfima grada del altar y dicho veneremur cernui se levantan hazen genuflexión. ${ }^{264}$

\subsection{Ceroferarios}

Los ceroferarios eran los encargados entre otros menesteres de llevar los ciriales con velas en todas las vísperas cantadas y maitines, misas, bendiciones y procesiones. Incluso ellos tenían que tener cierta cualidad musical, pues al explicar cómo deben colocar las velas en el altar la Consueta refiere que deben hacerlo con compás:

En el levantarlas [las velas] para poner, guardan ygualdad y compas que no ponga el uno antes que el otro, antes ambos vayan poniendo las velas cada qual de su lado si ay quatro las primeras de adentro del altar, siempre guarden ygualdad al ponerlas y quitarlas. ${ }^{265}$

Ese mismo sentido del ritmo debían tener al tocar las campanillas en un momento de la misa, al cantar el Sanctus:

\footnotetext{
${ }^{264}$ Consueta, fol. $177^{\mathrm{r}}$.

${ }^{265}$ Consueta, fol. $155^{\mathrm{r}}$.
} 
Cuando el organo o el coro dize Sanctus tocan las campanillas ambos a un tiempo con tres golpes pausados y quando el celebrante dize te igitur suben $\mathrm{y}$ en el pavimento antes de llegar a la peçina hazen genuflexión, llegan al altar cada uno por su lado cogiendo en medio al celebrante y diacono y bueltos algo eregiones buelven a hazer genuflexión y llegan a despavilar. ${ }^{266}$

Los ceroferarios también tocaban las campanillas en diversos momentos de la celebración religiosa o en distintas circunstancias, como cuando se exponía la hostia consagrada:

Quando el Sanctissimo Sacramento esta manifiesto [...] en sus lugares se ponen de rodillas toman los ciriales en las manos y quando el celebrante acava de consagrar toman las campanillas en las diestras y quando haze genuflexión para adorar las hostia consagrada a un tiempo dan dos toques las campanillas en las diestras y quando haze genuflexión para adorar la hostia consagrada a un tiempo dan dos toques con las campanillas, otros dos quando la elevan, otros dos quando la baxa, y los mismos dan al caliz excepto el Jueves y Viernes Sancto que no tocan. ${ }^{267}$

Habían de estar atentos a lo que se cantaba en cada momento porque de ello dependían en gran parte sus gestos y actuaciones, como cuando estaban en el Coro.

En el estar de pie y levantarse siguen el coro de los capellanes porque mientras se canta en el facistol estan en pie y a los psalmos sentados=quando se repite la antífona del $5^{\circ}$ psalmo hazen genuflexión al altar suben al facistol del celebrante y le hazen profunda y apartados un paso abaxo del facistol eregione y las manos puestas estan mientras se canta la capitula y entonado el Hymno le hazen profunda y se buelven a sus lugares quando llegan hazen genuflexión y se quedan eregione las manos puestas mientras se canta el hymno. ${ }^{268}$

La Consueta describe con todo detalle cómo salen en procesión y cómo actúan en cada ceremonia. Es muy interesante observar cómo durante el canto del Evangelio,

Cuando el Diacono entona el Initium o Sequentia Sancti Evangelio levantan a un tiempo los ciriales de suerte que parezca que tienen en medio

\footnotetext{
${ }^{266}$ Consueta, fol. $167^{\mathrm{r}}$.

${ }^{267}$ Consueta, fol. $168^{\mathrm{v}}$.

${ }^{268}$ Consueta, fol. $156^{\mathrm{r}}$.
} 
el libro, tienen los altos mientras se canta el evangelio sin hazer genuflexión ni venia a cosa alguna que se nombre en el evangelio. ${ }^{269}$

Al acabar la misa:

Cantado el Ite missa est cierra el misal y llevalo a la credencia, baxa a su lugar y toman los ciriales en las manos estan en pie, y quando el celebrante buelve a dar la vendicion se hincan de rodillas. ${ }^{270}$

La Consueta hace alusión a la conocida ceremonia del oficio de tinieblas por la que se iban apagando poco a poco las velas encendidas en la iglesia, labor que correspondía a los ceroferarios y lucernarios:

Las tres noches de tinieblas encienden su velas en el altar y quando se comienza el antífona del benedictus baxan del coro y se ponen en el altar mayor el mas antiguo al cornu Epistola y el otro al cornu Evangelii, y al verso Ut sine timore de manu inimicorum nostrorum, el mas moderno apaga la correspondiente vela de la esquina del altar de su lado y al otro verso el antiguo apaga la correspondiente y van apagando a cada verso la suya alternativamente como comenzaron.

Quando se repite la antífona al tiempo que el lucernario quita la candela blanca del triangular los ceroferarios apagan todas las luzes y lamparas de la Iglesia excepto las dos que arden delante del Sanctissimo Sacramento en el altar mayor y en el del sagrario que quando esta en ellos no se apagan y el jueves sancto no se apagan las del monumento. ${ }^{271}$

\subsection{Custos Sacristía}

Otro colegial semanalmente se hacía cargo de la función de Custos Sacristía que consistía en guardar la Sacristía.

asiste toda la mañana en ella con sobrepelliz desde que salen de oracion hasta que se cierra la Iglesia, su offiçio es llamar a los collegiales para que ayuden las missas rezadas y para esto no se a de ocupar en otro ministerio ni hazer falta de la Sacristía por la importançia que es acudir con tiempo y no detener las missas, pues redunda en gran comodidad de los demas exerciçios y ocupaciones de la casa, cuyda tambien de que el Sacristán

\footnotetext{
${ }^{269}$ Consueta, fol. $164^{\mathrm{v}}$.

${ }^{270}$ Consueta, fol. $169^{\mathrm{r}}$.

${ }^{271}$ Consueta, fol. $170^{\mathrm{v}}$.
} 
mayor ô menor no falte de la Sacristía porque quando el va a llamar no la dexe sola. ${ }^{272}$

Debía evitar que los colegiales formasen corrillos en la Sacristía o en la puerta y era su obligación ayudar a la última misa, celebrada a las once y media en invierno y a las once en verano.

\title{
3.8. Flavelario y coadjutor de la misa de tercia
}

Cuando la misa de tercia se celebraba sin diáconos, el turiferario más antiguo ejercía de coadjutor y si era necesario por el tiempo, de flavelario. El flavelario era el encargado de espantar las moscas del altar con el "flavelo" una especie de abanico usado a tal efecto:

\begin{abstract}
el prinçipal fin del flauelo es quitar las moscas de la oblata y después de auer consagrado â de estar con mucha atención para escusar que no lleguen y haze el mouimiento del flauelo sobre el altar con blandura para que no leuante la hostia ni derribe la hijuela, quando por alli andubieren moscas llega el flauelo de canto y las leuanta, al lado del evangelio esta hasta consagrar y registra y buelue las hojas del canon y si tiene flauelo lo pasa a la siniestra y con la diestra registra. ${ }^{273}$
\end{abstract}

Como coadjutor es el que le daba el hisopo al celebrante, registraba lo que tenía que decir y le colocaba los libros:

Acauado el tracto ô Alleluyas, toma el atril y misal y al pasar en medio haze genuflexión al altar y lo pone en el Cornu Euangelis y se queda en la peana a la siniestra del celebrante hasta que â respondido Gloria Tibi Dne. que se baxa de la peana y pone en derecho de el libro y las manos puestas esta al Evangelio y acauado sube y buelue el registro del Credo si lo ay ô del ofertorio y mientras el Credo está fuera de la peana detrás del preste, al tiempo del Incarnatus est quando el çelebrante se hinca de rodillas se pone â su diestra y le cubre con la casulla los pies y la tiende decentemente y alli haze genuflexión juntamente y leuantandose se buelue a su lugar. ${ }^{274}$

\footnotetext{
${ }^{272}$ Consueta, fols. $217^{\mathrm{r}}$

${ }^{273}$ Consueta, fol. $203^{\mathrm{r}}$.

${ }^{274}$ Consueta, fol. $202^{\mathrm{v}}$.
} 
En cuanto a su ministerio, la Consueta señala que puede haber diferencias entre la misa rezada y la misa cantada que el coadjutor debe observar:

A todas las ceremonias en que la missa cantada no diferençia de la rezada al boluer los registros y modo de estar que no este señalado en este Capítulo, el Coadjutor de la missa de terçia asiste y ministra de la misma forma q los de la missa rezada en el capítulo siguiente, no ministra las ampolletas ni lleua el Caliz ni haze lo demas que se noto hazian los çeroferarios supra capítulo $21 .^{275}$

\subsection{Pertiguero}

El Pertiguero debía ser un seglar, honrado, de buen aspecto, buena disposición y de anciana edad. Con los prebendados tenía la obligación de descubrirse al hablar hasta que le indicaran lo contrario. Su oficio consistía en acompañar al cabildo y a los prebendados todas las veces que fueran en procesión o por cabildo y en ceremonia a los oficios divinos, o cuando salían por comisión a algún recado al prelado o al abad.

Vestía ropa y gorra de seda negra con cetro o pértiga de plata y debía ir siempre delante. En la iglesia seguía un ritual de gestos complejo, sobre todo siguiendo la música

Mientras se canta la vendicion del cirio y a todo el demas officio donde se pone a Visperas y quando cantan en la letania a Peccatores te rogamos audinos se llega a las gradas y haze genuflexión al altar y acompaña a los celebrantes que van a tomar ornamentos para la missa y sale con ellos y asiste como los demas dias. ${ }^{276}$

En la Consueta de la Catedral cuidaba del orden de la iglesia, acompañaba al hebdomadario, al diácono, supervisaba al barrendero y al perrero y era el encargado de llamar a Cabildo. No dice nada de edad o aspecto, sí de cortés y sufrido.

\subsection{Tesorero}

El Tesorero era un prebendado que tenía a su cargo los bienes de plata del servicio de la Iglesia, supervisaba el orden de la Sacristía como, por ejemplo, controlando "que los seglares no entren en la Sacristía ni dexen en ella sus espadas"; así como los colores que debían emplearse según la ceremonia, y debía prevenir lo

\footnotetext{
${ }^{275}$ Consueta, fol. $202^{\mathrm{v}}$.

${ }^{276}$ Consueta, fol. $202^{\mathrm{v}}$.
} 
necesario para las procesiones. Ordenaba la limpieza y aderezo de las cuevas además de ser el responsable de comprar la cera.

\subsection{Sacristanes}

Los sacristanes eran dos seglares: uno "mayor" y otro "menor". Sus obligaciones están tan detalladas que es difícil resumirlas. Eran los encargados de la limpieza, de la preparación de los ornamentos, las vestimentas de los celebrantes y participantes en la ceremonia, los ciriales, los misales y manuales, así como de la apertura y cierre de las puertas de la iglesia.

De las ceremonias con música que necesitaban de ornamentos singulares que debían prevenir los Sacristanes, la Consueta señala entre otras las Visperas cantadas, en dónde los sacristanes sacaban los cetros y los pluviales ${ }^{277}$ o el canto de las letanías en el que era necesario que el sacristán sacara "al altar de los martyres los candeleros con velas que encienden los ceroferarios y an de servir en la Misa". 278

\subsection{Caniculario}

El caniculario se encargaba de la limpieza de la iglesia y del coro, regando la iglesia en verano para que no hubiera polvo, y lo mismo debía hacer con el claustro y la iglesia de Santiago en las Cuevas. Otra de sus obligaciones era el hacer los túmulos para las honras fúnebres y esparcir por la iglesia el alcacer, la juncia y las "gayombas". ${ }^{279}$ Vestía de morado con gorra también morada cuando asistía a la iglesia, y debía llevar un "azote” para castigar y echar fuera a los perros (de ahí su nombre). Cuidaba de que no entraran pobres a la iglesia o estuvieran a la puerta, ni hubiese "ciegos que rezen que inquietan los oficios y missas" o personas con cestas de comida. Asimismo vigilaba del carbón del brasero, de los libros de las procesiones, de que no llegaran hasta allí "cabalgaduras" y que no pastara el ganado en el entorno de la casa y de las cruces. Además cuando había repique de campanas debía subir a la torre para ayudar al campanero.

\footnotetext{
${ }^{277}$ Consueta, fol. $99^{\mathrm{r}}$.

${ }^{278}$ Consueta, fol. $104^{\mathrm{v}}$.

${ }^{279}$ Hierbas olorosas.
} 
La jerarquía de los distintos cargos y sus obligaciones en la Abadía del Sacromonte quedaban perfectamente descritas en la Consueta. Hasta qué punto se cumplían las disposiciones de la Consueta es difícil de establecer, pero puede decirse que este documento regía la vida diaria en la Abadía. Semanalmente se tenía lección de ceremonias, como recogen las Actas, y además un cabildo al mes en el que se leía la Consueta se dedicaba a Ceremonias y Loables costumbres. Puede concluirse por tanto que las instrucciones contenidas en la Consueta regían la organización, y muy especialmente el ceremonial del Sacromonte. La minuciosidad con que se describen las ceremonias de la Abadía contribuye a enriquecer notablemente el papel que la música tenía en el culto. 


\section{CAPÍtULO IV}

\section{MÚSICA Y CEREMONIAL I: LOS ESPACIOS CULTUALES. CONSIDERACIONES SOBRE LA MÚSICA EN LA ABADÍA}

Los Capítulo IV y V estudian el ceremonial en la Abadía del Sacromonte desde dos puntos de vista. En el Capítulo IV describo los diferentes espacios donde se desarrollaba el culto en la Abadía (iglesia y Cuevas), destaco la preminencia del canto llano sobre la polifonía y la música instrumental, y por último analizo el papel desempeñado por los colegiales del Colegio de San Dionisio Areopagita, contiguo a la Iglesia. En el Capítulo $\mathrm{V}$ estudiaré una selección de ceremonias particularmente relevantes en la Abadía siguiendo las detalladas descripciones de la Consueta (1632).

La música que se interpretaba en la Abadía del Sacromonte de Granada, como toda aquélla que se interpretaba en una institución religiosa, tenía una función ceremonial: acompañaba al culto y le estaba subordinada. Por tanto, si queremos comprender el verdadero lugar que la música ocupó en la Abadía y por ende en muchos otros centros eclesiásticos, debemos considerar en primer lugar que la música no era autónoma, sino que estaba supeditada al rito. Observar además las ceremonias en que la música tenía lugar, entendiendo como ceremonia "la acción o acto exterior arreglado por ley, estatuto o costumbre, para dar culto", ${ }^{1}$ contribuirá a recuperar el contexto real en el que la música se interpretaba. Como señala Norbert Elias, al ser observadores del siglo XXI nos faltan referencias objetivas para comprender la utilidad del rito: al igual que en la Corte, el ceremonial al que los participantes en la liturgia subordinaban sus actos fijaba las distancias que se debían guardar respecto de la multitud. Elias muestra la relación entre el ritual cortesano y eclesiástico, pues ve, en esta diferenciación que el ritual proporciona al rey, un símbolo de poder que también se manifiesta en el ceremonial litúrgico. La etiqueta en el ámbito de la liturgia se concretaba en el orden en cantar, en la prelación durante las procesiones o el asiento en el templo, convirtiéndose, al igual que en la sociedad cortesana, en una autorrepresentación de la sociedad eclesial. $^{2}$

\footnotetext{
${ }^{1}$ Véase "Ceremonia" en R.A.E., Diccionario de la Lengua Española (Madrid: Espasa-Calpe, 2000) Tomo I, p. 463.

${ }^{2}$ Norbert Elias, La sociedad cortesana (Méjico: Fondo de cultura económico, 1996), pp. 136, 180 y 187. Aunque Elías hace su estudio sobre la sociedad cortesana, centrándose en la Corte Francesa del Antiguo
} 
Por otra parte no hay que olvidar el aspecto simbólico de la cultura barroca tantas veces tratado en los estudios culturales y que gracias a la música adquiría nuevas connotaciones. En el Barroco, heredando una tradición que partía desde el Renacimiento, imágenes, gestos, palabras y música eran empleados como analogías que significaban una realidad paralela estableciendo una relación simbólica entre el hombre y el poder o la religión. Esta simbología afectaba a todos los ámbitos de la cultura y se materializó en la literatura, en la iconografía artística, la emblemática, y en todas las manifestaciones de la sociedad barroca. Desde la fiesta pública hasta la oratoria sagrada, las imágenes (ya fueran textuales, pictóricas o sonoras) fueron utilizadas como propaganda configurando su propio discurso en medio del ceremonial político, el ritual eclesiástico o la vida cotidiana. ${ }^{3}$

Las ceremonias que se desarrollaban en las instituciones religiosas gozaban de un alto componente de tradición, por lo que su transmisión era consuetudinaria, y hoy en día resulta muy difícil reconstruirlas con cierta exactitud, porque nos faltan fuentes que las describan con detalle. Además, como indica Harper, "la etapa final de reconstrucción de una ceremonia litúrgica, aquélla en la que se deben incluir los gestos, los movimientos, las acciones, los ornamentos y la vestimenta es probablemente lo más difícil, porque con frecuencia estos elementos son muy elaborados, complejos y muy lejanos de la experiencia moderna". 4 Sin embargo, en el caso de la Abadía se conserva un documento excepcional por su prolijidad y detalle: la Consueta de 1632. Comparada con otros documentos de este tipo, como el propio Ceremonial de la Catedral de Granada (que era considerado uno de los más completos) ${ }^{5}$, es muy exhaustiva sobre

Régimen, muchas de sus apreciaciones sobre el ceremonial son extrapolables al contexto litúrgico en el que se desarrolla este estudio.

${ }^{3}$ Para comprender el Barroco como cultura simbólica véase el estudio de José Antonio Maravall, La cultura del Barroco (Madrid: Ariel, 1975) y un estudio sobre las relaciones entre la Contrarreforma y el aspecto simbólico en José Luis Bouza Álvarez, Religiosidad contrarreformista y cultura simbólica del barroco, (Madrid: Consejo Superior de Investigaciones Científicas, 1990).

4 John Harper, The forms and Orders of Western Liturgy. From the tenth century to the eighteenth century. A Historical Introduction and Guide for Students and Musicians (Oxford: Clarendon Press, 1991), p. 198: "The final stage of reconstruction is probably the most difficult and the most elusive: the movements, gestures, actions, ornaments, and vestments of the liturgy are often elaborate, complex, and remote from modern experience".

${ }^{5}$ En el Prólogo de la propia Consueta del Sacromonte se menciona el prestigio alcanzado por la Consueta de la Catedral de Granada en la época. 
todo en lo que concierne a la descripción de todas las acciones y movimientos, gracias a lo cual se pueden reconstruir las ceremonias con mucha exactitud. La teatralidad del gesto litúrgico también debe considerarse para comprender la significación ceremonial. El gesto y el movimiento acompañados de la música son un remedo de la esfera teatral, convirtiendo a la ceremonia en una representación simbólica de significado religioso. Esta relación entre "ceremonia litúrgica y teatro" es para García de la Concha "absolutamente pertinente para el teatro medieval" y para Díez Borque es ampliable hasta los dos primeros tercios del siglo XVI. ${ }^{6}$ En el caso de la Abadía, como veremos, el gesto es indispensable en la ceremonia y su significado teatral es complementario a la simbología religiosa que representa. Pero ante todo es necesario examinar los espacios en los que ese ceremonial litúrgico tenía lugar.

\section{Los espacios cultuales de la Abadía: la iglesia y las Cuevas ${ }^{7}$}

La Abadía del Sacromonte es un curioso complejo de edificios ubicado en el Monte de Valparaíso, extramuros de la ciudad de Granada. Su peculiaridad reside en la amalgama de varios conceptos arquitectónicos cultuales: el Sacromonte engloba al mismo tiempo un calvario o sacromonte a la manera de los sacri monti italianos, un complejo de cuevas que recuerda al culto de las catacumbas romanas, un colegioseminario y un templo.

Los sacri monti (sacromontes) fueron originariamente una invención de los padres franciscanos que volvían del peregrinaje a Jerusalén con el objeto de recrear los santos lugares y proporcionar al fiel una peregrinación menos costosa, tanto en esfuerzo como en dinero. En el periodo que siguió al Concilio de Trento los sacri monti resurgieron en la zona de los Alpes italianos. Para edificar estos complejos religiosos se elegían lugares que poseían un valor devocional, ya fuesen antiguos santuarios o

\footnotetext{
${ }^{6}$ José María Diéz Borque, "Liturgia-Fiesta-Teatro: órbitas concéntricas de teatralidad en el siglo XVI", Dicenda, Cuadernos de Filología Hispánica, 6 (1987), p. 487.

${ }^{7}$ A pesar de la importancia artística de la Abadía, que fue declarada Monumento Histórico Artístico por Real Decreto 462 de 21/1/1979 (Bien de Interés Cultural en la legislación actual), no hay ningún estudio artístico monográfico sobre la Abadía. Los más completos son los trabajos de José Manuel GómezMoreno Calera, La Arquitectura religiosa granadina en la crisis del Renacimiento (1560-1650), (Granada: Universidad de Granada y Diputación Provincial, 1989) pp. 250-265; Javier Martínez Medina, "La Abadía del Sacromonte y su legado artístico-cultural”, ¿La historia inventada? Los libros plúmbeos y el legado sacromontano, ed. Por Manuel Barrios Aguilera y Mercedes García Arenal (Granada: Universidad de Granada y Legado Andalusí, 2008), pp. 215-295.
} 
espacios en los que pervivía la memoria de cultos paganos reconvirtiéndolos en centros cristianos. $^{8}$ Carlo Borromeo fue también impulsor de estos centros litúrgicos y quizás en él se inspirara Pedro de Castro de nuevo para la configuración sacromontana. ${ }^{9}$ A imitación de aquellos sacri monti italianos, el complejo abacial del Sacromonte era un espacio al que el peregrino accedía después de un camino que invitaba a la reflexión (denominado popularmente como "las sietes cuestas") y que se pobló de multitud de cruces, como recogen los cronistas de la época. Los fieles, al llegar, atravesaban un pórtico y encontraban varios edificios devocionales (iglesia y capillas de las Cuevas).

Las Sagradas Cavernas o Santas Cuevas del Sacromonte en las que aparecieron los Libros Plúmbeos y las supuestas reliquias de los mártires cristianos obligan a la comparación con el resurgir del culto a las catacumbas romanas que promovió San Felipe Neri en Roma. ${ }^{10}$ Como Borromeo, Neri gustaba de ir a rezar a las catacumbas, especialmente a la de San Sebastián, pero fue en 1578 cuando con el descubrimiento de la Catacumba de Priscila se desata en Roma la veneración de los fieles. ${ }^{11}$ Las "catacumbas" granadinas fueron descubiertas en 1595, unos años después de que las romanas alcanzaran su apogeo. La iglesia de la Abadía no llegó a alcanzar las proporciones que Castro soñó cuando encargó el proyecto al jesuita Pedro Sánchez; en este encargo se aprecia también cómo el Arzobispo quería ponerse a la vanguardia de la arquitectura del momento, pues eligió a un jesuita cuando éstos eran los "arquitectos de

\footnotetext{
${ }^{8}$ F. Fontana, R. Lodari, P. Sorrenti, Luoghi e vie di pellegrinaggio. I Sacri Monti del Piemonte e della Lombardia (Turín: Centro di Documentacione dei Sacri Monti, Calvari e Complessi devozionali europei, 2004), pp. 1-48.

${ }^{9}$ Aunque el Vía Crucis que llegaba a la Abadía (cuyas cruces hoy han desaparecido) fue creado por los franciscanos terciarios de Granada en 1633, desde el mismo momento del descubrimiento de las reliquias, Castro denominó al espacio "Sacro Monte", y muchos particulares y cofradías iban a colocar su cruz. Después los franciscanos le dieron la forma de Vía Crucis y cada cruz fue costeada por personalidades de la Granada de la época, entre los que figuraban el abad del Sacromonte, Pedro de Ávila, el Marqués de Estepa y Orlando de Levanto. Véase, Antonio Gallego y Burín, Granada, guía histórica y artística de la ciudad (Granada: Comares, 1996), p. 360. Un estudio somero sobre la fortuna de esta tipología devocional en España puede verse en José Miguel Muñoz Jiménez "Sobre la "Jerusalén restaurada": los Calvarios Barrocos en España”, en Archivo español de Arte, 69/ 274 (1996), pp.157-169.
}

\footnotetext{
${ }^{10}$ Simon Ditchfield, "Martyrs on the move: Relics as vindicators of Local Diversity in the Tridentine Church", en Martyrs and Martyrologies, Studies in Church History, vol. 30, editado por Diana Wood (Oxford: Blackwell, 1993), p. 287.

${ }^{11}$ Sobre el resurgir del culto de las catacumbas en Roma, véase Emile Mâle, El arte religioso de la contrarreforma: Estudios sobre la iconografia del final del siglo XVI y de los siglos XVII y XVIII (Madrid: Encuentro, 2001), pp. 125 y ss.
} 
la contrarreforma". Por último, además de la Iglesia y las Santas Cuevas, la Abadía tenía anejo un colegio-seminario para la formación de sacerdotes que contaba con otra capilla propia, la de San Dionisio Areopagita, en la que se desarrollaron como veremos otras ceremonias particulares. ${ }^{12}$

\subsection{Las Santas Cuevas del Sacromonte}

La singularidad de este espacio es casi única en el ámbito de la Península Ibérica. ${ }^{13}$ Las Cuevas fueron las primeras en sufrir las transformaciones y construcciones arquitectónicas casi desde el mismo descubrimiento de las reliquias. Las obras fueron encargadas primero a Justino Almerique y más tarde a Ambrosio de Vico, maestro mayor de obras de la Catedral de Granada. ${ }^{14}$ Las Cuevas se excavaron y se reforzaron arquitectónicamente, no estando exentas de cierta teatralidad, como la que vemos en la capilla del horno de San Cecilio, dónde se dejó la piedra de la caverna sin desbastar y se colocó un pequeño busto del santo con una lámpara encendida. Sin duda se buscaba el efecto dramático en el peregrino que llegaba a través de un estrecho y oscuro pasaje; véase Figura IV.1.

Un plano actual (vénse Figura IV.5) nos da a conocer el espacio de las uevas del Sacromonte en el que tuvieron lugar diversas ceremonias, como se verá más adelante. La acústica, excesivamente reverberante por los numerosos recovecos y pasillos, unida a la angostura del lugar provocarían interesantes efectos heterofónicos en la música allí cantada, por cuanto siempre que se entraba en procesión se entonaba algún himno o antífona (Salve, Te Deum, Ave Maris Stella). Exteriormente este espacio está delimitado por remates curvilíneos y caracterizado por las cúpulas barrocas de algunas capillas.

\footnotetext{
${ }^{12}$ Esta capilla es del siglo XIX, época en la que se construyó el Colegio Nuevo.

${ }^{13}$ Existen otros santuarios en cuevas, como el de la Santa Cueva en Altura (Castellón), pero son raros.

${ }^{14}$ Gómez-Moreno Calera, La arquitectura, p. 256.
} 
Figura IV.1. Horno de San Cecilio, Abadía del Sacromonte.

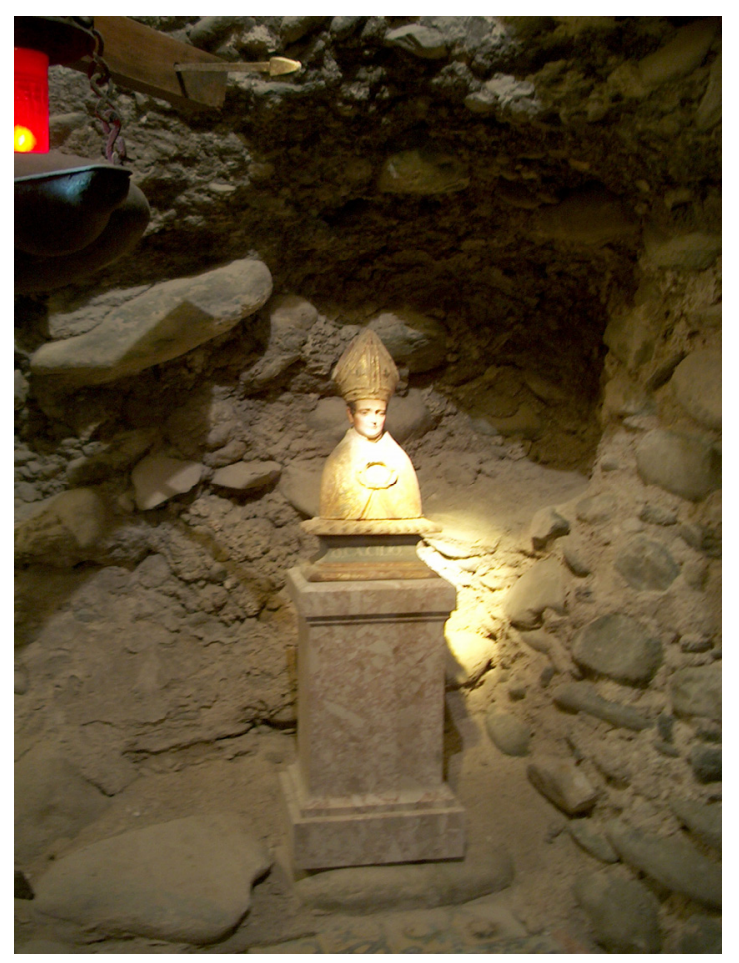

La Capilla de Santiago es la más grande de las que hay en las Cuevas y en ella puede verse un original retablo en forma de venera con una pequeña Inmaculada y otras esculturas de pequeño formato. El retablo estofado en oro, está decorado con los elementos de la letanía lauretana, que están presentes en otros espacios de las Cuevas, como la Capilla de la Dolorosa, en la que aparecen como relieves en la cúpula de piedra. El horno de San Hiscio, ante el que tenían que arrodillarse los canónigos y colegiales cuando entraban a las Cuevas, se sitúa en un espacio circular delimitado por pequeños arcos que sostienen una bóveda rebajada.

\subsection{La iglesia del Sacromonte}

La primitiva iglesia del Sacromonte, aunque en un primer momento considerada provisional, se convirtió en definitiva con el tiempo y no logró la amplitud de la proyectada por el arquitecto Pedro Sánchez, ni siquiera con la ampliación que sufrió en 1762 cuando le fueron añadidas las dos naves laterales. Una pintura de lo que debió ser la primera fábrica de la Abadía (ca.1621) nos muestra claramente las diferencias con la 
ampliación que se produjo después; véanse Figura IV.2 y Figura IV.3. Actualmente la iglesia consta de tres naves y crucero con un coro "levantado a los pies sobre bóveda deprimida". ${ }^{15}$ En el crucero, en el lado de la epístola, se encuentra una pequeña capilla funeraria que alberga el mausoleo del fundador Pedro de Castro, quien aparece representado en una escultura orante de mármol. La planta de la iglesia proyectada por Sánchez era basilical, lo que Gómez-Moreno Calera ${ }^{16}$ señala como inusual en las iglesias jesuíticas, por tener que incluir el coro de los canónigos en el centro (como era costumbre en las iglesias catedrales y colegiales). Pero lo que más nos interesa de este proyecto fallido, además de la amplitud de la iglesia y su monumentalidad, es que dedicaba uno de los cinco claustros a las procesiones; véase la letra $\mathrm{C}$ de la Figura IV.4). ${ }^{17}$

El retablo del altar mayor es del s. XVIII, en el estilo de Duque Cornejo, está atribuido a Blas Moreno, y se decora con las esculturas de los mártires de la Abadía. ${ }^{18}$ Las capillas del crucero están dedicadas a la Inmaculada Concepción, a San José (ambas esculturas son de Pedro Valero $)^{19}$ y a la Virgen del Rosario con San Dionisio Areopagita.

\footnotetext{
${ }^{15}$ Gómez-Moreno Calera, La Arquitectura, p. 264.

${ }^{16}$ El arquitecto Pedro Sánchez se encontraba en Granada desde 1611, donde construyó el crucero, cúpula y capilla mayor de la Iglesia del Colegio de San Pablo (hoy San Justo y Pastor). El proyecto de la Abadía está firmado en 1614, pero en 1615 ya se encontraba en Baeza, y en 1619 abandonó Andalucía. Fue discípulo de Villalpando, quién a su vez lo era de Herrera. Véase Alfonso Rodríguez G. de Ceballos, "El arquitecto hermano Pedro Sánchez", Archivo español de Arte, 43/169 (1970), pp. 51-81.
}

${ }^{17}$ Gómez-Moreno Calera, La Arquitectura, p. 261, recoge la explicación del plano de Sánchez que transcribo parcialmente: "Donde está la letra $\mathrm{C}$ es el claustro de las procesiones, este ha de ser los tres lados con el principal orden de arcos y un pedestal encima y sus remates y el corredor que mira a medio dia ha de ser con ventanaje para que se pueda cerrar por el sol y por el frio para ir al coro".

${ }^{18}$ Para un estudio iconográfico del retablo mayor de la iglesia, véase Martínez Medina, "La Abadía del Sacromonte", pp. 234-237. Los retablos colaterales primitivos fueron donados a la Iglesia de Deifontes, pues el Cabildo abacial era el dueño de las tierras de Deifontes y de la Iglesia, quizás por no ajustarse al programa iconográfico o porque al renovar el retablo principal quedarían obsoletos. Véase ASAC XI, fol. $325^{\vee}$ (3-IV-1777), [735]: "En medio de la Iglesia había necesidad de un facistol nuevo, y también de otro fijo en el Corto para la Calenda y todo se mandó hacer también como que los retablos viejos de los colaterales se diesen para la Iglesia de Dayfontes". Los retablos de la Iglesia de Deifontes ardieron durante la Guerra Civil.

${ }^{19}$ ASAC IV, fol. ¿?, (8-XI-1764),[674]: "Si a Fray Pedro del Santísimo Sacramento los días que viene a afinar el órgano se le ha de dar almuerzo o comida o los días que se llama clásicos para tocar instrumentos en misa y vísperas. Si a don Pedro Valero, tallista que está construyendo las imágenes de Nuestra Señora de la Concepción y del señor San Joseph que se han de colocar en los retablos laterales se le han de dar las dos hogazas". 
Las naves laterales, sin capillas (exceptuando la que se encuentra en el lado de la epístola, a los pies de la iglesia) están adornadas por siete lienzos de gran formato que narran los siguientes episodios: Crucifixión de San Pedro, Martitio de San Andrés, Martirio de San Cecilio, San Patricio y San Septentrio, ${ }^{20}$ Virgen de las Angustias, San Cecilio y su hermano Tesifón son curados por Jesucristo y Santiago predicando a los árabes. Colgados de las pilastras de la nave central una serie de pinturas anónimas con representaciones de los mártires del Sacromonte completan el programa iconográfico abacial: Santiago, San Cecilio, San Mesitón, San Hiscio, San Maximino y San Lupario, entre otros. $^{21}$

El coro situado a los pies del templo en alto y su sillería es obra de Díaz del Ribero. Tiene dos puertas, por una se accede a un rellano en el que se encuentra la puerta para la habitación del órgano y la librería coral, además de las escaleras de descenso a la iglesia; la otra puerta comunica con el plan del coro, que da a las habitaciones de los canónigos. La disposición de los asientos en el coro es particularmente interesante porque en él se desarrollaba gran parte de la actividad musical; véase Figura IV.6.

A las espaldas del retablo mayor y saliendo por la Capilla de la Virgen se accede a la Sacristía, donde se encuentra una mesa de cálices con incrustaciones de mármol de colores y unas grandes cajoneras en las que se guardaban los ornamentos y útiles para el culto; véase la letra E de la Figura IV.5. Además la sacristía era punto de partida y de llegada de las procesiones que tenían lugar en la Abadía.

El patio, por el que también transcurrían algunas procesiones fue, según GómezMoreno Calera, realizado según los planos de Sánchez por el cantero Ginés Martínez de Salazar, y representa "la introducción en Granada del patio afenestrado, de desarrollo típicamente protobarroco" (véase Figura IV.7). ${ }^{22}$

\footnotetext{
${ }^{20}$ San Septentrio o Septemtrio era uno de los compañeros de San Cecilio.

${ }^{21}$ Martínez Medina, “La Abadía”, pp. 240-242.

${ }^{22}$ Gómez-Moreno Calera, La Arquitectura, p. 264.
} 
Figura IV.2. Pintura anónima de la primitiva fábrica de la Iglesia del Sacromonte, (ca.1621).

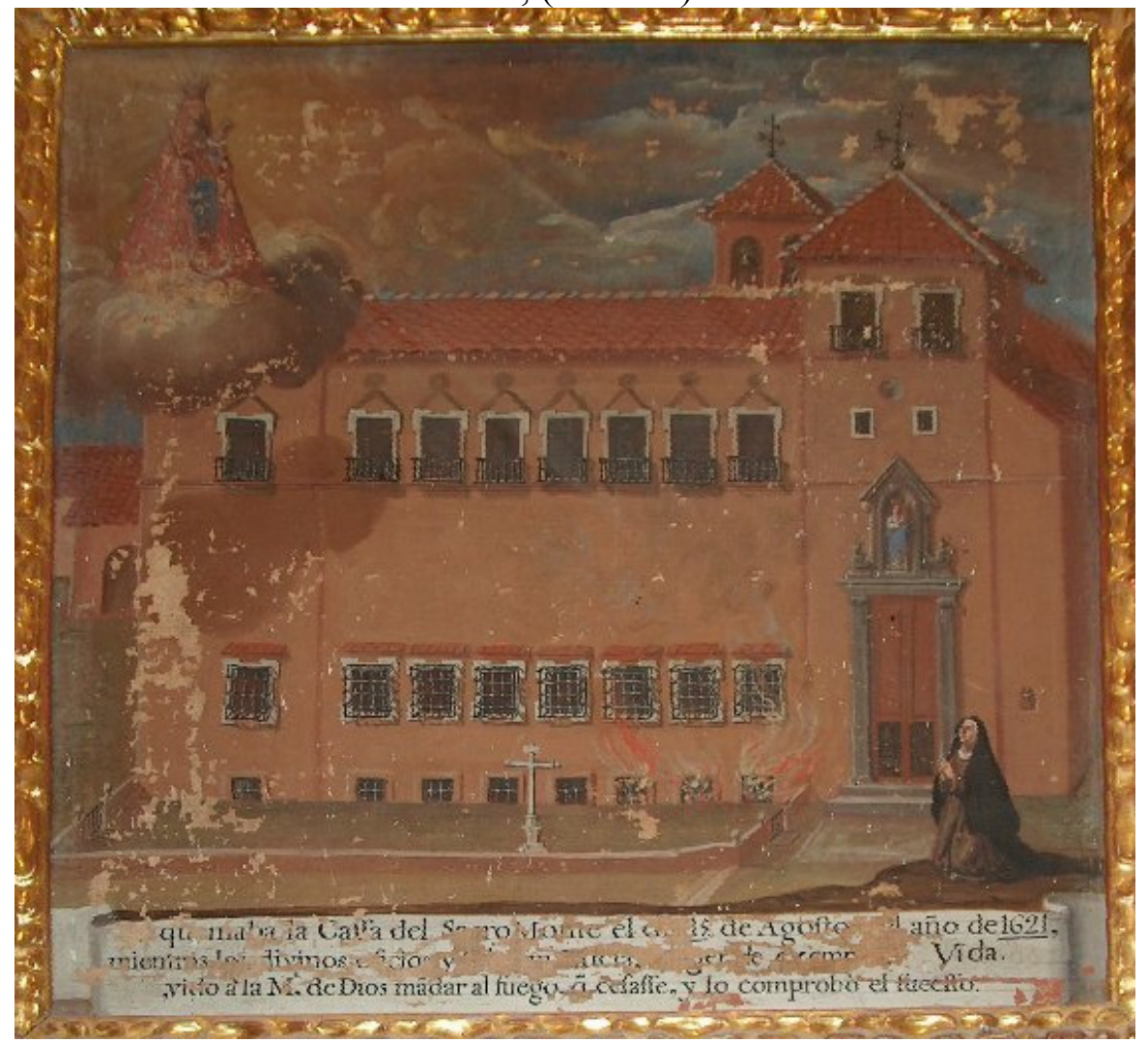

Figura IV.3. Dibujo actual de la Fábrica de la Iglesia. Fuente: TurespañaSubdirección General de Promoción Exterior del Turismo.

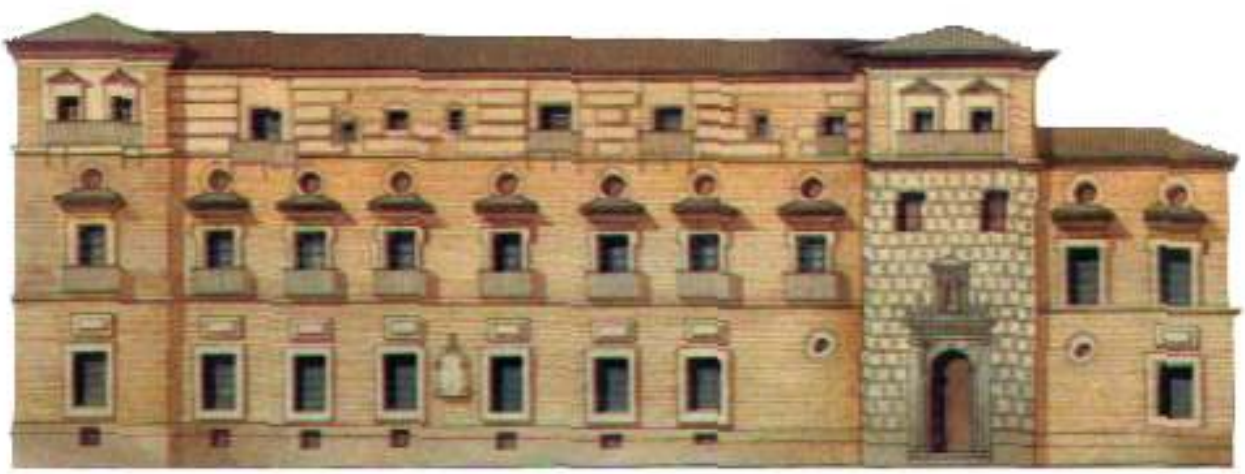


Figura IV.4. Proyecto del Arquitecto Pedro Sánchez para la Abadía del Sacromonte (1614). Fuente: Gómez-Moreno Calera, La Arquitectura, p. 260.

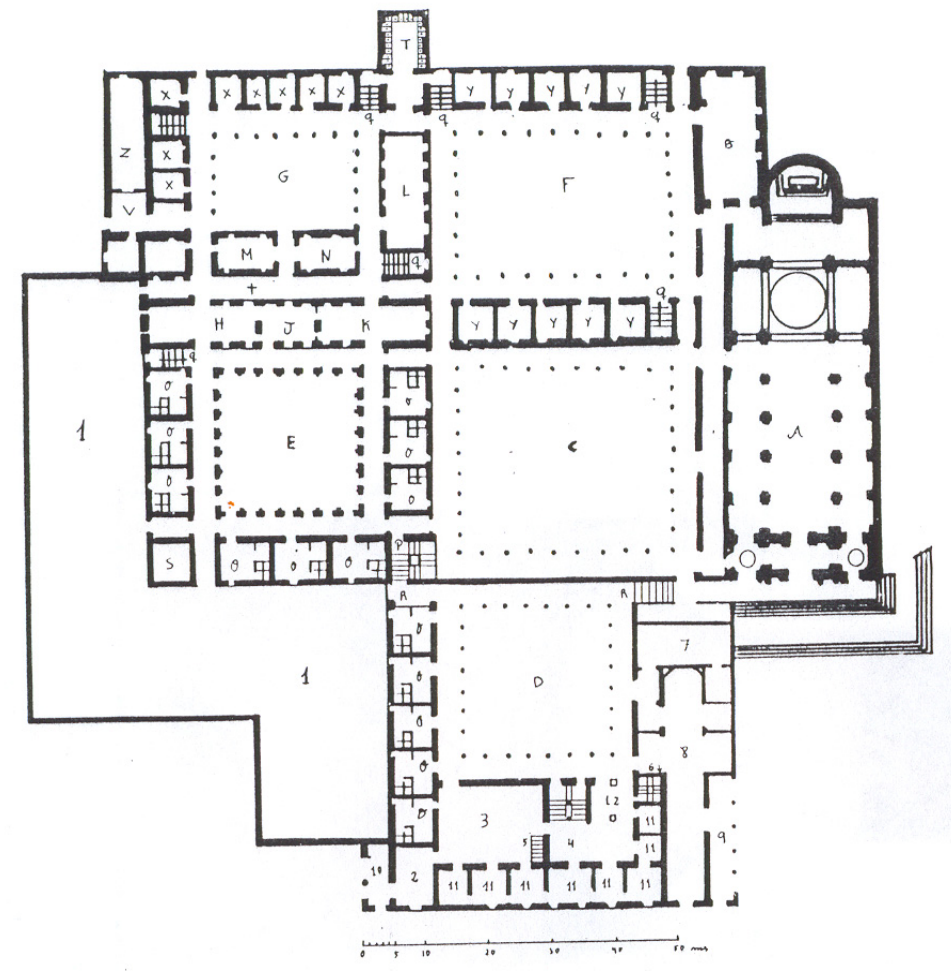

Fig. IV.5. Plano actual de la Iglesia y las Santas Cuevas por Margarita Martínez. Fuente: Mercedes Castillo, "El ceremonial de "la Salve de Nuestra Sra. en los Sábados y en sus fiestas” (1632), Revista de Musicología,28/1 (2005), p. 113.

A

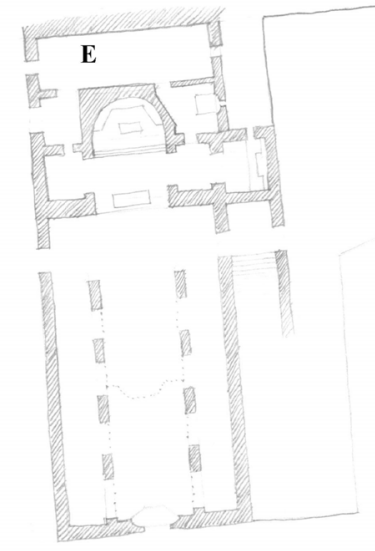

B

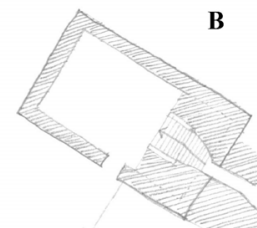


Figura IV.6. Distribución de los asientos del Coro de la Iglesia Colegial de la Abadía del Sacromonte de Granada.

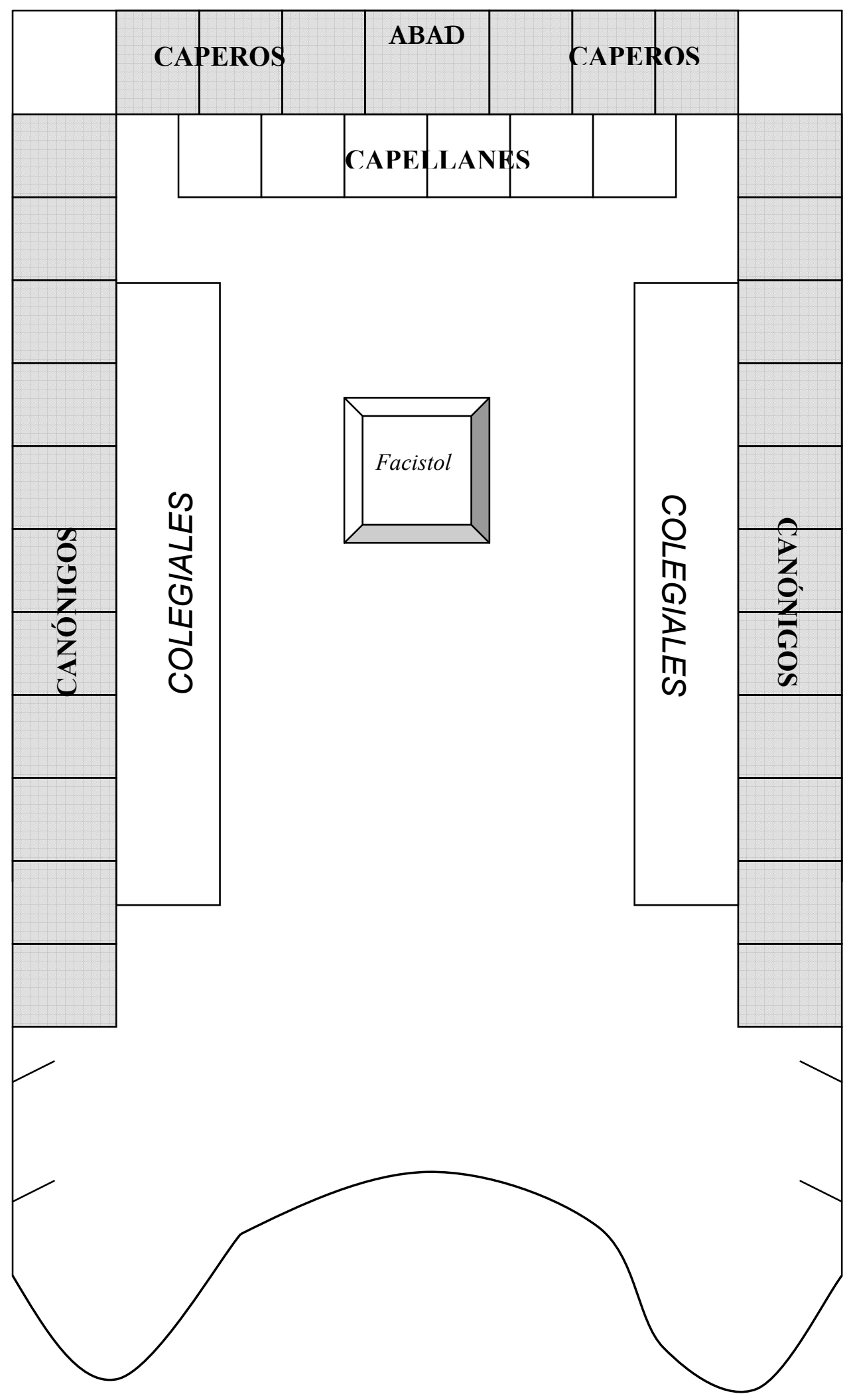


Figura IV.7. Claustro de la Abadía del Sacromonte.

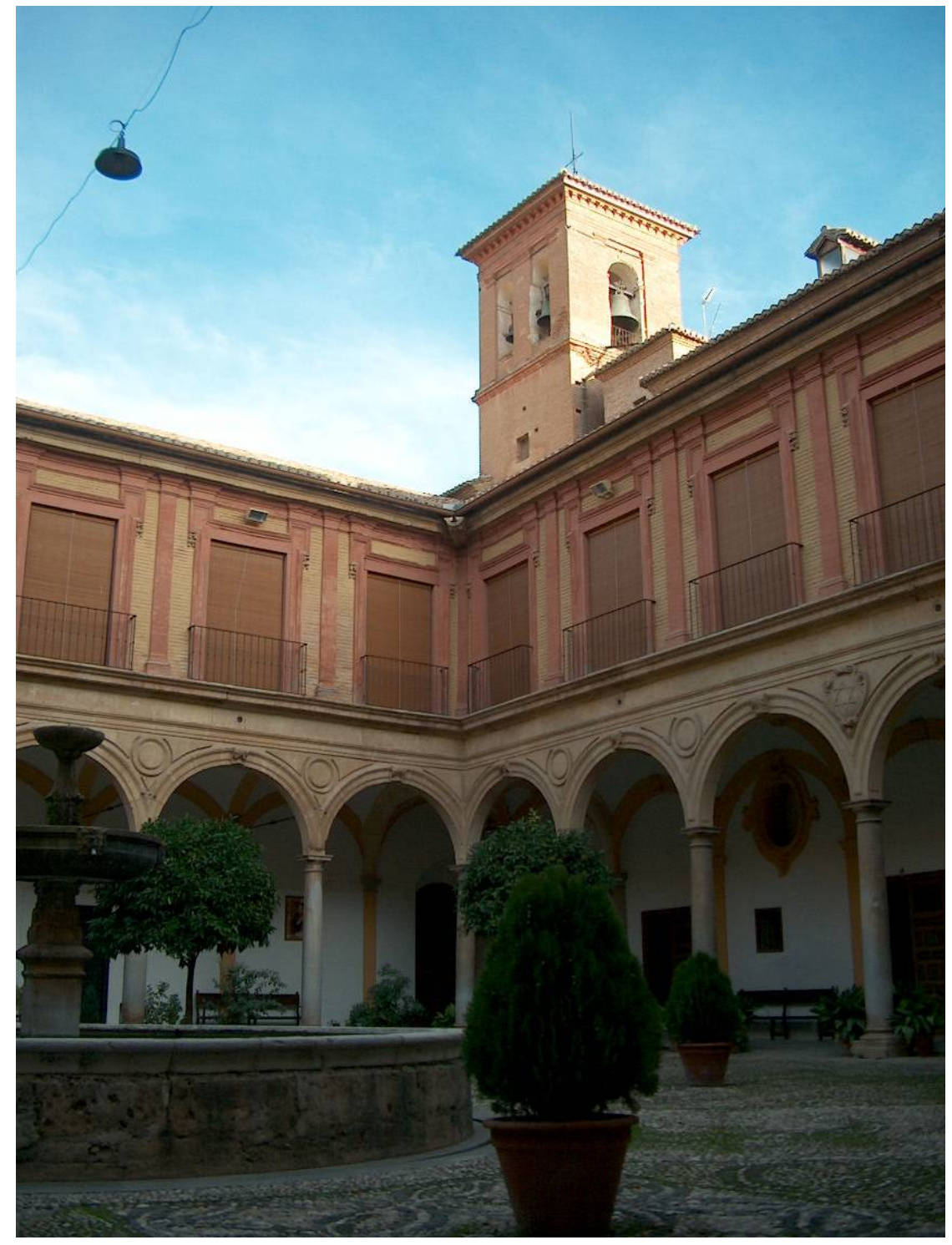




\section{La música en las ceremonias de la Abadía}

La música interpretada en las misas y oficios celebrados en la Abadía del Sacromonte era fundamentalmente canto llano. Probablemente por este motivo el estudio del fenómeno musical en la Abadía no haya sido objeto de atención por los musicólogos. El énfasis en el estudio del repertorio polifónico ha supuesto presentar en ocasiones una visión distorsionada de lo que fue la vida musical en las instituciones eclesiásticas, porque incluso en las más importantes (catedrales y capillas reales) las partes del rito que se desarrollaban en canto llano eran más numerosas y extensas que las secciones polifónicas.

\subsection{Canto llano versus polifonía}

Cantar: (...) canto, o es simple de una sola voz, y ésta puede ser arrimada a instrumento o por sí; o [de] muchas voces juntas y éstas hacen melodía y harmonía. De aquí nace la diferencia de canto llano, canto de órgano, contrapunto; y de cada cosa déstas hay su arte".

Sebastián de Covarrubias, Tesoro de la lengua castellana o española, 1611.

La música que se conserva en la Colegiata del Sacromonte y en el Archivo es exclusivamente monódica; no hay ni un sólo cantoral polifónico. Esta circunstancia (unida al hecho de que las Constituciones de 1647 especifican que el servicio debía hacerse en canto llano) y el carácter austero de Pedro de Castro reflejado en muchos aspectos de su fundación (como la ausencia de una capilla musical) podrían llevarnos a concluir que en la Abadía no se interpretó polifonía. Sin embargo algunas circunstancias que se presentarán a continuación parecen indicar que la polifonía sí tuvo su lugar en el Sacromonte, si bien de manera esporádica.

El hecho de que no se conserven fuentes polifónicas no es definitorio: la música polifónica, si admitimos su carácter ocasional en el Sacromonte, podía haberse escrito en papeles sueltos, y además queda la posibilidad de que algunos de ellos se encuentren 
en la Biblioteca de cuyos fondos musicales no tenemos noticia. ${ }^{23}$ Por otra parte, si los músicos eran contratados y venían de fuera, traerían sus propias partituras. ${ }^{24}$

Evidencias de la interpretación de música polifónica pueden encontrarse en la Consueta y en las Actas. Si leemos atentamente la Consueta, cuesta encontrar referencias al "canto de órgano", que es como se denominaba en la época al canto polifónico y si lo hace suele ser restrictivo: así en el Oficio del Domingo de Ramos la Consueta advierte que "No se canta nada a canto de órgano sino el canto llano con mucha deboción y pausa". ${ }^{25}$ La Consueta de la Catedral hace sin embargo más referencias a la polifonía que la sacromontana ya que no solo habla de canto de órgano, sino también de "canto baxo de fabordón", término que no figura aquí. ${ }^{26}$ Hay que considerar que la Consueta catedralicia es un siglo anterior a la sacromontana, y que en la práctica musical del siglo XVII el fabordón va perdiendo importancia por su sencillez y carácter improvisatorio. No obstante, llama la atención que en un acta capitular de finales del siglo XVII se recrimine a los colegiales por cantar "fabordón":

Y en lo que toca a ceremonias dijo el sr. Don Miguel de Medina que en las Vísperas cantadas estándolas cantando un coro algunos colegiales del otro cantaban fabordón cosa mal parecida y contra ceremonia, y se determinó que el sochantre diga a los colegiales cante cada uno en su coro. $^{27}$

\footnotetext{
${ }^{23}$ Aunque en el Catálogo de la Biblioteca de la Abadía, conservado en la Biblioteca del Hospital Real de la Universidad de Granada no se recogen fondos musicales, no he podido acceder a la Biblioteca de la Abadía por estar cerrada al público.

${ }^{24}$ La única fuente con música polifónica anterior al siglo XIX que se conserva en la Abadía es un ejemplar de la primera edición del Dodecacordon de Glareano: Glareani Dodekachordon, (Basileae: per Henrichum Petri, mense septembri ... 1547). Su buen estado de conservación descarta que se empleara como fuente habitual para la música y parece poco probable que se copiaran partituras sueltas de él.

El cómo y cuándo llegó este ejemplar a la Abadía es hoy por hoy un misterio: en España sólo hay 4 ejemplares catalogados en el CCPBE (BN, Universidad Complutense de Madrid y dos en Andalucía: uno en una Biblioteca privada y otro en la Abadía). Sabemos que Glareano enviaba copias de sus obras corregidas por él mismo a su círculo erasmista, y quizás el libro de la Abadía perteneciera a un seguidor de Erasmo, puesto que está corregido en los márgenes. Sobre las anotaciones de Glareano en sus libros y su relación con el círculo erasmista véase: Iain Fenlon, "Heinrich Glarean's books", Music in the German Renaissance, Sources, Styles and Contexts John Kmetz, ed. (Cambridge: Cambridge University Press, 2006), pp. 74-102.

${ }^{25}$ Consueta, fol. $376^{\mathrm{r}}$.

${ }^{26}$ Pilar Ramos, La Música en la Catedral de Granada, p. 100.

${ }^{27}$ ASAC IV, fol. 394 (1-VI-1677), [182].
} 
La polifonía había nacido como un embellecimiento del canto y como modo de solemnizar el culto; así ocurría también en la Abadía, donde la polifonía se empleaba para revestir y señalar las fiestas y momentos litúrgicos más importantes. De hecho puntualmente la Consueta alude a géneros polifónicos como el motete o la chançoneta. Motetes se cantaban en las cinco fiestas de la Virgen, como sustitución al último verso de la Salve, ${ }^{28}$ o en las fiestas de los Santos Mártires del Sacromonte cuando se bajaban las reliquias al altar para su adoración. ${ }^{29}$ En el recibimiento de reliquias, después de la procesión en el momento de la adoración, la Consueta especifica que si había gente principal, "toque el órgano, las chirimías o se canten motetes". 30 Esta condición "si había gente principal" nos indica que la polifonía sería más un medio de propaganda hacia el exterior, otorgando cierto prestigio al templo, que una necesidad imperiosa para cumplir con el culto divino.

Asimismo, durante la exposición del Santísimo Sacramento el organista podía ordenar que se canten "motetes al órgano", cumpliendo con la función de un maestro de capilla. En el cap.11 del Libro II, “del Sochantre” se dice:

En las fiestas de primera clase y principales de Nuestro [Señor] y Nuestra Señora puede cantar al organo el cuarto psalmo y el cantico del magnificat y en la missa algun motete al tiempo del alzar y esto en los otros dias no lo haga a su albedrío sino con licencia $(. . .)^{31}$

Ciertamente el sochantre solo no puede hacer polifonía, con lo que la expresión cantar al órgano podríamos entenderla como un canto "a solo" con el órgano. Sin embargo, la expresión "cantar al organo" en la Consueta sacromontana hay que interpretarla siempre como sinónimo de polifonía. Cuando había músicos en las ceremonias, la Consueta señala que el sochantre debía hacerse cargo de que los músicos observaran las ceremonias que se hacían en el coro:

\footnotetext{
${ }^{28}$ Consueta, fol. $311^{\mathrm{r}}$, §8. Aunque el Servicio de la Salve se acompañaba del canto de antífonas, no he encontrado ninguna referencia a que se sustituyera el último verso como en la Abadía. Sobre este particular, véase el epígrafe "El servicio de la Salve en la Abadía", en el Capítulo V.

${ }^{29}$ Consueta, fol. $360^{\mathrm{r}}, \S 4$.

${ }^{30}$ Consueta, fol. $279^{\mathrm{r}}$.

${ }^{31}$ Consueta, fol. $111^{\mathrm{r}}$.
} 
Que los menestriles no digan el verso de gloria Patri = que no toquen el primer ni postrer verso de los hymnos que todo esto lo dicen las vozes, y en lo que cantaren por el facistol les lleve el compas adviérteles lo que pueden cantar al órgano. ${ }^{32}$

Y algo más adelante:

$\mathrm{Si}$ algun forastero quisiese cantar algun motete o psalmo al organo tiene el sochantre la obligación de saber y ynformarse si lo puede hacer dignamente y si lo puede pide licencia al que preside y si juzgare que no es suficiente lo divierte de esto. El que preside en el coro de licencia para esto al que no fuere conocido sino es informado del sochantre. ${ }^{33}$

No es tampoco la expresión "cantar al órgano" sinónimo de "tocar al órgano", puesto que de dar permiso para tocar se encarga el organista (no el sochantre o el presidente), pues así lo estipula la Consueta en el apartado referente a su oficio al hacerlo responsable del mantenimiento del instrumento. Cabe preguntarse quiénes interpretaban la polifonía en el Sacromonte. En principio debemos señalar que aunque en el oficio de capellanes no se incluye la obligación del canto polifónico como tal, puede que los capellanes "cantores" junto con el sochantre fueran los responsables en algún momento de la interpretación de los motetes. Después de rastrear en las Actas Capitulares, puedo afirmar que muchos de los capellanes "sabían cantar", puesto que además su capellanía era "de coro". Así, cuando el Cabildo en 1629 se propuso admitir a dos capellanes eligió a uno que "cantaba muy bien"

Item propuso que tres sacerdotes pretendían ser capellanes del Sacro Monte el licenciado Herrera natural de Antequera, el maestro Blas Peinado sobrino del señor canónigo Sarmiento y otro natural de Úbeda que sabe muy bien cantar y conferido que se reciban en aprobación los dos de ellos no más, el licenciado Blas Peinado y el de Úbeda. ${ }^{34}$

\footnotetext{
${ }^{32}$ Consueta, fol. $111^{v}$.

${ }^{33}$ Consueta, fol. $111^{\mathrm{v}}$.

${ }^{34}$ ASAC II, fol. $112^{\mathrm{r}}$ (25-II-1630), [131].
} 
En una ocasión, un capellán del Sacromonte pasó a ser sochantre de Loja, ante el disgusto del Cabildo sacromontano que se vió utilizado por el capellán para mejorar su situación:

Yo el infrascripto secretario leí una petición del licenciado Lázaro de Santistevan capellán del coro de esta Iglesia en que da cuenta como el señor gobernador del arzobispado le ha dado provisión de la sochantría de la ciudad de Loja con cuarenta ducados de aumento, y pide licencia por cuatro días para ir a la dicha ciudad a comunicar este aumento con los distribuidores de la fábrica para que lo pasen. Y habiéndose oído la dicha petición y considerado conferido el caso se hizo relación al cabildo que el dicho licenciado Santistevan ha estado con mucha inquietud después que vino al Sacro Monte haciendo diligencias extraordinarias para no perseverar en él, de las cuales consta que no vino con ánimo de quedar en esta Iglesia sino solamente por acomodarse mejor en el oficio de sochantre de la ciudad de Loja. Lo cual entendido se determinó por todos los votos que no se le da licencia para hacer el dicho viaje y por cuanto algunos de los señores capitulares dijeron que había bastantes causas para despedir al licenciado Santistevan lo propuso así el señor Presidente y habiéndose conferido las causas se determinó por nueve votos de once que se despida al dicho licenciado Lázaro de Santistevan. ${ }^{35}$

Lo cual quiere decir de un lado que los capellanes de coro debían ser aptos para el canto, y de otro que ser capellán del Sacromonte debía conferir cierto prestigio. Además, los capellanes, junto con los colegiales y el hebdomadario, estaban obligados a asistir a la lección de canto que debía dar el sochantre.

Parece que la Consueta contemplaba la inclusión de polifonía como se señala en este pasaje, en el que los capellanes parecen cantar polifonía junto con "la música", expresión que en esta época suele utilizarse como sinónimo de "capilla de música":

Estan los prebendados y capellanes sentados a los psalmos lecciones de maytines del martirologio a la tabla de los officios, los Collegiales se sientan a todo lo dicho excepto a los psalmos, mas los que ministran reuestidos en el officio cantado tambien se sientan y si dizen a punto de organo respondiendo la musica se sientan o si la musica lo dize todo se sientan todos: los cetreros no se sientan, mas estan en medio del Coro las mangas baxas, excepto a los canticos que se retiran y ponen como los demas Collegiales eregione. ${ }^{36}$

\footnotetext{
${ }^{35}$ ASAC II, fol. 242 ${ }^{\mathrm{r}}$ (29-IX-1632), [160].

${ }^{36}$ Consueta, fol. $9 \mathrm{v}$. La cursiva es mía.
} 
Otras alusiones a la "música" en la Consueta indican que mientras la capilla de música interpretaba, los prebendados debían rezar el texto de la pieza en cuestión

\begin{abstract}
Acavado el introito en el altar se levantan los Prebendados y se sientan hasta que el çelebrante entona Gloria ín excelsis que entonces se levantan y cantan el gloría con el Choro y se sientan quando el preste la acaua pero si la dize la musica la dizen rezada puestas las manos. ${ }^{37}$
\end{abstract}

Hasta aquí podemos ver escasas aunque ciertas referencias a la polifonía, pero dado que las Constituciones estipulaban que el servicio religioso en la Abadía había de hacerse en canto llano, prestaremos ahora atención a las indicaciones que sobre su interpretación proporciona la Consueta.

Al igual que la polifonía era un recurso para solemnizar el culto, dentro de la práctica del canto llano existían diversos medios para diferenciar la importancia de las fiestas. La primera referencia significativa sobre la forma de solemnizar el culto la encontramos en el Capítulo 5 del Libro I, titulado: "Quando se dize el oficio cantado o en tono". La expresión "en tono" debe ser contextualizada, pues en este caso no es sinónimo de "cantado" como pudiera parecer al leer sólo el enunciado. Si leemos este párrafo se desvela como un término diverso:

La Antiphona de Nuestra Señora que se dize después del officio para salir del Coro siempre se dize en tono, excepto el miércoles Santo después de Completas que se canta con toda solemnidad la Antiphona Ave Regina Caelorum porque se despide con el officio. ${ }^{38}$

Por tanto, la expresión "en tono" vendría a ser una especie de "recitado" o "cantilación", como aparece también en la Consueta de la Catedral, ${ }^{39}$ quedando para los días menos

\footnotetext{
${ }^{37}$ Consueta, fol. $10^{\mathrm{r}}$. Otra referencia a la música en la Consueta se refiere a la interpretación del "Credo": "Acauado el evangelio todos quitan las manos y los Collegiales se ponen en medio del choro mas se quedan todos en pie, entona el çelebrante el Credo y si aí musica los prebendados bueluen a poner las manos y lo dicen rezado y hazen genuflexión al incarnatus est y en acauando el Credo se sientan y cubren los bonetes = si no aí musica los prebendados cantan el Credo con el Choro y hazen genuflexión con el preste y se sientan quando el preste lo acaua y quando el choro Canta el Incarnatus est se decubren y sentados como estan se inclinan profundamente". Consueta, fol. $12^{\mathrm{r}}$.

${ }^{38}$ Consueta, $17^{\mathrm{v}}$. La cursiva es mía.

${ }^{39}$ Ramos López, La Música en la Catedral de Granada, p. 101.
} 
solemnes como ya se señalaba en las obligaciones de los canónigos en las Constituciones de la Abadía de $1616 .^{40}$ En ambas instituciones los maitines siempre son cantados y como era de esperar por su importancia, en la Catedral hay más festividades cantadas. Es curioso que en la Catedral aparecen mezclados ambos tipos de rezos (cantado y en tono) en un mismo oficio mientras que en la Abadía no se dan a la vez.

La Consueta señala otros factores que indican mayor solemnidad, y diferencian la importancia del día :

a) Quiénes y cuántos eran los actores del canto:

En las fiestas de primera clase casi siempre serán los capellanes (que son supuestamente los mejores cantores) los que canten las partes alternantes con el coro o los solos; en el resto de los días serán los colegiales cantores (que aún están aprendiendo). De otra parte, cuanto más solemne era la ceremonia, encontraremos un mayor número de actores, y tan solo un cantor para los oficios en las vísperas:

Los versos de las horas menores y completas en dias de primera clase, sanctos del Sacromonte y fiestas principales de nuestra señora dicen capellanes; los otros dias dos Collegiales cantores y en las ferias uno, los mismos los Versículos de las conmemoraciones. ${ }^{41}$

b) La "morosidad del compás":

A esta exigencia alude la Consueta del Sacromonte continuamente, y en ello se deja sentir la influencia de la Consueta catedralicia, si bien es verdad que es una constante generalizada en otros centros eclesiásticos de la época, no hay que olvidar que la Catedral de Granada se hizo famosa por la solemnidad y duración de sus oficios, que en algunos casos superaban las cinco horas. ${ }^{42}$ En la Consueta sacromontana no se estipula la duración exacta, pero sí que la ceremonia se debe hacer más lenta cuanto

\footnotetext{
${ }^{40}$ En tono vendría a significar lo que hoy se conoce como "recto tono".

${ }^{41}$ Consueta, $22^{\mathrm{r}}$. La cursiva es mía.

${ }^{42}$ López-Calo, La música en la Catedral de Granada, I, p. 43: "En la catedral de Granada en los primeros decenios del siglo XVI el oficio más breve duraba unas cinco horas; eran muy frecuentes los de seis horas y media; y no eran raros los que pasaban de las siete horas". Se conserva una tabla con la duración de cada uno de los actos litúrgicos además de venir especificados en el reglamento del Chantre.
} 
más solemne: “(...) y en la pausa de tono y compás se atiende a la solemnidad del día”, ${ }^{43}$ o bien:

Las Visperas de fiesta de primera clase y principales de Nuestra señora, Sanctos del Sacromonte se dize con toda solemnidad y gravedad y mas espacio los que fueren entre ellas mas solemnes y se ha de tener gran cuydado con la morosidad del compas, pues encomienda tanto la religión del Coro de este Sacromonte y no tiene otra cosa mas con que solemnizar ni diferenciar las fiestas. ${ }^{44}$

Los días festivos de segunda clase deben hacerse con menos solemnidad y compás "más ligero". 45 La separación entre los versos también ayuda a la suntuosidad de la ceremonia como indica el siguiente párrafo:

El officio de la Semana Sancta especialmente los maytines de las ferias 5 y 6 se dize con mucha pausa y devoción haziendo mas mediación en los Versos y el punto algo mas baxo que cuando se canta en fiestas que ay organo. ${ }^{46}$

El "órgano" en este contexto parece significar el instrumento, no el "canto polifónico", por dos motivos: en la Semana Santa no intervenía el órgano y además parece que variar la afinación era más fácil precisamente porque no había órgano. Por otra parte la referencia al "punto baxo" parece indicar que el tono grave es más solemne que el agudo. En este sentido la Consueta abacial da algunas indicaciones más, como "el punto o cuerda que se lleva en el canto en la misa y oficio de difuntos es baxo, grave y el compás moroso". Como recoge Marcelino Díez, esto era una práctica común en las catedrales y colegiatas españolas. ${ }^{47}$

\footnotetext{
${ }^{43}$ Consueta, fol.13ํ. La cursiva es mía.

${ }^{44}$ Consueta, fol. $54^{\mathrm{v}}$.

${ }^{45}$ Consueta, fol. $19^{\mathrm{v}}$.

46 Consueta, fol. 19". Aquí mediación no debe entenderse como "mediatio", sino como pausa o detenimiento entre los versos.

${ }^{47}$ Díez Martínez, La música en Cádiz, p. 129. Díez recoge algunos ejemplos de los trabajos de Antonio Gallego y María Gembero en referencia a la relación entre el tono grave y la solemnidad, como la
} 
c) Presencia del órgano:

La música de órgano es la única presencia de música instrumental constante de la que tenemos noticia en el Sacromonte, y el único músico instrumentista al que se refiere la Consueta. No cabe duda que la música de este instrumento realzaba las ceremonias: "El mismo tenor que en las Vísperas se a de observar en la missa y quando y como ay organo estos dias se dize lib 2 cap $^{\circ} 12$ de organo que en el se diferencia tambien la solemnidad". ${ }^{48}$

\subsection{Música instrumental versus música a cappella}

Una de las diferencias principales de la organización musical en la Abadía respecto a otras instituciones eclesiásticas como las catedrales, es que durante la mayor parte de su existencia careció de capilla musical y de ministriles. Ni en la Consueta ni en las Constituciones se estipula el oficio de maestro de capilla; tampoco se dice nada acerca de ministriles fijos. Aparte de la presencia de un organista, poco sabemos sobre la música instrumental interpretada en el Sacromonte. Con esto no podemos excluir la existencia de música instrumental en la Abadía, pero sí afirmar que, al igual que la polifonía, ésta se utilizaba en contadas ocasiones.

En la bula de fundación del Sacromonte tampoco se alude a cantores ni a instrumentistas, a excepción del organista, hecho que llama la atención si observamos que los centros de prestigio en aquella época sí contaban con capilla de música. ${ }^{49}$ Por eso resulta sorprendente que Pedro de Castro prescindiera de un elemento que de seguro habría generado una imagen de magnificencia y poder acorde con sus expectativas de crear un centro de peregrinación de primer orden. Aunque no existen estudios económicos sobre la Abadía, una institución fundada con un capital inicial de 15.000 ducados de renta, que mantenía a 20 canónigos, un Abad, seis capellanes y otro personal anejo al culto (pertiguero, sacristán, campanero, etc.), además de tener a su cargo un colegio con numeroso alumnado y contar con muchas fundaciones particulares,

polémica del sochante de la colegiata de Toro con el organista, o las afirmaciones del maestro de la Catedral de Pamplona, Francisco de la Huerta (1781).

${ }^{48}$ Consueta, fol. $19^{\mathrm{v}}$. La cursiva es mía.

${ }^{49}$ Sobre la colegiata como institución musical, véase la "Introducción” a este Volumen. 
privilegios y exenciones económicas por parte de reyes y papado, seguro que habría podido mantener una capilla básica para desarrollar su culto con polifonía; sólo hacían falta cuatro capellanes (la Institución tenía ya dotados a seis) y algunos ministriles (la capilla del Colegio del Corpus Christi de Valencia fundada por Ribera tenía dotados a cinco o seis ministriles). ${ }^{50}$

Si bien es verdad que a finales del siglo XVII, una vez muerto Castro y condenados los Libros Plúmbeos por el Papa, la Abadía entraría en un periodo de crísis económica que sí condicionaría la presencia de una capilla musical, en el momento de la fundación, la existencia o no de una capilla de música no fue tanto un problema económico como ideológico. En efecto, de todas las razones por las que la Abadía carece de capilla, los factores ideológicos parecen ser los que más influyeron a Castro. La primera cuestión, que ya ha sido señalada en el epígrafe anterior, es el desarrollo del culto en canto llano instituido por Castro en las Constituciones. Ya hemos visto en el primer capítulo su carácter austero y su afán de reformador tridentino, que le condicionarían en su interpretación de la necesidad o la oportunidad de una capilla musical en su "centro ideal tridentino". Aunque Trento no prohibió la utilización de la polifonía como se ha señalado, ni de los instrumentos, sí que hizo un intento de reformar los abusos que se habían introducido en el aspecto musical. Fellerer señala que "contrariamente a la creencia popular, el Concilio no se ocupó de detalles musicales y problemas estilísticos, sino que hizo hincapié sobre actitudes fundamentales, y estableció líneas para futuros desarrollos". 51 Estas líneas fueron concretadas en los concilios y sínodos provinciales, y en lo estipulado en cada diócesis por su obispo. Casos extremos los encontramos en Bolonia, bajo el control de Paleotti, quién llegó incluso a mandar que se retirasen los órganos de los conventos, como estudia Craig

\footnotetext{
${ }^{50}$ Constituciones de la Capilla del Colegio y Seminario de Corpus Christi (Valencia: Iuan Bautista Mançal, 1625), Capítulo XXI De los menestriles, p. 20: "Mandamos que la capilla tenga siempre asalariados un juego de menestriles, que sean en número 6 , o por lo menos 5 ; conviene a saber, dos Tiples, dos Contrabaxos, un tenor y un Contralto".

${ }^{51}$ K. G. Fellerer, "Church Music and the Council of Trent”, Musical Quarterly, 39/4 (1953), p. 576. Así puede verse en los decretos del Concilio de Trento publicados por H.J. Schroeder, The Canons and Decrees of the Council of Trent (Illinois: Tan Books and Publishers, 1978 [1941]), p. 151: Sesion XXII, Cap. IX Decree concerning the things to be observed and avoided in the celebration of Mass (...) "They shall also banish from the churches all such music which, whether by the organ or in the singing, contains things that are lascivious or impure; likewise all wordly conduct, vain and profane conversations, wandering around, noise and clamor, so that the home of God may be seen to be and may be truly called a house of prayer".
} 
Monson. ${ }^{52}$ En Granada, Castro había asistido como vocal al Concilio Diocesano que Pedro Guerrero convocó en 1572. Las Constituciones Synodales resultantes de este evento llaman la atención sobre la vigilancia de las canciones que se cantaban en los templos, ${ }^{53}$ pero poco más sobre la interpretación o no de música instrumental o de polifonía.

La prohibición de la polifonía que algunos reformadores llevaron a cabo iba aparejada con la ausencia de instrumentos en los que ésta se apoyaba. Luego si el servicio se llevaba a cabo en canto llano, no era necesario nada más que un órgano o un realejo. Casi con toda seguridad, Castro conocía las ideas de Felipe II y la prohibición de la polifonía que el Rey hizo en El Escorial, en el punto 38 del documento fundacional, en 1567:

Que se digan y celebren [las ceremonias] en canto llano e no haya en ninguna manera, ni en ningún día, ni fiesta, canto de órgano y que en lo demás se diga y se celebre con la mayor devoción y pausa que fuere posible. ${ }^{54}$

Castro no prohibió el "canto de órgano", pero al igual que Felipe II decretó que las ceremonias se desarrollaran en canto llano. Sin duda el ejemplo de Felipe II tuvo que pesar en el ánimo del Arzobispo, quién estaba muy cercano al Monarca, como ya hemos señalado anteriormente.

Otras razones de orden práctico podrían haber influído en Castro, como la proximidad de la Colegiata del Salvador que sí contaba con capilla de música y que dado su carácter "extravagante" podría prestar servicio en el Sacromonte en las solemnidades más importantes para ella. Castro conocía muy bien esta institución pues

\footnotetext{
${ }^{52}$ Craig A. Monson, Disembodied Voices. Music and Culture in an Early Modern Italian Convent (Los Angeles: University of California Press, 1995). Alfonso Paleotti llegó a prohibir la ejecución de toda música excepto el canto llano en el convento de los Santos Vital y Agrícola en 1569 (p. 36); su sucesor en la sede, Gabriele Paleotti, endureció esta normativa y elaboró diversos decretos prohibiendo las ejecuciones musicales de músicos en los conventos, (p. 38).

${ }^{53}$ Francisco Javier Martínez Medina, Historia y crítica de la poesía lírica culta "a lo divino" en la España del Siglo de Oro (Alicante: Francisco Javier Sánchez Martínez, 1995), p. 125.

${ }^{54}$ Citado por Michael Noone, Music and Musicians in the Escorial Liturgy Under the Habsburgs, 15631700 (Rochester: Boydell \& Brewer, 1998) p. 306.
} 
le había procurado Constituciones para su gobierno. ${ }^{55}$ Pero se siguen varios inconvenientes de esta posible colaboración: el primero es qué ocurriría cuando tuviesen que concurrir a una fiesta solemne para ambas instituciones, como los maitines de Navidad. De aquí que podamos sugerir una colaboración ocasional y puntual, pero no la razón para prescindir de la creación de una capilla musical propia.

Quizá la situación geográfica de la Abadía, relativamente alejada de la ciudad, podría esgrimirse como un argumento más, pues al culto diario no asistiría mucha gente y la necesidad de "lucimiento" y demostración de poder quedaría reducida a los días más solemnes, cuando se contrataría música por parte del Cabildo. Aunque esto podía ser cierto, las numerosas fundaciones sugieren un interés constante por parte de los granadinos en el culto abacial, poniendo de manifiesto que esta institución ocupaba un lugar preferente en la sociedad granadina.

La doctrina de Santo Tomás de Aquino puede ser otra de las causas: Castro lo designó como enseñanza obligatoria en el Colegio de San Dionisio Areopagita, y durante muchos años se siguió impartiendo su filosofía. ${ }^{56}$ Hemos de suponer que Castro conocía y admiraba sus ideas, que respecto a la música pueden concretarse (como las de la mayoría de los santos padres) en la aceptación de la música vocal pero no de la instrumental en lo que concierne a su uso en el templo. ${ }^{57}$

Su cercanía con el entorno jesuítico, quizás por su educación en el Colegio jesuita de Valladolid y sus contactos con la orden (de hecho el arquitecto elegido para el Sacromonte fue el jesuita Pedro Sánchez) debió también influir en esta austeridad

\footnotetext{
${ }^{55}$ Las Constituciones para el Salvador las había elaborado Justino Antolínez, quién fue el primer Abad del Sacromonte y mano derecha de Castro; véase Royo Campos, Abades, p. 17.

56 "Por lo que toca a la Doctrina, que en dichas Clases se enseña, nunca podrá ser otra que la del Angelico Doctor Sto. Thomas, debiendo siempre los señores Cathedraticos de dicha Facultad arreglarse puntualísimamente a la Doctrina que se enseñó, ya en la Suma, ya en los Setenciarios, y demás obras del Sto. Doctor, comunmente recibidas en la Iglesia, y así lo tienen de rigurosa obligación" en Praxis de Estudios que debe observarse en las Escuelas del Sacro-Monte de Granada. Fundadas a beneficio del Insigne Collegio de Sr. San Dionisio Areopagita, por el Ven. Illmo. Sr. D. Pedro de Castro, Arzobispo de Sevilla (S.1: s.e., ca. 1751).

${ }^{57}$ A este respecto, véase Richard Viladesau, Theology and the Arts Encountering God through Music, Art and Rhetoric (Nueva York: Paulist Press, 2000), p. 20: "Aquinas agrees with the fathers concerning the use of instruments in church: Musical instruments were an accomodation to the less spiritually developed stage of Old Testament religion and/or are to be understood allegorically (ad $4 \mathrm{am}$ ). (Note that, unlike some of the fathers, Aquinas had no objection to instrumental music outside the church; he only thought it inappropriate to sacred functions.) But song is different from instrumental music: It is useful in the service of the word to provoke the souls of the weak ("animi infirmorum"-quoting Augustine) to devotion (ibid. corpus)".
} 
musical. Como señala Ramos López los jesuitas en sus comienzos desdeñaron la música; Ignacio de Loyola excluyó los coros y los órganos en sus casas en el primer documento fundacional de la orden. ${ }^{58}$

A pesar de lo instituido en las Constituciones del Sacromonte, podemos encontrar contradicciones a esta supuesta austeridad. Así lo reflejan las alusiones a la música instrumental y a la polifonía en las Actas Capitulares y en la Consueta, en fechas posteriores a la muerte de Castro, acaecida en 1623. En la Consueta se indica que el organista tiene la obligación de cuidar y mantener los "instrumentos músicos". 59 Complementaria a esta es otra procedente de las Actas de la Junta de Asistentes ${ }^{60}$ en la que se determinó la venta de unos "violones":

En esta dicha Junta los señores Manrique, Presidente Sarmiento y Valencia administradores determinaron que se vendan los violones porque no son de provecho y se echan a perder y se remitió al Sr. Manrique el aderezarlos. ${ }^{61}$

El origen y función de estos instrumentos en la Abadía no está claro pero debieron ser usados en algún momento en las principales ceremonias, y estarían allí para facilitar a los músicos el desplazamiento, pero en 1629, cuando se decide venderlos ya no eran necesarios. De otra parte sabemos por las Actas y la Consueta que en las festividades más solemnes, como el día de San Cecilio, y el día del Corpus, y el día de la Concepción, se encargaba a los comisarios de la fiesta (dos canónigos nombrados por el cabildo) contratar "la música", ${ }^{62}$ (véase la Tabla IV.1).

\footnotetext{
${ }^{58}$ Pilar Ramos López "Mysticism as a Key Concept of Spanish Early Music Historiography", Early Music: context and ideas, 2, Congreso celebrado en Cracovia (Polonia) del 11 al 14 de Septiembre de 2008, p.70 y ss. Véase: http://www.muzykologia.uj.edu.pl/conference/PDF/16Ramos.pdf (consultado el 10 de Noviembre de 2008).

${ }^{59}$ Consueta , fol. $115^{\mathrm{r}}$.

${ }^{60}$ Los asistentes se reunían para debatir y decidir cuestiones específicas relativas a los aspectos económicos de la Abadía.

${ }^{61}$ Libro de Junta de Asistentes, 29-XI-1629, fol. 170v. Unos meses después (22-VI-1630) se pide que "se vendan los violones con su Arca por el precio que costaron supuesto no son necesarios en el Sacro Monte".

${ }^{62}$ Consueta, fol. 436 r.
} 
Tabla IV. 1. Fiestas para las que estaba estipulada la contratación de música en el Sacromonte. Fuente: Consueta, $1632 .{ }^{63}$

\begin{tabular}{|l|l|l|}
\hline Fiesta & Música & Observaciones \\
\hline San Cecilio & Capilla de la Catedral & $\begin{array}{l}\text { Pagada por el Ayuntamiento: } \\
\text { chançonetas, motetes. }\end{array}$ \\
\hline $\begin{array}{l}\text { Ascensión del } \\
\text { Señor }\end{array}$ & $\begin{array}{l}\text { Música o Instrumentos } \\
\text { "de iglesia" }\end{array}$ & $\begin{array}{l}\text { Durante la hora de oración } \\
\text { después de la misa }\end{array}$ \\
\hline Procesiones & Reliquias & $\begin{array}{l}\text { Chirimías u órgano o motetes } \\
\text { durante la adoración }\end{array}$ \\
\cline { 2 - 3 } & Recibimiento del Rey & Canta la música \\
\hline $\begin{array}{l}\text { Salves de las } \\
\text { cinco fiestas de } \\
\text { Nuestra Señora }\end{array}$ & $\begin{array}{l}\text { Motete en lugar del } \\
\text { último verso }\end{array}$ & \\
\hline $\begin{array}{l}\text { Santísimo } \\
\text { Sacramento } \\
\text { manifiesto }\end{array}$ & $\begin{array}{l}\text { Toque el órgano y } \\
\text { ordene otra qualquiera } \\
\text { musica de monocordio, } \\
\text { o violones y se canten } \\
\text { algunos motetes al } \\
\text { órgano }\end{array}$ & \\
\hline $\begin{array}{l}\text { Inmaculada } \\
\text { Concepción }\end{array}$ & $\begin{array}{l}\text { Se les libra [a los } \\
\text { comisarios] cantidad de } \\
\text { dineros para que } \\
\text { traigan música }\end{array}$ & \\
\hline
\end{tabular}

Entre de las obligaciones del sochantre se incluye que cuando hay músicos "les advierte las ceremonias que se observan en nuestro coro acerca del cantar", con lo que se confirma que no debían ser habituales. Sin embargo, uno de los deberes del organista es: "Quando este manifiesto el Sanctissimo Sacramento es bien que algunos intervalos toque el organo y ordene otra cualquier musica de monocordio, o violones y se canten algunos motetes al organo" Y por otro: "Tiene a su cargo los instrumentos mussicos que [h]ubiere que no se destemplen ni pierdan adereza y limpia el organo (...)". ${ }^{64}$ Otras alusiones a la música instrumental son de tipo restrictivo; en ese mismo capítulo de la Consueta, se dice: "Guitarra ni otro instrumento semejante no se ha de tocar en el Sacro Monte". Otra prohibición aparece en el capítulo que habla de los Visitadores (Capítulo 8, Libro II): "No permiten que a la vista de la Casa e Iglesia las mujeres anden sin

\footnotetext{
${ }^{63}$ Estos días podrían ser los que según las Actas Capitulares del Sacromonte ASAC X, fol. ¿? (8-XI1764), [674], se denominan "clásicos para tocar instrumentos": "Si a Fray Pedro del Santísimo Sacramento los días que viene a afinar el órgano se le ha de dar almuerzo o comida o los días que se llama clásicos para tocar instrumentos en misa y vísperas".

${ }^{64}$ Consueta, fol. $115^{\mathrm{r}}$.
} 
mantos que no aya bailes ni guitarra ni canten ni toquen instrumento alguno". Curiosamente la guitarra se prohíbe en ambos casos, sin duda por su vinculación exclusiva en esta época a la música popular. ${ }^{65}$ En otro documento diferente de la Consueta, llamado "Normas colegiales", en el que se encuentran todos los deberes y obligaciones de los colegiales del Colegio de San Dionisio Areopagita, se señala que estaba prohibido a los colegiales tocar cualquier instrumento. ${ }^{66}$ Pero esta norma estaba dirigida a los colegiales y no al culto de la Iglesia.

El personalismo de Castro al fundar la institución no podía perpetuarse in aeternum, de modo que al morir Castro los canónigos tomarán sus propias decisiones sobre la utilización de la música instrumental y la polifonía. De hecho podemos ver un cambio en la consideración de la música instrumental y polifónica en tres momentos de la vida de la Abadía. El primero de ellos tuvo lugar en 1625, dos años después de la muerte de Castro, cuando se debate en un Cabildo la conveniencia de traer música o ministriles a la misa solemne de San Dionisio Areopagita, por asistir a ella el Marqués de Mondéjar y el Conde de Tendilla. ${ }^{67}$ La decisión del Cabildo va aún en la línea austera de Castro: "pareció más conveniente que no se hiciese sino que se oficiase la misa en su canto llano y solemnidad como en este Sacro Monte se acostumbra". ${ }^{68}$ Este

\footnotetext{
${ }^{65}$ La consideración de la guitarra en esta época viene marcada además porque se ve como sustituta de la vihuela, según Covarrubias Tesoro de la lengua, p. 1017, la guitarra es "instrumento bien conocido y ejercitado en perjuicio de la música, que antes se tañía en la vihuela, instrumento de seis y algunas veces de más órdenes. Es la guitarra, vihuela pequeña en el tamaño, y también en las cuerdas porque no tiene más que cinco cuerdas, y algunas son de solas las cuatro órdenes. Tienen estas cuerdas requintadas, que no son unísonas, como las de vihuela, sino templadas en quintas; fuera de la prima que está en ambos instrumentos, es una cuerda sola. Si mudais a guitarra el acento de la penúltima y se la ponéis en la antepenúltima dirá guitara, mudada la $\mathrm{G}$ en $\mathrm{C}$ dirá cítara, del nombre griego xiı $\theta \propto \varrho \alpha$, cíthara".
}

${ }^{66}$ Normas colegiales, p. 72: "También se prohíbe tocar instrumento alguno porque no corresponde a la veneración de este santuario". Este documento impreso del siglo XVIII se conserva en la sala de las vitrinas sin encuadernar.

${ }^{67}$.José L.G. de la Paz en La Casa de Mondéjar,

http://www.uam.es/personal_pdi/ciencias/depaz/mendoza/monde5.htm [Acceso al documento 24-X2008]. “Íñigo González de Mendoza y Mendoza, VII Conde de Tendilla y V Marqués de Mondéjar desde 1604. Se casó con Ana Cabrera de Vargas y al morir ésta ingresó en la Compañía de Jesús donde murió como novicio en 1647. Recuperó el título honorífico de Alcaide de la Alhambra para la familia en 1624, pues desde 1604 lo había poseido el Duque de Uceda, luego favorito de Felipe III. Entonces volvió desde sus estados alcarreños a La Alhambra, entrando solemnemente el 29 de junio con toda su casa y su hijo, el Conde de Tendilla, y siendo recibido por toda la nobleza y caballería de Granada"

${ }^{68}$ Junta de Asistentes, 8-X-1625, fol. 75r. 
comentario confirma que las Constituciones se habían puesto en práctica. Sin embargo, un segundo caso muestra el cambio de actitud: En 1633, una capilla de música se ofreció para servir en la Abadía. El Cabildo elaboró un calendario de fiestas a las que debería asistir y estipuló los límites del salario que se les asignaría por cada fiesta (de cuatro ducados a cincuenta reales), ${ }^{69}$ además de la comida en el refectorio de los colegiales:

Lo segundo propuso el señor Abad que una capilla de músicos se ha ofrecido servir al Sacromonte y venir a celebrar las fiestas que les pusiesen por obligación por precio moderado y este cabildo los quisiere recibir por capilla de esta Iglesia y que de aquí adelante tengan ese nombre que ellos desean para estimación suya, y parece que si se reciben se le podrá seguir a esta Iglesia nuevo (...) y gravedad. Entraron a Cabildo los Señores don Paulo de Valencia, Doctor Gabriel de Ledesma, Licenciado Alonso González de Aradillas, canónigos. Y habiéndose conferido el punto se determinó por dos partes de tres que se trate de concierto con estos músicos, y si vinieren en las condiciones que este cabildo o sus comisarios les propusieren se le reciban. Y la primera condición es que el precio que se les ha de dar por cada fiesta sea de cuatro ducados a cincuenta reales lo que asentaren últimamente los comisarios, y que se les ha de dar de comer el día que vinieren en el refectorio de los colegiales. La segunda que han de venir puntualmente a cantar en las fiestas que se siguen, las tres fiestas del Sacromonte San Hicsio, San Mesitón y San Tesifón, y no entra en este número San Cecilio porque aquel día corre la música por cuenta de la ciudad. El día de San Dionisio Areopagita, las cinco fiestas de holgar de Nuestra Señora, primer día de Pascua de Navidad con los Maitines, segundo y tercero. Día de Año Nuevo y de la Epifanía. Primer día de Resurrección con maitines y procesión. Día de la Ascensión, Primer día de Pentecostés con tercia, día de la Santísima Trinidad. El día octavo del Corpus Christi, día de San Pedro, día de Santiago, la Dedicación de esta Iglesia, día de Todos los Santos, las tres fiestas de los Arcángeles San Miguel, San Gabriel, y el Ángel de la guarda. El día de la Cruz de Mayo. A todas estas fiestas han de tener obligación de asistir y cantar con la misa mayor y segundas vísperas, y fuera de esto han de venir a las primeras los días de nuestro Señor y Nuestra Señora y las fiestas del Sacro Monte que son los santos Hicsio, Mesitón, Tesifón y Dionisio y de todas las demás fiestas dichas todas las veces que la víspera fuera día de holgar. Ítem siempre que haya procesión, Salve y Adoración de Cruz o Reliquias en las fiestas dichas han de asistir y cantar en ellas. Nombraronse por comisarios para tratar y concertar todo esto con los músicos a los señores Agustín Manrique Presidente y Francisco Hurtado canónigo y que sus mercedes asienten con ellos todas estas condiciones aquí referidas, y todas las demás que parecieren convenientes y ajustadas para que esto se haga como se debe. Y que si en alguna de las condiciones que aquí van expresadas no vinieren los músicos se vuelva a consultar al Cabildo. ${ }^{70}$

\footnotetext{
${ }^{69}$ Un ducado equivalía a 11 reales, por lo que el pago estaría entre los 44 a los 50 reales, véase Javier Cordero y Ricardo J. Hernández, Velázquez un logístico en la Corte de Felipe IV (Madrid: Eds. Díaz de Santos, 2000), p. 44.

${ }^{70}$ ASAC II, fol. ¿? (3-II-1633), [167].
} 
Pero a los músicos les pareció exagerado el número de fiestas a que les oligaba el cabildo, pues acaso lo que querían era utilizar el nombre de la Abadía para conseguir prestigio y poder tocar para más instituciones o eventos. Finalmente se decidió reducir el número de sus actuaciones a seis fiestas en lugar de las veintiséis:

Lo primero que en Cabildo de tres de febrero se determinó que se tratase de concierto con una Capilla de músicos que se ofreció a servir al Sacromonte y porque se le pidieron veintiséis fiestas les ha parecido cosa dura y así se vuelve a proponer si estas fiestas se reducirán a menor número para que se haga el concierto y habiéndose conferido se determinó por mayor parte que las fiestas que han de venir se reducen a las seis particulares del Sacromonte las cuales son estas que se siguen San Hicsio, San Mesitón, San Tesifón, la Asunción de Nuestra Señora, la Concepción y la Octava de Corpus Christi y que con este número se haga el concierto guardando las demás condiciones que en el acto capitular de tres de febrero están expresadas. ${ }^{71}$

El coste de tener una capilla de música a tiempo completo (26 fiestas) supondría un coste de entre 1144 a 1300 reales anuales más el gasto de comida, aproximadamente el equivalente al sueldo del sochantre y organista juntos. A tiempo parcial (seis fiestas al año) tendría un coste aproximado entre 264 a 300 reales, la mitad del sueldo de un Sochantre. $^{72}$ Nada más se dice de esta capilla en las Actas Capitulares, y no tenemos ninguna evidencia de su continuidad en el Sacromonte.

El tercer momento que marca la ruptura total con las disposiciones mandadas por el fundador se produjo en 1640, cuando el Cabildo contrató una capilla de música estable para que sirviera en la Abadía.

Y estando así capitularmente juntos propuso el señor abad que en 28 del mes de Julio próximo que pasó se juntaron los señores de este cabildo y los demás que faltan y trataron y confirieron si recibirían Capilla de Música para el servicio de esta Iglesia y considerado y conferido se acordó que la había. Y atento a que este Sacro Monte está muy alcanzado los señores canónigos quieren señalarle salario a su costa en el cual cada uno ofreció ciertas cantidades, como consta de una cédula que está a fin de este libro firmada por los señores canónigos. Y para señalar las fiestas a que acudir dicha Música fueron nombrados por

\footnotetext{
${ }^{71}$ ASAC II, fol. 261 ${ }^{\mathrm{v}}$ (2-III-1633), [169].

${ }^{72} \mathrm{El}$ sochantre además ganaría las distribuciones y la comida, con lo que las ganancias finales serían mayores, teniendo derecho a habitación.
} 
comisarios a los señores canónigos Manrique y Ayllón, los cuales señalaron las fiestas que estarían se asentaron en el dicho papel. Todo lo cual los dichos comisarios lo trataron con Francisco de los Reies Maestro de Capilla y sus músicos y ministriles y vinieron en que acudirían a todas las festividades que se le señalaba por la cantidad en que en dicha cédula se contiene teniendo título de Capilla de esta Iglesia del Sacro Monte y que otorgarían escritura. La cual de hecho se otorgó ante Antonio Ruiz de Prado escribano en 27 de Junio próximo pasado. Últimamente propuso el señor Abad que el dicho Antonio Ruiz de Prado venía a hacer relación de la dicha escritura para que este cabildo la acepte si entraría y conferido se determinó que entre. El cual entró y leída la dicha escritura la aceptó el cabildo. ${ }^{73}$

Nada más sabemos de esta capilla ni de estos músicos y en particular del maestro de capilla Francisco de los Reyes, pero debieron actuar por un tiempo en la Abadía. Parece que en 1661 todavía existía ésta u otra capilla, pues se mandó para las fiesta de la Inmaculada estuviese la "música de la Iglesia" en la misa mayor solemne. ${ }^{74}$ Por el contrario, en 1703, para el funeral del canónigo Rafael Andrés de Ascargorta, que había sido sobrino del arzobispo Martín de Ascargorta, se trajo a la música de la Catedral, por lo que probablemente ya no hubiera la capilla en el Sacromonte.

Algunas actas reflejan la existencia de instrumentos en el Sacromonte, como se ha señalado antes, cuando se intentó vender unos violones. Aparte de ellos encontramos un clavicordio, un "organillo de palo" y otro "vigolón":

Ítem propuso el sr. Medina como don Alonso Colmenares Capellán Real de Granada ofrecía el aderezar el clavicordio que dejó el licenciado Valenzuela con condición de que se le diera el organillo de palo que está desbaratado y se determinó para otro cabildo este punto. Y que al Sochantre no se le dé el vigolón que pide. ${ }^{75}$

A pesar de la prohibición de la Praxis de Estudios que debía seguirse en el Colegio de San Dionio, los colegiales a veces tocaban instrumentos:

También propuso el Sr. Rienda que había muchos días de estudio oído tocar vihuela y otros instrumentos que solo se permiten en los días

\footnotetext{
${ }^{73}$ ASAC II, fol. 472 ${ }^{\mathrm{v}}$ (1-VI-1640), [213].

${ }^{74}$ ASAC IV, fol. 36 (8-II-1661), [278].

75 ASAC V, fol. 47 v (19-V-1679), [327].
} 
festivos y de asueto; y se determinó también que en este punto se guarde el Praxis y Consueta. ${ }^{76}$

Tabla IV.2. Ocasiones documentadas para las que se contrató música en el Sacromonte (1600-1799). Fuentes: Actas Capitulares, Libro de la Junta de Asistentes. Juan Ruiz. ${ }^{77}$

\begin{tabular}{|c|c|c|c|c|}
\hline FECHA & MOTIVO & MÚSICA & PAGADOR & OBSERVACIONES \\
\hline 1600 & & Catedral & & \\
\hline 1601 & & Catedral & & \\
\hline 27-III-1626 & $\begin{array}{l}\text { Misa en acción de } \\
\text { gracias a Ntra. Sra. } \\
\text { por librar a la } \\
\text { ciudad de las } \\
\text { tempestades }\end{array}$ & ¿? & $\begin{array}{l}\text { Cabildo de } \\
\text { Caballeros } 24\end{array}$ & $\begin{array}{l}\text { Ofrecieron } 400 \text { reales } \\
\text { para música y olor } \\
\text { cuatrocientos reales }\end{array}$ \\
\hline $16-\mathrm{XI}-1627$ & $\begin{array}{l}\text { Recibimiento de } \\
\text { reliquias }\end{array}$ & $\begin{array}{l}\text { "Música y } \\
\text { ministriles" }\end{array}$ & & \\
\hline $9-\mathrm{I}-1630$ & $\begin{array}{l}\text { Fiestas deSan } \\
\text { Cecilio }\end{array}$ & & Ayuntamiento & \\
\hline $30-X I I-1632$ & $\begin{array}{l}\text { Acción de gracias } \\
\text { por el Libro Mudo. }^{78}\end{array}$ & $\begin{array}{l}\text { Misa solemne } \\
\text { a Ntra. Sra. Y } \\
\text { Arcángel San } \\
\text { Gabriel }\end{array}$ & $\begin{array}{l}\text { Marqués de } \\
\text { Estepa }\end{array}$ & \\
\hline $14-I I-1633$ & Fiesta de San Hiscio & $\begin{array}{l}\text { Se traiga } \\
\text { música }\end{array}$ & & $\begin{array}{l}\text { "Se concierte por lo que } \\
\text { menos que se pueda" fol. } \\
\text { 249.r }\end{array}$ \\
\hline 29-I-1637 & $\begin{array}{l}\text { Día de Ntra. Sra. } \\
\text { Purificación }\end{array}$ & $\begin{array}{l}\text { que han de } \\
\text { estar } \\
\text { descubiertas } \\
\text { las reliquias }\end{array}$ & & $\begin{array}{l}\text { Se dé a los músicos } 30 \\
\text { reales y de comer porque } \\
\text { asistan a la fiesta. }\end{array}$ \\
\hline $20-I-1638$ & ¿San Cecilio? & & & $\begin{array}{l}\text { La comida que se da a los } \\
\text { músicos sea la misma que } \\
\text { se da al colegio. }\end{array}$ \\
\hline $11-X-1638$ & $\begin{array}{l}\text { Novena sin } \\
\text { especificar motivo }\end{array}$ & & & $\begin{array}{l}\text { que hubiese fuegos y } \\
\text { música a costa de los que } \\
\text { hiciesen las fiestas, y misa } \\
\text { solemne por la mañana. }\end{array}$ \\
\hline 1640 & $\begin{array}{l}\text { Festividades } \\
\text { señaladas en la } \\
\text { Consueta }\end{array}$ & $\begin{array}{l}\text { Capilla de } \\
\text { Música del } \\
\text { Sacromonte }\end{array}$ & $\begin{array}{l}\text { Cabildo del } \\
\text { Sacromonte }\end{array}$ & $\begin{array}{l}\text { Permanencia } \\
\text { indeterminada en el } \\
\text { Sacromonte. }\end{array}$ \\
\hline
\end{tabular}

${ }^{76}$ ASAC V, fol. 246 v (1-IX-1685).

77 Juan Ruiz Jiménez, "Música y devoción en Granada (siglos XVI-XVIII): funcionamiento "extravagante" y tipología de plazas no asalariadas en las capillas musicales eclesiásticas de la ciudad", Anuario musical: Revista de musicología del CSIC, 52 (1997), pp. 39-76. Para estas noticias Juan Ruiz tuvo en cuenta las Actas Capitulares de la Capilla Real y la Catedral.

${ }^{78}$ El Libro Mudo fue uno de los Libros Plúmbeos llamado así porque no fue posible traducirlo. 


\begin{tabular}{|c|c|c|c|c|}
\hline FЕСНА & MOTIVO & MÚSICA & PAGADOR & OBSERVACIONES \\
\hline 8-II-1661 & $\begin{array}{l}\text { Inmaculada } \\
\text { Concepción } \\
12 \text { de febrero }\end{array}$ & $\begin{array}{l}\text { Música de la } \\
\text { Iglesia }\end{array}$ & Cabildo & $\begin{array}{l}\text { Misa mayor solemne con } \\
\text { la música de la Iglesia o } \\
\text { de la (...) se manifieste el } \\
\text { santísimo Sacramento y la } \\
\text { Reliquias como el día de } \\
\text { San Cecilio poniendo en } \\
\text { el lugar que pareciere más } \\
\text { conveniente. }\end{array}$ \\
\hline $11-I I-1695$ & $\begin{array}{l}\text { Funeral de Don } \\
\text { Baltasar de Rienda }\end{array}$ & $\begin{array}{l}\text { ¿Capilla de } \\
\text { Música de } \\
\text { San } \\
\text { Jerónimo? } \\
\end{array}$ & $\begin{array}{l}\text { Sobrino Fray } \\
\text { Sebastián de } \\
\text { Santiago monje } \\
\text { jerónimo } \\
\end{array}$ & \\
\hline 18-VI-1703 & $\begin{array}{l}\text { Oficios y exequias } \\
\text { por Rafael Andrés } \\
\text { de Ascargorta }\end{array}$ & $\begin{array}{l}\text { Música de la } \\
\text { Catedral. }\end{array}$ & Cabildo & $\begin{array}{l}\text { por obsequio especial del } \\
\text { Cabildo al Sr. Arzobispo. }\end{array}$ \\
\hline $\begin{array}{l}\text { 13-VIII- } \\
1703\end{array}$ & $\begin{array}{l}\text { Promoción del Abad } \\
\text { Baltasar de la Peña } \\
\text { al obispado de Ávila }\end{array}$ & Ministriles & & Nombrado por Felipe V \\
\hline 23-I-1706 & $\begin{array}{l}\text { Segundas Vísperas } \\
\text { de San Cecilio }\end{array}$ & & Cabildo & \\
\hline 1721 & Misa & Catedral & & \\
\hline 21-III-1729 & $\begin{array}{l}\text { Se traiga música el } \\
\text { día que suban sus } \\
\text { Majestades }\end{array}$ & & & $\begin{array}{l}\text { Visita de Felipe V y su } \\
\text { esposa Isabel de Farnesio. }\end{array}$ \\
\hline 1730 & San Cecilio & Catedral & & \\
\hline 1739 & $\begin{array}{l}\text { Traslado de los } \\
\text { restos de Don Pedro } \\
\text { de Castro }\end{array}$ & Catedral & & \\
\hline 1739 & Fiesta de Santiago & & $\begin{array}{l}\text { Cía. Soldados de } \\
\text { la Alhambra. }\end{array}$ & \\
\hline 1748 & $\begin{array}{l}\text { Misa y procesión. } \\
\text { Responso de } \\
\text { difuntos. }\end{array}$ & Catedral & & \\
\hline 1750 & $\begin{array}{l}\text { Vísperas de San } \\
\text { Cecilio }\end{array}$ & Capilla Real & $\begin{array}{l}\text { No se les dio } \\
\text { licencia LC, } 124\end{array}$ & \\
\hline 1757 & & $\begin{array}{l}\text { Capilla Real, } \\
4 \text { músicos }\end{array}$ & & \\
\hline $11-\mathrm{XI}-1776$ & Sr. Chinchilla Abad. & $\begin{array}{l}\text { Pífano y } \\
\text { tambor: para } \\
\text { proclamar la } \\
\text { elección del } \\
\text { Abad. }\end{array}$ & & \\
\hline \multirow[t]{2}{*}{$\begin{array}{l}\text { 19-VIII- } \\
1792\end{array}$} & \multirow[t]{2}{*}{$\begin{array}{l}\text { Promoción del Abad } \\
\text { Miguel Álvarez } \\
\text { Cortés a Obispo de } \\
\text { Cartagena de Indias }\end{array}$} & $\begin{array}{l}\text { Música } \\
\text { militar del } \\
\text { Regimiento } \\
\text { de Milicias } \\
\end{array}$ & Cabildo & \multirow[t]{2}{*}{$\begin{array}{l}\text { Presentado por Carlos IV. } \\
\text { En la placeta, que se } \\
\text { adornó, se colocaron dos } \\
\text { tablados para la música. }\end{array}$} \\
\hline & & $\begin{array}{l}\text { Real } \\
\text { Maestranza } \\
\text { de Granada } \\
\text { con músicos }\end{array}$ & Maestranza & \\
\hline 28-VI-1793 & $\begin{array}{l}\text { Provisión abadia en } \\
\text { Miguel Álvarez }\end{array}$ & $\begin{array}{l}\text { Trompetas y } \\
\text { atabales }\end{array}$ & Cabildo & \\
\hline
\end{tabular}




\section{La Música en el Colegio de San Dionisio Areopagita}

El Colegio de San Dionisio Areopagita fue fundado por Don Pedro de Castro casi al mismo tiempo que la Iglesia colegial, con la intención de crear un ColegioSeminario al estilo tridentino en el que se formarían sacerdotes para la atención al culto divino. Para ello obtuvo la bula de fundación por el papa Paulo V el 20 de noviembre de 1609 , lo que permitía a los colegiales el estudio de leyes, teología y arte. En 1621, Gregorio XV le concedió el privilegio de poder obtener los grados académicos en cualquier universidad, previo examen. Con el tiempo, esta fundación fue adquiriendo nuevas prebendas y privilegios que le fueron otorgadas por los sucesivos papas y reyes. ${ }^{79}$ Así, en 1640 le fue concedido por el Rey el poder usar beca morada y manto pardo. ${ }^{80}$

Benedicto XIV le otorgó los estudios de Derecho y dos cátedras, una de Historia Eclesiástica y otra de Lenguas Orientales (griego, hebreo y árabe) en 1752, con lo que los alumnos interesados en estudiar en el centro ya no se limitaban a los que querían seguir la carrera eclesiástica.

Aparte de las noticias contenidas en las Actas y los oficios descritos en la Consueta para los colegiales, tenemos dos documentos impresos en el siglo XVIII que transmiten algunos detalles de la vida musical de los colegiales. El primero de ellos es la Praxis de Estudios que recoge las estrictas normas que rigieron el colegio y el horario dedicado al estudio, con conferencias y lecciones prácticas que hicieron que gozara de prestigio en los siglos XVIII y XIX, pues formó a destacadas personalidades de la historia española, no sólo en el ámbito religioso, sino también en el político e

\footnotetext{
${ }^{79}$ El seminario fue confirmado por Gregorio XIV (15-IV-1623), Urbano VIII (6-VIII-1623), y Benedicto XIV (21-VIII-1752). Ver Aldea Vaquero, Diccionario de Historia Eclesiástica, p. 2337.

${ }^{80}$ Calero Palacios, Catálogo, 25. Aunque la Praxis de Estudios del siglo XVIII señala que "vestirán Manto de buriel obscuro, Bonete negro de bayeta, y para salir Beca de paño rosado, ó Avito clerical." Véase Praxis de Estudios, que debe observarse en las Escuelas del Sacro-Monte de Granada. Fundadas, a beneficio del Insigne Collegio de Sr. San Dionysio Areopagita, por el Ven. Illmo. Sr. D. Pedro de Castro, Arzobispo de Sevilla. Ya nuevamente amplificadas, en virtud de Indulto Apostolico de Nuestro Santisimo Padre Benedicto XIV, y Real Cedula de Nuestro Catholico Monarca Señor Don Fernando VI, por los Señores Abad, y Cabildo de la Insigne Iglesia Collegiata de dicho Sacromonte, Patronos del referido Collegio, [post. 1752], p. 5.
} 
intelectual. ${ }^{81}$ El otro es la Praxis de Ceremonias del Colegio de Teólogos de San Dionisio Areopagita, que describe todas las rúbricas que debían guardar en todos los actos en los que participaba el Colegio. ${ }^{82}$

\subsection{La música y los colegiales}

Ya que la atención al culto divino mediante la formación de sacerdotes era una de las intenciones del arzobispo Castro, puede entenderse el papel que la música desempeñaba en la fundación del Colegio en un momento en el que el canto llano era básico para la formación litúrgica de los colegiales.

La Consueta de 1632 estipula algunos oficios del coro que debían desempeñar los colegiales. Estos oficios no aparecen explicitamente ni en el Praxis de ceremonias ni en el Praxis de estudios, con lo que no está claro si desaparecieron en el siglo XVIII o si, como ya no era necesario que todos los colegiales asistieran al coro, no era preciso indicar las obligaciones de unos pocos. Entre los oficios de los Colegiales relacionados con el coro se encontraban los Colegiales Cantores, el Kalendario, Intonario y Versicularios. ${ }^{\mathbf{8 3}}$

Al principio, al ser tan solo dieciocho ${ }^{84}$ los colegiales y tener como fin el ser sacerdotes, tenían la obligación de asistir a todos los puntos del coro. ${ }^{85}$ Con la ampliación de los estudios que se podían cursar, y consecuentemente del número de colegiales, ya no sería necesaria la asistencia de todos al Coro. De esta manera se permitiría a los colegiales compaginar mejor sus obligaciones cultuales con el estudio. Así podemos constatarlo en el Praxis de Estudios

\footnotetext{
${ }^{81}$ Praxis de Estudios, ver nota 2.

${ }^{82}$ Praxis de las Ceremonias que deben observarse por los Colegiales del Insigne Colegio de Theólogos del Señor S. Dionisio Areopagita sito en el Sacro Ilipulitano Monte, extra-Murosde la Ciudad de Granada. Con licencia. En Granada en la Imprenta Real [17??].

${ }^{83}$ De las funciones y obligaciones de cada uno de ellos da detenida cuenta la Consueta y nosotros en el Capítulo III.

${ }^{84}$ Calero Palacios, Catálogo, p. 26.

85 En varias ocasiones en las Actas se hace referencia a los pocos colegiales que hay y su asistencia al coro: ASAC III, fol. 137 r (21-VII-1648), [237]; ASAC III, fol. 146 r (2-X-1648), [238]; ASAC III, fol. $147 \mathrm{v}(31-\mathrm{X}-1648)$, [239].
} 
Ordena el Santo Concilio de Trento, asistido en esto como en todo lo demás, del Espiritu Santo, el que los Jobenes Seminaristas, alternenen de tal modo en los Ministerios Eclesiasticos, y en los Literarios Exercicios, que sin que el Culto Divino padezca algun menoscabo les quede también tiempo bastante para el estudio: Hos pueros in eos classes, quod ei videbitur divisos, iuxta eorum numerum adatem, ac in disciplina Ecclesiastica progressum, partim, cum ei oportunum videbitur Ecclesairum Ministerio addicet partim in Collegio erudiendos retinebit. Teniendo, pues, presente tan Santo Decreto nuestro Ilmo. Y Ven. Fundador, establece en las Constituciones particulares del Collegio, en la Const. 7. que: Puede el Sr. Abad, con las dos partes del Cabildo, eximir del Choro a alguna parte de los Collegiales, los dias de estudio, para que puedan estudiar con mas commodidad. ${ }^{86}$

La asistencia al coro era rotativa en los días festivos de segunda clase, y en los días llanos se estipulaba que a las horas menores (que en la Abadía no eran cantadas) debían asistir seis colegiales. A la Misa de Tercia iban cuatro colegiales al Coro como Versicularios y Lucernarios, cuatro al Altar y uno como intonario; a Vísperas tan solo cuatro al Coro. En los días que había especial asistencia al coro, denominados en el Praxis "Choro para todos", el número es bastante elevado (Ver Tabla 1).

Para cumplir con su cometido correctamente, los colegiales recibían lecciones de canto del Sochantre, circunstancia que estaba establecida por las Constituciones y quedaba reflejada en la Consueta ("del Oficio de Sochantre”). A las lecciones debía asistir de vez en cuando el Rector del Colegio para comprobar que eran de provecho y que se desarrollaban adecuadamente. ${ }^{87}$ Son numerosas las referencias en los libros de Actas a estas lecciones, pero casi de manera exclusiva en el siglo XVII, con lo que la ausencia de noticias en los siglos posteriores quizás indica la no pervivencia en el tiempo de esta costumbre. Por las Actas conocemos que no siempre se dieron lecciones de canto y que ello iba en "perjuicio de la Iglesia". ${ }^{88}$ La falta de asistencia era cometida tanto por el Sochantre como por los colegiales y todos eran penados con multas económicas o supresión de comidas. En varias ocasiones a los colegiales se les suprimió

\footnotetext{
${ }^{86}$ Praxis de Estudios, p. 6.

${ }^{87}$ Consueta, 87 r: "El Rector acudirá algunas veces a lección de canto para que estén con compostura y tengan cuidado de aprovechar y informarse de lo que allí pasa, para que lo que fuere digno de remedio pueda avisar y corregir".

88 ASAC V, fol. 52 r (31-VII-1679), [190].
} 
la cenay al Sochantre se le aplicó medio real de pena por incumplir con su obligación de dar clase ${ }^{89}$

\begin{abstract}
Y tercero se propuso que había mucha necesidad de reformación en la lección de canto, y así en la puntualidad de en ella, como en el modo de enseñar a los colegiales. Se determinó que el sochantre cuide de cumplir esta obligación puntualmente avisándole de lo que está a su cargo y debe hacer. Item que el día que dejare de asistir sin licencia del señor Abad o Presidente de la casa, se le apunte medio real de falta. Asimismo que todos los que conforme a la Constitución deben asistir a la dicha lección de canto lo hagan con toda puntualidad los días en que se tuviere, en primer lugar los colegiales, el hebdomadario, los huéspedes de aprobación y capellanes, porque todas estas personas mandan las Constituciones que asistan a la lección de canto. Y porque esto se cumpla con efecto un colegial tenga cuidado de avisar al sochantre y al hebdomadario cuando fuere hora de tener la dicha lección. ${ }^{90}$
\end{abstract}

Las lecciones se consideraban necesarias para el buen funcionamiento del coro y por ello se procuraba su buen desarrollo. ${ }^{91}$ Las Constituciones estipulaban que además de los colegiales, a esta lección debían asistir el hebdomadario, los huéspedes de aprobación y los capellanes. Poco o nada sabemos de cómo se desarrollaban estas lecciones de canto llano ${ }^{92}$ que se debían hacer "al echar las campanas"93 y no "después de salir de Vísperas"; las faltas eran multadas por el Rector. ${ }^{94}$ Tenían lugar durante media hora "todos los días que no fueren fiesta o asueto o no ubiere Vísperas o Completas o Salve cantada o rasura por la tarde", y se les hacía "exercicio de la práctica" y examen. ${ }^{95}$ La última referencia a las lecciones de canto en las Actas data de principios del siglo XVIII cuando se acuerda que se le pida al Sochantre que "dé doctrina a los colegiales en el modo de cantar para el buen régimen del coro por haber

\footnotetext{
${ }^{89}$ ASAC IV, fol. 185 r (1-IX-1668) [155]; ASAC IV, fol. 200 r (2-IV-1669), [157]; ASAC IV, fol. 245 v (7-VIII-1670), [161].

${ }^{90}$ ASAC II, fol. 146 v (2-X-1630), [140].

${ }^{91}$ ASAC V, fol. 55 r (1-IX-1679), [191].

92 ASAC IV, fol. 245 v (7-VIII-1670), [161].

${ }^{93}$ ASAC IV, fol. 182 r (2-VIII-1668), [154].

${ }^{94}$ ASAC V, fol. 52 r (31-VII-1679), [190].

${ }^{95}$ Consueta, Libro I, Capítulo 11, "Del Oficio de Sochantre”, fol. $111 \mathrm{r}$.
} 
en esto algunos defectos". ${ }^{96}$ La ausencia de referencia a las clases de canto en las Actas durante el siglo XVIII y en la Praxis parece constatar su desaparición, aunque estuviese estipulada en las Constituciones. A finales del siglo XVIII una noticia en las Actas habla de la "mala voz de algunos colegiales"

Por cuanto se había reparado que la máxima general de que todos los colegiales indistintamente canten las Calendas y Fratres en el coro, inducía desorden e indecencia en lugar de el decoro y gravedad que exige el divino culto, haciendo risibles los actos más serios de la religión la ineptitud y mala voz de algunos colegiales. Se mandó prevenir al señor Rector a fin de que diga y haga instruir los que son más aptos para cumplir con este ministerio. ${ }^{97}$

Hay que tener en cuenta que a partir de la aprobación de los Estudios en Lenguas Orientales y Derecho, no sólo los eclesiásticos se formarían en el Sacromonte, por lo que no todos los colegiales necesitaban la misma formación litúrgica.

Además de a estas lecciones de canto del Sochantre, las Constituciones y la Consueta mandaban que los colegiales acudieran a "Conferencias de Ceremonias" en donde se les instruía sobre los movimientos, gestos, orden, oraciones y demás particularidades que debían observar en el desarrollo de los actos litúrgicos. Hay que advertir que debido a la complejidad de muchas de las ceremonias, la variedad de movimientos y gestos que debían realizar sería difícil de recordar, sobre todo para aquellas ceremonias que no se celebraban a diario, como las fiestas específicas de cada santo y algunas procesiones. Según indica el Praxis de Ceremonias [1772], en estas reuniones o "Conferencias" que se celebraban en la Capilla los sábados después del almuerzo, el Rector advertía a los colegiales de las faltas que habían cometido durante la semana. Les corregía mandando salir en medio de la Capilla a dos colegiales (uno moderno y otro antiguo) para que se ejercitaran. También practicaban ceremonias difíciles y en ellas podían los colegiales modernos preguntar si tenían alguna duda. ${ }^{98}$

\footnotetext{
${ }^{96}$ ASAC VI, fol. 239 r (1-X-1705), [353].

97 ASAC XII, fol. 328 r (2-VI-1794), [550].

${ }^{98}$ Praxis de Ceremonias, pp. 115-116. Instrucción XXXIV, "De la Conferencia de Ceremonias".
} 


\section{Tabla IV.3. Asistencia de los colegiales al coro ("Choro para todos") según Praxis deEstudios, que debe observarse en las Escuelas del Sacro-Monte de Granada (ca.1752).}

\begin{tabular}{|c|c|c|c|}
\hline $\begin{array}{l}\text { Domingos y Días de } \\
\text { Precepto de todo el año a } \\
\text { todos los puntos }\end{array}$ & $\begin{array}{l}\text { Primeras Vísperas con } \\
\text { solemnidad y asistencia a todos } \\
\text { los puntos: } \\
\text { Circuncisión } \\
\text { Epiphanía } \\
\text { San Cecilio } \\
\text { Purificación } \\
\text { San Septentrio y Patricio } \\
\text { San Hiscio } \\
\text { San Mesitón } \\
\text { Anunciación de Ntra.Sra. } \\
\text { San Tesiphon } \\
\text { San Juan Bautista } \\
\text { San Pedro y San Pablo } \\
\text { Santiago } \\
\text { Asunción de Ntra. Sra. } \\
\text { Dedicación de Ntra. Iglesia } \\
\text { Natividad de Ntra. Sra. } \\
\text { San Miguel Arcángel } \\
\text { San Dyonisio } \\
\text { Todos Santos } \\
\text { Concepción de Ntra. Sra. } \\
\text { Natividad del Señor } \\
\text { San Esteban } \\
\text { San Juan Evangelista }\end{array}$ & $\begin{array}{l}\text { Fiestas movibles de primera } \\
\text { clase: } \\
\text { Jueves Santo } \\
\text { Viernes Santo } \\
\text { Sábado Santo } \\
\text { Pasqua de Resurrección } \\
\text { Ascensión } \\
\text { Pentecostes } \\
\text { Trinidad } \\
\text { Corpus con su Octava }\end{array}$ & $\begin{array}{l}\text { Otros que por Consueta } \\
\text { tienen solemnidad y } \\
\text { asistencia en Primeras } \\
\text { Vísperas, Misa y Segundas, } \\
\text { pero no en horas menores: } \\
\text { San Gabriel } \\
\text { La Transfiguración } \\
\text { Angeles Custodios } \\
\text { Aquellos aniversarios que se } \\
\text { echasen en tabla con primeras } \\
\text { o segundas vísperas o Misa }\end{array}$ \\
\hline $\begin{array}{l}\text { Asistencia a Misa y } \\
\text { segundas Vísperas los } \\
\text { días de } 2^{\text {a }} \text { clase que lo } \\
\text { son por Consueta: } \\
\text { San Sebastian } \\
\text { San Joseph } \\
\text { Dolores de Ntra.Sra. } \\
\text { San Marcos } \\
\text { San Lucas } \\
\text { Visitación de Ntra. Sra. } \\
\text { Las Nieves } \\
\text { Presentación } \\
\text { Expectación }\end{array}$ & $\begin{array}{l}\text { Todos los Sábados del año a las } \\
\text { Misas de Ntra. Sra. } \\
\text { Aniversarios de Difuntos de } \\
\text { cada mes y otros que se echasen } \\
\text { en tabla (como los del Sr. } \\
\text { Fundador, Sus Padres y Difuntos } \\
\text { de la Casa por noviembre). }\end{array}$ & $\begin{array}{l}\text { Todas las Procesiones: } \\
\text { Domingos en las noches } \\
\text { Candelas } \\
\text { Palmas } \\
\text { Jueves, Viernes, Sábado Santo } \\
\text { y Domingo de Pascua. } \\
\text { Letanías Mayores y Menores. } \\
\text { Días de Corpus y Octava. } \\
\text { Las que se celebran pro } \\
\text { gratiarum actione } \\
\text { Viernes infraoctavo de Corpus } \\
\text { Días de la Asunción } \\
\text { San Dyonisio } \\
\text { Sto. Thomas Cantuariense } \\
\text { Difuntos de noviembre } \\
\text { Siempre que el cabildo } \\
\text { determine Rogativa, o acción } \\
\text { de gracias, pro re gravi, } \\
\text { recibimiento de alguna } \\
\text { reliquia, } \\
\text { San Francisco de Paula, } \\
\text { Domingo segundo de } \\
\text { Quaresma, } \\
\text { Recibimientos de Rey o Reina, } \\
\text { Legado o Prelado de esta } \\
\text { Diócesis. }\end{array}$ & $\begin{array}{l}\text { Salves de Ntra.Sra. (Sábados } \\
\text { en Santas Cuevas y las que se } \\
\text { cantan en la Iglesia después de } \\
\text { Vísperas los días: } \\
\text { Concepción } \\
\text { Natividad, } \\
\text { Purificación, } \\
\text { Asunción, } \\
\text { Anunciación, } \\
\text { Expectación, } \\
\text { Presentación, } \\
\text { Visitación, } \\
\text { y Nieves de Nra. Sra.) } \\
\text { No se asisten a las Salves en el } \\
\text { choro después de Completas } \\
\text { los días de Quaresma. }\end{array}$ \\
\hline
\end{tabular}


Entre las estrictas normas que debían obedecer los colegiales hay una que nos apena especialmente: la prohibición de tocar instrumentos. De ella se deriva que los colegiales formalmente no aprendían a tocarlos, lo que confirma la visión peyorativa que de la música instrumental (exceptuando la de órgano) tenía la Institución. Esta prohibición aparece expresa en diversos documentos y el motivo que se da es porque "no se corresponde con la veneración de este Santuario",99 aunque en las Actas se refleja que esta advertencia era desoída de vez en cuando

El señor Rector cele y cuide que los colegiales no armen ruido en el tiempo en que se dicen las misas de la intermedia, ni toquen ni usen instrumentos músicos en el Colegio en tiempo alguno del año como cosa opuesta a la moderación y exemplar conducta que deben guardar los eclesiásticos, evitando de este modo la instrucción en bailar y danzar que se iba introduciendo en los más de los colegiales $^{100}$

Por supuesto si la música instrumental era contraria a una conducta ejemplar, el baile y la danza lo serían aún más, así como la asistencia a comedias. La guitarra era además un instrumento con una baja consideración social en la época, pues se relacionaba directamente con las clases más populares, como Covarrubias recoge en su Diccionario. ${ }^{101}$ En la Consueta ya aparecía esta prohibición en varias ocasiones, unida también a la exclusión de los bailes y los cantos. ${ }^{102}$

\footnotetext{
${ }^{99}$ Praxis de Ceremonias, p.72, Instrucción XXI, "de la modestia en el vestir y de varias prohibiciones".

${ }^{100}$ ASAC XI, fol. 355 r (6-III-1778), [477].

${ }^{101}$ La consideración de la guitarra en esta época viene marcada además porque se ve como sustituta de la vihuela. Sebastián de Covarrubias Orozco, Tesoro de la Lengua Castellana o Española, Edición de Felipe C.R. Maldonado (Madrid: Castalia, 1995), p. 614, "Instrumento bien conocido y ejercitado en perjuicio de la música, que antes se tañía en la vihuela, instrumento de seis y algunas veces de más órdenes. Es la guitarra, vihuela pequeña en el tamaño, y también en las cuerdas porque no tiene más que cinco cuerdas, y algunas son de solas las cuatro órdenes. Tienen estas cuerdas requintadas, que no son unísonas, como las de vihuela, sino templadas en quintas; fuera de la prima que está en ambos instrumentos, es una cuerda sola (...)".

${ }^{102}$ Consueta, fol. $115^{\mathrm{v}}$ : "Guitarra ni otro instrumento semejante no se ha de tocar en el Sacro Monte". Otra prohibición aparece en el capítulo que habla de los Visitadores (Capítulo 8, Libro II, fol. 89v): "No permiten que a la vista de la Casa e Iglesia las mujeres anden sin mantos que no aya bailes ni guitarra ni canten ni toquen instrumento alguno".
} 
Poco espacio les quedaba a los colegiales para otro tipo de música que no fuera el canto llano y la del órgano en la Iglesia, pues también les estaba prohibido asistir a comedias o a fiestas públicas. ${ }^{103}$

Y habiendo el señor Rico manifestado algunos desórdenes que se notaban por haber algunos muchachos quebrantado la clausura de nuestra casa para ir a funciones de Granada, y que se oían muchas veces cantar y tocar guitarra, se acordó que en cuanto a los colegiales quede al cuidado y prudencia del señor Rector evitar en lo posible los juegos en el claustro y el uso de guitarra, que tocan frecuentemente. ${ }^{104}$

Resulta llamativo el empleo de la música por parte de los colegiales para expresar su rechazo a alguno de los canónigos, a la vez que encontramos una elocuente convivencia entre la expresión popular de la música y la culta (en este caso religiosa). Parece que la elección del Abad Chinchilla en 1776 no gustó a algunos colegiales que se dedicaron a cantar coplas en contra del Presidente y del Vicerrector, tachándolo de “soplón”. Por lo divertido y elocuente del documento merece la pena transcribirlo

\begin{abstract}
Después de tan execrable maldad se había observado en repetidas noches al tiempo que dicho Presidente salía de la Mesa Primera hacían los antiguos mucho ruido con silbos y voces descompasadas sin que se pudiese conocer a alguno en particular por la confusión con que gritaban. Que habiéndose retirado el Presidente de vacaciones a su tierra la habían tomado con el actual Vicerrector, afirmando públicamente que él había sido el que había dado al señor rector el referido aviso, tratándole con indecible desprecio e influyendo en los colegiales antiguos y modernos para que así le tratasen. Además de esto habían llenado las paredes de letreros, fijando la palabra "soplón" y en dos sitios públicos esta: "López cap sumus multitudo magna soplarium vel solplonorum" notándose también que al salir el Vicerrector de la mesa primera cantaban con algazara y alboroto una copla cuyo estribillo era: Sopla que sopla fuelle que fuelle, sin que por la confusión de voces pudiese conocerse alguna en particular. Que todo esto tenía puesto al Colegio en el mayor desorden e inquietud pues aún los que no querían adherir a la opinión de estos revoltosos no se atrevían a contradecirlos no sólo por haber traido ya su partido mayor número de colegiales. ${ }^{105}$
\end{abstract}

\footnotetext{
103 ASAC XI, fol. 281r (10-IV-1776), [731]. La prohibición está expresada también en la Praxis de Ceremonias "También se prohibe tocar instrumento alguno, que no corresponde a la veneración de este Santuario", p. 72.

${ }^{104}$ ASAC XII, fol. 244r (4-VIII-1791), [802].

105 ASAC XI, fol. ¿? (6-V-1776), [732]. No he podido localizar en ningún cancionero la copla que los colegiales cantaban con "algazara y alboroto" y que es citada textualmente por el secretario del cabildo.
} 
Las protestas de los colegiales no acabaron aquí. No sólo robaron el badajo de la campana para que no pudiera repicar, sino que irónicamente emplearon además música religiosa, cantando el Invitatorio del oficio de difuntos. Por último decidieron apedrear a los músicos (tambores y pífanos) que solían anunciar la proclamación del Abad:

Muchos colegiales, animados del espíritu de libertad e independencia que ya hace tiempo les domina, habían llevado tan a mal la promoción de dicho señor Chinchilla a la abadía que para manifestar su disgusto y sentimiento unidos en cuadrillas habían quitado la lengüeta a la campana del Colegio para que aunque alguno quisiera no la pudiera tocar, como es costumbre jamás interrumpida hasta este caso en el acomodo de todo colegio y elecciones de Abad y señores prebendados; y que para mayor demostración de su enojo la habían vestido de luto, cubriéndola con una sotana y ciñéndola con una cuerda: que en la clase de Teología habían levantado con bancos un túmulo o tumba y habían cantado el Invitatorio de difuntos y parte de un responso. Que habían vestido de bayetas negras la ventana de un cuarto: que habían pisado con rumba y algazara los bizcochos que uno o dos señores canónigos les echaron desde un corredor, que habían hablado desenfrenadamente sin ningún reparo muchas palabras injuriosas e infamatorias contra el constante y conocido mérito y literatura del referido señor Abad electo, que a los tambores y otros dos pífanos que dicho señor Rector había hecho venir de Granada para que tocasen en celebridad de la elección luego que esta se publicara como ha sido siempre uso y costumbre, los habían obligado a retirarse andar huyendo y no tocar, lo que enfado consiguieron. Y ultimamente que este bullicio se había hecho casi general, y había tenido toda la apariencia de un motín o tumulto injustísimo en todo concepto y absolutamente difamatorio de la buena educación que acomodo e infinitos desvelos del cabildo se les procuraba y del buen olor que siempre ha difundido esta /comunidad hasta en las más remotas provincias de estos reinos (...) pero que sabía de cierto por la unánime declaración de tres testigos oculares, que el maestro Ojeda había apedreado a los referidos tambores, y por el dicho de uno de los sacerdotes de casa que el mismo maestro Ojeda había entregado la expresa lengüeta de la campana para que se volviese a poner. ${ }^{106}$

Quizás por los sofocos que todo este escándalo debió de provocarle, el Abad electo Chinchilla murió once días después de este suceso. ${ }^{107}$

Quizás fuera un contrafactum de alguna canción popular. La estructura sintáctica de la frase recuerda al popular tanguillo granadino de La Reja, cuyo estribillo reza "Dale que dale, toma que toma".

${ }^{106}$ ASAC XI, fol. 309 r (11-XI-1776), [468].

${ }^{107}$ El Abad Chinchilla murió el 22-XI-1776. 


\subsection{De los colegiales sochantres.}

Algunos de los colegiales, bien porque eran buenos cantores, bien por necesidad, suplían al sochantre temporalmenteo incluso por más tiempo, llegando a veces a percibir el salario de éste. ${ }^{108}$ Un ejemplo de colegial que empieza como ayuda de sochantre y acaba sirviendo una capellanía de coro es el colegial Francisco de Mora: tenía buena voz (2-III-1630); cuando se licenció continuó como ayuda de sochantre e incluso percibió un salario (2-VII-1633). Tan sólo tres meses después se le subió el sueldo y podía gozar del hábito de capellán de coro (3-X-1633), y poco después se pidieron las informaciones de limpieza de sangre (18-XII-1633) para pasar definitivamente a capellán (29?-VI-1634).

Las referencias a estos colegiales "comprometidos" con el coro continúan durante todo el siglo XVII, pero desaparecen en el XVIII, tal vez debido a la supresión de las lecciones de canto y la ampliación de los estudios de los colegiales, que ya no se limitan a la formación eclesiástica y por tanto dedican menor tiempo al culto, centrándose más en los estudios. Otro suceso contribuyó quizás a la separación de los colegiales de la función de sochantre. En 1685 se nombró sochantre a un colegial, el maestro Bartolomé Hervás, que a juicio del canónigo Bustamante "no era sujeto científico" y no sabía "solfa", con lo que el deterioro del culto divino era evidente y además no daba clases a los colegiales. El episodio tiene su agravante en que se rechazó a un aspirante a la sochantría que había sido músico de la Catedral de Toledo porque al colegial le pagarían menos ${ }^{109}$. El suceso terminó con la contratación de un nuevo sochantre, don Pedro de Castro y Pimentel, después de un año de ejercicio del colegial.

\footnotetext{
108 A veces puntualmente, cuando el Sochantre falta se le sustituye por un colegial "de los antiguos" ASAC II, fol. 402 r (2-IV-1640), [208]. En 1633 se le da a Mora colegial algún salario por suplir el oficio de Sochantre. ASAC II, fol. 261 v (2-III-1633) [167].

${ }^{109}$ Para seguir la polémica completa, véanse: ASAC V, fol. 229r (2-V-1685),[218]; ASAC V, fol. 240r (3-VII-1685), [223]; ASAC V, fol. 275v (1-VIII-1686), [234]; ASAC V, fol. 282v (27-IX-1686), [235].
} 
Tabla IV.4. Colegiales que ejercieron como Sochantres en la Abadía del Sacromonte. Fuentes: Actas Capitulares.

\begin{tabular}{|c|c|c|}
\hline Colegial & Fecha de cabildo & Asunto \\
\hline \multirow[t]{4}{*}{ Juan Villar de Vago } & $16-X I-1621$ & Ayuda de costa por suplir al Sochantre \\
\hline & 17-III-1625 & Lleve título de Sochantre por su buena voz \\
\hline & $25-\mathrm{X}-1627$ & $\begin{array}{l}\text { Se le vaque Capellanía de Vega por estar } \\
\text { ausente dos meses }\end{array}$ \\
\hline & $10-\mathrm{XI}-1627$ & $\begin{array}{l}\text { Se escribe al Cardenal de Jaén para que } \\
\text { volviera, pues estaba ordenado a título del } \\
\text { colegio }\end{array}$ \\
\hline Ximena & 2 -III-1630 & $\begin{array}{l}\text { Junto con Mora por su buena voz ayuda de } \\
\text { sochantre para cantar el Tracto de Cuaresma }\end{array}$ \\
\hline \multirow[t]{5}{*}{ Francisco de Mora } & 2-III-1630 & Ver "Ximena" \\
\hline & 2-VII-1633 & Se le asigna un real diario de salario \\
\hline & $3-\mathrm{X}-1633$ & Aumenta salario y otros privilegios \\
\hline & 18-XII-1633 & Pruebas de limpieza para ser capellán \\
\hline & 29?-VI-1634 & Toma posesión como capellán \\
\hline \multirow[t]{3}{*}{ Jiménez } & 9-III-1647 & \multirow{2}{*}{$\begin{array}{l}\text { Goce de la beca entera con cuantía de } 3000 \\
\text { maravedíes }\end{array}$} \\
\hline & 5-VII-1647 & \\
\hline & $2-V I-1648$ & $\begin{array}{l}\text { Necesidad de que se ordene de misa para ser } \\
\text { Capellán de esta Iglesia }\end{array}$ \\
\hline \multirow[t]{2}{*}{ Francisco Martínez } & 26-VII-1650 & Se le dé la capellanía de Vega \\
\hline & 2-I-1651 & Dé lección de canto a los colegiales \\
\hline \multirow[t]{3}{*}{ Jiménez II } & $22-I I I-1656$ & Se reciba por Sochantre \\
\hline & 28-IV-1657 & Tenga habitación fuera del Colegio \\
\hline & $2-V-1657$ & Falta y se busca otro Sochantre \\
\hline \multirow[t]{7}{*}{ Cecilio de la Torre } & 6 -VII-1680 & Ayuda de costa de 200 reales \\
\hline & $3-X I-1683$ & Entre a comer en el refectorio de señores \\
\hline & $9-X I-1683$ & Pueda asistir al coro por la mañana \\
\hline & $1-\mathrm{XII}-1683$ & $\begin{array}{l}\text { El arzobispo pide al cabildo se obligue a } \\
\text { sustentarlo por pedir persona competente }\end{array}$ \\
\hline & $2-\mathrm{I}-1685$ & $\begin{array}{l}\text { No se le da silla en el coro alto a pesar de } \\
\text { que el Arzobispo de Almería lo haya } \\
\text { nombrado dignidad en su Iglesia }\end{array}$ \\
\hline & $2-V-1685$ & Se despide porque no quiere ser Sochantre \\
\hline & $28-V-1685$ & $\begin{array}{l}\text { Pide dinero por no haber recibido en cinco } \\
\text { años salario de sochantre pero se le niega }\end{array}$ \\
\hline \multirow[t]{4}{*}{ Bartolomé de Hervás } & $2-V-1685$ & $\begin{array}{l}\text { Se le nombra Sochantre a pesar de haber } \\
\text { otro candidato músico de la Catedral de } \\
\text { Toledo, pero se aducen razones económicas }\end{array}$ \\
\hline & 3 -VII-1685 & $\begin{array}{l}\text { Comete muchas faltas y el Abad promete } \\
\text { buscar sujeto científico }\end{array}$ \\
\hline & 1-VIII-1686 & $\begin{array}{l}\text { Más quejas sobre la ineptitud del colegial } \\
\text { para el oficio de Sochantre }\end{array}$ \\
\hline & 27-IX-1686 & $\begin{array}{l}\text { Se le despide pero se le perdona la pensión } \\
\text { por haber perdido tiempo de sus estudios y } \\
\text { salud }\end{array}$ \\
\hline $\begin{array}{l}\text { Otros colegiales: } \\
\text { Esteban de Rojas } \\
\text { Marcos Palomino }\end{array}$ & $28-V-1685$ & $\begin{array}{l}\text { No percibieron salario por su servicio como } \\
\text { sochantres }\end{array}$ \\
\hline
\end{tabular}




\subsection{De las Ceremonias propias del Colegio}

Un número limitado de ceremonias se celebraban en la Capilla del Colegio o eran de obligada asistencia para todos los colegiales. Entre ellas la Praxis de Ceremonias describe en su Instrucción XXVII la "Del Exercicio de la Disciplina". 110 Tenía lugar los viernes después de rezar el Rosario, durante el Adviento también los miércoles y en Cuaresma los lunes, miércoles y viernes. En la iglesia se colocaba cada colegial en su sitio, algo separados (para no golpearse con la disciplina de otro), se apagaban las luces y se decía en voz alta el Miserere, un verso el Rector o un colegial que lo cantase bien y el otro la Comunidad. La Praxis describe:

Acabado el Gloria Patri se dicen las oraciones: Respice quae sumus Domine: Deus qui culpa offenderis: Defende quaesumus Domine: Ecclesiae tuae y últimamente la de los Santos de la Casa Deus qui per Beatos Pontifices, las cuales concluidas responden todos Amen y se finaliza con un fervoroso acto de contrición, diciéndolo todo con pausa de modo que se gaste un cuarto de hora. ${ }^{111}$

Luego se traía luz y el Rector comprobaba que todos los colegiales habían traído sus disciplinas mientras salían de la Iglesia.

Dos fiestas más se celebraban en el Colegio con mayor solemnidad: el día de su patrón, San Dionisio Areopagita y la fiesta de la Virgen del Rosario.

\subsubsection{La Fiesta de Nuestra Señora del Rosario}

Los colegiales pertenecían a la Hermandad del Rosario, por lo que designaban a dos comisarios que se encargaban durante todo el año de pedir limosna para que se celebraran misas rezadas en sufragio de las almas de los cofrades. Asimismo, cuidaban de sus alhajas y vestidos que guardaban en un arca grande y de la cera para sus cultos.

El primer Domingo de Octubre celebraban la Fiesta, adornando la Capilla de la Virgen del Rosario con colgaduras, láminas y cornucopias, llenando de velas el altar y

\footnotetext{
${ }^{110}$ Praxis de Ceremonias, p. 97.

${ }^{111}$ Praxis de Ceremonias, pp. 98-99.
} 
el retablo. También adornaban la imagen de la Virgen. En la víspera se repicaba en la torre y a la noche se cantaba el Rosario con asistencia del órgano (estando todo el retablo y el altar encendido). En el coro cantaban los sochantres y algunos colegiales de buena voz; el resto de los colegiales cantaban en la Iglesia y en la capilla. El día de la fiesta, el Colegio debía juntarse mientras se celebraban las horas en la iglesia. Concluidas éstas, se cantaba la Misa por el rector quien la aplicaría por la Hermandad. Las distribuciones eran de cuatro reales para el organista en cada punto, a los sochantres, campanero y caniculario. Después de dicha Misa de Tercia, todo el Colegio iba a su Capilla a oir sermón de un colegial sobre las excelencias del Rosario. Por último, en la noche, se volvía a cantar el Rosario.

\subsubsection{San Dionisio Areopagita, patrón del Colegio}

La elección de San Dionisio Areopagita como patrón protector del colegio es narrada de esta manera por Heredia Barnuevo:

Diole por patrono, o por mejor dezir lo señaló el cielo, al Señor San Dionisyo Areopagita; pues aviendo ordenado el V. Prelado echar cédulas de todos los Sanctos Doctores, assi de la Iglesia Griega, como de la Latiina, y que fuesse Patrono el que saliesse por suerte; hecho sorteo por tres vezes, todas tres salió el mismo Doctor. ${ }^{112}$

La coincidencia no es baladí, pues como señala la Consueta, fue san Dionisio el que supuestamente le dio a San Cecilio "la preciosa e inestimable reliquia del paño con que Nuestra Señora limpió sus lágrimas al pie de la cruz: la qual se guarda en la Iglesia Catedral". 113

Cada 9 de Octubre dos comisarios adornaban la Capilla del Santo con colgaduras y cornucopias y el Altar con la cera acostumbrada. La fiesta consistía en una Misa solemne, con aparato de primera clase. Según la Praxis de Ceremonias [1772] la oficiaba el Rector, pero según la Consueta (1632) la decía el Abad, y el sermón era predicado por un colegial al que como premio se le daba un pañuelo y dos libras de

\footnotetext{
${ }^{112}$ Heredia Barnuevo, Mistico Ramillete, p. 147.

${ }^{113}$ Consueta, fol. $40 \mathrm{r}$.
} 
chocolate. ${ }^{114}$ El día de la víspera de la fiesta, a las 12, se daban repiques y por éstos se anunciaban las vísperas de la noche. Para ello había asignados ocho reales al campanero y otros ocho al caniculario porque ayudaba a encender el Altar. Por la tarde, a la hora de las Vísperas, que se cantaban en el coro, se juntaba el Colegio en la Sacristía, y después de las Completas, el Rector tomaba la capa y con los demás ministros y colegiales subía en procesión a la capilla del santo donde cantaban las vísperas solemnes con asistencia de los Sochantres a los que se les gratificaba con ocho reales por cada punto a cada uno. Concluidas las Vísperas volvía la Procesión a la Sacristía.

El día de la Fiesta, al tiempo de la misa mayor en la Iglesia, se juntaba de nuevo el Colegio en la Sacristía, se vestía el Rector para decir la misa que aplicaba por el Colegio por lo que se le regalaba "una torta real o plato de dulce decente". Con los Diáconos (que podían ser colegiales ordenados in sacris o capellanes) se dirigía en procesión a la capilla, y concluida la misa bajaban otra vez en procesión a la Sacristía como en las Vísperas.

El rosario se rezaba en la capilla durante toda la octava y al final debía cantarse el himno Deus tuorum con el altar y el retablo encendidos. Además en las ocho noches de la octava se tenían lecciones de oposición en la Capilla del Colegio con asistencia del Cabildo.

La Praxis de Ceremonias es especialmente severa en cuanto a la celebración de otros actos "profanos" para festejar al Santo Patrón; así indica que: "No se permiten comedias, Autos, entremeses, juegos ni cosas semejantes sino que se guardará la misma regla que en los demás días, para conservar el buen olor de la Comunidad y evitar el desorden que traen y la pérdida de la buena crianza". ${ }^{115}$ Aunque en la práctica, una reseña en las actas nos indica que a veces obtuvieron permiso para bailar, cantar y tocar "algunos instrumentos":

Después propuso el señor Abad, que habiendo pedido algunos colegiales permiso para hacer en alguno o algunos días en la Octava del señor San Dionisio juegos u otras diversiones por sí o por otros hombres que han venido otras veces, lo exponía su señoría al Cabildo,

\footnotetext{
${ }^{114}$ Praxis de Ceremonias, p. 118.

${ }^{115}$ Praxis de Ceremonias, p. 120.
} 
que habiendo conferido los inconvenientes y perjuicios experimentados en semejantes diversiones acordó no se permitan de ningún modo y que el señor rector lo mande y prohiba con el mayor rigor. Y que estando así mandado diversas veces quede con mayor firmeza establecido así para en adelante y que sólo a discreción del señor Rector puedan divertir el quiete hasta las diez los mismos colegiales sin quitarse los mantos con algunos bailes, relaciones e instrumentos que sepan tocar o cantar y no con vestidos de mujer ni otros profanos para comedias, loas ni nada semejante. Y que también mande y cele el señor Rector que ni los que leen en dicha octava, ni en otros tiempo, ni los que tengan sabatinas de ningún modo den refrescos, meriendas ni se les permita gastar cosa alguna ni en público ni e secreto por dichos motivos. ${ }^{116}$

Como ahora reseñaremos, los colegiales legistas supieron esquivar la prohibición al menos en una ocasión y representaron una Loa.

\subsection{La Loa a la Inmaculada Concepción de los colegiales}

Cada Facultad tenía una advocación propia, siendo la de la Facultad de Derecho, la Inmaculada Concepción. En varias ocasiones las Actas señalan la conveniencia o no de celebrar más actos que los estrictamente formulados por la Consueta. Un año se celebró una Loa, escrita por Juan Pedro Maruján y Cerón y representada por los colegiales. En esta Loa se estipulaba la presencia de música, por lo que los colegiales debieron contratar músicos. Al Cabildo le pareció un gasto desmesurado, pues hasta se llegó a imprimir la obra. ${ }^{117}$

En el punto de Constituciones propuso el Señor Abad que deseaba tomase el cabildo la providencia más seria, y concebida en los términos más rigurosos a fín de evitar que en adelante se hiciesen funciones por los colegiales o en el colegio de cualquier género que fuesen por haber manifestado la experiencia de que permitiéndose alguna, aunque leve diversión, en llegando el caso de ejecutarla, se advierten excesos casi irremediables, ya por la circunstancia del tiempo, ya por otras que no es preciso referir, como últimamente se ha palpado en la Octava de Concepción del año próximo, en que los colegiales juristas hicieron una Loa con tales aparatos y disposiciones, que no puede menos de haberles causado crecidas sumas de dinero, y a cuya representación a pesar de las precauciones tomadas por su Señoría y el señor Rector, se vió concurrir

\footnotetext{
${ }^{116}$ ASAC X, fol. 302r (4-X-1765), [678].

${ }^{117}$ Loa, en celebridad del solemne día de la Purissima Concepción de María Santíssima Señora Nuestra, para representarse por los cavalleros collegiales juristas del Insigne Colegio del Sacro Monte de Granada. Producción de la Idea de Don Juan Pedro Maruján y Cerón. Impressa en Granada en la Imprenta Real, [1767].
} 
en número muy crecido con personas extrañas, incovenientes que sin duda eran gravísimos para una comunidad del carácter de la nuestra, y que pedían un remedio muy eficaz y que cortase de raya estas corrupciones. Lo que oido y meditado por todos los señores capitulares acordaron las determinaciones: que en adelante, ni en las octavas de San Dionisio ni de la Concepción ni en otro tiempo se permitiese a los colegiales género alguno de función, ni que sobre esto se vuelva a admitir en cabildo pretensión alguna. Asimismo sobre cierta proposición que hizo el señor Rector de visitas, principalmente de mujeres, a los colegiales se decretó que en este particular quedase a la prudencia de los señores Abad y Rector. ${ }^{118}$

La loa es un género teatral de los denominados breves, que guarda similitudes con otros como los entremeses, sainetes y prólogos, los cuales solían acompañar a una obra de mayor extensión. La bibliografía existente sobre este género teatral es amplia, si bien los estudios de loas que se refieren a la música no lo son tanto. ${ }^{119}$ Covarrubias alude a su etimología latina como alabanza y "Cerca de los representantes, loa es el prólogo o preludio que hacen antes de la representación". ${ }^{120}$

El autor de esta Loa del Sacromonte es el poeta gaditano Juan Pedro Maruján y Cerón (1708-1772) que tradujo y adaptó al español muchas de las óperas de Goldoni. ${ }^{121}$ Noticias sobre él pueden encontrarse en las cartas de Diego Alejandro de Gálvez al Conde del Águila conservadas en la British Library de Londres. ${ }^{122}$

\footnotetext{
${ }^{118}$ ASAC XI, fol. 70 r (8-I-1768), [686].

${ }^{119}$ Sobre la loa es clásico el estudio de José Subirá, "Loas escénicas desde mediados del siglo XVIII", Segismundo IV/7-8 (1968), pp. 73-94. Las loas que más se han estudiado desde el punto de vista musical son las de Calderón de la Barca; véase M. L. Lobato, "Fonction et conception de la musique dans les loas de Calderón”, ed. Irène Mamezarz, Le rôle des formes primitivies et composites dans le dramaturgie européenne (París: Klincksieck, 1992), pp. 137-152. Á. Cardona Castro, "Función de la música, la voz humana y el baile a través de los textos de El laurel de Apolo (loa para la zarzuela y zarzuela) y a través de la loa La púrpura de la Rosa", Calderón, Actas del Congreso Internacional (Madrid: CSIC, 1983) vol.II, pp. 1077-1089. Últimamente también las loas producidas fuera de la Península han recibido atención; véase David Irving, "Musical politics of empire: the loa in 18th-century Manila", Early Music, XXXII/3 (2004), pp. 385-402.

${ }^{120}$ Covarrubias, Tesoro de la Lengua, p. 718.

${ }^{121}$ Andrés Navarro Lázaro "Las traducciones castellanas de las óperas bufas de Carlo Goldoni: el caso de La Buona Figliuola", Res Diachronicae Virtual 3: Estudios sobre el siglo XVIII, Número monográfico coordinado por Mara Fuertes Gutiérrez, Ma José García Folgado y José Luís Ramírez Luengo, pp. 175181.

${ }^{122}$ Véase Francisco Aguilar Piñal, La Real Academia Sevillana de Buenas Letras de Sevilla en el siglo XVIII (Madrid: Consejo Superior de Investigaciones Científicas, 1966), p. 52.
} 
Desconocemos la relación de este poeta gaditano con el Sacromonte, pero no hay duda de que la Loa le fue encargada expresamente por los alumnos juristas del Sacromonte, por las constantes referencias al Colegio y a Pedro de Castro. Por varias obras impresas en Granada que se refieren a eventos en la ciudad, parece que el poeta residió un tiempo en la ciudad. ${ }^{123}$

Figura IV.8. Portada de la Loa representada en el Sacromonte en 1767.

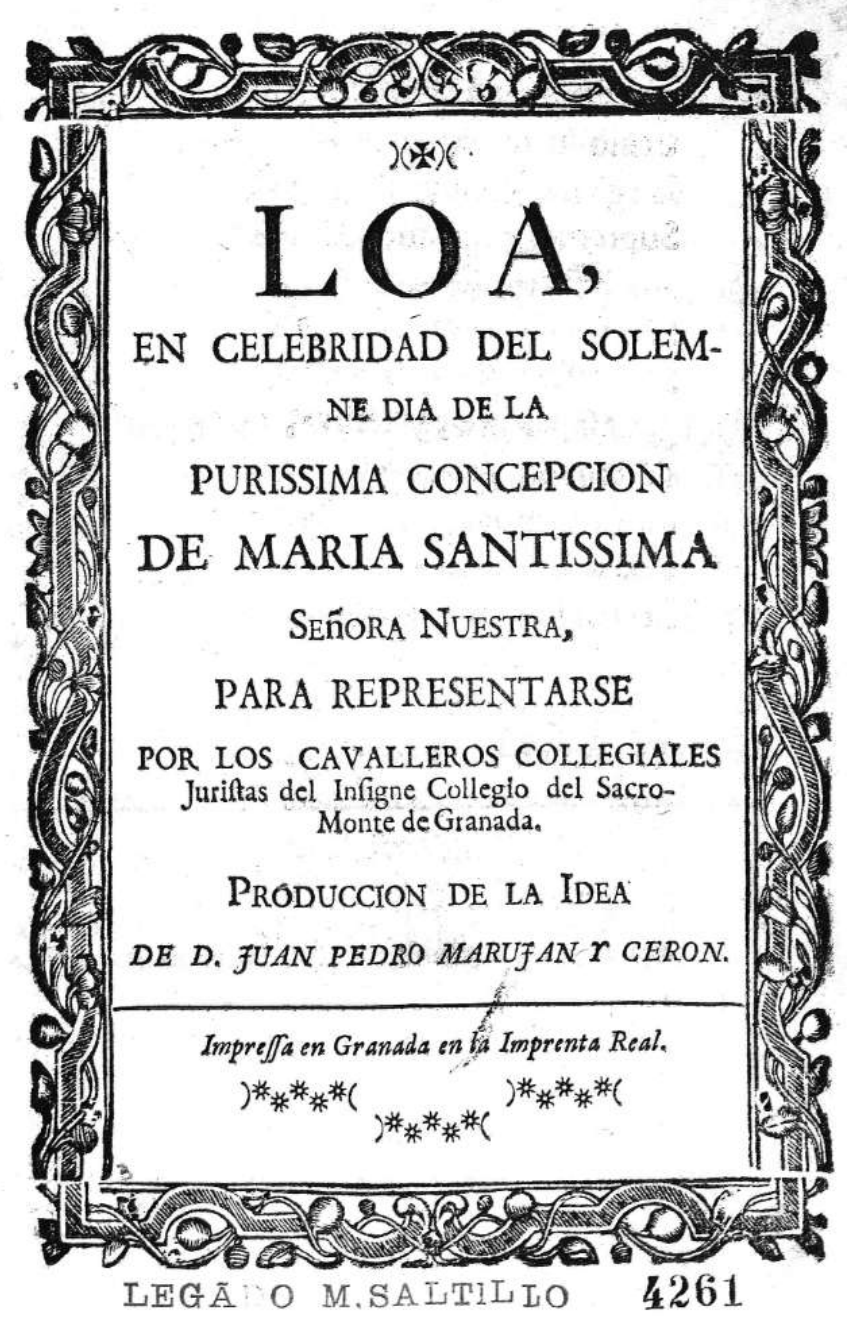

Aunque casi todos los personajes que intervienen en la Loa son femeninos (La Jurisprudencia, La Gracia, La Seriedad, La Ingenuidad, La Limpieza, La Subtileza, La Aplicación) en el texto queda claro que todos los que la representaron eran hombres,

\footnotetext{
${ }^{123}$ Entre ellas una relación del traslado de las reliquias de San Juan de Dios a su nuevo templo. Véase para dichas obras: María José López-Huertas Pérez, Bibliografía de impresos granadinos de los siglos XVII y XVIII (Granada: Universidad y Diputación Provincial, 1997).
} 
probablemente los mismos colegiales juristas. ${ }^{124}$ La música interviene en tres momentos de la Loa siempre con el mismo cuatro: justo al comienzo de la Loa, después de la primera intervención de la Jurisprudencia y al final. El cuatro alude a la Inmaculada Concepción como patrona del colegio de juristas y al Sacromonte. El texto reza así:

Sea siempre alabada

Siempre bendita,

De María la Pura

Concepción Limpia:

Viva siempre aclamada,

Siempre aplaudida,

De la llena de Gracia

La Luz Divina.

Viva el mas Sacromonte,

Que el Orbe admira,

De Ciencias y Virtudes

Custodia digna.

Y en su culto brillante

Felices vivan,

La fama y lucimiento

De los Legistas.

Según José Subirá “se designaban 'cuatros' aquellas piezas entonadas a cuatro voces simultáneas. (...) Cuando triunfó la monodía y se opuso al tradicional contrapunto, el 'cuatro' o 'a cuatro' se desintegró paulatinamente, sin perjuicio de seguir subsistiendo tal denominación en desacuerdo con la realidad". ${ }^{125}$ La música de esta Loa no se conserva, pero hay algunas alusiones en el texto que describen algo la pieza. Parece que este cuatro comenzaba con un ritornello instrumental, pues se señala la presencia de la "Música" y explícitamente uno de los personajes antes de la última intervención exclama:

Señores acompañantes empieza la Sinfonía

\footnotetext{
${ }^{124}$ La Gracia interviene dicidiendo: "Cada qual hable, según aquel lugar, que le es debido, que hablar a duo aquí no es permitido; pues a Dios gracias somos hombres todos, y no imitamos mugeriles modos." Loa, p.17.

${ }^{125}$ José Subirá, “Loas escénicas”, p. 54.
} 
del Retornelo del quatro,

y luego será segunda

de voces representantas,

y de las voces solfistas,

y en aplauso de la Virgen,

dirán acordes, y unidas.

Música y todos: Sea siempre etc.

Por las indicación de que cantan "música y todos", incluyendo voces "solfistas" que "dirán acordes y unidas", es probable que se interpretara el cuatro (precedido de un ritornello instrumental) a cuatro voces con acompañamiento instrumental.

Podemos concluir que la relación de los colegiales con la música fue muy estrecha en cuanto a lo que al servicio litúrgico concierne, pues además de intervenir en el Coro y en los oficios relacionados con él (versicularios, acólitos, intonario etc..) desempeñaron el cargo de sochantre en diversas ocasiones. Sin embargo, las Actas recogen esporádicamente menciones a la vida musical profana de los colegiales que demuestran que: 1) la música instrumental y profana estaba mal vista por las autoridades y canónigos del Sacromonte en tanto que no era venerable; y 2) a pesar de las prohibiciones, los colegiales seguían manteniendo cierta actividad musical fuera del culto. 



\section{CAPÍTULO V MÚSICA Y CEREMONIAL II: \\ LAS CEREMONIAS DE LA ABADÍA DEL SACROMONTE. DESCRIPCIÓN Y ESTUDIO CONTEXTUAL.}

El objeto de este capítulo es describir el ritual de algunas ceremonias que se desarrollaban en la Abadía del Sacromonte, bien por ser ejes de la liturgia (misa y vísperas), por su interés singular (festividades propias y exclusivas de la Abadía) o por su importancia en el ámbito litúrgico católico postreformista. Mi intención es enmarcar estas ceremonias en el contexto sociocultural de la época.

La misa y las vísperas son las ceremonias de celebración diaria que vertebran el resto de las festividades y ritos, por eso su estudio en la Abadía es necesario para entender cómo se desarrollaba el culto y las similitudes y diferencias con las rúbricas del Caeremoniale Episcopurum. Entre las festividades propias de la Abadía encontramos las celebraciones de San Cecilio, uno de los supuestos santos encontrados en las cavernas, primer obispo de Granada y luego patrón de la ciudad, para el que se creó un oficio y un ritual propio. Las ceremonias en las que participaba el Ayuntamiento de Granada y el Cabildo catedralicio daban una dimensión cívicoreligiosa muy rica para entender las relaciones jerárquicas en los núcleos urbanos de la España moderna. Relacionaré estas ceremonias con el culto a otros santos patrones en España, como San Julián en Cuenca o San Segundo en Ávila. Además estudiaré la producción musical dedicada al culto a San Cecilio conservada en el Sacromonte, la Catedral y la Capilla Real.

De las ceremonias seleccionadas en este Capítulo, los ritos funerarios por el fundador de la Abadía, Pedro de Castro, y por sus padres suponen una exploración de uno de los fines de la creación del Sacromonte: servir de panteón familiar a imitación de Felipe II en el Escorial y de tantas otras capillas nobiliarias. Al mismo tiempo haré un recorrido por la historia de la familia Castro, incidiendo en la figura de Cristóbal Vaca de Castro, cuyo status sociopolítico y económico obtenido gracias a su empresa indiana como pacificador y administrador del Perú permitió al Arzobispo de Granada fundar el Sacromonte. El mausoleo de Vaca de Castro en el Sacromonte era "honrado" cada año en diversas fechas con un ritual que sigue los estándares para este tipo de ceremonias en el Antiguo Régimen. 
El culto a la Virgen y al Santísimo generó un variado repertorio de actividad cultual en el mundo de la Contrarreforma; aunque muchos de estos cultos hunden sus raíces en la Edad Media, cobraron nuevo protagonismo en una época de reafirmación doctrinal frente a las creencias de los protestantes. La Abadía, nacida en la época de mayor difusión de las ideas contrarreformistas, no pudo sino ser el reflejo perfecto de la jerarquía contrarreformista, contribuyendo de una manera especial a la difusión de la creencia en la Inmaculada Concepción, pues reavivó el debate inmaculista por la presencia de esta opinión en los Libros Plúmbeos.

Con frecuencia se ha señalado la desigual acogida de la reforma planteada por Trento en las diferentes iglesias, llegándose a afirmar en ocasiones que no se logró hacer efectiva de manera completa en muchos casos. Dejando a un lado la posibilidad que la Bula Quo Primum Tempore de Pío V daba a las diócesis u órdenes de que continuaran con sus rezos propios si tenían una antigüedad superior a dos siglos, el resto fue sometiéndose poco a poco, aunque el nivel de aceptación varió según la zona geográfica y la disposición y formación de sus mandatarios eclesiásticos. En el caso de la Abadía, una institución como ya se ha señalado de marcado carácter contrarreformista, no cabe la menor duda de que nació con las nuevas normas, y que no cupo en ella el rito antiguo. El ceremonial de la Abadía se creó con la intención de seguir el "nuevo rezo romano", es decir, el aprobado por Pío V en 1570 después de las disposiciones del Concilio de Trento. Los canónigos redactores de la Consueta, conscientes de la necesidad de cumplir con el nuevo rezado, habían analizado el ceremonial de la Catedral granadina y concluyeron que no se adaptaba a las directrices emergentes. Por ello son particularmente interesantes las apreciaciones que sobre el desarrollo de las ceremonias y su relación con la música revelan las descripciones ceremoniales, pues nos ayudan a comprender el papel asignado a la música en la nueva liturgia a los ojos de los eclesiásticos. En este capítulo analizaré algunas de estas ceremonias, tratando de poner en relación las diferentes rúbricas que proporciona la Consueta acerca de la música, los gestos y cualquier otra indicación que intervenga en la regulación del rito. 


\section{Las ceremonias de la Misa Cantada}

El ceremonial de la misa cantada en la Abadía sigue el esquema tridentino que dividía la misa en dos partes: la misa de los catecúmenos y la misa de los fieles. La música tiene lugar en el Asperges (los domingos), y en el resto del Propio y Ordinario de la Misa, por lo que en los siguientes párrafos describiré especialmente estos momentos. Para comparar la ceremonia de la Misa me he fijado en el Capítulo IV del Libro III, de la Consueta y en el Libro II, Capítulo VIII del Caeremoniale. ${ }^{1}$ La primera diferencia viene de que no son ceremonias completamente equivalentes; aunque las misas solemnes pontificales son misas cantadas, no todas las misas cantadas son pontificales.

Figura V.1. Caeremoniale Episcoporum (Roma: Giannini et Mainardi, 1729), p. 330.

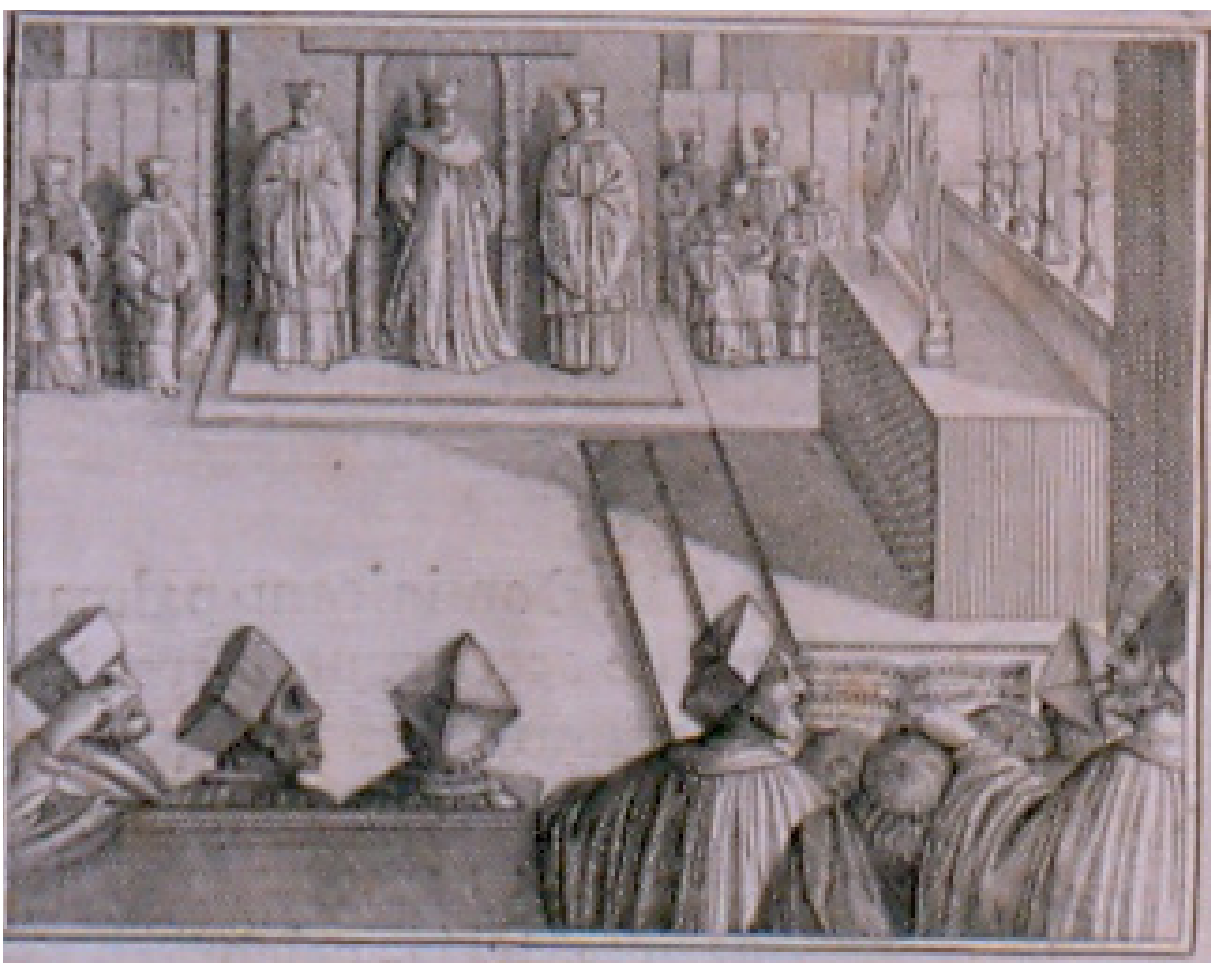

\section{Asperges}

En el Caeremoniale, la ceremonia del Asperges está indicada en el capítulo XXXI, 3 y sigue el mismo esquema que en la Abadía. La ceremonia de la aspersión del

\footnotetext{
${ }^{1}$ Por problemas de acceso al documento, para este estudio hemos utilizado una edición del Caeremoniale Episcoporum, del siglo XVIII, véase Caeremoniale Episcoporum (Roma: Caroli Giannini et Hieronymi Mainardi impressorum cameralium, 1729), BNE 3/28078.
} 
agua se celebraba sólo los domingos y era un símbolo de purificación del espacio y de los asistentes. El celebrante recibía el hisopo con el que realizaba la aspersión: en tres veces rociaba primero hacia el medio del altar, luego al lado del Evangelio y después al lado de la Epístola. Seguidamente se echaba agua a sí mismo y mientras entonaba la antífona del Asperges o la del Vidi aquam (si era tiempo de Cuaresma) echaba agua al diácono y subdiácono. Entonada, devolvía el hisopo al diácono y después proseguían con la antífona, el Psalmo y Gloria Patri y repetían la antífona. Aunque la Consueta no es clara a este respecto, parece que simultáneamente al rezo del celebrante y del diácono y subdiácono, el coro cantaba la antífona con el psalmo y volvían a repetir la antífona. Durante el canto de la antífona y el psalmo, un capellán hace la aspersión al coro y al pueblo en la Iglesia. Mientras se efectuaba la repetición de la antífona por el coro, el capellán cerimoniario daba el manual al Diácono quien lo ponía abierto delante del celebrante, para que éste, acabado el coro, dijera los versos y oración.

\section{Introito}

La Consueta señala que el Introito debía cantarse inmediatamente después de responder "amén" a la oración del Asperges, o si no es domingo, cuando deja de sonar el esquilón. Lo comienzan a cantar "todos los del coro alto, el sochantre y versicularios". Parece contradictorio que algo más abajo señale que "los del choro alto no se hincan de rodillas hasta el tiempo dicho y se están assi mientras el celebrante y Diáconos dizen Introito y hazen la confesión y entran en el altar."

Al Gloria Patri todos inclinaban la cabeza a la cruz que había en medio del altar, y se repetía el Introito.

\section{Kyrie}

Acabado el introito el celebrante se volvía hacia el diácono y subdiácono "que todos se vean los rostros y dizen los Kyries alternatim”. Esta indicación nos habla de la importancia que en la interpretación del canto llano tenía la coordinación y la necesidad de verse para poder hacerlo. El alternatim era con el órgano, pues sabemos que intervenía en las misas de domingo y fiestas dobles de primera y segunda clase según se señala en las obligaciones del organista (Libro II, Capítulo 12), y con el coro el resto de las misas cantadas. El punto 23 advierte que cuando el coro o el órgano dicen el último Kyrie, el cerimoniario se adelantaba unos pasos y hacía comedimiento al celebrante, que con los diáconos se descubría y levantaba y después de besar el altar entonaba el Gloria. 


\section{Gloria}

En las indicaciones del Gloria destacan las inclinaciones de cabeza al nombrar a Jesús, a María y en algunas frases. Cuando se decía el verso "in excelsis", los diáconos debían subir a los lados del celebrante y haciendo genuflexión con las manos puestas decían Gloria, inclinando las cabezas junto con el resto del coro al "Adoramus te", "gratias agimus tibi", "suscipe deprecationem nostram" y al nombre de "Jesucristo". Sin embargo, el Caeremoniale, no indica ninguno de estos movimientos y señala que al decir Deo, el celebrante junta las manos e inclina la cabeza. ${ }^{2}$

En el Sacromonte, cuando el coro cantaba las palabras señaladas anteriormente, el celebrante también hacía una inclinación profunda y los diáconos se quitaban los bonetes.

¿Qué sucedía si había música?

En el coro cuando entona la Gloria el celebrante todos los prebendados se levantan y sin bonetes las manos puestas la dicen rezada quando ay mussica, inclinan las cabezas a las mismas palabras y acabada de rezar la Gloria se sientan y cubren, cuando no la hay [la música], la cantan [el Gloria] con el coro y se sientan cuando se sientan los de la missa y cuando se cantan las dichas palabras se quitan los bonetes y profunde inclinan.

Como hemos señalado anteriormente, esta costumbre de rezar la oración mientras sonaba la música ya está señalada en el Caeremoniale Episcoporum, para otras ocasiones (capítulo XXVIII, puntos 6, 7 y ss), y se trataba de una práctica común.

En el último verso del Gloria, el celebrante se volvía al pueblo y cantaba "Dominus Vobiscum". Si no había Gloria, cantaba dicho verso inmediatamente después de los Kyries, se acercaba el celebrante al libro y siguiendo a los diáconos cantaba las oraciones, al tiempo que el cerimoniario alumbraba y volvía los registros. Todos de pie, inclinaban las cabezas a los nombres de Jesucristo, María, del Santo de quien se dijera la oración y del Pontífice que viviera.

\footnotetext{
${ }^{2}$ Caeremoniale, p. 239.
} 


\section{Epístola}

Cuando la epístola se cantaba, era el subdiácono el que se encargaba de hacerlo desde el atril. A su lado estaba el ceroferario quien debía inclinar la cabeza junto con él si se pronunciaba el nombre de "Jesucristo". Si la epístola no se cantaba, era el celebrante quien la leía después de las oraciones, y continuaba leyendo el gradual, versos y aleluyas, tractos o secuencias conforme a la misa. A las palabras rezadas por el celebrante o cantadas por el subdiácono "in nomine iesu omne genu", si la epístola era de la cruz u otra en que se había de hacer genuflexión se hacía en el mismo sitio del coro. Si la misa era del Spiritu Sancto o de Feria de Cuaresma se hincaban de rodillas el celebrante, el diácono y el cerimoniario al verso "veni creator spiritus" y al verso del tracto "adiuvanos" en medio del altar.

En la misa del Espíritu Santo el coro cantaba inmediatamente después de la Epístola el gradual "y si es día de órgano lo toca con son grave y moroso, luego el coro las Alleluyas versos tractos o sequentias". 3

El verso veni creator spiritus siempre lo cantaba el coro mientras el celebrante y los diáconos se hincaban de rodillas en medio del altar, los demás lo hacían en sus lugares (lo mismo se hace al tracto de cuaresma en el verso adiuva nos en las ferias de cuaresma).

Antes de leer el evangelio, el diácono, con las manos puestas, cantaba Dominus vobiscum a la respuesta.

\section{Evangelio}

Las rúbricas respecto al Evangelio son prácticamente idénticas a las que proporciona el Caeremoniale. Durante el evangelio también debían inclinar las cabezas a las palabras de "Jesús", "María" y también al nombre de cualquier santo, pero menos

profundamente. Terminado de cantar el Evangelio por el diácono, le llevaba el libro abierto al celebrante quien debía besarlo y entonar "per evangelica dicta deleantur nostra delicta".

\footnotetext{
${ }^{3}$ Consueta, fol. $255^{\mathrm{r}}$.
} 


\section{Credo}

El Credo es uno de los momentos centrales de la misa en la época de la Contrarreforma, habida cuenta de que con esta oración se ponía de manifiesto las creencias católicas. En el ceremonial abacial, muchos de los versos comportaban una acción paralela. El celebrante comenzaba entonándolo y al verso In unum Deum subían con él el diácono y el subdiácono colocándose a los lados y a la vez hacían genuflexión. Luego levantados "con las manos puestas" proseguían el Credo. Cuando acababan de decir descendit de coelis los tres se hincaban de rodillas de nuevo, extendiendo la casulla del celebrante. El coro continuaba el Credo al mismo tiempo que el resto de los prebendados, que estaban descubiertos y en pie, lo decían rezado con las manos puestas. Si había "música", es decir si había capilla de música, se hincaban de rodillas al “incarnatus est" y lo decían rezado. Si por el contrario no había capilla de música ayudaban a cantarlo al coro, haciendo genuflexión al "Incarnatus est". En el Caeremoniale, las rúbricas son menos específicas y tan sólo señalan la genuflexión del Incarnatus est. ${ }^{4}$

En el coro bajo (es decir, colegiales y capellanes) cantaban el Credo y debían hincarse de rodillas al "incarnatus est". Una vez dicho "homo factus est" se levantaban y proseguían el Credo, bajando la cabeza al "simul adoratur". El coro alto (los prebendados) cuando cantaba el coro "Incarnatus est" se descubrían e inclinaban el cuerpo "profunde" hacia el altar. El celebrante puesto el bonete inclinaba "profunde" la cabeza, los diáconos se quitaban los bonetes y la inclinaban algo más.

\section{Prefacio}

Al finalizar el Credo, el celebrante entonaba el Prefacio mientras que en el coro se levantaban. Cuando el celebrante decía "suplice confesione dicentes" o palabras semejantes, el diácono y el subdiácono subían a la diestra y siniestra del celebrante respectivamente, haciendo genuflexión a la vez que el celebrante.

\footnotetext{
${ }^{4}$ Véase Caeremoniale, Libro II, cap. VII, §52, p. 247.
} 


\section{Sanctus}

Cuando se cantaba "Benedictus qui venit" el celebrante y el diácono se signaban de la frente al pecho, ${ }^{5}$ y dicho por segunda vez "hosanna in excelsis" hacían genuflexión, ${ }^{6}$ quedándose el diácono "en la peana" un paso atrás del celebrante y el subdiácono se volvía a su lugar.

Cuando el coro o el órgano comenzaban el Sanctus, los ceroferarios tocaban tres veces las campanillas “a un compás dos golpes cada vez”, dejándolas junto a los ciriales. Subían y hacían genuflexión a los lados del subdiácono y se llegaban a despabilar.

El coro cantaba alternatim con el órgano si era día de órgano, teniendo cuidado de no cantar el "benedictus qui venit" hasta después de que hubiera sido alzado el cáliz "si no es cuando se canta motete o chanzoneta en su lugar". Este comentario es de suma importancia porque nos habla de la costumbre de acompañar con música el momento de la elevación. Esta música bien podía ser un motete, con texto latino o una chanzoneta, con texto en castellano.

Después el celebrante decía “Te igitur” y proseguía el canon con las ceremonias que mandaba el ordinario. En el memento dejaba el cerimoniario la palmatoria sobre el altar y se apartaba un paso.

\section{Consagración}

Durante la consagración y elevación del Santísimo Sacramento se hincaban todos de rodillas en el coro y el órgano tocaba "más grave y dulcemente", 8 si no era día de órgano, acabado el primer "hosana in excelsis" el coro y todos quedaban en silencio hasta que después de haber alzado el cáliz se proseguía con el "Benedictus qui venit". 9 " Véase Figura 5.2.

\footnotetext{
${ }^{5}$ Igual que en el Caeremoniale, Libro II cap. VIII pp. 255-256.

${ }^{6}$ No se indica en el Caeremoniale.

${ }^{7}$ Sin correspondencia en el Caeremoniale.

${ }^{8}$ Correspondencia con Caeremoniale $§ 71$.

${ }^{9}$ Correspondencia con Caeremoniale $§ 71$.
} 
Figura V. 2. Caeremoniale Episcoporum (Roma: Giannini et Mainardi, 1729), p. 257.

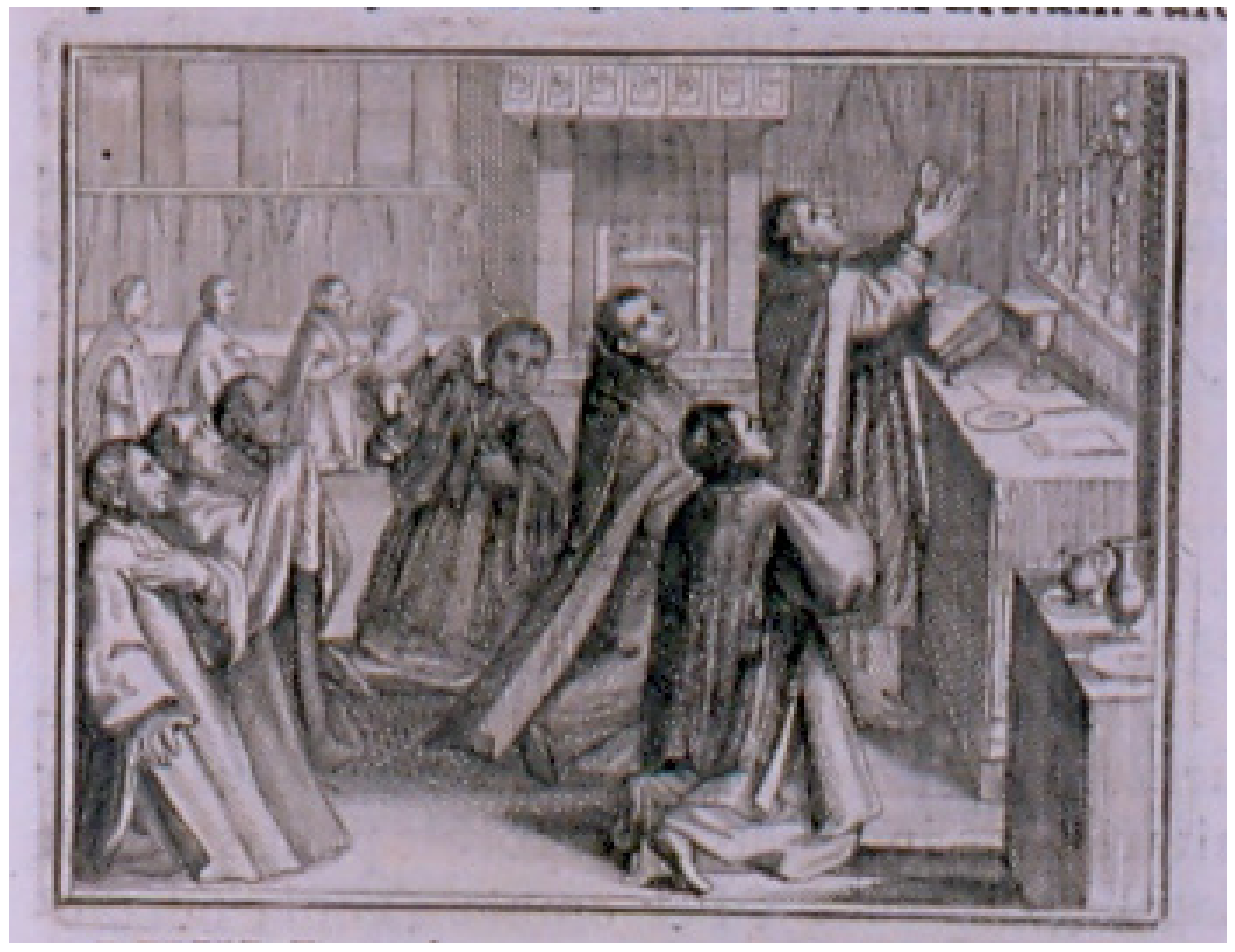

\section{Padre nuestro}

El celebrante lo cantaba y cuando decía "et dimite nobis", el diácono hacía genuflexión y subía a la diestra del celebrante. Cuando comenzaba el verso "et ne nos inducas”, el subdiácono después de hacer genuflexión subía al lado de la Epístola y le daba la patena al diácono, que después de limpiarla y besarla se la daba al celebrante. ${ }^{10}$

Cuando el celebrante entona el "Pax Domini" salía el pertiguero y los turiferarios, con cendales y paces en la mano derecha, levantada hasta el rostro.

\section{Comunicanda}

La cantaban en el coro mientras el celebrante consumía y acabada de cantar en el coro, si era día que había órgano, tocaba hasta el "Dominus Vobiscum" mientras estaban sentados los del coro.

\footnotetext{
${ }^{10}$ Correspondencia con Caeremoniale $\$ 74$, p. 258.
} 
La Consueta sigue al Caeremonialis Episcoporum muy de cerca como se ha podido comprobar por las descripciones anteriores, ampliando en la mayor parte de las veces los gestos y las rúbricas en lo que a la celebración de una misa solemne se refiere. Para corroborar esta dependencia de la Consueta hacia el Caeremonialis Episcoporum, en el siguiente epígrafe estableceré las comparaciones pertinentes entre los dos documentos con respecto a otra ceremonia: las vísperas.

\section{Las Vísperas cantadas según la Consueta (1632)}

La Consueta describe pormenorizadamente las Vísperas cantadas que se realizaban todos los días festivos del año (domingos inclusive) y todos los días que se hubiesen dotado para ello. La hora de Vísperas, tradicionalmente celebrada a la caída del sol, ${ }^{11}$ tenía lugar en la Abadía a las 2.30 p.m. desde octubre hasta el primer domingo de Cuaresma, y a las 3 p.m. el resto del año, según las Constituciones de 1616. Al igual que en monasterios, catedrales e iglesias colegiales, la hora de Vísperas podía celebrarse dos veces si la fiesta era importante y en los domingos: las $1^{\text {as }}$ vísperas el día antes de la fiesta y $2^{\text {as }}$ vísperas, el mismo día de la fiesta.

La estructura del servicio que sigue la Abadía es la romana (o catedralicia), en la que se emplean cinco salmos con sus cinco antífonas en lugar de las cuatro que tiene el uso monástico. ${ }^{12}$ Se comienza con el versículo y el responsorio Deus in adiutorium. La elección de los psalmos depende de si es una semana del tiempo ordinario o una determinada fiesta. A continuación, el capitulum, una breve lectura, y un himno ocupan la sección previa al canto del Magnificat. Éste a su vez va precedido y seguido de una antífona. El final del oficio incluye oraciones y el

\footnotetext{
${ }^{11}$ Willi Appel, Gregorian Chant, p.13.

12 En la estructura del servicio sigo la descripción que proporcionan Steiner y Falconer: Ruth Steiner and Keith Falconer. "Vespers." In Grove Music Online. Oxford Music Online, http://www.oxfordmusiconline.com/subscriber/article/grove/music/29261 (consultado el 9 de Septiembre, 2008).
} 
Benedicamus Domino. Al igual que ocurre con el ceremonial de la misa, la Consueta sigue las rúbricas principales que da el Caeremoniale Episcoporum de 1600, concretando en los espacios abaciales los movimientos y ampliando algunas consignas, adaptándolas a las circunstancias sacromontanas (como los actores de la liturgia). Por ello, indicaré las correspondencias oportunas Consueta-Caeremoniale. De la lectura atenta de las rúbricas que proporciona la Consueta pueden extraerse dos tipos principales de informaciones: 1) las referidas a la coreografía de movimientos y gestos realizados por los actores y el orden de intervención de éstos; y 2) las que arrojan luz sobre aspectos interpretativos que normalmente pasan desapercibidos en la reconstrucción ceremonial.

Respecto al primer grupo de datos la Consueta es extremadamente precisa, indicando en todo momento en qué lugar y qué movimientos realizan los actores de la ceremonia. Estas indicaciones no son secundarias a nuestro juicio, pues condicionan en cierta manera la interpretación del canto, y por tanto no pueden entenderse de manera separada. Un ejemplo puede ayudar a comprender la importancia del gesto y su influencia en la interpretación de la música con fines ceremoniales. El primer acontecimiento musical de las Vísperas es la entonación por el celebrante del versículo Deus in adiutorium mientras se persigna. El celebrante no sólo canta sino que realiza un movimiento en cuatro partes que necesariamente condicionaría el tempo. De hecho los cuatro movimientos que se realizan al persignarse (frente, pecho, hombro izquierdo, hombro derecho) están indicados en la Consueta y podrían coincidir con los cuatro acentos principales del versículo. ${ }^{13}$ La asociación de movimiento y acentuación se haría de manera intuitiva e inconsciente, pero hacerlo sin tener en cuenta los acentos es más difícil y antinatural.

La música marcaba también el inicio o el fin de algunos movimientos, como si los actores de la liturgia siguieran la coreografía de un ballet; así la Consueta señala que "permanecen en pie" hasta la demediación del $1^{\text {er }}$ verso del Psalmo, o "acabado el psalmo se levantan", o "inclinan la cabeza al Gloria Patri", o se "hincan de rodillas".

\footnotetext{
${ }^{13}$ El Caeremoniale Episcoporum indica lo siguiente respecto al canto del verso Deus, in adjutorium meum: "Et pro unoquoque verbo tangit manu, primo frontem, deinde pectus, mox humerum sinistrum, ultimo dexterum, et in fine jungit manus ante pectus". Caeremoniale Episcoporum, libro II, cap. $1, \S 5$, p. 186. Frente a lo señalado en la Consueta, este movimiento constaría de cinco partes y coincidiría con cada una de las cinco palabras del verso.
} 
Igualmente el tempo musical viene marcado por las acciones, como indica la rúbrica siguiente

El compás del canto y del órgano sea de suerte que dé lugar a que todo el coro sea turificado, mas cuando no hay órgano la turificación cesa cuando se comienza a repetir la antífona que los turiferarios sueltan las cadenas de los turíbulos por la escalera ${ }^{14}$

En este "ballet" litúrgico, el que canta, o los que cantan, siempre ocupan una posición destacada: en el centro, de pie, al facistol, puestas las manos o portan el cetro. El canto es símbolo de poder, es el lenguaje que emplea la jerarquía para comunicarse con Dios.

La posición también tendría consecuencias acústicas: que el cantor se encuentre de pie ayuda a que se escuche mejor y facilita una mayor proyección de la voz. Por el contrario, los versos que se cantan de rodillas o con la cabeza inclinada, deberían proporcionar variaciones acústicas que apagarían un poco el volumen.

Las rúbricas aclaran la práctica interpretativa en cuanto a la elección de los tonos. En las Vísperas, el Hymno debía cantarse "en el mismo tono que la Capítula", lo que resulta bastante lógico si consideramos que van seguidos. Otra referencia en cuanto al tono la proporciona un término que se repite en la Consueta y que merece ser analizado detenidamente: "preintonar".

En un principio podría parecer un sinónimo de "entonar", pero en el contexto abacial significa "dar el tono al que entona". El término "preintonar" no aparece en ninguno de los diccionarios de español de la época (ni en el actual), probablemente porque estaba tomado directamente del latín "preintonare" que aparece en algunas Consuetas y ceremoniales. ${ }^{15}$ Tuvo que ser una palabra relativamente común en el entorno del canto llano. Dos ejemplos encontrados fuera de la Abadía parecen reforzar este uso común de la palabra y su significado. Prueba de su fortuna es la aparición aún en la actualidad de esa palabra en un libro dedicado a la práctica de la música

\footnotetext{
${ }^{14}$ Consueta, fol. $235^{\mathrm{v}}$.

${ }^{15}$ Véase los Estatutos de 1531 de la Catedral de Sant'Ambrogio en Vigevano: "statuimos et ordinamus: quod cantor habeat locum et vocem imediate post Decanum in capitulo (...) et habeat intonare introitum misse: gradualia: offerenda: antiphonas et omnia que preintonare solent ab aliis in missa"; citados por Christine Getz, "The Sforza restoration and the founding of the ducal chapels at Santa Maria della Scala in Milan and Sant'Ambrogio in Vigevano", Early Music History, 17 (1998), p. 157.
} 
instrumental y el canto en la liturgia. Hablando de las cualidades que debe tener un buen organista se reseña "deberá dar el tono justo, saber transportar un canto según las posibilidades del coro o del solista, conocer el manejo de la registración, decidir si hace falta o no preintonar un canto". 16

La costumbre de la preintonación se seguía practicando a principios del siglo XIX, tal y como recoge la visita del obispo Folgueras a la Iglesia matriz de La Palma (1830-1832):

Tenía lugar durante la celebración de la misa, y consistía en adelantarse de unos hombres vestidos con capas desde el coro hasta el altar mayor para "preintonar" el canto del gloria al celebrante, quien se volvía de espaldas al tabernáculo para recibir la "preintonación".

El obispo encontró esta costumbre de la "preintonación" desacertada y la prohibió en todas las Iglesias de la Isla. ${ }^{17}$

La preintonación obedecería a una cuesión de orden práctico. Los que preintonan suelen ser los más formados musicalmente, con lo que darían el tono adecuado, para evitar que el celebrante comenzara o muy agudo o demasiado grave.

En la siguiente Tabla se encuentra el esquema del oficio de Vísperas con las rúbricas que proporciona la Consueta, estableciendo con notas a pie de página las oportunas correspondencias con el Caeremoniale.

\footnotetext{
${ }^{16}$ La cursiva es mía. P. Tena y otros, Música instrumental y canto (Barcelona, Centre de Pastoral Litúrgica, 1994) p. 71.

${ }^{17}$ Citado por Víctor J. Hernández Correa, "Rodríguez López y el género chico: entre la tradición y la modernidad", Cartas diferentes. Revista canaria de patrimonio documental, 2 (2006), p.132.
} 
Tabla V.1. Esquema de la hora de Vísperas según el Caeremoniale Romano y la Consueta de la Abadía del Sacromonte.

\begin{tabular}{|c|c|}
\hline \multicolumn{2}{|c|}{ OFICIO DE VÍSPERAS } \\
\hline $\begin{array}{l}\text { Incipit } \\
\text { Pater noster, }\end{array}$ & Celebrante lo dice en secreto \\
\hline $\begin{array}{l}\text { Ave maría } \\
V . \text { Deus }\end{array}$ & Lo entona el celebrante mientras se persigna \\
\hline $\begin{array}{l}R \text {. Domine, ad adjuvandum me festina. } \\
V \text {. Gloria Patri, et Filio, et Spiritui Sancto. } \\
R \text {. Sicut erat in principio, et nunc, et } \\
\text { semper, et in saecula saeculorum. Amen } \\
\text { Alleluia }\end{array}$ & Todos inclinan la cabeza profundamente ${ }^{18}$ \\
\hline \multicolumn{2}{|c|}{$\begin{array}{l}\text { Acabado el } A \text { Alleluia el sochantre hace comedimiento al Capero más antiguo del coro de la semana, éste } \\
\text { le hace venia al celebrante que le corresponde y le entona la antífona. } \\
\text { Permanecen todos en pie hasta la demediación del primer verso del Psalmo, los comitantes alzan el } \\
\text { pluvial del celebrante que se cubre y se sienta. Los cetreros dan los bonetes y toman los cetros haciendo } \\
\text { venia, los caperos se sientan y cubren, el coro de prebendados se sienta también. }{ }^{19}\end{array}$} \\
\hline $\begin{array}{l}\text { Psalmi } \\
\text { Ant. (1) }\end{array}$ & $\begin{array}{l}\text { La antífona se canta entera si es doble, si es fiesta } \\
\text { semidoble sólo el principio. }\end{array}$ \\
\hline $\begin{array}{l}\text { Psalmus } \\
V \text {. Gloria Patri, et Filio, et Spiritui Sancto. } \\
R \text {. Sicut erat in principio, et nunc, et } \\
\text { semper, et in saecula saeculorum. Amen }\end{array}$ & $\begin{array}{l}\text { Capellanes cantores con el Sochantre entonan el psalmo y } \\
\text { a la mediación hazen comedimiento al coro de la semana y } \\
\text { se lo encomiendan, y se van a sentar. } \\
\text { Acabado el psalmo se levantan capellanes cantores y } \\
\text { sochantre, se llegan al facistol a cantar la antífona, y si es } \\
\text { doble, al fin de la primera que se repite van a la silla del } \\
\text { más digno prebendado y le hazen comedimiento y el } \\
\text { prebendado aunque sea el Abad se quita el bonete y les } \\
\text { baja la cabeza. }\end{array}$ \\
\hline \multicolumn{2}{|c|}{$\begin{array}{l}\text { Acabada la primera antífona le preintonan (capellanes cantores y sochantre) el principio de la segunda al } \\
\text { Abad. El Prebendado en respondiendo a la cortesía que le hacen los capellanes cantores cuando le } \\
\text { preintonan la antífona se levanta y echa las mangas e igualmente se levantan todos los prebendados y } \\
\text { echan las mangas y entonando la antífona se sientan. }\end{array}$} \\
\hline $\begin{array}{l}\text { Ant. (2) } \\
\text { Psalmus } \\
V \text {. Gloria Patri, et Filio, et Spiritui Sancto. } \\
R \text {. Sicut erat in principio, et nunc, et } \\
\text { semper, et in saecula saeculorum. } \\
\text { Amen } \\
\text { Ant. (2) }\end{array}$ & $\begin{array}{l}\text { Abad la entona. } \\
\text { Cuando los psalmos se dicen a versos con el órgano, el } \\
\text { verso que al órgano toca lo dicen los caperos con voz } \\
\text { inteligible, "no recio". }\end{array}$ \\
\hline \multicolumn{2}{|c|}{$\begin{array}{l}\text { La primera antífona siempre entona el celebrante por el coro de la semana, la segunda entona el Abad } \\
\text { por el otro Coro aunque no sea el suyo, mas los otros prebendados entonan las antífonas alternativamente } \\
\text { cada uno por su coro y aunque comienzan de los mas antiguos no se guarda el orden de la antigüedad } \\
\text { sino de los coros de suerte que la segunda antífona la dice el Prebendado del coro y así van sucediendo } \\
\text { excepto que la segunda dice siempre el Abad si está en su silla, por el coro que no es de la semana, la } \\
\text { primera antífona y primer psalmo es del coro de la semana, el segundo del otro y asi alternativamente se } \\
\text { prosiguen las antífonas y psalmos, si es semidoble la primera antífona entona como se ha dicho el } \\
\text { celebrante, y las otras entonan por el orden referido los capellanes y colegiales comenzando del más } \\
\text { digno. }\end{array}$} \\
\hline
\end{tabular}

${ }^{18}$ Correspondencia con Caeremoniale Episcoporum, libro II, cap. $1, \S 5$ y $§ 6$, p. 186. Este punto coincide exactamente con las rúbricas de la Consueta.

${ }^{19}$ Correspondencia con Caeremoniale Episcoporum, libro II, cap. 1,§7, p. 187. 


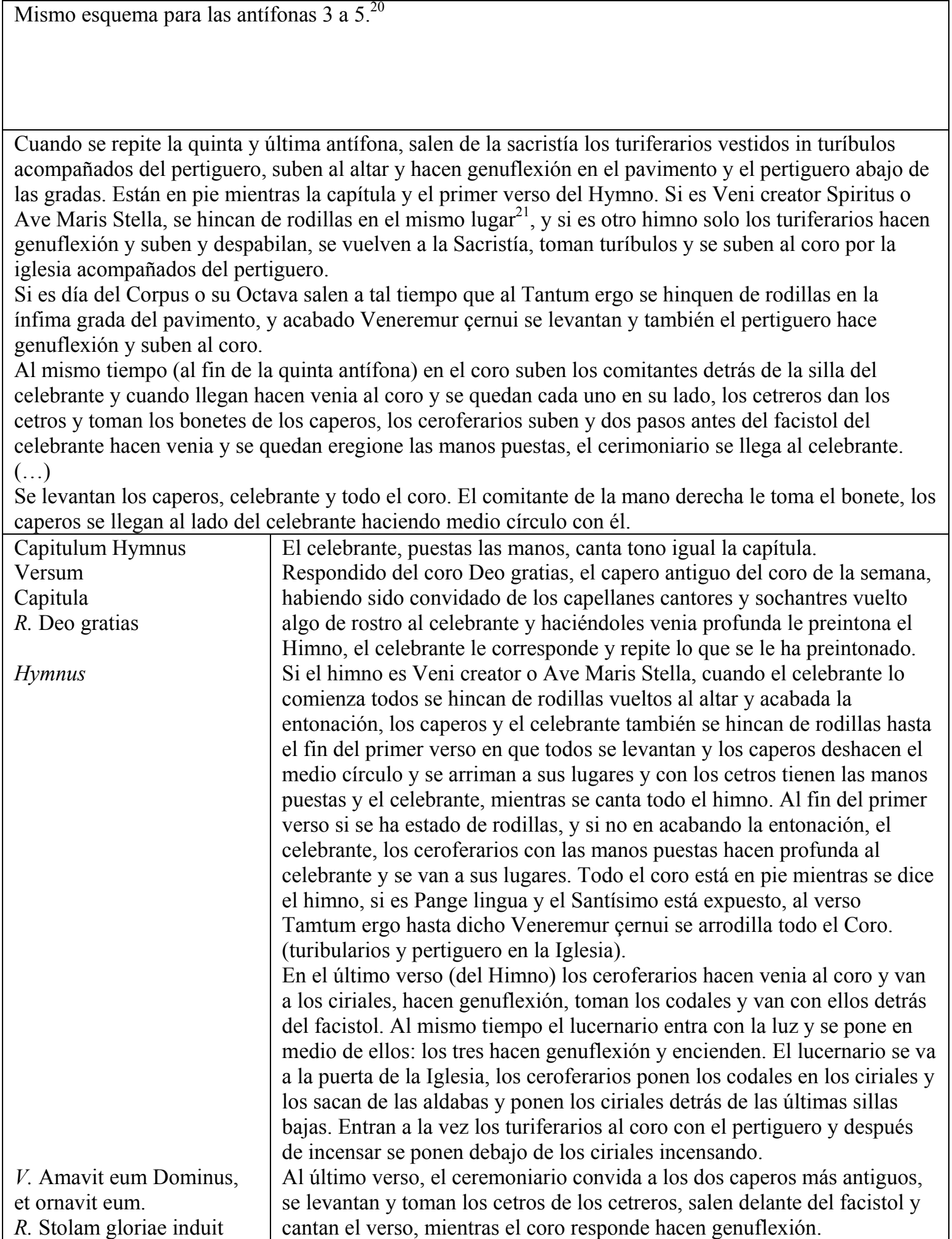

\footnotetext{
${ }^{20}$ Caeremoniale Episcoporum, libro II, cap. 1,§7-11, pp. 186-188. La Consueta es algo más prolija en la descripción de los movimientos y las acciones que tienen lugar durante esta sección.

21 "Si vero fuerint Hymni Veni Creator Spiritus, aut Ave Maris Stella, dum Episcopus intonat, omnes genuflectunt, et statim ipse quoque Episcopus ibi in suo genuflexorio ante altare, si adest, genuflectit; sin minus, in sua ipsa sede super aliquo pulvino, ad id parato, permanens in genuflexione usque ad finem primi versus" Caeremoniale Episcoporum, libro II, cap. 1,§12, p. 189.
} 


\begin{tabular}{|c|c|c|}
\hline eum. & & \\
\hline $\begin{array}{l}\text { Canticum beatae Mariae } \\
\text { Virginis Lucas 1:46-55 } \\
46 \text { Magnificat I anima } \\
\text { mea Dominum: } \\
47 \text { Et exsultavit spiritus } \\
\text { meus in Deo, salutari meo. } \\
48 \text { Quia respexit } \\
\text { humilitatem ancillae suae: } \\
\text { ecce enim, ex hoc beatam } \\
\text { me dicent omnes } \\
\text { generationes. } \\
49 \text { Quia fecit mihi magna } \\
\text { qui potens est: et sanctum } \\
\text { nomen ejus. } \\
50 \text { Et misericordia ejus a } \\
\text { progenie in progenies } \\
\text { timentibus eum. } \\
51 \text { Fecit potentiam in } \\
\text { brachio suo: dispersit } \\
\text { superbos mente cordis sui. } \\
52 \text { Deposuit potentes de } \\
\text { sede, et exaltavit humiles. } \\
53 \text { Esurientes implevit } \\
\text { bonis: et divites dimisit } \\
\text { inanes. } \\
54 \text { Suscepit Israel, puerum } \\
\text { suum, recordatus } \\
\text { misericordiae suae. } \\
55 \text { Sicut locutus est ad } \\
\text { patres nostros, Abraham, et } \\
\text { semini ejus in saecula. } \\
V \text {. Gloria Patri, et Filio, et } \\
\text { Spiritui Sancto. } \\
R \text {. Sicut erat in principio, et } \\
\text { nunc, et semper, et in } \\
\text { saecula saeculorum. Amen }\end{array}$ & $\begin{array}{l}\text { El capero del coro de la semana hace profunda } \\
\text { al celebrante y le preintona la antífona del } \\
\text { Magnificat. Acabada la repetición del } \\
\text { celebrante, le alzan el pluvial los comitantes. } \\
\text { Si es dia que hay órgano, se sienta. Al fin de la } \\
\text { antífona el cerimoniario convida a los primeros } \\
\text { caperos y como antes van delante del facistol, } \\
\text { entonan el Magnificat y vuelven con venia, } \\
\text { encomendándolo al coro de la semana. } \\
\text { Cuando comienzan a entonar el magnificat, el } \\
\text { celebrante se levanta y da el bonete al } \\
\text { comitante diestro, todos los prebendados se } \\
\text { levantan y ponen las manos y así están } \\
\text { mientras se canta toda. } \\
\\
\text { Despedido el celebrante al último verso del } \\
\text { hymno, el sochantre convida a los caperos que } \\
\text { digan el verso y dicho, el sochantre convida al } \\
\text { que preside que preintone la antífona y } \\
\text { entonada si es doble se van a sentar y si es } \\
\text { semidoble, sin apartarse entona el magnificat y } \\
\text { lo encomienda como se dijo supra. Si es } \\
\text { semidoble y el celebrante no ha salido del coro } \\
\text { en cantando los caperos el verso, en el mismo } \\
\text { lugar se ponen ambos eregione, y el de la } \\
\text { semana hace venia desde allí y preintona la } \\
\text { antífona al presidente. } \\
\text { Hecha la venia al coro, el celebrante con todos } \\
\text { los ministros que salen en ceremonia hace } \\
\text { genuflexión entre la varandilla y el facistol por } \\
\text { el mismo orden que la hicieron al entrar, van } \\
\text { descubiertos por todo el coro y el celebrante } \\
\text { cerimoniario y comitantes las manos puestas, } \\
\text { en saliendo del coro da el comitante el bonete } \\
\text { al celebrante y se cubre [acorto movimientos } \\
\text { fol.231v] bajan a la iglesia, turifican y } \\
\text { vuelven diciendo el Magnificat a versos los dos } \\
\text { coros comenzando el celebrante con los del } \\
\text { coro de la semana saliendo al Claustro vuelve } \\
\text { el bonete, el celebrante y cúbrese [siguen más } \\
\text { movimientos] } \\
\text { Turificación: el compás del canto y del organo } \\
\text { sea de suerte que dé lugar a que todo el coro } \\
\text { sea turificado.3. }\end{array}$ & $\begin{array}{l}\text { Si es día que no hay } \\
\text { órgano, el celebrante no } \\
\text { aguarda a entonar la } \\
\text { antífona del magnificat, } \\
\text { sino que después del } \\
\text { primer verso del hymno } \\
\text { se despide del coro y } \\
\text { sale de suerte que entre } \\
\text { en la iglesia cuando se } \\
\text { comience el Magnificat. }\end{array}$ \\
\hline
\end{tabular}

${ }^{22}$ Caeremoniale Episcoporum, libro II, cap. $1, \S 14$.

${ }^{23}$ El Caeremoniale Episcoporum, libro II, cap. 1,§16, p.191, indica que: "Quod si interim, expleto Cantico, Episcopus inciperet Versiculum Dominus vobiscum, pro Oratione dicenda, debet cessare thurificatio: animadvertendum tamen, ut cantus Magnificat ita protrahantur, ut et thurificatio simul terminetur". 


\begin{tabular}{|c|c|c|c|}
\hline \multirow[b]{2}{*}{ 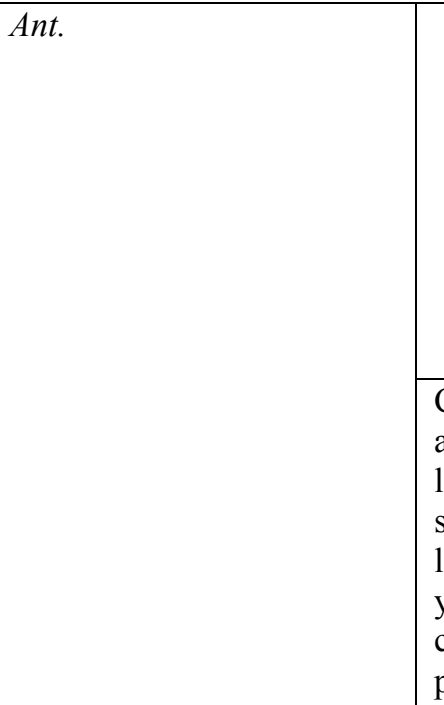 } & & & $\begin{array}{l}\text { la turificación cesa } \\
\text { cuando se comienza a } \\
\text { repetir la antífona. }\end{array}$ \\
\hline & \multicolumn{3}{|c|}{$\begin{array}{l}\text { Cuando se comienza a repetir la antífona los comitantes suben y el } \\
\text { antiguo da el bonete y levantan el pluvial al celebrante, los cetreros dan a } \\
\text { los caperos y toman los cetros y al hacer esto todos hacen venia y se } \\
\text { sientan celebrante, caperos y prebendados. Al final de la antífona levantan } \\
\text { los ceroferarios los ciriales y se llegan al facistol del celebrante a un lado } \\
\text { y otro y al llegar hacen reverencia y a este mismo tiempo se levanta el } \\
\text { celebrante y caperos, dejando los bonetes y recibiendo los cetros y se } \\
\text { ponen a los lados del celebrante que hacen un medio círculo. }\end{array}$} \\
\hline \multicolumn{2}{|c|}{$\begin{array}{l}\text { Oratio } \\
V \text {. Domine exaudi orationem meam } \\
R \text {. Et clamor meus ad te veniat } \\
\text { Oremus } \\
\text { R. Amen. } \\
V \text {. Domine exaudi orationem meam } \\
R \text {. Et clamor meus ad te veniat }\end{array}$} & \multicolumn{2}{|c|}{$\begin{array}{l}\text { Acabada la antífona, el celebrante puestas las manos canta } \\
\text { Dominus vobiscum, y respondido canta oremus y la oración, a la } \\
\text { conclusión bajan los ciriales y si hay otras oraciones, dichas las } \\
\text { antífonas, los últimos caperos bajan convidados del ceremoniario } \\
\text { a decir los versos de ellas. } \\
\text { No hacen genuflexión hasta dicho el Benedicamus. }\end{array}$} \\
\hline $\begin{array}{l}\text { Conclusio } \\
V \text {. Benedicamus Domino. } \\
R \text {. Deo gratias } \\
V \text {. Et fidelium animae per } \\
\text { misericordiam Dei requiescant in } \\
\text { pace. } \\
R \text {. Amen. }\end{array}$ & $\begin{array}{l}\text { sicut } \\
\text { m: } \\
\text { la }\end{array}$ & $\begin{array}{l}\text { Dicho por el celebrante "fidelium } \\
\text { animae" se baja con los otros caperos } \\
\text { que dan los cetros y toman los bonetes, } \\
\text { y con los comitantes que se bajan } \\
\text { detrás de los caperos que dijeron el } \\
\text { benedicamus . } \\
\text { Si después de Vísperas no hay } \\
\text { completas, se ha de salir del coro dicho } \\
\text { por el celebrante "Fidelium animae" } \\
\text { puestas las manos todos los del coro } \\
\text { excepto los ceroferarios. Dicen todos } \\
\text { secreto Pater Noster, y el celebrante } \\
\text { Dominus det nobis sua paçem. Y se } \\
\text { hincan todos de rodillas excepto los } \\
\text { ceroferarios y dicen en tono la antífona } \\
\text { de nuestra señora. Y dicha el celebrante } \\
\text { se levanta y dice el verso y oración, y } \\
\text { respondido Amen, el Divimun } \\
\text { auxilium, el que preside hace señal y se } \\
\text { levantan todos. }\end{array}$ & $\begin{array}{l}\text { Si hay órgano, cuando } \\
\text { el coro ha respondido } \\
\text { Deo Gratias, salen los } \\
\text { turiferarios con } \\
\text { sobrepellices de la } \\
\text { capilla de los mártires. } \\
\text { [etc] puntos } 33 \text { y ss. }\end{array}$ \\
\hline
\end{tabular}

${ }^{24}$ La Antífona de Nuestra Señora no aparece en el ceremonial romano tridentino. 
En relación con las rúbricas referidas a la práctica alternatim, en este caso con el órgano y el coro, la Consueta nos añade un detalle sugerente para la interpretación que si bien parece obedecer a la práctica propia de la Abadía, podría ser común a otros centros. "Quando los psalmos se dizen a versos con el organo, el verso que al organo toca lo dizen los caperos, no reçio mas en boz inteligible" ${ }^{25}$. Es decir que al mismo tiempo que el órgano tocaba, los caperos debían decir el verso correspondiente, probablemente no cantándolo sino recitándolo. El adjetivo "reçio" significa en este contexto "con volumen alto", tal y como sugiere Covarrubias cuando indica que "Hablar reçio" es sinónimo de "hablar alto". ${ }^{26}$ Algo parecido a la expresión "decir en tono" que aparece con frecuencia en la Consueta y que en esta ceremonia también se aplica a la antífona de nuestra señora que se dice al final del oficio. ${ }^{27}$

\footnotetext{
${ }^{25}$ Consueta, fol. $227^{\mathrm{v}}$.

${ }^{26}$ Covarrubias, Tesoro de la lengua castellana, p. 852.

${ }^{27}$ Consueta, fol. $237^{\mathrm{r}}$.
} 


\section{La Música en la Fiesta de San Cecilio, patrón de Granada.}

En el Capítulo II he señalado la importancia de San Cecilio en la creación de la Abadía y su adopción como patrón de Granada desde el momento en el que se descubrieron sus supuestas reliquias en las Cuevas del Sacromonte. En este epígrafe me centraré en las diferentes fiestas y celebraciones que festejaron con música a este Santo, desde el momento del reconocimiento de las reliquias en el Sínodo de 1600 hasta el siglo XIX, y a la música que se conserva compuesta para conmemorar a San Cecilio.

\subsection{Los orígenes de la fiesta de San Cecilio: 1600}

\subsubsection{La música durante la celebración del Sínodo para la calificación de las Reliquias}

Las primeras celebraciones más significativas coincidieron con la calificación de las reliquias de San Cecilio por el Sínodo Provincial convocado a tal efecto por el arzobispo Pedro de Castro en 1600. A dicho Sínodo se emplazó a las principales autoridades eclesiásticas de España, entre las que se encontraban el obispo de Santiago, el Abad de Alcalá la Real y numerosas legaciones de otros prelados y autoridades civiles, como la enviada por Felipe III. Todo el fervor religioso estuvo acompañado de música en las diferentes funciones religiosas que se celebraron en 1600, y así lo describió Bermúdez de Pedraza:

Domingo nueve de abril de este año de mil y seiscientos, mandó el Arzobispo publicar por las parroquias y monesterios la calificación para los deziseis de Abril; exortando á la ciudad ayunasse tres días de la primera, o segunda semana siguiente, oyendo en el jueves de cada una dellas la Missa mayor del Espíritu Santo, que se cantaría descubierto el Santísimo Sacramento del altar en sus parroquias, (...) También se hizieron muchas devociones publicas, y secretas (...) El lunes siguiente diez de Abril se començó en la Iglesia Catedral un solene nevenario de Missas de nuestra Señora, con asistencia del Arzobispo, y toda la ciudad. En fin de cada Missa se hizo procesión por el círculo de la capilla mayor, cantando la musica la ledania, y una antífona y rogativa en la capilla de nuestra Señora de la Antigua, devotísima imagen de talla, trayda por los Reyes católicos a esta ciudad. La solemnidad y el servicio de las Missas; el concurso y 
devoción de la gente fue tanta, que cualquiera quedara corta en descrevirla. ${ }^{28}$

Las reuniones del Sínodo tuvieron lugar entre el 16 y el 30 de Abril de 1600 y durante esos días se celebraron funciones religiosas y procesiones:

El Domingo siguiente deziseis de Abril celebró de Pontifical [en la Catedral] el Arçobispo de Granada, presentes los Obispos de Galipuli, Guadix, y Abad de Alcalá la Real. Todos tres sentados en el teatro del altar mayor en sillas con sitiales de terciopelo carmesí. (...) La Missa fue del Espíritu santo, y el sermón de aquellas palabras de San Mateo (...) El Martes siguiente deziocho de Abril, huvo una general procesión de la iglesia catredal a san Cecilio. ${ }^{29}$

El miércoles 19 de abril se dijo la última de las misas de Nuestra Señora, y se comenzó el proceso de la calificación de las Reliquias. Justino Antolínez, atento cronista del evento reseña todas las oraciones y las intervenciones del coro y la música:

Después de dada la paz, tomó el arçobispo amito, manípulo, estola, capa y mitra; y acabada la missa, començó el coro una antíphona, y dixeron el psalmo "Salvum me fac, Deus", estando el arçobispo y assistentes de rodillas. Acabado el psalmo y repetida la antíphona, se levantó y, quitada la mitra, dixo dos oraciones (...) Dichas estas oraciones, se començó la letanía y processión al altar de nuestra Señora de la Antigua, donde se cantó un motete y el preste dixo las tres oraciones acostumbradas.

Volvió la processión al altar mayor, púsose el prelado de rodillas y, en acavando los cantores de dezir en la litanía el verso "Ut obsequium servitutis nostrae", que está en el pontifical, se levantó; y, buelto al pueblo, con el báculo en la siniestra, echó la bendición y dixo: Ut hanc presentem synodum visitare, disponere et benedicere digneris. Resp: te rrogamos, audi nos.

Volviose a poner de rodillas, y prosiguieron la litanía hasta el fin. Sentóse luego en una silla arrimada al altar y dio la bendición al diácono, que cantó el Evangelio que comiença "In illo tempore, convocatis Iesus duodecim Appostolis, dedit illis virtutem et potestatem super omnia demonia". Acabado el evangelio se levantó en

\footnotetext{
${ }^{28}$ Bermúdez de Pedraza, Antiguedades y excelencias de Granada (Madrid: 1608), fol. 174 . Bermúdez de Pedraza no asistió personalmente a la Junta de Calificación, pero sí que pudo hacerlo a los festejos y celebraciones.

${ }^{29}$ Bermúdez de Pedraza, Antiguedades, fol.174 $-175^{\mathrm{r}}$.
} 
pie y entonó el hymno "Veni creator". Prosiguió la música y, acabado el hymno, dixo el prelado la oración que comiença "Mentibus nostri" ${ }^{30}$

Aunque se presentaron tesis en contra, las reliquias fueron autentificadas. Tras la última sesión el viernes 28 de abril repicaron todas las campanas de la ciudad. Al día siguiente, sábado 29 de Abril, "Por la mañana fue el Arçobispo a la iglesia mayor a dar gracias, donde huvo una solene procesión, cantando la musica un dulce Te Deum laudamus. "31

\subsubsection{Las fiestas por la aprobación de las reliquias}

La sentencia de aprobación de las reliquias se hizo pública el 30 de Abril de 1600 en la Catedral de Granada: ${ }^{32}$

Leyda la sentencia repicaron las campanas de la Santa Iglesia, y con ellas las de toda la ciudad. Tañeron los menetriles, tocó el organo, y el Alhambra disparó su artilleria. Acabado este ruido començó la musica otro mas suave; cantando un Te Deum laudamus, con tal destreza y harmonia, que no espero oir otro mejor: los cantorcillos vestidos de damasco carmesí, y blanco, hizieron un coloquio, entretexiendo con la musica chançonetas, y con ellas una bien ordenada dança, haziendoles la musica el son. ${ }^{33}$

Justino Antolínez lo cuenta así:

Leyda la sentencia, se hizo señal. Respondio la torre con las campanas, luego, las parrochias y conventos y la Alambra con la artillería. Todo era alegría y reguzijo: los músicos y ministriles cantaron y tañeron a versos el "Te Deum laudamus", los seises, bien adereçados y vestidos de tela de plata, hizieron el pabimento o presbiterio del altar una ensaladilla de música y representación en alabança de los sanctos. ${ }^{34}$

\footnotetext{
${ }^{30}$ Justino Antolínez de Burgos, Historia eclesiástica de Granada (Granada: Universidad de Granada, 1996), pp. 553-554.

${ }^{31}$ Bermúdez de Pedraza, Antiguedades, fol. $176^{\mathrm{V}}$. Antolínez comenta esta ceremonia especificando que “Cantose solemníssimamente el "Te Deum laudamus”, Historia Eclesiástica, p. 563.

${ }^{32}$ Para el Proceso de calificación de las reliquias, véase Justino Antolinez, Historia eclesiástica, p. 545 y ss. Antolinez sí asistió personalmente al evento por lo que recoge con detalle los asistentes, las reuniones y los textos de aprobación.

${ }^{33}$ Bermúdez de Pedraza, Antigüedades y excelencias de Granada, fols. $179^{\mathrm{v}}-180^{\mathrm{r}}$.

${ }^{34}$ Antolínez, Historia eclesiástica, p. 569.
} 
El texto de la ensaladilla mencionada por Antolínez fue compuesto por un tal Ortega, beneficiado del coro de la Catedral como reflejan las Actas Capitulares de la misma:

Se acordó se den a Ortega, beneficiado que reside en el coro, doscientos reales por el trabajo de tres chançonetas que ha compuesto para tres festividades pasadas y para la ensaladilla que hizo para las calificaciones [de las reliquias del Sacromonte] comunicado con su señoría le pareció que hasta que se haya dado orden de redimir dos mil ducados no hay que hablar de ello. ${ }^{35}$

La música de esta ensaladilla seguramente la compuso Luis de Aranda, ${ }^{36}$ Maestro de Capilla de la Catedral, aunque la partitura no se conserva.

\subsubsection{La fiesta en la Plaza de Bib-Rambla}

Aunque algunos autores señalan la utilización de la plaza de Bib-Rambla como espacio de festejo y reunión de los musulmanes, "como espacio público es un producto cristiano "37 que asume las funciones de las plazas mayores en Castilla: fiestas reales, autos de fe, ejecuciones públicas, recibimiento de obispos y otros festejos públicos. Durante los primeros años tras la Reconquista se decidió ampliar este espacio (1516-

35 A.C.C.G., 16-6-1600, t.9, fol. 247․ Citado en Pilar Ramos, La música en la Catedral de Granada (Granada: Diputación Provincial de Granada, 1994), p. 106. La autora recoge un acta anterior donde se señala que el Maestro de Capilla pone en música lo compuesto por Ortega.

${ }^{36}$ Luis de Aranda († Granada, ca. 24-IV-1627), fue niño de coro y Maestro de Capilla de la Catedral de Granada. Tras la muerte de Jerónimo de Aliseda, y después de superar una dura oposición (de la que se conserva el programa), tomó posesión de su plaza el 21 de Abril de 1592, y en ella permaneció hasta su muerte. Se conserva un memorial de defensa autógrafo en el que se pueden observar sus opiniones estéticas sobre la música. La mayor parte de sus obras se ha perdido, y las que se conservan son de una gran belleza, en opinión de López Calo. Las obras conservadas son: Cogitavit Dominus, Lamentación, 4V, E:GRcr; Domine, ne in furore tuo, Motete, 4V, E:GRcr; In omnem terram, Motete, 4V, E:GRc; Laboravi in gemitu meo, Motete, 4V, E:GRc; Regina caeli, 4V, E:GRc; Salus populi ego sum, Motete, 5V, E:GRcr. Véase López-Calo, "Luis de Aranda", DMEH, vol.I, p. 555-556.

${ }^{37}$ M a José Martínez Justicia, "Lo Barroco en la Historia de la Plaza de Bibarrambla: Funciones y Formas", en Actas del Coloquio de Urbanismo Barroco, Archidona II Centenario de la Plaza Ochavada 1786-1986, coord. MåDolores Aguilar García (Málaga: Universidad de Málaga, 1989) p. 249. 
1519) y desde 1526, año en que Navaggiero visita Granada, tenemos constancia de la celebración de actividades festivas. Tampoco ha de olvidarse que era paso obligado de la procesión del Corpus (al menos desde 1501). Ejemplo de que era un lugar empleado con frecuencia para los actos públicos es la construcción por parte del Ayuntamiento de la Casa de los Miradores (proyecto de Diego de Siloe de 1540) aún en construcción en 1566, y desde la que las autoridades civiles y en ocasiones las religiosas contemplaban los espectáculos. No se conservan relaciones de sucesos y fiestas durante estos años, por ello es muy importante esta descripción en el proyecto de Siloé, pues es la primera tan detallada. Para conocer la estructura y situación de la Plaza, ningún documento mejor que la Plataforma de Ambrosio de Vico dibujada por éste en 1597 y grabada entre 1609 y 1613 por Francisco Heylan y el testimonio de Lucio Marineo Sículo. ${ }^{38}$ La plaza es de planta rectangular, al suroeste seguía la línea de la muralla y una de sus puertas era el Arco de las Cucharas.

Al menos tres cronistas recogen las celebraciones que la ciudad organizó en la Plaza de Bib-Rambla la tarde del 30 de Abril de 1600: Justino Antolínez y Bermúdez de Pedraza son coetáneos al hecho y fueron testigos presenciales. Sin embargo, el relato más completo es el que proporciona Heredia Barnuevo, pero su obra, aunque basada en un testigo ocular, se publicó en $1741{ }^{39}$ En la descripción de la celebración concurren la arquitectura efímera, la representación, los fuegos de artificio, y por supuesto la música, elementos necesarios en la fiesta barroca. ${ }^{40}$ Heredia Barnuevo es el que mejor describe la construcción efímera situada en el centro de la plaza: un castillo, dividido en tres cuerpos en cuyas fachadas aparecían lienzos con pinturas alusivas a la vida de San Cecilio y sus compañeros mártires, acompañadas de cartelas con textos tomados de la Biblia. En más de 30.000 cifra Barnuevo el número de asistentes que presenciaron la fiesta en una iluminada plaza, "tan clara como si fuera de día". La representación dio

\footnotetext{
${ }^{38}$ Martínez Justicia, "Lo Barroco en la Historia de la Plaza de Bibarrambla”, pp. 249-272.

${ }^{39}$ Heredia Barnuevo, Místico Ramillete, p. 87. Para su relato cita entre otras fuentes a Francisco Núñez Pérez, prior del convento de San Agustín de Granada, que participó en el Sínodo para la calificación de las reliquias. Núñez dejó una historia manuscrita del descubrimiento de las reliquias que no he podido localizar.

${ }^{40}$ Para un acertado análisis del significado simbólico de los personajes y hechos de la fiesta, véase Pilar Ramos, La Música en la Catedral de Granada, p.37; la autora sólo cita la descripción de Bermúdez de Pedraza.
} 
comienzo la tarde del 30 de abril de 1600, con la entrada de una galera por una esquina de la plaza que

con una efigie de bulto de San Cecilio (....) dio vuelta espaciosamente a la plaza, suspendiendo su numeroso concurso con la música de sus clarines, chirimías y otros instrumentos, que dulcemente en ella resonaban. Fue en esta forma arrimándose al soberbio castillo, y de repente conmutó los acentos armoniosos en marciales ecos, resonando las cajas, timbales y clarines a combate, y disparando la gruesa artillería que llevaba. ${ }^{41}$

Antolínez completa la misma escena con la siguiente descripción:

apareció y entró por la Puerta de las Orejas tocando trompetas, sacabuches y chirimías una gallarda galera con todas sus xarcias, másteles y velas (...) Venía en la popa un caballero armado (...) Desembarcó el caballero, y acercándose con gran denuedo al castillo, le salieron a impedir el passo dos monstruosos salvajes con dos maças de fuego (...). A este punto, se vio baxar por el ayre, volando con gran furia, un águila y, parando en lo alto del castillo, lo encendió con el fuego que venía echando por la boca (...) Disparó a este tiempo la Alhambra su artillería(...) con este ruido, reguzijo y alboroto se acabó la fiesta. ${ }^{42}$

Bermúdez concreta la situación de los músicos y el carácter de la música:

Entró en ella con gran ruydo de menestriles, trompetas, campanas y atabales una hermosa galera (...)y en la popa de ella iba el patrón de la nave, y nuestro San Cecilio, y en la camara de popa los menestriles, y musica cantando tan dulcemente que a (ser) tal, hizieran envidiosa la vida de la galera. ${ }^{43}$

La simbología de la representación no viene explicada en ninguna de las tres fuentes que narran esta fiesta. Pilar Ramos ofrece dos interpretaciones de la posible simbología: la dama es la virgen rescatada de entre la herejía representada por los salvajes y el dragón, por el capitán de una nave en la que viajaba San Cecilio. La otra es que la dama sea la ciudad de Granada, rescatada de la herejía islámica (el castillo, los

\footnotetext{
${ }^{41}$ Heredia Barnuevo, Mistico Ramillete, pp. 89-90.

${ }^{42}$ Antolinez, Historia eclesiástica, p. 571.

${ }^{43}$ Bermúdez, Antigüedades y excelencias., p. 181.
} 
salvajes y el dragón) por el capitán (el cristianismo, la religión de San Cecilio). En el rescate tiene un importante papel el águila (símbolo de los Reyes Católicos) ${ }^{44}$ y obviamente, de los Austrias reinantes.

La filiación de estos elementos se puede rastrear en las fiestas renacentistas y medievales. El tema del salvaje lo podemos encontrar en el arte desde el siglo XIV, y es frecuente en la novelas de caballería (como el Libro de Alexandre); de las narraciones caballerescas pasó como elemento decorativo a la arquitectura principalmente. Fiestas con salvajes se dieron también en el Renacimiento; Leonardo da Vinci dirigió fiestas con lacayos disfrazados de salvajes, y en Toledo también aparecen salvajes participando en danzas junto con los seises en la Catedral. ${ }^{45}$ El dragón y la dama tienen que ver con la leyenda de San Jorge, tan popular en la Edad Media y recogida por la Leyenda Dorada. Jorge salvó de las fauces del dragón a la hija del rey y domó a la criatura en nombre de Cristo, pero luego fue decapitado durante las persecuciones de Diocleciano. En las representaciones más antiguas aparece con la palma del martirio. ${ }^{46}$ Sin duda aquí, con la inclusión de San Cecilio, cobran un matiz diferente, pero siguen en la estela de la tradición pues al igual que San Jorge, Cecilio padeció el martirio en la época de un emperador romano (Nerón).

La fiesta continuó en los días sucesivos: el 1 y el 3 de Mayo se mostraron de nuevo las reliquias y "a la noche hizieron los caballeros una famosa máscara con luzidas y costosas libreas". ${ }^{47}$

\subsubsection{La primera misa en el Sacromonte}

El primer acto litúrgico público en el Sacromonte tuvo lugar antes de la construcción del santuario, y supuso el origen de la historia del culto a San Cecilio y sus compañeros mártires en la Abadía. Esta solemne celebración tuvo lugar el domingo 7 de mayo de 1600, cuando el Arzobispo don Pedro de Castro decidió celebrar la primera misa pontifical al aire libre en la cima del Monte Valparaíso, donde posteriormente se

\footnotetext{
${ }^{44}$ Pilar Ramos, La música en la catedral, p. 37.

${ }^{45}$ José Ma de Azcárate, "El tema iconográfico del salvaje”, Archivo Español de Arte, XXI (1948), pp. 81-99.

${ }^{46}$ Rosa Giorgi, Santos. Los Diccionarios del Arte (Barcelona: Electa, 2002), p. 181.

${ }^{47}$ Antolínez, Historia eclesiástica, p. 571.
} 
alzaría la Abadía. A dicha misa asistieron, además de las dignidades eclesiásticas y civiles de Granada y sus contornos, un numeroso público. Con esta solemne celebración gran parte de la ciudad debió acudir al Sacromonte, por lo que éste quedó confirmado como un espacio de culto oficial para la ciudad, legitimando así las numerosas procesiones y peregrinaciones que desde el descubrimiento de la reliquias se habían llevado a cabo por los fieles, cofradías y congregaciones religiosas de forma espontánea. Más de cuatrocientas cruces se habían colocado desde el descubrimiento de las reliquias, sin que las autoridades pudieran hacer nada para evitarlo. Una historia manuscrita que no se llegó a publicar de Pedro Velarde de Rivera, poeta y canónigo de la Iglesia Colegial del Salvador, narra así la colocación de las cruces y su acompañamiento musical:

\begin{abstract}
Y así los procuradores del Pirú y Nueva España que se hallaron en estas partes mostraron poderes bastantes de sus ciudades para señalar sitios en el sancto monte en nombre de sus Repúblicas para tener sus asientos y cruces en él, y otras muchas gentes, naciones y Pueblos, como thesoros de devoción maravillosa han enarbolado muchas devotas cruces soberanos estandartes, haciendo procesiones de mucha devoción acompañadas de cantores y ministriles y otros instrumentos de contento, danças y bailes, invenciones de todas maneras en señal de regocijo y alegrías espirituales que muchos devotos cristianos han hecho y se van continuando a los santos sepulchros. ${ }^{48}$
\end{abstract}

En el día de la primera misa en el Sacromonte después de la calificación de las reliquias, Antolínez y Barnuevo narran cómo sobre las cavernas del Monte Valparaíso se dispuso un altar y

Celebrose la missa con grande majestad, solemnidad de música y varios instrumentos; y, quando el prelado alçó el Sanctissimo Sacramento, hizo salva el Alambra con toda la artillería. Fue uno de los mas bellos y devotos spectáculos que a avido en el mundo ver a un mesmo tiempo más de cien mil personas de rodillas $(\ldots)^{49}$

\footnotetext{
${ }^{48}$ Pedro Velarde de Rivera, Historia Eclesiástica del Monte Santo ciudad y Reyno de Granada dirigida a la magestad del Rey don Phelipe nuestro señor tercero de este nombre (BNE, Mss. 1583), f. 19 $9^{\mathrm{r}}$. De Velarde sólo sabemos que fue canónigo del Salvador (lo que él nos dice en el título de su obra) y que pareció pertenecer o estaba cercano a la Academia de Don Pedro de Granada y Venegas (1600).

49 Antolinez, Historia eclesiástica, p. 573. El dato es algo exagerado si tenemos en cuenta que la población total de Granada en aquella época rondaba entre los 35.000 y los 40.000 habitantes. Ver: Antonio Luis Cortés Peña y Bernard Vincent, Historia de Granada, La época moderna siglos XVI-XVIII, Tomo III, (Granada, Don Quijote, 1986), p. 48.
} 
Las salvas de artillería son un elemento común en las celebraciones urbanas cuyo significado para las gentes de la época podemos intuir: al igual que el repique de campanas, el estruendo de las salvas comunicaría a varios kilómetros a la redonda que se estaba produciendo un hecho relevante para los ciudadanos. Con salvas de artillería se festejaban y anunciaban los nacimientos de los miembros de la familia real, las victorias en las batallas y con el tiempo esta costumbre fue adquiriendo el significado de regocijo. El mismo Velarde amplía el sentido de emplear la artillería:

$\mathrm{Y}$ a todas o las mas procesiones han acompañado escuadrones de soldados escopeteros exercitandose en la milicia disparando con orden y a sus tiempos su arcabucería haciendo sus salvas a muchas partes, templos y puestos de la ciudad manifestando la fee, y buen zelo que tienen en sus ennoblecidos ánimos de imitar tan valerosos, y primeros capitanes de nuestra sancta fee catholica, y Religión Christiana reconociendo lo mucho que ama Dios la vida de los justos que se exercitan de obras de virtud y charidad, y en demostración del bien y contento desto nos propone y canta nuestra sancta madre Iglesia $(\ldots)^{50}$

Siendo el Arzobispo el celebrante no es de extrañar que los músicos fueran los de la Catedral, como reseña Barnuevo:

Aquí asistieron el Real acuerdo con su Ilmo. Señor Presidente, la noble Ciudad con su ilustre Corregidor, Justicia y Regimiento; el Cabildo de la Sancta Metropolitana Iglesia, con el numeroso coro de Capellanes, Colegio y Capilla de Música. ${ }^{51}$

Bermúdez es más prolijo en su descripción:

El Domingo siguiente siete de Mayo celebró de Pontifical por primera Missa en el santo monte Ilipulitano, el Arçobispo de Granada. Estava fabricado en el un gran tabernáculo de madera de ciento y cicuenta pies en largo, y cincuenta en ancho; en tapizado de doseles carmesíes: el altar mayor venía a estar sobre las cavernas de los Santos: el coro con su facistor, organos y menestriles: ocupava hasta cincuenta pies: (...)la Missa fue de nuestra Señora del tiempo: y después della se vistieron de

\footnotetext{
${ }^{50}$ Velarde de Rivera, Historia Eclesiástica, fol.

${ }^{51}$ Heredia Barnuevo, Mistico ramillete, p. 91.
} 
Pontifical los tres Prelados, y adoraron juntos con el Arçobispo las santas reliquias, y después las dieron a adorar al pueblo, con gran ruydo de menestriles y artilleria: porque el Alambra traxo para este efeto a un monte frontero del santo la suya. Después de adoradas las reliquias por el pueblo las llevaron en procesión a la caverna de San Cecilio, donde las Dignidades, y Canónigos, cantaron el psalmo Laudate pueri Dominum: y la musica el antífona Benedicamus Patrem et Filium cum Spiritu Sancto, laudemus, et superexaltemus eum in secula, Alleluia. Y el Arçobispo dixo una oración con que encerraron las reliquias en un arca de hierro sobre un altar. La gente que huvo fue innumerable, que el menor tanteo fue de cien mil personas: la fiesta la mayor, y las mas solene que ha tenido esta ciudad. ${ }^{52}$

Esta última descripción no deja lugar a dudas sobre el papel destacado que en este tipo de celebraciones tenía la música ya que hasta se tomaron la molestia de fabricar un coro con su facistol y asientos, e incluso se detalla el nombre de las antífonas que se interpretaron, con lo que de haber conservado el Archivo musical de la Catedral todos los libros de polifonía, habría sido posible la reconstrucción del universo sonoro que rodeó a las gentes de Granada en aquel significativo día.

Las fiestas tanto religiosas como seculares duraron todo el mes de mayo. El Cabildo de la ciudad participó desde el principio en todos los actos y fiestas en honor a San Cecilio y compañeros mártires. ${ }^{53}$ Unos años después, debido a una epidemia de peste que asoló la ciudad, se ofreció una hermosa lámpara votiva de plata por parte del Cabildo de la ciudad a San Cecilio. Y de aquí surgió el compromiso por parte del Ayuntamiento, de subir a honrar al patrón todas los años en la víspera y en el día del Santo, "sin que en dos siglos y medio hayan destemplado su fervor las muchas nieves, ni apagado el fuego de su devoción las muchas aguas, ni retardado el cumplimiento de su voto la distancia y aspereza del camino". ${ }^{54}$ El Ayuntamiento participaba activamente en la organización de la fiesta en la Abadía como se tratará más adelante.

\footnotetext{
52 Bermúdez de Pedraza, Antigüedad y excelencias, fols. $181^{\mathrm{r}}-181^{\mathrm{v}}$

53 Henríquez de Jorquera, Anales, p. 255: "Celebránse grandes festividades y en particular en los días de sus mártires. Sube el cavildo y rejimiento de la ciudad con su correjidor el dia de San Cecilio a celebrar la fiesta y comen con los canónigos de la comunidad".

${ }^{54}$ Heredia Barnuevo, Místico Ramillete, p. 98.
} 


\subsection{El establecimiento de la Fiesta y su celebración en el Sacromonte, 1601.}

El primer documento oficial del que tenemos noticia que recoge el establecimiento de la festividad de San Cecilio como patrón de la "Santa Iglesia de esta Ciudad" es un acta capitular de la Catedral de 1601, año siguiente a la calificación de las reliquias:

Se acordó que el primero día de febrero que fue el dia que padeció martirio el Sr. S. Cecilio según ha aparecido por las láminas en el Monte Valparaíso que hoy se llama el Monte Santo se celebre su festividad con oficio doble de muchos mártires, se digan vísperas y misas de pontificial, haya procesión de capas y ofrenda y sermón y comunión y si su Señoría el Arzobispo de esta Santa Iglesia que es o fuere no celebrara este día pontificial por alguna causa en tal caso no habrá ofrenda y celebrará el Deán y en su ausencia la mayor dignidad después de él. Los maitines se dirán según y como se dicen los de Santiago que se pongan luminarias la noche antes en el cimborrio y torre de esta Sant Iglesia y donde más se suelen poner y que se repiquen las campanas y se tañan chirimías en el dicho cimborrio y torre y haya cohetes etc. esto todo después de Laudes como el día de San Pedro y las segundas vísperas se digan todas de la purificación y que para las primeras y fiesta de dicho Sr. S. Cecilio se quiten las capas negras los prebendados $\mathrm{y}$ finalmente se celebren con toda la solemnidad posible y debida como a Patrón de esta Santa Iglesia comunicado con su Señoría le pareció todo se haga así y se mandó llamar a cabildo para el sábado 3 de febrero para prever y determinar todo lo que contiene acerca de esto y para confirmar lo que este día se hubiere determinado. ${ }^{55}$

Otro documento que confirma el patronazgo de San Cecilio sobre Granada data de 1646. Es el "Decreto para que se guarde dia de fiesta el de San Zezilio obispo Patrón de Granada. Siendo Arzobispo en ella D. Martín Carrillo y Alderete. Año de 1646". ${ }^{56}$ El hecho de que Don Pedro de Castro no hubiera declarado fiesta de guardar este día se debió, según Bermúdez de Pedraza, a que era contrario a la multiplicación de las fiestas porque producían "daño a las almas, y perjuizio de los trabajadores, mucha libertad en los vicios, y poca veneración de los santos". 57

\footnotetext{
${ }^{55}$ Actas Capitulares de la Catedral de Granada (30-1-1601), t. 9, f. $264^{\mathrm{r}}$. Citado por Pilar Ramos, La Música en la Catedral de Granada, p. 35.

${ }^{56}$ Véase la transcripción de este documento en el Apéndice 6.

${ }^{57}$ Bermúdez de Pedraza, Místico Ramillete, p. 102.
} 
Para nuestro estudio el documento más relevante sobre la celebración de la festividad de San Cecilio, es la propia Consueta sacromontana. Hay que tener en cuenta que cuando se finaliza de redactar la Consueta en 1632, la fiesta llevaba celebrándose más de treinta años, con lo que más que regular una fiesta ex novo, recoge ya una tradición consolidada. En el Libro IV se encuentra el capítulo 5, titulado: del officio y festividad en el día de Nuestro Glorioso Patrón San Cecilio. Nos informa de la liturgia que se ha de seguir ese día que es la de Comun Plurimorum martyrum ut in breviario ${ }^{58}$ excepto la oración que es la que se encuentra allí escrita. La misa es Intret in conspectu tuo Domine genitus compeditorum, e indica también la epístola, y el evangelio utilizados. Un comentario advierte que estaba pendiente la aprobación por el Papa de un rezo propio, hecho que se produjo en 1702, pero que no se anotó en este ejemplar de la Consueta. ${ }^{59}$

Ya se ha señalado la participación en la fiesta del Cabildo de la ciudad, que asistía a las primeras vísperas y a la misa. Además nombraba a dos caballeros veinticuatro y jurado $^{60}$ que se encargaban de que: 1) se aderezara la Iglesia de Santiago $^{61}$ y el Pórtico Rico de las Cuevas; 2) se construyeran altares que representaran algo de la historia de San Cecilio y de sus compañeros mártires; 3) de la alfombra para el teatro; $\left.{ }^{62} 4\right)$ de la cera, los fuegos y la música. Estaban asistidos en sus labores por dos prebendados "comissarios" del Sacromonte que eran nombrados anualmente por el Cabildo. A través de las Actas de Cabildo del Ayuntamiento podemos conocer quiénes eran los encargados, y el dinero que se dedicaba por parte del Ayuntamiento para la celebración de la Fiesta. Así tenemos constancia de la entrega el 25 de Julio de 1618 de "25.255 maravedíes a los de la Fiesta de San Cecilio". ${ }^{63}$ La celebración de la fiesta de

\footnotetext{
${ }^{58}$ Común de muchos mártires como en el Breviario.

${ }^{59}$ La Consueta consultada para este estudio es la original de 1632.

${ }^{60}$ Así se llamaba en Andalucía a lo que en Castilla se conocía por regidor, por ser veinticuatro el número de regidores.

${ }^{61}$ La Iglesia de Santiago está en las Cuevas, por lo que se deduce de la lectura de otros pasajes de la Consueta, y probablemente se refiere a la cueva llamada de Santiago.

62 Teatro aquí es equivalente a lo que se construía para albergar al Cabildo de la ciudad dentro de la Iglesia, o simplemente al conjunto de bancos y escabeles que utilizarían sus miembros.

63 Índices de los Libros de Cabildo del Ayuntamiento de Granada, 25-VII-1618.
} 
San Cecilio, como todas las solemnidades importantes, se empezaba a celebrar desde el día antes, la víspera.

\subsubsection{Las ceremonias el día de la Víspera de la Fiesta de San Cecilio en la Abadía}

Los días 31 de Enero, a prima se decía la Calenda con toda solemnidad y a ella debía asistir todo el Colegio. ${ }^{64}$ Para Vísperas se comenzaba a tocar cuando el Cabildo de la ciudad llegaba a Puente Quebrada, al pie del Sacromonte. Los ministriles y trompetas también tocaban al llegar el Cabildo a las gradas de la cuesta empedrada, desde donde continuaban a pie. Los repiques no cesaban hasta que la comitiva alcanzaba los hornos o Cuevas donde se suponen sufrieron martirio los santos. Cuando asistía el Arzobispo, era recibido por el Cabildo del Sacromonte y el Colegio que le acompañaban a su sitial, o bien si lo deseaba, al coro en el puesto del Abad.

Más adelante la Consueta especifica desde dónde tocaban los ministriles: "suben al coro y por la ventana tocan quando la ciudad llega a la Iglesia de Sanctiago o a su teatro". ${ }^{65}$ Las Vísperas debían celebrarse con toda solemnidad y además en ellas se interpretaban chanzonetas: "no se dexe de dezir todo el hymno ni otra cosa por chanzonetas que estas se pueden dezir acabado el hymno antes de los versículos". 66 Es curiosa esta mención a las chanzonetas, porque en toda la Consueta solamente las encontramos dos veces más. Y no sólo eso, sino que no existen otras alusiones a otros géneros de música con instrumentos. La chanzoneta es un género que en este contexto es sinónimo de villancico, es decir una canción con acompañamiento instrumental, en lengua vulgar; poco tiene que ver con lo que en Italia se conocía con este nombre, como bien apunta Ramos López. ${ }^{67} \mathrm{La}$ autora analiza este término en el contexto de la Consueta catedralicia, desmitificando el origen granadino que López-Calo le había atribuido al responsabilizar a Fray Hernando de Talavera del nacimiento de este género.

\footnotetext{
${ }^{64}$ Como es costumbre en el Breviario Romano, se decía la Kalenda (o recitación o canto de los elogios de los santos cuya fiesta o conmemoración del día natalis o del día de la depositio tenía lugar al día siguiente según el Martirologio Romano) después de prima. En el rito romano y monástico la recitación se realizaba por lo general en el tono romano de las lecciones de maitines, pero había iglesias que disponían de recitativos propios no siempre puestos por escrito sino transmitidos por tradición oral. Véase: Ismael Fernández de la Cuesta, "Calenda [Kalenda], canto de la" en DMEH, vol. 2, p. 9250.

${ }^{65}$ Consueta, fol. $339^{\mathrm{r}}$. La Iglesia de Santiago es la que está en las Cuevas.

${ }^{66}$ Consueta, fol. $340^{\mathrm{r}}$.

${ }^{67}$ Ramos López, La Música en la Catedral de Granada, pp.28 y ss.
} 
La principal diferencia que encontramos con las chanzonetas de la Catedral, es que si bien éstas eran sustitutas de los nocturnos de maitines o cantos para la procesión del Corpus, en el Sacromonte aparecen:

1) Como música para rellenar espacios vacíos en el culto, como durante la adoración de las reliquias durante la misa del día de San Cecilio: "quando baxa el Diacono la reliquia haze el hostiario señal a la torre y repican con todas las campanas y la música toca los ynstrumentos o canta algunas chanzonetas mientras dura la adoración". 68

2) Para solemnizar los momentos litúrgicos más importantes: "el coro canta los Sanctos y versos que se siguen alternativamente con el órgano si es día, mas el Benedictus qui venit no lo canta hasta después de haber alzado el Cáliz si no es quando se canta motete o chanzoneta en su lugar".

3) Como modo de solemnizar una víspera importante. Así, en la hora de Vísperas se pueden decir chanzonetas después del himno (ver arriba). ${ }^{69}$

Esta ampliación del uso de la chanzoneta responde a que con el paso del tiempo (hay que considerar que la Consueta de la Catedral es casi un siglo anterior a la del Sacromonte) lo que en un principio se empleó solamente en los maitines y en la procesión del Corpus, fuera extendiéndose a otros momentos y celebraciones litúrgicas.

Los instrumentos claro está siguen presentes durante la celebración de las vísperas: "Al Benedicamus Domino responden largo las chirimías o órgano y el celebrante". ${ }^{70}$

Las completas se cantan y la fiesta termina "Después que la ciudad ha tomado los caballos y pasado de la primera cuesta comienzan los fuegos como se dixo libro 2 de

\footnotetext{
${ }^{68}$ Consueta, fol. $350{ }^{\mathrm{r}}$.

${ }^{69}$ Consueta, fol. $340^{\mathrm{r}}$.

${ }^{70}$ Consueta, fol. $341^{\mathrm{v}}$.
} 
campanero capítulo 12".71 Para un resumen de las celebraciones y las rúbricas de esta fiesta, véase Tabla 5.2.

Tabla V.2. Resumen de la Víspera de la Fiesta de San Cecilio (día 31 de Enero, Fuente: Consueta, 1632.

\begin{tabular}{|c|c|c|c|}
\hline 31 de Enero & \multicolumn{3}{|c|}{$\begin{array}{c}\text { Fiesta de la Vísperade San Cecilio } \\
\text { (Fuente: Consueta, 1632) }\end{array}$} \\
\hline Prima & \multicolumn{3}{|c|}{ Calenda solemne con la asistencia de todo el Colegio. } \\
\hline Tercia & \multicolumn{3}{|l|}{ Misa Mayor. } \\
\hline Después de Misa & \multicolumn{3}{|c|}{$\begin{array}{l}\text { Se cierra la Iglesia y el Tesorero adereza el altar para las Santas Reliquias, que } \\
\text { se colocan en el Altar Mayor descubiertas y bajo un dosel, con un gran número } \\
\text { de velas en los nichos. } \\
\text { Comisarios preparan el Teatro con escaños, y la Puerta del Pórtico, cubren el } \\
\text { pasillo de la Iglesia al Pórtico con alfombras y colocan braseros para quemar las } \\
\text { pastillas de olor. }\end{array}$} \\
\hline Toque a Vísperas & $\begin{array}{l}\text { Se toca la campana } \\
\text { a Vísperas cuando } \\
\text { la Ciudad llega a } \\
\text { Puente Quebrada: } \\
\text { tocan los } \\
\text { ministriles y las } \\
\text { trompetas. Cuando } \\
\text { llegan a las gradas } \\
\text { de la cuesta } \\
\text { empedrada se apean } \\
\text { y van a pie. El } \\
\text { repique dura hasta } \\
\text { que alcanzan los } \\
\text { hornos. Van a la } \\
\text { Iglesia de Santiago } \\
\text { (Cuevas) con los } \\
\text { canónigos que los } \\
\text { han recibido, salen } \\
\text { por la Puerta de } \\
\text { poniente y entran a } \\
\text { la Iglesia donde } \\
\text { ocupan su lugar en } \\
\text { el Teatro. }\end{array}$ & $\begin{array}{l}\text { Si sube el } \\
\text { Arzobispo, el } \\
\text { Abad y el Colegio } \\
\text { lo aguarda, si sube } \\
\text { por la primera } \\
\text { cuesta, en la } \\
\text { puerta de reja del } \\
\text { compás y entran } \\
\text { por la puerta de } \\
\text { casa y lo } \\
\text { acompañan hasta } \\
\text { el sitial del coro. } \\
\text { Si sube por la } \\
\text { cuesta empedrada, } \\
\text { lo reciben en la } \\
\text { Cruz de los } \\
\text { Canteros y entran } \\
\text { por la puerta del } \\
\text { callejón al } \\
\text { claustro. }\end{array}$ & $\begin{array}{l}\text { Al tocar a vísperas: ceroferarios } \\
\text { encienden las velas. El Tesorero, el } \\
\text { prebendado con la llave del Abad y } 4 \\
\text { colegiales sacan las reliquias y las } \\
\text { colocan en el altar, ponen flores y } \\
\text { ramilletes. } \\
\text { Comisarios de la ciudad: encienden } \\
\text { altares en el Pórtico y en las Cuevas. } \\
\text { Sacristán cirios en los hornos y echan } \\
\text { pastillas que llenen la Iglesia de olor. } \\
\text { Ministriles suben al coro y por la } \\
\text { ventana tocan cuando la ciudad llega } \\
\text { a la Iglesia de Santiago o a su Teatro. }\end{array}$ \\
\hline Vísperas & \multicolumn{3}{|c|}{$\begin{array}{l}\text { Con toda solemnidad. } \\
\text { No se deje de decir todo el himno por chanzonetas u otra cosa que se pueden } \\
\text { hacer acabado el himno antes de los versículos. } \\
\text { Al Magnificat se incensan las reliquias, también al coro. } \\
\text { Al Benedicamus Domino responden largo las chirimías ó el órgano. } \\
\text { Al finalizar se quedan dos prebendados para capitular a las Completas. }\end{array}$} \\
\hline Completas & Cantadas & & $\begin{array}{l}\text { Cuando la Ciudad pasa la primera } \\
\text { cuesta comienzan los fuegos. }\end{array}$ \\
\hline
\end{tabular}

\footnotetext{
${ }^{71}$ Consueta, fol. $342^{\text {r }}$.
} 


\subsubsection{El día de San Cecilio}

El 1 de febrero se celebraba la fiesta de San Cecilio con toda solemnidad, por lo que la Consueta recuerda que las horas se deben decir "a compás moroso". Como en las vísperas, también asistía el Cabildo de la ciudad y el prelado, y todo debía hacerse conforme estaba señalado para el día anterior. La liturgia especifica la celebración de la misa Intret in conspectu tuo, y el común de muchos mártires; véase Tabla V.3.

Tabla V.3. Resumen de la Fiesta de San Cecilio (día 1 de Febrero), Fuente: Consueta, 1632.

\begin{tabular}{|c|c|}
\hline $\begin{array}{l}1 \text { de Febrero } \\
\text { FIESTA }\end{array}$ & $\begin{array}{l}\text { Fiesta de San Cecilio } \\
\text { (Fuente: Consueta, 1632) }\end{array}$ \\
\hline Antes de Tercia & $\begin{array}{l}\text { Al salir de Oración y antes de abrir la Iglesia se encienden todas las luces que } \\
\text { estarán todo el día, se descubren las Reliquias. Las Horas se dicen a compás } \\
\text { moroso conforme a la solemnidad del día. Se designa a dos colegiales que } \\
\text { asistan a los sacerdotes forasteros que dicen misas en el altar del Pórtico y en la } \\
\text { Iglesia de Santiago en las Cuevas, para toda la gente que no cabe en la Iglesia. }\end{array}$ \\
\hline Tercia & $\begin{array}{l}\text { Se toca cuando la ciudad llega a Puente Quebrada (recibimiento como en la } \\
\text { Víspera) } \\
\text { Introito (coro) } \\
\text { Kyrie alternatim: entona el prelado responden celebrante, diácono y asistentes. } \\
\text { Gloria: lo entona el celebrante y lo prosiguen los diáconos con el prelado. } \\
\text { Epístola: la canta el subdiácono } \\
\text { Evangelio: lo canta el diácono. } \\
\text { Credo: lo entona el Celebrante. Al Incarnatus est se hincan de rodillas todos } \\
\text { excepto el celebrante y el diácono } \\
\text { Celebrante se situa con la Reliquia en medio del altar. Al bajar el diácono la } \\
\text { reliquia hace el ostiario señal a la torre para que repiquen las campanas, y la } \\
\text { música toca los instrumentos o canta algunas chanzonetas y se hace la } \\
\text { adoración de la Reliquia. }\end{array}$ \\
\hline Después de Misa & $\begin{array}{l}\text { La Iglesia permanece abierta por el gran concurso de gente. Los comisarios de } \\
\text { la ciudad cuidan de que se quiten las alfombras, los comisarios del Sacromonte } \\
\text { que se quite el teatro y los escaños. Se disponen celadores para que no haya } \\
\text { desorden y no entren hombres y mujeres juntos a las Cuevas }\end{array}$ \\
\hline Vísperas & $\begin{array}{l}\text { Se dicen a las tres y media son todas de los Santos con conmemoración de } \\
\text { Nuestra Señora conforme a las rúbricas del Breviario, celébralas el Abad. }\end{array}$ \\
\hline Al ponerse el sol & $\begin{array}{l}\text { Se encierran las Reliquias. El adorno de ellas se deja para el día siguiente que es } \\
\text { el de la Purificación de Nuestra Señora. } \\
\text { Los comisarios de la Ciudad hacen que se descuelgue todo el adorno de el } \\
\text { Pórtico y las Cuevas. }\end{array}$ \\
\hline
\end{tabular}


Como en el resto de las grandes solemnidades, la misa era cantada en todas sus partes (incluido el evangelio y la epístola). La única novedad musicalmente hablando es lo que se ha comentado más arriba sobre las chanzonetas, pues es al final de esta misa cuando se produce el momento de la veneración pública.

\subsection{La aprobación del rezo propio y su música, 1704}

Hasta la aprobación del nuevo rito, la festividad de San Cecilio se "comuneaba", es decir se celebraba por el común de muchos mártires, por lo que en el primer siglo de la festividad la solemnidad tendría que ser expresada a través de otros elementos, quizás con la composición de villancicos y chanzonetas ex profeso para la festividad.

El hecho de que pasara más de un siglo desde la calificación de las reliquias hasta la aprobación del nuevo rito no sorprende si tenemos en cuenta toda la polémica que rodeó los descubrimientos y el largo proceso que culminó con la condena de los libros (aunque no de las reliquias) en 1682. Antes de este momento crítico para la historia de la Abadía, se había tratado de conseguir un rezo para San Cecilio en 1665, pero no sabemos hasta que punto este proceso se llevó a Roma y si fue denegado o paralizado

Fue este cabildo para dar noticia el señor Abad de cómo el cabildo de la Santa Iglesia de Granada trata de pedir rezo propio del señor San Cecilio a su Santidad y para esto tiene nombrado comisarios para que consulten en esta Santa Iglesia si se ha pedido otra vez y si se ha negado o si hay algún inconveniente para que no se pida y logre el efecto. $^{72}$

Nada vuelve a hablarse del rito propio hasta 1692, fecha en la que encontramos cierta preocupación en el Cabildo para que se incluya la oración propia de San Cecilio en los "directorios anales" para que se conozca en todo el Arzobispado. ${ }^{73}$

Lo que hizo reactivar el proceso de la consecución de un rito propio para honrar a San Cecilio tuvo que ver con el nuevo rezo que se había concedido a San Torcuato, patrón de Guadix. Un acta de mayo de 1693 refiere la necesidad de escribir al obispo de

\footnotetext{
${ }^{72}$ ASAC IV, fol. $98^{\mathrm{r}}$ (7-II-1665), [285].

${ }^{73}$ ASAC V, fol. 499 (12-IV-1692), [411].
} 
Guadix y a Roma, porque lo narrado en el recién estrenado oficio de San Torcuato va contra lo aprobado en el Sínodo Provincial de la calificación de las reliquias de 1600. Finalmente se decidió dejar pasar este hecho, pues sin duda supondría un inconveniente el enfrentarse con la Sagrada Congregación de Ritos en un momento en el que sólo habían pasado diez años desde la condena papal de los libros plúmbeos.

Según se indica en un documento manuscrito que aparece junto con el nuevo rito impreso en Roma conservado en el Archivo Municipal de Granada, el nuevo rezo para honrar a San Cecilio:

\begin{abstract}
se sacó en virtud de informes, memoriales y papeles, que el Señor Don Diego Luis del Castillo, arcediano y natural de esta dicha ciudad, envió a la Corte de Roma; por comisión de dicho Señor Illmo. Arzobispo y Cabildo, al dr don Joseph Eugenio de Luque su Maestro de Ceremonias y su Agente en dicha Corte; para la Consecución de dicho Officio y Missa. ${ }^{74}$
\end{abstract}

Finalmente el nuevo rezo se concedió y aprobó por la Sagrada Congregación de Ritos el 26 de Agosto de 1702, a instancia del Arzobispo Martín de Ascargorta y el Cabildo catedralicio. ${ }^{75}$ Como consta en el impreso, el nuevo rezo fue aprobado por el Cardenal Colloredo. ${ }^{76}$ La noticia llegó a Granada en septiembre de 1703, y cuando fue comunicada por la Catedral a la Abadía se determinó que se repicase solemnemente al mismo tiempo que la Catedral y el resto de las Iglesias de Granada, y por la noche se pusieran luminarias y al día siguiente se celebrase procesión al horno del santo y se dijese misa solemne por el Abad. ${ }^{77}$ La aprobación del nuevo rezo supuso un motivo de fiesta para la Granada de comienzos del siglo XVIII.

El 1 de febrero de 1704 fue el primero en que se celebró la festividad de San Cecilio con el nuevo rito. Según $\mathrm{M}^{\mathrm{a}}$ José Cuesta los actos celebrados con tal motivo son

\footnotetext{
${ }^{74}$ El impreso se conserva en el Archivo Municipal de Granada, en la sección de Festejos. Leg. 1930, pieza 52.

${ }^{75}$ Martín de Ascargorta (Córdoba 1639-Granada 1719) fue canónigo del Sacromonte antes de ser obispo de Salamanca y luego de Granada. Donó grandes sumas de dinero al Sacromonte, obras de arte y patrocinó la construcción del Colegio Nuevo.

${ }^{76}$ Leandro Colloredo (1639-1709), cardenal de San Pietro in Montorio y consultor de la Sagrada Congregación de Ritos. Véase: Gaetano Moroni Romano, Dizzionario di erudizione storico-ecclesiastica, vol. XIV (Venecia: Tipografía Emiliana, 1842) p. 248.
}

${ }^{77}$ ASAC VI, fol. 197 ${ }^{\mathrm{r}}$ (24-IX-1703), [482]. 
similares a los que tienen lugar con motivo de las proclamaciones reales, y muestra las similitudes de esta celebración con los actos llevados a cabo por la Proclamación al trono de Felipe V en 1701 en Granada. ${ }^{78}$ Más tarde, en 1727, encontramos referencias en las Actas Capitulares del Sacromonte (y de la Catedral) en que se pide la extensión del rezo a todos los dominios de España por parte del Arzobispo de Granada don Francisco Perea y Porras, quién había sido exhortado por el Cardenal Belluga a tal fin. ${ }^{79}$ Además se pide también que "se le concedan lecciones nuevas en que se refiriese su martirio y prodigios con más extensión de las que tienen". ${ }^{80}$ La extensión del rezo a todos los dominios de España en 1729 hizo que se repitieran las celebraciones. ${ }^{81}$

\subsubsection{Los villancicos que se hicieron con motivo de la aprobación del nuevo rito}

No conservamos la música de los villancicos compuestos con motivo de la aprobación de nuevo rezo a San Cecilio, pero sí sus letras, y dado que son ilustrativas de la importancia de la ocasión para la que fueron compuestas me detendré en analizar el impreso de 1704 en el que aparecen: ${ }^{82}$

${ }^{78} \mathrm{M}^{\mathrm{a}}$ José Cuesta García de Leonardo, Fiesta y Arquitectura efímera en la Granada del siglo XVIII
(Granada:Universidad de Granada y Diputación de Granada, 19959, pp. 25, 173-174. Recoge varias
noticias referentes a la celebración por la concesión del rito de San Cecilio contenidas en las Actas
Capitulares de la Catedral señalando que la publicación se hacía "con atabales y chirimías" y "repiques
solemnissimos" estando los vecinos de Granada obligados a colocar luminarias. (Cabildo de 22 de
septiembre de 1703 , libro 21 , Cabildo de 16 de Octubre de 1703 , libro 21 ) y por la extensión en 1729 en
la que para publicar la noticia subieron "a tocar en la torre dos Cajas y dos Clarines" y disparando desde
ella "una palma real y veynte y quatro dozenas de coetes Mayores" (Actas Capitulares de la Catedral de
Granada, 13-VI-1729, libro 25). Sobre el proceso de solicitud de la extensión del rito, véae ASAC VII,
fol.105 $5^{\mathrm{r}}(28-\mathrm{VI}-1727)$, [561].

${ }^{79}$ El Cardenal Luis de Belluga y Moncada (Motril 1662-Roma 1743) fue uno de los clérigos más ilustres de su época. Fue canónigo de Zamora, Córdoba, Obispo de Cartagena y Cardenal desde 1719. Además fue también virrey y capitán general de Valencia y Murcia (1706). Durante la Guerra de Sucesión apoyó a Felipe V, por lo que organizó fuerzas armadas que contribuyeron a la victoria en la batalla de Almansa. A él se debe la fundación de los pueblos de Dolores (Murcia), San Fulgencio y San Felipe Neri (Alicante). Escribió numerosas obras y pasó sus últimos años en Roma donde gozó de la estimación de los Pontífices; véase Germán Bleiberg (dir.), Diccionario de Historia de España (Madrid: Revista de Occidente, 1968), Tomo I, p. 496. El Cardenal Belluga fundó además la Colegiata de Motril y fue protector del Sacromonte.

\footnotetext{
${ }^{80}$ ASAC VII, fol. $115^{\mathrm{r}}(21-\mathrm{X}-1727),[563]$.

${ }^{81}$ Véase nota 78.

${ }^{82}$ Para este estudio he utilizado el ejemplar de dicho impreso que se encuentra en el Fondo Antiguo de la Biblioteca Universitaria de Granada, Hospital Real signatura C-38-40(41), véase Lo-Hue: 1415 (Tomo III, p. 1648). Una transcripción de los textos puede verse en el Apéndice 6 de este estudio. La descripción
} 
Granada, Catedral-1704, San Cecilio

VILLANCICOS,/ QUE SE HAN DE CANTAR EN LA S ${ }^{\text {TA }}$ IGLESIA/

Metropolitana y Apostolica de Granada,/ à los Maytines del Señor/ SAN CECILIO MARTYR,/ SU PRIMER OBISPO, Y PATRONO;/ y en las quatro Festividades, que se celebran con el motivo / de tener principio su nuevo Rezo en su dia primero/ de Febrero de este año de mil setecientos / y quatro.

Portada con grabado representando un jarrón con flores enmarcado por orla tipográfica. -Texto a dos columnas salvo en las páginas uno y dos. - El colofón en la última página: Impresso en Granada, En la Imprenta de la Sâtissima Trinidad, por Antonio / de Torrubia, Impressor del Illustrissimo Señor D. Martin de Ascargorta, / y de la Santa Iglesia Cathedral Metropolitana y Apostolica. / Año de 1704.

1. Villancico I. Kalenda.

a. [Estribillo].- Granada escucha, que en culto/ de tu primero Pastor

b. Coplas.- Rompa el Metropolitano / Coro la flamante voz

2. Villancico II.

a. [Estribillo].- Oy el Patron de Granada, / como de la Fe Ministro

b. Coplas.- De su Ministerio Sacro / oy llega a estrenar lo antiguo

3. Villancico III.

a. [Estribillo] Quatro Ruiseñores / del ameno Soto

b. Coplas.- O que dulces celebran / à CECILIO glorioso

4. Villancico IV.

a. [Estribillo] A CECILIO oygo cantar / en el Coro, y el Altar

b. Coplas.- En la musica passada / fiò la Palma, y Cayado

de este impreso de Villancicos sigue el modelo de Álvaro Torrente y Miguel Ángel Marín, Pliegos de Villancicos en la British Library (Londres) y la University Library (Cambridge) (Kassel: Reichenberger, 2000). 
5. Villancico V.

a. Que sonora armonia / oy, en Granada suena

b. Coro Esso es; pero no es así.

c. Serà aplaudir suave / en un Templo tu Fiesta

d. Coro.- Esso es; pero no es así.

e. Coplas.- Atended, que le aclama / Patron vuestro feliz

6. Villancico VI. Para dos Seises.

a. Alfonso el camino toma, / y vamos à la Ciudad

b. Coplas.- De S.Cecilio el Rezo / mi voz aplaude

7. Villancico VII. Para un Seise.

a. El Zelo tan devoto / como en sus ansias activo

b. Coplas.- Canta el Catholico zelo / ya alegre; pues renacido

8. Villancico VIII.

a. A la Fiesta, à la Fiesta Zagales, / à la Fiesta de el Grande Cecilio

b. Coplas.- A celebrar las glorias de un Prelado / invicto, cuyo nombre

9. Villancico IX. [De negros]

a. Quatro Neglillos oy vienen, / nazidos junto à la Arabia

b. Coplas.- Xacara và Ruminguilla. / Diga ziol Pazqualiyo.

La estructura de los villancicos sigue la norma general de los del siglo XVII y su función: sustituir a los responsorios de maitines de las principales fiestas. También en el número más frecuente (nueve), y el de comenzar con el llamado villancico de Calenda.

El villancico de Calenda según López-Calo, a partir de mediados del siglo XVII "adquiere una forma definida que se caracteriza por una mayor solemnidad y extensión, y estaba prácticamente escrito siempre para el máximo número de voces e instrumentos de que dispusiese la capilla". ${ }^{83}$ El que tenemos aquí es efectivamente de los más

\footnotetext{
${ }^{83}$ López-Calo, "Villancico", DMEH, vol. X, pp. 567-568.
} 
extensos de esta serie, y como las kalendas del martirologio romano habla del santo, en este caso de su martirio y el nuevo rezo que se celebra. El estribillo de este primer villancico resume la celebración: Escucha su canto,/que suena mejor; /pues ya no es agena/ que es propria la voz. El nuevo rezo hace posible que no se emplee la fórmula del común de muchos mártires, que era el que se seguía hasta entonces. Por lo demás la calenda señala a Cecilio como el primer Obispo de Granada, alude a su martirio en las Cuevas donde fue quemado y la mención al "grano fecundo", que sin duda guarda relación con el evangelio que se lee en la nueva misa. Señala como actor de la música al Cabildo metropolitano (el de la Catedral), lo que confirma la importancia que la fiesta de San Cecilio tuvo para la Catedral, y no se limitó a la Abadía. El resto de las estrofas narra hechos de la vida de San Cecilio, como su obispado granadino y su martirio; además menciona como el rito ha venido de Roma y que durante siglos Granada lo ha alabado (incluso bajo el dominio árabe).

El villancico II señala la epístola de los tesalonicenses (que efectivamente está en el rito) y de nuevo el evangelio del grano fecundo. Las noticias sobre San Cecilio que aparecen en los textos de los villancicos se basan en lo que aparece en las láminas sepulcrales y los libros plúmbeos aparecidos en el Sacromonte, sobre todo en lo referente a ser discípulo de Santiago (Jacobo) y su provenir de Arabia. Puesto que Inocencio XI, en una Bula de 1683, había condenado como heréticos los textos plúmbeos, su contenido no podía utilizarse en sermones, libros u oraciones bajo pena de excomunión. ${ }^{84}$ Sin embargo, éstos pasaron la censura eclesiástica, quizás por privilegio del arzobispo Ascargorta, que había sido canónigo del Sacromonte y un reconocido protector de la Abadía.

La composición de nueva música para el rito recién aprobado es algo que se menciona en el tercer villancico con la frase "siendo nuevo el punto, la letra, y el tono". Aunque como veremos más adelante, esta afirmación con respecto a la Misa de San Cecilio es discutible, pues las tres versiones en canto llano que conservamos de la Misa difieren bastante entre sí, y algunas de las antífonas son literalmente de otras festividades, como el introito Gaudeamus omnes. Los cuatro ruiseñores de Valparaiso

\footnotetext{
${ }^{84}$ Testimonio de la actuación de la Inquisición en este sentido puede verse en Roma, cuando el jesuita Carlo Salviati, tras utilizar los libros plúmbeos como argumento a favor de la Inmaculada Concepción, fue denunciado por un dominico y hubo de retractarse públicamente en el púlpito. Véase, Henry Charles Lea, Chapters from the Religious, p. 113.
} 
son una metáfora del coro de la Abadía, pues con ese nombre de Valparaiso se conoce al monte donde está la Colegiata.

Se vuelve a insistir en la novedad de la "letra y el punto" en el Villancico IV, con una graciosa imagen: En la musica passada fió la Palma, y Cayado, su Martyrio y Obispado á una $N$ Colorada. ${ }^{85}$

El quinto villancico se presenta para coro y solista pues las entradas del coro están señaladas en el texto, y sigue como en los anteriores presentando el nuevo rito que es de "primera clase con octava".

El sexto villancico está indicado para dos seises, que dialogan entre sí sobre la novedad del rezo, y lo que cuentan las lecciones de su oficio. Las intervenciones de cada uno están señaladas en el texto con números. Como en el resto de los villancicos de la serie, se intenta poner de manifiesto la pervivencia del cristianismo en Granada, incluso "entre moros".

Para un seise solo es el villacinco VII que agradece al Papa Clemente la concesión del nuevo rito. El octavo y penúltimo de la serie es una invitación a celebrar la nueva fiesta, cuenta cómo ha venido un breve de Roma aprobando el rezo, y para que no quede duda identifica con su nombre, Gaudeamus omnes, la Misa que se ha de cantar ese día.

El último villancico es el de carácter más popular y es un villancico "de negros". En él se intenta recoger un acento diferente, por lo que las palabras cambian la "s" por la "z", y la "r" por la "l”. Las intervenciones de los cuatro negrillos están señaladas en el texto, y además dos de ellos son mujeres: Pazquala y Juanilla. ¿Quiénes interpretarían estos papeles?, lo más probable es que los seises, pero no deja de ser curioso la aparición de dos mujeres en una ocasión en la que probablemente, como casi siempre en la Iglesia, no cantaban. Este villancico refiere además el origen árabe de San Cecilio, y el deseo de la extensión del rito "hasta en Guinea".

A diferencia de otros muchos impresos de la época no se especifica ni el compositor ni el autor de los textos. Probablemente serían del maestro de capilla de la Catedral de Granada, ya que entraba dentro de sus obligaciones la composición de villancicos. El maestro de capilla en esa época era Gregorio López de Guevara

\footnotetext{
${ }^{85}$ En el Breviario se indica con una $\mathrm{N}$ roja (de ahí la referencia a la "N colorada" en el villancico) el lugar donde el celebrante debía decir el nombre del santo que se conmemoraba ese día si no tenía oficio propio.
} 
(†Granada, 6-IX-1713), pero desgraciadamente no se conserva apenas música suya, y entre lo poco no hay ninguna obra en castellano. ${ }^{86}$

El papel del Ayuntamiento en la fiesta se refleja en el protocolo detallado con el que se recibía a los caballeros veinticuatro en el Sacromonte. El Cabildo del Sacrmonte les entregaba pastillas de olor y éstos ofrecían ramos de flores a los canónigos. ${ }^{87}$ Además, por otros documentos sabemos que el Ayuntamiento se encargaba de contratar la "música" para ese día a la Catedral. Así las Actas Capitulares del Sacromonte reflejan un acuerdo por el que se trata de contratar a una capilla de música que acuda a tocar en las diversas festividades importantes a lo largo del año litúrgico. En él se excluye a caso hecho la festividad de San Cecilio, porque "la música ese día la paga la ciudad". 88

En la documentación del Archivo Provincial de Granada, en la sección de Festejos, encontramos algunos documentos de finales del siglo XIX en los que los gastos para la Festividad de San Cecilio siguen estando a cargo del Ayuntamiento. En todos ellos se contrata la Capilla de Música de la Catedral para esta festividad y su celebración en la Abadía, aunque podemos encontrar referencias a otras capillas que asistieron al Sacromonte, como la de la Capilla Real en $1756,{ }^{89}$ esto explicaría que se conserve un motete de Antonio Cavallero dedicado a San Cecilio en el Archivo de la Capilla Real; véase en el Apéndice 7 la transcripción de esta obra.

\footnotetext{
${ }^{86}$ Gregorio López de Guevara parece que inició su formación musical como niño de coro de la Catedral de Valladolid. Su primer magisterio de Capilla lo ejerció en la catedral de Santo Domingo de la Calzada (La Rioja), de allí pasó a Oviedo y por último a Granada (1674), donde permanecería hasta su muerte en 1713. Su obra fue muy extensa, aunque desgraciadamente se ha perdido casi toda su producción, y lo que resta está en latín, por lo que no podemos ver el estilo posible de estos villancicos. Las obras que se conservan son las siguientes: Beatus vir, Ps, 8V, ac, E:GRcr; Dixit Dominus, Ps, 12V, ac, E:SD; In exitu Israel de Aegypto, Ps, 8V, ac; Letanía, 5V, ac; E:GRc, Misa, 8V, ac; Pasión del Viernes Santo, 4V, E:OV. Véase: López-Calo, "López de Guevara, Gregorio", DMEH, vol. 6, pp. 1012-1013.

${ }^{87}$ Véase el Ceremonial que debían guardar los Caballeros Veinticuatro en su subida a la Abadía en la víspera y en el día de San Cecilio transcrito en el Apéndice 6.

${ }^{88}$ ASAC II, fol. ¿? (3-II-1633), [167].

${ }^{89}$ Juan Ruíz Jiménez, “Música y devoción”, p.76.
} 
Tabla V.4. Cuadro comparativo de los Ritos de San Cecilio Fuentes: Consueta (1632) e Impreso del Oficio y Misa de San Cecilio (1704).

\begin{tabular}{|c|c|c|c|}
\hline \multicolumn{2}{|c|}{ RITO SAN CECILIO } & SIGLO XVII & SIGLO XVIII \\
\hline \multicolumn{2}{|c|}{ LITURGIA } & Comum plurimorum martyrun & $\begin{array}{l}\text { Missa de S. Caecilio Episcopo et } \\
\text { Martyre. Patronor Principali } \\
\text { Ecclesiae et Dioecesis Granatensis. }\end{array}$ \\
\hline \multicolumn{2}{|c|}{ ORACIÓN } & $\begin{array}{l}\text { Deus qui per Beatum Pontifizem et } \\
\text { martyrem tuum Caecilium multum } \\
\text { Hispaniae populum ad te accer firi } \\
\text { volvisti praesta que sumus ut } \\
\text { ecclesia tua eodem rectore } \\
\text { gubemetur, quem ei volvisti } \\
\text { praesse Pastorem et Beatorum } \\
\text { discipulorum eius martyrum } \\
\text { Septentrii et Patricii nos festa } \\
\text { tuaeantur, et eorum commendet } \\
\text { oratio veneranda. Per Dominum } \\
\text { etc. }\end{array}$ & $\begin{array}{l}\text { Deus, qui nos per beatum Caecilium } \\
\text { martyrem tuum atque Pontificem ad } \\
\text { agnitionem tui nominis veniri } \\
\text { tribuisti, concede propitius, ut per } \\
\text { quem superni muneris rudimenta } \\
\text { suscepimus, per eum subsidia } \\
\text { perpetuae salutis impetremus. Per } \\
\text { Dominum nostrum etc. }\end{array}$ \\
\hline \multirow[t]{4}{*}{ MISA } & Introito & $\begin{array}{l}\text { Intret in conspectu tuo Domine } \\
\text { gemitus compeditorum }\end{array}$ & Gaudeamus omnes \\
\hline & Gradual & Gloriosus Deus in Sanctus & Beata gens \\
\hline & Ofertorio & Mirabilis Deus & Mirabilis Deus \\
\hline & Comunión & Et si coram hominibus & Ego vos elegi \\
\hline \multicolumn{2}{|c|}{ EPÍSTOLA } & $\begin{array}{l}\text { Sancti per fidem vicerunt regna } \\
\text { (Hebreos } 11,33 \text { ) }\end{array}$ & $\begin{array}{l}\text { Fratres fiduciam habuimus in Deo } \\
\text { (San Pablo a los Tesalonicenses, } 1 . \\
\text { cap. 2) }\end{array}$ \\
\hline \multicolumn{2}{|c|}{ EVANGELIO } & $\begin{array}{l}\text { Cum audientis praelia et seditiones } \\
\text { (San Lucas } 21,9-19 \text { ) }\end{array}$ & $\begin{array}{l}\text { In illo tempore dixit Iesus discipulis } \\
\text { suis: Amen, Amen dico vobis (San } \\
\text { Juan, 12) }\end{array}$ \\
\hline
\end{tabular}

\subsubsection{La Misa propia de San Cecilio}

La música para San Cecilio se encuentra presente de una manera específica en tres de los cantorales del Sacromonte (LC XXII; LC XLII y LC XLVI) . En el primero (LC XXII), como ya se ha señalado, se conserva el propio de la misa; se trata de un fascículo añadido a otro cantoral, pues no coincide ni en la numeración, ni en las características grafológicas y de iluminaciones. En el segundo (LC XLII) se transcriben 
unas letanías a San Cecilio en un cantoral fechado en $1697,{ }^{90}$ y en último (LC XLVI) aparecen las antífonas para la conmemoración de San Cecilio.

En la Catedral de Granada encontramos música para la misa de San Cecilio, en el Cantoral Ms. LXXXVII, escrito e iluminado por Fray Pedro de Granada en 1704. ${ }^{91}$ El cantoral de la Catedral es más completo que los del Sacomonte porque incluye la música de parte del gradual. En la Capilla Real está la misa de san Cecilio en uno de sus libros y resulta sorprendente que también difiere de las versiones de la Catedral y el Sacromonte. Curiosamente las fuentes de la Misa conservadas en las tres instituciones granadinas no concuerdan. Aunque respetan el texto aprobado por la Sagrada Congregación de Ritos, las melodías de algunas piezas ofrecen pequeñas variantes (repercusiones omitidas, melismas acortados) y en otros casos las melodías son completamente diferentes. Resultan llamativas, sobre todo, las diferencias entre la versión catedralicia y la sacromontana, pues el Cabildo de aquella subía a la celebración de San Cecilio y al parecer, no cantaba la misma versión de la Misa que la que aparece en las fuentes del Sacromonte. ¿Cuál puede ser la explicación de estas variantes? Si tenemos en cuenta que alguna de las secciones del Propio no son nuevas (por ejemplo, el introito Gaudeamus omnes lo encontramos en otras festividades como la de Santa Ágata), podemos deducir que para cada versión de la misa se emplearon cantorales distintos como fuente de las secciones identificadas. Para el resto de las secciones para las que no he encontrado en la tradición gregoriana del texto, cabe la posibilidad de que sean paráfrasis de otras existentes, o, fueran invención del copista o del sochantre ${ }^{92}$.

La no existencia de una versión musical unificada de la Misa de San Cecilio pone de manifiesto varias cuestiones: 1) la creación de música para nuevos ritos no tenía

\footnotetext{
${ }^{90}$ Estas Letanías mayores pro San Cecilio,se harían con motivo de alguna rogativa o procesión y datan de 1697. Aparecen en un libro que se hizo por un devoto para que se cantara la salve en las sagradas Cuevas, por lo que es lícito pensar que estas letanías también habrían de cantarse allí.

91 Véase, Álvarez del Castillo, La miniatura de los Corales de la Catedral de Granada: Estudio y Catalogación, Tesis doctoral, Universidad de Granada, 1980. La misa de San Cecilio se encuentra en el folio 55v y ss. La referencia del copista la localiza en un Acta Capitular de la Catedral ( Libro 21, f.90. Doc. 615). Por la referencia a Fray Pedro de Granada que aparece en ASAC se puede deducir que debía ser el copista oficial de la Catedral, véase ASAC V, fol. 499 ${ }^{\mathrm{r}}$ (12-IV-1692), [411].

${ }^{92}$ En la Colegiata de Antequera se pagaba al sochantre por la composición del canto llano.
} 
que ser necesariamente aprobada en Roma por la Sagrada Congregación de Ritos; 2) la música ocupaba un lugar secundario en la creación de u nuevo rito, y 3) que en Granada existieron diversos talleres de copia. El cantoral de la catedral está copiado por un monje de San Jerónimo, pero de los otros en la Capilla Real y el Sacromonte, no tenemos datos.

Es curioso comprobar lo poco que se ha estudiado la composición de gregoriano en las épocas tardías. Sabemos que en los años posteriores al Concilio de Trento se canonizaron numerosos santos que contaron con un rito propio, pero escasa o nula atención se ha prestado a la génesis musical de estos oficios y misas. Santa Teresa, San Carlos Borromeo, San Felipe Neri, San Juan de Ribera son algunos de los santos de la Edad Moderna que contaron con nuevos ritos en canto llano, pero poco se ha dicho sobre ellos. Aunque es peligroso comparar estos santos tan relevantes con las festividades en la Abadía, debemos suponer que el proceso de creación de nuevos ritos tendría algunas características comunes.

Según Marcelino Díez los sochantres y los maestros de capilla solían componer estas piezas que no estaban en los libros oficiales para cubrir las necesidades cultuales de las catedrales en lo referente a santos patronos y oficios de nuevos santos. Incluso en unas oposiciones a maestro de capilla en la Catedral de Cádiz se pidió a los aspirantes la composición de un himno en canto llano. ${ }^{93}$

\subsection{La liturgia para el San Cecilio medieval}

La liturgia mozárabe para los Siete Varones Apostólicos, entre los que se encuentra San Cecilio, se recoge en diversas fuentes. Las oraciones que debían decirse el día de su fiesta se hallan en el Eucologio de Silos, que data del siglo IX, en los Pasionarios de Silos y Cardeña ${ }^{94}$ del siglo X, donde encontramos su historia, y también en el Martirologio de Lyon. ${ }^{95}$ Del siglo IX es la composición de la misa del

\footnotetext{
${ }^{93}$ Marcelino Díez Martínez, La Música en Cádiz: la Catedral y su proyección urbana durante el siglo XVIII (Cádiz: Universidad de Cádiz, 2004), pp. 126-127. Díez aporta varios ejemplos en los que se reflejan pagos a sochantres por la composición de canto llano.

${ }^{94}$ Ángel Fábrega Grau, Pasionario Hispánico (siglos VII-XI). Tomo I: Estudio.Monumenta Hispaniae Sacra. Serie Litúrgica: vol. V, (Madrid-Barcelona: Consejo Superior de Investigaciones Científicas Instituto P. Flórez, 1953).

${ }^{95}$ Justo Pérez de Urbel, “Origen de los Himnos Mozárabes” Bulletin Hispanique, 28 (1926), pp. 209-210.
} 
Sacramentarium de Toledo; el Antifonario de León contiene las antífonas para el oficio. Pero la primera pieza dedicada a estos santos parece ser el himno Urbis romuleae jam toga candida, probablemente escrito en Toledo el siglo VIII por San Eugenio en opinión de Justo Pérez de Úrbel. ${ }^{96}$ El día de la fiesta era el quince de mayo (Kalendas Maias). Las referencias a San Cecilio en la Misa y Oficio son escasas; de él se dice en los maitines: Cecilius cetibus Angelorum precatu suo adsociet. En el resto de las ocasiones se le menciona en una enumeración de sus compañeros.

Por desgracia, las melodías del canto hispánico-mozárabe no se conservan y sus únicos testimonios son algunos cantorales con notación difícil de transcribir. En el siglo XVI, el Cardenal Cisneros, preocupado por la conservación de esta tradición que se encontraba presente en cierta medida en seis de las parroquias toledanas, mandó copiar y transcribir estos cantos. Pero la comparación de estas melodías con los cantorales primitivos (que nos permiten conocer la dirección melódica y el número de notas) arroja que nada queda de aquéllos en éstos. ${ }^{97}$

¿Queda algo de la liturgia mozárabe en la nueva liturgia de San Cecilio del siglo XVIII? En principio tan sólo tienen en común la epístola (San Pablo a los Tesalonicenses) y un versículo de los maitines (Beata Gens) que aparece en la misa en lugar de en el Oficio, como aparece en la liturgia mozárabe. Por otra parte es normal que los que crearon el nuevo rito en el siglo XVIII no acudieran a la antigua liturgia porque en ella San Cecilio no era mártir; tampoco figuraba como el santo principal y nada se decía de su obispado en Iliberri.

En el siglo XVIII se compusieron otros himnos para la liturgia de San Torcuato y sus compañeros mártires, que podían ser utilizado para la celebración colectiva o individual de los santos. Son de Faustino Arévalo y aparecen en su Himnodia Hispánica, ${ }^{98}$ pero no sabemos que se empleara efectivamente en ninguna diócesis o que se le compusiera música.

\footnotetext{
${ }^{96}$ Pérez de Urbel, “Origen”, pp. 209-210.

${ }^{97}$ Juan Carlos Asensio. El canto gregoriano. Historia, liturgia, formas.... (Madrid: Alianza Música, $2003)$ pp. 97.

${ }^{98}$ Elena Gallego Moya (Ed), Los Himnos de la Hymnodia Hispanica, Faustino Arévalo, S.J. (Salamanca: Universidad de Alicante, 2002), pp. 322-330.
} 


\subsection{Otras músicas para San Cecilio en la Catedral de Granada y en la Capilla Real}

Dada la importancia de San Cecilio como patrón de Granada, no es de extrañar que se conserven obras dedicadas al santo. Además, la vinculación de la capilla de música catedralicia a la fiesta celebrada en el Sacromonte hace pensar en una probable interpretación de estas obras también en la iglesia de la Abadía.

En el Archivo de la catedral de Granada se conservan varias obras para San Cecilio, aunque todas menos una pertenecen al último cuarto del siglo XIX y principios del siglo XX. Los autores son Celestino Vila de Forns (1830-1915), maestro de capilla de la Catedral, Guillermo Prieto y Pedro Gutiérrez Achútegui.

La obra polifónica más antigua es el himno anónimo a doble coro (aunque los coros son iguales) con acompañamiento de órgano. Está encuadernado con otros himnos de Gregorio Portero, aunque éste no figura firmado y como los otros, probablemente sea del XVIII, con escritura arcaizante, respetando las reglas del contrapunto clásico. El texto de este himno aparece en otras obras en la Catedral dedicadas al común de un mártir, y también a San Esteban.

La obra conservada en la Capilla Real dedicada a San Cecilio es un motete a 8 voces con acompañamiento de órgano, de Antonio Caballero ( $\imath$ ?, ¿1728? - Granada, 1822), también en un estilo policoral que recuerda al stile antico. ${ }^{99}$ Las demás obras dedicadas a San Cecilio son del maestro de capilla de la Catedral, Celestino Vila de Forns (1830-1915) y de otros dos maestros de capilla de esta institución, véase la Tabla V.5. ${ }^{100}$

\footnotetext{
${ }^{99}$ Fue maestro de la Capilla Real de Granada de 1757 hasta su muerte en 1822. Durante ese periodo intentó opositar a otras plazas mejor remuneradas sin éxito. En el archivo de la Capilla Real se conservan inventariadas unas 221 obras, de las cuales la mayoría están escritas en español y son villancicos con acompañamiento instrumental. Véase, $\mathrm{M}^{\mathrm{a}}$ Angustias Ortiz, "Caballero, Antonio", DMEH, vol. II, pp.822823.

${ }^{100}$ Véase la edición de una selección de estas obras polifónicas destinadas a San Cecilio en el Apéndice 7.
} 
Tabla V.5. Relación de las obras dedicadas a San Cecilio conservadas en la Catedral y en la Capilla Real de Granada.

\begin{tabular}{|c|c|c|c|c|}
\hline Autor & Título & $\begin{array}{c}\text { Referencia } \\
\text { Catálogo } \\
\text { López-Calo }\end{array}$ & Instrumentación & Observaciones \\
\hline Anónimo & $\begin{array}{l}\text { Hic nempe } \\
\text { mundi gaudia }\end{array}$ & ACG 236 & $\begin{array}{c}\text { Doble coro } \\
\text { (SATB) y } \\
\text { órgano }\end{array}$ & $\begin{array}{c}\text { Himno } \\
\text { Los dos coros } \\
\text { son iguales. }\end{array}$ \\
\hline $\begin{array}{l}\text { Antonio } \\
\text { Caballero }\end{array}$ & Iste Sanctus & ACRGr 559 & $\begin{array}{l}\text { SSAT, SATB, } \\
\text { órgano. }\end{array}$ & Motete \\
\hline \multirow[t]{5}{*}{$\begin{array}{l}\text { Celestino Vila } \\
\text { de Forns } \\
(1830-1915)\end{array}$} & $\begin{array}{l}\text { Salve Patrón } \\
\text { de Granada }\end{array}$ & ACG 987 & $\begin{array}{l}\text { STB, dos } \\
\text { violines, } \\
\text { clarinete y } \\
\text { violón }\end{array}$ & $\begin{array}{l}\text { Himno a San } \\
\text { Cecilio }\end{array}$ \\
\hline & $\begin{array}{l}\text { Pues de Dios } \\
\text { sois estimado }\end{array}$ & & SATB & $\begin{array}{c}\text { Gozos } \\
\text { Texto original } \\
\text { a San } \\
\text { Jerónimo }\end{array}$ \\
\hline & $\begin{array}{c}\text { Oh, Dios } \\
\text { infinito y santo }\end{array}$ & ACG 975 & $\begin{array}{l}\text { SATB, dos } \\
\text { violines, } \\
\text { clarinete y } \\
\text { contrabajo }\end{array}$ & $\begin{array}{c}\text { Gozos a San } \\
\text { Cecilio }\end{array}$ \\
\hline & $\begin{array}{l}\text { Cecilio, pues } \\
\text { en Granada }\end{array}$ & ACG 950 & $\begin{array}{l}\text { SATB, dos } \\
\text { violines, } \\
\text { clarinete, } \\
\text { contrabajo y } \\
\text { órgano }\end{array}$ & $\begin{array}{c}\text { Gozos a San } \\
\text { Cecilio }\end{array}$ \\
\hline & $\begin{array}{c}\text { Deus tuorum } \\
\text { militum }\end{array}$ & ACG 897/12 & SATB & $\begin{array}{l}\text { Canon de dos } \\
\text { guías }\end{array}$ \\
\hline $\begin{array}{l}\text { Guillermo } \\
\text { Prieto }\end{array}$ & $\begin{array}{l}\text { Cecilio, pues } \\
\text { en Granada. }\end{array}$ & ACG 1542 & $\begin{array}{c}\text { STB, dos } \\
\text { violines, } \\
\text { contrabajo y } \\
\text { órgano } \\
\text { obligado. } \\
\end{array}$ & $\begin{array}{c}\text { Gozos a San } \\
\text { Cecilio }\end{array}$ \\
\hline $\begin{array}{c}\text { Pedro } \\
\text { Gutiérrez } \\
\text { Achútegui }\end{array}$ & $\begin{array}{l}\text { Scriptae sunt } \\
\text { in caelo }\end{array}$ & ACG 1368 & $\begin{array}{c}\text { STB, dos } \\
\text { violines, flauta, } \\
\text { clarinete, dos } \\
\text { cornetines en si } \\
\text { bemosl, trompa } \\
\text { en do, figle y } \\
\text { órgano. }\end{array}$ & $\begin{array}{c}\text { Texto } \\
\text { acomodado } \\
\text { "Cecilio pues } \\
\text { en Granada" }\end{array}$ \\
\hline
\end{tabular}




\section{Las honras fúnebres por el fundador de la Abadía del Sacromonte y por sus padres}

\subsection{La familia Vaca de Castro y su relación con el Sacromonte}

Como se ha señalado en el Capítulo I, la fundación de la Abadía fue posible gracias a la fortuna personal de Pedro de Castro, Arzobispo de Granada, que era hijo del licenciado Cristóbal Vaca de Castro, Gobernador del Perú. Don Pedro había heredado el mayorazgo que su padre había fundado gracias a las ganancias obtenidas en su empresa indiana.

No se sabe con certeza la fecha y lugar de nacimiento de aquel Gobernador del Perú, aunque parece probable que hubiera nacido en la provincia de León alrededor de 1492. Cristóbal Vaca de Castro era Oidor de la Chancillería de Valladolid, cuando en 1540 fue comisionado por Carlos I para gobernar el Perú; en ese momento el territorio se encontraba inmerso en una guerra civil entre los seguidores de dos de sus conquistadores: Pizarro y Almagro. Al morir asesinado Francisco Pizarro, Vaca de Castro, siguiendo las instrucciones reales, se proclamó gobernador, pero tuvo que luchar con la oposición del hijo de Almagro, Diego de Almagro, en la llamada Batalla de Chupas, para hacer valer los intereses del Rey.

Figura V.3. El Licenciado Vaca de Castro, Gobernador del Perú. Fuente: Antonio de Herrera, Historia general de los hechos de los Castellanos en las islas $i$ tierra firme del mar oceano (Madrid: Imprenta Real, por Juan Flamenco, 1601-1615), vol. 4.

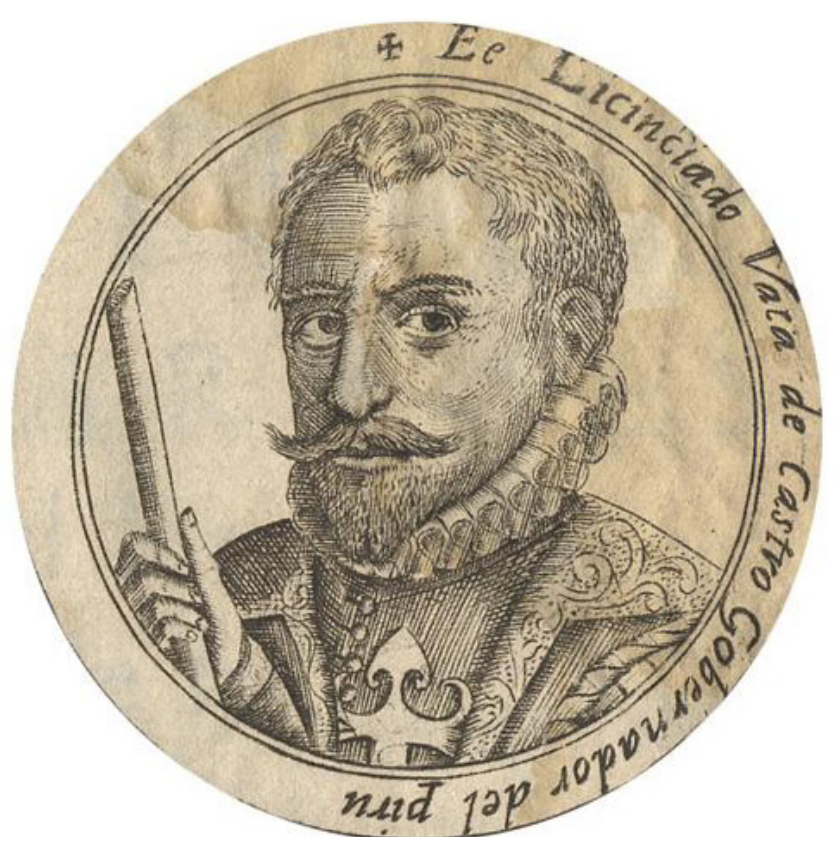




\subsection{Iconografía musical en unos cuadros indianos.}

En la Abadía se conservan seis grandes lienzos anónimos del siglo XVII que narran los hechos más conocidos del gobernador en el Perú. A través de tres de ellos podemos reconstruir diversas ceremonias y prácticas musicales que se llevaron a cabo por los españoles en el Nuevo Mundo pocos años después del descubrimiento. Son un documento único para ilustrar las primeras actividades musicales de los españoles en el Perú, ${ }^{101}$ aunque hay que tratar de deslindar las convenciones del género pictórico del reflejo "histórico" de los acontecimientos retratados. En este sentido es útil comparar los cuadros con otros documentos coetáneos a los hechos, como diversas crónicas que trataré a continuación.

Los seis cuadros del Sacromonte, junto con otros elogios para perpetuar la memoria de su padre, parece que fueron encargados por su hijo el arzobispo Pedro de Castro. Este esfuerzo debemos considerarlo como fruto de la mentalidad renacentista: al igual que los antiguos griegos y romanos celebraban sus victorias militares, los conquistadores de Indias proclamaban sus hazañas. En esa época proliferaron memoriales, relaciones, elogios y otros documentos que además servían a sus protagonistas como defensa de sus intereses económicos y como justificación moral de sus empresas indianas. ${ }^{102}$ Además de estos testimonios gráficos existe una "Relación" que según Casiano García parece haber sido escrita en Cuzco, mientras Vaca de Castro estaba allí. ${ }^{103}$ Esta narración pudo servir de base a las otras relaciones (la de Calvete de Estrella y la de Herrera), y quizás también a los cuadros. De ahí que en uno de ellos, el que refleja los prolegómenos de la batalla, aparezca en primer plano un personaje sentado, escribiendo la historia. Todos juntos, cuadros y relaciones, suponen un

\footnotetext{
${ }^{101}$ Respecto a la música en Cuzco poco sabemos de la actividad española antes de 1546, fecha desde la que se conservan las Actas Capitulares de la Catedral. No hemos encontrado ningún acontecimiento musical "español" en Cuzco anterior a esa fecha, aunque la Catedral había sido erigida en 1536 y hemos de suponer que se iniciara a la par la actividad musical. Para los comienzos de la música en Cuzco, véase: Robert Stevenson, "Cuzco Cathedral:1546-1750" en Inter-American Music Review, II (1979), pp. 1-25; Robert Stevenson, The Music of Peru (Washington D.C: Pan America Union-General Secretariat, 1959).

${ }^{102}$ Simón Valcárcel Martínez, Las Crónicas de Indias como expresión y configuración de la mentalidad renacentista (Granada: Universidad de Granada, 1997), p. 144. En el caso que nos ocupa se debe más a un intento por devolver el prestigio perdido y deteriorado por la cárcel y el proceso judicial al que injustamente se vio sometido Vaca de Castro.

${ }^{103}$ P. Casiano García O.S.A., El licenciado Vaca de Castro gobernador del Perú (Madrid: Ediciones Religión y Cultura,1957). Me ha sido imposible localizar el legajo que cita García, aunque confiamos en que aparezca una vez se vuelva a catalogar el archivo.
} 
esfuerzo de propaganda política para devolver el prestigio a Vaca de Castro, que culminará, una vez muerto el licenciado, con la dotación por el aniversario de su muerte fundado por su hijo, el arzobispo Pedro de Castro, en la Abadía. Los cuadros de la Abadía, probablemente se pintaran durante los primeros años del siglo XVII y narran los siguientes episodios: "La llegada a los Reinos del Perú", "Prolegómenos de la Batalla de Chupas", "El desarrollo de la Batalla", "La entrada triunfal a Cuzco", “Ajusticiamiento de Almagro el Joven" y "Llegada de Vaca de Castro a España".

Figura V.4. Prolegómenos de la Batalla de Chupas. Óleo sobre lienzo. Abadía del Sacromonte, Sala Capitular.

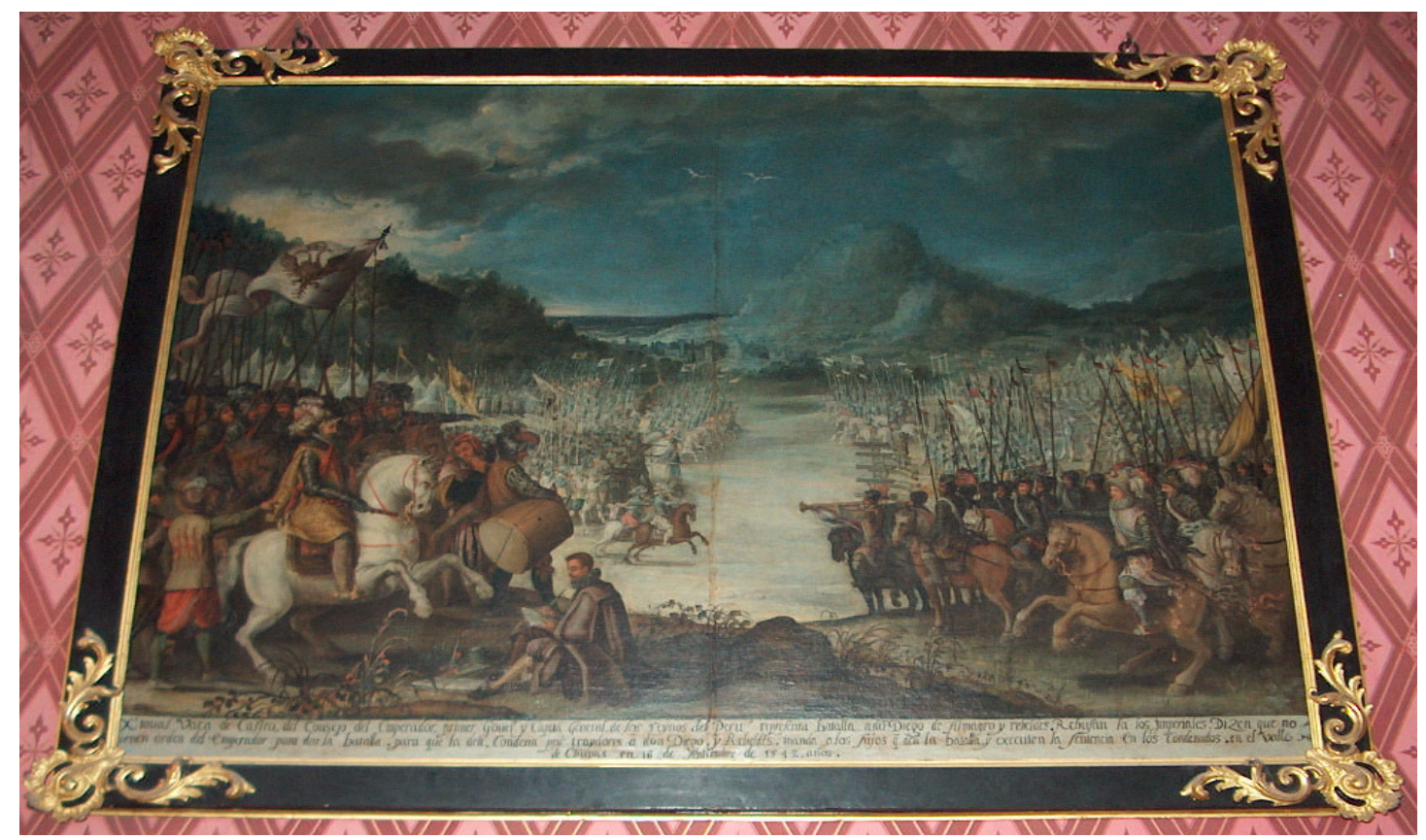

\subsubsection{Prolegómenos de la Batalla de Chupas}

El segundo de esta serie de lienzos, "Prolegómenos de la Batalla" (Figuras V.4. y V.5.) refleja el momento anterior a la Batalla de Chupas, que tuvo lugar el 16 de septiembre de 1542. En este cuadro, vemos en primer plano, justo delante del gobernador Vaca de Castro vestido con los atributos imperiales, a un soldado músico tocando un "atambor" y a otro tocando un "pífaro". El atambor está representado con bastante exactitud y es fácil su identificación: se aprecian los dos parches, tensados por las cuerdas, un bordón y un pequeño oído. Las cuerdas tenían la función de ajustar las 
pieles del tambor para mantener la tensión. Un instrumento similar al aquí representado podemos encontrarlo en el Theatrum Instrumentorum de Praetorius (1620), con el bordón y el oído. ${ }^{104}$ Es importante no confundir este instrumento con el atabal, aunque en muchas ocasiones se haya utilizado indistintamente uno u otro vocablo para referirse de manera genérica a un instrumento de percusión. ${ }^{105}$ La representación del pífaro en el cuadro es muy esquemática y por tanto difícil de identificar, pero tanto en las fuentes pictóricas como en las literarias, el atambor y el pífaro siempre apraecen unidos y asociados a la música militar o de batalla. ${ }^{106}$

La representación de estos instrumentos en las pinturas de batalla es algo frecuente, sobre todo desde el Renacimiento, pues son elementos indispensables en la contienda, incluso llegaron a convertirse en un tema por sí solos, acompañados con frecuencia del portador de la bandera. ${ }^{107} \mathrm{La}$ realidad sonora de la que eran clara metáfora para los espectadores de la época actúa en un doble plano: primero, como actualización del hecho figurado, pues la dimensión sonora posee la capacidad de situarnos en un momento temporal vívido, y segundo como reforzador de la situación dramática de la lucha (el golpe seco de tambor ayuda a crear la tensión propia del momento previo al combate). Pero ¿cómo era la realidad sonora que representaban estos instrumentos para los espectadores a los que estaban dirigidas estas pinturas? Para

\footnotetext{
${ }^{104}$ Michael Praetorius, Theatrum Instrumentorum (Wolfenbütel, 1620), Lám. XXIII.

${ }^{105}$ Covarrubias, Tesoro de la lengua, p. 134: "ATAMBOR de guerra o caja, vide supra atabal. [...] Ni estos atabales, ni los de los judíos, ni los que refiere Plutarco de los partos serían como las cajas de atambores que hoy día se usan en la guerra, con dos haces y un sonido, que parece encienden los corazones de los soldados para pelear; de manera que los demás que tienen un haz serán atabales o atabalillos". En la voz "atabal", Covarrubias, Tesoro de la lengua, p.133, también señala que "con los atabales andan juntas las trompetas, como con los atambores los pífaros": "ATABAL por otro nombre dicho atambor o caxa, por ser una caxa redonda, cubierta de una parte y de otra con pieles rasas de becerros, que comúnmente llamamos pergaminos, al son de los cuales el campo se mueve, o marchando o peleando [...]. Con los atabales andan juntas las trompetas, como con los atambores los pífaros, y uno y otro vocablo tienen el mismo origen".

${ }^{106}$ Covarrubias, Tesoro de la lengua, p. 822: "PÍFARO un instrumento músico de boca, que se tañe juntamente con el atambor de guerra, suena como soplo, sin meterle en la boca, que al sonido de cerca hace pif, para formar con aquel soplo el sonido en el pífaro, y de allí, por onomatopeya, tomó el nombre".

${ }^{107}$ Hale presenta este tema como propio del renacimiento de los países del norte, donde llegó a gozar de cierta fortuna. Artistas como Durero, Altdorfer, Urs Graf y otros muchos cultivaron la representación de este "trío". Véase, John Rigby Hale, Artist and Warfare in the Renaissance (New Haven \& Londres: Yale University Press, 1990), pp. 73 y ss.
} 
tratar de reconstruir el sonido y las funciones de estos instrumentos en la guerra hemos de acudir a lo que nos cuentan las fuentes de la época: tratados militares y musicales.

Figura V.5. Prolegómenos de la Batalla de Chupas. Detalle. Abadía del Sacromonte,

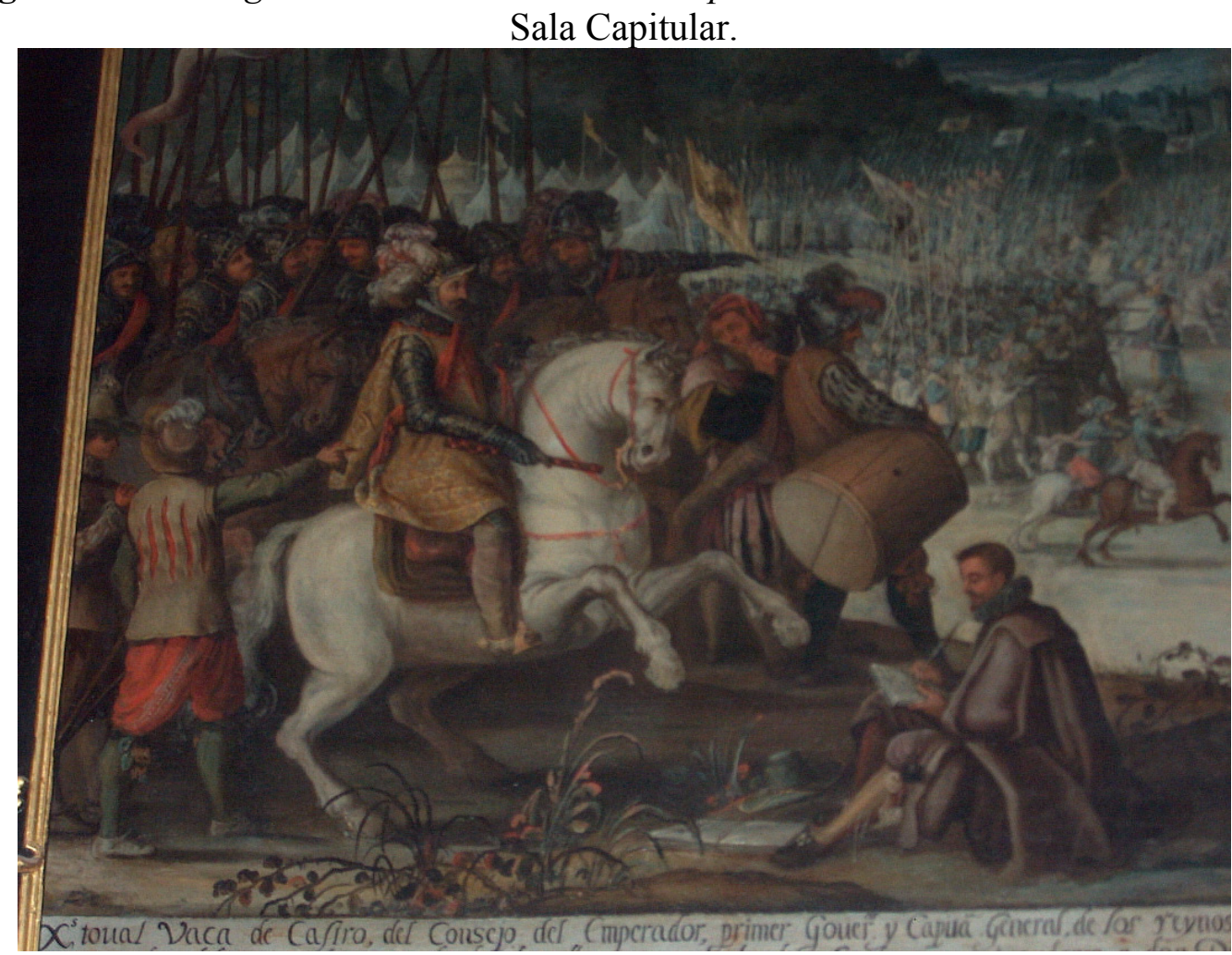

Desde Vegecio $^{108}$ (siglo IV) hasta Maquiavelo ${ }^{109}$ (siglo XVI), los tratados militares suministran una información preciosa acerca del uso de los instrumentos en la batalla. Sin duda la introducción de los tercios españoles en el siglo XVI supuso una revolución en la táctica militar europea, por el nuevo papel asignado a la infantería con los piqueros y arcabuceros. ${ }^{110}$ De la Vega ${ }^{111}$ y Thomas Styward ${ }^{112}$ dedican atención a las funciones y obligaciones de los oficiales músicos:

\footnotetext{
${ }^{108}$ Renatus Flavius Vegetius, De re militari (Bolognia, 1515).

${ }^{109}$ Nicolo Machiavelo, Libro dell'arte della guerra di Nicolo Machiauelli cittadino, et secretario fiorentino (Londres, 1587).

${ }^{110}$ A.A.V.V., El Gran Capitán: de Cordoba a Italia al Servicio del Rey (Cordoba: Cajasur, 2003), p. 97.

${ }^{111}$ Luis Gutierrez de la Vega, A compendious treatise entituled, De re militari, containing principall orders to be observed in martiall affaires. Written in the Spanish tongue. And newlie translated into English, by Nicholas Lichefild, (Londres, 1582).
} 
[el Coronel] debe designar un oficial de tambor, el cual se encargará del resto de los tambores, teniendo cuidado de que le obedezcan: y de que cada uno haga la parte que pertenezca a su oficio, como en sonar la marcha, una llamada, la carga, la retirada.

En otro momento Styward señala que los tamborileros y pífaros deben ser "hábiles en los sonidos y usos de sus instrumentos". En los esquemas de colocación de los soldados siempre se sitúan los atambores y pífaros en la retaguardia, para que todos los soldados puedan escucharlos, ${ }^{113}$ véanse Figura V.6 y V.7.

Figura V.6. Thomas Styward, The Pathwaie to Martiall discipline (1581), p. 137.

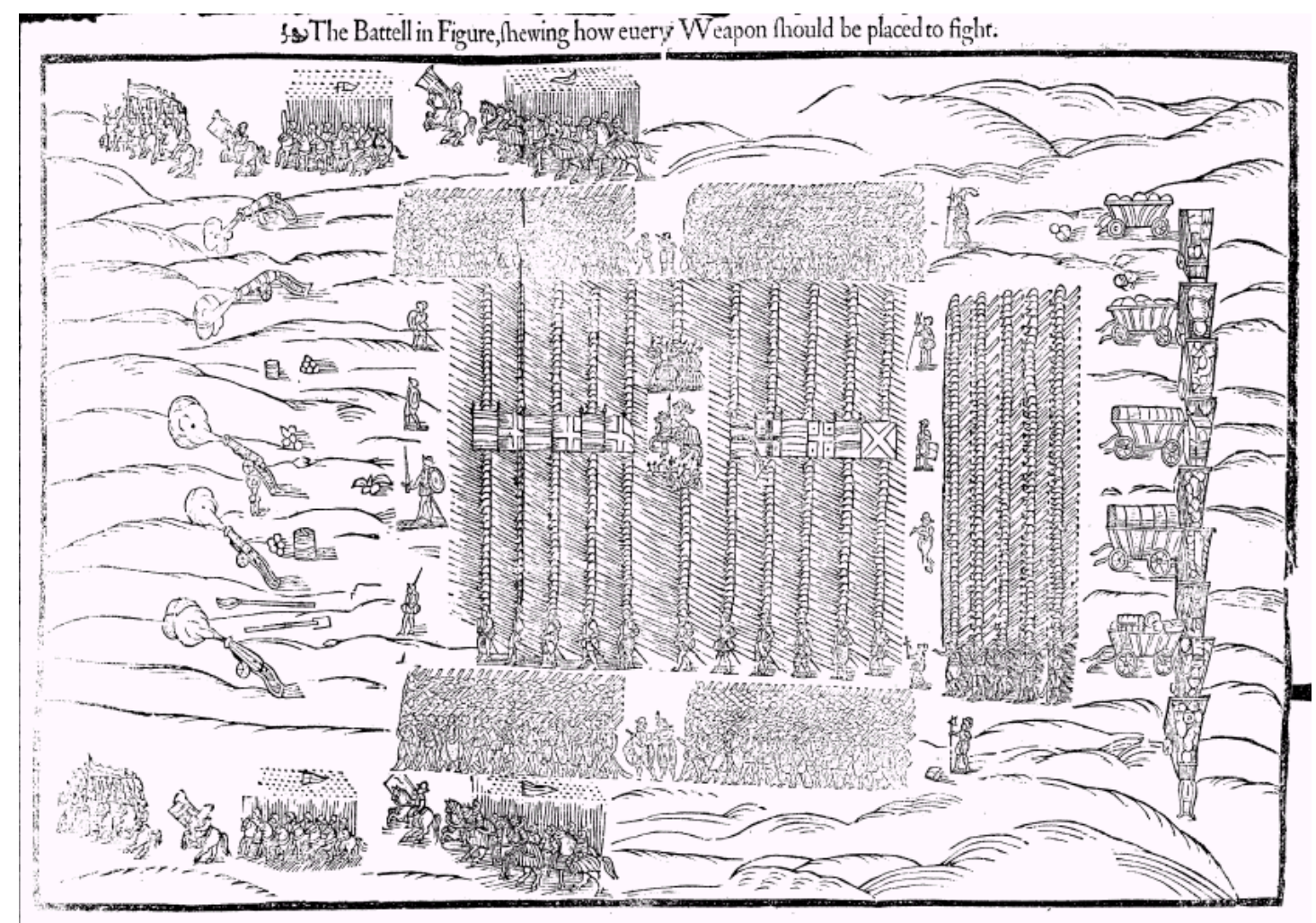

112 Thomas Styward, The pathwaie to martiall discipline, devided into two bookes, verie necessarie for young souldiers, or for all such as loveth the profession of armes (Londres, 1581), p. 18.

"He [the coronell] must appoynt a generall Drum, which shall take care of the rest of the Drums, having a care that they use obedience: and that everie one do his part that belongeth to his office, as in sounding the march, a call, the charge, the batteile, the retrait etc."

${ }^{113}$ Thomas Styward, The pathwaie, p. 38. En la lámina de la p. 137, puede apreciarse esta disposición en la retaguardia de los atambores y pífaros. 
Figura V.7. Thomas Styward, The Pathwaie to Martiall discipline (1581), detalle, p. 137.

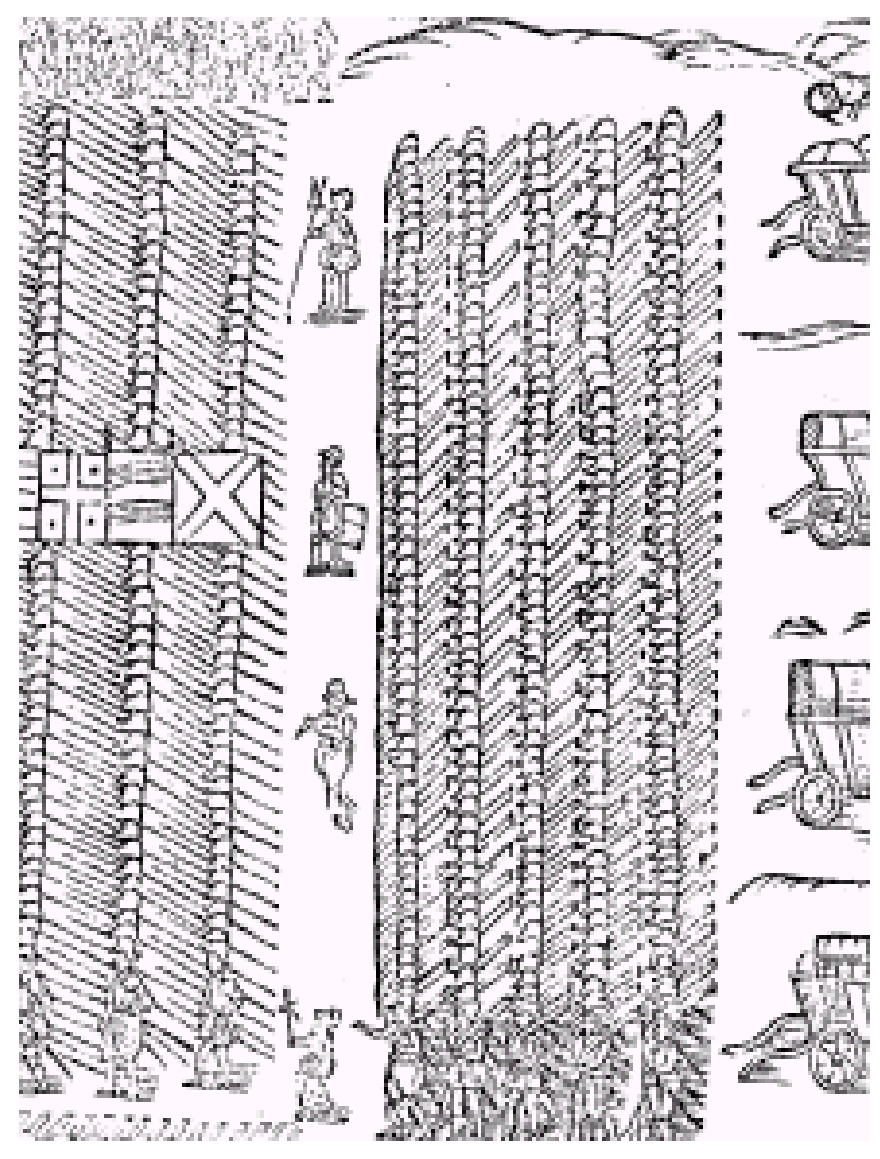

Un documento de la guardia de Felipe II describe los toques de las trompetas y los atabales, pero nada dice acerca de atambores y pífaros. ${ }^{114}$ Curiosamente una aproximación a lo que pudo ser este lenguaje musical de guerra, lo encontramos en Orchesographie (1588), un tratado de danza, escrito por Thoinot Arbeau. Para Arbeau en la batalla:

El sonido de todos estos instrumentos sirve como un signo y señal a los soldados para que cambien de cuartos, avancen o se retiren: y en un encuentro con el enemigo, para darles bravos corazones, audacia y coraje para atacar al enemigo y defenderse de una manera más viril y vigorosa. Ahora, si no fuera

\footnotetext{
${ }^{114}$ Luis Robledo (ed.), Aspectos de la cultura musical en la corte de Felipe II (Madrid: Fundación Caja Madrid, 2000). Robledo recoge un documento de la guardia de Felipe II en el que se recogen los toques de las trompetas y atabales, pero nada dice de los pífaros y atambores.
} 
por estos, los hombres marcharían confusamente y sin orden lo que les causaría estar en peligro de ser derribados y derrotados. ${ }^{115}$

Y a continuación Arbeau pasa a enumerar todas las fórmulas rítmicas posibles para el tambor de guerra, que se caracterizan por combinar mínimas, semimínimas y fusas en tiempos binarios o ternarios; al final de cada fórmula se incluyen tres silencios de mínima antes de la repetición (para que el soldado pueda contar y poner siempre el pie izquierdo en la primera y quinta nota de la serie, y así marchar siempre a la par de los demás). ${ }^{116}$

Figura V.8. Arbeau, Orchesographie, pp. 9 y ss. Tabulature contenant toutes les diversités des battements du tambour (selección).

1)

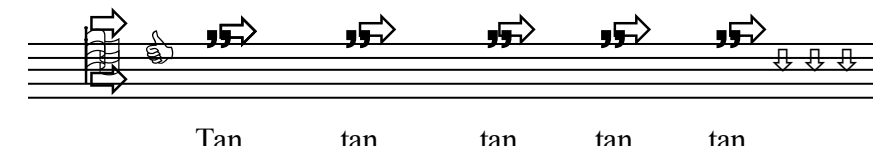

2)

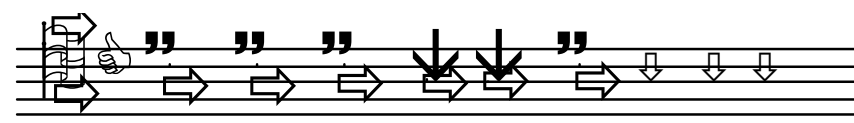

Tan $\tan \tan$ te re $\tan$

3)

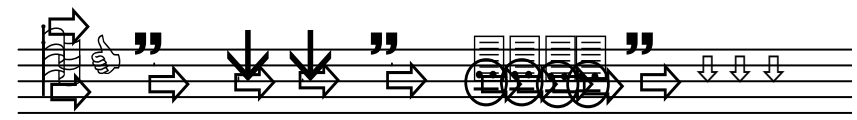

Tan te re $\tan$ fre $\tan$

En cuanto a la música de los pífaros, Arbeau advierte que es improvisada y que sólo necesita ir a compás con el tambor. Lo más llamativo de las explicaciones de Arbeau se refiere al modo de articulación de la lengua, que debe ser con las sílabas té, té, té, y no relé, relé, relé, pues el sonido producido por la primera articulación es más

\footnotetext{
${ }^{115}$ Thoinot Arbeau (Jehan Tabourot), Orchesographie (Langres, 1588).

« Le bruict de tous les dicts instruments, ser de signes \& advertisements aux soldats, pour desloger, marcher, se retirer : \& à la recontre de l'ennemy leer donne coeur, hardiesse, \& courage d'affaillir, \& se deffendre virilement \& vigoureusément. Or pourroient les gens de guerres marcher confusément \& sans ordre cause qu'ils feroient en peril d'estre reversés \& deffaicts ».

${ }^{116}$ La fórmula más simple es la compuesta por cinco "tan" (Figura V.8. ejemplo 1). Arbeau usa los términos "tan", "tere", y "fre" según emplee, mínimas, semínimas o fusas respectivamente, (Figura V.8. ejemplos 2 y 3). También sugiere que puede emplearse un compás ternario cuando se quiere que los soldados marchen más deprisa.
} 
afilado y violento y por lo tanto más adecuado que el otro para la música en el combate. ${ }^{117}$ También indica Arbeau el uso del modo frigio o tercer modo, pues incita a la guerra. En esto sigue los tratados de la época que vuelven a resucitar la teoría griega sobre los ethoi y su correspondencia con los modos empleados en las melodías.

Figura V.9. Arbeau, Orchesographie, pp. 18 y ss.: "Tabulatura du Fifre, ou Arigot du troisieme ton".

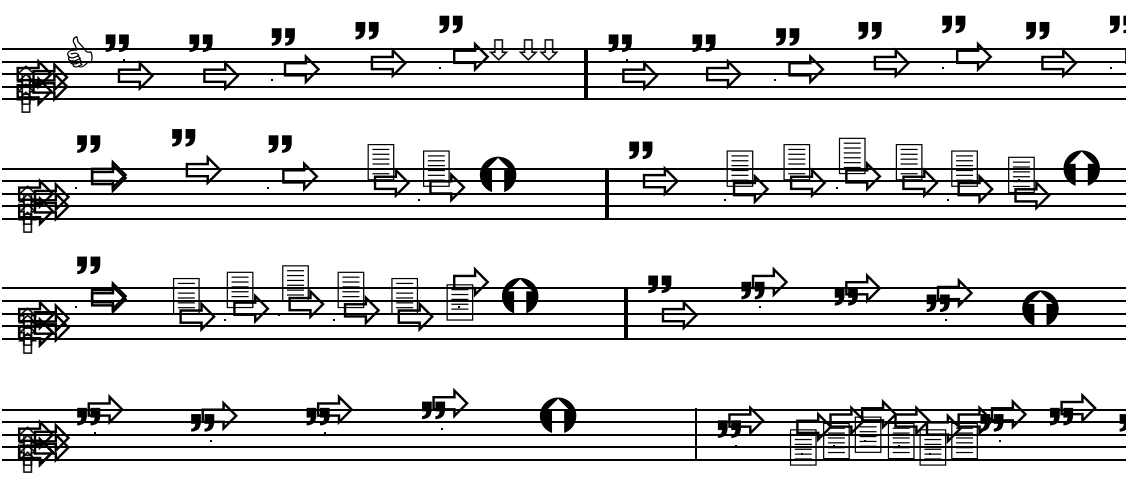

\subsubsection{EI desarrollo de la Batalla de Chupas}

En el siguiente lienzo (Figuras V.10. y V.11.) el atambor aparece roto y tirado por el suelo; es un símbolo, sin duda, del caos reinante en la batalla. Ya los soldados no pueden marchar al son de la música, sino que ahora son los gritos y los bramidos de la lucha lo que se escucha. El atambor roto o abandonado, se convirtió en un elemento comúnmente representado en las escenas de batalla sobre todo a partir de los siglos XVII y XVIII donde se multiplica su presencia. Precisamente, Consigli, en su libro sobre la batalla en la pintura de los siglos XVII y XVIII, aunque no comenta la presencia de este elemento en particular, recoge una selección de pinturas en las que aparece un tambor abandonado en la escena de batalla, la mayor parte de las veces rasgado. ${ }^{118}$ La representación de un tambor roto en el campo de batalla aparece también

\footnotetext{
117 Opiniones semejantes sobre la articulación de la flauta podemos encontrarla también en la obra de Silvestro Ganassi, Opera Intitulata Fontegara, La qual insegna a sonare di flauto (Venecia, 1535), Capítulo V.

${ }^{118}$ Sirva como ejemplo la Battaglia contro gli Amaleciti de Belisario Corenzio (1558-1646), un fresco que se encuentra en la Iglesia de San Severino e Sossio en Nápoles. Este autor fue conocido en España por su serie de los episodios de la vida y batallas de Juan de Austria, y de hecho se conservan algunas
} 
en fecha tan temprana como la del dibujo de Urs Graf titulado Battlefield de 1521. Aquí el tambor aparece rasgado en una esquina de la escena, lo que viene a ser un comentario sobre el después de la batalla. ${ }^{119}$

Figura V.10. Anónimo, Desarrollo de la Batalla de Chupas. Abadía del Sacromonte, Sala Capitular.

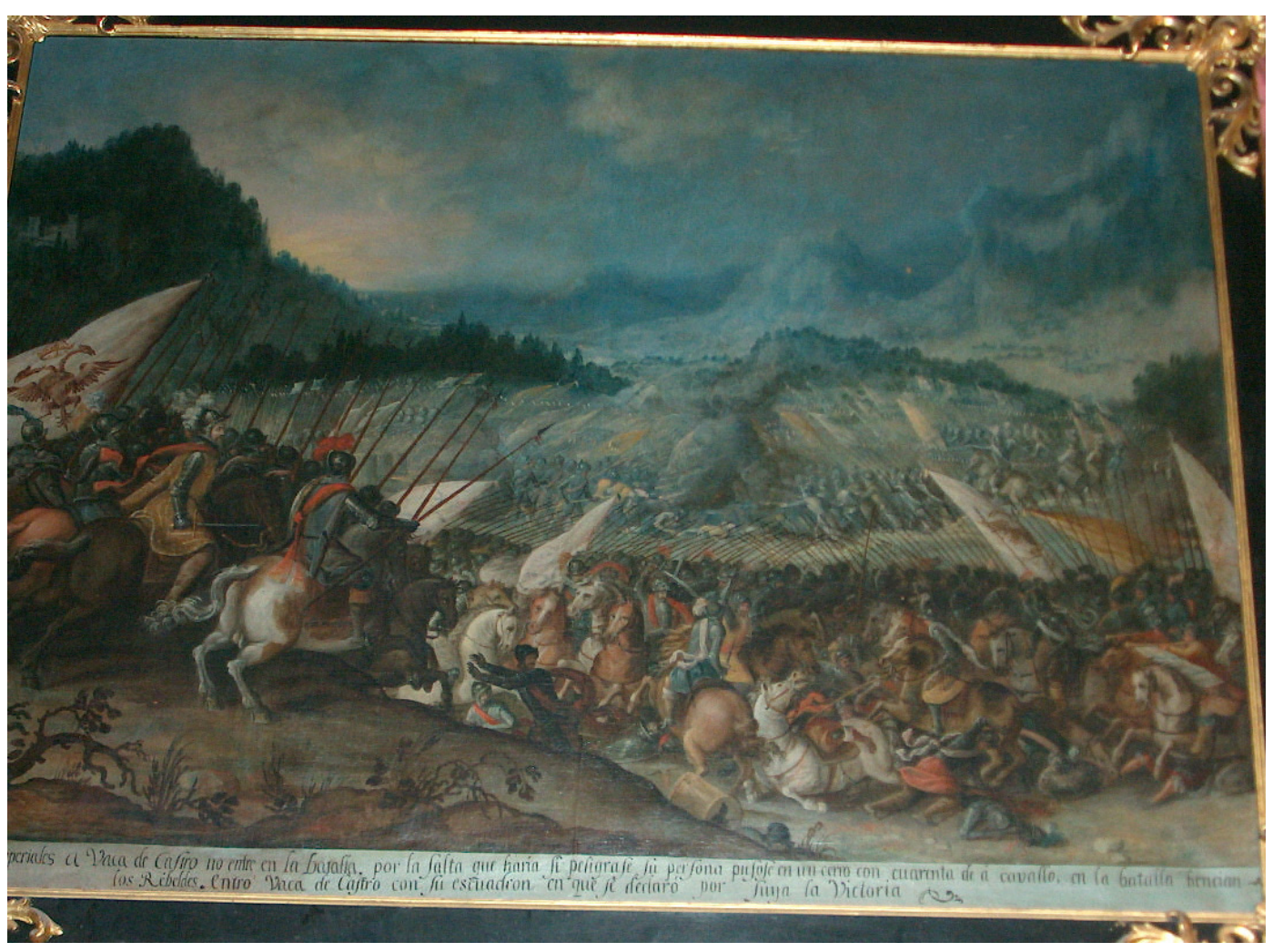

obras suyas en la Biblioteca Nacional de Madrid; véase PatriziaConsigli, La Battaglia nelle pittura del XVII e XVIII sicolo (Parma: Silva, 1994).

${ }^{119}$ Hale, Artist and Warfare, pp. 175-176. 
Figura V.11. Anónimo, Desarrollo de la Batalla de Chupas. Detalle. Abadía del Sacromonte, Sala

Capitular.

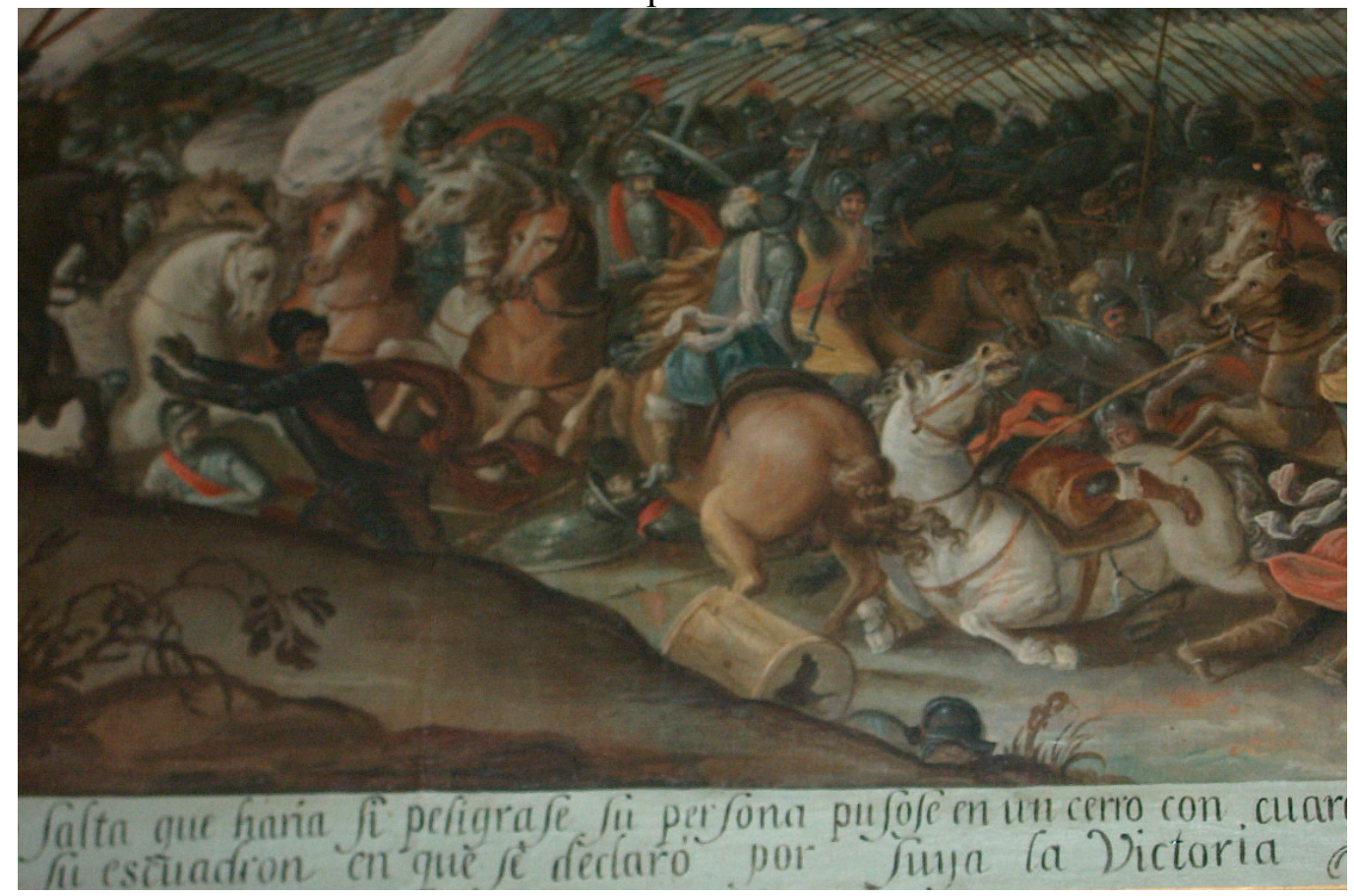

\subsubsection{La entrada triunfal a Cuzco}

En último lugar, el cuadro que representa "La entrada triunfal a Cuzco", (Figuras V.8. y V.9.) puede asociarse directamente con varios elogios que el arzobispo Pedro de Castro encargó para honrar la memoria de su padre, y con una "Relación" manuscrita de los hechos que parece haber sido escrita en Cuzco cuando aún se encontraba allí el gobernador Vaca de Castro; ${ }^{120}$ de esta "Relación" parecen derivar las otras dos narraciones, aunque cada una en un estilo diferente. La más sucinta es la crónica encargada al famoso cronista de Indias Antonio de Herrera, escrita alrededor de 1623, donde encontramos la siguiente descripción de la entrada triunfal de don Cristóbal en Cuzco:

Escribió a todas las Ciudades, a los obispos y personas de consideración de la Provincia del Peru la Victoria que nuestro Señor le havia dado [...] Partio Vaca de Castro de Goamanga y en onze de Noviembre año de 1542 entró en

\footnotetext{
${ }^{120}$ Esta relación manuscrita es la que transcribe el P. Casiano García O.S.A. El licenciado, p.144, y la que aquí seguimos. Parece haber sido ignorada y desconocida por los otros estudiosos de la vida de Vaca de Castro.
} 
la ciudad del Cuzco a fuero de guerra con grande regocijo de Pifanos, arcabuceria, trompetas y caxas. Los esquadrones de a caballo e infantería puestos en orden. Las vanderas tendidas y las del contrario arrastrando por el suelo. Saliole a reçivir, la ciudad, entregaronle las llaves, estavan las calles ricamente aderezadas, a trechos muchos arcos triunfales. Apeose cerca de la iglesia, ${ }^{121}$ recibieronle con el Tedeum laudamus, oyó misa y sermón y aviendo dado gracias a Nuestro Señor por la merced recebida se aposentó en la casa que le tenian prevenidas. ${ }^{122}$

La "Relación" manuscrita del Archivo del Sacromonte es particularmente interesante y prolija, pues describe con detalle todos los aspectos de la ceremonia, incluida la música, las construcciones efímeras, los participantes y el recorrido de la procesión. Hay varios momentos musicales dignos de destacar en esta descripción, algunos de los cuales guardan correspondencia o con el cuadro del Sacromonte, o con la crónica de Herrera, o con el Elogio de Calvete de Estrella:

\section{La entrada triunfal}

Llegó a Limatambo viernes 9 de este presente año, y el domingo 11, llegando a una legua de la ciudad, ordenó a la gente de la manera que había de entrar, que era de esta manera: (...)y luego iba el Gobernador en un caballo morcillo a la estradiota, y tras él iban diez pajes vestidos de terciopelo negro, y otros criados de su casa, y a sus lados iba la gente de la guardia, y a la mano derecha, porque el Gobernador iba un poco delante, iba la bandera y estandarte Real, la cual traía al Alférez General.(...) Y los capitanes Nuño de Castro y Guevara, con sus banderas tendidas con cierta copia de arcabuces en su ordenanza y concierto, y detrás de cada uno de ellos llevaban otras dos caídas que se habían tomado en la batalla, y delante de las cuatro banderas iban las trompetas. Los otros ministriles, y los dichos capitanes Castro y Guevara con la gente, iban junto al dicho Gobernador. ${ }^{123}$

\footnotetext{
${ }^{121}$ Esta iglesia debemos identificarla como la Catedral de Cuzco, que se había erigido como tal por su arzobispo Fray Vicente de Valverde, el 5 de septiembre de 1538, gracias a la Bula anterior de Paulo III. Véase Francisco Javier Hernáez, Colección de bulas, breves y otros documentos relativos a la Iglesia de América y Filipinas, 2 vols. (Bruselas:Alfredo Vromant, 1879), II, p. 719; Balthasar de Tobar, Compendio Bulario Índico (Sevilla: Escuela de Estudios Hispanoamericanos, 1966). Según Stevenson, "Cuzco Cathedral", p. 1, en aquel momento la Catedral se encontraba en Sunturhuasi, y en 1552 fue trasladada a su actual ubicación en Cochavapa. Sobre Cuzco, véase también Geoffrey Baker, Improvising Harmony. Music and society in Colonial Cuzco (Durham y Londres: Duke University Press, 2008).

${ }^{122}$ Antonio de Herrera, "Elogio a Vaca de Castro", Revista de Archivos, Bibliotecas y Museos, XXXVII (1917), 95.

${ }^{123}$ García, El licenciado, p. 143.
} 
Aunque probablemente el pintor no estuvo allí, como sugiere la representación idealizada de la ciudad, recoge esta entrada con algún detalle. ${ }^{124}$ Egberto Bermúdez señala cómo con este tipo de ceremonias, la nueva nobleza indiana trataba de imitar las entradas de los reyes, sirviéndose para ello de todos sus elementos: banderas, artillería, fanfarrias de trompetas y tambores, pífanos y otros instrumentos de viento fueron empleados como símbolos de prestigio y poder siempre que aparecían en público los nuevos gobernadores y virreyes. ${ }^{125}$ Así vemos en este cuadro anónimo como Vaca de Castro va precedido de una comitiva de músicos que van tocando y anunciando su llegada a las puertas de Cuzco y cómo todos estos elementos están presentes en esta entrada.

Figura V.12. Anónimo, Entrada triunfal a Cuzco. Abadía del Sacromonte, Sala Capitular.

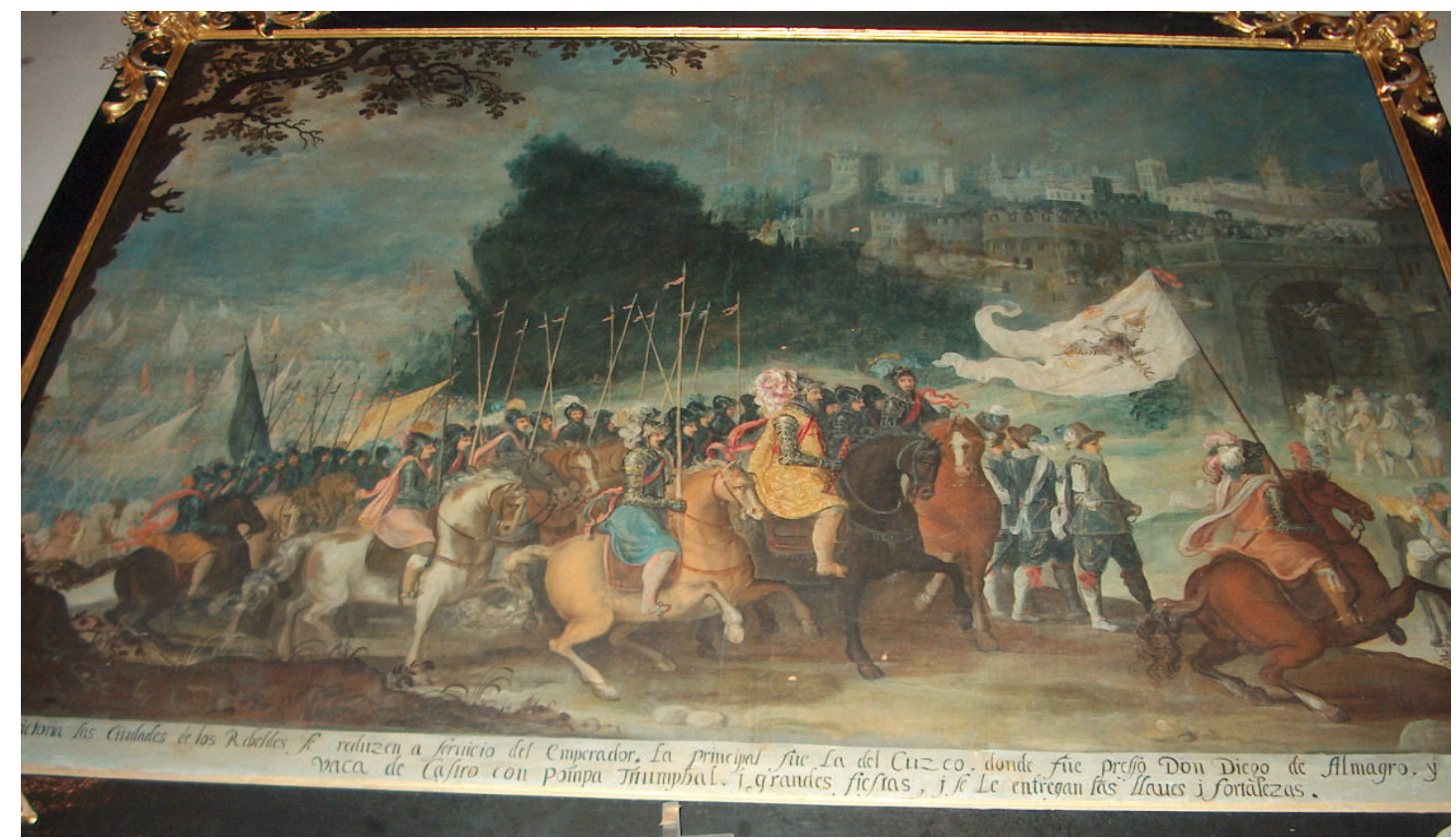

${ }^{124}$ Richard L. Kagan , Imágenes urbanas del mundo hispánico 1493-1870 ( Madrid: Viso, 1998), pp.166 y ss., recoge varias de las imágenes de Cuzco hechas en el siglo XVI. La primera imagen de Cuzco impresa fue una ilustración para la Primera parte de la crónica del Perú (1553) de Pedro Cieza de León, si bien el artista anónimo de esta xilografía dibuja la ciudad muy superficialmente siguiendo vagamente la descripción de Cieza y es en realidad una vista imaginaria. La que aquí presentamos tampoco se corresponde con la imagen real de Cuzco, y además puede decirse que guarda alguna similitud con aquella imaginaria hecha para Cieza.

${ }^{125}$ Egberto Bermúdez, "Urban Music life in the european colonies: examples from America 1530-1560", Music and Musicians in renaissance Cities and Towns, ed. por Fiona Kirby (Cambridge: Cambridge University Press, 2000). 


\section{La arquitectura efimera}

En una calle muy larga, que comienza desde la entrada de la ciudad que atraviesa la mayor parte de ella, hasta llegar a la iglesia mayor, había puestos muchos arcos triunfales y muy espesos y anchos, encubiertos de juncias rojas y flores(...) y a las ventanas de las casas muchos paños de sedas de diversos colores, y puestas a ellas las damas y mujeres españolas, y otras señoras principales de la tierra. (...) a la entrada de la plaza de la ciudad, (...) estaba hecha un castillo de madera, torreado y almenado con sus puertas muy grandes $\mathrm{y}$ bien pintadas, todo cubierto de diversas flores y rosas y otras frescas verduras. Y al pie del dicho castillo y puertas estaba hecho de bulto Cupido con un arco grande y su flecha enarbolada.

Y desde lo alto del castillo, hasta el pie del dicho bulto, estaban puestas unas cuerdas muy tirantes, y en medio de ellas, junto a las almenas del dicho castillo, puesto un niño de edad de seis o siete años, vestido de un alba de lana y su estola y alas y diadema a la manera de ángel y unas dos llaves grandes en las manos; y las puertas del castillo do había de entrar estaban cerradas, y luego que el dicho señor Gobernador llegó junto allí, el dicho ángel desde lo alto bajó por las cuerdas en el aire, y así como llegó junto a donde el Gobernador estaba, hasta el altor de su caballo, y sin ningún detenimiento, extendió las manos y le dio las llaves de la ciudad, las cuales el dicho Gobernador recibió y llevó en sus manos. ${ }^{126}$

Las construcciones efímeras o "aparatos" como se denominaban en la época, eran parte indispensable de la entrada. Arcos triunfales y castillos son elementos comunes: los primeros son un remedo de los arcos romanos y los segundos tienen que ver con la simbología medieval. El Cupido y el niño ángel con las llaves aparecen con frecuencia en entradas: el acto de entrega de las llaves de la ciudad es una ceremonia que se representaba desde la Edad Media, y se hacía sobre todo a los reyes. ${ }^{127}$ En el Elogio de Calvete de Estrella, más elaborado y poético, pues es fundamentalmente un poema laudatorio no una crónica histórica, el Cúpido (al que identifica con el niño) canta al licenciado Vaca de Castro:

\footnotetext{
${ }^{126}$ Relación manuscrita Archivo del Sacromonte (transcripción de Casiano García, op. cit., pp. 144-145).

${ }^{127}$ En la entrada de Fernando de Aragón en Valencia en Julio de 1507 fueron dos los ángeles que descendieron de la puerta con las llaves cantando; véase Tess Knighton and Carmen Morte García, "Ferdinand of Aragon's entry into Valladolid in 1513: the triumph of a christian king", Early Music History, XVIII (1999), p. 127. Las autoras mencionan también la presencia de ángeles en la entrada de Isabel la Católica en Barcelona en 1481 (tres en esta ocasión); véase también Emilio Ros-Fábregas, "Music and Ceremony during Charles V's 1519 visit to Barcelona", Early Music, XXIII/3 (1995), 375391.
} 
De aquí salió volando un bello joven-semejante a Cupido-; y a su paso, de las llaves doradas hace entrega a Vaca, caballero sobre airoso corcel, y así le cantó $^{128}$ con suave voz: "Por ti están del Perú abiertos los muros; y las puertas del Cuzco, su metrópoli, por ti libres están. He aquí las llaves de la ciudad; y sin demora alguna, oh gran libertador, penetra en ella y rige al Cuzco y a las ricas Indias, gracias a tu valor, de los tiranos ya libres".

En efecto, él de las llaves se hace cargo; y oyendo del mancebo el dulce canto $^{129}$, en la ciudad penetra ${ }^{130}$

En la pintura podemos observar un personaje alado delante de la puerta. Sobre ella pueden verse en pequeño un grupo de personas, de las que algunas pueden ser identificadas como cantores y ministriles, que podrían haber acompañado la aparición de este Cupido.

\footnotetext{
129 José López de Toro traduce "cantum" por "voz", pero el contexto muy bien podía ser "canto"; lo mismo sucede en otras ocasiones que se especifican. Manuel Díaz Gito, La Vacaida de Calvete de Estrella (Alcañiz-Madrid: Instituto de Estudios Humanísticos, 2003), p. 303, traduce ese mismo pasaje por "entona con dulce voz". También apunta, basándose en la "Relación" manuscrita del Sacromonte que eran dos ángeles en lugar de uno los que entregaron las llaves a Calvete.
}

${ }^{130}$ Juan Cristóbal Calvete de Estrella, Elogio de Vaca de Castro, estudio y traducción por José López de Toro ( Madrid: CSIC, 1947), p. 165. 
Figura V.13. Anónimo, Entrada triunfal a Cuzco. Detalle. Abadía del Sacromonte, Sala Capitular.

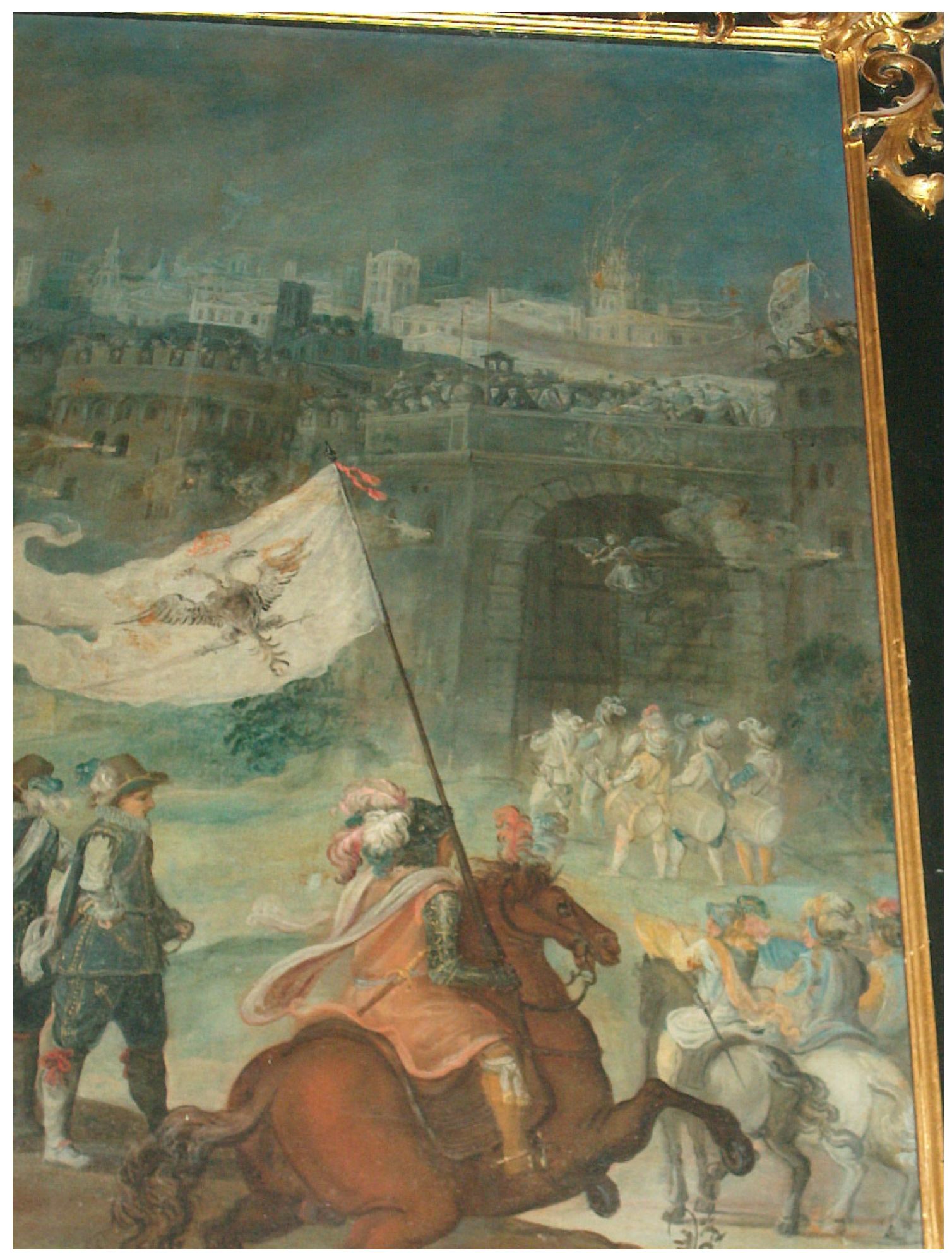




\section{La música}

Y de arriba del castillo soltaron arcabuces y munición que allí había. Y así como entró el Cabildo, dignidades y clérigos de la dicha iglesia estaban tras las puertas del castillo con sus capas y báculos en las manos, y le hicieron su acatamiento, y empezaron a cantar por canto de órgano algunas epístolas y villancicos al propósito de la venida del señor Gobernador y libertad que había dado a la tierra, y del ánimo y sagacidad con que había vencido a los que la tenían usurpada y tiranizada.Y acabados siguen su camino a la iglesia e iban cantando ciertos salmos y canciones buenas y al parecer de todos muy sabrosas para loar a Dios, y todas en loor de la historia que había habido de recuperación de la tierra y libertad de los habitantes de ella, y así fueron cantando hasta la iglesia el salmo "Te Deum Laudamus" 131

Ésta es, si no la primera, una de las noticias más tempranas que se refieren a la interpretación de música polifónica en Cuzco. Stevenson, en un artículo sobre la música en la Catedral de Cuzco señala un inventario de 1546 que recogía la existencia de 16 libros de canto llano, pero ninguno de polifonía. ${ }^{132}$ La circunstancia de que fueran "epístolas" nos indica que probablemente para éstas se empleara un tipo simple de polifonía, quizás improvisada como el fabordón, en lugar de un contrapunto elaborado. La presencia de polifonía en este contexto debe ser interpretada como símbolo del poder y la realeza. ${ }^{133}$ Es interesante la composición de villancicos ex profeso para el acontecimiento, porque refleja la continuidad de la práctica musical hispana a la vez que la existencia de músicos con un grado relativamente alto de especialización. El programa musical se completa con "salmos y canciones buenas y muy sabrosas para loar a Dios" y el obligado Te Deum. En esto coincide con el relato más sucinto de Herrera y con el Elogio de Calvete. El canto del Te Deum es un lugar común en las ceremonias de recibimiento de reyes y personajes nobles desde la Edad Media, debido en gran parte a su carácter procesional. El que aquí nos ocupa pudo ser monódico, aunque también encontramos este himno tratado polifónicamente en el Renacimiento. El hecho de que las actas de la Catedral de Cuzco solo se conserven

\footnotetext{
${ }^{131}$ Relación manuscrita Archivo del Sacromonte (transcripción de Casiano García, p. 145).

${ }^{132}$ Véase Robert Stevenson, "Music in Cuzco", p. 2.

133 " It is clear that from at least the mid fifteenth century onwards, art music-composed music performed by professionals-was associated with power in general and kingship in particular”, Tess Knighton,

"Ferdinand's de Aragón...", p. 156.
} 
desde 1546 (y la entrada tuvo lugar el 11 de noviembre de 1542), nos deja con la duda. $^{134}$

El Elogio de Calvete señala dos momentos musicales más, que probablemente sean invención del poeta en el caso de esta entrada a Cuzco, pero que eran algo frecuente en otras entradas:

Retumban los cañones con alegres estampidos y corren por los aires estruendosos clamores y sonidos. Luego de Castro los hechos celebran con sonoras melodías y pregonan con grandes alabanzas-que van hasta las nubesque de Castro, merced a la sagaz inteligencia y al preclaro talento, de los crueles y feroces tiranos se vio libre la ciudad, y el Perú sacudió el yugo ominoso de Almagro (...).Ver podrías todo el Cuzco saltar de gozo y resonar con cantos de júbilo los coros por las plazas. Más amenos resultan los festines, con las chanzas alegres y donaires, y los cantos festivos que el poeta español arrancaba de su lira de marfil, celebrando las victorias del magnánimo Carlos ${ }^{135}$

Las sonoras melodías. Dejando a un lado las posibles licencias poéticas que Calvete se pudo haber tomado, estas canciones de alabanza al licenciado Vaca de Castro podemos identificarlas con los villancicos que señala la relación anónima, aunque también podían ser otro tipo más simple de canción, como el romance. La composición de romances es algo propio de la lírica hispánica y con amplia presencia en el folclore de donde pasó a la música cortesana en el siglo XVI. Estos cantos de alabanza podían ser romances, por su carácter de gesta muy apropiado para narrar hechos. ${ }^{136}$

Los cantos del poeta a Carlos V. Calvete sin duda pretendía reafirmar que Vaca de Castro no quería usurpar la autoridad real como sus enemigos habían pretendido, por lo que esta alusión al canto laudatorio de las gestas del emperador no es un hecho baladí. Estos cantos bien podían ser también romances, pues Calvete nos advierte del argumento de algunas de ellas, como las victorias sobre los protestantes, la paz con Francia, etc.

\footnotetext{
134. Véase Robert Stevenson, "Music in Cuzco", p. 2.

${ }^{135}$ Calvete de Estrella, Elogio, pp. 165-167.

${ }^{136}$ Aunque no indica sus fuentes, José Quezada et alii, La música en el Perú (Lima: Patronato Popular y Porvenir Pro Música Clásica, 1988), p. 74, señala que "los romances en esta época adoptaron formas coloquiales y dialogadas. Además de los que se cantaron a Gonzalo [Pizarro] y sus hazañas, se tiene conocimiento de los que se hicieron a la muerte de Almagro y los que rememoraban al rebelde Hernández Girón". Calvete no estaría sino dando testimonio de una costumbre que existía en el Perú.
} 
Vaca de Castro contó con poco tiempo para gobernar, ya que dos años después de su llegada, en 1542, con la puesta en vigor de las Leyes Nuevas (que supusieron un duro golpe para los caciques) Carlos I, que sabía las dificultades a las que se enfrentaban dichas ordenanzas, nombró a Blasco Núñez de Vela primer virrey del Perú. Pero mientras tanto sabemos gracias a la relación anónima que Vaca de Castro contaba con sus propios ministriles pues

Una de las principales causas, y aun la mayor, por donde ha habido las alteraciones pasadas y las muertes de los Gobernadores, ha sido la poca estimación en la que los tenían y no tener en sus casas tantas personas de calidad como el cargo y oficio que tenían convenía y era menester. Y como el Gobernador es sabio, y en gastar para lo que toca a su autoridad del oficio y reputación de su persona no nad escaso, tiene casa de muy señor, (...) y tiene por su mayordomo a Fulano de Carranza, y por camarero a Antonio Quiñones (...) teniendo guarda de arcabuceros y alabarderos de que es capitán el capitán Pero Ansúrez; y sus ministriles. ${ }^{137}$

El nuevo Virrey desconfiaba del anterior gobernador Vaca de Castro, que fue encarcelado y tuvo que huir a España. Acusado por pizarristas y almagristas de haberse enriquecido en el Perú, sufrió cautiverio injustamente durante once años en España. En 1556 le fue devuelta la libertad, probada la falsedad de tales imputaciones, y fue repuesto en el Consejo de Indias, nombrado Comendador de la Orden de Santiago e indemnizado por los gastos y sacrificios que le reportó su misión en el Perú.

Con la renta de 20.000 ducados obtenidos por los repartimientos de indios vacos y sus tributos, Vaca de castro fundó un "mayorazgo" para preservar la cohesión familiar y garantizar los bienes sustentadores del linaje. ${ }^{138}$ Este mayorazgo fue heredado por su hijo Don Pedro de Castro, quien gracias a estos bienes pudo fundar la Abadía del Sacromonte. Particularmente interesante es la descripción de las honras fúnebres que tuvieron lugar en la Abadía con ocasión del traslado de los cuerpos del gobernador del Perú y su esposa desde Valladolid a Granada, y la de otros miembros de esta ilustre dinastía. Las Actas capitulares y los cronistas de la época completan las fuentes que nos ayudan a revivir las conmemoraciones fúnebres de la familia Cabeza de Vaca.

\footnotetext{
${ }^{137}$ Relación manuscrita Archivo del Sacromonte (transcripción de Casiano García, p. 146).

$138 \mathrm{M}^{\mathrm{a}}$ Isabel Viforcos Marinas y Jesús Paniagua Pérez, El leonés D. Cristóbal Vaca de Castro: gobernador y organizador del Perú (Madrid: S.A. Hullera Vasco-Leonesa, 1991), p. 120.
} 


\subsection{Las Honras Fúnebres de la Familia Cabeza de Vaca en el Sacromonte}

El papel que desempeñaban las honras fúnebres y las exequias en la sociedad del Antiguo Régimen estaba acorde con la mentalidad renacentista; eran una demostración pública de la valía del difunto, y una forma de "proclamar el triunfo sobre la muerte, mero tránsito hacia la gloria y la fama”. ${ }^{139}$ En ellas la música juega un papel no menos importante al lado de la arquitectura efímera con la construcción de túmulos y catafalcos, las luces, el incienso, y las palabras del sermón destinadas a conmover a los oyentes ensalzando las cualidades del difunto.

Las honras no solo tenían lugar el día del óbito, sino que en algunos casos se perpetuaban anualmente en lo que se denomina con el nombre de Fundaciones. Con la aportación de una suma determinada de dinero o por el legado de algunos bienes y tierras, el donante se aseguraba una misa perpetua por su alma.

En el Sacromonte las honras fúnebres que se hacían por Don Pedro de Castro y sus padres, que están también allí enterrados, eran un acontecimiento importante dentro de las celebraciones anuales. Don Pedro de Castro decidió trasladar los restos de su familia a la Capilla que había fundado en el Sacromonte el 18 de Enero de $1602 .{ }^{140}$ Para ello hubo de obtener una bula de Clemente VIII para conmutar el testamento de su padre, ${ }^{141}$ que había fundado una capilla en el Convento de San Agustín en Valladolid. La entrega de los cuerpos del licenciado Cristóbal Vaca de Castro, su abuelo Garci de Castro, su madre María de Quiñones y su hermano Antonio de Castro hubo de esperar hasta 1613, pues la Iglesia de la Abadía se hallaba en proceso de construcción.

\footnotetext{
${ }^{139} \mathrm{M}^{\mathrm{a}}$ Dolores Campos Sánchez Bordona, Honras fúnebres reales en el León del antiguo Régimen (León: Universidad de León,1995), p.115.

${ }^{140}$ Existe una relación impresa de esta visita cuya referencia proporciona Jenaro Alenda y Mira, Relaciones de solemnidades y Fiesta Públicas en España, Madrid, 1903, p. 121.

${ }^{141} \mathrm{M}^{\mathrm{a}}$ Isabel Viforcos Marinas y Jesús Paniagua Pérez, El leonés, p.128.
} 
En 1618, don Pedro obtuvo permiso de cuatro meses para ausentarse de la diócesis sevillana de la que había sido nombrado obispo después de su estancia en Granada, y dirigirse al Sacromonte para visitar la tumba de sus padres. Con este motivo se celebrarán unas honras fúnebres, que con toda probabilidad se corresponderían con la ceremonia descrita en la Consueta y que detallaremos más abajo. El Arzobispo estableció el 3 de Noviembre como día para conmemorar el aniversario de la muerte de sus padres, tal y como queda reflejado en la Consueta. Don Pedro fundó además tres aniversarios perpetuos más en el Sacromonte: en el día de la Concepción, el día de la Asunción y en el día de su propio entierro. ${ }^{142}$

\subsection{La muerte del Arzobispo Pedro de Castro y sus honras fúnebres}

Heredia Barnuevo en su obra sobre la vida del arzobispo Pedro de Castro, escrita a mediados del siglo XVIII, describe las circunstancias de la muerte de Castro y su traslado al Sacromonte. ${ }^{143}$ La muerte del prelado, acaecida en Sevilla el 20 de diciembre de 1623, donde había sido nombrado arzobispo, constituyó todo un acontecimiento en la época, pues Don Pedro estaba considerado como uno de los personajes más ilustres de su tiempo. No en vano, el cortejo fúnebre que casi dos meses después lo trasladó al Sacromonte, se detuvo en todas las poblaciones importantes del camino para rendirle tributo: Écija, Carmona, Antequera, Loja y Santa Fe le honraron con misas cantadas y responsos. Al llegar a Granada entró en procesión solemne hasta la Catedral, donde en el exterior se le cantó un solemne responso. Luego, conducido dentro al túmulo situado entre los dos coros, se le cantó Vigilia. Al día siguiente se celebró una misa pontificial y finalmente, por la tarde fue trasladado al Sacromonte. El coro de la Catedral le cantó otra vigilia en el coro alto de la Colegiata, formando ésta el suyo en la iglesia. Una vez acabada la visita se interpolaron los capitulares de uno y otro cabildo para los responsos y el entierro. El jueves 5 de Febrero de 1624 volvió la

\footnotetext{
${ }^{142}$ Dos de los aniversarios están destinados a honrar a la Virgen. No hay que olvidar el importante papel que jugó Don Pedro en la propagación de la creencia de la Inmaculada Concepción y su marcado carácter marianista.

${ }^{143}$ Heredia Barnuevo, Mistico ramillet., p. 214, recoge los últimos momentos de la vida de Don Pedro: "Sintiéndose enfermo y con el Cabildo a su alrededor le dio a entender que había llegado el momento de que se le cantase la "dulcísima antífona" de la Inmaculada Concepción de Nuestra Señora Conceptio tua, y con la cabeza inclinada por la devoción murió escuchando aquel final acento de la antífona Donavit nobis vitam sempiternam".
} 
metropolitana a celebrarle misa con igual pompa. Del 17 de Febrero al 5 de Marzo se repitieron las honras por las diversas congregaciones e iglesias de Granada, "cerrando las dichas honras la Universidad con grande majestad y grandeça”. La visita más destacada que recibió el difunto fue la del Rey Felipe IV, que el 6 de Abril de ese mismo año, Sábado Santo, visitó el sepulcro.

\subsection{Las honras fúnebres en la Consueta}

La Consueta dedica un capítulo ${ }^{144}$ íntegro para describir esta ceremonia, la cual se celebraba al menos dos veces al año: el 20 de diciembre, día de la muerte de Don Pedro, y el 3 de Noviembre, fecha instituida por él como aniversario de la muerte de sus padres. A estos aniversarios tenían obligación de asistir todos los prebendados del Sacomonte, que además debían decir una misa al mes por el fundador. El Abad debía celebrar la vigilia y la misa, y si faltaba por causa muy grave la celebraba el Presidente. La Consueta describe con todo detalle cómo debía erigirse el túmulo, qué mobiliario litúrgico debía emplearse, la forma en la que se incensaba, cuándo y cómo se cantaba.

\section{El túmulo}

La Consueta explica cómo debía ser el túmulo que se hacía el día anterior a la conmemoración (19 de Diciembre). Se situaba a la altura del crucero, con una altura de más de metro y medio y estaba cubierto por paños negros sobre los que se situaban los atributos del arzobispo: la mitra y la casulla. Rodeando este catafalco se colocaban candeleros grandes con velas y doce hachas en la cabecera. En el resto de la iglesia se encendían las lámparas y el altar se vestía con frontales negros. La escenografía se completaba con el atuendo negro del celebrante. La Figura V.14. ilustra cómo solían hacerse en la época los túmulos de los prelados.

\footnotetext{
${ }^{144}$ Consueta, f. $438^{\mathrm{r}}$ : Capítulo 24, del officio en el dia de las honras que se hazen por el Illmo. Fundador y por sus padres.
} 
Figura V.14. Caeremoniale Episcoporum (Roma: Giannini et Mainardi, 1729), p. 428.

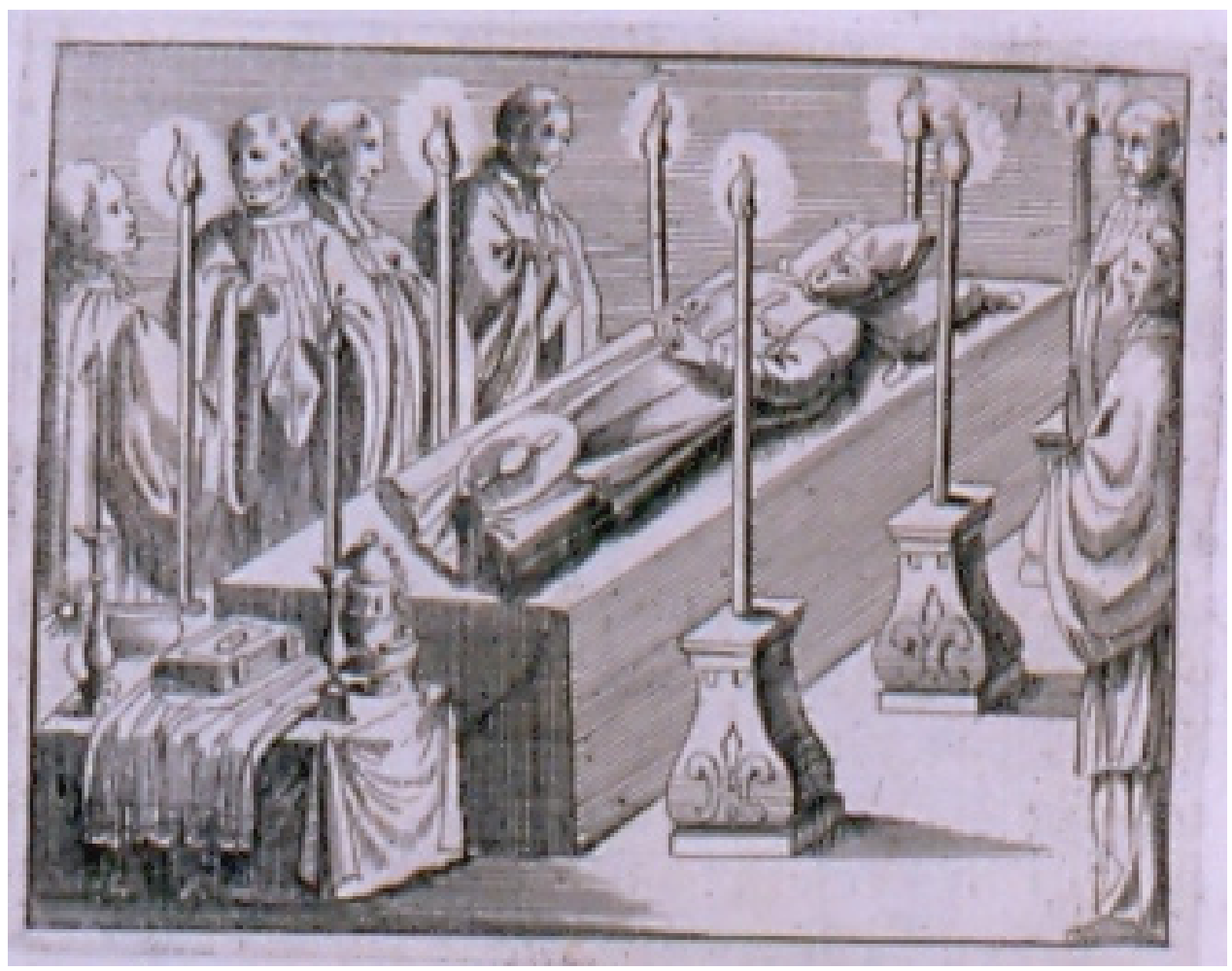

\section{- La Vispera del día de la conmemoración}

Las honras comenzaban el día anterior al aniversario (19 de diciembre), como todas las fiestas importantes con el oficio de difuntos. La campana anunciaba a las doce del medio día con tres clamores de media hora la preparación para el oficio. Después, con el toque de vísperas, los versicularios transportaban los libros al coro y llevaban los cantorales del oficio de difuntos al pie del facistol del coro, que no serían colocados y abiertos en él hasta después de Vísperas.

La Vigilia, acabada las Vísperas, se comenzaba sin invitatorio; en cambio se doblaban las antífonas "y se canta con mucha solemnidad". Las lecciones las cantaban el Abad y dos prebendados que habían sido previamente designados por el maestro de ceremonias. Al terminar las oraciones bajaban todos del coro a la sacristía donde recogían el turíbulo, los cetros y la cruz, y en riguroso orden salían en procesión hacia el túmulo rodeándolo. La Consueta describe el canto del responso así: 
Puestos en esta disposición el Sochantre comienza el responso Libera me domine de morte aeterna, y al verso convida a los caperos y los cetreros pasan y les dan los cetros como se dijo supra capítulo del día de los difuntos numero 8 cantase el responso con mucha solemnidad y cuando se repite por ultima vez cum veneris iudicare el turiferario hace genuflexion al altar y desde su lugar viene hasta donde esta el celebrante y da la naveta al Cerimonario. ${ }^{145}$

Este responso alrededor del túmulo incluye una bendición con agua y otras oraciones; se finaliza cuando el celebrante dice:

Requiem aeterna dona ei domine, con la diestra hace la señal de la cruz sobre el túmulo y siempre observa lo mismo, los caperos en medio del coro y con los cetros cantan Requiescant in pace R/ Amen y entonando la antífona si iniquitates observaverit Domine y el salmo de profundis, alternatim se entra en la Sacristia como se dijo supra. ${ }^{146}$

\section{-El día de la conmemoración o aniversario}

Al día siguiente, día 20 de diciembre, que es propiamente el día del aniversario de la muerte del Arzobispo, se recordaba como el día precedente con los tres clamores de las campanas. La misa de tercia, que era la que se cantaba diariamente en la Abadía (la de las otras horas eran rezadas), se destinaba a la conmemoración. La Consueta especifica que dicha misa debía de ser Misa de Requiem, celebrada como señala el capitulo quince del libro tercero de la Consueta. Esta misa de Requiem se comienza con el Introito con la peculiaridad de que se omite el salmo Iudica me Deus. Refiriéndose al diácono y al celebrante la Consueta señala que "a los kiryes si hay lugar se sientan". Este permiso hace pensar que este Kyrie no estaría interpretado por el coro y el celebrante (porque de esta forma no podrían sentarse). Quizás estuviera destinado a los capellanes para los que normalmente estaba reservada la interpretación de la polifonía.

Un dato significativo de esta ceremonia es que no era obligatorio cantar la secuencia Dies Irae. Puede que la supresión de casi todas las secuencias por el Concilio de Trento propició que se perdiera interés por este tipo de obras. El resto de indicaciones que hacen referencia a la música se centran en indicar quién y cómo ha de cantar. De esta forma, la Epístola es cantada por el subdiácono "con el rostro vuelto al

\footnotetext{
${ }^{145}$ Consueta, fol. $440^{\mathrm{v}}$

${ }^{i 46}$ Consueta, fol. $441^{\mathrm{r}}$.
} 
altar"; el Evangelio lo canta el diácono que baja desde el coro, vuelto al pueblo; y el diácono canta con el rostro hacia el altar el Requiescant in pace. Las honras finalizan como en el oficio del día anterior: cantando el responso alrededor del túmulo, solo que en esta ocasión entra la procesión a la Sacristía con el de Profundis.

El capítulo de la Consueta dedicado a esta ceremonia concluye con una sugerente indicación acerca del tempo y tono: "el punto o cuerda que se lleva en el canto en la misa y oficio de difuntos es baxo, grave y el compás moroso". La indicación sobre el compás no sorprende pues era costumbre en la época asimilar solemnidad con compás "moroso" o lento. A esta exigencia de "morosidad" alude la Consueta continuamente; y en ello se deja sentir la influencia de la Consueta catedralicia. Si bien es una constante generalizada en otros centros eclesiásticos de la época, no hay que olvidar que la Catedral de Granada se hizo famosa por la solemnidad y duración de sus oficios, que en algunos casos superaban las cinco horas. En la Consueta del Sacromonte no se estipula la duración exacta, pero sí que la ceremonia se debe hacer más lenta cuanto más solemne:

\footnotetext{
y en la pausa de tono y compás se atiende a la solemnidad del día: Las vísperas de fiesta de primera clase y principales de Nuestra señora, Santos del Sacromonte se dice con toda solemnidad y gravedad y más espacio los que fueren de ellos más solemnes, y se ha de tener gran cuidado con la morosidad del compás; pues encomienda tanto la religión del coro del Sacromonte y no tiene otra cosa más con que solemnizar ni diferenciar las fiestas.
}

Lo más original de la Consueta es la referencia al tono o punto que debe ser grave o bajo. Esta asociación entre tono bajo y solemnidad no es tan frecuente encontrarla, ni siquiera en otro momento de la Consueta. Acaso los tonos agudos se prestaran más al lucimiento de los cantores y resultase poco apropiado para un entierro o una conmemoración de difuntos. El interés de la descripción de esta ceremonia radica en que pocas veces se estudian los aniversarios particulares y muchas la celebración de exequias reales. Por ello su análisis puede acercarnos a una práctica litúrgica más común de lo que las honras fúnebres por los reyes podían suponer. Su semejanza con las descripciones de las exequias reales es patente, sobre todo en cuanto a la presencia de un túmulo funerario con los atributos de poder, en este caso báculo y mitra. 


\section{El culto a la Virgen en la Abadía}

\subsection{EI culto a a Inmaculada Concepción en el siglo XVII}

La primera piedra era "de mármol blanco labrada (...) tenía una cruz orlada con esta inscripción en caracteres árabes: A MARÍA NO TOCÓ EL PECADO ORIGINAL

Heredia Barnuevo, Mistico Ramillete, p.133.

Si no se conociesen los antecedentes de "invención y creación" del mito sacromontano resultaría llamativo que la primera piedra de una iglesia en la España contrarreformista estuviera escrita en árabe e hiciera referencia a la Virgen María y su Concepción Inmaculada. Pero en este epígrafe lo que nos interesa es llamar la atención sobre cómo desde el mismo momento de la "ideación" de los descubrimientos, la Virgen ocupó un lugar de indiscutible preferencia en el culto abacial por un doble motivo: de un lado la virgen María aparece con protagonismo propio en los Libros Plúmbeos y en especial por las referencias que se hacen a su Inmaculada Concepción; y por otro, el pensamiento inmaculista de Pedro de Castro como paradigama de los ideales de la Contrarreforma.

Entre los Libros Plúmbeos que se encontraron en las Cuevas del Sacromonte, y que posteriormente fueron condenados por Inocencio XI en 1682, se hallaban dos que mencionaban la Inmaculada Concepción de la Virgen que, aunque era una creencia popular, aún no había sido declarada dogma por la Iglesia. ${ }^{147}$ El debate sobre el inmaculismo ya se había abierto antes de los hallazgos del Sacromonte, así que éstos vinieron a reafirmar la posición de los inmaculistas. El fundador de la Abadía, Pedro de Castro, fue el gran defensor y uno de los principales impulsores de este dogma. Escribió varias cartas al Consejo de Castilla pidiendo la intercesión del monarca español en Roma, y sus esfuerzos no sólo cristalizaron en el Sacromonte, sino también en la

\footnotetext{
${ }^{147}$ Los libros se titulan Libro de los fundamentos de la religión y De la doctrina de la Iglesia.
} 
diócesis sevillana de la que fue obispo en los últimos años de su vida. ${ }^{148}$ En el Sacromonte fundó un aniversario dedicado a la Inmaculada y además impuso la obligación a los canónigos y colegiales de hacer un voto solemne en el que prometían defender esta creencia. De hecho, el lema del Sacromonte, que aparece en numerosas cartelas e inscripciones es "A María no tocó el pecado primero", frase que se menciona con frecuencia en los Libros Plúmbeos.

\section{La música en las relaciones de festejos sobre la Inmaculada.}

Algunos estudios han puesto de manifiesto el papel que tuvieron los descubrimientos de la Abadía y Pedro de Castro en la difusión de la creencia de la Inmaculada Concepción, ${ }^{149}$ pero poco se ha dicho sobre la repercusión musical ${ }^{150}$ que la propagación de la devoción a la Inmaculada Concepción suscitó en la Península y sus territorios transoceánicos en el siglo XVII. ${ }^{151}$ Aunque en España los motetes a la Concepción no eran desconocidos a los músicos del XVI, ${ }^{152}$ la proliferación de festejos

\footnotetext{
${ }^{148}$ Para un estudio más detallado sobre el papel de Pedro de Castro en la difusión del dogma ver entre otros: Manuel Barrios Aguilera, Los falsos cronicones contra la historia (Granada: Editorial Universidad de Granada, 2004), pp. 133 y ss.

${ }^{149}$ Véanse los estudios de Barrios Aguilera.

${ }^{150}$ Véanse los trabajos de Borgerding y O'Connor: Todd Borgerding, The Motet and Spanish Religiosity, ca.1550-1610 (Tesis Doctoral, Universidad de Michigan, 1997), su tesis es hasta 1610 (que es cuando llega Castro a Sevilla); Michael Brian O'Connor, The Polyphonic Compositions on Marian Texts by Juan de Esquivel Barahona: A Study of Institutional Marian Devotion in Late Renaissance Spain, (Tesis doctoral, Universidad del Estado de Florida, 2006).
}

${ }^{151}$ En el Mss. 9956, fols. $100^{\mathrm{r}}-100^{\mathrm{v}}$, de la BNE se conserva la copia de una carta de Diego de Acuña, Gobernador y Capitán General de Cartagena de Indias informando a Felipe II que desde hacía dos años se celebraba la devoción de la Inmaculada y de los conflictos que a propósito de la Concepción habían surgido entre dominicos y franciscanos; aunque está sin fechar, la copia data de Junio de 1617, con lo que bien podría estar haciendo referencia a 1615. En Perú encontramos relaciones sobre celebraciones a la Inmaculada Concepción con fechas tan tempranas como 1618, como por ejemplo la Relación de las fiestas que a la Inmaculada Concepción de la Virgen Nuestra Señora se hicieron en esta ciudad de los reyes del Perú, Francisco del Canto, 1618; y en 1619 el voto de la Universidad de Lima, Relación de las fiestas triumphales que la insigne Vniuersidad de Lima hizo a la Imnaculada [sic] Concepcion de Nuestra Señora ... / por Diego Cano Gutierrez (Lima : Francisco Lasso, 1619). En Méjico encontramos la Breve relación de las fiestas, que los artífices plateros, vezinos de México celebraron a la Purissima Virgen Maria, el día de su inmaculada Concepción. Año de 1618.

${ }^{152}$ Michael Brian O'Connor, The Polyphonic Compositions, p.107, señala algunos motetes de Guerrero con textos alusivos a la Concepción, como Sancta et Inmaculada o Conceptio tua Dei genitrix. Cristóbal de Morales, Juan Ginés Pérez de la Parra y Joan Pau Pujol tienen motetes sobre el texto Conceptio tua, la antífona del Magnificat para las segundas Vísperas como señala O'Connor, p. 158. De Vivanco recoge el $O$ virgo Benedicta, dedicado a la Concepción, siguiendo los textos de los antiguos breviarios hispanos; véase p. 109. Vivanco empleó también otros textos asociados a la Inmaculada Concepción, pero evitando 
para reafirmar este culto demandó la creación de numerosas obras musicales, especialmente chanzonetas y villancicos. Alrededor de 1615 comenzaron a hacerse fiestas en toda España para celebrar la Inmaculada Concepción de María, de modo que el fervor popular fue extendiéndose rápidamente por toda la Península. De Granada a Sevilla, de Toledo a Madrid, no hubo ninguna población importante que no hiciera su fiesta en la tradición más puramente barroca, integrando arquitectura efímera, música y poesía. Las descripciones de algunas de estas fiestas nos han llegado impresas en forma de relaciones. Andalucía destaca en el número de relaciones y fiestas, especialmente Sevilla donde era arzobispo Pedro de Castro. ${ }^{153}$ En todas las relaciones de desagravios, votos solemnes, fiestas por la proclamación, justas poéticas, etc., la música en forma de coplas, chançonetas o villancicos y motetes actuaban en la propagación de la creencia. Algunas de estas fiestas duraban ocho días y se desarrollaban en diferentes iglesias de la ciudad, con procesiones y máscaras, como por ejemplo la celebrada en Jerez de la Frontera en 1615 o la que se hizo en Toledo en 1616 a la que asistió el Rey.

Las celebraciones se producían en dos esferas diferenciadas, pero en ocasiones convergentes: la religiosa (con la celebración en la iglesia de misas y vísperas) y la

los símbolos más específicos, quizás debido a la tensión generada por los inmaculistas y sus detractores a finales del XVI.

${ }^{153}$ Para los comentarios que siguen me he basado en las siguientes relaciones: Alonso Ferriol y Caycedo, Libro de las fiestas, que en honor de la immaculada Concepcion de la Virgen Maria... celebró su Devota... Hermandad. En San Francisco de Granada. Año de mil y seiscietos y quince (Granada: Martin Fernandez, 1616); Relacion del voto que hizo y octauario que celebró la ciudad de Xerez de la Frontera, en honra de la Inmaculada Concepcion (Sevilla: Alonso Rodriguez Gamarra, 1616); Solenissimas fiestas que la insigne ciudad de Toledo hizo a la Inmaculada Concepcion (Seuilla: Francisco de Lyra, 1616); Relacion de las famosas fiestas que se hizieron en la Vniuersidad de Alcala de Henares, despues de auer hecho voto de guardar y tener en ella el ... misterio de la Inmaculada Concepcion ... : lleua al fin tres cartas, la vna del ... Obispo de Osma ... Francisco de Sosa al padre fray Antonio de Trejo, General de toda la orden de San Francisco, donde da cuenta de su viage a Roma ... al negocio del Inmaculado misterio de nuestra Señora, y otras dos cartas, la vna de vn Secretario del Rey ... y respuesta a ella (Alcala de Henares : en casa de la viuda de Iuan Gracian, 1617); Pedro de Escalante, Segunda Relacion de la fiesta que se hizo en Sevilla lunes diez y nueve de Setiembre a la santa imagen de la Concepcion con ocasion de la procesion que sus Cofrades hizieron para boluerla del Conueto de San Francisco al de Regina (Sevilla: Alonso Rodriguez Gamarra,1616); Alonso Saez, Relacion de la fiesta que el colegio mayor de Santa Maria de Iesus Uniuersidad de... Seuilla hizo en la publicacion de un Estatuto en que se jurò la Concepcion limpissima de nuestra Señora... (Sevilla: Francisco de Lyra, 1617), Copia segunda, (Sevilla: Gabriel Ramos Bejarano, 1618); Copia tercera (Sevilla: Gabriel Ramos Bejarano, 1618); Copia quarta (Sevilla: Gabriel Ramos Bejarano, 1618); Copia quinta (Sevilla: Gabriel Ramos Bejarano, 1618); Copia sexta (Sevilla: Gabriel Ramos Bejarano, 1618); Relación sumaria de cómo la Universidad de Barcelona renovo el decreto del Iuramento antigamente en ella establecido acerca de la inmaculada concepción de la Virgen Madre de Dios, y S.N. y de las fiestas que con esta ocasión se hizieron en toda la Ciudad por el mes de Noviemb. 1618 sacada de la que se embio al Rey nuestro Señor (Barcelona: Sebastián Matevat, 1619). 
profana (con máscaras, comedias, toros, cañas, etc.). Las procesiones pueden analizarse desde ambas perspectivas, pues se trata de sacralizar un recorrido de exhibición en el que lo profano cobra protagonismo. Elementos comunes a la mayoría de las celebraciones eran los adornos de la iglesia y los claustros con ricas telas, brocados y sedas, pinturas alusivas al misterio con cartelas con versos y jeroglíficos, altares adornados con multitud de objetos y flores. En todas las relaciones no faltan tampoco las luminarias, los fuegos artificiales, los toques de campanas y en ocasiones las salvas de artillería. La música tenía especial papel en todos los ámbitos de la fiesta: durante las procesiones con las danzas, los ministriles y también con la presencia de instrumentos musicales como los pífanos, atabales, chirimías y trompetas. En las procesiones era frecuente que se cantaran coplas y otro género frecuente en la época como la chançoneta. En la Iglesia, junto a las chançonetas, el género más nombrado es el motete, aunque hay referencias a otras formas como en la relación de 1618 que narra las fiestas que se hicieron en el Convento de la Merced de Sevilla, donde se bailó "una Italiana a seys, cantandola mientras ellos la dançavan tres tiples maravillosos, con la letra de un Hymno Español, que por agradable lo puse aquí". ${ }^{154}$ Veamos la utilización de dos de estos géneros en las fiestas: las coplas y las chançonetas.

Las coplas

La copla toma su denominación del tipo de verso que fue más utilizado para este tipo de canciones. Covarrubias define copla como "Cierto verso castellano, que llamamos redondillas, cuasi COPULA, porque va copulando y juntando unos pies con otros para medida y unos consonantes con otros para las cadencias". ${ }^{155}$ Por el contexto en el que suele aparecer este vocablo, las coplas referidas a composición musical debían de ser monódicas en la mayoría de los casos.

Las coplas a la Inmaculada Concepción más conocidas y que más se cantaron fueron las de "Todo el mundo en general". Estas famosas coplas habían sido compuestas en 1614, por Miguel Cid y Bernardo del Toro como refiere Alfonso de

\footnotetext{
${ }^{154}$ El himno transcrito en esta relación consta de 29 estrofas de cuatro versos heptasílabos y comienza: Gloriosamente bella, unicamente noble, los cielos te apelliden, te aclamen las naciones. Es una glosa de los elementos de la letanía lauretana.

${ }^{155}$ Covarrubias, Tesoro de la lengua, p. 351.
} 
Vicente, ${ }^{156}$ y fueron difundidas en un impreso (con texto y música) a partir de enero de 1615. Correa de Arauxo escribió unas glosas sobre este canto que llegó a ser muy popular, tanto que podemos aventurar su transmisión al Sacromonte como veremos en siguientes epígrafes. Aparte de la elaboración de Correa de Arauxo, esta melodía nos ha llegado impresa tan solo de manera monódica, y aunque su interpretación estaba destinada al pueblo y por ello se ejecutaría normalmente a una sola voz, encontramos referencias a que también se interpretó de manera polifónica y con instrumentos. En la relación que narra las fiestas que se hizieron en 1617 en el Colegio Mayor Santa María de Jesús de la Universidad de Sevilla con motivo del juramento a la Inmaculada Concepción se describe una de estas versiones polifónicas de la copla:

\begin{abstract}
Seguiase una Capilla de ministriles, que con suave armonia significavan, y casi claro hablava la letra tan famosa, y tan solemne. Todo el mundo en general, \&c. En sus contrapuntos, tocava el tiple las coplas, y respondiendo las demas vozes, repetian el estribillo, con que causavan notable alegria. ${ }^{157}$
\end{abstract}

Estas coplas a la Inmaculada fueron un fenómeno sociológico sin precedente, pues se utilizaron a modo de himno e insignia entre los que defendían la creencia como queda reflejado en los siguientes documentos. El primero de ellos es un diálogo o coloquio (a la manera de los platónicos) en el que un "tomista" y un "congregado" 158 discuten sobre los fundamentos de la Inmaculada Concepción; e ilustra cómo cantar las Coplas a la Inmaculada era un acto de devoción que recibiría recompensa en el cielo. Además se menciona de nuevo a Pedro de Castro como ejemplo de creyente en la Inmaculada.

T. Alomenos no se llamaran v.m. i los de su opinión malogrados, que bien lo an publicado estos dias en todas las procesiones que an salido, con la Canción de Miguel Cid. C. Señal es que v.m. nos mirava, i no iva con nosotros. T. No basta que les viesse abrir las bocas con tanta gracia que me provocavan a risa C. Luego v.m. no cantará las coplas por las calles? T. No por cierto Señor, basta que las canten los niños, que no es esto necesario para salvarse, teniendo

\footnotetext{
${ }^{156}$ Alfonso de Vicente "Música, propaganda y reforma religiosa en los siglos XVI y XVII", Studia Aurea, 1 (2007), pp. 28 y ss.

${ }^{157}$ Relacion de la fiesta, que el Colegio Mayor de Santa María de IESUS Universidad de la Ciudad de Sevilla hizo, en la publicación de un Estatuto, en que se juró la Concepción limpissima de nuestra Señora sin mancha de pecado original (Sevilla: Francisco de Lyra, 1617).

158 Tomista, seguidor de Santo Tomás de Aquino. Congregado, perteneciente a una congregación religiosa.
} 
en su coraçon la estima que se debe tener a los Misterios de Dios,i de su Madre, i a lo que se enseña en la fé, i pudiendo cantar en su coraçon i alabar a Dios. Y donde es esto, i poner retulos en las puertas de mi casa, no estoi de parecer de hazerlo, porque no es menester.C. En verdad? Pues yo las cantaré por v.m. toda mi vida, en la calle $\mathrm{i}$ en casa: i las haré cantar a mis hijos $\mathrm{i}$ criados, i pondré todos los Retulos que pudiere, a imitación de nuestro devoto Prelado don Pedro de Castro i Quiñones, que lo puso con tanta majestad i grandeza en la puerta de la Iglesia mayor desta Ciudad; i assi como lo siento en el coraçon, lo publicaré con la boca, i entenderé que por el afecto con que dixere las coplas en alabanza de la Virgen, tengo de tener premio en el cielo, $\mathrm{i}$ a favor desto, entiendo aquella sentencia de nuestro Redemptor; El que me confessare delante de los ombres yo lo onrare delante de mi Padre. ${ }^{159}$

Pedro de Castro podría haber sido el responsable de la impresión de las Coplas "Todo el mundo en general" (en el ejemplar conservado sólo figuran la música con el texto de la primera estrofa), junto con la instrucción de su uso que pide se enseñe a los niños en las escuelas para que se canten cada sábado y las vísperas de las fiestas de la Virgen. ${ }^{160}$ Este hecho debió de molestar a los dominicos, que según el Memorial que mandó hacer el Arzobispo:

truxeron nombres de hereges, comparandolos con los que cantavan estas coplas a N. Señora, (...) y contra el Arzobispo dezian otras cosas picantes. (...) $\mathrm{Y}$ asimismo se prueva, que yendo los dichos religiosos de santo Domingo, por las calles davan bofetadas a los niños que les oyan cantar la opinión pia (...) y que hablando los dichos padres Dominicos en sus sermones, de la glossa que habla de la limpia Concepción, y se cantava en la dicha ciudad, la llamavan glossilla inventada por Satanas. ${ }^{161}$

\footnotetext{
159 Francisco Pacheco, Coloquio entre vn congregado, y un tomista, tratando de la Concepcion inmaculada de la Virgen santissima, Maria S. nuestra, a la insigne cofradia de los Nazareos[sic], $i$ Santissima Cruz de Ierusalen, e impresso por su cuenta / por Francisco Pacheco (Sevilla: Francisco de Lyra, 1620).

${ }^{160}$ Madrid, BNE, Mss 9.956, fol. 12.

${ }^{161}$ Memorial Sumario de las veynte y quatro informaciones que el Arzobispo de Sevilla mandó hazer, cerca de las contradicciones, que los religiosos de santo Domingo han hecho a los que defienden y siguen la opinión pia, de que la Virgen N.S. fue concebida sin pecado original (s.f, s.1., s.e.), fol. $1^{\mathrm{v}}-3^{\mathrm{r}}$.
} 
Figura V.15. Transcripción de la copla de Bernardo del Toro y Miguel Cid, Todo el mundo en general. Fuente: Impreso conservado en la Biblioteca Nacional de Madrid, Mss. 9.956, fol. 12. Transcripción: Mercedes Castillo.

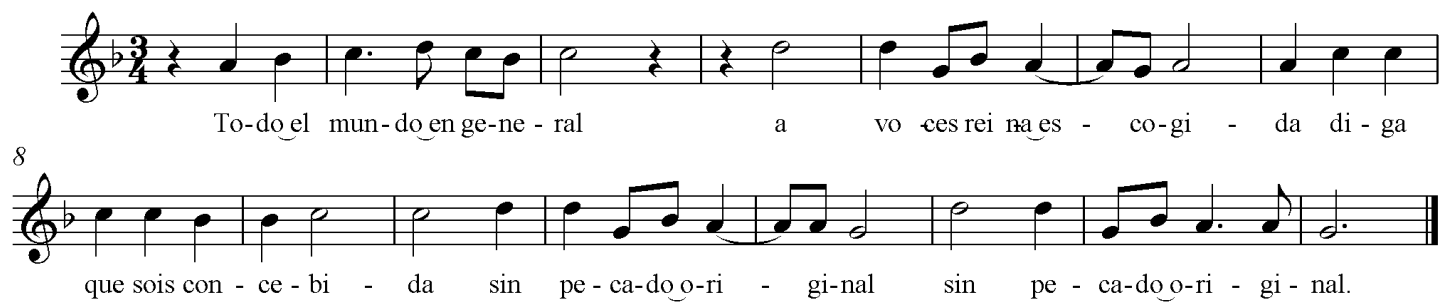

En el mismo memorial se recoge la respuesta de la devoción popular que se sirvió una vez más de las Coplas:

Que por aver juntadose toda la ciudad de Sevilla, en numero sobre mas de cuarenta mil personas de todas las religiones, y señores de titulo, Cavalleros, y Habitos, Alcaldes mayores, y dignidades, Racioneros, y Beneficiados, y el Clero, Cavalleros particulares, y Hombres llanos, oficiales y gente mas humilde y de todos oficios, sin guardar orden en los lugares, y que con universal aclamacion salieron cantando a vozes en medio del dia la cancion de la limpia Concepción de Nuestra Señora, desde la Santa Iglesia mayor por muchas calles de la ciudad hasta la Iglesia de San Pedro en su dia. ${ }^{162}$

Los dominicos contraatacaron con otras coplas contrarias a la creencia compuestas por Fray Pedro Beltrán de las que sólo nos queda los versos que recoge el mencionado sumario: Que por tener a María tan grandes obligaciones, y terminaban, Que seos da a vos. Lope de Vega, reinterpretó estas coplas a lo inmaculista, defendiendo a aquellos que cantaban las coplas. La mayoría de las informaciones contra los dominicos hacen referencia a incidentes protagonizados por las Coplas. En una ocasión se narra cómo un dominico tiraba piedras a un mozo cordonero que cantaba las coplas mientras trabajaba, otro encerró en una casa a un niño que cantaba, ${ }^{163} \mathrm{o}$ dominicos que insultaban a los cantores llamándoles "perros Iudios, cornudos, y

\footnotetext{
${ }^{162}$ Memorial Sumario, fol. $5^{\mathrm{r}}$.

${ }^{163}$ Memorial Sumario, fol. $8^{\mathrm{r}}$.
} 
putos". ${ }^{164}$ Otro caso que recoge el Memorial nos dice que además estos papeles de coplas se vendían por la calles ${ }^{165}$

\begin{abstract}
Parece, que estando un hombre forastero que vendia coplas en compañía de otros cantandolas de la limpia Concepción de nuestra Señora, junto al hospital donde se recogen los dichos forasteros, que es frontero del convento de San Sebastián, Orden de Santo Domingo de la dicha villa [Aracena], salio del dicho convento fray Gonzalo de la Fuente Prior, con otros quatro o cinco frayles, diciéndole al dicho hombre que no sabia lo que se dezia en cantar que la Virgen fue concebida sin pecado original, y que mentia como borracho: y le dieron de empellones, y cayó en el suelo, y uno de los dichos frailes saco de debaxo del escapulario un palo, y le dio muchos palos, y le hirio en la cabeça, y le sacó mucha sangre. ${ }^{166}$
\end{abstract}

Probablemente estas informaciones son algo exageradas, puesto que querían desacreditar a los dominicos y estaban comisionadas por el Arzobispo, pero sí que muestran varios puntos: de un lado que la música ayudó a propagar la creencia y de otro, que cantarlas era tomar partido por uno de los bandos. Quizás no se encuentre otro caso igual en el que la música actúe como propaganda religiosa tan veloz y eficazmente como lo hizo en los territorios ibéricos del siglo XVII. Su eficacia pudo verse reforzada entre otros aspectos por la utilización que de éstas hicieron los sacerdotes, pues las coplas fueron tema de sermones por parte tanto de los dominicos (de los cuales no conservamos ninguno, porque lógicamente no pasarían la censura arzobispal para imprimirse) y de los concepcionistas que pervivieron en el tiempo. Uno de ellos, el del padre Michael de Avellano lo analizaré más adelante. El otro de los sermones que cita las coplas de Todo el Mundo en general es el del Padre Ioan de Pineda de la Compañía de Jesús, celebrado en el Octavario votivo a la Inmaculada en la Iglesia de San Antonio Abad de Sevilla en abril de 1615:

Mas este alegrarse, es juntamente cantando, i tañendo. Quien no canta esta primera limpieza, i esta admirable, i milagrosa Concepción, sino canta otra letra, o lleva otro punto, está claro, que no puede hazer consonancia, ni

\footnotetext{
${ }^{164}$ Memorial Sumario, fol. $9^{\mathrm{r}}$.

165 También recogen como en la villa de Aracena pegaban a los niños pedradas, Memorial Sumario, fol. $50^{\mathrm{r}}$.

${ }^{166}$ Memorial Sumario, fol. $12^{\mathrm{v}}$.
} 
acordada música con las demas, que en general cantan, i dizen: Todo el mundo en general, a vozes, Reina escogida ${ }^{167}$. I aun añade, i lee Jerónimo, cantabunt quasi in Choris. Como lo vemos oi en la Iglesia, que con admirable consonancia, i correspondencia, no de dos solos, sino de muchos coros, canta aquí uno, i le responde otro, i otros. Aquí una Cofradía, i allá otra, i otras muchas por su orden: aquí una procesión, i allá otra, i muchas: aquí una Religión, i luego por su orden todas. Aquí canta una ciudad, i allá responde otra, i un Obispado, una Provincia, un Reino, i allá otros Obispados, otras Provincias, otros Reinos enteros, sicut cantantium in choris. ${ }^{168}$

Pineda utiliza imágenes musicales para hacer entendible su sermón y además resalta la necesidad de que todos canten el concepto a la vez y en el mismo "punto" para estar acordes, quizás en alusión a los dominicos, que estaban en clara oposición al misterio. En el siguiente párrafo vemos como la estructura de la capilla de música y sus funciones diferentes (llevar el canto llano, hacer el contrapunto) le sirven para explicar los diferentes niveles de profundidad de conocimiento de la creencia:

Pero volviendo a aquel, omnes oculi mei in te, pareceme, que es esta una capilla de acordadísima musica, en que esté el Maestro cercado de toda su gente, i aquí delante junto a el libro tiene los niños, i todos los ojos en el facistol, en el libro, i en el punto, omnes oculi mei in te. Unos llevan el canto llano, otros el contrapunto. I los niños; Todo el mundo en general, a vozes Reina escogida. I luego toda la capilla. La gente mas llana, con sus senzilla, i pia devocion, llevan el canto llano: el contrapunto lleva el docto Teologo con sus agudezas: el grave Escriturario con sus misteriosas profundidades, i reconditos sentidos de sagrados lugares; el erudito Eclesiastico con su varia lección de Santos, i Doctores. I si me preguntais, quien es el Maestro de Capilla, que los entona, i a cada uno le de su voz, al niño i al viejo, al alto i al baxo: responderos è, que el Espiritu santo. Si no quereis, que lo sea el santo i devotísimo Pontifice, i señor nuestro Paulo V que dizen es devotísimo desta fiesta (...) i con tal o tales maestros cantad en voz alta de dia, i de noche, i cante todo el mundo en general, respondiendo al que lo entone; Praecinite Domino, que según su propiedad, es Respondete Domino. Responded a Dios, que os entona, i no deseéis, ni perdais la voz, i el punto que os da. Oculi mei in te, los ojos arriba, sicut laetantium, que con esso le dais musica a Dios, alegre, i dulce, i qual al principio del Psalmo se dize, Bonus psalmus Deo Nostro, la gloria que a Dios con esta fiesta de su Madre le dais, yo os asseguro, que os torne bien, bonus (utilis) psalmus. (...). ${ }^{169}$

\footnotetext{
${ }^{167}$ La negrita es mía.

${ }^{168}$ Juan de Pineda, Sermón del padre Ioan de Pineda de la Compañía de Iesus...a la Inmaculada Concepción...que la insigne Cofradía de Santa Cruz en Ierusalen de los Nazarenos, celebró en la iglesia de San Antonio Abad, en Sevilla a los 26 de abril de 1615 (Sevilla: Alonso Rodríguez Gamarra, 1617), p. 15 .

${ }^{169}$ Pineda, Sermón del padre Ioan, pp. 16-17.
} 
La propagación de las Coplas al Nuevo Mundo fue inmediata, pues ya se

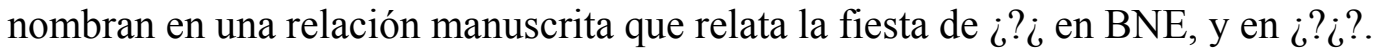

Pedro de Castro y su informe al Rey.

\section{Las chançonetas}

De los géneros aludidos en las relaciones sobre fiestas dedicadas a la Inmaculada hay que reseñar que al menos en las consultadas para este estudio, cuya cronología abarca de 1615 a 1619 aproximadamente, el de las chanzonetas se menciona en todas menos en la relación de Toledo (1616), donde en lugar de chançonetas el género citado es el del villancico. Esto sugiere que según las zonas se empleaba un género u otro, o bien que se denominaba de diferente forma a un tipo de piezas parecidas o que el género de la chançoneta terminó adoptando el calificativo de villancico con el tiempo.

\subsubsection{Dos fiestas a la Inmaculada: Granada 1615 y Sevilla 1617.}

De entre todas las fiestas a la Inmaculada de las que ha quedado constancia escrita, nos interesan principalmente dos por su relación con el Sacromonte: la que se celebró en Granada en 1615, por ser una de las más tempranas y porque su justificación parte de los hallazgos del Sacromonte; y la que se celebró en Sevilla en 1617, por ser Pedro de Castro el promotor y por el papel asignado a la música en ella.

\section{Granada, $1615^{170}$}

Cuando se celebró esta fiesta de la Inmaculada Concepción en Granada ya hacía cinco años que Castro había marchado a Sevilla a ocupar su silla episcopal. Pero desde la Abadía se seguía alimentando este clima mariano, con sus cultos y devociones. Además, desde su partida a Sevilla, Castro había visitado el Sacromonte en varias ocasiones. Prueba de este apoyo a la Inmaculada Concepción se refleja la portada de la relación del Libro de fiestas de Ferriol en donde aparece un grabado de Bernardo Heylan de la Virgen con el lema "Tota pulcra es amica mea et macula non est in te" y en castellano: "Alabada sea la Purísima Concepción de la Madre de Dios concevida sin pecado original". Lo más curioso y lo que pone en conexión directa este grabado con la

\footnotetext{
${ }^{170}$ Alonso Ferriol y Caycedo, Libro de las fiestas, que en honor de la immaculada Concepción de la Virgen Maria... celebró su Devota... Hermandad. En San Francisco de Granada. Año de mil y seiscietos y quince (Granada: Martin Fernandez, 1616).
} 
Abadía es la inscripción en árabe que aparece en la parte derecha y su identificación como escrita por San Cecilio y San Tesifón en el Monte Santo.

Esta fiesta granadina de la Inmaculada tuvo lugar en el Convento de San Francisco y fue organizada por la Hermandad de la Concepción. ${ }^{171}$ Junto a la narración de la fiesta se recogen diversos poemas, fruto de la justa poética que se celebró.

El lunes 7 de diciembre, la iglesia se encontraba entera revestida "de ricas y vistosas sedas. Dixeronse visperas con mucha solemnidad, y diversidad de música, toda la Capilla de la Catedral, y ministriles, que acudieron por toda la octava". ${ }^{172} \mathrm{Al}$ día siguiente aparecieron decorados con telas, pinturas, sonetos y altares los dos claustros y los cuatro cuarteles del convento. En uno de ellos se encontraba un instrumento curioso o "invención" como lo denomina la relación:

\begin{abstract}
Avia entre otras invenciones, una maravillosa, demas de cien campanillas de oro, y plata, puestas con tal artificio, que (sin verse el como) se tocavan con mucho concierto, al passar la procesión. Yo vi a un galán de los que de si hazen mucho aprecio, destos oyentes de sí mismos, acudir puntualisimo toda la octava a prevenir lugar, desde donde mejor gozase el milagro, y creyeralo yo (aún sin verlo) que a hombre que se escucha, no le avia de agradar otra armonia, que la de lenguas de campanas por la habitación. ${ }^{173}$
\end{abstract}

La procedencia exacta de esta máquina musical es difícil de establecer, pero sabemos que este tipo de artificios respondían a la curiosidad y concepción del mundo del hombre del Renacimiento que recuperó este interés por los "ingenios" a través de los tratados de la Antigüedad. En palabras de Alfredo Aracil: "Estos y otros artificios, por su capacidad para sorprender eran útiles llaves que abrían las puertas de la atención y la memoria de la gente, para inculcar cualquier enseñanza como una catequesis moral en la España barroca". ${ }^{174}$ Así parece demostrarse en la relación de esta fiesta, ya que el

\footnotetext{
${ }^{171}$ La Hermandad de la Concepción parece haber sido creada por los Reyes Católicos cuando estaban en Santa Fe, sitiando Granada; a la intercesión de la Inmaculada Concepción le atribuyeron la rápida victoria.

${ }^{172}$ Ferriol y Caycedo, Libro de las fiestas, fol. $11^{\mathrm{v}}$.

${ }^{173}$ Ferriol y Caycedo, Libro de las fiestas, fol. $14^{\mathrm{r}}$.

${ }^{174}$ Alfredo Aracil, Juego y artificio. Autómatas y otras ficciones en la cultura del Renacimiento a la Ilustración (Madrid: Cátedra, 1998), p. 301.
} 
"galán” que gustaba de escucharse a sí mismo queda maravillado por otros sonidos que no son los de su voz. Quizás este instrumento musical era semejante a los que proyectó Athanasius Kircher y que se encuentran recogidos en los catálogos de Sepi y Buonanni, como el Horologium rotale Musica sonans, "en el que por medio de campanillas sonaba el cántico de la Salve Regina, y a las medias horas el Ave Maris Stella, con una suavísima y precisa melodía". ${ }^{175}$ Otra intervención musical tuvo lugar durante la misa, pues

Al Ofertorio, al manifestar el cuerpo, y sangre de nuestro Redentor, y al consumir cantó la música maravillosas chançonetas, por ser el Maestro, de los que con mas primor hazen esto: sustituyeron sus pausas los ministriles, sin excesso de los musicos (con ser tan buenos) y assi tuvo fin la fiesta por la mañana. ${ }^{176}$

Este Maestro con mayúsculas bien pudo ser Luis de Aranda, maestro de capilla de la Catedral de Granada, quien como él mismo afirmó en un memorial dirigido al Cabildo de la Catedral sus chançonetas eran famosas hasta en las Indias, se las solicitaba Ambrosio de Cotes cuando era maestro de la Capilla Real y también se cantaban en la Capilla de Felipe II. ${ }^{177}$

La procesión tuvo lugar después por la ciudad y a ella acudieron casi todas las órdenes religiosas de Granada y muchísima gente: "Este confusso orden turbavan algunas vezes, quatro danças curiosas en las libreas, y mucho mas en su ministerio, que luzidas, y diestras adornaron su parte la procesión." ${ }^{178}$ Por la noche

Dieron fuegos artificiales, campanas, luminarias y chirimías, señal de fiesta para el día siguiente, en el qual, y en los demas de la octava fue al misma (excepto la salida por las calles, y el concurso de las religiones) pero en lo demas fue tan festiva en Missa, y Sermón del Padre fray Michael de Avellano, a quien se debe gran parte de lo luzido de esta fiesta. ${ }^{179}$

\footnotetext{
${ }^{175}$ Alfredo Aracil, Juego y artificio, p. 309.

${ }^{176}$ Ferriol y Caycedo, Libro de las fiestas, fol. $15^{\mathrm{r}}$.

${ }^{177}$ López-Calo, La música en la Catedral de Granada, I, pp. 300-301, transcribe el famoso memorial de Aranda al Cabildo de la Catedral.

${ }^{178}$ Ferriol y Caycedo, Libro de las fiestas, fol. $16^{\mathrm{r}}$.

${ }^{179}$ Ferriol y Caycedo, Libro de las fiestas, fol. $17^{\mathrm{v}}$.
} 
El sermón de Fray Miguel de Avellano al que hace referencia la crónica fue publicado en 1617. ${ }^{180}$ Estaba estructurado sobre los versos de la Copla "Todo el mundo en general, diga a voces reina escogida que fuisteis concebida sin pecado original", y contiene un hermoso ejemplo de cómo la estética musical formaba parte del lenguaje barroco. Avellano divide la copla en cuatro partes que son los cuatro puntos sobre los que argumenta su discurso de alabanza y defensa de la Inmaculada Concepción. El punto en el que la música destaca es el de "Todo el mundo en general a vozes". Hablando de la división del mundo (eternal, angelical, material y racional) siguiendo a Boecio y a Francesco Giorgi Veneto ${ }^{181}$ describe cómo la música hace referencia a la idea de la Concepción. Así, siguiendo a Platón menciona el mundo eterno de las Ideas, entre las que Avellano dice:

entre las Ideas divinas avia coros de musica acordada, que con armoniosas vozes cantavan la limpieza y santidad de la Idea del trono de Maria, como a la mas perfeta y principal de todas: estas eran las vozes del mundo eternal ${ }^{182}$

En el mundo angelical, son los ángeles los que celebraron las fiestas de la Inmaculada Concepción con sus voces; más concreta es la relación del mundo material: “Toda esta fábrica del cielo, y la tierra estan dando vozes, publicando la limpieza de Maria; en el cielo el movimiento de los Orbes, a quien Iob cap. 38 llamó particular armonia, Conceneii coeli". ${ }^{183}$ Esta idea recoge el concepto pitagórico de la música de las esferas, en el que la música se concreta en la expresión de la Inmaculada Concepción de la Virgen. Además añade que:

\footnotetext{
${ }^{180}$ Declamación que hizo el reverendo Padre Fray Michael Avellan, Lector de Teologia. En las Fiestas de la Inmaculada Concepción de nuestra Señora, que se celebraron en San Francisco de Granada, sobre el Epitalamio; Todo el mundo en general (que á sido tan bien recibido, y celebrado en toda España) aplicado al Evangelio (Granada: Martin Fernandez, 1617).

${ }^{181}$ Según Cesare Vasoli, Francesco Giorgi Veneto (1466-1540) fue un teólogo franciscano, autor de De Harmonia Mundi totius cantica tria, (Venezia, Bernardini de Vitalibus, 1525), Scripturam Sacram Problematam (Venezia, Bernardini de Vitalibus, 1536) y un largo poema doctrinal en lengua vernácula. Todas sus obras revelan una mezcla compleja de temas herméticos y cabalísticos, derivados no solamente de Ficino y Pico della Mirandola, sino también de un conocimiento directo de la mística hebráica; véase Cesare Vasoli, "Giulio Camillo Delminio et l'Art Transmutatoire", Sylvain Matton (ed.) Alchimie et philosophie à la Renaissance (París: Vrin, 1993), p. 195.

${ }^{182}$ Declamación que hizo el reverendo, fol. $3^{\mathrm{v}}$

${ }^{183}$ Declamación que hizo el reverendo, fol. $4^{\mathrm{r}}$
} 
Todas las cosas materiales del universo, con vozes mudas llevan el canto llano en esta fiesta de su Concepción. Y el mundo racional (que es el hombre, donde ellas estan subidas de punto) lleva en contrapunto: todo lo dio a entender el Espíritu Santo (...), quando repartió sus dones en lenguas de fuego a los Apostoles, haziendo de vozes discordes una consonancia celestial para predicar la fe. (...) y este mismo Espíritu es en el que este tiempo meve los corazones de los fieles, y les comunica particulares vozes, para que hagan una musica muy acordada, y una consonancia celestial, celebrando la Concepción de la Virgen. ${ }^{184}$

Puede observarse que Avellano emplea en su explicación la terminología musical que hace referencia a los estilos y conceptos musicales propios de su época. Menciona el canto llano y el contrapunto que son las dos maneras principales de componer en aquel momento, pues aún está lejos en la Granada de principios de siglo XVII la monodía acompañada. El concepto estético de la música se deja traslucir en las alusiones a las consonancias o voces acordadas (siempre positivas, con adjetivos como celestial) y la disonancia o discorde, que deben ser sustituidas por las consonancias, al igual que sucede en la práctica musical en la que la disonancia está regulada. Y en la conclusión de su sermón hace alusión a los santos del Sacromonte como mentores de la creencia: "Diganlo todos (...) diganlo las tres personas de la Santisima Trinidad a tres vozes acordadas; Tota pulcra (...) .Diganlo todos los Martires, y entre ellos los ilustrisimos del Monte Santo de Granada, que en sus Arabes lámnas lo dexaron escrito". ${ }^{185}$

\section{Sevilla, 1617}

Hasta tal punto fue Pedro de Castro impulsor de esta creencia que pidió a Felipe III que se mandase a los prelados y universidades de su reino que escribieran al Papa sobre su parecer acerca de este misterio de la Inmaculada Concepción, lo que el rey decretó el 17 de mayo de 1617. Como resultado de estas gestiones y el envío de diversos embajadores a Roma para abogar por este asunto, Paulo V formuló un Breve por el que condenaba a quien dijera públicamente que María fue concebida con pecado

\footnotetext{
${ }^{184}$ Avellano, Declamación que hizo el reverendo, fol. $4^{\mathrm{v}}$.

${ }^{185}$ Avellano, Declamación que hizo el reverendo, fol. $8^{\mathrm{r}}$. Durante las fiestas debieron representarte alguna obra teatral, pues se conserva un: Coloquio pastoril en defensa de la Inmaculada Concepción de la Virgen María de Lope de Vega impreso en 1615.
} 
original. Cuando el Breve llegó a Sevilla, donde Castro era ya arzobispo, se hicieron grandes fiestas. Además el prelado propuso un juramento público de defensa de dicha creencia al que debían asistir los Cabildos de Sevilla (ciudad y catedral). Esta solemnísima función de juramento está relatada en varias fuentes, entre ellas un impreso fechado en 1617 en Sevilla y una relación manuscrita del maestro de ceremonias de la Catedral de Sevilla, que nos ha llegado en la transcripción del siglo XVIII que de ella hace Barnuevo. $^{186}$ De ésta última llaman la atención dos hechos de singular importancia, pues vemos cómo Castro utiliza la música como propaganda para servir a su propósito: ensalzar y convencer, familiarizar al pueblo con la opinión de que María era Inmaculada.

Cuando se recibió en Sevilla el Breve de Paulo V se formó una procesión de más de 600 personas, de la Cofradía de los Nazarenos

A aquella hora salió la cofradía de los Nazarenos, con una procesión lucidísima de más de seiscientas personas, todos con velas de a libra encendidas, cantando con festivísimo alboroto las coplas de Todo el mundo en general. ${ }^{187}$

Del juramento latino, que se conserva impreso en varias fuentes, sabemos que el diácono lo cantó de esta forma

Cantola el dicho diácono en viva voz con particular entonación que se compuso para ello, y al tiempo que se llegó a la cláusula: Ó felix etc, el Prelado y todos los demás del Altar y del Coro se hincaron de rodillas hasta el fin de dicha fórmula, escepto (sic) el Diácono que la cantaba que se quedó en pie, y entonó esta postrera cláusula un punto más alta que las demás. Fue semejante entonación a la lección de la Kalenda de la Vigilia de Navidad, aunque con alguna diferencia en las entonaciones. Acabada que fue de cantar, respondieron los músicos en el coro: Deo Gratias, y al punto se levantaron todos como antes. ${ }^{188}$

Es curioso que el juramento se cantara en lugar de leerse, pero no debe extrañar del todo si se consideran varias razones como que el canto diferencia la voz divina de la

\footnotetext{
${ }^{186}$ Heredia Barnuevo, Místico Ramillete, pp. 175-181.

${ }^{187}$ Heredia Barnuevo, Místico Ramillete, p. 174.

${ }^{188}$ Heredia Barnuevo, Místico Ramillete, p. 179.
} 
humana, se le imprimía mayor solemnidad al momento y si la Catedral estaba llena, hecho que probablemente ocurriera, se escucharía mejor el texto cantado que hablado. La descripción es preciosa en tanto que nos especifica con sumo detalle cómo fue esa entonación, era "semejante" a la de la Kalenda de Navidad aunque variada de ésta. También es interesante cómo el arrodillarse los actores en el coro coincide con la subida de un punto en la entonación de la última cláusula, como enfatizando la procedencia de las palabras (divinas de lo más alto). La Relación indica que al final de la misa se interpretaron "chançonetas". ${ }^{189}$ Acabado de hacer el juramento por el prelado

hizo señal la torre de la Santa Iglesia, organos y instrumentos de música respondieron. Por las puertas angulares de la Iglesia entraron a un tiempo las danças con instrumentos musicos, grande estruendo, y alboroto, como significando que de todas las partes del mundo venian a festejar la solemnidad de la purissima Concepción. ${ }^{190}$

Figura V.16. Portada de la Relación del solemne juramento (Sevilla: Francisco de Lyra, 1617)

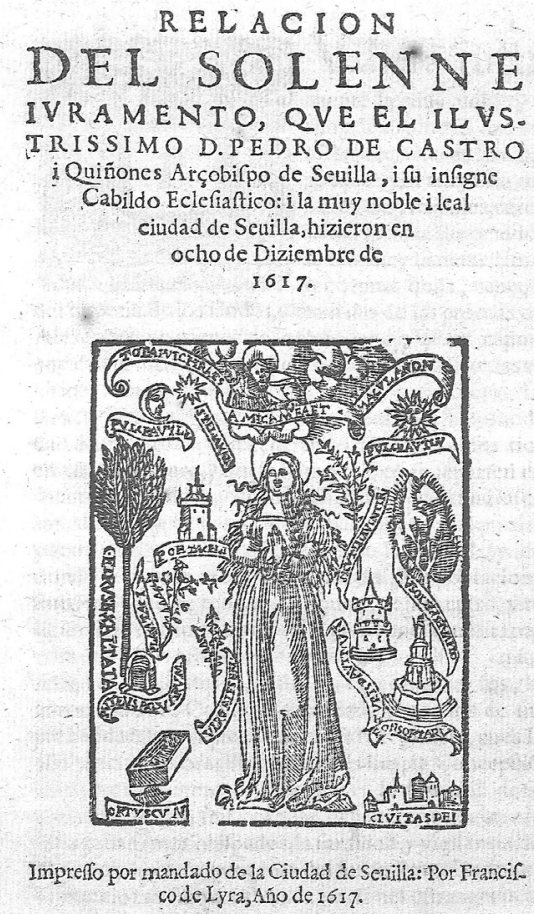

${ }^{189}$ Relación del solemne juramento, que el ilustrísimo D. Pedro de Castro (Sevilla: Francisco de Lyra, 1617), fol. $14^{\mathrm{v}}$.

${ }^{190}$ Relación del solemne, fol. $13^{\mathrm{r}}$. 
Esta fiesta en la Catedral de Sevilla ilustra la importancia que para Castro tenía la ceremonia y cómo se podía utilizar para convencer al pueblo e impresionarlo, y al mismo tiempo para revestirse de prestigio. El juramento, junto con la descripción de la fiesta fue mandado imprimir por el Arzobispo, y así se hizo por Francisco de Lyra en 1617. En la portada de la relación y juramento se conserva grabado de la Inmaculada Concepción con los atributos de la letanía lauretana; véase Figura V.16.

\subsection{La fiesta de la Inmaculada Concepción en el Sacromonte}

En el Sacromonte el día de la Concepción era una fiesta de especial significación como atestigua la existencia de diversas fundaciones: la del chantre de la Catedral de Sevilla, Olalla de Rojas, la del gremio de los Cordoneros, la del canónigo Pedro Gómez o la de María de Orozco. ${ }^{191}$ Asimismo Castro había dotado la celebración en sus Primeras Vísperas, Maitines, Laudes, Misa de Tercia y Segundas Vísperas. La Consueta en el primer párrafo del capítulo dedicado a describir la ceremonia justifica la importancia de la fiesta en el Sacromonte de esta manera

Este dia es festivissimo en este Sacro Monte por ser como lo es el solar de la Concepción o archibo donde desde el tiempo de los Apostoles se an guardado las mas autenticas scrituras y privilegios que ay por esta Verdad fuera de la escritura sagrada y por aver dado causa de su descubrimiento para que en toda Spaña y en todo el mundo se aya ferborizado la devocion de este misterio y crezido tanto la solemnidad con que oy se celebra ${ }^{192}$.

Como en otras celebraciones solemnes, el Cabildo elegía a dos canónigos como comisarios para organizar los pormenores de la fiesta: debían adornar los altares con flores, contratar música, encargar fuegos "muy lucidos" y "olores", y que se limpiara la Iglesia y aderezase la ropa blanca. Es curioso que esta celebración fuera una de las pocas que se mantuviese en el contrato del Cabildo con una capilla de música en 1633. ${ }^{193}$ La Consueta no especifica mucho más sobre el desarrollo de la fiesta de la

\footnotetext{
${ }^{191}$ Consueta, fol. $437^{\mathrm{r}}$. El día de la Concepción en el Sacromonte se mantenía descubierto el Santísimo todo el día para venerar también el Corpus Christi. La Consueta señala esta "loabilísima costumbre" como origen de la expresión de los fieles: "Alabado sea el Santísimo Sacramento y la Virgen concebida sin pecado original".

${ }^{192}$ Consueta, fol. 436 r.

${ }^{193}$ ASAC II, fol. ¿? (3-II-1633), [167]; ASAC II, fol. 261 v (2-III-1633), [169].
} 
Concepción. El día de la víspera se celebraban las Vísperas a las 2.30, y a las 5 los Maitines que eran cantados con toda solemnidad. En 1632, fecha de finalización de la Consueta, un acta capitular nos habla de la realización de un calenda que se había hecho nueva para la fiesta de la Concepción, y se leyó en el cabildo que determinó se colocara al final del libro en el que estaban las fiestas y santos del Sacromonte. Esta calenda debía cantarse por un prebendado el día de la Víspera con igual solemnidad que el resto. ${ }^{194}$ Hasta ese momento y parece que incluso después, en Granada no se rezaba el oficio reformado de Pio V, sino el oficio Sicut Lilium. ${ }^{195}$

Otro hecho que se celebró en el Sacromonte con especial solemnidad tuvo lugar 1761 cuando Clemente XIII, a instancias de Carlos III, concedió el copatronato (junto con Santiago) de la Inmaculada Concepción a todos los dominios españoles:

Propuso el señor Abad era notorio como habían venido ya las bulas de la Santidad de nuestro Beatísimo Padre Clemente XIII concediendo la gracia impetrada por nuestro católico monarca don Carlos III (que Dios guarde) en nombre de todo el Reino de España que junto en Cortes le había suplicado a su Majestad uniformemente la solicitase de la Santa Sede, comprehensiva de la aprobación Apostólica del Copatronato de la Concepción Inmaculada de la Madre de Dios de todo el español dominio, sin perjuicio ni diminución del ínclito apóstol Santiago su antiguo y venerado Patrón y predicador evangélico y que la Iglesia Metropolitana había solemnizado la novedad de gracia tan favorable para Granada, singularmente entre todas las ciudades $\left[135^{\vee}\right]$ del reino con sus repiques de campanas, y las memorias, y lo mismo el Ayuntamiento de la ciudad y religiones y todo el pueblo, y que teniendo esta Iglesia más obligación, que otra alguna de España, expresar su alborozo y alegría por tan singular favor de la Santa Sede, es de sentir que se esmerare y distinguiese en su celebración a medida de su posibilidad y religiosidad de su instituto, y que le parecía que bastaría por ahora para cumplir con el público, que tres noches se solemnizase la noticia comunicada por nuestro monarca con tres repiques de todas las campanas y luminarias y el jueves antes de misa de tercia se cantase el Te Deum con procesión a las Santas Grutas; y mañana miércoles con que se celebra al señor San Indalecio, primicias de la fe que confió Santiago a nuestro Reino se cantase una misa solemne en el altar de nuestra Señora de la Concepción Inmaculada sito en las Sagradas Cavernas de este nuestro Santo Monte, donde se halló el documento antiquísimo de su inmunidad, que venera nuestra privada piadosa creencia, como executoria de este mariano privilegio, con esperanza resignada siempre al infalible oráculo del Vaticano, de que nos la declarara y decretara por tal p LC XXIX Sara toda la Iglesia, esgrimiendo el

\footnotetext{
194 ASAC II, fol.247v (2-XI-1632), [162].

195 Pedro Martínez Ybargueu, Resolución moral en que se prueba a tenido y tiene la Santa Yglesia Metropolitana de Granada y su Arçobispado privilegio para rezar el Oficio SIcut Lilium en la Fiesta de la Inmaculada Concepción de Nuestra Señora y su Octava, concedido por la Silla Apostólica/ dispuesta por el P.Fr. Pedro Martínez Ybargueu (Granada: Imprenta Real de Baltasar de Bolivar, 1666).
} 
¿? Por cuya declaración tanto va suspirado y suspira el orbe católico: y oída la propuesta referida se resolvió uniformemente, que se ejecutase así y se le diesen al público estas señas de especial parte que tenía nuestra Iglesia en el alborozo de gracia semejante. ${ }^{196}$

En 1762, un decreto del Papa proclamaba el nuevo rezo de la Concepción con lo que se decidió elaborar un nuevo libro para el coro. El resultado es un libro de preciosa factura como se describe en el Capítulo VI con una ilustración de la Inmaculada. ${ }^{197}$ El culto fue ampliado en 1767 con la adición por el Papa Clemente IX de un nuevo verso cantado a la letanía lauretana, añadiendo "Mater Inmaculata" después de "Mater intemerata" y con la obligación de rezar el oficio propio de la Concepción todos los sábados del año que las fiestas no lo impidiesen. En el mismo acta se refiere que en el Sacromonte además se tenía por costumbre añadir un verso propio (Concepta sine peccato) al final de dicha letanía y que se debía seguir diciendo. En 1771 se fundó un aniversario en la Octava de la Concepción por Faustina Miranda:

Item se determinó que en la memoria que va a fundar doña Faustina Miranda en la octava de la Concepción que es una misa cantada en el día octavo con sus Vísperas con dos capas sea con Manifiesto dicha misa según pide la fundadora. ${ }^{198}$

La Concepción era además la patrona de los colegiales juristas, por lo que en ocasiones ellos organizaban fiestas en su honor. Aunque el Cabildo intentaba controlar las celebraciones y seguir con la austeridad tradicional en el Sacromonte, con frecuencia se prohibían alborotos. ${ }^{199}$

La Salve es otra ceremonia íntimamente relacionada con el culto a la Inmaculada Concepción, además porque se llevaba a cabo en las cinco fiestas de guardar de la Virgen, siendo una de ellas la de la Concepción.

\footnotetext{
${ }^{196}$ ASAC X, fol. 135 r (16-VI-1761), [650].

${ }^{197}$ Véase LC LIV del Catálogo.

${ }^{198}$ ASAC XI, fol. 228 r (8-XI-1771), [708].

${ }^{199}$ Sobre la Loa que organizaron los colegiales juristas a la Inmaculada Concepción véase el Capítulo IV.
} 


\subsection{La estructura del rito de la Salve}

El rito de la Salve fue frecuente en las catedrales españolas al menos desde finales del siglo XV; Toledo, Palencia, Jaén, Sevilla y Granada entre otras muchas celebraban este servicio. ${ }^{200}$ En la Abadía del Sacromonte se instituyó este rito gracias a la fundación de uno de sus primeros abades, Don Pedro de Ávila, según consta en el Acta Capitular del 5 de mayo de 1614:

El señor don Pedro de Ávila dijo que su merced tenía devoción y quería hacer servicio a Nuestra Señora de que en su Capilla de las Cavernas se dijese todos los sábados una Salve cantada. A la cual asistiesen Sochantre, capellanes y colegiales entre los cuales se distribuyesen 3 reales cada sábado y asimismo su merced pondría la cera para ese año. Todos los señores canónigos agradecieron mucho este servicio que se hacía a Nuestra Señora en este Sacro Monte y aceptaron y mandaron se siguiese por este año que corra desde hoy dicho día con la distribución dicha, la cual se hiciese de la manera que el señor Don Pedro ordenase de que ofreció dar un memorial. Y pasado este año se trataría si convendría aceptarlo en adelante y el modo en que se distribuya la limosna y estipendio que para ello se dejare ${ }^{201}$

Robert Snow en su estudio sobre el Servicio de la Salve afirma que ningún documento describe exactamente el contenido de este rito y que sólo puede deducirse de los libros conservados la estructura aproximada. ${ }^{202}$ Para España, señala que ésta podría

${ }^{200}$ Véase Juan María Suárez Martos, El Rito de la Salve en la Catedral de Sevilla durante el siglo XVI (Sevilla: J.M. Suárez, 2003), p. 42.

${ }^{201}$ ASAC I, fol.76 (14-V-1614), [24]. El mismo don Pedro unos meses después dotó también otra Salve en la Iglesia los días de las fiestas de la Virgen: ASAC I, fol. 82 ${ }^{\mathrm{r}}$ (1-VIII-1614), [27] "Propuso el señor Don Pedro de Ávila, Presidente y canónigo de esta Santa Iglesia que su merced tenía devoción que se dijese en este sacro Monte en la Capilla de Nuestra Señora a mano izquierda del altar mayor Salve a nuestra Señora todas las Vísperas de las nueve fiestas de Nuestra Señora, cantada y con el acompañamiento y distribución que tiene dotada para este año para que se dijesen los sábados en la Capilla de la Concepción, pero quería que éstas se dijesen en la Iglesia y dotarlas en cuatro reales cada una y la de la Víspera de la Concepción de Nuestra Señora en ocho reales, y si hubiere organista entre en distribución como uno de los capellanes, y por este año se aceptó por el Cabildo y señores del para los dichos días en la manera de la que se dice en ella en la capilla de la concepción y que se tome la razón de esto en el libro de los aniversarios de los colegiales con día, mes y año".

En ASAC I, fol. 114 r (29-VI-1615) se ratificó la dotación con sus distribuciones correspondientes y unos años después se volvió a aumentar la dotación; véase ASAC I, fol. 214r (12-I-1619).

202 Robert J. Snow, A New-World Collection of Polyphony for Holy Week and the Salve Service: Guatemala City, Cathedral Archive Music Ms 4 (Chicago: University of Chicago Press, 1996) p. 68: "By the late fifteenth century these services had been expanded to include more than the Salve Regina, as a number of contemporary documents, financial and otherwise suggest; unfortunately, none states exactly what was included in a Salve service. One can, however, determine with some certitude what transpires in the Salve services held daily at the Cathedral of Seville from two sixteenth-century manuscripts that contain music clearly intended for use in the independent Salve services held at that church." 
consistir en dos conmemoraciones de la Virgen, siendo la segunda específica del tiempo, después de las cuales se hacía otra conmemoración a los santos que protegían de las plagas. ${ }^{203}$

Suárez Martos sin embargo es capaz de establecer el ritual que se seguía en Sevilla a partir no sólo de las fuentes polifónicas sino también gracias al Ceremonial del siglo XVI, distinguiendo entre las Salves de Completas (es decir, la Salve que se cantaba al final del Oficio de Completas, como un añadido), tal y como aparecen en el Breviario Hispalense o en el Breviario Romano de Pio V; ${ }^{204}$ y las Salves de los Sábados, que incluirían además un motete y diversas antífonas. En la Catedral de Sevilla el rito de la Salve incluía motetes en polifonía y, por lo que parece deducirse de la descripción que proporciona Suárez Martos, era una ceremonia bastante extensa en la que se incluían además varias antífonas con sus versos, destinadas a rogar contra las epidemias y un Ave María. ${ }^{205}$

\footnotetext{
${ }^{203}$ Snow, A New-World Collection, p. 74.

${ }^{204}$ El esquema es diferente en ambos Breviarios. El esquema que luego se parecerá más al rito de la Salve en la propia Catedral de Sevilla y en la Abadía es el del Ceremonial Romano, por los versos u oraciones que recoge.
}

\section{Breviario Hispalense (Salamanca, 1563)}

Cántico de Simeón: Nunc dimittis

Antífona: Salva nos domine vigilantes

Oracion: Visita quae sumus

Antífona: Salve Regina

Verso: Ora pro nobis

Respuesta: Ut digni...

Oración: Protege domine famulos...

Breviario Romano de Pio V (Roma, 1568)

Antífona: Salve Regina

Verso: Ora pro nobis sancta dei genitrix

Respuesta: Ut digni efficiamur promissionibus Christi

Oración : Omnipotens sempiterne Deus...

${ }^{205}$ Suárez Martos, El Rito de la Salve, pp. 74-75. 
Tabla V.6.: Resumen del ceremonial de la Salve en la Abadía del Sacromonte (Fuente: Consueta (1632), Libro IV, Capítulo 12, fol. 307r-312r).

\begin{tabular}{|c|c|c|c|c|c|}
\hline & \multicolumn{2}{|c|}{ Salves en los Sábados } & $\begin{array}{l}\text { Salves en las } \\
\text { Fiestas de } \\
\text { Señora }\end{array}$ & \multicolumn{2}{|c|}{ Salves de Cuaresma } \\
\hline \multirow{2}{*}{$\begin{array}{l}\text { Lugar de } \\
\text { celebración }\end{array}$} & Buen tiempo & Mal tiempo & \multirow{2}{*}{$\begin{array}{l}\text { Iglesia } \\
\text { (Pavimento bajo) }\end{array}$} & \multirow{2}{*}{$\begin{array}{l}\text { Iglesia } \\
\text { (Coro) }\end{array}$} & \multirow{2}{*}{$\begin{array}{l}\text { Los sábados } \\
\text { en las } \\
\text { Cuevas. }\end{array}$} \\
\hline & $\begin{array}{l}\text { Capilla de la } \\
\text { Concepción en } \\
\text { las Santas Cuevas }\end{array}$ & $\begin{array}{l}\text { Iglesia } \\
\text { (Pavimento bajo) }\end{array}$ & & & \\
\hline Hora & \multicolumn{2}{|c|}{$\begin{array}{l}\text { Después de completas desde ler sábado } \\
\text { octubre hasta Sábado Santo. } \\
\text { A las seis de la tarde desde sábado ante } \\
\text { dominicam in albis hasta último de } \\
\text { septiembre. }\end{array}$} & $\begin{array}{l}\text { Después de } \\
\text { completas } \\
\text { (excepto el día de la } \\
\text { Asunción que se } \\
\text { dice después de la } \\
\text { procesión). }\end{array}$ & \multicolumn{2}{|c|}{$\begin{array}{l}\text { Después } \\
\text { de completas. }\end{array}$} \\
\hline Preparación & $\begin{array}{l}\text { Velas, bujías, } \\
\text { pastillas de olor y } \\
\text { flores. }\end{array}$ & $\begin{array}{l}\text { Cuatro velas en } \\
\text { el altar mayor. } \\
\text { Facistol alto con } \\
\text { paño blanco. }\end{array}$ & \begin{tabular}{|l|} 
Facistol con paño \\
blanco. Cuaderno \\
de la Salve y Misal \\
registradas las \\
oraciones (ponen \\
sobre el altar al \\
cornu Epistola) \\
\end{tabular} & \multicolumn{2}{|c|}{$\begin{array}{l}\text { Facistol con paño del } \\
\text { color de los frontales. } \\
\text { Libro de la fiesta de la } \\
\text { Asunción abierto por } \\
\text { donde está la imagen de } \\
\text { la Virgen (LC XVI). }\end{array}$} \\
\hline $\begin{array}{l}\text { Estructura } \\
\text { del rito }\end{array}$ & $\begin{array}{l}\text { Procesión (desde } \\
\text { la Iglesia hasta } \\
\text { las Cuevas) } \\
\text { Salve } \\
\text { Verso: Ora pro } \\
\text { nobis } \\
\text { Oración: } \\
\text { Omnipotens } \\
\text { Sempiterne Deus } \\
\text { Antífona: } \\
\text { Conceptio tua }\end{array}$ & $\begin{array}{l}\text { Salve a versos con } \\
\text { el órgano. } \\
\text { Verso: Ora pro } \\
\text { nobis } \\
\text { Oración: } \\
\text { Omnipotens } \\
\text { Sempiterne Deus } \\
\text { Antífona: } \\
\text { Conceptio tua }\end{array}$ & $\begin{array}{l}\text { Salve } \\
\text { Verso: Ora pro } \\
\text { nobis } \\
\text { Oración: } \\
\text { Omnipotens } \\
\text { Sempiterne Deus } \\
\text { Antífona: } \\
\text { Conceptio tua } \\
\text { excepto el día de } \\
\text { la Asunción que no } \\
\text { se dice } \\
\text { Verso: Elegit eam } \\
\text { Deus } \\
\text { Oración: Famulis } \\
\text { Tuis }\end{array}$ & \multicolumn{2}{|c|}{$\begin{array}{l}\text { Antífona de Nuestra } \\
\text { Señora: (Conceptio } \\
\text { tua) } \\
\text { Padre Nuestro } \\
\text { Ave María } \\
\text { Credo } \\
\text { Salve } \\
\text { Verso } \\
\text { Oración: Omnipotens } \\
\text { Sempiterne Deus } \\
\end{array}$} \\
\hline $\begin{array}{l}\text { Otras } \\
\text { observacion } \\
\text { es }\end{array}$ & & $\begin{array}{l}\text { Interviene el } \\
\text { órgano: da el tono y } \\
\text { luego prosigue a } \\
\text { versos la Salve. }\end{array}$ & $\begin{array}{l}\text { En las cinco fiestas } \\
\text { de guardar de } \\
\text { Nuestra Señora se } \\
\text { dice motete al } \\
\text { órgano en lugar del } \\
\text { último verso. }\end{array}$ & \multicolumn{2}{|c|}{$\begin{array}{l}\text { Salve a versos } \\
\text { (alternatim) con el } \\
\text { órgano, aunque sea } \\
\text { tiempo de Pasión. }\end{array}$} \\
\hline
\end{tabular}

Como puede verse en la Tabla V.6., en la Abadía del Sacromonte la Salve se cantaba todos los sábados del año, también en las Vísperas de las fiestas de Nuestra Señora y en la Cuaresma. En la Abadía podemos distinguir dos esquemas diferentes, de un lado, las Salves en los Sábados y en las Fiestas de la Virgen; y por otro, las Salves 
de Cuaresma. Las Salves del primer grupo siguen en esencia el esquema del Breviario Romano y de la primera parte del ritual de la Catedral de Sevilla, con la salvedad que el motete polifónico es sustituido en la Abadía por una antífona que es siempre la misma: Conceptio tua. Las Salves de Cuaresma seguían otra estructura, ya que incluían además otras oraciones como el Credo, el Padre Nuestro y un Ave María.

De la comparación de las estructuras del rito de la Salve, tanto en Sevilla como en la Abadía, podemos ver la diversidad posible de esquemas en este servicio, aunque en todos encontramos la combinación entre la Salve, sus versos, antífonas y/o motetes. En el Apéndice 3 puede verse la reconstrucción musical de este servicio con las rúbricas e indicaciones pertinentes para su celebración en el Sacromonte. La Consueta recoge detalladamente todas las partes del rito de la Salve y permite hacer una reconstrucción completa de cómo se desarrollaba la ceremonia, incluyendo los movimientos y acciones de los participantes que acompañaban la música. Música y ceremonial quedan indisolublemente unidos en la Consueta y nos proporcionan un aspecto contextual nuevo e inédito que pocas veces se tiene en cuenta en la reconstrucción de este rito.

La Salve se cantaba en la Abadía en tres escenarios diferentes: en las Cuevas, en la iglesia y en el coro de la iglesia. Las Cuevas, Cavernas u Hornos, es el lugar donde se encontraron las reliquias de San Cecilio y los libros plúmbeos. Dentro de ellas se construyeron varios altares y capillas, de los cuales dos están dedicados a la Inmaculada Concepción. La Capilla que está al lado del horno de San Cecilio tiene un altar presidido por la imagen de la Inmaculada Concepción. Se trata de un altar barroco labrado en piedra, que completa el programa iconográfico de la Inmaculada con los elementos de la letanía lauretana: el sol, la luna, espejo, torre de David, puerta del Cielo entre otros. $^{206}$ El otro altar en las Cuevas dedicado a la Inmaculada es el de la Iglesia de Santiago, y debido a su mayor tamaño es probable que fuese el escenario más frecuente para la Salve. En la iglesia se cantaba la Salve los sábados que el tiempo impidiera hacerlo en las Cuevas, también en las Fiestas de Nuestra Señora y en la Cuaresma. Cuando la Salve se hacía en la iglesia se cantaba en el pavimento bajo (en la iglesia, no en el coro) salvo en Cuaresma que sí se cantaba desde el coro. Se encendían cuatro velas en el Altar Mayor, y los versicularios sacaban un facistol con un paño blanco que se ponía a los pies de las gradas en la Iglesia donde colocaban el libro de la Salve.

\footnotetext{
${ }^{206}$ Sobre los atributos de la letanía lauretana, su significado y origen, véase Manuel Trens, María. Iconografia de la Virgen en el Arte Español (Madrid: Plus Ultra, 1947), pp. 165 y ss.
} 
La Salve que se cantaba en la Abadía, como la mayor parte del servicio litúrgico en esta Institución, era en canto llano. A veces se solemnizaba añadiendo el órgano, que tocaba alternatim con el coro. Aunque la Consueta sólo recoge esta práctica cuando la Salve se cantaba en la iglesia, en las Cuevas existía, según refieren las actas capitulares, un órgano realejo que podría hacer este papel. Una de las indicaciones más interesantes que proporciona la Consueta, es que en las Salves de las fiestas de guardar de Nuestra Señora en lugar del último verso se decía "un motete al órgano", lo que quiere decir que se debía cantar un motete en polifonía. La sustitución de un verso por un motete en polifonía es una práctica de la que no tenemos constancia en otros centros pero que probablemente fuera habitual. Desgraciadamente no se conserva ningún libro de polifonía en la Abadía, por lo que no podemos precisar nada más al respecto.

\subsubsection{El ceremonial de la Salve de los Sábados}

La Salve se cantaba en el Sacromonte a diferente hora según la época del año: después de Completas (desde el primer sábado de octubre hasta el Sábado Santo inclusive), y a las seis de la tarde desde el sábado ante dominicam in albis (el siguiente al Sábado Santo) hasta el último de septiembre. Al toque de la campana para cantar la Salve, los colegiales acudían a la iglesia y se situaban en dos coros en el crucero, guardando el orden por antigüedad y dignidad. Desde allí salían por la puerta principal en procesión, cubiertos con el bonete del que se despojaban al llegar al horno de San Cecilio, en las Cuevas próximas. Una vez en la capilla de la Cueva, a los tres golpes de "La Gorda" (una de las campanas), todos se arrodillaban excepto el sochantre que se levantaba para ir a entonar la Salve y dos colegiales llamados versicularios, que sostenían el libro de la Salve; el coro contestaba de rodillas. Al verso "O dulcis Virgo Maria" se levantaban dos canónigos comitantes y se acercaban a otro, el hebdomadario y los tres se dirigían al altar donde hacían genuflexión.

Acabada la Salve, los colegiales cantores entonaban el verso "Ora pro nobis" y los comitantes tomaban el libro para que el hebdomadario pudiera decir la oración con las "manos puestas", es decir con los brazos abiertos. Terminada la oración, el hebdomadario y los comitantes se arrodillaban y el coro respondía Amén a la oración. Los versicularios se quedaban de pie con el libro y pasaban la página para cantar la antífona Conceptio tua, que el sochantre entonaba inmediatamente y el coro respondía 
"al mismo compás que la Salve". Los colegiales cantores cantaban otra vez el verso al final de la antífona Conceptio tua, "Elegit eam Deus" y el hebdomadario se levantaba y decía la oración "Famulis tuis". Luego acompañaban al canónigo a su lugar, donde hacían genuflexión. Colegiales y rector se hincaban de rodillas y se iban por el orden que habían venido; antes de salir de las Cuevas hacían oración a los Santos (primero en el horno de San Cecilio y luego en el de San Hiscio). Después, los participantes en el rito de la Salve volvían a la Iglesia donde todos juntos se arrodillaban, y finalmente se iban a la Sacristía donde dejaban los sobrepellices y visitaban al Santísimo Sacramento.

\subsubsection{Las fuentes musicales del rito de la Salve en la Abadía}

En el Archivo de la Abadía se conservan dos libros de coro en los que está recogida la Salve: son los Cantorales LC XLII y LXVI, gracias a los cuales se puede reconstruir la música de este rito. Ambos son de formato parecido (60 x 40), no tan grandes y voluminosos como los cantorales ordinarios para el servicio del coro. El primero de ellos, el cantoral LC XLII, data de 1697 (ochenta y tres años después de la fundación de la Salve) y una inscripción dice: "Mandó hacer este libro un devoto para que se cante la Salve en estas sanctas Cuebas. Anno Domini 1697”; en otra página se lee "Francisco de Aguilar fecit". Este cantoral (bastante deteriorado), recoge las oraciones preceptivas para la Salve y unas "Letanías mayores a San Cecilio", que probablemente se cantarían también en las Cuevas. La iluminación de la letra "S" de Salve representa a la Inmaculada, según la iconografía conocida como "Tota Pulchra". ${ }^{207}$ Se trata de una mujer joven, vestida con túnica blanca y manto azul, con el pelo largo cayendo sobre los hombros, con las manos juntas. Desgraciadamente faltan los folios que contenían desde el final del primer verso hasta mediado el quinto verso de la Salve.

El otro cantoral LXVI, está mejor conservado y, aunque es algo posterior, recoge la Salve y su antífona, pero no las oraciones que sí contiene el otro, además de una antífona para las Vísperas del Sábado Santo. En la reconstrucción del rito de la Salve que presento en el apéndice 3 he tomado la música del cantoral LC LXVI, y las oraciones del cantoral LC XLII; véase Tabla V.7.. Las aclaraciones sobre las acciones

\footnotetext{
${ }^{207}$ MORENO GARRIDO, Antonio. "La Iconografía de la Inmaculada en el grabado granadino del siglo XVII". En: Cuadernos de arte de la Fundación Universitaria, 7 (1986), pp. 3-25.
} 
que tienen lugar durante la ceremonia las he extractado de la Consueta siguiendo el rito de la Salve en los sábados. He mantenido la ortografía latina presente en los cantorales, tanto en las oraciones como en el texto de las antífonas.

Tabla V.7. Fuentes musicales para la reconstrucción del rito de la Salve en la Abadía.

\begin{tabular}{|c|c|c|c|c|c|c|}
\hline$L C X L I I$ & $\begin{array}{l}\text { Salve } \\
\text { incompleta falta } \\
\text { desde final } \\
\text { primer verso } \\
\text { hasta mediado } \\
\text { el quinto verso. }\end{array}$ & \multirow[t]{2}{*}{$\begin{array}{l}\text { Verso: } \\
\text { Ora pro } \\
\text { nobis, } \\
\text { texto sin } \\
\text { música }\end{array}$} & $\begin{array}{l}\text { Oración: } \\
\text { Omnipotens } \\
\text { sempiterne } \\
\text { Deus }\end{array}$ & \multirow[t]{2}{*}{$\begin{array}{l}\text { Antífona: } \\
\text { Conceptio } \\
\text { tua }\end{array}$} & \multirow{2}{*}{$\begin{array}{l}\text { Verso: } \\
\text { Elegit } \\
\text { eam } \\
\text { Deus, } \\
\text { texto } \\
\text { sin } \\
\text { música }\end{array}$} & $\begin{array}{l}\text { Oración: } \\
\text { Famulis tuis }\end{array}$ \\
\hline$L C L X V I$ & Salve completa & & No figura & & & No figura \\
\hline
\end{tabular}

\subsubsection{La significación de la Salve en la Abadía del Sacromonte}

Como en otras iglesias colegiales y catedrales, en la Abadía el canto de la Salve se acompañaba de oraciones y de una antífona o motete. Como hemos visto, en el caso de la Abadía siempre es la misma antífona la que sigue a la Salve: Conceptio tua. Se trata de una antífona de tema mariano, por lo que no parece significativo que acompañe a la Salve. Pero en la Abadía la aparición de esta antífona requiere un detenido análisis y debe ser puesta en relación con el inicio del culto a la devoción de la Inmaculada Concepción, que había sido uno de los ejes ideológicos en la creación de la Abadía. En un Acta Capitular se hace referencia a que la Salve es para honrar a la Inmaculada Concepción:

Propuso el señor Abad que su merced quería en honra de Nuestra Señora y de su Inmaculada Concepción dotar la Salve que se dice en las Cuevas todos los sábados y los días de Nuestra Señora en la Iglesia para que asistiesen todos los señores canónigos, capellanes y colegiales, y que sobre los tres reales que tenía el colegio y capellanes de distribución aumentaba otros cinco más que hicieran ocho y se distribuyesen por sus puntos dando una a cada colegial, dos al capellán, tres a los señores canónigos y seis al señor Abad en la misma forma que se ganan y distribuyen los aniversarios, y en cuanto a la asistencia y falta de ellos que juntar los tres reales de la distribución del colegio era juzgando 
que sería en más y que les alcanzaría la cual dotación hace por todos los días de su vida. ${ }^{208}$

Sabemos por un acta capitular de 1632 que después de la Salve se cantaban unas coplas a la Inmaculada Concepción, y al haber remitido la controversia sobre la Concepción

\begin{abstract}
se dejen de cantar las dichas coplas y que en su lugar se diga la antífona, versos y oración que usa la Iglesia en las Vísperas de la Concepción que es la antífona Conceptio tua dei genitrix y que esta se diga solamente por devoción libre y voluntaria y como una de las demás ceremonias se escriba en la Consueta y que se haga y ejecute como las otras y que luego se borre de la Consueta en todos los lugares en que estuviere escrito que se canten las coplas después de la Salve. ${ }^{209}$
\end{abstract}

Puede que estas Coplas sean las coplas famosas de Miguel Cid "Todo el Mundo en general". Aunque el acta indica que se dejaron de cantar estas coplas, otras coplas a la Virgen se conservan escritas, entre las oraciones que deben saber los colegiales del Sacromonte, en la "Praxis de las ceremonias, que deben observarse por los colegiales" de 1772. ${ }^{210}$ Dichas Coplas las cantaban los colegiales a la Inmaculada Concepción en su Capilla a la Virgen todas las noches de las Vísperas, y días de nuestra Señora curiosamente junto con la antífona Conceptio tua. En las coplas (alrededor de unas 21 estrofas) el verso final de cada una de las estrofas hace alusión de nuevo al dogma: "Por que fuisteis concebida sin pecado original" y bien podrían ser un contrafacta de las de Miguel Cid. Como he señalado anteriormente, las coplas debían conocerse en Granada en una fecha tan temprana como 1615, pues fueron elegidas como argumento para el sermón de Fray Michael de Avellano en las fiestas del Convento de San Francisco de Granada. Habida cuenta que las Coplas se crearon y difundieron en Sevilla en tiempos del arzobispo Pedro de Castro, parece lógico pensar que alguno de sus colaboradores (o

\footnotetext{
${ }^{208}$ ASAC I, fol. $215 \mathrm{v}$ (12-I-1619), [55].

${ }^{209}$ ASAC II, fol. ¿? (7-X-1632), [161].

${ }^{210}$ Praxis de las Ceremonias, que deben observarse por los Colegiales del Insigne Colegio de Theólogos, y Juristas del Señor San Dionisio Areopagita, sito en el Sacro Ilipulitano Monte, extra-Muros de la Ciudad de Granada (Granada: Imprenta Real, 1772), pp. 167-171.
} 
él mismo) que habitualmente viajaban entre Sevilla y Granada, introdujeran el canto en el Sacromonte y en Granada. ${ }^{211}$

Sobre la interpretación de las Coplas de los colegiales sacromontanos, un acta capitular de 1769 refiere "que en las Coplas no se guarde el tono ridículo que de algunos años han seguido, pero sí el grave y serio que antes para lo que podrá el sochantre concurrir algunas noches". ${ }^{212}$ La antífona Conceptio tua se conviertió en sustituta de las Coplas a la Inmaculada Concepción en el rito de la Salve, pero guardaba el mismo significado ideológico. Para comprender la relevancia de esta antífona de la Inmaculada Concepción en la Abadía se puede decir que en la biografía del fundador don Pedro de Castro, escrita en el siglo XVIII por Diego Nicolás Heredia Barnuevo, esta antífona se menciona en el momento de la muerte de tan excelso prelado:

\begin{abstract}
Viéndose cercado de su nobilísimo Cabildo (...) le dio a entender que había llegado el momento de que se le cantase la "dulcísima antífona" de la Inmaculada Concepción deNuestra Señora. Empezaron todos al punto a entonar el Conceptio tua, y al oír el Mariano enfermo la primer voz, levantó el brazo con indecible esfuerzo, y quitándose la cofia de la cabeza, la inclinó profundamente, permaneciendo inmóvil en esta tierna y reverente postura hasta que clausuló el último periodo de su vida, con aquel final acento de la antífona Donavit novis vitam sempiternam. ${ }^{213}$
\end{abstract}

La iconografía presente en la Abadía sirve para reforzar visualmente lo que el servicio de la Salve pretende: señalar a María bajo el misterio de la Inmaculada Concepción. La tipología iconográfica de la que hablamos es la de la "Tota Pulchra" 214 que he descrito anteriormente. No sólo en las capillas de las Cuevas donde se cantaba la Salve encontramos esta imagen en varias esculturas barrocas de pequeñas dimensiones, sino en otros lugares relacionados con la Salve. Al menos tres altares están dedicados a esta advocación en la Abadía: dos en las Cuevas (capilla de San Cecilio y de Santiago) y otro en la iglesia ( en el crucero, en el lado del Evangelio). En los altares de las Cuevas la Virgen aparece acompañada de los elementos de la letanía

\footnotetext{
${ }^{211}$ Algunos de los primeros sochantres del Sacromonte provenían de Sevilla: Gregorio Núñez, Simón Torres y Juan Díaz.

${ }^{212}$ ASAC XI, fol. 126 r (3-VIII-1769), [694].

${ }^{213}$ Heredia Barnuevo, Místico Ramillete, p. 214.

${ }^{214}$ Moreno Garrido, Antonio. "La Iconografía de la Inmaculada en el grabado granadino del siglo XVII", Cuadernos de arte de la Fundación Universitaria, 7 (1986), pp. 3-25.
} 
lauretana, esculpidos en piedra en la Capilla de San Cecilio o pintados sobre el retablo en la Capilla de Santiago. En uno de los libros de la Salve, el LC XLII, algo deteriorada se encuentra la imagen que ilustra la letra uncial que es una Inmaculada "Tota Pulchra".

El rito de la Salve al emplear en un primer momento las Coplas "Todo el mundo en general", y en un segundo la antífona Conceptio tua, se convierte en este contexto en un elemento de exaltación religiosa de un dogma aún no establecido oficialmente por la Iglesia. Se trata de la reutilización de un rito existente (el servicio de la Salve) para rendir culto a un dogma nuevo, que es además uno de los pilares ideológicos de la Abadía.

El rito de la Salve se siguió celebrando en la Abadía durante varios siglos. En la Praxis de ceremonias de 1772 queda dentro de las obligaciones de los colegiales el asistir a las Salves todos los sábados del año. Un libro dedicado a Granada de finales del siglo XIX narra cómo los canónigos iban en procesión a las Cuevas los sábados por la noche cantando el himno Ave Maris Stella; con casi toda seguridad se trataría de la procesión para el rito de la Salve de los sábados:

\begin{abstract}
Al toque de oraciones se junta el Cabildo en la Iglesia, y con cirios en las manos, cantando la letanía, se dirigen a las tortuosas y estrechas galerías donde se guardan las cenizas de los mártires; la luz de los ciriales y el canto de los Sochantres se quiebra con fantásticos reflejos y extraños ecos, en aquellos laberínticos subterráneos, en cuyos rincones parpadean misteriosas luces, y se abren silenciosos altares... Al final, en las entrañas de la tierra, en pequeña capilla, todos se detienen, $y$, después de breves oraciones se entona el himno Ave maris stella, con cuyos sublimes acentos, a paso acelerado, regresa la procesión, que pasa como sueño dantesco, bajando las cabezas, oprimida por la estrechura de las piedras, entre luces y sombras vacilantes. ${ }^{215}$
\end{abstract}

El rito de la Salve en la Abadía se convirtió en el acto de culto más frecuente en las Cuevas de los mártires, y uno de los que más permanencia tuvo en el tiempo en este espacio cultual tan singular. Con esta temprana devoción a la Inmaculada Concepción, pues como dogma no fue definido por la Iglesia Católica hasta 1854, los canónigos de la Abadía del Sacromonte de Granada dotaban de un nuevo significado al rito de la Salve al mismo tiempo que trataban de reafirmar los orígenes de su fundación.

${ }^{215}$ A.A.V.V., Granada 1899 (Granada: Albaida, 1995), pp.136-137; es edición facsímil de la de 1899. 


\section{CAPÍTULO VI}

\section{LOS LIBROS DE CORO DE LA ABADÍA DEL SACROMONTE DE GRANADA ${ }^{1}$}

\section{La formación de la biblioteca coral de la Abadía del Sacromonte}

El origen de la biblioteca de los libros de coro de la Abadía está estrechamente ligado al inicio del culto en la Iglesia Colegial del Sacromonte. Sin embargo, como ocurre con el resto de los fondos bibliográficos de la Abadía, ésta no solo dispone de cantorales coetáneos y posteriores a la fecha de su fundación (1609), sino que cuenta con libros más antiguos. $^{2}$ De su procedencia nada sabemos, quizá pertenecieran al fundador Don Pedro de Castro, pues depositó sus propios libros en la Abadía $^{3}$, o probablemente se trajeran de algún otro centro litúrgico, comprados de segunda mano antes de que se encargaran los libros propios o procedentes de la exclaustración del siglo XIX, como parece ser el caso de los que se conservan del Convento de San Antonio de Padua. En la actualidad se conservan setenta y nueve cantorales en el Sacromonte; véase el Catálogo al final de este volumen. ${ }^{4}$

El cantoral más antiguo (LC I) es de formato pequeño y no guarda semejanza con ningún otro: ni en tamaño, ni en la caligrafía latina (más angulosa), ni en la notación musical, que, aunque es cuadrada, recuerda a las figuras de la notación mensural negra. Su repertorio es el propio de un Intonario, pues contiene diversas entonaciones y recitativos para las lecturas y numerosos himnos, entre ellos el famoso himno a San Juan Bautista "Ut queant laxis" pero en su versión hispana, que comentaré más adelante. Su datación debe ser estimada antes de la reforma de Pío V, por las similitudes que guarda con el Intonarium

\footnotetext{
${ }^{1}$ Un estudio sobre las características del soporte de los libros de canto llano de la Abadía y su estado de conservación ha sido realizado por Javier Bueno Vargas en su tesis doctoral; véase Javier Bueno Vargas, Los libros de coro en pergamino e ilustrados de la Abadia del Sacromonte de Granada: estudio histórico medioambiental, de materiales y técnicas (Tesis Doctoral), Universidad de Granada, 2002.

${ }^{2}$ La más antigua de las fuentes musicales de la Abadía es un fragmento pregótico que aparece en la encuadernación de la Divina Misa Sancti Ihoanni (1528); véase Calero Palacio, La Abadía, p. 35. No he podido consultar dicho fragmento.

${ }^{3}$ Calero Palacios, La Abadia, p. 28.

${ }^{4}$ Para referirme a los cantorales utilizaré la numeración en dicho Catálogo, en que también incluyo las numeraciones antiguas.
} 
Toletanum, 1515, y por la escritura, más angulosa y parecida a la gótica, que podría datarse en torno a la última década del siglo XV o principios del XVI.

Los otros cinco cantorales anteriores a 1600 (LC II-VI) forman un grupo homogéneo. Sus dimensiones son similares (alrededor de 685 x 500 x 170), siendo un poco más reducidas que las de los grandes cantorales. La numeración es original y en cifras romanas, excepto el LC VI que está sin numerar, además las letras unciales de todos ellos están finamente decoradas en rojo y azul con una filigrana menuda, dentro de la tradición mudéjar. ${ }^{5}$. Gracias al primero de estos libros, LC II, conocemos la fecha y el nombre del corrector: "Digo yo Juan Ramos beneficiado de cantar que este libro va corregido y enmendado de punto y letra y firmelo yo a seis de Mayo de 1558 años". 6 Este copista intervino junto con un tal Francisco de Heredia en varios de los cantorales que se conservan en la Colegiata de Santa Fe. Ambos parecen ser los copistas del cantoral que conserva el Oficio de la Toma de Granada y que se encuentra en dicha Iglesia. ${ }^{7}$

El repertorio de estos seis cantorales es muy amplio y abarca desde la liturgia de la Semana Santa, pasando por el ordinario de las misas diarias, hasta un libro de vísperas. Destaca sobre todo el repertorio los Kyrie tropados, pues los tropos y secuencias (salvo cuatro), fueron abolidos y retirados de la liturgia por el Concilio de Trento en 1565. El que inicia la serie de siete kyries es el conocido Kyrie Cunctipotens, que aparece en el LC IV fol. XVII ${ }^{\mathrm{v}}$ y ss. y que comentaré más adelante.

\footnotetext{
${ }^{5}$ Este tipo de decoración era bastante frecuente en la época de hecho, unas letras muy parecidas se encuentran entre otros, en los cantorales de la Catedral de Palencia, véase López-Calo, Catálogo de música de la Catedral de Palencia, (Palencia: Diputación Provincial, 1980). Para un estudio de algunos de los principales manuscritos conservados con esta decoración véase: Frances Spalding, Mudéjar Ornament in Manuscripts, (Nueva York: Hispanic Society, 1953).

${ }^{6}$ LC II, fol. $1^{\mathrm{r}}$.

${ }^{7}$ María Elisa Varela Rodríguez, "In festo deditionis urbis granatensis" en Fray Hernando de Talavera, Oficio de la Toma de Granada, textos de Francisco Javier Martínez Medina, Pilar Ramos López, Elisa Varela Rodríguez y Hermenegildo de la Campa (Granada: Diputación Provincial, 2003), p. 69. Para un estudio de la biblioteca coral de Santa Fe, véase Gonzalo Roldán Herencia, La colección de cantorales de la Iglesia Colegial y Parroquial de Santa Fe (2003), Trabajo de Investigación inédito presentado en la Universidad de Granada para la obtención del Diploma de Estudios Avanzados (DEA).
} 


\subsection{Los cantorales copiados ex profeso para la Abadía}

En 1618 un tal Pedro Marañón, “escriptor” de libros de la ciudad de Málaga, se comprometió a realizar nueve libros con el Santoral de Misas para la librería del Sacromonte. El contrato que se encuentra en uno de los cantorales (LC VII) es apenas legible, pero aún así nos facilita algunos datos interesantes, como los nombres de los que encargaron la obra: el Abad Pedro de Ávila (1617-1651) y los canónigos Agustín Manrique $^{8}$ y Francisco Hurtado Ossorio. El primero de los cantorales en copiarse fue el LC VII que contiene el propio de las misas de los santos desde San Andrés (30 de noviembre) hasta San Marcelo Papa y Mártir (16 de enero). Aunque el contrato indica que se trataba de nueve libros, actualmente hay once libros con características similares: son de gran formato (alrededor de $860 \times 600 \times 100$; hoja 810 × 560; caja $640 \times 380$ ); tienen cuatro pentagramas por página; la foliación es con numeración arábiga; y están ilustrados ricamente con iluminaciones similares.

Las iluminaciones son en su mayoría de calidad, y hay al menos una por libro, que suele situarse en el folio $1^{\mathrm{v}}{ }^{9}$ En ellas aparece una orla que rodea la caja de escritura, con diversas decoraciones (grutescos, flores, pájaros); figura también el escudo del arzobispo Pedro de Castro, o bien la estrella del Sacromonte. Una cartela con la inscripción "Praesulis en [sic] Petri praeclari stemmata fulgent, Qui hoc sacri officii scribere fecit opus" $" 10$ aparece colocada en la parte superior de la orla; véanse Figuras VI.1. al VI.4.

\footnotetext{
${ }^{8}$ Fue uno de los redactores de la Consueta; véase el Capítulo II de este estudio.

${ }^{9}$ Desafortunadamente muchas de ellas han sido arrancadas.

${ }^{10}$ Una clara alusión al obispo y fundador del Sacromonte, Pedro de Castro: "He aquí que relucen los títulos de gloria del preclaro obispo Pedro que acometió esta obra de escribir el sacro oficio".
} 
Figura VI.1. Abadía de Sacromonte, LC VII. Introito de la Vigilia de San Andrés, fol. $1^{\mathrm{v}}$. Foto: Javier Ruiz

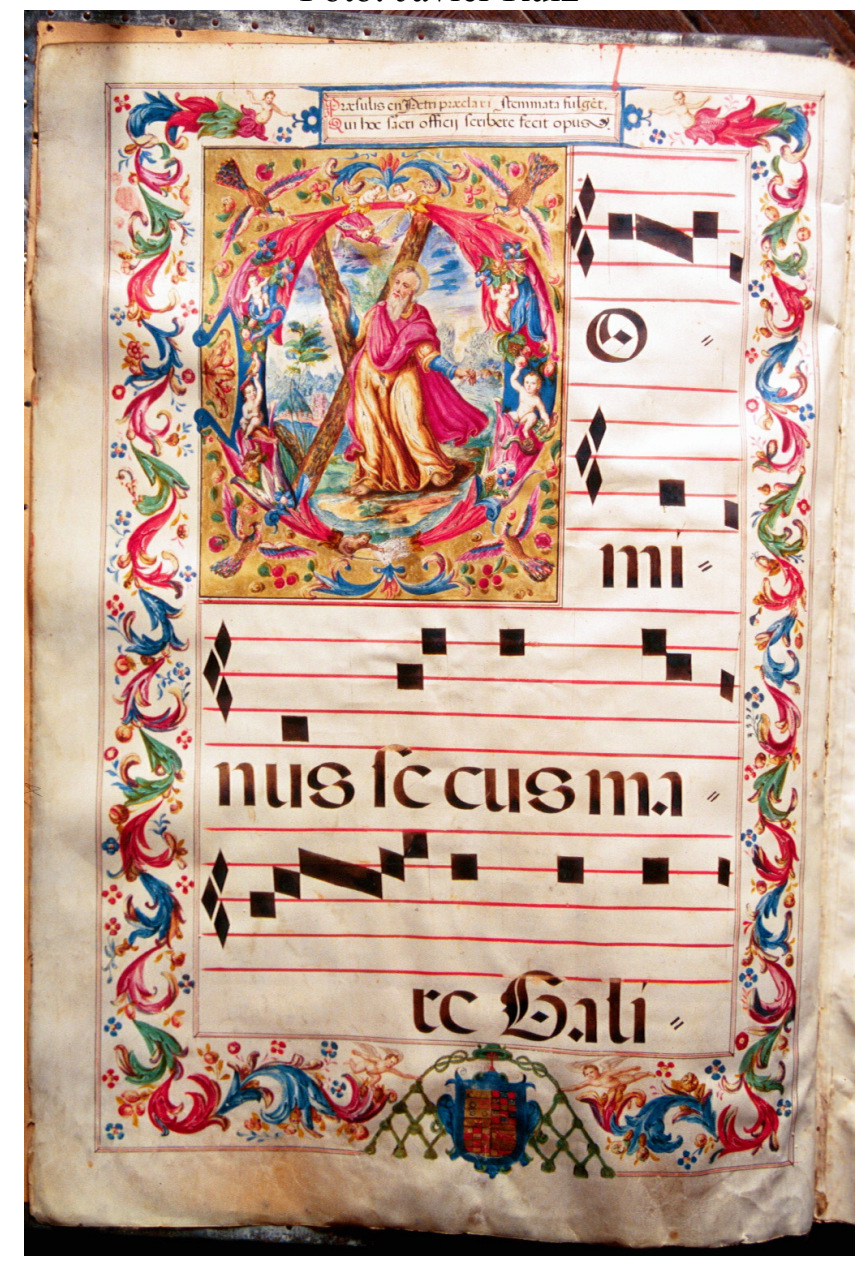

Figura VI.2. Abadía de Sacromonte, LC VII. Introito de la Vigilia de San Andrés, fol. $1^{\mathrm{v}}$. Detalle. Foto: Javier Ruiz.

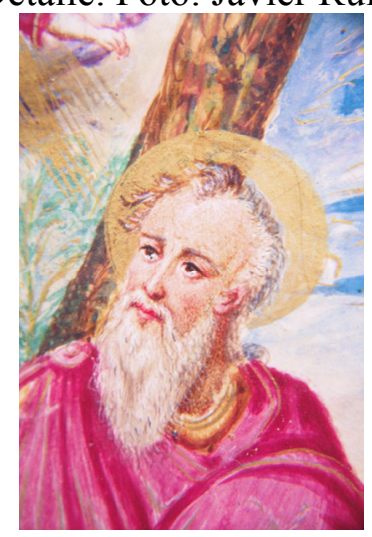


Figura VI.3. Abadía de Sacromonte, LC XVII. Misas votivas de la Virgen, fol. ¿? . Foto: Javier Ruiz.

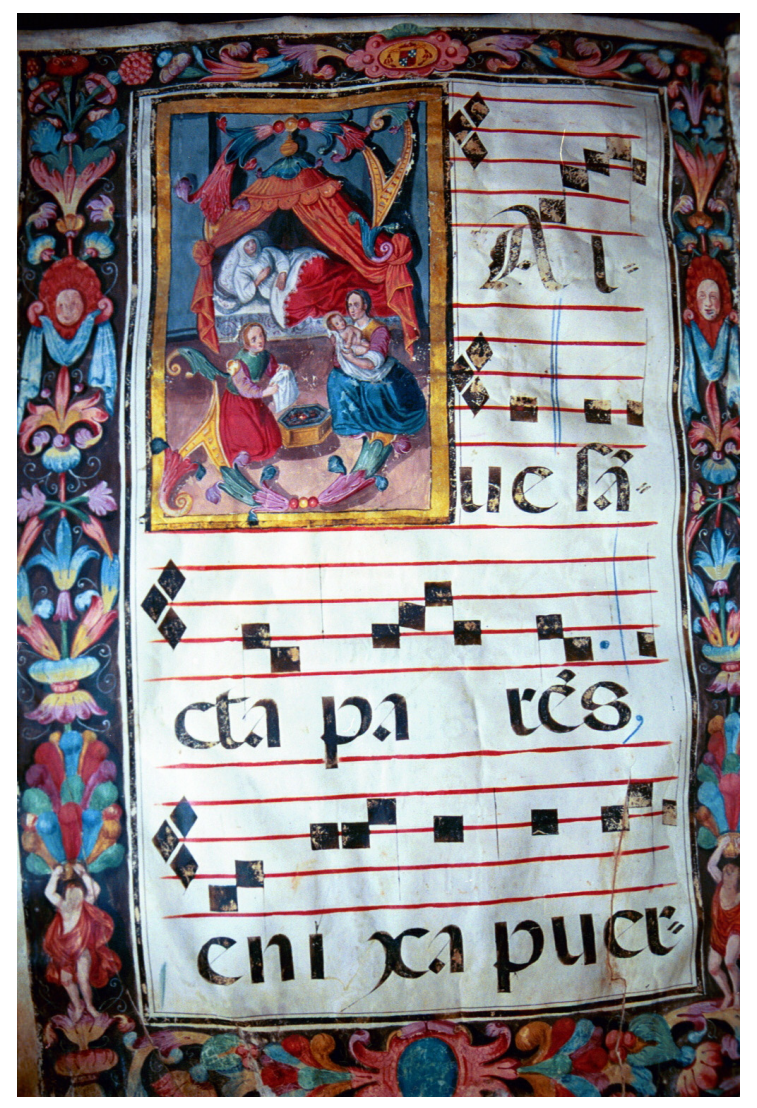

Figura VI.4. Abadía de Sacromonte, LC VIII. Inicial miniada con San Pedro en su Cátedra, fol. $1^{\mathrm{v}}$. Detalle. Foto: Javier Ruiz.

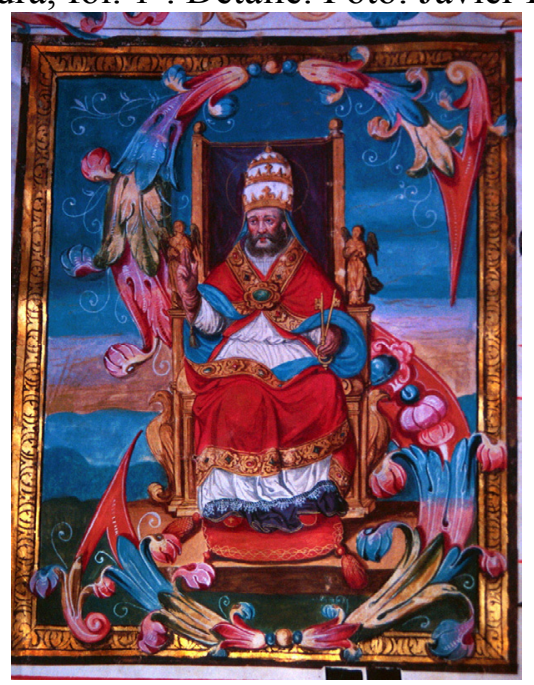


Siguiendo el orden del santoral podemos establecer la siguiente lista de cantorales copiados por Pedro Marañón; véase Tabla VI.1.

Tabla VI.1. Libros Corales copiados por Pedro Marañón.

\begin{tabular}{|l|l|l|}
\hline Libro Coral & $\begin{array}{l}\text { Antigua } \\
\text { Signatura }\end{array}$ & $\begin{array}{l}\text { Repertorio } \\
\text { (Misas del Propio de los Santos) }\end{array}$ \\
\hline LC VII & 19 & San Andrés a San Marcelo \\
\hline LC VIII & 20 & Cátedra de S. Pedro a conv. S. Pablo \\
\hline LC IX & 21 & Santa Águeda a San Vital \\
\hline LC X & 22 & San Felipe y Santiago a S. Agustín \\
\hline LC XI & 23 & San Bernabé a San Pedro y S.Pablo \\
\hline LC XII & 24 & San Pedro a San Ignacio \\
\hline LC XIII & 25 & Santiago Apostol a San Ciriaco \\
\hline LC XIV & 18 & San Lorenzo a Natividad de la Virgen \\
\hline LC XV & 27 & Invención Cruz a Sto. Ángel Custodio \\
\hline LC XVI & 28 & San Simón a San Clemente \\
\hline LC XVII & 17 & Misas votivas de la Virgen \\
\hline
\end{tabular}

Aunque no tenemos ninguna noticia más en las Actas Capitulares acerca de la labor de Pedro Marañón en la librería de la Abadía, muchos de los cantorales pudieron salir de su taller, pues son muy similares aunque las ilustraciones son de inferior calidad; véase Tabla VI.3. Cabe la posibilidad de que los cantorales de Marañón sirvieran como modelo a unas manos menos expertas y no procedieran de su taller. Una de las orlas que más se repite en esta segunda serie tiene en las esquinas una interesante alusión a los libros plúmbeos: en círculos aparece una especie de escritura árabe, simulando la apariencia de estos libros plúmbeos; como ejemplo véase la Figura VI.5. que reproduce un detalle del LC XIX. (316, olim17). 
Figura VI.5. Detalle de la iluminación del Cantoral LC XIX, representando a un libro plúmbeo.

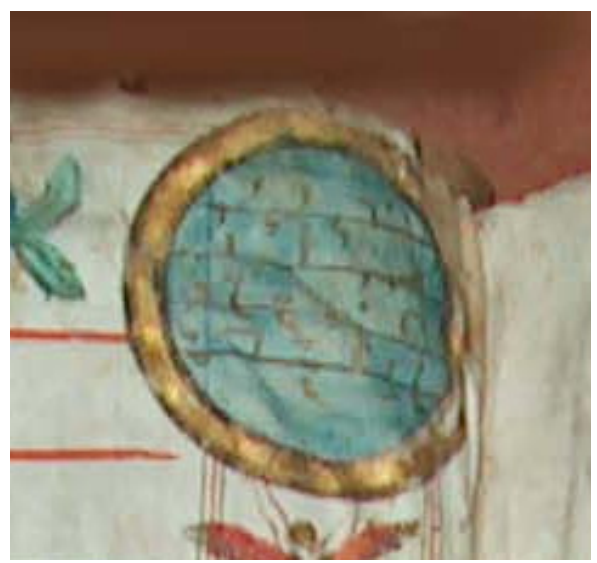

Tabla VI.2. Libros similares a los copiados por Pedro Marañón, pero con iluminaciones más toscas, ordenados según su repertorio.

\begin{tabular}{|l|}
\hline Libros de Misas (Propio de los Santos) \\
\hline LC XVII / 316 / 17 \\
\hline Libros de Misas (Común de los Santos) \\
\hline LC XVIII / 328 / 30 \\
\hline LC XIX / 330 /31 \\
\hline LC XX / 332 / 32 \\
\hline Libros de Vísperas \\
\hline LC XXI / 312 / 14 \\
\hline LC XXII / 333 / 33 \\
\hline LC XXIII / 325 / 26 \\
\hline LC XXIV / 329 / 29 \\
\hline LC XXV / 335 / 35 \\
\hline Libros de Difuntos \\
\hline LC XXVI / 314 / 16 (Oficio) \\
\hline LC XXVIII / 372 / D \\
\hline Pasionario \\
\hline LC XXVII / 23 / 55 \\
\hline
\end{tabular}


Según Llordén, Pedro Marañón reclamó en su testamento la cantidad que le adeudaba el Sacromonte, de la que debía a su hijastro Lucas de Cáceres 600 reales, pues había colaborado en la hechura de los libros. ${ }^{11}$ Tal vez sea este Lucas de Cáceres el escritor de estos cantorales de inferior factura.

Una referencia en las Actas indica que en 1640 se intentó contratar de nuevo a Pedro Marañón para copiar el Dominical de Misas en diversos volúmenes, pero finalmente no se hicieron, pues los libros que corresponden a este repertorio son muy posteriores y los realizó otro copista:

Propuso el señor Abad que era necesario se haga el Dominical de Misas porque un libro de papelón en que hoy se canta después de remendado muchas veces está tan hecho pedazos que ya no se puede cantar por él y faltando $\mathrm{P}^{\mathrm{o}}$ Marañón que ha hecho los demás libros del coro no se hallaba persona que los haga ni en tanta comodidad- y se determinó por todos los votos que si el dicho Pedro Marañón vecino de Málaga quiere hacer el dicho dominical en los cuerpos que pudiere acomodarlo a las pagas y precio y en las condiciones que ha hecho los nueve cuerpos del santoral de Misas que haga y se encomience, todo lo cual se le encomendó al Señor Sarmiento para que le escriba y de el orden. ${ }^{12}$

Pedro Marañón no llegó a hacer esos libros porque seguramente murió aquel mismo año; su actividad documentada la Catedral de Málaga va de 1606 a $1640 .{ }^{13}$ Los libros de canto llano de la Catedral de Málaga son de similar factura a los del Sacromonte. Incluso repiten la cartela con el texto que emplea en los cantorales de la Abadía, cambiando Petri por Ludovici, pues fue el obispo Luis Fernández de Córdoba quién encargó los cantorales para la Catedral malacitana. La ejecución de ambas librerías debió de correr pareja, ya que la de Málaga no daría comienzo antes de 1615 , año en que el obispo llegó a dicha diócesis. ${ }^{14}$

\footnotetext{
11 Andrés Llordén,"Notas históricas de los escritores de libros corales de Málaga", Anuario Musical, 15(1960), p.187.

${ }^{12}$ ASAC II, fol. 471 r (1-VI-1640), [213].

${ }^{13}$ Llordén, "Notas históricas”, p.181.

${ }^{14}$ Antonio Martín Moreno et alii, Catálogo del Archivo de Música de la Catedral de Málaga, vol. I (Granada: CDMA, 2003), p.5.
} 
Pedro Marañón aparece como "puntador" de otros libros en la catedral malagueña, entre ellos los del maestro de capilla y polifonista Esteban de Brito. ${ }^{15}$

Es interesante señalar aquí algunos datos que porporciona Llordén y que sitúan a la librería sacromontana en los circuitos oficiales de producción de libros en la Península. Pedro Marañón era natural de Husillos en Palencia y había entrado al servicio de la Catedral malagueña por orden del arzobispo de Málaga Juan Alonso de Moscoso, escribiendo los libros de canto para las iglesias de Antequera en $1606 .{ }^{16}$ En 1615 le fueron encargados los libros para Ronda y en 1630 los de Coín. Es interesante destacar que encargaba pieles de Segovia para sus libros como consta por un encargo al mercader Juan de Arenas. También figura como mercader de libros, siendo considerado por el obispo de Málaga como su librero oficial. Su volumen de venta y copia de libros debió ser bastante elevado, razón por la que en 1622 otorgó un poder al racionero de la catedral, Juan Muñoz, para que cobrara sus débitos. En 1631 Marañón pedía nueve reales y medio por la hoja grande y cuatro por la pequeña, precio que era menor que cuando hizo los cantorales para el obispo Luís Fernández de Córdoba. Las ilustraciones, al igual que las de los Libros de la Catedral de Málaga, podían ser de un tal Juan de Toledo, a quién compró letras iluminadas en varias ocasiones. ${ }^{17}$ Aunque, como hemos señalado antes, el contrato para los libros del Sacromonte tiene fecha de 1618, en 1636 aún no había finalizado su relación con el Sacromonte, pues otorgó una escritura a Pedro Sarasa, mercader vecino de Granada para que pudiera cobrar el dinero que le debía el Cabildo sacromontano por los libros de coro. Finalmente en 1640 el Cabildo le dio la cantidad de 2.286 reales como pago por los libros.

\footnotetext{
${ }^{15}$ Martín Moreno et al., Catálogo del Archivo, vol. I, pp. 149 y 151.

${ }^{16}$ Estas referencias biográficas y las que siguen han sido extractadas de Llordén.

${ }^{17}$ Véase María Julieta Vega García-Ferrer, Los Cantorales de Canto Llano en la Catedral de Málaga (Granada, CDMA Junta de Andalucía, 2007) p. 32.
} 


\subsection{Libros patrocinados por Bartolomé de Torres.}

Canónigo desde 1610 y Abad entre 1657 y 1662, Bartolomé de Torres encargó la copia de tres libros (LC XXXI- LC XXXIII) y un oficio al Dulce Nombre de Jesús que se encuentra encuadernado en un volumen misceláneo: LC XXIX; véase Tabla VI.4.

Tabla VI.3. Libros de Coro del Sacromonte patrocinados por Bartolomé de Torres.

\begin{tabular}{|l|l|}
\hline Libros de Coro & Repertorio \\
\hline LC XXIX & Oficio del Dulce Nombre de Jesús fols. 44-53 \\
\hline LC XXXI & Dominical de Misas (Feria V in coena Domini hasta Sábado in albis) \\
\hline LC XXXII & Dominical de Misas post Pentecostés (1-12) \\
\hline LC XXXIII & Dominical de Misas post Pentecostés (13-23) \\
\hline
\end{tabular}

En el LC XXIX, donde se encuentra el oficio del Dulce Nombre de Jesús, cuya fiesta dotó el mismo Bartolomé de Torres, ${ }^{18}$ se haya una inscripción que dice: "Mandó escrevir este oficio del Dulce Nombre de Iesus, el Señor Dr. Don Bartolomé de Torres, Canónigo de este Sacro Monte, por su devoción este Año de 1656". ${ }^{19}$

Las inscripciones en los folios $1^{\mathrm{r}}$ de los LC XXXI y LC XXXII indican que se copiaron en Córdoba entre 1656 y 1657. El LC XXXIII no tiene dicha inscripción debido a la falta del folio $1^{\mathrm{r}}$, pero continúa con el repertorio del volumen anterior y tiene las mismas características de escritura. En la inscripción sólo aparecen las iniciales del copista: F.D.Q.F. (de la orden de predicadores). Aunque de excelente ejecución, estos cantorales no llegan a la riqueza de los copiados por Pedro Marañón.

\footnotetext{
${ }^{18}$ Bartolomé de Torres fundó algunos aniversarios entre los que se encuentran: la fiesta del Nombre de Jesús en ambas vísperas y en misa de tercia, la fiesta de la aparición del arcángel San Miguel, San Bartolomé Apóstol, la Nona de la Ascensión, Vigilia y Responso para el día de su muerte cantado en la iglesia.

${ }^{19}$ LC XXIX, fol. $53^{\mathrm{v}}$.
} 


\subsection{El "Cuaderno de la Salve" y otro oficio de Francisco de Aguilar (1657)}

De mediados de siglo XVII es también un curioso "quaderno" (LC XXX), como lo denomina la Consueta, que contiene la Salve, además de las Letanías mayores a San Cecilio. En una de las orlas que decora la caja de escritura aparece escondido el nombre del copista: "Francisco de Aguilar fecit, Anno Domini 1657"; en el folio $11^{\mathrm{v}}$ también se lee: "Mandó hacer este libro un devoto para que se cante la Salve en estas sanctas Cuevas. Anno Domini 1657”. Francisco de Aguilar también copio parte del LC XXIX, como puede verse por la firma que aparece en la orla del folio $28^{\mathrm{r}}$. Las ilustraciones de estos cantorales son sencillas, pero hermosas, aunque desgraciadamente la de la "S" que ilustra una Inmaculada está muy deteriorada.

Este copista aparece en la Catedral de Málaga, como autor del cantoral $\mathrm{n}^{\mathrm{0}} 57$, que contiene la inscripción "Francisco de Aguilar faciebat. Anno 1656". ${ }^{20}$

\subsection{Libros corales copiados en tiempos del Abad José de Escalante (1662-1684)}

Una inscripción en el folio $1^{\mathrm{r}}$ de dos cantorales (LC XXXVI y LC XXXVII) indica que fueron copiados en 1663 por Julianus Ferrer, mercedario, en tiempos del Abad José de Escalante:

"Anno/ Ab inventione Sacrarum Cinerum/ in Cavernis huius Sacrimon/tis illipulitani sexagessimo octavo. /Regnante in Hispania Philippo IV,/; Rome Gubernante Eclessiam Alessandro VII de mandato ad mo/dum Per illustris capituli sub eius capite /DDrD Josepho de Escalante; Dre Christophoro de Vega Pretere /huic Operi A se manuscripto ultima impo/suit manu Pf Julianus Ferrer/Ordinis Beate $\mathrm{M}^{\mathbf{0}}$ de Mercedes/ redemptionis Captivorum Die $1^{\circ}$ mensis Augusti eiusdem anni Domini /1663"

\footnotetext{
${ }^{20}$ De este copista, Francisco de Aguilar, encontramos otros trabajos en la Catedral de Málaga, al menos desde 1656; véase Martín Moreno et al., Catálogo del Archivo, vol. I, p. 26. Julieta Vega García-Ferrer, Los Cantorales de Canto Llano, p. 33, señala que trabajó entre 1696 y 1697, aunque parece una confusión de fechas por 1656-1657.
} 
Durante el mandato del Abad José de Escalante se efectuó el rescate de muchos cautivos por las limosnas de la Abadía a la orden de los mercedarios, por la que el Abad sentía cierta "afinidad espiritual". ${ }^{21}$ Tal vez por eso encargó a un copista de dicha orden estos cantorales. De todos los cantorales del siglo XVII, éstos son los más sencillos, en lo que a factura se refiere y sus iluminaciones son de calidad inferior.

\subsection{Otros libros corales del siglo XVII}

Los siguientes cantorales no guardan una relación de total semejanza con ninguno de los grupos descritos hasta el momento, pero sí que por sus características generales se sitúan en el siglo XVII, antes que en XVIII; véase Tabla VI.5.

Del siglo XVII es también un libro con los Oficios de Semana Santa, impreso en Madrid, en la Tipografía Real en 1616 (LC). Este libro nos interesa por dos motivos: contiene una interesante introducción en castellano en la que explica los motivos por los que se ha llevado a cabo la impresión del libro, entre ellos la conveniencia para el servicio litúrgico de las iglesias pobres que no podían costearse los grandes libros de pérgamino, y porque señala que es "cum cantu toletano". 22

Tabla VI.4. Libros corales sin procedencia definida.

\begin{tabular}{|c|c|c|}
\hline LIBRO & REPERTORIO & \\
\hline LC XXXVIII & Libro del oficio & \\
\hline $\begin{array}{l}\text { LC XXXIX } \\
\text { LC XL } \\
\text { LC XLI } \\
\text { LC XLII }\end{array}$ & $\begin{array}{l}1^{\text {a }} \text { Parte del dominical de Vísperas } \\
2^{\text {a }} \text { Parte del dominical de Vísperas } \\
3^{\text {a }} \text { Parte del dominical de Vísperas } \\
\text { Ordinario de la misa }\end{array}$ & $\begin{array}{l}\text { Guardan cierta } \\
\text { similitudes con los } \\
\text { Cantorales copiados } \\
\text { por orden de } \\
\text { Bartolomé de Torres }\end{array}$ \\
\hline $\begin{array}{l}\text { LC XLIII } \\
\text { LC XLIV }\end{array}$ & \multicolumn{2}{|c|}{$\begin{array}{l}\text { Semana Santa } \\
\text { Mixto: maitines de Santiago, misa de San Camilo y oficio de } \\
\text { los siete Dolores de la Virgen }{ }^{23} \\
\text { Vísperas del común de confesores }\end{array}$} \\
\hline
\end{tabular}

\footnotetext{
${ }^{21}$ Zótico Royo, Abades del Sacromonte, p. 65-66.

${ }^{22}$ Para más información sobre lo que se entendía en la época con esta expresión; véase Ismael Fernández de la Cuesta, "Toledano, canto" en DMEH, 10, pp. 321-326.

${ }^{23}$ Sólo una parte de este cantoral puede fecharse en el siglo XVII, pues contiene además la misa de San Camilo (canonizado en 1746) y el oficio de los siete Dolores de la Virgen (instituida oficialmente en septiembre de 1814).
} 


\subsection{Los cantorales del siglo XVIII.}

La Abadía conserva seis cantorales manuscritos (LC L al LC LV) del siglo XVIII. Cinco de ellos proceden del Convento de San Antonio de Padua, y probablemente llegaron a la Abadía tras la exclaustración en el siglo XIX. ${ }^{24}$ Aunque los libros tienen las correspondientes inscripciones sobre su procedencia, sólo uno (LC L) tiene fecha: 1735. Es probable que los otros cuatro se copiaran en la misma época. Son libros de pequeño formato, carecen de iluminaciones y contrastan con el tamaño y riqueza de los de la Abadía.

El sexto cantoral manuscrito (LC LV) fue copiado en 1762 ex profeso para la Abadía por Joseph Julian de Toxar, siendo Abad Martín Vázquez (1762-1776). Este libro recupera la buena factura de los cantorales creados para esta librería: una bella ilustración de la Inmaculada Concepción da prueba de ello. El copista también intervino en la librería coral de la Colegiata del Salvador de Granada, la de la Capilla Real y de la Catedral. ${ }^{25}$

La librería coral de la Abadía también conserva algunos cantorales impresos del siglo XVIII; véase Tabla VI.6.

Tabla VI.5. Impresos conservados en la Abadía del siglo XVIII.

\begin{tabular}{|c|c|c|c|c|}
\hline $\begin{array}{l}\text { Libros de } \\
\text { Coro }\end{array}$ & Título & Ciudad & Impresor & Fecha \\
\hline LC LVII & Missale Romanum & $\begin{array}{l}\text { Antuerpiae } \\
\text { (Amberes) }\end{array}$ & $\begin{array}{l}\text { Balthasaris Moreti ex } \\
\text { Tipographia Plantiniana }\end{array}$ & 1704 \\
\hline LC LVIII & Salterium Romanum & Venecia & Nicolaum Pezzana & 1716 \\
\hline LC LIX & $\begin{array}{l}\text { Graduale Romanum } \\
\text { (Propium de tempore) }\end{array}$ & $\begin{array}{l}\text { Olisipone } \\
\text { (Lisboa) }\end{array}$ & Ex Typographia Regia & 1791 \\
\hline LC LX & $\begin{array}{l}\text { Graduale Romanum } \\
\text { (Propium de Sanctis) }\end{array}$ & $\begin{array}{l}\text { Olisipone } \\
\text { (Lisboa) }\end{array}$ & Ex Typographia Regia & 1796 \\
\hline
\end{tabular}

\footnotetext{
${ }^{24}$ Fundado por el genovés Rolando de Levanto en el año 1636, el Convento de San Antonio de Padua de Granada desapareció con la desamortización en el siglo XIX, de él solo nos quedan algunas obras de arte y estos libros.

${ }^{25}$ Ruiz Jiménez, La Colegiata del Salvador, p.104, señala que era vecino de la fortaleza de la Alhambra y que no sabe canto llano. Ma Angustias Álvarez Castillo, "Los Libros Litúrgicos: Los Cantorales", El Libro de la Catedral de Granada, ed. por Lázaro Gila Medina (Granada: Cabildo Metropolitano de la Catedral de Granada, 2005) Vol. 2, pp. 957, reproduce algunas de las miniaturas que Toxar hizo para los cantorales de la Catedral de Granada entre 1761 y 1768.
} 


\subsection{Los cantorales de los siglos XIX y XX.}

De la colección de cantorales de la Abadía, once se copiaron entre 1816 y 1905; véase Tabla VI.7.

El copista Río, que firma el cantoral LC LXIII y probablemente hiciera además el cantoral LC LXIII, podría bien ser Fray José del Río, monje de San Jerónimo que es nombrado en las Actas Capitulares de la Catedral de Granada:

Fray José del Río, monje procurador del real monasterio de San Jerónimo, manifestó la instrucción y habilidad para la composición de libros de coro y demás, suplicando al Cabildo le nombrase por escritor de esta santa iglesia, y se acordó que en los casos que ocurran se le tendrá presente. ${ }^{26}$

Tabla VI.6. Libros corales copiados entre 1816 y 1905.

\begin{tabular}{|c|c|c|}
\hline Libros & Fecha & Copista \\
\hline LC LXII & 1816 & Río? \\
\hline LC LXIII & 1817 & Río \\
\hline LC LXIV & 1828 & $¿ ?$ \\
\hline LC LXV & Sin fecha & $¿ ?$ \\
\hline LC LXVI & 1888 & ¿Miguel Ramos? \\
\hline LC LXVII & Sin fecha & Miguel Ramos y Ramos \\
\hline LC LXVIII & 1904 & Miguel Ramos y Ramos \\
\hline LC LXIX & \multirow[t]{4}{*}{ Sin fecha } & \multirow{4}{*}{$\begin{array}{l}\text { Sin datos, aunque } \\
\text { probablemente pudieran ser } \\
\text { del mismo Miguel Ramos }\end{array}$} \\
\hline LC LXX & & \\
\hline LC LXXI & & \\
\hline LC LXXII & & \\
\hline LC LXXX & ca. 1863 & Manuel Martín Rodríguez \\
\hline LC LXXV & 1905 & Miguel Ramos y Ramos \\
\hline
\end{tabular}

${ }^{26}$ ACCG, vol. 47 (10-9-1830), folio 436); citado en López Calo, Catálogo del Archivo de Música de la Catedral de Granada, p. 391. 
A finales del siglo XIX se produce un resurgir de la actividad copiadora con el sochantre del Sacromonte Miguel Ramos y Ramos y el subchantre de la Catedral Manuel Martín Rodríguez. De éste último, López Calo cita que en el cabildo de 27 de enero de 1863 ,

Se dio cuenta de un escrito del beneficiado y sochantre de esta santa iglesia don Francisco de Paula Rosas, acompañado de un libro de coro, formado por el salmista de esta santa iglesia don Manuel Martín Rodríguez para la colegiata del Sacromonte, con los oficios del Santo Ángel Custodio del reino, preciosa Sangre de Nuestro Señor Jesucristo, San Pantaleón, mártir, y San Vicente, mártir, y manifestando haber llamado su atención lo elegante y bien escrito de dicho libro y su método de canto llano; y como en esta santa iglesia se carecía de él y era de necesidad, por cuanto no lo había de dichos oficios y era menester atenerse a papeles pequeños de música, de lo cual se seguían inexactitudes y faltas reparables al par que eran también irremediables, e interesa sobre ello la consideración del Cabildo; y en su vista se acordó dar comisión a los señores chantre y Carrillo para que adopten las disposiciones que estimen convenientes sobre ello y de proporcionar fojas de pergamino donde puedan hallarse, si conceptuasen económicos sus costos. ${ }^{27}$

El cantoral a que hace referencia esta noticia es el LC LXXX, que efectivamente contiene los oficios señalados y cuyas iniciales se encuentran graciosamente ilustradas. El copista fue salmista y posteriormente sochantre de la Catedral, donde permaneció hasta su repentina muerte en 1903. Su voz era portentosa según diversos testimonios de la época y había estudiado canto en la famosa escuela del tenor italiano Giorgio Ronconi quién le aconsejó que saliera al extranjero donde podría hacer carrera lírica, pero Martín prefirió permanecer en Granada. Rechazó las ofertas que le hicieron de la Capilla de Palacio de Madrid y de la Capilla Sixtina. ${ }^{28}$

\footnotetext{
${ }^{27}$ López-Calo, Catálogo, Tomo III, p.404.

${ }^{28}$ Estas noticias sobre el tenor Manuel Martín están tomadas de José González Martínez, Ritornello, Miradas al pasado musical de Granada, Granada: Centro de Documentación Musical de Andalucía, 2005, pp. 230232. Su apodo fue el de "Tronchapinos", porque según refiere la tradición local si daba una voz desde la torre de la Catedral se le escuchaba en Santa Fe y un día mató un perro sólo con su voz. Puede que García Lorca se inspirara en él para el Sacristán "Tronchapinos" de su obra La Casa de Bernarda Alba, quién poseía dotes canoras.
} 
Las características comunes a todos libros de coro del siglo XIX son su gran austeridad, pues emplean papel como material, no contienen apenas iluminaciones ${ }^{29}$ y se sirven de neumas cada vez más simplificados. Del siglo XIX también se conservan dos impresos, entre ellos un Manuale Granatense de 1826; véase Tabla VI.8.

Tabla VI.7. Libros Impresos en el siglo XIX conservados en la Abadía.

\begin{tabular}{|l|l|l|l|l|}
\hline Libro & Título & Ciudad & Impresor & Año \\
\hline LC LXXIII & $\begin{array}{l}\text { Manuale } \\
\text { Granatense }\end{array}$ & Granada & $\begin{array}{l}\text { Ioannem } \\
\text { Stephanum } \\
\text { Alonso }\end{array}$ & 1826 \\
\hline LC LXXIV & $\begin{array}{l}\text { In festo } \\
\text { Immaculatae } \\
\text { Conceptionis }\end{array}$ & Madrid & $\begin{array}{l}\text { Litografía de B. } \\
\text { Álvarez }\end{array}$ & 1864 \\
\hline
\end{tabular}

\subsection{La vida de los cantorales}

Los cantorales de la Abadía del Sacromonte estuvieron en uso durante más de trescientos años, por lo que no es de extrañar que algunos se encuentren muy deteriorados. Además el trato dispensado a los libros era motivo de preocupación por parte del Cabildo que sabía de lo costoso de este tipo de objetos. Los colegiales que debían llevar los libros eran advertidos con frecuencia de que cumpliesen su cometido con cuidado

Item propuso el señor Vega que algunos colegiales ayudaban las misas sin sobrepelliz y que llevaban los libros al coro y del coro a la librería cargando cada colegial con un libro, de que se seguía dar golpes con ellos y echarlos a perder. Encargose al señor rector y al señor Maestro de Ceremonias se les advirtiese a los colegiales lo que deben hacer de ayudar a misa con sobrepellices y de llevar los libros entre dos colegiales. ${ }^{30}$

\footnotetext{
${ }^{29}$ Sólo está ilustrado el del Ángel Custodio de Manuel Martín.

${ }^{30}$ ASAC IV, fol. 198 (2-III-1669), [295].
} 
Tanto se preocupaba el Cabildo por el cuidado de los libros que en la Consueta se dedica un capítulo al oficio de Versiculario ${ }^{31}$. Este oficio ha sido poco estudiado por ser un trabajo auxiliar y no estrictamente musical. Con frecuencia se ha confundido con el que debía entonar los versos o versículos, pero en realidad eran los que señalaban el versículo. Además eran los encargados de preparar, colocar, registrar las oraciones y pasar los folios de los cantorales en el facistol. En la Consueta encontramos la descripción más completa que conocemos de este oficio:

vuelven las partes altas primero para que se vea la dicción que se sigue, el versiculario de la mano derecha las vuelve, el otro las recibe y asienta debajo del clavo, para igualarlas y allanarlas usan de la mano cubierta con las mangas de la sobrepelliz para que no se ensucien los libros. Tienen punteros para señalar el versículo que se ha de decir en la diestra. ${ }^{32}$

Para registrar las oraciones usaban una especie de separadores, indicadores o punteros hechos de caña que rajaban por la mitad para marcar el folio correspondiente. Algunos de estos artefactos se han conservado señalando folios en los cantorales, véase Figura VI.6.

Figura VI.6. Señalador de caña.

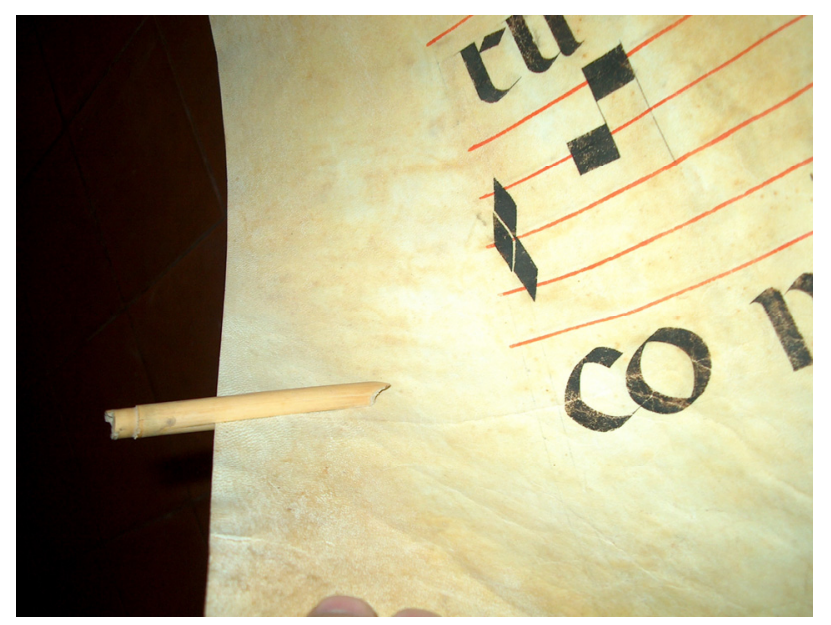

\footnotetext{
${ }^{31}$ Consueta, Libro II, Capítulo 16, De los Versicularios, fols. 137-142.

${ }^{32}$ Consueta, $140 \mathrm{v}$.
} 
Se conservan varios facistoles en la Abadía. Además de en el coro de la iglesia, uno de ellos se encuentra en una de las crujías del patio en la planta superior; véase Figura 6.7. En las Actas encontramos diversas referencias a estos muebles, que debían ser renovados con frecuencia por su uso constante.

Los libros fueron "aderezados" en varias ocasiones, como reflejan las Actas. ${ }^{33}$ Entre los que se dedicaron a este menester sobresalen los monjes del Monasterio de San Jerónimo de Granada. Nada sabemos de este taller de copia y reparación: tan sólo que ya estaban activos a principios del siglo XVII, cuando los encontramos copiando nuevos libros para la Colegiata del Salvador, y que continuaban con su labor a mediados del siglo XVIII, ${ }^{34}$ y al menos hasta principios del XIX. ${ }^{35}$ Para la Catedral también copiaron algunos libros, entre ellos el que contiene la Misa para San Cecilio de Fray Pedro de Valencia, cuyo rito propio fue aprobado en 1704 y extendido a todos los reinos de España en 1729. ${ }^{36}$

En 1686 un religioso de San Jerónimo que se encontraba aderezando los libros de coro de la Abadía se encargó también de la copia del oficio de San Justo y Pastor con "pieles buenas de Segovia" (LC XXV), ${ }^{37}$ de la misa de Nuestra Señora del Carmen y de la Misa de San

${ }^{33}$ ASAC V, fol. $218^{\mathrm{r}}$ (3-II-1685), [354]; ASAC V, fol. 263 ${ }^{\mathrm{v}}$ (2-V-1686), [368]; ASAC V, fol. 267 ${ }^{\mathrm{r}}$ (12-VI1686), [371] ; ASAC V, fol. 267 (21-VI-1686), [372]; ASAC V, fol. ¿? (15-IX-1686), [375]; ASAC V, fol. ¿? (12-X-1686), [376]; ASAC V, fol. 469 ${ }^{\mathrm{r}}$ (1-IV-1690), [397]; ASAC VI, fol. 65 ${ }^{\mathrm{V}}$ (3-VIII-1696), [436]; ASAC VI, fol. $86^{\mathrm{r}}(8-\mathrm{V}-1697)$, [443]; ASAC VI, fol. $86^{\mathrm{r}}$ (8-V-1697), [443]; ASAC VI, fol. 253 ${ }^{\mathrm{v}}$ (3-VII1706), [496]; ASAC VI, fol. $423^{\mathrm{r}}$ (s.f.), [535]; ASAC VII, fol. (6-IX-1730), [572]; ASAC VII, fol. v (9-X1731), [577]; ASAC VIII, fol. 224 r (20-II-1739), [607]; ASAC IX, fol. 98 v (3-IV-1749), [625]; ASAC IX, fol. $158^{\mathrm{r}}$ (3-VII-1752), [629]; ASAC XI, fol. $102^{\mathrm{r}}$ (16-I-1769), [692]; ASAC XI, fol. $165^{\mathrm{r}}$ (4-IV-1771), [703]; ASAC XI, fol. ¿? (10-XII-1773), [719]; ASAC XI, fol. 260 ${ }^{\mathrm{r}}$ (4-V-1775), [723]; ASAC XI, fol. $272^{\mathrm{v}}$ ?

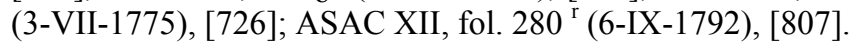

34 Juan Ruíz Jiménez, La Colegiata del Salvador en el contexto musical de Granada, (Granada: Tesis Doctoral inédita, 1995) p.103. Conocemos el nombre de un escritor de libros de San Jerónimo de Granada, Fray Cayetano de San Bernardo, citado por Isabel Mateo Gómez, Isabel Mateo Campos y otros, El Arte de la Orden Jerónima: Historia y Mecenazgo (Madrid: Encuentro, 1999), p. 319.

\footnotetext{
${ }^{35}$ Ver lo referente al copista Río en el epígrafe sobre los cantorales del siglo XIX.

${ }^{36}$ Sobre este oficio véase el Capítulo V de este estudio.

${ }^{37}$ ASAC V, fol. $263^{\mathrm{v}}$ (2-V-1686), [368].
} 
Ignacio (ambos en el LC XIV). ${ }^{38}$ Este mismo monje se encargó de dividir el Salterio en dos libros porque era muy pesado y voluminoso ${ }^{39}$.

En otra ocasión será un librero ${ }^{40} \mathrm{o}$ el propio sochantre ${ }^{41}$ los que se encarguen del arreglo, pero en el resto de las ocasiones no conocemos o el nombre o la procedencia del que realiza los trabajos. En 1706 el cabildo le da a Francisco Gómez dinero por “componer" los libros (que en esta ocasión indica reparar) y le encarga que escriba la Misa de San Julián "que se saque por la de la Catedral de Granada". (LC XXII).

Figura VI.7. Facistol de la Abadía.

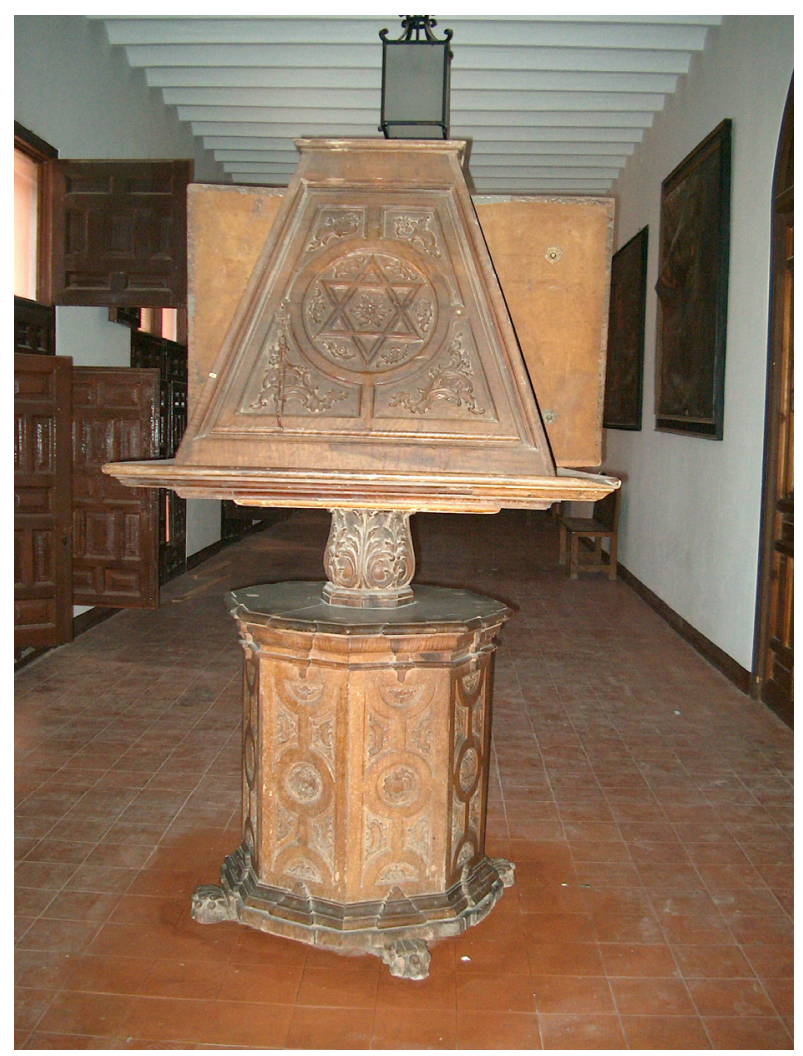

\footnotetext{
${ }^{38}$ ASAC V, fol. $267^{\mathrm{r}}(12-\mathrm{VI}-1686),[371]$

${ }^{39}$ ASAC V, fol. 267 ${ }^{\mathrm{r}}$ (12-VI-1686), [371].

${ }^{40}$ ASAC VI, fol. $86^{\mathrm{r}}(8-\mathrm{V}-1697)$, [443].

${ }^{41}$ ASAC XI, fol. $260^{\mathrm{r}}(4-\mathrm{V}-1775),[724]$; ASAC XI, fol. 260 ${ }^{\mathrm{r}}$ (4-V-1775), [723]. ASAC VI, fol. $253^{v}$ (3-VII-1706), [496] ; ASAC XI, fol. $272^{\vee}$ ? (3-VII-1775), [726]; ASAC XI, fol. $266^{\mathrm{r}}$ (1-IX-1775), [728]; ASAC XII, fol. $102^{\mathrm{r}}(28-\mathrm{VII}-1786)$, [776]
} 


\section{El repertorio de los Cantorales de la Abadía}

\subsection{Origen y filiación de los Cantorales de la Abadía}

En la Abadía, salvo algunos ejemplares que se añadieron con el tiempo, el grueso de la colección se copió en Málaga, después de Trento. ¿Qué repertorio siguieron?. El canto llano de la tradición romana oficial sufrió profundas modificaciones después de Trento, aunque ya antes había sido objeto de mutilaciones para ser adaptado a las prácticas y gustos de los músicos de la época. ${ }^{42}$ Ante la decisión de Gregorio XIII de ejecutar las disposiciones de Trento y preparar una edición del canto llano de la Iglesia de Roma, Felipe II conminó al músico Fernando de las Infantas, para que se opusiera a la reforma. ${ }^{43}$ Las razones que impulsaron a Felipe II, además de la resistencia al cambio de la tradición propia, son claramente económicas; muchas catedrales e iglesias colegiales habían invertido grandes sumas de dinero en formar sus librerías para el coro. ${ }^{44}$ El resultado fue satisfactorio, porque si bien no se paralizaron las labores de reforma, se hicieron con tal lentitud que no tuvieron consecuencias drásticas para el canto llano fuera de Roma. ${ }^{45}$

La tradición de canto española contenida en la mayor parte de los cantorales no reformados de la época se denominó "Canto Toledano". Este término en el siglo XVI no se refería a los cantos de la antigua tradición hispanorromana, visigótica o mozárabe (como se emplea hoy en día) sino al "canto litúrgico de texto latino practicado en España." ${ }^{46}$ Como podemos ver, en un libro de canto llano para los oficios de Semana Santa, conservado en la Abadía e impreso en Madrid en 1616, se hace la indicación de que sigue "cum cantu

\footnotetext{
42 Juan Carlos Asensio, El canto gregoriano. Historia, liturgia, formas (Madrid: Alianza Música, 2003), pp. 122-123. La edición medicea ha sido considerada la responsable de la transformación de los cantos pero ya había otras ediciones durante todo el siglo XVI.

${ }^{43}$ Asensio, El canto gregoriano, p. 123.

${ }^{44}$ Ismael Fernández de la Cuesta "Spanish plainchant publications to 1601”, Inter-American Music Review, $\mathrm{XVI} / 2$ (2000), p.4.

${ }^{45}$ Fernández de la Cuesta "Toledano, canto", DMEH, X, p. 322.

${ }^{46}$ Para una discusión sobre este término, véase Fernández de la Cuesta “Toledano, canto”, DMEH, X, p. 321.
} 
toledano"; es decir la tradición hispana del siglo XVI, la que sigue todos los cantores se saben y tienen más o menos aprendida por sus cantorales antiguos.

Aunque en los últimos años han comenzado a surgir estudios sobre el canto llano, el repertorio español sigue siendo muy desconocido. Las peculiaridades sobre la formación del repertorio en canto llano, su filiación, la supuesta "uniformidad" de los cantos, la práctica interpretativa, la creación de nuevos ritos y piezas son aspectos casi olvidados. Por ello se hace muy difícil emprender un estudio del repertorio cuando hay estudios muy parciales. Con la esperanza de arrojar alguna luz sobre parte del repertorio me centraré en el estudio de algunos oficios y obras que por su peculiaridad pueden ser interesantes, como el himno a San Juan Bautista Ut queant laxis en una versión melódica distinta a la transmitida en las fuentes internacionales, los Kyries tropados contenidos en un cantoral del siglo XVI, o el Oficio de la Toma de Granada, que es exclusivo del ámbito hispano.

\section{2. ¿Un himno universal con melodía hispana?: Ut queant laxis.}

El cantoral más antiguo de la Abadía (LC I) es un Intonario que contiene las entonaciones para las lecturas y numerosos himnos, entre ellos el famoso Ut queant laxis dedicado San Juan Bautista. ${ }^{47}$

La melodía de este himno en LC I difiere de la versión que Guido d'Arezzo empleó en su método para recordar las notas. Según se deduce de los últimos estudios, Guido utilizó la melodía de una oda de Horacio para este himno cuyo texto era de Pablo el Diácono y mantuvo la fuente originaria musical (Horacio) en secreto, ${ }^{48}$ luego es posible que otra versión anterior de la música del himno sobreviviera en algunos repertorios. ¿Podría ser esa melodía que acompañaba al himno de Pablo el Diácono el origen de la melodía del cantoral abacial?. Aunque es poco probable y casi imposible de demostrar el origen de la melodía hispana, es interesante estudiar las versiones melódicas de este himno.

\footnotetext{
${ }^{47}$ Está confeccionado en folios de pergamino de 360 × $265 \mathrm{~mm}$. y la caja de escritura mide 285 x 180 . No tiene tapas ni guardas, tan sólo los folios cosidos. Está escrito sobre pauta de cinco líneas rojas con notación cuadrada con diversas interpolaciones textuales a modo de rúbricas.

${ }^{48}$ Stuart Lyons, Horace's Odes and the mistery of do, re, mi with full verse translation of the Odes (Oxford: Aris \& Phillips, 2007).
} 
La Figura VI.8 presenta la transcripción de la melodía del himono Ut queant laxis tal y como aparece en el Cantoral LC I de la Abadía; la melodía está en el modo I sin transportar, a diferencia del conocido guidoniano que está en el modo II.

Figura VI.8. Himno Ut queant laxis para la festividad de San Juan Bautista. Fuente LC I, fol. sin numerar, Abadía del Sacromonte.

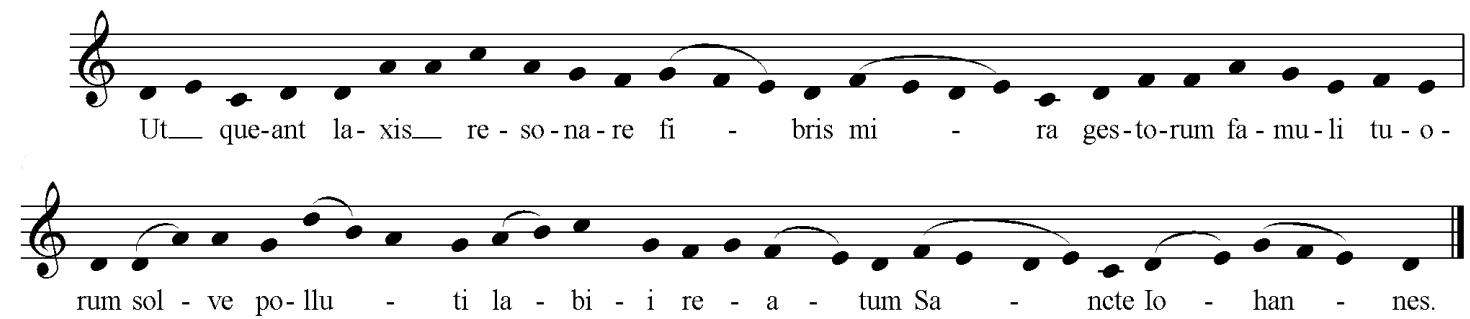

Según Fernández de la Cuesta este himno "solía cantarse en las iglesias de España con otra tonada que no tiene relación alguna con los grados de la escala". ${ }^{49}$ Sin embargo, la versión aretina del himno debió popularizarse pronto en España, pues ya en el siglo XVIII, Faustino Arévalo en su obra Hymnodia Hispánica al hablar del himno Ut queant laxis no menciona la versión melódica hispana, dedicando una larga extensión a la historia del himno. ${ }^{50}$ En relación con la afirmación de Fernández de la Cuesta hay que advertir que en el Intonarium Toletanum de 1515 aparecen dos versiones distintas del himno Ut queant laxis. Una de ellas es para la vigilia de san Juan Bautista en maitines al nocturno y la otra para las Vísperas. La primera versión aparece en el Himnario Oscense (siglo XI) y en otras fuentes no hispanas, ${ }^{51}$ mientras que la segunda versión coincide casi al completo con la de la Abadía del Sacromonte.

\footnotetext{
${ }^{49}$ Fernández de la Cuesta "Toledano, canto", DMEH, p. 325.

${ }^{50}$ Faustino Arévalo, Hymnodia Hispánica (Romae: ex Typographia Salomoniana ad Divi Ignatii, 1786), pp. 164-168.

${ }^{51}$ Denis Harbinson, "The Hymn Ut queant laxis", Music and letters, 52/1(1971), p.57, cita la misma melodía que la versión oscense en una publicación parisina del siglo XIX : Offices de l'église du matin et du soir, suivant le rit Romain entièrement notés en plain-chant d'après le Graduel et l'Antiphonaire (París, 1887) p. 578.
} 
El ejemplo VI.9 muestra la versión del LC I de la Abadía y la que aparece en el Intonarium Toletanum (1515) para facilitar su comparación. Como puede observarse las diferencias son mínimas, pues en realidad se trata de la misma tradición interpretativa; los dos himnos incluso coinciden bastante en la agrupación neumática. Las notas que cambian suelen estar muy próximas (un "si" por un "do", un "sol" por un "la") o bien son adiciones, como notas de paso (el "re" de Ioannes) o supresiones en cadencias (el "fa" que no está en polluti, o el último "fa" de Ioannes).

Figura VI.9.: Dos versiones del himno Ut queant laxis. Fuentes: Abadía, Cantoral LC I e Intonarium Toletanum (Alcalá: Brocar, 1515).
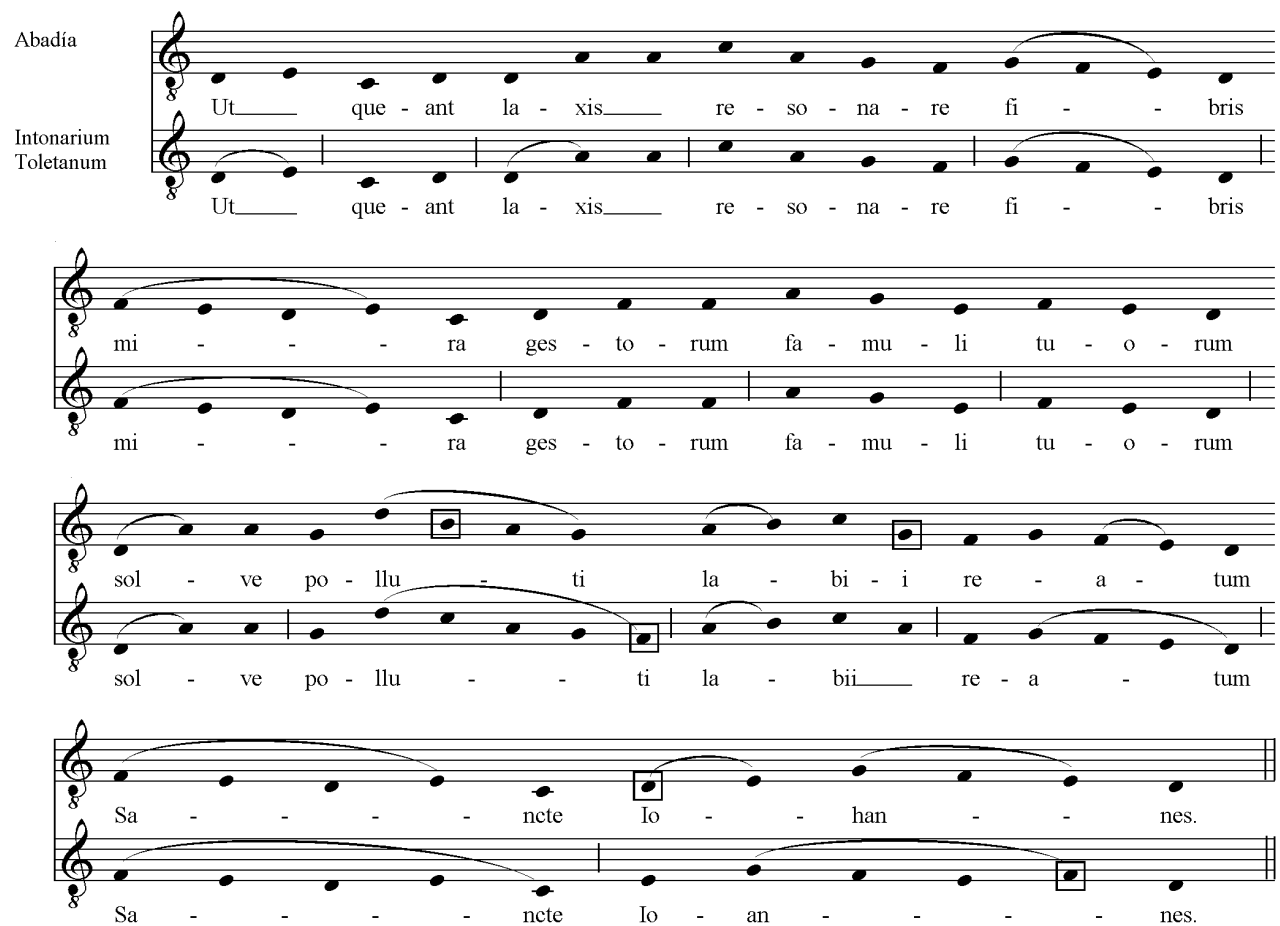
Aún existe al menos una variante más de este himno, que se encuentra en un cantoral de la Catedral de Augsburgo (véase la Figura VI.10.), que no guarda relación con ninguna de las tres versiones citadas anteriormente (la aretina, la de Huesca o la abacial). ${ }^{52}$

Figura VI.10. Himno Ut queant laxis, en un cantoral de la catedral de Augsburgo conservado en Copenhague.

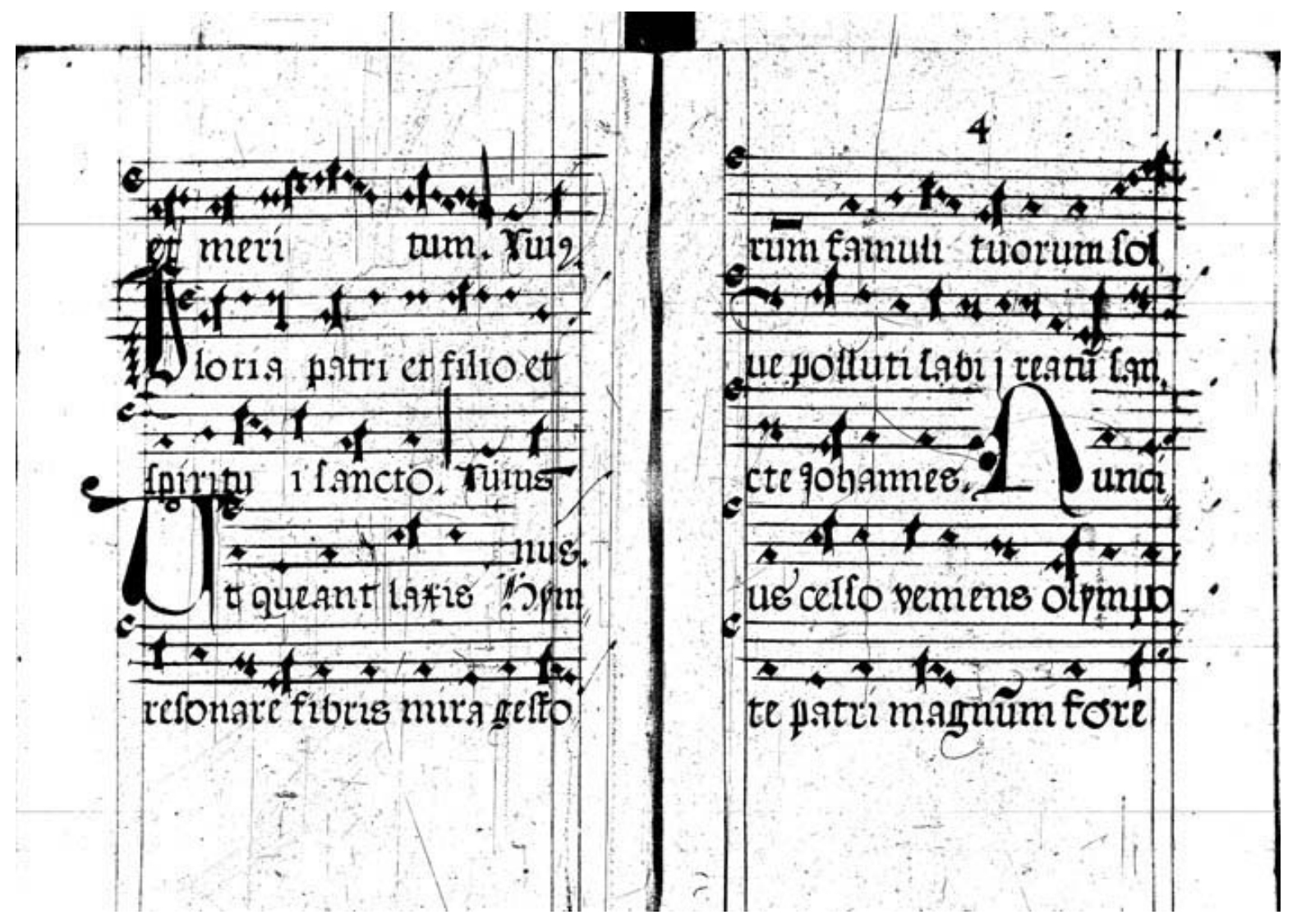

La variedad de versiones melódicas con que el himno Ut queant laxis se cantaba en la Europa del siglo XVI nos hace recapacitar sobre dos hechos: por un lado la unificación de las liturgias y el papel que en ello jugó el Concilio de Trento y, por otro la formación de

\footnotetext{
${ }^{52}$ DK-Kk 3449 8o IX, actualmente en København (Copenhague), Det kongelige Bibliotek Slotsholmen, Gl. Kgl. Samling, fol. 3v. Consultado en CANTUS: A Database for Latin Ecclesiastical Chant. http://publish.uwo.ca/ cantus/ [Consultado el 8 de Mayo de 2008]
} 
los repertorios musicales y sus variantes melódicas respecto de la permanencia geográficotemporal de los textos, pues curiosamente la letra del himno es la misma para todas las melodías en sitios tan distantes como Augsburgo y Toledo.

\subsection{Una colección de Kyries tropados en el cantoral LC IV}

El Cantoral LC IV forma parte de un pequeño grupo de cantorales que se encuentran en la Abadía del Sacromonte, pero que no fueron creados para su servicio. La fecha de 1558 en uno de ellos y las características del repertorio (que contiene diversos tropos) sitúan este corpus de canto llano antes de la reforma de Pío V (1570), quien tras el Concilio de Trento suprimió los tropos y las secuencias en gran número. En Granada en 1544, se imprimió un interesante libro que contiene como veremos diversos Kyries tropados.

Todos estos cantorales presentan una tipología similar: unas medidas semejantes (encuadernación 735 × 545 × 115; hoja 700 x 470; caja 490 × 320), escritos en cinco pentagramas por página sobre pergamino y foliación en numeración romana. Además todos están decorados siguiendo la tradición mudéjar que se desarrolló en España entre los siglos XII al XVI. ${ }^{53}$ Esta decoración de las letras capitales en rojo y azul, imitando el trazado de las labores de lacería árabes con patrones que se repiten y medallones geométricos, podemos encontrarla en toda la Península, aunque especialmente en las zona central (Castilla) y Andalucía. ${ }^{54}$ Un ejemplo significativo de este tipo de cantorales se conserva en la Catedral de Sevilla formado por 36 cantorales en estilo mudéjar que según Frances Spalding datan de la segunda mitad del siglo XVI.

Pero los cantorales más cercanos a éstos de la Abadía son los que se encuentran en la Colegiata de Santa Fe, que tienen la misma decoración y están corregidos por el mismo

\footnotetext{
${ }^{53}$ Frances Spalding, Mudejar ornament in manuscripts (Nueva York: The Hispanic Society of America, 1953), p. 2.

${ }^{54}$ Spalding, Mudejar ornament, p. 2.
} 
beneficiado, un tal Juan Ramos. ${ }^{55}$ ¿Formarían parte estos libros de un corpus único con los de Santa Fe? ¿Serían creados para Santa Fe o provendrían de otro centro? Quizás pertenecieran a otra librería de una iglesia granadina y tras la exclaustración del siglo XIX se dispersaran entre varias iglesias. Si fuera este el caso ¿podrían ser estos cantorales los desaparecidos de San Jerónimo, que provendrían del scriptorium de Guadalupe según señala Spalding? ${ }^{56}$

El contenido del LC IV del Sacromonte comprende la Misa de Réquiem y el ordinario de las misas diarias en segundo, cuarto y octavo tono, pero de todo este repertorio prestaremos especial atención a los Kyries que en esta colección aparecen con tropos.

\section{Los Kyries tropados del LC IV del Sacromonte}

Un tropo es la adición de texto, música o ambos elementos a un canto preexistente. Este fenómeno se produjo principalmente entre los siglo IX al XII, aunque en algunos lugares siguieron interpretándose hasta aproximadamente 1570, fecha en la que Pio V reformó el breviario y suprimió las adiciones a los cantos. Desde los estudios de Bjorck se hace necesario distinguir entre los tropos de los Kyries propiamente dichos (interpolación creada ex novo) y las prósulas o Kyries con texto latino (es decir adición de texto a un melisma preexistente). ${ }^{57}$ Entre las características que según Bjorck distinguen un Kyrie tropado del Kyrie con texto se encuentran su independencia musical (la melodía difiere del Kyrie al que tropa), una tendencia marcada a ser neumático mientras que el textual es

\footnotetext{
${ }^{55}$ La única referencia que tenemos de Juan Ramos es la que él mismo nos proporciona en su rúbrica: "Juan Ramos, beneficiado de cantar, digo que este libro va enmendado de punto y letra y firmelo yo 1558 años".

${ }^{56}$ Spalding, Mudejar ornament, p.52. Spalding da cuenta de la venta en 1500 de los cantorales de Guadalupe porque se decidió elaborar una nueva librería. Los cantorales de Guadalupe fueron vendidos al Convento de San Jerónimo en Granada, la colegiata de San Isidoro de León y el Convento de Santa María de la Luz cerca de Niebla. De la librería del Monasterio de San Jerónimo de Granada sólo tenemos esta noticia y que Felipe II decidió donarles los Cantorales que se hicieron en primera instancia para El Escorial (entre 1564 y 1567) porque las pieles de Segovia eran blancas de un lado y amarillentas por otra. Véase Vicente Rabanal, Los Cantorales de El Escorial (Madrid: Imprenta del Monasterio de El Escorial, 1947) p. 9.

${ }^{57}$ David A. Bjorck, “The Tropo Kyrie”, Journal of the American Musicological Society, 1980. Bjorck señala que la principal diferencia entre estos dos tipos de Kyries es que en los Kyries con tropo, éste no guarda relación musical con la melodía del Kyrie al que tropa, mientras que en los Kyries con texto latino o prósulas, la adición forma una unidad con el Kyrie. La mayoría de los Kyries son prósulas, no tropos; Bjorck identifica un número aproximado de 25 Kyries con tropo.
} 
silábico y suelen ser raros después del siglo XIII, mientras que los Kyries con texto pueden encontrarse aún en el siglo XVI.

Los Kyries que se encuentran en este cantoral son siete y todos ellos aparecen en otras fuentes, si bien algunos son más comunes que otros. Estos Kyries aparecen en su forma abreviada o reducida (normalmente el primer elemento de cada tres) que es como indica Prado, la manera en la que persisten en el siglo XVI. ${ }^{58}$

\section{Cunctipotens genitor}

Cunctipotens genitor deus omni creador eleison

Criste dei splendor virtus patrisque sophia: eleison

Ars? Bonum? Sacrum spiramen nexos amorque eleison

Se trata de un Kyrie del repertorio temprano aquitano (sigo $\mathrm{X})^{59}$ con bastante difusión en España. Castro Caridad lo documenta en troparios de la Catedral de Vic (siglos XII y XIII), en otra fuente española conservada en la Biblioteca Nacional de París procedente de Gerona, también del siglo XII, Tortosa (siglo XIII), Huesca (siglo XII), Salamanca (XII), Toledo siglo XII y Silos XI (Sal2637). ${ }^{60}$

La aparición del tropo en el manuscrito de la Abadía está simplificada: de los nueve versos del texto tropado (véase Analecta Hymnica número 4, en adelante $\mathrm{AH}^{61}$, Repertorium Hymnologicum $\mathrm{n}^{\mathrm{o}} 4128$, en adelante $\mathrm{RH}^{62}$ y Bjorck ${ }^{63}$ ) en esta versión aparece

\footnotetext{
${ }^{58}$ Germán Prado, “El Kyrial español” en Analecta Sacra Tarraconense, XIV (1941) p.115.

${ }^{59}$ David A. Bjorck, The Aquitanian Kyrie Repertory of The Tenth and Eleventh Centuries, p.144

${ }^{60}$ Eva Ma Castro Caridad, Tropos y troparios hispánicos (Santiago de Compostela: Universidad de Santiago, 1991) Las referencias de los manuscritos que señala son las siguientes: PA 495 FOL.8V, Hu 4 fol. 126, Sal 2637, f.262 Bv; y Mont 73, f.1. Con un orden diferente de elementos en Aemil 52, f.232 y Tol35.10 (1-46579); Vic 105 (add), f.51, Tort 135, fol.3 v. Víc 106 copia el incipit en las misas II de feria de Pascua (f.55) y Feria II de Pentecostés (f.68).

${ }^{61}$ C. Blume y G.M. Dreves, Analecta hymnica medii aevi, xlvii: Tropen des Missale in Mittelalter, (Leipzig, 1905).

${ }^{62}$ U. Chevalier, Repertorium Hymnologicum: catalogue des chants, hymnes, proses, séquences, tropes en usage dans l'église latine despuis les origines jusqu'à nos jours, 6 vols. (Lovaina y Bruselas, 1892-1921).

${ }^{63}$ Bjorck, The Aquitanian Kyrie, p.61.
} 
el primero de cada tres. En cuanto a la melodía sigue la vaticana IV, con alguna pequeña variante (inclusión de notas de paso y algunos melismas cambiados).

\section{Rex virginum amator}

Rex virginum amator deus Marie decus eleison

Christe Deus de patre homo natus maria matre eleison

O Paraclete obumbrams corpus Marie eleison

Prado señala que "muy frecuente es en los Cantorales españoles el siguiente tropo marial" pero no indica ninguna fuente ni época de aparición. ${ }^{64}$ No se encuentra en el repertorio galicano recogido por Bjorck. El texto aparece en AH 8, RH 17533. Es en realidad un contrafactum del Cunctipotens, pues tienen la misma melodía. En el cantoral de la Abadía viene indicado como "Primus toni in festivitatibus sancti beatissime virgine Marie". Castro Caridad no lo recoge en ninguno de los troparios hispanos entre los siglos XI-XIII por lo que puede considerarse su introducción en España algo más tardía. Aparece también en un cantoral toledano del siglo XVI, conocido como el Cantoral Beinecke. ${ }^{65}$

\section{Pater excelse}

Pater excelse mariam preparans eleison Iesu benigne mariam consecrans eleison Spiritus alme mariam deumbrans? Eleison

Según Candelaria este texto es una adición tardía al repertorio de tropos, y sólo se encuentra en fuentes hispanas, entre las que señala el Kyrial Beinecke, que es la fuente más antigua encontrada para el texto, un impreso sevillano de 1538 y otro granadino de 1544 que comentaremos a continuación. La música es la del Kyrie vaticano número $9 .{ }^{66}$

\footnotetext{
${ }^{64}$ Germán Prado, “El Kyrial español”, p. 117.

${ }^{65}$ Lorenzo Candelaria, "Tropes for the Ordinary in a 16th-century chantbook from Toledo, Spain”, Early Music, XXXIV/4 (2006), pp.587-611. Una reproducción de las hojas donde aparece este Kyrie se encuentra en la pp. 588-589.

${ }^{66}$ Lorenzo Candelaria, "Tropes for the Ordinary”, p. 594-595.
} 


\section{Summe Deus}

Summe deus qui cuncta creas eleison

Vel christe patris speculum

Qui procedes ab utroque flamen : eleison

El texto de este Kyrie se corresponde con los recogidos en AH 47, 24 y RH 19673, melódicamente coincide con Melnicki 161. ${ }^{67}$ Castro Caridad señala que este tropo, junto con Cunctipotens genitor, "son composiciones de tradición textual relativamente estable" y muy frecuentes en los repertorios europeos. ${ }^{68}$ Según Bjorck, este kyrie es en realidad una parodia del Cunctipotens genitor que aunque está en tono de re termina en la. Sin embargo la versión abacial sí termina en re (las cadencias intermedias en la) y presenta algunas variantes melódicas respecto a la que recoge Bjorck, además de tener el texto simplificado como en el resto de los Kyries de la colección abacial.

\section{Rector Cosmipie}

Rector cosmipie devotis nobis subveni : eleison Orbis redemptor cruore ?? proprio miseris : eleison Qui supera et inferi [falta texto] eleison

Este tropo se corresponde con los recogidos en AH 47, 53; RH 32762 y la melodía con la vaticana ad lib. III y Melnicki 198. ${ }^{69}$ Respecto al Kyrie aquitano que recoge Bjorck presenta algunas variantes, aunque frase 4 igual. ${ }^{70}$ Eva Castro Caridad ${ }^{71}$ p. 232 nota 31:

\footnotetext{
${ }^{67}$ M. Melnicki, Das einstimmige Kyrie des lateinischen Mittelalters, Forschungsbeiträge zur Musikwissenschaft, I (Regensburg, 1955) citado en Lorenzo Candelaria, “Tropes for the Ordinary”, p.605

${ }^{68}$ Castro Caridad, Tropos y troparios, p. 228, señala que tuvo su origen en a zona noroeste y fue poco conocido en los repertorios meridionales, dónde se localiza sólo en Palencia. Algunas de las fuentes españolas para este tropo según Castro son: Vic 105, Hu 4, Aemil 51, Sal 2637, Tol 35.10, el gerundense BaBC, M. 911, Mont 73, Tort 135, Pa 1871, Pa 778, Pa 1086.

${ }^{69}$ Candelaria, "Tropes for the ordinary", p. 605.

${ }^{70}$ Bjorck, The Aquitanian, p. 144.

${ }^{71}$ Castro Caridad, Tropos y troparios, pp. 232-233, documenta este tropo en los siguientes manuscritos:Hu 4, f.127v; Aemil 51, fol. 235; Tol 35.10;Ma BN, 1361, fol. 180 (sólo da el primer elemento); Mont 73, f.10v. Orden distinto de los elementos: Sal 2637, f.264B (1-36547-9); Tort. 135, f.6v. Los otros testimonios son los troparios de Moissac, Pa 1871 y Pa 1177 y el tolosano MaBN 136. Los manuscritos hispanos occidentales dan la lectura del elemento 8: Et semper o qui in trinitate, en lugar del corrupto Et permanens simples de Pa 1871.
} 


\section{Kyrie Fons Bonitatis}

Kyrie fons bonitatis pater ingente a quo bona cuncta procederunt: eleison Christe agies celi compos regie melos glorie: cui simper astans pro lumine angelorum de cantat apex: eleison

Kyrie spiritus alme coherens patri natoque unusque consistendo fians ? ab utroque: eleison

El texto concuerda con AH 5, 47 y RH 6429 y la melodía es igual a la vaticana II y la que recoge Melnicki 48. ${ }^{72}$ Según Castro Caridad "la melodía del siglo X, procede de Alemania e Inglaterra; el texto se originó en la zona de transición, de donde se difundió a otras regiones a partir del siglo XII. No fue una de las piezas constituyentes del repertorio meridional, ya que sólo se registra en el tropario narbonense, $\mathrm{Pa} 778$, y en los troparios hispánicos aquí mencionados". Dichos troparios son: Hu 4, f.137 (add); Sal 2637 f. 264Bv; Tol 35.10, f.119; y Tort 135, f.1. ${ }^{73}$

\section{Kyrie Cunctipotens Domine Miserator}

Kyrie cunctipotens domine miserator eleison Christe verbum ca[ro factum de virgine, eleison]

Candelaria señala que esta melodía sólo ha sido encontrada en fuentes hispánicas. ${ }^{74}$ El Kyrie que aparece en el cantoral sacromontano presenta la misma reducción que da Prado siguiendo un cantoral burgalés del Siglo XVI. ${ }^{75}$ Castro Caridad lo documenta en Mont 73 f. 7v; Tol 45.10 f.117v; MaBN 1361, f.180v. ${ }^{76}$

\footnotetext{
${ }^{72}$ Candelaria, "Tropes for the ordinary", p. 606.

${ }^{73}$ Castro Caridad, Tropos y troparios, p. 234.

${ }^{74}$ Candelaria, "Tropes for the ordinary”, p. 594. La melodía la recoge Germán Prado, Supplementum ad Kyriale ex codicibus hispanicis excerptum (París, 1934).

${ }^{75}$ Germán Prado, “El Kyrial español”, p. 115.

${ }^{76}$ Castro Caridad, Tropos y troparios, p. 302
} 


\section{Estructura del Kyrial}

Todos los Kyries que aparecen en esta colección del Sacromonte están recogidos en el Cantoral Beinecke, pero en éste último aparecen muchos más Kyries y otros tropos para el Gloria, además de repertorio polifónico. De este hecho sólo podemos deducir que el cantoral de la Abadía sigue el repertorio Kyrial común en el siglo XVI en la Península Ibérica. Sin embargo, mucho más interesante es la relación que guarda con otra recopilación de Kyries, la contenida en el impreso Oficia ad Missas (Granada, 1544), un curioso libro que compila el repertorio que debía usarse en las iglesias granadinas a mediados del siglo XVI. Para ver las relaciones entre las dos colecciones de Kyries, véase la Tabla VI.8.

Las dos colecciones guardan el mismo orden de aparición de las piezas (del modo primero en adelante) y las rúbricas que indican las fiestas. Tan sólo hay un Kyrie que no aparece en Oficia ad missas y que sí está en el cantoral abacial, el Kyrie Summe Deus. Melódicamente los Kyries son iguales, la única diferencia palpable es que en el impreso aparecen con frecuencia simplificadas las repeticiones de los Kyries para que el intérprete las complete, mientras que en el cantoral de la Abadía suelen aparecer completos. La relación entre ambas colecciones es clara: el orden en el que aparecen los Kyries (ordenados por tonos) es lógico y común, pero las rúbricas y los Kyries elegidos señalan que o bien el cantoral abacial siguió la copia del Officia ad Missas o bien ambos parten de una fuente común. 
Tabla VI.8. Comparación del contenido y las rúbricas de las dos colecciones de Kyries (Abadía Cantoral LC IV y Officia ad Missas, 1544)

\begin{tabular}{|c|c|}
\hline \multirow[t]{2}{*}{ CANTORAL LC IV } & OFICIA AD MISSAS \\
\hline & \begin{tabular}{|l}
$\begin{array}{l}\text { Incipit primus tonus in festis duplicibus } \\
\text { maioribus }\end{array}$ \\
\end{tabular} \\
\hline \multicolumn{2}{|c|}{ Cuncti potens } \\
\hline \multicolumn{2}{|c|}{ Primus tonus festivitatibus beatissime virginis mariae } \\
\hline \multicolumn{2}{|c|}{ Rex virginum amador } \\
\hline \multicolumn{2}{|c|}{ In diebus sabbatis qui sit offm beate virginis } \\
\hline \multicolumn{2}{|c|}{ Pater excelse } \\
\hline Item primus tonus pro aliis festis & \multirow[b]{2}{*}{ FALTA/NO FIGURA } \\
\hline Summe Deus & \\
\hline \multicolumn{2}{|c|}{ Item primus tonus festibus simplicibus } \\
\hline \multicolumn{2}{|c|}{ Kyrie sin tropar } \\
\hline \multicolumn{2}{|c|}{ Incipit Secundus tonus } \\
\hline Rector cosmipie & $\begin{array}{l}\text { Rector cosmipie (sólo el primer elemento con los } \\
\text { kyries sin los otros versos: orbis redemptor; qui } \\
\text { supera etc) }\end{array}$ \\
\hline \multicolumn{2}{|c|}{ Incipit tertius tonus in festis duplicibus maioribus } \\
\hline Kyrie fons bonitatis pater ingenite & $\begin{array}{l}\text { Kyrie fons bonitatis pater ingenite } \\
\text { Pero falta el verso kyrie spiritus alme, aunque sí } \\
\text { tiene la triple invocación del kyrie último) }\end{array}$ \\
\hline Item tertius tonus in aliis festis & $\begin{array}{l}\text { [Está borrado en el impreso pero podría poner la } \\
\text { misma inscripción] }\end{array}$ \\
\hline \multicolumn{2}{|c|}{ Kyrie Cunctipotens domine miserator } \\
\hline & Quartus tonus incipit \\
\hline & Rex magne domine \\
\hline & Quintus tonus in festivitatibus angelorum \\
\hline & O Pater inmense dux noster \\
\hline & FALTAN HOJAS \\
\hline
\end{tabular}




\subsection{El Oficio de la Toma de Granada}

De los cantorales conservados en la Abadía, el LC LXIX es particularmente interesante por contener parte del Oficio de la Toma de Granada "In festo deditionis civitatis Granatae", lo que indica que esta fiesta se celebró alguna vez en la Abadía al menos en el siglo XIX. ${ }^{77}$ El origen y creación de este Oficio singular han sido estudiados por Pilar Ramos López, quién ha hecho un interesante análisis de la significación musical y política de esta obra creada por el confesor de Isabel la Católica y luego Arzobispo de Granada, el jerónimo Fray Hernando de Talavera. Ramos demuestra cómo los modos elegidos por Talavera en la composición de las piezas siguen la teoría del ethos y "despliega en una ceremonia clave todos los recursos retóricos a fin de convencer al auditorio de sus tesis: los reyes han vencido como premio a su fe y por voluntad de Dios, reapropiándose de un territorio ocupado por los infieles". ${ }^{78}$ La autora afirma que el Oficio "sólo se cantaría en Granada los primeros años", ya que únicamente conoce la existencia de dos fuentes (el texto completo del Oficio en el Archivo de Simancas y el Cantoral con la versión musical en la Iglesia Colegial de Santa Fe) y no hay noticias en las Actas o en la Consueta de la Catedral de Granada sobre su interpretación. Aduce como razones probables para su desaparición: el auge de la polifonía frente al canto 1lano, el Concilio de Trento y la supresión de textos no uniformes, así como la inclusión en el Índice de libros prohibidos por la Inquisición del libro de Talavera Católica Impugnación, lo que lógicamente llevaría a despreciar el resto de sus obras. Sin embargo, la presencia del Oficio de la Toma en un cantoral del Sacromonte de finales del siglo XIX y en otros de diversas épocas de conventos femeninos estudiados por Julieta Vega ${ }^{79}$ sugiere que la tradición de cantarse este Oficio pudo conservarse continuadamente o de forma ocasional en algunas instituciones eclesiásticas de Granada.

\footnotetext{
${ }^{77}$ Según Pilar Ramos, "Historia política en música", El oficio de la toma de Granada de Fray Hernando de Talavera (Granada: Diputación, 2003), pp.46 y ss.: el oficio habría tenido poca vigencia en Granada.

${ }^{78}$ Ramos López, El oficio, p.63.

79 Julieta Vega García-Ferrer, Isabel la Católica y Granada: el Oficio de la Toma de Fray Hernando de Talavera, (Granada: 2004), pp. 80 y ss. Señala que se conservan partes del oficio y de la misa en la Capilla Real de Granada y en diversos monasterios de clausura, manuscritos e impresos.
} 


\section{El Oficio de la Toma de Granada en Santiago de Compostela}

Además del Oficio de la Toma de Granada compuesto por Hernando de Talavera existía al menos otro para conmemorar este día y probablemente otro más sin confirmar, que hasta el momento no han sido estudiados. Se trata de dos oficios sobre la Toma de Granada creados para Compostela y Burgos, lo que supone dos hechos: 1) la trascendencia del hecho político y la necesidad de que quede reflejado en una composición musical; y 2) el Oficio de la Toma no fue un hecho aislado restringido a Granada, sino que afectó a otros centros peninsulares.

Lo que nos llama la atención sobre el/los Oficios de la Toma es el hecho de componer en canto llano música para la conmemoración de un acontecimiento político, que obviamente tuvo una repercusión religiosa significativa. Es curiosa en España en el siglo XVI la no existencia de un género como el "motete de estado" que conmemoraba victorias y hechos políticos relevantes. A excepción del de Cristóbal de Morales para la paz de Francia, no podemos recoger mucho más. Sin embargo, se ha señalado cómo otros géneros (el villancico, el romance anteriormente) ocuparon este papel de propaganda de Estado. ${ }^{80}$ En esta línea los oficios de la Toma vienen a cubrir el vacío que el género del "motete de estado" dejó en la Península, siendo el canto llano el responsable de las funciones de aquél. La creación de oficios y misas con significación política es un fenómeno peculiar del que pueden citarse algunos ejemplos. Por su carácter local, deberían ser anteriores a las disposiciones de Trento, ya que éstas disminuyeron la autonomía de cada diócesis para fijar sus celebraciones a la vez que unificaron el Breviario a través de la Sagrada Congregación de Ritos. Los oficios de Hernando de Talavera que conmemoran la Toma de Granada y el oficio por la Victoria sobre los Benimerines de Alfonso XI (1340) son efectivamente de finales del siglo XV. Sin embargo algunos de estos oficios de contenido político son posteriores: como el oficio que conmemora la Batalla de Nördlingen, en la que luchó el Infante Cardenal Don Fernando (7-IX-1634) y está contenido en el Breviario de Toledo. Fuera de los ejemplos españoles puede citarse, en el Breviario de París, la fiesta por la Victoria de Felipe el Hermoso (1268-1314) y en la Iglesia Anglicana, la fiesta por la

\footnotetext{
${ }^{80}$ Véase, Pablo L. Rodríguez, "The villancico as music of state in $17^{\text {th }}$ century Spain”, Devotional Music in the Iberian World, 1450-1800, ed. Por Tess Knighton y Álvaro Torrente (Londres: Ashgate, 2007), pp.189198.
} 
Decapitación de Carlos I (30-I-1649) y la Fiesta perpetua para dar gracias a Dios por librarnos de los papistas (5-XI-1605). ${ }^{81}$

En este contexto, la Toma de Granada no sólo sería el primero de los oficios políticos de los que tenemos noticia, sino que se presenta como un caso excepcional, ya que según Faustino Arévalo, nada más y nada menos que tres oficios parecen haber sido creados para conmemorarla. De los tres, el más conocido y estudiado es el de Fray Hernando de Talavera (1428-1507) confesor de la Reina Isabel. Parece lógico que Talavera, primer arzobispo de Granada después de la reconquista de la ciudad, creara y mandara interpretar este oficio en la iglesia granadina, pero su difusión y pervivencia en el tiempo es difícil de determinar. Hasta el momento las fuentes musicales sólo han sido encontradas en Granada y aunque parecía haber dejado de interpretarse poco después de su creación, la aparición de nuevos ejemplos copiados en el siglo XIX ponen en duda esta afirmación. ${ }^{82}$

Otro oficio conmemorativo de la Toma de Granada es el creado por Fray Diego de Muros, titulado "Exaltationis Fidei", que fue compuesto para la Iglesia de Santiago de Compostela y del que daremos noticia a continuación. Al contrario que el de Talavera, la pervivencia de este oficio en el tiempo parece más que probada como veremos.

El tercer oficio de la Toma de Granada del que tenemos noticia, aún sin localizar, estuvo destinado a la Iglesia de Burgos y fue compuesto a instancias de Juan Rodríguez de Fonseca (1451-1524) por Juan Maldonado (1485-1558), un humanista que sostuvo una fluida correspondencia con Erasmo de Rotterdam. Sin embargo este oficio fue mandado eliminar del Breviario de Burgos por Antonio de Rojas, sucesor de Fonseca en la sede episcopal "juzgando supersticioso a Fonseca". ${ }^{83}$ Puede que el arzobispo Rojas,

\footnotetext{
${ }^{82}$ Pilar Ramos afirma que tan sólo en Santa Fe pudo haberse interpretado este oficio más allá de los primeros años, pues en la Catedral y en la Capilla Real no se tienen noticias, pero la aparición de una copia del siglo XIX en la Abadía del Sacromonte y de otros ejemplos en diversos conventos de Granada parecen poner en tela de juicio esta teoría.

${ }^{83}$ Faustino Arévalo, Hymnodia Hispánica, p. 368.
} 
anteriormente arzobispo de Granada, fuera también el responsable de la supresión del oficio en la iglesia granadina.

Queda por ver si catedrales tan relevantes como las de Toledo o Sevilla también usaron de éstos u otros oficios para conmemorar la Toma de Granada, al menos durante el reinado de los Reyes Católicos.

\section{Exaltationis Fidei: La historia de un oficio}

Si las razones de Fray Hernando para componer el oficio pueden adivinarse como obispo de Granada ¿qué fue lo que movió a Fray Diego de Muros?, ¿por qué conmemorar la victoria de Granada en una sede tan lejana como Santiago? La respuesta la encontramos en la necesidad del Cabildo compostelano de cumplir con las prerrogativas del denominado Voto a Santiago o Voto de Granada, por lo que debió ser comisionado directamente por los Reyes Católicos o por el Cabildo de la Catedral de Santiago de Compostela.

\section{EI Voto a Santiago}

Los Reyes Católicos, en acción de gracias al apóstol Santiago por la victoria obtenida, otorgaron en 1492 el privilegio a la Catedral de Santiago de obtener una parte de las cosechas de los territorios recién reconquistados en el Reino de Granada. Santiago, desde la leyenda medieval de su intervención en la Batalla del Clavijo en la que Ramiro I venció a los moros, había sido un símbolo de legitimación de los reyes cristianos. No en vano en algunas ceremonias de coronación de los Trastámara se empleaba una figura articulada de Santiago, que simbolizaba la transmisión del poder divino al rey.

Los Reyes Católicos conocedores de la importancia de la propaganda para la unificación y pacificación de sus tierras también emplearon a Santiago como protector y emblema de sus batallas. Por ejemplo, en el Retablo de la Cartuja de Miraflores puede verse a Fernando orante protegido y acompañado por la figura del santo. Según las crónicas, cuando el 6 de enero de 1492, cuatro días después de la firma de las capitulaciones con Boabdil, los Reyes entraron en el palacio de la Alhambra, un heraldo gritó: 
¡Santiago!, ¡Santiago!, ¡Santiago!, ¡Castilla, Castilla, Castilla!, ¡Granada, Granada, Granada! Por los muy altos y poderosos señores Don Fernando y Doña Isabel...que han ganado esta ciudad de Granada y todo su reino por fuerza darmas de los infieles moros.

La voz del heraldo fue seguida de disparos de bombardas y cañones, y por el atronador Tedeum cantado por el ejército. ${ }^{84}$ Esta triple invocación al santo estuvo presente en la conquista de otras plazas junto con el llamado pendón de Santiago que portaban en la batalla como insignia. Los Reyes Católicos hicieron de Santiago su símbolo protector. ${ }^{85}$

El texto del privilegio firmado por Isabel y Fernando establecía lo siguiente: 1) las obligaciones de pago de los territorios sometidos (en el siglo XVI, tras la concesión del voto de Granada por los Reyes Católicos, un 65\% de la España peninsular estaba sujeta al pago de este gravamen); 2) la distribución de las rentas a los beneficiados (el cabildo de Santiago recibía el 50\%, el Arzobispo el 33\% y el depósito de la Música de la Catedral compostelana y el Hospital Real de Santiago un 7\% cada uno); ${ }^{86}$ y 3) las obligaciones de los beneficiados, entre las que se encontraba la celebración de la fiesta religiosa el día 2 de enero (día de la Toma de Granada), para la cual debían componerse misa y oficios nuevos:

Es más que se haga en cada un año para siempre jamás una fiesta solemne con sus vísperas e completas e maytines, e otro dia Missa solemne cantada con Diácono e Subdiácono, según se suele hazer en las fiestas más principales del año, la qual queremos que por memoria del dia que se nos entrego la dicha ciudad de Granada que fue el segundo dia del mes de Enero que agora passo, deste presente año de mil e cuatrocientos e noventa e dos años, sea obligado a los dichos venerables Deán e cabildo fazer dezir el segundo dia del mes de Enero de cada un año para siempre jamas la Missa e oficios e oraciones que en esta solemnidad se an de celebrar e dezir, e an de ser los que agora nuevamente se ordenaren e compusieren, en conmemoración e memoria de

\footnotetext{
${ }^{84}$ Narración sobre la caída de la dinastía de los Nazarí, citado por J. N. Hillgarth, Los Reyes Católicos, 1474-1516 (Barcelona; Buenos Aires; México D.F.: Grijalbo, 1984), p. 48.

${ }^{85}$ Una musicalización de la triple invocación a Santiago puede verse en la ensalada "La Guerra" de Mateo Flecha el Viejo.

${ }^{86}$ Ofelia Rey Castelao, La historiografía del Voto de Santiago: recopilación crítica de una polémica histórica (Santiago: Universidad de Santiago, 1985), pp.16-17.
} 
esta sancta victoria, la qual dicha missa e conmemoraciones e oficio sean obligados de dezir e celebrar los dichos venerables Deán e cabildo e dinidades, e beneficiados de la dicha santa yglesia perpetuamente según dicho es. ${ }^{87}$

El privilegio fue redactado en primera instancia el 15 de mayo de 1492 en Granada y ratificado en Alcalá de Henares el 23 de diciembre de 1497. Por tanto la institución de la fiesta de Granada en la Catedral de Santiago fue un hecho, al menos desde 1497 (pues además para esa fecha ya se disponía de los Breviarios impresos), aunque probablemente se celebrara desde tiempo antes, y se mantuvo vigente hasta la abolición del voto en 1834 . Prueba de su vigor en el tiempo lo demuestran las alusiones en documentos oficiales, como en las Constituciones del Arzobispo Blanco, de 1568 que señalan en su punto 22 en qué procesiones las dignidades y cardenales debían llevar capas y mitras, figurando entre ellas "La fiesta de Granada". ${ }^{88}$ Bien entrado el siglo XVIII aún se componen motetes polifónicos para la Fiesta de Granada, como uno atribuido a José de Vaquedano o el del italiano Buono Chiodi, ambos maestros de capilla de la Catedral de Santiago.

\section{Las fuentes del Oficio: Los breviarios de Compostela y el libro de coro de la Catedral.}

El oficio de Fray Diego de Muros vio pronto la luz en la imprenta con la aparición del Breviario Compostelano. El Cabildo de Santiago encargó la impresión a dos artífices casi a la vez: a Juan de Porras el 12-II-1496 (quién acababa de imprimir el Misal Compostelano) y al alemán Nicolás de Sajonia afincado en Lisboa tan sólo cinco meses después (28-VII-1496).

Tras diversos pleitos entre los impresores y el Cabildo parece que el Breviario que fue distribuido fue el de Juan de Porras, avalado por el arzobispo Alonso de Fonseca, y

\footnotetext{
${ }^{87}$ En la ciudad de Granada a tres dias del mes de Iulio de mil y quiniêtos y nouenta y seys años ... en nôbre de la santa Yglesia, Arçobispo, Dean y Cabildo y gran Hospital real de señor Santiago, de Galizia, presento una peticion y priuilegio... [Certificación y Privilegio de los Reyes Católicos de 1497 para la cobranza del voto de Santiago, suscrita por el escribano Luys de Leyua]. [Granada: s.n., 1596]

${ }^{88}$ José López Calo, La Música en la Catedral de Santiago de Compostela, vol.VII-I (Santiago: Universidad de Santiago, 1993), p. 392.
} 
Sajonia hizo lo propio fuera de la diócesis. ${ }^{89}$ De este Breviario de Juan de Porras no se conserva ningún ejemplar aunque en 1541 el cabildo encargó al impresor Vasco Díaz de Tanco de Fregenal la impresión de 1000 breviarios "dichos breviarios han de ser del molde que hizo Ju de Porra en Veneçia". 90

Afortunadamente, del Breviario de Nicolás de Sajonia sí se conservan dos ejemplares $^{91}$. El oficio de Muros se encuentra en las siete últimas páginas de este Breviario, en un apéndice foliado con nueva numeración y no en el lugar que le correspondería en el calendario litúrgico ( 2 de Enero). La autoría del oficio se declara en la rúbrica que dice así:

Officium Exaltationis Fidei, quod ordinavit reverendus in Christo Pater Didacus de Muros Episcopus civitatensis, pro victoria civitatis et regni Granatae. Regis et reginae nomine totiusque regni gratias agens Deo

Tres sujetos llevaron el mismo nombre, Diego (Didacus) de Muros, en la época del oficio, sin embargo el único que fue obispo "civitavensis" fue el mercedario Fray Diego de Muros, obispo de Ciudad Rodrigo (1487) y hombre de confianza de los Reyes

El otro ejemplar del Breviario Compostelano que contiene el Oficio "Exaltationis Fidei" para la Toma de Granada es de 1569, impreso en Salamanca por Matias Gast. El texto del Oficio difiere del Breviario de Sajonia, empezando por la rúbrica, que se acorta eliminando el nombre de Muros y dando además otro nombre a la fiesta Exaltatio fidei seu Festum Granatae. Las principales diferencias estriban en las lecciones o lecturas. Para Odriozola, es el único Breviario post-tridentino que aún conserva el rito español.

\footnotetext{
${ }^{89}$ Benito Rial Costas, Producción y comercio del libro en Santiago (1501-1553) (Santiago: Calambur, 2007), p.38.

${ }^{90}$ Rial Costas, Producción y comercio, pp. 63, 106-107. De los Breviarios de Vasco Díaz de Tanco tampoco se conserva ningún ejemplar.

${ }^{91}$ Antonio Odriozola, “Los libros litúrgicos impresos para la diócesis compostelana (siglo XV)”, Cuadernos Gallegos, XXX (1976-1977), p. 94; para una edición del texto del contrato suscrito por Sajonia y una descripción exhaustiva de este Breviario, véase pp. 103-104.
} 
Pero aunque estos Breviarios contienen el texto íntegro del Oficio, no hacen alusión ni a la Misa ni a la música de ambos. Desgraciadamente, del Misal Compostelano impreso en 1496 sólo se conservan hojas sueltas y entre ellas no se encuentra la misa de la Toma. ${ }^{92}$ En la Catedral no hemos localizado aún ningún texto que pudiera relacionarse con una Misa para la fiesta de Granada.

La única fuente musical localizada hasta el momento para este oficio es un Cantoral de la Catedral de Santiago de Compostela. Poco se ha estudiado sobre la librería de Coro de la Catedral, tan sólo contamos con algunas noticias que proporciona Benito Rial sobre los encargos del cabildo a diversos artífices en el siglo XVI y el Inventario que elaboró James Boyce, inédito hasta la fecha. Según este inventario, los libros que se conservan en la actualidad datan de los siglos XVI al XIX. Probablemente la librería de Santiago, como la mayoría de las existentes en las catedrales españolas, fue renovándose con el paso de los siglos y aquellos cantorales que debieron existir en el XVI fueron sustituidos progresivamente por otros, conservando y ampliando el repertorio. ${ }^{93}$

El Cantoral 22, de grandes dimensiones ( $80 \times 54$ x 10.50, Hoja 53 x 75'5, Orla 49 x 73, Caja de escritura 34,5 x 57,5) se encuentra algo deteriorado en la encuadernación y la ornamentación que aparece muy retocada. La orla de grutescos tiene conchas o veneras, símbolo de Santiago, en las 4 esquinas. Tiene 4 pentagramas por página en tinta roja, notación cuadrada.

En el folio 100 v, aparece la rúbrica "In secundis vesp. Circumcisionis, post comm. S. Steph”, y debajo, a lápiz, "Pa[ra] Granada” y “por Granada”.

Aunque Boyce lo cataloga en su inventario como del siglo XVII, una anotación en el libro nos hace datarlo en el siglo XVIII: "F. Thomas Couxil scripsit Ano Dni 1742".

\footnotetext{
92 Para conocer más sobre este Misal Compostelano, véase Antonio Odriozola, "El misal compostelano impreso en 1495 la singular historia de un incunable del que sólo quedan hojas sueltas" Varia Bibliográfica: Homenaje a Simón Díaz (Kassel: Reichenberger, 1988), pp. 499-519.

${ }^{93}$ Sobre los encargos del cabildo compostelano de libros de coro en el XVI véase las noticias que proporciona Rial Costas, Producción y comercio del libro, pp.125 y ss.
} 


\section{El texto del oficio Exaltationis Fidei}

El título del Oficio es significativo de la intención de los Reyes Católicos de identificar la guerra de Granada con la religión: exaltación de la fe o aumento de la fe (como aparece en el encabezado del Breviario de 1497). Este título recuerda curiosamente al de otra festividad religiosa, la exaltación de la cruz, fiesta del 14 de Septiembre. Esta fiesta se originó en Jerusalen cuando Constantino decidió consagrar los santos lugares, celebrándose una ceremonia en la que se exaltaba y veneraba la cruz. Cierto paralelismo puede establecerse con Granada, que había sido como Jerusalem, objeto de una cruzada.

El texto, de indudable valor político, comienza por resaltar en las primeras vísperas la alegría por la victoria (laude, gaude, in cantico letitiae...) resaltando el papel de Fernando e Isabel como liberadores "de la secta de Mahoma". En la conmemoración de Santiago, se incide en el papel de este santo como patrón y protector de España, pues no hay que olvidar que el Oficio se compuso para la Iglesia de Santiago y para dar gracias al Santo.

Pero es quizás en las lecciones de Maitines donde Muros presenta a los Reyes como los verdaderos artífices de la victoria. En la primera lectura describe la invasión de los musulmanes, en la segunda se encarga de exaltar a las personas que junto a los Reyes Católicos participaron en la reconquista: el Papa, Julio II, Pedro de Mendoza, arzobispo de Toledo. Las tres lecturas del segundo nocturno inciden en los fundamentos teológicos de la fe cristiana que son presentados a modo de "Credo". Y las lecturas del tercer nocturno están inspiradas en las parábolas, en el valor de la fe y la acción de gracias de los reyes católicos. El resto del Oficio incide en los mismos conceptos de celebración del triunfo y acción de gracias.

\section{Cómo suena el Oficio}

La creación de nuevas piezas de gregoriano después de la estandarización del repertorio es algo que ha recibido escasa atención por parte de los estudiosos del canto 
1lano. Pero ejemplos cómo éste hace plantearnos qué pautas seguirían los compositores para crear sus piezas. Hernando de Talavera utilizó el contrafacta en parte de su oficio, pero también manejó con solvencia la teoría del ethos y la modalidad como ha demostrado Pilar Ramos. Su intención retórica nos sitúa en una perspectiva que incide de nuevo en la propaganda política. ${ }^{94}$

Al igual que Talavera, los textos de las antífonas de Muros recuerdan con frecuencia a los textos del repertorio de canto llano: Lauda Hesperia Dominum es un texto nuevo, pero recuerda a Lauda Jerusalem Dominum. Otras veces el texto es el mismo: Nisi Dominus (psalmo 126). Respecto a la música es difícil establecer concordancias con el repertorio; parece que las conservadas en el Cantoral 22 son compuestas ex profeso conservando el carácter de composición centonizada del gregoriano. Al no haberse conservado todo el Oficio en un solo volumen (como sí ocurre con el oficio de Talavera), no podemos tener una idea completa de las cualidades musicales del Oficio. Puede que las otras piezas se conservaran en Cantorales diferentes (ej.: los himnos en un Himnario).

A priori, el Oficio de Diego de Muros es menos ambicioso en extensión: las antífonas musicadas que conservamos del oficio de Muros son bastante más breves que las de Talavera y menos elaboradas. Sin embargo, no sería oportuno comparar los dos oficios de Talavera y de Muros en términos definitivos puesto que del oficio de Muros conservamos tan sólo una pequeña parte.

\section{La fortuna del oficio}

El Oficio "Exaltationis Fidei”, aunque recibió varias impresiones, parece que no se interpretó más allá de la diócesis de Santiago, pues fuera del Breviario Compostelano no se ha localizado ningún otro ejemplar. Sabemos que en la biblioteca de la reina Isabel se encontraba este oficio de Muros junto con el de Talavera ${ }^{95}$ aunque ¿cuál de los dos oficios

\footnotetext{
${ }^{94}$ Pilar Ramos López, "Historia política en música" en Fray Hernando de Talavera, Oficio de la Toma de Granada, textos de Francisco Javier Martínez Medina, Pilar Ramos López, Elisa Varela Rodríguez, Hermenegildo de la Campa. pp. 59 y ss.

${ }^{95}$ Francisco Javier Sánchez Cantón, Libros, tapices y cuadros p.83 Cit. En Álvaro Fernández de Córdova y Miralles, La Corte de Isabel (1474-1504) Ritos y Ceremonias de una Reina, p.281.
} 
se emplearía en la capilla de los reyes? Pues la fiesta por la toma de Granada figura entre las fiestas que se debían celebrar en la Capilla Real. ${ }^{96}$ Este oficio no pasó del todo desapercibido a autores como Juan Tamayo de Salazar, quién en su extensa obra Anamnesis sive commemoratio omnium sanctorum, donde recoge todos los santos y fiestas particulares de las diócesis españolas, copia el Oficio parcialmente del Breviario Compostelano impreso en 1569. ${ }^{97}$ Faustino Arévalo, el himnógrafo del siglo XVIII, recoge la noticia de Tamayo de Salazar y apunta la existencia de los oficios de Talavera y Maldonado.

El texto del Breviario de 1497 lo reimprimió el mercedario Manuel Rodríguez Carriazo, en los años 60 del pasado siglo, pero no estudió ni analizó el significado político del texto, ni localizó la fuente musical del Oficio. ${ }^{98}$

\section{El oficio de la Toma de Granada de Heranando de Talavera en la Abadía}

¿Qué motivos pudieron impulsar a la copia de este oficio en el siglo XIX? Aunque este cantoral puede reflejar el repertorio de otro supuesto cantoral preexistente en la Abadía que se copiara de nuevo por su mal estado, también dudamos que la fiesta se celebrara ininterrumpidamente en la Abadía hasta finales del siglo XIX por varias circunstancias: ni en la Tabla de Registro de los Libros del Coro, ni en las Actas encontramos ninguna referencia a la existencia de un cantoral para la celebración de esta fiesta, tan sólo se menciona de pasada en la Consueta que la Calenda de la Dediçión de Granada la haría un capellán, ${ }^{99}$ que hay fuegos la noche antes por la Fiesta de la Toma, ${ }^{100}$ que ese día no se

\footnotetext{
${ }^{96}$ Knighton, p.

${ }^{97}$ Juan Tamayo de Salazar, Anamnesis sive commemoratio ómnium sanctorum (Lyon: 1651), pp. 51-55.

${ }^{98}$ Manuel Rodríguez Carriazo, “Oficio de la exaltación de la fe”, Estudios, 19 (1963), pp. 323-343.

${ }^{99}$ Consueta, fol. $14^{\mathrm{v}}$.

${ }^{100}$ Consueta, fol. $46^{\mathrm{v}}$.
} 
puede tomar Recle porque es la octava de San Esteban, ${ }^{101}$ y que el campanero debe tocar para ese día con el esquilón "a lengua". ${ }^{102}$

Quizás el IV centenario de la Toma de Granada en 1892 fuera el motivo para intentar recuperar esta música que estaba presente en diversos cantorales de la ciudad. Si observamos el Oficio completo que se conserva en la Iglesia Colegial de Santa Fe encontramos que lo que se mantiene en el cantoral de la Abadía es tan sólo una pequeña parte del Oficio (le faltan las cinco antífonas de primeras vísperas, los maitines completos, laudes, los responsorios de Tercia, Sexta y Nona, una antífona de las segundas vísperas y la Misa completa) pues sólo reproduce las antífonas del Magnificat de las primeras y segundas vísperas.

El segundo interrogante que se plantea es la fuente que fue utilizada para copiar las antífonas de las vísperas, pues de las fuentes conservadas conocidas no sigue fielmente ninguna de ellas. Con la que guarda más semejanzas es con la conservada en el Cantoral de Santa Fe pero difiere ligeramente en el texto y en la música.

En la versión abacial se suprime la palabra "fratres" aunque no los melismas que corresponden a dicha palabra en el Cantoral de Santa Fe. El VI modo en el que la pieza está escrita sufre una transformación al poner el si bemol en la armadura en Sacromonte. Las repercusiones desaparecen en la antífona de la abadía al mismo tiempo que se simplifica la escritura neumática (sólo punctum), se añaden barras que no están escritas en Santa Fé, no hay cambios de clave (en la de Santa Fe la parte más aguda de la antífona se escribe en Do en $\left.4^{\mathrm{a}}\right)$, y algún neuma es cambiado (dedit).

\footnotetext{
${ }^{101}$ Consueta, fol. $65^{\mathrm{v}}$.

${ }^{102}$ Consueta ,fol. $127^{\mathrm{r}}$.
} 
Figura VI.11. Antífona Magnificemus Dominus. Abadía LC LXIII, fols. $1^{\text {v }}$ 4 v $^{\mathrm{v}}$.
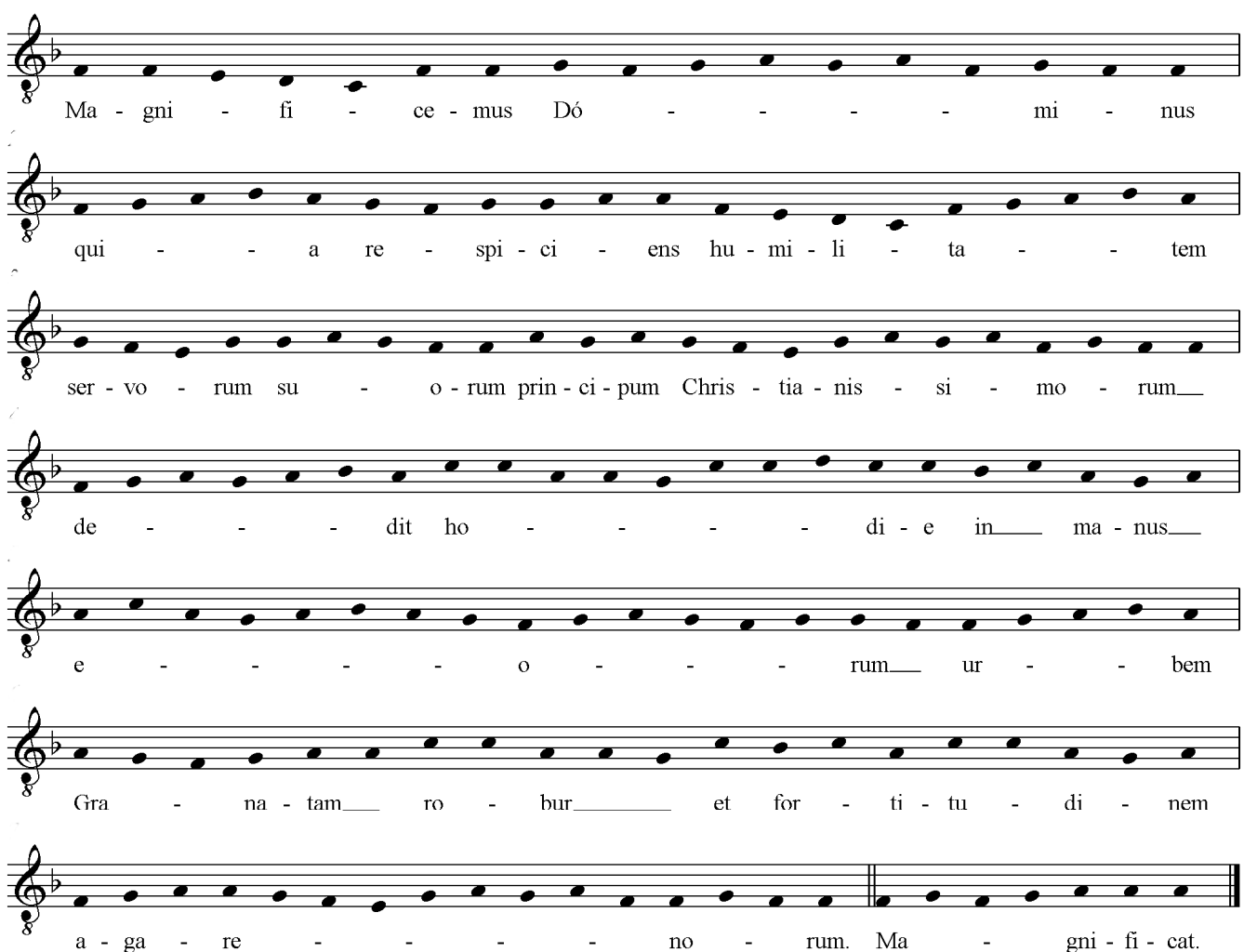

V. Benedicamus Patrem et Filium eum Sancto Spiritu.

R. Laudemus et super exaltemus eum in saecula.

En la antífona Fecit Potentiam el texto permanece igual en ambas versiones, salvo una corrección del latín de la versión de Santa Fe (misericordia sue por misericordiae suae). La música que corresponde a la palabra "deposuit" difiere completamente en las dos versiones, y por último señalaremos que el Cantoral de la Abadía presenta repercusiones en lugares donde Santa Fe no las recoge. 
Quedan aún muchos aspectos por aclarar para una mejor comprensión y conocimiento de los Oficios de la Toma de Granada, como las posibles filiaciones con otras piezas del repertorio de canto llano, la posible interpretación de secciones polifónicas del oficio o la localización (en el caso del Oficio Exaltationis Fidei) de la música del resto del oficio y misa. Los Oficios de la Toma fueron para los Reyes Católicos un medio no sólo de propaganda, sino también de legitimación de su soberanía. Con su vinculación a Santiago quisieron de un lado señalar el valor de la Conquista como cruzada, y de otro se erigían en continuadores de la tradición de los reyes cristianos que simbolizaron en Santiago la unidad de los diferentes reinos cristianos. 


\section{CONCLUSIONES}

La abadía del Sacromonte de Granada, fundada en 1609, pese a su denominación actual no es una "abadía" sino una iglesia colegial, como indican los documentos fundacionales y su estructura organizativa, ya que no tenía una comunidad monástica sino un cabildo secular. Esta circunstancia hace que las conclusiones obtenidas en este estudio deban ser contextualizadas en el entorno de las colegiatas y no en el de las abadías.

Las iglesias colegiales tuvieron una gran repercusión en la configuración de la sociedad religiosa, regulando la vida cultual de la España de la Edad Moderna junto con las catedrales con las que se disputaban los privilegios. Sin embargo, en el contexto hispano de la época, puede afirmarse que la colegiata como centro de producción musical es un fenómeno peninsular que no fue exportado a los territorios de ultramar, exceptuando la Colegial de Guadalupe en Méjico, que tuvo como primer modelo a la Colegiata del Sacromonte. Las razones de esta exclusión pueden entenderse por la rápida expansión de las órdenes religiosas en Hispanoamérica, de cuyas filas salieron numerosos obispos, la falta de patronato privado y, probablemente, el temor por parte de los obispos a una posible interferencia en el gobierno de la diócesis.

La controversia sobre las reliquias del Sacromonte tuvo una amplia repercusión en la España de finales del siglo XVI y principios del XVII; incluso Felipe II (coleccionista de reliquias) siguió el proceso muy de cerca. Prueba de la popularidad de esa controversia en su época es la alusión a ella que el mismo Cervantes hace en $E l$ Quijote. Dentro del panorama español intelectual de la Edad Moderna, la Abadía fue una institución contrarreformista prestigiosa e influyente, pues tanto sus canónigos como los colegiales de San Dionisio Areopagita ocuparon puestos relevantes en la administración (oidores, consejeros, secretario), la Iglesia (obispos, tanto en España como en América), o en la vida cultural (escritores y académicos de la historia). Todos estos factores la convierten en un objeto de estudio significativo para comprender un capítulo de la historia cultural de España en la Edad Moderna. La desamortización de Mendizábal en el siglo XIX y las diversas reformas económicas que supusieron la desaparición de gran parte de las colegiales españolas no afectaron a la Abadía especialmente por dos motivos: el autoabastecimiento (gracias a sus rentas) y el contar 
en la Corte con importantes validos. Entre ellos destacan Francisco de Saavedra, antiguo colegial de San Dionisio y Ministro de Hacienda con Carlos IV, que ayudó a que las primeras medidas contra los bienes eclesiásticos no se aplicaran al Sacromonte; y José María Velluti, oficial mayor del Ministerio de Hacienda, quien obtuvo diversas exenciones fiscales. Estas influencias contribuyeron a que la Abadía consevara su estatus de iglesia colegial hasta la actualidad, siendo una de las pocas que se mantuvieron después del siglo XIX.

Los estudios musicales sobre las colegiatas han seguido el esquema de los catedralicios sin tener en cuenta la mayor variedad tipológica de aquéllas. Esta circunstancia ha empobrecido la visión que se tiene sobre las iglesias colegiales e invalida muchos de sus resultados. A diferencia de las catedrales, las colegiatas, al no gozar de los diezmos para su financiación, dependían más estrechamente del patronazgo y las fundaciones, lo que les proporcionaba mayor individualidad y especificidad, pues cada patrón establecía el carácter de la institución. De aquí la importancia del patronazgo como configurador de la institución y su influencia en la música. En el caso del Sacromonte, sus características peculiares están determinadas en gran parte por la personalidad de su fundador, el entonces Arzobispo de Granada Pedro de Castro (15341623). Su formación, ideales y relaciones personales determinaron en gran medida el carácter de la fundación, para la que él mismo redactó sus Constituciones (1616). El nacimiento de la Abadía no pudo darse sin la confluencia de diversas circunstancias: la aparición de las reliquias de los santos mártires del Sacromonte junto con los Libros Plúmbeos, la realidad sociocultural de la Granada de finales del siglo XVI y, por último, el interés de Pedro de Castro, Arzobispo de Granada, por llevar a cabo la fundación. La aparición de las reliquias de San Cecilio no fue casual. Los moriscos, sometidos a una presión mayor que culminaría con su expulsión general que decretó Felipe III en 1609, buscaron una salida en las falsificaciones del Sacromonte, con las que pretendían encontrar un lugar en la nueva sociedad que se habría de formar sin ellos. Aprovecharon el clima contrarreformista que retomó y animó el culto a las reliquias, a los santos mártires primitivos y a creencias como la Inmaculada Concepción, reconocida en los textos plúmbeos, para intentar justificar un sincretismo de prácticas musulmanas y cristianas. Granada recuperaba así cierto protagonismo después de que Felipe II trasladara el panteón real a El Escorial. Los descubiertos enterramientos de los 
mártires venían a ser algo más que las tumbas reales; eran el nuevo panteón sacro de España, sólo comparable a Santiago de Compostela.

Como colegiata, la finalidad del Sacromonte era la de solemnizar el culto, y dentro de éste la música ocupaba un lugar preeminente. La mayoría de las colegiatas contaba con una capilla de música, al igual que las catedrales. Sin embargo, en la Abadía el servicio musical sólo estaba integrado por el coro de canónigos, capellanes y colegiales, un sochantre y un organista. Esta falta de capilla musical que posibilitaba la interpretación de obras polifónicas con o sin instrumentos no puede achacarse a un supuesto patrón estructural de las colegiatas de su época como revela el análisis de algunas de ellas. El estudio de tres casos significativos de colegiales fundadas por nobles en los tiempos de creación del Sacromonte (Lerma, Zafra y Olivares) pone de manifiesto que los patronos particulares preferían capilla musical. Además, las principales colegiatas españolas, denominadas "insignes" contaban con capilla musical, por lo que resulta llamativa la carencia de ésta en el Sacromonte, que del mismo modo ostentaba el título de "insigne". El hecho de que Castro no dotara al Sacromonte de una capilla musical está relacionado con su particular interpretación de las consignas de Trento: en el servicio litúrgico en la Abadía prescinde de la polifonía, pues ya en las Constituciones se especifica que el servicio había de hacerse en canto llano. Vista en perspectiva, la restricción del servicio coral al canto llano hecha por Castro no es una simple decisión económica (si bien a finales del XVII y durante el siglo XVIII será la principal razón por la que se prescinda de capilla coincidiendo con una etapa de crisis económica), sino una consecuencia lógica de su concepto de austeridad tridentina y de su fijación con la fundación regia del momento: El Escorial de Felipe II. Además de “imitar" el decreto firmado por Felipe II en que prohibía la polifonía en El Escorial, Castro llega más allá prescindiendo hasta de ministriles.

La Abadía es el centro tridentino por excelencia. Castro estaba familiarizado con los mandatos del Concilio, no sólo por haber asistido al sínodo que el arzobispo Pedro Guerrero convocó en Granada a la vuelta de Trento, sino también por sus lecturas, entre las que se encontraban las Actas de Carlos Borromeo. Su inclinación por las disposiciones contrarreformistas puede verse en su interés por las obras pías, por recoger el episcopologio, fundación de un centro de peregrinaje en el Sacromonte, la labor misional materializada en las misiones sacromontanas y la creación en la Abadía 
de un seminario para la instrucción de eclesiásticos, pero sobre todo, la preocupación por el detalle en las ceremonias y la devoción pública al igual que muchos de los obispos españoles. El detalle con el que legisló su fundación y los documentos que para su gobierno ideó reflejan en parte esta obsesión por el decoro cultual. La perfección de la Consueta (1632), aunque no es obra suya directamente, obedece no obstante a su idea del culto.

De entre todos los centros religiosos de la época, la fundación que más inspiró a Castro fue El Escorial de Felipe II. A pesar de que los resultados obtenidos en ambas instituciones son muy diferentes, sin duda por la diversa dotación económica, las similitudes desde el punto de vista ideológico son evidentes. Castro, en estrecha relación con el Rey por sus cargos (presidente de las chancillerías de Valladolid y Granada, su permanencia en la Corte al lado de su padre que era consejero real) pudo conocer de primera mano las intenciones del Rey al fundar el Escorial. La familiaridad de ambos fundadores con los decretos de Trento es fundamental a la hora de articular las dos instituciones. Cuando Castro decide crear el Sacromonte, no lo hace sólo como lugar de culto a las reliquias (algo que también era El Escorial, considerado un gran relicario), sino como panteón familiar, imitando al Rey y estableciendo diversos aniversarios por sus padres, abuelo y hermano. Del mismo modo que Felipe II había instaurado un rígido horario conventual de oraciones y obligaciones para los monjes jerónimos escurialenses, Castro designó otro igual de exigente para los canónigos. En sintonía con Trento ambos templos están dedicados al culto de santos mártires de la Iglesia española primitiva: San Lorenzo en El Escorial y los mártires granadinos en el caso de la Abadía, aunque el templo esté consagrado a la Asunción de la Virgen. También en el aspecto exterior Castro quiso hacer un pequeño Escorial, ya que para la reforma del primer proyecto, eligió a un arquitecto jesuita, Pedro Sánchez, cuyos edificios se encuentran en la línea austera inaugurada por Herrera en El Escorial.

La Abadía es una institución peculiar que no se ajusta exactamente a ninguna tipología colegial ni a ningún establecimiento fundado en el espíritu de Trento. De la comparación de la Abadía con otras colegiatas, bien por ser creada siguiendo los decretos tridentinos, como el Colegio del Corpus Christi de Valencia instituido por Juan de Ribera, bien por compartir el mismo entorno, como la Colegiata del Salvador de 
Granada, ha de concluirse que fue única, pues sus aspiraciones fueron muy diferentes de las del resto de los centros de su época.

En relación a la estructura musical del Sacromonte, la lectura y análisis de la Consueta nos proporciona una imagen jerarquizada y completa de los oficios del coro, lo que permite conocer las obligaciones de todos y cada uno de los participantes en la liturgia respecto a la interpretación musical, constituyendo un ejemplo inusitado de descripción de cargos que no suelen describirse con tanto detalle, como el intonario o el versiculario.

Las plazas de sochantre y organista rara vez se convocaban en el Sacromonte por el sistema de edictos, antes bien los canónigos escribían a sus conocidos en otros centros religiosos para buscar a personas aptas para el cargo, ahorrándose el dinero de las ayudas de costa. Al candidato se le sometía a un periodo de prueba o venía a juzgarle un experto de fuera que certificara su aptitud para el oficio. Al eliminar la competitividad por ausencia de convocatoria pública y oposiciones, el nivel de exigencia y la calidad de los candidatos era menor, lo que explica que la mayor parte de los músicos que sirvieron por un tiempo en la Abadía no vivnieran de centros de prestigio y rara vez promocionaban a ellos. A excepción del organista Miguel Rabaza, que permaneció varios años en el Sacromonte y luego sirvió en la Corte hasta su muerte, no encontramos otro músico de relevancia en el panorama nacional. Sin duda la obligatoriedad de residencia en el Sacromonte (inexcusable para los sochantres y algo menos estricta para los organistas) limitaba asimismo el número de candidatos interesados, aunque de otra parte podría ser un incentivo, ya que la habitación y la comida estaban incluidas en el salario.

En un primer momento la mayoría de los 39 sochantres que he documentado provenían de Sevilla, quizás mandados por Castro que se encontraba ya en la sede sevillana. Alguno de ellos pudo ser el transmisor directo a Granada de las coplas "Todo el mundo en general" dedicadas a la Inmaculada Concepción, lo que explicaría su temprana presencia en el Sacromonte y su aparición en un sermón impreso con motivo de la celebración de la Inmaculada en el Convento de San Francisco de Granada en 1615.

A través de las Actas Capitulares he podido documentar veinte organistas. La Consueta da indicaciones precisas sobre en qué momento del día intervenía el organista 
según las festividades, el instante exacto dentro de la ceremonia y además especifica cómo debía tocar. Esto ayuda a comprender el papel del órgano dentro de las ceremonias y su relación con el canto llano, mostrando detalles desconocidos de la práctica interpretativa del alternatim en el siglo XVII.

El estudio de la ceremonia, que ha sido con frecuencia soslayado en gran parte de los trabajos sobre catedrales, colegiatas e iglesias de monasterios y conventos, proporciona una nueva clave para entender la música, cuyo carácter eminentemente funcional no puede analizarse fuera del rito al que acompaña. La ceremonia religiosa es una reminiscencia de la teatralidad, por lo que la música que en ella participa debe ser analizada como un elemento más de la representación. Sin la reconstrucción ceremonial no se puede entender el papel que la música religiosa tenía para la sociedad de la Edad Moderna y por lo tanto perdemos gran parte de su significado. La creación del ceremonial en el Sacromonte tuvo varias etapas. Aunque al principio se tomó como modelo la Consueta de la Catedral de Granada, al ser anterior a las disposiciones de Trento, se dejó porque no se ajustaba al Ceremonial Romano. El modelo más próximo para la Consueta es el Caeremoniale Episcoporum (1600); el libro II es sin duda la base de los libros III y IV de la Consueta. Sin embargo, la Consueta es mucho más detallada y amplia en la descripción de oficios. Estas divergencias surgen de los diferentes destinatarios, pues el Caeremoniale estaba consignado para todas las catedrales e iglesias colegiales del orbe católico, mientras que la Consueta podía y debía ser más específica al regular las directrices para un centro concreto.

La Consueta del Sacromonte proporciona las indicaciones para reconstruir con todo detalle las ceremonias. Gracias a la regulación tan detallada de todos los aspectos cultuales podemos reconstruir entre otras cosas los toques y las campanas que debían sonar según las diferentes festividades y momentos del día, recuperando parte del universo sonoro de un canónigo del Sacromonte y redescubriendo el código de un lenguaje lleno de significado para los habitantes de la Abadía.

Los espacios cultuales en los que se desarrollaban las ceremonias tienen que ver con la naturaleza del Sacromonte como cento de culto a las reliquias y como lugar de peregrinaje. Por su situación en lo alto de un monte y el viacrucis que acompaña la subida, está estructurado a la manera de los sacri monti italianos, lugares de culto a los que Carlos Borromeo, reformador tridentino, prestó especial atención. Las Cuevas que 
albergaban las supuestas reliquias de los mártires son un trasunto del resurgir del culto a las catacumbas reavivado por San Felipe Neri en Roma. La iglesia fue el único espacio contrarreformista fallido, pues el proyecto completo del arquitecto jesuita Pedro Sánchez no se llegó nunca a realizar.

Pese a lo que afirman las Constituciones sobre el desarrollo del servicio litúrgico en canto llano y aunque no se conservan fuentes polifónicas, sí que hay constancia de que se interpretó música polifónica en la Abadía, si bien de manera esporádica. Las actas capitulares señalan que los colegiales cantaban fabordón y se les prohibió. También la Consueta emplea expresiones como "cantar al órgano" o "a punto de órgano", alude puntualmente a géneros polifónicos (motete, chançoneta) y señala la necesidad de interpretarlos "si había gente principal", lo que de otra parte nos habla del uso propagandístico de la polifonía. Cabe la posibilidad de que estos géneros polifónicos fueran interpretados por los capellanes de coro, quienes debían de saber cantar a voces. La casi total ausencia de polifonía como modo de solemnizar la ceremonia propició la diferenciación en la categoría de las fiestas mediante otros recursos referidos a la interpretación del canto llano: quiénes y cuántos eran los actores del canto llano, si la fiesta era cantada o "en tono", la velocidad y el tono en el que se interpretaba y la presencia del órgano. La ausencia de legislación sobre capilla de música y ministriles en las Constituciones no impidió que se interpretara música instrumental en el Sacromonte, si bien al igual que la polifonía se hizo en contadas ocasiones. Resulta contradictoria esta decisión de excluir a los ministriles de la Abadía, pues la presencia de una capilla de música habría otorgado prestigio al centro, que es lo que Castro quería. La dotación de 20 canónigos no hace plausible que fuera por falta de dinero, sino, al igual que en la restricción al canto llano, fue una concreción exagerada de Trento como ya habían hecho otros arzobispos en Italia. Castro, si bien consiguió la prohibición de las comedias por el Rey, dada su personalidad pragmática, limitó la austeridad musical al Sacromonte en lugar de extenderla a toda la diócesis. En el ánimo del Arzobispo pudieron influir otros aspectos como la situación geográfica de la Abadía, alejada de la ciudad, y la doctrina de Santo Tomás de Aquino, que instauró como obligatoria en el Colegio de San Dionisio; dicha doctrina puede sintetizarse en la prohibición de la música intrumental en el servicio litúrgico. 
A pesar de lo legislado por Castro, en fechas posteriores a su muerte sí existen testimonios de la existencia de una capilla de música propia y de instrumentos en la Abadía que debía cuidar el organista y que se vendieron. En 1640 el Cabildo del Sacromonte contrató a "Francisco de los Reies Maestro de Capilla y sus músicos y ministriles" para que actuaran en "todas las festividades que se les señalaba". No ha sido posible establecer cuánto tiempo funcionó esta capilla, pero la Consueta estipulaba que se debía contratar música para algunas fiestas más solemnes como la Inmaculada, la Asunción o el Corpus. Algunas actas capitulares dan cuenta de estas actuaciones, como la que tuvo lugar con motivo del funeral en 1703 de Rafael Andrés de Ascargorta, sobrino del Arzobispo Martín de Ascargorta, a la que asistió la capilla de música de la Catedral de Granada.

Aunque muchas ceremonias litúrgicas conservaron su esencia, otras variaron ostensiblemente con la reforma del Breviario por Pío V y el Caeremoniale Episcoporum. No se sabe hasta qué punto aquellos centros que tenían una tradición cultual secular fueron capaces de adoptar completamente el nuevo rito romano, pero la Abadía, que nació con la Contrarreforma, es en este sentido un centro modélico, porque casi desde el mismo inicio se amoldó a las disposiciones de Trento. El análisis del Ceremonial que describe la Consueta de la Abadía para la Misa y las Vísperas (ejes fundamentales de la liturgia) revela que los canónigos redactores del documento abacial siguieron de cerca las rúbricas que proporciona el Caeremoniale Episcoporum de 1600, aunque con diversas adaptaciones (al lugar y a los actores) y ampliando algunas consignas. Dichas descripciones ceremoniales son imprescindibles para comprender el movimiento que acompañaba a la música y algunos aspectos interpretativos de singular importancia: desde el tempo con el que se debían interpretar las antífonas, que venía marcado por las acciones y movimientos que debían realizar tanto los cantores como otros actores de la liturgia, hasta la elección de los tonos.

El estudio de algunas ceremonias particulares que se celebraron en el Sacromonte revela que en la Abadía del Sacromonte se convirtió en un espacio litúrgico conectado con la ciudad. Desde el primer momento, con las celebraciones por la calificación de las reliquias, no puede entenderse el Sacromonte sin su proyección en la ciudad y viceversa. La fiesta, marcada por las celebraciones litúrgicas en la Catedral y otras iglesias, junto a las procesiones y a las fiestas seculares en la Plaza Bibarrambla 
(que como espacio de fiesta acogería luego en las celebraciones del Corpus arquitecturas efímeras relacionadas con el Sacromonte) muestran que el Sacromonte debe analizarse en su contexto urbano y no limitarse a los confines físicos de la Abadía. Entre las festividades propias de la Abadía encontramos las celebraciones de San Cecilio, uno de los supuestos santos encontrados en las cavernas, primer Obispo de Granada y luego patrón de la ciudad, para el que se creó un oficio y un ritual propio. Las ceremonias sacromontanas en las que participaba el Ayuntamiento de la Ciudad (que corría con los gastos) y el Cabildo Catedralicio, daban una dimensión cívicoreligiosa muy rica para entender las relaciones jerárquicas en un núcleo urbano de la España moderna.

Los ritos funerarios por el fundador de la Abadía, Pedro de Castro, y por sus padres suponen una exploración de uno de los fines de la creación del Sacromonte: servir de panteón familiar a imitación de Felipe II en el Escorial y de tantas otras capillas nobiliarias. El ritual sigue los estándares para este tipo de ceremonias en el Antiguo Régimen convirtiendo la muerte en un tránsito hacia la fama. El estatus sociopolítico y económico alcanzado por Cristóbal Vaca de Castro gracias a su fortuna obtenida en América como pacificador y administrador del Perú, permitió a su hijo el Arzobispo de Granada fundar el Sacromonte. Además, el análisis de otros documentos conservados en la Abadía sobre Vaca de Castro, como cuadros y relaciones, ponen de manifiesto cómo éste se sirvió de la música para reafirmar su prestigio.

El Sacromonte es esencialmente un lugar de culto contrarreformista en lo referente a la devoción de la Inmaculada Concepción, al Santísimo Sacramento y a las reliquias de los primeros mártires cristianos. La devoción a la Virgen y al Santísimo generó un variado repertorio de actividad ritual en el mundo de la Contrarreforma; aunque muchos de estos cultos hunden sus raíces en la Edad Media, cobraron nuevo protagonismo en una época de reafirmación doctrinal frente a las creencias de los protestantes. La Abadía, nacida en la época de mayor difusión de las ideas contrarreformistas, no pudo sino ser el reflejo perfecto de su época contribuyendo de manera especial a la difusión de la creencia en la Inmaculada Concepción, pues reavivó el debate inmaculista por la presencia de esta opinión en los Libros Plúmbeos. Las coplas "Todo el mundo en general" surgidas en Sevilla cuando Pedro Castro era allí arzobispo, y que pronto fueron interpretadas en el Sacromonte, contribuyeron de manera 
singular a la difusión del dogma. La reconstrucción del rito de la Salve tal como se celebraba en el Sacromonte nos proporciona la descripción de una estructura hasta ahora casi desconocida, que nos permite relacionarla con la práctica musical en la Catedral de Sevilla y probablemente con otras instituciones religiosas. El rito de la Salve en la Abadía se conviertió en una reafirmación de la creencia en la Inmaculada no sólo por la utilización de las Coplas "Todo el mundo en general”, sino también por el uso de la antífona 'Conceptio Tua'.

La librería coral del Sacromonte que presento en el Catálogo está integrada por 79 cantorales de canto llano, en su mayoría manuscritos, cuyo corpus fundamental está formado por libros copiados en un taller malagueño durante la primera mitad del siglo XVII. Este taller fue el mismo que completó la colección de los cantorales de la Catedral de Málaga, lo que sitúa a la librería del Sacromonte al mismo nivel que la de una iglesia catedral. Se trata de una colección que recoge todo el repertorio necesario para el culto en un centro contrarreformista, por lo que analizando el calendario que cubría podemos hacernos una idea de las fiestas que se celebraban en la Abadía y en otros centros de similar importancia durante los siglos XVII, XVIII y XIX. La colección no sólo dispone de cantorales coetáneos y posteriores a la fecha de su fundación (1609), sino que cuenta con libros más antiguos. De su procedencia nada sabemos, quizá pertenecieron al fundador Don Pedro de Castro, pues depositó sus propios libros en la Abadía, o más plausiblemente se trajeran de algún otro centro litúrgico, comprados de segunda mano antes de que se encargaran los libros propios o procedentes de la exclaustración del siglo XIX, como parece ser el caso de los que se conservan del Convento de San Antonio de Padua. Estos últimos son libros de pequeño formato, carecen de iluminaciones y contrastan con el tamaño y riqueza de los de la Abadía.

El análisis de los cantorales ha revelado la existencia de un repertorio específico para la diócesis granadina, como la Misa de San Cecilio o el Oficio de la Toma de Granada, y otro repertorio de origen anterior a Trento: el himno Ut queant laxis que presenta diversas variaciones melódicas y un Kyriale que guarda relación con un interesante y prácticamente desconocido impreso granadino del siglo XVI. El estudio de la producción de canto llano dedicada al culto a San Cecilio conservada en el Sacromonte, la Catedral y la Capilla Real, muestra la existencia de importantes variantes, lo que pone de manifiesto que la creación de música para nuevos ritos no 
tenía que ser necesariamente aprobada en Roma por la Sagrada Congregación de Ritos (sino sólo el texto).

Mi estudio del Oficio de la Toma de Granada conservado en la Abadía ha permitido compararlo con otro Oficio de la Toma diferente que he descubierto en la Catedral de Santiago de Compostela. Este segundo Oficio lo compuso Fray Diego de Muros por orden de los Reyes Católicos para conmemorar el mismo suceso de la Toma fuera de la diócesis de Granada; su música (véase Apéndice 5) había permanecido hasta ahora inédita.

El análisis del himno Ut queant laxis conservado en el cantoral más antiguo que se encuentra en la Abadía, ha demostrado de un lado que la variante melódica que presenta sigue una de las recogidas en el Intonarium Toletanum de 1515 y que existen diversas versiones de este himno, que sin embargo conserva el mismo texto en todas ellas. La variedad de melodías con las que se cantaba este himno en la Europa del siglo XVI indica que la unificación de la liturgia debió ser más estricta en relación a los textos que a la música. El Kyrial recoge siete kyries abreviados que parecen corresponderse con el repertorio más común en la Península Ibérica, guardando una relación muy estrecha con el Cantoral Beinecke y el impreso Oficia ad Missas (Granada, 1544).

La Abadía del Sacromonte fue una de las iglesias colegiales más relevantes dentro del panorama religioso en la España de la Edad Moderna por lo que su estudio era necesario para ayudar a completar la visión que tenemos sobre este tipo de instituciones desde el punto de vista de la producción musical. Esta Tesis Doctoral ha puesto de manifiesto cómo el Sacromonte puede considerarse como el centro tridentino español por excelencia, pues su filosofía y su estructura responden estrictamente a las directrices de Trento. Su especificidad queda de manifiesto al compararla con el resto de iglesias colegiales de su época, ya que si bien comparte el mismo estatus jurídico, su organización musical (al prescindir de capilla de música e instituir el servicio litúrgico en canto llano) es única y original. 

CATÁLOGO DE LOS LIBROS DE CANTO LLANO DE LA ABADÍA DEL SACROMONTE 



\section{Introducción}

El presente Catálogo recoge y describe todos los libros de canto llano que se conservan en la Abadía del Sacromonte de Granada. En total son setenta y nueve cantorales manuscritos e impresos de los siglos XVI al XX, de diferentes procedencias, aunque la mayor parte fueron copiados ex profeso para el Sacromonte en el siglo XVII. Los setenta y cinco cantorales están repartidos en tres ubicaciones distintas aunque próximas: 1) la llamada habitación del órgano, aneja al coro de la Iglesia; 2) la Sala del Tránsito, cercana al coro; y 3) el Archivo. El orden y la colocación actual de los cantorales dependen de su tamaño y del espacio disponible, no encontrándose ordenados por su función litúrgica.

Existen cuatro inventarios de los Libros de Coro. El primero y más antiguo de los que se conservan es la tabla de registros del coro que aparece en una obra manuscrita anónima titulada Breve compendio de ceremonias eclesiásticas (1760-61) que se encuentra en el Archivo de la Abadía. ${ }^{1}$ El segundo de estos inventarios es el Registro de los Libros de Coro del Sacro-Monte, hecho en papel sobre madera que se encuentra en la librería del coro. Debió de ser ejecutado a finales del siglo XIX, porque incluye diversas fiestas que no fueron aprobadas hasta entonces; véase la reproducción de ese Registro en la Figura C.1. De finales del siglo XIX es también el Índice General de los Libros del Coro, manuscrito que especifica día a día qué libros se han de utilizar en el Coro y que emplea la misma numeración que el Registro anterior; véase la primera página de este Índice en la Figura C.2. El cuarto y último inventario es el Inventario de bienes muebles de la Abadía que incluye la mayoría de estos cantorales y fue realizado en la década de los noventa del siglo XX.

\footnotetext{
${ }^{1}$ Una descripción de este manuscrito se encuentra en Calero Palacios, La Abadía, p.127.
} 
Figura C.1. Detalle del Registro de los Libros de Coro del Sacro-Monte, Abadía del Sacromonte de Granada.

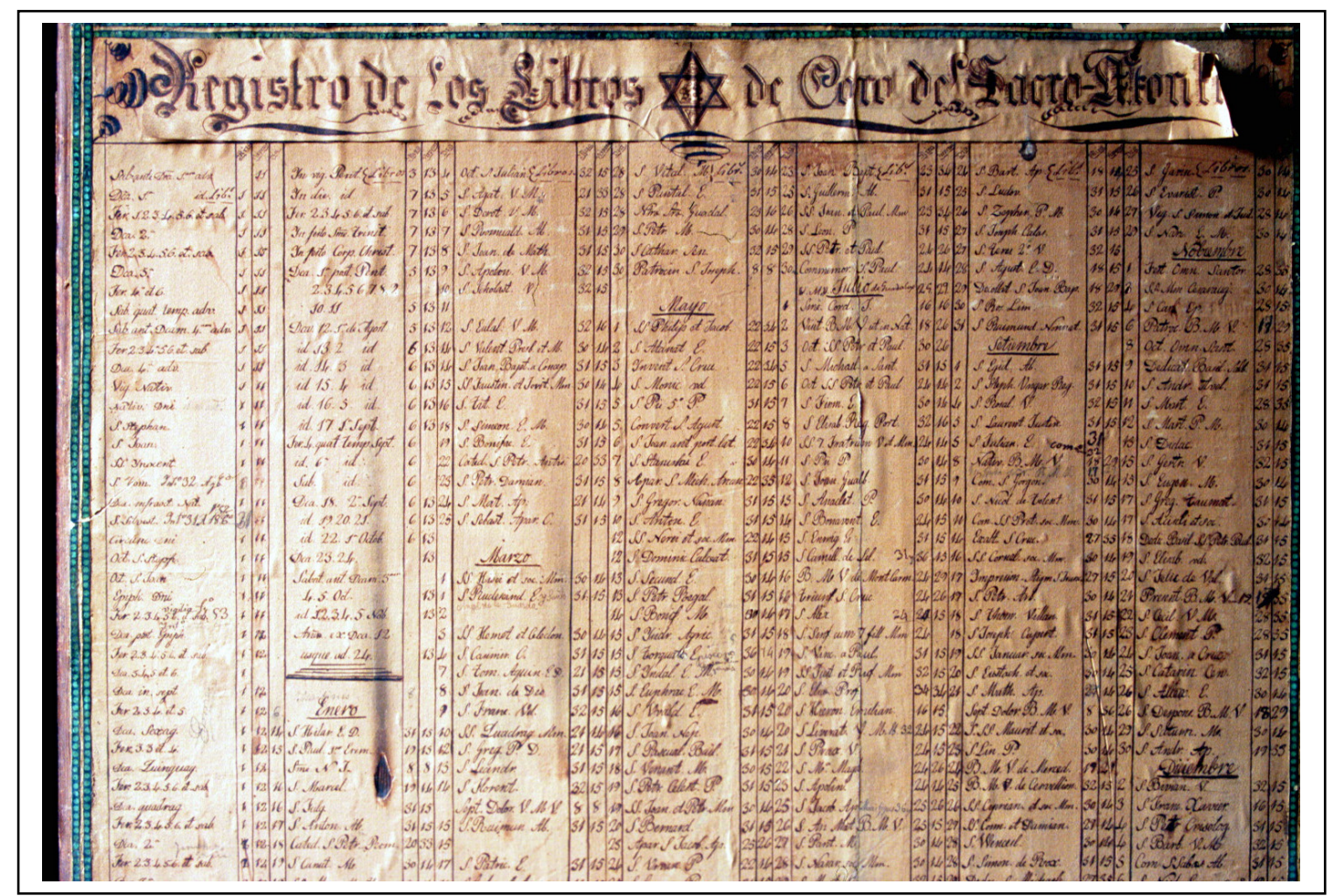

Figura C.2. Primera página del Índice General de los Libros de Coro, s.s. de la Abadía del Sacromonte de Granada.

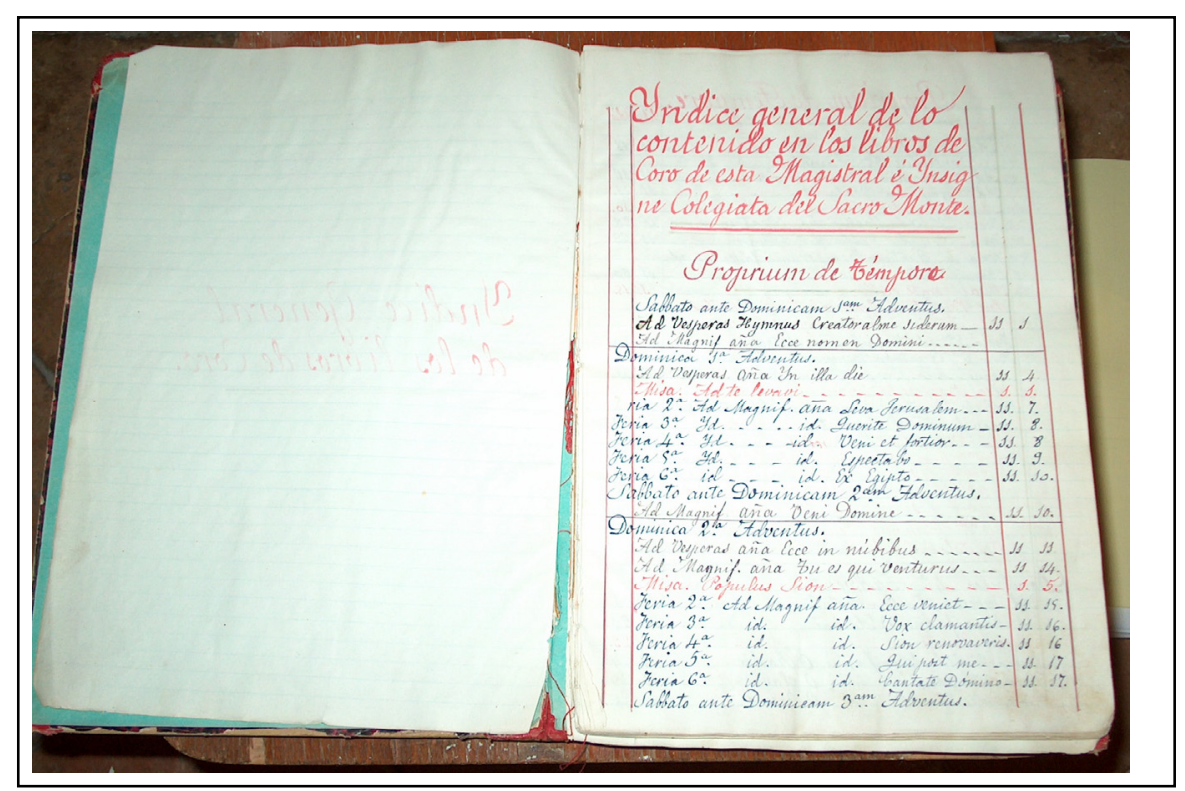

Debido a la diversidad de inventarios, actualmente los libros de canto llano del Sacromonte tienen una, dos y a veces tres números de identificación cada uno; en ocasiones algunos libros tienen una letra que no figura en ningún inventario. Los 
números que aparecen en los libros proceden de: 1) el Registro de los Libros de Coro del Sacro-Monte (1 al 36); 2) el Índice General de los Libros del Coro (1 al 50); y 3) Inventario de bienes muebles (299 al 387 y 5418 a 5449). Para facilitar el estudio de estos libros en el presente Catálogo los he ordenado cronológicamente asignándoles un número romano desde el I al LXXIX. Sugiero que esta nueva, y espero definitiva, signatura de cada libro conste de las iniciales LC (Libro de Coro), seguidas del número romano asignado en este Catálogo y los números de cada cantoral que figuran en otros inventarios históricos desde el más reciente al más antiguo. Por ejemplo: LC VII/318/19. Dentro del presente estudio me refiero a los libros de forma abreviada, utilizando únicamente el número asignado en el Catálogo.

Cada registro en este Catálogo consta de dos partes: la ficha gráfica en la que cada libro tiene una foto de la primera página; si esa página no contiene música, se incluye otra imagen donde aparece la primera página con música. La segunda parte contiene la signatura, tal como hemos detallado anteriormente y la descripción de los aspectos codicológicos del libro, como son los materiales, medidas, foliación, número de pentagramas por página, fecha, íncipit, además de la festividad o uso litúrgico, el índice (si lo tiene) y otras observaciones, donde se recoge cualquier aspecto de interés que no estuviera especificado en ninguno de los apartados anteriores.

Según el contenido, los libros de coro pueden ser: Libro de Misas, los que contienen el propio de la misa; Libro de Vísperas, los que tienen los himnos y antífonas del Magnificat propio de esta hora canónica; Pasionario, el que contiene los textos y música de las pasiones según los cuatro evangelistas; Procesionario, libro de pequeño formato que contiene los cantos para las procesiones, como la del día de la Purificación o el Domingo de Ramos; Salterio, el que contiene los salmos para las horas; Intonario, contiene las fórmulas de entonación para las lecturas y las entonaciones de los versos y algunos himnos. Cuando el libro tiene título, y en él aparece su denominación, lo hago constar, como en Breviarios, Graduales, Misales y Manuales de Coro; si el libro tiene repertorio mixto, he optado por denominarlo simplemente Cantoral.

Todos los libros manuscritos están escritos sobre pentagramas en tinta roja y en notación cuadrada; los tetragramas sólo han aparecido en libros impresos. En cuanto a los materiales hay que destacar que los libros más antiguos son de pergamino, mientras que casi todos los modernos son de papel. Las medidas van expresadas en milímetros (alto, ancho y grosor) seguidas por la medida de la hoja y la de la caja de escritura. La 
foliación está presente en casi todos los libros y muchos conservan la numeración original arábiga en tinta roja. Otros tienen numeración romana y suelen ser casi siempre los más antiguos; el último grupo presenta numeración a lápiz más reciente, posiblemente añadida en el momento en que se hizo el Catálogo de Bienes Muebles de la Abadía a finales del siglo XX. De cada libro se señala el número máximo de pentagramas que hay por página, aunque hay que tener en cuenta que en algunos libros, como los salterios, el texto de las oraciones se entremezcla con la música, por lo que el número de pentagramas por página no es fijo.

Cuando la fecha de copia no aparece en el cantoral ni en otra documentación, se sugiere en la ficha el siglo al que pertenece, utilizando dos criterios: 1) el análisis comparativo de los aspectos externos (medidas, caligrafía y ornamentación) cuando existe un ejemplar datado de similares características; y 2) el repertorio que implique una fecha post quem.

El copista del libro solo se recoge cuando está explícito en el cantoral, lo que no suele ser frecuente. Conocemos el nombre de siete copistas y un corrector; véase Tabla VI.2.

Tabla C.1. Copistas de Cantorales del Sacromonte de Granada

\begin{tabular}{|l|l|}
\hline Copistas & Cantorales \\
\hline $\begin{array}{l}\text { Juan Ramos (1558) } \\
\text { corrector }\end{array}$ & LC II y posiblemente LC III, LC IV, LC V, LC VI \\
\hline $\begin{array}{l}\text { Pedro Marañón (1618) } \\
\text { Lucas de Cárceres }\end{array}$ & LC VII-XVI y posiblemente LC XVII-XXVIII \\
\hline $\begin{array}{l}\text { Francisco de Aguilar } \\
\text { (1657) }\end{array}$ & $\begin{array}{l}\text { LC XXX y LC XXIX (Maitines de Navidad, fols. 26- } \\
\text { 39) }\end{array}$ \\
\hline $\begin{array}{l}\text { F.D.Q.F. orden de } \\
\text { predicadores (Córdoba) } \\
\text { 1656-1659 }\end{array}$ & $\begin{array}{l}\text { LC XXIX (al menos el Oficio del Dulce Nombre de } \\
\text { Jesús fols. 54 y ss.), LC XXXI, LC XXXII, LC XXXIII } \\
\text { y probablemente LC XXXIV, LC XXXV, LC XLII }\end{array}$ \\
\hline Julianus Ferrer (1663) & LC XXXVI, LC XXXVII \\
\hline $\begin{array}{l}\text { Joseph Julián de Toxar } \\
\text { (1762) }\end{array}$ & LC LV \\
\hline $\begin{array}{l}\text { Manuel Martín } \\
\text { Rodríguez (1893) }\end{array}$ & LC LXXX \\
\hline $\begin{array}{l}\text { Miguel Ramos y Ramos } \\
\text { (1904) }\end{array}$ & LC LXVII, LC LXVIII, LC LXXV \\
\hline
\end{tabular}

Las abreviaturas del texto se han desarrollado cuando era necesario para su correcta comprensión. En las descripciones de los impresos no se indica el íncipit, ni las medidas de la hoja y la caja ya que la ficha gráfica es suficiente para identificarlo. Si el 
cantoral contiene iluminaciones se indica el número del folio en el que figuran y a continuación se recoge la letra uncial entre comillas y una breve descripción de la ilustración. No siempre se indican todas las festividades para las que sirve el cantoral, pero sí su uso litúrgico (ordinario o propio de la misa, vísperas, horas menores y otros). Si el cantoral contiene un Índice, se transcribe literalmente.

Finalmente la ficha incluye un apartado de observaciones en el que se detalla: el estado de conservación del libro, inscripciones de interés, origen del cantoral y peculiaridades de la notación. A este respecto hay que aclarar que la expresión "indicaciones mensurales" viene a señalar la existencia de ciertos elementos en la notación cuadrada que nos indican algún valor temporal de las notas, indicaciones de compás, distinción entre figuras largas y breves o divisiones de compás. ${ }^{2}$

\footnotetext{
${ }^{2}$ Para un estudio de la mensurabilidad en la interpretación del canto llano; véase F. Javier Lara Lara, "Los teóricos españoles y la interpretación medida del canto llano" en Nassarre, Revista Aragonesa de Musicología, Vol. 20, n¹, 2004, pp. 103-156.
} 
[N'I]

LIBRO S.S. (olim $\tilde{\text { N}})$

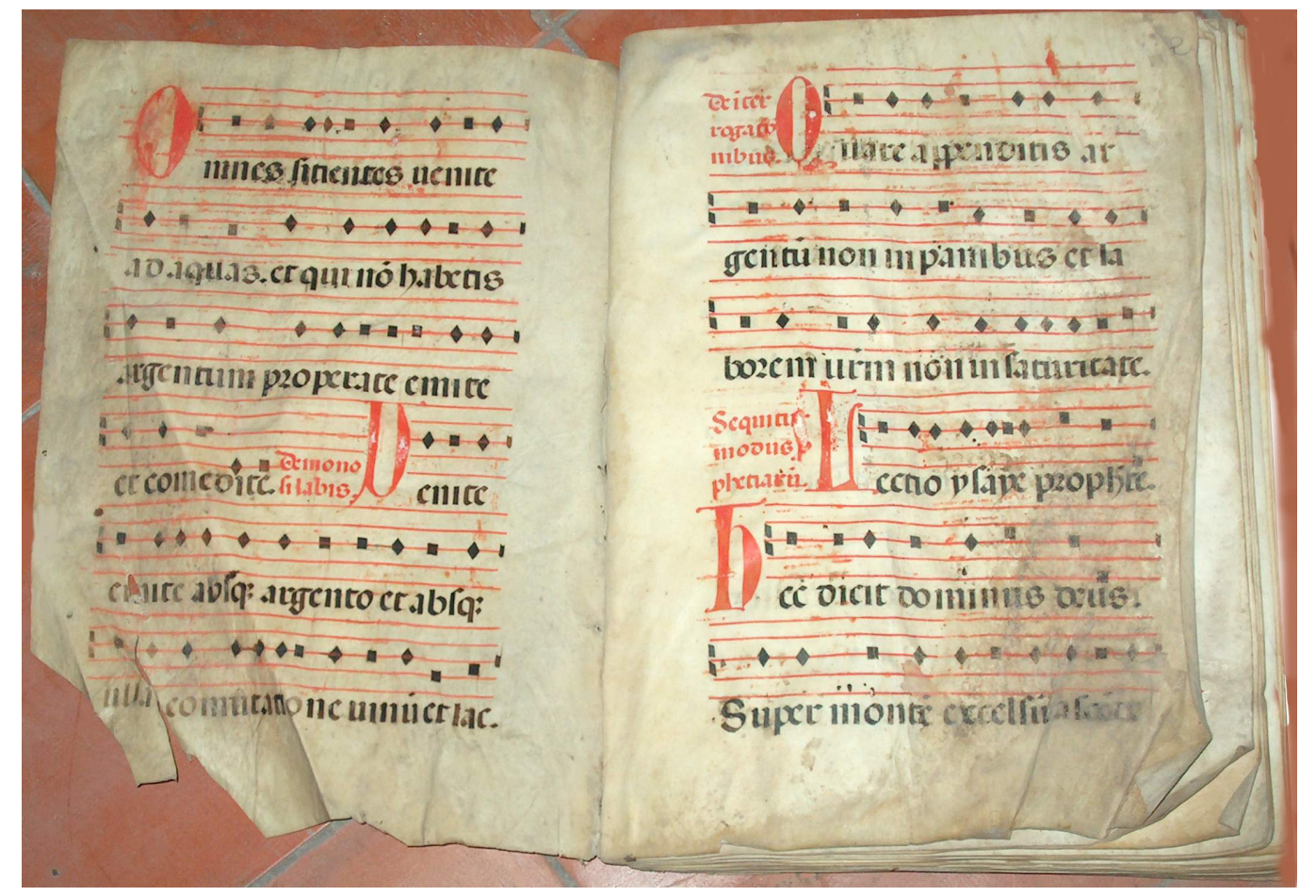




\section{LIBRO S.S. $($ olim $\tilde{\mathbf{N}})$}

Cantoral. Manuscrito sobre pergamino. Seis pentagramas por página.

Medidas: encuadernación: 360 x 265 x 40; hoja 360 x 265; caja 285 x 180 .

Ubicación: Estante A-1.

Foliación: 73 folios en numeración arábiga.

Fecha: Siglo XVI

Incipit:

Fol. $1^{\mathrm{v}}$ Omnes sitientes venite ad aquas et qui non habetis

\section{Festividad o uso litúrgico:}

Intonario.

\section{Otras observaciones:}

Hay restos de inscripciones en la primera hoja pero son ilegibles.

Deteriorado, faltan cubiertas. Contiene el himno a San Juan Bautista "Ut queant laxis", pero en otra versión distinta a la conocida. Véase Capítulo VI del estudio. Contiene las entonaciones de las horas e himnos. 
[N'II]

LIBRO 299 (olim I)

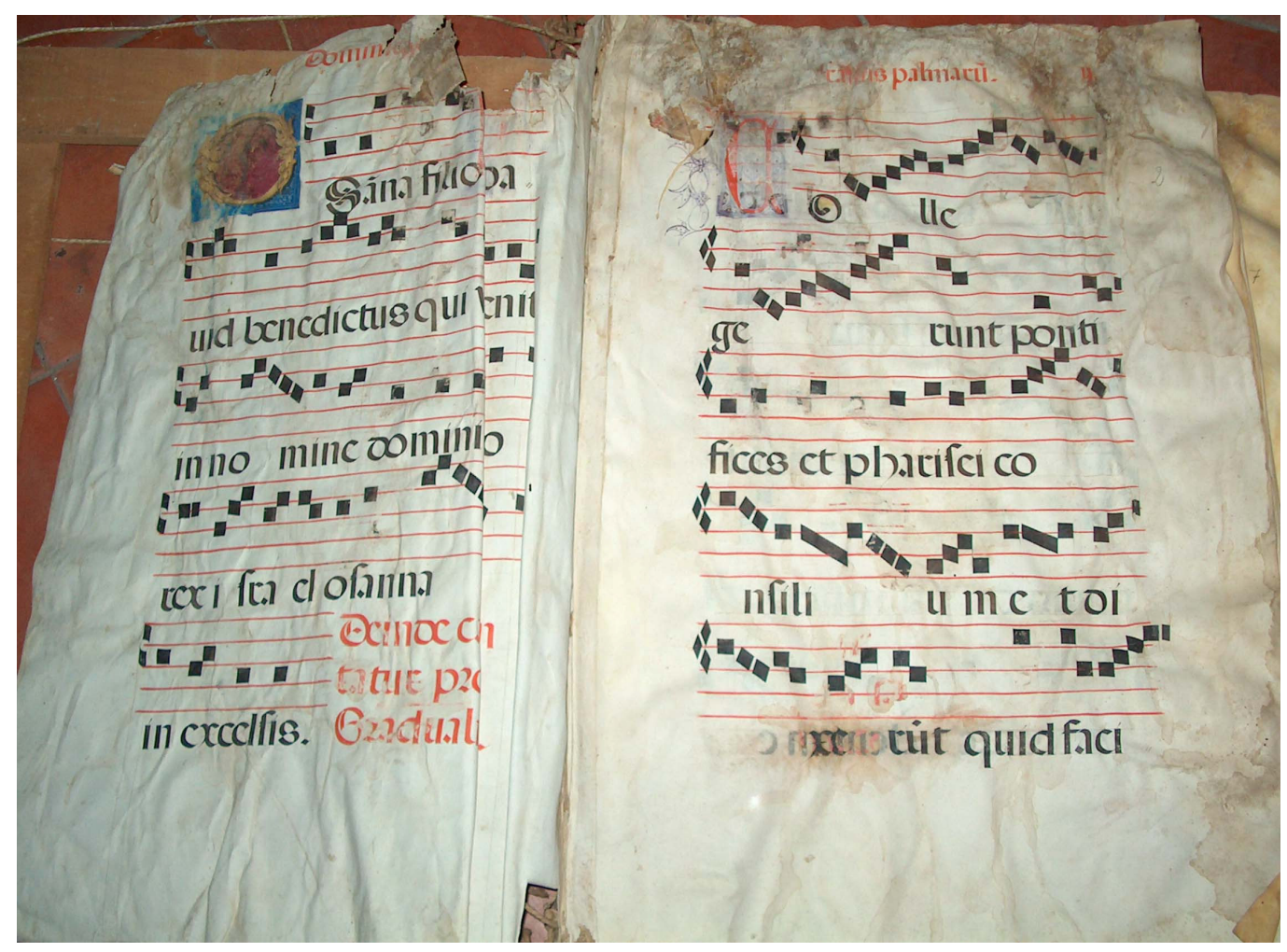




\section{LIBRO No 299 (olim 1)}

Cantoral. Manuscrito sobre pergamino. Cinco pentagramas por página.

Medidas: encuadernación 690 × 480 × 80; hoja 690 × 480; caja 470 × 310 .

Ubicación: Estante A-1

Foliación: 108 folios en numeración romana original, faltan cuatro folios.

Copista: Juan Ramos (corrector)

Fecha: 1558

Incipit texto:

Fol. $1^{\mathrm{v}}$ Osana filio David

\section{Iluminaciones:}

Fol. $1^{\mathrm{v}}$ “O” en color azul, negro y amarillo.

\section{Festividad o uso litúrgico:}

Semana Santa, del Domingo de Ramos al Sábado Santo.

\section{Otras observaciones:}

En el folio CVIII" se encuentra la siguiente inscripción: "Digo yo Juan Ramos beneficiado de cantar que este libro va corregido y enmendado de punto y letra y firmelo yo a seis de Mayo de 1558 años". Mal estado de conservación, sin cubiertas y con la parte superior corroída. La práctica alternatim está señalada en algunas piezas, ver folio LXXI. 
[N'III]

LIBRO 344 (olim 43)

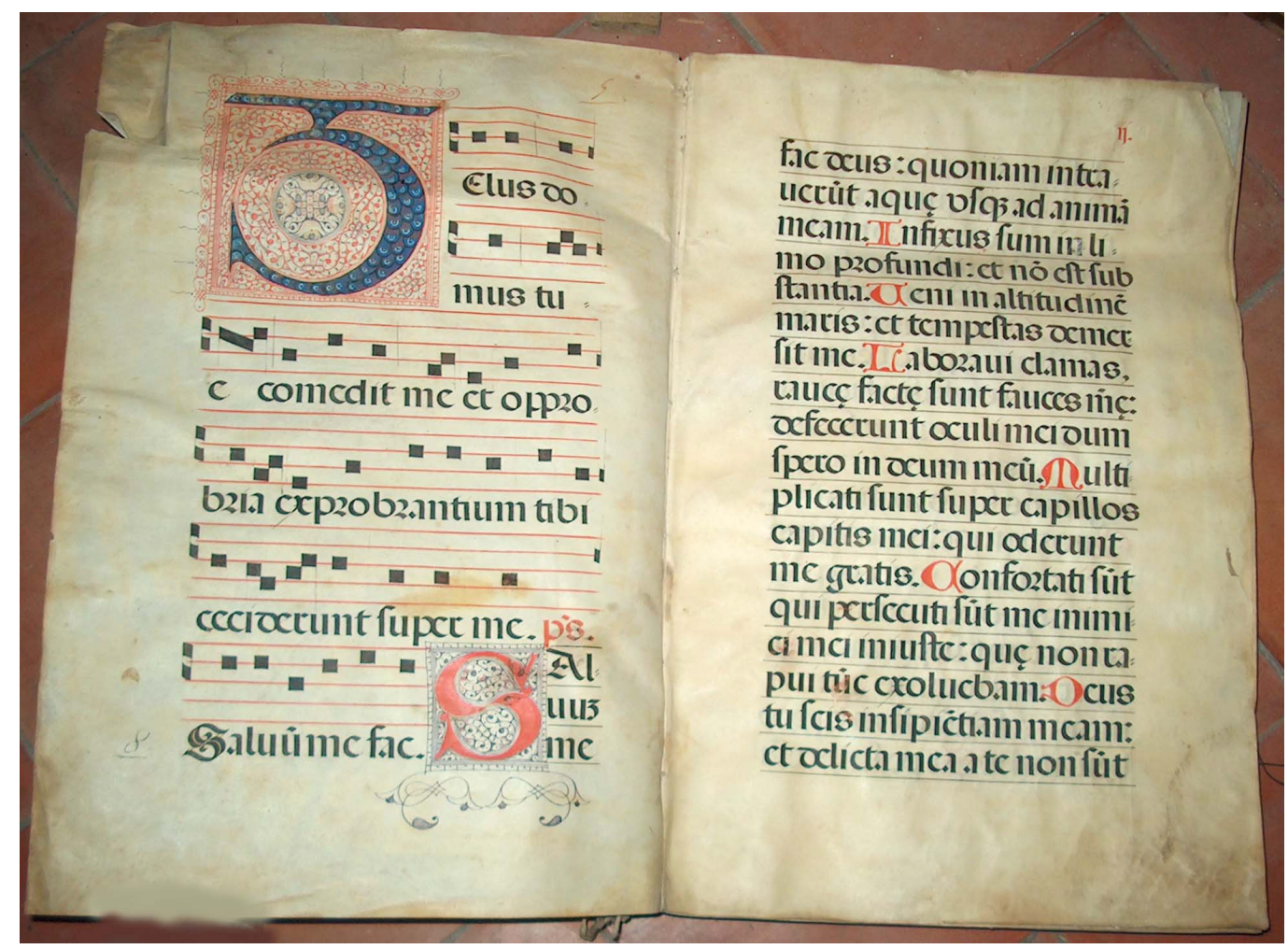




\section{$\left[\mathbf{N}^{\mathbf{0}}\right.$ III $]$}

\section{LIBRO No 344 (olim 43)}

Cantoral. Manuscrito sobre pergamino. Seis pentagramas por página.

Medidas: encuadernación 560 × 390 × 70; hoja 550 × 370; caja 420 × 240 .

Ubicación: Estante A-1

Foliación: 140 folios en numeración romana original, pero hay cinco folios más sin numerar.

Fecha: Siglo XVI

Incipit texto:

Fol. $1^{\mathrm{v}}$ Telus domus tue comedit me et opprobia exprobrantium tibi ceciderunt super me.

Ps. Salvum me fac.

\section{Iluminaciones:}

Fol. $1^{\mathrm{V}}$ “T” en tinta roja y azul (140 x 140). Decoración múdejar.

\section{Festividad o uso litúrgico:}

Nocturnos y oficios de Semana Santa(Libro Semana Mayor)

\section{Otras observaciones:}

Sin pastas. Alterna secciones con música y secciones con oraciones. 
[N'IV]

LIBRO 378 (olim J)

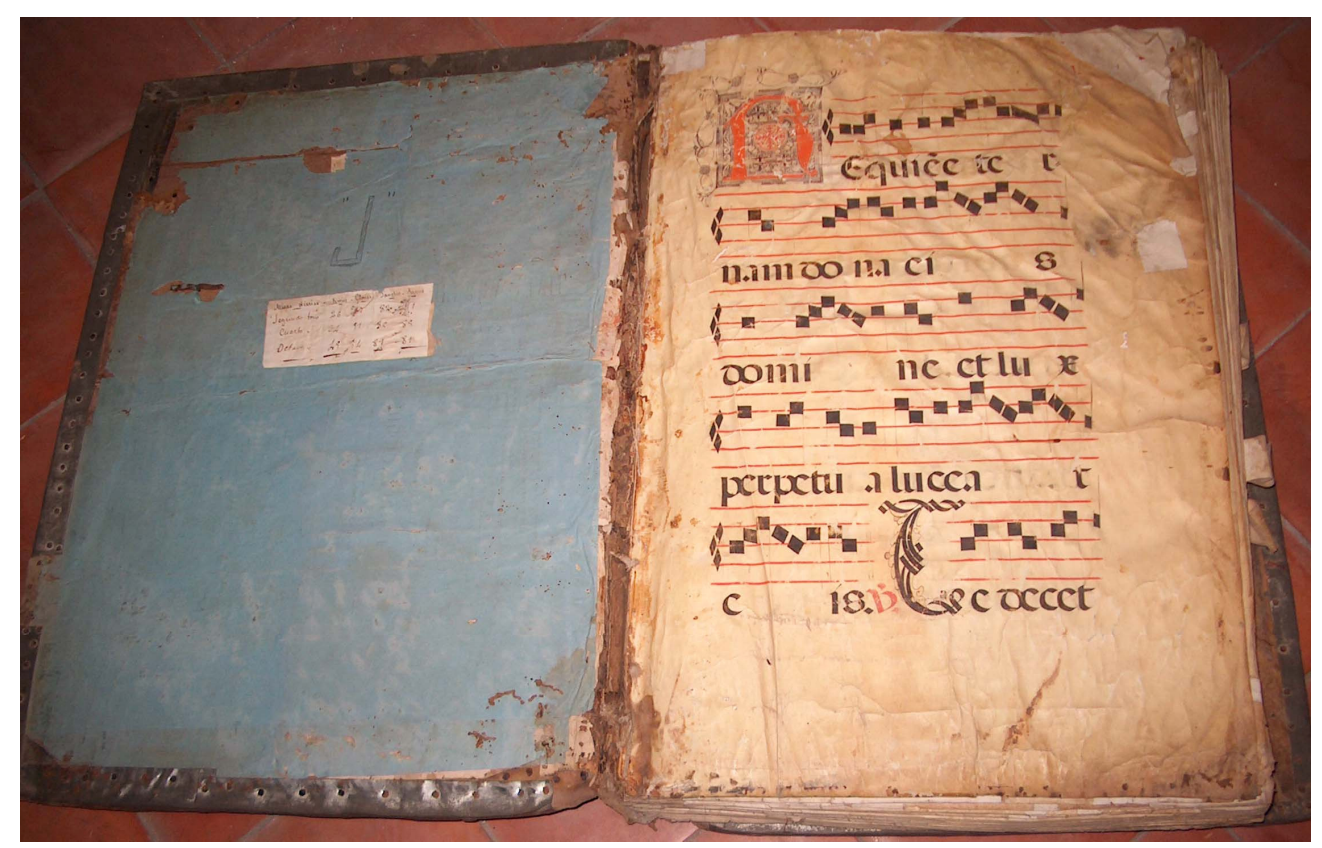




\section{LIBRO 378 / J /quirial}

Cantoral. Manuscrito en pergamino. Cinco pentagramas por página.

Medidas: encuadernación 735 × 545 × 115; hoja 700 × 470; caja 490 x 320

Ubicación: Estante C-2

Foliación: 112 folios en numeración romana original.

Fecha: Siglo XVI

Incipit:

Fol. $1^{\mathrm{r}}$ Requiem aeternam dona eis

\section{Festividad o uso litúrgico:}

Misa de difuntos y Ordinario de las Misas diarias en segundo, cuarto y octavo tono.

Índice:

Hoja de guarda:

\begin{tabular}{|l|l|l|l|l|}
\hline $\begin{array}{l}\text { Misas } \\
\text { Diarias }\end{array}$ & Kyrie & Gloria & Sanctus & Agnus \\
\hline $2^{\mathbf{o}}$ Tono & 26 & & 82 & 41 \\
\hline $4^{\mathbf{o}}$ Tono & 34 & 91 & 89 & 89 \\
\hline $8^{\mathbf{o}}$ Tono & 49 & 94 & 91 & 81 \\
\hline
\end{tabular}

\section{Otras observaciones:}

Está bien conservado y en las guardas hay restos de libro impreso. En el folio $34^{\mathrm{v}}$ aparece el tropo Kyrie Cunctipotens y otros Kyries tropados. Para un estudio de estos Kyries véase el Capítulo VI de este estudio. 
[ $\left.\mathrm{N}^{\circ} \mathrm{V}\right]$

LIBRO 376 (olim H)

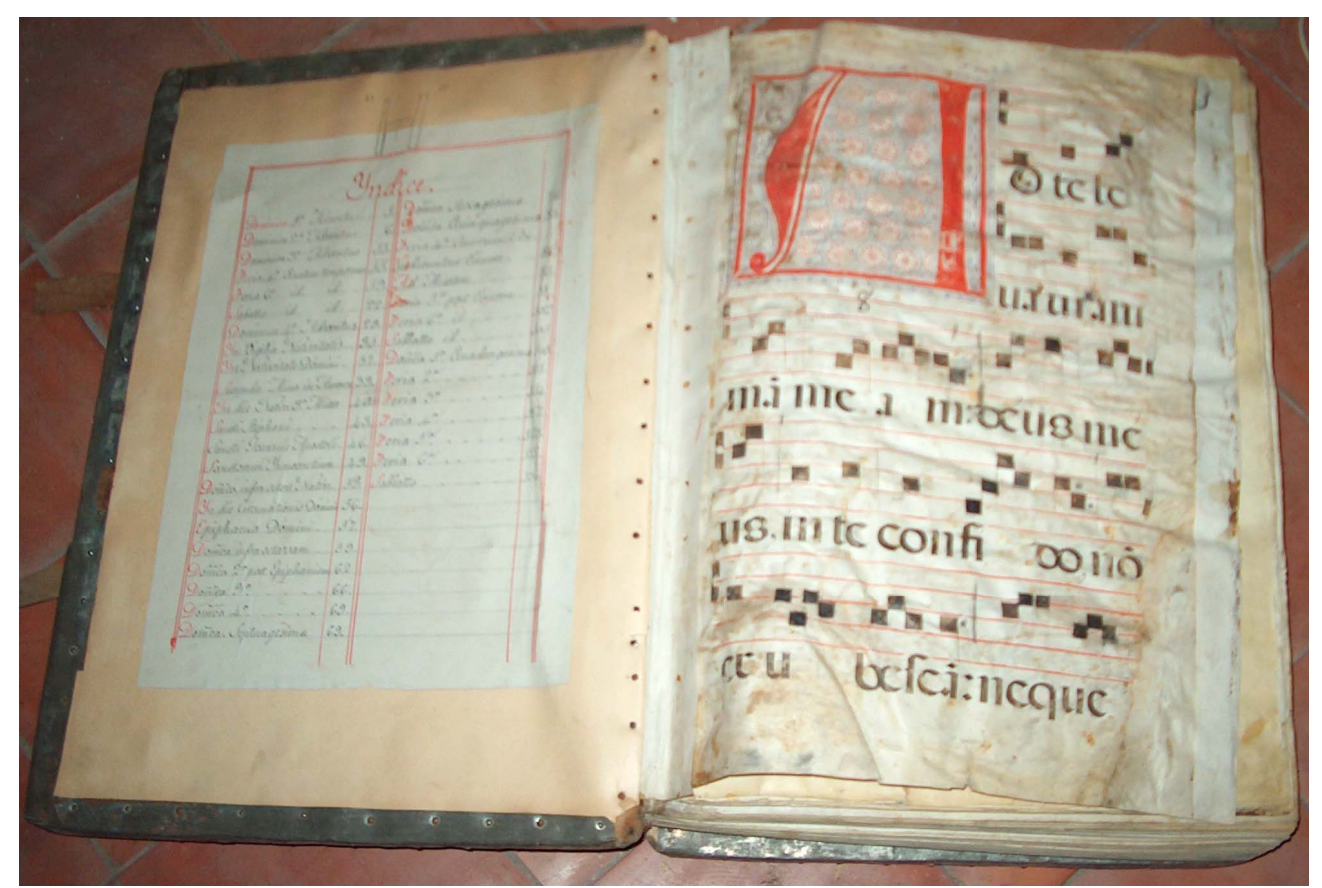




\section{$\left[\mathbf{N}^{\circ} \mathbf{V}\right]$}

\section{LIBRO 376 / H / 1}

Libro de Misas. Manuscrito en pergamino de 146 folios. Cinco pentagramas por página.

Medidas: encuadernación 630 × 475 × 130; hoja 560 × 430; caja 470 × 320 .

Ubicación: Estante A-1

Foliación: 146 folios en numeración romana original.

Fecha: ¿Siglo XVII?

Incipit texto:

Fol. $1^{\mathrm{v}}$ Ad te levavi animam meam

\section{Iluminaciones:}

Fol. $1^{\mathrm{v}}$ "A” en rojo y decoración en tinta azul (180 x 190)

Fol. $11^{\mathrm{r}}$ "P” en rojo y decoración en tinta azul (185 x 170)

\section{Festividad o uso litúrgico:}

Misas desde el primer domingo de Adviento hasta el sábado antes de segundo domingo de cuadragésima.

\section{Índice:}

Hoja de guarda:

Misa $1^{\mathrm{a}}$ Adventus "Ad te levavi" 1/Misa 2a "Populus Sion" 5/ $3^{\mathrm{a}}$ Gaudete in Domino 10/Feria 4a Rorate Coeli 19/Sabato Quatuor Temporum Adventus 22/Dominica $4^{\text {a }}$ Misa Rorate 29/In vigilia Nativitatis "Hodie" 33/Ad primam missam in nocte "Dominus dixit" 37/ Ad secundam ...."Lux fulgebit" 39/ Ad tertiam ..."Puer natus" 40/Misa "Sederunt principes" 43/ Misa "In medio ecclesia" 45/Misa "Ex ore infantium" 49/Dominica infra octava nativitatis Domini 53/In Epiphania Domini "Ecce advenit"57/Dominica infra octavam Epiphania "In excelsis" 60/Dominica 2a post Epiphaniam 65/

\section{Otras observaciones:}

El libro está en buen estado de conservación. La mayoría de las piezas son de estilo marcadamente melismático. En el Índice general de los Libros de Coro aparece como "Libro 1". 

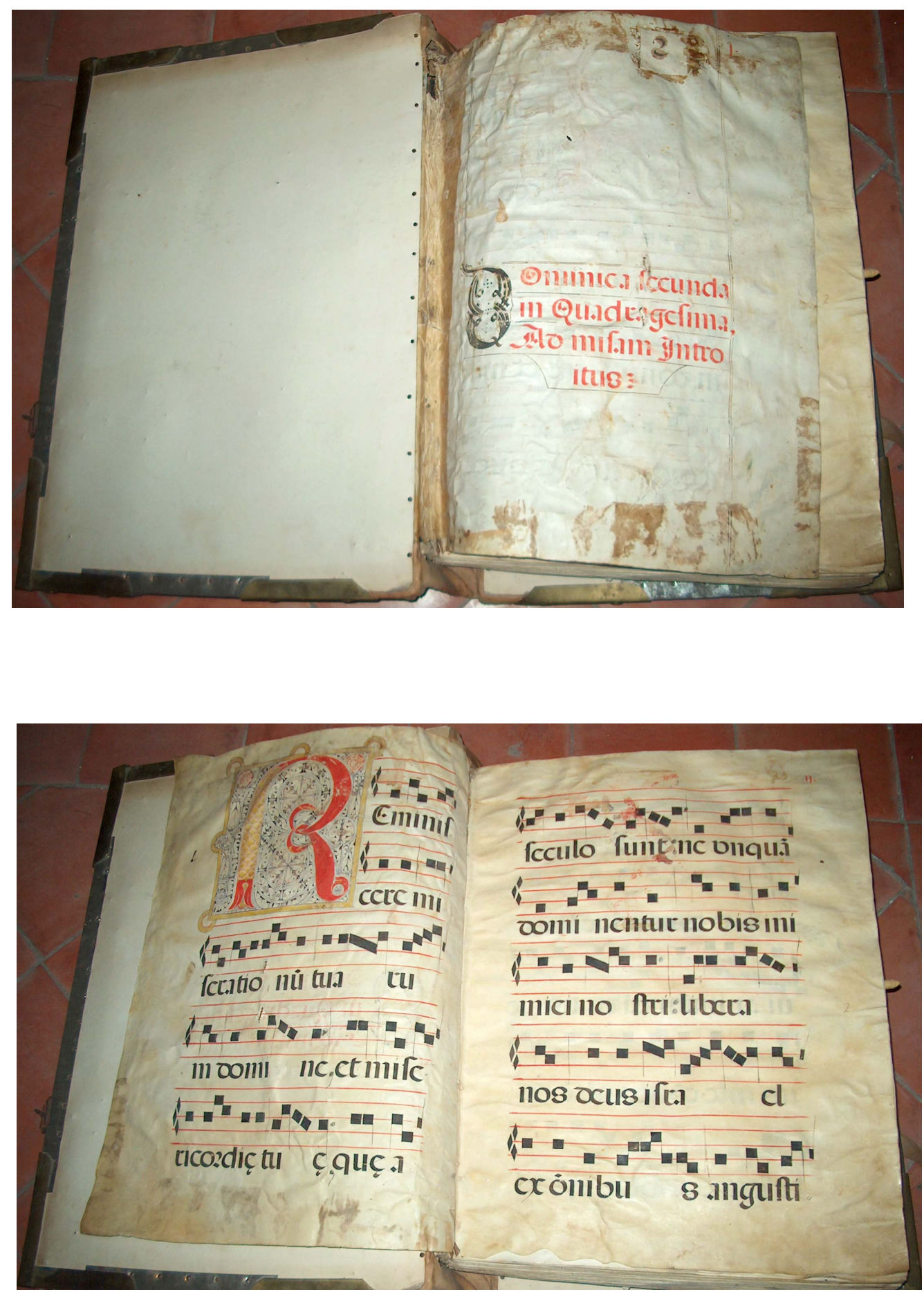


\section{$\left[\mathbf{N}^{0} \mathbf{V I}\right]$}

\section{LIBRO 300 (olim 2)}

Libro de Misas. Manuscrito en pergamino de 153 folios. Cinco pentagramas por página.

Medidas: encuadernación 685 × 500 × 170; hoja 590 × 460; caja 490 × 310 .

Ubicación: Estante A-1

Foliación: 153 folios en numeración romana original.

Fecha: Siglo XVI

Incipit:

Fol. $1^{\mathrm{v}}$ Domenica secunda in Quadragésima, ad Misam introitus

\section{Iluminaciones:}

Fol.1 " $\mathrm{V}$ " en tinta roja, amarilla y azul. (195 x 195).

\section{Festividad o uso litúrgico:}

Propio de las misas de Domingos de Cuadragésima, Pasión y Semana Mayor .

Índice:

Sin índice.

\section{Otras observaciones:}

lo

Seguía utilizándose en el siglo XIX pues el Índice general de los Libros de Coro presenta como "Libro 2". 
[N $\left.{ }^{\circ} \mathrm{VII}\right]$

LIBRO S.S. (olim 44bis)

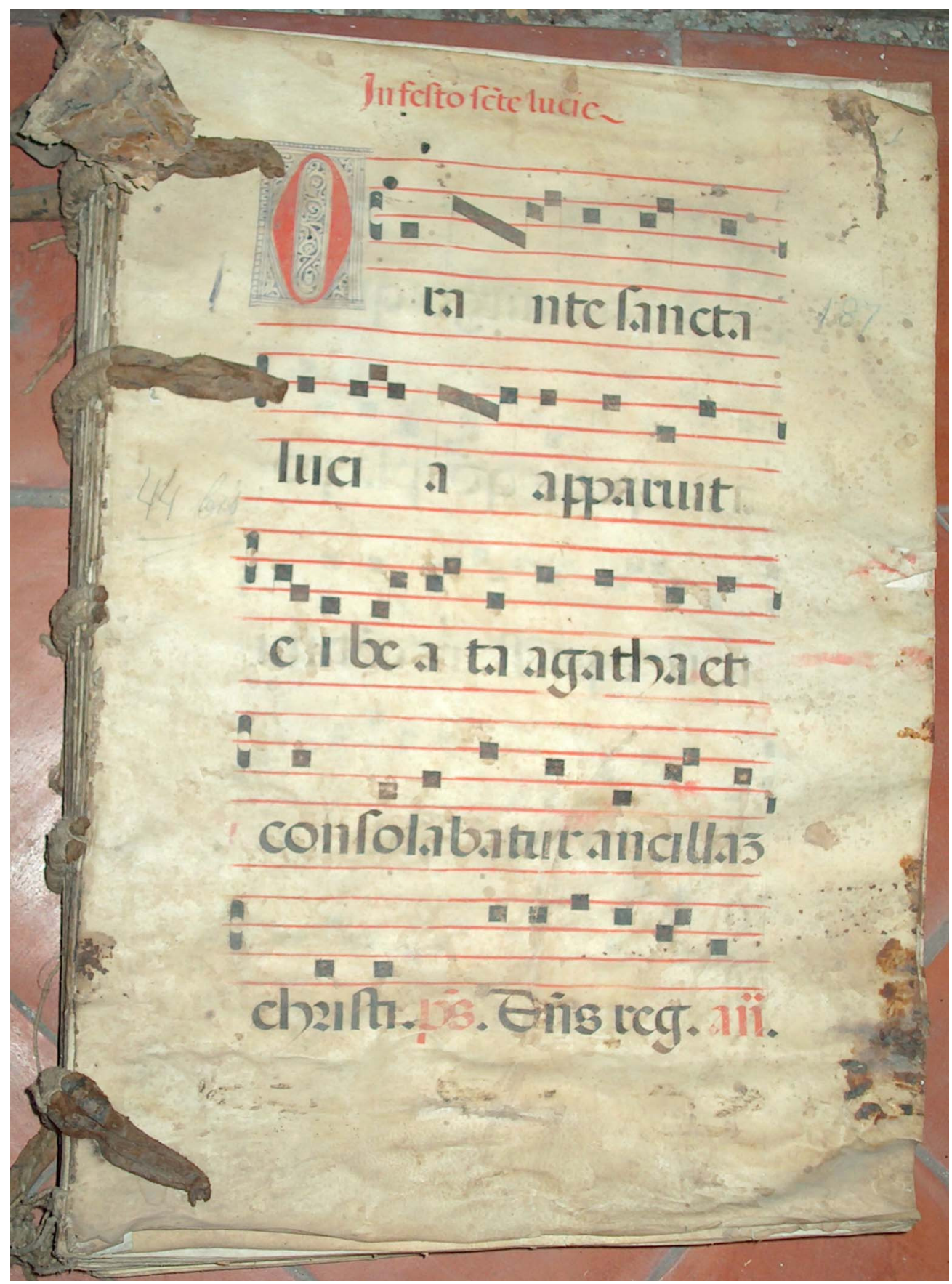




\section{$\left[\mathbf{N}^{0} \mathbf{V I I}\right]$}

\section{LIBRO s.s. / 44bis}

Cantoral. Manuscrito en pergamino de 159 folios. Cinco pentagramas por página.

Medidas: encuadernación: 520 × 370 × 70; hoja 520 × 370; caja 235 × 31 .

Ubicación: Estante A medio

Foliación: 183 folios en numeración arábiga posterior a lápiz. Faltan folios del 2 al 25.

Fecha: Siglo XVI

Incipit:

Fol. $1^{\mathrm{r}}$ Orante sancta Lucia apparuit

\section{Festividad o uso litúrgico:}

Propio de los santos (Vísperas)

Índice:

Sin índice

\section{Otras observaciones:}

Se encuentra deteriorado, le falta la parte inferior y no tiene cubiertas. Para las Vísperas de Santa Lucía existe también el Cantoral 333 olim 33, folio 29, como está indicado en el Índice general de los Libros de Coro. 
[N ${ }^{\circ}$ VIII]

LIBRO 345 / 43bis

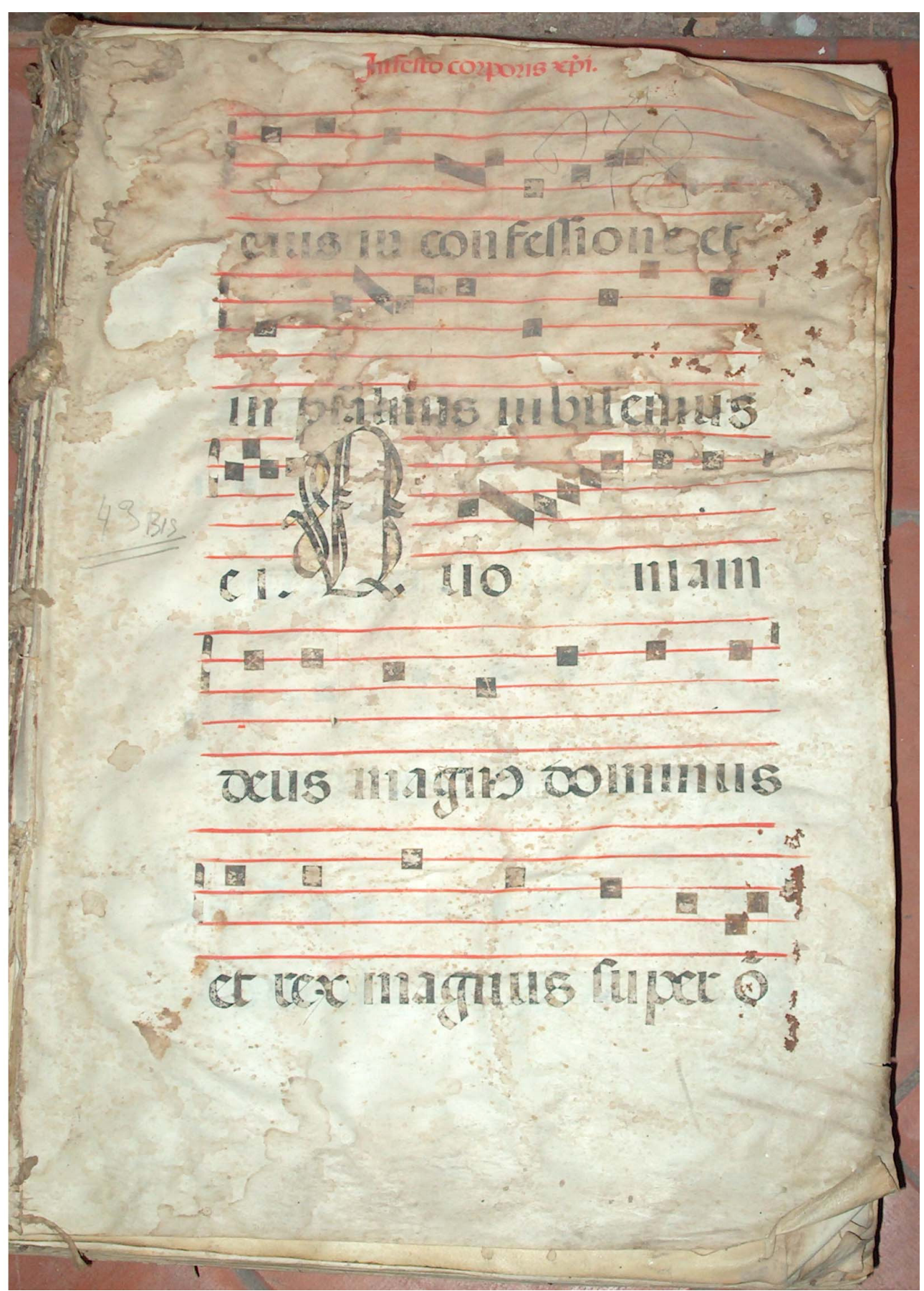


$\left[\mathbf{N}^{0}\right.$ VIII]

\section{LIBRO 345 / 43bis}

Cantoral. Manuscrito en pergamino de 247 folios. Cinco pentagramas por página.

Medidas: encuadernación 520 × 355 × 90; hoja 500 × 340; caja 370 × 240 .

Ubicación: Estante A-1

Foliación: 1-247 en numeración arábiga reciente a lápiz. Al menos le falta primera hoja.

Fecha: Siglo XVI

Incipit:

Fol. $1^{\mathrm{r}}$ In festo corporis Christi/

Fol. $1^{\mathrm{r}}$ [Venite, exultemus Domino ..] eius in confessione

Festividad o uso litúrgico:

Comienza con parte del Invitatorio de maitines de la Fiesta del Corpus Christi.

\section{Otras observaciones:}

Se encuentra bastante deteriorado, sin cubiertas. 
[N ${ }^{\circ}$ IX]

LIBRO 318 (olim 19)
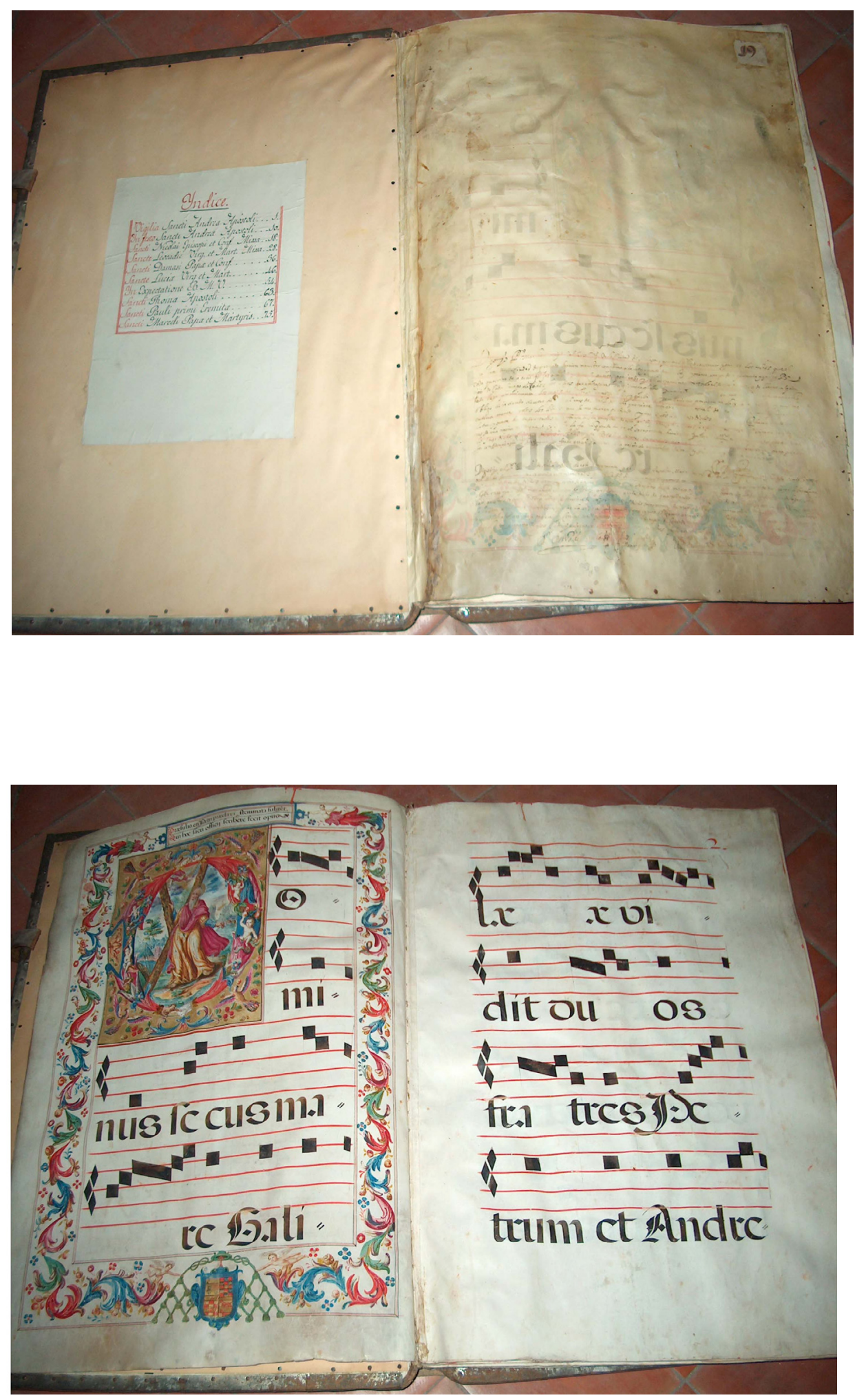


\section{$\left[\mathbf{N}^{\mathbf{0}} \mathbf{I X}\right]$}

\section{LIBRO 318 / 19}

Libro de Misas. Manuscrito en pergamino de 75 folios. Cuatro pentagramas por página.

Medidas: encuadernación 920 × 620 × 110; hoja 880 × 610; caja 640 × 400

Ubicación: Estante B-1

Foliación: 1-75 en numeración original arábiga.

Fecha: Siglo XVII

Incipit:

Fol. $1^{\mathrm{r}}$ Digo yo $\mathrm{P}^{\mathrm{o}}$ Marañón escriptor de libros de la ciudad de Málaga.

Fol. $1^{\mathrm{v}}$ Dominus secus mare

\section{Iluminaciones:}

orla.

Fol. $1^{\mathrm{v}}$ "D” ilustra figura de San Andrés con pájaros. Escudo episcopal en la

\section{Festividad o uso litúrgico:}

Misas del propio de los Santos desde San Andrés a San Marcelo Papa.

\section{Índice:}

Hoja de guarda:Indice/ Vigilia Sancti Andrea Apostoli 1 / In festo 10/ Sancti Nicolai Episcopi et Conf Missa 18 / Sanct Leocadie Virg et Mart Missa 28 / Sancti Damasi papae et Conf Missa 36 / Sancte Luciae Virg et Mart 46 / In Expectatione BMV 54 / Sancti Thomae Apostoli 63 / Sancti Pauli Primi Eremite 67/ Sancti Marceli Papae et Martyris 75

\section{Otras observaciones:}

Muy buen estado de conservación. Una inscripción en la cartela sobre la ilustración dice: "Praesulis en Petri praeclari stemmata fulgent, Qui hoc sacri oficii scribere fecit opus", clara alusión al mecenazgo de los libros por Pedro de Castro, fundador de la Abadía y Arzobispo de Granada ${ }^{3}$.

\footnotetext{
${ }^{3}$ Ver estudio introductorio para más información sobre esta cartela.
} 

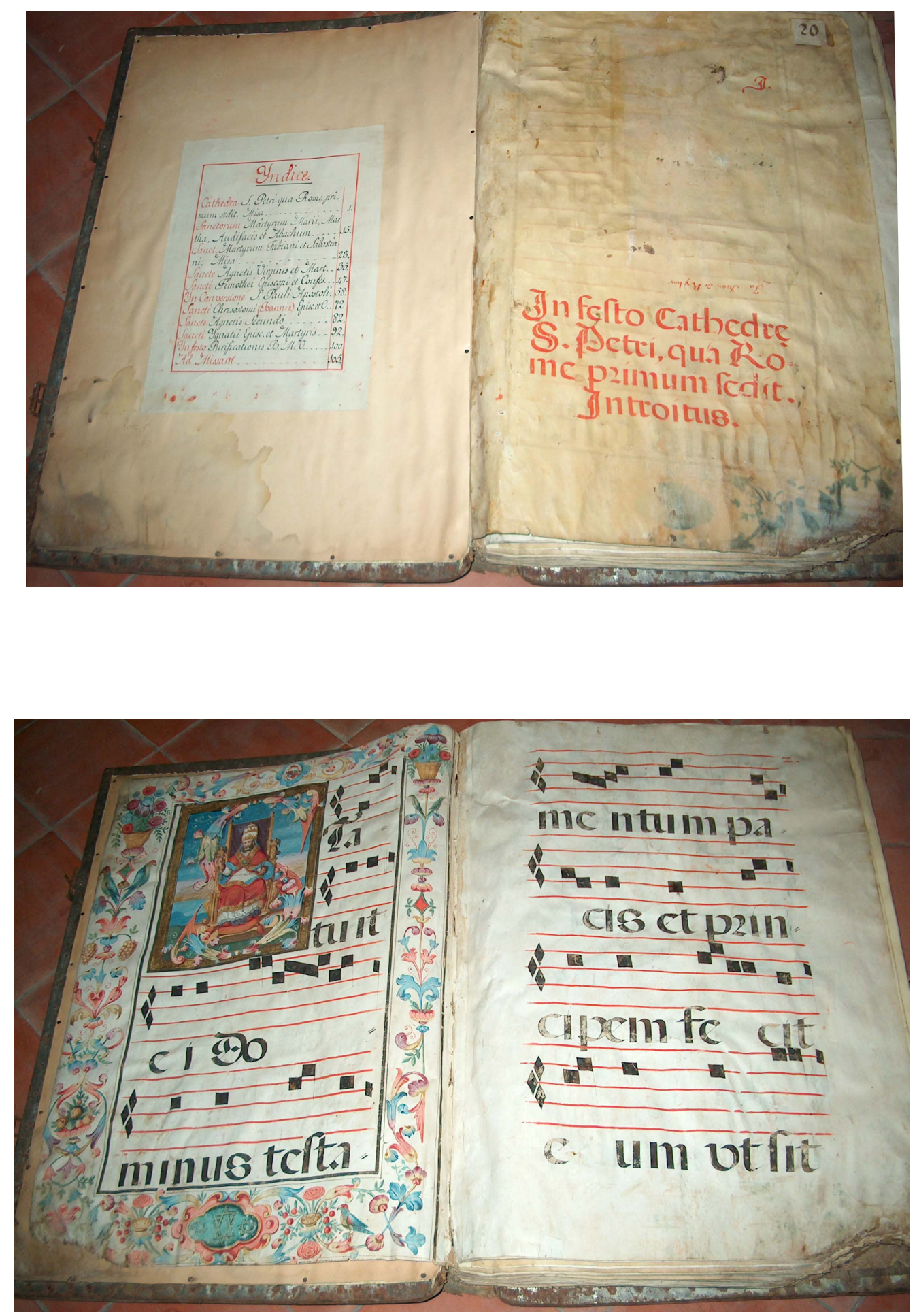
Libro de Misas. Manuscrito en pergamino de 117 folios. Cuatro pentagramas por página.

Medidas: encuadernación 870 × 615 × 160; hoja 810 × 570; caja 640 × 380 .

Ubicación: Estante C-1

Foliación: 1-117 en numeración arábiga original.

Fecha: Siglo XVII

Incipit:

Fol. $1^{\mathrm{r}}$ In festo Cathedre S.Petri, qua Rome primun fedit. Introitus

Fol. $1^{\mathrm{v}}$ Statuit ei Dominus testamentum

\section{Iluminaciones:}

Fol.1" "S" ilustra San Pedro en su cátedra. Orla con aves y granadas.

Fol.104 Circuncisión de Jesús: sacerdote con monaguillo, la Virgen sostiene a Jesús recién nacido. Orla con aves y ángeles

\section{Festividad o uso litúrgico:}

Misas desde la fiesta de San Pedro en su cátedra hasta la misa de la fiesta de la Purificación de la Virgen.

\section{Índice:}

Hoja de guarda:

Indice / In festo Cathedre S.Petri 1/ Sanctorum Martyrum Marii Martha.

Audifacis et Abachum 15 / Sanct. Martyrum Fabiani et Sabastiani Misa 23/

Sancta Agnetis Virginis et Mart 35 / Sancti Timothei Episcopi et Confes 47 / In

Conversione Pauli Apostoli 58/ Sancti Chrisostomi (Joannis) Episc.etc 72/

Sancte Agnetis Secundo 82/ Sancti Ygnatii Episc. Et Martyris 92/ In festo

Purificationis BMV 100/ Ad Missam 105

\section{Otras observaciones:}

Se conserva bien, aunque la esquina inferior derecha de todos los folios está roída Una inscripción en el fol. $1^{\mathrm{v}}$ encima del título y bocabajo dice: ja Juan de Rybas. 

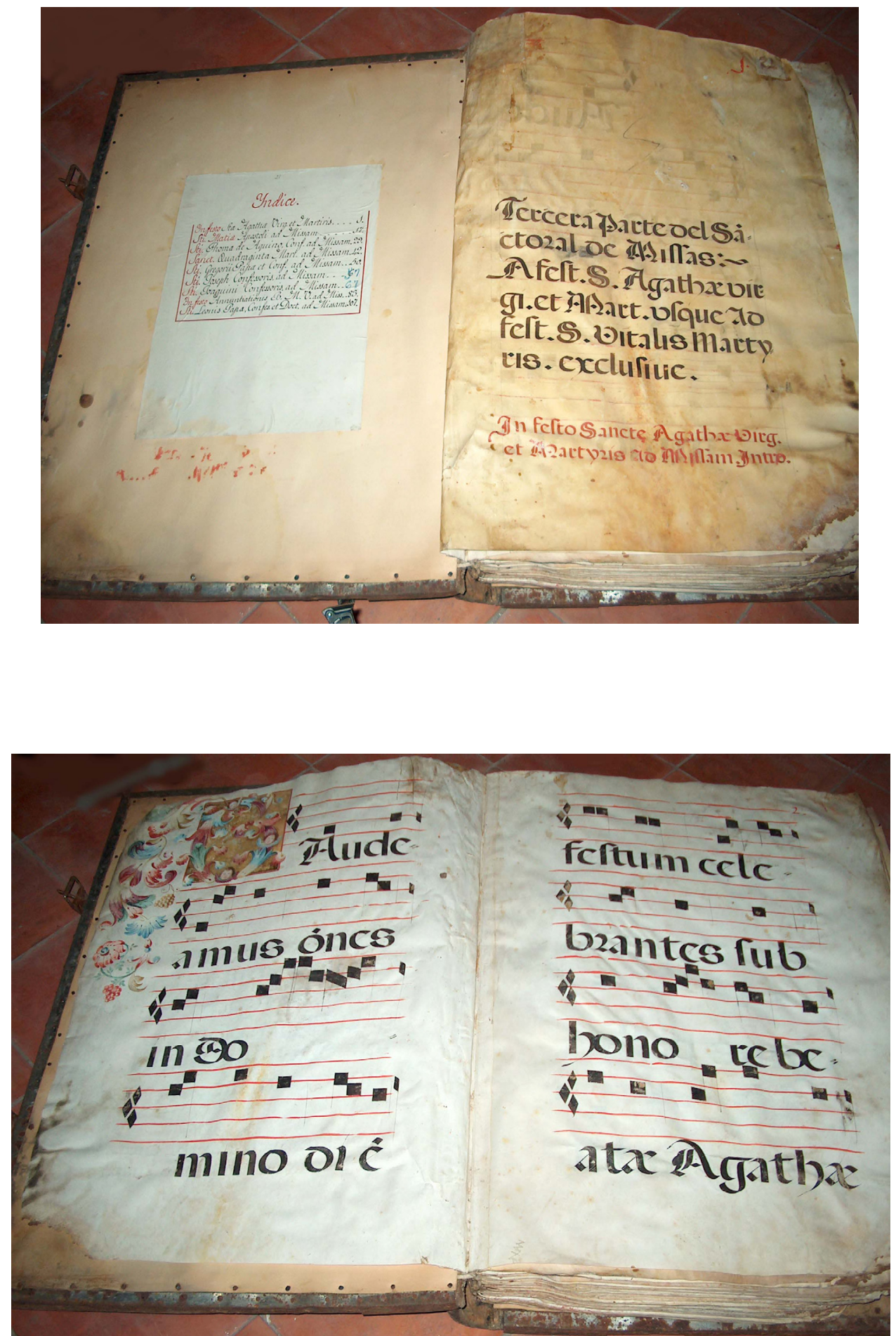
$\left[\mathbf{N}^{\circ} \mathbf{X I}\right]$

LIBRO 320 / 21

Cantoral. Manuscrito en pergamino de 112 folios. Cuatro pentagramas por página.

Medidas: encuadernación 880 × 620 × 130; hoja 810 × 590; caja 630 × 375

Ubicación: Estante C-1

Foliación: 1-112 en numeración arábiga original.

Fecha: Siglo XVII

Incipit:

Fol. $1^{\mathrm{r}}$ Tercera parte del santoral de Missas. Ad fest. S.Agathae virgi et Mart usque ad fest S.Vitalis Martyris exclusive

Fol. $1^{\mathrm{v}}$ Gaudeamus omnes in Domino diem festum

\section{Iluminaciones:}

Fol.1 " G" con querubines, $(170 \times 150)$

Fol.82 "V" Anunciación con orla dorada, (320 x 220)

\section{Festividad o uso litúrgico:}

Propio de las misas desde Santa Águeda a San Vital mártir.

\section{Índice:}

Hoja de guarda:

In festo Sta Agatha Virg. et Martiris 1/ Sti. Matiae Apostoli ad Missam 17/ Sti.

Thomae de Aquino, Conf. Ad Missam 29/ Sanct. Quadraginta Mart. Ad Missam

42/ Sti. Gregorii Papa et Conf. 50/ Sti. Joseph Confessoris 57/ Sti. Joaquini

Confessoris 67/ In festo Annuntiationis B.M.V. 83/ Sti. Leonis Papa, Confes. et Doct 107

\section{Otras observaciones:}

Se estado de conservación es regular pues la esquina inferior derecha está deteriorada. 
[ $\mathbf{N}^{\circ} \mathbf{X I I ]}$

LIBRO 321 / 22
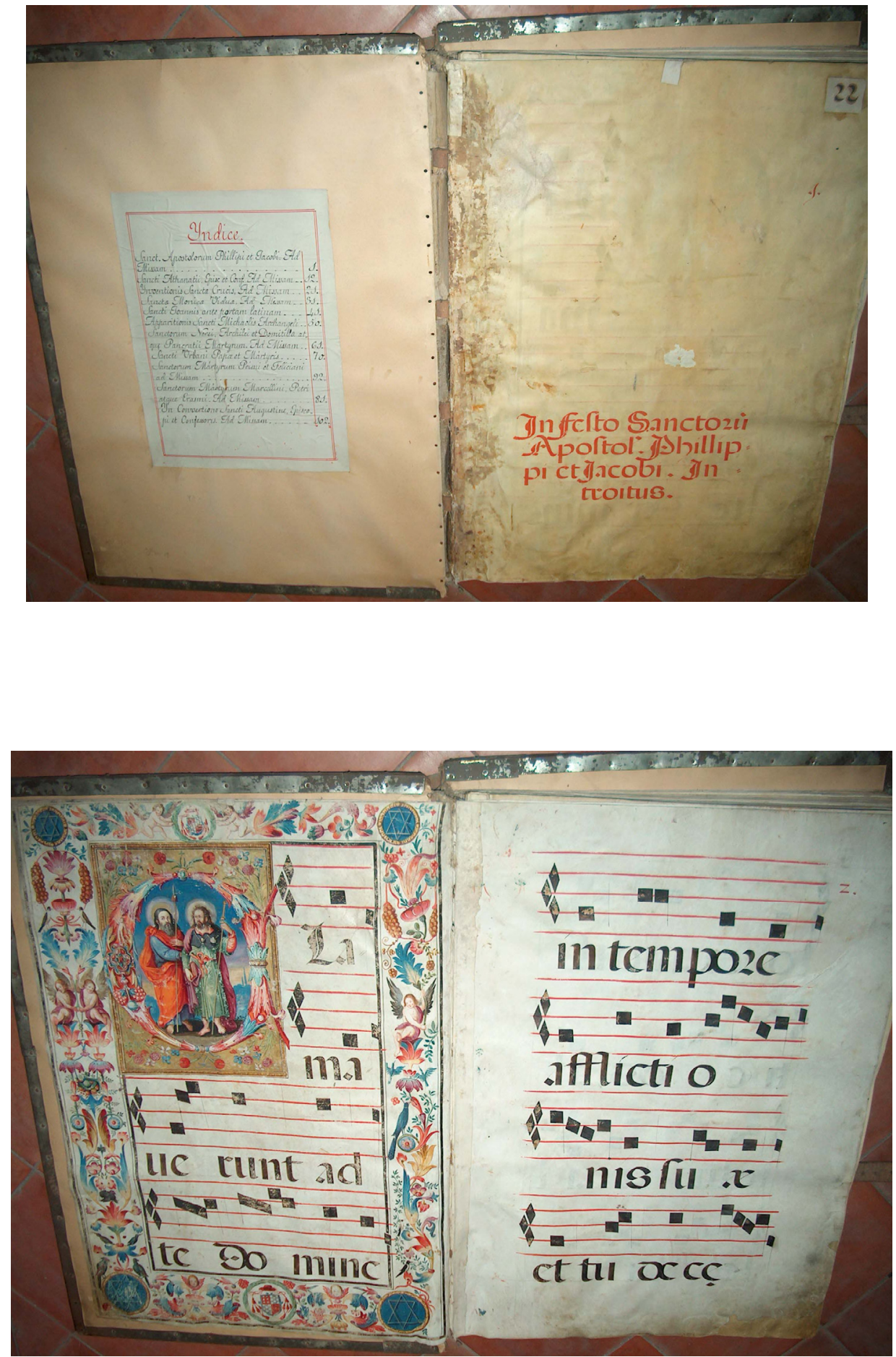
$\left[\mathbf{N}^{\circ} \mathbf{X I I}\right]$

LIBRO 321 / 22

Libro de Misas. Manuscrito en pergamino de 111 folios. Cuatro pentagramas por página.

Medidas: encuadernación 870 × 610; hoja 810 × 590; caja 645 × 380

Ubicación: Estante C-1

Foliación: 1-111 en numeración arábiga, original.

Fecha: Siglo XVII

Incipit:

Fol. $1^{\mathrm{r}}$ In festo Sanctorum Apostol Philippi et Jacobi Introitus

Fol. $1^{\mathrm{v}}$ Clamaverunt ad te Domine

\section{Iluminaciones:}

Fol.1 "C" ilustra Santos Felipe y Santiago

\section{Festividad o uso litúrgico:}

Misas del Propio de los santos desde San Felipe y Santiago hasta San Agustín.

Índice:

Hoja de guarda:

Indice/Sanct.Apostolorum Phillip et Jacobi Ad Missam 1/Sancti Athanantii, Episscet Conf Ad missam 12/Ynventionis Santae Crucis, ad missam 21/ Sancta Monica Vidua Ad Missam 31/Sancti Joannis ante portam latinam 41/Apparitionis Sancti Michaelis Arcangeli 58/Sanctorum Nerei, Archilei et Domitilla atque Pancratii Martyrum ad Missam 61/Sancti Urbani Papa et Martyris 70/Sanctorum Martyrum Primi et Feliciani ad Missam 92/Sanctorum Martyrum Marcellini, Petri atque Erasmi Ad missam 81/In Convertione Sancti Augustine, Episcopi et Confessoris ad Missam 102

\section{Otras observaciones:}

El cantoral se encuentra en buen estado de conservación. 

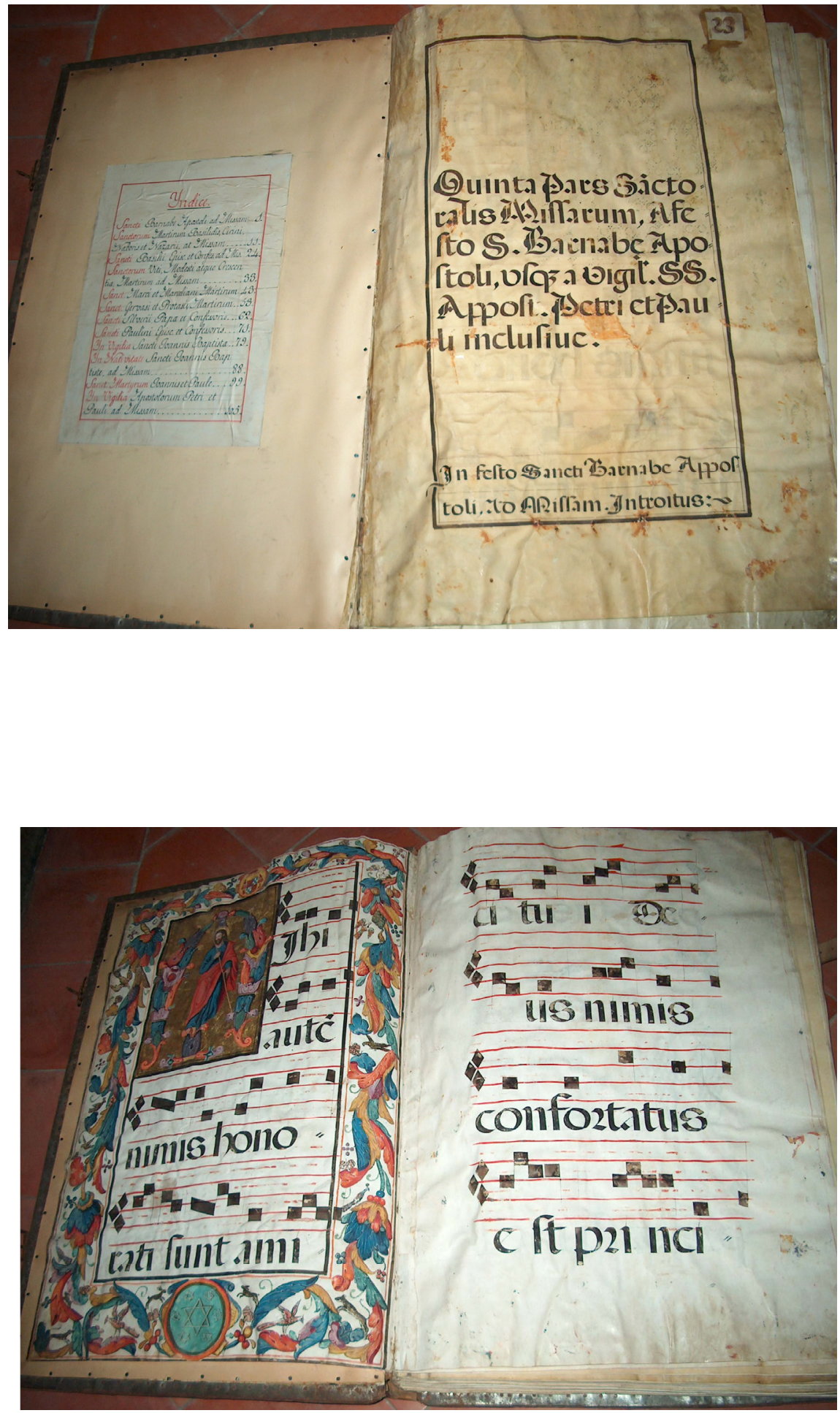
LIBRO 322 / 23

Libro de Misas. Manuscrito en pergamino de 113 folios. Cuatro pentagramas por página.

Medidas: encuadernación 895 × 610 × 125; hoja 820 × 570; caja 640 × 380

Ubicación: Estante C-1

Foliación: 1-113 en numeración arábiga original.

Fecha: Siglo XVII

Incipit:

Fol. $1^{\mathrm{r}}$ Quinta Pars Sanctorum Missarum a festo San Bernabé Apostolis

Fol. $1^{\mathrm{v}}$ Mihi autem

\section{Iluminaciones:}

Fol.1v "M" ilustra figura de Jesucristo, orla sobre fondo dorado, $(240 \times 315)$

Fol.88v “O”ilustra ángeles y niño Jesús, (315 x 255)

\section{Festividad o uso litúrgico:}

Misas del propio de los Santos, desde la San Bernabé hasta vigilia de San Pedro y San Pablo.

\section{Índice:}

Hoja de guarda:

Indice/sancti Bernabe Apostoli ad Missam 1/ Sanctorum Martirum Basilidis, Cirini, Naboris et Nazarii, ad Missam 11/ Sancti Basilii Episc. Et Confes. ad Mis.24/ Sanctorum Viti, Modesti atque Crescentis, Martirum ad Missam 33/ Sanct.Marci et Marceliani Martirum 43/ Sanct. Gervasi et Protasii Martirum 53/ SanctiSilverii Papa et Confesoris 62/ Sancti Paulini Episc. et Confessoris 71/ In VigiliaSancti Ioannis Baptistae 79/ In Nativitate Sancti Ioannis Baptiste, ad Missam 88/Sanct. Martyrum Ioannes et Paule 99/ In Vigilia Apostolorum Petri et Pauli ad Missam 105

\section{Otras observaciones:}

Se encuentra en buen estado de conservación. 
[N ${ }^{\circ}$ XIV]

LIBRO 323 (olim 24)
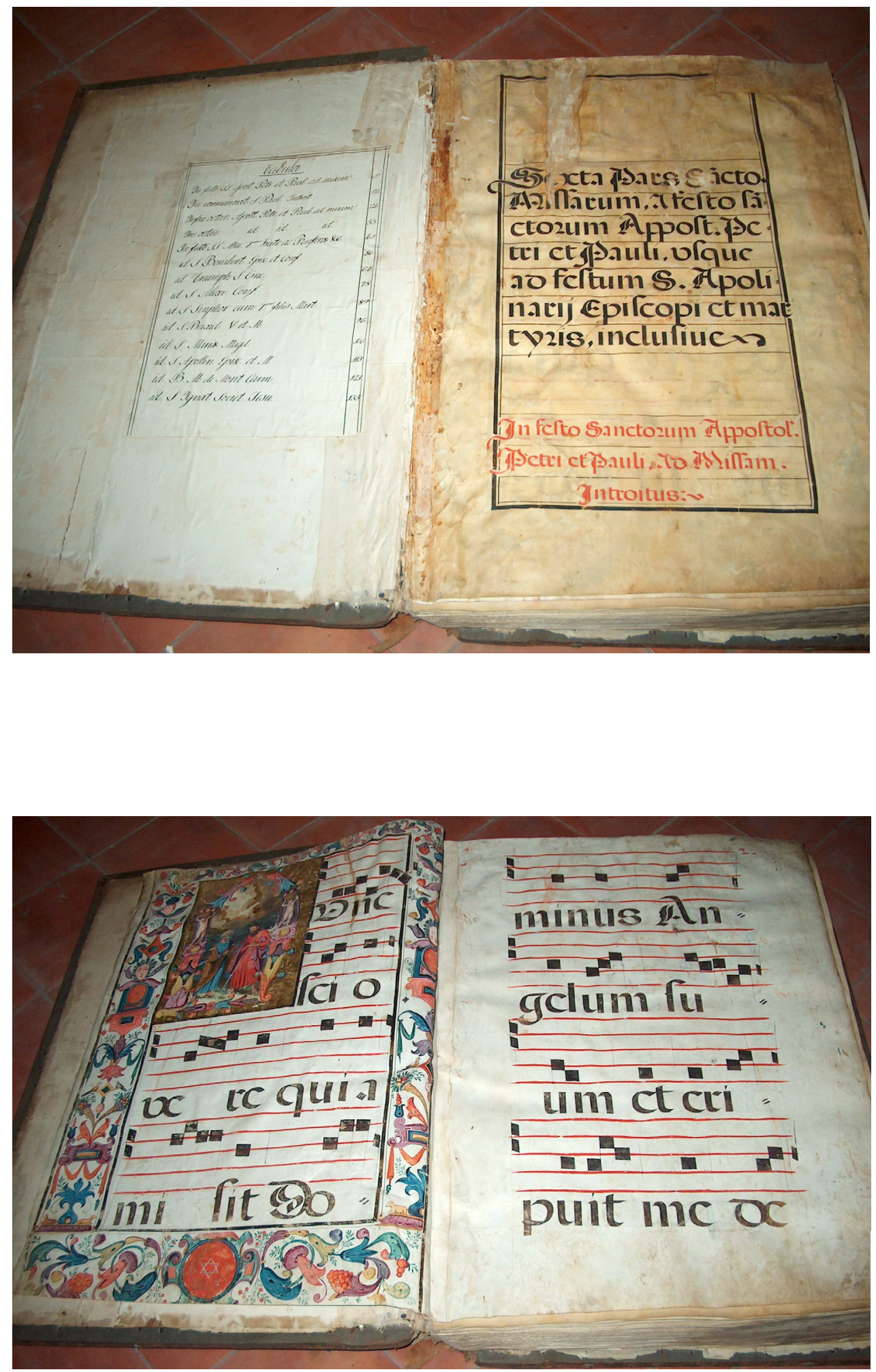


\section{$\left[\mathbf{N}^{0} \mathbf{X I V}\right]$}

\section{LIBRO 323 / 24}

Libro de Misas. Manuscrito en pergamino de 139 folios. Cuatro pentagramas por página.

Medidas: encuadernación 830 × 630 × 155; hoja 780 × 580; caja 640 × 380 .

Ubicación:Estante C-1

Foliación: 1-139 en numeración arábiga original.

Fecha: Siglo XVII

Incipit:

Fol. $1^{\mathrm{r}}$ Sexta pars Sanctorum Missarum a festo Sanct Apostoli Petri et Pauli, usque ad festum S. Apolinarii Episcopi et martyris, inclusive

Fol. $1^{\mathrm{v}}$ Nunc scio vere quia misit Dominus

\section{Iluminaciones:}

Fol.1 "N" ilustra San Pedro y San Pablo, y orla con grutescos (320 x 230)

Fol.124v “G” B.M. Monte Carmelo, grutescos sobre fondo azul (280 x 220)

\section{Festividad o uso litúrgico:}

Misas del propio de los santos desde la fiesta de San Pedro y San Pablo, hasta San Ignacio.

Índice:

Tabula/In festo SS.Apost. Petr. Et Pauli ad missam 1/ In commemorati. S. Pauli Introit 12/ Ynfra octava Apost. Petri et Pauli ad missam 26/ In octav. (Apost. Petri et Pauli ad missam) 33/ In festo SS. Septem Fratrum Martyrum et Rufina et Secunda Virginum et Martyrum 45/ In festo S. Bonavent. Episc. et Conf. 56/ Triumph S. Cruc. 67/ In festo S.Alexi. Conf. 78/ In festo S. Sinphor cum 7 filiis Mart. 89/ In festo S. Bernard. V. et M. 96/ In festo S.Mario Mag. 106/In festo S. Apollin. Episc. et M. 115/ B.M. de Mont. Carm. 125/ In festo S. Ygnat. Societ. Iesu 155

\section{Otras observaciones:}

Se encuentra en buen estado de conservación. 

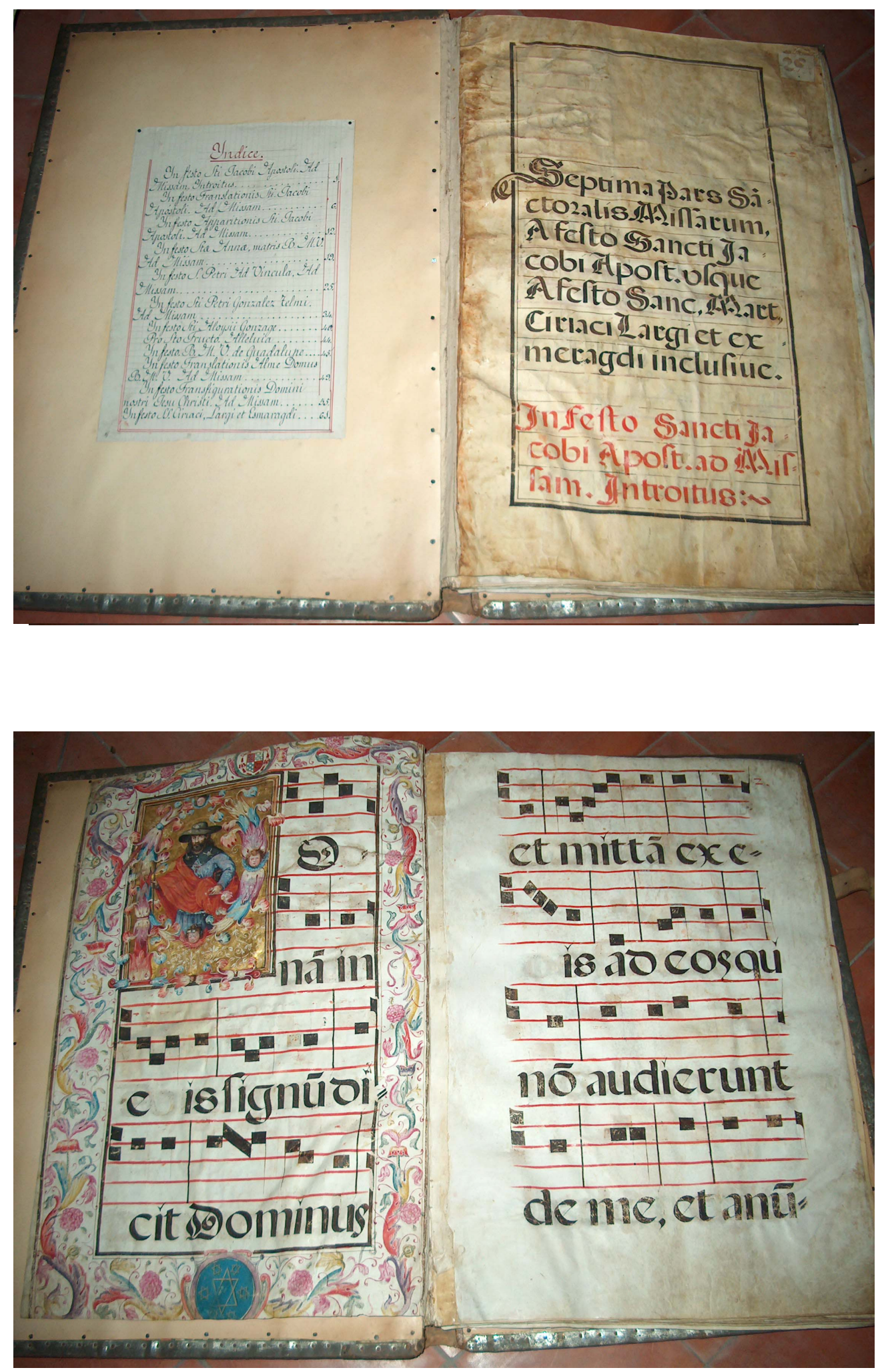


\section{LIBRO 324 / 25}

Libro de Misas. Manuscrito en pergamino de 68 folios. Cuatro pentagramas por página.

Medidas: encuadernación 860 × 600 × 80; hoja 785 × 560; caja 640 × 380 .

Ubicación: Estante B-1

Foliación: 1-68 en numeración arábiga original.

Fecha: Siglo XVII

Incipit:

Fol. $1^{\mathrm{r}}$ Septima pars Sanctor. Missarum. A festo Sancti Iacobii Apost. Usque a festo Sanc. Mart Ciriacs Largi et Smaragdi Inclusive.

Fol. $1^{\mathrm{v}}$ Ponam in eis signum

\section{Iluminaciones:} peregrino.

Fol.1 "P" sobre fondo dorado ilustra figura del Apostol Santiago como

Fol.12 "N" ilustra figura de Santiago matamoros.

Fol.65 ${ }^{\vee}$ ilustra figura de Jesús resucitado.

\section{Festividad o uso litúrgico:}

Misas del propio de los Santos desde Santiago Apostol hasta San Ciriaco.

\section{Índice:}

Hoja de guarda:

Indice/In festo St Jacobi Apostol ad missam Introitus 1/ id traslationis Sti Jacobii Apostoli Ad missam 6/id Aaparitionis Sti Jacobi Apostoli id 12/ id Sancta Anna, matris BMV id 19/id S.Petri ad vincula id 25/id Sti. Petri Gonzalez Teleri aad Missam 34/ id Sti Aloysii Gonzaga 40/Pro Sto Fructo Allelia 44/ In festo BMV de Guadadalupe 45/ In festo translationis Alma Domus BMV ad missam 49/id transfiguracionis Domini nostri Gesu Christi ad missam 55/id SSCiriac, Largi et Esmaragdi 61

\section{Otras observaciones:}

Buen estado de conservación. 


\section{[No XVI] \\ LIBRO 317 (olim 18)}
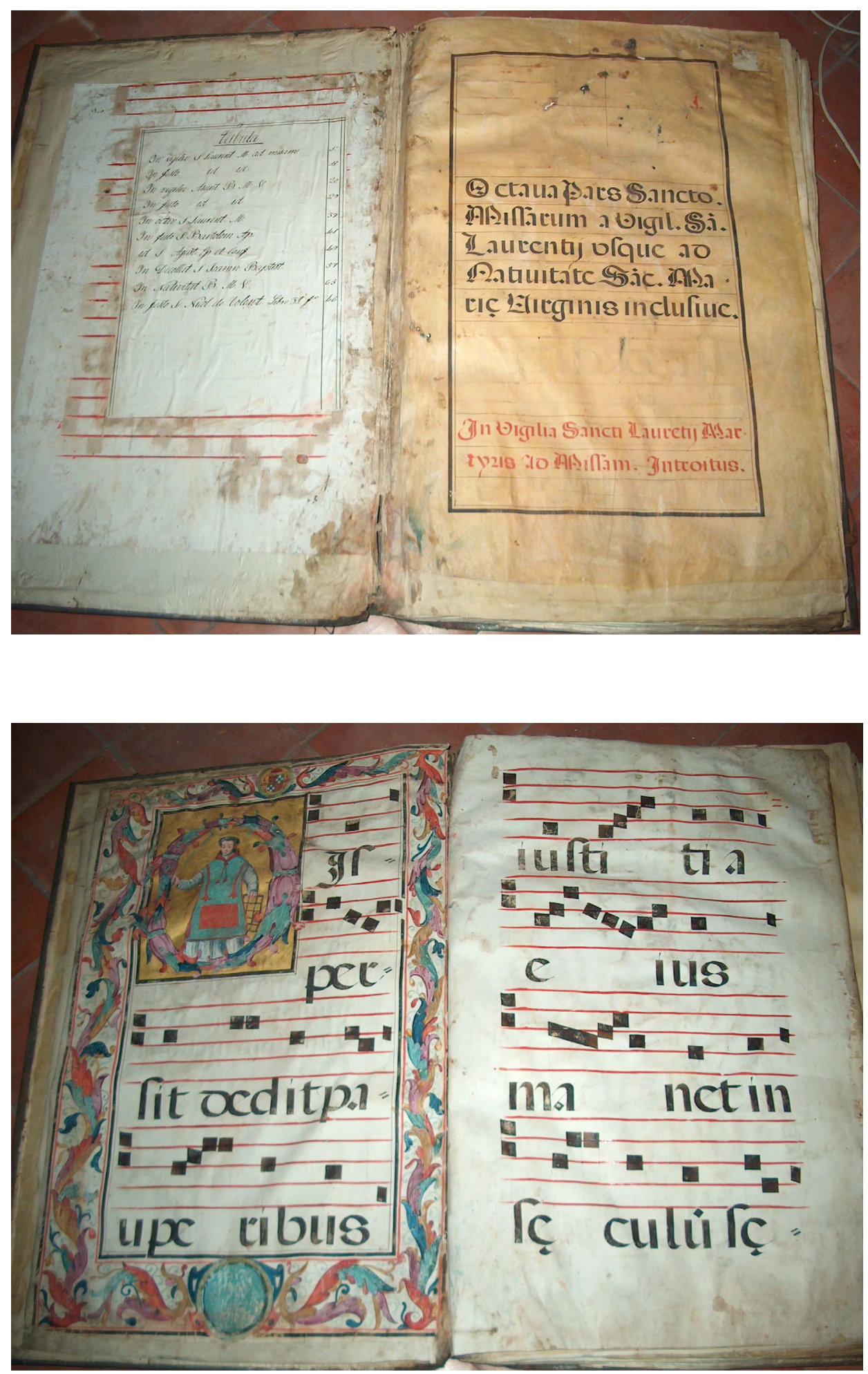
$\left[\mathbf{N}^{0} \mathbf{X V I}\right]$

\section{LIBRO 317 / 18}

Libro de Misas. Manuscrito en pergamino de 77 folios. Cuatro pentagramas por página.

Medidas: encuadernación 860 × 580 × 120; hoja 800 × 550; caja 630 × 370 .

Ubicación: Estante C-2

Foliación: 1-71 en numeración original arábiga, faltan los folios 13 y 14. En el folio 69 continúa la numeración del 66 al 71.

Fecha: Siglo XVII

Incipit:

Fol. $1^{\mathrm{r}}$ Octava pars Sanctorum /Missarum a Vigilia Sant /Laurenty usque ad/ Nativitate Sancta Ma/rie Virginis inclusive

Fol. $1^{\mathrm{v}}$ Dispersit dedis pauperibus

\section{Iluminaciones:}

Fol.1 " "O" ilustra San Lorenzo con parrilla en la mano sobre fondo dorado. Orla con escudo episcopal arriba

Fol.29 " $G$ " ilustra María subida en nube sobre ciudad nueva (Jerusalem), orla sobre fondo oscuro.

Fol.68 " $\mathrm{V}$ " ilustra nacimiento de la virgen, con orla sobre fondo oscuro.

\section{Festividad o uso litúrgico:}

Propio de la misa de santos desde San Lorenzo hasta la Natividad de la Virgen.

\section{Índice:}

Hoja de guarda: Indice/ In Vigilia S Lauren M ad missam 1/ In festo id id 11/ In Vigilia Asunt BMV 20/ In festo id id 29/ In Octava S Laurent M 37/ In festo S Bartoloom Ap 41/ id S.Agusti Ep et Conf 49/ In Decollat S.Joanni Baptist 57/ In Nativitat BMV65/In festo S. Nicol de Tolent libro 31 fol 46

\section{Otras observaciones:}

Se encuentra en buen estado de conservación. 

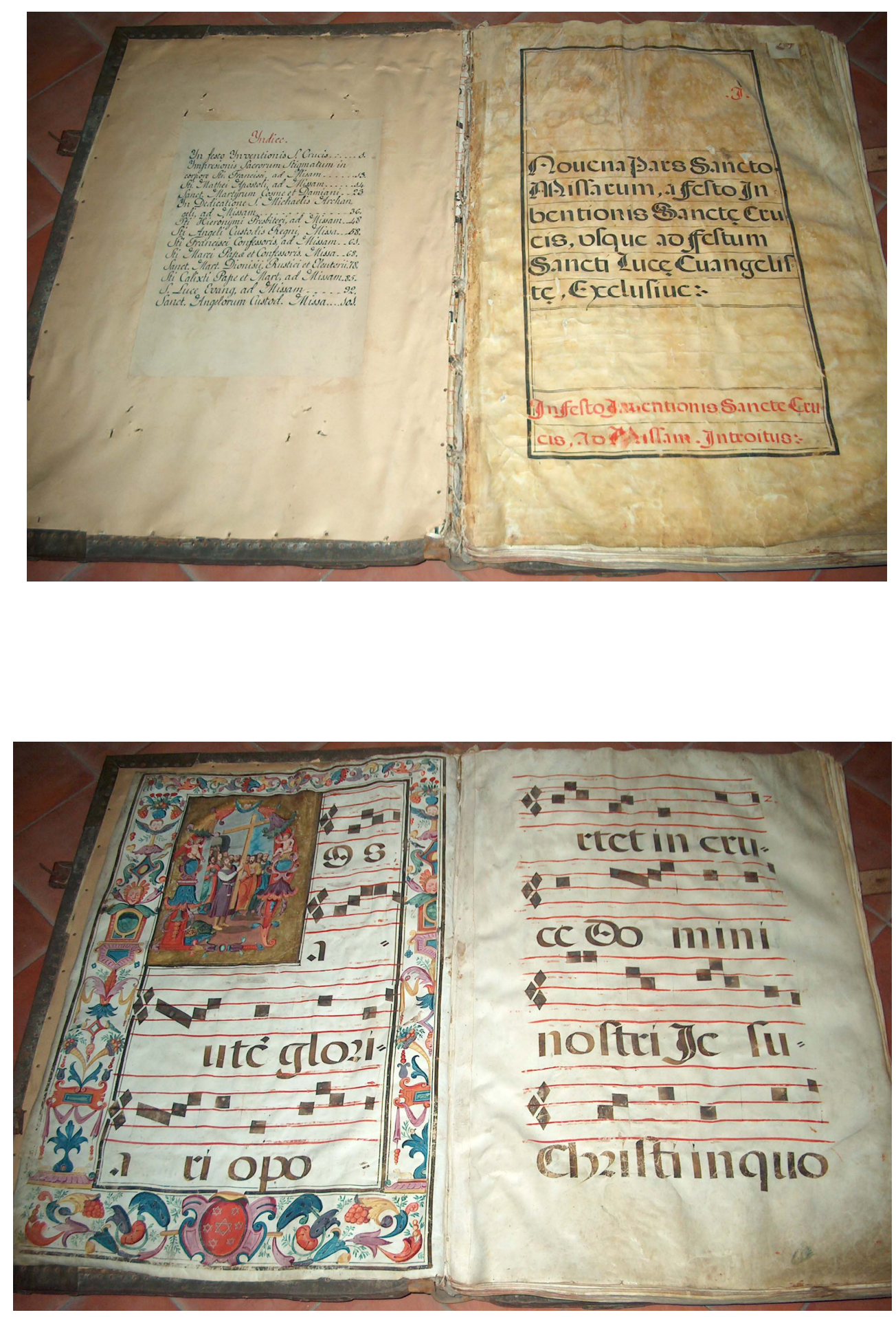
$\left[\mathbf{N}^{0} \mathbf{X V I I}\right]$

LIBRO 326 / 27

Libro de Misas. Manuscrito en pergamino de 104 folios. Cuatro pentagramas por página.

Medidas: encuadernación 890 × 610 × 130; hoja 830 × 585; caja 640 × 380 .

Ubicación: Estante C-1

Foliación: 1-104 en numeración arábiga original.

Fecha: Siglo XVII

Incipit:

Fol. $1^{\mathrm{r}}$ Novena pars Sancto Missarum a festo inventionis Sancte Crucis, usque ad festum Sancti Luce Evangeliste, Exclusive.

Fol. $1^{\mathrm{v}}$ Nos autem gloriari oportet in cruce Domino

\section{Iluminaciones:}

Fol.1 "N” ilustra Jesús con cruz (Invención de la cruz) (325 x 230)

\section{Festividad o uso litúrgico:}

Misas de propio de Santos desde la fiesta de la Invención de la Santa Cruz hasta Santo Ángel Custodio.

\section{Índice:}

Hoja de guarda:

Indice/In festo Ynventionis S.Crucis 1/Ympresionis Sacrorum Stigmatum in corpore Sti. Francisci ad Missam 13/Sti.Mathei Apostoli ad Missam 14/Sanct Martyrum Cosme et Daminiani 23/In dedicatione S.Michaelis archangeli, ad Missam 36/ Sti.Hieronymi Presbiteri ad Missam 48/Sti.Angeli Custodis Regni, Missa 58/Sti.Francisci Confessoris ad Missam 61/Sti.Mar Papa et Confessoris, Missa 68/Sanct. Mart. Dionisii, Rustici et Elenteni 78Sti.Calixti Pape et Mart.

Ad

Missam 85/S.Luce Evang. Ad Missam 92/Sanct. Angelorum Custod. Missa 101

\section{Otras observaciones:}

Se encuentra en buen estado de conservación. 


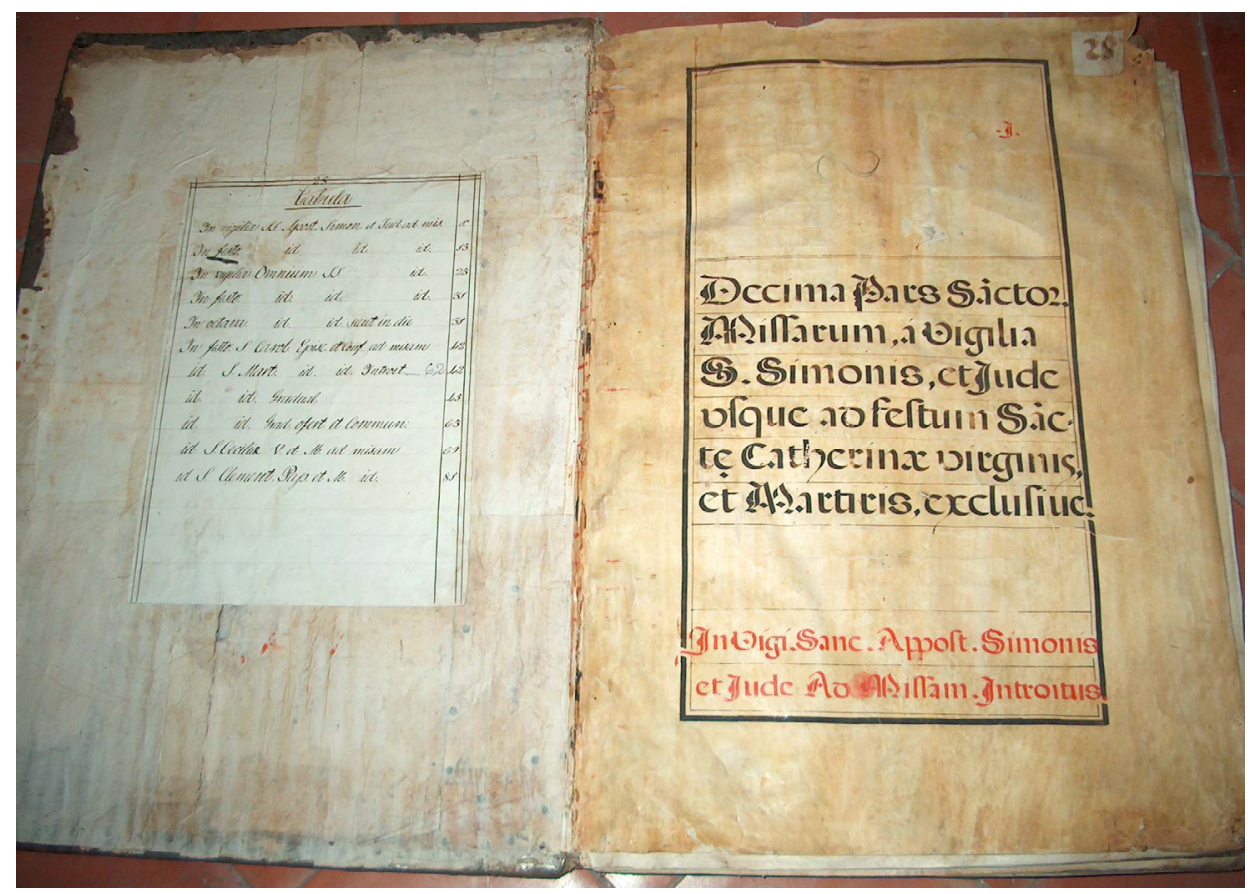




\section{$\left[N^{0}\right.$ XVIII]}

\section{LIBRO 327 / 28}

Libro de Misas. Manuscrito sobre pergamino. Cuatro pentagramas por página.

Medidas: encuadernación 860 x 590 × 85; hoja 810 × 565; caja 630 × 370 .

Ubicación: Estante C-2

Foliación: 87 folios en numeración arábiga original, faltan folios. Número total de folios: 76.

Fecha: Siglo XVII

Incipit:

Fol. $1^{\mathrm{r}}$ Decima pars Sanctos Missarum, a Virgine S.Simonis, et Jude utque ad festum Sacte Catherinae virginis et Martiris, exclusive

\section{Iluminaciones:}

Fol.1 v "I" ilustra San Simón y San Judas. Orla con flores y símbolo de la Abadía.(310 x 240)

Fol.30 "G" ilustra figura de Cristo y todos los Santos. Orla con flores, escudo y símbolo de la Abadía. (320 x 230)

\section{Festividad o uso litúrgico:}

Misas del propio de los santos, desde San Simón y San Judas hasta San Clemente Papa.

\section{Índice:}

Hoja de guarda:

Tabula/ In vigilia SS. Apost. Simon et Jud ad mis. 1/ In festo SS. Apost. Simon et Jud ad mis 15/ In vigilia Omnium SS. Ad mis. 25/ In festo Omnium SS. Ad missam 31/ In octava Omnium SS. Sicut in die 31/ In festo S. Carol. Episc. et Conf. Ad misam 42/ In festo S. Mart. Episc. et Conf. Introit 42 (62)/ In festo S. Mart. Gradual 45/ In festo San Mart. Grad. Ofert. et Communi. 63/ In festo S. Ceciliae V.et M. Ad misam 69/ In festo S. Clement. Pap. et M. id. 81

\section{Otras observaciones:}

Se encuentra en buen estado de conservación y parece contener un fascículo añadido. 


\section{[N $\mathbf{N}^{0} \mathbf{X I X ]}$ \\ LIBRO 316 (olim 17)}
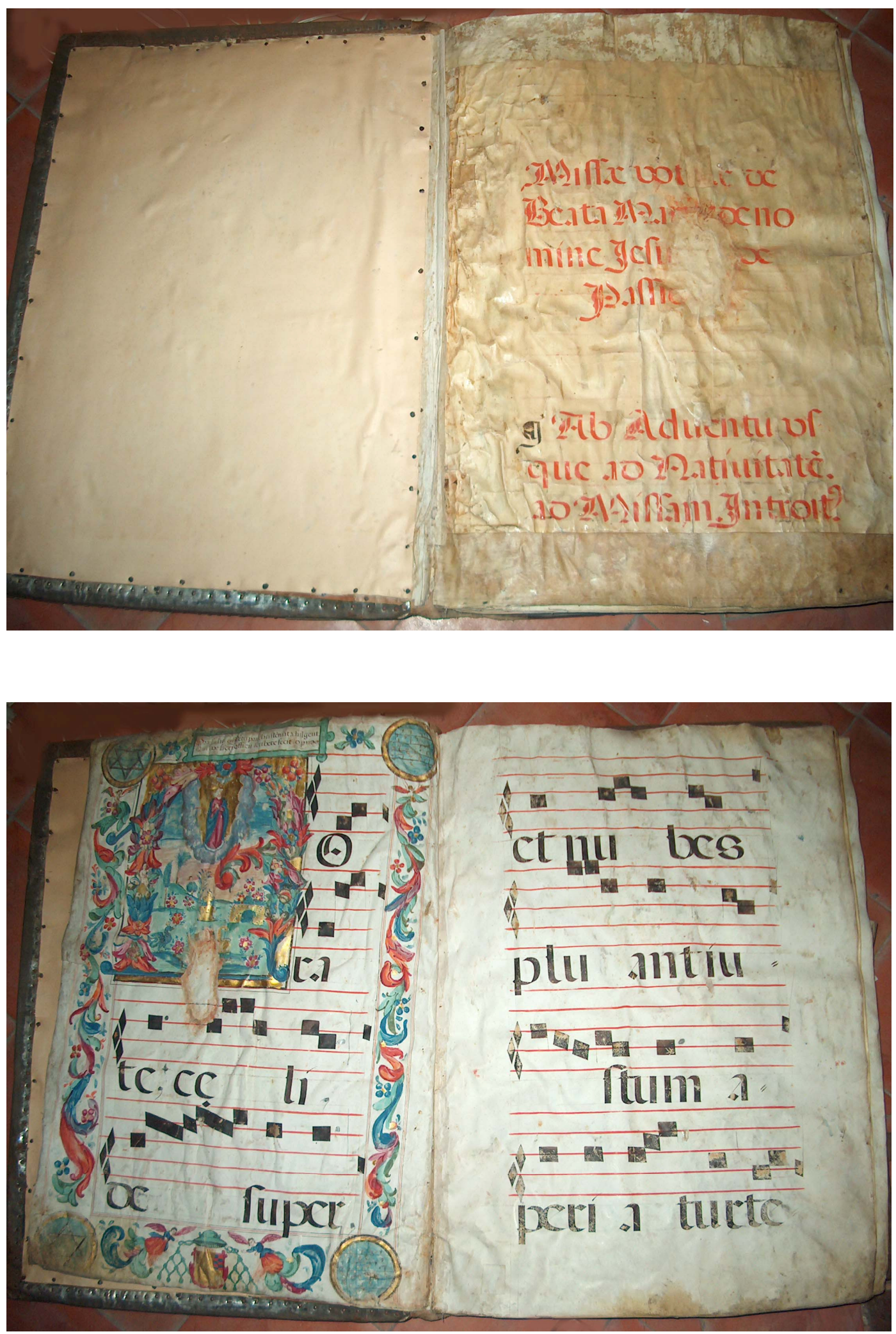


\section{$\left[\mathbf{N}^{\circ} \mathbf{X I X ]}\right.$}

\section{LIBRO 316 / 17}

Libro de Misas. Manuscrito en pergamino de 50 folios. Cuatro pentagramas por página.

Medidas: encuadernación 820 × 590 × 140; hoja 780 × 560; caja 630 × 370

Ubicación:Estante C-2

Foliación: 1-40 + 73-83 en numeración arábiga original.

\section{Incipit:}

Fol. $1^{\mathrm{r}}$ Missae vot(...) de Beata $\mathrm{M}(\ldots)$ homine Jesu(...)ilegible Ab Adventu usque ad Nativitate ad Missam Introit.

Fol. $1^{\mathrm{v}}$ Rorate coeli de super

\section{Iluminaciones:}

Fol. 1v "R" ilustra Virgen María con los elementos de la letanía lauretana, túnica roja, manto azul. Orla alrededor de la caja, en las esquinas aparecen dos estrellas sacromontanas, y en las otras dos círculos con inscripciones simulando escritura árabe, como si fueran hojas de los libros plúmbeos.

\section{Festividad o uso litúrgico:}

Propio de Misas (Misas votivas de la Santísima Virgen)

\section{Otras observaciones:}

Su estado de conservación es regular aunque la música legible. 
$\left[\mathbf{N}^{\circ} \mathbf{X X}\right]$

LIBRO 328 (olim 30)

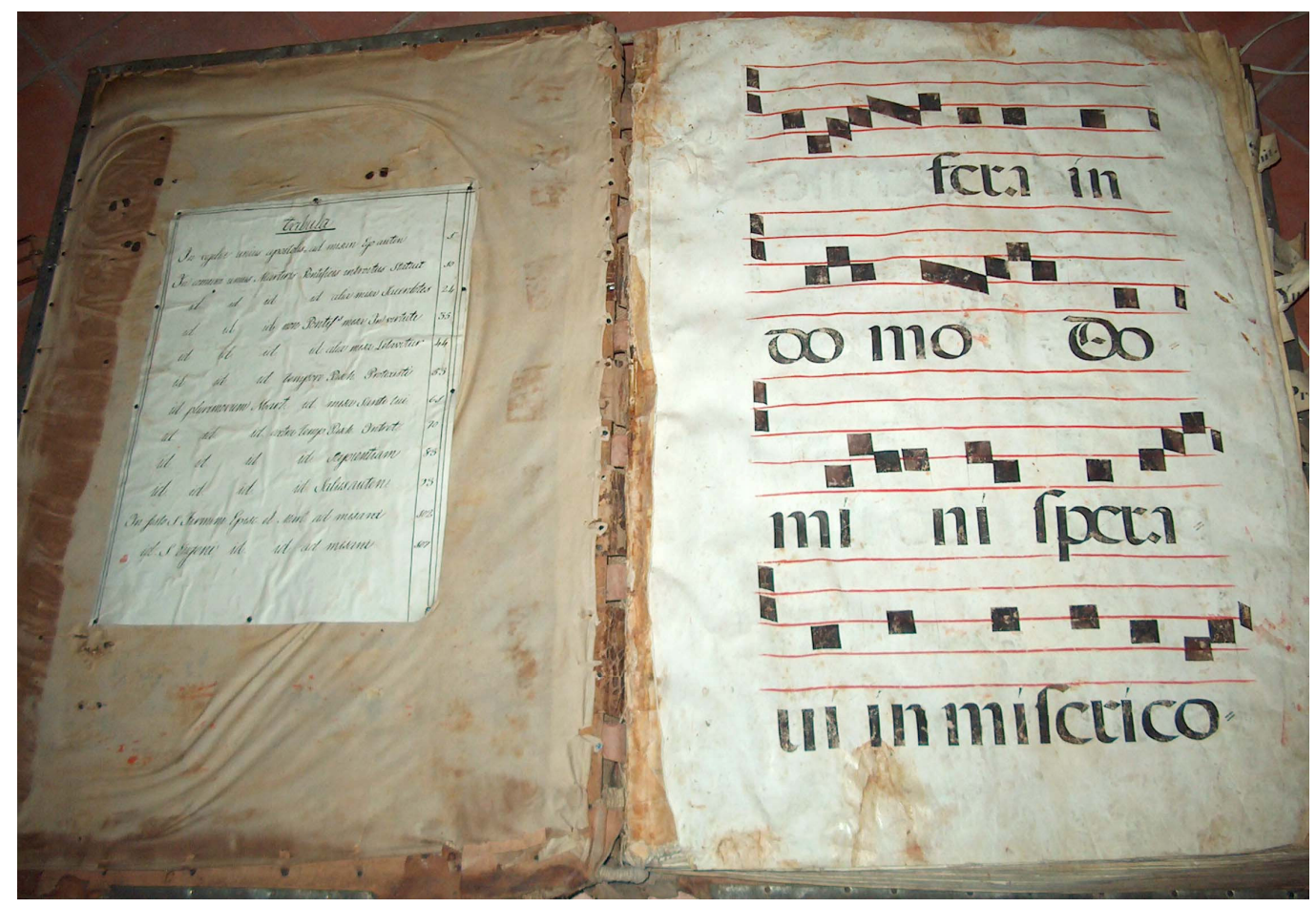




\section{LIBRO 328 / 30}

Libro de Misas. Manuscrito en pergamino de107 folios. Cuatro pentagramas por página.

Medidas: encuadernación 850 × 600 × 140; hoja 780 × 560; caja 640 × 395 .

Ubicación: Estante C-2

Foliación: 2-108 en numeración arábiga, original. Falta el primer folio.

Fecha: Siglo XVII

Incipit:

Fol. $2^{\mathrm{r}}(\ldots)$ fera in domo Domini

\section{Festividad o uso litúrgico:}

Común de las misas para mártires pontífices y no pontífices.

Índice:

Hoja de guarda:

Tabula/In vigilia unius apostolis:ad missam Ego autem 1/In comuni unius Martiris Pontifices Introitus statuit 10/ id id id alia misa sacerdotes 21 id id id non Pontifs. Misa In virtute 35/id id id alia misa Letavintur 44/ id id id tempore pasch. Protexisti 53/id pluviorum mart. Rel. Misa Sancti ? 61/id id id extra temp Pasch. Intret 70/ id id id id Sapientiam 83/ id id id id Salus autem 93/ In festo S. Firmini Episc. Et Mat.Ad misam 102/Id. S. Eugeni id id ad misam 107

\section{Otras observaciones:}

Se encuentra en buen estado de conservación aunque falta la primera hoja. 


\section{[N $\left.\mathrm{N}^{0} \mathrm{XXI}\right]$ \\ LIBRO 330 (olim 31)}

$\left[\mathbf{N}^{\circ} \mathbf{X X I}\right]$

LIBRO 330 / 31

Libro de Misas. Manuscrito en pergamino de 84 folios. Cuatro pentagramas por página.

Medidas: encuadernación 890 x 590 x 110; hoja 570 x 820; caja 380 x 640 .

Ubicación: Estante B-1

Foliación: 84 folios en numeración arábiga, original.

Fecha: Siglo XVII

Incipit:

Fol. $1^{\mathrm{r}}$ Secunda pars comunis A Missa ?? Comune Confes/Pontificis usque/ad Comune Cofes/non Pontificium/In Comuni Confe/soris Pontificis ad/Missa Introitus

Fol. $1^{\mathrm{v}}$ Statuit ei Dominus testamentum pacis

\section{Iluminaciones:}

Fol.1 "S" ilustra dos pájaros.

\section{Festividad o uso litúrgico:}

Común de santos confesores pontífices y confesores no pontífices.

\section{Índice:}

Hoja de guarda:

Indice/ In comin. Confessoris Pont. Missa statuit 1/ Id yd Missa Sacerdotes 17/ Id. Doctor Missa In medio 27 / Id. Confessoris non Pont. Missa on justi 35/ Id id Missa Justus ut Palma 46/ In dedicat. Ecclesia Missa 63/ S. Joseph Calasan Missa 76/ S. Joseph Acupert Missa

\section{Otras observaciones:}

Su estado de conservación es malo pues está bastante parcheado aunque la música se lee bien. 

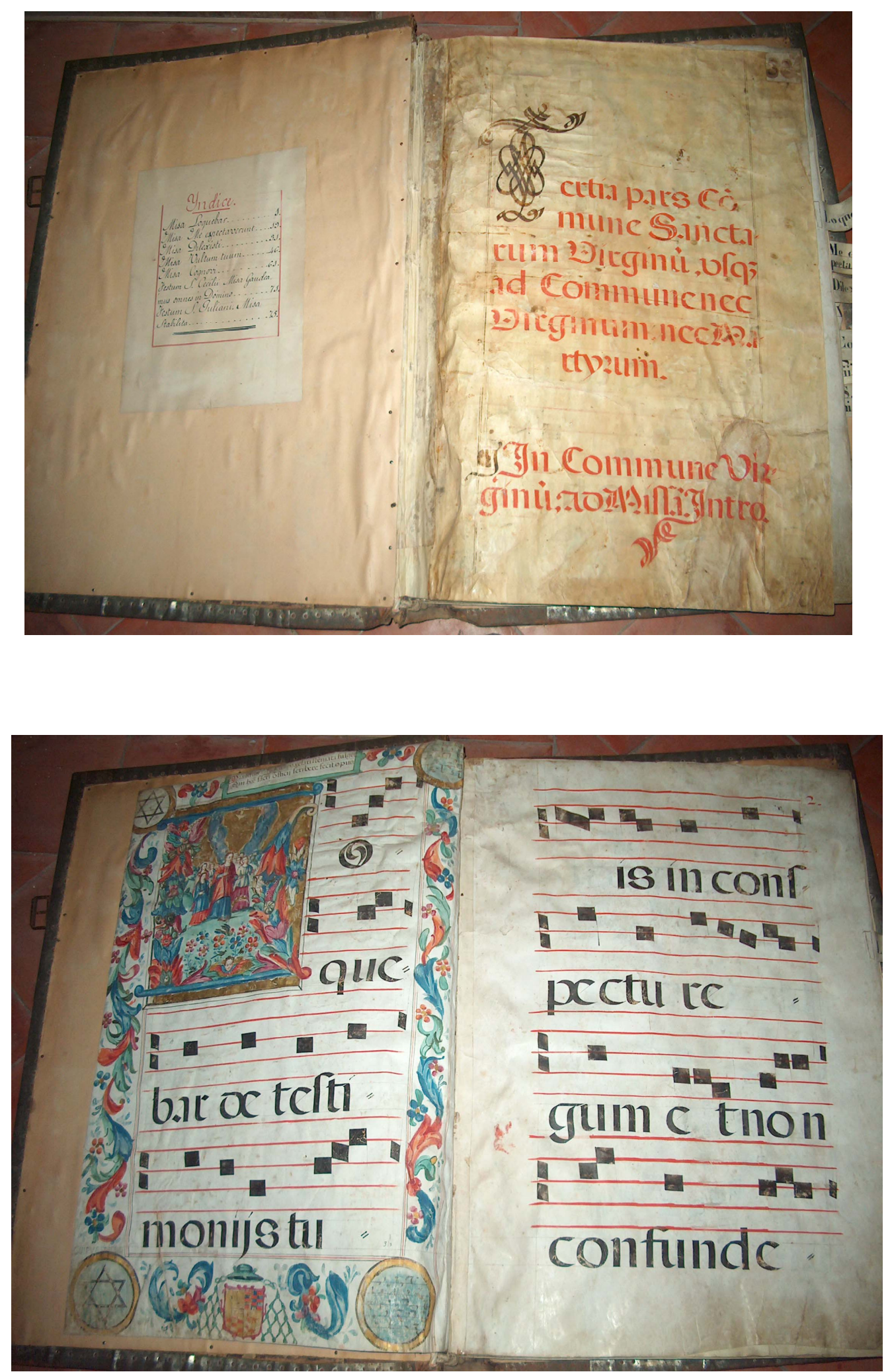
$\left[\mathbf{N}^{\circ} \mathbf{X X I I}\right]$

LIBRO 332 / 32

Libro de Misas. Manuscrito en pergamino de 80 folios. Cuatro pentagramas por página.

Medidas: encuadernación 875 x 630 x 110; hoja 710 x 560; caja 635 x 380 .

Ubicación: Estante B-2

Foliación: 1-80 en numeración arábiga original.

Fecha: Siglo XVII

Incipit: virginum

Fol. $1^{\mathrm{r}}$ Tetra pars Comune Sanctarum Virginis, usque ad Commune nec nec Martyrum/ In comune virginum, ad Missa Intro.

Fol. $1^{\mathrm{v}}$ Loquebar de testimoniis tuis

\section{Iluminaciones:}

Fol $1^{\mathrm{v}}$ "L" con ocho figuras de mujer, en tonos rojo, azul, verde y dorado. Orla con estrellas sacromontanas en las esquinas y círculos con escritura árabe como hojas de libros plúmbeos. Escudo episcopal de don Pedro de Castro y cartela con inscripción.

Fol. $71^{\mathrm{v}} \mathrm{"G}$ " y orla con estrellas.

Fol. $75^{\mathrm{V}}$ "S", sin completar.

\section{Festividad o uso litúrgico:}

Misas del común de santos, vírgenes y Misa de para la fiesta de San Cecilio.

Índice:

Hoja de guarda:

Indice/ Misa Loquebar 1/ Misa Me espectaverunt 19/ Misa Dilexisti 31/ Misa

Vultum tuum 46/ Misa Cognovi 61/ Festum S. Cecilii misa Gaudeamus omnes

in Domino 71/ Festum S. Juliani Misa Stabilita 75

\section{Otras observaciones:}

Se encuentra en buen estado de conservación. Figura la misa para la fiesta de San Cecilio. 
[N'XXIII]

LIBRO 336 (olim 8)
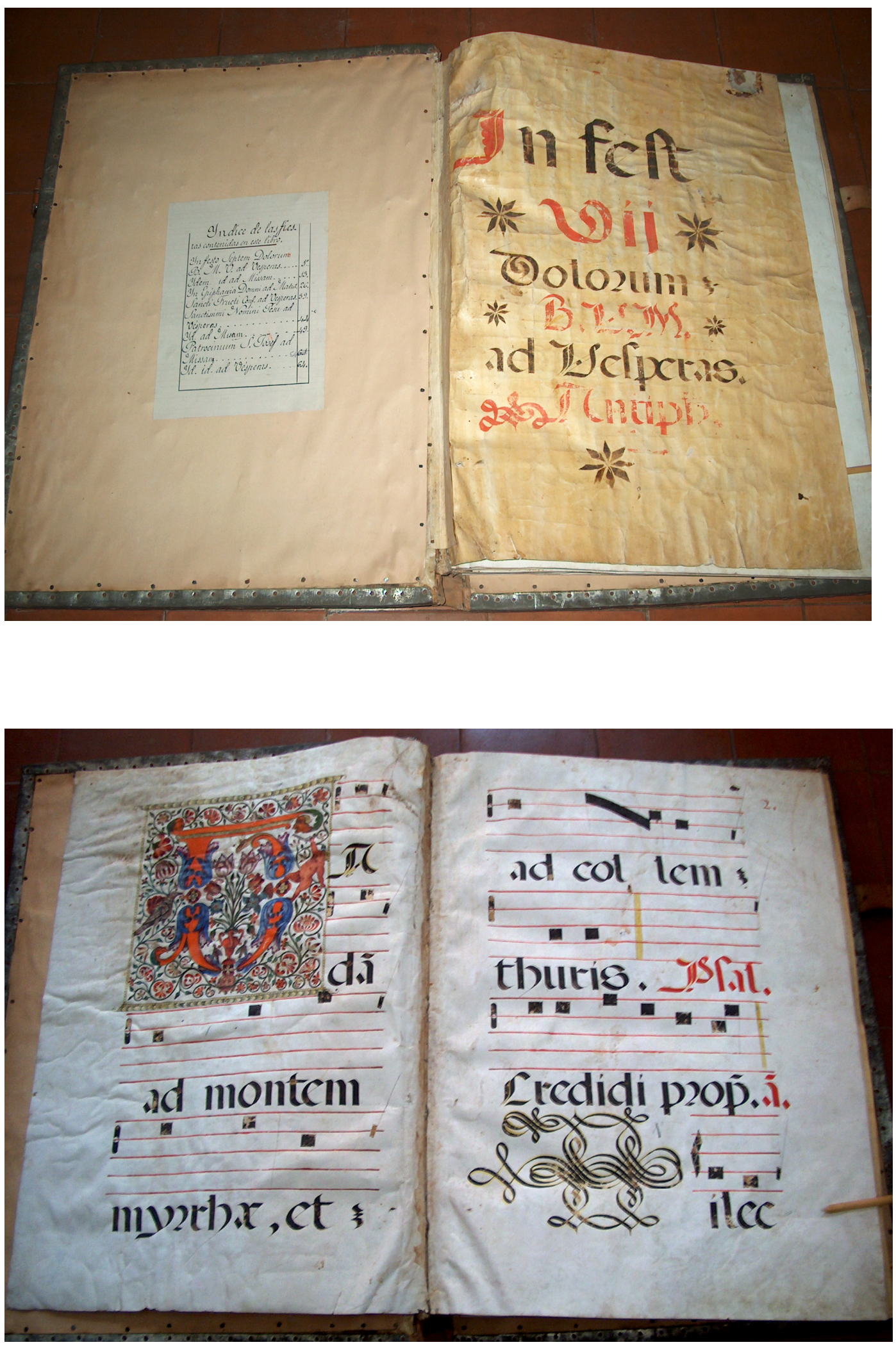


\section{$\left[\mathbf{N}^{0} \mathbf{X X I I I}\right]$}

\section{LIBRO 336 / 8}

Libro de Misas. Manuscrito en pergamino de 54 folios. Cuatro pentagramas por página.

Medidas: encuadernación 875 × 630 × 110; hoja 710 × 560; caja 635 x 380 .

Ubicación: Crujía de la primera planta.

Foliación: 1-54 en numeración arábiga, en tinta roja (coetánea) y en negra posterior.

Fecha: Siglo XVII

Incipit texto:

Fol. $1^{\mathrm{r}}$ In fest./ VII / Dolorum/ B.V.M./ ad Vesperas/ Antiph.

Fol. $1^{\mathrm{v}}$ Vadam ad montem myrrhae

\section{Iluminaciones:}

Fol. $1^{\mathrm{v}} \mathrm{V} \mathrm{V}$ " con jarrón con azucenas, flores, pájaros y putti.

Fol. $13^{\mathrm{v}}$ "S" con Jesús Crucificado acompañado de San Juan y la Virgen.

Fol. $25^{\mathrm{v}}$ "A" roja y azul sobre recuadro rosa con grutescos y putti en azul.

Fol. $28^{\mathrm{r}}$ “O” roja y negra con forma de ocho. Caja con orla en amarillo y negro

Fol. 43 " "O" roja que encierra a un niño Jesús que porta el orbe terrestre. En las esquinas querubines y una inscripción que dice "Iesu, Decus Angelorum. Iesu, Dulcis memoria, Iesu, Rex admirabilis"

Festividad o uso litúrgico: Fiestas del propio incluidas en el índice.

Índice:

Indice de las fiestas contenidas en este libro/ In festo Septem Dolorum B.M.V. ad Vesperas 1/ Ydem ad Missam 13/ In Epiphania Domini ad Matutinum 26/ Sancti Fructi Conf. Ad Vesperas 39/ Sanctissimi Nomini Iesu ad Vesperas 44/ Id ad Missam 49/ Patrocinium S. Josef ad Missam 54/ Id. Ad Vesperas 64

\section{Otras observaciones:}

Parece estar formado por varios cuadernos de diversas épocas. Al final texto que dice: "Mandó hacer escrevir este Oficio del Dulce Nombre de Iesus, el señor Don Bartolomé de Torres, Canónigo de este Sacro Monte, por su devoción, este Año de 1656". La ilustración del folio $28^{\mathrm{r}}$ es similar a la caja del Cuaderno de la Salve. 


\section{[N ${ }^{\circ}$ XXIV] \\ LIBRO 312 (olim 14)}
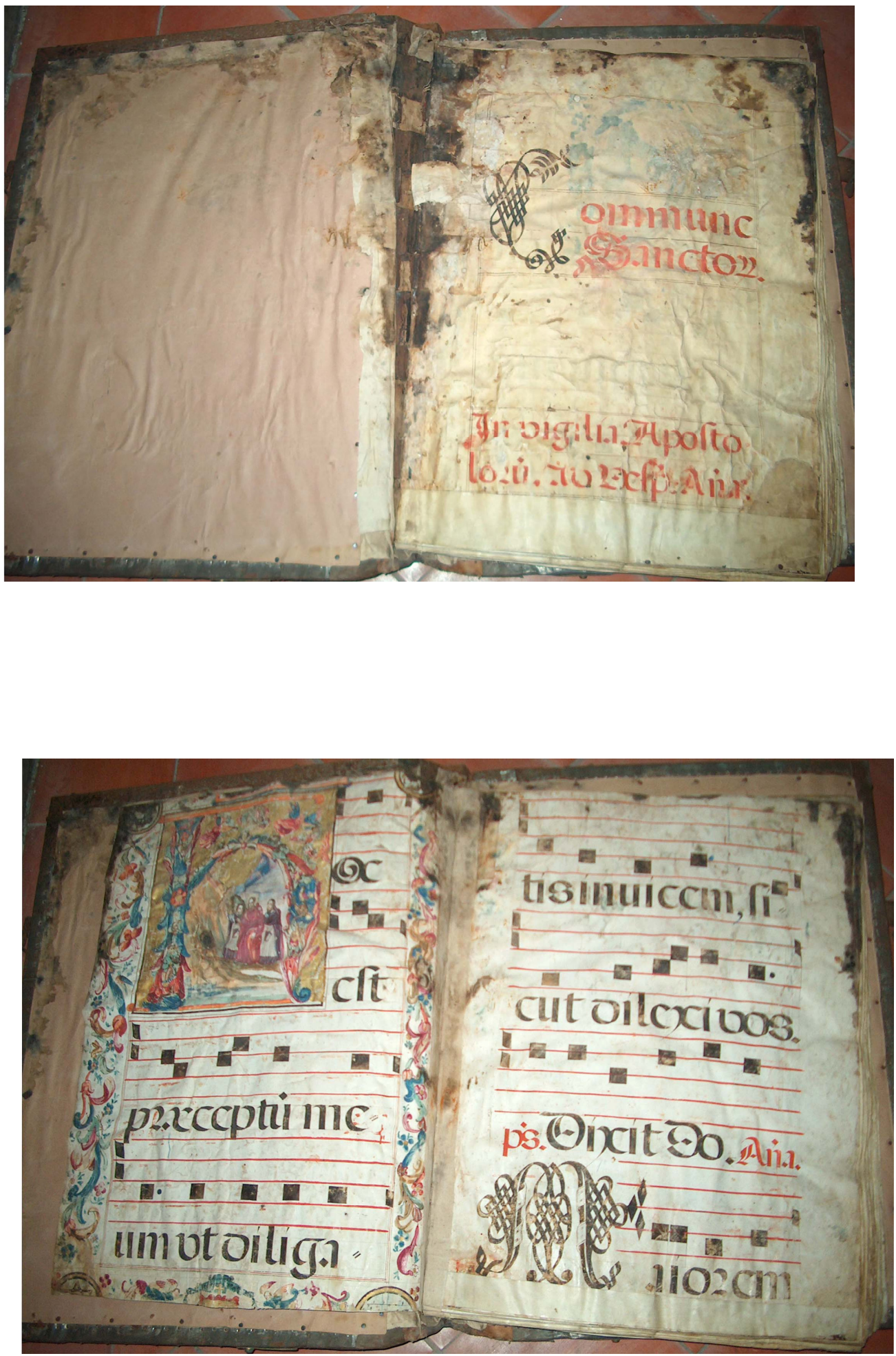


\section{$\left[\mathbf{N}^{\circ}\right.$ XXIV]}

\section{LIBRO 312 / 14}

Libro de Misas y Vísperas. Manuscrito en pergamino de 58 folios. Cuatro pentagramas por página.

Medidas: encuadernación 790 × 610 × 100; hoja 685 × 550; caja 630 × 380

Ubicación: Estante A-2

Foliación: 1-37 + 40-60 en numeración arábiga origina. Faltan los folios 38 y 39 .

Fecha: Siglo XVII

Incipit:

Fol. $1^{\mathrm{r}}$ Comune Sanctorum/In vigilia Apostol(orum) ad vesp(eras)/An(tífon)a.

Fol. $1^{\mathrm{v}}$ Hoc est praeceptum meum

\section{Iluminaciones:}

Fol.1 "H" ilustra Jesucristo con dos apóstoles con ciudad, y orla (300 x 280).

Fol.42 "O" ilustra personaje masculino en hábito negro sentado escribiendo $(300 \times 260)$

\section{Festividad o uso litúrgico:}

Vísperas del común de Santos.

\section{Otras observaciones:}

Se encuentra bastante deteriorado y reencuadernado porque la orla aparece guillotinada. La notación es cuadrada, pero hay ejemplos de indicaciones mensurales en un himno de la página $5^{\mathrm{v}}$. 
[N $\left.{ }^{\circ} \mathbf{X X V}\right]$

LIBRO 329 (olim 29)

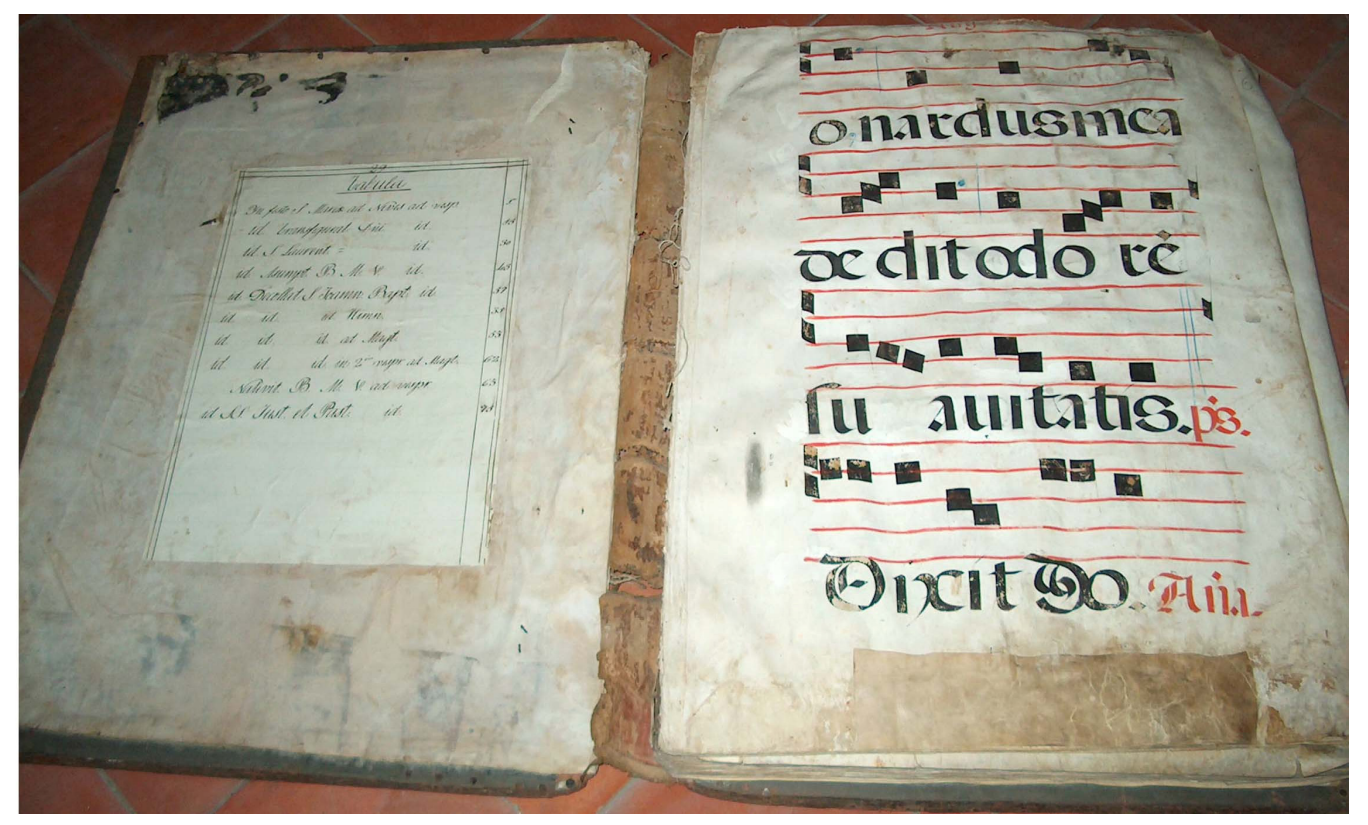




\section{$\left[\mathbf{N}^{0} \mathbf{X X V}\right]$}

\section{LIBRO 329 / 29}

Libro de Vísperas. Manuscrito en pergamino de 73 folios. Cuatro pentagramas por página.

Medidas: encuadernación 790 × 600 × 150; hoja 750 × 565; caja 625 × 370 .

Ubicación: Estante C-1

Foliación: 2-78 en numeración arábiga posterior a lápiz. Faltan folios 1, 50,51,55,56.

Fecha: Siglo XVII

Incipit:

Fol. $2^{\mathrm{r}}(\ldots)$ o nardus mea dedit odore suavitatis

\section{Iluminaciones:}

Fol.65 "I" sobre fondo rojo, $(310 \times 220)$

Fol.77 "I" sobre fondo rojo, $(190 \times 130)$

\section{Festividad o uso litúrgico:}

Vísperas desde la fiesta de Santa María de las Nieves hasta la fiesta de San Justo y Pastor.

Índice:

Hoja de guarda:

Tabula/ In festo S. Mariae ad Nives ad vesp. 5/ In festo Transfigurat Dni. Ad vesp 16/ In festo S. Laurent ad vesp. 30/ In festo Assumpt. B.M.V. ad vesp 43/ In festo Decollat S. Ioannes Bapt ad vesp 57/ In festo Decollat S. Ioannes Bapt Himn. 58/ In festo Decollat S. Ioannes Bapt ad Mayt. 59/ In 2 vespr. ad Mayt. 62/ In festo Nativit. B.M.V. ad vispr 65/ In festo SS. Just. Et Past. Ad vesper 75

\section{Otras observaciones:}

Se encuentra desencuadernado, hojas deterioradas en la parte superior. 
[N $\mathbf{N}^{0} \mathbf{X X V I ]}$

LIBRO 313 (olim 15)

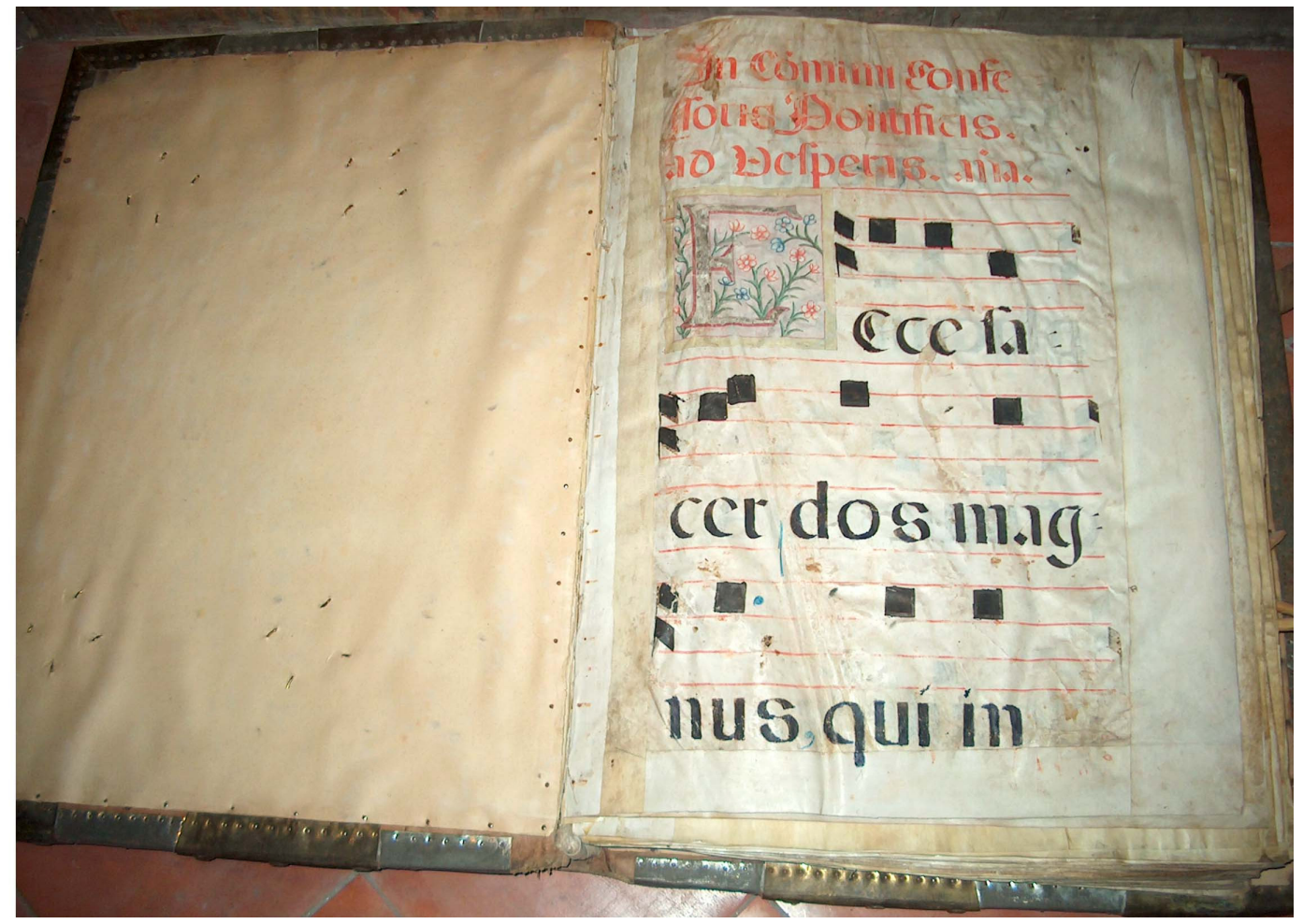




\section{$\left[\mathbf{N}^{0} \mathbf{X X V I}\right]$}

\section{LIBRO 313 / 15}

Libro de Vísperas. Manuscrito en pergamino de 74 folios. Cuatro pentagramas por página.

Medidas: encuadernación 790 × 600 × 110; hoja 720 × 530; caja 560 × 375 .

Ubicación: Estante C-2.

Foliación: 1-74 en numeración arábiga a lápiz. La foliación original es romana (pero no comienza en el folio 1). Tiene tres foliaciones diferentes.

Fecha: Siglos XVII Y XVIII

Incipit texto:

Fol. $1^{\mathrm{r}}$ In comune confessoris Pontificis ad Vesperas antífona

Fol. $1^{\mathrm{r}}$ Ecce sacerdos magnus

\section{Iluminaciones:}

Fol.1 " "E" adornada con flores rojas y azules $(150 \times 150)$

Fol.52 "S" azul sobre fondo rojo (130 x 110)

Fol.59 "R" en la que aparece mariposa volando cerca de una vela.

\section{Festividad o uso litúrgico:}

Vísperas (Antífonas del magnificat para el comun de confesores, papas y no papas).

\section{Otras observaciones:}

Se encuentra en estado de conservación regular. En el folio CXXV/59 hay una poesía en honor a Santa Teresa y un emblema de Filippo Picinelli (Mondo Simbolico, 1680) alusivo al poema. 
[N $\mathrm{N}^{\circ}$ XXVII]

LIBRO 333 (olim 33)

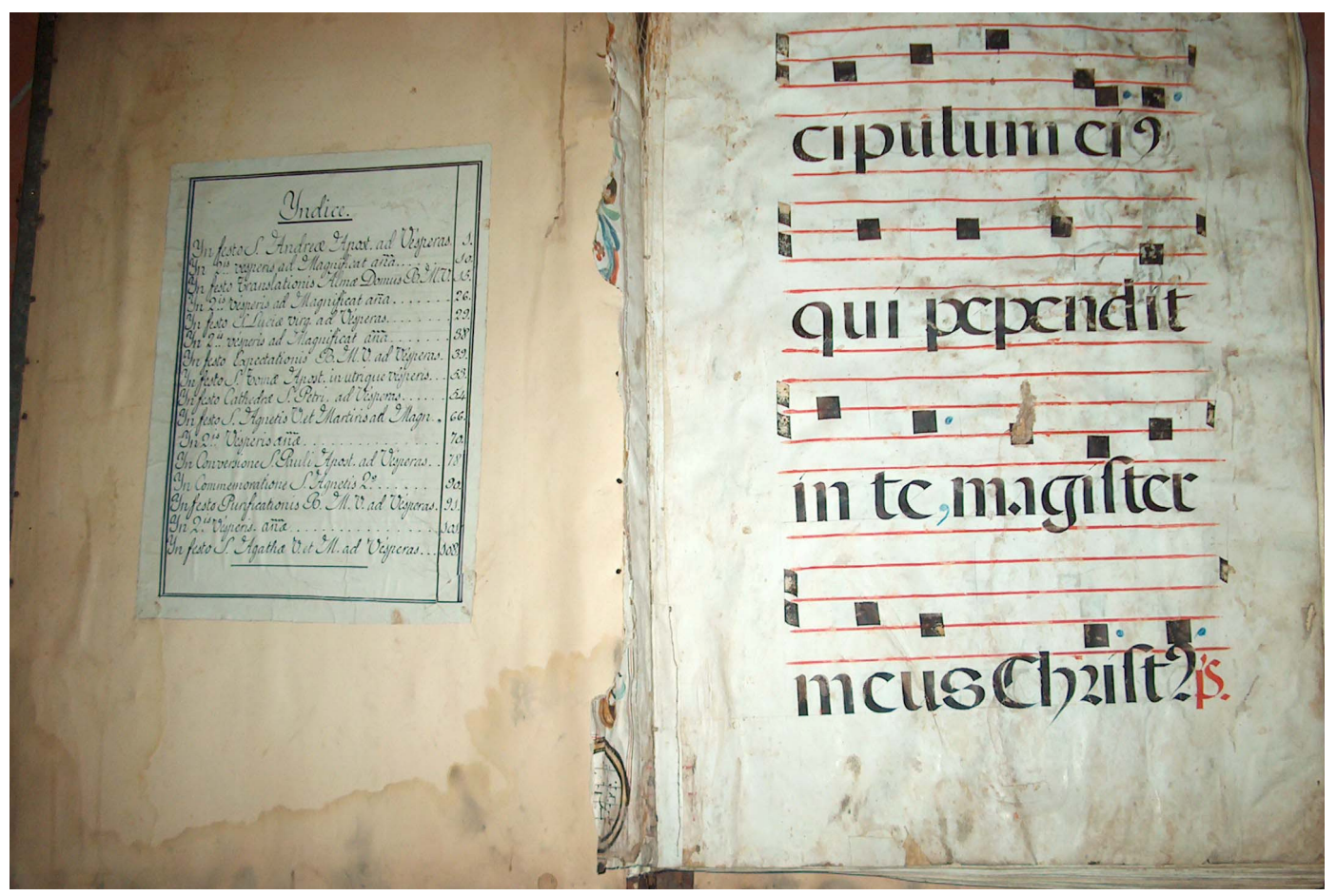




\section{[N $\mathbf{N}^{\circ}$ XXVII]}

\section{LIBRO 333 / 33}

Libro de Vísperas. Manuscrito en pergamino de 114 folios. Cuatro pentagramas por página.

Medidas: encuadernación 910 × 620 × 170; hoja 800 × 570; caja 620 × 375 .

Ubicación: C-2

Foliación: 1-117 en numeración arábiga original. Faltan los folios 1, 48, y 49.

Fecha: Siglo XVII

Incipit:

Fol. $2^{\mathrm{r}}$ (dis?)cipulum eis qui pependit in te

\section{Festividad o uso litúrgico:}

Vísperas desde la fiesta de San Andrés hasta la fiesta de Santa Ágata.

Índice:

Hoja de guarda:

Indice/In festo S.Andrea Apost. Ad Vesperas 1/In 2is vesperis ad Magnificat antíphona 10/In festo Translationis Alma Domus BMV 15/ In 2is vesperis ad Magnificat antíphona 26/ In festo S.Lucia virg. Ad Vesperas 29/ In 2is vesperis ad magnificat antíphona 38/ in festo Expectationis BMV ad Vesperas 39/ In festo S.Tomas Apost in utrique vesperis 53/In festo Cathedra S.Petri, ad Vesperas 54/In festo S.Agnetis V.et Martiris ad Magn 66/ In 2is vesperis antíphona 70/ In conversione S.Pauli Apost ad vesperas 78/In Commemoratione S.Agretis $2^{\text {a }}$ 90/In festo Purificationis BMV ad Vesperas 91/ In 2is Vesperis antíphona 101/In festo S.Agatha $\mathrm{V}$ et $\mathrm{M}$ ad Vesperas

\section{Otras observaciones:}

Aunque la notación es cuadrada, en el folio $44^{\mathrm{r}}$ aparece indicaciones mensurales con la particularidad de que la pieza comienza con dos silencios. Esto nos habla de un comienzo anacrúsico. Restos del folio 1 muestran orla similar a la de otros cantorales como del taller de Pedro Marañón. 
[N $\mathrm{N}^{\circ}$ XXVIII]

LIBRO 308 (olim 10)

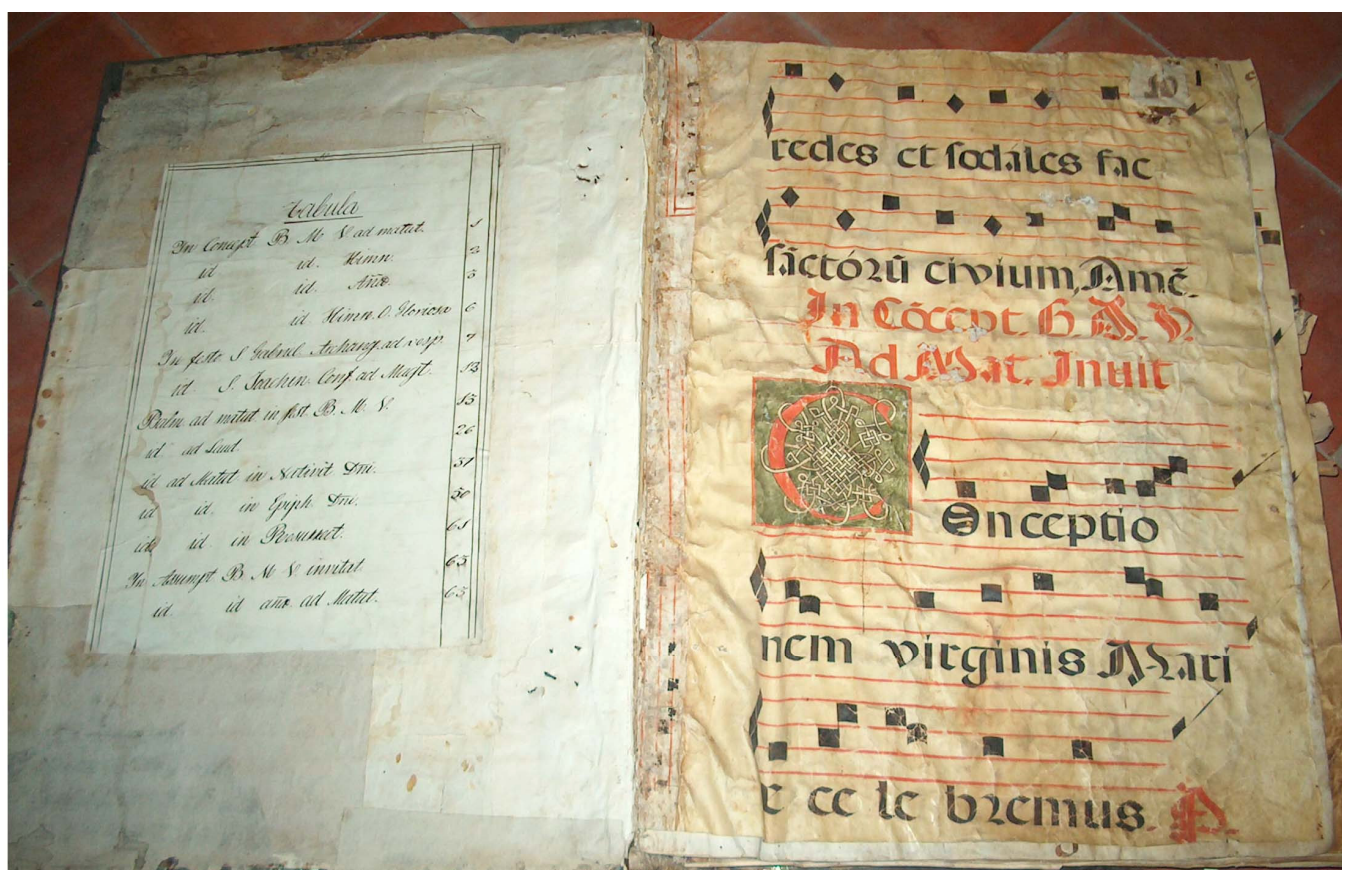




\section{$\left[\mathbf{N}^{0}\right.$ XXVIII $]$}

\section{LIBRO 308 / 10}

Libro de Vísperas. Manuscrito en pergamino de 65 folios. Cinco pentagramas por página.

Medidas: encuadernación 740 × 530 × 95; hoja 670 × 470; caja 640 × 380 .

Ubicación: Estante B-1

Foliación: 2-66 folios en numeración arábiga original. Falta la primera hoja. Sección $\sin$ música del 14r al 62v, y del 63r al 66v.

Fecha: Siglo XVII

Incipit:

Fol. $2^{\mathrm{r}}(\ldots)$ redes et fodates fac factoru civiuum Ame. In conceptione B.M.V. Ad matutinum invitatorio

\section{Festividad o uso litúrgico:}

Vísperas y maitines.

Índice:

Tabula/In conceptione BMV ad matutinum 1/ id id Himn. 2/ id id Antíphona 3/ Himn O Gloriosa 6/ In festo S. Gabriel Archang.ad vesp 7/S. Joachin Conf ad Magt 12/ Psalm ad matut in fest BMV 13/ id ad laud 26/ id ad matuti in Nativit Dni 37/ id in Epiph Dni 50/ In Resurrect 61/In Assumpt BMV invitat 63/ id antíphona ad Matut 63

\section{Otras observaciones:}

Su estado de conservación es regular, se encuentra muy deteriorado por el uso. 
[N ${ }^{\circ}$ XXIX]

LIBRO 325 (olim 26)
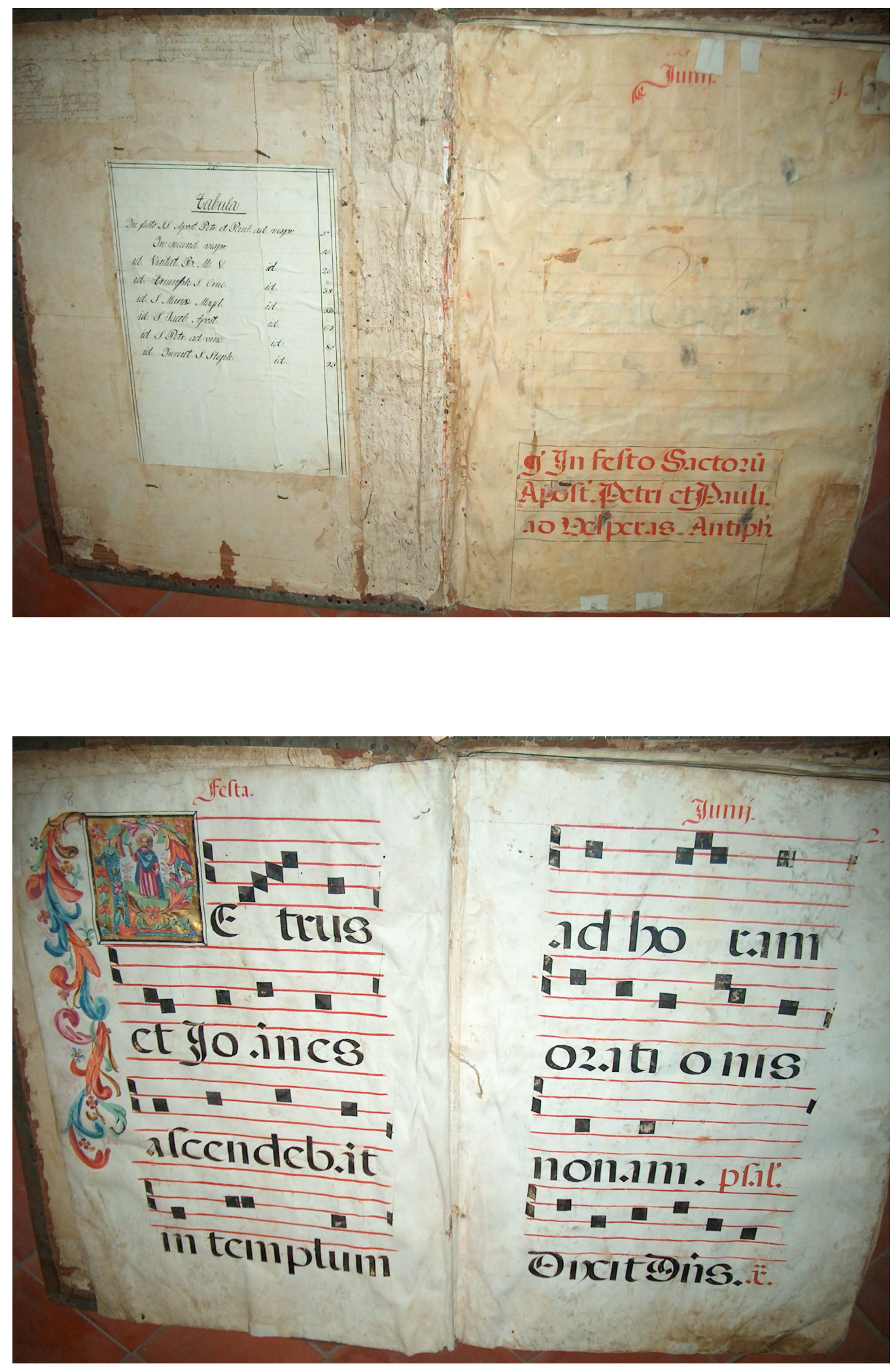


\section{$\left[\mathbf{N}^{0} \mathbf{X X I X ]}\right.$}

\section{LIBRO 325 / 26}

Libro de Vísperas. Manuscrito en pergamino de 102 folios. Cuatro pentagramas por página.

Medidas: encuadernación 870 × 650 × 150; hoja 840 × 590; caja 630 × 365 .

Ubicación: Estante C-1

Foliación: 1-102 en numeración arábiga, a lápiz posterior. Faltan folios de la foliación arábiga en tinta roja original: 8 al 11, 14, 15, 35, 36, 50, 51 .

Fecha: Siglo XVII

Incipit:

Fol. $1^{\mathrm{r}}$ In festo Sanctorum Apostoli Petri et Pauli

Fol. $1^{\mathrm{v}}$ Petrus et Ioannes ascendebat in templum

\section{Iluminaciones:}

Fol.1 "P" ilustra San Pedro, (155 x 170)

Fol.66 "E" ilustra Santiago "matamoros", (310 x 255)

\section{Festividad o uso litúrgico:}

Antífonas de las vísperas desde San Pedro y San Pablo hasta las vísperas de San Esteban

Índice:

Hoja de guarda:

Tabula/In festo SS Apost. Petri et Paul. Ad vepr. 1\%/In secund. Vespr. 16/Id Visitat BMV id 26/ id Triunph. S.Cruc. Id 38/id.S.Maria Magd id 54/ id S. Jacob Apost. Id 67/ Id S. Petri ad Vinc. Id 80/Id Invent. S. Steph. Id 93

\section{Otras observaciones:}

Se encuentra en buen estado de conservación. 
[ $\left.\mathbf{N}^{\circ} \mathbf{X X X}\right]$

LIBRO 335 (olim 35)

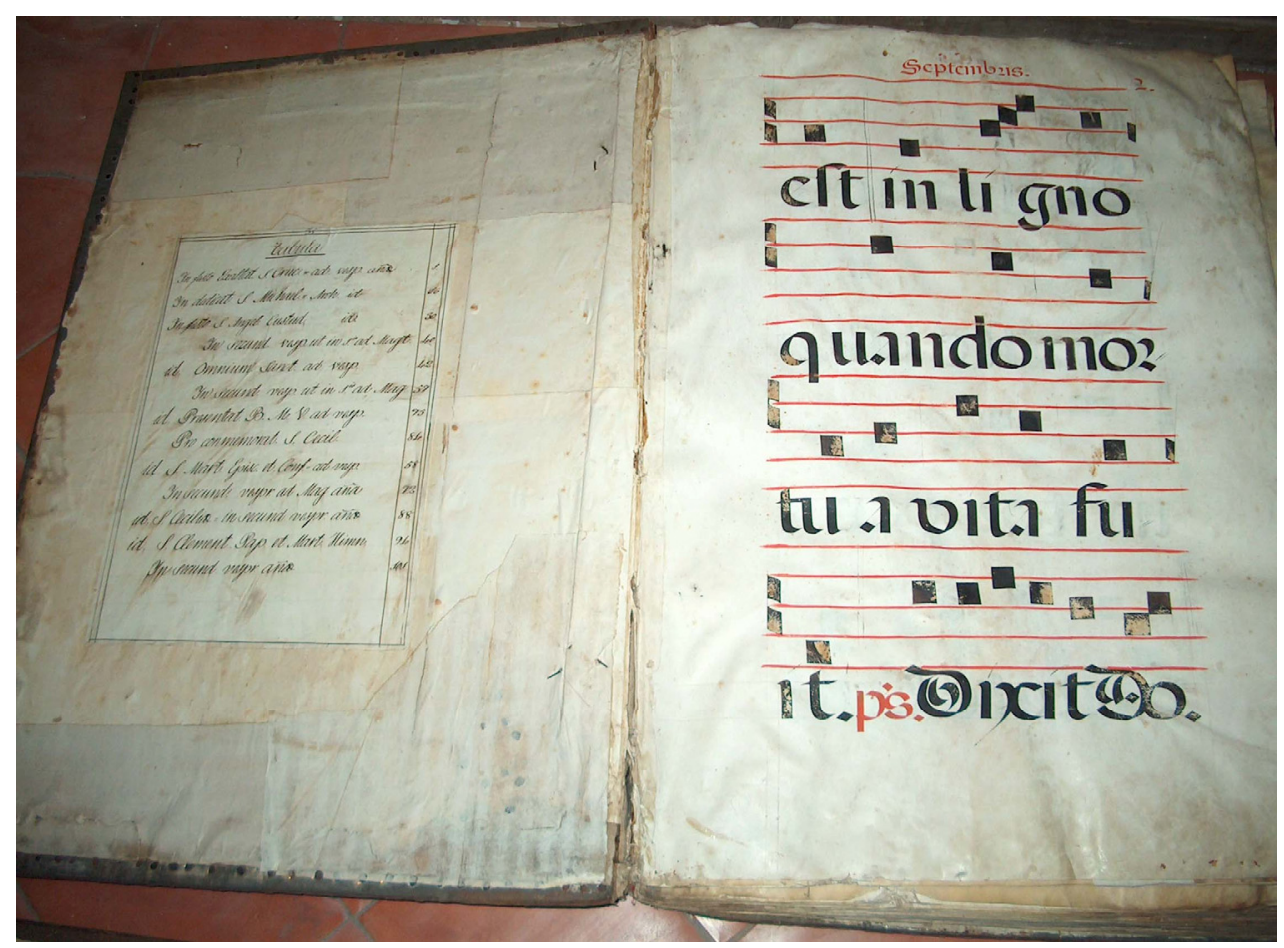




\section{$\left[\mathbf{N}^{\circ} \mathbf{X X X}\right]$}

LIBRO 335 / 35

Libro de Vísperas. Manuscrito en pergamino de 93 folios. Cuatro pentagramas por página.

Medidas: encuadernación 890 × 670 × 120; hoja 830 × 600; caja 640 × 375 .

Ubicación: Estante B abajo

Foliación: 1-107 en numeración arábiga original. Faltan los folios 1, 13, 14, 23, 26, 27, 54, 55, 70, 71, 86, 87, 99, 100 .

Fecha: Siglo XVII

Incipit:

Fol. $1^{\mathrm{v}}$ Septembris/ (...)est in ligno quando mor tua vita fuit ps. Dixit Dominus

\section{Festividad o uso litúrgico:}

Vísperas desde la fiesta de la exaltación de la Cruz hasta San Clemente.

\section{Índice:}

Hoja de guarda:

Tabula/ In festo Exaltat. S. Cruci ad vesp. Antíphona 1 / In dedicat S.Michael Arch. Id 16/ In festo S.Angel Custod. Id. 30 / In secund. Vesp. Ut in 1 ad Magt. 40/ id. Omnium Sanct ad vesp. 42/ In secund. Vesp. Ut in $1^{\text {a }}$ ad Magt. 57/ id Presentat. B.M.V. Ad vesp. 75/ Pro conmemorat. S. Cecil. 84/ id. S.Mart. Episc. Et Conf. Ad vesp. 58 / In secund. Vespr. Ad Mag. Antíphona 72/ id. S.Cecilia in secunda vespr. Antíphona 88/ id S. Clement. Pap. Et Mart. Himn 94/ In secund vespr. Antíphona 101.

\section{Otras observaciones:}

Su estado de conservación es regular. Aparecen indicaciones mensurales, como en el folio $21^{\mathrm{r}}$. 


\section{[N $\left.\mathrm{N}^{\circ} \mathrm{XXXI}\right]$ \\ LIBRO 314 (olim 16)}
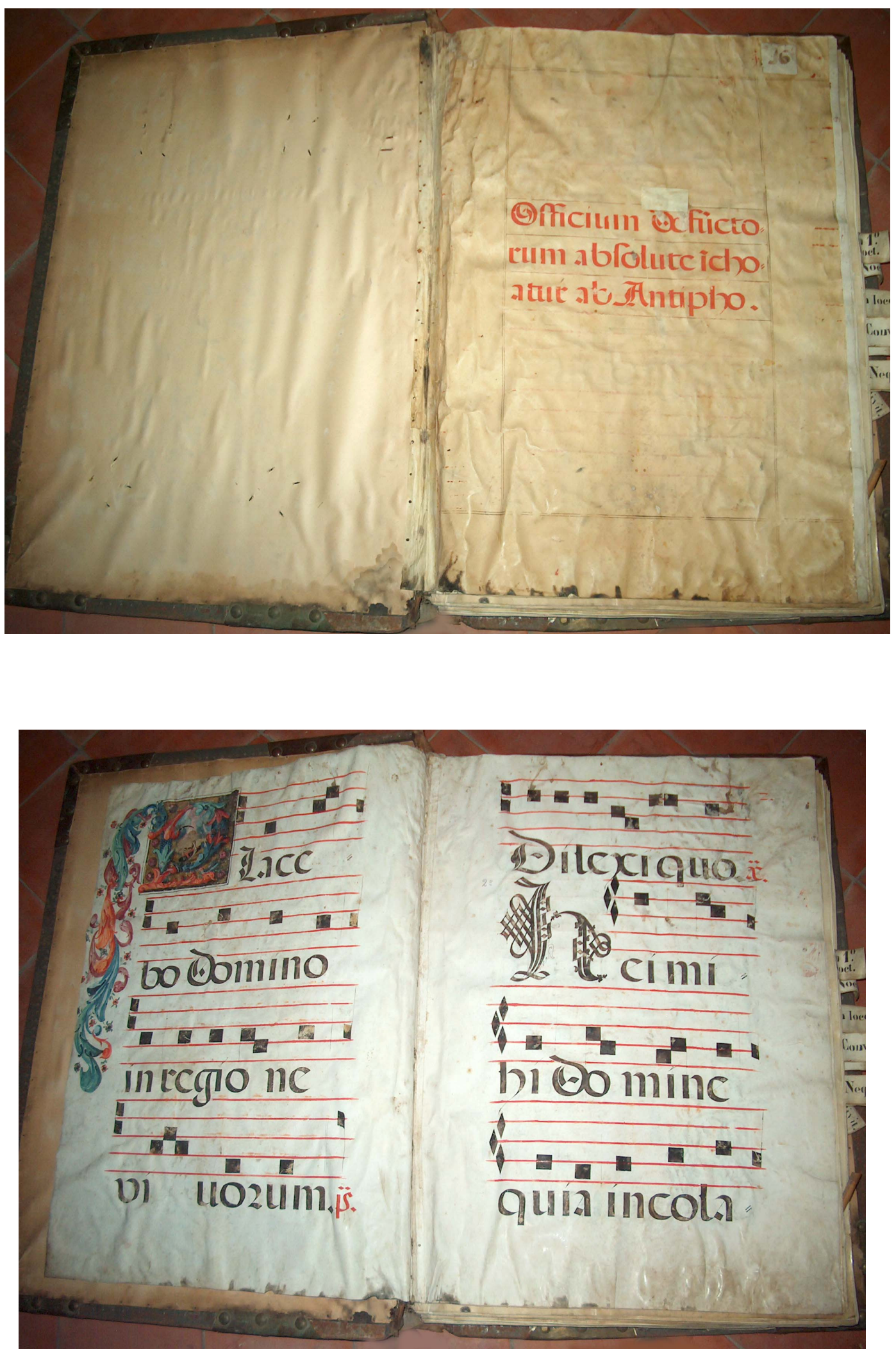


\section{$\left[\mathbf{N}^{\circ} \mathbf{X X X I}\right]$}

\section{LIBRO 314 / 16}

Cantoral. Manuscrito sobre pergamino. Cuatro pentagramas por página.

Medidas: encuadernación 900 × 640 × 180; hoja 765 × 560; caja 630 × 385

Ubicación:Estante C-2

Foliación:130 folios en numeración arábiga.

Fecha: Siglo XVII

Incipit:

Fol. $1^{\mathrm{r}}$ Officium defunctorum absolute inchoatur ab Antiphona.

Fol. $1^{\mathrm{v}}$ Placebo Domino in regno

\section{Iluminaciones:}

Fol.1" "P" con esqueleto con guadaña y sarcófago $(160$ x 160)

\section{Festividad o uso litúrgico:}

Oficio de difuntos.

\section{Otras observaciones:}

Su estado de conservación es bueno. Contiene lecturas y otros intercalados y no coincide con el 16 de la tabla de registros de libros corales del siglo XIX. 


\section{[N $\mathrm{N}^{\circ}$ XXXII] \\ LIBRO 23 (olim 55)}
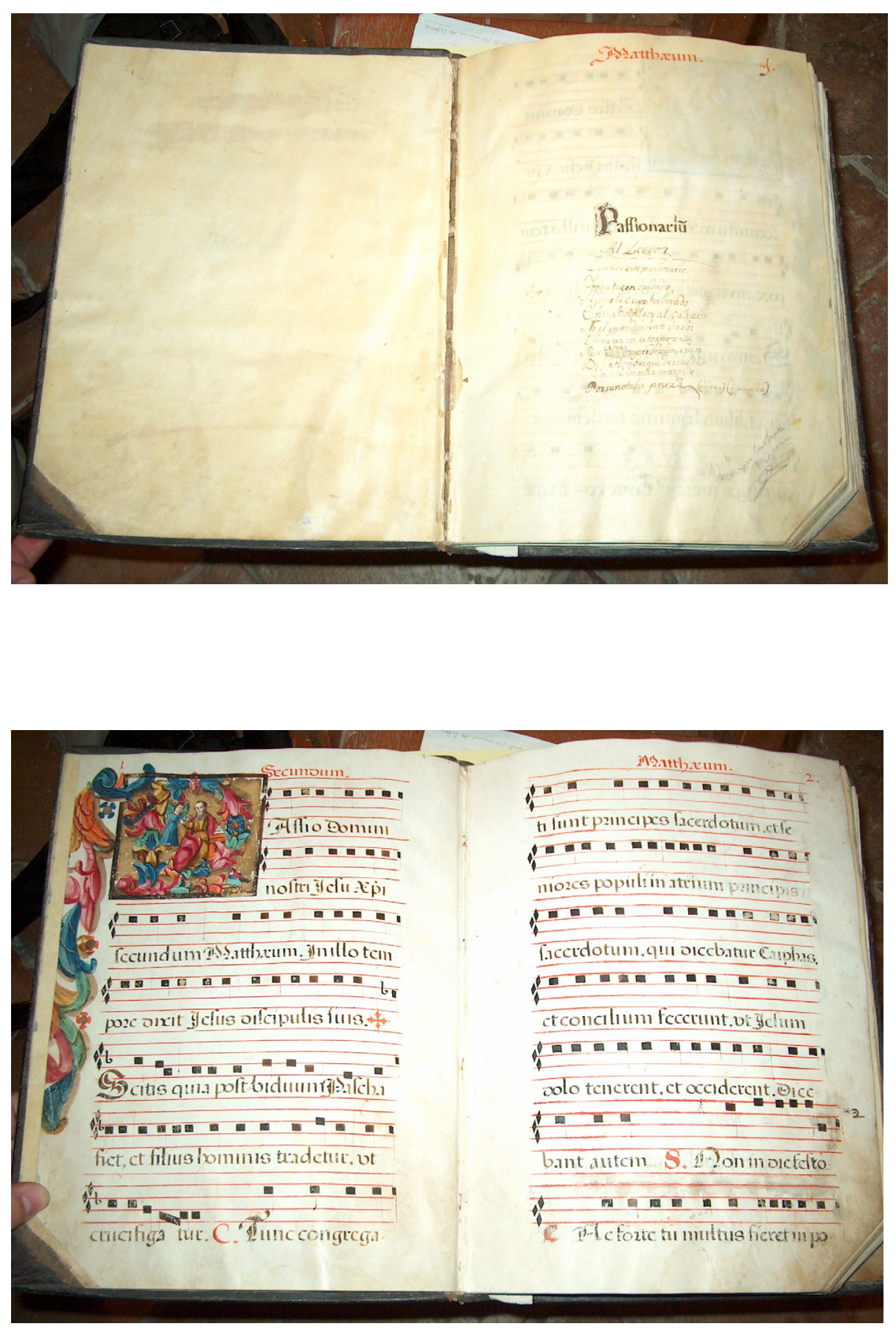


\section{$\left[\mathbf{N}^{0} \mathbf{X X X I I ]}\right.$}

\section{LIBRO 23 / 55}

Pasionario. Manuscrito en pergamino de 114 folios. Siete pentagramas por página.

Medidas: encuadernación 350 × 260 × 80; hoja 330 × 250; caja 280 × 175 .

Ubicación: Vitrina 4-1.

Foliación: 1-114 en numeración arábiga original.

Fecha: Siglo XVII

\section{Incipit texto:}

Fol. $1^{\mathrm{r}}$ Matthaeum/ Passionariu/

Fol. $1^{\mathrm{v}}$ Passio Domini nostri

\section{Iluminaciones:}

Fol.1" "P" ilustra San Mateo con el ángel. Orla pequeña a la izquierda (90 x 90)

Fol.34v. "P" ilustra San Marcos con el toro $(90$ x 90)

Fol.61 "P" ilustra San Lucas con el león $(90$ x 90)

Fol.91" "P” ilustra San Juan con el águila $(90$ x 90)

\section{Festividad o uso litúrgico:}

Contiene las pasiones según los cuatro evangelistas.

\section{Otras observaciones:}

Su estado de conservación es excelente. La encuadernación es posterior, pues el papel de las guardas es impreso. En el folio $1^{\mathrm{r}}$, después del título se puede leer la siguiente poesía:

Al lector/leiendo este pasionario/Imita tu con cuidado/Al que la cruz ha llevado/en sus hombros al calvario/No en el entendimiento vaxio:/Diviertas en la torpeza/Pues es mas perdizion esas/Del hombre que descuidado/A los vicios se ha entregado/Por su notable pereza (tibieza)(flaqueza) 
[N $\mathbf{N}^{\circ}$ XXXIII]

LIBRO 372 (olim D)

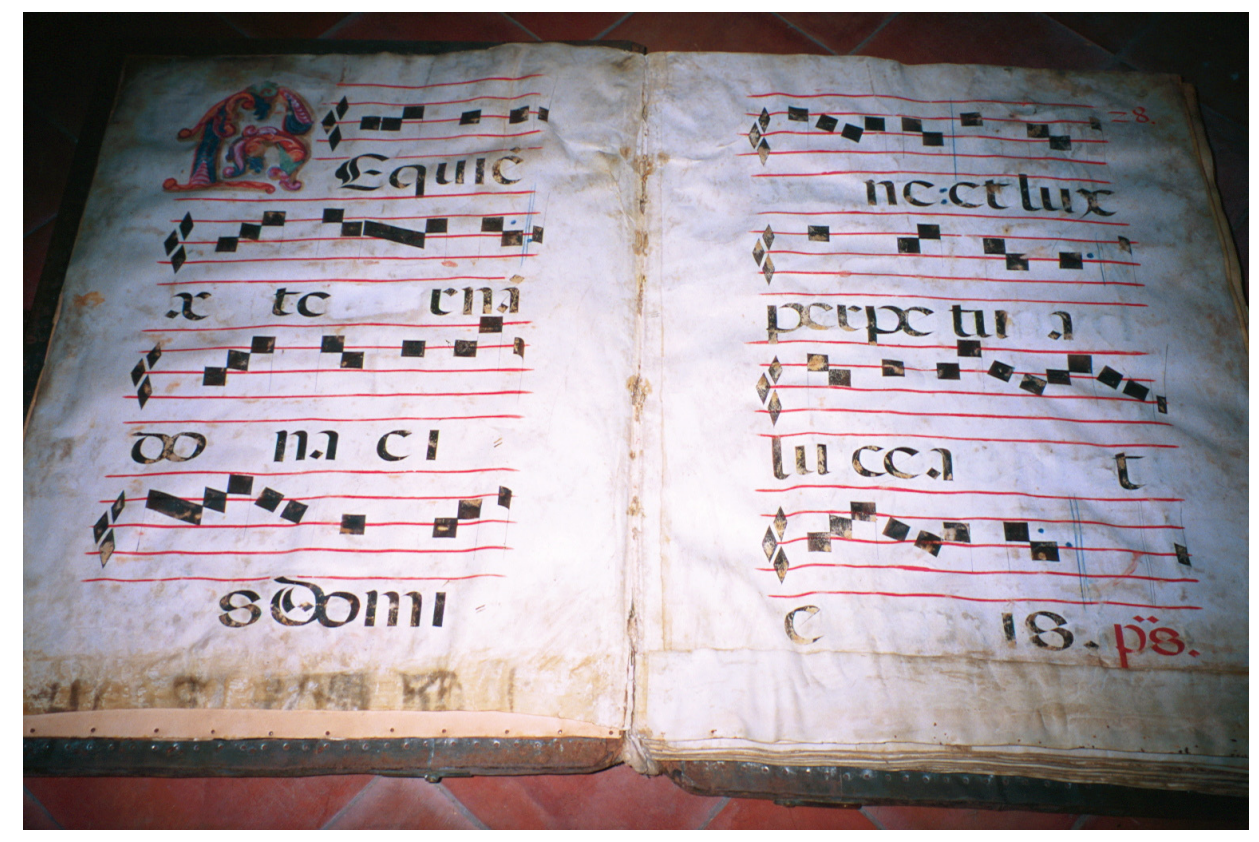




\section{[No XXXIII]}

\section{LIBRO 372 / D}

Cantoral. Manuscrito en pergamino de 41 folios. Cuatro pentagramas por página.

Medidas: encuadernación 835 x 610 × 100; hoja 780 × 580; caja 630 × 390 .

Ubicación: Estante C-1.

Foliación: 27-68 en numeración arábiga original, pero comienza en el folio 27.

Fecha: Siglo XVII

Incipit texto:

Fol.1 ${ }^{\mathrm{v}}$ Requiem aeternam

\section{Festividad o uso litúrgico:}

Misa de Requiem

Otras observaciones:

Su estado de conservación es regular. 


\section{[No XXXIV] \\ LIBRO 309 (olim 11)}
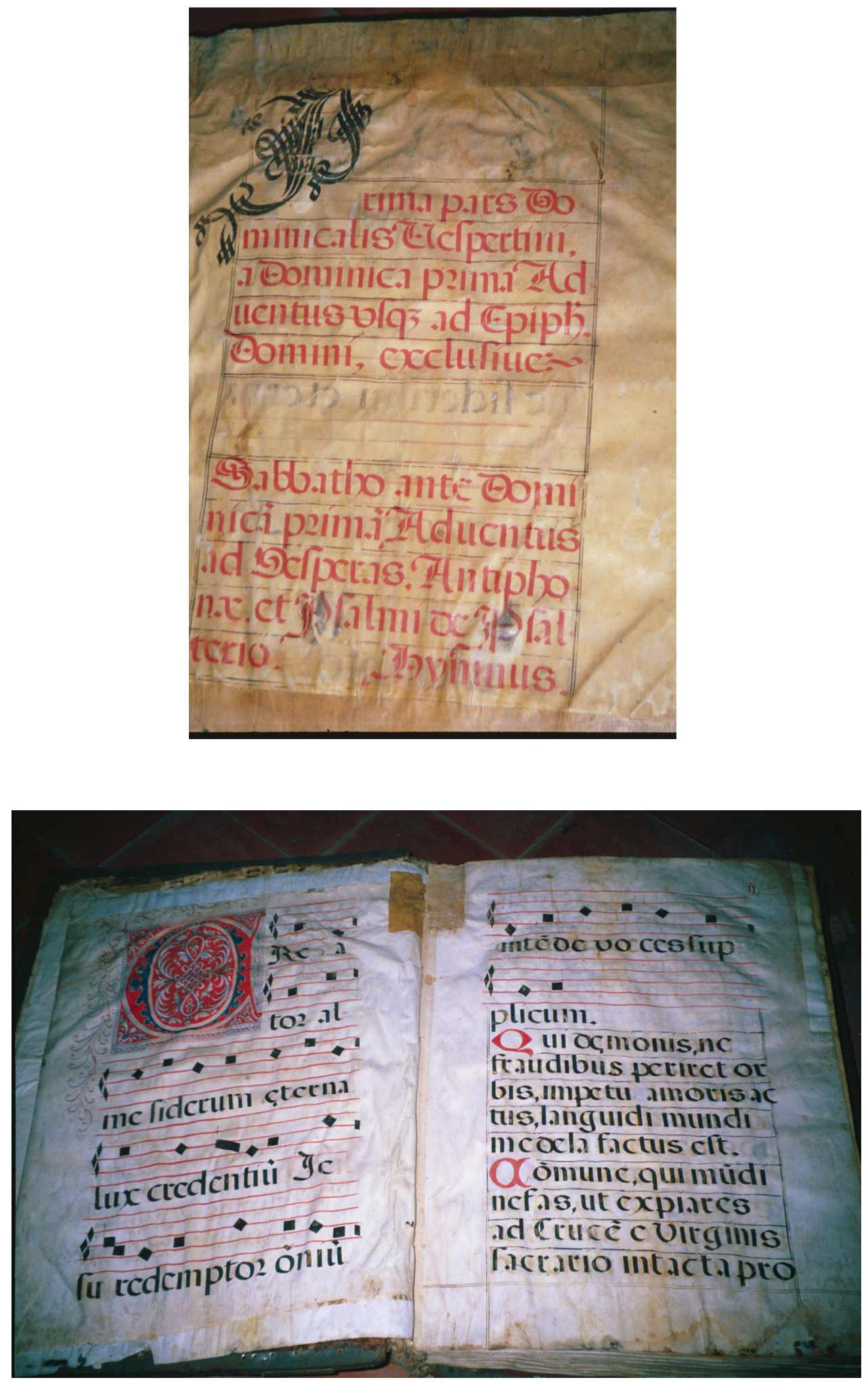


\section{$\left[\mathrm{N}^{\mathrm{o}} \mathrm{XXXIV]}\right.$}

\section{LIBRO 309 / 11}

Libro de Vísperas. Manuscrito en pergamino de 109 folios. Cinco pentagramas por página.

Medidas: encuadernación 760 × 550 x 100; hoja 690 × 520; caja 550 x 350 .

Ubicación: Estante B-1

Foliación: 1-109 en numeración romana original

Fecha: Siglo XVII

Incipit:

Fol. $1^{\mathrm{r}}$ Prima pars Dominicalis Vespertini a Dominicas prima adventus usq ad Epiph Domini exclusive/Sabbatho ante Dominicam primam Adventus ad vesperas et Psalmi de Psalterio Hymnos

\section{Iluminaciones:}

Fol. $2^{\mathrm{v}}$ "C", tinta roja, azul y blanca.

Fol.34 "R", tinta roja, azul y blanca.

\section{Festividad o uso litúrgico:}

Vísperas de Adviento hasta Epifanía

\section{Otras observaciones:}

Buen estado de conservación. 
[N $\mathrm{NXV}^{\circ}$

LIBRO 310 (olim 12)
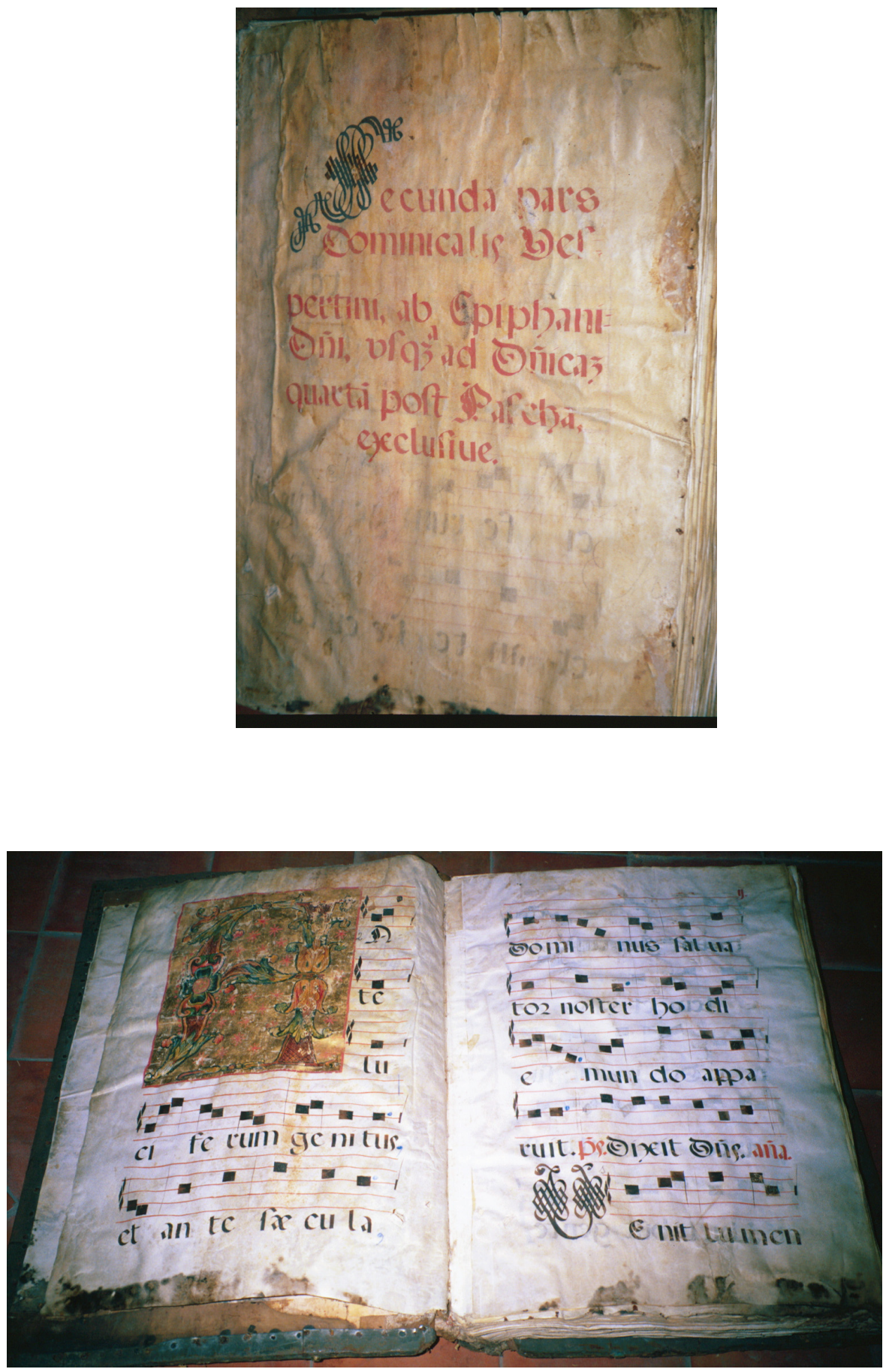


\section{$\left[\mathbf{N}^{0} \mathbf{X X X V}\right]$ \\ LIBRO 310 / 12}

Libro de Vísperas. Manuscrito en pergamino de 98 folios. Cinco pentagramas por página.

Medidas: encuadernación 775 × 525 x 120; hoja 700 × 500; caja 555 x 340

Ubicación: Estante B-2

Foliación: 1-98 en numeración romana original.

Fecha: Siglo XVII

Incipit:

Fol. $1^{\mathrm{r}}$ Secunda pars dominicalis vespertini, ab Epihani Domini. Usque ad Domenicas quarta post Pascha., exclusive

Fol. $1^{\mathrm{v}}$ Ante luciferum genitus

\section{Iluminaciones:}

Fol.1" "A" sobre fondo dorado con estrella sacromonte pequeña.

Fol.LX" "S" en rojo y azul muy fina.

\section{Festividad o uso litúrgico:}

Segunda parte del libro de vísperas del domingo de Epifanía al $4^{\circ}$ Domingo de Pascua.

Índice:

No tiene

\section{Otras observaciones:}

Su estado de conservación es bueno. 


\section{[N ${ }^{\circ} \mathbf{X X X V I ]}$ \\ LIBRO 311 (olim 13)}
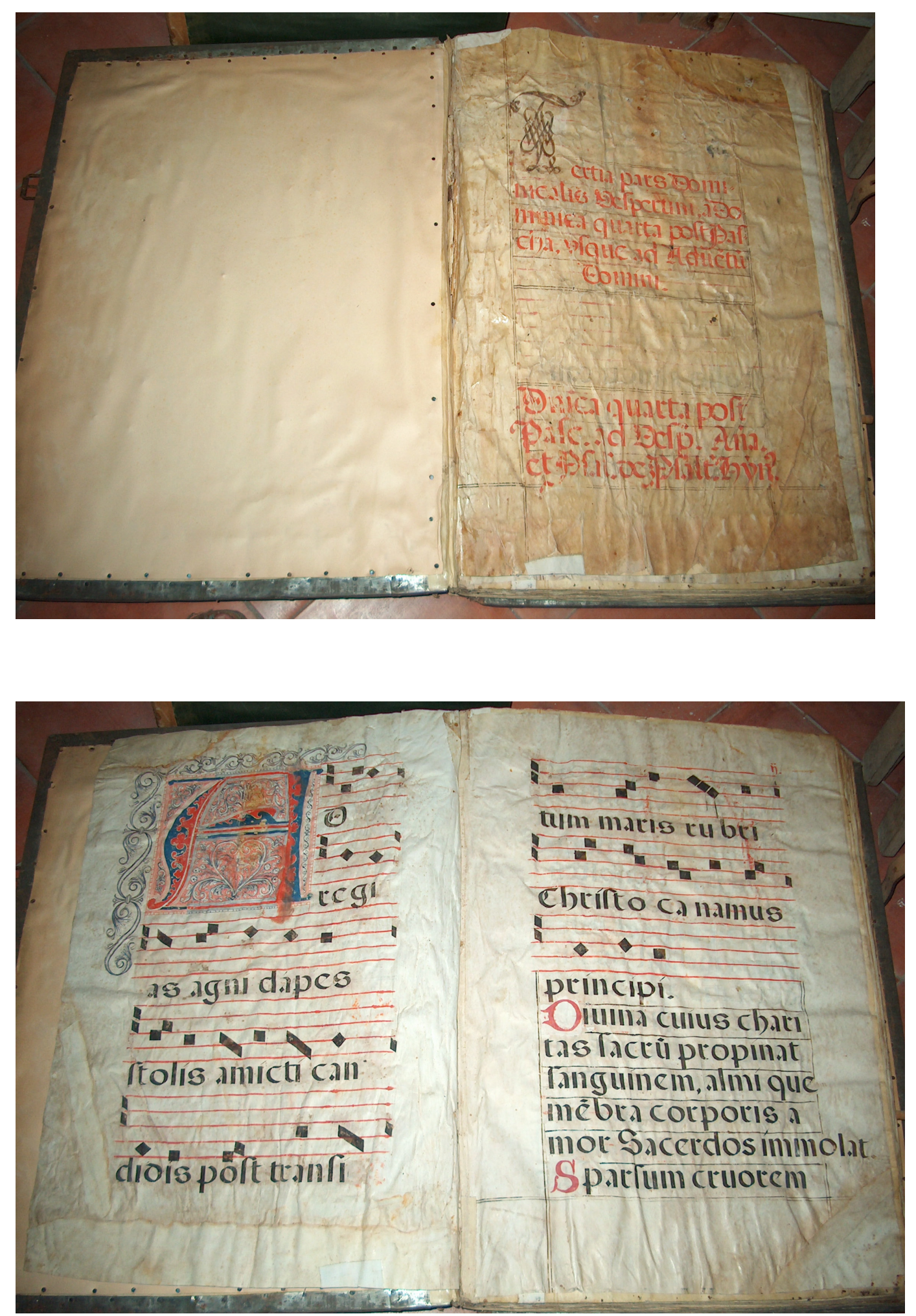


\section{[No XXXVI]}

\section{LIBRO 311 / 13}

Libro de Vísperas. Manuscrito en pergamino de 113 folios. Cinco pentagramas por página.

Medidas: encuadernación 750 × 600 × 130; hoja 740 × 515; caja 550 × 330

Ubicación:Estante C-1

Foliación: 1-113 en numeración romana original.

Fecha: Siglo XVII

Incipit:

Fol. $1^{\mathrm{r}}$ Tertia pars dominicalis vesperum a Dominici quarta post Paschalis usque ad Adventu Domini

Fol. $1^{\mathrm{v}}$ Ad regias

\section{Iluminaciones:}

Fol. 1" A" rojo, azul y gris.

Fol.19" "Q" en rojo, azul y gris.

\section{Festividad o uso litúrgico:}

Antífonas para el tiempo ordinario (desde Pascua a Adviento)( $3^{\mathrm{a}}$ parte del L. De Vísperas Dominicales. Domingo $4^{\circ}$ después de Pascua)

\section{Otras observaciones:}

Su estado de conservación es regular. 
[N ${ }^{\circ}$ XXXVII]

LIBRO 303 (olim 31)
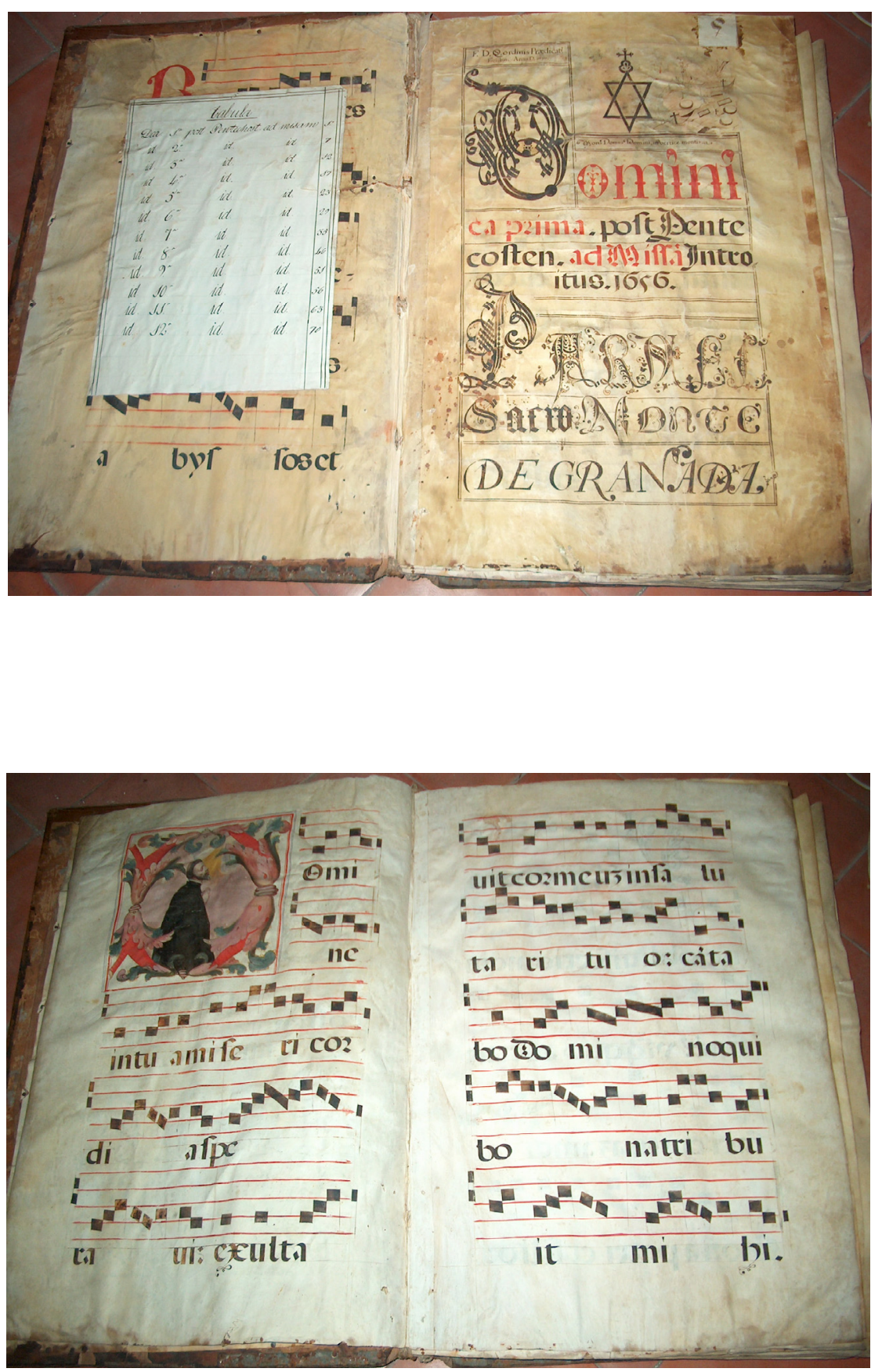


\section{[No XXXVII]}

\section{LIBRO 303 / 31}

Libro de Misas. Manuscrito en pergamino de 76 folios. Cinco pentagramas por página.

Medidas: encuadernación 800 × 540 x 100; hoja 755 × 515 ; caja 620 × 365 .

Ubicación: Estante B-1.

Foliación: 76 folios en numeración arábiga posterior a lápiz. De la numeración orginal faltan los folios 41 al 45 .

Fecha: $1656-1657$

Incipit:

Fol. $1^{r}$ F.D.Q. Ordinis Praedicat Faciebat. Anno D. 1656. Mons. Domus Domini, in vertice montium. Dominica prima, post Pentecostem. Ad Missa Introitus. 1656 PARA EL SACROMONTE DE GRANADA.

Fol. $1^{\mathrm{v}}$ Domine in tua misericordia

\section{Iluminaciones:}

Fol. 1v "D" ilustra monje orando de perfil, hábito negro.

\section{Festividad o uso litúrgico:}

Misas Domingos de Pentecostés, desde la $1^{\mathrm{a}}$ a la $12^{\mathrm{a}}$

Índice:

Hoja de guarda:

Dca $1^{\mathrm{a}}$ post Pentechost. Ad missam 1 /idem $2^{\mathrm{a}}$ idem $7 /$ id. $3^{\mathrm{a}}$ id. $12 /$ id. $3^{\mathrm{a}}$ id. $17 /$ id. 4 id 23/(igual hasta Dominica 12 en los folios:29, 35, 46, 51, 56, 63, 70).

\section{Otras observaciones:}

Su estado de conservación es bueno aunque la encuadernación en piel repujada se encuentra suelta.En el fol. 76 : "Acabose en ij. 8 Agosto 1657. Mandolo eferevit S. Doctor Bartolomé de Torres. Canónigo y Presidente deste Sacromonte".

Probablemente la imagen de la figura orante en la letra "D" represente a D.

Bartolomé de Torres. 


\section{[N'XXXVIII]}

LIBRO 304 (olim 9,2)

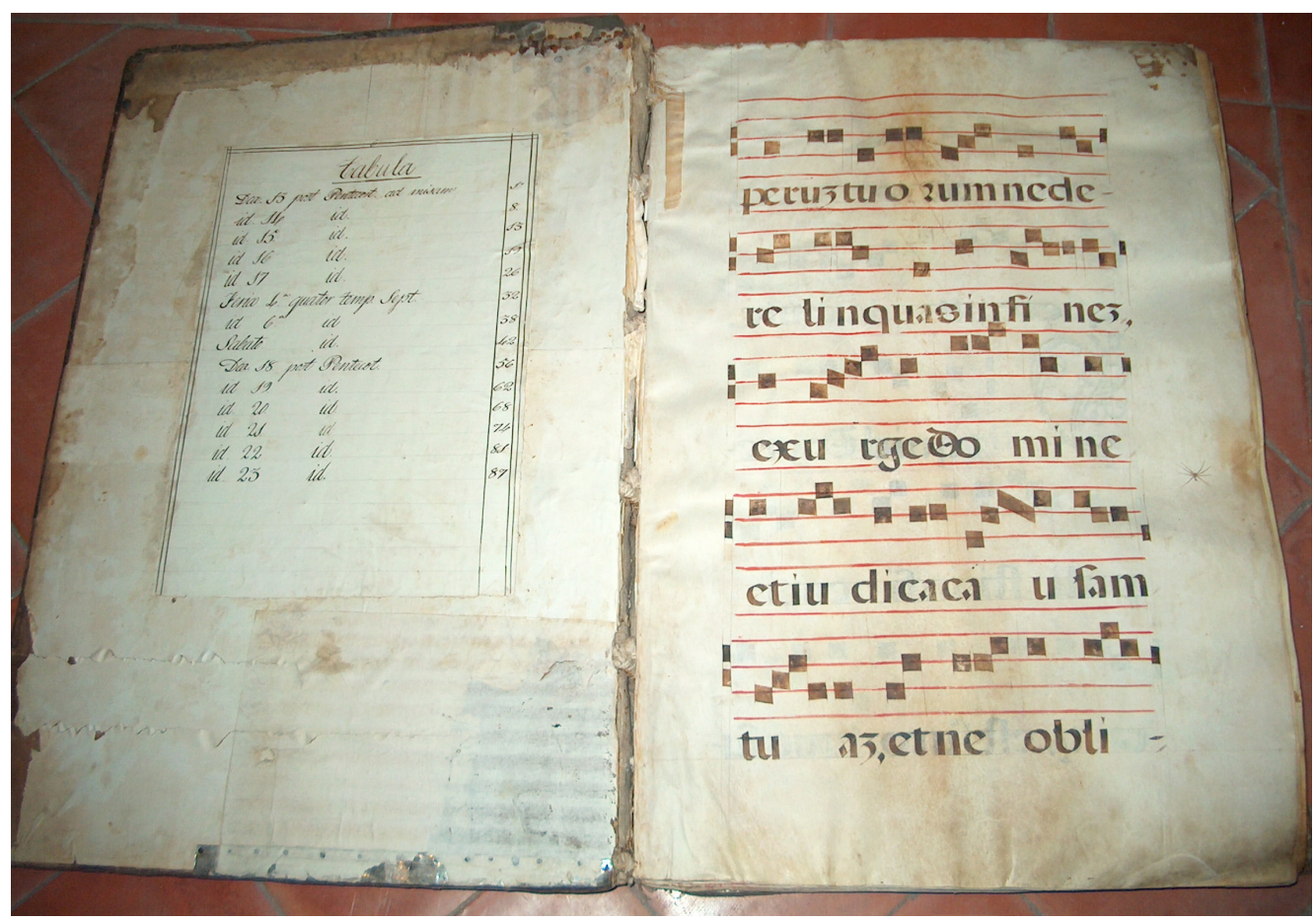




\section{[ $\mathbf{N}^{0} \mathbf{X X X V I I I ]}$}

\section{LIBRO 304 / 9 / 2}

Libro de Misas. Manuscrito en pergamino de 91 folios. Cinco pentagramas por página.

Medidas: encuadernación 800 × 535 x 90; hoja 760 × 505; caja 600 x 345 .

Ubicación: Estante C-2.

Foliación: 2-92 en numeración arábiga original. Falta el folio 1.

Fecha: $1656 ?$

Incipit texto:

Fol. $1^{\mathrm{v}}(\ldots)$ perus tuorum nedere.

\section{Iluminaciones:}

"I" como columna en azul, negro y amarillo (120 x 120)

"A" en rojo y amarillo con flores en tinta negra (120 x 110)

\section{Festividad o uso litúrgico:}

Misas del tiempo ordinario. (Pentecostés desde la 13 a la 23)

Índice:

Tabula/Dominica 13 post Petecost. Ad missam 1/Dca. 14 id. 8/Dca. 15 id 15/ Dca. 16 id 19/Dca. 17 26/ Feria $4^{a}$ quator temp. Sept. 32/ Feria $6^{a}$ id. 38/Sabato id. 42/Dca. 18 post Pentecot. 56/id 19 id 62/ id 20 id 68/id 21 id 74/ id 22 id 81/ id 23 id 87/

\section{Otras observaciones:}

Su estado de conservación es bueno aunque le falta el primer folio. 


\section{[N ${ }^{\circ}$ XXXIX] \\ LIBRO 301 (olim 3)}
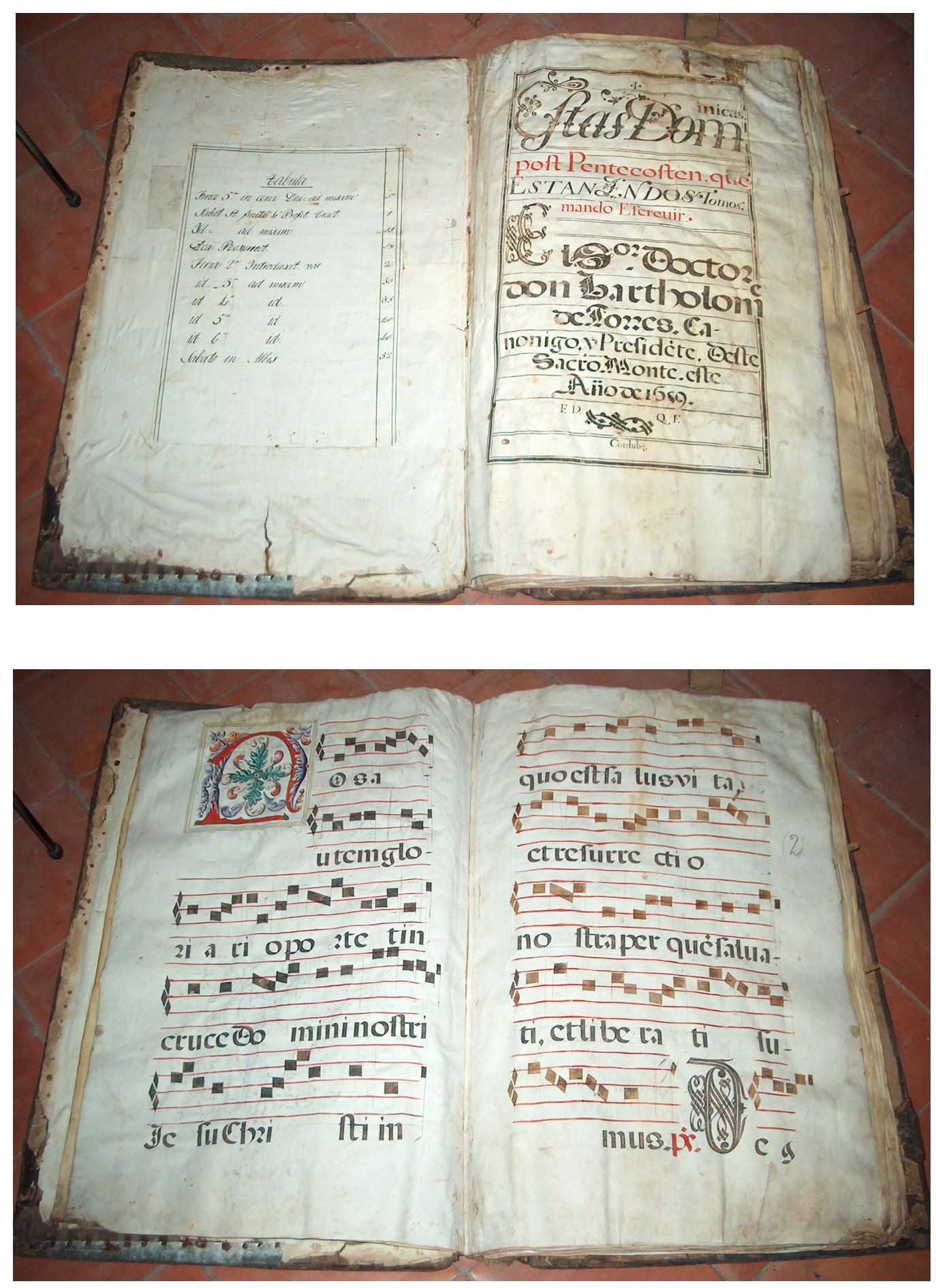


\section{$\left[\mathbf{N}^{0} \mathbf{X X X I X ]}\right.$}

\section{LIBRO 301 / 3}

Libro de Misas. Manuscrito en pergamino de 58 folios. Cinco pentagramas por página.

Medidas: encuadernación 795 × 530 x 110; hoja 745 x 480; caja 600 x 340 .

Ubicación: Estante C-1.

Foliación: 1-58 en numeración arábiga original.

Fecha: 1659

Incipit:

Fol. $1^{\mathrm{r}}$ Sancta Dominicas post Pentecostem que están en 2 tomos. Mandó escribir el Sr. Doctor Don Bartolomé de Torres, canónigo y presidente deste Sacromonte. Este año de 1659. Cordube.

Fol. $1^{\mathrm{v}}$ Nos autem gloria

\section{Iluminaciones:}

Fol.1" "N" en tinta roja, verde y azul.

Fol.17 " $\mathrm{R}$ ” ilustra una imagen de Jesús saliendo del sepulcro vigilado por romanos.

\section{Festividad o uso litúrgico:}

Misas después de Pentecostés.

Índice:

Tabula/Feria V in cena Domini ad misam 1/ Sabat. St. Finita $4^{\text {a }}$ Profet. Tract. 9/ Yd. Ad misam 15/ Dca. Resurrect 18/ Feria $2^{\text {a }}$ Introduxit vos 26/ id. $3^{\text {a }}$ ad misam $30 /$ id $4^{\text {a }}$ id $35 /$ id $5^{\mathrm{a}}$ id 40/ id $6^{\mathrm{a}}$ id 46/ Sabato in Albis 52

\section{Otras observaciones:}

$\mathrm{Su}$ estado de conservación es bueno, salvo las pastas que están algo deterioradas. 
[N'XL]

LIBRO 302 (olim 4)
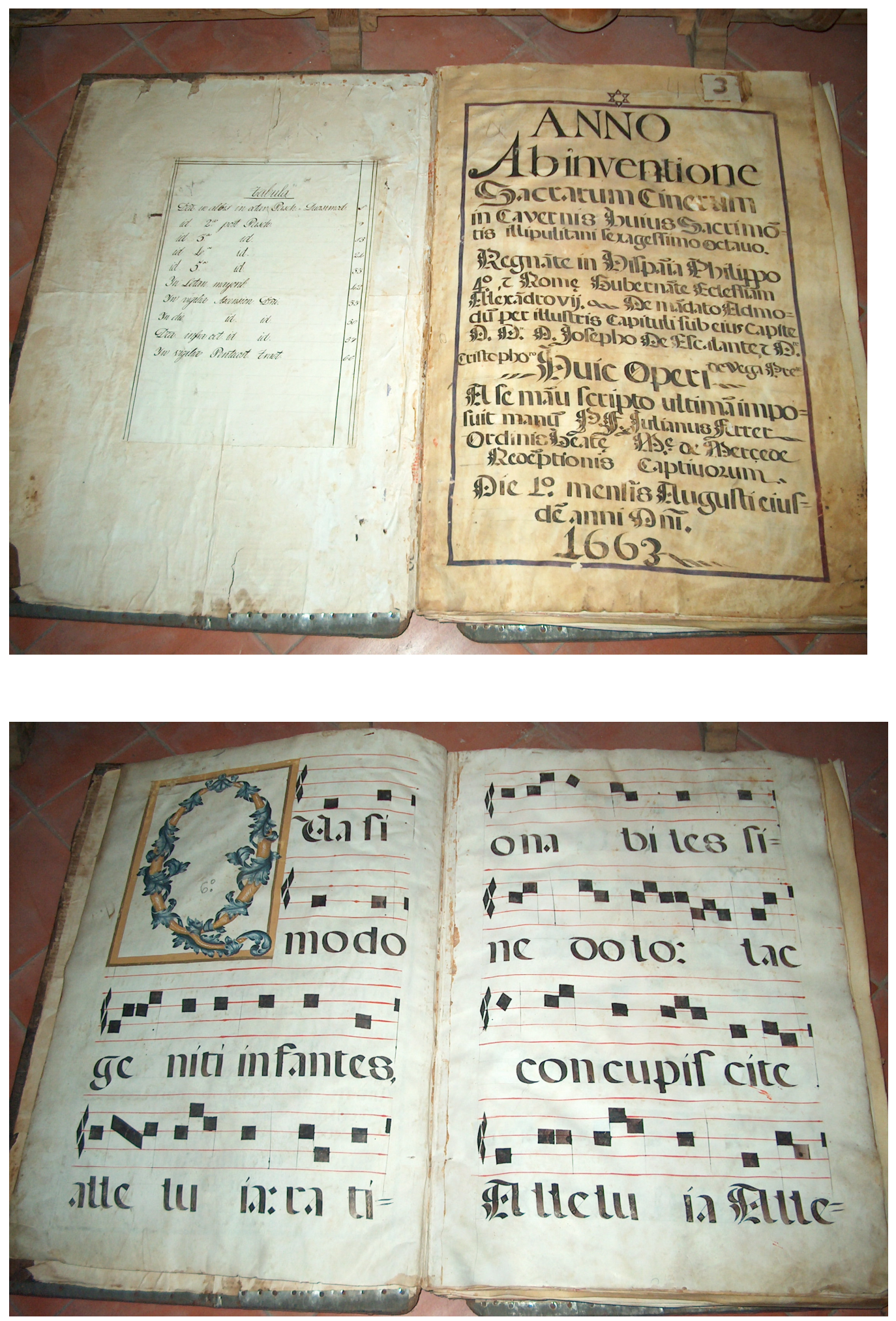
$\left[\mathbf{N}^{0} \mathbf{X L}\right]$

LIBRO 302 / 4

Libro de Misas. Manuscrito en pergamino de 71 folios. Cuatro pentagramas por página.

Medidas: encuadernación 850 × 600 × 130; hoja 815 × 560; caja 690 × 430 .

Ubicación: Estante B-2

Foliación: 1-71 en numeración arábiga posterior a lápiz.

Fecha: 1663

Incipit:

Fol. $1^{\mathrm{r}}$ Anno /Ab inventione Sacrarum Cinerum / in Cavernis huius Sacrimon/tis illipulitani sexagessimo octavo./ Reginate in Hispania Philippo / IV, Rome Gubernate Eclessiam / Alessandro VII de mandato ad mo/dum Per illustris capituli sub eius capite / D. Dr. D. Josepho de Escalante, Dre. Christophoro de Vega Presidente/ huic operi a se manuscripto ultima impo/suit manu Pf Julianus Ferrer / Ordinis Beate M de Mercede / Redemptionis captivorum / Die $1^{\circ}$ mensis Augusti eius de anni Domini / 1663.

Fol.1 ${ }^{\mathrm{v}}$ Quasimodo geniti infantes

\section{Iluminaciones:}

Fol.1 "Q" en tinta azul,blanca y marrón (340 x 255)

Fol. "V" en tinta azul, roja y marrón. (335 x 255)

\section{Festividad o uso litúrgico:}

Domingos: in albis y Pasena.Letanías mayores.Ascensión, Vigilia Pentecostés.

Índice:

Tabula/Dca in albis in oct. Pasch Quasimod 1/ id $2^{\mathrm{a}}$ post Pasch $9 /$ id $3^{\mathrm{a}} 15 / \mathrm{id} 4^{\mathrm{a}}$ id 24/ id 5a id 33/ In Letan mayoribus 42/ In Vigilia Ascension Dni 33/ In die id id 50/ Dca infra oct id id 57/ In vigilia Pentecost tract. 66

\section{Otras observaciones:}

Su estado de conservación es bueno. 
[N $\left.{ }^{\circ} \mathrm{XLI}\right]$

LIBRO 305 (olim L)
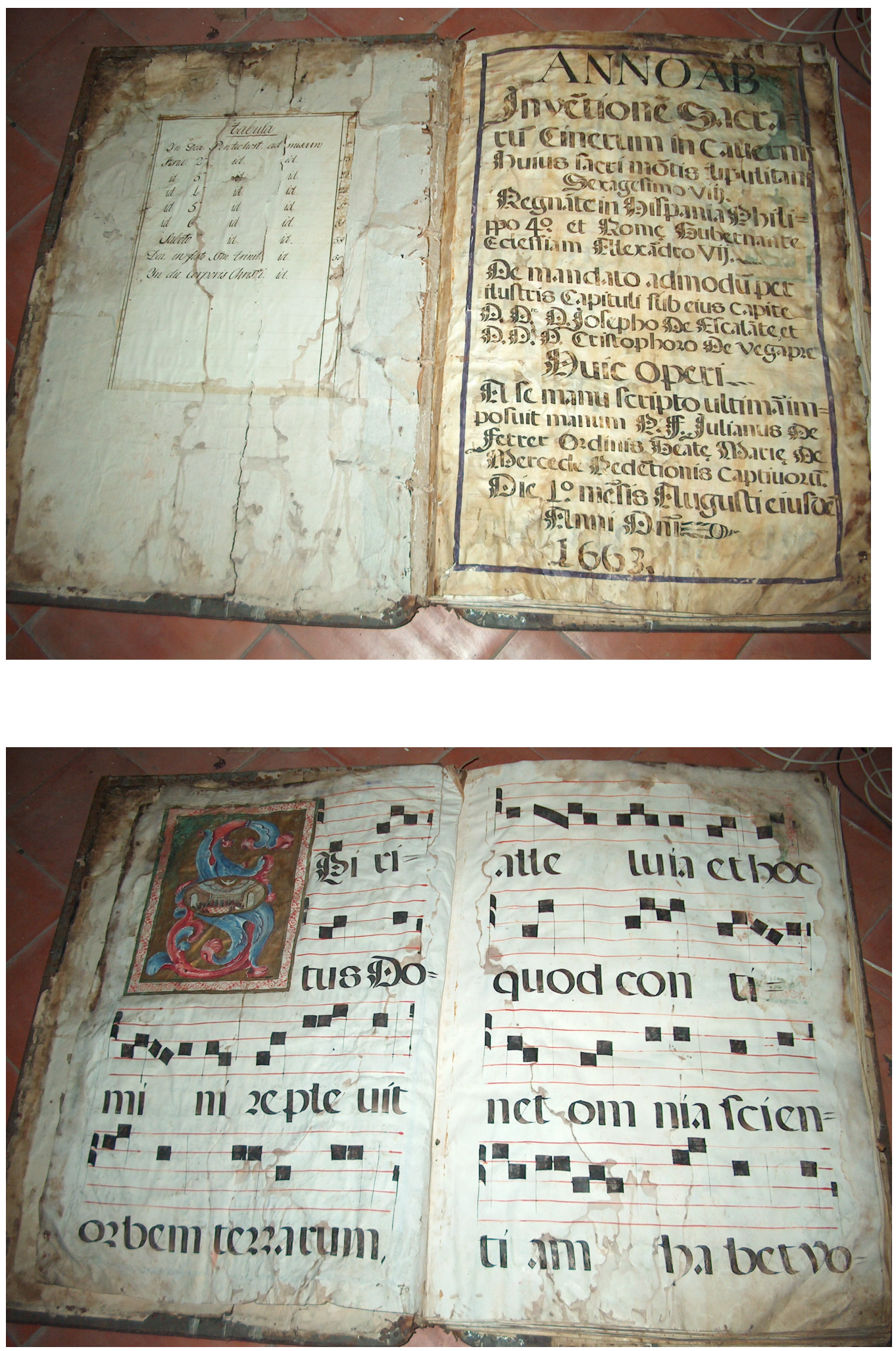
$\left[\mathbf{N}^{0} \mathbf{X L I}\right]$

LIBRO 305 / L

Libro de Misas. Manuscrito en pergamino de 72 folios. Cuatro pentagramas por página.

Medidas: encuadernación 750 × 585 × 120; hoja 790 × 530; caja 685 × 430.

Ubicación: Estante C-2.

Foliación: 1-72 en numeración arábiga, posterior a lápiz.

Fecha: 1663

Incipit:

Fol. $1^{\mathrm{r}}$ Anno Ab Inventione Sacra/rum Cinerum in Cavernis/huius Sacri Montis ilipulitani/sexagesimo viij/ Regnate in Hispania Phili/ppo $4^{\circ}$ et Rome gubernate/ Eclessiam Alexandro vij/De mandato admodum per/ilustris capituli sub eius capite/D.dre.Djosepho de Escalante et D.Dre.D Cristophoro de Vega prete./Huic operi/A se manuscripto ultimarum=/posuit manum P.F. Julianus Ferrer Ordinis Beate Marie de/ Mercede redemptionis Captivorum/Die $1^{\circ}$ mesis Augusti eius de/Anni Dni/1663

Fol.1 ${ }^{\mathrm{v}}$ Spiritus Domini replevit

\section{Iluminaciones:}

Fol. $1^{\mathrm{v}}$ "S" en rojo y azul sobre fondo dorado. Apóstoles con Espíritu santo en forma de paloma (325 x 245)

Fol.13 ${ }^{\mathrm{r}}$ C" con pájaro en amarillo, malva y azul ( $\left.180 \times 160\right)$

Fol.26 ${ }^{\mathrm{r}}$ "D" con pájaro y flor en amarillo y malva (160 x 150$)$

Festividad o uso litúrgico: Propio de las misas de Domingos de Pentecostés y Ferias, Trinidad y Corpus Christi

Índice:

Tabula/ In Dominica Pentechost. Ad misam 1/ Feria $2^{\text {a }} 15$ / Feria $3^{\text {a }} 20$ / Feria $4^{\text {a }} 26$ / Feria $5^{\mathrm{a}} 1 /$ Feria $6^{\mathrm{a}} 31$ / Sabato 38/ Dca. In festo Ssm. Trinit. 50/ In die Corporis Christi 60

\section{Otras observaciones:}

En los folios $6^{\mathrm{v}}$ y ss. hay ejemplos de indicaciones mensurales. 
[N ${ }^{0} \mathrm{XLII]}$

\section{LIBRO ¿? (olim 43)}
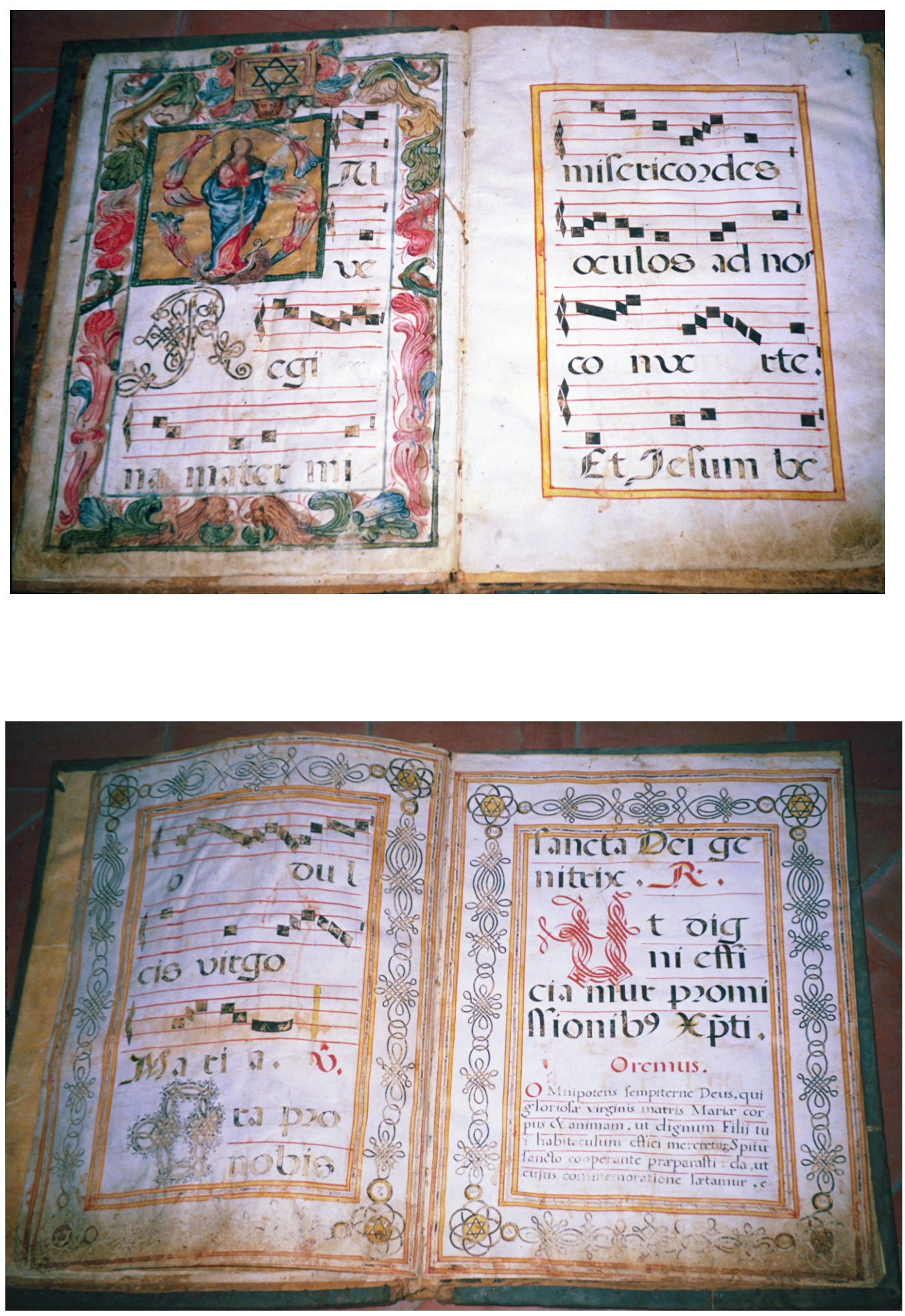


\section{$\left[\mathbf{N}^{0} \mathbf{X L I I}\right]$}

\section{LIBRO s.s. / 43}

Cantoral. Manuscrito en pergamino de 13 folios. Cuatro pentagramas por página.

Medidas: encuadernación 600 × 420 × 50; hoja 555 × 400; caja 400 × 260

Ubicación: Estante A-1.

Foliación: 1-15 en numeración arábiga original. Faltan folios intermedios.

Fecha: 1657

Copista: Francisco de Aguilar.

\section{Incipit:}

Fol. $1^{\mathrm{v}}$ Salve Regina Mater mi(..)

\section{Iluminaciones:}

Fol.1 "S" ilustra imagen de la Inmaculada Concepción con túnica blanca y manto azul sobre fondo dorado (185 x 180).

Fol. $7^{\mathrm{v}}$ "L" ilustra figura de un ángel (120 x 100).

\section{Festividad o uso litúrgico:}

Salve y Letanías mayores a San Cecilio.

\section{Otras observaciones:}

En el fol. $3^{\mathrm{v}}$ hay una inscripción en la orla: “Anno Domini 1697”. Folio 4r:."Francisco de Aguilar fecit et ¿?". En el Folio 11 "v: "Mandó hacer efte libro un Devoto para que se cante la Salve en estas sanctas Cuebas. AnnoDomini 1697”. Algunos folios están sueltos. En las guardas aparece un grabado con la siguiente leyenda: "Altar de Anima perpetuo, como el de San Juan de Letrán de la Corte de oma (....) en 30 de mayo de 1752. Joseph Julian de Toxar me escribia en Granada". La "S" ilustrada está muy deteriorada. 
[N'XLIII]

LIBRO 369 (olim A)

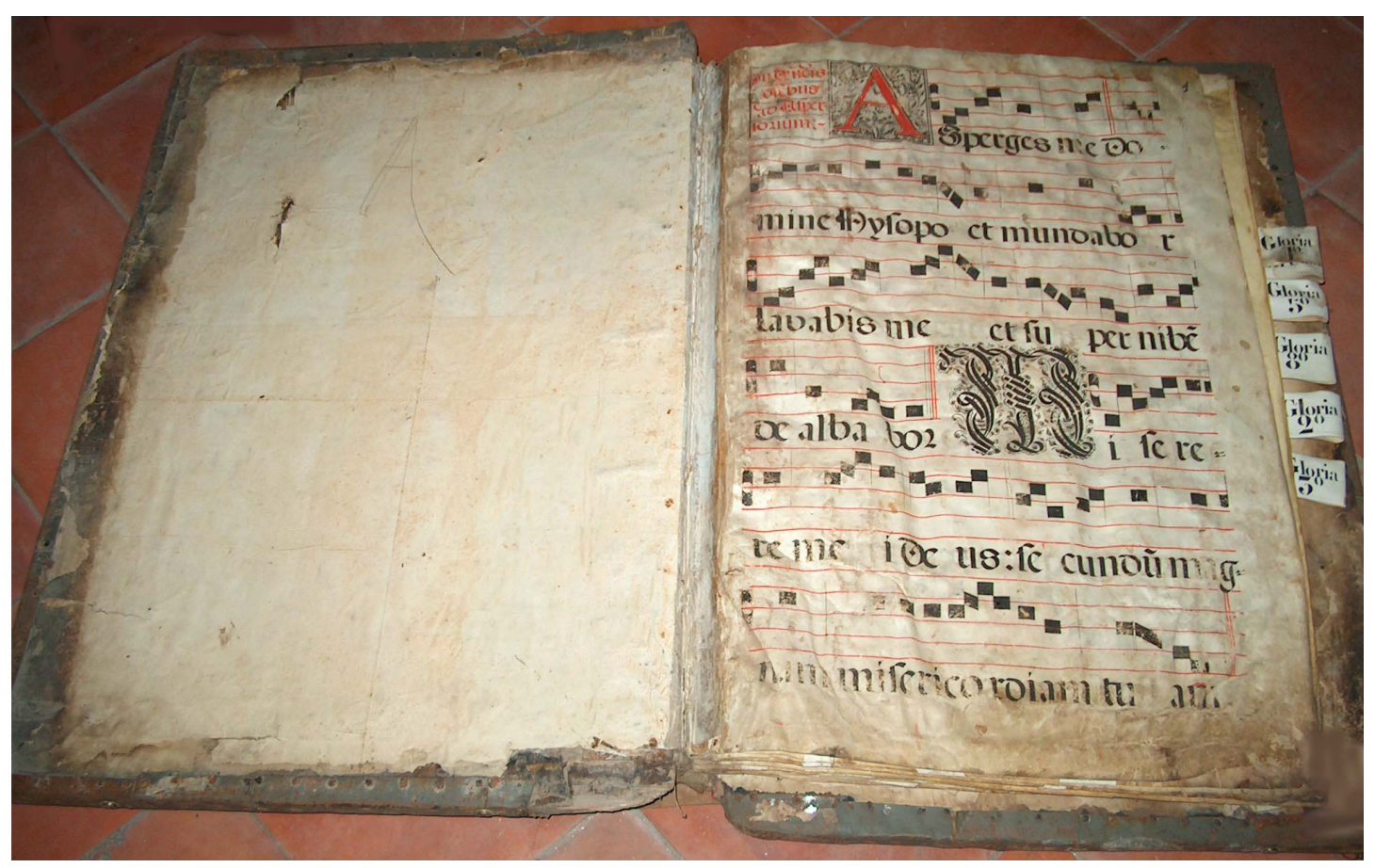




\section{[No XLIII]}

\section{LIBRO 369 / A}

Cantoral. Manuscrito en pergamino de 39 folios. Seis pentagramas por página.

Medidas: encuadernación 800 × 570 x 70; hoja 710 x 500; caja 640 x 410 .

Ubicación: Estante C-1

Foliación: 1-39 en numeración arábiga posterior, a lápiz.

Fecha: ¿Siglo XVII?

Incipit:

Fol. $1^{\mathrm{r}}$ Asperges me Domine hysopo et mundabo

\section{Festividad o uso litúrgico:}

Ordinario de la misa

Otras observaciones:

Muy deteriorado, no tiene portada. Guarda cierta similitud con el Cantoral XXXIX. 
[N'XLIV]

LIBRO 347 (olim 44)
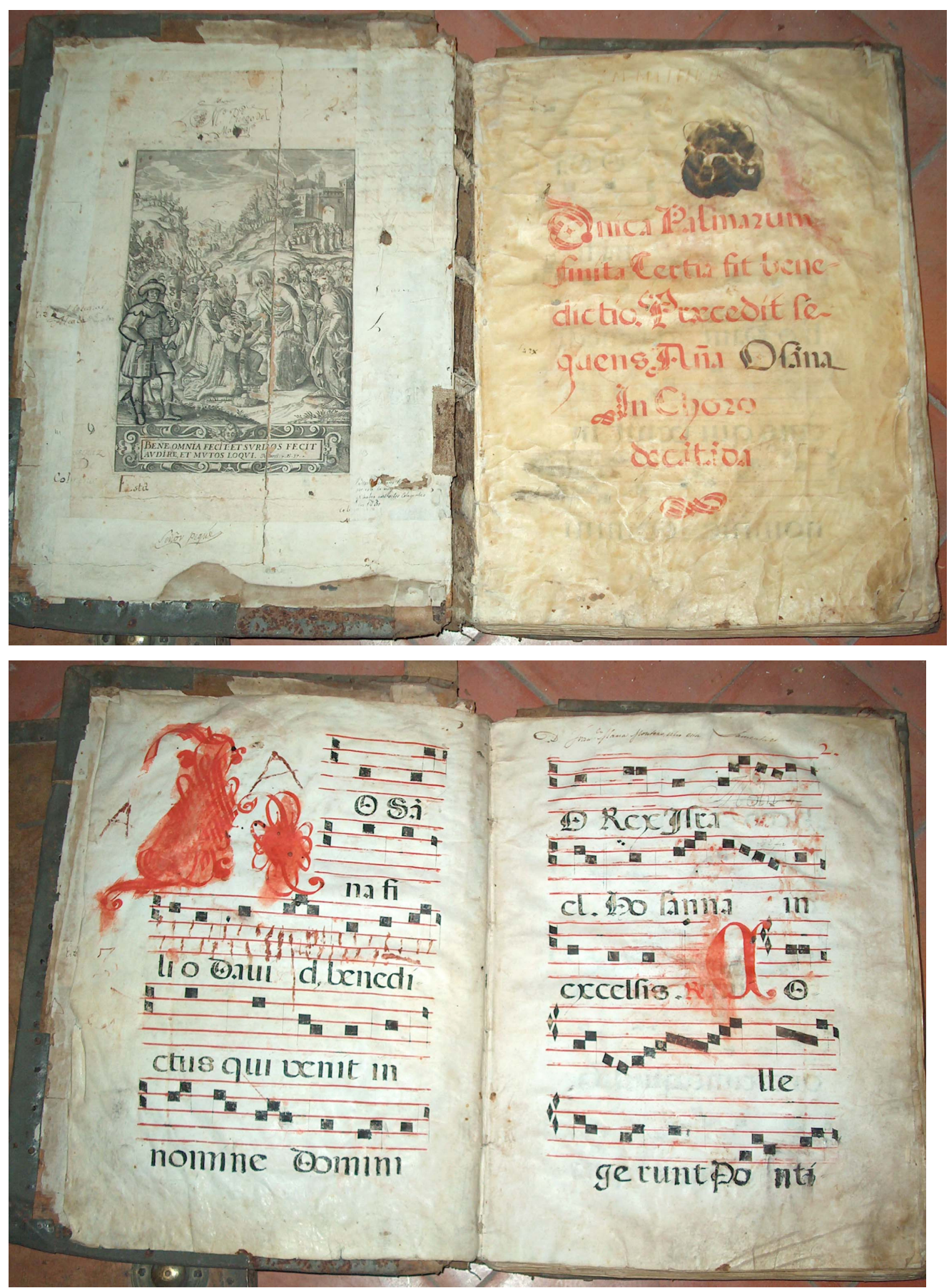


\section{$\left[\mathbf{N}^{0} \mathbf{X L I V}\right]$}

\section{LIBRO 347 / 44}

Cantoral. Manuscrito en pergamino de 64 folios. Cinco pentagramas por página.

Medidas: encuadernación 535 × 385 x 80; hoja 505 × 360; caja 385 × 250.

Ubicación: Estante A-2

Foliación: 64 folios en numeración arábiga original.

Fecha: Siglo XVII

Incipit:

Fol. $1^{\mathrm{r}} \mathrm{D}$ (omi)nica Palmarum/ finita tertia sit bene/dictio. Praecedit se/quens An(tifon)a Ofana/ In Choro /de cantanda

Fol.1 ${ }^{v}$ Hosanna filio David

\section{Festividad o uso litúrgico:}

Semana Santa.

\section{Otras observaciones:}

Aparecen bemoles el mi y el si. En las guardas hay dos ejemplares de un grabado de F.Heylan "Jesucristo cura a San Cecilio y San Tesifón", deteriorado por dibujos a lápiz. Numerosas inscripciones dan testimonio de quien "echaba las lamentaciones":

Fol. $9^{\mathrm{r}}$ Ramón María Valdivia echo esta lamentación el año de 1834 y 1835 y 1836. Silvestre Pérez Vinet echo esta lamentación el año de 1837 y 38

Fol. $32^{\mathrm{r}}$ Libro de las lamentaciones Manuel al Hoxaer Izquierdo. Año de 1788.

Fol. $46^{\mathrm{r}}$ Esta lamentación y la siguiente la echo Dionisio Torres vecino de la ciudad de Llerena extremeño. 



\section{$\left[\mathbf{N}^{0} \mathbf{X L V}\right]$}

LIBRO 368 / R

Cantoral. Manuscrito en papel de 174 folios. Siete pentagramas por página.

Medidas: encuadernación 550 × 370 x 110

Ubicación: Estante A-2

Foliación: 1-174 en numeración arábiga original, faltan cuatro folios.

Fecha: ¿Siglo XVII?

Incipit texto:

Fol. Indice/Proprium de tempore (...) Antífona Mayores/Comune Sanctorum

\section{Festividad o uso litúrgico:}

Vísperas (Proprium de tempore, y comun sanctorum)

\section{Otras observaciones:}

Aparecen indicaciones mensurales en el himno de la página 154, como compás binario. 
[No'XLVI]

LIBRO 340 (olim 40)

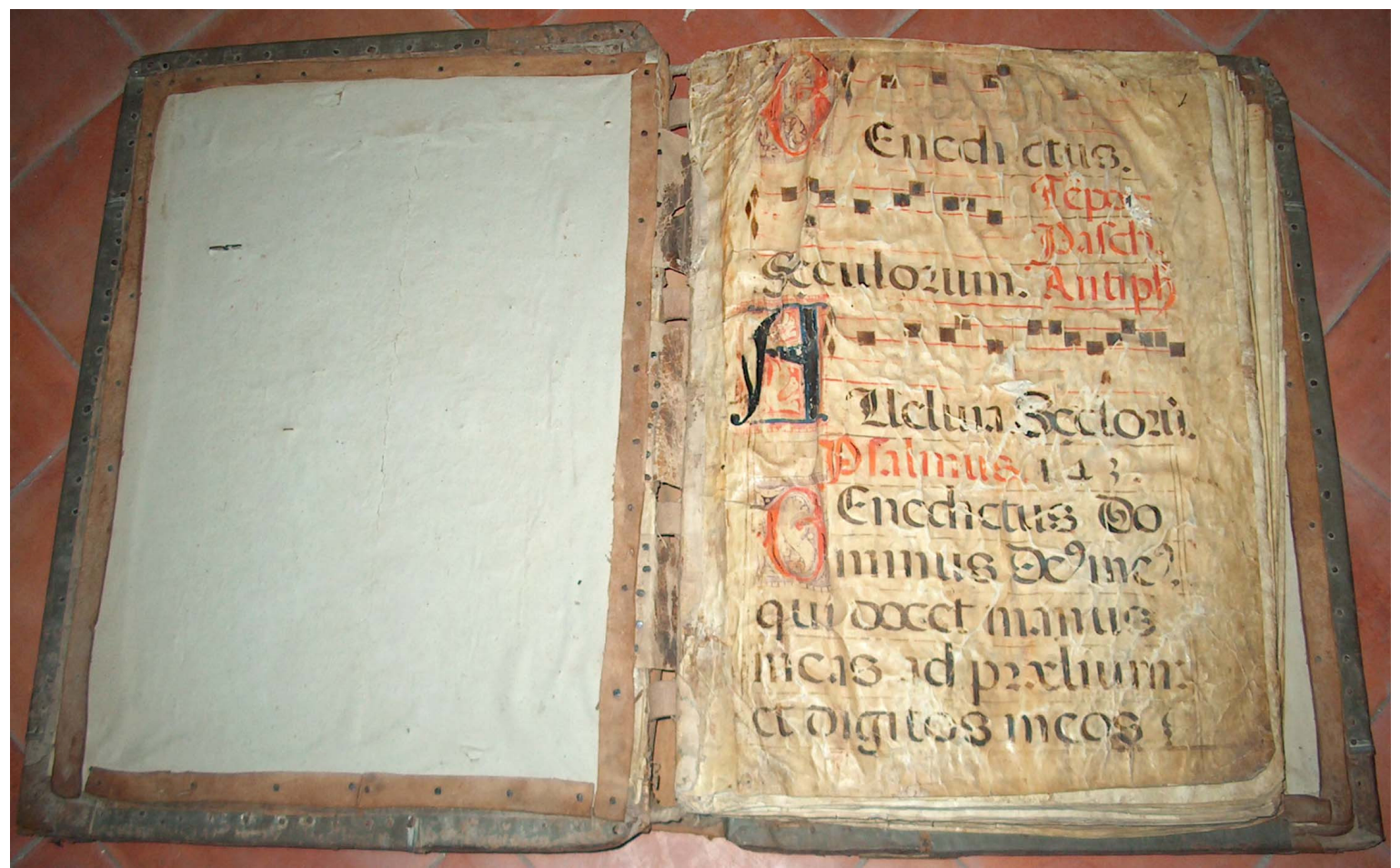




\section{$\left[\mathbf{N}^{\mathbf{o}} \mathbf{X L V I}\right]$}

\section{LIBRO 340 / 40}

Libro de Vísperas. Manuscrito en pergamino de 59 folios. Cinco pentagramas por página.

Medidas: encuadernación 680 x 500 x 110; hoja 590 x 460; caja 550 × 330.

Ubicación: Estante C-1

Foliación: 1-59 folios en numeración arábiga a lápiz, posterior. No se corresponde con la foliación original que también es arábiga.

Fecha: ¿Siglo XVIII?

Incipit texto:

(...) benedictus seculorum. Tempo pasch. Antifona

\section{Festividad o uso litúrgico:}

Libro de horas (Vísperas para San Cecilio)

\section{Otras observaciones:}

La encuadernación, que es posterior pues los folios están cortados, se encuentra bastante deteriorada. Alterna secciones con oraciones, sin música. 
[N'XLVII]

LIBRO 336 (olim 36)

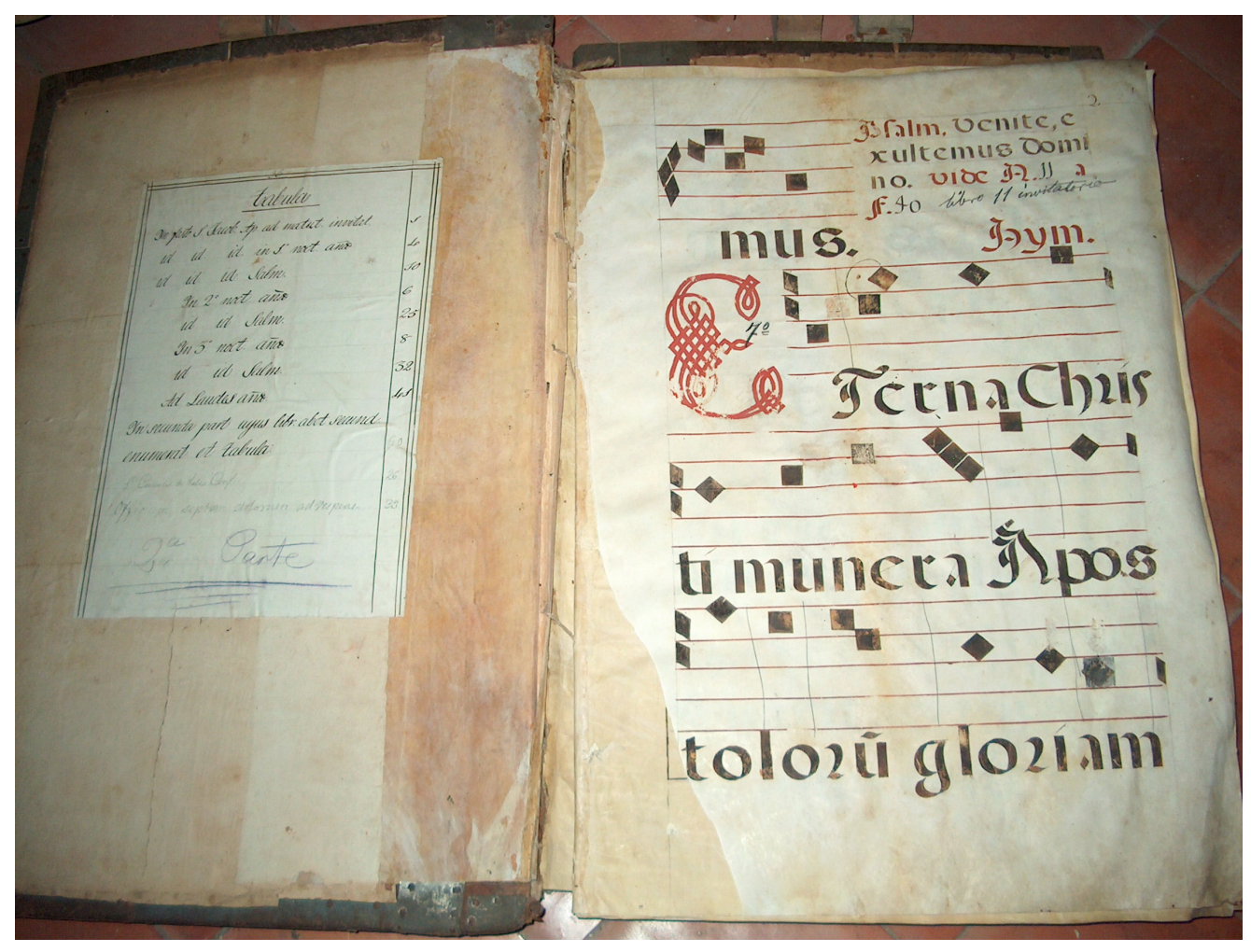




\section{[No XLVII]}

\section{LIBRO 336 / olim 36}

Libro Misa y Vísperas. Manuscrito sobre pergamino. Cuatro pentagramas por página.

Medidas: encuadernación 865 x 570 x 110; hoja 780 × 555; caja 615 x 440 .

Ubicación: Estante B-2

Foliación: 1-84 en total, numeración arábiga original en dos secciones (2-49) y (1-34)

Fecha: Siglo XVII

\section{Incipit:}

Fol. $2^{\mathrm{r}}$ (...)mus./ Psalm. Venite, exultemus Domino Vide A 11 a f.40/ Himn./ Eterna Christi munera Apostolorum gloriam

\section{Iluminaciones:}

No tiene.

\section{Festividad o uso litúrgico:}

Primera parte: Oficios Santiago apóstol. Segunda parte: vísperas y misas de San Vicente, San Francisco Carraciolo, San Juan Cantii; San Camilo de Lelis y San Torcuato.

\section{Índice:}

Hoja de guardas:

Tabula/In festo S. Jacob Ap. Ad matut. Invitat. $1 /$ id is is in $1^{\circ}$ noct.antíphona $4 /$ id id id Salm. 10/ In $2^{\circ}$ noct antíphona 6/ iid id Salm 25/In $3^{\circ}$ noct antíphona 8/ id id Salm 32/ Ad laudes antíphona 41 / In secunda part uyus libr. Abet secund/ enumerat et tabula: /San Camilis de Lelis Conf 26/ Officium septem dolorem ad vesperas 33

\section{Otras observaciones:}

El lomo se encuentra desencuadernado y roto. Falta además el primer folio. Puede que se trate de 2 libros encuadernados en uno, lo que explicaría las dos secciones numeradas diferentes. En el folio $52^{\mathrm{r}}$ aparece notación mensural. 
[N'XLVIII]

LIBRO 357 (olim 53)

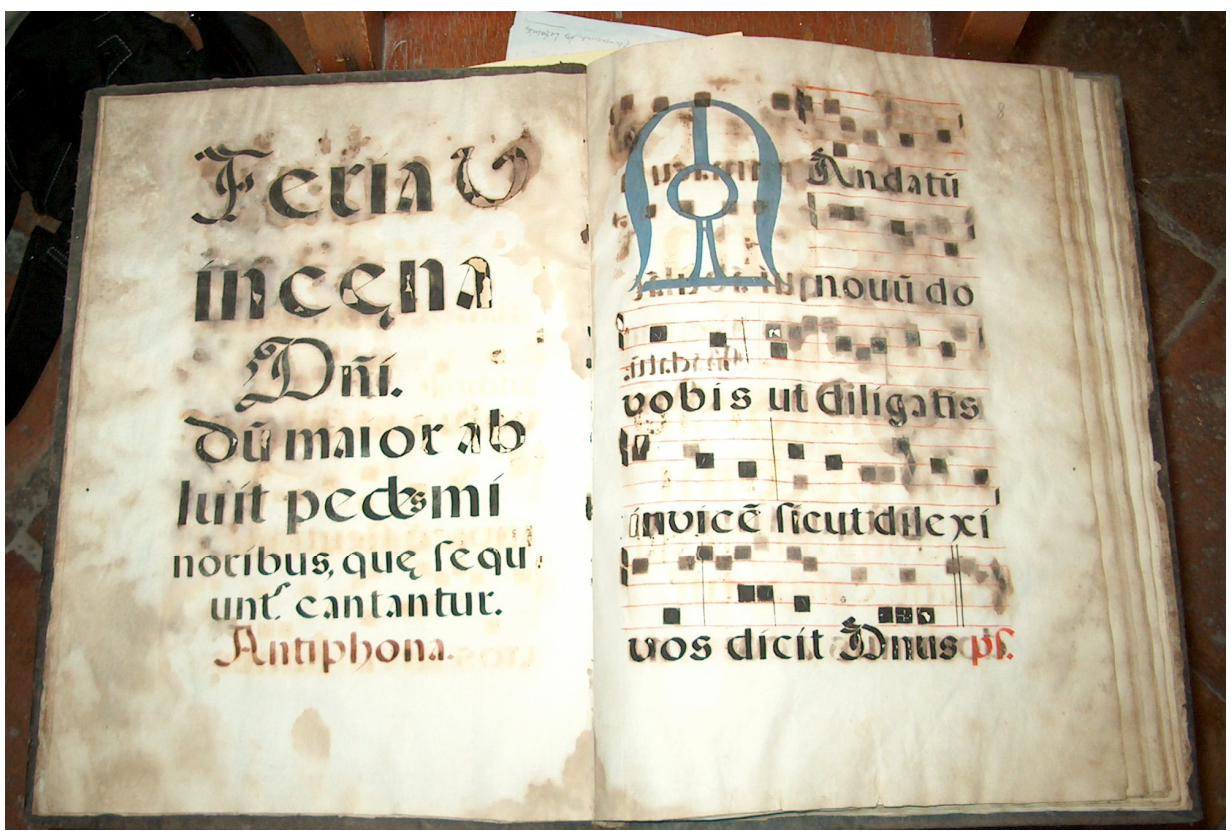




\section{$\left[\mathbf{N}^{0}\right.$ XLVIII]}

\section{LIBRO 357 / 53}

Cantoral. Manuscrito en papel de 35 folios . Cinco pentagramas por página.

Medidas: encuadernación 360 × 250 × 300; hoja 340 × 235; caja 255 x 170.

Ubicación: Vitrina 4, arriba

Foliación: 1-35 en numeración arábiga posterior, a lápiz.

Fecha: $i$ ?

Incipit texto:

Fol. $1^{\mathrm{r}}$ Feria $\mathrm{V}$ in cena Domini maior abluit pedes minoribus, que secunt cantatur. Antiphona

\section{Iluminaciones:}

No tiene.

\section{Festividad o uso litúrgico:}

Feria V in coena Domini.

Índice:

No tiene.

\section{Otras observaciones:}

Se encuentra muy deteriorado, la tinta ha perforado el papel. Contiene indicaciones sobre la interpretación: como por ejemplo en el folio $17^{\mathrm{v}}$ "Duo cantores cantat in medio chori". 


\section{[N'XLIX] \\ LIBRO S.S. (olim N)}
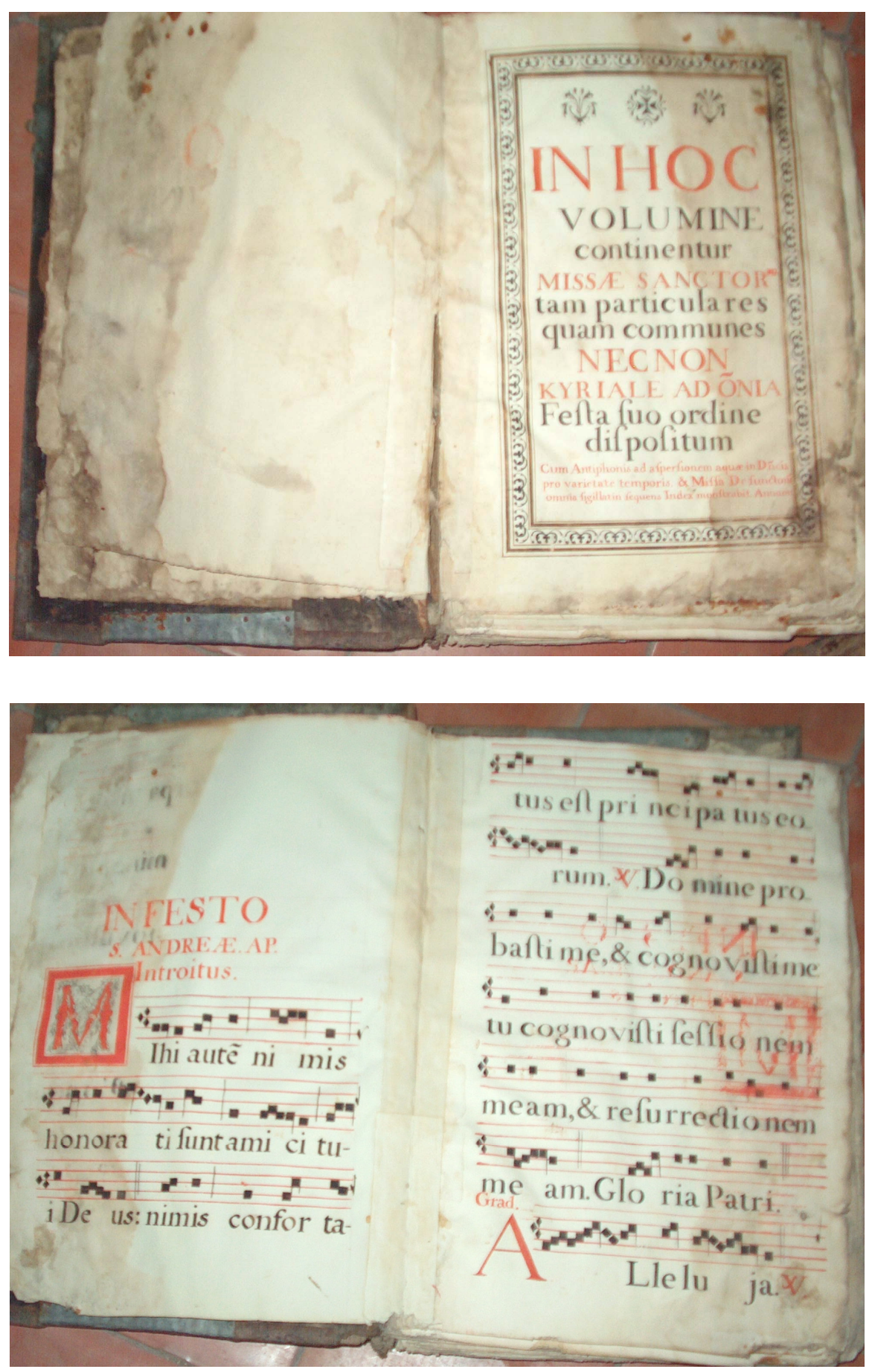


\section{$\left[\mathbf{N}^{0}\right.$ XLIX]}

\section{LIBRO s.s. / N}

Libro de Misas. Manuscrito en papel de 168 folios. Siete pentagramas por página.

Medidas: encuadernación 525 × 340 x 95; hoja 485 x 330; caja 445 x 260 .

Ubicación: Estante A-2.

Foliación: 168 en numeración arábiga, original.

Fecha: 1735

Incipit:

Fol. $1^{\mathrm{r}}$ "In hoc volumine continentur Missae Sanctorum tam particulares quam communes necnon Kyriale ad omnia Festa suo ordine dispositum cum Antiphonis ad aspersionem aquae in Dominicis pro varietate temporis \& Missa defunctorum omnia figillatin sequens Index monstrabit. Anno 1735”

\section{Iluminaciones:}

No tiene.

\section{Festividad o uso litúrgico:}

Propio de las Misas, del propio y del común de los santos.

Índice:

No tiene.

\section{Observaciones:}

En la parte superior de la guarda aparece una etiqueta con el texto "Del Convento de San Antonio de Padua". Contiene índice detallado. En el folio $1^{v}$ aparece un Agnus Dei no incluido en el índice y que probablemente fuera incluido con posterioridad. Aparecen restos de una hoja de música impresa a modo de remiendo. 


\section{$\left[\mathbf{N}^{0} \mathbf{L}\right]$}

\section{LIBRO 356 (olim 52, Ñ, Kyrie)}

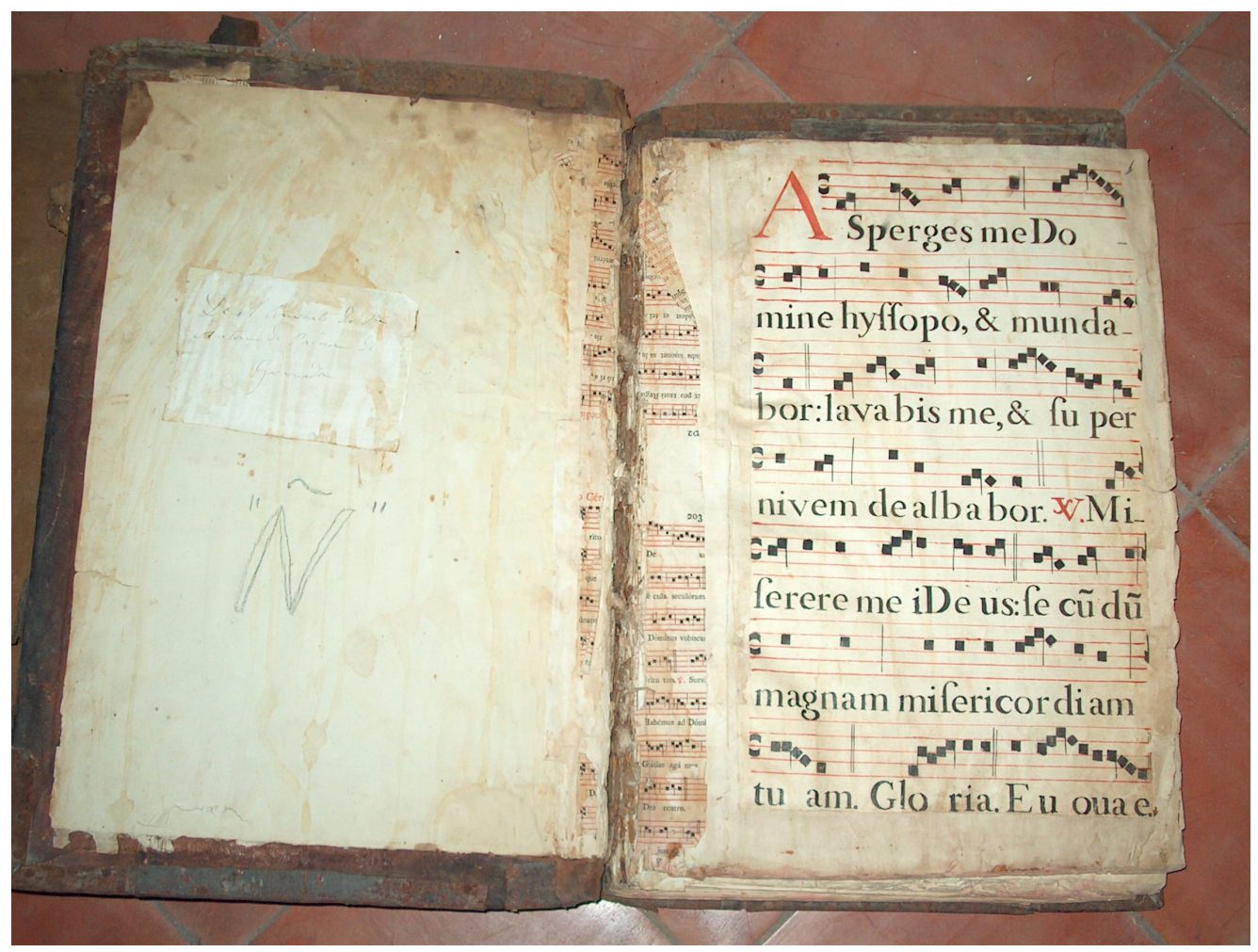




\section{$\left[\mathbf{N}^{0} \mathbf{L}\right]$}

\section{LIBRO 356 / 52 / Ñ /Kyrie}

Cantoral. Manuscrito en papel de 83 folios. Siete pentagramas por página.

Medidas: encuadernación 550 × 370 × 60; hoja 490 × 350

Ubicación: Estante A-2

Foliación: 1-83 en numeración arábiga a lápiz, posterior.

Fecha: ca. 1735

Incipit:

Fol. $1^{\mathrm{r}}$ Asperges me Domine hyssopo

\section{Iluminaciones :}

No tiene

\section{Festividad o uso litúrgico:}

Ordinario de las misa.

Índice:

No tiene

\section{Otras observaciones:}

El último cuadernillo se encuentra suelto. Tiene indicaciones mensurales. Contiene una etiqueta que dice "Del Convento de San Antonio de Padua de Granada". Los refuerzos están hechos con un impreso musical. 
[N'LI]

LIBRO 380 (olim L, comunes)

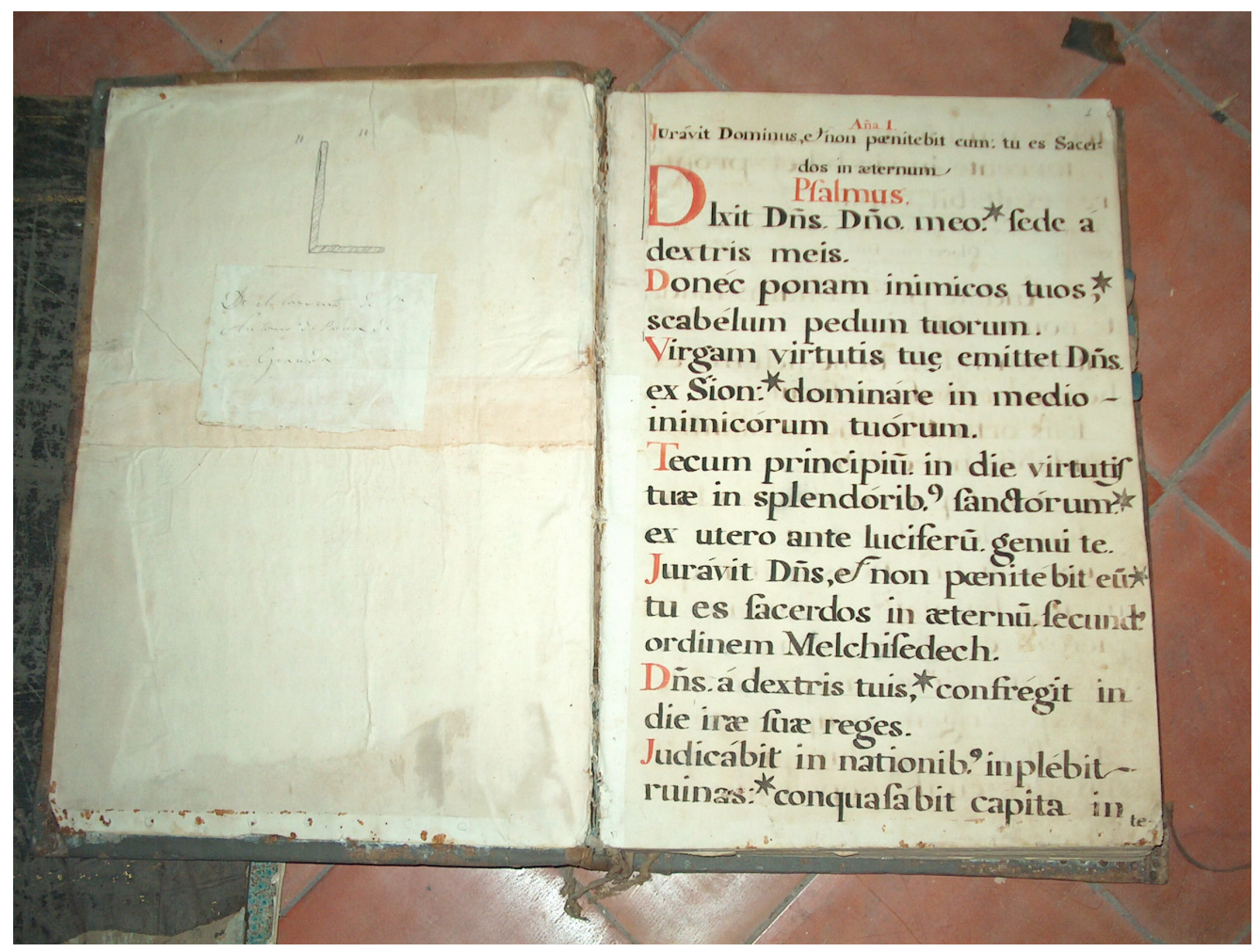




\section{$\left[\mathbf{N}^{0} \mathbf{L I}\right]$}

\section{LIBRO 380 / L / comunes}

Cantoral. Manuscrito en papel de 139 páginas. Cuatro pentagramas por página.

Medidas: encuadernación 525 × 370 × 80; hoja 500 × 345

Ubicación: Estante A-2

Foliación: 1-139 en numeración arábiga original.

Fecha: ca.1735

Incipit texto:

Pág 1. An(tifon)a 1. Iuravit Dominus et non paenitebit cum: tu es Sacerdos in aeternum. Psalmus: dixit $\mathrm{D}$ (ominu)s D(omi)no Meo

\section{Iluminaciones:}

No tiene.

\section{Festividad o uso litúrgico:}

Vísperas del común y varios santos.

Índice:

No tiene

\section{Otras observaciones:}

En las guardas tiene una etiqueta que dice: "Del Convento de San Antonio de Padua de Granada". Aparecen indicaciones mensurales en la página 126. 

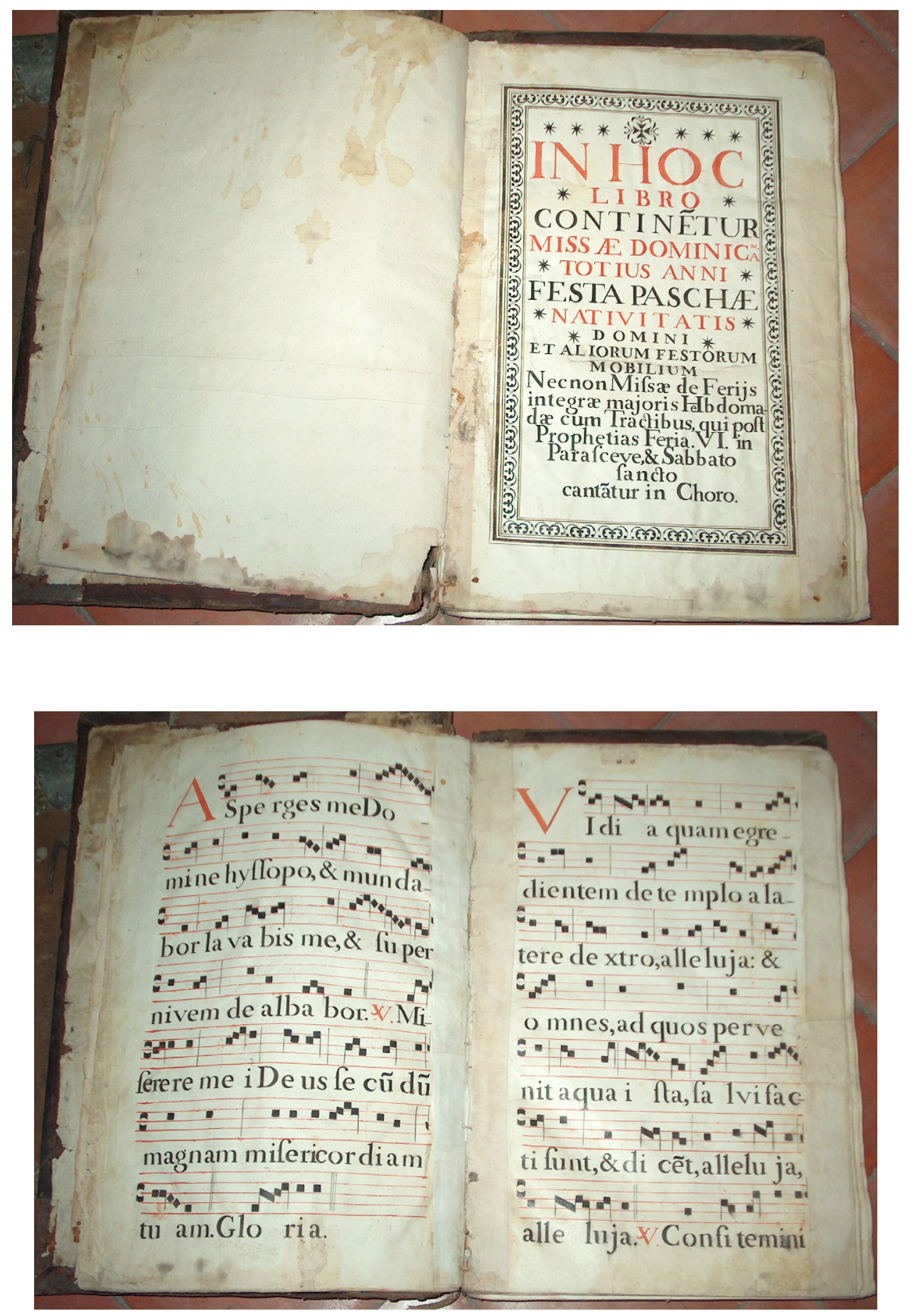


\section{$\left[\mathbf{N}^{\mathbf{0}} \mathbf{L I I}\right]$}

\section{LIBRO 355 / 51 / Mise Tempore}

Cantoral. Manuscrito en papel de 145 folios. Siete pentagramas por página.

Medidas: encuadernación 560 × 370 x 80; hoja 510 × 340; caja 430 × 265 .

Ubicación: Estante A-2

Foliación: 1-145 en numeración arábiga posterior a lápiz.

Fecha: ca. 1735

Incipit:

Fol. $1^{\mathrm{r}}$ In hoc libro continentur Missae Dominica totius Anni festa Paschae nativitatis Domini et aliorum festorum mobilius Necnon Missae de ferijs integrae majoris Hebdomadae cum Tractibus, qui post Prophetias feria VI in paresceve\& Sabbato sancto cantatur in choro

\section{Iluminaciones:}

No tiene.

\section{Festividad o uso litúrgico:}

Misas dominicales para todo el año

Índice:

No tiene.

\section{Otras observaciones:}

Se encuentra en buen estado de conservación. En el lomo se lee, además de los dos números del volumen: Mise Tempore. Contiene una etiqueta en las guardas interiores delanteras que indica que es "Del Convento de San Antonio de Padua de Granada". 


\section{[N'LIII] \\ LIBRO 359 (olim 57)}
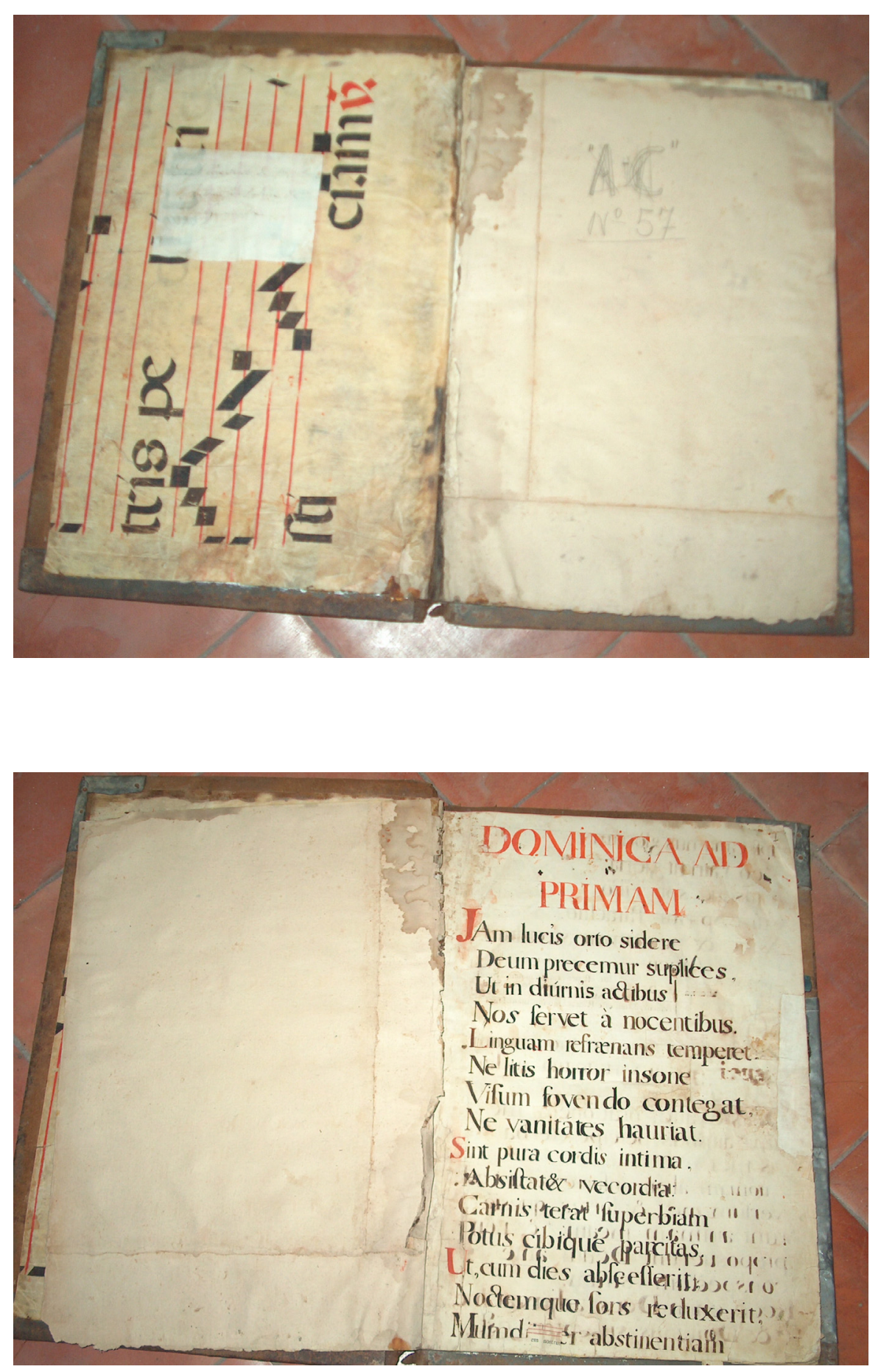


\section{$\left[\mathbf{N}^{0} \mathbf{L I I I}\right]$}

\section{LIBRO 359 / 57}

Cantoral. Manuscrito en papel de 56 folios. Diez pentagramas por página.

Medidas: encuadernación 540 x 370 x 45; hoja 505 x 350; caja 470 x 300 .

Ubicación: Estante A-2

Foliación: 1-56 en numeración arábiga, a lápiz, posterior.

Fecha: ca. 1735

\section{Incipit:}

Fol. $1^{\mathrm{r}}$ Dominica ad Priman Jam lucis orto sidere Deum precemur suplices Ut in diurnis actibus

\section{Iluminaciones:}

No contiene.

\section{Festividad o uso litúrgico:}

Horas menores

Índice:

No tiene.

\section{Otras observaciones:}

Algunos folios están deteriorados en la parte inferior. En las guardas delanteras hay una etiqueta con el texto: "Del Convento de San Antonio de Padua de Granada". En la guarda superior hay una hoja de cantoral en pergamino. La música comienza en el folio 26. 

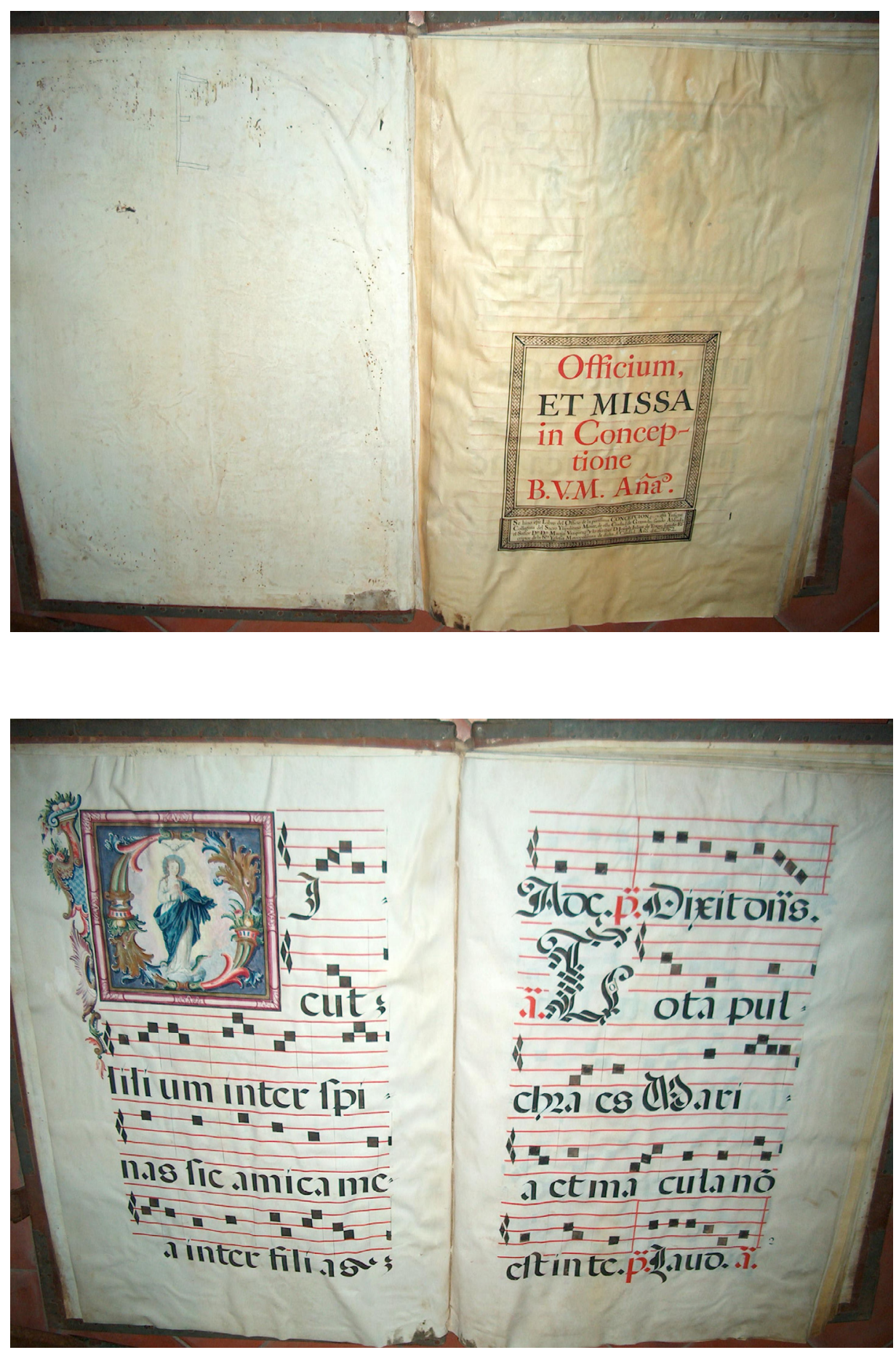


\section{$\left[\mathbf{N}^{\mathbf{0}} \mathbf{L I V}\right]$}

\section{LIBRO 373 / G? /E}

Cantoral. Manuscrito en pergamino de 42 folios. Cinco pentagramas por página.

Medidas: encuadernación 860 × 600 x 70; hoja 805 x 550; caja 580 × 375 .

Ubicación: Estante C-1

Foliación: 1-42 en numeración arábiga.

Fecha: 1762

Incipit:

Fol. $1^{\mathrm{r}}$ Officium, et Missa in Conceptione BVM. Antífona. Se hizo este libro del Officio de la purissima Concepcion, para esta Ynsigne Collegiata del Sacro Ylipulitano Monte, de esta ciudad de Granada siendo Abbad, el Señor Dr Dn Martin Vazquez y lo escribió D. Joseph Julian de Toxar.1762

\section{Iluminaciones:}

Fol.1 "S" ilustra Inmaculada Concepción con túnica blanca y manto azul (240 x 240)

Fol.35 "A"

\section{Festividad o uso litúrgico:}

Oficio y misa para la festividad de la Inmaculada Concepción.

\section{Otras observaciones:}

Buen estado de conservación. 

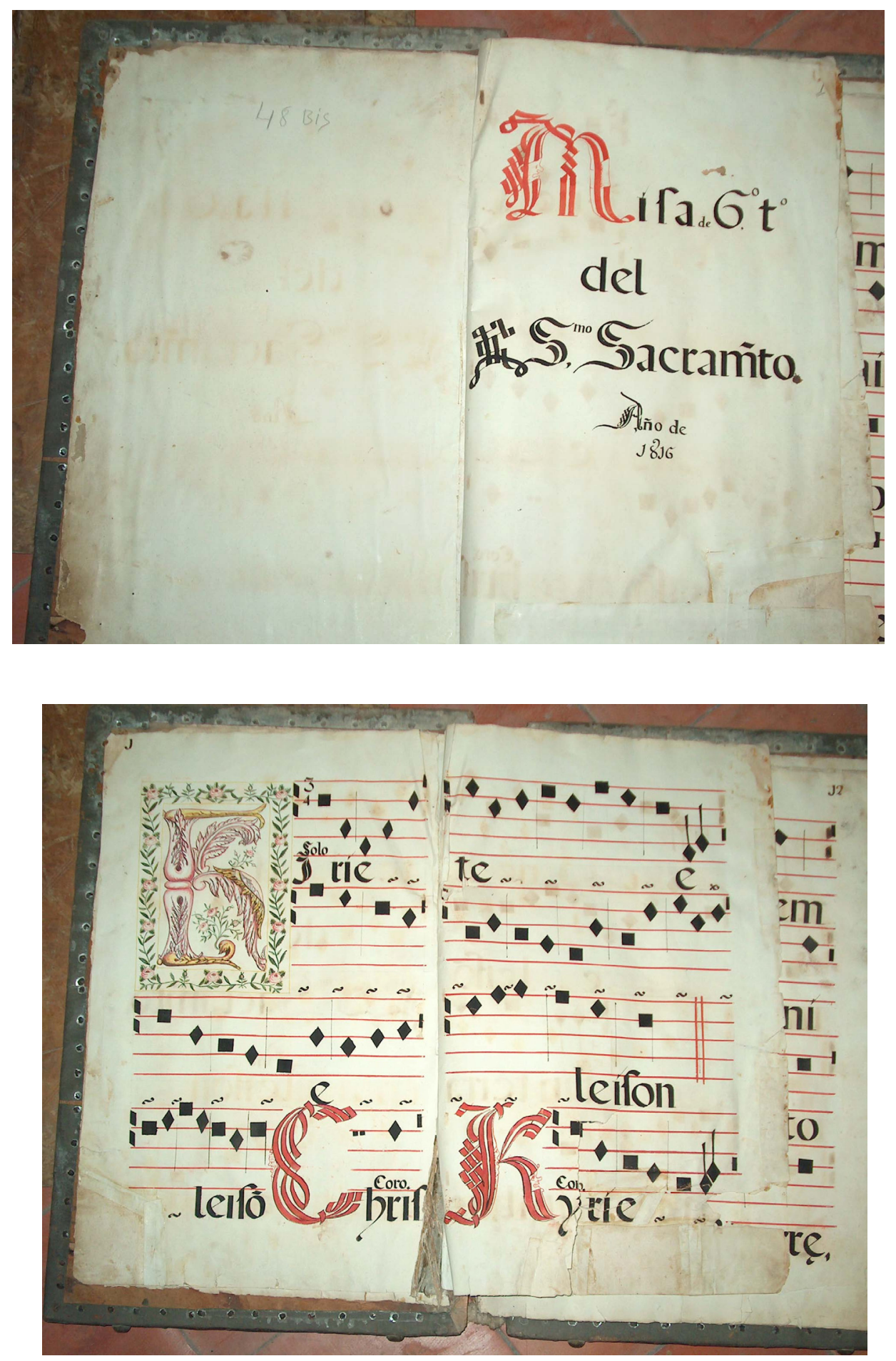
$[\mathbf{L V}]$

\section{LIBRO No 352 / 48bis}

Cantoral. Manuscrito en papel de 47 folios. Cuatro pentagramas por página.

Medidas: encuadernación 610 × 400 x 60; hoja 540 × 360 .

Ubicación: Estante A-2

Foliación: 1-57 en numeración arábiga original. Faltan los folios del 4 al 11, 34, 35.

Fecha: 1816

Incipit:

Fol. $1^{\mathrm{r}}$ Misa del $6^{\mathrm{o}}$ tono del Smo. Sacramento Año de 1816

Fol. $1^{\mathrm{v}}$ Kyrie eleison

\section{Iluminaciones:}

Fol.1 ${ }^{v}$ "K" en tinta rosa, verde negra y amarilla.

\section{Festividad o uso litúrgico:}

Misa del sexto tono del Santísimo Sacramento.

Índice:

No tiene.

\section{Otras observaciones:}

El cantoral tiene muchas hojas rotas. Aparece escritura mensural (compás $3 / 4$ ). Señala la alternancia entre solo y coro. 

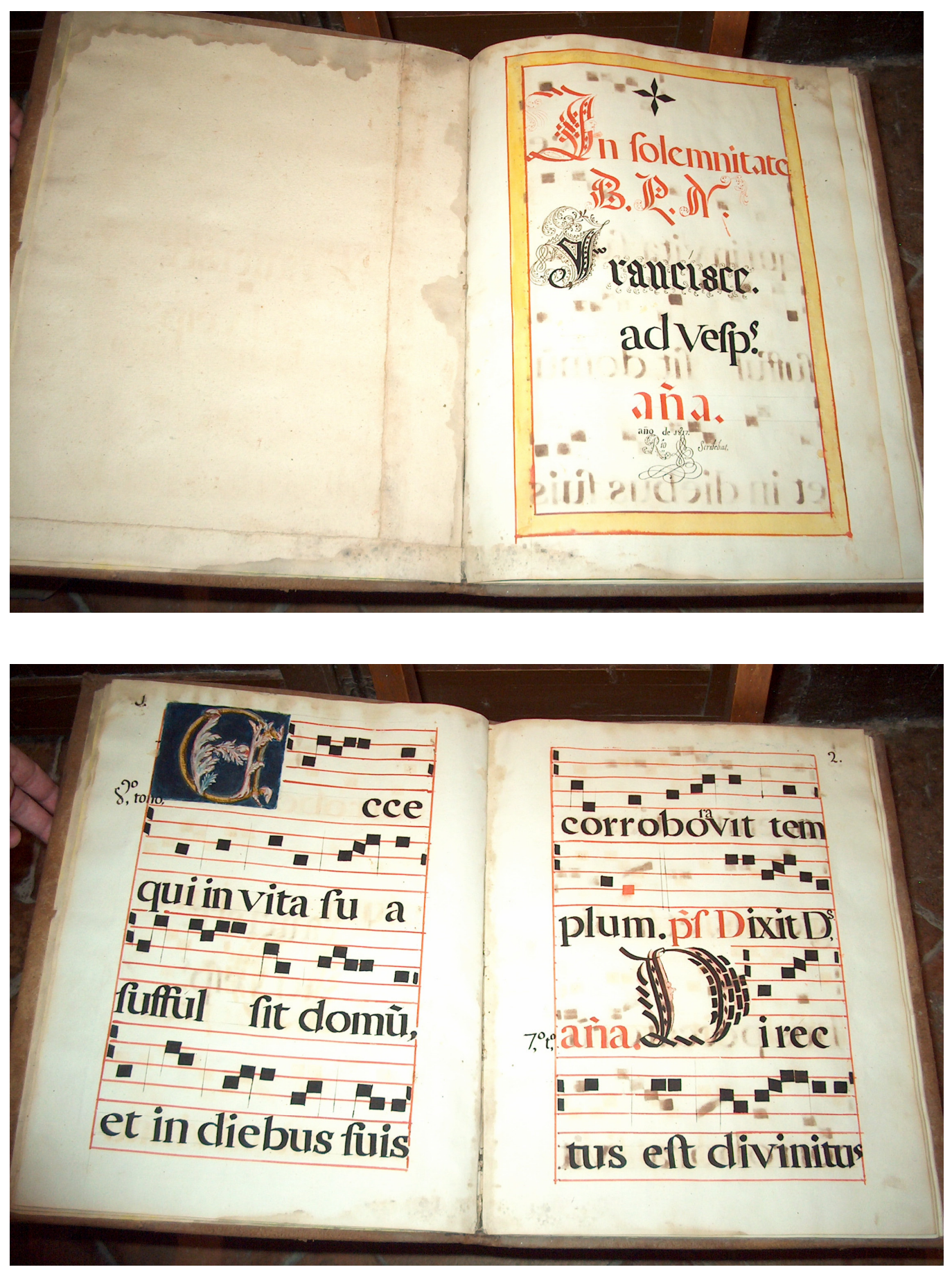


\section{$\left[\mathbf{N}^{\mathbf{0}} \mathbf{L V I}\right]$}

LIBRO 382 / M

Cantoral. Manuscrito sobre papel de 25 folios. Cuatro pentagramas por página.

Medidas: encuadernación 440 × 335 x 40; hoja 420 × 320; caja 350 × 220 .

Ubicación: Vitrina 4-1

Foliación: 25 folios en numeración arábiga original.

Fecha: 1817

Copista: Rio

Incipit:

Fol. $1^{\mathrm{r}}$ In solemnitate B.P.N. Francisce ad vesps. A(tifo)na. Año de 1817. Rio scribebat.

\section{Iluminaciones:}

No tiene.

\section{Festividad o uso litúrgico:}

Vísperas de Beato Padre Nuestro San Francisco y San Juan Capistrano

Índice:

No tiene.

\section{Otras observaciones:}

Se encuentra en buen estado de conservación. En las guardas delanteras aparece una etiqueta que dice: "Del Convento de San Antonio de Padua de Granada". 


\section{[N'LVII]}

LIBRO 341 (olim 41, A, G)
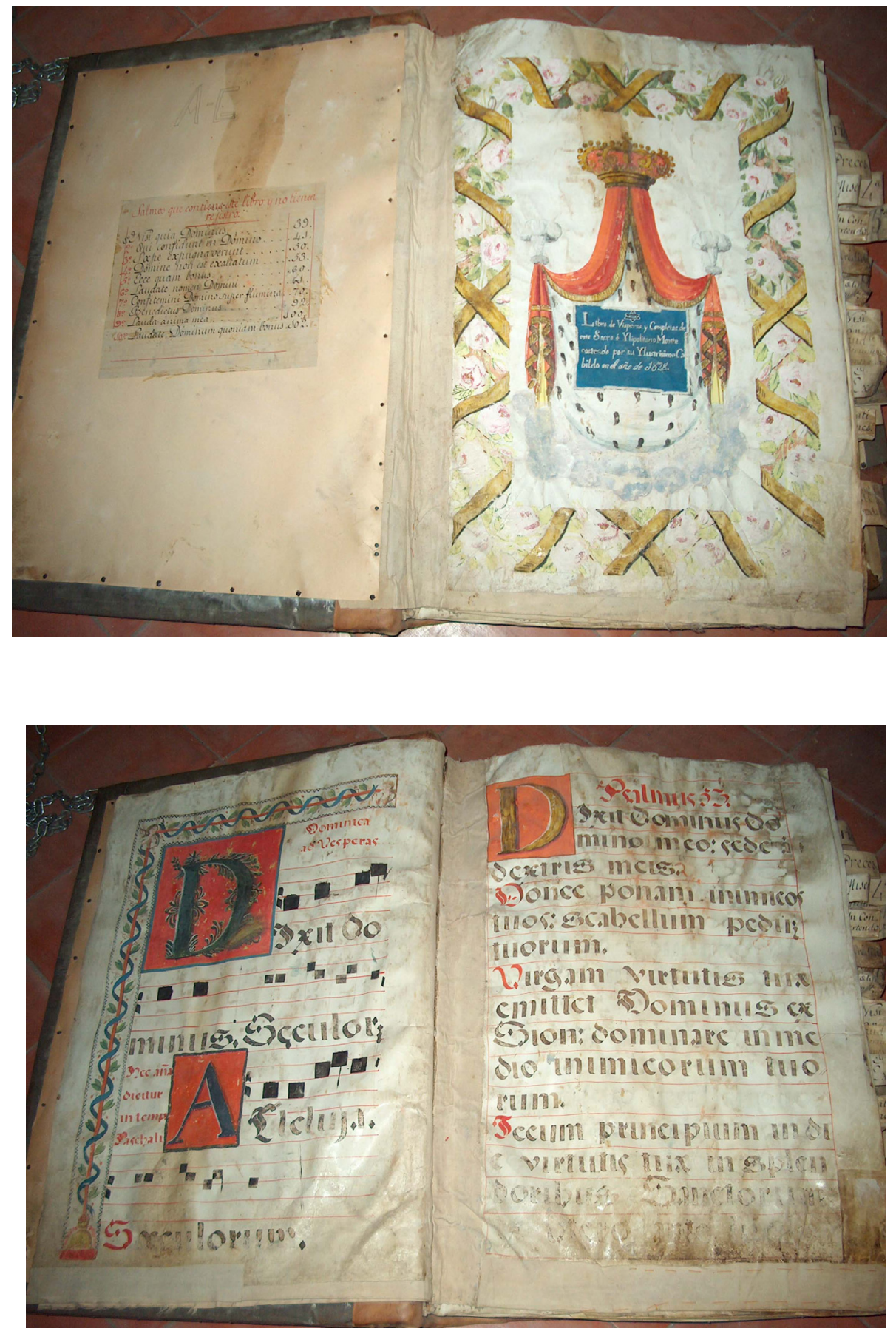


\section{$\left[\mathbf{N}^{0} \mathbf{L V I I}\right]$}

\section{LIBRO 341 / 41 / A / G}

Libro Vísperas. Manuscrito sobre pergamino de 161 folios. Cuatro pentagramas por página.

Medidas: encuadernación 845 × 600 x 150; hoja 800 × 550; caja 790 x 430.

Ubicación: Estante C-2

Foliación: 1-161 en numeración arábiga a lápiz, posterior.

Fecha: 1828

\section{Incipit:}

Fol. $1^{\mathrm{r}}$ Libro de Visperas y Completas de/ este Sacro e Ylipulitano Monte/ costeado por su Ylistrusimo Ca/bildo en el año de 1828

\section{Iluminaciones:}

Fol.1 "D" azul sobre fondo rojo con orla con ángeles

\section{Festividad o uso litúrgico:}

Vísperas y completas.

Índice:

Salmos que contiene este libro y no tienen registro $/ 1^{\circ}$ Nisi quia Dominus $39 / 2^{\circ}$ Qui confidunt $41 / 3^{\circ}$ Saepe expugnaverunt $50 / 4^{\circ}$ Domine non est exaltatum $53 / 5^{\circ}$ Ecce quam bonus $60 / 6^{\circ}$ Laudate nomen Domini $61 / 7^{\circ}$ Confitemini Domino super flumina $70 / 8^{\circ}$ Benedictus Dominis $92 / 9^{\circ}$ Lauda anima mea $100 / 10^{\circ}$ Laudate Dominum quoniam bonus 102

\section{Otras observaciones:}

Se encuentra en buen estado de conservación. 

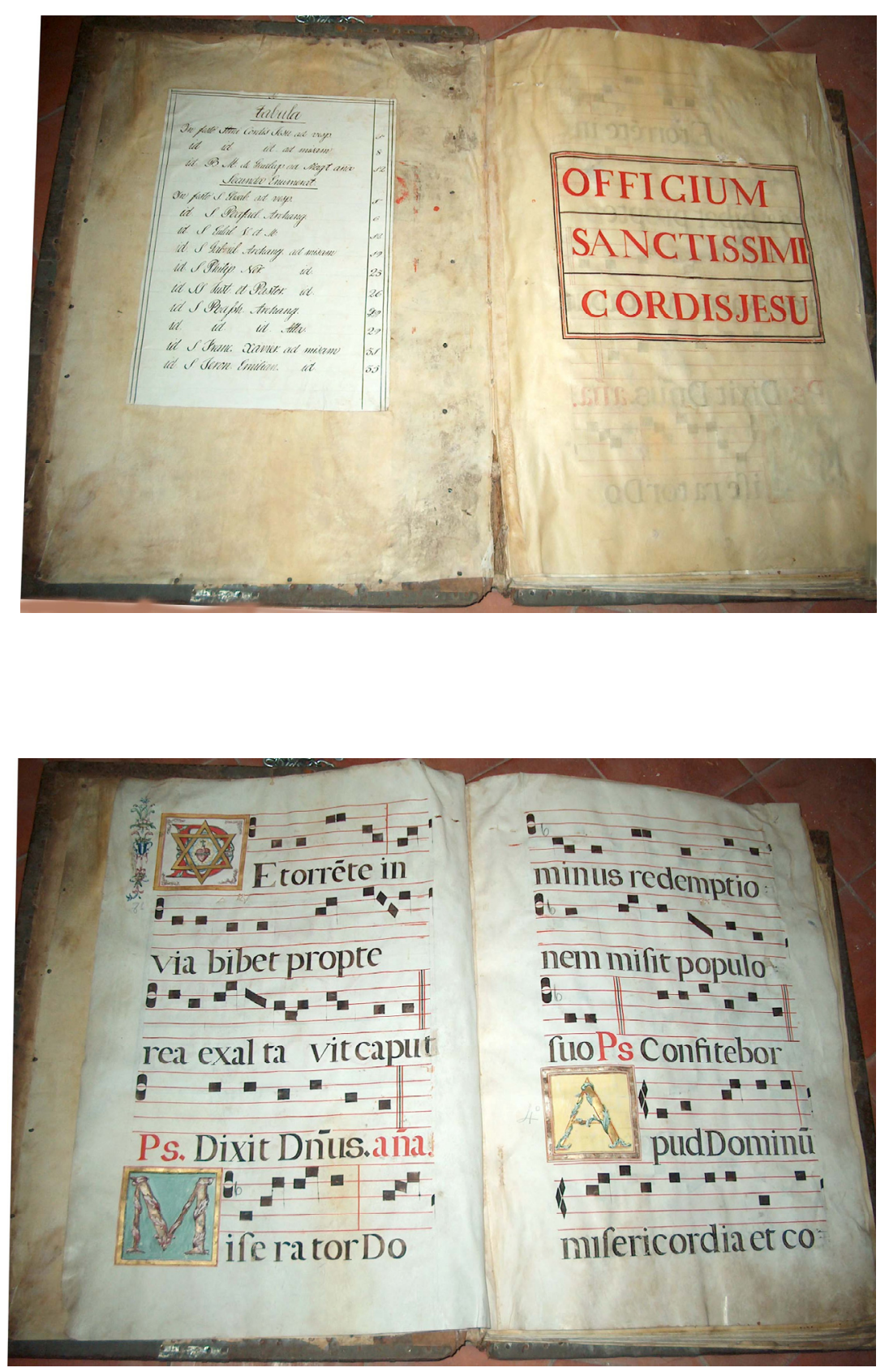


\section{[No LVIII]}

\section{LIBRO 315 / 16 bis}

Libro Misa y Vísperas. Manuscrito sobre pergamino de 53 folios. Cuatro y cinco pentagramas por página.

Medidas: encuadernación 800 × 580 × 80; hoja 740 × 520; caja 590 × 360

Ubicación: Estante C-2

Foliación: 53 folios con numeración arábiga a lápiz.

Fecha: Siglo XIX

Incipit texto:

Officium Sanctissimi Cordis Jesu

\section{Iluminaciones:}

Fol.1 ${ }^{\mathrm{v}}$ : "D" corazón de Jesús con estrella de David (115 x 115)

Fol.19r: "M" (325 x 260)

Fol.24ㄴ: "B" (215 x 180)

Fol.32 $2^{\mathrm{r}}:$ "B" $(210 \times 180)$

Fol.48v: "E" Anunciación, (180 x 140)

\section{Festividad o uso litúrgico:}

Misas y vísperas de santos

\section{Índice:}

Tabula/In festo Stmi. Cordis Jesu ad vesp. 1/id id ad misam 8/ id BM Guadup. Ad magt. antíphona 12/Secunda enumerat/ In festo S.Elisab ad vesp. 1/ id S.Raphael Archang.6/id S.Eulal. V.et m 12/id S.Gabriel Archang. Ad Missam 19/id S.Philip Ner id 23/id SS. Inst et Pastor id 26/ id S Raphael Archang 19/ id id id Alla. 29/ id S.Franc. Xavier ad misam 31/ id S. Jeron. Emili. Id 35

Otras observaciones: Se encuentra en buen estado de conservación. 
[N'LIX]

LIBRO 387 (olim P2)
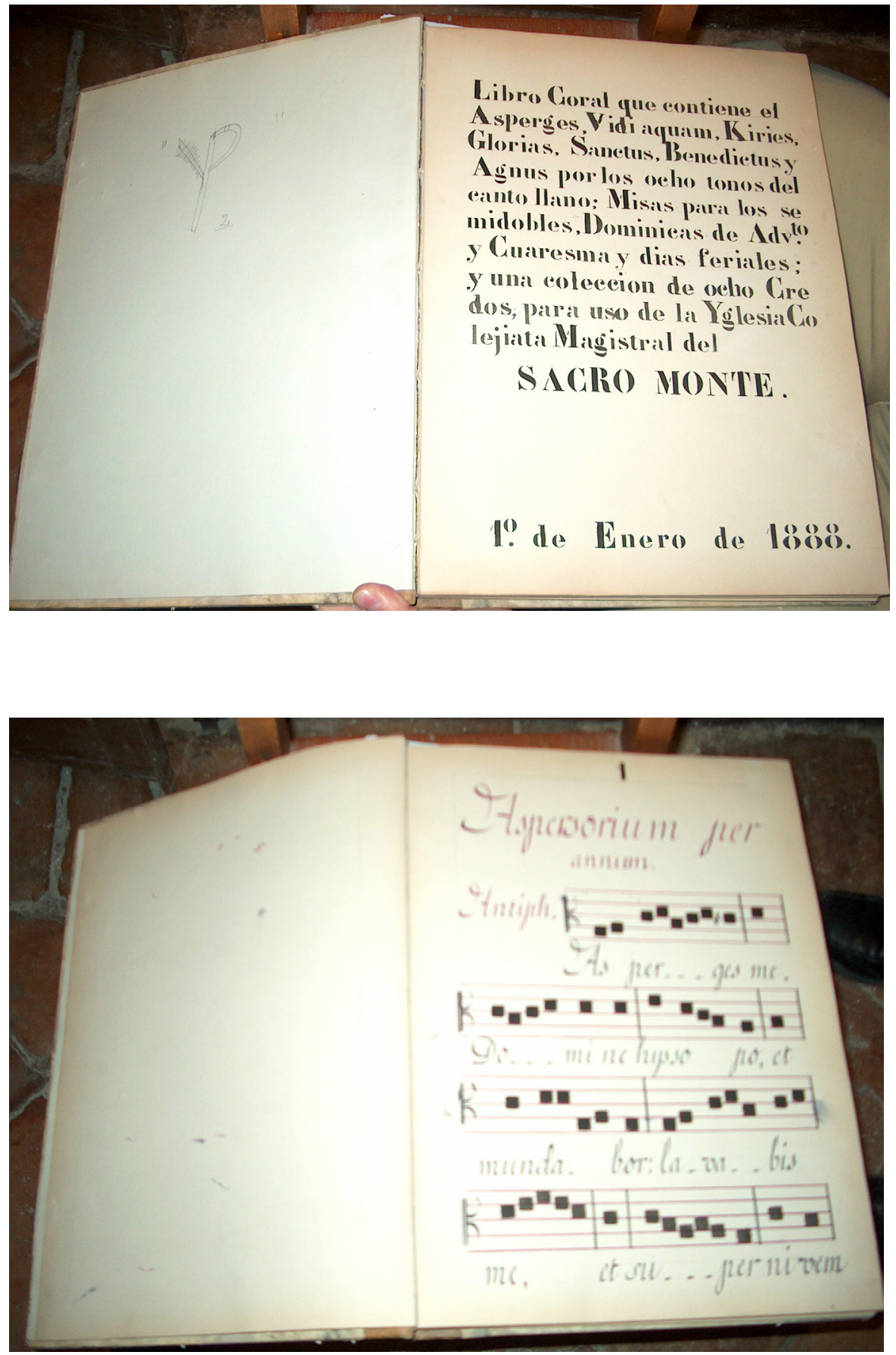


\section{$\left[\mathbf{N}^{\mathbf{0}}\right.$ LIX]}

\section{LIBRO 387 / P2}

Cantoral. Manuscrito en papel de 173 folios. Cinco pentagramas por página.

Medidas: encuadernación 435 × 320 × 430; hoja 425 × 305; caja 375 × 245

Ubicación: Vitrina 4-2

Foliación: [I]1-173 folios en numeración arábiga original.

Fecha: 1888

\section{Incipit:}

Fol. $0^{\mathrm{r}}$ Libro coral que contiene el Asperges, Vidi aquam, Kyries, Glorias, Sanctus, Benedictus, Agnus, por los ocho tonos del canto llano; Misas para los semidobles, Dominicas de Adviento y Cuaresma y días feriales y una colección de ocho Credos para uso de la Yglesia.

Fol. $1^{\mathrm{r}}$ Asperges me

\section{Iluminaciones:}

No tiene.

\section{Festividad o uso litúrgico:}

Ordinario de la Misa

\section{Índice:}

No tiene.

\section{Otras observaciones:}

Se encuentra en buen estado de conservación. Contiene indicaciones mensurales. 


\section{[No' $\mathbf{L X ]}$ \\ LIBRO 386 (olim P1)}
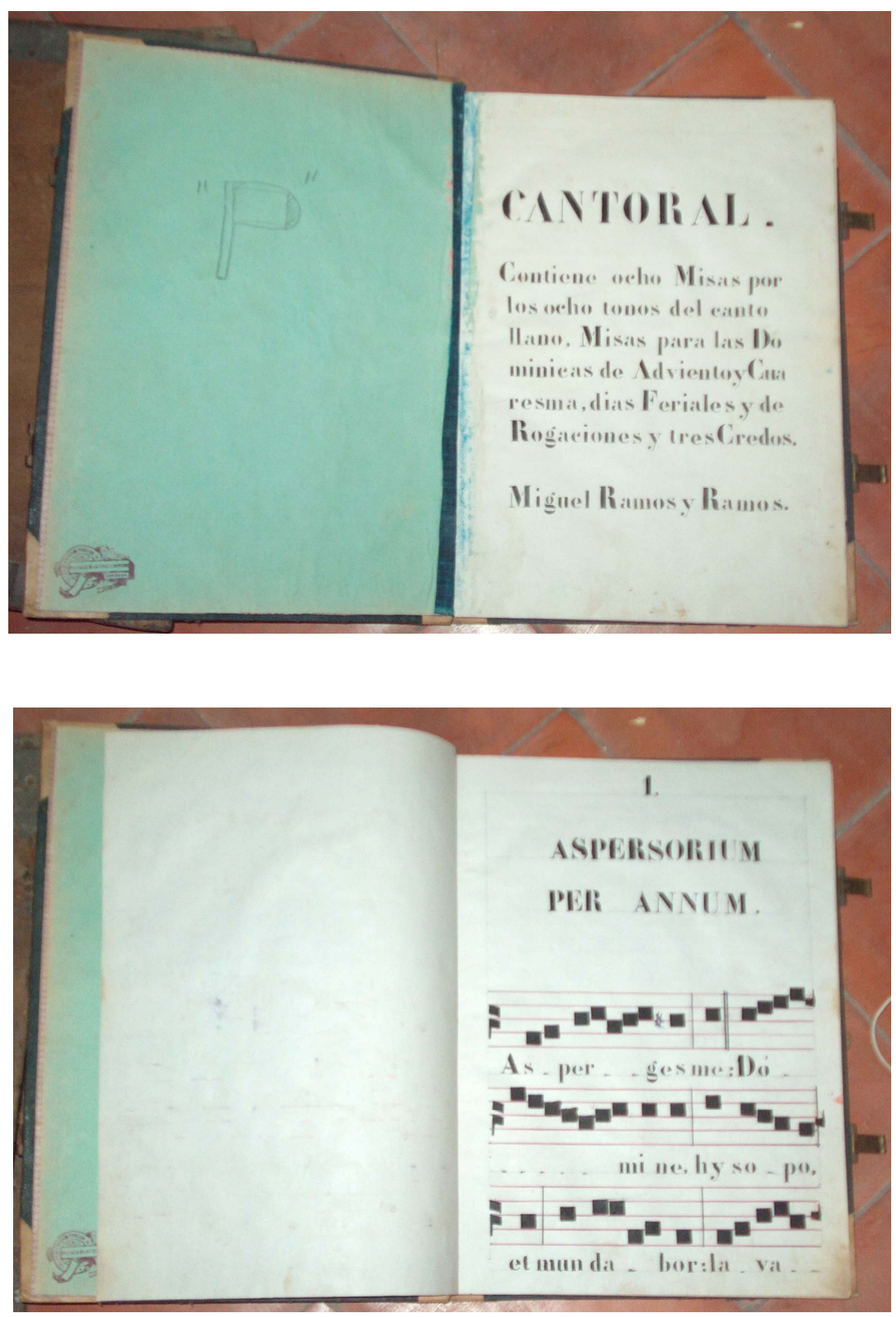


\section{$\left[\mathbf{N}^{0} \mathbf{L X}\right]$}

\section{LIBRO 386 / P1}

Cantoral. Manuscrito en papel de 130 páginas. Cinco pentagramas por página.

Medidas: encuadernación 425 × 325 x 30; hoja 425 x 300; caja 375 x 250 .

Ubicación: Estante A-2

Foliación: 1-130 páginas en numeración arábiga original.

Fecha: Finales del siglo XIX ó principios del siglo XX.

Copista: Miguel Ramos y Ramos

\section{Incipit:}

Fol. $0^{\mathrm{r}}$ Cantoral.Contiene ocho Misas por los ocho tonos del canto llano, Misas para las Dominicas de Adviento y Cuaresma, días feriales y de rogaciones y tres credos. Miguel Ramos y Ramos.

Fol. $1^{\mathrm{r}}$ Asperges me

\section{Iluminaciones:}

No tiene.

\section{Festividad o uso litúrgico:}

Misas para los domingos de Adviento y Cuaresma, días feriales y de rogaciones.

\section{Otras observaciones:}

Se encuentra en buen estado de conservación En las guardas aparece un sello: "taller de encuadernación de Enrique Martínez y Ropero. Granada." Aparece un "Credo Lusitano". 

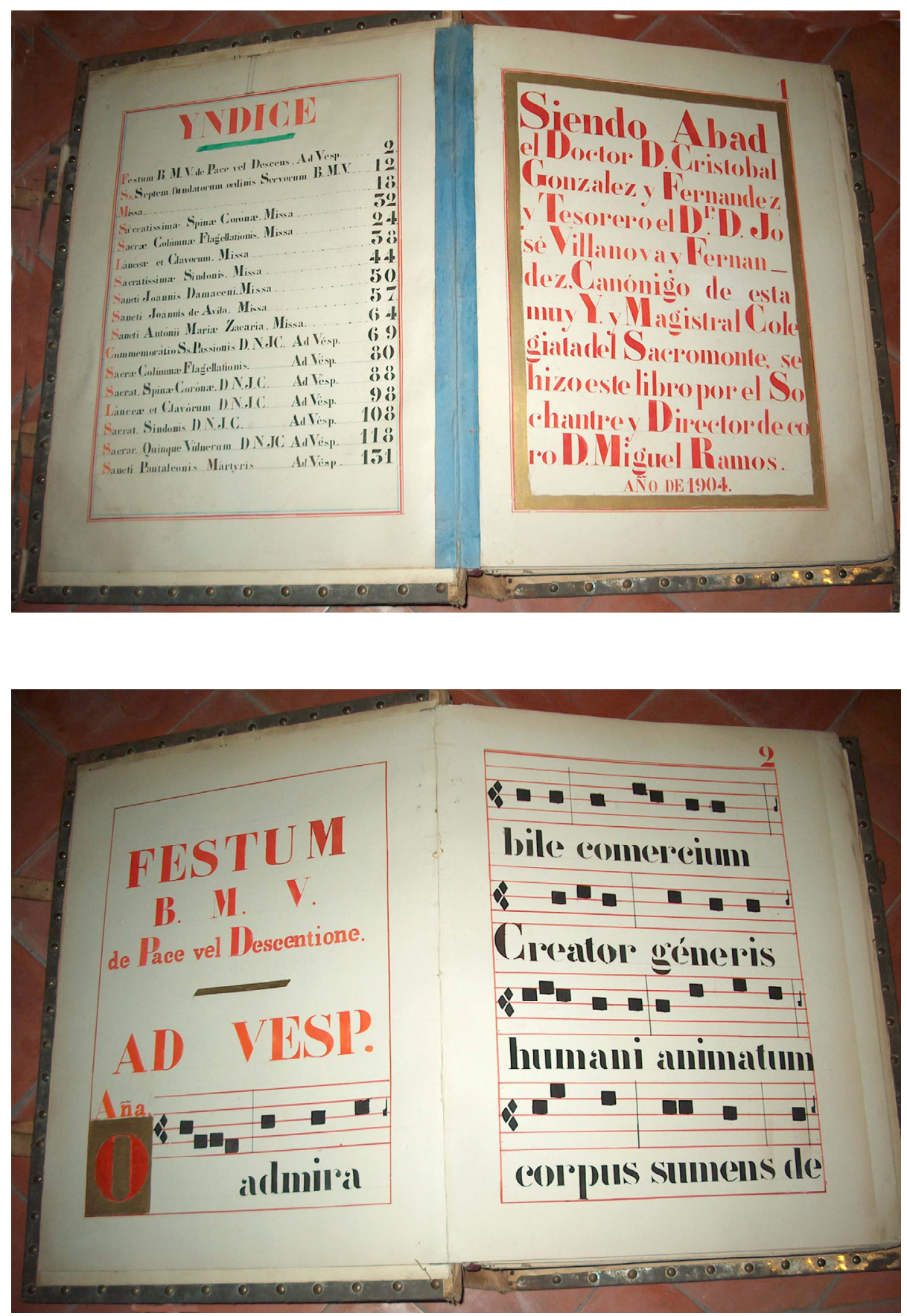


\section{$\left[\mathbf{N}^{\mathbf{0}} \mathbf{L X I}\right]$}

\section{LIBRO 377 / I}

Cantoral. Manuscrito en papel de 104 folios. Cinco pentagramas por página.

Medidas: encuadernación 720 × 550 × 230; hoja 655 × 495; caja 530 × 370

Ubicación: Estante C-2

Foliación: 140 folios en numeración arábiga original.

Fecha: 1904

Copista: Miguel Ramos

\section{Incipit:}

Fol. $1^{\mathrm{r}}$ Siendo Abad el Doctor D.Cristobal González y Fernandez y Tesorero el dr D.José Villanova y Fernández, canónigo de esta muy Ylustre y Magistral Colegiata del Sacromonte se hizo este libro por el sochantre y director de coro D.Miguel Ramos. Año de 1904.

Fol. $1^{\mathrm{v}} \mathrm{O}$ admirabile comercium

\section{Festividad o uso litúrgico:}

Misas y Vísperas del propio.

\section{Índice:}

Indice/Festum B.M.V. de Pace vel Desceus Ad Vesp. 2/ Ss. Septem fundatorum ordinis Servorum B.M.V. 12/ Missa 18/ Sacratissima Spinae Coronae Missa 32/ Sacrae Columnae Flagellationis Missa 24/ Lanceae et Clavorum Missa 38/ Sacratissimae Sindonis Missa 44/ Sancti Joannis Damaceni Missa 50/ Sancti Joannis de Avila Missa 57/ Sancti Antonii Mariae Zacaria Missa 64/ Commemoratio Sa. Passionis D.N.J.C. Ad Vesp. 69/ Sacrae Columnae Flagellationis Ad Vesp. 80/ Sacrat. Spinae Coronae D.N.J.C. Ad Vesp. 88/ Lanceae et Clavorum D.N.J.C. Ad Vesp. 98/ Sacrat. Sindonis D.N.J.C. Ad Vesp. 108/ Sacra. Quinque Vúlnerum D.N.J.C. Ad Vesp. 118/ Sancti Pantaleonis Martyris Ad Vesp. 131

Otras observaciones: Se encuentra en buen estado de conservación. Los himnos están en notación mensural, ternaria. 
[N'LXII]

LIBRO 375 (olim G)
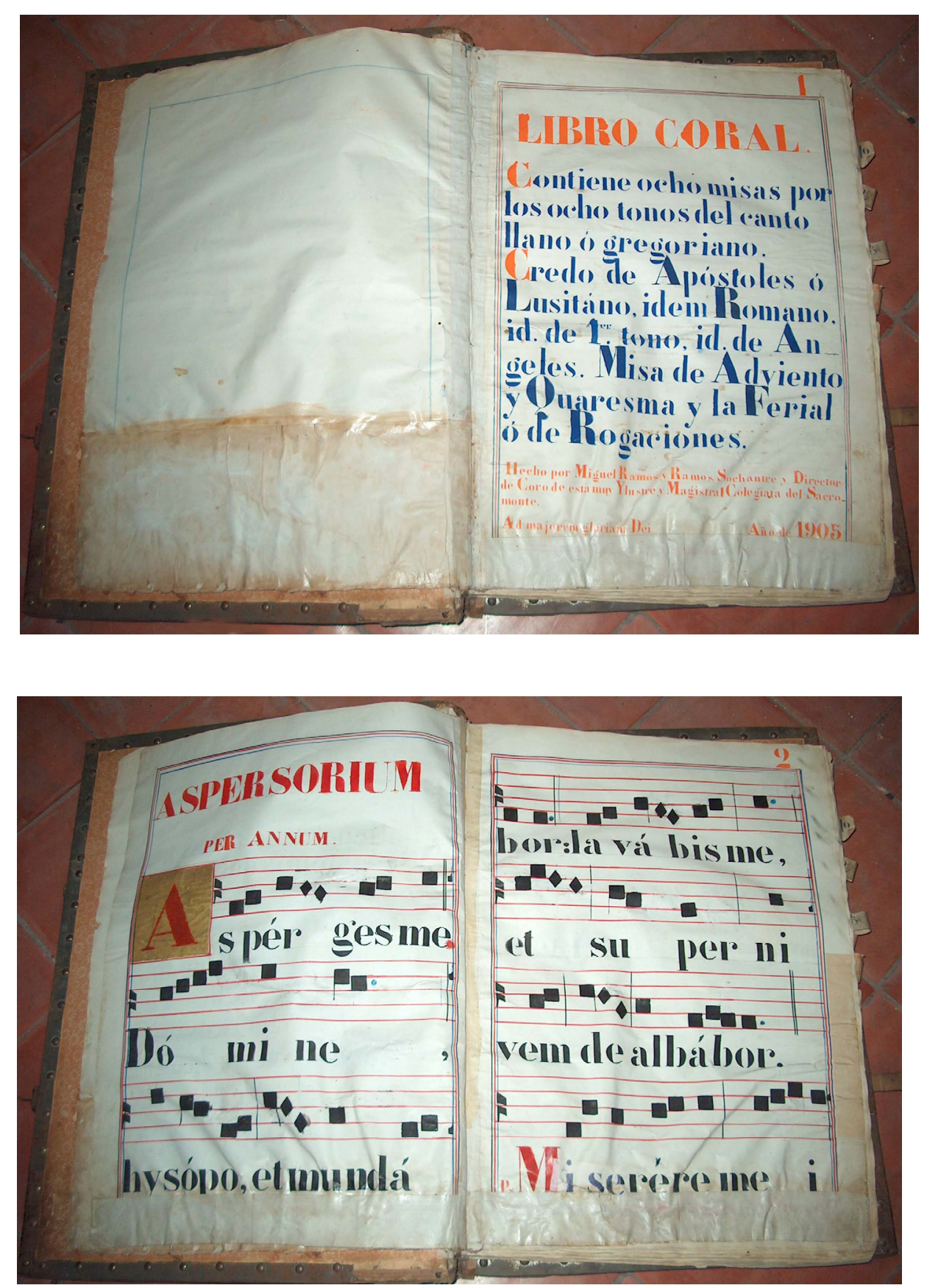


\section{$\left[\mathbf{N}^{\circ} \mathbf{L X I I}\right]$}

\section{LIBRO 375 / G}

Cantoral. Manuscrito en papel de 140 folios. Cinco pentagramas por página.

Medidas: encuadernación 675 x 490 x 50; hoja 620 x 470; caja 515 x 390 .

Ubicación: Estante A-1

Foliación: 1-140 en numeración arábiga original.

Fecha: 1905

Copista: Miguel Ramos y Ramos

\section{Incipit:}

Fol. $1^{\mathrm{r}}$ Libro Coral. Contiene ocho misas por los ocho tonos del canto llano o gregoriano. Credo de Apóstoles o Cristiano, idem romano, idem de primer tono, idem de ángeles. Misa de Adviento y Quaresma y la Ferial o de Rogaciones. Hecho por Miguel Ramos y Ramos Sochantre y director de coro de este muy ilustre y magistral Colegiata del Sacromonte. Ad majorem gloriam Dei. Año de1905.

Fol. $1^{\mathrm{v}}$ Asperges me

\section{Iluminaciones:}

No tiene.

\section{Festividad o uso litúrgico:}

Ordinario de la misa.

\section{Otras observaciones:}

Se encuentra en buen estado de conservación. Tiene indicaciones mensurales. Señala alternancia coro y órgano. 

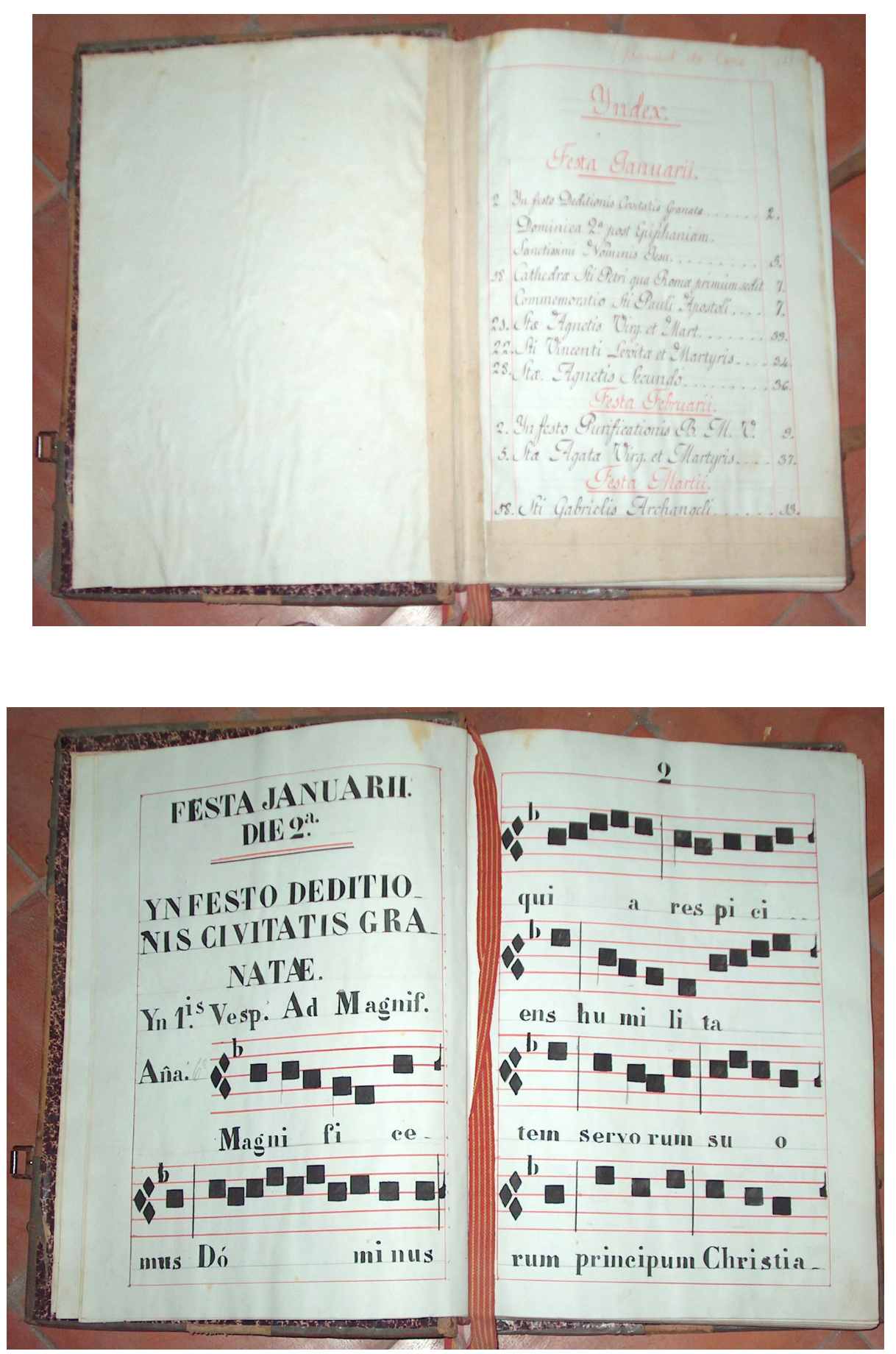
[No $\left.\mathbf{N}^{0} \mathbf{L I I I}\right]$

LIBRO 353 / 49 / 40

Manual de coro. Manuscrito en pergamino de 217 páginas. Cuatro pentagramas por página.

Medidas: encuadernación 475 × 340 × 75; hoja 440 × 310; caja 380 × 250 .

Ubicación: Estante A-2

Foliación: 1-217 en numeración arábiga original

Fecha: Finales del siglo XIX o principios del XX

Incipit:

Fol. $1^{\mathrm{r}}$ Yndex

Fol. $1^{\mathrm{v}}$ Magnificemus Dominus

\section{Iluminaciones:}

No tiene.

\section{Festividad o uso litúrgico:}

Antifonario de Santos para todo el año. Contiene fiesta de la Toma de Granada.

\section{Otras observaciones:}

Se encuentra en buen estado de conservación. Aparece los cantos para: In festo Deditionis Civitatis Granata. 
[N'LXIV]

LIBRO 358 (olim 56)
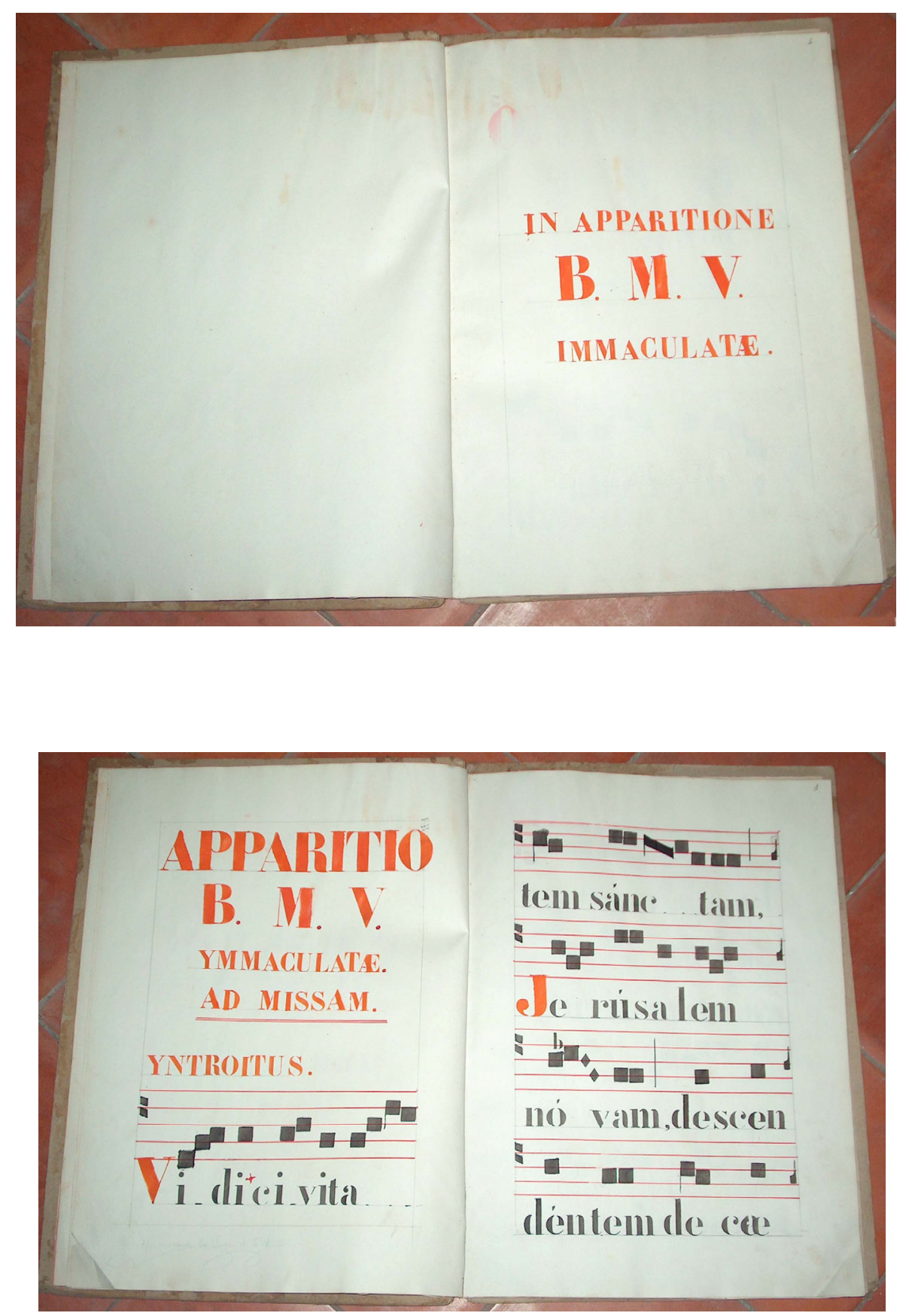


\section{$\left[\mathbf{N}^{0} \mathbf{L X I V}\right]$}

LIBRO 358 / 56

Cantoral. Manuscrito sobre papel de 28 folios. Cuatro pentagramas por página.

Medidas exteriores: encuadernación 480 × 355 x 20; hoja 460 × 335; caja 360 × 235 .

Ubicación: Estante A-2

Foliación: 1-28 en numeración arábiga original.

Fecha: S. XX

Incipit texto:

Fol. $1^{\mathrm{r}}$ In Apparitione B.M.V. Immaculatae

\section{Iluminaciones:}

No tiene.

\section{Festividad o uso litúrgico:}

Oficio de la Aparición de la Virgen.

Índice:

No tiene.

\section{Otras observaciones:}

Se encuentra en buen estado de conservación. En folio $1^{\mathrm{v}}$ a lápiz azul hay una inscripción "Aparición de la Virgen de Fátima." 
[N $\left.{ }^{\circ} \mathbf{L X V}\right]$

LIBRO 371 (olim C)
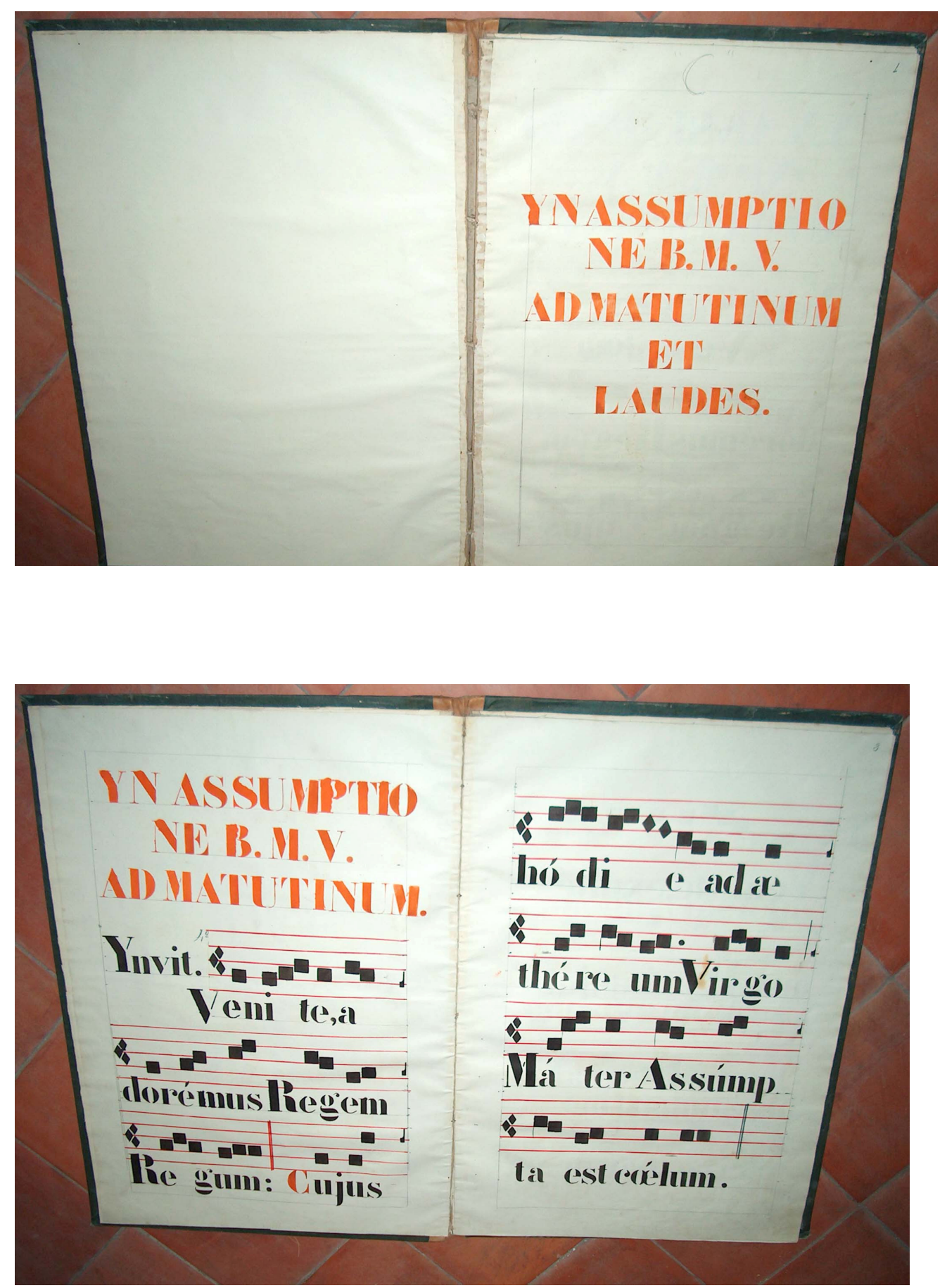


\section{$\left[\mathbf{N}^{\circ} \mathbf{L X V}\right]$}

\section{LIBRO 371 / C}

Cantoral. Manuscrito en papel de 22 folios. Cuatro pentagramas por página.

Medidas: encuadernación 690 × 480 x 20; hoja 670 x 460; caja 570 x 360 .

Ubicación: Estante C-1

Foliación: 22 folios sin numerar.

Fecha: Finales del Siglo XIX o principios del XX

Incipit:

Fol. $1^{\mathrm{r}}$ In Assumptione B.M.V. Ad Matutinum et Laudes

Fol. $1^{\mathrm{v}}$ Venite, adoremus Regem

\section{Iluminaciones:}

No tiene.

\section{Festividad o uso litúrgico:}

Maitines y laudes de la Asunción

Índice:

No tiene.

\section{Otras observaciones:}

Se encuentra en buen estado de conservación. 
LIBRO 351 (olim 48)

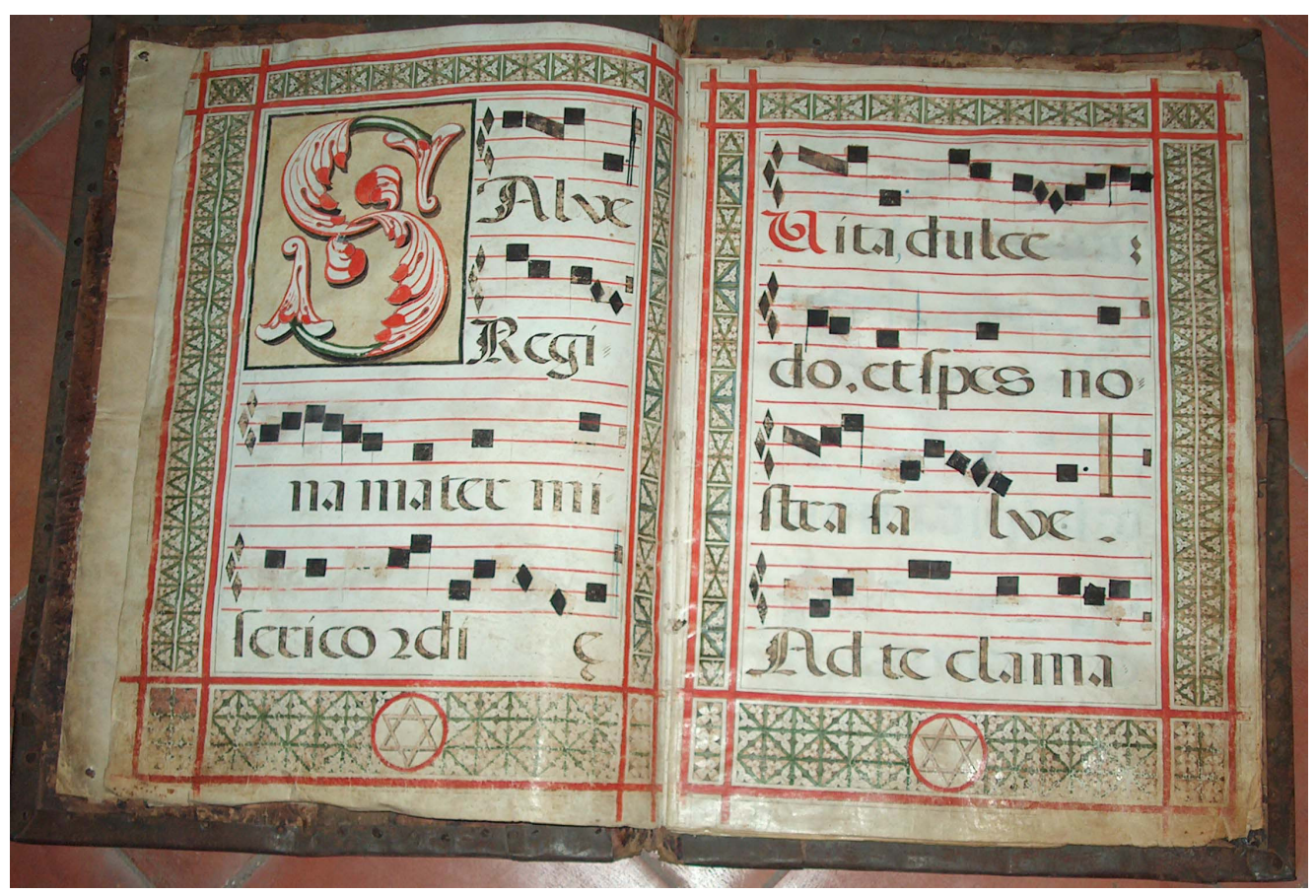


[LXVI]

LIBRO 351 / 48

Cantoral. Manuscrito en pergamino de 10 folios. Cuatro pentagramas por página.

Medidas: encuadernación 555 x 385 x 35; hoja 490 × 360; caja 360 × 250 .

Ubicación: Estante A-2

Foliación: Sin numerar.

Fecha: $i$ ?

Incipit:

Fol. $1^{\mathrm{v}}$ Salve Regina

\section{Iluminaciones:}

Fol.1 "S" roja y verde sobre fondo amarillo (170 x 140)

\section{Festividad o uso litúrgico:}

Salve

Índice:

No tiene

\section{Otras observaciones:}

Se encuentra desencuadernado. La estrella de David que aparece en la orla indica que el Cantoral se copió ex profeso para el Sacromonte. 
[N'LXVII]

LIBRO 5422
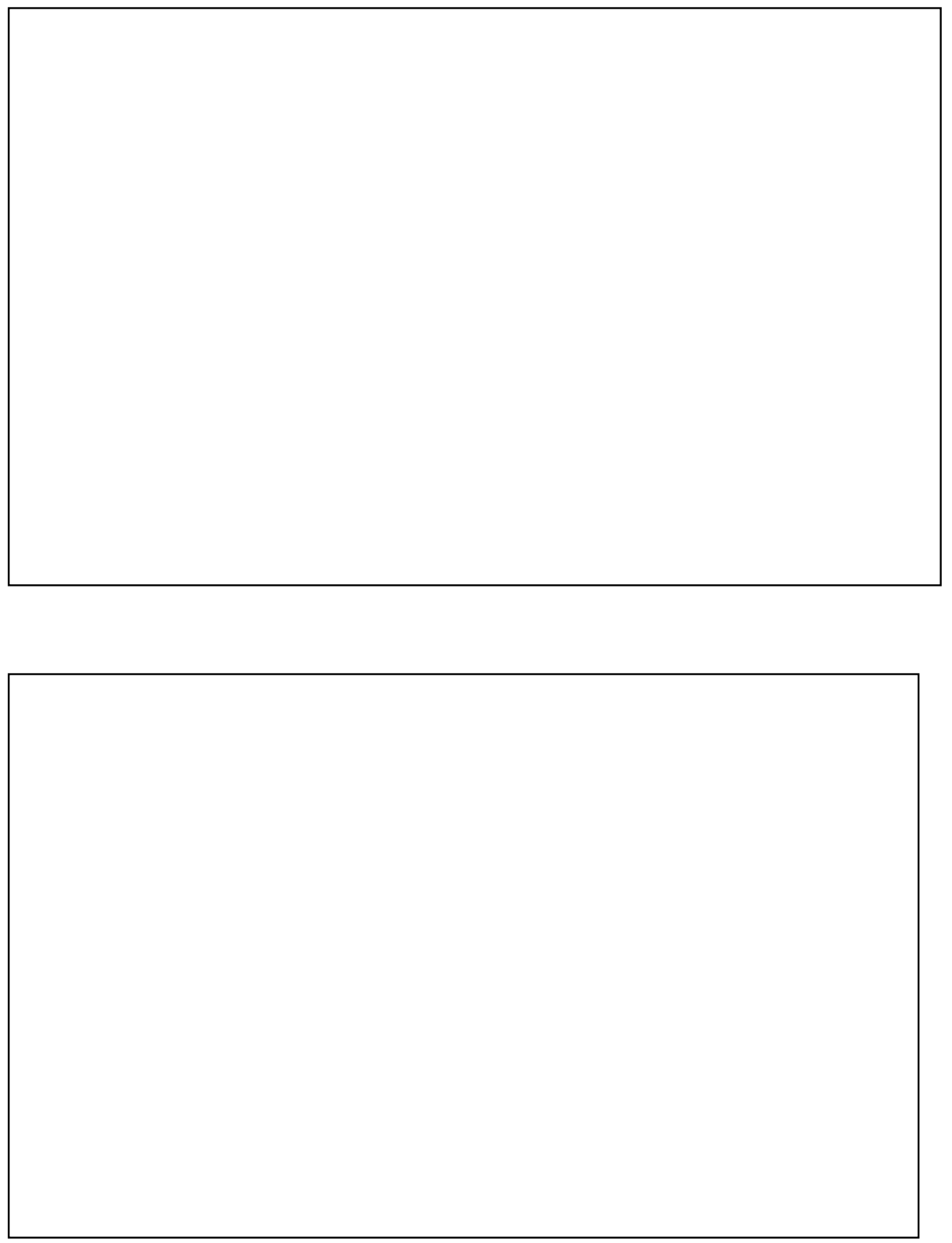


\section{[N $\mathbf{N}^{0}$ LXVII]}

\section{LIBRO 5422}

Procesionario. Manuscrito en papel pautado de 30 folios. Diez pentagramas por página.

Medidas: encuadernación 218 x 155 x 100; hoja 210 × 150

Ubicación: Vitrina 4-2

Foliación: 30 folios sin numerar.

Fecha: Siglo XX

Incipit:

Procesionario

\section{Festividad o uso litúrgico:}

Cantos para la procesión del día de la Purificación de Nuestra Señora.

Otras observaciones:

Buen estado de conservación. 

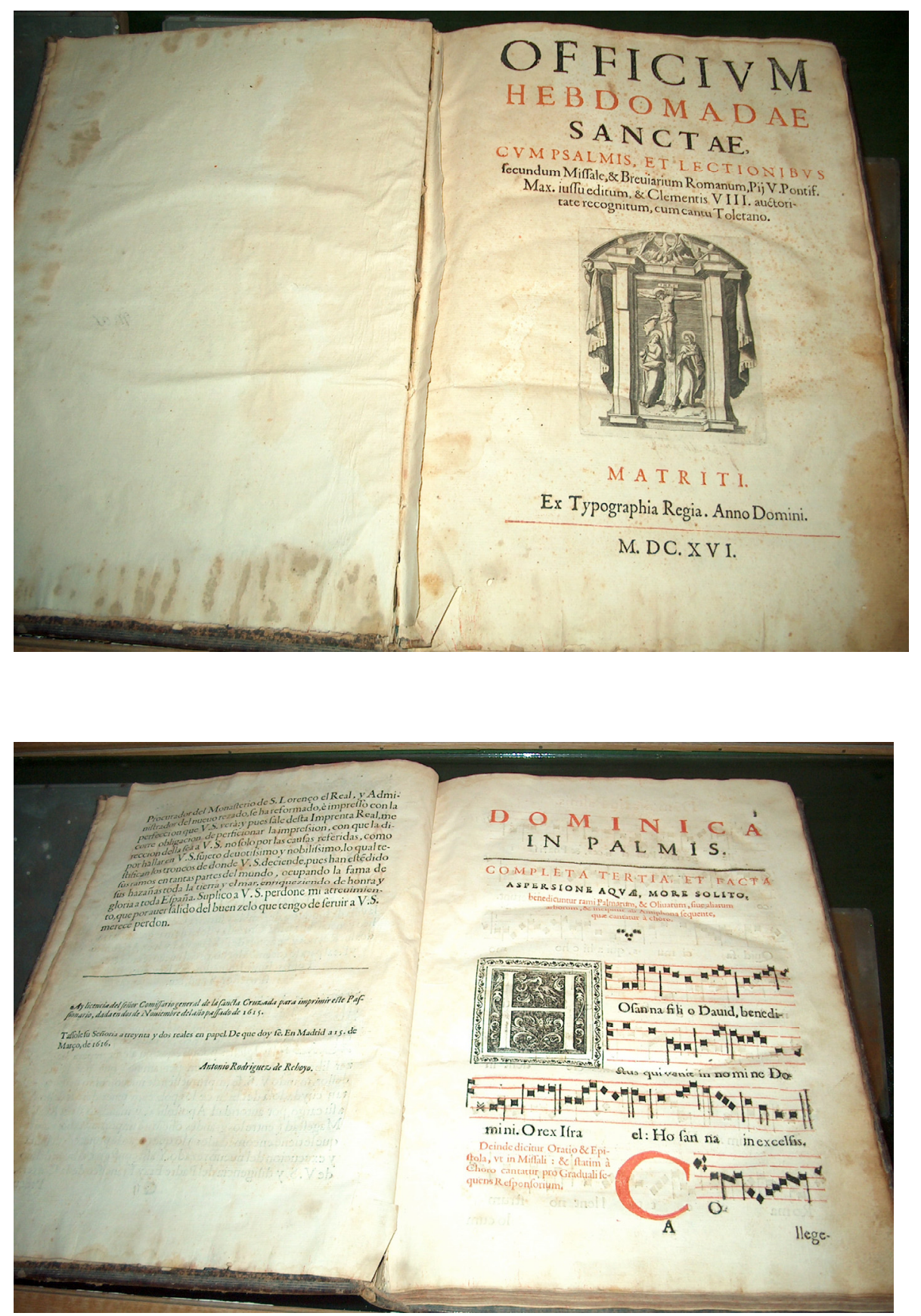


\section{$\left[\mathbf{N}^{0}\right.$ LXVIII]}

\section{LIBRO 5438}

Officium Hebdomadae Sanctae. Impreso sobre papel de 226 páginas.

Medidas: encuadernación 425 x 300 x 160

Ubicación: Vitrina 2-2

Páginas: 226 páginas

Fecha: 1616

Lugar de Impresión: Matriti (Madrid)

Impresor: Typographia Regia

Otras observaciones:

Título completo: OFFICIUM/HEBDOMADAE/SANCTAE,/CUM PSALMIS ET LECTIONIBUS/secundum Missale\&Breviarium Romanum Pii V Pontifif./ Max. Iussu editum, \& Clementis VIII, auctori/tate recognitum, cum cantu Toletano grabado/ MATRITI/Ex Typographia Regia. Anno Domini/M.DC.XVI.

La introducción, en castellano, explica los motivos por los que se realizó esta impresión. En la página 61 la notación del Credo es mensural.

Existe otro ejemplar de este libro en la Colegiata de Castellar (Jaén); véase estudio. 
[N'LXIX]

LIBRO 5434

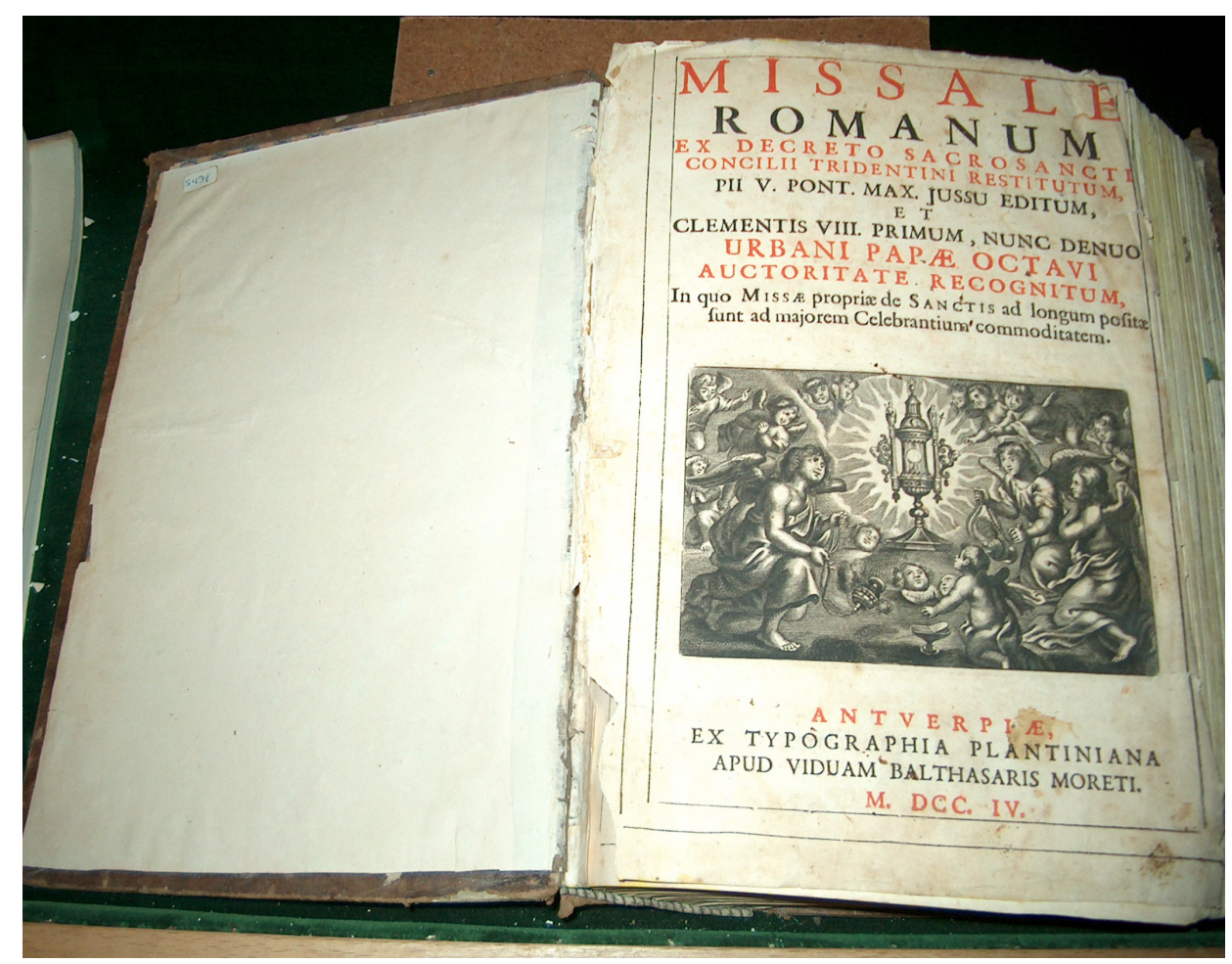




\section{$\left[\mathbf{N}^{\circ} \mathbf{L X I X ]}\right.$}

\section{LIBRO 5434}

Missale Romanum. Impreso sobre papel.

Medidas: encuadernación 300 × 200 × 80

Ubicación: Vitrina 1-1

Páginas: 623 impresas + añadidas siglos posteriores

Fecha: 1704

Lugar de Impresión: Antuerpiae (Amberes)

Impresor: Typographia Plantiniana, Balthasaris Moreti.

\section{Otras observaciones:}

Título completo: MISSALE/ ROMANUM/ EX DECRETO SACROSSANCTI/ CONCILII TRIDENTINI RESTITUTUM, /ET / CLEMENTIS VIII PRIMUM, NUNC DENUO/ URBANI PAPAE OCTAVI/ AUCTORITATE RECOGNITUM,/ IN QUO MISSAE propriae de SANCTIS ad longum positae/ sunt ad majorem Celebrantium commoditatem/ANTUERPIAE, EX TYPOGRAPHIA PLANTINIANA/ APUD VIDUAM BALTHASARIS MORETI/ MDCCIV.

Contiene añadidos de siglos posteriores 


\section{[N $\left.{ }^{\circ} \mathbf{L X X}\right]$ \\ LIBRO 381 (olim LL)}
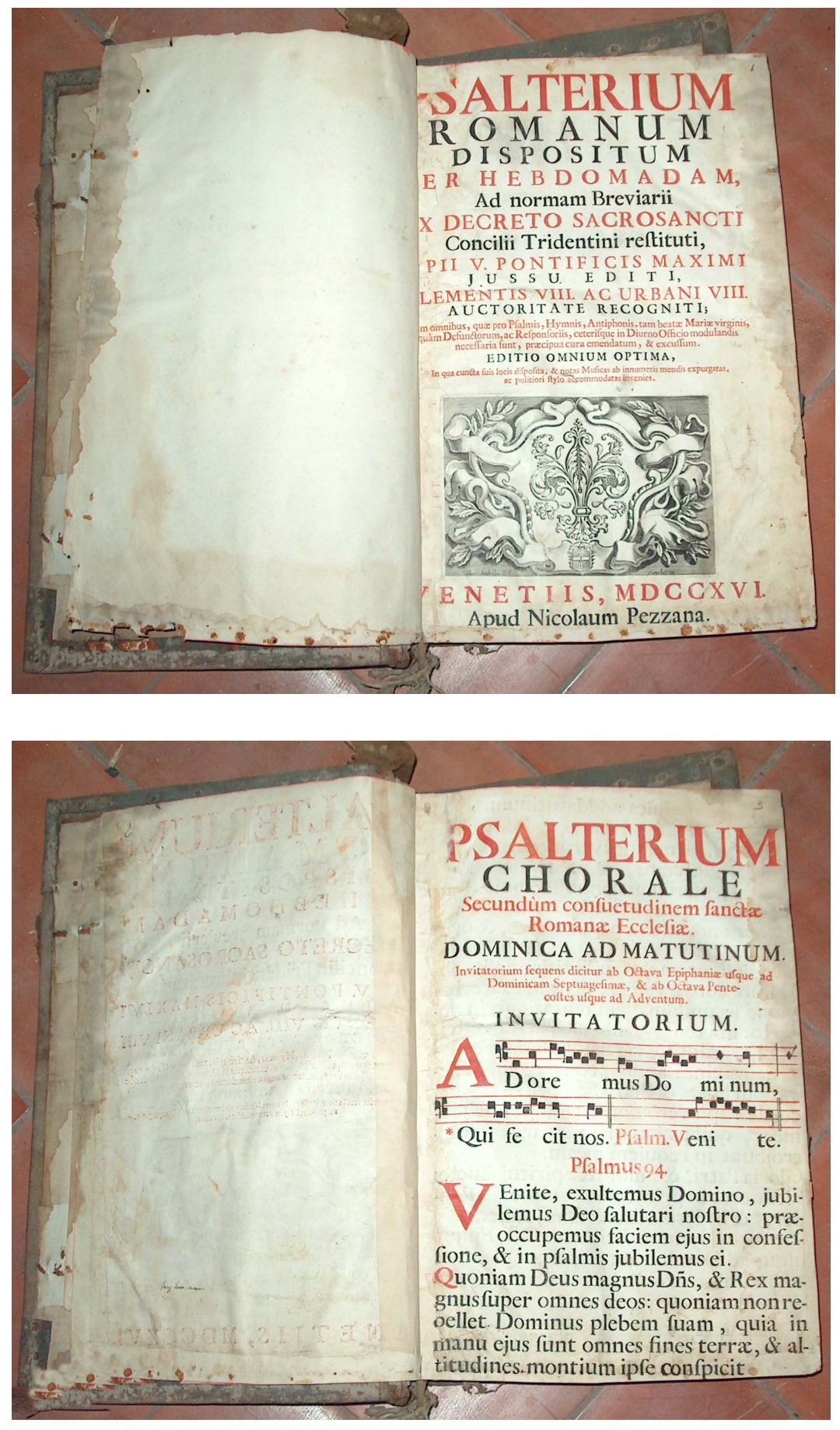


\section{$\left[\mathbf{N}^{\mathbf{0}} \mathbf{L X X}\right]$}

\section{LIBRO 381 (olim LL)}

Salterio. Salterium Romanum. Impreso sobre papel.

Medidas: encuadernación 460 × 320 x 100

Ubicación: Estante A-2

Páginas: $446+46$

Fecha: 1716

Lugar de Impresión: Venecia

Impresor: Nicolaum Pezzana

\section{Otras observaciones:}

Título completo: Salterium Romanum dispositum per Hebdomadam, Ad norman Breviarii ex decreto Sacrosancti Concilii Tridentini restituti, B? PII V. Pontificis Maximi Jussu editi, Clementis VIII ac Urbani VIII. Auctoritate recogniti; cum omnibus, quae pro Psalmis, Hymnis, Antiphonis, tam beatae Mariae virginis, quam defunctorum, ac Refponsoriis, ceterisque in Diurno Officio modulandis necessaria sunt, praecipua cura emendatum, \& exeussum.Editium Omnium Optima, In qua cuncta suis locis disposita,\& notas Musicas ab innumeris mendis expurgatas, ac politiori stylo accommodatas invenies venetiis, MDCCXVI Apud Nicolaum Pezzana.

Se encuentra en buen estado de conservación. Tiene una etiqueta en la que dice "Del Convento de san Antonio de Padua de Granada". 
[N $\left.{ }^{\circ} \mathbf{L X X I}\right]$

LIBRO 5485

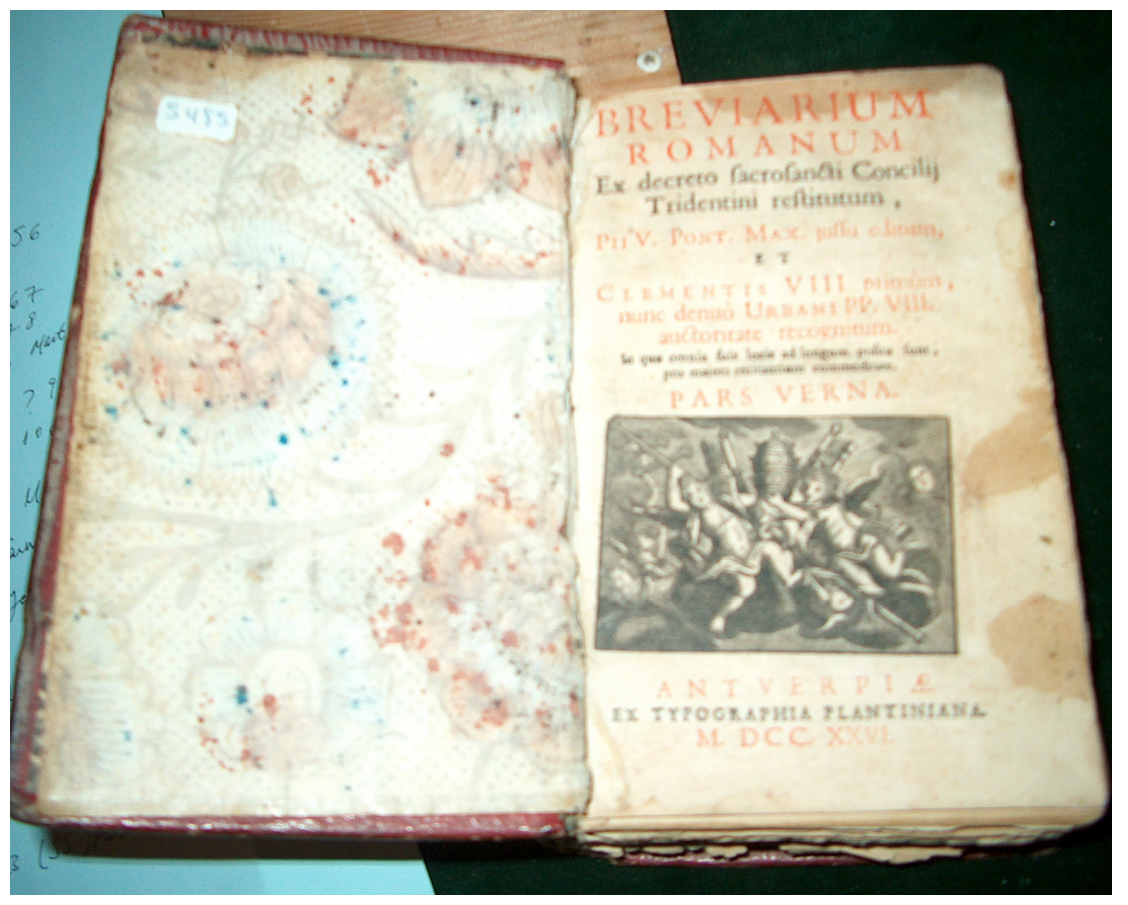




\section{$\left[\mathbf{N}^{\mathbf{0}} \mathbf{L X X I}\right]$}

\section{LIBRO 5485}

Breviarium Romanum. Impreso sobre papel de 1094 páginas.

Medidas: encuadernación 165 × 100 x 60

Ubicación: Vitrina 1-1

Páginas: $644+\mathrm{CDI}+46$

Fecha: 1726

Lugar de Impresión: Antuerpiae (Amberes)

Impresor: Typographia Plantiniana

Otras observaciones:

Falta primera hoja.

Título completo: Breviarium Romanum/ Ex decreto (...)/In quo omnia suis locis ad longum posita sunt,/ pro majori recitantium commoditate/ Pars Verna/ ANTUERPIAE/ EX TYPOGRAPHIA PLANTINIANA/ MDCCXXVI 


\section{[N'LXXII]}

LIBRO 342 (olim 42)

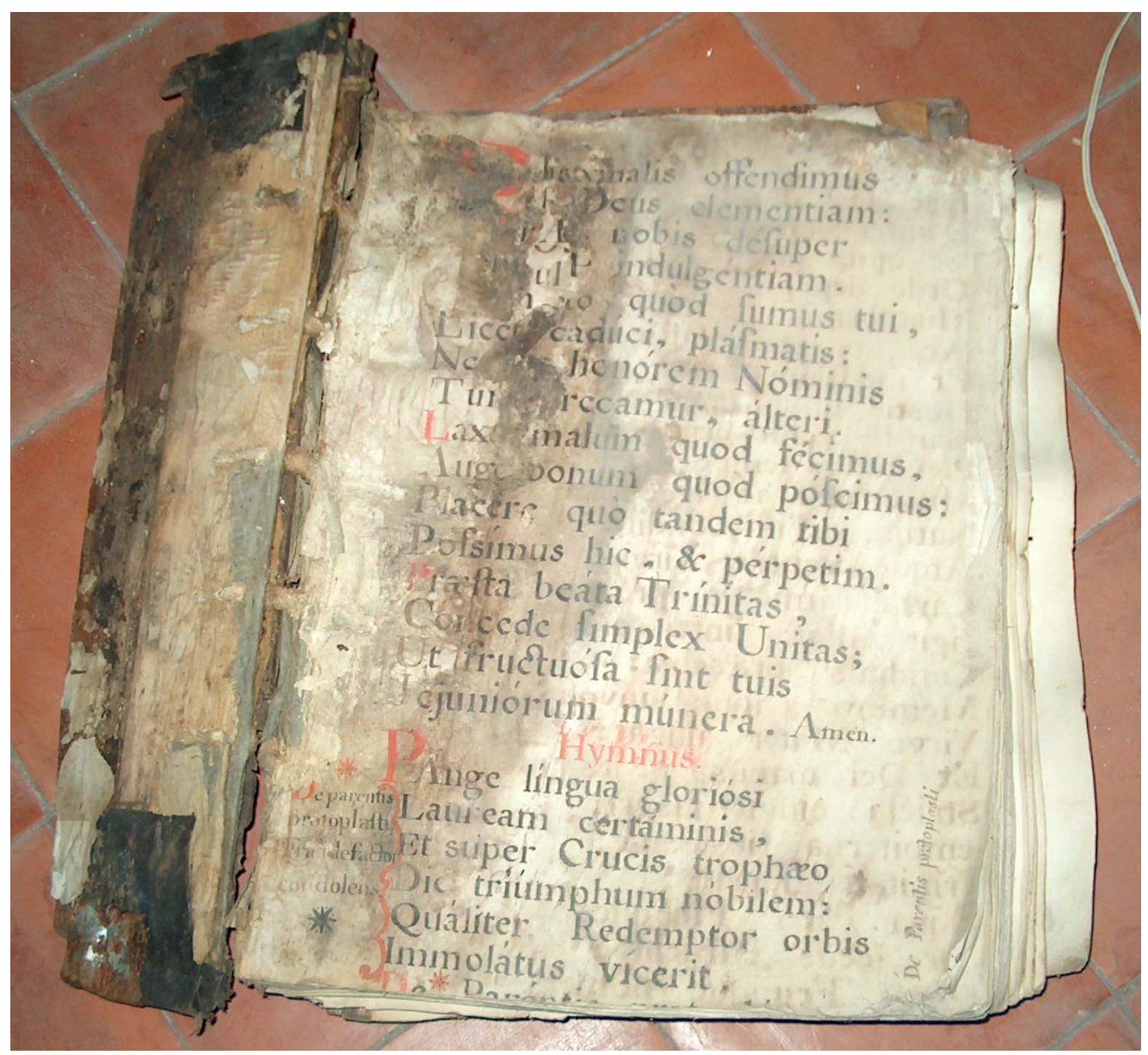




\section{$\left[\mathbf{N}^{0} \mathbf{L X X I I ]}\right.$}

\section{LIBRO 342 / 42}

Salterio. Manuscrito e Impreso sobre papel.

Medidas: encuadernación 600 x 430 x 120

Ubicación: Estante A-1

Páginas: 383 páginas numeradas (impresas), más 10 sin numerar (manuscritas).

Fecha: $i$ ?

Lugar de Impresión: ¿?

Otras observaciones: Falta la cubierta delantera. Es similar en la encuadernación y letra a los del Convento de San Antonio de Padua.

Incipit del texto: (...) offendimus/ (¿?) Deus elementiam:/ nobis désuper/ indulgentiam. Uso litúrgico: para los oficios (Maitines, laudes y horas menores para la semana). 
[N ${ }^{\circ} \mathbf{L X I I I ]}$

LIBRO 362 (olim T)

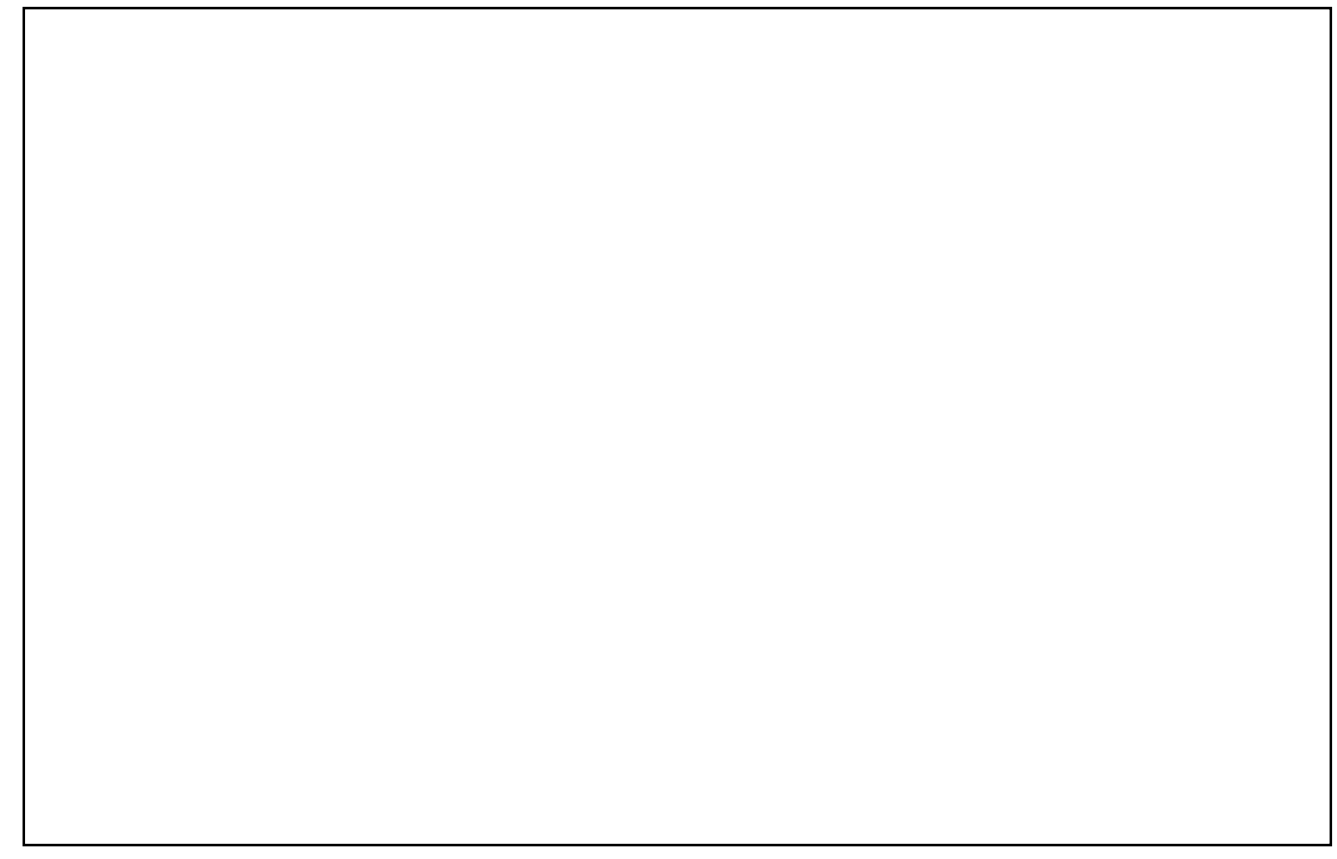




\section{$\left[\mathbf{N}^{0} \mathbf{L X I I I ]}\right.$}

LIBRO 362 / T

Breviario. Impreso sobre papel.

Medidas: encuadernación 425 x 300 x 160

Ubicación: Estante C-2

Páginas: 1162pag $+168 p a g+170 p a g+129$ hojas (sin numerar) +29 hojas ( $\sin$ numerar).

Fecha: 1781

Lugar de Impresión: España

Ilustraciones: grabado por M. Rodríguez.

Otras observaciones: Falta primera hoja. 


\section{[N'LXXIV]}

LIBRO 348 (olim 45, olim 1, olim M)

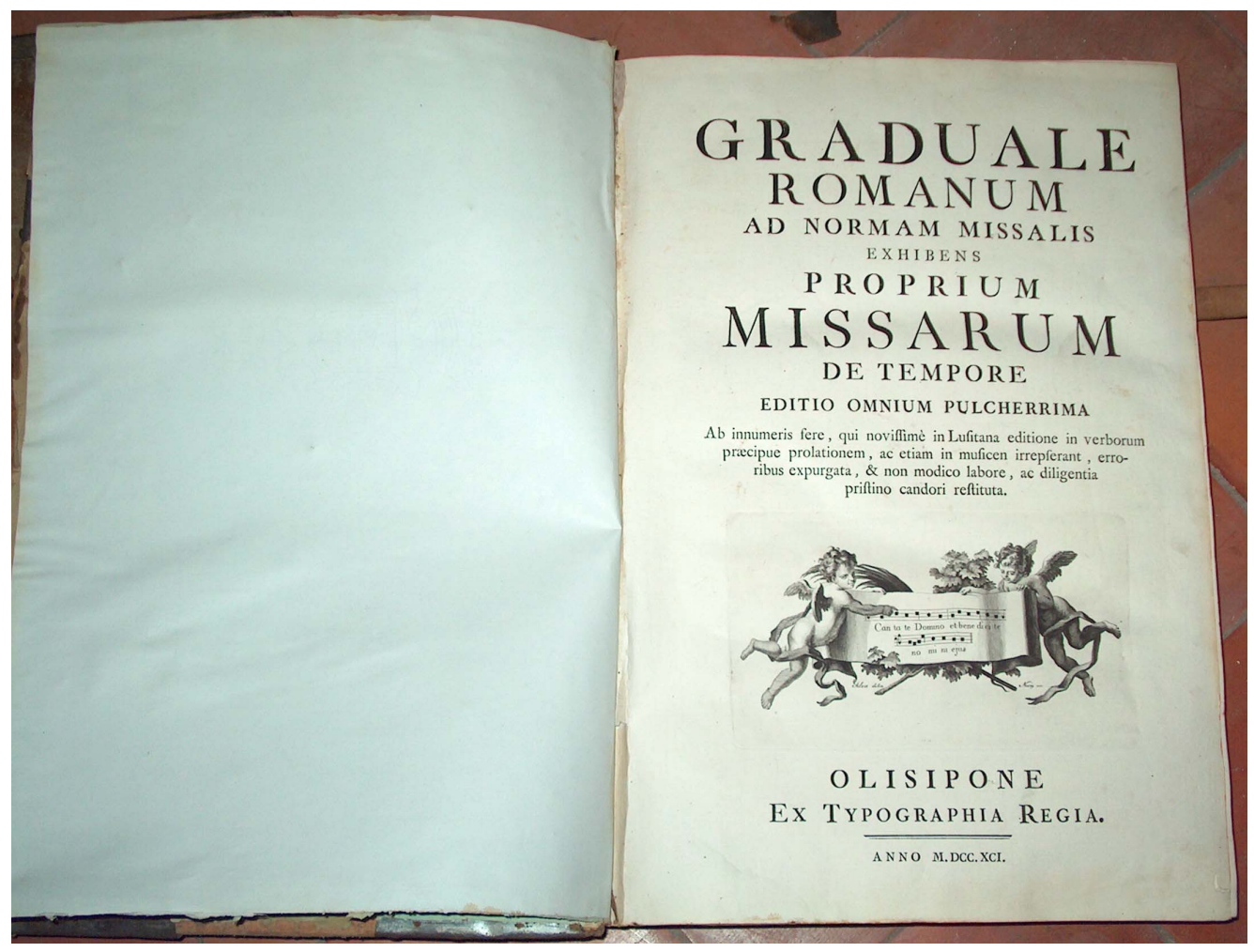




\section{$\left[\mathbf{N}^{0} \mathbf{L X X I V ]}\right.$}

LIBRO 348 / 45 / 1 / M

Gradual: GRADUALE ROMANUM. Impreso sobre papel.

Medidas: encuadernación 560 x 400 x 100

Ubicación: Estante A-2

Páginas: $476+63$

Fecha: 1791

Lugar de Impresión: Lisboa (Olisipone)

Impresor: Imprenta Regia

Otras observaciones:

GRADUALE ROMANUM AD MISSALIS EXHIBEUS PROPRIUM MISSARUM DE TEMPORE EDITIO OMNIUM PULCHERRIMA Ab innumeris fere, qui novissime in Lusitania editione in verborum praecipue prolationem, ac etiam in musicen irrepserant erroribus expurgata \& non modico labore, ac diligentia pristino candori restituta.OLISIPONE EX TYPOGRAPHIA REGIA. ANNO M.DCC.XCI. 
[N $\left.{ }^{\circ} \mathbf{L X X V}\right]$

LIBRO 350 (olim 47, olim 4, olim, 3 olim M)

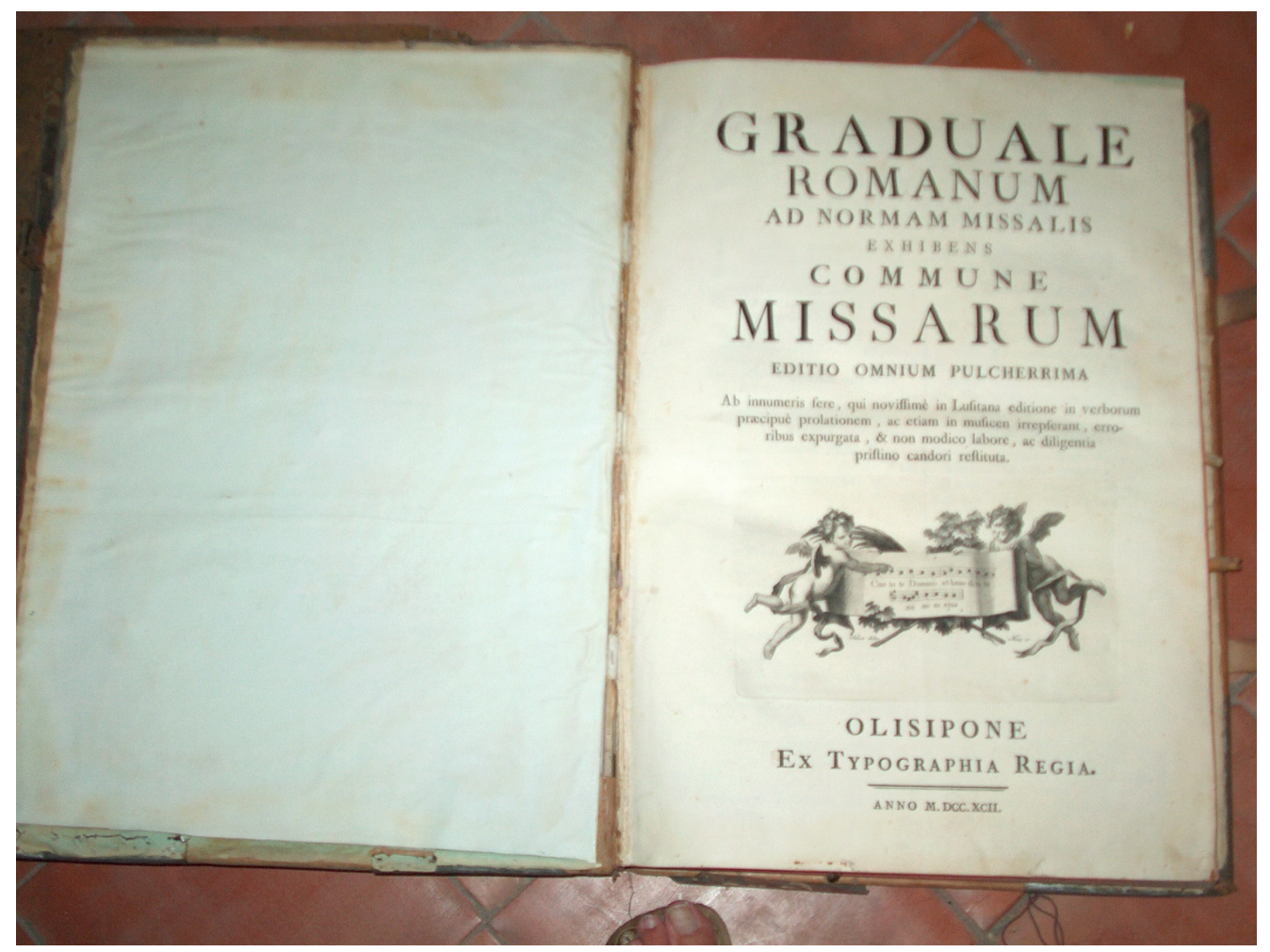




\section{$\left[\mathbf{N}^{0} \mathbf{L X X V}\right]$}

LIBRO 350 / 47 / 4 / 3 / M

Gradual: GRADUALE ROMANUM. Impreso sobre papel.

Medidas: encuadernación 560 x 400 x 100

Ubicación: Estante A-2

Páginas: $476+63$

Fecha: 1792

Lugar de Impresión: Lisboa (Olisipone)

Impresor: Imprenta Regia

Otras observaciones:

GRADUALE ROMANUM AD NORMAN MISSALIS EXHIBEUS COMMUNE MISSARUM EDITIO OMNIUM PULCHERRIMA Ab innumeris fere, qui novissime in Lusitania editione in verborum praecipue prolationem, ac etiam in musicen irrepserant erroribus expurgata \& non modico labore, ac diligentia pristino candori restituta.OLISIPONE EX TYPOGRAPHIA REGIA. ANNO M.DCC.XCII. 


\section{[N'LXXVI] \\ LIBRO 361 (olim S)}

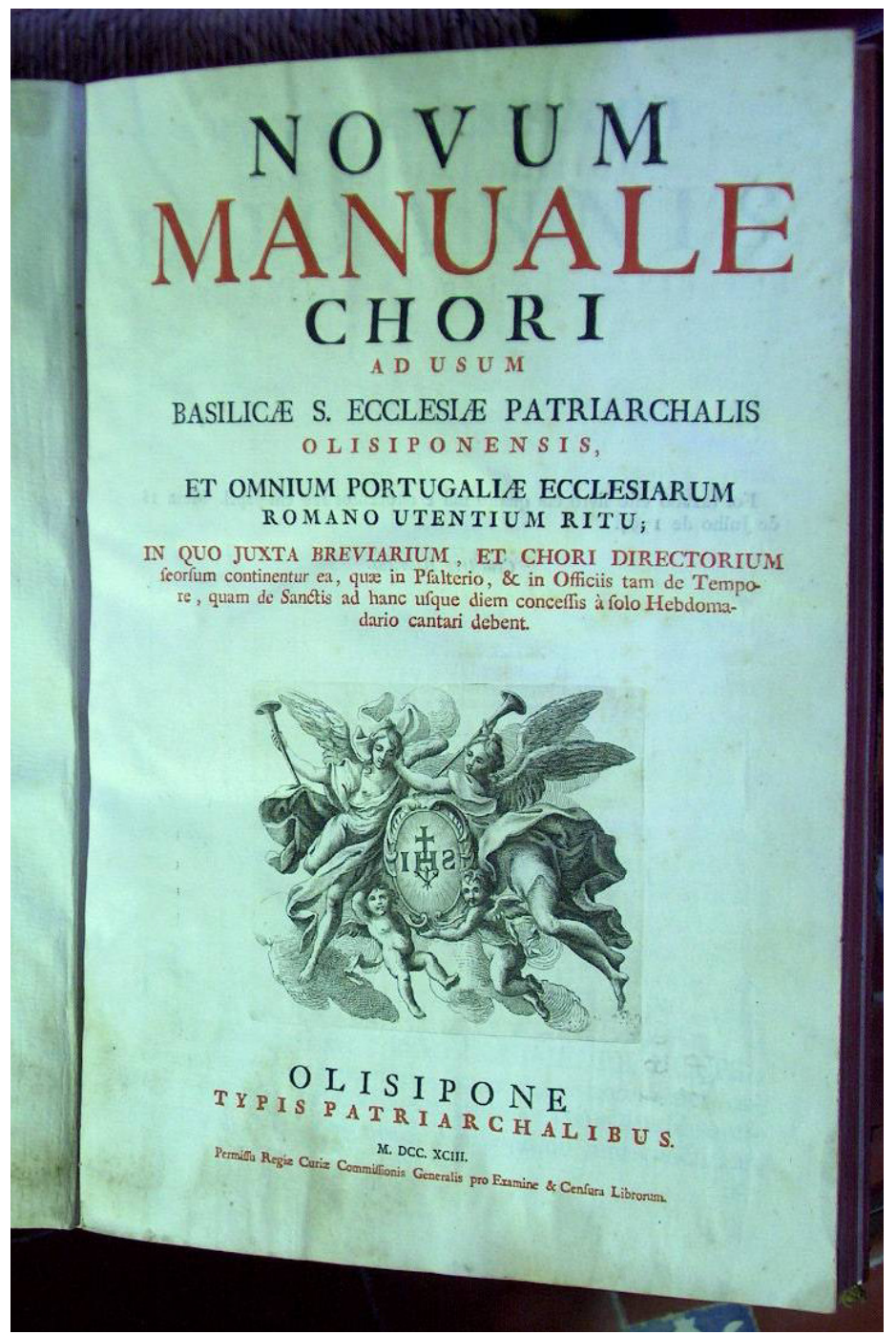




\section{[No LXXVI]}

\section{LIBRO $361 / S$}

Manual de coro: NOVUM MANUALE CHORI. Impreso sobre papel.

Medidas: 418 x 284 x 50

Ubicación: Vitrina 4-2

Páginas: $331+\mathrm{XXXIV}$

Fecha: 1793 (MDCCXCIII)

Lugar de Impresión: Lisboa (Olisipone)

Impresor: Typis patriarchalis

Otras observaciones: Buen estado de conservación 


\section{[N'LXXVII]}

\section{LIBRO 349 (olim 46, olim 2, olim M)}

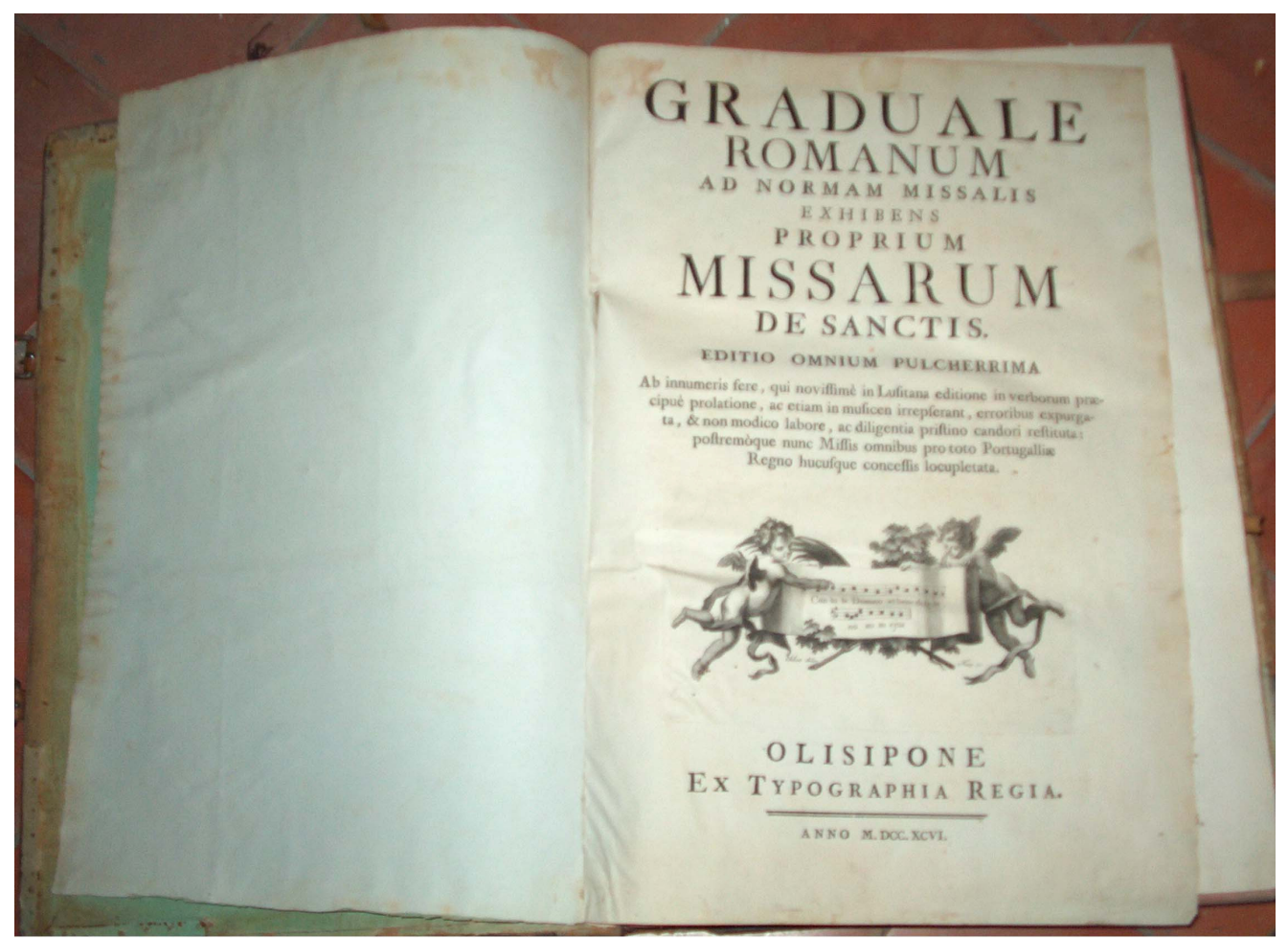


[No LXXVII]

LIBRO 349 / 46 / 2 / M

Gradual. GRADUALE ROMANUM. Impreso sobre papel.

Medidas exteriores: 555 x 400 x 100

Ubicación: Estante A-2

Páginas: $428+63$

Fecha: 1796

Lugar de Impresión: Lisboa (Olisipone)

Otras observaciones: Contiene el propio de las Misas de los Santos. 
[N'LXXVIII]

LIBRO 5505

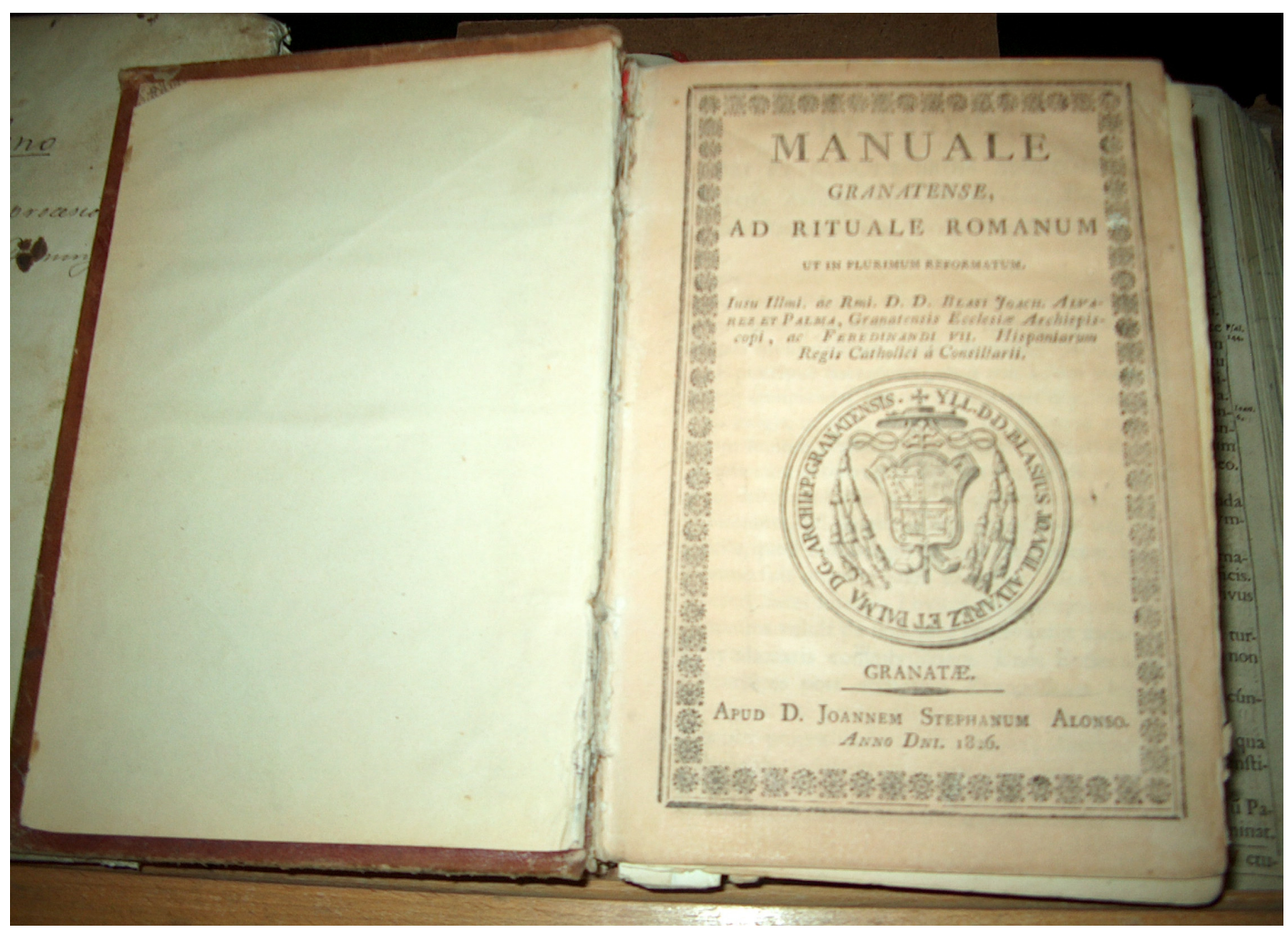




\section{[No LXXVIII]}

\section{LIBRO 5505}

MANUALE GRANATENSE. Impreso sobre papel.

Medidas exteriores: $195 \times 120$ x 16

Ubicación: Vitrina 1-2

Páginas: 361

Fecha: 1826

Lugar de Impresión: Granada

Impresor: Joannem Stephanum Alonso

Otras observaciones: Título completo: MANUALE/ GRANATENSE,/ AD RITUALE ROMANUM/ UT IN PLURIMUM REFORMATUM,/ Iusu Illm. Ac Rmi. D.D. Blasi Joach.Alva/rez et Palma, Granatensis Ecclesiae Archiepis/copi, ac Ferdinandi VII Hispaniaru/ Regi Catholici a Consiliarii/ GRANATAE/ Apud D. JOANEM STEPHANUM ALONSO/ANNO DNI. 1826 
[NºXXIX]

LIBRO 365 (olim X)

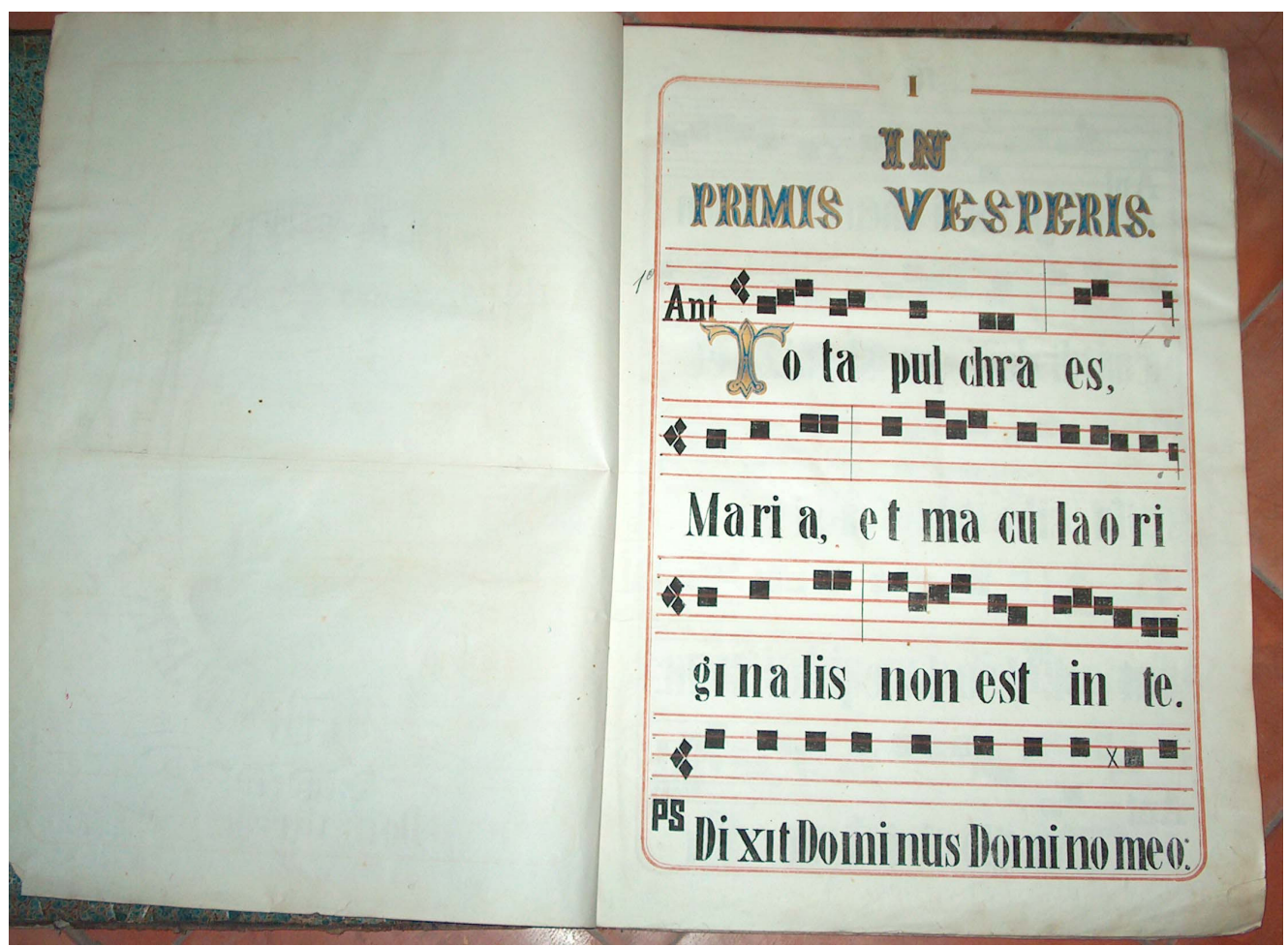




\section{$\left[\mathbf{N}^{\mathbf{0}} \mathbf{L X X I X ]}\right.$}

\section{LIBRO 365 / X}

Cantoral: In festo Immaculatae Conceptionis. Impreso sobre papel.

Medidas exteriores: $610 \times 442 \times 25$

Ubicación: Estante A-2

Páginas: 55

Fecha: 1864

Impresor: Litografía B. Álvarez

Lugar de Impresión: Madrid

Ilustraciones: litografía de la Inmaculada en la portada interna.

Otras observaciones: Se encuentra desencuadernado. 



\section{BIBLIOGRAFÍA}

ABADÍA DEL SACROMONTE, ACTAS DE CABILDO [A.S.A.C.] Tomos 1-12 (Años 1610-1799).

Caeremoniale Episcoporum (Roma: Caroli Gianini et Hyeronimi Mainardi impressorum cameralium, 1729).

Constituciones que an d guardar el Abbad y canónigos de la Iglesia Collegial que fundamos en el Sacro Monte, dadas año de 1616 (Madrid, Biblioteca Nacional, ms. 6437).

Constituciones Synodales del Arçobispado de Granada/ hechas por el ... señor Don Pedro Guerrero Arçobispo de la sancta Yglesia de Granada, en el sancto Sínodo que su señoría Reverendissima celebro a quatorze dias del mes de Octubre del año M.D.L.XXII. (Granada: Hugo de Mena, 1573).

Consueta de esta Insigne Iglesia del Sacromonte Illipulitano, 1632 (Ms., s.s. Abadía del Sacromonte)

Archivo Real de Palacio, Organistas, Expediente de Antonio Literes doc. No1.

Archivo de Palacio, nº153 fo 95, 5-12-1768.

Índice General de los Libros del Coro, post. a 1886. (Ms., ss, Abadía del Sacromonte)

Memorial Sumario de las veynte y quatro informaciones que el Arzobispo de Sevilla mandó hazer, cerca de las contradicciones, que los religiosos de santo Domingo han hecho a los que defienden y siguen la opinión pia, de que la Virgen N.S. fue concebida sin pecado original (s.f, s.l., s.e.). fol. 1v $-3 \mathrm{r}$.

AA.VV., Diccionario de Historia de España (Madrid: Revista de Occidente, 1973) Tomo I, p.

AA.VV., Granada 1899 (Granada: Albaida, 1995).

AA.VV. "Guadalupe, Basílica de", Diccionario Porrúa, Historia, Biografía y Geografía de México, $\sigma^{a}$ Ed. (México: Porrúa, 1955), p. 1565.

AA.VV., El Gran Capitán: de Cordoba a Italia al Servicio del Rey (Cordoba: Cajasur, 2003).

Avellán, Miguel de, Declamación que hizo el reverendo Padre Fray Michael Avellan, Lector de Teologia. En las Fiestas de la Inmaculada Concepción de nuestra 
Señora, que se celebraron en San Francisco de Granada, sobre el Epitalamio; Todo el mundo en general (que á sido tan bien recibido, y celebrado en toda España) aplicado al Evangelio (Granada: Martin Fernandez, 1617).

Acuña, Diego de, Copia de la carta que Don Diego de Acuña, Governador y Capitán general de la Ciudad y Provincia de Cartagena en las Indias occidentales, escrivio a la Catolica Majestad del Rey Don Felipe $3^{\circ}$ sobre negocios de la Concepción de nuestra Señora, Fols. 100r -100v. BNE Mss. 9956.

Albanell, Galcerán, Manuale granatense ad Rituale Romanum ut in plurimum reformatum / iussu ... Galcerandi Albanell, Granatensis Ecclesiae Archiepiscopi...(Madrid: Theresiam Iuntam, 1625).

Aldea Vaquero, Quintín, Tomás Marín Martínez y José Vives Gatell (eds.), Diccionario de Historia Eclesiástica de España (Madrid: Instituto Enrique Flórez, Consejo Superior de Investigaciones Científicas, 1972-1987).

Alenda y Mira, Jenaro. Relaciones de solemnidades y Fiesta Públicas en España (Madrid: Sucesores de Rivadeneyra, 1903).

Alonso, Carlos, Los apócrifos del Sacromonte. Estudio histórico (Valladolid: Estudios Agustinianos, 1979).

Álvarez del Castillo, $\mathrm{M}^{\mathrm{a}}$ Angustias. La miniatura de los Corales de la Catedral de Granada: Estudio y Catalogación, Tesis doctoral (Universidad de Granada, 1980).

."Los Libros Litúrgicos: Los Cantorales" en Gila Medina, Lázaro (ed.), El libro de la Catedral de Granada (Granada: Cabildo Metropoltano de la Catedral de Granada, 2005), vol. 2, 883-961.

Álvarez Solar-Quintes, Nicolás, "Nuevas noticias de músicos de Felipe II, de su época, y sobre impresión de música”, Anuario Musical, XV (1960), 195-228.

Andrés, Ramón, Diccionario de instrumentos musicales: de la antigüedad a J. S. Bach (Barcelona: Península, 2001).

Anónimo, Sacrarum cerimoniarum sive rituum ecclesiasticorum sanctae romanae ecclesiae libri tres (Coloniae Agrippinae: apud haeredes Arnoldi Birckmanni, 1572).

Anónimo, Relación del descubrimiento de las Reliquias ([Granada]: Iuan Rene, 1595).

Anónimo, En la ciudad de Granada a tres dias del mes de Iulio de mil y quiniêtos y nouenta y seys años ... en nôbre de la santa Yglesia, Arçobispo, Dean y Cabildo y gran Hospital real de señor Santiago, de Galizia, presento una peticion $y$ 
priuilegio... [Certificación y Privilegio de los Reyes Católicos de 1497 para la cobranza del voto de Santiago, suscrita por el escribano Luys de Leyua] (Granada: s.n., 1596)

Anónimo, Relacion del voto que hizo y octauario que celebró la ciudad de Xerez de la Frontera, en honra de la Inmaculada Concepcion (Sevilla: Alonso Rodriguez Gamarra, 1616).

Anónimo, Solenissimas fiestas que la insigne ciudad de Toledo hizo a la Inmaculada Concepcion (Sevilla: Francisco de Lyra, 1616)

Anónimo, Relación del solemne juramento, que el ilustrísimo D. Pedro de Castro...(Sevilla: Francisco de Lyra, 1617).

Anónimo, Relacion de las famosas fiestas que se hizieron en la Vniuersidad de Alcala de Henares, despues de auer hecho voto de guardar y tener en ella el ... misterio de la Inmaculada Concepcion ... : lleua al fin tres cartas, la vna del ... Obispo de Osma ... Francisco de Sosa al padre fray Antonio de Trejo, General de toda la orden de San Francisco, donde da cuenta de su viage a Roma ... al negocio del Inmaculado misterio de nuestra Señora, y otras dos cartas, la vna de vn Secretario del Rey ... y respuesta a ella (Alcala de Henares : en casa de la viuda de Iuan Gracian, 1617).

Anónimo, Relacion de la fiesta, que el Colegio Mayor de Santa María de IESUS Universidad de la Ciudad de Sevilla hizo, en la publicación de un Estatuto, en que se juró la Concepción limpissima de nuestra Señora sin mancha de pecado original (Sevilla: Francisco de Lyra, 1617).

Anónimo, Relación de las fiestas que a la Inmaculada Concepción de la Virgen Nuestra Señora se hicieron en esta ciudad de los reyes del Perú (Lima: Francisco del Canto, 1618)

Anónimo, Copia segunda (Sevilla: Gabriel Ramos Bejarano, 1618).

Anónimo, Copia tercera (Sevilla: Gabriel Ramos Bejarano, 1618).

Anónimo, Copia quarta (Sevilla: Gabriel Ramos Bejarano, 1618).

Anónimo, Copia quinta (Sevilla: Gabriel Ramos Bejarano, 1618).

Anónimo, Copia sexta (Sevilla: Gabriel Ramos Bejarano, 1618).

Anónimo, Relación sumaria de cómo la Universidad de Barcelona renovo el decreto del Iuramento antigamente en ella establecido acerca de la inmaculada concepción de la Virgen Madre de Dios, y S.N. y de las fiestas que con esta ocasión se hizieron en 
toda la Ciudad por el mes de Noviemb. 1618 sacada de la que se embio al Rey nuestro Señor (Barcelona: Sebastián Matevat, 1619).

Anónimo, Praxis de las Ceremonias, que deben observarse por los Colegiales del Insigne Colegio de Theólogos, y Juristas del Señor San Dionisio Areopagita, sito en el Sacro Ilipulitano Monte, extra-Muros de la Ciudad de Granada (Granada: Imprenta Real, 1772).

Anónimo, Consueta de ceremonias y gobierno, de la Santa Iglesia Catedral Apostólica y Metropolitana, de la Ciudad de Granada (Granada: Nicolás Moreno, 1819).

Anónimo, Las buenas e loables costumbres, y ceremonias que se guardan en la Santa Iglesia de Granada, y en el Coro de ella (S.1: s.n., s.f.) BNE 2/69800(2).

Antolínez de Burgos, Justino, Historia eclesiástica de Granada, Edición y estudio de Manuel Sotomayor Muro (Granada: Universidad, 1996).

Appel, Willi, Gregorian Chant (Bloomington \& Indianápolis: University of Indiana, 1990).

Aracil, Alfredo, Juego y artificio. Autómatas y otras ficciones en la cultura del Renacimiento a la Ilustración (Madrid: Cátedra, 1998).

Arbeau, Thoinot (Jehan Tabourot), Orchesographie (Langres: Iehan des Preyz, 1588).

Arévalo, Faustino, Hymnodia Hispánica (Roma: Typographia Salomoniana ad Divi Ignatii, 1786).

Arrizabalaga, José $\mathrm{M}^{\mathrm{a}}$, "El órgano histórico de la Iglesia de la Colegiata de Santa María de Zenarruza, Marquina (Vizcaya)", Nassarre, VII/2 (1991), 9-32.

Asensio, Juan Carlos, El canto gregoriano. Historia, liturgia, formas.... (Madrid: Alianza Música, 2003).

Azcárate, José Ma de, "El tema iconográfico del salvaje", Archivo Español de Arte, XXI (1948), 81-99.

Baker, Geoffrey, Improvising Harmony. Music and Society in colonial Cuzco (Durham y Londres: Duke University Press, 2008).

Ballús Casóliva, Glòria, La Música a la collegiata basílica de Santa Maria de la Seu de Manresa: 1714-1808. Dades documentals per a la seva reconstrucció amb una 
aproximació al repertori litúrgic conservat, Tesis Doctoral (Universidad Autónoma de Barcelona, 2004).

Banda y Vargas, Antonio de la, La Colegiata de Osuna (Sevilla: Caja San Fernando de Sevilla y Jerez, 1995).

Barrios Aguilera, Manuel "Introducción” en Nicolás Heredia Barnuevo, Místico Ramillete, Granada, Universidad, 1998 [1741].

y Valeriano Sánchez Ramos, Martirios y mentalidades martiriales en la Alpujarra (Granada: Universidad, 2004).

"Las misiones en la sociedad posrepobladora: las del Sacromonte de Granada", en Manuel Barrios Aguilera y Ángel Galán Sánchez (eds.), La historia del Reino de Granada a debate, viejos y nuevos temas. Perspectivas de estudio (Málaga: Diputación, 2004).

"El Sacromonte de Granada y la religiosidad contrarreformista" en José Ruíz Fernández y Valeriano Sánchez Ramos (eds.), La religiosidad popular y Almería: actas de las III Jornadas (Almería: Instituto de Estudios Almerienses, 2004), 15-37.

Los falsos cronicones contra la historia (Granada: Universidad, 2004).

- y Ángel Galán Sánchez (eds.), La historia del Reino de Granada a debate, Viejos y nuevos temas, Perspectivas de Estudio (Málaga: Diputación, 2004).

- y Mercedes García Arenal (eds.), Los Plomos del Sacromonte. Invención y Tesoro (Valencia: Universidad de Valencia, Universidad de Granada, Universidad de Zaragoza, 2006).

. y Mercedes García Arenal (eds.), ¿La historia inventada? Los libros plúmbeos y el legado sacromontano (Granada: Universidad de Granada y Legado Andalusí, 2008).

Baudrillart, Alfred, Albert Vogt y Urbain Rouziés, Dictionnaire d'histoire et de géographe ecclésiastiques, Publié sons la direction de Alfred Baudrillart, Albert Vogt et Urbain Rouziés (Paris: Letouzey et Ané, 1913).

Benítez Sánchez-Blanco, Rafael, "De Pablo a Saulo: traducción, crítica y denuncia de los libros plúmbeos por el P. Ignacio de las Casas, S.J." en Al-Qantara, XXIII/2 (2002), 404-436.

"Estudio introductorio" a Henry Charles Lea, Los moriscos españoles: su conversión y expulsión (Alicante: Universidad, 2001), 9-76. 
Bermúdez, Egberto, "Urban Music life in the european colonies: examples from America 1530-1560", en Fiona Kisby (ed.), Music and Musicians in renaissance Cities and Towns (Cambridge: Cambridge University Press, 2000), pp. 167-180.

Bermúdez de Pedraza, Francisco, Historia Eclesiástica de Granada, Prólogo de Ignacio Henares Cuellar. Ed. Facsímil de la publicada en 1638 (Granada: Archivum Universidad, 1989). 1608).

Bjorck, David A. "The Tropo Kyrie", Journal of the American Musicological Society, XXXIII/1 (1980) 1-41.

. The Aquitanian Kyrie Repertory of the Tenth and Eleventh Centuries (Ashgate: Aldershot, 2003).

Bleiberg, Germán (dir.), Diccionario de Historia de España, IV vols. (Madrid: Revista de Occidente, 1968).

Blume, Clemens y Guido Maria Dreves, Analecta hymnica medii aevi, xlvii: Tropen des Missale in Mittelalter (Leipzig: Fues, 1905).

Bonet Correa, Antonio, "Entre la superchería y la fe: el Sacromonte de Granada", Andalucía monumental. Arquitectura y ciudad del Renacimiento al Barroco. (Sevilla: Andaluzas Reunidas, 1986).

Boronat y Borrachina, Pascual, El beato Juan de Ribera y el Real Colegio del Corpus christi, estudio histórico (Valencia: Impr. de F. Vives y Mora, 1904).

Borrás, Josep y Antonio Ezquerro, "Chirimías en Calatayud", Revista de Musicología, XXII/2 (1999), 53-85.

Bourligueux, Guy, "El violinista Pascual Juan Carriles, su familia y sus amigos", Anuario Musical, XLII (1987), 189-228.

Bouza Álvarez, José Luis, Religiosidad contrarreformista y cultura simbólica del barroco (Madrid: Consejo Superior de Investigaciones Científicas, 1990).

Brown, Peter, The cult of the saints. Its rise and function in Latin Christianity (Chicago: Chicago University, 1981).

Bryant, David y Elena Quaranta, Produzione, circolazione e consumo. Consuetudine e quotidianità della poliphonia sacra nelle chiese monastiche e parrochiali dal tardo 
medioevo alla fine degli antichi regimi, Quaderni di Musica e Storia-5 (Venezia: Fondazione Ugo e Olga Levi, 2006).

Bueno Vargas, Javier, Los libros de coro en pergamino e ilustrados de la Abadía del Sacromonte de Granada : estudio histórico medioambiental, de materiales y técnicas, Tesis Doctoral (Universidad de Granada: 2002).

Cabanelas, Dario, El morisco Alonso del Castillo (Granada: Patronato de la Alhambra, 1965).

Calahorra Martínez, Pedro, "Dos inventarios de los ss. XVI y XVII de la Colegial de Daroca y dos pequeñas crónicas darocenses", Revista de Musicología, III/1-2 (1980), 33-76.

. (ed.), Polifonía Aragonesa II: Obras de los Maestros de la Capilla de Música de la Colegial de Daroca (Zaragoza) en los siglos XVII y XVIII (Zaragoza: Institución Fernando el Católico, 1985).

Calero Palacios, $\mathrm{M}^{\mathrm{a}}$ del Carmen, La Abadía del Sacromonte de Granada. Catálogo de Manuscritos (Granada: Universidad, 1999).

Calvete de Estrella, Juan Cristóbal, Elogio de Vaca de Castro, estudio y traducción por José López de Toro (Madrid: CSIC, 1947).

Campos Sánchez Bordona, $\mathrm{M}^{\mathrm{a}}$ Dolores y $\mathrm{M}^{\mathrm{a}}$ Isabel Viforcos Marinas, Honras fúnebres en el León del antiguo Régimen (León: Universidad de León, 1995).

Candelaria, Lorenzo, "Tropes for the Ordinary in a 16th-century chantbook from Toledo, Spain”, Early Music, XXXIV (2006) 587-611.

Canga Argüelles, José, Diccionario de hacienda (Madrid: Atlas, 1968).

Cano Gutiérrez, Diego, Relacion de las fiestas triumphales que la insigne Vniuersidad de Lima hizo a la Imnaculada [sic] Concepcion de Nuestra Señora (Lima: Francisco Lasso, 1619).

Cárdenas, Inmaculada, "La Música en la Colegiata de Olivares", Anuario Musical, XXXVI (1981), 91-130.

- Música Barroca Andaluza en las Colegiatas de Osuna y Olivares, Tesis Doctoral (Universidad de Sevilla, 1980).

Caro Baroja, Julio, Las falsificaciones de la Historia (en relación con la de España)(Barcelona: Seix Barral, 1992). 
Casares Rodicio, Emilio (ed.), Francisco Asenjo Barbieri. Documentos sobre música española y epistolario (Legado Baribieri) (Madrid: Fundación Banco Exterior, 1986).

. (dir.), Diccionario de la Música Española e Hispanoamerica, 10 vols. (Madrid: Sociedad General de autores y Editores de España, 1999-2002).

Castro Caridad, Eva $\mathrm{M}^{\mathrm{a}}$, Tropos y troparios hispánicos (Santiago de Compostela: Universidad de Santiago, 1991)

Castro y Quiñones, Pedro, Gnomon seu gobernandi Abbati, et canonicis Sacri Montis Illipulitani praescripta Ab Yllustriss ${ }^{\circ}$ et Rss ${ }^{o}$ Domino D. Pedro De Castro et Quiñones Archiepiscopo Granatensi, et posteabis palensi, eius dem Ecclesiae Collegiatae Fundatori. Et ab Urbano VIII Pontifici Maximo Confirmata (Granada: Ex tipografia Regia apud Sanchez, 1647).

Catalán Algás, $\mathrm{M}^{\mathrm{a}}$ del Carmen y otros, Libros de Acuerdos y Resoluciones del Cabildo de la Colegiata de Daroca (Zaragoza) 1529-1852. (Zaragoza: Institución Fernando el Católico, 1990).

Centurión, Adán, Información para la historia del Sacromonte llamado de Valparaíso y Antiguamente ilipulitano (Granada: Bartolomé de Lorenzana, 1632).

Chevalier, Ulrich, Repertorium Hymnologicum: catalogue des chants, hymnes, proses,séquences, tropes en usage dans l'église latine despuis les origines jusqu'à nos jours, 6 vols. (Lovaina y Bruselas: Imprimerie Lefever, Imprimerie Polleunis \& Ceuterick, Imprimerie F. Ceuterick, Société des Bollandistes, 1892-1921).

Consigli, Patrizia, La Battaglia nella pittura del XVII e XVIII secolo (Parma: Silva, 1994).

Cordero, Javier y Ricardo J. Hernández, Velázquez un logístico en la Corte de Felipe IV (Madrid: Eds. Díaz de Santos, 2000).

Cordero, Rosario, La Música en la Colegiata de San Salvador de Sevilla, Tesis Doctoral (Sevilla: Universidad de Sevilla, 2001).

Corral Báez, Francisco Javier, La Capilla de Música de la Catedral de Guadix en el siglo XVIII, Tesis Doctoral (Granada: Universidad de Granada, 1997).

Cortés Peña, Antonio Luis y Bernard Vincent, Historia de Granada. La época moderna. (Granada: Diputación Provincial, 1984).

Cotarelo y Mori, Emilio, Bibliografia de las Controversias sobre la licitud del teatro en España, edición facsímil, estudio preliminar e índices de José Luís Suárez García (Granada: Universidad, 1997). 
Cubí, Manuel, Vida del beato Juan de Ribera (Barcelona: Herederos de la Viuda Pia,1912).

Cuesta García de Leonardo, $\mathrm{M}^{\mathrm{a}}$ Josefa, Fiesta y arquitectura efimera en la Granada del siglo XVIII (Granada: Diputación Provincial, 1995).

Covarrubias Orozco, Sebastián de, Tesoro de la Lengua Castellana o Española (1611) Edición de Felipe C.R. Maldonado (Madrid: Castalia, 1995).

de la Cuadra Blanco,Juan Rafael, Simbología y génesis proyectiva: El Escorial y las fuentes históricas del Templo de Jerusalén, Tesis Doctoral (Universidad Politécnica de Madrid, 1994).

Díaz Gito, Manuel A, La Vacaida de Calvete de Estrella (Alcañiz-Madrid: Instituto de Estudios Humanísticos, 2003).

Díaz Mohedo, Ma Teresa, La capilla de música de la Iglesia Colegial de Antequera en la segunda mitad del siglo XVIII: el magisterio de José Zameza y Elejalde (Antequera: Centro de Documentación Musical de Andalucía, 2004).

. "Música y músicos en la Colegiata de Antequera"en La Real Colegiata de Antequera. Cinco siglos de Arte e Historia (1503-2003) (Antequera: Ayto. de Antequera y Archivo Histórico Municipal, 2004), 259-.

Díez Borque, José María. "Liturgia-Fiesta-Teatro: órbitas concéntricas de teatralidad en el siglo XVI”, Dicenda, Cuadernos de Filología Hispánica, VI (1987), 485-500.

Díez Martínez, Marcelino, La Música en Cádiz: la Catedral y su proyección urbana durante el siglo XVIII (Cádiz: Universidad de Cádiz, 2004).

Ditchfield, Simon. "Martyrs on the Move: Relics as vindicators of local diversity in the Tridentine Church" en Diana Wood (ed.), Martyrs and Martyrologies, Studies in Church History vol. 30 (Oxford: Blackwell Publishers, 1993), 283-294.

Dompnier, Bernard. "La musique, le culte et les dévotions: Un mode de distinction" en Bernard Dompnier (ed.), Maîtrises et chapelles aux XVIIe et XVIIIe siècles: Des institutions musicales au service de Dieu (Clermont-Ferrand : Presses universitaires Blaise-Pascal, 2003).

Echevarría, Juan de, Paseos por Granada y sus contornos (Granada: Valenzuela, 1814).

Elías, Norbert, La sociedad cortesana (Méjico: Fondo de cultura económico, 1996).

Escalante, Pedro de, Segunda Relacion de la fiesta que se hizo en Sevilla lunes diez y nueve de Setiembre a la santa imagen de la Concepcion con ocasion de la procesion que 
sus Cofrades hizieron para boluerla del Conueto de San Francisco al de Regina (Sevilla: Alonso Rodriguez Gamarra,1616).

Escalera Pérez, Reyes, La imagen de la sociedad barroca andaluza: estudio simbólico de las decoraciones efimeras en la fiesta altoandaluza. Siglos XVII y XVIII (Málaga: Universidad, 1994).

Ezquerro, Antonio y Ma Cinta Guerrero, "La Música en la Real Colegiata del Santo Sepulcro de Calatayud", Revista de Musicología XXII/2 (1999) 11-52.

Ezquerro, Antonio y Joseph Pavía (eds.), Música de atril en la Colegiata de Santa María de Calatayud (Zaragoza: Institución Fernando el Católico, 2002).

Ezquerro, Antonio y Josep Borrás, "Chirimías en Calatayud", Revista de Musicología, XXII/2 (1999), 53-85.

Fábrega Grau, Ángel, Pasionario Hispánico (siglos VII-XI). Tomo I: Estudio. Monumenta Hispaniae Sacra. Serie Litúrgica: vol. VI. (Madrid-Barcelona: Consejo Superior de Investigaciones Científicas Instituto Padre Flórez, 1953).

Falcón Márquez, Teodoro, Iglesias de Santa María y San Pedro: Arcos de la Frontera (Sevilla: Caja de Ahorros Provincial San Fernando, 1995).

Fellerer, Karl Gustav, "Church Music and the Council of Trent", Musical Quarterly, XXXIX/4 (1953), 576-594.

Fenlon, Iain, "Heinrich Glarean's books" en John Kmetz (ed), Music in the German Renaissance, Sources, Styles and Contexts (Cambridge: Cambridge University Press, 2006), 74-102.

Fernández de Bethencourt, Francisco, Historia genealógica y heráldica de la Monarquía Española, Casa Real y Grandes de España (Madrid: Jaime Rates, 1907).

Fernández de Córdova y Miralles, Álvaro, La Corte de Isabel (1474-1504) Ritos y Ceremonias de una Reina (Madrid: Dyckinson, 2002).

Fernández de la Cuesta, Ismael. "Canto toledano", Diccionario de la Música Española e Hispanoamericana (Madrid: SGAE, 1999), pp. 321.326.

. "Kalenda" en , p. 1925.

. "Spanish plainchant publications to 1601", Inter-American Music Review, vol. XVI, n², 2000, p.4.

Ferreres, Juan B., Instituciones Canónicas, 2 vols. (Barcelona: Editorial Pontificia, 1934). 
Ferriol y Caycedo, Alonso, Libro de las fiestas, que en honor de la immaculada Concepcion de la Virgen Maria... celebró su Devota... Hermandad. En San Francisco de Granada. Año de mil y seiscietos y quince (Granada: Martin Fernandez, 1616).

Ferro Ríos, Inmaculada y Cea Galán, Andrés, Catálogo de órganos de la provincia de Granada (Sevilla: Junta de Andalucía, 1995).

Fontana, F.; Lodari, R.; Sorrenti, P, Luoghi e vie di pellegrinaggio. I Sacri Monti del Piemonte e della Lombardia (Turín: Centro di Documentacione dei Sacri Monti, Calvari e Complessi devozionali europei, 2004).

Gaddis, John Lewis, El paisaje de la Historia. Cómo los historiadores representan el pasado (Barcelona: Anagrama, 2004).

Gallardo, Bartolomé José, Ensayo de una Biblioteca Española de libros raros y curiosos (Madrid, Rivadeneyra, 1866).

Gallego y Burín, Antonio, Granada, guía histórica y artística de la ciudad (Granada: Comares, 1996).

Gallego Moya, Elena (Ed), Los Himnos de la Hymnodia Hispanica, Faustino Arévalo, S.J. (Salamanca: Universidad de Alicante, 2002).

Ganassi, Silvestro, Opera Intitulata Fontegara, La qual insegna a sonare di flauto...", (Venecia, 1535).

García, Casiano, El licenciado Vaca de Castro, gobernador del Perú. (Madrid: CSIC, 1957.

García, Ferrán. "Los órganos de la Colegiata de Gandía”, Cabanilles, XXIII (1987), pp.730.

García García, Bernardo J. "Las fiestas de corte en los espacios del valido: la privanza del duque de Lerma" en María Luisa Lobato, Bernardo J. García García (Coords.), La fiesta cortesana en la época de los Austrias (Valladolid : Junta de Castilla y León, Consejería de Cultura y Turismo, 2003).

García Villada, Zacarías. Historia Eclesiástica de España (Madrid: Compañía Iberoamericana de Publicaciones, 1929), pp. 147-169.

Garrido Atienza, Miguel, Las fiestas de la Toma (Granada: Archivum, 1998). 
Getz, Christine, "The Sforza restoration and the founding of the ducal chapels at Santa Maria della Scala in Milan and Sant'Ambrogio in Vigevano" en Early Music History, 17 (1999), pp. 109-159.

Gila Medina, Lázaro, El Libro de la Catedral de Granada (Granada: Cabildo Metropolitano de la Catedral de Granada, 2005), 2 vols.

Giorgi, Rosa, Santos. Los Diccionarios del Arte (Barcelona: Electa, 2002).

Glareani, Heinrich, Dodekachordon (Basileae: per Henrichum Petri, mense septembri ... 1547).

Godoy Alcántara, José Historia de los falsos cronicones (Madrid: Imprenta de Rivadeneyra, 1868).

Gómez, Fermín de los Reyes "Los libros de nuevo rezado y la imprenta española en el siglo XVIII”, Revista general de Información y Documentación, 9/1 (1999), p. 119.

Gómez-Moreno Calera, José María, La Arquitectura religiosa granadina en la Crisis del Renacimiento 1560-1650 (Granada: Universidad y Diputación Provincial, 1989).

Gómez de Liaño, Ignacio, Los juegos del Sacromonte, edición facsímil con estudio preliminar de Manuel Barrios Aguilera y César García Alvarez (Granada: Universidad de Granada, 2005).

González Martínez, José. Ritornello, Miradas al pasado musical de Granada, Granada: Centro de Documentación Musical de Andalucía, 2005

Guerrero, Pedro, Constituciones Synodales del Arçobispado de Granada / hechas por ... Pedro Guerrero Arçobispo de la Sancta Yglesia de Granada, en el sancto Synodo que su Señoria Reuerendiassima celebro a quatorze dias del mes de Octubre del año M.D.LXXII (Granada: Hugo de Mena, 1573).

Gutiérrez Cordero, Rosario. La música en la Colegiata de San Salvador de Sevilla, Tesis Doctoral (Universidad de Sevilla: 2001).

Gutierrez de la Vega, Luis, A compendious treatise entituled, De re militari, containing principall orders to be observed in martiall affaires. Written in the Spanish tongue. And newlie translated into English, by Nicholas Lichefild (Londres, 1582).

Hagerty, M.J., Los libros plúmbeos del Sacromonte (Madrid: Edaf, 1980).

Hale, John Rigby, Artist and Warfare in the Renaissance (New Haven \& Londres, Yale University Press, 1990). 
Harbinson, Denis “The Hymn Ut queant laxis” Music and letters, 52/1 (1971), p.55-58.

Harper, John., The forms and Orders of Western Liturgy. From the tenth century to the eighteenth century. A Historical Introduction and Guide for Students and Musicians (Oxford: Clarendon Press, 1991).

Henríquez de Jonquera, Francisco. Anales de Granada. Descripción del Reino y Ciudad de Granada. Crónica de la Reconquista (1482-1492). Sucesos de los años 1588 a 1646 Estudio preliminar e índices por Pedro Gan Jiménez y Luis Moreno Garzón (Granada: Archivum, 1987).

Heredia Barnuevo, Diego Nicolás, Místico Ramillete (Granada: Archivum, 1998).

Heredia Barnuevo, Diego Nicolás, Mystico ramillete historico, chronologyco, panegyrico, texido de las tres fragrantes flores del nobilissimo antiguo origen, exemplarissima vida, y meritissima fama posthuma del Ambrosio de Granada ... el Illmo. y V.Sr. Don Pedro de Castro, Vaca y Quiñones ... Arzobispo de Granada, y Sevilla, y Fundador Magnifico de la Insigne Iglesia Colegial del Sacro Monte Illipulitano / dalo a la luz publica el doct. D. Diego Nicolas de Heredia Barnuevo...(Granada : en la Imprenta Real, 1741).

Heredia Flores, Víctor, "Las Iglesias colegiales españolas y la Real Colegiata de Antequera", La Real Colegiata de Antequera. Cinco siglos de Arte e Historia (1503-2003) (Antequera: Ayto. de Antequera y Archivo Histórico Municipal, 2004), pp.53-102.

Hernáez, Francisco Javier, Colección de bulas, breves y otros documentos relativos a la Iglesia de América y Filipinas, 2 vols. (Bruselas: Alfredo Vromant, 1879).

Hernández, Bernardo, "Monedas y medidas" en Francisco Rico (ed), Miguel de Cervantes, El Ingenioso Hidalgo Don Quijote de la Mancha (Barcelona: Crítica, 2005).

Hernández Correa, Víctor J., "Rodríguez López y el género chico: entre la tradición y la modernidad", Cartas diferentes. Revista canaria de patrimonio documental, n2 (2006) p.132.

Herrera, Antonio de "Elogio a Vaca de Castro", Revista de Archivos, Bibliotecas y Museos, XXXVI-XXXVII (1917), pp. 13-42 y 85-122.

Hiley, David, Western plainchant: a handbook (Oxford: Oxford University Press, 1993).

Hillgarth, J. N., Los Reyes Católicos, 1474-1516 (Barcelona; Buenos Aires; México D.F.: Grijalbo, 1984). 
Hollis, George Truett "El diablo vestido de fraile: some unpublished correspondence of Padre Soler" en Malcolm Boyd y Juan José Carreras (eds.) Music in Spain during the Eighteenth Century (Cambridge: Cambridge University Press, 1998), pp. 192206.

Hoppin, Richard, La Música Medieval ( Madrid: Akal, 1995).

Iglesias Arias, J.A. y J.M. Voces Jolías, Villafranca del Bierzo (León: Ediciones Lancia, 1988).

Isusi Fagoaga, Rosa "Los Rabassa: un linaje de músicos de origen catalán", Revista Catalana de Musicología, II (2004), pp. 79-94.

Jacobs, Arthur, La Música Coral (Madrid: Taurus, 1986).

Jiménez, Juan. Vida del Beato Juan de Ribera (Valencia: Joseph de Orga, 1798).

Jiménez Aznar, Emilio. “Organería en Borja. El órgano de la Iglesia Colegial” I (15061574), Nassarre, III/2, pp.27-60; II (1574-1712), Nassarre, VI/1, pp.41-84; III (1712-1980), Nassarre, VII/1, pp. 23-104.

- Actos del Cabildo de la Colegial y del Capitulo Parroquial de Santa María la Mayor de Borja (Zaragoza), 1546-1954. Zaragoza: Institución "Fernando el Católico", 1994.

, "Los Bajones de la colegial de Borja", Cuadernos de estudios borjanos, vol. 31$32, n^{\circ} 117,1994$, pp. 227-254.

Jiménez Cavallé, Pedro, "La música en la Santa Capilla de San Andrés. Notas históricas" Boletín del Instituto de Estudios Giennenses, 129 (1987), pp. 9-29.

, "El mecenazgo musical de la iglesia en la provincia de Jaén durante el siglo XVI" Nassarre: Revista aragonesa de musicología, 4/1-2, (1988), pp. 127-140.

_, La música en Jaén (Jaén, Diputación provincial, 1991).

, "La oposición al magisterio de la capilla de la Catedral de Jaén en 1711" Boletín del Instituto de Estudios Giennenses, 147 (1993), pp. 235-253.

, "Los Seises de la Catedral de Jaén durante el siglo XVI", Boletín de Estudios Giennenses, CLIII (1994), pp. 493-520.

."Francisco Carrillo, organista y canónigo de la catedral de Jaén (1580-1620): Notas biográficas", Nassarre: Revista aragonesa de musicología, 12/ 2 (1996), pp.185196. 
, Documentario Musical de la Catedral de Jaén (Granada: Centro de Documentación de Andalucía, 1998).

Kagan, Richard L., Imágenes urbanas del mundo hispánico 1493-1870 (Madrid: Fundación Caja Madrid, 1998).

Kirk, Douglas Karl, Churching the Shawms in Renaissance Spain: Lerma, Archivo de San Pedro, Ms. Mus. 1, Tesis Doctoral (Faculty of Music McGill University, Montreal, 1993).

Knighton, Tess, Música y músicos en la Corte de Fernando el Católico, 1474-1516 (Zaragoza: Institución Fernando el Católico y Diputación de Zaragoza, 2001).

y Carmen Morte García, “Ferdinand of Aragon's entry into Valladolid in 1513: the triumph of a christian king", Early Music History, XVIII (1999), pp. 119-163.

Lara Lara, Francisco Javier. "La música litúrgica monódica en la Catedral de Córdoba en el siglo XVI”, Revista de Musicología, XX/I (1997), pp. 1-15.

"Los teóricos españoles y la interpretación medida del canto llano" Nassarre, revista aragonesa de musicología, vol. 20, n¹ 1, 2004, pp. 103-156.

. La Música en la Catedral de Córdoba. Los libros corales de la misa. Granada: Universidad de Granada, 2003.

Lea, Henry Charles. Chapters from the Religious History of Spain, connected with the Inquisition (New York: Burt Franklin, 1967) [Philadelphia, 1890].

Linage Conde, Antonio, "La Abadía (=Prelatura "nullius" territorial) de Alcalá la Real en la geografía y la historia de la Iglesia", en Abadía. I Jornadas de Historia en la Abadía de Alcalá la Real, Jaén, Diputación Provincial, 1997, pp. 181-202.

López-Calo, José, Catálogo de música de la Catedral de Palencia (Palencia: Diputación Provincial, 19809.

La música en la Catedral de Granada en el siglo XVI (Granada: Fundación Rodríguez Acosta, 1963).

. Historia de la Música española III: el siglo XVII (Madrid: Alianza, 1983).

Catálogo de Música de la Catedral de Granada, (Granada: Centro de Documentación Musical de Andalucía, 1992), 3 vols. 
. La Música en la Catedral de Santiago de Compostela 12 vols. (La Coruña: Diputación Provincial de la Coruña, 1993).

- Catálogo de Música de la Capilla Real (Granada: Centro de Documentación Musical de Andalucía, 1995), 2 vols.

López-Huertas, María José, Bibliografía de Impresos Granadinos de los siglos XVII y XVII, 3 tomos (Granada: Universidad de Granada, 1999).

López Martín, Juan, La Iglesia en Almería y sus obispos (Almería: Instituto de Estudios Almerienses, Caja Rural de Almería y Unicaja, 1999).

Llordén, Andrés, "Notas históricas de los escritores de libros corales de Málaga", Anuario Musical, XV (1960), pp. 179-193.

. "Notas históricas de los maestros organistas de la Catedral de Málaga", Anuario Musical, XXII (1967), pp. 145-172.

. "Notas Históricas de los Maestros de Capilla en la Colegiata de Antequera", Anuario Musical, XXI-XXII (1976-1977), 115-156.

. "Maestros Organistas de la Colegiata de Antequera", Anuario Musical, XXXIIIXXXV (1980), 51-79.

Lyons, Stuart, Horace's Odes and the mistery of do, re, mi with full verse translation of the Odes (Oxford: Aris \& Phillips, 2007).

Madoz, Pascual, Diccionario geográfico-estadístico-histórico (Valladolid: Ámbito, 1987).

Mâle, Emile, El arte religioso de la contrarreforma: Estudios sobre la iconografia del final del siglo XVI y de los siglos XVII y XVIII (Madrid: Encuentro, 2001).

Mansilla Reoyo, Demetrio. "Panorama histórico-geográfico de la Iglesia española en los siglos XV y XVI", Historia de la Iglesia en España, Ricardo García-Villoslada (dir.), Vol. 3, Tomo 1, 1979, pp. 3-24.

Machiavelo, Nicolo, Libro dell'arte della guerra di Nicolo Machiauelli cittadino, et secretario fiorentino (Londres, 1587).

Maravall, José Antonio, La cultura del Barroco (Madrid: Ariel, 1975).

Marín López, Rafael, El Cabildo de la Catedral de Granada en el siglo XVI (Granada: Universidad, 1998). 
Marín López, Miguel Ángel, “¿Una historia imposible? Música y devoción en Úbeda durante el antiguo régimen", Úbeda en el siglo XVI, José Manuel Almansa Moreno (coord..) y Arsenio moreno Mendoza (dir.) (Úbeda: Editora y distribuidora el olivo, 2002), pp. 141-166.

Marín López, Javier. "Música y Patronazgo Musical en Castellar (Jaén) en tiempos de Tomás Micieces II, 1679-1685”, Boletín del Instituto de Estudios Giennenses, 187 (2004), pp. 549-595.

Martín Moreno, Antonio, Catálogo del Archivo de Música de la Catedral de Málaga. (Granada: CDMA, 2005).

. "Cinco siglos de Historia Musical”, Gila Medina, Lázaro. El Libro de la Catedral de Granada (Granada: Cabildo Metropolitano de la Catedral de Granada, 2005), 2 vols., pp. 813-857.

Martín Palma, J, La última crisis de la Abadía del Sacromonte. Veinticico años de historia (1950-1975) (Granada: 1995).

Martínez Justicia, Ma José, "Lo Barroco en la Historia de la Plaza de Bibarrambla: Funciones y Formas", Actas del Coloquio de Urbanismo Barroco, Archidona II Centenario de la Plaza Ochavada 1786-1986, coord. Ma Dolores Aguilar García (Málaga: Universidad de Málaga, 1989) pp. 249-272.

Martínez Medina, Francisco Javier, Historia y crítica de la poesía lírica culta "a lo divino" en la España del Siglo de Oro (Alicante: Francisco Javier Sánchez Martínez, 1995). . ed. Jesucristo y el emperador cristiano (Córdoba: Cajasur, 2000). . San Cecilio y San Gregorio (Granada: Comares, 2002).

. "La Abadía del Sacromonte y su legado artístico-cultural" en Manuel Barrios Aguilera y Mercedes García Arenal (eds.) ¿La historia inventada? Los libros plúmbeos y el legado sacromontano (Granada: Universidad y Legado Andalusí, 2008).

Martínez Ybargueu, Pedro, Resolución moral en que se prueba a tenido y tiene la Santa Yglesia Metropolitana de Granada y su Arçobispado privilegio para rezar el Oficio SIcut Lilium en la Fiesta de la Inmaculada Concepción de Nuestra Señora y su Octava, concedido por la Silla Apostólica/ dispuesta por el P.Fr. Pedro Martínez Ybargueu (Granada: Imprenta Real de Baltasar de Bolivar, 1666). 
Mateo Gómez, Isabel, Isabel Mateo Campos y otros, El Arte de la Orden Jerónima: Historia y Mecenazgo (Madrid: Encuentro, 1999).

Merkley, Paul, "The role of liturgical elements in fifteenth century Ceremonial" en Chant and its peripheries: Essays in honour of Terence Bailey (Ottawa: Institute of Mediaeval Music, 1998), pp. 339-358.

Monson, Craig A., Disembodied Voices. Music and Culture in an Early Modern Italian Convent (Los Angeles: University of California Press, 1995).

Morales Padrón, Francisco, Jamaica española (Sevilla: Escuela de Estudios Hispanoamericanos, 1952).

Moreno Garrido, Antonio, "La Iconografía de la Inmaculada en el grabado granadino del siglo XVII”, Cuadernos de arte de la Fundación Universitaria, 7 (1986), pp. 3-25.

Moroni Romano, Gaetano, Dizzionario di erudizione storico-ecclesiastica, vol. XIV (Venecia: Tipografía Emiliana, 1842).

Muneta, Jesús María, Obras de los maestros de la capilla de música de la colegial de la Catedral de Albarracín (Teruel) siglos XVII y XVIII (Zaragoza: Institución Fernando el Católico, 1986).

- Polifonía a 4 y más voces, siglo XVII: Colegiata de Alquézar (Zaragoza: Publicaciones de la Federación Aragonesa de Coros, 1993).

. “La Colegiata de Alcañiz”, Nassarre, vol. XII/2, 1996, pp.315-330.

Muñoz Jiménez, José Miguel, “Sobre la "Jerusalén restaurada": los Calvarios Barrocos en España”, Archivo español de Arte, 69/274 (1996),pp. 157-170.

Murcia Rosales, Domingo, “Aproximación a la economía de la Abadía, a través de los Libros de Fábrica", Abadía. III Jornadas de Historia en la Abadía de Alcalá la Real (Jaén:Diputación Provincial, 2001), pp.283-290.

.et alii., El patrimonio artístico de Alcalá la Real: Iglesia Mayor Abacial (Alcalá la Real: Ayuntamiento de Alcalá la Real, Área de Cultura, 2002).

Nieto Miguel, Ignacio. Música para una Colegiata. Villancicos del siglo XVII en Alquézar (Valladolid: Glares Gestión Cultural, 2001). 
Noone, Michael, Music and Musicians in the Escorial Liturgy Under the Habsburgs, 15631700 (Rochester: Boydell \& Brewer, 1998).

Politics of austerity and musical style in Philip II's Escorial (Armidale, N.S.W.: University of New England, [1990?])

O'Connor, Michael Brian. The Polyphonic Compositions on marian texts by Juan de Esquivel Barahona: A study of institutional marian devotion in late renaissance Spain, Tesis doctoral (Universidad del Estado de Florida, 2006).

Odriozola, Antonio "Los libros litúrgicos impresos para la diócesis compostelana (siglo XV)”, Cuadernos Gallegos, Tomo XXX (1976-1977).

. "El misal compostelano impreso en 1495 la singular historia de un incunable del que sólo quedan hojas sueltas" Varia Bibliográfica: Homenaje a Simón Díaz (Kassel: Reichenberger, 1988), pp. 499-519.

Ollero Pina, José Antonio, "La carrera, los libros y la obsesión del arzobispo D. Pedro de Castro y Quiñones (1534-1623)", De libros y bibliotecas : homenaje a Rocío Caracuel, (coord.) por Sonsoles Celestino Angulo (Sevilla: Universidad de Sevilla,1995), pp.265-276.

O'Neill, Charles E. y Joaquín María Domínguez (directores), Diccionario histórico de la Compañía de Jesús: biográfico-temático (Madrid: Universidad Pontificia de Comillas; Roma Institutum Historicum, 2001).

O'Regan, Noel, Institucional Patronage in Post-Tridentine Rome. Music in Santissima Trinità dei Pellegrini (1550-1650) (Londres: Royal Music Association, 1995).

Orozco Pardo, José Luis, Christianópolis: urbanismo y Contrarreforma en la Granada del seicientos (Granada: Universidad, 1988).

Ortíz de Zúñiga, Diego y Antonio María Espinosa y Carzel, Anales eclesiásticos y seculares de la muy noble y muy leal ciudad de Sevilla, Tomo IV (Madrid: Imprenta Real, 1796).

Pacheco, Francisco, Coloquio entre vn congregado, y un tomista, tratando de la Concepcion inmaculada de la Virgen santissima, Maria S. nuestra, a la insigne cofradia de los Nazareos[sic], i Santissima Cruz de Ierusalen, e impresso por su cuenta / por Francisco Pacheco.. (Sevilla: Francisco de Lyra, 1620).

Palacios Sanz, José Ignacio. La música en las colegiatas de la provincia de Soria (Soria: Diputación Provincial de Soria, 1997). 
. "Música y músicos en la Colegiata de Berlanga de Duero (Soria)", Nassarre, vol.XII/2, pp. 355-411.

. y Luis Magaz, El órgano de la colegiata de Medinaceli (Soria). Historia y restauración (Valladolid: Asociación "Manuel Marín" de Amigos del Órgano,1996).

Paz, José L.G. de la. La Casa de Mondéjar,

http://www.uam.es/personal_pdi/ciencias/depaz/mendoza/monde5.htm [Acceso al documento 24-X-2008].

Peinado de Santaella, Blas, Memoria y defensa jurídica por los títulos de fundador y derecho de patronato de la Insigne Colegial Iglesia del Sacro Monte de Granada, devidos al Ilustrisimo y Reverendísimo señor Don Pedro de Castro y Quiñones, Arzobispo de Sevilla \& Contra la memoria que el maestro D. Alonso Ximenez Baltodano, Canonigo de dicha Iglesia, ofrece a el Real Consejo de la Cámara. Por el doctor d.Blasio Peynado de S.Ella, Canonigo de dicha S. Iglesia del Sacro Monte, y Catedrático de Prima de Teología de sus escuelas (Granada: Imprenta Real-Baltasar de Bolívar 1652).

Peñas García, Ma Concepción, Catálogo de los Fondos Musicales de la Real Colegiata de Roncesvalles (Pamplona: Gobierno de Navarra, 1995).

Pérez de Heredia y Valle, I., «El Concilio Provincial de Granada en 1565. Edición crítica del malogrado concilio del arzobispo Guerrero», Subsidia, 26, Ed. Inst. Esp. de Hist. Ecl. (Roma, 1990).

Pérez de Urbel, Justo y Díez, Enrique, Misal Devocionario con ritual (Madrid, Barcelona: Editorial Científico M.E.; 1943).

Pérez de Urbel, Justo, “Origen de los Himnos Mozárabes”, Bulletin Hispanique, 28 (1926), pp. 209-210.

Pérez Mancilla, Victoriano, La música en la Iglesia de Huéscar, Tesis Doctoral (Universidad de Granada, 2009).

Prado, Germán, “El Kyrial español”, Analecta Sacra Tarraconense, XIV (1941) p. 97-128.

Praetorius, Michael Theatrum Instrumentorum (Wolfenbütel, 1620)

Praxis de Estudios que debe observarse en las Escuelas del Sacro-Monte de Granada. Fundadas a beneficio del Insigne Collegio de Sr. San Dionisio Areopagita, por el Ven. Illmo. Sr. D. Pedro de Castro, Arzobispo de Sevilla (S.1: s.e., ca. 1751). 
Preciado, Dionisio, "Juan García de Salazar, Maestro de Capilla en Toro, Burgo de Osma y Zamora (†1710)", Anuario Musical, XXXI-XXXII, pp. 65-113.

. "Noticias musicales de la Catedral de Tudela (Navarra) entre los años 1516 y 1652" (Pamplona: Aranzadi, 1958).

Querol, Miguel, "El Archivo de Música de la Colegial de Jerez de la Frontera", Anuario Musical, XXX, pp. 167-180.

Quezada, José et alii, La música en el Perú (Lima: Patronato Popular y Porvenir Pro Música Clásica, 1988).

Rabanal, Vicente, Los cantorales del Escorial (Madrid: Imprenta del monasterio del Escorial, 1947).

"Ceremonia", R.A.E., Diccionario de la Lengua Española (Madrid: Espasa-Calpe, 2000) Tomo I, p. 463.

Ramos López, Pilar, La Música en la Catedral de Granada en la primera mitad del siglo XVII: Diego de Pontac (Granada: Diputación Provincial, 1994).

"La música en la Capilla Real de Granada a través de las Constituciones de 1758", De musica hispana et aliis: Miscelánea en honor al Prof. Dr. José LópezCalo, S.J., en su 65 cumpleaños, vol. 1, pp. 669-690.

. "Historia política en Música", El oficio de la Toma de Granada de Fray Hernando de Talavera (Granada: Diputación, 2003).

. "Mysticism as a Key Concept of Spanish Early Music Historiography", Early Music: context and ideas, 2, Congreso celebrado en Cracovia (Polonia) del 11 al 14 de Septiembre de 2008, p.70 y ss.

Véase,http://www.muzykologia.uj.edu.pl/conference/PDF/16Ramos.pdf (consultado el 10 de Noviembre de 2008).

Ramírez Palacios, Antonio, "El Controvertido Nombramiento de Francisco Correa de Araujo como Organista de San Salvador de Sevilla", Revista de Musicología, XII/2, pp. 431-449.

Repetto Betes, José Luís, La Capilla de Música de la Colegial de Jerez (1550-1825) (Jerez de la Frontera: Centro de Estudios Históricos, 1980).

Rey Castelao, Ofelia, La historiografía del Voto de Santiago: recopilación crítica de una polémica histórica (Santiago: Universidad de Santiago, 1985) 
Rial Costas, Benito, Producción y comercio del libro en Santiago (1501-1553) (Madrid: Calambur, 2007).

Ribera, Juan de, Constituciones de la Capilla del Colegio y Seminario de Corpus Christi (Valencia: Iuan Bautista Mançal, 1625).

Robledo Estaire, Tess Knighton, Cristina Bordas Ibáñez, Juan José Carreras, Aspectos de la cultura musical en la corte de Felipe II (Madrid: Fundación Caja Madrid Colección Patrimonio Musical Español, 2000).

Robres Lluch, Ramón, San Juan de Ribera (Barcelona: 1960).

. San Juan de Ribera: Patriarca de Antioquía, Arzobispo, Virrey y Capitán General de Valencia(1532-1611): humanismo y eclosión mística (Valencia: Edicep, 2002).

Rodríguez, Pablo L., "The villancico as music of state in $17^{\text {th }}$ century Spain", Devotional Music in the Iberian World, 1450-1800, ed. por Tess Knighton y Álvaro Torrente (Londres: Ashgate, 2007), pp.189-198.

Rodríguez Carriazo, Manuel, “Oficio de la exaltación de la fe”, Estudios, 19 (1963), pp. 323-343.

Rodríguez G. de Ceballos, Alfonso "El arquitecto hermano Pedro Sánchez", Archivo español de Arte, 43: 169 (1970: enero/marzo) pp. 51-81.

Roldán Herencia, Gonzalo. La colección de cantorales de la Iglesia Colegial y Parroquial de Santa Fe (2003), Trabajo de Investigación inédito presentado en la Universidad de Granada para la obtención del Diploma de Estudios Avanzados (DEA).

Romero Lagares, Joaquín, Juan Pascual Valdivia, Maestro de Capilla de la Colegial de Olivares (1760-1811), Tesis doctoral (Universidad de Sevilla: 2004).

Catálogo del archivo de música de la antigua Colegial de Olivares (Madrid: Sociedad Española de Musicología, 2006).

Ros, Carlos, Los arzobispos de Sevilla, luces y sombras en la sede hispalense (Sevilla: 1986).

Ros-Fábregas, Emilio, "Historiografía de la música en las catedrales españolas: nacionalismo y positivismo en la investigación musicológica" CODEXXI, vol. I, (1998), p. 71.

"Music and Ceremony during Charles V's 1519 visit to Barcelona", Early Music, XXIII/3 (1995), pp. 375-391. 
. "The Cardona and Fernández de Córdoba Coats of Arms in the Chigi Codex", Early Music History, 21 (2002), pp. 223-258.

Royo Campos, Zótico, Reliquias martiriales y escudo del Sacromonte (Granada: Archivum, 1993).

. Abades del Sacromonte (Granada: Anel, 1964).

. El Colegio del Sacromonte y la Universida de Granada. Granada: Prieto, 1963.

Ruíz Jiménez, Juan. "La Colegiata del Salvador en el Contexto Musical de Granada", tesis doctoral (Universidad de Granada, 1995).

"Música y devoción en Granada (siglos XVI-XVIII): Funcionamiento "extravagante" y tipología de plazas no asalariadas en las capillas musicales eclesiásticas de la ciudad”, Anuario Musical, LII (1997), pp. 39-75.

. "Patronazgo musical en la Capilla Real de Granada durante el siglo XVI. 1.-Los músicos prebendados", Encomium musicae: Essays in memory of Robert J. Snow, pp. 341-363.

. Organería en la diócesis de Granada, 1492-1625 (Granada: Diputación Provincial, 1995).

. "Difusión del repertorio de los maestros de capilla de Granada en el siglo XVI" en Revista de musicología, 20(1), pp. 171-184.

Ruiz Preciado, Jorge y Velázquez Pasquier, Isabel, Catálogo del Archivo de Música de la Colegiata de San Miguel de Alfaro (Logroño: Instituto de Estudios Riojanos, 2007).

Sadie, Stanley, ed. The New Grove's Dictionary of Music and Musicians, 28 vols. (Londres: MacMillan, 2001).

Saez, Alonso, Relacion de la fiesta que el colegio mayor de Santa Maria de Iesus Uniuersidad de... Seuilla hizo en la publicacion de un Estatuto en que se jurò la Concepcion limpissima de nuestra Señora... (Sevilla: Francisco de Lyra, 1617)

San Cecilio, Fray Pedro de. Anales de la orden de descalzos de nuestra señora de la Merced Redempción de Captivos Christianos Año 1669, Barcelona, por Fray Pedro de san Cecilio, Coronista general y Definidor por la Provincia de Andaluzía, de dicha orden, natural de Granada (Barcelona: 1669), 2 vols.

Sanchez Ocaña, Juan, El Sacro Monte de Granada. Imaginación y Realidad (Granada: Ayuntamiento de Granada, 2007). 
Sarmiento Pérez, José, "Reforma beneficial en la Iglesia Colegial de Zafra (1770-1850)", Revista de estudios extremeños, 59/2, 2003, pp. 687-723.

Schroeder, H.J. The Canons and Decrees of the Council of Trent (Illinois: Tan Books and Publishers, 1978 [1941]).

Schulte, Augustin Joseph, "Cæremoniale Episcoporum." The Catholic Encyclopedia. Vol. 3. New York: Robert Appleton Company, 1908. Acceso: 18 Sept. 2008 http://www.newadvent.org/cathen/03133a.htm

Serna Cantoral, Diego de la, Vindicias catholicas granatenses: relacion breue de las reliquias que se hallaron en la ciudad de Granada en una torre antiquissima, y en las cauernas del Monte Illipulitano de Valparayso cerca de la ciudad, sacado del processo y aueriguaciones, q[ue] cerca dello se hizieron (Leon de Francia: [s.n.], 1706).

Shiels, W. Eugene, King and church. The rise and fall of the patronato real (Chicago: Loyola University Press, 1961).

Snow, Robert J., A New-World Collection of Polyphony for Holy Week and the Salve Service: Guatemala City, Cathedral Archive Music Ms 4 (Chicago: University of Chicago Press, 1996)

Sola, Emilio. "Cervantes y el Islam. Sin la luz de la fe", El Español en el Mundo: anuario del Instituto Cervantes 2004, coord. por Paz Lorenzo (Barcelona: Plaza \& Janés, 2004), pp. 13-38.

Soriano Fuertes, Mariano, Historia de la Música Española desde la venida de los Fenicios hasta el año de 1850 (Madrid y Barcelona: Martín y Salazar/Narciso Ramírez,1856).

Sotomayor, Manuel y José Fernández Ubiña (coords.), El concilio de Elvira y su tiempo (Granada: Universidad, 2005).

Spalding, Frances, Mudéjar Ornament in Manuscripts (Nueva York: Hispanic Society, 1953).

Steiner, Ruth and Keith Falconer, "Vespers", Grove Music Online. Oxford Music Online, http://www.oxfordmusiconline.com/subscriber/article/grove/music/29261 (acceso Septiembre 9, 2008).

Stevenson, Robert Louis, "Cuzco Cathedral:1546-1750", Inter-American Music Review (1979) vol. II, pp. 1-25. 
Stevenson, Robert, The Music of Peru (Washington D.C.: Pan America Union-General Secretariat, 1959).

Styward, Thomas, The pathwaie to martiall discipline, devided into two bookes, verie necessarie for young souldiers, or for all such as loveth the profession of armes (London, 1581).

Suárez Martos, Juan María, El Rito de la Salve en la Catedral de Sevilla durante el siglo XVI (Sevilla: J.M. Suárez, 2003).

Tamayo de Salazar, Juan, Anamnesis sive commemoratio ómnium sanctorum (Lyon: 1651).

Tejerizo Robles, Germán, Villancicos barrocos en la Capilla Real de Granada: 500 letrillas cantadas la noche de Navidad (1673 a 1830) 2 vols. (Sevilla: Andaluzas Unidas, 1989).

Tena, $\mathrm{P}$ et alii. Música instrumental y canto (Barcelona: Centre de Pastoral Litúrgica, 1994).

Tineo, Primitivo. "La recepción de Trento en España (1565). Disposiciones sobre la actividad episcopal" en Anuario de Historia de la Iglesia, 5 (1996) pp. 241-296.

Tobar, Balthasar de, Compendio Bulario Índico (Sevilla: Escuela de Estudios Hispanoamericanos, 1966).

Torre Molina, M $\mathrm{M}^{\mathrm{a}}$ José de la , "Tradición e innovación en las capillas catedralicias españolas: las "Constrituciones" de 1766 de la Capilla de Música de la Catedral de Málaga y suvigencia en el primer tercio del siglo XIX", Revista de Musicología, 28/1 (2005), pp. 295-309.

Torrente, Álvaro y Marín, Miguel Ángel, Pliegos de Villancicos en la British Library (Londres) y la University Library (Cambridge) (Kassel: Reichenberger, 2000).

."Function and liturgical context of the villancico in Salamanca Cathedral", Devotional Music in the Iberian World, 1450-1800, ed. por Tess Knighton y Álvaro Torrente (Londres: Ashgate, 2007).

Trens, Manuel, Iconografía de la Virgen en el Arte Español (Madrid: Plus Ultra, 1947).

Valcárcel Martínez, Simón, Las Crónicas de Indias como expresión y configuración de la mentalidad renacentista (Granada: Universidad, 1997).

Valladar, Francisco de Paula, Apuntes para la "historia de la música en Granada", desde los tiempos primitivos hasta nuestra época por Francisco de Paula Valladar, 
Cronista de la Provincia, premiados por el Liceo de Granada en público certamen en Octubre de 1897 (Granada: Tip. Comercial, 1922).

Varela Rodríguez, María Elisa, "In festo deditionis urbis granatensis", Fray Hernando de Talavera, Oficio de la Toma de Granada, textos de Francisco Javier Martínez Medina, Pilar Ramos López, Elisa Varela Rodríguez y Hermenegildo de la Campa, (Granada: Diputación Provincial, 2003).

Vasoli, Cesare "Giulio Camillo Delminio et l'Art Transmutatoire", Sylvain Matton (ed.) Alchimie et philosophie à la Renaissance (París: Vrin, 1993).

Vega García-Ferrer, Julieta, Isabel la Católica y Granada: el Oficio de la Toma de Fray Hernando de Talavera (Granada: 2004).

La música en los conventos femeninos de clausura en Granada (Granada: Editorial Universidad de Granada, 2005).

Los Cantorales de Canto Llano en la Catedral de Málaga (Granada, CDMA Junta de Andalucía, 2007).

Vegetius, Renatus Flavius, De re militari (Bolognia, 1515)

Velarde de Rivera, Pedro. Historia Eclesiástica del Monte Santo ciudad y Reyno de Granada dirigida a la magestad del Rey don Phelipe nuestro señor tercero de este nombre (BNE, Mss. 1583).

Vicente Delgado, Alfonso de, El órgano en la Colegiata de Lerma (Valladolid: Asociación de amigos del órgano, 19969.

."Música, propaganda y reforma religiosa en los siglos XVI y XVII", Studia Aurea, 1 (2007), pp. 28 y ss.

Viforcos Marinas, $\mathrm{M}^{\mathrm{a}}$ Isabel y Jesús Paniagua Pérez, El leonés D. Cristóbal Vaca de Castro: gobernador y organizador del Perú, (Madrid: S.A. Hullera Vasco-Leonesa, 1991).

Viladesau, Richard, Theology and the Arts Encountering God through Music, Art and Rhetoric (Nueva York: Paulist Press, 2000).

Villanueva, Jaime, Viage literario por las Iglesias de España (Madrid: Imprenta Real, 1803-1852). 
Watanabe-O'Kelly, Helen y Anne Simon, Festivals and ceremonies: A bibliography of works relating to court, civic, and religious festivals in Europe 1500-1800 (Londres: Mansell, 2000).

Wright, Anthony D. "The borronean ideal and the Spanish church", John M. Headley y John B. Tomaro, eds., San Carlo Borromeo, Catholic Reform and Ecclesiastical Politics in the Second Half of the Sixteenth Century (Washington: The Folger Shakespeare Library, 1988).

"San Juan de Ribera and Saint Charles Borromeo.The Counter-Reformation in Spain and Italy Compared", Bernard Vogler (ed.), Miscellanea historiae pontificiae, viii (Bruselas y Lovaina: Universidad, 1987), pp. 221-8. 



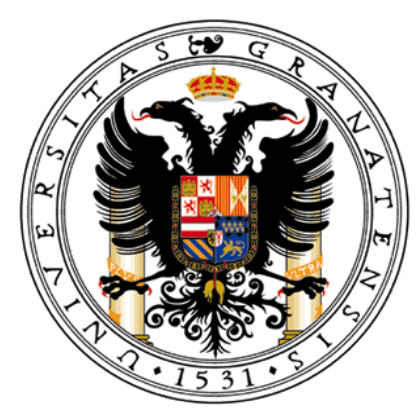

\title{
MÚSICA Y CEREMONIA EN LA ABADÍA DEL SACROMONTE DE GRANADA (SIGLOS XVII-XIX)
}

\author{
Tesis Doctoral \\ presentada para la obtención del Título de Doctor \\ Mención "Doctorado Europeo" \\ MERCEDES CASTILLO FERREIRA
}

Realizada bajo la dirección del Prof. Dr. EMILIO ROS-FÁBREGAS

\section{VOLUMEN II: APÉNDICES}

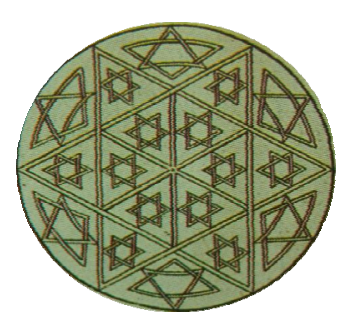

UNIVERSIDAD DE GRANADA

FACULTAD DE FILOSOFÍA Y LETRAS

DEPARTAMENTO DE HISTORIA DEL ARTE Y MÚSICA

PROGRAMA DE DOCTORADO EN HISTORIA Y CIENCIAS DE LA MÚSICA

GRANADA, 2009 
(C) 2009 por Mercedes Castillo Ferreira 




\section{ÍNDICE}

\section{VOLUMEN II: APÉNDICES}

Introducción

\section{APÉNDICE 1. EDICIÓN DE LA CONSUETA (1632) DE LA ABADÍA DEL}

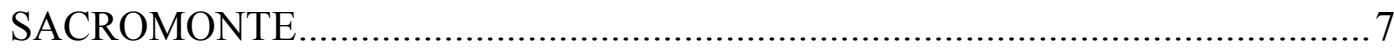

Libro I: Del Choro y cosas que en él y en la Iglesia se han de observar.....

Capítulo 1. Del choro y lo que se a de observar en el de la cortesía y policia. ...14

Capítulo 2. Quando y como se comienzan los oficios en el Choro y

quando están en pie, sentados, eregione y de rodillas............................16

Capítulo 3. Quando estan de rodillas, o en pié, sentados o

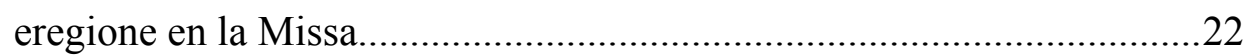

Capítulo 4. De la Prima y Kalendas y demas horas en tono..................................24

Capítulo 5. Quando se dize el officio cantado o en tono .....................................27

Capítulo. 6. De la solemnidad de los oficios y capas pluviales ...........................28

Capítulo 7. Quien entona en las horas y lo que ha de hazer

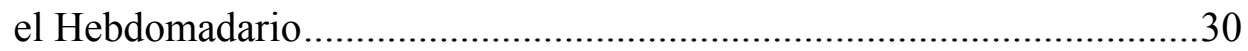

Capítulo 8. De los colores que usa la Iglesia y

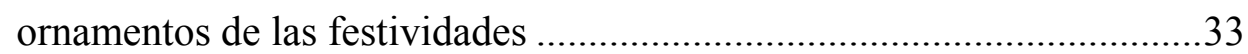

Capítulo 9. Del gasto y repartimiento de la cera y de las lámparas.......................35

Capítulo 10. Del hábito de los Prebendados y Ministros

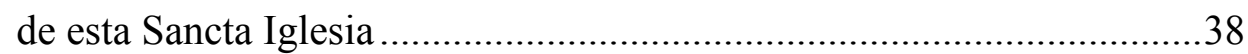

Capítulo 11. Quien celebra en el altar y haze officio en el choro.........................40

Capítulo 12. De la dignidad y orden de las fiestas que se celebran en este Sacro Monte y adorno de ellas....................................................43

Capítulo 13. De los Comisarios que nombra el Cabildo para las fiestas y de los fuegos

Capítulo 14. De los aniversarios que se celebran en esta Sancta Iglesia

Capítulo 15. De los asientos de los Prelados, Cabildos y Señores en esta Iglesia y Choro

Libro II: De los Officios de los Prebendados y Ministros de Esta Sancta Iglesia ....

Capítulo 1. Del Presidente del coro y licencias que ha de dar. 55

Capítulo 2. Del apuntador y collector de Missas 


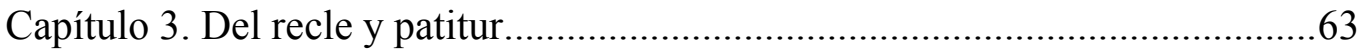

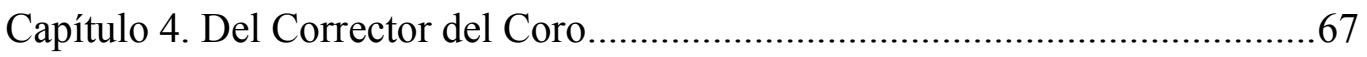

Capítulo 5. Del Maestro de Çeremonias .............................................................68

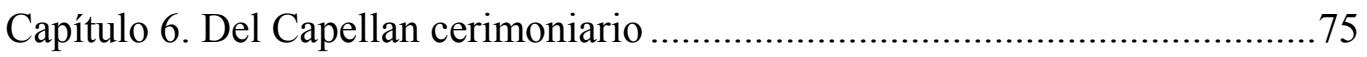

Capítulo 7. Del Rector en el Colegio y colegiales................................................78

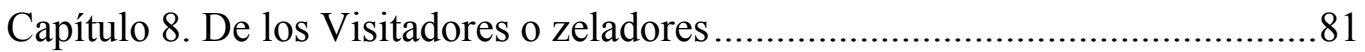

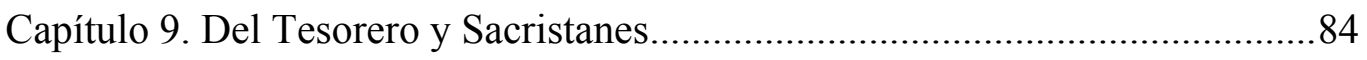

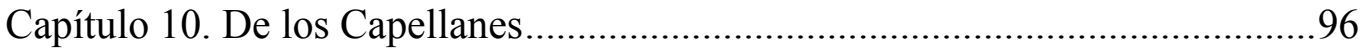

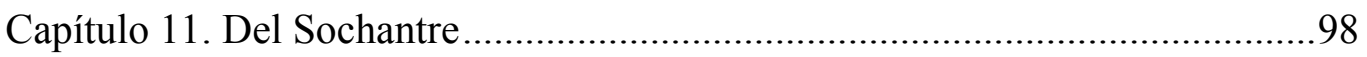

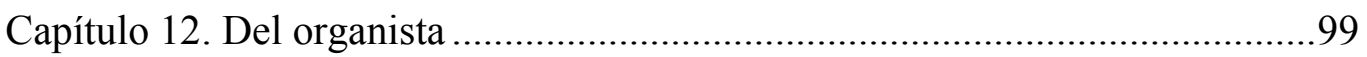

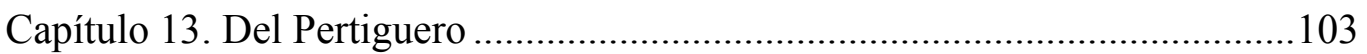

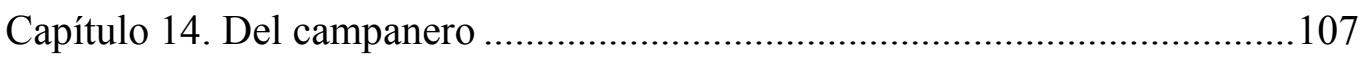

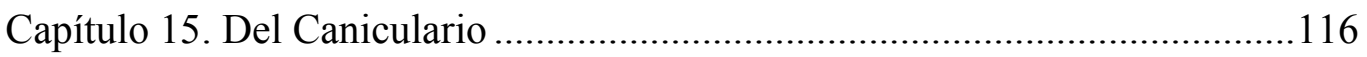

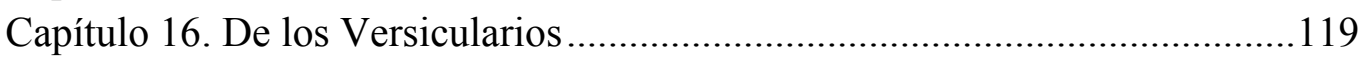

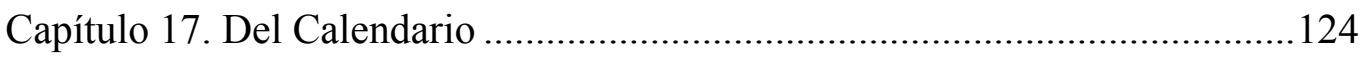

Capítulo 18. De los Colegiales Cantores ............................................................126

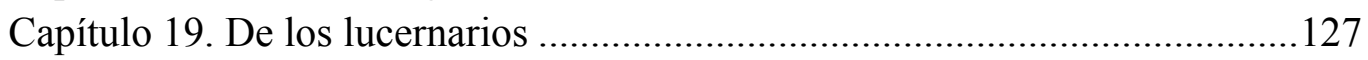

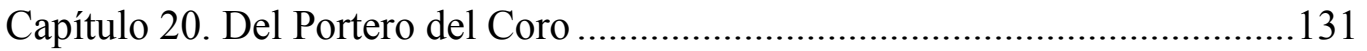

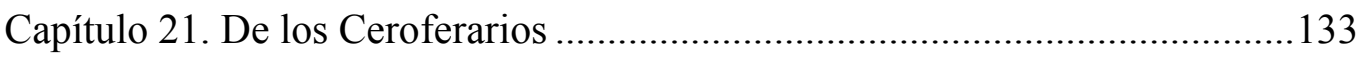

Capítulo 22. De los Turiferarios y modo de la turificación................................147

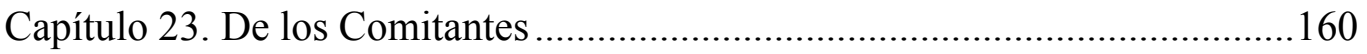

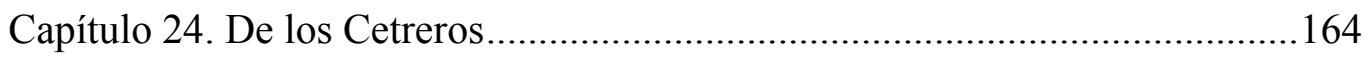

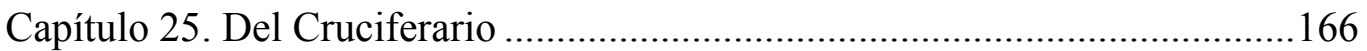

Capítulo 26. Del Flavelario y coadjutor de la Missa de Tercia ..........................167

Capítulo 27. Del coadjutor de la Missa Rezada.................................................170

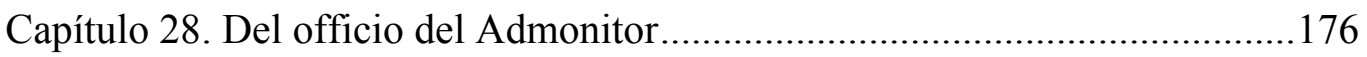

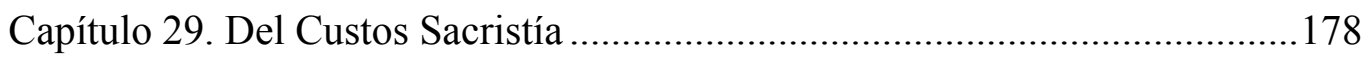

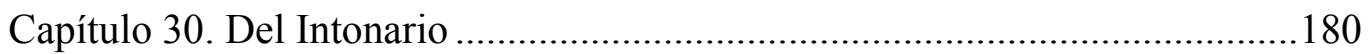

Capítulo 31. De la Tabla de los Oficios.........................................................180

Libro III: Del modo con que se celebran los divinos oficios

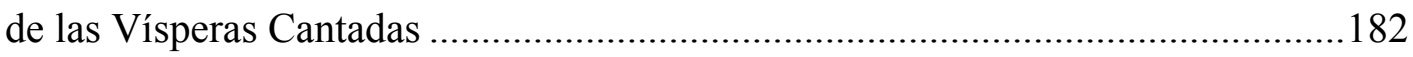

Capítulo 1. De las Vísperas cantadas............................................................182

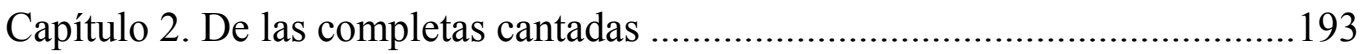

Capítulo 3. De los maytines y laudes...................................................................195

Capítulo 4. De la missa cantada y de los oficios de

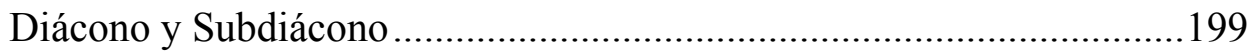

Capítulo 5. De los días que hay procesión y como se celebra ...........................221

Capítulo 6. De los días que hay sermón y de las ceremonias

que en él se observan

Capítulo 7. De los días que hay comunión general y de 
las ceremonias con que se hace y de la comunión particular .228

Capítulo 8. Como se descubre y encierra el Sanctissimo

Sacramento y en los jubileos de 40 horas

Capítulo 9. Como se renueva el Santísimo Sacramento y

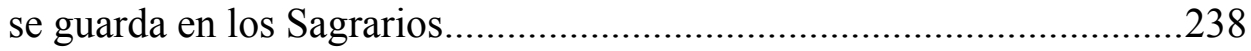

Capítulo 10. De la missa cantada sin Diáconos .................................................241

Capítulo 11. De la Missa de Nuestra Señora in Sabbatho .................................243

Capítulo 12. De las Salves de Nra. Señora en los sabados

$\mathrm{y}$ en sus fiestas

Capítulo 13. De las rogativas y devociones que se hacen

en las necesidades del bien público ....................................................249

Capítulo 14. De los oficios de difuntos y sus aniversarios ...............................252

Capítulo 15. De la Missa solemne de Réquiem ...............................................255

Capítulo 16. De la Missa rezada delante del Prelado .........................................258

Libro IV: De las ceremonias particulares en los oficios del tiempo......................259

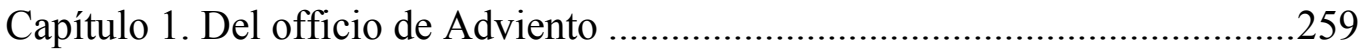

Capítulo 2. Del officio en la Vigilia de la Natividad .........................................260

Capítulo 3. Del Officio en el día de la Natividad de

Ntro. Señor Jesucristo.

Capítulo 4. Del Officio en el día de la Epifanía de Nuestro

Señor Jesucristo

Capítulo 5. Del officio y festividad en el día de Ntro.

Glorioso Patrón San Cecilio .................................................................266

Capítulo 6. Del officio en el día de la purificación ...........................................278

Capítulo 7. Del officio en las fiestas de los Sagrados

Mártires de este Sacro Monte

Capítulo 8. Del oficio en el Miércoles de Ceniza y en el

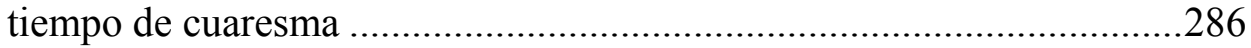

Capítulo 9. Del officio en la Dominica in Passione............................................289

Capítulo 10. Del officio en el Domingo de Ramos ............................................293

Capítulo 11. De los maytines de Tinieblas de la

quarta, quinta y sexta feria de Semana Sancta......................................298

Capítulo 12. Del officio del Jueves Sancto.......................................................300

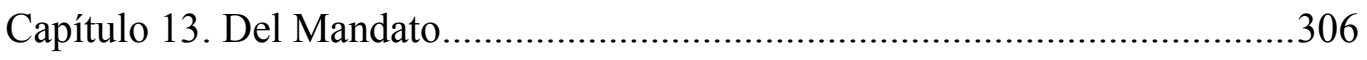

Capítulo 14. Del officio del Viernes Sancto ........................................................309

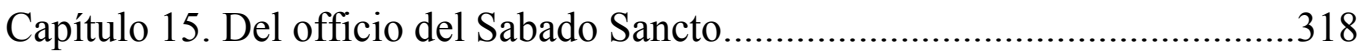

Capítulo 16. Del officio en el dia de la Pasqua de Resurrección........................323

Capítulo 17. Del officio en el día de San Marcos,

Letanías Mayores y menores antes de la Ascensión...............................327

Capítulo 18. Del officio en el día de la Ascensión del Señor ............................331 
Capítulo 19. Del officio en la Vigilia y dia de Pentecostés....

Capítulo 20. Del officio en la Solemnidad de el Sanctissimo

Sacramento y en su Octava...................................................................333

Capítulo 21. El officio de Nuestra Señora en el día de la Asumpción

Capítulo 22. Del officio en el Dia de la Conmemoración de los Difuntos

Capítulo 23. Del officio en el Día de la Inmaculada Concepción de Nuestra Señora

Capítulo 24. Del officio en el día de las honrras que se hacen por el Illmo. Fundador y por sus padres

Capítulo 25. Del officio en la muerte y entierro de los

Prebendados y ministros de Sacro Monte.

Capítulo 26. De las Sagradas Cuevas y cómo se han de enseñar

Capítulo 27. De las missiones y estilo que se tiene y ha de guardar en ellas

Capítulo 28. Cómo se ha de renovar el Sanctissimo Sacramento en el altar del Sagrario todos los jueves.

Capítulo 29. El modo con el que se an de celebrar las missas y responsos cantados, por las ánimas del purgatorio, según las intención del Doctor don Pedro Dávila, Abbad de este Sacramento que las fundó y se admitió en Cabildo de 27 de septiembre de 1633,

en la forma siguiente.

\section{APÉNDICE 2. NOTICIAS DE INTERÉS MUSICAL CONTENIDAS EN LAS ACTAS CAPITULARES DE LA ABADÍA DEL SACROMONTE (1611-1799)}

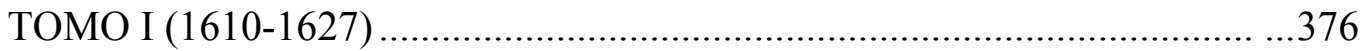

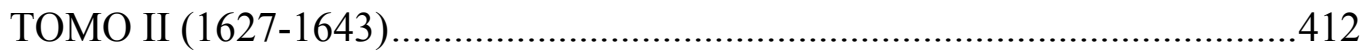

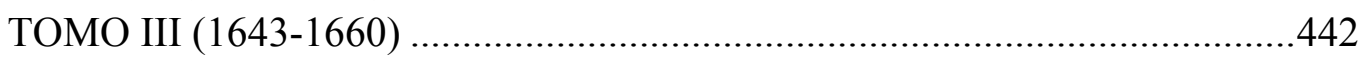

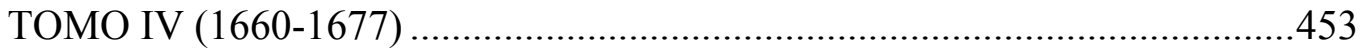

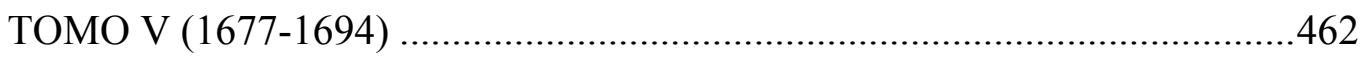

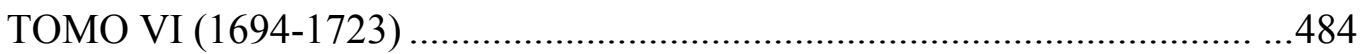

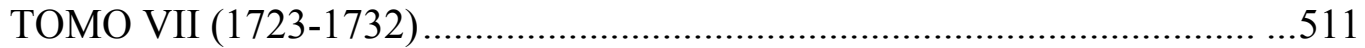

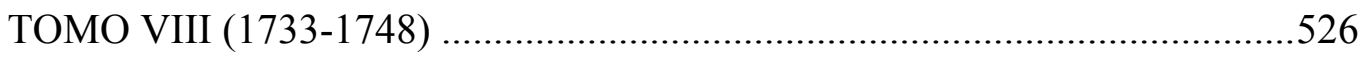

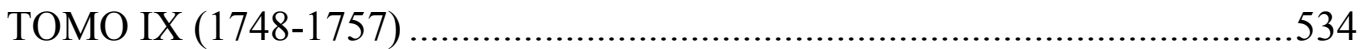

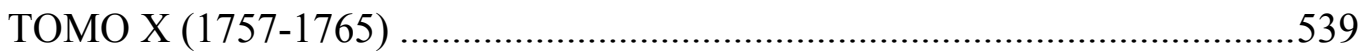

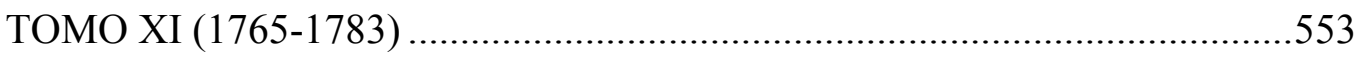

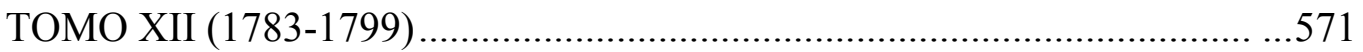


APÉNDICE 3. RECONSTRUCCIÓN DEL RITO DE LA SALVE SEGÚN LAS FUENTES CONSERVADAS EN LA ABADÍA DEL SACROMONTE

APÉNDICE 4. EDICIÓN DE LA MISA PARA LA FIESTA DE

SAN CECILIO, PATRÓN DE GRANADA SEGÚN EL

CANTORAL LC XXII (olim 332, olim 32) DE LA

ABADÍA DEL SACROMONTE

APÉNDICE 5. EDICIÓN DEL OFICIO EXALTATIONIS

FIDEI (UN NUEVO OFICIO DE LA TOMA DE GRANADA HASTA

AHORA INÉDITO) SEGÚN EL CANTORAL 26,

FOLS. 101-107, DE LA CATEDRAL DE

SANTIAGO DE COMPOSTELA

APÉNDICE 6. DOCUMENTOS RELATIVOS A LA CELEBRACIÓN DE LA

FIESTA DE SAN CECILIO

APÉNDICE 7. EDICIÓN DE OBRAS POLIFÓNICAS DEDICADAS A

SAN CECILIO QUE SE ENCUENTRAN EN LOS ARCHIVOS DE LA

CATEDRAL Y DE LA CAPILLA REAL DE GRANADA.

1. Anónimo. Hic nempe mundi gaudia. Himno a San Cecilio para doble coro y órgano (Fuente: ACG 236).....

2. Antonio Caballero (¿1728?-1822). Iste Sanctus. Motete a 8 a San Cecilio, SSAT, SATB, órgano y acompañamiento (Fuente: ACRGr 559)

3. Celestino Vila de Forns (1830-1915)

Salve, Patrón de Granada. Himno a San Cecilio, a 3vv (STB), dos violines, clarinete y violón (Fuente: ACG 987) ......

Cecilio, pues en Granada. Gozos a San Cecilio,

a 4vv. (SATB), dos violines, clarinete, contrabajo y órgano

(Fuente: ACG 950)

Deus tuorum militum, canon de doble guía, a 4 vv (SATB)

(Fuente: ACG 897/12). 



\section{Introducción}

El presente Volumen II contiene seis Apéndices con documentos y ediciones musicales. El Apéndice 1 presenta la transcripción completa de la Consueta (1632) del Sacromonte de Granada, un documento único especialmente rico en detalles respecto al papel de la música en el ceremonial de la Abadía. El Apéndice 2 contiene todas las noticias de interés musical que aparecen en las Actas Capitulares del Sacromonte desde 1607 a 1800.

Para la edición de los textos he seguido dos criterios generales distintos por la diversa naturaleza de los documentos y su diferente utilidad. En el caso de las Actas, al ser un compendio de textos de diferentes épocas y autores sin unidad estilística, he optado por actualizar y modernizar tanto la ortografía como la puntuación; de esta manera además se facilita la búsqueda de términos. Por el contrario, la Consueta constituye un documento unitario, que aunque redactado por un equipo, se conserva manuscrito por la mano de un solo copista; además, su valor como documento histórico hace aconsejable una edición que respete la integridad del texto. Por eso, en la edición de la Consueta he seguido los criterios de la Colección de Textos Teatrales Hispánicos del Siglo XVI, ${ }^{1}$ y que se resumen en las siguientes diez normas: 1) modernización de la puntuación y de la acentuación; 2) desarrollo de las abreviaturas junto con la separación y conjunción de palabras de acuerdo con el uso moderno (tan bien=también), aunque respetando las contracciones propias del siglo XVI (desta, dellos); 3) simplificación de consonantes dobladas sin ningún valor fonológico como tales y modernización de la $r$ doble; 4) mantenimiento de la $h$ tal como la usa el texto; 5) modernización de las grafías en el caso de $u$ y $v$ según sus valores vocales $u$, consonantes $v ; 6$ ) modernización de las grafías en los casos de $i, y$, cuando representan un valor fonológico de $/ \mathrm{i} /$; 7) modernización de otras grafías que en modo alguno tienen que ver con rasgos fonéticos distintos de los actuales: qual $=$ cual, quando=cuando, officio=oficio; 8) se mantiene la vacilación $\mathrm{b} / \mathrm{v}$ y la diferenciación de las grafías s/ss, aún cuando no correspondan a fonemas sordos y sonoros; 9) se mantienen la diferenciación de las grafías alguna vez correspondientes a los fonemas fricativos y africados interdentales, dentales o alveolares

\footnotetext{
${ }^{1}$ Véase una relación de estos criterios en Teresa Ferrer, Nobleza y espectáculo teatral (1535-1622) (Valencia: UNED, US, UVA, 1993), pp. 96-97.
} 
(braço, pozo, passo, casa, plazer); y 10) se mantienen las diferentes grafías que correspondieron a los fonemas fricativos sordos y sonoros (tajadores, cruxen, regocixar, pareja, muger).

El Apéndice 3 es una reconstrucción detallada del rito de la Salve tal como se celebraba en la Abadía a partir de las propias fuentes tanto musicales como documentales del Sacromonte. El Apéndice 4 reconstruye la Misa para la Festividad de San Cecilio, patrón de Granada utilizando la música conservada en el cantoral LC XXII y los textos impresos en Roma, conservados actualmente en el Archivo Histórico de Granada. El Apéndice 5 presenta la edición de un nuevo Oficio de la Toma de Granada (Exaltationi fidei), hasta ahora también inédito, cuya música se encuentra en un cantoral de la Catedral de Santiago de Compostela. Por último, el Apéndice 6 reúne la edición de las obras polifónicas dedicadas a San Cecilio que aparecen en los archivos de la Catedral y de la Capilla Real de Granada anónimas y pertenecientes a los compositores Antonio Caballero (1728?-1822) y Celestino Vila de Forns (1830-1915); estas obras, que cubren un amplio espectro cronológico, contribuyen a completar el panorama musical de una fiesta tan emblemática para la ciudad como la de San Cecilio, patrón de Granada. ${ }^{2}$ La primera de estas obras es el motete anónimo Hic nempe mundi gaudia, segunda estrofa del himno Deus tuorum militum, que en el Breviario Mozárabe se encuentra en los Oficio de Vísperas y Laudes correspondientes a la festividad de un mártir de especial relevancia (de cuatro a seis capas). Aunque figura como anónimo, aparece en un libro de himnos a dos coros que recoge los himnos de Gregorio Portero, maestro de capilla de la Catedral de Granada entre1713 y 1755, por lo que es probable que fuera también obra suya. A pesar de que el título del himno indica que es para doble coro, en realidad las voces del segundo coro repiten las partes del primero, lo que hace pensar que pudiera interpretarse en dos coros enfrentados, buscando más el efecto acústico que la policoralidad; el texto es el siguiente:

Hic nempe mundi gaudia Et blanda fraudum pabula Imbuta felle deputans
Los placeres del mundo rechazó, y se apartó de los perniciosos engaños del pecado; él supo de sus gozos empapados de hiel,

\footnotetext{
${ }^{2}$ En los Archivos de la Catedral de Granada y Capilla Real se conservan varias obras más dedicadas a San Cecilio de Guillermo Prieto y Pedro González Achútegui, pero no las he transcrito por estar incompletas.
} 
Pervenit ad celestia $\quad$ y así alcanzó el paraíso.

Antonio Caballero (1728?-1822) fue maestro de la Capilla Real de Granada desde 1757 hasta su muerte; durante ese periodo intentó opositar a otras plazas mejor remuneradas sin éxito. En el Archivo de la Capilla Real se conservan inventariadas unas 221 obras suyas, de las cuales la mayoría están escritas en español y son villancicos con acompañamiento instrumental. ${ }^{3}$ El motete Iste Sanctus de Caballero, dedicado a San Cecilio en la portada, utiliza el siguiente texto de la antífona del Magnificat para las vísperas de un mártir:

Iste Sanctus pro lege Dei sui certavit usque ad mortem, et a verbis impiorum non timuit fundatus enim erat supra firmam petram.
Este Santo luchó por la ley de su Dios hasta la muerte, y no temió las amenazas de los impíos pues estaba asegurado sobre una piedra firme.

Celestino Vila de Forns (Belpuig, Lérida, 1830 - Granada, 1915) fue maestro de capilla de la Catedral de Huesca durante 20 años, y pasó en 1877 a la de Granada, dónde permaneció hasta su muerte; su producción musical conservada es ingente y está a la espera de un estudio monográfico. ${ }^{4}$ Interesado por la música antigua, este compositor se adelantó a las disposiciones del Motu proprio del papa Pío X (22-XI1903), escribiendo en 1902 su Fasciculus himnorum octo vocibus, Ad instar musicae seculi XVI, al que pertenece el himno Deus tuorum militum dedicado a San Cecilio, escrito como canon de doble guía con el texto siguiente:

Deus tuorum militum, Sors et coroma premium Laudes canentes absolve nexu criminis.
Dios, corona y guarda de tu soldado y recompensa extrema, líbranos de todos los males a quienes cantamos la victoria de tu mártir.

El Apéndice 6 también incluye de Celestino Vila de Forns otras tres obras en español dedicadas a San Cecilio: Salve, Patrón de Granada, himno a 3 voces (STB) con

\footnotetext{
${ }^{3}$ Véase,M $M^{\mathrm{a}}$ Angustias Ortiz ,"Caballero, Antonio”, DMEH, vol. II, pp. 822-823.

${ }^{4}$ Véase José López-Calo, “Vila de Forns, Celestino”, DMEH, IX, pp. 891-895.
} 
acompañamiento de dos violines, clarinete y violón (ACG 987); y Cecilio, pues en Granada (1895), gozos con acompañamiento de violines, clarinete, contrabajo y órgano (ACG 950) y la obra a cappella Deus tuorum militum. 


\section{APÉNDICE 1.}

\section{EDICIÓN DE LA CONSUETA (1632) DE LA ABADÍA DEL SACROMONTE}

Este ejemplar no es recogido por el Catálogo de manuscritos del Sacromonte ${ }^{5}$ por lo que daremos aquí la descripción de este volumen.

CONSUETA / DE esta Insigne Iglesia del / Sacromonte Illipulitano.

Manuscrito sobre papel, 215 × 155 × $60 \mathrm{~mm}$. 516 folios [16 folios sin numerar (Portada, Prólogo y Tabla de contenidos) + 500 folios en numeración arábiga coetánea] Letra humanística corriente.

Falta la cubierta delantera, la de atrás es de madera forrada de piel marrón, repujada. Restos de cierre metálico. Cantos dorados y troquelados

Folio $470^{\mathrm{r}}$ se encuentra el colofón. Del f. 471 al 488, disposiciones posteriores (nuevas fundaciones y festividades). Del f.489 al 500 en blanco.

Ésta debe ser la Consueta original, pues todos los folios están rubricados por tres firmas en el recto y en el vuelto, la del abad Pedro de Ávila junto con la de dos prebendados Francisco de Barahona y Agustín Manrique. ${ }^{6}$

En la página $473^{\mathrm{v}}$ y $474^{\mathrm{r}}$ hay una orden con fecha de 30 de Diciembre de 1764 para que se imprima la Consueta, pero no sabemos si se llegó a hacer efectiva. Todo indica que no, pues existe otra copia manuscrita del siglo XIX, que de seguro no se hubiera realizado si se encontrara impresa. ${ }^{7}$

\footnotetext{
${ }^{5} \mathrm{M}^{\mathrm{a}}$ del Carmen Calero Palacios. La Abadía del Sacromonte de Granada. Catálogo de Manuscritos. Granada, Universidad, 1999. La autora recoge una copia de ésta del s. XVIII, pero no da el asiento de la que aquí nos ocupa. He podido consultarla gracias al Archivero y bibliotecario, Don Vicente Redondo, que me permitió su lectura. Se encuentra actualmente en el Archivo del Sacromonte.

${ }^{6}$ Véase el Capítulo II del presente estudio.

${ }^{7}$ El Catálogo Colectivo del Patrimonio Bibliográfico Español no recoge ningún ejemplar de esta posible edición.
} 



\section{CONSUETA}

\section{DE esta Insigne Iglesia del}

Sacromonte Illipulitano 
Tabla de la Consueta de Ceremonias

\section{LIBRO I: DEL CHORO Y COSAS QUE EN ÉL Y EN LA IGLESIA SE HAN DE OBSERVAR}

Capítulo 1. Del choro y lo que se a de observar en el de la cortesía y policia. fol. 2 .

Capítulo 2. Quando y como se comienzan los oficios en el Choro y quando están en pie, sentados, eregione y de rodillas. fol. 5.

Capítulo 3. Quando estan de rodillas, o en pié, sentados o eregione en la Missa. fol. 11

Capítulo 4. De la Prima y Kalendas y demas horas en tono. fol.. 13.b.

Capítulo 5. Quando se dize el officio cantado o en tono. fol. 16.b.

Capítulo. 6. De la solemnidad de los oficios y capas pluviales. fol. 18.b.

Capítulo 7. Quien entona en las horas y lo que ha de hazer el Hebdomadario. fol. 20.b.

Capítulo 8. De los colores que usa la Iglesia y ornamentos de las festividades. fol. 24.

Capítulo 9. Del gasto y repartimiento de la cera y de las lámparas. fol. 28.

Capítulo 10. Del hábito de los Prebendados y Ministros de esta Sancta Iglesia. fol. 32.

Capítulo 11. Quien celebra en el altar y haze officio en el choro. fol. 35.

Capítulo 12. De la dignidad y orden de las fiestas que se celebran en este Sacro Monte y adorno de ellas. fol. 38.b.

Capítulo 13. De los Comisarios que nombra el Cabildo para las fiestas y de los fuegos. fol.43.

Capítulo 14. De los aniversarios que se celebran en esta Sancta Iglesia. fol. 47.b.

Capítulo 15. De los asientos de los Prelados, Cabildos y Señores en esta Iglesia y

Choro. fol. 52.

\section{LIBRO II DE LOS OFFICIOS DE LOS PREBENDADOS Y MINISTROS DE ESTA SANCTA IGLESIA}

Capítulo 1. Del Presidente del coro y licencias que ha de dar. fol. 55.

Capítulo 2. Del apuntador y collector de Missas. fol. 58.

Capítulo 3. Del recle y patitur fol. 64 buelto.

Capítulo 4. Del Corrector del Coro. fol. 68.

Capítulo 5. Del Maestro de Çeremonias. fol. 71.

Capítulo 6. Del Capellan cerimoniario. fol. 80.

Capítulo 7. Del Rector en el Colegio y colegiales. fol. 84 .

Capítulo 8. De los Visitadores o zeladores. fol. 88.b.

Capítulo 9. Del Tesorero y Sacristanes. fol. 91.

Capítulo 10. De los Capellanes. fol. 108.

Capítulo 11. Del Sochantre. fol. 110.

Capítulo 12. Del organista. fol. 112.

Capítulo 13. Del Pertiguero. fol. 116.

Capítulo 14. Del campanero. fol. 121.

Capítulo 15. Del Caniculario. fol. 133.

Capítulo 16. De los Versicularios. fol. 137.

Capítulo 17. Del Calendario. fol. 143. 
Capítulo 18. De los Colegiales Cantores. fol. 146.

Capítulo 19. De los lucernarios. fol. 147.

Capítulo 20. Del Portero del Coro. fol. 153.

Capítulo 21. De los Ceroferarios. fol. 155.

Capítulo 22. De los Turiferarios y modo de la turificación. fol. 174.b.

Capítulo 23. De los Comitantes. fol. 192.b.

Capítulo 24. De los Cetreros. fol. 197.b.

Capítulo 25. Del Cruciferario. fol. 200.

Capítulo 26. Del Flavelario y coadjutor de la Missa de Tercia. fol. 202.

Capítulo 27. Del coadjutor de la Missa Rezada. fol. 206.

Capítulo 28. Del officio del Admonitor. fol. 214

Capítulo 29. Del Custos Sacristía. fol. 217

Capítulo 30. Del Intonario. fol. 219.

Capítulo 31. De la Tabla de los Oficios. fol. 219.b.

\section{LIBRO III DEL MODO CON QUE SE CELEBRAN LOS DIVINOS OFICIOS DE LAS VÍSPERAS CANTADAS}

Capítulo 1. De las Vísperas cantadas. fol. 222.

Capítulo 2. De las completas cantadas. fol. 238.b.

Capítulo 3. De los maytines y laudes. fol. 240.

Capítulo 4. De la missa cantada y de los oficios de Diácono y Subdiácono. fol. 245.b.

Capítulo 5. De los días que hay procesión y como se celebra. fol. 274.b

Capítulo 6. De los días que hay sermón y de las ceremonias que en él se observan. fol.

281.

Capítulo 7. De los días que hay comunión general y de las ceremonias con que se hace y de la comunión particular. fol.284.

Capítulo 8. Como se descubre y encierra el Sanctissimo Sacramento y en los jubileos de 40 horas. fol. 290.

Capítulo 9. Como se renueva el Santísimo Sacramento y se guarda en los Sagrarios.fol. 297.

Capítulo 10. De la missa cantada sin Diáconos. fol. 301.

Capítulo 11. De la Missa de Nuestra Señora in Sabbatho. fol. 303.

Capítulo 12. De las Salves de Nra. Señora en los sabados y en sus fiestas. fol. 307.

Capítulo 13. De las rogativas y devociones que se hazen en las necesidades del bien

público. fol. 312 .

Capítulo 14. De los oficios de difuntos y sus aniversarios fol.316

Capítulo 15. De la Missa solemne de Réquiem. fol. 320

Capítulo 16. De la Missa rezada delante del Prelado. fol. 323.

\section{LIBRO IV DE LAS CEREMONIAS PARTICULARES EN LOS OFICIOS DEL TIEMPO.}

Capítulo 1. Del officio de Adviento. fol. 325.

Capítulo 2. Del officio en la Vigilia de la Natividad de Ntro. Señor. fol. 326.

Capítulo 3. Del Officio en el día de la Natividad de Ntro. Señor Jesucristo. fol. 328.

Capítulo 4. Del Officio en el día de la Epifanía de Ntro. Señor Jesucristo. fol. 332. 
Capítulo 5. Del officio y festividad en el día de Ntro. Glorioso Patrón San Cecilio. fol. 335.

Capítulo 6. Del officio en el día de la purificación de Nuestra Señora. fol. 352.

Capítulo 7. Del officio en las fiestas de los Sagrados Mártires de este Sacro Monte. fol. 358.

Capítulo 8. Del oficio en el Miércoles de Ceniza y en el tiempo de cuaresma. fol. 363.

Capítulo 9. Del officio en la Dominica in Passione. fol. 367.

Capítulo 10. Del officio en el Domingo de Ramos. fol. 372.

Capítulo 11. De los maytines de Tinieblas de la quarta, quinta y sexta feria de Semana Sancta. fol. 379 .

Capítulo 12. Del officio del Jueves Sancto. fol. 382.

Capítulo 13. Del Mandato. fol. 389.

Capítulo 14. Del officio del Viernes Sancto. fol. 393.

Capítulo 15. Del officio del Sabado Sancto. fol. 403.

Capítulo 16. Del officio en el dia de la Pasqua de Resurrección. fol. 410.

Capítulo 17. Del officio en el día de San Marcos, Letanías Mayores y menores antes de la Ascensión. fol. 415.

Capítulo 18. Del officio en el día de la Ascensión del Señor. fol. 420.

Capítulo 19. Del officio en la Vigilia y dia de Pentecostés. fol. 421.

Capítulo 20. Del officio en la Solemnidad de el Sanctissimo Sacramento y en su Octava. fol. 423.

Capítulo 21. El officio de Nuestra Señora en el día de la Asumpción. fol. 429.

Capítulo 22. Del officio en el Dia de la Conmemoración de los Difuntos. fol. 432.b.

Capítulo 23. Del officio en el Día de la Inmaculada Concepción de Nuestra Señora. fol. 436.

Capítulo 24. Del officio en el día de las honrras que se hacen por el Illmo. Fundador y por sus padres. fol. 438 .

Capítulo 25. Del officio en la muerte y entierro de los Prebendados y ministros de Sacro Monte. fol. 443.

Capítulo 26. De las Sagradas Cuevas y cómo se han de enseñar. fol. 455.

Capítulo 27. De las missiones y estilo que se tiene y ha de guardar en ellas. fol. 462.

Capítulo 28. Como se ha de renovar el Sanctissimo Sacramento, en el altar del Sagrario todos los Jueves. fol. 466. 


\section{PRÓLOGO}

[i]

Siempre desde el principio y primera fundación de esta insigne Iglesia Colegial del Sacro Monte se tuvo atención a que en ella el Culto Divino se tratase en onra de Dios y de la Virgen gloriosissima Conçebida sin mancha de culpa original y de los Sanctos mártires que aquí padecieron con el mayor lustre asseo y magestad de ceremonias que fuese posible, para cuyo efecto por que la Iglesia Cathedral de Granada ha florecido siempre con opinión de que en ella se hazen las Ceremonias y ofiçios ecclesiásticos con más primor [que] en otras Iglesias de España. Se le pidió copia de la Consueta o libro de las Çeremonias por donde se rije y se usó del en esta Iglesia del Sacro Monte por algunos años celebrándose los oficios

$\left[\mathrm{i}^{\mathrm{v}}\right]$

divinos conforme al estilo de la Iglesia Cathedral aunque mejoradas muchas ceremonias en el decoro puntualidad y perfección con que se hazían.

Duró la práctica de estas Ceremonias hasta que la esperiencia y el estudio dieron a conocer que la consueta de la Iglesia Cathedral no estava conforme ni ajustada con el Çeremonial Romano que los Summos Pontifizes an mandado guardar en toda la Iglesia y asimismo que por ser el templo de este Sacro Monte tan desigual en fábrica y echura al de la Iglesia Cathedral, muchas ceremonias no venían vien y otras pedían diferente disposición; que reconocidos estos inconuinientes con el deseo y atención que se a tenido siempre a que el Culto divino y la gravedad de las Çeremonias vaya en más aumento y se perficione se determinó por el Cabildo de este Sacro Monte que se hiciese libro de Ceremonias propio para esta Iglesia tanteado con su capazidad y echura y en todo conforme al Çeremonial Romano sin exceder ni faltar punto de su disposición y preceptos. Esta reformación y ajustación de çeremonias,

[ii]

con el cuidado de hazer este libro y consueta, se cometió a los Licenciados Bartolomé de Torres, Canónigo de esta Iglesia Colegial como consta de tres actos Capitulares: primero en 25 del mes de Agosto de 1620 años; el $2^{\circ}$ en 23 de diciembre del mismo año, y el $3^{\circ}$ en 20 de enero de 1621 . Y sin duda se deve mucho al señor Canónigo Bartolomé de Torres, porque en el tiempo que le duró la Comissión hizo gran parte de consueta, con que desde luego se comenzó a reducir la celebración de los oficios Divinos a la forma del cerimonial Romano con mucha aprovación y aplauso de todos los que lo entendieron, de tal manera que la Iglesia Cathedral, tomando exemplo del Sacro Monte, reformó también muchas de sus ceremonias antiguas y las ajustó al Çeremonial Romano. 
Más porque (como se refiere en un acta Capitular 21 de Abril de 1623 años) la falta de salud y las ocupaciones no dieron lugar a que el señor canónigo Bartolomé de Torres llevase al fin y pusiese en perfección

$\left[\mathrm{ii}^{\mathrm{V}}\right]$

la consueta como se deseaba, en 14 días del mes de Abril de 1625 años el Cabildo la encomendó de nuevo a los señores Licenciados Agustín Manrrique y Don Francisco de Barahona, Canónigos de esta Sancta Iglesia, los cuales cumplieron su comisión assí que el señor Don Francisco de Barahona, con mucho cuidado estudio y atención iba disponiendo este libro en primera mano, como lo dispuso y acabó desde el principio hasta el fin con toda la claridad y elegancia de estilo que sufre y después el Señor Canónigo Agustín Manrique, segundo comissario con el señor don Pedro Davila Abad, por la parte que tiene en todas las Comisiones. Y lo volvían a ver y procuraban ajustar de su punto con el Ceremonial y ritual Romano consultándolo también con el Señor Maestro de ceremonias de esta Iglesia y luego los dos señores Comissarios con el Señor Abad rubricavan al fin de cada capítulo lo que avía pasado por este último examen y aprovación.

Llegaron con esta diligencia hasta el Capítulo 12 del Libro $3^{\circ}$, de donde no pasaron por la ocurrencia de muchos negocios y urgencia de los señores

[iii]

comissarios y así en este estado alló la Consueta el Señor Cardenal Spínola el año de 1627 que visitó esta Iglesia y considerando la mucha importancia de este libro y que por ser la solemnidad de las ceremonias y el ornato primor del culto divino tan principal instituto del Sacro Monte, era bien que se hubiese reducido a methodo. Lo mismo que por la obra se practicava ordenó por un su decreto, que es el de la visita, que la consueta de la Iglesia que es este libro de las ceremonias se acavase dentro de seis meses, y aunque se deseó y propuso y se comenzó a executar así fueron tantas las justas ocupaciones y el peso de los negocios que se ofrecieron adelante, que suspendieron por muchos días la execución de este decreto del Sr Cardenal Spínola, hasta que el año de 1632, en Cabildo de 2 de marzo, se determinó que la parte de la consueta que no estava vista por los Señores Comissarios la viesen y aprovasen los señores Prebendados juntos en forma de

$\left[\mathrm{iii}^{\mathrm{V}}\right.$ ]

Cabildo como más largamente consta de aquel acto Capitular que es el que se sigue.

"Lo $2^{\circ}$ se determinó por mayor parte que para que se acave de ver y aprovar la consueta de la Iglesia en la parte que no está vista ni aprovada por los señores Comissarios que los años pasados nombró este Cabildo para este efecto se lea en el Cabildo la dicha parte que no está vista ni aprovada y los Señores Prebendados Capitularmente juntos la oigan 
examinen y aprueven para que esto se pueda executar más facilmente se determinó también por mayor parte que todos los jueves después de Completas se tenga Cabildo en que la Consueta se vaya leyendo y aprovando hasta que se acave de pasar".

Luego a cuatro de marzo se juntó el primer Cabildo en que se comenzó a leer y repasar la consueta y porque pareció que los Sres. Comisarios avían llegado hasta el Capítulo XIII del libro 3, se prosiguió desde el Capítulo siguiente que es el XIV del mismo libro, como se ve en el acta Capitular de aquel día que es en esta manera.

"Conforme a lo determinado en Cabildo de

[iv]

de dos de marzo se juntó este Cabildo para comenzar a leer la consueta de la Iglesia y examinar lo que en ella está escrito y aprovar lo que al Cabildo pareciere en la parte que no está aprobada por los comissarios. Y así se comenzó a poner en execución este día y yo el infrascripto secretario empeze a leer desde el capítulo xiv del Libro $3^{\circ}$, que es lo que no esta pasado ni aprovado por los otros comissarios."

Continuose en otros Cabildos esta diligencia y con las ocupaciones ordinarias de los Señores Capitulares se volvió a suspender todo aquel año hasta que en el de 1633 en siete días del mes de Henero se tubo Cabildo sobre este mismo punto y se voluió a determinar que la parte de la consueta que no estava vista se viese y aprouase por el Cabildo, juntandose para este efecto Capitularmente los Señores Prebedados tres días cada semana y esta resolución se comenzase a executar desde el día siguiente 8 de Henero.

$\left[\mathrm{iv}^{\mathrm{v}}\right]$

en que se tubo el primer Cabildo y sin intermissión se fueron continuando hasta 17 de febrero en que se acavó de ver la Consueta y se determinó que se sacasen dos copias del borrador, cuya parte se vió y aprovó en el Cabildo y que aviéndolas autorizado el secretario; la una que a de ser el original se ponga en el archibo, con que esta insigne obra de la Consueta que tanto trabajo y desvelo a costado vino a tener fin y perfección en 18 de Noviembre de 1633 años, aviendo entendido con su disposición las personas que en este prólogo van nombradas, cuya diligencia es razón que se estime y que sus nombres queden muy encomendados a la posteridad de los que sucedieren en esta Sancta Iglesia, y no se deven menos que recomendación que cada uno de los que pusieron la mano en esta obra al Señor D. Pedro Davila segundo ${ }^{8}$ Abad de este Sacro Monte por que su cuidado continuo y superintendencia para que este libro se acavase y su afecto al culto divino y al mayor decoro y lustre de esta Iglesia an vencido los inmensos estorbos y dificultades que an sobrevenido en tan largo discurso de tiempo. $\mathrm{Y}$ el que esto escribe, que es el Secretario del Cavildo, da fe que es verdad toda la relación que este Prólogo se contiene, porque gran parte de lo que en ella queda escrito pasó por su mano y para lo demás se valió de los Libros del Cabildo que están en su poder, donde vió los decretos originales y sacó lo que ubo menester para esta relación.

\footnotetext{
${ }^{8}$ Tachado: "primer"
} 
Así lo certifico en 18 de Noviembre de 1633 años.

Martin Vazquez Siruela ${ }^{9}$.

LIBRO PRIMERO

DEL CORO, Y COSAS QUE EN ÉL Y EN LA IGLESIA SE HAN DE OBSERVAR.

[fol. $2^{\mathrm{r}}$ ]

Capítulo 1. Del Choro y lo que se á de observar en él, de la cortesía y policía.

1. Las ceremonias todas se fundan en misterio, o en cortesía. Y lo que les da Vida es la puntualidad y consonançia, esta se ha [de] observar sumamente en esta Iglesia. Para que sea a indicio de la voluntad prompta con que se deve acudir al culto divino, especialmente en el oficio del Choro y altar; y así cuando comienza el esquilón se junten los prebendados capellanes y colegiales en el Choro con puntualidad, porque antes de comenzar el divino oficio an de estar todos en sus sillas y lugares preparándose con devoción.

Entrando en el Choro y entre la varandilla y facistol puestos de rodillas hazen oración al altar maior un rato, levántanse y echa genuflexión. Van los prebendados por su coro a sus sillas y se sientan, el que llega a la suia haze comedimiento a los otros prevendados, primero a los del otro Choro y luego a los del suio y todos asimismo le responden quitados los bonetes y levantándose un poco los

[fol. $\left.2^{\mathrm{v}}\right]$

Capellanes y colegiales se levantan a los prevendados y no se sientan hasta que el prevendado llegue a su silla. = lo mismo guardan todas las vezes que entra o sale algún prevendado.

Cuando entra el Abad y después de hazer oración pasa del facistol, los prevendados de un Coro y otro se levantan, (y auque estén con sobrepelliz baxan las mangas, los capellanes y colegiales) y en pie aguardan que el Abad llegue a su silla y de ella les saluda y responden los prebendados con alguna humillación, y luego todos se sientan. Ansimismo cuando el Abad baxa a dezir lección ó salir en ceremonia, en levantándose de su silla se levantan y están así hasta que en medio del Choro haze comedimiento al un Choro y al otro y le corresponden. Y cuando buelve en cerimonia o sube de dezir la lección, están en pie hasta que llega a su silla.

Los capellanes entran en el choro sin bonetes y las mangas rebueltas a los brazos y antes de llegar a sus sillas hazen humillación al choro y los prebendados les quitan los bonetes.

\footnotetext{
${ }^{9}$ Aparece la rúbrica.
} 
Los colegiales entran en dos choros por los lados del facistol, los de la mano derecha por la parte siniestra y los otros por la derecha y pasan del facistol, los que van delante se quedan en las primeras sillas dexando lugar desocupado ${ }^{10}$ para

[fol. $3^{\mathrm{r}}$ ]

Para los versicularios y lucernarios y en vísperas y maitines para los turiferarios $=10$ s otros se ponen por sus antigüedades los más antiguos los primeros. Más cercanos a las sillas de los capellanes, y así todos juntos hazen venia al que preside y luego hincan de rodillas bueltos al altar y así aguardan hasta que dexa el esquilón.

Hechos los comedimientos devidos, según los órdenes referidos se sientan en sus sillas y lugares o se quedan en las misericordias y los colegiales se quedan de rodillas hasta comenzar y aguardan con silencio y en dexando el esquilón se levantan y comienzan las oras.

-Ninguno pueda entrar en el Choro a los oficios sin sobrepelliz o capa.

-Ningún huésped puede entrar en el Choro con sobrepelliz.

-Ninguno dentro del Choro se quite el sobrepelliz ni se la vista, ni capa Canonical sino es cuando toman el pluvial o le dexan ni hagan otra cosa semejante.

-Ningún capellán ni Colegial fuera de las horas cante ni entone, ni lea en el choro solo para registrar se le pueda leer y el Corrector pasar las lecciones. Epístolas, Evangelios y calendas y todo esto muy quedo de suerte que no se pueda oir en la Iglesia.

-En el choro se ha de estar con suma modestia,

[fol. $\left.3^{\mathrm{v}}\right]$

compostura y silencio.

-Ningún prebendado ni capellán se arrime con otro a leer por un libro cosa alguna del rezo.

-Ningún Colegial mientras el oficio tenga diurno, ni horas en la mano que solo a de decir con el Choro por el libro grande.

-Ninguno en el Choro mientras se dize el oficio ni fuera del lea ni firme cartas I ni otra cosa, ni averigüe cuentas que solo el apuntador puede tomar pluma en el Choro para apuntar.

\footnotetext{
${ }^{10}=\mathrm{va}$ entre reglones $=\mathrm{y}$ los capellanes bajan una manga $\mathrm{y}$ los Colegiales ambas $=\mathrm{y}$ no vale lo al margen $=$ $\mathrm{no}=$
} 
-Sentados no tengan una pierna sobre otra ni tendidos los pies ni puestos en el antepecho ni sentados de medio lado ni la cabeza caída al lado reclinada en la mano ni tendidos los brazos sobre los de la silla, y cada uno solo se sirva del un brazo de la silla estando la otra ocupada y cuando estubieren afirmados en la misericordia $(+$ no $)+$ sacados los pies ni arrimados las espaldas ni cabeza porque se hiciera fealdad.

-No aia burlas, señas, risas ni se embíen mensages ni salgan de sus sillas ni muden lugar sin particular oficio o causa, no se hagan aire con el bonete ni limpien sudor ni otra cosa con la sobrepelliz.

-Si algún lego estubiere en el choro guarde el mismo orden y ninguno le tenga conbersación.

-Ninguno tosa ni escupa con ruido que pueda

[fol. $\left.4^{\mathrm{r}}\right]$

estorbar a otros a oir la oración, capítula o lección: especialmente los capellanes y colegiales escusen escupir cuando están eregione, y si escupieren sean reprendidos del Presidente y maestro de Ceremonias.

Ningún huésped entre en el Coro mientras los oficios sin licencia del que preside y el portero sepa del maestro de ceremonias que asiento se le a de dar y en ninguna manera no siendo prebendado de otra Iglesia o persona grave eclesiástica se le a de dar entre los prebendados, mas se le dé asiento sigun la cualidad de su persona.

-A los Superiores de las religiones y a otros personas eminentes se les de asiento entre los prebendados.

-Cuando el Abad o algún prevendado llama algún capellán va con modestia, baxas las mangas y descubierto. Está así hasta que se va y lo mismo el prebendado el pecho inclinado, y si llama a el Colegial va con mucha humildad baxas las mangas y puestas sobre el brazo siniestro y al llegar y mientras lo abla está el Colegial inclinada un poco la cabeza con mucha modestia y cortesía y el prevendado cubierto y el Colegial nunca, cuando es llamado o lleva algún recaudo echa.

[fol. $\left.4^{\mathrm{v}}\right]$

la mano a las varandillas de las sillas baxas.

[fol. $\left.5^{\mathrm{r}}\right]$

Capítulo 2. Cuándo y cómo se comienzan los oficios en el Choro y cuando están en pie, sentados, eregione, y de rodillas.

1. En dexando el esquilón se levanta el Sochantre y haze comedimiento al que ha de hazer el oficio, el cual se levanta luego, y juntamente todos los del Choro alto y baxo 
los prebendados en sus sillas Eregione y los Capellanes en las suyas. Los colegiales se ponen en el plano del Choro en medio de los rostros al facistol, dizen en secreto Pater Noster y Ave María, y a prima y maitines Credo, y el que haze el oficio comienza la ora y ninguno del Choro se sienta hasta la mediación de el primer verso del psalmo.

2. Acavado el sicut erat en el oficio cantado los capellanes salen de sus sillas y se llegan al facistol a cantar, los prebendados cantan desde sus sillas.

3. Si alguno entra en el Choro a tiempo que comienza Deus in audiutorium, o Gloria Patri, o Himno, oración, Evangelio, Magnificat, Benedictus, Nunc dimittis, o preces y cuando están Eregione las manos puestas, no pasa del facistol adelante sino allí aguarda en pie, oflexis genibus, como estubieren

[fol. $\left.5^{\mathrm{v}}\right]$

en el choro hasta acavar alguna cosa de las del Gloria Patri se detiene en la parte donde se le coge y al sicut erat sube a su silla con los comedimientos del Capítulo precedente exçepto los que entran o salen en çeremonias.

Ay en el choro de esta Sancta Iglesia tres cuerpos o hierarquías diferentes de los que ministran y asisten al oficio divino; el primero forma el presidente cuando está con pluvial y los caperos asimismo con pluviales; el segundo el de los prevendados en sus sillas altas; el tercero el de los capellanes colegiales y demás ministros que llamamos Choro baxo $=\mathrm{y}$ en el sentarse y levantarse deven guardar la uniformidad siguiente:

-Siempre que el presidente se levantare todos los choros se deven levantar caperos prevendados capellanes y colegiales, y cuando algún prebendado se levantare a hazer algo que toca al oficio común y público del Choro como entonar alguna antíphona los demás prebendados y choro baxo se deven levantar, no el presidente ni caperos.

Cuando algún capellán se levantare a lo mismo todos los del Choro baxo se deven levantar, no los prevendados ni el Choro del preste.

El choro del preste y caperos (su puesto que en nuestra Iglesia son prebendados) es la suprema hierarchia

[fol. $6^{\mathrm{r}}$ ]

a la cual los otros choros deven seguir. La $2^{\mathrm{a}}$ es el Choro de los prebendados al cual sigue la terçera, porque la superior no deve seguir a la inferior.

No se guarda el orden en el sentarse que los inferiores sigan a los superiores por que el sentarse es acto de preeminenzia y así los prevendados se sientan y no los colegiales, y los prevendados están sentados cuando se repite la antíphona y no los capellanes ni colegiales y así cuando entra el Abad en el Choro los prebendados Capellanes y colegiales se levantan y no el Presidente ni caperos.

Cuando el Abad o algún prevendado entran en el Choro los Caperos no quitan el bonete ni el presidente a nadie de ninguna condición o estado que sea, levántese al Prelado con bonete y hace la humiliación, y los caperos ha hazen también quitados los bonetes. 
Todas las vezes que los prebendados Caperos Capellanes o colegiales llegan al medio del Choro a dezir lección Calenda o entonar antíphona Versos \& al llegar y despedir hazen genuflexión al altar maior.

Todas las vezes que llegan al presidente a intimarle

[fol. $6^{\mathrm{v}}$ ]

antíphona o himno le hazen venia antes y después y el presidente le corresponde al capero con otro algo menor la misma hazen a los prebendados, el sochantre o Capellanes cantores o Ceremoniario que encomienda lección o advierte otra cosa y el prebendado responde con otro comedimiento, cuando el sochantre intima al Choro de la semana el himno o psalmo haze el mismo comedimiento, mas el choro no le corresponde, mas si en el oficio cantado los caperos intiman al Choro les corresponde queuitándose los bonetes y baxando la cavezas, y cuando ay prevendados se da paz o incienso, siempre el que la recive combida al que se le sigue en su choro y reçivida haze algún comedimiento al que la trae maior o menor conforme a la cualidad del ministro.

Los Capellanes y colegiales al recivir la paz no se combidan unos a otros, mas siempre hazen comedimiento después de recivida al que la trae.

Todas las vezes que se ofreze hazen muchas reverencias al altar Presidente o choro, no se a de entender sino a la comodidad del que la haze como si uno se apartase del celebrante para $^{11}$

\section{[fol. $7^{\mathrm{r}}$ ]}

ir al Prelado o al Abad y ubiese de pasar por delante del altar, primero a de hazer reverenzia al celebrante, luego detrás del facistol genuflexión al altar y últimamente al que llega que así lo pido el orden.

Todos los que entonaren Antíphona Himno o cosa semejante an de estar en pie, baxas las mangas y el bonete quitado.

Están en pie a las Capitulas Himnos, Versos, Cánticos, responsorios, breves, preces, oraciones, hasta acavar la hora.

A la antíphona de nuestra Señora se está en pie todo el tiempo pascual y todos los Domingos, desde las vísperas del Sábado.

Al Gloria Patri no se levantan, mas quitan los bonetes inclinan la caveza y hombros hasta dicho el Spiritu Sancto, asimismo inclinan la cabeza al último verso de los Himnos, y al verso Benedicamus, Patrem et filium cum Sancto Spiritu, a los nombre de Iesus, y de Maria y del Santo de quien se reza y del Pontífice que vive. A las preces de cuaresma y adviento y ferias de ayuno están de rodillas todos los rostros al altar y

${ }^{11}=$ al margen: antes $=$ prestado siempre $=$ 
generalmente cuando están de rodillas miran al altar hasta acabar la ora que solo el Hebdomadario se levanta para dezir a prima la comfesión y se queda en pie

[fol. $\left.7^{\mathrm{v}}\right]$

cuando el choro la repite hasta acabar la oración, en las otras horas se levanta al Dominus Vobiscum y todas las oraciones y se buelve a poner de rodillas a la antíphona de Nuestra Señora y para la oración se levanta: a todo el verso del Himno Veni creator Spiritus, y al de Ave Maris Stella, y al o crux ave spes unica se arrodillan en todo; en el pange lingua cuando está el Sanctíssimo Sacramento descubierto, al tantum ergo sacramentum veneremur cernui $=$ en el invitatorio de maitines al Venite adoremus $e$ procidamus ante Deum = en el Te Deum laudamus a todo el verso Te ergo quae sumus tuis famulis subveni quos pretioso sanguine redimisti = el presidente y caperos están en pie al entonar el Veni creator y al Ave maris stella mas luego se hincan de rodillas.

-En los maitines están en pie al invitatorio y himno hasta la dimidíación del primer verso del psalmo: a los Versículos de cada nocturno bendiçiónes y absoluciones $=$ a las lecciones de evangelio hasta el et reliqua, al Te Deum laudamus.

-Cualquiera que pide Vendiçión para capitula o lección \& está profundamente inclinado hacia el que la pide y está así hasta que la aya dado fin o es que está el Sanctíssimo Sacramento

[fol. $8^{\mathrm{r}}$ ]

manifiesto o abierto el sagrario, o alzan en el altar maior que no se buelve al que la pide sino se inclina profundamente hazia el altar. Cuando dize tu autem Domine miserere nobis haze genuflexión al altar y todos los del Choro se levantan excepto en las lecciones de maitines que el Choro de los prebendados se queda sentado, y el baxo se levanta.

-Los que llegan al medio del Choro a decir lección después de la genuflexión, buelven y hazen comedimiento al Abad o Presidente de la casa y al choro y otro, la misma hazen cuando la acavan después de la genuflexión y se les corresponde.

-Puestas las manos tiene el Hebdomadario o celebrante siempre que comienza la ora hasta el Saeculorum Amen, siempre que comienza antíphona o himno, siempre que Capitula dize preçes Versos y oraciones. Si tiene capa persevera con las manos puestas todo el himno y asimismo los caperos y ministros revestidos.

-Todo el coro tiene las manos puestas a los Cánticos Magnificat, Nunc dimittis y Benedictus a todas las preces que no están de rodillas, al Pater Noster en fin de la ora y a la antíphona de Nuestra Señora cuando se dize en pie, no a la oración.

-A la confesión de Prima cuando no están de rodillas y a la de completas y los que la dizen

[fol. $8^{\mathrm{V}}$ ] 
están profundamente inclinados hasta la absolución, el misereatur, e indulgentiam, el coro alto tiene puestas las manos mientras se le da incienso o paz hasta el último del coro alto, luego las quitan, el coro baxo las tiene puestas mientras dan al choro alto y baxo, siempre que los colegiales tienen puestas las manos se retiran del medio del Choro a sus asientos.

El Coro de los prebendados siempre está de una suerte en sus sillas que los de los lados siempre están Eregione, que no se buelven al altar a cosa ninguna que se cante o reze sino es cuando se hincan de rodillas. El Choro baxo esta Eregione a las Capitulas, Cánticos, preces, en pie bendiciones y absoluciones.

-En los maitines de difuntos están en pie al Invitatorio y cuando entonan las antíphonas se sientan hasta los Versículos de los nocturnos que a ellos se levantan y dizen el Padre Nuestro. Y dicho todo secreto se sientan.

-En prima además de las cosas que se comprehende en las generales dichas tienen los colegiales baxas las mangas de la sobrepelliz al Símbolo de San Atanasio. Y todo el Coro puestas las manos desde la preciosa, hasta que el Hebdomadario dize oremus que quitan las manos y el Choro baxo buelve al altar en

[fol. $\left.9^{\mathrm{r}}\right]$

pie Eregione y puestas las manos a la absolución después de la lección breve y assí puestas y profundamente se inclinan al Dominus nos benedicat y al benedicat nos de completas

-cuando alzan el Sanctíssimo Sacramento en el altar maior todos se buelven y hincan de rodillas excepto el que dize Capitula, preçes, oración, Calenda o lección breve. Cuando están de rodillas no ponen las manos, ni buelven eregione a cosa alguna que lo pide. Cuando están en pie: solo el Hebdomadario se levanta a dezir la confesión.

-En las preces flexis genibus el Hebdomadario se levanta para dezir adiutorium nostrum in nomine Domini y en pie haze la confesión y se está en pie hasta dicha la oración, el Choro lo haze de rodillas.

-El Hebdomadario todas las vezes que comienza el Deus in audiutorium se signa, excepto el que tres vezes dice la prima, sígnase asimesmo todas las vezes que dize, auditorium nostri in nomine Domini y cuando dize en prima Dominus benedicat et ab omni malo defendat, y en completas al benedicat nos omnipotens Deus.

-Siempre que están en pie los del Coro alto y no es tiempo de capa tienen las mangas baxas y los colegiales cuando están en pie. Solamente las tienen

[fol. $\left.9^{\mathrm{v}}\right]$ 
puestas en hombros cuando se dizen las psalmos, ansimismo las tienen todos baxas cuando están de rodillas

Sentados siempre tienen los bonetes puestos excepto a los comedimientos y en pie siempre tienen los bonetes quitados y cuando alzan en algún altar o está el Sanctíssimo Sacramento descubierto.

Están los prebendados y capellanes sentados a los psalmos, lecciones de maitines del martirologio, a la tabla de los oficios. Los colegiales se sientan a todo lo dicho excepto a los psalmos, mas los que ministran revestidos en el oficio cantado también se sientan y si dizen a punto de órgano respondiendo la música se sientan o si la música lo dize todo se sientan todos: los cetreros no se sientan, mas están en medio del Coro las mangas baxas, excepto a los cánticos que se retiran y ponen como los demás colegiales eregione.

-El Coro baxo está en pie mientras el Abad dice lección o el Hebdomadario con capa, y el capellán cerimoniario le asista.

-Cuando alzan en algún altar los prebendados y capellanes se quitan el bonete los colegiales, baxan las mangas si están en pie porque ninguno sentado ha de tener las mangas baxas, los Versicularios nunca tienen las mangas en los hombros sino baxas sobre el brazo siniestro, de la misma manera las lleva cualquiera que va por el Coro y mientras está de rodillas

[fol. $10^{\mathrm{r}}$ ]

-Cuando salen dos a dezir versos acavándolos hazen genuflexión y luego venia el uno al otro.

-Cuando se lee la tabla de los oficios, cualquiera que en ella se nombra, si es prevendado o capellán se quita el bonete y si está sin él, baxa la cabeza y si es colegial se levanta un poco.

Todas las vezes que pasa uno de un choro a otro, sea por detrás del facistol y hagan genuflexión al altar mayor, mas si algún capellán o colegial ubiere de decir algún recaudo a los prebendados de la cabezera del Coro, no a menester ir de uno a otro ni dar la buelta detrás del façistol.

-El Viernes y Sábado Santo que no ay Sanctíssimo Sacramento en el altar, los prebendados y no los demás, en vez de genuflexión, hazen profunda.

-Todas las veces que se abre el Sagrario de el altar maior para renovar o otra cosa, todos los del choro buelven al altar y hazen genuflexión.

-El Hebdomadario acavada la oración y Fidelium animae los del Coro baxo se buelven Eregione y ambos coros alto y baxo pone las manos para el Pater Noster hasta que el Hebdomadario dice Dominus det nobis suam Pacem, para la Antíphona de Nuestra Señora que se buelven al altar y hincan de rodillas, si se dize en pie. 
Se quedan todos las manos puestas y solo los

[fol. $10^{\mathrm{v}}$ ]

colegiales se buelven al altar.

Acavada la Oración el que preside haze señal y si están en pie hazen todos genuflexión, si de rodillas se levantan y la buelven a hazer y luego el un coro al otro y los de un mismo coro entre sí, se hazen comedimiento y despiden, si acavado el oficio no se ha de salir del Choro sino se prosigue con decir misa cantada o comenzar otro oficio. Dicho el Pater Noster las manos puestas ut supra, el Hebdomadario dize Dominus det nobis suam pacem y no se dice la Antíphona ni oración de Nuestra Señora ni se haze comedimiento.

-El Coro baxo está en pie a todas las Antíphonas, y los capellanes no se sientan hasta la mediación del verso primero.

-En las lecciones breves de prima y completas por ser tan breve el espacio podrán los que quisieren quedarse arrimados en las misericordias

-En todo el oficio que se celebrare estando el Sanctíssimo Sacramento descubierto o abierto el Sagrario, como los jueves, y ansimismo en todas las fiestas y oficios de Nuestra Señora podrán los que quisieren estar en pie aunque los demás estén sentados.

[fol. $11^{\mathrm{r}}$ ]

\section{CAPÍtulo 3. Cuándo están de rodillas, o en pie, sentados, o, Eregione en la Missa.}

-Demás de las cosas generales dichas en la misa ay otras particulares que el Choro deve observar.

-Sentados aguardan todos que dexe el esquilón excepto el Colegio que está de rodillas, si es Domingo salen los de la missa a hazer el aspersorio y todos los del Choro se levantan y están en pie hasta que se ha dicho la oración Ex audi nos Domine. Suben los que celebran al altar y todos los del Coro alto se ponen de rodillas y no los del baxo porque ayudan a cantar y así están hasta que se acava el introitu; y el celebrante llega al altar.

Si no ay aspersorio, en dexando el esquilón se levantan Sochantre, Capellanes y colegiales y llegan a cantar el introitu. Los prevendados se quedan sentados hasta que el çelebrante comienza el introitu que todos se ponen de rodillas como se dixo supra.

Acavado el introito en el altar, se levantan los Prebendados y se sientan hasta que el çelebrante entona Gloria in excelsis que entonces se levantan y cantan el Gloria con el 
Choro y se sientan cuando el presidente la acava, pero si la dize la música la dizen rezada puestas las

[fol. $11^{\mathrm{v}}$ ]

manos y inclinan la Cabeza al Adoramus te, Gratias Agimus tibi Domine fili Unienite Iesu Christe suscipe deprecationem nostram, tu solus altissimus Iesu Christe, acavada se sientan, y cuando las dichas palabras, se inclinaren, canta el Coro quitan los bonetes.

Acavada la Gloria, el celebrante dize Dominus Vobiscum y los Prebendados se levantan y están en pie a las oraçiónes. A la Epístola se sientan todos los del coro y si es de la cruz, hincan todos las rodillas al In nomine Iesu omne genuflectatur. Acavada la Epístola los prebendados se quedan sentados, al gradual, Alleluyas, Versos, tractos y sequentia, y los capellanes y colegiales se levantan a cantar al façistol.

-Cuando se dize el Verso Veni Sanctae Spiritus repletuorum corda etc, se hincan de rodillas.

-Acavadas las Alleluias, tracto o secuencia al Dominus Vobiscum del evangelio se levantan todos y ponen las manos y los colegiales se retiran a sus lugares.

-A las palabras initium, o sequentia Sancti Evangeli todos se signan.

-Cuando en el evangelio del día de la Natividad se canta Verbum caro factum est y en la Epiphanía et procidentes adoraverunt eum y en la feria 4 post Dominicam 4am, quadragessima

[fol. $12^{\mathrm{r}}$ ]

Et procidens adoravit eum, se hincan de rodillas.

-Acavado el evangelio todos quitan las manos y los colegiales se ponen en medio del choro, mas se quedan todos en pie. Entona el çelebrante el Credo y si ai música, los prebendados buelven a poner las manos y lo dicen rezado y hazen genuflexión al incarnatus est y en acavando el Credo se sientan y cubren los bonetes. Si no ai música, los prebendados cantan el Credo con el Choro y hazen genuflexión con el presidente y se sientan cuando el presidente lo acava y cuando el choro Canta el Incarnatus est se descubren y sentados como están se inclinan profundamente.

En el día de la Anunçiación de Nuestra Señora y en el día de la natividad del Señor a todas tres misas, cuando el Coro canta el incarnatus est se levantan los prebendados y ponen de rodillas.

El Coro baxo canta el Credo en pie y se arrodilla al incarnatus est, y es conbeniente que mientras se canta el Credo no dexen el facistol los colegiales ni entren o salgan con recaudos, ni los llamen para ellos. 
Acavado el Credo dize el çelebrante Dominus Vobiscum y los prevendados se levantan y dicho el Oremus del ofertorio se sientan, los

[fol. 12 $\left.2^{\mathrm{v}}\right]$

del Coro baxo se sientan si lo toca el órgano, y sino después de cantado.

Acabado el ofertorio, el çelebrante entona el prefacio Per omnia saecula saeculorum y todos se levantan y están en pie hasta la comunicanda, al elevar el Sanctíssimo Sacramento todos se arrodillan y an alzando se levantan y cuando no ay que cantar los capellanes de retiran a su sillas y los Colegiales a sus lugares.

Al reçivir el incienso ponen todos las manos y los prebendados se combidan con comedimiento lo mismo a la paz, mas si cuando acavan de dar la paz al coro alto los colegiales están cantando no se buelven Eregione ni ponen las manos ni se les da paz y lo mismo a los capellanes y se salen los de las pazes por las últimas sillas del Coro alto cuando no an de dar la paz al Coro baxo y están ambos arriba

Acabados los Agnus y reçivida la paz se sientan los prebendados a la antíphona post communio y se levantan cuando el celebrante dize Dominus Vobiscum. Y están en pie a las últimas oraciones y hasta que se acava la missa, cuando el celebrante hecha la vendiçión inclinan las cabezas todos y hazen genuflexión al Verbum caro factum est

[fol. $13^{\mathrm{r}}$ ]

del último evangelio, al cual acavado todos se levantan y con la cortesía acostumbrada a los coros se despiden, mas si la misa es de feria de ayuno o de adviento o vigilia, o de difuntos se hincan de rodillas a las oraciones primeras y últimas y cuando comienzan Sanctus, Sanctus hasta que se dize el Pax Domini Sit semper Vobiscum. En las ferias de cuaresma acavada la misa no se despiden mas inmediatamente se comienzan las vísperas.

[fol. 13 ${ }^{\mathrm{v}}$ ]

\section{Capítulo 4. De la Prima y Calendas y demás horas en tono.}

1. Cuando dexa el esquilón haze el Sochantre comedimiento al Hebdomadario y comienza la prima. Están en pie todo el Himno hasta la dimidíaçión del primer Verso del psalmo, los prebendados se sientan y los capellanes, los Colegiales en medio del Coro, al facistol, dizen los psalmos y en la pausa del tono y compás se atienda a la solemnidad del día.

-Cuando se acabe la antíphona an de estar todos en pie y los colegiales se ponen Eregione. Dize el Hebdomadario la Capítula, buélvense y el sochantre señala dos 
cantores que digan los versos. Si fuere día de primera Clase los an de dezir capellanes y las ferias de adviento y cuaresma y de entre año y vigilias las dize un Colegial solo, las del tiempo de pascua dos. Si ai preces de rodillas todos se buelven al altar y se ponen flexis genibus hasta acavada la oración. Si las preçes no son de aiuno o de adviento, los prebendados y capellanes ponen las manos y los colegiales se retiran a sus lugares Eregione y puestas las manos el Hebdomadario dize la comfesión inclinado profunde y el coro misereatur tui; luego todo profunde inclinado haze la confesión

[fol. $14^{\mathrm{r}}$ ]

y hecha la absolución se endereza y está las manos puestas hasta que el Hebdomadario dize Dominus Vobiscum que todas las quitan y los colegiales se buelven al altar.

Cuando se dize la Conclusión de la oración el Colegial Calendario llega al façistol pequeño y haze comedimiento al Presidente del Coro y luego genuflexión al altar y dicho el Venedicamus domino comienza la Calenda cantada con la pausa que pide la solennidad del día.

Cuando comienza la leienda de la festividad, si es de primera clase, todos los del Coro se levantan y están en pie hasta que se acabe la leyenda de la festividad. Asimismo están en pie a las Calendas de las fiestas de la çircuncisión de Nuestro Señor Iesuchristo y de la Sanctissima Trinidad y de la transfiguraçión, Concepción, Natividad, Anunciaçión, Purificación de Nuestra Señora, San Ceçilio, San Hisçio, San Messitón, San Thesiphón y San Dionisio Areopagita, San Estevan y San Joan Evangelista y la invençión de la Cruz.

A las Calendas de las fiestas de segunda clase o que como tales se celebran en este Sacro Monte, Presentación, espectación, Visitaçión y Nieves, Ángel Custodio, San Gabriel, San Ioseph, Señora Santa Antíphona, Translación de Sanctiago se quitan los bonetes y se levantan un poco. ${ }^{12}$

[fol. 14 ${ }^{\mathrm{v}}$ ]

A las otras de los Sanctos de quien se reza se quitan los bonetes y abaxan las cabezas conforme fuere la fiesta, mas no se lebantan ni se descubren a las Calendas de la Septuagésima y feria quarta cinerum, mas se descubren a las del Domingo de Ramos y feria quinta in cena Domini.

-La Calenda de la Natividad de nuestro Señor Iesuchristo dize un Prebendado que señala el maestro de Çeremonias con la solemnidad y ceremonial que se dirá en su día.

-Las Calendas de: San Ceçilio, Hiscio, Messitón, Thesiphón y Sanctlago el Çebedeo dizen prebendados, la de la Dediçión de Granada. Purificaçión, Asumpción de Nuestra Señora y dedicación de esta Sancta Iglesia y el día de la resurección dizen capellanes.

12 =tachado Sant joaquin= 
-Cuando el Calendario dize Valibi aliorum se levantan todos y ponen las manos y los colegiales se quedan Eregione al praetiosa y todo lo que se sigue hasta que el Hebdomadario comienza la oración Dirigere. Acabada [la oración], el Colegial Calendario está ya en el facistol pequeño y pide la bendición. Para la lección breve está inclinado profundamente al que se la da, mas al altar cuando está el ${ }^{13}$

[fol. $15^{\mathrm{r}}$ ]

Sanctíssimo Sacramento descubierto o alzan en el altar maior, dada la bendición todos los del Coro baxo se sientan y el Choro alto se sientan en las sillas o se queda en las misericordias, y cuando dize tu autem Domine se levantan, ponen las manos al adiutorium y se inclinan profunde al Dominus nos benedicat y acavado el Calendario lleva el facistol de la Calenda al hueco de la ventana.

El día de Pentecostés se dize Pater Noster y Regina Coeli por que se apartan del Coro dicha Prima, que la tercia se dize como se verá en su día.

Acabada prima dizen secreto Pater Noster y Ave Maria y del mismo modo dizen tercia sexta y nona. Están en pie hasta la mediación de el primer verso, levántanse a la Capítula y están así hasta el fin de la hora si no es a las preces. A los Versos del día de Navidad y otros que se repiten Verbum Caro factum est no se hincan de rodillas.

Acabada Nona se dize la antíphona de Nuestra Señora y se despiden del Coro, mas si se ha de comenzar alguna Vigilia o misa cantada no se dize la Antíphona sino solo el Pater Noster Secreto y Dominus det nobis suam pacem.

[fol. $\left.15^{\mathrm{v}}\right]$

-Los sábados dicho el Dominus det nobis suam pacem todos se sientan y el Colegial Calendario tiene la tabla de los oficios y puesto junto al facistol de la Calenda la lee y acabada se entona la Antíphona de Nuestra Señora.

Las vísperas en cuaresma excepto los domingos se dizen inmediate post missam y estos días entran a completas a las tres y en dando el último golpe de la plegaria, el Colegial haze genuflexión al altar mayor y puesto en medio del Coro, y luego se buelve profunde inclinado al Hebdomadario, y pide la bendición, y dada, mientras dize la lección breve el Coro baxo, se sienta y el alto se sienta también o se arrima en las misericordias. Y al tu autem Domine se levantan todos y puestos Eregione los colegiales las manos puestas hazen la confesión y después de la absolución, a la cual todos están inclinados profunde, se ponen en medio del Coro y el Hebdomadario dize Converte nos Deus est y prosigue la ora como las demás.

Al Nunc dimittis todos ponen las manos y los colegiales retirados a sus asientos se buelven Eregione y a la antíphona Salva nos al altar

[fol. $16^{\mathrm{r}}$ ]

${ }_{13}=$ al margen $=$ La Concepción 
y todos las manos puestas y inclinados profunde y los colegiales Eregione están al Venedicat nos \& y bueltos al altar dizen la antíphona de Nuestra Señora en pie o de rodillas, como pidiere el día o tiempo, y se dize siempre aunque se aia de comenzar otro ofiçio. Hecha señal se levantan hazen genuflexión y unos a otros comedimiento y se despiden.

[fol. $\left.16^{\mathrm{v}}\right]$

\section{Capítulo 5. Cuándo se dize el ofiçio cantado o en tono.}

1. Siempre que ay maitines se dizen cantados porque son días solennes. Los ay la noche de natibidad de nuestro Señor Iesu Christo, feria 5 y 6, el Sabatho de la Semana Santa, la mañana de resurección, la Concepción de Nuestra Señora.

-Cántase el invitatorio, Himnos, antíphonas, psalmos, lecciones y responsorios, mas cuando es día de órgano toca los responsorios. Prima, tercia, sexta y nona se dizen todos los días de el año en tono y consecutive, la Vigilia de la Natividad se dize la prima cantada con toda solennidad; el día de Pentecostés la tercia cantada, el de la Ascensión la nona como se vera en sus días.

2. Las vísperas se dizen cantadas todos los días de fiesta de todo el año. Primeras y segundas vísperas cantadas tienen todas las fiestas de primera clase y las siguientes.

3. La Natividad de Nuestro Señor Iesu Christo: la Circunçisión: la Epiphanía, la Resurección, la Ascensión $=$ Pentecostés = la Sanctissima Trinidad, Corpus Christi: $=$ Transfiguración, las fiestas de Nuestra Señora: Concepción, Natividad, Anunciación, Purificaçión y Asumpción, las fiestas de los Sanctos Mártires de este Sacro

\section{[fol. $17^{\mathrm{r}}$ ]}

Monte, San Ceçilio, San Hisçio, San Messitón y San Thesiphón, Sanctlago el Çebedeo y dedicación de esta Sancta Iglesia y otros días festivos de este Sacro Monte, San Dionisio Areopagita, San Miguel, San Grabriel y el Ángel Custodio.

4. Las segundas vísperas cantadas se dizen las fiestas de la presentación, expectación, aunque sea transferida, Visitación y Nieves de Nuestra Señora y todos los días que estubiere descubierto el Sanctísimo Sacramento o sea en su octava, o en jubileo, o en día de alguna rogativa o deboción pro re gravi.

-Todos los días desde el Sábado ante Dominicam in passione hasta la feria quarta maioris Hebdomadae inclusive como sean las vísperas de la feria por la çeremonia de la Vexilla.

5. Y demás de los días referidos se dizen las vísperas cantadas todos los días que ubiere dotación y se dirán con la solemnidad que pidiere la dotación o aniversario. 
6. Los sanctos que se transfieren no tiene vísperas cantadas, excepto las vísperas de Nuestra Señora y Sanctos del Sacro Monte, que se an de celebrar con la misma solemnidad que en sus días.

7. Completas cantadas de primeras y segundas vísperas se dicen todos los días de primera clase del breviario y las que como tales se celebran en el Sacro Monte, SanctIago El Cebedeo, San

[fol. $17^{\mathrm{v}}$ ]

Çecilio, San Hisçio, San Messitón, San Tesifón, San Dionisio Areopagita, Dedicación de la Iglesia y las fiestas de Nuestra Señora, Concepción, Natividad, Anunçiación, Purificaçión, Asumpción, los días de de San Estevan, y San Joan Evangelista, el día Octavo del Corpus Christi, las segundas, el día de Santo Mathías, día de Sant Ioseph y primeras y segundas de Sant Gabriel = cuando estas fiestas se celebraren en feria de cuaresma, mas si las primeras vísperas de alguna de ellas fueren en Domingo no se dicen completas cantadas.

8. La Antíphona de Nuestra Señora que se dize después del ofiçio para salir del Coro siempre se dize en tono, excepto el miércoles Sancto después de completas que se canta con toda solennidad la Antíphona Ave Regina Çaelorum porque se despide con el ofiçio.

9. La Missa de tercia o maior que es lo mismo todos los días se dize cantada.

10. Es cantado el ofiçio de la Vendiçión de Candelas, ceniza y ramos. Cántase todo el ofiçio del Lavatorio y el Viernes Sancto y Sábado Sancto por la mañana excepto las horas y Vendiçión del nuevo fuego y el de la Vigilia de Pentecostés.

[fol. 18 ${ }^{\mathrm{r}}$ ]

11. Cántanse las vísperas de los difuntos el día de todos los Santos y las Vigilias que se dizen los días siguientes por los aniversarios y assimismo se canta todo el ofiçio que se haze en los entierros,

[fol. 18

\section{Capítulo 6. De la solemnidad de los ofiçios y capas pluviales.}

1. La missa de tercia se celebra en Diáconos todos los días del año.

El que celebra toma pluvial a las vísperas siempre que son cantadas, excepto las vísperas feriales del tiempo de pasión.

Ay caperos y toman pluviales todos los días que lo toma el çelebrante, excepto en las vísperas de aniversarios o dotaçiones ordinarias que no son solennes.

Ay seis capas los días de la Natividad del Señor, Epiphanía, resurección, 
Ascensión, Pentecostés, Corpus Christi, Todos Sanctos, S. Ceçilio, San Hisçio, San Messitón, San Thesiphón, San Pedro, SanctIago el Zebedeo, la Dedicaçión de esta Sancta Iglesia, la Concepçión y Asumpçión de Nuestra Señora.

-Ay cuatro capas, la Çircunçisión, segundos y terceros de resurección y Pentecostés, Sanctissima Trinidad, octava del Corpus a las segundas vísperas, Transfiguraçión del Señor y Iueves Santo a la procesión Anunciaçión. Natividad. Purificación de Nuestra Señora, Natividad de San Ioan Baptista, San Estevan,

[fol. $19^{\mathrm{r}}$ ]

San Ioan Evangelista, San Miguel, Sant Gabriel, El Ángel Custodio, San Dionisio Areopagita.

-Dos capas todos los demás días de domingos y fiestas de guardar y los días de la presentación Visitación, expectación y Nieves de Nuestra Señora.

-A maitines ay cuatro o seis capas conforme ubo en las vísperas de la fiesta.

-Los maitines de la Concepción de Nuestra Señora y de los de la Natividad y resurección se dizen con toda solennidad y a compás moroso.

-Las vísperas de la fiesta de primera clase y prinçipales de Nuestra Señora, Sanctos de el Sacro Monte se dizen con toda solennidad y gravedad y más espacio que las que fueren entre ellas más solennes y se a de tener gran cuidado con la morosidad del compás, pues encomienda tanto la religión del Coro de esta Sacro Monte y no tiene otra cosa más con que solemnizar ni diferenciar las fiestas.

-Las Completas Cantadas de los días de San Hiscio, Messitón y Thesiphón y Anunciación que fueren en días feriales de cuaresma y las del Sábado Sancto son con la misma solemnidad

[fol. $19^{\mathrm{v}}$ ]

y pausa que las vísperas de primera clase.

-Los días otros festivos y de Segunda clase se deven diferençiar en alguna menos solennidad y compás y este será más ligero los otros días de dobles o Domingos ordinarios.

-El mismo tenor que en las vísperas se a de observar en la missa y cuándo y cómo ay órgano estos días se dize libro 2 capítulo 12 de órgano, que en él se diferençia también la solennidad.

-El ofiçio de la Semana Sancta especialmente los maitines de las ferias 5 y 6 se dize con mucha pausa y devoción haziendo más mediación en los Versos y el punto algo más baxo que cuando se canta en fiestas que ay órgano, los maitines del Sábado Santo y 
oficio del día hasta la missa sufre el compás más ligero excepto la Vendiçión del cirio pascual que es muy solenne.

Los días festivos que ubiere algún aniversario solenne y la misa ha de ser de aniversario y por el que lo haze y fundó la missa de terçia de constituçión se puede celebrar y cantar con menos solennidad.

[fol. $20^{\mathrm{r}}$ ]

-Si acaso ubiere entre dicho puesto en esta Sancta Iglesia, ningún ofiçio ni la missa a de ser cantada sino en tono aunque aya Diáconos en la missa, ase de dezir la Epístola y Evangelio en tono y no en los púlpitos sino en un façistol en el pavimento, mas a las vísperas, ni el celebrante ni caperos toman pluviales y la Iglesias a de estar cerrada y solo un postigo entre avierto, con guarda que no entre sino el que tubiere privilegio.

[fol. 20v]

\section{Capítulo 7. Quién entona en las horas y lo que ha de hazer el Hebdomadario.}

1. Los oficios divinos se comienzan, una semana en un Coro y otra en otro, para esto ay una tablilla donde esta escrito Hic est Chorus, y se pone en la cuarta silla de como entran para señal que es el Coro de la semana el del lado donde está. El Coro de la Semana es el que comienza el primer Verso del primer psalmo, el Verso que se sigue otro coro y así prosiguen alternatim todos los psalmos en las horas que no ay antíphonas entre ellos. Mas en vísperas maitines y laudes, que al fin de cada psalmo ay Antíphona, repetida la primera y comenzada si es doble el segundo psalmo, entona el sochantre y encomienda al otro Coro y así entre los coros se prosiguen los psalmos alternativamente.

El Coro de la semana dize los primeros Versos de los himnos y de los cánticos

[fol. $21^{\mathrm{r}}$ ]

y generalmente el prinçipio de cualquiera cosa de diferente orden se encomienda al coro de la semana.

Los Himnos de las horas menores y de las vísperas y completas entona el sochantre y dicho el prinçipio haze comedimiento al coro de la semana y lo encomienda para que lo prosiga. Cuando los maitines son cantados entona el sochantre con los caperos el himno.

En las vísperas y laudes cantadas, el sochantre preintona el Himno al Capero del Coro y el Capero con el çelebrante lo entona y prosigue el Coro de la semana. Cuando no ay caperos el sochantre preintona el Himno al çelebrante y lo mismo el himno de prima, tercia y nona cuando son cantadas. El Himno de completas entona siempre el sochantre aunque sean cantadas.

-Generalmente a todas las horas entona el Hebdomadario o el que celebra el principio de ellas Deus in adiutorium etc, o Convertenos Deus etc, o Domine labia mea etc. 
-Las Antíphonas entona a las horas menores el Colegial Cantor del Coro de la Semana y lo mismo la Antíphona de Completas, mas la antíphona de prima, terçia

[fol. $21^{\mathrm{r}}$ ]

y nona cuando son cantadas entona el celebrante.

En vísperas de doble, sean cantadas o en tono, y en los laudes siempre entona la primera antíphona por el coro de la semana; y la Antíphona de los Cánticos Magnificat y Benedictus, el que celebrare en aquella hora y si no ubiere especial çelebrante el que haze oficio de Hebdomadario. La sigunda Antíphona encomiendan, si fuere oficio cantado, los Capellanes Cantores al Prebendado más antiguo del otro Coro. El Abad es del Coro diestro y aunque el celebrante que dixo la primera antíphona sea del mismo coro, dice siempre la sigunda antíphona por el otro Coro; y las otras alternativamente los prebendados de ambos Coros.

-Las Antíphonas de las Commemoraçiónes las entona el Sochantre y todo el coro, mas las antíphonas maiores que son las de la $\mathrm{O}$, aunque entren por commemoración, entona el celebrante o Hebdomadario.

-En las vísperas de semidoble simples o ferias, sean cantadas o en tono, y en las vísperas de doble cuando son cantadas, la primera Antíphona entona el celebrante, la sigunda el capellán del Coro opuesto y las

[fol. 22 ${ }^{\mathrm{r}}$ ]

demás alternativamente los otros capellanes y colegiales de suerte que el que digere la antíphona sea del Coro que a de comenzar el psalmo.

-Los psalmos cantados o en tono siempre entona el Sochantre y los Cánticos de Magnificat y Benedictus si son en tono o en oficio que no ay Caperos. El Magnificat o el Benedictus cantado entona el Sochantre con los Caperos, el Nunc dimitis cantado el sochantre.

Los versos de las horas menores y completas en días de primera clase, Sanctos del Sacro Monte y fiestas principales de Nuestra Señora dizen capellanes, los otros días dos colegiales cantores $\mathrm{y}$ en las ferias uno, los mismos los Versículos de las commemoraciones.

Los Versículos de maitines cantados los capellanes y los de vísperas cantadas cuando no ay caperos. Los primeros caperos entonan los Versos del día y el Magnificat; los segundos los otros Versos si ay commemoraciones y el Venedicamus Domino.

La lección breve de prima y completas dize el Calendario Colegial.

El Benedicamus Domino de las horas menores

[fol. 22 ${ }^{\mathrm{v}}$ ] 
y de completas dize siempre el que haze el ofiçio, el de vísperas cuando no son cantadas si son de segunda clase dos Capellanes, en las otras fiestas dos colegiales, y si es feria uno, en vísperas y laudes cantadas los caperos y si ay cuatro o más, los segundos.

-El Hebdomadario, o quien celebra, dize la Capitula en todas horas en tono o cantadas, dize los Versos de las prezes a que responde todo el Coro: dize la confesión y haze la absolución, dize el Dominus Vobiscum y todas las oraciones y dize el fidelium animae y dize los Versos en la antíphona de Nuestra Señora.

-Ninguno en el Coro especialmente el Hebdomadario dize algo de memoria si no por el breviario o psalterio.

-En la misa maior el Sochantre entona todo lo que se canta introitu Kyries, Gloria, Credo, Sanctus, Agnus Dei etc, porque todos le deven seguir, en las ferias encomienda el primer Kyrie a un capellán o colegial que lo canta solo, el segundo canta todo el Coro. El tercero encomienda a otro que lo cante solo, el cuarto el Coro y así alternativamente mas el postrero dize también

[fol. 23 ${ }^{\mathrm{r}}$ ]

todo el Coro.

-cuando no ai órgano entona el Sochantre el gradual y el primer Verso dize

todo el Coro, el sigundo en las ferias encomienda a uno, en los otros días a dos el primer aleluya dicen dos cantores, uno cuando es feria, el sigundo todo el Choro, y el Verso dizen los dos o uno respective al día y las últimas dicciones dize todo el coro y el otro Aleluya lo comienzan los dos y le acava el Coro, Los Versos del tracto los dize un cantor y el Coro alternatim, mas el tracto de las ferias 2, 4 y 6 de cuaresma lo dizen tres , a quien el sochantre lo encomienda cada uno su Verso,

-En las fiestas prinzipales encomienda los Versos del Aleluya a capellanes.

-En las procesiones entona el Sochantre el himno o Antíphona y en las letanías la antíphona exurge Domine, y el Verso Deus Auribus nostris audivimos. Los Prebendados Caperos entonan el Kyrie Eleyson y toda la letanía y el coro responde lo mismo. En los que ay responsos combida a los caperos a que salgan a dezir los Versos en las estaciones.

Siempre que combida el sochantre o capellán

[fol. 23 ${ }^{\mathrm{v}}$ ]

cantor a prebendados haze profunda y primero al del coro diestro.

[fol. $\left.24^{\mathrm{r}}\right]$ 


\section{Capítulo 8. De los colores que usa la Iglesia y ornamentos de las festividades.}

1. Usa la Iglesia de color blanco desde la missa del Sábado Sancto hasta acavada la Nona de la vigilia de Pentecostés, en todo el oficio de tiempo excepto en las procesiones y misas de las letanías.

-En todas las fiestas de nuestro Señor Iesu Christo y de nuestra Señora y por sus octavas, excepto la vendiçión y procesión de las candelas en la Vigilia de la Epiphanía y feria quinta in cena Domini, a la misa y procesión y los Diáconos al lavatorio y el presidente de morado.

-En la fiesta de la dedicación de la Iglesia, Todos los Sanctos, Natividad de San Ioan Baptista y sus octavas, festividades de los Ángeles o fiesta principal de San Ioan Evangelista y todas las fiestas de San Pedro y San Pablo, excepto la principal en 29 de Junio y la Commemoracion de San Paulo, en todas las fiestas de los Sanctos y Santas que no fueron mártires, en la fiesta de la Sanctissima Trinidad, y en todas las

[fol. $24^{\mathrm{v}}$ ]

missas botivas de las dichas fiestas en cualquiera día que se digan, en la missa pro sponso et sponsa, en los recivimientos del Rey o Reina, legado Apostólico y prelado, en las processiones y missas del Sanctíssimo Sachramento y en las pro gratiarum actione excepto si es la missa del Spiritu Sancto.

-Usa del color Carmessí desde la missa de la Vigilia de Pentecostés hasta acavada la missa y ofiçios del Sábado siguiente, en todas las missas y procesiones del Spiritu Sancto, en todas las festividades de la Cruz, en todas las fiestas de los Apóstoles, y en todas las fiestas de los Sanctos y Sanctas Vírgenes y no Vírgenes que ubieren sido mártires y en las fiestas de sus translaciones o cualquiera que celebrare algo que aya sido después de sus muertes.

-En las fiestas de San Ioan Evangelista ante portam Latinam, en la degollación de San Ioan Baptista, el día de los Inoçentes cuando cae en Domingo, mas en su octava siempre en todas las octavas de las dichas fiestas y en las Dominicas que caen infra octavam.

[fol. 25 $\left.5^{\mathrm{r}}\right]$

-Color morado la Vigilia de Natividad de Nuestro Señor Iesu Christo, en la fiesta de los Inoçentes cuando no cae en Domingo, en todo el oficio de tiempo del adviento desde las primeras vísperas de la primera Dominica, y en todas las Dominicas aunque caigan en infraoctava o día octavo de fiestas de blanco o de Carmesí y desde las primeras vísperas de la Dominica Septuagésima hasta acavar la letanía el Sábado Sancto. En todas las Dominicas y ferias que se rezare de tiempo, exçepto el jueves Sancto y Viernes Sancto, en la Vigilia de Pentecostés desde acavada Nona hasta comenzar la missa.

-En todas las Vigilias de Nuestra Señora y de Apóstoles y de otros Sanctos en todas las témporas del año exçepto las ante Dominicam Trinitatis que por ser oficio del Spiritu Sancto son de Carmesí, en todas las Vendiciónes de Candelas, çeniza, y palmas \& y en 
todas estas procesiones en las del Sábado Sancto del fuego y pila, en todas procesiones de letanía y rogativas.

En las otras procesiones se usa del color de la festividad o oficio de que se haze

[fol. $25^{\mathrm{v}}$ ]

la procesión, como las dominicas intra annum, Verde, en las del

Sanctíssimo Sachramento y pro gratiarum actione, y de Nuestra Señora en blanco.

En los días que se traen o reçíven reliquias de Mártires, Carmesí, en las de los comfesores blanca y generalmente el color que pide el ofiçio.

-Color Verde en todo el ofiçio de tiempo, desde la feria 2 post Dominicam Trinitatis hasta acavada la Nona, el sábado ante Dominicam adventus y desde la octava de la Epiphanía exclusive hasta el Sábado acabado el ofiçio matutino ante Dominicam Septuagésima.

-Color negro el Viernes Sancto a todo el oficio de la mañana y desde las primeras vísperas de los difuntos, el día de todos los Sanctos hasta acavada la missa del día siguiente en todas las proçesiónes entierros honras y aniversarios de difuntos.

-En el uso de estos colores ha de aver tanta uniformidad que todo cuanto sirbiere en altares Cálizes missas y ministros y velos de Cruzes y paces etc, a de ser de un color.

[fol. $26^{\mathrm{r}}$ ]

-El Pertiguero usa de solo tres colores blanco, Carmesí y negro en la gorra y capa; blanco o carmesí en todas las fiestas de primera y segunda clase y que como tales se celebraren que piden estos colores, en todas las demás fiestas dobles y semidobles Dominicas Simples y ferias de cualquier color que sean, usa la ropa negra.

-A de aver gran cuidado que los colores anden conforme al rezo y cuando se muden sea con puntualidad, de suerte que cuando entre el ofiçio esté ya puesto su color, mas cuando las vísperas se parten entre dos ofiçios de diferentes colores se ponen dos frontales: el del color del oficio del día siguiente debaxo y el del ofiçio de aquel día enzima que tenga sus puntas y éste se ha de quitar al tiempo que se repite la antíphona del quinto psalmo, por que a la capítula del ofiçio siguiente esté en el altar su color, mas si en estas vísperas ay pluviales an de salir del color del día siguiente por que no ay comodidad de mudarlos a la capitula, en los colaterales son los frontales del color que a de quedar para el día siguiente

[fol. 26 ${ }^{\mathrm{v}}$ ]

de la fiesta, reservando siempre los más preciosos para las fiestas de la primera clase, en todo lo cual el Thesorero a de usar de su prudencia y buena elección. 
[fol. $\left.28^{\mathrm{r}}\right]$

\section{Capítulo 9. Del gasto y repartimiento de la cera y de las lámparas.}

-La cera que se ha de gastar en este Sacro Monte sea muy buena blanca y de pavilo delgado, en lo cual se ha de esmerar la diligençia y prevención del Tesorero. Siempre se gasta cera blanca en todo el ofiçio y missas del año excepto los días siguientes:

Al ofiçio del Viernes Sancto y a las tinieblas las seis velas del altar y las catorze del candelero triangular, las vísperas y missa de la commemoración de los difuntos y a todas sus vigilias misas y entierros, sino es en las onras que se hazen por el fundador y sus padres, en el altar de anima los días que se sacan casullas negras se pueden poner velas de çera común.

En el altar maior se ponen seis velas los días de primera y segunda clase y que como tales se celebran, dobles maiores, Domingos y demás días de fiesta de guardar y las velas serán mayores o menores conforme a la Solennidad de la fiesta a disposición del Thesorero en todas las fiestas Votivas que

[fol. $\left.28^{\mathrm{v}}\right]$

se çelebran solennemente pro re gravi, y en las procesiones que se hizieren en ellas = en la procesión que se haze pro gratiarum actione; el día de la Asumpción en la tarde, seis velas se ponen en las completas solennes de cuaresma primeras y segundas de los Sanctos del Sacro Monte y de la Anunciación de Nuestra Señora y las del Sábado Santo; en los dobles menores, en las ferias maiores y semidobles cuatro, en ferias menores y simples dos, en cualquiera fiesta transferida el día que se rezare de ella se pongan las mismas velas que si fuese su día propio.

La fiesta que pide seis o cuatro velas se entiende en primeras y segundas Vísperas, en maitines y laudes y missa maior.

A las oras menores todo el año se ponen velas, excepto a la prima de la Vigilia de Navidad que se ponen cuatro, seis a la tercia del Spiritu Sancto y a la nona de la Ascensión.

A las completas siempre dos velas, excepto las solennes en cuaresma que se dixeron arriva.

A la Salve que se dize en la cuaresma después de completas se ponen siempre cuatro velas

[fol. 29 $\left.{ }^{\mathrm{r}}\right]$

y seis cuando las avido en completas. 
A la que se dize los sábados cuatro, sino es día de Nuestra Señora que se ponen seis en la Iglesia.

Arde un çirio grande en el blandón de plata en el pavimento siempre que estuviere descubierto el Sanctíssimo Sacramento, o reliquias de los Sanctos y a primeras y a segundas vísperas y misa maior los días de la çircuncisión, Epiphanía, San Ceçilio, Purificación, Sant Hisçio, S. Messitón, Anunçiación, San Thesiphón, los tres días de resurección: Asçensión; los tres días de Pentecostés, la Sanctissima Trinidad, Corpus Christi, San Ioan; S. Pedro; SanctIago; Transfiguración, Asumpción, Dedicaçión de Nuestra Sancta Iglesia, Natividad de N. Señora; San Dionisio; Todos Sanctos, Conçepción; Natividad de Nuestro Señor; San Estevan; San Ioan Evangelista; y si alguna de las dichas fiestas se transfiriere en el día que se rezare de ella.

No se apaga este çirio mientras estubiere descubierto el Sanctíssimo Sacramento o reliquias de los Sanctos y en los otros días no se apaga hasta después de completas. También arden en las Completas Solennes, en las ferias de cuaresma que se reza de los Sanctos Hisçio

[fol. $29^{\mathrm{V}}$ ]

Messitón y Thesiphón, y a las de la Anunciación y Sábado Sancto, a la tercia el día de Pentecostés y nona de la Asçensión.

Arden las seis velas de el altar maior siempre que esta descubierto el

Sanctíssimo Sacramento, y demás de estas seis velas arden otras doze bugías fuera de los triangulares y cornucopias, más o menos conforme se pudieren acomodar que se ponen en lo alto, seis Velas de a media libra en los nichos de los Sanctos y bassas de estas columnas.

-Cuando están manifiestas las reliquias arde la misma çera, mas de las seis Velas del altar, se apaguen las cuatro y queden ardiendo las dos de las esquinas, mientras no se digere la missa maior vísperas y completas, que en estas oras arden todas seis.

-Los ciriales de la missa se apagan mientras el sermón, mas si está el Sanctíssimo Sacramento o reliquias manifiesto quedan ençendidos.

-En las fiestas de Nuestro Señor, Natividad, Circunçisión y Epiphanía se pone el cirio IHS y arden todo el día dos bugías a los lados y el día de la Ascensión, después de ençerrado el Sanctíssimo Sacramento, se pone el cirio en el dosel y arden dos velas.

[fol. $30^{\mathrm{r}}$ ]

-El día de la Invención de la Cruz desde las primeras vísperas se pone sobre el tabernáculo del Sanctíssimo Sacramento la cruz de plata vien adornada con dosel y flores y arden seis velas y dos bugías a las primeras vísperas y completas no más, y el mismo día de la fiesta arden todo el día. Los días del Triumpho y Exaltación se pone la Cruz sobre el Tavernáculo con Viso Carmesí, con dos bugías que arden todo el día estando la Iglesia avierta. Si fuere día de fiesta arden juntamente dos velas en el altar. 
-Los días de la Conçepción de Nuestra Señor y los días de los Sanctos del Sacro Monte arden de la mañana a la noche dos Velas en el altar maior, y el día de la Asumpción arden seis velas sobre las Urnas desde primeras vísperas y todo el día de la fiesta mientras está la Iglesia avierta y en los Colaterales dos belas. En el de la Conçepción en su día arden dos Velas hasta la noche y desde primeras vísperas. El día de la Natividad de Nuestro Señor, desde que comienzan a dezir las missas rezadas en todos los altares, no se apagan las Velas mientras queda el Cáliz en el altar.

[fol. 30 $\left.0^{\vee}\right]$

-Cuando las fiestas de San Messitón y Thesiphón ocurrieren en la semana de passión que están los altares cubiertos con velos negros, no se pueden manifestar las reliquias en el altar mayor y así se haze un altar en el pavimento baxo donde se ponen, y en él arden cuatro velas a las esquinas del altar y seis o ocho o más bugías en los candeleros triangulares y en otros pequeños y dos velas en el altar mayor, y si en otro altar se descubrieren, ardan seis velas.

-Todos los días se sacan hachas al alzar el Sanctíssimo Sacramento en las missas mayores aunque se digan dos en un día, seis en todas las fiestas de primera clase que como tales se celebran en este Sacro Monte y también en las de segunda clase de Nuestro Señor y Nuestra Señora, San Estevan, San Ioan Evangelista y jueves y Sábado Sancto y los días que estubiere el Sanctíssimo Sacramento o reliquias manifiestas, y cuando estas fiestas vienen en jueves al renovar el Sanctíssimo Sacramento.

-Cuatro hachas las fiestas menores de Nuestra Señora, todos los otros días de segunda clase y Domingos y fiestas de guardar y Vigilia de Pentecostés y cuando se renueva el Sanctíssimo

[fol. $\left.31^{\mathrm{r}}\right]$

Sacramento, los demás días del año dos excepto el Viernes Sancto no se sacan.

-En los aniversarios de nuestro fundador y sus padres seis hachas, en ofiçio de cuerpo presente y honras de prevendados, las mismas y en los demás aniversarios y entierros cuatro.

-Los días de los Sanctos Çecilio, Hisçio, Messitón, Thesiphón, arden en los hornos de las Sanctas cuevas y en la de la Conçepción, y en la Cueveçita de Nuestra Señora de junto al horno de San Çeçilio, en cada lugar de éstos, un çirio desde las primeras vísperas hasta la noche del día siguiente y el día de San Çeçilio en los altares de las cuevas y los que se hazen en la Iglesia de SanctIago y en el Pórtico arden velas.

-En el altar de la Conçepción de la Cueva de San Çeçilio y en otro cualquiera a donde fuere alguna procesión, arden cuatro velas, feria cuarta rogationum va la estación al horno de San Çeçilio y en él arden las velas que para su adorno combiniente dispusiere el Thesorero. 
-Los días que ubiere maitines en el Coro se ponen dos blandones junto al façistol con hachas y velas en sus candeleros enfrente de los asientos de los Prebendados a cada uno la suya.

-El día de la purificaçión para la vendiçión

[fol. $\left.31^{\mathrm{v}}\right]$

de las candelas se dan velas de a libra a todos los prebendados, de a media al sochantre y capellanes, de a cuatro onzas a los colegiales, y si ubiere algunas personas de obligación o huéspedes por respecto de el Sacro Monte, se les da vela conforme a su calidad, avisando el maestro de çeremonias al Abad de las personas que ay a quien se deven dar, y el Abad o Pressidente assimismo tengan cuidado de que se cumpla con los que ubiere.

Al mayordomo de esta Santa Iglesia de a libra, al Pertiguero de a media, al Sacristán maior de a media, a los otros Sacristanes, al campanero y Caniculario de a cuatro onzas.

-Los sábados a la missa de Nuestra Señora en el altar de la Concepción se ponen cuatro velas y al alzar se sacan cuatro hachas $=$ y si sábado fuere día de alguna fiesta de Nuestra Señora seis velas y seis hachas en las mayores, en las menores cuatro.

En el monumento se ponga la çera combeniente vien repartida, que aya por lo menos cinco dozenas de luzes, y si se ubiere de quitar sea por parezer del Abad, maestro de ceremonias y Thesorero.

[fol. $32^{\mathrm{r}}$ ]

-Las lámparas de la capilla maior arden todos los días de primera y segunda clase, todas las fiestas de Nuestro Señor, = todas las fiestas de Nuestra Señora y todos los días que esta Sancta Iglesia çelebrare como fiestas de primera y segunda clase desde las primeras vísperas, Señora Santa Ana; San Ioachin y San Ioseph; el Domingo de Ramos hasta medio día, las Vigilias de Navidad de Nuestro Señor y Pentecostés.

-La lámpara del altar de la Conçepçión arde todos los días de fiesta y los sábados hasta mediodía.

-Desde el primer día de cuaresma hasta San Miguel de Septiembre cuando se çierra la Iglesia a medio día se apagan las lámparas que arden por la fiesta y se atizan y encienden para vísperas.

[fol. $32^{\mathrm{v}}$ ]

\section{Capítulo 10. Del hábito de los Prebendados y Ministros de esta Sancta Iglesia.}

1.Todos los prevendados Clérigos y capellanes que son de este Sacro Monte traigan el cabello corto sin señal de tufos, la barva redonda a navaja sin claros ni mostachos ni bozo, mantos o sotanas que lleguen al empeine del pie, bonetes castellanos, no traigan vestido ni calzas de color ni de seda, ni calzado acuchillado ni guantes picados dentro ni 
fuera de casa. Y fuera de casa pueden usar de guantes, mas no picados ni de olor de ningún genero, porque no se ha de hazer deliçia lo que se ha de ordenar para decençia de las manos consagradas.

-No pueden traer sombreros de tafetán ni con toquilla ni cosa de seda, excepto cuando sirve de forro en sombreros, bonetes, cuellos de ropas y lobas, listones en las delanteras de las ropas y manteos, cordones de seda en los sombreros. Listones para çeñirse las capas canonicales, no pueden ser de seda.

-No traigan sobrepellizes de olan ni Cambray

[fol. $33^{\mathrm{r}}$ ]

ni cosa semejante ni con randas ni puntas ni lenzuelos con puntas ni cuadros ni faldriqueras adobadas, porque los canónigos de el Sacro Monte no an de dar de sí otro olor sino el que dize San Pablo Christi bonus odor sumus in omni loco, y si en algo de esto dicho en este Capítulo ubiere exceso o descuido, lo prohiba y castigue el Abad como lo ordenan las constituçiones.

-No traigan por el Coro e Iglesia ropas debaxo de las sobrepellizes con los cuellos sacados.

-Capas Canonicales traen los Prebendados a todas oras, pónenselas acavadas las segundas vísperas de todos los Sanctos y si cae esta fiesta en sábado acabadas las segundas vísperas del domingo siguiente para las vísperas de los difuntos. Y las usan en todos los días festivos y solennes hasta entonar la Gloria. El Sábado Santo que las quitan y hasta otras vísperas del día de los difuntos no se las ponen.

-Pónense capas en cualquiera día o fiesta el año para los entierros,Vigilias y misas de cuerpo presente de los prebendados que se entierran en el Sacro Monte y para los entierros de los Señores Arzobispos de Granada

[fol. $33^{\mathrm{v}}$ ]

si se mandan enterrar en él y en honras solemnes que se hizieren por Sumos Pontifiçes y no en otras.

-No pueden confesar en la Iglesia ni asistir al Coro ni Cabildo sin capa o sobrepelliz conforme al tiempo.

-Los colegiales del Colegio de Señor San Dionisio an de traer mantos enteros de paño de color leonado obscuro y pardo, mangas negras limpias y aseadas.

-Bonetes pueden traer puestos por el campo cuando salen fuera de casa a las sacras cuevas y de noche por la casa i en tiempo de frío y en su colegio y [en] general donde les leen y en sus conferencia y en el portel fuera del que pregunta y en todas las procesiones que no son del Sanctíssimo Sacramento los ponen en saliendo la procesión 
de la Iglesia y no antes y ninguno dexe de llevarlo y pierda la distribución el que no lo llevare.

A de traer bonete en el altar y cuando acompaña al Colegial que supliere por Maestro de cerimonias y Pertiguero y todas las vezes que van en forma de Colegio, excepto cuando desde la Sacristía van de ceremonia al coro que no an

[fol. $\left.34^{\mathrm{r}}\right]$

de traer bonetes en otro tiempo ni en otra manera alguna puestos ni en la mano, traeranlos doblados y metidos en el pecho para tenerlos a mano cuando se ofrezca alguna ocasión de las dichas en que pueden usar de ellos

Cuando ayudan al adorno y limpieza de la Iglesia o coro, no an de ir con mantos por que no maltraten los que an de servir al culto divino. Usarán en estas y semejantes ocasiones de sotanillas.

2. A Granada irán con sotanilla y ferreruelos largos y negros.

-No an de traer media de color ni zapato picado ni chinelas ni guantes ni cuellos senzillos ni engomados, ni pañuelos con puntas ni randas.

-Cuando ablan con algún prebendado están siempre descubiertos, mas si son de orden Sacro cuidará el Prebendado de hazerles señal que se cubran.

-Por la casa y sacristía anden y estén con mucha modestia y silençio, las acciones muy políticas y urbanos en la cortesía con todos y con los forasteros muy comedidos y compuestos para que todos echen de ver

[fol. $34^{\mathrm{v}}$ ]

en ellos la religión y virtud que profesan y en todo guardaran el orden que se les da en sus constituciones y consueta

[fol. $35^{\mathrm{r}}$ ]

\section{Capítulo 11. Quién çelebra en el altar y haze oficio en el choro.}

1. Los canónigos de Canongía colada que son los Capitulares pueden hazer oficios de Hebdomadarios y dezir missa en el altar mayor.

2. En el altar mayor cada día se dize la missa de prima y la missa de tercia Conventual y no se puede dezir otra missa rezada ni cantada excepto las missas cantadas de los anibersarios perpetuos y los que hazen otras comunidades y los que establecieron los canónigos, aunque sean temporales, y las missas de los entierros en este Sacro Monte y las de los aniversarios o onras por los prebendados del. 
3. Missa rezada se puede dezir con licençia del Abad, Prebendado, Canónigo o dignidad de Cathedral, oidor o inquisidor o persona semejante, Provincial de religión, o Varón insigne en ella, también se puede dezir la misa última en el altar mayor en días de mucho concurso.

\section{Cuando alguna persona grave y de respecto}

[fol. $\left.35^{\mathrm{v}}\right]$

quisiere por su devoción mandar dezir alguna missa cantada se deve permitir.

-Missa cantada que aya de oficiar el Cabildo del Sacro Monte en el choro no la puede dezir persona alguna si no fuere Prelado consagrado.

5. Si la Cathedral vine a dezir alguna missa solenne se les dexa el altar choro y Iglesia y lo mismo cuando viene alguna religión a dezir alguna missa por alguna rogativa o causa urgente.

El Prebendado que dize la missa de prima el día de Navidad puede decir consecutivamente la terçera, pero cuando este día es sábado las podrá dezir todas tres por que la segunda missa se dixo cantada en lugar de la de Nuestra Señora.

6. Cuando ordena el Cabildo algún novenario de misas de Nuestra Señora o otros por alguna causa grave o publica como salud de Rey, Reina o Príncipe, Paz o salud Universal etc, se pueden dezir estas missas en el altar mayor al tiempo de la oración y abrir el Sagrario y si la missa fuere cantada se dirá después de nona o de la procesión si la ubiere.

7. El Abad celebra los días siguientes: Natividad

[fol. $36^{\mathrm{r}}$ ]

de Nuestro Señor Iesuchristo, San Estevan, San Ioan evangelista, Epiphanía, San Çeçilio, Purificación de Nuestra Señora, San Hiscio; San Messitón; San Thesiphón; primero día de Resurección; Ascensión; primero día de Pentecostés; Corpus Christi y el día octavo, Sant Ioan Baptista; San Pedro y San Pablo; Santiago el Zebedeo; Asumpción; Dedicación de la Iglesia: San Dionisio Areopagita = Todos los Sanctos; Concepción de Nuestra Señora y en estos días çelebra las primeras vísperas y misa de tercia excepto en el día octavo de Corpus Christi y las fiestas de los Sanctos ( que se dizen vísperas por la mañana) que çelebra las segundas: celebra también la misa el miércoles de çeniza el Domingo de Ramos; jueves y Viernes y Sábado Sancto.

-Celebra los maitines de la Concepción de Nuestra Señora; de la Natividad de nuestro señor Iesuchristo y la missa primera y los maitines de resurección.

-Celebra las procesiones de la Purificaçión de Nuestra Señora; de los Ramos; de jueves y Viernes y Sábado Sancto: la de la mañana de resurección, el día de Corpus Christi y el día octavo y la procesión que se haze 
[fol. $\left.36^{\mathrm{v}}\right]$

El día de la Asumpción de Nuestra Señora a las Sanctas cuevas pro gratiarum actione y también si se ofreze hazer alguna fiesta y procesión pro re gravi et publica

-En las oras menores haze el ofiçio el Abad en la prima de la Vigilia de la Natividad. En la tercia de Pentecostés = en la Nona día de la Asçensión y dize la oración Respice en todas las horas del ofiçio in triduo maioris hebdomadae y en su ausencia el que preside; y haze el Lavatorio el jueves Sancto y en su ausencia el Pressidente o el más antiguo.

-Celebra el Abad las Vigilias y missa en el aniversario de difuntos que se haze a tres de Noviembre por el Señor Cristóbal Vaca de Castro y en el aniversario que se haze por nuestro illustrísimo fundador a veinte de Diciembre, día de su dichosa muerte; y en las onras que se hizieren por Summo Pontífice, Rey o Reina o Príncipe heredero, también celebra en el oficio de entierro y dize la missa a los Prebendados que se entierran en el Sacro Monte.

[fol. $\left.37^{\mathrm{r}}\right]$

-El Pressidente de la casa çelebra los dichos días y oficios en ausençia del Abad y cuando ambos faltan de casa çelebre el Canónigo Semanero y en su ausencia el que se sigue por turno.

-El Pressidente de la casa çelebra siempre el oficio y missa funeral de los capellanes y colegiales cuando se entierran en el Sacro Monte.

-Todos los demás días los Prebendados por su turno de semanas, en vísperas maitines, missas y procesiones y cuando el semanero no puede dezir la missa o bísperas solennes, pasa al que se sigue en turno por su antigüedad. Y el que dize la missa lleva la limosna sin que se pueda suplir uno por otro y avisa al Colector para que la encomiende al que le viene por turno.

-En la muerte y entierro de los otros ministros de la Iglesia y criados de casa celebra el que se sigue en turno de aniversarios.

-Los aniversarios que se celebran en esta Santa Iglesia y los que se celebran de vísperas maitines y missa celebra el Abad y los canónigos capitulares por su turno.

-En las horas menores haze siempre el oficio el semanero y en su ausençia el que se le sigue en esta forma: que si falta algún día o días el que se le sigue en antiguedad toma

[fol. $\left.37^{\vee}\right]$ 
el pluvial y dize la missa y ese es el que haze el oficio en las horas menores, si falta algún punto, el inmediato que se le sigue en el Coro capitula aquella hora.

-De diácono se visten los prebendados por su turno y no pueden trocar entre sí porque es en detrimento del turno.

-El Pressidente de la casa solo está exceptuado de vestir Dalmática.

-Cuando el Abad celebra el prebendado semanero se viste de Evangelio y el más moderno de Epístola. El día de San Çeçilio y cuando algún Prelado asistiere a la missa la semana Sancta y cuando ubiere otro día de gran solennidad nombrará el maestro de ceremonias los que fueren más a propósito atendiendo así a las çeremonias como al canto.

-En los Aniversarios se visten los diáconos Semaneros y en la missa de terçia los que se le siguen y no pueden trocar unos con otros.

-Pluviales nunca visten Capellanes, siempre los toman prebendados así capitulares como los de aprobación y los semaneros en las vísperas de aniversarios y en las

[fol. $38^{\mathrm{r}}$ ]

otras (si las ay que los pidan) los que se siguen.

[fol. $\left.38^{\mathrm{v}}\right]$

\section{Capítulo 12. De la dignidad y orden de las fiestas que se çelebran en este Sacro Monte y adorno de ellas.}

1. En esta Sancta Iglesia se celebran las fiestas con la solennidad que les da la Iglesia Romana el primer grado tienen las fiestas de primera clase, el segundo las de segunda, luego los dobles mayores y respective los demás por sus grados y entre los que son de una línea son preferidas las más dignas conforme rúbrica 11 del breviario de concurrençia officii.

2. Las fiestas de primera clase que pone el breviario y para nuestra Iglesia son las [de la] Natividad de Nuestro Señor Iesuchristo, Epiphanía, Resurrección cum tribus precedentíbus et dobus subsequentibus, la Ascensión, Pentecostés cum duobus sequentibus, Corpus Christi, Nativitas S. Ioanis Baptista, San Pedro y San Pablo, SanctIago el Zebedeo, Asumpçion de Nuestra Señora, la dedicación de la Iglesia a 21 de Agosto, Todos los Sanctos, San Çeçilio.

[fol. $39^{\mathrm{r}}$ ]

a primero de febrero. 
3. Demás de estas se celebran en esta Sancta Iglesia con toda solennidad como de primera clase y con derecho a la propiedad de serlo, las fiestas de la Concepción $(+)$, Natividad, Anunciación y Purificación de Nuestra Señora, por ser esta Iglesia dedicada a su Magestad Soberana, y entre estas las de más solennnidad y grandeza es la fiesta de la Conçepción. Las fiestas de San Hisçio, San Messitón y San Thesiphón, por aver padecido martirio en este Sacro Monte y estar en el todos los Cuerpos y reliquias y particularmente por ser titulares de esta Iglesia a quienes está dedicada, como consta de las bullas de la erección y así a estas fiestas se les deven guardar los derechos de primera clase y en el rezo que si ocurrieren con los domingos de Segunda clase. 2.3.4. de adviento y cuaresma Septuagessima, Sexagessima y quincuagéssima se á de rezar de estas fiestas con commemoración de la dominica excepto la Anunciaçión $(+)$ que si concurriere con 2.3.ò 4 Dominica de cuaresma se transfiere al primero día desocupado, mas si concurren con estas las fiestas del número precedente, an de ser preferidas. ${ }^{14}$

[fol. 39 $]$

-Mas se çelebran en esta Sancta Iglesia con solennidad de primera clase (aunque no tanta como la que se da a las fiestas precedentes): La Çircuncisión del Señor; la Sanctíssima Trinidad; la Octava del Corpus Christi; la Transfiguración; la Dedicación de San Miguel. El Ángel de la guarda. San Gabriel. San Estevan, y San Ioan Evangelista; las fiestas de segunda clase son $(+)$ la Invención de la cruz San Lorenzo San Simón y Iudas, San Andrés, Santo Thomé.

Las fiestas que se celebran con solennidad de segunda clase son Presentación, Visitaçión, expectación y nives de Nuestra Señora, Sant Ioseph, la translación de SanctIago solo en la missa y el día de la Commemoración de los difuntos.

Las dobles en esta Sancta Iglesia se zelebran con más solennidad que los otros son: San Sebastián $=$ San Ioachin $=$ San Ioan ante Portam latinam $=$ la Apariçión de San Miguel = San Bernavé, Santa Maria Magdalena, San Françisco, el Triunpho y exaltación de La Cruz = el Baptismo del Señor o octava de la Epiphanía = la Dominica in albis = las octavas de la Asumción. ${ }^{15}$

[fol. $\left.40^{\mathrm{r}}\right]$

y Conçepción de Nuestra Señora y la de San Çeçilio, en estas fiestas se añade alguna más demonstración de solennidad en adornos y çera y pausa del ofiçio que en los otros días dobles.

Todos los jueves que se rezare de la feria, excepto las ferias de adviento y cuaresma y Vigilias, la missa principal es del Sanctíssimo Sacramento y se celebra con la solennidad de doble de sigunda clase y no se dize más de una oración en la missa porque es la solennidad pro re gravi que su Magestad la pidió a todas las Iglesias que se

\footnotetext{
${ }^{14}(+)$ no se conceptúa por que es de $1^{\mathrm{a}}$ clase y con $8^{\mathrm{a}} \ldots . . .$. ilegible.

${ }^{15}$ Va al margen: San Mathias: St Marcos: San Philipe y Sanctiago St Matheo San Lucas

$(+)$ al margen izquierdo "es de $2^{\mathrm{a}}$ classe $\mathrm{p}^{\mathrm{a}}$ toda la $\mathrm{Ygl}^{\mathrm{a}} .=$ "
} 
hiziese assí, porque su Santidad conzediese el rezo del Sanctíssimo Sacramento las dichas ferias.

-La fiesta de San Dionisio Areopagita a nueve de octubre tiene otra especial solennidad que es missa de Abad, celebrase porque es el que dió a San Çeçilio la preciosa e inestimable reliquia de la mitad del paño con que Nuestra Señora limpió sus lagrimas al pie de la cruz = la cual se guarda en la Iglesia Cathedral. Posee por él esta Ciudad tan gran Thesoro de sçiencia y salud y porque es patrón del Colegio Ecclesiástico de este

[fol. $40^{\vee}$ ]

Sacro Monte eminente Doctor insigne mártir, compañero y amigo de San Çeçilio.

-Ramos, junçia y gayomba se echa por el suelo de la Iglesia la pascua de Resurección, Ascensión del Señor: Pentecostés: Corpus Christi y toda su octava, Natividad de San Ioan Baptista, San Pedro y San Pablo; SanctIago el Zebedeo. Asumción y Natividad de Nuestra Señora, y en estos días se echan por el pavimento alto muchas flores y yervas olorosas y por las gradas se ponen mazetas y en el altar vasos y ramilleteros con ramilletes y por el tavernáculo, cornisa de las Urnas, tablas y pedestales del retablo se ponen flores y ramilletes como lo manda el ceremonial, mas en las colunnas y pilastras ni en otra parte se hincan clavos ni otra cosa para ponerlos y se pongan con todo cuidado no se maltrate el retablo y se pueden poner Sanctos que tengan reliquias. Este adorno sea más o menos conforme a la grandeza del día que exceda en las fiestas de Nuestro Señor y de la Asumpción.

-Por el pavimento y no más se echan flores y algunos ramilletes en el altar los días de la Invención de la Cruz. Sanctissima Trinidad

[fol. $41^{\mathrm{r}}$ ]

Transfiguración del Señor.

-Los días de la Concepçión de Nuestra Señora y San Çeçilio es decente echar por la Iglesia tomillo y almoradux y el altar se deve adornar con ramilletes y flores y todos los días que estubiere descubierto el Sanctíssimo Sacramento y reliquias se adorne el altar y tavernáculo con flores y los días que está el Sanctíssimo Sacramento manifiesto no echa el Caniculario las flores en el pavimento alto, mas un colegial o dos con sobrepelliz las sacan en fuentes de plata y con las devidas reverenzias suben y las echan.

-Ramos de árboles se ponen por la Iglesia y Pórtico para la proçesión del Sanctíssimo Sacramento, mañana de resurección, Corpus Christi y octava.

-En todos los días referidos los altares colaterales se adornan con flores y ramilletes.

-El brasero grande con pomo muy bien aderezado se saca los días de sus vísperas: Natividad de Nuestro Señor IesuChristo, San Estevan, San Ioan Evangelista, La Epiphanía, San Çeçilio, San Hisçio, San Messitón, San Tesiphón, $1^{\circ}$ y $2^{\circ}$ de 
[fol. $41^{\mathrm{v}}$ ]

Resurección y Pentecostés $=$ Ascensión. Corpus Christi. Y toda su octava. San Pedro. San Tiago el Zebedeo: Todos Sanctos: Concepción. Anunciación. Purificación y Asumpción de Nuestra Señora.

-La Credencia avajo con la plata se pone los días de Natividad, San Estevan, San Ioan. Epiphanía $=$ primero y segundo de Resurección y Pentecostés. Asçensión, Corpus Christi. Y siempre que estubiere el Sanctíssimo Sacramento descubierto = San Ioan. San Pedro. SanctIago el Zebedeo. Todos Santos, Concepción. Natividad. Anunciación: Purificación y Asumpción de Nuestra Señora. San Çeçilio. San Hisçio. San Messitón. San Thesiphón: dedicación de la Iglesia y jueves Sancto a la misa y Lavatorio y San Dionisio Areopagita y cualquiera otro que se celebrare como de primera clase. La Credenzia arriba con tres fuentes (las dos de las armas y la de los esmaltes) con gradilla y frontal se pone los días de la çircunçisión. San Gabriel. Los terceros días de resurección y Pentecostés, Sanctissima Trinidad, invención de la Cruz; la transfiguraçión: San Miguel. El Ángel de

[fol. $\left.42^{\mathrm{r}}\right]$

la guarda. San Ioseph cuando no se transfiere.

-Los demás días de segunda clase se sacan dos fuentes grandes y la pequeña y se ponen sobre la Credençia sin gradilla ni frontal.

-Todos los días que se pone la credenzia con toda la plata se pone el bufete con frontal rico.

-En los altares Colaterales se ponen mayores alfombras todas las fiestas de primera clase nombradas en el primero y segundo número.

-Los días que se saca toda la plata en la credençia los demás altares se sirven con plata, candeleros, ampolletas, Cruzes etc.

-Los días de primera clase y que como tales se çelebran, se cubre el pavimento alto y gradas con alfombras. Y los días de segunda clase y que como tales se çelebran en el pavimento alto se pone alfombra que lo cubra todo.

-Los candeleros y Cruz rica se ponen los días de primera clase o que como tales se celebran en este Sacro Monte según esta consueta = cuando salen los candeleros salen los ciriales y plata más rica.

[fol. $42^{\mathrm{v}}$ ]

-El Coro se adorna con flores y ramos muy curiosamente sin que se ponga en la cornisa ni hinque clavo los días de la mañana de resurección, para maitines; Ascensión, para 
Nona; Pentecostés, para tercia; Corpus Christi, para la missa; y vísperas sigundas del día octavo. Asumción de Nuestra Señora, San Ioan. San Pedro.SantIago, para vísperas y missa.

-Para la prima de Vigilia de Navidad se adorna todo el Choro y andenes de las sillas altas con alfombras muy bien puestas y ajustadas y se ponen braseros y pomos de olor.

[fol. $\left.43^{\mathrm{r}}\right]$

\section{-Capítulo 13. De los Comisarios que nombra el Cabildo para las fiestas y de los fuegos.}

1. Para las fiestas que con más solennidad se celebran en este Sacro Monte, nombra el Cabildo algunos días antes dos prebendados comissarios para que se encarguen de todo lo que ubiere extraordinario perteneciente a la celebridad y adorno por que mejor pueda acudir el Thesorero a sus obligaciones que en tales días son mayores y piden más asistençia.

2. Nombra comissarios para la fiesta de la Conçepción de Nuestra Señora, San Çeçilio, fiesta del Corpus Christi y su octava, Asumpción de Nuestra Señora y para estos días el Rector del Colegio con consulta del Abad, nombra dos o más colegiales comisarios que cuiden y executen todo lo que los prebendados les ordenaren anexo a la fiesta.

3. Para la fiesta de la Concepçión y del Sanctisimo Sacramento se les dé libranza para que gasten en fuegos, olores, flores, etc.

[fol. $\left.43^{\mathrm{v}}\right]$

4. El día de San Ceçilio no gasta nada la fábrica por que haze la fiesta toda el Cabildo de la ciudad de Granada, y así los comisarios, prebendados son para reçivir y tratar y asistir con los Cavalleros comisarios de la çiudad.

5. Dánles memoria de la çera que an de traer y alfombras que son menester para el teatro, dízenles el estilo con que se suele adornar el Pórtico y la Iglesia de las cuevas y les dan notiçia de todo lo necesario para que la fiesta sea grandiosa.

6. Cuidan y soliçitan se les dé el recaudo y aderezos de la Sacristía y que las colgaduras no se maltraten y que nada se pierda. Ofrézenles con mucha benevolencia lo que ubieren menester y que ellos son señalados para les ayudar y servir.

7. Cuando comieren o zenaren en casa los de la ciudad les lleven al refectorio y comen con ellos y en todo les acompañan: y cuando viene la ciudad son los que salen a recivirla y despedirla con otros dos prebendados.

8. Los fuegos de la noche de San Çeçilio son

[fol. $44^{\mathrm{r}}$ ] 
a cargo de la ciudad y los Comissarios Prebendados cuiden que en la torre se repique con mucha solennidad.

9. El Cabildo del Sacro Monte deve combidar al Señor Arzobispo que suba asistir y onrrar la fiesta. Y assí a combidarlo baxan los Comissarios Prebendados y si concede el subir, cuidan de aderezarle el aposento y avisan cuando sube para que el Cabildo salga a recivirlo y mandan que la torre esté a punto para repicar cuando sube y lo mismo cuando se va.

10. Si ubiere algún Prelado en Granada o persona grave y el Señor Arzobispo no ubiere de asistir en la fiesta, avisarán al Cabildo si es vien combidarlo y baxarán a ello y le prebendrán hospedage.

11. Para la fiesta de la Concepción previenen ramilletes y tomillo que echar en la Iglesia, los fuegos y cohetes que les pareciere de suerte que sean muy buenos y cumplidos para la Iglesia. Hacen a su elección algunas invenciones de luzes curiosas para los maitines y para que la ropa blanca se adereze mejor dan olores al Thesorero y para los

[fol. 44 $\left.{ }^{\mathrm{v}}\right]$

pomos e incensarios hazen limpiar la Iglesia y ayudan al demás adorno que el Tessorero dispusiere y ordenare.

12. Para la fiesta de la Asumpción no se da libranza particular, mas la fábrica gasta lo necesario en fuegos que los Comisarios previenen cazuelas, luminarias y cohetes, muchos ramilletes y juncia y olores y con el Tesorero adornan el altar con las luzes y flores conforme se ha dicho en sus capítulos.

13. Para la fiesta del Sanctíssimo Sacramento que es la más prinçipal, cuidan los comissarios por todos ocho días que aya juncia y gaiombas y otras yervas olorosas bastantes para echar todos los días flores y rosas para el pavimento, las yerbas se echen en la Iglesia frescas todas las mañanas antes de abrirla también se renuevan por el pavimento las flores por el alto se echan después de aver descubierto el Sanctíssimo Sacramento, procuran muchos ramos y ramilletes para las jarras y ponen algunas en los altares colaterales $=$ todos los días renuevan el pomo y dan pastillas para los inçensarios.

[fol. $\left.45^{\mathrm{r}}\right]$

14. Es a su cargo totalmente el hazer los altares para la procesión y adornar el pórtico, el mismo día del Corpus ay procesión después de la missa y assí la noche antes tienen adornada la Iglesia con Ramos y Juncia, quitados los confesionarios, la rexa de la puerta y paredes enramadas con gayombas y fresnos y otros ramos.

15. En medio de la Iglesia, debaxo del Choro, hazen un altar adornado con frontales ricos, ropa olorosa. Enzima hazen una o dos o tres gradas vien adornadas con láminas y reliquias y otras curiosidades con flores y ramilletes con luces y buxías encima se pone el niño JESÚS, o los Sanctos o imágenes que les paresciere, alfombras por ambos lados. 
16. Para el día octavo asimismo, de la noche antes, hazen el mismo altar debaxo del Coro o éste y otros pueden hazer por los arcos cuelgan el pórtico y lados de la puerta de la Iglesia, en el testero del Pórtico hazen otro altar muy vien aderezado a su elección muchas flores y luzes.

\section{Si la procesión es por el Claustro pueden}

[fol. $45^{\mathrm{v}}$ ]

con más descanso y espacio hazer y adornar los altares, no cuelgan las calles del claustro sino los cuadros que caen entre los dos arbotantes a donde se hazen altares con los tres, y en el de la puerta de la Iglesia no se haze porque no aí allí estaçión, mas se entra derecha hasta el altar maior, los altares en el Claustro con lo más y mejor que ubiere, las calles y patios con muchas mazetas, gayombas y juncias, asisten al quitar y guardar estos aderezos.

18. Si en estas fiestas el Predicador no fuere de casa los Comissarios lo reciuen y aposentan. Finalmente en sus fiestas cuidan los comisarios de todo lo perteneciente a ellas y sobre [instan] a los ministros y colegiales para que acudan a lo que les ordenaren excepto lo que es el altar y ceremonias que está a cargo del maestro y Tesorero.

19. Para la fiesta de San Dionisio, patrón del Colegio, no nombra el Cabildo Comisarios prebendados sino el rector del Colegio señala cuatro o seis colegiales que se encargan del adorno y celebridad y son a su cargo los fuegos y luminarios, hazen un

[fol. $46^{\mathrm{r}}$ ]

altar en el Arco que está frente de la puerta del Pórtico, adornada con dosel y Láminas en que ponen el quadro del Santo y muchas flores y curiosidades, Ara y recaudo para çelebrar y arden en él desde las primeras vísperas y todo el día seis velas, sirven en todo lo que toca al adorno de la Iglesia al thesorero y se esmeran en que toda la fiesta sea muy cumplida y celebre.

20. Si se ofreçiere celebrar alguna fiesta Solenne o la ciudad de Granada o la chanzilleria ubiere de hazerla a estos Sanctos o se ofreciere alguna beatificaçión o Canonización de Sancto en que el Cabildo del Sacro Monte aya de baxar a cosa semexante, se an de nombrar dos o cuatro Comissarios prebendados que confieran el orden que se deva guardar, y de él den cuenta al Cabildo y determinado lo que se ubiere de hazer lo executen. Prevengan lo necesario y dispongan todo lo perteneciente a la tal fiesta con el adorno y magestad devida.

21. Las noches que ay fuegos en el Sacro Monte

[fol. $\left.46^{\mathrm{v}}\right]$

son la del día de año nuevo por la fiesta del día siguiente que es la toma de Granada, ponénse luminarias por todos los valcones y ventanas, tres o cuatro en cada una, 
prinzipalmente en las que miran a la ciudad, la noche Víspera de San Ceçilio son a cargo de los Comissarios de la Ciudad, la noche Víspera de la octava del Corpus ay luminarias por todas las ventanas y cazuelas de fuego por las plazetas y muchos cohetes, cuidan de ello los comisarios. La noche Víspera de San Pedro ay los mismos fuegos, cuida de ellos el thesorero. La noche Víspera de señor Sanctiago el Zebedeo ay los mismo fuegos son a cargo de los comissarios de los soldados y suple cuando faltan el Sacro Monte y Thesorero. La noche víspera de la Asumpçión, los mismos fuegos a cargo de los comisarios prebendados =la noche Víspera de San Dionisio son a cargo del Colegio, la noche Víspera de la concepción de Nuestra Señora, las luminarias y cazuelas y cohetes son más en abundancia y todo más luzido, están a cargo de los comisarios prevendados.

-22.Los colegiales ponen y quitan siempre las luminarias de los valcones y ventanas de los aposentos con mucho cuidado no se

[fol. $\left.47^{\mathrm{r}}\right]$

manchen con sebo y en acavándose los fuegos los sacan donde el Caniculario las puso para que el las halze en su lugar y cuando es menester reparallas lo hazen dos o tres días antes.

23. Para los maitines de la resurección ponen en la Iglesia y choro, luminarias galanas y curiosas con velas de çera y acavada la procesión las alzan.

24. En fiestas públicas y Comunes, como entrada de Rey, canonización de Sancto, o naçimiento de Príncipe o Victoria Insigne o cosa semejante, cuando en la ciudad ay fuegos, es combeniente que los aya en el Sacro Monte y así el Abad con consulta de los asistentes o del uno lo determinará y el Thesorero cuidará de ellas.

[fol. $\left.47^{\mathrm{v}}\right]$

\section{Capítulo 14. De los Aniversarios que se çelebran en esta Sancta Iglesia.}

1. El día de la Combersión de San Pablo, ay aniversario dotado con solennidad por el Señor Doctor Don Paulo de Cordoua y Valencia, Prebendado de esta Iglesia en primeras y segundas vísperas y en missa de tercia, celébrase con la solennidad de primera clase.

2. La missa de tercia es según la erección de la Iglesia y así por el fundador del aniversario, en vez de ella se dizen dos missas rezadas que se ponen en la tabla aquella semana y se reparten entre los prebendados a quien le tocan por turno y la primera se dize en lugar y al tiempo de la missa penúltima y así sale el prebendado del Coro en Ceremonia al comenzar el ofertorio.

3. Todos los días de aniversario que ay semejantes missas, la una se dize por

[fol. $48^{\mathrm{r}}$ ] 
penúltima y no ai otra penúltima, el día de la Anunçiación de Nuestra Señora ay aniversario solenne de primera clase en la misa de tercia y si fuere feria, en las segundas completas del día y si se celebrare después de pascua, en las sigundas vísperas por Doña Leonor de Guebara. Ay sermón por la fundación del aniversario.

4. El día de SanctIago Apóstol hazen un aniversario los soldados de la Alhambra en una missa que se les canta con toda solennidad a las cinco de la mañana, y así se entra en oración este día anticipando media hora el relox y se tendrá la oraçión antes o después conforme vinieren. En la torre repican a esta missa cuando comienzan las esquadras a subir la cuesta. En la Iglesia se pone un escaño que no hagan testero ni Cabezera para el Capitan, Alferez y Cabos.

5. Acavada la missa se dizen las oras con mucha solennidad.

6. Si otros aniversarios se fundaren con la misma solennidad se an de zelebrar en la dicha forma y no se admitan de fundaçión menor

[fol. $48^{\mathrm{v}}$ ]

que a cuatro mill maravedís si no son de prebendados, mas otros aniversarios ordinarios se celebren como dobles mayores y puedense admitir de dos mill maravedís.

7. El día de Sant Andrés en sus segundas vísperas y el día siguiente en una missa Votiva del Sancto y el día de la octava de la Concepción de Nuestra Señora en las primeras vísperas y missa que se dize el día, son aniversarios por el lizenciado Pedro Gomez Canónigo de la Colegial de San Salvador.

8. Las vísperas son las mismas que se dizen el día y de fundaçión y la missa se dize inmediatamente después de nona.

9. Si el día octavo de la Concepción cayere en Domingo no se reza de la octava por ser Domingo de adviento. Y si este aniversario se celebra el 14 de diziembre y a treze, después de las vísperas de Santa Luçia se cantan las vísperas de la Concepción y al día siguiente la missa post nonam.

10. El día de San Hiaçinto a 16 de Agosto ay aniversario de requiem por el Doctor Don Bartolome olalla de Roxas chantre

[fol. $49^{\mathrm{r}}$ ]

y Canónigo de la Sancta Iglesia de Sevilla, fundador del Patronato para pobres que dejó en este Sacro Monte. Dízese la vigilia inmediate post nonam y consecutive la missa con solennidad del día doble mayor

11. Otros aniversarios que se fundaren ente todas cosas se guarden la voluntad del fundador como no sea contra la erección u constituciones de esta Sancta Iglesia o consueta reçibida, y la Vigilia se diga la tarde antes después de completas, si no fuere fiesta de primera o segunda clase que en tal caso se dirá Vigilia y misa del día siguiente 
post nonam, como se haze a 16 de Agosto y conforme fuere la dotaçión gruesa se deve añadir solennidad y ornato.

12. En los aniversarios prinzipales, que son los del Señor Christóval Vaca de Castro y de Nuestro Ilustrísimo Fundador, se guarda toda la solennidad de doble de primera clase: se dize libro 4 Capítulo 24.

13. A tres de Noviembre se çelebra el del señor Vaca de Castro, pónese túmulo en el cuerpo de la Iglesia cubierto de paños negros alto media vara, la tumba en medio con paño

[fol. $49^{\mathrm{v}}$ ]

de brocado, y en el túmulo alrededor de la tumba, los candeleros ricos con velas y doze baldones con hachas y la cruz grande a la cabezera.

14. A dos de Noviembre por la tarde se dize la Vigilia con mucha solennidad y el día siguiente, la missa a la hora de la missa de terçia. Y ésta se dirá inmediate post nonam, si la conmemoraçión de los difuntos se transfiere por ser el día ínmediato al de todos Sanctos, [si es] Domingo se transfiere también este aniversario al día siguiente.

15. A veinte de Diziembre día de la muerte de Nuestro Ilustrísimo Fundador se celebran sus honras, házese el túmulo más alto de un estrado y más ancho, cubierto de luto encima la tumba con paño de brocado y a la cabezera hazia el altar, dos almohadas de brocado con la mitra rica y casulla en el cuerpo de la tumba, por el túmulo los candaleros ricos y otras doze hachas y la cruz grande a la cabezera y la cruz Arzobispal a los pies del túmulo. Pónese junto a la Cruz grande el azetre de agua Vendita con hisopo y todos los Sacerdotes

[fol. $50^{\mathrm{r}}$ ]

que dizen missa rezada dizen responso rezado en el túmulo.

16. La Vigilia se dize la tarde antes con más solennidad, la missa a la hora de la de terçia y ésta, post nonam.

17. El modo de doblar en estos aniversarios y en los demás se dize libro 2 Capítulo 14 del campanero, y las ceremonias del oficio se dizen libro 4 Capítulo 24 de los oficios, en los días de estas honras.

18. El día después del aniversario del Señor Vaca de Casto se haze aniversario por los padres de los prebendados, la tarde antes se dize la Vigilia y el día siguiente la missa immediate post nonam.

19. El día siguiente se haze otro por los prebendados, Capellanes y colegiales de esta Iglesia y por los demás difuntos della en la misma forma. La tarde de antes la Vigilia $\mathrm{u}$ el día siguiente la missa post nonam, para ambos se pone en el cruzero una señal de 
túmulo, una alfombra grande tendida en el suelo y la tumba en ésta, y un paño de damasco negro encima, cuatro blandones con hachas a las esquinas.

[fol. $50^{\mathrm{v}}$ ]

20. Todas las vezes que ay esto después de la missa se haze la absolución en la forma que se dize en el libro3 Capítulo 14 de los ofiçios y aniversarios de difuntos, y cuando no ay túmulo ni señal del se acava la missa sin responso ni absolución.

21. Ay más en esta Iglesia tres aniversarios del Colegio que son: del Señor San Çeçilio, del Señor San Thesiphón y de San Philipe y Sanctlago. Son en una missa cantada que se dize de esta Sanctos post nonam, a de ser dentro de sus octavas en día no impedido, con fiesta doble o feria maior. Dizen la missa y visten dalmática los Prebendados; asisten en el Choro el Rector del Colegio Capellanes y colegiales, son por Gonzalo Ruiz de Aguado procurador que fue de la Chanzillería.

22. Todos los primeros lunes de mes que no sea fiesta de guardar dize el Colegio un responso por Ellizendo Luis de Vega capellán que fue de esta Iglesia.

23. Asisten los capellanes y colegiales y el Rector del Colegio dize la oración y en su ausencia el capellán más antiguo, no el sochantre.

[fol. 51 $\left.{ }^{\mathrm{r}}\right]$

24. Hazen los ortolanos un aniversario y fiesta de la exaltación de la cruz, no es perpetua. Ase conservado por gusto que tubo el Arzobispo Nuestro fundador por aver comenzado esta deboción aún antes de la erección de esta Iglesia, es en la missa sola, ay sermón. La missa de tercia se dize con la misma solennidad que pide el día y media hora antes de su ordinario y la missa de la fiesta se dize después con toda su solennidad =y cuando se admiten aniversarios solennes o Votivos que no sean en la Missa de terçia se guarde la misma hora que se ha dicho en el de la Cruz, cuando no fueren solennes se dirá la missa inmediate post nonam.

25. Solenne se llama cuando en el ornato, çera y celebridad imita las fiestas de primera o segunda clase.

26. Para cualquier aniversario o dotación que se aya de hazer después de nona o completas, al fin de sexta y de vísperas haze señal el portero del Coro con la campanilla para que vengan los que faltan y los ministros se prevengan.

[fol. $\left.51^{\mathrm{v}}\right]$

27. Al fin de sexta el capellán çerimoniario haze comedimiento al que ha de celebrar la missa, luego al diácono y al subdiácono, y si faltaren los que se siguen en turno. En este tiempo dos colegiales, de los que se siguen a los acólitos, y los Turibularios ponen las mangas en los brazos, baxan los prebendados y en el plano del coro todos con los ministros hazen venia y el Coro se levanta, salen y van por la Iglesia a la Sacristía y se 
visten para que inmediate post nonam salgan a la missa y se buelven al coro los dos colegiales.

28. Quién zelebra en estos aniversarios, quíen gana y a qué hora se pierde se dize en el libro 2, Capítulo 2. de apuntador.

[fol. $\left.52^{\mathrm{r}}\right]$

Capítulo 15. De los asientos de los Prelados Cabildos y señores en esta Iglesia y choro.

1. Cuando viene el Prelado a esta Sancta Iglesia se le pone sitial en medio del cruzero, alfombra grande, mesa cubierta con un dosel, dos almohadas enzima y otras dos abaxo, donde se hinca de rodillas, todo cubierto con cendal Carmesí o morado como fuere el tiempo, enciéndense seis velas en el altar.

2. Si a de asistir a vísperas en el choro se le pone dosel y almohadas de brocado, y en dexando el esquilón, baxa todo el Cabildo con el Pertiguero, Capellanes y colegiales a su aposento y aguarda que salga y lo acompaña hasta el coro y entre la Varandilla y facistol está otro tapete con almohada donde haze oración.

3. Sube a su silla y su camarero y maiordomo se quedan en las sillas de los capellanes,

[fol. $\left.52^{\mathrm{v}}\right]$

4. Si asiste en la missa se alarga en el pavimento alto al lado del evangelio con una peana y todo se cubre de alfombras, pónese la silla o Sitial rico con sus almohadas y enzima un missal registrada la missa, dos escabelos planos o taburete para los asistentes y este lugar tiene el Prelado y otro cualquiera Obispo que asistiere a la missa.

5. Cuando algún grande o señor de título quisiere asistir en el Choro en la última silla del derecho, se le adereza el asiento echando un paño sobre la varandilla en frente de la silla y enzima una almohada, y si está el Sanctíssimo Sacramento descubierto no se pone y si ay sitial o almohada cuando se descubre, se le quita.

6. Si ubiere se asistir en la Iglesia, debaxo del arco de la capilla del Rosario se le pondrá alfombra y silla, y si fuere grande, sitial y si no almohadas en el suelo y lo mismo al Pressidente de Granada.

7. Si algún tribunal como el de la chanzilleria o Inquissición viniere, se le haze teatro, a la Inquissición se pone en el arco

[fol. $53^{\mathrm{r}}$ ]

de la capilla del Rosario alfombras sillas y almohadas. 
8. A la chanzillería se haze Teatro desde la grada del pavimento baxo por el cruzero, escaños de un lado y otro y el testero viene en la línea derecha de la pila del agua vendita que está a la diestra de la puerta del Pórtico.

9. Los escaños de los lados se desbian de la grada poca más de bara para dar lugar a que pasen las missas a los altares colaterales.

10. Todo el suelo se cubre de alfombras y los escaños y en el medio del testero se pone silla y sitial para el Pressidente y a los lados de ella, los escaños y en medio se pongan los braseros con pomos.

11. Al Cabildo de la Ciudad se haze el Teatro de la misma manera más baxo hasta pasada la puerta del Pórtico, no se pone silla, ni sitial, ni almohadas y los escaños se cubren con alfombras.

12. El Cabildo de la Iglesia Catthedral, si viene a alguna fiesta, tiene su lugar en el Choro y altar, pero todo se les dexa y los prebendados de esta Iglesia están con sus sobrepellizes o capas conforme al tiempo, mas no entran

[fols. $53^{\mathrm{v}}$ ]: ILEGIBLE

[fol. $54^{\mathrm{r}}$ ]: En blanco.

\section{LIBRO $2^{\circ}$}

De los oficios de los Prebendados y ministros de esta Sancta Iglesia.

[fol. $\left.54^{\mathrm{v}}\right]$

En blanco.

[fol. $\left.55^{\mathrm{r}}\right]$

\section{Capítulo 1. Del Presidente del coro y licencias que a de dar.}

1. En el choro de esta Sancta Iglesia preside el Abad y en su ausençia, el Pressidente señalado por el Cabildo aquel año, cuya silla es la primera a la mano siniestra del Abad.

2. En ausencia de los dos, preside el Canobigo más antiguo y a falta de prebendado preside el huésped de aprovación y no aviéndole, el capellán más antiguo, pero no le pide liçençia el último que sale del coro alto, el Sochantre nunca preside.

3. No preside Canónigo fuera de su silla, sino estando con pluvial, o no aviendo otro prebendado de colaçión en el Coro.

4. El Abad preside siempre aunque esté fuera de su silla. 
5. El Pressidente tiene obligación de ser el primero al ofiçio divino, así para dar exemplo como para ver que esté todo prevenido de los Versicularios, limpias las

[fol. $\left.55^{\vee}\right]$

sillas y los libros registrados y generalmente cuiden que todos hagan sus oficios de Iglesia y coro con puntualidad.

6. Es a su cargo el hazer observar en el coro todas las çeremonias de polizía y comedimientos que se dixeron en el libro primero, Capítulo 1 y todo lo en él contenido. A de tener muy ínpromptu para que se pueda observar sin relaxaçión y sobre todo silençio.

7. A de avisar a cualquiera que faltare en algo y a de ser ovedezido en mucha benignidad y sumisión que es la que no estorva los avisos del remedio, entendiendo todos que ovedezen a Dios y en cosas de su casa y servicio.

8. Y para que todo lo dispuesto en el capítulo del Choro se guarde irremissiblemente, pueda multar conforme a los constitución al que siendo avisado no obedeçiere.

9. Tenga mucho cuidado en que se lleve el compás y pausa en el ofiçio divino que pidiere la festividad y sea ante todo inclinado al compás moroso, como combiene a coro de Prebendados exemplares que tratan de oraçión

[fol. $56^{\mathrm{r}}$ ]

y ninguno se entrometa en ésto por su authoridad. El maestro de çeremonias cuide de lo mismo y cuando advirtiere que en ésto ay falta, avise al que preside para que lo remedie.

10. Esté el Pressidente muy advertido en que se pronuncia vien y con distinçión lo que se rezare y leiere y que se huellen los finales de los versos el un Coro al otro sino que se aguarden todos con gran uniformidad y sobre todo que la demediación se haga con alguna pausa y maior en las fiestas grandes.

11. El Pressidente a de velar mucho sobre las salidas y entradas en el Choro mientras el ofiçio divino y especialmente repreender cuando entran muchos juntos al comenzar la hora, por la disonancia que haze verlos allí parados antes del façistol.

12. Sea mui exacto en dar licencias para salir del Coro, guarde una prudente observancia, no se den con façilidad y la causa sea justificada. No se dé a muchos juntos porque no hagan falta al Coro, excepto los días de Concurso para ir a confesar, y por esta razon cuide que los que toman Recle no sea en tiempo que muchos estén ocupados o enfermos, y el Abad o Pressidente de

[fol. $56^{\mathrm{v}}$ ]

casa, aunque no este en el choro, ordenen que si hazen falta los que toman Recle no lo tomen aquel día que así lo ordena la constitución. 
13. Las licencias para salir del Coro o actos de comunidad donde ay distribución son en cinco maneras: o tomando Recle, ésta a ninguno la deve negar si no es por falta que hará; o tomando Patitur, y ésta no se puede negar, o pudiendo y ésta se dé sino hiziere falta o haziendo presente para negoçio propio, y ésta solo puede ser por tiempo que al prinçipio de la hora puede entrar sin perder en aquella ora, y si pasado este tiempo no buelve, tiene obligación el Pressidente de hazer que el apuntador lo apunte en Recle o falta como fuere el día y en ésto a de ser muy exacto, porque estas lizenzias son principios de la anchura y relaxaçión en la ressidençia, o le haziendo presente para negocio de la comunidad y éste da el Abad y en su ausencia el Pressidente por quienes corre conozer la causa y necesidad y no por otro.

14. Para negoçio de la comunidad en que se haze presente, no puede el que preside

[fol. $57^{\mathrm{r}}$ ]

en el Coro dar licencia al Prebendado sin que la tenga primero del Abad y en su ausencia del Pressidente de la Casa según esta mandado en la Visita del Señor Cardenal Spinola num ${ }^{\circ} 27$ en que encarga estrechamente la conzienzia.

15. Para las neçessidades corporales el tiempo que ubiere menester en conçiençia.

16. El Abad y Pressidente an de velar en que los negocios y ocupaçiones de la casa y del confesonario no los guarden para el tiempo de horas los que los tienen a su cargo si en otras los pudieren acomodar.

17. El Prebendado puede embiar por ella al Pressidente con un colegial mas los capellanes y colegiales an de ir a ellos a pedirla.

18. Tenga cuidado el Pressidente, en entrando en el choro por la mañana, embiar los comfesores a dezir missa si pidieren confesiones, primero los dos semaneros y luego los otros conforme al concurso y a los Diáconos a fin de nona.

19. Si ambos puntadores faltan del Coro señalará a un prebendado que apunte en aquella hora.

20. Tiene obligación de avisar al Puntador

[fol. $\left.57^{\mathrm{v}}\right]$

apunte una falta al que leíendo o cantando, en el altar o choro, missa o oficio divino errare alguna cosa, o dixere algún mal acento notable, estando en esto el juicio del Corrector, mas si el que herrare se enmienda luego antes de dezir otra dicción no se repunta falta.

21. Si la falta y yerro es conoçido se le apunte luego. 
22. Si fuere dudoso tiene obligación de mirar el missal o breviario en que se hizo la falta para ver si fue por yerro de imprenta, y si es, tenga cuidado de ordenar al Corrector la enmiende luego en el libro y avisar al que la dixo para que se enmiende.

23. El Pressidente tiene cuidado en el choro si faltan ambos Correctores señalar un prebendado que pase Evangelio, Epístola, Calenda y lo demás y prohiva que ninguno enmiende su authoridad y corrija así en el choro como en la missa estando ausentes los otros correctores.

[fol. $\left.58^{\mathrm{r}}\right]$

\section{Capítulo 2. Del apuntador y Collector de las Missas.}

1. El Cabildo elige cada un año un prebendado que hace oficio de Collector y apuntar, el cual tiene cuidado del libro de la Colecturía de las missas que se mandan dezir en esta Sancta Iglesia, otro libro donde apunta las missas de tercia y de prima, vestuarios y capas; otro donde apunta las missas rezadas de memorias perpetuas; otro donde se apuntan las horas y missa, manual de oración proçesiónes y maitines donde en los cuadrantes de los días apunta los Recles y patitur y faltas del Abad, canónigos, Capellanes y colegiales en todas las horas y exercicios que ubiere distribuçión. Y con claridad y distinción apunte cada cosa en su libro y sea uniforme al modo que los otros apuntadores ubieren guardado. Otro donde apunta las conferencia y Salves, otro de aniversarios; otro de las missas de Villalobos.

[fol. $58^{\mathrm{V}}$ ]

2. En el libro del punto están los cuadrantes vien reglados uniformes con distinción; al margen el año y los nombres del Abad y Prebendados, cada uno correspondiente a su casa, en la cabezera el mes y los números de los días correspondiente cada uno a su casa, todo vien escrito y limpio, para lo cual al prinçipio del año pedirá al Abad mande al oficial de la contaduria lo regle y escriva con curiosidad.

3. Al prinçipio del cuadrante de los capellanes se ponga este título = Capellanes; y no se repita más en aquel cuadrante.

4. Guarde uniformidad en el apuntar que será con las letras y forma que se sigue:

-Los cuatro puntos de cada día que son Oración mental, horas menores, missa de tercia, vísperas y Completas, los señale con los cuatro angulos de cada Casilla en esta forma

\begin{tabular}{|lll|}
\hline ora & & hor \\
& & \\
& s s S & \\
& & \\
& & \\
Miss & & vis \\
\hline
\end{tabular}


5. Las letras son F, para la falta, $\mathrm{P}$ para patitur, $\mathrm{R}$ para recle, $\mathrm{S}$ para sermón, $\mathrm{H}$ para recreazión, en que se le

[fol. $\left.59^{\mathrm{r}}\right]$

añaden a cada uno quinze días de recle $=$ si el

6. Cabildo determina las recreaciones/s 6/:con esta advertencia: que si es de todo el día se pone letra grande Gótica que llena la Casilla y pequeña para puntar cada punto.

7. La falta que se apunta al que erró cantando o leyendo se pone con una, f, con un punto encima para que se conozzca de qué es y si fueren muchas aquel día se vaian poniendo en la mesma casilla y forma, falta de asistencia se pone en el angulo que le toca.

8. A los capellanes que faltan con liçençia se apunta con A grande para todo el día, pequeña para cada punto.

9. En el libro de manuales solo se apunta el que falta por que no se goza en ellos de Recle ni Patitur y la letra es $\mathrm{O}$ y ningún otro apuntador use de otras letras porque no cause confusión.

10. Cuando se da liçençia para fuera de Granada al Abad, Canónigo o otro cualquiera ministro de la Iglesia se entrega la lizenzia al apuntador y él toma razón con día y mes en el libro del punto en la cassilla que corresponda

[fol. $\left.59^{\mathrm{v}}\right]$

al día en que comienza a cesar de la dicha liçençia y en la razón dize por qué días lleva la liçençia y si se le haze presente o toma recle y en la licencia pone como a tomado la razon y cuando buelve a ressidir pone el día en la Cassilla que corresponde de al que se presenta en el Coro.

11. Tiene obligación el apuntador de comunicar las dudas que se le ofreçieren acerca del apuntar con el Abad y en su ausencia con el Pressidente de la casa.

12. Ninguno puede salir del Choro ni acto donde se gana distribución sin licencia y si saliere le apunte en falta aquella hora y más si pareciere consultando con el Abad o presidente.

13. El apuntador cuide mucho de ir al coro antes que dexe el esquilón que su ofiçio le obliga a ser de los primeros el que ha de apuntar las faltas de otros y ansimismo en todos los ejerçiçios donde ay distribución. 
14. El tiempo que se apunta, es en la oración mental y conferençias no aviendo entrado antes de dar el primer cuarto $=$ en las horas

[fol. $60^{\mathrm{r}}$ ]

menores no aviendo entrado antes del Gloria Patri del sigundo psalmo de prima; en la missa de terçia o de aniversarios no aviendo entrado antes de acavar La Epístola o primera prophecía /3/ = En las vísperas no aviendo entrado antes del Gloria Patri del primer psalmo y lo mismo en las Completas de cuaresma = en la Salve de los sábados no aviendo entrado antes de $A d$ te clamamus $=$ En las proçesiónes no aviendo venido antes de salir el presidente de el pavimento enlosado $/ \mathrm{x} /=$ En los maitines de la Epiphanía y en los de jueves Viernes y Sábado Sancto no aviendo entrado antes del último verso del segundo psalmo $=$ en el nocturno de difuntos no aviendo entrado al requiem aeternam del primer psalmo.

15. Vea el apuntador los que faltan en oración y oras y embie a saver si a estado en patitur; y en horas y missa de tercia embie a saver si están confesando; o si falta el Abad a saver de él si está ocupado para que pueda apuntar la hora antes de salir del Coro y si alguno avisare que esta ocupado con liçencia ${ }^{16}$

[fol. $\left.60^{\mathrm{v}}\right]$

embiara a saver si la tiene y el que está ocupado con liçençia avisará en el punto para que se le haga presente.

16. Los que estubieren ocupados en sus ofiçios y ministerios de la comunidad con licençia del Abad o Presidente tienen obligación de avisar al apuntador con tiempo y si no avisa se le pone Recle o falta conforme el día, y el apuntador cuide de saver si an tenido liçençia.

17. A los demás que faltan apunte con Recle o falta como fuere el día.

18. Cuando se dividen las horas menores como el día de la Ascensión y Pentecostés y en cuaresma las vísperas y completas, el que no ubiere entrado al Gloria Patri del primer psalmo de completas pierde las vísperas, y asimismo al Gloria Patri del primer psalmo de nona el día de la Ascensión y al de terçia y sexta el día de Pentecostés pierde las horas.

19. A los que dizen missa de prima o tercia o aniversario solenne, o toman Dalmática o capas se les apunta para que gane las

\footnotetext{
${ }^{16}$ =va sacado en dos partes al margen desde $=$ en la Vigilia hasta lo rubricado $=\mathrm{y}$ la otra, desde en los maitines Salta las rubricas. Lo que
}

Nota. En el margen derecho: 3 en la vigilia de Pentecostés no aviendo entrado antes que se acave la primera profecia. + En los maitines al fin del invitatorio antes de comenzar el Sermón o antíphona. 
[fol. $61^{\mathrm{r}}$ ]

distribuçiones de ellas, por que en ésto no pueden suplir unos por otros.

20. El que dize la missa de prima gana las horas como aya salido antes del Gloria Patri del segundo psalmo y como esté dando gracias mientras durante las horas, y el apuntador tiene obligación de saver si está dando gracias.

21. En los aniversarios se gana distribuiçión conforme y a los tiempos que se a dicho de las horas y missas de fundación si otra cosa no dispusiere el que dota el aniversario.

22. Las memorias y aniversarios ganan los interesentes y los que están en missiones y en casa confesando como aya sido con especial liçençia del Abad o Pressidente de casa y el que saliere a dezir missa de tabla $=$ y el que predicare en la missa o si esta del anibersario y el que saliere a zelar, embiado del Abad o Pressidente $=$ y otro cualquiera que estubiere ocupado en algún ministerio y servicio de la casa o Iglesia aunque fuera de Granada como tenga la dicha special liçençia para ocuparse en tiempo del aniversario

[fol. $\left.61^{\mathrm{v}}\right]$

mas si el que está fuera de Granada en semejantes negocios lleva salario, no gana ni manuales ni aniversarios: ésto se entiende si la dotación del aniversario no dispone otra cosa que la voluntad del que la dota i se admite se deve guardar.

23. Los manuales de Oración, conferençias, maitines y processiones ganan los interesentes y ocupados y en missiones conforme se dixo en el número precedente y no otros.

24. Las distribuciones que no son manuales se ganan en patitur y recle, y missiones y ocupaciones del Sacro Monte.

25. En las memorias y aniversarios los seis capellanes ganan la parte que un Canónigo interesente, y el Colegio Eclesiástico gana otra parte si no dispusiere otra cosa la dotación.

26. Los canónigos de aprovaçión después de los dos primeros años y no antes ganan los manuales, memoria y aniversarios de la misma suerte que los canónigos de Colación.

- El sochantre y organista siendo Capellanes

[fol. $62^{\mathrm{r}}$ ]

ganan los manuales de oración y conferençias y los otros asistiendo a ellos personalmente.

-El apuntador a de estar muy vien en todo esto que toca a las interesençias, y a los tiempos en que se gana y en todo lo que se dixere en el capítulo siguiente para que pueda apuntar conforme su obligación. 
-El apuntador tiene a su cargo que cada uno aya firmado en los libros de las missas de fundación las que ubiere dicho y lo demás que ubiere de firmar al fin de cada terçio para que se pueda hazer la Nomina de él.

-Si al que tubiere missa prima o tercia le viniere otra de aniversario o fiesta por turno el apuntador le avise que escoja para que la que dexare pueda encomendar al que sigue en el turno y si no, le avisa con tiempo, corre por el apuntador en conçiençia satisfacerle el interés, mas si el que tiene missa de prima o terçia está puesta en la tabla otra, el tal avise al apuntador la que dexa para que la encomiende.

-Cuando se haze la tabla el Colegial monitor

[fol. $62^{\mathrm{v}}$ ]

si concurriere tocarle otra missa de turno al Hebdomadario, o de missa de prima o a uno dos missas de diferentes turnos, le avisará que escoja y le pondrá la que escogiere en la tabla y después el prebendado no podrá decir la otra.,---

-El apuntador cuida que en los días que ay aniversario y vestuarios con distribucion se vistan en ellos diáconos semaneros, y en la missa de terçia se vistan los que le siguen por turnos.

-El apuntador es colector para recivir y repartir las missas que se mandan dezir en este Sacromonte, y ay persona señalada que las reçiva y reçiva la limosna de ellas y cada noche le tome cuenta el colector y las que ubieren caído, las transcriba en su libro de Colecturía en que a de poner el día en que cayeron, el nombre de la persona que las manda deçir, de quién y por quién y reciva el dinero de ellas.

-Encargue mucho a la persona señalada para esto: que si traxeren alguna missa a

[fol. $\left.63^{\mathrm{r}}\right]$

dezir por algún instante [de] neçesidad, le avise luego para que dé orden que se diga aquel día y cumpla con lo que la Charidad dicta en estos casos.

-Reparte por turno las missas de colecturía entre los canónigos y capellanes de el Sacro Monte, igualmente y para ésto dará un papel a cada uno de las que manda dezir y no dexa ninguno sin ellas sino es al que aviendole señalado missas no las quisiere dezir. A ningún sacerdote que no fuere del Sacro Monte puede dar a dezir estas missas, ni a los de el Sacro Monte para que se digan fuera de él.

-Aviendo dicho las missas cuidará que las firme cada uno y le dará de limosna sesenta y seis maravedíes y se quedará el Colector con los dos y ninguno las firme antes de dezirlas.

-Cuando se diere de limosna por cada missa más de dos Reales, se hará cargo della en el libro de la colecturía, porque la

[fol. $63^{\mathrm{v}}$ ] 
demasía perteneze a la fábrica menor (y se entriegue al Tessorero y al fin del año) si no es otra la voluntad expresa del que las manda dezir.

-Al fin de cada año tenga firmadas las missas que se ubieren dicho y entregue el libro a los contadores para que ajusten la cuenta de lo que perteneze a la fábrica, y se entregue al Tesorero, y en fin del año el alcanze de missas y de dineros de ella al Colector para que las mande dezir, al cual pertenezen los dos maravedíes de cada una y en ningún caso queden las missas que no se ubieren dicho aquel año en poder del colector que sale. Juntamente con el Colector y apuntador se nombra otro Prebendado por segundo apuntador, para que en ausencia del primero apunte en el choro y entre los dos se acomode de manera que uno de ellos siempre asista en el Choro y exercicios de distribución.

-No fíen la llave del punto sino es con orden

0 entre los dos sea como de manera que uno de ellos siempre asista en el Choro

[fol. $64^{\mathrm{r}}$ ]

del Abad o Pressidente, ni consientan que anden otros con los libros del punto.

-Siendo elegido el Colector y apuntador hagan juramento de fidelidad y hazer bien su oficio y de guardar con todos una ley especialmente en las faltas que apuntan por aver errado algo.

-Las faltas del yerro, aunque las oiga en el Choro no las apunte sin orden del Corrector o Pressidente del coro y cuando no ubiere estado en el Coro se ynforma de los dichos si las ha avido y si las apuntará

[fol. $64^{\mathrm{v}}$ ]

\section{Capítulo 3. Del Recle y Patitur.}

1. El Abad y canónigos y los de aprobación tienen cada año Cincuenta días de Recle para sus negocios y ocupaciones particulares, los cuales pueden tomar en junto o por días o por puntos, mas de tal suerte que no lo tomen muchos juntos por que no se haga falta al choro y administración de Sacramentos que se hiziera si muchos juntos lo tomasen, lo cual ha de prevenir al Abad o Pressidente.

A cada capellán puede dar el Abad treinta días de liçencia para sus negocios, en los cuales también gana las distribuciones, y pueden ser por junto o por puntos con que no sea el punto de oración sino es dándola para todo el día.

Tienen más el Abad, canónigos y los de aprobacion y capellanes otros quinze días cada año, los cuales pueden gozar de recle o lizençia cuando el Cabildo determinare las recreaçiones allándose ${ }^{17}$

\footnotetext{
${ }^{17}$ En margen izquierdo: Recles 1 Cavildo 3 de mayo de 1782.6 días á cada Canónigo, o Capp”.pr. un Panegirico en nxa.Iglsia. $=$ Apr.cada sermón en el Sepulcro $=2$ pr.cada conferencia spiritual $=$
} 
[fol. $65^{\mathrm{r}}$ ]

en ellas por comunidad y no de otra suerte.

-No se puede tomar Recle estando en el Sacromonte los días que en él se çelebran con solennidad, que son los siguientes: miércoles Sancto a la missa y vísperas; jueves, Viernes y Sábado Sancto a ningún punto; Vigilia de Pentecostés a la missa; Vigilia de la Natividad a la prima, miércoles de ceniza a la çeremonia de tomarla; día de los difuntos a la missa proçesión y responsos, día octavo del Sanctíssimo Sacramento en ningún punto; días de la presentación, Visitaçión, Expectación y Nieves de Nuestra Señora a ningún punto; la Dedicación de esta Iglesia a ningún punto, San Dionisio Areopagita en ningún punto; día del Ángel custodio en missa ni vísperas; día de San Gabriel en missa ni vísperas ni completas; los días en que se rezaren transferidos; San Hisçio, San Messitón, San Thesiphón en ningún punto. En las vísperas cantadas que son de Constitución

[fol. $\left.65^{\mathrm{v}}\right]$

y en las cantadas que el Cabildo expresare que no se entone Recle. En las vísperas cantadas del tiempo de passión que se haze la será si asisten a ella se puede tomar recle en las vísperas, si no asisten no se pueden tomar y lo mismo se ha de entender en la missa del miércoles de çeniza que la pueden tomar en Recle el que asiste en la çeremonia de la ceniza y si no asiste no.

-El punto de oración no se puede tomar de recle ni de licencia los capellanes sino es tomando todo el día y si a queste día que se toma de Recle por aver tomado el punto de oración ay punto de los señalados en el número preçedente que no se puede tomar de Recle, deve asistir a él el que tomó la oraçión de Recle o ponelle falta en ella ó en el punto la que el quisiere.

-No se puede tomar de recle el día de la toma de Granada que es octava de San Estevan por la mañana

[fol. $\left.66^{\mathrm{r}}\right]$

-No se puede tomar en Recle Domingo ni fiesta alguna, así de la Iglesia, como de las que el Sacro Monte çelebra con solennidad que son las dichas, ni las que en el Cabildo ordenare que no se tome Recle, ésto se entiende estando dentro del Sacro Monte yendo a Granada si: con que aya salido de casa al tiempo que pierde no aviendo entrado en el Choro, lo cual se dexa a su conciençia para que avise al apuntador si perdió.

-El tiempo que se gasta en la rasura ordinaria de la Comunidad se haze presente

2 pr.cada sermón a Misión en Granada, cuando se haga pro-..., y 4 á cada uno de las Misioneros que la hagan pr.nombramiento, y por 5 días $=8$ a cada Misionero de la Misión de afuera. 
-El que estubiere ausente en negoçio suyo más tiempo que el que tubiere de Recle no gana las distribuçiones cotidianas de los cuatro puntos hasta que se presente en el Choro, y así aunque el apuntador le aya puesto recle los contadores se los baxan y pongan por faltas, como se ha de hazer en los que ubiere tomado más dentro del Sacro Monte, y si estubiere sin licençia por avérsele acavado o aver ido sin ella,

[fol. $\left.66^{\mathrm{v}}\right]$

pierde la gruesa y distribuciones que coresponden aquellos días aunque tenga recle.

-Cuando se haze presente por estar en confesonario o en otra ocupación de Comunidad, en acavando, ay obligacion de ir al choro si aún no se ha acavado el oficio divino y no se puede ocupar en otra cosa fuera de aquello para que se le dió liçencia expresa.

-El apuntador cuida que los Capellanes estén en el Coro al prinçipio de la missa de tercia, mas no pierden si entran antes que se acave la Epístola o primera propheçía.

-Al legitimamente enfermo se le pone patitur todos los días y puntos que lo estubiere y cuando sale de Patitur se a de presentar en el choro al tiempo que estén en oraçión, horas, missa maior, vísperas o completas, y sino se a presentado en el coro no puede baxar del Sacro Monte ni gozar de preferencia por ocupación ni de recle ni sermón, y si saliere del Sacro Monte sin averse presentado en

[fol. $67^{\mathrm{r}}$ ]

el coro, todos los puntos que tenia de Patitur se los ponen en recle o perdido según los días.

-Si se ofrece negocio grave y de priesa que combiene haga el que está en patitur, sea suyo o del Sacro Monte y no puede aguardar a alguna de las horas dichas pueda el Abad o Pressidente darle liçençia que se presente en el Coro a hacer oración u avise al apuntador como sale de Patitur para que apunte conforme al negocio a que fuere.

-Si estando el Abad, prebendado o ministro ausente de Granada con licencia en negocio propio, cayere en emfermedad que le impida bolver a su ressidençia, todo el tiempo que le durare, aunque se le aia acavado la liçençia no incurre en las penas impuestas a los que están sin licençia, mas no goza de patitur si no de su recle y si no lo tiene, falta.

-Si está en negocio del Cabildo y cae enfermo yendo o viniendo via recta o estando en él, se le haze presente y gana las distribuciones, mas no si lleva salario, y si no, gana distribuciones manuales y aniversarios.

-Patitur no se deve tomar con liviana causa

[fol. $\left.67^{\vee}\right]$

y cuando justamente lo tomaren ganan las distribuciones como interesentes, mas no los manuales aniversarios y particulares dotaciones. 
-El Prebendado que tiene sermón encomendado para esta Iglesia goza de seis días de presencia para que estudie, los cuales puede tomar por junto o puntos como no sea el de oración si no es tomando todo el día, ni los puede tomar en día de fiesta si no es con especial licencia del Abad y no aviéndole encargado el sermón más que ocho días antes.

-El Semanero puede tomar recle en su semana sino es con muy urgente causa y special liçencia del Abad o Pressidente.

-Los maestros de Artes y Theología que hace la constitución, presentes al tiempo que leen cuando son semaneros, no gozan de la presencia y así deven acudir al Coro su semana y no faltar sino con urgente causa y licencia excepto si la lección es al tiempo de prima o vísperas.

-Ninguno puede salir de Patitur para ganar aniversario ni manual alguno [fol. $\left.68^{\mathrm{r}}\right]$

ni

ni Vestuario o Capa ni dezir missa de prima o tercia si no es aviendo estado fuera de patitur dos puntos antes, mas para el manual de la oración basta aver asistido en la hora de oración desde el tiempo que se gana.

-El Abad no puede hazer ausencia de Granada sin licençia in scriptis del Cabildo conforme a quien perteneze el darla en la forma que disponen las constituciones y el que estubiere ausente sin la tal licencia no gana cosa alguna.

La misma licençia in sciptos a menester el Abad y los prebendados y capellanes para quedarse a dormir en Granada, la cual no se dará sin urgente causa y necesidad y en ninguna manera sea causa recreación fiesta o recoçijo, excepto la recreación que haze la comunidad.

-Para los negocios de la administracion o otras perteneçientes al sacro monte que se ofrezen siete o ocho leguas alrededor de Granada, da el Abad la liçençia con tal que la causa sea aprobada por la Junta de administración o asistentes conforme fuere el negoçio, y para que el Abad salga a semejantes negocios, no es menester más licencia que la Aprobaçión de la Junta. ${ }^{18}$

[fol. $\left.68^{\mathrm{v}}\right]$

respective al negocio avisando al Pressidente y para estas cossas no es necesaria licencia in scriptis.

-A los puntos de los aniversarios de los padres no se puede faltar sino es con lizenzia y el que sin ella faltare es penado en dos reales por cada punto, los cuales manda el Colector dezir de missas por los dichos difuntos.

\footnotetext{
18 "Va al margen/ni el Canónigo prioste o ministro sin licencia del Abad, o del Cabildo"=entrerremglones: Liçençiado.: Aproba= testado del Abad="
} 
-En todo lo que acerca del hazer presente recle y Patitur se ofreçiere el Abad o Pressidente guarden puntualmente en primer lugar lo que está determinado en las constituciones o visitas y si en eso ubiere duda, declare el Abad en lo que tocare lo que se a de hacer.

-Los maestros que leen a los Colegiales puedan tomar de puntos de sermón en los días de fiesta fuera del punto de la Oración y que ésto sea hasta seis puntos en los días de fiesta que anteçedieren el sermón.

[fol. $\left.69^{\mathrm{r}}\right]$

\section{Capítulo 4. Del Corrector del Coro.}

1. El día de las elecciónes nombra el Cabildo un prebendado que haga aquel año oficio de Corrector.

-Es a su cargo prevenir no se digan yerros o malos acentos en el coro y altar en los divinos ofiçios y para ésto tiene obligacion de mirar y corregir los missales breviarios y Calendarios y cualquier libro por el cual se aya de cantar o leer en tono cualquier cosa del ofiçio.

-En acavando Completas baxa de su silla y en el façistol pequeño en que a puesto el Colegial Calendario el missal, pasa en medio del coro para el día siguiente la Epístola y Evangelio a los diáconos semaneros y a los que se siguen, si ubiere de aver otra missa y tiene mucho cuidado que no se salgan del Coro los diáconos sin pasar el diácono primero, luego el subdiácono.

-Si ha de aver maitines haze que los señalados pasen las lecciones que les tocan y últimamente pasa al Calendario la lección del

[fol. $69^{\mathrm{v}}$ ]

Martirologio, y le haze repetir y pronunciar los nombres para que los digan con distinçión y claridad y espeçialmente cuida de avisarle si ay Calenda particular de alguna fiesta movible y si se le olvidare al Colegial de dezir aviéndosela pasado, avisará para que le den una penitencia por que es falta notable.

-Assimismo cuando en la missa del día siguiente ubiere prophecías, la tarde antes tiene obligación de pasarlas a los que las ubieren de dezir y generalmente todo lo que se ubiere de leer y cantar en el ofiçio divino, cuida de pasarlo para que se diga y pronunçie vien.

-Es oficio de mucha importançia, porque en el leer bien no solo está la decencia que se deve guardar hablando con Nuestro Señor, sino también interviene la authoridad y reputación del Cabildo de hombres doctos, y así deve cuidar mucho de ello.

-Cuando alguno yerra en cualquiera cosa que cante, diga en tono o lea en el oficio divino y missa el Corrector y no otro lo enmienda y corrige de modo que no se dé 
[fol. $70^{\mathrm{r}}$ ]

nota, que menos incombeniente es dexar lo de enmendar que hazerlo con estrepito y nota.

-El Pressidente cuida que ninguno otro enmiende cosa alguna por su authoridad.

-En el Refectorio Corrige al lector, cuando yerra da un golpe pequeño en la messa con el cuchillo y si haciendo la señal no se enmienda a la sigunda vez le dirá la palabra que le enmienda al que sirve para que se lo diga al lector.

-Señala el Cabildo en sus elecciones otro prebendado que haga ofiçio de Corrector en ausencia del primero y es a su cargo hazer todo lo dicho y ha de aver especial cuidado que por lo menos uno no falte del coro y refectorio.

-El coRector cuide y ordene que el semanero y otro cualquiera diga todo lo que perteneze al ofiçio divino por el breviario y missal y los otros libros; porque no se exponga a errar diciendo de memoria: y que para las preçes que se dizen flexis genibus tenga un diurno.

-Es a cargo del Corrector del Coro los libros del Canto y todos los que sirven en él

[fol. $\left.70^{\mathrm{v}}\right]$

y assí visita la libreria para que estén vien tratados y puestos y que en el coro los suban y baxen en el facistol sin maltratarlos, y es superintendente de los Versicularios en ésto y les advertirá como lo an de hazer y avisar al Rector los descuidos para que les de penitençias.

-No estando el Corrector en el refectorio corrige al que preside y no otro aunque él se descuide o el que señalare y lo mismo en el Choro y señala quien pase lo que se a de dezir en el ofiçio siguiente.

[fol. $71^{\mathrm{r}}$ ]

\section{Capítulo 5. Del Maestro de çeremonias.}

1. El día de las Elecciónes elige el Cabildo un Prebendado para maestro de ceremonias que sea advertido en todo lo que toca al coro y altar y oficios divinos, puntual y asistente en ellos. Su obligación prinçipal es la observancia de todo lo que en esta consueta se contiene, cuida que todos los prebendados cumplan con las ceremonias establecidas, y que los ministros de la Iglesia y choro hagan con gran perfección todo lo que perteneçe a sus oficios.

2. En los oficios de Pressidente de choro apuntador y Corrector Tesorero y Rector del Colegio le toca avisarlos de lo que en ellos deven hacer los prebendados perteneciente a çeremonias. 
3. En esta consueta se guardan las del ceremonial y missal Romano y algunas de las que por loable costumbre observa la Iglesia Cathedral

[fol. $\left.71^{\mathrm{v}}\right]$

modificadas conforme al sitio y disposición de la Iglesia y coro de este Sacro Monte para que con mejor estilo y modo se puedan observar sin interrupçión.

4. En el primer Cabildo de cada mes en primer lugar se trata de çeremonias como se guardan las de la consueta, a de tener las que ay en ella muy inpromptu para que por olvido o inadvertencia no se decrete alguna contraria.

5. Y cuando según el caso o circunstancia ocurre alguna que no esté expresa en la consueta y el Cabildo la determina, la ha de poner en un cuaderno y executarla algún tiempo. Y conforme sale a la execución que no tenga incombinientes, antes tenga decencia y hermosura, lo referirá al Cabildo para que decrete se ponga en la consueta.

Mas si el maestro de çeremonias se le ofreze alguna necesaria que no esté en la consueta porque ésta no puede prevenir todas las concurrençias y casos particulares la propondrá al Abad para que lo determine en la junta de asistentes, y lo que

[fol. $\left.72^{\mathrm{r}}\right]$

la junta decretare pondrá en la consueta en un appendix, después de averla executado algún tiempo la propondrá el Abad al Cabildo para que vea si se pondra en la consueta en el Capítulo que combenga.

-En las dudas que se le ofrecieren en la observançia de las çeremonias que están en la consueta asimismo a de acudir al Abad y junta de asistentes y guardar a lo que la junta declarare y lo pondrá en otro apendiçe de declaraciones y el día en que se decrete.

-La consueta acetada por el Cabildo no se puede mudar ni alterar y cuando fuera muy urgente la causa para mudarla o alterarla en algo se llamará Cabildo ante Diem. Y comferido se guardará lo que determinare por la maior parte, lo cual se a deboluer a comferir y determinar en otro Cabildo de suerte que para que tenga fuerza la mudanza o alteraçión en cualquiera de las ceremonias de esta consueta, a de ser por dos Cabildos

[fol. $72^{\mathrm{v}}$ ]

en que concurra la mayor parte.

- Tenga mucho cuidado de prebenir todo lo que se ha de observar en todos los casos que ocurrieren para que esté vien instruido y mande lo que combiene y se deve hazer por que todos le an de obedezer sin réplica aunque parezca que yerra poque se estorbe turbacion en los oficios que causará la contradición.

-Mas si en algo herrare se tratará depués en la Junta de asistentes y se le advertirá y corregirá. 
-En los casos que de improviso suceden y que no están en la consueta ni puede aver tiempo para tratarse en la junta de asistentes avisará al Abad lo que determina hazer y que por falta de tiempo no se trata en junta y ansi lo mandará con que después la Junta o Cabildo aprueve aquello o otra cosa para tal caso si mejor le pareçiere.

-Cuando comienza el esquilón va a Sacristía y asiste para que todo se prevenga

[fol. $73^{\mathrm{r}}$ ]

a tiempo para que los ministros vistan vien las alvas parexas y iguales que no descubran nada de los mantos y esto mismo mandará hagan con cuidado todos los que visten a los que çelebran.

-Haze observar el silençio en la Sacristía en todo tiempo, especialmente cuando concurren a las procesiones missas y vísperas y que en la Iglesia no aya ruido de conbersaciones ni niños: mandará a un Colegial que salga a remediallo.

-No permite que en la Sacristía se traten negoçios ni se confieran çeremonias, ni otras cosas, que no aya seglares espeçialmente por las mañanas y siempre que se ayan de vestir prebendados y prevenir para oficios divinos.

-Que en el pavimento enlosado no aya mugeres sentadas ni entren a oir missa y encargará al capellán que reçive las missas que cuando pasare eche toda la gente fuera del y lo mismo mandará al sacristán que salga

$\left[\right.$ fol. $\left.73^{\mathrm{v}}\right]$

a despejarle siempre que ubiere gente.

-Para que ésto se guarde, pues lo pide la decencia y authoridad de la Iglesia, encargará mucho a los prebendados que los días de concurso salgan a dezir missa a los altares del Cruzero y mientras ubiere alguno desocupado no salgan a los otros.

Los prebendados cuidarán de observar esto por que deven ayudar a que se guarde toda deçençia.

-A los colegiales que ayudan las missas rezadas mandará que las saquen, y cuando no los dexaren salir avisen quien an sido para que ello pueda advertir y bolver a encargar.

-Mientras se dize el ofiçio divino especialmente se a de despejar el pavimento y así desde el coro deve embiar a ello y avisar a los coadjutores de missas rezadas que tengan mucho cuidado que cuando dizen la missa no se llegue la gente demasiadamente a la grada ni a el sacerdote

[fol. $74^{\mathrm{r}}$ ]

y asimismo los instruye en lo que deven hazer cuando el sacerdote da la sagrada comunión. 
-Advierta los ornamientos o ropa blanca que no estubieren para servir para que se laue y los que ubieren necesidad de aderezo no siruan hasta que el Thesorero los ubiere aderezado.

-Cuando entra a tiempo o día de ceremonias particulares, como tiempo de adviento, de cuaresma, de passión, de semana sancta, día de Navidad, San Cecilio, Resurección, Ascensión, Pentecostés, Corpus Christi, día de los difuntos, de proçesiónes, de entierros, o onras; tiempo antes prevee lo que la consueta dispone, y con el Colegial admonitor y capellán cerimoniario lo trata y instruye al Hebdomadario y Diáconos y previene y ordena a los demás ministros lo que deven hazer y prevenir, todo lo visita por que este como deve y cuando llegue el día y el tiempo esté muy en todo.

[fol. $74^{\mathrm{v}}$ ]

-A los Prebendados avisará de todo lo que ubieren de hazer para que no aya falta en nada.

-Haze la tabla de los ofiçios del coro y Iglesia de Prebendados, Capellanes y colegiales cada semana y repártelos por su turno y en el de los prebendados lo guarda sin poder alterarlo y cuando se ofreciere causa urgente lo consulte con el Abad y el ora en que tienen los oficios es el siguiente.

-Habdomadarius, Díaconus, Subdíaconus: Missa $1^{\text {a }}$. Missa penúltima, Cantores primi, Cantores $2^{\circ}$, Paenitentiarius Virorum. Paenitentiarius mulierum, Vissitatores: Missa última.

-Debaxo de los escritos cada uno en su renglón pone una raya y de la misma manera escrívelos de los colegiales por este orden,

Versicularii; Çeroferarii; Thuriferarii; lucernarii; Comitantes; cetreri 1, cetreri 2. Cantores; Kandelarius;

[fol. $\left.75^{\mathrm{r}}\right]$

Fauilarius; Cruciferarius, ostiarius, Intonarius; Custos Sacristiae.

-Devajo pone una raya y luego si en aquella semana ay día o días en que çelebra el Abad lo expresa, en qué puntos y quién se visten con él.

-Luego pone si ay procesión; luego si ay otros aniversarios y quién çelebra en ellos guardando en todo el modo que se ha observado en ponerlos y el turno y por quien son y en qué puntos se ganan.

-Luego pone las missas rezadas las ferias en que se dizen, quién y por quién, y la missa de Santa Maria in Sabatho y si ay comida de probres y missa. 
-Luego los aniversarios pro defuntis: qué días, qué puntos, quién çelebra y por quién y para saver el turno si dudare algo lo embíe a preguntar con el Colegial admonitor al apuntador.

-Si ay maitines en aquella semana pone quién dize las lecciones por su orden:

$\left[\right.$ fol. $\left.75^{\mathrm{v}}\right]$

la primera el más moderno y así por su antigüedad; la 7 el subdiácono; la 8 el Diácono, la 9 el celebrante

-En las lecciones de las tinieblas, no se les da lección a los diáconos, dízenlas por sus antigüedades; y las lamentaçiones reparte a los cantores y prebendados que las digan vien y la última lección siempre dize el Abad o el Pressidente en su ausençia.

-Cuando en la semana se dize missa de témporas también la pone en la tabla y las prophecías y los colegiales que las an de dezir para que con tiempo las pasen y prevengan.

-En los turnos de los prebendados guarda la antigüedad.

En los turnos de los colegiales se suceden los ofiçios los que salen de versicularios, entran a çeroferarios, y estos la semana siguiente son Turiferarios y la siguiente lucernarios, luego comitantes luego cetreros.

[fol. $76^{\mathrm{r}}$ ]

-La Semana Sancta en una tabla pone los oficios de toda aquella semana desde el domingo y los que los hazen por el orden de los días, quién canta las personas en las passiones, quién se viste, señalando los que fueren más a propósito sin atender a los semaneros, y por estos vestuarios no pierden su turno; quién dize lecciones, prophecías, y los oficios de los capellanes y colegiales y el ministerio a que cada uno a de acudir, y esta tabla no se lee el Sábado, mas se pone en el Coro al otro lado de la puerta.

-Visitará los altares y la Iglesia para ver si se guarda el asseo y polizia en todo, color y ornamentos convenientes. Cuando se ubieren de mudar avisa a los sacristanes para que con orden del Thesorero lo executen.

-Tienen cuidado de dar orden al Campanero en todo lo que toca a su oficio y el Campanero efectuará con puntualidad lo que el maestro de çeremonias le mandare y el

[fol. $\left.76^{\mathrm{v}}\right]$

tiempo y modo en que se ha de tocar que se refiere ex professo en el Capítulo 14 de campanero.

-Para que las proçesiónes y descubrir el Sanctíssimo Sacramento para los altares que se ubieren de hazer y cosas semejantes en que se mezcla el adorno con la ceremonia se comunicará con el Thessorero para que ambos ordenen lo que combenga. 
-En las procesiones previene las antíphonas y versos y oraciones que se an de dezir y lo que en ellas se ha de cantar.

-En las bendiçiones previene todo lo que se ha de hazer y da orden al Colegial admonitor y çerimoniario y manda que en la Iglesia se haga un coro de los escaños en la distançia y capaçidad bastante para los prebendados y clero, y mira como se pone y el lugar del facistol que no estorve a los que suben al altar por ver las çenizas 0 Palmas.

-Que los colegiales Versicularios aderezen

[fol. $77^{\mathrm{r}}$ ]

el coro; que todos los días limpien las sillas en verano, lo rieguen para vísperas y lo cierren; que parra la Calenda de Navidad lo aderezen con alfombras y braseros y pomos de olor con flores para la nona de la Ascensión, maitines de Resurección, tercia de Pentecostés, Segundas vísperas de Corpus Christi y día octavo y día de San Ioan y Asumpción de Nuestra Señora.

-Todas las semanas tiene una hora de lección de çeremonias, a los colegiales el Domingo y a ella asiste el capellán çeremoniario.

-En ibierno será una ora antes de la çena y en verano dispues de vísperas, la cual se puede mudar a otra si pareçiere más combeniente con orden del Abad. En ella haze exerçitar las çeremonias de Versicularios, ceroferarios y Turibularios y los demás oficios los instruye que los hagan con buen aire y gallardía, especialmente las genuflexiones las Venias el inçensar: y es a cargo del Colegial admonitor avisar las faltas que a avido aquella semana y las corrije el maestro

[fol. $\left.77^{\mathrm{v}}\right]$

de çeremonias.

-Los demás colegiales proponen sus dudas y preguntas y se confiere, y todo lo que se advierte al admonitor lo apunta en el cuaderno que ay para esto y tiene cuidado que se observe.

-Anima a los colegiales que tomen con cuidado el aprender las ceremonias, que es cosa de tanta importançia como el culto divino con que se sirve la magestad de Dios y toda la authoridad de la Iglesia se ocupa en examinar y determinar las que se deven guardar.

-Las faltas que los colegiales hizieren en las ceremonias del coro y altar reprehenda y castigue de suerte que entiendan que es fata en su prinçipal instituto y que deven aprovechar en esto, pues por solo el serbicio del coro e Iglesia se les da estudio y crianza y cuando combiniere darles penitencias lo avisará al Rector del Colegio y si omitiere la execución lo avisará al

[fol. $78^{\mathrm{r}}$ ] 
Abad o Pressidente que lo remedie.

- Dos vezes al año haze que se diga missa en seco, la una missa rezada y la otra cantada y deven asistir a ella el Abad Prebendados y capellanes y colegiales para que sean todos uniformes en las ceremonias y se advierta en lo que ubiere falta, y cada uno sin dureza se dexe perficionar en sus obligaciones.

Cuando de alguno fuere advertido que algún prebendado o capellán del Sacro Monte falta en las ceremonias y deçençia en la missa rezada procuren oirle una y en lo que viere faltar advertírselo.

-Cuando algún sacerdote viniere al Sacro Monte por pretensor, después de algunos días le oirá una missa y le advertirá las cosas en que no se conforma con el estilo de esta Iglesia.

-Cuando algún forastero dixere missa en el Sacro Monte, no con la dezencia que debe, lo advertirá al Abad o Pressidente para que otra vez no le den recaudo y no concienta que ninguno que no sea del Sacro Monte

[fol. $\left.78^{\vee}\right]$

de la comunión sino fuere persona de toda satisfación y grave.

-Cuida de los recivimientos que se hazen a los Prelados o señores y Cabildo que vienen a este Sacro Monte; avisará al Abad quiénes y cuántos an de salir a recivir y hasta dónde y de todo les instruirá y si se a de poner coxín o sitial, y si fuere prelado que se saque hisopo a la pila de la puerta de la Iglesia para que se lo dé el más digno de los que vienen con él si fueren Prebendados o sino de los de casa, y avisará al campanero para que repique a la venida y a la ida.

-Cuando alguna persona quisiere entrar en el coro, sabrá del luçernario quién es y le dirá la silla donde lo ubiere de llevar y los Prebendados no le combiden con la suya si no le dexen pasar a la señalada por el maestro de ceremonias, mas todos le hagan cortesía.

-En la distribución de velas o Palmas tenga cuidado que algún capellán o Colegial la lleve en acabándolas de reçibir el Clero a la persona de respeto y obligación

[fol. $\left.79^{\mathrm{r}}\right]$

que ubiere en la Iglesia sino es de las que esta consueta señala que pueden subir por ella al altar que a estas hará que un capellán combide a subir en acabando el clero.

-Los que pueden subir son grandes y títulos, Oidores y alcaldes de Corte y de Hijosdalgo fiscales. Inquissidores, y fiscales de su consejo, Prebendados de Cathedrales y colegiales, Veinticuatros y Jurados, Corregidores y Alcaldes mayores y Cavalleros de hábito y alguno otro insigne en nobleza. 
-Tiene mucho cuidado que en el Coro se observe el compás que pide la solennidad del día y que ninguno por su authoridad lo apresure ni detenga y avise al Pressidente para que lo modere.

-A los Versicularios avise las antíphonas que se an de dezir y las que an de registrar por su orden; a los cantores los versos para que con poca advertençia no los trueque y que todos los que ministran en el facistol sean muy diestros y prestos en bolver los

[fol. $79^{\mathrm{v}}$ ]

Psalmos, Himnos y Antíphonas y todo lo demás para que el sochantre y los otros a quien toca puedan entonar sin embarazo ni detençión.

-Si cuando salen en ceremonia del coro o Sacristía faltare algún prebendado o capellán de los señalados para vestuarios u otros oficios, avise al que se sigue en turno y si el que es avisado sale de su silla y baxa al plano del Coro antes que llegue al propietario es el que se viste y gana la distribución. Cuando falta para salir en çeremonia alguno de los colegiales señalados nombra ha otro y sale aunque haga falta a otra cosa.

Tenga un papel en que ponga los turnos de los colegiales, assí de los oficios como de los que asisten al coro y ríjase por él para guardarlo y señale los colegiales que an de ser compañeros en los oficios, de suerte que sean iguales en la estatura y dispossición, y esto a de guardar con más cuidado

[fol. $80^{\mathrm{r}}$ ]

en los çeroferarios cuando faltare alguno por enfermedad o ausencia señalara compañero que le sea igual y cuando diere lugar la igualdad y semejanza acomodará al Colegial menos diestro con el que lo fuere más para que exercitando el oficio juntos se baian instruyendo los menos diestros.

-Cuando viene una fiesta prinzipal como día de San Cecilio o que a de asistir algún prelado o Señor a la missa, si los colegiales que aquella semana tienen oficios por tabla no fueren tan diestros en las ceremonias y parezer puede señalar otros que ministren aquel día y generalmente atendiendo al mayor lustre y destreza, puede en estas ocasiones trocarlos y señalar para ellos los que más a propósito le pareçieren.

[fol. $80^{\mathrm{v}}$ ]

\section{Capítulo 6. Del capellán çerimoniario.}

1. El Abad nonbre uno e los capellanes que asista con los que celebran para dirigir todo lo que toca a çerimonias, y aunque el solo puede nombrar es combeniente que sea con parezer de los asistentes. 
-A de ser elegido por persona de Virtud y satisfación, de buena dispossiçión que sepa vien todo lo que enseña el çeremonial y missal Romano reformado y consueta de esta Sancta Iglesia.

-Su oficio es ser coadjutor y ministro principal del prebendado maestro de çeremonias y este ministerio lo an de executar de suerte y con tal subordinación que aunque al cerimoniario le toque in solidum assí el saver las çeremonias como el advertirlas y enderezarlas en los actos que asiste, no se impida el uno al otro sino en todo a de estar subordinado al prebendado y executar las órdenes y también a de ser la

\section{[fol. $81^{\mathrm{r}}$ ]}

execución de modo que el uno por el otro no se descuide.

-Al principio de cada mes advierte el Abad los días de sermón que ay en aquel mes de tabla, para que con tiempo prevenga al que ubiere de predicar y si se ubiere de combidar de fuera, va en persona a hazerlo con la decençia y cortesía que se debe.

Advierta a los Colegiales las faltas que hizieren y si lo desobedecieren y no enmendaren, dé cuenta al maestro de çeremonias para que avise al Rector les de penitençias.

A los Prebendados en cuales quiera actos que celebraren advierta las ceremonias que an de hazer y cosas que an de dezir.

-Cuando comienzan a tocar a missa mayor o a vísperas cantadas va a la Sacristía para que con tiempo se saque todo el recado que fuere necesario y se lleve al altar y los ministros se vistan con puntualidad y que llamen con tiempo a los prevendados para que así como dexa el esquilón salgan a la missa o procesión y que estén en el coro a vísperas u maitines antes que dexe.

[fol. $81^{\mathrm{v}}$ ]

Prevee a los que visten los colegiales que sea con hermosura y decencia.

-Asiste todos los días en la missa y en vísperas siempre que son cantadas aunque no aya caperos, en las missas de Nuestra Señora en Sábado asiste por él un Colegial y cuando asiste en la missa mayor tiene la Palmatoria, buelve los registros al presidente y le señala lo que ha de dezir.

Cuando el celebrante esta en el Cornu epistolae está a su mano derecha fuera de la peana y cuando se pasa el missal al cornu evangelii se pone en la peana a la siniestra del çelebrante algo apartado donde le alumbra y registra con puntualidad, alumbra siempre que reza o canta algo el celebrante por el libro, cuando está en los mementos pone la palmatoria en el altar y cuando el presidente dize quam oblationem se hinca de rodillas fuera de la peana, y cuando se sientan se pone al otro lado Eregione entre la credenzia y el altar mientras cantan el evangelio se pasa al lado de la Epístola junto al escaño buelto el rostro al púlpito del evangelio, pone y quita siempre el paño

[fol. $82^{\mathrm{r}}$ ] 
de hombors al çelebrante cuando a de descubrir o ençerrar o llevar en procesión el Sanctíssimo Sacramento o reliquias.

-Acompaña siempre al çelebrante con mucha compostura y modestia va un paso delante de los comitantes inmediatos a los caperos o celebrante.

-Para las procesiones previene todo lo neçesario y anda por ellas ordenando al clero que proceda con compás y correspondencia y si ay personas Ecclesiásticas o Seglares de authoridad les señala lugar, que será cuatro pasos después del celebrante.

-Asiste en el coro a todas horas y en el prebendrá que todo se haga conforme a las reglas de consueta, avisando a los acólitos, cetreros, comitantes que acudan a tiempo a sus ministerios y combidando a los Caperos para los Versos a tiempo que no vaian tarde y los digan atropellados.

-Cuando ay aniversario avisa que toquen con tiempo y a la ora que se ha de salir puesto en el plano del coro combida al presidente, luego al

[fol. 82 $\left.2^{\mathrm{v}}\right]$

Diácono, luego al subdiácono con humiliación, y cuando baxan se pone detrás de ellos y todos juntos hazen venia y los acompaña; así mesmo en la missa en tono si la ubiere.

-Es ovedecido de todos en lo que advirtiere y especialmente los colegiales le ovedezcan en todo lo que les ordenare tocante a sus oficios de coro e Iglesia.

-Asista en la lección de çeremonias a la hora y del modo que ordenare el Abad.

-Cuando alguno de los capellanes faltare en alguna çeremonia se lo advertirá con mucha hermandad y si no se enmendare lo avisa al maesto de çeremonias.

-Cuando algún prebendado no hiziere lo que le advirtiere, no le replicará sino dará cuenta de ello al maestro de çeremonias.

-Estará con cuidado para conozer los Colegiales que se corrijen y enmiendan y se aprovechan para que pueda dar consejo de que sean elejidos para Admonitores y los que son descuidados y reveldes para estar más sobre ellos y avisar de sus yerros al maestrro de çeremonias.

[fol. $83^{\mathrm{r}}$ ]

-Asimismo [se] llega [a] la custodia y después de quitado el Sanctíssimo Sacramento la toma y cubre con el cendal de hombros del celebrante y la aparta a un lado.

-Cuando se acava la missa da los bonetes, al diácono el suyo y el del presidente, y al subdiácono se lo da el Acólito, o Flavelario. 
-Generalmente ministra al çelebrante el hisopo mas cuando ay diácono se lo da, y el diácono al celebrante.

-En vísperas cuando a dicho el çelebrante el Pater Noster y Ave Maria se llega a él, toma de su mano el bonete y alza la punta del pluvial de la mano derecha y la tiene así hasta que ha entonado el Deus in auditorium que la suelta u buelve el bonete; siempre que le da el hyssopo para echar agua en los responsos le alza la punta del pluvial.

-Al Asperges los domingos sino ay otro capellán, después de entonado por el presidente, va a la Sacristía y toma estola y con el colegial que lleva el açetre, sube al coro y echa el agua y luego al pueblo en la Iglesia, bendize el agua si el

[fol. 83 $\left.3^{\mathrm{v}}\right]$

Sacristán mayor no es sacerdote.

-En todos los demás casos que se ofrezen como entierros, onras, rogativas, reçivimientos, deve ir al maestro de çeremonias y consultarle lo que se ha de hazer y prevenir y asista a todo, disponiendo y ayudándole.

[fol. $84^{\mathrm{r}}$ ]

\section{Capítulo 7. Del Rector del Colegio y Colegiales.}

1. El Rector govierna el Colegio en todos los exercicios que están a su cargo en lo tocante a vida y costumbres estudios y ceremonias y así cuida de que en todo aprovechen y se mexoren.

-Lo primero los anima a la virtud y frequencia de Sacramentos, que por lo menos cada ocho días comulguen y los días de comunión general que ninguno falte a ella y al que faltare le dé penitencia y una repreensión pública.

-Tiene cuidado que anden limpios y aseados como personas que sirven el altar y son como de la cámara de Dios.

-Persuádeles que éste es el prinçipal instituto que tienen y así en primer lugar deven poner en él su cuidado y cuanta obligaçión tienen así por ésto como porque se crian para sacerdotes obligados al culto y ceremonias de la missa con toda

[fol. $84^{\mathrm{V}}$ ]

deçençia y puntualidad.

-De la manera que según ordena la consueta de la casa todas las cosas que pertenezen al govierno moral y espiritual del colegio comunica con el Abad, así lo que toca a lo Eclesiástico y divino, dándole cuenta de los que aprovechan en las ceremonias, y los que tienen talento y de las faltas que hazen y de las dudas que se ofrezen, o con el maestro de çeremonias o con el Thesorero que como este es una de los principales 
partes de esta fundación y de la cual depende todo el lustre y autoridad del culto divino, así su importançia, pide mayor cuidado del Abad y del Rector.

-El cual no mude ni altere cosa alguna de turno y disposiçion en los oficios de la Iglesia de lo que el maestro de çeremonias ubiere ordenado y si lo ordenado por el maestro de ceremonias tubiere algún estorbo para cumplirse por otras ocupaciones del Colegio se lo avisará. Y todo con el orden que

\section{[fol. $\left.85^{\mathrm{r}}\right]$}

diere el Abad se compondrá con mucha hermandad porque deven considerar Rector, Maestro de ceremonias y Thesorero y los demás que no an de tirar cada uno para sí, sino que son miembros que se an de venir para la la conservaçion de un cuerpo.

-Cuando los compañeros señalados para los oficios no conviniere que lo sean avisará al maestrro de çeremonias que los mude, el cual lo deve hazer.

-Cuando fuere reçivido alguno de nuevo en el Colegio, lo procure aficionar a la Iglesia y culto divino y encargará a alguno de los más antiguos y aficionados a ésto para que le trate de ello y le vaya instruyendo.

-Cuando el Thesorero embiare a pedir Colegiales para el adorno de la Iglesia, para aderezar la ropa ò prevenir lo necesario, para ofiçio divino, reçivimiento, o cosa semejante le embíe los que pidiere en número y personas excepto que si algún incombiniente ay en que tal o tal Colegial acuda, con consulta del Abad

[fol. $85^{\mathrm{v}}$ ]

y sin nota pueda embiar otro en su lugar.

-Cuando pidiere el Thesorero colegiales para limpiar las Sanctas cuevas, embíe los de más devoción y afecto y que sepan estimar hazer aqueste servicio a los Sanctos.

-Cuando ubiere embiado colegiales a estos o semejantes ministerios los visite que en ellos estén con el cuidado y modestia que deven y especialmente en la Iglesia con silencio y diligençia.

-Procure embeverlos en afecto y estima de sus superiores y especialmente de los Prebendados que tienen ofiçio de governarlos en alguna cosa, como son maestro de çeremonias, Tesorero, lectores y Correctores para que así, con más obediençia y gusto, hagan lo que se les ordenare.

-Los días de Santa Catharina mártir y Sancto Thomas de Aquino ay comunión general de todo el Colegio, mas no de tabla y assí no se haze en el altar mayor sino en el sagrario y para esto el Rector comete a dos colegiales que lo aderezen con frontales y luzes 
[fol. $86^{\mathrm{r}}$ ]

y pongan aparador y les dize la missa y asisten todos y los comulga.

-Para que los colegiales con más veras se mejoren en todas las çeremonias del coro e Iglesia y hagan los oficios con más cuidado y el rector sepa el que en esto pone y quien son; ha de asistir una vez cada mes a la lección de ceremonias que da el maestro en la cual dirá lo que se le ofreciere digno de reformación y las faltas que allí se dixeren que an hecho los Colegiales, verá con el maestro de ceremonias que penitençias merecen y las dará.

- Tiene cuidado que todos los días asista al coro el número de Colegiales que el Cabildo tiene señalado y cuando falta alguno del turno, señalar otro en su lugar y si del coro faltan los que están señalados los embíe a buscar y ver en lo que se an detenido y castigue el descuido que en esto ubiere sin escusa.

-Los días de fiesta y solennes en que no se puede tomar Recle asiste al coro todo el Colegio,

[fol. 86 $6^{\mathrm{v}}$ ]

-Conforme al turno del maestro de ceremonias, manda que el Colegial admonitor haga otra tabla cada semana de los oficios de los colegiales, de los que asisten al coro, que missas ayudan y los viernes en la noche haze que se lea después de la meditaçión y el sábado por la mañana se ponga en la sacristía.

-Manda que en el Colegio aya otra tabla perpetua, o de cada terçio en que están puestos los nombres de los colegiales por sus antigüedades y los turnos de compañeros en los ofiçios.

-Y si el mestro de çeremonias usare de alguna singularidad con algún Colegial aliviándole de los oficios cargosos o cargándole de ellos, o de otra cualquiera suerte no guardare igualdad, o no observare los turnos avise al Abad que sepa la causa y si es bastante procure aliviar al Colegial del quebranto que sintiere con mejorarlo en otras cosas del Colegio.

[fol. $87^{\mathrm{r}}$ ]

-Cuando el maestro de ceremonias le avisare que dé algunas penitencias a los Colegiales por faltas que en ellas an hecho, las execute con todo cuidado para que los colegiales no pretendan más licençia y el maestrro de çeremonias no quede frustado y desalentado en su ministerio, mas si le pareze que excede en la frecuencia o gravedad de ellas, dará cuenta al Abad para que ordene lo que le combiniere.

-El Rector, acudirá algunas vezes a lección de canto para que estén con compostura y tengan cuidado de aprovechar y informarse de lo que allí pasa, para que lo que fuere digno de remedio pueda avisar y corregir. 
-Tiene cuidado que los Colegiales que tienen oficios de la Iglesia y an de acudir a algún ministerio del Colegio con tiempo se encargue a otro y prebenga para que no haga falta y pretendan los Colegiales escusa con esto, porque los ministerios de la Iglesia an de ser

[fol. $87^{\mathrm{v}}$ ]

en primer lugar. Y los Collegiales sean muy cuidadosos de avisar y recordar al Rector de los oficios que tienen para que lo pueda prevenir todo.

Los colegiales sirven la Iglesia y Coro en todos los oficios y ministerios que les pertenezen y ayudan las missas rezadas.

-Para ir al choro a las horas y missa salen del Colegio juntos con mucha compostura y silencio, cuando comienza la gorda y van a la sacristía y toman sobrepellizes y aguardan con silençio arrimados a los caxones y si quisieren estar en la capilla de los mártires ha de ser de rodillas en oración, preparándose para ir al coro y no sentados.

-Los que no tienen oficios salen cuando comienzan a tocar a las horas o a missa y van a la sacristía a vestirse y ponerse cado, los versicularios al coro y donde quiera que los exercieren sea con mucho

[fol. $88^{\mathrm{r}}$ ]

silençio y sin porfías.

-Cuida que se tenga la lección de Canto los días y horas conforme a la constitución y que el ministro del Colegio avise al sochantre y a los Capellanes canónigos de aprovaçión y semanero y si alguno faltare haga se avise al Abad o Presidente.

-No hagan corrillos por ninguna parte de la casa y menos en la Sacristía ni en la entrada; sean muy obedientes al maestro de çeremonias y al Tesorero en todo lo que les ordenaren.

[fol. $88^{\mathrm{V}}$ ]

\section{Capítulo 8. De los Visitadores o zeladores.}

1. Este Sacro Monte fue elegido de Dios para depósito del Sancto Tessoro que ay encerrado en los libros que aquí dexaron guardados el Apóstol Santiago y sus disçípulos, nuestos gloriosos Mártires, consagrolo el glorioso Apóstol con su presencia y habitación de tantos días y en él fundó su primera Iglesia donde celebró el SacroSanto misterio de la missa y lo dexó ennoblecido con título de Iglesia Apostólica.

-En este Sacro Monte vivieron mucho tiempo los gloriosos Çeçilio y Thesiphón, aquí hazian sus juntas y Concilios, de aquí salian a predicar y conbertir las gentes y aquí padeçieron martirio y quedaron guardadas sus reliquias seguras por muchos siglos y aora descubiertas y veneradas en esta Iglesia. 
-Todo lo cual haze este Sacro Monte, un gran Santuario y monte donde con tantas cosas se agradó el beneplácito de Dios, y como todo ésto pide de los que viven en él gran cuidado en el servicio de su Magestad, así obliga a que todos los

[fol. $89^{\mathrm{r}}$ ]

que vienen sea con pasos limpios y corazones puros y cuando están en él, sea con la honestidad y compostura que pide un lugar tan santo y tan mirado de Dios y así para que no aya ofensa suya ni cosa que parezca mal y los hombres y mugeres den buen exemplo; se señalan en la tabla cada semana a dos prebendados que hagan oficios de visitadores o zeladores.

-Este oficio es el de maior confianza que aya en este Sacro Monte y del cual depende la reputación de la Virtud y Vida exemplar que aquí se profesa y obliga a que los estraños no se desmanden en él, por lo cual prinzipalmente an de corregir los excesos y componer la gente con su modestia y honestidad.

-Los días que ay concurso o se avisa al Abad que ay necesidad o ellos lo saven, el Abad los embía a zelar especialmente desde el coro, cuando están en los oficios divinos y fuera de ellos visitan el Sacro Monte conforme la neçesidad que ay.

-Salen por la Iglesia y miran que en ella no aya ruido, risas de mugeres, que no coman sino todos estén con la devida veneracion, que no hablen los hombres con las mugeres, que no hagan

[fol. $89^{\mathrm{v}}$ ]

ala ni corrillo cerca de ellas, que no se sienten en las sillas de los confesionarios y especialmente que no estén parados en la puerta mirando las que entran y salen.

-En el Pórtico y plaçetas, no permitan mugeres tapadas que estén como señuelo para provocar a combersaçiones, que no hablen los hombres con ellas aunque digan son de su casa.

-Cuando ay gente baxan a visitar el campo y alamedas, la placeta de la cruz de los herreros y detrás de la casa de la Iglesia, y en ninguna parte consienten las dichas cosas, puestos, pláticas ni miradas sospechosas.

-No permiten que a la vista de la casa e Iglesia las mugeres anden sin mantos, que no aya bayles ni guitarra ni canten ni toquen instrumento alguno: que no aya mesas de fruta, ni turrón, ni consienten que ninguno venda ni pregone cosa alguna de comer por todo el Sacromonte

[fol. $9 \mathrm{o}^{\mathrm{r}}$ ] 
exçepto a los aguadores que se les ha de dexar. Que no aya meriendas delante de la Iglesia, que las personas que parezen sin sospecha las amonesten que estén con modestia.

-No consientan juegos de bolas ni bolos ni otros a los muchachos ni a otros y mucho más prohíven los de los naipes.

-Si andubieren cavalgaduras, mandan que las salgan a echar para estorbar qualquiera cosa de éstas y avisar a las personas que no den mal exemplo, se lo advierten con mucha cortesía y modestia y si los hombres y mugeres no quieren dexar la conbersación, se están allí hasta que los apartan y siguen que no se buelvan a juntar.

-Van a las cuevas para que en las entradas y apreturas no aya cosa descompuesta. Tienen cuidado que no entren hombres y mugeres juntos, que los unos no entren hasta ayan salido los otros.

-Especialmente el día de San Cecilio se pone un Canónigo o capellán y con un Colegial señalados por el Abad en la Iglesia de

[fol. $\left.90^{\mathrm{v}}\right]$

SanctIago por donde se a de entrar a las Sanctas cuevas, y entrando las mugeres a los hombres cierra y no abre hasta que ayan salido por la Iglesia y cueva de San Çeçilio, para lo cual ha de aver otro en aquella puerta que la tenga çerrada y la abra para que salgan y para que nadie quede dentro entra a visitar el colegial que está con el prebendado en la Iglesia de SanctIago y esto mesmo se haze los días de concurso como se dixo libro1. cap 16; y cuando an salido çierra y avisa al de la entrada que abra para que entren; los zeladores an de mirar se haga todo esto con mucho cuidado y fidelidad.

-Cuando ay mucha gente en el sacromonte y cuando fueren avisados de algo suban juntos a dar una buelta por detrás de la casa y si hallaren sospecha de alguna cosa no permitan quede allí gente sino los diviertan y aparten.

-Con los que fueren protervos y arrojados en responder porque no se descomidan procure

[fol. $91^{\mathrm{r}}$ ]

estar mansos y comedidos et vincant in bono malum, de suerte que atajen la ofensa de Dios y que no perseveren en el mal exemplo que dan.

-Todas las vezes que vieren venir gente a horas y partes escusadas que pueden criar sospecha an de salir a zelarlos.

-Cuando se pudieren juntar los dos zeladores para esto por estar el uno ocupado, el otro avisará al Abad o Pressidente que le señale compañero el cual lo hará conforme la ocurrencia y causa le ordenará que vaya solo. 
-De este oficio de Visitadores se an de encargar con muchas veras los prebendados, pues todo se ordena a estorbar pecados y al vien público de las almas, cosa de tan servicio de Dios y propia de los que viven en este Sacro Monte. Y si todos están dedicados a remediarlos mediante la administraçión continua de los sacramentos, también por este medio los an de escusar de exemplo de los santos que hizieron cosas grandes para estorbarlos y así es razon que sacrifiquen su comodidad

[fol. $91^{\mathrm{v}}$ ]

y gusto, y es especial serviçio remuneratorio a estos Sanctos que nos dan el descanso y sustento guardarles su Iglesia y monte con la devida veneraçión.

-Aunque aya aniversario o manual o procesión o maitines pueden salir a zelar dos juntos como sea con liçençia de quien puede hazer presente y lo mismo se guarde para salir del coro a zelar.

-Cuando sintieren en el Pórtico que de noche que habla alguna muger o mochacho que estén cerradas las puertas avisaran al Abad o Pressidente, el cual con algunos criados saldrá a ver qué gente y si hallaren alguna muger que devan recogerla, procuren la acomodar en algún carmen o molino que aya gente de satisfación hasta la mañana que se remedie según pareciere.

[fol. $\left.92^{\mathrm{r}}\right]$

\section{Capítulo 9. Del Tesorero y Sacristanes.}

1. El Tesorero se haze cargo por el Inbentario de toda la plata, ornamentos y demás vienes de la Sacristía e Iglesia, y al fin de el año lo buelve a entregar al Tesorero que entra de nuevo, en la misma forma haze este entrego y cargo al Pressidente y asisten los sacristanes a quien segundariamente se entregan estos vienes.

-En el libro de el inbentario se asientan las cosas que de nuevo se an hecho y se quitan las que se an consumido y así se haze nuevo cargo al Tesorero.

-Ay dos libros de el inbentario, el uno está en el Archivo y el otro tiene el Tesorero, no ay en uno más ni menos ni diferentes partidas que en otro, lo que se asienta o borra juntamenten en ambos.

-El Tesorero govierna todo lo que perteneze a la Iglesia, Sacristía y Santas cuevas cuida de la limpieza de todo, del aseo y postura de los ornamentos y plata que esté

[fol. $92^{\mathrm{v}}$ ] 
todo en sus lugares, que se saque con tiempo lo que ubiere de servir y se buelva a su lugar; que no estén los caxones aviertos ni sacados; que no anden las cosas fuera de ellos.

-A los Sacristanes manda que sean muy cuidadosos de todo curiosos y aseados, que no aya por los caxones, ni por el suelo alfombras arrolladas, capas sin sombreros ni cosa indeçente; que los seglares no entren en la sacristía ni dexen en ella sus espadas.

-Asiste en la Iglesia y Sacristía los días que se adereza para las fiestas, avisa los colores y ornamentos y plata que a de servir en ellas; que los altares se pongan con mucho aseo; tengan tres manteles y los de ençima más largos que por los lados lleguen al suelo y hagan frente y esquinas muy curiosas, haze guardar silençio a los Colegiales.

En las procesiones y reçivimientos y en todas las demás cosas previene y ordena todo lo

[fol. $93^{\mathrm{r}}$ ]

necesario y las cosas que an de servir y como se an de poner.

-Manda que las Santas cuevas se limpien por lo menos cada tres semanas conforme a la consueta de Cassa, especialmente antes de las fiestas de los Sanctos y otras prinçipales y los días que ay procesión a ellas y que se aderezen y adornen con flores y ornamentos como mejor le pareçiere combenir.

-Que todos los días vaya el Sacristán a aderezar las lámparas dos vezes, a hora que no haga falta en la Sacristía.

-Es a su cargo que se compre en junto y con tiempo la çera que sea la mexor, blanca, y de pavilo de algodón, reçívela por junto y la pone en un aposento con dos llaves, la una tiene él y la otra el contador, al cual toma la razon de la cera que entra y sale en un libro particular que está con la misma çera.

-Al principio de cada mes se saca la neçesaria y la pondrá en un caxón aparte y guardará la llave, y de allí entregará al Sacristán la que fuere menester cada día: codales y çiriales y hachas para alzar en la missa maior

[fol. 93v]

el número y calidad de velas que pide el día y a la noche mandará que se limpie y guarde, encarga mucho el cuydado y que no se desperdiçie, los cabos que no puedan servir y las raeduras tendrá en un apartado con su llave.

- Otro caxon abierto abrá donde cada día limpien los Codales y Velas que sirven los Çiriales y Candeleros y cuando aya cantidad de esta junta cuydará que se llame a official que labre hachas y cera amarilla y comun que fuere neçesaria para la Semana Sancta y officios de difuntos $=$ y por peso entregará al official y recivirá la nueva y de todo se tomará razón en el libro de la çera. 
- No consienta que Colegial ni Sacristán ni otra persona se sirva de los Codales para ninguna otra cosa fuera del servicio de la Iglesia; para la letania de Nuestra Señora entregará el luçernario un cabo de buxia y no le dará otro sino trae el que se acava.

Es a su cargo que se saque agua de olor

$$
\text { de }
$$

de rossa y trébol y otras flores la qual guarda debaxo de su llave.

-Así mesmo previene el olor neçesario para los pomos, ramos, flores y ramilletes, para adornar la Iglesia los días solennes y todo lo que gastare en esto se le reciba en quenta con sola su relaçión jurada

Ansi mismo en otras cosas importantes y necesarias del servicio comun de la Iglesia puede gastar como no pasen cada partida de quantidad de ocho reales y también se le recivirán en quenta con su relación jurada.

-Para las fiestas prinzipales manda aderezar y roziar con agua de olor la ropa blanca que a de servir y que la de los altares y missa esté mas olorosa y los paños para comulgar que se muden a tiempo conveniente de suerte que siempre parezca limpia, especialmente los corporales y los purificadores, que esté vendita la ropa que manda el misal que se vendiga $=$ que se adereze la rota y descosida y que no sirva hasta estar

$[$ fol.94v $]$

Aderezada $=$ Para las pasquas y fiestas prinçipales de nuestra Señora y de los Sanctos mandará quitar el polvo de la Iglesia, paredes y cornisas de ella y a todos los retablos y que todas las noches el Sacristán blandamente limpie lo que alcanzare de ellos.

-Que en verano se riegue la Iglesia y se pongan y quiten las esteras a su tiempo.

-A de tener siempre las llaves de la plata y ornamentos y escuse todo lo posible que se muestren y lo que fuere del servicio ordinario podrá entregar al Sacristán por quenta.

-Guarda debaxo de su llave las de los sagrarios y la del Colateral. Saca todas las mañanas para las comuniones y acavadas las missas tiene cuydado de ençerrarla.

-Manda que todas las semanas se consagren formas y antes si faltaren que las corten los Sacristanes con mucha curiosidad que no sean quebradas

[fol. 95r]

ni manchadas y las purifiquen de las partículas: sea esto siempre las Visperas de las fiestas y de concurso a la ultima missa. 
-Que por lo menos dos vezes en la Semana se limpien los calaizes, patenas y las pilas de el agua vendita, los sabados en la noche se frieguen y la de la Sacristía.

-Que dos vezes al año limpie el platero la platta de la Iglesia para el día de San Çeçilio y Asumpción de Nuestra Señora confrme la consueta de la casa, o para la Navidad y Corpus Christi.

-Que todos los días que sirviere con agua no se encierre sin enjugarla.

-Tiene una llave de las reliquias que están en la alacena al cornu Epistolae, cuyda que no se manifiesten sino con mucha deçençia con sobrepellices y çirios encendidos.

-Tiene una llave de dos que tiene el apartado que está dentro del archibo donde están las bulas apostólicas de la Erección y Constituciones originales y otras cosas que

[fol. 95v]

Manda la constitución.

-Es a su cargo hazer el monumento, avise al Abbad o Presidente en su ausencia para que se busque lo neçesario si acaso faltare y con los aderezos de la casa lo procure hazer con el mayor aseo, curiosidad y riqueza de la forma que le pareciere consultandolo con el Abbad.

-Guarda debaxo de su llave los doseles y sitiales y telas que se encierren limpios o sin polvo y que no sirvan sino en cosas de la Iglesia-

-Visita todas las noches las puertas de la Iglesia que queden çeradas y llevarse las llaves a su aposento, dexa encerradas las llaves de la plata y ornamentos y llevase la llave.

-Entra en su poder la limosna de los hornos y si otras se ofrecen y tiene libro donde asienta las partidas y se haze el cargo y datta de ella.

-Generalmente es a su cargo que los sacristanes y demas ministros de la

[fol. 96r]

Iglesia cumplan con todo lo que están obligados que es lo siguiente.

-Los sacristanes mayor y menor personas de virtud y satisfación dan seguridad y si se les puede entregar algunas cosas de la Sacristía.

-Las vezes que se manifestare el Sanctissimo Sacramento ò reliquias de los Sanctos haze sacar el dosel y pone el adorno conveniente enforme le pareciere.

-El Sacristán mayor es un substituto del Tesorero en todo y a de ejecutar sus ordenes y según su disposición, limpia los calizes y patenas, lava los corporales y puificadores, 
corta las hostias para lo qual tiene instrumentos o tixeras que no sirven a otra cosa, alza todos los días la llave del sagrario y la entrega al Tesorero.

-Los miércoles en la noche si es sacerdote con sobrepelliz y estola y velas.

[fol. 96v]

Encendidas limpia los sagrarios del polvo y las custodias de platta donde está el Sanctissimo Sacramento, zahumalos con olores y echa flores azahar, rosas, violetas $\mathrm{u}$ mosquetas y las que otro miércoles hecho y saca seca, las coge en una salvilla y las echa en la peana $=$ lleva corporales en que pone la custodia o relicario mientras haze este oficio y asistele el Sacristán menor con sobrepelliz.

-Si es sacerdote los Domingos por la mañana bendize el agua.

-En la capilla de la Sacristía pone el Jueves, Viernes y Sabado Sancto. Cada quince días corporales $=$ dos vezes en la semana purificadores y es sobrestante del Sacristán menor en todo.

[fol. 97r]

-El Tesorero le entrega las cosas del servicio ordinario de la Iglesia y el Sacristán menor y tiene cuydado de perdirle quenta algunas vezes y el la da al Tesorero al fin del año.

Cuando se entrega la ropa e la Sacristía al lavadero está presente el Sacristán menor la quenta y la ve y haze la memoria y prepara la que tubiere necesidad de aderezo y la one aparte y solicita con el Tesorero que se adereze, y cuando la traen la recive y haze que el Sacristán menor la ponga en sus divisiones, vien acondicionada y con curiosidad.

Al prinçipio de cada mes va a los hornos y saca la limosna que ay y la entrega al Tesorero.

-Siempre que se adereza la Iglesia o hazen altares o el monumento asiste a dar recaudo neçesario.

-El día de San Cecilio escribe en un memorial las cosas de la Sacristía que

[fol. $97^{\mathrm{V}}$ ]

los comissarios de la ciudad pidieren para adorno del Pórtico y altares y a quien las entrega y cuide de cobrarlas.

-Los días de las fiestas principales y para sus octavas no más viste al niño Jesús de la Sacristía [con] ropa del color del día y camisas y valona limpia y en todo el otro tiempo tiene la ropa morada. 
-El Sacristán menor duerme en la Sacristía para su custodia y guarda y luego en tocando a orazión se levanta y lo primero adereza las lámparas y enciende las que an de arder aquel día y cuida mucho ardan siempre sin apagarse.

-Trae una lamparilla a la sacristía que pone en una alhazena que está detrás de la puerta aque sale a la capilla de los mártires, la cual arde toda la mañana para que ençiendan los cero

[fol. $98^{\mathrm{r}}$ ]

ferarios y coadjutores =acavadas las misas la apaga y para vísperas la enciende.

-Luego abre las ventanas y barre la Sacristía y el verano la riega y sacude el polvo a los caxones todos los días y a los capiteles de los escaparates cada quinze días. Tiene agua en un cántaro limpio para las missas.

-Saca los ornamentos para las misas y los pone con mucha curiosidad y deçencia en color y calidad conforme al día y las cassullas para la missa de prima y altar de ánima.

-Saca los Calizes missales y Vinageras que todos los días lava y trae vino en un jarro que tiene encerrado en un caxón y echa vino y agua en ellas y tiene cuidado de cerrarlas.

Antes de abrir la Iglesia saca al altar del sagrario un vaso de agua con un lienzo encima y lo pone al lado del sagrario in Cornu epistolae para que el sacerdote que da

[fol. $98^{\mathrm{V}}$ ]

la comunión se purifique $=$ y otro vaso mayor y toalla limpia olorosa, pone en la losa de las ampolletas para que se purifiquen los que comulgan.

-En el bufete de jaspe pone los ornamentos para la missa maior con sus çíngulos y albas, el terno cubre siempre con un paño de seda por la decencia y guarda del polvo; a nada de esto que pone en el bufete se a de llegar ni servir en otras missas por que no se alle falto al tiempo del vestirse.

-Si es Domingo saca el pluvial del Presidente y lo pone tendido en el caxón del testero.

-Si es día solenne pone una mesa baxo de la peana del escaparate de la plata larga y en ella unas gradillas y las cubre con manteles y allí pone toda la plata que el Tesorero a sacado para servir en la missa que no combiene ande por los caxones. Saca los çiriales y çetros que ubieren de servir y acavadas las missas limpia y encierra la plata y los ornamentos dobla y

[fol. $\left.99^{\mathrm{r}}\right]$

pone en sus lugares. Alza y encierra los missales y manuales, ampolletas candeleros y los atriles pone sobre el caxón de las sobrepellizes, encierra los mosqueadores y todo lo demás y escombra la Sacristía. 
-Para las Vísperas cantadas saca los çetros y pluviales: el del Presidente pone tendido en el bufete de jaspe, y los de caperos tendidos en el caxón donde están las casullas, y después de vísperas lo encierra todo, cada cosa en su lugar con mucha distinçión y sin alterar ni trocar porque esté cierto donde estare cada cosa y al tiempo que fuere menester lo halle presto.

-Todas las Vísperas de las fiestas, sábados y los miércoles después de la hora de comer havre la Iglesia, a medio día la çierra y de ninguna manera dexe dentro muger ni persona alguna.

-Por la mañana la abre en saliendo de oraçión y a la tarde en tocando a vísperas cierra la media hora antes de las Aves Marias con la llave y dexa aviertos los

[fol. $99^{\mathrm{v}}$ ]

postigos y çerrada la puerta de hierro el verano y cuaresma y los Viernes del año hasta que tocan a letanía.

-Luego adereza a los altares muda frontales, si el día siguiente y vísperas antes de comer en el altar maior puede poner debaxo el frontal que piden las tales Vísperas, mas en los colaterales pone las que se an de quedar el día siguiente, y para el día de todos Santos a de poner en todos los altares los frontales negros debaxo de los blancos.

-Tiene muy gran cuidado de poner los visos del Sagrario del altar maior conforme en el color a a los frontales, mas desde el día de la resurección hasta la Asçensión, no se pone viso por que esté descubierta la figura de Christo nuestro Señor resuçitado.

-Todas las noches limpia los altares y sacude el polvo, saca los candeleros y velas atriles y tablillas del evangelio de San Ioan, toallas y campanillas y los pone en la losa de las ampolletas, y pone despaviladeras en todos los altares y

[fol. $\left.1 \mathrm{oo}^{\mathrm{r}}\right]$

y mosqueadores desde la fiesta de resurección hasta el día de todos los Santos inclusive.

-Desde el día de San Andrés hasta el de la anunçíaçión inclusive pone un brasero en medio de la Sacristía, y todos los días previene brasas para los inçensarios.

-Cada ocho días pone toalla limpia en el lavatorio de la Sacristía y antes si ocurriere alguna fiesta de primera clase y tiene gran cuidado no se enxuguen en ella las manos y rostro, sino los sacerdotes para dezir missa, y cuida también que en el caxón de los turibularios aya siempre una toalla limpia en que se enxuguen, cuando se lavan para llevar las pazes por que no echen a perder los çendales con que las llevan, y asimismo cada ocho días fregará el pilar del agua porque no crie tova. 
-Todos los Domingos en saliendo de oraçión, previene el agua y sal para vendezir, pone la cruz. libro y estola y hisopo y vaso con la sal en el bufete de la Sacristía en que pone las ampolletas y junto a él los cantaros

[fol. $100^{\mathrm{v}}$ ]

y açetres llenos de agua.

-Limpia las pilas el sábado en la noche y por la mañana el domingo antes de abrir la Iglesia les echa agua y guarda un cántaro para la semana.

-Los jueves se renueva con solennidad el Sanctíssimo Sacramento del altar mayor y si no es día solenne que está puesto frontal y terno rico lo saca del color de la missa y el frontal le pone frente de puntas y arrima al caxón frontero de la puerta saca seis candeleros y velas, la llave en la salvilla de plata y en otra un vaso de plata en que pone la forma que se ha de consagrar.

-En çerrando la Iglesia a medio día entra todo el recaudo de los altares en la Sacristía y los dexa compuestos, pone sobre la ara tendidas las tablas de las palabras de la consagración abaxo las letras, y las cubre con el tafetán y enzima pone la cruz y si para vísperas se mudan otros frontales o manteles los pone a esta hora.

Cada quinze días limpia el polvo a las

[fol. $1 \mathrm{ol} 1^{\mathrm{r}}$ ]

lámparas de la Iglesia y friega los cubillos y platos y requiere los cordeles para ver si están rozados para renovarlos por que no aya peligro de quebrarse y caer las lámparas. Cada quinze días sacude las alfombras de los altares y barre las peanas debaxo de ellas y de las esteras y quita los manteles y limpia el polvo que ay devajo de ellos en las aras y altar y limpia los candeleros de azofar con polvo de ladrillo y vino, no dexa que se tomen.

-Cada mes quita las peanas de la Sacristía y barre debaxo de los caxones y recorre los caxones de los ornamentos para que si están arrugados o mal puestos los iguales y limpie el polvo y las cosas que en el mes se ubieren trocado las buelva a sus caxones y lugares propios y asimismo cada mes limpia la pisçina.

-Cuide mucho que en la sacristía no se crien arañas ni otros animalexos y para los ratones arma las musçipulas y pone diligencia hasta cogerlos.

-Tiene siempre inciendo limpio y quebrantado

[fol. $101^{\mathrm{V}}$ ]

no muy molido, hostias çercenadas que no falten.

-Anda siempre con sobrepelliz y no sale de la Iglesia sin ella y la lleva siempre que fuere a las cuebas. Por las mañanas ni a las tardes cuando están en los oficios o ay 
concurso de gente, y cuando la Iglesia está avierta por ningún caso llega a ningún altar a poner o quitar algo sin sobrepelliz ni menos otro ningún ministro ni Colegial.

Aunque no esté ordenado de Corona puede tocar los cálizes y el Colegial que no la tubiere los puede llevar al altar.

-No puede prestar nada de la Sacristía ni puede dar recaudo para que ningún forastero diga missa sin licençia si no fuere persona grave y conoçida ni saque ornamento alguno para que administre el forastero algún Sacramento que no lo puede hazer sin liçençia.

-Los Roquetes y amitos y collares que visten los Colegiales los a de poner en los caxones para esto señalados en el de las sobrepellizes, y todas las cosas que

[fol. $102^{\mathrm{r}}$ ]

ubieren de servir como paños de pazes de façistol, fundas de missales, bolsas, cingulos y todo lo demás lo a de sacar de los caxones y poner cada cosa en su lugar porque los Colegiales no anden en los caxones y rebuelvan lo que ay en ellos.

-La noche antes de la fiesta para el sermón de la mañana pone al paño del púlpito del color conveniente y lo quita en çerrando la puerta a mediodía y si el sermón es por la tarde pone el paño a mediodía.

-Para los sábados, las Salves de la cuaresma y para las vendiçiones que se hazen en el coro de la Iglesia tiene prevenido paño de facistol del color del ofiçio.

-Previene los Ramos y çeniza, y para los días de vendiçión pone en el pavimento alto al cornu epistolae bufete con sobre mesa morada y una toalla enzima y las fuentes con las Velas o Palmas y abaxo de las gradas pone el día de las palmas cantidad de ramos de oliva y laurel

[fol. 102 ${ }^{\mathrm{v}}$ ]

para el pueblo y de éstos guarda con cuidado para hazer çeniza que se vendize el miércoles primero de cuaresma.

-Previene los velos negros como se dirá en los días particulares de estos oficios y las alfombras neçecarias para la seña del pendón y adoración de la cruz, las ha de detener en la Sacristía vien dobladas y puestas en lugar conbeniente que no estorben ni parezcan mal.

-Todas las vezes que el çelebrante en el altar ha de tomar pluvial o dexarlo y tomar casulla, el sacristán lo saca puesto sobre el brazo siniestro y el manípulo en la diestra y aguarda junto a la peana del altar de los mártires, y cuando le haze señal el çerimoniario sale y se la pone al preste y toma el ornamento que dexa y puesto sobre el mismo brazo lo entra en la Sacristía. 
-Los días de comunión general previene las formas en un vaso de plata y en una salvilla las pone en la mesa del aparador que está en la Sacristía, y la cubre con una

[fol. 103 ${ }^{\mathrm{r}}$ ]

hixuela redonda y siempre que se an de consagrar formas las pone cubiertas en vaso y salvilla de plata.

-Pone también un vaso con vino aguado para que se purifiquen los Colegiales con una toalla limpia y olorosa.

-Todos los días que se gana indulgencia y se saca anima pone una tablilla que lo dize sobre la pila del agua vendita de la puerta prinzipal.

-El Miércoles Sancto saca y previene el candelero triangular, y el mismo día adereza y adorna la capilla del Sepulchro con frontal rico y alfombra, pone la lámpara y cazoleta de olor porque el jueves acavada la comunión se a de mudar allí el Sanctíssimo Sacramento y guardar con mucha deçençia, cubre la puerta que sale a la Capilla del rosario con un velo de tafetán que no se puede correr ni alzar por que no aya paso por ella mientras el Sanctíssimo Sacramento está en aquel altar. Haze el monumento y da el recado para el [que] prepara el Arca de el Sanctíssimo Sacramento para el jueves

[fol. $\left.103^{\mathrm{v}}\right]$

Sancto, límpiala, zahúmala con ricos olores, pone Corporales limpios, los más ricos que ay y paño preçioso para cubrirla y pónela sobre el caxón de las casullas; tiene juntos y muy limpios los candeleros de la Sacristía y los de casa con sus velas cortado el pavilo y quemado sobre los caxones últimos.

-Para todas las procesiones del Sanctíssimo Sacramento previene el palio y armado en sus varas lo arrima a la pared de la Sacristía donde está el caxón de los amitos, saca la cruz con cendal o manga.

-Ençerrado el Sanctíssimo Sacramento saca las velas y pone por las gradas del monumento con buena proporción y distancia y cuida de despavilarlas y que no se queme nada.

-Al quitar el monumento ayuda y dobla las sedas y paños que an servido después de averla limpiado y todo lo va poniendo en sus lugares.

-Para el Viernes Sancto previene un lecho cubierto de un paño de oro morado

[fol. 104 ${ }^{\mathrm{r}}$ ]

en que se ha de poner la cruz para la adoración y lo cubre con un cendal de oro y seda transparente saca dos fuentes para el ofertorio y la ofrenda de aquel día es suya. 
-El Viernes Sancto en la noche saca la columna del cirio pascual y pone en el plano del cruzero, arrimada a la grada junto al pulpitillo del evangelio como no estorbe, y en ella el cirio, cortado el pavilo y comenzado a quemar para que se encienda con façilidad, hechos en él los agujeros para clavar los cinco granos del incienso los cuales tiene hechos en forma de piña con buena proporçión.

-Pone en la Sacristía la Caña con tres candelas blancas.

-El sábado Sancto, mientras oración, a la puerta de la Iglesia prinzipal por la parte de dentro pone un bufete con dosel morado y toalla porcima y sobre él todo lo que se diçe libro 4 capítulo 15 número 1. Enciende la lumbre y pone unas paxuelas en una salvilla para encender la vela. Una cruz con cru-

[fol. $\left.104^{\mathrm{v}}\right]$

çifixo, una fuente con los cinco granos de incienso, un candelero con una vela apagada, el acetre de agua vendita y hisopo, fuera de la Iglesia en la lonja, un brasero con carbones.

-Mientras están en la vendiçión del nuevo fuego baxa todas las lámparas de la Iglesia para que a su tiempo las pueda encender el Luçernario.

-Cuando se cantan las letanías saca al altar de los mártires los candeleros con velas que encienden los ceroferarios y an de servir en la missa = ayudanle los ministros como se dize en sus capítulos que de suerte tocan estas cosas a ellos y al sacristán que corren por cuenta de todos, y no las an de dexar unos por otros---

-Quitados los velos negros el sacristán los sacude y dobla y liados con sus cordeles los alza y pone en caxón o arca que estén guardados del polvo y ratones.

-Para la Gloria tiene muchas fuentes

[fol. $105^{\mathrm{r}}$ ]

de flores y yervas para que echen por el pavimento.

-El Viernes Sancto en la tarde cuelga y adorna la Sacristía ricamente, en medio pone un altar con los más ricos paños que ubiere con alfombras por ambos lados y encima una o dos gradas ricamente cubiertas con sus corporales con muchas velas flores y ramilletes, previene y limpia la custodia y formas para consagrar y cuando acava la missa, donde se consagra, enciende las velas del altar y pebetes y pomos y acompaña el Sanctíssimo Sacramento que se pone en él.

-Los ornamentos que se visten los que çelebran en la procesión los pone sobre una messa que previene entre el altar y el caxón del testero de la Iglesia, adorna para los maitines con muchas flores y ramos y enciende con tiempo las lámparas ya acavados los maitines abre la Iglesia para que entre la gente y goze de la proçesión.

-Para encerrar y desençerrar el Sanctíssimo 
[fol. $105^{\vee}$ ]

Sacramento como no sea en la misa y para las procesiones saca pluvial y estola y cendal blanco y lo pone al cekebrante como se dixo arriva.

-La Custodia cuando está sin el Señor a de estar siempre cubierta de un çendal.

-Para todas las proçesiónes en que ay palio tiene cuidado de levantar las lámparas del medio del pavimento y del Cruzero que estén vien altas que no pueda el palio llegar a ellas.

-Los días que ay gayombas flores y ramos por la Iglesia las echa y pone antes de abrirla.

-Cuando se hazen altares, entrega el aderezo que le piden y lo buelve a cobrar y previene las velas y candeleros que le pidieren los comissarios de la fiesta para poner en ellos y en el de la Iglesia.

-Los Viernes en la noche adereza el altar de la Concepción para la missa del sábado con frontal rico y pone al lado Epistolae una credenzia con su mantel saca

[fol. $106^{\mathrm{r}}$ ]

cuatro candeleros atril alto y paño de façistol, ponga el terno que ha de servir en la missa de Nuestra Señora en el caxón del testero de la Sacristía porque la mesa es para el de la missa mayor, y si fuere el mismo que a de servir en ambas missas lo ponga en la mesa.

-El día de todos los Sanctos, en çerrando la Iglesia, pone en el cruzero un túmulo no muy alto cubierto con paños y ençima la tumba con paño de brocado con coxín y mitra.

-Los blandones negros para doce hachas, la cruz grande y el guión y sus pies y previene el hisopo y açetre y todas las vezes que se hazen onras saca y pone el adorno y hachas como se dize en el libro tercero Capítulo---del oficio de los difuntos y lo mismo en los entierros libro 4 capítulos 24 y 25 y acabado el ofiçio lo alza y pone todo en su lugar.

-Tiene cuidado que los blandones y pies de cruzes estén limpios guardados y vien aderezados porque no hagan falta cuando ubieren de servir. Ésto es también a cargo

[fol. $\left.106^{\mathrm{V}}\right]$

del Caniculario, mas no se a de descuidar uno por otro porque corre por cuenta del Sacristán el que esté todo lo que sirve en la Iglesia vien puesto y acondiçionado.

-Los días que ay brasero tiene cuidado de çebar el pomo con agua de olor.

-Los días que en los altares del cruzero que son los que se dixeron libro1, capítulo 9 del gasto de la cera, arden velas todo el día el Sacristán las ençiende antes de abrir la 
Iglesia y después de çerrada a mediodía y a la noche las apaga y cuida que ningún coadjutor de missa las apague, y si por descuido lo hiçiere que las buelva a ençender.

-El Sacristán para acudir a tantas cosas y tan importantes al culto divino y ministrar los ornamentos, plata y çera que sean necesarios para los ofiçios y otras cosas que se ofrezen en esta Iglesia que es tan visitada y de tanto concurso deve asistir siempre en la Sacristía y no hazer ausencia de ella espeçialmente por la

[fol. $\left.107^{\mathrm{r}}\right]$

mañana sino a cosa urgente y no se deve descuidar con el Colegial Custos Sacristiae porque éste tiene otro ofiçio distinto que es llamar a los adjutores y es incompatible con guardar la Sacristía y si el Sacristán faltase era fuerza o hazer falta al llamar o dexarla sola con riesgo de que faltase algo donde tantos entran y no conocidos y así para aver el Sacristán de acudir a otro ministerio y hazer ausencia de la Sacristía avise al Thesorero donde vaya que para que prevenga quien asista y cuando fuere a Granada le dexe las llaves y en ningún caso salga del monte sin dexarlas.

-Su cuidado de mas de lo dicho sea en esmerarse en la limpieza y aseo de los altares y Iglesia y Sacristía y que todo esté vien puesto que no se maltraten los ornamentos y entienda que todo esto es de gran servicio de Dios y que puede ganar mucho con su Magestad y estos Sanctos.

-Por cuenta del Sacristán maior corre todo lo que se ha dicho en este Capítulo

[fol. $\left.107^{\mathrm{v}}\right]$

del sacristán menor, así para ordenarle que lo haga como para asistirle y ayudarle en todas las cosas que no pudiere hazer solo pues todas son deçentes y dignas en el servicio de Nuestro Señor que todos las hagamos, los de los ofiçios por obligación y los demás por devoçión y faltando el Sacristán menor se encargará de todo porque no aia falta.

-Los días de mucho concurso cuidará de avisar al Abad o Pressidente ordenen que la missa última se diga en el altar maior por que todos puedan oirla.

[fol. $108^{\mathrm{r}}$ ]

\section{Capítulo 10. De los Capellanes.}

1. La Erección de esta Iglesia instituye seis capellanes de coro ad nutum Amobles, para ellas elige el Cabildo personas de virtud conoçida de buena disposición y que sepan cantar.

2. En el coro se sientan en las sillas baxas por sus antiguedades, elige el Abad uno por çeremoniario y ayudante del maestro de çeremonias. 
3. El Cabildo puede elegir otro que haga ofiçio de Sochantre, y todos an de hazer los oficios y ministerios que el Cabildo señalare y el maestro de çeremonias les echare por tabla como comitantes y cantores, etc.

4. An de ser muy obedientes al Abad y Pressidente y executar todo lo que les ordenaren, acuden al mostrar las sagradas reliquias las cuevas y cosas semejantes.

5. Asisten en el Coro a todas oras an de cantar en el façistol grande junto a él fuera de sus sillas en pie y sin bonetes, alléganse

[fol. $\left.108^{\mathrm{V}}\right]$

A las sillas de los prebendados, y desde el plano del coro les encomiendan las antiphonas con humiliación $=$ Los Domingos echan el agua en el coro y al pueblo cuando son comitantes, Van a los lados del preste, un paso adelante, ministra el uno la naveta y el otro alza el pluvial. Son muy corteses ablando con los prebendados, no se cubren hasta que el Prebendado les haze señal y el prebendado sea también muy cortés en mandar luego que se cubran $=$ En el coro guarden las cortesias como se dixo lib.1.Cap. 1.

6. No gozan de recle mas el Abbdad les puede dar treinta días de liçencia por junto o por puntos, como no sea el de la oración solo en que ganen y el Cabildo prorrogarla nemine discrepante por otros veinte $=$ Mas perdiendo les puede el Abbad prorrogar otros treinta días y el Cabildo lo que quisiere.

7. No puede decir missa mientras las horas ni missa mayor sini es dando kiçençia el Abbad ò Presidente de la

[fol. 109r]

Casa atento la urgente neçesidad que ubiere y esto sea rera vezes.

8. No pueden salir del coro sin liçceçcia y si locontrario hicieren se les quite la hora o día y si ubiere exceso sea penado por el Abbad o Cabildo.

9. Cuando asiste a la misa algun prelado o el Presidente de Granada o algun Señor de título sacan la paz detrás de los colegiales que llevan las del coro y pueblo con su çendal y la da con las Venias acostumbradas a la persona señalada y el que señale el maestro de çeremonias cumpla con este ministerio.

10. El miércoles primero de cuaresma ponen la ceniza al pueblo en el altar de la Concepción con sobrepelliz y estola como se dizo en su día lib.4 C.8 y su ay personas de respeto como son oydores o inquisidores, Cavalleros, grandes señores o señores de título baxan y los combidan que suban por velas o palmas en sus días en el lugar que se refiere lib.4 cap. 6 y capt $^{\circ} 10$ y si ay algunas Señoras semejantes

[fol. $109^{\mathrm{v}}$ ] 
Ellos les baxan las velas o palmas.

11. En el coro cantan las prophecias que les encomiendan cuando las ay y las Kalendas los días que se señalan lib.1 cap.4.

12. Capitulan cuando no ay Prebendados ni huéspedes de aprobación en el Coro, y esto desde sus sillas y por sus antigüedades como también presiden a falta de ellos.

13. Dizen por su turno la missa ultima y sean muy cuydadosos en esto por que no falte missa a hora tan neçesaria.

14. Acompañan al Cabildo en todas las procesiones y recibimientos que se hiçieren.

15. Tienen lugar inmediatamente delante de los canónigos.

[fol. $110^{\mathrm{r}}$ ]

\section{Capítulo 11. Del Sochantre.}

1. A de ser elegido para Sochantre clérigo aunque no sea ordenado, de virtud, asiento y cordura como el que a de vivir en este Sacro Monte de buena persona y aspecto que sea diestro y sepa cumplir con su offiçio.

2. Sientase en las sillas baxas y precede a los capellanes en el coro y los demas actos, mas no preside ni capitula.

3. Cuando comienza la gorda para entrar en horas o missa va al coro vee como y que registran os Colegiales que sea todo ajustado con el breviario y misal porque al tiempo de cantar no aya detenimiento ni desorden y que todos los libros que ubieren de servir los traigan y los que no cupieren en el façistol los pongan al pie señalados con sus hierros lo que se ubiere de decir.

4. Asiste en todas las horas y entona como se dixo lib.1.cap.7 tiene mucho cuydado que se lleve el compás conforme a la

[fol. $110^{\mathrm{v}}$ ]

solemnidad del día y para ajustarlo lo detiene o apresura, mas nunca ni en ningun día vaya corrido y que siempre se haga la mediación, ni comienze el coro Verso hasta acavado el otro.

5. Todo lo que entona es puesto en medio de el coro baxas las mangas el bonete qitado y cuando preintona buelve al coro o persona a quien conbida y en comienda el verso o antiphona con humillación.

6. Generalmente da punto a todo lo que se canta y corrije los hierros haze callar al que desentona, está muy atento a todo lo que se canta en el altar para responder a tiempo y en el mismo punto. 
7. En las procesiones va el Sochantre en medio y cuyda que todos respondan a compás y en el mismo tono y lo en que van cantando guarden todos el compas, reparte los libros de los proicesionarios a los que mas saven cantar para que ayude mejor.

[fol. $\left.111^{\mathrm{r}}\right]$

8. En las fiestas de primera clase y principales de Nuestro Señor y Nuestra Señora puede cantar al organo el cuarto psalmo y el cantico de magnificat y en la missa algun motete al tiempo del alzar y esto en los otros días no lo haga a su albedrío sino con licencia y avisando primero.

9. Todos los días que no fueren fiesta o fuere o no ubiere Visperas o copletas o Salve cantada $\mathrm{O}$ rasura por la tarde tiene obligación a dar lección de Canto a los Colegiales por espacio de media hora en la qual an de asistir todos con mucha puntualidad y el Sochantre el primero, y les haze exerçicio de la practica y a todos examina y pide quenta y cuyda que esten con atención y cuydado avisa de ello al Rector y ponga todo cuydado que salgan aprovechados y diestros que es de grande importancia que sepan para ayudar al Coro.

10. Cuando ay musicos los advierte las ceremonias que se observan en nuestro coro acerca del Cantar.

[fol. $\left.111^{\mathrm{v}}\right]$

11. Que los menestriles no digan el verso del Gloria Patri = que no toquen el primer ni postrer verso de los Hymnos que todo lo dizen las Vozes, y en lo que cantaren por el facistol los lleve el Compas advierteles lo que pueden cantar al organo.

12.Si algun forastero quisiere cantar algun motete o psalmo al organo tiene el Sochantre obligación de saber y informarse si lo puede hazer dignamente y si lo puede pida licencia al que preside y si juzgare que no es suficiente lo advierta de esto.

13.El que preside en el Coro no de licencia para esto al que no fuete reconoçido ó sino es ynformado del Sochantre.

Cuando algun colegial hiciere officio de Sochantre por estar vacante el offiçio o estar ausente el Sochantre propio se puede sentar en el banco de los Colegiales y esto se entienda estando señalado para hazer el officio.

[fol. $112^{\mathrm{r}}$ ]

\section{Capítulo 12. Del organista y días que ay organo.}

1. El organista sea muy diestro y suficiente como para Iglesia tan principal no puede faltar del Sacro Monte ningun día que pida organo. 
2. Si faltare sea multado en su salario y el Abbad o Presidente no le de licencia para faltar en día que a de tañer sino es con muy urgente causa.

3. Ay organo en los oficios divinos todas las fiestas dobles del año.

4. Yten todas las Dominicas si no es las de adviento y cuaresma, septuagésima = sexagésima y quinquagessima, mas la dominica terçia de adviento que comienza Gaudere y la quarta de quadragessima que comienza Laetare se toca el orano a la missa.

5. Ay organo en todos los Sanos y días semidobles y en las missas de las ferias de

[fol. $112^{\mathrm{v}}$ ]

las rogaciones y en las missas votivas que se celebran con solennidad de doble.

6. En los Santos simples, excepto la missa de Santa Maria in Sabatho, y en las ferias, excepto feria quinta in coena Domini y Sabatho Sancto a las missas y en las Vigilias excepto la de Navidad, Epiphanía, Ascensión y Pentecostés y en las Témporas excepto las de la Sanctíssima Trinidad no se toca órgano.

7. A la missa en las Dominicas y fiestas dobles de primera y segunda clase y que como tales se çelebran, toca el órgano los Kyries y Gloria alternatim con el coro, el gradual y ofertorio y alternatim Sanctus y cuando alzan toca con más dulzura y gravedad y después de Hosana in excelsis toca hasta el Pater Noster y los Agnus alternatim después de cantada la antíphona comunicanda toca hasta las oraçiones post comunionem y responde siempre al Deo Gratias, mas el Sábado Santo juntamente responde el coro.

8. En los otros dobles toca con menor solennidad para que aya diferencia de los mayores.

[fol. $\left.113^{\mathrm{r}}\right]$

9. En los aniversarios y missas que no se çelebran solemnemente como de primera clase $\mathrm{y}$ en las semidobles se toca en menos solemnidad que en los dobles ordinarios.

10. En las Vísperas de las Dominicas hasta Idta rey Gaudete se toca órgano aunque lo ubo en la missa. ${ }^{19}$

11. A las Vísperas de primera y segunda clase toca el órgano a versos en el $1^{\circ}, 3^{\circ}$ y $5^{\circ}$ psalmo, en el himno y Magnificat con tal distinción y advertençia que en las fiestas más solemnes toque con más pausa y morosidad más dulze y gravemente.

12. En las Vísperas de los otros dobles y dominicas toca el himno y Magnificat a versos y siempre toca los Versos al Cántico Magnificat y Benedictus de suerte que de lugar a la Turificación del altar y del Choro.

${ }^{19}$ (al margen Por clemen X 1673) 
13. En los maitines solemnes de la Concepçión y Natividad de Nuestro Señor Iesuchristo toca el himno a versos y los psalmos a versos en los de Natividad 1.3.4.6.7.9. $=$ en la Concepçión los mismos $=$ en los de la resurección

[fol. 113 ${ }^{\mathrm{V}}$ ]

\subsection{3. y siempre y el te deum a versos.}

14. En los laudes toca todos los psalmos himno y cántico y siempre responde el Deo gratias.

15. Toca los responsorios los del último nocturno toca con más espacio para dar lugar a vestirse.

16. En las completas cantadas cuando son inmediatamente después de las Vísperas toca a versos el himno y cántico Nunc dimittis excepto en las completas del día de todos Sanctos que se dizen después de las Vísperas de los difuntos que aunque son cantadas no toca nada el órgano.

17. En las completas cantadas en los días solennes que vienen en feria de cuaresma cuando las Vísperas se an dicho ante prandium como en la fiesta de San Mathías, San Gabriel, San Ioseph toca el himno y Nunc dímittis como en las que se dizen $\mathrm{n}^{\mathrm{o}}$ precedente.

18. En las Completas de San Hisçio, San Messitón, San Tessiphón, Anunçiación de Nuestra Señora y Sábado Santo toca todos

[fol. $114^{\mathrm{r}}$ ]

los psalmos y himnos y Cántico con mucha solemnidad como en Vísperas de primera clase.

19. El himno y psalmos a versos con la misma solennidad toca en la prima de la Vigilia de Natividad, en la terçia del día de Pentecostés y en la nona el día de la Ascensión.

20. Nunca toca el órgano el primer verso de himno ni psalmo ni el Gloria Patri de psalmo ni cántico mas para que las bozes lo digan y según el orden alternativo toca en vaçío un verso y lo mismo a los himnos para que el coro diga en el Pange lingua el Tantum ergo Sacramentum, y en el Vexilla, O Crux ave spes unica y en todos los himnos el último verso.

21. En el Te Deum laudamus no toca el verso Te ergo quae sumus, el verso que toca el órgano lo deven dezir todos los caperos en las horas que los ay en voz intelligible que no haga disonancia, mas si lo dize alguna voz al órgano no es neçesario

[fol. 114 ${ }^{\mathrm{v}}$ ] 
22. En las proçesiónes del Sanctíssimo Sacramento excepto las del Jueves Sancto y en las de las reliquias cuando se reçiven o llevan en procesión por alguna causa toca el órgano a versos el himno que canta el coro mientras la procesión anda en la Iglesia, lo mismo en otras cualesquiera festivas que se hagan.

23. Todas las vezes que se manifiesta el Sanctíssimo Sacramento, toca antes y después del verso tantum ergo Sacramentum que canta el coro, cuando se encierra toca un rato luego dize el Coro el Tantum ergo y el preste la oración y toca mientras la muestra al pueblo hasta que çierra el sagrario y cuando se renueva toca un rato antes del tantum ergo, mas no toca después de la oraçión que dize el Presidente.

24. En las Salves que se dizen en la Iglesia los Sábados y fiestas de Nuestra, Señora y la cuaresma antes de entonarla el Sochantre toca y luego a versos.

25. En los fallecimientos de Prelado y todas

[fol. $115^{\mathrm{r}}$ ]

las vezes que viene a esta Sancta Iglesia y entra por ella toca lo mismo cuando otro prelado o Cardenal viene a visitar este Sanctuario.

26. En los reçivimientos de dignidades o personas seculares por grandes que sean no se toca órgano excepto al de Rey o Reina.

27. Cuando está manifiesto el Sanctíssimo Sacramento es vien que algunos intervalos toque el órgano y ordene otra qualquiera música de monocordio, o violones y se canten algunos motetes al órgano.

28. Tiene a su cargo los instrumentos mussicos que ubiere que no se destemplen ni pierdan, adereza y limpia el órgano algunas vezes al año y lo templa por la tarde en día que no aya concurso de gente y esto sea para las fiestas principales.

29. Tiene la llave del órgano y no la entrega a nadie que lo maltrate.

30. Si por alguna grave causa dieren liçencia para hazer ausençia a de prevenir persona que toque vien para que supla los días que faltare, y corre esto por

[fol. $\left.115^{\mathrm{V}}\right]$

su cuenta y la fábrica solamente dará de comer al substituto los días que viniere a tocar.

31. Puede dar el órgano que toque alguna vez a persona que lo pueda hazer dignamente.

32. Guitarra ni otro instrumento semejante no se ha de tocar en el Sacro Monte ni menos en la Iglesia.

[fol. $\left.116^{\mathrm{r}}\right]$ 


\section{Capítulo 13. Del Pertiguero.}

1. Este oficio lo tiene seglar, ha de ser elegido persona onrada, de buena disposición y curioso y procura el Cabildo que sea de anciana edad y venerable aspecto, muy cortés y morigero y dócil para hazer y ovedezer en cuanto fuere instruido.

2. Con los Prebendados abla descubierto y está así hasta que le manden cubrir.

3. Donde quiera que los encontrare se destoca y para hasta que pasan.

4. Si tiene ropa y encuentra algún prebendado que con sobrepelliz o capa va al coro le ofreze acompañarlo.

5. Su ofiçio es acompañar al Cabildo y a los prebendados todas las vezes que van en procesión o por Cabildo y en çeremonia a los oficios divinos, o cuando del Cabildo salen por Comissión a algún recaudo al Prelado o al Abad dentro de casa.

6. Sirve su oficio con ropa y gorra de seda de color negra conforme se dixo libro 1, Capítulo 8.

[fol. 116 $\left.{ }^{\mathrm{V}}\right]$

y con cetro o pértiga de plata la cual tiene siempre en la mano derecha y cuando se quita la gorra pasa la pértiga a la siniestra y viste la ropa sobre su ábito de seglar, calzón y ropilla deçente, y negro.

7. Acompaña en los oficios divinos todos los domingos y fiestas de guardar de todo el año y todas las fiestas de primera y segunda clase y que como tales se celebran en este Sacromonte, libro 1, Capítulo13, y siempre que son las Vísperas cantadas, y todos los jueves a la missa o los días en que se renueva el Sanctíssimo Sacramento.

8. Acompaña día de çeniza, Jueves, Viernes y Sábado Sancto, Vigilia de Navidad y de Pentecostés a la missa, todos los días que se celebra con solennidad por estar el Sanctíssimo Sacramento o reliquias manifiestas: o se celebra fiesta Votiva pro re graui, o aniversario solenne, los días de los difuntos y aniversarios o honras solennes y entierros $\mathrm{de}^{20}$

[fol. $\left.117^{\mathrm{r}}\right]$

9. En todas las procesiones y recivimientos siempre que fuere el Cabildo por Cabildo.

10. Asiste a la puerta del Cabildo cuando le tienen para guardarla y hazer los recaudos y llamamientos neçesarios y siempre que el Cabildo le llamare para otro cualquier acompañamiento.

\footnotetext{
${ }^{20}$ Faltan palabras en el original.
} 
11. El lugar que tiene es delante de todos siempre porque acompaña como guía, excepto cuando baxa todo el coro en ceremonia o salen a algún reçivimiento que entonzes va inmediatamente antes de los prebendados como se dize avajo.

12. En la missa está en el medio del pavimento enlosado = cuando ay blandón se pone al lado y cuando dos en medio un paso delante de ellos.

13. En Vísperas y maitines después que baxa del coro se asienta en escabel plano junto al púlpito del evangelio y jamás dexa pasar ni cruzar ni sentarse nadie en el pavimento mientras se celebran los oficios.

14. En el coro se pone en la última silla baxa del lado siniestro debaxo de la silla

[fol. $\left.117^{\mathrm{V}}\right]$

del apuntador enfrente del facistol y desde allí haze genuflexiones y venias al altar y al coro.

15. Va a vestirse antes de la gorda y en todos los actos acude con puntualidad el primero.

16.En la missa sale y cuando pasa por el altar quita la gorra y se pone en medio del pavimento haze genuflexión con todos.

17. Al Introito, psalmo y comfesión está de rodillas cuando entra el çelebrante. Al altar se levanta y en toda ella está en pie, mas al alzar el Sanctíssimo Sacramento y cuando ay comunión está de rodillas.

18. Está cubierto siempre que los de la missa están sentados y en la Gloria quita la gorra al adoramus te; gratias agimus tibi; susçipe deprecationem nostram, y cuando se nombra a Jesucrito.

19. En el Credo está sin gorra aunque estén sentados y siempre que están en pie en el altar los celebrantes está descubierto excepto a la Epístola, gradual o tracto

[fol. 118 ${ }^{\mathrm{r}}$ ]

o sequençia y ofertorio.

20. Haze genuflexión todas las vezes que en la Epístola, gradual, versos o tracto y Evangelio la hazen los que çelebran y en el Credo al Incarnatus est en su mismo lugar.

21. Acompaña a ida y buelta los turiferarios cuando van a inçensar al coro.

22. En acavando el Presidente el Pater Noster va a la puerta de la sacristía y sale acompañando a los de las pazes y después que la an recivido del subdiácono va con 
ellos al coro y buelve de la manera que con los turiferarios y aunque aya más de dos pazes no acompañan mas que los que van al coro.

23. En la comunión general comulga con todos los ministros, el último llega a las gradas $\mathrm{y}$ en ellas dexa tendida la pértiga, sube con las devidas genuflexiones, comulga y al baxar se hinca de rodillas en la ínfima grada y toma la pértiga

[fol. $118^{\mathrm{v}}$ ]

y se buelve a su lugar.

24. Sube también el último por la vela y palma dexando la pértiga de la misma manera, tendida sobre las gradas y de la misma manera la buelve a tomar.

25. En los días de la çeniza de las candelas y palmas, acavada la vendiçión va al coro y puesto en medio haze comedimiento al que preside y al coro diestro y siniestro y combida para que vaian al altar a tomar lo que se a vendezido y va delante de los primeros que van y se pone en su lugar haziendo comedimiento y allí se queda buelto el rostro al púlpito del evangelio porque no tenga las espaldas a los que vienen sino que pasen por delante de él.

26. El Jueves Sancto acavado el Pater Noster de la missa sube al Choro y de la misma manera combida al Cabildo que baxe a la Comunión y los acompaña y se queda antes de subir la grada del pavimento baxo.

27. El Sábado Santo cuando comienzan nona

[fol. $119^{\mathrm{r}}$ ]

sube al coro a acompañar los prebendados cuando baxan a la vendiçión del fuego.

28. Mientras se canta la vendición del çirio y a todo el demás oficio está en pie en el escavelo debaxo del arco donde se pone a Vísperas y cuando cantan en la letanía Peccatores te rogamus audinos se llega a las gradas y haze genuflexión al altar y acompaña a los celebrantes que van a tomar ornamentos para la missa y sale con ellos, asiste como los demás días.

29. Va con el subdiácono hasta el púlpito de la Epístola y cuando sube le haze comedimiento y se buelve a su lugar y cuando baxa se llega a recivirlo y lo acompaña hasta las gradas.

30. Va con el Diácono al púlpito del evangelio y mientras lo canta se pone en medio de los çeroferarios, un poco desviado de ellos el rostro al Diácono, a la buelta le acompaña hasta las gradas y le haza comedimiento apartándose a un lado y está en medio de los ceroferarios hasta que el Diácono ha incensado al preste que haze 
[fol. $\left.119^{\mathrm{v}}\right]$

genuflexión se buelve a su lugar.

31. Si ay sermón va a la puerta de la Sacristía y sale con el predicador y cuando llega a las gradas le hazen comedimiento y lo lleva al pulpito y cuando sube le haze el mismo comedimiento.

32. Si la Credençia está en el Pavimento baxo, cantado el oremus del ofertorio se llega a las gradas y acompaña al Subdiácono que va por el Cáliz y buelve con el.

33. Siempre acompañará a los prebendados Diáconos y predicador al reçivirlos y despedirlos del acompañamiento les haze humiliaçion $=\mathrm{y}$ siempre que los que van en çerimonia hazen venia o genuflexión haze el lo mismo.

34. En las Visperas acompaña y sale y haze en su lugar genuflexión con todos en el coro al altar y al coro las mismas Venias y genuflexiones y se pone junto a la grada de la silla del apuntador y después de aver pasado la ceremonia se llega a su silla y todas las vozes que entra en el coro a aguardar después de aver hecho

[fol. $120^{\mathrm{r}}$ ]

genuflexión y al coro Venia inmediatamente se va a ella.

35. Cuando el Preste está en su lugar se despide del Choro con humillación baxa y en el pavimento se sienta como se dixo.

36. Cuando salen los turifararios a despavilas los acompaña y mientras se dize la capitula y despavilan está enfrente del altar llegado a las gradas y la gorra en la mano y buelve con ellos y cuando salen con los tutibulos para el coro los acompaña y cuando ellos se arrodillan al Veni Creator, Ave Maris Stella o tantum ergo haze el lo mismo en el Pavimento enlosado $=\mathrm{y}$ en su lugar aguarda al celebrante que baxa a ynçensar y lo acompaña y cuando llega a las gradas se buelve a un lado para que el celebrante pase por delante y le haze comedmiento y mietras dura la ynçensaçion está en medio de los ceroferarios, sube al coro y se pone en su silla donde está hasta que acavan las Visperas, buelve con la ceremonia y en la Sacristía se pone abaxo del bufete el rostro al çelebrante que está en el testero y así está

[fol. $120^{\mathrm{v}}$ ]

mientras hazen la confesión, y con todos haze venia al cruçifixo y los acompaña al coro.

37. Y si inmediate después de completas ay Salve, se sienta en su silla y baxa con el preste a la Iglesia y mientras dizen la oracion está de rodillas en el pavimento y acavada lo acompaña a la Sacristía. Si no ay Salve, los que subieron en ceremonia al coro están en sus lugares, se despide del coro y buelve a la Sacristía. 
38. La cuaresma en las Completas cantadas con su ropa y pertiga se sienta en su lugar en el pavimento y lo aguarda y que /de/ se comienza la Salve sube al coro y acompaña al que baxo a decir la oración.

39. En las Visperas feriales desde el Domingo de pasion haze lo mismo al principio de ellas se sienta en el pavimento y al segundo psalmo sube al coro para acompañar a los Prebendados que baxan a la seña y en la Iglesia se pone al fin de las alfombras en medio frente del altar y está en pie = no dexa llegar a nadie a

[fol. $121^{\mathrm{r}}$ ]

Las alfombras ni cruzar por ellas y al verso o Cruz Ave Spes Unica está de roillas, buelve con ellos al coro.

40. En los días de Nuestra Señora que se dize Salve en la Iglesia está de rodillas en la grada del pavimento detrás del facistol que ponen para cantarla y cuando es tiempo se levanta y acompaña al prevendado que va a decir la oración, mas cuando va por el no pasa de los Colegiales.

41. Cuando acompaña a todo el coro que baxan en ceremonia no va delante de los Colegiales sino después de ellos y de los capellanes inmediatamente delente de los prebendados y en el mismo lugar va cuando salen a algun recibimiento, mas en las procesiones y demas actos de ceremonias va delante de todos como se a dicho.

42. A los maytines y laudes acompaña y está como se a dicho en las Visperas.

[fol. $121^{\mathrm{v}}$ ]

\section{Capítulo 14. Del Campanero, modo de tocar, y hora de entrar en el coro.}

1. El Campanero ha de ser persona de virtud y satisfación vive dentro del Sacro Monte en la torre.

2. Tiene especial cuidado del relox en traerlo concertado y ajustado y por ningún caso o respecto particular lo apresure y detenga, límpialo y aderézalo a menudo, no consiente que nadie que no lo entienda ande en él y así no fía las llaves de la torre.

3. A de ser muy asistente en casa porque no haga falta en su ofiçio que es muy continuo y notable que por él se rije el coro e Iglesia.

4. Es a su cargo tocar a todas las horas y demás cosas que se ofrezen por el orden siguiente:

5. Desde el primer día de Otubre hasta el primero día de cuaresma, miércoles de çeniza exclusive, se toca a oraçión a las cinco y media de la mañana y se entra a oraçión a las seis hasta las siete

[fol. 122 ${ }^{\mathrm{r}}$ ] 
6. A horas se entra a las siete y media y a missa de diez a vísperas a las dos y media.

7. Desde el día de la çeniza hasta el de Resurrección exclusive, se entra en oración a las cinco y media y en horas a las siete, en missa a las diez. En Vísperas hasta el primer Sábado y los demás días feriales en acabando la missa mayor y a las completas de estos días y vísperas de las dominicas a las tres.

8. Desde el día de Resurrección hasta el último de septiembre inclusive se entra en oración a las çinco, en horas a las seis y media, en missa mayor a las nueve, en vísperas a las tres.

9. En los maitines de la conçepçión de Nuestra Señora y en miércoles, Jueves y Viernes Santo se entra a las çinco de la tarde, en los de la Navidad a las doze de la noche, en los de Resurrección a las tres de la mañana.

10. En la oraçión de la noche desde primero

[fol. $122^{\mathrm{v}}$ ]

de Octubre hasta Pascua de Resurrección exclusive se entra media hora antes de cenar o de conferencias el día que las ay y desde la Resurrección hasta fín de Septiembre se tiene inmediatamente después de Vísperas y para entrar y salir en la oración de la tarde toca el campanero con la campana del refectorio.

11. Los días que ay procesión de Ramos, Pasión, Sermón o Vísperas cantadas después de la missa se entra media hora antes en missa.

12. En el lavatorio el Jueves Sancto se entra a las dos de la tarde.

13. El Sábado Sancto son los ofiçios consecutivamente después de horas y así no toca a ellos.

14. A la oración de la mañana toca media hora antes de entrar en ella y baxa llamando por todos los aposentos, despierta y da luz al que la pide. En la media hora se visten, súbese a la torre para ser puntual y en dando la hora de entrar como se dijo al principio toca con esquilón

[fol. $123^{\mathrm{r}}$ ]

unas bueltas que es la señal de entrar y están una ora en oraçión, y cuando quiere dar la hora para salir aguarda con el cordel en la mano y andando el relox comienza a tocar a prima, la mañana de la Natividad de Nuestro Señor Iesuchristo y Viernes Sancto y mañana de Resurrección no toca a oraçión por que no la ay aquestos días.

15. A horas, toca media hora el primer cuarto con la campana a media buelta, en dando el cuarto dexa la campana que toque hasta que ella se para y toca la gorda a medio cuarto y luego el esquilón por tres vezes a buelta y últimamente a lengua hasta que acava de dar el relox, y de esta forma toca siempre a las horas, a missa, a Vísperas y 
Maitines cuando no se repica, excepto que a los maitines el miércoles Sancto toca una hora, media con dos campanas a media buelta como día doble, un cuarto la gorda, otro el esquilón.

16.Aunque acava de tocar a missa no dexa

[fol. $\left.123^{\mathrm{v}}\right]$

la torre porque aguarda a tocar la plegaria cuando alzan y le hazen señal y lo mismo cuando entran a las dos y media en Vísperas o completas no dexa tampoco la torre porque a de tocar la plegaria a la espiración.

17. Después de alzar si ay Vísperas ante prandium toca de la forma que se ha dicho con las campanas, mas no toca la gorda sino inmediatamente el esquilón a lengua en breve espaçio de suerte que acave de tocar el esquilón a lengua cuando acavan la missa y assí no tocará el esquilón a buelta para abreviar.

18. La cuaresma toca todos los días a la Salve con la campana de la Asumpción a buelta entera, excepto los Sábados que repica para la que se dize en las cuevas, si las completas son cantadas comienza a tocar a la mitad de ellas y si no, inmediate después de la plegaria hasta que acavan toca por tres vezes como a sermón.

19. Si en la missa a de aver plegaria o

[fol. $124^{\mathrm{r}}$ ]

rogativa en tocando la de alzar toca con la campana a media buelta cuando le hazen señal que es acavado el Pater Noster y dexa acavada la rogativa que le harán señal.

20. Cuando en las Vísperas ay seña toca cuando le hazen señal con la campana a media buelta y de la misma manera siempre que ay rogativa, toca a nublo en las tempestades y a estas cosas toca siempre con la campana de la Asumpción.

21. A la oración de la noche y conferençias haze señal para entrar y salir con la campanilla del refectorio.

22. Al sermón de la mañana toca la campana gorda a bueltas enteras por tres vezes, veinte bueltas cada vez que duren todas tres vezes media ora, la noche antes a las ocho en ibierno y a las nueve en Verano y por la mañana, en acavando de tocar a horas buelve a llamar otro tanto si el sermón es por la tarde toca a las tres

[fol. $124^{\mathrm{v}}$ ]

vezes dando las doze.

23. La Plegaria del altar y de las tres y las Aves Marias toca con la campana gorda tres golpes con tal proporçión que puedan rezarse tres Pater Noster, y dando el último golpe a la del alzar toca con la campana de San Çeçilio tres cuatro medias bueltas y los días 
dobles de primera y segunda clase con la de la Asumpción de la misma manera después de las Aves Marias, mas si al repique después o Vísperas después de la missa sin tocar estas medias bueltas toca a Vísperas o repica, mas después de la plegaria de las tres no toca nada.

24. Todos los días del año toca a la oraçión de la mañana con la campana de la Asumpción.

25. Los días de primera y segunda clase en este Sacro Monte y el día de la Vigilia de la Natividad toca a las horas con la misma campana, los demás días con la de San Çeçilio.

26. Todos los domingos y dobles que no se repica

[fol. $125^{\mathrm{r}}$ ]

toca a missa maior y a vísperas con dos campanas, la de San Çeçilio y la de la asumpción, comienza con aquella algunas medias bueltas y luego con la otra y así prosigue alternativamente todo el cuarto, luego las gorda y el esquilón.

-Los demás días de ferias simples y semi dobles toca con la campana a media buelta.

27. A completas la cuaresma toca los días solemnes con la campana de la Asumpción sola, los otros días con la de San Çeçilio sola.

28. El miércoles Sancto, a los maitines con la de la Asumpción y con la de San Çeçilio.

29. Solamente para entrar en missa mayor o Vísperas o maitines se repica, nunca para entrar en prima ni en completas (excepto el día de la Natividad de Nuestro Señor Iesuchristo que se repica para entrar en prima por dezirse entonces la sigunda missa; si fuere Sábado da los repiques a la ora de la missa de Nuestra Señora que se dize la sigunda de la Natividad y a prima toca en la forma ordinaria) y el día

$\left[\right.$ fol. $\left.125^{\mathrm{v}}\right]$

de Pentecostés que se repica para entrar en terçia, porque sirve aquel repique para la misa.

30. De la misma forma y solennidad que en una fiesta, se repica a primera Vísperas, se repica a missa, maitines y laudes si los ay y segundas Vísperas.

31. El modo de repicar es, comienzan los esquilónes y campana del relox a lengua como el espacio de un Credo, luego entra la campana de San Çeçilio y esquilón de San Dionisio juntamente a buelta entera como espacio de dos Credos, luego la Campana de 
la Asumpçión y después de otros dos Credos la gorda y estas cuatro campanas andan a buelo ni apriesa ni muy despaçio porque así hazen música.

32. Acavado el primer repique se quedan las que andan a buelo la campana arriba y la cabeza abaxo porque al sigundo comienzan con más presteza; al último se quedan las campanas abaxo y las que andan a lengua no cesan hasta un rato después de aver parado las otras.

33. Cuando se repica a missa y Vísperas se adelanta un cuarto de hora y dura el repique

[fol. $\left.126^{\mathrm{r}}\right]$

media hora y en ella se dan tres al último cuarto gorda y esquilón siempre de una manera como se ha dicho.

34. A maitines se toca una hora y en la media se dan tres repiques, un cuarto de gorda otro de esquilón.

35. Para laudes se toca cuando en el coro comienzan el Te Deum laudamus y para ello hazen señal a la torre y con las mismas campanas que tocó a maitines da un solo repique mas este sirve para la missa primera, la noche de Navidad que se dize después de maitines y para las laudes toca dos repiques cuando an alzado en esta missa.

36. Siempre que se ha repicado a Vísperas en dando la oración de las Aves Marias se repica con esta diferencia que los días de primera clase se dan tres repiques a lengua los demás días se da uno.

37. Se repica con todas las campanas los días siguientes Natividad de Nuestro Señor, Epiphanía, San Çeçilio, San Hisçio, San Messitón, San Tesiphón; Primero de Resurección,

[fol. $126^{\mathrm{V}}$ ]

Ascensión, Primero de Pentecostés, Corpus Christi y su octava a la missa y a las sigundas Vísperas, Conçepción, Natividad, Anunciación, Purificación y Asumpción de Nuestra Señora, Natividad de San Ioan, San Pedro y San Pablo, SanctIago el Zebedeo, Dedicación de la Iglesia, San Dionisio Areopagita, Todos los Sanctos.

38. Con todas las campanas, mas no la gorda, la circunçisión del Señor, segundos y terceros de Resurección y Pentecostés, Sanctíssima Trinidad, Transfiguración del Señor, San Estevan, San Ioan Evangelista, estos días con más solennidad que los que se siguen: San Andrés, Santo Thomás, San Phelipe y SanctIago; la Invención de la Cruz, Señora Santa Ana, San Lorenzo, San Bartolomé, San Matheo, San Simón y Iudas, San Miguel, El Ángel de la guarda, San Gabriel, San Ioseph, Presentación, Visitación, Expectaçión de Nuestra Señora y fiestas de las nieves, como también las demás fiestas de Nuestra Señora; los Inocentes, la translación de SanctIago, [San] Fernando

[fol. $\left.127^{\mathrm{r}}\right]$ 
39. A la missa= repica con los esquilónes y relox a lengua, y a buelo con la de San Dionisio y San Çeçilio, los días de la toma de Granada, San Sebastián, Santo Mathías, San Marcos, San Bernavé, La Magdalena, San Francisco, San Lucas, San Silbestre.

40. A las bísperas y missa de los aniversarios se toca conforme es la solennidad con que se çelebra: si con toda solennidad como de primera clase con todas las campanas como el día de la combersión de San Pablo y si con menos no se toca la gorda como en el aniversario de la exaltación de la cruz.

41. A la Salve los Sábados desde primero Sábado de Octubre hasta el Sábado Sancto toca sus tres repiques mientras dizen completas porque inmediatamente después de ellas se dize y desde el Sábado in alvis hasta el último de septiembre toca a las cinco y media de la tarde los tres repiques que duran media hora hasta las seis y dexa con tres golpes de la gorda. Los días de Nuestra Señora se dize la Salve en la Iglesia y en verano y ibierno toca en comenzando a completas porque

[fol. $127^{\mathrm{v}}$ ]

se dize inmediatamente después de ellas.

42. El Jueves Sancto a la Gloria repica muy solennemente con todas las campanas todo el tiempo que dura el cantarla y no toca más campanas para cosa alguna hasta el Sábado Sancto a la Gloria.

43. Comienza a tocar con la matraca a las dos para el mandato hasta las dos y media por tres vezes que duren media hora y cuando dexa la terçera vez la trae más espaçio para que se entienda que es señal de entrar en los oficios, de esta forma toca con la matraca para entrar en tinieblas media hora y el Viernes Sancto a las horas y para el oficio toca de ocho y media hasta las nueve, para entrar en completas a las tres y media hasta las cuatro, y para tinieblas que se dizen consecutivamente haze una señal dando algunas bueltas a la matraca.

44. El Sábado Sancto ay hora de oración y sin tocar campana ni matraca llama

[fol. $128^{\mathrm{r}}$ ]

por los aposentos a las çinco y media y a las seis para entrar en oraçión haze señal con la matraca pequeña, a las siete para las horas toca con la grande por tres vezes como se ha dicho media hora, y para la Gloria repica solennemente con todas las campanas mientras se canta y en tocando la plegaria del alzar da dos repiques muy solennes con todas las campanas para vísperas.

45. A las proçesiónes se toca de esta manera: cuando ay proçesión el día siguiente si es por la mañana, la noche antes a las ocho si es hibierno y a las nueve si es verano, se tocan tres repiques con los esquilónes y relox a lengua y San Dionisio y San Ceçilio a buelo y por la mañana, en tocando el esquilón para entrar en oraçión, se dan otros tres 
de la misma forma. Si la procesión es por la tarde, inmediatamente que dan las doze se tocan los dichos tres repiques que dura media hora, y de esta regla se sacan las procesiones del Jueves Viernes y Sábado Santo que no se repica.

[fol. 128 $8^{\mathrm{V}}$ ]

46. Cuando la procesión de la tarde es solenne como la de la octava del Corpus, día de la Asumpción de Nuestra Señora o algún recivimiento de reliquias, se dan los dichos tres repiques con todas las campanas, mas si es de alguna rogativa con las dichas número preçedente.

47. Cuando andan las procesiones se tocan cortos y con muy poco intervalo los repiques que duran hasta que se acava.

48. A las procesiones del Sanctíssimo Sacramento, de reliquias y de la Asumpçion de Nuestra Señora, andan todas las campanas y la gorda, a las de Purificación, Ramos, letanías o otras rogativas, andan todas excepto la gorda.

49. Todas las vezes que a de estar el Sanctíssimo Sacramento manifiesto, el ençerrar y desençerrar, se repica con todas las campanas en esta forma: cuando sale la çeremonia de la Sacristía para desençerrar hazen señal a la torre y toca dos repiques con algún intervalo; y cuando sea de encerrar

[fol. 129 ${ }^{\mathrm{r}}$ ]

da un repique un cuarto antes cuando sale la çeremonia le hazen señal y haciendo pausa da otros dos.

50. Todos los jueves se renueva el Sanctíssimo Sacramento en el altar mayor y acavada la missa le hazen señal y da dos repiques o intervalo breve sin la gorda.

51. Los Sábados para la missa de Nuestra Sra a los tres cuartos de la oraçión da un repique con los esquilónes y relox a lengua y con San Dionisio y la asumpçion a buelo, cuando da la ora, da otro que sirve de señal de salir de la oraçión y con algún intervalo da el terçero, no toca al fin del campana ni esquilón sino da tres golpes con la gorda, y en alzando en la missa de Nuestra Señora toca a las horas con la campana que pide el día y algunos golpes de la gorda y cuando le hazen señal dexa con el esquilón a lengua.

52. A la Salve de los Sábados toca tres repiques con los esquilónes y Sanctiago y la Asumpción a lengua que dura media hora, en acabando

[fol. $129^{\mathrm{v}}$ ]

el ultimo día dá los tres golpes con la gorda $=\mathrm{Si}$ las salves en día de Nuestra Señora la asumpcion abuelo.

53. Todos los jueves que se reza de feria excepto las de cuaresma, adviento y Vigilias la misa mayor es del Sanctissimo Sacramento y se celebra con solemnidad y así a de 
repicar en ella como en los días de segunda clase. = Ell día de San Cecilio acavada la missa se dan las reliquias que las adore la ciudad. Los días de San Hisçio, San Messiton y San Tessiphon se dan para que las adore el Cabildo del Sacro Monbte y mientras dura la adoración a de repicar con todas las campanas y con la gorda.

54. En los recibimientos repica al Rey o Reyna, al Prelado y a todos los Obispos, Arzobispos, Cardenales que vinieren a visitar este Sanctuario con todas as campanas = repica cuando viene el Rey o Reyna a las doze del día si a de ser por la tarde y por la mañana en amaneciendo, y luego con breve intervalo dá sus repiques

[fol. $130^{\mathrm{r}}$ ]

desde que sube por la cuesta del chapiz todo lo que dura la venida esta da y buelta.

55. Al Prelado repica tres repiques, desde que comienza a subir la cuesta, que duren hasta que aya acavado. La oracion en la Iglesia y al despedirlos da otros tres hasta que están en lo ultimo de la cuesta.

56. El día de San Cecilio se repica a la missa cuando se comienza a descubrir la çiudad por la puente quebrada y se dan seis o mas repiques que duren hasta que la Ciudad toma su asiento en la Iglesia y lo que repica a la adoración de las reliquias dura hasta que la Çiudad llega a la Cruz de los canteros.

57. La noche que ay fuegos por la celebridad del día siguiente repican mientras duran los fuegos y regocijos, ocho ônueve repiques cortos y con muy breve intervalo.

58. Estas noches son las Visperas de la toma de Granada, de San Çeçilio o Octava de Corpus Christi: de San Pedro y San Pablo,

[fol. $130^{\mathrm{v}}$ ]

Sanctiago el Zebedeo, la Asumpción y Concepción de Nuestra Señora, San Dionisio Areopagita y cuando por alguna fiesta de la ciudad o regocijo o causa publica o Canonicacion de un Sancto o por otra Causa ubiere fuegos repicará de la misma manera y todas las vezes que en la Catedral se repicare por alguna de las causas dichas o semejante, y por la entrada de nuevo Prelado, a de repicar a la misma hora que en Granada y con todas las campanas.

59. Todas las noches toca a las animas, excepto el Jueves Sancto (desde el día de la resurrección hasta fin de septiembre, a las nueve de la noche y desde primero de octubre hasta la dicha pascua a las ocho y media, dá nueve golpes con la campana gorda repartidos en tres vezes cada vez, tres y cada vez haze un poco de pausa.

60. El día de todos los Sanctos a las doze del día (como no sea sabado que si lo es es el Domingo siguiente) dá tres dobles o Clamores con todas las campanas por los difuntos, duran media hora. 
[fol. $131^{\mathrm{r}}$ ]

61. En saliendo los prebendados con las capas negras de la Sacristía como se dize libro 4 , capítulo 22 , le haze el portero del coro señal y dobla de la misma manera con mucha pausa y sentimiento y por toda la tarde duran los clamores con pequeños intervalo inmediatamente al ultimo golpe de las Avemarias dá tres clamores y otros hasta las diez de la noche, por la mañana en entrando en oracion dá tres Clamores que duran media hora poco mas en acabando de tocar a horas da otros tres o quatro Clamores repartidos hasta que es hora de tocar a missa mayor y después de la plegaria de alzar da otros clamores que duran hasta acavados los responsos y procesion y de profundis de la Sacristía.

62. Los días de los Aniversarios solennes por Nuestro Ilustrisimo fundador y por sus padres toca el día que se dize la Vigilia a las doze del día a tres clamores con todas las campanas que duren media hora y no toca mas hasta que se comienza la Vigilia.

[fol. $131^{\mathrm{v}}$ ]

que da un clamor y prosigue con otros hasta que se acava el responso y de profundis en la Sacristía $=$ en tocando la oración da otro clamor largo y en entrando en la oración por la mañana da otros tres por espacio de media hora y no da otros hasta que ha tocado la plegaria del alzar en la missa del Aniversario que buelve a tocar clamores con poco intervalo hasta que se acava el de profundis en la Sacristía.

63. Este mismo estilo y orden de tocar guarda cuando en este Sacro Monte se hazen honras por muerte de Papa o Rey o Reina o Prelado que se entierra en él.

64. En los otros Aniversarios de difuntos que se hazen en esta Sancta Iglesia, como el de los hermanos difuntos y de los padres de los prebendados y ministros, no toca hasta que se comienza la Vigilia y reparte los clamores con todas las campanas mientras dura el oficio y lo mismo a la missa y comienza después de aver alzado en ella que duren hasta el fin del responso y de profundis que se dize en la Sacristía.

65. En otros aniversarios dotados guarda

[fol. $\left.132^{\mathrm{r}}\right]$

este orden de tocar, y si las vigilias y missa se dizen por la mañana juntamente no da más que tres clamores, uno en la Vigilia, otro después de alzar, otro al responso. Si el aniversario es por Prelado o persona grave toca todas las campanas, en los otros todas excepto la gorda.

66. Cuando en la Ciudad doblan por Rey o Reina o Prelado da también los clamores largos todo el tiempo que dura en la Cathedral y comienza cuando comienza la Cathedral. 
67. En las muertes de los de casa toca los Clamores en esta distinçión y diferençia: por los prebendados con todas las Campanas y desde que espira y todo el día, excepto el tiempo que toca a las horas y missa y mientras se dize y la hora desde comer hasta después de Vísperas y más frequentemente mientras el entierro y oficio. Acabado el responso último del ofiçio sobre la sepultura, no toca más y nueve días, al responso que se dize después de missa y Vísperas da un clamor y a la Vigilia y missa del noveno día como se dize libro 4, Capítulo $25, \mathrm{n}^{\circ} 22$ da tres Cla

[fol. 132 $\left.2^{\mathrm{v}}\right]$

mores, uno en la Vigilia, los otros dos después de alzar en la missa hasta el del responso.

68. Por los Capellanes y Colegiales Sacristanes y Pertiguero, tocan todas las campanas excepto la gorda, cuando espira tres Clamores, y mientras se haze el entierro y ofiçio hasta que está en la sepultura.

-Por los más ministros de la casa y criados toca con todas las campanas excepto la gorda y de la Asumpción: un clamor largo cuando espira y después mientras dura el entierro y ofiçio.

69. En el tocar cualquiera cosa que sea, ha de ser muy puntual de suerte que tenga el cordel en la mano cuando da la hora y luego inmediatamente sin intervalo ni detenimiento ni de media Ave Maria comienza a tocar según el orden referido.

70. Pone en la Iglesia las alfombras para las postraciones y llama al Caniculario que le ayude a sacarlas y tenderlas con mucho orden y vien puestas las alza y dobla con mucho orden y buelbe a

[fol. $133^{\mathrm{r}}$ ]

su lugar acabado el ministerio.

[fol. 133 ${ }^{\vee}$ ]

\section{Capítulo 15. Del Caniculario.}

1. Está a su cargo la limpieza de la Iglesia y coro y se ha de esmerar mucho en esta.

2. Barre y todos los Sábados y miércoles para Vísperas y las de las fiestas prinzipales y a la noche todos los días que a avido gran concurso de gente o flores y junçia por el suelo.

3. En verano la riega cada dos días antes de abrirla por la tarde y por la mañana hecha un roçio porque no levante polvo. 
4. El Coro barre dos vezes cada semana y en verano lo riega todos los días antes de prima y Vísperas y a medio día çierra las ventanas y echa las cortinas.

5. Deshollina la Iglesia y sacude las paredes todas las vezes que el Abad o Pressidente o Thesorero lo mandare y para esto tiene cañas y baras largas y paños que los guarda y previene.

6. Barre todos los Sábados en la tarde el Pórtico y cada mes lo deshollina y sacude las paredes y limpia lo que está escrito con carbones, lo mismo haze en los pilares y

[fol. $134^{\mathrm{r}}$ ]

paredes del patio, y tiene mucho cuidado que los muchachos ni otra persona escriva ni pinte nada y si los ve los castigue y inquiera el que lo ha hecho para reñirle.

7. El día siguiente al concurso de gente barre el Pórtico.

8. La Iglesia de SanctIago de las Cuevas las barre cada quinze días y limpia el altar y varandilla.

9. Cuando los Colegiales barren las Cuevas les lleva las escobas, espuertas y agua y saca el polvo y la basura y lo echa en el barranco que está delante de la Cueva de San Çeçilio.

10. Dos vezes en la semana barre las escaleras y tránsito del coro y en el verano lo riega todos los días.

11. Cada Sábado barre las salas baxas y el verano las riega todos los días y cada Sábado y Vísperas de fiestas prinçipales barre el Patio, Claustro y portal y siempre cuida que toda la casa esté límpia que no aya basura, ni papeles, ni cosa que parezca mal.

12. Las escobas, espuertas, cántaros y calderas de regar tiene guardadas con llave en aposento

[fol. $134^{\mathrm{v}}$ ]

particular que no estén fuera de él nunca, sino cuando sirven.

13. A sus tiempos pone y quita las esteras de la Iglesia, Choro y Sacristía y Salas baxas $\mathrm{y}$ antes de ponerlas las sacude y barre, lo mismo cuando las quita.

14. Las Vísperas de San Çeçilio saca y sacude las esteras de la Iglesia, ayúdale a esto el campanero y el ayuda a sacar y poner las alfombras para las postraçiones en la Iglesia y todas las vezes que para otras cosas se ubieren de poner alfombras las lleva y trae y pone donde y como ordena el Tesorero y Sacristán. 
15. Ayuda a colgar y aderezar el Pórtico y cualquiera cosa que colgare, luego dobla y limpia los tapiçes y doseles, ayuda a hazer el monumento, enrrama la Iglesia y Pórtico para las fiestas del corpus y de San Ioan.

16. Lleva los escaños para hazer los teatros y coros en la Iglesia, los bancos los días que ay sermón, sube al tránsito del coro tres o cuatro para que los prebendados se sienten, éstos sube al prinçipio de cuaresma y no los baxa hasta pasada pascua y en los otros días

[fol. $135^{\mathrm{r}}$ ]

los baxa pasado el día del sermón.

17. Haze los túmulos para las honras y trae y lleva la tumba, los hacheros y pies de las cruzes, y todo lo limpia y guarda en su lugar y así ay algo quebrado avisa para que se adereze.

18. El Iueves y Viernes Sancto previene alcázer y va delante de la procesión echándolo vien repartido por la Iglesia, echa la junçia y gaiombas por la Iglesia y para el pavimento saca las flores y rosas en fuente de plata, nunca sube al pavimento alto, desde el baxo las exha vien repartidas.

19. Siempre que llega o se aparta de las gradas haze genuflexión al Sanctíssimo Sacramento y cuando pasa por delante del altar.

20. Cuando asiste en los oficios divinos en la Iglesia viste ropa morada de paño cerrada y gorra morada, trae un azote largo de cordeles y castiga cualesquiera perros que entran en la Iglesia, no consienta que estén en ella aunque las mugeres los traigan y guarden en sus faldas.

[fol. $135^{\mathrm{v}}$ ]

21. No dexa que pidan pobres por la Iglesia ni que estén a la puerta ni çiegos que rezen que inquietan los oficios y missas.

22. No dexa que los muchachos parlen ni jueguen por la Iglesia y si llorare algún niño que en todo caso lo saquen fuera.

23. No consienta que persona alguna entre en la Iglesia con cestas de comida ni hato, que como esta Iglesia está en un desierto piensan que se pueden tomar lizenzia para ésto, y por prevenir esta y otra cualquiera cosa indecente en la Iglesia, donde se deve guardar tanto decoro es más importante el Caniculario y deve asistir a ésto con cuidado y mucho más que las mugeres no coman en parte alguna de la Iglesia.

24. Cuando ay sermón antes que el predicador suba al Púlpito cierra las puertas de la Iglesia dexa una entre avierta y se sienta en un banquillo para que no entre gente con ruido y no consienta que muchachos lo hagan.

25. Para las procesiones lleva a donde va 
[fol. 136 ${ }^{\mathrm{r}}$ ]

el facistol y libros y cosa semejante y lo buelve a traer.

27. Va un rato antes de la procesión para ahuyentar los perros.

27. Para las tinieblas trae el Candelero triangular y las escalerillas y lo pone en su lugar, acetre de agua para mojar la mano y lo buelve a alzar en su lugar, más de una noche para otra lo entra en la capilla del rosario.

28. Los días que se pone brasero en la Iglesia lo ençiende y saca y entra las vezes que es menester a çebarlo.

29. Tiene las llaves del carbón y ençiende el brasero en la Sacristía y después de aver servido lleva la çeniza a la coçina, pone un librillo en que los turibularios baçien los incensarios y la çeniza y carbones bacia todos los días.

30. Tiene muy gran cuidado que no anden cavalgaduras por el Sacro Monte, que no pasen de los marmolillos del compás, que no estén en la plaçeta de las Cuevas ni en toda la cuesta empedrada ni suban por ella ni en la alameda y si ubiere alguna salga luego a hazer

[fol. $\left.136^{\vee}\right]$

que la saquen por detrás de la casa a la plazeta de la cruz de los herreros, y cualquiera que las viere sea obligado a avisar al Caniculario y el salir a echarlas.

31. El mismo cuidado a de tener que no pazca ganado alguno por el Sacro Monte especialmente por todo el distrito de las Cruzes y por detrás de las Cuevas.

32. Es obligado a subir a la torre siempre que ay repique de Campanas para ayudar y las noches que ay fuegos sacar y prevenir las luminarias ponerlas y enzenderlas y después alzarlas, y asimismo prevenir recaudo y leña para las cazuelas de fuego encenderlas y cuydarlas.

[fol. $137^{\mathrm{r}}$ ]

\section{Capítulo 16. De los Versicularios.}

1. Dos Colegiales por tabla cada semana hazen ofiçio de versicularios.

2. En comenzando a tocar las horas y missa salen juntos del Colegio, al más antiguo va a ver el cuadernillo y breviario para saver de quien se reza y haze el ofiçio y dize la missa para prevenir los libros convenientes y el más moderno por la mañana limpia las sillas del coro, los asientos espaldares y brazos y los dos rincones, lo mismo haze todas las vezes que an barrido el coro e Iglesia. Van juntos al aposento de los libros y los grandes llevan siempre entre ambos sobre los hombros. 
3. Para las horas menores ponen el psalterio matutino y el libro de las antífonas del oficio registran los psalmos los responsorios breves. Ponen un facistol grande alto en medio del coro y en el martirologio.

4. Para misa mayor llevan el libro de los Kyries y Gloria y el de la missa apuntada y los ponen en el facistol y si en la missa ay Credo

[fol. $137^{\mathrm{v}}$ ]

ponen el libro al pie del facistol para su tiempo.

5. Si en la missa ay prophecías ponen en medio del Coro un facistol alto y en el un missal para cantarlas, y acavadas las propheçías cuando las ay, el Versiculario más antiguo trae al hueco de la ventana el facistol y el missal pone en el facistol grande para que por él se rijan en el introito, versos, graduales, tractos y comunicandas y aunque los versicularios tengan registrado todo esto conforme al missal por que no se olviden o truequen, es vien tener el missal en el facistol grande avierto.

6. Cuando dizen el evangelio quitan del facistol el libro de la missa y ponen el del Credo registrado el cual se ha de dezir y acavado le vaxan y buelven el de la missa. El Credo solenne registran en las fiestas de primera y segunda clase. El otro que está también en el libro grande para todos los Domingos y fiestas dobles del año, para las infraoctavas el segundo que está en el libro pequeño.

[fol. $138^{\mathrm{r}}$ ]

7. Cuando ay sermón, mientras se dize el evangelio entran los escaños y ponen entre la varandilla y facistol para que se sienten a oir los prebendados y después del sermón los sacan.

8. Para Vispèras llevan el psalterio vespertino y los libros de las antíphonas del ofiçio. Si las Vísperas no son cantadas y ay conmemoraciones no llevan para ellas libro grande sino el libro pequeño y le ponen registradas las commemoraciones en el facistol.

9. Si son cantadas, llevan los libros grandes y si se parten las Vísperas entre oficios que están en diferentes libros, cuando el celebrante dize la Capítula, quitan el uno y ponen el otro y si ay commemoraçiones mientras se dize la oración precedente ponen el libro de la antíphona para la commemoraçión sub sequente: el psalterio no quitan porque en él tienen registrado el Venedicamus Domini que se a de dezir.

10. Para las completas basta el psalterio, mas quédanse en el facistol los libros que últimamente se pusieron.

[fol. 138 ${ }^{\mathrm{v}}$ ] 
11. Llevan asimismo todas las tardes un facistol alto y un missal y el martirologio lo cual ponen en un rincon de la ventana para que se pase la Epístola y Evangelio y Calenda.

12. Llevan para las oras y vísperas otro facistol pequeño que ponen en la barandilla enfrente de la silla al que haze el oficio en el coro para las horas lo ponen antes de entrar en el coro y el breviario registrado; lo mismo para las vísperas cuando no son cantadas.

13. Cuando son cantadas ponen en medio del coro una alfombra pequeña y si es fiesta de primera o segunda clase alfombra grande, ponen en la cabezera de ella un taburete para el celebrante como tres cuartas desviado de las sillas de los capellanes, aunque la alfombra a de llegar a ellas, delante del taburete ponen un facistol baxo con paño de seda y en él, el breviario registrado y si ay caperos cubren con dos tapetes, que solo sirven de esto los vancos donde se sientan.

[fol. $\left.139^{\mathrm{r}}\right]$

14. Para los maitines llevan los libros neçesarios, ponen las alfombras como para vísperas, mas el taburete del celebrante y facistol con su paño lo ponen en el hueco de la ventana hasta que se entona el Tedeum laudamus, que quitan el façistol alto que pusieron en el medio del coro para las lecciones y en su lugar ponen el pequeño y le ponen el breviario y traen el taburete y ponen donde a de estar como en Vísperas.

15. Cuando ay Preces flexis genibus ponen juntamente el facistol y breviario enfrente de la silla del que haze el ofiçio un psalterio pequeño registradas las preçes para que por ellas se diga o un diurno.

16. Los días que después de las horas i Vísperas ay Vigilia de difuntos y missa o otro ofiçio o missa, cuando llevan los libros del ofiçio del día, llevan también los que son para el oficio que se sigue y los ponen en el hueco de la ventana, de suerte que para todo lo que se ubiere de cantar en los ofiçios que se hazen en el día llevan los libros con tiempo y los tienen registrados y los suben y baxan con

[fol. $\left.139^{\mathrm{v}}\right]$

agilidad de suerte que a su tiempo lo señalen por que no aya interrupçión ni mora en nada.

17. Llevan asimismo los hierros para señalar las hojas, los punteros para apuntar el verso que se a de dezir, la vara del sochantre para que lleve el compás.

18. Cuando acavan de registrar y poner en el coro todo el recaudo necesario se ponen las sobrepellizes, baxan a la Sacristía para subir con los demás en ceremonia.

19. Asisten a los lados del façistol grande y nunca se apartan para cosa alguna excepto que si no ay otro Colegial en el coro el más moderno sale a hazer la señal a la torre para que el campanero toque la plegaria o doble al Aniversario, etc. 
20. Tienen las mangas baxas echadas sobre el brazo siniestro, están con mucha atención los ojos en el libro para bolver las hojas con puntualidad y buelven las

[fol. $\left.140^{\mathrm{r}}\right]$

puntas altas primero para que se vea la dicción que se sigue, el versiculario de la mano derecha las buelve, el otro las recive y asienta de baxo del clabo para igualarlas y allanarlas, usan de la mano cubierta con las mangas del sobrepelliz porque no ensucien las hojas, cuando las puntas altas están caidas las levanta y igualan con los punteros, los cuales tienen siempre en la mano diestra para apuntar el verso que se a de dezir y cada uno apunta los versos de la plana que está en su lado y todo lo que se ha de dezir y lo que se ha de dexar de dezir cubren con la manga de la sobrepelliz.

21. Y como suele por inadvertenzia trocarlo el coro, los Versicularios an de prevenir y enmendar el hierro señalando con tiempo porque como los hierros que se hizieren en ésto son más notables así deven estar con más cuidado de que no se cometan.

22. En ninguna manera hurguen las hojas con los clavos para levantarlas ni hallar los registros porque las carcomen y rompen los hierros.

[fol. $140^{\mathrm{v}}$ ]

23. A los lados del façistol están siempre en pie, que no se hincan de rodillas al introitu ni a las preçes ni oraciones, porque no hagan falta a su ministerio de bolver las hojas y señalar los versos. Mas a la elevaçión del Sanctíssimo Sacramento en la missa de prima y de terçia se hincan de rodillas de suerte que no hagan falta y al Homo factus est del Credo y a la oraçión de las antíphonas de Nuestra Señora al fin del ofiçio que no tienen ya que hazer.

24. Acavados los ofiçios van al aposento de los libros quítanse las sobrepellizes porque con ellas nunca los an de llevar ni traer ciérranlos y baxan sobre los hombros y los ponen en su lugar; de suerte que al ponerlos y baxarlos y mudarlos no los arrastren ni den golpes ni maltraten ni los dexen fuera del estante. Y los hierros y clavos y bara y el facistol pequeño del breviario no lo dexan en el Coro, mas siempre con lo demás lo llevan.

25. El aposento tengan limpio y vien aderezado todos los libros puestos vien.

[fol. $\left.141^{\mathrm{r}}\right]$

las alfombras dobladas, ençierren en el todo lo que sirve en el Coro alfombras, tapetes façistoles, taburetes, missales, calendario y proçesiónarios, le an de barrer y componer los Sábados cuando salen del ofiçio.

26. Dos vezes cada semana y las Vísperas de las fiesta tienen cuidado de que se barra el coro y riegue al verano todos los días. 
27. Los que salen lo an de dexar limpio, mudar o descubrir la tablilla de el Hic est Chorus al de la semana, y el Domingo en la noche llenan de agua vendita la pila del Coro y asimismo la llevan a los aposentos.

28. Cuando alguna de las horas menores es cantada como la prima de la Vigilia de Navidad; la terçia de Pentecostés, la nona de la Asçensión, ponen enfrente de la silla del Abad, el façistol pequeño con paño de seda y con el breviario registrado y acavada la hora que çelebra el Abad, quitan el paño y el façistol ponen en la silla del que ha de hazer el oficio en las otras horas.

29. Para la prima de la Vigilia de Navidad

[fol. $\left.141^{\mathrm{v}}\right]$

cubren los andenes de las sillas altas y el plano del coro hasta el façistol grande con alfombras vien puestas, en medio del coro ponen facistol alto con paño de seda morado y el martirologio, con cubierta de terciopelo morado brasero y pomos con olor.

30. Para tercia de Pentecostés y nona de la Ascensión y maitines de Resurrección, missa de Corpus Christi y sigundas Vísperas del día octavo, aderezan el coro con muchos ramos y flores y pomos, asimismo para las Vísperas de los otros días que se dixeron en el libro $1^{\circ}$ Capítulo 12 Del adorno de la Iglesia y coro.

31. Cuando ay procesiones reparten los proçesonarios, cuando se haze algún ofiçio en la Iglesia como en las bendiçiones etc, disponen el Coro en la forma que a de estar y como se dixo libro 1 capítulo 15, ponen un facistol alto con el libro por donde se a de cantar esto mismo, previenen y registran a donde quiera que hiziere estaçion la procesión que se haze y si ubiere muchas estaçiones en acabando en una llevarán el façistol

[fol. $142^{\mathrm{r}}$ ]

y libro a la otra y registraran asimismo las antíphonas que se ubieren de dezir.

32. En las Salves tienen el libro donde está apuntada en las manos y están en pie cuando se dize en las Cuevas, cuando en la Iglesia ponen facistol alto en que cantan las Epístolas, pónenle paño y enzima la salve apuntada y están en pie a los lados de éll.

33. Tienen a su cargo avisar cuando es menester aderezar los libros y no consienten que anden fuera del aposento ni que los traigan en otros usos, tienen llave de ellos y no la entregan a nadie y nunca dexen avierto.

34. Los que salen por el memorial que an de tener de los libros tapetes, vanquillos, hierros y todo lo demás que perteneçe al coro que guardan en la librería de él, hazen entrego a los Versicularios que entran y si faltare algo al entrego, los unos y los otros tengan obligación a dar cuenta al Tesorero y al Abad o Pressidente.

35. En faltando el Calendario, el menos 
[fol. 142 $\left.2^{\mathrm{v}}\right]$

antiguo pone el recaudo, y avisa a los que an de pasar la Epístola y Evangelio.

[fol. $\left.143^{\mathrm{r}}\right]$

\section{Capítulo 17. Del Calendario.}

1. Cada semana por tabla se señala un Colegial que cante la lección del martirologio en prima sean señalados por turno los que fueren aptos.

2. Todos los días después de completas a de poner en medido del coro el facistol alto con el missal y llamar a los Prebendados Diáconos que pasen la Epístola y Euangelio que se an de cantar el día siguiente. Y si ubiere propheçías tenga prebenidos a los que están señalados para dezirlas que no se vayan y llámelos por su orden para que las pasen y últimamente, él pase la Calenda.

3. Cuando faltaren los dos correctores avise al Presidente que señale otro Prebendado que pase.

4. Cuando es Calenda que a de dezir Prebendado o capellán, avisa en acabando completas al maestro de çeremonias que señale el que la ha de dezir y avísele que se queda a pasarla y al colegial después pase la lección breve de prima porque siempre la ha de dezir

[fol. $\left.143^{\mathrm{v}}\right]$

aunque no diga la Calenda.

5. Cuando el que haze el ofiçio dize la conclusion de la oraçión de prima, el Calendario por entre el coro de los colegiales y los asientos va al facistol alto donde está el martirologio y haze genuflexión al altar aviendo hecho antes humiliación al que preside y respondido del coro Deo gratias entona la Calenda que canta con más pausa según la solennidad del día.

6. Pone mucho cuidado en la buena pronunciacion claridad y distinçión y pausas que de la apuntaçión, en todo lo cual se ha de esmerar como lo pide su ciencia y profesión.

7. Cuando acava, haze genuflexión al altar y al coro, venia como al prinçipio, se pone en su coro Eregione al lado del facistol.

8. Cuando el que haze el oficio comienza la oraçión Dirigere, llega al facistol con las mismas reverencias que a la Calenda y respondido el Amén, se buelve profunde inclinado al que haze el oficio, de suerte que no buelva las espaldas al altar, y dize Iube Domine benediçere y esté

[fol. $\left.144^{\mathrm{r}}\right]$ 
inclinado hasta que le da la vendiçión, lee la lección breve y cuando dize Tu autem Domine miserere nobis, haze genuflexión y con venia al que preside se aparta a un lado y pone eregione con los demás Colegiales.

9. Cuando está el Sanctíssimo Sacramento descubierto o cuando alzan en la missa de prima para pedir la bendiçión no se buelve al que haze el ofiçio mas se inclina profundamente al altar y en acavando prima lleva el facistol al hueco de la ventana.

10. Los Sábados al tercer psalmo de Nona se aparta al hueco de la puerta al lugar del portero del Coro y toma la tabla de los oficios y la pasa para que la lea con claridad y distinción y cuando se dize el Pater Noster para la antíphona de Nuestra Señora sube al lugar donde dixo la Calenda y haze genuflexión al altar y después de aver dicho Dominus det nobis suam pacem y respondido et vitam aeternam Amen, antes que se comiençe la antíphona de Nuestra Señora lee la tabla no en tono sino en boz baxa de suerte que la

[fol. $\left.144^{\mathrm{v}}\right]$

oigan vien y acavada haze genuflexión y el coro dize la antíphona.

11. El Sábado Sancto lee la tabla después de completas y cuando se dize la antíphona Regina coeli sale a pasarla y mientras dizen secreto Pater Noster y Aves Maria y Credo sube al lugar donde se dize la Calenda y la lee, llega y acava con las mismas reverencias.

12. Cuando en la missa ay una propheçía, la a de dezir el Calendario, cuando ay muchas diga una la que le tocare conforme su antigüedad.

13. En las completas dize siempre la lección breve, sale de su lugar y pónese en medio del coro entre los Colegiales çerca del facistol grande y haze genuflexión y aviendo dicho el fidelium animae o acabando el órgano cuando lo ay, profunde inclinado al que haze el ofiçio, dize el Iube Domine como se dixo a la lección de prima y fiestas [del] Sanctíssimo Sacramento descubierto inclinado al altar.

14. El Calendario Colegial es uno de los señalados al coro y nunca falte de él ni

[fol. $145^{\mathrm{r}}$ ]

salga a cosa alguna hasta que aya cumplido con las cosas que a de decir conforme a su oficio: Si estubiere indispuesto o ocupado avise con tiempo al Rector para que señale otro Colegial que pase y cante la Calenda.

15. La Vigilia de Navidad ayuda a los Versicularios a adornar el coro y después a alzar las alfombras y demás recaudo.

16. Las Calendas de Navidad, SanÇeçilio, San Hisçio, San Messitón, San Tessiphón Sanctlago el Zebedeo dizen prebendados y así los versicularios ponen una alfombra 
pequeña donde se suele poner para Vísperas y en medio de ella ponen un facistol alto y tiene cuidado de subir paño de seda de el color del ofiçio y funda del mismo color para el martirologio, lo cual tendrán cuidado de llevar a la Sacristía después de las horas. Las Calendas de la Dediçión de Granada; de Resurrección, de la Asumpción y dedicaçión de esta Sancta Iglesia dizen capellanes.

\section{Cuando el Prebendado dize la Calenda}

[fol. $145^{\mathrm{v}}$ ]

el Capellán Çerimoniario lo combida; cuando se dize la oración, baxa de su silla la falda de la capa tendida y haze genuflexión al altar delante de el façistol de la Calenda y luego buelve al coro. Y al Abad primero y luego al coro de la semana y luego al otro haze comedimiento, el Coro de los prebendados le responde con otro, los Colegiales y capellanes con otro mayor y todos se quedan en pie hasta que se acava la leyenda de la festividad y acabada la Calenda con las mismas reverenzias se buelve a su silla.

18. Cuando la dize capellán, a la conclusión de la oración va de su silla y haze genuflexión al altar y al coro y profunda como se dixo en el número 5 y en acabando, haze lo mismo y se buelve a su lugar.

19. El Sábado en pasando la Calenda haze señal a la torre para que de el tercer repique todos y los días de Nuestra Señora lo mismo.

[fol. $\left.146^{\mathrm{r}}\right]$

\section{Capítulo 18. De los Colegiales Cantores.}

1. Dos Colegiales por la tabla se señalan cada semana que hazen ofiçio de cantores. Su lugar en el coro es después de los lucernarios y en las Salves en la Iglesia y cuebas después de los Comitantes.

2. Su oficio es decir las antíphonas de las horas y los resposorios breves y versos, las antíphonas de prima, tercia, sexta y nona y de completas dize el cantor del coro de la Semana y si faltare el otro cantor cuando la prima, tercia y nona, es cantada, entona la antíphona el celebrante, mas en las completas aunque sean cantadas entona la antíphona el Colegial cantor y la antíphona Salvanos.

3. Dizen los responsorios breves y versos en las horas menores en tono cuando el que çelebra dize Capítula sale cada uno de su coro y lugar y se juntan entre los de los Colegiales y juntos hazen genuflexión al altar dizen los responsorios breves y luego los Versos y acavados hazen genuflexión y luego el uno

[fol. $\left.146^{\mathrm{V}}\right]$

al otro venia y se buelven a su lugar. 
4. En las ferias excepto las del tienmpo de pascua y en las Vigilias excepto las de Navidad, Epiphanía, ascensión y Pentecostés, el Colegial cantor del coro de la semana dize solo los responsorios y versos, sale cuando se dize la Capítula y haze genuflexión $\&$.

5. En las fiestas de primera clase y principales de Nuestra Señora y Sanctos de este Sacro Monte dizen los responsorios y versos dos capellanes como se dixo libro 1, Capítulo7.

6. Dizen el Venedicamus Domino en todas las vísperas en tono excepto las fiestas de segunda clase que las dizen los capellanes.

7. En las missas que no son de primera o segunda clase, dizen el verso del introito y el Gloria Patri y el Incarnatus est del Credo hazen primero donde se juntan genuflexión y acavado venia el uno al otro y siempre que se juntan a dezir algo

[fol. $\left.147^{\mathrm{r}}\right]$

se hazen estas reverençias.

8. En las fiestas de primera y segunda clase dizen estas cosas dos Capellanes.

9. En las fiestas de cuaresma y adviento y entre año y Vigilia de Santos las dize un Colegial cantor solo y en estos días dize el primer Kyrie y el Coro el otro, el terçero el sigundo Colegial cantor.

10. En la Salve cantada siempre dizen el verso Ora pronovis Sancta Dei Genitrix.

11. En las Commemoraçiónes cantadas de las vísperas que no ay caperos dizen los Versos y asimismo en las que se cantan en las estaçiones que hazen las procesiones.

12. Sean muy puntuales en salir a tiempo para dezir y coger el punto que les diere el Sochantre porque no desentonen.

13. Está a su cargo avisar al Sochantre que días cantan los versos los Capellanes y cuando éstos faltan los dizen los colegiales cantores aunque sean cantados.

[fol. $147^{\mathrm{v}}$ ]

\section{Capítulo 19. De los Luçernarios.}

1.- Están a su cargo las luçes que se encienden y arden en el coro y para esto en los días de Visperas y maytines cantados cuando anda la gorda, ençiende el moderno el farol de la escalera donde pueda enzender a su tiempo las luzes que a de llevar al coro y entonzes mira si esta avierta la puerta de la Concepción y si no avisa al Sacristán que la abra y abre la puerta el Claustro por donde pasa la ceremonia $=$ y también lo enciende 
para la missa del día de la purifiacion de Nuestra Señora y de la conmemoración de los difuntos.

2. Cuando se dize la capitula de las Visperasy laudes cantadas, el luçernario moderno sale a encender en el farol y entran en el coro al ultimo verso del hymno y se pone entre el facistol y la varandilla y a este tiempo llegan los çeroferarios con los codales y lo cogen en medio y todos tres hazen genuflexión dales luz y se van a los çiriales y el luçernario con genuflexión

[fol. $148^{\mathrm{r}}$ ]

se buelve a su lugar, y cuando el çelebrante se despide para yr a incensar haze venia al coro y sale primero y ençiende su codal y con el aguarda en la puerta de la Conçepçion por la parte del Claustro para ençender los çiriales si el ayre se los a apagado y de allí se buelve a la puerta del coro por la parte de fuera para ençenderlos si a la buelta se an apagado y detrás de todos se entra en el coro y con genuflexión al altar y venia al coro se pone en su lugar hasta la conclusión de la oración ultima que sale y con el codal ençendido aguarda en la puerta de la Concepción para encender los çiriales si fuere necesario y después buelve al coro y apaga el farol y entra a su lugar.

3. El luçernario del coro del semanero cuando se repite la antiphona del maginificat pone delante de la silla del Prebendado que a de çelebrar las completas el atril pequeño para que el Comitante ponga el breviario para las completas si se ubieren de decir.

4. Para los maytines de la Concepción, de la Natividad y Resurrección ponen dos hacheros con hachas al facistol grande y por

[fol. $148^{\mathrm{v}}$ ]

la barandilla candeleros con velas frontero de cada silla de los prebendados y antes que acave el esquilón lo ençienden todo $=$ mas en los maytines de tinieblas aunque ponen todo esto cuando anda la gorda no lo encienden hasta que falte la luz de el día y llevan despaviladeras y ponenlas en los hacheros y los versos de cada nocturno despavilan.

5. Llevan la palmatoria con su vela y el Gloria Patri del ultimo psalmo de cada nocturno la encienden y ponen en la barandilla al lado diestro y a su tiempo la toman y alumbran las lecciones y dichas las tres del nocturno la apagan y para las otras la buelven a encender y lazen lo mismo para la capitula y oración de Laudes.

6. Cuando ay nona lección con capa cuando baxa el celebrante de su silla sale el luçernario del coro siniestro de su lugar y en una hacha enciende su codal y se pone detrás de el facistol para dar luz a los acolitos como se hizo a Visperas.

7. Para los mayrines de tinieblas previenen las quinze candelas y ponen en el candelero triangular y encienden antes que se comienze

[fol. $\left.149^{\mathrm{r}}\right]$ 
el officio.

8. El mas moderno se queda en el pavimento y con una mano de palo enrezada apaga las candelas, una al fin de cada psalmo así de maytines como de laudes, comienza por la mas baxa de la parte del evangelio y la segunda la que corresponde en el otro lado y assí alternativamente y cuando las ubiere de apagar moja la mano en un açetre de agua que a puesto al pie del candelero.

9. Cuando repite la antiphona del Benedictus sube y quita la candela mayor blanca y encendida la tiene un rato sobre el altar en el Cornu epistolae y cuando se comienza Christus factus est pro novis la esconde en el Cornu Epistolae del altar hasta que se acava el miserere y cesa el estrepitu que la saca y tiene en la mano sobre el altar hasta que traygan otra luz.

10.Acavado el offiçio del lunes y Viernes Santo, mañana de resurrección y todas las del Sanctissimo Sacramento y otras en que se ayan de llevar candelas, los luçernarios las

[fol. $149^{\mathrm{v}}$ ]

reparten a los Prebendados dan hachas a los otros velas de a media libra o quarteron y si ay personas de fuera que acompañan la procesión que sean nobles y de respeto las dan de a libra y todas las dan encendidas y después de la procesión las recogen y alzan con cuenta y orden.

12. En la procesión de la purificaçión de Nuestra Señora, el clero recive las candelas de mano del çelebrante y cuando se acavan de repartir, los dos lucernarios llevan al coro dos velas encendidas y cada uno por el suyo las encienden comenzando de los más antiguos.

13. En la missa cuando se comienza el Aleluya o tracto después de la Epístola salen ambos del coro y traen luz y ençienden por el mismo orden las candelas y antes de alzar hazen lo mismo.

14. Todos los días cuando el coro ha respondido en el prefacio dígnum et iustum est los lucernarios, y si es día de cuatro o seis hachas los Colegiales que ellos avisan se ponen las mangas y juntos buelven a hazer venia al coro y salen a la Sacristía y toman hachas y antes de alzar salen, y si ay dos hachas los lucernarios

[fol. $150^{\mathrm{r}}$ ]

las sacan y se ponen de rodillas en la ínfima grada en medio de los çeroferarios, si ay cuatro o seis salen por su orden y en el pavimento hazen dos coros un poco más adentro del lugar de los çeroferarios y juntos hazen genuflexión y de rodillas están a la elevaçión del Sanctíssimo Sacramento. 
15. Sacan las hachas los que se ponen en el coro siniestro en la mano derecha y los del coro diestro en la mano siniestra, para que cuando entran y salen, estén de rodillas las hachas hagan proporçión correspondiéndose por la parte de adentro de los coros que hazen.

16. Acavando de alzar, se levantan y juntos buelven a hazer genuflexión y en su orden de los dos coros se buelven a la Sacristía, mas a las missas que ay comunión general o son de ferias de adviento o de ayuno, o de difuntos se quedan hasta que ha consumido el çelebrante o acavado la Comunión.

17. Cuando se muda el frontal a la capítula salen los lucernarios al prinçipio del cuarto psalmo, entran por la Sacristía y aguardan en la capilla de los mártires y cuando se comienza el Gloria Patri del quinto psalmo

[fol. $150^{\vee}$ ]

suben al altar hazen genuflexión y quitan el frontal y juntamente el viso y lo baxan a la Sacristía con tanta puntualidad que cuando se comienze la capítula ya esté descubierto el frontal que ha de quedar y puesto el frontal en la sacristía, el más antiguo va al altar y muda el viso.

18. Y si en el altar ay más de dos velas, aguardan en la capilla de los mártires y acavado el Venedicamus Domino de vísperas suben y apagan las que ay, dexan dos solas para completas; luego buelven al coro.

19. A prima y a las Vísperas que no son cantadas al, segundo golpe de la gorda los luçernarios suben al altar mayor y ponen las velas ençendidas y acavadas las horas, cuando baxan los Colegiales en ceremonia, van los primeros y sin hazer genuflexión en el pavimento enlosado suben y hazen dos en el alto y apagan.

20. Cuando en las Vísperas que no son cantadas ay más de dos velas en el altar, al tiempo que se repite la antíphona de magnificat hazen venia. Salen del coro y en la capilla de los mártires aguardan y respondido Deo gratias suben

[fol. $\left.151^{\mathrm{r}}\right]$

al altar y con las devidas reverenzias apagan las velas, dexando solamente dos en las esquinas y las que apagan dexan en el suelo junto a los platos de despavilar y se buelven al coro.

21. Todas las noches en tocando a letanía, el luçernario más moderno lleva un codal ençendido al coro y lleva el libro de la letanía, pónese de rodillas junto al Christo y teniendo la luz alumbra al que dize la letanía de Nuestra Señora, la cual dicha lo alza y apaga y guarda el codal y para ésto y las demás vezes que ha de enzender el Sacristán mayor le da un codal y no le da otro sino truxere el cabo de la que ya no está para servir. Y advierta si lo gasta en otras cosas y los luçernarios deven no hazerlo, antes si save que otros gastan la çera de la Sacristía y se sirven de ella en cosa que no es del culto divino, son obligados a avisar de ello al Rector y Tessorero. 
22. El luçernario más moderno en ausencia del hostiario tiene cuidado de la puerta del coro y de los recaudos, y de salir a ver los que confiesan y de la campanilla para hazer señal en la torre.

23. En los maitines de resurección y Navidad ponen luminarias en la Iglesia y coro y en las demás.

[fol. $151^{\mathrm{v}}$ ]

fiestas que se pusieren en las ventanas sino ubiere comisarios, es su ofiçio ponerlas y quitarlas.

[fol. $\left.152^{\mathrm{r}}\right]$

\section{Capítulo 20. Del Portero del Coro.}

1. El Portero los días que van todos los Colegiales al coro se sientan en un escabelo en el hueco de la puerta por la parte de adentro en el frontero del altar, y cuando no van todos, se pone después del Versiculario en el coro del apuntador, tiene cuidado con la puerta y con los que llegan a recaudos.

2. Si llegare Colegial o sacristán con sobrepeliz an de entrar en el coro a dar el recaudo y el portero no tiene que llegar a el, mas a todos los demás que lo llamaren sale a ver lo que quieren, entra con los recados y está con advertenzia cuando el Abad o Pressidente llamare o otro Prevendado va ha ver lo que mandan.

3. Haze los recaudos del apuntador para saber los que faltan y por qué causa, como se dixo en su lugar Capítulo del apuntador, haze los recaudos del maesto de ceremonias.

4. Cuando alguna persona grave quisiere entrar en el coro avisa al Abad o Pressidente quienes y sepa del maestro de çeremonias a que coro y silla lo a de llevar y lo acompañe y lleve hasta el lugar señalado y allí lo dexe

[fol. $152^{\mathrm{v}}$ ]

con comedimiento y se buelva a su lugar.

5. Cuando esta en el escavel, en estar en pie o sentado se sigue al coro alto, y estando allí no cante ni diga en tono nada, aunque sea con el coro, porque disuena en la Iglesia.

6. No ha de entrar con recaudo en tiempo que se comienze hora ni cuando se dize himno, Capítula, preçes, Cántico, oración, Gloria Patri, antíphona y oración de Nuestra Señora y en la missa mientras están de rodillas al Introito y alzar, cuando se dizen las oraçiónes, evangelio, Gloria rezada en el coro alto y Credo hasta el Homo factus est. 
7. Siempre entra y sale con las mangas de la sobrepelliz baxas puestas sobre el brazo izquierdo y anda con igualdad y compostura. Cuando llega a los recaudos no eche la mano a la vanrandilla, aguarda la respuesta con compostura y modestia.

8. Tiene cuidado de avisar al organista que dexe de tocar cuando en el altar hiçieren señal con la campanilla para que el çelebrante entone el prefacio o Pater Noster.

9. Es a su cargo hazer señal con la campanilla para que en la torre toquen o dexen de tocar a todos los actos que ocurrieren y para

[fol. $\left.153^{\mathrm{r}}\right]$

convocar a los aniversarios.

10. Los Sábados en la missa de Nuestra Señora, cuando cantan la antíphona post communio, haze señal para que el campanero toque el último signo para las horas menores.

11. Cuando post nonam ay aniversario de algún Sancto o de difuntos, en comenzando sexta, haze señal para que vengan los que faltan y si es de difuntos en acabando non a haze señal para que doblen, a la Vigilia y al responso buelve a hazerla.

12. Los días que hay responso haze señal para que acudan al coro los capellanes y Colegiales que faltan en acavando sexta.

13. En la missa de tercia haze señal para la plegaria del alzar, y si ha de aver rogativa haze señal cuando comienza el Pater Noster, el preste en las Vísperas de la feria haze señal cuando entona el himno Vexilla regis.

14. Para la Salve los Sábados desde primero de Octubre hasta la resurrección, en comenzando completas, haze señal para que repiquen para la de la cuaresma no a menester hazerla, porque en tocando el campanero la plegaria de las tres, toca como se dixo en su lugar.

[fol. $153^{\mathrm{v}}$ ]

15. Cuando ay Vigilia después de las completas haze señal, cuando las comienzan para que vengan los que faltan y entonando la antíphona del nocturno la buelven a hazer para que doblen.

16. Desde el día de la Resurrección hasta fin de Septiembre en acavando completas haze señal para la oraçión que se tiene por la tarde.

17. Por las mañanas en la hora de oraçión asiste en el coro en el lugar donde se suele sentar y allí la tiene y guarda la puerta, y avisa de los recaudos que llegaren.

18. Los días que ay procesión cuando el celebrante haze genuflexión para comenzar a proçeder, va a hazer señal para que repiquen. 
[fol. $\left.154^{\mathrm{r}}\right]$

\section{Capítulo 21. De los Çeroferarios.}

1. Los Çeroferarios sirven de llevar los Çiriales con velas en todas las Vísperas cantadas $\mathrm{y}$ maitines, missas, bendiçiones y procesiones.

2. Cuando comienzan a tocar van juntos a la Sacristía y con mucho silencio se visten amito, roquete y collar, después de vestidos no se an de ocupar en otra cosa, mas que en prevenir y sacar el recaudo necesario que según su oficio les toca.

3. En el oficio cantado ençienden en el altar mayor y cuando se a de descubrir el Sanctíssimo Sacramento o reliquias ençienden antes de que se abra la Iglesia todas las luzes que an de arder; a Vísperas, maitines y missa ençienden en comenzando la gorda.

4. Para Vísperas y maitines, después de vestidos, previenen las velas que an de arder en el altar y los codales de los Çiriales, acomodan el pavilo y cortan si es nuevo, y comienzanles a quemar. Salen al sigundo golpe de la gorda de la Sacristía con las velas

[fol. $\left.154^{\mathrm{v}}\right]$

ençendidas, el que va al cornu evangeli las lleva en la mano diestra y el que va al cornu epistolae en la siniestra, llévanlas algo estendido el brazo y en altura iguales, llegan a la grada ínfima y hazen profunda, suben al pavimento alto, hazen genuflexión siempre que suben al pavimento alto, la hazen cuando suben juntos, el lugar donde la hazen es a los lados del lugar donde suele estar el Subdiácono con la patena y cuando sube uno y a de cruzar al otro lado en el mismo lugar del Subdiácono si no esta allí y si esta al lado del Subdiácono que corresponde ha su lugar.

5. Hecha genuflexión llegan al altar y en medio de él, el uno buelto el rostro algo açia el otro, buelven a hazer genuflexión, ponen las velas en los candeleros si ay seis, primero las dos que están junto al Tavernáculo del Sanctíssimo Sacramento, luego las dos que se siguen y las últimas las de las esquinas, en el levantarlas para poner guardan igualdad y compás que no ponga el uno antes que el otro, antes ambos juntos

[fol. $\left.155^{\mathrm{r}}\right]$

vayan poniendo las velas cada cual de su lado si ay cuatro las primeras de adentro del altar, siempre guarden igualdad al ponerlas y quitarlas.

6. Y puestas las velas miren si los candeleros quedan en proporción y distancia igual, los primeros que se ponen junto al ara cada cual de su lado cuatro dedos desbiados de ella, los últimos se ponen a los cantos del altar y los otros en medido guardando el medio con proporción, si ay cuatro los dos se ponen junto al ara como se dixo y los otros en los cantos del altar y los que ubiere siempre se ponen un coto metidos de la 
frente del altar hecho esto se apartan y hazen genuflexión en el pavimento y se buelven a la Sacristía.

7. El más moderno enciende y saca el çirio si es día de blandón, luego ençienden los codales de los çiriales sin dexarlos de la mano, después de encendidos se ponen en la puerta de la Sacristía cada uno a su lado y aguardan para salir y todo esto se ha de hazer con tal tiempo y orden que no se detenga la salida.

[fol. $155^{\mathrm{v}}$ ]

8. Salen en çeremonia como se dize en el libro 3, Capítulo 1 de las vísperas, van después de los çetreros, llevan los çiriales altos, puesto el brazo hacia el preste por el pie del çirial y el otro más alto en buena proporçión y de esta suerte los llevan siempre.

9. Entran en el coro con los ciriales baxos, el del coro siniestro se queda en su lado y aparta un poco el rostro buelto al altar, el otro pasa por entre el façistol y la varandilla sin hazer genuflexión y se pone en el lugar correspondiente a su compañero, hazen genuflexión y mientras el çelebrante haze oración van a las esquinas de la Barandilla y ponen los çiriales y apagan los codales, despídense con genuflexión, y detrás del celebrante pasan del facistol y con él hazen venia en el coro, quédanse en el segundo asiento de cómo entran y buelven Eregione.

10. En el estar en pie y levantarse siguen el coro de los capellanes porque mientras se canta en el facistol están en pie, y a los psalmos sentados. Cuando se repite la antíphona del $5^{\circ}$ psalmo hazen genuflexión al altar y suben al

[fol. $\left.156^{\mathrm{r}}\right]$

facistol del çelebrante y le hazen profunda y apartados un paso abaxo del façistol Eregione y las manos puestas están mientras se canta la capítula y entonado el Himno la hazen profunda y se buelven a sus lugares y cuando llegan hazen genuflexión y se quedan Eregione las manos puestas mientras se canta el himno.

11. Al último verso hazen venia al coro van a los çiriales hazen genuflexión, toman los codales van al facistol donde llega el luçernario, cógenlo en medio y todos tres hazen genuflexión, encienden y toman los çiriales y llévanlos baxos y se ponen al prinçipio de los asientos de los Colegiales, y Eregione aguardan que el celebrante se despida y con él hazen venia al coro y salen un paso o dos y bueltos al altar hazen genuflexión con todos, el çeroferario del coro diestro después del Turiferario pasa por entre la varandilla y el çelebrante sin hazer genuflexión ni venia y cuando empareja con su compañero salen juntos y con los çiriales baxos van después de los Turiferarios.

[fol. $\left.156^{\mathrm{v}}\right]$

12. Cuando entran en la Iglesia, levantan los çiriales y van en çeremonia como cuando salieron, en la grada se apartan un poco más afuera de las aldabas de los ciriales para dar lugar que entre ellos quepa, el celebrante y comitantes hazen profunda con los demás y 
cuando el celebrante sube, baxan los çiriales y los tienen en las manos, hazen genuflexión con todos y están en pie mientras la turificación, acabada hazen genuflexión con todos levantan los çiriales, buelven al coro por el orden que vinieron, entran los ciriales baxos y van delante hasta llegar al principio de los asientos donde hazen genuflexión con todos y pasa el çelebrante y comitantes y con todos hazen profunda y allí aguardan Eregione los ciriales en las manos sentados en el suelo.

13. Cuando se acava la antíphona, los alzan y con ellos altos van al facistol del celebrante, hazen reverençia y se ponen en el lugar que estubieren a la capítula y tienen los çiriales altos mientras se canta la oraçión, al Per Dominum nostrum los baxan y a

\section{[fol. $\left.157^{\mathrm{r}}\right]$}

todas las demás que ubiere los tienen baxos, dicho el fidelium animae si no se dizen completas sino antíphona de Nuestra Señora se quedan en pie y los çiriales baxos hasta después de la oración. Despídense con todos y salen del coro como se dixo que salieron al Magnificat.

14. Entran en la Iglesia los çiriales altos en el pavimento, cogiendo en medio a los caperos y çelebrante, hazen genuflexión con los çiriales altos y en pasando de las lámparas, los baxan y arrímanse cada uno en su lado a la puerta de la Sacristía Eregione y en pasando toda la çeremonia entran en la Sacristía, ponen los çiriales en su lugar apagan los codales, van al caxón donde se desnudan, doblan los amitos y roquetes y los collares ponen curiosidad que no se maltraten, toman las sobrepellizes para bolver con todos en ceremonia.

15. El lugar que llevan en la çeremonia siempre es delante de los comitantes, en el coro entran y con todos hazen genuflexión y profunda y se ponen entre los Colegiales después de los lucernarios que no se sientan si no es cuando

[fol. $\left.157^{\mathrm{v}}\right]$

están revestidos.

16. Para maitines previenen los çiriales con velas, déxanlas apagadas y en su lugar en la Sacristía por que acompañan la ceremonia con sobrepellizes, cuando se comienza el tercer psalmo del último nocturno se ponen las mangas en los brazos, hazen reverenzia al coro, baxan a la Sacristía y se visten y con los ciriales baxos y sin ençender se buelven al coro, entran y cada uno en su lugar hazen genuflexión y ponen los çiriales en su lugar, en el responsorio último van los çiriales y como en vísperas toman luz y con ellos ençendidos y levantados van al facistol del celebrante y le asisten con ellos altos mientras dize la última lección, hasta entonado el Te Deum laudamus, que altos los llevan a su lugar, y cuando llegan y se apartan hazen genuflexión, apáganlos y buelven a su lugar donde en las laudes se sientan a los psalmos como en vísperas, a la capítula y Benedictus hazen lo mismo que se dixo porque las laudes se ofician con las mismas ceremonias.

[fol. $158^{\mathrm{r}}$ ] 
17. Para los maitines de Navidad los ceroferarios con los versicularios tienen muy limpio y vien escombrado el aposento de los libros del coro y en él un brasero de lumbre, ponen los çeroferarios una mesa con un dosel o alfombra y en ella ponen los ornamentos para el çelebrante y diáconos, dalmáticas y pluvial con sus estolas, albas, cíngulos y los amitos, ponen aparte sus amitos, collares y roquetes, los ciriales con sus codales y un blandón para una hacha, la cual encienden a la sexta lección de los maitines, cierran y llevan la llave al coro.

18. En comenzando el tercer Nocturno, baxa el çelebrante y diáconos y con todos hazen reverençia. Van al vestuario y los ayudan a vestir y se visten ellos amito, roquete y collar y con los ciriales encendidos los acompañan y entran en el coro como se dixo a vísperas.

19. Mientras oran, ponen los çiriales en su lugar y los apagan y ellos se van a sus asientos, en el octavo responsorio van a tomar luz del lucernario y con los ciriales altos asisten al çelebrante mientras canta la nona lección, entonado el Te Deum los baxan y aguardan

[fol. $\left.158^{\vee}\right]$

allí hasta que al Dominus Voviscum los levantan a la oración como en la de Vísperas y al per Dominum Nostrum los baxan y salen acompañando para la missa, en la cual asisten como en las demás.

20. Para la missa mayor, después de vestidos, sacan primero los atriles con sus paños para la Epístola y evangelio, tómanlos con la siniestra por debaxo del paño y sobre la tabla del atril hazen algunas doblezes del paño por que no arrastre y ponen sobre ellos la mano diestra porque no se desdoble.

21. Salen juntos y en el medio del Pavimento hazen genuflexión, sube cada uno a su púlpito y juntos asientan los atriles y de las doblezes del paño van estendiendo y dexando caer, igualmente por la parte anterior que baxe cuatro dedos de la vasa de la barandilla del púlpito y miren que no cuelgue uno más que otro.

22. Si estubieren alzando el Sanctíssimo Sacramento en el altar de la Conçepción o del Sagrario, se hincan de rodillas y luego juntos prosigan su ministerio, baxan y hazen genuflexión en el pavimento y se entran en la Sacristía.

[fol. $159^{\mathrm{r}}$ ]

23. Para las missas de aniversarios que no son solennes, saca el más antiguo un facistol alto con paño de seda y lo pone en el pavimento baxo que mira al cornu epistolae del altar y dicha la Epístola, el más moderno lo lleva al otro lado [al] lugar correspondiente al Cornu evangelii y pónelo que mire al pueblo, esto mismo para las missas de difuntos, mas el facistol no a de tener paño. 
24. El Capellán çerimoniario registra los misales, uno para la missa y otro para la Epístola y Evangelio, los çeroferarios preveen los registros y si es día primae clasis les ponen fundas, ponen los misales en una fuente de plata y el hostiario de plata con hostias.

25. Saca luego el más antiguo las ampolletas y salvilla con agua y vino y el más moderno el flavelo y las campanillas. Van al altar hazen genuflexión, llegan a la credenzia y pónenlo, buelven a hazer genuflexión y buelven a la Sacristía y cubren con el cendal de hombros la fuente de los misales, y la saca el más moderno en las dos manos, y el más antiguo lleva el Cáliz.

[fol. $\left.159^{\mathrm{v}}\right]$

[Falta por error en la numeración]

[fol. $\left.160^{\mathrm{r}}\right]$

[Falta por error en la numeración]

[fol. $160^{\mathrm{v}}$ ]

Con su çendal, bolsa y Corporales, suben al pavimento alto y juntos hazen genuflexion y van a la credençia y pone el Cáliz el mas antiguo y luego descubre la fuente y toma el misal de la missa y lleva con su atril al altar abre el registro de ella y saca los demas, en el entretanto, el más moderno arrima la fuente y compone lo que ay en la credençia y todo ello lo cubre con el cendal de suerte que cayga de un lado y otro de ella y quede cubierto Cáliz, misal de evangelio, ampolletas, campanillas y hostiario, hazen genuflexuiion y buelven a la Sacristía.

26. Si es día solemne que se saca la plata a la credenzia sacan primero las fuentes, cada uno la suya arrimada al pecho y haziendo las devidas reverencias al altar, las ponen en la credenzia y después en una de las pequeñas, sacan misales y hostiario y el demas recaudo para la missa en la fuente saca uno y otro el flavelo y la palmatoria y llave del sagrario si fuete día etc. cubierta con un cendal

[fol. $161^{\mathrm{r}}$ ]

Ultimamente saca el mas antiguo el Cáliz sino está sacado y el moderno el aguamanil y con el çendal lo cubre todo como se dixo.

27. Si es día de comunión general sacan el vaso con las formas en salvilla de plata y Cáliz con agua y vino para la ablucíon y toalla de lienzo ençima del y todo lo ponen en la credencia.

28. Cuando la credençia está en el arco de la capilla no suben al pavimento alto cuando sacan el recaudo mas en el baxo frontero del altar hazen genuflexión y van a la credencia y ponen en ella todo el recaudo de la missa y todas las fuentes grandes y pequeñas. Vease lib.1 cap.12. del adorno de la Iglesia. 
29. Los días que ay responso rezado sacan a la credencia hisopo con agua vendita y el manual.

30. Cuando sacan lo último, en dexándolo puesto en la credençia si ay quatro o seis candeleros se llegan al altar con genuflexión y dexando en su lugar los ultimos de las

[fol. $\left.161^{\mathrm{v}}\right]$

esquinas, los otros los meten adentro de la tabla de el altar para dar lugar al missal y atril y lo demas $=\mathrm{Si}$ ay seis los primeros ponen junto al tavernáculo, los otros en la misma línea, mas todos en igual distançia unos de otros como cuando se ponen en la frente del altar para Visperas.

31. Todo esto an de tener hecho con tiempo de suerte que ayuden a vestir a los que celebran y en dando la gorda salen a encender como en Visperas, ai ay blanden sca el çirio ençendido el mas moderno y el mas antiguo la palmatoria con su codal apagado si no la a sacado en fuente con el demas recaudo.

32. Buelven a la Sacristía cuando comienza a lengua el esquilón, ençienden los codales de los çiriales y sin dexarlos se ponen en la puerta a aguardar como en Visperas.

33. Salen a la missa así como en el coro se comienza el introito van después del Turifarario, llevan los çiriales altos y con cuydado que al salir de la capilla de los mártires

[fol. $162^{\mathrm{r}}$ ]

No topen con las lamparas, el mas antiguo pasa sin hazer venia al altar a ponerse del lado del Cornu Epistolae como dos pasos desviado de la grada = el mas moderno en saliendo de debaxo de las lamparas se buelve el rostro al altar y se retrae dos pasos aía el pulpito de el evangelio y pasan por delante del Capellán ceremoniario, el flavelario y celebrantes por el orden que se dirá en el libro 3 capt $^{\circ} 4$ de missa cantada, aviendo pasado se llegan ambos a la grada y cogen en medio al celebrante y Diáconos y todos juntos hazen profunda al altar, y mientras suben, los ceroferarios baxanlos çiriales y se hincan de rodillas.

34. Si ubiere Asperges llegan a la grada y con los çiriales altos hazen genuflexión levantanse y los baxan y quedan en pie hasta que el celebrante sube las gradas que se ponen de rodillas y tienen los çiriales en las manos y assí están mientras se haze la confesion $=\mathrm{y}$ cuando el celebrante

[fol. $162^{\mathrm{v}}$ ]

Entra en el altar ponen los çiriales en las aldavas y se levantan, si ubiere Turíbulos el mas antiguo sube con el turibulario haze genuflexion en el pavimento. 
35. Cuando el preste haze genuflexión llega al altar y en la peana ffrente del atril haza otra vez genuflexión juntamente con la que haze el preste para incensar la Cruz, levantase toma el atril y misal y se aparta con el fuera de la peana junto al escaño y lugar que se sienta el Diácono y cuando el preste a yncensado la tabla del altar del Cornu Epistolae, llega al altar a tiempo que haga genuflexión con el Preste y pone el atril en su lugar y allí haze genuflexión y se baxa a su lugar dando la buelta hazia dentro.

36. De suerte que es regla general que siempre que suben o baxan al altar para cualquiera cosa Çeroferarios, Turiferarios, comitantes, luçernarios, o otros cualesquier ministros y Prebendados para cualquiera accion, la buelta que dan para bolverse siempre por la parte de adentro volviéndose los

[fol. $163^{\mathrm{r}}$ ]

rostros.

37. Están en pie mientras se haze la Turificacion y el celebrante dize el Introyto, Kiries y Gloria, a las oraçiones y gradual, y mientras el Evangelio rezado y Credo, mas cuando el celebrante a dicho los Kyries, Gloria y Credo y se van a sentar ellos se hincan de rodillas.

38. En las ferias de adviento y de cuaresma, Vigilias y temporas que se ayunan y missas de difuntos están de rodillas a las oraçiones excepto las Vigilias de Natividad de Nuestro Señor, Epiphania, Ascensión y Pentecostés y Temporas de la Sanctissima Trinidad que aunque se ayunan están en pie, a las oraciones están en pie mientras se canta el prephacio y todas las veces que se dice Dominus Vobiscum y Orate frates y a la comunicanda rezada, a todo lo demas están de rodillas = todo lo qual las acciones que hazen en la missa y cuando se levantan y ponen de rodillas se dize específicamente en el lib.3.cap.4 de missa cantada.

[fol. $\left.163^{\mathrm{v}}\right]$

39. Cuando se sienta el subdiácono tenga cuidado el más antiguo de darle bonete cuando llega al asiento y de levantarle la dalmática y echarla por detrás del escaño, cuando se levanta la alze y saque de suerte que no se maltrate.

40. Están con mucha devoçión en toda la missa sin bolver la caveza a una parte ni a otra, los ojos en el altar para enderezar alguna vela si se torciere, y para acudir con tiempo a cualquiera cosa que se ofereçiere, mas cuando ay flavelario u otro Colegial asistente no corre ésto por cuenta de los çeroferarios.

41. Tienen las manos puestas a las oraçiónes a la Gloria y Credo rezado.

42. Cuando comienza el preste la última oración, el más antiguo si la credençia está en lo alto sube y haze genuflexión, toma el missal y lo da al subdiácono por su mano derecha, si la credençia está en el arco de la capilla del rosario en su lugar, haze 
genuflexión, lleva el missal al subdiácono, haze genuflexión antes de darlo y luego se lo da

[fol. $\left.164^{\mathrm{r}}\right]$

por la mano derecha, y allí aguarda y junto con el haze genuflexión y lo baxa acompañando al púlpito o facistol de la Epístola, va un paso delante al lado siniestro del Subdiácono, cuando llega a las gradas del púlpito se aparta y buelve de rostro al Subdiácono el cual le da el missal.

43. Sube el Subdiácono tras el çeroferario, con el missal arrimado al pecho y dásele cuando ha llegado al atril y mientras canta la Epístola aguarda allí las manos puestas detrás de él, junto a la grada superior, buelto el rostro al Subdiácono, no del todo sino algo inclinado al otro púlpito porque no esté de espaldas al altar.

44. Después de la Epístola acompaña al Subdiácono, haze con él genuflexión en el pavimento y cuando le buelve el missal lo reçive y da el Diácono por la mano derecha, haze genuflexión y se buelve a su lugar.

45. Sacan los çiriales de las aldabas y con ellos baxos en las manos están mientras dize el Presidente el evangelio rezado, y cuando el Diácono haze genuflexión para ir al evangelio

[fol. $164^{\mathrm{v}}$ ]

la hazen los ceroferarios y levantan los çiriales y llevándolos altos lo acompañan van delante del Subdiácono y detrás del Turiferario baxan la grada del Pavimento y ponen delante del púlpito, baxan los ciriales y el uno buelto el rostro al otro.

46. Cuando el Diácono entona el Initium o Sequentia Sancti Evangeli levantan a un tiempo los çiriales, de suerte que parezca que tienen en medio el libro, tienen los altos mientras se canta el evangelio, sin hazer genuflexión ni venia ni cosa alguna que se nombre en el Evangelio. Acabado [el Evangelio] suben la grada y acompañan como a la venida y siempre que van y vienen juntos pasan por el lado de la lámpara del pavimento que cae al púlpito del evangelio, que no la cogen en medio: pónense en la grada en sus lugares, no hazen genuflexión y tienen los çiriales altos hasta que el Diácono aya incensado al çelebrante.

47. Si ay sermón los ponen en las aldabas y apagan sino está el Sanctíssimo Sacramento o reliquias manifiestas, que estos días los dexan encendidos y para el sermón se sientan

[fol. $165^{\mathrm{r}}$ ]

con los Turiferarios en la peana del altar.

48. Si no ay sermón, en aviendo inçensado al çelebrante, los baxan y tienen en la mano hasta que ha dicho el Dominus Vobiscum o entonado el Credo si lo ay, que los ponen en 
las aldabas y se quedan en pie y cuando el çelebrante dize rezado el Incarnatus est que se hinca de rodillas, también ellos y juntamente con el celebrante se levantan.

49. Cuando el çelebrante se va a sentar acabado el Credo que reza, aviendo alzado la Dalmática se hinca de rodillas, mas si cuando en el coro cantan Incarnatus est, están en pie buelven a hincarse de rodillas y si el çelebrante no está asentado, se buelven a lebantar y si está se quedan de rodillas.

50. Cuando el celebrante entona el Oremus del Ofertorio, el más antiguo sube y al lado siniestro del Subdiácono haze juntamente genuflexión con él y lo acompaña delante a la credençia y allí le pone el cendal sobre los hombros con ambas manos, y entonando el Subdiácono el cáliz toma el, las Vinageras y el paño de manos y delante lo acompaña al cornu epistolae pone allí las Vinageras y después que el Subdiácono

[fol. $165^{\mathrm{v}}$ ]

ha dexado el Cáliz en el altar le quita el çendal de los hombros con ambas manos y lo pone en el escaño y después que el Subdiácono a administrado al Diácono el agua y vino, le buelve a poner el çendal por ambos hombros para que reciva la patena $\mathrm{y}$ juntamente baxa con el recaudo para el agua manos.

51. Y al tiempo suben los Turiferarios y el ceroferario más moderno y juntos el subdiácono en medio, los Turiferarios a los lados a todos tres cogen en medio, los çeroferarios y todos hazen genuflexión. El Turiferario más antiguo sube a dar la naveta y el çeroferario antiguo entre el escaño y cornu epistolae aguarda la Turificación, el moderno hecha la genuflexión se aparta a la credençia un paso más abaxo del çerimoniario y cuando el celebrante ha incensado la oblata y el diácono quita el Cáliz llega, y al mismo tiempo junto con el Presidente haze genuflexión, levántase y toma el atril y con él se aparta al lugar donde estava junto a la credençia y cuando el celebrante ha incensado el cornu evangelii que pasa

[fol. $\left.166^{\mathrm{r}}\right]$

al de la Epístola, llega con el atril y juntamente con el haze genuflexión, levántase, déxalo en el altar, pasa por detrás del Subdiácono al cornu epistolae y pone más abaxo del que tiene la fuente y le toma la toalla aviéndose labado el çelebrante, con ambas manos le echa la toalla graciosamente que se vaya desplegando y al echarla la vesa primero.

52. Cuando no se da aguamanos con la fuente, cuando a puesto el antiguo el cendal al Subdiácono, toma la salvilla y vinageras y báxase con él a hazer genuflexión con los Turiferarios que suben como se ha dicho.

53. Cuando la credencia está abaxo, el ceroferario antiguo haze genuflexión abaxo al tiempo que el Subdiácono la haze arriva, mas cuando va por el aguamanil haze genuflexión en lo alto y baxa las gradas y de la credençia lleva la fuente y aguamanil y cuando sube haze donde la hizo primero y pone junto al escaño con la fuente y aguamanil, y siendo el Presidente inçensado del Diácono se llega un poco y le echa 
aguamanos y mientras se enxuga vaçia el agua de la fuente y pone el aguamanil sobre el escaño.

[fol. $\left.166^{\mathrm{V}}\right]$

y con ambas manos tiene la fuente en que reçive la toalla haziendo humiliaçión [y] demonstración de vesarla, luego la toma el más moderno y sin doblarla pone sobre el brazo izquierdo y del altar toma la salvilla y ampolleta y el más antiguo la fuente y aguamanil y juntos van a la credenzia, hazen genuflexión cuando pasan en la segunda grada cogiendo en medio al Subdiácono y todo lo dexan en ella vien puesto y se van a sus lugares haziendo genuflexión juntos al pasar en medio la grada.

54. Si no ay aguamanil, el Ceroferario más antiguo no se muda del lado del altar y el moderno sube a hazer genuflexión con todos y todo lo demás que queda referido y con la ampolleta y salvilla sirve el aguamanos por el mismo orden.

55. Siempre echa el agua con tiento que no salpique ni caiga fuera de los dedos y nunca está en la peana cuando la echa, sino fuera de ella.

56. Cuando no pueden hazer genuflexión en el pavimento por estar en lugar donde

[fol. $167^{\mathrm{r}}$ ]

la an de hazer el Subdiácono se baxen de la grada y allí la hagan.

57. Cuando dexan todos este recaudo en la credençia toman las campanillas con mucho tiento, sin que se toquen y baxen con ellas a su lugar y las ponen en la grada y ellos están en pie.

58. Dicho en el coro Dignum est, iustum est dobla el moderno en su lugar la toalla y las buelve a poner sobre el brazo siniestro y cuando suben a despavilar antes de hazer la genuflexión en el pavimento alto, la dexa en la Credenzia.

59. Cuando el órgano o el coro dize Sanctus tocan las campanillas ambos a un tiempo con tres golpes pausados y cuando el çelebrante dize Te igitur suben y en el pavimento antes de llegar a la peçina hazen genuflexión, llegan al altar cada uno por su lado cogiendo en medio al çelebrante y diáconos y bueltos algo eregion e buelven a hazer genuflexión y llegan a despavilar.

60. Toman primero las velas de junto al Tabernáculo, el que está al Cornu epistolae, quita la vela con la mano derecha y pásala

[fol. $167^{\vee}$ ]

a la siniestra y el de Cornu evangelio la quita y se queda con ella en la diestra, cógenlas de manera que de tres partes de las velas, la una queda arriva sobre la mano y con ellas hazen genuflexión del mismo modo, bueltos así algo de rostro y con cuidado no caiga çera en los ornamentos ni frontal, van con ellas, cada uno a su cornu altar y puesta una 
rodilla en el suelo y baxo el cuerpo las despavilan y cuidan que no queden humeando las pavesas, levántanse, llegan a ponerlas sin hazer genuflexión, pónenlas y toman las segundas y hazen genuflexión como la primera vez y con el mismo orden despavilan las terceras y aguárdanse para quitarlas y ponerlas para hazer genuflexión y levantarse a un mismo tiempo con mucha igualdad.

61. Cuando no ay más que dos velas, suben y hazen genuflexión en el pavimento cerca de la peana. Van a las esquinas del altar toman las despaviladeras y despavilan sin quitarlas de los candeleros si alcanzan, y si no las

[fol. $168^{\mathrm{r}}$ ]

quitan y sobre la copa del candelero las despavilan y puestas baxan las despaviladeras a su lugar y sin hazer genuflexión en la peana la hazen cuando suben y se baxan a su lugar.

62. Cuando el Sanctíssimo Sacramento esta manifiesto hazen genuflexión al quitar y poner la vela y de esta forma despavilan siempre, ceroferarios Turiferarios y otros cuales quiera ministros que despavilen.

63. En sus lugares se ponen de rodillas toman los çiriales en las manos y cuando el celebrante acava de consagrar toman las campanillas en las diestras y cuando haze genuflexión para adorar la hostia consagrada, a un tiempo dan dos toques con las campanillas en las diestras y cuando haze genuflexión para adorar la hostia consagrada, a un tiempo dan dos toques con las campanillas, otros dos cuando la elevan, otros dos cuando la baxa, y los mismo dan al

[fol. $\left.168^{\mathrm{V}}\right]$

Cáliz, excepto el Jueves y Viernes Sancto que no tocan.

64. Están de rodillas hasta el Et ne nos inducas del Pater Noster, que a este tiempo el antiguo sube y haze genuflexión con el Subdiácono a su diestra, y cuando dexa la Patena, le quita el çendal y lo pone sobre el escaño y haziendo otra genuflexión se baxa a su lugar, híncase de rodillas y después de la comunión sube a la credençia, lleva las Vinageras para la abluçión y aguarda, hasta que el Subdiácono se las buelve a dar y entonzes le da el paño del Cáliz que cuando se hizo el ofertorio dobló y puso sobre el altar al cornu epistolae y el moderno en consumiendo el Sanguis se pone en pie.

65. Buelve a la credençia las vinageras y paño de ombros y aylli aguarda a que el Subdiácono traiga y ponga el Cáliz en la credençia que entonzes lo cubre todo con el çendal toma el missal y pasa al cornu epistolae y a su tiempo ministra

[fol. $\left.169^{\mathrm{r}}\right]$

el missal para el Ite missa est o Benedicamus Domino, para lo cual se pone abaxo de la peana el rostro buelto al coirnu Evangelio y con ambas manos tiene el misal levantaddo 
de suerte que lo alto del misal empareze con la frente, cantado el Ite missa est cierra el missal y pasa a ponerlo en la credencia y se baxa a su lugar.

66. Cuando ay comunión al tiempo de consumir suben ambos çeroferarios y el antiguo lleva el vaso de vino aguado con una toalla ençima y el moderno las vinageras ponenlo todo en el altar al, cornu epistolae, toman el cendal de hombros del Subdiácono y con ambas manos tienen el paño mientras comulgan todos y están de rodillas en las esquinas de la peana como se dixo libro 3 capítulo 7, de la Comunión general, acabada la comunión doblan el paño y buelven a la credençia el vaso y toalla y las ampolletas. El moderno va a su lugar, el antiguo se queda allí para ministrar el missal para el Ite missa est, ut supra.

[fol. $\left.169^{\mathrm{V}}\right]$

67. Cantado el Ite missa est, çierra el misal y llévalo a la credençia, baxa a su lugar y toman los çiriales en las manos están en pie, y cuando el celebrante buelve a dar la bendición, se hincan de rodillas y se levantan al Evangelio último y están los ciriales baxos y cuando el çelebrante haze genuflexión en el Evangelio la hazen también, y cuando la haze para despedirse del altar cuando baxa, levanta los ciriales y le acompañan como al venir, mas los días que se dize responso rezado cuando baxa el antiguo de ministrar el missal al Ite missa est se trae consigo el Manual e Hisopo que pone en la punta del escaño y a su tiempo lo da la çerimoniario para dezir el responso y dicho lo buelve a poner allí, excepto cuando ay flavelario que este haze lo que se ha dicho de ministrar el çendal y el missal al Ite missa est y baxar el Manual e hisopo, [igualmente] aguarden en pie con los çiriales baxos

[fol. $\left.170^{\mathrm{r}}\right]$

hasta que se ha dicho el responso.

68. En la Sacristía ponen los çiriales en su lugar apagan los codales, salen al altar y lo primero apagan las velas, hazen genuflexión en el pavimento frontero del altar, suben y en la peana buelven a hazer algo bueltos el rostro, quitan las primeras velas de junto al tavernáculo y tómanlas como se dixo supra $\mathrm{n}^{\circ} 60$, llévanlas donde se despavilan y las apagan y dexan tendidas en el suelo y de esta suerte las demás. A las últimas que apagan las toman todas, el del Cornu evangelii sus tres con la mano diestra /3/ y algo apartadas del cuerpo con buen aire hazen genuflexión en el pavimento y las llevan a la Sacristía y las ponen en su lugar, quitan lo demás que a servido en la missa y componen el altar y la cruz en su lugar $\& .^{21}$

69. Si está el Sanctíssimo Sacramento descubierto o reliquias o el día de la Cruz de maio no las apagan y si ay Vísperas cantadas después de la missa quitan el Cáliz y missal y artril y ponen en la credenzia y sacan la cruz sobre la ara

[fol. $170^{\mathrm{v}}$ ]

${ }^{21}=\mathrm{va}$ al margen $=\mathrm{el}$ del cornu Eptae sus tres con la siniestra= 
y los candeleros a la frente del altar y si son las primeras Vísperas ençienden las velas que an de arder y quitan el frontal y llevan a la sacristía buelven y mudan el viso y llevan el Cáliz y demás recaudo.

70. Si las Vísperas son cantadas después de la missa no se desnudan, mas si se muda color toman collares combenientes y acompañan con los çiriales altos, si no son cantadas después de quitar el recaudo y poner las velas que an de arder en su lugar se desnudan y toman sobrepellizes y acompañan al çelebrante al coro.

71. Las tres noches de tinieblas ençienden sus velas en el altar y cuando comienza el antíphona del Benedictus baxan del coro y se ponen en el altar mayor el más antiguo al cornu epistolae y el otro al cornu Evangelii, y al verso Ut sino timore de manu inimicorum nostrorum, el más moderno apaga la primera vela de la esquina del altar de su lado y al otro verso el antiguo apaga la correspondiente y van apagando a cada verso la suya alternativamente

[fol. $\left.171^{\mathrm{r}}\right]$

como comenzaron.

72. Cuando se repite la antíphona al tiempo que el luçernario quita la candela blanca del triangular, los çeroferarios apagan todas las luzes y lámparas de la Iglesia, excepto las dos que arden delante del Sanctíssimo sacramento en el altar mayor y en el de el sagrario que cuando esta en ellos no se apagan y el Jueves sancto no se apagan las del monumento.

73. Los días que los diáconos usan planetas después de vestidos y puestos los atriles sacan un escabelo que ponen junto a la credencia y en el ponen la estola ancha y collar y cuando se comienza la penúltima oración sube el ceroferario antiguo y toma de la credençia el misal collar y estola ancha y pónelo sobre el escaño, quita al Subdiácono la planeta y pónela en el lugar donde se sienta el Subdiácono, pónele el collar, dale el libro y acompáñalo a decir la Epístola more solito = cuando ay flavelario en la missa haze todo lo contenido en estos dos parrafos, y el ceroferario antiguo sube solo a acompañar

[fol. $\left.171^{\mathrm{v}}\right]$

Al Subdiácono al tiempo que junto con el haga genuflexion.

74. Acavada la Epístola después de aver besado la mano al celebrante le tma el misal y pone en el escaño, quita el collar y ponele sobre el escaño y buelve a ponerle la planeta, ponela en el escaño, viste la estola ancha y collar y dale el misal y entonzes lleva la planeta al escabelo de junto a la credenzia y ponela en el decentemente.

75. El tiempo de quitar la planeta al Diácono es en las Dominicas de adviento cuando el coro comienza el Alleluya después del gradual, en las dominicas de cuaresma cuando comienza el tracto $=$ en las ferias que no ay tracto ni alleluya cuando comienza el gradual en las ferias 2.4 y 6 de cuaresma, cuando comienza el segundo verso del tracto 
que es Domine me mineris, en poniendo la planeta en el escabelo haze genuflexión y se va a su lugar, cuando ay adiutor o asistente en la missa quita la planeta, ministra la estola como se a dicho.

[fol. $172^{\mathrm{r}}$ ]

Los

76. Los días de passion tienen prevenidos tres atriles altos en que se a de cantar, cubrenlos con paños morados. El Viernes Sancto los dexan desnudos y cuando comienza el tracto van a la Sacristía y los sacan al pavimento alto, el del christo ponen en medio del pavimento buelto al pueblo el que lo a decantar metido algo dentro hazia la peana, el que canta el texto al lado del evangelio que mire no totalmente al pueblo sino a la capilla del rosario, el que canta los altos al lado de la Epístola ynclinado de la misma manera a la capilla de los martyres, an de estar estos dos atriles un paso desviados de las pilastras de las esquinas del pavimento jnto a la grada y mientras se canta la pasion asisten el antiguo al que canta los altos, el moderno al del texto están las espaldas a las pilastras teniendo a la parte de adentro los atriles y eregione las manos puestas.

77. El Viernes Sancto para los oficios de la mañana y el Sabado Sancto y la Vigilia de Pentecostés ponen las velas apagadas en el altar

[fol. 172 ${ }^{\mathrm{v}}$ ]

Y los sabados dichos, no las encienden los ceroferarios, mas otros dos Colegiales cuydan de sacarlas encendidas a su tiempo y el Sabado Sancto sacan los ceroferarios los Atriles como se dize, lib.4.Capítulo 15.n 2 .

78. El Jueves Sancto con el recaudo de la missa sacan un Cáliz consagradop con vino y agua para dar la purificación a los Sacerdotes y oro vaso con vino y agua para los que no lo son, sacan quatro estolas blancas para los Sacerdotes.

79. El Viernes Sancto sacan a la credencia con el recaudo de el offiçio una toalla o mantel que tienden sobre el altar cuando están postrados los que çelebran salen sin çiriales mas sacanlos cuando sale la cruz para la proçesion.

80. El Sabado Sancto se bisten, sacan las velas, atril y misal que ponen en el altar, los facistolespequeños con paños blancos que ponen en los pulpitos del Evangelio y Epístola y para yr a la Vendicion del fuego

[fol. $173^{\mathrm{r}}$ ]

el

Antiguo saca la caña con las tres candelas y el moderno va al lado del Colegial Cruciferario que lleva la Cruz y a la buelta de la procesion buelven ambos acompañando al Subdiácono que trae la Cruz, cuando llegan a las gradas del pavimento alto el modernotoma la caña con las tres candelas y acompaña al diacono cuando recivida la vendicion va sl pulpito del evangelio a cantar la del çirio y se queda en el crucero al lado diestro del pulpito, un paso mas al altar de la Concepción de lo que se pone el 
acólito moderno cuando tiene el çirioal en tal distançia que el diacono comodamente con su diestra alcanze y tome una de las candelas para ençender el çirio a su tiempo, tiene la caña baxa asentadaen el suelo = Acavada la Vendcion se entran en la Sacristía y lleva la caña acompañan la Cruz, buelven a salir las manos puestas y se ponen en sus lugares, al pecadores se entran con los demas a la Sacristía, mudan collares y mientras se visten los que celebran sacan el recaudo para la missa excepto las

[fol. $173^{\mathrm{v}}$ ]

Velas y los atriles y con los çiriales y codales encendidos salen a la missa more solito.

81. Cuando van al Evangelio, no acompañan con los çiriales, sino las manos puestas mas se ponen en el lugar que suelen lo mismo a la missa de la Vigilia de Pentecostés y a las de difuntos.

82. Cuando se canta el Evangelio en el pavimento se ponen delante del facistol eregione teniendolo en medio y acavado cada uno por su lado se bueklven el rostro adentro, así se ponen las manos puestas cuando el evangelio es de difuntos.

83. Cuando están en el altar con çiriales y a de aver proçesion al tiempo que quiere salir la cruz toman los çiriales y altos Van a la capilla de los martyres y salen con la Cruz y se ponen en la grada como se duxo lib.3cap.5 de las proçesiones y en ellas van un paso delante del cruciferario, llevandolo en medio, mas si la proçesion es del Sanctissimo Sacramento los ceroferarios de la missa no se mudan de

$\mathrm{su}$

[fol. $\left.174^{\mathrm{r}}\right]$

su lugar porque salen otros dos con çiriales acompañando la cruz, los de la misa van junto al palio, los ciriales baxos.

84. Los Sabados para la missa de Nuestra Señora salen de oracion comenzando el primero reqipque sacan el recaudo y encienden como a las demas, en ella están de rodillas siempre sinoes cuando acompañan a decir el evangelio y cuando buelven al oremus del ofertorio o al Credo si lo ay se buelven a poner de rodillas, tienen siempre los ciriales en las manos y así no ministran a cosa alguna.

85. Los Sabados después de comer acudirn a la Sacristía a limpiar los çiriales y despaviladeras del altar mayor.

[fol. $\left.174^{\mathrm{v}}\right]$

\section{Capítulo 22. De los Turiferarios y modo de Turiferación.}

1. Los Turiferarios sirven de llevar Turíbulos e incienso en todos los officíos en que se suele ministrar. Visten como los ceroferarios, amitos roquetes y collares. 
2. En todas las missas cantadas y en todas las Vísperas cantadas de Dominicas y Sanctos, y en todos los maitines cantados excepto las tres noches de tinieblas y en todas las proçesiónes y Vendiçiones sirven con Turíbulos e incienso.

3. Van juntos a la Sacristía en comenzando la gorda y el moderno avisa a los que son Diáconos y a los que toman pluviales según la tabla $=$ si los señalados no pueden o se escusan llama a los que se siguen en turno y sea con puntualidad de suerte que estén en la Sacristía para vestirse con tiempo y en viniendo ayuda a vestir $=$ el antiguo se viste y previene brasas e incienso y aguarda a salir con la missa.

4. Siempre van delante de los ceroferarios cuando

[fol. $175^{\mathrm{r}}$ ]

Salen con Turíbulos y todas las vezes que salen en ceremonia que suben y baxan del coro guardan este modo de llevar los turíbulos en la mano derecha toman el incensario que la chapa de las cadenas, levantan la cubierta del inçensario cuatro dedos de la copa y para esto dan una buelta al dedo pulgar con la cadenilla de la cubierta y meten en el la aldabilla toman en la misma mano derecha la naveta por el pie y la tapa levantada, llevan el brazo un poco alto de suerte que el codo empareje con la cíntura doblado un poco y desviado del cuerpo.

5. Cuando salen a la missa y a las proçesiónes y todas las vezes que aguardan para ministrar el inçienso excepto las que en sus propios lugares se notaren se ponen en el pavimento baxo, el antiguo al arco de la capilla del rosario, el moderno al de la capilla de los mártires de baxo

[fol. $\left.175^{\mathrm{v}}\right]$

De las lámparas bueltos Eregione y meneando los incensarios con buen aire desviados porque no se frieguen los roquetes y meneanlos con tal proporción que cuando el uno envía el incensario hazia el altar mayor, el otro lo envía al contrario hazia la Iglesia y ansi trocados guardan siempre un mismo orden.

6. Cuando suben al pavimento alto hazen la genuflexión en los lados de el lugar donde suele estar el Subdiácono con la patena y luego se apartan a las pilastras del arco algo más adentro y se buelven Eregione y de la misma manera menean los incensarios, este es el lugar en el pavimento alto excepto lo particular que an de hazer y se notará en sus lugares.

7. Cuando suben al coro después de aver hecho genuflexión sus lugares son dos pasos más abaxo de las gradas primeras que suben a las sillas Eregione mirando al facistol grande y meneando los incensarios de la

[fol. $176^{\mathrm{r}}$ ]

Misma manera. 
8. Cuando se dize que se ponen en su lugar se ha de entender en los referidos conforme la parte donde estubieren.

9. En las procesiones el lugar que llevan es después del Pertiguero delante de los ceroferarios que van con la cruz excepto en las del Sanctíssimo Sacramento.

10. Para Vísperas después de aver llamado los caperos se van al coro con los demás colegiales en çeremonia y su lugar es después de los luçernarios y en acabando el primero psalmo ponen las mangas de sobrepelliz en los brazos buelven a hazer venia y pasado el facistol hazen genuflexión juntos van a la Sacristía, no por la Iglesia, previenen brasas en los incensarios vien encendidas y navetas con incienso y lo dexan en la Sacristía y salen a la capilla de los mártires.

11. Cuando se repite la quinta antíphona salen y miden el tiempo de suerte que cuando lleguan al pavimento alto se acabe en las gradas, hazen profunda en el pavimento genuflexión, levántanse y allí se quedan

[fol. $176^{\mathrm{v}}$ ]

en pie mientras dizen la capítula. Si el himno es Veni Creator Spiritus o Auemaris Stella se hincan de rodillas allí mismo mientras se dize el primer verso, levántanse y sin hazer genuflexión se van al altar: si el himno es otro acabada la capítula hazen allí genuflexión y se van al altar y en medio el uno buelto el rostro al otro hazen genuflexión y despavilan de la manera que se dixo en el capítulo precedente de los ceroferarios $n^{\circ} 60$.

12. Puestas las últimas velas sin hazer genuflexión se baxan de la peana y la hazen donde primero, buelven a la Sacristía, toman los turíbulos y navetas echan incienso salen con el Pertiguero y en el pavimento pasa el antiguo delante al lado de la Epístola y bueltos al altar hazen genuflexión, mas el día del Corpus y su octava miden el tiempo de salir de manera que cuando en el coro se canta tantum ergo ellos se hinquen de rodillas en la yn

[fol. $177^{\mathrm{r}}$ ]

ínfima grada del altar, y dicho Veneremur cernuí se levantan hazen genuflexión, y esto se entienda si el Sanctíssimo Sacramento está manifiesto y entonzes también el Pertiguero se hinca de rodillas en el pavimento enlosado van por la Iglesia al coro entran en el coro al tiempo que los çeroferarios después de aver tomado luz van a poner los codales en los çiriales; hazen genuflexión al altar entre el facistol y la varandilla el antiguo en el lado del coro diestro y el moderno en el lado del coro siniestro y bueltos al coro hazen profunda y se apartan a sus lugares y meneando los incensarios aguardan.

13. Cuando el Presidente despide paran los incensarios y toman las navetas en la diestra: hazen juntamente venia al coro. Van en ceremonia y cuando llegan a las gradas se ponen junto a los ceroferarios por la parte de adentro y cogen en medio a los comitantes y preste y hazen profunda. Suben todos juntos y los turiferarios 
[fol. $\left.177^{\mathrm{v}}\right]$

Se apartan a sus lugares y en ellos hazen genuflexión cuando el preste la haze con los comitantes en la peana cuando llega a besar el altar el antiguo llega con el incensario y naveta en la diestra y pónese en el cornu epistolae que tenga en derecho de su brazo diestro el lugar del candelero de en medio y allí buelve a hazer genuflexión cuando la hazen los comitantes y el preste vesa el altar, tomale el comitante la naveta y el toma elincensario por el extremo de las cadenas con la mano siniestra y en la diestra las cadenas por junto a la cubierta que esta levantada de la copa cuatro dedos y levanta el incensario para que el preste eche tres vezes incienso y de la misma manera avierto y levantado lo tiene hasta que le aya hechado la vendición y el tiene inclinado el cuerpo algo por la reverenzia, luego dexa correr la cadenilla de la cubierta para que se cierre y lo da al comitante

[fol. $178^{\mathrm{r}}$ ]

reçiviendo del la naveta y se aparta a su lugar haziendo abaxo de la peana genuflexión con la naveta en la mano siniestra cerrada y arrimada al pecho y tomada con toda la mano por el cuerpo de ella.

14. El moderno se queda a todo esto en su lugar meneando el incensario, acavada la turificación se llega y reçive el incensario y se aparta, tomalo en la mano derecha alza la cubierta y toma la naveta por el pìe en la misma mano, lo mismo haze su compañero $=$ hazen genuflexión cuando el preste y buelven al coro como vinieron.

15. Todas las vezes que el Turiferario ministra la naveta y turíbulo para que el celebrante turifique guarda el mismo orden que aquí se a dicho.

16. En la puerta del coro echan inçienso, entran y pasan a sus lugares y hazen genuflexión con el preste, dan lugar a que pasen por delante de ellos los comitantes y el preste y luego con todos venia al coro

[fol. $178^{\mathrm{v}}$ ]

Y cuando el preste sube a su lugar se va detrás del facistol toman las navetas con toda la mano por el cuerpo y rodean las cadenas del incensario a la mano diestra de suerte que con el puño llegue a lo alto de la cubierta y çerrado el incensario y la naveta con la siniestra arrimada al pecho hazen genuflexión y así parten cada uno por su coro y llegando un paso antes del facistol del preste hazen venia, el moderno se queda allí, el antiguo sube un paso y inciensa al celebrante con tres ductos y le haze venia, en acavando apartase un pocoy juntos hazen venia a los caperos y los inçiensan con dos ductos y les hazen venia, y de la misma suerte inciensan si ay más caperos.

17. Luego pasan a las gradas junto a las sillas de los capellanes suben y llegan a incensar los prebendados, el antiguo al Abad, el moderno al Pressid

[fol. $179^{\mathrm{r}}$ ] 
Inciensan con dos ductos, luego a los prebendados como se siguen por el mismo orden con esta advertençia que cuando ínciensan los de las sillas del testero no buelven las espaldas al altar sino en obliqueuo miran e inciensan al prebendado, cuando ha incensado al Abad se retrae dos pasos o tres y inciensa al que se sigue de la misma manera y cuando ha incensado a este se buelve el rostro y pasos para incensar a los demás, porque no ha de dar más pasos atrás, el moderno cuando ha incensado al Pressidente se buelve el rostro y pasos para inçensar los que se siguen, en incensando a los del Coro alto se buelven por el orden y baxan por las gradas donde subieron y luego inciensan a los capellanes a cada uno con un ducto y buélvense los rostros para baxar por el plano de el coro y pasados los caperos van incensando a los Colegiales a cada uno con un ducto sin pararse ni detenerse sino andando

[fol. $179^{\mathrm{v}}$ ]

los rostros hazia el altar mas un poco inclinados a los que inciensan y si la repetición de la antíphona los cogiere antes de acavar la incensaçión dexan de inçensar y se salen, si les coge en las sillas altas por el mismo anden y si en las baxas por el plano del coro, al Pertiguero también le dan un ducto. Acavada la incensaçion sueltan las cadenas de los incensarios van detrás del facistol, alzan las cubiertas, toman las navetas en las diestras, alzadas las tapas hazen genuflexión al altar, luego venia al coro y el moderno aguarda que con él empareje el antiguo y juntos salen y por la Iglesia se buelven a la Sacristía.

18. De este modo inciensan siempre en el coro excepto que en las missas como no ay Presidente ni caperos se van derechos y hecha venia suben ha inçensar al coro alto.

19. El modo de inçensar es que cada uno de los que inciensan con tres o con dos ductos antes y después le hazen venia

[fol. $180^{\mathrm{r}}$ ]

y ninguna a los que inciensan con un ducto.

20. A solo el Prelado y çelebrante cuando está reuestido se inciensa con tres ductos y también se dan tres cuando otro Obispo ubiere entre los Prebendados.

21. A los Caperos, Al Abad y a los prebendados y a los huéspedes que estubieren entre ellos en las sillas altas se inciensan con dos ductos.

22. A los Capellanes y a los demás del coro baxo aunque en el este algún prebendado y otros ministros aunque estén reuestidos con un ducto.

23. Al Como ministros y pueblo inciensan coin una mano teniendo las cadenas del incensario rodeadas en ella y el inçensario por lo alto de la cubierta, no meneen ni saquen el brazo mucho para dar los ductos que solo con el juego de la muñeca se menea el incensario con buen aire y compás. 
24. Al Sanctíssimo Sacramento se inciensa con dos manos, en la siniestra tienen la naveta por el cuerpo de ella y la sumidad de las cadenas del incensario y con la diestra las tienen por junto a lo alto de la cubierta ponen la siniestra

[fol. 180 ${ }^{\mathrm{v}}$ ]

junto al pecho y la diestra con el incensario un poco más baxa que el pecho diestro, y desde aquí sacan los brazos y envían el incensario todo lo que alcanza el brazo diestro tendido y levantandolo que iguale en altura con el rostro y cuando incensan de rodillas lo levantan todo lo que alcanzare el brazo siempre inciensan con el incensario bien cerrado porque no caiga ascuas ni çeniza.

25. Cuando inciensan el coro alto siempre comienzan a la par, y aunque en el un choro ay muchos prebendados y en el otro uno este aguarda abaxo junto a las gradas en las sillas baxas a que su compañero acabe.

26. Cuando llegan a las sillas de los capellanes para /ir/ a inçensar al coro alto y no ubiere prevendados en alguno el Turiferario de aquel coro no tiene que subir aguarda en aquel lugar que baxe su compañero.

27. En la Sacristía dexan los incensarios y se desnudan, toman sobrepellizes y si ay más de dos velas en el altar aguardan en la capilla de los martyures y cuando ha respondido el coro Deo Gratias suben y las apagan

[fol. $181^{\mathrm{r}}$ ]

more solito y dexan las dos de las esquinas y se buelven al coro.

28. Cuando el Sanctíssimo Sacramento o reliquias están manifiestas y la cruz en sus fiestas, no apagan las velas y cuando las Vísperas an sido anteprandium tampoco se quedan encendidas hasta que a buelto la ceremonia a la Sacristía y salen los ceroferarios a apagar.

29. Para maitines llaman los caperos y vanse al coro con los demás y en el Te Deum laudamus salen del coro al prinçipio de él y por de fuera de la Iglesia se van a la capilla de los mártires, allí aguardan al verso Iudex crederis esse venturas que salen a compás, que cuando an hecho genuflexión en el pavimento alto se aya acavado, y cuando comienza el verso Te ergo quae sumus tuis famulis subveni se hincan de rodillas y lo están a todo él. Acabado se levantan y sin hazer genuflexión, van a despavilar y en la peana la hazen y despabilan de la misma manera supra capítulo $22, \mathrm{n}^{\circ} 60$. Buélvense al coro y al fin del primero psalmo de laudes salen y en la

[fol. 181 ${ }^{\mathrm{v}}$ ]

Sacristía se visten y despavilan a la capítula y lo demás ofician de la misma manera que se dixo a Vísperas, porque en todas las çeremonias las Vísperas y laudes son semejantes. En los maitines de Navidad salen al prinçipio de la novena lección, vístense y despavilan vestidos. 
30. En la missa mayor que ay asperges sale el antiguo con incensario y el moderno con sobrepelliz, lleva el açetre de agua vendita y hisopo asido con el asa, llévalo tendido el brazo y va detrás del celebrante, el antiguo pasa a su lugar y al mismo lado el moderno, hazen todos genuflexión y aunque se queda de rodillas el celebrante en la grada, el antiguo se levanta y pone Eregione meneando el incensario mientras dura el Asperges, el moderno se levanta y da el hisopo mojado al cerimoniario para que él lo dé al diácono y después lo reçive y parte con el Capellán al coro a echar agua, llevará siempre el açetre tendido el brazo, cuando entra en el coro haze genuflexión y se pone detrás del façistol en derecho del Crucifixo en pie y el acetre

\section{[fol. $182^{\mathrm{r}}$ ]}

en el suelo. Cuando el capellán pasa de un coro a otro, levanta el acetre para que tome agua, cuando ha echado el capellán agua toma el hisopo y acetre y le siguen por la Iglesia y después de aver echado agua al pueblo se va a la Sacristía y dexa el açetre y se viste y previene el incensario y brasas.

31. En la missa mayor que no ay asperges sale el más antiguo y pónese en su lugar donde haze venia y cuando el çelebrante haze genuflexión en la peana se hinca de rodillas, no eregione sino buelto al altar y cuando están de rodillas los turiferarios tienen el incensario y naveta en la mano derecha como cuando salen y levantado de suerte que no asienten en el suelo los incensarios. Está de rodillas mientras el çelebrante dize el Introito y haze la confesión y cuando dize Indulgentiam et remissionem \& sube y haze genuflexión juntamente con el ceroferario que sube al mismo tiempo y cuando el celebrante llega a besar el altar sube a la peana y al lado diestro, el diácono, algo apartado, haze genuflexión y ministra al Diácono la naveta

\section{[fol. $\left.182^{\mathrm{v}}\right]$}

del mismo modo que se dixo en vísperas $\mathrm{n}^{\mathrm{o}} 13$, apártase a su lugar, haziendo baxo de la peana genuflexión donde suele y baxa y se va a la sacristía.

32. Después de comenzada la Epístola buelve a salir, haze genuflexión en medio del pavimento al altar y se va a su lugar y en el buelve a hazer profunda hacia el altar y se queda meneando el incensario. Cuando el celebrante acava de decir el evangelio rezado, sube haze genuflexión y va al altar a ministrar la naveta al Diácono como se ha dicho, ehado el incienso toma la naveta haze genuflexión y baxa las gradas y se pone en medio de los turiferarios y en este lugar haze venia y cuando los diáconos hazen genuflexión para partir se la hazen también junto a la grada. Acompaña delante de los çeroferarios, y cuando llega a la escalera del púlpito se aparta un paso debaxo del arco las espaldas a la capilla de los mártires y da lugar que pase por delante del el Diácono y Subdiácono y sube tras ellos y dicho Dominus Vobiscum da el incensario al Subdiácono y lo buelve

[fol. $183^{\mathrm{r}}$ ]

a reçivir. Siempre que da el incensario o naveta a los Diáconos o a otro cualquiera revestido, haze humiliación antes y después, baxa las gradas haze genuflexión al altar 
pasa por detrás del ceroferario y debaxo del púlpito se pone en medio de ellos un paso adelante y buelto el rostro al altar del sagrario se queda meneando el inçensario y haze humiliación con la cabeza y se hinca de rodillas cuando el Diácono.

33. Si el Evangelio no se dize en púlpito sino en el pavimento se aparta de la misma manera y después de reçivido el incensario pasa por detrás de en medio de los ceroferarios el rostro al púlpito de la Epístola.

34. Acavado el Evangelio acompaña como vino, sube al pavimento, haze genuflexión, da al diácono el Turíbulo, buélvelo a reçivir y si ay sermón haze genuflexión y se va a la Sacristía y lo dexa y sale con su compañero a sentarse en la peana y acabado el sermón, sin detenerse un punto, van ambos y toman los incensarios con brasas que abrá prevenido el Sacristán menor

[fol. $183^{\mathrm{v}}$ ]

y salen luego que el celebrante entona el Credo o Dominus Vobiscum.

35. Si no ay sermón no haze genuflexión en el pavimento, sino baxa las gradas a tiempo que ya llega el moderno con su turíbulo y naveta en la diestra y ambos juntos hazen genuflexión junto a la grada en medio de los ceroferarios y luego cada uno se aparta a su lugar y en él hazen profunda al altar y venia el uno a otro, y se quedan eregione meneando los incensarios.

36. Si ay Credo cuando dize el coro Que qui propter nos homines toman las navetas e incensarios, levantadas las cubiertas en las diestras y van juntos a la grada al tiempo que comienzan el Incarnatus est y se hincan de rodillas en ella en medio de los çeroferarios hasta que ha dicho el Homo factus est que se levantan, hazen genuflexión, buelven a sus lugares y allí hazen profunda al altar y en sola esta ocasión se hincan de rodillas en la grada, las demás vezes

[fol. $184^{\mathrm{r}}$ ]

abaxo junto a ella.

37. Al tiempo que el Subdiácono viene con la patena cubierta, suben al pavimento y lo cogen en medio y juntos hazen genuflexioin y en levantándose el antiguo llega al altar a dar la naveta al diácono more solito, y en dándole el incensario con la naveta en la siniestra, arrimada al pecho, se va al lado diestro del Subdiácono donde haze genuflexión y está mientras la Turificación, toma el incensario del diácono y con ambas manos lo inçiensa con dos ductos y luego lo pone en la diestra y la naveta y juntos hazen genuflexión y baxan con el Pertiguero delante, van por la Iglesia al coro, al entrar echan incienso y Turifican como se dixo supra $\mathrm{n}^{\circ} 16$ excepto que si está el Sanctíssimo Sacramento descubierto o avierto el sagrario, cuando hazen la venia al coro detrás del facistol no buelven totalmente las espaldas al altar, mas se ponen de medio lado.

38. Baxan del coro y sin detenerse entran por la Iglesia y suben al pavimento hazen genu 
[fol. $\left.184^{\mathrm{v}}\right]$

flexión y inciensan como en el coro, uno al capellán çerimoniario, otro al flavelario si lo ubiere y buelven a hazer genuflexión, baxan y inciensan cada uno al ceroferario de su lado que se buelven las manos puestas a reçivir el incienso, lléganse a la grada del pavimento baxo y el rostro al pueblo, juntos en el medio de ella, el antiguo da tres ductos y se aparta, cada uno a su lado junto a los púlpitos y da tres ductos con que inciensan al pueblo y luego se buelven a sus lugares devajo de las lámparas y al llegar hazen profunda al altar y venia uno a otro y se quedan eregione menando los incensarios.

39. A la infra actionem cuando el celebrante tiende las manos sobre la oblata ,echan incienso en los incensarios y a un tiempo suben por medio de los ceroferarios al pavimento, hazen genuflexión y van a ponerse de rodillas en la peana del altar, los pies fuera, el moderno en la esquina, el rostro que mire al Cáliz,

\section{[fol. $185^{\mathrm{r}}$ ]}

el antiguo se pone arrimado al Cornu epistolae y enciensa con dos manos como se dixo supra $\mathrm{n}^{\mathrm{o}} 24$, tres ductos a la elevación de la hostia, y tres a la elevación del Cáliz, con tal proporción que duren lo que durare la elevación, se levantan juntamente con el Presidente, alzan las cubiertas y toman las navetas y inçensarios en la diestra, hazen genuflexión a los lados del subdiácono y se van a la Sacristía.

40. En las missas de requiem no ay incienso hasta el ofertorio y al tiempo que el celebrante dize Dominus Vobiscum después del evangelio, sale el más antiguo y haze venia en la grada entre los ciriales, sube y haze genuflexión y da la naveta al diácono como se ha dicho, y después de aver incensado, toma el incensario y baxa a las gradas y se ponen en su lugar more solito y al tiempo de consagrar sube haze genuflexión, da el incensario al subdiácono que inciensa a la elevación y él se pone de rodillas, dos pasos atrás del subdiácono y acavada la turificación rezive el incensario, tómalo en la diestra con la naveta como

[fol. $185^{\mathrm{v}}$ ]

Suele, haze genuflexión y se va a la Sacristía.

41. En aviendo alzado, dexan los incensarios en la Sacristía, lávanse las manos y el Sacristán tiene siempre para que se enxuguen una toalla en los caxones de turibularios, pónense cendales sobre ambos ombros, toman los portapazes, y cuando el çelebrante entona Per omnia Saecula Saeculorum, después del Pater Noster salen de la capilla de los mártires, hazen venia al subir las gradas, suben y en suviendo hazen genuflexión a los lados del subdiácono y luego se levantan y se apartan un poco, cada uno a su lado y pónense de rodillas, cuando el Diácono se levanta para ir a dar la paz al subdiácono, se levantan y el antiguo da a vesar la paz al subdiácono y le responde et cum spiritu tuo y apartado el Subdiácono, toca con su portapaz al del compañero y dízele Pax tecum y 
responde el compañero et cum spiritu tuo, si ay otros acólitos con portapazes los dos juntamente tocan las otras dos cada uno al suyo y les dizen Pax tecum y responden

[fol. $186^{\mathrm{r}}$ ]

Etc, mas no besa ninguno el portapaz que lleva, hazen todos genuflexión y los Turiferarios suben al coro, los otros dos se quedan para el pueblo y van por el pavimento después que los de las primeras pazes an entrado por la puerta de la concepción.

42. Los turiferarios entran en el coro, hazen genuflexión detrás del facistol y sin hazer venia al coro suven a las sillas altas por donde suben a incensar y van dando paz cada uno por su coro, desde los más dignos y después de averla dado, hazen venia a cada prebendado y no antes a ninguna persona por eminente que sea, y cada prebendado les responde baxando algo la cabeza, báxanse juntos y danla al coro baxo y haxen venia después, a cada uno que la dan dize Pax tecum, hazen genuflexión y sin hazer venia al coro, se van por la puerta de la Concepción a la Iglesia, suben al pavimento y hazen grenuflexión y dan paz al capellán y al flavelario y hazen genuflexión baxan y la dan a los ceroferarios y se van a la Sacristía,

[fol. 186 ${ }^{\mathrm{V}}$ ]

doblan los cendales y ponen en su lugar, desnúdanse si no an de bolver a servir en procesión o en encerrar el Sanctíssimo Sacramento y aguardan allí para ayudar a desnudar a los de la missa.

43. Para las proçesiónes de las letanías y Gratiarum actione y otras semejantes sale un Turiferario detrás del Pertiguero y sin hazer venia, pasa al arco de la capilla del rosario, que es su lugar y cuando el celebrante haze venia, la haze también, sube al pavimento y en su lugar haze genuflexión con todos y luego por el cornu epistolae llega y ministra la naveta al Diácono como se ha dicho, en echando el preste la vendición al incienso haze genuflexión y báxase al pavimento y se pone de baxo del púlpito de la Epístola, donde eregione se queda meneando el incensario y cuando el preste haze genuflexión para despedirse del altar, la haze también acia el altar y pónese delante de los ceroferarios y allí va toda la procesión meneando el incensario, no buelto totalmente de espaldas a la cruz sino de lado

[fol. $\left.187^{\mathrm{r}}\right]$

en bolviendo la proçesión, si no ay missa, se entra en la sacristía delante de la cruz, si la ay, se queda en su lugar como en las demás missas.

44. Para las vendiçiones de las candelas, çeniza y Ramos, sale el antiguo con incensario después del Pertiguero y se va a su lugar como se ha dicho, el moderno sale con sobrepelliz, saca el acetre de agua vendita, va detrás del celebrante como al Asperges y haze venia con todos y sube al pavimento y pónese junto a la rexa de las reliquias, el rostro algo buelto al altar, en la de la çeniza y en las demás dexa el acetre y se pasa al otro lado por estar allí el bufete, el del Turíbulo sube al pavimento con las 
acostumbradas reverenzias. En la Vendición de las candelas, cuando el celebrante comienza la oración Domine Iesu Christe qui hodierna die \&, en la de la çeniza cuando comienza la oración Omnipotens Sempiterne Deus qui Niniuitis etc, En la de las palmas cuando comienza la oración Benedit quae sumus Domine etc, ministra la naveta more solito, y cuando reçive el in

[fol. $187^{\mathrm{v}}$ ]

censario pónelo en la diestra como suele, haze genuflexión y se baxa a su lugar donde aguarda para ir en la procesión y va como se dixo $\mathrm{n}^{0}$ precedente. En la vendición de la çeniza que no ay proçesión, en reçiviendo el Turíbulo, se va a la Sacristía y lo dexa y sale a tomar la çeniza con los demás ministros y buelve a salir con él para la missa. El moderno, en aviendo echado agua a lo que se vendize, toma el hisopo y con el açetre haze genuflexión y lo lleva a la Sacristía.

45. El Jueves Sancto, no ay Pazes, mas cuando comienzan los Agnus, salen al altar mayor, suben al pavimento con las devidas reverenzias y cada uno por su lado se ponen en pie junto a los çeroferarios que tienen el paño y cuando llega a comulgar el Subdiácono y se va a hincar de rodillas, le pone el de su lado una estola y a los Sacerdotes que llegan se les ponen antes que hagan genuflexión, las estolas son cuatro y cuando llegan dos se las ponen

[fol. $188^{\mathrm{r}}$ ]

y al partirse los primeros les quitan las que tenian y mientras se da el Sanctíssimo Sacramento están de rodillas.

46. Acavada la Comunión se van a la Sacristía y se visten otros dos acólitos, roquetes y collares y todos cuatro salen con Turíbulos y navetas acabada la missa y llegan a las gradas y hazen venia, y todos cuatro en hilera suben cada dos, en su lado hazen genuflexión y se apartan en su lugar meneando los incensarios a buen compás, en tomando pluvial el celebrante, llegan todos cuatro y junto a la peana en hilera hazen genuflexión y se levantan infra libro 4, Capítulo 12, $\mathrm{n}^{\mathrm{o}} 8 \mathrm{y}$ el antiguo da la naveta al diácono y los demás la toman en la siniestra y en ella también la chapa de las cadenas y la arriman al pecho y levantan la diestra con el incensario avierto, el çelebrante echa incienso en todos cuatro y apártanse algo y ponen de rodillas, y cuando el çelebrante buelve con el Sanctíssimo Sacramento en las manos se llegan, hazen genuflexión y levántanse y con la diestra lo toman por

\section{[fol. $188^{\mathrm{v}}$ ]}

junto a la cubierta, y tendido el brazo como se dixo $\mathrm{n}^{0} 24$ todos cuatro igualmente comienzan a inçensar al Sanctíssimo Sacramento y en pie todos cuatro continuan la turificaçión de la misma manera, hasta que sale del pavimento y allí junto a la grada hazen genuflexión todos cuatro y los de en medio se quedan y turifican de la misma manera mientras baxan las gradas andando pasos atrás, los otros se baxan y ponen en el cuerpo de la proçesión y andan con ella meneando los turíbulos. 
47. Cuando llegan a baxar las gradas del pavimento baxo echan inçienso y cogen en las manos los turíbulos y llegan; los que turifican se apartan y reçiven en medio los que llegan y todos cuatro igualmente hazen genuflexión y se quedan a turificar los recién llegados y los otros se van al cuerpo de la procesión, cuando inciensan van dando pasos atrás, y siempre el rostro al Sanctíssimo Sacramento. De esta manera se renuevan a trechos y descansan y inciensan mientras dura la

[fol. $\left.189^{\mathrm{r}}\right]$

procesión y cuando llegan a las gradas del monumento, los dos se quedan en lo baxo y los otros dos las suven haçia atrás y de rostro van incensando hasta que el celebrante llega al pavimento y cada uno se aparta por su lado y se ponen de rodillas y cuando ha inçensado el celebrante, el Sanctíssimo Sacramento puesto en el arca, reçive el antiguo el turíbulo y todos se levantan hazen genuflexión y se baxan y van a la Sacristía.

48. El Viernes Sancto salen para la procesión los cuatro y suben al monumento donde reçiven incienso ut supra y baxan inçensando por las gradas, y en el discurso de la proçesión inciensan dos y se remudan como se dixo en el número precedente, en llegando al pavimento del altar suben y cada dos se ponen en su lado, y cuando pasa el Sanctíssimo Sacramento le hazen genuflexión y se levantan y eregione se quedan meneando los incensarios y cuando es tiempo, llega el antiguo y ministra la naveta more solito para que se inciense la oblata y después reçive el incensario y todos cuatro

[fol. $189^{\mathrm{v}}$ ]

hazen genuflexión y se baxan y van a la Sacristía y se desnudan.

49. El Sábado Sancto para la procesión del fuego se visten los Turiferarios y el antiguo toma la naveta con incienso y el Turíbulo sin brasas en la mano diestra, todo more solito, a su lado siniestro el más moderno no lleva nada, acabada la bendiçión el antiguo, echa del fuego vendito brasas en el incensario, el moderno toma la fuente de los cinco granos y se pone al lado diestro de su compañero llévala levantada con ambas manos, así van en la procesión después del Pertiguero, llegan y suben al pavimento alto y luego baxan y el de la fuente se pone al lado siniestro del diácono que canta la bendición y la tiene levantada hasta que fixa los granos que se lleva a la Sacristía.

50. El antiguo ministra la naveta y turíbulo al Diácono que pide la bendición para cantar el exultet y reçivida lo acompaña al púlpito y se queda a su diestra y a su tiempo le da el turíbulo para

\section{[fol. $\left.190^{\mathrm{r}}\right]$}

que inciense el libro, buelve a tomar el turíbulo y haze genuflexión y se va a la Sacristía, desnúdanse y van al coro a las propheçías y a su tiempo baxan a los ministerios que tienen encomendados y a vestirse para la missa solenne en la cual sirven como en las otras, excepto que como se comienzan luego Vísperas en consumiendo el Sanguis salen 
los dos Turiferarios more solito y con las devidas reverencias se van debaxo de las lámparas a sus lugares y cuando se comienza el magnificat suben al pavimento y haxen genuflexión. El moderno se aparta a su lugar, el antiguo ministra la naveta al Diácono como suele y acavada la Turificación del altar y preste, toma el incensario rodea él y su compañero las cadenas en la mano y a un tiempo inciensa el antiguo al diácono y el moderno al subdiácono y hazen genuflexión y van al coro y buelven al altar a inçensar como en las otras Vísperas.

51. Para las procesiones del Sanctíssimo Sacramento salen cuatro turiferarios y inciensan del mismo modo que se dixo en el Jueves Santo y cuando llegan al altar donde se haze estación,

[fol. $190^{\mathrm{v}}$ ]

el antiguo da la naveta al Diácono para que inçiense el celebrante, y mientras está de rodillas y los demás en pie meneando los incensarios en sus lugares a la ida y venida de la procesión, inciensan todos cuatro juntos y mientras se dize la oraçión están en pie Eregione en sus lugares meneando los incensarios y cuando ponen al çelebrante el cendal en los hombros, echan todos cuatro incienso y se van a la peana y junto a ella se ponen y de rodillas inçiensan todo el tiempo que está buelto el Sanctíssimo Sacramento al pueblo; y en asentando la custodia sobre el altar, se levantan, cierran los incensarios y los cogen en las diestras con la navetas, hazen genuflexión y se baxan.

52. Para descubrir el Sanctíssimo Sacramento sale uno y sube al pavimento con las devidas reverenzias y ministra la naveta more solito.

53 Los jueves que se renueva el Sanctíssimo Sacramento al fin de la missa sale el Turibulario más antiguo y sube al pavimento y ministra.

54. Siempre que esta descubierto o sobre el altar el Sanctíssimo Sacramento, el Turiferario

[fol. $191^{\mathrm{r}}$ ]

haze genuflexión al llegar y tiene el brazo y Turíbulo levantado mientras echa el celebrante el incienso y buelve a hazer genuflexión abaxo de la peana del altar, no al cornu epistolae sino las espaldas al pueblo y el rostro al primer candelero de junto al tabernáculo.

55. Para las procesiones de difuntos y responsos que se dizen en la Iglesia, cuando ay túmulo para Sacerdote, sale el antiguo con un inçensario y naveta al tiempo que baxa el celebrante del pavimento, haze con el genuflexión en el baxo junto a la grada en medio de los çeroferarios que es lugar donde siempre la hazen en el pavimento baxo, acompaña y quédase al púlpito de la Epístola en derecho de la Cruz, el moderno con sobrepelliz saca el açetre y hisopo y se pone al púlpito del Evangelio eregione de su compañero y antes de comenzar los Kyrie Eleyson baxan a un tiempo cada uno por su lado y el del açetre pasa por detrás del subdiácono al lado del Diácono, el antiguo reçibe incienso 
[fol. $\left.191^{\mathrm{v}}\right]$

en el Turíbulo more solito y ambos van con el Presidente hasta el túmulo y dan el hisopo y el Turíbulo a su tiempo y mientras echan agua y Turifican el túmulo, se están allí y acavado esto cada uno se buelve por su lado a la Sacristía libro 4, capítulos 24 y 25 .

56. En las estaçiones de la procesión, el de el acetre se queda para ir detrás del celebrante y el del turíbulo se buelve junto a la Cruz de donde baxa cuando entona el Kyrie Eleyson.

57. Los Turibularios cuidan que esté prevenido inçienso y quebrantado, limpio de piedras y otras cosas, cuidan de pedir pastillas para las fiestas prinzipales, es a su cargo sacar los pevetes y cazoletas de olor cuando está descubierto el Sanctíssimo Sacramento y sacan los peveteros cuando los ceroferarios sacan el recaudo para la missa. Generalmente es a su cargo mínistrar y servir en cualquiera cosa de olor o zahumerio como no sea en tiempo que hagan falta a los oficios divinos y a su ministerio. A cargo del

[fol. $192^{\mathrm{r}}$ ]

moderno está ayudar la missa de prima, para lo cual en saliendo de oración y los Sábados en alzando la missa de Nuestra Señora, se desnuda el roquete, viste sobrepelliz y saca el Cáliz con hostia, la vinageras, palmatoria apagada y flavelo cuando es tiempo y una campanilla y todo lo pone sobre la credencia, pone el atril y tablilla del Evangelio de San Joan en el altar, registra el missal ayuda a vestir y sale con la missa sacando solamente el missal y lenzuelo, ayuda como a las demás y al fin no apaga las velas y acabada se va al coro y después de horas entra en la Sacristía el recaudo que sacó.

[fol. $192^{\mathrm{v}}$ ]

\section{Capítulo 23. De los Comitantes.}

1. Acompañan en las Vísperas maitines y laudes cantadas y siempre que se va y viene al coro en ceremonia.

2. Los días de primera y segunda clase acompañan cuatro, los otros días dos; los capellanes acompañan los días de primera y segunda clase; la circuncisión, la transfiguración, los días de la Concepción, Natividad y Anunciaçión de Nuestra Señora, San Hisçio, San Tesiphón, San Messitón, San Dionisio Areopagita y van junto al celebrante, acompañan siempre con sobrepellices, no visten otra cosa.

3. Siempre hazen genuflexión y venia cuando el preste la haze y todas las vezes que entran en el coro y cuando de sus lugares van a otro a hazer algún ministerio, cuando llegan hazen venia al coro. 
4. Los lugares que tienen cuando van en ceremonia a Vísperas y maitines son después de los ceroferarios, inmediatamente antes de los Caperos, en el Coro se ponen después de los cetreros hacia el facistol.

[fol. $193^{\mathrm{r}}$ ]

5. Van a la Sacristía cuando anda la gorda y cuando comienza el esquilón ponen al çelebrante estola y pluvial. En la genuflexión que hazen en el pavimento se ponen delante de los ceroferarios y cogen en medio a los caperos y celebrante.

6. Por la Iglesia nunca llevan las manos puestas sino es cuando van y buelven de incensar que se dize el magnificat o Benedictus, mas van con mucha compostura y gravedad.

7. En saliendo de la Iglesia cogen al celebrante las puntas del pluvial que no arrastre ni lo pise al suvir la escalera, lo mismo hazen cuando salen del coro y baxan.

8. En haziendo genuflexión en el coro se van tras los cetreros y hazen venia con ellos y pasan a la silla del celebrante y pónense detrás de ella cada uno a su lado, y siempre que están allí, tienen ambas mangas de la sobrepelliz baxas y puesta sobre el brazo siniestro del modo que las tienen los Versicularios cuando están al fasçistol. Y cuando se quisiere sentar, alzan el pluvial y lo ponen por las espaldas de la silla decentemente y que no arrastre por el suelo, sino recogido sobre la alfombra. Si no es tiempo de comenzar las Vísperas se

[fol. $193^{\mathrm{V}}$ ]

quedan allí, y cuando el celebrante se levanta para entonar Deus in adiutorium, le alzan el pluvial y cuando se sienta lo buelven a poner como al prinçipio. Vanse a sus lugares.

9. Cuando se repite la última antíphona, van a la silla del çelebrante y le alzan el pluvial cuando se levanta a dezir la capítula y se quedan allí hasta que van a incensar y todas las vezes que se sentare y levantare; cuando entona la antíphona del magnificat, en entonando el magnificat, se ponen las mangas de la sobrepelliz en los brazos y toma el antiguo el bonete y se van detrás de los cetreros y con todos hazen venia al coro y en saliendo da el comitante el bonete al celebrante, alzan la capa y al entrar en la Iglesia la sueltan y buelve el comitante a tomar el bonete y lo arrima al pecho.

10. Llegan al pavimento, los dos primeros comitantes se quedan detrás de los çeroferarios, los otros dos se ponen a los lados del celebrante y lo cogen en medio y hechos un medio çírculo hazen venia al altar, alzan las puntas del pluvial y suben con el celebrante y hazen genuflexión con el un paso atrás. Cuando

[fol. 194 $\left.{ }^{\mathrm{r}}\right]$

el celebrante vesa el alta,r hazen otra genuflexión en la peana a sus lados algo desviados del altar y el que lleva el bonete lo dexa sobre el escaño. 
11. Cuando llega el Turiferario, el comitante antiguo le da lugar que pase y se ponga a su mano diestra, toma la naveta y con la cuchar dentro, besa la extremidad del cabo de la cuchar, y dala al celebrante y cuando llega a tomarla le vesa la mano (si el Sanctíssimo Sacramento está manifiesto, no besa al dar ni reçivir cuchar ni incensario ni mano) y luego dize Benedicite Pater reverendo, a este tiempo el otro comitante pasa por detrás del celebrante y le alza el pluvial por la parte del brazo diestro y lo tiene levantado mientras echa el incienso y vendición. Después de ella, cuando el celebrante dexa la cuchara en la naveta, le vesa la mano y después la cuchara, buelve la naveta al Turiferario y toma el Turíbulo con la mano derecha por la extremidad de las cadenas y con la siniestra por junto a la cubierta, besa la chapeta de las cadenas y dalo al celebrante y cuando lo recive, le vesa la mano diestra.

[fol. 194 ${ }^{\mathrm{v}}$ ]

12. A este tiempo el otro comitante suelta la punta del pluvial y se buelve a la siniestra del celebrante y hazen ambos con él genuflexión y cuando se levantan, cada uno por su lado alzan el pluvial, con la una mano la punta y con la otra un poco más arriba y van y vienen con él dando los pasos con el mismo compás, el rostro buelto al altar del mismo modo que lo lleva el celebrante y hazen genuflexión con él.

13. En el cornu epistolae se acava la incensación, sueltan el pluvial y el antiguo al reçivir el incensario, besa la mano al celebrante y después el incensario por lo alto de las cadenas buélvelo al Turiferario y ambos se van con el celebrante al medio del altar y hazen venia y después saliendo de la peana hazen genuflexión como cuando llegaron y el antiguo toma el bonete.

14. Los capellanes o Colegiales ordenados en su lugar, solo acompañan cuando el celebrante baxa a incensar al altar, no a las idas y venidas al coro y entonzes los

[fol. $\left.195^{\mathrm{r}}\right]$

Colegiales comitantes se quedan como se dixo detrás de los Ceroferarios y ellos suben y ministran del mismo modo que se ha dicho $\mathrm{n}^{\circ}$ preçedente.

15. En el coro nunca los capellanes comitantes llegan a la silla del celebrante a levantar la capa que aquel ministerio es de los comitantes Colegiales.

16. Buelven al coro diciendo el magnificat a versos y saliendo de la Iglesia da el bonete al celebrante y alzan el pluvial al entrar en el coro, buelve a tomar el bonete, haze genuflexión con el celebrante, medio paso atrás y así la hazen siempre al entrar y salir del coro y en el pavimento un paso atrás entran por los coros, hazen venia y en sus lugares aguardan a que se acave el Magnificat que entonzes suben al celebrante para alzar la capa cuando fuere menester y cuando el çelebrante se sienta le da el comitante el bonete y lo buelve a tomar cuando dize las oraciones y si fuere neçesario le levantará el breviario para la capítula. 
17. Para las oraciones, en acabando las oraciones, el comitante del coro del Hebdomadario toma el breviario y sube a ponerlo en el atril y lo abre por el registro de las

[fol. $\left.195^{\mathrm{V}}\right]$

completas, buélvese a su lugar, y allí se están hasta que se ha dicho el Venedicamus, que se van a sus lugares. Cuando el celebrante baxa de su silla le dan el bonete y delante de los cetreros hazen venia al coro, salen y baxan a la Sacristía more solito y quitan al celebrante la estola y pluvial ponénlo sobre el bufete vien puesto y danle la capa Canonical si la traen y el antiguo dize la lección breve de completas y la antíphona Miserere o Alleluya y se buelven al coro con las devidas reverencias.

18. Para los maitines llevan al coro para el celebrante pluvial y estola, excepto los días particulares que en su lugar se advertirá. Ponen el pluvial recogido sobre la silla del celebrante y la estola enzima, buelven a la sacristía y acompañan y cuando el coro o el órgano dize el octavo responsorio, baxa el celebrante a decir la nona Lección. Van a la silla quítanle la capa canonical si la trae y pónenla en su silla en el coro alto y ponen la estola y pluvial y un paso atrás a sus lados están en pie mientras dize la lección.

[fol. $196^{\mathrm{r}}$ ]

19. En las Vigilias de difuntos acompañan a la lección como se a dicho, mas no ponen el pluvial hasta después de ella. A las laudes acompañan y ministran como se a dicho en Vísperas.

20. Para la Salve que se dize la cuaresma después de Completas acompañan todos los días de primera y segunda clase y fiestas cuatro comitantes y los otros días dos, y cuando comienza el coro el verso et Iesum \& que baxa el prebendado de su silla, se levantan y ponen las mangas y hazen venia al coro y luego genuflexión al altar, cuando llegan al pavimento hazen todos venia y los dos se quedan en los lugares de los ceroferarios, los otros dos suben y a los lados del Prebendado hazen genuflexión y cuando quiere decir la oración, se levantan y el uno le toma el bonete y el otro le buelve el registro de la oración y se buelven de rodillas mientras la dize y acavada se levantan y hazen genuflexión con él, el que tiene el bonete se lo da y el otro abre el misal por la estampa del canon y se baxan a la sacristía y en la puerta de la Capilla de los mártires

[fol. 196 ${ }^{\mathrm{V}}$ ]

le dan la falda de la capa. Salen, apagan y entran el missal y façistol, cuando ay dos, suben al pavimento y hazen lo que se ha dicho.

21. Los días de Nuestra Señora se dize Salve en la Iglesia y cuando el coro comienza el verso 0 dulcis Virgo \& se levantan los comitantes y van por medio del coro al lugar donde está el prebendado que ha de decir la oración y le hazen comedimiento y los dos señalados por tabla van juntos a él y los otros dos delante y éstos se quedan junto a las gradas y los otros dos suben "+" como se ha dicho. 
Los Sábados se dize la Salve en las Cuevas y al Verso o dulcis Virgo \& se levantan los dos comitantes y combidan al prebendado y lo llevan a la peana del altar y en pie están mientras la oración porque tienen el libro donde está y acavada buelven con el prebendado a su lugar.

22. Todas la vezes que sale prevendado del coro a deçir missa de tabla lo acompaña un comitante, pónese las mangas y haze

[fol. $197^{\mathrm{r}}$ ]

juntamente con él venia al coro, va delante, entran por la Iglesia, hazen genuflexión en el pavimento y pasan a la Sacristía.

[fol. $\left.197^{\mathrm{v}}\right]$

\section{Capítulo 24. De los Cetreros.}

1. Los cetreros sirven siempre sobrepellizes en las Vísperas cantadas, maitines y Laudes que ay pluviales o caperos y en las procesiones en que se hazen estaçiones.

2 Para Vísperas van a la Sacristía cuando comienza la gorda y ponen los pluviales a los caperos ,cada uno al de su coro y si ay cuatro o seis, tantos son los çetreros y los más antiguos visten a los prebendados más antiguos: toman los cetros y aguardan en la puerta de la Sacristía y salen delante de los ceroferarios. Los del coro diestro llevan los cetros en la mano diestra y los del siniestro en la siniestra. Llévanlos algo caidos, la maza atrás como que asientan sobre el hombro y los Cabos levantados del suelo una cuarta: hazen genuflexión en el pavimento detrás de los ceroferarios puestos en coro, buélvense por la parte de adentro, los rostros uno al otro y de esta suerte se buelven todos los ministros que dan buelta para subir o baxar, entrar

[fol. $198^{\mathrm{r}}$ ]

o salir de cualquiera parte.

3. Entran en el Coro y hazen con todos genuflexión y levántanse y van a sus lugares aunque el preste y caperos se queden orando, llegan a los bancos de los caperos, hazen venia al coro y buélvense el rostro al altar. Cuando llegan los caperos si es hora de comenzar Vísperas, danles los cetros y tómanles los bonetes: los más antiguos cetreros a los más antiguos prebendados y siempre que dan o reçiven los çetros hazen venia, a los caperos.

4. Entonada la primera antíphona buelven los bonetes y toman los cetros con la manga de la sobrepelliz y con ellos están siempre en pie, bueltos al altar; los del coro diestro tienen los çetros en la siniestra y los del siniestro en la diestra, de suerte que siempre los cetros an de caer por la parte de adentro del coro. 
5. Cuando se repite la quinta antíphona dan los cetros y toman los bonetes, y si es doble, cuando la antíphona del magnificat la dize entera, entonándola buelven a dar los bonetes y toman los cetros, al fin de la antíphona los

[fol. 198 $\left.{ }^{\mathrm{v}}\right]$

más antiguos dan los çetros y toman los bonetes a los primeros caperos que van a entonar la Magnificat y después, los otros dan los cetros y toman los bonetes y los doblan y ponen en sus asientos, y al magnificat se retiran y buelven Eregione, las manos puestas como los demás Colegiales, mas si fuere día de cuatro comitantes y no ubiere capellanes, los dos cetreros primeros acompañan al preste detrás de los ceroferarios. Después del Gloria Patri dan los bonetes y toman los çetros, porque se asientan los caperos cuando se repite la antíphona y al fin de ella buelven a dar los cetros y al fin de las Vísperas, cuando se parten de sus asientos, los caperos les dan los bonetes y toman los cetros y salen, hazen genuflexión a los lados delante de los ceroferarios y acompañan como vinieron.

6. En la Sacristía ponen los cetros en su lugar y quitan los pluviales cada uno a quien vistió y si ay capas canonicales las visten, asisten a la çeremonia

[fol. 199

y acompañan.

7. Para los maitines que ay pluviales llevan los cetros y pluviales al coro cuando anda la gorda y ponen los pluviales en los asientos de los caperos, los cetros ponen en el hueco de la ventana, buelven y acompañan como a Vísperas, en el coro hazen las devidas reverenzias y están en sus lugares cuando se dize el Gloria Patri. Salen los caperos más antiguos a dezir el invitatorio y al mismo tiempo los cetreros más antiguos van por los cetros, y con ellos se llegan al facistol grande cuando se llegan los caperos, donde todos cuatro hazen genuflexión y le dan los cetros y en levantándose, cantan los caperos el invitatorio y los cetreros se están a sus lados y en entonando el himno, toman los cetros y los llevan a donde están los otros y se buelven a su lugar.

8. En comenzando el octavo responsorio, los dos más antiguos desnudan las capas canonicales a los dos Prebendados caperos primeros si los ay y las ponen en sus sillas altas, vístenles los

[fol. 199 $\left.9^{\mathrm{V}}\right]$

pluviales y tráenles los çetros, y se los dan y toman los bonetes, acavada la nona lección, los más modernos ponen los pluviales a los otros caperos de la misma forma, y para las laudes ministran dando los çetros a los mismos tiempos y ocasiones que se dixo en Vísperas.

9. Para las procesiones de difuntos y responsos que se dizen en el túmulo, los çetreros más antiguos con los cetros salen de la Sacristía con los demás acavada la missa y se 
ponen detrás de los çeroferarios los primeros del Coro de los Colegiales sino es cuando procede la procesión y al tiempo que el Sochantre combida a los caperos para dezir el verso hazen genuflexión al altar y baxan cada uno por su coro y dan los cetros y se apartan un poco a los lados y luego buelven a tomar y se van con ellos a sus lugares y esto hazen a todos los versos de los responsos en las estaciones que ubiere. Y acavada la procesión o responso se buelven a la Sacristía delante de los ceroferarios que esté es su lugar siempre que

[fol. $\left.200^{\mathrm{r}}\right]$

salen en çeremonia.

\section{Capítulo 25. Del Cruçiferario.}

1. Las semanas que ubiere procesión se señala por tabla un Colegial que lleva la Cruz sea el más dispuesto y acomodado y diestro en llevarla. Viste arneto roquete y collar. Sale con la Cruz de la Sacristía al tiempo combeniente infra libro 3, capítulo 5, y en el arco de la capilla de los mártires la reçiven los ceroferarios y se van a la grada del pavimento baxo y el Cruçiferario asienta en ella la Cruz y él esta abaxo de la grada, y el Crucifixo buelto al altar, cuando es tiempo de proceder levanta la Cruz y la lleva, el Crucifixo adelante con cuidado que no vaya ladeada sino derecha, no para ni baxa la Cruz sino donde se hiciere estación.

2. En las estaciones de las procesiones en que se lleva el Sanctíssimo Sacramento y de las reliquias, para el Cruciferario donde

[fol. 200 $\left.{ }^{\mathrm{v}}\right]$

le coge cuando el celebrante llega al altar en que se haze la estación sino es en el altar del pórtico que sienta la cruz junto a la puerta y no entra hasta después de la estación; y en las procesiones de difuntos para y asienta la Cruz en el mismo lugar donde va la estaçion.

3. Cuando va la procesión a la Cueva de San Ceçilio, para la Cruz en la puerta y los ciriales a los lados, puestos de rostro a la procesión, las espaldas a la Cueva del fundamento y allí aguardan hasta que sale.

4. El Cruciferario mientras lleva la Cruz no haze humiliación ni venia ni genuflexión a ninguna imagen ni altar ni cosa que se nombre y así cuando llega a los altares a sentar la Cruz y a la grada del pavimento la asienta sin hazer mudanza.

5. Cuando buelve la procesión a la Iglesia, asienta la Cruz en la grada del pavimento baxo y los ceroferarios junto a ella se ponen en medio de la grada, la procesión pasa

[fol. 201 $\left.{ }^{\mathrm{r}}\right]$ 
por los lados por entre los ceroferarios y púlpitos hasta que se acavan las oraciones que a de decir, mas en las procesiones que no ay preçes ni oraçiones sino inmediate se comienza la missa, sin parar en la grada se entra derecho en la Sacristía y pone la Cruz en su aldaba, no arrimada a los rincones y se desnuda.

6. El Domingo de Ramos, para la Cruz en la puerta prinçipal de la Iglesia y al tiempo que el Subdiácono ha de herir la puerta, la inclina y tiene por la manzana.

7. El Jueves Santo cuando llega la proçesión al monumento asienta la Cruz junto a la última grada en la parte del púlpito de la Epístola y el Viernes Sancto cuando van a desençerrar la asienta del otro lado acia el arco Toral.

8. El Sábado Sancto lleva la Cruz cuando se va a la vendiçión del nuevo fuego y a la buelta, en llegando al pavimento, la asienta en la grada junto al púlpito del Evangelio y cuando el Diácono sube a cantar el Praeconio se pone frontero del púlpito y libro, en medio del lugar

[fol. $201^{\mathrm{v}}$ ]

que suelen tener los ceroferarios, asienta la Cruz en el suelo, que el Cruçifixo mire al Atril y libro del Diácono. Acabada la bendiçión la lleva a la Sacristía acompañándole los Çeroferarios.

[fol. $202^{\mathrm{r}}$ ]

\section{Capítulo 26. Del Flavelario y Coadjuntor de la Missa de Terçia.}

1. Cuando la missa de terçia se çelebra sin Diáconos, el Turiferario más antiguo es coadjutor y si es tiempo de flavelo juntamente es Flavelario que son ministerios que no se impiden. Va a la Sacristía cuando anda la gorda, registra el missal y viste al Hebdomadario y sale con él delante y detrás de los çeroferarios, en el pavimento alto haze genuflexión con el preste a su lado diestro, un paso más atrás y cuando la haze, toma el bonete y con él se pasa al lado siniestro y de rodillas, un paso atrás está y responde al psalmo del Introito y haze la confesión y cuando el preste entra en el altar, se levanta y pasa al Cornu epistolae, dexa el bonete doblado en el escaño y a la diestra del celebrante fuera de la peana asiste y buelve los registros que caen a aquel lado y para bolver los que están del otro pasa por detrás de el preste y haze genuflexión a su siniestra mirando al tavernáculo y los buelve a su

[fol. $202^{\mathrm{v}}$ ]

tiempo y cuando no ay que bolver a aquel lado, se pasa al otro haziendo genuflexión.

2. Acavado el tracto o Alleluyas, toma el atril y misal y al pasar en medio, haze genuflexión al altar y lo pone en el Cornu Evangelis y se queda en la peana a la siniestra del celebrante hasta que ha respondido Gloria Tibi Domine, que se baxa de la peana y 
pone en derecho del libro y las manos puestas está al Evangelio y acavado sube y buelve el registro del Credo si lo ay o del ofertorio y mientras el Credo está fuera de la peana detrás del preste, al tiempo del Incarnatus est cuando el çelebrante se hinca de rodillas se pone a su diestra y le cubre con la casulla los pies y la tiende decentemente y allí haze genuflexión juntamente y levantándose se buelve a su lugar.

3. A todas las ceremonias en que la missa cantada no diferençia de la rezada, al bolver los registros y modo de estar que no esté señalado en este Capítulo, el Coadjutor de la missa de terçia asiste y ministra de la misma forma que los de la missa rezada en el capítulo siguiente, no ministra las ampolletas ni lleva el Cáliz ni haze

[fol. $203^{\mathrm{r}}$ ]

lo demás que se notó hazían los çeroferarios supra Capítulo 21.

4. Todas las vezes que se llega o aparta del altar o pasa de un lado a otro, haze genuflexión; dicho el Dominus Vobiscum se llega y registra el ofertorio, y cuando el preste ha sacado los corporales de la bolsa, la toma y pone arrimada al tavernáculo al lado del Evangelio y luego toma el flavelo de la credenzia y haze aire: el prinçipal fin del flavelo es quitar las moscas de la oblata y después de aver consagrado ha de estar con mucha atención para escusar que no lleguen y haze el movimiento del flavelo sobre el altar con blandura para que no levante la hostia ni derribe la hijuela, cuando por allí andubieren moscas, llega el flavelo de canto y las levanta, al lado del evangelio está hasta consagrar y registra y buelve las hojas del canon y si tiene flavelo lo pasa a la siniestra y con la diestra registra, cuando quiere consagrar se pone de rodillas en la peana, los pies fuera, el rostro al missal y el flavelo en la siniestra, con la diestra alza la casulla cuando el çelebrantre haze la

[fol. $\left.203^{\mathrm{V}}\right]$

Genuflexión, la tiende y cubre los pies y cuando eleva el Sanctíssimo Sacrameto la levanta y ni suelta hasta que cuando haze genuflexión la dexa atendida.

5. En aviendo tomado la abluçión, dexa el flavelo en la credenzia y toma el atril y missal y lo lleva al cornu epistolae y allí esta para registrar las oraciones como a las primeras y cuando el celebrante va a decir el último Dominus Vobiscum se llega y registra el Ite missa est o Benedicamus Domino. Si se ha de decir Benedicamus, dexa el missal en el atril llegado al ara y buelto acia dentro del altar, que las espaldas del missal miren al rincón del altar cornu epistolae, para el Ite missa est cuando el celebrante se buelve para el Dominus Vobiscum toma el missal y se pone en la peana delante del celebrante y lo abre por donde está el registro el que a de decir y lo levanta que lo alto del missal llegue a la frente, acabado lo cierra y pone en el atril y cuando echa la vendición se hinca de rodillas delante del preste responde al Evangelio último y está como al primero.

6. Cuando se acava llega a la credenzia y

[fol. $204^{\mathrm{r}}$ ] 
toma el hisopo y manual para el responso. Va al escaño y toma el bonete y por la diestra lo da al preste cuando haze genuflexión en la peana, báxase a las gradas y de camino baxa el hisopo y manual y pónese a la diestra del preste entre él y el Çeroferario, pónele delante el manual avierto y al Kyrie Eleyson le da el hisopo y acavado el responso, lo lleva a la Sacristía y acompaña como vino y desnuda al preste y le pone la sobrepelliz y capa si la ay y si ha de bolver al coro, lo acompaña, haze genuflexión entre la varandilla $\mathrm{y}$ façistol a la mano diestra del Presidente y entra por el coro diestro y haze venia.

7. En la missa que ay Diáconos, sale el flavelario detrás de todos y quédase al lado del Evangelio, haze venia y en lo alto genuflexión con todos y en ella toma el bonete al Subdiácono y acavada la confesión lo lleva al escaño, al lugar del Subdiácono y se buelve al del Evangelio y toma el flavelo y entre la credenzia y la rexa de los libros es su lugar, salvo que después del ofertorio se llega algo más a la peana para poder mejor ver y echar las moscas.

[fol. $204^{\mathrm{v}}$ ]

8. Todas las vezes que se van a sentar va el flavelario al cornu epistolae y pasa el flavelo a la siniestra y con la diestra alza al Diácono la dalmática para que no se siente sobre ella y mientras están sentados se queda allí y al levantar se la alza y se pasa al lado del Evangelio a su lugar y todas las vezes que se sientan haze lo mismo, en su lugar haze aire convenientemente y especialmente cuida de no dexar que anden moscas por el altar.

9. En aviendo besado el Presidente el evangelio, el subdiácono da el libro al flavelario, el cual pasa el flavelo a la siniestra y con la diestra toma el missal y lo pone en la credencia si ay Credo, dicho Et Homo factus est dexa el flavelo y acompaña al Diácono a la credenzia, va delante y haze genuflexión con él y en la credencia alza el çendal y el Diácono toma la bolsa y buelve a cubrir la credencia con el çendal como se estava y allí se queda hasta que el Diácono ha desdoblado los corporales que lo buelve [a] acompañar a su asiento donde le alza la dalmática.

10. En aviendo dicho Dominus Vobiscum del ofertorio, dexa el flavelo y pasa al lado del Subdiácono y haze genuflexión con él y lo acompaña a la credenzia, pónele el zendal sobre

[fol. $205^{\mathrm{r}}$ ]

ambos hombros de suerte que la mayor parte cuelgue a la derecha. Va con el Subdiácono y en dexando el Cáliz en el altar, le quita el çendal y pone sobre el escaño y dobla el paño del Cáliz y cuando se haze el ofertorio del Cáliz le buelve a poner el çendal en ambos hombros (al margen y dentro de un cuadro "y si viene delante del subdiácono a su lugar y con él haze genuflexión con los demás").

11. Cuando el Presidente dize el Pater Noster sicut et nos domittimus, dexa el flavelo y al lado del Subdiácono haze genuflexión y va tras del cornu epistolae y cuando el Diácono ha reçivido la patena, quita con ambas manos el çendal al Subdiácono y lo 
pone sobre el escaño y haze con él genuflexión y lo acompaña delante a su lugar y pasa al suyo y buelve a tomar el flavelo y donde estubiere dexa el flavelo para recivir la paz y la reçive puestas las manos, cubre la credenzia con el çendal después que en ella ha puesto el Subdiácono el Cáliz.

12. Mientras dize el preste la última oraçión, pasa al cornu evangelis, dexa en la credencia el flavelo y toma el missal, registra el Ite missa est, pasa al cornu epistolae por detrás

[fol. $\left.205^{\vee}\right]$

del Subdiácono, por la diestra del Diácono le muestra el missal abierto para que prebenga lo que ubiere de cantar y cuando se dize el último Dominus Vobiscum se llega y pone eregione el Diácono la espaldas a la rexa de las reliquias y la diestra al altar, el libro avierto y alto para que cante el Diácono el Ite missa est. Si fuere Benedicamus Domino se pone la espaldas al cornu epistolae y el rostro buelto algo al pueblo.

13. En acavando el Diácono, cierra el libro haze genuflexión, toma el bonete del Subdiácono y pasa al Cornu evangelis, dexa el missal en la credenzia y cuando hazen genuflexión para despedirse del altar le da el bonete y si ay responso toma de la credenzia el hisopo y manual y baxa las gradas por medio de los çeroferarios y se pone detrás del Cornu epistolae y ministra como se dixo supra $\mathrm{n}^{\circ} 16$, y lo demás que allí se dixo.

14. Cuando no ay flavelario hazen los çeroferarios todo lo que se ha dicho del çendal, missal etc, como se dixo supra Capítulo 21 de los çeroferarios.

15. Cuando ay planetas, cuando comienza la oración de la missa, lleva el collar al cornu epistolae, quita la planeta al Subdiácono, pónela sobre el escaño, pónele el collar compone la

[fol. 206 $\left.{ }^{\mathrm{r}}\right]$

alba si es menester, el çeroferario da el missal y acompaña como se dixo Capítulo $\mathrm{n}^{\circ} 21$, cuando buelve el Subdiácono le quita el collar y pone la planeta y al diácono la quita y viste al tiempo y como se dixo en el Capítulo 21 que lo haze el çeroferario en falta de flavelario: en tiempo que no ay flavelos asistirá un Colegial en el altar mayor a la missa de tercia los días de primera clase y los que ay vendiçiones y hará todo lo que suele hazer el flavelario excepto el ministrar el flavelo.

\section{Capítulo 27. Del Coadjuntor de la Missa Rezada.}

1.En siendo llamado el Colegial para ayudar la missa rezada, dexará con presteza lo que hiziere y acudirá con puntualidad, tomará sobrepelliz y en viendo a la persona que ayuda sacará su amito del caxón y lo pondrá sobre el ornamento y el lenzuelo sobre el missal mientras el Sacerdote se lava las manos y pone hostia, reveerá los registros del missal de quien es la missa y oraciones para que en el altar los buelva y señale 
[fol. 206 ${ }^{\mathrm{v}}$ ]

con destreza. Llega y quita la capa cuando la ay, correrá el botón o quitará el corchete de la capilla y la echará doblada en el brazo siniestro, tomará con ambas manos los cabos del cuello de la capa y la doblará y puesta en la siniestra, alargará la derecha y reçivirá la falda y la llevará sobre un caxón donde la dexará bien puesta y la capilla enzima y tenga advertençia donde la dexa por que no la trueque cuando la buelve a poner.

2. Ayudará a quitar la sobrepelliz recogiéndola desde baxo hasta el ombro siniestro, con tiento al sacarla de la cabeza de modo que quede del revés las mangas adentro; si tubiere ropa la cogerá del cuello por las espaldas del Sacerdote trayéndola hazia abaxo hasta que saque los brazos y lo pondrá en su lugar. Luego llega a ayudar a vestir y mientras el Sacerdote está de rodillas previene alba que le venga bien. Vístela y da el cíngulo y ajusta de suerte que caiga igualmente redonda, que cubra el vestido negro y que no haga puntas y un dedo alto del suelo. Después de vestida la casulla pregunta a que altar a de salir y lleva el

[fol. $207^{\mathrm{r}}$ ]

Codal ençendido y lo pone en el candelero. Entra en la sacristía, toma el missal y el lenzuelo, las ampolletas con bastante vino y agua y si va al sagrario toma la Salvilla con la llave, el missal lleva en el brazo siniestro arrimado al pecho y en la misma mano la salvilla de la llave, y en la diestra la de las ampolletas. Sale con compostura un paso delante del Sacerdote, todas las vezes que pasa por el pavimento haze genuflexión al altar mayor.

3. Todos los ornamentos que viste el Sacerdote antes de ponérselos o dárselos los besará, puesto el amito lo que cae sobre los brazos levanta y dobla sobre el hombro, la alba plegada desde lo baxo hasta el cuello con ambas manos echa por la caveza del Sacerdote y luego le tiende la manga diestra para que vista primero el brazo diestro, luego la siniestra. Dale el cíngulo por detrás el manípulo y estola y mira que la cruz de la estola caiga en medio del cuello, la casulla toma de suerte que la parte de atrás caiga sobre su brazo siniestro y la de adelante sobre el diestro de suerte que la abertura caiga igualmente sobre la cabeza que no se haya estregando por

[fol. $207^{\mathrm{V}}$ ]

ella y con ambas manos la emparejará por las espaldas y con el recaudo en las manos a la salida de la Sacristía haze juntamente venia con el Sacerdote al cruçifixo y la misma hará al entrar.

4. Llegando a la peana del altar, si fueren el de los mártires o de la Conçepçión, se apartará un poco para que el Saçerdote pase por delante, de suerte que a de cuidar quedarse a la diestra del Saçerdote cuando llegue a hazer venia o genuflexión si hubiere Sanctíssimo Sacramento, la cual haze juntamente con el Sacerdote y le toma el bonete. Sube al altar, pone las vinageras en la lossa y el missal en el atril, el lenzuelo entre el 
atril y la Ara, el bonete en el clavo mientras el Sacerdote abre el missal y reconoce los registros, ençiende las velas y luego apaga el codal y pónese de rodillas a la siniestra del Sacerdote un paso atrás, puestas las manos le responde en el mismo tono y compás que lleva el sacerdote y aguarda que acave de decir sin hollarle los finales, cuando en la confesión dize tibi Pater y te Pater, inclina un poco la cabeza hazia el Sacerdote

[fol. $208^{\mathrm{r}}$ ]

al mea culpa se hiere tres vezes el pecho.

5. Cuando el Sacerdote entra en el altar se levanta y pone detrás de él y cuando besa el altar haze genuflexión en la peana si ubiere Sanctíssimo Sacramento y si no, venia, y llega al Cornu epistolae a la diestra del Sacerdote, un paso atrás mientras dize el Introito, inclina la cabeza al Gloria Patri tiene puestas las manos siempre que no hiziere otra acción. Siempre inclina la cabeza al Gloria Patri, al nombre de Jesucristo y de María y al Sancto que se reza, y al Pontífice que vive, responde alternativamente al Kyrie Eleyson cuando el Sacerdote va al medio del altar, registra la Gloria si la ubiere y se baxa de la peana al medio del altar, al fin de la Gloria subirá a registrar las oraciones y se baxará al medio del altar para coger en frente al Sacerdote cuando buelve a dezir Dominus Vobiscum siempre que el Sacerdote bolviere al pueblo deve estar avajo de la peana eregione rostro a rostro; cuando en las oraciones ay flectamus genua se hinca de rodillas con el Sacerdote y responde

[fol. $\left.208^{\mathrm{v}}\right]$

Levate. Todas las vezes que el Sacerdote buelve al pueblo y él le responde, le haze venia. A las oraciones y Epístolas está como al Introito: a la diestra del Sacerdote. En fin de la Epístola y de las propheçías responde Deo Gratias excepto a la quinta propheçía de Daniel que no le responde.

6. Acavado el Verso o tracto o sequençia toma con ambas manos el atril y missal y lo pasa al otro lado, siempre que pasa de un lado a otro haze venia en medio del altar o genuflexión: si ubiere Sanctíssimo Sacramento en el mismo lugar se queda en la peana, responde y sígnase cuando el Sacerdote y luego se pasa al Cornu epistolae y está las manos puestas, mientras se dize el Evangelio mira al libro y está fuera de la peana, responde al fin Laus tibi christi, pasa a registrar si ay Credo y está detrás del Sacerdote fuera de la peana mientras lo dize y al Incarnatus est a la mano derecha del Sacerdote se hinca con él de rodillas y cubre con la casulla los pies del Sacerdote y se levanta y buelve detrás y después de aver respondido al Dominus Vobiscum sube y registra el ofertorio

[fol. 209 ${ }^{\mathrm{r}}$ ]

y allí se está mientras el Sacerdote lo lee y leido registra las oraciones del ofertorio y pasa al cornu epistolae.

7. Siempre que llegue a registrar y el Sacerdote ubiere de hazer genuflexión, sea a tiempo que la haga con el Sacerdote y cuando estubiere registrando, si el Sacerdote 
hiziere genuflexión, dexe el registrar y hágala con el Sacerdote y levantando se registre de manera que nunca a de estar en pie cuando el Sacerdote hiziere genuflexión, especialmente si está cerca del altar.

8. Toma las vinageras, tiene el plato en la siniestra, pone el paño con que se cubre sobre el altar con la diestra, da la vinagera del vino, que la puede tomar el Sacerdote por el asa y al darla y reçivirla la vesa y haze una venia.

9. Recive la vinagera y pónela sobre el pañito con que se cubren que está en el altar y da la del agua, aviendo echado la bendición, vesa primero la vinagera y luego la mano del Sacerdote y el recivirla vesa primero la mano y después la vinagera, excepto cuando es misa de requiem que no vesa mano ni

[fol. $209^{\mathrm{v}}$ ]

Vinagera, pónela en la salvilla y déxala en la losa, pasa al otro ,lado registra la oración del ofertorio del Cáliz si lo pide el missal, buelve y toma la toalla con ambas manos por las dos esquinas de ella y la salvilla en la siniestra y la vinagera del agua en la diestra y en la misma esquina del altar al cornu epistolae aguarda allí, llega el Sacerdote échale agua en las puntas de los dedos que caiga en medio del plato, pone con presteza la vinagera en el plato y todo en la esquina del altar y despliega la toalla con buen aire sobre las manos del Sacerdote, mientras se enxuga pone la vinagera en el altar junto a esotra, vaçia el agua del plato en la porcelana que está al rincón del altar en el suelo y en el plato o salvilla rezive la toalla: al echarla y al reçivirla la vesa y haze venia, toma del plato la toalla por la punta con la siniestra y échala sobre el brazo siniestro, pone las vinageras en la salvilla y cúbrelas y pónelas en la losa.

10. Vase avajo de la peana detrás del

[fol. $\left.210^{\mathrm{r}}\right]$

Sacerdote, responde al orate frates y suve a registrar las oraciones secretas y mientras las dize y comienza el prefacio, está en el mismo lugar un paso desviado del altar, en aviendo respondido Dignum et iustum est se baxa y pone detrás de el Sacerdote, dobla la toalla, llévala a su lugar y trae la campanilla, híncase de rodillas y en diçiendo Sanctus da tres toques de dos golpes cada uno en buena proporción, luego la pone en la peana en el suelo donde no estorbe y pasa a registrar el canon y registra las hojas hasta que el Sacerdote dize el memento, luego se pasa al otro lado y si es tiempo de flavelo lo toma y quita las moscas, acavado el memento arrima el flavelo al altar y enciende el codal, despabila las velas no muy baxo y al lado derecho del Sacerdote se pone de rodillas en la peana, los pies fuera y cuando se hinca de rodillas a adorar la hostia consagrada, le tiende la casulla deçentemente con la siniestra y cuando se levanta el Sacerdote la alza y con la diestra da tres toques de a dos

[fol. $\left.210^{\mathrm{v}}\right]$ 
golpes con la campanilla, el primero cuando se hinca el Sacerdote de rodillas, el segundo cuando levanta la hostia, el tercero cuando la abaxa y lo mismo hará a la elevación del Cáliz.

11. En acavando de tocar, después de asentado el Cáliz, dexa la campanilla, levántase y toma el flavelo, pasa al lado del Evangelio y registra y haze genuflexión con el Sacerdote y se buelve al otro lado donde se pone de rodillas y quita las moscas, si no ay flavelo pone las manos.

12. A la última elevación de hostia y Cáliz no toca la campanilla y levántase antes que el Sacerdote haga genuflexión y pasa a registrar el Pater Noster y con él haze genuflexión y buélvese a su lugar, lo mismo haze al Pax Domini.

13. A los Agnus no responde, estase al lado diestro hasta que el Saçerdote purifica los corporales, que se levanta y lleva la campanilla y flavelo y pone en su lugar y toma la salvilla de las vinageras, haze genuflexión con ellas en el cornu epistolae cuando el Sacerdote eleva el Cáliz

[fol. $211^{\mathrm{r}}$ ]

para consumir y aguarda, echa la purificación, vino solo primero, y la segunda vez vino y luego agua: échala con mucho tiento que no salpique los lados de la copa del Cáliz por dentro ni fuera y así no levanta la ampolleta sino lo que basta para que no toque en el labio del Cáliz ni dedos del Sacerdote, pone las vinageras en su lugar y apaga el codal.

14. Pasa el missal al lado de la Epístola, registra la antíphona post communio, y dicha que el Sacerdote va a vesar el altar, se va tras él y pone avajo de la peana en medio y responde al Dominus Vobiscum y cuando el Sacerdote se buelve al missal, sube a su diestra a registrar las oraçiónes y dichas se baxa al medio del altar para responder al Dominus Vobiscum, Ite missa est, o Benedicamus \&.

15. Si el Evangelio último fuere propio y no el de San Juan, cuando el Sacerdote está inclinado diciendo la oración Placeat tibi Sancta Trinitas, pasa el atril y misal al lado del Evangelio y se buelve a baxar en medio para rezivir la bendición y se buelve a subir a la peana

[fol. $\left.211^{\mathrm{v}}\right]$

al lado del Evangelio y acabado, apaga la vela de aquel lado y lleva las despaviladeras y atril y missal al otro, asienta el Atril en su lugar, apaga la otra vela, toma el missal y luego el bonete del Sacerdote y lenzuelo en la siniestra y con la diestra la salvilla de las ampolletas y baxa de la peana y con el sacerdote haze venia o genuflexión y haziéndola le da el bonete.

16. Si el Evangelio último es el de San Juan, se queda en el medio del altar baxo de la peana y aviendo respondido Gloria tibi Domine sube, toma el missal en la siniestra y el bonete y pasa al lado del Evangelio y un paso atrás del Sacerdote haze genuflexión con él al Verbum caro y acavado el Evangelio, apaga la vela y pasa al otro lado y apaga la 
otra y toma la salvilla de las ampolletas y baxa de la peana y da el bonete como se dixo arriba.

17. Si después de la missa en el altar del Sagrario se ubiere de comulgar mientras el Sacerdote dize el Evangelio último, enciende

[fol. $212^{\mathrm{r}}$ ]

el codal, pone la toalla y avisa que la lleguen a la boca y cuando el Sacerdote abre el Sagrario, se hinca de rodillas y haze confesión, cuando el Sacerdote dize Indulgentiam etc toma la campanilla y cuando buelve con el Sanctíssimo Sacramento y dize Ecce Agnus Dei da tres toques de a dos golpes continuados, cuando comienza el Sacerdote a dar la comunión se levanta y toma el vaso del agua y la toalla y va dando la purificación, dos pasos del Sacerdote y cuando pone el Sanctíssimo Sacramento en el altar, acabada una vuelta, avisa si ay más personas quede otra.

18. Acavada la comunión dexa el vaso y toalla y dobla y pone en su lugar la que tiene los que comulgan y si le sobra tiempo, está de rodillas hasta que se encierre el Sanctisimo Sacramento y eche la vendiçión el Saçerdote que se levanta y apaga el codal y las velas etc, y haze lo demás como en número preçedente, salvo que la salvilla de la llave toma y lleva con la siniestra después de aver dado el bonete.

19. Entrando en la Sacristía se aparta a la siniestra las espaldas a la toalla del lavatorio

[fol. $212^{\mathrm{v}}$ ]

y al pasar por delante el Sacerdote le haze venia y mientras el Sacerdote pone el Cáliz, dexa en su lugar las ampolletas y missal, va al caxón donde ayuda a desnudar la Casulla, buelve de revés con blandura que no se maltrate y déxala tendida que no se arrugue, la estola y manípulo haziendo comedimiento al tomarla, toma el cíngulo y con algunos doblezes lo echa sobre el brazo siniestro. Va recogiendo la alba desde abaxo hasta el hombro siniestro por donde desnuda primero a que el brazo ayúdala a sacar de la cabeza y desnuda el derecho y la dobla por medio, el cuello y las mangas adentro, y luego da otros dos doblezes y la pone sobre la casulla y debaxo de ella el cíngulo, toma el amito y pónelo junto al lenzuelo y da al Sacerdote si fuera prebendado la ropa o sobrepelliz, las mangas de ella se echará por los hombros a las espaldas y la recogerá por la parte de adelante hasta la abertura, y llegará por las espaldas y se la echará por la cabeza y la tirará que se estienda, si ubiere capa Canonical toma la capilla doblada en el brazo siniestro

[fol. $213^{\mathrm{r}}$ ]

y sobre ella la falda de la capa y el cuello con ambas manos y por las espaldas le dará la capa, luego le pondrá la capilla vien cubierto, el cordón o corchete con la buelta queda sobre el ombro, que no se parezca, mas a de quedar sobre la capilla descuvierto el cuello de la capa, pareja por toda la redonda y luego le da la falda que no rodea al brazo y le coge con el lenzuelo con las çintas y lo pone en el caxón del Saçerdote. 
20. Si el Sacerdote forastero es persona grave a quien se deva respecto y cortesía el coadjutor pedirá amito limpio propio de los huéspedes y le ayudará y ministrará como a los prebendados de casa y sabrá a que altar gusta de salir.

21. A los que vienen a dezir missa ayudará de la misma manera y les pondrán los amictos que están en los caxones de los huéspedes y no consentirán que salgan sin bonete, daranles alguno de los que en la Sacristía estubieren prevenidos para esto, no los llevaran a la capilla de las reliquias,

[fol. $\left.213^{\mathrm{V}}\right]$

ni del rosario, ni del Sagrario aviendo otro altar desocupado o desocupándose presto.

22. Los días de fiesta, si algún altar del Cruzero estubiere desocupado, en ninguna manera sacara el Coadjutor recaudo a los de adentro, prinçipalmente al de las reliquias. An de cumplir con la gente que está en la Iglesia para oir missa y que no se llene de ella el pavimento.

23. El Coadjutor de la missa última es el Custos Sacristiae y hará lo que se dize en su oficio Capítulo 29, nº 11.

24. Las missas rezadas se sirven con palmatorias en esta forma, estando vestido el Sacerdote, el coadjutor aviendo savido a que altar a de salir, toma una palmatoria enciende el codal y la pone sobre la salvilla o plato de las vinageras, tómalas y con el dedo pulgar coje la palmatoria y tomando el demás recaudo sale acompañando al Sacerdote, en llegando al altar pone el bonete en el clavo, la palmatoria sobre el altar, las Vinageras en su lugar y el misal en el suyo, enciende con ella las velas y la buelve a poner sobre el altar al Cornu

[fol. 214 $\left.{ }^{\mathrm{r}}\right]$

Epistolae y apaga el codal y haze lo demás como se a dicho arriba. Cuando el sacerdote acaba el primero memento, sube a la peana al lado de la Epístola, toma la palmatoria, enciende de el codal, porque si las velas al despavilar se apagan, tenga allí con que bolverla a ençender, pónela a aquel lado junto al ara y cuando el Sacerdote consumida la hostia toma la patena para purificar el corporal, sube, toma la palmatoria y alumbra a la patena para que el Sacerdote vea las partículas que en ella ubiere, pónela junto a la ara y si fuere menester alumbra otra vez a la patena, ministra las Vinageras, despabila ambas velas y luego la apaga, pasa el missal, y la palmatoria pone en la salvilla o plato y así la lleva, acavada la missa a la sacristía y si hiciere obscuro o fuere muy de mañana alumbra con ella a toda la missa.

\section{Capítulo 28. Del Ofiçio del Admonitor.}

1. Deve ser muy observante de las constituçiones,

[fol. 214 ${ }^{\mathrm{v}}$ ] 
loables costumbres, çeremonias y avisos de policía por que ha de mover más con su exemplo que con las amonestaciones que es su ofiçio: dar y hazer a los colegiales en todas las cosas sobre dichas para que en ninguna aya falta en cuanto fuere posible, estudiará muy de propósito todas las çeremonias, especialmente las que tocan a los oficios de Colegiales, para que de todas pueda advertir y enderezar en sus ocasiones, y cuando sea neçesario hazerlo sea en tiempo y ocasión y lugar que no quebrante el silençio ni estorve a los divinos oficios y ejercicios, en cuanto fuere posible advierta y prevenga las çeremonias para que a tiempo crudo no se haga desorden.

2. En el coro, altar y Sacristía no se traten de çeremonias, no se avisen sino las que fuere forzoso para aquella acción que se ha de hazer y porque no aya falta, advertirlas ha con mucha modestia y charidad, y cuando le replicaren que no se deve hazer, si iubiere tiempo avise al maestro de ceremonias, y si no, dexe de porfiar y si no obedeçieren, a su tiempo lo haga saber para que se remedie y castigue.

3. Todo lo que advirtiere ser fuera de orden contra constituciones policia y ejercicios del

[fol. $215^{\mathrm{r}}$ ]

Colegio, lo avisará al Rector y lo que fuere contra çeremonia y poliçía al maestro de çeremonias y cuide que se enmiende y si no se enmendaren bolverá a avisar para que se proceda como pidiere el caso y a los que procuran cumplir con sus obligaçiones en colegio y çeremonias, dará a conocer al Rector y maestro de ellas para que se les encomienden ofiçios y otras cosas cuando conbiniere y asimismo a los descuidados para que se tenga cuidado con ellos y los podrá avisar si lo reçivieren vien antes que denuncie sus faltas a los superiores.

4. Tendrá cuidado saber del Maestro de çeremonias todos los domingos si ha de aver lección de ellas, llevará en un papel las faltas que a avido aquella semana y las propondrá sin nombrar a nadie, ansimismo las dudas que se an ofrecido y ofrecen y en las ocasiones, nunca avise cosa de que tubiere duda y no estubiere çierto, mas pregúntelo al maestro de çeremonias si ubiere lugar o si no al capellán ceremoniario, o a otro prebendado, lo que se advirtiere en la lección de ceremonias y las dudas que se resolvieren y faltas que se corrigieren advertirá en un cuadernillo para

[fol. $\left.215^{\mathrm{v}}\right]$

que no se olvide de ellas y vea si ay enmienda y se ejecutan.

5. Tendrá una tabla en el Colegio, donde tiene puestos los Colegiales por sus antiguedasdes, y en otro apartado los compañeros en los oficios y en otro los Turnos de ellos y de ir al coro.

6. Haze todos los viernes la tabla de los oficios de los Colegiales, rigiéndose por la tabla del coro que haze con el maestro de çeremonias, en la cabecera de ella pone los prebendados que son diáconos y caperos para que el Turibulario los vea y sepa a quién ha de llamar y los confesores de aquella semana, luego pone los oficios de los 
Collelgiales por el mismo orden que están en la tabla de los prebendados, luego los que asisten al coro aquella semana y al otro lado de la tabla los Colegiales por el orden que an de ayudar a missa, la missa de prima el Turiferario moderno, la missa penúltima a uno desocupado; la última al custos Sacristía; las missas ordinarias por este orden: la primera el refitolero, luego los çeroferarios, Turiferario más antiguo, lector del

[fol. 216 ${ }^{\mathrm{r}}$ ]

refectorio de los Prebendados, el que sirve, el que lee en el de los Colegiales, el que se sirve a segunda en el primero refectorio y luego en el suyo, y en la tabla no los pondrá por los nombres de estos ofiçios sino por los de los Colegiales, después de éstos las demás missas ayudan por sus antigüedades y así los escribirá y esta tabla leerá los viernes en la noche en el Colegio después de leída la meditación, y el Sábado cuando van a la missa de Nuestra Señora la llevará a la Sacristía.

7. Los viernes en la tarde irá con la tabla de los ofiçios de los Prebendados al Maestro de ceremonias, si estubiere toda escrita limpiará el lado de las semanas más antiguas y en ella escribirá los oficios que dictare como se dixo en su capítulo, después de los oficios se escriben las missas y aniversarios y la llevará al Abad y en su ausençia al pressidente para que la revea y para que escrivan la Conferençia espiritual y puesta la conferençia la entregará al Versiculario más antiguo el Sábado por la mañana para que la lleve al coro.

8. Cuando faltare capellán o Colegial ordenado

[fol. $216^{\mathrm{v}}$ ]

que asista a las missas solennes con Diáconos y a las Vísperas y ofiçio cantado, el Admonitor suple, asiste y acompaña de la misma manera que si fuera capellán y en tales casos usa de su bonete, y puesto acompaña y cuando asiste lo tiene en la mano.

9. Cuando reçiven algún Colegial nuevo está a su cargo darle notiçia de las Constituçiones y costumbres del Colegio y comenzarlo a dirigir en las ceremonias y ante todo lo enseñará a ayudar a missa rezada y para ésto le dará algunas lecçiones, lo llevara a la sacristía e Iglesia cuando estubiere çerrada y en el mismo altar con las cosas que sirven en la missa hará que se ensaie, crie en el, estima y reverenzia de tan alto ministerio como ayudar a missa que los ángeles se tubieran con servir en cualquiera ministerio del culto divino.

[fol. $\left.217^{\mathrm{r}}\right]$

\section{Capítulo 29. Del Custos Sacristiae.}

1. Todas las semanas se señala un Colegial que guarda la Sacristía, asiste toda la mañana en ella con sobrepelliz desde que salen de oración hasta que se cierra la Iglesia, su ofiçio es llamar a los Colegiales para que ayuden las missas rezadas y para esto no se a de ocupar en otro ministerio ni hazer falta de la Sacristía por la importançia que es acudir con tiempo y no detener las missas, pues redunda en gran comodidad de los 
demás exerciçios y ocupaciones de la casa, cuida también de que el Sacristán mayor o menor no falte de la Sacristía porque cuando él va a llamar no la dexe sola.

2. Luego que va a la Sacristía, ordena que el Sacristán traiga vino y agua que a de estar en sus basijas solo para esto diputadas y guardadas en el escaparate pequeño. Tiene cuidado que el sacristán llene las ampolletas y que todas las vezes que las traen los Adjutores acavadas las missas las buelva a llenar.

3. No deja en la Sacristía que estén seglares ni se miren en a los espejos, en viendo algunos les pregunten si buscan alguien y encargán-

[fol. $\left.217^{\mathrm{v}}\right]$

dose de hazerlo los despida con cortesía que aguarden en la Iglesia o claustro.

4. No consienta que los Colegiales hagan corrillos en la Sacristía, ni en la puerta y los avise y al maestro de ceremonias y Rector si fuere menester.

5. El tiempo que estubiere en la Sacristía y no tubiere que hazer, ocupará en estudiar y portarse de suerte que los de casa y de fuera siempre le allen de manera que les dé ejemplo.

6. Cuando viniere Sacerdote forastero a decir missa sabrá quien es y si trae lizenzia o recaudos (esto para los no conoçidos) y avisará al Tesorero o al Abad o Pressidente para que ordene si dirá missa y procure que se le dé lugar y recaudo para que se despache con brevedad y gusto.

7. Todos los días verá la tablilla para saver a quién y por qué orden ha de llamar quien ayude. En entrando el Sacerdote en la Sacristía preguntará si va a decir missa y mirará quien le sigue y lo llamará sin detenimiento, si respondieren que no está en el Colegio pida por el que se sigue y sin remissión lo llame y venga.

[fol. $218^{\mathrm{r}}$ ]

8. Encárguesele mucho que cuide y advierta quién viene tarde y que el mismo día lo avise al Rector y cuando llama al Colegial que ayude a tal persona no consienta que le dexe de ayudar y trueque con otro. Si repararen en las missas largas dé cuenta al Rector para que lo reprenda y por su autoridad no altere el orden de los que ayudan a missa por querer acomodar a uno tales missas y a otros otras.

9. Tenga cuidado que ningún Colegial se quede sin ayudar a missa por ocupaçión que tenga pues la deve acomodar de suerte que tenga lugar para ayudar si alguno se quedare lo avise al rector.

10. Cuando el Rector ordenare que algunos ayuden más missas de las que les tocan acomode el llamar de suerte que tenga efecto. 
11. Ayuda la missa última y siempre la a de llevar al altar del sagrario, mas si fuere día de mucho concurso, avisará al Abad y Presidente dispongan se diga en el altar mayor y acavada guarda la Sacristía hasta que el Sacristán ha cerrado la Iglesia.

12. La missa última sale a las onze y media en ibierno y en verano a las onze por lo cual.

[fol. $\left.218^{\mathrm{v}}\right]$

el custos Sacristiae no a de tener en el Colegio ofiçio que le impida en esta hora, estará a punto y sacará recaudo que no aya detenimiento porque acavada la missa se acuda con tiempo a las mesas.

13. Si algún Prebendado u otro Sacerdote no ubiere dicho missa cuando acava la mayor avise al Abad o Pressidente que se llamen y dexen sus ocupaçiones y vayan a dezir missa porque si se quedan para el tiempo de la misa última la dilacion causará desorden en los ofiçios Colegio y horas de Comunidad.

[fol. 219 $]$

\section{Capítulo 30. Del Intonario.}

1. A menester mucha adbertençia y cuidado en alzar, porque cualquiera falta que haga es causa de notable disonancia y desagrado.

2. Antes de comenzar la missa o cualquiera ofiçio en que aya órgano ha de ir y si no a llegado el organista le avise y con tiempo están ambos en el órgano, no se aparta de la mesa de la escalera y está a punto en todas las ocasiones en que se a de tocar, especialmente a los finales de las Epístolas y aunque hagan serial que çese el órgano no a de dexar de alzar hasta que el organista dexe.

3. Esté en su ministerio sin sobrepelliz, alzará con blandura y destreza que no se topen los palos ni cadenas ni se rozen los cordeles ni de golpes, cuida el organista de aderezarlos cuando fuere menester y ayuda y asiste al organista cuando limpia y adereza el órgano.

[fol. 219 $]$

\section{Capítulo 31. De la Tabla de los Ofiçios.}

1. De todos los ofiçios sobredichos haze la tabla el Maestro de Çeremonias como se dixo en este libro Capítulo5, $\mathrm{n}^{\mathrm{o}} 21$. 
2. El Abad no entra en turno de missas de terçia, mas entra en el de missas de prima y aniversarios y missas rezadas de tabla.

3. El turno se guarda desde el más antiguo; pone los oficios por el orden que se dixo en el $\mathrm{n}^{\mathrm{o}}$ çitado, los huéspedes de aprovación se ponen en la tabla por Diáconos cuando les viene por turno (aunque concurran con prebendado de Canongía colada) pero siempre hazen ofiçio de Subdiácono sino es que el Subdiácono es huésped de aprovación y el Canónigo de colaçión que se vistiere de Diácono por esta concurrençia no pierde el turno sino se continue conforme a la tabla, el turno de caperos va por ambos Coros que an de ser cada cual de su coro, el de los Diáconos no, que ambos pueden ser de un coro.

[fol. $220^{\mathrm{r}}$ ]

4. En el turno de los Confesores a de trocar el de mugeres y hombres de suerte que el que una semana es confesor de hombres otra lo sea de mugeres, si tubiere lizenzia y para cada semana tenga señalados dos por compañeros con orden del Abad o Pressidente de la casa.

5. El turno de los oficios de los Colegiales se sucede como se dixo en el mismo capítulo y otras cosas perteneçientes a la tabla se allarán en los capítulos del apuntador, maestro de çeremonias y admonitor.

6. No entran en turno ni se asientan en la tabla los ofiçios que se les seguían los que están fuera de Granada, mas si vienen a tiempo se les guarda el turno en la forma siguiente.

7. Si el que está fuera de Granada es en ocupación y negoçio del Sacro Monte y viene antes que se aya ganado punto de distribuçión, entra en el lugar y oficio que le tocava como si estubiera en el Sacro Monte, como, tocale al Pressidente ser Hebdomadario, no está en el Sacro Monte cuando se haze la tabla pónese el que se le sigue y si viene antes que el que está

[fol. $\left.220^{\mathrm{v}}\right]$

puesto aya comenzado la semana en punto que se gana manual, como el Sábado en las Vísperas si ubo pluvial, o el Domingo antes que diga la missa de terçia, si el Pressidente ha estado en negocio del Sacromonte, toma la semana que le venía, mas si el que está escrito ha comenzado a ganar en distribuiçión, manual de pluvial o missa prosigue con su semana y no entra el Pressidente.

8. Si estando en casa la semana antecedente y la subsequente le toca el ofiçio y se ofreze salir de Granada a algún negoçio de el Sacromonte en que a de estar algunos días de la semana que le toca, lo an de poner en la tabla y en viniendo si quisiere proseguirá su semana.

9. Si el que está fuera de Granada en negoçio proprio suio viene antes de leerse la tabla en el coro, deve entrar en el ofiçio que por turno se seguía, mas si viene después de leída la tabla, no entra. 
10. Si estando en casa algún prebendado dixere que no le echen en tal o tal oficio de distribución y el maestro de çeremonias

[fol. $221^{\mathrm{r}}$ ]

guardando el turno pusiere al que le sigue después de leída la tabla en el coro no puede pretender entrar en el oficio que dexó pasar.

11. La tabla se lee todos los Sábados como se dixo Capítulo 17 del Calendario y la ponen en un clabo detrás de la puerta a la mano diestra y ninguno se puede atrever, a mudar, quitar, borrar ni escribir de nuevo en ella cosa alguna, mas el que advirtiere cosa digna de mudarse o yerro en los Turnos lo avise al Abad o al Pressidente en su ausencia, para que con el orden devido se trate lo que se ubiere de hazer.

12. En la Tabla se escrive la Conferençia Spiritual de un Viernes para otro, aunque el immediato no sea día de conferencias porque así abrá más lugar y tiempo de exerçitar la virtud y no se borre de la tabla la conferençia escrita hasta que se aya tenido.

\section{Fin del Libro Segundo.}

[fol. $221^{\mathrm{v}}$ ] Es hoja en blanco.

Folio sin numerar.

\section{LIBRO $3^{\circ}$. DEL MODO CON QUE SE CELEBRAN LOS DIVINOS OFICIOS.}

[fol. $\left.222^{\mathrm{r}}\right]$

\section{Capítulo 1. De las Vísperas Cantadas.}

1. Regularmente comienzan los oficios en las sagradas Solennidades de las primeras vísperas, y assí después de referidos los oficios de los ministros que sirven en el culto divino consiguientemente se ha de tratar de ellas.

2. Los çeroferarios y turiferarios, çetreros y comitantes, en siendo ora, acuden a la Sacristía y hazen lo que toca a sus oficios como se dijo en sus Capítulos.

3. Cuando viene el celebrante y caperos, en comenzando la gorda se visten y si es tiempo de capas se las quitan los Comitantes al celebrante, los çetreros a los Caperos, cada cual a los de su coro y las ponen sobre los caxones por su orden que cada uno alle la capa que quitó para que buelba a poner, luego ayudan a poner

[fol. $\left.222^{\mathrm{v}}\right]$ 
las mangas de las sobrepellizes tendidas por los hombros cada cual a quien quitó la capa, los comitantes ponen al celebrante estola y al dársela le hazen reberencia y se la dan a besar y luego le ponen el pluvial y los çetreros los ponen a los caperos, mas no estolas, luego toman los cetros y se van a la puerta de la Sacristía y ponen delante de los Ceroferarios que están con los ciriales encendidos aguardando y a a la primera buelta del esquilón salen por este orden: El Pertiguero puesta la gorra y la Pértiga en la mano derecha, los çetreros dos o cuatro, los ceroferarios con los ciriales altos, los comitantes dos o cuatro conforme fuese el día, el capellán çerimoniario, los caperos si ay cuatro o los dos modernos delante, los antiguos llevan en medio el celebrante y si no ay más que dos, lo llevan en medio y el cerimoniario va inmediatamente delante de ellos.

4. Al salir por el arco de la capilla de los mártires por debaxo de las lámparas el

[fol. $223^{\mathrm{r}}$ ]

Pertiguero va al medio del pavimento al lugar donde se suele poner el blandón y si lo ay puesto al lado del blandón por el del púlpito del Evangelio, los cetreros que salen a la mano derecha se quedan al lado del Evangelio y los otros pasan al de la Epístola y se ponen en coro unos detrás de otros el rostro al altar y no hazen venia ni genuflexión al pasar. Los çeroferarios: el que sale a la mano derecha se queda al lado de la Epístola y se ponen en Coro delante de los çetreros, tan desbiados de las gradas que por delante de ellos pasen los comitantes y los demás, los comitantes: si ay cuatro, el primero del coro diestro se queda a la siniestra del ceroferario y el otro pasa a la diestra del otro ceroferario a la capilla del rosario. Los otros cada uno en su coro se quedan delante de los ceroferarios, el capellán pasa al medido del pavimento delante del Pertiguero si son solos dos comitantes se quedan delante de los çeroferarios.

[fol. $223^{\mathrm{v}}$ ]

los caperos pasan y se quedan en el lado de su coro, los que pasan al lado de la Epístola quitan el bonete al pasar por medido del altar, luego todos en una línea y en medio el celebrante, el cual cuando a llegado al medio frontero del tabernáculo, se quita el bonete y con él los caperos que no lo avian quitado y Capellán y el Pertiguero la gorra y todos juntos como están hazen genuflexión, si esta el Sanctíssimo Sacramento decubierto desde la capilla de los Mártires, desde donde descubren el altar salen sin bonetes todos descubiertos.

5. Levántanse de la genuflexión juntos y cúbrense y dan la buelta por de dentro los rostros unos a otros y por el mismo orden que salieron cubiertos, las manos puestas los últimos caperos llevando en medio el çelebrante proçeden y si ay blandón y el celebrante es del coro derecho, pasa por el lado del púlpito de la Epístola, si es del Coro siniestro por el del

[fol. $\left.224^{\mathrm{r}}\right]$

Evangelio y al altar de la Concepción hazen venia sin quitarse los bonetes. Salen al Claustro y los dos últimos Comitantes se quedan y llegan al celebrante y alzan las puntas del pluvial, y así lo llevan hasta el tránsito del Coro, y el primer Cetrero cuida de 
adelantarse para abrir la puerta si está çerrada. En llegando a la puerta de la Concepción baxan los Ceroferarios los çiriales y así los llevan hasta que los ponen en sus lugares en el coro, suben por la escalera en buen orden y en llegando al tránsito del coro se rehazen en el orden, sueltan los comitantes el pluvial, pónense en sus lugares y éntranse en el coro.

6. El Pertiguero al entrar se quita la gorra y pasa a la grada que sube a la silla del apuntador, los cetreros pasan a sus coros y se ponen como en el Pavimento, a los lados del facistol grande por donde entran a los Coros, bueltos al altar, los ceroferarios entran los Çiriales baxos y el del lado derecho se queda

[fol. 224 $\left.4^{\mathrm{v}}\right]$

delante del Pertiguero y el otro pasa al lugar correspondiente, los Comitantes delante de ellos, el çerimoniario pasa al otro Coro y se pone delante del Comitante antiguo, los caperos y celebrante pasan por delante de los comitantes y los que pasan al coro diestro, quitan los bonetes al altar y cruçifixo de la barandilla, mas no hazen venia y se ponen en una línea junto a la barandilla y estando en medio el celebrante hazen y todos los ministros con ellos genuflexión al altar, el Pertiguero se levanta y buelve el rostro al façistol, los çetreros se levantan y pasan al coro a sus lugares junto a los asientos de los Caperos y si los Colegiales están de rodillas por no aver dexado el esquilón, se levantan y arriman a sus asientos, levantando los asientos y metiéndose entre los eloxes, y los cetreros cuando llegan hazen venia al Coro, los çeroferarios se levantan y van a poner los çiriales en las aldabillas y en poniéndolos hazen genuflexión, el cerimoniario, Capellanes, Comitantes,

[fol. $\left.225^{\mathrm{r}}\right]$

Caperos y celebrante se quedan de rodillas y hazen oración [por] espacio de un Pater Noster, levántanse y buelven a hazer genuflexión y cúbrense y las manos puestas los que llevan pluviales y los comitantes delante, y el cerimoniario en su lugar se buelven a entrar por el coro, cada cual por el suyo, dexando en medio al facistol grande, y si el celebrante es del coro derecho pasa por el otro lado del facistol, dejándolo a su mano derecha y si es del coro siniestro dexa el facistol a su siniestra, a todo esto está el Pertiguero la gorra quitada.

7. En llegando al facistol el Çerimoniario Caperos y çelebrante se quitan el bonete y todos los del Coro, si están sentados se descubren, levantan y baxan las mangas, a tres pasos pasado el facistol el ceremoniario se queda y pone detrás del celebrante y los Comitantes se arriman a sus lugares y los dos primeros pasan a la silla del celebrante cada uno a su lado, como se dixo libro 2, Capítulo 23, número ¿?, y los caperos pasan un poco y se ponen en una línea teniendo en $\mathrm{m}^{\circ}$

\section{[fol. $\left.225^{\vee}\right]$}

al celebrante y de rostro al Coro del testero, hazen comedimiento baxando las Cabezas, primero al Abad, luego al coro de la semana, luego al otro llevando el rostro inclinado por todo el coro, desde el prinçipio hasta donde ubiere prebendados y todo el coro por el 
mismo tenor los resaluda con el mismo comedimiento, al cual acabado dexan que pase el celebrante delante y luego pasan ellos todos a sus lugares, cuando hazen venia al Coro hazen simul a los Comitantes que se quedaron en sus lugares y el cerimoniario y pertiguero.

8. Llegando a sus lugares, si no a dexado el esquilón, se sientan y todo el Coro alto, el cerimoniario pasa a su silla, el pertiguero haze comedimiento al coro y se buelve, para ir haze genuflexión al altar y se baxa a su lugar al pavimento como se dixo libro 2 capítulo $13 \mathrm{n}^{\mathrm{o}}$. Si ha dexado el esquilón se quedan en pie, o se levantan todos en dexando, y los cetreros dan

[fol. $226^{\mathrm{r}}$ ]

haziendo venia los cetros a los Caperos, que siempre que están en pie los tienen, y el celebrante dize secreto Pater Noster y Ave Maria, luego se llega el cerimoniario y le haze comedimiento y le toma el bonete y le alza el pluvial por el lado diestro y el celebrante entona Deus in adiutorium etc y diciéndole, se signa desde la frente al pecho y del hombro siniestro al diestro con la señal de la cruz.

9. En acavando de entonar, suelta el cerimoniario el pluvial y le buelve el bonete, los Caperos están en sus lugares, al Gloria Patri todos profundamente inclinan la cabeza siempre, acavado el Alleluya o Laus tibi Domine, el Sochantre haze comedimiento al Capero más antiguo del coro de la semana, y el Capero haze venia al celebrante, llegándose un poco a él y el celebrante le corresponde y le intona la antíphona y después se hazen el mismo comedimiento.

10. Quédanse todos en pie hasta la dimidiaçión del primer verso del psalmo que los Comitantes alzan el pluvial del celebrante, cúbrese

[fol. 226 $]$

y siéntase, los çetreros dan los bonetes y toman los cetros haziendo venia y los caperos se sientan y cubren, y el coro de los prebendados también se sienta y los çeroferarios en sus lugares.

11. Cántase la antíphona toda si es doble y si semidoble, el prinçipio y los capellanes cantores con el Sochantre entonan el psalmo y a la mediación hazen comedimiento al coro de la semana y se lo encomiendan y se van a sentar, acabado el psalmo se levantan y llegan al façistol a cantar la antíphona y si es doble, el fin de la primera que se repite, van a la silla del más digno prebendado y le hazen comedimiento y el prebendado, aunque sea el Abad, se quita el bonete y les baxa la cabeza y acavada la primera antíphona, le preintonan el principio de la sigunda.

12. La primera antíphona siempre entona el celebrante por el coro de la semana, la sigunda entona el Abad por el otro Coro aunque no sea el suyo, mas los otros prebendados entonan las antíphonas alternativamente cada

[fol. $\left.227^{\mathrm{r}}\right]$ 
uno por su coro y aunque comienzan de los más antiguos no se guarda el orden de la antigüedad, sino de los coros, de suerte que la segunda antíphona la dize el Prebendado del coro que no es de la semana, aunque sea más moderno que el primero que está en el otro coro y así van suçediendo excepto que la segunda dize siempre el Abad si está en su silla, por el coro que no es de la semana, la primera antíphona y primer psalmo es del coro de la semana, el segundo del otro y así alternativamente se prosiguen las antíphonas y psalmos, si es semidoble la primera antíphona entona como se a dicho el çelebrante, y las otras entonan por el orden referido los capellanes y Colegiales comenzando del más digno, véase el primero libro, capítulo 7 de quién entona el coro.

13. El Prebendado, en respondiendo a la Cortesía que le hazen los capellanes cantores cuando le preintonan la Antíphona, se levanta y echa las mangas y simul se levantan todos los prebendados y echan las mangas y entonando la antíphona se sientan, mas los caperos

[fol. $\left.227^{\mathrm{v}}\right]$

no se levantan.

14. Cuando los psalmos se dizen a versos con el órgano el verso que al órgano toca lo dizen los caperos no reçio, mas en boz inteligible.

15. Cuando se repite la quinta y última antíphona salen de la Sacristía los Turiferarios vestidos sin turíbulos acompañados del Pertiguero y suben al altar y en el pavimento hazen genuflexión y el Pertiguero abaxo de las gradas, están en pie mientras la Capítula y el primer Verso del Himno, si es Veni Creator Spiritus o Ave Maris Stella, se hincan de rodillas en el mismo lugar y el Pertiguero en el suyo, y si es otro himno, ellos solos hazen genuflexión y suben y despabilan como se dixo libro 2, Capítulo 21, de çeroferarios número 62, y Capítulo 22, de turiferarios, y se buelven a la Sacristía y toman Turíbulos y se suben al coro por la Iglesia acompañados del Pertiguero y si es día del Corpus o su octava salen a tal tiempo que al

[fol. $\left.228^{\mathrm{r}}\right]$

tantum ergo se hinquen de rodillas en la ínfima grada del pavimento y acabado Veneremur çernui se levantan y también el Pertiguero, hazen genuflexión y suben al coro, ésto se entiende si está el Sanctíssimo Sacramento manifiesto, mas el Pertiguero se hinca de rodillas en el Pavimento enlosado.

16. En el mismo tiempo, al fin de la quinta y última antíphona, en el coro suben los comitantes detrás de la silla del celebrante y cuando llegan hazen venia al coro y se quedan cada uno en su lado, los çetreros dan los çetros y toman los bonetes de los caperos haziéndoles venia, los ceroferarios suben y dos pasos antes del façistol del celebrante hazen venia y se quedan eregione las manos puestas, el çeremoniario se llega al çelebrante, todo esto se haze a un tiempo que es cuando se acaba la antíphona y se levantan los caperos y çelebrante y todo el coro, el comitante de la mano derecha le toma el bonete, los caperos se llegan al lado del celebrante que hagan 
[fol. $\left.228^{\mathrm{v}}\right]$

con él medio círculo, y el celebrante, puestas las manos canta en tono igual la capítula y respondido del coro Deo Gratias, el capero antiguo del coro de la semana, aviendo sido combidado de los capellanes cantores y Sochantres, buelto algo de rostro al çelebrante y haziéndole venia profunda le preintona el himno, el celebrante le corresponde y repite lo que se le ha preintonado, si el himno es Veni Creator Spiritus o Ave Maris Stella, cuando el celebrante lo comienza, todos se hincan de rodillas bueltos al altar y acavada la entonaçión, los caperos y el çelebrante también se hincan de rodillas hasta el fin del primer verso que todos se levantan y los caperos deshazen el medio círculo y se arriman a sus lugares y con los çetros tienen las manos puestas y el çelebrante mientras se canta todo el himno, al fin del primer verso si se a estado de rodillas y si no en acavando la entonaçión, el çelebrante, los çeroferarios con las manos puestas

[fol. $229^{\mathrm{r}}$ ]

hazen profunda al celebrante y se van a sus lugares y todo el coro está en pie mientras se dize el himno, si el himno es pange lingua y está el Sanctíssimo Sacramento manifiesto al Verso Tantum ergo, hasta dicho Veneremur Cernui se arrodilla todo el Coro y los Turibularios y Pertiguero en la Iglesia.

17. En el último Verso de él, los çeroferarios hazen venia al coro y van a los ciriales, hazen genuflexión y toman los codales y van con ellos detrás del façistol, al mismo tiempo entra el lucernario con la luz y se pone en medio de ellos y todos tres hazen genuflexión y encienden, el lucernario se va a la puerta de la Iglesia, los çeroferarios ponen los codales en los çiriales y los sacan de las aldavas y sin hazer genuflexión los llevan y se ponen después de las últimas sillas bajas eregione, los çiriales asentados en el suelo y al mismo tiempo entran los turiferarios en el coro con el Pertiguero haviendo

[fol. 229 $9^{\mathrm{v}}$

echado inçienso y hazen genuflexión y se ponen abaxo de los çiriales meneando los incensarios, como se dixo libro 2 Capítulo 22, $\mathrm{n}^{\mathrm{o}}$ y el Pertiguero se pone en el lugar que se dixo, libro2, Capítulo 13, $\mathrm{n}^{\mathrm{o}}$.

18. En el mismo tiempo, al último verso del Himno, el çeremoniario combida a los caperos, si ay más de dos a los más antiguos, primero al del coro de la semana y luego al otro y se levantan y los cetreros les dan los cetros y toman los bonetes y ambos salen al plano del coro y delante del facistol hazen genuflexión al altar y cantan el verso, mientras el coro responde hazen genuflexión y luego venia el uno al otro y si es ofiçio doble se van a sus lugares y acavado de responder al verso, el capero del coro de la semana haze profunda al celebrante y le preintona la antíphona del cántico Magnificat como se ha dicho que entonó la primera

[fol. $230^{\mathrm{r}}$ ] 
y el himno acavada la repetición del celebrante, le alzan el pluvial los comitantes, si es día en que ay órgano se sienta y los çetreros con venia dan los bonetes y toman los cetros y los caperos se sientan y todo el coro de los prebendados y al fin de la antíphona, el çerimoniario combida a los primeros caperos como se dixo supra, los cuales dan los bonetes y toman los çetros y van al plano del coro, hazen en medio genuflexión y entonan el magnificat y buelven con venia y lo encomiendan al coro de la semana hazen genuflexión y el uno al otro venia y se van a sus lugares.

19. Cuando comienzan a entonar el Magnificat, el celebrante se levanta y da el bonete al comitante diestro y todos los prebendados se levantan y ponen las manos y así están mientras se canta toda.

20. En llegando los caperos a sus lugares, sale el celebrante de su silla por el lado de su coro y va al plano de él dos pasos abaxo de

[fol. $\left.230^{\mathrm{v}}\right]$

su façistol y los comitantes van tras él y luego buelve el rostro al coro, el çeremoniario un paso atrás del çelebrante, los comitantes más abaxo, los çeroferarios buelven el rostro al coro, los turiferarios dexan de menear los incensarios y los toman en las diestras por lo alto de las cadenas y levantan las cubiertas y las de las navetas que con la misma mano toman por el pie y levantan el brazo con gallardía more solito y se buelben de rostro al coro y también el Pertiguero, todo ésto lo hazen todos a un tiempo cada uno lo que le toca y assí todos simul hazen venia al coro como al entrar.

21. Si es día que no ay órgano por cualquiera causa que sea, el celebrante no aguarda a entonar la antíphona del magnificat, sino después del primer Verso del himno se despide del coro en la misma forma dicha, para lo cual los ceroferarios también se adelantan a encender

[fol. $\left.231^{\mathrm{r}}\right]$

y los Turiferarios a subir y sale de suerte que entre en la Iglesia, cuando se comienze el magnificat.

22. Despedido el celebrante al último verso del himno, el sochantre combida a los caperos que digan el verso y dicho, el sochantre combida al que preside que preintone la antíphona e intonada si es doble, se van a sentar y si semidoble sin apartarse entona el magnificat y lo encomiendan como se dixo supra $\mathrm{n}^{\mathrm{o}}$. Si es semidoble y el celebrante no a salido del coro, en cantando los caperos el Verso, en el mesmo lugar se ponen ambos eregione, y el de la semana haze venia desde allí y preintona la antíphona al preste.

23. Hecha la venia al coro, el celebrante con todos los ministros que salen en çeremonia, haze genuflexión entre la varandilla y el façistol por el mismo orden que la hiçieron al entrar, van descubiertos por todo el coro y el celebrante cerimoniario y Comitantes.

[fol. $\left.231^{\mathrm{v}}\right]$ 
las manos puestas, en saliendo del coro da el comitante el bonete al celebrante y se cubre y el çerimoniario al baxar la escalera los comitantes alzan el pluvial, y así van hasta entrar en la Iglesia que lo sueltan y el comitante derecho toma el bonete y lo dobla y arrima al pecho, el çerimoniario se descubre y van las manos puestas como al salir del Coro, más espacio conforme a la solemnidad. El Pertiguero, los Turiferarios, los çeroferarios, los comitantes, el çerimoniario y últimamente el çelebrante llegan al Pavimento y el Pertiguero se aparta al lado del Evangelio y quita la gorra y buelve el rostro al púlpito de la Epístola para tenerlo a los que pasan en çeremonia, los turiferarios se ponen junto a la grada a la parte de adentro de las aldavillas cada uno en su lado, los ceroferarios llegan a la grada a sus lugares que son las aldavillas para los çiriales, los comitantes

[fol. $232^{\mathrm{r}}$ ]

si ay cuatro, los segundos se queden en el pavimento en derecho de los ceroferarios y los primeros se ponen junto a las gradas a la parte de dentro de los turiferarios y cogen en medio al çelebrante y el ceremoniario se pone detrás de él y entonzes el pertiguero se pasa al medio del pavimento a su lugar detrás del çerimoniario, así puestos todos juntos hazen venia y los ceroferarios también, los primeros comitantes alzan las puntas del pluvial.

24. Suben al pavimento alto el celebrante, los comitantes de sus lados, los Turiferarios y el cerimoniario, que puesto detrás del celebrante en medio de los turiferarios aunque algo apartados y el çelebrante y Comitantes junto a la peana y los demás donde están, hazen genuflexión y los ceroferarios al subir, todos baxan los çiriales y asientan en la grada, levántanse todos y el comitante pone el bonete sobre el escaño o en la rexa de las reliquias, llega el celebrante

[fol. $232^{\mathrm{v}}$ ]

en medio de los comitantes y el Turiferario antiguo al altar, él lo besa en medio y simul los comitantes y Turiferarios hincan la rodilla, el çerimoniario se aparta al lado de la Epístola junto a la rexa de las reliquias y el Turiferario antiguo por aquel lado ministre la Naveta al Comitante como se dixo libro 2, Capítulo 22, de Turiferarios. $\mathrm{n}^{\mathrm{o}} 13$ y capítulo 23, de comitantes $\mathrm{n}^{\mathrm{o}}$, mientras el comitante de la mano derecha besa la del celebrante, el otro pasa por detrás y le alza el pluvial por el lado diestro mientras echa incienso y la vendición, que en echándola lo suelta y se va a su lado, el comitante diestro toma el Turíbulo y lo vesa por la sumidad de las cadenas y lo da al celebrante y le vesa la mano y luego ambos, cada cual por su lado, alza las puntas del pluvial como se dijo en su capítulo $\mathrm{n}^{\mathrm{o}}$, el celebrante toma con la siniestra el nudo de las cadenas del

[fol. $233^{\mathrm{r}}$ ]

Turibulario y con la diestra las cadenas por junto a la cubierta y haze genuflexión y con él los comitantes, para hazerla afirma la siniestra en que tiene el nudo de las cadenas en la frente del altar y la diestra con el inçensario tiene baxa y fuera de él y todas las vezes 
que inciensa haze genuflexión de esta suerte: levántanse y el çelebrante pone la mano siniestra en derecho del hombro siniestro y con la diestra envía el Turíbulo y con tres ductos inçiensa la Cruz, luego haze genuflexión afirmando la siniestra como se dixo arriba y los comitantes siempre hazen genuflexión con él, levántanse y inciensa con tres ductos la distancia que ay desde la Ara hasta el Cornu epistolae, da los ductos altos como que inciensa las velas que están en los candeleros, cada ducto da en derecho del lugar en que se suele poner cada candelero cuando ay seis y dalos al compás de cada paso que da.

25. Llega al Cornu epistolae y turifica el lado del altar por donde cuelga el mantel con dos ductos, uno más baxo que otro, luego inciensa la tabla del altar que está al mismo lado de la Epístola con tres

[fol. $233^{\mathrm{v}}$ ]

ductos metiendo el Turíbulo por cima de ella todo lo que alcanza el brazo y los reparte y entra el turíbulo por la distancia que suele aver entre un candelero y otro, cuando llega al medio del altar haze genuflexión y pasa a inçensar el lado del Evangelio: primero con tres ductos enderezados a los lugares de los candeleros, luego con dos ductos inçiensa el lado de altar como el de la Epístola y luego la tabla de la misma manera y al mismo compás, y cuando da el postrer ducto de la tabla no llega a hazer genuflexión al medio del altar sino se buelve al Cornu evangelis y por la frente del altar en derecho de la frontalera inciensa aquel lado con tres ductos dados a compás de los pasos y llega al medio del altar haze genuflexión y con otros tres ductos inciensa la frente del lado de la Epístola de la misma manera y llegando al Cornu da el Turíbulo al comitante, el cual besa la mano y da el turíbulo al Turiferario y mientras dura toda esta acción está el compañero en su lugar meneando el Turíbulo y él con la naveta al pecho, eregione, a todas

[fol. $234^{\mathrm{r}}$ ]

las idas y venidas les siguen los comitantes al çelebrante y llevan al pluvial levantado con ambas manos y algo apartados del çelebrante, lo que alcanzaren las puntas del pluvial tendido. La incensación toda la haze con buen aire y gravedad, no haciendo meneos con el cuerpo ni cabeza, embiará y retraerá el turíbulo con los ductos con buen compás, ni muy apriesa ni espacio y siempre moverá primero el pie del lado que va por el altar y del Cornu Evangeli al de Epístola moverá siempre primero el diestro y al mismo tiempo que muebe el turíbulo para el ducto.

26. Cuando está el Sanctíssimo Sacramento descubierto, en reçiviendo el turíbulo, se hinca el çelebrante de rodillas en medio del altar, algo desbiado del y de rodillas turifica con tres ductos el Sanctíssimo Sacramento levantando el Turíbulo que suba porçima de la frente del altar, levántase y haze genuflexión y prosigue la turificación como está dicho en los números precedentes incensando primero la

[fol. $234^{\mathrm{v}}$ ]

cruz y prosiguiendo con lo demás 
27. Este modo de turificar el altar se guarda siempre así en las laudes como en la missa, exçepto que en la missa inciensa primero la oblata como se dirá en su lugar y después el altar como se a dicho y los diáconos lo acompañan yendo y viniendo con él, mas no levantan la Casulla, cuando inciensa el altar a víspera y laudes nunca dize nada el celebrante.

28. Llega al medio del altar y haze venia profunda y los comitantes se baxan de la peana y el derecho toma el bonete que puso sobre el escaño cuando subió y se lo arrima al pecho, baxa el celebrante y allí le acomodan y emparejan el pluvial y hazen genuflexión y simul los turiferarios y cerimoniarios, çeroferarios y comitantes $\mathrm{y}$ Pertiguero. Al baxar de las gradas levantan los çeroferarios los ciriales, baxan primero los Turiferarios, luego los comitantes, luego el çerimoniario, luego el çelebrante y como van llegando al pavimento baxo se van poniendo por su orden en los lugares que vinieron y descubiertos y las manos puestas los que las

[fol. $235^{\mathrm{r}}$ ]

llevan desocupadas, buelben diciendo el Magnificat a versos los dos coros, comenzando el celebrante con los del coro de la semana, saliendo al Claustro buelve el bonete al çelebrante y cúbrese, toman los cavos del pluvial y los ceroferarios baxan los ciriales y suben al coro como la primera vez y de la misma manera entran y se ponen y hazen genuflexión excepto que entran descubiertos y como no van caperos, los comitantes se ponen en la misma línea del celebrante, teniéndolo en medio y al entrar le toma el comitante el bonete, hecha genuflexión inmediatamente se levantan los çeroferarios, se quedan eregione antes de llegar a las sillas baxas y abaxo de ellas los Turiferarios, y en su lugar el Pertiguero, solo suben y entran por sus coros los comitantes çerimoniario y celebrante.

29. Los Comitantes con el celebrante llegan al plano del coro junto la alfombra y hazen comedimiento y con él todos los que vinieron como cuando entraron la primera vez, el celebrante pasa a su silla y los comitantes se quedan en sus lugares hecha venia los Turiferarios van detrás del

[fol. $\left.235^{\mathrm{v}}\right]$

facistol y çierran los turíbulos y toman las navetas en las siniestras arrimadas al pecho y cada uno por su coro entran hasta el çelebrante y simul le hazen profunda y el antiguo le inciensa con tres ductos haziéndole antes y después venia y el Çelebrante, cuando le quiere inçensar el turiferario, buelve al Capero más antiguo de su coro y le haze cortesía, inclinándole la cabeza y combidándole con el incienso de la manera que lo hazen prebendados, el capero le responde a la cortesía con otras, inçensando el çelebrante incensan ambos juntos a los caperos, cada uno los de su coro y luego suben y hazen la inçensacion por todo el como se dixo libro 2, Capítulo 22, de turiferarios $\mathrm{n}^{\circ} 16$.

30. El Compás del Canto y del órgano sea de suerte que dé lugar a que todo el coro sea turificado, mas cuando no ay órgano la turificación çesa cuando se comienza a repetir la antíphona que los turiferarios sueltan las cadenas de los turíbulos y por la escalera de 
junto al apuntador y maestro de Çeremonias se salen y se van detrás del facistol y hazen genuflexión y los toman

[fol. $\left.236^{\mathrm{r}}\right]$

en las diestras con las navetas, more solito y hazen venia al coro y se van por la Iglesia a la Sacristía.

31. Cuando se comienza a repetir la antíphona, los comitantes suben y el antiguo da el bonete y levantan el pluvial al çelebrante, los cetreros los dan a los caperos y toman los cetros y al hazer ésto todos hazen venia y se sientan çelebrante y caperos y prebendados, al fin de la antíphona levantan los çeroferarios los ciriales y se llegan al facistol del celebrante a un lado y otro y al llegar hazen reverençia y a este mismo tiempo se levanta el celebrante y Caperos dexando los bonetes y reçiviendo los cetros y se ponen a los lados del çelebrante que hazen un medio círculo, los prebendados se lebantan descubiertos, las mangas baxas y acavada la antíphona el celebrante puestas las manos canta Dominus Voviscum

y respondido canta oremus y la oración, a la conclusión baxan los çiriales y si ay otras oraciones, dichas las antíphonas los últimos caperos si ay más de dos y si no los dos, baxan combidados del çeremoniario a dezir los versos de ellas, hazen genuflexión al llegar y aunque aya oraciones se quedan allí para dezir los versos de todas y no

[fol. 236 $\left.6^{\mathrm{v}}\right]$

hazen genuflexión hasta que an dicho el venedicamus y hechas se hazen venia y a este tiempo, dicho por el çelebrante fidelium animae, se baxa con los otros caperos si los ay, que al mismo tiempo dan los çetros y toman los bonetes y con los comitantes, que se baxan detrás de los caperos que dixeron el Venedicamus y los ceroferarios a sus lugares abaxo de las sillas baxas, los caperos y celebrante bueltos al coro hazen un medio çírculo, el celebrante en medio y todos los que acompañan simul hazen comedimiento al un coro y otro como cuando entraron y por sus lados se baxan detrás del facistol donde se ponen como a la venida y hazen genuflexión, levántanse y no se cubren hasta que los caperos de la mano derecha an pasado por delante del çelebrante hecha la genuflexión se levantan y retiran hazia el facistol para dar lugar que pasen por delante los cetreros, çeroferarios, comitantes y çerimoniario, luego pasan los caperos descubiertos como se ha dicho y últimamente sale el preste.

32. Si después de Vísperas no ay completas y se ha de salir del coro dicho por el celebrante

[fol. $237^{\mathrm{r}}$ ]

fidelium animae puestas las manos todos los del coro excepto los çeroferarios dizen todos secreto Pater Noster y el çelebrante Dominus det nobis sua paçem y se hincan todos de rodillas, excepto los çeroferarios y dizen en tono la antíphona de Nuestra Señora. Y dicha el celebrante se levanta y dize el verso y oración y respondido Amen, el 
Divinum auxilium etc, el que preside haze señal y se levantan todos y los prebendados en sus sillas aguardan que los de la ceremonia se buelvan y despidan como se dixo número precedente.

33. Si ay completas cuando el órgano o el coro a respondido Deo Gratias, salen los turiferarios con sobrepellizes de la capilla de los mártires y suben al altar y con las devidas genuflexiones, apagan las velas si ay más de dos, que éstas dexan encendidas para completas como se dixo libro 2, Capítulo 22 de turiferarios num .

34. Cuando salen del coro se ponen por el orden que vinieron en medio de los caperos últimos el celebrante, levantale el pluvial los comitantes y puestas las manos

[fol. $237^{\mathrm{v}}$ ]

y bonetes proçeden, y cuando entran por la Iglesia los ceroferarios levantan los ciriales y con el mismo tenor llegan al pavimento, el Pertiguero se aparta al lado del Evangelio a la capilla de los mártires, los cetreros se llegan a la grada y por dentro de los çeroferarios los comitantes que cogen en medio, los caperos y éstos al celebrante y todos para que quepan en este orden hazen un medio círculo vien proporcionado, quedándose el preste adonde se pone el blandón o al lado del si lo ubiere, el cerimoniario se pone detrás del celebrante y así puestos todos simul hazen genuflexión y no se cubren hasta que los caperos de la mano derecha ayan pasado por delante del celebrante, entran en la Sacristía por el orden que salieron $n^{\circ}$.

35. El Pertiguero se queda junto al caxón del niño JESÚS, los cetreros pasan a poner los çetros junto al escaparate, los ceroferarios se quedan a la puerta de la Sacristía, los comitantes entran con los caperos y celebrante y en llegando al bufete de piedra ambos le quitan el pluvial y

[fol. 238 ${ }^{\mathrm{r}}$ ]

estola y le ponen tendido en el bufete y le ponen la capa, si traen los cetros hazen lo mismo con los caperos y tienden los pluviales sobre el Caxón de las Casullas bien puestos no arrugados.

36. En entrando el celebrante los ceroferarios apagan los codales, entran en la Sacristía ponen los çiriales en su lugar desnúdanse los collares y roquetes y lo ponen en su caxón y toman sobrepellices.

[fol. 238 ${ }^{\mathrm{v}}$ ]

\section{Capítulo 2. De las completas cantadas.}

1. En despidiéndose el çelebrante y ministros del coro, si se an de seguir completas, cuando haze genuflexión detrás del facistol, sale al medio del coro el colegial Calendario, haze genuflexión al altar y las manos puestas se buelve profunde inclinado al que haze el ofiçio, y si está el Sanctíssimo Sacramento descubierto, inclinado al altar 
dize cantado Iube Domine benediçere, y así esta hasta que le dan la bendiçión que se endereza y buelve y dize tu autem Domine, se hinca de rodillas y todo el coro se levanta $\mathrm{y}$ el que haze el oficio prosigue y las completas se dizen con las mismas ceremonias que si fueran rezadas como se dixo libro $1^{\circ}$, Capítulo 4 , de las horas menores.

2. En la Sacristía aviendo dexado los Ciriales, el celebrante se pone en la peana del caxón del testero y abaxo se ponen en dos coros los caperos, cerimoniario, comitantes y çeroferarios por su orden y en su coro cada uno.

[fol. 239 $\left.{ }^{\mathrm{r}}\right]$

[3]. El Pertiguero un paso abaxo del bufete de piedra en medio, el rostro al çelebrante, todos sin bonetes y las mangas de la sobrepelliz rodeadas a los brazos; el comitante más antiguo inclinado al celebrante dize Iube Domine benediçere, el celebrante Noctem quietam \& a la cual bendición esté profunde inclinado, luego dize la lección breve el çelebrante Adiutorium nostrum, y haze la confesión inclinado hasta que se dize el misereatur tui que se endereza y los demás se inclinan cuando hazen la confesión, y al tibi y Te Pater le buelven la cabeza y inclinados están hasta que el çelebrante acaba el indulgentiam etc, enderézanse, y el que dixo la lección dize la antíphona y luego todos se buelven y hazen profunda al cruçifixo que está en el testero y se despiden y bueltos proceden en dos coros por su orden: el Pertiguero delante y baxa voçe comienza el celebrante con el coro de la semana cum invocarem y a versos prosiguen las completas.

4. En el Pavimento el Pertiguero se pone en medio en su lugar y los demás se van quedando en sus coros hasta que todos hazen un medio çírculo como cuando entraron y hazen genuflexión y proceden al

[fol. 239 $]$

coro por la Iglesia con el mismo orden el Pertiguero, Cerimoniario, Capellanes y celebrante cubiertos se quitan los bonetes a la imagen de la Concepción al pasar por su altar.

5. Llegan y entran en el coro donde entre la varandilla y facistol hazen el medio círculo, el celebrante en medio, a su lado los más dignos y luego como se siguen y si no caven en medio çírculo los que entran delante se ponen en dos coros por los lados del façistol los rostros al altar y todos hazen genuflexión y levantándose profunda entran por el coro por el orden que se vienen, en pasando del façistol se quitan los bonetes y todo el coro de prebendados y capellanes se levantan descubre y hecha las mangas y en el plano del coro puestos como cuando entraron a vísperas hazen comedimiento al coro Capítulo 1, $\mathrm{n}^{\mathrm{o}}$ y el coro les responde y se sienta, mas si el çelebrante es el Abad no se sientan hasta que está en su silla, de la cual haze venia a todo el coro primero al de la semana. Hecha venia al coro, el çelebrante la haze a los caperos primero a los del coro de la semana y pasa primero a su silla y en pasando los caperos se

[fol. $240^{\mathrm{r}}$ ] 
hazen venia y se van a sus sillas y en llegando a ellas, hazen venia al presidente del coro y a los prebendados colaterales y acávanse las completas more solito.

\section{Capítulo 3. De los Maitines y Laudes.}

1. Cuando comienza la gorda acuden todos los que tienen oficios a la Sacristía, los Turiferarios llaman al Celebrante y Caperos, los çeroferarios ya an puesto y encendido en la Iglesia y altar todo el demás recaudo concerniente al ofiçio, los comitantes llevan al coro el pluvial y estola para el celebrante y lo ponen en la silla que está sobre el tapete aperçivida para sentarse revestido, los çetreros llevan los çetros y pluviales de los caperos al coro y ponen los çetros en el hueco de la ventana y los pluviales

[fol. $\left.240^{\mathrm{v}}\right]$

en los asientos de los Caperos y todo prevenido, el Pertiguero viste ropa y gorra del color conbeniente y todos los ministros con sobrepellices, el celebrante y caperos su abito Canonical al tiempo señalado salen.

2. El Pertiguero delante, luego los çetreros sin çetros, los ceroferarios sin çiriales, luego los comitantes, el cerimoniario caperos y detrás de todos el celebrante, en el Pavimento se ponen y hazen genuflexión como cuando salieron diciendo completas, Capítulo preçedente, número 3, van por la Iglesia cubiertos y en silencio entran en el coro y el Pertiguero se aparta a donde suele y los cetreros se ponen en dos coros y los ceroferarios y comitantes y caperos y çelebrante se ponen entre la varandilla y el facistol, en una línea derecha y todos juntos hazen genuflexión y entran en el coro por sus lados y en pasando del facistol grande, se descubren puestos en un medio çírculo, como cuando entran a completas capítulo precedente, $\mathrm{n}^{\mathrm{o}} 5$, hazen comedimiento al coro y entre sí $\mathrm{y}$ pasa pri-

[fol. $\left.241^{\mathrm{r}}\right]$

mero el celebrante y si es el Abad se quedan todos en pie hasta que está en su silla, si es Canónigo en respondiendo a la cortesía, los Prebendados se sientan y el celebrante y caperos se van a sus sillas y en dexando el esquilón, el cerimoniario haze profunda al celebrante en señal que comience y todos se levantan y dizen en secreto Pater Noster, Ave Maria y Credo, lo cual dicho el celebrante claravoz, haziendo una cruz en los lavios dize labia mea aperies, el coro responde Etos meum annuntiabit laudem tuam, luego el celebrante signándose con una cruz desde la frente al pecho dize Deus in audiutorium y cuando se dize Gloria Patri, todos se inclinan profunde y al sicut erat se enderezan y el cerimoniario combidaron profunda a los caperos más antiguos que vayan a dezir el Invitatorio.

Los caperos con sus hábitos canonicales baxan simul cada uno por su lado y en el medio del coro se juntan, de este tiempo los cetreros más antiguos van por los cetros y con ellos se llegan al facistol grande de cuando llegan los caperos donde hazen genuflexión 
[fol. $\left.241^{\mathrm{v}}\right]$

todos cuatro y les dan los cetros y en levantándose, comienzan el Invitatorio y el coro lo repite y los dos con el sochantre dizen los versos del Psalmo venite exultemus, y al Procidamus ante Deum todo el coro se hinca de rodillas y se levantan al Ploremus coram, y prosiguen y cuando últimamente se repite el Invitatorio por el coro, dan los cetros a los cetreros y todos cuatro hazen genuflexión, los cetros los llevan a sus lugares y los caperos suben y donde primero hazen venia al coro y le responde y se suben a las sillas y mientras dura el Invitatorio todo el coro está en pie y las mangas

4. Cuando se acava de repetir el Invitatorio los capellanes cantores hazen genuflexión y se llegan en el plano del coro en derecho de la silla del celebrante y le hazen profunda y le preintonan el himno y el celebrante lo repite y le hazen profunda y lo prosiguen a versos el un coro y el otro o todo el coro y el coro al último verso de los himnos donde se nombran las personas de la Santissima Trinidad siempre inclinan profunde las cabezas

[fol. $242^{\mathrm{r}}$ ]

como al Gloria Patri, al himno todos están en pie y los capellanes cantores al se llegan al celebrante y le preintonan la primera antíphona con las devidas reverencias cántala el coro y ellos con el sochantre entonan el primer psalmo y lo encomiendan al coro de la semana con venia y a la mediación del primer verso se sientan y cubren los prebendados y capellanes Dízense los psalmos y los versos de ellos alternativamente como en vísperas y al final los capellanes y cantores encomiendan las arias cap. $1^{\circ} \mathrm{n}^{\circ}$.

5. Al fin de la repetición de la aria del tercer psalmo, los capellanes cantores hazen genuflexión al altar en medio del coro y cantan el verso del nocturno y cuando comienzan todo el coro se levanta, responde el choro y el celebrante clara voz dice Pater Noster secreto lo demás hasta et ne nos inducas intentationes, responde el choro sed liberanos a malo, el celebrante clara voz dize la absolucion exaudi Domine, en el entre tanto del Pater Noster el ceremoniario profunda al Prebendado que a de decir la primera lección y lo combida, el prebendado le haze cortesía y si

[fol. $\left.242^{\mathrm{v}}\right]$

Es tiempo de capas suelta a la falda y baxa al plano del coro donde está el facistol pequeño con el breviario, haze genuflexión y a su lado el cerimoniario y buelve al coro a hazer venia al Presidente y a un coro y a otros y cuando se ha respondido Amen, a la absolución buelve y profunde inclinado y las manos puestas al celebrante dize entonado Iube Domine benedicere, el celebrante le da la bendición sin hazer con la mano la señal de la Cruz a la cual está inclinado para pedilla, da el bonete al cerimoniario cuando el coro responde Amen se buelve al libro el lucernario, alumbra con la palmatoria por la mano siniestra y _el cerimoniario se va a su lugar y cuando dize Tu autem Domine Miserere nobis hazen genuflexión y se lebanta haze las devidas reverenzias al coro y acompáñale el ceremoniario como a la venida a su silla. 
6. El responsorio lo puede dezir el órgano y si lo canta el coro los dos capellanes cantores dizen el verso.

7. Al fin del responsorio el cerimoniario combida al prebendado a dezir la

[fol. $243^{\mathrm{r}}$ ]

segunda lección, el cual baxa haze las devidas reverencias, pide y se le da la bendición, asistenle a ella, acavala y se va de la misma manera que se a dicho a la primera y el responsorio lo mismo y todo lo demás, si las lecciones del primer nocturno las dizen colegiales o capellanes, el cerimoniario no los combida mas los avisa con el monitor

8. Las lecciones de Segundo y tercero nocturno dizen prebendados los que señala el maestro de ceremonias y pone en la tabla como se dixo libro 2 cap $5 \mathrm{n}^{\mathrm{o}} \quad$ y en el primer nocturno siempre capellanes y colegiales de los más aptos para decirlas, comienzan desde el más moderno prebendado que dize la $4^{\mathrm{a}} \mathrm{y}$ así van por sus antiguedades desde la $4^{\text {a }}$ hasta la $8^{\text {a }}$, la nona siempre dize el celebrante.

9. A septima lección que es del evangelio todo el coro está en pie hasta que el que canta dize et reliqua que cuando comienza la homilia se sientan todos.

10. Los que cantan las lecciones no tienen las manos puestas sino en el libro como teniéndolo con ellas.

\section{El que dize leccio Sancti Evangelii no se}

[fol. $243^{\mathrm{v}}$ ]

signa ni el libro ni nadie del coro.

12. Las lecciones se cantan con claridad y distincion que se entiendan vien de todo el coro en tono devoto y acostumbrado lo que en los días particulares se deve hazer diferente de esto se notará en sus capítulos.

13. Al fin del tercero responsorio los capellanes cantores con las devidas reverenzias combidan al prebendado que se sigue en orden para la cuarta antíphona y como se hizo en el primer nocturno por el mismo orden en cuanto Antiphonas, Psalmos, Lecciones, Versos, Responsorios se haze en el segundo y el tercero.

14. En el octavo responsorio el cerimoniario combida al celebrante con profunada y luego a los dos caperos más antiguos los cuales baxan de sus sillas con las faldas tendidas y en medio del coro simul teniendo el celebrante en medio hazen genuflexión al altar y luego venia a los prebendados como a los demás y ellos les responden y si fuere el Abad se levantan, llegan los comitantes y los cetreros más antiguos quitanles las capas si las tienen, llevanlas a sus sillas. Vistenles pluviales de color combeniente y al celebrante estola. los cero 
[fol. $244^{\mathrm{r}}$ ]

ceroferarios que al principio del tercero nocturno se fueron a vestir roquetes_y collares y bolvieron y como se dijo libro 2 Capítulo 21, num. hazen a este tiempo venia al coro y llegan a los ciriales con genuflexión y toman los codales llega el lucernario a darles luz $\mathrm{y}$ hazen genuflexión y encienden y con los ciriales altos van al facistol del celebrante y en llegando hazen reverencia.

15. El $8^{\circ}$ responsorio se canta o toca el órgano con tal pausa y compás que de lugar a que se haga todo lo referido.

16. El celebrante vestido con pluvial buelve inclinado al más digno del coro y dize Iube Domine benedicere, el cual da la bendición y buelve el celebrante a dezir la nona lección asistente los comitantes, detrás el cerimoniario al lado diestro, el lucernario alumbrando al siniestro y los dos después de los caperos que inmediate le asisten a sus lados, los ceroferarios delante con los ciriales levantados hasta el Tu autem Domine que los baxan (y todo el coro bajo de capellanes y colegiales está en pie a toda ella) al cual el celebrante y todos los que le asisten excepto los ceroferarios se hincan de rodillas.

[fol. $244^{\mathrm{v}}$ ]

17. Levántanse y sin bolver a hazer venia al coro el capero del de la semana le entona el Te Dem laudamus prosiguiendo a versos, están a todo el himno en pié y los caperos con los cetros en las manos y puestas las manos y el celebrante también, acabado de entonar el Te Deum el ceremoniario haze reverencia a los otros caperos y baxan y sus cetreros les quitan las capas y ponen en sus sillas y les visten los pluviales, danles los cetros y toman los bonetes.

18. Al principio del Te Deum laudamus salen los Turiferarios del coro y van a la capilla de los mártires por de fuera de la Iglesia y aguardan a tiempo que cuando llegue al pavimento alto y ayan hecho genuflexión se comienze el verso Te ergo quaesumus que se hinquen de rodillas y se estén a todo el y luego se levantan y hazen genuflexión y despavilan como se dixo libro2 capit. 22 num $^{\circ} 61$.

19. En el coro al Te ergo quaesumus todos se hincan de rodillas, acavado el Te Deum laudamus los ceroferarios llevan los ciriales baxos a sus lugares y los apagan y se buelven a sus asientos.

[fol. $\left.245^{\mathrm{r}}\right]$

20. El celebrante inmediatamente haziendose cruz de la frente al pecho, alzándole el pluvial el cerimoniario dice Deus in auditorium y prosigue el coro y el estar en pie. Sentarse y entonar las antíphonas, los Psalmos, Capítula, himno, incensar al Benedictus y todas las demás ceremonias de laudes se hazen como se dixo cap ${ }^{\circ} 1$ de las Vísperas porque en todo esto son semejantes. 
21. Cuando se levantan de la genuflexión al Te ergo quaesumus, los comitantes quitan el facistol alto donde se dixeron las lecciones que lo pusieron los Versicularios sin paño en el medio del coro y lo llevan al hueco de la ventana y traen el facistol pequeño con paño y en él ponen el brevario delante del celebrante como a Vísperas.

[fol. $\left.245^{\mathrm{v}}\right]$

\section{Capítulo 4. De la Missa cantada y de los oficios del Diácono y Subdiácono.}

1. De estos oficios no se hizo capítulo particular por que todo lo que se tiene de decir de ellos se dize en este Capítulo de la missa y fuera de ella no tiene cosa particular que ejercer.

2. Los días y tiempos que a la missa cantada solemne toca el organo se an dicho en el libro 2. cap. 12 del organista.

3. Para la missa mayor se pone una credencia o bufete cubierto con una toalla de lienzo limpia que cuelgue igualmente por los lados y frente, está al lado del Evangelio arrimada a la pilastra del lado del pavimento alto, en ella ponen los ceroferarios el Cáliz $\mathrm{y}$ hostiario, salvilla y vinageras, campanillas, misales, el mosqueador, fuentes y palmatoria y todo el demás recaudo necesario conforme al día y la fiesta y lo cubren todo con un cendal de seda del color conveniente, lo qual sacan al tiempo y por el

[fol. $246^{\mathrm{r}}$ ]

el orden que se dixo lib. 2 Capítulo 21 de ceroferarios, ponen en los púlpitos los atriles o sacan facistol en el mismo $\mathrm{cp}^{\circ} \mathrm{n}^{\mathrm{o}}$

Cuando comienza la gorda el celebrante y Diáconos se llegan al bufete de piedra donde están los ornamentos y se visten, ayudan los Ceroferarios, Turiferario moderno y custos sacristiae y visten las alvas y roquetes con gran curiosidad y igualdad especialmente los días que an de quedar in albis. El Diácono viste primero su Dalmática y collar y luego el Subdiácono y entre ambos ponen al celebrante la casulla si no es que a de vestir pluvial que dexa manipulo y casulla y los que ayudan a vestirse se lo ponen y vestidos están alrededor del bufete, el celebrante frontero del Crucifixo, el Diácono a su diestra, el Subdiácono a la siniestra aguardan con devoción y silencio y los ceroferarios y demas ministros a la puerta de la sacristía more solito.

5. En dexando el esquilón salen por este orden, el Pertiguero, el Turiferario antiguo, los ceroferarios, los ciriales levantados, el cerimoniario, el Subdiácono, el

[fol. $246^{\mathrm{v}}$ ]

Diácono el celebrante, y los Domingos que ay asperges, el Turiferario moderno con sobrepelliz y el acetre y hisopo en la diestra tendido el brazo en la siniestra el manual los de la missa cubiertos y las manos puestas y el Pertiguero y cerimoniario cubiertos.

6. En pasando de ls lamparas el Pertiguero se va al medio del pavimento a su lugar y se buelve el rostro al altar, el Turiferario pasa debaxo de las lamparas de la capilla del 
rosario a su lugar, el ceroferario antiguo pasa al lado de la Epístola frontero de la aldavilla de su cirial, dos pasos desviados de la grada, el moderno en el lado del Evangelio en el mismo lugar y distancia y se buelven al altar, el cerimoniario pasa por delante del y se va al medio del pavimento delante del Pertiguero, el Subdiácono pasa por delante del ceroferario y se pone a la siniestra del otro ceroferario, el celebrante pasa y por en medio de ellos el del acetre pasa por detrás del ceroferario y se va al

$\left[\right.$ fol. $\left.247^{\mathrm{r}}\right]$

lado de la Epístola y se pone a la diestra de su compañero turiferario, puestos así los ceroferarios y los de la missa se llegan a la grada /quitan los bonetes/ y hazen profunda y con ellos todos los demás ministros y los ceroferarios baxan los ciriales y asientan en la grada y se quedan en pie, hecha la profunda el celebrante y Diáconos se ponen de rodillas en la grada y /cerimoniario/ llega y toma de mano del Turiferario moderno el hisopo mojado en el agua vendita y haze venia y dáselo al diácono por su mano diestra, el Diácono lo vesa y da al celebrante.

7. Todas las vezes que el Diácono da alguna cosa al celebrante es con humillación de la cabeza y besando primero la cosa que da y luego la mano del celebrante y todas las vezes que recive algo de mano del celebrante haze la misma venia y primero besa la mano del celebrante y luego la cosa que recive. Si está el Sanctissimo Sacramento manifiesto haze la venia, mas no vesa al dar

\section{$\left[\right.$ fol. $\left.247^{\mathrm{v}}\right]$}

ni al recibir ni las cosas ni las cosas ni las manos * Recive el celebrante el hisopo y rocia tres vezes, primero hazia el medio del altar en la peana, luego al lado del Evangelio, luego al de la Epístola, luego se echa agua a sí, luego al Diácono y Subdiácono y cuando a ellos entona la antiphona Asperges o Viadiaquam, y entonada da el hisopo al diacono y se levantan y rezado prosiguen y el Psalmo y Gloria Patri y repiten la antíphona.

El Coro toma la antíphona y la canta y Psalmos hasta cuando repite la antíphona el cerimoniario da al Diácono el manual el qual pone avierto delante del celebrante y lo tiene con la mano siniestra y el Subdiácono alarga la diestra para tenerlo y en acavando en el coro dize el celebrante los versos y oración las manos puestas.

10.Cuando el cerimoniario buelve el hisopo al turiferario sale de la Sacristía un Capellán con sobrepelliz y estola del color y haze genuflexión detrás de él.

Al margen:*'Si el Celebrante es el Abad hace el aspersorio antes un capellán con sobrepelliz y estola, conforme a la Bulla del S.Gregorio 13 que está al principio del Misal Romano".

[fol. $248^{\mathrm{r}}$ ] 
Celebrante y al mismo tiempo el del acetre y se levantan y van al coro, el del acetre detrás, el brazo tendido, entran y hazen genuflexión detrás del facistol y dale el hisopo al Capellán y asienta el acetre en el suelo y se queda en pie frontero del Crusifixo.

11.El Capellán, descubierto, pasa por el coro del que entonzes preside en el y sin subir a las sillas altas, sino desde el plano del coro en derecho de las sillas de los prebendados echa agua a cada uno comenzando del mas antiguo y haziendo con la cabeza antes y después inclinación a cada uno y los Prebendados ynclinan la cabeza antes y después inclinación a cada uno y los Prebendados ynclinan la cabeza, y luego por el mismo coro echa a los capellanes y Colegiales sin hazer inclinación, mas ellos sí.

12. Pasa por detrás del facistol haze genuflexión, alzanle el acetre, moja el hisopo y va al otro coro y echa agua de la misma forma, llegal al facistol hazen genuflexión y van por la Iglesia y echa agua al pueblo y se va a la Sacristía donde dexa el acetre el Turiferario y se viste roquete y collar y previene el incensario cuando

[fol. $248^{\mathrm{v}}$ ]

pasa por detrás del facistol hace genuflexión, álzanle el acetre, moja el hisopo y va al otro coro y echa agua de la misma forma, llega al facistol, hazen genuflexión y van por la Iglesia y echa agua al pueblo y se va a la Sacristía donde dexa el acetre el Turiferario y se viste roquete y collar y previene el incensario.

13. Cuando el coro responde Amen sale de la capilla de los martyres y responde, aguarda el Sacristán con la casulla tendida en ambos brazos y el manípulo, llega por detrás del celebrante, da el manípulo al Subdiácono el qual lo besa y da el celebrante, y luego Diácono y Subdiácono quitan el pluvial y el Sacristán alza la casulla y juntamente se ayudan a vestir y dan el pluvial al Sacristán que lo tiende en ambos brazos y lleva a la Sacristía a su lugar, el Diácono bestida la casulla da el bonete al celebrante y todos tres se cubren y suben al pavimento y detrás al lado derecho del Diácono el cerimoniario y al siniestro el Subdiácono también un

[fol. $249^{\mathrm{r}}$ ]

un paso atrás el flavelario si lo ay.

14. Cuando no es Domingo no ay asperges y así en llegando a la grada y poniéndose por el orden que se dixo supra $\mathrm{n}^{\mathrm{o}}$ hazen profunda y suben cubiertos.

15. Llegan a la peana del altar y en ella se ponen los bonetes, el del celebrante toma el Diácono y todos tres hazen genuflexión y el cerimoniario en su lado y el flaveario en el suyo levantanse y el cerimoniario toma los bonetes de el celebrante y diacono y los pone en el escaño en sus asientos y el flavelario toma el del Subdaiacono y no lo lleva al escaño hasta que an entrado en el altar, mas si no ay flavelario pone el cerimoniario los /dos/ bonetes en el escaño y pasa y haze genuflexión y toma el del Subdiácono y lo lleva al escaño a su asiento y se pone de rodillas junto al escaño cerca del lugar del Diácono. 
16. Cuando hazen genuflexión los de la missa se hincan de rodillas, los ceroferarios en sus lugares teniendo en las manos los ciriales, el Turiferario en su lugar

[fol. $249^{\mathrm{v}}$ ]

Con el incensario y naveta en la diestra levantado que no toque al suelo, el Pertiguero en su lugar, todos los del Coro alto, el Sochantre y Versicularios comienzan a cantar el yntroito de la missa inmediatamente que responden Amen a la oración del Asperges, porque los días que no lo ay lo comienzan cuando dexa el esquilón, mas los del choro alto no se hincan de rodillas hasta el tiempo dicho y se están assí mientras el celebrante y Diáconos dizen el Introito y hazen la confesión y entran en el altar.

17. Levantanse de la genuflexión el celebrante y Diáconos y Santinguandose desde la frente al pecho todos tres, el celebrante dize In nomine Patris, etc. Dize el Psalmo y respondenle los Diáconos todos profunde inclinan las cabezas al Gloria Patri, cuando dize el celebrante Adiutorum nostrum etc. Él solo se signa y se inclina cabeza y cuerpo cuando haze la confesión y al mea culpa se hiere tres vezes en el pecho, está inclinado hasta que los Diáconos acaban el

[fol. $\left.250^{\mathrm{r}}\right]$

el misereatur tui que se endereza, y ellos se ynclinan de la misma manera y haze la confesion y el tibi Pater y Te Pater buelven al celebrante la cabeza inclinada y se hieren tres vezes al mea culpa y se quedan inclinados, el celebrante dice Misereatur vestri et Indulgentiam et remissionem etc. Signándose de la frente al pecho y cuando dize Deus tu conversus unificabis nos se inclina como están los Diáconos y assí dize y responden a los otros versos y cuando dize Oremus abre y eleva algo las manos y las buelve a juntar y todos tres se enderezan y entran en el altar, a este tiempo se levantan todos y los del coro alto, y el Turiferario y ceroferario antiguo suben y cuando el celebrante llega a vesar el altar los Diáconos a sus lados simul y el Turiferario y ceroferario en sus lugares hazen genuflexión, las genuflexiones que hazen los Diáconos junto al altar, a los lados del celebrante, son mirando al tabernáculo y así es algo buelto el rostro el uno al otro y afirman el Diácono la diestra y el Subdacono la siniestra.

[fol. $\left.250^{\mathrm{v}}\right]$

En el altar.

18. Levantanse de la genuflexión y el Diácono apartase algo del altar y el Turiferario llega a el por la parte de la Epístola y se pone en derecho del lugar del candelero de en medio y el Diácono toma la naveta avierta y alargala al celebrante besando el Cavo de la cuchara que sale deella y luego la mano y entonces el Turiferario alza la diestra con el Turibulo avierto y lo alarga hacia el celebrante y el Diácono dize Benedicite Pater reverende, toma el celebrante la cuchara y saca tres vezes incienso y lo echa en las brasas del Turíbulo, dexa la cuchara en la naveta y vesa el diacono mano y cuchara y teniendo el Turiferario el Turibulo alto y levantada la cubierta hecha con la diestra la vendicion el celebrante diciendo Ab illo benedicaris in cuius honore cremaberis, suelta el Turiferario la cubierta y toma la naveta del Diácono y dale el Turibulo, el Diácono, 
toma con la diestra la sumidad de las cadenas y con la siniestra por junto a la cubierta, besa las cadenas por la

[fol. $\left.251^{\mathrm{r}}\right]$

sumidad y dalas a la mano siniestra del celebrante y a la diestra vesando se la da el tirifero, el Turiferario se aparta a su lugar, el celebrante y Diáconos hazen genuflexión y turificación como se dixo cap.1 de Visperas números 24 y 25 y mientras dura la turificación el cerimoniario está arrimado al asexa de las reliquias y el flavelario al otro lado entre el retable y lacredenzia.

19. Cuando a echado el incienso el ceroferario antiguo llega a hazer genuflexión en frente del atril cuando el celebrante y Diáconos la hazen en medio el altar, levantase y toma el atril y misal y se aparta entre el cerimoniario y Turiferario y lo tiene con dos manos y cuando el celebrante pasa a incensar el lado del Evangelio llega a tiempo que haze genuflexión con el y lo pone y se va a su lugar como se dixo lib.2 cap. 21 de turiferarios núm ${ }^{\circ}$.

20. Acavada la incensación del altar en el cornu Epistolae, el celebrante da al Diácono el Turibulo y pone las manos buelto eregione al Diácono el qual lo inciensa con tres ductos.

\section{[fol. $251^{\mathrm{v}}$ ]}

haziendole antes y después de darlos venia, buelve el diacono el turibulo al turiferario el qual lo toma en la diestra y con la naveta levantada la tapa more solito haze genuflexión y baxa por medio de los ceroferarios y se va a la sacristía y enla Turificación los Ceroferarios están en pie y el Pertiguero descubierto.

21. Buélvese el celebrante al misal, el Diácono detrás en la peana a su lado diestro el Subdiácono detrás del Diácono fuera de la peana a su lado diestro que hagan un principio de circulo, el cerimoniario fuera de la peana al cornu Epistolae aplica la palmatoria y alumbra el Introito, el celebrante y Diáconos se signan de la frente al pecho y el celebrante lo dize voz intelligibili, y al Gloria Patri todos ynclinan profunde la cabeza a la Cruz del medio del altar, repetido el introito se buelve el celebrante algo hazia el Diácono y Subdiácono que todos se vean los rostros y dizen los Kyries alternatim y acabados se van al medio del altar, el Diácono a la diestra y el Subdiácono pasa a la siniestra y a un tiempo el celebrante haze profunda y ellos genuflexión y si en el coro no están

[fol. $252^{\mathrm{r}}$ ]

en el penúltimo Kyrie se van a sentar y llevan las manos puestas. Siempre van y vienen con gravedad, no pasos apresurados y el Pertiguero está la gorra quitada y les haze venia a yda y buelta, llegan al escaño y el Diácono da el bonete al celebrante con demostración de ósculo, el subdiácono le alza la casulla de suerte que ni se asiente sobre ella ni la doble, el ceroferario alza la a Dalmática al subdiácono y el flavelario al Diácono y si no lo ay, él mismo se la aparta para no sentarse sobre ella. 
22. Cuando se apartan del altar ya a dexado el cerimoniario la palmatoria y se llega al missal y registra la Gloria si la ay y lo llega algo a la Ara y se va al otro lado frontero del Diácono y los ceroferarios se ponen de rodillas.

23. Cuando el Órgano o choro dize el último Kyrie sale dos o tres pasos de su lugar y haze comedimiento al celebrante que con los diáconos se descubren y se levantan, dexan los bonetes en el escaño y van las manos puestas el celebrante en medio y a la diestra el Diácono y el subdiácono a la siniestra, el cual alarga más el paso sin perder su lado porque es

$\left[\right.$ fol. $\left.252^{\mathrm{v}}\right]$

mayor la distancia que anda, llegan al altar y el celebrante lo vesa y al mismo tiempo los Diáconos a sus lados hazen genuflexión y el cerimoniario pasa al lado de la Epístola y toma la palmatoria, los Diáconos se baxan detrás del celebrante uno detrás de otro y el celebrante entona la Gloria cuando dize In excelsis, suben los Diáconos a sus lados, hazen genuflexión y las manos puestas simul dizen la Gloria, inclinan las cabezas al Adoramuste Gratias Agimus tibi, suscipe deprecationem nostram y al nombre de JHS cuando comienza a entonar la Gloria los ceroferarios se levantan y ponen las manos y el Pertiguero sin gorra todos inclinan la cabeza a las palabras dichas.

24. Cuando acavan de decir la Gloria el celebrante haze profunda y los Diáconos genuflexión y se van a sentar como la primera vez y los ceroferarios se hincan de rodillas. Sentados se cubren y cuando el coro canta las palabras dichas el celebrante se ynclina profunde, y los Diáconos se quitan los bonetes, el Pertiguero la gorra y todos los demas ministros inclinan las cabezas profunde.

[fol. $253^{\mathrm{r}}$ ]

25. En el coro cuando entona la Gloria el celebrante todos los prebendados se levantan y sin bonetes las manos puestas la dizen rezada, cuando ay música, inclinan las cabezas a las mismas palabras y acavada de rezar la Gloria se sientan y cubren, cuando no la ay la cantan con el coro y se sientan cuando se sientan los de la missa y cuando se cantan las dichas palabras se quitan los bonetes y profunde se inclinan.

26. Al último verso de la Gloria el cerimoniario sale como al fiun de los Kyries y hazen venia y los combida a levantar. Levantanse y van al altar como la primera vez, cum debitis reverentiis y los Diáconos se ponen uno en pos de otro, y el cerimoniario buelve al lado de la Epístola y el celebrante se buelve al pueblo y canta Dominus Vobiscum = si no ay Gloria hazen esto inmediatamente que van al fin de los Kyries = Va el celebrante al libro y en pos de los Diáconos y canta las oraciones a las quales están uno en pos de otro y el cerimoniario alumbra y buelve los registros y todos inclinan las cabezas a los nombres de JHS y de Maria y del Sancto de quien se dize la oración y del Pontifice que vive y todos están en pie.

[fol. $\left.253^{\mathrm{v}}\right]$ 
27. Cuando en las oraciones ay flectamus genua, el Diácono lo dize diciendolo primero que todos, se hinca de rodillas y luego todos los demás excepto el celebrante y el Subdiácono responde Levate y primero que todos se levanta y luego todos los demás.

28. Al principio de la última oración sube el ceroferario y haze genuflexión en su lado, va a la credencia toma el misal y en medio haze genuflexión y se lo da al Subdiácono por su mano diestra y el Subdiácono lo toma y pone el lomo del misal sobre el brazo siniestro y las hojas arriva y arrimado al pecho, y de este modo se lleva siempre el misal, a quocumque deferatur, va a la peana y en el medido de ella al altar haze genuflexión y el ceroferario la haze donde está y el Pertiguero se quita la gorra y llega a la grada enmedio de los ceroferarios, baxa el Subdiácono y acompañale delante el ceroferario y el Pertiguero que llegando al púlpito de la Epístola se buelve de rostro y haze reverencia al Subdiácono el qual da el misal al ceroferario que está eregione del Pertiguero se puso al principio de las gradas, las espaldas bueltas a la rexa de la capilla del

[fol. $\left.254^{\mathrm{r}}\right]$

del rosario y le haze venia al sudiacono.

29. Cuando la Epístola se canta en Atril en el pavimento, en llegando el ceroferario se pone a la diestra del Subdiácono, el qual no da el libro al ceroferario sino inmediatamente lo pone en el atril, el Subdiácono sube y tras el el ceroferario y en estando en la última grada da el misal y el Subdiácono le pone en el atril y canta la Epístola y hazen genuflexión en ella al tiempo y en las que manda el missal al nombre de JHS, el Subdiácono inclina la cabeza algo acia el altar y el ceroferario volviéndola al altar y lo mismo el Pertiguero.

30. Acavadas 1s Oraciones el celebrante prosigue y dize la Epístola y Gradual, Versos y Alleluyas, tractos o secuencias conforme pide la missa y en acavandola de leer se sientan el preste y diacono y asimismo cuando se dizen Prophecias y tractos de ellas mientras el celebrante lee todo lo referido el Diácono está a su diestra en la peana, el cerimoniario alumbra, el ceroferario que quedó en su lugar se hinca de rodillas, en el coro todos se sientan, cuando el celebrante dize rezado In nomine Iesu omne genua. Si la Epístola es de la Cruz u otra en que se aya de hazer genuflexión la haze

[fol. 254 $]$

y el Diácono y cerimoniario y aunque están sentados cuando el Subdiácono canta las palabras dichas la buelve a hazer en su mismo lugar del asiento y todos los del coro y si la missa es del Spiritu Sancto o de feria de cuaresma se hinca de rodillas el celebrante Diácono y cerimoniario al verso Veni creador spiritus y al verso del tracto Adiuvanos etc. En medio del altar.

31. Poco antes que se acave la Epístola sale el Turiferario antiguo, turibulo y naveta en la diestra levantada more solito y haze genuflexión en el pavimento en medido de los 
ceroferarios y se va a su lugar debaxo de las lamparas de la capilla del rosario y aguarda meneando el incensario more consueto.

32. Acavada la Epístola cierra el Subdiácono el libro y lo arrima al pecho y baxa y delante el Ceroferario y el Pertiguero que se queda junto a la grada y buelve a hazer reberencia, cuando sube el Subdiácono y ceroferario y hazen genuflexión donde la hicieron y el Subdiácono va al Cornu Epistolae y tiene el libro por lo baxo del con ambas manos y lo alto pone hazia el celebrante el qual po

[fol. $\left.255^{\mathrm{r}}\right]$

pone la mano encima y el subdiácono las vesa, si es prebendado se inclina el cuerpo, si es capellán de rodillas y el celebrante lo bendize da el libro al ceroferario y este lo da al Diácono y se va a su cirial, el subdiácono pasa el atril y missal al cornu Evangely y en medio haze genuflexión, y tras el va el cerimoniario con la palmatoria y asimismo haze genuflexión, el celebrante va al medio del altar y dize / */ el evangelio rezado puestas las manos y el subdiácono se está a su mano siniestra y responde y cuando el celebrante pide la bendición los ceroferarios sacan los ciriales de las aldavillas y los tienen en las manos baxos mientras dize el Evangelio hasta que van con el Diácono, acavado el Evangelio el subdiácono responde Laus tibi, mas el celebrante no vesa el missal.

33. En la missa del Spiritu Santo no dize el preste el evangelio hasta que en el coro se a dicho Veni Sancto Spiritus porque a el an de estar todos de rodillas, el coro canta inmediatamente después de la Epístola el gradual y si es día de órgano lo toca con son grave y moroso, luego el coro las Alleluyas, Versos, tractos o sequentias.

$=$ al margen $=/ * /$ el munda cor deum y Iube Domine benedicere $\mathrm{y}$ dize $=$

[fol. $255^{\mathrm{v}}$ ]

34. El verso Veni Creador Spiritus siempre lo canta el coro y el celebrante y Diáconos uno en pos de otro en medio de el altar se hincan de rodillas los ceroferarios, cerimoniario y flavelario y Pertiguero en sus lugares y todos los del coro en los suyos, lo mismo se haze al tracto de cuaresma en el verso adiuvanos en las ferias de cuaresma.

35. En levantándose o si no ay genuflexión en acavando el Evangelio rezado el celebrante se pone en el medio buelto al altar y el Subdiácono se va detrás del a su lugar, el Diácono que mientras lo decia el celebrante estava en el lado de la Epístola pasando el libro avierto sobre el altar sobre el Ara, las hojas hacia el tabernáculo y a este tiempo sube el turiferario y haze genuflexión y se baxa a las gradas y buelto al altar se pone en medio de los ceroferarios, el Diácono se hinca de rodillas en el medio del altar detrás del celebrante y dize Mun

[fol. $256^{\mathrm{r}}$ ]

Munda Cor meum, etc., levántase, toma el libro e ynclinándose si fuere Prebendado y si no de rodillas pide la bendición diciendo Iube Domine benedicere y el celebrante dize 
Dominus sit in corde tuo, y cuando dize In nomine Patri etc. le da la vendición y pone la mano en la extremidad del libro y el Diácono la vesa.

36. En a quel mismo lugar haze genuflexión y al mismo tiempo el Subdiácono donde está y los ceroferarios y Turiferarios en los suyos y el Pertiguero se llega y en levantandose van a decir el Evangelio, el Pertiguero delante, el Turiferario, los ceroferarios los ciriales altos mas si es missa de réquiem no los llevan sino las manos puestas y últimamente el Diácono con el libro arrimado al pecho.

37. El Pertiguero baxa la grada del pavimento /baxo/ y se pone sin gorra eregione del Atril del púlpito algo apartado para dar lugar a los ceroferarios y turiferarios el qual en llegando a las gradas del púlpito se aparta las espaldas a la capilla de los martyres, los ceroferarios

Al margen=y el Subdiácono las manos puestas=

[fol. 256 $\left.{ }^{\mathrm{V}}\right]$

ambos van por el lado de la lampara que cae al púlpito del Evangelio que a esta yda y venida no la cogen en medio y baxan la grada y se ponen junto al púlpito eregione los ciariales baxos que cojan en medio el atril,el Subdiácono cuando llegua a las gradas se para y pone eregione del Turiferario, las espaldas al púlpito de la Epístola y el Diácono llega y dale el libro pasa y ambos le hazen venia sube al púlpito y tras él el Subdiácono y trs este el Turiferario, cuando el Subdiácono llega a la última grada da el libro al Diácono y lo pone y abre y los ceroferarios baxan los ciariales $=$ el Subdiácono se queda en aquel lugar puestas las manos, no totalmente al libro sino algo al altar y el Turiferario está en las gradas más abaxo.

38. El Diácono puestas las manos canta Dominus Vobiscum y el celebrante se buelve de rostro al púlpito del Evangelio puestas las manos y se retira al Cornu Epistolae y el cerimoniario junto al escaño el rostro al Diácono y el flavelario dexa el flavelo y puestas las manos se buelve también algo el rostro al

\section{[fol. $257^{\mathrm{r}}$ ]}

al Diácono que por estar en el lado del Evangelio puede bolver totalmente porque no diera las espaldas al altar, en el coro todos se levantan, echan las mangas y ponen las manos = El Diácono en respondiendo Et cum spiritu tuo prosigue Sequentia o Initium, Sancti Evangelii y comenzando simul los dedos juntos dextero pollice signa el principio del Evangelio y luego así con tres cruzes frente, boca y pecho y de esta suerte se signan siempre al Evangelio y juntamente se signa el Diácono y todos los del altar y coro excepto el Turiferario y ceroferarios los quales al mismo tiempo levantan los ciriales a compas de suerte que cojan en medio el libro.

39. Acavada de signar toma el Subdiácono el Turibulo y dalo al Diácono el qual en la siniestra la extremidad de las cadenas y la diestra junto a la cubierta con tres ductos inciensa el libro, uno en medio y dos a los lados comenzando del lado derecho del misal algo altos que alcanzen también a las velas de los ciriales, esta yncensación se a de 
hacer mientras el coro responde Gloria tibi Domine, buelve el Turibulo al Subdiácono y este

[fol. $257^{\mathrm{v}}$ ]

al Turiferario que lo pone en la diestra y la naveta baxa y haze genuflexión al altar y vase debaxo del púlpito y se pone entre los ceroferarios y Pertiguero, el rostro al altar del Sagrario y se queda mientras el Evangelio meneando el incensario.

40. En el discurso del Evangelio si se nombra a JHS, el Diácono al libro, todos los demás hazia el altar ynclinan profunde la cabeza, si se nombra a Nra. Señora el Diácono al libro y todos los demás ynclinan la cabeza y algo menos al Sancto que se nombrare, si se a hazer genuflexión, el Diácono al libro todos los demás al altar, excepto los ceroferarios que a ninguna cosa se mueben ni hazen venia.

41. Acabado el Evangelio con ambas manos toma el Diácono el libro y lo da al Subdiácono, el qual avierto lo lleva con ambas manos arrimado al pecho y baxan y a este tiempo el Pertiguero, Turiferario y ceroferarios suben por su orden como vinieron buelven reciviendo después de todos al Subdiácono y al Diácono, en llegando a las gradas el Pertiguero se aparta hazia la

[fol. $258^{\mathrm{r}}$ ]

capilla del rosario, el Turiferario se queda junto a la grada y a su mano derecha llega el ceroferario antiguo y se pone en su lugar y el otro en el suio y a su diestra el subdiácono y en medio del y del Turiferario el Diácono hazen todos tres venia y suben juntos, el Diácono haze genuflexión llega al celebrante que aguarda en la misma postura y lugar que oyó el Evangelio cantado y le aproxima el libro avierto y al mismo tiempo el diácono le señala con el yndice el principio del Evangelio que signó sin dezir cosa alguna, el celebrante lo vesa diciendo Per Evangelica dicta deleantur nostra delicta, y en vesandolo cierra el subdiácono el libro y haze genuflexión y sale de la peana y lo da a flavelario y se va a su lugar, si no ubiere flavelario lo da al cerimoniario que para este efecto pasa al otro lado por detrás del Diácono y haze juntamente con el genuflexión y lo pone en la credenzia y mientras esto se haze en acabando de vesar el libro el Diácono toma el Turíbuloy con las de

[fol. $\left.258^{\mathrm{v}}\right]$

devidas venias inciensa al celebrante con tres ductos, y a todo esto los ceroferarios están con los ciriales levantados, buelve el Turibulo el Turiferario haze genuflexión y se va y los ceroferarios baxan los ciriales y el Pertiguero se va a su lugar.

42. El celebrante recive la yncensación las manos puestas y en acavando así se va al medio del altar, y el Diácono detrás del y el subdiácono detrás del Diácono, el cerimoniario buelve el registro del Credo que el Turiferario se baxa sale de la Capilla de los mártires su compañero y llega a la grada al mismo tiempo y ambos hazen genuflexión y se apartan a sus lugares y en ellos hazen venia al altar y uno a otro y se quedan meneando los Turíbulos more solito. 
43. El Celebrante entona el Credo y cuando dize In unum Deum suben el Diácono a la diestra y el subdiácono a la siniestra y simul hazen genuflexión modo solito y se levantan y las manos puestas todos tres prosiguen el Credo y cuando acaban de dezir descendit de Coelis todos tres se hincan de rodillas y los Diáconos tienden la

[fol. $\left.259^{\mathrm{r}}\right]$

casulla que cubre los pies del celebrante y el flavelario y Cerimoniario también se hincan de rodillas, toma el choro el Credo y Cantanlo los prebendados descubiertos en pie y las manos puestas lo dizen rezado. Si ay mussica hincanse de rodillas al Incarnatus est y dicho rezado se sientan y si no ay música ayudan a cantarlo al coro y hazen genuflexión al Incarnatus est y en acabando de rezar el Credo en el altar se sientan y cubren en el coro baxo. Cantan el Credo y se hincan de rodillas al Incarnatus est, dicho Homo factus est se levantan y prosiguen el Credo y baxan la cabeza al simul adoratur, acabado el Credo el celebrante haze profunda y los Diáconos genuflexión y las manos puestas se van a sentar modo solito y los ceroferarios se ponen de rodillas.

44. Cuando el coro canta Et Incarnatus est los prebendados se descubren y inclinan el cuerpo profunde hazia el altar, los del coro baxo se hincan de rodillas, el celebrante puesto el bonete inclina profunde la cabeza, los diáconos se quitan los bonetes y la inclinan algo más, el cerimoniario y fla

[fol. $\left.259^{\mathrm{v}}\right]$

velario se hincan de rodillas en sus lugares y el Pertiguero en el suyo, los Turiferarios paran los yncensiarios y los toman en la diestra con las navetas levantadas. Van a la grada y en medio de los ceroferarios se hincan de rodillas todo esto se haze en tiempo que cuando comienzan Et incarnatus est, esté hecho y de esta manera persisten hasta que se acava Et homo factus est que se enderezan y levantan, los Turiferarios se van a sus lugares y en llegando hazen venia y dan a los turíbulos como antes, el Diácono se levanta dexa el bonete pone las manos y haze venia al celebrante, va y delante el flavelario y si no lo ay al mismo tiempo sube el ceroferario moderno y le coge delante delante en lugar y tiempo que simul con él haga la genuflexión al altar, llegan a la credencia y el ceroferario o flavelario alza el cendal con que está cubierta y el Diácono toma la bolsa de corporales buelve a cubrirla la Credencia como estava el que la descubrió o el Diácono con ambas manos lleva la bolsa levantada hasta los ojos y le acom

[fol. $260^{\mathrm{r}}$ ]

acompaña el que vino, llega a la peana y haze genuflexión y un paso mas abaxo a su diestra el ceroferario y se buelve a su lugar, el Diácono llega al altar y saca los corporales y la bolsa pone arrimada al tabernáculo del Sanctissimo Sachramento al lado del Evangelio y desdobla los corporales y haze genuflexión en la misma peana y se va a su asiento, las manos puestas y cuando llega haze venia al celebrante y se sienta $=$ y al carnis resurrectionem el cerimoniario los combida y se levantan y val al altar como se 
dixo supra $\mathrm{n}^{\mathrm{o}} \quad \mathrm{y}$ el celebrante lo besa y los Diáconos hazen genuflexión y se ponen detrás para el Dominus Vobiscum.

45. Si ay sermón se predica antes de entonar el Credo y así incensando el celebrante se buelve al altar y los Diáconos se ponen uno en pos de otro hasta que sale el Predicador y el Turiferario se va a la Sacristía y se haze lo que se dize en el Capítulo siguiente de Sermone y acavado el sermón se entona el Credo y haze lo que está referido en los números precedentes o si no ay Credo se dize Dominus

[fol. $260^{\mathrm{v}}$ ]

\section{Vobiscum infra.}

46. Si no ay Credo en siendo incensado el celebrante se buelve al altar y lo besa y el cerimoniario registra el ofertorio y los Diáconos se ponen detrás more solito, buelven al pueblo y dize Dominus Vobiscum y buelve y dize Oremus y dicho a un mismo tiempo el Diácono sube a la diestra del celebrante y haze genuflexión y el Subdiácono en su lugar juntamente con el Ceroferario /antiguo/ que sube a acompañarlo a la credencia que si está en lo baxo se haze como se dixo lib.2 Cap.21 de ceroferarios $\mathrm{n}^{\mathrm{o}}$ en llegando a ella el ceroferario le pone el cendal, o el flavelario si lo ay sobre ambos hombros que pende la mayor parte al derecho, el Subdiácono toma con la siniestra el Cáliz, patena y hostia y la cubre con la parte de cendal que pende del diestro lado y la diestra pone encima, el Ceroferario toma la salvilla de las ampolletas y la toalla y si ay comunión la salvilla y vaso con las formas y si ay flavelario va delante y lleva la fuente y aguamanil si es día de

[fol. $261^{\mathrm{r}}$ ]

Plata y si no ay flavelario va delante y lleva la fuente y aguamanil, dexa el ceroferario las ampolletas y lo que lleva en el Cornu Epistolae y buelve por la fuente y aguamanil que pone en el escaño hasta su tiempo, detrás del flavelario va el Subdiácono con el Cáliz cubierto y alto hasta los ojos y detrás el ceroferario con las cosas dichas en el medio del pavimento simul hazen genuflexión y al Cornu Epistolae el flavelario se aparta algo y llega el Subdiácono por la diestra del Diácono, el qual le toma el Cáliz y lo pone en el altar y en el mismo Cornu Epistolae el ceroferario pone las ampolletas y lo demás, el Diácono descubre el Cáliz y el flavelario y si no lo huviere el ceroferario quita al Subdiácono el cendal de los hombros y lo pone sobre el escaño.

47. El Diácono quita el paño al Cáliz y el ceroferario lo dobla y dexa en el mismo plano del altar (o el flavelario si lo ay, y si el paño es rico lo dobla menos que no se maltrate y lleva a la Credencia.

48. El Diácono pone la hostia en la Patena, pone el Vaso de las formas sobre el Corporal

[fol. $261^{\mathrm{v}}$ ]

Y las descubre da la patena cn hostia al celebrante besando patena y mano, en el interin el Subdiácono limpia con el purificador el Cáliz. 
49. El celebrante toma la patena y con ambas manos la levanta hasta en derecho de la boca y dice Suscipe Ste. Pater etc. En el ínterin el Subdiácono da la ampolleta del vino al diacono el qual echa en el Cáliz acabado el ofertorio de la hostia el celebrante haze con la patena la Cruz, sobre el corporal dexa en el la hostia y la patena pone fuera del al lado del Diácono y aparta a una esquina del corporal el vaso de las formas y lo cubre si lo ay, hecho esto el Subdiácono muestra al celebrante la ampolleta del agua descubierta y dize Benedicite Pater Reverende y el celebranbte junta las manos y dize Deus qui humanae substamtiae y echa la bendicion y luego el Subdiácono hecha algunas gotas de agua en el Cáliz, el Diácono lo limpia con el purificador y lo levanta y con la mano diestra lo toma por el pie que dexe desocupado todo el nudo y balaustre del Cáliz y se lo da

\section{[fol. $262^{r}$ ]}

al celebrabnte besándolo y luego la mano, el celebrante con la diestra lo toma por el nudo y con la siniestra por el pie y lo levanta en derecho de los ojos y dize offerimus tibi Domine... y el Diácono toca conla diestra al pie del Cáliz y sumissa voz dice la misma oración, haze el celebrante la Cruz con el Cáliz y lo asienta mas allá de la hostia y el diacono lo cubre con la hijuela y mientras dize la Oración in spiritu humiliatis.. el Diácono limpia la patena y la pone en la diestra del Subdiácono que la coje en el cendal que le a puesto el flavelario o ceroferario mietras se haze el ofertorio del Cáliz y con la parte que sobra del mismo cendal la cubre.

50. El Subdiácono con la siniestra tiene el un cavo del cendal y con la diestra la patena cubierta y levantada en derecho de lo sojos, del Cornu Epistolae va a su lugar y a este tiempo los dos Turiferarios se juntan en medio de los Ceroferarios y hazen profunda al altar y suben y con ellos el ceroferario moderno y cogen en medio al Subdiácono que llega a su lugar y todos quatro hazen

[fol. $262^{\mathrm{v}}$ ]

genuflexión simul el Subdiácono en medio, a la diestra el Turiferario antiguo, a la siniestra el moderno y a la siniestra de este el Ceroferario y en el mismo lugar se quedan y el antiguo sube al lado de la Epístola y modo solito ministra la naveta y turibulo y hechado incienso toma la naveta y se buelve a la diestra del Subdiácono y el Ceroferario antiguo que estava arrivase pone a la diestra del Turiferario de suerte que los cuatro con elSubdiacono en medio hagan un medio circulo.

51. El Diácono ministra la Cuchara y el celebrante echa incienso como se dixo supra $\mathrm{n}^{\mathrm{o}}$ , mas al bendecir dize laoración per Intercessionem Beati Michaelis Stantis adixtris altaris..., el celebrante toma el turibulo more solito y turifica la oblata haziendo con el tres Cruzes sobre hostia y Cáliz, el qual asegura con la diestra el Diácono teniendolo por el pie después de las tres Cruzes haze tres Circulos también que coxan hostia y Cáliz, los dos de la mano derecha a la siniestra y el tercero al contrario, a la primera Cruz

[fol. $263^{\mathrm{r}}$ ] 
que haze dize incensum istud, a la segunda A te Benedictus, a la tercera Ascendat ad te Domine, al primer Circulo et descendat super nos, al segundo y tercero misericordia tua.

52. Acavada la turificación de la oblata el Diácono aparta el Cáliz de sobre el Ara y lo pone en la tabla de el altar y el celebrante y el hazen genuflexión y el celebrante prosigue la turificación de la cruz y del altar de la misma manera y con los mismos ductos y genuflexiones que se dixo Supra lib.2. cap.22 y en Capítulo $1^{\circ}$ de Visperas $n^{\circ}$ 24 y 25 excepto que en esta turificación dize aquellos versos Dirigitur Domine oratio mea sicut incensum... los quales va dispensando en tal proporción que a cada ducto que da diga algunas palabras y se acava en el postrer Ducto al Cornu Epistolae.

53. Yncensada la oblata sube el Ceroferario moderno y haze genuflexión simul con el celebrante a su mano siniestra y en levantandose toma el Atril y misal y se retira con el a su lugar y cuando el celebrante acaba de incensar la frente del altar del lado del Evangelio llega y haze genuflexión con el celebrante y pone

[fol. $263^{\mathrm{v}}$ ]

El Atril en su lugar y por detrás del Subdiácono haze genuflxión y pasa al Cornu Epistolae.

54. El Diácono acompaña en esta turificación al celebrante yendo siempre detrás del y así cuando pasa al Cornu Evangeliys se aparta a la esquina de la peana y dexa pasar al celebrante y luego lo sigue, mas cuando llega a dar el último ducto al Cornu Epistolae se adelanta dos pasos y se pone fuera de la peana frontero del celebrante y recive el turibulo vesandole la mano y el turibulo y el celebrante al darlo dize Accendat...

55. El Diácono inciensa con tres ductos al celebrante con las devidas Venias y luego va el Subdiácono y lo inciensa con dos ductos y antes y después se hazen cortesía, da el Turibulo y pone las manos y el Turiferario lo inciensa con dos ductos haziendole antes y después reverenzia y luego se pone en su lugar delante del Subdiácono y los Turiferarios toman los incensarios y navetas en las diestras more solito hazen genuflexión y a este tiempo se llega el Pertiguero a la grada baxan y acompañados del van al coro y lo inciensan como se dixo lib.2 Capítulo de Turiferarios $\mathrm{n}^{\circ} 16$.

[fol. $264^{\mathrm{r}}$ ]

56. En apartándose el Diácono a incensar al Subdiácono, llegan los ceroferarios, el antiguo con la salvilla y ampolleta de el agua o fuente y aguamanil como fuere el día y el moderno con la toalla. Vease lib.2 Capítulo de Cerofer, $\mathrm{n}^{\mathrm{o}}$ y echan aguamanos al celebrante que se laba y limpia diciendo el psalmo lababo inter inocentes, recive la toalla en lasalvilla el ceroferario antiguo, todo lo hazen con las devidas reverencias, el moderno la toma con ella y las ampolletas o fuente y aguamanil se van a la Credenzia por detrás del Subdiácono y haziendo genuflexión y lo dexan en ella y se van a sus lugares. Cap. Supra citato. 
57. El celebrante al Gloria Patri del Psalmo ynclina la cabeza a la Cruz, dexa la toalla y las manos puestas va al medio del altar y las pone como manda el ordinario y dize Aliquantulum inclinado la oración Suscipe Santa Trinitas... besa el altar y da la buelta y dize Orate frates y el cerimoniario registra las oraciones secretas y las dize y al fin entona el prefacio, en el coro se levantan y los Diáconos están a todo el uno pos de otro. Cuando dice Suplice confesione dicentes ó palabras semejantes conforme fuere el prefacio suben el Diácono a la diestra y el Subdiácono a la siniestra y hazen genuflexión y simul con el

[fol. 264 $\left.{ }^{\mathrm{v}}\right]$

celebrante dizen Sanctus ... y al Benedictus qui venit el celebrante y Diácono se signan de la frente al pecho, dicho segunda vez Hosanna in excelsis hazen genuflexión y el Diácono se queda en la peana un paso atrás del celebrante y el subdiácono se va a su lugar.

58. En acavando de incensar el coro, entran los Turiferarios por la Iglesia y suben al pavimento y ynciensan al Cerimoniario y flavelario, luego a los ceroferarios y luego al pueblo y se van debaxo de las lámparas a sus lugares y hazen venia al altar y aguardan meneando los yncensarios todo como se dixo libro 2 capítulo $22 \mathrm{n}^{\mathrm{o}}$.

59. Cuando el coro y el órgano comienza Sanctus, los ceroferarios tocan tres vezes las campanillas a un compás dos golpes cada vez dexanlas junto a los ciriales y suben y hazen genuflexión a los lados del subdiácono y llegan a despavilar como se dixo libro 2. Capítulo 21 de Ceroferarios n ${ }^{\circ} 61$.

60. Al mismo tiempo que comienzan Sanctus salen de la sacristía dos, cuatro, o seis Colegiales con sobrepellices y hachas conforme a la solemidad del día y se ponen y están como se dixo libro2 Capítulo19 de lucernarios $\mathrm{n}^{\mathbf{0}} \quad$ llegan a hazer la genuflexión al mismo tiempo que baxan los

[fol. $265^{\mathrm{r}}$ ]

ceroferarios y se hincan de rodillas en sus lugares.

61. El cerimoniario buelve las hojas del prefacio y canon y alumbra, el Diácono está desde el Te igitur hasta que comienza el Pater Noster en la peana a la diestra del celebrante un paso atras el coro canta los sanctos y versos que se siguen alternativamente con el órgano si es día, mas el Benedictus qui venit no lo canta hasta después de aver alzado el Cáliz si no es cuando se canta motete o chanzoneta en su lugar, el celebrante dize el Te igitur, y prosigue el canon con las ceremonias que manda el ordinario, en el momento dexa el ceremoniario la palmatoria sobre el altar y se aparta un paso.

62. Cuando el celebrante después de aver dicho Hanc igitur oblationen comienza a hazer los signos, los Turiferarios ponen incienso en los Turíbulos y ellos y navetas en las diestras van a la grada en medio de los ceroferarios hazen simil profunda suben y 
hazen genuflexión a los lados del subdiácono y llegan a la peana y se ponen de rodillas para incensar como se dixo libro 2 Capítulo $^{\circ} 22$ de turiferarios.

63. Mientras la consagración y elevación de el Sanctissimo Sacramento se hincan todos de rodillas en el coro, toca el órgano más grave y dulcemente, si no es día de órgano, acavado

[fol. $265^{\mathrm{v}}$ ]

el primer Hosana in excelsis el coro y todos quedan en silencio hasta que después de aver alzado el Cáliz prosigue Benedictus qui Venit, el celebrante consagra su ay formas, el Diácono las descubre y aproxima el vaso y dichas las palabras las aparta y cubre, y cuando el celebrante se hinca de rodillas para adorar el Sanctissimo Sachramento, el Diácono y Subdiácono se hincan de rodillas donde están, mas el cerimoniario se aparta y haze la genuflexión en el canto de la peana arrimado al mismo cornu Evangelii, el celebrante se levanta y eleva la hostia, el Diácono alza las fimbrias de la casulla los Turiferarios ynciensan con tres ductos como se dixo en su lugar, los ceroferarios que al Hanc igitur oblationen sin sacarlos de las aldavas asen los ciriales con las siniestras, a una con las diestras tocan tres vezes cada una con dos golpes duplicados, el portero del coro haze señal a la torre y toca el campanero la plegaria.

64. Asienta el celebrante la hostia en el Corporal y haze genuflexión y tiendele el Diácono la casulla y ambos se levantan, el Diácono descubre el Cáliz y dexa la hijuela sobre

[fol. $266^{\mathrm{r}}$ ]

el Corporal y se hinca de rodillas, el celebrante lo consagra y haze genuflexión, levantase y elevado y los Turiferarios ynciensan y los ceroferarios tocan de la misma manera y cuando va a sentar el Cáliz se levanta el Diácono y cuando lo a asentado lo cubre con la hijuela y hazen juntos genuflexión y luego se levantan y con ellos el Subdiácono y cerimoniario y flavelario y Turiferarios que componen more solito los Turíbulos y hazen genuflexión a los lados del Subdiácono y se van a la Sacristía. También se levanta el Pertiguero y los del coro y el Diácono se queda a la diestra en su lugar y el cerimoniario registra y alumbra y el coro prosigue Benedictus qui Venit in nomine Domine y los de las hachas se levantan y buelven a hazer genuflexión y se van, mas si ay Comunión espera hasta que se haga o si es día de feria de ayuno o de adviento o missa de requiem se están hasta aver consumido.

65. El Celebrante prosigue con el canon y haze el memento segundo y están todos como se dixo al primero, mas nunca el Diácono tiene las manos debaxo de la Dalmática ni tampoco el Subdiácono.

[fol. $266^{\mathrm{v}}$ ]

66. Cuando el celebrante dize Per quem haec omnia semper bona creas, el Diácono haze genuflexión y quitada la hijuela y con el celebrante buelve a hazer genuflexión y a levantarse y a los signos de la hostia sobre el Cáliz y a la elevación está las manos 
puestas y la cabeza profunde ynclinada, el Subdiácono y los demás no se ynclinan de rodilals mas ynclinan la cabeza cuando el celebrante purifica los dedos, el Diácono sin hazer genuflexión toma la hijuela y en acavando de purificarse el celebrante cubre el Cáliz y simul con él haze genuflexión y se va detrás del abaxo de la peana y delante del Subdiácono.

67. El Cerimoniario registra el Pater Noster y alumbra, el celebrante lo canta y cuando dize Et dimitte nobis, el Diácono donde está haze genuflexión y sube a la diestra del celebrante y cuando comienza et ne nos inducas, el Subdiácono donde está haze genuflexión y sube al Cornu Epistolae y da la patena al Diácono el qual la descubre y toma con la mano sin cendal ni paño y limpia con el purificador besa y dá al celebrante y le besa la mano si ay

$\left[\right.$ fol. $\left.267^{\mathrm{r}}\right]$

Flavelario haze genuflexión con el Subdiácono y va detrás del y dada la patena le quita el cendal de los hombros y lo pone sobre el escaño, si no ay flavelario sube al mismo tiempo el ceroferario antiguo y haze genuflexión con él y quita el cendal y pone en el escaño y haze allí genuflexión y el Subdiácono se va a su lugar y el ceroferario se buelve al cirial, dada la patena al celebrante el Diácono haze genuflexión y decubre el Cáliz.

68. Cuando el Subdiácono haze genuflexión para subir con la patena el Pertiguero la haze en su lugar y va a la Sacristía para salir con las pazes.

69. Cuando flage la hostia el celebrante, el Diácono está profunde inclinado y con la diestra asegura el Cáliz teniendolo por el pie hasta que a echado la partícula cubre el Cáliz.

70. Cuando el celebrante entona el Pax Domini sale el Pertiguero y Turiferarios sobre los roquetes y collares con cendales y pazes en las manos diestras levantadas hata el rostro, el Pertiguero se aparta un poco y haze genuflexión y al mismo tiemepo llegados los Turiferarios a la grada hazen

\section{$\left[\right.$ fol. $\left.267^{\mathrm{v}}\right]$}

profunda, suben hazen genuflexión a los lados del Subdiácono, lebantanse y apartan un poco y bueltos algo de rostro se hincan de rodillas, el Subdiácono haze con ellos genuflexión y sube a la siniestra del celebrante hazen todos tres genuflexión y dizen los Agnus y hierense los pechos y después de Dona nobis pazem el Diácono se hinca de rodillas donde está, mirando al Sanctissimo Sacramento, y el Subdiácono haze genuflexión y se va a su lugar detrás del celebrante, el qual en acabando la oración Domine Iesuchriste qui dixisti Apostolis tuis besa el altar y al mismo tiempo el Diácono se levanta y lo besa fuera del Corporal, el celebrante echa el brazo diestro por el ombro siniestro y le besa el hombro derecho de suerte que se toquen las mexillas y le dize Pax tecum, el Diácono echa el brazo derecho por el hombro siniestro del celebrante prosigue las oraciones y el Diácono haze genuflexión y va al Subdiácono y de la misma manera se abrazan y dan osculo en los hombros. 
71. El Diácono pasa a la siniestra del celebrante

[fol. $268^{\mathrm{r}}$ ]

y los turiferarios se levantan y el antiguo llega el portapaz al Subdiácono el qual lo besa y dize Pax tecum y responde el Turiferario et cum spiritu tuo.

72. Hazen genuflexión y con ellos el Pertiguero y los acompaña el coro, entran y dan la paz primero a los mas antiguos vuelven al altar y la dan a los ministros del y todo se haze con las ceremonias y reverencias que se dixeron lib.2 cap.22 de Turiferarios $\mathrm{n}^{\mathbf{0}} \quad \mathrm{y}$ cuando ay quatro pazes.

73. Cuando llega el Diácono por la diestra del celebrante y el Subdiácono por la siniestra simul hazen genuflexión y siempre la hazen y se levantan juntamente con el celebrante y mientras consume están las manos puestas y profunde ynclinados, el celebrante ora un poco después de aver recibido la hostia y el Subdiácono haze genuflexión y descubre el Cáliz a este tiempo los ceroferarios dexan los ciriales y sube el antiguo haze genufexión y de la

[fol. $268^{\mathrm{v}}$ ]

Credencia lleva las ampolletas y por el cornu Epistolae las ministra, el Subdiácono toma la del vino y echa para la primera purificación, a las segunda echa primero bino y luego agua haciendo siempre venia, buelve la salvilla y ampolletas al ceroferario y toma el paño del Cáliz y pasa al lado del Evangelio, el Diácono mientras las purificaciones se llega al missal y registra la Comunicanda, la qual la cantan en el coro mientras el celebrante consume y acavada de cantar en el coro si es día que ay organo buelve a tocar hasta el Dominus Vobiscum y a ella se sientan los del Coro.

74. Toma el Diácono el Atril y missal y el Subdiácono el paño del Cáliz y pasan cada uno a su lado y pasa el diacono por delante de el Subdiácono y hazen genuflexión, el sudiacono detrás.

75. Si ubiere Comunión se celebra con las ceremonias y reverencias que se dicen abaxo en su propio Capítulo.

76. El Diácono pone el misal en su lugar, el Subdiácono toma el Cáliz y con el purificador lo purifica y primero la patena, pone el purificador sobre el Cáliz, la patena encima

[fol. $269^{\mathrm{r}}$ ]

cubierta con la hijuela, luego dobla los corporales encierralos en la bolsa y últimamente cubre el Cáliz y pone sobre la bolsa, saca la Cruz al medio del altar y pone las palabras de la consagración debaxo de ella, toma el Cáliz con la siniestra y pone la diestra enzima de la bolsa, haze genuflexión y llevalo a la credencia donde el ceroferario lleva las ampolletas y aguarda que ponga el Subdiácono el Cáliz y toda la cubre con el 
cendal como estaba al principio de la missa, toma el libro y va detrás del Subdiácono, hazen genuflexión en medio y el Subdiácono se pone detrás del Diácono le enseña el Ite missa est, o Benadicamus registrado, si ay flavelario haze él todo esto de cubrir la credenzia y ministrar el misal.

78. Si en el ynter que el Subdiácono limpia el Cáliz y haze lo rferido en el num ${ }^{\circ}$ precedente el celebrante se llegal al altar a decir Dominus Vobiscum, el Subdiácono cesa de su ministerio pone las manos y se aparta un poco y buelve el rostro al celebrante que viene y cuando buelve a proseguir las oraciones prosigue su ministerio.

79. Si se ubiere de renovar el Sanctissimo

$\left[\right.$ fol. $269^{\mathrm{v}}$ ]

Sacramento dexa los corporales en el altar y se haze como dirá abaxo Capítulo 8.

80. El celebrante aviendo tomado la purificación se aparta y dize las oraciones y el cerimoniario que se viene con el alumbra y registra y mientras las dize está el Diácono detrás cuando el coro responde a la ultima conclusión, van el çelebrante, Diácono y Subdiácono las manos puestas al medio del altar y lo vesa y al Dominus Vobiscum, el Diácono se buelve el rostro al pueblo apartandose un poco al lado de la Epístola, mas si está el Sanctissimo Sacramento descubierto se buelve a la reza de las reliquias y el ceroferario o el flavelariosi lo ubiere le abre el libro y lo levanta en derecho del rostro y lo tiene mientras canta el Ite missa esto, si es Benedicamus Domino, el Diácono se buelve sino en el lugar que está buelve algo el rostro al libro que el ceroferario abaxo de la peana las espaldas a la esquina de el altar en la parte de la Epístola le tiene avierto.

81. En el ínterin que el Diácono lo canta el celebrante lo dize rezado buelvese y echa la bendición, a la qual todos los ministros

[fol. $270^{\mathrm{r}}$ ]

y del coro y los Diáconos y prebendados se humillan profunde.

82. Si el Evangelio ultimo no es Initium de San Joan, cuando el çelebrante dize la oracion Placeat tibi Sancta Trinitas haze el Subdiácono genuflexión y llega toma el Atril y misal y lo pasa al cornu Evangelis haziendo en medio genuflexión, cuando el çelebrante dize el Evangelio ultimo están los Diáconos uno en post de otro y le responden, echada la Bendición los ceroferarios sacan los ciriales de las aldabas y los tienen baxos al Evangelio ultimo mientras se dize, el cerimoniario toma los bonetes del çelebrante y Diácono, al qual se los dá y el flavelario o ceroferario acabada de cantar el Ite missa est, cierra el libro y lleva el bonete al Subdiácono y se lo da, pone el libro en la Credençia y si ay responso toma el hisopo y manual y se va a su lugar. Si el flavelario lleva el bonete del Subdiácono aguarda y no se lo dá hasta que acabado el Evangelio se despiden y hazen genuflexión en la peana que es al tiempo quado el cerimoniario los dá al Diácono = Al Verbum Caro del Evangelio

[fol. $270^{\mathrm{v}}$ ] 
de San Joan todos hazen genuflexión en sus lugares.

83. Acabado el Evangelio el celebrante llega al medio del altar y el Diácono se aparta a la diestra y el susbdiácono a la siniestra fuera de la peana y simul hazen profunda, baxa el celebrante al medio de los Diáconos y toman los bonetes y hazen genuflexión y con ellos el Cerimoniario flavelario, Pertiguero y ceroferarios, los que hazen $\mathrm{Si}$ a de aver responso que si lo ay el flavelario toma el hisopo y manual y baxa por el lado siniestro del Ceroferario moderno y por detrás de ellos haziendo genuflexión en medio llega al lado diestro del antiguo.

84. El celebrante y Diáconos se cubren y buelven al pueblo y baxa el Cerimoniario delante luego el subdiácono y último el celebrante y a este tiempo los ceroferarios levantan los ciariales y el Pertiguero haze profunda al celebrante y va delante a la Sacristía por el orden que vinieron.

85. Si ay responso el celebrante baxa en medio de los diáconos y solo el cerimoniario delante que se aparta en baxando al lado

[fol. $\left.271^{\mathrm{r}}\right]$

diestro del Diácono y los çeroferarios no levantan los çiriales, estando en el pavimento baxo se buelven al altar y el Çerimoniario de mano del flavelario ó ceroferario, toma el manual y lo da al Diácono y dizen el responso. Al Kyrie Eleyson se descubren, da el hisopo al diácono y este lo da al çelebrante sin besarlo y echa agua tres vezes en el Pavimento cuando dizen Pater Noster, luego el Diácono lo recive y buelve al cerimoniario y cuando el celebrante dize después Requiem Eternam, echa la bendición sobre el pavimento y acaban el responso y oración y todos hazen genuflexión y se apartan un poco de la grada para dar lugar a que pasen el ceroferario y cerimoniario y se van a la sacristía, los ceroferarios se quedan en la puerta y todos los demás entran y el Pertiguero les haze reverencia, llegan al bufete y primero se desnuda el subdiácono, luego el Diácono y ambos quitan la casulla al celebrante, ayudan los turiferarios y flavelario, ponen los ornamentos vien puestos con mucha curiosidad que no queden arrugados, dan las sobrepellizes

[fol. $\left.271^{\mathrm{v}}\right]$

o capas, doblan los amitos y ponen en sus caxones.

86. El Cerimoniario lleva siempre el lenzuelo del celebrante y cuando entran en el altar pone entre el Ara y el Atril y cuando se despiden con la venia lo toma y en la Sacristía lo da al que ayuda a desnudar al celebrante para que lo doble con el amito.

87. Si está el Sanctíssimo Sacramento descubierto, al salir a la missa se descubren desde que se pueda ver al altar y llegan así. Cuando se inciensa al principio de la missa, primero inciensa al celebrante el Sanctíssimo Sacramento hincado de rodillas y a sus lados los Diáconos asimismo genuflexos con tres ductos, a la incensación de la oblata se inciensa de la misma manera después de la oblata: No se besa mano ni cosa alguna al 
dar ni al recivir en el Evangelio último, no se signa el altar, todas las bezes que se llegan y se apartan del altar hazen genuflexión.

Para que aya uniformidad se señalaran aquí cuándo se llegan al altar después de dicho el psalmo y confesión. Cuando

[fol. $272^{\mathrm{r}}$ ]

vienen de decir el Introito, cuando se apartan a decir las oraçiones, cuando se llegan para pasar al Evangelio: cuando vienen de labarse las manos. Cuando va a decir las oraciones últimas y cuando llega de decirlas y cuando va a decir el Evangelio último después de aver echado la bendición y cuando llega de decirlo.

89. A los Kyiries, Gloria y Credo que cuando no está descubierto el Sanctíssimo Sacramento se van a sentar, se queda en pie en medio de el altar uno en pos de otro y asimismo el çerimoniario y flavelario en sus lugares, los çeroferarios están de rodillas y el Pertiguero en pie y descubierto a toda la missa.

90. Para labarse las manos sale el çelebrante fuera de la peana al Cornu epistolae y buelto el rostro a los candeleros del altar eregione en el rincón del çeroferario le tiene la fuente y le echa aguamanos y por la diestra el compañero le echa la toalla y las manos puestas desde la esquina al medio del altar donde haze genuflexión, todas las demás ceremonias y reverencias haze conforme mandan las rúbricas del ordinario.

\section{El Celebrante en las Elevaciones de}

[fol. $272^{\mathrm{v}}$ ]

las manos, juntarlas y apartarla, en las humillaciones de la cabeza y cuerpo, en el besar del altar, modo de hazer los signos, dar las bendiciones, postura del cuerpo y manos, pronunciación de palabras alta o baxa, en los golpes de pechos, manos sobre el Corporal, fuera dedos en la frente del altar y todas las demás particularidades comunes a las missas rezadas observa las rúbricas generales y particulares del misal nuevo, en algunas partes de la missa que se an referido en el Capítulo precedente, se an expresado algunas de estas ceremonias, en otros no, no porque no se ayan de guardar sino por no multiplicar las cosas que son corrientes comunes y savidas: cuando se an notado es por la particular concurrencia que tienen con las cosas propias de este capítulo e instituto. Asimismo no se an expresado otras particulares observaciones ni acciones que deven hazer los ministros y los que asisten a la missa mayor, porque todas ellas quedan dichas en los particulares Capítulos de sus oficios y señalado el tiempo que las an de ejercer y aquí se an dexado porque este capítulo no creçiese superflua y demasiadamente:

[fol. $273^{\mathrm{r}}$ ]

veánse los capítulos del modo de estar en la missa libro 1, capítulo 3; del sochantre, libro 2, Capítulo 11. Lucernarios, Capítulo 19; Organista, Capítulo 12. Cantores, Capítulo 18; campanero, cap 14; Ceroferarios, capítulo 21; Versicularios, capítulo 16 y otros. 
93. La missa penúltima se dize mientras la mayor y es acción que en alguna manera pertenece a ella. Dícese todos los días de fiesta y todos los festivos que se celebran en el Sacromonte con solemnidad, sale el prebendado señalado por la tabla del coro al ofertorio y acompaña al coadjutor, entra por la Iglesia y al pasar por el pavimento, el Pertiguero se buelve y haze reverencia, hazen genuflexión al altar y el Turiferario de la capilla de los mártires para el incensario y le da lugar que pase, entra en la Sacristía y se viste y está a punto para salir en alzando y sale al altar de la Concepción o del sagrario, si ay sermón sale a decir la missa en acavando de predicar y así está antes en la sacristía.

94. En las missas de los Aniversarios que no son Solennes, libro 1, capítulo 14, de los Aniversarios, número ¿?. No se dize la Epístola y Evangelio en los púlpitos, sacan los ceroferarios un facistol alto con paño al pavimento baxo y lo

$=\mathrm{Al}$ margen $=$ Portero del choro. Cap $.20=$

$$
\text { [fol. } \left.273^{\mathrm{v}}\right]
$$

ponen al lado de la Epístola, libro 2, Capítulo 21, de Ceroferarios, y el subdiácono cuando va a cantar la Epístola no dexa el libro, él mismo lo pone en el façistol y el rostro al altar la canta y le asiste en çeroferario a la diestra que lo baxa a acompañar como se dixo supra $\mathrm{n}^{\mathrm{o}}$.

95. Acavada la Epístola, el otro ceroferario pasa el Atril al lado del Evangelio y lo buelve al pueblo y cuando baxa el Diácono a decirlo como se dixo supra $\mathrm{n}^{\mathrm{o}}$, los ceroferarios pasa cada uno por su lado, cogiendo el atril y sin baxar los ciriales se ponen delante de él por la parte que mira al pueblo, el Diácono pone el libro y el subdiácono se pasa a su mano diestra y el Turiferario a la diestra del subdiácono y en aviéndole ministrado el Turíbulo, por detrás del Subdiácono pasa y haze genuflexión y se pone delante de los ceroferarios un poco apartado el rostro al púlpito de la Epístola y se queda meneando el incensario, el Subdiácono pasa delante del facistol y toca el libro con las manos de rostro al Diácono en medio de los ceroferarios como que sustenta el libro en que se canta el Evangelio, lo demás se haze como se dixo en los números referidos.

\section{[fol. 274 ${ }^{\mathrm{r}}$ ]}

96. En estas missas y en otras semejantes no sirve más que un turiferario, sale a los mismos tiempos que se a dicho y se pone en su lugar y ministra de la misma manera, excepto que al ofertorio no sube a incensar el coro, sino acabada la Turificación se baxa a su lugar debaxo de las lámparas de la capilla del Rosario, porque cuando ay uno siempre haze el oficio y toma el puesto del antiguo y a su tiempo sube con las devidas reverencias a incensar a la Elevación del Sanctíssimo Sacramento y se pone en el lado de la Epístola y Turifica de la misma forma y en acabando de incensar se va a la sacristía con las acostumbradas reverencias y se desnuda y va al coro porque tampoco ay pazes. 
97. Las Ceremonias que se observan en la missa y en las Vísperas cuando asiste a ellas el Prelado se refieren infra, libro 4, capítulo 5, de la Solennidad del Glorioso Señor San Cecilio.

98. Las Ceremonias que se observan en las missas de difuntos se refieren en su propio lugar.

[fol. $\left.274^{\mathrm{v}}\right]$

\section{Capítulo 5. De los días que hay Procesión y cómo se celebra.}

1. La Purificación de Nuestra Señora, Domingo de Ramos, Jueves y Viernes Sancto al encerrar y desencerrar el Sanctíssimo Sacramento, el Sábado Sancto para la bendición del nuevo fuego, la mañana de Resurrección acavando los maitines, las letanías mayores el día de San Marcos, las menores antes de la Ascensión, el día del Corpus Christi, el día octavo en la tarde del día de la Asumpción de Nuestra Señora por la tarde, Voto del Cabildo pro gratiarun actione y el día de la commemoración de los difuntos: éstos son los que ay consueta y puede aver procesión cuando el Cabildo lo determinare en rogativa o gratias pro re gravi.

2. También ay procesión para recivir alguna reliquia con solemnidad y para recivir Rey, Reina, legado o Prelado.

3. Las procesiones de las fiestas y días que se refirieron en el número primero, en cuanto a lo general que toca a todas se dize aquí y en particular que tienen se dize en el libro 4, en los

[fol. $275^{\mathrm{r}}$ ]

los capítulos de sus días

4. Las otras procesiones que se ofrecen como no tienen día señalado pertenecen a este lugar.

5. Cuando deja el esquilón ya an de estar todos en la Sacristía los que se visten junto a sus vestuarios y los otros en sus coros, arrimados con silencio y modestia, siendo hora y vestidos sale el Pertiguero, luego un Turiferario, luego los Ceroferarios, Cruciferario, Clero y ministros por su orden, entre los últimos el capellán Cerimoniario, después Subdiácono y Presidente que llevan las manos puestas.

6. El Pertiguero baxa del pavimento enlosado buelto al altar mayor y se pone en medio delante del Cruciferario, la Cruz sobre las gradas y los ceroferarios a sus lados bueltos al altar y los ciriales sobre la grada, el Turiferario se pone en el arco de la capilla de Nuestra Señora, el clero por su orden en dos coros desde las gradas del pavimento alto por todo el baxo y crucero, los del coro pasan al de la Epístola, los más modernos baxan y se quedan por sus antigüedades de suerte que

[fol. $275^{\mathrm{v}}$ ] 
el más antiguo está junto a las gradas; el celebrante y Diáconos, antes de subirlas hazen humiliaçión al Sanctíssimo Sacramento, suben y en el presbiterio hazen genuflexión y todos con ellos excepto el Cruciferario, levántanse y sube el Turiferario y el celebrante pone incienso more solito y el Turiferario baxa y se pone debaxo del púlpito de la Epístola, el rostro al altar de la Concepción y meneando el incensario, el sochantre entona la Antíphona o himno, el Diácono dize Procedamus in paze conforme pide la procesión.

7. Las procesiones de la Purificación, todas las del Sanctíssimo Sacramento y de los difuntos se an de hazer por el claustro, en estando cubiertas las cuatro calles y limpio que se pueda andar por ellas; ahora se haze como se dize en sus días: Jueves, Viernes y Sábado Sancto se hazen por dentro de la Iglesia, y la mañana de resurrección. Las de letanía y rogativas van a las Sanctas Cuevas como se dize en sus propios capítulos, Libro 4; al tiempo del proceder hazen todos genuflexión al altar mayor y el cle

[fol. $\left.276^{\mathrm{r}}\right]$

clero está parado y el Pertiguero, Turiferario, Cruçiferario y ceroferarios pasan delante y luego les siguen por su orden y cuando el celebrante y Diáconos se buelven por detrás del çelebrante pasa el Diácono a la diestra y el Subdiácono a la siniestra.

8. Si la proçesión va fuera de la Iglesia, proceden sin parar, mas con mucha pausa y compás y para hazerlo guardar igualdad en la distancia y correspondencia en los coros, el capellán çerimoniario discurre por la procesión avisando lo que ubiere que avisar y con el mismo orden van y buelven a las Cuevas o adonde se ha de hazer la estación como se dirá en el Capítulo de las letanías y buelven con el mismo compás que fueron Diácono y coro diestro a la diestra del celebrante.

9. Si la proçesión es por el Claustro, guía el Pertiguero por la puerta de la Concepción y por el Claustro de la mano derecha y haze la primera estación cuando llega al postrer arco del Claustro, allí para arrimado a la Columna de la esquina y los ceroferarios y Cruciferario debaxo del Arco arbotante baxan la Cruz y ciriales, acabada la estación

[fol. $\left.276^{\mathrm{v}}\right]$

prosigue la procesión por el Claustro de las capillas y se haze la segunda y tercera de la misma suerte; en el cuarto claustro de la escalera que tiene la puerta de la Iglesia enfrente, no se haze estación, mas entra la proçesión por ella al altar mayor y en la grada primera de las tres, en donde se ponen los çeroferarios, para el cruciferario y Ceroferarios, el clero se queda como estubo y el celebrante y Diáconos los últimos, donde se haze la cuarta estación y si no se sigue la missa se entran en la sacristía por el orden que salieron.

10. Si las estaciones son dentro de la Iglesia, después de aver entonado lo que se ha de cantar, procede el Pertiguero, Turiferario, Cruciferario y Ceroferarios hasta a la cinta de las lossas del arco toral, donde asientan la Cruz y Ciriales y el clero pasa delante al 
cuerpo de la Iglesia y se van quedando detrás de los ceroferarios los más modernos y los últimos los más antiguos y el celebrante y diáconos se ponen al fin en medio de los dos coros, frontero de la Cruz y çiriales y así se haze la primera estación.

\section{[fol. $\left.277^{\mathrm{r}}\right]$}

11. Para la segunda procede el Pertiguero al altar del sagrario y pónese debaxo del púlpito de la Epístola y el Turiferario debaxo del cuadro de San Andrés, mas a la peana del altar, el Cruçiferario y Çeroferarios hasta asentar en ella la Cruz y çiriales y el clero les sigue y el çelebrante y diáconos se quedan los últimos donde les alcanza, todos haziendo angulo al altar y así se haze la segunda estación.

12. Para la tercera pasa el Pertiguero al altar de la Concepción y se pone debaxo del púlpito del Evangelio, el Turiferario entre la puerta y la peana y en ella la Cruz y çiriales y el clero le sigue y se quedan bueltos al altar del mismo modo que en la segunda, al pasar todos por delante del altar mayor hazen genuflexión sino es los de la Cruz y ciriales.

13. Para la cuarta sube el Pertiguero al pavimento y se pone en el arco de la capilla de los mártires y el Turiferario en el del rosario, la Cruz y çiriales en la primera de las gradas y el Clero por su orden por el Pavimento y Crucero y el çelebrante y Diáconos en medio frente del altar mayor. Acavada la estación el Pertiguero, Turiferario, Cruz y ceroferarios y los demás procesionalmente entran

(rubricado)

[fol. $\left.277^{\vee}\right]$

en la sacristía mas si se sigue missa, el turiferario se queda en su lugar, el Cruciferario va con la Cruz a la sacristía y los cerofararios la acompañan hasta la capilla de los mártires y luego se buelven a sus lugares y el Cerimoniario y celebrantes suben al altar donde se quita la capa, toman manípulos y se viste casulla.

14. Para recivir reliquia antes que acave la señal de congregar están todos en la sacristía y vestidos el celebrante con capa y los Diáconos con Dalmáticas sin manípulos y para el palio los caperos de la semana y de la precedente con pluviales.

15. Hazen un altar muy vien adornado de color conveniente al Sancto cuya es la reliquia, si está asentado con el que la trae que suba por la cuesta principal, al altar se haze en el compás empedrado que está delante de los padrones del horno de San Cecilio, si ha de subir por la otra cuesta el altar se haze en el Compás cercado que está delante de la casa, en medio de él un poco más abaxo de la Cruz blanca.

-En el altar se pone el niño JESÚS o la Cruz o cuerpos de Sanctos, candeleros ricos con velas encendidas, flores y otras cosas de adorno y

[fol. $278^{\mathrm{r}}$ ] 
hermosura y alfombras por ambas partes y en él está un cofre, rico, de los de terciopelo carmesí o la caxa de plata o cosa semejante en que meter la reliquia y un paño rico para cubrillo, asismismo junto al altar está el palio que ya an sacado cuatro colegiales.

16. Cuando se avisa que el que trae la reliquia llega cerca del altar, sale la proçesión de la Sacristía por el orden que se dixo, mas no para en el pavimento ni el celebrante sube al altar, mas todos le hazen genuflexión y en silencio van al altar, los capeross van los últimos antes del preste y Diáconos.

17. El que trae la reliquia llega al altar y en ella pone y haze genuflexión y aguarda que llegue la procesión, la Cruz y ciriales se quedan en buena proporción y distancia y los prebendados cercan el altar, el celebrante y Diáconos llegan a él y hazen todos genuflexión, el que trae la reliquia la saca y testifica como es aquella verdaderamente la reliquia de tal o tal Sancto, dala al celebrante el cual la pone en el cofre y haze genuflexión, luego entrega los papeles y testimonios que trae de que aquella es la tal reliquia al Secretario del Cabildo, luego llegan los Turibularios y more solito (rubricado)

\section{[fol. $\left.278^{\mathrm{v}}\right]$}

echa el celebrante incienso en ellos y reçive de mano del Diácono uno y haze genuflexión y inciensa con tres ductos la reliquia, buelve a hazer genuflexión y al Diácono el incensario cierra el cofre y tomale en sus manos y ayudante los brazos los Diáconos, los caperos toman el palio de mano de los Colegiales y reçiven debaxo de él al celebrante y Diáconos, órdenase la procesión, en ella cantan el Te Deum laudamus o los Himnos propios o comunes del Sancto y los Turibularios por medio, meneando los incensarios y cebándolos de incienso y pastillas, detrás del palio va el que truxo la reliquia en medio de dos Prebendados los más antiguos si es persona constituida en dignidad o insigne en nobleza.

18. Entran en la Iglesia y los ciriales y Cruz asientan en la grada del pavimento enlosado, en el cual los caperos despiden el palio, el celebrante Diácono y Cerimoniario suben al altar mayor y en él ponen la reliquia y hazen genuflexión, los Turibularios suben y el celebrante inciensa la reliquia, luego la saca del cofre y con un cendal en los hombros la toma en las manos y se buelve y la manifiesta

[fol. $279^{\mathrm{r}}$ ]

al pueblo, y en este acto los Turibularios de rodillas la inciensan un rato, luego suben todos a adorarla por su orden, preeminencia y antigüedades: primero los prelados, luego los caperos, luego el clero, luego los seglares si ay personas nobles en oficio o calidad. Mientras dura este acto se toca el órgano, chirimías o se cantan motetes.

19. Después de la adoración el celebrante deposita y encierra la reliquia en el lugar donde ha de estar sino es que se ha determinado se diga missa solemne de tal Sancto o pro gratiarum actione o las tercia, cuando se queda sobre el altar y después de la missa se coloca. 
20. Cuando viene el Rey a visitar el Sacro Monte, la Iglesia y altares, maravillosamente aderezados, sale de la Sacristía la procesión, no ay turibularios ni caperos, los ornamentos blancos ricos, el preste que será el Abad o Presidente lleva capa y en las manos una Cruz de plata dorada pequeña con un cendal blanco, llega la cruz y ciriales al medio de la Iglesia y el clero baxa y se va quedando, los más modernos junto a la Cruz y los más antiguos abaxo y el celebrante y Diáconos junto a la pila del agua vendita, el rostro a la puerta donde el

(rubricado)

[fol. 279 $]$

ministro del capellán mayor de su Magestad. Tiene puesto en un tapete y coxín de terciopelo, allí espera y el Rey, llega al coxín y el Prelado más digno que con su magestad viene o su capellán mayor o él. Éste echa el agua vendita y luego llega el celebrante y le da a vesar la Cruz, estando inclinado haviendo hecho antes humiliación y después la haze, levántase y sube la procesión y canta la música y el Rey va detrás del Presidente, los Diáconos en medio de la procesión, suben al altar y la Cruz y clero se queda como suele. Al Rey se le pone sitial en el pavimento enlosado y en altar al Cornu epistolae está el libro a donde canta al preste las oraciones señaladas y el Rey está de rodillas; cuando dize el Presidente Regem nostrum buelve un poco el rostro y haze venia a su magestad.

21. Las reliquias de los Sanctos están manifiestas sobre el altar y acabadas las oraciones baxa el preste y Diáconos con la reliquia y haziendo venia antes y después, se la da a vesar y i hubiere principe o Infante o personas Real cuando esté en el sitial con su magestad se la da también, pero no se le ha de dar la Cruz en la puerta de la Iglesia, que está es ceremonia propia del Rey, (rubricado)

[fol. $\left.280^{\mathrm{r}}\right]$

así se hizo el año 1624 Sábado Sancto por la tarde, que su Majestad del Rey Philipe 4 visitó la primera vez este Sacro Monte y fue la primera Iglesia que visitó en Granada aunque se le hizo instancia por Don Garzerán Albaner Arzobispo de ella y su Maestro para que fuese primero a su Iglesia y asistió con su magestad, el Infante Don Carlos, su hermano, a quien no se le dió la Cruz a vesar sino solo la reliquia. Después fueron a visitar las Santas Cueuas y la procesión se entró en la sacristía. El Duque del Infantado Mayordomo maior de su Magestad dispuso los grandes entre los Cánonigos.

22. Cuando viene el Prelado a visitar, entre la rexa y la puerta de la Iglesia se pone una alfombra grande y sitial con sus coxines y cuando llega cerca, sale la procesión de la Sacristía, no ay caperos, el celebrante con pluvial y los Diáconos con Dalmáticas, y el Prelado por la una frente y el celebrante y Diáconos por la otra. Juntamente llegan al sitial y el Diácono saca la Cruz mayor de la bara en que la lleva el Cruciferario y la da al celebrante y el Prelado que está de rodillas y la vesa ponénla en su hasta, luego el preste da el hisopo al Prelado el cual rocía a sí mismo y después a los circunstantes, luego el

(rubricado)

[fol. $\left.280^{\vee}\right]$ 
mismo preste tomará la naveta del incienso teniendo el Turibulario el incensario la ofrecera al Prelado el cual pone incienso bendiciéndole more solito y el Presidente le inciensa en la forma acostumbrada y prosiguen en procesión cantando el responsorio Sacerdos et Pontifex y tocando el órgano y el Prelado se queda en su sitial y el celebrante sube al altar donde dize los versos protector noster y la oración Deus humiliu visitador como en el manual, luego el Prelado echa la bendición y se vuelve la procesion a la Sacristía.

[fol. $\left.281^{\mathrm{r}}\right]$

\section{Capítulo 6. De los días que ay Sermón y de las Ceremonias que en él se observan.}

1. El Abad tiene a su cargo encomendar los sermones a los Prebendados que le pareciere teniendo atencion para las personas y días, puede también combidar persona de fuera para que predique que tenga las partes de satisfación que se requieren para predicar en esta Iglesia, clérigo particular sino fuere acepto y señalado, con bentajas de virtud y acepción no lo combide, mas si alguno pretendiere el Sacro Monte le puede dar sermón algún día extraordinario de la tabla.

2. Al Predicador de fuera, el Presidente de casa recive y hospeda y cuida de su regalo, que le asista algún capellán o Colegial para lo que ubiere menester.

3. Ay sermón todos los Domingos de Adviento y cuaresma, los de cuaresma en la tarde abrá también sermón de alguna historia Sagrada que mueba al pueblo a penitencia y

[fol. $\left.281^{\mathrm{v}}\right]$

confesión con algún ejemplo.

4. Ay sermón el día de San Estevan, por el misterio del Sacro Sancto nacimiento de Nuestro Señor Iesuchristo, la Circuncisión, Epiphanía, Jueves Sancto al mandato, el segundo día de Resurrección, la ascensión, el segundo día de Pentecostés, la Sanctíssima Trinidad, el Domingo infra octavam, Corporis Christo y el día octavo, la Concepción, Natividad, Anunciación y Asumpción de Nuestra Señora, San Cecilio, San Hiscio, San Messitón, San Tessifón, San Pedro, Santiago el Zebedeo, San Miguel de Septiembre, San Dionisio Areopagita, Todos los Sanctos, San Andrés, la Inbención de la Cruz.

5. Abra sermón cuando se celebrare alguna fiesta extraordinaria o honras si el Cabildo lo determinare.

6. Predica el Prebendado con su hábito Canonical conforme al tiempo, Capa o Sobrepelliz, los otros Clérigos no prebendados de esta Iglesia con sobrepelliz.

7. En las fiestas solennes de primera y segunda clase acompañan al Predicador cuatro comitantes los Domingos dos acabado de cantar el Evangelio suben dos Colegiales

[fol. 282 ${ }^{\mathrm{r}}$ ] 
comitantes a quitar de los púlpitos los facistoles y paños, éntranlos en la sacristía donde ya está el Predicador y llega a este tiempo el capellán Cerimoniario y salen los comitantes delante a los cuales se llega en la capilla de los mártires el Pertiguero, después de los Colegiales va el cerimoniario, el último el predicador, al llegar a las gradas el Pertiguero se aparta hacia la capilla del rosario y el rostro al predicador le haze reverenzia, los comitantes quedan en el pavimento por el orden que vinieron y todos hazen profunda al altar, sube el predicador y cerimoniario al pavimento alto donde hazen genuflexión, levántase y el cerimoniario se queda en pie, el predicador llega a la peana del altar y de rodillas dize la oración munda Cor meum, a este tiempo los Diáconos se ponen cada uno a su lado del Presidente, el Diácono avisa al preste y se buelve, el predicador si es Prebendado en pie y profunde inclinado pide la bendición Iube Domine Benedicere, si no es Prebendado de rodillas y dada la bendición besa la mano al celebrante, haze genuflexión al altar y comedimiento a los Diáconos y va al púlpito, acompañando los mismos que vinieron y al subir la primera grada, todos le hazen venia si en la Iglesia

(rubricado)

[fol. 282 ${ }^{\mathrm{V}}$ ]

o capilla ay personas graves les hazen comedimiento, a ida y buelta sube y predica, la cabeza cubierta sino es que está descubierto el Sanctíssimo Sacramento que cuando lo está, el predicador y todos salen descubiertos desde la Capilla de los mártires y se buelven hasta allí y el Predicador no besa la mano al celebrante cuando le da la bendición.

8. Si asiste el Prelado en la missa, hecha genuflexión al Sanctíssimo Sacramento, se buelve al Prelado y le hazen profunda doblando las rodillas, luego las hinca y dize Iube Domine benedizere, y dada la bendición le pide las Indulgentias Pater reverendissima, dada la bendición le besa la mano, vuelve a hazer profunda y genuflexión al Sanctíssimo Sacramento, da la buelta para baxarse, el rostro al Prelado inclinando la cabeza.

9. Acabado el Sermón buelve con las mismas cortesías a vesarle la mano y al fin de el Sermón no echa la bendición mas dize: su Illustrissima la echara a todos y publica las Indulgentias.

10 Sube al púlpito y está con silencio un rato, compónese mientras la gente se sosiega, luego quitado el bonete se signa more solito, acabada la (rubricado)

[fol. $\left.283^{\mathrm{r}}\right]$

la salutación, antes de decir nada quitado el bonete inclinado al Prelado, le pide Venia diciendo Illustrísimo y Reveredísimo Señor. Si entre el sermón, hablara con él, inclina la cabeza. 
11. Si el sermón fuere por causa extraordinaria como publicacián de Jubileo pro Gratiarum actione Vel in adventu Principii o cosa semejante, se predica al Evangelio, mas si fuere de difuntos se predica acavada la missa y no se pide vendición, mas sale al Predicador con el acompañamiento dicho y en las primera grada de rodillas haze un rato oración y luego sube al púlpito.

12. En el sermón del miércoles de ceniza no se pide la vendición sino es que está algún Prelado, en los otros de las ferias se puede pedir por la costumbre que ay y todos se predican en acabando el Evangelio.

13. En el sermón de Pasión que en España se predica al alba no se pide bendición.

14. En los sermones que se predican por las tardes en acavando la Salve sale el Predicador de la Sacristía acompañado de dos Colegiales y el Pertiguero sube solo al pavimento alto, ora como dos Credos y con la devidas genuflexiones baxa y se va al púlpito.

15. Cuando se determinare en el Cabildo al- (rubricado)

[fol. $\left.283^{\mathrm{v}}\right]$

guna fiesta extraordinaria en que aya de haber sermón, le toca el combidar predicador y así o botará a quien se ha de combidar, o por botos se lo cometerá a algún Prebendado y elegida la persona el Cabildo la embiará a combidar sino fuere de casa con el Capellán Cerimoniario.

16. Si el Abad o Cabildo ubiere de combidar a algun Prelado para que predique lo embiaran a combidar con dos prebendados.

17. Cuando viniere será hospedado honoríficamente, sabran de él los que le combidan si quiere predicar en silla o en el púlpito y la silla le pondrán con sitial en el pavimento alto. El púlpito adornarán con dosel rico en las espaldas y otro que cubra la venera dorada que haga como cielo, y cuatro prebendados cuatro Colegiales, Cerimoniario y Pertiguero van a su aposento y lo acompañarán hasta el púlpito y acavado el Sermón también hasta su aposento. (rubricado)

[fol. $\left.284^{\mathrm{r}}\right]$

\section{Capítulo 7. De los días que ay Comunión general y de las ceremonias con que se haze y de la Comunión particular.}

1. Los días siguientes: día de San Estevan, Domingo primero de adbiento y cuaresma, Jueves Sancto, Epiphanía: sigundo día de resurrección y Pentecostés. Ascensión. Copus Christi. Concepción. Natividad. Anunciación. Purificación y Asumpción de Nuestra Señora, San Hiscio, San Messitón, San Tessiphón, San Pedro, Sanctlago el Zebedeo, Todos los Sanctos, San Dionisio Areopagita, la Conversión de San Pablo; si no ay Aniversario con otra missa que si lo ay el día siguiente de Señora Santa Ana.

2. Previene el recado el sacristán, formas, vasos de plata y en su salvilla cubierta con hijuela rica, vino aguado en un vaso con una toalla olorosa enzima, sacando los 
Ceroferarios y cuando el celebrante consume el Sanguis pone en las aldabas los ciriales, suben al pavimento hazen juntos genuflexión, el antiguo toma el paño de hombros (rubricado)

\section{[fol. $\left.284^{\mathrm{V}}\right]$}

del subdiácono, el otro el vaso del bino y toalla y los lleva al altar y pone al Cornu epistolae, toman el paño y se hincan de rodillas en la peana, el Diácono se pasa a la diestra del celebrante y el subdiácono a la siniestra y puestos fuera de la peana arrimados a los Cornus del altar, eregione profunde inclinados hazen la confesión, los Colegiales baxan del Coro después de cantada la Comunicanda, en el pavimento enlosado se ponen de rodillas en dos coros, teniendo en medio los de las hachas donde ellos suben a ponerse de rodillas en la primera grada, en el lugar de los Ceroferarios si no vienen a tiempo los Turiferarios que si vienen a tiempo, ellos son los que ocupan este lugar

3. Hecha la comisión buelve el celebrante a hazer la absolución, si los de las pazes ya las an dexado en la sacristía suben y se ponen en medio de los Ceroferarios de rodillas, buelve el celebrante con el Sanctíssimo Sacramento, el vaso tiene con ambas manos y con el pollize ${ }^{22}$ y índize de la derecha una de las formas dice el Ecce Agnus Dei y los Turiferarios o los dos Colegiales que están en el lugar de los Ceroferarios tocan las campanillas por tres vezes con golpes doblados cada vez.

[fol. 285 ${ }^{\mathrm{r}}$ ]

4. Dize el Çelebrante tres vezes Domine non sum dignus y comienza a comulgar los ministros por el que está al Cornu epistolae que así va sobre su mano derecha y cuando los ha comulgado sobre la misma mano se buelve al altar el Diácono, toma el vaso del bino aguado y toalla y les da para la purificación; limpia con el cavo de la toalla el lavio del vaso por donde bevió el ministro y éste con el otro cavo se limpia los suyos.

5. Cuando da la purificación el Diácono, suben los Turiferarios, los que an comulgado se levantan y abren un poco y en medio de ellos se ponen los que an subido y todos juntos hazen genuflexión, luego se levantan y los cerofararios se ponen de rodillas en las esquinas de la peana eregione y tienen el paño con ambas manos tendido y llano en forma de mesa, los otros dos que se llegan se ponen de rodillas en la peana, buelve el celebrante y los comulga y buélvese al altar. Acavado de dar el Sanctíssimo Sacramento, los ceroferarios sueltan de la una mano el paño y déxanlo colgar y el Diácono les da la purificación.

6. Luego suben otros dos Colegiales sin hachas y levantándose los Turiferarios que acavan de comulgar los recíven en medio y todos (rubricado)

[fol. $285^{\mathrm{v}}$ ]

cuatro hazen genuflexión y levantándose los dos que an comulgado, que son los Turiferarios, se quedan de rodillas junto los Ceroferrios y este mismo orden de hazer genuflexión los que llegan en medio de los que an comulgado van siguiendo los demás

\footnotetext{
${ }^{22}$ Pollize, léase pollice: pulgar en latín.
} 
7. Cuando ya an comulgado los dos que subieron sin hachas después de los Turiferarios suben, los dos primeros que tienen hachas van con ellas al pavimento alto y las dan a los Turiferarios que se quedaron de rodillas junto a los Ceroferarios y sin ellas y con los que acavan de comulgar hazen la genuflexión como se ha dicho y los dos que acaban de comulgar (si ay Colegiales ayudando a missa rezada) van en su lugar para que los adjutores baian a comulgar. Cuando a los dos de las hachas les dan la purificación suben otros dos con hachas y en medio de los otros hazen todos cuatro genuflexión y levántanse y dan las hachas a los que acavan de comulgar y con ellas se baxan a su puesto, luego suben los otros dos con las hachas si ay seis y hazen lo mismo y los últimos de las hachas que comulgan después de la genuflexión tomas las hachas que los primeros dexaron a los

[fol. $286^{\mathrm{r}}$ ]

Turiferarios que están en el pavimento alto y se baxan a su lugar.

8. Si ay Colegiales nones, los últimos suben tres y se cruzan con los que an comulgado, de manera que los dos de los lados cojan en medio a los dos que an comulgado y estos al que subió en medio de los tres y así hazen la genuflexión y se baxan con los que an comulgado.

9. Después de los Colegiales, comulgan los sacristanes, si ay Capellanes que no estén de missa comulgan antes de todos y primero que los Ceroferarios y Turiferarios.

10. Si an de comulgar algunas personas seglares de las que pueden subir al altar mayor, como Consejeros, Inquissidores, Veinteycuatros, Señores de título o Caballeros de hábito comulgan después de todas las sobrepellices.

11. El último de todos Comulga el Pertiguero, llega a las gradas dexa en ellas tendida la Pértiga, sube y con las genuflexiones que los demás comulga.

12. Acavada la comunión el celebrante consume si an quedado formas, el Diácono se buelve al lado del libro y el Subdiácono (rubricado)

[fol. $286^{\mathrm{V}}$ ]

a la derecha, los Ceroferarios se levantan, cogen el paño y buelven a la creedencia el vaso y toalla, los de las hachas y todos los demás se levantan y a un tiempo hazen genuflexión, las hachas se entran en la sacristía, los otros al coro y mientras dura la comunión toca el órgano si es día, la Comunión del Jueves Sancto tiene cosas particulares como se dirá en su día.

13. En el altar mayor no se comulga más que los días y gente que se ha dicho, en el altar del sagrario está el Sanctíssimo Sacramento para administrarlo al pueblo en esta forma: acavada la missa el Coadjutor enciende el codal y pone la toalla y avisa que la tengan junto a la barba, con las manos tendidas por que si cayere alguna particula no caiga en el suelo, el Sacerdote dexa los corporales sobre la Ara sin meterlos en la bolsa y sobre ellos pone el Cáliz y acavado el Evangelio último quita el Cáliz y desdobla los 
corporales y abre el sagrario, haze genuflexión saca el relicario y quítale la cubierta y capillo y déxalas detrás del relicario sobre el (rubricado)

[fol. $\left.287^{\mathrm{r}}\right]$

Corporal y quita la hijuela y haze genuflexión, en el ínterin el Coadjutor dize la confesión y acavada, el Sacerdote sobre su mano derecha da media buelta hazia el pueblo y dize misereatur et indulgentiam et remissionen, buelve al altar y haze genuflexión, toma con la siniestra el relicario por el nudo y con el índice y pollize ${ }^{23}$ de la diestra una de las formas y sobre el mismo relicario la levanta y buelve al pueblo y dize Ecce Agnus Dei Ecce qui tollit pecata mundi, el coadjutor toca la campanilla tres vezes y otras tantas dize el Sacerdote Domine non sum dignus y dicho la tercera vez sin decir otra cosa, va a comulgar y comienza por el que está al Cornu epistolae para que siempre vaya el Sacerdote sobre su manao derecha. En llegando a cada uno haze con la forma la señal de la Cruz sobre el mismo relicario y cuando entra la forma dize a cada uno Corpus Domini Nostri Iesuchristi Custodiat animam tuam in vitam alternan. Amen.

14. Cuando comienza el Sacerdote a comulgar el coadjutor dexa la campanilla y se levanta y toma el vaso y toalla y un paso después del Sacerdote va dando la purificación y no consiente que ninguna muger después de aver

[fol. $\left.287^{\vee}\right]$

comulgado se cubra totalmente el rostro con el manto. Limpia cada vez el vaso: el Sacerdote en acavando la primera buelta, se buelve al altar sobre su mano derecha y pone el relicario sobre el Ara sin soltarlo de la mano sinistra y aguarda que le avise el Coadjutor si ay mas quien comulga a los demás y el coadjutor da la ablución cuando se buelve al altar que no ay más que comulguen dice la Antíphona o Sacrum con Vivium etc, y el verso Panem de Caelo y el coadjutor responde omne delectamentum \& pone el relicario sobre el Ara y haze genuflexión, cubre las formas con la hijuela y purifícase los dedos en el vaso de agua que para este fin está en el altar. Cubre el relicario con el capillo y enciérralo en el Tavernáculo y haze genuflexión y en todo ésto dize la Oración Deus que nobis sub Sacramento mirabili etc. Levántase y cierra el Tabernáculo con cuidado que quede cerrado, quita la llave y pone su salvilla, buelve al pueblo y echa la vendición a los que an comulgado diciendo beneditio Dei omnipotentis Patris \& filii \& Spiritus Sancti descendat super vos et maneat semper. Dobla (rubricado)

[fol. $288^{\mathrm{r}}$ ]

Dobla los corporales y pone en la bolsa sobre el Cáliz y en el ínterin que esto se haze el Coadjutor dexa el vaso de la purificación, quita la toalla y la dobla y pone en su lugar, apaga el codal y velas, toma las ampolletas y palmatoria, misal y llave y bonete y discendunt ab altari more solito.

15. Si es necesario dar la comunión antes de la missa el Sacerdote puesto el Cáliz al lado del Evangelio desdobla los Corporales en el ínterin el Coadjutor enciende el codal $\mathrm{y}$ pone la toalla, abre el Sagrario y haze todo lo que se ha dicho en los números

${ }^{23}$ Pollize, léase pollice: en latín, dedo pulgar. 
precedentes y purificase los dedos echa la bendición, cerrado el Tavernáculo pone el Cáliz sobre los corporales y baxase de la peana haze genuflexión y comienza la missa In nomina Patris \&a.

16. Cuando no se dize missa y ay necesidad de administrar la Comunión sale el Sacerdote y si es Prebendado en tiempo de capas se pone la estola sobre la capa y so $\mathrm{n}$ o con sobrepelliz y estola y en la mano bolsa con corporales y cubierto, el Coadjutor con la llave y luz llega al altar haze genuflexión en la peana sube y desdobla los Corporales y el Coadjutor enciende las velas y dexa el codal encendido, el Sacerdote con las devidas reverencias abre

[fol. $288^{\mathrm{v}}$ ]

y da la comunión y haze todo lo que se dixo supra $\mathrm{n}^{\mathrm{o}} 14$.

17. Para llevar el Sanctíssimo Sacramento a los enfermos sale un comitante y enciende en el altar del sagrario, sale el Sacerdote con sobrepelliz estola y pluvial blanco, cuatro Colegiales con hachas enzendidas, el comitante con la bolsa de los corporales y campanilla, llegan al altar y hazen lo que se dixo en el número precedente, saca el relicario y dexa la puerta del tabernáculo avierta, llévalo cubierto con su capillo en la siniestra y el Comitante coge los corporales en la bolsa y va delante tocando la campanilla, acompañan las hachas y detrás del Sacerdote va otro Colegial con el açetre del agua vendita. Llegan al aposento del enfermo donde ay prevenido un altar curioso, oloroso y limpio, pone el comitante los Corporales y el Sacerdote los descoge y pone enzima el relicario, haze genuflexión, levántase y echa agua vendita y buelve a hazer genuflexión y saca el Sanctíssimo Sacramento y comulga al enfermo como se ha dicho y si es Sacerdote le ponen una estola y buelven al altar donde dexan el Sactíssimo Sacra (rubricado)

[fol. $289^{\mathrm{r}}$ ]

Sacramento a la ida y bueta van diciendo psalmos y himnos el Sacerdote y los demás alternatim.

[fol. $289^{\mathrm{v}}$ ]

\section{Capítulo 8. Cómo se descubre y encierra el Sanctíssimo Sacramento y en los Jubileos de 40 horas.}

1 Si el Sanctíssimo Sacramento se ha de descubrir antes de la missa de prima, el día antes ordena el Thessorero al Sacristán mayor que prevenga formas ajustadas y puestas en el cerco y sigundo sol de la custodia, dos puestas las cruzes que hagan haz por ambas partes, pónelas en el vaso donde se consagran las formas y cúbrelas con hijuela rica, el vaso pone en la salvilla y dalas al coadjutror de la missa de prima que las lleve al altar mayor y lleva las llaves del Sagrario y el que dize la missa de prima las consagra y cuando ha consumido el Sanguis y tomado la ablución abre el Sagrario, haze genuflexión, saca el relicario y pone en él las formas consagradas, en el mismo cerco las 
cubre y buelve a meter el relicario y haze genuflexión cierra el Sagrario y acava su missa.

2. Si se a de descubrir por la tarde o para la missa mayor se haze esto el mismo día en

[fol. $290^{\mathrm{r}}$ ]

la missa de prima como se ha dicho.

3. Los ceroferarios se visten encienden las velas que an de arder como se dixo libro 2, Capítulo 21, de Ceroferarios y previenen los que tienen otros oficios lo que les toca, el Intonario está en el órgano y el organista.

4. Cuando se viste el celebrante con pluvial blanco, el Ceroferario antiguo saca la custodia cubierta con cendal blanco y la pone en el altar a la parte de la Epístola, el Sacristán menor sube la escalerilla y la pone en el pavimento junto a la credençia que no estorbe y los Prebendados y Colegiales salen y se ponen de rodillas en el pavimento.

5. Si se descubre antes de la missa de prima cuando quieren salir, haze señal en la torre y repican con las campanas señaladas libro 2, Capítulo 14, de campanero $\mathrm{n}^{\mathrm{o}}$

6. En la Sacristía está el Pertiguero cerimoniario, los ceroferarios vestidos con çiriales encendidos, el Turiferario antiguo con Turíbulo y naveta, dos comitantes y el que a de celebrar aquel día la missa de tercia o el que a de decir la missa de prima si se descubre después de Oración y antes de prima salen por el orden que a la missa y en el pa-

[fol. $290^{\mathrm{v}}$ ]

vimento se ponen en sus lugares y hazen profunda los ceroferarios en las gradas, el cerimoniario, turiferario o Comitantes y celebrante suben y hazen genuflexión como cuando van a incensar supra Capítulo 1, de vísperas $\mathrm{n}^{\circ} 24$, excepto que los ceroferarios, en baxando los Ciriales se quedan de rodillas, cuando hazen la genuflexión el celebrante da el bonete al cerimoniario y lo

7. pone sobre el escaño o escabelo llega el celebrante al altar y lo vesa y al mismo tiempo llega el Cerimoniario y pone la bolsa sobre la Ara y los comitantes hazen genuflexión y el moderno pone la salvilla y llave en el altar al lado de la Ara.

8. Cuando hazen la genuflexión, comienza el sochantre el himno Pange lingua y todo el coro lo canta a versos con el órgano lo que alcanzaren hasta que esté el Sanctíssimo Sacramento en su sitial.

9. Desdobla el çelebrante los Corporales y el Cerimoniario combida a los prebendados que suban a asistir, suben y se ponen a los lados y el celebrante abre el Sagrario y todos hazen genuflexión, levántanse y el comitante de (rubricado)

[fol. $291^{\mathrm{r}}$ ] 
de la mano derecha le alivia algo el pluvial y el celebrante saca el relicario y sin dexarlo de la mano el Prebendado de la mano derecha lo descubre y el celebrante toma el cerquillo por la patilla donde están las hostias consagradas y lo pone sobre el corporal y el prevendado de la mano siniestra las descubre con un cavo de él y el otro buelve a cubrir el relicario y el celebrante lo encierra, hazen todos genuflexión y cierra la puerta del sagrario y echa la llave.

10. El Cerimoniario descubre la custodia, echa el cendal sobre el brazo siniestro, el celebrante y todos hazen genuflexión, levántanse, toma el cerquillo con la mano diestra y el Prebendado pone el cerquillo con las hostias en su lugar, vien asegurado y dexa la vidriera abierta hasta que a incensado y hazen genuflexión, a este tiemepo llega el Turiferario por el lado de la Epístola con el Turíbulo y naveta como suele y el prebendado ministra la cuchara al celebrante del mismo modo que se a dicho que haze el comitante Capítulo 1, de Vísperas, n 24 y el Diácono, Capítulo 4, de missa, no ¿?, excepto que no vesa la mano

$=$ tachado consagradas $/ \mathrm{y}$ al margen consagradas $=$ (rubricado)

[fol. $291^{\mathrm{v}}$ ]

ni cuchara ni dize Benedictio ni el celebrante echa vendición.

11. Regla general es que jamás se vesa nada al dar ni recivir al çelebrante cuando esta el Sanctíssimo Sacramento descubierto y cuando se ha de incensar solo el Sanctíssimo Sacramento y no el altar ni otra cosa no se pide ni echa bendición al incienso, mas cuando se ha de incensar la oblata o el altar, sí, aunque se inciense entonzes y primero el Sanctíssimo Sacramento.

12. Recibe el celebrante el Turíbulo y de rodillas inciensa con tres ductos el Sanctíssimo Sacramento y todos están de rodillas, levántanse y buelven a hazer genuflexión, buelve el Turíbulo al Prebendado y éste al Turiferario, el cual haze genuflexión y se va el Cerimoniario, pone el cendal por los hombros al celebrante, el cual cierra la Vidriera y mete el torzal del alfiler por el filete que no se vea y buelve la custodia, apártese un poco al lado de la Epístola, llega el comitante moderno y pone la gradilla, baxa la peana el celebrante y en derecho de la grada haze genuflexión al Sanctíssimo Sacramento sube y en el último escalón se baxa doblando las rodillas y to (rubricado)

[fol. $292^{\mathrm{r}}$ ]

y toma la custodia por enzima del cendal y la suba al sitial y la pone igual y derecha que venga en medio del dosel y los ceroferarios tocan con las campanillas como a Sanctus y los prebedados al subirle alzan algo los cavos delanteros del pluvial por que no lo huelle. Pone si ay ramilletes de flores de suerte que no cubran el pie de la custodia.

13. Baxa el celebrante y el último escalón de la gradilla lo baxa de lado quedándose al de la Epístola, quita el Comitante la gradilla y el cerimoniario el çendal, pónese en el medio del altar y hazen genuflexión y con él todos los demás y el celebrante y los comitantes, Çerimoniario, Çeroferarios y Pertiguero se van a la Sacristía por el orden que vinieron y ninguno se cubre hasta aver entrado en la capilla de los mártires; en la 
Sacristía se desnudan y lo ceroferarios buelven y componen el altar, sacan los candeleros y la Cruz en medio, llevan el zendal, llave y Corporales echándolos que tienen cuidado flores.

14. Si el Sanctíssimo Sacramento se a de descubrir, en acavando la missa de prima, (rubricado)

[fol. $292^{\mathrm{v}}$ ]

el que la dize consagra dos hostias en su cerquillo y las dexa en el corporal y cuando a consumido y purificado el Cáliz, lo cubre y aparta al lado del Evangelio y el adjutor lo lleva a la Credençia, pone las hostias consagradas en medio del corporal y las cubre con el cavo de él, acavada la missa, haziendo las genuflexiones que manda el ordinario rúbrica del Jueves Sancto.

15. Cuando ha consumido, los lucernarios salen y con las devidas reverenzias encienden las velas que an de arder. Sale el Turiferario y pónese en su lugar y los comitantes sacan (el antiguo) la custodia cubierta con çendal blanco y la pone en el altar al lado de la Epístola, el moderno la Salvilla y llave, en acavando la missa se hinca de rodillas en la peana en medio del altar y se está así con su casulla hasta que en el coro an acavado las horas, que Vaxan en ceremonia al pavimento y se ponen en dos coros de rodillas por sus antigüedades y el sochantre entona el Tantum ergo. El Cerimoniario que baxó con el coro sube y al mismo tiempo el Turiferario y dos prebendados que asistan ministran el incienso.

[fol. $293^{\mathrm{r}}$ ]

inciensa y sobre la casulla le pone el cerimoniario el çendal y con las devidas reverencias, lo sube y pone como queda dicho, mas al irse a la Sacristía solamente lo acompaña el adjutor y los comitantes se quedan componiendo el altar.

16. Si se descubre al principio de la missa mayor, los ceroferarios encienden todas las velas que an de arder y sacan el demás recaudo para la missa; salen por el mismo orden que se dixo Capítulo 4, de missa solemne, $\mathrm{n}^{\mathrm{o}}$, y el flavelario es quien quita y pone la gradilla, los Diáconos ministran de la misma manera que los prebendaos y todo lo demás se haze como queda dicho supra $\mathrm{n}^{\mathrm{o}} 12$ y los siguientes, excepto que el celebrante está con casulla y que aviendo incensado el Sanctíssimo Sacramento y puesta la gradilla se hinca de rodillas con el çendal por los hombros y el Diácono toma otro cendal blanco pequeño y haze genuflexión y toma la custodia y se la da al celebrante que está de rodillas y en aviéndola recivido, haze genuflexión y se levanta y ayuda a levantar al celebrante, el cual sube y la pone como se a dicho. Y se dize la missa como se dixo en el capítulo $4, \mathrm{n}^{\mathrm{o}}$ y siguientes.

[fol. $293^{\mathrm{v}}$ ]

17. Si se descubre para vísperas, encienden los ceroferarios y sale el celebrante y caperos por el orden que se dixo, Capítulo 1, de Vísperas, $\mathrm{n}^{\circ}$, pero sale un Turiferario con Turíbulo después del Pertiguero, el cual por estar los prebendados en el pavimento 
baxo, se pone fuera de él en el Crucero y los demás se ponen como hizieron la profunda

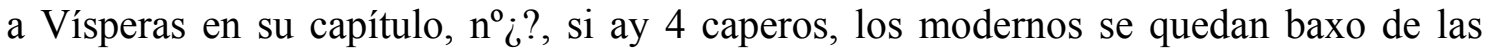
gradas y los dos comitantes modernos, los caperos y comitantes antiguos suben y el cerimoniario con el celebrante y hazen genuflexión y cuando llegan al altar la buelven a hazer señal, el celebrante que solamente lo vesa, llega el Turiferario por el lado diestro del capero de la mano derecha y da la naveta y los caperos ministran del mismo modo que los prebendados supra $\mathrm{n}^{\mathrm{o}} 12$ y lo demás se haze como en el y en las siguientes se dize, mas el capero no da el Sanctíssimo Sacramento al celebrante que ésto solo lo haze el Diácono y puesto en su lugar, los prebendados y el clero se vam al coro y luego los de la çeremonia de Vísperas more solito.

18. Si se descubre a la noche para alguna rogativa o devoción se guarda lo mismo que

[fol. $294^{\mathrm{r}}$ ]

Cuando se descubre ante primam, excepto que no se sube a dosel porque no se pone sino en medio del altar sobre la Ara.

19. Para enzerrar el Sanctíssimo Sacramento salen Pertiguero, Turiferarios, Ceroferarios, Comitantes y Cerimoniarios y último el celebrante con pluvial, descubiertos desde la capilla de los mártires: los Prebendados y Clero están en el pavimento de rodillas more solito y el órgano toca suavemente. Llegan al altar, hazen genuflexión en la peana, los Turiferarios quedan en sus lugares en el pavimento alto meneando los Turíbulos y luego el celebrante lo vesa, desdobla el Corporal, aparta y pone el comitante la gradilla, haze genuflexión delante de ella y el Cerimoniario le pone por los hombros el zendal, sube y baxa la custodia y el último escalón por el lado que se quede sobre la peana del altar al de la Epístola, aparta el comitante la gradilla y el celebrante pone la custodia sobre el Corporal sin abrir el Viril, haze genuflexión y el Cerimoniario le quita el cendal, suben dos prebendados a asistir y el de la mano derecha le ministra la naveta, pone incienso y turifica de rodillas el Sanctíssimo (rubricado)

[fol. $294^{\mathrm{v}}$ ]

Sacramento como se dixo supra $\mathrm{n}^{\mathrm{o}} 12$ y 13, levántase y buelven a hazer genuflexión y da el Turíbulo y el Turiferario se buelve eregione de su compañero.

20. Echado el incienso cesa el órgano y mientras la Turificación, el Sochantre entona el Verso Tantum ergo Sacramentum y el coro lo canta y se levantan dos Colegiales cantores y cantan el Verso panem de Coelo y responde el Coro Omne delectamentum etc, y luego el celebrante buelto al altar, en medio puestas las manos, canta Oremus, y los prebendados se ponen de rodillas a sus lados y los demás en sus lugares, excepto los Turiferarios que se quedan en pie y canta la oración Deus qui nobis sub Sacramento mirabili, por el misal que aplica el cerimoniario y los prebendados asistentes tienen cada uno por sus lado reclinado sobre la frente del altar concluye la oración, con qui vivis et regnas per omnia Secula seculorum y respode el coro Amen, y buelve a tocar el órgano y los Prebendados cierran el missal y se levantan y lo dan al Cerimoniario y 
luego ellos y el celebrante hazen genuflexión, levántanse y el cerimoniario le pone el cendal y con él toma la Custodia (rubricado)

[fol. $295^{\mathrm{r}}$ ]

y levantada hasta el rostro no más se buelve al pueblo y los prebendados le sustentan los brazos.

21. Cuando se buelve, los turiferarios echan incienso en los Turíbulos y toman las navetas y extremidad de las cadenas en las sinistras y por junto las cubiertas con las diestras y se van a hincar de rodillas junto a la peana de en medio y los brazos tendidos y levantando los Turíbulos todo lo que alcanzan, turifican el Sanctíssimo Sacramento mientras el celebrante, con la misma custodia, bendize al pueblo haciendo una Cruz en esta forma:cuando se ha buelto totalmente levanta la custodia con ambas manos con mucho espacio [al margen de la hoja aparece dibujado el signo de la + ] hasta que el nudo empareje con la frente y con el mismo espacio la baxa hasta que descubra todo el rostro, luego la levanta hasta en derecho de él y se buelve sobre la mano siniestra hazia el Cornu epistolae y la lleva en aquella altura hasta que se buelve de la misma manera hazta el Cornu Evagelii con lo cual forma los brazos de la Cruz y por aquel lado acava de dar la buelta y pone la custodia sobre el Corporal y los Turiferarios se levantan y hazen genuflexión. (rubricado)

\section{[fol. $295^{\mathrm{v}}$ ]}

y llevando los Turíbulos more solito se van a la Sacristía y mientras se bendize el pueblo con la custodia, los ceroferarios tocan a un compás las campanillas como cuando las tocan a alzar en la missa.

22. El Celebrante abre la Vidriera y saca el cerquillo con las hostias consagradas, el Prebendado de la mano diestra aparta la custodia al lado de la Epístola, el Cerimoniario la cierra y cubre con un çendal, el celebrante pone el Sanctíssimo Sacramento en el Corporal y lo cubre con el Cavo, abre el prebendado el Sagrario o Tabernáculo y hazen genuflexión, saca el celebrante el relicario y el Prebendado lo descubre y sin dexarlo de la mano pone en el el celebrante el cerquillo, el Prebendado cubre el Sanctíssimo Sacramento con las hijuelas y zendal o capillo y el celebrante lo pone en el sagrario, haziendo genuflexión y el cerimoniario quita el cendal al celebrante, el cual cierra el Sagrario que quede (cierto esta) çerrado, quita la llave y pone en su caxica, apártanse y en la peana hazen genuflexión, donde el cerimoniario da el bonete al celebrante, los prebendados se baxan no acompañándolo y el celebrante se cubre y con los que salieron en

[fol. $296^{\mathrm{r}}$ ]

ceremonia se va a la Sacristía sin echar otra Bendición, en acavando de decir el coro Amen a la oración Deus qui nobis, el órgano toca suavemente hasta que se van a la Sacristía. 
23. Si el Sanctíssimo Sacramento se encierra inmediate después de la missa mayor, se observa lo mismo que se ha dicho en los números precedentes, excepto que el celebrante no dexa la casulla sino solo el manípulo y con la casulla exerse este acto y el Diácono es el que sube por la custodia y la toma con un çendal y la da al celebrante que está de rodillas de la misma forma que se dixo supra $\mathrm{n}^{\mathrm{o}} 16$.

24. Y si se encierra inmediate después de Vísperas, baxa todo el coro como después de missa en Ceremonia y detrás los caperos y celebrante y los caperos antiguos suben y sirven de asistentes como los Diáconos cuando se encierra después de missa y lo demás se haze como queda referido.

25. En los jubileos de las cuarenta horas se guardan las mismas ceremonias y es lo que se a dicho al descubrir y encerrar.

26. No se encierra a medio día, si es tiempo de inbierno se descubre a las primeras Vísperas de las fiestas en que comienza y si ay

[fol. $296^{\mathrm{v}}$ ]

maytines se encierra y después de ellos, los demás días se descubre antes de oración y se encierra a las cinco de la tarde, de manera que se repartan las 40 horas cavales en los tres días y medio; si es tiempo de verano por ser los días mayores, en los tres se pueden coger las 40 horas y así no se descubre a las primeras Vísperas del primer día, sino desde antes de la Oración y cada día esté descubierto treze horas y media poco más o menos.

26. Los colegiales asisten en oración de dos en dos o cuatro en cuatro por su turno como lo señalare el admonitor con cosulta del Rector todo el tiempo que no fuere de Coro.

[fol. $297^{\mathrm{r}}$ ]

\section{Capítulo 9. Cómo se renueva el Sanctíssimo Sacramento y se guarda en los sagrarios.}

1. Todos los jueves se dize la missa de tercia con la solemnidad de segunda clase, es la missa del día y fiesta del Sancto, aunque en el rezo sea simple se toca el órgano, las ferias que no son de cuaresma /ni/ y el adviento /ni/ Vigilias es la missa del Sanctíssimo Sacramento como se dize libro 1, Capítulo 12, de la solennidad de las fiestas. Esta solemnidad se da porque se renueva el Sanctíssimo Sacramento en el altar mayor y la instituyó el Cabildo por la deboción que en esta Sancta Iglesia se tiene a este divino misterio, en cuyo culto y servicio se ha de emplear y emplea con tanto cuidado.

2. Para la missa mayor los Ceroferarios sacan el frontal conveniente a la solemnidad, encienden seis velas en el altar, llevan la llave del Sagrario en su caxa y salvilla y ponen en la Patena hostias

(rubricado)

[fol. $297^{\mathrm{v}}$ ] 
[para] la missa y otra cercenada y ajustada para el relicario, dízese la missa como se dixo en el capítulo 4.

3. Al ofertorio después de leido del celebrante, el Diácono abre la puerta del Sagrario y hazen genuflexión y simul todos los de el coro y altar, tira de la tablilla donde está el relicario y echa por detrás las cortinas, de suerte que quede manifiesto, hazen genuflexión y dexa la puerta abierta y en las genuflexiones llegadas y retiradas y todo lo demás guarda las ceremonias como cuando esta el Sanctíssimo Sacramento descubierto.

4. Hecho el ofertorio de la hostia, pónela que se a de guardar en un canto del corporal y cuando consagra la toma en la mano y dize las palabras y luego la buelve a dexar donde estava.

5. Cuando a consumido la hostia, hazen genuflexión y el Diácono saca el relicario y pónela en la patena y purifica el relicario y pone en él la hostia nuevamente consagrada, el Diácono la cubre con la hijuela y buelve el relicario donde estava y haze genuflexión y el celebrante consuma la hostia que sacó.

y (rubricado)

[fol. $298^{\mathrm{r}}$ ]

y luego haze genuflexión y toma el sanguis ministrando el subdiácono las purificaciones more consueto.

6. Acavada la missa, si es día de órgano responde al Ite missae est y haze un poco pausa y luego comienza a tocar el Pange lingua y sale un Turiferario con Turíbulo y cuatro o seis Colegiales con hachas, según las que ha avido en la missa al tiempo de alzar: llega a las gradas y en medio de los ceroferarios haze profunda, sube y en el pavimento, haze genuflexión y llega donde suele a dar la naveta al Diácono, el cual la ministra al celebrante, echa incienso sin vendición como se ha dicho, cesa el órgano y mientras la incensación en el Coro cantan el Verso Tantum ergo Sacramentum, el celebrante inciensa de rodillas y todos con él, con tres ductos more solito, levántanse y con el Turíbulo buelve a hazer genuflexión y da el Turíbulo al Diácono y éste al Turiferario que haziendo genuflexión se va a la Sacristía; cantan en el coro el verso Panem de Coelo etc, y responden en el ínterin, aplica el Atril y missal el Diácono registrada la Oración Deus quí nobis, que la concluye

(rubricado)

[fol. $298^{\mathrm{v}}$ ]

con qui vincis et Regnas Per omnia Saecula Saeculorum, cuando dize Oremus los Diáconos se hincan de rodillas a sus lados y acavada la oración se levantan y todos tres hazen genuflexión, responde el coro Amen.

7. Levántanse y el celebrante saca el relicario, pónele la cubierta y cúbrelo con el capillo, éntralo en el Sagrario, haze genuflexión, levántase, echa las cortinas y cierra, 
pone las llave en su casa y apártanse como en las demás missas y si es día de responso lo dizen etc.

8. De los jueves se exceptua el Jueves Sancto, que consume la hostia que estava en el relicario y la nuevamente consagrada pone en el Cáliz para la procesión, con las ceremonias que se dizen en su día libro 4, Capítulo 12.

9. El día de la Ascensión no se inciensa sino la ostia que se pone en la Custodia para quedar manifiesta la hora y no se dize la oración, porque aunque renueve el Sanctíssimo Sacramento y consume la hostia que sacó en poniendo la nuevamente consagrada en el relicario, lo encierra en el Tavernáculo y no enciende al fin ni dize la oración.

10. El día del Corpus lo mismo, porque ese rechaza

Pro (rubricado)

[fol. $299^{\mathrm{r}}$ ]

procesión, en acavando la missa, el día octavo lo mesmo y en acavando la missa se encierra el Sanctíssimo Sacramento y assí no se inciensa al fin de la missa sino la hostia de la custodia, dize la oración, después lo muestra al pueblo.

11. Cuando el día de los difuntos cae en jueves se renueva el Sanctíssimo Sacramento el miércoles día de todos los Sanctos.

12. Cuando el día de San Cecilio cae en jueves se renueva el Santíssimo Sacramento el viernes siguiente, día de la purificación de Nuestra Señora, los demás jueves, aunque sea fiesta Solenníssima se renueva como se a dicho.

13. En el altar del Sagrario se renueva siempre que ay necesidad de consagrar formas, lo que se hará siempre las Vísperas de fiesta en que suele aver mucho concurso y frequencias de Sacramentos especialmente las Vísperas de fiestas principales de Nuestra Señora, Vísperas de pascua y fiestas de los Santos, conságrase en la missa última, llevan el capillo con las formas vien çercenadas y purificadas, cuando a consumido el Sacerdote el Corpus y el Sanguis abre el Sagrario, saca el relicario y consume la hostia grande y pone la nuevamente consagrada, saca el capillo, (rubricado)

[fol. $299^{\mathrm{v}}$ ]

si ay quien comulgue, da la comunión con las formas que antes avía y consume las que sobraren y purifica el Capillo que saco y en ninguna manera lo dexe en el sagrario, pone el de las formas nuevas, no echa la Vendición, encierra el Sanctíssimo Sacramento y acava su missa more solito y el Coadjutor se trae la llave y el Capillo en sus salvillas.

14. El Sanctíssimo Sacramento se guarda en sus sagrarios del altar mayor y Colateral que nunca falte, porque no se dé ocasión a los fieles que sin estar en ellos hagan reverencia y adoren el Sanctíssimo Sacramento y assí que del altar colateral se lleva á 
algún enfermo se quede la puerta del sagrario avierta para que se conozca no estar allí su Magdestad.

15. El Jueves Santo, en acavando la missa, el que está en el altar de la Concepción se lleva a la Capilla de la Sacristía porque no lo ha de aver más que en el monumento.

16. En los sagrarios ha de aver Aras consagradas cubiertas con Corporales sobre que an de estar los relicarios, an de estar muy limpios y el Tesorero como se dixo libro 2, capítulo 9 los a de limpiar y zahumar todos los

mier (rubricado)

[fol. $300^{\mathrm{r}}$ ]

miércoles en la noche, será conveniente tener dentro coginillos de flores adobados de ámbar, estén los Sagrarios muy vien dorados, ajustados que no aya agujero ni raya por donde pueda entrar ni aún polvo, tengan sus camillas ricas y con cortinas bordadas que cubran vien las puertas; los relicarios de plata dorados de figura redonda y el suelo o vado para que se pueda vien purificar sobre las formas se ponen hijuelas que lleven todo el redondo, y aunque por la parte superior estén bordadas, que lleven perlas y granates, la parte inferior que toca al Sanctíssimo Sacramento a de ser de lienzo llano, sin bordadura ni lábor, sobre esta hijuela puede aver otra de ámbar o de seda, las cubiertas de plata que ajusten muy bien y sobre ellas capillos ricos bordados o de tela que el Thesorero cuidará que estén vien aderezados sanos y hermosos y de hazer otros cuando fuere neçesario.

17. Los vasos de plata, relicarios y capillos en que inmediatamente se pone el Sanctíssimo Sacramento, an de estar benditos, muy

$\left[\right.$ fol. $300^{\mathrm{v}}$ ]

limpios y dos capillos en que se consagran las formas en el sagrario, uno que las tiene y otro en que se llevan para remudar y se trae el que se purifica y se guarda dentro de una caxa de madera redonda y forrada, la cual se pone donde se guardan los cálizes y las llaves del sagrario o se guarden con mucho cuidado como se dixo Capítulo 9, del Tesorero.

18. Cada ocho días se renueva el Sanctíssimo Sacramento en el altar del sagrario y esto será en los Sábados y lo ha de hazer el Tesorero o encomendarlo a quien lo haga porque corre por su cuenta del modo que se a dicho.

[fol. $301^{\mathrm{r}}$ ]

\section{Capítulo 10. De la Missa cantada sin Diáconos.}

1. Si algún día por particular necesidad de enfermedad general o otra causa no ubiere quien se vista, la missa de tercia se canta y celebra sin Diáconos, no sirven en ella Pertiguero, çerimoniario ni Turiferario; los ceroferarios sacan todo el recaudo 
necesario, excepto Atriles o facistol, en dejando el esquilón comienzan en el coro y salen los ceroferarios con los ciriales levantados. Un colegial coadjutor que es Turiferario más antiguo y detrás el celebrante con las manos puestas y cubierto, llegan a la grada y puestos en una línea hazen todos profunda. Quédanse los ceroferarios en sus lugares, baxan los çiriales y se hincan de rodillas, cuando en la peana haze el celebrante genuflexión y a su diestra el coadjutor y le toman el bonete y se pasa a la siniestra y responde a la conforme

[fol. $301^{\mathrm{v}}$ ]

y todo en lo demás como en las missas rezadas.

2. El Coadjutor que haze también oficio de flavelario sirve de responder al celebrante de mudar el misal y açercalo y apartarlo para que el çelebrante pueda cantar y haze todo lo que se dixo en el libro 2, capítulo 26, $\mathrm{n}^{\mathrm{o}}$ y $\quad \mathrm{y}$

3. Los ceroferarios están de rodillas o en pie a las mismas cosas y tiempos que a la missa cantada con Diáconos, excepto que como en esta missa el celebrante no se sienta a los Kyries ni a la Gloria ni al Credo, ellos no se hincan de rodillas sino a toda la Gloria se están en pie hasta que la acave el coro y en el Credo, después de la genuflexión al Incarnatus est se buelven a levantar.

4. Para el Evangelio sacan los ciriales y los levantan al Sequentia o Initium sin moverse de sus lugares y acavados los baxan y ponen en sus saldadillas.

5. Cuando el celebrante dize Oremus del ofertorio suben ambos y de la credenzia

[fol. $302^{\mathrm{r}}$ ]

llevan el Cáliz, ampolletas y toalla y lo ministran como a la missa con Diáconos y como se dixo libro 2, Capítulo 21, de ceroferarios, $\mathrm{n}^{\circ}$.

6. El celebrante dize los Kyries rezados en medido del altar como en las missas rezadas y acavadas no se siente mientras los acava el coro, lo mismo a la Gloria ni Credo está en medio del altar y el rostro buelto al Sanctíssimo Sacramento y las manos puestas siempre que buelve a cantar Dominus Vobiscum o decir Orate frates el coadjutor se pone delante como en la missa rezada, lo mismo al dar la Vendición.

7. El Coadjutor registra y haze todo de más que el presvítero asistente.

8. El Celebrabte purifica el Cáliz y lo limpia con el purificador, dobla los corporales y los cubre como en las missas rezadas, lo dexan en el altar que los ceroferarios los llevan a la Sacristía cuando acabada la missa quitan el demás recado.

9. Para el Ite missa est el coadjutor le pone y tiene el misal y lleva reacudo

$\left[\right.$ fol. $\left.302^{\mathrm{v}}\right]$ 
para el responso.

10. En estas missas combiene que el compás del coro sea más ligero y menos solemne, y que el órgano toque con más brevedad los Versos que tocare: véase libro 2, capítulo 12 del organista, y asimismo el canto del çelebrante pues el misal lo pone diferente para los días menos solennes y las çeremonias, pasos y genuflexiones de los ministros asimismo no deven ser con tanta pausa y morosidad como los otros días.

[fol. $303^{\mathrm{r}}$ ]

\section{Capítulo 11. De la Missa de Nuestra Señora in Sabbatho.}

1. A los tres cuartos de la oración comienza el campanero el repique y salen los ceroferarios de ella y se visten y sacan recaudo. Lo primero adornan el altar con flores, el Sacristán a puesto la noche antes alfombra y frontal, ençienden cuatro, mas si el Sábado es día de alguna de las nueve fiestas de Nuestra Señora ponen seis, el Cáliz y ampolletas ponen sobre una Credenzia apercibida para esta missa y puesta en la pilastra del arco del púlpito del Evangelio, sacan facistol con paño blanco y lo ponen en el lado de la Epístola. A cuatro pasos de la peana, no ay palmatoria y todo lo demás como a la missa de tercia y a esta missa asiste por el cerimoniario el Turiferario antiguo con bonete y el moderno se viste.

$\left[\right.$ fol. $303^{\mathrm{v}}$ ]

2. Todos los Sábados del año (excepto el Sábado Sancto y el día de pascua de Navidad, que este día en lugar de la de Nuestra Serñora se dize la segunda del día) y asimismo el día de la circuncisión y Epiphanía, se celebra missa de Nuestra Señora la que señala para el tiempo el ordinario al fin del misal, mas si es día de Nuestra Señora, se dize la de la fiesta de los Sábados que son octavas o infra octavas de las fiestas de la Asumpción, Natividad y Concepción se dize la missa de la fiesta con Credo y más Solemnidad que los otros Sábados. Siempre se dizen tres Oraciones aunque sea día doble, sino es que es día de Nuestra Señora que se dizen las que pide la missa de la festividad, si ay commemoraçión se dize después de la oración del Spiritu Sancto, si las conmemoraciones son dos o tres o cuatro no se dize la oración del Spiritu Sancto, aunque se queden en pares y al fin de ellas no se dize la conclusión Et famulos tuos, etc.

3. Dados los tres golpes con la gorda después

[fol. $304^{\mathrm{r}}$ ]

del terzero repique, que comienzan en el coro el Introito y salen de la Sacristía el Turiferario, los ceroferarios, un Colegial. Asisten con bonete, el subdiácono, Diácono y celebrante las manos puestas y cubiertos, llegan a la grada del pavimento alto y puestos en una línea como cuando quieren subir a la missa mayor todos juntos hazen genuflexión al altar mayor, el celebrante cubierto y los demás sin bonetes dan la buelta por dentro y llegan al altar de la Concepción, el ceroferario moderno pasa al lado del 
Evangelio, el antiguo se queda en el de la Epístola y apartado de la peana y el Turiferario a su diestra, de suerte que dé lugar a que pasen los de la missa por delante, el Colegial asistente se queda arrimado a la Credenzia eregione del Turiferario y así pasan por medio de ellos, el Diácono se queda delante del Ceroferario del lado de la Epístola y el Subdiácono pasa delante del otro y el celebrante en medio haze profunda al altar y los Diáconos y los demás genuflexión.

\section{Los ceroferarios en el lugar donde están}

[fol. $304^{\mathrm{v}}$ ]

que será por dos pasos poco menos de la peana, allí están de rodillas siempre con los ciriales en las manos y no se levantan a cosa alguna más que a ir al Evangelio.

5. El Turiferario se hinca de rodillas a la diestra del Ceroferario, un paso apartado de él y en derecho del Cornu epistolae, el asistente Colegial haze genuflexión a la diestra del Diácono y toma los bonetes y pasa a la otra parte y toma el del Subdiácono y se buelve al Cornu Epístola, donde está de rodillas hasta acavada la comfision y que entran en el altar que se levanta y dobla los bonetes y pone en la credenzia.

6. Entran en el altar los de la missa more solito y llega el Turiferario y con las devidas reverencias por el lado de la Epistolae ministra la nabeta y turíbulo como se dixo Capítulo $4, \mathrm{n}^{\mathrm{o}}$. Diácono y celebrante en la Turificación aguarda lo mismo, excepto que cuando llega al medio del altar y pasa por delante por no aver Sanctíssimo Sacramento no haze genuflexión sino profunda a la cruz, mas los Diáconos hazen genuflexión y ésto observa todas le vezes y en todas las ocasiones sino es después de aver consagrado: los Kyries, la Gloria y Credo se

[fol. $305^{\mathrm{r}}$ ]

dizen como en la missa de tercia, mas no se sientan mientras el coro los acava de cantar, sino en medio del altar está uno en pos de otro.

7. A la conclusión de la última oración, el Colegial asistente da el libro al subdiácono, el cual haze genuflexión en el medio del altar, el libro arrimado al pecho y va a decir la Epístola y a la buelta vesa la mano al celebrante, si es Prebendado se inclina y si no, se hinca de rodillas, lo mismo haze el Diácono cuando pide la vendición, pasa el misal y el Colegial asistente el atril al lado del Evangelio y al que dize el celebrante se levantan los ceroferarios, mas no los ciriales, sale el Turiferario y el Diácono pide la Vendición y hazen genuflexión y van a decir el Evangelio de la misma manera que se dixo en el $\mathrm{n}^{\mathrm{o}}$ del capítulo 4.

8. El Colegial asistente toma el Atril y misal mientras las incensaciones, ministra las ampolletas, echa agua manos y la toalla como en las missas rezadas y da las campanillas a los ceroferarios para que toquen a Sanctus y al alzar y después las buelve a la Credenzia, pone y quita el paño de hombros al Subdiácono, el custos Sacristía tiene prevenido un pomo de 
[fol. $305^{\mathrm{v}}$ ]

plata con brasas y lo saca detrás de los que sacan hachas, echa pastillas y lo pone en el altar al lado de la Epístola, si a de poner pebetes y otros olores al mismo tiempo los saca: el Turiferario inciensa al alzar como se dixo Capítulo $4, \mathrm{n}^{\circ}$ y acavado su ministerio se desnuda y saca el recaudo de la missa de prima, y si tiene lugar sube al coro para baxar en ceremonia con el que la dize: Aviendo quien pueda cantar al órgano, el que preside en el coro cuide de embiarle para que se diga, lo mismo cuidará en las Salves de las cinco festividades de guardar de Nuestra Señora o si ubiere realejo en las cuevas los Sábados del año.

9. Salen cuatro hachas para la elevación del Sanctíssimo Sacramento con las çeremonias y acostumbradas reverenzias libro 2, Capítulo 19, de lucernarios $\mathrm{n}^{\circ}$.

10. En el coro cuando comienzan los Agnus salen todos los Colegiales lucernarios a encender en el altar mayor para las oras que se dizen inmediatamente y aguardan en la Sacristía para ayudar a desnudar a los de la missa y bolver con ellos en ceremonia y el prebendado de missa de prima se rodea las mangas de la sobrepelliz al brazo, haze cortesía al Preste.

[fol. $306^{\mathrm{r}}$ ]

Y sale delante un coadjutor y va a la sacristía no por la Iglesia para vestirse a tiempo que cuando se comienze prima salga a decir la missa.

11. En acabando la de Nuestra Señora, da el asistente los bonetes y en lo baxo de la peana dize el çelebrante un responso Qui Lazarum resuçitasti con la oración Fidelium Deus omnium conditor etc, por los padres y demás difuntos del Abad Doctor Don Pedro Dávila, fundador de este aniversario y después de sus días en primer lugar por el dicho Señor Abad, no se da hisopo ni se echa agua vendita. Van a la sacristía por el orden que vinieron y en el pavimento hazen genuflexión, de la misma manera entran y los ceroferarios apagan los ciriales y dexan en sus lugares y antes de desnudarse quitan el recaudo primero el frontal y los candeleros y Velas y ponen los dos que sirven para las missas ordinarias, entran las ampolletas, Cáliz misales y el facistol, doblan el paño y todo lo ponen en sus lugares y se desnudan.

12. Los de la missa se desnudan ayuda el asistente y lucernarios que vaxaron a encender

[fol. $306^{\mathrm{v}}$ ]

y comienzan prima, dicho el himno diciendo los psalmos buelven al coro acompáñanlos los dos Colegiales lucernarios y el que asistió en la missa, hazen genuflexión en el pavimento y entran en el coro como se dixo en el Capítulo 2, de completas, que entran los que buelven de las Vísperas y en pasando del facistol, con las devidas reverenzias saludan al coro y todos se levantan y los Diáconos dexan pasar totalmente al celebrante y házenle profunda y luego se van a sus sillas.

[fol. $307^{\mathrm{r}}$ ] 


\section{Capítulo 12. De las Salbes de Nuestra Señora en los Sábados y en sus fiestas.}

1. Todos los Sábados del Año ay salve, dotación del Abad Don Pedro Dávila, dízese en las cuebas, en la de San Cecilio donde ay altar de la Concepción de Nuestra Señora, desde el primer Sábado de octubre hasta el Sábado Sancto se dize (inclusive) inmediatamente después de completas y así al fin de las Vísperas comienzan a tocar como se dixo libro 2, Capítulo 14, de campanero $\mathrm{n}^{\mathrm{o}}$, desde el Sábado ante Dominicam in albis, hasta el último de Septiembre se dize a las seis de la tarde y comienza a tocar a las cinco y media supra Capítulo 14, de Campanero, los días que por mucho agua o nieve no dieren lugar a ir a las cuevas se dize en la Iglesia en el altar mayor, que también es de Nuestra Señora, a elección del Abad o Presidente a quien lo a de preguntar el capiller

$\left[\right.$ fol. $307^{\mathrm{v}}$ ]

del Colegio.

2. El Colegial que tiene cuidado de la capilla del Colegio tiene a su cargo el prevenir lo necesario para la salve en las Cuevas cuida de que se barran y esté limpio y sin polbo el altar y retablo libro 2, Capítulo 9, de Tesorero, Capítulo de Colegiales, Capítulo 15 de Caniculario. Lleva agua vendita para la pila y la laba todos los Sábados, tiene a su tiempo cuidado de llevar rosas, flores y yervas olorosas para adornar el retablo, tabernáculo y altar, lleba cuatro candeleros pequeños y cuatro buxías porque no hagan humo al retablo, cuando comienza el tercer repique las enciende y los pebetes y pastillas en un pomo de plata, lleva el cuaderno donde está apuntada la Salve y su sobrepelliz doblada y después de aver puesto todo el recaudo se la pone y asiste con los demás y en acavándola apaga y buelve todo lo que truxo a la Sacristía y cierra las cuevas y en ninguna manera las dexa aviertas para que entre gente ni las muestre sin expresa orden del Abad o Presidente.

\section{3. $\mathrm{Al} 2^{\circ}$ repique van todos los Colegiales}

\section{[fol. $308^{\mathrm{r}}$ ]}

a la sacristía y con mucho silencio toman sobrepellices, y cuando comienza el tercero salen en ceremonia por la capilla de los mártires y detrás de todos el Rector, en el crucero se ponen en dos Coros, pasando abaxo los modernos y quedándose los antiguos junto a la grada y en medio el Rector, hazen juntos genuflexión y van por la Iglesia, salen por la puerta principal y en saliendo se ponen los bonetes, van con mucha modestia y compostura que se edifique la gente de verlos, al pasar por las rexas de los hornos se quitan los bonetes y hazen profunda, los prebendados van con mucha deboción a haçer esta estación, no en corrillos ni conversaciones, ni parándose en la plaçeta como quien deve dar ejemplo a todos los que los vieren, cuando se topan con el colegio le quitan el bonete aunque vaya sin el rector y los Colegiales quitan los bonetes a los Prebendados y en pasando dos pasos de ellos se buelven a cubrir; los Prebendados también hazen reverencia a los hornos con mucho cuidado que vean todos en la reverençia que se tienen aquellos Sanctos lugares. 


\section{[fol. $308^{\mathrm{v}}$ ]}

4. Llegan a la Cueva de San Cecilio y los prebendados se ponen de rodillas en dos coros guardando la dignidad de coro y antigüedad de las personas, los más antiguos los primeros junto a los arcos colaterales del altar arrimados a las paredes, los Colegiales se ponen en dos coros en medio los más modernos más juntos al altar pasan delante de todos los Versicularios y en dando los tres golpes de la gorda se levantan y entre ambos tienen el cuaderno de la Salve, el sochantre que se puso en medio de los Colegiales se levanta y entona la Salve y todo el coro prosigue, entonándola se hinca de rodillas al verso $O$ dulçis Virgo Maria se levantan los comitantes primeros y se llegan al Hebdomadario y si falta, al que le sigue en antigüedad, y le hazen cortesía, levántase y va acompañado de ellos hasta que sube en la peana del altar, donde hazen genuflexión y se levantan, entonando los Colegiales cantores el Verso Ora pro nobis los comitantes ministran el libro, registrada la oración entre ambos lo tienen ante el Prebendado, que la dize en pie y las manos puestas y los Versicularios se

[fol. $309^{\mathrm{r}}$ ]

quedan con el cuaderno en pie y buelven la antíphona Conceptio tua etc, y el Hebdomadario y comitantes acavada la oración se quedan allí de rodillas.

5. El Coro responde Amen y el sochantre inmediatamente entona la antíphona Conçeptio tua etc, prosíguela el coro al mismo compás que la salve, los Colegiales cantores dizen el Verso elegit eam etc y el Hebdomadario se levanta y dize la oración famulis tuis, etc, concluye con per christum etc, y la $1^{\mathrm{a}}$ con pereundem etc, y acavada la antíphona Conceptio tua etc, cierra el cuaderno y pone sobre la peana y el comitante de la mano derecha, que al hazer genuflexión tomó el bonete, lo buelven y hazen genuflexión y acompañan al Prebendado hasta su lugar y se hincan de rodillas y el que preside haze señal, levántanse los Colegiales y Rector, hazen genuflexión y se van por el orden que vinieron y en la rexa del horno de San Cecilio se hincan de rodillas y hazen oración a los Sanctos hasta que el rector se levanta, lo mismo hazen en la rexa del horno de Señor San Hiscio y van por la Iglesia, hazen juntos genuflexión en el pavimento y entran a la Sacristía donde

$\left[\right.$ fol. $309^{\mathrm{v}}$ ]

Con mucho silencio dexan las sobrepellices y visitan el Sanctíssimo Sacramento, los prebendados se van como vinieron y visitan los hornos y lugares sanctos.

6. Cuando el Sábado no se puede ir a las cuevas, encienden los lucernarios en el altar mayor cuatro velas, los Versicularios sacan facistol alto con paño blanco y lo ponen abaxo de la grada del pavimento baxo, ponen el cuaderno de la Salve y entonándola se levantan y asisten en pie mientras se canta, todos se ponen de rodillas en dos coros desde la dicha grada por el crucero y cuerpo de Iglesia comenzando desde el facistol, los Colegiales modernos por sus antigüedades, el Órgano da el tono y luego prosigue a Versos, los comitantes llevan al prebendado al mismo tiempo que se dixo hasta el pavimento donde se haze genuflexión y dize la Oración Ut supra. Quédanse allí de 
rodillas, el coro canta la antíphona de la Concepción y el Hebdomadario la oración, la cual acabada haze genuflexión junto con los comitantes y çerimoniario (que acompañará si fuere día de fiesta) y se entran en la Sacristía. El que preside haze

[fol. $310^{\mathrm{r}}$ ]

señal y todos juntos se levantan y hazen comedimiento el un coro al otro, los colegiales se van a la Sacristía por su orden y los lucernarios apagan y los versicularios quitan el facistol.

7. Los días de Nuestra Señora ay Salve en la Iglesia por la misma Dotación y en el inbierno y verano se dize inmediatamente después de completas, excepto el día de la Asumpción, que se dize después de la procesión y después de dicha en las tres festividades del verano se tiene la oración, los ceroferarios que buelven con la ceremonia, en saliendo por la puerta de la Concepción, se van a la sacristía, sacan el facistol con paño blanco y el cuaderno y un misal registradas las oraciones que ponen sobre el altar al cornu epistolae y se van al coro, cuando se dize a las seis sacan ésto los Versicularios y siempre son los que lo quitan, al fin de completas va el Pertiguero al coro a acompañar al Cabildo, entra en la Iglesia por la puerta de la Concepción y levantan a la gente del Crucero y del cuerpo de la Iglesia de suerte que dé lugar a que se ponga el Cabildo en dos coros ut supra, cuando esta la Salve a las seis en comenzando a

\section{[fol. $\left.310^{\mathrm{v}}\right]$}

tocar va el Pertiguero a la Sacristía y se viste y sale a la Iglesia y haze el lugar como queda dicho, en comenzando la Salve se pone de rodillas en la grada del pavimento baxo al lado del Evangelio y cuando el cerimoniario se levanta para combidar al prebendado se levanta el Pertiguero y va delante por entre el coro de los colegiales y capellanes hasta que comienza el de los prebendados donde para y juntamente haze comedimiento al prebendado, en estos días acompañan cuatro Colegiales comitantes.

8. Acompaña el Pertiguero delante, luego dos comitantes, luego el cerimoniario, luego los otros dos comitantes más antiguos y el último el Prebendado, el cual, si es tiempo de capas, suelta la falda, el Pertiguero va quitada la gorra y el cerimoniario el bonete, mas el Prebendado en pasando del coro de los Canónigos se cubre y ésto guarda en todas las Salves y días, llegan a las gradas y el Pertiguero se queda y aparta hazia la capilla de los mártires y haze cortesía, los dos primeros

\section{[fol. $311^{\mathrm{r}}$ ]}

Comitantes se quedan en el lugar de los çerofararios, los otros dos suben y el cerimoniario y prebendado en el pavimento alto hazen genuflexión y simul los que quedaron en el baxo, dichos los versos dize la oración en pie estando los demás todos de rodillas y acavada se hinca de rodillas, dice el coro la antíphona Conceptio tua, levántase, dize la oración famulis tuis etc, y acavada, con el mismo acompañamiento, se va a la Sacristía: el día de la Asumpción de Nuestra Señora se dize la Salve después de la procesión como se verá libro 4 capítulo y no se dize la antíphona Conceptio tua. Cuando alguna de las 9 fiestas de Nuestra Señora cae en Sábado se dize una Salve no 
más y ésa en la Iglesia con la solemnidad dicha y se ganan dos distribuciones. A las Salves de las fiestas se encienden seis velas y el blandón si ha ardido a los oficios. Y en las cinco fiestas de guardar de Nuestra Señora se dize motete al órgano en lugar del último verso, los Sábados en que está de manifiesto el Sanctíssimo Sacramento a las reliquias de los Sanctos no se va a las cuevas

\section{[fol. $311^{\mathrm{v}}$ ]}

como se dize en la salve en la Iglesia ut supra.

10. Desde el primer Sábado de cuaresma hasta el martes de la Semana Sancta inclusive ay Salve después de completas por special rogativa y costumbre de esta Sancta Iglesia y dízese en ella, excepto los Sábados que se va a las cuevas a decirla porque nunca se dizen dos, una inmediatamente después de otra. En completas salen los ceroferarios en acabando la capítula y con las devidas reverencias, sacan al altar un facistol alto con paño de color de los frontales y lo ponen en el pavimento alto en medio de él, junto a la peana y enzima el libro donde está la oración (en su funda) avierto por donde está la imagen de Nuestra Señora de la Asumpción en su misa de 15 de Agosto. Si las completas son solennes de seis velas, déxanlas encendidas y el cirio del blandón si no ay más de dos velas encienden otras dos y banse al coro.

11. Acavada la antíphona de Nuestra Señora y Pater Noster y Ave Maria y Credo entona el órgano y luego el sochantre salve y a versos

[fol. $\left.312^{\mathrm{r}}\right]^{24}$

se dize con el órgano aunque sea tiempo de pasión, en los días de fiesta sube el Pertiguero al coro a acompañar. Al verso et Iesum Benedictus \& se levanta el cerimoniario y los comitantes, dos o cuatro conforme la solemnidad del día libro 2, Capítulo 23 de comitantes y con el Pertiguero hazen comedimiento, el Hebdomadario, el cual se levanta y en el plano del coro buelve y se despide de él con comedimiento, en la barandilla hazen genuflexión, en entrando por la puerta de la Concepción a la Iglesia suelta la falda de la capa. Van al pavimento donde unos se quedan y otros suben y se dize la oración Ut supra $\mathrm{n}^{\mathrm{o}} 5,6$ y 7 y acavada se entran en la Sacristía y en la puerta alzan los comitantes las falda y la dan al brazo del prebendado, los días que no son de fiesta ni solennes acompañan solo dos comitantes, el día de la Anunciación de Nuestra Señora si es infra quadragessimam esta Salve se dize en la Iglesia supra $\mathrm{n}^{\circ} 6$ y

[fol. $\left.312^{\mathrm{v}}\right]^{25}$

\section{Capítulo 13. De las rogativas y devociones que se hazen en las necesidades del vien público.}

24 Vimos este Consueta por Comision de el Cabildo hasta aquí que es el fin del Capítulo 12 del Libro $3^{\mathrm{o}}$ y lo rubricamos y firmamos $===$ (Aparecen las rúbricas y firmas de Dor. Don Francisco; Don Agustin Manrique y Don Francisco Barahona)

25Hay una anotación manuscria en el margen superior izquierdo con el siguiente texto: =Desde este Capítulo 13 se comenzó a leer en Cabildo de 4 de marzo de 1632,conforme a lo determinado en otro Cabildo en dos días del dicho mes de marzo de dicho año= 
1. En las necesidades que se ofrecen de las cosas spirituales de la Iglesia y temporales de la salud y vien público de estos Reynos, Çiudad y casa del Sacro Monte se deve acudir con la oración a Nuestro Señor Universal refigugio y fortaleza en ellas, y así que instare la causa, el Abad a consulta de los asistentes y Maestro de çeremonias las deve ordenar en la forma y modos que más conviniere, si no fuere en las rogativas públicas que entonzes las ordenará el Cabildo.

2. Cuando la rogativa se haze en la missa de tercia en acavando el celebrante el Pater Noster cantado, se hinca de rodillas y todos los ministros y los del coro, el cual entona comienza la antíphona sub tuum praesidium cum fugimos Sancta Dei genitrix, y dícela toda, luego el Verso monstrare esse matrem jumat per te preces qui pro nobis natus tui

[fol. $313^{\mathrm{r}}$ ]

Esse tuus Gloria Patri, etc, y se buelve a repetir la antíphona sub tuus presidius etc, y Kyrie Eleyson, Christe eleyson, Kyrie Eleyson y el celebrante en el mismo tono dice Pater Noster y prosigue secreto usque ad et ne nos inducas in tentationem Ps. Sed liberanos a malo y diçe el coro los psalmos a verso, y el preste los versetes y oraciones conforme a la necesidad según lo disponen el manual y ritual romano, que están en esto conformes, comenzando siempre por la antíphona sub tuus presidius como está dicho y diciendo primero la oración de Nuestra Señora concede y la de los Sanctos y si ay procesión o letanía se haze antes de las preces conforme al manual.

3. La última oración concluye Per Dominum nostrum etc, en la primera no ay conclusión, levántase y todo el coro y frange la hostia y prosigue la missa y mientras dura la rogativa toca el Campanero a media buelta la campana de la Asumpción, libro 2, capítulo 14 del campanero.

4 Si se determinan las nueve misas de

[fol. $313^{\mathrm{v}}$ ]

Nuestra Señora cantadas, se dicen con toda solemnidad como en sus días, después de la missa de tercia si son rezadas. Se dizen mientras en oración en el altar mayor y se abre el Sagrario, enciende el coadjutor cuatro belas y dos buxías a la puerta del Sagrario. Lleva la llave de el Sagrario, sácase la casulla rica para el que la dize y en llegando al altar abre el sagrario, saca el relicario a la puerta, quítale el capillo y echa por detrás de él las cortinas.

Dize su missa con las genufexiones acostumbradas, cuando está el Sanctíssimo Sacramento manifiesto en estas misas no se dize Gloria ni dize Credo, acabando la missa si aún dura la oración, se pone de rodillas en la peana y en dando la hora se lebanta cubre el relicario y cierra el sagrario.

5. Si se descubre el Sanctíssimo Sacramento es con las çeremonias que se dixo Capítulo \& y la missa se celebra con solennidad como los días de la infra octava de Corpus Christi y todo el tnpo. que está descubierto como no sea de coro será cosa muy 
[fol. $314^{\mathrm{r}}$ ]

deçente que asistan los Señores Prebendados en Oración y el Rector señalará dos o cuatro Colegiales que asistan de la misma manera sin faltar que la necesidad lo pide y mas en este Sacro Monte que es casa de oración.

6. Si se determina procesión, se haze a las cuevas sagradas al altar de Nuestra Señora de la Concepción, donde se haze la deprecaçión con la rogativa sobredicha y las oraciones de la Concepción de los Sanctos y de la necesidad. Si la causa se continua se pueden hazer otras procesiones a los Sanctos hornos, a la Iglesia de Sanctiago donde se dize lo mismo y a estas procesiones se repica como a las letanías menores. Estos días es combiniente que aya disciplina a la noche como a la de los Viernes.

7. Puede también descubrirse el Sanctíssimo Sacramento a la noche y traerlo en procesión y entonzes se haze de esta suerte: toca el campanero las campanas a plegaria a media buelta una hora antes de la cena y si ha de aver procesión hora y media, júntanse todos los Prebendados, capellanes y

[fol. $314^{\mathrm{v}}$ ]

Colegiales en la Sacrisstía. Si ha de aver procesión con sobrepellices o capas, conforme al tiempo los ceroferarios y el Hebdomadario toma estola y pluvial, en el altar mayor se tiene el frontal del día y los ceroferarios encienden seis velas en los candeleros ordinarios y cuatro bugías, el Sacristán tiene encendidas las lámparas. Salen de la Sacristía more solito un Turiferario con su turíbulo y naveta, los ceroferarios con ciriales encendidos, luego todo el clero por su orden y último el celebrante, las manos puestas. Salen todos cubiertos, los çeroferarios se ponen en sus lugares y el clero por el pavimento y Cruzero. Sube el celebrante, Turiferario, cerimoniario que combida dos prebendados, dos comitantes y en la peana hazen genuflexión y descubren el Sanctíssimo Sacramento de la misma forma que se suele supra Capítulo 8, número , y dexan la custodia sobre la Ara y las cuatro bugías, dos delante y dos detrás, buélvese la çerimonia a la Sacristía y se desnuda el celebrante, mientras se haze todo esto

[fol. $315^{\mathrm{r}}$ ]

toca la campana a plegaria.

8. Sale el celebrante y ministros a la Iglesia con los demás, donde tienen una hora de oración o media y al fin de ella buelve el Hebdomadario a la Sacristía, donde toma pluvial y sale con los ceroferarios y Turiferarios y cermoniario y el lucernario con la palmatoria y vela encendida, los ceroferarios se quedan en sus lugares y los Turiferarios debaxo de las lámparas meneando los Turíbulos, los demás suben y el celebrante de rodillas en la peana dize la letanía mayor y todos responden. El lucernario alumbra, acabadas las preçes y las Oraciones se levantan y suben dos prebendados y los Turiferarios y a este tiempo saca un Colegial el palio sin bastidor y lo da a los prebendados caperos, aunque no toman pluviales sino con su hábito canonical. Echa el 
celebrante incienso en los Turíbulos y Turifica el Sanctíssimo Sacramento more solito y el çerimoniario le pone cendal y toma la custodia y ordena la procesión.

9 Va el Pertiguero delante con ropa blanca, la Cruz pequeñas Arzobispal con cendal

[fol. $315^{\mathrm{v}}$ ]

blanco y con ella los ciriales, el clero por su orden, todos con velas encendidas que reparten los luçernarios, los turiferarios incensando alternativamente uno y luego otro desde que baxan del pavimento alto, los Prebendados comitantes sustentan los brazos al celebrante, pueden ir descalzos todos, excepto el çelebrante. Cántase el himno Pange lingua y más propiamente el Verbum supernum prodiens, nec patris linquens dexteram, no se toca el órgano ni se repican las campanas, mas toca a plegaria desde que salen de la Sacristía a la procesión hasta que se acava, anda alrededor de la Iglesia, no se haze estación y en llegando al altar mayor se inciensa y muestra al pueblo y encierra como en las demás procesiones y se buelven a la Sacristía ut moris est.

10. Si ay procesión se descubrirá el Sanctíssimo Sacramento en la forma que se escribió arriva en el $\mathrm{n}^{\mathrm{o}} 4$, cuando se dize la missa mientras la hora de oración que se tiene por la mañana y estase así descubierto la media ora de oración

[fol. $316^{\mathrm{r}}$ ]

que se tiene por la tarde y luego se bolverá a encerrar y tendrá cargo de hazer esto el Hebdomadario y si faltare, el Señor Prebendado que se sigue.

11. Puédense çelebrar algunas missas solennes en las cuevas del Spíritu Sancto o de Sanctiago el Zebedeo o de los demás Santos mártires, dízese en el altar de la Concepción de NuestraSeñora, por la parte detrás se pondrá un bufete con tapete, donde se pongan los ornamentos y se vistan en el arco del lado de la Epístola, se pondrá la credençia y los dos arcos será el lugar de los Turiferarios, los ceroferarios tendrán siempre los ciriales en las manos como en las missas de Nuestra Señora in Sabbatho y asistirá un Colegial, la Epístola y Evangelio se cantará como en las missas de Nuestra Señora los Sábados, poniendo un atril que se quitará en acabando el Evangelio, los Versicularios para el coro pondrán escaños arrimados a las paredes que hagan testero y en medio un facistol para el libro de canto. Se incensará el coro y dará paz y lo demás como en la missa solenne.

[fol. $316^{\mathrm{v}}$ ]

\section{Capítulo 14. De los oficios de difuntos y sus aniversarios.}

1. Vísperas de difuntos no se celebran en esta Sancta Iglesia por que no ay obligación de decir en el coro su ofiçio, como ni el menor solo el día de todos los santos se çelebran, mas si alguno las dexare dotadas en algún aniversario se dirán con las ceremonias y observaciones que se dirá en lu lugar, libro 4, Capítulo 22, de la commemoración de los difuntos, excepto lo propio de aquel día, que es salir lo prebendados con capas canonicales. 
2. En los entierros de los del Sacro Monte se haze el oficio ut infra libro 4, Capítulo 25, número 11. Cuando se dize un nocturno, el Invitatorio lo dizen los Colegiales, mas en el entierro de los prebendados siempre lo dizen los caperos con su hábito canonical y cetros de plata, los cuales dan los cetreros como se dixo supra capítulo 3, de maitines, mientras se dize el Pater Noster Ave Maria y Credo el cerimoniario los combida y cum solitis reveretiis, baxan, lo cantan y se buelven, acavado el Invitatorio entonan las antíphonas, los prebendados por

[fol. $317^{\mathrm{r}}$ ]

su orden y se doblan como en fiesta doble y a la mediación del primer verso del psalmo se sienten como en los demás maitines, cuando se dize el Versículo del nocturno se lebantan y dicho, el que çelebra dize clara voce: Pater Noster y díçese todo secreto, las lecciones del primer nocturno las dizen siempre Colegiales y capellanes los que el maestro de çeremonias señalare.

3. Los versos de los responsorios siempre dizen dos Colegiales cantores, las lecciones del segundo y tercero nocturno dizen Prebendados señalados por el Maestro de ceremonias, la última dize el Presidente del coro, en el ínterin que el Pater Noster el cerimoniario combida al prebendado, el cual baxa de su silla la falda de la capa tendida si las traen y con las devidas reverenzias al altar y al coro, llega al facistol hasta donde lo acompaña el cerimoniario que luego se va a su silla y el Prebendado dize su lección, ya acavada haze las reverençias y el cerimoniario lo acompaña hasta que sube a su silla, a los Prebendados que dizen lecciones no asiste ninguno si es de noche solo el lucernario alumbrará con la palmatoria.

[fol. $317^{\mathrm{v}}$ ]

En el coro no se pone adorno alguno ni alfombra ni paño en el facistol.

4. Si se an de decir laudes, se prosiguen después de la última lección y se celebran como las vísperas, los ceroferarios al Benedictus van por los çiriales y los comitantes ponen el pluvial al celebrante y dize versos y oración Ut infra libro 4, Capítulo 22, de la commemoración de los difuntos, luego baxan al entierro como se dize en el mismo libro, capítulo 25. Si no ay laudes, después de la tercera lección se canta el responsorio y los ceroferarios traen los ciriales y los comitantes ponen el pluvial y el celebrante dize los Versos y oraçiónes y luego baxan al entierro.

5. Si la Vigilia es por la mañana que luego se a de decir la missa, a la penúltima lección baxan a bestirse more solito y para el tercero responsorio no ay çiriales, ni se pone pluvial al que dixo la lección porque no se dizen Versos ni Oraçión sino inmediatamente se canta la missa y después se baxa al entierro.

6. En las onras del Señor Cristóval Vaca de Castro y en las del Ilustrísimo fundador los

[fol. $318^{\mathrm{r}}$ ] 
Prebendados caperos con su hábito canonical dizen los versos de los responsos en la Iglesia y el requiescant in paze y se celebra como se dize infra libro 4, Capítulo 24.

7. A 4 de Noviembre haze aniversario por los padres difuntos de los Prebendados y ministros de esta Santa Iglesia, ponen los sacristanes en el Cruçero alfombras grandes y enzima un paño negro, cuatro blandones y hachas a las esquinas y la Cruz grande con çendal negro junto a la grada del pavimento y la tarde antes se dize la Vigilia conforme al día sin Invitatorio y después de la tercera lección, el que la dize toma pluvial y los çeroferarios llevan los çiriales como se a dicho y concluye el responso con los Versos y Oración y dos Colegiales dizen el Requiescant in paze. No se baxa a la Iglesia a decir el responso, sino derechos se van los que están rebestidos a la Sacristía y los luzernarios apagan las hachas y los ceroferarios las cuatro velas del altar.

8. El día siguiente post nonan se dize la missa como en el Capítulo siguiente y acavada, el Diácono canta Requiescant in paze y el celebrante dize Placeat tibi Sancta Trinitas etc, y besa el altar y llegase al Cornu epistolae

[fol. $318^{\mathrm{v}}$ ]

y el Sacristán saca pluvial y le quita la casulla y manípulo y se lo pone, sale el Turiferario antiguo con Turíbulo y naveta y el moderno con sobrepelliz saca acetre de agua vendita, suben al pavimento, hazen genuflexión y se ponen Cornu Epistolae ambos primero el del Turíbulo y después el del acetre en el coro en respondiendo al Requiescant in paze comienzan a cantar el responso liberame Domine de morte Eterna y mientras se canta, el çelebrante con su pluvial está al Cornu epistolae el rostro al libro y los Diáconos detrás uno en pos de otro.

9. Cuando se repite el responsorio después del Verso Requiem aeternam, llega el Turiferario y da la naveta al Diácono y éste llega por el Cornu epistolae y el celebrante se buelve algo sobre su mano derecha y echa incienso en el Turíbulo sin bendeçirlo ni decir nada. En acavando el último Kyrie, el celebrante en el mismo cornu epistolae, el rostro al altar, dize Pater Noster y mientras lo dize secretamente se pasa al medio del altar y se buelve de rostro al pueblo y el Diácono a la diestra y el Subdiácono a la siniestra le alzan las fimbrias del pluvial, llega el del acetre y da el hisopo mojado al Diácono el cual lo

[fol. $319^{\mathrm{r}}$ ]

da al celebrante y desde allí rozia tres bezes hacia el paño y luego recive el Turíbulo de mano del Diácono y Turifica otras tres vezes, buelve el Turíbulo y el al cornu epistolae y los Diáconos detrás uno en pos de otro dize Et ne nos inducas intentationem $\mathrm{R} / \mathrm{Sed}$ liberanos a malo con los demás Versos que están en el misal al fin de las rúbricas y la oración Deus qui nos Patrem et matrem, con la conclusión Per Dominum Nostrum Iesum Christum, qui tecum, etc. R/. Amen y en el coro dos Colegiales dizen Requiescat in paze R/. Amen. Luego el celebrante se pasa al Cornu evangelio con los Diáconos detrás, en medio del altar y asimismo y dize el Evangelio de San Iuan y cabada la missa se van a la Sacristía. 
10. A la tarde después de completas dize otra Vigilia por los Prebendados y ministros de esta Sancta Iglesia ya difuntos, en el cruzero está la misma demonstración de túmulo, paño negro, cuatro hachas y la cruz y en el altar cuatro velas, el día siguiente post nonam se dize la missa y haze la absolución como queda referido a estos aniversarios.

[fol. $319^{\mathrm{v}}$ ]

El campanero dobla con todas las campanas y los clamores comienzan con el oficio y duran hasta que se acava, libro 2, Capítulo 14, de campanero y a estos aniversarios no pueden faltar ningún prebendado y el que faltare será multado en dos Reales. Uno por cada punto las faltas se dizen de missas por los difuntos por quien es el aniversario.

11. La oración que se dize en este aniversario es Deus Veniit largitor et humane salutis amator quae sumus clementiam tuam ut nostre congregationis fratres y dexase propinquos et benecfatores etc. En estos aniversarios çelebran el Abad y los prebendedos como se van siguiendo, ${ }^{26}$ no se çelebran en Domingo, transfiérese a la feria segunda y el Domingo después de completas se dize la Vigilia para la cual siempre se pone el paño negro y blandones.

En los aniversarios que se hazen por otros difuntos no se pone en el Crucero la demonstración de Túmulo que se ha dicho, sino en acavándose la missa se tenderá un paño negro

[fol. $320^{\mathrm{r}}$ ]

sobre las gradas del altar y sobre él se hará la absolución de la misma forma que se a dicho cuando ay demonstración de túmulo y si fuere por seglar no se inciensa.

\section{Capítulo 15. De la Missa solemne de Requiem.}

1. Para las missas y oficios de difuntos el adorno del altar y credençia es llano y común, los ceroferarios encienden cera amarilla, excepto en los aniversarios ${ }^{27}$ solennes, no sacan el recaudo para la missa cubierto con çendal negro, en la credençia nunca se pone frontal ni aparador, para la Epístola y Evangelio sacan al pavimento baxo un facistol sin paño alguno (en la missa de difuntos no se inciensa el altar al prinzipio sino la oblata) no se pide vendición para

[fol. $320^{\mathrm{v}}$ ]

\footnotetext{
${ }^{26}$ Tachado: "y el que por enfermedad o ausencia no pudo celebrar el día que le cupo celebra luego el aniversario siguiente".

Al margen: Va testado=por su turno todos los años $=$ y el que por enfermedad o ausencia no se pudo celebrar el día que le cupo celebra luego el aniversario siguiente.

${ }^{27}$ Va testado: Que se hacen por Nuestro Ilustrísimo Fundador o sus padres.
} 
alguna cosa, no se vesa la mano del celebrante cuando se le da o reçive algo de él, déxanse las cosas que señala la rúbrica, no acompaña el Pertiguero sino en los aniversarios solennes y día de la commemoracion de los difuntos.

2. Dízense las missas de difuntos cuando no es aniversario solemne o entierro después de Nona. Salen del coro como queda referido libro 1, Capítulo de Aniversarios, comenzada la missa en el coro salen de la Sacristía los ceroferarios, cerimoniario, Subdiácono, Diácono y celebrante hazen venia en la ínfima grada y en la peana genuflexión, dizen el introito sin el psalmo Iudicame Deus y dichos los Versos después de la confesión, llegan al altar el celebrante, lo vesa y los Diáconos a sus lados hazen genuflexión, inmediatamente van al cornu epistolae y se ponen more solito y al decir el Introito de la missa, el celebrante no se signa, sino haze la señal de la Cruz con la diestra sobre el misal teniendo la siniestra sobre el altar, a los Kyries si ay lugar se sientan.

3. Si es día de la muerte o deposicion del

[fol. $321^{\mathrm{r}}$ ]

difunto o en día tercero, séptimo, trigésimo o aniversario, se dize tan solamente una oración y en tal caso, se dize la sequentia Dies ire, Dies illa, en las otras missas se dize ad libitum, en las cuales es necesario que en el altar se sepa si la dizen o no, porque a su tiempo se vaya a decir el Evangelio; dichas las oraciones el ceroferario da el misal al Subdiácono y lo acompaña al facistol cum debitis reverentiis ; canta la Epístola el rostro buelto al altar y el ceroferario a su diestra un pie atrás y acavada sube al altar y haze genuflexión y da el libro al ceroferario y no vesa la mano al celebrante, mas pasa el misal al Cornu evangelio y el ceroferario al facistol.

4. Cerca del fin de la sequentia y si no se dize el tracto, el Diácono con el libro que tiene al Cornu epistolae, pasando el Evangelio porque no lo pone en medio del altar sobre la Ara, va y detrás del celebrante se hinca de rodillas y dize munda cor meum y levántase y haze genuflexión y con el el Subdiácono y ceroferarios y sin pedir vendición baxa a cantar el Evangelio y los ceroferarios llevan Ciriales, mas acompañan las manos puestas, el Diácono pone el libro

[fol. $321^{\mathrm{v}}$ ]

en el facistol, canta el Evangelio el rostro al pueblo, el subdiácono se pone en frente de él y tiene las manos en el libro, los çeroferarios con las suyas puestas están eregione a un lado y otro del subdiácono, signa el Diácono el libro y así, mas acavado el Evangelio cierra el libro y no lo da al subdiácono sino llévale como lo traxo y cuando llegan al pavimento alto hazen genuflexión y da el libro al ceroferario que lo pone en la credencia.

5. El celebrante en acavando el Evangelio no aguarda porque no a de vesar el libro ni ser incensado ya, si se buelve al medio del altar el rostro buelto a él, el Diácono y Subdiácono después de aver hecho genuflexión y aver dado el libro se ponen detrás del çelebrante uno en pos de otro y el celebrante buelve y dize Dominus Vobiscum, a este tiempo sale el Turiferario con Turíbulo y Nabeta y haze genuflexión y se pone en su 
lugar, el Subdiácono trae el Cáliz y el ceroferario la salvilla y ampolletas y se haze el ofertorio more solito excepto que el Diácono pone la patena debaxo del Corporal y la cubre con el purificador y el Subdiácono se va a la

[fol. $322^{\mathrm{r}}$ ]

siniestra del celebrante, sube a su tiempo el Turiferario y da la nabeta al Diácono que la ministra al celebrante, el cual hecha incienso, lo vendize y turifica la oblata y altar como suele yendo siempre a sus lados los Diáconos.

6. Buelve el Turíbulo al Diácono, el cual inciensa al celebrante y no es incensado por otro y así da el turíbulo al Turiferario, al cual haze genuflexión y se baxa a su lugar donde buelve a hazer venia al altar y allí se queda meneando el incensario hasta que el celebrante dize hanc igitur oblationem que echa incienso y sube, haze genuflexión y el Subdiácono se pone a la diestra del celebrante, toma el Turíbulo, híncase de rodillas en la peana, inciensa el Sanctíssimo Sacramento a la elevación de la hostia y Cáliz, el Turiferario después de aver dado el Turíbulo al subdiácono se aparta dos pasos y se hinca de rodillas con la nabeta en la mano siniestra arrimada al pecho.

7. Asienta el celebrante el Cáliz, haze genuflexión, levántase y al mismo tiempo el subdiácono y Turiferario que recive el Turíbulo haze genuflexión y buélvese a la Sacristía

[fol. $322^{\mathrm{v}}$ ]

el subdiácono, aunque no tiene la patena está en su lugar baxo de la peana detrás del celebrante, entre los dos se pone el Diácono como suele cuando el celebrante canta el Pater Noster y cuando llega el sicut et nos dimittimus, ambos a un tiempo hazen genuflexión y suben al altar: el Diácono a la diestra y el Subdiácono a la siniestra y hazen genuflexión, el Diácono saca la patena y con el purificador la limpia y sin vesarla la da al celebrante; a los Agnus no se hieren los pechos y dichos hazen genuflexión a los lados y pasa el Diácono a la siniestra y el Subdiácono a la diestra sin darse paz y ministran hasta el fin de la missa como en las otras.

8. Dicho por el çelebrante el último Dominus Vobiscum, el Diácono canta el rostro al altar Requiescant in paze aunque la missa se aya dicho por un solo difunto, si se ha de hazer absolución por aver señal de lecho de difunto en el Cruzero, cuando el çelebrante dize Placeat tibi Sancta Trinitas, el Sacrsitán saca pluvial y sale el Turiferario con Turíbulo y otro con el acetre y se haze como se dixo en el Capítulo precedente, número 8.

Si hay responso se dize el

[fol. $323^{\mathrm{r}}$ ]

Evangelio último y luego toma el celebrante pluvial y baxa al túmulo y se canta como se dize libro 4, Capítulos 24 y 25. Si no ay túmulo ni señal de él, se acava la missa more solito y se entran en la Sacristía. 
9. Las demás cosas tocantes a las ceremonias de la missa solemne se hazen como se dixo supra Capítulo 4: en las missas de difuntos cuando son honras solennes y de entierro y en el día de la commemoracion de los difuntos se reparten velas encendidas a los prebendados, capellanes y Colegiales. Y se hará en este modo al fin de la sequentia: los lucernarios las darán comenzando de los más antiguos y las tendrán encendidas mientras se canta el Evangelio y las buelven a dar encendidas para la elevación del Sanctíssimo Sacramento y después de consumir las buelven a recoger y apagar y con ellas se van a la capilla de los mártires para darlas al clero cuando sale, porque todas las vezes que en la missa an tenido velas encendidas las an de sacar cuando se dize el responso en la Iglesia y siempre cuando la missa es de entierro Ut infra libro 4, Capítulo25.

[fol. $323^{\mathrm{v}}$ ]

10. En el Coro están de rodillas a las oraciones desde que dizen Sanctus hasta después de aver dicho Pax Domini, y los luzernarios que sacan hachas al alzar se quedan con ellas de rodillas hasta aver el celebrante consumido el Sanguis. El punto o cuerda que se lleva en el canto en la missa y oficio de difuntos es baxo, grave y el Compás moroso.

\section{Capítulo 16. De la Missa rezada delante del Prelado.}

1. Si el Prelado oye missa en alguna de las tribunas, la missa se dize como suele sin hazer humiliación, ni ceremonia particular con él como si no estubiera presente, si quiere oir missa en el altar mayor se pone sitial y si en la capilla de la Sacristía se pone el sitial en la del rosario frontero del altar: al cardenal se le haze siempre humillación, aunque no sea Prelado, al legado en las Iglesias del distrito de su iurisdición, al Patriarca y Arzobispo en las Iglesias de toda su Provincia, al Obispo solamente en las de su Diocessis y a ninguno fuera de ellas.

2 El Sacerdote que ubiere de decir la missa se

[fol. $324^{\mathrm{r}}$ ]

viste en la Sacristía y aguarda que el Prelado salga a su sitial e inmediatamente sale y se llega al altar donde haze genuflexión, si ay Sanctíssimo Sacramento y si no, venia profunda, luego se buelve al Prelado y le haze venia profunda y está inclinado hasta que el prelado le echa la bendiçión que es señal que comienze, entonces se pone cerca del medio del altar como suele, buelve a hazer profunda al altar y el rostro derecho totalmente al altar comienza In nomine Patris, etc. En la comission en lugar de decir Vobis fratres y vos frates inclinándose algo hazia el Prelado dice Tibi Pater y Te Pater y dichos los Versos Deus tu conversus hasta Orem, antes que comienze la oración Aufera nobis haze otra reverenzia al Prelado y se va derecho al medio del altar sin decir nada y en llegando a él, ínclinado, dice la Oración Aufera nobis y Oramus te Domini.

3. Para decir el Evangelio no pide vendición, mas después de dicho, no vesa el libro ni dize per Evangelica dicta, sino el que ayuda o un capellán del Prelado, toma el libro y avierto donde está el principio del Evangelio lo lleba al Prelado y sin hazerle antes 
[fol. $324^{\mathrm{v}}$ ]

reverencia lo da a vesar, cierra el libro y después le haze reverenzia y lo buelve al atril. Aviendo dicho la primera oración después de los Agnus Domine Iesuchristi qui dixisti, besa al célebrante el Porta Paz y dize Pax tecum y el que llevó el libro lo lleva al Prelado y se lo da a vesar haziéndolo después y no antes de la reverenzia.

4. Al fin de la missa vesa el altar y dize Benedicat Vos omnipotens Deus, buélvese al pueblo y al Prelado con venia inclina la cabeza y el Prelado le da la vendición y licencia y dize Pater filius et Spiritus Sanctus y hecha la vendicíon hazia la parte contraria de donde está el Prelado, da la buelta entera y dize el Evangelio último y acabando se buelve al prelado y le haze devida reverenzia. Toma el Cáliz y en la grada el bonete como suele y antes de ponérselo haze profunda al altar y al Prelado y se cubre y va a la Sacristía y no haze reverencia a otra ninguna persona.

[fol. sin numeración]

\section{LIBRO $4^{\circ}$. DE LAS CEREMONIAS PARTICULARES EN LOS OFICIOS DEL TIEMPO.}

[fol. $325^{\mathrm{r}}$ ]

\section{Capítulo 1. Del Oficio del Adviento.}

1. En las Dominicas y ferias de Adviento en la missa usan los Diáconos de planetas y para cantar la Epístola y Evangelio se las quitan como se dixo libro 2, capítulo 21, de çeroferarios, número 46. Y el Diácono asiste y ministra en la missa con la estola ancha y collar hasta que el çelebrante a consumido el Sanguis y mientras el Subdiácono ministra el vino y agua para la purificación el Ceroferario moderno sube y haze genuflexión y llega al escabelo donde está la planeta y la lleva al Cornu Evangelii donde está el Diácono quítale la estola ancha y collar y pone la planeta y el Diácono pasa el misal y el ceroferario dexa la estola y collar en el escabelo y haze genuflexión y se baxa a su lugar.

2. En la $3^{\text {a }}$ Dominica Gaudete in Domino usan los Diáconos Dalmáticas y en las

[fol. $325^{\mathrm{v}}$ ]

Ferias que se repite la misma Gaudete en la cual ay órgano, en el Domingo úsase el color morado en el oficio del tiempo, el primer Domingo ay comunión general. 
3. La siete antíphonas de la $\mathrm{O}$ que se dizen en los siete días antes de la natividad de Nuestro Señor Iesuchristo, las comienza el Hebdomadario aunque entren por commemoración, preentonadas uno de los cantores si los ay y si no, el sochantre haziéndole antes y después la devida reverenzia de la manera que se haze a la antíphona del magnificat. Dízense éstas con el compás y solennnidad que se dizen las Vísperas de segunda clase.

\section{Capítulo 2. Del oficio en la Vigilia de la Natividad de Nuestro Señor.}

1. La noche antes los Versicularios adornan el coro con alfombras, pónenlas

[fol. $326^{\mathrm{r}}$ ]

por todo el plano hasta el facistol grande y por todos los andenes de las sillas altas, vien cubierto todo para la postración, previenen las flores y algunas yerbas olorosas, por la mañana, en tocando a prima, llevan un brasero con brasas y pomo de olor, hecha las flores y yerbas por el suelo, ponen en su lugar un facistol pequeño con paño morado y sobre el libro de las Calendas cubierto con funda de seda morada, ponen frontero de la silla del Abad el facistol del Hebdomadario con paño morado y sobre el breviario.

2. Haze el oficio a prima el Abad y en su ausencia el Presidente, y en ausencia de ambos, el que preside en el coro señala el Maestro de Ceremonias un Prebendado de los más antiguos que sepa cantar y tenga boz para la Calenda, el cual la pasa y revee la noche antes, en dexando el esquilón se levantan y dicho secreto el Pater Noster, Ave Maria y Credo comienza el Abad cantando con solemnidad de primera clase Deus in adiutorium. La antíphona Iudea et Hierusalem, preintona el Sochantre y capellanes

$\left[\text { fol. } 326^{\mathrm{v}}\right]^{28}$

cantores al Abad, dízense los primeros psalmos con órgano y con toda solemnidad.

3. Al fin de la Oración Domine Deus omnipotens qui ad principium etc, el cerimoniario haze comedimiento al prebendado señalado para la Calenda, el cual se levanta y dexa caer la falda de la capa y sale de su silla y va al facistol de en medio del coro, haze genuflexión al altar y buelve al coro y haze cortesía a un lado y a otro y todos le corresponden, responde Deo Gratias todos los del coro se sientan y el prebendado comienza en tono competente a cantar octavo Calendas Ianuari lunas y en diziendo la luna todos se levantan y están descubiertos y él prosigue Anno a creatione mundi, etc en el mismo tono hasta las palabras Novemque post conceptionem de cursis mensibus y subiendo como estaba apuntado en el martirologio dize In Bethlem, a éstas palabras todos los del coro se hincan de rodillas, excepto el que las canta, el cual levantando el tono dize en el de Passión Nativitas Domini nostri Iesu Christi secundum carnem.

\footnotetext{
${ }^{28}$ En el margen izquierdo aparece la siguiente leyenda = aunque la consueta dice que canta el s. la Calenda con capa canonical es...casa el que de canse coin Capa plubial; Y no obstante esto es más de dos años que ....(Vbo?) rito de Cardenales para que se Cántase con plubial.
} 
[fol. $327^{\mathrm{r}}$ ]

4. Cuando se comienzan estas palabras todos los del coro se postran y los Prebendados sueltan las faldas para quedar decentementecubiertos y en acabándolas se postran también el que canta y están así un breve rato en consederarjicion de tan alto misterio significado con la postración la humilldad con que el eterno Dios descendió al ser Nuestra baxeza, solo el que haze el oficio se queda de rodillas y después de un rato dixe en tono baxo grave y deboto la oración Nos omnes gratias agamus Domino Deo nostro qui condolens nostris miseriys homo fieri voluit carnem susmens exillibata Virgine $U t$ nos ha fauce díaboli liberaret ipsum, laudemus gratias illi per omnia referentes (toda ella subrayada)

5. Acavada la oración están un poco en silençio y luego el Abad haze señal y todos se levantan los Prebendados cogen las faldas y el que canto haze genuflexión y venia al coroy sube a su silla y todos se sientan y un capellán nombrado por el maestro de çerimonias prosigue la lección de el martirologio eodem díe natalis Sancte Anastasio etc. en el tono que se suele cantar el ordinario y la prima se prosigue cantada mas no ay órgano, acavada la Calenda la lección

[fol. $327^{\mathrm{v}}$ ]

breve dize cantada el Colegial Calendario.

6. En el altar mayor se ponen cuatro velas y el que dize la missa de prima procure aver alzado antes que se comienze la Calenda y en acavando prima si estubiere acavada la missa o si no en acauandola el coadjutor apague las dos Velas dexando las de las esquinas como suelen estar.

7. En el coro se prosiguen las horas con la pausa y solemnidad de doble mayor y haze el oficio el semanero: no se pueden tomar Recle a la prima, en acavando las horas los versicularios y lucernarios quitan los libros y alfombras y doblan y llevan a su lugar y los paños fundas y demás recaudo, la missa se dize con solemnidad y órgano el coro se yunciensa y se le da paz como en las missas de fiesta.

8. Las Vísperas celebra el Abad, seis capas el compás como de la fiesta que no ay otra en todo el año más solemne. Libro2 Capítulo 12 de la Solemnidad de las fiestas.

[fol. $328^{\mathrm{r}}$ ]

\section{Capítulo 3. Del ofiçio en el día de la Natividad de Nuestro Señor Iesu Christo.}

1. A los maitines toca el Campanero ha las onze de la noche con todas las campanas solemnemente duran los repiques más de media hora, gorda y esquilón que dexa acavando de dar el relox las doze, los Versicularios ponen todo recaudo en el coro, los luzernarios lo que les toca y encienden en el coro y los çeroferarios en el altar como se dixo libro2 Capítulo 16 de Versicularios y 19 de Luçernarios, 21 de çeroferarios, los çetreros llevan al coro los cetros y los pluviales de caperos, en el aposento de la libreria del Coro ponen los çeroferarios un bufete y en el los ornamentos albas amitos y 
cíngulos Dalmáticas y pluvial para el çelebrante y Diáconos y los ciriales con codales como se dixo libro 2, Capítulo $21 \mathrm{n}^{\mathrm{o}}$.

2. Cuando comienza el esquilón salen en ceremonia de la Sacristía como se dixo libro $3^{\mathrm{o}}$, Capítulo $3 \mathrm{n}^{\mathrm{o}} 1,2$ y 3 y se cantan los maitines

[fol. $328^{\mathrm{v}}$ ]

como se dixo en los números siguientes, cuando el que celebra entona el /himno/ Criste Redemptor omnium, alza algo las manos y las junta y inclina la cabeza al altar como cuando en la missa dize oremus por la reverencia de la diuina invocación, toca el órgano a los psalmos 1.3.4.6.7.9. los responsorios los tocará el órgano con pausa, en comenzando el Séptimo psalmo Misericordías Dni in eternum cantabo, entra el Pertiguero en el coro y haze genuflexión al altar y comedimientos al coro y se pone en su lugar y luego el cerimoniario haze venia al Abad y luego al Diácono y Subdiácono para que baxen los ceroferarios y dos comitantes se ponen las mangas en los brazos, los prebendados le quitan el bonete al cerimoniario y se levantan baxan de sus sillas y en el plano del coro el celebrante en medio el Diácono a la diestra el Subdiácono a la siniestra el cerimoniario un paso atrás del subdiácono y los Colegiales todos hazen venia al un coro y otro y en la barandilla hazen todos genuflexión al altar mayor

[fol. $329^{\mathrm{r}}$ ]

como cuando entran de completas y salen el Pertiguero delante los çeroferarios, los comitantes el çerimoniario, los Diáconos y el celebrante van al vestuario donde ya esta ençendida una hacha y los prebendados acavan de rezar los psalmos del tercer nocturno y mientras los ceroferarios se visten roquetes y collares y encienden los codales los comitantes /visten/ a los Diáconos albas Dalmáticas etc. y al celebrante alba estola y pluvial y van al coro inmediatamente en çerimonia, el Pertiguero los ceroferarios, los comitantes el cérimoniario los Diáconos y el celebrante hazen genuflexión en la varandilla, levántanse y en pasando el facistol se quitan los bonetes y todo el coro se levanta hazen venia more solito y pasan el celebrante a su taburete que a puesto el lucernario y con el los comitantes para alzar el pluvial, los Diáconos a los bancos de los caperos y todos se sientan hasta que se acavan los psalmos del nocturno, los

[fol. $329^{\mathrm{v}}$ ]

ceroferarios después de la genuflexión que hazen al entrar, llevan los ciriales a poner en las aldavillas more solito mas no los apagan.

3. El Celebrante dize Pater Noster acabados los Versos del nocturno y haze la absolución y da las Vendiçiones como a los demás, el subdiácono pide la vendiçión y canta la 7 lección y al decir lectio Sancti Evangelis secundum Lucam, no se signa así ni al libro, lo cual se guarda en todas las lecciones de Evangelio en los maitines todo el coro está en pie hasta que dize Et reliqua, canta la lección al tono de las otras y haze 
genuflexión cuando dize, tu autem Domine. etc. el Diácono dize la 8 lección, pide la Vendición al celebrante y lo demás como en la pasada.

4. Al fin del octavo responsorio los ceroferarios van por los ciriales hazen genuflexión tomanlos llevanlos altos hasta el (tachado "fin de ella") facistol de las lecciones como para la oración de Vísperas y tienenlos

[fol. $330^{\mathrm{r}}$ ]

altos hasta el fin de ella, el celebrante algo buelto al más antiguo del coro dize las manos puestas Iube Domine benedizere y da la Vendición Verba Sancti Evangelio donat nos xptus filius Dei, canta la lección, los Diáconos le asisten ha sus lados y están en pie todos hasta $\&$ reliqua que se sientan los del coro alto y todos los del baxo se queda en pie hasta el fin, haze genuflexión al decir Tu autem Domine, levántanse y los capellanas cantores preIntonan el Te Deum laudamus, al cual están todos en pie y los ceroferarios se quedan allí los ciriales baxos: En comenzando la nona lección los Turiferarios van a la sacristía y se visten salen al altar a tiempo que al te ergo que sum, estén de rodillas en el pavimento alto acabado se levantan despabilan more solito y el antiguo previene el Turíbulo con brasas para la missa, acavado el Te Deum el celebrante dize Dominus Vobiscum y los ceroferarios levantan los ciriales canta la oración y los capellanes cantores el Venedicamus responde el órgano y toca

[fol. $330^{\mathrm{v}}$ ]

largo, mientras toca el órgano el Deo Gratias se despiden del coro con la Venia acostumbrada y salen el Pertiguero, ceroferarios y dos comitantes, Çerimoniario, Diáconos y celebrante y hecha genuflexión al Sanctíssimo Sacramento van derechos a la Iglesia y entran por la puerta de la Concepción. Cuando llegan los ceroferarios al púlpito del Evangelio cesa el órgano y comienzan en el coro a cantar el Introito de la missa y el Sacristán a la capilla de los mártires saca la casulla y manípulo y cuando llega el celebrante a las gradas sale y le quita el pluvial y se la pone como al Asperges, el Turiferario antiguo toma el Turíbulo y sale al arco de la capilla del rosario.

6. Suben los de la missa y la çelebran con las mismas ceremonias que se dixeron libro 3 , Capítulo 4 de missa solemne y con la soslennidad que pide el día, al Incarnatus est los que celebran en su lugar y todos los del coro se hincan de rodillas y lo mismo a la $2^{\mathrm{a}} \mathrm{y}$ $3^{\mathrm{a}}$ missa y en el día de la Anunciación

[fol. $331^{\mathrm{r}}$ ]

7. Acavada la missa los que la celebran se entran en la Sacristía y se desnudan de sus ornamentos y toman sobrepellizes y el celebrante estola y pluvial, los Diáconos sus capas canonicales y se buelven al coro Sin ir en cerímonia, vestido el celebrante de pluvial sale con el Pertiguero çeroferario y comitantes y va al coro.

8. Después que el órgano ha respondido al Ite missa est, al más digno del coro comienza las laudes Deus in adiutorium meum intende signándose de la frente al pecho. Se cantan las laudes con toda solemnidad y el órgano toca a todos los psalmos, viene de la 
Sacristía el çelebrante y en çerimonia como a vísperas y entran en el coro y hazen genuflexión, no oran sino inmediatamente se levantan y entran en el coro more solito y todo el coro se levanta y hechas las acostumbradas venias se sienta en su lugar y las laudes se prosiguen con las mismas cerimonias que las vísperas libro 3 , Capítulo $3, \mathrm{n}^{\mathrm{o}}$ 10 .

\section{$\left[\right.$ fol. $\left.331^{\mathrm{v}}\right]$}

9. Para las missas rezadas en todos los altares tiene el sacristán puestos vasos de agua limpia con pañicos para el purificatorio, hostiarios con hostias, braserillos con lumbre, los colegiales coadjutores no apagan las Velas cuando se queda el Cáliz en el altar sin purificallo por no aver acavado el Sacerdote las tres missas.

10. Este día no se toca a oración por que no ay la hora acostumbrada, a prima se toca a su hora con tres repiques solennes con todas las campanas, anda la gorda y el esquilón como para missa mayor y sirve esta para la segunda missa in Aurora que la dize el de la missa de prima y si fuere Sábado la segunda missa se dize en el altar de Nuestra Señora de la Concepción (* tachado "en lugar") del aniversario que fundó el Señor Don Po Dávila Abad, tres repiques se dan con todas las campanas a la ora ordinaria de la misa de Nuestra Señora mas no se

[fol. $332^{\mathrm{r}}$ ]

toca gorda ni esquilón y en alzando se toca a prima como en los demás Sábados de entre año, esta $2^{\mathrm{a}}$ missa no se suele cantar en esta Iglesia y así el prebendado de missa de prima deve tener dicha la primera missa ya si cuando dexa el esquilón sale al altar mayor y dize la $2^{\mathrm{a}}$ lux fulgebit y puede inmediatamente decir la $3^{\mathrm{a}}$ y si fuere Sábado las podrá decir todas tres en el altar mayor.

11. Si se haze dotación para que se cante la $2^{a}$ missa se ha de tocar tres cuartos de hora antes y en alzando en ella tocará el campanero a prima sin repique como en los otros días de fiesta y como se toca en los Sábados y en dexando el esquilón se comienza prima y se dizen las oras con la solenidad de tal día y el de la missa de prima puede decir la que quisiere.

12. A la missa mayor que es la $3^{\mathrm{a}}$ missa se toca a su hora con todas las campanas y la celebra el Abad con toda solennidad y asimismo las segundas Vísperas.

[fol. $332^{\mathrm{v}}$ ]

13. El día de San Estevan çelebra el Abad y esta es la comunión general, celebra tan vien las Vísperas y el día de San Iuan Evangelista, mas las segundas Vísperas celebra el Hebdomadario. 


\section{Capítulo 4. Del oficio en el día de la Epiphanía.}

1. Se çelebra con la misma solemnidad que el día del naçimiento, seis capas, Comunión general y por ser día en que la Iglesia celebra la ofrenda que las gentes hizieron al señor recíen nacido ha de ayer ofrenda de los prebendados.

2. Levantándose el Pertiguero de la genuflexión al Incarnatus est, haze otra con que se despide del altar y sube al coro, combida al Cabildo el cual baxa en cerimonia y se pone en dos coros como suele

[fol. $333^{\mathrm{r}}$ ]

en el pavimento enlosado, los modernos se quedan los primeros y por sus antiguedades se van llegando a las gradas y el Pertiguero en medio después de los más modernos el celebrante haze el ofertorio de hostia y Cáliz y dize in Spiritu humilitatis y Veni Santificator etc. buélvese el rostro a la Iglesia como al Dominus Vobiscum, mas no vesa el altar, los Çeroferarios traen de la crecencia una fuente y se ponen de rodillas Eregione a los lados del celebrante tienen la fuente en medio delante del çelebrante en altura que le llega a la cinta quita el celebrante el manípulo: llegan primero los Diáconos hazen genuflexión en la Peana, levántanse y el Diácono vesa el manípulo y ofreze y luego el Subdiácono hazen genuflexión y buelven se a su lugar diestra y siniestra del celebrante.

3. Los Prebendados suben después de dos en dos las faldas de las capas rendidas comienzan los más antiguos y prosiguen por su orden, en la peana hazen genuflexión y se levantan y

[fol. $333^{\mathrm{v}}$ ]

el mas antiguo vesa y ofreze haziendo primero venia al compañero luego el otro hazen genuflexion y cuando baxa suben otros dos y los q ue van entran por medio de los que vienen, mientras que dura la ofrenda se canta al organo un motete del día y acavada el celebrante se pone el manipulo y se buelve al altar, los ceroferarios llevan la fuente y ofrenda a la Credenzia, los Prebendados juntos hazen genuflexion y se buelven con el Pertiguero al coro, los Turiferarios suben al pavimento y el antiguo ministra el Turibulo y Naveta para incensar la oblata como suele lib 3 cap 4 de missa solenne $n^{\circ}$ y el Pertiguero se baxa para subir al coro con los Turiferarios y el Abbad y maestro de Ceremonias, an de mandar que ningun Prebendado falte a este acto y los que estubieren confesando se levanten y vayan a el como se haze en las procesiones, lo que ofrecieren los Prebendados es para el Sacristan, es combenientissimo se haga esta ceremonia para dar

[fol.334r]

dar especial solemnidad a este gran día y tan propia suya, todos los de las pasquas se haze en la Iglesia de Granada y otras .... 
4.Si se dotaren los maytines de la Epiphania tienen la misma solennidad que los de la Natividad y en ella se an de guardar las condiciones de la Dotación, comienzase absolutamente de la antiphona Afferte Domino filiy Dei y en el 3 nocturno se dize de esta manera, el Venite mientras se canta o toca el organo el 6 responsorio, el cerimoniario combida por sus antiguedades a todos los caperos que se levantan y baxan al plano del coro donde hazen venia a los Prebendados como a las lecciones, a este tiempo los cetreros toman los cetros y al tiempo que los caperos llegan al facistol grande se los dan y todos hazen genuflexion al altar y acavado el responsorio todos con el Sochantre cantan la antíphona Venite adoremus eum quia ipse est Dominus Deo noster, repitela el coro y los caperos dizen

[fol.334v]

los Versos del psalmo Venite extem Domino como en los demçás invitatorios reoitiendo siempre el coro la antiphona Venite adoremos, a la hora de estos maytines cuando los ubiere será la misma que los de la Concepción.

\section{Capítulo 5. Del officio y festividad, en el día de Nuestro Glorioso Patrón San Cecilio.}

1. A primero de Febrero, es Nuestro Glorios Martyr y Pontífice San Cecilio deiscipulo de Nro. Señor IesuChristo y después fue del Gran Apostol Sanctiago el Zebedeo, es Patron de esta Ciudad, su primer Obispo y el que la convirtió a la fee especialmene lo es de este Sacro Monte. Vivió en sus cavernas, en ellas tubo su Iglesia, padeció en ellas martirio, y oy en

[fol. $335^{\mathrm{r}}$ ]

La que está dedicada a la Asumpción de la Sanctissima Virgen Maria, madre de Dios están colocadas sus Sanctissimas Reliquias donde son servidas con toda debocióm y reverencia.

2. Padecieron juntamente con el sus discípulos, Septemtrio y Patricio Sacerdote y así de todos se celebra la fiesta de Comun plorimorum martyrum est ut infra Deus qui per Beatum Pontifizem et martyrem tuum Cecilium multum Hispanie populum ad te accersiri voluisti presta quesumus ut eclesia tua eodem rectore gubernetur, quem ei voluisti precius martyrum Septemptry et Patriciy nos festa tueauntur, Et eorum commendet oratio veneranda. Per Dominum Nostrum... La missa es Intret inconspectu tuo Domine gemitas Compendiorum, la Epístola Sancti perfidem vicerunt regna, el Evangelio Cum audieritis prelia et sediciones y Epístola y Evangelio se la da como propio

$\left[\right.$ fol. $\left.335^{\mathrm{v}}\right]$ 
por la gran conveniencia que tienen con los misterios de la Vida de San Cecilio y así en las missas Votivas que se dixeren de San Cecilio en el tiempo de Pascua aunque todo el officio de ellas sea confrome al tiempo, la Epístola a de ser la dicha.

3. Del mismo común de muchos martyres se reza por toda la actava por ser tanvien San Septemptrio y Patricio. Patrones y titulares de esta Iglesia como consta de las Bullas de la Erección y hasta que aya rezo propio aprobado por su Santo, si el día octavo de San Cecilio ocurriera con las Dominicas con Conmemoración de la octava en ambas Visperas, laudes y missa y a prima y a completas no se dicen prezes y en la missa no mentan la Oración suya y la de los Sanctos y en tal caso el Sabado se dizen las Visperas antíphonas y psalmos de la octava mas no se doblan las antíphonas sino se comienzan como en semidoble, la Capitula se dice

$\left[\right.$ fol. $\left.336^{\mathrm{r}}\right]$

la Dominica con conmemoración de la rubrica undécima de Concurrentia officis \& 10 .

4. Asiste a la fiesta el Cabildo de la Ciudad de la Ciudad de Granada viene a las primeras Visperas y a la missa nombra dos comisarios Veintyquatro y jurado, aderezan la Iglesia de Sanctiago y el Pórtico rico y curiosamente hazen altares que repesenten algo de la historia y martirio de los Sanctos, previenen fuegos y música, traen alfombras para el teatro, toda la cera que se pone en el altar mayor y collaterales en los altares de la fiesta y cirios para el blandon y los hornos, de todo lo qual les dan memoria los prebendados comisarios nombrados por el Saro Monte y asisten a los de la Ciudad para dar orden en que se ponga en parte segura las colgaduras y alfombras, plata y lo demás que truxeron para la fiesta y que se les de lo que para ella fuera necesario de la Sacristía como se dixo lib 1 cap.13 de comisarios.

5. La Vispera de San Cecilio, a prima, se dize la Kalenda solemnemente a la qual an de asistir todo el Colegio, ponen en el coro el

$=\mathrm{Va}$ al margen $=$ actava lo qual se colige de la

$\left[\right.$ fol. $\left.336^{\mathrm{v}}\right]$

aderezo que se dixo lib 2 cap 15 de los versicularios y 16 del Calendario y lib $1^{\circ}$ cap 4 , en acavando la missa mayor se cierra la Iglesia y el Thessorero adereza el altar, con todo el adorno para descubrir las Sanctas reliquias, es combeniente se colloquen descubiertas en el altar mayor ponese el dosel y por la tabla y nichos bastante numero de velas lib $1^{\circ}$ cap. 9 del gasto de la cera, los comissarios hazen y ordenan el theatro, los escaños se ponen desde la grada del pavimento a xedrezado y desviados de ella lo que basta para el paso de las missas a los collaterales y de la cerimonia para Visperas, corren hasta la puerta del Pórtico cubrenlos con alfombras y todo el suelo yntermedio, donde se ponen los braseros y bufetes de plata para los pomos de olor, de los quales cuydan los comisarios de la ciudad, aderezada la Iglesia no se abre hasta poco antes que llegue la ciudad en primeras Visperas,

$\left[\right.$ fol. $\left.337^{\mathrm{r}}\right]$ 
emparejala con el pie del Sacro Monte, tocan los ministriles y trompetas en llegando a las gradas de la cuesta empedrada todos se apean y suben a pie por la reverenzia y debocion que se deve a tan sancto lugar, duran los repiques hasta que la ciudad llega a los hornos, a este tiempo los comissarios prebendados y los otros dos señalados salen por la puerta del Pórtico y van a la Iglesia de Sanctiago, entran por la puerta del poniente y se ponen a la del medio día en dos coros, los modernos dentro de la Iglesia y los antiguos en el mismo umbral y por medio de ellos pasa el Cabildo de la Ciudad hazen a todos comedimiento, si viene corregidor y alcalde mayor los prebendados modernos cogen en medio al alcalde mayor y otro veintyquatro y los antiguos cogen en medio al corregidor y dos veintyquatros que vienen a sus lados si, solo viene el alcalde mayor los Prebendados modernos cogen en medio dos veintyquatros y los antiguos al alcalde y veintyquatros que vienen a sus lados y a si van por la Iglesia de Sanctiago, salen

$[$ fol.337v]

por la puerta del Poniente y entran en la Iglesia por la del Pórtico estando la ciudad en su teatro se despiden con cortesía.

7. Si por el tiempo de aguas o nieves, la ciudad no sube por la cuesta empedrada y quiera subir a caballo por la primera se apean en la placeta antes de entrar en el Compas, y los Prebendados que les salen a recibir por la puerta principal de la Iglesia, llegan a la puerta de la rexa del compas que está frento y se ponen y la acompañan como se dixo en el número precendente, entran por la puerta principal y se va a su teatro donde los dan.

8. Si el Señor Arzobispo a de venir a las Visperas el resto del Cabildo del Sacro Monte con el Abbad y el Collegio lo aguarda a recibir si sube por la cuesta primera en la puerta de rexa del Compas que está junto a la cuesta y entra por la de la casa y va a la Sala donde aguarda que sea ora y todo el Cabildo y Colegio lo acompaña hasta el sitial, si sube por la cuesta empedrada el Cabildo sale de suerte que lo encuentra en la Cruz de los canteros y entra por la puerta

[fol. $338^{\mathrm{r}}$ ]

del Callejón al Claustro y si no es hora se va a la Sala.

9.Si el Prelado quiere estar en el Coro a las Visperas en la silla del Abbad se pone el sitial, el dosel de brocado por encima de la sillas de los capellanes que cuelgue y cubra las dos sillas que están en medio, encima se pone un cojín de brocado y otro a los pies de la silla, en la segunda de los capellanes de un lado y otro se sientan camarero y crucero entre el facistol y las varandillas, se pone tapete y cojín, cuando es hora el Colegio y Cabildo lo acompaña al coro y como van entrando hazen genuflexión al Sanctissimo Sacramento y pasan por un lado y otro del facistol a lo plano, a la entrada el mas digno le da el hisopo besandolo y la mano y cuando hecha el agua a los prebendados le hazen profunda, los otros se hincan de rodillas, entra y haze oración detrás del facistol, los que van junto al prelado dos o tres pasos atrás del, los otros en los lugares donde están de rodillas oran y se levantan juntamente con el Prelado, entra 
por el plano del coro por el lado derecho, todos se ponen eregione y al pasar le hazen profunda, cuando llega a las gradas para subir, los inmeditos que van

[fol. $338^{\mathrm{v}}$ ]

delante se detienen y apartan un tanto y le hazen profunda, subese y ponese en su silla a donde todos le buelven a hazer profunda, los prebendados suben a sus sillas por las primeras gradas de la entrada y en llegando a ellas buelven a hazer profunda doblando algo las rodillas los dos mas antiguos le asisten en las dos immediatas, si quiere estar en el altar a las visperas se pone al lado del Evangelio el Sitial como se dixo lib. 1 cap. $\mathrm{n}^{\mathrm{o}} 1$ y 2 y dos escabelos rasos para los asistentes que son prebendados de la Cattehredal si los trae y si no los mas dignos del Sacro Monte y le asisten en su avito canonical.

10. Cuando comienzan a tocar a Visperas los ceroferarios encienden en el altar todas las velas y el Thessorero y prebendado que tiene la llave del Abbad con sus capas Canonicales y el Thessorero con estola y cendal carmessi por los hombros y quatro Collegiales con hachas van al altar y sacan las reliquias y las coloca en el lugar que esta prevenido y sera en el altar de por si en el pavimento baxo o en el altar mayor como pareciere a la junta de asistentes ponen las flores y ramillete, los lucer

[fol. $339^{\mathrm{r}}$ ]

lucernarios encienden en los altares collaerales, Los Comisarios de la Ciudad hazen que se enciendan en los altaresdel Pórtico de las Cuevas, el Sacristan los cirios en los hornos, ponen al mismo tiempo los braseros y pomos, echan pastillas que llenen la Iglesia de olor, los ministriles suben al coro y por la ventana tocan cuando la ciudad llega a la Iglesia de Sanctiago o a su Teatro.

11. A este tiempo ya están vestidos para visperas el Abbad y Caperos y salen immediatamente en Cerimonia para yr al coro more solito, si està el Prelado en su sitial en el altar se lebanta cuando el celebrante y caperos hazen genuflexion al Sanctissimo Sacramento y hecha buelven los rostros al Prelado y descubiertos le hazen profunda, los ceroferarios doblan algo las rodillas sin baxar la cabeza ni doblar el cuerpo, los demas ministros genuflexion, cuando baxan la grada del pavimento que tienen en frente a la Ciudad se levanta y los de la ceremonia todos le van haziendo cortesia al corregidor y a un lado y otro. El Pertiguero y cetreros

[fol. $339^{\mathrm{v}}$ ]

profunda, los ceroferarios no la hazen, el cerimoniario y Caperos se quitan los bonetes y baxan la cabeza, el Preste la baxa sin quitarse el bonete y de esta misma manera las hazen siempre y pasan por delante de la Ciudad.

12 Suben al coro y si está alli el Prelado todos como van entrando en el plano del Coro le hazen reberenzia los cetreros cuando llegan a su lugar genuflexion, los caperos celebrantes y los otros ministros le hazen profunda y luego venia al un coro y otro cuando los comitantes llegan a ponerse detrás de la silla del celebrante, para alzarle la capa le hazen genuflexion todas las vezes que los capellanes llegan a sus sillas, hazen 
primero al Prelado genuflexion y también todos los demas ministros que entran o salen del coro y se llegan a la silla del celebrante le hazen genuflexión, mas los cetreros cuando buelven a dar los cetros o tomarlos no hazen reverencia al Prelado, adviertase que la genuflexion que se haze al Prelado no es tan grande como la que se haze al Sanctissimo Sacramento que esta debe llegar la

[fol. $340^{\mathrm{r}}$ ]

rodilla al suelo, la del Prelado no ha de llegar mas se a de hazer con buen aire y gracia y sin detenimiento.

13. Las Vísperas que se dizen con toda solennidad y no se dexe de decir todo el himno ni otra cosa por chanzonetas que estas se pueden dezir acabado el himno antes de los versículos, todas las vezes que salen del coro si el Prelado está en el hazen reberencia como cuando entraron, baxan ha incensar el maginificat Ut moris est, a la ida no hazen Venia a la Ciudad, si el Prelado está en el altar le hazen reverenzia como cuando salieron, sube al altar el celebrante y dos Comitantes, el Cerimoniario y Turiferario más antiguo, que el otro se queda en su lugar en el Pavimento debaxo de las lámparas de la capilla de los mártires, hazen genuflexión en el pavimento alto more solito y el çelebrante llega y vesa el altar y para, en el ínterin el Çerimoniario y Turiferario llegan al sitial, hazen genuflexión y el Turiferario da la naveta al asistente más antiguo el cual la toma y haziendo profunda al Prelado se la muestray açerca y ynclanado dize Benedicite Pater Reberendissime y mientras hecha la Vendición y están ynclinados

Nota. En el margen derecho aparece el dibujo de una mano apuntando "ala ida no"

[fol. $340^{\mathrm{v}}$ ]

el asistente, el Turiferario y cerimoniario, llega el asistente la nabeta, vesa la cuchara y mano del Prelado y el Turiferario llega con el Turíbulo alto y levantada la cubierta con tal distancia y postura que el Prelado pueda con mucha suavidad echar incienso, echada la vendición se enderezan y el asistente vesa la mano y cuchara y buelve la nabeta al Turiferario, a todo esto el cerimoniario está a la diestra del Turiferario, los comitantes al lado de la Epístola enfrente del Prelado, el çelebrante en medio de el altar el rostro buelto a la Cruz, el çerimoniario y Turiferario con genuflexión se apartan del Prelado y los comitantes haziéndolas al Prelado suben a los lados del celebrante el Turiferario da el Turíbulo al comitante de la mano derecha el cual lo da al celebrante vesando Turíbulo y mano, el celebrante lo recibe sin echar vendición ê incienso a la cruz, luego sin apartarse del medio del altar inciensa las reliquias si están en el altar mayor, luego el altar more solito como se dixo libro 3. Capítulo $1 \mathrm{n}^{\mathrm{o}}$

[fol. $341^{\mathrm{r}}$ ] 
14. Acabada la incensación del altar si las reliquias están en el pavimento baxo, baxa el preste con todos los ministros y las inciensa con tres ductos en la forma que se inciensa la Cruz en el altar, buelve el Turíbulo y el Cerimoniario y Turiferario llegan al sitial cum solitis reverentiys y el Turiferario da el Turíbulo al asistente más antiguo, el cual con genuflexion antes y después inciensa con tres ductos al prelado, buelve el Turíbulo al celebrante y comitantes, en el ínterin están como y donde estubieron mientras el Prelado echó el incienso $\mathrm{n}^{\circ}$ precedente, incensado el Prelado el celebante haze reberançia a la Cruz y en la peana genuflexión, los demás en el pavimento, como se suele, luego al Prelado la reberenzia que cuando subieron, y baxando del pavimento baxo venia a la ciudad como al salir supra $\mathrm{n}^{\mathrm{o}} 11$

15. Si el Prelado esta en el coro entran con las reberencias dichas los Turiferarios cuando suben para baxar al maginificat y el más moderno se queda parado donde suele y el más antiguo sube por las primeras gradas de el coro derecho y lleva el Turíbulo y da la nabeta

[fol. $\left.341^{\mathrm{v}}\right]$

al Prebendado asistente, el cual pide la Vendición al Prelado, el cual hecha incienso y bedize como se dixo arriba y luego se buelve el Turiferario a su lugar y cuando baxa el celebrante a incensar no buelve a echar incienso ni a vendezir, mas inciensa con el que hechó u vendixo el Prelado.

16. Cuando buelven de la incensación entran en el coro con las devidas reverencias, van los Turiferarios a la silla del celebrante y el más moderno se queda parado en su lugar y el más antiguo sube por las gradas del coro derecho que están junto a las sillas de los capellanes y da el Turíbulo al asistente el que con las reverenzias díchas inciensa al Prelado y el Turiferario se baxa y haziendo humiliación los dos inciensa al celebrante luego a los caperos more solito y luego al coro.

17. Al Benedicamus Domino responden largo las chirimias o órgano y el çelebrante y caperos se despiden con los ministos que los acompañan, en saliendo del coro los demás prebendados quedando uno o dos para

[fol. $342^{\mathrm{r}}$ ]

capitular a las completas, salen acompañando al Prelado hasta su sala y de allí van los cuatro Prebendados que recibieron la Çiudad al theatro donde le hazen el debido comedimiento y cogen los lugares y en medio a los que traxeron y los despiden un poco fuera del Pórtico, casi al emparejar con la Cruz de los ortelanos porque a la buelta no entra la Ciudad por la Iglesia de las Cuevas, buélvense al coro, el cual quedó prosiguiendo las completas cantadas después que la Ciudad a tomado los caballos y pasado de la primera cuesta comienzan los fuegos como se dixo libro 2 de Campanero Capítulo 14.

18. El día de San Cecilio en saliendo de oración y antes de abrir la Iglesia se encienden todas las Velas de el altar mayor y colaterales y çirios de los blandones y se descubren las reliquias como se hizo a vísperas y las luzes arden en todos los altares todo el día las 
horas se dizen a compás morsoso conforme a la solemnidad del día, el Rector del Colegio señala dos Colegiales de satisfación uno que

[fol. 342 ${ }^{\mathrm{v}}$ ]

asista en el altar del Pórtico y otro en la Iglesia de Sanctlago de las Cuevas, mientras las horas, llevando el recaudo necesario para dezir missa a ambos altares y a la credencia del de las Cuevas un hostiario con algunas hostias y dos vasos con agua y vino que no sea necesario ir cada vez a la Sacristía por ello. Ayudan las missas de los Clérigos forasteros y las demás que se dixeren en aquellos altares para que el gran concurso de gente que no toda puede gozar de la Iglesia no se quede sin missa, çelan que no aya desorden ni cosa indecora, y de lo que ubiere que no puedan remediar en la gente avisando al Presidente que embie çeladores, acabadas las missas buelven todo el recaudo a la Sacristía y entregan al Sacristán.

19. Comienzan a tocar a missa cuando la Ciudad llega a la puente quebrada, los repiques y el recibimiento como a Vísperas supra 7.8.9 y lo mismo al Prelado que ubiere de asistir y en la missa siempre se le pone el sitial en el Pavimento alto de el

[fol. $343^{\mathrm{r}}$ ]

altar, la Ciudad en su teatro y el Prelado en su sitial comienza en el coro el Introito y al mismo tiempo salen los de la missa y al pasar al ponerse en ala hazen cortesía a la Ciudad voluiendo algún tanto el rostro en la ínfima grada hazen profunda al altar y luego al Prelado que está en pie con sus asistentes.

20. Si es Domingo que ay asperges no comienza el coro después que el celebrante ha hechado tres vezes agua hazia el altar como se dixo lib 3 cap-4 num-8. y entonado el Asperges se levanta con los ministros y no echa agua a si ni a ellos, mas buelve el hisopo al Diácono, el Diácono al çerimoniario, el cual sube al pavimento haze genuflexión al altar y llega al sitial y la haze al Prelado y da el hisopo al asistente más antiguo el cual lo da con profunda lo da al Prelado vesando el hisopo y mano el Prelado echa agua a si, al celebrante y Diáconos, luego a los asistentes y demás ministros que todos al recivirla le hazen pro

[fol. $343^{\mathrm{v}}$ ]

funda, buelve el hisopo y el asistente le vesa la mano y hisopo y se lo da al çerimoniario el cual baxa a su lugar y el Capellán con estola sube al coro y echa agua more solito, baxa y entra por el Teatro de la Çiudad sin bonete, llega al Corregidor echa agua y luego por los Veinticuatros de la mano derecha y luego por el otro lado haziendo antes y después a cada uno comedimiento aviendo acavado desde junto al púlpito del Evangelio, echa agua al pueblo que esta aquel lado, pasa al de la Epístola y haze lo mismo haziendo al pasar siempre genuflexión al altar y cortesía a la Çiudad, entran en la Sacristía haziendo reverenzia al Prelado. 
21. Suben al pavimento el celebrante Diáconos y cerimoniario y antes de llegar a la puerta hazen genuflexión, siempre que el Prelado está en el atar la hazen, no en la Peana donde suelen sino inmediate en acauano de subir la tercera grada, luego profunda al Prelado el cual sale de su silla y pasa por delante del preste y Diáconos y haze genuflexión al Sanctíssimo

[fol. $344^{\mathrm{r}}$ ]

Sacramento y pónese abaxo de la peana donde se suele hazer la confesión, al mismo tiempo llegan el preste y Diáconos y el asistente más antiguo pasa por detrás de ellos al Cornu epistolae el preste toma a su mano derecha al Prelado un paso más atrás, el Diácono a la siniestra del Presidente y el Subdiácono a la del Diácono y el asistente más antiguo a la diestra del Prelado un paso más atrás haze el Prelado la comfesion y responde el Presidente y demás ministros y cuando ellos la hazen y dizen Tibi Pr. y Te Pr. inclinan las cabezas hazia el aviendo el Prelado dicho Indulgentiam etc. y respondido Amen, el celebrante y Diáconos se retraen un poco para que por delante de ellos buelva a su sitial y el asistente buelve por detrás del celebrante y Diáconos los cuales suben a la peana aviendo pasado el Diácono por detrás del celebrante a su mano diestra y el subdiácono acercadose a la siniestra y dizen more solito los Versos Deus tu conuersus etc. llega el celebrante al altar y lo vesa y los Diáconos hazen genuflexión, en el ynterin el Cerimoniario y Turiferario llegan al sitial á que el Prelado Vendiga y eche el incienso

\section{[fol. $\left.344^{\mathrm{v}}\right]$}

lo cual se haze como a Vísperas y se dixo supra $\mathrm{n}^{\mathrm{o}} 13$ excepto que si las reliquias están en el altar de por si, no baxa a yncensarlos y lo mismo al ofertorio, buelve el Turiferario y da el Turíbulo al Diácono y este al celebrante el cual inçiensa more solito y buelve el Turíbulo al Diácono de quien es incensado y el Diácono al Turiferario el cual acompañado del maestro de Ceremonias cum debitis reuerentijs al altar y al Prelado, buelve al asistente y le da el Turíbulo porque es incensado el Prelado y después se va a la Sacristía.

22. Repetido el Introito el celebrante se llega al medio del altar y buelve el rostro al Prelado teniendo a su mano derecha el altar, el Diácono a la sinistra del celebrante y el Subdiácono a la del Diácono hazen un medio círculo, hazen humuliacion al Prelado y dizen con el alternativamente los Kyries. Comienza el Prelado y responde el celebrante diáconos y asistentes, acabados le hazen profunda, los Diáconos genuflexión al altar y el

[fol. $345^{\mathrm{r}}$ ]

çelebrante profunda y se van a sentar el lugar del Capellán Çerimoniario cuando el Prelado esta en el altar es en la segunda grada abaxo del escabelo del Crucero que está junto al escaño donde se sienta el celebrante y diáconos, allí está siempre que están sentados y tiene buelto el rostro al Prelado.

23. Acavados los Kyries por el coro se levantan y al llegar a la peana hazen profunda al Prelado llegan al altar more solito y pónense los Diáconos detrás del çelebrante el cual 
entona la Gloria y el çelebrante se buelve y los Diáconos detrás del çelebrante se buelve y los Diáconos en el lugar donde están de rostro al Prelado como a los Kyries y puestas las manos cuerpo derecho prosiguen con el Prelado la Gloria acavada le hazen profunda y al altar la devida reverenzia y se van ha sentar, acavada la Gloria en el coro van al altar y dicha la oración el subdiácono toma el Epistolario haze genuflexión al altar y profunda al Prelado va a cantar la Epístola y cuando buelve después de la genuflexión al altar se llega

\section{[fol. $345^{\vee}$ ]}

al sitial y profundamente inclinado alarga el misal de suerte que pueda el Prelado poner la mano en lo alto del, la cual vesa y echa reverenzia y al altar genuflexión buelve el libro al Çeroferario y el pasa el misal: este día se podrá escusar la palmatoria si está el Prelado en el altar porque el çerimoniario cuando alumbra al lado del Evangelio no puede estar en postura conbeniente por la estrechura del pavimento.

24. En acavando de leer el Evangelio el çelebrante, el Diácono pone el libro de los Evangelios sobre la Ara como suele y se baxa al medio del altar en la peana y de rodillas dize munda Cor meum y en el ínterin el çerimoniario y Turiferario llegan al sitial para que el Prelado eche incienso supra $a^{\circ}{ }^{\circ} 13$, el Diácono se levanta y toma el libro y va con el al sitial y profunde inclinado pide la Vendición Iube Domne Venedizere bendize el prelado pone la mano sobre lo alto del libro vesala el Diácono y con la reverencia devida se aparta y haze con los demás genuflexión al altar como en las otras missas y va a cantar el Evangelio y a la

[fol. $346^{\mathrm{r}}$ ]

buelta el Subdiácono, lleva el libro avierto al Prelado para que lo Vese y no le haze reverenzia antes sino después de çerrado el libro, el Turiferario da el Turíbulo al asistente el cual incensa al Prelado y echa la devida reverenzia se buelve.

25. Sale el Predicador con el devido acompañamiento sube al Pavimento y haze genuflexión y profunda al Prelado, llegase al sitial y si no es Canónigo se pone de rodillas y pide la Vendición Iube Domine venediçere: dada la vendición le vesa la mano y se levanta o endereza buelve ha hazerla profunda luego al altar genuflexión y al celebrante reverenzia y baxa y a la Çiudad haze comedimiento y lo demás que se dixo en su propio lugar libro $3^{\circ}$. Capítulo 6 de sermón. Acavado el sermón el celebrante entona el Credo y lo prosigue en la postura y modo que se dixo en la Gloria y al Incernatus est se hincan de rodillas así como están rostro al Prelado acavado el Credo se van a sentar como se dixo supra $\mathrm{n}^{\mathrm{o}} 23$ y cuando en el coro cantan el verso Incarnatus esto aunque el Prelado asistentes y todos los demás se

[fol. $\left.346^{\mathrm{v}}\right]$

hincan de rodillas el celebrante y Diáconos.

26. Dicho el ofertorio mientras el Diácono echa el vino en el Cáliz el Subdiácono toma la ampolleta del agua en su salvilla y acompañado del cerimoniario va al sitial y 
profunde ynclinado pide la vendición Benedizite Pater reberendissime y bendezida por el Prelado le besa la mano que pone sobre la ampolla que ya ha cerrado el Subdiácono y hecha profunda buelve con ella al altar y hecha agua en el Cáliz diziendo el celebrante la oración Domine qui humane substantie etc. mientras el celebrante ofreze el Cáliz el Turiferario llega al sitial con el Cerimoniario para que el Prelado ponga incienso como se a dicho, el Diácono da la patena al Subdiácono el qual cuando llega a su lugar, después de la genuflexión al altar, haze profunda al Prelado juntamente con el ceroferario que sube para quitar el atril y misal para la yncensación, el Turiferario moderno se queda en su lugar en el Arco de la capilla de los martyres como se dixo en las Visperas Supra $n^{0} 13$, el Turiferario buelve y dá el Turibulo al Diácono por la mano derecha como que

\section{[fol. $\left.347^{\mathrm{r}}\right]$}

el Diácono lo da al celebrante con los saludos acostumbrados y inciensa la oblata y altar more solito como se dixo arriva $\mathrm{n}^{\mathrm{o}} 21$ y el Diácono cuando le acompaña cuide de su postura de suerte que no buelva las espaldas al Prelado, el ceroferario moderno llega cum debitis reuerentijs a quitar el missal y con el se aparta al lado de la Epístola junto al otro Ceroferario el rostro al sitial y cuando lo lleva y buelve haze reverenzia al Prelado y en poniendolo en el altar buelve al Cornu epistolae para servir al agua manos como suele.

27. Incensado el altar reçive el Diácono el Turíbulo y inçiensa al çelebrante y lo da al Turiferario el cual con el cerimoniario va al sitial con las devidas reverencias y lo da al asistentte el cual inciensa al Prelado, buelve el Turíbulo y el Turifeerario le da al Diácono el cual inciensa al subdiácono y después el Turiferario inciensa a los asistentes primero al de la mano derecha y al pasar de el uno al otro haze genuflexión al Prelado, luego va al Cornu epistolae e inciensa al Crucero y con las debidas reverencias baxa y en

\section{[fol. $347^{\vee}$ ]}

la última grada lo reçibe su compañero y juntos buelven a hazer genuflexión al altar y profunda al Prelado, van al coro y lo demás hazen como en las otras missas, y cuando se buelven a sus lugares debaxo e las lámparas después de las reberencia al altar hazen otra al Prelado la misma hazen cuando suben ha incensar a la elevación y el Turiferario moderno se pone en la peana de rodillas casi arrimado al altar para que no buelva las espaldas al Prelado.

28. Los Turiferarios con sus collares y roquetes y otros Colegiales con sus sobrepellizes todos cuatro con cendales carmesíes por los hombos sacan pazes y después de ellos va un capellán asimismo con çendal en brazo saca otra para el Prelado llegan a las gradas en medio de los Çeroferarios y todos cinco en ala, el capellán en medio haze venia al altar sube el Capellán y los dos Turiferarios y hazen genuflexio en el pavimento y juntamente los otros dos que se quedaron abaxo la hazen en la grada y todos cuatro buelven a quedarse de rodillas, el

[fol. $348^{\mathrm{r}}$ ] 
Capellán lleva su paz, pónela en el altar y apártase en pie al lado del Cerimoniario,da la paz el celebrante al Diácono el qual toma con un cendal en la mano el portapaz y va al sitial, llega sin hazer reverencia y da la paz al Prelado y después le haze reverencia, buelve el portapaz al Capellán que lo trajo y da paz al Subdiácono y este la da al Turiferario mas antiguo vesando el portapaz que trae more solito, el moderno da paz a los asistentes y haze reverencia al Prelado al pasar del uno al otro y cuando da la paz al de la mano siniestra, el antoguo da paz al crucero, cuando se levantan los Turiferarios con las pazes se levantan los dos que quedaron abaxo, Y aviendo pasado el Subdiácono al Cornu Epistolae el Capellán de la paz se pone en medio de los Turiferarios y todos cinco juntos hazen genuflexión y al Prelado profunda, baxan y el Capellán entra en la Sacristía y los quatro proceden con el Pertiguero, los Turiferarios

\section{[fol. $\left.348^{\mathrm{v}}\right]$}

delante que con el suben al coro y los otros dos se entran por el Teatro de la Ciudad y dan paz por un lado y otro comenzando del Corregidor, haziendo después a cada uno cortesía y no antes de darla en acabandose entran en la Sacristía haziendo genuflexión al altar y reverencia al Prelado en el pavimento baxo, la misma hazen cuando buelven del coro los otros dos donde dieron paz como se suele.

29. Mientras el Celebrante en el lugar y modo que suele dize la oración Placeat tibi Sancta Trinitas, el Prelado sale de su situal llega al medido del altar, el celebrante y apartado al Cornu Evabgelij llevando el rostor al Prelado como cuando se aparta y pone en el Cornu epistolae, al comenzar el Diácono el Evagelio cantado el Prelado haze genuflexión y vesa el altar buelve al pueblo teniendo a su diestra al Celebrante y al del Celebrante el Asistente moderno y luego el Subdiácono a la siniestra al Cornu epistolae al asistente antiguo y al Diácono: al

[fol. $\left.349^{\mathrm{r}}\right]$

tiempo dizen Benedicat vos etc. el çelebrante y asistente antiguo se inclina un poco y todos los demás y en el coro y pueblo se hincan de rodillas, vase el Prelado ha su sitial con los asistentes y el celebrante dize el Evangelio último y después se buelve al medio del altar.

30. Saca el Sacristán el pluvial y el celebrante al Cornu epistolae ayudado de los Diáconos se quita la casulla y manípulo y el Sacrisatan la recive y viste el pluvial, llega un comitante a la gradilla, salen seis Colegiales con hachas y se ponen en su lugar conpetente dexando aún más lugar en medio, el çerimoniario pone un çendal al celebrante por los hombros sube con otro en las manos el Diácono y baxa el hueso que está sobre el cofre y dalo al çelebrante que en medio del altar el rostro a el lo recive en las manos con el zendal haziendo humuliacion profunda, quita el comitante la gradilla y baxa a la Sacristía, el celebrabte con la reliquia se pone en medio de el altar casi arrimado ha el el rostro

[fol. $\left.349^{\mathrm{v}}\right]$ 
al pueblo el Diácono a la diestra y el Subdiácono a la siniestra le alzan las puntas del pluvial.

31. El Cerimoniario llega al sitial y con genuflexión combida al Prelado sale con los dos asistentes y llega al medio del altar y haze genuflexión en la peana, y el çelebrante llega y le da a vesar la reliquia, levántase y buélvese a su silla acompañado de los asistentes los cuales buelven y arrodillados vesan y adoran la reliquia, en el ínterin baxa el cerimoniario y llega cuatro pasos antes del asiento del Corregidos y con profunda lo combida y haze a un lado y otro comedimiento para que suban a adorar las reliquias, el Corregidos y Cabildo van por sus antiguedades de dos en dos y el llegar al pavimento baxo dexan las baras porque no an de subir con ellas a hazer la adoración y el çerimoniario esté en el pavimento para avisarles si acaso se olvidaren, suben y de rodillas en la peana adoran y vesan la reliquia

[fol. $\left.350^{\mathrm{r}}\right]$

y a la venida y buelta hazen comedimiento al Prelado, sube todo el Cabildo y los Porteros cuando baxa el Diácono la reliquia haze el hostiario señal a la torre y repican con todas las campanas y la música toca los ynstrumentos o canta algunas chanzonetas mientras dura la adoración, a la cual, el Prelado y asistentes y todo el Cabildo, pueblo y coro están en pie y descubiertos, acavada la adoración el çelebrante buelve al altar y dexa en ella reliquia en medio delante de la Cruz y el cerimoniario le quita el çendal y da los bonetes hazen genuflexión y profunda al Prelado y al baxar las gradas venia a la Çiudad y se van a la Sacristía, mas si las reliquias están en altar de por si acavada la missa el Presidente y Diáconos, aviendo tomado primero el preste la capa baxan con los demás ministros y en el se haze la adoración como se ha dicho, en la capilla de los mártires están ya los prebendados y en pasadando los de la missa salen al pavimento y haziendo las devidas reverencias a la Çiudad al pasar al altar

[fol. $350^{\mathrm{v}}$ ]

y al Prelado se ponen de suerte que no estén de espaldas a la Çiudad y acompañan al Prelado y aviendo entrado por la Sacristía los que vuelven y salen con la Çiudad como se dixo en Vísperas.

32. Sale el Tesorero con çendal y estola y sube la reliquia si están colocadas en el altar mayor, la Iglesia no se cierra a mediodía por el gran concurso de la gente, los comisarios de la Çiudad Cuidan que se alzen las alfombras, los del Sacro Monte que se quuite el Teatro y los escaños se entren en el Claustro porque no estorben, al Abad y Presidente ordena bastante número de celadores para que todo el día visiten el Sacro Monte y escusen los desordenes y cosas mal parecidas de la gente y que no entren hombres y mugeres juntos en las Cuevas y para esto señala el Rector un Colegial que este en la Iglesia de Sanctiago con el Prebendado que asitiere allí en la entrada de las Cuevas, y en la puerta de la Concepción ha de aver un capellán para que no dexe entrar por allí nadie y asiste

[fol. $\left.351^{\mathrm{r}}\right]$ 
a que salga la gente; por la Iglesia de Sanctiago entran una vez hombres y otra mugeres, en entrando los que ay que entrar el Colegial va con ellos para que con brevedad salgan por la puerta de las Cabernas y aviendo salido todos avisa para que entren otros de nuevo.

33. Las Vísperas se dizen a las tres y media son todas de los Sanctos con commemoracion de Nuestra Señora conforme a las rúbricas del breviario çelebralas el Abad en poniendose el sol se encierran las reliquias, mas el adorno de ellas en la parte donde estubieron este día se queda para descubrirlas al día siguiente de la Purificación de Nuestra Señora, los comisarios de la çiudad haze que se descuelgue y alze todo el adorno de el Pórtico y Cuevas. El día antes de la Víspera la junta de asistentes cuida de nombrar los que an de decir missa en las Cuevas y en el Pórtico los dos an de acompañar con los comisarios del Sacro Monte, los que antíphona de zelar, quien ha de dar las reliquias

[fol. $\left.351^{\mathrm{v}}\right]$

quien a de asistir al altar por la tarde para las personas graves que vinieren y todo lo demas tocante al Culto divino.

[fol. $\left.352^{\mathrm{r}}\right]$

\section{Capítulo 6. Del offiçio en el día de la purificación de Nuestra Señora.}

1. Celebra el Abbad la bendición, procesion y missa ay Comunión general, en el altar está puesto el dosel y en el se pone el JHS con dos bugias que arden todo el día propio porque fue el primero que entró Su divina majestad en carne mortal en el templo, previene el Tesorero bastante numero de velas de a libra para los prebendados, mayordomos y personas nobles a quien se ubiere de dar como son Prelados, Señores de título, oydores, Inquisidores, alcaldes de corte o de Hijosdalgo, fiscales, Corregidor, alcaldes mayores, veinticuatros y otros huéspedes si los ubiere por respeto del Sacro Monte, de a media libra para los Capellanes y Sochantres, Organista, Pertiguero, menores para los Colegiales, Sacristanes, Campaneros, Caniculario; Los

[fol. $352^{\mathrm{v}}$ ]

Versicularios de la noche antes ordenan con escaños un coro desde el arco Toral por el Cuerpo de la Iglesia, dexando entre los escaños y la pared distancia por donde pase la gente, enb el Cruzero abaxo de la grada del pavimento baxo cuando tocan a missa ponen un facistol de los altos con el libro para cantar en el la Vendición, el Sacristán pone en el pavimento alto al lado de la Epístola un bufete con sobremesa morada y en tocando a missa saca y pone sobre el la fuente de plata mayor con la çera que se ha de bendecir y abaxo de las gradas hecha el romero para que tome el pueblo.

2. Los Ceroferarios se visten collares morados y sacan el recaudo para la missa mayor a la hora que suelen en los púlpitos ponen facistoles con paños blancos y el recaudo de la missa en el aparador cubren con çendal 
[fol. $\left.353^{\mathrm{r}}\right]$

blanco, ponen frontal morado en el altar mayor sobre el blanco y ençienden el çelebrante viste alba stola y pluvial morado, los Diáconos planetas morados y ninguno toma manípulos, en dexando el esquilón salen Pertiguero Turiferario Çeroferarios con çiriales y velas encendidas Çerimoniario Subdiácono Diácono Celebrante cubiertos y las manos puestas y detrás el Turiferario moderno con sobre pelliz y el acetre con agua vendita y hisopo hazen venia al altar en la ínfima grada y si es Domingo hazen el aspersorio more solito, suben al altar, el Pertiguero y Turiferario se quedan en sus lugares y el Turiferiario moderno sube y pone el Acetre y hisopo junto al bufete y se pone en pie al lado del Evangelio hasta que se acava la bendición, los que suben hazen genuflexión en la peana, llegan y el Çelebrante los vesa, y los Diáconos hincan la rodilla.

Luego va al Cornu epistolae

[fol. $353^{\mathrm{v}}$ ]

y el Diácono y Subdiácono uno en pos de otro detrás del Çelebrante comienza la vendición. El Choro de Prebendados y Colegiales que está en el que se hizo en la Iglesia responde en comenzando la oración, Domine Iesu Christe qui hodierna die etc. el Turiferario con su Turíbulo sube con las devidas reberençias y da al Diácono la nabeta, acabada la oración, y el Diácono, la ministra al Celebrante more solito el cual hecha incienso y luego el Turiferario moderno da el hisopo mojado al Diácono el cual lo da al çelebrante y este hecha tres vezes agua vendita sobre las candelas diciendo la antíphona Aspergesme Domine sin canto ni psalmo, buelve el hisopo al Diácono y el Turiferario y el del Turíbulo lo da al Diácono y el al Çelebrante, el cual asimismo Turifica tres vezes las candelas, todo

\section{[fol. $\left.354^{\mathrm{r}}\right]$}

esto da y reçive el Diácono con los acostumbrados ósculos.

3. Mientras el Çelebrante inciensa el Pertiguero va y combida al Cabildo que suba a recivir las Velas, suben de dos en dos primero los más antiguos, llevan las faldas de las capas tendidas acavada la incensación de las candelas buelve el Çelebrante el Turíbulo al Diácono y este al Turiferario el cual se va a la Sacristía junto con sus compeñaros que lleva el Acetre y hisopo, el çelebrante se pone en medio del altar el rostro a la Cruz, el Diácono a la diestra y el Subdiácono a la siniestra, cuando llegan al Pavimento alto los dos Canónigos primeros avisa el Çerimoniario y se buelven de rostro los Prebendados hazen genuflexión y el más antiguo sube a la peana dexando a su diestra al çelebrante y ambos se buelven de rostro teniendo en medio la Ara y Cruz, el Çerimoniario toma una de las velas venditas y la da al Canónigo más antiguo el cual la vesa y con reverencia profunda se la da al Çelebrante

[fol. $354^{\mathrm{v}}$ ] 
el cual luego la entrega al Çerimoniario que se la guarda para la proçesión, luego el Canónigo más antiguo se baxa de la peana al lado de su compañero y el Ceroferario sube a dar las velas al Çerimoniario para que se las de al Diácono, el cual las da al Çelebrante que puesto en medio del altar las espaldas a el las distribuye primero al Canónigo más antiguo de quien reçibio la Vela, luego a los Diáconos luego al otro Canónigo, los Prebendados reçiven las velas en pie haziendo humiliación y en reçiviendolas las vesan y no la mano del Çelebrante *, cuando se comienza la distribución el Coro canta la antíphona. Lumen ad revelationem Pentium y prosiguen hasta que se acava la distribución de las candelas, los Prebendados con las candelas hazen genuflexión y baxan y a este tiempo suben los que se siguen en antigüedad las faldas tendidas y entran por medio de los que vienen y con las mismas reverençias y forma reciuen las velas al reçibirlas siempre el más antiguo haze comedimiento al otro y siempre suben tres el más antiguo va en medio y este pasa por medio de los dos que

Al margen: * Lo contrario dice el misal, pero no habla con los Canónigos porque no hacen lo que aquí se ordena con arreglo al Ceremonial de Obispos y según el deben besar también la mano.

[fol. $355^{\mathrm{r}}$ ]

que vienen, y estos por medio de los otros dos que van, en acabando los prebendados suben los capellanes de dos en dos y reçiben las velas de rodillas vesando la vela y la mano al celebrante, después de los capellanes suben los ministros de el altar que están rebestidos Turiferarios y çeroferarios y después los demás Colegiales por su orden reçiven todas las velas de rodillas vesando mano y vela, luego sube el Pertiguero y al subir dexa la Pértiga tendida en la grada, lo cual haze (tachado " $n$ ") siempre que sube a reçivir alguna cosa, comulgar o adorar reliquias, si ay nobles y magistrados de los que se nombraron $\mathrm{n}^{\mathrm{o}} 1$, el çerimoniario los va a combidar que suban por velas y de la misma manera las reçiven de rodillas vesando la mano y vela y suban antes que el Pertiguero, si asiste algún Prelado en la missa después de aver reçivido la vela el çelebrante va con los asistentes y puesto en medio del altar la reçive

\section{[fol. $\left.355^{\vee}\right]$}

del çelebrante que se la da con reverenzia buélvese a su sitial y el celebrante la da al prebendado de quien la recibió, luego a los Diáconos, luego a los asistentes, más combiniente fuere a prevenir al Prelado que se sirua de ir ha dar la vela al celebrante y si quiere se haze como esta dicho.

5. Al fin de la distribución de las candelas, los luçernarios llevan dos encendidas y por ambos coros ençienden comenzando de los Prebendados más antiguos y el Pertiguero y ceroferarios se llegan a la capilla de los mártires a recivir la Cruz y sale con el Turiferario delante y se ponen en sus lugares, el Turiferario en el arco de la capilla de Nuestra Señora, la Cruz en la grada del Pavimento baxo, los çeroferarios a sus lados, el Pertiguero detrás del Cruciferario, el çelebrante acavada la distribuiçion se pone al Cornu epistolae buelto al missal y los Diáconos detrás

[fol. $\left.356^{\mathrm{r}}\right]$ 
uno en pos de otro, luego el coro canta la antíphona exurge Dne. Adiuuanos etc. liberanos pter nomen tuum y el psalmo Deus auribus nostris etc. Gloria Patri y repite la antíphona. Exurge, luego el çelebrante dize Oremus y si esta fiesta cae después de la Septuagésima y no es Domingo el Diácono dize Flectam genua y el Subdiácono la oración exaudi quae sumus Domine.

6. Al fin de ella sube el Turiferario cum solitis reverentiis, y aviendo respondido el coro Amen, el çelebrante se va al medio del altar y el Turiferario llega y da la naveta al Diácono y el celebrante pone incienso todo de la misma manera que se suele hazer el Turifeasrio se vaxa y pone debaxo el 'púlpito de la Epístola y el Diácono en medio del pavimento buelto el rostro al pueblo entona Procedamos in paze y responde el coro In nomine Christi Amen, en el ínterin que se pone incienso los Versi

[fol. $\left.356^{\vee}\right]$

cularios entran en la Sacristía el facistol y libro y quitan el escaño que haze testero en el coro y los demás arriman algo para que no estorben el paso a la proçesión.

7. Respondido In nomine Christi Amen procede el Pertiguero Turiferario, la Cruz en medio de los Çeroferarios por medio del coro y van siguiendo los Colegiales, Capellanes y Prebendados por sus antigüedades, el celebrante y a la diestra el Diácono y el Subdiácono a la siniestra, más los Prebendados cuando buelven para seguir la Cruz truecan coros para que el derecho tome su lugar que es la diestra del celebrante cuando comienza ha andar la Cruz el coro comienza la antíphona Adorna Thalamum tuum, en la torre hecha la señal comienzan a repicar, la procesión sale por la puerta principal y da una buelta por la plazeta y entra por la puerta del Pórtico. Si lo cuatro lados del

[fol. $357^{\mathrm{r}}$ ]

claustro están desembarazados que pueda por ellos andar la proçesión, los Versicularios no tienen que llegar los escaños, mas entra la procesión por el Claustro como se dixo lib 3. Capítulo 5 de proçesiones.

8. Cuando buelve la procesión a la Iglesia en llegando al pavimento no haze estación y así entran en la Sacristía y los Colegiales y Prebendados al salir por la puerta de la Saxristia apagan las velas y con ellas se van al coro el çelebrante y Diáconos toman ornamentos blancos para la missa y mientras se visten los çeroferarios quitan el bufete donde estubo la çera, la missa se dize con la solemnidad del día y çerimonias, libro 3. Capítulo4 de missa solemne, después de la Epístola salen los luzernarios y traen dos velas enzendidas y enzienden las de los prebendados y Colegiales para el Evan

[fol. $\left.357^{\vee}\right]$

gelio, acabado las apagan y las buelven ha enzender para la elevación de el Sanctíssimo Sacramento y las tienen enzendidas hasta después de la comunión. 
9. Si la fiesta de la Purificación viniere en las Dominicas, Septuagésima, Sexagésime o quinquuagessime no se transfiere, rézase de la fiesta missa y vísperas con commemoracion de la Dominica + y si la Anunciación de Nuestra Señora cayere en las Dominicas tercera o cuarta de cuaresma no se transfiere + al primero día desocupado, este día de la purificación antes de abrir la Iglesia se descubren las reliquias en el lugar y con el mismo adorno que el día de San Çecilio y todo el día están manifiestas y este día si ubiere mucho concurso y los demás que lo ubiere cuidará el Abad o Pressidente que se diga la missa última

Nota. Al margen derecho consta lo siguiente: "En Cabildo celebrado en 22 de marzo de 1629 se mandó así y" + Interim ex Ceremoniali Episcop. Libro2 Capítulo 46 Cathedralis ex Decreto.

[fol. $358^{\mathrm{r}}$ ]

En el altar mayor aunque la diga huésped de aprobación o capellán.

\section{Capítulo 7. Del Oficio en las Fiestas de los Sagrados Mártires de este Sacro Monte.}

1. El Primero de Marzo, es día del Glorioso mártir y Pontífice San Hiscio que padeció con sus cuatro discípulos las Sanctos Turilo, Panuncio, Maronio y Centulio, rézase el oficio del común de muchos mártires, las lecciones del Segundo nocturno del Sermón de San Çipriano (+) Nemo est qui nesciat, las del tercero, la Homilía de San Ambrosio sobre el Evangelio de San Lucas Descendens Iesus de monte etc. Si vienen antes de quaresma se reza de octava

Nota. Al margen derecho “+ Debe decir San Iuan Crisóstomo

[fol.358v]

por todos los días desocupados hasta el miércoles de Ceniza que (tachado "para")/cesa/ la octava en cualquier día que la coxa y no se reza más ni haze commemoracion de ella y así el martes en la tarde se dize las Vísperas como día infraoctauo aunque el miércoles sea el octavo no se doblan las antíphonas y a completas no se dizen preces y allí çesa el rezo de la octava, la missa es Sapientiam Sanctorum, la Epístola Sancti per fidem, el Evangelio Descendens Iesus de Monte etc. la misma se dize en las Votivas per annum mas en tiempo de pascua se dize la missa de muchos mártires o uno de tiempo de pascua excepto la Epístola que a de ser Sancti per fidem.

2. Celebra el Abad las primeras Vísperas y missa, mas si cae en feria después de la Dominica prima quadragessimo en el Sábado antes de ella çelebra las segundas Vísperas y Comunión general, las reliquias se descubren del

[fol.359r]

mismo modo con tanta cera y adorno como el día de San Cecilio desde las primeras Vísperas hasta puesta de sol y por la mañana en salliendo de oración antes de abrir la 
Iglesia hasta la noche excepto a medio día se cierra la Iglesia y quedan mientras esta cerrada dos velas y dos bugías encendidas.

3. Antes de abrir la Iglesia por la tarde los Versicularios ordenan un Coro o Teatro con escaños como se dixo. Capítulo Precedente $\mathrm{n}^{\mathrm{o}} 1$ y en la adoración de las reliquias se guarda este orden, que excepta la fiesta de San Cecilio en los otros días de los Sanctos del Sacro Monte y en el de la fiesta de la Cruz de Mayo haze el oficio de la adoración el Semanero para lo cual sale del Coro a tiempo que cuando se acava el oficio y a baxado el Cabildo al Teatro de la Iglesia sale puntualmente vestido al altar y se comienza luego la adoración sin que aguarde el Cabildo en el Teatro que a de venir a el en acavándose las completas o la Salve si la ubiere y el tiempo que en el estubiere sea de rodillas, cuando no ubiere Salve des-

Nota. Almargen derecho "S Cruz de Mayo// subrayado doble.

[fol. $\left.359^{\mathrm{v}}\right]$

pués de las completas sale el Hebdomadario del coro a vestirse para hazer el oficio de la adoración, luego que llega al coro en ceremonia antes que se acaven las completas, y entonces no pasa por la Iglesia, acompáñanle el Pertiguero, Comitantes, Çeroferarios y Cerimoniario en llegando a la Sacristía, los ceroferarios toman roquetes y Collares Carmesíes. El Çelebrante se quita la capa y sobre la sobrepelliz toma estola y pluvial rico Carmesí y seis Colegiales toman hachas encendidas y salen en Ceremonia, el Pertiguero, los Ceroferarios con ciriales encendidos, los Comitantes, el Cerimoniario y Celebrante cubiertos llegan a la ínfima grada y hazen profunda al altar y mientras sube salen los de las hachas y en dos coros se ponen como suelen.

4. Sube al altar el Celebrante, el Cerimoniario y Comitantes y otro sube la gradilla y hazen genuflexión y el Celebrante llega y vesa el altar en medio apártase un poco y pone el comitante la gradilla y delante de ella el Celebrante haze genuflexión y el Cerimoniario pone al levantarse por ambos hombros çendal carmesí, sube y los comitantes le alzan las fimbrias de la vestidura y puntas del pluvial que no las huelle, toma con el çendal la rerliquia y la baxa y el Comitante le quita la

[fol. $360^{\mathrm{r}}$ ]

gradilla y el la pone sobre el altar, a este tiempo cuando baxa la reliquia toca el órgano o se cantan motetes y en la torre hecha señal repican todas las campanas, lo cual dura hasta acavada la adoración.

5. Puesta la reliquia en el altar el Pertiguero haze genuflexión y va a combidar al Cabildo suben los prebendados de dos en dos comenzando los más antiguos las faldas tendidas y llegando al pavimento alto hazen genuflexión y a este tiempo el celebrante toma con el cendal la reliquia y se buelve y pone en medio del altar, los Prebendados de rodillas en la peana.Vesan y adoran la reliquia que el celebranbte les da y levántanse, buelven a hazer genuflexión y se van cuando ya vienen otros dos que pasan por medio de los que van y de esta suerte el Cabildo y demás clero y últimamente el Pertiguero mientras van y vienen el celebrante no se muda de lugar ni se buelve siempre esta de 
rostro al pueblo y los comitantes de un lado y otro le alzan las puntas del pluvial como para incensar acavada la adoración el Celebrante buleue a subir la reliquia y poner en el dosel y se buelve con su acompañamiento a la Sacristía cum debitis reuerentijs, á puesta del sol se encierran

[fol. $360^{\mathrm{v}}$ ]

las reliquias.

6. Si el día del Glorioso San Hisçio y sus discípulos cayere en Dominica quincuagéssime o en segunda, tercera o cuarta de cuaresma se reza de los Sanctos, mas si viene en miércoles de çeniza o en la Dominica primera de cuaresma se transfiere el día siguiente y en este caso las reliquias se cubren en su mismo día, mas no en las primeras Vísperas y aunque la missa sea de la feria o Dominica con ornamentos morados, el adorno de las reliquias y velas que arden es el mismo, y en segundas vísperas deldía que seran las primeras de la fiesta se haze la adoración como se dixo en los números precedentes y el día siguiente que se reza el Sancto no se descubren las reliquias aunque la solemnidad es como si fuera el mismo día.

7. A 15 de marzo se celebra la fiesta del Glorioso Mártir San Messitón por ser el tiempo en que se alló su lamina la primera de todas que declaró era sagrado y celestial el Tesoro que se buscaua y assí juntamente se celebra la fiesta de la invención de estas sagradas reliquias por lo cual esta día es muy solemne y festivo, principio del gran bien que Dios descubrió en este Sacro Monte y de todo el Culto adoración y

[fol. $361^{\mathrm{r}}$ ]

Servicio que en el se le haze, rezase de comun de un mártir la oración Presta quesumus omnipotens Deus ut intercedente Beato Messitom Martire tuo etc. acuritis adversitatibus liberemur in Corpore etc.prauis cogitationibus, mundemur in mente etc. las missa es Letabitur iustus in Domino, la Epístola de San Pablo ad Thimotheum: Charisime memor esto Dnm. Iesum Christum, el Evangaelio nihil opertum quod non rebelabitur, y cuando se celebra en tioempo de pascua se dize el oficio de un mártir tempore Paschali y la missa Votiua Prótesis ti me Deus con la Epístola y el Evangelio nihil opertum por ser propio del descubrimiento de las reliquias.

8. En las Dominicas 2.3.y 4 de cuaresma se reza del Sancto, si viene en la Dominica In Passione se tranfiere al siguiente día, si en la Dominica Palmarus se transfiere Post Dominicam in Albis y se reza el Sancto después de la Anunciación y en las segundas Vísperas de Nuestra Señora se haze conmemoración de SanMessiton si es día desocupado en que se pueda rezar del, en el día del Sancto se muestran las reliquias y se haze la adoracion por el mismo.

[fol. $361^{\mathrm{v}}$ ]

modo y regla que se dixo en el día de San Hiscio excepto que si cae en el tiempo de pasión en que los altares están cubiertos con velos negros, las reliquias no se ponen en el altar mayor, en el Pavimento enlosado se pone un bufete cubierto con paño de 
brocado o bordado y encima del se colocan las Sanctas Reliquias con todo el adorno de cera y flores y ornamentos.

9. Cuando el çelebrante baxa a incensar al magnficat después del altar inciensan las reliquias baxan del pavimento enlosado y los ceroferarios se ponen junto a la grada casi en (tachado "derecho de los púlpitos") y el celebrante en medio en frente del altar de las reliquias, les haze profunda y buelve a tomar de mano de el comitante el Turíbulo sin que buelva a hechar incienso y haziendo profunda por la frente del altar inciensa con tres ductos las reliquias de la manera que se haze a la Cruz.

10. La adoradion se haze en el mismo lugar y así cuando salen se ponen avajo de la grada del Pavimento. Çeroferarios y las hachas y los demás los de las hachas y los çeroferarios en todas las adoraciones están de rodillas los demás en pie. El Abad çelebra las primeras Vísperas si se dizen en tiempo de pascua

[fol. $362^{\mathrm{r}}$ ]

celebra la fiesta en Domingo, si en feria de cuaresma çelebra las segundas ay comunión general.

11. El Primero de Abril es día del Glorioso mártir y Pontífice San Thessiphón, hermano de San Cecilio, padeçieron con él los Sanctos discípulos San Maximino y Lupario, es de Comuni Plurimorum martyrum. La oración Deus qui per Beatum Pontifizem et martyrem tuum Thessiphonem multum Hispanie populum ad te accersiri voluisti, presta quesumus ut Ecclessia tua eodem rectore gubernetur quem ei voluisti pre esse pastorem et beatorum discipolorum eius martyrum Maximini et Ludet oratio veneranda Per Deum. etc. de suerte que en la oración de San Cecilio y San Thessiphón se nombran los Sanctos sus discípulos y en la de San Hiscio que es la misma no se nombran por que son muchos, la missa de San Thessiphón es salus autem iustorum a Domino etc. la Epístola Sancti Perfidem, el Evangelio sedente Iesu super montem oliveti etc. (subrayado esta es la que de septiembre).

12. Si la fiesta de San Thessiphón cae en la cuarta Dominica de Cuaresma se reza de los Sanctos con Conmemoración de la Dominica, si viene en la Dominica In Passione se transfiere a la

[fol. $362^{\mathrm{v}}$ ]

feria tercia, si vienen en la Dominica Palmarun se transfiere post Dominica in albis y se celebra después de la fiesta de la Anunciación. Si también es transferida como se dixo de San Messitón supra $\mathrm{n}^{\mathrm{o}} 8$ y el oficio es de Comun plurimorum martyrum tempore paschali la missa es del mismo tiempo y común excepto la Epístola que es Sancti perfidem, si la fiesta de San Thessiphón viene en el tiempo de passión las reliquias se descubren en el Pavimento donde se haze la adoración y lo demás que se dixo en los números 8,9 y 10. Si el primero de Abril y día de San Thessiphón viene después de la Dominica in albis se celebra en su mismo día y con octava del oficio de la comun del tiempo. 
13. Si viene en la semana de pascua ese día se descubren las reliquias en el altar mayor como se dixo en la fiesta de San Hiscio y la missa Vísperas se dizen de la feria cantadas con solemnidad de segunda clase y la adoración se haze acavada completas de los Sanctos se reza en el día desocupado después de la Anunciación y se rezará de octava los días que ubiere hasta 8 de abril que es el propio día octavo.

Si la fiesta de San Thessiphón viene en Do

[fol. $363^{\mathrm{r}}$ ]

Domingo de Ramos o en alguno dela Semana Santa se transfiere iusta rúbricas Breuiarii, mas no se descubren las reliquias y si viniere en las ferias $2,3^{\mathrm{a}}$ o $4^{\mathrm{a}}$ en la missa ay vísperas arden seis velas en el altar porque ese día es como de fiesta en este Sacro Monte, lo mismo se ha de hazer en la fiesta de la Anunciación de Nuestra Señora si viniere en las fiestas dichas o en las de Semana de Pascua.

Todos los días de los Sanctos del Sacro Monte cuando se haze la adoración de las reliquias (fuera de la fiesta de San Cecilio) y /en/ el día de la cruz de Mayo haga el oficio de la adoración el Semanero y para este efecto salgan del coro a tiempo que cuando se acave el oficio y aya baxado el Coro al Teatro de la Iglesia salga puntualmente vestido al altar y se comienze luego la adoración sin aguarde el Cabildo en el teatro y el tiempo que en el estubiere sea de rodillas, cuando no ubiere Salve después de las completas salga el Hebdomadario del coro a vestirse para hazer el oficio de la adoración, luego que llega del coro en ceremonia antes que se acaven las completas y entonzes no pase por la Iglesia

$=$ entrerenglones $/ \mathrm{en}=$

[fol. $\left.363^{\mathrm{v}}\right]$

\section{Capítulo 8. Del Oficcio en el miércoles de çeniza y en el tiempo de Quaresma.}

1. El Domingo de Ramos el Sacristán guarda alguno de los benditos para hazer çeniza para la cuaresma siguiente, el martes en la noche los quema y la ceniza muy limpia de carbones y otras cosas la recoge en una salvilla de plata y el miércoles tiene cuidado de poner en la credencia una salvilla, una ampolleta de las grandes llena de agua y una toalla límpia doblada y cuando tocan a missa saca la salvilla de las çenizas y la pone sobre el altar al Cornu epistolae, los Versicularios ordenan en la Iglesia un choro de escaños como se hizo el día de la purificación y ponen un facistol y libro para cantar, y en dexando el esquilón ya están todos en el coro en la Iglesia y salen para la Vendición el Pertiguero, Turiferario con Turíbulo y naveta Çeroferarios con Çiriales encendidos el Cerimoniario, Súbdiácono y Diácono con planetas moradas y sin manípulos, el

[fol. $364^{\mathrm{r}}$ ]

Çelebrante con alba estola y pluvial morado también sin manípulo, detrás el Turiferario moderno con sobrepelliz saca el acetre de agua vendita hazen profunda puestos en sus lugares ante la ínfima grada como cuando salen a las demás missas y el coro comienza a cantar la antíphona Exaudinos Domine con el psalmo salvum me fac Deus Gloria Patri y se repite la antíphona Exaudi al modo de los Introitos. 
2 .Quedase el Pertiguero Turiferario en sus lugares suben al altar hazen genuflexión en la Peana como a las missas, el çelebrante llega y lo vesa en medio, el Turiferario pone elAcetre y hisopo al lado de la Epístola y retirase al lado del Evangelio donde está en pie hasta acavada la imposición, llega el çelebrante al Cornu epistolae al misal y los Diáconos detrás y acavada la antíphona exaudinos Domine sin volverse al pueblo dize Dominus Vobiscum y canta las oracíones de la Vendición las manos juntas como todas las demás de las otras Vendiçiones, al fin de la cuarta Oración Omnipotens Sempiterne Deus qui Niniuitis, sube el Turiferario y ministra al Diácono la naveta y el celebrante echa

\section{[fol. $\left.364^{\mathrm{V}}\right]$}

incienso more solito, luego el Diácono le da el hisopo que toma del Thuriferario menos antiguo con agua vendita y el celebrante rozia tres vezes las çenizas diciendo la antíphona aspergesme sin canto ni psalmo, uuelue el hisopo al Diácono de quien lo recive el Turiferario que lo dió, llegase el Turíferario y da al celebrante el Thuribulo y el al celebrante el cual Thurifica con tres ductos la çeniza buelve el Turíbulo y el Turiferario se va con el a la Sacristía---

3. A este tiempo el Pertiguero va al coro combida al Cabildo y los dos Prebendados más antiguos salen con las faldas tendidas y van al altar y hazen genuflexión en la peana y a este tiempo el celebrante se pone en medio del altar el rostro buelto al pueblo. El Diácono toma el vaso de las çenizas y pasa a la diestra del çelebrante por delante del y de los prebendados y haze genuflexión en medio del Sanctíssimo Sacramento y tiene el vaso mientras dura la imposición llega el prebendado más antiguo y sube a la peana dexando a su diestra al celebrante y ambos se buelven algo de rostro teniendo en medio la ara y Cruz, toma un poco

\section{[fol. $365^{\mathrm{r}}$ ]}

de ceniza con el índize y pulgar y buelto al çelebrante que algún tanto baxa la cabeza se la pone diciendo Homo quia pulvis es, y a este tiempo en el coro comienzan a cantar la antíphona Immutetur habitu y canta las que se siguen todo el tiempo que dura la imposición, el çelebranmte recivida la ceniza se pone en medio del altar y el Prebendado se baxa de la peana inclina la cabeza y el celebrante le pone la çeniza diuciendo a todos los demás las mismas palabras Memento Homo etc., luego el Diácono teniendo el mismo vaso de las cenizas se llegal al medio delante del celebrante y se inclina y reçive la çeniza y buelve a su lugar, llega el Subdiácono y luego el otro Prebendado y reçiven la çeniza inclinados, el subdiácono se buelve ha su lugar a la siniestra del çelebrante los Prebendados hazen genuflexión y se buelven.

4. Vienen otros de la misma manera y entran por medido de los que buelven y reciven la ceniza y por el mismo orden todos los demás, los Capellanes y Colegiales y demás ministros reçiven la çeniza de rodillas, últimamente el Pertiguero y si ay personas nobles supra Capítulo 6. $\mathrm{n}^{\mathrm{o}} 1$. suben combidados del Cerimoniario a recivir la çeniza

$\left[\right.$ fol. $365^{\mathrm{v}}$ ] 
arrodillados después de todo el clero y antes del Pertiguero, acabada la imposición se buelve a llegar al misal y canta la oración Concedenos Domine, cuando la acava suben al coro alto para oficiar la missa y el Turiferario moderno buelve a la sacristía el acetre acavada la oración el Sacristán saca la Casulla y manípulos y quita al çelebrante el pluvial al Cornu epistolae y los çeroferarios ministran el agua y toalla y el celebrante algo desviado a lo último del altar laba las manos, luego el sacristán le pone la Casulla y da los manípulos y en el coro comienzan el Introito.

5. Un Capellán con estola morada y sobrepelliz puesta sale de la Sacristía acavada la imposición de la çeniza en el altar mayor sube y lleva el vaso de las cenizas al altar de la Concepción donde la pone al pueblo que se arrodilla y a cada uno dize las palabras memento Homo etc. y mientras la pone esta cubierto.

6. La missa comienza y prosigue con las Çeremonias dichas libro 3, Capítulo 4 de missa solemne, los Çeroferarios quitan las planetas al Subdiácono para cantar la Epístola y al

[fol. $366^{\mathrm{r}}$ ]

Diácono para el Evangelio como se dixo supra Capítulo 1 del oficio del adviento y libro 2, Capítulo 21, n. 46 acavada la Epístola cuando lee el çelebrante el tracto y dize verso adiuvanos Deus en el mismo lugar se hinca de rodillas y el Diácono detrás y el cerimoniario en su lugar.

7. Los Versos de este tracto de cuaresma Domine non secundum peccata nostra y Domine nememineris y Adiuvanos Deus que se dize en las ferias $2^{\mathrm{a}}, 4^{\mathrm{a}}$ y $6^{\mathrm{a}}$ de cuaresma, en el coro se cantan con solemnidad y espacio, el sochantre encarga cada verso a un capellán o Colegial que sepa vien cantarlo y lo dize solo, cuando en el Verso adíuuanos llega a aquellas palabras Propter nomen tuum todo el coro las canta y dize cuando acua el çelebrante el tracto y a buelto el subdiácono de decir la Epístola pasa el misal y el çelebrante dize el Evangelio more solito y acavado se pone en medio del altar y el Diácono detrás y el subdiácono detrás del Diácono y a sí están mientras se canta el tracto, cuando en el coro comienzan el segundo verso Domine nememineris sube el Çeroferario y quita al Diácono la Planeta y pone la estola ancha y collar como se dixo en su lugar y se baxa, (tachado "a este tiempo sube el Turibulario"

$=$ en me $=$ us" tchado. A este tiempo sube el Turibulario=

$[$ fol.366v]

y el Diácono se pone detrás del celebrante y cuando en el coro comienzan el tercer Verso adiuuamos Deus en los lugares donde están se hincan de rodillas y el çerimoniario y Pertiguero donde están cuando el coro canta las últimas palabras + el Diácono pide la vendición more solito y van a cantar el Evangelio.

8. A las oraciones y a lo demás que se dixo librol Capítulo 3 de cpomo están en la missa, están de rodillas en el coro y después de las de la comunión el Diácono buelto al pueblo canta humiliate Capita Vestra Deo y el çelebrante dize la oración super populum. 
9. La primera Dominica de cuaresma ay Comunión general y en todas las missas del tiempo usan los Diáconos planetas excepto en la misa de la Dominica cuarta letare Hierusalem en la cual se toca el órgano, mas no a las Vísperas desde el Sábado ante Dominicam Iam. quadragessime se comienzan las Salves de la cuaresma y se dizen como se refirió libro 3 Capítulo 12 de las Salves $\mathrm{n}^{\mathrm{o}}$ 9. 10 y están todos flexis genibus aunque sea Domingo.

Nota.- Al margen izquierdo:Sube el Turiferario y ministra la naveta al Diácono hechase incienso y pedida la vendición more solito. Van a cantar el Evangelio.

$=$ va entrerenglones desde sube $=$ CAPÍTULO 9.

Digo al margen $=$ testado........"

[fol367r]

\section{Capítulo 9. Del Officio en la Dominica in Passione.}

1. El Viernes /antes/ de la Dominica in Passione el Tesorero manda que se cubran los altares con velos negros para que están cubiertos a las Vísperas del Sábado siguiente cubrenlos por la noche y dexan los Velos vien puestos y ajustados de suerte que no se descubra nada del retablo, si el Sábado ante Dominica In Passione se celebraren las fiestas de San Messitón o San Tessiphón o Anunciación de Nuestra Señora, los Velos no se ponen el Viernes sino el Sábado en la noche acabada la fiesta pero antes de Vísperas cubren las Cruzes de los altares y el Christo de la Varandilla del Coro con Velos morados de seda, los luzernarios al fin de la missa salen con ellos de la Sacristía y en apartándose el celebrante del altar suben y ambos juntos cubren la Cruz mayor, baxan y cada uno va a su altar de los colaterales y las cubren, y últimamente suben al coro cubren el Christo cuando el Sábado no es alguna de las

[fol. $\left.367^{\mathrm{v}}\right]$

fiestas dichas se cubren cuando se ponen los Velos.

2. Las Cruzes cubiertas están hasta el Viernes Sancto que se manifiesta la Cruz para la adoración y assí mientras en ella los luzernarios descubren las Cruzes de los altares y las del coro. Los velos cubren los retablos hasta el Sábado Sancto a la Gloria aunque en este tiempo se reze de fiesta por solemne que sea. El mismo Viernes en la noche, aunque no cubran los altares, el Sacristán pone en el pavimento alto un pie para el pendón al lado del Evangelio delante de la credenzia por la parte que mira a las gradas y por la mañana, mientras en oras, pone el pendón en su hasta y lo arrima al escaparate y cuando ponen los velos cubre el pavimento alto y las gradas con alfombras que están puestas todo el tiempo de pasión hasta acabada la missa el jueves Sancto que las quita y en la Sacristía previene todas las que son menester para cubrir el suelo, para las ena., pónelas dobladas en una parte que no se maltraten ni huellen.

3. Todos los días que se rezare de feria y Dominica en que 
se dize el himno Vexilla Regis prodeunt, se cantan las Vísperas; en comenzándolas el Sábado, el Campanero y el Caniculario sacan alfombras y cubren con ellas, vien puestas, tendidas en proporción, todo el Pavimento baxo desde las gradas del altar hasta la puerta del Pórtico y el sacristán o el Pertiguero, los días que lo ubiere, despexan de mugeres todo el crucero y haze que salgan fuera abaxo de las alfombras al cuerpo de la Iglesia y los Domingos y días de fiesta que ubiere feria ponen unos bancos por el fin de las alfombras junto a la puerta del Pórtico con que atajan la gente, al tercer psalmo de las Vísperas, salen del choro los Prebendados solos en dos choros ordenadamente. Delante los acompañan solos dos comitantes y como salen, van por de fuera de la Iglesia y entran en la sacristía, donde se ponen las capillas sobre los bonetes y el Abad o Presidente o más antiguo en su ausencia, toma el pendón y van a entrar en la Iglesia por la puerta de la Sacristía los más modernos delante, los comitantes se ponen a un lado y otro

\section{$[$ fol.368v]}

de la puerta para tener las faldas y recogerlas cuando buelven cada uno a los de su coro.

4. Al entrar a la Iglesia por la puerta de la Sacristía dexan caer las faldas y las manos puestas de dos en dos, con espacio que no se huellen, entran tomando sus coros de suerte que la cabeza del Coro sea el altar mayor y que así tomen los lados contrarios a los que tienen en el Choro alto como se haze en las proçesiones, y los primeros más modernos pasan a lo último y como van entrando se quedan por sus antiguedades, más cerca del altar el último. Entra el que trae el pendón en medio de los dos más antiguos, si en el un choro ay más Prebendados que en el otro el Maestro de Çerimonias los iguale haziendo pasar los más modernos del coro donde ay más al otro coro, puestos en orden en dos coros los rostros bueltos al altar y el del pendón con sus colaterales suben al altar hasta la peana y puestos así todos juntos hazen genuflexión y se están de rodillas hasta comenzar la capítula en el Choro, que dirá un capellán el día que no ubiere pluvial.

5. En comenzando la Cápitula todos se levantan y se quedan de rostro al altar y en acavando la Cápitula, los Prebendados se buelven eregione y los del pendón suben todos

[fol.369r]

la peana y se arriman al altar y buelven el rostro a la Iglesia, en aviendo respondido en el coro Deo Gratias a la Capítula, el que tiene el pendón entona el himno Vexilla regis prodeunt (el cual prosigue el coro de los prebendados y abaxa el pendón muy despacio al lado siniestro del altar del Cornu Epistolae de suerte que esté tendido por el pavimento alto y que toque la punta de la hasta en el suelo y así se a de inclinar todo lo que fuere necesario, los prebendados Colaterales juntamente tienen la hasta y lo baxan y se inclinan simul y están así un rato y levántanlo muy despacio y lo buelven a baxar y tender de la misma manera al lado diestro del Cornu evangelio y esto todo en tal proporción con lo que canta que cuando el coro de los prebendados acave la primera 
estançia del himno tenga el pendón derecho y los Colaterales, cuando está así, toman los lados de él, de suerte que quede descubierta al pueblo la Cruz colorada que tiene.

6. El Coro alto con el Sochantre, Capellanes y Colegiales prosigue la segunda estancia del himno Quo vulneratus in super etc. y mientras la canta los Prebendados se retraen abaxo dos pasos y el pendón y Colaterales lo tienen derecho como se dixo y se baxan de la peana.

[fol. $369^{\mathrm{v}}$ ]

Prosigue el coro de los Prebendados la tercera Impleta sunt quae concinit y el del pendón lo buelve a baxar a un lado y otro por el mismo orden y modo que la primera vez y cuando el coro prosigue, tiene derecho el pendón y la Cruz manifiesta y todos se retraen otros dos pasos, de suerte que en las estançias que canta el coro de los Prebendados, se haze la çeremonia de arrastar el pendón y en las que canta el coro alto está derecho y se retraen en buena proporción y distançia y van teniendo las faldas para que no se estorben y cubran vien en la postraçión.

7. Cuando el coro alto comienza el verso O Crux Ave spes unica, todos en él se hincan de rodillas y los Prebendados se buelven el rostro al altar y se postran todos, excepto el que tiene el pendón, que se queda de rodillas teniéndolo en la mano. En la ínfima grada, al postrarse, cuiden todos mucho de tener las faldas que queden vien cubiertos, que no se parezcan los pies y que todo el cuerpo esté llano con el suelo, no hagan arco ni comba, y los dos comitantes que salieron del coro con los Prebendados se ponen a una vanda y a otra y cuidan de poner vien las faldas, postrados están

[fol. $370^{\mathrm{r}}$ ]

hasta aquellas palabras últimas Donas veniam que se levantan y se ponen Eregione y cantan la última estançia Te summa Deus Trinitas, en la cual buelven a baxar el pendón de la misma manera y acavado el himno todos se buelven al altar y cuando en el coro cantan el Versículo Eripeme Domine llega el Sacristán y reçive el pendón y lo pone en el pie acomodado que se descubra la Cruz.

8. En el coro entona el que capituló la antíphona del magnificat y cuando se comienza el magnificat, los Prebendados juntamente hazen genuflexión al altar y se buelven como entraron, las manos puestas diciendo el magnificat. Comienzan los modernos y al salir de la puerta los comitantes les dan las faldas en los brazos, salen con espaçio dando lugar unos a otros que no se huellen y suben, en el tránsito del coro se quitan las capillas de las cabezas y ponen sobre el hombro como suelen y entran en el coro, hazen genuflexión y se van a sus sillas sin hazer otro comedimiento entre sí y acávanse de cantar las Vísperas y en saliendo los prebendados de la Iglesia, el Campanero y Canicularios doblan y alzan las alfombras y llevan a la Sacristía y ponen por su orden para que se buelvan a poner

[fol. $370^{\mathrm{v}}$ ]

de la misma manera el día siguiente. 
9. En comenzando el Vexilla el portero de el coro haze señal y en la torre toca el campanero la campana de la Asumpción, a media buelta, como a rogativa todo el tiempo que dura la seña y acavada buelve a hazer señal para que çese y entonzes baxa a alzar las alfombras como se a dicho.

10. Si este Sábado se rezare de fiesta doble, no se haze la ceremonia de la seña porque no se canta el himno Vexilla regis, mas en comenzando el magnificat de las Vísperas del Sancto sale un capellán del coro en Çerimonia y salen con él dos comitantes, cada cual en su lugar haze profunda al coro para despedirse, que no se ponen en medio del plano todos tres juntos, hazen luego genuflexión al altar y van por de fuera de la Iglesia a la Sacristía y el Capellán toma el pendón y le acompañan los dos comitantes y cuando el coro comienza la antíphona Ego sum qui testimonium etc. por la commemoracion de la Dominica entran por la puerta de la Concepçión y lleva el pendón al altar, suben al pavimento alto, hazen todos tres genuflexión y después lo pone en su pie al lado del Evangelio, buélvense a hazer

[fol. $371^{\mathrm{r}}$ ]

genuflexión y se baxan, por la capilla de los mártires se entran en la Sacristía.

11. Si este Sábado se rezare de fiesta semidoble en la cual se parten las Vísperas y los psalmos con sus antíphonas se dizen del Sancto y desde la Capítula se dizen de la Dominica y son todas cantadas, salen a la ora dicha a hazer la seña, el un coro y el otro canta el himno Vexilla regis con mucho espacio y solemnidad especialmente el Verso $O$ Crux Ave, que el mismo canto denote la devoción de aquel acto tan demostrativo y sentido de la muerte de Nuestro Redemptor.

12. El Domingo, si ay seña se haze de la misma manera, excepto que cuando salen del Coro los Prebendados, se cubren con las capillas en el tránsito del coro, mas las faldas no las sueltan hasta entrar en la Iglesia y todos los demás días lo mismo y los Turiferarios no salen al altar de la Capítula para despabilar y en el coro se quedan los caperos y el preste y en el verso antes de O Crux Ave spes unica salen del coro a incensar el altar con las devidas reverençias y cuando comienzan el magnificat

[fol. $371^{\mathrm{v}}$ ]

more solito y las alfombras no se quitan hasta que ha salido de la Iglesia para volver al coro el celebrante y ministros.

13. Todos los demás días de ferias se haze la seña como se a dicho el Sábado en las Vísperas antes de comer y los Domingos después de comer y el de Ramos de la misma manera que en el preçedente.

14. El Martes Sancto es el último día que ay salve y el miércoles el último de la seña y así acavada, el que tiene el pendón no le dexa, mas comenzando el magnificat hazen genuflexión y por el orden que lo traxeron lo buelven a llevar a la sacristía, salen diziendo el magnificat y en la salida de la puerta de la Sacristía los comitantes les dan 
las faldas, entran en la Sacristía y se ponen en dos coros y el del pendón pasa por medio hasta el caxón del testero donde lo da al Sacristán que lo alza y luego lo dobla y guarda, los prebendados allí se quitan las capillas y se buelven al coro, hazen la seña los Prebendados cada uno su día por sus antiguedades.

[fol. $372^{\mathrm{r}}$ ]

\section{Capítulo 10. Del Offiçio en el Domingo de Ramos.}

1. El maestro de çeremonias, cuando haze la tabla del Coro para la Semana de Ramos, escogerá los Diáconos que le pareçieren más a propósito, para los oficios de aquella Semana, los cuales no entran en turno, y la semana siguiente de pascua se continuará donde quedó. El Sacristán el Sábado en la noche pone en el Cornu epistolae, como hizo para la bendición de las candelas, bufete con sobre mesa morada y en la fuente grande de plata las palmas, que se an de bendecir y escoge las más hermosas, y las pone enzima de las otras para que se den al celebrante y Canónigos, y el que las ministra las alle las primeras; la fuente con las Palmas la pone sobre el bufete, y en derecho del, abaxo de las gradas, en el pavimento enlosado pone cantidad de Ramos de oliva, y de laurel; los Versicularios ordenan un coro de escaños, como el día de la Purificación, y cuando tocan a missa sacan el facistol y libro por donde se a de cantar, ençien

[fol. $372^{\mathrm{v}}$ ]

dense las lámparas; y el campanero toca a missa una hora antes de lo ordinario.

2. Mientras tocan a missa, los çeroferarios sacan el recaudo acostumbrado, como para las demás missas de cuaresma, ponen en los púlpitos façistoles con paños morados, y previenen otros tres altos que asimismo cubren con paños morados, en los cuales se ha de cantar la pasión, y los libros pasionarios, ençienden en el altar mayor; los Turiferarios previenen Turíbulo y acetre; los de la missa se visten, los Diáconos con planetas, y manípulos, como para las otras missas, y el celebrante alba, estola Cruzada, y pluvial, sin manípulo, y en dexando el esquilón salen Pertiguero, Turiferario, con roquete, y collar, Turíbulo y naveta, ceroferarios con sus ciriales ençendidos, el cerimoniario, Subdiácono, Diácono, y celebrante, y detrás el Turiferario moderno con sobrepelliz, y acetre de agua vendita, llegan a la ínfima grada, y se ponen como se dixo libro 3, Capítulo 4 de missa solemne, y hazen el aspersorio more solito.

3. Acavado el Aspersorio (en el cual no dizen el verso Gloria Patri, como tampoco en la Dominica in Passione) el Pertiguero, Turiferario

[fol. $373^{\mathrm{r}}$ ]

y Çeroferarios se quedan en sus lugares y suben las de la missa, y el del açetre hazen genuflexión donde suelen y el Turiferario pone el acetre junto al bufete, y se aparta al lado del Evangelio, donde está hasta acavada la Bendición que buelve el açetre a la Sacristía; cuando suben las gradas y el coro canta la antíphona, Hosanna filio David, el Çelebrante, y Diáconos, después de la genuflexión, se llegan al altar, y el çelebrante lo vesa, y los Diáconos buelven a hazer otra y luego se van al misal y se ponen uno en pos 
de otro, como suelen, y lee la antíphona, la qual acavada de cantar el celebrante como está, buelto al misal y las manos juntas, dize Dominus Vobiscum, y luego la oración Deus quem diligere etc. amare etc., al fin de ella sube el Ceroferario antiguo y quita al Subdiácono la planeta y pónele collar, dale el libro de las Epístolas, y lo acompaña more solito al púlpito donde canta la lección en tono de Epístola y buelve con él, todo con las devidas reverenzias, y besada la mano al celebrante, le buelve a poner la planeta.

4. Acavada la Epístola, el coro canta el gradual Collegerunt Pontifizes, y en el ínterin el Diácono pone el libro sobre el altar, y el celebrante se pone

$\left[\right.$ fol. $373^{\mathrm{v}}$ ]

en medio del, el Turiferario sube y como para los demás Evangelios echa el incienso y pide la Bendición, y acompañan los Çeroferarios con los ciriales, canta el Evangelio more solito, y a la buelta el celebrante vesa el libro, y es incensado, y en dexando los çiriales en las aldabas, el Çeroferario le pone la planeta y el Turiferario se baxa a su lugar donde aguarda meneando el incensario, el çelebrante va al misal, y buelto a el dize, Dominus Vobiscum, y la oración, Auge fidem, con lo demás, que pone el ordinario para la vendiçión, al fin de la oración, Benedictus quesumus Domine, el Turiferario sube y el celebrante pone incienso, toma el hisopo de mano del Diácono y rozia tres vezes las palmas, y ramos diciendo la antíphona, asperges, sin canto, ni psalmo, luego otras tres vezes los Turifica, y luego dize la Oración, Deus qui filium tuus Iesum, la cual acavada, se haze la distribución de las palmas por el mismo orden, modo, y ceremonias, que se hizo de las candelas, supra Capítulo $6 \mathrm{n}^{\mathrm{o}} 2$ y 3 y los subsecuentes, acavada la distribución, el Sacristán echa de los ramos benditos

[fol. $374^{\mathrm{r}}$ ]

por la Iglesia, para el pueblo, y el Cruciferario sale con la cruz cubierta con cendal negro y un Colegial, señalado por el maestro de çerimonias, toma el pendón, con que se haze la seña y se pone al lado sinisro del Cruciferario, en la grada del pavimento, y se ordena la procesión, como se dixo en los números referidos del día de la Purificación; los Diáconos dexan los manípulos, los cuales pone el Cerimoniario en el escañuelo donde esta la estola y collar y el celebrante dize la oración Omnipotens Sempiterne Deus, y poniendo incienso more solito, el Diácono dize Procedamus in paze, y comienza a andar la proçesión.

5. La cual siempre sale por de fuera de la Iglesia por la puerta del Pórtico, y por la plazeta, preçede el Pertiguero, luego el Turiferario, el que lleva el pendón, Cruciferario en medio de los çiriales, y el clero por su orden, en llegando a la puerta principal, cuatro, o cinco capellanes, o Colegiales, entran en la Iglesia y cierran las puertas, y la procesión se queda fuera por el mismo orden, que vino, cada cual en sus lugares, el del pendón junto a la puerta al lado diestro, el Turiferario al siniestro, y detrás de él, el 
Pertiguero, el Cruciferario entre los dos Ceroferarios, en medio de la lonja enlosada asientan la Cruz

Testado: el

[fol. $374^{\mathrm{v}}$ ]

y ciriales, el clero por su orden, como van llegando se quedan y paran, los Cantores dentro de la Iglesia cantan los Versos Gloria laus, etc. honor etc., y repítenlos el sochantre con el Clero de la procesión, los de dentro prosiguen como se dispone en el misal, y cantados todos, o parte de ellos, según la oportunidad del tiempo, el Çerimoniario llega al Subdiácono, y le haze venia, y va con el hasta la Cruz, la cual el Cruciferario dexa caer en las manos de un Colegial, para que el Subdiácono pueda tomar la hasta de ella, y toca la puerta con tres golpes y los de dentro la abren y entra la procesión por el mismo orden cantando la antíphona Ingrediente Domino.

6. Cuando comienza a andar la procesión, el Colegial portero haze señal a la torre y repican con todas las campanas mientras dura, cuando a salido de la Iglesia el Sacristán alza las palmas que sobraron y quita el bufete y de los ramos venditos guarda para hazer ceniza, y limpia el pavimento de ellos, si ubiuere Clérigos (que no sean prebendados) de otras Iglesias, y van en la procesión entre los capellanes, los Prebendados entre los Canónigos en lugar onrroso, porque en las procesiones

[fol. $375^{\mathrm{v}}$ ]

se guardan los lugares y antigüedades de la misma manera que en el coro. Las personas nobles, o seglares que ubiere, van detrás del celebrante dos o tres pasos, y si asistiere algún Prelado, va asimismo detrás, y le acompaña su familia.

7. Llegando la procesión al altar mayor, el Pertiguero se queda açia el púlpito del Evangelio, el rostro al de la Epístola, el Turiferario pasa a su lugar, al arco de la capilla del Rosario, el del pendón sube al pavimento y lo pone en su lugar, la Cruz se entra en la Iglesia y van con ella hasta el arco de la capilla de los mártires, los Ceroferarios, y luego se buelven a la ínfima grada a sus lugares, el clero entra en pos de la Cruz, y se van al coro llevando todos sus palmas, el çelebrante y Diáconos llegan a la ínfima grada entre los ceroferarios donde el Sacristán saca casulla y manípulo, quita el pluvial al çelebrante y se la pone, y suben al Pavimento y el çerimoniario toma los manípulos, y los da a los Diáconos, y hazen genuflexión, y comienzan la missa more solito.

8 El maestro de ceremonias tiene señalados

[fol. $375^{\mathrm{v}}$ ]

tres que canten la passión (si no lo ubiere de hazer alguno de los que están en el altar) los cuales mientras en el coro se canta el tracto se visten en la sacristía, amitos, albas, cíngulos y estolas moradas sobre el hombro siniestro, que cruzen por debaxo del diestro, y collares, los Çeroferarios sacan los Atriles altos con sus paños, y los suben al Pavimento alto, y ponen uno en medio del cerca de la peana, el otro al lado del Evangelio, y el otro al de la Epístola, no totalmente bueltos al pueblo, sino algo que se 
miren entre sí, y a la que está en medio. Al fin del tracto salen de la Sacristía los tres que an de decir la Pasión, dos Colegiales Comitantes delante con sobrepellizes, luego el que representa al Evangelista, luego el que representa al pueblo, luego el que representa al Christo, y cada uno saca el libro por donde ha de cantar cerrado, y arrimado al pecho, llegan a la ínfima grada entre los Çeroferarios y pónense en una línea, el que representa al Christo en medio, el Evangelista a su siniestra, y el del pueblo a la diestra los comitantes dos pasos atrás, hazen todos profunda, suben, y en Pavimento hazen genuflexión y cada uno va a su atril, y pone en el

[fol. $376^{\mathrm{r}}$ ]

el libro, los comitantes se buelven a entrar, los çeroferarios apagan los codales de los Çiriales y se ponen en el pavimento alto, el antiguo al lado del que haze el pueblo, al Cornu epistolae, y el moderno al Cornu evangelio al aldo del que haze el Evangelista, Eregione y las manos puestas, mientras dura la pasión y el comitante antiguo se queda asistiendo al que haze la persona de Christo.

9. No se canta nada a canto de órgano sino el canto llano con mucha deboción y pausa; mientras se canta la passión todos los del coro tienen las palmas en las manos y descubiertas las cabezas hasta acavado también lo que se canta en tono de Evangelio, y el celebrante en el Cornu epistolae buelto el misal como cuando se pone para decir el Evangelio que lo alto del mire al sagrario para que cuando lea la passión tenga el rostro al Cornu evangelio, y el Diácono a su mano siniestra, y el Subdiácono a la siniestra del Diácono, que todos tres miran como se a dicho al Cornu evangelio, y teniendo las palmas en las manos también, el çelebrante lee toda la pasión, en acavando de leerla en el mismo lugar que estando tres se retraen más al angulo del Cornu epistolae y se buelven algo a los que la

\section{[fol. $\left.376^{\mathrm{v}}\right]$}

cantan y cuando llegan a cantar Iesus autem exclamans voce magna emissit spiritum, todos, así en el coro, como en el altar, se hincan de rodillas hazia el Sanctíssimo Sacramento, y oran un rato en silençio, levántanse, y prosigue el Evangelista hasta lo que se a de cantar en tono de Evangelio, que cierran los libros, salen los dos comitantes a la ínfima grada y junto a ella y los de la passión en el Pavimento hazen genuflexión y se buelven a la Sacristía por el orden que vinieron llevando sus libros, y los Ceroferarios quitan los atriles, y ponen en la Capilla de los mártires encienden los çiriales y el Turiferario sale con su turíbulo.

10. El Ceroferario moderno quita al Diácono la planeta y pone estola ancha y Collar y da el libro de los Evangelios que lo pone en medio del altar sube el Turiferario y pide la bendición del incienso more solito y luego en medio de la peana de rodillas dize Munda Cor meum pide la vendición y va a cantar el Evangelio como suele, excepto que los çeroferarios no llevan çiriales aunque se ponen en su lugar acostumbrado y el Diácono dize Dominus Vobiscum ni 
[fol. $377^{\mathrm{r}}$ ]

Sequentia ni signa el libro ni así mas lo inciensa y acavado el Evangelio el celebrante vesa el libro y es inçensado y el subdiácono antes que el celebrante entone el Credo pasa el misal ala Cornu evangelio de la misma manera y con las mismas ceremonias se canta la pasión el martes y el miércoles excepto [que] no ay palmas.

11. Si cantan la pasión, los que celebran la missa, mientras se canta el tracto en el coro, los Çeroferarios apagan los çiriales sacan los atriles y ponen como se dixo y cuando sacan el recaudo para la missa sacan los tres pasionarios y una estola para el Subdiácono ponen los libros sobre los atriles quitan a los Diáconos las planetas y ponen al Subdiácono la estola Cruzada por debaxo de el brazo pónenles Collares y el que dize la missa para hazer la persona del Christo no dexa la casulla, pónense todos y cantan la Passión como queda referido y cuando llegan a lo que se a de cantar en tono Evangelio quitan los atriles y libros y el Subdiácono la estola y u collar y ponen la planeta y el Diácono estola ancha sube el Turiferario y todo lo demás se haze como en el número preçedente 12. Si el que celebra la missa no a de cantar la pasión

$\left[\right.$ fol. $377^{\mathrm{v}}$ ]

y los Diáconos si, sale de la Sacristía vestido uno en su lugar acompañado de un comitante y los çeroferarios quitan las planetas a los Diáconos como se a dicho, sube el que sale y haze genuflexión y toma el atril conforme la persona que representa y pone en el libro que el mismo sacó arrimado al pecho y cantan la pasión y el celebrante la lee, en el Cornu epistolae con la palma en la mano en la postura que se dixo $n^{\circ} 9$, los que çelebran no dexan las palmas de las manos hasta que se llega a lo que se a de cantar en tono de Evangelio, mas las dexan si ellos cantan la passión, el cerimoniario cuando suben al pavimento a decir la missa les toma las palmas y las arrima a un lado mientras se dize la confesión y cuando van a leer el Introito, las pone sobre el altar arrimadas a los velos la del celebrante en medio y las otras dos al Cornu Epistola y Evangelio la suya arrimada a la Credenzia. Acavada la missa, que en todo lo demás se dize como en el ordinario y con las ceremonias acostumbradas, les da los bonetes y luego las palmas y toma él la suya y con ella se buelven a la Sacristía donde se desnudan etc. a la tarde las Vísperas

[fol. $378^{\mathrm{r}}$ ]

y la seña como se dixo en el Capítulo precedente.

13. El Tesorero pasa el Sanctíssimo Sacramento del Sagrario al altar mayor para que el monumento se comienze con tiempo, de modo que no se haga falta y para esto el Sacristán quita el frontal, manteles, Ara y alfombra del altar del Sagrario, quita las esteras de todo aquel lado y lo barre y allí se arma el monumento y se adereza rica y curiosamente y de tal manera se ha de acomodar el trabaxar en él que los golpes y ruido no sean en tiempo de los oficios divinos, especialmente la missa y passión, el Tesorero en el altar de la Concepción previene y una peana cubierta con paño rico y enzima uno de los cofrecitos de terciopelo asimismo cubierto con paño rico morado, pone dentro 
unos Corporales todo muy limpio y oloroso y todas las mañanas antes de abrir la Iglesia pasa el Sanctíssimo Sacramento el relicario baxo de las formas para las comuniones ordinarias y en çerrando la Iglesia al mediodía lo buelve al altar mayor y siempre lo acompañan dos o cuatro hachas y el Sacristán todas estas mañanas tiene encendida la lámpara de la Concepción.

[fol. $378^{\mathrm{v}}$ ]

14. El Martes Sancto, si no fuere día de la Anunciación, puede cantar la pasión uno a tres vozes y así los Ceroferarios no sacaran más de un atril y lo pondrán al lado del Evangelio en el Pavimento y saldrá el que la a de cantar con el libro al pecho acompañado de un Comitante que llegarán con las devidas reverenzias y le asistirá mientras canta la pasión y los Ceroferarios se estarán en sus lugares y en llegando a lo que se a de decir en tono del Evangelio se volverá a la Sacristía y lo cantará el Diácono como se a dicho y si el celebrante hubiere de cantar la passión solo el atril se pondrá en medio y dexará la Casulla para cantarla, la cual tomará para cantar lo del tono Evangelio porque lo a de cantar por el misal sobre el altar.

15. El Miércoles Sancto pueden cantar la pasión entre tres de la suerte que se a dicho: el miércoles a la tarde después de completas se canta con solemnidad la antíphona de Nuestra Señora Ave Regina Celorum.

[fol. $379^{\mathrm{r}}$ ]

\section{Capítulo 11. De los maytines de tinieblas de la cuarta, quinta y sexta feria de la} Semana Santa.

1. El miércoles a las cuatro de la tarde comienza el Campanero a tocar a maitines con dos campanas como a Vísperas de fiesta doble, las cuales, tras media hora, un cuarto la gorda y otro [el] esquilón que dexa a las cinco, en la siesta se saca el candelero triangular y se pone, y en la misma ora los luzernarios ajustan las quince velas que an de ser de çera amarilla excepto la de en medio que a de ser blanca y las dexan puestas en el Candelero, baxo de la grada del Pavimento ajedrezado al lado de la Epístola y en el mismo pavimento detrás del candelero se ponen unas gradas dende las cuales alcanzen a poner y quitar la velas, cuando se toca la gorda pondrá el Sacristán junto a la escalera del pùlpito de la Epístola un acetre con agua y la mano para apagar las velas.

[fol. $379^{\mathrm{v}}$ ]

en comenzando el esquilón los luzernarios enzienden las quinze candelas, los Ceroferarios enzienden en el altar mayor otras seis de cera amarilla, los Versicularios ponen en el façistol los libros del oficio y en medio del coro façistol que se suele poner a la Calenda y en el libro de las lamentaciones ponen los hacheros y hachas candeleros y bugías para los prebendados, una en frente de cada silla como se dixo libro 3 Capítulo 3 de maitines, y estando todos en el coro antes que dexe el esquilón y un luzernario en la escalera del púlpito de la Epístola de la Epístola sentado para apagar a su tiempo las candelas del triangular. 
2. En dexando el esquilón los del Coro se ponen todos en pie y dizen secreto Pater Noster Ave Maria y Credo y acavado los capellanes cantores, con las devidas reverenzias, se llegan al que preside en el Coro y con el Sochantre le preintonan la antíphona Zelus Domus tue y acavada de cantar por el coro y comenzando el psalmo se sientan los Prebendados y Capellanes. Cántase todo el oficio con mucha pausa y deboción con solemnidad y espacio de primera Clase, al fin del psalmo apaga el luzernario la primera vela del candelero triangular del lado

[fol. $380^{\mathrm{r}}$ ]

del Evangelio y al fin del segundo psalmo, apaga la correspondiente de lado de la Epístola y al fín de cada uno de los demás psalmos de maitines y laudes va alternativamente por el mismno orden apagando una vela.

3. El maestro de Ceremonias señala quiénes an de decir las lecciones, las lamentaciones encomienda a los más diestros o Colegiales o Capellanes o Canónigos y si Cada uno de estas hierarchias dize la suya, comienza la primera el Colegial, la segunda el Capellán , la tercera el Canónigo y así respectivamente por sus órdenes y antigüedades, los demás que las ubieren de decir: en comenzando el versículo del nocturno todos se levantan y en respondiendo dizen secreto Pater Noster. Y el que ha de decir la lamentación llega con las devidas reverenzias y en acavando el Pater Noster se sientan después de sosegado y todo comienza la lamentación, los responsorios se cantan también con el devido espacio que en proporción corresponda al Compás de los psalmos de la misma suerte se dize la segunda y tercera lamentación.

\section{Las lecciones del segundo y tercero nocturno}

[fol. $380^{\mathrm{v}}$ ]

dizen los Prebendados por su antigüedades de suerte a la última diga siempre el presidente del Coro, el Abad o Presidente y en su ausençia el más antiguo, en cuanto a las reverenzias de baxar y subir a las lecciones, combidar para las antíphonas de los nocturnos y laudes se observa lo mismo que en los demás maitines como se dixo en su capítulo libro 3.

5. Cuando se comienza la antíphona del Benedictus los Çerofararios salen del coro en cerimonia y entran por la Iglesia y con las devidas reverencias suben al altar mayor y el moderno se pone al Cornu evangelio y el antiguo al Cornu epistolae con las despaviladeras en las manos y al Verso Ut sine timore, el moderno apaga la primera vela que está a su lado y al Verso siguiente el antiguo apaga la correspondiente que está a su lado y así a cada Verso alternativamente cada uno por su lado apaga una Vela de suerte que las postreras son las que están en medio del altar a los lados de la Cruz. Mientras se apagan las Velas de el altar el Sacristán apaga todas las luzes de la Iglesia excepto las lámparas que ardieren

[fol. $381^{\mathrm{r}}$ ] 
delante del Sanctíssimo Sacramento y en el Coro los luzernarios apagan las velas y hachas dexando una que alumbra para cantar el Verso Christus factus est etc..

6. Cuando se repite la antíphona del Benedictus los ceroferarios se vaxan a la Sacristía y el luzernario que apagó en el triangular sube a la grada y quita la vela blanca del candelero triangular y con ella sube al altar y así enzendida la tiene levantada un poco sobre el Cornu epistolae y cuando se comienza Christus factus est la esconde así enzendida detrás de el altar o del Velo en la parte baxa del Cornu epistolae y se pone delante porque no se trasluzca la luz. En el Verso Christus factus est lo cantan los Prebendados de los más diestros y al comenzarlo todos se hincan de rodillas y acavado el luzernario saca fuera del coro el hacha y cierra las puertas tras sí, el coro dize secreto Pater Noster y luego el psalmo Miserere en canto baxo devoto y lamentable y en acavando el Abad o Presidente del coro, estándose de rodillas y la cabeza algo inclinada dize rezada en tono baxo intelligible la Oración Respice quesumus Domine. Hasta qui tecum que lo dize en secreto y los

[fol. $381^{\mathrm{v}}$ ]

demás lo an de decir también en secreto, acavada la Oración el maestro de ceremonias haze algún ruido dando con la mano avierta sobre el asiento de la silla lo mismo hazen los demás del Coro por un breve espacio, luego el luzernario saca la Vela enzendida y pone sobre el Cornu epistolae y el lucernario entra el hacha en el coro y cesa el estrépito, levántanse todos y sin hazer venia en silencio salen del Coro.

7. El Jueves Sancto a la misma hora se entra en maitines y se dizen de la misma manera y con la misma solennidad y pausa y se haze todo lo que queda referido excepto que no se pagan las velas del monumento. El Viernes Sancto se dizen los maitines inmediatemente después de las completas y así, mientras tocan las completas, ponen y previenen todo lo neçesario para ello y se haze lo mismo mas el Compás del coro en el Canto es más ligero y apriesa y el candelero de tinieblas acavados los maitines lo entran en la Capilla de Nuestra Señora del rosario dos noches y el viernes lo alzan en su lugar.

8 El miércoles en la noche el Tesorero

[fol. $382^{\mathrm{r}}$ ]

adereza el altar de la Capilla de los Ángeles que en él se guarda el jueves el Sanctíssimo Sacramento, pone una cortina en el Arco que sale a la capilla del rosario de suerte que no se pueda alzar, para que esté secreto corre la de la vidriera, previene lámpara que arda y lo demás que le pareçiere combenir.

\section{Capítulo 12. Del officio del Jueves Sancto.}

1. A de estar acavado el monumento y en el arco del puesta una cortina de seda que cubra el altar y la arca, la cual el Tesorero ha de tener muy limpia y olorosa con corporales dentro, las horas se dizen con pausa en tono baxo y devoto a la ora ordinaria y en ellas todos estos tres días dize el Pressidente del Coro la oración Respice quesumus 
Domine, ninguno çelebra este día porque todos los Sacerdotes an de comulgar en la missa

$\left[\right.$ fol. $\left.382^{\mathrm{v}}\right]$

Solemne. El Sacristán previene la Cruz para la procesión y palio rico, dos cendales blancos bordados, uno grande para los hombros del celebrante y otro menor para cubrir el Cáliz del Sanctissimo Sacramento el qual a de ser ancho que quepa en él la forma grande consagrada que se ha de reponer en el monumento, tiene prevenidos y limpios bastante números de candeleros para las gradas del monumento y mientras se dizen las horas pone en ellos las velas, cortados los pavilos y comenzada a arder. Previene asimismo bastante número de hachas y velas para la procesión, dos hostias para el Cáliz de la missa y el Vaso dorado, las formas para la comunión muy limpias y purificadas.

2. Los Ceroferarios en comenzando a tocar a missa que será a las nueve, se visten y sacan recaudo ordinario, ay aparador como en fiesta de primera Clase y en el ponen los cendales para la procesión y quatro estolas para la comunión, todos los ornamentos de este día son blancos, un Vaso con agua y vino para la abución, el de las formas y el Cáliz ancho y lo cubren con cendal blanco, toda la mañana y mientras la missa hasta que quiere andar la procesión un prebendado

[fol. $383^{\mathrm{r}}$ ]

o Capellán a de dar la comunión en el altar de la Concepción a los seglares y a todos los ministros y Criados de la casa y en acavando la missa llevará el Sanctissimo Sacramento al altar de la Capilla de los Angeles prevenido para esto y le acompañarán quatro Collegiales con hachas que encomenzando la procesión no a de comulgar mas a nadie.

3. En dexando el esquilón salen a la missa more solito Lib.3 Cap.4. y entonando el Celebrante la Gloria los ceroferarios tocan las campanillas, los comitantes en las capillas de los martyres y del rosario tocan otras, el Organo tañe y en la torre todas las campanas y no se buelven a tocar hasta el Sabado Sancto a la Gloria, dura toda esta música mientras el coro canta todo el hymno, la missa se dize como en el ordinario, dízense los Agnus mas si no se da la paz y al ofertorio no se abre el Sagrario porque este día no se renueva el Sanctissimo Sacramento, mas después de haver consumido el celebrante la hostia que consagró en la missa, el Diácono abre el Sagrario y con las devidas genuflexiones saca el Relicario y del toma el celebrante la forma consagrada y la consume después de aver consumido

$\left[\right.$ fol. $\left.383^{\mathrm{v}}\right]$

el Sanguis. Antes de purificarse pone la hostia que consagró para el monumento en el Cáliz ancho que lo trae el çerimoniario de la Credencia y puesto el Sanctissimno Sacramento, el Diácono lo cubre con una hijuela y pone enzima una patena y todo lo cubre con el velo blanco y con un purificador la ata con el relicario y pónelo en medio del altar sobre la ara. 
4. En comenzando los Agnus el Pertiguero va al Coro y combida al Cabildo que baxe a la Comunión, dicha la Comunicanda baxan todos los Colegiales, Capellanes y Prebendados en Ceremonia entran por la puerta de la Concepción y en el Pavimento axedrexado se pone el Cabildo en dos Coros y los Capellanes y Colegiales abaxo de las gradas, los que tienen las hachas se quedan en su lugar en medio de los prebendados, en consumiendo el Sanguis el celebrante suben los Ceroferarios y toman el cendal blanco y se ponen en las esquinas de la peana y como se dixo libro 3, capítulo 7 de la comunión general, suben también los Turiferarios y toman de la Credenzia dos estolas y se ponen de rodillas un paso más abaxo y atrás de los Çeroferarios los Diáconos, comulgan los primeros

[fol. $384^{\mathrm{r}}$ ]

y se ponen de rodillas en la peana donde dizen la confesión, si el subdiácono es de missa, el Turiferario moderno llega y le pone la estola. Después de los Diáconos comulgan los Prebendados primero, los más antiguos suben con las faldas tendidas y en el Pavimento antes de hazer genuflexión, los Turiferarios les dan ha vesar las estolas y se las ponen y llegan a comulgar y el Diácono les da la ablución, suben otros dos y de la misma suerte les ponen las estolas y en medio de los que an comulgado todos juntos hazen genuflexión y llegan a comulgar y los Turiferarios quitan las estolas a los que an comulgado y de esta manera prosiguen la comunión con las çeremonias que se dixo en su capítulo ya citado, los luzernarios dan las faldas a los Prebendados en baxando de las gradas.

5. Acavada la Comunión todos se quedan de rodillas como están hasta la procesión, los de las hachas se entran en la Sacristía, los caperos de la semana entran y tomana pluviales blancos, el Cruziferario y otros dos céroferarios se visten.

6. La hostia consagrada para el monumento puesta en el Cáliz y cubierta con paño rico en medio del altar el celebrante Diáconos jamás se buelven de espaldas y al llegar en medio $\mathrm{y}$

[fol. $384^{\mathrm{v}}$ ]

desviarse siempre hazen genuflexión libro 3, Capítulo N 51, 52, 53, de manera que acavada la comunión cuando se aparta para decir la antíphona post communio haze genuflexión y el Diácono simul, el subdiácono que está al Cornu evangelis limpiando y cubriendo el Cáliz, dicha la antíphona, buelve y cuando llega vesa el altar y juntamente haze genuflexión, levántase y retraese un poco al Cornu evangelis y el rostro al Cornu Epistolae algo buelto al pueblo dize Dominus Vobiscum, buelve al altar haze genuflexión y va a decir la orarion y dicha cuando llega al medio del altar vesandolo haze genuflexión y de la manera dicha se buelve a decir Dominus Vobiscum y Ite missa est y el Diácono para cantarlo no buelve las espaldas al altar sino de lado el rostro frontero del escaño donde se sientan, buelve el celebrante el rostro al altar y no haze genuflexión dize Placet tibi y sin hazer genuflexión buelve a dar la Vendición como se bolvió al Dominus Vobiscum y dada no da la buelta entera sino buelve al altar donde haze genuflexión y va a decir el Evangelio último y no signa el altar sino así tan solamente estas 
[fol. $385^{\mathrm{r}}$ ]

mismas ceremonias se observan siempre que está el Sanctíssimo Sacramento descubierto, o como ahora está o avierto el Sagrario, al Orate fratres se vuelven, no buelta entera sino como se dixo al Ite missa est, véase Capítulo de missa solemne en los números referidos.

7. Acavada la missa saca el Sacristán pluvial blanco y el celebrante se retira al Cornu epistolae fuera de la peana que casi tenga el rostro al medio de el altar y le quitan la casulla y manípulo y le ponen el pluvial, quítanse los Diáconos los manípulos y llévalos con la casulla el Sacristán a la Sacristía, mientras salen cuatro turiferarios con Turíbulos y navetas y suben al pavimento alto hazen todos cuatro en hilera genuflexión y luego cada dos se apartan meneando los incensarios, luego la Cruz en medio de dos ceroferarios con ciriales encendidos, los cuales se van a la grada de el pavimento baxo como se dixo libro 3, Capítulo 5, de las procesiones, tras la Cruz salen los cuatro caperos con sus pluviales que se hincan de rodillas en el pavimento baxo en medio de los coros de los Prebendados y detrás de ellos los Cetreros sacan el palio y se paran en la

[fol. $385^{\mathrm{v}}$ ]

capilla de los mártires, hasta que sea hora de darlo, salen luego los luzernarios con hachas encendidas que reparten entre los Canónigos dando a cada uno la suya y velas para los demás y si ubiere personas nobles supra Capítulo $6 \mathrm{n}^{\circ} 1$, se les darán velas de a libra para que vayan detrás de la procesión.

8. El Celebrante con pluvial en medio de los Diáconos llega al medio del altar en la peana, llegan los cuatro Turiferarios y hazen genuflexión y se ponen en pie en hilera, el Diácono toma la naveta del más antiguo y ministra el celebrante sin vesar cuchara ni mano, el celebrante se buelve de suerte que no tenga las espaldas al Sanctíssimo Sacramento y echa incienso en todos cuatro incensarios tres cucharadass en cada uno sin bendecirlo ni decir nada, los Turiferarios recivido el incienso se ponen de rodillasn algo desviados, el Diácono dá el Turíbulo del antiguo al celebrante el cual inciensa de rodillas con tres ductos al Sanctíssimo Sacramento, levántase buelve el Turíbulo al Diácono y este al Turiferario y el cerimoniario pone el cendal blanco por los hombros al celebrante el cual se hinca de rodillas en la peana, el Diácono toma otro cendal blanco pequeño haze genuflexión y con él toma el Cáliz del Sanctissimo Sacramento y lo da al celebranbte

[fol. $386^{\mathrm{r}}$ ]

y aviéndolo dado haze genuflexión y el celebrante se levanta y ayudado de los diáconos tiene el Cáliz por encima del zendal con ambas manos y el Diácono lo cubre con la parte del cendal que sobra, buélvense de rostro a la Iglesia y pasan por detrás del celebrante el Diácono a la diestra y el Subdiácono a la siniestra y los Turiferarios se levantan y hecha genuflexión a los pies del celebrante inciensan continuamente todos cuatro el Sanctíssimo Sacramento hasta que sale el celebrante del pavimento alto, 
cuando el celebrante se buelve con el Sanctíssimo Sacramento, el Sochantre entona el Pange lingua el cual se canta por toda la procesión y los cetreros sacan el palio, los caperos se levantan y lo reciven, los dos modernos las baras delanteras, los antiguos las últimas, cada cual las de su coro.

9. Cuando llegan a las gradas los Turiferarios, juntos, hazen genuflexión y los dos de en medio se quedan incensando y los otros dos se baxan y andan por el cuerpo de la procesión y al salir del pavimento baxo el celebrante echan incienso en los Turíbulos y llegan y en medio de los dos que inciensan, todos cuatro hazen genuflexión y se quedan incensando y los otros se van por el cuerpo de la procesión y aviendo andado otro tanto trecho echan incienso y van a incensar haziendo

\section{[fol. $386^{\mathrm{v}}$ ]}

genuflexión en medio de los otros y de esta suerte se remudan por toda la procesión y van dos continuamente incensando y ay comodidad para echar incienso.

10. La Procesión anda por de dentro de la Iglesia y el Caniculario o campanero hecha alcázer por donde ha de ir el çelebrante con el Sanctíssimo Sacramento. Va debaxo del palio sustentanle los brazos los Diáconos, al dar la buelta por el otro lado cuando llega el Sanctíssimo Sacramento a la puerta de la Iglesia todos los que preceden van haziendo genuflexión excepto el de la Cruz y çiriales, los Çeroferarios que sirvieron en la missa van junto al palio un paso antes con los çiriales baxos, en llegando la proçesión al monumento la Cruz y çeroferarios que le acompañan se ponen en la grada del Pavimento baxo junto al púlpito de la Epístola bueltos de rostro a la procesión que viene, los dos coros de ella se retiran por su orden a la Capilla de la Concepción el rostro al monumento, cuando llegan los Çeroferarios que van junto al palio se quedan en la ínfima grada y se apartan para dar lugar por medio y el antiguo que se queda el primero buelve el rostro a la procesión porque no tenga las espaldas al Sanctíssimo Sacramento, cuando llegal el palio a la ínfima grada los cetreros lo toman y llevan a la

\section{[fol. $387^{\mathrm{r}}$ ]}

Sacristía y los caperos en pasando el çelebrante con todos los demás se hincan de rodillas, el celebrante sustentandole los brazos los Diáconos sube al monumento y tras el Tesorero y Cerimoniario y dos Turiferarios continuamente incensando suben las gradas de lado.

11. En llegando a lo alto los Turiferarios se apartan, el Sochantre entona el verso Tantum ergo Sacramentum, en tono devoto y de espacio, que dura hasta estar puesto en el Arca el Sanctíssimo Sacramento y llegando a la peana del altar donde esta el arca el Diácono toma un çendal blanco pequeño y se hinca de rodillas y el celebrante en pie le da el Cáliz del Sanctíssimo Sacramento y luego haze genuflexión, el Diácono se levanta con él y lo pone dentro de el Arca cuya puerta tiene avierta el Cerimoniario, cubre el Diácono el Cáliz muy vien con el velo rico que lleva enzima y haze genuflexión, llega el Turiferario antiguo y da la naveta al Diácono y la ministra al çelebrante que echa incienso como suele sin vendecillo ni dezir nada, todos están de rodillas, y el Diácono 
en dando el Turíbulo al celebrante y el en reçiviendolo se hincan de rodillas y el celebrante inciensa tres vezes el Sanctíssimo Sacramento levántase y buelve el Turíbulo al Diácono y éste al Turiferario, el celebrante hecha la llave al

[fol. $387^{\mathrm{v}}$ ]

arca y si es el Abad se la echa al Cuello y la trae siempre hasta el viernes a desençerrar si el que celebra no es el Abad y está presente, ha de subir al lado diestro del Tesorero al monumento donde le echan la llave, en ausencia del más antiguo.

12. Çerrada y cubierta el Arca, la Cruz, çeroferarios, Turiferarios, Caperos, Diáconos y celebrante y el Çerimoniario por el orden que suelen se van a la Sacristía y los luzernarios recogen las hachas y las velas de los prebendados y los demás que se van al coro donde dizen las Vísperas sin canto en tono baxo con pausa y devoción, el celebrante y Diáconos y caperos se desnudan y toman sus capas Canonicales y acompañados de los cuatro Turiferarios o cuatro Comitantes y del Cerimoniario y Pertiguero se buelven al Coro por la Iglesia con las faldas tendidas, al pasar por el altar mayor le hazen profunda y por el monumento genuflexión al Sanctíssimo Sacramento entran en el Coro por su orden con las faldas tendidas y entre la varandilla y facistol hazen profunda, entran en el plano del coro con la devida cortesía y todos se levantan mientras el Sanctíssimo Sacramento está en el monumento, todos en el Coro a todas las horas

[fol. $388^{\mathrm{r}}$ ]

están descubiertos y entran y salen con las faldas tendidas y siempre que van por la Iglesia o están en oración. También entran las faldas tendidas a los maitines de tinieblas el miércoles, jueves y Viernes Sancto y no a las demás horas de aquellos días excepto como se a dicho estando el Sanctíssimo Sacramento en el monumento, los Prebendados que asisten en el coro mientras el Sanctíssimo Sacramento está ençerrado en el monumento, estos días podrán si quieren por su devoción estar en pie y lo mismo cuando en los otros tiempos del año esta descubierto en el altar el Sanctíssimo Sacramento y cuando los jueves se abre el sagrario para renovar y en las missas y oficios de Nuestra Señora.

13. Mientras anda la proçesión el Sacristán ençiende todas las velas que tiene prevenidas en la Sacristía y ençerrado el Sanctíssimo Sacramento aunque todos se buelven como en el número precedente, cuatro o seis Colegiales con las hachas que llevaron los prebendados en la procesión se quedan de rodillas en el monumento hasta que traigan luzes, los Çeroferarios no se desnudan porque no aya dilación sino en dexando los çiriales salen y las seis velas con sus candeleros del altar mayor las llevan y ponen en el altar del monumento, luego

[fol. $388^{\mathrm{v}}$ ]

ponen el blandón con su çirio encendido delante del monumento y con los demás Colegiales ayudan a sacar las velas que ponen por las gradas, vien repartidas, comenzando de las más altas y el Sacristán tiene cuidado de despavilar y los que 
asistieren estaran adbertidos no se caigan pavesas y se queme algo, en el monumento jamás se ponen imágenes ni reliquias ni naran las ni cosa semejante sino çera y flores sueltas y en ramilletes.

14. En el suelo junto a la ínfima grada de pondrá un cojín negro de seda y en el tendido un Cruzifixo cubierto con çendal de seda negro y a los lados dos fuentes de plata para que la gente ofrezca por su devoción y estas llevaran el viernes pàra la ofrenda de la adoracion de la Cruz.

15. Acavadas las Vísperas los cuatro Comitantes el Cérimoniario los Diáconos y celebrante buelven a la Iglesia y los dos Comitantes van a la Sacristía y sacan dos fuentes de plata, llega el çelebrante Al altar mayor y comienza a desnudarlo ayudanle los Diáconos diziendo todos la antíphona diviserunt tibi vestimenta mea con todo el psalmo Deus Deus meus respice in me sin Gloria Prtri, luego van a los altares colaterales y los desnudan de la misma forma los frontales

[fol.389 $\left.9^{\mathrm{r}}\right]$

entran en la Sacristía los dos comitantes y los otros dos en las fuentes recogen los manteles y palios y lo demás que se puede echar en ellas y asimismo lo entran y en acavando de desnudarlos todos en la misma ceremonia se van a la Sacristía, a todo este acto tienen las faldas sueltas y al Sanctíssimo Sacramento hazen las devidas genuflexiones, luego sale el Sacristán y quita la Credenzia y el escaño donde se sientan en la missa y el Caniculario o Campanero que quita las alfombras de el pavimento del altar mayor y las alza en la Sacristía y las de los demás altares mas no quita las que tiene el monumento delante.

16. Desde que se encierra el Sanctíssimo Sacramento hasta que se desencierra el Viernes asisten delante del monumento los Colegiales de dos en dos y nunca faltaran aunque sea cuando celebran los oficios divinos y lo mismo se entienda en la octava del Corpus en cuanto se pudiere acomodar con los oficios de aquellos días, el Rector hará la distribución de las horas y de los Colegiales, la cual escribirá en una tabla o papel y la pondrá en el Collegio

$\left[\right.$ fol. $389^{\mathrm{v}}$ ]

o en la Sacristía donde mejor le pareçiere y los prebendados y Capellanes en cuanto fuere posible será conveniente que también asistan así por la reverenzia del Sanctissimno Sacramento como para que se anímen los Collegiales.

\section{Capítulo 13. Del Mandato.}

1. El mandato y labatorio se haze en la Iglesia, lábanse los pies a treze pobres a los cuales se les da de comer, en la sala del Cabildo se ponen las mesas con adorno de flores y yervas olorosas, el Abad o en su ausencia el Presidente o el más antiguo que ha de hazer el labatorio hecha la bendición, sirven los Canónigos y Colegiales. Antes de la comida el Rector del Colegio dispondrá que los Colegiales tengan cuidado de que se laven los pies a los pobres en secreto, a las dos de la tarde toca el Campanero la matraca 
media hora para el oficio del mandato, los Versicularios hazen un coro de Escaños en la capilla de la Concepción frontero al monumento y el testero delante de la puerta que

[fol. $390^{\mathrm{r}}$ ]

tiene çerrada el Sacristán para que no se mande hasta desençerrar el Sanstissimo Sacramento, ponen los Versicularios un atril alto sin paño y en el libro para cantar, por el Arco toral se ponen unos vancos que atajen toda la distancia de la Iglesia para que no entre la gente en el Crucero y delante de ellos, casi llegando al monumento, se pone el escaño donde se suelen sentar los de la missa, por la grada del Pavimento baxo desde el Púlpito de la Epístola al del Evangelio, dexando paso al crucero se ponen unos vancos altos cubiertos con alfombras donde se sienten los treze pobres.

2. Los ceroferarios ponen en el Pavimento detrás de estos vancos arrimada a la escalera del púlpito de la Epístola la Credencia con frontal rico blanco y el aparador con las fuentes de plata y aguamanil, dos toallas grandes ricas, una fuente con trece toallas para limpiar los pies a los pobres y la limosna que se les ha de dar igualmente a todos y para cada uno, puesto el dinero en un papel doblado y sellado, adornan la Credenzia aparador $\mathrm{y}$ vancos y todo el sitio donde se ha de hazer el labatorio con muchas flores y yervas olorosas sacan un atril alto

[fol. $390^{\mathrm{v}}$ ]

con paño blanco para cantar el Evangelio y lo ponen junto al escaño del celebrante, que mire al altar de la Concepción porque el Diácono no tenga bueltas las espaldas al monumento cuando lo cante los comitantes previenen dos cántaros de cobre en uno traen el agua caliente y en el otro fría y lo ponen en el suelo a los lados de la Credenzia y dos Colegiales traen los pobres a la Iglesia y hazen que se pongan en pie arrimados al banco y assí están hasta después de cantado el Evangelio que se descalzan el pie derecho.

3. Preparado todo esto en la Sacristía se viste el celebrante alba y amito, cíngulo, estola y pluvial morado, los diáconos, dalmática, estola y manípulos blancos los ceroferarios y Turiferarios, collares blancos y el Pertiguero ropa blanca y en haziendo el último signo la matraca salen el Pertiguero, Turiferario con Turíbulo y Naveta, Ceroferarios con Ciriales enzendidos, el Cerimoniario, Subdiácono, Diácono y celebrante como salen a las missas van al Crucero donde se ha de hazer el labatorio y hazen genuflexión al Sanctíssimo Sacramento, levántanse y el celebrante se pone

[fol. $391^{\mathrm{r}}$ ]

arrimado a su escaño el rostro al altar mayor, los Ceroferarios un paso delante del a un lado y otro con los ciariales baxos. Un comitante va a la Credenzia por el libro de los Evangelios, el Turiferario se llega al Diácono el cual ministra la naveta al Celebrante el cual hecha y vendize el incienso Ut mons est, toma el Diácono el libro y profunde inclinado no buelto de espaldas al monumento sino que lo tenga a su mano siniestra pide la vendición Iube Domne benedizere échala diciendo Dons sit in corde tuo etc. in labiis tuis ut digne et conpetenter annunties Evangelium suum. 
4. Dada la vendición va al atril alto delante el Turiferario, los Ceroferarios con los çiriales altos y el Subdiácono pasa por detrás y lo tiene con ambas manos, los Ceroferarios tienen en medio al Subdiácono, el Diácono abre el libro lo signa y Turifica y canta el Evangelio Ante Diem festum Pasche como lo haze a los demás Evangelios y el coro responde, acavado de cantar el Subdiácono lleva el libro avierto que lo vese el celebrante y no le haze antes humiliación sino después de aver vesado y el Diácono Turifica

[fol. $391^{\mathrm{v}}$ ]

al celebrante con tres ductos more solito, buelve el Turíbulo al Turiferario que se va con el a la Sacristía y los Ceroferarios llevan los ciriales a poner en las aldauillas de las gradas de el altar mayor en el ínterin que se haze el lavatorio y no los apagan.

5. Aviendo dexado los çiriales van a la Credenzia y en una fuente de plata llevan la toalla rica grande y el Cerimoniario quita al celebrante el pluvial y lo pone en el escaño y los Diáconos çiñen la toalla al çelebrante y llegan al primero pobre que entonzes todos se sientan y allí están y a un Colegial con la fuente grande de plata, otro con un jarro de plata en que tiene agua caliente, otro con agua fria, los Ceroferarios con las fuentes donde están las treze toallas y la limosna, el celebrante se arrodilla delante del pobre y el Subdiácono le alza y tiene el pie derecho, pone el Colegial la fuente de baxo y el Diácono hecha el agua, lábalo el çelebrante y enjúgalo con una toalla, haze la Cruz y vésalo, da la toalla al pobre y la limosna y de esta suerte prosigue labando a todos los demás, cuando la fuente estubiere llena de agua aplica otra otro Colegial y llevan a vaciar la otra, los que ministran el agua caliente

[fol. $392^{\mathrm{r}}$ ]

y fría estén siempre a punto, cuando comienza el lavatorio el Coro canta la antíphona Mandatus noun con lo demás que está en el misal por el orden que prefiriese.

6. Acavado el lavatorio los pobres se levantan y el celebrante y diáconos buelven a su lugar donde le quitan la toalla que tiene çeñida y los ceroferarios traen de la Credenzia y una fuentre y agua manil con agua olorosa y otra toalla rica y ministran el aguamanos y el celebrante se las laba buelven a la Credenzia el recaudo y traen los Çiriales y el Cerimoniario pone el pluvial al celebrante y un Colegial le llega el atril con el misal, póneselo delante de suerte que tenga el rostro al altar mayor en medio de los Diáconos y los Ceroferaarios tienen en medio el atril como al Evangelio y el çelebrante en pie descubierta la cabeza y las manos puestas dize Pater Noster secreto prosigue hasta Et ne nos inducas, á que responde el coro dize los demás versos pero ut in missale a la oración Adesto Domine quesumus, los Ceroferarios levantan los Çiriales hasta la conclusión. 
7. Respondido Amen llevan los çiriales a las aldabas y los apagan, el çelebrante y Diáconos se asientan en su escaño. El coro y los pobres en sus lugares los Collegiales en las gradas de el altar y sale el que

[fol. $392^{\mathrm{v}}$ ]

a de predicar si es prebendado con la falda tendida, acompáñalo el Pertiguero y cuatro Comitantes haze genuflexión al Sanctíssimo Sacramento, a ida y buelta llega el çelebrante y profunde inclinado pide la Vendición y dada more solito sube al púlpito y predica sin ponerse el bonete. Acavado el sermón los çeroferarios ençienden los Ciriales y va al çelebrante y el Pertiguero y Cerimoniario, Diáconos y celebrante hazen genuflexión al Sanctíssimo Sacramento y se buelven a la Sacristía y los Prebendados se van, los Ceroferarios y comitantes quitan la plata y aparador y todo lo que ha servido en el labatorio y lo alzan en la Sacristía, el Caniculario y Campanero quitan los vancos donde estubieron los pobres y las alfombras y el escaño del celebrante y los que atajan en el Arco Toral, los Versicularios alzan los facistoles y libros y acavado el oficio se toca a completas, las cuales se dizen en tono baxo y deboto y los maitines como se dixo en el Capítulo 11.

8. En acavando las tinieblas se cierra la Iglesia y echan fuera las mugeres, no se ha de abrir en toda la noche ni quedar ninguna dentro, está cerrada la puerta de palo y toda la noche velan Prebendados, Capellanes y Colegiales como

$\left[\right.$ fol. $393^{\mathrm{r}}$ ]

Se dixo en el Capítulo precedente $\mathrm{n}^{\mathrm{0}} 16$, al amanecer el Sacristán y luzernarios renuevan la cera del monumento y se abre la Iglesia.

\section{Capítulo 14. Del Officio del Viernes Santo.}

1. Los altares están desnudos sin manteles ni alfombras en las peanas, dízense las horas con pausa y solemnidad en tono baxo, entran a las siete y no se encienden velas en altar.

2. El Sacristán previene en la Sacristía los ornamentos casulla y planetas, collar y estola ancha para el Diácono, un cendal de seda blanco requemado de oro para los hombros del celebrante, la Cruz mayor con su bara de plata y con çendal negro, el palio, un coxín de terciopelo morado con oro y velo de gaza blanco entretexido con seda morada, y la sobremesa morada, un mantel pequeño para el altar mayor y un tapete pequeño que se ha de poner en la peana con un bufetillo para la Credencia cubierto con una toalla que nada de ella cuelgue ni sobre por ninguna parte, velas amarillas para el altar mayor y çiriales

[fol. $393^{\mathrm{v}}$ ]

candeleros y lo demás necesario para el oficio.

3. En acavando las horas el Campanero y Caniculario con orden de los Versicularios hazen un coro de escaños desde el Arco Toral por el cuerpo de la Iglesia para los 
Prebendados y cubren de alfombras el suelo hasta las gradas del altar mayor y ponen en la peana un tapete pequeño que no cuelgue nada de él, ni sobre por la frente de ella, dexan en la capilla de la Concepción otros escaños para los Capellanes porque allí ha de estar el Coro baxo y si los Versicularios ponen allí el facistol con el libro para el oficio frente del monumento que los que cantan tengan los rostros a él. El campanero toca con la matraca a las ocho y media hasta las nueve que entran en los oficios.

4. En comenzando a tocar acuden los ministros a la Sacristía, visten los Ceroferarios roquetes y collares negros, sacan la Credençia con la toalla como se dixo $\mathrm{n}^{\mathbf{0}} 2$ y pónenla en su lugar, ponen en ella el Cáliz con patena sin hostia, con bolsa y corporales y purificador, çendal negro y bolsa negra, salvilla con ampolletas con agua y vino, un mantel para el altar mayor y una toalla para las manos y no se saca otra cosa, en el altar mayor está la Cruz que a de servir para la adoración que ha de tener la imagen

[fol. $394^{\mathrm{r}}$ ]

de Christo Nuestro Señor cruçificado cubierta con un velo negro, de tal suerte puesto que se pueda descubrir la parte superior sin que se descubran los brazos está en medio del arrimada al Sagrario sacan los Çeroferarios seis candeleros con sus velas de çera común y amarilla, apagadas las cuales no encienden hasta que se ordena la proçesión y pónenlos en el altar por su orden como suelen, ponen atril y el misal registrado el oficio del día mas no avierto sino çerrado, previenen tres facistoles para la pasión, un escavelo junto a la Credenzia donde ponen las planetas y en el ponen el collar estola ancha y çendal negro, en la Sacristía se viste el celebrante y diáconos y en dexando la matraca salen.

5. El Pertiguero con ropa negra, los çeroferarios sin ciriales, las manos puestas, un Colegial de orden de lector con sobrepelliz y el libro de las Epístolas arrimado al pecho, el çerimoniario, Subdiácono, Diácono y celebrante y puestos por su orden como suelen ante la ínfima grada, el lector en el lugar del Turiferario antiguo, al arco de la capilla del rosario todos hazen profunda, los Çeroferarios se quedan en sus lugares, suben al Pavimento el celebrante, Diáconos y Çerimoniario, el cual en su lugar se hinca de rodillas y el Celebrante en medio de los Diáconos. Se postran en el Pavimento alto que caigan los

[fol. $394^{\mathrm{v}}$ ]

pechos y cabeza sobre la peana del altar y a este tiempo el Pertiguero, lector, Çeroferarios y Çerimoniario se hincan de rodillas y estén así mientras oran postrados que será un rato, lo que durase decir el psalmo de Miserere despacio, a la mitad de este espacio los Çeroferarios suben y toman el mantel de la Credenzia y el moderno por el Cornu evangelio lo echa sobre el altar y el antiguo por el Cornu Epistolae lo reçive y entre ambos lo estienden de suerte que cuelgue muy poco de él por la frente y lados del altar.

6. Echa Oración se lebantan el celebrante y Diáconos, suben al altar y lo vesa en medio y los Diáconos hazen genuflexión y se van a sentar a su asiento y sentados sale el lector en el pavimento baxo, al sitio donde se suele cantar la Epístola, y de rostro al altar haze 
genuflexión, teniéndose el libro Canta la primera lección en tono de profecía, cuando comienza sube el Çeroferario antiguo y haze genuflexión en la peana y toma el missal y lo da al Subdiácono, el cual lo tiene avierto y por él lee el çelebrante la prophecía y tracto, sentado, y buelve el misal al Çeroferario que a un lado apartado lo aguardava, el cual lo buelve al altar y se baxa a su lugar el lector, en acavando de cantar la lección haze genuflexión y por detrás de los

[fol. $395^{\mathrm{r}}$ ]

Çeroferarios sube al pavimento y haze genuflexión y pone el libro en la credenzia y buelve a hazer genuflexión y se va al coro, el cual acavada la lección canta el tracto con todos sus versos.

Al fin del tracto el celebrante y Diáconos van al altar derechos al libro, no al medio del altar y así no hazen genuflexión y acavado el tracto el çelebrante dize Oremus y el Diácono flectamus genua hincándose de rodillas el primero y todos los del altar y coro excepto el çelebrante, el subdiácono responde Levate y el primero se levanta y con él todos los demás, canta el celebrante la Oración Deus a quo $\&^{o} I u d a s$ y el Ceroferario sube y quita al Subdiácono la planeta, pónele collar y dale el libro y con las devidas reverenzias baxan y en el púlpito canta la segunda lección en tono de Epístola como suele, las demás excepto que al bolver no vesa la mano al çelebrante sino hecha genuflexión, en el Pavimento da el libro al çeroferario que lo buelve a la Credenzia y le quita el collar y pone la planeta, el çelebrante en el altar lee también esta lección y el tracto estando detrás del Diácono y a su lado fuera de la peana el Cerimoniario, mas no alumbra porque este día no ay palmatoria después de la Epístola. El coro canta en el tracto.

$\left[\right.$ fol. $395^{\mathrm{v}}$ ]

8. Mientras se canta el tracto los çeroferarios sacan tres atriles para la pasión, desnudos sin paño, y los ponen en el mismo lugar que para las otras passiones y si la an de cantar otros diferentes se visten en la Sacristía y salen acompañados como se dixo Capítulo 10, del oficio del Domingo de Ramos, $n^{\circ} 8$ y los siguientes, que todo se haze como en aquel día excepto que a lo que se canta en tono de Evangelio no se lleva incienso ni el Diácono pide la Vendición sino puesto el libro en medio del altar, él de rodillas, dize Munda Cor meum y luego lo toma y va a cantarlo acompañado de los çeroferarios que llevan las manos puestas y a la buelta el Diácono no da el libro al Subdiácono que él se lo trae porque el çelebrante no lo a de vesar sino en llegando al pavimento lo da al Çeroferario moderno que lo pone en la Credençia. El Diácono se queda in albis con la estola ancha hasta el fin del oficio, cuando a buelto el Diácono el celebrante, al Cornu epistolae, canta las oraciones como están en el misal, estando los Diáconos unos en pos de otro detrás del celebrante y cuando se nota en el ordinario el Diácono dize flectamus genua y el Subdiácono levate hincándose de rodillas y levantándose por el orden que se dixo supra $\mathrm{n}^{\circ}$

[fol. $396^{\mathrm{r}}$ ]

precedente. 
9. A la Oración Oremus et propter fidis Iudais los collegiales comitantes van a la sacristía y sacan la sobremesa morada y tienden desde la segunda grada del altar mayor en medio y lo restante que caiga sobre las alfombras del pavimento, luego sacan el coxín morado cubierto con la gasa blanca y morada y lo ponen arrimado a las gradas que la cabecera por lo largo de él esté sobre la ínfima grada y lo restante sobre el Pavimento, hecho esto con los ceroferarios van al monumento y los çeroferarios llevan dos fuentes de plata que están a los lados del Cruzifixo y las ponen a los del coxín y los comitantes toman el coxín que está en el monumento y el Christo y lo entran en la Sacristía y se buelven al Coro.

10. Acavadas las oraciones suben los çeroferarios y desnudan al çelebrante la casulla y ponen sobre el escaño y el celebrante en el mismo cornu epistolae baxa de la peana y se buelve algo el rostro a la cruz que está en el altar y el Diácono llega en medio de él, haze genuflexión y la toma y lleva y da al celebrante cubierta como está, y se pone a su diestra y el Subdiácono a la siniestra y todos tres bueltos de rostro al pueblo. El celebrante con la diestra descubre la parte superior de la Cruz y canta en tono baxo Ecce lignum Cruzis y ayudándole los Diáconos prosigue In quo salus mundi pependit y el coro poniéndole para ello el misal abierto, el Acólito antiguo

[fol. $396^{\mathrm{v}}$ ]

responde Venite adoremus, a las cuales palabras todos los del altar coro y pueblo se hincan de rodillas eçeto el celebrante, el cual sube la peana y las espaldas en el mismso ángulo o esquina del altar Cornu epistolae donde suele decir el Introito de la missa y de la misma manera, en medio de los Diáconos descubre el brazo diestro de la Cruz y cabeza del cruzifixo que en ella está pintado y levántala un poco y en tono algo más alto canta segunda vez Ecce lignum cruzis y con los Diáconos In quo salus mundi pependit y el Coro Venite adoremus y todos se arrodillan si no es el Çelebrante, que en levantándose todos pasa al medio del altar y descubre la Cruz del todo y el Çerimoniario toma el velo negro con que estava cubierta y lo pone en el escaño, levanta más la Cruz el celebrante y la voz y canta tercera vez Ecce lignum Cruzis, prosigue y responde el Coro, se arrodillan como la primera y segunda vez.

11. En levantándose todos de la tercera adoración, el celebrante desde el medio del altar donde está lleva la Cruz alta en buena proporción con ambas manos, va con mucha pausa y reverencia y devoción, sin hazer venia ni genuflexión a cosa alguna, baxa las gradas del Pavimento por el lado del Ceroferario más antiguo el cual y su compañero a deste

[fol. $397^{\mathrm{r}}$ ]

tiempo se apartan a las esquinas de los arcos de la capilla y buelven Eregione las manos puestas; el celebrante en el pavimento delante del coxín se hinca de rodillas y tiende la Cruz de tal manera que el cuerpo de ella esté sobre el coxín y la parte inferior caiga y toque sobre el alfombra o dosel morado y si fuere neçesario para que no se resbale la asegure con un cordón o çinta, levántanse y haze genuflexión a la Cruz y vase al arco de la capilla del rosario y a este tiempo baxan los Diáconos que se quedaron arrimados al altar donde acompañaron al celebrante y lo cogen en medio y se buelven de rostro a la 
Cruz y llega el Ceroferario más antiguo y descalza al celebrante y los Versicularios van al Coro a descubrir las Cruzes e imágenes, llevan los velos y entregan al Sacristán que los guarda.

12. El Celebrante las manos puestas, descalzo, los pies desnudos en mucha devoción y espacio se va al arco Toral donde comienza el coro de los Prebendados y al pasar por el monumento haze genuflexión, del coro sale el Prebendado más antiguo, la falda de la capa tendida la capilla echada sobre el bonete en la cabeza y descalzo, y reçive en el arco Toral, a su mano derecha, al celebrante y juntos hazen genuflexión y oran espacio de un Ave Maria, levántanse y van juntos las manos puestas junto a la grada del pavimento

\section{$\left[\right.$ fol. $\left.397^{\mathrm{v}}\right]$}

baxo hazen otra genuflexión y oran otro tanto espacio, junto al coxín hazen la tercera y después de aver orado, el çelebrante se levanta, llégase a la Cruz, híncase de rodillas y ofreze echando en la fuente de la mano derecha la moneda que quisiere y después de aver ofreçido, vesa la Cruz y se levanta. El Prebendado se queda de rodillas y en aviéndose levantado el celebrante se levanta y llega a ofrecer hincándose de rodillas y ofreze en la otra fuente y vesa la Cruz y con el celebrante que aguardava en pie levántase, hazen genuflexión y derecho se va el çelebrante al arco del rosario acompañándolo el Prebendado, el cual se buelve desde allí al coro y haze genuflexión al Sanctissmo Sacramento, llega el Çeroferario y pone al çelebrante la casulla y lo calza, el cual las manos puestas está allí todo el tiempo que durare la adoración.

13. Los Diacónos en el hábito que están, que es el Diácono in albis, con estola ancha y collar y el Subdiácono sin planeta, y sin manípulos, descalzos, van las manos puestas al Arco Toral y al pasar hazen genuflexión al Sanctíssimo Sacramento y donde hizo la genuflexión el celebrante, se buelven a la Cruz y juntos se postran y oran espacio de un Ave Maria, levántanse y antes de la grada del Pavimento hazen la segunda postración y çerca del coxín la terçera, en todas

\section{[fol. $398^{\mathrm{r}}$ ]}

oran un rato, luego ofrecen, vesan la Cruz como se dixo número precedente, levántanse, hazen genuflexión a la Cruz y derechos se van a su lugar a los lados del celebrante y están las manos puestas, todos los que se postraren cuiden de la igualdad en hazer la postración y en levantarse y poner el Cuerpo que no haga fealdad y que los pies queden cubiertos

14. Luego los Prebendados por su antigüedad, de dos en dos, cada cual de su coro, van a adorar la Cruz, las faldas de las capas tendidas y las capillas hechadas sobre la cabeza y descalzos y las manos puestas, hazen tres postraciones por el orden y en el lugar que las hizieren, los Diáconos hazen genuflexión a la Cruz y ofreçen, vésanla y buelven a hazerla y también al pasar por el monumento y hasta que an llegado al coro no salen los que siguen cálzanse y desde que el çelebrante comienza la adoración hasta el fin de ella, todos están con las capillas puestas sobre los bonetes en la Cabeza y todos ofrecen de la 
manera que se dixo del celebrante $\mathrm{n}^{\mathrm{o}} 12$ y si ay Prebendados nones, los últimos van tres , en medio el más antiguo.

15. Después de los Prebendados van los capellanes y luego los Colegiales que están vestidos y sirven en los oficios divinos al altar, luego

[fol. $398^{\mathrm{v}}$ ]

los demás por sus antigüedades, de dos en dos, las manos puestas y hazen tres postraciones por el orden que se a dicho y todos ofrecen de la misma manera, después de todo el Clero adoran los seglares del pueblo, si ay personas Illustres el Çerimoniario los combida y les avisa que no an de postrarse y adoran los primeros y luego los demás y cuidan los Colegiales comitantes que no aya desorden ni confusión sino que vayan de dos en dos, con espacio y devoçión.

16. Si asistiere algún Prelado en los oficios después que aya adorado el çelebrante, dos Prebendados más antiguos vayan con el Pertiguero a donde está y lo combiden para la adoración y lo acompañen a sus lados y entonzes no se postran los Prebendados sino hazen genuflexión juntamente con el Prelado y lo buelven a acompañar hasta su lugar y se buelven al coro. Si algún Prebendado de otra Iglesia asistiere en el coro, después de aver adorado los diáconos, haze la adoración acompañado de un Prebendado de esta Iglesia en el lugar que pidiere la silla que le an dado y lo prebendrá el Presidente del coro si quiere postrarse y si no, harán la genuflexión como el celebrante y el Prelado. Si no asistiere en el coro hará la adoración solo después de los Prebendados o le avisen vaya al coro

[fol. $399^{\mathrm{r}}$ ]

para hazerla con ellos en su lugar y todo el tiempo que dura la adoración de la cruz en el coro cantan los Improperios, como se dispone en el misal.

17. Çerca del fin de la adoración de la Cruz, los çeroferarios encienden las velas del altar y el Diácono sube y toma de la Credençia la bolsa de los Corporales y llega al altar y los estiende more solito y luego se baxa a su lugar. Los Çeroferarios al ençender ni el Diácono a poner los Corporales, a yda ni buelta no hazen genuflexión al altar sino venia profunda. Acavada la adoración, el Diácono va a la Cruz, híncase de rodillas y con ambas manos la levanta, a este tiempo el çelebrante y todos los del coro y Iglesia le hazen genuflexión, el Diácono con mucha reverençia la lleva al altar y la coloca en medio sin que al ir ni al llegar haga genuflexión ni venia a nadie, más dexándola en el altar la haze y se buelve al çelebrante, llegan los comitantes y alzan el coxín y dosel morado y lo entran en la Sacristía y el Sacristán alza las fuentes de la ofrenda y el dinero que ay ofrecido lo toma para sí: el çelebrante y Diáconos se suben al altar mientras se ordena la proçesión y los Prebendados se quitan las capillas.

18. Los Çeroferarios se van a la Sacristía y toman çiriales con velas enzendidas y otros dos están

$\left[\right.$ fol. $\left.399^{\mathrm{v}}\right]$ 
vestidos y toman otros çiriales y todos cuatro salen acompañando la Cruz mayor que saca otro revestido con collar negro, la Cruz descubierta y delante salen los cuatro Turiferarios con Turíbulos y navetas y cada dos se ponen en los arcos de las capillas, los Çeroferarios se van a la grada, a sus lugares, y los otros con la Cruz a la del pavimento baxo donde suelen en las proçesiones, cuando sale la Cruz, los Prebendados procesionalmente se llegan al pavimento y el Sacristán y los Colegiales luzernarios y otros llegan al monumento y quitan de las gradas todos los candeleros y velas y llevan a la Sacristía y apagan y solamente dexan las que arden en el altar donde está el Sanctíssimo Sacramento, luego el Pertiguero guía a la proçesión al monumento y en llegando todos, hazen genuflexión y los que no an de subir se quedan de rodillas, sube el celebrante con su casulla y los Diáconos, el Tesorero, Çerimimoniario y dos Turiferarios y si el çelebrante no lleva la llave, sube el Prebendado que la tiene conforme se dixo Capítulo 12 del Jueves Sancto y en llegando a lo alto, todos se ponen a los dos lados del altar y el celebrante y Diáconos en la peana hazen todos genuflexión y oran un rato, luego se levantan y suben al altar y el que tiene la llave la da al Diácono $\mathrm{y}$

$\left[\right.$ fol. $\left.400^{\mathrm{r}}\right]$

el cual abre la arca y hazen genuflexión, llegan los Turiferarios y ministrando el Diácono la nabeta el celebrante echa incienso en ambos Turíbulos sin bendición ni decir nada, toma el Diácono el Turíbulo del más antiguo y lo da al celebrante sin ósculo y el celebrante de rodillas inciensa tres vezes el Sanstissimo Sacramento estando todos los demás de rodillas.

19. Levántase y buelve el Turíbulo al Diácono y este al Turiferario y llega el Çerimoniario y pone por ambos hombros del celebrante un çendal blanco recamado de oro que cuelgue igualmente por ambos lados y se hincan de rodillas. El Diácono con otro çendal blanco pequeño saca el Cáliz con el Sanctíssimo Sacramento de la Arca y lo da al çelebrante y haze genuflexión, el çelebrante lo recive y se levanta y ayudándole los Diáconos que cubren el Cáliz sobre el velo que tenía con el çendal blanco que pende de los hombros del celebrante, el cual se buelve al pueblo con el Sanctíssimo Sacramento que tiene con ambas manos, cubiertas también con el çendal blanco y luego llegan los Turiferarios y hazen genuflexión y comienzan juntos a Turificar el Sanctíssimo Sacramento, a este tiempo sacan los Colegiales el palio y lo llevan al monumento y los Caperos con sus capas Canonicales lo reciven.

[fol. $\left.400^{\mathrm{v}}\right]$

y llevan en la procesión, los luzernarios reparten hachas y velas ençendidas como el día antes.

20. Comienzan a baxar las gradas y el coro entona el himno Vexilla Regis prodeunt que se canta por toda la proçesión, baxan primero los prebendados y personas que están arriba, luego el celebrante, a su diestra el Diácono y a la siniestra el Subdiácono sustentándole los brazos y los Turiferarios continuamente incensando, el Pertiguero guía la procesión por la pared de la Iglesia que está al Pórtico y da la buelta por la otra y 
echan alcázer y todo lo demás como el día antes, y llegando la procesión al pavimento la Cruz con sus çeroferarios se quedan en la grada donde suelen en el Crucero, los Colegiales y los Prebendados en el Pavimento, en las gradas del alto dexan los caperos el palio y los Colegiales lo entran en la Sacristía, el Çerimoniario, Maestro de Çerimonias, Diáconos y Celebrante suben al pavimento con los dos Turiferarios, que los otros dos se entran en la Sacristía. En llegando a las gradas y todos los del Coro y ministros del altar se hincan de rodillas y así están con las velas y hachas enzendidas hasta que se acava el oficio.

21. En llegando a la peana el Diácono en ella se hinca de rodillas y con un çendal blanco reçive del

[fol. $401^{\mathrm{r}}$ ]

celebrante el Sanctíssimo Sacramento, levántase con él y con mucha reverencia lo pone sobre el altar, quita el Çerimoniario el cendal blanco al çelebrante y todos hazen genuflexión al Sanctíssimo Sacramento. Llega el Turiferario y ministra el Diácono la naveta y el celebrante pone incienso y ministra sin bendecir ni dezir nada, luego de rodillas, inciensa tres vezes el Sanctíssimo Sacramento, levántase y da el Turíbulo al Diácono y Éste al Turiferario. El Subdiácono toma el Cáliz y Patena de la Credençia y el Ceroferarios antiguo la salvilla y ampolletas y van more solito al altar, toma el Diácono el Cáliz y lo descubre, pone el Purificador junto a los Corporales y toma la patena y teniéndola en las manos sobre el Corporal, el celebrante saca la hostia consagrada del Cáliz y la pone sobre la patena y el celebrante nunca vesa la mano ni cosa que da.

22. El Celebrante pone la hostia consagrada sobre el Corporal y dexa la patena a un lado fuera de él sin decir nada, en el ínterin el Diácono pone Vino en el Cáliz y el Subdiácono agua y el celebrante ni vendize ni dize la Oración acostumbrada, mas toma el Cáliz de mano del Diácono y sin decir

[fol. $401^{\mathrm{v}}$ ]

nada lo pone sobre el Corporal y el Diácono lo cubre con la hijuela, llega el Turiferario y more solito el celebrante pone incienso, sin bendición ni decir nada toma el Turíbulo y haze genuflexión y Turifica la oblata, Cruz y altar de la misma manera que en las demás missas y diciendo los mismos versos Inçensum istud etc. y al altar dirigitur Domine. etc. excepto que al fin cuando buelve el Turíbulo al Diácono no es incensado, pero dize la Oración accendat in nobis Dominus etc. el Diácono lo buelve al Turiferario y con su compañero haze genuflexión y se van a la Sacristía.

23. Después el çelebrante al Cornu epistolae, fuera de la peana sin volver las espaldas al Sanctíssimo Sacramento, se lava las manos sin decir el psalmo lavabo llega al medio del altar haze genuflexión y levantándose, puestas las manos juntas sobre el altar, inclinado, dize con boz baxa intelligible In Spiritu humilitatis etc., luego retirándose al Cornu evangelio dando medio buelta dize Orate fratres etc. buélvese por el mismo lado, inmediatamente canta Oremus Praeceptis Salutaribus moniti y todo el Pater Noster. Y 
el coro responde sed liberanos á malo y el celebrante dize secreto Amen y luego Canta en tono de Oración ferial Liberanos quesumus Domine etc.

[fol. $402^{\mathrm{r}}$ ]

y al fin de esta Oración responde el Coro Amen y el çelebrante no se signa con la patena.

24. Haze genuflexión, levántase, toma la patena y pónela debaxo de la hostia consagrada y toma con la diestra la hostia y levántala por zima de la cabeza de suerte que la pueda ver y adorar el pueblo y en esta elevación tiene el Cuerpo derecho sin humillarse nada y la mano siniestra sobre el altar, abaxa la hostia y sin dexarla de la mano ni hazer genuflexión la divide sobre el Cáliz more solito sin dezir nada y las dos partes pone sobre la patena y la menor hecha en el Cáliz que descubre y cubre el Diácono con la hijuela como suele, no se dize Pax Domini. Ni Agnus Dei, y dexadas las dos primeras oraçiónes dize la terçera Perceptio Corporis tui etc., acavada la oración haze genuflexión y levántase y toma la Patena con la hostia diciendo Panem Çelestem accipiam y teniéndola como suele con la siniestra, con grandíssima humilldad y reverenzia dize tres vezes hiriéndose el pecho Domine non sum dignus, sígnase con la hostia diciendo Corpus Domini Nostri Iesuchristi etc. recive el Cuerpo del Señor con gran reverencia.

25. Ora un poco y sin hazer genuflexión ni decir cosa alguna, aviendo el Diácono descubierto

[fol. $402^{\mathrm{v}}$ ]

el Cáliz lo toma y reçive la partícula que está en el vino, luego se purifica los dedos sobre el Cáliz, como en las otras missas sin decir nada y reçive también esta ablución. Pone el Cáliz en el altar y el Subdiácono lo limpia y cubre, dobla los corporales y el Çeroferarioo antiguo sube y quita al Diácono la estola y collar y pone la planeta y en ínterin el celebrante en medio del altar y sobre él las manos juntas dize inclinado quod ore sumpsimus Domine etc. y no dize otra cosa alguna ni da Vendiçión sino haziendo reverencia al altar se va él con los Diáconos çeroferarios, Cruz, Cerimoniario y Pertiguero, por su orden, a la Sacristía con mucho silencio.

26. En consumiendo el Sanctíssimo Sacramento, los luzernarios recogen las hachas y velas de todos y las apagan y entran en la Sacristía y en aviéndose entrado el celebrante, todos van al coro alto donde dizen Vísperas en tono baxo y deboto y los Ceroferarios salen apagadas las velas y entran en la Sacristía todo el demás recaudo y quitan las toallas del altar y Credençia, llevan el arca a la Sacristía y descomponen el altar y gradas.

27. Acavadas Vísperas el Sacristán çierra la

[fol. $403^{\mathrm{r}}{ }^{\mathrm{C}}$ 
Iglesia y alzan las alfombras y el Carpintero deshaze el monumento, asisten los Colegiales para reçivir las sedas y ornamentos las cuales doblan y limpian en la Iglesia sobre unas alfombras, llevan a la Sacristía y el Sacristán lo alza todo en su lugar y otros están en la Sacristía para colgarla y aderezarla para la mañana de resurrección. La Iglesia no se abre hasta que está desembarazada de todo y de la madera y barrida y limpia, los altares se quedan cubiertos más desnudos, sin manteles, frontales ni alfombras, en el mayor se queda descubierta la Cruz en que se hizo la adoración. A las cuatro se abre la Iglesia y dizen completas y consecutivamente tinieblas con compás más ligero, como se dixo capítulo 11.

\section{Capítulo 15. Del Oficio del Sábado Sancto.}

1. Para el Sábado Sancto el Sacristán adorna la noche antes los altares, pone alfombras y manteles y frontales morados y debaxo de ellos pone

$\left[\right.$ fol. $403^{\mathrm{v}}$ ]

los blancos que se an de descubrir a la Gloria, limpia las lámparas y adereza, saca la columna del çirio pascual y pónela junto al púlpito del Evangelio baxo de la grada del pavimento, pone en ella el çirio y haze los cinco granos de incienso que se an de poner en él, previene la caña o culebra y ajusta en ella las tres velas, en la Cruz mayor de las proçesiónes pone zendal morado, por la mañana pone en la puerta de la Iglesia un bufete con sobremesa morada. Lleva un brasero con carbones, pedernal, yesca y pajuelas, sobre el bufete pone una Cruz, un candelero con vela, el açetre con agua vendita y hisopo. Una fuente de plata con los çinco granos de incienso, el agua se vendize en la Sacristía mientras se dizen las horas, saca los ornamentos que an de servir, plata y recaudo para la missa, lo cual todo pone en la Sacristía con mucho orden y concierto y en el pavimento Credençia.

2. Las oras se dizen en tono baxo y en compás ligero, como de doble ordinario, en el altar están seis candeleros pequeños con velas apagadas y así están todo el oficio hasta el prinçipio de la missa, al fin de sexta el Çerimoniario combida al celebrante y Diáconos que salen de sus sillas y en el medio del coro more solito hazen venia y se

[fol. $404^{\mathrm{r}}$ ]

despiden de él y salen con los Çeroferarios y Turiferarios y en çerimonia van por la Iglesia a la Sacristía, donde los ministros se visten roquetes y collares morados, el Subdiácono planeta morada, el Diácono, si ha de cantar el preconio, Dalmática blanca, estola y manípulo y va en la procesión antes de los Diáconos, el çelebrante alba, cíngulo, estola y pluvial morado, mientras se visten los çeroferarios sacan el recaudo necesario al altar, atril y misal, ponen en los púlpitos facistoles con paños blancos y mientras la oración el Sacristán, fuera de la Iglesia saca lumbre con yesca y pedernal, de la cual ençiende los carbones del brasero.

3. Acavada nona todo el coro por su orden baxa y por de fuera de la Iglesia entran en la Sacristía donde ya están vestidos y todo preparado y se ordena la procesión a la puerta de la Iglesia en esta forma, el Pertiguero, el Çerimoniario, los dos Turiferarios con 
roquetes y collares, el antiguo lleva Turíbulo baçío sin brasas y naveta con incienso, va a la mano derecha, el moderno no lleva cosa alguna,

[fol. $404^{\mathrm{v}}$ ]

luego el que lleva la Cruz y algo detrás un acólito que lleva la caña con las tres candelas apagadas, luego el Clero por su orden, el Subdiácono, el Diácono y çelebrante, las manos puestas, van todos cubiertas las cabezas y en silencio por dentro de la Iglesia a la puerta donde está el bufete con todo lo que se dixo $\mathrm{n}^{0} 1$, cerca de la puerta los primeros se van quedando y los antiguos se llegan más a ella y el de la Cruz se pone al lado diestro junto al bufete y en llegando el celebrante bendize el fuego que está enzendido, como se dispone en el ordinario, luego vendize los cinco granos de incienso diciendo absolutamente la oración Veniat quesumus.

4. En tanto que los granos de incienso se vendizen el Turiferario toma de las brasas benditas y echa en el incensario y acavada la bendición del incienso el çelebrante hecha incienso de la naveta en las brasas del Turíbulo ministrándolo el mismo Turiferario y bendícelo como suele, luego un Versiculario toma el hisopo mojado en el agua vendita, vésalo y dalo al celebrante, el cual roçía tres vezes los granos de incienso y tres las brasas diciendo la antíphona Asperges me, sin canto ni psalmo, luego

[fol. $405^{\mathrm{r}}$ ]

el Turiferario le da el Turíbulo y Turifica tres vezes los granos y tres las brasas, luego un Çeroferario toma la vela que está allí y la enciende de las brasas venditas y el otro Çeroferario entrega al Diácono la caña con las tres candelas y el Turiferario moderno toma la fuente con los cinco granos y hecho ésto se ordena la buelta de la proçesión en esta forma, el Pertiguero, los Turiferarios, el antiguo con el Turíbulo y naveta en la diestra, la mano levantada no inçensando como en las otras procesiones, el moderno con la fuente y los cinco granos, con ambas manos levantada hasta el pecho, luego el Cruciferario con la Cruz levantada y a su siniestra el que lleva la vela ençendida del nuevo fuego y último el çelebrante.

5. Proceden y cuando el Diácono llega de baxo del Sigilo del coro inclina la caña y paran todos y el çerimoniario toma la vela ençendida y enciende una de las tres de la caña, levántala el Diácono, quita el bonete, híncase de rodillas y todos los demás con él, excepto el que lleva

[fol. $405^{\mathrm{v}}$ ]

la Cruz y canta él solo de rodillas lumen Christi y levantándose todos responde el coro Deo Gratias, cúbrense los bonetes y proceden en llegando al arco Toral buelve a inclinar la caña y el Çerimoniario ençiende otra vela y hincándose de rodillas como la primera vez canta en tono más alto lumen Christi y en el mismo responde el Coro Deo Gratias, y llegando a la grada del Pavimento baxo de la misma manera se enciende la tercera candela y canta en tono más alto lumen Christi y responde el Coro Deo Gratias en el mismo tono. 
6. Los Colegiales y Prebendados desde allí por la capilla de los mártires, derechos se van al coro, el Diácono da la caña al Çeroferario que la sacó, el cual se va a la grada del pavimento con ella. El Cerimoniario, Diácono y celebrante suben al altar, el Cruciferario se queda en la grada, en medio de los Turiferarios que tienen el Turíbulo y fuente con los granos de incienso y el Çeroferario de la caña se pone a la siniestra del moderno y el otro que tiene la vela enzendida del nuevo fuego con que se enzendieron las de la caña, a la diestra del Turiferario antiguo que todos cinco hazen una hilera, el Celebrante se pone al Cornu epistolae, las espaldas al

[fol. $406^{\mathrm{r}}$ ]

missal, no totalmente sino como se pone en las missas como cuando se canta el Evangelio y el Subdiácono está a su siniestra fuera de la peana, el Çerimoniario da el misal al Diácono, el cual con él al pecho, inclinado delante del çelebrante como cuando pide la bendición para Evangelio dize Iube Domine benedizere y el çelebrante Dominus su in corde tuo et in labiis tuis ut digne et competenter annuntias suum santus Paschale preconium, In nomini Patris et Spiritus Sancti. Amen y le echa la bendición.

7. Recivida, haze genuflexión y con el libro al pecho va al púlpito del Evangelio acompañado del Pertiguero y del Turiferario que sube para ésto hasta las gradas del Pavimento, cuando sube por las gradas del Pavimento cuando sube por las del Púlpito, el Cruciferario se pone en el lugar medio que suelen tener los Çeroferarios con los Çiriales, asienta la Cruz en el suelo que está mirando al atril, el Pertiguero se va donde suele estar al Evangelio cantado y el Çeroferario, que tiene la caña, se pone al lado diestro del púlpito, un paso más al altar de la Concepción de lo que se pone el acólito moderno en tal distancia que el Diácono pueda cómodamente con su diestra alcanzar y tomar una de las velas para ençender el cirio a su tiempo, tiene la caña baxa asentada en el suelo, el Turiferario del Turíbulo

[fol. $\left.406^{\mathrm{v}}\right]$

sube tras el diácono, el cual pone el libro y abre sobre el Atril, toma el Turíbulo y inciénsalo tres vezes more solito mas no lo signa ni a si buelve el Turíbulo y el Turiferario se baxa y sube el que tiene la fuente con los çinco granos a la última grada junto al Diácono y de baxo de las lámparas pone el Çeroferario que tiene la candela encendida y el Turiferario se va al lugar que tiene cuando se canta el Evangelio.

8. Entona el Diácono el exultet al cual todos en el coro e Iglesia todos están en pie y el celebrante las manos puestas y buelto de rostro al Diácono como al Evangelio cantado en diciendo Curuat imperia el mismo Diácono dexa de cantar y fixa los cinco granos de incienso en el cirio a modo de Cruz y de la fuente se baxa y va a la Sacristía y el Diácono prosigue su canto y cuando a dicho aquellas palabras Rutilans ignis accendit, toma una de las tres candelas de la caña y con ella ençiende el çirio y prosigue y llegando a las palabras Apis mater ecluxit el Ceroferario con la candela que tiene enciende todas las lámparas de la Iglesia y se va a la Sacristía y la dexa encendida sobre un candelero para encender con ella, a su tiempo, las velas del altar y ciriales y sale al altar. 


\section{Acabada la vendición del Cirio el Cruciferario}

[fol. $407^{\mathrm{r}}$ ]

acompañado del Turiferario se entran en la Sacristía, el Ceroferario de la caña la pone en un pie junto al pavimento alto al lado del Evangelio, el Diácono baxa y acompañado del Pertiguero se va al altar y no da a vesar el libro al celebrante, dexa la dalmática blanca y el Çeroferario de la caña le pone estola y planeta morada, si es otro que el de la missa en acavando el Canto detrás del Cruzifererio se entra en la Sacristía donde se desnuda, el Sacristán saca Casulla morada y los tres manípulos y quita el pluvial al çelebrante y da los manípulos y quita el pluvial al çelebrante y da los manípulos llévalo a la sacristía y la dalmática blanca y el Pertiguero se entra. Vestido el çelebrante en el coro se comienzan las propheçías sin título en un atril desnudo que está en medio del Coro. Dízenlas los que el Maesto de Çeremonias ha señalado en la tabla y la última dize el Presidente del Coro, mientras se cantan en el coro, el Çelebrante las lee en el altar al Cornu epistolae estando los Diáconos detrás de él, uno en pos de otro y en acavando de leer la prophecía se van a sentar hasta que se acava en el coro las Oraciones. El Diácono dize flectamus genua y el Subdiácono el levate hincándose

[fol. $407^{\mathrm{v}}$ ]

aquél primero de rodillas y con él todos excepto el çelebrante y levantándose el Subdiácono primero y con él todos.

10. Acavada la última prophecía los Çeroferarios quitan al Çelebrante la casulla y en medio de los Diáconos se postran todos tres delante del altar. Todos los demás se hincan de rodillas y en el medio del coro dos cantores Cantan la letanía como está en el misal respondiendo y repitiendo el mismo verso todo el coro. En llegando al verso Peccatores te rogamos audinos, el celebrante y Diáconos se levantan y ponen los ceroferarios la Casulla y se van a la Sacristía para vestirse, para la missa, de ornamentos blancos.

11. Cuando el coro canta los Kyries, solamente el Sacristán y Colegiales previenen y sacan al altar de los mártires los candeleros más ricos con velas ençendidas, los Çeroferarios llevan a la Credençia el recaudo que fuere menester para la missa y ençienden dos velas en el altar y los Prebendados salen del coro y dexan las capas negras Canonicales y buelven inmediatamente con sobrepellices a asistir a la missa y esto hecho con mucha diligençia y brevedad salen para la missa el Pertiguero, Turiferario con Turíbulo y naveta, Çeroferarios con los ciriales

[fol. $408^{\mathrm{r}}$ ]

ençendidos, çerimoniario y los de la missa more solito, en la peana del altar hazen genuflexión y el çelebrante dize el Introibo ad altare Dei con el psalmo Iudicame Deus con Gloria Patri y hecha la la Confesión sube al altar y vésalo en medio y lo inciensa alrededor como en las otras missas solennes.

12. Acavada la Incensacion y los Kyries en el coro, el çelebrante, en medio del altar y los Diáconos en pos de él como suelen, entona el himno Gloria In Excelsis Deo, y al 
mismo punto y desbiándose el Celebrante y Diáconos, los Colegiales que estarán para éste prevenidos, corren velos que cubren el retablo del altar mayor y los recogen y llevan a la Sacristía y se quitan del altar los ornamentos morados y al mismo tiempo otros Colegiales hazen lo mismo en los altares Colaterales, sácanse al altar mayor los candeleros ricos que están prevenidos en el de los mártires, mientras se haze todo esto y desde el mismo punto que se entona la Gloria, los Çeroferarios tocan las campanillas del rosario y de los mártires tocan otras, en el coro la prosiguen y juntamente toca el órgano y el portero haze señal en la torre y tocan todas las campanas y por las bóbedas hechan Alleluyas y muchas flores y yervas olorosas, todo lo cual dura hasta que se acava de

[fol. $\left.408^{\mathrm{V}}\right]$

cantar el himno que sea con mucho espacio y solemnidad.

13. Al fin de la Epístola no se toca el órgano porque no ay gradual y el çelebrante en el altar por el misal entona Alleluya, al cual todos los del Coro e Iglesia se levantan, cantando tres vezes alzando cada vez más la boz y el coro responde otra tres vezes en el mismo tono y prosigue el verso consitemini, y el laudare Dominum Omnes gentes el Diácono en el interim dize Munda Cor meus y pide la vendición del incienso y para sí con las mismas Ceremonias y tiempo que en las otras missas y va a cantar el Evangelio acompañado del Pertiguero, Turiferario, Çeroferarios que no llevan Çiriales sino las manos puestas y del Subdiácono, sube al púlpito y los demás se ponen en sus lugares, signa e inciensa el libro y acavado el Evangelio, el Subdiácono lo lleva que lo vese el Celebrante y el Diácono lo inciensa.

14. No se dize Credo sino Dominus Vobiscum y el çelebrante dize Oremus, mas no se dize ofertorio que no lo ay y assí el órgano no toca, el celebrante inciensa la oblata y altar y en el ínterin todo el Coro y Órgano están en silençio, a los Sanctus se toca el órgano como suele, dízese Pax Domini, mas no se da la paz, ni se dizen los Agnus, ni el Órgano los tañe y el celebrante dize las

[fol. $409^{\mathrm{r}}$ ]

tres Oraçiones mas no se dize post communio. Acavando la plegaria del alzar toca el Campanero a Vísperas con todas las campanas tres repiques breves y dexa con algunos golpes de esquilón a lengua.

15. En consumiendo el Çelebrante el Sanguis el coro comienza las Vísperas de las tres Alleluyas por antíphona, el psalmo laudate Dominum omnes gentes a versos con el órgano y repetida la antíphona Alleluya el celebrante en el altar al Cornu epistolae en el misal entona la antíphona de Magnificat Vespere auten sabbati, prosíguela el coro y acavada el Coro canta el magnificat a versos con el órgano con mucha solennidad, en comenzando las Vísperas salen los Turiferarios y se ponen debaxo las lámparas Eregione meneando los incensarios y en comenzando el magnificat suben, hazen genuflexión y el antiguo ministra la naveta al Diácono y el al çelebrante Ut moris est y hecha incienso y lo vendize e inciensa el altar como en las demás Vísperas, asistiéndole y acompañándole los Diáconos, buelve el Turíbulo al Diácono el cual Turifica al 
çelebrante y lo da al Turiferario y se pone en la esquina de la peana al Cornu epistolae y el Subdiácono a la del Cornu evangelio las manos puestas Eregione algún tanto

$\left[\right.$ fol. $409^{\mathrm{v}}$ ]

bueltos a la Iglesia y los Turiferarios a un tiempo los inciensan, el antiguo al Diácono y el moderno al Subdiácono hazen genuflexión y con el Pertiguero se van al coro y lo inçiensan more solito y se buelven a la Sacristía, los diáconos se juntan con el çelebrante y dizen a versos el magnificat y repetida la antíphona el çelebrante en medio del altar al pueblo dize Dominus Vobiscum y se va al misal donde dize la Oración con la conclusión Et famulos y buelve al medio del altar y dize Dominuus Vobiscum y el Diácono Ite missa est, Alleluya Alleluya y responde el coro y juntamente el órgano con toda solemnidad como cantaron la Gloria Deo Gratias, Alleluya, Alleluya, hecha la bendición y dize el Evangelio postrero y vanse a la sacristía.

16. A las tres entran en completas y se dizen con toda solemnidad, ay órgano a todos los psalmos, en el altar seis velas blandón y lámparas encendidas y arde el çirio pascual y no la caña de las tres candelas porque acavada la missa por la mañana el Sacristán la entra en la Sacristía y alza hasta otro año, antes de la antíphona Regina çeli, el Calendario lee la tabla de los oficios como suele, a la Salve se toca de suerte que los repiques se acaven poco después de las completas

[fol. 410 ${ }^{\mathrm{r}}$ ]

porque no se dize a las seis hasta el Sábado siguiente.

17. Acavados los oficios el Sacristán haze un altar en medio de la Sacristía adornado rica y curiosamente con dos gradas, en las cuales pone el número de velas y bugías conveniente, pone en el altarico más alto donde a de estar la custodia, palio y corporal, previene ramilletes y flores que poner en él y alfombras para ambos lados, la Sacristía está colgada con mucha curiosidad, los çercos y altos de la ventanas y puertas, saca el palio a la Capilla de los mártires y previene todo lo necesario para la procesión u oficios saca la custodia y limpia con cuidado, ajusta en el viril las formas que se an de consagrar y las pone sobre el altar cubiertas con un çendal blanco, la ropa blanca limpia y olorosa y todo como pide tan gran festividad.

\section{Capítulo 16. Del Oficio en el Día de Pascua de Resurrección.}

1. A las dos de la mañana toca el Campanero a maitines tres repiques con mucha solemnidad, gorda y esquilón, que dura una hora,

[fol. $\left.410^{\mathrm{v}}\right]$

en comenzando a tocar acuden los luzernarios y ponen en el coro blandones y hachas y en frente de las sillas de los Prebendados, candeleros y bugías, y por la barandilla del Coro, luminarias y por los púlpitos y gradas de los pavimentos el Sacristán enciende todas las lámparas y los Çeroferarios a su hora las velas del altar y çirios. De los blandones sacan el brasero con pomos vien aderezados $\mathrm{y}$ hechan yervas $\mathrm{y}$ flores 
olorosas por la Iglesia y Ramos en los altares ramilletes y flores, todo aderezado cuando anda el esquilón salen de la Saxcristia en Ceremonia, para los maitines van por la Iglesia y entran en el Coro como se dixo libro 3, Capítulo 3, de maitines $\mathrm{n}^{\mathrm{o}} 1$, y los siguientes y se cantan con las çeremonias que allí se notan.

2. En acavando la primera lección toca el Órgano el responsorios que se dize rezado y lo mismo el segundo, a todos los psalmos ay órgano y todo se canta y toca con la solemnidad que pide el día, en el segundo responsorio el celebrante y caperos se visten $\mathrm{y}$ el çelebrante dize la terçera lección como se dize en el Capítulo citado $\mathrm{n}^{\circ} 8 \mathrm{y}$ cuando se comienza el Te Deum laudamus, los otros dos Caperos toman pluviales y el

[fol. $411^{\mathrm{r}}$ ]

Presidente del Coro envía un Prebendado que diga missa y consagre, las laudes se prosiguen en el coro y ay organo a todos los psalmos libro 3, Capítulo 3, de maitines números 9 y 10.

3. El Prebendado va a la Sacristía, dize missa en la Capilla y consagra las formas para la custodia, las cuales en consumiendo pone en el Corporal y las cubre con el cavo de él y hasta el fin de la missa guarda las cerimonias y genuflexiones que suele cuando está el Sanctíssimo Sacramento en el altar supra capítulo 12, del Jueves Sancto número 6. Acavada la missa el Sacristán enciende las velas del altar que está en la Sacristía y el Coadjutor trae del la Custodia y el Prebendado pone en ella las formas consagradas con las devidas genuflexiones, pónele el Coadjutor un cendal por los hombros y con él toma la custodia y acompañanla con dos hachas y lleva y pone en el altar de la Sacristía y se hinca de rodillas y queda en Oración dando gracias hasta que baxe el coro el coadjutor y los demás también acompañan de rodillas al Sanctíssimo Sacramento, encíendense pevetes y hechan flores y todos asisten con mucha devoción y silencio.

[fol. $411^{\mathrm{v}}$ ]

4. Acavadas laudes y dicha la antíphona de Nuestra Señora Regina Celi baxan los del coro en forma de proçesión. Pertiguero, Çetreros, Çeroferarios, Clero por su orden, Caperos y Çelebrante por la Iglesia, entran todos en la Sacristia y adoran el Sanctíssimo Sacramento y entonzes el Prebendado que dixo la missa que hasta este tiempo ha de estar vestido y hincado de rodillas delante del Sanctíssimo Sacramento se ha de ir a desnudar, salen los luzernarios y ençienden velas en los altares Colaterales y apagan el çirio pascual, el celebrante y Diáconos sin detenerse pasan detrás del altar del Sanctíssimo Sacramento y se visten en una mesa que tiene los ornamentos y está entre el altar y caxón del testero sin que ninguno buelva las espaldas al Sanctíssimo Sacramento porque el çelebrante se pone de rostro a él y las espaldas al caxón del testero. Viste alva, estola y pluvial y los Diáconos dalmáticas, todos sin manípulos y vestidos pasan delante del altar donde se ponen de rodillas. Vístense otros dos Ceroferarios para acompañar la Cruz y otros dos Turiferarios, los luzernarios reparten hachas a los prebendados y velas

[fol. $412^{\mathrm{r}}$ ] 
encendidas a los demás.

5. El Çerimoniario aviendo inçensado el Sanctíssimo Sacramento pone çendal blanco sobre los hombros al çelebrante y el Diácono con otro pequeño toma la custodia con mucha reberençia y la da al çelebrante que está de rodillas y en reçiviendola se levanta y el Diácono haze genuflexión, buélvese el çelebrante con el Sanctíssimo Sacramento y los Turiferarios comienzan a incensar de dos en dos como se dixo Capítulo 12, del Jueves Sancto , y el Sochantre entona el Pange lingua que se canta en toda la procesión, sale el Pertiguero, Cruciferario y Çeroferarios y todos por su orden fuera de la sacristía, los cuatro Caperos con sus pluviales van en medio hasta la capilla de los mártires donde toman el palio, cuando sale el Sanctíssimo Sacramento de la Sacristía toca el Órgano y a versos el pange lingua mientras dura la proçesión que va derecha al altar de la Conçepción de nuestra Señora donde haze estación, el Cruziferario con los çeroferarios que se paran junto al arco Toral al portel de la tribuna, los Caperos con el palio antes de la peana en la peana, los Çeroferarios que van junto al Sanctíssimo Sacramento y en llegando el celebrante da

[fol. $412^{\mathrm{v}}$ ]

la custodia al Diácono que la reçive de rodillas y pone en el altar y hazen genuflexión excepto el Cruciferario y los çeroferarios, el Clero se queda de rodillas, el Çerimoniario quita el çendal al çelebrante y el Sochantre y coro cantan la antíphona Regina çeli mientras que el Turiferario llega y ministra la naveta al Diácono y este al celebrante, el cual hecha incienso sin vendecir ni decir nada, toma el Turíbulo de mano del diácono e inçiensa de rodillas con tres ductos el Sanctíssimo Sacramento.

6. Levántanse y buelven todos tres a hazer genuflexión y da el Turíbulo al Diácono, y este al Turiferario, acavada la antíphona dos cantores dizen el Versículo Gaude et letare Virgo Maria Alleluya y responde el Coro quia surrexit Dominus Vere Alleluya y mientras se canta los Diáconos ponen delante del çelebrante un misal avierto por la Oración Deus qui per resuretionem etc. tienenlo con la manos de suerte que lo alto de él descansa sobre la frente del altar y híncanse de rodillas mientras el Çelebrante en pie y las manos

[fol. $413^{\mathrm{r}}$ ]

puestas canta la dicha Oración. Acavada, el Coro responde Amen y el Çelebrante haze genuflexión y todos tres se levantan y el Subdiácono dexa el libro cerrado sobre el altar, al lado del Evangelio y el Çelebrante se hinca de rodillas en la peana y el cerimoniario le pone el Cendal y el Diácono haze genuflexión y toma la custodia y la da al çelebrante y dada, el çelebrante se levanta y él buelve a hazer genuflexión, de esta suerte se hazen siempre las estaciones en todas las procesiones del Sanctíssimo Sacramento.

7. La Procesión prosigue y anda alrededor de la Iglesia como el Jueves Sancto y cuando llega al pavimento la Cruz y Çeroferarios se quedan en la grada y el coro se va, quedando los modernos primero, los Caperos dexan el palio que lo entran en la Sacristía los Colegiales, los Çeroferarios se quedan en su lugar, el çelebrante y Diáconos suben y 
en la peana se hinca de rodillas el Diácono y reçive la Custodia y pone en el altar y el çelebrante la inçiensa como se dixo en los números precedentes y en el ínterin el Coro canta el verso Tantum ergo Sacramentum y los dos cantores el versículo Panem de Çelo prestitisti eis Alleluya y el Coro omne delectamentum in se habenten Alleluya.

[fol. $413^{\mathrm{v}}$ ]

Y el Çelebrante por el misal que tienen los Diáconos ut supra canta la Oración Deus qui nobis sub Sacramento mirabili etc. y acavada haze genuflexión y el Cerimoniario le pone el çendal, toma con él la custodia con ambas manos por el nudo del pie.

8. Buélvese por el lado diestro con ella al pueblo, los Diáconos no truecan manos, tiénenle ambos los brazos y el çelebrante de rostro al pueblo haze con ella la señal de la Cuz en esta forma, levanta la Custodia hasta que el nudo empareje con su frente, luego la baxa por línea recta hasta que por cima de ella descubre todo el rostro, luego la levanta hasta que empareje con él y se buelve al Cornu epistolae media buelta, luego sobre la mano derecha se busca al Cornu Euangelii con lo cual forma los brazos de la Cruz, todos estos mobimientos con mucha devoción y espacio y cuando se buelve a los lados el Diácono y Subdiácono se hincan de rodillas, cada uno cuando tiene frontero el Sanctíssimo Sacramento mientras se vendize el pueblo, los Turiferarios inçiensan de rodillas, los Çeroferarios tocan las campanillas y el organista el Órgano con mucha suavidad, como más extenso se dixo libro 3, Capítulo 8, número 12.

[fol. $414^{\mathrm{r}}$ ]

13. Y el çelebrante por el mismo lado del Evangelio, acavada de dar la buelta y pone la custodia sobre la Ara y ençierra el Sanctíssimo Sacramento como se dixo en el capítulo çitado número 14.

9. Ençerrado el Sanctíssimo Sacramento, los luzernarios recogen la çera, el Clero se levanta y la Cruz, Ceroferarios, Caperos y Diáconos y Celebrante se entran en la Sacristía en çeremonia donde se desnudan y el Tesorero con sobrepelliz y estola acompañado de cuatro o seis Colegiales que llevan hachas enzendidas sacan el Sanctíssimo Sacramento de la Capilla de la Sacristía donde se reservó el Jueves y rezando a versos el Te Deum laudamus lo lleva al altar del Sagrario donde lo encierra y para este día, la noche antes limpia los sagrarios y los perfuma y el relicario del altar mayor donde se ponen las hostias consagradas de la proçesión porque hasta que se pongan no ha de aver Sanctíssimo Sacramento en el altar mayor, mas no por eso se dexan de hazer las genuflexiones acostumbradas en los oficios y missa excepto el çelebrante cuando inciensa, que al pasar por el medio solo haze profunda.

10. A las seis toca a las horas el Campanero hasta la media y dízense con pausa y compás moderado. A las nueve se entra en missa que se celebra como se

[fol. $414^{\mathrm{v}}$ ]

dixo en su Capítulo 4, libro 3. Y al Ite missa est Alleluya Alleluya responde el Órgano con mucha solemnidad, a las tres se entra en Vísperas y estas horas son las de los 
oficios hasta fin de Septiembre. Siempre están en pie a la antíphona Hec Dies quam feçit Domini, sea cantada o rezada y cuando se canta, la entona el celebrante, en Vísperas, laudes o horas.

11. Si desde el miércoles hasta el Sábado viniere la fiesta de San Thessiphón o Anunciación de Nuestra Señora, todo el oficio, missa y Vísperas es de la feria, mas la missa y vísperas se canta con solemnidad. Ay seis velas en el altar y lámparas enzendidas, si en esta semana cayere la fiesta de San Marcos el mismo día se haze la proçesión y el oficio es del día y si fuere en alguna feria desde el miércoles hasta el Sábado ay seis velas en el altar y se cantan las segundas Vísperas.

12. El Çirio pascual arde el Sábado Sancto todo el officico de la mañana, el Domingo de Resurrección a los maitines y laudes, missa y Vísperas y de la misma suerte los días siguientes lunes y martes, el Sábado in albis a la missa y éste y todos los sábados a las Vísperas y

[fol. $415^{\mathrm{r}}$ ]

todos los Domingos a la missa y Vísperas aunque no se reze de ellos, el día de la Ascensión a las primeras Vísperas y a la missa hasta el fin de el Evangelio que lo apagan y no arde más ni otros días solennes y festibos que sean.

\section{Capítulo 17. Del Officio en el día de San Marcos. Letanías Maypres y Menores antes de la Asçensión.}

1. El día de San Marcos, la missa de prima es de letanías con Casulla morada. Si la fiesta de San Marcos viene a la Octava de Pascua, la missa principal es de la feria, y la de prima del oficio del día y si no viene es de San Marcos con los ornamentos color conveniente, si el día de San Marcos viene en las ferias $2^{\mathrm{a}}$ o $3^{\mathrm{a}}$ después de Pascua ay seis velas a la proçesión y missa, si en las demás

[fol. $415^{\mathrm{v}}$ ]

se ponen también seis, en el mismo día que se reza de San Marcos ay seis, este día va la proçesión a la Cueva de San Çecilio, la cual el Sacristán tiene adornada con muchas yerbas olorosas, Ramos de flores por el suelo, rexa y paredes y por el altar en el cual pone y arden cuatro velas.

2. El Sacristán tiene cuidado de ençender las velas a donde fueren las proçesiónes, en comenzando la gorda los Versicularios hazen llevar al Caniculario facistol con paño morado y libro por donde Cantar las antíphonas en las estaciones y misal para las oraciones, el Sacristán adorna la Iglesia, cuevas y altares donde fueren las proçesiónes estos días, en el altar de la Concepción, en la Cueva de San Çeçilio para el día de San Marcos como está dicho y para la feria segunda de las rogaciones pone manteles limpios, alfombra, muchos ramilletes y flores, cuatro velas, el suelo con ramos y juncos, para la feria terçera adorna la Iglesia de Señor Sanctiago, pone frontal Carmesí, 
alfombra, cuatro velas en la barandilla, ramilletes y jarras de flores y por el suelo, junçia y gayomba. Para la feria cuarta adorna el horno de

[fol. $416^{\mathrm{r}}$ ]

San Cecilio donde se haze estación, haze un altar en que pone la imagen de la Virgen o el niño, las velas y ornato que pareçiere, por la rexa y suelo muchas flores y este día arden dos velas en el altar de la Concepción y por toda la Cueva esparze junçia y flores y por el tránsito de las Cavernas pone muchas luzes y el Campanero repica desde que la proçesión comienza a andar hasta que buelve a entrar en la Iglesia, con cuidado que las pausas de los repiques sean en la distancia del horno de San Çeçilio hasta que da la buelta para entrar en la Cueva toda la procesión.

3. El día de San Marcos, en dejando el esquilón, salen de la Sacristía el Pertiguero con ropa negra, el Turiferario, la Cruz con dos Çeroferarios, el Clero por su orden, el Subdiácono, Diácono y çelebrante con ornamentos morados, Dalmáticas y pluvial sin manípulos, la Cruz y Çeroferarios se ponen en la grada del pavimento baxo detrás el Pertiguero, los Coros de los Colegiales por el Crucero y los Prebendados por el Pavimento, los más antiguos junto a las gradas, el Coro de la mano derecha se pone por el

\section{[fol. $\left.416^{\mathrm{v}}\right]$}

lado del Evangelio y el otro por el de la Epístola, el Çerimoniario, Diáconos y Çelebrante suben al altar y todos hazen genuflexión a un tiempo, excepto los de la Cruz y çiriales, oran un rato y quedándose los demás de rodillas, los del Pavimento alto se levantan y el Turiferario sube y da la naveta al Diácono el cual ministra al çelebrante que hecha incienso sin decir nada más de echar la vendición, el Turiferario se vaxa al Crucero junto al Çeroferario antiguo, el rostro al púlpito del Evangelio meneando el incensario, todo conforme se dixo libro 3 , Capítulo 5, de procesiones números 5 y 6 .

4. Levántanse todos y el Sochantre en el Coro canta la antíphona Exurge Domine adiuvanos et liberanos propter nomen tuum y dos cantores el psalmo Deus auribus nostris audivimus etc, y luego el Gloria Patri y después se repite la antíphona exurge, todo a semejanza del Introíto de la missa, acavada la antíphona todos se hincan de rodillas, excepto los Çeroferarios y Cruciferarios y Turiferario y dos prebendados, señalados por el maestro de Ceremonias, se ponen de rodillas en la ínfima grada del pavimento, en medio, y comienzan a cantar

[fol. $417^{\mathrm{r}}$ ]

la letanía y todo el coro repite lo mismo, después de aver cantado Santa Maria Ora Pro nobis se levantan todos, mas no se cubren hasta que está repetido Sancta Virgo Virginum Ora Pro nobis.

5. Proçeden como se dixo en el Capítulo çitado, con espacio, igualdad y uniformidad, no se para ni se haze pausa, el Compás del Canto cuando comienzan a andar un poco más ligero, salen por la puerta principal y van a hazer la estación a la Cueva de San 
Çecilio y cuando pasan por las rexas de los sagrados hornos, todos hazen profunda quitándose los bonetes, excepto el celebrante que no se lo quita y el de la Cruz y çiriales que pasan derechos. Cuando nombran a Sanctiago y al Sancto del día y a los del Sacro Monte quitan los bonetes después de Omnes Sancti Innocentes dizen a San Cecilio, San Hiscio, San Thessiphón y después a San Estevan etc.

6. Cuando llegan a la puerta de la Cueva, la cruz y çiriales no entran, báxanlos y se ponen más alla de la puerta, los rostros a la procesión que viene y entra en la Cueva y como van entrando se quitan los bonetes y no se los ponen hasta aver salido, excepto el celebrante y diáconos que solo se los quitan cuando se cantan las antíphonas y oraçiones

[fol. $\left.417^{\mathrm{v}}\right]$

todos hazen profunda al altar y entran por el Arco de la mano derecha que está junto a la puerta y proçeden alrededor así como los cantores llegan a la puerta dizen San Iacobe, S. Çeçili. S. Hisçi. S. Thessiphón, San Messiton, Ora Pro nobis, aunque los ayan dicho a la venida y prosiguen en el Sancto en que estavan cuando llegaron y por el Arco de la mano siniestra que esta junto al altar entran al Cuerpo de la Iglesia y los Colegiales se ponen en medio de dos coros y los Prebendados en sus dos coros arrimados a las paredes, el de la mano derecha se queda por el lado del Evangelio y el otro pasa al de la Epístola como al salir de la Sacristía y los modernos baxan abaxo y los antiguos se quedan junto al altar al cual hazen profunda el celebrabnte y Diáconos cuando llegan a la peana y çesan de cantar los Sanctos.

7. Luego el Sochantre y choro quedándose todos en pie y descubiertos, canta la antíphona Conceptio tua Dei genitrix Virgo etc. dos Colegiales cantores el verso Elegit eam Deus etc. preelegit eam Alleluya y el coro responde In tabernaculo suo habitare façit eam Alleluya y el celebrante,

[fol. $418^{\mathrm{r}}$ ]

teniéndole los Diáconos el misal avierto la Oración Famulis tuis, la cual dize con su conclusión, luego el coro canta la antíphona de San Cecilio de común de un mártir tempore Paschali con sus versos y el çelebrante dize la Oración de San Cecilio solo, y acavada con su conclusión se despiden del altar con profunda y los Prebendados cantores prosiguen la letanía donde la dexaron y van a la Iglesia y entran por la puerta del Pórtico, la Cruz y çiriales se ponen en la grada del pavimento donde estubieron al salir, el Turiferario debaxo de las lámparas de la Capilla del rosario, los Colegiales se van quedando por el Crucero y los Prebendados suben al Pavimento, los antiguos delante, el Çerimoniario, Diáconos y Çelebrante suben al altar, los Prebendados cantores se ponen en la grada ínfima donde comenzaron y todos se hincan de rodillas hasta acavar la letanía.

8. Acavada la letanía el Çerimoniario da el libro al celebrante, el cual se levanta y los Diáconos le tienen el libro y por él dize las Prezes y responde el Coro y luego las Oraciones y mientras las dize el Sochantre y Colegiales se van al coro a comenzar la missa. Acavadas las Oraciones, el Pertiguero, Cruz y los demás ministros, 
Çerimoniario, Diáconos y Celebrante se entran en la sacristía donde dexan los ornamentos morados y visten los conbenientes a la missa del día a la cual salen

[fol. $\left.418^{\mathrm{V}}\right]$

y se celebran more solito y los Prebendados se van al coro.

9. La feria segunda de las rogaciones si ay Sancto doble o semidoble, la missa de prima es de las rogaçiones, y la missa principal después de la proçesión es del Sancto. A la proçesión arden cuatro velas en el altar mayor y a la missa. La proçesión sale como se dixo supra números 3, 4, y 5. Y va a la Cueva de San Cecilio y se haze todo lo que en el día de San Marcos en los números referidos.

10. El Martes, la Missa de prima es de las rogaçiones y la de tercia del Sancto que se rezare de nueve lecciones. Va la procesión a la Iglesia de Señor Santiago, sale por la puerta del Pórtico y entra por la dicha Iglesia por la puerta del Poniente, la Cruz y ciriales llegan y paran junto la puerta de las Cuevas y los Colegiales se quedan en dos Coros y los Prebendados también cogiendo a los Colegiales en medio, todos se quedan en los lugares como van entrando, el Çerimoniario, Diáconos y celebrante suben a la tribuna y en la peana hazen genuflexión y se levantan y el coro canta la antíphona $o$ Beatum Apostolum, y dos cantores el Verso pretiosa in Conspectu Domini Alleluya Rex mors Sanctorum eius Alleluya, y el celebrante canta la Oración Esto Domine. Plebitue etc. con su conclusión per Christum Dominum

[fol. $419^{\mathrm{r}}$ ]

Nostrum, y todas las demás Oraçiones de las letanías se an de concluir de esta manera, luego antíphona y Verso de común de muchos mártires y tempore Paschali y el çelebrante dize la Oración de Sancto Hisçio y sus discípulos, luego prosigue la letanía y sale la procesión por la puerta del medio día y entra por la puerta principal de la Iglesia.

11. El Miércoles la missa de prima es de la Vigilia de la Ascensión y si ay Sancto doble o semidoble se le dize la missa en acavando nona y salen a ella el celebrante, que a de ser el que se sigue en el turno de los aniversarios, y la asistencia de esta missa es punto de distribución. A la hora ordinaria se toca a missa y la proçesión sale y va por la puerta principal de la Iglesia a la Cueva de San Cecilio, quédase la Cruz y çiriales, y entra por el arco primero de la mano siniestra y da la vuelta por toda la nave que rodea la Iglesia y en entrando todos se quitan los bonetes y no se los ponen hasta que salgan de las Cuevas, excepto el çelebrante y Diáconos y los cantores en cualquiera parte de la letanía que vayan aunque estén dichos entonan Sancte Iacobe Ora Pronobis y prosiguen andando dentro de las Cuevas todos los doze Sanctos mártires del Sacro Monte

[fol. $419^{\mathrm{v}}$ ]

por este orden Sancte Çeçili, Sancte Hisçi, Sancte Thessiphón, Sancte Messitón, Sancte Patriti, Sancte Septemtri, Sancte Turile, Sancte Panunti, Sancte Maroni, Sancte Çentuli, Sancte Maximine, Sancte Lupari, entran por las Cavernas a los hornos y hazen estaçión en el de San Çeçilio, si llegando allí no están acavados de Cantar los doze Sanctos, los 
acavan y luego cantan antíphona de Comuni plurimorum martyrum tempore Paschali y el çelebrante la oración de San Ceçilio y Thessiphón y de sus discípulos, luego se canta antíphona y Verso de un mártir del mismo tiempo y el çelebrante la Oración de San Messitón Presta quesumus etc. ut interçedente etc..

12. Luego prosigue la letanía de donde la dexaron cuando entraron en la Cueva y sale a la nave de la Concepción y por el arco que está junto a la puerta, va fuera y buelve a la Iglesia por la puerta del Pórtico donde se acava y dize la missa, en todas las estaciones que se hazen a la antíphonas, Versos y Oraciones están en pie, siempre arden las Velas en el altar mayor y a las missas de las rogaciones ay órgano y si alguno de estos tres días cayere fiesta de segunda Clase, a la proçesión arden también seis Velas, si fuere la fiesta de la Inbención

[fol. $420^{\mathrm{r}}$ ]

de la Cruz, el Sacristán adorna con ramos y flores la Cruz de los ortelanos y delante de ella pone dos blandones con dos hachas que enciende cuando las demás velas y la Procesión, a la ida haze allí estación para la Cruz y çiriales a un lado y los demás como van llegando y el çelebrante y Diáconos pasan a las gradas, ay prevenido façistol y libro, y el coro canta la antíphona de la Cruz, Cruzem Sanctta subiit con su verso y el celebrante la Oración Deus qui in preclara salutifere Cruzis, \& prosigue la letanía y procesión y las hachas no se apagan hasta que aya buelto a la Iglesia.

\section{Capítulo 18. Del Oficio en el Día de la Ascensión del Señor.}

1. El Tesorero manda la noche antes a aderezar el altar, poner el dosel y prevenir todo lo necesario para descubrir el Sanctíssimo Sacramento, muchas flores para el altar y pavimento.

2. En acavando Sexta se dize la antíphona Regina çeli y nona se reserva para su hora, en cantando $^{29}$

[fol. $\left.420^{\mathrm{v}}\right]$

el Evangelio sube un luzernario y apaga el çirio pascual y en çerrando la Iglesia el Sacristán lo quita y alza la Columna en su lugar. En la missa consagra el çelebrante las formas que ha de poner en la custodia y en acavando la Comunión las pone y cubre con el Corporal y este día se renueva como se a dicho en el Capítulo de renovación del Sanctíssimo Sacramento, y guarda en lo restante de la missa las çeremonias que se dixeron en el Capítulo del Jueves Sancto. Acavada la missa todo el coro baxa y se pone de rodillas por su orden en el Pavimento, sale un Turibulario y el celebrante pone el Sanctíssimo Sacramento en la Custodia y lo sube al dosel con las çerimonias que se dixeron libro 3, capítulo 8, de descubrir y ençerrar.

${ }^{29} \mathrm{Al}$ margen derecho : la de la missa mayor es media más tarde que la ordinaria de suerte que se venga a acavar a las onze. 
3. Puesto el Sanctíssimo Sacramento en el dosel dan las onze en el relox y el Campanero con todas las campanas da un solemne repique por principio de la hora de Oración, en la cual los Prebendados y Colegiales están de rodillas en el Pavimento y los de la missa en desnudándose buelven a asistir a ella, mientras la hora se procura aya música o instrumentos de Iglesia, a las doze da otro repique solemne el Campanero y el Órgano toca por fin de la hora y todos se van

[fol. $421^{\mathrm{r}}$ ]

al coro a cantar nona.

4. Los Versicularios lo tienen aderezado con muchas flores y en el lugar del çelebrante el façistol ordinario de Capitular con paño blanco y el breviario, en estando todos en sus sillas el Çerimoniario haze venia al celebrante y dize Pater Noster y Avemaria y comienza nona, entona el primer Verso el himno y Cántase la nona con mucha solennidad, ay órgano al himno y a todos los psalmos y acavada se dize la antíphona Regina çeli y todo el coro por su orden baxa a la Iglesia por la puerta de la Concepción y se pone en el pavimento de rodillas por el orden acostumbrado, el Pertiguero, Çerimoniario, ministros y çelebrante saldrán del coro al fin del segundo psalmo y el que queda presidiendo haze el ofiçio, entran por la Iglesia en ceremonia, van a la Sacristía y se visten los Çeroferarios y Turiferarios y el Çelebrante estola y pluvial y con el Pertiguero more solito, luego que llega el coro al pavimento, salen y ençierran el Sanctíssimo Sacramento como se dixo Capítulo 8, del libro 3. Y el Çelebrante después que lo ha encerrado nunca hecha Vendición y todos se levantan y van. A la tarde se entra en Vísperas una hora después de la acostumbrada.

[fol. $421^{\mathrm{v}}$ ]

\section{Capítulo 19. Del Ofiçio en la Vigilia y Día de Pentecostés.}

1. A las horas el Sábado está el altar mayor con frontal blanco y la missa de prima es del día y se dize con Casulla Carmesí, tócase a la missa mayor media hora antes y los Çeroferaros visten collares morados, quitan el frontal blanco queda el morado, ponen en el altar seis candeleros con velas que estén apagadas hasta el prinçipio de la missa, ponen Atril y missal. Los Diáconos y çelebrante visten planetas y Casulla morada con sus manípulos y en dexando el esquilón salen el Pertiguero con ropa negra, los Çeroferarios sin Çiriales, las manos puestas el Çerimoniario, Subdiácono y Diácono y çelebrante y ante la ínfima grada hazen profunda y en subiendo hazen genuflexión en la peana, los Çeroferarios y Pertiguero se quedan en sus lugares, el Çelebrante vesa el altar y los Diáconos hazen genuflexión y se van al missal.

2. En el Coro se comienzan las propheçías como está en el misal, las cuales lee el Çelebrante y se asienta en acavándolas de leer hasta que en el coro se acavan,

[fol. $422^{\mathrm{r}}$ ]

canta las oraçiónes y no ay flectamus genua, en acavando las propheçías que las dizen los señalados por tabla, la última dize el que preside, dos cantores en medio del coro 
cantan la letanía como el Sábado Sancto y todos se ponen de rodillas y el Çeroferario antiguo quita la casulla al çelebranbte y los Diáconos con planetas y él sin casulla, se postran en la peana. Al Verso Pecctores se levantan y toma la Casulla y se van a la Sacristía y los Çeroferarios sacan los façistoles con paños colorados y a la Credencia el de más recaudo para la missa y en comenzando solennemente los Kyries quitan el frontal morado y queda el colorado y Çiriales con velas y toman collares colorados y Çiriales con velas ençendidas.

3. Salen con ornamentos colorados el Pertiguero, Turiferarios, Çeroferarios, Çerimoniarios, Subdiácono, Diácono y çelebrante y hecha profunda more solito suben al altar y hazen genuflexión. Dize el psalmo del Introibo, Confesión y vesa el altar y lo inciensa more solito y en acavando los Kyries entona el Gloria in Exçelsis y los Çeroferarios tocan las Campanillas, el Órgano y torre de la misma manera que se dixo Sábado Sancto, al Evangelio no llevan los Çeroferarios Çiriales, van las manos puestas, mas se inciensa el libro y Çelebrante y lo demás de la

$\left[\right.$ fol. $422^{\mathrm{v}}$ ]

missa se dize como suele.

4. El día de Pentecostés se dize prima y acavada la antíphona Regina çeli y se toca a missa media hora antes, los Versicularios adornan el coro con muchas flores y en dexando el esquilón se comienza tercia cantada con toda solemnidad, como la nona el día de la Ascensión, el Celebrante entona el himno Veni Creator Spiritu y todos se arrodillan al primer Verso, en el altar arden las seis velas y el blandón y esta adornado con flores y ramilletes, toca el órgano el himno y a todos los psalmos y en fin del segundo el Çerimoniario combida al celebrante y diáconos, los cuales baxan y con las devidas reverençias se despiden del coro y con los ministros de la missa y Pertiguero van en çerimonia por la Iglesia y en la Sacristía se visten y el çelebrante con pluvial, inmediatamente salen more solito y se haze aspersorio y dize la missa con las çerimonias acostumbradas. Entiéndese que Salen immediatamente que se acava la tercia en el coro, la cual acava de oficiar el que preside y no se dize la antíphona de Nuestra Señora porque luego se sigue el aspersorio y dize la missa.

[fol. $423^{\mathrm{r}}$ ]

5. En acavando la missa sin intervalo se dizen en el coro sexta y nona en tono y los de la missa, en desnudándose buelven con el Pertiguero al coro en Çeremonia. La sexta y nona dize el Hebdomadario como las demás horas a la tarde y Vísperas y Completas cantadas y los dos días siguientes toda la semana se dize a tercia el himno Veni Creator, mas no se canta.

\section{Capítulo 20. Del Ofiçio en la solemnidad del Sanctissimo Sacramento y su Octava.}

1. Los Comisarios nombrados para esta fiesta cuidan del adorno de los altares y Pórtico para las proçesiones de las flores y yervas para todos los días, como se dixo libro 1, Capítulo 14 de Comisarios, antes que se abra la Iglesia por la tarde y mañana hazen que 
se hechen las flores y ençiendan las velas, se pongan los braseros y pomos, el maestro de Çeremonias previenen siempre que en la torre aya gente para repicar a punto, repica al descubrir y enzerrar el Sanctíssimo Sacramento, cuida también que todos estén a punto para sus ministerios, el Tesorero tiene para este día ropa blanca limpia y muy olorosa

[fol. $\left.423^{\mathrm{v}}\right]$

y los ornamentos más luzidos y vien puestos, previene que el día antes se consagre en la missa de prima dos formas en el sol pequeño de la custodia, saca la çera neçesaria para las proçesiones.

2. El Sacristán previene el palio y la Cruz grande, tiene limpia la Iglesia, las paredes y el suelo, limpia la custodia, la cual tiene siempre cubierta con un çendal blanco y todas las tardes la ençierra y por las mañanas saca con toda la plata, la cual pone en la Sacristía en un aparador con todo el demás recaudo para la missa y las Vinageras para las rezadas, la Víspera adorna el altar y pone el dosel y cuida de todo lo demás perteneciente al día y a su oficio, libro 2, capítulo 9, de Sacristanes, el Organista asiste con cuidado todos los días para la hora de ençerrar y descubrir y el Sochantre asimismo.

3. Algunas cosas que generalmente se guardan, cuando se trata del Sanctíssimo Sacramento por no repetir las muchas vezes se ponen al prinçipio aquí, aunque están adbertidas en otros Capítulos, siempre que el çelebrante ubiere de descubrir o ençerrar el Sanctíssimo Sacramento y se alla con casulla no la dexa, sino con ella exerze el acto como no aya de aver procesión.

[fol. $424^{\mathrm{r}}$ ]

Para esta toma pluvial y dexa la casulla, siempre que se da algo ó reçive no se vesa la mano ni nada: siempre que echa inçienso para inçensar el Sanctíssimo Sacramento como no aya de inçensar el altar, ni oblata no echa bendiçion ni dize nada: siempre antes de subir el Sanctíssimo Sacramento al sitial y después de averlo baxado lo inçiensa el çelebrante de rodillas: siempre que lo baxa y sube y mientras inçiensa, el coro canta el Verso Tantun Ergo Sacramentum y el Versículo i el Çelebrante dize la Oración, mas el Versículo y la oración no se dize cuando descubre.

4. Siempre asisten dos prebendados al Çelebrante cuando descubre o ençierra, si ay Caperos o Diáconos ellos asisten y cuando no suben dos de los que ay en el Pavimento con sus sobrepellizes y el asistente de la mano derecha ministra la cuchara e incensario y aplica la custodia. El Diácono haze lo mismo y demás de esto siempre da la custodia al Çelebrante que está de rodillas y la recive de rodillas y pone en el altar y sube al Dosel o sitial y de allí la baxa para darla al celebrante y antes de tomarla y después de averla dado haze genuflexión: siempre que el celebrante ha de tomar la Custodia el

[fol. 424 ${ }^{\mathrm{v}}$ ] 
Çerimoniario le pone Çendal blanco por ambos hombros y con él, las manos cubiertas toma la Custodia y cuando ha de inçensar siempre el Çerimoniario le quita el çendal y lo buelve a poner a su tiempo, siempre que bendize al pueblo con el Sanctíssimo Sacramento, los Turiferarios, que ubiere de rodillas a los pies del çelebrante, inçiénsale con un compás igual y moroso: siempre que el çelebrante pone el Sanctíssimo Sacramento en la Custodia lo inçiensa antes de çerrar la vidriera y siempre que lo baxa para ençerrarlo o llevarlo en proçesión lo inçiensa sin abrir la Vidriera.

5. Todas las vezes que se haze estación con el Sanctíssimo Sacramento en algún altar es de la manera que se dixo Capítulo 16, del oficio de la Pascua de Resurrección, números 5, 6 y 7, mas siempre el Verso que se canta es Tantum ergo Sacramentum o O Salutaris hostia, con sus Versículos y Oración siempre que se descubre o ençierra el Sanctíssimo Sacramento, es con las çeremonias genuflexiones y orden que se dixo libro 3, Capítulo 8: Siempre que se descubre o ençierra, el Órgano toca antes del Verso y después de la Oración mientras se bendize a

[fol. $425^{\mathrm{r}}$ ]

al pueblo y también repican en la Torre, siempre baxa el Coro al ençerrar y descubrir se juntan en el Pavimento: Siempre están descubiertos en Iglesia y Coro cuando está manifiesto el Sanctíssimo Sacramento y estubieren en parte donde se vea y lo mismo los que salen a decir las missas rezadas o cantadas. Siempre que está descubierto el Sanctíssimo Sacramento y no ubiere coro asisten en el Pavimento en Oración, Prebendados, Capellanes y Colegiales y cuidan que en la Iglesia aya mucho silençio, y ay declaración en la que Congregación de Ritos del año de 28 , que el predicador esté descubierto.

6. A las Vísperas primeras del Corpus no se descubre el Sanctíssimo Sacramento, mas está la Iglesia ricamente adornada como se dixo libro 1, Capítulo 13 y por el suelo mucha gayomba, flores y ramilletes por los altares. El día del Corpus toca el Campanero a levantar a las cuatro y media y todos van con sobrepellizes a la Iglesia, donde se tiene estos ocho días la hora de Oración Mental y de ella a las horas no ay intervalo, a las çinco y cuarto comienza a repicar para descubrir y duran dos o tres repiques con muy poca pausa hasta poco más de la media, a esta hora todos están en la Iglesia

[fol. $\left.425^{\mathrm{v}}\right]$

con sus sobrepellices, los Çeroferarios an ençendido y sacado toda la plata al aparador y la custodia cubierta con un Çendal blanco y los Versicularios puesto en el Coro los libros para las horas y los Comissarios adornan la Iglesia y la abre el Sacristán.

7. Al medio cuarto salen de la Sacristía un Turiferario con Turíbulo y naveta, los Çeroferarios con Çiriales encendidos, el Çerimoniario y el Çelebrante con estola y pluvial enzima de la sobrepelliz y el flavelario con la Salvilla y caxa de la llave y bolsa de corporales comienza a tocar el Órgano, llegan a la ínfima grada y hazen venia suben al altar y hazen genuflexión, el Çelebrante vesa, suben dos Prebendados asistentes, y el flavelario dexa la bolsa y llave y va a la Credençia y trae la custodia, el çelebrante 
desdobla el Corporal abre el Sagrario haze genuflexión saca el relicario, pone las formas del sol en el Corporal y cúbrelas con él cubre el relicario y buélvelo a encerrar, haze genuflexión, cierra el Sagrario, el Cerimoniario descubre la Custodia, el asistente abre el viril y la pone sobre el Corporal, el celebrante pone dentro el sol con las formas consagradas

[fol. $426^{\mathrm{r}}$ ]

hazen genuflexión y antes de cerrar la vidriera inçiensa de rodillas, levántase, haze genuflexión, da el Turíbulo y çierra el Viril y sube la custodia y pone en el dosel y las flores y ramilletes que ubiere, buélvese a la Sacristía donde se desnuda y buelven a la Oración.

8. En poniendo el Sanctíssimo Sacramento en el dosel, el que preside dize el himno Veni Creator Spiritu y después de la Oración del Spiritu Sancto dize la del Sanctíssimo Sacramento luego la de la Concepción y de los Sanctos y se tiene la hora de oración acostumbrada, los Çeroferarios adornan el altar y hechan flores por el pavimento que sacan en fuentes de plata a los tres cuartos de la Oración, el que ayuda a la missa de prima va a la Sacristía y saca el recaudo y compone el altar, en dando las seis y media, el Campanero toca el esquilón dos vezes a buelta y dexa con algunos golpes a lengua que es para entrar en horas y el que preside dize el psalmo Laudate Deum omnes gentes y la Oración actiones nostras etc.y se van al coro donde se dizen las horas con la solemnidad del día y el de la missa de prima sale y la dize con las genuflexiones devidas, de este modo se descubre, tiene la oración, dize la missa de prima y horas toda la octava.

[fol. $426^{\mathrm{v}}$ ]

9. Para la missa mayor, los Versicularios adornan el Coro con muchas flores y yerbas como para la nona y tercia de los días sobredichos, tocan a la hora ordinaria y dízese con las çeremonias y genuflexiones referidas libro 3, Capítulo 4, número. Ay Comunión general y en acavando la missa baxa el coro al Pavimento, donde se pone de rodillas more solito y los Caperos entran a tomar pluviales y salen cuatro Turiferarios, la Cruz con dos Çeroferarios, los cuatro Caperos, los Turiferarios suben al Pavimento, hazen genuflexión y cada dos se ponen en sus lados meneando los incensarios, la Cruz y Çeroferarios se van a la grada donde suelen, los Caperos se ponen de rodillas en medio del Pavimento, saca el Sacristán pluvial y pónelo al Celebrante que está al Cornu epistolae, quítale la Casulla y con los manípulos de todos tres la lleva a la Sacristía. Salen los luzernarios con hachas y velas enzendidas que reparten a los Prebendados y demás Clero, los Çetreros sacan el palio y lo dan a los Caperos.

10. El Diácono baxa el Sanctíssimo Sacramento y lo da al çelebrante como se a dicho, llegan los cuatro Turiferarios hazen genuflexión y se levantan y en pie se ponen en hilera junto a la peana abren y levantan los Turíbulos y el Celebrante pone

[fol. $\left.427^{\mathrm{r}}\right]$ 
incienso en todos cuatro y con uno inciensa el Sanctíssimo Sacramento, luego con el çendal puesto lo reçive de rodillas de mano del Diácono, buélvese al pueblo y los Diáconos truecan los lados por detrás del çelebrante y el Diácono a la diestra y el Subdiácono a la siniestra y ambos le sustentan los brazos, todos cuatro Turiferarios simul inçiensan hasta salir del Pavimento como se dixo en el Jueves Sancto, todos cuatro hazen genuflexión y los dos se quedan Turificando y se remudan como se dixo en el Capítulo 12 del Jueves Sancto, el Sacristán alza las lámparas del Pavimento y Crucero porque no estorben el palio lo cual haze en todas las proçesiones en que lo ay, ençiende en los altares.

11. Ordénase la procesión como se dixo en el Capítulo çitado y canta el coro el himno de Pange lingua a versos con el Órgano y acavado canta el de Sacris Solemniis, un Colegial en medio de ella seis u ocho pasos antes del palio va tocando una campanilla cada vez dos golpes y con pausas propoçionadas lleva la bolsa con corporales para poner en el altar donde se haze la estación, el flavelario va detrás del Çelebrante con el flavelo quitando blandamente las moscas y el Portero del coro haze señal a la torre. Cuando comienza la proçesión y repican hasta después de aver enzerrado, haziendo pausas breves

[fol. $427^{\mathrm{v}}$ ]

va la procesión por el lado de la Iglesia del Evangelio y pasa por delante del altar que está hecho debaxo del Coro que tiene la frente a la puerta y como van sin pararse pasan por el otro lado, mas los Turiferarios se quedan a los lados de la rexa meneando los incensarios, cuando está el palio delante del altar pasa el Çelebrante y se pone el Sanctisimo Sacramento como se dixo en el Capítulo 16 todos se hincan de rodillas y los que an pasado del altar se buelven a el y hincan de rodillas excepto el de la Cruz y los Çeroferarios Cántase el Tantum ergo inçiensa y dize la Oración Ut supra y en recibiendo el Çelebrante el Sanctíssimo Sacramento prosigue la proçesión al altar mayor , no se para, mas anda con mucho espacio y en llegando al altar encierran el Sanctíssimo Sacramento como se dizo libro 3, capítulo 8 y libro 4, capítulo 16 y encerrando la Iglesia quitan el altar de debaxo del coro.

12. A la tarde acuden todos a su tiempo a la Sacristía para vestirse a Vísperas y los prebendados a la Iglesia ençienden y hechan flores antes de abrirla y en andando el esquilón dos Vezes a vuelta, repica el Campanero para descubrir y salen y descubren el Sanctíssimo Sacramento como se dixo en su lugar libro 3, capítulo 8 y luego suben al coro donde se dizen las Vísperas y Completas con la solemnidad del

[fol. $428^{\mathrm{r}}$ ]

día y ceremonias ordinarias. Acavadas Completas vaxan al pavimento a asistir delante del Sanctíssimo Sacramento, a las cinco y media se visten los Çeroferarios y dos Turiferarios y el çelebrante pluvial y estola con sobrepelliz y en dando los tres cuartos en la torre repican y salen a ençerrar el Sanctíssimo Sacramento, la llave del Sagrario con su Salvilla la saca el flavelario por la mañana para descubrir y la dexa en el altar hasta que se ençierra que la buelve a la Sacristía y entrega al Sacristán que luego la 
ençierra porque nunca la an de dexar en el aparador de la Sacristía ni en la Credençia del altar, hasta que se ençierra que la buelve.

13. Todos los días de la octava se descubre y encierra Nuestro Señor a las horas que se an dicho con las mismas Çeremonias, dízense las horas con Compás moroso de doble mayor y especial cuidado de asistir en el Coro, las Vísperas son cantadas y ay dos Caperos sino es que es fiesta que pide más, toca el Órgano el 1, 3 y 5 psalmo, el hymno y magnificat, las Completas son en tono, si en la octava cayeren las Vigilias de San Juan y de San Pedro la missa de prima es de la Vigilia con casulla morada, la missa principal y las rezadas son del Sanctíssimo Sacramento, la mayor sin commemoración ni Evangelio de la Vigilia y las rezadas con ella y

[fol. $428^{\mathrm{v}}$ ]

Evangelio.

14. El Sábado a los tres cuartos de la hora de oración los Çeroferaros se visten y sacan recaudo para la missa de Nuestra Señora, la cual se comienza inmediatamente acavada la Oración y se dize more solito, a la tarde se dize la Salve en la Iglesia y acavada se viste el Çelebrante y sale a ençerrar, los días de San Juan y de San Pedro dentro de la octava se adorna la Iglesia y altares más que los otros días.

15. El día Octavo se haze la fiesta prinzipal, los Comisarios cuelgan el Pórtico y hazen el altar como se dixo en su capítulo y en estando los cuatro lados del Claustro cubiertos y desembarazados, la procesión ha de andar por ellos y ponen los altares ut supra, las primeras Vísperas de la octava se celebran con más solemnidad aunque no se repica, con ornamentos más ricos y compás más solemne ay dos caperos, el día 8 ay sermón, repica a la missa con solemnidad como doble, mas en lo demás es como de primera clase.

16. A las doze del medio día repica el Campanero con todas las campanas, con mucha solemnidad, tres repiques que duran media hora, antes de abrir la Iglesia adornan las puertas, rexas y paredes con ramos, ençienden en el altar y ponen algunas más velas y los Versicularios adornan el Coro con flores y gayombas con mucha curiosidad, a la

[fol. $429^{\mathrm{r}}$ ]

hora ordinaria tocan a Vísperas, repican como a las de primera clase, ay cuatro caperos y cuando anda el esquilón repican a desençerrar y salen y se haze como los demás días, las Vísperas se cantan con más solemnidad y las completas son cantadas, a las cinco y media comienzan ha repicar para la proçesión y los ministros acuden a vestirse a la Sacristía, cuatro Çeroferarios, cuatro Turiferarios, el de la Cruz, Pertigero, Caperos, Diáconos y Çelebrante aquellos toman pluviales ençima de las sobrepellices, los Diáconos sus Albas y Dalmáticas, el Çelebrante alba, estola y pluvial y todos tres sin manípulos.

17. En estando vestidos salen el Pertiguero, los cuatro Turiferarios, el de la Cruz y dos Çeroferarios, el Çerimoniario, los cuatro caperos, los otros dos Çeroferarios, el 
Subdiácono, Diácono y Çelebrante y todos se ponen en sus lugares como se hizo el día del Corpus. Sube el Çelebrante y Diáconos sacan los çetreros el palio y los luzernarios hachas y velas, baxa el Diácono el Sanctísimo Sacramento y ordenase la procesión $U t$ Supra y en el altar del Pórtico hazen la estación y si los Comissarios ubieren puesto otro debaxo del Coro haran allí otra y sale por la puerta prinçipal y el Órgano toca a Versos mientras está en la Iglesia la procesión, si es por el Claustro entra y sale por la puerta de la Concepción y haze las estaçiones en todos

$\left[\right.$ fol. $429^{\mathrm{v}}$ ]

los altares, buelve al mayor donde se encierra el Sanctíssimo Sacramento y se buelven a la Sacristía, los que están vestidos por el orden que salieron, y a la noche los comisarios asisten al quitar las colgaduras y altares, todo se alza y dobla con curiosidad y el Sacristán alza la plata y los ornamentos y adereza la Iglesia para el día siguiente conforme pidiere. En el día del Corpus y toda su octava y asimismo los días que está descubierto el Sanctíssimo Sacramento o avierto el Sagrario pueden estar en el coro en pie en todos los oficios, los que tubieren devoción de hazerlo.

\section{Capítulo 21. Del Ofiçio en el día de la Assumpción de Nuestra Señora.}

1. Este día es solemníssimo en esta Sancta Iglesia por ser la fiesta principal de la sagrada Virgen por tantos títulos Patrona y Señora de este Sacromonte y porque es la principal titular de esta Iglesia ay Sermón y Comunión general, los Prebendados comisarios cuidan de que la víspera, en la noche, aya muy buenos fuegos y se toque con solemnidad en la Torre, el Tesorero previene mucha junçia, flores y ramilletes para todos los altares, pone sobre las Urnas de las

\section{li}

[fol. $430^{\mathrm{r}}$ ]

Reliquias seis bugías que arden toda la tarde de Víspera y todo el día de la fiesta y en los altares Colaterales del Crucero arden en cada uno dos velas, los oficios se çelebran con la solemnidad que pide el día y en ellos no ay cosa especial que adbertir, a la tarde ay procesión solemne por Voto del Cabildo.

2. A las doze del medio día de la Assumpción toca el campanero a la procesión de la tarde y a las cinco y media comienza el repique para la procesión, luego acuden a la Sacristía a vestirse, los ministros y Prebendados de Ornamentos blancos, los Çeroferarios ençienden en el altar mayor seis velas en los Candeleros grandes, demás de las que arden sobre las Urnas a la Imagen de la Virgen, los Versicularios cuidan que aya en la Cueva de San Çecilio facistol y libro para cantar la antíphona y el Ritual para que el Çelebrante diga las Prezes y Oraçiónes y asimismo que en la Iglesia aya otro para cantar la antíphona y Salve, ambos ponen con paños blancos, el Sacristán adorna la Cueva de San Cecilio con muchas flores y juncia y el altar con ramilletes y cuatro velas que arden mientras dura la procesión, el çelebrante y Diáconos visten albas, dalmáticas y pluvial sin manípulos.

3. En estando todos vestidos salen el Pertiguero, Turiferarios, Çeroferarios, llevan en medio al de la Cruz y todos 
[fol. $430^{\mathrm{v}}$ ]

se van poniendo en sus lugares, luego sale el Colegio por sus antigüedades y se baxan al Crucero, luego salen los Capellanes y ponen delante del Colegio, luego los Prebendados y quedan en el Pavimento los más antiguos junto a las gradas como se dispone libro primero, Capítulo 3, Capítulo 5 de proçesiones, últimamente salen los Diáconos y çelebrante y antes de las gradas hazen venia y suben y el çerimoniario con ellos al pavimento y hazen genuflexión en la peana y todos los demás se hincan de rodillas, excepto el de la Cruz y çiriales, oran un rato espacio de dos Credos y sube el Turiferario y haze genuflexión y levántanse el çelebrante y Diáconos y ministrando el Diácono hecha al Çelebrante incienso en el Turíbulo y el Turiferario haze genuflexión y se baxa al Crucero junto y debaxo del púlpito de la Epístola.

4. Luego se levantan todos y el Sochantre entona el himno Te Deum laudamus el cual se canta en la procesión, que dicho el primer Verso comienza a andar por el orden que se a dicho, todos cuando se mueven de sus lugares hazen genuflexión al altar. Sale por la puerta prinçipal de la Iglesia, proceden con mucho espaçio mas sin hazer pausa, los Diáconos y çelebrante van las manos puestas, en llegando a la Cueva de San Çeçilio la cruz

[fol. $431^{\mathrm{r}}$ ]

y çiriales se quedan a la puerta y los Colegiales como van entrando llegan al altar los más modernos y así se van quedando en dos coros en medio y los Prebendados asimismo en dos coros y los cogen en medio, el celebrante y Diáconos pasan a la grada del altar y acavan de cantar, si no se a acavado el Te Deum laudamus, mas si se a acavado en la proçesión y comenzado otro himno antes de llegar lo dexan en el estado que está y todos se hincan de rodillas y el çelebrante dize las preçes siguientes.

Benedictus est Domine Deus Patrum nostrorum. R/Et laudabilis et gloriosus in secula.

V/ Benedicamus Patrem et filium com Sancto Spiritu. R/ Laudemus et super exaltemus eium secula.

V/ Benedictus es Domine in firmamento Çeli. R/ Et laudabilis et gloriosus est super exaltatus in secula.

V/Benedit Anima mea Domino. R/ Et noli obliuis ei omnes retribuciones eius.

$\mathrm{V} /$ Domine Exaudi orationem meam. $\mathrm{R} /$ Et clamor meus ad te veniat.

V/ Dominus Vobiscum. R/ Et cum spiritu tuo, el celebrante se levanta y dize Oremus y las tres oraçiones siguientes: Deus cuius missericordie no est in

[fol. $431^{\mathrm{v}}$ ] 
...numerus etc. la segunda. Deus qui Corda fidelium etc. la tercera, Deus qui neminem in te speranten nimis afligí permitis etc. las cuales con las preçes están en el ritual en la procesión Progratiarum actione, la última termina con Per Dominum nostrum Iesum Christum etc. y responde el Coro Amen y todos se levantan y canta el Coro la antíphona Conceptio tua Dei Genitrix Virgo y los Versículos Elegit eam Deus et preelegit eam y el Çelebrante la Oración famulis tuis.

6. En respondiendo Amen el Sochantre entona el Himno Ave Maris Stella y haciendo en este verso genuflexión al ay mageri, los Colegiales más modernos, que están juntos al altar, van saliendo por el arco de junto al que está al lado de la Epístola y siguen por el mismo orden, los Prebedandados y el çelebrante y Diáconos junto a la peana donde están se buelven las espaldas al arco del Cornu evangelio puestas las manos y bonetes mientras pasan los Prebendados descubiertos y los siguen los últimos, dan la buelta a la capilla y salen por el arco junto a la puerta del lado del Evangelio y buelven a la Iglesia y si se acava el himno Ave Maris Stella cantan

[fol. $432^{\mathrm{r}}$ ]

\section{O Gloriosa Domina.}

7. Entran por la puerta del Pórtico, la Cruz y Çiriales se ponen en la grada del Pavimento y el Turiferario debaxo de las lámparas y los Colegiales como van entrando llegan a la grada y todos se van quedando y después los Capellanes y Prebendados por el Cruzero y cuerpo de la Iglesia como cuando vaxan a la Salve, pasa por medio el çelebrante y Diáconos y sube a la peana de al altar donde hazen genuflexión y se levantan y acavado el himno que vienen cantando el Coro canta la antíphona de la Asumpción de Nuestra Señora Hodie Maria Virgo \& con su verso y el Çelebrante dize la oración Famulorum tuorum y en respondiendo el coro Amen toca el Órgano para prinçipio de la Salve como suele y en el ínterin el Turiferario delante, luego el de la Cruz acompañado de Çiriales, se van a la Sacristía y los Çeroferarios en dexando la cruz en la capilla de los mártires se buelven y ponen en las gradas del Pavimento junto a las aldavillas donde están de rodillas mientras se cantan la Salve, la cual entona el Sochantre en dexando el órgano y están todos de rodillas y acavada el Çelebrante se levanta y dize la Oración y acavada hazen genuflexión

[fol. $432^{\mathrm{v}}$ ]

y se van a la Sacristía, Pertiguero, Çeroferarios y Çerimoniario, Diáconos y çelebrante, antes de quitarse los collares y roquetes salen los çeroferarios a apagar las seis velas del altar y el Çirio blandón.

\section{Capítulo 22. Del Officio en el Día de la Commemoración de los Difuntos.}

1. El día de todos los Sanctos a las doze del mediodía da el Campanero tres Clamores pausados que duran media hora, el Caniculario y Sacristán ponen en el Crucero de la Iglesia un túmulo de media bara en alto sobre la tumba, con paño de brocado y dos almohadas en la Cabeza, con casulla y mitra rica, en el túmulo ponen los seis candeleros grandes con velas por los lados y doze hachas blancas, en la Cabezera del 
túmulo, sobre la grada del Pavimento, pone la Cruz mayor con çendal negro y a los pies en el arco Toral pone la cruz Arzobispal, en los altares tiene puestos de baxo de los blancos frontales negros y en la Sacristía prevenidas velas de çera común, los Çetreros y comitantes, en tocando a Vísperas, recogen las Capas negras

[fol. $433^{\mathrm{r}}$ ]

Canonicales de los Prebendados y llevan a la Sacristía y ponen dobladas sobre los caxones por el orden de las antigüedades.

2. A las Vísperas de los Sanctos se toca y dizen como la solemnidad del día y dicho Benedicamus Domino sin dezir Fidelium anima, baxa todo el coro de los Prebendados en Çeremonia por la Iglesia a la Sacristía, Pertiguero, Çétreros Çéroferarios, Comitantes, Çérimoniario, Prebendados, Caperos y celebrante. En dejando los Çíriales toman los Çèroferarios Collares negros, salen y quitan los frontales blancos, quedan los negros, ponen en los candeleros del altar velas amarillas ençendidas, dos Colegiales quitan de los otros altares los frontales blancos, los luzernarios ençienden la çera del túmulo, los Comitantes y çetreros visten a los prebendados las capas Canonicales, en la Sacristía, el Portero del Coro haze señal a la torre y comienzan a doblar y este día y el siguiente dobla como se dixo libro $2^{\circ}$ Capítulo 14 de Campanero, los Versicularios en el coro ponen los libros para las Vísperas de los difuntos y quitan el paño del façistol y déxanlo desnudo, los Comitantes llevan al coro estola y pluvial negro y ponen enzima de la silla del celebrante que está en el plano del coro.

3. Todo esto Prevenido salen de la Sacristía en ceremonia,

[fol. $\left.433^{\mathrm{v}}\right]$

el Pertiguero ropa negra, los Prebendados, de dos en dos comenzando los más modernos con las faldas de las Capas tendidas como pasan por el altar mayor hazen todos genuflexión, salen en tal distançia que no se embarazen con las faldas, van por sus coros, mas al salir del pavimento ajedrexado todos pasan por el púlpito del Evangelio que no cogen el túmulo, en medio en la puerta de la Concepçión están dos Comitantes que les dan las faldas y recogidas en los brazos suben al coro y estando todos en sus sillas se comienzan las Vísperas de difuntos, mientras dura este acto siempre doblan en la torre, las Vísperas se dizen como en el breviario y no se asientan hasta la mediación del primer verso del primer psalmo.

4. Al $5^{\circ}$ psalmo los Çeroferarios hazen venia y baxan a la Sacristía y se visten y toman Çiriales con velas amarillas ençendidas y por la Iglesia suben al coro con el Pertiguero, entran y con las debidas reverençias dexando los Çiriales en sus lugares, el Çelebrante entona la antíphona de magnificat y mientras se canta todos se sientan y el çelebrante baxa con las devidas reverencias al plano del coro y los comitantes le quitan la capa Canonical y ponen en su silla alta, pónenle estola y

[fol. $\left.434^{\mathrm{r}}\right]$ 
y pluvial negro y está en su lugar en pie, las manos puestas, mientras se canta el magnificat, cuando se repite la antíphona se sienta y cubre y los Prebendados acavada la antíphona se lebanta y clara voze dize Pater Noster y prosigue secreto, los Çeroferarios con las devidas reverencias, van por los Çiriales y se vienen al facistol del celebrante con ellos altos y los baxan en llegando al celebrante dize clara voze et ne nos inducas intentationem y R/ sed liberanos a malo y las otras preçes como en el breviario y a la oración lebantan los Çeroferarios los Çiriales y acabada dos cantores van al medio del coro al façistol grande donde cantan Requiescat in paze.R/ Amen.

5. Dicho secreto Pater Noster, con las debidas reverencias, se van Pertiguero, Çeroferarios, dos comitantes y en medio el Çerimoniario y el çelebrante: en el coro comienzan completas cantadas y no ay órgano al himno ni al Nunc Dimitis, y los de la Ceremonia en desnudándose buelven al coro con su capa canonical more solito, si el día de todos los Sanctos es Sábado, la commemoraçión de los difuntos se çelebra lunes y así todo lo dicho se haze el Domingo después de sus Vísperas.

6. El día de la missa de prima es de la infraoctava

[fol. 434 $\left.4^{\mathrm{v}}\right]$

de los Sanctos con casulla blanca y el altar mayor está de blanco mientras las horas y acabadas, los que apagan las velas, quitan el frontal blanco, queda el negro, la missa se dize como se dixo libro 3, Capítulo15 de missa de réquiem y acavada, el Pertiguero sube al coro a acompañar al Cabildo, el Sacristán saca Pluvial negro y lo pone al Celebrante en el Cornu epistolae y lo lleva a la Sacristía, la Casulla y manípulos, el Cruciferario sale y toma la Cruz y los çeroferarios baxan de sus lugares a acompañarla, el Cabildo sale por la capilla de los mártires detrás del Cruciferario y Pertiguero y de dos cetreros que sacan los cetros y se pone en dos coros y ordena la procesión como se dixo libro 3, Capítulo 5 de procesiones, número 10, y los siguientes, y los Çetreros se ponen de baxo de la grada, los primeros del coro, de donde van a su tiempo a dar los Çetros, el Turiferario moderno sale después de los Prebendados y con sobrepelliz saca el acetre de agua vendita y detrás del celebrante se va a lo último de la procesión.

7. La primera estación es en el Cuerpo de la Iglesia y se canta el responsorio Credo quod Redemptor meus vivit, en la segunda Qui Lazarum resusçitasti - en la $3^{\mathrm{a}}$, Domine cuando veneris iudicare, en la $4^{\mathrm{a}}$, liberame Domine De morte \& y el Hebdomadario en la primera estación dize

[fol. $435^{\mathrm{r}}$ ]

La Oración Deus qui inter Apostolicos Sacerdos, en la $2^{\mathrm{a}}$ Deus qui nos Patrem \& matrem, en la $3^{\text {a }}$ Deus Venie largitor, en la $4^{\text {a }}$ fidelium Deus omnium etc..

8. El Sochantre en todos los responsos poco antes del verso combida a los Caperos los cuales salen de sus coros con las capas Canonicales y los Çetreros hazen genuflexión al altar y vienen de sus lugares, con las devidas reverençias, dando cetros a los caperos que se ponen en el medio del coro y hazen genuflexión tomándolos, los Cetreros se apartan 
un poco entre los coros de los Colegiales, los Caperos dizen los versos con los çetros en las manos y acabados vienen por ellos los çetreros y dándoselos, todos cuatro, hazen genuflexión y se buelven a sus lugares, a todos los responsos los del coro están cubiertos, cuando al salir de sus coros para decir los versos se quitan los bonetes y hazen cortesía y los demás Prebendados les responden con la misma, los versos dicen descubiertos y al bolber a sus lugares hazen la misma cortesía al coro y los Prebendados a ellos, el celebrante y Diáconos nunca quitan los bonetes a estas cortesías.

9. Los Kyries se cantan a coros, de suerte que el coro de aquella semana dize el primero, y el otro coro el segundo y todos juntos el terçero, luego el Hebdomadario

[fol. $435^{\mathrm{v}}$ ]

dize Pater Noster, el Turiferarios da el hisopo al Diácono y él al celebrante, y el Çerimoniario le alza el pluvial del lado diestro y el Celebrante hecha tres vezes agua delante de sí, buelve el hisopo y el Colegial Comitante que tiene el libro que lo traxo del altar cuando se baxaron los de la missa, avierto por donde están las preçes y Oraciones, se pone delante del Çelebrante de suerte que lo alto del libro le llegue a la frente del que lo tiene y cantada la Oración lo cierra y se buelve detrás del celebrante al otro lado del que tiene el acetre.

10. En respondiendo a la Oración de la cuarta estación y cantado el verso Requiescant in paze el Sochantre entona la antíphona Si iniquitates observaris Domine y se dize toda entera, terçera abaxo, el Pertiguero se pone arrimado al pilar de agua, el Cruciferario y Ciriales llegan al caxón del testero y en la peana baxan la Cruz y Çiriales y se buelven de rostro a la procesión que como va entrando se queda en sus coros arrimados a los caxones Eregione y el çelebrante y Diáconos los últimos frontero de la Cruz, acaban así puestos el psalmo de profundis con Réqueuiem eternam, repiten la antíphona y luego el celebrante dize Fidelium anima per missericordiam Dei Requiescant in paze.

[fol. $436^{\mathrm{r}}$ ]

$\mathrm{R} /$ Amen y pasa con los diáconos cubiertos con las manos puestas y las cabezas baxas haziendo Venia y al pasar todos le hazen comedimiento quitando los bonetes, en llegando al bufete los Prebendados se van y ellos se desnudan etc..

En el Capítulo 14 que se sigue después del de abajo se dice cómo se hacen los oficios a tres y cuatro de Noviembre. Por los padres del Arzobispo mi Señor Y por los de los prebendados.

\section{Capítulo 23. Del Officio en el Dia de la Inmaculada Conçepción de Nuestra Señora.}

1. Este día es festivissimo en este Sacro Monte por ser como lo es el solar de la Concepción o archibo donde, desde el tiempo de los Apostoles, se an guardado las más autenticas scrituras y privilegios que ay por esta Verdad fuera de la escritura sagrada y por aver dado causa con su descubrimiento para que en toda Spaña y en todo el mundo 
se aya ferborizado la devoción de este misterio y crezido tanto la solemnidad con que oy se celebra.

\section{El Cabildo nombra prebendados Comisarios}

[fol. $\left.436^{\mathrm{v}}\right]$

con tiempo y demás del gasto de la fábrica que haze de flores y otras cosas, como suele en las fiestas de primera clase, les libra cantidad de dineros para que traigan música, hagan fuegos muy luzidos y acreçienten los olores, ramilletes y que más conviniere, límpiase la Iglesia y retablos para este día y la ropa blanca adereza el tesorero con especial cuidado

3. Ay costumbre desde que esta Sancta Iglesia se erigió de descubrir al Sanctíssimo Sacramento y como reçivida y asentada siempre se a observado y pareze aver sido prinçipio de la loabilísima costumbre que dizen los fieles siempre: Alabado sea el Sanctíssimo Sacramento y la Inmaculada Concepción de la Virgen María, madre de Dios Nuestra Señora sin pecado Original, ennoblece y acompaña grandemente esta fiesta la presencia manifiesta de su divina Magestad. Ay sermón y Comunión general.

4. Es Aniversartio por el Ilustrísimo y Reverendísimo Señor Don Pedro de Castro y Quiñones fundador de esta Sancta Iglesia en todos cuatro puntos, primeras Vísperas, maitines y laudes, missa de tercia y segundas Vísperas y a cada punto toman pluviales los Prebendados por su turno, celebra el Abad las primeras Vísperas, los maitines

\section{[fol. $\left.437^{\mathrm{r}}\right]$}

y laudes y la missa de terçia y en su ausencia, el Pressidente de la Casa y en ausencia de ambos, el Semanero como se haze en los otros días solennes y se dixo libro 1 Capítulo 11, De quien celebra. El Semanero dize siempre las segundas Vísperas, todos los Prebendados que no tubieren aquel día missa de tabla de otras dotaçiones y todos los demás capellanes y sacerdotes del Sacro Monte dizen missa por el fundador dotada en el mismo aniversario como consta de la escritura de fundación, missas de otras memorias solo se dizen este día las que son más antiguas que este aniversario y son las siguientes: La de Olalla de Rojas, la de los Cordoneros, la del Canónigo Pedro Gomez, la de María de Orozco y todas las demás que ay dotadas y adelante ubiere no se pueden decir aquel día y se dizen en el siguiente.

5. La Víspera de la fiesta se previene por el Thessorero el adorno de la Iglesia de suerte que no se dilate la hora de Vísperas, sino que puntualmente entren a las dos y media, dízense como se dijo en su Capítulo $1^{\circ}$, del libro 3, acavadas completas los Versicularios y los luzernarios adornan el coro para los maitines y ponen todo el recaudo neçesario, el Campanero en dando las cuatro toca solemnemente y a las

$\left[\right.$ fol. $437^{\mathrm{v}}$ ] 
cinco acaba con el esquilón a lengua e inmediatamente se cantan con toda solemnidad, libro 3, Capítulo3 de maitines. El Órgano toca el himno 1.3.4.6.7 y 9. psalmo y todos los de laudes, himnos y Cántico, los Responsorios toca el órgano, los luzernarios pueden poner por la Iglesia y Coro algunas imbençiones de luzes en señal de mayor festividad y alegria, lo cual todo recogen acavado el oficio.

6. El día de la Concepción se descubre el Sanctíssimo Sacramento antes de prima y después de Oración en la media hora, los Çeroferarios encienden y los demás previenen lo necesario y el que dize la missa de prima se viste para decirla y descubre el Sanctíssimo Sacramento y todos los Colegiales y Prebendados van a la Iglesia y en dando la media que dexa el esquilón, el Campanero comienza a repicar para el descubrir y el organista a tocar, salen y se descubre el Sanctíssimo Sacramento con las ceremonias y orden que se dixo libro3, Capítulo8, nº1.2.3. y 4 y los Prebendados van a la Iglesia

[fol. $438^{\mathrm{r}}$ ]

al coro a las horas, los çeroferarios y comitantes se entran en la Sacristía.

7. Después de la missa se ençierra el Sanctíssimo Sacramento, mas si ubiere jubileo de cuarenta horas que pida esté descubierto no se ha de ençerrar en todo el día y entonzes la Iglesia se queda avierta y Cuidan los Sacristanes que aya en la gente mucho silençio y que no coman ni beban en ella, lo mismo çelaran los Prebendados y Colegiales que asistieren en Oración, a las tres se entra en Vísperas.

8. Cuando su Sanctidad conçede los jubileos de cuarenta horas, el uno de ellos o si no fuere más de uno, ese se ha de señalar para la fiesta de la Concepción porque el tiempo pareze más conveniente y se a hecho así en los que se acabaron y en tal caso se manifiesta el Sanctíssimo Sacramento como se dize en el libro 3, Capítulo8, no 17.

\section{Capítulo 24. Del Offiçio de las onrras que se hacen por el Illustrísimo Fundador y por sus padres.}

1. A veinte de Diciembre del año de mill y

[fol. $\left.438^{\mathrm{v}}\right]$

Seisçientos y veinte y tres a las ocho de la mañana fue el fallecimiento y tránsito a mejor Vida de el incomparable Varon Ilustrísimo Señor Don Pedro de Castro y Quiñones, fundador de esta Sancta Iglesia por lo cual todos los años en el dicho día se çelebran sus honras y dichosa memoria y haze aniversario solemne.

2. El día antes que es diez y nueve del dicho mes en çerrando la Iglesia el Thessorero haze hazer un túmulo en medio del Cruzero alto como un estado el cual cubren de paños negros por todos lados que lleguen al suelo, encima se pone la tumba cubierta de brocado y en la cabeza dos coxines, la mitra rica enzima y una casulla en la tumba, por los lados se ponen los seis candeleros grandes con velas, doze hachas a la cabecera, la cruz mayor con çendal negro y a los pies el guión o Cruz arzobispal, ençiéndense las 
lámparas y para la Vigilia y missa arden en el altar seis velas, pónense frontales negros debaxo de los morados y en el Pavimento alto se pone una alfombra grande.

3. En dando las doze el Campanero comienza a doblar con todas las campanas y da tres clamores que duran media hora, en tocando a Vísperas los Versicularios llevan los libros del offiçio

[fol. $439^{\mathrm{r}}$ ]

de difuntos y los ponen al pie del façistol, breviario para las lecciones, los Comitantes llevan estola y pluvial negro para el çelebrante y lo ponen sobre el taburete que está en medio del plano donde suele, aunque no ay alfombra ni otro adorno, al $2^{\circ}$ psalmo de completas salen los luzernarios y çeroferarios y estos ençienden en el altar mayor y quitan el frontal morado y los luzernarios ençienden la çera del túmulo y quitan los frontales de los otros altares y siempre los que quitan el frontal del altar mayor después mudan el viso del color conveniente.

4. Acabadas Completas, el Portero del coro haze señal a la torre y el Campanero comienza los clamores con todas las campanas, los cuales duran hasta que se a acavado el offiçio haziendo entre uno y otro muy pequeña pausa, los Versicularios ponen los libros y en medio del coro, facistol alto con breviario para las lecciones y se comienza una Vigilia sin Invitatorio, conforme la feria que fuere, dóblanse las antíphonas y se cantan con mucha solemnidad, al fin del segundo psalmo los Çeroferarios, Cruciferarios y Turiferario hazen la reberençia devida y van a la Sacristía donde visten roquete y collares negros y los çeroferarios con los çiriales y velas enzendidas se buelven

$\left[\right.$ fol. $439^{\mathrm{v}}$ ]

al Coro con el Pertiguero delante hazen genuflexión y déxanlos en las aldavillas y se ponen en sus lugares.

5. El maestro de Çerimonias señala quien diga las lecciones, tres prebendados, la última dize el çelebrante que es el Abad y en su ausencia el Presidente, a los versículos del nocturno se levantan y el çelebrante dize Pater Noster, Y el çerimoniario combida al Prebendado de la primera lección, el cual baxa la falda de la capa tendida y con las devidas reberencias, libro 3, Capítulo 3, de maitines, la canta y se buelve a su silla. Al verso del Responsorio combida al segundo y el Abad para la terçera, y aviendo acavado la lección los comitantes le quitan le Capa Canonical y lleban a poner en su silla y le visten la estola y pluvial. No se dizen laudes y assí en acavando el $3^{\circ}$ responsorio el çelebrante en su lugar, en pie y puestas las manos dize Pater Noster los demás se hincan de rodillas y los Çeroferarios van por los Çiriales con las devidas reverencias, llegan al façistol del çelebrante y los baxan hasta que se an dicho las prezes y a la oración los tienen levantados y acavada los baxan, la oración es Deus qui inter Apostolicos Sacerdotes famulum tuum Petro fundatorem nostrum Pontificali feçisti Dignitate Vigere presta quesumus ut forum

[fol. $440^{\mathrm{r}}$ ] 
quoque perpetuo aggreguetur consortio Per Dominum nostrum Iesum Christum etc.

6. Dicho el último Pater Noster Secreto baxando todos del coro, el Pertiguero, los Çeroferarios, Colegiales y Prebendados por su orden y van a la Sacristía donde está el Turiferario con Turibulo y los Cetreros toman los Çetros, el Cruciferario toma la Cruz, que se ha llevado a la Sacristía del túmulo y los çeroferarios lo acompañan y salen en silencio por este orden de la capilla de los mártires, el Pertiguero, el Turiferario, la Cruz y Çiriales, los Çetreros, Colegiales, Capellanes, Prebendados, el çelebrante y detrás de él el otro Turiferario con açetre de agua vendita y un comitante con el libro para las Oraciones y al pasar todos hazen genuflexión al Sanctíssimo Sacramento.

7. El Cruziferario se pone en medio de la grada en la cabecera del túmulo y a sus lados los çeroferarios y los çetreros, los primeros de los coros como se dixo Capítulo 22, número 6. El Pertiguero baxo de la grada y púlpito del Evangelio, el Turiferario Eregione baxo del púlpito de la Epístola, el Clero pasa por ambos coros dexando en medio los Çeroferarios y túmulo, los más modernos se van quedando los primeros y los antiguos baxan abaxo de suerte que rodean el túmulo, el çe-

[fol. $440^{\mathrm{v}}$ ]

lebrante baxa el último y se pone en medio Eregione de la Cruz Arzobispal y a su lado diestro, algo desbiado, el çerimoniario y detrás de él, el del açetre al lado diestro y el del libro al siniestro.

8. Puestos en esta disposición el Sochantre comienza el responso liberame Domine de morte eterna y al verso combida, los Caperos y çetreros baxan y les dan los çetros como se dixo supra Capítulo, el día de los difuntos $n^{\circ}$ 8. Cántase el responso con mucha solennidad y cuando se repite la última vez Cum Veneris Iudicare el Turiferario haze genuflexión al altar y de su lugar viene adonde está el çelebrante, y da la naveta al Çerimoniario que la ministra a el Çelebrante, el cual sin quitarse el bonete hecha tres vezes inçienso en el Turíbulo, bendízelo more solito. Después del último Kyrie el çelebrante dize Pater Noster, y el Çerimoniario le da el hisopo, haziendo venia a la cruz, va al túmulo y llegando a la primera esquina del lado de la Epístola, el çerimoniario le alza el pluvial de la mano diestra y lo lleva alzado mientras se hecha agua, va delante del çelebrante aunque un paso al lado.

9. El Çelebrante hecha tres vezes agua por aquel lado, pasa por la cabecera del túmulo y al pasar por media haze genuflexión al Sanctíssimo Sacramento y venia a la Cruz lo cual observa

[fol. $441^{\mathrm{r}}$ ]

siempre en actos semejantes, alzado del Evangelio hecha otras tres vezes y a los pies del túmulo haze también genuflexión al pasar a la última vez que echa agua, llega el del açetre y reçive el hisopo y se buelve a la Sacristía y el Turiferario da el Turíbulo al Çerimoniario, el cual lo da al Çelebrante y alzándole el pluvial por el mismo orden y número que echó el agua Turifica el Túmulo, haze genuflexión al Sanctíssimo 
Sacramento y buelve el Turíbulo y con él se va el Turiferario a la Sacristía y el çelebrante se baxa a su lugar donde dize Et ne nos inducas intentationem $R /$ Sed liberanos a malo, el del libro se llega y pone delante como se a dicho. Por donde dize los versos y la Oración Deus qui inter Apostólicos Sacerdos etc. y cuando dize Réquiem aeternam dona eis Domine. Con la diestra haze la señal de la cruz sobre el túmulo y siempre observa lo mismo, los caperos en medio del coro con los çetros cantan Requiescant in paze $R /$ Amen, y entonando la antíphona Si Iniquitates observaberis Domine. Y el psalmo de profundis, alternatim, se entran en la Sacristía como se dixo supra, Capítulo 22, $\mathrm{n}^{\mathrm{o}} 10$. Los luzernarios apagan etc..

\section{En dando la Oración el Campanero da un}

$$
\text { [fol. } 441^{\mathrm{v}} \text { ] }
$$

clamor largo, de más de un cuarto de hora y el día siguiente, en dexando el esquilón para entrar en oración, da tres clamores que duran media hora y no dobla más hasta que se comienza la missa que buelve a sus clamores hasta que se a acavado el oficio, mas tiene cuidado de no dar ninguno desde que tocan a Sanctus hasta aver tocado la plegaria del alzar que sin tocar campana sola con todas da un clamor.

11. El día, acavada Nona sin decir antíphona De Nuestra Señora, se comienza la missa de terçia del día y salen para ella como se dixo en su lugar. a la hora ordinaria se toca a missa que es la del aniversario que por ser tan principal se dize a esta y se celebra como se dixo libro 3, capítulo 15, de missa de Réquiem, y acavada el Sacristán saca pluvial negro y lo pone al çelebrante more solito y todos los del coro baxan y por la puerta de la Sacristía entran en la Iglesia y se ponen por el mismo orden que el día antes y luego baxa el çelebrante y Diáconos pasan todos por el lado del túmulo Cornu epistolae y se ponen en lo último de la procesión.

12. El responso se canta y los Caperos con los cetros dizen el verso, el Çelebrante echa agua y Turifica el Túmulo de la misma suerte que el día

[fol. $442^{\mathrm{r}}$ ]

antes, excepto que el Diácono le ministra la naveta y hisopo y cuando rodea el túmulo para hechar agua y turificar, los Diáconos le acompañan alzando ambos cabos del pluvial y el çerimoniario se queda en su lugar. La oración es la misma y se entran en la Sacristía con el de Profundis como queda dicho y los luzernarios apagan la çera del túmulo y los Çeroferarios la del altar y quitan el recaudo, y encerrando la Iglesia, el túmulo, y las vísperas son del Apóstol.

13. Cuando el día Vigéssimo de Diciembre es Domingo este aniversario se transfiere al Martes y la Vigilia y responso se dize el lunes después de las Vísperas de Sancto Thomas.

14. El Aniversario por los padres del Ilustrísimo Señor fundador se celebra a tres de Noviembre si no fuere Domingo que se transfiere al lunes y así el día de la Commemoracion de los difuntos a las doze del día se dan tres clamores, el Túmulo que 
se haze no es tan alto como el de Veinte de diciembre y así se puede quedar el que se pone el día de todos Sanctos supra capítulo 22, números 1 y 2, mas se quita la mitra y Casulla y las almohadas de brocado se mudan y ponen a estotra parte de la tumba, como que tienen los pies del altar, como se ponen los lechos de los seglares, quítase también la Cruz Arzobispal

[fol. $442^{\mathrm{v}}$ ]

y la Vigilia missa y responsos, la çera los Clamores y todas las demás Çerimonias se celebran de la misma manera y con la misma solemnidad que se ha dicho en los números preçedentes, mas la Oración que se dize en la missa y responsos es (Deus indulgentiarum Domine etc. (la cual termina con per / xptus Dominum nostrum) así se terminan todas las de los responsos que se dizen en la Iglesia, (mas en los que se dizen en el coro con que se termina el oficio que se a hecho Vísperas nocturnos o laudes se terminan con per Dominum nostrum Iesum Christum qui te cum vivit et Regnat in unitate etc. y las que hablan con el hijo qui vivis et Regnas cum Deo Patre in únitate etc..

15. A estos Aniversarios ningún Prebendado puede faltar que no estén fuera de Granada, excepto los que estubieren ocupados en negocios del Sacro Monte y el que faltare es multado en dos reales por cada punto, los cuales se dizen de missas por difuntos en estos aniversarios çelebra el Abad estos: la Vigilia y la missa, y no se deve escusar sino por urgentísima causa y en su ausencia de Granada o enfermedad celebra el Presidente y en la de ambos (el Prebendado que se sigue en el turno de aniversarios porque este lo es y le tiene y al Cabildo señalada distribución al celebrante y Diáconos).

16. Todos los Prebendados de esta Santa Iglesia tienen

[fol. $443^{\mathrm{r}}$ ]

Obligación de decir en cada mes una missa por el Ilustrísimo Señor fundador y será conveniente que la del mes de Diciembre la digan el día que se hazen sus honras y así todas las missas rezadas que se dixeren en la Iglesia cuando se acaben dirá el Sacerdote un responso en el túmulo y el Sacristán pondrá todas las casullas y ornamentos negros y acetre en el túmulo.

\section{Capítulo 25. Del oficio en la muerte y entierro de los Prebendados y ministros de este Sacro Monte.}

1. En mandando el médico sacramentar al enfermo, se haga con toda diligençia y puntualidad, los enfermeros aderezan el aposento, hazen un altar muy curioso con manteles limpios y olorosos con dos velas ençendidas y alfombra, ponen un vaso de agua con su toalla para la ablución del enfermo, (otro vaso con purificador para que el Sacerdote se purifique los dedos) otra toalla limpia para el pecho del enfermo y si fuere Sacerdote una estola, encienden

$\left[\right.$ fol. $443^{\mathrm{v}}$ ] 
pebetes y pastillas y asisten allí hasta que se a acavado el acto, si el emfermo es Prebendado, el Abad le administra los Sacramentos, haze el ofiçio de la Sepultura y en su ausencia el Presidente, a todos los demás el Presidente de la casa y en su ausencia el más antiguo, para llevar el Sanctíssimo Sacramento al Prebendado, se juntan en la Sacristía todos Colegiales y Capellanes con sobrepellices y los Prebendados con su hábito Canonical y el Pertiguero con ropa negra, salen procesionalmente al altar del Sagrario y detrás el que a de llevar el Sanctíssimo Sacramento con sobrepelliz, estola y pluvial blanco, un çeroferario de la semana con la bolsa de Corporales, llave del sagrario y una Campañilla y el otro con el acetre de agua vendita y el Ritual Romano o el manual.

2. Antes de llegar, los luzernarios ençienden dos velas en el altar, las cuales arden hasta que buelve el Saanctissimo Sacramento a encerrarse y en llegando reparten velas ençendidas a todos los prebendados, Capellanes y Colegiales. El que haze el ofiçio haze la comfisión more solito, llega al altar y vésalo, desdobla los corporales, abre el Sagrario con las devidas reverenzias, saca el relicario y el Cerimoniario le pone un çendal sobre ambos hombros y con él toma con ambas

[fol. $444^{\mathrm{r}}$ ]

manos el relicario y dexa el Sagrario avierto hasta la vuelta. Van en forma de procesión, el Pertiguero delante los Colegiales y entre ellos, el que lleba la campanilla, tocándola de dos en dos los golpes y lleva la bolsa con los corporales, los Capellanes y Prebendados y el que lleva el Sanctíssimo Sacramento detrás del Açetre van diciendo a versos el Misserere y otros psalmos.

3. En entrando en el aposento del emfermo dize Pax huic Domus $R / E t$ ómnibus habitantibus ínea, pone el Colegial la bolsa sobre el altar y el Çerimoniario desdobla los Corporales, pone en ellos el relicario y haze genuflexión y todos los demás se hincan de rodillas, toma el hisopo y hecha agua vendita al enmfermo y çircunstantes y por el aposento diziendo la antíphona Asperges me Domine Hisopo et mundabor lavabis me et super nivem de albabor y el primer verso del psalmo Miserere mei, con Gloria Patri y repite la antíphona. Y luego dize Adiutorium nostrum in nomnei Domini con los demás versos y oración que está en el ritual página 79.

4. Haze las preguntas y el enfermo haze la protestación de la fee con mucho ferbor y devoción, luego pide perdón a todos los Prebendados y demás ministros de las faltas que a hecho contra la Charidad fraterna, del mal ejemplo que a dado y será conveniente ha personas de tanta virtud y

[fol. $444^{\mathrm{v}}$ ]

religión como los que viven en esta Sancta Iglesia que a todos los Prebendados los vese y abraze y todos llegan a cumplir con la devoción del emfermo, con mucho gusto y charidad, propia disposición para recivir y que se cree la última vez tan alto Sacramento. Hecho esto el enfermero pone la estola y toalla al enfermo, el cual con los çircunstantes dize con mucho espacio la comfissión y el Sacerdote misereatur y Indulgentiam, luego haze genuflexión, abre el relicario y saca una forma y elévala sobre el mismo relicario y 
muéstrala al enfermo y dize Agnus Dei Ecce qui tolit percata mundi, y tres vezes more solito Domine non sum dignus y aguarda que el enfermo diga las mismas palabras, dichas se allega y da el Sanctisismo Sacramento diciendo Accipe frater noster Viaticum Corporis Domini Nuestro Iesuchristi, qui te custodiat ab hoste maligno et perducat in Vitam aeternam Amen.

5. El Relicario buelve a poner en el altar y cúbrelo, purifícase los dedos sin dezir nada. El enfermero da la ablución al enfermo y el que administra de rodillas dize Dominus Vobiscum R/ Et cum spiritu tuo Oremus Dominus Sancte Pater Omnipotens aeterne Deus te fideliter deprecamur ut accipienti fratri Nuestro Sacro Sanctus Corpus Domini nostri IesuChristi filiy tui, tam Corpori, quam animae profit ad remedium

[fol. $445^{\mathrm{r}}$ ]

sempiternum qui tecum viuit et Regnat in unitate Spiritu Sancti, per omnia secula seculorum R/Amen, levántase y toma el relicario y con el haze la señal de la Cruz sobre el enfermo, sin dezir nada y por el orden que vinieron se buelven diciendo el psalmo laudate Dominus de Coelis y otros y llegando al altar el Sagrario, ponen los Corporales y sobre ellos el relicario haze genuflexión. Los demás de rodillas dize el verso Panem de Coelo prestitisti eis $R /$ omne delectamentum etc. y la Oración Deus qui nobis sub Sacramento mirabilis etc. y luego con el relicario la Cruz sobre el pueblo y lo ponga y ençierre en su lugar, los luzernarios recojan la çera y se buelvan a a Sacristía.

6. Si el enfermo no fuere Prebendado no acompaña el Sanctíssimo Sacramento el Cabildo, sino los Capellanes y todo el Colegio, mas todo lo demás se haze y elevar como queda referido.

7. Cuando el médico manda olear, los enfermeros aderezan el aposento, pongan una mesa con manteles limpios y en ella unos platos con siete pelotillas de estopa o de algodón, otro plato con migaron de pan y un vaso de agua con un lienzo para purificarse el Sacerdote, haze el oficio la persona que está dispuesto que dé el Viático con capa Canonical si fuere tiempo de ellas

[fol. $445^{\mathrm{v}}$ ]

y enzima estola morada, toma el vaso del Sacro olio que a de estar cubierto con capillo de seda morada y un luzernario lleva una hacha enzendida, el Cruciferario se pone un çendal morado sobre los ombros y con él, con ambas manos lleva una Cruz pequeña, acompañan cuatro Colegiales, los demás están en el aposento del enfermo. Si fuere prebendado está todo el Cabildo presente, Capellanes y Colegiales con el hábito del coro, si fuere capellán o Colegial o ministro asisten los capellanes y Colegiales como está dicho y será conveniente que asistan todos los Prebendados en cualquiera hábito que se allaren por la grande obra de misericordia y acto de Charidad que será grande en aquella hora y por el consuelo que recivirá el enfermo de que todos con sus oraciones le ayuden en aquel tranze; el Turiferario lleva el açetre de agua vendita y ritual Romano, salen por la puerta de la Sacristía y van al emfermo, entrando dize el Saçerdote Pax huic Domui R/ Et ómnibus habitantibus inca, pone el vaso del olio Sacro sobre la messa toma la Cruz y dala a vesar al emfermo, luego la rozia con agua vendita y al aposento in 
modo Cruzis y dize la antíphona Asperges me Ut supra, luego con palabras piadosas lo exhorta, consuela y prepara para recivir este

[fol. $446^{\mathrm{r}}$ ]

Sacramento, luego dize el verso adiutorium nostrum. In nomine Domine $R /$ qui fecit Çelum et terram. Dominus Voviscum P/ Et cum spiritu tuo, Oremus y las oraçiones Introe at Domine Iesu Christe. Ut in ritual o manual.

8. Luego se haze la comfisión general y la absoluçión missereatur tui indulgentiam etc. Y amonesta a los circunstantes que oren por el emfermo y diga los siete psalmos peniteçiales y las letanías en el interim que administra el Sacramento, acavada esta amonestación dize In nomine Patris et fili et Spiritus Sancti como está en el Ritual y lo unge y dize las prezes y Oraçiones Íbidem, buélvese a la Sacristía y el Sacristán quema las pelotas de algodón y migajón de pan y hechan las çénizas en la piscina y el Abad o Pressidente cuidan mucho que nunca falten al emfermo personas que le asistan en este tranze y que hagan todo lo que el ritual dispone en todo Visitatione infirmorum y cuando llegue al estremo se juntaran todos para hazer la recomendación del alma, tocárase para esto la campanilla de la Comunidad y lo mismo cuando an de juntarse para dar el Viático o el olio al enfermo y en espirando se dirá el responso sub Venite Sancti Dei. Todo como se dispone en el Ritual

[fol. $446^{\mathrm{v}}$ ]

o manual y se haga señal a la torre para que se doble con las campanas y a la hora que se expresó en el libro 2, Capítulo 14 de Campanero, número 6, conforme a la calidad de la persona difunta, vístenla conforme al estado. Al Sacerdote sobre vestidura talar, alba, amito, Cíngulo, manípulo, estola y planeta morada, al Diácono con estola y manípulo y Dalmática morada y al subdiácono con manípulo y tuniçela morada, al Colegial con manto y sobrepelliz y a todos se les pone bonete, al Sacerdote, Cáliz en las manos y a los demás Cruz, al Seglar con su mortaja y Cruz en la mano.

9. En estando vestido lo llevan a la Sala de Cabildo y lo ponen en su lecho sobre una alfombra y al Prebendado sobre un paño negro y le ponen cuatro hachas, a los Capellanes y Colegiales cuatro velas y a los otros criados dos y el Abad o Presidente señala quien asista y vele al difunto y llama a Cabildo para tratar del entierro. La hora será conforme a la de la muerte, de manera que pasen algunas que den seguridad de ella. El entierro se hará por el Claustro, estando los cuatro lados cubiertos y si no saldrá por la puerta de la casa por el compás y entrará por la puerta principal de la Iglesia.

[fol. $447^{\mathrm{r}}$ ]

10. En la cual los Sacristanes y Caniculario tendrán prevenido para poner el lecho del difunto en medio del crucero, para los Prebendados un tablado de más de media bara en alto, cubierto de paños negros, doze blandones para doze hachas. Veinticuatro candeleros para dos docenas de velas, seis en el altar. Para los capellanes y Colegiales pone una alfombra grande en el suelo sobre que se pone el lecho, seis blandones y ocho velas, cuatro en el altar. Para los criados pone una alfombra pequeña, cuatro blandones 
y seis velas y cuatro en el altar, pone todos los altares de negro y si es por la mañana, casullas para decir missa por el difunto.

11. Por los Prebendados y Capellanes se haze el oficio entero, invictatorio, tres nocturnos y laudes con sus responsos como se dispone en el ritual, por los Colegiales se dize un nocturno conforme a la feria y laudes y por los demás un nocturno con sus responsos. Adelántase el entrar en missa de terçia una hora, si a de ser por la mañana el entierro. De los difuntos de este Sacro Monte se entierran en las capillas del Claustro, en la de en medio los Prebedados en la de la mano derecha los Capellanes, Colegiales y Sacristanes y ministros de Iglesia y casa: los Prebendaods para entierro de

$\left[\right.$ fol. $\left.447^{\mathrm{v}}\right]$

Prebendados se ponen capas Canonicales aunque no sea tiempo de traerlas y con ellas asisten a los nocturnos y missa, no a los responsos del novenario a los otros entierros van con su hábito conforme al tiempo, al Prebendado difunto llevan Prebendados; al Capellán y Colegial, Colegiales con sobrepellices y bonetes, a los demás llevan Colegiales solos los mantos y bonetes y en todos los entierros los Colegiales llevan las hachas que an de arder al rededor del túmulo doze o seis o cuatro.

12. En siendo hora del entierro todos se juntan en la Sacristía y los luzernarios llevan a la Sala del difunto las velas y hachas necesarias. Vístense los Çeroferarios y Cruciferario roquetes y collares negros, el que haze el oficio, sobrepelliz, estola y pluvial negro. Salen por la puerta de la Sacristía al Claustro el Pertiguero con ropa negra, los çeroferarios con çiriales y velas enzendidas, el que lleva la Cruz con hasta y cendal negro y el Turiferario moderno con sobrepelliz con el acetre del agua vendita y el manual, luego el Clero por su orden y el último el celebrante. Van en forma de proçesión en silencio a la Sala, en llegando los luzernarios reparten las velas enzendidas y hachas y todos se ponen en dos coros alrededor del difunto, la Cruz y çiriales a los pies, el çelebrante a la cabezera y se canta

[fol. $448^{\mathrm{r}}$ ]

el responso Memento mei Deus con los Versos y Oración Tibi Domine Commendamus etc.

13. Luego se ordena la procesión del entierro a la Iglesia, el Pertiguero, Cruz y Çiriales, Turiferario con el açetre, el Clero por su orden en dos Coros y último el Çelebrante en medio que los cierre ambos, luego los de las hachas y luego el lecho del difunto y si fuere Sacerdote va delante del preste y las hachas después de los Capellanes. Comenzando a proçeder se cantará el psalmo ad te levavi animam meam etc. y se repetirá si se acavare antes de llegar a la Iglesia y en llegando a entrar en ella, se canta el responso Subvenite Sancti Dei y la cruz y çiriales paran en la grada del Pavimento baxo como suelen, el del açetre se queda junto a la puerta del Pórtico, los Colegiales y Prebendados se van quedando en dos coros y el último el çelebrante y se aparta un poco al lado diestro para dar lugar que pasen las hachas y lecho. Los que lo llevan se ponen en medio del Cruzero, si es sacerdote la cabeza al altar mayor y si no lo es los pies y los que llevan las hachas las ponen en los blandones y los luzernarios toman de las velas 
que an llevado los prebendados para poner alrededor del difunto las que an de ponerse según su calidad. Hecho esto el que haze el oficio se pone

[fol. $\left.448^{\mathrm{v}}\right]$

en medio entre los Coros frente del altar y Cruz y dize Pater Noster Secreto hasta $e$ ne nos inducas in tentationem $R /$ sed liberanos a malo. V aporta inferi $R /$ erue Domine etc. $\mathrm{y}$ si fuere Sacerdote V Sacerdotes tui etc. omitiendo el verso aporta inferi $V$. Domine exaudi orationem meam R/Et clamor meus ad te veniat V. Dominus Vobiscum $R / E t$ cum spiritu tuo. Oremus, con la oración Non intres in iuditio cum servo tuo etc. y si fuere sacerdote se dexa esta oración y se dize la que sigue Conçede quesumus omnipotens Deus etc..

14. Hecho esto, el de la Cruz la asienta y dexa en pie en medio de la grada. El Pertiguero Çeroferarios y Turiferario del acetre, Çerimoniario y preste entran en la Sacristía en donde se desnudan y si es por la tarde los Comitantes llevan el pluvial y estola al coro donde van los demás a hazer el oficio de difuntos conforme se declaró supra $\mathrm{n}^{\circ} 11$. Si es por la mañana cuando se comienza las laudes y si no las ay, mientras se dize el primer responso del nocturno, el Çerimoniario combida al preste y Diáconos avisa a los demás ministros y more solito vaxan por la Iglesia a vestirse para la missa, la cual se comienza inmediatamente acavado el ofiçio en el coro y se celebra como se dixo libro 3, Capítulo15 de missa de Réquiem y

[fol. $449^{\mathrm{r}}$ ]

dicho el Evangelio último, el Sacristán saca pluvial y lo pone al Çelebrante Ut martre est y se lleva a la Sacristía los manípulos y Casulla y los del coro procesionalmente baxan a la Iglesia y por la puerta de la Sacristía entran en la capilla de los mártires. Los luzernarios van dando a todos velas enzendidas, en el Pavimento van haziendo genuflexión y por sus coros, dexando en medio el lecho del difunto pasan y quédanse los modernos los primeros, después de los cetreros como se dixo Capítulo preçedente número 7. Luego sale el Cruciferario y Turiferario antiguo con Turíbulo y nabeta y el moderno con açetre de agua vendita si no estuviere vendita la sepultura, que si está no es necesario ni el el Turíbulo, mas si fuere difunto Sacerdote saldrán ambos. El Cruziferario toma la Cruz y al mismo tiempo los Çeroferarios con los çiriales altos baxan a acompañarla y pónense a sus lados, luego baxan el çerimoniario, el çelebrante y Diáconos y al pasar por el Pavimento baxo llegan y van con ellos, el del Turíbulo delante y el comitante con el manual y el del açetre detrás y van así a los pies del lecho y el çelebrante en medio de los Diáconos se pone frontero de la Cruz y altar.

15. Puestos en esta forma se entonará la antíphona Chorus

[fol. $449^{\mathrm{v}}$ ] 
Angelorum y se comenzará el psalmo In exitu Israel de Egipto. En comenzando a entonar la antíphona los luzernarios quitan las velas del túmulo y llevan a la Sacristía, los Colegiales que las traxeron toman las hachas y el lecho del difunto, los que lo traxeron y cantando el psalmo van a la sepultura Pertiguero, Çetreros Cruz y çiriales todos por su orden y último el Çelebrante y Diáconos y los otros ministros. Van al Claustro a la capilla donde se ha de sepultar, la cual tendrá el Sacristán aderezada, el altar con frontal negro manteles y cuatro velas y en la peana alfombra.

16. En entrando la Cruz y Çiriales paran en la pena del altar, los çetreros se ponen en las esquinas y el Clero por su orden, por las paredes los Colegiales y delante los Prebendados, si la sepultura no está vendita mientras se canta el psalmo In exitu y repite la antíphona Chorus Angelorum, el celebrante la bendecirá como está en el manual página 218. Acabada de bendecir y repetida la antíphona se entona el Responso ne recorderis: memento mei o otros y los Colegiales entran el difunto en la bóbeda y la çierran y el çelebrante dise los versos y oración y los caperos con su hábito Canonical y cetros entonarán Requiescant in paze $\mathrm{R} /$ Amen, y luego procesionalmente se vuelven

[fol. $450^{\mathrm{r}}$ ]

a la Sacristía por el orden que salieron, diciendo en tono la antíphona si iniquitates observaberis Domine y el psalmo de profundis, $3^{\mathrm{a}}$ abaxo y lo acavan y se despiden como se dixo en el Capítulo preçedente $\mathrm{n}^{\circ} 9$.

17. Cuando el oficio es por la tarde se haze todo lo dicho al fin del tercer responso, si se dize un nocturno sin laudes o al fin de las laudes cuando el oficio las pide de segundo a se dixo supra $\mathrm{n}^{\mathrm{o}} 11$ y entonzes después de la última lección el çelebrante se pone pluvial como se dixo Capítulo preçedente $\mathrm{n}^{\circ} 5$ para decir el responso, mas si se dizen laudes no se pone el pluvial sino para decir la oración con las mismas Çeremonias y al mismo tiempo que se dixo en el Capítulo 22 de la commemoraçión de los difuntos $\mathrm{n}^{\mathrm{o}}$, que se hizo a Vísperas. Acavada la oración baxan todos del coro Pertiguero, Çeroferarios y Clero por su orden y último el çelebrante y entran por la puerta de la Sacristía y Capilla de los mártires, donde los Çeroferarios se juntan con la cruz y los otros ministros están prevenidos y salen con las cosas neçesarias como se expresó supra $\mathrm{n}^{\circ} 14$.

18. Si el difunto fuere Sacerdote, todo el oficio se hará como queda dicho, la cabeza se pondrá al altar mayor, cántase el responso Ut supra $\mathrm{n}^{\circ} 13$, házese el ofiçio de Vigilia y missa conforme al

[fol. $450^{\mathrm{v}}$ ]

tiempo y acavadas las laudes o la missa cada cosa en su caso; baxan a la Iglesia y se ponen por el orden referido y el çelebrante con pluvial haze genuflexión al altar y reverenzia a la Cruz y pasa a ponerse a los pies del lecho frontero de la Cruz y altar, acompañando (si es después de la missa los Diáconos) el çerimoniario y siguiendo los Turiferarios, uno con Turíbulo, otro con el açetre y el Comitante con el manual, los luzernarios reparten velas enzendidas a todos. Sin quitar las que acompañan el lecho del difunto, al salir de la capilla de los mártires, como se dixo supra $\mathrm{n}^{\mathrm{o}} 14$, y puestos por el orden referido luego se entona el responso Credo quod Redemptor meus vivit y al fin de 
él, llega el Turibulario y more solito el Çelebrante ministrándole la Nabeta, el Diácono si lo ay y si no el Çerimoniario pone incienso y dicho el último Kyrie el Celebrante dize Pater Noster prosigue secreto hasta $E$ ne nos inducas intentationem $R /$ Sed liberanos a malo, luego el coro dize el psalmo Ad Dominum cum tribularen clamaui en tono terçera abaxo, y despacio y remata en Requiem aeternam, en comenzando el psalmo el çelebrante llega al hecho y haze genuflexión al altar, toma el hisopo y rodea el lecho rociándolo en cada lado tres vezes, luego toma el Turíbulo y de la misma forma lo Turifica haziendo siempre

[fol. $451^{\mathrm{r}}$ ]

que pasa por delante del altar genuflexión y reberençia a la cruz, todo como se dixo en el Capítulo preçedente números 8 y 9 . Acavado de incensarse se buelve a su lugar y los ministros también y entona Aporta inferi R/erue Domine aian eius. V/Requeuies cant in paze R/Amen y los demás versos y la oración Da nobis Domine Ut anima famuli tui. N.Sacerdotis etc.

19. Respondido Amen inmediatamente se entona el responso Ne recorderis peccata mea y al fin echa incienso y después del último Kyrie dize Pater Noster Y luego el coro entona el psalmo Levavi oculos meos in montes etc. y en el ínterin hecha agua vendita y turifica el lecho como se ha dicho y al fin dize los Versos y Oración Fac quae sumus Domine cum seruo tuo (Nombre Sacerdote) etc., luego se entona el responso Liberame Domine de morte eterna y se dize en tono el psalmo de profundis y se echa agua $\mathrm{y}$ turifica como las otras vezes y al fin dize los Versos y oración Inclina Domine aurem tuam etc. como se dispone en el manual y en respondiendo Amen, el psalmo In exitu Israel de Egipto y lo llevan a la sepultura y repetida la antíphona enpiezan el responso Iste recorderis verso y oración como se dispone en el manual, en el oficio de Sacerdotes folio 233 y de lo demás que queda referido supra números 15 y 16.

[fol. $451^{\mathrm{v}}$ ]

20. Cuando el entierro se ha hecho por la tarde, para la missa se pondrá lo mismo que se a dicho para el Cuerpo presente y para los Prebendados se pone sobre el tablado la tumba, para Capellanes y Colegiales se pone la tumba sobre la alfombra, y para los ministros de la casa alfombra y paño negro ençima sin tumba, el día siguiente sino fuere día de fiesta se dirá la missa y acavada tomará el çelebrante pluvial y todo el coro baxará a la Iglesia y entrará por la puerta de la Sacristía y se pondrá por su orden. Saldrá el Cruziferario que acompañarán los çeroferarios y los luzernarios repartirán velas en la Iglesia. Sobre el túmulo se dirá el responso liberame Domine, acabada la oración los luzernarios recogen las velas y apagan y la procesión se volverá derecha a la Sacristía diziendo en tono la antíphona Si Iniquitate y psalmo de profundis ut supra.

21. Si el difunto es Prebendado, el Sacristán dexará la capilla y altar aderezada nueve días y pondrá recaudo para decir missa y la Tumba cubierta con paño negro en medio de la capilla y cada día del novenario se dirá una missa rezada por turno de las que tienen obligación de decir y si algún prebendado tubiere missa de tabla dixela el que se sigue, demás de esto el Abad o Presidente cuide a todos nueve días se digan missa en ellas 
[fol. $452^{\mathrm{r}}$ ]

de las que los Prebendados tienen obligación de decir, que son todos los Sacerdotes presentes o ausentes del Sacro Monte, una missa rezada por Capellán, Colegial o ministro, por el Abad o Canónigos tres missas y los que no fueren Sacerdotes rezarán tres partes de rosario y oirán tres missas y los Diáconos y Subdiáconos rezaran tres nocturnos de difuntos y los mismos sufragios se haran por las personas del dicho Sacro Monte que murieren fuera de él, estando legítimamente ausentes en los casos que lo pudieren estar conforme a las constituciones y esto es disposición de la $\mathrm{S}^{\mathrm{a}}$ título 30 . $\mathrm{Y}$ por todos nueve días se le dirá un responso en esta forma, en acabando missa y en acabando Vísperas se haze señal a la torre y el campanero da dos o tres clamores largos. Baxa todo el coro y derecho por el Claustro va a la capilla donde los luzernarios an ençendido cuatro hachas sobre cuatro blandones y cuatro velas en el altar, en el ínterin llega el Semanero que se desnudó de la missa mayor y puestos por su orden se canta el Responso y el Sacerdote dize la Oraçión. Los días de primera y segunda clase no se dize este responso sino se transfieren al siguiente de suerte que se an de decir nueve días no impedidos con semejantes fiestas.

[fol. $452^{\mathrm{v}}$ ]

22. Al nobeno se dize una Vigilia y missa cantada y si es día de fiesta, el siguiente dirá la missa el que se sigue en turno de aniversario y el responso se dirá sobre el túmulo como se dixo supra $\mathrm{n}^{\circ} 20$ y dicho el responso en la Iglesia irán en proçesión a la capilla del entierro y dirá otro responso sobre la sepultura, sobre la cual tendrá puesta el Sacristán una alfombra y paño negro. Si el prebendado dexare dotado algún aniversario ante todas cosas se cumpla su voluntad en la disposición y se celebre como se dispuso en su lugar oficio de difuntos y todos los Prebendados tengan especial cuidado de decir con brevedad las missas de su obligación y el colector que sean antepuestas las que dexare mandadas decir en este Sacro Monte a todas las otras de Colecturía.

23. Si el Prebendado muriere fuera del Sacro Monte, luego que se tenga nueva de su muerte mandará el Abad doblar y se doblará todo aquel día desde que se save hasta la noche y cuando le pareciere al Abad juntará a Cabildo para tratar de las honras y señalado el día de la missa, la tarde antes se hará el oficio de difuntos después de Completas y entonzes comenzará a doblar el Campanero. Se dirán tres nocturnos y laudes

[fol. $453^{\mathrm{r}}$ ]

y en el Crucero de la Iglesia se pondrá túmulo y çera como se ha dicho, cuerpo presente sobre el túmulo, casulla en el altar seis velas, la cruz mayor a la cabecera.

24. Acavadas las laudes baxará todo el Cabildo y entrará por la capilla de los mártires donde los luzernarios darán velas ençendidas a todo el clero. Saldrán primero el Pertiguero, los çetreros con çetros, Çeroferarios y Cruciferario que tomará la Cruz y se juntarán como suelen el clero y el último, el çelebrante y detrás el Turiferario con Turíbulo y nabeta, otro con açetre de agua vendita y un comitante con el libro y puestos more solito se cantarán los responsos liberame Domine de morte aeterna y mientras se 
dize secreto el Pater Noster, el çelebrante hecha agua vendita y turifica el túmulo como se dixo en el Capítulo precedente números 8 y 9. Y acabado el responso en que se dize la Oración Deus qui inter Apostólicos Sacerdos etc. la Cruz y todos por su orden entran en la Sacristía canta la antíphona Si Iniquitates y psalmo de profundis ut ibidem.

25. El día siguiente después de Nona se dize la missa cantada y acabada, se baxa al responso de la misma forma que se ha dicho, en la torre doblan no más que mientras duran los oficios, házense nobenario de responsos, los cuales se dizen en

$\left[\right.$ fol. $453^{\mathrm{v}}$ ]

el coro al fin de la missa de terçia y al fin de las completas, la oración dirá en el responso de por la mañana el que presidiere en el coro y en el de la mañana el que presidiere en el coro y en el de la tarde del Hebdomadario; no abrá túmulo para decir estos responsos, pero el nono día se pondrá y se dirá su Vigilia y missa como si muriera en el Sacro Monte, a estas honras los Prebendados no toman capas Canonicales si no es tiempo en que las traen pero si las honras son de cuerpo que actualmente se traslada y reçive por aver mandado el Prebendado llevarse al Sacro Monte sepultura tan de estima, lo reçiviran con capas aunque no sea tiempo de traellas y el recibimiento se hará en esta forma.

26. El difunto ahora muera en Granada o lo trasladen de fuera de Granada se ha de traer de noche al Sacro Monte y subirá la litera por la cuesta primera y en el Compás, abrá un bufete cubierto de paño negro con cuatro hachas donde pondrán la caxa en la Iglesia, se pondrá el Túmulo como se dixo supra $\mathrm{n}^{\circ} 10$ y el Cabildo saldrá por él. Pertiguero, Cruz y Çiriales, el Clero por su orden y último el çelebrante, en llegando al compás los luzernarios reparten velas enzendidas y los Colegiales toman las hachas,

[fol. $454^{\mathrm{r}}$ ]

los Prebendados el cuerpo y se buelve la proçesión del entierro a la Iglesia y se haze el oficio de tres nocturnos y laudes y el oficio de la sepultura como se dixo supra $\mathrm{n}^{\circ} 18 \mathrm{y}$ 19 y el día siguiente la missa como queda referido, en los demás entierros de prebendados, el Campanero comienza a doblar aquella tarde desde que se acaban completas y duran los Clamores hasta hecho el entierro y el día siguiente dobla desde que se acaba de tocar ha horas hasta acabado el responso.

27. Si fuere translación traído de otra tierra después de días de su muerte que cuando se supo se le hicieron honras no se hará el novenario de responsos ni missa sino el ofiçio y entierro como queda referido en el número preçedente.

28. [Ilegilble] obligación de acudir al entierro ofiçio de sepultura [Ilegilble] dixesen por los Prebendados difuntos de esta Iglesia y el que [Ilegilble] de la Vigilia y entierro se le pongan cuatro faltas en el libro del punto [Ilegilble] 4 puntos antecedentes que ubiere ganado y si la missa fuere continuada con la Vigilia sea de baxo de una misma pena, pero si fueren puntos diferentes si se dixeren en dibersos días al que dexare de asistir a ella se le pondrán otras cuatro faltas en los cuatro puntosantes que tiene ganado y le 
[Ilegilble] se entiende en la Vigilia y missa que se dize en el fin del novenario y al que dexare de asistir a los Responsos por cada uno se le ponga una falta en la forma y que ninguno pueda faltar en ningún punto

[fol. $454^{\mathrm{v}}$ ]

de estos ni a los responsos, y que los maestros y los que estubieren ocupados dentro de casa aunque sea con licencia, ni se entienda que es la licencia para faltar de estos oficios y que para baxar ha Granada faltando de las Vigilias missas o entierro el Abad o Presidente tengan cuidado de no dar licençia para los negocios del Sacro Monte si no fueren tan graves y tan precisos que no se puedan dilatar para otro día, y que para los negocios propios de los Prebendados no se puedan dar licencia para ir a Granada si no es que quieran ir apuntándoles las faltas como arriba se señalan en las Vigilias, entierro y missas amonesta, a los enfermos no se les pone obligación mientras no estubieren actualmente en la cama no dexen asistir a estos oficios de los difuntos y particularmente al entierro y responsos y que la misma obligación de asistir y proporcionalmente con la misma pena tengan los Capellanes y Colegiales.

Item que para el novenario de missas rezadas que está dispuesto en esta consueta que se diga en la capilla del entierro se ponga en la tabla el orden de las missas y los que las an de decir.

En los entierros de los Capellanes y Colegiales y en todos los oficios de ellos aya la misma obligación de asistir que en los de los Prebendados y la pena sea la mitad de los que en estos se señaló guardándose la misma forma en señalarla en el libro del punto.

29. En Cabildo de 13 de agosto de 1633 se determinó que siempre el Celebrante y Diáconos tengan su distribución en las missas cantadas que se dicen o por los difuntos del Sacro Monte y que así a los que dixeren en la missa el día del entierro y el último día de el Novenario se les den de distribusión cosa por ser aquellas missas de las que tienen obligación decir según las constituciones. Item al preste se le pague la capa de la procesión del entierro, a los Diáconos no se les dé su distribución, conforme a ésto se an de entender el acto Capitular de $320 \mathrm{de} . . .$. y el $28 \mathrm{u}$ del mismo mes de....de 1.633 que tratan de lo mismo.

[fol. $455^{\mathrm{r}}$ ]

\section{Capítulo 26. De las Sagradas Cuevas y cómo se an de enseñar.}

1. Las Sanctas Cuebas, minas de tesoros Celestiales, donde el Apostol Sanctiago el Çebedeo hizo depósito de los libros y con su presençia y sacrificios consagró donde los Sanctos Mártires Cecilio, Hisçio, Thessiphón y Messitón sus discípulos vivieron, y celebraron el Sacrificio de la missa y los Sacramentos, donde murieron dando gloriosamente sus Vidas por la fee y sus reliquias y escritos tantos siglos se an conserbado para los nuestros, son las que hazen este monte, Sanctuario grande que todos deben Venerar y donde especialmente se emplea la devoción de los fieles que lo visitan y para acudir ha ella como se deve ha de aver persona señalada para mostrarlas en quien concurran con la Virtud ejemplar de este Sacro Monte, la prudencia y 
discreción que pide el ministerio para hazer la relación de todo el caso, venida de los Sanctos y descubrimiento de sus reliquias.

2. No se an de abrir ni mostrar en todas ocasiones mas el Sacristán o el Portero ha quien acudiere,

[fol. $\left.455^{\mathrm{v}}\right]$

la gente que las pide avisará al Presidente de la casa y si juzgaren conveniente el mostrar, las mandará a la persona dedicada ha esto que vaya y cuidará mucho que todos entren y estén con la deboción devida a tan Sanctos lugares, si fueren personas de satisfacción y todos de una casa podrá permitir que entren hombres y mugeres juntos como aya siempre de andar con ellos, los días de gran concurso están aviertas ambas puertas y en cada una un capellán o Colegial de guarda que no consiente que entren hombres y mugeres juntos sino una vez los hombres y otra las mugeres y no an de entrar los unos hasta que ayan salido los otros, entran por la puerta que está en la Iglesia de Sanctiago y saldrán por la de San Cecilio y para ésto el que está en aquella puerta ciérrela y entre llebando a la gente que salga por la otra sin que quede alguna persona y buelva a su puerta para que entren los hombres o las mugeres según los que an entrado antes.

3. El que enseña las Cuevas en casos y a personas particulares irá con ellos por la Cueva de San Cecilio y entrando todos, volverá a cerrar la puerta y hará que todos de rodillas hagan oración a Nuestra Señora y a los Sanctos y levantándose hará la relacion siguietse sin que

[fol. $456^{\mathrm{r}}$ ]

exçeda de ella cosa alguna. Que aquella Cueba se cree ser la Iglesia donde el Apóstol Sanctiago celebró y después los Sanctos mártires Cecilio y sus compañeros la tubieron por Iglesia propia que así se intitula San Cecilio, obispo Granatense que quiere decir de la Cueva de Saviduria y assí en ella predicó y administró los Sacramentos a los que se convertían a la fee y que la Capacidad y disposición de la Cueva formada en forma de Iglesia lo testifica y que en ella depositaron los libros y escritos que dexaron.

4. Llegándose al altar les mostrará las letras arávigas que están en el frontal y dirá que aquel es el idioma y forma de letra en que están escritos los libros y que aquellas letras dizen que a Maria no alcanzó el pecado Original, y por eso y aquel altar y Cueva está dedicado a la Inmaculada Concepción de Nuestra Señora.

5. Luego los entrará por uno de los Arcos del lado del altar y dará la buelta a la Cueva, les enseñará la piedra debaxo de la cual se alló el libro de Essentia Dei que estando baçiando toda aquella Cueva que estava terraplenada de arena y piedras, una niña acaso metió la mano debaxo de aquella y topó con un plomo

[fol. $456^{\mathrm{v}}$ ] 
y alzó la boz diciendo "ay que me he allado" y porque estava escura salió con ella toda la gente que estava de dentro y los Provissores del Arzobispo y como hasta treinta personas y saliendo a lo claro vieron el envuelto de plomo y una hoja grande que embolbía y guardava el libro de Essentia Dei en tres hojas de plomo escrito, del tamaño de una hostia poco más o menos y que de esta forma y materia son todos los libros aunque no de un tamaño el cual llevaron luego al Ilustrísimo Arzobispo.

6. Y aviendo salido a ver el libro sucedió una Ventura Verdaderamente milagrosa y fue que se hundio la Cueva y por eso no cogió ni hizo mal ha nadie que matara la gente si se undiera un poco antes y dando todos gracias a Nuestro Señor lo hizieron saber al Arzobispo, el cual mandó que se reedificase y hazer un muro grueso en que repara todo el Monte donde está la Cueva y se levanta desde el barranco hondo, para esta obra mandó el Arzobispo subir y aprovecharse de las piedras y desenvolver toda la tierra que se avía baciado, con esta ocasión se allaron en ella muchos libros y Nuestro Señor tomó por instrumento de su invención el intento de la obra.

[fol. $457^{\mathrm{r}}$ ]

7. Espeçialmente fue maravillosa la invención de tres de ellos, porque tomando un peón una piedra en la mano, de las que estavan en el barranco para echarla en el seron se abrió porque eran dos que estavan pegadas y en las cuales parecieron tres hoyos como quicios de puerta en cuyos huecos estavan tres libros, resplandeçe en esto como en otras muchas cosas de este descubrimiento la milagrosa providencia de Dios y que su magestad con su mano guíava todo este hecho, porque como esta piedra la sacasen con las otras de la Cueva y hechasen a rodar tan hondo el barranco abaxo se desunieran y cada una fuera por su parte y finalmente todo se desperdiçiara y perdiera si la piedra no se abriera, llegara entera a las manos del albañil, la echara en un cimiento o pared donde quedar sepultada y los libros ocultos para siempre, pues ni uno ni otro quiso Dios sino que se abriera para que los libros se descubrieran enteros y cabales.

8. Luego los llevará a la Cueva del fundamento y dirá como aquella piedra aguardava debaxo de sí el libro Fundamentum Eclessia, aquella puerta de rexa que está en la Cueva

$\left[\right.$ fol. $457^{\mathrm{v}}$ ]

del altar del Ecce Homo fue la entrada y prinçipio por donde se descubrieron las Cuevas, escogiendo Dios por instrumento para tan alto fin a unos ombres que buscaban un Tesoro en aquel lugar.

9. Íban cabando por donde llamaVa la tierra mobediza de que estavan llenos aquellos ramos y así se entiende según su disposición que aquí habitaban los Sanctos según la costumbre primitiba Iglesia que se juntaVan los fieles ha orar y ofrecer el Sancto Sacrificio de la missa en las Criptas y Cabernas de la tierra y para que quedase señal de Éstas y que no se arruinasen, el Arzobispo mandó calzar las paredes y hazer estos arcos y dexar juntamente descubiertos estos pedazos de techo que tenían. 
10. Luego dize que al cabo de muchos meses que acababan, hallaron en aquel sitio los hombres una

[fol. $458^{\mathrm{r}}$ ]

Lámina de plomo, de anchura de dos dedos poco más, y de largo dos palmos, en la cual avía escritas unas letras latinas muy dificultosas de leer por la estraña forma a que obligó el instrumento con que se esculpieron, la parte de la lámina escrita estava cubierta con otra parte de la misma para defender y guardar las letras, las cuales no entendieron ni açertaron a leer los que la hallaron aunque muy contentos, teniéndola por premisa çierta del Thessoro que buscavan, lleváronla a muchas personas que tampoco la acertaron, y últimamente a la Compañía de JESÚS donde la leyó el Padre Isidro Garçia y deçía "Cuerpo quemado de San Messitón mártir, padeció debaxo del Emperador Nerón", con lo cual visto que el Thessoro terreno que buscavan se avía trocado en celestial y divino fue llevada la lámina al Arzobispo, el cual luego se encargó de la obra y la prosiguió con extremada diligençia y gasto, y Dios que avía dispuesto su venida a este Arzobispado para poner esta obra en sus manos, viéndola ya en ellas, más liberalmente fue descubriendo otras minas que hazen relacion de los Sanctos Cecilio obispo y de Septemptrio y Patriçio sus discípulos, Hisçio Obispo de [falta] Turilo, Maronio, Panunçio y Çentulio

[fol. $458^{\mathrm{v}}$ ]

sus discípulos, Thessiphón obispo y de Maximino y Lupario sus discípulos.

11. Luego les muestra el horno de San Cecilio y haze de rodillas hagan oración levántase y dize como en aquel horno fueron quemados los siete Sanctos Cecilio, Thessiphón, Massiton, Septemptrio, Patricio, Maximino y Lupario, cuyas reliquias cenizas y partes de huesos se hallaron allí recogidas como que las avían puesto y juntado con cuidado y luego cubiertas de tierra, o ya que los fieles que las recogieron y pusieron las láminas, las cubrieron de tierra y arena y terraplenaron todos aquellos huecos para deshacer el rastro y memoria de Cuevas y así quedasen más inbiolablemente guardadas para el tiempo de la divina providençia o ya que con tan largo discurso de tiempo naturalmente con la tierra y arena que se desmoronava se ubiesen çerrado, lo çierto es que todo ello lo estava tanto que ni rastro ni señal de Cuevas avía, ni persona jamás las avía conocido.

12. Halláronse todas estas reliquias con un olor extraordinario y fragancia suavíssima que hasta oy conserban, indicio claro de su santidad que no pudo borrar la vezindad de la tierra y humedad en tantos años como estubieron envueltos con ellas, este mismo olor tienen los libros con ser de plomo y las cubiertas y piedras con que estavan

[fol. $459^{\mathrm{r}}$ ]

guardados.

13. Con el descubrimiento de estas láminas se declararon y confirmaron las reliquias que el año antes de 1.588, se hallaron en la Torre antiquísima Turpiana que derribaron 
para dar lugar al Edificio de la Iglesia mayor, Sábado día de San Ioseph a 19 de Marzo, cayó con las piedras que venían de lo alto una caxa de plomo alta de cuatro dedos y larga como un palmo en que se hallaron un pergamino escrito en varias lenguas, un hueso, un paño de lienzo cortado de esquina a esquina, en el pergamino una relación en lengua latina que deçía como era una propheçía de San Iuan Evangelista açerca del acabamiento del mundo, el hueso era de San Estevan primer mártir, y el paño la mitad de uno con que Dios y Señora nuestra, limpió sus lágrimas en la passión de su hijo sagrado Nuestro Redemptor IesuChristo, una Imagen de Nuestra Señora, guardáronse estas reliquias y no se acabó de averiguar si lo eran.

14. La Lámina que haze relación del martirio de San Cecilio, dize que comentó la Propheçía de San Juan que con otras reliquias está guardada en la parte superior de la inhabitable Torre Turpiana, con lo cual se conoció el nombre de

[fol. $459^{\mathrm{v}}$ ]

aquella Torre y se confirmó la Verdad de aquellas reliquias, y con esta correspondencia maravillosamente se comprueba la Verdad de las unas y las otras, siendo todo de tal suerte guiadas por la providencia de Nuestro Señor que se da la mano lo uno a lo otro, porque si no se ubieran descubierto las de la torre con la relación de la mina se hiziera diligençia para buscarlas y no fuera de provecho, porque no ubiera indicio entre tantas antiguas como ay en esta Ciudad, cuál era la Turpiana, quiso Dios que parecieran aquellas primero que fuesen premissas y prendas de las de este Sacro Monte y las unas se confirmasen con las otras.

15. Luego los llegará ha hazer Oración a la Cueveçita del lado del horno a la imagen de la Virgen Sanctíssima y dirá como en aquel lugar se ha apareçido Nuestra Señora y hecho muchos milagros en cuya memoria se ha puesto allí aquella imagen y que otros muchos an hecho los Sanctos en aquel horno, todos los cuales están comprobados en el proceso que se hizo para calificar las reliquias y cada día se experimentan muchos fabores de la protección de los Sanctos y de la Virgen María Señora nuestra y así en las rogativas y necesidades públicas se hazen procesiones a aquellas Sanctas Cuevas

[fol. $460^{\mathrm{r}}$ ]

16. [Ilegilble] el horno de San Hisçio y dirá la espeçial devoción que el Arzobispo y fundador Ilustrísimo de esta Sancta Iglesia y todos los de ella tienen con aquel horno, cuando se descubrió y se halló todo tan lleno de horrura y hollín como si el fuego ubiera sido muy reçiente y las piedras raxadas de la fuerza de él, indicio de haver sido grandíssimo. Halláronse las reliquias de los Sanctos Hisçio y los cuatro discípulos Turilo, Canario, Maronio, Centulio hechas unas massas de Çenizas a manera de las piedras que en la hoguera se convierten en Cal, efecto milagroso y que Dios Nuestro Señor lo ha usado con otros Sanctos mártires que an sido quemados, las cuales masas se conservan hasta oy con un olor celestial, cuando se descubrieron este horno avisaron al Arzobispo, y mandó que no llevasen a nada de él, y aquella noche a las dos de la madrugada vino con los criados de sus casas y entró en el de rodillas con gran devoción con sus mismas manos recogió en unas arcas todas aquellas Sanctas masas, solía decir 
missa en este horno con gran ternura y afecto y afirmava que eran lugares tan Sanctos que devíamos entrar en ellos de rodillas y la boca por el suelo.

17. Después de aver hecho oración en este horno, sacará la gente por donde entró y les dirá la grandeza de estos Sanctos, que estimados an sido siempre en la Iglesia Catedral pero aunque

[fol. $\left.460^{\mathrm{v}}\right]$

sus reliquias no se avían descubierto era manifiesta y conoçida su memoria: Cuanto les debe España por haver traido a ella el cuerpo del glorioso Apostol Sanctiago, y averla dado luz del Evangelio y Vida eterna con su predicaçión, de donde se an originado todos los vienes y Sanctos que goza y por aver sido la predicaçión de estos Sanctos tan temprana en España deve preçeder a todos los Reinos de la Christiandad.

18. Fuera ya de la Cueva de San Çeçilio les puede mostrar el barranco donde se hechava la arena y piedras que se sacavan de las Cuevas y donde avian caido entre ellas los libros y después de aver hechado esta tierra mezclada con tantas reliquias, jamás corrió avenida de agua que la arroye ni lleve de su lugar.

19. A las dudas que le preguntaren puede responder con satisfación y satisfaçer con discreçión, conforme queda referido, no dilatándose mucho, esto puede referir a las personas religiosas doctas o seglares que sean de calidad y capaçidad, porque a la gente ordinaria y común del pueblo no es necesaria tan larga relaçión. Vasta dezir cómo se allaron las reliquias, el martirio que padeçieron los Sanctos, los milagros que an hecho y otras cosas que los muevan a devoçión y reberençia.

20. Quando vinieren personas de mayor calidad

[fol. $\left.461^{\mathrm{r}}\right]$

y conocimiento el Abbad o Presidente emviará algún prebendado que les muestre las Cuevas, el cual, según las circunstançias, podrá alargarse en la relaçión, como los exámenes que se hizieron de las reliquias para hazer la calificaçión de ellas, que fue la más solemne que se ha hecho en nuestros tiempos, pues tardó el Arzobispo çinco años en hazer averiguaçiones exquisitas y comprobaçiones sólidas, dió muchas vezes cuenta de todo a Su Santidad, el Papa Clemente VIII. A la Magestad del Rey Cathólico Phelipe II- A su Consejo Supremo, y con vendiçión y de todos procedió a calificar las reliquias según que los Sacros Cánones y Conçilio Tridentino disponen, llamó y combidó para que se hallasen a ella los más insignes Prelados de España y muchos de ellos embiaron personas, y también los Cabildos Ecclesiásticos con las personas más doctas de la provinçia del Andaluçía y de esta Ciudad [tanto] Consejeros de esta Chanzillería como Prebendados y religiosos de todas las Religiones y los Prelados sufragáneos.

21. Y aviendo preçedido muchas oraçiones y rogativas públicas, muchos ayunos y limosnas, espeçialmente las que hizo el Arzobispo, fueron copiosíssimas, y aviéndose celebrado 
[fol. $\left.461^{\mathrm{v}}\right]$

privada y solemnemente muchas missas, después de averse visto y examinado el proceso con común acuerdo y con sentimiento de todos, pronunció la Sentençia de Calificación en que declaró ser los huesos y cenizas alladas en este Sacro Monte verdaderas reliquias de cuerpos Sanctos Mártires, de los que dizen las láminas instrumentos auténticos, la cual sentençia es la regla que la Iglesia tiene para admitir reliquias de Sanctos, y como suya no puede estar sujeta a falsedad, con lo cual cesan las dificultades que ubiere avido, es combeniente que sepan esto las personas graves y de calidad que visitaren este Sacro Monte porque muchos ignoran el hecho.

22. Si se ubieren de mostrar las reliquias, a de ser con lizençia y orden del Abbad o Pressidente, y a de ser en tiempo que no estén en los officios divinos, y es combeniente que sea después de aver visto las sagradas Cuevas, porque con el mayor reconoçimiento y reverençia que infunden aquellos Sanctos lugares, adore y venere las reliquias con mayor deboción. Lleváralos a la Iglesia donde esperan en el Pavimernto enlosado y dos Colegiales sacarán dos hachas y se pondrán de rodillas en los ángulos del altar: el del Cornu Epistolae más abaxo de la rexa, saldrá un Capellan con sobrepelliz, estola y Çendal Carmessí sobre los

[fol. $462^{\mathrm{r}}$ ]

hombros y los Prebendados con las llaves, haviendo hecho genuflexión al Sanctíssimo Sacramento, abrirá cada uno su puerta y los Colegiales avisarán a las personas que suban y se pongan de rodillas en la grada superior. El Capellán correrá la cortina y todos harán genuflexión a las reliquias, tomará con el çendal el hueso de la pirámide y lo dará a vesar a todos por el orden de Su Calidad y a todos los demás gente que llegare y últimamente a los Prebendados y personas de casa y cada vez que lo llegue dirá la antíphona Corpora Sanctorum in paze sepulta sunt et nomina eorum vivent in aeternum.

23. Después, conforme fuere la gente y devoçión, puede sacar uno de los cofres de las çenizas y el cofre de las masas de San Hisçio, y las aplicará de suerte que vean y conozcan vien esta maravilla, mas no será necesario que vaya poniendo a todos estos cofres sino a las personas de más cuenta, y les explicará cuyas y donde se hallaron aquellas çenizas y conforme a lo que refirió en las Cuevas buelve a poner las reliquias y todos hazen genuflexión, corre la cortina y los Prebendados çierran y se despiden y entran en la Sacristía.

[fol. $462^{\mathrm{v}}$ ]

\section{Capítulo 27. De las missiones y estilo que se tiene y se ha de guardar en ellas.}

1. La Junta de Asistentes señala todos los años algunos Prebendados y Capellanes que vayan â misionar por los lugares del Arzobispado, [a] los cuales determina los días que an de gastar en ella y por lo menos nombra tres personas, quinze o veinte días antes que ayan de ir, en los cuales cuida el Abbad o Pressidente de aliviarlos de las ocupaciones de la casa, que tengan tiempo de prevenirse de estudio para llevar hechas las pláticas y sermones y prinçipalmente de oraçión y recogimiento con que merezcan que Nuestro 
Señor les de luz y fervor para exercer con provecho grande de las almas tan alto ministerio.

2. Assimismo encargará el Abbad que todos los de casa en la oración y sacrificio de la missa encomienden a Dios muy particularmente esta obra, y los que van a ella y el Rector del Collegio aplicará por lo mismo los rosarios que los Collegiales rezaren. Es obra tan grande y de tanta gloria de Nuestro Señor y por la cual será servido de conserbar esta Iglesia y requiere tanto Spíritu, Verdad y Edificación que se â de tener por una de las prinzipales de esta

\section{[fol. $463^{\mathrm{r}}$ ]}

fundación y por lo mucho que le va, está obligada a poner en ella todo el cuidado que pide su grande importançia y que corra por cuenta de todos, y así que ayuden con oraciones y sacrificios; y para que personas de tanta religión y exemplo la comiensen como verdaderamente cosa Sagrada, se dispondrán conforme al uso de la Iglesia haziendo lo que sigue.

3. Uno, el más desocupado, a de dezir una missa el día que ubieren de partir, en la Cueva de San Çeçilio, en el altar de Nuestra Señora de la Conçepçión, ofrezida a Dios en onrra de su sagrada Madre, y de estos gloriosos mártires para que por su medio e interçesión les conçeda graçia y efficaçia para disponer las almas a su amistad y auxilios oportunos, para que salgan de pecado y pues como Suçesores y herederos del ministerio de estos sagrados mártires, que por combertir almas a Dios, dieron sus vidas. Se ofrezen a este ministerio sean también participantes de su spíritu y fervorosa charidad y en ella pedirán a Nuestro Señor lo mismo, después de ella dirán una letanía invocando todos los Sanctos de este sagrado Monte, y cuando fuere hora de partir, se juntarán en la Iglesia si estuviere çerrada ôo si avierta en el coro y de rodillas dirán el Itinerario de los Clérigos el que presidiere en ellos por más antiguo

[fol. $463^{\mathrm{v}}$ ]

y los demás responderán.

4. Partirán de suerte que lleguen al lugar primero donde van la tarde de vísperas de alguna fiesta, porque en ella se junta el pueblo y se les predica y dan notiçia de su ida. Llevarán la vendiçión del Prelado, sus casos y cartas para los beneficiados y curas que ayuden en lo que fuere menester para el buen suçeso de la missión y provecho de sus feligreses, procurando lo que fuere posible andar siempre juntos y no dividirse a lugares diferentes, sino en caso de que otra suerte no se pueda acudir a ellos y en los lugares que ubiere comodidad posar todos juntos, lo primero en la Sacristía o si ubiere alguna casa desocupada o en la que fuere gente de más satisfaçión y sin sospecha y en todo su modo de proçeder la darán de sí como los que llevan en crédito toda la del Sacro Monte.

5. En llegando al lugar, avisarán al benefiçiado o cura, darán cuenta de su ida, mostrarán las cartas de el Arzobispo, el que lleva a su cargo el gasto prebendrá posada y otro hará tocar la campana y con un compañero andará las casas del lugar avisando a hombres y 
mugeres que vayan a la Iglesia y lleven los niños y criados de su casa y en estando juntos se hará la plática con un exemplo que los mueva a dolor de sus pecados y hazer una buena confesión, encargándoles mucho se aprobechan de esta ocasión que por ventura estará en esos su salbaçión y diçiendo el poder que

[fol. $\left.464^{\mathrm{r}}\right]$

llevan del Señor Arzobispo para absolver y dispensa y acabada la plática se quedaran en la Iglesia para oir a los que quisieren confesarse y se aguardan para ir juntos a la posada.

6. El día siguiente, si fuere lugar mayor, abrá sermón en la missa enderazado al mismo intento y echará una Doctrina para la tarde a la cuala junten todos los del lugar, especialmente los niños y acavada la doctrina en la Iglesia se les dirá un exemplo. El rezo acomodan de suerte que no estorben las confisiones el dezir missa, de modo que toda la mañana duren para que comulguen los que ubieren confesado, al amanezer estén en la Iglesia, y el medio día alzen de mano, a las tres por la tarde buelvan y no excedan de las nueve de la noche, repartan la gente de suerte que los hombres que an de ir al campo a trabaxar se confiesen por la mañana o a la noche que no les estorbe su trabaxo y las mugeres y gente del lugar entre día y así se lo hagan saver en el púlpito.

7. Tengan especial cuidado de preguntar a todos la Doctrina Christiana y enseñarla a los que no la saven, guardar las buena crianza de los hijos y que les enseñen la Doctrina y que no juren ni echan maldiçiones. Si uviere en el lugar pecados públicos y escandalosos no salgan

\section{[fol. $\left.464^{\mathrm{v}}\right]$}

de él sin que queden remediados en todo los que les fuere posible, si ay enemistades las conpongan y reconçilien y de lo que no pudieren remediar hagan memoria para dar cuenta al Cabildo de esta Iglesia, consultando en él si fuere conbeniente dar noticia al Prelado. Si notaren en los Ecclesiásticos algo de esto, algunos descuidos en sus obligaçiones, abusos en sus ministerios, negligençias en el culto y limpieza de la Iglesia, de todo se hagan desentendidos y a nadie lo sinisiquen, mas al Prelado avisarán a la buelta, si pareciere al Cabildo aviéndoselo consultado, y en todo proçederán con tanta prudencia y circunspeçión que no den lugar a que se diga que van por celadores o visitadores de la Iglesia.

8. Oigan con mucha charidad las confisones generales y los que fuere necesario hazer por aver callado pecados y para esto animarán a los penitentes y façilitarán el trabajo y un día antes que ayan de partir se lo avisarán públicamente para que las gentes que quedan, acuda con tiempo y no se descuyde y de por pensar que an de estar mas días, mas no se partan sin que todos queden confesados y si quedaren algunos los conbiden que vayan al lugar donde desde alli fueren.

9. Este estilo se guardará en los lugares grandes y en ellos introducirán la devoción del Rosario de Nuestra Señora y así algunas noches los juntarán en la Iglesia y ençendidas 
velas en el altar los pondrán en dos Coros y rezarán con ellos el Sancto Rosario, luego les dirán un exemplo

[fol. $\left.460^{\mathrm{v}}\right]$

con que queden con más devoción a la Virgen Sanctíssima, enseñándoles que se valgan de su Soverana Magestad y Clemencia en todas sus necesidades, y dexarán muy encargado a los beneficiados y Sacristán que por lo menos, los días de fiesta se continúe este Sancto exerçicio.

10. En los lugares pequeños tanbién posarán y asistirán todos juntos, porque así los acavarán más presto y con más suavidad harán en ellos plática en llegando, y doctrina según la dispossición del tiempo y en todas partes con su exemplo y ferbor dexarán las almas encendidas de deseo de servir a Nuestro Señor y aborrecer el pecado. De un lugar a otro, si se pudiere, caminarán a pie por no ser cargosos a los vezinos y por imitar en algo a los Sagrados Apóstoles, y no pudiendo ir a pie, pagarán siempre las cabalgaduras y no las tomarán con violençia para no ser molestos en nada.

11. En el gasto y no reçivir nada, ni limosna para missas, obervan lo que manda la constituçión y la costumbre que siempre se a tenido y mientras andubieren en la missión no comerán gallina ni caza sino en casso de neçesidad, en volviendo al Sacro Monte derechos irán todos juntos a la

[fol. $\left.465^{\mathrm{v}}\right]$

Iglesia para hazer Oración y dar gracias a Nuestro Señor y si no fuere muy noche y van a las Cuevas y visitarán los lugares Sanctos, ofreçiendo a los Sanctos sus trabajos para que juntos con los suyos los ofrezcan a Dios, y haziendo muchos propósitos de servirlos en este ministerio y en lo demás de su casa, luego verán al Abbad ô Pressidente en su ausençia y luego en Cabildo darán cuenta de todo y después al Arzobispo como se ordena en las constituçiones, y el Cabildo encargará â uno de los que fueron a la missión que la escriba por extenso con todos los casos notables que allaren ô sucedieron que sean de edificación, el tiempo en que fueron, los días que gastaren, los lugares que andubieron, el fruto que se cogió, los Prebendados y Capellanes que iban y los que predicaron conforme al estilo que se da en el libro de las missiones, hecho para este efecto, para que los sucesores animados con el exemplo y relación que de todo se haze sigan los pasos de los primeros que tanto an trabaxado en este Sancto ministerio.

[fol. $466^{\mathrm{r}}$ ]

\section{Capítulo 28. Cómo se a de renovar el Sanctíssimo Sacramento en el altar del Sagrario todos los jueves.}

1.Se a de renovar el Sanctíssimo Sacramento todos los jueves en el altar del Sagrario, fuera del Jueves Sancto que será la renovacion el primo día de pascua, la noche antes el Sacristan pone frontal, alfombra, cuatro candeleros y Credencia con el demás recaudo y en la Sacristía Casulla y Roquete en el caxón frontero y lo demás necesario, así para la missa como para la Credençia, los días semidobles y ferias, blanco, que se a de dezir la 
missa del Sanctíssimo, los demás del color del día y ornamentos y todo debe ser como para fiesta de Segunda Clase, previene la hostia y formas en el Capillero de plata que an de aver y traido frescas y dos bugías con sus candeleros.

2. El Capiller del Colegio a la media de la oración sale a prevenir flores y adorna el altar para que esté todo aderezado antes de abrir la Iglesia.

[fol. $\left.466^{\mathrm{V}}\right]$

3. Dize la missa el Señor Prebendado que está señalado en la tabla y sale en Çeremonia con los luzernarios, al principio del último Psalmo de Nona, si no estubiere en el choro el Señor Prebendado le avisará el luzernario menos antiguo y en su ausencia su compañero para que venga al coro con tiempo para salir en Çeremonia, aunque esté en Partitur o en Recle o otra ocupación, si ubiere de dezir la missa; o al que se sigue en turno, entrarán por la Iglesia y en llegando a la Sacristía los luzernarios, sacan Cáliz que poner en el altar y una fuente, toalla, vinageras, buxías y pebetes y todo lo ponen en la Credencia y encienden las cuatro velas, el Custos Sacristiae previene a principio de nona los dos que se siguen a ayudar a missa más conformes, los cuales ayudan a vestir en el interin que los luzernarios ponen recaudo y salen a ayudar la missa el más antiguo, con missal y palmatoria de plata encendida y el otro con las formas en el Capillito de plata, cubiertas con una hijuela y en una salvilla y en ella la llave y la pone en la Credencia. El más antiguo registra y alumbra toda la missa con la palmatoria exçepto el Canon. Si no se ofreze alguna neçesidad, está de rodillas al lado siniestro del Sacerdote y le echa la toalla y el otro ministra lo demás.

[fol. $467^{\mathrm{r}}$ ]

4. Dicho el ofertorio lleva el moderno la salvilla de la Credencia con las formas y llave y la pone al lado derecho del Sagrario, que le abre el preste y encienden las bugías y pebetes y las ponen delante del Sanctíssimo, y a este tiempo comienza a tocar el órgano hasta aver consumido, que cierra el Sagrario y si ay quien cante se podrá cantar algo, para esto tiene prevenido el Intonario al Organista desde la noche antes, y a los Sanctus va por el pomo el moderno y le saca antes de alzar como en la missa de Nuestra Señora que tiene prevenido el Sacristán desde que sale de la missa y no se lo lleva hasta aver consumido.

5. Al consumir después de aver tomado el Sanguis saca el relicario y si ay quien comulgue de la Comunión, dé las formas antiguas y consume las que quedan y la hostia grande, y purifica los relicarios y pone las que de nuevo a consagrado, entra el relicario y inciensa tres vezes de rodillas more solito. Aviendo salido al principio de consumir el Turibulario menos antiguo y el lado de la Credencia se pone y aguarda para ministrar, acabado de incensar se cierra el Sagrario, apartan y apagan las bugías y pebetes y no antes y las ponen en la Credencia y se va el Turibulario

[fol. $467^{\mathrm{v}}$ ] 
a la Sacristía y çesa el órgano.

6. Al fin de la missa, abaxo de la peana, dize un responso rezado con la Oraçión fidelium fuerit de los días de fiesta por los padres hermanos y sobrinos del Señor Doctor Don Pedro Davila, Abbad de este Sacro Monte y los subcesores en los dos mayorazgos de sus hermanos y por las ánimas del Purgatorio que están más cerca de ver a Dios, y fueron más devotas del Sanctíssimo y de la Inmaculada Concepción de Nuestra Señora y del Arcángel San Miguel y del Ángel de la guarda y por la intención del Señor Abbad que dota estas missas, como consta del Cabildo de primero de Septiembre de MDCXXXIII y después de sus días en primer lugar por su ánima.

7. Los olores que se an de gastar en esta missa an de ser por cuenta del fundador, o, de otro que tuviera devoçión y no an de ser por cuenta de la fábrica.

[fol. $468^{\mathrm{r}}$ ]

Capítulo 29. El modo como se an de Çelebrar las Missas y responsos cantados los primeros lunes de cada mes, por las ánimas del purgatorio, según la intención del Doctor Don Pedro Davila Abbad de este Sacro Monte que las fundó y se admitió en Cabildo de 27 de Septiembre de 1633, en la forma siguiente.

Anse de dezir doçe missas cantadas de Requiem solennes con sus responsos los primeros lunes de cada mes, no siendo doble, ni haviendo dos missas cantadas que a de pasar al día siguiente no impedido en esta forma.

A los tres quartos de Oraçión se a de dar un doble solemne con todas las Campanas y otros dos correspondientes a los repiques de la missa de Nuestra Señora, hazer señal a lo último del cuarto de interbalo para entrar en ella.

An de asistir el Cabildo, Abbad y Canónigos Capitulares y Colegiales y se â de dezir en el altar mayor con solemnidad y Ornamentos de Segunda Clase. Después de alzar se an de dar dos dobles, y el último a de durar hasta acavado el Responso, conforme

[fol. $\left.468^{\mathrm{V}}\right]$

dispone la consueta en semejantes aniversarios y acabada la última oraçión de la missa an de baxar en la forma que el día de los difuntos a dezir el responso cantado en la Iglesia, Cabildo, Capellanes y Colegiales y saldrá delante la Cruz con çendal negro para el responso, con la ceremonia que suele y ponerse an en la forma acostumbrada en el cuerpo de la Iglesia, donde baxará el preste con capa y los Diaconos y llegando a su lugar después del Abbad y Pressidente se comenzará el responso general por las ánimas según el Ceremonial y dirá el Preste la Oraçión Fidelium y después de los días del Abbad que lo funda, otra Oración por su ánima y se irán con el Psalmo de Profundis a la Sacristía en la forma acostumbrada.

Dirán la Missa por el turno de aniversarios. Abrá de distribuçión diezisiete reales en cada Missa, que es uno mas de como fundó las missas de Nuestra Señora, porque an de llevar un Real cada uno de los Diáconos, y an de ser Canónigos, y cuatro el que dixere 
la Missa; uno para la fabrica, y diez de distribuçión a los que asistieren a la missa hasta acavado el responso.

Esta Missa se a de poner en el libro de memorias

[fol. $469^{\mathrm{r}}$ ]

y en el del punto con las de Nuestra Señora, por ser de un mesmo fundador. La cual es por las Ánimas del Purgatorio, y en primer lugar por la del fundador después que nuestro Señor fuere servido de llevarle, y por las de sus Padres, hermanos y sobrinos, y por los sucesores en los mayorazgos de sus hermanos Don Fernando Dávila, Veinticuatro de esta Çiudad y Don Antonio de Espinosa, asimismo veinticuatro, y por las ánimas del Purgatorio que estubieren más çerca de ver a Dios, prefiriéndose en este sufragio la que fue más debota de Nuestra Señora y del Sanctíssimo Sacramento y del Glorioso Arcángel San Miguel y del Ángel de la guarda y por la intención que aora tiene o tubiere el que funda esta memoria. Acavada la Missa buelven en çeremonia al coro como en la de Nuestra Señora.

Acavado el doble, con el responso, se toca el esquilón haziendo señal para entrar en prima como se haze en la octava del Sanctíssimo, que es lo que puede durar el subir al Coro de la Sacristía.

Y para que con más deboción acuda este Cabildo a ella y se anime y sea muy deboto de las ánimas de purgatorio y les ayuden con sufragios, ofreze desde luego perpetuamente la primera missa que se dixere

[fol. $469^{\mathrm{v}}$ ]

después de la muerte del Abbad o Canónigo que muriere de los que a la presente son o adelante fueren, para que la dicha primera missa sea sufragio para su alma con otra Oración por el tal difunto. Se a de dezir en primer lugar antes de las otras, no aviéndola menester la tal ánima â de ser por la intención dicha.

Y que si tubiere con qué, el dicho Abbad que hará este servicio a las ánimas y quisiere fundar otro ô otros lunes, se le admitan con las mismas condiciones, no haviendo otro del Cabildo que lo quiera fundar en las mismas condiciones.

[fol. $470^{\mathrm{r}}$ ]

El Licenciado Martín Bazquez Siruela, Canónigo de la Iglesia Colegial del Sacro Monte, el Secretario de su Cabildo, Çertificó que todo que todo lo que se contiene en este Libro de Ceremonias ô Consueta, dese el Capitulo XIII del libro $3^{\circ}$ que comienza en el folio 312, página $2^{\mathrm{a}}$, hasta el fin de este libro, que es en el $\operatorname{Cap}^{\mathrm{o}} 29$ del libro $4^{\mathrm{o}} \mathrm{f}^{\mathrm{o}}$ 469 , pag. $2^{\text {a }}$ hasta la mitad de ella, es la parte que vió y aprobó el Cabildo y que está conforme al borrador y que en cuanto a la otra parte que no vió el Cabildo sino los Señores Comissarios se hizo un decreto en tres días del mes de Noviembre de este año de 1633 que es en esta forma: Item se 
[fol. $\left.470^{\mathrm{v}}\right]$

determinó por mayor parte de votos que la parte de Consueta que vieron los Señores Comissarios en todo lo que estuviere rubricada de sus mercedes pase así y conforme a ella se saque la Copia que se a de poner en el archibo las demás y que sus mercedes den fee de que las Copias estan conformes a lo que vieron y pasaron mientras hubieron la comissión $=$ Así lo certifico y firme en el Sacro Monte a 18 de Noviembre de 1633 años.

Firmado y rubricado Martín Vazquez Siruela 



\section{APÉNDICE 2}

TRANSCRIPCIÓN DE LAS NOTICIAS MUSICALES CONTENIDAS EN LAS ACTAS CAPITULARES DE LA ABADÍA DEL SACROMONTE (1611-1799) 


\section{TOMO I}

\section{1}

[1] ASAC I, fol. $19 \mathrm{v}\left(i^{?}-\mathrm{X}-1610\right)$

Y puso así mismo el señor Abad que hay necesidad de un Sochantre que venga a servir al coro y una organista y órgano o realejo. Y se decretó que se busquen y se les señale salario competente, para que como capellanes sirvan, demás del cual salario, han de comer y dormir en el monte y tener los demás aprovechamientos y que todos los canónigos y hagan diligencias en esto.

[2] ASAC I, fol. 27 r (28-I-1611)

Y puso asimismo la necesidad que había en la iglesia de asientos para el coro y se decretó se hiciese en tres escaños de espalda y 4 bancos para el media y se cometió al señor don Pedro Dávila que los mande en hace.

Y puso asimismo que había necesidad de un fascista en y de un candelero de tinieblas.

Por lo puso asimismo que había necesidad de tres pasionarios nuevos toledanos apuntados y de un breviario de media cámara y de un Martirologio grandes de los modernos y cometió su al señor don Pedro de Ávila que los haga traer de fuera.

[Fol. $29 \mathrm{r}$ ]

El Sr. Pedro de Ávila puso la necesidad que tiene la iglesia de un Sochantre y a todos pareció que era muy necesario y se les cometió a los señores don Pedro el buscarlo y de avisar de lo que hubiere para el próximo cabildo.

\section{ASAC I, fol. 31 r (20-IV-1611)}

Este dicho día de los dichos señores capitulares habiendo tratado entre sí de dotar algunas fiestas en esta iglesia, acordaron que cada uno señalase la fiesta que tocaba y la cantidad en la que la dotaba a la que se escribiese en este libro. Y en cuanto a la cantidad de la dotación se determinó y acordó por todos los dichos señores que la dotación fuese de 2000 maravedíes para los interesantes a vísperas y para las fábricas dando la acera necesarias para las de las vísperas y misas de cada fiesta 11 reales y seis maravedíes y así en esta conformidad todos señalaron cada uno su fiesta en esta manera.

El señor don Agustín Manrique presidente señaló la fiesta de la Natividad de nuestra Señora para que en la misa del dicho día y segundas vísperas los señores prendados que estuviesen presentes gane en los dichos 2000 maravedíes por mitad en la misa y vísperas y por ratas en cada punto de los dos que son como esta dicha misa y vísperas segundas. 
El señor Ruiz de Ayala señaló la fiesta de la dedicación del glorioso arcángel san Miguel que es a los 29 de septiembre (...).

El señor Andrés Sarmiento señaló la fiesta del apóstol San Andrés para que en la misa cantada y en las segundas vísperas del dicho día ganen de distribución de los dichos 2000 maravedíes.

El señor don Bartolomé de Torres señaló la fiesta de la Ascensión de nuestra Señora.

El señor don Juan de la Fuente señaló la fiesta del glorioso patriarca San Joseph.

El padre Andrés de Velasco señaló la fiesta de la Santísima Trinidad.

El señor don Pedro de Ávila a señaló y dotó de interés ni maravedíes la fiesta de la Concepción Inmaculada de la Virgen Santa María nuestra Señora en tres puntos cada uno de a 1000 maravedíes para los señores canónicos intereses interesen interesa que son 1.. Los maitines de la dicha festividad que se han de decir a la oración. Otro punto la misa cantada del día y otro. Las segundas vísperas del dicho día.

El se ni el dicho señor don Pedro Dávila señaló asimismo y dotó la fiesta de la resurrección de nuestro Señor Jesucristo, que por su devoción quiere que se hagan en esta iglesia y para su dotación señala 2000 maravedíes que los dichos señores canónigos interesantes ande ganar en:. El primero y que sean los maitines y procesión que ha de andar alrededor de la iglesia con el Santísimo Sacramento y el segundo. En una misa cantada que luego se ha de decir el mismo día.

El señor don Francisco de Barahona señaló y de otro dos fiestas y en cada una de distribución para los dichos señores canónigos 2000 maravedíes en: que son misa cantada y segundas vísperas. Las fiestas son la una del bien aventurado Martín S. Laurencio en su mismo día y la otra del glorioso padre San Francisco en la forma dicha.

Todas las cuales festividades arriba dichas los dichos señores canónigos dotar un en la forma dicha y con condición que los que adelante vinieren no puedan ganar ni ganen las dichas distribuciones si no fuere dotando otra tal fiesta con la cálida que las de arriba lo está y así lo decretaron en el dicho su cabildo con lo cual se feneció.

ASAC I, fol. 41 v (14-IX-1611)

Que por ser mucha la correspondencia de puertas y ventanas de esta casa y estar muy continuada la iglesia y coro con los dormitorios de lo que hay necesidad muy grande y de que no se hable en la puerta del coro ni en las de los aposentos que están en el tránsito de el sino que los señores de re prebendados que tienen 
aposentos en el dicho tránsito se entre en sus aposentos a hablar y cierren las puertas para que así no se oiga en la iglesia ni en el coro.

1612

[5] ASAC I, fol. 49 v (19-II-1612)

Propuso el señor presidente si era conveniente que junto al coro se pusiese una lámpara para que alumbrase el tránsito de el y que está asistiese toda la noche y pareció a la mejor parte de todos los dichos canónigos que era conveniente y así le cometieron al señor canónigo Merino la hiciese pones.

\section{[6] ASAC I, fol. 50 r (20-III-1612)}

Propuso el señor presidente que era conveniente poner en las barandillas del coro cortinas y aún que algunos de los señores capitulares les pareció no ser necesarias, a la mayor parte pareció ser y así le cometieron al señor canónigo Antonio Merino comprase lienzo para las dichas cortinas.

[7] ASAC I, fol. 50 v (10-IV-1612)

Ítem propuso que atento que el arzobispo nuestro Señor envió órgano de Sevilla y manda en sus constituciones halla organista que lo toque pareciendo a propósito Juan de Oñate por haber ya experimentado su suficiencia era bien le admita el cabildo y así por parecer de todos fue admitido, y les fue señalado de salario 9000 maravedíes y aposento comida y todo lo demás perteneciente a su sustento y curarlo estando enfermo: juntamente todo el cabildo en conformidad se le recibió por colegial a Hernando de Oñate su hijo atento que sabía cantadas y tenía las demás partes necesarias.

[8] ASAC I, fol. 50 v (27-IV-1612)

Propuso asimismo que sería bien corregir los libros de canto que han hecho para el coro. Cometiósele por parecer de todos a los señores canónigos Agustín Manrique y Bartolomé de Torres y sus mercedes así lo admitieron.

[9] ASAC I, fol. 53 v (21-VIII-1612)

Propuso el señor canónigo Ayala que había muchos días que estaban hechos y guarnecida has unas palabras de consagración y un rótulo de Hic est chorus para poner en el coro y que por no estar doradas no servían y hacía en muy gran falta particular las del coro, y que o se tratase de dorarlas luego, o que sirviesen sin dorar: por el que al presente la fábrica no tenía dineros para que se dorasen. 
Pareció a todos los susodichos señores canónigos sirviesen sin dorar por algunos días mientras había orden de dorarla.

Propuso el señor presidente que era necesario poner en perfección la Consueta de las ceremonias que se señalase en dos o los que parecieran necesarios para acabar el y por comisión se cometió al señor D. Pedro de Ávila que sólo las acabase como quien más noticia de ellas tenía por haber ejercitado mucho tiempo el oficio de de maestro de ceremonias, su merced lo aceptó.

1613

[11] ASAC I, fol. 60 v (30-IV-1613)

Propuso el señor presidente que los aniversarios que hacen cada uno de estos señores siempre son en los días festivos y ocupados y de muchas confesiones y que es inconveniente que se digan en aquellos días dos misas cantadas una la conventual y otra la del aniversario, que se diese un medio para ello. Y se determinó por la mayor parte que si la misa del aniversario el señor cuya fuere quisiere que se le diga cantada que señale día dentro de la octava desocupado en que se diga y si no que la misa de la fiesta sea la conventual y se diga una misa rezada por el señor del aniversario y que no haya dos cantadas.

\section{ASAC I, fol. 61 r (14-V-1613)}

Propuso el señor canónigo Bartolomé de Torres que solía hacer su aniversario el día de la Ascensión de misa y nona, y la distribución de estos dos juntos era 2000 maravedíes y que en el cabildo pasado 30 de abril se determinó que por que no se ocupasen los días solemnes con dos misas una en tono que era la conventual y otra cantada solemne que era la de aniversario el señor canónigo cuya fuese la fiesta señalase otro día de la octava en que se dijese la misa, o que se dijese rezada por su intención y que la conventual fuese la cantada solemne que suplicaba se e tuviese por bien mudar la misa cantada que aquel día en las primeras vísperas de San Bartolomé dejando la nona de este dicho día que la Ascensión dotada en los mismos 1000 maravedíes que la tenía y que estas primeras vísperas de San Bartolomé las dotaba con capas y las segundas las capas en esta forma que el presidente tenga de distribución tres reales en cada una de las vísperas y los dos caperos cada dos reales en cada una de las vísperas. Y que señalaba para la distribución de vísperas y capas 1500 maravedíes y el señor presidente mando se saliese del cabildo para tratarlo como es costumbre y ver si tenía algún inconveniente y el dicho señor canónigo Torres se salió y tratado entre todos los demás señores que quedaron pareció por la mayor parte que no tenía inconveniente alguno y que antes era aumento del culto divino y así se determinó se aceptase esta dotación y se aceptó y se llamó al dicho señor canónigo Torres y se le dijo como se había aceptado y determinado que se hiciese de la manera que se había pedido . 
[13] ASAC I, fol. $61 \mathrm{v}(21-\mathrm{V}-1613)$

Propuso asimismo el señor presidente que convenía se hiciese una campana entre siete y ocho quintales para que hiciese música con las demás que estaban hechas y un esquiloncillo para llamar al coro de un quintal, y otra campanilla de 2 arrobas para los actos de comunidad atento a que no había metal sobrado de la fundación pasada, y la comodidad de el campanero en casa, y así se determinó por parecer de todos los presente señores.

[14] ASAC I, fol. 62 r (2-VII-1613)

Propuso el señor presidente que Francisco del Corral organista con orden de estos señores había servido desde el 25 de mayo de este dicho año que fue la vigilia de Pentecostés y que se había tratado de darle cada año 8000 maravedíes y de comer todos los días que estaba obligado a tañer por tarde y mañana y otros del verano que tiene que tañer a las primeras vísperas que por que no venga con el sol de la siesta también se le da de comer viniendo por la mañana y aunque esto estaba a así tratado y concertado no se había recibido por cabildo y que convenía se recibiese por ser suficiente para el tal oficio. Y que corriese el salario desde el dicho día que empezó a servir y a todos pareció bien.

[15] ASAC I, fol. 63 r (18-VIII-1613)

Asimismo propuso el dicho señor presidente que Gregorio Núñez le habían traído de Sevilla para el oficio de Sochantre, llamado por el señor don Pedro de Ávila canónigo y por orden y parecer de todos estos señores y que había servido de es de principio de agosto para que se experimentase si era suficiente para el dicho oficio, que se determinase si quedaría en el y que salario se le daría y todos conformes determinaron se recibiese por ser suficiente y de buena voz y se le señalaron 500 reales en cada un año pagados en tres tercios y casa, comida, médico y botica, Barbero y lavandera y que gozase desde primeros de agosto que empezó a servir el dicho oficio de Sochantre.

[16] ASAC I, fol. 64 v (2-IX-1613)

Propuso el dicho señor presidente que en cabildo que se hizo en 20 días del mes de abril de 1611 para mayor gloria de Dios y del culto divino y todos estos señores habían dotado fiestas cada uno escogiendo la de su devoción y que algunas de ellas por se en fiestas principales que hay gran concurso de gente y muchas confesiones por decirse la misa de de tercia en tono y la del aniversario cantada con toda solemnidad se gastaba el tiempo y no se podía cumplir bien y con las confesiones que le parecía que las inconveniente que se dijesen en tales días, y acordaron que se llamase a cabildo para otro día que fuese desocupado y hallándose los señores que en este estaban se vería más de propósito y se determinaría. 
Asimismo a se propuso que de los aniversarios así de estos señores canónigos que se hacen cada año como de los que otras personas hacen se le debía señalar al Sochantre parte y en cada un tuviese de distribución. Y todos acordaron que era bien se le señalase, y para determinar cuando ha de ser se remitió a otro cabildo.

[18] ASAC I, fol. 67 v (29-IX-1613)

Asimismo propuso el dicho señor canónigo Sancho y Ruiz de Ayala que él había tenido a su cargo, el metal y cuentas de las campanas y todos los gastos de ellas, que tenía ajustadas a las dichas cuentas que señalase en estos señores quien se las recibiese y conforme a todos nombraron por contadores para estas cuentas a los señores licenciado Bartolomé de Torres y Dr. don Pedro de Ávila, canónigos y con esto se acabó este cabildo y de ello doy fe.

[19] ASAC I, fol. $68 \mathrm{v}(20-\mathrm{X}-1613)$

Asimismo se propuso que de los aniversarios así de estos señores canónigos que se hace cada año como de los que otras personas hace se le debía dar al Sochantre parte en la distribución. Y todos acordaron que era bien se le señalase y para determinar cuanto ha de ser se remitió a otro cabildo.

Propuso el señor presidente si se había de señalar de los aniversarios algún estipendio al sochantre o capellanes y se acordó por la mayor parte que por ahora que hay capellanes al sochantre se le diese un real de cada aniversario y que cuando hubiese más capellanes se determinaría lo que más conveniente fuese en esto y en lo demás.

\section{ASAC I, fol. 70 r (23-XI-1613)}

Asimismo propuso el señor presidente como don Fernando de Quiñones mayordomo mayor del arzobispo mi señor con una inscripción de su señoría y sus seis ilustrísima y por su mandato venid de Valladolid y traía cuatro cuerpos de padre y madre y abuelos y hermano del dicho arzobispo mi señor y que la instrucción decía se entregasen al Abad y cabildo del dicho sacro monte y que para que se diese testimonio de la dicha entrega se habría llamado a la Rodríguez notario y escribano de su majestad y que aguardaban para los entregar. ordenaron los dichos señores entrasen y se hiciese lo que el dicho señor arzobispo mi señor mandaba y entró el dicho don Fernando de Quiñones y el dicho notario y el licenciado Juan de Estrada y el licenciado Martín Ruiz y el M ${ }^{\circ}$ don Paulo de Valencia presbíteros por testigos y en presencia de todos abrió el dicho don Fernando una caja negra aforrada en baqueta y clavazon negra y en 
cuatro apartados traía en cada uno una calavera y los huesos que cada cuerpo de por sí con sus cédulas escritas el nombre de cada uno de los dichos señores del padre del dicho arzobispo mi señor decía Cristóbal Vaca de Castro mi señor y otra muy señora doña María de Quiñones su madre otra el señor don Antonio de Castro su hermano y otra el señor García de Castro su abuelo, los cuales entregó $\mathrm{y}$ con juramento afirmo ser los cuerpos de los dichos señores referidos y haberlos sacado en su presencia de los sepulcros donde los depositaron y haberlos traído con mucha guarda y recato y en presencia de todos los dichos señores del cabildo no adquirió y testigos. S se llevaron en la misma caja cerrada con su llave y se entraron en la bóveda debajo del pavimento del altar mayor y la cerraron con su piedra volviéndose a el cabildo.

\section{4}

Propuso el señor presidente si se le daría el órgano del Sacromonte a Juan Bautista que de presente sirve en este ministerio las fiestas y días que le llaman y qué salario se le daría. Tratose de ello y remitiose para otro cabildo.

[23] ASAC I, fol. 75 v (2-V-1614)

El licenciado don Paulo de Córdoba y Valencia canónigo de esta Santa Iglesia y propuso que él tenía devoción en hacer fiesta y aniversario cada año a la conversión de San Pablo que es a veinte de enero y que este año y con beneplácito de todos los señores canónigos le había hecho el mismo día. Que suplicaba al señor Abad y cabildo acepten este aniversario y ofreció de limosna y estipendio a la misa y segundas vísperas y sacristía setenta reales que se repartiesen en el modo y manera que en el y los demás se acostumbra, como en los aniversarios que los demás señores hacen. Todos los dichos señores canónigos aceptaron el dicho aniversario mandando se celebre y reparta el estipendio en la manera y en las condiciones que en otros cabildos se tiene de presente, una de las cuales es que no lo ganen los enfermos, ni los que no hacen aniversarios sino los señores que estuviesen presentes, excepto los que estuvieren confesando o en misiones.

Y asimismo propuso el señor canónigo Juan de Estrada otro aniversario el día de San Juan evangelista con misa y segundas vísperas. Y el señor canónigo Martín Ruiz a otro aniversario el día de San Martín obispo ofreciendo cada uno de limosna y estipendio 70 reales para los aniversarios y asistir a misa y segundas vísperas. Aceptose por todos los señores canónigos con las mismas condiciones que el de arriba de Don Paulo de Valencia que de los setenta reales sede 11 y 6 a la sacristía y lo demás se reparta y distribuya en la manera que en los demás de los señores canónigos se hace.

El señor don Pedro de Ávila dijo que su merced tenía devoción y quería hacer servicio a Nuestra Señora de que en su Capilla de la Cavernas se dijese todos los 
sábados una Salve cantada. A la cual asistiesen Sochantre, capellanes y colegiales /

(76v) entre los cuales se distribuyesen 3 reales cada sábado y asimismo su merced pondría la cera para ese año. Todos los señores canónigos agradecieron mucho este servicio que se hacía a Nuestra Señora en este Sacro Monte y aceptaron y mandaron se siguiese por este año que corra desde hoy dicho día con la distribución dicha, la cual se hiciese de la manera que el señor Don Pedro ordenase de que ofreció dar un memorial. Y pasado este año se trataría si convendría aceptarlo en adelante y el modo en que se distribuya la limosna y estipendio que para ello se dejare.

\section{ASAC I, fol. 79 v (14-VII-1614)}

Propuso el señor don Pedro de Ávila presidente que el licenciado Gabriel Medrano y que hoy esta en el sacro monte como huésped, vino de Sevilla por mandado de el arzobispo de Sevilla mi señor recibido con capellán del coro de esta santa iglesia del sacro monte. Que ha estado en el algunos días que si les parecía a los señores canónigos que era a propósito para el dicho ministerio. Votaron todos los dichos señores serlo y así mandaron que fue se recibido y le recibieron desde luego por tal capellán del coro guardando en todo las constituciones de este sacro monte.

Últimamente propuso el señor Presidente que Juan Batista organista que ha servido en el Sacromonte seis meses atrás pagándoles cada venida de por sí, pretende se le asigne salario, que si parecía se le diese y qué cantidad. lo cual visto le recibieron por tal organista y señalaron que salario 10.000 maravedíes en cada un año con condición de que se le ha de ponerse multa y poner pena al arbitrio del señor presidente las veces que faltare en la cuantía que a su merced pareciere.

\section{ASAC I, fol. 82 r (1-VIII-1614)}

Propuso el señor Don Pedro de Ávila, Presidente y canónigo de esta Santa Iglesia que su merced tenía devoción que se dijese en este sacro Monte en la Capilla de Nuestra Señora a mano izquierda del altar mayor Salve a nuestra Señora todas las Vísperas de las nueve fiestas de Nuestra Señora, cantada y con el acompañamiento y distribución que tiene dotada para este año para que se dijesen los sábados en la Capilla de la Concepción, pero quería que éstas se dijesen en la Iglesia y dotarlas en cuatro reales cada una y la de la Víspera de la Concepción de Nuestra Señora en ocho reales, y si hubiere organista entre en distribución como uno de los capellanes, y por este año se aceptó por el cabildo y señores del para los dichos días en la manera de la que se dice en ella en la capilla de la concepción y que se tome la razón de esto en el libro de los aniversarios de los colegiales con día, mes y año. 
Propuso el señor presidente como en este Sacro Monte está el $\mathrm{P}^{\mathrm{o}}$ Gregorio Núñez en el oficio de Sochantre, hombre virtuoso y que acude bien a las obligaciones de su oficio, que no está ordenado de orden sacro, ni puede por no tener patrimonio o capellanía congrua, que si parecía para que se pudiese ordenar que el salario de quinientos reales que el Sacro Monte le da fuera de la comida en cada un año se le perpetuase por toda su vida en esta manera y con estas obligaciones: que él se obligue de no pedirlo si no fuere sirviendo el dicho oficio en el Sacromonte y de no dejarlo ni salir del Sacro Monte si no fuere teniendo otro tanto de renta y el Cabildo del Sacro Monte también se obligue de no se lo quitar mientras él no tuviere otro tanto. Con lo que se podía ordenar el dicho $\mathrm{P}^{\mathrm{o}}$ Gregorio Núñez y que así mismo el $\operatorname{lic}^{\circ}$ Gabriel Medrano tiene una capellanía en este Sacromonte de treinta y cuatro ducados de renta fuera de la comida, que era hombre virtuoso y muy buen teólogo si parecía se perpetuase la dicha capellanía en la misma forma para que con ella se pudiese ordenar. Lo cual visto por todos los dichos Capitulares mandaron se otorgase escritura perpetuándoseles el dicho salario y capellanía con las dichas condiciones. Mandáronles entrar y dieronles noticia de la merced que el Cabildo les hacía y agradecieronla mucho. Y otorgaron escritura ante Hernando Rodríguez, escribano de [...] en el oficio de Gregorio de Arriola.

\section{ASAC I, fol. 95 v (4-XII-1614)}

Los cuales otorgaron una escritura de perpetuación del salario que tiene el Sochantre Gregorio Núñez habiendo venido a licencia del arzobispo de Sevilla nuestro señor. La cual se y me entregó un para poner en el archivo ante Hernando ¿? del oficio de Gregorio de Arriola y el dicho Gabriel Núñez Sochantre hizo la aceptación y obligación como constaba en la dicha escritura a que me remito.

\section{5}

[30] ASAC I, fol. 104 r (10-II-1615)

En este mismo cabildo licenciado don Paulo de Córdoba y Valencia canónigo de la colegial de este sacro monte dijo que él tenía dotada una fiesta a la conversión del glorioso apóstol san Pablo en 25 de enero misas ni en segundas vísperas como aparece en el libro (...) y en el de los aniversarios a hoja 1260, que diría que también se tuviesen primeras vísperas cantadas con las mismas condiciones que en las segundas y en las que se guardan en los demás aniversarios para lo cual de nuevo ofrecía dotar en 1000 maravedíes los cuales se le repartiesen como se acostumbra en los demás. Que suplicaba a este cabildo admitiese la dicha dotación y mandase se celebrase en la forma acostumbrada, lo cual visto por todos los dichos señores capitulares dijeron que aceptaban la dicha dotación y 
mandaban se celebrasen y cantasen las dichas primeras vísperas y que el secretario del cabildo las escribiese en el libro de los aniversarios en la hoja donde está asentada la dicha fiesta y la trujese a otro cabildo para que por los señores capitulares la mandasen refrendar conforme está mandado en este cabildo.

\section{[31] ASAC I, fol. 114 r (29-VI-1615)}

Propuso así mismo el dicho señor Presidente que su merced por su devoción había dotado la Salve de Nuestra Señora el año pasado. Que se dijese cantada cada sábado en la Capilla de Nuestra Señora de la Concepción que está en este sacro Monte con distribución de (...) cada una para colegio y capellanes como más largamente consta en cabildo del año pasado de 14 de Mayo de 1614 y así mismo ofreció dar la cera que en ella se gastare como parece en este libro a folio 76. Y en el cabildo de primero de agosto del dicho de año de 1614 había dotado las vísperas de las fiestas de Nuestra señora se dijese la Salve en la Iglesia y de esta manera en la Capilla de Nuestra Señora con dotación de cuatro reales y de ocho la de la Concepción como más largamente consta del dicho cabildo que está en este libro a 81, que ya era pasado el año y quería dotar las dichas Salves en la forma contenida en dichos cabildos y que para la cera que se gastaría en ellas ofrecía dar 50 reales en cada un año que es lo que se ha experimentado que en ellas se gasta y ser más o menos y cuanto por el tiempo que su merced gozase de la canonjía de este Sacro Monte de cuya renta siempre quede sujeta a la paga de dichas Salves y cera, que si parecía a los Señores capitulares admitir la dicha dotación desde luego la hacía y perpetuaba en la forma dicha y habiéndolo tratado y conferido dijeron todos que agradecían mucho la dotación que su merced hacía en servicio de nuestra Señora y honor de esta Iglesia y la aceptaban y mandaban si se pusiese en el libro de los aniversarios y fiestas que esta Iglesia tiene la obligación de hacer y el modo en las distribuciones se guardase el que su merced del Presidente ordenase, el cual se pusiese distintivamente en el Libro de los aniversarios y puesto se trujese y leyese en el primero cabildo para que visto se ratificase y mandase guardar.

\section{ASAC I, fol. 116 v (3-VIII-1615)}

Asimismo propuso su merced que el señor canónigo Francisco Hurtado tenía devoción de hacer aniversario al glorioso San Cosme? o Bartolomé? con primeras vísperas y misa cantada dotando en dos puntos en 2000 maravedíes de distribución entre los asistentes y 6 maravedíes a la fábrica. Si se admitían y habiéndolo tratado la admitieron con que fuesen las segundas vísperas y se distribuyese dicha cantidad como está ordenado en los demás [aniversarios] que hacen los señores canónigos de esta iglesia.

\section{ASAC I, fol. 117 v (7-VIII-1615)}

Y en el propuso el señor presidente como el señor canónigo Gabriel de Ledesma quería dotar una aniversario en este Sacromonte y había elegido fuese el día de la dedicación del altar de nuestra señora de la concepción que ahora se quiere 
dedicar en este Sacromonte en la capilla (...) en el altar colateral del crucero de mano derecha del altar mayor. Y que este año y de en adelante se celebrase esta fiesta el mismo día que este año se dedicase el dicho altar. El cual dicho aniversario se celebrase en (...) que fuese una misa cantada después de nona con la solemnidad debida a la cual asistiesen los dichos señores canónigos, sochantre, colegio y capellanes de esta iglesia del Sacromonte y para ello lo dotaba en sesenta reales que se repartiesen en la manera que en las demás conmemoraciones que hacen los dichos prebendados de esta iglesia

\section{[34] ASAC I, fol. 118 v (1-IX-1615)}

Propuso asimismo como había en el Sacromonte grande necesidad de organista y que había muchos días que se andaba a buscar persona a propósito; que Julián de Villalar vecino de esta ciudad había venido a tañer algunos días al Sacromonte y se había experimentado que tocaba bien. Si parecía a sus mercedes se recibiese y asignase salario. $\mathrm{Y}$ habiéndolo tratado determinaron todos los dichos señores capitulares que se recibiese por organista del Sacromonte. Y con salario de quince mil maravedíes cada año el cual ha de ganar desde catorce de agosto de este año y además todos los días que venga a tañer que han de ser todos los días en que la iglesia reza oficio doble misa mayor y vísperas segundas. $\mathrm{Y}$ en los de primera clase y las primeras también. $Y$ en todas las fiestas y aniversarios que hiciese el Sacromonte o los señores de el y a los maitines nonas y otras cosas que se celebraren con solemnidad. De los cuales le diesen memoria el doctor don francisco de Barahona como maestro de ceremonias y al apuntador para que se las avisase al organista. El cual le ponga en el libro del punto y tenga cuidado de apuntarle si hiciere algunas faltas y en fin de cada tercio dará cuenta a los señores capitulares en su cabildo de ellas para que de esa manera en que cuando se deba multar conforme a los días y tiempos en que la hiciere.

\section{[35] ASAC I, fol. 121 r (15-IX-1615)}

Después dijo el señor presidente que el licenciado Gregorio Núñez sochantre de este Sacromonte pidió licencia apara ir a Málaga a ordenarse de luego que condiciones que se le habrían traído de Sevilla y por ser el dicho tiene no lugar de dar cuenta el cabildo que su merced se la dio para que se había (...)

\section{ASAC I, fol. 123 r (1-X-1615)}

Asimismo propuso su merced como el doctor Basilio de Torres canónigo de la esta Iglesia de Granada y de este Sacromonte había muerto uno o dos días hacia que su merced había mandado que le doblasen solemnemente en este Sacromonte y que aunque por no ser de los señores canónigos que asisten en este dicho Sacromonte no había obligación de hacerle exequias, con todo eso por ser persona tan benemérita parecía a sus mercedes sería razón hacerle sus honras con solemnidad y así su merced había avisado a todos los señores canónigos de este Sacromonte le dijesen cada uno tres misas y habiéndolo tratado pareció a todos los dichos señores capitulares que mañana se diga una misa cantada con su 
responso y se ponga tumba hachas blancas con su cruz y todo lo demás a la cual asistan todos los dichos señores canónigos colegiales y capellanes y se les avise esta tarde a todos los demás señores canónigos que están en la ciudad que no residen en este Sacromonte para que vengan a asistir a las dichas honras y asimismo nombraron por comisario al señor canónigo Andrés Sarmiento para que en nombre del abad y cabildo de este Sacromonte vaya a dar el pésame a la hermana del dicho señor Basilio de Torres a Claudio de Torres abad de la colegial del Salvador de esta ciudad y juntamente le convide para que asista mañana a las dichas exequias en este Sacromonte

[37] ASAC I, fol. 125 r ( $; ?-X I-1615)$

Y su merced dijo que gustaba mucho se celebrase su fiesta y aniversario en el día octavo de la fiesta de nuestra señora de la concepción misa cantada y segundas vísperas supuesto que la iglesia catedral metropolitana y todo este reino de Granada reza esta fiesta con octava (fiestas de Gabriel de Ledesma).

\section{6}

[38] ASAC I, fol. 128 r (2-II-1616)

Y el dicho señor presidente propuso como el señor canónigo Ibáñez había pedido que se le prestase un realejo que esta en el dicho Sacromonte que al presente no servia por haber otro y que para poderlo prestar el dicho señor presidente lo había comunicado con el señor licenciado don Justino Antolinez deán de la santa iglesia de Granada como administrador de los bienes y hacienda de este Sacromonte que tiene las veces del arzobispo mi señor y que el señor deán había respondido que atento a las buenas obras que el dicho señor canónigo Ibáñez había hecho al Sacromonte se lo podía prestar y que el arzobispo mi señor buscaría de ello que diesen sus mercedes lo que convenía se hiciese.

[39] ASAC I, fol. 130 r (9-IV-1616)

El señor presidente propuso como el licenciado Melchor de Ayala había estado cerca de un año en aprobaron en este Sacromonte para que se le diese una de las capellanías de coro y para haberlo de recibir se había escrito al arzobispo de Sevilla mi señor el cual lo remitió a el señor licenciado don Justino Antolinez deán de la santa iglesia de Granada y el dicho señor deán dijo que viniendo el cabildo en ello se le daría la dicha capellanía que votasen sus mercedes si era persona a propósito para que se le diese la dicha capellanía los dichos señor votaron que el dicho licenciado Ayala era persona a propósito y benemérito de ella y porque para habérsela de dar se ha de hacer primero información de limpieza conforme a las constituciones se determinaron se hiciese remitiéndola a su ordenación 
Concedió su santidad dos jubileos plenísimos por diez años fuera de los cuatro de los santos de el monte que había concedido, el uno para el día de san Andrés apóstol y el otro para el día de la Anunciación de Nuestra Señora, concedió también que dos veces en el año estuviese el santo sacramento descubierto por espacio de cuarenta horas y se ganase jubileo plenísimo visitando a questa santa iglesia mas concedió muchas indulgencias a los canónigos capellanes o colegiales de este Sacromonte que enseñasen la doctrina cristiana en el o en las misiones.

[41] ASAC I, fol. 143 v (6-XII-1616)

Luego dijo como Julián de Villalón organista se había ido a tañer a la iglesia mayor dejando el monte sacro sin órgano algunos días de fiesta y que pedía le dejasen hacer lo mismo otros muchos y respondiéndole que no convenía dijo que lo había de hacer aunque se despidiese determinaron que quede de todo punto excluido del órgano y despedido.

[42] ASAC I, fol. 144 v (9-XII-1616)

Dijo también como el licenciado Gregorio Núñez sochantre pide se le de licencia para ir a oponerse a una ración de Toledo con trabajo diósele licencia y para señalar el tiempo se cometió a el señor Juan de la Fuente lo consulte y sepa el estilo que en dar semejantes licencias a los cantores se guarda en otras iglesias.

[43] ASAC I, fol. 145 r (30-XII-1616)

Yo el secretario infrascripto lo leí a la letra y por haber en el cometido al Sr. Juan de la Fuente que supiese el estilo que en las iglesias se tiene en dar licencia a los cantores para hacer alguna oposición habiéndole pedido cuenta de su comisión dijo como se había informado del Sr. licenciado Justino Antolinez deán de la Santa Iglesia de Granada y le respondió que se le suele dar licencia por un mes en el cual los hacen presentes y lo demás que se tardaren que no ganen y así determinaron que esto se guarde de la misma manera con el licenciado Gregorio Núñez sochantre en la licencia que se le dio en el cabildo pasado.

Propuso asimismo como Ginés Valcés organista había estado algunos días para que se viese si era a propósito para el Sacromonte que viesen sus mercedes si convenía se recibiese y diese salario competente a cerca de lo cual se determinó se consulte con el licenciado Justino Antolinez deán de la Santa Iglesia de Granada 
[44] ASAC I, fol. 154 r $(; ?-; ?-1617)$

Asimismo propuso el Sr. Presidente que el licenciado Ginés Valcés organista ha días que esta en aprobación y que ha procedido que será cosa justa se reciba si parece convenir y ser a propósito, y luego por parecer de todos fue recibido y le señalaron de salario maraveds cada un año y mandaron que gane desde el día que esta sirviendo que fue 31 de diciembre del año pasado de seiscientos y dieciséis.

[45] ASAC I, fol. 155 v (23-IV-1617)

Propuso dicho Sr. presidente que el licenciado Ginés Valcés organista pide y suplica al cabildo le haga merced de escribir al Sr. obispo de Málaga le ordene porque tiene por cierto le será esta carta de mucha utilidad y provecho para este efecto. Determino el cabildo se le hiciese esta merced y se le cometió al señor canónigo Agustín Manrique escribir esta carta dijo mas el Sr. presidente como el dicho licenciado Ginés Valcés suplicase le de licencia para ir a Málaga a ordenarse. Se determino por parecer de todos se le de, y se remitió al Sr. Presidente que le determinase por cuantos días había de ser la dicha licencia

\section{ASAC I, fol. 160 r (12-VII-1617)}

Después de esto propuso el señor presidente que le parecía cosa puesta en razón y que convenía que en el Sacromonte iglesia colegial y dedicada al culto y servicio de Ntra. Sra. la virgen Maria se dijese los sábados misa de Ntra. señora con solemnidad pues es cosa que no solamente en todas las iglesias catedrales y colegiatas se hace con mucha solemnidad sino en todos los conventos y parroquias, y que así lo propone al cabildo para que viendo cuánta razón es que así se haga lo determine, y que para que siempre se diga sin que jamás falte en esta iglesia la misa los sábados visto cuan bien parece y como no se carga la comunidad no se desacomoda mucho el tiempo se le pedirá al Sr. deán escriba al arzobispo mi señor como por orden y devoción del cabildo se dice en esta iglesia colegial la dicha misa y que es cosa conveniente que su ilustrísima la dote para que asista el cabildo y perpetuamente sea servida la virgen santísima en esta su iglesia y casa y ofreció de su merced el señor presidente que en caso que el arzobispo de Sevilla mi señor no sea servido de dotarla la dotaría su merced para el colegio y capellanes, y que por turno digan la misa los señores prebendados de esta iglesia. Determinaron todos conformes que se diga y celebre la dicha misa desde el sábado que viene que son 15 de julio sin dotación y sea inmediatamente después de oración y que las horas se dilataren media hora mas para que haya tiempo en que con reverencia y devoción se diga la dicha misa y que se le pida al señor don justo Antolinez escriba al arzobispo mi señor lo arriba propuesto. 
Después de esto propuso el señor presidente que el licenciado Valcés organista parecía estar algo sentido porque de la distribución de los aniversarios que en esta iglesia se celebran no se le reparte y distribuye a el parte como a los demás ministros de ella pues el trabaja y tañe en ellos sin tener por algún titulo y razón en ellos. Después de haber tratado de esto entre si los señores capitulares determinaron atento a que el trabaja como los demás ministros y para obviar inconvenientes que de no darle la parte y distribución que pide se pueden seguir que se le de la distribución de cada uno que un capellán lleva que es la sexta parte que un canónigo

\section{ASAC I, fol. 163 r (12-IX-1617)}

El señor don Pedro Dávila mostró un testamento y codicilo que en la ciudad de Sevilla otorgo el señor doctor don Bartolomé Olalla de Rojas chantre y canónigo de la santa iglesia de Sevilla debajo de cuya disposición murió y leído por mí el infrascripto secretario en presencia de los dichos señores capitulares constó por algunas cláusulas de él que el dicho señor doctor don Bartolomé Olalla de Rojas instituyó y fundó un patronato de todos sus bienes y hacienda y nombró por patrón a los señores abad y canónigos de esta santa iglesia del Sacromonte señalando el orden con que se ha de administrar y distribuir. Asimismo voto un aniversario perpetuo que se le ha de decir en esta iglesia vigilia y misa de réquiem cantada con ministros, cada un año para siempre y lo dotó en 4000 maravedíes de distribución para los interesentes y una misa rezada al lunes de cada semana de lo que rezare la iglesia y la dotó en 4 reales de limosna para el que la dijese. Dejó también otros bienes a esta iglesia y casa como más largamente consta del dicho testamento [se aceptó]

Determinose se diesen a la sacristía para comprar unos misales de que en esta iglesia hay al presente mucha necesidad.

[49] ASAC I, fol. 165 v (10-X-1617)

Propuso luego que Joseph de Cea organista había estado propuesto desde 14 de septiembre que entró en el Monte hasta hoy para ver si era a propósito como organista de este Sacromonte y que parecía a propósito todos votaron se recibiese con 15000 maravedíes de salario con que haya de ser obligado asistir en el coro con sobrepelliz a todas las horas y que se le pueda dar licencia para que dos días en la semana pueda acudir a Granada a tomar lección de su maestro no haciendo falta en esta iglesia y que se ponga en el libro de el punto y gane salario desde el día dicho que entró en el Monte.

\section{ASAC I, fol. 177 v (16-XII-1617)}

Últimamente propuso el dicho Sr. abad como por haber enviado a decir el arzobispo mi señor que a su merced se le sumaran cuentas de ciertos maravedíes que habían entrado en su poder del licenciado Luis de Vega y enviado poder a 
este cabildo para ello y para que el alcance lo aplique el cabildo en utilidad de esta iglesia por el ánimo del dicho licenciado Luis de Vega el cabildo había aplicado el dicho alcance a la sacristía y fábrica menor para comprar unos misales de que habían mucha necesidad el cual alcance estaba ya entregado al señor Juan de la Fuente prefecto de la sacristía y comprados los dichos misales (...).

\section{8}

[51] ASAC I, fol. 189 r (11-IV-1618)

Ítem propuso que el Sr. canónigo Pedro de Santiago quiere instituir aniversarios en la forma que los demás señores lo tienen instituido por el tiempo que hubiere la prebenda de este Sacromonte en misa y segundas vísperas de la santa Madre Teresa de Jesús. Admitiose en la misma manera que los demás y se tome razón en el libro de los aniversarios, dotolo en dos mil maravedíes para los intercesantes y once reales y seis maravedíes para la fábrica.

[52] ASAC I, fol. v (26-IV-1618)

El dicho señor presidente propuso como Joseph de Cea Hinojosa organista había hecho algunos excesos por donde merecía ser despedido de esta Iglesia los cuales refirió en particular y que muchas veces se le había amonestado y avisado se enmendase y no lo había hecho y que consultado todo con el señor licenciado don Justino Antolinez de deán le había parecido conveniente que el cabildo lo despidiese, que viesen sus mercedes lo que se había de hacer. Por todos los votos se determinó ser conveniente y así que fuese despedido desde el día siguiente y que el señor presidente lo hiciese saber al dicho organista.

[53] ASAC I, fol. 195 r (28-VII-1618)

Ítem propuso que había necesidad de recibir organista, y que Jerónimo de Valenzuela vecino de Jaén había aparecido a propósito, determinóse que se recibiera y remitiose al $\mathrm{Sr}$. abad el concierto y condiciones que había que guardar, y que le pueda multar en la cantidad que a su merced pareciere en los días que hiciere falta o no cumpliera con las condiciones del concierto, el cual se cuenta desde 18 de julio.

Ítem propuso que el licenciado Fernando de Zafra subsochantre de esta Iglesia por estar con necesidad pedía alguna ayuda de costa. Determinose que por el trabajo particular que tiene en la superintendencia de los álamos que están en la subida de este dicho Sacromonte se le den cada año nueve fanegas de trigo pagadas por sus tercios y que se cuenta desde principio de este dicho mes de julio. 
En el cual dicho cabildo quiso asistir el Ilustrísimo señor don Pedro de Castro arzobispo de Sevilla y fundador de esta casa e Iglesia de Sacromonte que de presente estaba en el dicho Sacromonte. Y su Ilustrísima refirió el mucho gusto y contento que tenía de haber visto por los ojos el estado de las cosas de este Sacromonte. El servicio tan puntual que el coro y altar había, el buen ejemplo y virtud de todos los que en este Sacromonte están, así canónigos como colegiales y capellanes, y el buen gobierno que en todo había que esperaba en nuestro señor que lo había de conservar y aumentar cada día más. Que pedía muy encarecidamente se prosiguiese con toda puntualidad fidelidad en el servicio de Dios nuestro señor y en su mayor agrado. Que siéndoles fieles siervos de parte de su Majestad ofrecía, nunca nos faltaría. Que su Ilustrísima se partía luego a Sevilla que pedía le encomendasen amistad que el bien y aumento de este Sacromonte le llevaban que iba con mucho cuidado del aprieto en el que estaba la hacienda de este Sacromonte y de la poca renta que tenía para las muchas obligaciones y gastos, que tendría especial cuidado del aumento de ella. Que las muchas pensiones y otros gastos y limosnas que sus señorías pagaba no daban lugar a extenderse todo lo que quisiera, que su voluntad y deseo era muy grande, y conocía era muy poco todo lo que hasta aquí había hecho, para lo que deseaba. El señor Abad en nombre de todo el cabildo el mucho sentimiento que todos los del dicho cabildo y casa tenían de la partida de su ilustrísima y la edificación grande que a esta casa y a todos los de ella había dado su ilustrísima con su ejemplo, que todos se sentían muy alentados y obligados a imitar a su Ilustrísima en el servicio de Dios nuestro Señor y de estos santos gloriosísimos y a dar la vida en su servicio si fuese necesario. Agradeció asimismo las muchas mercedes que a este Sacromonte había y en especial la de la última donación que el día de la presentación de nuestra señora de este año había hecho a este Sacromonte. Después de esto el señor Abad le beso la mano y su Ilustrísima le echo su bendición y de la misma manera cada uno de los dichos señores capitulares le fue besando la mano y su Ilustrísima daba su bendición con lo cual todos se despidieron de su Ilustrísima y se acabó este cabildo.

1619

\section{ASAC I, fol. 215 v (12-I-1619)}

Propuso el señor Abad que su merced quería en honra de Nuestra Señora y de su Inmaculada Concepción dotar la salve que se dice en las cuevas todos los sábados, y los días de Nuestra Señora en la Iglesia para que se asistiesen todos los señores canónigos, capellanes y colegiales y que sobre los tres reales que tenía el colegio y capellanes de distribución aumentaba otro cinco más que hicieren ocho y se distribuyesen por sus partes dando una a cada colegial, dos al capellán, tres al señor canónigo y seis al señor Abad en la misma forma que se ganan y distribuyen los aniversarios y en cuanto a la asistencia y falta de ellos que juntar los tres reales de la distribución del colegio era juzgando que sería en más y que les alcanzaría la cual dotación hace por todos los días de su vida. 
Propuso el señor Abad que el licenciado Simón de Torres vecino de la ciudad de Sevilla ha estado en aprobación tres semanas poco más o menos para el oficio de sochantre que el dicho pide ser admitido, que sus mercedes ven lo que les ha parecido y si es suficiente. Y después de conferido entre los dichos señores determinaron se reciba el dicho Simón de Torres para el dicho oficio y se le dé el mismo salario que a el pasado.

[57] ASAC I, fol. 227 v (7-VIII-1619)

Propuso el Sr. Abad como por el Cabildo pasado de primero de agosto se había remitido para este el determinar si se ensancharía y alargaría el Coro de esta Iglesia, lo cual conferido entre los dichos señores capitulares todos excepto uno determinaron por votos públicos que se remitían en todo lo que fuere conveniente hacer en el Coro a los señores don Pedro de Ávila y don Francisco de Barahona canónigo.

[58] ASAC I, fol. 228 v (9-VIII-1619)

Y el señor Abad propuso que el sochantre de este Sacromonte se había encontrado este día con un capellán y los dos tenido algunas palabras pesadas, las cuales propuso al Cabildo el dicho señor Abad, y su merced pide al Cabildo determine el remedio que sepa bien poner en esto. Y todos los dichos señores habiendo considerado este negocio y ponderado cuanto desdoran estas cosas en comunidades y principalmente a la decencia de este sagrado monte, determinaron todos que el dicho sochantre fuese luego despedido y al capellán fuese castigado con saludable penitencia.

[59] ASAC I, fol. 229 v (2-IX-1619)

Y el dicho señor Abad propuso como era conveniente que en el coro de esta Iglesia se guardase el orden que en las otras iglesias se guarda cuando al decir el cántico de Magnificat los señores prebendados y capellanes en días que por la solemnidad o lo dice a versos con el órgano o con otra música y que para esto el que se le siguiese al más antiguo tendrá obligación de subir a ayudárselo a decir: Mas que no dirá capellán con canónigo y habiéndolo conferido entre si los dichos señores se determinó por mayor parte que se hiciese como está propuesto.

En este Cabildo Jerónimo de Valenzuela organista entró una petición pidiendo que se le aumentase el salario por no poder pasar con el que se le da y los dichos señores determinaron se quedase para otro cabildo y se pensase lo que en esto se haría. 
Asimismo el dicho señor Abad dijo que para este cabildo estaba remitido determinarlo que a Jerónimo de Valenzuela organista se le había de dar, que sus mercedes viese que se haría en esto. Y habiéndolo tratado todos los señores se determinó que se le haga gracia al dicho de cuatro fanegas de trigo por esta vez y que como adelante lo hiciese se le gratificará.

[61] ASAC I, fol. 232 r (1-X-1619)

En cuanto al compás que se ha de guardar en el coro que siempre ha de ser conforme a la solemnidad del día y en todas las circunstancias pertenecientes a esto atiendan todos al sochantre el cual ha de atender al que preside el cual cuide que todo se haga con rectitud y puntualidad.

Ítem propuso sus merced si se rezarían los salmos cuando los tañe a versos el órgano. Y se determinó se supiese como se hace en la Iglesia Mayor de Granada y así se ejecutase.

[62] ASAC I, fol. 232 v (5-X-1619)

Asimismo propuso el señor Abad como el coro de este Iglesia tenia necesidad de algunos libros de canto y que por falta de ellos se pasa incómodamente en el coro y todos los señores capitulares después de conferidos determinaron que se fuesen comprando y se comenzara desde luego por los mas necesarios. Y la disposición y comprada de ellos se cometió a los señores licenciados Agustín Manrique y Francisco Hurtado canónigos.

[63] ASAC I, fol. 233 r (10-X-1619)

Ítem propuso el señor Abad como las consuetas de Iglesia y casa estaban casi acabadas y para haberlas de trasladar y acabar era necesario verlas cada oficio de por si que el Cabildo cometiese estas consuetas a quien las viese. Y conferido entre todos por la mayor parte se cometieron la de la Iglesia a los señores licenciados Agustín Manrique, Pedro de Santiago y doctor don Francisco de Barahona. Y las de la casa se cometió a los señores licenciados Agustín Manrique, Bartolomé de Torres presidente, Juan de la Fuente canónigos, los cuales han de ver los oficios de las dichas consuetas y se traerán al Cabildo para que se determine lo que mas conviniere.

El dicho señor Abad propuso que había venido aviso que su Majestad del Rey don Felipe nuestro señor estaba indispuesto y con peligro de que la Santa Iglesia 
había comenzado hacer rogativas que seria conveniente que esta Iglesia también la hiciese y conferido por todos los dichos señores y conociendo lo mucho que importa la salud y vida de su Majestad atentas las obligaciones que tiene este Sacromonte, determinaron por votos públicos que todos los días se hiciese rogativa en la misa de tercia cantada, que todas las noches se dijese una letanía de Nuestra Señora, que en la oración de por la mañana y en la de la noche y en todas las misas y en los demás ejercicios de comunidad y particulares se suplicase afectuosamente a nuestro señor por la salud de su Majestad: que este día y el viernes siguiente tuviese toda la comunidad disciplina y el día de la Presentación de Nuestra Señora que es el siguiente a este en que se tiene este Cabildo y el domingo primero venidero comulgasen todo el Colegio y ministros de esta Iglesia y este domingo por la tarde se hiciese una procesión de rogativa que salga de esta Iglesia para las Sagradas Cavernas donde se hagan estaciones en la de Nuestra Señora y en las de los dos hornos donde padecieron nuestros sagrados Mártires, que el día de Nuestra Señora por todo el día y el domingo por la mañana estuviese descubierto el Santísimo Sacramento y que esto se continuase hasta que hubiese aviso de que Nuestro Señor había dado salud a su Majestad.

Últimamente propuso el señor Abad que se sentarían los colegiales en el coro atento que tienen ya donde sentarse. Lo cual conferido se determino que se asienten los dichos colegiales en el coro en el tiempo que la Consueta de la Iglesia lo dispone.

\section{ASAC I, fol. 236 r (4-XII-1619)}

Ítem propuso el señor Abad que el aniversario de San Andrés que en este Sacromonte doto el licenciado Pedro Gómez difunto, canónigo que fue de San Salvador no se había hecho y que tenia primeras vísperas cantadas, que si se haría el día siguiente y que hoy se tuviesen dos pares de Vísperas lo cual conferido por los dichos señores determinaron que por ser incomodidad decir dos pares de Vísperas unos del día haya otras del aniversario que hogaño se hiciese axial y de aquí adelante por todos los años las segundas vísperas del día de San Andrés sean las primeras de Aniversario y el día siguiente se diga la misa y si este día fuese domingo, se diga la misa el lunes siguiente.

[66] ASAC I, fol. 237 v (27-XII-1619)

El motivo de traer esta reliquia de San Indalecio sea tenido en este Sagrado Monte reliquia de los cuatro discípulos de Santiago que son San Indalecio, San Torcuato, San Segundo, y San Eufrasio con la de los otros tres que tenemos en este Sacromonte desde el cual se dividieron a predicar la santa fe en España y que en ejecución de esto se han hecho muchas diligencias por mano del doctor Don Pedro de Molina canónigo y por la de la Santa Iglesia del Provisor y Vicario General en el Arzobispado de Zaragoza, el cual habiendo tratado este negocio con el Abad y monjes de San Benito del Convento de San Juan de la Peña en las montañas de Jaca en el Reino de Aragón, en el cual dicho 
Monasterio esta hoy el cuerpo del glorioso San Indalecio discípulo de Santiago donde se traslado desde Almería muchos a en la perdida de España y que los dichos Abad y monjes no quisieron dar la reliquia para el Sacromonte sin carta y cedula de su Majestad que como patrón de aquel convento diese licencia y mandase dar la dicha reliquia para el Sacromonte y bula de Su Santidad en que les concediese facultad para darla y abrir el arca donde esta el dicho cuerpo del glorioso San Indalecio alzando cualquiera prohibición o censura que para esto haya en el derecho. Que las dichas bulas de Su Santidad se trajeron y asimismo $\mathrm{Su}$ Majestad escribió carta al dicho convento pidiendo esta reliquia para el Sacromonte. Que en virtud de estos recaudos y diligencias el dicho Abad y monjes habían abierto la dicha arca delante de muchos señores de titulo y gran concurso de gente y en presencia de notarios apostólicos habían entregado un hueso de la canilla de una pierna del cuerpo de San Indalecio al dicho doctor don Pedro de Molina para que la trajese al Sacromonte con la custodia y veneración debida. Que el dicho don Pedro de Molina ha venido a esta ciudad a traer la dicha reliquia de San Indalecio al Sacromonte y la quiere entregar hoy. Que sus mercedes viesen recibimiento que se hacia a la dicha reliquia, las ceremonias y los demás actos que convengan y habiéndolo tratado los dichos señores capitulares determinaron que al pie de la cruz de los soldados se ponga un altar adornado donde el dicho don Pedro de Molina pondrá la reliquia para entregarla, que el Abad y canónigos, capellanes y colegiales salgan por cabildo en procesión hasta el dicho altar con velas encendidas, cruz y ciriales y allí el dicho señor Abad que ira con pluvial acompañado de diáconos revestidos reciba la dicha reliquia de manos del dicho don Pedro y vuelvan con ella pasando por las sagradas Cavernas al altar mayor de esta Iglesia y allí primeramente por el diacono se lea en el pulpito del evangelio todos los recaudos y bulas de la traslación de esta reliquia $\mathrm{y}$ el dicho don Pedro haga juramento solemne públicamente de como ha traído la dicha reliquia en grande custodia y guarda $\mathrm{y}$ ser la misma individualmente que se le entrego para el Sacromonte, sin haber supuesto otra por ella y hecho el dicho juramento se muestre al pueblo y vayan adorándola todos los prebendados, capellanes y colegiales cantando el Te Deum laudamus y luego de esto y dicha su antífona y oración se entra en una caja en que no haya otra reliquia y se guarde. Y para otro Cabildo se queda el determinar donde se tiene de trasladar y la fiesta que en tal traslación se haya de hacer.

\section{0}

[67] ASAC I, fol. 249 v (4-V-1620)

Asimismo propuso el señor abad que el licenciado Juan Díaz de Rojas presbítero vecino de Sevilla y Capellán del coro de la Santa Iglesia de Sevilla vino della a este Sacromonte y entró en él sábado en la noche once de abril de este año de 1620. Y pretende la sochantría de él que está vaca, que a su merced le habían informado era hombre virtuoso. Y que dejaba en Sevilla más de dos mil reales de renta eclesiástica por venir al Sacromonte. Que ha hecho el oficio de sochantre desde entonces hasta hoy como los señores capitulares han visto; que la voz es buena y tiene experiencia en el dicho oficio. Si a sus mercedes parecía recibirle porque aunque la provisión de este oficio pertenece al Arzobispo mi 
señor por su vida y al señor Deán Don Justino Antolínez que hoy tiene sus veces, su merced gusta que el cabildo del Sacromonte le provea. Y habiendo conferido los dichos señores capitulares entre sí las calidades de dicho licenciado rojas voz y suficiencia para el oficio de sochantre y el salario que pedía, determinaron por todos los votos que fuese recibido desde hoy el dicho licenciado Rojas por Sochantre de esta Iglesia y se le diese de salario en cada un año quinientos reales, asistiendo siempre en el Sacromonte como se acostumbra y guardando las constituciones de él. Y demás de esto se le de la capellanía que dejó en este Sacromonte el licenciado Luís de Vega, de quien es patrón este cabildo, la cual de presente goza el licenciado Joan de Gálvez presbítero y capellán de este Sacromonte, el cual libre y espontáneamente la deja. Y al dicho licenciado Juan de Gálvez se le de una capellanía de coro de las seis que la fábrica paga.

$[250 \mathrm{r}]$

Y nombró al dicho licenciado Juan de Gálvez por capellán del coro de esta Santa Iglesia de el Sacromonte por el tiempo que fuere la voluntad de este cabildo en la manera y según se ordena en las constituciones de este Sacromonte. Y al licenciado Juan Díaz de Rojas sochantre, por capellán de la capellanía del licenciado Luís de Vega y con obligación de decir las misas en las fiestas y días que en ella se ordena. Asimismo por la voluntad que fuese de este cabildo, que los podrá quitar cada que le parezca sin causa alguna.

$[250 \mathrm{v}]$

El señor Abad propuso como en un cabildo del año pasado se había tratado que para la pascua de navidad se le hiciese alguna merced a Jerónimo de Valenzuela organista de este Sacromonte, atento que es pobre y el salario ser poco y acudir a su oficio con grande puntualidad y cuidado. Que si a sus mercedes parecía se le hiciese alguna gratificación, pues entonces no se le hizo. Y se determinó se le hiciese gracia de cuatro fanegas de trigo por esta vez.

Propuso el señor Abad como en este Sacromonte servían misales viejos en cuanto al oficio y otros que había modernos estaban rotos; que sus mercedes viesen si se comprarían algunos. Y se determinó que los misales que no fuesen de oficio reformado se quitasen de la sacristía y se comprasen los que faltasen, y los demás se aderezasen y rehiciesen de registros todo lo cual se cometió la señor doctor don Paulo de Valencia canónigo.

ASAC I, fol. 267 v (25-VIII-1620)

Asimismo propuso el señor Abad ser necesario que se hiciese la consueta de ceremonias de iglesia y sus mercedes votasen otro, atento a que el señor Doctor don Francisco Barahona canónigo a quien estaba cometido no puede. Lo cual 
visto por los dichos señores capitulares se determinó se hiciese la dicha consueta y para ello electo el señor licenciado Bartolomé de Torres canónigo.

Asimismo propuso el señor Presidente que las sillas del coro se estaban haciendo, era conveniente ver como se había de hacer y con qué diferencia la silla que está en medio del testero del coro que es la del señor Abad. Y se determinó se quedase esto para otro cabildo.

Ítem propuso el señor Presidente que había falta de misales correctos en la sacristía porque algunos de los que había eran del rezado viejo que sus mercedes viesen si se comprarían: y se determinó se comprasen los misales que fuesen necesarios.

[71] ASAC I, fol. 270 v (16-IX-1620)

Asimismo propuso el señor Abad como por el cabildo pasado se había dilatado para este el ver cómo se haría la silla del señor Abad que está en el testero del coro. Y conferido por los señores capitulares se determinó que la dicha silla fuese pareja con las demás hasta los alcotres y que de allí arriba fuese algo más alta y que sobre la cornisa de arriba se pusiese coronación.

$[271 \mathrm{r}]$

Íem propuso el señor Abad como el señor licenciado Cristóbal Aybar secretario del Arzobispo mi señor quería este año hacer un aniversario el día del glorioso Arcángel San Miguel viesen si le aceptaban. Y después de tratado se determinó que se hiciese en la forma que el año pasado se hizo y no de otra manera que es habiendo no mas que la misa de tercia y diciéndose dos misas rezadas.

\section{ASAC I, fol. 263 r (6-X-1620)}

Ítem propuso el señor Abad que era cosa justa y debida a la merced que el Arzobispo mi señor ha hecho a esta casa que se celebren unas honras $\mathrm{y}$ aniversarios cada año el día después de la conmemoración de los difuntos por Cristóbal Vaca de Castro mi señor, padre del Arzobispo mi señor perpetuamente con mucha solemnidad y cera, misa cantada y un oficio de difuntos o vigilia. Y todos los señores capitulares sin falta ninguna fueron de parecer se haga dicho aniversario perpetuamente como lo propone el señor Abad.

$[271 \mathrm{v}]$ 
Ítem propuso el señor Abad que el licenciado Juan de Rojas sochantre a quien el cabildo de más del salario de sochantre le había dado la capellanía de Vega, ha pedido que no se le baje de la renta de la dicha capellanía las faltas que hiciere no (...) que son doce maravedíes por cada vez según la escritura de su fundación que está en el archivo $\mathrm{n}^{\circ} 3$ y que estaba a pique de irse si no se le hacía esta merced. Y por parecer de todos se determinó se le bajen los doce maravedíes de cada punto de oración que faltare según lo dispone la fundación de la dicha capellanía más que por otra parte se le supliese de la renta de la fábrica lo que sumasen las dichas faltas porque hay necesidad de él en el Sacromonte y viene a ser poca cantidad.

Asimismo el señor Abad presentó un decreto firmado del Arzobispo de Sevilla mi señor en que su ilustrísima fundaba un aniversario perpetuo en la fiesta de la Inmaculada Concepción de Nuestra Señora y se han de distribuir ciento treinta ducados en primeras vísperas, maitines y laudes, misa mayor, segundas vísperas y en otras misas rezadas que allí se contienen. El cual decreto leí yo el secretario y el dicho cabildo lo aceptó haciendo gracias a su Ilustrísima y se me ordenó que asímismo lo cosiese con las dichas constituciones.

\section{ASAC I, fol. 276 r (27-XI-1620)}

Asimismo propuso el señor Abad como hay algunas ceremonias en la Santa Iglesia de Granada que no conforman con las del Ceremonial de Clemente VII. Que para ver si esta iglesia las ha de seguir sería bien que dos de estos señores vayan a consultar el fundamento que tienen para ello. Y se determinó que se hiciese así y se dio comisión para ello a los señores licenciado Bartolomé de Torres y Doctor don Francisco de Baraona canónigos.

$[276 \mathrm{v}]$

Últimamente propuso el señor Abad que era conveniente que sus mercedes viesen qué oficio se había de rezar en la fiesta de la Concepción de Nuestra Señora si el de la Iglesia de Granada sigue el breviario romano reformado tomen el de su Natividad. Y conferido por los dichos señores se determinó que se rezase el oficio de la Natividad de Nuestra Señora y que en esta conformidad el dicho señor Abad pidiese el consentimiento al Arzobispo mi señor.

[75] ASAC I, fol. 278 r (1-XII-1620)

Asimismo el señor Abad propuso como según la fundación del aniversario de la Inmaculada Concepción de Nuestra Señora, la fábrica no podía gastar en esta fiesta más de lo que gasta en otras, que era bien que el cabildo determine cuánto se había de gastar mas por cuenta del mismo aniversario. Y después de conferido se determinó por todos los votos que fuese en esta manera: que el gasto de cera, olor, luminarias y juncia y el demás adorno de la iglesia fuese por cuenta de la 
fábrica, y que el gasto de música, fuegos y otras cosas fuesen por cuenta del aniversario para lo cual el dicho cabildo señala en cada un año ciento diez reales, los cuales puedan gastar en esto los que fueren comisarios.

\section{ASAC I, fol. 278 v (6-XII-1620)}

Y luego el señor Presidente propuso como doña Leonor de Ávila hermana del señor Abad era difunta. Que atento a las obligaciones que por muchos títulos el Sacromonte le tiene, sería bien que el día siguiente se dijese una vigilia y misa cantada. Que sus mercedes viesen que les parecía y visto y tratado por los dichos señores se determinó por la mayor parte que se hiciese como el dicho señor Presidente lo proponía.

\section{ASAC I, fol. 279 r (15-XII-1620)}

Y luego el señor Abad propuso como los señores prebendados que habían sido comisarios en la fiesta de la Inmaculada Concepción de Nuestra Señora habían experimentado ser poca cantidad diez ducados para las cosas que se contienen en cabildo de primero de este mes. Y visto y tratado entre los dichos señores se determinó por todos los votos que se pudiesen gastar en la dicha fiesta hasta doce ducados y no más y que lo que un año sobre se guarde para otro.

Asimismo propuso el señor Abad cómo los libros de canto que se estaban haciendo se habían suspendido hasta que sus mercedes viesen si se proseguiría. Qué se haría en esto y conferido por los dichos señores se determinó que se fuese prosiguiendo en hacer los dichos libros de canto.

[78] ASAC I, fol. 280 r (23-XII-1620)

Y luego el señor Abad propuso como el señor licenciado Bartolomé de Torres canónigo, a quien estaba cometido hacer la consueta ha hallado que casi todas las ceremonias son encontradas con las del ceremonial romano de suerte que la consueta y ceremonial que hasta ahora se han usado en esta Iglesia es muy diferente de las ceremonias romanas. Que si parecía a sus mercedes que se siguiese en todo al ceremonial romano o se prosiguiese con la consueta de esta Iglesia que es conforme a la de la Santa Iglesia de Granada. Lo cual tratado y conferido muy por extenso la obligación que en esto tenía esta Iglesia si estaba obligada a seguir el ceremonial romano o si podía proseguir en conformarse con la Iglesia matriz. Por la mayor parte pareció que había obligación de conformarse con el ceremonial romano porque las bulas de su Santidad hablaban muy apretadamente en esta materia. Y así se determinó por mayor parte que la consueta que va haciendo para esta Iglesia el señor licenciado Bartolomé de Torres se conformase con el Ceremonial Romano excepto que algunas ceremonias que dispone el dicho ceremonial y que son de notable diferencia de las que hasta ahora se han usado como "el no levantarse al Gloria Patri" en los Salmos y otras de esta manera y que el ejercitarlas podía causar nota por no estar 
recibidas en muchas iglesias principales de España: se suspenda la ejecución y ejercicio de ellas hasta que se consulte a la Iglesia de Toledo y de Salamanca porque es la que escribió a Roma a la Congregación de ritos sobre las ceremonias. A la cual respondió la Congregación aquella declaración que; no era el intento de la Bula del ceremonial abrogar las loables costumbres de las iglesias y nombraron para que consultasen y escribieses a las dichas iglesias a los señores licenciados Bartolomé de Torres y Francisco Hurtado canónigos.

Ítem el señor Abad dijo cómo el señor licenciado Bartolomé de Torres canónigo había consultado a la Iglesia de Granada y al Maestro de ceremonias de la Iglesia de Sevilla sobre quién podía celebrar las misas primera la noche de Navidad celebrando en los maitines el Abad y que respondieron que lo más conforme al ceremonial es que celebrando el señor Abad los maitines celebre tambien la misa. $\mathrm{O}$ en caso que no celebre los maitines sino una de las dos cosas (o maitines o misa) que ha de celebrar la misa, de suerte que el más digno siempre haga todo el oficio o en caso que no haga todo el oficio el más digno simpre diga la misa. Y así lo admitió y determinó el cabildo.

\section{1}

[79] ASAC I, fol. 283 v (13-I-1621)

Ítem propuso el señor abad como Jerónimo de Valenzuela organista por petición que aquí se leyó suplicaba a sus mercedes le hiciesen merced de darle algo más de ayuda de costa sobre seis fanegas de trigo que se le daban atento ser poca cantidad esta para poder pasar en su casa. Lo cual oído y conferido por los dichos señores capitulares se determinó se quedase para otro cabildo.

[80] ASAC I, fol. 284 v (19-I-1621)

Ítem el señor abad propuso como por el cabildo pasado se había dilatado para este si se daría el ayuda de costa que pide Jerónimo de Valenzuela organista de este Sacromonte. Que sus mercedes votasen sobre ello. Y conferido entre los dichos señores capitulares se determinó por todos los votos que atento el buen servicio y puntualida que tiene en su oficio se le hiciese gracia por esta vez de tres fanegas de trigo.

[81] ASAC I, fol. 293 v (5-VI-1621)

Ítem propuso el señor Abad cómo el señor licenciado Bartolomé de Torres canónigo, a quien estaba cometido el hacer la consueta presentaba al cabildo el oficio y ceremonias de la fiesta del Corpus Christi y su octava para que sus mercedes lo viesen y aceptasen. Y oídas por los dichos señores las ceremonias dichas, las aceptaron excepto que en cuanto a la de descubrir a Nuestro Señor a las primeras vísperas se determinó que fuese por este año y se llevase desde el sagrario bajo a el altar mayor donde estuvies descubierto no más que mientras las vísperas. Y en cuanto a si estaban en el coro en pié a todo el oficio de estos 
días: y si habrá caperos toda esta infraoctaba: y si se comenzará la misa mayor más tarde que lo ordinario se remitió para otro cabildo.

Ítem propuso el señor Abad cómo por cabildo de quince de este mes se remitió para este cabildo el ver si se daría el aumento de salario que pedía Jerónimo de Valenzuela organista de este Sacromonte. Después de conferido entre los dichos señores capitulares se determinó por todos los votos que se le dieren otras seis fanegas de trigo, que con las que antes se le daban hagan un cahíz atento que el dicho representaba ser poco lo que se le daba y no poder pasar y quererse despedir siendo buen organista y puntual en su oficio.

Ítem propuso es señor Abad cómo se había dilatado el determinar en qué se multaría a los que en el coro o Iglesia errasen cantando por punto o entono. Y después de conferido entre los dichos señores capitulares se determinó por todos los votos que en los yerros que hiciesen el hepdomadario, diáconos prebendados, capellanes y demás ministros en la misa y demás oficios cantados o en tono, a cada uno por cada yerro que hiciese si fuere en el leer o en algún acento que sea notable al arbitrio del corrector o presidente del coro se le multe en un punto poniéndole el puntador falta de que tendría particular cuidado siendo avisado del corrector o presidente del coro. Y el que avisare al puntador tenga obligación de mirar el libro si la tal falta fue por yerro de impresión: y si le pareciere conveniente advertirle al que erre lo haga especialmente cuando de advertirle depende la enmienda para adelante. $\mathrm{Y}$ adviértase que si cuando uno errase el mismo se enmienda luego no se repita por falta.

\section{[83] ASAC I, fol. 304 r (23-IX-1621)}

Últimamente el señor Abad presentó al cabildo ciertas adiciones en razón de hacer y nombrar Racioneros al sochantre y organista y otras cosas que allí se contienen por ley: para que sus mercedes viesen si las aceptaban y después de visto y tratado se determinó que se aceptaban y aceptaron. Y asímismo que sobre algunas dudas que se ofrecían se escribiese al Arzobispo de Sevilla mi señor y que se sacasen dos traslados y el original se pusiese y cosiese con las constituciones de este Sacromonte.

\section{ASAC I, fol. 304 v (27-IX-1621)}

Ítem propuso el señor Abad cómo por cabildo de dieciseis del pasado se había dilatado para tratar en este qué cosas se harían en honra de la Virgen Nuestra Señora y memoria de la merced que a ésta casa hizo en librarla del fuego que el día antes se había emprendido. Y después de tratado por los dichos señores se determinó por todos los votos que el día por la tarde de la Asunción de Nuestra Señora haya procesión desde esta Iglesia a las Sagradas cavernas; que las vigilias de sus fiestas se ayune por comunidad; que todas las noches por este mismo fin se rece su letanía en la Iglesia. 
Ítem propuso el señor Presidente cómo la ciudad de Granada había decretado en su cabildo poner un Trofeo de la Inmaculada Concepción de Nuestra Señora y que por estar alcanzado su mayordomo no se había comenzado esta obra. Que a los comisarios de la ciudad parecía que se efectuaría esto prestándoles el Sacromonte hasta cantidad de seiscientos ducados de los cuales se hirían dando libranzas en el dicho mayordomo, para que el Sacromonte fuese cobrando la dicha cantidad (...) lo cual oído u conferido por los dichos señores se determinó por mayor parte de los votos, que no sacándolo de la hacienda antes de cumplir con sus obligaciones, se les preste la dicha cantidad, si puede ser de lo que hay en Sevilla no dando el cabildo resguardo alguno a quien lo diera. Y para lo que se hiciere en orden a esto y lo demás del Trofeo se nombraron comisarios los señores licenciados Andrés Sarmiento y Juán de la Fuente canónigos.

\section{ASAC I, fol. 309 r (9-XI-1621)}

Ítem propuso el señor Presidente cómo cierto clérigo contralto de Montilla pretendía ser sochantre en esta iglesia adonde vendría. Si sus mercedes parecía que viniese a aprobación y se determinó que se suspendiese por ahora el recibirlo.

\section{ASAC I, fol. 310 r (16-XI-1621)}

Asimismo propuso el Abad cómo Juán del Villa colegial de este Sacromonte suple el oficio de sochantre y que por ser pobre sería bien que se le diese alguna ayuda de costa, que sus mercedes lo viesen. Y después de conferido se determinó que por las dichas razones al dicho se diesen de ayuda de costa mientras suple en el dicho oficio otros mil maravedíes cada tercio de más de los mil que tiene por colegial y que comience a ganar desde primero de septiembre de este año.

El señor Abad propuso cómo por las muchas obligaciones y devoción que tenía a la Virgen María Nuestra Señora y amor aquestos santos lugares y cavernas, tan favorecidos y honrados y engrandecidos con los favores que la Reina de los ángeles les ha hecho y hace todos los días, era su voluntad que la misa de Nuestra Señora que hbía dotado por los días de su vida para que todos los sábados del año se dijese cantada con toda solemnida en el altar de su purísima Inmaculada Concepción, y la Salve que también había dotado en las santas cavernas de este Sacromonte para que todos los sábados por la tarde se cantase en la capilla de Nuestra Señora de la Inmaculada Concepción (...) después de la oración con aquella divina y general aclamación todo el mundo en general que a su purísima e Inmaculada Concepción se le hace por toda la universal Iglesia. El dotarla y perpetuarla, así la misa cantada que en honra de la Virgen María 
nuestra Señora se dice, como la Salve que se dice en las santas cavernas y que en esto se lo miraba su mercé gran cosa. La una era el mayor servicio de la Virgen María nuestra señora, la honra y grandeza de estos sagrados lugares a quién tenía tan inenarrable amor, y lo tercero que esto se hiciese con el mayor alivio y gasto de los señores capitulares, que sus mercedes lo viesen y dispusiesen como si fuera negocio propio de cada uno de los señores on la firmeza y seguridad que pedía para en adelante la perpetuidad de este servicio que a la Virgen María nuestra señora le deseaba hacer. Y que luego entregaría el dinero para que se echase la renta (...) y habiendo conferido entre sí los señores presidente y demás canónigos lo que el señor Abad había pedido (...) dijeron que era muy digno de que se aceptase el servicio que el señor Abad quería hacer a nuestra señora, y de que a su merced se le engrandeciese una obra tan grande como quería hacer y de tanto lustre para este Sacromonte y así se aceptó y que a su seguridad y perpetuidad se obligase el cabildo con toda la firmeza posible

\section{4}

\section{[89] ASAC I, fol. 381 v (2-I-1624)}

Últimamente sabiendo este cabildo por carta del señor canónigo Juan de la Fuente cómo el cuerpo del Ilustrísimo Arzobispo de Sevilla mi señor, que sea en gloria, está depositado en la capilla de Nuestra Señora de la Antigua de la Iglesia Mayor de Sevilla que sería conveniente el traerlo a éste sagrado monte donde tiene su entierro. Lo cual tratado y conferido por los dichos señores capitulares se determinó por la mayor parte que luego se ha de traer el cuerpo de su Ilustrísima habiendo hallanado primero las dificultades que en ello pueda haber.

\section{[90] ASAC I, fol. 382 v (3-I-1624)}

Y luego el señor Abad propuso cómo estaban convidadas las religiones para que en este Sacromonte hiciesen honras y novenario por el Arzobispo mi señor que está en gloria. Y como ellas lo habían admitido y agradecido y que en orden a esto habían enviado su legacía con dos religiosos de las dos órdenes de Santo Domigo y San Agustín ofreciendo de acudir a esto con grande afecto y voluntad conforme se reconocían obligados al dicho señor Arzobispo de Seilla mi señor. Que sería bien que éste cabildo enviase dos señores capitulares que en su nombre lo agradeciesen y aceptasen en la forma que aquí fue resuelto en cabildo y se determinó que fuese así y se nombraron para ello los señores doctor don Francisco de Varaona y Maestro Gabriel de Ledesma canónigos. Y asímismo se les cometió el ir a la iglesia colegial del Salvador de esta ciudad para agradecer aquél cabildo la oferta que de sí había hecho a éste para el mismo efecto.

[91] ASAC I, fol. 400 v (4-IV-1624)

Y luego el señor canónigo Bartolomé de Torres como comisario y maestro de ceremonias mostró un memorial de los que se habían de hacer en orden a recibir a su majestad el Rey nuestro señor que la noche antes había entrado en Granada y conferidos se determinaron las siguientes por mayor parte de votos: que 
cuando subiese a este Sacromonte, este cabildo, capellanes y colegiales procesionalmente le saliesen a recibir por la calzada hasta cruz de los canteros, o por el camino de las mulas hasta salir de la reja. Que al apearse su majestad se le puesiese un sitial y se le mudase a la iglesia. Que en cuanto a recibirlo con palio se hiciese lo que en la Iglesia Catedral.

Que se quitasen los velos de los altares y se pusiesen las reliquias manifiestas como el día del glorioso San Cecilio. Que se adornasen y limpiasen las cuevas (...). Que si se hayare dosel prestado se ponga en la sala en que estaba prevenida la colación. Que los señores capitulares no saliesen con capas pluviales. Que luego en nombre de este cabildo fuesen a visitar a su majestad los señores doctor don Pedro de Ávila Abad, liceniados Agustín Manrique, Andrés Sarmiento, y doctor don Paulo de Valencia canónigos.

\section{ASAC I, fol. 418 r (2-IX-1624)}

Ítem se determinó por mayor parte de votos que una campana antigua que parecía tener cinco o seis arrobas y de tres asas con las armas y cigüeña de hierro se entregase al licenciado Burgos que al presente lee latín en la universidad por cuanto dice pertenecer por escritura y ser de una capilla que estaba encima de la puerta de las orejas de esta ciudad de Granada: y que desta entrega se tome recibo y haga escritura de volverla siempre que a éste Sacromonte muestre títulos por dónde la posee.

\section{ASAC I, fol. 420 v (24-IX-1624)}

Ítem yo el secretario leí una petición de Jerónimo de Valenzuela organista de este Sacromonte en que pedía a sus mercedes que le excusasen de venir a tañer en los días semidoble por el trabajo que en esto tenía y no poderse sustentar con lo que este Sacromonte le daba, para procurarlo él por otra parte en estos días. Y oída esta petición y conferido sobre ella y por razones que allí se dijeron se determinó por todos los votos que no se dejasen de tañer los días semidobles, y que al dicho organista se le haga alguna equivalencia, y el cuánto y el cómo se hará se cometió a la junta de administración que lo vea y ejecute.

\section{ASAC I, fol. 417 v (2-XII-1624)}

Ítem el señor Abad propuso cómo se acercaba el día en que se cumplía un año que hacía muerto el Arzobispo de Sevilla don Pedro de Castro y Quiñones mi señor. Que sería bien aquél día y de allí en adelante todos los años hacer un aniversario por su Ilustrísima, como lo dejó mandado en su testamento. Y asimismo si se había de dar algunas distribuciones en ese aniversario. Y después de conferido se determinó por todos los votos que perpetuamente a los veinte de diciembre, se celebre un aniversario y honras por el Arzobispo de Sevilla mi señor, con la solemnidad y aparato que tan gran príncipe y tan insigne fundador se debe, y que esto se haga sin alguna distribución. Y en cuanto al modo y disposición de la celebración se comete a la junta de ceremonias que hará memorial de ellas y se traiga a cabildo. 
Y luego el señor presidente propuso como el día siguiente era domingo tercero de Adviento y aunque era octava de Nuestra Señora no se rezaba de ella en las vísperas desde la capitula este día que era sábado. Y que conforme a la fundación del aniversario del canónigo Pedro Gómez se deben decir en esta octava de la Concepción vísperas y misa de Nuestra Señora. Que si a sus mercedes parecía que este día de hoy dijeren "después de las vísperas y completas de este sábado" otras vísperas cantadas de Nuestra Señora. Y después de conferido se determinó por mayor parte, que por esta vez se dijesen estas vísperas por las razones dichas.

\section{ASAC I, fol. 429 r (18-XII-1624)}

Y luego estando así juntos el señor maestro de ceremonias recibió el memorial y orden de ceremonias que se habían de hacer en el aniversario y honra del Arzobispo mi señor. Y se ordenó a el señor maestro de ceremonias lo escribiese en la Consueta. Y por mayor parte se determinó y puso pena de dos maravedíes al prebendado que faltase a este y a los demás aniversarios de difuntos.

\section{5}

\section{ASAC I, fol. 445 v (13-III-1625)}

Todos llamados y prevenidos un día antes para la provisión de las cuatro capellanías del coro de esta iglesia, que en cabildo atrás está determinado se provea. Y luego propuso el señor Abad que en el cabildo de trece de agosto del año pasado, está determinado de proveer las capellanías del coro desta iglesia, y que por ciertas razones y congruencias se habían dilatado de proveer y por si este cabildo se determinase a ordenar colegiales a título de colegio que sustentasen de la renta de las dichas capellanías ahora cuando hubiesen acuerdo de cursar la teología, según las constituciones dan facultad, que estaban excluidos los colegiales que se habían propuesto para el dicho fin como consta de los cabildos antecedentes, que no había razón para dilatar más la provisión. Y oído y conferido se determinó por la mayor parte se provean luego pues están opuestos a ellas todos los once colegiales que han acabado de cursar la teología. Y luego se dieron cédulas con los nombres de los dichos opositores, y se votó la primera capellanía y salió nombrado en ella el señor Nicolás Fernández de Biezma colegial por ocho votos de los doce que es este cabildo y en la segunda salió nombrado el señor don Pedro de Montilla colegial por nueve votos, y en la tercera salió nombrado por siete votos el señor Juan Cano Mexía; y en la cuarta capellanía salió nombrado por ocho votos el señor Francisco Cano Guerrero colegial. Y después de esto se llamó a cabildo para tratar de las informaciones que se les han de pedir. 
Ítem propuso el señor Abad cómo el señor Juan Villar de Vago colegial, estaba ordenado de orden sacro a título de colegio, y que la consueta de las ceremonias dispone que cuando el sochantre está ordenado de orden sacro se siente en la silla más antigua de los capellanes aunque dejara otros capellanes sacerdotes y más antiguos, que parecía era conveniente se le diese al dicho Juan Villar colegial título de sochantre y que se cubra y se siente como dicho es en la silla más antigua pues lo merece por su buena voz y por las demás partes que en él se conocen y para el dicho oficio de sochantre. Y oído y conferido se determinó por todos los votos se le de título de sochantre del coro de esta iglesia, y se siente en la silla más antigua de la mano derecha del coro viejo de los capellanes y se cubra.

[99] ASAC I, fol. 458 r (9-VI-1625)

Ítem en este cabildo se leyó una petición de Jerónimo de Valenzuela organista de este Sacromonte en que decía cómo el salario que al presente se le daba no era competente para poder pasar y no hacer falta a las obligaciones de su oficio en esta iglesia, que sus mercedes le hiciesen merced de algún aumento para con esto traer a su mujer que estaba en Jaén, o no habiendo lugar que se le diese licencia para ir a aquella ciudad a la disposición de sus cosas para poder volver a servir a esta iglesia. Y oída esta petición se dilató para otro cabildo el ver lo que se haría en esta parte y petición.

[100] ASAC I, fol. 458 v (10-VI-1625)

Ítem el señor Abad propuso cómo por el cabildo próximo pasado se había dilatado para este el ver y determinar si se le daría algún aumento a Jerónimo de Valenzuela organista conforme lo suplicaba allí por su petición. Y después de conferido se determinó por mayor parte de votos que por las razones que allí representaban y por otras que a este cabildo le movieron que el dicho Jerónimo de Valenzuela se le de los días que no comiere en este Sacromonte o cenare la ración de carne para comer y cenar que es libreta y media o lo que montare en dineros a como le saliere el Sacromonte; y en los días de pescado se le hará el cómputo como si fueran de carne.

[101] ASAC I, fol. 463 r (22-VI-1625)

Y luego el señor Abad propuso cómo se había tenido noticia de la muerte del señor Cardenal Duque de Lerma, pío del señor Cardenal de Jaén, y que ya sabían sus mercedes cómo el dicho señor Cardenal de Jaén había hecho honras en la muerte del Arzobispo de Sevilla mi señor que por esta razón y por otras en que este cabildo estaba obligado al dicho señor Cardenal, sería bien pareciendo a sus mercedes que en este Sacromonte se celebrasen honras por el dicho señor Duque de Lerma. Y habiendo oído al señor Abad y conferido atentas las razones dichas 
se determinó por todos los votos que el día siguiente se celebrasen las honras dichas, diciendo por la mañana vigilia y misa de difuntos con toda solemnidad. Y que el señor Abad dijese la misa, a todo lo cual asistiesen todos aunque no se les obligaba a ello a los que no quisieren. $\mathrm{Y}$ asimismo se determinó que los señores comisarios escribiesen al señor Cardenal de Jaén dándole el pésame de la muerte del señor Cardenal Duque de Lerma.

[102] ASAC I, fol. 472 v (4-IX-1625)

Y luego el señor presidente propuso cómo el señor licenciado don Justino Antolínez Deán de la Santa Iglesia de Granada, estaba muy enfermo y en peligro y que suplicaba se le dijesen dos misas solemnes cantadas en este Sacromonte de la Inmaculada Concepción de Nuestra Señora, en su altar, ofreciendo la limosna que este cabildo quisiese para que nuestro Señor le diese salud o le diese disposición para morir en su santa gracia. Que sus mercedes viesen si se haría, y oído y conferido se determinó por todos los votos que se dijesen las dos dichas misas solemnes en los dos días siguientes, inmediatamente después de las horas menores, asistiendo este cabildo y todos los demás ministros. Y esto sin que se recibiese limosna ni otra distribución alguna por cuanto este cabildo desea la salud del dicho señor Deán y servirle en esto y en todo lo demás que fuere necesario para la ,mejora de su salud y bien de su alma.

[103] ASAC I, fol. 478 r (2-X-1625)

Ítem en este cabildo tratando de ceremonias, se determinó por mayor parte que en la misa solemne después de haber cantado el coro en Benedictus qui Venit toque el órgano aquel espacio de tiempo que no se canta. $\mathrm{Y}$ asimismo se determinó que en el coro mientras cualquier señor prebendado entona alguna antífona, los demás estén levantados y con las mangas de las sobrepellices bajas, por cuanto ha de estar de la misma forma el dicho señor intonante y que esta ceremonia y la pasada se escriban en la Consueta.

[104] ASAC I, fol. $479 \mathrm{v}(12-\mathrm{X}-1625)$

Y luego el señor presidente hizo nueva presentación al cabildo del privilegio original escrito en vitela con cordones de seda y oro y caja de plata, en que su Majestad el Rey nuestro señor, se constituía por patrono, amparo y protector de este Sacro Monte y su iglesia y casa. El cual privilegio había tenido en custodia y guarda, en la ciudad de Sevilla, el licenciado Cristobal de Aybar. Secretario del Arzobispo mi señor, que sea en Gloria. Y todo el cabildo con señales de alegría estimó este favor y merced tan grande y como tal lo recibió y mandó que se echase cubierta dorada y luego se encerrase en el archivo de las cuatro llaves donde tiene en custodia los demás sus privilegios y bulas. 
Ítem se determine por todos los votos que el licenciado Juan Villar sochantre de hoy en adelante gane los manuales en la forma y como lo disponen las constituciones que gane el sochantre.

\section{6}

[106] ASAC I, fol. 487 v (2-I-1626)

Y estando así juntos se trató de ceremonias y se determinó que en cuanto a la pronunciación de los acentos, se observase como venía apuntado en lo hoy nuevamente reformado por Plantino.

Y luego el señor presidente propuso cómo el cabildo de veinticuatros de esta ciudad de Granada, este día en la iglesia Catedral había asistida y hecho solemne fiesta a Nuestra Señora en hacimiento de gracias a nuestro señor por haber librado esta dicha ciudad de las avenidas y tempestades (...) han sido combatidas y atribuladas. Que asimismo habían determinado por la mayor razón de venir a este Sacro Monte y en su iglesia decir otra misa solemne a nuestros santos gloriosos y adorar sus sagradas reliquias. Que si a sus mercedes parecía se admitiese que su venida había de ser de allí a dos días, y que ofrecían para la cera, música y olor cuatrocientos reales. Todo lo cual oído y conferido por los dichos señores capitulares todos aceptaron la dicha venida y dijeron se agradeciese mucho, adornase la iglesia y se pusiese un teatro grave en esta ocasión conforme era debido.

[108] ASAC I, fol. 498 r (12-V-1626)

Y luego propuso el señor Abad cómo el señor Arzobispo de Granada don Galcerán Albanés era muerto, que vieran sus mercedes qué se haría acerca de sus honras. Determinose por mayor parte que se diga esta tarde una vigilia y luego, otro día después de horas, se cante una misa por su Ilustrísima.

Ítem el señor Abad propuso cómo el señor Arzobispo había dejado en su vida al Sacromote unos libros que por la mano había escrito, que sus mercedes les aceptasen. Determinose por todos los votos que se aceptaba.

\section{[109] ASAC I, fol. 504 v (7-VII-1626)}

Y luego el señor presidente propuso cómo el señor Deán había tenido noticia que el señor Arzobispo de Santiago su hermano, era muerto. Que si a sus mercedes parecía se le hiciesen algunas honras para con eso agradecer algo de lo mucho que esta iglesia debía a su Ilustrísima y al señor Deán de Granada. Y por todos los votos se determinó que se dijese vigilia y misa cantada de difuntos con 
solemnidad, después de horas este dicho día y que el señor maestro de ceremonias los dispusiese y diese orden que se doblase a su tiempo.

Ítem al señor licenciado Agustín Manrique que le cometió el hacer adornar los libros de canto y misales y breviarios por mayor parte de votos.

[111] ASAC I, fol. 513 v (19-IX-1626)

Item en este cabildo el señor Abad propuso como el licenciado Juan del Villar sochantre, pedía se le aumentase el salario que se le daba. Que sus mercedes lo viesen y votasen. Y después de conferido se determinó por mayor parte que al dicho señor licenciado Villar se le hiciese escrutinio secreto de limpieza viniendo él en ello y que aprobándolo este cabildo quedase nombrado de ello en la capellanía que fundó Luis de Vega.

Ítem el señor Abad propuso que sus mercedes diesen cuantos velos colegiales había de acudir de ordinario al coro. Y conferido se determinó por dos partes de votos que de aquí al nueve de septiembre del año que viene de mil seiscientos veintisiete acudan seis colegiales fijos todos los días de estudio y asueto. Y que el día que hubiese más de dos hachas en la misa, acudan los más que fueren menester al coro, para de allí salir a la misa. Y que para otro cabildo se viese si habían de acudir todos en las vacaciones.

[112] ASAC I, fol. 514 r (28-IX-1626)

Ítem en este cabildo se cometió al señor maestro Gabriel de Ledesma, canónigo, el hacer escrutinio secreto de la limpieza del licenciado Juan del Villar, sochantre, en orden a darle en aumento de salario la capellanía que fundó el licenciado Luis de Vega.

[113] ASAC I, fol. 520 r (7-XI-1626)

Ítem en este cabildo el dicho señor doctor don Paulo dio cuenta del escrutinio secreto en razón de la limpieza y calidades del licenciado Juan del Villar, sochantre. Y pareció que se le diese la capellanía que fundó el licenciado Luis de Vega por cuanto no pide información que cuando se haya de dar ésta se enviará informante y se le hará información.

1627

[114] ASAC I, fol. 535 r (2-I-1627)

Ítem el señor Presidente propuso cómo el sochantre de la iglesia pedía sus mercedes y presentaba petición suplicando le mandasen dar el lugar $\mathrm{y}$ 
precedencia que se le debe en todos los actos de comunidad como lo han tenido sus antecesores que es preceder en el coro y en otro cualquier acto a todos los capellanes de esta santa iglesia y habiéndosele ido.

\section{[115] ASAC I, fol. 549 v (7-IV-1627)}

Ítem se admitió como dicho señor don Francisco de Varaona maestro de ceremonias había mandado y ordenado que se tañese el órgano juntamente cuando el coro respondió al Ite Missa est del sábado santo y que era contra Consueta y se pidió al dicho señor presidente lo propusiese para que el cabildo votare sobre ello y el dicho señor presidente lo propuso y habiéndose conferido se determinó por todos los votos que se le advierta al dicho señor maestro de ceremonias no se haga otra vez esto ni otra cosa que no estuviere en consueta y conforme a lo determinado en el cabildo arriba referido y por mayor parte de votos se determinó que hizo su merced contra Consueta en esta dicha acción en ordenar y (...) juntamente el órgano y que incurrió en la pena de dos ducados y que por esto en particular no se ejecute por esta vez. 


\section{TOMO II}

[116] ASAC II, fol. 1 r (1-IX-1627)

Se propuso que algunas veces había tan pocos colegiales en el coro que no quedaban en él más de los versicularios y que el colegial que estaba por portero a la puerta del coro se estaba sentado en un banquillo sería conveniente que cuando faltasen colegiales en el coro entrase el dicho colegial portero a suplir por los que faltaban y habiéndose conferido se determinó por mayor parte de los votos que el colegial portero entre a suplir cuando falten colegiales que digan los versos.

(1v) Ítem se propuso que se decían algunos yerros cuando se cantaban las oraciones en famulos habiendo dicho los de acunctis o ecclesique porque se olvidaban o equivocaban en dejar las cláusulas que se han de dejar por estar todo escrito en la dicha oración en famulos que sería conveniente se remediase y habiéndose conferido se determinó por todos los votos que se escriban oraciones en de buena letra quitada las cláusulas para cuando se dicen las oraciones acunctis y otra para cuando se dice eclesie y se pongan en los misales.

[117] ASAC II, fol. 5 r (17-X-1627)

Dicho señor Abad propuso como habían venido unos peregrinos de Jaén a decir en esta Iglesia una misa cantada al Sr. San Cecilio que habían prometido en una enfermedad y que el cabildo tiene determinado que no se digan las dichas misas cantadas menos que dando dos mil maravedíes de limosna y que las personas que quieren decir la dicha misa por ser pobre no tienen más que cincuenta maravedíes que dar de limosna y que sus mercedes viesen si se diría la dicha misa y habiéndose conferido y atendiendo a la devoción de las dichas personas se determinó por todos los votos menos uno que se diga la dicha misa por los cincuenta maravedíes de limosna esta vez no más al no tener la persona que los ofrece más y que este cabildo le hace gracia y limosna.

[118] ASAC II, fol. 6 r (25-X-1627)

Ítem el dicho señor Abad propuso como el licenciado Villar sochantre hacía más de dos meses que estaba ausente sin licencia y que se decía que no había de volver, que sus mercedes viesen qué se había de hacer con él acerca del salario y capellanía que tenía y habiéndose conferido se determinó por todos los votos y que desde luego se le vaque y se le vaca al licenciado Villar la capellanía de Vega y el salario de Sochantre y los manuales porque ha estado ausente sin licencia y por otras causas.

Ítem el dicho señor Abad propuso que sus mercedes viesen si se pondría túmulo en la Iglesia el día de la conmemoración de los difuntos por el arzobispo mi 
señor y por sus padres y habiéndose conferido se determinó por mayor parte de votos que se ponga túmulo todos los años de aquí en adelante el día de la conmemoración de los difuntos desde sus vísperas por el arzobispo mi señor y por las dos partes de votos del cabildo se determinó que se ponga como se pusiese este año que es la tumba sobre una tarima con sus alfombras [fol. 9r] y sobre la tumba el paño de brocado con los cojines y mitra y doce varas lo más recogido que pudiese ser por que no ocupe mucho la Iglesia y que esta ceremonia se ponga en la Consueta.

Ítem el dicho señor Abad propuso como ya constaba a sus mercedes de cómo el licenciado Villar sochantre se había ido y que estaba ordenado a título de colegio que sus mercedes viesen si se haría diligencia para hacerle volver y si sobre ello se escribiría al señor Cardenal de Jaén y habiéndose conferido se determinó por mayor parte de votos que se haga diligencia para que el señor licenciado Villar vuelva al Sacro Monte y que sobre ello se escriba al señor Cardenal de Jaén.

\section{[120] ASAC II, fol. 11 r (16-XI-1627)}

Ítem se determinó por todos los votos que fueran nombrados comisarios los señores licenciados Bartolomé de Torres y el Po. de Santiago para que visiten al señor Obispo de Guadix a que fuese necesario para prevenir el día, el como y todo lo demás que fuese en orden al recibimiento de la reliquia y si les pareciese traer música y ministriles la traigan para este recibimiento.

\section{ASAC II, fol. 12 v (6-XII-1627)}

Y luego el señor Abad propuso como ya a sus mercedes constaba que esta Iglesia estaba sin sochantre que había necesidad de recibir persona que hiciese este oficio y que al presente el licenciado Jacinto de los Ríos siéndose sochantre que ha sido de la Iglesia del Salvador de Granada pretendía serlo de esta Iglesia y que ya sus mercedes habían visto la persona y le habían oído cantar que ahora viesen si era a propósito que le recibiesen si les pareciese y habiéndose oído y conferido fue recibido por los dichos los votos por sochantre de esta Iglesia el dicho licenciado Jacinto de los Ríos con seiscientos maravedíes de salario en cada año repartidos por puntos entre día fuera del punto la oración y con que si se le hubiese de dar después capellanía se le ha de bajar el salario la cantidad del supertoni que hubiese la capellanía y se le haya de hacer información si hubiese de tener capellanía.

\section{8}

[122] ASAC II, fol. 35 v (3-VIII-1628)

Y en este cabildo se leyó una petición del licenciado Jacinto de los Ríos, sochantre de este Sacro Monte en que pide al cabildo se le aumente el salario por algunas causas que en la dicha petición refiere y habiéndola oído los señores capitulares se remitió este asunto para otro cabildo. 
Luego el señor Abad propuso como ya sus mercedes habían en el cabildo pasado oído la petición del licenciado Jacinto de los Ríos sochantre Catalán [sic] en que suplicaba al cabildo se le aumentara el salario por diversas razones que en ella proponía que vieran sus mercedes si se le daría la capellanía de Vega que al presente estaba vaca y conferido se determinó que se le dé al dicho licenciado Jacinto de los Ríos la capellanía de Vega y que no se le haga información por cuanto esta capilla no es de la fundación del Sacro Monte y en la suya no la pide y que si el dicho licenciado Jacinto de los Ríos faltase la oración se le de de la fabrica lo que perdiere y todos estos maravedíes fuera del señor cano Valdivia se dieron en la fabrica los intereses [...] que hubiere el dicho Jacinto de los Ríos.

\section{9}

[124] ASAC II, fol. 75 v (2-VII-1629)

Ítem por todos los votos menos uno que las faltas que hiciere el sochantre y organista en sus oficios las apuntara el señor apuntador y que se les avise para que no hagan faltas y se les quiten las faltas a rata per cantidad de su salario y que el sochantre tenga obligación de entrar en el coro antes de empezar el Gloria Patri del Introito para que no sea falta y las faltas de la Capellanía han de ser según y como los demás capellanes pierden.

En este cabildo se leyó una petición del Maestro Jacinto de los Ríos sochantre de este Sacro Monte en que pide se le haga merced de darle ocho fanegas de trigo y doce de cebada para sembrar al cortijo que tiene arrendado para pagarlas al precio que lo fíen cuando vendiere el trigo el señor maestro y reservando de su salario el precio del mismo y habiéndolo oído y conferido se determinó por todos los votos menos uno que se le den las ocho fanegas de trigo y doce de cebada que pide a pagarlas al precio que corriere la primera vez que le de el maestro algo para vender el primero día y reservando de su salario hasta cuatrocientos de la primera que fuere corriendo para el dicho pago del trigo y la cebada, y el señor canónigo Torres pidió que se explicase su dicho voto que fue de parecer que no se le diese trigo ni cebada al dicho sochantre.

[126] ASAC II, fol. 97 r (2-XI-1629)

En primer lugar se trató de ceremonias de la Iglesia y se determinó se avise a los señores capellanes bajen la cabeza cuando se dice en el Credo simul adoremus en las misas cantadas. 
Y luego propuso el señor Presidente como el licenciado Juan de Gálvez se había ido a servir al Cardenal de Jaén y había idose sin licencia que sus mercedes viesen si se le vacaría la capellanía que servía en este Sacro Monte y por todos los votos se determinó que se le dé por vaca la dicha capellanía.

[128] ASAC II, fol. 101 v (16-XII-1629)

Ítem propuso el señor Abad que si a sus mercedes parecía se proveyesen una o dos capellanías a tesitura de la necesidad que había de capellanes para el servicio del coro e Iglesia y conferido se determinó por todos los votos que se provea solamente la capellanía que vaca por la ausencia del licenciado Juan de Gálvez que se provea en persona llamada de fuera o de la ciudad de Granada.

1630

[129] ASAC II, fol. 106 v (9-I-1630)

Propuso el Señor Presidente que el Cabildo de la ciudad de Granada ha determinado que no se nombren comisarios como fuese para la fiesta del Sr. San Cecilio sino que se den al Sacro Monte seis mil maravedíes para que el Monte haga su fiesta si se aceptarán estos seis mil maravedíes y que se le responderá si la ciudad envía legación acerca de esto y que ha de hacer y gastar el Sacro Monte en dicha fiesta $7 \mathrm{r}$ y conferido se determino que los seis mil maravedíes no se acepten y a los comisarios que vinieren de parte de la ciudad se les responda intimándoles las obligaciones que todas las ciudades tienen a sus santos patrones y lo mucho que honran sus reliquias y los lugares donde padecieron y están sus cuerpos y las grandes obligaciones en que está a su glorioso patrón San Cecilio y a este Sacro Monte y como el remedio de las necesidades presentes que padece todo este reino se ha de alcanzar de nuestro Señor por intercesión de este glorioso patrón honrándolo y reverenciando mucho sus reliquias y este lugar e Iglesia y casa suya celebrando el día de su martirio y cumpliendo el voto que de esto tienen hecho.

Ítem que este Sacro Monte haga su fiesta del glorioso Santo y Patrón San Cecilio muy cumplida de fuegos, olor y música y con toda solemnidad.

[130] ASAC II, fol. 110 r (4-II-1630)

Se trató en primer lugar de la guarda de Constituciones y loables costumbres y de la ceremonias y se propuso la mucha falta que hacía el sochantre en faltar del coro y más porque lo hacía sin licencia y se determinó que se le avise al sochantre que no falte del coro sin especial licencia y si faltase se le ha de multar en lo que pareciera conveniente de más de apuntarle en perdido el punto en el 
que faltare y que aunque tenga licencia para faltar ha de avisar al apuntador y si no le avisa le apuntan en falta como se acostumbra con todos los capellanes.

Ítem propuso que tres sacerdotes pretendían ser capellanes del Sacro Monte el licenciado Herrera natural de Antequera, el maestro Blas Peinado sobrino del señor canónigo Sarmiento y otro natural de Úbeda que sabe muy bien cantar y conferido que se reciban en aprobación los dos de ellos no más, el licenciado Blas Peinado y el de Úbeda.

[132] ASAC II, fol. 112 v (2-III-1630)

Determinose que se advirtiese al señor Rector y Maestro de Ceremonias que los días de fieónigo. Desta y los demás solemnes y los que hay tracto en la Cuaresma acudan a la lección Mora y Ximena, colegiales que saben cantar y tienen voz para que ayuden a cantar en la misa al Sochantre y si tuviesen oficios estos colegiales los suplan otros por ellos en aquel tiempo.

Ítem que la lección de ceremonias que se tienen los domingos con los colegiales se tenga en la parte y lugar que pareciere al maestro de ceremonias más conveniente.

Determinó por todos los votos que todo el camino de las cruces no se arriende nada a persona ni dentro ni fuera del Sacro Monte y que así mismo el Cortijo de Nicodemus no se arriende nunca a persona de casa en dejándolo el Sochantre y que entre tanto se le obligue a que cumpla las condiciones del arrendamiento.

\section{[134] ASAC II, fol. 131 r (4-VII-1630)}

Por tercero se leyó una petición de Jerónimo de Valenzuela organista, en que pide que se le de su ración en Granada donde quiere ir a vivir y se determinó por todos los votos que no se innove nada en lo que se haga ahora y que si se fuese a vivir a Granada se le de su salario y trigo y coma en el refectorio el día que viniese a hacer su oficio mas que se entienda que no lo han de curar ni lavar la ropa y que si se queda en el Sacro Monte ha de observar en todo el orden de la comunidad comer a primera mesa y las demás cosas.

\section{[135] ASAC II, fol. 132 v (24-VII-1630)}

Propuso el señor Presidente que el canónigo Miguel Díaz de Ayllón al que se le habían cometido las pruebas del licenciado Blas García de Santaella había ya remitido la información que si se leería luego y habiendo respondido todos los señores capitulares que se leyese lo hizo así el Secretario después de oída se confirió si se procedería al acto de aprobar la dicha información y pareció a todos que sí advirtiendo antes que si alguna vez el dicho licenciado Santaella 
[fol.135r] pudiere o hubiere de entrar en alguna canongía se le ha de hacer nueva información en cuanto a lo que toca a sus abuelos paternos porque aunque la información hecha está muy buena y cumplida cuanto a la parte de su madre, en cuanto a la de su padre está defectuosa, no en lo que toca a la limpieza, sino en la prueba de la naturalidad, y de la identidad de los abuelos paternos, lo cual se ha de suplir en la villa de Alcaudete de donde fueron naturales los dichos sus abuelos, o en otra cualquiera donde se hallare noticia, valiéndose para esto de la fe del bautismo de Alonso García Peinado de las Italias, padre del dicho licenciado Blas García de Santaella donde se dirá cuyo hijo fue y tomando juramento cuando no se pueda hacer otra cosa a los mismos parientes del dicho. Con este advertimiento se procedió a la aprobación de las dichas informaciones, $\mathrm{y}$ por todos los votos secretos de habas blancas y negras salieron aprobadas, determinándose asimismo que las dichas informaciones se entren en el archivo debajo de las cuatro llaves. Luego se procedió a la provisión de la capellanía y por todos votos secretos de habas blancas y negras salió proveído en la dicha capellanía del coro el licenciado Blas García de Santaella, el cual fue llamado y entró en la sala de cabildo y se le leyó la constitución 2 título 22 y juró de guardar lo que en ella se contiene, y lo firmó de su nombre en este libro de actas capitulares de la forma siguiente

Yo el licenciado Blas García Peinado de Santaella digo que en 24 de Julio de este presente año de 1630 estando juntos en cabildo los señores prebendados del Sacro Monte fui llamado a él, y delante de los señores capitulares me fue leída por el canónigo Martín Vázquez Siruela una constitución que dijo ser la 2 del tit 22 del tenor siguiente: las dichas capellanías no han de ser beneficios colativos en ningún tiempo, si no servicios manuales y amovibles ad nutum y así podrán ser los dichos capellanes ser excluidos siempre que parezca al cabildo conociendo en ello las dos partes de tres, sin que tengan la obligación de dar causa para ello, y lo que se determinare en esta razón se ha de ejecutar sin embargo de apelación ni de otro recurso alguno. Para que esto se haga con mayor quietud se leerá esta constitución a cualquiera capellán que fuera nombrado antes de ser admitido, y lo consentirá, y su consentimiento se escribirá y lo firmará en el libro capitula. Igualmente y habiendo oído (fol. $135 \mathrm{v}$ ) vuelto el tenor de la dicha constitución y el dicho licenciado Santaella, estando nombrado en una de las capellanías del coro de esta santa Iglesia digo que consciente en todo lo que manda la dicha constitución 2 del título 22 y que conforme la acato y mando que el cabildo de este Sacro me excluyese en la forma que ordena la dicha constitución obedeceré sin embargo de apelación ni de otro recurso alguno, y sin obligar al cabildo a que de las causas que tuviere para mi exclusión, en fe de que así lo consiente lo firmo de mi nombre según que en la dicha constitución se ordena.

(...)

Asimismo juró el dicho la obediencia conforme a estas constituciones de la manera y forma que en el título final se contiene.

Ítem juró de tener la opinión que de la Inmaculada Concepción de Nuestra Señora.

[136] ASAC II, fol. $₫ ?(i ?-V I I I-1630)$ 
Lo cuarto se leyó una petición de Jerónimo de Valenzuela organista del Sacro Monte en que pide que se le dé su ración en Granada y por mayor parte se determinó que se guarde lo ya otra vez determinado acerca de este punto en cabildo de cuatro de Julio.

Examinose este día el licenciado Blas García de Santaella, capellán de este Sacromonte que por estar graduado de bachiller en Teología fue el último de los opositores el examen fue de teología escolástica argumentaron los señores doctores den Pablo de Valencia, doctor Gabriel de Ledesma y Martín Vázquez Siruela, examinadores nombrados por el cabildo. Duró el examen hora y media la cual concluida se acabo el acto de este cabildo del que doy fe.

Examinose este día de teología moral el licenciado Pedro de Mansilla, capellán de este Sacro Monte.

\section{[139] ASAC II, fol. 145 v (30-IX-1630)}

El Señor Presidente propuso que entre el organista y el sochantre de esta santa Iglesia hubo un encuentro muy pesado, y que habiéndole su merced reprendido al uno y al otro, el organista había respondido libre y descortésmente y de hecho se había ido a Granada faltado en las primeras vísperas y del día de San Miguel, publicando que se iba despedido en razón de lo cual pasaron otras lanzas que refirió el señor Presidente, proponiendo que los señores capitulares viesen lo que en este caso se había de hacer así en castigar las libertades y excesos del organista como en echar alguna pena al sochantre: por la culpa que tuvo en el caso y para que le sirva de corrección.

Después de propuesto este punto entró en el cabildo el señor canónigo Bartolomé de Torres y habiéndose conferido sobre él se determinó por mayor parte atento a que el organista se despidió él mismo por su voluntad, por autoridad y decreto del cabildo se tiene por despedido y si acaso alegase no haberlo dicho de veras no obstante esto se cumpla y ejecute este decreto del cabildo y si después pudiere que lo vuelvan a recibir entonces verá este cabildo lo que más conviniere y hubiere motivos bastantes para ello lo hará con las condiciones que fuere razón.

Ítem que al licenciado Jacinto de los Ríos sochantre, por la parte que tuvo en el caso lo llamen a la Junta de Asistentes, y allí se le reprenda con severidad lo que hizo de parte del Cabildo. Y se le avise apretadamente que ponga enmienda en algunas cosas que en el cabildo se advirtieron.

[140] ASAC II, fol. 146 v (2-X-1630)

Y tercero se propuso que había mucha necesidad de reformación en la lección de canto, y así en la puntualidad de en ella, como en el modo de enseñar a los colegiales. Se determinó que el sochantre cuide de cumplir esta obligación 
puntualmente avisándole de lo que está a su cargo y debe hacer. Ítem que el día que dejare de asistir sin licencia del señor Abad o Presidente de la casa, se le apunte medio real de falta. Asimismo que todos los que conforme a la Constitución deben asistir a la dicha lección de canto lo hagan con toda puntualidad los días en que se tuviere, en primer lugar los colegiales, el hebdomadario, los huéspedes de aprobación y capellanes, porque todas estas personas mandan las Constituciones que asistan a la lección de canto. Y porque esto se cumpla con efecto un colegial tenga cuidado de avisar al sochantre y al hebdomadario cuando fuere hora de tener la dicha lección.

$[147 \mathrm{r}]$

Leyose una petición de Jerónimo de Valenzuela organista que fue de este Sacro Monte en que suplica que el cabildo lo vuelva a restituir en el oficio que tenía. $\mathrm{Y}$ habiéndose conferido sobre ello fue acordado por mayor parte que el decreto en que este cabildo lo despidió no se revoque al presente, sino que permaneciese así por algunos días condenado hasta que al cabildo le parezca otra cosa.

\section{$[150 \mathrm{v}]$}

Luego propuso el señor Presidente que habían sido llamados para recibir a Jerónimo de los Ríos organista, que los días antes se había despedido y suplicaba lo volviesen a recibir y fue recibido con que viniese dentro de casa y que no salga sin licencia, y guarde el orden y constituciones de los capellanes en cuanto conviene a su estado de seglar, y en cuanto al salario el mismo que se tenía antes en manuales y no

\section{[141] ASAC II, fol. 157 r (¿?-XII-1630)}

Ítem propuso el señor Presidente como el maestro Pedro de Mansilla capellán ausente escribe una carta a canónigo renunciando a su capellanía y se leyó la dicha carta y conferido se determinó por todos los votos dar por vaca dicha capellanía y borrar del punto y que se le busquen luego dos capellanes

[142] ASAC II, fol. 159 r (22-XII-1630)

Ítem se leyó una petición de Jerónimo de Valenzuela organista en que pide que el salario de las doce fanegas de trigo que se le quitó los días pasados se le devuelva, igualmente y habiéndose conferido se determinó que se remita a los señores Hurtado Ossorio y Ledesma para que lo traten (...) 
Ítem se propuso que el sochantre canta con notable fuga y velocidad algunas antífonas lo cual desdice de la gravedad de esta Iglesia y es necesario que se le avise para que en esto haga reformación.

Ítem que ninguno de los señores prebendados, fuera del señor presidente del coro o maestro de ceremonias no abrevie ni alargue el compás del coro, sino que se guarde lo que en otros cabildos se ha determinado acerca de este punto.

\section{ASAC II, fol. 166 v (9-II-1631)}

Propuso el señor Abad que el licenciado Juan de Padilla sacerdote que ha venido al Sacromonte para ser capellán ha estado quince días en aprobación, y que así vea el cabildo si proseguirá en ella o será recibido para que se le haga las pruebas en la forma que ordena la Constitución, y antes de votar se confirió sobre lo que se haría y habiendo parecido a la mayor parte que se podía votar se tomaron los votos secretos de habas blancas y negras y por mayor parte de habas blancas fue admitido el dicho Licenciado Juan de Padilla para que se le hagan las pruebas y confiriéndose sobre quién iría a hacer las dichas pruebas por mayor parte fue nombrado el señor canónigo Bartolomé de Torres.

\section{[145] ASAC II, fol. ¿? (13-II-1631)}

Propuso el señor Presidente como el señor canónigo Bartolomé de Torres en ejecución de lo que el cabildo cometió a su merced a 9 de febrero, tenía ya dispuesto el viaje para ir a hacer las pruebas al licenciado Juan de Padilla que pretende ser capellán del coro de esta Iglesia, y que para esto era necesario salir de Granada, y que así pedía su merced licencia al cabildo para ir donde fuese menester a hacer las dichas informaciones por los días que parecieren necesarios.

[fol. $167 \mathrm{r}$ ]

Si se dio a su merced la dicha licencia y por mayor parte se determinó que fuese por quince días que se han de contar desde el mismo punto que su merced partiere del Sacromonte, y que sean gastados de sus reales. Ítem que de los quince días al dicho señor licenciado Padilla no se le cuenten más de los que se ocupare el licenciado canónigo Bartolomé de Torres en hacer la misma información.

Propuso el señor Presidente como el señor canónigo Bartolomé de Torres comisario nombrado para la información del licenciado Juan de Padilla había 
venido y la presentaba, y habiéndola entregado se leyó por mi el infrascripto secretario a la letra, y después se confirió lo que hubo que tratar acerca de ella, y habiéndose dado votos de habas blancas y negras fue votada y aprobada por todos diez votos de habas blancas. el señor Presidente propuso que ya los señores capitulares han visto y experimentado la persona y costumbres del dicho licenciado Juan de Padilla que si había alguna cosa que advertirse o que debería recibirle por capellán de esta santa Iglesia y habiéndose conferido.

$[172 \mathrm{v}]$

Tomado los votos salió elegido por capellán del Sacromonte por todos diez votos secretos. Fue llamado a cabildo y se le leyó la Constitución 2 del título de capellanes y después hizo el juramento de ella y de las demás constituciones como en ellas se contiene y de guardar y observar la opinión de la Inmaculada Concepción conforme al decreto y voto de este cabildo, y demás de haber jurado lo que se contiene el la segunda constitución dicha, conforme a lo que en ella se ordena lo firmó de su nombre en el libro de actas capitulares como sigue (...)

[147] ASAC II, fol. 182 v (1-VII-1631)

Ítem se advirtieron otras ceremonias y entre ellas que el sochantre es poco [...] en su oficio y que falta algunas veces al coro y lección de canto y se determinó que se guarde (en cuanto a faltar a la lección de canto sin licencia) lo que está ordenado en cabildo de 1 de octubre de 1630 poniéndole medio real de falta cuando faltare sin licencia, que cuando faltare en el coro se le ponga así mismo falta del punto a que no asistiere mas que si esto fuere con notable exceso se tratará de echarle por más grave.

[148] ASAC II, fol. 187 r (31-VII-1631)

Propuso el señor Presidente que el licenciado Juan de Padilla capellán de esta Iglesia había usado una descompostura con Jerónimo de Valenzuela organista hasta darle de mojicones y hacerle sangre en la cabeza y lastimándole la mano con mucho escándalo de toda la casa, sobre el cual hecho por orden del señor Abad había estado recogido en su aposento desde el día que el caso sucedió, y habiéndose tratado en la Junta de la pena.

Que se le ha de dar viene teniendo al cabildo a que tome en ello la resolución que más conviniere: y habiéndose conferido y considerado el y todas las circunstancias del caso por siete votos de ocho se determinó que al dicho licenciado Juan de Padilla en pena del exceso que cometió (por ser cosa nunca vista ni que se esperaba ver en esta casa) para satisfacer el escándalo y mal ejemplo, y por otras razones que en el cabildo se representaron, se le quite la capellanía y sea despedido del Sacro Monte, y que antes que se vaya se le dé una reprensión muy severa aseándole la acción que hizo y notificándole este auto del cabildo y que conforme a él se vaya luego a su casa. 
Lo cuarto que es mucha la falta que hay de capellanes en la Iglesia y coro, y por mayor parte se determinó que se haga diligencia de llamar a algunos para que se puedan escogerlos y se nombraron para hacer esta diligencia los señores Agustín Manrique Presidente y Miguel Díaz de Ayllón, canónigo.

[150] ASAC II, fol. 202 v (19-XII-1631)

Propuso el señor Presidente que conforme a lo determinado en cabildo de 18 de noviembre el licenciado Juan de Abolafia, sacerdote de la ciudad de Loxa ha venido a pretender una capellanía del Sacromonte llamado de los señores Agustín Manrique Presidente y Miguel Díaz Ayllón, canónigo a quién el cabildo nombró para hacer esta diligencia, y según la relación que se tiene de sus costumbres es persona de muy buenas partes, y se propone para que los señores capitulares vean si será recibido para que se le hagan las pruebas, y habiéndose conferido, se tomaron los votos de habas blancas y negras, y por once votos de habas blancas fue admitido para que se le hagan las pruebas. Y tratándose de la persona que las iría a hacer, fue nombrado por mayor parte el señor licenciado Francisco Hurtado Ossorio, canónigo.

\section{2}

[151] ASAC II, fol. 209 r (14-I-1632)

El señor canónigo Francisco Hurtado Ossorio, a quien este cabildo nombró por informante para las pruebas de limpieza y costumbre del licenciado Juan de Abolafia que pretende ser capellán de esta Iglesia presentó la información que traía hecha del dicho licenciado Juan de Abolafia, la cual había hecho en la ciudad de Loxa y de la villa de Martos de donde fueron naturales los padres y abuelos del dicho pretendiente guardando en todo la instrucción y rigiéndose por el interrogatorio que para semejantes informaciones este cabildo tiene ordenado. Y así mismo presentó otra información que ahora 28 años hizo un hermano del dicho licenciado Juan de Abolafia de la villa de Martos de la limpieza y naturaleza de sus abuelos paternos para que junto con la que se había hecho contase más de la limpieza y calidad del dicho licenciado Juan de Abolafia, y habiéndose leído toda la información a la letra que traía hecha el señor canónigo Francisco Hurtado Ossorio y parte de la otra se procedió a votar y por todos los votos secretos de habas blancas se aprobó la dicha información y se mandó que se colocase en el archivo debajo de las cuatro llaves. Y que juntamente se pusiese con ella un traslado de la que ahora 28 años hizo el hermano de este pretendiente.

[fol. $209 \mathrm{v}]$ 
Luego se trató de recibir al dicho licenciado Juan de Abolafia y por todos los votos de habas blancas fue recibido por todas las condiciones y advertencias y requisitos que las constituciones ordenan.

Tratose también de loables costumbres, y se avisó que en la sacristía se guardase silencio; que se sirviese cuidado en celar los días de concurso y en que no faltase la lección de canto.

[153] ASAC II, fol. 212 r (7-II-1632)

Juntose este cabildo para que el licenciado Juan de Abolafia a quien este cabido tiene recibido por capellán del coro como parece del auto capítulo de 14 de.

[fol. $212 \mathrm{v}$ ]

Habiendo propuesto el señor Presidente, entró en la sala de cabildo en donde en presencia de los dichos señores capitulares le fue leída la Constitución 2 del título 22 por mí el infraescripto secretario y la propuso de guardar con todo lo que en ella se dispone y manda y fimallo de su nombre en este libro de los actos y luego hizo el juramento de la obediencia y de observar y tener la opinión de la Inmaculada concepción de nuestra Señora conforme al decreto y voto de este cabildo. Y además de haber jurado lo que se contiene en la dicha constitución 2 conforme a lo que en ella se ordena lo firmó de su nombre en este libro de la forma siguiente.

[154] ASAC II, fol. 216 r (2-III-1632)

Ítem que la capellanía de Vega está hoy vacante, y tiene obligación el cabildo aunque no haya falta en que se digan las misas, y se determine en este libro de este libro de los Actos capitulares, y luego hizo juramento d

[155] ASAC II, fol. 223 r (2-VI-1632)

Ítem se determinó que los colegiales que digan los versos (...)

[156] ASAC II, fol. 225 v (4-V-1632)

Lo segundo que se aderece un misal antiguo Plantiniano encuadernándolo de nuevo.

$[226 \mathrm{r}]$ 
Lo sexto se trató si sería conveniente dejar de decir las coplas de la Concepción que se han dicho hasta ahora después de la Salve los sábados y días de Nuestra Señora y pareció que para determinar esto se llame a Cabildo.

Lo segundo se determinó que por ahora mientras no hubiere más número de capellanes prosigan los colegiales diciendo las epístolas en el coro los días que no hubiere diácono.

Lo primero que si conforme a lo que se trató en el cabildo de 4 de mayo se omitirían las coplas de la Concepción que se dicen y en caso que se quiten si se dirá otra cosa en lugar de ellas, y habiéndose conferido este punto hubo siete votos para que se dejasen de decir, y cinco para que se continuasen, y atento a que esta ceremonia, dicen, está escrita en la Consueta, y para quitar una cosa que está escrita en la Consueta se requieren dos partes de tres en dos cabildos llamados, no quedó declarada esta determinación hasta que se averigüe esta duda. Con advertencia que uno de los siete votos con que se dejaren de decir las dichas coplas fue condicional, si se subrogase otra cosa en lugar de ellas.

[228r]

Ítem todos los señores capitulares convinieron en que estas coplas se decían voluntariamente, y por mera devoción comenzada en el tiempo que las controversias de la Concepción que andaban tan vivas en toda España pedían estas demostraciones de piedad, y que no hay obligación ni por aniversario, ni por otro respecto alguno a decir estas coplas.

[158] ASAC II, fol. 234 r (2-VIII-1632)

Segundo que el licenciado Lázaro de Santistevan capellán del coro de esta Iglesia pide por veinte días licencia para ir a Loja a negocios que se le han ofrecido, habiéndose conferido por mayor parte se le dio licencia por todos los dichos veinte días.

Yo el infrascripto secretario leí una petición del licenciado Lázaro de Santistevan capellán del coro de esta Iglesia en que da cuenta como el señor gobernador del arzobispado le ha dado provisión de la sochantría de la ciudad de Loja con cuarenta ducados de aumento, y pide licencia por cuatro días para ir a la dicha ciudad a comunicar este aumento con los distribuidores de la fábrica para que lo pasen.

[242 r] 
Y habiéndose oído la dicha petición y considerado conferido el caso se hizo relación al cabildo que el dicho licenciado Santistevan ha estado con mucha inquietud después que vino al Sacro Monte haciendo diligencias extraordinarias para no perseverar en él, de las cuales consta que no vino con ánimo de quedar en esta Iglesia sino solamente por acomodarse mejor en el oficio de sochantre de la ciudad de Loja. Lo cual entendido se determinó por todos los votos que no se le da licencia para hacer el dicho viaje y por cuanto algunos de los señores capitulares dijeron que había bastantes causas para despedir al licenciado Santistevan lo propuso así el señor Presidente y habiéndose conferido las causas se determinó por nueve votos de once que se despida al dicho licenciado Lázaro de Santistevan y que desde este punto se le vaca la capellanía y para determinar esto dijeron todos los señores capitulares que lo votaron que se daban por llamados como si lo fueran veinticuatro horas antes y se avisó a los que no estaban en cabildo para que viniesen a dar su voto. Ítem porque no se llamó particularmente para este punto dijeron que aunque esto se había hecho con toda justificación con todo eso para mayor seguridad y firmeza se volviese a confirmar el día siguiente en cabildo llamado ante diem.

[160] ASAC II, fol. 242 r (29-IX-1632)

Y estando así capitularmente juntos se determinó de nuevo que se le despide al licenciado Lázaro de Santistevan y que se da por vacante.

[fol. $242 \mathrm{v}$ ]

La capellanía del coro de esta Iglesia que tuvo hasta el día pasado 28 de este mes de septiembre.

\section{[161] ASAC II, fol. ¿? (7-X-1632)}

Lo primero si las coplas de nuestra señora que se suelen decir después de la Salve se dejarán de decir de aquí en adelante atento a que esta devoción tuvo principio en tiempo que andaban muy vivas las controversias de la Concepción las cuales están ya sosegadas, y parece que ya no vienen a propósito. Y habiéndose considerado esto seis de los señores capitulares de once que había votaron que las dichas coplas de aquí en adelante se dejen de decir y en lugar suyo se cante la antífona con su oración y versos de la Concepción de Nuestra señora, y que el decirse esta antífona en lugar de las coplas sea solamente por devoción libre y voluntaria sin obligación ninguna y por el tiempo que a este cabildo le pareciere. Los otros cinco señores folio $\mathrm{v}$ que las coplas se prosigan diciendo como se ha hecho hasta ahora. Y habiendo votado antes de escribirse este decreto salieron de cabildo don Francisco de Barahona, don Gabriel de Ledesma, Alonso González de Aradilla, y el señor Presidente dijo que su merced toca hacer cuentas los decretos, y por cuanto ni uno del señor Cardenal Espínola en que ordena que lo que estuviere determinado en Cabido y recibido en la Consueta no se pueda mudar si no es por dos cabildos llamados y viniendo en ello dos partes de tres de los capitulares le parece a su merced que aunque hay 
mayor parte de votos para que se dejen las coplas no está determinado porque en cabildo de 28 de noviembre de 1620 se determinó que se digan las dichas coplas después de la Salve, y es ceremonia que también está recibida en la Consueta. Ítem volvieron a entrar en cabildo los señores Ledesma y Aloon. Y para decidir esta controversia que también quedó pendiente en cabildo de 4 de Junio donde por mayor parte así mismo se votó que se quitasen las coplas, se miraron los decretos de visita y los autos capitulares que de esto trataba y entre los decretos de visita ninguno se halló que prescribiese orden acerca de esto. Y quien lo prescribe es un cabildo que se tuvo en 28 de enero de 1628 en el cual insistió el señor cardenal Espínola y en é se dicen estas palabras en la forma que aquí se sigue: que no se pueda alterar cosa alguna de la dicha Consueta si no fuere por dos actos capitulares llamados ante diem. De lo cual consta que no se requieren dos partes de tres, sino solamente mayor parte, la cual hubo en este cabildo y en el pasado de 4 de Junio y así últimamente queda determinado por dos actos capitulares que son el de hoy y el que se tuvo en cuatro de junio de este año que se dejen de cantar las dichas coplas y que en su lugar se diga la antífona, versos y oración que usa la Iglesia en las Vísperas de la Concepción que es la antífona Conceptio tua dei genitrix y que esta se diga solamente por devoción libre y voluntaria y como una de las demás ceremonias se escriba en la Consueta y que se haga y ejecute como las otras y que luego se borre de la Consueta en todos los lugares en que estuviere escrito que se canten las coplas después de la Salve .

\section{ASAC II, fol. 247 v (2-XI-1632)}

Octavo se leyó una calenda que se ha hecho de nuevo para la fiesta de la Concepción, y la recibió este cabildo determinando que se ponga al fin del libro con las demás de los santos y fiestas de este Sacro Monte y que la víspera de Nuestra Señora la cante un señor prebendado con la solemnidad que las otras.

\section{[163] ASAC II, fol. 250 v (30-XII-1632)}

Propuso el señor Presidente como el Marqués de Estepa en acción de gracias por el hallazgo del libro mudo pide que las vísperas de esta tarde se digan con alguna solemnidad y música que quiere pagar su señoría, que el día siguiente se diga una misa solemne a Nuestra Señora y Arcángel San Gabriel y apóstol Santiago por el mismo intento. Lo cual conferido por los votos se determinó que se haga lo uno y lo otro se haga en la forma que el señor Marqués lo pide.

\section{3}

\section{[164] ASAC II, fol. 254 r (20-I-1633)}

Lo segundo que en la Consueta está ordenado que los prebendados que están en el coro cuando se entona la Gloria y Credo en el altar poniendo las manos lo recen la cual ceremonia tiene de inconveniente que en el interim que lo están realizando suele hacer falta al facistol, y conferida esta ceremonia por todos los votos se determinó que de aquí adelante los prebendados cuando no hay música, 
no digan la Gloria y Credo rezados en el coro, sino que vayan siguiendo el canto llano, y acompañando a los que cantan en el facistol desde que se entonan, y estarán de pie mientras el Presidente los dice en el altar y cuando se arrodillare para decir el Incarnatus est rezado harán ellos lo mismo, y esto se entiende los días que no hay música que es menester que ayuden a cantar que cuando la hubiere han de rezar el Credo y Gloria puestas las manos conforme lo dispone el ceremonial.

[165] ASAC II, fol. ¿? (24-I-1633)

Estando así capitularmente juntos propuso el señor Abad (...) que ha llamado a cabildo para tratar si el día de San Cecilio será conveniente convidar el Cabildo de la ciudad de Granada que viene a esta Iglesia a celebrar la fiesta del Santo. Y habiéndose conferido este negocio ponderando las razones que por una parte y otra se ofrecen se determinó por todos los votos menos dos, que aunque en otros años no ha convenido hacer esta acción de convidar el Cabildo de la ciudad ahora se ofrecen circunstancias que hacen fuerza para que se haya de hacer esta demostración con la ciudad, y que así efectivamente se convide para que aquel día se quede a comer.

\section{[166] ASAC II, fol. 255 r (24-I-1633)}

Se ha llamado a cabildo para tratar en él si el día de San Cecilio será conveniente convidar el cabildo de la ciudad de Granada que viene a esta Iglesia a celebrar la fiesta del Santo. Y habiéndose conferido este negocio, ponderando las razones que por una parte y otra se ofrecen se determinó por todos los votos menos tres, que aunque otros años no ha convenido hacer esta acción de convidar el cabildo de la ciudad, ahora se ofrecen circunstancias que hacen fuerza para que se haya de hacer esta demostración con la ciudad, y que así efectivamente se convide para que aquel día se quede a comer en el Sacromonte pero que en esto se disponga de modo que no quede asentado para siempre y en algún tiempo puedan alegar prescripción, y así cunado la forma con que esto se ha de hacer se determina que este decreto sea perpetuo y valga y se practique en los años siguientes mientras este cabildo no lo revocare pero que así este año como los siguientes esta acción se hace libre y voluntariamente para dejarla cuando a este cabildo le pareciera convenir habiendo inconvenientes que a ello obliguen. Y que para hacer saber esto a la ciudad no se de legacía ahora ni en ningún año sino que se les convide cuando se les saliere a recibir. Y ahora se le haga saber al señor don Fadrique de Ávila veinticuatro (como a persona particular, y que tiene particular 256r afecto a este Sacro Monte y que trataría este negocio con satisfacción y gusto de este cabildo) como se ha decretado, en que haya relación a la ciudad por comisión del Sacro Monte, que es con las condiciones siguientes. Primero que la ciudad venga por disposición (...) Veinticuatros, sus jurados, dos comisarios de la fiesta, la justicia, corregidor o alcalde mayor, un escribano de cabildo, los tres porteros y cuatro alguaciles, y que no se ha de quedar criado ni otra persona de la ciudad. Los porteros y alguaciles han de comer en el refectorio del colegio, ni se ha de poder sacar plato del refectorio. Y esto es lo que se ha de decir al Señor don Fadrique de Ávila. Ítem pareció a este cabildo 
que aquel día no coman en el Sacromonte ni se convide a persona ninguna por respeto del Sacro Monte ni de los particulares a primera ni a segunda mesa en ninguno de los refectorios y ni en otra parte, sino es cuando pareciere convidar al prelado o gobernador, y el predicador que ha de comer siempre con sus compañeros, en la mesa se ha de leer como se acostumbra y se ha de guardar silencio y compostura religiosa. Y los platos han de ser el día de pescado ocho los dos de ellos de dulce, y el día de carne seis los dos de ellos también de dulce. Esto sin principio y postre. No se han de llevar platos enteros a la mesa sino es comiendo el arzobispo.

\section{[167] ASAC II, fol. ¿? (3-II-1633)}

Lo segundo propuso el señor Abad que una capilla de músicos se ha ofrecido servir al Sacromonte y venir a celebrar las fiestas que les pusiesen por obligación por precio moderado y este cabildo los quisiere recibir por capilla de esta Iglesia y que de aquí adelante tengan ese nombre que ellos desean para estimación suya, y parece que si se reciben se le podrá seguir a esta Iglesia nuevo (...) y gravedad. Entraron a Cabildo los Señores don Paulo de Valencia, Doctor Gabriel de Ledesma, Licenciado Alonso González de Aradillas, canónigos. Y habiéndose conferido el punto se determinó por dos partes de tres que se trate de concierto con estos músicos, y si vinieren en las condiciones que este cabildo o sus comisarios les propusieren se le reciban. Y la primera condición es que el precio que se les ha de dar por cada fiesta sea de cuatro ducados a cincuenta reales lo que asentaren últimamente los comisarios, y que se les ha de dar de comer el día que vinieren en el refectorio de los colegiales. La segunda que han de venir puntualmente a cantar en las fiestas que se siguen, las tres fiestas del Sacromonte San Hicsio, San Mesitón y San Tesifón, y no entra en este número San Cecilio porque aquel día corre la música por cuenta de la ciudad. El día de San Dionisio Areopagita, las cinco fiestas de holgar de Nuestra Señora, primer día de Pascua de Navidad con los Maitines, segundo y tercero. Día de Año Nuevo y de la Epifanía. Primer día de Resurrección con maitines y procesión. Día de la Ascensión con la. Primer día de Pentecostés con tercia, día de la Santísima Trinidad. El día octavo del Corpus Christi, día de San Pedro, día de Santiago, la Dedicación de esta Iglesia, día de Todos los Santos, las tres fiestas de los $\mathrm{Ar} /$.

\section{[fol. $258 \mathrm{r}$ ]}

Arcángeles San Miguel, San Gabriel, y el Ángel de la guarda. El día de la Cruz de Mayo. A todas estas fiestas han de tener obligación de asistir y cantar con la misa mayor y segundas vísperas, y fuera de esto han de venir a las primeras los días de nuestro Señor y Nuestra Señora y las fiestas del Sacro Monte que son los santos Hicsio, Mesitón, Tesifón y Dionisio y de todas las demás fiestas dichas todas las veces que la víspera fuera día de holgar. Ítem siempre que haya procesión, Salve y Adoración de Cruz o Reliquias en las fiestas dichas han de asistir y cantar en ellas. Nombraronse por comisarios para tratar y concertar todo esto con los músicos a los señores Agustín Manrique Presidente y Francisco Hurtado canónigo y que sus mercedes asienten con ellos todas estas 
condiciones aquí referidas, y todas las demás que parecieren convenientes y ajustadas para que esto se haga como se debe. Y que si en alguna de las condiciones que aquí van expresadas no vinieren los músicos se vuelva a consultar al Cabildo.

[168] ASAC II, fol. ¿? (17-II-1633)

Acabose de ver la Consueta y se determinó que se saquen dos copias del borrador y la una que ha de ser el original se ponga en el Archivo autorizada del secretario del Cabildo, y al principio el decreto de que no se pueda mudar ceremonia de las que en ella recibidas sino por dos cabildos llamados y para que esto quedase en perfección se propusieron algunas dudas que resultaban y se resolvieron y la resolución se mandó escribir en la Consueta como en papel aparte.

[169] ASAC II, fol. 261 v (2-III-1633)

Lo primero que en Cabildo de tres de febrero se determinó que se tratase de concierto con una Capilla de músicos que se ofreció a servir al Sacromonte y porque se le pidieron veintiséis fiestas les ha parecido cosa dura y así se vuelve a proponer si estas fiestas se reducirán a menor número para que se haga el concierto y habiéndose conferido se determinó por mayor parte que las fiestas que han de venir se reducen a las seis particulares del Sacromonte las cuales son estas que se siguen San Hicsio, San Mesitón, San Tesifón, la Asunción de Nuestra Señora, la Concepción y la Octava de Corpus Christi y que con este número se haga el concierto guardando las demás condiciones que en el acto capitular de tres de febrero están expresadas.

[fol. $262 \mathrm{r}$ ]

Lo tercero se determinó que cuando algún colegial hiciere oficio de Sochantre por estar vacante el oficio o estar ausente el sochantre propio, se pueda sentar en el banco de los colegiales, y que esto se entienda del colegial que estuviere señalado para hacer el oficio.

Lo quinto que en días pasados se determinó que el verso que en las vísperas cantadas toca el órgano lo digan rezado los caperos dos o cuatro que estuvieren con pluviales en el coro, y ahora de nuevo se determina que lo puedan decir los caperos o el sochantre en la cuerda del órgano. Y habiendo hecho experiencia de cual de estos dos modos es más acomodado se tomará la última resolución en lo que se ha de hacer.

[170] ASAC II, fol. 275 r (2-VII-1633)

Lo primero si se dará algún salario a Mora porque haga el oficio de Sochantre y habiéndose conferido por todos los votos se determinó que se le dé algún salario competente y tratando sobre la cantidad que se le asignaría pareció a la mayor 
parte que se le diese un real cada día. Y esto por modo de salario sin distinción de manuales y con presupuesto que no se le da.

[fol. $275 \mathrm{v}]$

Oficio de Sochantre en propiedad sino por suplemento en el interim que este cabildo no dispusiere otra cosa. Ítem se determinó por mayor parte que se que de en el colegio y coma en el refectorio de los colegiales y gane los aniversarios del colegio y todo lo que fuera de los 3000 maravedíes que da la fábrica a cada colegial porque estaban embebidos en el salario que este cabildo le daba hoy.

[171] ASAC II, fol. 278 v (12-VIII-1633)

Ítem que el licenciado Juan de Abolafia que fue Capellán de esta Iglesia se le entregue (fol. 79 r) una información de limpieza que cuando fue recibido como capellán se leyó en este Cabildo no la que hizo el señor prebendado que este cabildo nombró por informante sino otra a que a pedimiento del aspirante tenía hecha un hermano del licenciado Abolafia y juntamente con la otra se presentó en este Cabildo.

Lo cuarto que arbitrio se tomará para buscar y recibir Capellanes por la mucha falta que hacen a esta Iglesia, y si para este efecto se pondrán edictos y lo mismo para proveer el oficio de Sochantre. Y conferido por todos los votos se determinó que sin poner edictos se busquen personas a propósito para proveer dos capellanías. Nombraronse para hacer estas diligencias a los Señores don Bartolomé de Torres y Gabriel de Ledesma y sus mercedes llamen los que les parecieren más a propósito y venidos estén en casa ocho días más o menos los que parecieren necesarios para hacer experiencia de sus personas y conocer si son a propósito para esta Iglesia y en cuanto a la provisión del oficio de Sochantre se determinó por todos los votos que se pongan edictos ubicándose a los mismos señores Bartolomé de Torres y Gabriel de Ledesma la disposición de ellos y fijarlos a donde pareciere a ellos más conveniente.

[fol. $283 \mathrm{v}]$

Lo segundo por mayor se determinó que los capellanes que fueran recibidos para el Coro de esta Iglesia según la comisión que tienen los señores canónigos (fol. 284 r) Bartolomé de Torres y los días que estuvieren antes en aprobación se puedan poner sobrepellices y se les procure ejercitar en todos los oficios y ocupaciones que han de hacer después, y en particular el licenciado Juan de Arroyo que está hoy en aprobación para Capellán entre en la Sacristía y allí se ocupe de los ministerios que se le encomendaren por el Señor Tesorero.

[fol. $285 \mathrm{v}]$

Y estando así capitularmente juntos propuso el señor Abad que de algunos días a esta parte ha estado en aprobación para una capellanía del coro el licenciado Juan de Arroyo clérigo presbítero natural de la villa de Alcaudete y se propone al 
Cabildo para que vean los señores capitulares si es persona apropiada para esta Iglesia y habiéndose conferido y tomado los votos secretos por todos los votos de habas blancas se admitió el dicho Juan de Arroyo para que se le hagan las pruebas y después de vistas se tratará de recibirlo por Capellán. Y por todos los votos se cometieron las pruebas a los señores canónigos Don Paulo de Valencia y don Gabriel de Ledesma que estaba ausente del Sacromonte para que uno de sus mercedes el que mejor se acomodase la pueda hacer y dase a cada uno de sus mercedes la comisión in solido.

\section{[172] ASAC II, fol. 287 r (3-X-1633)}

Lo primero si al licenciado Mora cambiaría en una capellanía del coro y se le dará aumento de salario por hacer como hace oficio de Sochantre. Y habiéndose conferido se determinó por la mayor parte que por ahora se le aumente el salario de esta forma que gane como si fuese capellán de suerte que el salario todo iguale con la renta que un capellán tiene y que lo gane por sus puntos como ellos. Y porque no siendo Capellán ni Sochantre no puede ganar manuales ni Aniversarios se determinó que todo esto se le supla de la fábrica por modo de salario. Y que acuda a oración al coro y se siente en silla de Capellán la segunda del coro derecho y haga las ceremonias del coro como si fuera Capellán, y mude de hábito si tuviese gusto, y viva en aposento aparte. Pero en las demás cosas se quede el licenciado Mora como está de (...) Hasta que se ordene de Epístola que entonces este Cabildo determinará lo que conviniere.

\section{ASAC II, fol. 287 v (10-X-1633)}

Vieronse las informaciones del licenciado Juan de Arroyo pretendiente de una Capellanía del Coro de esta Iglesia. Las mandó el señor canónigo Don Gabriel de Ledesma a quien este cabildo cometió hacer las dichas informaciones. Y luego yo el infrascripto secretario las leí todas desde el principio hasta el fin y habiéndolas oído los señores capitulares se procedió a votos. Y por todos los votos secretos de habas blancas se admitieron las dichas informaciones. Entraron en cabildo los señores Don Pedro de Ávila Abad, licenciado Bartolomé de Torres y Francisco Hurtado Ossorio canónigo. Ítem luego se procedió a la provisión de la capellanía habiendo propuesto el señor Abad si el dicho licenciado Arroyo cuyas informaciones estaban ya aprobadas sea recibido por Capellán. Por todos los votos de habas blancas se recibió en una de las Capellanías del coro de esta Iglesia. Y siendo llamado al cabildo hizo en sus manos del señor Abad el juramento que las Constituciones ordenan, y siéndole leídas por mi el infraescripto secretario las Constituciones segunda del título 22 las consintió y prometió de guardar lo que en ellas se contienen y de no reclamar ni apelar ni hacer acto alguno judicial contra el derecho que tiene este cabildo de poderlo excluir de esta Capellanía que ahora se le da cuando este mismo cabildo tuviere voluntad sin obligarle a dar causa de la expulsión. Y que en señal de así lo consiente lo firma de su nombre. 
Lo sexto si se recibiría una persona que ha venido al Sacro Monte a pretender el oficio de Sochantre. Y conferido se determinó que se haga más experiencia de lo que sabe y que para esto los señores Agustín Manrique Presidente y canónigo Francisco Hurtado Ossorio lo examinen y conforme a lo que sus mercedes juzgaren se hará relación al Cabildo y tomará resolución.

[175] ASAC II, fol. 290 r (28-X-1633)

Tratose en este Cabildo si se recibiría a la persona que en el Cabildo pasado se propuso para Sochantre porque ya los Señores a quien se les cometió lo habían examinado y les parecía que tiene bastante suficiencia y habiendo oído la relación sus mercedes hicieron por todos los votos que se le recibe por Sochantre y se le señala seiscientos reales por salario que es la cantidad que este Cabildo suele señalar otras veces a los que sirven este oficio los cuales se le han de repartir por sus puntos fuera de la oración como con los demás sochantres se ha hecho y que con esto pueda ganar sus manuales y sus aniversarios de por sí según la facultad que dan las Constituciones. Y cometese a los señores Agustín Manrique Presidente y a Gabriel de Ledesma canónigo hagan saber este decreto y le intimen sus obligaciones.

[176] ASAC II, fol. 290 r (29-X-1633)

Fiesta de los hortelanos.

Lo segundo si a Juan Rodríguez colegial que fue del Sacro Monte y estaba ordenado de subdiácono será nombrado con una de las Capellanías de esta Iglesia y habiéndose conferido se tomaron los votos secretos de habas blancas y negras y por siete votos de habas blancas fue nombrado para que se le hagan las informaciones para una de las capellanías de esta Iglesia. Y el señor canónigo Andrés Sarmiento pidió se escribiese aquí su voto el cual es que no viene en que se provea esta capellanía por esta más alcanzada la fábrica.

[178] ASAC II, fol. ¿? (13-XI-1633)

Estando así capitularmente juntos propuso el señor Abad que por estar así nombrado Juan Rodríguez natural de Villanueva de los Infantes colegial que fue del Sacro Monte para que se le hagan las pruebas para una capellanía del coro que pretende era necesario determinar el acuerdo y nombrar la persona fol $292 \mathrm{v}$ por quien se han de hacer las informaciones. Y habiéndose conferido sobre esto se determinó que las pruebas del dicho Juan Rodríguez no vaya persona de este Cabildo sino que se remitan para que se hagan donde se deben, conforme a la facultad que para ello dan las Constituciones que de esto trata y aconseje con decreto de visita, por la persona o personas a quien este cabildo cometiere, y conforme a la dicha Constitución. 
Se determinó que los Jueves del Adviento en que se reza de la Feria se cante en el altar el coro oficio ferial pero que sea el compás algo detenido conforme pide la renovación del Santísimo Sacramento que se hace en aquella misa.

[180] ASAC II, fol. 295 v (18-XII-1633)

Lo primero si el licenciado Mora se nombrará en una capellanía del coro para que se le hagan las pruebas. $\mathrm{Y}$ habiéndose conferido se tomaron los votos secretos de habas blancas y negras y por siete votos de habas blancas fue admitido para que se le hagan las pruebas. Confiriose sobre el modo y la persona que las había de hacer, y por todos los votos se determinó que vaya persona del cabildo a hacer estas pruebas y tratándose en particular quién sería por mayor parte se determinó que fuera don Gabriel de Ledesma.

1634

[181] ASAC II, fol. 299 v (12-I-1634)

Lo cuarto se determinó por todos votos menos uno que las faltas del Sochantre no siendo capellán en los manuales de oración y conferencias no las ganen los capellanes ni las de los capellanes el sochantre no siendo/300r capellán y que esto se ejecute así siempre porque parece lo más conforme a la Constitución.

[182] ASAC II, fol. 305 r (3-VI-1634)

Lo cuarto se determinó por todos los votos que al licenciado Juan de Padilla Capellán de este Sacro Monte se le dé un testimonio que pide de cómo este Cabildo le recibió por Capellán habiendo aprobado sus informaciones.

\section{ASAC II, fol. 310 r (23-VI-1634)}

Lo segundo se abrió y leyó la información del licenciado Francisco de Mora que por comisión particular de este Sacro Monte remite el señor canónigo Miguel Díaz de Ayllón y habiéndola leído yo el infrascripto secretario y confiriéndose sobre ella por todos los votos de habas blancas fue aprobada la dicha información. Fue recibido el licenciado de Mora en una de las capellanías del coro de esta Iglesia y juntamente se determinó que desde el día siguiente 24 de Junio cesa el salario que este cabildo le tenía asignado por Ayudante de Sochantre. Fue luego llamado a la sala de Cabildo y habiéndole yo el infraescripto Sr. leído la Con 2 del título 22 de capellanes la cometió y juró de guardar y firmó de su nombre. 
Lo tercero se abrió y leyó la información del licenciado Juan Rodríguez que por comisión particular de este Cabildo se ha hecho en el obispado de Cuenca y otras partes. Y habiéndola leído yo el infrascripto secretario y confiriéndose sobre ella por todos los votos de habas blancas fue aprobada. Luego se procedió a proveer la capellanía y por todos los votos de habas blancas fue recibido el licenciado Juan Rodríguez en una de las capellanías del Coro de esta Iglesia. Fue luego llamado a la sala de Cabildo donde en manos del señor Abad y con la ceremonia acostumbrada hizo el juramento de la obediencia y de la Concepción, y yo el infrascripto secretario le leí la Constitución 2 del título 22 de los capellanes y la cometió y juró de guardar y firmó de su nombre.

\section{5}

[185] ASAC II, fol. 334 r (2-V-1635)

Ítem propuso el señor canónigo Agustín Manrique que este cabildo sea llamado para ver si en él el organista se hará alguna reformación en cuanto al salario o en otra cosa por algunas razones que en el cabildo se propusieron, y conferido pareció que la resolución de este punto se dilate hasta que estén presentes el señor Abad y los demás señores capitulares que faltan.

[186]

ASAC II, fol. 352 v (30-XII-1635)

Ítem por todos los votos nombró este cabildo al licenciado Vela sochantre de esta Iglesia para servir la capellanía de Vega.

\section{6}

[187] ASAC II, fol. 352 v (1-I-1636)

Tratose de ceremonias y loables costumbres y propuesto si se estaría el atril del coro o se pone en las barandillas, siempre en el lugar del hebdomadario y se determinó por mayor parte que no se innove de lo que se ha hecho y está en la Consueta.

[188] ASAC II, fol. 369 r (22-VII-1636)

Estando así capitularmente juntos se leyó la información del licenciado Juan de Aranda capellán que por comisión de este cabildo hizo el señor licenciado don Francisco de Robles, y oída se aprobó por todos los votos secretos de habas blancas y por los mismos fue electo en la capellanía. Leyosele la Constitución 2 del título de capellanes y dicho la consentía y guardaría como en ella se conviene y hizo juramento de guardar esta y las demás Constituciones de este 
Sacromonte y defender la opinión pía de la Inmaculada Concepción de Nuestra Señora.

Lo cuarto se mandó llamar y se llamó a cabildo para el día siguiente para nombrar capellán que estaba como substituto la capellanía que como tal servía don Fernando de Linares mayordomo del ilustrísimo señor presidente de Castilla arzobispo de Granada que está ausente muchos días ha.

[190] ASAC II, fol. 371 r (29-VIII-1636)

Y estando así capitularmente juntos determinaron que por cuanto don Fernando de Linares capellán nombrado en substitución mientras dura el pleito que sobre la dicha capellanía se trae, está ausente algunos días y ni se sabe cuando vendrá se nombre en su lugar substituto que sirva la dicha capellanía que es una de las tres que dejó fundada en su capellanía de San Ildefonso el señor jurado P[edro] Martínez y la señora doña Beatriz Allegro su mujer. Y se nombró al licenciado Cristóbal Vílchez con declaración que si el dicho don Fernando de Linares no viniere dentro de los treinta días que los dichos señores fundadores le dan para poder hacer ausencia quede nombrado en adelante para la dicha substitución y servicio y se le dé nombramiento de este cabildo al dicho Cristóbal Vílchez con que acabó este cabildo de que doy fe.

\section{ASAC II, fol. 374 v (3-XI-1636)}

Lo segundo se determinó que de aquí en adelante el Réquiem eternam que se dice al fin de los salmos cuando se celebra oficio de difuntos se diga por los dos coros de manera que uno diga Réquiem aeternam dona eis Domine y el otro et lux perpetua luceat eis.

[192] ASAC II, fol. ¿? (1-XII-1636)

Y estando así capitularmente juntos se trató de ceremonias y loables costumbres y se determinó que por cada falta que hiciere el organista en el órgano se le ponga diecisiete maravedíes en el libro de punto y si por su culpa faltare a todo un punto entero se le ponga dos reales.

1637

[193] ASAC II, fol. 388 r (30-V-1637)

Cabildo (...) para abrir una carta que a este cabildo envió el licenciado Antonio Ruiz Velásquez su capellán (...) y lo que se contuvo fue el no poder volver de la ciudad de Jaén a donde estaba, a servir la capellanía de este cabildo y que así la despedía: y el cabildo admitió su despedimiento con que se acabó este cabildo. 
Para si se le escribía al señor Cardenal Spínola para el pésame por la señora marquesa de Leganés su hermana. (...) y se acordó por todos los votos se escribiese y le diese el pésame al cardenal por los comisarios de cartas. Igualmente se le llamó a cabildo para si se diría también una misa cantada por el alma de dicha señora marquesa atendiendo a las obligaciones que el Sacro Monte tiene al dicho señor cardenal.

[195] ASAC II, fol. 392 r (24-VII-1637)

Y en cuanto a la renta de las misas que han de decir cantadas los beneficiados y a la asistencia de el capellán del Sacro Monte y limosnas que se han de repartir las Pascuas de Navidad, y otros días determinados si se ha de reservar la renta que fuere necesario para esto de un año para otro, dejando el primer año de repartir y que sería de las limosnas y si se han de reservar. Igualmente a los dichos señores para que vean el testamento y se informe a este cabildo.

$\mathrm{Y}$ en cuanto a la licencia que pide el licenciado Vílchez se le da en conformidad de lo dispuesto por el fundador de la Capellanía por los treinta días que la pide.

[196] ASAC II, fol. 397 r (9-XI-1637)

Para tratar si se ha de proveer la capellanía que tenía el licenciado Renzano (...) y habiéndose conferido de la capellanía arriba referida se le remitió asimismo para

[197] ASAC II, fol. 398 r (29-XI-1637)

Y para nombrar capellán de una de las capellanías que se sirven en el Señor San Ildefonso (...) tratose lo primero de la dicha capellanía y provisión de ella, y se acordó por mayor parte que los señores canónigos Torres y Cruzado vean las condiciones de la fundación y que consulten lo que se debe guardar acerca del nombramiento de capellanes.

Vísperas cantadas al obispo de Tortosa por su muerte, en el coro.

[198] ASAC II, fol. $400 \mathrm{v}(2-\mathrm{XI}-1637)$

Y al sochantre que ande con más cuidado en lo que toca a su oficio y salga de su silla para encomendar la antífonas y versículos a los colegiales y entonarles.

\section{[199] ASAC II, fol. 402 r (10-XII-1637)}

Leyose en el dicho cabildo una petición de Jerónimo de Valenzuela organista de este Sacro Monte en que suplica a este cabildo que para ayuda a sus órdenes se le haga merced atento a sus servicios, de perpetuarle 30 ducados de su salario. Y habiéndose conferido y ofrecido algunas dificultades, se defirió para otro cabildo 
adonde con mayor acuerdo y prevención se delibere y determine a cerca de lo pedido por el dicho Jerónimo de Valenzuela.

(Dionisio Portocarrero, obispo de Guadix)

\section{8}

[200] ASAC II, fol. ¿? (20-I-1638)

Ítem se determinó y que la comida de los músicos sea la misma que se da a el colegio y a cuenta de la fábrica.

[201] ASAC II, fol. $430 \mathrm{v}(11-\mathrm{X}-1638)$

Acordose que hubiese sermón estos nueve días y se encargaron de sermones los señores Dtor. Don Francisco de Barahona, licenciado don Alonso de Aradillas, licenciado Don Martín Vázquez Siruela, doctor don Luís Francisco de Mendizábal, licenciado don Cristóbal Luís Milán y que se descubriesen las reliquias por la mañana en saliendo de oración y estuviesen hasta la tarde después de la Salve que se dijese la Salve cantada todos estos días después de ella la letanía. Y que por la mañana estuviese descubierto el Santísimo Sacramento, que hubiese fuegos y música a costa de los que hiciesen las fiestas, y misa solemne por la mañana.

\section{9}

[202] ASAC II, fol. 438 v (31-I-1639)

Tratose luego si era apropósito para sochantre el licenciado Francisco de Montoro que lo es al presente de la Iglesia de Guadix, y si se recibiría y con el mismo salario que tenía el licenciado Vela sochantre que fue de este Sacro Monte. Y conferido se acordó por todos los votos que se recibe por sochantre de este Sacro Monte al licenciado Montoro y se le señala y da el mismo salario que tenía el licenciado Vela y que comience a correr desde mañana primero de febrero, día de San Cecilio.

Lo tercero fue si se le perpetuará al licenciado Montoro sochantre de este Sacro Monte la capellanía para que se pueda ordenar con ella. Y por todos votos se acordó se le perpetúe en la forma que se pueda y convenga. Y que antes de otorgar escritura en razón de ello se vean en el cabildo las condiciones que se han de poner en ella, para que elija lo que le pareciera más conveniente.

ASAC II, fol. 441 r (25-II-1639)

Propuso el señor Abad que era menester comisarios para las condiciones de la escritura de la perpetuación de la capellanía del sochantre y conferido se acordó 
por todos los votos que se nombran por comisarios para lo referido a los señores Abad y Presidente.

En relación al aniversario de la señora doña Catalina de Soria. Ítem que la asistencia de estos señores sea por sus antigüedades en turno comenzando por el Abad y el señor Presidente de los dos primeros, y luego como se sigue y el que faltare avise al que se sigue y haya cuidado de avisar un cuarto de hora antes que se acabe la hora para que se prevengan los que han de venir, y el que faltare pierde su turno, sin que pueda trocar ni dilatarlo por su ocupación. Y entra en el turno el que se sirve en antigüedad como en la semanería de diáconos. Y han de haber entrado delante del Santísimo Sacramento al primer cuarto de la hora como se practica en la oración y cuiden de dar este aviso a los señores que se siguen. Los colegiales que asisten en aquella hora en el monumento y los capellanes entren en turno acabado "'el primer turno de estos señores aunque se supla con un señor del segundo turno si fuere necesario. Y entren en turno los dos capellanes, el sochantre y organista en dos horas y si alguno o algunos de ellos faltaren se supla de ellos mismos en las dichas dos horas.

[206] ASAC II, fol. ¿? (¿?-VI-1639)

Item se propuso que esta Iglesia, conforme a sus Constituciones, tiene todos los privilegios que su Santidad ha concedido a todas las Iglesias Colegiales insignes de los Reinos de España. Que se hiciese diligencia para obtenerlos. Y a los señores Don Miguel de Ayllón y Don Rodrigo Cruçado se les encargó hiciesen esta diligencia en las Iglesias de San Salvador de Sevilla, Úbeda, Zafra, Baza, Villafranca, Aragón, Cataluña. Y a el señor Don Blasio de Santaella, de la de Antequera. Y al señor don Luis de Mendiçabal de las Iglesias de Osuna, Jerez y Olivares. ${ }^{30}$

[207] ASAC II, fol. 457 v (13-X-1639)

Propuso el señor Abad que estaba vaca una beca porque el Maestro Arroyo se ordenó de misa, si se proveería y conferido se acordó por mayor parte de votos que lo propuesto por el señor abad se suspende para verlo y tratarlo con mayor acuerdo en otro cabildo.

[208] ASAC II, fol. 461 v (9-XII-1639)

Propuso el señor Abad que conforme al cabildo de 24 de febrero de este presente año se determinó que se perpetuase a el licenciado Montoro sochantre renta para que se ordene in sacris que en estas primeras órdenes que no tiene desea ordenarse. Que vea el cabildo si se hará luego para que tenga efecto el ordenarse (...) y conferid se acordó por todos los votos que se le perpetúe la capellanía del licenciado Vega de cincuenta ducados de renta. Y por que tiene catorce ducados

\footnotetext{
${ }^{30}$ Abadía del Sacromonte, Actas Capitulares (desde ahora A.S.A.C.), Tomo II, junio de 1639.
} 
de pensión a una monja de nuestra señora del Carmen; la fábrica le supla los dichos catorce ducados y les perpetue del salario /

(fol. 462r) que le da mientras no vacare la dicha pensión. Todo esto sea y se haga con obligación de residencia en el Sacro Monte asistencia en el coro y misas y demás obligaciones que tiene la dicha capellanía.

[209] ASAC II, fol. 462 r (11-XII-1639)

(...) para otorgar la escritura de perpetuación de la capellanía del licenciado Vega. El licenciado Francisco de Montoro sochantre de este Sacro Monte ante Manuel de Aguilar escribano real, ante quien pasó y se otorgó en el dicho día, mes y año.

\section{0}

[210] ASAC II, fol. 465 r (19-I-1640)

Propuso el señor abad que estaba en este monte un clérigo presbítero vecino de Alcaudete que pretendía una de las capellanías del coro de este Sacro Monte. Que se confiriese si era conveniente dársela o no, y consultado se acordó por todos los votos no se provea por ahora.

Trataron de ceremonias y loables costumbres y se determinó que vaya un colegial de los antiguos todos los días a horas al coro siempre que el sochantre falte.

[212] ASAC II, fol. 469 v (13-IV-1640)

Confiriose que fiestas se harían en honra de Nuestra Señora la Virgen Santa María madre de Jesucristo nuestro señor, en desagravio de los sacrilegios que estos días se pusieron en un cartel contra su pureza y nuestra fe católica: y se bajaría en procesión al triunfo y determinose que los señores canónigos licenciados Miguel Díaz de Ayllón y don Francisco de Robles se informen que fiestas hay en Granada para que conforme a ello este cabildo resuelva las que ha de hacer y si bajará en procesión. Y en el interim que no determine otra cosa se mandó en este que en nueve días desde hoy haya fuegos a la noche con repique de campanas y que la misa de tercia se diga con solemnidad de primera clase y de Nuestra Señora de las nueve fiestas y rogativa y procesión a las cuevas con cruz ciriales y capa y se cante la letanía de Nuestra Señora y el último día se haga procesión solemne en que se ha de llevar la imagen de las cuevas; se hagan altares y baje la procesión por una cuesta hasta el camino y suba por la otra a la tarde después de vísperas. 
Propuso el señor Abad que era necesario se haga el Dominical de Misas porque un libro de papelón en que hoy se canta después de remendado muchas veces está tan hecho pedazos que ya no se puede cantar por él y faltando P[edro] Marañón que ha hecho los demás libros del coro no se hallaba persona que los haga ni en tanta comodidad- y se determinó por todos los votos que si el dicho Pedro Marañón vecino de Málaga quiere hacer el dicho dominical en los cuerpos que pudiere acomodarlo a las pagas y precio y [fol.471 v] en las condiciones que ha hecho los nueve cuerpos del santoral de Misas que haga y se encomience, todo lo cual se le encomendó al Señor Sarmiento para que le escriba y de el orden. (...)Tratose de ceremonias y se determinó que haya cuidado en que el compás del coro vaya con la solemnidad que piden las fiestas.

[fol. $472 \mathrm{v}]$

Y estando así capitularmente juntos propuso el señor abad que en 28 del mes de Julio próximo que pasó se juntaron los señores de este cabildo y los demás que faltan y trataron y confirieron si recibirían Capilla de Música para el servicio de esta Iglesia y considerado y conferido se acordó que la había. Y atento a que este Sacro Monte está muy alcanzado los señores canónigos quieren señalarle salario a su costa en el cual cada uno ofreció ciertas cantidades, como consta de una cédula que está a fin de este libro firmada por los señores canónigos. Y para señalar las fiestas a que acudir dicha Música fueron nombrados por comisarios a los señores canónigos Manrique y Ayllón, los cuales señalaron las fiestas que estarían se asentaron en el dicho papel. Todo lo cual los dichos comisarios lo trataron con Francisco de los Reyes Maestro de Capilla y sus mariacas y ministriles y vinieron en que acudirían a todas las festividades que se le señalaba por la cantidad en que en dicha cédula se contiene teniendo título de Capilla de esta Iglesia del Sacro Monte y que otorgarían escritura. La cual de hecho se otorgó ante Antonio Ruiz de Prado escribano en 27 de Junio próximo pasado. Últimamente propuso el señor Abad que el dicho Antonio Ruiz de Prado venía a hacer relación de la dicha escritura para que este cabildo la acepte si entraría y conferido se determinó que entre. El cual entró y leída la dicha escritura la aceptó el cabildo.

[214] ASAC II, fol. 478 r (1-X-1640)

Ítem se leyeron las pruebas que traía hechas el doctor Mesa de la limpieza del licenciado Rienda pretendiente de Capellanía de este Sacro Monte y fueron admitidas por todos votos, y luego se procedió a votar la Capellanía y por votos secretos se le dio haciendo el juramento conforme a las Constituciones como luego de hecho lo hizo y el de defender la limpieza de la Virgen Santa María nuestra señora. 
[215] ASAC II, fol. i? (3-VII-1641)

Propuso el señor Presidente que el licenciado Cosme Pinero pretende la sochantría de este Sacro Monte, vea este cabildo si se le dará. Y conferido se acordó por todos los votos que se recibe por sochantre de este Sacro Monte al dicho licenciado Cosme Pinero, y se le asignan de salario 600 reales en cada un año.

[216] ASAC II, fol. 496 v (1-X-1641)

Tratose de ceremonias y loables costumbres por cabildo ordinario de mes y conferido no hubo cosa que advertir mas que al sochantre se le advierta que cumpla con las obligaciones de su oficio.

[217] ASAC II, fol. 496 v (15-X-1641)

Propuso el señor Abad como el licenciado Cosme Piñero sochantre pidió licencia para ir a Granada el domingo a medio día y no ha vuelto hoy martes, que vea el cabildo lo que conviene hacer de demostración y conferido se acordó por todos los votos que sea despedido de este Sacro Monte

(497r) de esta comunidad como se despide desde luego para que aunque vuelva no sea recibido en ella.

[218] ASAC II, fol. $497 \mathrm{v}(25-\mathrm{X}-1641)$

Se acordó por todos los votos que se recibe desde luego por sochantre al dicho licenciado Pedro de Raia con el salario acostumbrado.

1642

[219] ASAC II, fol. 507 v (31-III-1642)

Propuso el señor Abad que aumento se le dará al licenciado Casas si se quiere quedar por Sochantre de este Sacro Monte y conferido se determinó se le dé silla alta, 100 ducados en dinero mientras que superviviere porque luego que muera se ha de quedar solo en la renta que suele dar a los sochantres, y la Capellanía de Vega con título de Maestro de Capilla.

\section{ASAC II, fol. 514 v (2-VIII-1642)}

Tratose de ceremonias y loables costumbres y se encargó que haya uniformidad en los que celebran las misas cantadas y mucha compostura en el coro. 
Recibiese por sochantre de este Sacro Monte al maestro Matías de Aranda por todos los votos y que se le dé de salario 600 reales y el servicio de la capellanía de Vega con sus cargas y misas y que goce la renta de ello.

\section{3}

[222] ASAC II, fol. 525 v (3-II-1643)

Tratose de como no estaba para trabajar el sochantre que se despediría y conferido se acordó por mayor parte que no se despedida más que se sepa que si no está con gusto que el cabildo no disgustara de que se vaya y encargose de esto al Señor canónigo Aradillas.

\section{TOMO III}

[223] ASAC III, fol. 5 v (12-XII-1643)

Propuso el señor Abad que se ha tenido junta de asistentes acerca de que el licenciado Aranda Sochantre, no faltare de ordinario a horas menores ni a Vísperas y que habiéndoselo cometido al Señor Canónigo Sarmiento se lo dijo y le respondió que se despedía de la sochantría y que hacía dejación de ella. Respecto de lo que a él se ha llamado a este cabildo para que vea si aceptárale dicha dejación y lo que convenga hacer en razón de ello. Y conferido se acordó por todos los votos que se aceptaba y se aceptó por este cabildo, la dejación que hace el dicho licenciado Aranda de la dicha sochantría, y que se haga luego en la contaduría la cuenta de lo que monta lo que ha ganado mientras la ha tenido y que se le pague lo que se le debe.

[224] ASAC III, fol. 6 r (29-XII-1643)

Propuso el señor Abad diciendo que un racionero de Granada le ha hablado de algunos de estos señores y dice que tiene en Sevilla un amigo que se llama Miguel Antonio que desea ser Sochantre de este Sacro Monte y que lo tiene por persona a propósito. Y conferido se acordó por todos los votos que se le avise que venga luego a ver si nos contenta y se contenta de esta comunidad. Que venido y experimentado se tratará de su recibo.

\section{4}

[225] ASAC III, fol. 17 r (1-VIII-1644)

Se acordó que a los capellanes, sochantre y organista, se les de aviso de lo que se ha tratado en este cabildo en cuanto a sus obligaciones en el coro, acudir con puntualidad, y guardar la cortesía que dispone la Consueta con los señores, y que 
los capellanes se traten en su aviso y compostura conforme a las Constituciones y Consueta.

\section{5}

[226] ASAC III, fol. 30 r (2-I-1645)

Lo primero se trató de ceremonias y se determinó que se le diese por escrito el oficio al sochantre para que se ajuste a todo lo que en él se contiene.

[227] ASAC III, fol. ¿? (29-I-1645)

Propuso el señor Abad, que había tenido noticia de que el Cabildo de la ciudad de Granada había determinado enviar legacía a este cabildo con determinación que si el día de San Cecilio no se les daba de comer por la incomodidad de volverse tan tarde a la ciudad, no podía asistir a hacer la fiesta; y conferido se determinó por mayor parte de votos, que si los comisarios de la ciudad daban a entender cualquier cosa en orden a lo dicho, se convidase a la ciudad para comer. Y el señor canónigo Ayllón dijo que era de contrario parescer y asimismo que antes de esta determinación se le diese cuenta al señor Arzobispo y lo mismo dijo el señor canónigo Mesa y el señor canónigo Santaella menos el de dar cuenta a su ilustrísima (...)

Ítem se nombraron por comisarios para la fiesta de San Cecilio a los señores Aradilla y a Gamero.

[228] ASAC III, fol. 471 r (30-I-1645)

Propuso el señor Abad que ayer Jueves 29 de este mes habían venido los comisarios de la ciudad para la fiesta de San Cecilio, proponiendo de parte de su cabildo del deseo que tenían de hacer fiesta debida a tan grave patrón y conforme a sus obligaciones haciendo el Sacro Monte de su parte lo que pudiere, obligando a la ciudad con todo agasajo. Por todo lo cual se determinó, a los señores canónigos y comisarios Aradillas y Gamero a convidar la Ciudad y al señor Arzobispo, Ítem se determinó que el señor canónigo Santaella se encargue de todo lo necesario en orden a la comida para el día de San Cecilio, y su merced dijo que haría todo lo posible con muchísimo gusto, y determinose también que le señor canónigo Santaella vaya por comisión de este cabildo a convidar a los señores inquisidores don Tomás de Monroy y don Diego de Ozores. Se determinó que los señores comisarios reciban y agasajen con todo cumplimiento a los comisarios de la ciudad.

Propuso el señor Abad que el licenciado Francisco de Moya presbítero natural de Alcalá pretende una capellanía de este Sacro Monte y conferido se determinó se reciba en aprobación por todo los votos. 
Y discurriéndose por algunos arbitrios se determinó que ningún colegial dietario gane los 3000 maravedíes de salario, y que se reduzcan las becas a seis y no más, lo cual se ha de ejecutar desde San Pedro de este año, que es cuando se acaba el curso, las cuales seis becas se han de repartir de modo que solo el colegial que hace oficio de sochantre tenga la una beca entera, y las demás que son cinco se repartan a disposición del cabildo, pero de modo que ninguno deje de pagar 450 reales con que lo más que se le pueda remitir solo será media porción y pagase la otra media.

Ítem que se redujesen las becas todas a seis, y no más, lo cual se ha de ejecutar desde el día del señor San Pedro, que es cuando se acaba el curso, las cuales seis becas se han de repartir, con que Jiménez colegial que hace oficio de sochantre, solo quede con una beca entera y goce de los 3000 maravedíes y las otras cinco se repartan en diez a disposición del cabildo, pero de modo que ninguno deje de pagar 450 reales.

[fol. $94 \mathrm{r}]$

Que la beca de Jiménez que hace oficio de sochantre sea fuera de las seis y que queden las once que hasta ahora han pagado las medias porciones (...)

[232] ASAC III, fol. ¿? (9-IX-1647)

Ítem se leyó una petición que presentó el licenciado Valenzuela organista en que pide se le paguen las cantidades que se le deben de días festivos se determinó por todos los votos se le paguen.

Ítem se leyó una petición del licenciado Caro, que está en aprobación para capellán, en que pide se le acomode y se determinó se le dé la capellanía de Vega con las cargar y obligaciones que pide dicha capellanía, y que por ahora no se le dé otra cosa.

\section{ASAC III, fol. 113 r (29-XII-1647)}

Ítem se determinó que Jiménez colegial goce la capellanía de Vega desde el año que viene de 1648, acudiendo a oración al coro, y con los demás cargos y obligaciones de dicha capellanía y que dé a los colegiales lección de canto. 
Y el señor Abad propuso que la capellanía que los días pasados se dio al maestro Garrido se la perpetuaría el Cabildo y se determinó que por ser cosa grave se deje para otro cabildo, y que todo lo que fuere de gracia vendrá en ello el Cabildo

\section{[236] ASAC III, fol. 132 r (2-VI-1648)}

El señor Presidente propuso si sería bien darle licencia al licenciado Jiménez colegial y sochantre de este Sacro Monte para que se ordene de Misa por tener necesidad la Iglesia de capellán y se votó por todos los votos para que se ordene atento a que la necesidad de capellán es grande

[237] ASAC III, fol. 137 r (21-VII-1648)

Ítem el señor rector Xerez propuso que los colegiales eran pocos, y ocupados y enfermos y que no podían acudir al coro y que fueran cuatro como en tiempo de lección y se determinó que vayan todos en época de vacaciones

\section{ASAC III, fol. 146 r (2-X-1648)}

Se determinó que por falta de colegiales no se sirve el coro como se debe que acudan al coro por la mañana dos teólogos y que las lecciones por ahora se tengan por la tarde.

[239] ASAC III, fol. 147 v (31-X-1648)

Se determinó que las lecciones de teología no se tengan mientras dura el coro sino que sean antes o después por la mañana.

Ítem se determinó que se le avise al señor rector que los colegiales sean puntuales para ir al coro con tiempo los que han de ir a registrar y que las cortesías que se han de guardar entre sí (...).

\section{9}

Leyose una petición del licenciado Jerónimo de Valenzuela para su paga y se acordó que hará diligencia con los mayordomos para que le paguen. 
Ítem quedó llamado también a este cabildo por ver si convendría favorecer el cabildo a Francisco Martínez colegial antiguo y muy pobre que a la presente hace oficio de Sochantre: en darle la capellanía del licenciado Luís de Vega de todo lo cual tratado y conferido yo el infraescripto secretario acepta relación al señor Abad que por estar indispuesto no puede hallarse en este cabildo y con esto se acabó.

Tratose de favorecer en este cabildo a Francisco Martínez colegial que a la presente hace oficio de sochantre con la capellanía del licenciado Luís de Vega y se acordó se hiciese dicho favor de darle la dicha capellanía.

[244] ASAC III, fol. 203 v (30-VIII-1650)

En este cabildo se recibió a Francisco Martínez colegial por sochantre y con este título se le señaló perpetua la comida de colegial, con que quede dentro del colegio con que vacó la beca de dicho Francisco Martínez (...).

Le hizo favor el cabildo a Francisco Martínez colegial de otorgar la obligación que tiene hecha de perpetuarle el sustento y comida de un colegial hasta que tenga con que sustención para que se pueda ordenar a título de ello, y asimismo le dio la capellanía del licenciado Luís Vega que vacó por promoción a una canongía al licenciado Pablo Ximénez Alexandre. Y asimismo se obligó el dicho licenciado Francisco Martínez de asistir y recibir en esta casa y en ella hacer el oficio de sochantre y capellán y todas las demás cosas que se le ordenasen como más largamente consta de dicha obligación y dio más tarde las gracias al cabildo el dicho licenciado Martínez.

\section{1}

[246] ASAC III, fol. 229 r (2-I-1651)

No hubo caso particular que advertir más que se prosiguiese como es costumbre ceremoniando los colegiales e intimando al que hace oficio de sochantre les de lección de canto. 
Leyose también una petición del licenciado Martínez colegial y sochantre ya ordenado de subdiácono a título de colegio en la que suplicaba al cabildo le hiciese merced de darle licencia para ordenarle de evangelio en las órdenes que vienen de la Trinidad y conferido se determinó se le dé licencia atento a haber hallado enmienda en las cosas por las que se le había suspendido en otro cabildo.

[248] ASAC III, fol. 232 r (22-IX-1651)

Propuso el señor Presidente como el licenciado Francisco Martínez colegial y sochantre pretende ir a ordenarse de diácono que atento a que el cabildo le tiene suspendida la licencia de ir a Granada ni a parte alguna, vea ahora el cabildo si se le podía hacer el favor que al presente de ir a ordenarse de diácono, y conferido se le dio licencia y se determinó, (como está ordenado en otro cabildo que se examinen los colegiales que pretenden ordenarse por examinadores de casa primero que vayan a pedir las órdenes) y para este examen como para otros de los que pretenden ordenarse en estas órdenes primeras, se nombraron por examinadores a los señores don Blasio Peinado Santaella y Pablo Ximenez Alexandre.

\section{2}

[249] ASAC III, fol. 278 v (26-I-1652)

Item se propuso si se recibiría un sochantre que se ha ofrecido y se determinó por mayor parte que por ahora no se reciba el dicho sochantre hasta que se haya ido Martínez a su tierra que hoy bastantemente hace oficio de sochantre.

Y el licenciado Martínez que hace oficio de sochantre suplicaba a este cabildo le hiciese merced y gracia de unas faltas que se le pusieron en el libro del punto el año de 1650 y por principio de 1652, de la capellanía de Vega en que está nombrado por capellán por haber estado enfermo aquellos días y habérsele olvidado el avisarlo. Y conferido se acordó por todos votos que se le perdonasen dichas faltas por cuanto algunos de estos señores les constaba ser verdad su enfermedad, y que de aquí en adelante asista a todos los puntos conforme a la fundación. 
Y en este cabildo se determinó que se llame para el lunes por la mañana después de horas para el dicho punto y para si se recibirá un sochantre que ha venido en que hay grandes conveniencias para el servicio de la Iglesia.

[252] ASAC III, fol. 297 r (1-VII-1652)

Se trató el punto de recibir el sochantre para que está llamado en el cabildo anterior y se determinó por todos votos se reciba con el salario ordinario que se ha dado a los demás.

Pidió licencia el sochantre par air a Jaén a unos aumentos que le ofrecían y se le dio por quince días.

\section{ASAC III, fol. 318 v (28-X-1652)}

Llamose para ver qué se hará para el hacimiento de gracias por los beneficios que Dios nos ha hecho por darnos la victoria de Barcelona y conferido se determinó que se haga procesión a las Santas Cavernas cantando el Te Deum Laudamus (...)a hora de misa se diga con solemnidad de primera clase mañana 29 de octubre, que se pongan luminarias esta noche y la siguiente con otras de fuegos.

\section{3}

ASAC III, fol. 329 v (2-I-1653)

También se determine que en el órgano o en el coro no cante nadie sin licencia del que presidiere en el coro y que se le avise así al organista.

Determinose que el señor Don Cristóbal de Vega aprenda a cantar las misas de tercia antes que cante otras.

[256] ASAC III, fol. 333 v (6-I-1653)

Segundo punto fue qué se haría porque se ha sabido que mañana viernes vienen con los hermanos que vienen a la estación la Religión de San Francisco para pedir a Dios agua por intercesión de estos Santos del Sacromonte y se determinó que desde que asomen por la Puente Quebrada hasta que bajen las cuestas, se repique con solemnidad y que en la Iglesia se toque el órgano cuando entren y en 
cuanto al recibimiento se remitió a los señores Abad y Presidente para que conforme a lo que en este cabildo se ha conferido lo dispongan.

Propúsose como el licenciado Martínez, sochantre y capellán, pide licencia para ir a su tierra. Y conferido se determinó que se le dé dicha licencia por veinte días.

\section{[258] ASAC III, fol. 355 r (28-VI-1653)}

Item se determinó que el licenciado Martínez Sochantre mude de hábito y se quite el manto y entre tanto se vaya prosiguiendo la pena que en otro tiempo se le echó y no ha innovado el cabildo de que no salga del circuito de la casa.

\section{ASAC III, fol. 355 v (2-VII-1653)}

Item se determinó que el licenciado Martínez, sochantre, pida perdón al señor Presidente y a la Junta, del desacato que hubo dándole algunos avisos en el responder y hablar cosas fuera de propósito y que el señor Xerez cuide de que haya esta entrega y le amoneste lo que ha de hacer y del modo que se ha de portar con humildad y respeto y que desde luego se quite el manto que todavía tiene de colegial y se ponga sonata, que se eche de ver donde quiere que anduviere o asistiere que no es colegial.

Luego se leyó una petición de Valenzuela acerca de pagarle lo que se le debía y se determinó que se hiciera lo que pedía.

\section{ASAC III, fol. 370 r (28-XII-1653)}

Propuso el señor Abad como el licenciado Martínez sochantre había ayer llegado a la cocina a pedir cierta cosa, y que avisándosele, respondido por donde lo dijo, que fue por una ventana que no se podía, entonces quiso entrar dentro la cocina y habiendo hallado la puerta cerrada, como está determinado que esté así por muchos inconvenientes que se han experimentado de que esté abierta, tomó una piedra muy grande y dio tantos golpes en ella que sacó entonces un pestiguillo que tiene y dio con él en tierra. Y habiéndosele propuesto a la Junta de Asistentes determinó por todos votos que el licenciado Martínez se expeliese de casa porque de otras Juntas y Cabildos se le ha castigado y penado por otros muchos graves excesos suyos y que no ha tenido enmienda antes, se ve su incorregibilidad como en el caso sucedido. Que viese el cabildo sin orden del cual no se puede hacer dicha expulsión lo que convendría. Y conferido y trayendo a la memoria otros muchos arrojos suyos y excesos por donde se le ha castigado y penado otras veces, se determinó que se expela de la casa por tres 
partes de cuatro de los votos que se hallaron, aunque no eran necesarios tantos para dicha expulsión.

\section{4}

[262] ASAC III, fol. 378 r (28-V-1654)

Llamose a este cabildo ante diem para ver sis e recibiría el sochantre Español que escribió quería venir. Y se determinó por mayor parte se reciba y no se le dé cuenta hasta saber en secreto qué ocasión ha tenido en Jaén.

\section{5}

[263] ASAC III, fol. 401 v (2-IV-1655)

Acerca de ceremonias se propuso que en la primera antíphona es ceremonia estar en pie hasta la mitad del primer verso del salmo. Y que otra ceremonia acerca del Asperges, que es privilegio de España, que salga un capero a decirlo con estola y sobrepelliz.

Propuso el señor Don Pedro Ponce, que Valenzuela le ha pedido proponga que por lo que ha servido, sea servido de perpetuarle la comida que hoy se le da y el cabildo determinó que se le perpetúe con dos condiciones: que se le ha de dar estando en el Sacromonte y sirviendo el órgano mientras pudiere, lo cual constare por declaración por los medios que nombrare el Sacromonte y estando en todo sujeto a la disposición del cabildo para obligarle a que asista a su órgano y a las demás obligaciones que tienen otros cualesquiera capellanes del Sacromonte.

ASAC III, fol. 422 r (7-XI-1655)

Llamose a este cabildo para ver qué medios se tomarían por haber el licenciado Valenzuela ejecutado al mayordomo por su salario. Y se determinó que el señor Presidente le diga a Valenzuela que espere por quince días porque no se le haga molestia al mayordomo de que se cumpla el término para que se saquen la décima.

\section{6}

Memorial que dió el señor Villoslada de la Hacienda de fábrica y de los gastos que de presente tiene. 
$[\ldots]$

Item tiene obligación de sustentar un Sochantre 01100 Reales

Gana de salario el Sochantre 600 reales

Gana el organista 600 reales y 8 fanegas de trigo que computadas a 18 reales un año con otro son 144 que hace por todo 744 reales

Gana el campanero 22 reales todos los meses que suman 264 reales

Sustento del campanero 1100 reales

[266] ASAC III, fol. 432 v (22-III-1656)

Propuso después el señor Abad si se recibiría por Sochantre a Jiménez colegial, dándole la comida de colegial mismamente. Y se determinó que sirva de Sochantre con su hábito de colegial y con toda la comida de colegio, sin salario alguno y sin preminencia de sochantre y que asista en el colegio y esto sea por el tiempo que al cabildo pareciere no recibir otro sochantre y que por esto se le exonere de los tercios del colegio.

1657

[267] ASAC III, fol. 464 v (28-IV-1657)

Item por haberse quejado el señor Doctor Santaella, Rector del Colegio en cabildo, de que Jiménez, sochantre, es muy nocivo en el colegio a los colegiales y que los echa a perder con sus libertades. Y representado mucho, se decretó que al punto saliese del colegio y se le pusiese en aposento aparte y lo ejecutase el dicho selor Rector, y que el señor Secretario del Cabildo le intime que desde luego acudiese a todas las horas del coro y vísperas y misa mayor, y si no lo cumpliese, al punto se tuviese por despedido del Sacromonte y que el señor Presidente le diese de comer.

[268] ASAC III, fol. (2-V-1657)

Item propuso el señor Presidente si se recibiría un Sochantre para que sirva el coro por haber faltado Jiménez, y se determinó que no se recibiese por razones de alcance de la casa y que Cámara se quede colegial como se está de media porción y porque supla el oficio de Sochantre acuda al coro como tal, porque la fábrica da la mesa 50 ducados para su sustento con lo que el susodicho no pagará nada para sus alimentos.

\section{8}

[269] ASAC III, fol. 489 r (9-IV-1658)

Y propuso el señor Abad qué demonstración de solemnidad, honras y oficios se habían de hacer por el Excelentísimo Señor Don Adán Centurión y Córdoba, Marqués de Estepa, la persona más benemérita y bienhechor de esta casa e Iglesia, que fue como otro Colón, el primer descubridor de las Indias y riquezas 
de los libros de este Sacromonte con su primera traducción, hecha con tanta costa y trabajo, con que diole a otras muchas que se han hecho en Roma. Y asimismo hizo otras muchas obras ayudando los negocios de Roma, todas dignas de su mucha devoción y grandeza. Y se decretó por todos votos que luego se doblase con todas las campanas y se hiciese un novenario de misas cantadas con sus vigilias la tarde antes de cada misa y se comenzase desde hoy, día de la fecha de este cabildo, con asistencia de todos los Señores Prebendados y Colegio. Y que cada Señor le dijese una Misa, y que el Señor Abad como cabeza comenzase el primer oficio y misa del novenario, que se pusiese túmulo alto en la Capilla, como se celebran las honras del Arzobispo mi señor, con la misma cera de hachas y velas, plata y ornamentos y paño y coines de brocado para cubrir el túmulo como se hace con el señor Vaca de Castro, padre del Arzobispo mi señor. Que fuesen dos señores Prebendados luego a dar el pésame al señor Marqué de Leganés su pariente, por hallarse presente en esta ocasión en Granada y estar aposentado en el Palacio del dicho Señor Marqués de Estepa, y fueron designados para esta comisón el señor Doctor Don Blasio de Santaella y el Señor Don Pablo de Alexandre. Item se determinó que luego se partiese a Estepa dicho señor Doctor Santaella, a dar el pésame de parte del Cabildo a la Señora Marquesa, mujer del difunto y asu hijo heredero del estado y al señor Marqués de Armenia, hermano del difunto. Y para el gasto de este viaje se le señalaron 200 reales. Y se le encargó recoja todos los papeles tocantes a los libros del Sacromonte que tuviese en su poder el dicho Señor Marqués, en particular las copias de los mismos libros originales con los mismos caracteres, que son los que se tuvo en Roma el señor Don Bartolomé de Torres Abad, y los corrigió con los de los intérpretes nombrados en las congregaciones que para esto tuvieron en Roma en presencia de los señores cardenales y del secretario nombrado para ello. Y que trujese razón de lo que dispuso en su testamento en orden a lo perteneciente a este Sacromonte y si le mandó algo y que tratase y se informase.

\section{9}

\section{ASAC III, fol. 518 v (1-VIII-1659)}

Sólo se cometió al señor Alexandre que hiciese diligencia de vender los violones y el reloj antiguo y organillo de madera, y que con lo que se hiciese se pusiesen las rejas del corpus de los balcones y se arreglen otras cosas.

[271] ASAC III, fol. 525 v (2-X-1659)

Se advirtió que los misales y el breviario están maltrados y se determinó se aderecen.

Item se determinó que los colegiales no vayan al campo sin el señor Rector o en su ausencia, de señor prebendado y que no saquen vihuela fuera de casa. 
Item se determinó se reciba por sochantre al licenciado Cosme Español, con salario de 60 ducados cada año y que se le dé comida de señores. Item se determinó que al señor don Juan de Leiva se dé la carta de favor que ha pedido a ésteque escriba al señor Cardenal Sandoval, para un músico de la Capilla Real de Granada que se va a oponer a Toledo.

[273] ASAC III, fol. 570 r (3-VIII-1660)

Item se determinó que al licenciado Jerónimo de Valenzuela, se le libren 400 reales a cuenta de su salario.

Item se determinó que a Cosme Español, sochantre, se le dé silla alta.

\section{TOMO IV}

\section{1}

Ítem se determinó que se aumente el salario al Sochantre, dándole 300 maravedíes cada cuatro meses.

En este cabildo, propuso el señor don Cristóbal de Vega había tenido un disgusto con el maestro Bustamante en que le había hablado y tratado con mucho desahogo y descortesía de que había seguido muy mal ejemplo convenía poner remedio a esto. Y se determinó por todos los votos se le diese por el señor secretario una reprehensión en nombre del cabildo y que el dicho capellán diga las misas últimas hasta la semana de este año y se advierta no tenga diurno en el coro y cumpla con sus obligaciones y de ejemplo.

[276] ASAC IV, fol. 4 v (4-I-1661)

Ítem se leyó una petición del organista que se remitió a la Junta para ver lo que en ella pide.

Ítem se comenzó a leer la Consueta como está determinado.

Propuso en este cabildo el señor don Miguel de Medina que había venido de la ciudad de Jaén, Francisco Antonio de Aguilera al Sacromonte a pretender del 
oficio de Sochantre que estaba vaco por promoción al de Plasencia por el licenciado Español. Y que el susodicho parecía ser capaz y de buena voz para dicho oficio y a propósito para maestro de coro, y que le tenía examinado dichos oficios Medina y el licenciado Valenzuela. Habiéndose conferido dicho asunto se determinó por todos votos menos uno, se recibiese dicho sochantre por ahora con salario de 600 maravedíes y que las faltas que hiciere en la asistencia a las otras misas y vísperas y los demás oficios divinos y obligaciones de Coro del oficio de Sochantre se le quiten de su salario además del cual ha de ganar los manuales como los demás capellanes.

\section{[278] ASAC IV, fol. 36 r (8-II-1661)}

Llamose para ver en qué forma se dispondría la fiesta que tenía dotada hacer esta Iglesia de la Inmaculada Concepción de Nuestra señora respecto de haber resuelto sus señorías y obispo que no se hagan procesiones en Granada. Y conferido se determinó que el domingo que viene 12 de febrero se diga misa mayor solemne con la música de la Iglesia o de la (...) se manifieste el santísimo Sacramento y la Reliquias como el día de San Cecilio poniendo en el lugar que pareciere más conveniente, haya sermón a don Pablo presidente por la tarde se haga procesión por las cuestas del Sacromonte con nuestra Señora y que ara asistir a ella se convide a la ciudad de Granada con legacía a su cabildo para lo cual se nombraron a los señores presidente y por comisario para disponer la fiesta y altar a los señores y Escalante.

\section{2}

[279] ASAC IV, fol. $50 \mathrm{v}(i ?-\mathrm{X}-1662)$

Ítem se leyó una petición del maestro Bustamante en que suplica al cabildo le dé licencia para irse a Sevilla y que su señoría le honre con títulos honoríficos como no salió forzado si no en la necesidad de mudar de temple de tierra respecto de sus achaques y que ha procedido siempre acuerdamente y conforme los estatutos de este Sacro Monte y se dirimió le diese el cabildo una ayuda de costa para situarse. Y se determinó por todos votos la licencia y con claridad que esa licencia no era reservable la capellanía que tiene y que dicha capellanía se le ha de vacar, y se acordó por todos votos se le diesen los testimonios que pide, y por los mismos votos se determinó se le den diez ducados de ayuda de costa por su viaje respecto a su necesidad y que dichos diez ducados se saquen de la fábrica.

[280] ASAC IV, fol. 51 v (23-X-1662)

Propuso el señor Abad la necesidad que había de capellán, y habiéndose conferido salió elegido por todos votos don Pedro Maçuela y Morón natural de Alcalá la Real, cuyas pruebas se cometieron por todos votos al señor don Pedro Ponce presidente. 
Se determinó que al licenciado Aguilera, sochantre, se le perpetúe la capellanía de Vega por escritura con las calidades de su fundación y que han tenido los antecesores.

[282] ASAC IV, fol. 70 v (¿?-XI-1663)

Asimismo se aprobó el nombramiento de capellán que se hizo en el licenciado Francisco de Aguilera, de la capellanía que fundo el licenciado Luís de Vega para que a tributo de ella se ordene y todo ello ante Antonio Ruiz de Prado.

\section{ASAC IV, fol. 72 v (3-XII-1663)}

En ceremonias se reparó que los señores Caperos no repiten los versos que dicen el órgano que según Consueta deberían repetir.

\section{5}

\section{[284] ASAC IV, fol. 95 r (10-I-1665)}

Fue este cabildo para dar noticia el señor Abad de cómo el licenciado Aguilera, sochantre de esta Santa Iglesia, estaba para ir a Córdoba, llamado por segunda vez para sochantre de aquella Santa Iglesia/

(fol. $95 \mathrm{v}$ ) y que por lo mucho que convenía tener al sujeto al servicio de esta Iglesia se confiriese si será conveniente algo del salario para impedir que saliese de ella, y conferido se determinó que se le añadan 200 reales más una capellanía en que se hace mención en los cabildos antecedentes que fundó de una misa cada día Joan Cebrián Jaén que tiene aceptada el cabildo se le consigne para que la goce saliendo el cabildo con ella, que en caso de que no sea visto se vea el cabildo obligado al saneamiento de esta manda, y en caso de que salga con ella queda nombrado en dicha capellanía.

Fue este cabildo para dar noticia el señor Abad de cómo el cabildo de la Santa Iglesia de Granada trata de pedir rezo propio del señor San Cecilio a su Santidad y para esto tiene nombrado comisarios para que consulten en esta Santa Iglesia si se ha pedido otra vez y si se ha negado o si hay algún inconveniente para que no se pida y logre el efecto. Y conferido se determino se nombre por comisario a don Joan de Xerez que entró en esta ocasión y se le dio noticia de lo que se trataba.

\section{ASAC IV, fol. 103 r (1-VI-1665)}

Se reparó no seguían los colegiales con la lección de canto con que se observe la Constitución en esta materia y se determinó se observe dicha Constitución en la hora que se dispone. 
Se determinó se le den cartas al Sochantre para el Obispo de Jaén pidiéndole lo ordene.

Ítem se leyó una petición del licenciado Francisco de Aguilera sochantre de este Sacromonte en que pedía que atento a que no podía ordenarse con la renta a las dos capellanías y salario de 300 reales de ayuda de costa por no ser renta colativa ni fija, suplicaba a el cabildo la perpetuase /

(fol.110 r) en 40 ducados de aquella que tenía por sochantre o una comida $\mathrm{s}(\ldots . .$. se determinó por mayor parte.

\section{6}

[288] ASAC IV, fol. 131 v (1-X-1666)

Ítem propuso el licenciado don Julián de Xerez que puesto que había muchas tardes en que había vísperas cantadas a que a esta razón no tenía estudio los artistas, que si se le hacía presente el señor catedrático en los días que había vísperas que tuviere lección. Se determinó por todos votos que habiendo vísperas y completas cantadas que no haya lección, mas cuando no fueran cantadas las completas sino solo las vísperas que se haga presente.

\section{7}

\section{[289] ASAC IV, fol. 142 r (22-III-1667)}

Así mismo se leyó una petición del licenciado Valenzuela, organista de este Sacro Monte en que suplicaba al Cabildo licencia para imponer una memoria de trece misas rezadas en el altar de Nuestra Señora del rosario a cuatro maravedíes de limosna que se han de decir los primeros domingos del mes y el de octubre se han dar dos y tres reales para el sacristán y se admitió dicha memoria y el principal que son cien ducados que los reciba el señor don Lope para que se impongan.

[290] ASAC IV, fol. 142 v (29-VI-1667)

Así mismo se otorgó escritura recibiendo la memoria que ha fundado el licenciado Jerónimo/

(fol. 143 r) de Valençuela de las misas de nuestra Señora del Rosario los primeros domingos de cada mes de cien ducados de principal. 
Se acordó que los colegiales tienen poco ejercicio de canto y ceremonias y que en ambas cosas están muy bastos que se le encarga al señor sochantre ponga cuidado en esto.

\section{8}

[292] ASAC IV, fol. 166 v (15-III-1668)

Este cabildo fue para disponer las cosas necesarias tocantes al curato de Dayfontes y asistir al señor don francisco de Peralta visitador general de este Arzobispado que va a poner el Santísimo Sacramento y pila del Bautismo. Y se determinó por todos votos que el señor Abad y el señor Julián de Xerez le acompañen y asistan al señor visitador y los demás señores prebendados que quisieren ir a Dayfontes y el sochantre y ocho colegiales que nombrare el señor Abad. Y esto se ejecute con toda brevedad por justas causas y el gasto de tiempo que durare se cometió al infrascripto secretario como proveedor y que compre dos capas para dicho señor visitador y dulces para postres y todo lo demás que le pareciere conveniente para cumplir decentemente. Y así mismo se determinó se ajuste la cuenta de los derechos y demás gastos que se han hecho en la pretensión de dicho curato por los señores comisarios y se les despache libranza.

[293] ASAC IV, fol. 182 r (2-VIII-1668)

Ítem se determinó que los colegiales tengan lección de canto al echar las campanas, y que el que faltare sea multado al arbitrio del señor Rector.

[294] ASAC IV, fol. 185 r (1-IX-1668)

Se advirtió que cuando esté bueno el sochantre dé lección de Canto a los Colegiales a la hora que dispone la Constitución y que al colegial que no asistiere se le quite la cena y el señor rector les diga se vistan modestamente sin traer mangas ni medias blancas.

[295] ASAC IV, fol. 198 v (2-III-1669)

Ítem propuso el señor Vega que algunos colegiales ayudaban las misas sin sobrepelliz y que llevaban los libros al coro y del coro a la librería cargando cada colegial con un libro, de que se seguía dar golpes con ellos y echarlos a perder. Encargose al señor rector y al señor Maestro de Ceremonias se les advirtiese a los colegiales lo que deben hacer de ayudar a misa con sobrepellices y de llevar los libros entre dos colegiales.

Advirtió el señor Rienda sobre la Lección de Canto que los colegiales querían tener y que se faltaba a esto así por parte de ellos como del sochantre por cuanto 
dichos colegiales no acudían. Determinose el remedio a esta falta a que la remediase el señor Presidente y penase a su voluntad a los que faltasen a dicho ejercicio.

[297] ASAC IV, fol. ¿? (2-I-1670)

Se reparó que los colegiales no tenían lección de Canto y se determinó que el Sochantre la tenga a su hora acostumbrada.

[298] ASAC IV, fol. 237 r (1-IV-1670)

Advirtió el señor Presidente en cuanto a los colegiales se haga guardar la ceremonia de ponerse en la capilla de los mártires para desde allí vengan en orden al Coro. Ítem que los viernes se pongan a la hora de oración en la Capilla de Nuestra señora del Rosario y Capilla de los Santos Mártires porque no se remezclen con la gente que tales días vienen a la Iglesia. Ítem que los demás días no pasen del arco toral en dicha hora ni se sienten en los confesionarios.

[299] ASAC IV, fol. ¿? (7-VI-1670)

(...) Se le diesen más al Sochantre por su necesidad adelantados 200 maravedíes de los efectos de dicho trigo y cebada y se tome razón en la contaduría para la libranza siguiente.

Propuso el señor Vega la falta de asistencia que tenían los colegiales a la Lección de Canto Llano que tanto importa al servicio de este Sacro Monte y haberse determinado muchas veces que asistan en medio de esto faltan mucho./Con que se determinó que el Sochantre diese lista al señor Rector de los que faltasen para que les quitase las comidas o las cenas todas las veces que habiendo ejercicio faltasen.

\section{2}

[301] ASAC IV, fol. 301 r (30-IV-1672)

Ítem por ser muy frecuentes las confusiones que ocurren en esta Santa Iglesia principalmente los días festivos y (...) estar imposibilitado el capellán de asistir a ayudar las Misas de Tercia se hacía menester que el Maestro Castilla asista dichas misas los días de Domingo, asuetos y demás fiestas que se ofreciesen.

Fue este cabildo para ver si el organista que era de esta santa Iglesia se habría de recibir por haber escrito pidiendo se readmitiese que hállase con mucha 
necesidad en Sevilla. Determinose no se reciba, por cuanto sin haber dado cuenta al Cabildo, se fue y se despidió y no haber seguridad para otra ocasión de que deje de hacer lo mismo. Y por estar la Iglesia sin organista, y había el Señor Abad empezado a hacer algunas diligencias con el Racionero Garay Maestro de Capilla de la Santa Iglesia de Granada en orden a buscar y solicitar quien venga a ser organista a su satisfacción se dio comisión al señor Abad para que continúe en la solicitación.

[303] ASAC IV, fol. 319 v (2-XII-1672)

Ítem se determinaron los puntos siguientes y se dio comisión al señor Abad para que ajustase con el Racionero Garay la venida del organista de la Capilla Real a servir el órgano de esta Iglesia, para que ajustase el salario que se le había de dar y lo demás que pareciese conveniente para este fin.

1673

[304] ASAC IV, fol. 322 v (21-I-1673)

Se libren al licenciado Aguilera Sochantre 40 ducados de ayuda de costa por cuanto por la falta de organista ha sido excesivo su trabajo.

ASAC IV, fol. 323 v (11-III-1673)

El licenciado Figueroa, sacristán mayor de esta Iglesia por ser sacerdote y sus buenos procedimientos se le dé asiento en el Refectorio de los Señores a mesa segunda en el lugar más abajo del organista, si este fuere sacerdote.

[306] ASAC IV, fol. 324 r $(i ?-I V-1673)$

Ítem se determinó que se ajuste la cuenta del licenciado Valenzuela difunto y los señores albaceas cumplan el testamento, y que el Señor Peña sepa de su hija si quiere que se venda ahora el trigo que le perteneció de su salario.

ASAC IV, fol. 325 r (1-VI-1673)

También ¿? De cómo en este cabildo quedó elegido por organista al señor don Juan Riscos y se le dieron 400 reales de salario y comida de colegio.

[308] ASAC IV, fol. 331 v (4-XI-1673)

Este cabildo de Ceremonias, Constituciones y loables costumbres donde se reparó que el Sochantre asista a la lección de Canto.

[309] ASAC IV, fol. 344 r (3-I-1674) 
El señor Rector cuide de que los colegiales vayan a la Lección de Canto.

[310] ASAC IV, fol. 337 v (2-IV-1674)

Ítem se determinó que prosiga la lección de canto, y que el señor Rector aliente a los colegiales sacerdotes para que se pongan de confesores.

1675

[311] ASAC IV, fol. 356 r (19-II-1675)

Se dio comisión al señor Barzia para que conforme si en la Iglesia las dominicas de septuagésima y quincuagésima se toca el órgano.

[312] ASAC IV, fol. 359 r (2-V-1675)

Se advirtió que los colegiales cuando van a cantar la Kalenda o lección alguna después de hacer genuflexión al altar mayor hagan venia al cabildo.

1676

[313] ASAC IV, fol. 373 r (23-VI-1676)

Diose licencia al sochantre por tres meses por constar necesita de cura.

[314] ASAC IV, fol. 373 v (1-VI-1676)

Determinose que asistan al coro seis colegiales () y también los sacerdotes como siempre ha sido costumbre. Que los días de primera clase se harán en el coro con toda celebridad y espacio.

[315] ASAC IV, fol. 374 v (1-VII-1676)

Al maestro Rojas se le remita todo lo que le diere por la posesión este año del oficio de Sochantre que está haciendo. Y que mientras lo sirviere no pague alimentos de su porción.

[316] ASAC IV, fol. 375 v (18-VII-1676)

Fue este cabildo para tratar de hacer diligencias del sochantre por la falta que hay en casa. Y a este punto se dio comisión al sr. Zerda para que de parte de este Cabildo hable al Maestro Garay, Racionero de la Santa Iglesia de Granada 
para que solicite persona a propósito, y dé su aprobación para lo que se resigna el Cabildo a su voluntad.

Fue este cabildo para ver si conforme al informe del racionero Garay se tomaría por Sochantre de esta Iglesia al licenciado do Ju[lio] del Castillo, y habiéndose oído y diose la aprobación y dicho racionero y sacerdote, se recibió por Sochantre y se le asignaron por salario 1200 reales, y los dos censos de vino y seis reales para lavar la ropa todos los meses.

[318] ASAC IV, fol. 381 v (1-X-1676)

Se aliñen las celosías del órgano por estar muy maltratadas y ser ocasión

Leyose una petición del organista se le diese licencia/ de cuatro días.

Ítem se leyó una petición del Sochantre pidiéndose se le diese testimonio que para ser recibido hizo examen ante el Racionero Garay.

[319] ASAC IV, fol. ¿? (23-X-1676)

Al sermón de San Cecilio se le dé a Don Pablo de Alexandre.

Ítem se leyó otra petición del organista pidiendo refectorio de señores y demás emolumentos, que según consta se le den al organista, y se determinó que por un año del Colegio ración sola de señores y que por este tiempo no pueda presentar en el Cabildo y se acabó el cabildo.

1677

[320] ASAC IV, fol. ¿? (22-V-1677)

Cabildo para ver si se harían algunas rogativas por las necesidades presentes, falta de pan y de agua. Se determinó que en nueve días empezando desde hoy sábado se haga la procesión a las cuevas llevando la Imagen de Nuestra Señora Concepción al Sagrario cantando su letanía y que se digan dos misas cantadas después de oración y que la primera se diga mañana domingo y la segunda el domingo que viene.

[321] ASAC IV, fol. 394 r (1-VI-1677)

Y en lo que toca a ceremonias dijo el sr. Don Miguel de Medina que en las Vísperas cantadas estándolas cantando un coro algunos colegiales del otro cantaban fabordón cosa mal parecida y contra ceremonia, y se determinó que el sochantre diga a los colegiales cante cada uno en su coro guardando 


\section{TOMO V}

1678

[322]

ASAC V, fol. 25 r (14-III-1678)

Se dio licencia al Maestro Aguilar por ocho meses para ir a su tierra y a otras partes en negocios que se le han ofrecido.

[323] ASAC V, fol. 25 v (24-IV-1678)

Ítem se escriba carta al señor Obispo de Jaén a favor del Maestro Aguilar.

ASAC V, fol. 33 v (10-IX-1678)

Ítem propuso el señor Peña que los colegiales pedían licencia al cabildo para cantar una misa en la Capilla del Rosario el primer domingo de octubre y se denegó esta licencia.

\section{9}

[325] ASAC V, fol. 43 r (18-III-1679)

Y fue este cabildo para tratar un punto remitido de la Junta de Asistentes acerca de si se le ha de dar al Sochantre alguna ayuda de costa atendiendo a la enfermedad que se está quedando en su casa y su mucha necesidad y se determinó que todos los días se le enviare el Mandadero una libra de carne y una hogaza y que por cuenta del censo de Abril se le libren y adelanten doscientos reales de su salario y si continuare más la enfermedad determinara el cabildo lo que más convenga.

\section{ASAC V, fol. 45 r (1-V-1679)}

Ítem se le dieron al Sochantre por esta vez doscientos reales de haber vendido todos sus gastos y estar muy necesitado por los gastos que ha tenido en su enfermedad (...) que se curó en su casa y respecto de que hubiera gastado mucho más si se hubiera curado en casa.

[327] ASAC V, fol. $47 \mathrm{v}(19-\mathrm{V}-1679)$

Ítem propuso el sr. Medina como don Alonso Colmenares Capellán Real de Granada ofrecía el aderezar el clavicordio que dejó el licenciado Valenzuela con condición de que se le diera el organillo de palo que está desbaratado y se determinó para otro cabildo este punto.

Y que al Sochantre no se le dé el vigolón que pide. 
Fue este cabildo para ver si al organista se le dará licencia para ir a la oposición del órgano de Almería y se le dio dicha licencia por veinte días y que si fuere necesario más tiempo por alguna circunstancia escribiere desde allá pidiendo nueva licencia.

En él se reparó que había días que no asistían los colegiales a la lección de canto en perjuicio de la Iglesia. Y se determinó que todos los colegiales asistan a la dicha lección y que por ningún tiempo sea la lección después de salir de Vísperas.

$[$ fol. $52 \mathrm{v}]$

Dieron cuenta el Sr. Medina y el Sr. Morales de la graduación que tuvieron de lugares en el refectorio de los ser para los Ministros en virtud de la comisión que les dio el Cabildo, la cual fue así, primero el sochantre, luego el Capellán, después el Maestro Valbuena por catedrático de Artes, y en cuarto lugar el Organista, luego el licenciado Figueroa y después el Contador, y se dio por bien hecha y que así se obrare y practique en adelante.

Leyose petición del licenciado don Juan Riscos organista de la casa pidiendo licencia al cabildo para ceder su lugar sin perjuicio de sus sucesores al licenciado Figueroa por sacerdote y más condecorado y se determinó se esté en el lugar que se le ha señalado y que le toca por su oficio.

[330] ASAC V, fol. 55 r (1-IX-1679)

Ítem se reparó por la prisa con que se solía decir el Credo en las misas cantadas no se daba lugar a que el Presidente se sentase a que el presente se sentase al tiempo que está denominado se siente, por lo cual en el coro se seguía a los señores alguna inconveniencia y disconformidad. Y se determinó se le diese al sochantre de lugar para que uniformemente se siente el coro cuando se sentare el Presidente

Ítem se reparó que por falta de la asistencia de algunos colegiales a la Lección de Canto estaban los colegiales con poca compostura y respeto al Sochantre y aprovechaban poco. Se determinó que el colegial semanero asista a dicha lección según lo ordena la Consueta.

[331] ASAC V, fol. 58 r (12-IX-1679)

Propuso el señor Morales como el licenciado don J[uan] Riscos organista de casa por la devoción que tenía a Nuestra Señora del Rosario quería fundar un aniversario en los mismos puntos que tiene de celebridad la fiesta, añadiendo solo el que las Completas fuesen cantadas para cuya distribución daba noventa reales a treinta con cada dicho de los tres puntos, y doce reales para dos misas al ofertorio que la una se habría de dar con el altar del Rosario y para en el de la Concepción. Y a los Diáconos y capas fuera de la distribución de Mesa 
Capitular añadía un real más, y por cuanto aquel día no hay Salve dotada la dotaba y fundaba en dieciocho reales de distribución. Todo lo cual se había de pagar de lo perteneciente a su nómina en el interim que no daba el principal para la $¿$ ?, que suplicaba al cabildo se le admitiese y se admitió dicha fundación, y en este punto expresaron su voto el señor Ponce, el Sr. Valdivia dijeron no eran del parecer se admitiera esta fundación.

[332] ASAC V, fol. 69 r (3-XI-1679)

Ítem que se tenga lección de canto a los colegiales a la hora acostumbrada, y que el Rector a lo menos los días de primera clase se le releve del oficio que tuviere para que asista al coro a cantar.

Propuso el señor Xerez como el organista pedía licencia al cabildo para tener en su puesto a un hermano suyo por la conveniencia de que tiene a estar dándole de su comida y se negó dicha licencia por algunos inconvenientes que se presentaron.

\section{0}

[334] ASAC V, fol. 80 r (2-IV-1680)

Propuso el Sr. Xerez sobre don Juan Riscos organista ha prece en que negándole el Sr. Abad la licencia para que pernoctare en Granada se quedó en la ciudad aquella noche y que en las respuestas que dio al Sr. Abad anduvo indecente y faltó de atención en ellas con dicho señor, echósele de pena veinte ducados y que en los seis meses no baje a Granada. Suplicó el Sr. Abad al cabildo sobre esta pena, y aliviose en orden a los maravedíes y que quede la de no bajar a Granada excepto cuando a el Sr. Abad pareciese ser caso muy preciso.

ASAC V, fol. ¿? (30-IV-1680)

Ítem por haberse llevado Nuestro Señor a don J del Castillo, Sochantre de este Sacro Monte y haber muerto en su casa de enfermedad de dolor de costado, se trató de su entierro, y se determinó se trajese el cuerpo como así lo disponen las Constituciones y se enterrase en este Sacro Monte en la bóveda perteneciente donde se enterraban los colegiales.

\section{[336] ASAC V, fol. 86 r (6-VII-1680)}

Ítem se leyó una petición del colegial Torre que hace oficio de Sochantre en que pide una ayuda de costa por ser muy pobre y estar muy necesitado de vestido y otras cosas y se le libraron doscientos reales por esta vez.

Ítem se determinó que corran sus porciones para la cuenta conveniente por cuanto es colegial actual y no quiere ser sochantre en propiedad. Ítem propuso 
el Sr. Morales que habiendo vacado la capellanía de Vega por muerte del Sochantre don $\mathrm{J}^{\mathbf{o}}$ del Castillo y que aunque era el cabildo y es siempre capellán en todas sus vacantes no puede hacer diligencia de su cobranza por estar empleado de acreedores y haber cedido y conviniéndose con don Diego de Ventumilla $^{31}$ por algún tiempo, hiciera menester nombrar nuevo capellán.

[337] ASAC V, fol. 93 v (9-X-1680)

Ítem hablose sobre la capellanía que vacó por muerte del Sochantre ser conveniente proveerla en quien la litigie y quedose para el cabildo del Sábado.

[338] ASAC V, fol. 94 r (22-X-1680)

Para dar la Capellanía que vacó por muerte del Sochantre la cual se dio al colegial Flores y que dispense el Sr. Arzobispo en lo del sacerdocio.

\section{1}

[339] ASAC V, fol. 119 v (22-X-1681)

Ítem se leyó una petición de don J[uan] de Riscos organista de este Sacro Monte por la cual suplicaba y pedía al cabildo le multiplicase hasta el salario del licenciado Valenzuela su antecesor a causa de haber ocho años que servía y ser a sus cuestas a su madre viuda y a sus hermanas y determinó el cabildo se le diese desde este año seis fanegas de trigo y doscientos reales del vino.

1682

[340] ASAC V, fol. 132 v (25-IV-1682)

El licenciado don J[uan] de Riscos suplicó al cabildo fuese sentido de mandar se le diese testimonio que ha asistido en esta Santa Iglesia por organista y se determinó se le diese.

Se propuso en el cabildo antecedente que respecto de los muchos y repetidos calores, que convendría se bajase el coro a la Iglesia, y conferido el punto se determinó no convenía por graves inconvenientes que se seguían.

\footnotetext{
${ }^{31}$ Ilegible, podría ser Venturilla o Entumella.
} 
Propuso el infrascripto señor canónigo y secretario que por faltar señores que se vistiesen de Diácono y Subdiácono en las Misas de Tercia, se vestían algunos colegiales que decían muchos solecismos en lo que cantaban. Se determinó que antes que llamen para los vestuarios a los colegiales se avisen a todos los señores si se quieren vestir, y si no pudieren, los colegiales que se vistieren pasen primero lo que hubiesen de cantar.

[343] ASAC V, fol. ¿? (3-XI-1683)

Ítem se determinó que el maestro Torre entre a comer en el Refectorio de los señores.

[344] ASAC V, fol. ¿? (9-XI-1683)

Y se determinó que el Maestro Torre en el tiempo de oración de por la mañana pueda asistir en el coro.

[345] ASAC V, fol. 178 r (1-XII-1683)

Ítem se determinó que por cuanto el señor Arzobispo pide persona competente al Maestro Torre que hace oficio de Sochantre que este cabildo se obligue a sustentarlo mientras no tuviere con que. Que se haga un escrito de obligación en la forma que el Arzobispo pide.

1684

[346] ASAC IV, fol. ¿? (3-I-1684)

Fundación que propone don José de Barzia en honor al Santísimo Sacramento de asistencia a su cada una de las mañanas de los ocho días con ciertas condiciones que están aquí expresadas.

Fundación de hora y media de asistencia al Santísimo Sacramento cada mañana de las de su Octava desde la hora de las siete y media hasta las nueve, repartidas en dos asistencias de tres cuartos de hora cada una la cual han de hacer dos señores y dos colegiales desde las siete y media hasta las ocho y cuarto, y los otros tres cuartos de hora siguientes hasta las nueve otros dos señores y dos colegiales, que todos han de asistir dentro del pavimento junto al Altar Mayor y no en otra parte. Se ha de distribuir a cada uno de los señores dos reales por cada tres cuartos de hora, y medio real a cada uno de los colegiales la cual distribución se ganará estando en el sitio antes de pasar el primer cuarto como se estila en las horas de oración. El turno lo ha de empezar el Señor Abad (que tendrá doblada la distribución) y el señor que se siga como el señor Presidente y demás señores por sus antigüedades; y en caso que no pueda asistir el señor que se sigue en su antigüedad, pasa al siguiente en la forma que se estila para las 
Misas de Prima, para lo cual ha de avisar el colegial al señor que se sigue en el último de los tres cuartos, como se hace el Jueves [182 r] Santo. Ítem se asigna al Organista un real cada día para que en el espacio de la hora y media toque el órgano por lo menos cinco o seis veces, y por cuanto dichas distribuciones de los señores parece importan en los ocho días sesenta y cuatro reales la de los colegiales medio real cada uno dieciséis maravedíes, ocho maravedíes del organista, seis maravedíes más para los turnos del Señor Abad que gana doble; todas esta cantidades vienen a montar noventa y cuatro maravedíes. Para cuyo principal señala dicho Don Joseph de Barcia 1880 maravedíes que se han de sacar en primer lugar de los que montaren las nóminas de Patronatos que ha dicho señor se le están debiendo en esta Iglesia, con calidad y condición que en el ínterim que este cabildo, por la estrechez de los tiempos, u otras causas no lo tienen de que pagar dichas nóminas de Patronatos, para que de cuanto de ellas tocare a dicho señor Barzia se saque e imponga el capital de dicha memoria; dicho señor don Joseph de Barcia se obliga a pagar los dichos noventa y cuatro reales en cada un año empezando desde luego su obligación y la primera paga desde la Octava del Corpus próximo siguiente de este año de 1684; con expresión y advertencia que luego que haiga medios y efectos para pagar a los señores prebendados de esta Iglesia las nóminas de Patronatos, y la paga de ellos alcanzare a dicho don Joseph de Barcia según el orden de su antigüedad y lugar en dicha paga; se ha visto no se queda el señor con la obligación de pagar los dichos noventa y cuatro maravedíes en cada un año; porque como queda arriba expuesto se han de sacar los dichos 1880 maravedíes para el principal de dicha memoria de ciertos réditos se ha de pagar que llegue (...) Todo lo cual visto y entendido por este cabildo, aceptó dicha fundación con todas y cada una de las calidades y condiciones arriba mencionadas, y entrando dicho señor don Joseph de Barcia en el cabildo se le dio las gracias de y dicho Sr. firmó este contrato para mayor fuerza y validación.

[347] ASAC V, fol. 200 r (5-VIII-1684)

Y en él se determinó que en el Coro se observe igualdad en el canto y lo que se reza en tono bajo.

[348] ASAC V, fol. ¿? (2-IX-1684)

En él se determinó que en las ocasiones en que sucediere que estén los coros de los señores prebendados iguales, los señores menos antiguos se puedan pasar de un coro a otro y no los señores más antiguos.

[349] ASAC V, fol. 204 r (7-X-1684)

Se les pague el trigo que se está debiendo a los señores Valenzuela, Ortiz, canónigos que fueron de esta Iglesia; y al licenciado Valenzuela, organista que fue de esta Iglesia todos difuntos, se le pague el trigo que se le está debiendo de su salario. 
Sería conveniente que al Maestro Torre se diera lugar en el Coro alto por haber noticia que subió el Sr. Arzobispo de Almería le había dado una dignidad de su Iglesia, y se determinó no convenía por muchos inconvenientes que de ello seguirían.

(...)

Se respondan a las cartas del Obispo de Almería, en agradecimiento de haber ordenado al Maestro Torre.

\section{ASAC V, fol. 315 r (7-I-1685)}

Fue este cabildo para otorgar un poder al licenciado don Juan de Riscos organista de este Sacro Monte que va a la Calahorra a la cobranza y disposición de lo procedido de la hacienda de dicha Calahorra que toca y pertenece a la memoria del señor don Cristóbal Gómez de la Vega en que se le da la facultad de que renta a este Sacro Monte a todos los granos procedidos de dicha hacienda y así mismo para que cobre al licenciado don Juan de Villosa, administrador que ha sido y es de esta hacienda todas las cantidades en que está todo alcanzado y lo que fuere de cuenta, y así mismo para que cobre.

\section{ASAC V, fol. 216 v (14-I-1685)}

Leyose una carta del licenciado don Juan de Riscos que está en la Calahorra en la disposición de Archivo y Rentas de la memoria del señor Vega en que da cuenta de cómo los labradores arrendatarios de dicha hacienda no quieren pagar ni ajustar sus débitos, más que dando dos fanegas de cebada o mijo por cada una de las de trigo de las que deben.

\section{ASAC V, fol. 217 v (28-I-1685)}

El segundo punto fue para ver si se daría un poder al criado de don Luís de los Ríos oidor de esta corte para cobrar los seis mil maravedíes que debe Martín de Córdoba y se respondió que no se le dé y que se suspenda esto por ahora hasta que venga el organista.

[354] ASAC V, fol. 218 r (3-II-1685)

Así mismo se determinó que se aderezasen los libros del coro.

Halló el memorial y razón que dio don Juan de Riscos de la comisión que de este cabildo ha tenido para conducir los granos de la hacienda del señor Vega de la 
Calahorra a este Sacro Monte y hacer arrendamientos de la hacienda perteneciente a dicha obra pía. Y otros particulares, y se reconoció cumplida su misión con toda diligencia y cuidado por lo que se determinó que el señor Peña le dé las gracias (...).

Propuso el señor Aguilar un punto tocante a Ceremonias que se han de guardar en el coro de este Sacro Monte y fue que el músico que ha venido de Badajoz pretendiendo la plaza de sochantre, no es a propósito para este ministerio por cuanto, no sabe bien canto llano ni su voz es de esperanza para que en adelante pueda regir el coro de esta Santa Iglesia, y así, que el cabildo viese en esta materia lo que convenía determinar para la decencia del coro de esta Santa Iglesia. A lo cual se resolvió por mayor parte que el dicho pretendiente se remita a don Joan de Rojas racionero de la Santa Iglesia de Granada para que vea su suficiencia, y con su juicio procederá el cabildo a lo que más convenga, al decoro y decencia que debe haber en el canto de los Divinos Oficios en esta Santa Iglesia.

[357] ASAC V, fol. 229 r (2-V-1685)

Fue con llamamiento ante diem para tratar de proveer la sochantría de esta Iglesia, por causa de que el Maestro Torre se ha despedido de ella, y no quiere ser Sochantre. Y en cuanto a esto lo que se resolvió fue que supuesto que el Maestro Torre se ha despedido y también estar la casa tan sumamente alcanzada y no poder pagar salario a un Sochantre, se nombre como de hecho nombró este cabildo en este ministerio al colegial Hervás a el cual no se le lleve la porción que como colegial paga, y se esté en el colegio a la disposición y gobierno, que los demás colegiales debajo del dominio del señor Rector y que no pierda el estudio ni confesiones, y que se perfeccione en el canto llano y que en esta forma pase la casa, supuesto que tiene contraídas tantas obligaciones de justicia, que obli [fol. $229 \mathrm{v}$ ] gan a cercenar aún de lo necesario: y consiguientemente se determinó que supuesto que la plaza de Sochantre está proveída, y la casa no tiene medios para proveer otra plaza por sus muchos alcances, se le notifique al Maestro Torre que la casa está alcanzada con deudas que la obligan en justicia a la satisfacción, y que por esa causa lo más a que se puede alargar es a acudirle con el sustento este mes de mayo, mientras dispone su viaje, y que no puede otra cosa por sus muchos alcances.

Y en el tocante a la elección de Sochantre el señor Bustamante expresó su voto, y dijo que contradecía la elección hecha en el colegial don Bartolomé Hervás, y que su parecer era que se eligiese el pretendiente, que hay en esta casa que ha sido músico de la Santa Iglesia de Toledo; así porque era más decencia, y lustre del Divino Culto, como porque no era ahorro alguno a la casa el elegir al colegial.

[fol. $231 \mathrm{r}]$ 
Ítem que la procesión de domingo en la noche se haga solamente con la jerarquía que antiguamente antes de la fundación del señor Escalante, y esto hasta que se pague lo que se está debiendo de dichas procesiones, y se dé providencia por la parte de dicho señor Escalante.

Se determinó que el señor don Lucas de Bustamante baje mañana lunes a Granada y vea a Cecilio Bernal nuestro procurador y lleve el pleito que le envía don Juan Riscos para que viendo el dicho Cecilio Bernal el estado que tiene, nos aconseje lo que debemos hacer, y lo que se ha de enviar a decir a don Juan Riscos: y con efecto el dicho señor aceptó dicha comisión y tomó el pleito y la carta que don Juan Riscos envía al cabildo para con dichas informaciones consultar al señor don Cecilio Bernal.

Ítem se leyeron dos cartas que vinieron por el correo para el cabildo (...) y otra del licenciado Francisco Palomino i? sochantre de la colegial de Úbeda, en que se muestra pretendiente de la Sochantría de esta Iglesia y el cabildo determinó que yo el infrascripto escriba al susodicho diciéndole como esa plaza está ahora ocupada pero que si en adelante hubiere lugar, se tendrá en memoria su pretensión.

Y además de esto se determinó, que supuesto que esta noche se hace procesión con Nuestra Señora a las Sagradas Cuevas se cante en ellas después de acabada la letanía, una Salve a Nuestra Señora que es la que pidió dicho don Jerónimo por su carta (Jerónimo de Ribera, vicario de la villa de Estepa fue antiguo colegial del Sacro Monte)

En primer lugar se leyó una petición del maestro don Cecilio de la Torre en que dice que ha estado ejerciendo el oficio de Sochantre de esta Iglesia más tiempo de cinco años ,y que por haber de hacer viaje a su tierra necesitaba de dinero y por no habérsele dado salario alguno por dicha ocupación, pedía al cabildo que le mandase señalar en cada un año de los que ha servido cantidad competente, suponiendo para esto el que a otros sochantres se le ha dado de más de el sustento; más de tres mil maravedíes cada año. A lo cual se determinó por mayor parte que no se le dé socorro alguno de la comunidad a dicho don Cecilio porque no debérsele dar porque lo primero, siempre ha rehusado el título de Sochantre; y demás de esto ha necesitado en esta casa otros colegiales el oficio de Sochantre, sin llevar salario/ como es constante pues lo fue don Esteban de Rojas colegial, y don Marcos d Palomino, y demás de esto que aún no queriendo dicho maestro Torre ser Sochantre y a vista de ello le dio el cabildo los años pasados una capellanía de las del Sr. Torres y demás de eso le concedió el título de colegial para ordenarse, demás de lo cual se le han dado muchos socorros de maravedises y comida de prebendado, la cual no se le debe dar pues no se le da 
de presente al Sochantre que hoy hay, y antiguamente hay ejemplar de no haberse dado demás de lo cual ha sido colegial y no se le ha llevado porción, sino solo el primer año, por todo lo cual se denegó dicha petición por mayor parte del Cabildo.

[361]

\section{ASAC V, fol. 237 r (1-VI-1685)}

Ítem que los señores caperos que van a cantar el Benedicamus Domino, en vísperas, den los cetros a los colegiales cetreros antes de volver al coro la cara para hacer la venia.

\section{ASAC V, fol. 240 r (3-VII-1685)}

Así mismo propuso el Sr. Bustamante que el cabildo disconforme de proveer la Sochantría en sujeto científico y que pueda gobernar el coro con toda perfección, y dar a los colegiales lección de canto llano como es de costumbre antigua y loable de esta Santa casa en que se había mirado siempre con especial cuidado lo que pertenecía al culto divino y al mayor punto del coro el cual había descendido mucho porque el colegial que hacía el oficio de Sochantre con muchas faltas y se determinó por mayor parte que en este punto se conviniese lo determinado en el cabildo en el que se mandó proveer de oficio de Sochantre al colegial Bartolomé de Hervás y el Sr. Abad mandó expresar su voto que estaba pronto a dar parte para pedir buscar sochantre científico y de buena voz para que gobernase el coro y pudiese ser maestro de los que quisiesen aprender el canto llano.

Juan Riscos pide casas que se le den por vida.

[363]

\section{ASAC V, fol. 246 v (1-IX-1685)}

También propuso el Sr. Rienda que había muchos días de estudio oído tocar vihuela y otros instrumentos que solo se permiten en los días festivos y de asueto; y se determinó también que en este punto se guarde el Praxis y Consueta.

\section{[364] ASAC V, fol. 250 r (21-X-1685)}

Fue este cabildo para tratar del entierro del Sr. Abad don Juan de Xerez y Oñate que murió el día 20 sábado a las nueve de la noche y se determinó que de la forma acostumbrada se hiciere luego en este mismo día por la mañana el entierro para que así se le cantase su misa de cuerpo presente, el cuerpo se sepultase en la bóveda que está en la capilla de los frontales, a la cual se llevaría para este fin se llevase también el cuerpo del Sr. abad Escalante que estaba depositado en el hueco del altar de dicha capilla. Y así mismo en este cabildo dio cuenta el Sr. Rienda de que el Abad difunto había dejado poder para hacer testamento nombrando por herederos al Sr. Rienda y al dicho Sr. Peña y por albaceas a dichos dos y también al Sr. Cuadrado y al Sr. Paz. 
Se trató sobre el coro y se determinó primeramente que el Sochantre lea la Kalenda los días clásicos y que asista al coro y que no empiece las horas sin estar presente algún señor u otro sacerdote, que capitule. También que no encomiende la Kalenda a quien no estuviere instruido y que cualquier canónigo acuda al Sr. Maestro de Ceremonias para ser instruido en lo que deba hacer.

\section{6}

[366] ASAC V, fol. 258 r (2-I-1686)

Fue llamado ante diem para dicha obligación y para el punto de si se ha de dar licencia al licenciado don Juan Riscos organista de este Sacro Monte para que se ordene, haciéndole gracia el cabildo para que se ordene a título de organista (...) Y pasando al segundo punto sobre hacerle gracia al señor Don Juan Riscos organista de este Sacro Monte que se ordenase a título de ministro organista de él, se determinó para que se ordenase a dicho título de organista que se escritura obligándose el Sacro Monte a alimentarle mientras y hasta que hubiese beneficio colativo o capellanía para que asista al ministerio de el órgano con toda puntualidad.

Se requería al dicho cabildo que hay falta de ministros en la Iglesia, y en especial de Maestro Ceremoniario y Sochantre, siendo el derecho primero de esta Iglesia y hacienda la fábrica para el divino culto (...).

[368] ASAC V, fol. 263 v (2-V-1686)

Y juntamente se determinó se prosiguiese en aderezar los libros de el Coro, y se pagase al religioso de San Jerónimo el resto de los dos libros que ha aderezado y vaya aderezando los demás, por cuanto dicho religioso se conviene en cuando se le vaya socorriendo por meses como se pudiere los aderezara.

[fol. 264 r ]

Ítem propuso el señor Presidente que en los libros del Coro que está aderezando el Religioso jerónimo da noticia de no estar el oficio de San Justo y Pastor si le parece al cabildo se le añada dicho oficio. Y determinó el cabildo se añadiere y que sea de pieles buenas de Segovia.

ASAC V, fol. $i ?(29-V-1686)$

Fue este cabildo llamado ante diem para nombrar informante para las pruebas del licenciado don Pedro de Utrera, capellán electo a la capellanía de este Sacro Monte. 
Leyose y otorgose otra escritura que hace el cabildo a favor del licenciado don Juan Riscos organista para que se ordene a título de su ministerio y rentas que le da la casa.

\section{ASAC V, fol. 267 r (12-VI-1686)}

Y también para la disposición del aderezo de otros libros del Coro, y en que forma se había de poner y descubrir esta Octava del Hábeas a nuestro Sr. Sacramentado.

Ítem en cuanto a los libros del coro se determinó que a el religioso se consultase si podía disponer el libro del Salterio en dos cuerpos por cuanto era muy pesado y grueso de lo cual se encargó el Sr. Presidente.

Determinose juntamente que se añadiese a los santorales la misa de Nuestra Señora del Carmen y la de San Ignacio.

Ítem se determinó se hiciese un facistol nuevo y capaz de los libros por cuanto es muy pequeño y está muy viejo el que hay, y se caen y echan a perder los libros. $\mathrm{Y}$ juntamente que se compren un breviario grande para capitular los señores semaneros en el coro.

\section{ASAC V, fol. 267 v (21-VI-1686)}

Y procediendo a otros puntos dio noticia el Sr. Presidente como el religioso de la Iglesia de San Jerónimo que adereza los libros de coro dice dispondrá la división de el Salterio de Vísperas poniéndolo en dos tomos y aderezando lo mucho que tiene que aderezar. Y determinose lo hiciese así, porque así conviene APRA su duración, y evitar un gasto grande que si así no se hace y acomoda costará dentro de poco el hacer otro nuevo salterio que importará muchos ducados.

\section{ASAC V, fol. 275 v (1-VIII-1686)}

Y yo el infrascripto secretario (don Lucas de Bustamante) advertí el mucho tiempo que ha está grandemente minorada la solemnidad del culto divino y como por saltarse una grave Constitución que dispone haya un sujeto Sochantre que asista a las funciones pertenecientes a dicho culto divino y que sea su obligación enseñar el canto llano los colegiales para que puedan ayudar y obrar en el coro sin los accidentes que se experimentan se ofrecen y no hay de ellos quien sepa cosa alguna por razón de haber hecho Sochantre a un colegial que no sabe para sí ni para enseñar a los otros, y así pedía al cabildo buscase Sochantre digno de serlo y ejercer dichas obligaciones para que con toda puntualidad, decencia y experiencia se ejerza el divino culto como siempre se ejerció, y siendo como es el principal ministro y el total régimen del coro que deba la fábrica sustentar y para eso tiene en fábrica mil reales de renta, y así expresaba mi voto y requería al cabildo se hiciese, y separasen las haciendas de fábrica, patronatos y mesa, y así separadas se administrasen y se supiesen lo que cada 
una daba para que así se repartiese en sus ministerios y obligaciones conforme alcanzasen, siendo la primera obligación el culto divino y sus buenos y proporcionados ministros. Aquí expresó el Sr. Cuadrado en contra diciendo que se esté a lo hecho y determinado por el cabildo del dos de mayo del año pasado de 1685 en orden a lo del Sochantre, que entonces nombró el cabildo a dicho colegial por cuanto en este año ha servido bien este año pasado y va estudiando solfa, y sabe lo necesario y que está con resolución de dar lección de solfa a los colegiales con que se cumple la Constitución, y que no lleva salario, y que su comida es de colegio. Y yo dije que tenía que expresar sobre esto y es que las inconveniencias y faltas grandes que se han experimentado sin gobierno el coro y habiéndose advertido al pueblo muchos defectos e indecencias y sustentándole la casa a este colegial y perdonándole 50 ducados de pensión cada año, y que con otros tantos viniera a esta Iglesia otro cualquiera buen Sochantre como siempre los ha venido y que así se debe hacer con las circunstancias que ordenan las Constituciones en orden a este Ministerio que es el /

(276 r) primero y principal de esta Iglesia y de su erección el culto divino y por tal primero lo ponen nuestras Constituciones en honra de Dios y de los Santos Mártires y al cumplimiento de tal tiene grandes rentas la fábrica y está obligada toda la hacienda. $\mathrm{Y}$ así pedía se cumpliesen las Constituciones en la conformidad que lo ordenan. (Al margen: Y juntamente que el cabildo del 2 de año del año pasado de 1685 está reclamado por mí y es nulo por no haberse citado al Sr. Cerda que estaba aunque enfermo dentro de este Sacro Monte)

Procediendo a la Sochantría de esta Iglesia de que era pretendiente el licenciado don Pedro de Castro y Pimentel mozo de 19 años de notable voz para sochantre y ciencia, y calidades para dicho ministerio, colegial que ha sido del Colegio Eclesiástico de la Iglesia catedral de Málaga. Fue admitido en dicha sochantría por todos votos, y se le señalaron por ahora mil maravedíes de su salario en cada un año/

(fol. 283 r) y comida y refitorio de señores y demás conveniencias y juntamente que se le dará capellanía de las antiguas que suele dar este cabildo de las del jurado Pedro Martínez u otras semejantes para ayudarle a que se ordene si asistiere a su ministerio y obligación de virtu temporis. $\mathrm{Y}$ por cuanto el licenciado Hervás colegial actual que es deste Sacromonte ha asistido a dicho ministerio de la sochantría más ha de un año que ha perdido la salud y parte del tiempo de sus estudios se determinó e hizo gracia este cabildo de la porción que pagan los colegiales en cada un año hasta que cumplan sus años de su asistencia al colegio.

\section{[375] ASAC V, fol. ¿? (15-IX-1686)}

Ítem por cuanto propuso el Sr. Paz la instancia que hace el religioso jerónimo que ha aderezado los libros del coro a que se le vaya pagando lo que se le debe y que se le podía repartir un poco trigo. Se determinó se le repartiesen seis fanegas bajándolas del repartimiento de los señores. 
Pensando (el cabildo) en si se había de proseguir el aderezo de los libros de el Coro por gozar de la ocasión que hay y hoy se ofrece por la conveniencia de su aderezo, se determinó se prosiga en los que estuvieren más desbaratados y en los descuadernados para que se encuadernen, y juntamente se hagan los estantes convenientes para que no se maltraten.

[377] ASAC V, fol. 289 v (2-XII-1686)

Ítem tratose sobre los procederes del sochantre don Pedro Pimentel y determinó el cabildo que en todo caso fuese despedido luego de este Sacromonte y no se le dejase sacar de él cosa alguna hasta que se ajustase lo que está debiendo y satisficiese.

Ítem se votó se buscase y se hiciese diligencia de Sochantre digno de esta Iglesia porque es ministro principal para el régimen y culto divino.

\section{7}

[378] ASAC V, fol. 295 v (17-I-1687)

El punto segundo fue en orden a que se hiciese diligencia de buscar Sochantre del señor Barquero Y el señor Paz quedó de escribir a Baeza a un conocido suyo por si se determinaba a venir.

[379] ASAC V, fol. 297 v (3-III-1687)

Después se trató si se recibiría por Sochantre a don Francisco Palomino. Para lo cual habían precedido las diligencias de examinar las suficiencia lo cual hizo don Francisco Antonio Rico, racionero y organista de la Santa Iglesia Catedral de Granada, cuyo parecer se propuso en cabildo por un papel suyo en que decía estar suficiente para ejercer oficio de Sochantre en esta Santa Iglesia, con lo cual quedó recibido al cabildo y se le señaló de salario 800 reales, Ropa, y vino, aniversarios y manuales para que pudiere ganar su distribución.

[380] ASAC V, fol. 300 v (27-III-1687)

Fue este cabildo para notificar a los señores de la muerte del señor Bustamante de haber muerto esta madrugada en Granada donde había pasado a curarse con licencia del cabildo. Y también se trató del modo con que había de enterrar por no poder hacerse en la forma ordinaria por las circunstancias de este día del Jueves santo y se determinó que habiendo traído el cuerpo lo depositasen en la sala de cabildo con algunas luces, y que de allí se tomase para llevarlo a la bóveda rezando sub missa voce el responso. Acostumbrado sin más dobles ni otra pompa por el embarazarlo así el uso de la Iglesia en estos días, que hasta 
que llegase un día desocupado de fiesta doble en que se le cantaría la misa y se le harían los demás sufragios según las Constituciones que dispone.

Propuso el Sr. Aguilar que no se guardaba ceremonia en el coro porque sin disturbios de días y solemnidades en el coro iban muy apresurados los colegiales en las horas y demás oficios, y se determinó de le diga al Sochantre lleve y hubiere el coro con la solemnidad que el día pidiere.

$[382]$

ASAC V, fol. $301 \mathrm{v}(19-I V-1687)$

Ítem se determinó que a Juan Riscos se le libren cuatro fanegas de trigo que se le debían de lo que se halló el año pasado y se le libraron de la porción de trigo del licenciado Castellano y otras dos en el alhorí por ser las que se le restaban.

[383] ASAC V, fol. 306 r (2-VI-1687)

Advirtiose que algunos colegiales no guardaban la ceremonia de tener puestas las manos cuando se cantaba el Evangelio y se determinó se les advierta para que la guarden.

[384] ASAC V, fol. ¿? (14-VI-1687)

Leyose una petición de don Juan Riscos en que pedía a el cabildo se ajusten todas sus cuentas así las de la Calahorra, como en la de los años que por su cuenta se ha celebrado el aniversario de Nuestra Señora del Rosario, y lo que se le debe de su salario y que liquidadas todo se ajuste si debe o se le debe.

\section{8}

[385] ASAC V, fol. 326 v (4-V-1688)

El señor Presidente que no había en el coro diferencias en las horas los días de primera clase y dobles de las ferias, y se determinó se le advierta al Sochantre y que lleve el coro/

(327 r) como los días lo pidiere.

[386] ASAC V, fol. 432 v (31-VII-1688)

Fue este cabildo para oír unos autos del señor Provisor que venía a hacerle saber Cristóbal de León notario mayor de dicho arzobispado, y antes que entrase dicho notario se determinó se leyese una carta del reino y se leyó y en ella pide su majestad con el motivo del estrago que ha causado en la ciudad y reino de Nápoles un terremoto si hay haberes tale $\_? ¿$ ? se haga una misa pidiendo a Dios 
nuestro señor se digne aplacar su ira poniendo por intercesora a María santísima Nuestra señora, poniendo este cabildo en ejecución lo que su majestad demanda empezando a sus católicos, determinó que el día cinco de agosto en el que se celebra la festividad de las Nieves se diga una misa cantada con toda solemnidad fuera de la de tercia y que se le diga después de horas, y que por nueve días se diga en el Coro después de la Misa de Tercia las preces acostumbradas de que usa la Iglesia y que se haga una procesión a las sagradas cavernas de este Sacro Monte y que se escriba a su majestad de haberle ejecutado.

[387] ASAC V, fol. 429 r (1-VI-1688)

Después propuso el señor Morcón como era loable que los colegiales y ministros de este sacro Monte comulgasen/ los jueves y domingos y que el sochantre respecto de no decir misa por su impedimento sería conveniente observase esta loable costumbre y se determinó se le diga y se le dé a entender la observancia de ellos y en consideración que en él habrá sido no tener noticias de esta costumbre.

[388] ASAC V, fol. 446 r (18-IX-1688)

También dicho señor abad se quejó del licenciado don Juan Riscos por el poco respeto y atención que había tenido con dicho señor Abad, con el que debe proceder de esta suerte por dignidad y cabeza de esta Insigne Iglesia. Y oído el hecho y razones que motivaron al señor Abad para su sentimiento, pareció al cabildo que para que ningún maestro de la casa osase otra vez a descomedirse en palabra, ni en hecho con algún señor capitular se llame en el primer cabildo que se celebrare a dicho licenciado Riscos y se le dé una reprehensión.

[389] ASAC V, fol. 449 v (16-XI-1688)

Después se leyó una petición del licenciado don Alonso López de Aguilar en que pedía y suplicaba al cabildo le advirtiese de admitirle por uno o dos meses con la obligación de asistir al coro o a todos los oficios y sin más emolumento de la comida respecto de hallarse convaleciente y muy falto de medios para hacer oposición a la Sochantría. Y se determinó se admita hasta la Pascua de Reyes dando la comida y cena de colegio y que duerma en casa y que el padre abad disponga y señale cuarto en que pudiera quedarse de noche.

1689

[390] ASAC V, fol. 434 r (22-I-1689)

Ítem se leyeron dos peticiones una del licenciado don Alonso de Aguilar en que pedía al cabildo se servía de admitirlo para Sochantre señalándole el salario que don Alonso (...). 
Después propuso el señor Abad si habría el Cabildo de dar licencia al Sochantre para ir a oponerse a Toledo y se determinó que fuese con condición que viniese antes de oncena y no había vuelto por semana Santa se tuviese por despedido o que dejase el viaje para después de Pascua.

[392] ASAC V, fol. 464 r (2-I-1690)

Fue el primero que propuso el señor Rienda que en el coro se tenían las horas con demasiada aceleración, y que se seguía notable distracción y no poder seguir el tono ni cumplir con la obligación, y se resolvió se le notificase al Sochantre pusiese especial cuidado en que [464 v] alguna pausa en la mediación de los versos más o menos según la solemnidad del día para que cesare el desorden que hasta aquí había.

[393] ASAC V, fol. 465 v (3-II-1690)

Se determinó que uniformemente se observase la ceremonia de poner las manos juntas ante pectus de suerte que se vean al tiempo de los cánticos del Magnificat, $\mathrm{y}$ otros cualesquiera que se cantan o rezan en el coro, y al Evangelio y en todo como lo ordena la Consueta.

Después leí en cabildo una petición del licenciado Riscos en que suplicaba llevar su ración cruda de carne al Carmen de las Velas, atento a que viven en él su madre y hermana y que podía con esto ayudarlas en algo y así mismo quedarse a dormir para hacerlas compaña en la soledad que tienen dicho sitio. Y se determinó se le dé dicha ración conforme a lo que se diere cada día en la cocina. Ítem suplicó en dicha petición se le diere aumento de salario y este punto se difirió para otro cabildo de ceremonias.

Fue este cabildo para leer una petición de don Francisco Palomino de León, en que suplicaba al cabildo hiciese el favor de conferirle el patitur en Granada acudiéndole con médico, cirujano y lo demás para curarse un achaque de orina que padece. Se requiere juntamente con su sustentación. Y se determinó que no se le concediere porque el achaque que padece no es tan grave, ni de aquellos a los que la Constitución permite se les conceda ese alivio, porque ha de ser de calidad que a juicio de médico corra riesgo el curarse en el Sacro Monte por alguna especialísima asistencia de que necesite la enfermedad, y a que no se le pue/da acudir por la distancia que hay de Granada con los medicamentos puntuales. 
Luego propuso el señor Abad que don Gaspar de Loxa pretendía que el Cabildo lo recibiese por sustituto del Sochantre, y se determinó que no era conveniente hasta hallar persona de habilidad y voz que pudiese gobernar el coro.

Y que el tesorero cuide que los Libros del Coro que están dados a aderezar se concluyan y se traigan.

\section{ASAC V, fol. $474 \mathrm{v}(19-\mathrm{V}-1690)$}

El segundo punto fue si se admitiría un sochantre que al presente ejercía este oficio de segundo Sochantre en la Catedral de Granada, y se determinó se reciba por ser/

[fol. 475 r] Cabildo anterior al 17 de junio. Ítem se confirió qué salario se le concedería al licenciado don Francisco Palomino, atento a que se había recibido otro sochantre por no poder seguir el coro con la solemnidad y decencia que se debe según las fiestas por el defecto de su vista, y que es un pobre sacerdote, $y$ que en algo puede ayudar. Y se determinó que se le den 500 reales en cada un año entrando en ellos lo que había de percibir por la ropa, vino y demás emolumentos y asistencia del coro, con cargo que asista a los puntos del coro, y que de no asistir se le señale dicha cantidad, que para esto solo ha de servir la puntuación en el cuadrante de las distribuciones cotidianas. Así mismo se le dieron 30 días de recle en todo el año de asistencia.

[399] ASAC V, fol. ¿? (29-VII-1690)

Después leí una petición de don Juan Riscos en que pedía se le diere por libre de la clavería de la Calahorra, y algún premio por los años que la ha servido y se difirió este punto para el Cabildo de Ceremonias (...)

Ítem que el licenciado Riscos prosiga este año en la administración de la Calahorra y que para lograr el premio que pide en la asistencia de dicha administración, así de este año como del trabajo de recoger los frutos de la obra pía de los antecedentes se curse petición al Provisor para que con vista y reconocimiento de los meritos que le asisten a dicho licenciado Riscos le señalase lo que pareciere convenir por dicho trabajo.

[400] ASAC V, fol. ¿? (9-IX-1690)

Que don Joan Riscos vaya a la Calahorra a ver y a componer la hacienda de la obra pía.

Después leí el auto que dio el Provisor a la petición del licenciado Riscos, mandando se le señalen 50 ducados por el trabajo de su administración en cada un año que la tuviese y en los que la ha tenido, y que dicho salario se ha de sacar 
de las décimas de la hacienda y no de otra parte. Y se determinó se le pidiere a dicho Provisor revocare dicho auto, en cuanto a que se saque dicha cantidad de las décimas por estar aplicadas al cabildo por el trabajo que tiene en cuidar de dicha Hacienda.

[401] ASAC V, fol. 476 r (3-X-1690)

Ítem que don Joan de Riscos que al presente se halla en la Calahorra por comisión del cabildo, para atender a la obra del molino grande, no permaneciere allá todo el tiempo que durase dicha obra, si no que se vuelva por la falta que hace en el órgano.

Primeramente se leyeron dos cartas escritas al cabildo, la una de don Miguel Ambrosio de Vago, natural de Madrid, pretendiendo la Sochantría de esta Insigne Iglesia. Y se le determinó se responda que por ahora no hay necesidad de Sochantre.

\section{1}

[403] ASAC V, fol. 487 r (3-IV-1691)

Luego se trató de Constituciones y se advirtió que el Sochantre no faltase del coro a sus horas, que si después quisiere confesar lo hiciese.

[404] ASAC V, fol. 487 v (20-IV-1691)

Se leyó una petición de don Francisco Palomino Sochantre sobre una pretensión; y se determinó se despache para el primer cabildo venidero.

[405] ASAC V, fol. 488 r (1-VI-1691)

Ítem que al Sochantre Miguel de Riscos ${ }^{32}$ difunto se le ajuste la cuenta de lo que se le debe y se le pague, mas se determinó que se ajuste la cuenta al sr. Pedro de Castilla.

[406] ASAC V, fol. ¿? r (24-VI-1691)

A don Francisco de Palomino, sochantre actual suscribiese su sochantría y se conviniese el 25 del mes de Julio próximo (...), por cuanto había servido dicha sochantría por cosa se le libraran 200 reales por su trabajo

$$
\text { ASAC V, fol. } 490 \text { r (3-VIII-1691) }
$$

\footnotetext{
${ }^{32}$ Puede ser un error del secretario, porque en ningún otra acta se menciona a ningún Miguel de Riscos sochantre.
} 
Tratose del Breviario que había legado el señor Cristóbal Carval. A voluntad al coro y como fue legado condicional que se escribiere los días más solemnes de nuestra señora y por cuanto el coro tenía necesidad de Breviario que tuviere los santos nuevos comparecese del un albacea respecto al cabildo que se llevase al coro los días referidos, y más lo que hubiese menester de los santos nuevos por estar los del coro maltratados.

[408] ASAC V, fol. ¿? r (9-VIII-1691)

Ítem leyéndose los cabildo antecedentes se advirtió que en el cabildo del día 23 de Junio se había dejado de escribir lo que en dicho cabildo se había dispuesto en razón de dar las gracias a Nuestro Señor y a su bendita Madre y a los santos Mártires hizo Modesto y Crescencia que el día 15 de Junio fue cuando cayó el rayo en esta casa, y se determinó que urgía las gracias y en dicho cabildo se dispusieron días de nuestro padre San Pedro que de memoria perpetua que todos los años el viernes infraoctavo del santísimo sacramento, en habiéndose concluido con los oficios de la Iglesia, saliese en procesión todos con luces a las cuevas cantando el Te Deum laudamus y en dichas cuevas se dijere la antífona y oración a nuestra señora y se hiciese conmemoración de los dichos mártires yendo con capa pluvial y diáconos y de vuelta se cantase el Ave Stella concluyéndose en la Iglesia con la oración de gracias y demás acostumbradas para que este agradecimiento quedase en perpetua memoria.

\section{2}

[409] ASAC V, fol. 496 v (4-II-1692)

Se determinó que en el coro se empiecen los oficios divinos inmediatamente que cesa el último toque del esquilón, como se ordena en la Constitución que habla de este punto y que el Sochantre no se detenga ni aguarde la señal ni aviso que se suele hacer desde la Iglesia sino que instantáneamente que cesa el esquilón la torre se comience en el coro.

[fol.497 r]

Se determinó que a don Juan Riscos se le dé el aceite que pidiere a más de la razón que tiene por título de organista para la asistencia y trabajo de la contaduría durante la liquidación de la hacienda en que está trabajando y reconocimiento de cuentas y demás papeles de esta cuenta; y que el que se le hubiere cargado en sus pliegos desde que está entendiendo en esto se le baje y descargue por redundar en mayor conveniencia de esta comunidad la aplicación $\mathrm{y}$ trabajo que en esto tiene y ha tenido.

$$
\text { ASAC V, fol. } 497 \text { v (10-III-1692) }
$$

Se determinó que se le amoneste al Sochantre gobierne el coro con las pausas y solemnidad que piden las festividades de modo que no se falte a la decencia de los divinos oficios, y que si amonestado y corregido no se enmienda se le multe 
por cada falta en seis maravedíes quedando a discreción del señor que presidiere en el coro imponerle dicha multa. Y así mismo se determinó que el señor Abad examine a dicho Sochantre, y sepa si tiene dispensación para decir misa de Nuestra Señora y de Requiem por su poca vista en los días prohibidos y decretos, y se le imponga grande cuidado en que no cometa ningún yerro en el santo Sacrificio de la Misa y que él mismo prevenga al que le ayudare tenga cuidado con sus acciones y ceremonias en que no haga alguna en que falte a cosa grave.

[411] ASAC V, fol. 499 r (12-IV-1692)

Se determinó se busque en los Archivos de casa el fundamento que esta Iglesia tiene para que se dé a san Cecilio la oración especial que se le da en su día, y per annum, y hallado se le participe a Fray Pedro de Granada para que la ponga en los directorios anales, y se tenga esta noticia en todo este arzobispado. Y para esto nombró el cabildo al señor Presidente para que con su gran cuidado y celo cuide de esta materia.

[412] ASAC V, fol. 519 v (1-X-1692)

Si el Evangelio que se dice de San Juan en las misas de requiem cantadas se ha de decir con la capa pluvial después del responso o antes.

\section{3}

$[413]$ ASAC V, fol. 536 r (4-IV-1693)

Se determinó que de ninguna manera se le permita a don Francisco Palomino Sochantre, el sacar carne cruda de la cocina por ser mucha falta de gobierno lo que se sigue de hacer lo contrario.

[414] ASAC V, fol. 538 v (7-V-1693)

En cuanto al oficio de san Torcuato que nuevamente se ha extendido por toda la Iglesia, se determinó que respecto de haber reconocido el señor Zerda, Sr. Monzón y Sr. Valbuena a quien se cometió por el cabildo para que vieran y reconocieran, que su narración historial se opone inmediatamente a la sentencia canónica que se dio en el concilio provincial que celebró el Ilustrísimo Señor don Pedro Vaca de Castro y Quiñones sobre la calificación del lugar muerte y reliquias de los santos mártires señor San Cecilio, Hiscio y san Tesifón. Que se escriba una carta al señor Obispo de Guadix noticiándole del reparo que se ha hecho y mudándole un traslado de la sentencia y lo mismo al cabildo de la Iglesia catedral de Guadix y que al mismo tiempo se escriba a Roma por un ¿? Remitiendo un tanto de la sentencia hasta haya la confirmación de dicho concilio y resolución en él tomados y con el recado que parecieran convenientes a la más pronta y eficaz [fol] 539r prevención para obviar los inconvenientes tan graves que a la extensión de dicho oficio se pueden inferir contra este Sacro Monte y Reliquias de los Santos Mártires. 
(Al final se decide no escribir, y se determinó que se rezase el oficio según la

Se propuso si el Sochantre seguiría pidiendo la limosna para la obra de Nuestra Señora de las Cuevas los viernes en el Santo Sepulcro y se determinó que sí con tal de que asista a la Misa mayor, y que a las horas asista el maestro Torres, y el maestro Segura (...).

Y que el Sochantre les enseñe [a los colegiales] el canto de las Epístolas y Calendas que se dicen en el coro.

[417] ASAC V, fol. $547 \mathrm{v}(10-\mathrm{X}-1693)$

Y el Cabildo concedió al Sochantre por vía de limosna por no haber cedido dicha circunstancia y estar en casa curándose atendiendo su necesidad y pobreza libra y media de carne y una hoja por tiempo de quince días.

Se determinó que el sujeto que había venido a prueba para la Sochantría, de la ciudad de Jaén, que por no ser al propósito del Coro ni ser lo que había necesidad este Sacro Monte que se volviera a su tierra despidiéndole honestamente y dándole una ayuda de costa de cien maravedíes para el viaje.

Se pidió licencia para que se le pueda decir a Nuestra Señora el día de la fiesta del Rosario una misa cantada con toda solemnidad posible y con lo más precioso que haya en la Sacristía, con advertencia que los comisarios de dicha Hermandad hayan de pedir dicha licencia el año que quisieren que se haga dicha fiesta.

Se advirtió que en el Coro se guarde uniformidad y que los señores residan en sus sillas el tiempo que estuvieren en el Coro.

\section{4}

[419] ASAC V, fol. 554 v (2-I-1694)

Se determinó que la Procesión de Nuestra Señora se haga a la hora acostumbrada, y a la hora que siempre se ha hecho sin variar de horas ni en Invierno ni en Verano no obstante los inconvenientes que se propusieron en Cabildo y por haberse dudado si la Letanía que se le dice a la Virgen que se hace en casa sería de las prohibidas en algunos decretos que había expedido la Inquisición, para que no se dijeran si no es la lauretana y la mayor del Breviario; 
se encargó al señor Abad de llevársela a los Señores inquisidores para que la viesen y determinasen si se habría de decir en adelante. Determinó el cabildo que el Sermón de San Cecilio lo diga el señor Solís.

Se determinó en la petición de don Juan Riscos, contador y organista de este Sacro Monte, en que pedía se le aumentase el salario, respecto de su excesivo trabajo que tenía y el cabildo le aumentó hasta 1500 reales en cada un año en consideración a lo que ha trabajado y actualmente trabaja en la liquidación de obras pías y de los Patronatos y Mesa capitular y liquidar los alcances que cada mesa tiene/4906 no se le admitió al Señor Juan Riscos la dejación que hizo del oficio que el cabildo le encargó de ropero por el buen cobro y cuidado que siempre ha puesto en él y la individual razón que da de todas las prendas y alhajas siempre que se le pide.

\section{TOMO VI}

[420] ASAC VI, fol. i? (7-VIII-1694)

Se determinó por el cabildo se reciba Sochantre para el mejor culto del altar y servicio de Coro y que al actual pretendiente de Baza se le examine y se haga información (extrajudicial) de sus costumbres y siendo a propósito se admita no obstante tener el cabildo el que al presente rige el coro. Al margen: se reciba segundo Sochantre.

\section{ASAC VI, fol. 9 r (1-X-1694)}

Se determinó se le advierta al Sochantre no dé la comunión, o la dé con mucho cuidado por haberse hallado algunas partículas de hostia junto del altar del Sagrario y ser factible habérsele caído del copón sin verlas respecto del accidente de la vista que padece, y se encargó al señor Abad en advertírsele.

[422] ASAC VI, fol. ¿? (1-XII-1694)

Que las kalendas las pase con el señor Maestro de Ceremonias antes de decirlas en el coro y al admonitor se le mande nombre de persona que tenga buena voz para que las cante.

\section{5}

[423] ASAC VI, fol. 22 r (20-I-1695)

Habiéndose tratado sobre el punto de las honras de la mujer de don Diego de la Serna que se hacen en el Convento de las madres capuchinas de esta Ciudad de Granada se determinó que el señor Abad celebre la misa en dichas honras que el maestro Collado se vista de epístola y se le haga recaudo al maestro Torres para el evangelio, y que el maestro Baltán haga el oficio de Maestro de Ceremonias, y que el gasto de música y cera sea por cuenta del cabildo para lo cual se mandó librar lo necesario al señor Tesorero. 
Se determinó que se tabicasen las dos puertas de la escalera del órgano por haberse conocido algunos inconvenientes estando abiertas en el ínterim que durase el hacer la obra de la Portería.

[425] ASAC VI, fol. 24 r (11-II-1695)

Fue este cabildo sin citación ante diem por no haber habido tiempo y ser preciso, por haber muerto el día diez en la noche el señor don Baltasar de Rienda canónigo que fue de este Sacro Monte. Juntose el cabildo para determinar cuando había de enterrar a dicho señor y se determinó que se enterrase el sábado por la mañana que se contaron doce de este presente mes de febrero, y que juntamente se le concedía al padre Fray Sebastián de Santiago religioso del convento del señor San Jerónimo sobrino de dicho señor difunto que trajese la música que gustase para el oficio de difuntos, y entierro, y para que encargue el sermón que el convento concede haiga el día de las ánimas, con advertencia de que el gasto que resultase corre de su cuenta por no ser estilo ni haber [fol. 24v] se hecho con otros señores prebendados que han muerto en esta comunidad.

[426] ASAC VI, fol. 27 v (2-V-1695)

Diosele licencia al Sochantre para que se vaya a Granada a convalecer de sus sangrías y concediósele el que se lleve carne y pan que le toca hasta el día de la Ascensión.

[427] ASAC VI, fol. 33 v (9-VII-1695)

Leyose una petición que presento el Sochantre en que pide se le mande librar de su salario del tercio que cumplió fin de abril de este año de 95, y así mismo los aniversarios que se han celebrado desde que está en este Sacro Monte por no haber cobrado ninguno desde el dicho tiempo y se determinó que en cuanto a su salario se le libre luego que se ponga precio a las comidas que para huéspedes se tenían para que de él se le rebaje lo que hubiese tomado el dicho Sochantre y en cuanto a los aniversarios que se vea el Cabildo en que fue admitido el Sochantre para ver si se admitió por salario determinado y visto responderá el cabildo.

[428] ASAC VI, fol. 36 v (19-VIII-1695)

Leyose una carta del Rey nuestro señor en que manga se hagan rogativas por las necesidades públicas de esta Monarquía y el buen suceso en las guerras y se determinó que por tiempo de nueve días después de la Misa de Tercia se digan las preces que el manual señala para semejantes necesidades y al fin de dichos nueve días se diga una misa cantada de Nuestra Señora al tiempo de la misa de Tercia, y que los señores comisarios de cartas respondan a la carta de su majestad. 
Leyose una carta del señor Obispo de Cádiz que escribe al señor abad diciendo como una persona de aquella ciudad tenía devoción de fundar una memoria perpetua de una misa en cada semana (...).

[430] ASAC VI, fol. $40 \mathrm{v}(24-\mathrm{X}-1695)$

Se leyó un papel del Sochantre que pedía que estando en Granada como estaba por algunos accidentes aunque no necesitaba para su curación de médico se le diese la comida según y en la forma que se le da cuando está presente en casa y se le determinó no se le diese por prevenirlo así la Constitución.

[431] ASAC VI, fol. 41 r (3-XI-1695)

Se determinó que por estar mucha parte del año fuera don Juan Riscos en dependencias de su hacienda y hacer mucha falta en los dos empleos de contador y organista se le den muy pocas licencias para ausentarse y la que se le diere fuera por pocos días y en ocasión que se reconozca no hacer falta el ninguno de dichos empleos. Y que respecto de haber faltado [fol. $41 \mathrm{v}$ ] con todo octubre y parte de noviembre en que se ha hecho para la falta en uno y otro ejercicio se le prorrateen los días que ha faltado de más de los ocho primeros para que llevo licencia y se le baje lo que correspondiere de lo que ha de percibir como contador y organista y que en adelante se le haga el mismo prorratio en cualquier falta y se le baje de su salario. Se determinó que con gran cuidado cada uno de los señores busque sujeto que ejerza la plaza de Sochantre y se amoneste al que hoy la ejerce la asista con puntualidad y a oración y que se le multe las faltas que hiciere para que atienda con vigilancia al culto divino.

\section{6}

[432] ASAC VI, fol. 48 r (3-I-1696)

Y el licenciado don Francisco Palomino, sochantre de esta Iglesia presentó una petición en que decía respecto de no haber tomado nada de los aniversarios que se habían celebrado después que estaba en casa, mandase el cabildo se le librase la cantidad de maravedíes que ha dicho Cabildo le pareciese, y que juntamente por los que en adelante se habían de celebrar se le mandase señalar la distribución que por la asistencia de dichos aniversarios le perteneciere y por no haber tiempo se dejó la determinación para otro cabildo.

$\mathrm{Y}$ en orden a una petición que el Sochantre tiene representada para que se le mande dar una ayuda de costa por cuenta de los Patronatos que ha servido desde 
que el Cabildo le recibió (que dice no haber cobrado nada) y para en adelante le mande señalar el Cabildo algún aumento a su salario por el servicio y asistencias de dichos patronatos. Mandó el cabildo se busque en lo que fue admitido a la Sochantría para que viendo las condiciones de su admisión determinar lo que más conviniera. Y en cumplimiento de lo determinado ví el cabildo que se celebró el cabildo pasado de tres de marzo del 1687 en que fue admitido por primera vez y se le señaló por su salario 800reales, ropa y vino aniversarios, manuales y demás distribuciones. Y en el cabildo que se celebró el 23 de Junio del año pasado de 1691 se recibió segunda vez en las condiciones que antecedentemente estaba recibido.

[434] ASAC VI, fol. 54 v (2-IV-1696)

Se determinó se le librasen al Sochantre 200 reales por todo lo que se [fol. 55 r] le está debiendo de aniversarios y misas hasta el año pasado de 95; y que para en adelante cojan sus libranzas de otros aniversarios con la de los señores Prebendados.

[435] ASAC VI, fol. 59 r (2-V-1696)

Primeramente se determinó se buscase Sochantre respecto de estar el licenciado don Francisco Palomino que al presente lo es con achaques, y corto de vista y hacerle notable falta para su ministerio.

Primeramente se determinó que los Libros de Coro que tuvieren algunos cuadernos despegados se lleven a encuadernar, y a uno que le faltan dos mayúsculas que se lleve también a que se le echen.

[437] ASAC VI, fol. 74 r (12-XI-1696)

Al margen: se den 50 reales de ayuda de costa al que hizo oposición ala sochantría de esta Iglesia.

Primeramente se determinó que a don M. de la Puente [fol. 74 v] que de la ciudad de Antequera vino a hacer la oposición a la Sochantría de esta Iglesia se le den 50 reales de ayuda de costa por conocer ser muy pobre.

[438] ASAC VI, fol. $87 \mathrm{v}(i ?-\mathrm{X}-1696)$

Y en lo que toca a la súplica que el señor Abad propuso al cabildo por parte del Diego de la Serna fiscal en el consejo de órdenes, que pedía al cabildo fuera servido de pedirle una misa cantada a los Santos Mártires de este Sacro Monte por haberle restituido a perfecta salud estando muy quebrantado de ella. Se determinó se dijese un día de la semana próxima venidera que no estuviera impedido con fiestas dobles. 
Se confirió si la Sochantría se proveería en don Joseph Garrido vecino de Alcalá la Real que había venido a hacer oposición a ella por parecer ser sujeto de ciencia y habilidad y de buenas costumbres para esta casa y se determinó que siendo examinado por persona inteligente y constando de su aprobación fuese admitido a dicha sochantría quedando para otro cabildo el tratar de salario y como había de quedar don Francisco Palomino que estaba en dicho ejercicio.

[fol. $83 \mathrm{v}]$

Conferido por el cabildo de la suficiencia, habilidad y voz de don Joseph Garrido natural de Alcalá la Real para el ejercicio de la Sochantría se recibió por Sochantre en la forma. Y como la Constitución habla de este oficio señalándose por salario de 700 reales y para que así mismo se le añade con los alimentos, habitación y silla del coro por la naturaleza que pertenece a sochantría principal, y por consiguiente de lavar la ropa al ropero de la comunidad. Y al licenciado Francisco Palomino, que había estado ejerciendo dicho oficio por hallarse impedido de la vista, y atendiendo por sacerdote y trabajo determinó el cabildo recibirlo por una de las capellanías de la fábrica para que según su distribución gane los manuales juntamente con la porción de ropa y vino y aniversarios.

Ítem se determinó no se admitiese por el Cabildo sustituto del órgano si no que asistiere el propietario, y que en sus ausencias precisas por enfermedad pueda asistir el que en otras ocasiones hubiere suplido

[441] ASAC VI, fol. 85 r (16-III-1697)

Por instar la Semana Santa y hallarnos sin Sochantre que pueda hallar el peso del coro, se determinó [fol. $85 \mathrm{v}$ ] los señores hagan la diligencia que pudieren para que algún músico de la Iglesia Mayor o de la Capilla Real venga a ayudar y caso que no haya, que don Francisco Palomino y el Maestro Collado se ayuden para cumplir los oficios en el ínterin que se halla Sochantre.

[442] ASAC VI, fol. 86 r (11-IV-1697)

Lo primero se admitió por Sochantre al don Francisco Zabalza con salario de 100 ducados, y más los aniversarios entrando desde luego en lo demás, obvenciones de comida, asiento y cuarto como Sochantre principal y que si quisiese de lavar la ropa a la ropería de la comunidad y respecto de haber venido aquí de Toledo sin prevención de cama ni otros trastos precisos se le mandó despachar libranza de doscientos reales para que se avíe de lo que necesitase y que si hubiere menester más se le librara: y así mismo a don Agustín Aranda que 
vino de Málaga a hacer oposición a la Sochantría se le mandaron librar cien reales de ayuda de costa para que se vuelva.

Para [que] la Junta despache libranza de cincuenta reales al Sochantre y asimismo vea que se le debiera dar a salvador de la Paz por el tiempo que estuvo supliendo en el órgano por la enfermedad de don Joan Riscos y que se le libre.

Ítem que se aderecen los Libros del Coro por ese librero que ha venido acudiéndole el señor alba y el señor Tesorero para lo que fuere necesario.

ASAC VI, fol. 87 r (5-VI-1697)

Se advirtió se dijera al Sochantre por el señor abad acudiera con puntualidad a su obligación de coro apercibiéndolo para que si no cumplía se pasaría a multarle.

[445] ASAC VI, fol. 87 v (10-VI-1697)

Fue para tratar qué se había de hacer con el Sochantre, que de segunda se había quedado en Granada por ¿? Sin licencia del señor abad estando prevenido donde si faltaba muchas faltas a su obligación. Y el cabildo determinó se le multara con dos ducados y privación de bajar dos meses a Granada con apercibimiento de que se pasaría a más si no (...).

[446] ASAC VI, fol. 87 v (19-VI-1697)

Lo primero se volvió a recibir para la Sochantría como antes que estaba don Francisco Senabra y Mendoza.

[447] ASAC VI, fol. 90 r (3-VIII-1697)

Se determinó que por causas que el cabildo se conoce, se le haga saber a don Francisco Palomino que no confiese a personas extrañas a este Sacro Monte, ni se siente a confesar en la Iglesia y que en las ausencias y enfermedades del Sochantre don Francisco Zabalça asista a el coro.

[448] ASAC VI, fol. 91 v (2-IX-1697)

El licenciado Palomino presentó petición pidiéndole al Cabildo que respecto de haber en esta falta de Sochantre recargando el oficio en él, y serle ya muy gravoso que el cabildo se sirviera de señalarle el salario que había antes tenido como tal Sochantre, y se determinó que continúe como está cobrando y que después por el tiempo que así lo haga se le dé alguna ayuda de costa.

[449] ASAC VI, fol. 94 v (4-XI-1697) 
No se advirtió cosa especial si no es el que se buscara a un músico que hiciera oficio de sochantre en el interim que había sujeto al propósito que lo sea en propiedad y juntamente se busque sujeto al órgano en el interim que don Joan Riscos está ocupado en dependencias de la Comunidad y que en cuanto [fol. 95 r] al salario que se le hubiere de dar se le avise a don Juan Riscos, es de Constitución el que mientras está ocupado en negocio de la Comunidad con señalamiento de salario no percibe los emolumentos de Prebendas o exercicio en el interim que no lo reside para que en vista de esta advertencia con su respuesta determine el cabildo lo que bien tenga. Se determinó se hagan esteras para el coro por ser mucha su necesidad.

\section{ASAC VI, fol. 97 v (14-XII-1697)}

Lo primero se leyó una carta del licenciado Francisco Hernández Matheos pretendiente de la sochantría en que pedía licencia al Cabildo para venir a oponerse y el cabildo se dio por desentendido de dicha carta por no hacer juicio de su suficiencia para dicho ejercicio.

\section{8}

[451] ASAC VI, fol. 98 v (3-I-1698)

Ítem se leyó una petición de don Francisco Palomino en que pedía ayuda de costa y se determinó no había lugar por ahora.

Se trató de recibir por segundo organista a don Atanasio de Alvons.

[453] ASAC VI, fol. ¿? (18-I-1698)

Se recibió al señor don Atanasio de Alvons por segundo organista para que supla las faltas y ausencias de don Juan Riscos y se le señalaron 600 reales que son los mismos que se le daban a dicho don Juan que por no asistir por ahora a su plaza se mandaron aplicar a quien sustituye y se le señaló el cuarto inmediato al del señor Ramírez; y de los 600 reales de su salario se le mandó librar doscientos para que al presente se vista.

[454] ASAC VI, fol. 102 r (22-I-1698)

Para tratar del premio que se le había de dar a don Juan Riscos, por la cobranza que se le tiene encargada de los restos antiguos, y habiendo hecho un cuerpo de todos y paresciendo a unos señores se les podía dar el 15\%, a otros señores les pareció era mucho el premio, y el señor Abad se en cargó de llamar a don Juan Riscos para tratar este punto estando él presente. Se despidió a don Francisco Antonio, vecino de Cazorla, que vino a pretender la Sochantría y no pareció al cabildo tenía la voz que era menester a este ejercicio. 
Se recibió a don Cristobal de Ortega por seis meses por una comida ordinaria sin otra cosa y con condición que en este tiempo ha de saber la solfa necesaria para gobernar bien el Coro y para ser examinado y ver si se ha de recibir absolutamente; y que si en el tiempo de los seis meses viniendo otro a cumplir la plaza de Sochantre que tenga la voz y suficiencia necesaria para ejercer dicha plaza se ha de admitir y dicho don Cristóbal por consiguiente ha de quedar despedido.

Que el órgano se componga para San Cecilio en lo más principal y se continúe después hasta dejarle perfectamente templado.

\section{ASAC VI, fol. 108 r (5-IV-1698)}

$\mathrm{Y}$ al organista segundo se le mandaron librar doscientos reales por cuenta de su salario para algunas cosas que dice tenía necesidad. Ítem se determinó que el licenciado sochantre de la Catedral que pretende la Sochantría de casa venga una tarde a cantar, y regir el coro para reconocer si conviene o no el recibirle.

\section{ASAC VI, fol. 108 v (12-IV-1698)}

El pretendiente de Sochantre le despidió el cabildo por ser casado y no poder tener su habitación dentro del Sacro Monte.

[458] ASAC VI, fol. 109 r (17-IV-1698)

Primeramente se determinó se escribiese a su Santidad para informarle del horror que se contiene en el oficio de San Torcuato

[459] ASAC VI, fol. 109 v (1-V-1698)

Y despidió el cabildo a don Cristóbal de Ortega que estaba recibido por seis meses para que en ellos estudiara el canto llano, y por su poca aplicación y causas que para ello tuvo el cabildo le despidió antes de cumplir el tiempo de los seis meses, y se le permitió se estuviese en casa hasta las témporas de la Santísima Trinidad, porque no pierda las órdenes de Evangelio que está solicitando, y esto si fuere conveniencia suya y si quisiere se vaya desde luego a Granada a solicitar su orden.

[460] ASAC VI, fol. 111 v (11-VI-1698)

Determinose también que el señor Proveedor don Bernardo Allen diese por gastos de provisión 60 reales al organista don Atanasio agotado el trabajo que tuvo en la celebridad de la Octava del Corpus. 
Que se le den doscientos reales por una vez al Sochantre por lo que ha servido al coro desde que se le bajó el salario de tal Sochantre de ayuda de costa.

[462] ASAC VI, fol. 114 v (2-IX-1698)

Ítem se determinó que por cuanto el facistol del coro está muy maltratado por se echen a perder los libros, se llame a Francisco Gutiérrez y vea si con la madera que hay en casa y lo que procede de la [...] que se saca del Cortijo de Nicodemus y cien reales más que se le libren de la Hacienda de la Fábrica se puede hacer uno nuevo aprovechando del viejo lo que pudiera servir, para lo cual se dio comisión al señor Ferrero.

\section{9}

[463] ASAC VI, fol. 127 r (4-IV-1699)

Y viendo la falta tan notable de no tocarse el órgano en las funciones y misas por determinación del cabildo se encargó el señor Allen en hacer diligencia si había quien viniera a tocarlo con habilidad para que discordara con el coro.

Leyóse una petición del Sochantre don Francisco Boteller en que pide se le libren doscientos maravedíes para componer su cuarto y a cuenta de su salario mandó el cabildo se le librase.

Y pidió don Francisco Palomino se le diere alguna ayuda de costa en atención a lo que tiene sin vida la plaza de Sochantre y mandó el cabildo no se le diera cosa alguna sino que se contentara con lo que tiene.

[464] ASAC VI, fol. 132 v (3-VIII-1699)

Diósele al organista Thomás de Barragán doscientos reales de salario y la comida que tenía, o si quería seiscientos reales sin comida.

[465] ASAC VI, fol. 133 v (22-VIII-1699)

Leyóse un memorial de Don Juan Riscos, en que hacía notorio al Cabildo tener fenecidas y del todo ajustadas más de cuarenta cuentas que había de los señores prebendados de este Sacro Monte desde el año de 1679 hasta fin del año de 1692; representó también su mucho trabajo en ajustarlas por el tiempo de más de dos años; sin haber interesado maravedíes algunos ni comida/alguna por la plaza de organista, en cuya consideración pedía al cabildo se le diera satisfacción pues se hallaba necesitado, y sin la que por dar parte pudiera haber tenido en esta ocasión. 
[466] ASAC VI, fol. 139 r (4-II-1700)

Ítem que se haga un facistol grande para el coro con la madera de nogal que tiene la casa.

[467] ASAC VI, fol. 141 r (28-III-1700)

Ítem el dicho Sr. Allen presentó dos cuentas, una de gastos que el dicho señor tiene hechas en Dayfontes, y otras de lo que importó el gasto de la librería de Coro, las cuales se remitieron al Sr. Delgado para que las viese.

[468]

ASAC VI, fol. $141 \mathrm{v}(4-\mathrm{IV}-1700)$

Ítem que se le den a don Thomas Barragán teniente de organista cien reales de aumento de salario.

[469] ASAC VI, fol. 148 r (13-IX-1700)

Ítem se admitió por Sochantre de este Sacro Monte a don Joseph Perera sochantre de la Iglesia de Almería con salario de diez reales y sus aniversarios, y el señor abad fue del sentir contrario; por ser el dicho casado y juzgarlo por inconveniente.

ASAC VI, fol. 150 r (6-XI-1700)

Se le dieron cien reales a don Francisco Palomino por recompensa de trabajo que se le ha acrecido por el tiempo que ha suplido la Sochantría.

[471] ASAC VI, fol. 150 v (22-XI-1700)

Ítem que al sochantre mozo don Joseph Perera se le libren doscientos reales por cuenta de su tercio a fin de diciembre y se le hizo gracia de una hogaza de pan más todos los días.

ASAC VI, fol. 151 r (1-XII-1700)

Por último que al organista se le dé comida entera de señores.

1701

[473] ASAC VI, fol. 152 r (3-I-1701)

Que el pertiguero y organista se lleven la carne el mismo día que les tocase, sin que se les permita de dar alguna para tomarla en tanto.

[474] ASAC VI, fol. 163 r (29-VIII-1701) 
Admitiose por organista interino a don Laureano Gómez con cuatrocientos reales de salario y comida de colegio y cena de señores.

[475] ASAC VI, fol. 171 r (23-III-1702)

Ítem que a don Joseph Perera se le dieron de aumento sobre los mil reales que tenía, doscientos en cada año.

[476] ASAC VI, fol. $173 \mathrm{v}(2-\mathrm{V}-1702)$

Dieron se a don Laureano Gómez tres fanegas de trigo por esta vez en atención al trabajo que ha tenido de refinar el órgano y cantar la Semana Santa.

Y el señor Arcediano de Granada otra (beca) de cincuenta ducados que pidió al cabildo para un sobrino suyo, cuya gracia se le concedió por el grande celo con que solicita el nuevo rezado de nuestro patrono San Cecilio en la Corte Romana, que por cuanto dicho su sobrino parece estar enfermo habitual que en caso de ser necesario curarlo no sea a costa de la casa por ser achaques contraídos antes de ser colegial.

Se dio licencia a don Francisco Palomino sochantre para que diga misa en la Capilla de San Dionisio a horas que no falte a la hora de oración, y que el Sacristán le dé recado para este efecto.

Se determinó que al organista se le dé comida de señores como la ha tenido su antecesor, y en cuanto al aumento que pide de más se dejó para otro cabildo.

\section{3}

[480] ASAC VI, fol. 189 v (18-VI-1703)

Se determinó que los oficios y exequias por el prebendado Sr. Andrés Rafael de Ascargorta que goza de triple empiecen esta tarde y mañana se diga la misa, y al mismo día se diga la vigilia y misa con asistencia de la música de la Catedral por especial obsequio que este cabildo quiere hacer al Sr. Arzobispo de esta Ciudad, de que fue sobrino dicho señor difunto sin que sirva de ejemplar. 
Dio cuenta a este cabildo el Señor $\mathrm{Abad}^{33}$ como su Majestad de que lo había renombrado obispo de la Santa Iglesia de Ávila (...) Se determinó se hiciese demostración con repique de campanas y por la noche se pusieren hachas en todos los balcones y ventanas de la casa y se llamaran ministriles que tocaran al tiempo de dichos repiques y se pusieren luminarias.

[482] ASAC VI, fol. 197 r (24-IX-1703)

Leyose un papel del señor Arcediano de Granada en que da noticias como la Santa Iglesia Catedral hace demostración solemne por la Concesión del nuevo rito de nuestro patrono el señor San Cecilio por la Sagrada Congregación de Ritos, y el culto del glorioso Santo. Se determinó se echen repiques solemnes al mismo tiempo que en la Catedral y demás Iglesias y Conventos, y por la noche se pongan luminarias y al día siguiente se celebre procesión al horno del santo, y se diga misa solemne por el Abad.

\section{4}

[483] ASAC VI, fol. 201 r (2-I-1704)

Y que al organista no se le diese aceite.

[484] ASAC VI, fol. 207 r (29-III-1704)

Ítem se propuso por mí el infrascripto secretario como sabiendo con certeza muchos desaciertos que cometía don Francisco Palomino en las confesiones, y que habiéndoselo corregido muchas veces, no tenía enmienda, me pareció no haber otro remedio, que dar cuenta a su Ilustrísima para que lo remediase como con esto le dí noticia a su Ilustrísima el señor Arzobispo, mandó que se le notificase como su Abad le había suspendido y revocado la licencia de confesar y por ahora contestaba con esto, sin pasar al castigo como merecía. Y habiendo los señores capitulares oído mi propuesta se determinó por todos votos el señor don Juan de Cieza canónigo presidente se lo notificase de la misma forma que lo había mandado su Ilustrísima.

[485] ASAC VI, fol. 193 v (1-VII-1704)

Se leyó una petición de don Francisco Palomino, sochantre que fue de este Sacro Monte pidiendo algún socorro para sus alimentos, y se determinó que no tenía dicho Sacro Monte de donde hacer limosna respecto de sus muchos alcances.

${ }^{33}$ Promoción del Sr. Abad don Baltasar de la Peña al Obispado de Ávila, por Felipe V. 
Ítem se leyó una petición del organista don Laureano, que ahora suple el órgano por don Juan Riscos, en que pedía al cabildo le hiciese gracia de concederle el que pudiere llevar el platillo, y ración de carne de la noche cruda, y así mismo el aceite que se acostumbra dar al organista todas las semanas; y habiéndose votado sobre esto se le concedió se llevase la carne cruda y que no se le diese el aceite.

\section{5}

[487] ASAC VI, fol. ¿? (2-IV-1705)

Se determinó que en los días de primera clase se canten las Vísperas con más solemnidad y pausa que en las otras conforme es estilo.

[488] ASAC VI, fol. ¿ $?(2-V-1705)$

Se determinó que se procure guardar la Consueta, en especial en lo que toca a las ceremonias del coro, y que la Misa se guarde orden de la voz que unas veces ha de ser algo levantada y otras veces secreta de suerte que solo el sacerdote la oiga en especial en el canon.

\section{ASAC VI, fol. 234 r (7-VII-1705)}

Se leyó un memorial de don Laureano Gómez, organista de esta santa Iglesia en que suplica se le dé de salario más de lo ordinario cien reales y seis fanegas de trigo, Y se resolvió se avisase al propietario organista, para ver si ha de volver y según eso resolver en este punto.

[490] ASAC VI, fol. 234 r (16-VII-1705)

Leyose un memorial de don Laureano Gómez en que pide se le perpetúe la renta del órgano, con ánimo de ordenarse como su Ilustrísima se lo prometió; y se determinó se le escriba a don Juan Riscos para busque o venga a servir el órgano o lo deje, y según esto determinar o no perpetuarle a dicho Laureano la renta. Y se determinó también se le den de salario otros cien reales más que pidió en otro cabildo.

[491] ASAC VI, fol. 236 v (5-VIII-1705)

Se determinó que el Presidente en la misa cante según el día arreglándose al tono del Misal y si no supiere sino otro, que en el coro respondan acomodándose al tono del Presidente para que haya uniformidad. Se resolvió que el día de la dedicación de la Catedral se celebre en casa como doble menor. Se determinó que los colegiales aprendan los tonos de la Kalendas, y epístolas. Se determinó, 
que las Vísperas y Maitines de la Asunción se canten en la Iglesia por evitar el mucho calor que en el Coro se experimenta.

Que al sochantre se le diga doctrina a los colegiales en el modo de cantar para el buen régimen del coro por haber en esto algunos defectos.

[493] ASAC VI, fol. 239 v (3-X-1705)

Habiendo alguna duda acerca si se había de celebrar el aniversario de nuestra señora del Rosario por estar ausente don Juan Riscos quien lo pagaba, se determinó que respecto de no haber escrito cosa en contrario dicho don Juan Riscos, y de haber pagado con toda puntualidad los antecedentes años dicho aniversario no era razón se hiciese alguna desconfianza de la cosa, que pudiera con razón sentir. $\mathrm{Y}$ así que se celebrase dicho aniversario, como en años antecedentes se ha ejecutado a devoción de dicho señor don Juan de Riscos.

\section{6}

[494] ASAC VI, fol. 244 v (23-I-1706)

Propuso el señor abad si habíase de traer música y determinó el cabildo que la hubiere en las segundas Vísperas del señor San Cecilio y se les advirtiese que las cantasen con toda solemnidad, encomendose al señor Montoya.

[495] ASAC VI, fol. 253 r (12-VI-1706)

Se leyó una petición de Laureano que fue organista interino por ausencia de don Juan Riscos pidiendo se le dé testimonio de haber asistido el órgano y por haber venido dicho don Juan de Riscos lo despidió el cabildo. Se determinó se le dé testimonio de haber asistido al órgano interino.

Determinó el Cabildo se le dé a don Francisco Gómez por cuenta del trabajo de componer los libros del Coro y que se escriba la Misa del señor San Julián y que la saque por la de la Catedral de Granada.

[497] ASAC VI, fol. 259 v (1-XI-1706)

Mandó el cabildo que se le escribiese a don Juan Riscos que subiese a residir su órgano. 
[498] ASAC VI, fol. 267 r (7-II-1707)

Por la noticia feliz del preñado de su majestad.

Mañana ocho de febrero se cantase por el señor Abad misa solemne con la asistencia del cabildo y colegio y después se hiciese también procesión solemne a las Sagradas Cuevas y se fuese cantando el himno de Te Deum laudamus, en acción de gracias del beneficio recibido y súplica para el feliz éxito y alumbramiento de la Reina nuestra señora.

[499] ASAC VI, fol. 273 v (2-V-1707)

Luego que se confirme la feliz victoria en nuestro reino de Valencia contra nuestros enemigos se cante misa solemne por el señor prebendado a quien tocare en turno, se haga Procesión a las Sagradas Cuevas cantando el himno Te Deum laudamus.

\section{[500] ASAC VI, fol. 274 v (2-VI-1707)}

Se propuso por el señor Abad la pretensión y súplica que don Juan Riscos, organista de este Sacro Monte hace a los señores Abad y cabildo para que se sirvan darle licencia para mudar la puerta del pórtico de esta Iglesia a lares más abajo y en el sitio de la puerta que se pueda hacer un altar al señor San Antonio, con correspondencia del altar del Santo Nacimiento y pareciendo al cabildo dicha pretensión piadosa, en mayor culto y ornato de dicha Iglesia se determinó se le diese dicha licencia, con condición que fuese de cuenta y gasto de dicho don Juan Riscos todo el gasto que tuviese la mudanza de dicha puerta y altar, así de jornadas de material y comidas de los oficiales y no en otra forma.

[501] ASAC VI, fol. 275 v (16-VI-1707)

Propusose por el señor Abad que ilustrísimo señor don Martín de Ascargorta arzobispo de Granada y ministro de esta casa que actualmente residía en ella, había determinado llenado del amor a este santuario y estimación de este cabildo hacer una escalera principal por la Iglesia sobre el pórtico de ella para que con más comodidad y decencia se subiese y bajase del coro, y así mismo hacer un oratorio y librería para el servicio del Coro; y que para empezar estas obras rogaba la urbanidad y benignidad de su Ilustrísima y el consentimiento del cabildo y que así lo declaraba y lo daba a entender. Y oída por el cabildo la dicha propuesta del señor Abad se determinó se le diesen a su Ilustrísima las gracias por los favores tan especiales que le debe este cabildo y que su Ilustrísima mandase comenzar dichas obras cómo y cuándo fuese servido y que en cuanto pudiese concurrir este cabildo al gasto de esta obra concurriese. 
Se determinó así mismo que mañana 31 del mes de Agosto celebrase el señor Abad Misa solemne y se hiciese Procesión con asistencia del cabildo, y colegio a la capilla del señor Santiago cantando el Te Deum Laudamus; todo por acción de gracias por el inexplicable beneficio que Dios nuestro señor ha dado a la Cristiandad de habernos concedido un príncipe en España.

[503] ASAC VI, fol. 282 r (6-IX-1707)

(...) y se determinó que el lunes de la semana siguiente se dijese vigilia y misa cantada con dobles, y último responso por el alma de dicho don Diego de la serna en atención a haber sido tan inclinado a mayor crédito de este santuario, y haber trabajado en sus escritos para este fin.

\section{8}

[504] ASAC VI, fol. 284 r (27-IV-1708)

Que al señor Sochantre se le dé una hogaza por el mayor y muy continuo trabajo de más de los tres meses.

ASAC VI, fol. 290 v (11-V-1708)

Pidió don Atanasio de Albons suplemento que fue de organista de este Sacro Monte si se dé testimonio de cómo cumplió con su obligación y se le mandó dar.

[506] ASAC VI, fol. 291 r (1-VI-1708)

Se determinó que los colegiales tengan Conferencias de Ceremonias y que no entren con recados siempre que se digan himnos cánticos de benedictus, magníficats y cuando el coro está eregione.

Se determinó se despida al señor Torres por causa de la porción.

\section{ASAC VI, fol. 300 r (3-VIII-1708)}

Y se le advierta al sochantre las entonaciones del coro sean con modestia no se convirtiera en escándalo en la Iglesia.

[508] ASAC VI, fol. 301 r (27-VIII-1708)

Se determinó en accimiento de gracias se dijese el jueves treinta de este mes después de horas la Misa mayor y después se hiciese una Procesión por la Iglesia con uno de los relicarios de las cenizas de los mártires del sacro Monte y después se dijese la misa mayor por el señor Abad y en dicha procesión se cantase el Te Deum laudamus y así mismo se pidiese a Dios nuestro señor destruyese la langosta que a los campos tanto mal hace. 
Tratose de la observancia de nuestras constituciones y en vista de una de ellas se votó se hiciese citación a todos los Señores Prebendados que estuvieren dentro y fuera de casa, para mañana después de horas, para tratar de la provisión de plazas de organista de que tiene hecho nombramiento don Juan Riscos, por causa de no servir dicha plaza y estar preso en la cárcel eclesiástica de esta ciudad de orden del señor Provisor de Granada.

Que se notifique al Sochantre no encomiende los versículos de los Introitos de las Misas, y el Incarnatus del Credo a sujetos que no sepan Música por la disonancia y yerros que se cometen.

El primero que habiendo tenido noticia este cabildo de la prisión a Don Juan de Riscos que por la pretensión que ante el señor provisor hizo una mujer pidiendo su honra en una información que se estaba haciendo las diligencias para una letra y por ser algo de tanta nota y contra la fama y crédito de tantos años conservada de este Sacro Monte se propuso en dicho Cabildo que para dar satisfacción al pueblo sería conveniente despedir la plaza de organista a dicho don Juan de Riscos; se determinó se suspenda dicha resolución hasta pasada la sentencia del juez que entonces viera el cabildo lo más conveniente y bien de esta comunidad o corrección y castigo de dicho don Juan de Riscos.

\section{0}

[511] ASAC VI, fol. 326 r (2-VI-1710)

Yo el infrascripto propuse al cabildo como don Joseph Perera sochantre de este Sacro Monte quien se había despedido del mes de mayo del empleo que tenía, se hallaba con otro ánimo por diferentes pláticas que conmigo había tenido en las cuales me había insinuado que de buena gana continuaría en su ejercicio si el Cabildo gustaba, y que por este fin tenía buscada casa en la ribera del Darro inmediata a este Sacro Monte para así ser más puntual en cumplir con su obligación y que deseaba saber si el Cabildo lo recibía o no, que yo lo propusiese, así convine. Y el Cabildo lo recibió en la forma que antes estaba, y con la condición de que sea humilde y obediente al señor Abad, y que los señores que hubieren escrito haciendo diligencia para Sochantre, que escriban se suspenda si había algunos que viniesen; y si acaso viniese alguno llamado que del salario de don Joseph se le pague el costo del viaje.

Propusose la pretensión que don Blas de Ledesma tiene de segundo organista por los años que ha servido y sirve el órgano; y el señor abad lo nombró por 
ausencias y enfermedades del primero, señalándole salario competente por la facultad que dicho señor Abad tiene en virtud de las Constituciones.

Diose por despedido a don Joseph Perera sochantre quien voluntariamente despidió su plaza ante el señor Presidente.

\section{2}

[514] ASAC VI, fol. 344 v (5-III-1712)

(...) y así mismo se resolvió que dando noticia al señor Arzobispo que como el cuarto donde están los Libros de Coro se hundía y podía causar gran daño a la demás casa, se derribara para precaver el daño mayor que se podía seguir y en esta forma se disolvió este cabildo.

[515] ASAC VI, fol. i? (9-III-1712)

En cuanto a la petición de don Juan de Riscos no tenía lugar por ahora el despacho hasta haber justificado enteramente su residencia en los dos años de 1710 y 1711.

\section{ASAC VI, fol. 349 r (29-VII-1712)}

Así mismo que el aniversario de Nuestra señora del Rosario que se celebraba por don Juan Riscos que no se celebre hasta que pague y que de su renta se cobre lo que debe.

[517] ASAC VI, fol. 349 v (3-VIII-1712)

Y así mismo se resolvió que a la composición que pedía don Juan de Riscos en el pleito que tiene no se podía dar oídos, y así que se siguiera en justicia.

\section{ASAC VI, fol. 353 v (7-XI-1712)}

También se resolvió en dicho cabildo que a don Blas de Ledesma que suple la plaza de organista en ausencia de don Juan de Riscos se le dé todo el salario que gana éste, sólo aquellos días que el dicho don Blas tocare en ausencia de don Juan de Riscos, y que esa gracia se entienda hecha desde el día primero de este mes de noviembre de 1712 . 
Se leyó una petición de don Juan Riscos contra una pretensión que dice tiene don Blas de Ledesma; pero como dicho don Blas no ha pedido cosa alguna ante dicho Cabildo, no hubo que decir a dicha petición.

ASAC VI, fol. 376 r (6-VI-1714)

También se le concedió a don Blas de Ledesma la renta de un mes que toca al organista por haber suplido la falta del organista propietario dicho mes.

\section{ASAC VI, fol. 376 v (8-I-1714)}

También se le concedió a don Juan Riscos la petición que propuso acerca de mudar la librería para componer dicho cuarto para su habitación y que los libros se mudasen al cuarto del maestro Sánchez; dando para esto don Juan Riscos su gasto para habitación del dicho maestro Sánchez.

\section{ASAC VI, fol. 377 r (4-VIII-1714)}

Y también que vea si había de abrir ventana don Juan de Riscos en su cuarto y puerta a la escalera principal del cuarto que antes era librería. Y se determinó que abriese ventana la que empezó a abrir pero en cuanto a abrir puerta que no se abra ésta hasta que maestros vengan y declaren no haber inconveniente alguno.

\section{5}

[523] ASAC VI, fol. 381 v (10-I-1715)

Tratose otra especie que propuso el señor Presidente sobre el Sochantre de esta Iglesia, y por no haberse dado citación para dicha proposición se determinó se diere citación ante diem para tratarla en otro cabildo pleno.

Ítem se propuso como el Presidente y Salvador de Santa Ana, religioso agustino que al presente sirve la plaza de Sochantre en esta Iglesia como había hecho diferentes confesiones generales a distintos sujetos de esta comunidad, cuyo modo de examinarles y mortificarles, con diferentes disciplinas que por su mano daba a los penitentes, pareció al Cabildo tan horroroso y escandaloso, y de tan malas consecuencias como jamás se ha oído ni practicado en esta Insigne Iglesia, que siempre ha florecido con tanta rectitud, prudencia, circunspección y utilidad común en la administración de los Santos Sacramentos a los fieles; determinó despedir como en efecto despidió a dicho sujeto corrigiéndole semejantes 
desaciertos y mirando por el crédito y buen nombre que en todos tiempos tenía y había conservado esta Insigne Iglesia.

Nota al margen: fue admitido otra vez en cabildo de 23 de marzo

Ítem que se le permita al padre Fray Salvador de Santa Ana que sirva la plaza de Sochantre hasta marzo.

\section{ASAC VI, fol. 385 v (18-III-1715)}

Se trató sobre la expulsión del padre Fray Salvador de Santa Ana, y habiendo escrupulizado de ésta, por haberles parecido después una determinación muy fuerte, se confirió este punto y se determinó se volviese a admitir la plaza de Sochantre que había servido, con la condición que no había de venir su hermano Fray Francisco de Santa Ana, que yo el infrascripto secretario le avisara de esta determinación.

\section{[527] ASAC VI, fol. 386 r (2-IV-1715)}

Ítem se determinó que don Joseph Perera venga quince o veinte días al coro, para experimentarlo y ver si puede servir la plaza de Sochantre.

Ítem se determinó que por cuanto Joseph Perera parece no está para poder servir la plaza de sochantre se le diga se vaya. Ítem se determinó que se hagan diligencias para buscar sujeto que pueda servir cumplidamente la plaza de Sochantre. Item que se busque para esta Semana Santa sujeto que supla la plaza de Sochantre. Ítem que mientras suplen don Juan de Berrotaran dicha plaza se le den 30 reales en cada un mes, y al maestro Montes 15 reales en cada un mes.

\section{ASAC VI, fol. 388 v (9-V-1715)}

Ese dicho día murió don Juan de Riscos y se determinó que al día siguiente se le diese sepultura a su cuerpo en la bóveda de la capilla que está a un lado de la clave en la nave del claustro que va a la portería/

(fol. 389 r) y que se le tuviera el Oficio entero de difuntos y misa de cuerpo presente por ser capellán (que gozaba de una de las capellanías que fundó el señor Vega se fundasen en esta Iglesia) como consta de la Consueta.

[530] ASAC VI, fol. ¿?(20-V-1715)

Ítem se le dio la plaza de organista en propiedad de este Sacro Monte por todos votos a don Blas de Ledesma y con el mismo salario, trigo y demás emolumentos que lo tenía su antecesor. 
Ítem se admitió y nombró por Sochantre de esta Santa Iglesia al Maestro don Alexandro de Montes y se le señaló salario de sesenta ducados, aniversarios, comida de señores, y las demás cosas que como a tal sochantre le pertenecen; y que para el día de la [fol. 390 v] Purísima Concepción se había de examinar por examinadores inteligentes.

[532] ASAC VI, fol. 391 r (6-VIII-1715)

Ítem leí un memorial presentado por don Blas de Ledesma, organista en propiedad de este Sacro Monte en que [fol. $391 \mathrm{v}$ ] pretendía le hiciese el cabildo gracia de perpetuarle la renta de dicho órgano para que a título de ella pueda pretender las Sagradas Órdenes. Y oído y entendido se determinó por todos votos se le perpetuase dicha renta.

\section{6}

[533] ASAC VI, fol. 398 v (8-I-1716)

Ítem se le aumenten al sochantre 20 ducados de salario que con éstos y 60 que tenía tiene 80 ducados de salario.[fol. 399 r] Ítem se encargó al señor Abad de decir a una migo suyo veintiquatro que dijera a ese cabildo de la ciudad:

Que si los comisarios de la Ciudad por el día de san Cecilio no daban ramos a los colegiales no se les propondría a que asistiesen a la Ciudad en la mesa dicho día. Ítem que el señor Abad encomiende el sermón de San Cecilio.

\section{ASAC VI, fol. 399 r (21-I-1716)}

Propuso y dijo el señor Abad que don Gaspar Barona caballero veintiquatro de Granada y maestro de Ceremonias de su Cabildo con comisión de dicha Ciudad y en su nombre había dado al señor Abad el recado siguiente:

Que la Ciudad de Granada deseaba con las mayores veras conservar la antigua y noble que con el Ilustrísimo Cabildo del Sacro Monte había conservado, y los grandes vínculos, así de religión como de fidelidad de gastos, y política que entre los dos cabildos se habían conservado inviolablemente. Y respecto de que en los años antecedentes había la Ciudad reconocido la distribución e inquietudes que en el día de nuestro gran patrono el señor San Cecilio se habían ocasionado con el colegio de este Sacro Monte por pretender que los caballeros comisarios de la Ciudad que subían al coro a dar ramos de flores a los señores prebendados los habían de dar también a dicho Colegio, y no los Maceros de la Ciudad, y que esto no era estilo ni costumbre a que la ciudad no podía asentir, por su grande representación,y aún con el mismo cabildo de la Ciudad [fol. 399 v] no se haría eso, si no es que dichos Maceros los repartían, y no los comisarios y que con ninguna comunidad lo practicaba la Ciudad si no es con el Cabildo de este Sacro Monte, por la especialísima veneración y amor con que le atendía. Suplicaba dicho don Gaspar al señor Abad propusiese a este Cabildo que los ramos para dichos colegiales se entregasen al Sacristán de esta Iglesia para que 
él los diese a dicho Colegio y que el señor Abad se sirviese de avisar por escrito a manos de dicho don Gaspar Barona lo acordado por dicho Cabildo, para que en él que se ha de celebrar en la ciudad el día 22 martes del mes corriente se viese y confiriese lo que conviniere a la Ciudad determinar acerca de la Fiesta de Nuestro Patrón, Y oído y conferido dicho recado y propuesta, y atento a la grande representación de la Ciudad de Granada a las donaciones, gastos y solicitudes que siempre ha tenido dicha ciudad desde la Fundación de este Sacro Monte y el honor a los Santos Mártires con nuestro Patrón y Señor San Cecilio, que se le sigue de la devota y en con cuya asistencia de la ciudad su Víspera y a la que así mismo siendo una casa de oración, religión y de predicación de tener a Dios y demás virtudes, y no era razón, ni del agrado de Dios, que en este Santuario, y en tan plausible y célebre día de tan grande concurso se diese escándalo por el colegio y se nombrase, y se oyeren palabras de desprecio como se ha experimentado en algunos años poco antes de éste; por ocasión de quejarse de si la Ciudad por manos de sus comisarios daba al Colegio los ramos o no y no habiéndolos querido tomar de los Maceros había tomado el Colegio este pretexto para no querer servir las mesas de este Cabildo, que convida a ellas a la Ciudad en el día del señor San Cecilio y por modo de una comunidad entra a comer dicha Ciudad pretendiéndole y presidiéndole el señor Abad y señor Presidente canónigo de este sacro Monte. Y teniendo presente este cabildo el título 25 de sus apostólicas Constituciones de regimene domus en el párrafo segundo en el que se manda que los colegiales de este Sacro Monte estén obligados a servir las mesas de los señores prebendados y capellanes, determinó el Cabildo, que el señor Abad escriba a don Gaspar de Barona para que así lo participe a la Ciudad de Granada, y que en cuanto a servir las mesas en el Refectorio así a este Cabildo como a la Ciudad este día de San Cecilio cumpla dicho Colegio con su obligación que tiene jurada de hacerla, y cumplirla como incesantemente y con todo rigor se ha observado y guardado sin interrupción hasta ahora; y que este mandato del cabildo se le intime a dicho Cabildo por merced delante del señor Abad y el señor rector de él. Y que no habiendo hecho todo el Colegio el juramento de obedecer al señor Abad lo hagan solemnemente como lo mandan muchos sagrados estatutos luego in continenti; y hecho que sea el señor Abad les mande sub pena iusti iuramenti obedezcan a su merced en lo que les manda, y sea el precepto que dicho colegio tome los ramos en la Sacristía en donde los comisarios de la ciudad los dejarán, y que así mismo cumplan dicha Constitución citada de servir las mesas en dicho día, sin innovarse [fol. 400 r] sub pena de que sean duramente castigados.

[535] ASAC VI, fol. 423 r (s.f.)

Gastos y obligaciones anuales de la fábrica del Sacro Monte

13.- Así mismo tiene su gasto de 40706 reales de los salarios del enfermero y lavandera, de los dichos dieciocho colegiales, del salario de organero, de campanas, y reloj, ramos y juncia, esteras de Iglesia, Coro y sacristía, misales y Libros de Coro, aderezos de cañería (...). 
Se determinó que el capellán cerimonario cuando convide las antífonas no se quede en mitad del coro si no que llegue a la barandilla y que al tiempo de convidar la antífona se levanten todos los señores.

En cuanto a ceremonias se advirtió que cuando se está eregione en el Coro no se pase ni para salir ni para entrar. Y que se le advierta al Sochantre que en las horas haga pausa o mediación en la mitad de los versos, de suerte que no vaya el coro atropellado.

[538] ASAC VI, fol. 458 v (7-III-1717)

Leyose un memorial del Sochantre de esta Iglesia en que suplicaba al cabildo la gracia de perpetuarle "con grua" para ascender a los sagrados órdenes. Se determinó por todos votos después de conferido el punto se le concediese. Solo el señor Don Antonio Gómez dijo que suspendía el suyo hasta que se diese citación para este punto, y aunque los señores que se hallaban presentes a este cabildo podían ceder la citación el señor don Pedro Valbuena faltaba y podía no siendo citado justamente se podía reclamar este decreto y por este motivo dijo se expresase su voto, y los demás señores dijeron se avisase al Sr. Pedro Valbuena y si no consintiese en lo determinado se remitiese a otro cabildo la determinación pero no oponiendo dicho Señor, quedase en su fuerza lo decretado.

Al margen: concédase al Maestro Montes que se ordene a título de la Sochantría.

\section{ASAC VI, fol. 456 r (22-IX-1717)}

Primeramente se confirió si la Capellanía de Coro de esta Iglesia, que está vacante por promoción mía a la prebenda se había de suspender su elección y nombramiento o si se pasaría luego a nombrar capellán que la sirva, y se determinó que respecto de no hacer mucha falta el capellán de presente, se dilatare por espacio de dos meses la provisión de dicha capellanía.

[540] ASAC VI, fol. 457 v (4-IX-1717)

No se reparó otra cosa si no es la bajadas del sochantre a Granada sin licencia, se determinó se le mandase por el señor Abad multar y corregir para que tenga enmienda, y que no se le permita bajar con tanta frecuencia: y respecto de que el punto de horas padecía alguna falta de asistencia se determinó que el señor semanero asistiese a él. 
[fol. $458 \mathrm{r}$ ]

Se propuso que la Capellanía de la casa según estaba determinado por Cabildo venía a ajustarse en tiempo que los señores iban, no podían asistir y se les hacía agravio y en atención a este inconveniente se resolvió que para el día doce del mes de diciembre se difiriese la elección.

[541] ASAC VI, fol. ¿? (26-XI-1717)

Fue esta cita ante diem por ser la materia acelerada, de solicitar don Álvaro de Mendoza y don Lorenzo de Mendoza su hijo y don Juan de Sanmartín 24 de esta ciudad se les concediese licencia para hacer fiesta de Santa Bárbara en esta Iglesia, consignando la distribución que el cabildo determinase para el punto único de misa mayor en el que deseaban los asistiese este cabildo y por ser tan inmediato el día de la santa se pasó a determinar sin citación que se les concediese a los susodichos la licencia, y que en cuanto al punto de la distribución se dejase a su arbitrio.

[542] ASAC VI, fol. 459 r (13-XII-1717)

Fue para efectos de proveer la capellanía de coro que este Sacromonte tiene vaca por mi ascenso [Miguel de la Peña y Avilés] a canongía, y habiendo preguntado el señor Abad si estaban citados respondiendo que sí y luego pasé con la urna a que dejen los votos de los señores capitulares que eran once, los recopilé y siete cédulas fueron para don Miguel de Aguilera con que salió electo dicho don Miguel de Aguilera colegial actual de este Sacro Monte, y luego se pasó a votar su informante para hacer las pruebas de limpieza a dicho maestro Don Miguel de Aguilera capellán electo según previenen nuestras Constituciones.

\section{8}

[543] ASAC VI, fol. 460 r (11-I-1718)

En cuanto a ceremonias se advirtió se procurase hubiese uniformidad en las ceremonias de las misas cantadas y rezadas como en las misas del coro, y dijo el señor Abad como había advertido y era notorio la poca asistencia que hacían al coro el maestro Sánchez y el maestro Peregrina y eso proviene de que no ganan la renta de sus capellanías en distribuciones del coro teniendo punto en el cuadrante y apuntándoles las faltas y que proponía al cabildo eso para que lo remediaseis habiéndose conferido ese punto y así mismo ponderados los grandes inconvenientes que se siguen de que dichos capellanes administren las haciendas de dichas capellanías, sin la dicha asistencia al coro, con el de sus cobranzas.

[544] ASAC VI, fol. ¿? (14-II-1718)

Toma de posesión el Miguel Rodríguez de Aguilera. 
Ítem el señor Cózar presentó y leyó las informaciones que por comisión del Cabildo pasó a hacer a la Ciudad de Málaga de la limpieza, vida y costumbres del maestro don Miguel Rodríguez de Aguiar nombrado por dicho Cabildo en la Capellanía de esta Iglesia que vacó por mi ascenso a canongía; y habiendo pasado a votar dichas pruebas se aprobaron por todos votos y luego entró en la sala capitular con sobrepelliz dicho maestro don Miguel de Aguiar y le leí en voz alta el párrafo segundo del título 22 de nuestras Constituciones en que dice que dicha Capellanía colativa y que es amobiles ad nutum capituli con causa o sin ella concurriendo de tres partes las dos del cabildo, habiendose enterado de la sustancia de dicho párrafo se hincó de rodillas ante el señor Abad.

[545] ASAC VI, fol. 466 r (27-III-1718)

Se acordó nombrar Capellán para la tercera Capellanía de Vega a Juan Berrotarán

[546] ASAC VI, fol. ¿? (12-XII-1718)

Ítem que a la Escuadra de la Alhambra se le conceda que empiece su fiesta el día de la Traslación del señor Santiago en esta forma: que uno de los señores le diga una misa con la limosna de sus reales, a los capellanes restantes dos reales, para la fábrica dos reales, y los cinco reales restantes hasta quince que es la limosna que dan se apliquen para sochantre y Organista y que no asista el cabildo y que del colegio asistan cuatro colegiales.

\section{0}

[547] ASAC VI, fol. 494 r (2-IV-1720)

Ítem se le aumentó a don Alexandro de Montes, Sochantre de esta casa, 20 ducados de salario sobre los demás que tiene.

[548] ASAC VI, fol. 499r (6-VIII-1720)

Se determinó que para el día que suba el Ilustrísimo don Tomás de Montes ${ }^{34}$ se le reciba con sobrepellices por ser el traje del tiempo y desde que [...] se repiquen las campanas y si sube por la cuesta primera el cabildo y colegio salga a recibirle hasta el pilarillo y si por el sepulcro a la escalera del horno de San Cecilio y entrando a a la Iglesia se le cante el Te Deum laudamus en hacimiento de gracias por lo interesado que es esta casa en que haya vuelto con tantos honores y aplausos a ella.

\footnotetext{
${ }^{34}$ Al margen: Sobre el recibimiento de don Tomás de Montes ex-abad del Sacromonte, estuvo en Roma, luego inquisidor.
} 
[549] ASAC VI, fol. 50 r (20-III-1721)

Se mandó así mismo, que al Sochantre, pertiguero y capellanes del señor Vega no se les de la comida en los días que no estuvieren en este Sacro Monte que lo mismo se observa con los señores prebendados que debieron gozar de mayores exenciones. Y se determinó que este decreto no se entienda con el licenciado don Blas de Ledesma organista de este sacro Monte en atención a que así está determinado en otro cabildo; y por otras causas y motivos justificados que tiene el cabildo para determinar dicha exención con este ministro.

[550] ASAC VI, fol. 508r (4-V-1721)

En orden a Constituciones solo se notó la notable falta de don Alexandro de Montes, sochantre de esta Iglesia, para cuyo remedio se acordó que no se le dé la ración que le pertenece por su ministerio no tampoco a cuenta de su pliego, y que al religioso que suple por él se le satisfaga a cuenta del salario de dicho sochantre, que a éste se le notifique por primera monición que asista y viva en el Sacro Monte conforme a Constituciones, con apercibimiento de que no haciéndolo así se procederá contra él según halla lugar en derecho.

[551] ASAC VI, fol. 509r (10-VI-1721)

Ítem se escribió que no se admita no oiga memorial del sochantre en orden a que se le suspenda la multa respecto de estar determinado en cabildo ejecutado por la Junta.

[552] ASAC VI, fol. 511r (8-VIII-1721)

Se mandaron dar al sochantre don Alexandro de Montes seis fanegas de trigo por una vez, por ayuda de costa, respecto de haber estado muy malo.

1722

[553] ASAC VI, fol. ¿? (4-V-1722)

Se resolvió que los capellanes del señor Vega ayuden las misas de los Aniversarios de difuntos y que asistan a encomendar las antífonas en los nocturnos según les toque la semana y que al capellán que asista a ayudar la misa se le ponga presente en horas, y al que asistiera al nocturno o vigilia después de por la tarde se le ponga presente en Vísperas, que el día que faltare se le quite la comida. Y se entienda durará esta determinación mientras se finaliza el pleito de dichas capellanías.

[554] ASAC VI, fol. ¿? (11-IX-1722)

Fue para determinar el funeral que se le debía hacer a don Blas de Ledesma, Presbítero organista que fue de esta Iglesia, se determinó se le dijese un 
Nocturno y Laudes el día antes de su entierro, y al siguiente día antes de horas se celebrase misa de cuerpo presente y se le diese inmediatamente sepultura.

\section{3}

[555] ASAC VI, fol. ¿? (18-IX-1723)

Se habló del funeral que se le debía hacer a don Felipe de Montoya, canónigo que fue en esta santa Iglesia. Se determinó que el día inmediato siguiente al de su muerte a la hora de misa de tercia se le dijese misa de cuerpo presente y luego se le diese sepultura y que la misa de tercia se dijese inmediatamente a las horas y así mismo que el mismo día de su entierro por la tarde a la hora de las cinco se le cantasen tres mortuarios y laudes de difuntos.

[556] ASAC VI, fol. 16 r (12-X-1723)

Fue para nombrar organista por muerte de don Blas de Ledesma, y para los demás puntos que eran expresos. Se determinó por todos votos dar la plaza de organista a don Mathías de Barragan, y se le señalaron 872 reales de salario y seis fanegas de trigo: los 872 reales de esta forma 600 de situado y el resto de ropa y vino. 


\section{TOMO VII}

[557] ASAC VII, fol. 30 r (4-IV-1724)

Fue para leer una carta de su Majestad el señor don Luís I en que avisa la muerte repentina de nuestro muy señor padre Inocencio XIII pidiendo sufragios y mandando se haga en esta Santa Iglesia las más fervorosas rogaciones para que el señor elija para cabeza de la Iglesia sujeto (...) y se decretó que el día 6 y 7 se hicieran honras por su Santidad en la forma acostumbrada cantando la Vigilia con Invitatorio el día seis por la tarde, y el día 7 la Misa al tiempo de la mayor.

[558] ASAC VII, fol. 46 r (11-XII-1724)

Se trató de Constituciones y Loables costumbres y a este punto entró don Diego Ferrer Presidente, que propuso los graves daños que se seguían de las fiestas que los colegiales acostumbraban en las octavas del señor San Dionisio y se determinó, que no se les permita a los colegiales que no se les permita fiesta alguna en que haya de venir gente alguna a hacerla aunque sea de música.

1725

[559] ASAC VII, fol. 67 r (10-XII-1725)

Ítem el Sr. Viana propuso como don Alexandro de Montes, sochantre de este Sacromonte tenía una haza en término de La Zubia, que era propia suya y de sus tres hermanos y que determinaba venderla por precisión que tenía a que entraban gustosos sus hermanos, y se determinó que se comprasen con todas las seguridades de vidas a la seguridad del señor Montes y precediendo la aprobación del abogado del Cabildo, de pasarse a hacer la escritura por el señor Viana que se le dio poder, y hecha que se otorgase por el Cabildo. Y el dinero con que se ha de pagar la haza referida que sea del gasto del que hay en arcas de la Mesa Capitular, y con estas determinaciones se finalizó el cabildo.

1726

[560] ASAC VII, fol. 87 r (11-XII-1726)

Reparó el Sr. Valbuena sobre puntos de Constituciones que el organista andaba en la comunidad con melena y bonete, debiendo andar arreglado a las Constituciones como los demás cortado el pelo y con tafos, y que así mismo se quedaba todas las noches fuera del Sacro Monte como también el Sochantre hacía lo mismo, que esto porque le hacía peso lo proponía el dicho señor al Cabildo para que remediase este inconveniente en la forma a la que el Cabildo le pareciere conveniente. En cuanto al reparo de andar dicho organista con pelo largo se determinó, que lo dijese de parte del cabildo al organista que eligiese 
uno de dos medios precosa mente o que anduviese con sombrero si no se quería quitar/

(fol. 87 v) la melena o que si quería traer en la comunidad bonete, que se había de cortar el pelo y traer tufos, en cuanto al dormir fuera del Sacro Monte el organista y sochantre habiendo representado el Sr. Abad los motivos que había para permitirles lo hiciesen, así se determinó que el sochantre se le dijese que había de dormir algunas noches de entre semana dentro del Sacro Monte y que el organista tuviese más libertad para que pudiese faltar de noche al Sacro Monte.

\section{7}

\section{[561] ASAC VII, fol. 105r (28-VI-1727)}

Ítem el Sr. Abad propuso como dicho Sr. Deán había dado a entender que el Cabildo de la Santa Iglesia en uno que había celebrado había determinado promover la extensión de el rezo del Sr. San Cecilio, patrón de Granada y que había animado a este fin el Ilustrísimo señor Arzobispo, que parece había tenido carta del eminentísimo señor Cardenal Belluga en que refería a su Ilustrísima pretender todas las Iglesias extensión del rezo de sus patrones, y que sería bien lo hiciese la de Granada, y que con este motivo se había ofrecido en dicho cabildo de la Santa Iglesia que se pidiesen a el de este sacro Monte las noticias que hubiere seguras de la vida del Santo para hacer la dicha pretensión y que con efecto se le encargó al dicho sr. Deán (sabiendo que subía a este Sacro Monte para el punto de componer su censo) que solicitase dichas noticias por parte del cabildo como lo había ejecutado y conferido este punto dijo el Sr. Ferrer que tenía [fol. $105 \mathrm{v}$ ] entendido que de este negocio lo promovía el Sr. Linero canónigo de este Sacro Monte y provisor en Murcia como supo de este sacro Monte. Y que fuese bien que las noticias que hubiese se le diesen a este señor para que las remitiese a Roma.

[fol. $106 \mathrm{v}$ ]

Propuso el señor Abad que a Don Joseph de Campo Redondo, canónigo de la Santa Iglesia se le había escrito por el agente del Real Patronato que había conseguido Bulas de su Santidad para la Fundación de una Iglesia Colegial en Mexico extramuros de la Ciudad en la Iglesia de Nuestra Señora de Guadalupe, y que había sido con condición de que había de ser dicha fundación según las Constituciones de este Sacromonte en cuya suposición, y [ilegible] Dicho Agente, que en este Sacromonte se había hecho impresión de ellas el año de 1647, interesaba a dicho canónigo para que solicitase tres trasumptos impresos de dichas Constituciones para remitirlos a México, y oido y entendido lo referido, y que el señor Avilés dijo saberlo sobredicho por haber visto la Carta de dicho Agente, se acordó que se saquen de el Archivo los tres trasumptos impresos; y que se remitan a el señor Campo Redondo. 
[562] ASAC VII, fol. 114r (13-IX-1727)

Se le añadió a Don Mathias de Barragán a su singular cantidad el medio cahíz de trigo que tenía don Blas de Ledesma de último momento de salario

[563] ASAC VII, fol. 115r (21-X-1727)

Propuso el Sr. Abad que era notorio como el ilustrísimo señor Arzobispo de Granada don Francisco Perea y el ilustrísimo Cabildo de su Metropolitana solicitaban en la Corte Romana patrocinados del eminentísimo señor Cardenal Belluga, extensión del rezo del señor San Cecilio y de los Santos Mártires de este Sacro Monte y así mismo que se le concediesen lecciones nuevas en que se refiriese su martirio y prodigios con más extensión de las que tienen, y que para este efecto necesitaban ver en el Proceso de calificación de las Santas Reliquias las más singulares y extraordinarias maravillas que en él se hayan comprobadas en el tiempo de su descubrimiento e invención; para que sacando de ellas testimonio auténtico en debida forma se pueda presentar en la Sagrada Congregación y conforme a él formar las nuevas lecciones que pretenden: y habiendo conferido el punto con la madurez que requiere se determinó que se conceda la pretensión dicha y(fol. 115 v)Don Joseph dignidad abad de Santa Fe y don Alonso de Paula canónigo magistral que en esta sala del Sacro Monte y con asistencia del señor don Diego Antonio Ferrer y don Miguel de la Peña y Avilés canónigo de este Sacro Monte y de mi el infrascripto secretario todos nombrados por este cabildo para abrir el Archivo donde para dicho proceso y manifestarlo, vean en él los milagros y prodigios que les parecieren más convenientes y singulares para el dicho efecto que habiendo hecho elección de los que han de sacar testimonio lo saquen en presencia de los dichos señores comisarios de la Santa Iglesia y de los así nombrados por el cabildo de este Sacro Monte y el infrascripto canónigo secretario sin que ningún acontecimiento pueda sacarse de dicho proceso de la sala capitular de dicho Sacro Monte donde está dicho proceso debajo de cuatro llaves y que cuanto se hubiere de sacar de él y en él ver dentro de dicha sala capitular y no en otra forma obligándose a ejecutarlo así los dichos canónigos de este cabildo y el infrascripto sub pena prestiti iuramenti y de haberse así ejecutado ha de darse testimonio por el infrascripto jurado in verbo sacerdotis el cual testimonio se ha de firmar en este libro capitular y el notario o notarios que sacasen dichos prodigios han de dar testimonio de todo lo referido, cuyo traslado de él ha de quedar referido en dicho proceso y se volverá a encerrar en el archivo con la dicha asistencia.

[564] ASAC VII, fol. 116r (21-X-1727)

En cinco días del mes de noviembre deste presente año de 1727 certifico que viendo como a las tres de esta tarde subieron a este Sacro Monte los señores don Joseph de Franquis y Don Alonso Pantoja uno abad dignidad de la Santa Iglesia metropolitana de Granada y otro magistral de ella y ambos comisarios del Ilustrísimo cabildo de dicha santa iglesia han entrado en la dicha sala capitular y pasado a el cuarto de la Abadía, y propuesto el señor Abad de la pretensión si será venida salieron todos los referidos y con dichos los señores don De la Peña 
y Avilés y don Francisco Catalán canónigo de este Sacro Monte [fol. 116 v] del cabildo de este sacro monte para lo que era referido, el Sr. catalán nombrado por el señor Abad y el Sr. Avilés nombrado por el cabildo y los expresados juntos salieron a la sala capitular donde está el archivo de esta iglesia donde se guarda el proceso de la calificación de las santas reliquias de los ínclitos santos de este Sacromonte y habiendo llegado a él, el dicho Sr. abad de este Sacromonte me entregó a mí cuatro llaves de dicho archivo y en presencia de los referidos señores, conviene saber: el Sr. doctor don Bartolomé Collado abad de esta ilustre Colegial, el Sr. doctor don Miguel de la Peña y Avilés y el Sr. don Francisco Catalán comisarios y canónigos de dicho SacroMonte y los Sres. Franquis Abad de Santa Fe dignidad de la santa Iglesia de Granada y Dr. don Alonso Pantoja, canónigo magistral de ella abrí dicho archivo con las dos primeras llaves y luego dentro de él abrí el interior con otras dos llaves y apareció dentro el libro Proceso de las Santas reliquias, el cual habiéndolo sacado empezó el Sr. Abad de Santa Fe (sentados todos en dicha sala capitular) a leer algunos milagros que constan en dicho proceso y la maravilla de las luces y aras y lo que tocaba a las santas reliquias halladas en la Torre Turpiana y habiendo leído y entendido parte de dichos prodigios y apuntado los más singulares que al parecer presenta querer obrar que al que en presencia de todos los referidos volví a encerrar dicho libro Proceso en el mismo sitio y lugar que estaba según como se halla y echadas las cuatro llaves hasta hoy al Sr. Abad de dicho Sacromonte y no se sacó de él [fol. $117 \mathrm{r}$ ] el dicho proceso traslado o copia alguna de cosa por requerir más y deber proceder acuerdo del Ilustrísimo señor arzobispo y Cabildo de la Santa Iglesia maravilla determinada de que había de sacar y de que lo referido es verdad juro in verbo sacerdotis en virtud de lo mandado por el cabildo de 21 de octubre de 1721 lo firmo aquí como canónigo secretario. Don Luís Francisco de Viana, canónigo secretario.

\section{[565] ASAC VII, fol. 118r (23-XII-1727)}

Dicho señor provisor don Diego de Heredia y el señor canónigo don Luís de Aguilar avisaban 7206 de Madrid que el Sr. Benedicto XIII que Dios guarde muchos años)había exaltado a la púrpura cardenalicia al señor arzobispo de Toledo don Diego de Astorga y que había regocijándose toda la Corte con esta noticia y que su excelencia el señor Cardenal Belluga había escrito la enhorabuena de esta exaltación al señor Damasio como tan interesado en ella, y que siéndolo esta casa por tantos títulos y así que haber su eminencia explicándose siempre como su benefactor por la Fundación del Colegio que hizo y confianza de haber enviado sus familiares al Colegio de este Sacromonte como que haber a tanto al Sr. Dr. Don Cristóbal Damasio, canónigo de esta casa que ha recibido tan singulares donaciones de ricos ornamentos esta Iglesia parecía que debía en ella celebrarse esta exaltación y con efecto conferido el punto se determinó que se celebre en esta forma: que se repiquen las campanas y pongan luminarias y se cante en acción de gracias el Te Deum por el cabildo y colegio esta tarde de día 23 y se le permita al colegio celebre esta exaltación con algunas demostraciones. 
[566] ASAC VII, fol. 151r (10-IX-1728)

Propuso el Sr. Don Pedro Valbuena que la sochantría estaba días hacía vacante y que no se proveía y el que estaba supliendo no tenía habilidad suficiente, y que por estas causas se hacían algunas faltas, y se satisfizo por el Sr. Abad que la causa de no haber llamado por dicha provisión era no se había hecho diligencia de que se declarase por el señor Provisor que libre el cabildo de la obligación que contrajo en virtud del decreto en que perpetuó a don Alexandro de Montes la renta de la Sochantría bastante para que se pudiese ordenar a su título y conferido este punto se determinó que se hagan ante el señor Provisor las diligencias necesarias para que la

que se precise a don Alejandro a que resida su plaza y no lo haciendo se declare el cabildo por libre de la obligación contraída por falta de la residencia que dicho don Alexandro tiene en esta Iglesia respecto de haber admitido la Sochantría de la Real Capilla y estarla sirviendo y que todas las diligencias que en orden a esto se ejecuten sean dirigidas por los abogados de la Comunidad y que hasta que esto esté hecho no se nombre sochantre en propiedad.

1729

[567] ASAC VII, fol. ¿? (21-III-1729)

En cuanto al primer punto se determinó se traiga Música el día que suban sus majestades.

[568] ASAC VII, fol. 220 r (2-VI-1730)

Y el señor presidente propuso que advertía no se había hecho nombramiento de sochanttre de cuantos habían venido a pretender, y que el que estaba interino sirviendo la plaza no era suficiente porque aunque la voz fuese bastante para esta iglesia, no sabía la solfa, que era menester para el gobierno de el coro, por cuya cuasa se originaban en el voz desentonos, que estos días se habían oído tan contra el culto divino y determinó que se trate de proveer dicha plaza de sochantría y de buscar sujeto a propósito y que se guarden en todo y por todo y cumplan las constituciones.

[569] ASAC VII, fol. 223 r (6-VI-1730)

Se trató de la nominación de sochantre que hallábase para esta plaza mucho tiempo ha y no haberse hecho diligencias de proveerla, y conferida la materia y la necesidad que había de hacer cuanto antes esta provisión por no estar servida 
por el interino como se necesita, se determinó que se cite cuanto antes para proveerla en atención haber pretendientes.

[570] ASAC VII, fol. 223 r (4-VII-1730)

Que mandó avisar a un sochantre pretendiente de Málaga ofreciéndole ciento veinte ducados de renta al año y una comida de colegio con el cuartillo de la oración de manual, y la asistencia de la oración por la noche dotación del señor Peña con calidad y condición que preceda examen de su suficiencia.

[fol. $229 \mathrm{v}$ ]

Ítem se determinó que el salario del sacristán mayor fuese de setenta ducados y una comida de colegio habiendo el sujeto que sirva dicha sacristía con la obligación de segundo sochantre y que se viese así y no siendo de estas calidades y con estas obligaciones se quedase con el salario que de presente tiene.

[571] ASAC VII, fol. 229 r (4-VIII-1730)

Propuso el señor abad cómo ya sabían los señores que estaban presentes que el día veintiocho del pasado se habían hecho las oposiciones a la sochantría vacante y que habían subido a ser jueces examinadores don Juán de Rosas sochantre de la catedral y don Josef de María músico tenor de su capilla los que habían dado su parecer en informe sobre la ciencia y calidad de voces de los opositores el cual se contenía en un papel que convendría se leyese para que en su vista se nombrase el sujeto más a propósito para servir dicha plaza y oído y entendido se pasó a votar y por todos votos fue nombrado para dicha sochantría de esta Iglesia don Josef Gómez natural de Málaga y se le señaló el salario siguiente una comida [fol. $230 \mathrm{v}$ ] de colegio en la misma forma que se da a un colegial, y ciento y veinte ducados en maravedíes, y a más del referido salario le permitió que pueda ganar el cuartillo del manual de la oración por las mañanas y la distribución de la media hora de oración por la noche en los jueves y domingos dotación del señor Peña asistiendo a una y otra oración, y con la carga y obligación de residir a todos los puntos de coro que tiene esta iglesía así cantados, como rezados y de servir todos los Aniversarios, Procesiones, Salves y demás que por este cabildo se le mande, sin que por razón de dichos servicios de aniversarios y demás que se le mande y en adelante se pueda ofrecer ayga de percibir cosa alguna más que el espresado salario consignado por cuanto en él se considera la paga de dicho trabajo y servicio. Propuso el seños Abad que ya sabían también los señores presentes la gran necesidad que tenía el coro para estar bien servido de sujeto de voz que ayudase al sochantre y que estando la plaza de sacristán mayor vacante días a y con necesidad de su provisión y hallándose al presente don Josef de Contreras con voz bastante para servir el coro y con salud y robustez para poder servir la plaza de sacristán mayor parecía buena ocasión para lograr que la sacristía y coro estuviesen bien servidos y oída y conferida dicha propuesta hallándose este cabildo citado para el punto de proveer la plaza de sacristán mayor se pasó a votar y por todos votos salió 
nombrado en dicha plaza dicho don Josef Contreras con la carga y obligación precisa de asistir al coro en todos los puntos rezados de él

$[230 \mathrm{r}]$

$\mathrm{Y}$ en todos aquellos cantados que se celebrasen en este Sacromonte con solemnidad de primera clase o bien por ser las festividades de dichos días de primera clase por la Iglesia o por consueta de este Sacromonte o por sus constituciones o por dotación particular de algún fundador de aniversario de suerte que en todos aquellos días clásicos en la forma dicha haya de tener obligación de ayudaren el coro a el sochantre en todos los puntos de dichos días y por razón de la sacristía se le asignaron los mismos cuarenta ducados de salario que ha tenido siempre consignados y una comida de colegio en la misma forma que a un colegial y por razón del oficio de ayuda del sochantre en que asímismo fue nombrado se le señalaron treinta ducados cada año de suerte que el salario que ha de gozar por razón de dichos dos empleos ha de ser de setenta ducados y la dicha comida de colegio se concertó y se convino dicho salario con uno y otro sujeto.

[572] ASAC VII, fol. (6-IX-1730)

Se determinó que el señor rector tenga a los colegiales nuevos las conferencias de ceremonias contra (...) y que a los antiguos y a los que van entrando hágaseles de lección de canto llano por el sochantre en el tiempo que ordena la consueta. Ítem que no se borren de los libros de coro himnos algunos ni cosas algunas de las que están escritas en dichos libros de coro, ni puede escribirse cosa alguna nueva en ellos sin orden expresa del cabildo y que las misas que hay en los dichos libros de que ya no se reza en aquellos días sino es de otros por cuya causa las hojas de tales misas no sirven se queden como están y sólo se puedan borrar aquéllas hojas de dichas misas que fuesen necesarias para escribir en ellas el verbo Sederet Himnos que falta para el oficio de difuntos, y que para escribir oficio de el patrocinio del señor san Josef nuevamente con rédito se pueda ejecutar los mismo y que yo el infrascripto secretario notifique así a don Josef Sanchez y asímismo la gloria de primera clase sepa dónde para y se vuelva a incorporar en el libro de donde se arrancó.

[573] ASAC VII, fol. 240 v (6-X-1730)

Reparó el señor Balbuena que los dos sochantres nuevos hacían algunas faltas notables en la canturía y régimen de el coro, y se mandó que el señor presidente les previniese que antes de entrar en coro separasen lo que hubieren de cantar para que así en la gramática como en el punto no se experimentase las disonancias que hasta aquí.

[fol. $241 \mathrm{r}$ ]

Ítem propuso el señor presidente que el organista había sido avisado por su señoría de que no cumplía con la obligación de tocar el órgano de algunos días a 
esta parte en las noches de los domingos al volver de la procesión de las sagradas cuevas a la iglesia y que había respondido estaba informado no ser de su obligación sino introducción de algunos años a esta parte y que no podía tocar a dicho tiempo que se le seguía notar incómodo y que si el cabildo quería buscase organista que cumpliese con dicha carga entraba gustoso en estarle sirviendo hasta tanto que lo hallase y oído y conferido este punto se determinó que se cite a cabildo para tratar de él por no estar citado este para dicho punto.

\section{1}

[574] ASAC VII, fol. 264 r (27-VI-1731)

Se leyó un memorial del organista don Matias Barragán en que representaban que hacía más de ocho meses que el afinador del órgano no subía a templarlo y que estaban los fuelles rotos y las

$[265 \mathrm{v}]$

A la hora para que cuando se lograse oportunidad y se determinó que así para éste como para los gastos de las exequias y juros se librase a dicho agente lo preciso (cabildo de julio)

[575] ASAC VII, fol. 268 r (10-X-1731)

Se nombró por organero y en la misma plaza y con el mismo salario don J. Feliz al padre Fray Francisco Alexo que es religioso del señor san Francisco en atención a haberse despedido dicho don Juan por sus accidentes y imposibilidad.

[576] ASAC VII, fol. 272 r (8-X-1731)

Se leyó una carta de Panamá escrita por don Juan de Molina en que avisaba haber llegado allí con feliz viaje y que las reliquias de las sagradas cenizas de los mártyres que se le habían dado certificadas por el señor abad estaban ya colocadas en aquella santa iglesia catedral y que el ilustrísimo señor obispo de aquella Diócesis les había señalado rezo el día primero de febrero para su culto y que el rezo del señor san Cecilio concedido ya a todos los dominios

(...) trompetas gastadas y se determinó que respecto de ser dicho organero ministro antiguo se le avise que se ha echado de ver esta gran falta y que estando imposibilitado como está se despida de la asistencia al empleo para que el cabildo nombre a otro.

[577] ASAC VII, fol. v (9-X-1731)

Ítem se leyó un papel de don Josef Sánchez en que refería los aderezos que había hecho en los libros del coro y los cuadernos nuevos que había hecho y himnos y el libro del oficio del señor Santiago y lo poco que se le había satisfecho todo lo referido y el nuevo libro de Glorias y Kyries y Credos que sucedía lo mismo y echa la cuenta y su papel y entendido lo que había trabajado y aunque no había 
pedido cosa era sujeto que se hallaba con bastantes estrecheces y que la buena voluntad de escribir a la comunidad con que lo había hecho era digna de remuneración se determinó que se diesen veinticuatro fanegas de trigo que al presente valen cerca de cincuenta pesos y con esto se le pagase todo la ejecutado y trabajado hasta el día presente en beneficio de la librería.

[578] ASAC VII, fol. 272 v (8-X-1731)

Dominios de $\mathrm{Su}$ Majestad no había llegado todavía aquellos reinos y quedaba haciendo recaudación de dos mil pesos que habían de servir de capital y una memoria de misas que se había de (....) en este santuario siendo de beneplácito de este cabildo para cumplir dicha voluntad de un devoto de aquella ciudad y oído y entendido lo expresado se mandó que se le escriba las gracias.

[579] ASAC VII, fol. v (17-XI-1731)

Se mandaron observar y cumplir ceremonias y especialmente la de no pernoctar en la ciudad sin grave necesidad y la de que el sochantre de lección de canto al colegio a la hora de la campana para vísperas

1732

[580] ASAC VII, fol. 284 r (11-I-1732)

Propuso el señor abad que la en la junta de asistentes se había tratado sobre las faltas en que había incurrido don Josef Contreras que se había resuelto no convenía que se mantuviese en la sacristía así por haber vendido cera que su atesorio para remendar una capa encarnada que parecía que tenía un pequeño agujero por la zona vieja.

[581] ASAC VII, fol. 298 v (26-V-1732)

Tratando de constituciones propuso el señor presidente que en el cabildo celebrado el día seis de octubre del año pasado de mil setecientos treinta trataron de constituciones y su observancia y de ceremonias y loables costumbres para que estaba aquel cabildo citado se había propuesto entre otros puntos que el organista Mathías de Barragán había sido avisado por el señor presidente de que no cumplía con la obligación de tocar el órgano de algunos días a aquella parte en las noches de los domingos al volver la procesión de las sagradas cuevas a la iglesia y que había respondido está informado no ser de su obligación sino de su introducción; y que no podía tocar a dicho tiempo porque se le seguía notable incómodo y que si el cabildo quería buscar organista que cumpliese con dicha carga entraba gustoso en estarles sirviendo hasta tanto que lo hallase y que en vista de esto en el citado cabildo se había resuelto se citase a otro cabildo para determinar lo conveniente que no se había tomado determinación alguna sobre el referido punto de este citado día de seis de octubre de mil setecientos treinta: que el día treinta de diciembre de mil setecientos treinta y uno año en el que el cabildo de oficios con el motivo de haber dicho organista entrado un memorial al 
cabildo representado hallarse con un gran accidente enfermo en su casa pedía se le

[fol 299 r]

Diese alguna ayuda de costa graciosa para su curación y hallase muy alcanzado de medios se había determinado que se le diesen seis fanegas de trigo sin embargo de no habérselo sabido merecer dicho organista con la obediencia de lo que se le había mandado en orden a que tocase en las dichas procesiones, y se acordó que el señor canónigo secretario se lo diese así a entender al padre de dicho organista, y para que en adelante no se le disimulara sin obediencia; todo lo cual propuso dicho presidente había pasado así como era notorio y constaba de los expresados cabildos y lo era tambien que dicho organista había convalecido de su enfermedad y subido a este Sacromonte y no había querido tocar el órgano en las dichas procesiones no obstante todo lo referido, y aun estando algunas noches dentro de casa había llevado adelante su tema, con lo que suplicaba dicho señor presidente a el cabildo que se precisase y mandase al señor secretario a que se le había mandado notificar el decreto del cabildo referido de treinta de diciembre de mil setecientos treinta y uno que dijese su señoría qué es lo que había respondido el dicho organista, pues dicha respuesta no se había dado a el cabildo en tanto tiempo y era razón que se diese; y oída la referida propuesta se mandó que el señor abad que el señor secretario dijere lo que había respondido dicho organista a la

[fol. $299 \mathrm{v}$ ]

Varios medios en orden a lo que sería más conveniente para el buen régimen del coro como el servicio de la sacristía, y se determinó que respecto de que el dicho pretendiente estaba haciendo posta en la ciudad y que se le hacía molestia se le dijese por el señor abad que se restituyese a su casa y patria hasta que se tomase la deliberación por el cabildo de los que en orden a lo dicho le convenía; y se mandó que el señor abad citase para proveer cuanto antes la plaza vacante de la sacristía y que solicitase saber si don Josef Gómez quería entrar en la sacristía y dejar la sochantría y que en este caso se supiese que por el señor abad si el que pretendía la sochantría entró dicho don Josef que parece hayarse en la sochantría en la santa Iglesia primera de esta ciudad de ayudante de sochantre vendrá a servir la plaza de este Sacromonte.

Propuso el señor abad que su señoría la señora presidenta de esta ciudad había enviado un recado con un paje al señor Viana se sirviese pasara a verla y habiéndolo hecho había esta señora dado a este señor un recado cortesano para su señoría el señor abad y para todos los señores capitulares de este cabildo suplicándoles fuesen servidos de admitir a don Mathias de Barragán a la plaza del órgano que había despedido respecto de estar ya llano en tocar en las procesiones los domingos en la noche en lo que se interesaba dicha señora por estar dando lección a dos hijas suyas dicho don Mathias; y oído y entendido el punto se determinó lo que había respondido dicho organista a la referida la notificación y dicho señor secretario dijo que después de haber convalecido 
dicho organista le había hecho saber el decreto del cabildo y que había respondido que el cabildo buscase que le sirviese la plaza con dicha carga que él no podía servirla así: y oído y entendido lo expresado se determinó que en atención a ser despedida la que dicho organista hacía se le admitiese y se diese la tal plaza por vacante y se la notificase por mí el infrascripto canónigo secretario al dicho don Mathias que entregase la llave del órgano, y que desde luego está admitido su despedimiento del servicio de la plaza y el señor abad buscase quien supliese hasta que se provellese.

\section{[582] ASAC VII, fol. 300 r (5-V-1732)}

Propuso el señor abad que sobre el último punto que se trató en el cabildo antecedente el cual se leyó como es constitución no había dado citación según estaba mandado por el cabildo antecedente por cuanto no tenía su señoría seguridad de si el sujeto que pretende la sacristía mayor y ayuda de sochantre tendría la bastante ciencia para el gobierno del coro y que con esta duda había llamado al pretendiente y se había informado de que tenía ciencia del canto de órgano bastante para cantar un papel y ciencia del canto llano suficiente pero que le faltaba la prática del gobierno de coro por cuyo motivo había suspendido su señoría citar sobre este punto hasta hacer al cabildo el referido informe y oído y entendido se confirieron

[Fol. $300 \mathrm{v}]$

Varios medios en orden a lo que sería más conveniente para el buen régimen del coro y servicio de la sacristía y se determinó que respecto de que dicho pretendiente estaba haciendo está en la ciudad y que si le hacía molestia se le dijese por el señor abad que se restituyese su casa patria.

[Fol. $301 \mathrm{r}]$

Se determinó por todos votos que se responda a este empeño de esta señora que obedeciendo al cabildo el dicho Don Mathias y arreglándose a las constituciones de este Sacromonte están estos señores en darle gusto y para darle esta respuesta se nombraron los señores Viana y Cathalán; y se mandó que de las resueltas avisasen dichos señores al señor abad para vista de ellas se cite a cabildo para tratar de dicha admisión y de las calidades y condiciones con que haya de ser.

\section{[583] ASAC VII, fol. 301 r (10-VI-1732)}

Propuso el señor abad que ya sabían los señores capitulares estaba citado para tratar y determinar las condiciones con que se había de admitir a Don Mathias de Barragán al órgano caso de que el cabildo determine su admisión por atención a la súplica que sobre ello tiene interpuesta la señora presidenta de Granada y que para dicho efecto sería conveniente que antes de pasar a los votos confiriesen el punto los señores capitulares y habiendolo conferido por todos votos menos el del señor Barbbuena que no asintió a tal admisión se determinó que se vuelva a admitir al servicio del órgano a don Mathias Barragán con las calidades y 
condiciones siguientes la primera que ha de tocar todas las noches de las procesiones de Nuestra Señora en que no quería tocar, y ha de tocar en todas las misas vísperas y demás ocasiones que se ofrezca y se lo mande el cabildo y por cada vez que lo deje de tocar ha de ser multado en cuatro reales por la tal falta la cual multa queda determinada desde ahora por este cabildo para cuando se ejecute que el que falta de las dichas la segunda que ha de venir a tocar consabido (...) sea decente, y al andar por la casa con hábito clerical que sea decente, y al andar con él por la casa y por cada día que a esto falta ha de ser multado en otros cuatro reales la tercera que ha de comulgar en este Sacromonte de quince en quince días y el día que a esto faltare sin licencia del señor abad y causa justa por ello ha de ser multado a más de la comida de aquél día en cuatro reales por cuando es informado al cabildo que en la santa iglesia catedral de esta ciudad es práctica que los ministros casi todos los meses tengan comuniones generales y faltando a ellas se les multa en cuatro reales y lo que a qué día les corresponde. Siendo las faltas por ausencias por negocios properar prenda a el organista primero en la comida y salario de los tales días y que esta la gane el segundo que supliere y que siendo las faltas por enfermedad por cuya curación sea en este Sacromonte o en Granada de consentimiento de todo el cabildo no pierda el organista primero cosa alguna y en este caso pague la comunidad al segundo que suple otro tanto que paga al primero en cada día de los que fuere el suplimiento y que no siendo así la enfermedad como va expresado pierda el organista primero comida y salario y lo gane el segundo y por cuanto la elección y nombramiento del sujeto para dicha plaza de sustituto que por este cabildo se aumenta y de las demás que ha aumentado se ha pretendido por el señor abad pertenecer a ser digno que en fuerza de la constitución quinta del título nueve de Abate como consta el cabildo celebrado el día diez de octubre de mil setecientos veintiseis cuyo punto se declaró por todo el cabildo digno de consulta al Ilustrísimo señor Arzobispo como consta del celebrado el día once de diciembre de mil setecientos veintiseis lo que no se ha ejecutado para que tenga efecto el tal nombramiento de sustituto dijo el señor abad que sin servir o perjudicar al derecho que tenía por su dignidad a tal nombramiento por sí sólo nombraría la persona que nombrase el cabildo y echa para ambas partes la protesta de que no sirva de (...) salario cuya práctica se hace más propia de esta casa y su instituto y después de bien conferido se determinó por todos votos ser conveniente que el servicio del órgano que haya otra plaza más de las que ha habido de ministro y que esta sea de sustituto de organista o organista segundo de cuyo cargo y obligación sea tocar el órgano en las ausencias y enfermedades del organista primero para que por este medio se obvie lo que hasta aquí ha pasado de enviar dicho organista primero para suplir sus faltas a sujetos que ha sido indecencia hacerles por su oído que toquen el órgano. Y al sujeto dicho sustituto se determinó que se le consigne el salario comida que al primero perteneciere en aquellos días que dejare de tocar y viniere el sustituto al suplir de forma que ha de tener dicho sustituto la obligación de tocar en todas las faltas del primero y no ha de tener más salario que el que perdiere dicho organista primero en los tales días que faltare por cuanto las faltas del organista primero pueden ser en tres maneras unas por ausencias por negocios propios que tenga que hacer otras por enfermedad que tenga dándose en este Sacromonte o en Granada de licencia y consentimiento de todo el cabildo y otras por enfermedad que tenga y se esté 
curando en la ciudad por su voluntad y sin consentimiento de todo el cabildo; para estos tres casos se determinó [Fol. $312 \mathrm{v}$ ] así que viesen sus señoría qué medios se tomaría y conferido el punto se determinó que estando como estaba citado para él y siendo tan difícil la liquidación como lo era se ajustase dicha cuenta repartiendo dicha cantidad (...)

Sirva este acto de por juicio ni que el que se altere el estado en que está el derecho cada una de las partes sobre el referido punto de común consentimiento se nombró por parte a Don Miguel Rabaza para el dicho empleo de sustituto perpetuo del organista primero don Mathias Barragán y se señaló en el salario que queda expresado y se mandó que yo el infrascripto secretario se lo comunique así a dicho don Mathias para que se le hubiere cuenta en la referida cuenta sirva la plaza y si no la deje y para que esté avisado de las multas en que ha incurrir por sus faltas las que se apunten los señores puntadores que los señores canónigos contadores las rebajen del (..) en la libranza.

[584] ASAC VII, fol. 305 v (14-VII-1732)

De constituciones se mandó que a el organista se le notifiquen las condiciones que se le pusieron para volver a admitirle respecto de que por mí el infraescripto secretario no se le han notificado por no haber podido (...)

\section{[Fol 306 r]}

Ítem se determinó que el organista don Mathias Barragán se le notifique las condiciones con que fue admitido y con que pidió la señora Presidenta de Granada su admisión y que se haga cargo el señor presidente de hacerlo saber

\section{[585] ASAC VII, fol. 308 r (24-VII-1732)}

Expuso el señor abad cómo don Mathias Barragán con el motivo de estar accidentado había despediose de servir el órgano de esta iglesia y para que se proveyese esta plaza en que conviniese había dado su señoría citación y declarándose de ver pasar a hacer nombramiento en ella se pasó a votar y por todos votos se nombró o don Miguel Rabaza en la referida plaza de organista de esta iglesia con el salario y obligaciones siguientes primeramente que ha de tocar el órgano en todos los puntos que al cabildo le pareciere sean misas vísperas maitines laudes y declarándose de ver pasar a hacer nombramiento en ella se pasó a votar y por todos votos se nombró a don Miguel Rabaza en la referida plaza de organista desta iglesia con las [siguientes condiciones] primeramente que ha de tocar el órgano en todos los puntos que al cabildo le pareciere sean misas, vísperas, maitines, laudes, horas, procesiones, letanías o cuales quiera otros de los que sean de Consueta de esta comunidad o que no sean sino de aniversarios o fundaciones particulares o bien ya fundadas o que en adelante se fundasen segunda que ha de entrar a tocar el órgano con hábito clerical y no en otra forma. Ítem que ha de residir en este Sacromonte y no ha de poder pernoctar en Granada ni bajar a la ciudad [Fol. 308 v] sin licencia del señor abad o del 
cabildo (...) se ha de arreglar a las santas y loables costumbres de esta casa y en conformidad de esto ha de confesar y comulgar con la frecuencia que se pratica en ella por los demás ministros que no son sacerdotes y cumpliendo estas obligaciones se le consignó de salario la comida con platillo según al organista antecesor todos los días que cumpliere con su obligación y residiere y no en otra forma y se le señala los mismos maravedíes que al antecedente pagados por tercios del año por vía de más salarios y cada mes media fanega de trigo a más de la referida comida y maravedíes y se determinó que se le apunte en un papel al dicho don Miguel las obligaciones de su cargo y el salario que para ello se le consigna y se le exprese que ha de perder a prorata de las faltas que hiciere de la dicha consignación la cantidad que le correspondiere para que firme dicho papel y firmado se guarde para que siempre conste a lo que se obligó.

Ítem se determinó que a don Mathias se den las seis fanegas de trigo que le consignó el cabildo por vía de limosna que estuvo malo y que se prorrateen las doce de su salario que ha gozado de forma que le tocan once hasta fin de julio por fin de agosto la paga de dicho trigo.

\section{[586] ASAC VII, fol.? ¿? v (14-VIII-1732)}

Se mandó se escriba y se firme un papel por el organista nuevo como está decretado en el Cabildo de su nombramiento.

La viuda de Luciena de Oña y Cárdenas, acabadas las dichas cuentas había dispuesto hacer donación de un Niño Jesús de talla, hechura singular del viejo Mora con una urna de talla y adornado el Niño con pulseras de perlas y un collar y una cruz de esmeraldas y otras alhajitas de valor. Cuya donación quería hacer y hacía para que se colocara en la Capilla de Nuestra Señora de las Cuevas de este Sacromonte, otorgándose por este Cabildo intrumneto de que no se sacaría de dicho sitio.

\section{[587] ASAC VII, fol. 318 r (1-IX-1732)}

Item se pasó a nombrar teniente de Sacristán y por todos votos salió nombrado Don Francisco Borja, natural de Málaga con el cargo y obligación de servir el empleo de Sacristán menor y de ayuda de Sochantre, asistiendo al Coro todos los días a los puntos rezados y a todos aquellos que fuesen cantados o bien de aniversarios, procesiones, salves, letanías, o otros a este modo o bien fuesen con solemnidad de primera o segunda clase, o de precepto o de Consueta de este Sacromonte, porque a todos los dichos puntos cantados ya sean de misa, vísperas o maitines ha de asistir al coro a ayudar al Sochantre y se le señaló de salario así de dicha ayuda de sacristán como de sochantre, 44 ducados por año y una comida de colegio y que se le lean estas obligaciones con que es admitido, y yo el infrascripto entere de ellas. 
[588] ASAC VII, fol. 322 v (3-X-1732)

Item propuso el Señor Presidente como don Francisco de Borja, Ayudante de Sacristán y Sochantre nombrado en el cabildo de primero de Septiembre de este año había ido a ver a su Señoría y representarle como el trabajo que tenía de asistir al Coro y Sacristía era grande y no podía con todo y que el trabajo de la Sacristía de abrir cajones, traer alfombras y candeleros era muy fuerte y le lastimaba el pecho, imposibilitándole de cantar en el Coro, que si el cabildo no le moderaba la carga de la Sacriatía dándole cosa fija que pudiera hacer no podía proseguir en la plaza. Habiendo conferido la materia se determinó que mientras don Pedro de Flores sacristán mayor esté presente, solo sea de cargo de dicho don Francisco Borja el doblar los ornamentos y limpiar y componer los cálices porque de esta suerte quede libre para asistir al Coro.

[589] ASAC VII, fol. 325 r (8-X-1732)

Item propuso el señor Presidente, el Padre Fray Francisco Alexo, organero nombrado en el cabildo de 10 de septiembre de 1731 para templar el órgano y afinarlo había hecho muchas faltas y ausencias que había hecho de esta ciudad a la que habiendo vuelto y vistole el organista don Miguel Rabaza para que subiese a templar dicho órgano que está todo destemplado y descompuesto, había subido dicho Padre y había afinado sólo las trompetas dejando lo demás sin templar diciendo era sólo de su obligación lo que había hecho. Que si parecía al cabildo se llamase a dicho padre y se le hiciese cargo de su obligación que era componer todo el órgano y de no ejecutarlo se nombrase otro. Se determinó se ejecutase como lo pensaba su Señoría.

\section{[590] ASAC VII, fol. 333 r (22-XII-1732)}

Ítem se determinó que respecto don Francisco de Borja ayudante de sacristán y sochantre parecía no estar gustoso en su conveniencia en que no cumplía con las cargas señaladas por el cabildo que le notificase las cumpliese según consta del cabildo celebrado el día primero de septiembre en que se le admitió no obstante de habérsela moderado en el celebrado el día tres de octubre y que asimismo de la fianza que ordenan las constituciones y de no escripturar como en este cabildo se ordena se tomara la proveniencia que fuese más conveniente para que deje dicha también de no ejecutare como en este cabildo se ordena se tomara la solución que fuera más conveniente.

\section{3}

[591] ASAC VII, fol. 355 r (13-IV-1733)

Ítem se determine que se libren ciento cincuenta reales del Patronato del señor Olalla de Roxas para vestir a la madre, tía y dos hermanas del organista Rabasa las cuales son pobres de solemnidad por haber quedado con la muerte del padre de dicho organista del todo desvalidas. 
[592] ASAC VIII, fol. (...) v (2-I-1734)

Propuso el señor abad como don Josef el sochantre se había entrado en la Cartuja y que escribía desde ella despidiéndose de la plaza, y oída la carta se dio por vacante la sochantría y se admitió el despedimiento del dicho don Josef. Se trató sobre el sochantre nuevo y se encargó el señor Abad de visitar al padre prior de San Agustín de los Descalzos para ver si el vicario que tienen que es una gran voz lo podían dejar que viniese a casa. Ítem se determinó que supla el vicario de San Antón que está en casa no más que hasta fin de este mes.

[593] ASAC VIII, fol. 35 r (18-III-1734)

Ítem propuso el señor abad que los dos Padres Vicarios de la Casa Grande del señor San Francisco habían subido a cantar en el coro y a pretender que respecto de hallarse vacante la sochantría se les hiciese la gracia de sacar licencia de su reverendo general para que la sirvieran y pasarla por el nuncio para que los sujetase a este cabildo y que ellos partirían la renta y servirían dicha plaza que habiendo conferido el punto y viendo la penuria que se padece de semejantes voces y que los dos de los padres son y han sido singulares y de mucho lleno se determinó que se les diga que se escribirá por el cabildo ha dicho reverendísimo general luego que se vea si hay en ello un especial reparo o dificultad y que con efecto no hallándose se ejecute así.

[594] ASAC VIII, fol. 42 r (10-V-1734)

Leyose el memorial del maestro Moreno en que suplicaba al cabildo fuese servido concederle la gracia de darle el nombramiento de título de colegio y por todos votos se determinó que atento a estar fuera del colegio no estaba apto para ello.

[595] ASAC VIII, fol. 58 v (26-X-1734)

Ítem propuso el señor a abad cómo el padre vicario Fray Juán de Dios hacía días que estaba supliendo la sochantría, y deseaba que se le declarase por el cabildo si había de quedar o no sirviéndola y habiendo conferido el punto se determinó que se quede sirviendo dicha sochantría y que sea con la obligación de asistir a todos los puntos de coro así de Constitución como de Memorias que hay en la Iglesia y en la misma forma que los demás sochantres de ella; y se le señalaron de salario por este empleo ochenta ducados librados por tercios del año, y una comida de señores, y el anual de oración que pueda ganarlo, y los descubrimientos de parte de noche que permitieren las dotaciones de ellos, y dicho decreto se declaró ser hecho bajo la condición de que dicho Padre Vicario tenga licencia de sus superiores y de no tenerla al presente la consiga dentro de tres meses contados desde el día de este decreto, y bajo de la condición de que se mantenga en salud y no contraiga enfermedad que le imposibilite en tal empleo, y que cada que la 
tal suceda ha de retirarse a su convento aunque haya conseguido la licencia arriba dicha.

\section{5}

[596] ASAC VIII, fol. 70 r (3-III-1735)

Ítem se leyó un memorial del sochantre que es el Padre Vicario sobre pedir licencia para salir a decir misa al tiempo de la oración por tener lugar para poder decirla y tomar algún desayuno antes de ir a horas; y en atención a lo largo de este punto y lo que cansa la voz de un sochantre y que tiene necesidad de lo referido se acordó que se le diese la licencia que pedía y que puede salir a la media de oración a decir misa estando en la oración desde que da la hora hasta salir a decirla.

[597] ASAC VIII, fol. 71 v (24-V-1735)

De constituciones ceremonias y loables costumbres no hubo cosa de reparo y dándose se observen guarden y cumplan todos y que el señor rector procurase que el maestro Ríos se arreglare en todo a la vida y costumbres de colegial sin permitirle licencia ni anchura alguna por título de estudiar solfa ni otro motivo alguna.

[598] ASAC VIII, fol. 79 v (30-VII-1735)

Ítem leí otro memorial del Padre Vicario en el que representaba al cabildo la puntualidad y trabajo con que se hacía la sochantría desta Iglesia y que habiendo tenido antes más salario que se había dado a otros suplicaba al cabildo se sirviese darle algún aumento al que tenía señalado: y se determinó que se le aumentasen veinte ducados de forma que goza cien ducados de salario y con las mismas obligaciones y condiciones del cabildo de su admisión al empleo.

1736

[599] ASAC VIII, fol. 128 v (26-IV-1736)

Y se determinó que al sochantre se le de ajuste la cuenta del cuartillo que gana por su asistencia a oración, y se le libre lo que tuviere servido y no se tuvo presente cuando se formó la nómina general de débitos.

[600] ASAC VIII, fol. v (;?-XII-1736)

Item se dió commission por el Cabildo al Señor Abad para que dé una corrección fraterna a Fray Juan de Dios, Vicario del Coro, a fín que deshiciese el comercio con los colegiales, con quienes concurre a tomar tabaco de humo y a 
tener algunas conversaciones que inquietan y perturban la paz de los colegiales trascendiendo muchas veces sus chismes a perturbar la paz de los señores Prebendados, de que es forzoso se sigan muy malos efectos: por cuyo motivo es lo más conveniente que el referido Vicario trátelo de cumplir su ministerio sin censurar las operaciones de los señores capitulares.

[601] ASAC VIII, fol. 168 v (11-I-1737)

Item se leyó un memorial del Señor Canónigo Tesorero en que hacía presente al cabildo la gran necesidad que había de atender al reparo así de la Sacristía y de sus ornamentos particularmente, los ordinarios ya indecentes y hechos pedazos los cálices y patenas necesitando de dorarse y los corporales sin poder servir como también de la Librería del Coro y Manual ordinario de responsos que están todos muy maltratado, pidiendo al Cabildo se le librase alguna cantidad que subvenir respecto de que no hacerlo así sería cada día mayor y casi irremediable el daño. Y habiendo oído dicho memorial se determinó se entregase dicha memoria al Señor Abad para que en la Junta de Administración se tuviese presente para que fuesen librando poco a poco medios para remedio de lo expresado habiendo ofrecido para él y que vía de limosna el señor Catalán.

[602] ASAC VIII, fol. 204 v (27-IX-1738)

Item se resolvió por todos votos excepto el del Señor Vázquez que suspendió el suyo, que al religioso del Carmen del Calzado, que hasta de presente ha estado sirviendo la Sochantría de esta Iglesia, se despida del servicio de dicha Sochantría desde el día de hoy; y que yo el infrascripto después de salir de Vísperas haga saber al dicho religioso este decreto y que se lo notifique y salga de casa luego al punto, permitiéndole de benignidad pueda prestar algún motivo por el que publique le ha convenido irse a quién no puede asistir dicha conveniencia. Item se acordó que la procesión que el Día de San Dionisio se hace para traer su Reliquia desde su Capilla a la Iglesia tenga distribución como las demás procesiones, según la cosa que nuestras Constituciones señalan.

[603] ASAC VIII, fol. 205 v (27-X-1738)

Leí después un memorial del señor Vicario Fray Francisco de Dios en que explicaba al Cabildo volviese a admitir a su empleo queriendo arreglarse y por todos votos se le denegó su petición y en cuanto al modo se expresó el decreto del cabildo antecedente en que se acordó se notifique a dicho religioso que él se despidiese.

[604] ASAC VIII, fol. 206 v (16-XI-1738)

Sobre lo que propuso el señor Cózar de las repetidas faltas en el organista en el cumplimiento de su obligación porque era dicho de que se multase por ser sus 
faltas tocantes al culto diario y que se cumpliese con más severidad, y habiendo el Señor Abad dicho le había castigado con las últimas que le habían notado pareció al cabildo se le agreguen las multas si repetía las faltas y lo mismo con los demás ministros que fuesen flojos en cumplir su obligación.Item propuso el señor Abad varios pretendientes a la plaza de sochantre vacante en esta Iglesia y que el más proporcionado le pareció don Joseph Bravo que por sus costumbres, como por su habilidad para dicho empleo, lo que dicho y entendido se admitió a dicho don Joseph Bravo por todos votos en la dicha plaza de Sochantre con la misma renta y condiciones que los antecesores.

[605] ASAC VIII, fol. 210 r (12-XII-1738)

Item propuso el Señor Abad como don Joseph bravo sochantre Segundo de la Catedral y nombrado de esta Iglesia en el cabido celebrado en 16 de noviembre próximo pasado, avisaba no había podido evacuar las dificultades que había tenido para subir a ejercer la plaza de este Sacromonte en que estaba electo y aunque lo deseaba y lo había deseado siempre mucho, se veía precisado con este sentimiento a despedirla respecto de las mercedes e instancias que en la catedral le hacían y que los beneficios que de su cabildo había reunido le ligaban a no poder hacer otra cosa. En virtud de lo cual y de hallarse nuevamente vacante dicha plaza de sochantre representaba dicho señor Abad y proponía al cabildo si sería conveniente pasar a elegir en ella alguno de los pretendientes. Y por todos votos se determinó se suspenda hasta que experimentados y probados dichos pretendientes en el coro se pueda hacer juicio del mejor.

[606] ASAC VIII, fol. 223 r (1739)

[Fue para tratar de la sochantría que está] vacante en esta Iglesia, y pedía lo admitiese el cabildo a prueba el tiempo que fuese sentido. Y se determinó se reciba a prueba por ocho o quince días; y que el Señor Salzedo y yo el infrascripto tengan a su cargo el llamar de la Santa Iglesia Catedral de esta ciudad a D. Antonio Larzia, sochantre primero de dicha Iglesia y a D. Joseph de Mena, músico, para que le examine de la calidad de su voz y suficiencia, y den por escrito su parecer, para que en su vista resuelva el cabildo lo que tuviere por más conveniente.

[607] ASAC VIII, fol. 224 r (20-II-1739)

Item se pasó a votar la plaza de sochantre vacante en esta isigne Iglesia, y para lo que en el cabildo antecedente se dio comisión al Señor Salzedo y a mí el infrascripto, para que subiesen de Granada personas inteligentes para examinar a D. Diego Diez, que pretendía dicha plaza, y a los demás que quisieren concurrir a dicha posición, por lo que antes de votar dí cuenta al cabildo, cómo antes de hacer examen de la calidad de voz y suficiencia de D. Diego Diez, único pretendiente a dicha plaza vacante, había hecho especial información de su vida y costumbres, atendiendo a lo que en este punto tanto nos encarga nuestro Ilustrísimo Fundador en la Constitución primera del título veintiocho en que se 
trata de Vita, et honestitate personarum Sacri Montis, en cuya conformidad había hecho dirigente examen de sus costumbres, y de todas las personas que le conocen no supe cosa por donde no pueda ser admitido a dicho empleo que pretende; para los que todos hablan bien de la (...) de sus buenas inclinaciones y deseos que tiene de ordenarse por su mucha afición a la Iglesia. En vista del cual informe y en cumplimiento de lo ordenado por el cabildo el día quince del presente habían subido de la Catedral de Granada D. Antonio García sochantre primero de dicha Iglesia y D. Joseph de Mena, músico, los que en el coro, después de varias antífonas y himnos, haciéndole varias preguntas a los que se hallaron presentes varios señores capitulares, y después por escrito el dicho D. Antonio García y D. Joseph de Mena dieron su parecer el que allí tenía firmado de los dos. Y habíendole leído y asegurando ser la voz de dicho pretendiente de buena calidad, no fingida y quedaba esperanza de que en teniendo más edad tendría más voz y que en cuanto a su suficiencia le juzgaban capaz para servir dicho empleo, se procedió a votar. Y por todos votos fue absolutamente nombrado por sochantre de esta Insigne Iglesia D. Diego Díez, natural de esta ciudad y sochantre que era en la colegial de Santa Fe. Y se previno por el cabildo que en atención a lo acordado por las juntas en el modo que ha de aguardarse con los ministros en su ausencias y enfermedades, se determinó se hagan saber dichas determinaciones al referido sochantre y que las firme para que sepa las cargas y obligaciones con que el cabildo le ha recibido. Así mismo atendiendo el cabildo con su acostumbrado celo a la mayor decencia del culto divino, teniendo presente ser este tiempo de Cuaresma el de mayor trabajo en el coro y ser el dicho sochantre nuevamente admitido y no tenía mucha práctica y ejercicio en el coro, para ocurrir a que no se faltase a la debida solemnidad en tan sagrado tiempo, se determinó que el señor Fray Joseph Mínguez, religioso tercero que hasta de presente ha suplido la plaza de sochantre, continúe asistiendo y ayudándole al nuevo sochantre por espacio de dos meses que se ha de contar desde primero de marzo hasta el último de abril de este año, y que en dicho tiempo desde hoy día de la admisión del dicho D. Diego Díez han de asistir los dos al coro partiendo la renta a razón de diez ducados y que a los dos se les de comida de colegio en dichos dos meses y que desde primero de mayo se quedara solo en su plaza el dicho D. Diego Díez tomando enteramente su comida y demás emolumentos que por tal sochantre debe gozar y así mismo su renta enteramente sobre lo que difirió el cabildo para entonces determinar si había de tomar el salario de cien ducados o de ochenta que era lo que comúnmente se daba a la entrada a los sochantres que han servido hasta el presente en dicha Iglesia.

Item propuso el señor Presidente la grande necesidad que había de componer la librería del coro y que de diferirlo más, sería la composición más costosa, por lo que juzgaba era preciso tratar este punto. Sobre lo que se resolvió, que no siendo tiempo oportuno para dicho aderezo, se dejase para el verano y que yo el infrascripto como canónigo tesorero tenga a mi cuidado dicha composición y que en las juntas de señores administradores se podrá entonces pensar el modo que sea más útil a la comunidad y así para costear dicha composición de libros que se difieren pasen de mil reales como para pagar otras deudas que tiene esta comunidad y para parte de los débitos de nóminas que son considerables, se 
determinó que desde el día quince del próximo mes de marzo se trate vender la cantidad de trigo que fuese necesario para pago de dichas deudas y alvio de las referidas urgencias.

[608] ASAC VIII, fol. 235 v (23-IV-1739)

Item sobre la solemnidad con que se ha de celebrar la traslación de los venerables huesos de nuestro Ilustrísimo Fundador al nuevo depósito se resolvió se celebre Misa de Difuntos con la hora de Misa de Tercia, con asistencia de Música, y después halla sermón siguiéndose los responsos y demás ceremonias que corresponde a la solemnidad de vida.

[609] ASAC VIII, fol. 242 r (i?-VII-1739)

[La compañía de soldados de la Alhambra quiere] celebrar en este Sacromonte a nuestro patrón de España Señor Santiago, en el presente pretendía solemnizar los cultos del Santo con sermón y música, lo que proponía a cabildo para que sobre este particular providenciase lo que por más conveniencia tuviese. La cual proposición oída, se tuvo presente lo ocupado del día y más este año por ser sábado en que se celebra solemnemente Misa de Nuestra Señora en este Sacromonte por lo que se resolvió se hable a dicha hermandad no poderse conceder lo que pretende en el todo, concediéndose en que traiga la música o que en caso de querer haiga sermón, que se transfiera la fiesta para un día de la octava que sea más desocupado.

[610] ASAC VIII, fol. 268 v (1-VIII-1740)

Y leí una carta del Rey Nuestro Señor (que Dios guarde) en que daba cuenta a este cabildo de la muerte de la Señora Doña Mariana de Neoburgo, Reina Viuda del Señor Carlos II para que en esta Iglesia le celebrasen los sufragios que en semejantes ocasiones se han acostumbrado. La que oída y conferida sobre el funeral y demostraciones que se debían hacer, se determinó que los días tres y cuatro de este mes se celebrasen exequias con toda solemnidad, con dobles de campanas desde el mediodía, túmulo alto, vigilia aquella tarde y Misa al día siguiente a la hora de la de tercia, celebrándola el Señor Abad y así mismo que dicho día cuatro se celebrasen por el alma de dicha Señora las misas que pudiesen por los sacerdotes de casa y así mismo quedó nombrado por comisario el Señor Viana para responder a la carta de Su Majestad.

1742

[611] ASAC VIII, fol. 296 v (18-I-1742)

Leí un memorial en que el sacristán, el sochantre y el organista de esta Iglesia pedía se les guardase la antigua costumbre de darles para el día de San Cecilio, platos, servilletas y los demás aditamentos de mesa, el que entendido y habiendo 
propuesto el Señor Abad como la costumbre que los referidos alegaba se había quitado por providencia de la Junta de Asistentes. Se resolvió que dichos ministros acudiesen con su súplica a la junta y allí se presentasen si tenían que.

[612] ASAC VIII, fol. 343 v (8-VII-1743)

Item propuso el Señor Presidente como el Señor Pastor le había dado cuenta de las repetidas faltas que en su oficio cometía el organista y especialmente en la procesión de los domingos, por lo que hallándole dicho señor de más antiguo el domingo antecedente a el pasado, le multó en la cena y que no obstante el domingo pasado volvió a cometer la misma falta por lo que parecía incorregibilidad y así lo proponía a el cabildo para el remedio. Lo que entendido se acordó a dicho organista se le multase doble en toda la comida de hoy y se le reprehendiese según pedía el caso y con el infrascripto le notificase de parte del cabildo cómo tenía obligación de tocar a las procesiones de todos los domingos y que si así en esto en lo demás faltaba a su obligación, providenciaría el cabildo medios más eficaces para hacérsela cumplir.

\section{4}

[613] ASAC VIII, fol. v (i?-V-1744)

Item leí un memorial de don Diego Díez sochantre de esta Iglesia, en el que en atención a lo que ha servido y a los vivos deseos que tiene de ascender al primer sacerdocio, a lo que por falta de congrua se haya imposibilitado, suplicaba al cabildo le hiciese la gracia de perpetuarle alguna renta para este fin en aquel mejor modo que tuviese por conveniente.

[614] ASAC VIII, fol. 374 v (31-VII-1744)

Propuso el Señor Abad si se pasaría a hacer la escritura de obligación de congrua según estaba acordado en el cabildo del doce de mayo de este presente año a favor de Don Diego Díez sochantre de nuestra Iglesia. Lo que oído se acordó se efectuase en la forma que se determinó en dicho cabildo y su disposición se cometió a los señores canónigos administradores.

[615] ASAC VIII, fol. 388 r (3-XII-1744)

Propuso el Señor Viana como el maestro Don Gregorio Eugenio de Espínola, colegial que fue en este Sacromonte y beneficiado que es de Nuestra Señora de las Angustias de esta ciudad quería fundar en esta Iglesia algunas memorias para cuya dote había ya entregado a dicho señor alguna cantidad para que las impusiesen en tierras en lo que actualmente estaba entendiendo. Pues que deseaba dicho Don Gregorio que desde este año empezase a correr una de ellas, que es la Prima cantada con la calenda solemne en la víspera de la festividad de la Inmaculada Concepción de Nuestra Señora la que ha de ser en la misma forma 
que se celebra en la vigilia de la Navidad de Nuestro Señor con órgano, repiques y capa pluvial el señor prebendado que cantase la calenda para cuyo dote ofrece setenta reales, los que este año pagaba de su bolsillo, distribuidos en la forma siguiente: sácanse lo primero de dicho dote cuatro reales de una misa rezada que se ha de decir antes o después de dicha Prima y otros cuatro de la capa al señor prebendado que cantase la calenda. Al organista dos reales y tres por mitad al sacristán y campanero y los cincuenta y siete restantes para las distribuciones de los señores asistentes, capellanes, colegio y fábrica; tomando a dos partes el Señor Abad una cada uno de los señores, una el colegio, otra la fábrica y otras los capellanes en la forma que para casos semejantes ordenan las constituciones. Todo lo cual oído y conferido se admitió dicha fundación y por este año se mandó celebrar como queda expresado y se encargó a dicho Señor Viana que de parte del cabildo de las gracias de su atención al referido Don Gregorio de Espínola.

\section{5}

[616] ASAC VIII, fol. 416 r (11-X-1745)

Leí un memorial por el que pedía el sochantre se le concediese salir a la media de oración a decir Misa y que se le hiciese presente para ganar el manual, por el mucho trabajo y no tener tiempo bastante para decir Misa y estar pronto para ir a horas. Lo que oído y entendido se le concedió como lo pedía.

\section{6}

[617] ASAC VIII, fol. 462 r (25-VII-1746)

En él propuso el Señor Abad como Don Miguel Rabaza, organista de esta Iglesia, por urgentes motivos que lo ocupaban en la corte pedía prorrogación de licencia para mantenerse allí, lo que oído se acordó prorrogarle otros tres meses.

[618] ASAC VIII, fol. 469 r (8-VIII-1746)

Item leí una carta de Su Majestad (que Dios guarde) el Señor Don Fernando VI, cuyo tenor es en esta forma: el Rey. Venerable Abad y cabildo de la Iglesia colegial del Sacromonte de Granada. El sábado 9 del corriente fue Dios servido de pasar de esta a mejor vida al Rey Don Felipe V, mi amado padre, y lo que me deja el justo dolor y sentimiento que podéis considerar, de que os he querido avisar para que os halléis con esta funesta noticia, y encargaros como lo hago, ejecutéis en esta Iglesia las honras y funerales que en semejantes ocasiones se hubiesen practicado, como lo fio de vuestro celo en que me dase de vos por servido. De Buen Retiro a veintiséis de Julio de 1976. Yo el Rey: por mandado del Rey nuestro señor, Don Íñigo de Torres y Oliverio.Y oída se acordó por todos votos se hagan las honras que manda su Majestad en la forma prevenida por nuestra consueta para casos semejantes. 
[619] ASAC VIII, fol. 473 r (2-IX-1746)

Se acordó que desde mañana tres del corriente se empiece rogativa y se continúe por nueve días, diciendo después de la Misa de tercia Sub tuum praesidium con el salmo acostumbrado y las oraciones de Nuestra Señora de los Santos Martires y la última Pro Rege, y así mismo que mañana sábado a la hora de la salve se vaya a ella procesionalmente con pluvial y diáconos cantando la letanía de Nuestra Señora y cantada la salve en las cuevas se vuelva cantando el himno Ave Maris Stella y se concluya en la Iglesia con el Conceptio tua.

[620] ASAC VIII, fol. 496 r (20-XII-1746)

Se acordó prorrogar a Don Miguel Ravaza por tiempo preciso de dos meses la licencia para estar ausente de esta Iglesia.

[621] ASAC VIII, fol. 552 v (18-VII-1747)

Propuso el Señor Abad que la campana que cae hacia las cuevas se había cascado por el lado donde la hace el badajo y conferido el punto pareció a dicho señor y a la mayor parte que se mudase la dicha cascada y se pusiese en el sitio donde está la que sirve para el reloj en caso que lo permita el arco donde esta se halla que parece ser más angosto que el que es menester para dicho efecto y que la que sirve de reloj se ponga en el arco que cae en las Santas Cuevas.

\section{TOMO IX}

\section{8}

[622] ASAC IX, fol. 29 r (19-VII-1748)

Item propuso al Señor Presidente si parecía al cabildo concederle al sochantre licencia para que dijese mientras oración porque estaba accidentado y así podría sostener más bien el grave trabajo que tenía en el coro. Y se determinó que diese memorial y se licitase para ello en atención a estar acordado por el cabildo lo contrario.

[623] ASAC IX, fol. 48 r (13-I-1749)

Propuso también en cuanto a ceremonias dicho Señor Baeza que había varias veces usado suspenderse el órgano durante la Misa de tercia.

Que no toquen las campanas mientras tocan el órgano. 
[624] ASAC IX, fol. 50 v (28-I-1749)

Se determine que se permitiese usar de sobrerropa al sochantre en vista de su ninguna robustez para resistir los males y crudos aires que se estaban actualmente experimentando y le eran notoriamente nocivos a su delicada salud y que se concediese el mismo beneficio al sacristán para que pudiera servir y asistir a la Iglesia con decencia.

[625] ASAC IX, fol. 98 v (3-IV-1749)

Después propuso el señor Chinchilla, como Tesorero, que el dicho M. Sánchez había compuesto doce libros de Coro y que quería, aunque menos que el maestro oficial, se le hiciese alguna gratificación, y se determinó que por sí el Señor Chinchilla lo regulase y lo satisfaciese.

[626] ASAC IX, fol. 105 v (4-XI-1749)

Después propuso el señor Abad en atención a la quebracía tan irremediable que había padecido la campana de las Santas Cuevas, que era precisa su composición en fundición nueva, y resuelto por todos votos que se fundiese cuando los presentes ahogos y grandes gastos lo permitiesen. Se dio comisión al señor Chinchilla tesorero, para que por su mano corra estas obras, y también para este caso quedo determinado para maestro de la referida fundición Joseph Lorenzo Colona, maestro de dicha ciudad bajo las precisas que ofrece el cabildo en memorial aquí presentado por cuyo tenor ha de otorgar la escritura que el dicho Corona ofrece.

\section{1}

[627] ASAC IX, fol. ¿? (14-IV-1751)

En el cabildo celebrado el 14 de abril de este año de 1751 se dio comisión a los Señores doctores Cathalan y don Luís Francisco de Viana, sus comisarios para exponer al señor gobernador[eclesiástico] las dudas siguientes:

Duda primera:

Hay en este Sacro Monte situadas no pocas memorias de aniversarios de difuntos, cuyos fundadores ordenaron se celebrasen en dos puntos, uno de Vigilia, y otro de misa cantada y expresaron que el de la vigilia cantada se cumpliese por la tarde después de Vísperas que preceden al día asignado para el día de la misa, y cumpliendo así el Cabildo se sigue al Colegio el perjuicio considerable de que pierden dos medias clases en sus estudios: una el curso de Filosofía la tarde de la Vigilia a causa de su asistencia a ella y tener por parte de tarde las clases de filosofía según la práctica de estas escuelas desde su creación, otra el caso de teólogos en la mañana de la misa cantada, causa también de deber asistir a ella y tener a este tiempo señaladas sus lecciones de Teología según 
dicha práctica, a cuyo perjuicio se añade el que no puedan tener éstos aquellos actos literarios de Sabatina que debían tener y tendrían en conformidad a el praxis de sus estudios, si las vigilias y misas de aniversarios semejantes se celebran en dos puntos como va expresado y no continuados uno a otro en un solo punto después de horas menores, en cuyo cumplimiento de esta forma vendrá a perder uno y otro curso precisamente media clase. Esto supuesto y que las Constitución tercera del título 18 prescribe que no se admita memoria, o fundación o aniversario ni obra pía que no sea arreglada a las Constituciones. De esta causa se duda si podrá el Cabildo cumplir semejantes aniversarios de difuntos celebrándoles la vigilia y la misa en punto al referido tiempo.

Resolución:

A la primera mandó su señoría que todas las memorias y aniversarios que proponen se celebren en un punto continuado de vigilia y misa para que de este modo no se cause tanto perjuicio a los colegiales en la asistencia a sus estudios y cátedras y la Fábrica tenga beneficio de ello, y por cuanto de ello no resulta reparo sustancial a las ánimas de los fundadores. (Don Juan Antonio de los Fueros, colegial en el mayor y viejo de San Bartolomé en la Universidad de Salamanca, canónigo doctoral de la santa Apostólica Metropolitana Iglesia de Granada, chanciller mayor de su Imperial Universidad, gobernador, provisor y vicario general de este arzobispado por el Ilustrísimo señor den Felipe de los Fueros, mi señor arzobispo de Granada al Consejo de su Majestad)

\section{[628] ASAC IX, fol. 139 r (-XI-1751)}

En cuanto a ceremonias y loables costumbres de licencia del señor Abad propuse yo, el infrascripto secreatrio, como había notado que con el motivo de estar recien entrado el curso y no haberse podido instruir todavía en als ceremonias de coro los modernos había algunas faltas indispensables en las Calendas y frases que lo proponía al cabildo que si se podía poner algún remedio, lo que oido y entendido se determinó por todos votos que se instruyan los modernos para poderlo hacer sin nota ni desquite de la reverencia que se debe al culto divino lo hiciese el colegial antiguo por el moderno, y en aquellos actos que no asisten los antiguos por estar ocupados en sus clases, que se determine por el admonitor moderno de los más instruidos para que supla el defecto del que le toca hacerlo por su oficio.

\section{[629] ASAC IX, fol. 158 r (3-VII-1752)}

Teniendo presente la propuesta que hizo el señor Presidente en razón del estado en que se hallaba el órgano, y la librería del coro a causa de entonar los colegiales y conducir los libros y atirándolos por las escaleras del trascoro y aún de este la barandilla cuando éste está en la Iglesia, y así mismo la flata de hojas y desencuaderno de ellos, cuando los vuelven a la librería y dejan caer de golpe en el suelo se confirió si convendría relevar a los colegiales del trabajo material de 
entonar y conducir al coro los libros, alfombras y banquillos y para este trabajo material destinar a los dos mozos del colegio y al que se hace preciso aumentar juntamente con el caniculario quedando precisamente a cargo de los colegiales entonario y versiculario el cuidado de que los tales criados concurran a entonar y conducir lo referido. Y por todos los votos se determinó ser conveniente se le relevase de dicha materialidad, y que esta fuese de cargo y obligación de los mozos de colegio, y de dicho caniculario, y que por ese especial trabajo se asignase alguna cantidad de los aniversarios que tocan al Colegio, sobre todo lo cual para su formalización se dio comisión a los señores asistentes con la precisa obligación de traer al Cabildo el modo y forma que han dado para la práctica y observancia de este acuerdo [158v] para que en su vista aprueben por el cabildo y se den al señor rector las providencias que convengan para su observación. La relevación del trabajo material que servían los colegiales en los oficios de entonario y versicularios, entonando y porteando los libros de la librería al coro, y se aprobó como en él se contiene confirmado el cabildo la determinación de que los entonarios y versicularios queden relevados únicamente del trabajo material de entonar y portear los libros, banquillos y alfombras del coro y de ninguna manera les quiten de las demás obligaciones de sus respectivos oficios y sin con la nueva de que se les imponen de que cuiden que las personas destinadas para estos trabajos los cumplan con puntualidad y den aviso de sus faltas al rector para que las castigue. Y se confirió asimismo la providencia [160r] de que se aumente un criado para el servicio del colegio por el crecido número de sus individuos. El dicho trabajo de entonar y portear los libros y banquillos sea de cargo de los tres mozos de colegio teniendo por semana en su forma que la tiene ajustada la Junta con la asignación de un ducado más a cada uno que deberá pagar el señor Rector del producto de los aniversarios que toca al colegio. Item se determinó en la Junta y se aprobó por el cabildo se notifique al caniculario barra y limpie dos días cada semana y que se lo notifique y conmine para que lo cumpla.

\section{4}

[630] ASAC IX, fol. 241 v (4-II-1754)

Item se concedió licencia al Sochantre don Diego Díez para que salga a decir misa a la media hora de oración todos los días en atención a su quiebra de salud.

[631] ASAC IX, fol. 347 v (9-III-1754)

Después presenté un memorial del maestro don Diego Díez nuestro sochantre en que hacía presente al cabildo los quince años que contaba ya en tan trabajado empleo, y el estado tan notorio de su salud, y pedía se le diese por el cabildo algún alivio y ayuda.

[632] ASAC IX, fol. 279 r (13-III-1754)

Sobre las cuentas del órgano nuevo. El órgano que se ajustará en 600 ducados aunque el maestro pide 700, y que comenzará por el verano próximo. 
[633] ASAC IX, fol. ¿? (10-XII-1756)

Después leí un memorial a nombre de don Diego Díez subchantre en que suplica que en atención a los años de servicio y estrecheces de su familia se dignase el cabildo consignarle en los nuevos aniversarios que después de su admisión se han fundado y sirven alguna cuota que tuviesen por coveniente y entendido se le concedió una parte proporcional a la consignada en otros aniversarios a los sochantres sus antecesores.

[634] ASAC IX, fol. ¿? (11-I-1757)

Después propuso el señor Aragón como obrero que sobre el deseo que había entendido de los mas señores de que se igualase con la debida armonía la tribuna del órgano, colocando enfrente el balcón antiguo de dicha tribuna, tenía el grande reparo de falta de caudales para una repisa tan firme como necesitaba tan pesada porción de hierro, la dificultad de (...) y los costados de dicho balcón para que volase suficientemente la capacidad y contener varios músicos el día de Nuestro Patrón y Titular señor San Cecilio u otro que ocurriera de semajante solemnidad, destino que se consideraba de dicha obra: se añadía el cuelgo con que cargaría la pared. Y que por el contrario: dicho balcón se vendiese con reputación proporcionada a su grande costo y se podría muy bien costear la obra poniendo en lugar del mencionado balcón de hierro otro de madera con imitación e igualdad al de la tribuna del órgano, y aún fuera sobrar dinero para alivio de las muchas y continuas urgencias de la Sacristía. Y entendida dicha propuesta y conferida con la debida madurez, se acordó se venda por dicho señor Aragón y señor Sánchez Tesorero el referido balcón de hierro y se haga con su producto repisa y baranda igual de la del órgano con la circunstancia que por bajo de lamesa alta se eche una caña. 


\section{TOMO X}

[635] ASAC X, fol. ¿? (30-XII-1757)

Después se leyó un memorial de don Diego Díez sochantre de nuestra Iglesia en que pide una ayuda en costas por su pobreza, lo que oido y entendido se deteminó que informen los señores contadores sobre que más se podía librar a dicha ayuda de costa.

1758

[636] ASAC X, fol. ¿? (9-II-1758)

Y asimismo se le mandase al Sochantre que no dijese misa en las capillas mientras oración si no en la Iglesia pena de 4 reales de multa por la vez que lo hiciere.

[637] ASAC X, fol. 75 r (5-XII-1758)

Después se vió un memorial de don Diego Díez sochantre de este Sacro Monte pretendiendo una libranza.

[638] ASAC X, fol. ¿? (4-III-1759)

Y yo el infrascripto secretario Propuse con el señor Abad como el señor don Luís de Viana le tenía comunicado como quería fundar una memoria en el día del señor San Mesitón, quince de marzo, por la singular devoción que tenía a este mártir, y en cuyo día celebramos también el descubrimiento de las reliquias de los demás santos nuestros mártires, y asimismo dotar su adoración en este día cuya fundación la tenía dicho señor ideada en esta forma, y suplicaba al cabildo concediese con su devoción admitiendo esta carta-memoria en su agradecimiento por lo mucho que debe a dicho santo. En primer lugar cinco misas rezadas, limosna a quince reales de los que se ha de llevar cuatro entre los señores canónigo, comenzando por el señor abad y siguiendo después desde a donde quedase el turno en el año antecedente. Esta es su voluntad que se ha de decir en el mismo día a excepción del señor Abad, que puede tener en él la solemne de tercia, se le guarda para el siguiente. Asimismo a cada señor de los que asistan a la adoración de las santas Reliquias se le dan cinco reales a distribución y doble al señir Abad, dos reales a cada capellán y (...) al maestro Vélez y al maestro Montero. Dos reales al sochantre, dos al sacristán, dos al pertiguero, cuatro al organista y uno al caniculario. Asimismo no quiere que haya ausencias. De todo lo que prometió dicho señor hacer instrumento perpetuo 
por el que constase ser esta su voluntad, de lo que entendido el cabildo admitió dicha memoria y dotación.

[639] ASAC X, fol. 81 r (4-V-1759)

Acerca de ceremonias notó el señor abad la omisión que advertía en la asistencia de los colegiales a el coro.

Leí después un memorial de Don Diego Díez Sochantre de nuestra Iglesia en que hace presente al Cabildo lo gastado en su salud, habiéndose habido su (...) y con la concretud notoria que van ya para 21 años; por lo que le parecía (...) tanto de la caridad como del honor al cabildo discurrir con (...) un ayudante así para que el culto divino estuviese más bien servido, como para que él fatigado tuviese algún desahogo. En el mismo hecho de consecuencia este punto se tocó estar mal servida la Sacristía (bajo cuyo título de Sacristán de menor (...) está ordenado el dicho Don Diego) a causa de lo mucho que hay que hacer en ella, y don Pedro de Flores, después de haber sido siempre no del mayor primor para el empleo de Sacristán, hoy ya con los años y las enfermedades estaba más torpe, pidiendo de un día a otro nuestro mismo interés otro sustituto de Sacristán mayor. Teniendo presente el Cabildo estas cosas, y disueltas algunas dificultades sobre los fondos para aumentar en ministros, se acordó uniformemente, que el dicho don Diego se haga cargo de buscar sujeto proporcionado para el empleo de Sochantre, a quién se le darán 50 ducados y una comida de colegio; y al mismo tiempo el mencionado Diego Díez tome de su cargo el gobierno de la Sacristía igualmente con don Pedro de Flores sin inmutarse ni a uno ni a otro nada en su renta, y si la que se destina a el nuevo cantor sea parte de la limosna de las misas últimas (que bajados los dos reales que se pueden descontar por la intención del celebrante) ceden los señores graciosamente para este efecto y lo que faltase se supla o de la mesa capitular si tiene con qué, o de los patronatos que hay para pobres en atención a los que últimamente disfrutan este beneficio parece son tan acreedores como los que más a el santo fin de sus fundadores; quedando asimismo a cargo del sochantre antiguo ir enseñando al nuevo en cuyo alivio se trae, y además esperando el cabildo no se niegue a concurrir a la mayor solemnidad de los días clásicos y puntos extraordinarios, los que para entonces los deja a su libertad y singular celo del culto divino.

[640] ASAC X, fol. ¿? v (6-VIII-1759)

Propuso el Señor Abad como ya constaba a los señores la orden dada por el mismo cabildo en el celebrado el 4 de Mayo a don Diego Díez para que buscase si había quien viniera de ayuda de Sochantre sobre 50 ducados y una comida de colegio; en vista de cuya diligencia se había presentado don Pedro Herrero, Sochantre de Baeza, y cuya habilidad y voz habían oido ya los Señores en los dos días que había cantado, que lo proponía al Cabildo para que si se había de admitir y que despidiese su conveniencia, o si no que se volviere a ella. Y habiéndoles parecido muy bien a todos se admitió por todos votos y se dio orden a la Junta para que arbitre el modo del dicho salario, y con estas determinaciones se disolvió dicho cabildo. 
[641] ASAC X, fol. ¿? (19-IX-1759)

Sobre loables costumbres propuso el señor Sánchez el notable exceso que había así por parte de cualquier electo canónigo en los gastos que hacía con el cabildo y sus individuos en la posesión de su prebenda y con el colegio, y que era más el desperdicio y desorden en notable detrimento del electo de lo que resultaba en obsequio de cada uno. Conferida dicha propuesta y conferidas sus razones se acordó de ahora en adelante que ningún canónigo en obsequio y posesión de canonicato pueda ni dé refresco ni hacer otros gastos con los colegiales (...) se mandó también que el colegio no hiciese más demostración con el canónigo electo habiendo sido colegial que tocar la campana y lo más la caxa y clarín y media docena de cohetes.

Que en la octava de San Dionisio ni en otros días no puedan hacer comedias, ni entremeses si no es que tengan sus quietes, estudio y demás actos de comunidad como en los días regulares.

[642] ASAC X, fol. ¿? (5-II-1760)

Después por el señor Abad se propuso que constaba al cabildo la donación que se hizo a esta iglesia la donación del cuerpo del señor don Máximo por el señor don Pedro Afán de Ribera, canónigo de la Santa Católica y Apostólica Metropolitana Iglesia de la Ciudad de Granada con los autos y testimonios de su identidad declarados por el señor juez de ordinario a fin de que todo ello se colocase al arbitrio de este cabildo y que asimismo se había hecho donación a esta Iglesia al mismo efecto de las reliquias de San Desiderio y Santa Liberata con sus respectivos instrumentos de identidad declarados por dicho señor, y que también se había hecho dicha donación por doña Clara de Palomar, un reliquia de una de las muchas vírgenes que parece llamarse Revocata, que todas dichas reliquias se habían recibido por este cabildo con toda solemnidad repique de campanas y entonando el Te Deum laudamus se les había dado pública adoración y se les había mandado depositar en la Sacristía de esta Iglesia interim el cabildo pudiera ponerlas en relicarios decentes como todo ello resultaba de los cabildos celebrados en los días 1 y 15 de mayo del año pasado de 1752, y que en atención a ese menester colocarlas en sitio decente para pública adoración, en que el señor don Luís Pérez capellán de las Santas Cuevas ofrecía a hacerles sus vanos. Oida la propuesta se acordó que el cuerpo del señor Máximo se colocase en un vano de la Capilla de Nuestra Señora del Rosario, y que las reliquias restantes se colocasen en el altar en la capilla de los Dolores que había construido el referido don Luis Pérez en urnas separadas.

[643] ASAC X, fol. 99 v (15-IV-1760) 
Fue para tratar de decir la misa de cuerpo presente de don Diego Díez sochantre de este Sacromonte y también sobre su Vigilia y entierro. En cuanto a la misa dijo el señor Abad que aunque era día de primera clase se podía decir por estar la costumbre de la rúbrica en contrario, lo mismo dijo al de la vigilia y entierro, pero que para dar lugar a todo que se anticipase el reloj una hora y que primero se hiciere el oficio del día, a lo que se avinieron los demás.

[644] ASAC X, fol. 101 v (17-IV-1760)

Que a la familia del Sochantre difunto se le libren cien reales de limosna por una vez.

[645] ASAC X, fol. $101 \mathrm{v}(28-I V-1760)$

Fue para oir la censura de los jueces del concurso de opositores a la Sochantría, y proveer esta plaza en quien se juzgase más apto. (...) leidos los pareceres de los examinadores antes de recibir los votos de los señores capitulares leí un memorial de don Joseph de Cárdenas, opositor desistiendo de la oposición y del derecho que mediante ella podía tener adquirido a dicha por decir no le tenía cuenta entrar en ella. Pasóse después a votar por votos públicos y habiendo dado todos sus votos al padre Fray Joseph Díez, religioso mercedario hasta que llegó al señor Yparraguirre quién me había preguntado si el dicho padre don Joseph había presentado la licencia de su padre provincial para poder faltar de su convento y asistir a este Sacromonte, a lo que habiendo respondido que su merced no me había entregado licencia alguna aunque había oído decir que se la había prometido, sobre cuya respuesta fundó dicho señor su voto y es como se sigue: es fuerte cosa que el cabildo le dé un salario tan decente a dicho padre y que no le pueda hacer que asista, a lo menos en algunos días a nuestro coro, pues siempre que su superiores le mandasen lo necesitaban en su convento, le era preciso obedecerles. Fundolo también en las razones que en el Cabildo antecedente el señor Abad propuso, e hicieron fuerza a dicho Señor $y$ actualmente dice que le hacían para no votar a dicho Padre, y que estando propuesto por los dos Sochantres examinadores, que eligió el cabildo en primer lugar, don Joseph Velasco, sochantre segundo de la Capilla Real así por su voz y destreza en el Canto Llano como por sus prendas y virtudes que el uno de los dichos examinadores expresaba, le era preciso en conciencia votar por el Sochantre en este Sacromonte a dicho don Joseph Velasco, fuera de que el ayudante de Sochantre, don Diego Díez que Dios haya, don Pedro y este estaba entendido en que por este cabildo estaba avisado para que despidiese en Baeza, y le parecía no era aire del Cabildo despedirlo.

\section{[646] ASAC X, fol. 102 v (16-V-1760)}

Sobre el punto de ceremoias se trató como siempre lo atrasado que estaban los colegiales en las ceremonias de la Iglesia, como asimismo el abandono y maltrato de la librería en poder de mozos, las más veces abierta y siempre al riesgo de ser estropeada por la codicia de las vitelas y láminas de muchos de sus 
oficios, sobre cuyos asuntos se resolvió que el maestro Martín Martínez Saavedra les imponga a presencia del señor Rector en la Capilla y saque para ello de la Consueta lo que juzgare conveniente y en orden a la Librería que se nombre un colegial Bibliotecario al que se le librase de oficios por este empleo, y tenga el cargo de abrir y cerrar la librería, instruir a los versicularios en lo que toca al día y en dónde está cada cosa.

[647] ASAC X, fol. ¿ ? (4-IX-1760)

Y que [los colegiales] no hagan gastos en la Octava de la Concepción, más que poner seis velas en el altar para las lecciones que el gasto que hacen los ursulistas cuando acaban sus mesas no exceda de una caxa y clarín.

\section{1}

[648] ASAC X, fol. 128 v (6-V-1761)

Se presentó otro memorial de don Pedro Herrero, segundo sochantre de nuestra Iglesia en el que pedía al Cabildo licencia (después de haberse ido sin ella) para ir por un mes a Madrid, lo que sabido y entendido por el cabildo como también la desobediencia que tuvo al señor presidente, quien con muy justa causa le había negado la licencia de ir, acordó no tener lugar su súplica y que desde ese día se dé por despedido para que solicite buscar otra conveniencia que no tenga la carga de la obediencia. Al margen: despídese a don Pedro Herrero segundo cantor.

[649] ASAC X, fol. 131 r (1-VI-1761)

Se previno que el señor lector cuidara la tabla de los libros del coro y que el Sochantre vaya a la campana a registrar los libros sin aguardar a más tarde.

[650] ASAC X, fol. 135 r (16-VI-1761)

Propuso el señor Abad era notorio como habían venido ya las bulas de la Santidad de nuestro Beatísimo Padre Clemente XIII concediendo la gracia impetrada por nuestro católico monarca don Carlos III (que Dios guarde) en nombre de todo el Reino de España que junto en Cortes le había suplicado a su Majestad uniformemente la solicitase de la Santa Sede, comprehensiva de la aprobación Apostóica del Copatronato de la Concepción Inmaculada de la Madre de Dios de todo el español dominio, sin perjuicio ni diminución del ínclito apóstol Santiago su antiguo y venerado Patrón y predicador evangélico y que la Iglesia Metropolitana había solemnizado la novedad de gracia tan favorable para Granada, singularmente entre todas las ciudades [135v] del reino con sus repiques de campanas, y las memorias, y lo mismo el Ayuntamiento de la ciudad y religiones y todo el pueblo, y que teniendo esta Iglesia más obligación, que otra alguna de España, expresar su alborozo y alegría por tan singular favor de la Santa Sede, es de sentir que se esmerare y distinguiese en su celebración a medida de su posibilidad y religiosidad de su instituto, y que le 
parecía que bastaría por ahora para cumplir con el público, que tres noches se solemnizase la noticia comunicada por nuestro monarca con tres repiques de todas las campanas y luminarias y el jueves antes de misa de tercia se cantase el Te Deum con procesión a las Santas Grutas; y mañana miércoles con que se celebra al señor San Indalecio, primicias de la fe que confió Santiago a nuestro Reino se cantase una misa solemne en el altar de nuestra Señora de la Concepción Inmaculada sito en las Sagradas Cavernas de este nuestro Santo Monte, donde se halló el documento antiquísimo de su inmunidad, que venera nuestra privada piadosa creencia, como executoria de este mariano privilegio, con esperanza resignada siempre al infalible oráculo del Vaticano, de que nos la declarara y decretara por tal para toda la Iglesia, esgrimiendo el (...) Por cuya declaración tanto va suspirado y suspira el orbe católico: y oída la propuesta referida se resolvió uniformemente, que se ejecutase así y se le diesen al público estas señas de/ especial parte que tenía nuestra Iglesia en el alborozo de gracia semejante.

\section{[651] ASAC X, fol. 141 r (6-VII-1761)}

Item se pidio por mí el infrascripto que el cabildo nombrase señores comisarios que recogieran los privilegios de las Insignes Iglesias colegiales de este continente para que se cumpla la Constitución del título De los Privilegios, lo que parece difícil más no obstante nombró el cabildo a los señores Aragón y al señor Moreno por comisarios y lo aceptaron gustosos tomando a su cargo el trabajo de informar e inteligenciarse por las historias en el todo de las dichas insignes iglesias colegiales iglesias anteriores a la nuestra para pedir sus privilegios.

\section{[652] ASAC X, fol. 143 r (4-IX-1761)}

Sobre ceremonias y loables costumbres propuso el señor Vázquez que en atención a que estando en coro se padecían de equivocaciones con las campanillas cuando se tocaban para misas particulares pedía que el cabildo determinara lo que tuviera por conveniente para obviar lo que notaba y así el cabildo determinó que mientras haya misa en el altar mayor, bien sea de oración de prima, de tercia o de aniversario que no se toquen estas campanillas fuera de las que vienen en las referidas misas: ni aún mientras se da la sagrada comunión y para que tenga efecto la dicha resolución que el Sacristán tenga especial cuidado de recogerlas y guardarlas en los referidos tiempos y que todo se guarde en las ceremonias y loables costumbres.

\section{2}

[653] ASAC X, fol. 176 r (8-I-1762)

Es para tratar del funeral y entierro de don Sebastián Muñoz y Ortega, canónigo de este Sacromonte, a quien Dios nuestro Señor asó a llevarse a las nueve de la 
noche, poco antes de celebrarse este cabildo en el que se determinó que a la mañana del siguiente día se cantasen un Invitatorio y los dos primeros nocturnos, y a la tarde el tercero y laudes de Difuntos.

[654] ASAC X, fol. 179 r (1-II-1762)

Acordase el cabildo el modo y hora del oficio y sepultura de dicho señor Abad (Luis de Viana) y conferido se determinó por pluralidad que después de Vísperas del día siguiente se le tuviese el sepelio con la pompa y solemnidad acostumbrada y el día 3 concluidas las vísperas y adoración de las Sagradas Reliquias se cantasen los tres nocturnos y el día 4 jueves los Laudes y Misa por el señor Presidente a quien toca y pertenece hacer el oficio.

[655] ASAC X, fol. 185 v ( $?$ ?-II-1762)

Propuse la pretensión hecha por Fray Joseph Díez ayudante de sochantre de nuestra Iglesia sobre que había avisado a los señores solicitando que a su hermano don Francisco de Paula que le ayudaba por su quebrantada salud se le consignase alguna ayuda de costa o ración diaria, así que me parecía causa piadosa, es constante y se va impidiendo día a día y que su hermano no es suficiente para servir solo el cargo de subcantor con que se hacía más notable durante la necesidad o falta de ministro, con las que se advertían en el coro algunos días, y que siendo acreedor dicho religioso de la conmiseración del cabildo por su buena vida ambles prendas y méritos de su hermano don Diego antecesor en su empleo de más de 20 años, no pareciéndome equitativo grabar la mesa capitular con nuevos salarios, o pensiones y si de la más consideración el atender a la mayor decencia del divino culto, el proveer de nuevo Sochantre, clérigo o religioso, podría mantenerse dicha señor Joseph para que le acompañase o ayudase consignándole alguna comida y al arbitrio de que celebre las misas última queriendo ceder los señores de este su derecho o advirtiendo el más ap medio que le dictase su caridad y prudencia; sobre cuya propuesta se acordó se trate en adelante con actación a todos los señores.

\section{[656] ASAC X, fol. 189 r (28-III-1762)}

Acerca de lo tratado sobre la subchantría en el cabildo antecedente, aunque en este se confirió largamente el punto se resolvió solamente que se admita o busque uno que pueda servir completamente pero se difirió a otro cabildo el determinar sobre otras circunstancias del asunto.

[657] ASAC X, fol. i? (15-IV-1762)

Item para resolver sobre lo propuesto en los cabildos celebrados en 8 y 28 de marzo próximo pasado, acerca de la necesidad de subcantor de nuestro coro por haber solicitado Fray Joseph Díez que lo es que a su hermano Don Francisco de Paula que le ayuda por estar algo enfermo y cansado se le concediese algún salario o ración; y habiéndose en dichos dos cabildos diferidose tratar de este punto hasta en este, y conferidose en él largamente el punto citado, no dando la 
constitución facultad para nombrar segundo subcantor ni para gravar la Mesa Capitular y atendiendo el cabildo así a la obligación de dicho religioso que debe por sí sólo asistir y cantar en todos los puntos de coro, como a su quebrantada salud, virtud y buenas prendas; determinó, que aunque se ve la necesidad de nuevo Sochantre y que pudiera despedirlo y buscarse otro, usando de la acostumbrada conmiseración, se mantenga dicho Fray Joseph en su empleo con tal que su hermano le ayude y supla lo que él no pudiese, sin que ahora ni en adelante pida salarios ni ayuda de costa por el trabajo que en ello tenga por tener dicho religioso la total obligación y servirle a el su hermano don Francisco y no a la Comunidad, dándole o concediéndole el cabildo el tiempo de un año para prueba de si puede continuar en estos términos, y para que en él instruya y ejercite a su hermano.

\section{[658] ASAC X, fol. 194 r (27-VII-1762)}

Después hizo presente el señor Abad, que en atención al decreto y mandato de su Santidad que se reze un nuevo oficio de Nuestra Señora de la Concepción en su día, se hacía preciso escribir un libro para nuestro Coro, sobre que tenía hablado con algunas (...) en su costa. Lo que entendido por el cabildo se le dio de sus señorías comisión para que a su arbitrio lo mande hacer.

[659] ASAC X, fol. 195 r (3-VIII-1762)

Además se notó la aceleración introducida en los oficios divinos y se mandó se le advierta al Padre Vicario de coro de su obligación.

[660] ASAC X, fol. 200 v (8-IX-1762)

Sobre ceremonias propuso el señor Presidente que siendo de Consueta que después del versículo en las vigilias o nocturnos de difuntos se diga en alta voz Pater Noster le parecía se observase así, como que la secuencia en las misas de réquiem que se celebran semidobles, o que no fuesen solemnes se omitiese como se previene en dicha Consueta, o fuese ad limitum de cantarla o omitirla. Y en ambos reparos convino la mayor parte del cabildo y acordó se diga por el celebrante Pater Noster en voz alta y sea la secuencia ad limitum del señor Abad o Presidente del Coro.

[661] ASAC X, fol. ¿? (1-XII-1762)

Sobre ceremonias propuso el señor Presidente era de Consueta que los señores Presidente y Caperos al cantar los himnos estuviesen con las manos juntas y lo mismo todos los señores y Capellanes en todos los himnos así cantados como rezados (...) y pareció a su señoría conveniente se observó a lo que asintió el cabildo y mandó así se cumpla en adelante.

[662] ASAC X, fol. 206 v (4-II-1763) 
Sobre Constituciones propuso el señor Presidente la obligación a que nos estrecha de el culto divino y su mayor decencia de la armonia y canto del coro en que se notaban frecuentes faltas por la falta de oido del señor Padre Vicario, que aún con la ayuda de su hermano no basta a lo que nuestro coro necesita y que cumplido ya un año que se le dio de término para su cumplimiento y enseñanza y prueba de su hermano no parecía competente nos mantuviésemos así, y que en ello resolviese le cabildo: que convino se cite para otro en que se decida sobre este particular.

\section{[663] ASAC X, fol. 207 v (11-II-1763)}

Fue para resolver el punto que quedó pendiente en el Cabildo antecedente sobre la necesidad de nuevo subchantre. Sobre el primer punto se confirió y visto que Fray Joseph Díez por su corta salud y falta de oído aún con la ayuda de su hermano no podía subsistir por mucho tiempo en su empleo que requiere sujeto de robustez y habilidad: se determinó se haga desde luego diligencia de buscarlo y que todos los señores se encarguen en preguntar y saber cuál sea a propósito y den cuenta en los sucesivos cabildos para que se determine apruebe y nomine, y se despida al Padre Vicario con el decoro correspondiente a su religiosidad y compasión del cabildo, el que con este motivo se trató o reparó haber igual o mayor necesidad de nuevo organista por la corta inteligencia del que hoy existe y se acordó que también [208r] se piense y haga diligencia de esto en la misma forma que para el sochantre.

\section{[664] ASAC X, fol. 212 r (24-III-1763)}

Propuso el señor Abad se había conferido en el cabildo de 11 de febrero la falta de oído del Padre Vicario y por tanto su desentono aún con la yuda de su hermano y que no era bastante para la decencia del Divino Culto, y que habiéndose resuelto se hiciese diligencia por todos los Señores al de Sochantre como de organista por no haberse el que tenemos aplicado en más de quince años que sirve y tener corta habilidad e inteligencia por lo que ha descompuesto el órgano nuevo, le parecía a su señoría se nombrase desde luego pues aparecían sujetos hábiles para dichos empleos que podía escoger el cabildo. Y habiendo oído todos los señores que en éste se hallaban presentes las fundadas razones del señor Abad, se acordó se despida al Padre Vicario Fray Joseph Díez religioso mercedario, y don Joseph del Águila, organista, y se nombre por todos votos subchantre al padre Fray Rodrigo de la Rosa, del Orden de Predicadores suspendiendo yo el infrascripto mi voto por ser mi pariente dentro del cuarto grado, y para organista a Fray Francisco López agustino descalzo lego, sujetos de especial inteligencia y actitud para nuestro coro. Y que en atención al que el Padre Díez ha servido bien y es de buenas costumbres, y su hermano don Diego que murió después de haber ocupado más de veinte años el mismo empleo, se le dé a su madre anciana mientras viva una ración de tres cuartos y dos libras de pan en cada día y adon Joseph del Águila la misma limosna por el tiempo de un año, mientras pueda buscar conveniencia, por ser mozo casado y de obligaciones.(el infrascripto es Don Manuel Gómez de Mesa) 
[665] ASAC X, fol. 213 r (6-IV-1763)

Propuso el señor Abad que con motivo de haberse recibido el nuevo organista y sacristán se había ofrecido en la cocina duda sobre los platillos de primera clase por darse una ración y una hogaza al organista despedido y dos raciones al sacristán jubilado, y se determinó que al nuevo organista se le dé en todo la comida, aceite y lo demás como a los señores prebendados, menos una ración diaria que se da a su antecesor, pues para la hogaza que también se le da, se le suspende y rebajan por ahora 20 ducados anuales y las 6 fanegas de trigo que antes estaban consignadas al organista.

[666] ASAC X, fol. 226 v (1-X-1763)

Para oir la notificación consabida sobre la justificación que pretende el organista pasado, a fin de que por justicia se le restituya el empleo. Antes de evacuar el primer punto se dispensó y mandó por el cabildo entrase el notario, quien de licencia del cabildo dijo que su diligencia consistía en haberse quejado el señor provisor don Joseph del Águila de que habiendo servido 17 años el empleo de organista en esta Iglesia, que le nombró en concurso de oposiciones, se le había despojado por el mes de marzo de este año, y había pedido se le oyese en justicia con información de litigante pobre y se le admitiese justificación de su suficiencia/ante dicho señor provisor con citación de este cabildo para que se restituyese a su empleo. Lo que oido se le mandó al notario saliese del cabildo para conferir y determinar que respuesta se le había de dar lo que se acordó fuese firmado por mi el infrascripto secretario del tenor siguiente:

En cabildo celebrado en este Sacromonte extramuros de la Ciudad de Granada el primero de octubre de 1763, se oyó el Auto del señor Provisor sobre la instancia del señor don Joseph del Águila y se respondió que sin que fuese visto perjudicarse el cabildo en asunto del recurso sobre jurisdicción que se haya presente en el Real y Supremo Consejo de la Cámara y mediante a que el dicho don Joseph no es individuo titular y sí criado doméstico que fue asalariado de los que mantiene el Cabildo a su voluntad, cuando quiere y cómo quiere servirse de ellos según el gobierno económico y gubernativo de su casa en que primitivamente está encargado en sus Apostólicas Constituciones, protestaba y protestó no le parece perjuicio dicha citación.

Doctor don Manuel López de Mesa, canónigo

E hizo señal el señor Abad con la campanilla como era costumbre para que entrase el pertiguero a quién se le mandó entrase por segunda vez el notario a quién dijo su Señoría que dicha respuesta por escrito del cabildo era lo que se le respondía o notificación para que la arrimase en su respectivo lugar en los autos: lo cual leyó el notario y dijo no poder tomarla por no tener licencia ni facultad para ello ni de ser de su carga y oficio más que la diligencia hecha para su notificación, y oir la respuesta, y replicándosele una, dos y tres veces la admitiese o copiase a la letra pues no podía ni debía el cabildo darse por citado 
ni responder en otros términos en que no faltaba a la atención y política al señor Provisor ni a él le podía parar perjuicio recogerla o insertarla en los autos con éstas (...) reconvenciones se hubo de resolver a tomarla como con efecto la tomó y guardó saliendo inmediatamente de la Sala Capitular.

[667] ASAC X, fol. 229 v (8-XI-1763)

Sobre ceremonias se notó la falta de oído y voz del Padre Vicario, que aún se mantiene con su hermano por nohaberse hallado aún sochantre a propósito para nuestra Iglesia, y se acordó se haga ña más eficaz diligencia por parte de los Señores, y que mientras sirva el Padre en lo rezado y sólo acompañe a su hermano en lo cantado para dar los tonos.

1764

[668] ASAC X, fol. ¿? (10-I-1764)

Se propuso que aunque la Consueta previene, que en el día que hay Kalenda y Prima cantada, por cuya solemnidad se encienden seis velas en el altar mayor, y que acabadas se apaguen las cuatro no parecía decente se hiciese así si no había consumido las especies sacramentadas el señor Prebendado que celebrase la misa de Prima; se acordó que arreglado a dicha Consueta procure comenzar la misa con alguna antelación proporcionada para poder acabar con la Prima, y que si por algún motivo se descubriese más, no se apaguen las cuatro velas hasta después de consumir.

[669] ASAC X, fol. 255 v (16-III-1764)

Pareció conforme a la mayor decencia y devoción que la Secuencia de todas las misas de Réquiem cantadas se diga (y no el Pater Noster entonado, por el que las dice en las Vigilias) aunque está mandado lo contrario en Cabildo de 8 de noviembre de 1762: por lo que se deberá tener éste por uno de los dos precisos para revocar dicha determinación en el siguiente; y que se observe y prevenga la pausa en el coro, que corresponde a cada día y solemnidad según su rito como está mandado.

[256r]

Últimamente se expuso la pretensión de Fray Francisco López nuestro organista de que se le concediese la comida por entero por no darse a su antecesor la ración que se le suspendió: y por lo mismo acordó no haber lugar por ahora a dicha súplica.

[670] ASAC X, fol. 256 v (3-IV-1764)

Además se resolvió que en todas las Misas de Difuntos se cante la Secuencia y se diga en las Vigilias el Pater Noster secreto. 
[671] ASAC X, fol. ¿? (17-V-1764)

Y por lo que respecta al aniversario del señor San Miguel que se determinó se echase en tabla este año se celebre en la tarde de este día después de las vísperas del santo que ocurre las cantadas con las completas de ángeles, y mañana que es día de rito semidoble se celebre la misa de Tercia después de Horas en turno de aniversarios ordinarios y la Misa mayor a la hora acostumbrada, y las segundas vísperas del modo dicho las primeras, todos tres puntos por el señor semanero y este mismo orden se ha de guardar en los aniversarios atrasados que se celebrasen después.

[672] ASAC X, fol. $₫ ?(i ?-V I-1764)$

Se mandó que el órgano vaya con pausa en las Completas de primera clase y que toque algún rato después de cada lección de maytines y que sea bastante, para que se puedan rezar los responsorios. Y que el atril donde se canta la Kalenda se ponga en el coro antes de comenzar las horas, y hasta que se haya acabado no se quite de ningún modo.

[673] ASAC X, fol. 266 r (27-VIII-1764)

Propuso el señor Abad había venido el día antes un notario que entendía en el recurso o queja puesta ante el señor Provisor por don Joseph del Águila, solicitando se le volviese a su empleo de organista en que le habia despedido el cabildo en 24 de Marzo de 1762, de cuyo primer pedimiento y auto notificado al cabildo y su respuesta consta con el celebrado a primero de octubre del mismo año, y que confidencialmente había dicho a su señoría pretendía dicho don Joseph se le diese un testimonio de lo acaecido en nuestra dependencia para pasar a la Corte a poner su demanda a la Real Cámara, pero que el recado político que traía del señor Provisor se reducía a que pidiese permiso para requerir al Cabildo de las diligencias de dicho testimonio, y que por no volver otro día (...)/ lo pondría por diligencia, y el cabildo acordó así se hiciese pero con arreglo o inversión de la respuesta que se dio con consulta de abogados en el celebrado en dicho día primero de octubre.[267r] Se notaron en que faltaban los colegiales en el Coro, y se previno al señor Rector los advirtiera para su observancia.

[674] ASAC X, fol. ¿? (8-XI-1764)

Si a Fray Pedro del Santísimo Sacramento los días que viene a afinar el órgano se le ha de dar almuerzo o comida o los días que se llama clásicos para tocar instrumentos en misa y vísperas. Si a don Pedro Valero, tallista que está construyendo las imágenes de Nuestra Señora de la Concepción y del señor San Joseph que se han de colocar en los retablos laterales se le han de dar las dos hogazas. 
A Fray Pedro si no consta de contrato o gracia del cabildo o práctica antigua no se le dé desayuno ni comida en los días que venga a afinar el órgano, pero que en los que se llama a tocar se le asista con la comida al medio día que se da a los señores.

\section{5}

\section{[675] ASAC X, fol. 289 v (7-IV-1765)}

Fue por el motivo de haberse ofrecido duda sobre si los señores Molina y Mesa (que habían cantado las pasiones en la Semana Santa y haber pasado en ella el turno de la hebdomada de misa de tercia, que no tomaron por dicho motivo en la inteligencia de que la tomarían después por dicha ocupación) deberían tomar por sus antigüedades la Semana de Pascua y siguiente. Conferido el punto y visto haber estado dicho señores legítimamente ocupados sin parecer regular y bien visto que hubiesen, siendo celebrantes de la misa solemne, cantado el texto o los altos de la Pasión y que no debían perder su turno, se acordó que ahora y para siempre que en adelante suceda semejante (así no pierdan los señores que hagan la Pasión su derecho a Misa de Tercia o a otra cualquier ocupación o subsidio que sea incompatible en la misma hora).

\section{[676] ASAC X, fol. 290 v (6-V-1765)}

Sobre ceremonias se notó la incuria en ellas de los colegiales, la ninguna instrucción que se les daba: la poca asistencia de los antiguos a coro y altar y otras muchas y menudas deben corregirse y enseñarse [291r] y se le encargó al señor abad el prevenir al señor Rector luego que en breve se restituya de su viaje que procure dar remedio, celo y consigne con el myor rigor a los colegiales y que no cumplan como deben en esta parte.

Presentose el memorial de estado, firmado de Lorenzo Tacón que noticioso de estar vacante el empleo de subchantre de esta Iglesia lo pretende en el modo que tenga a bien el cabildo, y proveerlo y confesando ser principiante y no del todo bien instruido en el canto llano pide se le admita si place su voz y deseo de ejercitarse, instruirse y adelantarse con la presente renta y emolumentos que sean proporcionados a su ministerio. Y oído y conferido, y vista la falta de voces que se experimentan y que el Padre Vicario no puede continuar aún con la ayuda de su hermano don Francisco de Paula Díez, se determinó que se/restituya a su convento como expuso cuando se admitió y nombró con la mira que instruyese a dicho su hermano, que no apareciendo tampoco puede servir. Sólo dicho empleo, y que siempre conviene más para nuestro coro dos cantores medianos bien instruidos, se nombró por primero a don Francisco de Paula Díez, con la renta anual de 50 ducados, la distribución de Descubrimiento y una (...) de oración; dos raciones de carne para todo el día, pan, postres y demás subsidios que gozan los ministros. Y por segundo cantor se nombró a don Lorenzo Tacón con sólo la renta de 30 ducados annuos sin otra distribución; y con igual ración y demás gajes que se da a los colegiales: con la prevención que se ha de notificar y han de firmar su consentimiento al pie del asiento de extensión de este cabildo: 
que su mente y acuerdo es, que han de ser examinados en fin de cada año, que han de portarse y vivir como Ministros de esta Iglesia, en la modestia, traje, devoción y frecuencia de Sacramentos; y si por algunas faltas en esto, o por otro cualquier motivo, tuviese a bien el cabildo removerlos, no han de poder pedir causa de su exclusión, ni alegar derecho en contrario, por parecer así conveniente esta determinación.

[677] ASAC X, fol. 292 r (17-V-1765)

Fue para presentar un memorial del padre Fray Joseph Díez que en su vista resolver lo que mejor parecía: Leyese el memorial del dicho religiosos en que hace presente al cabildo la estrechez de medios de su casa y familia y la avanzada edad de su madre, suplicando también a su nombre, que atendiendo a los méritos de sus hijos y al tiempo que han servido la subchantría en que por no poder continuar el padre Fray Joseph, está nombrado con menor cuantía y ración, don Francisco, su hermano se sirva el cabildo aliviarla con algún diario subsidio que al mismo tiempo ceda en alivio y honor de dicho religioso. Conferido el punto, y visto muy despacio no haber fondos ni $i$ ? En el cabildo para señalar ni consignar socorros ni ración a los dependientes de los ministros que se inhabilitan ni criados que se despiden; y que el Padre Fray Joseph ha cesado en el oficio de subchantre en el que se admitió por gracia $y$ conmiseración del cabildo por los méritos de su hermano don Diego de justo conociendo su falta de oído y decadencia de voz, y admitiendo también a su hermano don Francisco con la esperanza de que lo enseñase y sustituyese, y con la moral certeza de que siempre que pareciere al cabildo se restituiría a su convento: se acordó que no hay nuevo motivo para hacer novedad ni reponer la determinación del cabildo antecedente en esta última parte a la que se debe estar, no habiendo causa ni pretexto alguno para que dicho padre se mantenga y viva en esta casa [292v]ni menos hay facultades en el cabildo para dar a su madre cosa alguna, subsistiendo en el empleo s hijo don Francisco de Paula Díez, a cuyo favor se declaró sea su ración y demás gajes la misma que la que goza el organista al presente, que (a excepción de una ración de carne diaria) es la que se da a los señores capellanes igualmente y con iguales extraordinarios y postres. Ni tampoco que se admitan memoriales de su madre y hermano en dicho asunto por motivos justos que se tuvieron presentes.

[678] ASAC X, fol. 302 r (4-X-1765)

Después propuso el señor Abad, que habiendo pedido algunos colegiales permiso para hacer en alguno o algunos días en la Octava del señor San Dionisio juegos u otras diversiones por sí o por otros hombres que han venido otras veces, lo exponía su señoría al Cabildo, que habiendo conferido los inconvenientes y perjuicios experimentados en semejantes diversiones acordó no se permitan de ningún modo y que le señor rector lo mande y prohiba con el mayor rigor. Y que estando así mandado diversas veces quede con mayor firmeza establecido así para en adelante y que sólo a discreción del señor Rector [302v] puedan divertir el quiete hasta las diez los mismos colegiales sin quitarse los mantos con algunos bailes, relaciones e instrumentos que sepan tocar o cantar y no con vestidos de 
mujer ni otros profanos para comedias, loas ni nada semejante. Y que también mande y cele el señor Rector que ni los que leen en dicha octava, ni en otros tiempo, ni los que tengan sabatinas de ningún modo den refrescos, meriendas ni se les permita gastar cosa alguna ni en público ni e secreto por dichos motivos.

\section{[679] ASAC X, fol. 308 v (2-XI-1765)}

Sobre ceremonias expuso el señor Mendiola no parecía la más conforme la de salir el Presidente antes de entonar la Magnificat como se acostumbra en las vísperas dominicales [309r] que no se toca órgano pues bajando a incesar con alguna ligereza y llevando el cántico con pausa se podrá evitar la deformidad que se experimenta con la imprecisión en ceremonias o poca advertencia de los colegiales en tales días. Y vista ser la tal ceremonia expresa en a Consueta (aunque tal vez se practicaria o mandariase porque en los antiguos subía la ceremonia por el claustro y escalera grande) no se resolvió en este Cabildo, y se previno a los señores prevengan para el siguiente el modo o medio que puedan acordarse.

\section{TOMO XI}

\section{6}

\section{[680] ASAC XI, fol. 16 r (2-XII-1766)}

Después se presentaron dos memoriales el uno de don Francisco de Paula Díez, subchantre primero que pide al cabildo le conceda la íntegra ración de carne en las tres porciones que la gozan los ministros de su clase y se acordó no haber lugar por ahora en que cumplido el año en 7 de abril que vendrá de su aprobación como se determinó en su nombramiento y admisión, resuelva el cabildo lo conveniente.

\section{[681] ASAC XI, fol. 37 v (5-V-1766)}

Después se leyó un memorial de don Pedro de Torres y Mata sochantre salmista de la Catedral de Málaga que pretende serlo de nuestra Iglesia, en que habiendo cantado algunos días y parecido bien al cabildo que oyó también un memorial de don Lorenzo Tacón que se admitió a prueba por un año cumplido en 7 de abril próximo pasado y pide se le examine y aumente renta, habiéndose conferido sobre ambos memoriales y visto el poco o ningún adelantamiento del don Lorenzo, precipue en la latinidad, que en su admisión se le encargó por condición se aplicase y no lo ha hecho causando irrisión y disonancia en el Coro. Se determinó se retire y no asista al coro y que por tiempo de tres meses que se le dan por término para que solicite otra conveniencia, se le continúe la ración y salario que le corresponde, y en los mismos términos que los ha gozado en el año y ha estado, y fue admitido para aprobación: y se admitió y nombró en su lugar a dicho don Pedro de Torres con las condiciones siguientes, que con su compañero don Francisco de Paula Díez ha de admitir y firmar al fin de la 
extensión de este cabildo: que entre los dos no ha de haber diferencia alguna y sí una conforme uniformidad para la asistencia del coro y divino culto: que alternativamente han de entonar por semanas, poniéndose al lado derecho el que fuese cantor semanero, qe han de asistir a todos los puntos del coro si no es que el señor abad dé licencia para que falte alguna vez uno u otro, que tenga necesidad o accidente) que se han de portar y vivir como ministros de nuestra Iglesia en devoción, y buen ejemplo. Y que siempre que al cabildo parezca despedirlos o removerlos de su obligación no han de poder pedir causa de su exclusión; y por su trabajo y obligaciones se les consigna por ahora 50 ducados de renta anual pagados por meses como a los demás ministros, sin carga ni pensión

[38r] de asistir a los Descubrimientos ni oración y la misma comida y raciones que goza el contador mayor e iguales asistencias de comunidad sin ropa y vino que se da sólo a los señores y capellanes.

\section{7}

\section{[682] ASAC XI, fol. 23 v (10-III-1767)}

Leyose un memorial en que nuestro Sochantre don Pedro de Mata pide por una vez alguna ayuda de costa y limosna por hallarse por mucha falta de la ropa precisa para su decencia y se le libraron 200 reales sobre el patronato de Olalla de Rojas.

[683] ASAC XI, fol. ¿? (4-V-1767)

Se presentaron sendos memoriales (...) y don Francisco de Paula Díez nuestro sochantre, alcanzado por una vez el socorro de doscientos reales de vellón a disposición de la Junta de Señores Administradores.

\section{[684] ASAC XI, fol. 29 r (6-VII-1767)}

Item por orden del Señor Abad leí yo, secretario, un edicto del señor arzobispo de Granada en que se contiene la gracia de nuestro muy santísimo padre el señor Clemente IX? Que hoy gobierna felizmente la Iglesia de haber condescendido a las devotas súplicas, tierna devoción y característicos esmeros de nuestro Católico Monarca (que Dios guarda) por el piadosísimo misterio de la Inmaculada Concepción de María Santísima, señora nuestra, para que en la letanía o Salve de la Iglesia que comunmente se llama lauretana, se diga y cante el verso Mater Inmaculata después del Mater intemerata, y porque así mismo en todos los sábados del año no impedidos por las fiestas, oficios (...) que expresa el Breve pontificio se rece el oficio propio de la Concepción, a cuya consecuencia, el cabildo particularmente interesado en los progresos de la devoción a este misterio acordó fijar dicho edicto en el sitio acostumbrado de sus claustros y observarlo con especialísima complacencia en todas sus partes; sin que por ello deje de cantarse en este nuestro Sacromonte al fin de dicha Letanía 
el verso Concepta sine peccato, que de tiempo inmemorial se ha cantado y rezado en nuestros Divinos Oficios y eclesiásticas intenciones.

[685] ASAC XI, fol. ¿ ? (4-IX-1767)

Asimismo se leyó un memorial dado por los sochantres, el vicepertiguero y organista de esta nuestra iglesia en que pedían al cabildo la gracia de que se les restituyese la partes de su pertenencia a dinero alegando la escasez de (...) y se resolvió que no había lugar a esta pretensión porque podía ser perjudicial a la Comunidad y que de hecho se gravaría esta si se concediese.

\section{8}

[686] ASAC XI, fol. 70 r (8-I-1768)

En el punto de Constituciones propuso el Señor Abad que deseaba tomase el cabildo la providencia más seria, y concebida en los términos más rigurosos a fín de evitar que en adelante se hiciesen funciones por los colegiales o en el colegio de cualquier género que fuesen por haber manifestado la experiencia de que permitiéndose alguna, aunque leve diversión, en llegando el caso de ejecutarla, se advierten excesos casi irremediables, ya por la circunstancia del tiempo, ya por otras que no es preciso referir, como últimamente se ha palpado en la Octava de Concepción del año próximo, en que los colegiales juristas hicieron una Loa con tales aparatos y disposiciones [fol. $70 \mathrm{v}$ ] que no puede menos de haberles causado crecidas sumas de dinero, y a cuya representación a pesar de las precauciones tomadas por su Señoría y el señor Rector, se vió concurrir en número muy crecido con personas extrañas, incoveniente que sin duda eran gravísimos para una comunidad del carácter de la nuestra, y que pedían un remedio muy eficaz y que cortase de raya estas corrupciones. Lo que oído y meditado por todos los señores capitulares acordaron las determinaciones: que en adelante, ni en las octavas de San Dionisio ni de la Concepción ni en otro tiempo se permitiese a los colegiales género alguno de función, ni que sobre esto se vuelva a admitir en cabildo pretensión alguna. Asimismo sobre cierta proposición que hizo el señor Rector de visitas, principalmente de mujeres, a los colegiales se decretó que en este particular quedase a la prudencia de los señores Abad y Rector.

[687] ASAC XI, fol. 71 r (8-I-1768)

Después el sñor Mesa hizo presente al cabildo la necesidad que había de componer la campana, que tantos días estaba sin uso y que se presentaba una ocasión favorable de ponerla al corriente con equidad, y se le dio facultad para que dispusiese a la mayor oportunidad dicha compostura a expensas de la tesoreria.

[688] ASAC XI, fol. 76 v (4-II-1768) 
El ilustrísimo señor don Joaquín de Yparraguirre del cuerpo de vuestra señorías hablando con el debido respeto dijo: "Me hallo días ha impulsado de devoción al Santo Apostol señor Santiago el Zebedeo, patrón de este Reino y [77r] estando en que por desahogar un algo mi devoción al Santo apostol y atendiendo a mis cortas facultades, ya que siendo el maestro de nuetros señores mártires y teniendo estar dotadas en sus vísperas la $1^{\mathrm{a}}$ cantada con toda solemnidad por el maestro Spínola, y ser maestro me he determinado a dotarla para que el Santo Apostol tenga el mismo culto, y siendo la dotación cada uno de los capellanes dos reales, para el organista un real, para el sochantre otro real, para el campanero lo restante".

[689] ASAC XI, fol. 82 r (1-V-1768)

El señor Molina a su tiempo advirtió el fraude con que se podía eludir los sochantres de nuestra Iglesia la determinación que el cabildo, celebrado a 7 de abril próximo había tomado para conseguir de ellos una puntual asistencia al coro, y para evitarlo se mandó dar otro destino a los maravedíes que se señalaron en el cabildo citado por multas de las faltas de dichos Sochantres, y fue este el de misas que dijere nuestro sacristán por los fieles difuntos (...).

[690] ASAC XI, fol. 88 r (1-VI-1768)

También se mandó que los señores Sochantres pidan licencia al señor Presidente del coro para el echar el Alabado.

[691] ASAC XI, fol. 94 r (8-VIII-1768)

En el punto de Ceremonias y loables costumbres se notó la diferencia que hay entre los sochantres en traer la genuflexión al altar y venir al coro cuando salen de su sitio al medio para cantar; y siendo bueno que hagan uno y otro se mandó que guarden uniformidad entre sí los dos.

[692] ASAC XI, fol. 102 r (16-I-1769)

Últimamente a nuestro Sochantre don Pedro de Torres se le mandaron librar contra la tesorería (...) por el trabajo que ha hecho en los libros del coro y se le dio licencia para que se ausente desde el 17 hasta el 30 del presente mes para ir a Almería a hacer oposición.

[693] ASAC XI, fol. 119 v (2-VI-1769)

En el dicho punto de Constituciones a proposición de los señores Abad y Rector se mandó imprimir el Praxis del señor Pastor en lo que abraza de costumbres de los colegiales, ceremonias de colegio y coro que estuvieron omitidas en el impreso de estudios, reformándose antes por los señores Aragón y Mesa, (a 
quienes para este efecto se les dió desde luego comisión) en aquellos puntos que por la variación de las [120r] cosas y novedades ocurridas en los estudios, facultades, número de colegiales y del dicho nuestro seminario de San Dionisio estuvieron alterado y no en observancia por determinaciones capitulares.

Otro de Juan de Santamarina y Ribera en que pedía se le admitiese por cantor de nuestro coro, y se acordó de responder que por ahora no se trata de admitir cantor nuevo.

\section{[694] ASAC XI, fol. 126 r (3-VIII-1769)}

En Ceremonias y Loables costumbres considerados los abusos introducidos en el Rosario, en la Salve, en la antífona Conceptio Tua de los Domingos, y en las Coplas de Nuestra Señora, se mandó que el Rosario no lo canten los colegiales sino que lo recen a medio tono con gravedad y que se haga esto antes de salir en las tardes de asueto del verano sin diferirlo por la meditación, que en la Salve de los Sábados y en el Conceptio de los domingos no se adelanten al Sochantre; y en fin que en las Coplas no se guarde el tono ridículo que de algunos años han seguido, pero sí el grave y serio que antes para lo que podrá el sochantre concurrir algunas noches.

\section{[695] ASAC XI, fol. 130 r (2-X-1769)}

Que mientras que sale a la luz el Praxis que está comisionado les haga saber y observar a los alumnos (con las mayores penas) las siguientes de que se nota en el día inobservancia y desprecio:

(...)

Que a todos los puntos de coro extraordinarios se echen la tercera parte de antiguos y dos de los modernos, entendiéndose por punto de coro en los mismos términos y número de asistentes la salve de los sábados y todas las procesiones y la de los domingos: que a la misa de tercia en los días que hay coro para todos no asistan los Comitantes y cetreros para bajar a sacar las luces o hachas sino que bajen 6 o 4 antiguos según el rito y que siempre queden dos en el coro a excepción de los días festivos de la Cuaresma que son las Vísperas por la mañana y bajan los Comitantes y Cetreros a sacar las hachas y subir con los cetros. Que los Versicularios vayan al coro a registrar los libros, a la primera campanada de gorda.

\section{[696] ASAC XI, fol. ¿ ? (16-X-1769)}

Además se leyó el memorial que expresa la citación del Reverendo Padre Guardián de los Padres Capuchinos que suplican al Cabildo celebre y costee una de las fiestas que han de consagrar a su nuevo Santo canonizado San Serafín de Montegranario. Y se acordó condescender en los mismos términos que se celebró y costeó en las fiestas dedicadas a los santos Joseph de Leonisa y Simón de Simaringa en el año pasado de 74. Nombraron comisarios a los señores Casas y Villavicencio. 
Últimamente presentó el señor Moreno las Constituciones en lengua castellana firmadas de nuestro Ilustrísimo Señor Fundador que se presentaron en la secretaría del Señor arzobispo cuando pretendió don Felipe Castañeda tomase el cabildo a censo 2000 ducados que el secretario le había confiado con la obligación de volver estas mientras el cabildo no le propusiese.

[697] ASAC XI, fol. 133 v (9-XI-1769)

Leyese un memorial de un pretendiente a la plaza de segundo sochantre y se difirió para cabildo en que se traiga citado para el punto.

[698] ASAC XI, fol. 135 v (4-XII-1769)

Y se admitió en la plaza de segundo Sochantre a don Juan Ramírez Calderón, con renta de 30 ducados anuales y comida de ministro, dejándole al primero su comida de prebendado con 50 ducados anuales y además un cuartillo en oración y distribución en descubrimiento, debiéndose advertir que esta renta del sochantre nuevo debe sacarse de la que se rebaja al antiguo y de la ración que se le tiene reprimida al organista y si algo faltase para el complemento de la comida de ministro que se le haya y de los treinta ducados se ha de sacar de los intereses del ahorro de la administración que tocan a los individuos del cabildo que a los que este efecto los señores presentes eludimos la parte que fuese necesaria y yo quedé en el encargo de comunicarlo a los ausentes y si me pareciere para obtener su consentimiento en este último punto.

[699] ASAC XI, fol. 143 r (10-IV-1770)

Los sochantres en las festividades que celebra el Colegio de nuestra señora del Rosario y su patrono San Dionisio lucren cada uno una peseta por cada punto con condición que las ha de perder el que no asista, que la torta que se acostumbra a dar al señor Rector por su Misa Cantada sea de 3 libras.

[700] ASAC XI, fol. 146 r (7-V-1770)

Item se mandó que los Sochantres confiesen de mes a mes cuya ejecución se dejó al cuidado del señor Abad, y habiéndose notado que el segundo no observa la constitución de residencia, se mandó la guardase no pernoctando a su arbitrio en Granada

[701] ASAC XI, fol. 154 r (2-XII-1770)

Item sobre el tercer punto de la citación en cuanto a la súplica de nuestro Sochantre don Francisco de Paula Díez se le aumentó su salario dándole su renta 
fija el cuartillo diario que tenía asignado por asistencia a la hora de oración de la mañana.

[702] ASAC XI, fol. 159 r (3-XII-1770)

Item para nombrar señores comisarios y resolver sobre la pretensión de Don Pedro de Torres nuestro sochantre pasado.

Que don Pedro de Torres admitido para segundo sochantre en los mismos términos que antes estuvo y se le impone perpetuo silencio en cuanto a pedir más salario.

[703] ASAC XI, fol. 165 r (4-IV-1771)

Item leyose un memorial dado por el padre Fray Juan de San Agustín en que manifestaba no habérsele totalmente satisfecho por la obra de la composición de algunos libros de coro en cuyo asunto se determinó que el suplicante se entienda con el señor Abad.

[704] ASAC XI, fol. 169r (11-VI-1771)

Se acordó por lo que toca a Ceremonias que para que en el Choro se observe la debida formalidad, se arreglen todos al Sochantre y que ninguno lo abrevie o alargue la pausa que lleva en él, a excepción del señor Abad o el señor Prebendado que entonces presidiese.

[705] ASAC XI, fol. 170r (11-VI-1771)

Se difirió una resolución para otro cabildo como la mudanza del órgano al lado de enfrente de modo que entrando en la pared facilite el dar los balcones y quede más desahogado el cuerpo de la Iglesia.

[706] ASAC XI, fol. 171v (11-VI-1771)

Ítem el señor Rico trajo el trabajo que tenía hecho sobre la formación del nuevo Praxis del colegio, para la expedición de este negocio tan importante.

[707] ASAC XI, fol. ¿? (12-VII-1771)

Sobre el primer punto de la citación se acordó la mudanza y colocación del órgano en el sitio que está enfrente del que hoy ocupa de modo que internándose en la pared, facilite el que se quiten todos los reparos que agobian el cuerpo de la Iglesia.

[708] ASAC XI, fol. 228 r (8-XI-1771) 
Item se determinó que en la memoria que va a fundar doña Faustina Miranda en la octava de la Concepción que es una misa cantada en el día octavo con sus vísperas con dos capas sea con Manifiesto dicha misa según pide la fundadora.

[709] ASAC XI, fol. 229 v (2-XII-1771)

Item se leyó un memorial de nuestro sochantre don Francisco de Paula pidiendo una memoria por estar falto de ropa y se libraron 100 reales de la mesa capitular.

1772

[710] ASAC XI, fol. $i ?(2-I-1772)$

Leyose últimamente otro memorial de Don Francisco de Paula Díez, nuestro Sochantre en que alegaba necesidad y pedía lo necesario para una sobrepelliz y se denegó esta pretensión.

[711] ASAC XI, fol. 193r (4-II-1772)

Sobre el otro del uno de nuestros sochantres, quejándose de ultrajes hechos a su persona por parte de algunos mozos de la cocina y se remitió a la Junta de señores Asistentes.

[712] ASAC XI, fol. 195v (6-III-1772)

Ítem que los Sochantre estén a lo menos a la segunda de gorda en el Coro, para que puedan instruir a los Colegiales Versicularios en lo perteneciente a cada uno de los puntos de Coro y esté todo registrado antes de comenzarse el Divino Oficio, y que así se les haga saber por mí el infrascripto Secretario.

[713] ASAC XI, fol. 196r (2-IV-1772)

Se mandó poner remedio en muchas faltas que se advierte en el coro y cocina.

Se acordó de que el señor que presidiese en el coro cuide de que la pausa en el canto y rezo sea correspondiente al rito.

[714] ASAC XI, fol. 198v (2-VI-1772)

En punto de ceremonias se acordó que los Sochantres no hubiesen de usar del recle si no en aquellos días en que no haya punto de Coro para todos, que los dos juntos asistiesen a la Procesión y a la Salve, so pena de ser multados en una ración el que faltare sin causa legítima.

[715] ASAC XI, fol. 220r (3-VI-1773) 
Ítem se presentó otro memorial de Don Pedro de Torres Nuestro Sochantre, quien pedía se le prestase por el Cabildo 20 pesos para sacar unas alhajas que tenía empeñadas en el monte de Piedad en lo que se determinó que don Agustín de Quevedo, nuestro contador, reciba de arcas el dicho dinero para sacar las alhajas, las que entregue en depósito al señor Abad y la referida cantidad se vaya desquitando en los salarios siguientes de don Pedro de Torres.

\section{[716] ASAC XI, fol. 229r (3-VIII-1773)}

Ítem con el afecto tan grande que profesa a nuestros Santos Mártires y a esta santa Casa don Joaquín de Iparraguirre, ofreció fundar una memoria en el día de la Dedicación de Nuestra Iglesia, ya con Calenda cantada como una Misa a cada uno de los Señores Prebendados, todo lo cual se admitió gustosamente dándole repetidísimas gracias al señor Iparraguirre.

[717] ASAC VII, fol. 230r (2-IX-1773)

Ítem se propuso estar defectuosos los sochantres en la asistencia al Coro, y que necesitaban un especial arreglo o determinación a fin de evitar las referidas faltas sobre lo cual se juzgó se tenga presente en otro cabildo para completamente determinarlo.

[718] ASAC XI, fol. 236r (8-IX-1773)

Ítem se determinó en orden a los Sochantres sobre las faltas diversas que se advierten para que aleguen enfermedad, se les asista y favorezca solo en los términos y circunstancias que ordenan nuestras Constituciones para los individuos enfermos de nuestra santa Casa, y en todas las demás faltas voluntarias, quedó remitida la Junta de Señores Asistentes que también tienen prevenidas nuestras constituciones, para el castigo y remedio correspondiente.

[719] ASAC XI, fol. ¿? (10-XII-1773)

Ítem habiéndose leído un memorial de nuestro Sochantre don Pedro de Torres, en que pedía una limosna para ayuda a vestirse, alegando el tal cual trabajo había puesto y pondría en componer los Libros de Coro, se determinó se le libren 150 maravedíes? Que dará el señor Tesorero agregando esta cantidad a las cuentas de fábrica o tesorería. En ceremonias y loables costumbres se determinó que haya en la Capilla del Colegio algunos días conferencias de ceremonias con asistencia del señor Rector o el Presidente y el Capellán Maestro de Ceremonias. Ítem que en la procesión del Corpus se den velas a todos los colegiales que asistiesen que entregará primero nuestro Sacristán al Admonitor quien le ha de dar cuenta de ellas después al finalizar la procesión.

[720] ASAC XI, fol. ¿? (18-VI-1774) 
Se leyó un memorial de Don Pedro el Sochantre pidiendo diez pesos prestados a cuenta de su salario, y se le dio facultad al señor Álvarez a que se los preste de las rentas de recaudación.

[721] ASAC XI, fol. ¿? (7-XI-1774)

Se leyó un memorial de don Pedro de Torres y Mata, nuestro Sochantre, en que pedía una limosna y se acordó darle ciento y cincuenta maravedíes del patronato del señor Olalla de Roxas, para que de mano del señor Miguel Álvarez, recaudador general de las rentas de este Sacro Monte invierta en vestir con arreglo a la fundación de este patronato la mujer e hijas del dicho Sochantre.

[722] ASAC XI, fol. 290r (31-XI-1774)

A don Francisco de Paula Díez se le mandaron librar del Patronato del señor Olalla de Roxas cien maravedíes del total, que se han de repartir en este presente año a los pobres, pero con la condición de que se distribuyan de mano del señor Álvarez, con arreglo a la fundación a las hermanas del señor don Francisco.

\section{5}

[723] ASAC XI, fol. 260r (4-V-1775)

Ítem se determinó se le libren diez pesos a don Pedro el Sochantre por mano del señor Mesa presentando dicho señor lo que tenga obrado o trabajado en los Libros del Coro.

\section{[724] ASAC XI, fol. 260r (4-V-1775)}

Ítem se determinó se libren diez pesos a Don Pedro el Sochantre por mano del señor Mesa presentando a dicho señor lo que tenga obrado o trabajado en los Libros del Coro.

\section{[725] ASAC XI, fol. 260r (15-V-1775)}

Manifestó el Señor Abad una carta de su Majestad que Dios guarde participando al Cabildo el feliz parto de la serenísima Princesa su muy amada Nuera, y encargando se diesen en nuestra Iglesia las correspondientes gracias de que se daría su Majestad por recibido [fol. $260 \mathrm{v}$ ] a la merced de lo cual se determinó que al día siguiente se dijese una misa cantada por el señor Prebendado que estuviese en turno de aniversario y se pasase cantando el Te Deum Laudamus procesionalmente a nuestras Santas Cuevas.

[726] ASAC XI, fol. 272v? (3-VII-1775) 
Ítem que se llame al oficial de don Francisco Guzmán, escribano, y vea lo que ha hecho nuestro sochantre don Pedro en los Libros del Coro, cesando éste por ahora en este trabajo, y se le dé un socorro de 200.

[727] ASAC XI, fol. ¿? (6-VIII-1775)

Habiéndose leído un memorial de nuestro Sochantre don Pedro de Torres pidiendo lo que se les restaba del trabajo en la composición de los Libros del Coro, se determinó que por mano del señor abad se le libre por ahora la correspondiente al débito que dice tiene del arrendamiento de su casa a la religiosa de Santa Catalina de Siena, y que no siga en hacer más cosa nueva en dichos Libros, sino es únicamente y cuanto antes concluir lo que al presente tiene entre manos.

[728] ASAC XI, fol. 266r (1-IX-1775)

Ítem que se le libre a don Pedro de Torres nuestro Sochantre lo que se le resta por el trabajo que ha dado en los Libros del Coro y que sin nueva orden del cabildo se vuelva a introducir en semejantes asuntos.

[729] ASAC XI, fol. 271 v (9-XI-1775)

Ítem que se le anticipen en su paga por ahora dos mesadas a don Pedro nuestro sochantre.

[730] ASAC XI, fol. 273 r (4-XII-1775)

Ítem se concedieron 600 reales por iguales partes a nuestro organista y dos Sochantres del Patronato del señor Olalla de Roxas, con comisión al señor Salazar para que los emplee a beneficio de las familias de los referidos con arreglo a la fundación de dicho Patronato.

1776

[731] ASAC XI, fol. 281 r (10-IV-1776)

Se mandó se lleve a debido efecto el que en el Colegio ni en público ni en secreto se hagan comedias ni cosa que en algún modo se le pueda dar ese nombre aunque sea en los quietes.

[732] ASAC XI, fol. ¿? (6-V-1776)

Después de tan execrable maldad se había observado en repetidas noches al tiempo que dicho Presidente salía de la Mesa Primera hacían los antiguos mucho ruido con silbos y voces descompasadas sin que se pudiese conocer a alguno en 
particular por la confusión con que gritaban. Que habiéndose retirado el Presidente de vacaciones a su tierra la habían tomado con el actual Vicerrector, afirmando públicamente que él había sido el que había dado al señor rector el referido aviso, tratándole con indecible desprecio e influyendo en los colegiales antiguos y modernos para que así le tratasen. Además de esto habían llenado las paredes de letreros, fijando la palabra "soplón" y en dos sitios públicos esta: "López cap sumus multitudo magna soplarium vel solplonorum" notándose también que al salir el Vicerrector de la mesa primera cantaban con algazara y alboroto una copla cuyo estribillo era: "Sopla que sopla fuelle que fuelle", sin que por la confusión de voces pudiese conocerse alguna en particular. Que todo esto tenía puesto al Colegio en el mayor desorden e inquietud pues aún los que no querían adherir a la opinión de estos revoltosos no se atrevían a contradecirlos no sólo por haber traído ya su partido mayor número de colegiales.

[733] ASAC XI, fol. 290 r (30-VI-1776)

Ítem se acordó que todo el dinero correspondiente a los señores y demás ministros hasta el campanero por la función de la hermandad del Espíritu Santo en adelante se ponga en la Contaduría para que así salga el repartimiento hecho para todos y nadie tenga que pedir cosa alguna a los mayordomos, y se dio comisión al señor Salazar para que impusiese en la práctica que ha habido en cuanto a los Sochantres y campanero para que no haya exceso en adelante.

\section{[734] ASAC XI, fol. 309 r (11-XI-1776)}

Muchos colegiales, animados del espíritu de libertad e independencia que ya hace tiempo les domina, habían llevado tan a mal la promoción de dicho señor Chinchilla a la abadía que para manifiesta su disgusto y sentimiento unidos en cuadrillas habían quitado la lengüeta a la campana del Colegio para que aunque alguno quisiera no la pudiera tocar, como es costumbre jamás interrumpida hasta este caso en el acomodo de todo colegio y elecciones de Abad y señores prebendados; y que para mayor demostración de su enojo la habían vestido de luto, cubriéndola con una sotana y ciñéndola con una cuerda: que en la clase de Teología habían levantado con bancos un túmulo o tumba y habían cantado el Invitatorio de difuntos y parte de un responso. Que habían vestido de bayetas negras la ventana de un cuarto: que habían pisado con rumba y algazara los bizcochos que uno o dos señores canónigos les echaron desde un corredor, que habían hablado desenfrenadamente sin ningún reparo muchas palabras injuriosas e infamatorias contra el constante y conocido mérito y literatura del referido señor abad electo, que a los tambores y otros dos pífanos que dicho señor Rector había hecho venir de Granada para que tocasen en celebridad de la elección luego que esta se publicara como ha sido siempre uso y costumbre los habían obligado a retirarse andar huyendo y no tocar, lo que enfado consiguieron. Y últimamente que este bullicio se había hecho casi general, y había tenido toda la apariencia de un motín o tumulto injustísimo en todo concepto y absolutamente difamatorio de la buena educación que acomodo e infinitos desvelos del cabildo 
se les procuraba y del buen olor que siempre ha difundido esta [fol. $309 \mathrm{v}$ ] comunidad hasta en las más remotas provincias de estos reinos.

(...) pero que sabía de cierto por la unánime declaración de tres testigos oculares, que el maestro Ojeda había apedreado a los referidos tambores, y por el dicho de uno de los sacerdotes de casa que el mismo maestro Ojeda había entregado la expresa lengüeta de la campana para que se volviese a poner.

[735] ASAC XI, fol. 325 v (3-IV-1777)

En medio de la Iglesia había necesidad de un facistol nuevo, y también de otro fijo en el Corto para la Calenda y todo se mandó hacer también como que los retablos viejos de los colaterales se diesen para la Iglesia de Dayfontes.

[736] ASAC XI, fol. ¿? (9-V-1777)

Se presentó un memorial por don Pedro de Torres y Mata sochantre de nuestra Iglesia, pidiendo alguna limosna de comida durante el tiempo de verano para excusarse de salir a su casa y subir a Vísperas con el rigor del calor, y se le concedió media ración de carne guisada y en las vigilias taza y platillo, que todo se libró sobre el Patronato de Soria.

[737] ASAC XI, fol. 331 r (9-VI-1777)

Y a los colegiales que este año pusieron un altar para nuestra función del Corpus se les dé lo que por hierro y equivocación dicen haber gastado en su adorno del común de los repartimientos del colegio y que para otra vez solo se adorne el claustro (...) con lo que dispongan el señor Abad, Tesorero y Rector.

[738] ASAC XI, fol. 334 v (7-VIII-1777)

Ítem se determinó que estando el coro abajo en la Iglesia ganase el señor Yparraguirre todos los aniversarios y demás distribuciones con tal que asista en el coro alto, teniendo en consideración sus graves accidentes, y que el lugar más propio para los Divinos Oficios es el alto, y el situarlo abajo en el verano es por conveniencia particular.

[739] ASAC XI, fol. 339 r (19-IX-1777)

Fue para leer una carta del Rey Nuestro Señor, Dios le guarde, en la cual manifiesta su majestad la singular piedad con que la divina majestad se ha dignado conceder el beneficio del feliz y dichoso parto de Nuestra señora que había dado a luz una infanta a las nueve y cincuenta minutos de la mañana del día once del mes de la fecha, y que siendo dicho beneficio de universal consuelo a sus reinos y vasallos, nos lo participaba para que concurriésemos a rendir a Dios las más devotas gracias disponiendo se ejecutase lo mismo en Nuestra 
Iglesia de que se daría su Majestad por servido y concluía de San Ildefonso a 20 de Septiembre de 1777. La cual oída y entendida por todos los vocales se acordó uniformemente que al día siguiente se cantase una misa con toda solemnidad en acción de gracias y gratitud a nuestro Dios por la dispensación de tal misericordia, precediendo a dicho acto una devota procesión dirigida a las Santas Cuevas en que se cantase el Te deum y demás antífonas y oraciones que acostumbran decirse con las asistencia del cabildo y colegio y que si alguno faltase perdiese dos puntos de coro sin otra recompensa por asistir que la excusa de no perder.

[740] ASAC XI, fol. 345 r (11-XI-1777)

Ítem leí un memorial del padre Fray Francisco López organista de esta nuestra Iglesia, en que pide que frente a la notoria pobreza y necesidad de su madre se le conceda la parte de ración que se suspendió a dicha plaza cuando entró en ella, y se acordó que tome desde hoy sus tres raciones en los mismos términos que cada uno de nosotros, con la precisión de que se aplique este aumento al socorro de su madre y hermanos.

[741] ASAC XI, fol. ¿? (9-XI-1777)

Leí otros dos memoriales de don Francisco de Paula y don Pedro de Torres sochantres de esta nuestra Iglesia, en que solicitan alguna ayuda de costa para hacerse alguna ropa que solicitan, y se mandaron librar a cada uno ciento cincuenta reales de vellón de los caudales de la fábrica.

\section{8}

[742] ASAC XI, fol. 349 r (6-I-1778)

El señor Moreno, hablando de ceremonias, dijo que le parecía bien que cuando los señores dentro del coro se ponen capas pluviales lo hiciesen sobre las de coro para evitar la incomodidad de quitárselas y llevarlas a la sacristía y porque así se hacía en todas las Iglesias Catedrales y Colegiatas de que tenía noticia. Y se acordó que el señor Rico viese la Consueta sobre este punto e informase después al cabildo, y en el ínterim no se innovase.

[fol. $350 \mathrm{r}]$

Ítem propuso el señor Abad que había necesidad urgente de desmontar el órgano $\mathrm{y}$ de que se formase un libro de Coro sin solfa para lo ordinario y rezado con que se evitarían crecidos gastos a la comunidad. Y se acordó que todo se hiciese en tiempo oportuno y para su ejecución se comisionaron a los señores Abad y Rico.

[743] ASAC XI, fol. 355 r (6-III-1778)

Que los dos sochantres comulguen en comunión general a más de las comuniones que harán en cada mes del año, y sobre la residencia que de noche 
hace en Granada don francisco de Paula sochantre, que no la haga en adelante, o exponga al cabildo las causas que tenga para ello. El señor Rector cele y cuide que los colegiales no armen ruido en el tiempo en que se dicen las misas de la intermedia, ni toquen ni usen instrumentos músicos en el Colegio en tiempo alguno del año como cosa opuesta a la moderación y exemplar conducta que deben guardar los eclesiásticos, evitando de este modo la instrucción en bailar y danzar que se iba introduciendo en los más de los colegiales.

\section{[744] ASAC XI, fol. 361 r (7-V-1778)}

Ítem se denegó al Sochantre don Francisco de Paula la súplica que hacía para no residir de noche en este Sacro Monte, en atención a ser hombre mozo y exigirlo así nuestra Constitución. Ítem pidió don Pedro de Torres que en atención a su pobreza y serle muy molesto el ir a comer a su casa en tiempo de verano se le concediese alguna limosna de comida para no bajar ni aumentar el gasto/en perjuicio de su familia. Y se le concedió para el tiempo del medio día media ración guisada, y en días de vigilia, platillo y taza, todo por cuatro meses y pagándolo el Patronato de Soria.

\section{[745] ASAC XI, fol. 361 v (1-VI-1778)}

Ítem para oír una providencia del señor Provisor de este Arzobispado relativa a el depósito de la persona de nuestro organista y padre Fray Francisco López, mientras dure la instancia de su demanda en razón de anular su profesión religiosa, y oída que se ha de resolver lo que al Cabildo parezca más conveniente. Estando así congregados dijo el señor Abad que el notario que había de notificar la providencia del señor Provisor, espera la licencia del Cabildo para entrar en él, y concedida entró e hizo presente como habiendo puesto demanda nuestro organista Padre López ante el señor Provisor de esta diócesis sobre nulidad de su profesión, su señoría le señalaba esta casa para que mientras durase el pleito estuviese en ella sujeto a las órdenes del señor abad y señor Presidente en calidad de depositado, concediéndole dichos señores las licencias que le parezcan prudentes para salir al seguimiento de dicho pleito. Después salió el dicho notario, y conferido el punto se admitió el dicho depósito en los términos que se hizo la notificación y se le manifestó al notario que volvió a entrar.

Ítem el señor Rico dijo que los colegiales se estaban ensayando hacer una comedia en obsequio del señor Abad electo, luego que tomase posesión, y que para ello tenían dispuesto diese cada colegial cierta proporción de dinero y se acordó no hubiera comedia en conformidad de lo mandado en otro cabildo anterior, se volviese a cada colegial su dinero en el caso de haberlo entregado, y para obsequio del señor abad y diversión de los colegiales en la toma de posesión, de la masa de gastos extraordinarios del colegio se compre por el señor Rector una ternera, que lidien y les sirva de platillo extraordinario en dicho día.

[746] ASAC XI, fol. 380 v (6-XI-1778) 
Si la vigilia que se canta por los padres del señor Fundador en su aniversario, día tres de noviembre, se ha de cantar ese mismo día o la tarde del día dos después de las Vísperas de Todos los Santos, con que se disolvió este cabildo.

Ítem se determinó que en acción de gracias por haber cesado los repetidos terremotos el inmediato domingo se expusiese en la misa de tercia la reliquia de San Cecilio, y la tarde del mismo se llevase a las Santas Cuevas en solemne procesión cantando el Te Deum Laudamus.

[747] ASAC XI, fol. ¿? (2-XII-1778)

Ítem que en orden a celebrar o cantar las vigilias de los aniversarios que siguen después de la vigilia de Todos los Santos, se esté a lo que mande la Consueta.

[748] ASAC XI, fol. 386 v (22-I-1779)

Se presentó una carta del rey, y abierta y leída resultó ser una orden de su Majestad para dar cuenta al Cabildo del feliz parto de la excelentísima Princesa de Asturias en que dio a luz una robusta infanta, y en acción de gracias mandó el cabildo se cantase el Te deum con todas las demostraciones de alegría acostumbradas.

[749] ASAC XI, fol. 389 r (8-IV-1779)

Que los himnos se canten en sus respectivos tonos según las diferencia de los tiempos eclesiásticos.

[750] ASAC XI, fol. 391 r (3-V-1779)

Sobre la fábrica de un libro nuevo Psalterio para vísperas en nuestro coro cuyo punto se remite por Junta de administración (...) fue este cabildo para tratar si se han de usar de capas pluviales en las misas cantadas en los días de fiesta como se acostumbra en otras iglesias catedrales y colegiales. Hágase libro nuevo de que se habla la citación.

[751] ASAC XI, fol. 398 v (6-IX-1779)

A don Pedro de Torres, uno de nuestros sochantres se le da licencia por quince días y diez pesos por una vez para ir a tomar los baños de Graena.

[752] ASAC XI, fol. 400 v (4-X-1779)

Para el aumento del culto divino, se mandó que los sochantres hiciesen la pausa conveniente para que el órganos toque los versos las veces que le pertenecen, tanto en las misas como en el oficio, siendo de más o menos duración según fuese la solemnidad del día. 
Se acordó que por ahora los señores caperos observen en la misa el siguiente rito; a saber; que salgan de la sacristía con toda ceremonia y suban al coro al esquilón; que allí para cantar el Introito lo mismo se ha de observar para los demás que deben cantar (que es todo lo que cantan los sochantres). Los dos señores más antiguos salgan de sus lugares, y se emparejen con los dos señores más modernos que no se moverán de su sitio, y en este, todos, vuelto el rostro hacia el Facistol, cantarán: que bajen al primer Kyrie para la Gloria, y que luego que hayan subido las gradas del pavimento bajo tomen los cetros, por delante: que en habiendo avisado la Gloria, se vuelvan al coro en el que no se sentarán, sino en la Epístola y Ofertorio; y que canten la Comunicanda, y fenecida, se bajen a la Sacristía.

[753] ASAC XI, fol. ¿? v (6-XII-1779)

Ítem se concedieron a cada uno de nuestros dos sochantres, don Francisco de Paula Díez y don Pedro de Torres ciento y veinte reales que se les ha de entregar en ropa para sus familias de la memoria del señor Olalla de Rojas.

1780

[754] ASAC XI, fol. 280 r (20-III-1780)

Fue para abrir una carta del Rey Nuestro señor, (que Dios guarde) en que nos participa del feliz y dichoso parto de la princesa Nuestra Señora, que dio a luz en el Real sitio del Pardo un infante a las tres y cuarto de la mañana del día cinco de este mes, para que concurramos con el fervor y devota disposición propia de nuestro amor y religioso celo a rendir a su Divina Majestad las más debidas gracias por la misericordia y benigna protección con que nos favorece; y en su cumplimiento se acordó que el segundo día de Pascua antes de Misa de Tercia se hiciese procesión desde Nuestra Iglesia a las Santas Cuevas cantando el Te Deum y demás antífonas y oraciones que en semejantes casos se acostumbra, con asistencia del Cabildo y Colegio.

[755] ASAC XI, fol. ¿? v (6-VII-1780)

Ítem don Pedro de Torres nuestro sochantre, suplicó le diese licencia y alguna limosna para ir a los baños de Graena a curarse del reumatismo que padecía y se le concedieron quince días de término y ciento y cincuenta reales contra la fábrica.

[756] ASAC XI, fol. ¿? (14-VII-1780)

Ítem habiéndose notado algunos defectos que se debían reformar para la mayor decencia del culto divino, así nuestro órgano, como su organista, se acordó que el señor tesorero convidase por un día a alguno de los organistas de san Jerónimo para que dicho facultativo viendo nuestro órgano, y observando el 
modo con que lo toca nuestro organista diga lo que se deba mandar sobre ambos puntos.

[757] ASAC XI, fol. 319 v (1-IX-1780)

Ítem don Pedro de Torres nuestro sochantre presentó memorial suplicando que en atención a los malos tiempos, su pobreza y larga familia, por modo de limosna y por el tiempo que el cabildo gustase le diese una hogaza diaria aunque fuese pan de Mozos, y se le concedió desde el día y por el tiempo de cuatro meses de las Rentas de Fábrica.

[758] ASAC XI, fol. 425 v (30-XI-1780)

Fue para oír una carta que el Rey, que abierta incluía una Real Cédula fechada en San Ildefonso a 21 de julio de 1780, dirigida al cabildo con carta de don Antonio María Salazar, secretario del Consejo y escribano de cámara más antiguo en que nos previene que su Majestad manda que en las funciones Santisimi Corporis Christi, no haya danzas, tarasca ni gigantones, y se acordó se responda de su recibo.

[759] ASAC XI, fol. 427 r (4-XII-1780)

Se asignó (...) a cada uno de los dos Sochantre 120 reales de fábrica.

\section{1}

[760] ASAC XI, fol. 432 v (9-II-1781)

Ítem por don Pedro de Torres y Mata nuestro sochantre se presentó memorial suplicando le diese una hogaza del pan de Mozos en atención a la carestía de los víveres y larga familia con que se hallaba y se le concedió por cuatro meses contados desde el día de esta gracia a costa de las rentas de Fábrica.

[761] ASAC XI, fol. 440 v (3-VII-1781)

Y con acuerdo de los señores Álvarez y Villalta y sin que gaste la Comunidad se eche solería al Coro de lo que más bien parezca.

Ítem el Maestro Reverendo Prior de San Agustín Descalzo de esta ciudad suplicó por memorial se le entregasen sin intervención del organista de este Sacro Monte su súbdito, los treinta ducados que éste debe dar a su Prelado de la renta que le ha consignado el Cabildo y se denegó.

[762] ASAC XI, fol. 443 v (3-VIII-1781) 
A don Pedro de Torres y Mata, nuestro sochantre, se le concedieron por vía de limosna para ir a los baños de Graena, ciento cincuenta reales de vellón de la renta de Fábrica con quince días de licencia y más al arbitrio del señor Abad si lo juzgase necesario para que dicho viaje no sea precipitado.

[763] ASAC XI, fol. 452 r (4-II-1782)

Se mandó que los lucernarios tanto antiguo como moderno no canten en los puntos de coro para todos, porque teniendo sus asientos fuera de él, causan disonancia en la Iglesia, y que el moderno no salga de su lugar para tomar la paz.

[764] ASAC XI, fol. 470 r (12-VIII-1782)

Ítem don Pedro de Torres nuestro sochantre pidió una limosna para ir a los baños de Graena y se le libraron cien reales de mesa para dicho fin.

[765] ASAC XI, fol. 471 v (2-IX-1782)

El señor Presidente insistió, consiguiente a su dictamen en las juntas y cabildos anteriores, en que se aminores los gastos y se supriman las plazas o empleos que no son de Constituciones, y que así se expresase su voto, como que los Sochantres no se curen en sus casas, estando de más el uno de los dos. Se acordó no se haga novedad por ahora.

[766] ASAC XI, fol. 476 r (5-XII-1782)

Ítem se mandó que cuando los señores salen a cantar lección u otra cosa en medio del coro, suelten enteramente la falda de la capa como está determinado muchas veces.

\section{TOMO XII}

[767] ASAC XII, fol. 9 v (2-VI-1783)

Igualmente se mandó se le intime al padre López que cuando los sábados si canta la Salve en la Iglesia la acompañe con el órgano, que el campanero avise para las mañanas y diga el Bendito y toque a los cuartos de los señores antes de la gorda para Vísperas.

[768] ASAC XII, fol. ¿? r (6-X-1783) 
Fue para leer una carta del Rey Nuestro señor en la que participaba su Majestad al Cabildo la agradable noticia del feliz parto de la Princesa que había dado a luz dos infantes gemelos uno a las ocho y otro a las 11 del día 5 de septiembre. Mandaba su Majestad en ella se diesen por el Cabildo las debidas gracias al Omnipotente lo que se ejecutó al día siguiente cantando solemnemente el Te Deum.

\section{5}

[769] ASAC XII, fol. 31 r (14-II-1785)

Que habiendo leído yo el secretario un memorial de don Pedro de Torres nuestro sochantre sobre pedir que se le prorrogue la gracia concedida por el cabildo para percibir por su salario tres hogazas de pan de mozos según había corrido hasta el día de San Cecilio próximo pasado se acordó conceder dicha prórroga hasta el último día del mes de agosto próximo futuro.

[770] ASAC XII, fol. 33 r (2-III-1785)

A un memorial de don Pedro de Torres nuestro sochantre con que solicitaba en fuerza de su pobreza se le perdonase el pago de 67, que resultaba deber en la cocina y que aseguraba tener satisfechos, se condescendió piadosamente a su petición.

[771] ASAC XII, fol. 36 r (4-IV-1785)

En cuanto a la mayor decencia del culto divino, se propuso por el señor Moreno que le parecía conveniente y se debía discriminar (... que alguno de los señores canónigos cantase la Calenda, debía el coro bajo mantenerse en pie o solamente el tiempo que durase el elogio de la festividad, más también todo el tiempo que durase la Kalenda, y conferenciando el punto se resolvió no se hiciese novedad en la práctica, y que se viese la Consueta en caso de hacer novedad.

[772] ASAC XII, fol. 37 r (6-IV-1785)

Vista ya la Consueta por los señores acerca del punto tocado en uno de los cabildos anteriores por el señor Morenos sobre que el coro bajo debía mantenerse en pie, durante todo el tiempo de la Kalenda que cantase algún señor prebendado por estar éste con estola y capa pluvial, (...) se acordó que el coro bajo se mantuviese en pie todo el tiempo que durase la Kalenda.

[fol. $37 \mathrm{v}$ ]

Asimismo propuso el señor Abad que se debía cantar el Sacriis Solemniis al tiempo de ocultar a su Majestad cuando se expone públicamente. Y conferido el punto se determinó que dicho señor abad se hiciese cargo de ventilar este punto con arreglo a nuestra Consueta y práctica de la Catedral: de lo cual debía dar parte al Cabildo para la resolución. 
[773] ASAC XII, fol. 42 r (1-VII-1785)

También se hizo presente si se debía decir en la oración Et famulos principem o principes por haber notado variedad: y conferido el punto se determinó con arreglo a lo resuelto en otros cabildos y a la práctica de la Capilla del Palacio del Rey, que uniformemente se dijese por todos principes habiendo príncipe y princesa.

[774] ASAC XII, fol. 46 v (1-IX-1785)

Se leyó un memorial de nuestro sochantre don Pedro de Torres en que suplicaba al cabildo le continuase por el tiempo de su voluntad la gracia de tres hogazas diarias de pan de Mozos por su situación, y por todos votos se mandó continuar dicha gracia por un año.

[775] ASAC XII, fol. ¿? (5-XII-1785)

Se leyó otro memorial de nuestro sochantre don Pedro de Torres en que pide al cabildo un vestido de que se halla sumamente necesitado: y se determinó que también el señor tesorero le mandase hacer chupa, calzones medias y zapatos.

1786

[776] ASAC XII, fol. 102 r (28-VII-1786)

Leyó otro memorial de nuestro sochantre don Pedro de Torres en que pide se le perdone lo que está debiendo y que debía haber pagado de su salario para la gracia que el cabildo le tiene hecha de tres hogazas diarias de pan de Mozo (...), y se le acordó que se le perdone lo que está debiendo a fin de Julio y siga disfrutando de la gracia dicha de las tres hogazas satisfaciendo por ellas el real y medio de dicho su salario, pero que esto no entre en su poder si no en el del señor Proveedor, y con destino al canon de huéspedes de donde corresponde y quedó admitida de su oferta de compensa (...) los Libros del Coro en agradecimiento a lo mucho que dice deber al cabildo según lo expresa en dicho memorial.

[777] ASAC XII, fol. 104 r (7-VIII-1786)

Se leyeron dos memoriales, uno del maestro Martínez Saavedra, nuestro capellán y otro de nuestro sochantre don Francisco Díez, en que piden alguna ayuda de costa para ir a los baños y se mandaron librar treinta ducados a cada uno, el primero contra la Mesa Capitular, y el segundo contra la Fábrica.

[778] ASAC XII, fol. 109 r (25-X-1786)

Se leyó un memorial de nuestro sochantre don Pedro de Torres en que pide la gracia de que juntamente con la carne en crudo que baja a su casa, se pueda bajar 
en crudo los demás del condimento a su puchero de tocino y berzas. Y se acordó no hacer este ejemplar por los graves prejuicios que pueden por él producirse.

[779] ASAC XII, fol. ¿? v (7-V-1787)

Últimamente se leyó un memorial de nuestro sochantre don Pedro de Torres en que pedía al cabildo algún socorro por limosna, se decretó se le librase a favor de su mujer. Y este lo costease la memoria de Olalla de Rojas.

[780] ASAC XII, fol. ¿? v (3-VIII-1787)

También propuse haber advertido que don Pedro de Torres, nuestro sochantre, parecía usaba para el coro de las sobrepellices propias del colegio y que éste no debía surtir al sochantre de sobrepelliz, sobre cuyo particular se determinó que ni don Pedro de Torres, ni otro alguno usase de las sobrepellices de e colegio, y que se lo permitiese dicho uso hasta el próximo día de Santiago, a fin de que entre tanto pudiesen hacerlas propias, y que pasado este término de ningún modo se valgan ni usen dentro del colegio.

[781] ASAC XII, fol. ¿? v (7-XII-1787)

Últimamente leí un memorial de nuestro sochantre don Pedro de Torres en que solicitaba al cabildo le perdonase ciertos reales que debía al cajón de la cocina y se dispuso que no ha lugar esta súplica, acordando al mismo tiempo que con ninguno que no sea sacerdote se lleve cuenta en la cocina ni se dé nada fiado.

[782] ASAC XII, fol. 134 r (4-IX-1787)

Ítem después recordé yo que no se observaba lo mandado por cabildo de julio próximo en orden a que el sochantre Torres y el maestro Sahavedra, no usasen de las sobrepellices del colegio, añadiendo que al primero le habían hurtado una de estas sobrepellices ajenas en el tiempo ya prohibido por lo cual se acordó que dicho decreto se lleve a total y debido efecto, concediendo quince días a último término para que las hagan.

(..)y que así los sochantres como el órgano, observen aquellas pausas que entre verso y verso debe haber en el canto.

[783] ASAC XII, fol. ¿ ? (8-X-1787) 
También tratándose de culto divino, quedó el señor Abad encargado en avisar a los capellanes asistan a vestirse en las misas cantadas sin causar tardanzas.

[784] ASAC XII, fol. 158 v (12-XII-1787)

Así mismo había notado que en algunos aniversarios de difuntos se cantaba otra misa que la señalada par aniversario, (...) se mandó que siendo (como es expreso en la rúbrica del misal poderse decir la una o la otra misa en dicho aniversario se cante la que diga y señale nuestra Consueta: y que si no la señalare se traiga el caso a cabildo para que haga entre las dos la elección que mejor le parezca.

\section{8}

[785] ASAC XII, fol. ¿? (11-II-1788)

Ítem para dar cuenta de la necesidad de (y de la composición del órgano de nuestra Iglesia.

[786] ASAC XII, fol. ¿? (12-II-1788)

Para lo respectivo al órgano se dio comisión al señor Bejarano, para que se informara de peritos tanto de la calidad y necesidad de la obra que necesita cuanto el costo que tendrá.

Últimamente se presentaron cuatro memoriales pidiendo limosnas o perdones de los sochantres, pertiguero y dos mujeres, y se acordó se tendrán presentes para cuando haya arbitrio.

[787] ASAC XII, fol. ¿? (8-IV-1788)

También se leyó otro memorial de nuestro sochantre don Pedro de Torres, pidiendo al cabildo le prestase novecientos maravedíes por acudir a cierto empeño a que no se asintió por los motivos que se expresaron y estimaron en más justos.

[788] ASAC XII, fol. ¿? (5-V-1788)

También se leyó un memorial de nuestro sochantre don Pedro de Torres pidiendo limosna para ropa y que diera el cabildo orden se le pagaran dos meses de postres que se le deben pertenecientes a la administración de Villaroel, y otros tres meses pertenecientes a la recaudación interina de nuestra casa y se acordó que se le pague por ahora solamente lo que se le debe respectivo a nuestra recaudación.

[789] ASAC XII, fol. ¿? (30-VI-1788)

Fue para dar cuenta de la muerte del licenciado don Marcos Lamar colegial del señor San Dionisio Areopagita, natural de la ciudad de Guayaquil en las Indias, 
hijo de don Marcos Lamar y de doña Josefa Cortazar, verificada en la tarde del expresado día 30 de junio, en cuya virtud se acordó que en el día inmediato primero de Julio se cante el oficio de difuntos con Laudes, como es de costumbre en nuestra Iglesia para tales casos; y con asistencia general cante la misa de Requiem el señor Presidente, y que todos y cada uno de los canónigos, capellanes y sacerdotes de la casa apliquen una misa rezada.

\section{[790] ASAC XII, fol. ¿? v (12-XI-1788)}

Se acordó y mandó (habiendo entrado en Cabildo el Señor Méndez) que se componga el órgano de nuestra Iglesia.

[791] ASAC XII, fol. ¿? r (30-XII-1788)

Fue para abrir una carta del Rey Nuestro Señor que Dios guarde, la que abierta y leída por mí, se vio que en ella su Majestad daba al Cabildo la triste noticia de haber muerto el día catorce de este mes el Señor Rey Don Carlos III, su augusto padre y encargaba se le hicieran en esta Nuestra Iglesia las honras y funerales que en semejantes casos se habían acostumbrado, de que su Majestad se daba por servido, en cuya virtud se acordó que se hagan dichas honras en nuestra Iglesia como su Majestad lo manda, para lo cual se guarde el orden prevenido en nuestra Consueta, que es el que sean estos funerales como los que se hacen a los Padres de nuestro venerable Fundador, que sea en dos indistintos puntos el uno al siguiente viernes próximo por la vigilia y el otro el sábado por la mañana para la misa que habrá de celebrar el señor Abad, a la hora acostumbrada de la misa de tercia.

\section{[792] ASAC XII, fol. ¿? (s.f.)}

Después se leyeron dos memoriales, el uno de don Pedro de Torres, Sochantre, en que pedía por Dios y en caridad, que se le aumentase en alguna cosa la taza de potaje que es costumbre dar en los días de vigilia, y se determinó que en caridad de limosna y por solo lo que queda de esta Cuaresma se le aumente una taza más.

[793] ASAC XII, fol. ¿? (30-XII-1788)

Después se leyó un memorial del maestro López organista en el que nos daba cuenta de haber sacado de su santa bula de secularidades pero que era con la cláusula de que había de tener suplicaba el consignamiento de 60 ducados sobre el trabajo de su salario.

Se acordó que en habiendo comentado que dicha Bula esta parada y apuntada por el Supremo Concejo se daba.

[794] ASAC XII, fol. ¿? r (1-IX-1789) 
Se leyó u n memorial de don Pedro de Torres en que pedía por Dios y por los Santos se le diese alguna limosna, por ocurrir algunas en muchas necesidades, y se acordó se decretase que por ahora no daba lugar y se le dijese que asista que asista a su obligación con más beatitud.

\section{[795] ASAC XII, fol. ¿? r (4-X-1789)}

Que se conserven las loables costumbres de esta casa y el culto divino se aumente en lo que sea posible, a cuyo fin se prevenga al organista que haciendo el coro las pausas que debe, toque en ellas los versículos que le corresponden y no se cantan, como es de su obligación.

[796] ASAC XII, fol. 200 v (2-XII-1789)

Ítem se leyó otro memorial de don Francisco Díez nuestro sochantre que solicita de la piedad del Cabildo se le dé alguna limosna para acudir en estas Pascuas algunas de sus necesidades y se acordó se le librasen 10 ¿¿ del Patronato del Señor Olalla.

[797] ASAC XII, fol. 205 v (20-II-1790)

El señor Abad añadió que un sobrino de dicho Ilustrísimo Abad de Alcalá la Real don Esteban Lorenzo de Mendoza (le había buscado y entregado diez pesos que consignaba dicho señor en su testamento para que esta comunidad le dijese una Vigilia y Misa y que en él también dejaba a nuestra librería varios juegos de libros en cuya inteligencia se acordó que se reciban luego que los envíen los Albaceas que en el primer día desocupado se celebre otra misa por el dicho señor Abad y se le cante la Vigilia todo con la mayor solemnidad en reconocimiento y atención de la memoria de dicho señor difunto.

[798] ASAC XII, fol. 216 v (5-VII-1790)

Habiéndose mandado que nuestro Sochantre, don Pedro de Torres no vaya de hábitos de coro y procesiones como lo ha hecho alguna vez

[799] ASAC XII, fol. 223 v (10-IX-1790)

Se concedió al Padre López, nuestro organista, el préstamo de 701 reales a cuenta de su salario y postres bajo de las seguridades correspondientes.

[800] ASAC XII, fol. 231 r (13-XII-1790) 
Se mandaron librar cien reales de vellón de Mesa Capitular por título de limosna a nuestro Sochantre don Francisco de Paula.

\section{1}

\section{[801] ASAC XII, fol. 240 r (4-IV-1791)}

Se leyó un memorial de nuestro Sochantre don Pedro de Torres en que pedía algún socorro y se resolvió se le comprasen zapatos, medias, sotana y museta.

[802] ASAC XII, fol. 244 r (4-VIII-1791)

Y habiendo el señor Rico manifestado algunos desórdenes que se notaban por haber algunos muchachos quebrantado la clausura de nuestra casa para ir a funciones de Granada, y que se oían muchas veces cantar y tocar guitarra, se acordó que en cuanto a los colegiales quede al cuidado y prudencia del señor Rector.

Evitar en lo posible los juegos en el claustro y el uso de guitarra, que tocan frecuentemente.

[fol. $248 \mathrm{r}$ ]

Habiéndose observado algunas faltas en los sochantres de nuestra Iglesia, se determinó que en las procesiones vaya el colegial a la derecha del sochantre, que en el coro alto y bajo se ponga un sochantre entre los colegiales y no antes de ellos, que en las comuniones y adoración de reliquias vayan los sochantres después de los colegiales, y que si éstos hacen alguna falta en el coro, no sean reprehendidos por los sochantres si no que éstos den cuenta al Abad o Presidente.

[803] ASAC XII, fol. 253 r (5-XII-1791)

Se leyó un memorial del Sochantre don Francisco de Paula y se le concedieron ciento y veinte reales de limosna sobre rentas de mesa capitular.

[804] ASAC XII, fol. 253 v (19-XII-1791)

Es para tratar si se ha de anticipar la hora de empezar nuestro Maitines en la noche vigilia de la Navidad de nuestro señor Jesucristo a ejemplo de la Santa Iglesia Catedral y de la Insigne Iglesia Colegial de Nuestro Salvador. Se determinó que imitando a la Catedral sean en nuestra Iglesia los maitines de la Navidad a las diez y media, y que en ellos y en todos los demás días en que tenemos maitines en nuestra Iglesia sean cantados nuestros responsorios.

[fol. $254 \mathrm{r}]$ 
En orden a lo que se ofrece con la ocasión de suspensión de misas y aniversarios suspendidos en el Cabildo antecedente se resolvió que la misa de la Virgen que se cantaba los Sábados siga cantándose y por turnos, y libremente cada a uno aplique por quien quiera (...) que la Procesión de los Domingos se siga también y se haga no por medio de la Iglesia sino por la Capillas, y el gasto de la cera sea por cuenta de la fábrica.(...) Que los Aniversarios de Difuntos, que se cantaban todos los meses, se suspendan igualmente que los demás Aniversarios y Misas por un año.

\section{2}

[805] ASAC XII, fol. 271 r (8-IV-1792)

Fue para abrir y leer una carta del Rey nuestro Señor para avisar del feliz parto de la reina nuestra señora y encargaba se dieran a Dios las más gracias, en cuya atención se decretó que a dicho fin se cante en procesión solemne, que vaya a las Santas Cuevas, el Te Deum.

[806] ASAC XII, fol. ¿? v (19-VIII-1792)

Fue para dar cuenta el señor Abad de haberle nombrado su Majestad para Obispado de Cartagena de Indias en el distrito del Nuevo Reino de Granada, y manifestar al Cabildo sus afectos en orden a que si éste lo tenía a bien, dispusiera se cantara el Te Deum en acción de gracias a la Santísima Trinidad, y no permitiera que se hiciera por parte del Colegio funciones que pudieran llamar la atención del pueblo o pertubar el orden y el sosiego de nuestra Comunidad, añadiendo que esta serán sus intenciones o deseos, habiendo anteriormente significado que todos sus ascensos los debía a esta casa y a la buena educación que desde sus tiernos años había recibido en ella, y habiéndose conferido el punto reconociendo todos el grande honor que resultaba al Cabildo de los $\dot{\imath} ? \dot{\iota} ? \dot{i}$ y grandes méritos que está adornada la persona de su Ilustrísima, el señor Abad, acordamos que en lo relativo al Te Deum y cualquier otra cosa de piedad y religión con que quiera su Ilustrísima dar a Dios las gracias de su acomodo, se celebre todo a su voluntad y siguiendo su beneplácito, más por lo que respecta a que el Colegio no haga funciones en presentación de su debido júbilo se haya el Cabildo cortado, queriendo por un lado complacer a su Ilustrísima con su condescendencia a cuanto pide, y discorde por otro dar y que dé el colegio señales públicas y nada equívocas de la complacencia que le asiste y honor por recibir en la exaltación de su cabeza; en cuya atención y para proceder con más seria deliberación sobre este asunto se acordó que se cite de nuevo a Cabildo a fin de resolverlo con el deseado acierto, mediante los motivos que se tomen y las consideraciones que hagan los señores capitulares para regular sus votos.

[807] ASAC XII, fol. 280 r (6-IX-1792) 
Después propuso el señor Lara que los Libros de Coro necesitaban componerse y se resolvió que dicho señor quedase encargado de hacer la composición necesaria y que más convenga.

1793

[808] ASAC XII, fol. 288 r (21-II-1793)

Y que se recordara a los Sochantre que no tomen el día de descanso semanal el día en que hay o aniversarios o coro para todos. Que por ahora se componga el libro de los Kyries y no se haga otro nuevo.

[809] ASAC XII, fol. 292 v (17-V-1793)

Leyose un memorial de don Pedro de Torres, nuestro Sochantre en el cual pedía alguna distribución el aniversario, descubrimientos, a lo cual se respondió no haber lugar.

[810] ASAC XII, fol. ¿ ? (28-VI-1793)

Y es para proveer la Abadía, única dignidad de esta Nuestra Insigne Iglesia, vacante por la promoción y ascenso del Ilustrísimo señor don Miguel Álvarez Cortéz, que la obtenía a la mitra de Cartagena de Indias: y habiendo elección canóniga acordar las cartas acostumbradas a favor del así electo para la imprecación de las Bulas de su Santidad y Real Cédula de su Majestad, todo de acuerdo con nuestras Apostólicas Constituciones (...)

Y llamado entró el pertiguero en la Sala Capitular, y ordenó el señor Mesa que publicara estar electo abad de esta Insigne Iglesia, en paz, sin contradicción y de unánime consentimiento, señor Don Cayetano Márquez (...) después el señor Abad electo pronunció un discurso de cuyas palabras no pude dar testimonio el que solo suscribe porque estando muy inmediato a la puerta de la sala capitular, el ruido de la campana, trompetas, atabales y voces de aclamación sólo le dejaron percibir lágrimas y afectos como de un ánimo tan lleno de sorpresa por la elección como tocado de gratitud y reconocimiento.

[811] ASAC XII, fol. 311 r (7-X-1793)

Se leyó un memorial de nuestro Sochantre don Pedro de Torres que pedía algún socorro con respecto al tiempo tan estrecho que se experimenta, que se mandó responderle tuviese en consideración el muy esquivo que diariamente le da la mesa capitular por la permuta que de sus sueldo en tres hogazas que vale mucho más que el sueldo que deja de percibir. 
[812] ASAC XII, fol. 314 v (2-XII-1793)

Se Leyeron memoriales de nuestro sochantre Díez y el organista López pidiendo algún socorro. Se le concedieron al primero cien reales, del segundo nada pues este año había percibido quinientos reales que se daban al que acostumbra a venir a arreglar el órgano en todo el año, y no habiendo venido éste, tampoco lo ha hecho el López, en cuyo favor siempre ha salido esta libranza. Y en orden a esto se mandó que en otra ocasión se viese lo que convendría hacer para que el órgano fuese, como convenía, arreglado.

[813] ASAC XII, fol. 316 r (9-I-1794)

Que se decida en el cabildo próximo y con la instrucción competente si a el organista corresponde ración de canónigo o de colegial, por habérsele asignado cuando fue admitido dos raciones solamente y habérsele aumentado después otra, durante la vida de su madre por los motivos y las razones que expuso.

[814] ASAC XII, fol. 321 r (6-III-1794)

Se vio también un memorial de nuestro sochantre don Pedro de Torres que solicitaba se le diese alguna cantidad de limosna para satisfacer los réditos de dos meses del arrendamiento de casa que no podía satisfacer por su pobreza y se le denegó dicha solicitud.

[815] ASAC XII, fol. 325 v (3-IV-1794)

También se acordó se observasen nuestras Constituciones y Loables Costumbres con toda puntualidad y que se aumente el culto divino en cuanto sea posible a cuyo fin se dio comisión al señor Lara para que haga se limpie el órgano que tiene de ello gran necesidad.

[816] ASAC XII, fol. 327 r (5-V-1794)

Se leyó otro memorial de nuestro Sochantre don Pedro de Torres en que pedía se le diesen de limosna o se le prestasen cien reales para satisfacer una deuda que le afligía y amenazaba gran perjuicio. Se acordó se le presten los cien reales por el proveedor y los cobrase del valor de las raciones que deje de tomar y cuyo importe lo paga él mismo.

\section{[817] ASAC XII, fol. 328 r (2-VI-1794)}

Por cuanto se había reparado que la máxima general de que todos los colegiales indistintamente canten las Calendas y Fratres en el coro, inducía desorden e indecencia en lugar de el decoro y gravedad que exige el divino culto, haciendo risibles los actos más serios de la religión la ineptitud y mala voz de algunos 
colegiales. Se mandó prevenir al señor Rector a fin de que diga y haga instruir los que son más aptos para cumplir con este ministerio. Propuso un capitular que le parecía haber exceso de culto en las procesiones de los domingos por ser práctica universal de todas las iglesias ir cubiertos presidente y sacerdote en semejantes procesiones y acá por el contrario descubiertos como en las del Santísimo Sacramento: se acordó exonerar de ejecutar los decretos y ritos de procesiones para la restitución de este punto.

\section{[818] ASAC XII, fol. 334 r (15-VIII-1794)}

El Padre López sobre que se le diera o despachara la justificación que por el afinado de nuestro órgano estaba señalada a su maestro Fray Pedro del Sacramento por decir que a este la ha satisfecho antes de su muerte el Padre López. Se decretó atento a que no había Fray Pedro afinado el órgano, no había hecho suya la gratificación por el cabildo para premio de su trabajo, pero que en aclaración a lo que el Padre López ha hecho o suplido en su órgano.

\section{[819] ASAC XII, fol. 343 v (4-IX-1794)}

Se leyó un memorial de nuestro Sochantre don Pedro de Torres en que manifestaba la aflicción de su familia por sus continuas enfermedades y no podía subsistir por su escasa renta de 50 ducados por el excesivo precio de las carnes y no serle ya permitido el llevar a su casa en especie la carne que deja de consumir de su ración. Se acordó que la renta de este se aumentase a 80 ducados bajo la precisa condición de que cuando el enfermo y curándose en su casa, si para su alimento usare de su puchero, solo pueda llevárselo a este fin ya cocido y con una sola ración.

\section{[820] ASAC XII, fol. 344 r (6-X-1794)}

Y dio comisión al señor Méndez para que cuide del arreglo que deben observar los sochantres y organista en la alternativa de los versículos que se tocan y cantan.

\section{[821] ASAC XII, fol. 345 v (12-X-1794)}

Los sochantres y pertiguero deberán tener igual ¿? En el punto para que de sus faltas dé noticia el señor apuntador al señor Proveedor por meses o semanas para que éste deje de darles otras tantas comidas como faltas hayan tenido o la mitad de ellas si la falta hubiese sido solamente por la mañana o por la tarde y ellos las hubieren tomado en los días que faltaron pero se exceptúan de esta pena en los días que usan de los primeros del recle que les está concedida (...).

\section{[822] ASAC XII, fol. 348 r (16-XII-1794)}

A nuestro sochantre don Pedro de Torres que pidió se le diese alguna limosna para ocurrir a su notoria falta de ropa, se determinó que el señor tesorero le diese chupa, sotana y calzones o lo que estimase serle más necesario. 
[823] ASAC XII, fol. 350 r (12-I-1795)

También se ofreció duda de si la cantidad mandada invertir en ropa de don Pedro de Torres, limosna concedida en el cabildo ordinario que se mandó pagar de tesorería, había de ser por libranza extraordinaria por el señor tesorero o si este señor había de hacer el gasto del ordinario de fábrica y se acordó esto segundo mandando tildar la libranza para este efecto hecha por contaduría y el asiento del libro de toma de razón.

[824] ASAC XII, fol. 373 v (4-IX-1795)

Quejándose después y lastimándose mucho el señor Presidente González de la precipitación y atropellamiento con que se rezaba el oficio divino en el coro los días semidobles y siguiendo otros señores dando estas mismas justísimas quejas se acordó que se avisara al señor Mesa y se le notificara el decreto capitular de que como corrector de coro, corrigiera y pusiera remedio a un abuso tan deplorable y escandaloso.

[825] ASAC XII, fol. 392 v (8-X-1795)

El segundo punto fue que estando como efectivamente estaba corriente la limosna de 20 reales que dejó el señor Spínola para que se diera una misa cantada por el alma del Señor Conde de Santiago, y que habiendo sida aceptada dicha memoria por el cabildo, le parecía justo se celebrara dicha misa cantada, con cuyo dictamen también convino el cabildo acordando que dicha misa fuese de turno y que se celebrase en las Santas Cuevas con el sobredicho estipendio de los 20 reales.

[826] ASAC XII, fol. 391 r (3-XII-1795)

Seguidamente se leyeron tres memoriales de los sochantres y del mozo de aposentos que pedían les socorriese el cabildo y se les concedió cien reales a cada Sochantre y sesenta a Albea.

[fol. $391 \mathrm{v}$ ]

Se acordó después que al organista se le anticipen 150 reales que pide por cuenta de su salario, porque le hacen falta, según expone en un memorial.

[827] ASAC XII, fol. 398 v (12-V-1796)

Se mandó prevenir a los sochantres sobre la acentuación de algunas palabras latinas. 
A un memorial del padre López maestro organista, en pretensión de optar cuarto. Mandó el cabildo primero que ocupe el cuarto que dejó el caniculario, segundo que en adelante no dé al cabildo memoriales sobre dicho asunto (...).

[828] ASAC XII, fol. 400 v (18-VI-1796)

Propuso el señor Abad que el día 15 del presente bajó por la tarde a la ciudad como había de costumbre nuestro organista don Francisco López, y dirigiéndose a casa de nuestro Sochantre don Pedro de Torres le entregó las llaves del órgano, para que las trajese al día siguiente asegurándole se ausentaba para no volver más, y que no le volvería a ver hasta el Valle de Josafat, diciéndole también con falsedad que de todo tenía ya noticia el señor abad y que en segundo, al amanecer del día siguiente había enviado por el ajuar de su cuarto, cuya llave entregó de su orden el conductor de la a nuestro primer contador.

En vista de tan extraña despedida se acordó dar por vacante su plaza, y que poniendo el señor Abad un interino, examinemos a los pretendientes que ya empezaban a acudir y tratar de informar de sus respectivas habilidades y conductas, se hiciera en otro cabildo la elección de sucesión para dicha plaza, acordándose al mismo tiempo si este empleo se había de unir con el de contador que está vacante, y la renta que recibió en su pasado se le debería asignar.

[829] ASAC XII, fol. 401 r (5-VII-1796)

Ítem para nombrar persona que sirva la plaza de organista de nuestra Iglesia vacante por la ida voluntaria de don Francisco López, antes Fraile Francisco López de Loreto, que la ha tenido en propiedad.

[fol. $401 \mathrm{v}$ ]

Se eligió a pluralidad de votos a don Luís de Ledesma para servir la plaza vacante de organista, con la obligación también de afinar el órgano y servir en las horas compatibles con este oficio la plaza de contador tercero de nuestra contaduría. Asignándole de sueldo anual 3000 reales, comida diaria ordinaria cuanto a ración y propio o extraordinario de colegiales en los días que lo hiciera.

[830] ASAC XII, fol. 403 r (30-VII-1796)

Se pasó también a nombrar organista, y leídos todos los memoriales y todos los informes correspondientes consultándose a los señores mejor servicio de la Iglesia, la falta de la contaduría y el menor costo de sirvientes, se nombraron a don Luís de León y Cisneros para que sirviese el órgano en los días de fiesta con la obligación de afinarlo, siendo su salario de cien ducados en cada un año, y se nombró también a don Serafín Martín para que sirviese el órgano en los demás días del año, siendo también de su obligación el asistir también a la contaduría y todo con el estipendio de cien ducados en cada un año y ración de colegio. 
[831] ASAC XII, fol. 403 r (23-VIII-1796)

Se leyó también otro memorial de don Manuel de Torres pidiendo alguna gratificación por el tiempo que había suplido las faltas del órgano, y acordó el cabildo se le diesen 150 reales.

[832] ASAC XII, fol. 404 r (3-X-1796)

Se dio comisión al señor Lara, canónigo Tesorero, para que se componga una misa para los días solemnes.

[833] ASAC XII, fol. 409 r (10-XII-1796)

Se leyeron otros dos memoriales con igual súplica (de ayuda de costa) de nuestro sochantres don Francisco Díez y don Pedro de Torres, y se acordó que al segundo nada se diese y no volviese a pedir hasta ser más puntual en el cumplimiento de su obligación, y que al primero se le libren cien reales previniéndole no se excuse de cantar seguidamente como suele hacer con notable perjuicio del coro.

[834] ASAC XII, fol. 416 v (10-I-1797)

Se decretó también que quede en toda su función y vigor el decreto capitular anterior en que se manda a los contadores en este nuestro sacro Monte que solo el don Serafin Martín pueda con licencia expresa del señor Abad por razones que suscribe el cabildo, faltar del dicho Sacro Monte y pernoctar en Granada, pero que ha de subir los domingos y días festivos a instruirse en el órgano.

[fol. 417 r] A don Pedro de Torres, nuestro sochantre, que mediante memorial pedía un socorro para salir de un apuro en el que se hallaba, decretó el cabildo que atendiendo a sus constantes faltas por una parte, y por otra a su necesidad se le librasen 60 reales, y que volviendo a faltar al esplendor de una hora, se le multase en una de las tres hogazas que se le dan, y en dos horas en dos hogazas, y de todo un día se le primase de las tres y que en su lugar se le diera su real y medio.

Dispuso la petición que incluye una orden del señor Intendente de Granada en que por orden superior mandaba que se le diera cuenta y razón de todas las hermandades que hubiese en este Sacro Monte, sus Constituciones, etc sobre lo que decretó el cabildo se remitiera al señor Intendente las Constituciones de la sola y única hermandad que hay en este Sacro Monte que es la del Espíritu Santo. 
[835] ASAC XII, fol. 451 v (2-VI-1797)

Leyose otro memorial de don Pedro de Torres, el sochantre, exponiendo al cabildo la necesidad en que se veía de hacerse ropa de verano, como capa, chupín, y calzones, se dignase a adelantarle 300 reales a cuenta del sobrante de sus raciones. Y los sobrantes eran de sus postres cada mes: con cuyo motivo quejándose el señor Proveedor del abuso que advertía en la cocina de sacar el don Pedro y otros sus comidas o crudas o cocidas y a las horas que gustaban sin orden ni mercado, acordó el cabildo que ninguno pudiese sacar nada de su comida en crudo y sin haberse antes aviado y que lo habían de sacar a la hora competente que le señalase el señor Proveedor; que al don Pedro se le diese como lo pedía, y en el caso de que nada debiese en la cocina de las cuentas acabadas, y se le adelantase el importe de unos y chupa negra decentes.

[836] ASAC XII, fol. 452 r (10-VI-1797)

Fue para leer una carta del Ilustrísimo señor don Pedro Vejarano, electo obispo de Buenos Aires, que dando al cabildo esta plausible noticia, y asegurando, que el honor de haber sido individuo suyo lo había proporcionado a gracia de su Majestad, le suplicaba, que rogara a Dios le diera toda la suficiencia de que necesitaba para el exacto cumplimiento de su ministerio tan elevada y arduo. Y el cabildo, alegrándose mucho de sus ascensos acordó que yo como su secretario/452r capitular escribiese a dicho señor, dándole mil enhorabuenas de su nueva dignidad, y asegurándole en tanto el cabildo para algún desahogo de su alegría y para agradecer al cielo colme a su no se qué de sus mayores bendiciones, hubiera repiques generales un Te Deum cantado en procesión a las Santas Cuevas.

[837] ASAC XII, fol. ¿? (3-VII-1797)

A nuestro sochantre don Pedro de Torres que mediante un memorial pedía al cabildo se dignara por un afecto de su piedad concederle la gracia de sacar y levarse a su casa por mantener a su familia su puchero y guisado a las horas oportunas para dicho fin, y también de que se le prestasen 300 reales para vestirse; acordó el cabildo concederle ambas gracias con tal que nada ha de sacar en crudo de nuestra cocina, y que los 300 reales se le presten del cajón de dicha cocina donde se cobrarán con el sobrante de la raciones de don Pedro, como él mismo lo promete en su memorial. También a don Francisco de Paula se concedió como a don Pedro el que pudiese sacar de la cocina y llevar a su casa su ración de guisado después de ya marcado en manteca o en aceite, como acostumbra a hacerlo o componerlo.

[838] ASAC XII, fol. ¿? (1-IX-179)

Sobre Constituciones, Ceremonias y Loables costumbres y sobre el culto divino dijo y propuso el señor González el desarreglo y desconcierto que había en el 
órgano los días de trabajo y el que principalmente había habido en los maitines de la Asunción, cuya razonable propuesta conceptuándola el cabildo por justísima, por una gran reforma de que necesita el dicho órgano, deseando sumamente el cabildo el que se toque siempre causando devoción y edificación al coro con su arreglo y acompañamiento y no distracción y disipación su arreglo y desentono, acordó que el dicho secretario intimara a don Serafín de Montijano, nuestro organista de los días de trabajo la orden capitular de que se le señalaban cuatro meses de término para que dentro de ellos se instruyere más de lo que estaba en los tonos y acompañamientos del órgano, de suerte que a fin de los cuatro meses pudiese tocarlo como debe, y apetece el cabildo y que así no lo hiciese se tratará de removerlo; cuya orden cumpliendo el infraescripto con su obligación intimó al señor Montijano: también el mismo señor González deseando se reforme cuanto se pueda nuestro Coro, propuso al cabildo las faltas clásicas de nuestro sochantre don Pedro de Torres, tanto en punto de su asistencia al coro como en su canto, notándosele una suma implicación y ningún esmero aún en las semanas en que le toca el gobierno o dirección del Coro: el cabildo convencido de su verdad y de la justicia con que pedía dicha reforma, después de varios medios que para la reforma y enmiendo del don Pedro se propusieron, se adoptó últimamente el que el señor Abad, llamando al señor don Pedro, viese, si con suavidad o con su autoridad pudiese reformarlo y hacerle que cumpla con más exactitud su obligación.

[839] ASAC XII, fol. 441 v (12-XI-1797)

Fue para abrir una carta que resultó ser del excelentísimo señor don Francisco Sahavedra, colegial que fue en este Insigne del señor San Dionisio Areopagita, dando noticia de haberlo el rey promovido a su secretario de estado y del despacho universal de Hacienda, y ofreciendo sus facultades a disposición del cabildo con el modo más patético y expresivo, en cuya atención se acordó primero que a día inmediato se hiciese con toda solemnidad procesión a las Santas Cuevas, cantando el Te Deum, y después en la Iglesia se celebrase le señor abad una misa cantada en acción de gracias a Dios por este beneficio. Segundo que al día siguiente a lo referido hiciese el colegio por su parte igual función en su capilla, cantando el Te Deum antes y celebrando después el señor Rector al mismo fin otra misa solemne, tercero que se saque retrato fiel al dicho señor para perpetuar su memoria y nuestra gratitud. Cuarto que también a la señora su esposa, (a más de la carta de contestación a dicho su excelentísimo) se le escriba por el cabildo dándole los más enérgicos parabienes y expresivas enhorabuenas. Quinto, y por el señor Rector se le conteste a la carta de dicho señor ministro respecto a su ascenso se le conceda a su colegio tres días de asueto y uno de campo, y últimamente queriendo el cabildo sensibilizar su complacencia por todos los modos posibles, acordó dar comisión al señor Villalva, colegial y canónigo que ha sido de esta casa. 
[840] ASAC XII, fol. 444 r (1-XII-1797)

Se leyeron luego varios memoriales, uno de don Francisco Díez, nuestro sochantre que exponiendo hallarse muy atrasado y con falta de una capa, pedía una ayuda de costa para hacerla, más el cabildo no hallando arbitrios de donde hacerle dicha gracia, acordó no haber lugar su petición.

1798

[841] ASAC XII, fol. 449 v ( $₫ ?-~ ¿ ?-1798)$

En cuanto a ceremonias en la Iglesia, habiéndose observado bastantes faltas en los colegiales, y haberse ofrecido a instruirlos el maestro don Martín de Saabedra, capellán de coro en ella, se acordó que con asistencia del señor Rector y en las ocasiones que se señale se facilite esta enseñanza tan útil y precisa para el decoro correspondiente al culto divino. $\mathrm{Y}$ en lo que toca a la asistencia $\mathrm{y}$ aumento de éste se hizo presente la decadencia de los dos únicos cantores o sochantres que por sus crecidas edades como por sus achaques habituales y distancia de sus domicilios y demás ocurrencias que se da entre los mismos de que se dimanan frecuentes faltas en el coro, y para remediarlas, se acordó encomendar al señor Lara y al infrascripto secretario la diligencia de buscar sujetos idóneos para el mencionado oficio que fijen su residencia en esta casa, prefiriéndose a los que tengan o quieran seguir el estado eclesiástico, y a los sochantres actuales don Francisco de Paula Díez y don Pedro de Torres se les haga entender este proyecto del cabildo, y que para haberles de conceder algún premio al tiempo de su retiro, es menester que procuren granjearlo, evitando faltas de asistencia y poniendo cuidadoso esmero en el desempeño de las obligaciones de su oficio.

Se leyó memorial del sochantre don Pedro de Torres y Mata pretendiendo se le perdone un resto de 80 o 90 reales que debe al cajón de huéspedes por resto de una mayor cantidad que se le prestó de aquel fondo. Se acordó perdonarle 80 reales y que pague lo demás hasta la total solvencia de su adeudo.

[842] ASAC XII, fol. 45 r (7-III-1798)

En lo tocante al culto divino se acordó continuarlo con todo el esmero posible y lo hice presente en virtud del acuerdo y comisión que se me había fiado en hacer diligencia de cantores o sochantres que sirvan nuestro coro había entendido que tomaría de buena voluntad este establecimiento, un presbítero de excelente conducta y gran voz que sirve en la Real Capilla de esta ciudad de cuya actitud en la música trae muy buenos informes nuestro sochantre don Pedro de Torres, y pone que para dejar enteramente su plaza podría el cabildo recomendarlo al excelentísimo señor ministro de hacienda suplicándolo lo colocase en algún empleo de rentas con que se pudiese alimentar en su ancianidad y sostener su larga familia. A que se acordó que el señor abad por sí ejecutase esta buena obra 
respecto de no parecer conveniente al cabildo moleste en esta materia la atención del referido señor ministro.

\section{[843] ASAC XII, fol. ¿? r (1-VI-1798)}

De igual modo se acordó la asistencia y aumento del culto divino, con cuyo motivo hizo presente el señor Lara que en seguida de la comisión dada por el cabildo acerca de proporcionar cantores o sochantres para el mejor desempeño del coro en vista de las faltas que se convierten en los actuales por su mucha edad, achaques que padecen, y tener su domicilio fuera de esta casa, había sabido que el padre Fray Juan Ribera de la Presentación religioso presbítero agustino descalzo del convento de esta ciudad residente ahora en el de Sevilla apetecía venirse a servir una de estas plazas y sobre ellos había escrito a nuestro organista don Luís de León quien informaba exactamente de la idoneidad, suficiencia, buena voz y arreglada conducta del susodicho. Por lo que conferenciado el asunto y atendiendo a todas las circunstancias que ofrece la materia y madurez con que debe tratarse se acordó que por mí el secretario se practique la diligencia que se me ha encomendado a fin de resolver acertadamente en la pretensión del expresado religioso, y les haga entender a los sochantres actuales el esmero y vigilancia con que el cabildo trata de traer persona que sirva adecuadamente el coro de esta Iglesia en fuerza de los continuados defectos que se experimentan de los mismos, y por consiguiente habrán de sufrir el preciso desfalco de sus rentas para la dotación del que se admita de nuevo, teniéndose en consideración por el cabildo (para la asignación que traía de quedar a cada uno) el desempeño que respectivamente se les advierta de sus deberes, y puntual asistencia al coro con el cuidadoso esmero de quien ha de llevar cumplidamente los divinos oficios.

[844] ASAC XII, fol. ¿? (4-IX-1798)

También repara en el estilo de irse cantando y repitiendo en dicha procesión [Procesión de la virgen a las cuevas]la letanía de nuestra señora, cuyas preces dice no se conforman a las establecidas para semejantes casos en el ceremonial citado de obispos donde se prescribe que en procesiones de la virgen se canten sus tres himnos, los salmos de vísperas y siempre la Magnificat; y caso que haya de continuarse cantando la letanía sea sin repetición como se observa en las de rúbrica del breviario romano.

Todo lo cual enterado el cabildo acordó que no se use de paño de hombros en dichas procesiones, siguiendo la costumbre de ella en todo lo demás, mientras no se encuentre decreto prohibitivo que obligue a la reforma de las preces que de tiempo muy antiguo se usan en esta comunidad, sobre lo cual podrá consultar el maestro de ceremonias. 
[845] ASAC XII, fol. ¿? (8- $; ?-1798)$

Se hizo presente un memorial de nuestro sochantre don Pedro de Torres en que solicita un socorro de ropa para su familia del patronato destinado a este fin y se acordó tenerlo presente en el cabildo donde se trate de este repartimiento.

[846] ASAC XII, fol. ¿? (25-X-1798)

Y entendida la necesidad de composición que tenía el órgano de nuestra iglesia, y que su costo que importaba 1500 reales de vellón debía salir de fábrica sin libranza se acordó quedara el señor tesorero comisionado para efectuar dicha obra, suspendiendo por ahora otra de colocar el asiento del organista con la correspondiente tribuna hacia la Iglesia que también se propuso.

[847] ASAC XII, fol. ¿? (6-XI-1798)

Deseando el aumento del culto divino se mandó además de la obra del órgano ya acordada en el anterior extraordinario, volver su teclado a la Iglesia, componer y añadir unos pitos y registros cuyo costo está evaluado en 400 ducados que se pagarán en varios plazos. 
APÉNDICE 3

EDICIÓN Y RECONSTRUCCIÓN CEREMONIAL DEL RITO DE LA SALVE SEGÚN LAS FUENTES CONSERVADAS EN LA ABADÍA DEL SACROMONTE. 



\section{Salve Regina}

Abadía del Sacromonte de Granada

Transcripción y reconstrucción: Mercedes Castillo Ferreira

\section{Cantoral LC LXVI}

Cantoral LC XLII

Consueta: Colegiales y canónigos de rodillas en dos coros. A los tres golpes de la gorda los versicularios abren y sostienen el libro de la Salve. El Sochantre que se encuentra en medio de los colegiales se levanta y entona el comienzo de la Salve que prosigue el coro:

\section{Cantoral LC LXVI:}
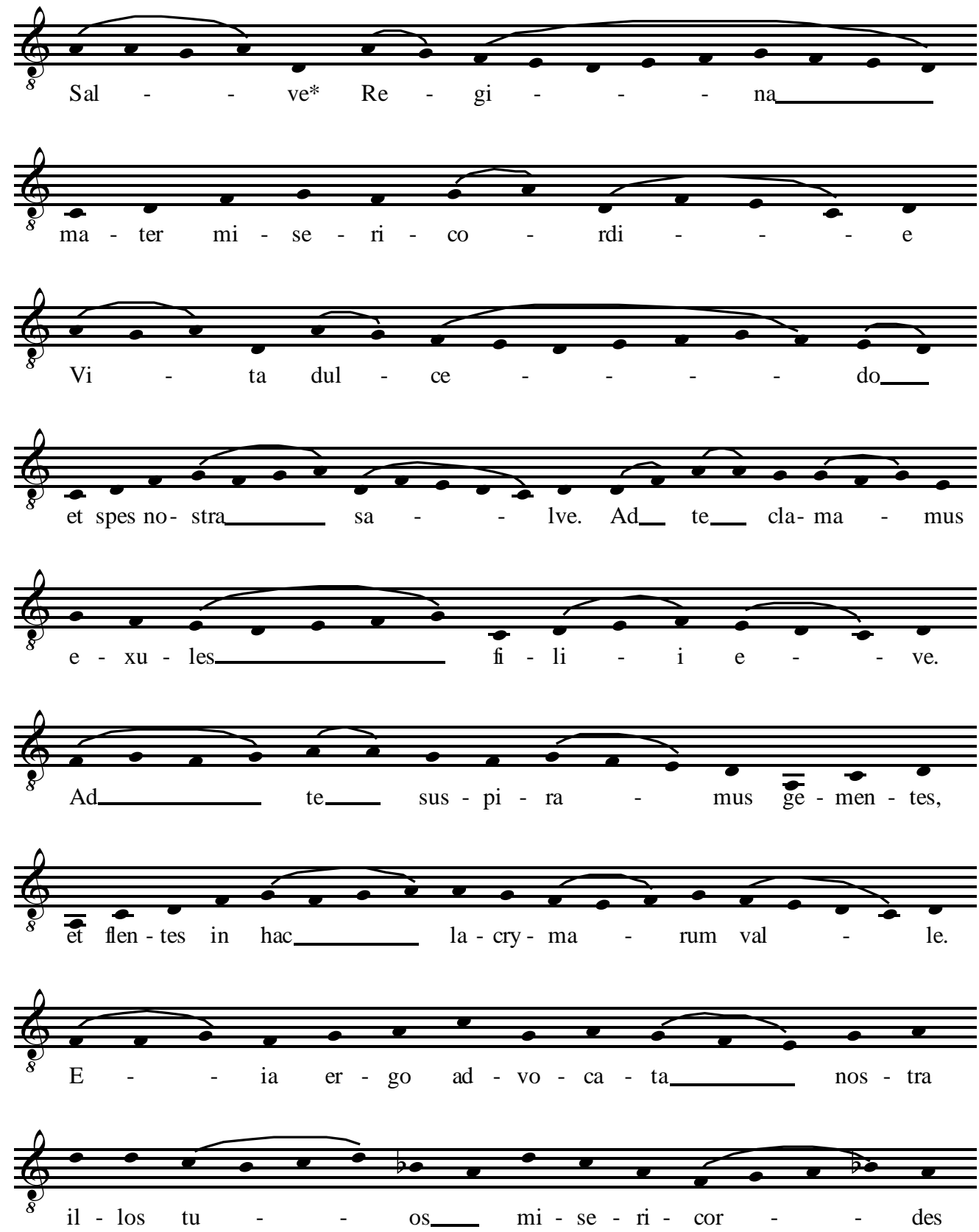

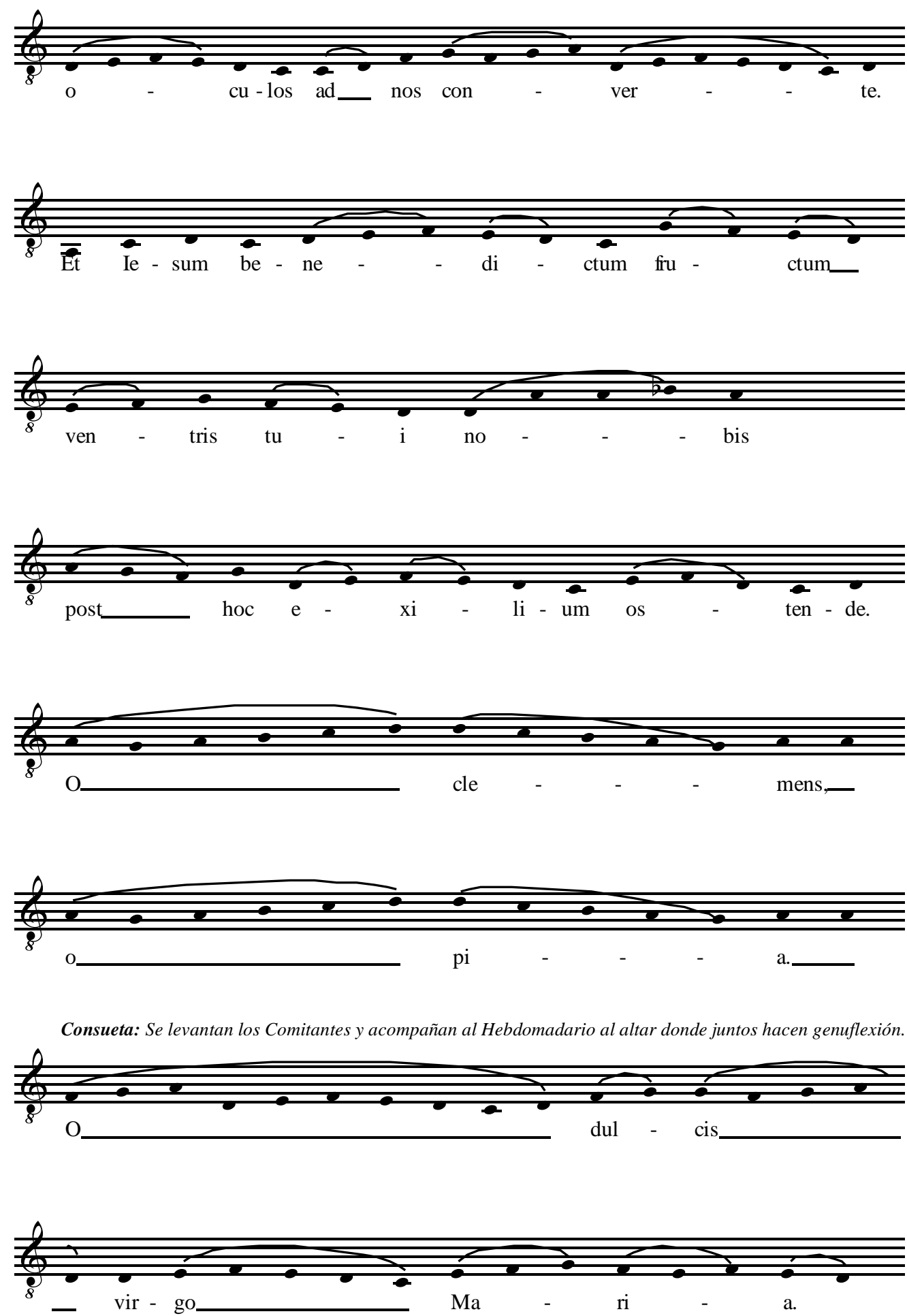

Consueta: Los colegiales cantores entonan el verso "Ora pro nobis"

Cantorales LC XLII y LC LXVI: V. Ora pro nobis sancta Dei genitrix.

R./ Ut digni efficiamur pro missionibus Christi.

Consueta: Los Comitantes sostienen el libro para que el Hebdomadario pueda decir la oración con las manos puestas: 


\section{Cantoral LC XLII:}

\section{Oremus}

Omnipotens sempiterne deus, qui gloriosa virginis matris Mariae corpus \& animam, ut dignum Filii tui habitaculum effici mereretur, Spiritu sancto cooperante praeparasti da, ut cuius commemoratione laetamur, e [...] pia intercessiones ab instantibus malis \& a morte perpetua liberemur. Per eundem Christum dominum nostrum.

R./ AMEN. (Coro)

\section{ANTÍFONA}

Consueta: El Sochantre entona el comienzo y prosigue el coro al mismo compás que la Salve.

Cantoral olim LC XLII

Cantoral olim LC LXVI
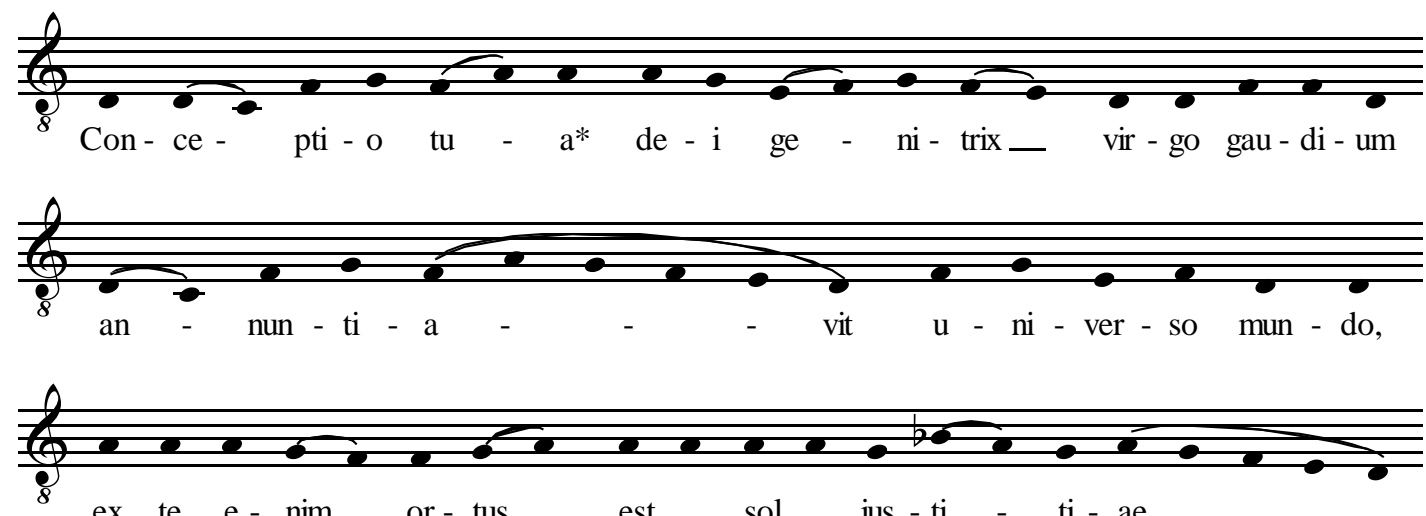

ex te e - nim_ or - tus__ est__ sol__ ius - ti - ti - ae
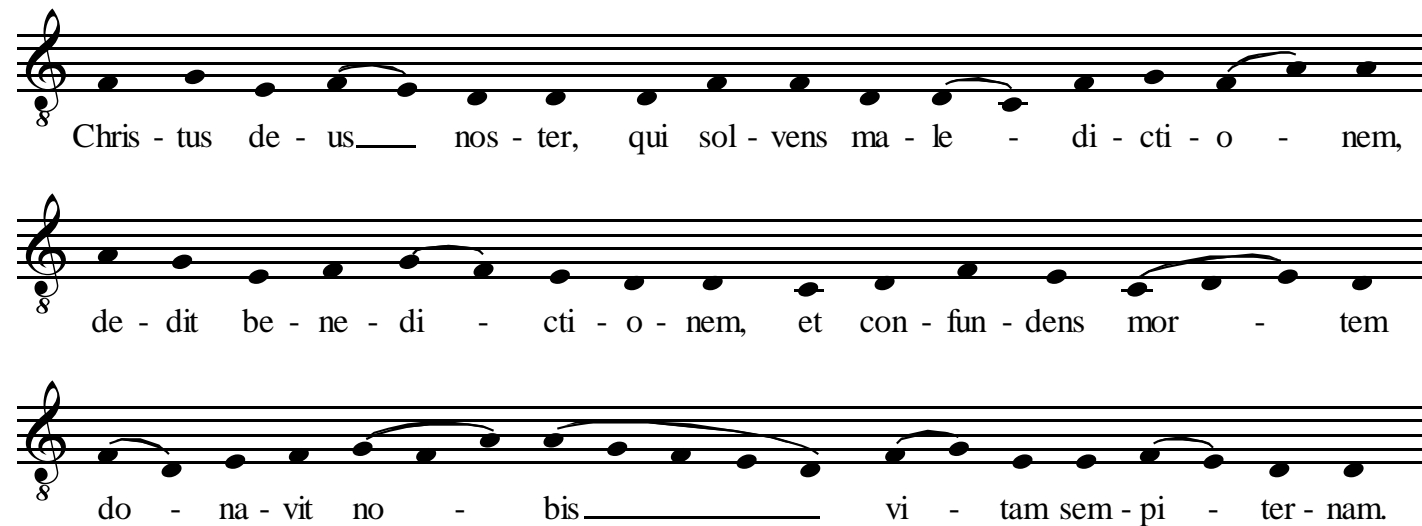

Consueta: Los colegiales cantores entonan el verso

Cantoral olim LC XLII y LC LXVI: V. Elegit eam Deus, et praelegit eam. 


\section{R./In tabernaculo suo habitare facit eam.}

Consueta: El Hebdomadario se levanta y dice la siguiente oración

\section{Cantoral LC XLII:}

\section{Oremus}

Famulis tuis, quae sumus Domine, caelestis gratiae munus impertire: ut quibus beatae Virginis partus extitit salutis exordum, Conceptionis eius votiva commemoratio, pacis tribuat incrementum. Per Dominum Iesum Christum.

\section{R./ AMEN (Coro)}

Consueta: Los Comitantes hacen genuflexión y acompañan al Hebdomadario a su lugar y se hincan de rodillas.

El que preside hace señal y se levantan colegiales y Rector, los cuales hacen genuflexión y se van por donde vinieron. Al llegar a la reja del horno de San Cecilio se hincan de rodillas y hacen oración a los santos mártires hasta que el Rector se levanta. Lo mismo repiten en la reja de San Hiscio. Finalmente van a la Iglesia y juntos hacen genuflexión al altar mayor. En la Sacristía dejan los sobrepellices y visitan al Santísimo Sacramento. Los prebendados se van como vinieron y visitan las cuevas y hornos santos. 
APÉNDICE 4:

EDICIÓN DE LA MISA PARA LA FIESTA DE SAN CECILIO, PATRÓN DE GRANADA. 



\section{MISSA \\ DE S. CAECILIO \\ EPISCOPO, ET MARTYRE \\ Patrono Principale Ecclesiae, et Diócesis \\ Granatensis}

Transcripción y Edición: Mercedes Castillo

INTROITO
Música: Archivo del Sacromonte, LC XX, fols.7175.

Texto: MISSA DE S. CAECILIO EPISCOPO, ET

MARTYRE Patrono Principale Ecclesiae, et

Diócesis Granatensis, Archivo Palacio de los

Córdova,
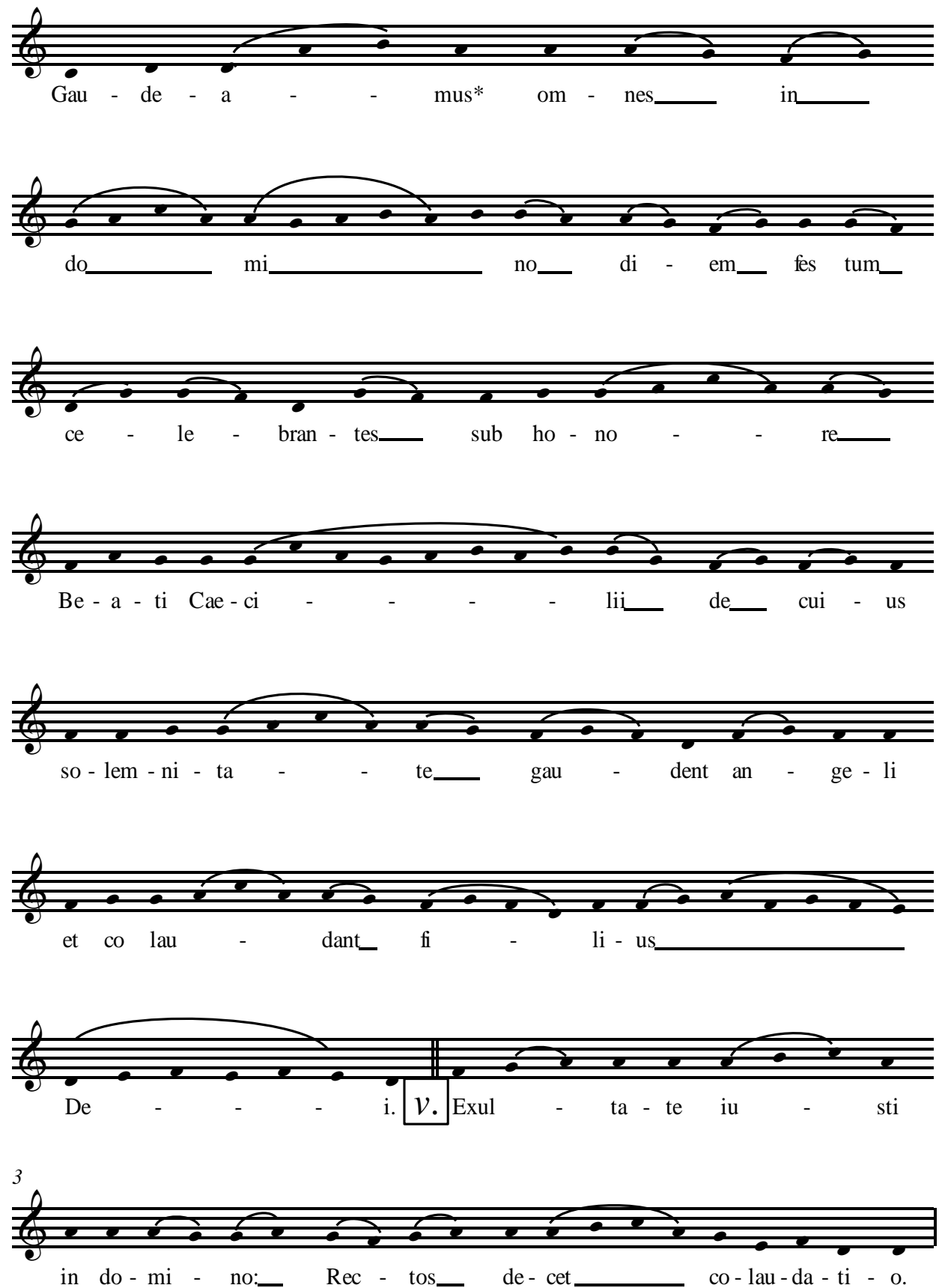
Gloria Patri, \&c, Gaudeamus \&c.

Kyrie eleison.

Gloria in excelsis Deo \&c.

\section{ORATIO}

Deus, qui nos per beatum Caecilium martyrem tuum, atque Pontificem ad agnitionem tui nominis venire tribuisti, concede propitius, ut per quem superni muneris rudimenta suscepimus, per eum subsidia perpetuae salutis impetremus. Per Dominum nostrum \&c.

\section{Lectio Epistolae B.Pauli Apostoli Thessalonicenses.}

Fratres fiduciam habuimus in Deo nostro loqui ad vos Evangelium Dei in multa solicitudine. Exortatio enim nostra non de errore, neque de immunditia, neque in dolo, sed sicut probati sumus a Deo, ut crederetur nobis Evangelium. Ita loquimur non quasi hominibus placentes, sed Deo, qui probat corda nostra. Neque enim aliquando fuimus in sermone adulationis, sicuti scitis; neque in occasione avaritiae. Deus testis est. Neque quaerentes ab hominibus gloriam, neque a vobis, neque ab aliis, cum possemus vobis oneri esse, ut Crhisti Apostoli, sed facti? Sumus paruuli in medio vestrum, tamquam si nutrís foveat? Filios suos. Ita desiderantes vos, cupidi volebamus tradere vobis non solum Evangelium Dei, sed etiam animas nostras, quoniam charissimi nobis facti? Estis. Memores enim estis fratres laboris nostri, \& fatigationis, nocte ac die operantes, ne quem vestrum gravaremus, praedicavimus in vobis Evangelium Dei. Vos testes estis, \& Deus quam sancte, \& et iuste, \& et sine querela vobis qui credidistis, fuimus sicuti scitis, qualiter unumquemq; vestrum sicut Patri filios suos deprecantes vos, \& consolantes, testificati sumus, ut ambularetis digne Deo, qui vocavit vos in suum Regnum, \& Gloriam.
Gloria al Padre, etc, Gaudeamus etc, Señor ten piedad.

Gloria a Dios en el cielo etc.

\section{ORACIÓN}

Oh Dios, que nos hiciste conocer tu nombre por medio de tu santo mártir y pontífice Cecilio,: haz propicio que, por quien recibimos las enseñanzas del soberano don, alcancemos también los auxilios de la perpetua salud. Por el Señor etc.

\section{Lectura de la Carta de San Pablo Apostol a los Tesalonicenses.}

Y sabéis también que nuestras exhortaciones no procedían de error, ni de conscupiscencia, ni de engaño; sino que de probados por Dios, se nos había encomendado la misión de evangelizar; y así hablamos, no como quien busca agradar a los hombres, sino sólo a Dios, que prueba nuestros corazones. Porque nunca, como bien sabéis, hemos usado de lisonjas ni hemos procedido con propósitos de lucro. Dios es testigo; ni hemos buscado la alabanza de los hombres, ni la vuestra, ni la de otros; y aún pudiendo hacer pesar sobre vosotros nuestra autoridad como apóstoles de Cristo, nos hicimos como pequeñuelos y como nodriza que cría a sus niños; así llevados de nuestro amor por vosotros, queremos no sólo daros el Evangelio de Dios, sino aún nuestras propias vidas: tan amados vinisteis a sernos. Ya os acordaréis, hermanos, de nuestras penas y fatigas y de cómo día y noche trabajábamos para no ser gravosos a nadie, y así os predicamos el Evangelio de Dios. Vosotros y Dios sois testigos de nuestra conducta santa, justa, irreprochable con los que creíais. Sabéis que como un padre a sus hijos, así a cada uno os exhortábamos y alentábamos y os conjurábamos a andar de modo digno de Dios, que os llamó a su reino y gloria. 
GRADUALE
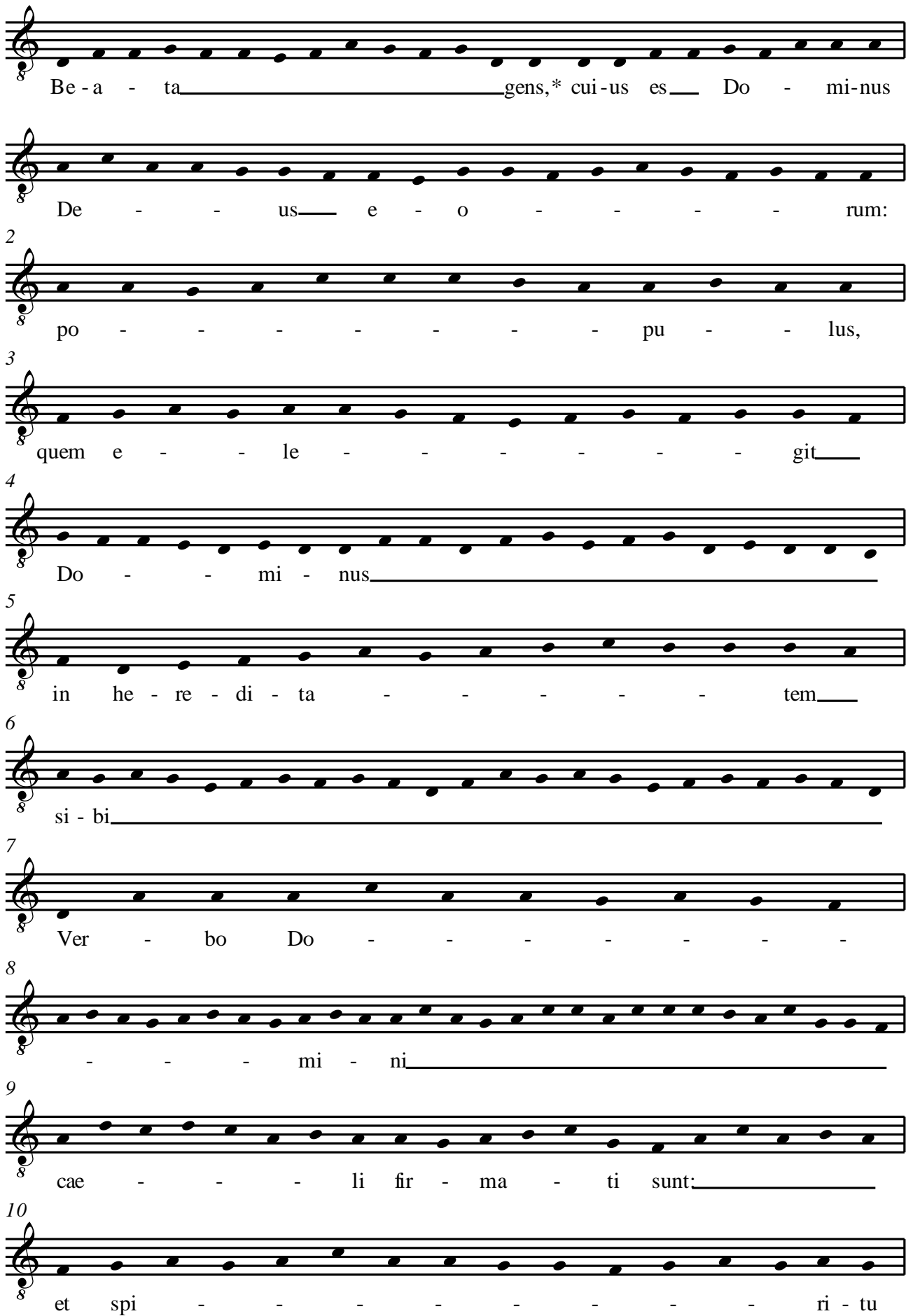

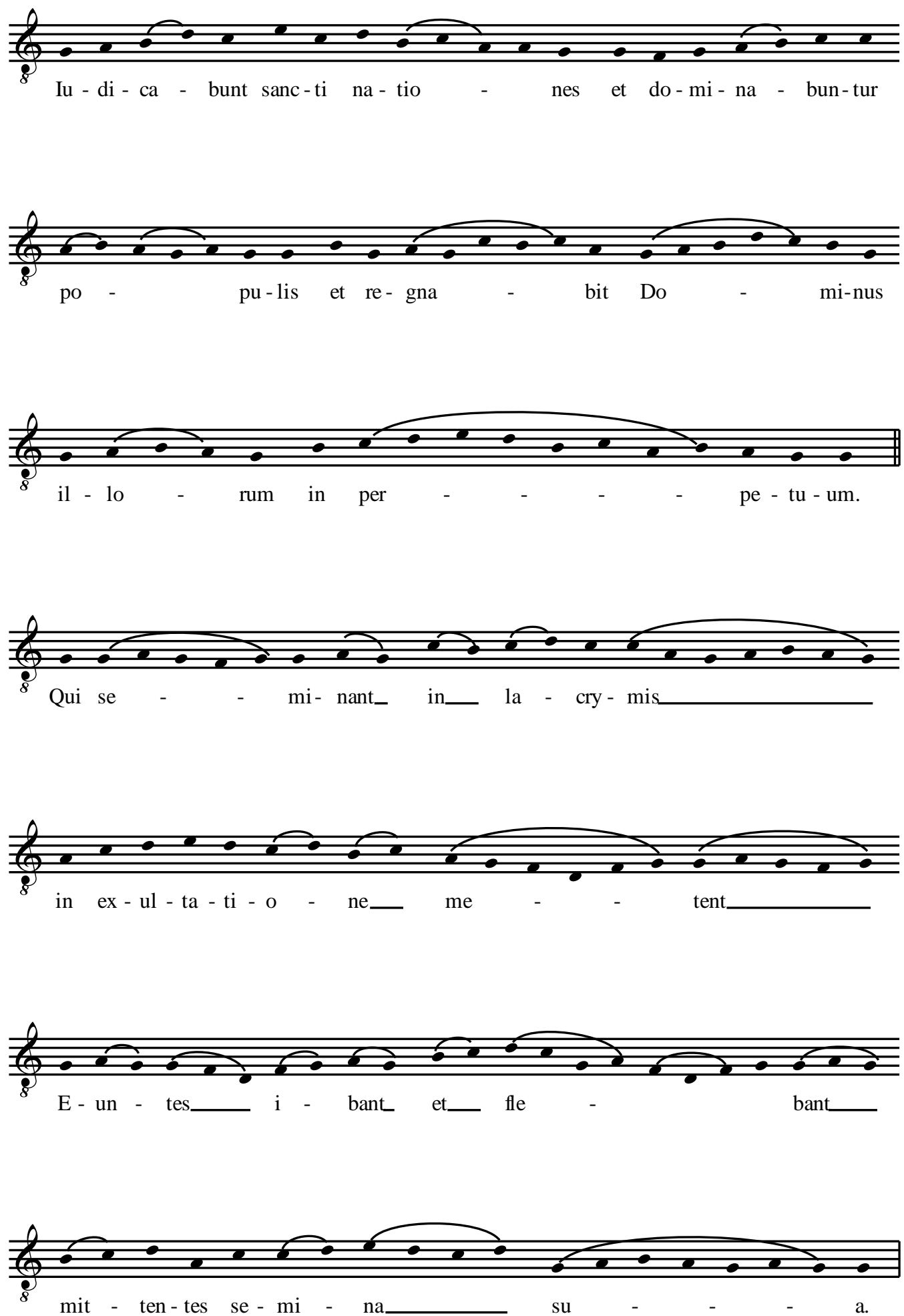
Sequentia sancti Evangelii secundum Ioannem

In illo tempore dixit Iesus discipulis suis: Amen, Amen dico vobis, nisi granum frumenti cadens in terram mortuum fuerit, ipsum solum manet, si autem mortuum fuerit multum fructum affert. Qui amat animam suam perdet eam, et qui odit animam suam in hoc mundo in vitam aeternam custodit eam. Si quis mihi ministrat, me sequatur, et ubi ego sum, illic et minister meus erit; si quis mihi ministraverit, honorificabit eum Pater meus.

\section{Credo}

Lectura del Santo Evangelio según

San Juan 12, 24-26

En aquel tiempo dijo Jesús a sus discípulos: En verdad, en verdad os digo que, si el grano de trigo no cae en la tierra y muere, quedará solo; pero si muere, llevará mucho fruto.

El que ama su vida, la pierde; pero el aborrece su vida en este mundo, la guardará para la vida eterna. $\mathrm{Si}$ alguno me sirve, que me siga, y donde yo esté, allí estará también mi servidor; si alguno me sirve, mi Padre le honrará.

\section{Credo}

\section{OFERTORIUM}
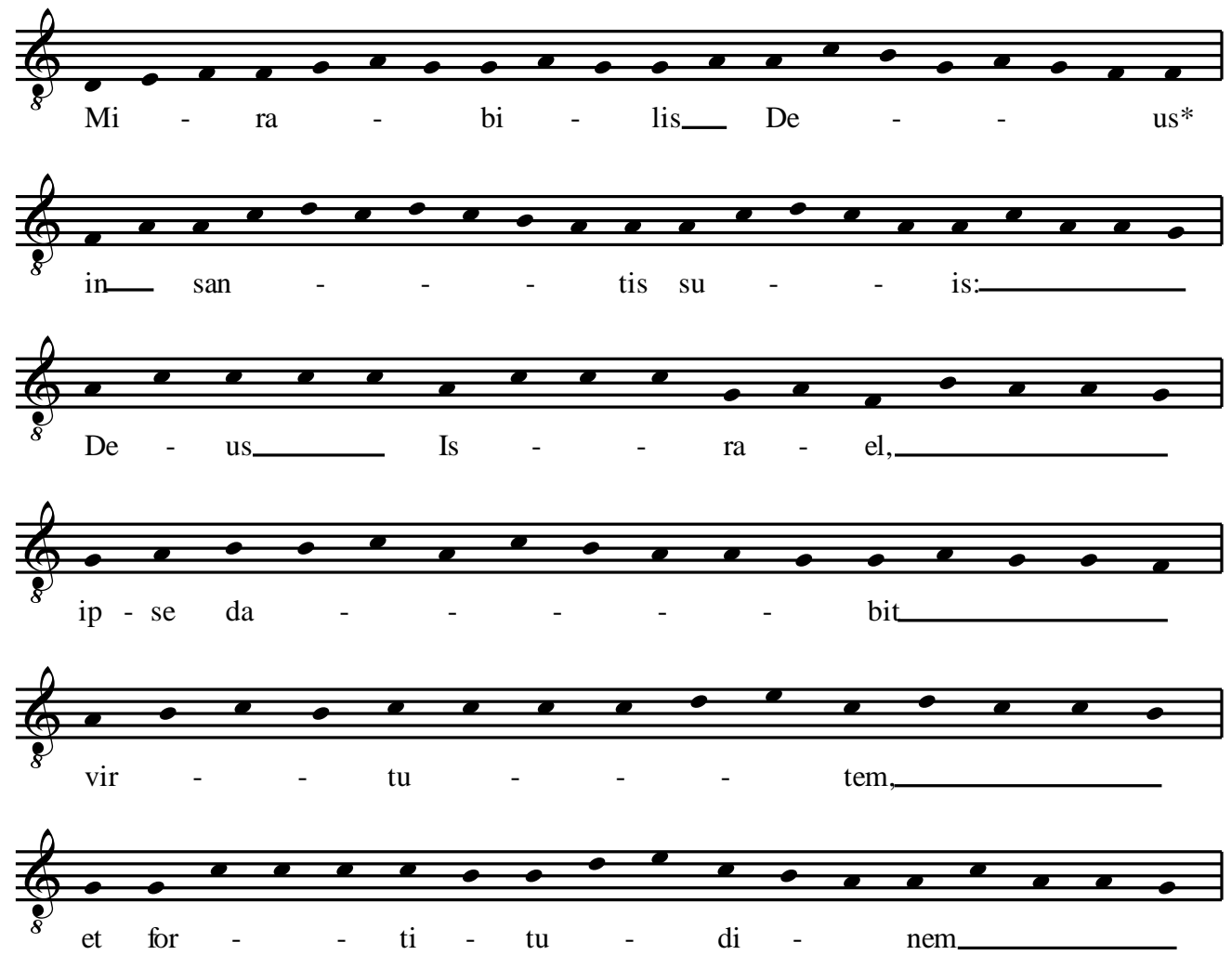

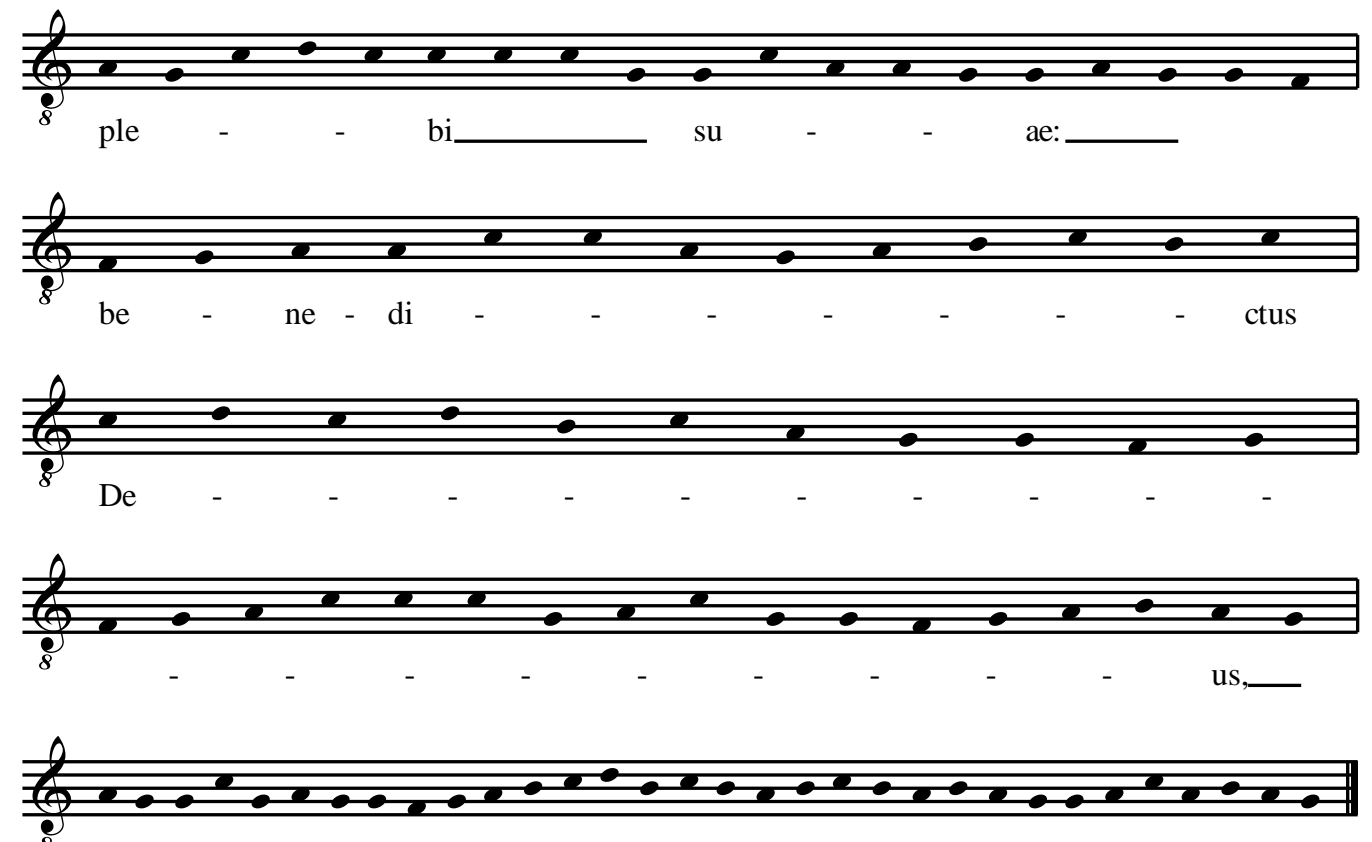

al - le

lu - ia

\section{Secreta}

Munera tibi Domine oblata sanctifica, et qui nobis per ministerium beati Caecilii martyris tui, atque Pontificis veritate Evangelii patefieri voluisti, concede, ut quod ab illius ore didicimus gratia tua adiuti operari valeamus. Per Dominum nostrum Iesum Christum.

\section{COMMUNIO}

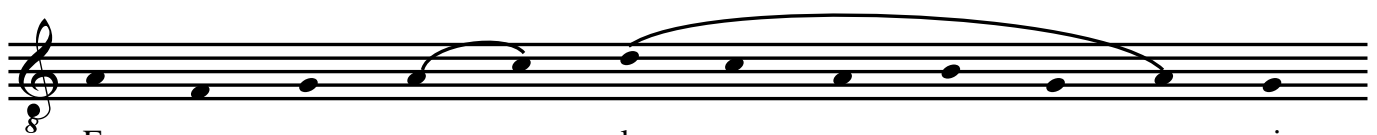

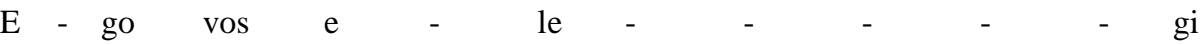
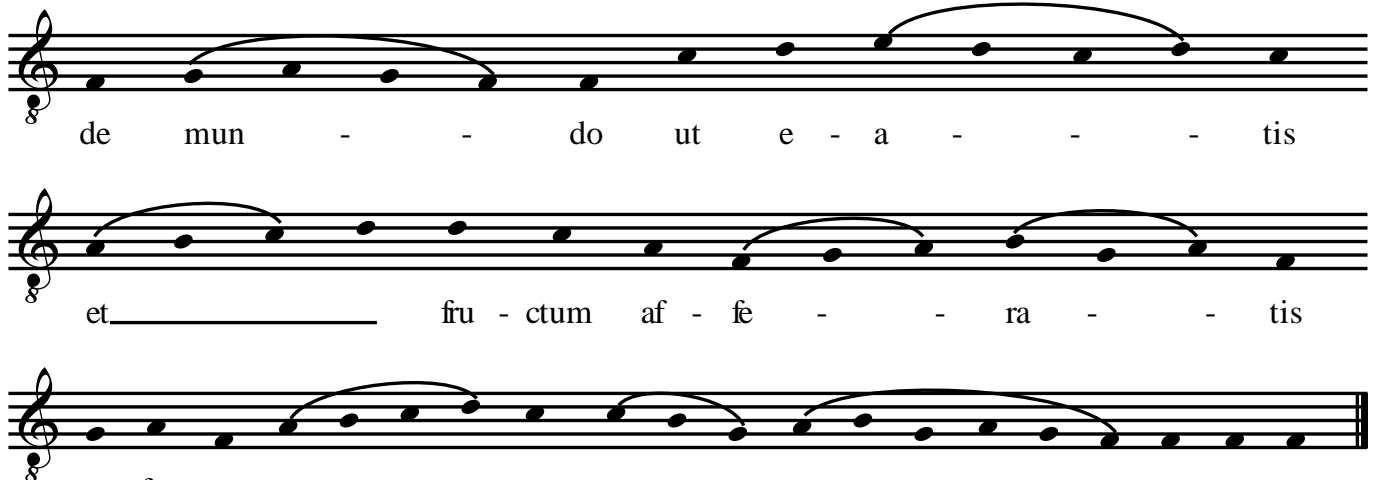

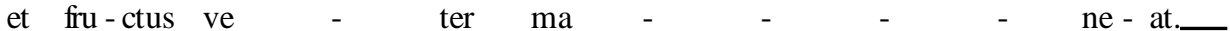




\section{Postcommunio}

Deus, qui frumenta tui eloquii, per beatum Pontificem, et martyrem Caecilium efurientibus populis dispertire fecisti, concede famulis tuis toto mentis affectu feruare, quod docuit, ut illuc quoque eodem apud te obtinente, mereamur subsequi, quo pervenit. Per Dominum nostrum nostrum Iesum Christum filium tuum, \&c. 
Consueta: Los colegiales cantores entonan el verso

Cantoral olim LC XLII y LC LXVI: V. Elegit eam Deus, et praelegit eam.

$R$./ In tabernaculo suo habitare facit eam.

Consueta: El Hebdomadario se levanta y dice la siguiente oración

Cantoral LC XLII:

\section{Oremus}

Famulis tuis, quae sumus Domine, caelestis gratiae munus impertire: ut quibus beatae Virginis partus extitit salutis exordum, Conceptionis eius votiva commemoratio, pacis tribuat incrementum. Per Dominum Iesum Christum.

\section{R./ AMEN (Coro)}

Consueta: Los Comitantes hacen genuflexión y acompañan al Hebdomadario a su lugar y se hincan de rodillas.

El que preside hace señal y se levantan colegiales y Rector, los cuales hacen genuflexión y se van por donde vinieron. Al llegar a la reja del horno de San Cecilio se hincan de rodillas y hacen oración a los santos mártires hasta que el Rector se levanta. Lo mismo repiten en la reja de San Hiscio. Finalmente van a la Iglesia y juntos hacen genuflexión al altar mayor. En la Sacristía dejan los sobrepellices y visitan al Santísimo Sacramento. Los prebendados se van como vinieron y visitan las cuevas y hornos santos. 


\section{APÉNDICE 4:}

EDICIÓN DE LA MISA PARA LA FIESTA DE SAN CECILIO, PATRÓN DE GRANADA. 

MISSA

DE S. CAECILIO

EPISCOPO, ET MARTYRE

Patrono Principale Ecclesiae, et Diócesis

Granatensis

Transcripción y Edición: Mercedes Castillo

INTROITO
Música: Archivo del Sacromonte, LC XX, fols.7175.

Texto: MISSA DE S. CAECILIO EPISCOPO, ET

MARTYRE Patrono Principale Ecclesiae, et

Diócesis Granatensis, Archivo Palacio de los Córdova,
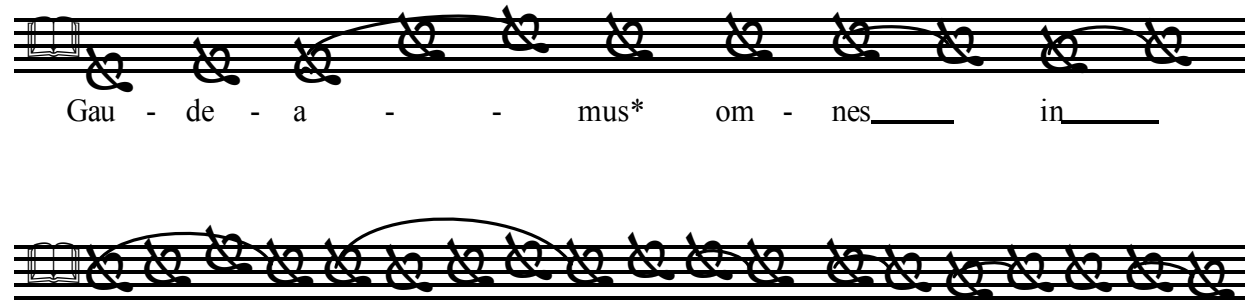

do__ mi_ no__ di $\quad$ _ em_ fes tum_
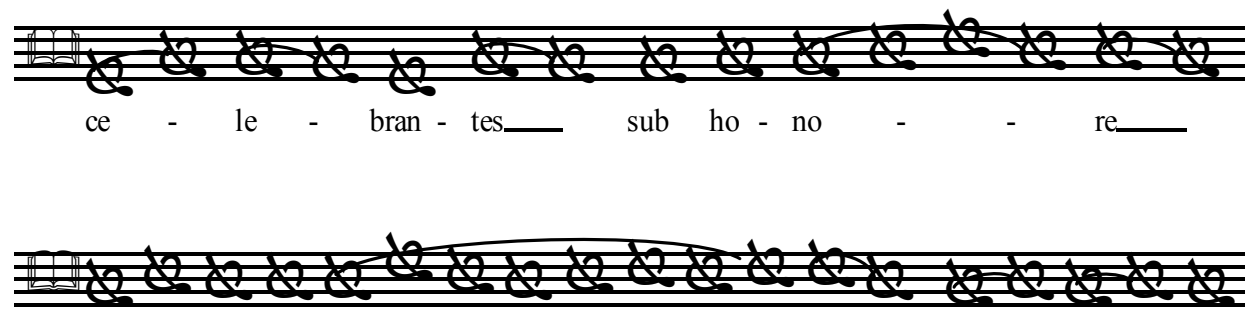

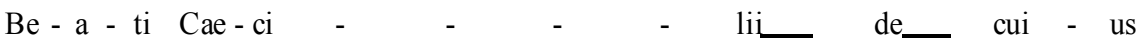
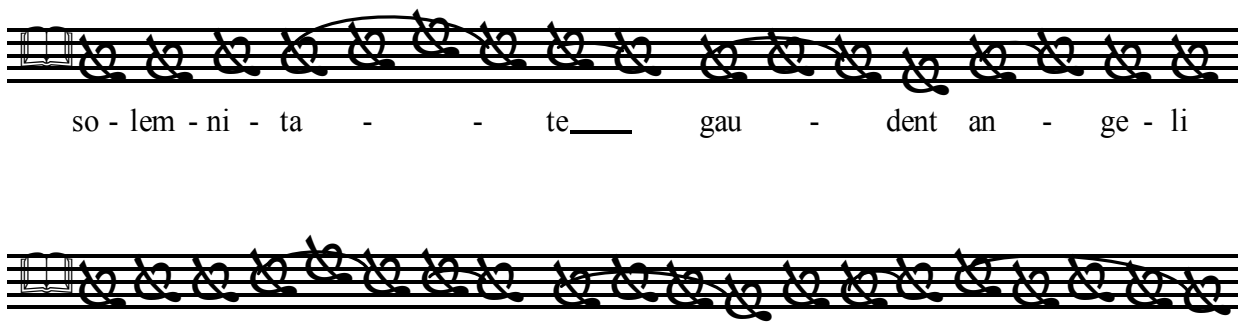

et co lau - dant_ fi $\quad$ - li - us

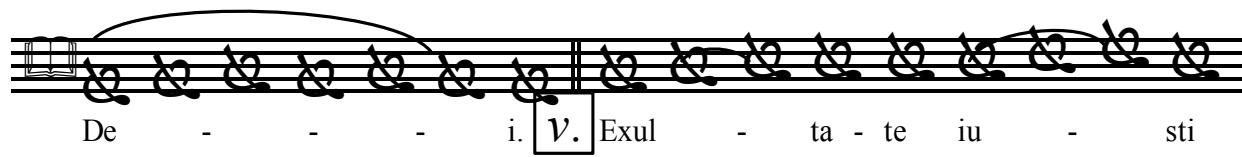

3

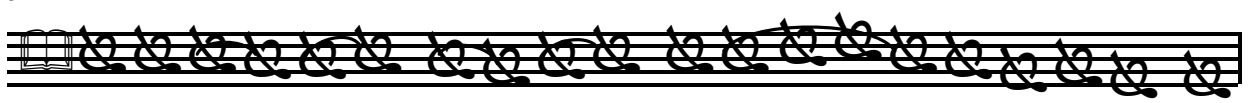

in do - mi - no:_ Rec - tos_ de - cet_ co-lau-da - ti - o. 
Gloria Patri, \&c, Gaudeamus \&c.

Kyrie eleison.

Gloria in excelsis Deo \&c.

\section{ORATIO}

Deus, qui nos per beatum Caecilium martyrem tuum, atque Pontificem ad agnitionem tui nominis venire tribuisti, concede propitius, ut per quem superni muneris rudimenta suscepimus, per eum subsidia perpetuae salutis impetremus. Per Dominum nostrum \&c.

\section{Lectio Epistolae B.Pauli Apostoli Thessalonicenses.}

Fratres fiduciam habuimus in Deo nostro loqui ad vos Evangelium Dei in multa solicitudine. Exortatio enim nostra non de errore, neque de immunditia, neque in dolo, sed sicut probati sumus a Deo, ut crederetur nobis Evangelium. Ita loquimur non quasi hominibus placentes, sed Deo, qui probat corda nostra. Neque enim aliquando fuimus in sermone adulationis, sicuti scitis; neque in occasione avaritiae. Deus testis est. Neque quaerentes ab hominibus gloriam, neque a vobis, neque ab aliis, cum possemus vobis oneri esse, ut Crhisti Apostoli, sed facti? Sumus paruuli in medio vestrum, tamquam si nutrís foveat? Filios suos. Ita desiderantes vos, cupidi volebamus tradere vobis non solum Evangelium Dei, sed etiam animas nostras, quoniam charissimi nobis facti? Estis. Memores enim estis fratres laboris nostri, \& fatigationis, nocte ac die operantes, ne quem vestrum gravaremus, praedicavimus in vobis Evangelium Dei. Vos testes estis, \& Deus quam sancte, \& et iuste, \& et sine querela vobis qui credidistis, fuimus sicuti scitis, qualiter unumquemq; vestrum sicut Patri filios suos deprecantes vos, \& consolantes, testificati sumus, ut ambularetis digne Deo, qui vocavit vos in suum Regnum, \& Gloriam.
Gloria al Padre, etc, Gaudeamus etc, Señor ten piedad.

Gloria a Dios en el cielo etc.

\section{ORACIÓN}

Oh Dios, que nos hiciste conocer tu nombre por medio de tu santo mártir y pontífice Cecilio,: haz propicio que, por quien recibimos las enseñanzas del soberano don, alcancemos también los auxilios de la perpetua salud. Por el Señor etc.

\section{Lectura de la Carta de San Pablo Apostol a los Tesalonicenses.}

Y sabéis también que nuestras exhortaciones no procedían de error, ni de conscupiscencia, ni de engaño; sino que de probados por Dios, se nos había encomendado la misión de evangelizar; y así hablamos, no como quien busca agradar a los hombres, sino sólo a Dios, que prueba nuestros corazones. Porque nunca, como bien sabéis, hemos usado de lisonjas ni hemos procedido con propósitos de lucro. Dios es testigo; ni hemos buscado la alabanza de los hombres, ni la vuestra, ni la de otros; y aún pudiendo hacer pesar sobre vosotros nuestra autoridad como apóstoles de Cristo, nos hicimos como pequeñuelos y como nodriza que cría a sus niños; así llevados de nuestro amor por vosotros, queremos no sólo daros el Evangelio de Dios, sino aún nuestras propias vidas: tan amados vinisteis a sernos. Ya os acordaréis, hermanos, de nuestras penas y fatigas y de cómo día y noche trabajábamos para no ser gravosos a nadie, y así os predicamos el Evangelio de Dios. Vosotros y Dios sois testigos de nuestra conducta santa, justa, irreprochable con los que creíais. Sabéis que como un padre a sus hijos, así a cada uno os exhortábamos y alentábamos y os conjurábamos a andar de modo digno de Dios. aue os llamó a su reino v gloria. 


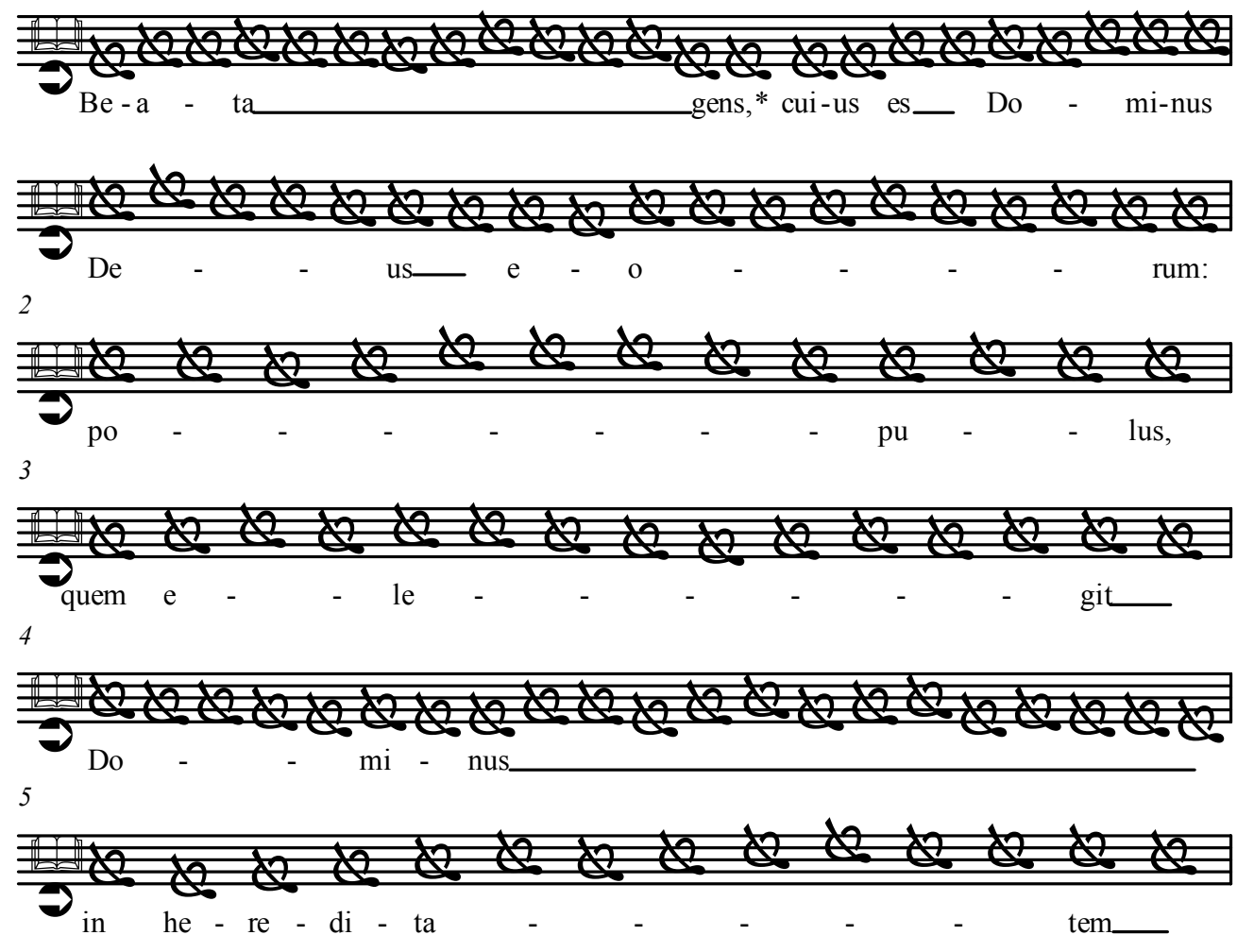

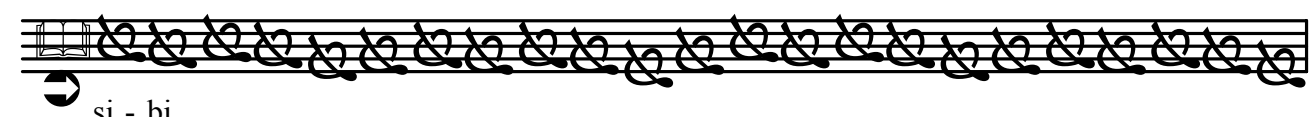

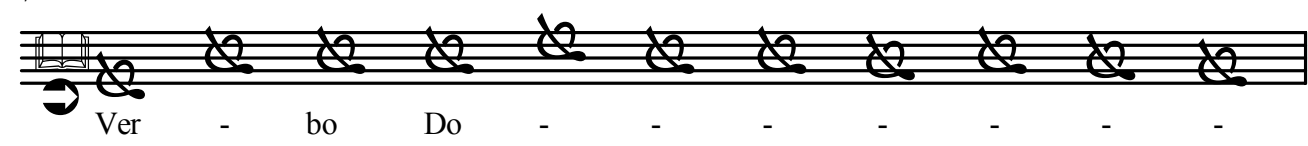

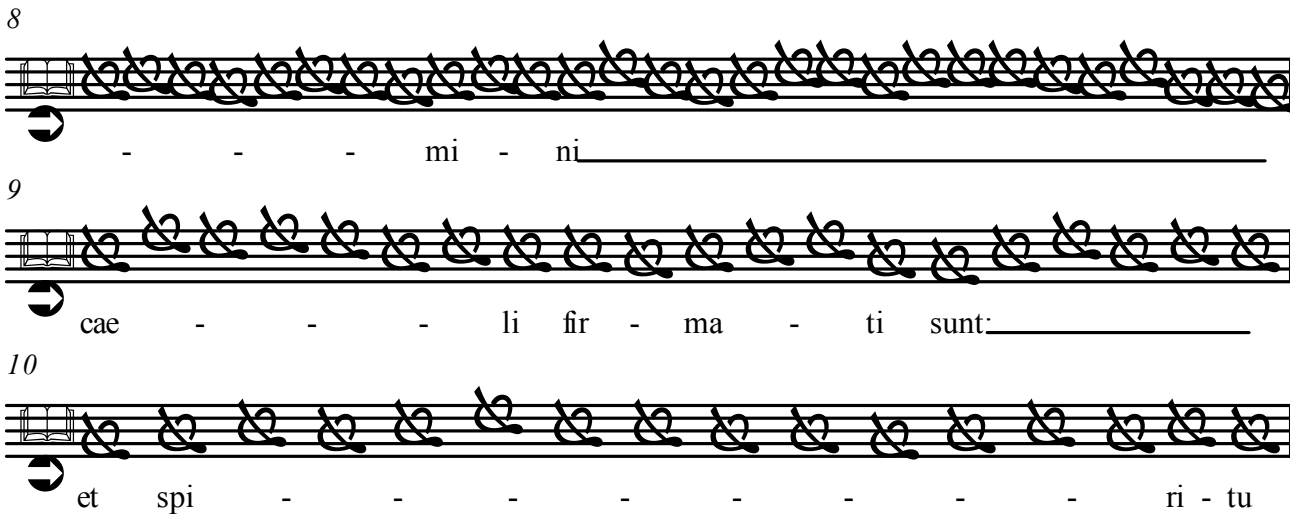




\section{Iu - di - ca - bunt sanc-ti na-tio -}

\section{\% W

po - pu-lis et re-gna - bit Do
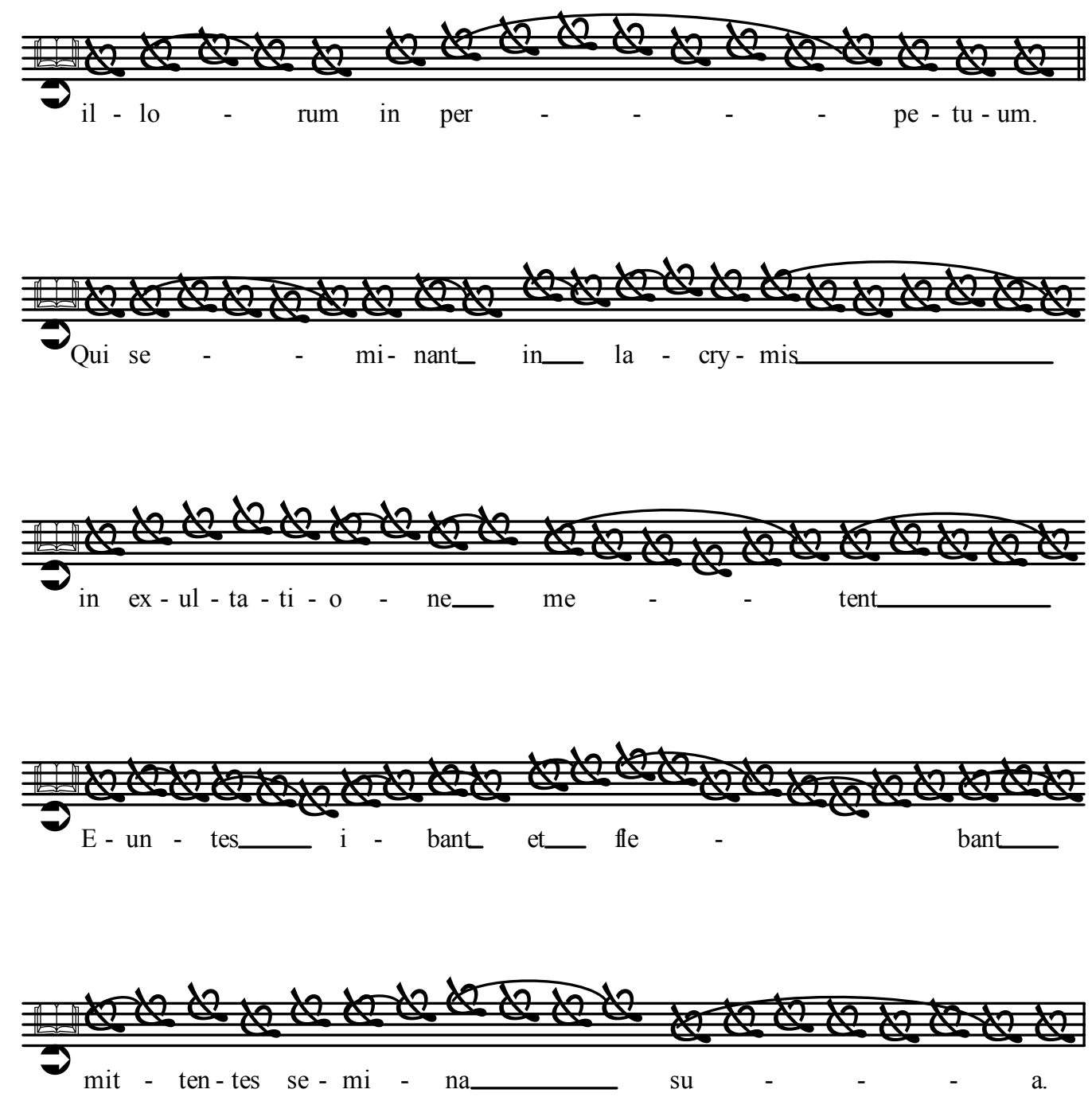
Sequentia sancti Evangelii secundum Ioannem

In illo tempore dixit Iesus discipulis suis: Amen, Amen dico vobis, nisi granum frumenti cadens in terram mortuum fuerit, ipsum solum manet, si autem mortuum fuerit multum fructum affert. Qui amat animam suam perdet eam, et qui odit animam suam in hoc mundo in vitam aeternam custodit eam. Si quis mihi ministrat, me sequatur, et ubi ego sum, illic et minister meus erit; si quis mihi ministraverit, honorificabit eum Pater meus.

Credo
Lectura del Santo Evangelio según

San Juan 12, 24-26

En aquel tiempo dijo Jesús a sus discípulos: En verdad, en verdad os digo que, si el grano de trigo no cae en la tierra y muere, quedará solo; pero si muere, llevará mucho fruto. El que ama su vida, la pierde; pero el aborrece su vida en este mundo, la guardará para la vida eterna. $\mathrm{Si}$ alguno me sirve, que me siga, y donde yo esté, allí estará también mi servidor; si alguno me sirve, mi Padre le honrará.

\section{Credo}

\section{OFERTORIUM}
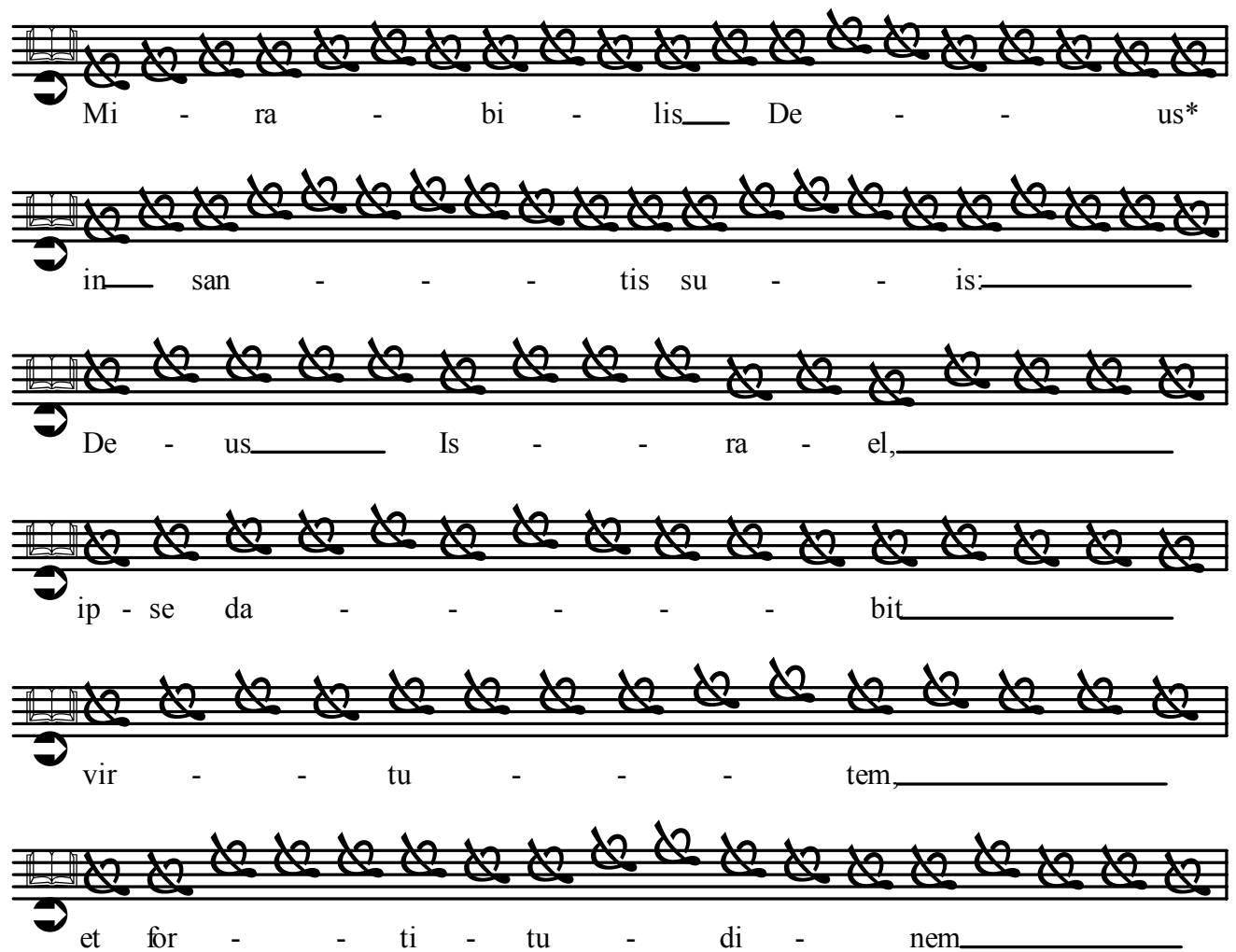

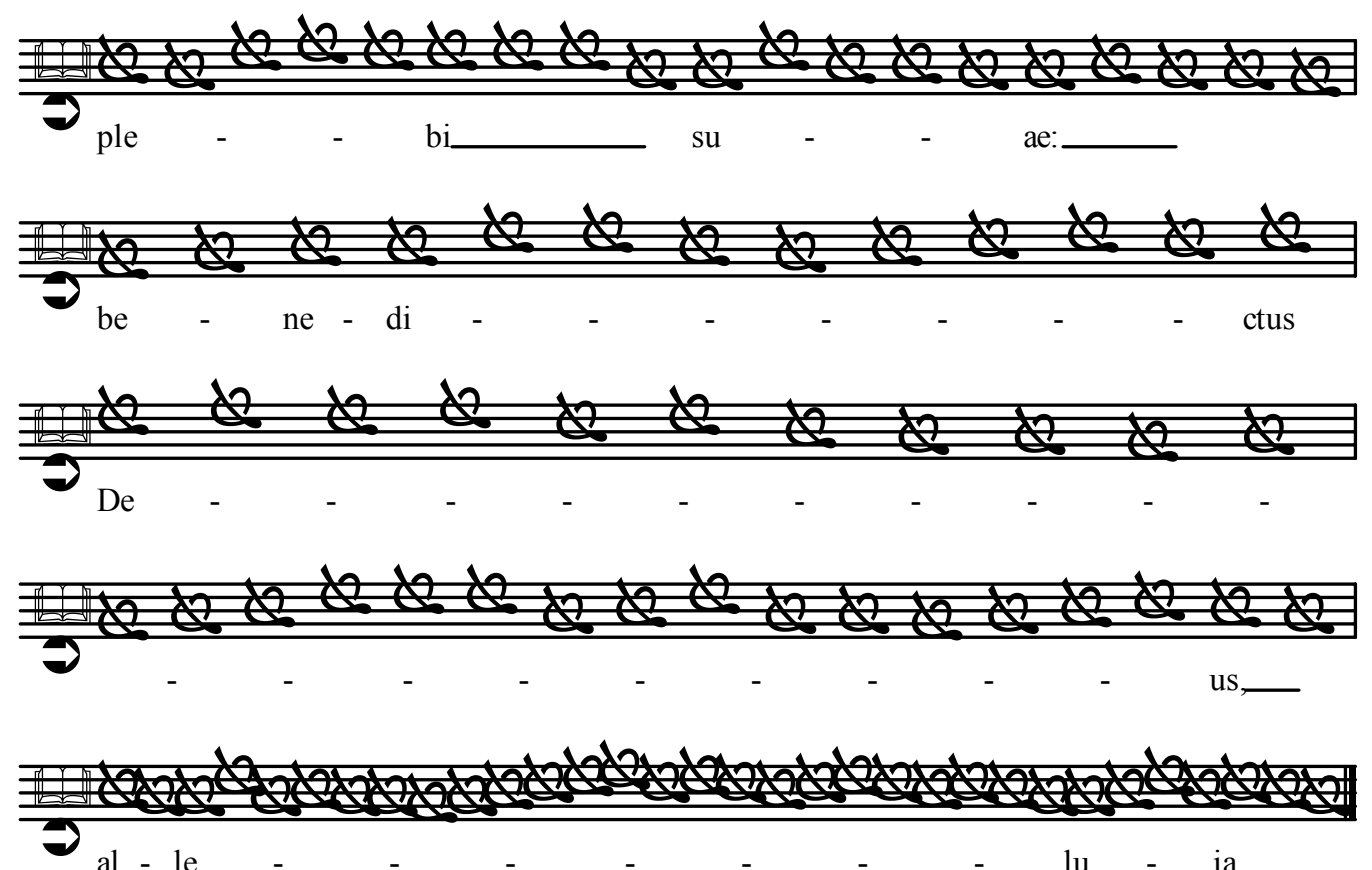

Secreta

Munera tibi Domine oblata sanctifica, et qui nobis per ministerium beati Caecilii martyris tui, atque Pontificis veritate Evangelii patefieri voluisti, concede, ut quod ab illius ore didicimus gratia tua adiuti operari valeamus. Per Dominum nostrum Iesum Christum.

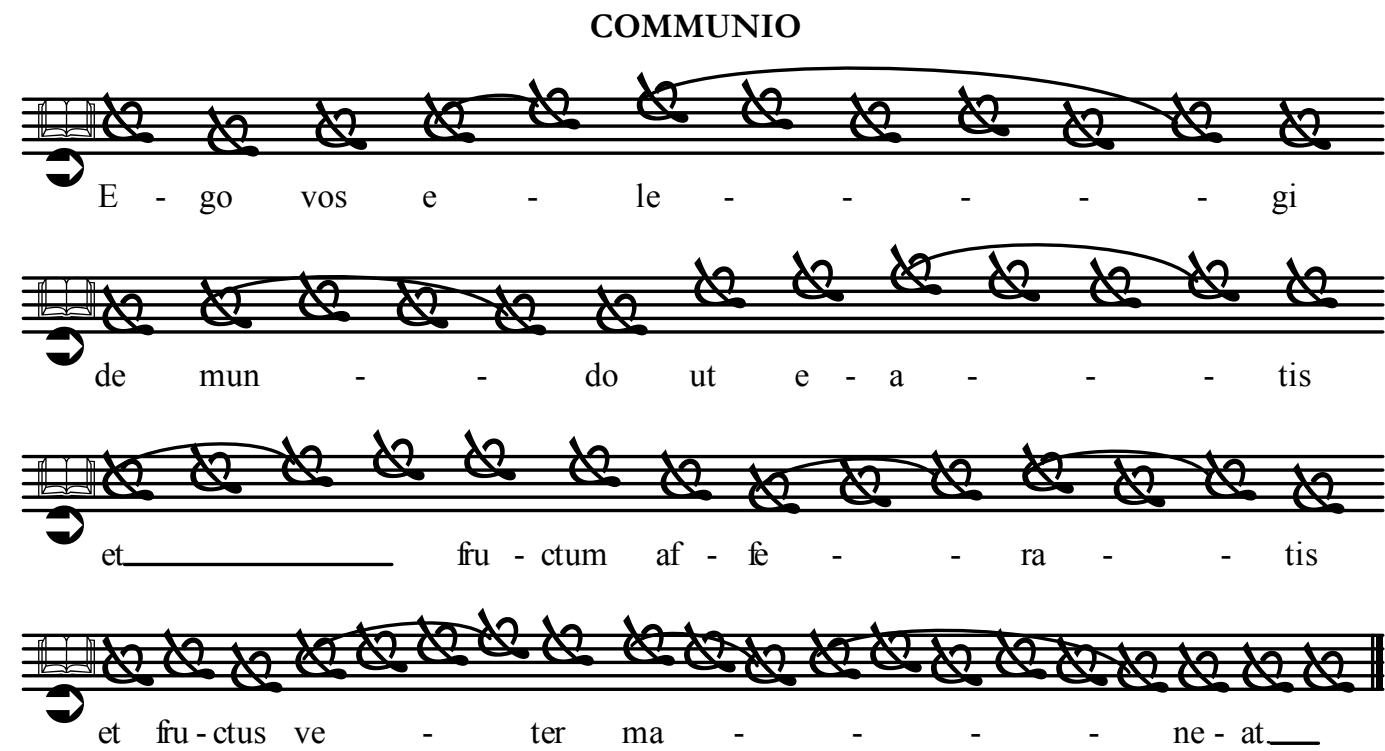




\section{Postcommunio}

Deus, qui frumenta tui eloquii, per beatum Pontificem, et martyrem Caecilium efurientibus populis dispertire fecisti, concede famulis tuis toto mentis affectu feruare, quod docuit, ut illuc quoque eodem apud te obtinente, mereamur subsequi, quo pervenit. Per Dominum nostrum nostrum Iesum Christum filium tuum, \&c. 



\section{APÉNDICE 5.}

EDICIÓN DEL OFICIO EXALTATIONIS

FIDEI (UN NUEVO OFICIO DE LA TOMA DE GRANADA HASTA AHORA INÉDITO) SEGÚN EL CANTORAL 26,

FOLS. 101r-107v DE LA CATEDRAL DE SANTIAGO DE COMPOSTELA 



\section{OFICIO \\ EXALTATIONIS FIDEI \\ Para la Fiesta de Granada a 2 de Enero}

Fuentes:

Texto: Diego de Muros, Breviario Compostelano, 1542

Música: Cantoral 26, ff. 101-107, Catedral de Santiago de Compostela

\section{Ad Magnificat}

Antífona
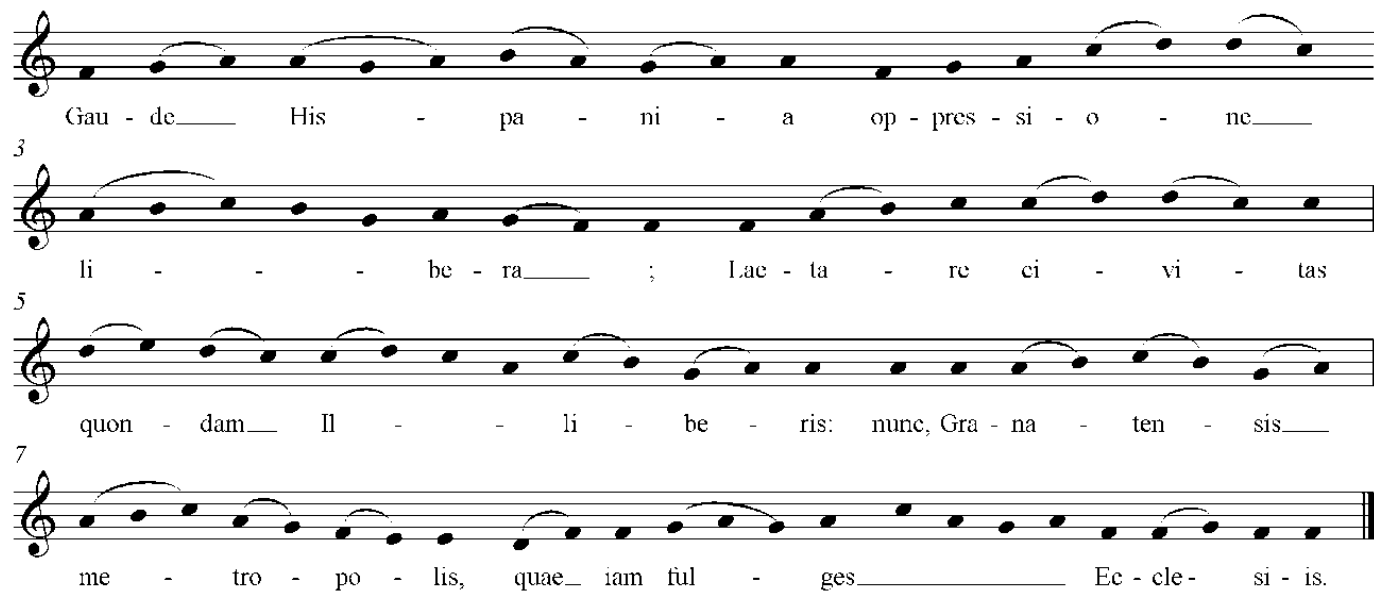

V/Omnia per Christum facta sunt. $R /$ Et sine ipso factum est nihil.

In Secundis vesperis

Antífona

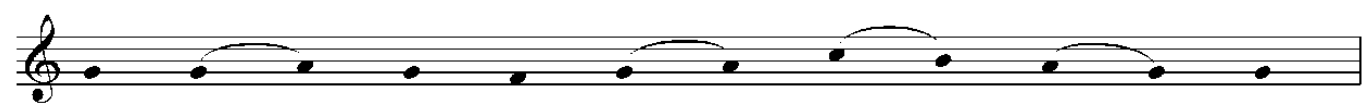

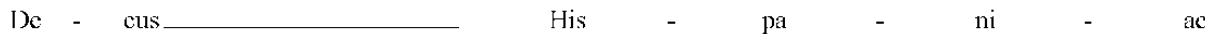
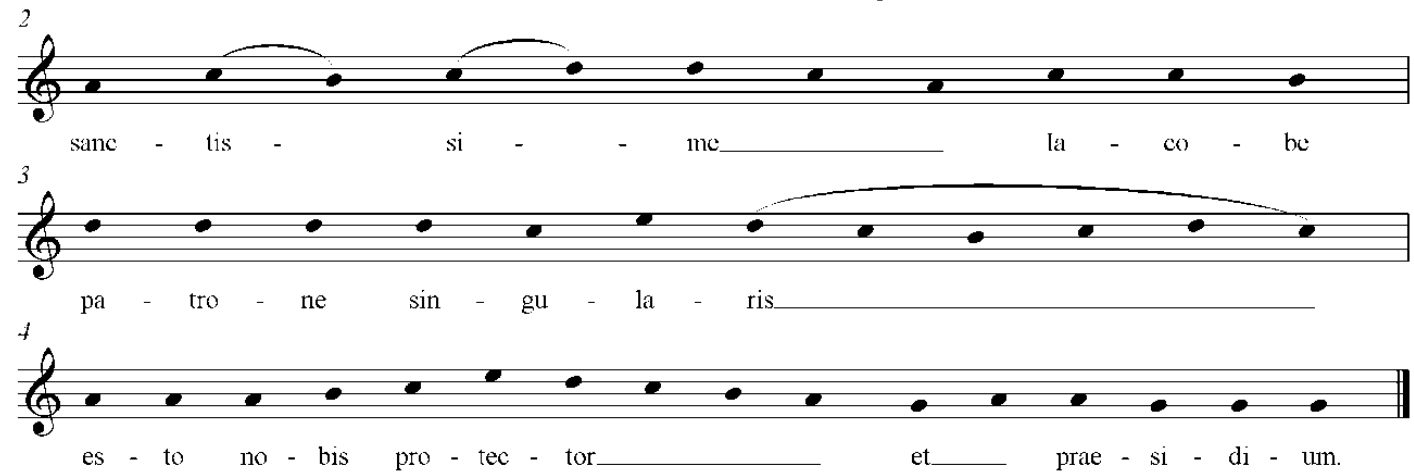

V/ Apostoli Jacobi commemorationes laetemur. R/ Cuius patrocinio, et ope[ra] munimur. 
Pro stabilitate civitatis et regni

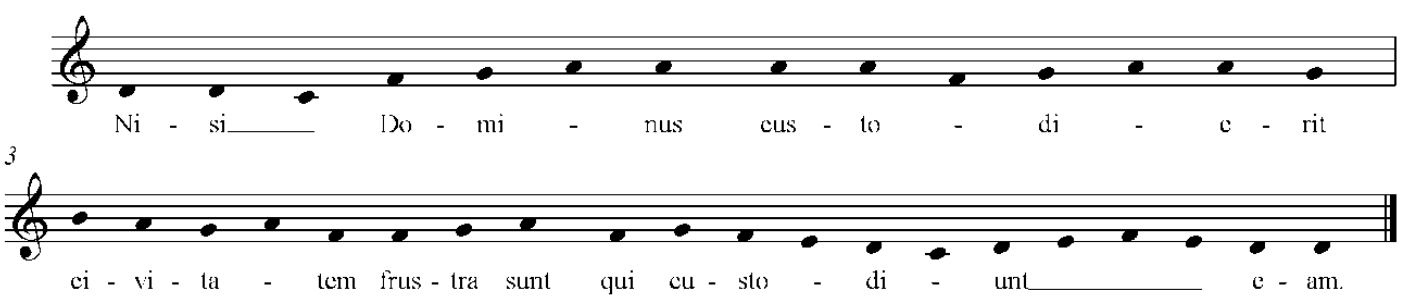

V/ Dominus custodiat te. R/ Dominus protectio tua.

\section{Ad completor. Ut in nativitate domini}

\section{Ad laudes}
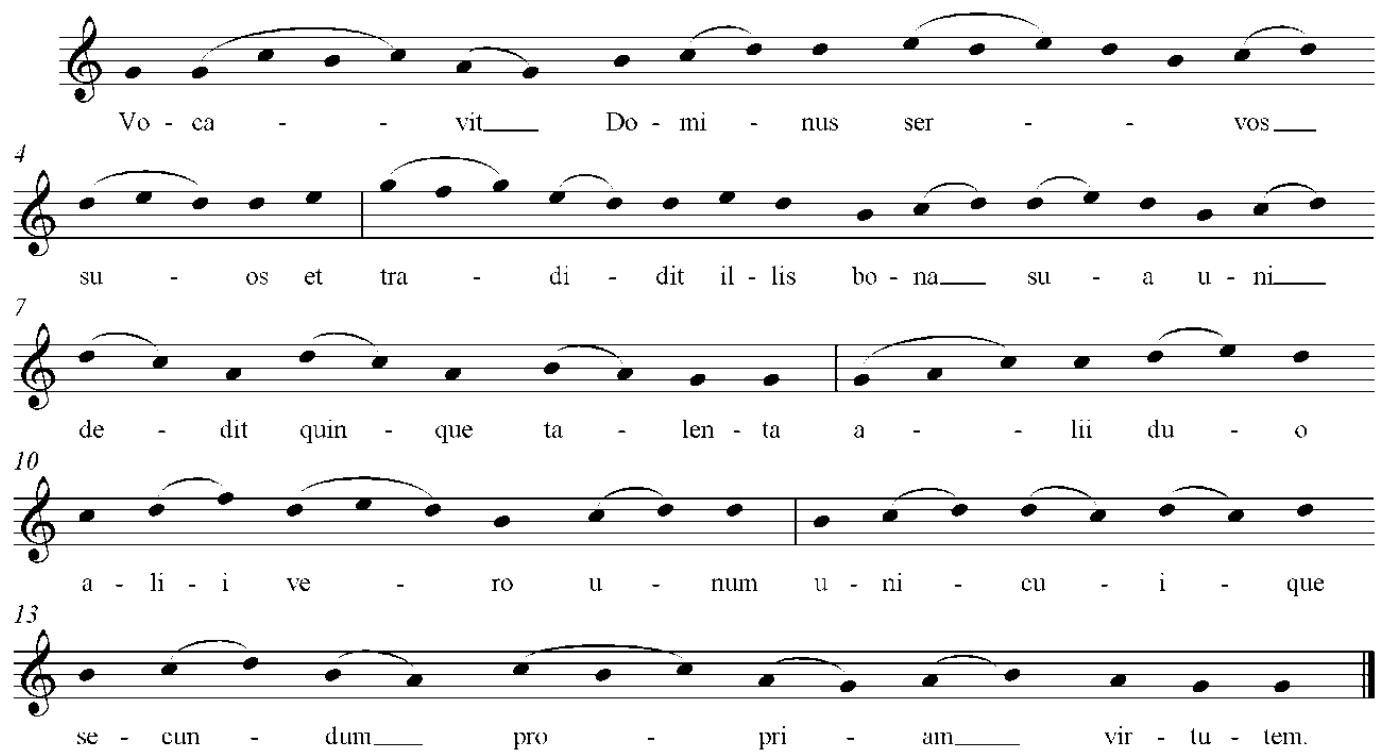

V/ Magnificavit dominus facere nobiscum. R/ Et facti sumus laetantes.

Fiat conmemoratio sancti Stephan...

Victoriam psallentes

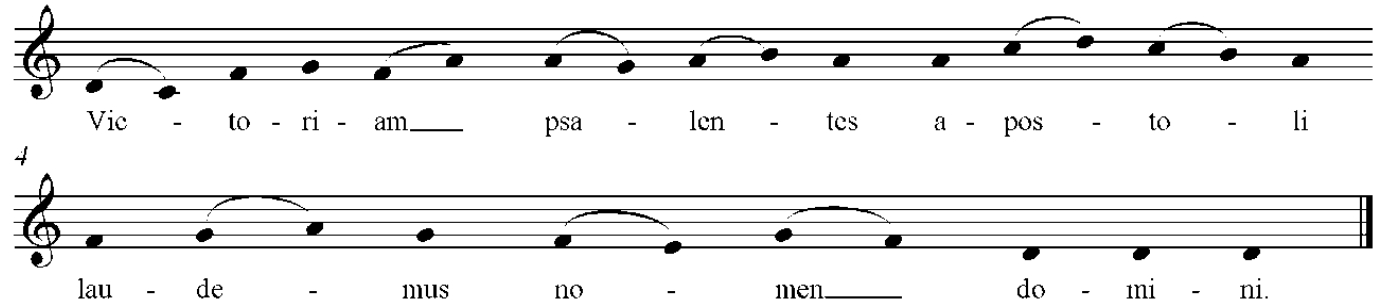

V/ Esto nobis Jacobe Apostole Dei. R/ Turris fortitudinis a facies inimici. 

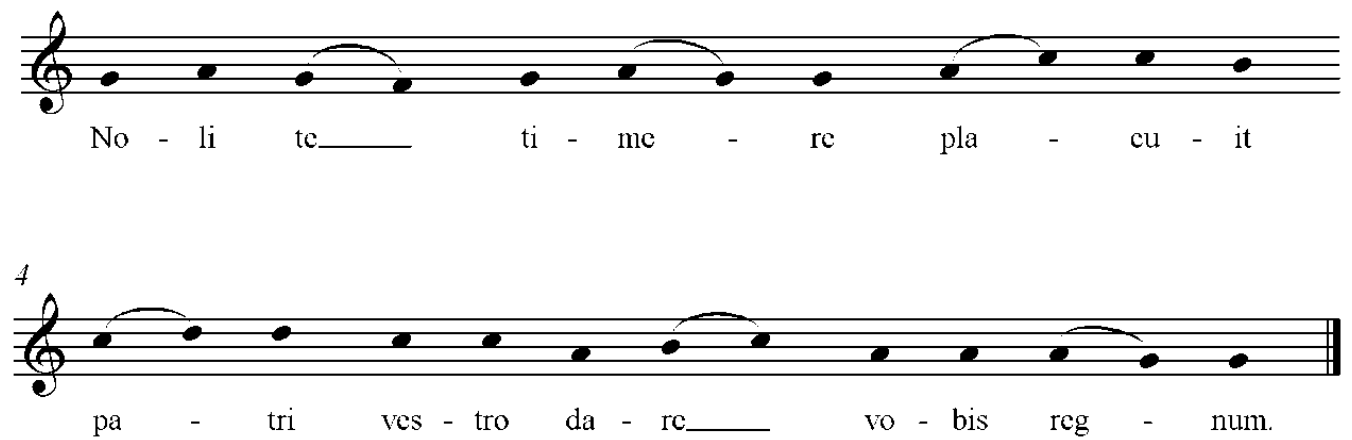

V/Potens in circuitu eius. R/ Dominus in circuitu populi sui.

In II vesperis post commemorationes Octavarum sequitur antíphona

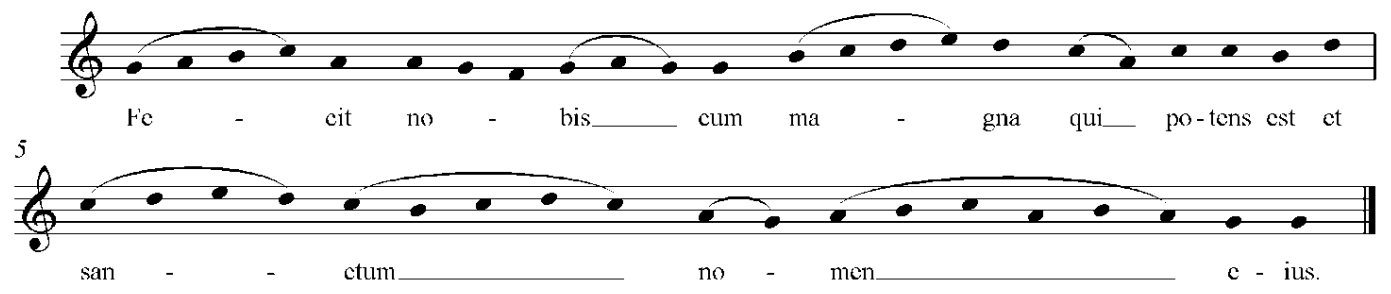

V/Dominus custodiat te. R/Dominus protectio tua. 

APÉNDICE 6. DOCUMENTOS RELATIVOS A LA CELEBRACIÓN DE

LA FIESTA DE SAN CECILIO. 

Decreto para que se guarde día de fiesta el de S. Zezilio ob. Patrón de Granada. Siendo arzovispo en ella D. Martín Carrillo y Alderete. Año de 1646. Archivo Municipal de Granada Leg. 1930, Pieza 52.

Martín Carrillo y aldrete por la gracia de Dios y de la santa sede Apostólica Arzobispo de Granada de consejo de su Magestad. Hacemos saber a todos los vecinos y moradores estantes y habitantes en esta Ciudad de Granada assi eclesiasticos como seculares de qualquier estado calidad y condicion que sean, como nuestro muy sancto Padre Urbano Octavo de gloriosa recordación por su bulla plomada expedida en Roma a trece días del mes de Septiembre de el año de seicientos y quarenta y dos y vigesimo de su Pontificado, quiso? Algunas fiestas de las que por diversas raçones, devocion, voto o costumbre se mandaban guardar reduciendolas a las expresadas en la dicha Bulla; en la qual su sanctidad declara poderse guardar constituir en cada Ciudad por dia calendo y festivo el en que se celbrare la fiesta de uno de sus principales Patronos como mas claramente se contiene en dicha Bulla. Yconsiderando que el glorioso Obispo y Martyr San Cecilio es tal Patrono de esta ciudad y fue el primer Prelado de esta nuestra Sancta Iglesia Metropolitana que con su evangelica predicacion y sagrada Doctrina la instituió nuestro ¿? En la Santa Fe de nuestro señor Jesu Christo dejando en ella por singular prenda de su amor sus sagradas ceniças y reliquias de su cuerpo por cuios señalados Beneficios le ha tenido y tiene particular devoción recibiéndole como le tiene recibido por su Patrono y Avogado espeçial Lo qual nos ha sido significado con fervoroso affecto y repetidas instancias por nuestra sancta Iglesia y por esta Gran ciudad de Granada pidiendo mandasemos guardar preceptibamente el dia en que se celebra la festividad y Martyrio del dicho su glorioso sancto Obispo y Patrono y que por tal dia festivo y de guardar se declare y mande publicar en toda esta ciudad. Y reconociendo ser justa la dicha peticion y conforme a la piedad y devoción con que en esta ciudad se veneran y reverencian las reliquias de este sagrado obispo y Martyr que es justo auidar y fomentar cuanto nos fuera posible esta devocion y reconocer con especial culto y veneracion los Beneficios y Mercedes que esta ciudad ha recibido y continuamente recibe de este su sagrado Patrono: mandamos que desde oy dia de la fecha en adelante para siempre jamas se tenga y guarde por di festivo y de guardar en toda esta Ciudad el primer dia del mes de Febrero en cada un año que es el mesmo en que derramó su sangre en las cabernas del Sacromonte Illipulitano el glorioso Obispo y Martyr San Cecilio, en defensa de la fee y verdad que nos enseño passando de esta vida a la eterna a donde esta siempre defendiendo y amparando esta ciudad de Granada. Y para que sea notorio y se guarde, cumpla y execute mandamos se publique en toda ella en la forma acostumbrada. Dado en nuestro palacio Arçobispal de Granada a veinte y ocho del mes de Henero de mil y seicientos y quarenta y seis años.

Martín Carrillo Aldrete Arzobispo de Granada (firma)

Por mandato de su Señoría Illmo el Arzobispo mi Señor

El Lcdo. D. Tendillo secretario 
VILLANCICOS,/ QUE SE HAN DE CANTAR EN LA S ${ }^{\text {TA }}$ IGLESIA/ Metropolitana y Apostolica de Granada,/ à los Maytines del Señor/ SAN CECILIO MARTYR,/ SU PRIMER OBISPO, Y PATRONO;/ y en las quatro Festividades, que se celebran con el motivo / de tener principio su nuevo Rezo en su dia primero/de Febrero de este año de mil setecientos / y quatro.

Impresso en Granada, En la Imprenta de la Sâtissima Trinidad, por Antonio / de Torrubia, Impressor del Illustrissimo Señor D. Martin de Ascargorta, / y de la Santa Iglesia Cathedral Metropolitana y Apostolica. / Año de 1704.

\section{VILLANCICO I.}

Kalenda.

Granada escucha, que en culto de tu primero Pastor, oy tu Metropoli sacra rompe del labio la muda prision.

Escucha su canto, que suena mejor; pues ya no es agena, que es propria la voz.

\section{COPLAS}

Rompa el Metropolitano

Coro la flamante voz; pues no ya en comun dedica à CECILIO, sino en individuo su veneracion.

Escucha su canto, que suena mejor.

Cante ya con proprio acento à aquel Inclyto Patron, que hizo à su llama (aun resuelta en cenizas) prender en la Fe Granadina su ardor.

Pues ya no es agena, que es propria la voz.

Suene ya de su Martyrio la gloriosa aclamacion; pues aunque la voz le oculte la Pyra; muy bien del incendio se vé el resplandor. Escucha su canto, que suena mejor.

Sepa Granada, que como grano, que en ella cayó 
muerto en su tierra, produxo mas fertil el fruto Ortodoxo de su Religion.

Que ya no es agena, que es propria la voz.

Oyga, que del Evangelio tan constante luz le dio

CECILIO, que vió (jamás apagado en siglos de sombras) durar su calor.

Escucha su canto, que suena mejor.

Digalo entre siglos tantos ocupados del error, permanecer venerado en el Templo, que fue de su Fe inmemorial possession. Pues ya no es agena, que es propria la voz.

Puede ya en essas cabernas, que su Martyrio ahumó, oir la alegria el culto ya proprio, que como prestado escuchaba el dolor. Escucha su canto, que suena mejor.

Cante el armonioso zelo del sacro Cabildo oy, que no lo elija, sino lo publique de Roma el oraculo nuestro Patron.

Pues ya no es agena, que es propria la voz. Escucha, \&c.

\section{VILLANCICO II}

OY el Patron de GRANADA, como de la Fe Ministro, sobre ser Obispo, y Martyr, se ha hecho del Santo Officio.

Ay que propicio,

ay que suave resuena en su Clave el Sacro Diploma, que su Esposa le traxo de Roma, y venera en tan alto exercicio:

y con razon;

pues mira, que oy su Patron ha encontrado con su Officio.

COPLAS

De su Ministerio Sacro 
oy llega a estrenar lo antiguo nuevo Culto, en cuyo acento flamante brilla el Martyrio. La duracion de su Templo en el Solar Granadino canta, sin que lo arruinassen no pocos infieles siglos. Canta Epistola, que calla, desde quando por escrito á los Tesalonicenses el Apostol se la dixo.

Fecundo Grano le canta, que aun ya muerto, ha producido tantos en el Evangelio, como en la Granada viudos. Discipulo de Jacobo, y de Pedro electo Obispo, plantó la Fe en Iliberria, primer Pastor de Aprisco. Fenix fue, que de la Arabia á su feliz suelo vino, donde oy su ardiente ceniza renueva el segundo nido. Y oy su Apostolica Iglesia con proprio, y reciente estilo, para celebrar su dia de lo comun se ha salido. Ay que propicio, \&c.

\section{VILLANCICO III}

Quatro Ruiseñores

del ameno Soto

de Valparayso

oy cantan sonoros, siendo nuevo el punto, la letra, y el tono.

O que festivos, ó que gozosos, ó que suaves, ó que canoros componen primero la pluma, que el coro, siendo nuevo el punto, la letra, y el tono.

COPLAS

$\mathrm{O}$ que dulces celebran 


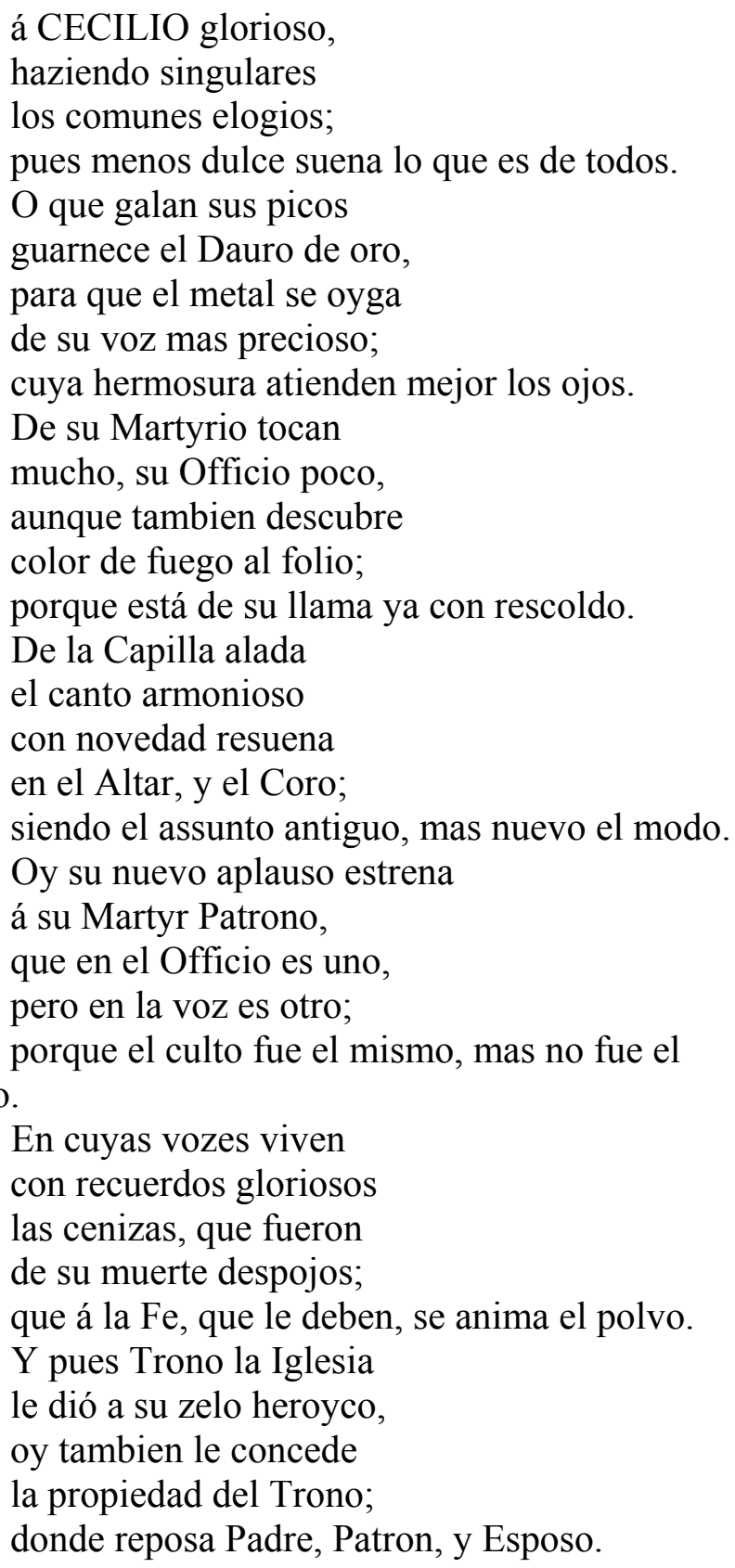

\section{VILLANCICO IV}

\section{A CECILIO oygo cantar}

en el Coro, y el Altar.

Letra, y punto, que lo alaba, es nuevo, y es singular.

No vés, que el antiguo hablaba

De muchos, y era plural? 
Pues á su exemplar

En su Fiesta mi canto renuevo,

Si la letra lo viste de nuevo;

que á CECILIO oygo cantar

en el Coro, y el Altar.

COPLAS

En la musica passada

fió la Palma, y Cayado, su Martyrio y Obispado

á una N Colorada;

mas la Iglesia de Granada

ya le aplaude en su lugar.

A Cecilio oygo cantar, \&c.

Lo particular, aunque

Martyr, y Obispo, su dia

solo en especie aplaudia, ya en individuo se vé;

pues su Iglesia, á quien la $\mathrm{Fe}$ debió, le sabe pagar.

A Cecilio oygo cantar, \&c.

Ya su Martyrio se aclama,

y el fuego, que lo eterniza,

aun oculta en su ceniza,

oy nos dá luz de su llama;

su heroyco fin de la fama

viva en la voz circular.

A Cecilio oygo cantar, \&c.

Que con permanencia rara

de larga edad no ha faltado, aunque de infieles cercado, á su Culto Templo, ni Ara; con reflexion lo declara el oraculo sin par.

A Cecilio oygo cantar, \&c. Que es de Granada Patron, la Santa Iglesia refiere, cuyo Titulo le adquiere su Fe, mas no su eleccion; fundóse en la Religion renombre tan singular.

A Cecilio oygo cantar, \&c. En buen hora el lucimiento de un Coro tan Superior logre a su primer Pastor celebrar con proprio acento; de tan generoso intento llegue el aplauso á escuchar. A Cecilio oygo cantar 
en el Coro, y el Altar, \&c.

\section{VILLANCICO V}

Que sonora armonia oy en Granada suena, que alboroçada llena sus terminos al muro, al Templo, al dia? Si será su alegria que al Gran Cecilio celebrar oi?

Coro. Esso es; pero no es assi.

Será aplaudir suave en un Templo su Fiesta, que en nuestra vida puesta su grandeza bellisima no cabe?

Será aclamar el grave Esplendor de su Ornato Carmesí?

Coro. Esso es; pero no es assi.

Pues que será su aplauso?

Es lo que ví?

Coro. Esso es; pero no es assi.

Pues una Apostolica voz, que oy estrena el Sacro Patron, ilustra serena el Templo, la almena, el dia, el pais. Atended, que ya es propria la voz, escuchad, oid.

\section{COPLAS}

Atended, que le aclama

Patron vuestro feliz, desde que por el yugo Catholico, os trocó el yugo Gentil. Escuchad de CECILIO

el proprio Culto, si la confusion de el gozo aquello, que celebra, dexa oir.

Oid el Sacro Officio, que impetró á la Matriz del Orbe Fiel su Iglesia, y expidió su Apostolico Buril.

Primer Classe, y Octava tiene su Fiesta, á fin de que uno, y otro dia emprenda la ansia de aclamarle mil.

Esso es; pero no es assi, \&c.

VILLANCICO VI

Para dos Seises 
Alfonso el camino toma, y vamos á la Ciudad.

Si Thomas, que ay novedad, que diz que vino de Roma; porque es el Officio, que estrena este año CECILIO, y pidió su Sacro rebaño, y se le concede por su Santidad.

I Pues en verdad, que es mas proprio su canto de nuestra edad: y assi yo se lo cantaré.

2 Cantaréselo yo, que soy chiquitito.

1 Que soy pequeñito, que letra, que es nueva, cantará mejor, si es nuevo el cantor.

COPLAS

1De S.CECILIO el Rezo

mi voz aplaude, que es nuevo, y su Martyrio nuevo flamante.

$2 \mathrm{Y}$ aunque es antigua su Santidad, su Officio fresco es de el dia. De su Officio el contexto su Iglesia canta; pero al venir de Roma, dicen que es gracia. 1 Bien, que en la Historia de su Rezo, essa gracia se oye, que es gloria. La Epistola qué canta su dia grande, no la han visto las Missas, ni los Missales.

2Tambien oy hallo Missa nueva, sin? O fin? Nuevo Missacantano.

Sus Lecciones afirman, que tuvo Templo en Granada, con todos sus Sacramentos. 1 Sin que, aun estando entre Moros tuviesse jamás ceffacio.

Diz, que en el Monte Sacro su muerte tuvo, y lo alto en sus Cuevas se vió profundo. 
2 Pero en su Officio

se clarea la llama

de su Martyrio.

En fin su Iglesia estrena

su Fiesta propria,

aunque no es de su mano

la letra, y forma.

1Su zelo cumple,

y á fe que no es el Rezo

de los Comunes.

VILLANCICO VII

Para un Seise.

El Zelo tan devoto, como en sus ansias activo, afecto el mas Gigante con las ternuras de niño. O como se quexaba! siendo á su detenido desseo explicacion la voz de los suspiros, por ver de S.CECILIO en siglos tantos un Culto, aunque adequado, no cumplido. Mas ya convierte alegre La quexa en regozijo, y manifiesta el gozo en canticos festivos; pues si es concepto de CECILIO el zelo, el zelo es quien celebra á S.CECILIO.

COPLAS

Canta el Catholico zelo ya alegre; pues renacido logra a su primero Padre en la propiedad del Rito. Canta festivo la Gloria á Dios, que amante, y benigno la que concede a sus Santos, admite como servicio. Canta á CECILIO el honor, que Patron, Martyr, y Obispo goza en reverentes Cultos quanto dió á tan Fieles Hijos.

Las gracias al Gran Clemente, que del Orbe Pastor digno su clemencia haze mas grata para el Granadino aprisco. Y el Vitor á quien? A nuestros Sacros Prelado, y Cabildo; 
y pues hazen otra Pasqua,

si dán aguilando, Vitor.

\section{VILLANCICO VIII}

A la Fiesta, á la Fiesta Zagales, á la Fiesta de el Grande Cecilio, que cantar oy su Officio, y sus glorias, si suena á alegria, mandato es preciso. Venid á la Iglesia, y al Culto Sagrado, que de el Templo, que es Corte Divina sereis Cortesanos.

Zagales corriendo, que en un Breve que viene de Roma expresso el aviso del Papa tenemos. Venid Zagalejos, que cantarle la gala á CECILIO, si suena á alegria mandato es preciso.

\section{COPLAS}

A celebrar las glorias de un Prelado invicto, cuyo nombre ha llegado hasta Roma, donde le aclaman las veneraciones.

La Tyara Sagrada le concede Officio tan acorde, que todo es alegria, y hasta en la Missa Gaudeamus omnes. Oy su Cabildo Ilustre le dedica en Aras, oblaciones festivas; pues cumplido tiene en el Rezo su desseo noble. $\mathrm{O}$ bien ayas Cecilio! Feliz goza de tu mansion, y el Orbe te aclame, porque fuiste Victima Sacra en el dichoso Monte.

\section{VILLANCICO IX}

Introduccion.

Quatro Neglillos oy vienen, nazidos junto á la Arabia, a festejar su Paisano con una graciosa Xacara. Estrivillo.

1Tuca, tuca Rumingo. 2 Vaya, vaya Pazquala.

3 Canta, canta Juaniya.

4 Anda, anda y con glazia.

$1 \mathrm{Y}$ que cantalemo? 
2 Una Xacariya.

3 Que zia del ampa.

4 Que zi no ay Negliyo

la fezta no ez nada.

1 Afuela? Asuela?, que vá de guzto.

2 Quien dilemo?

$3 \mathrm{La}$ aleglia,

que viene a pedil de boca

Xacariya.

4 Que contiene?

1 Ez el cazo.

De aquel Obizpo del Monte,

Que lou diablo zán tembrando.

2 Linda Xacara.

3 Puez vaya.

4 Corra, ziga.

1 Bien ha dicho.

2 Puez al cazo.

Repiquenze laz Campanaz, todo alcabuz eche chizpaz, y lo relox ande zuelto, aya buya, y glitelia, venga, corra, ziga.

Tuquen divelzaz Canzionez, zacambuche, y chilimiaz, trompetillaz y clarinez. Zagalez, y Zagaliyaz, tudoz digan, ziga, ziga, vaya, vaya la Xacariya. COPLAS

1 Xacara vá Ruminguiya.

2 Diga ziol Pazqualiyo.

3 Y á quien cantamo la Xacara.

4 Al ziolo Zan ZEZILIO.

O que bueno, ó que lindo.

Ayá nazió en el Arabia, y fue ayá nuezo vezino, y como eztámo tan zelca, él zerá nuezo plimiyo.

O que bueno, ó que lindo.

Ziego nazió la Zantica, y con zu padle ze vino á Jeruzalen, adonde fue zano por Jezu Chrizto.

O que bueno, ó que lindo.

Aven Adi ze yamaba, y tlueca el nomble en ZEZILIO, 
que dize Plendicandola,

y pol ezo queman vivo.

O que bueno, ó que lindo.

Con aquel Zanto, que mata

á lo Moro, y lo Morizco,

vino á Ezpaña pala zel

de aquezta Iglezia el Obizpo.

O que bueno, ó que lindo.

Aquel Ziolo de Roma,

que llaman Papa benigno,

pala que el Zanto tlabaje,

de ayá le ha imbiado Offizio.

O que bueno, ó que lindo.

Queilalo nuezo Ziolo,

que plezto veamo cumpliro,

que azta en Guinea se reze

de aquezte Zanto Bendito.

O que bueno, ó que lindo.

En laz Cabelnaz del Monte

Acabó nueztlo ZEZILIO,

y volandico a la Glolia

ze fue á ezpelal lo Negliyo.

O que bueno, ó que lindo. 


\section{CEREMONIAS, QUE ESTA CIUDAD DE GRANADA HA DE OBSERVAR Y GUARDAR.../recopilada nuevamente por el Sr. Don Juan de Morales (SI: sn, 1752)}

(Granada: Imp. Joseph de la Puerta)

Biblioteca Casa de los Tiros A-1-13

\section{DIA TREINTA Y UNO DE ENERO, y primero de Febrero}

5 El Dia treinta y uno de enero por la tarde, và la Ciudad al Sacro-Monte, en coches, à las Visperas de Nuestro Patron Señor San Cecilio, y llegan los coches hasta la plazeta de la Cruz de los Canteros, por el camino nuevo que se ha hecho, y en la Puerta de la Hermita del Señor Santiago estàn quatro Prebendados de dicho Sacro-Monte, los dos mas antiguos en el umbral de dicha Capilla, y los dos mas modernos dentro de ella, và pasando la Ciudad por medio de dichos Señores Prebendados, y en llegando los Cavalleros Veintiquatro penultimos à entrar en la dicha Capilla, los Prebendados que están dentro los toman en medio, y van acompañandolos; y los dos Prebenda/

12 dos mas antiguos, que estàn en el umbral de la Puerta, toman en medio al Señor Corregidor, y a los Cavalleros Veintiquatros, que van con dicho Señor, y de esta manera van hasta la Iglesia, y en la Puerta están los dos Cavalleros Comissarios de la Fiesta, Veintiquatro, y Jurado, para recibir à la Ciudad; y en estando en los escaños se despiden los Prebendados haziendo cortesías à la Ciudad, y en acabando las Visperas vuelven los quatro Señores Prebendados, y se ponen en el mismo sitio, que estaban quando entrò la Ciudad en la Iglesia; y los Comissarios de la Fiesta se ponen en la Puerta, à donde recibieron, por donde sale la Ciudad, y se passa por medio de dichos Señores Prebendados, tomando en medio à los propios Capitulares que traxeron, y vàn acompañando hasta en medio de la plazeta, que se despiden, y la Ciudad toma sus coches en el mismo sitio que los dexaron, y los Cavalleros Comissarios de la Fiesta dàn a la Ciudad Pastillas, despues de aver tomado assiento, y salen à darlas por fuera del Aprisco, con los dos Porteros mas modernos, y estando la Ciudad sentadda, a el tiempo, que se dàn se pone en pie el Cavallero como se van dando, y siguiendo al Cavallero inmediato se vuelve a sentar el que ha tomado. En la misma conformidad vuelve la Ciudad el primer dia de Febrero a la Fiesta de Señor San Cecilio à dicho Sa/

13 cro-Monte, y asiste a Missa, y Sermon, recibiendo en la misma forma, que el dia antecedente, excepto que se dàn Ramos à la Ciudad, que los dàn los Porteros, $\mathrm{y}$ los Cavalleros Comissarios suben al Coro con los Porteros, y dàn los Ramos solo à los Canonigos, y despues sale un Cavallero Veintiquatro con un Portero à dar los Ramos al Preste, Diacono, y Subdiacono despues que estàn sentados, y al tiempo de finalizar la Missa, viene à la Ciudad el Maestro de Ceremonias con el Pertiguero, y combida para besar la Reliquia, y luego que se acaba la Missa và la Ciudad al Altar Mayor, llegando primero el Cavallero Corregidor en medio de dos Cavalleros Veintiquatros à besar la Reliquia que tiene el Preste, y antrs de llegar el Cavallero Corregidor, alarga la Vara, ò Baston al Portero, y luego la 
vuelve à tomar, y después suben a besarla los dos Cavalleros, que se siguen, entrando por medio, y los cavalleros que vienen van por fuera, dexando bastante lugar a los Cavalleros que llegan, de forma, que no se atropelle, y vayan llegando con mucha veneración, y seriedad; y si en los ultimos Cavalleros quedassen tres, han de llegar juntos, para que no quede uno solo. 


\section{APÉNDICE 7.}

EDICIÓN DE OBRAS POLIFÓNICAS DEDICADAS A SAN CECILIO QUE SE ENCUENTRAN EN LOS ARCHIVOS DE LA CATEDRAL Y DE LA CAPILLA REAL DE GRANADA 



\section{HIC NEMPE MUNDI GAUDIA}

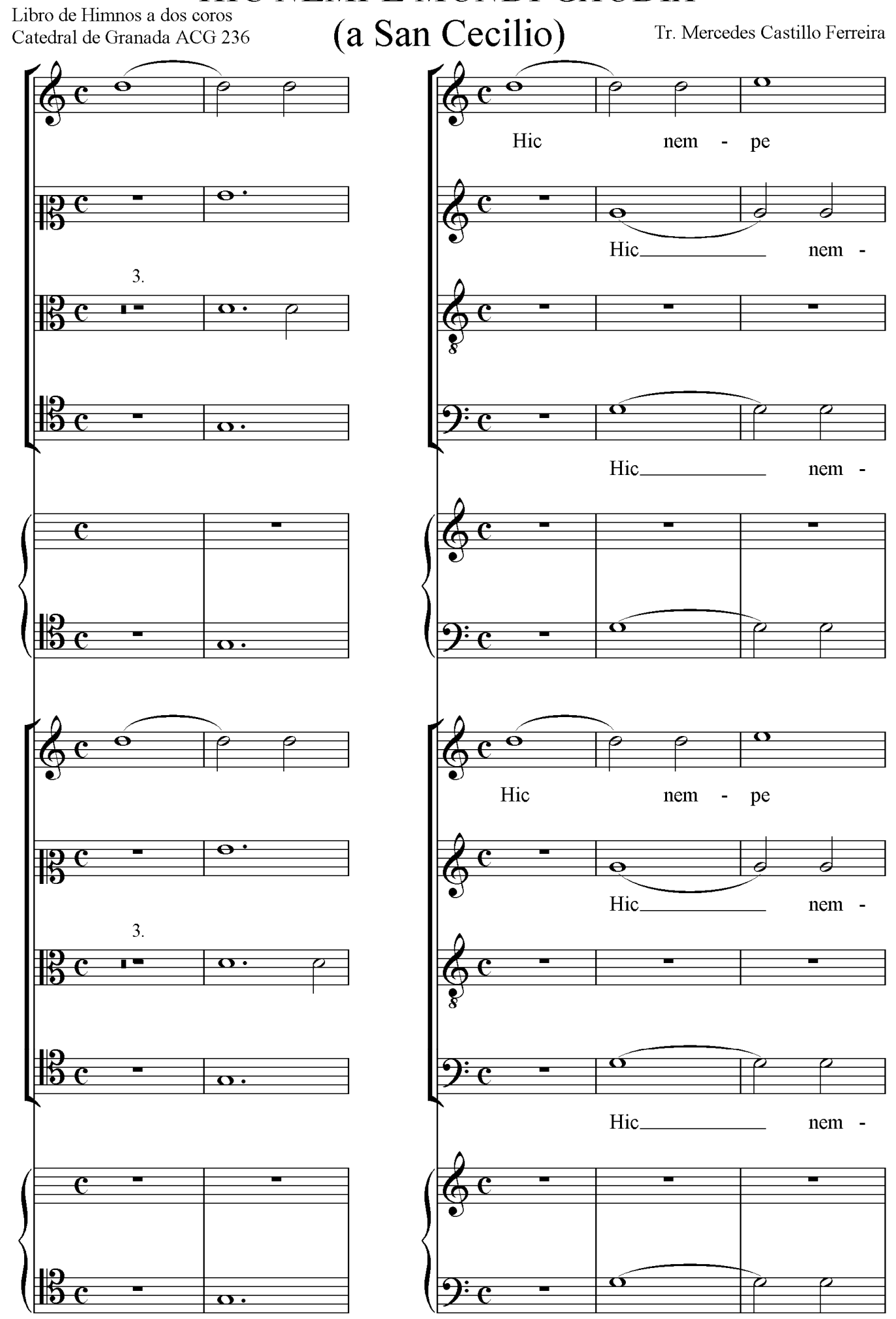




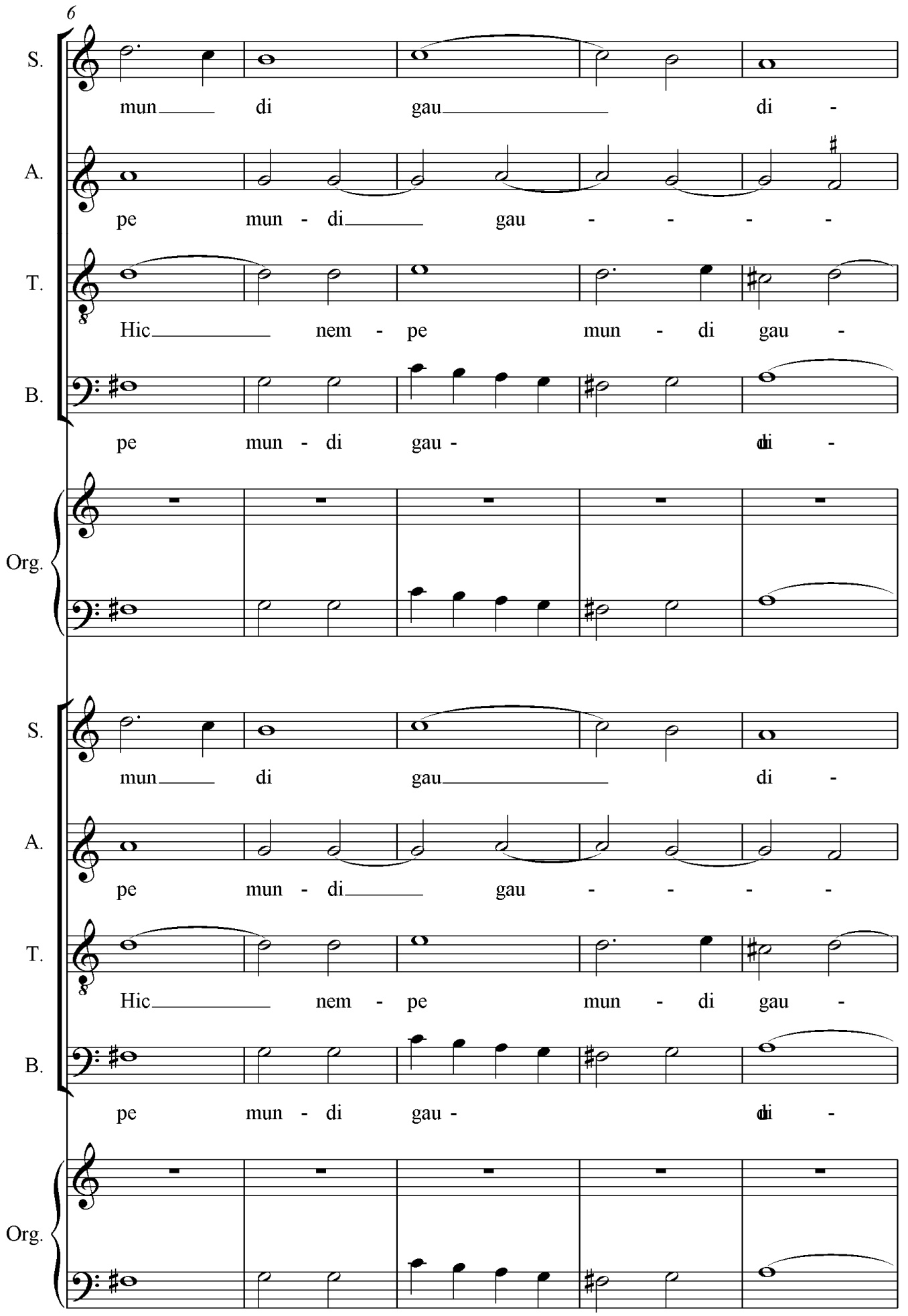




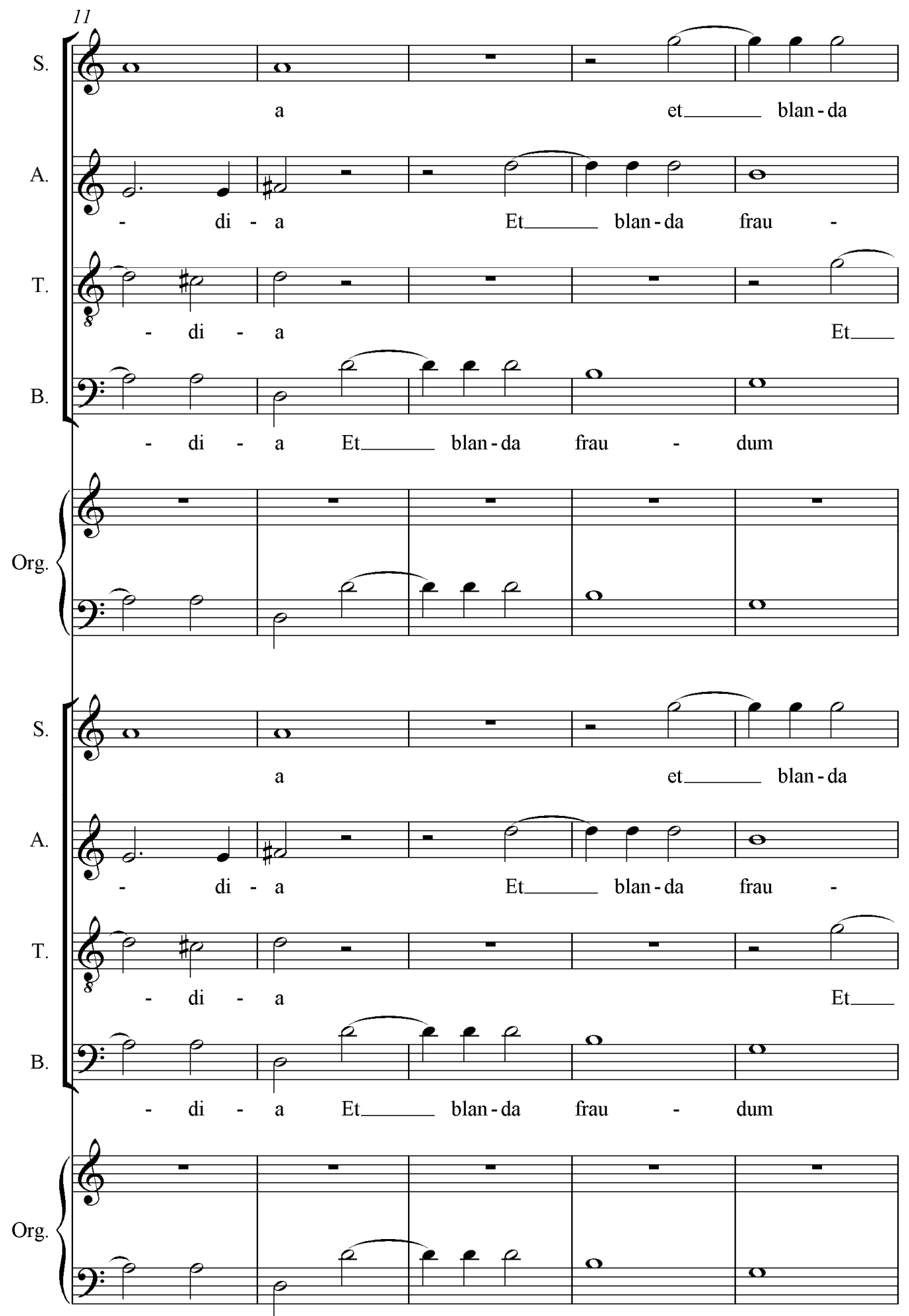




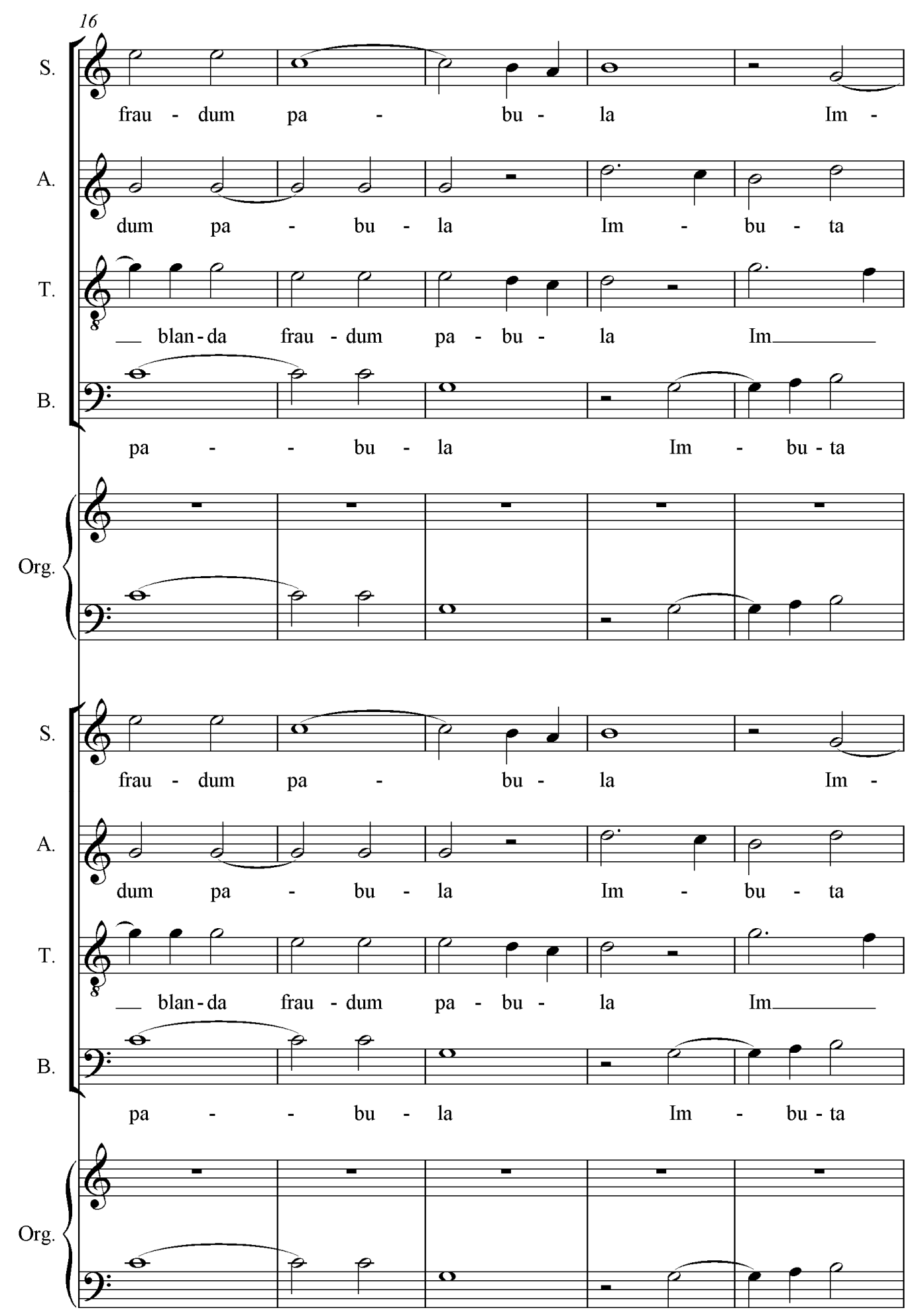




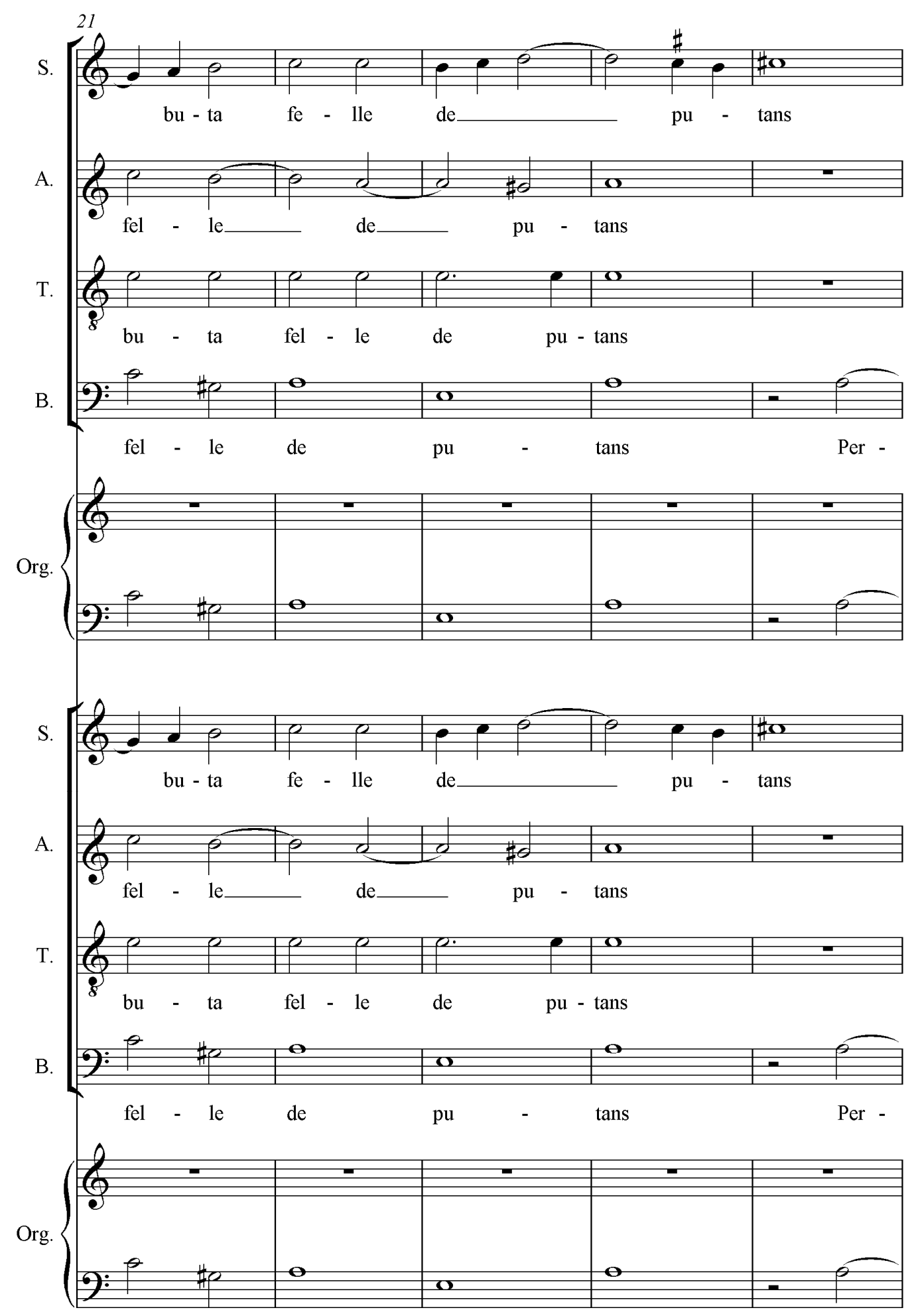




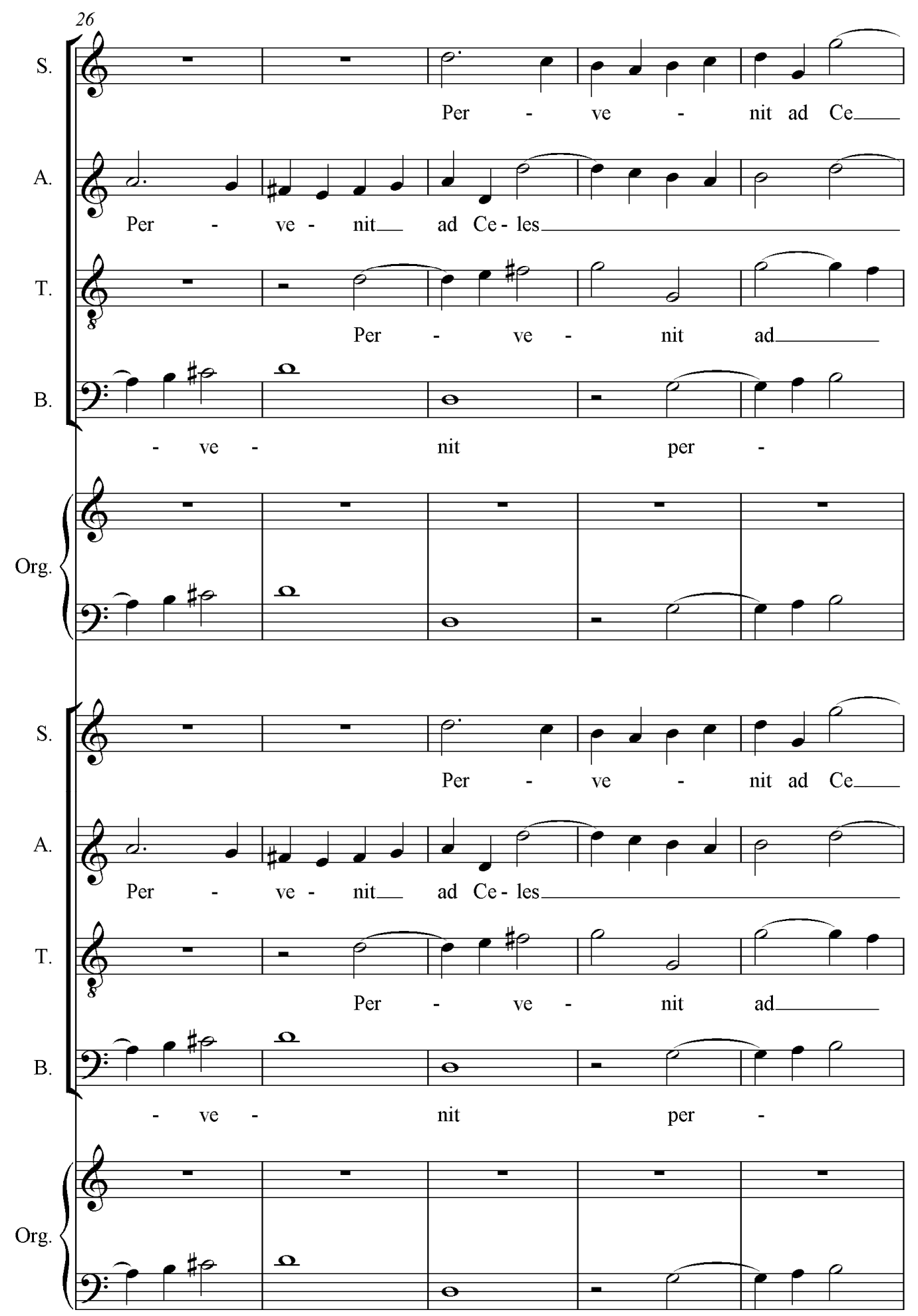




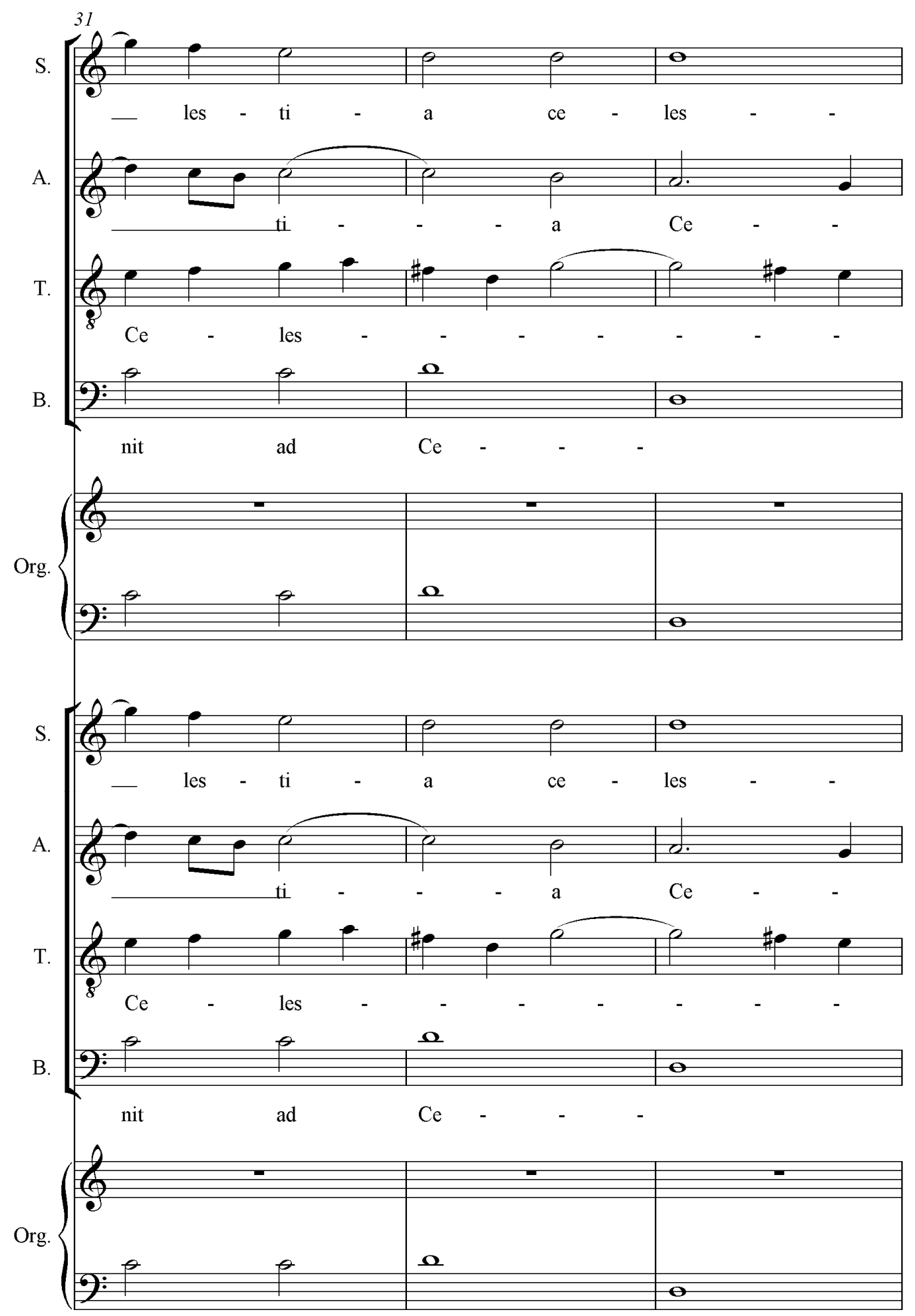




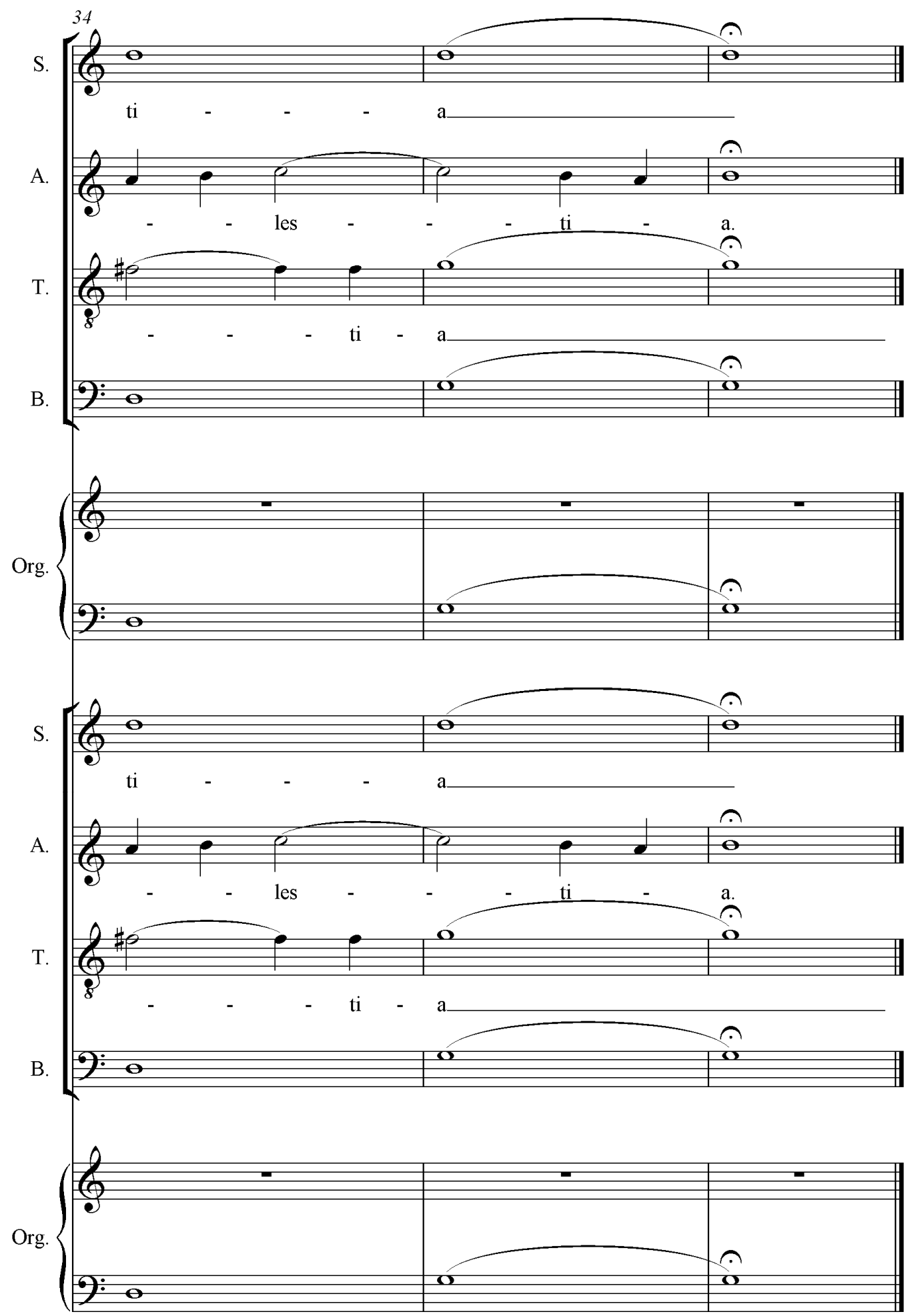




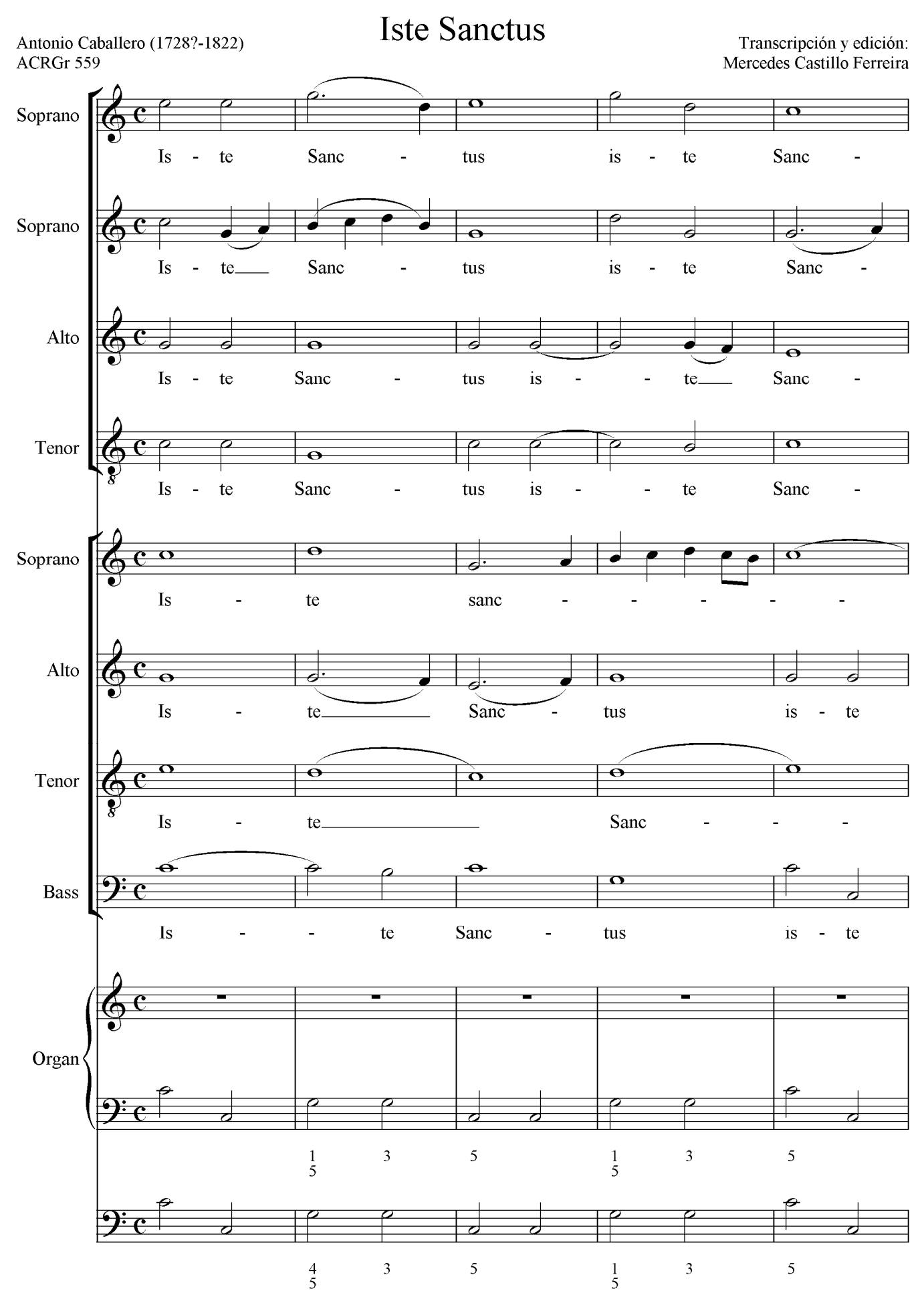




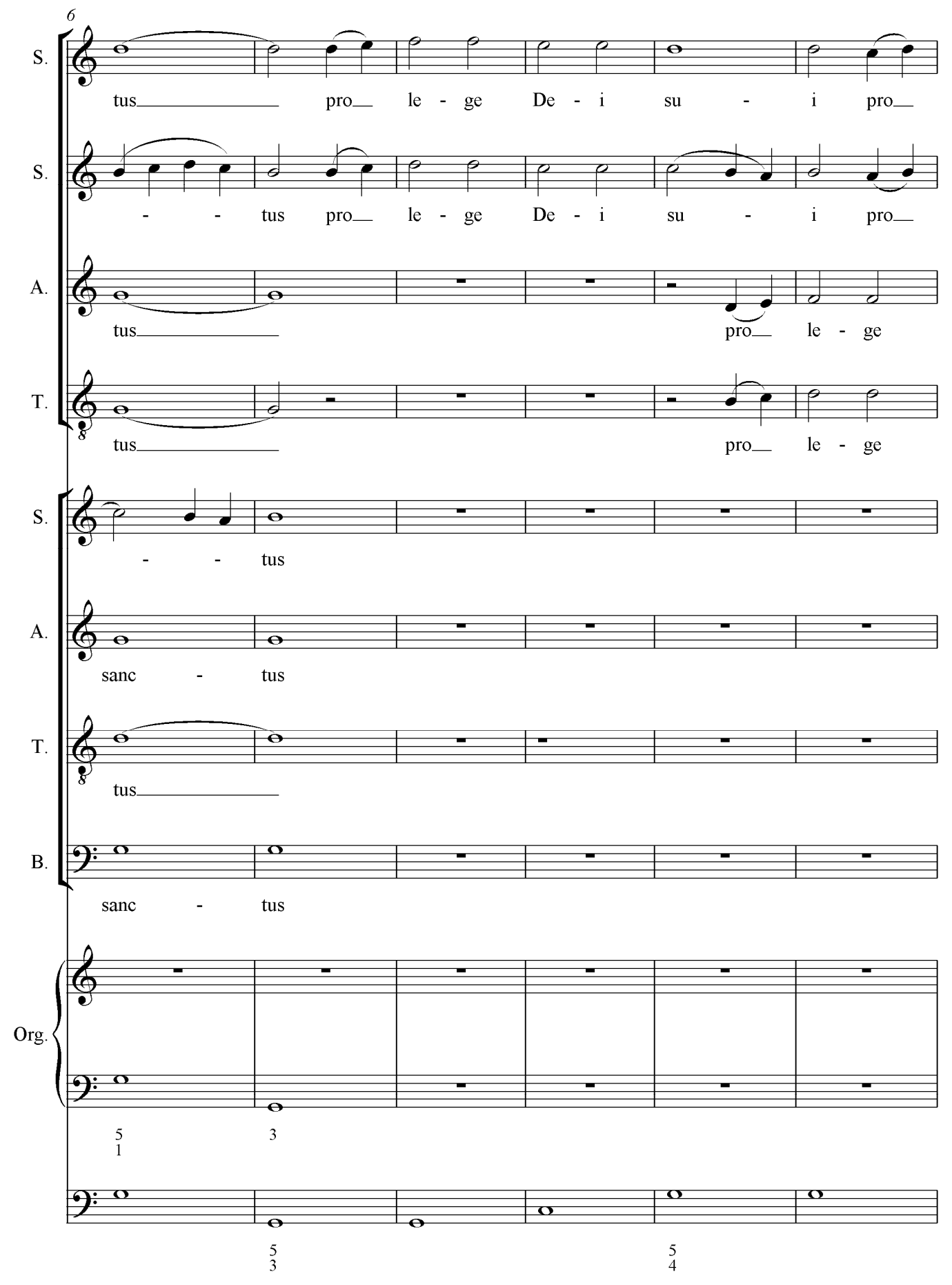




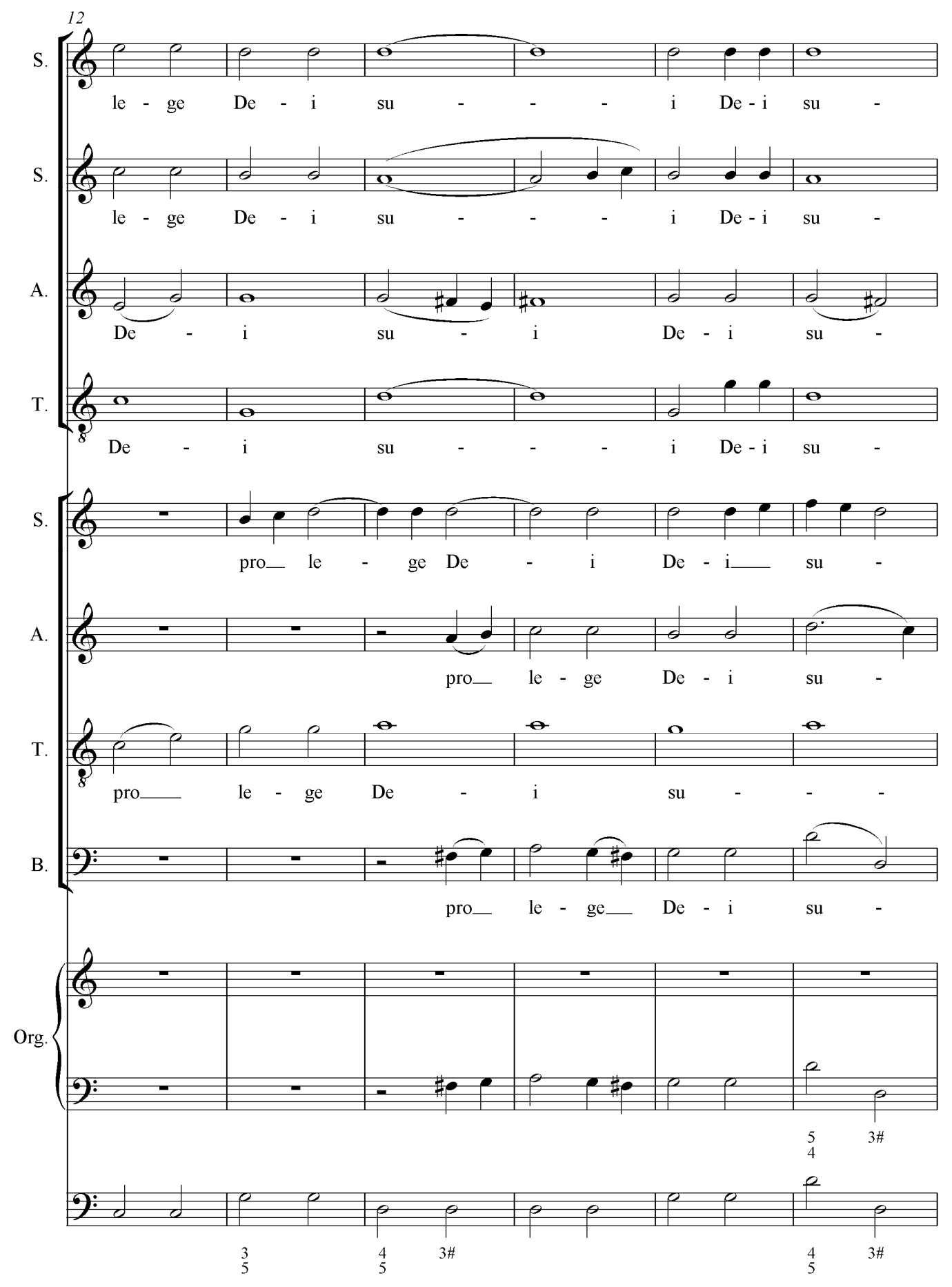




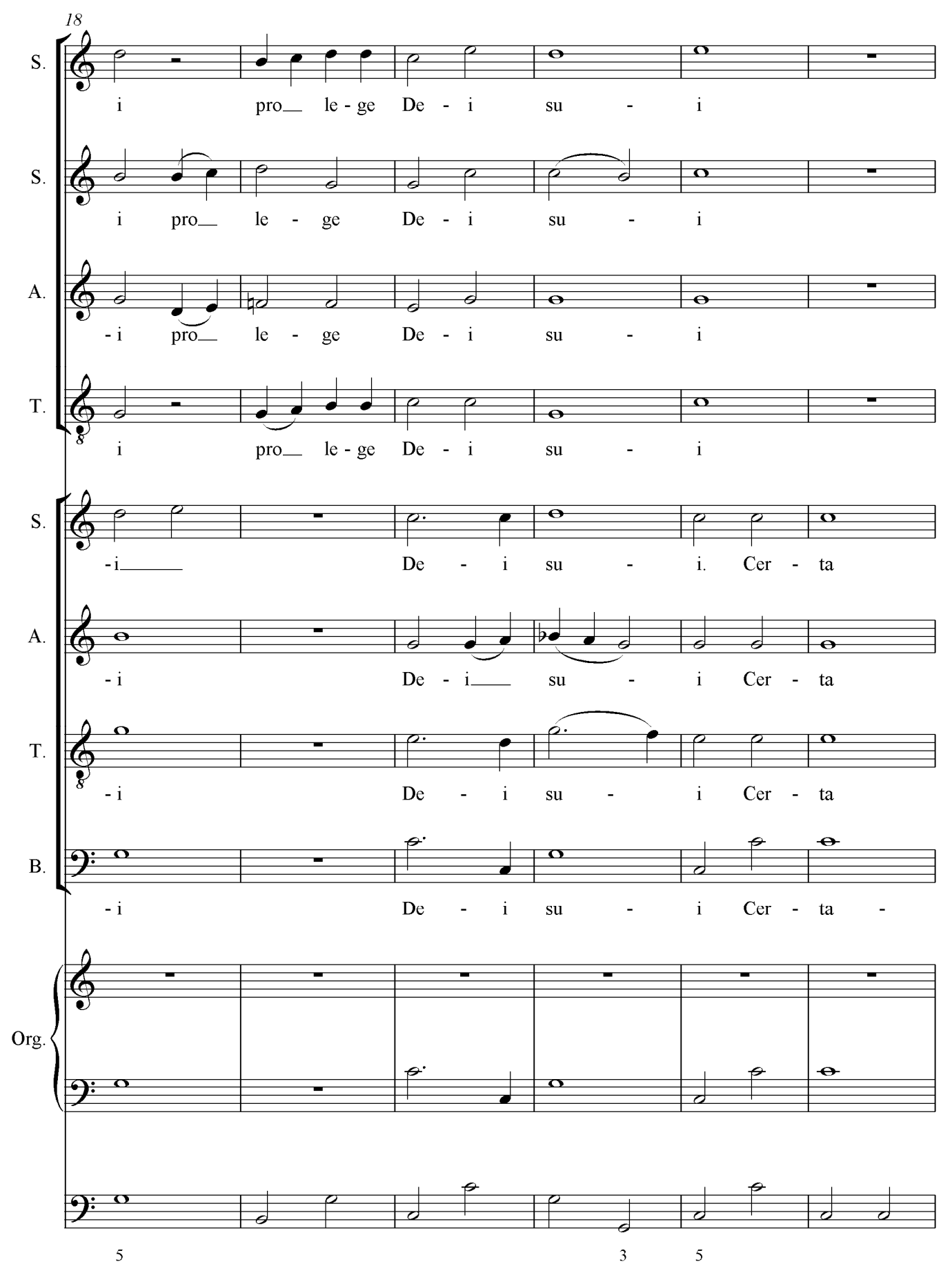




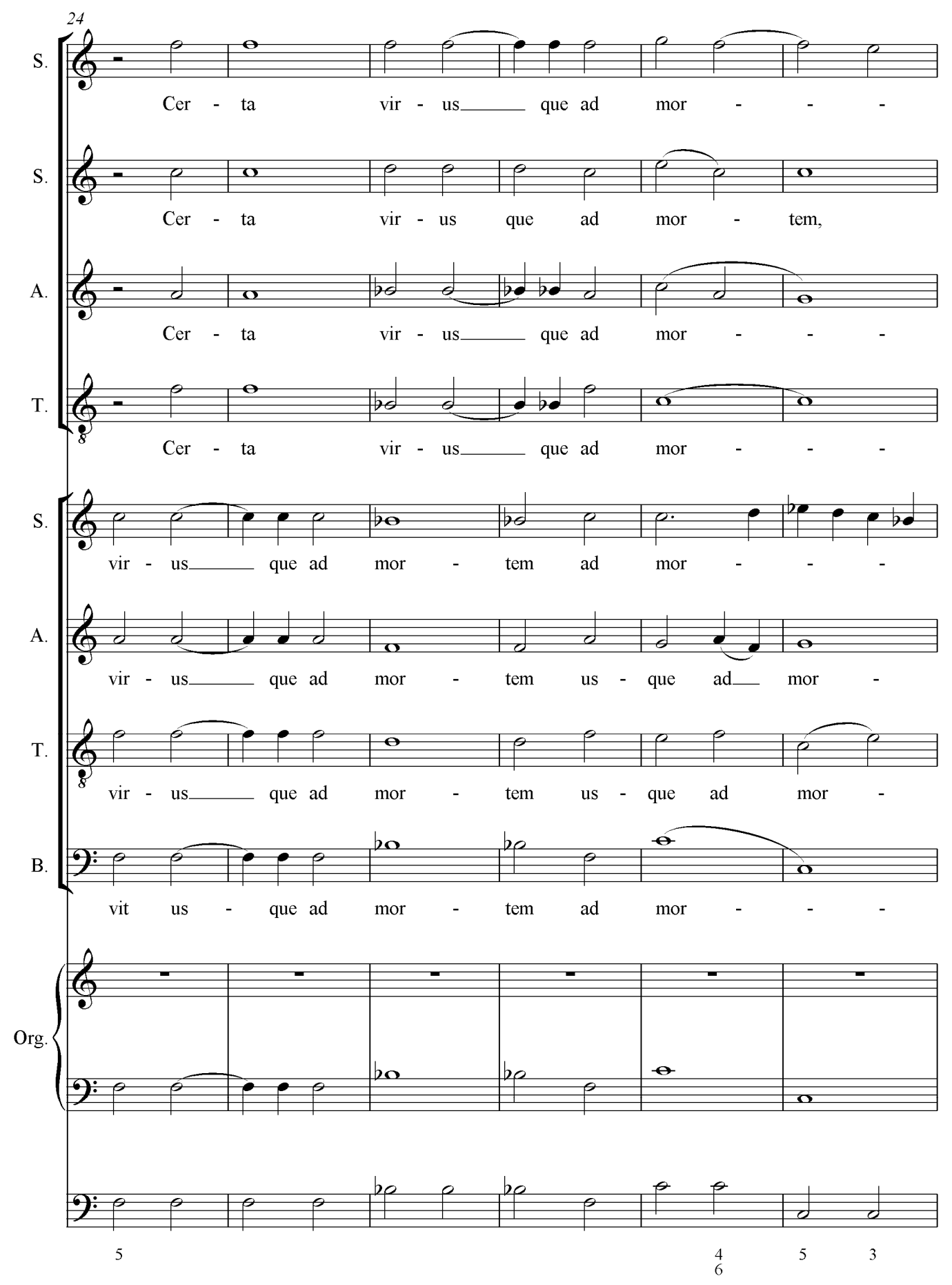




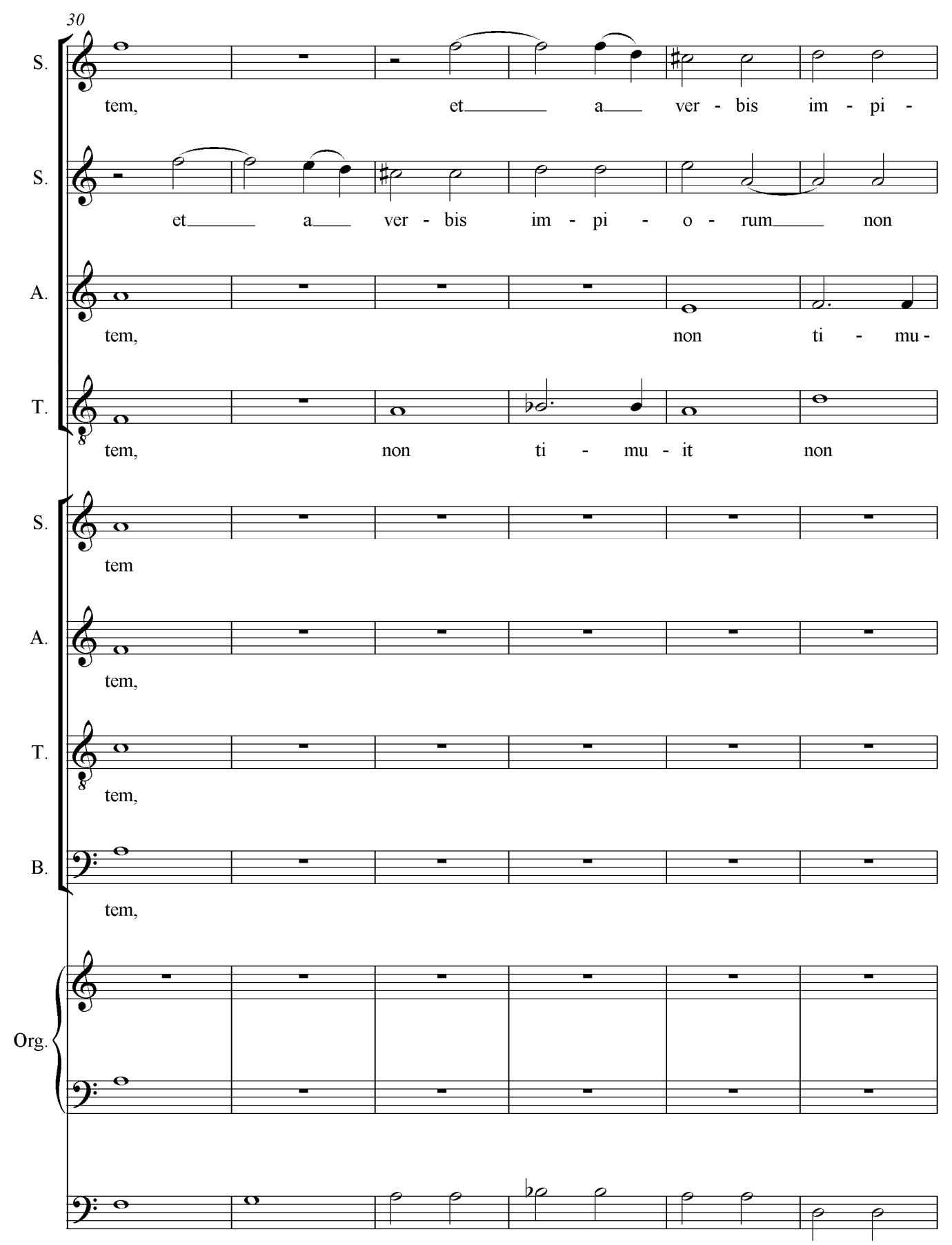




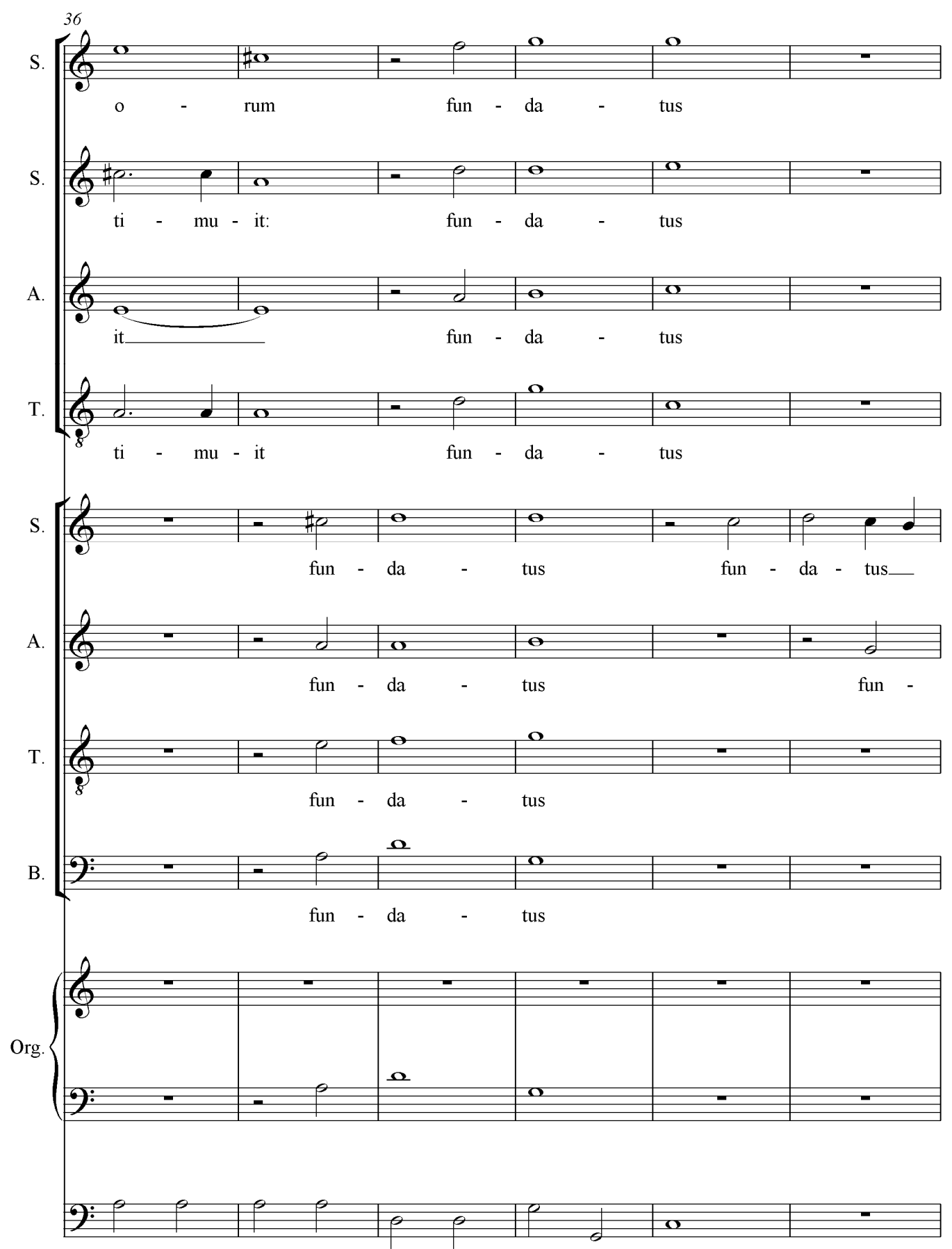




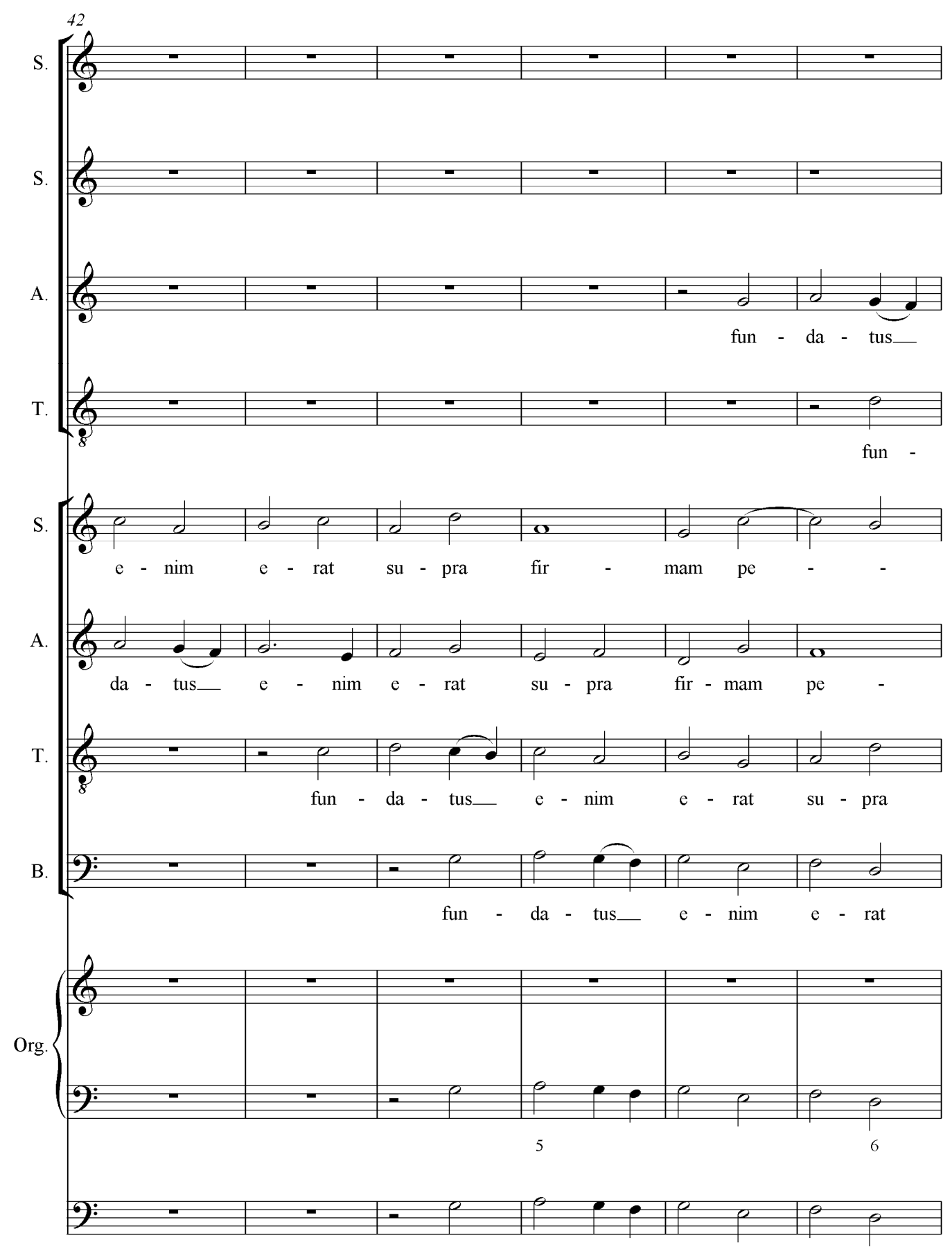




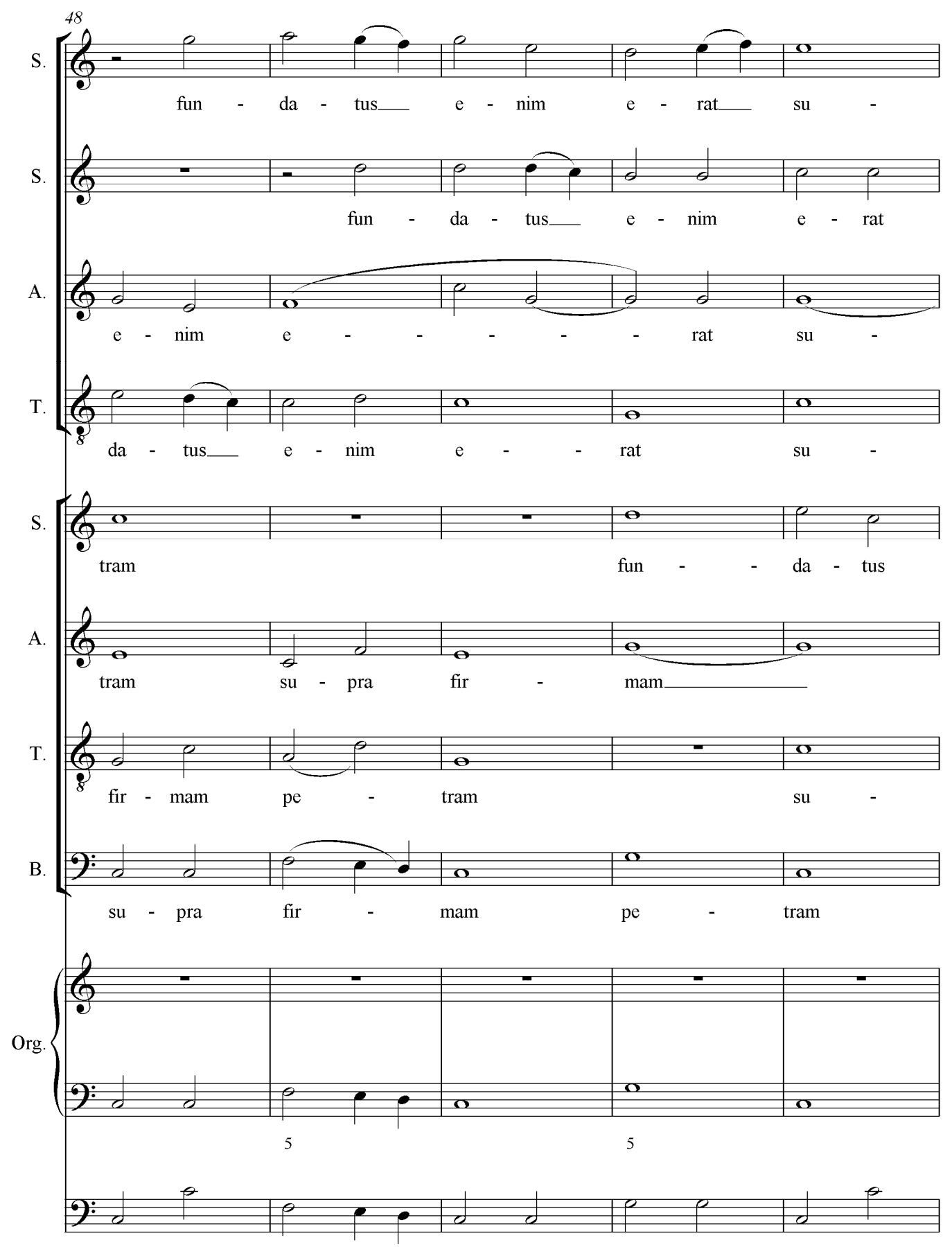




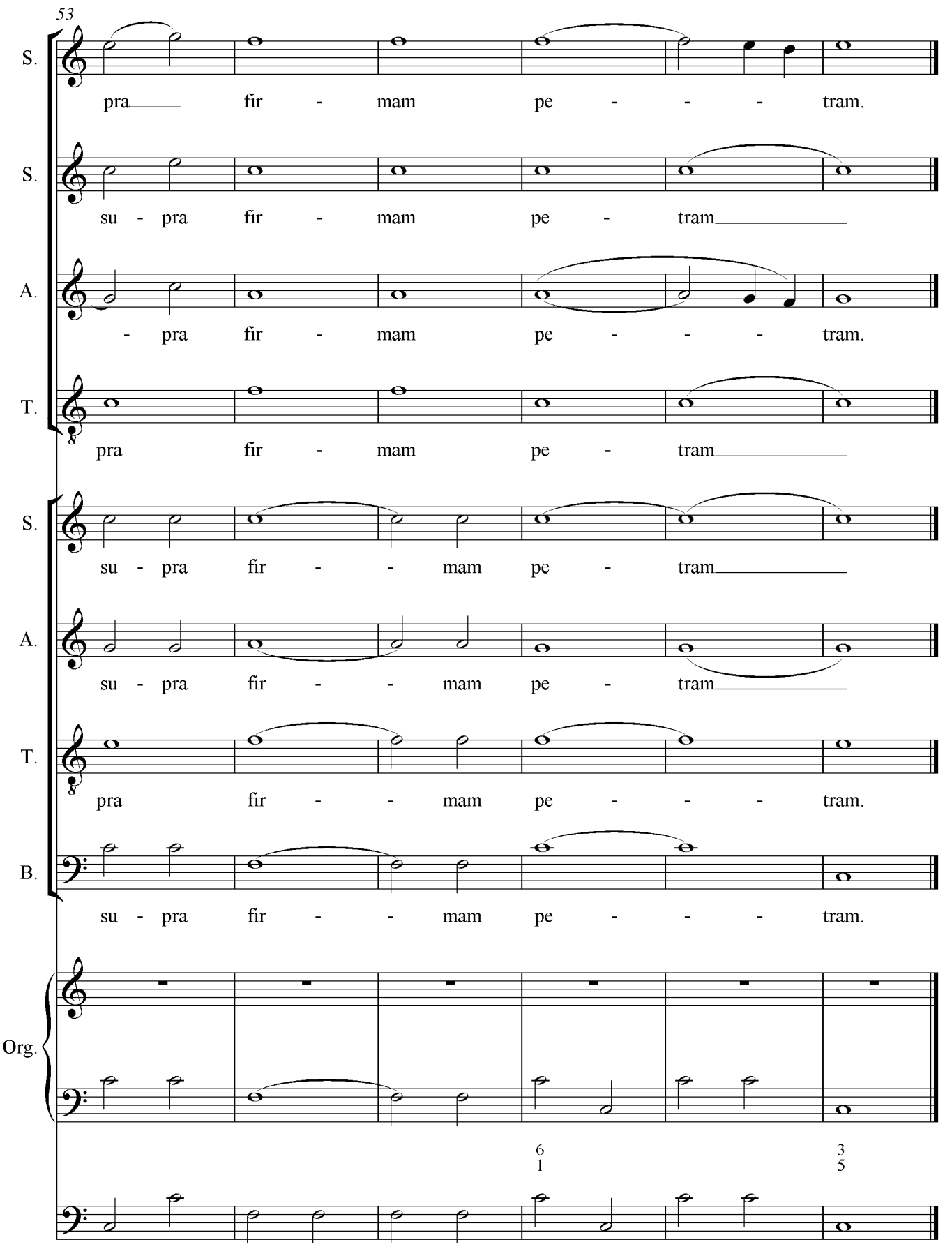


Salve, Patrón de Granada

Transcripción y edición: Mercedes Castillo Ferreira
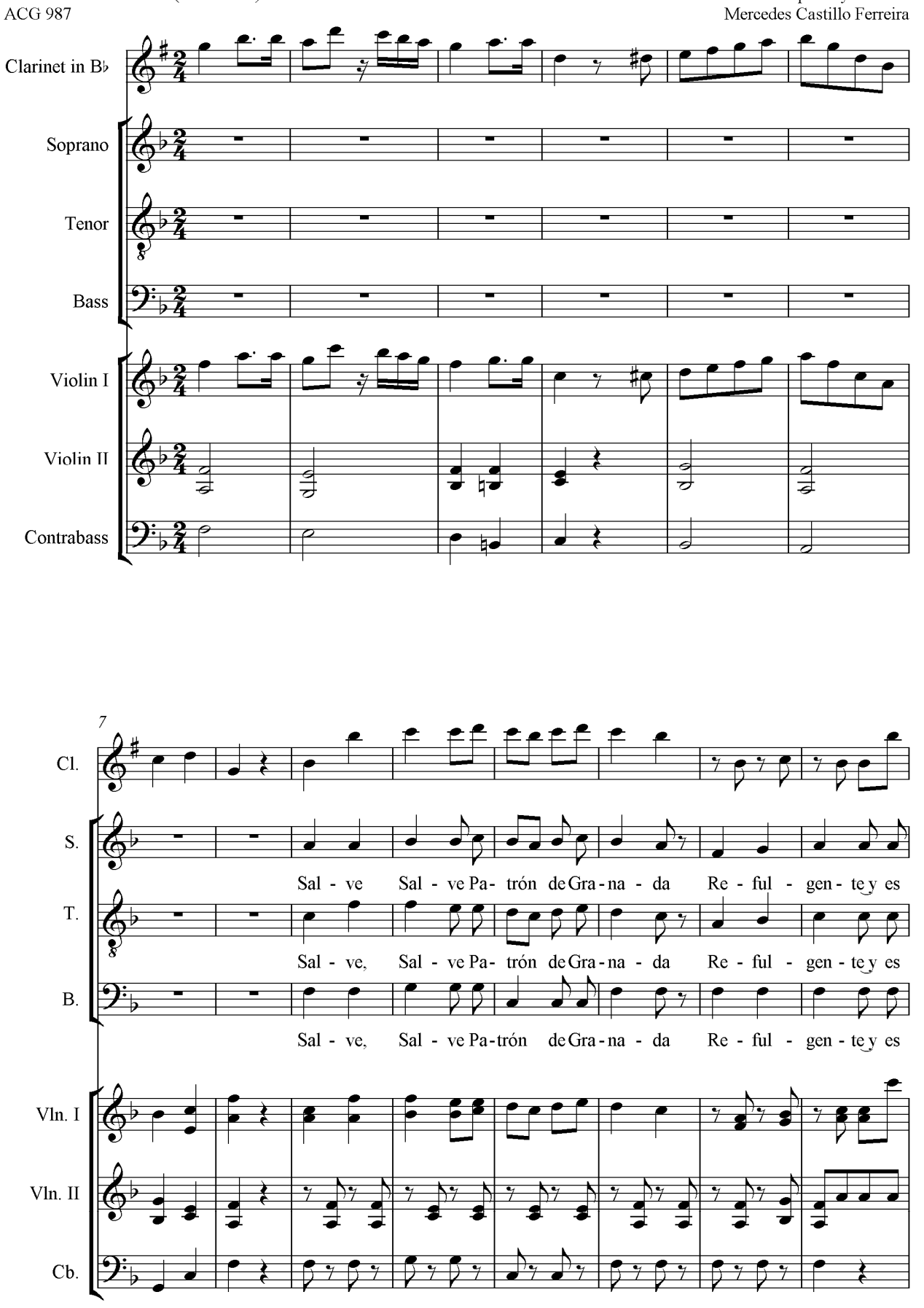

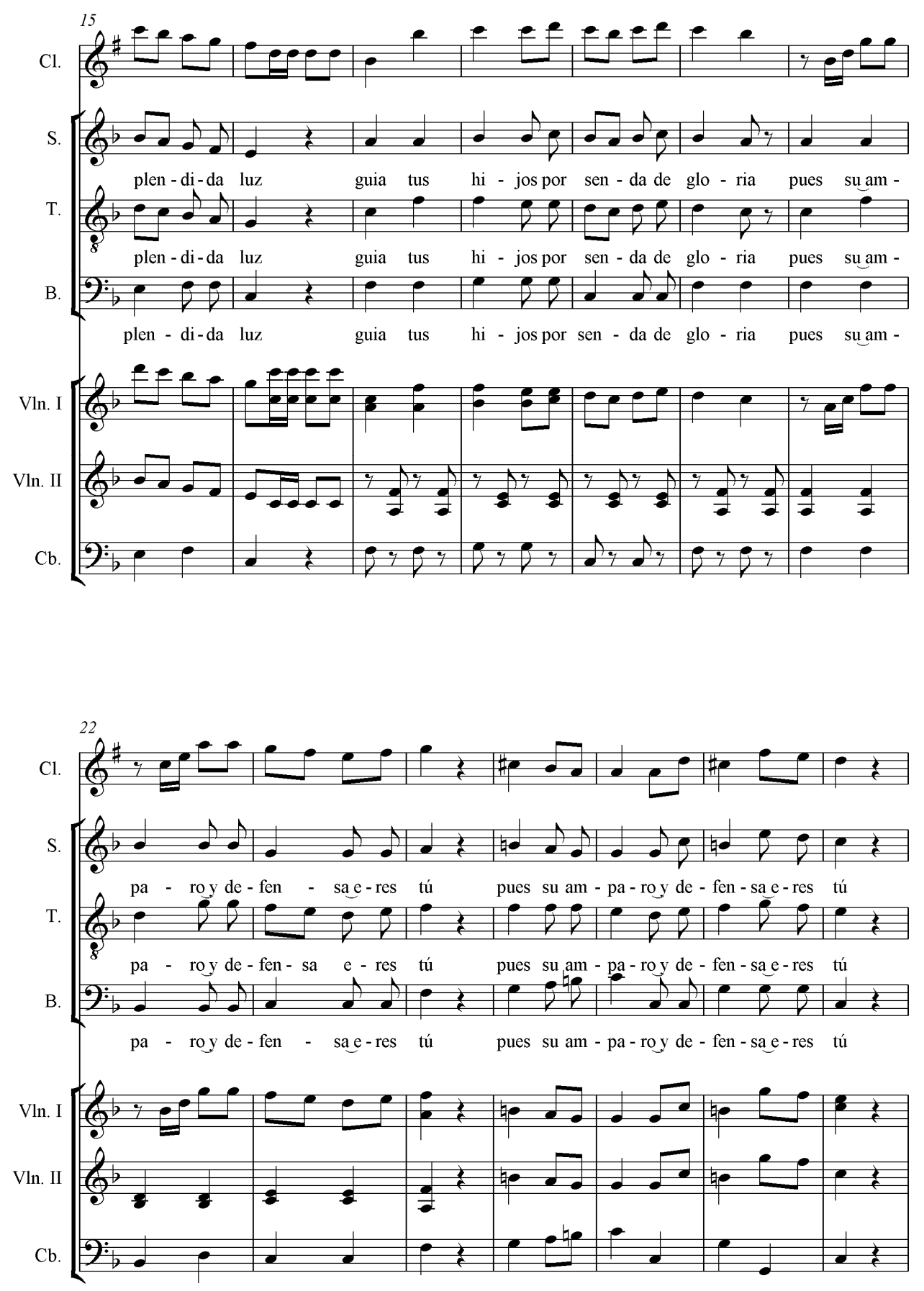

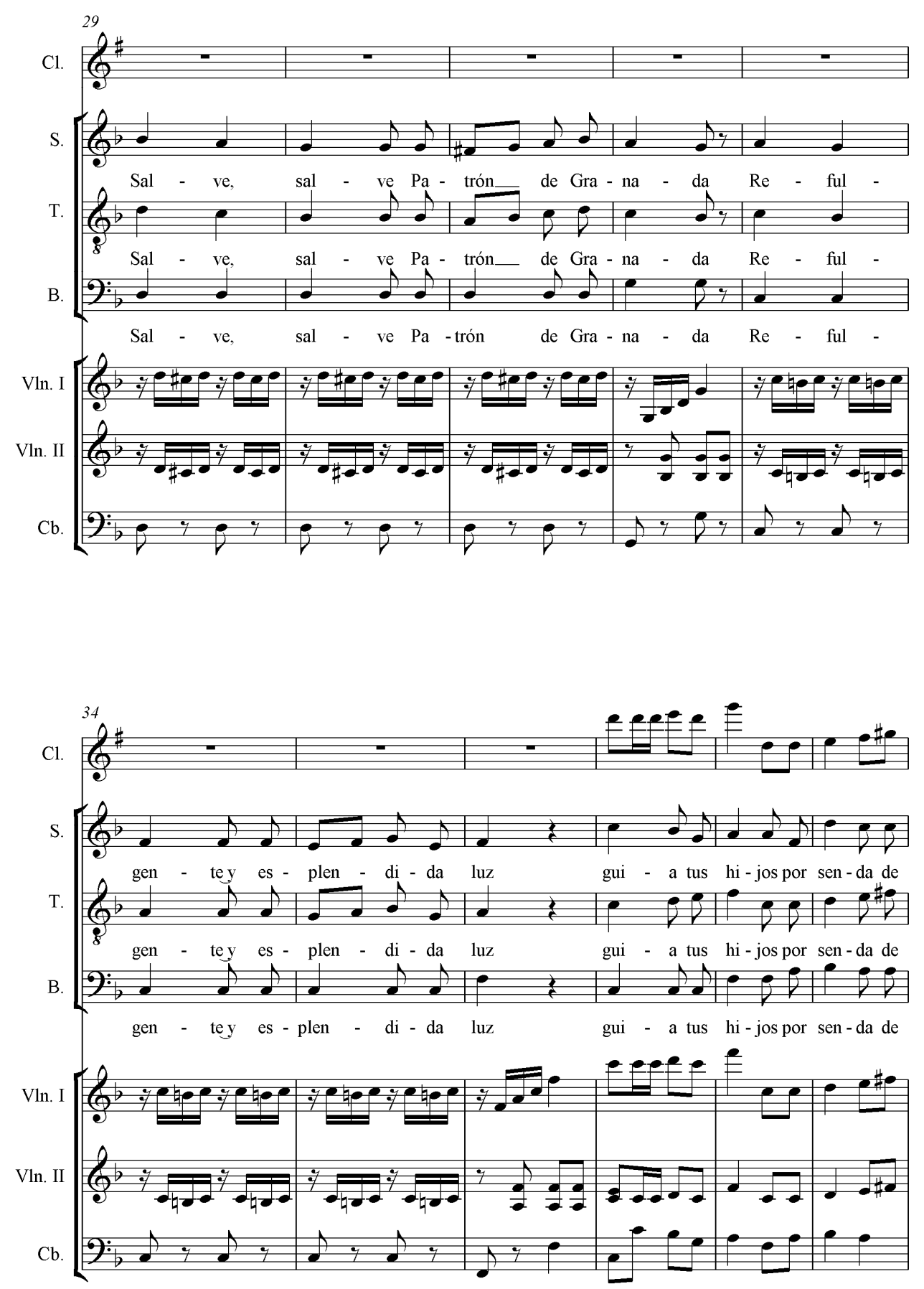


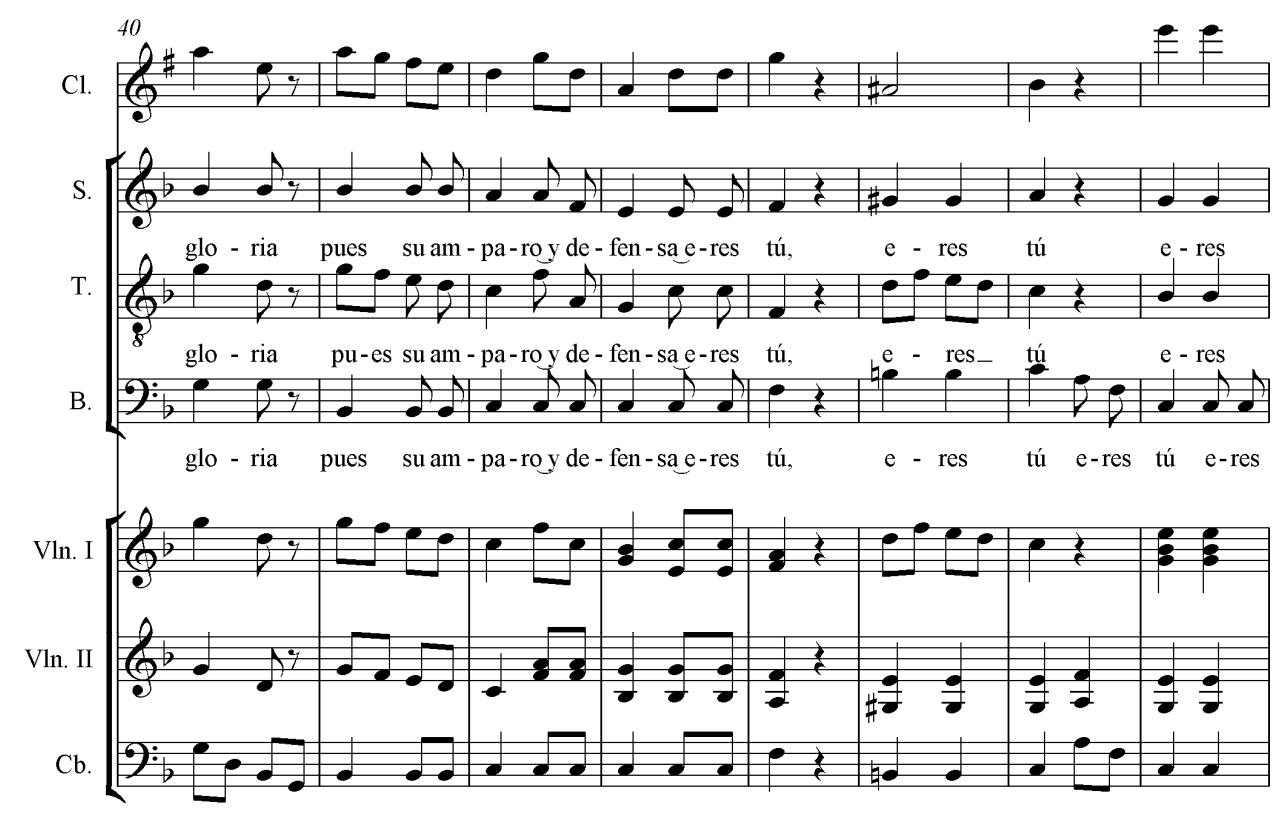

Coplas: Dúo.

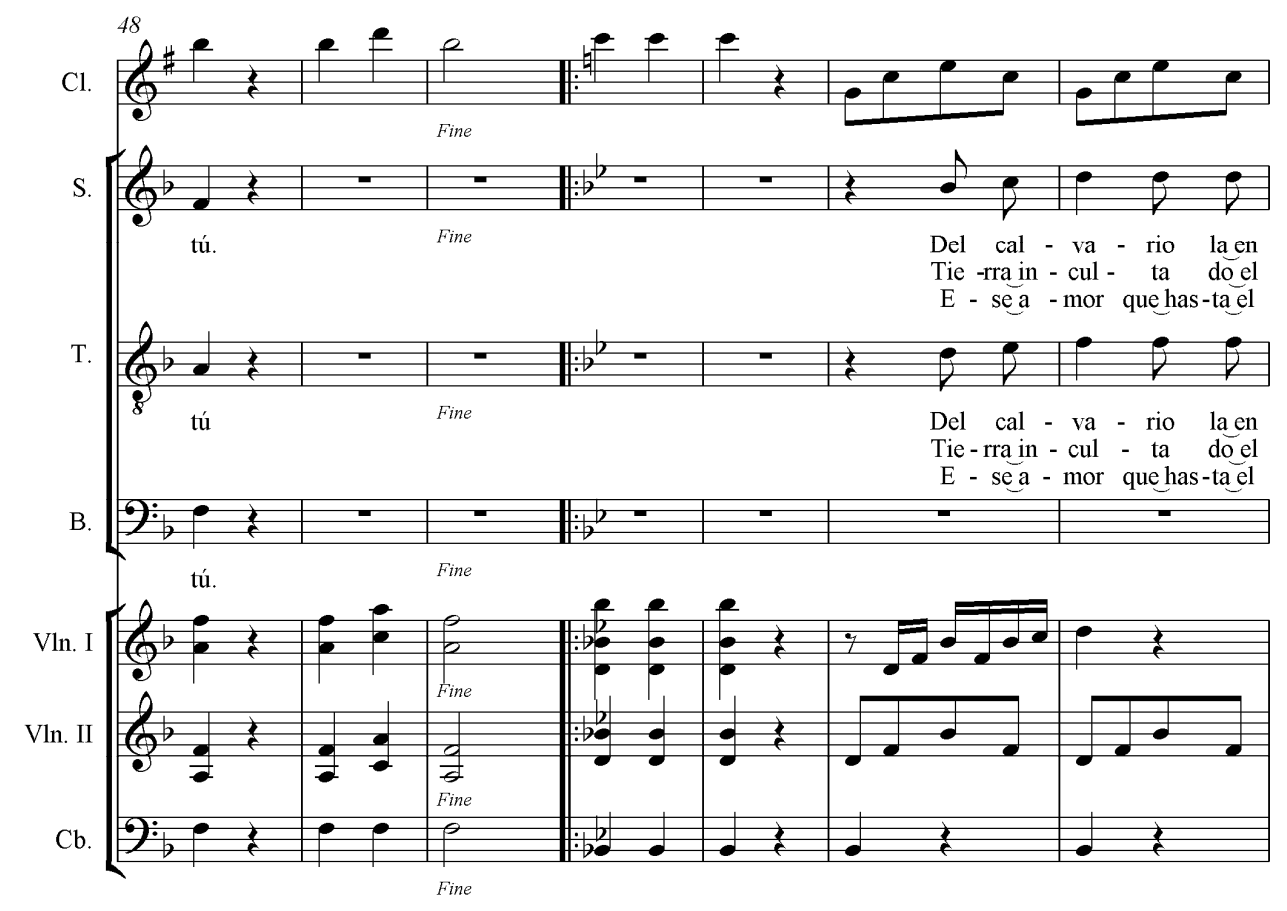



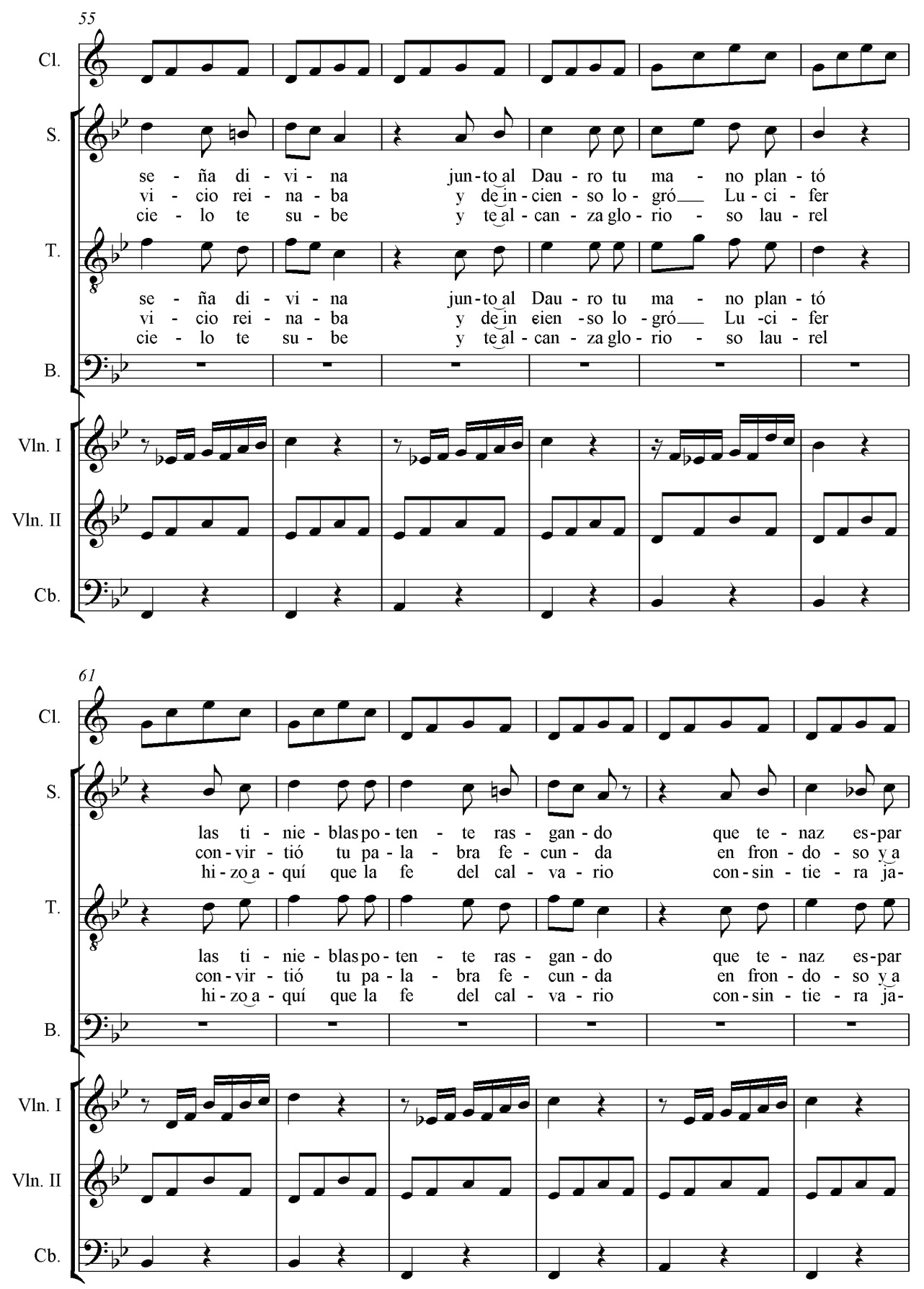

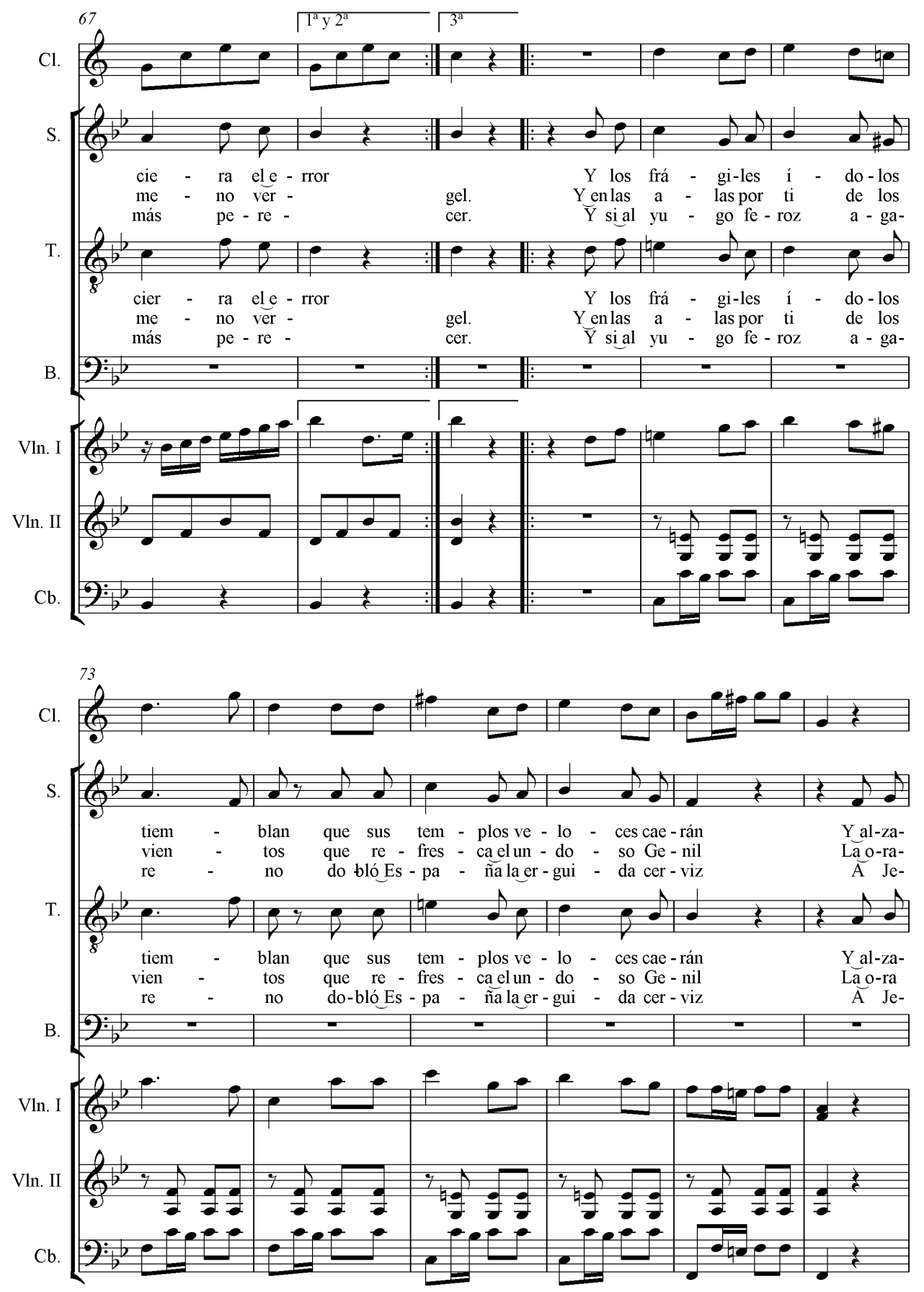

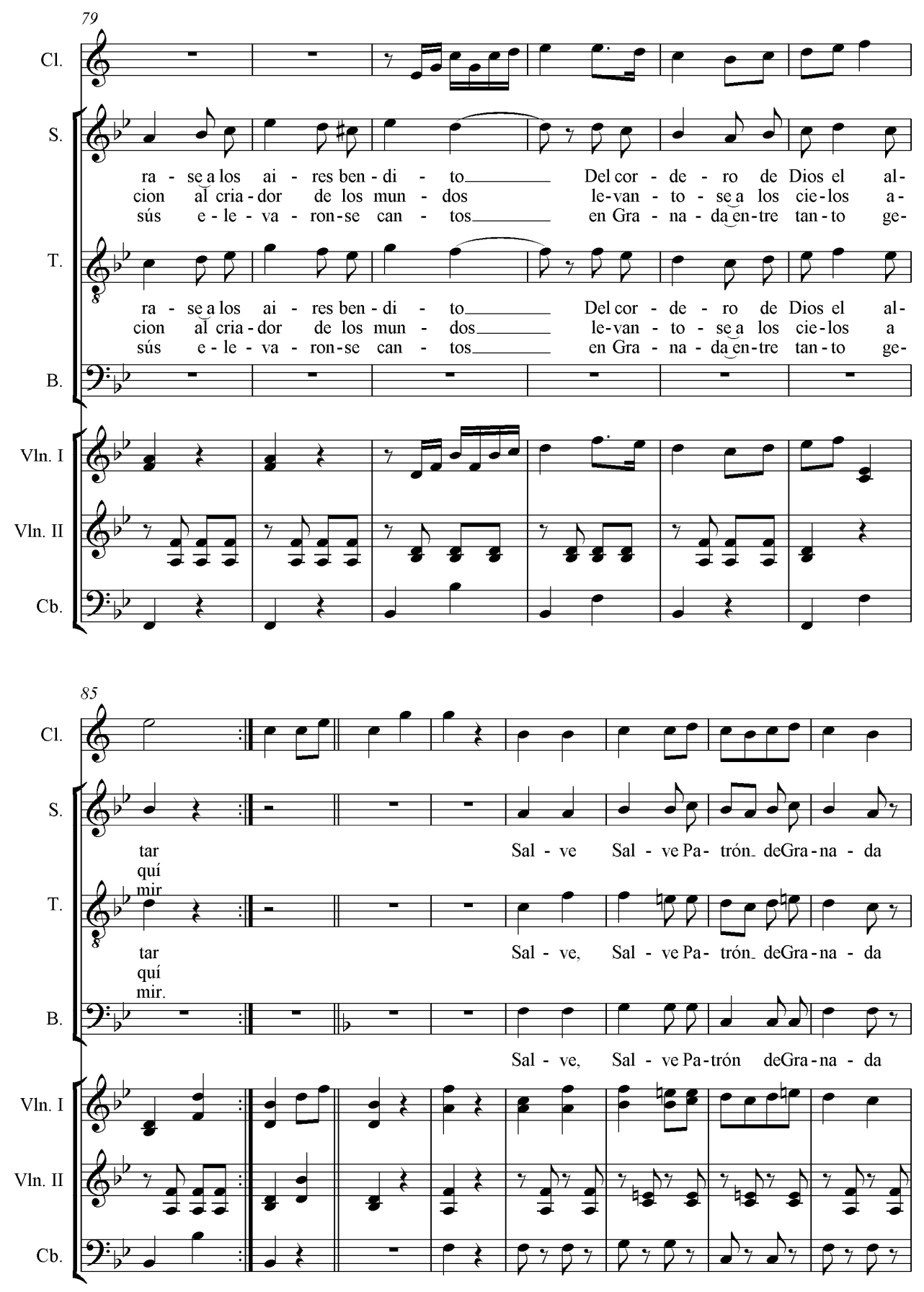

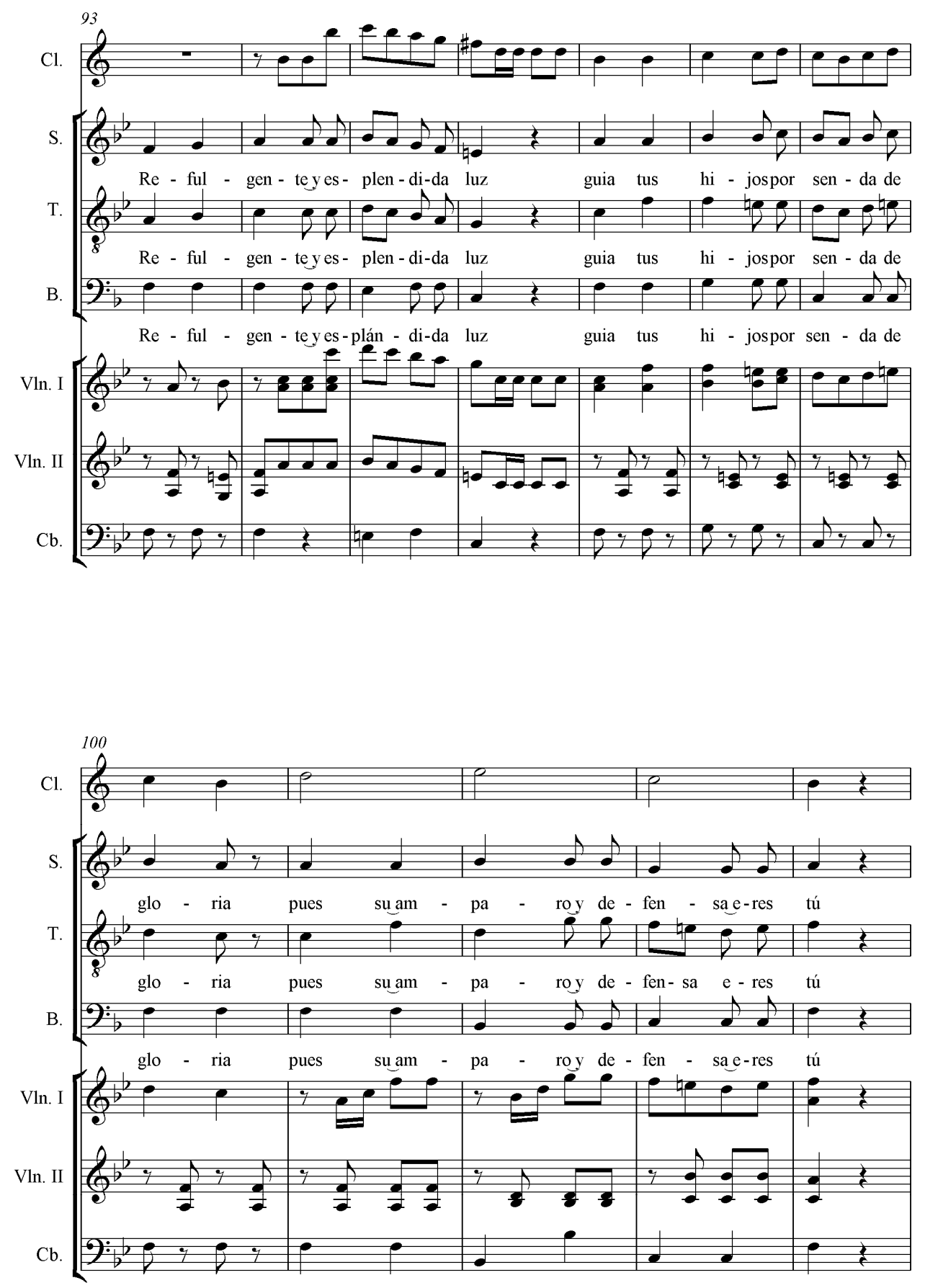


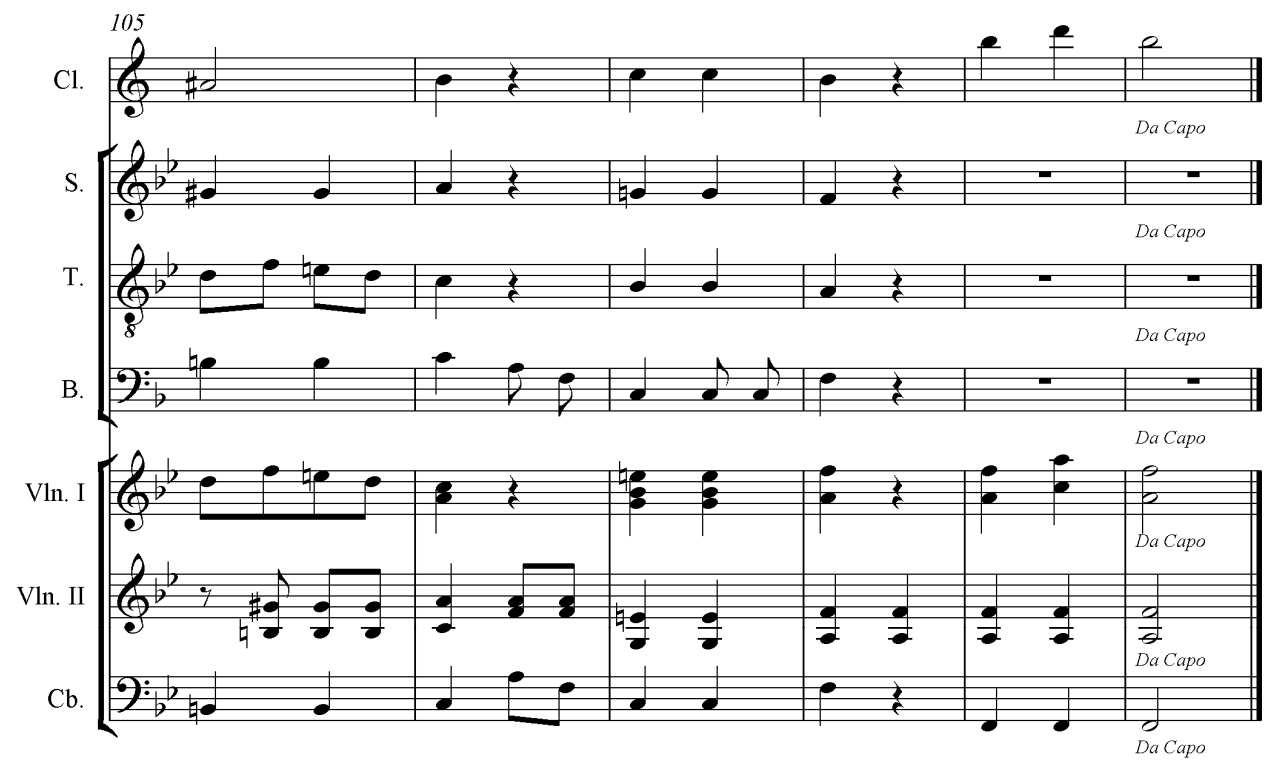



Cecilio pues en Granada

Gozos a San Cecilio
Transcripción y edición: Mercedes Castillo
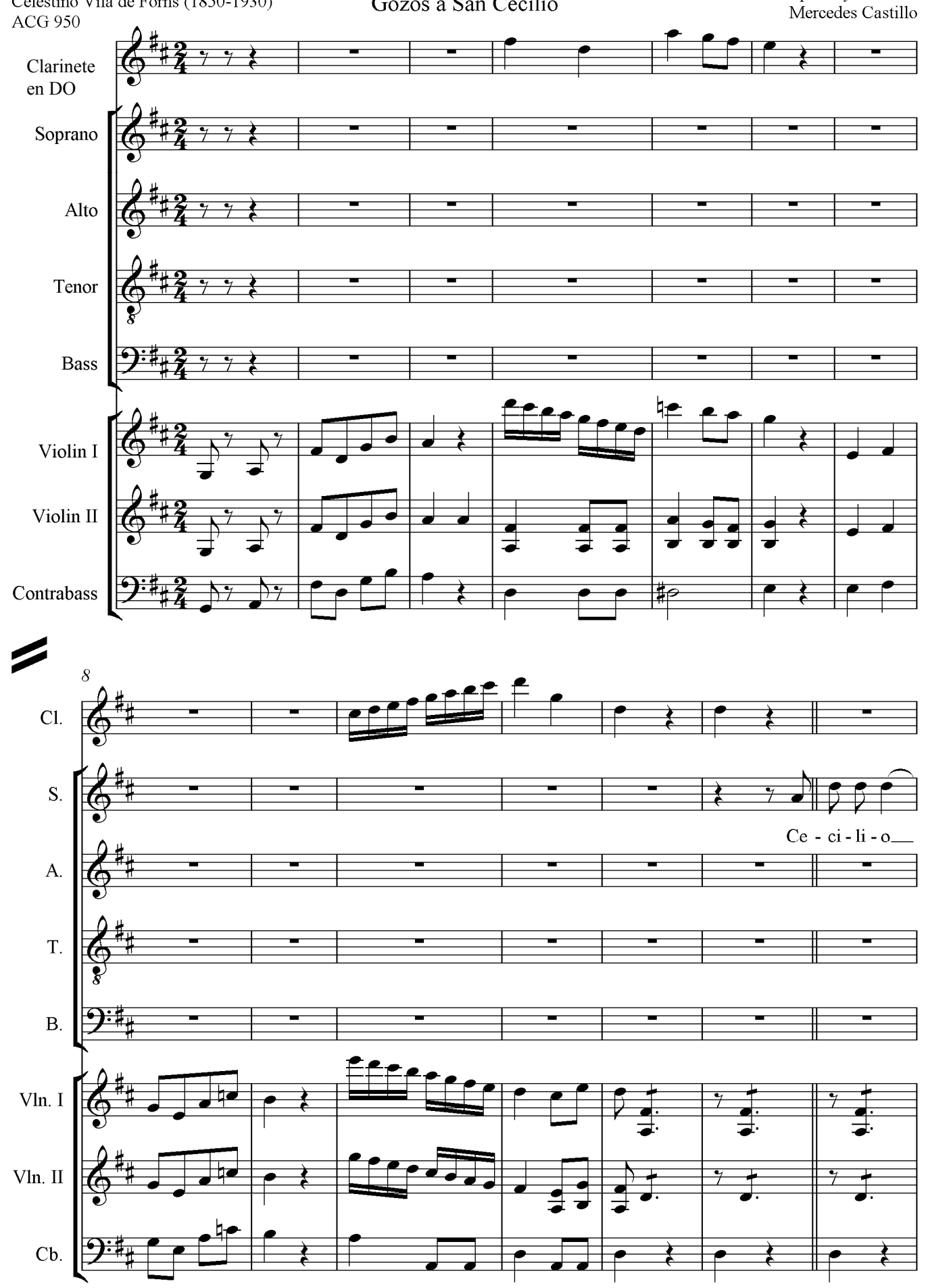


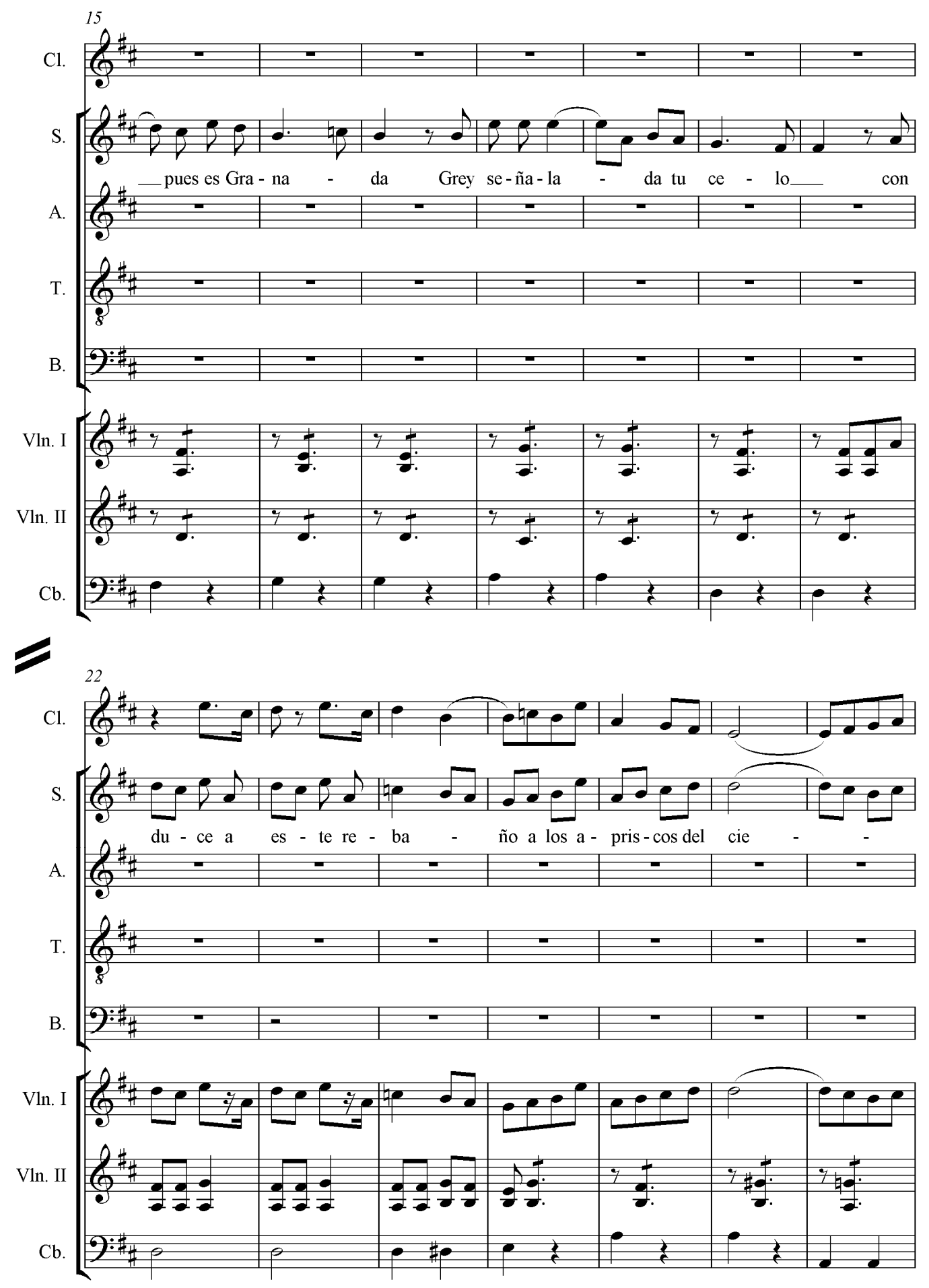



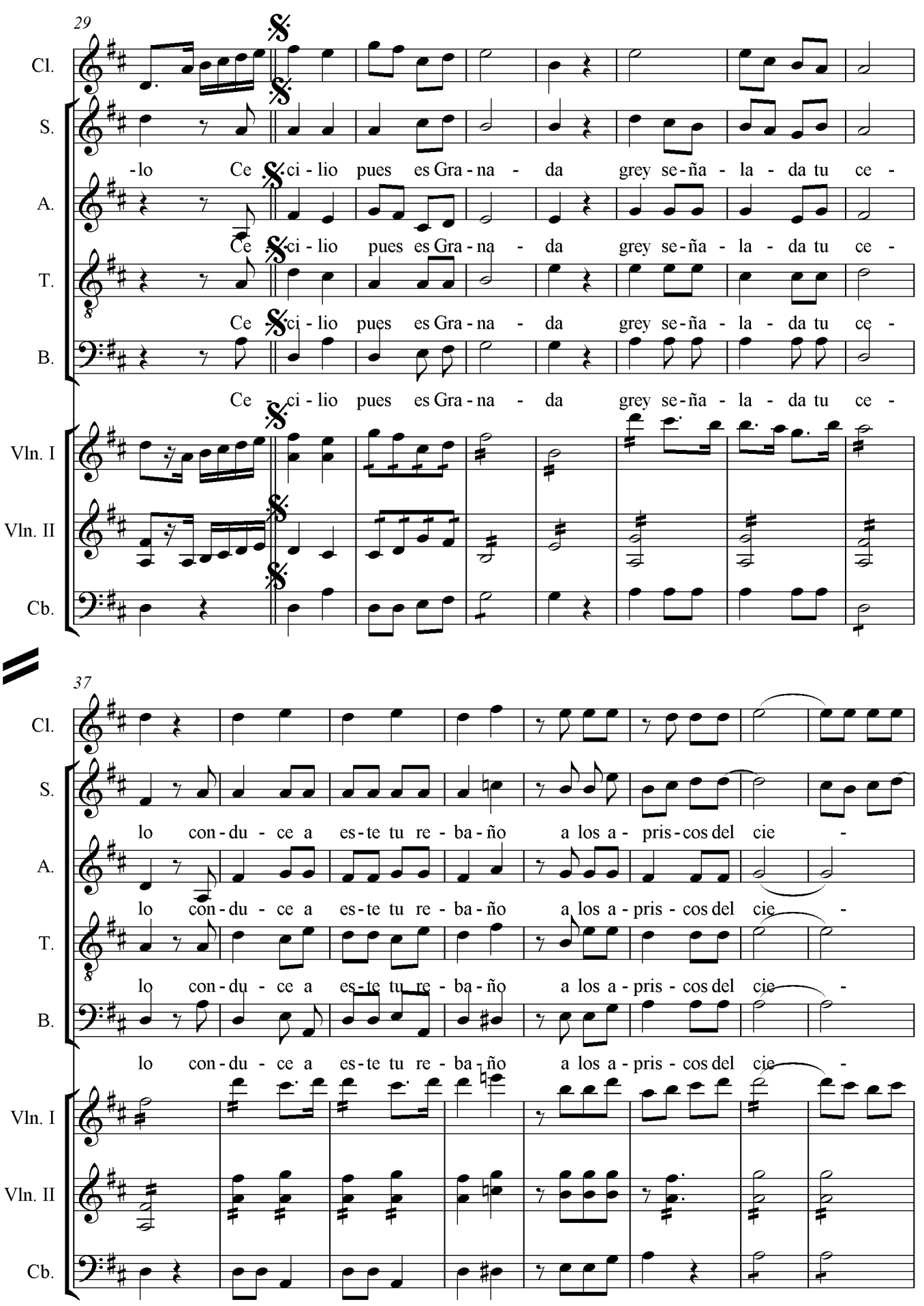


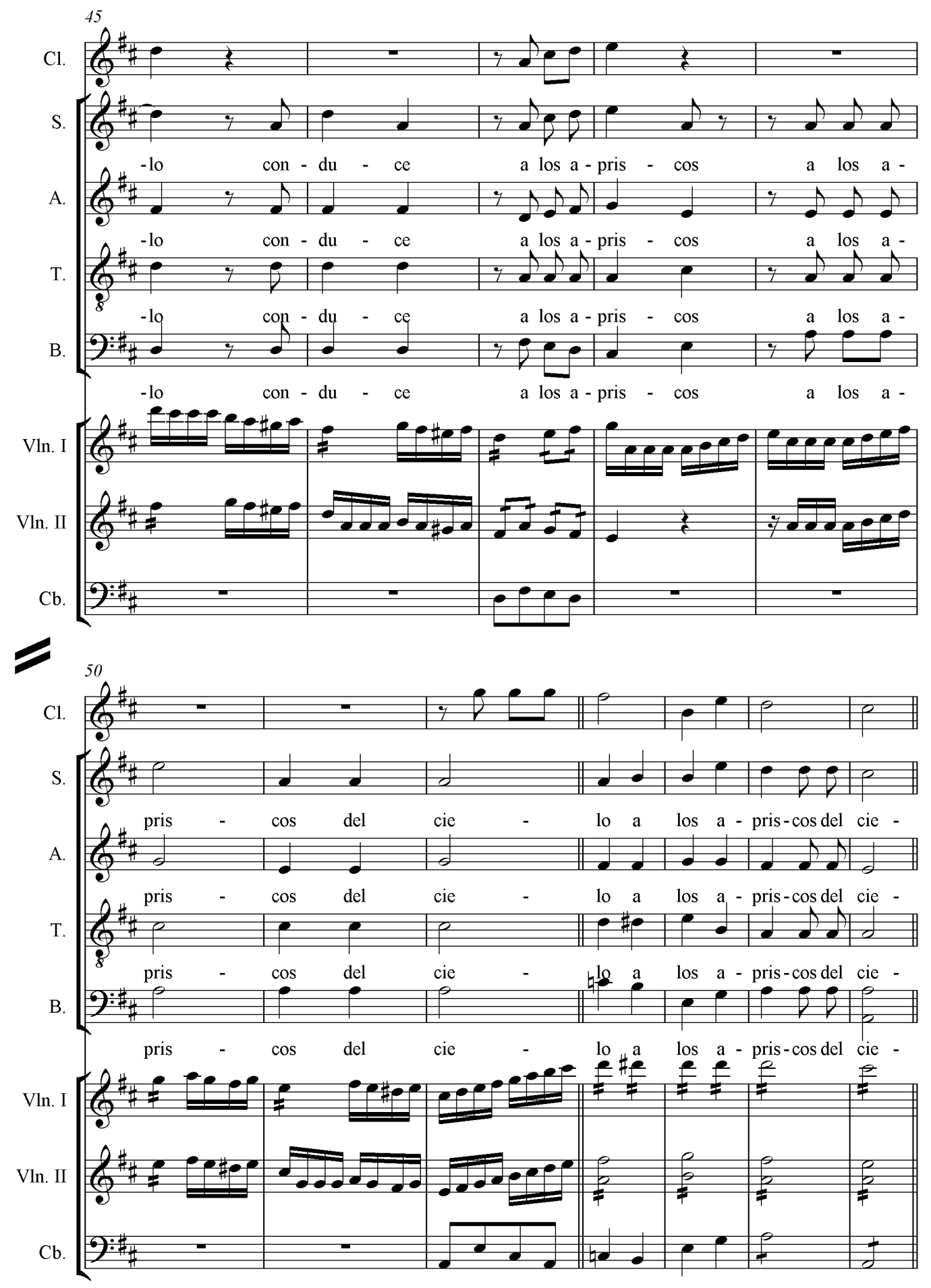



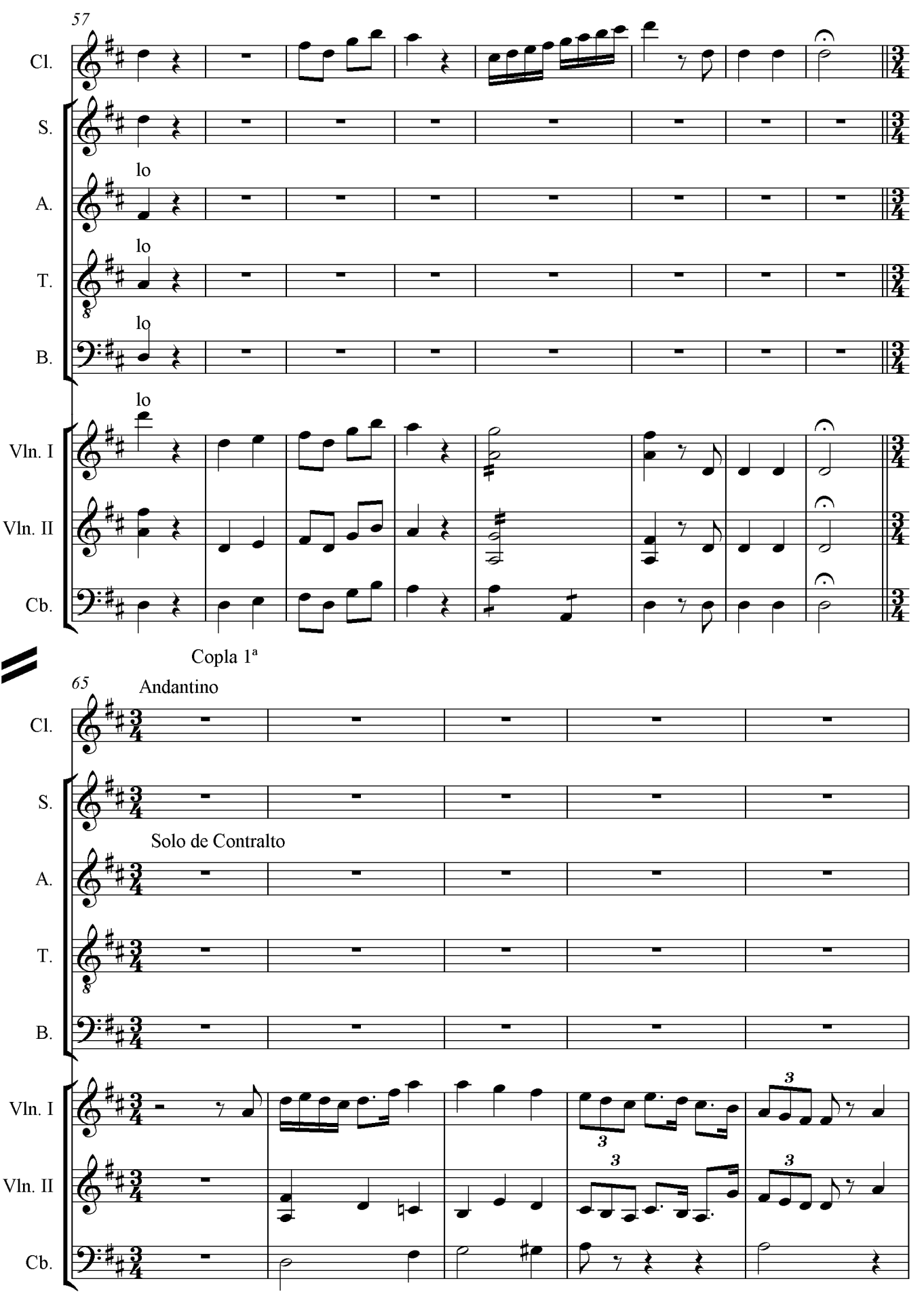


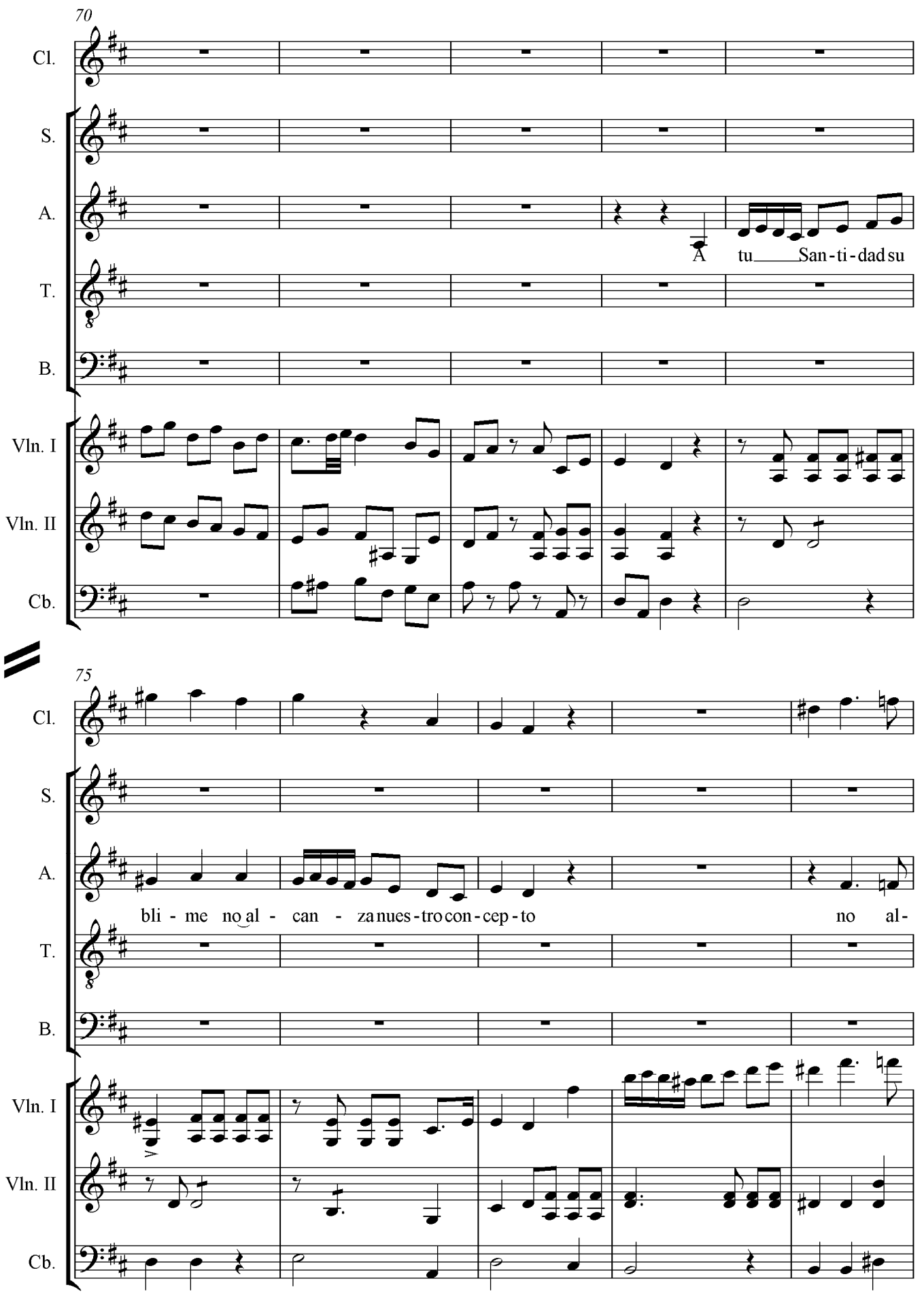



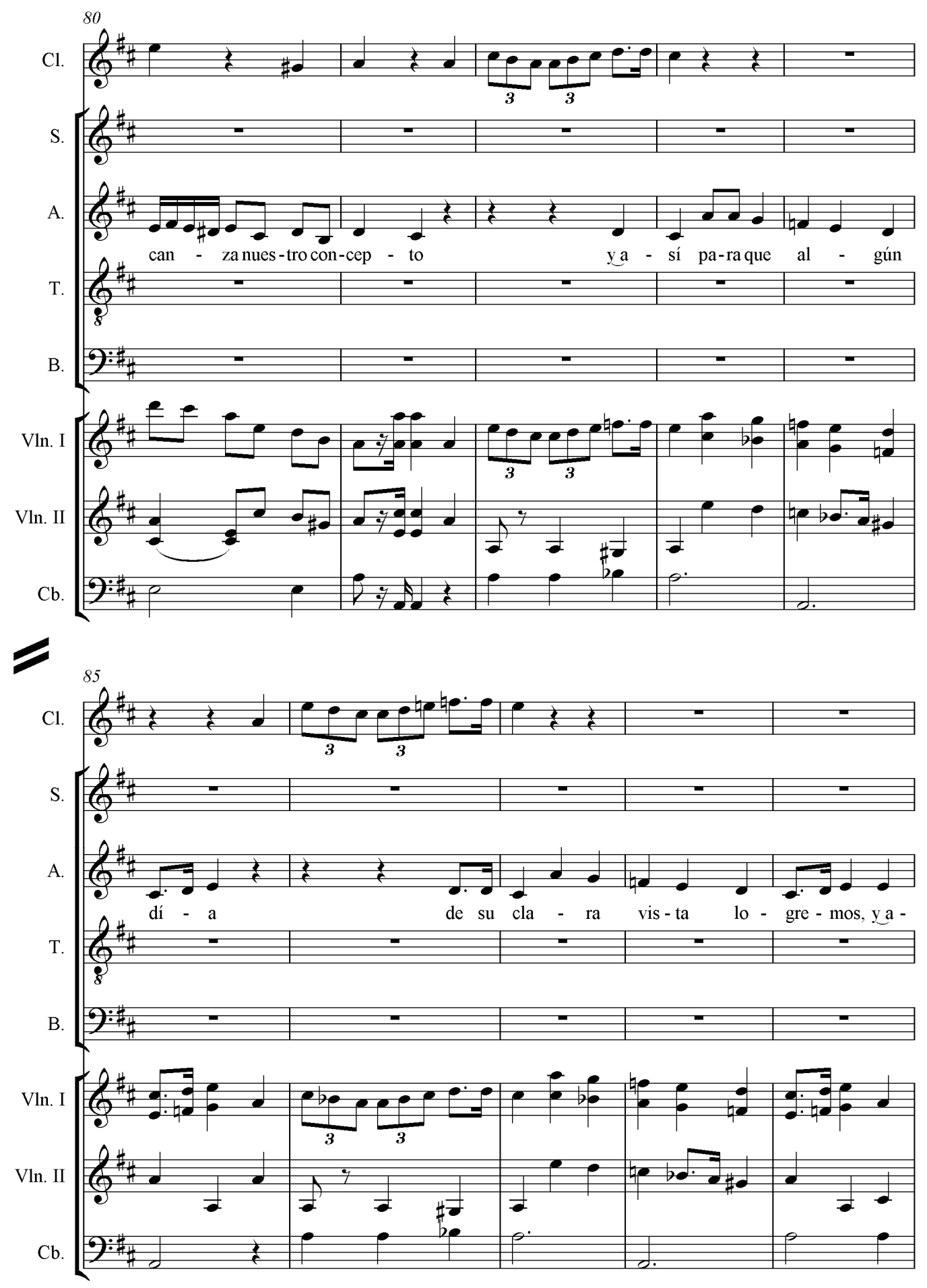


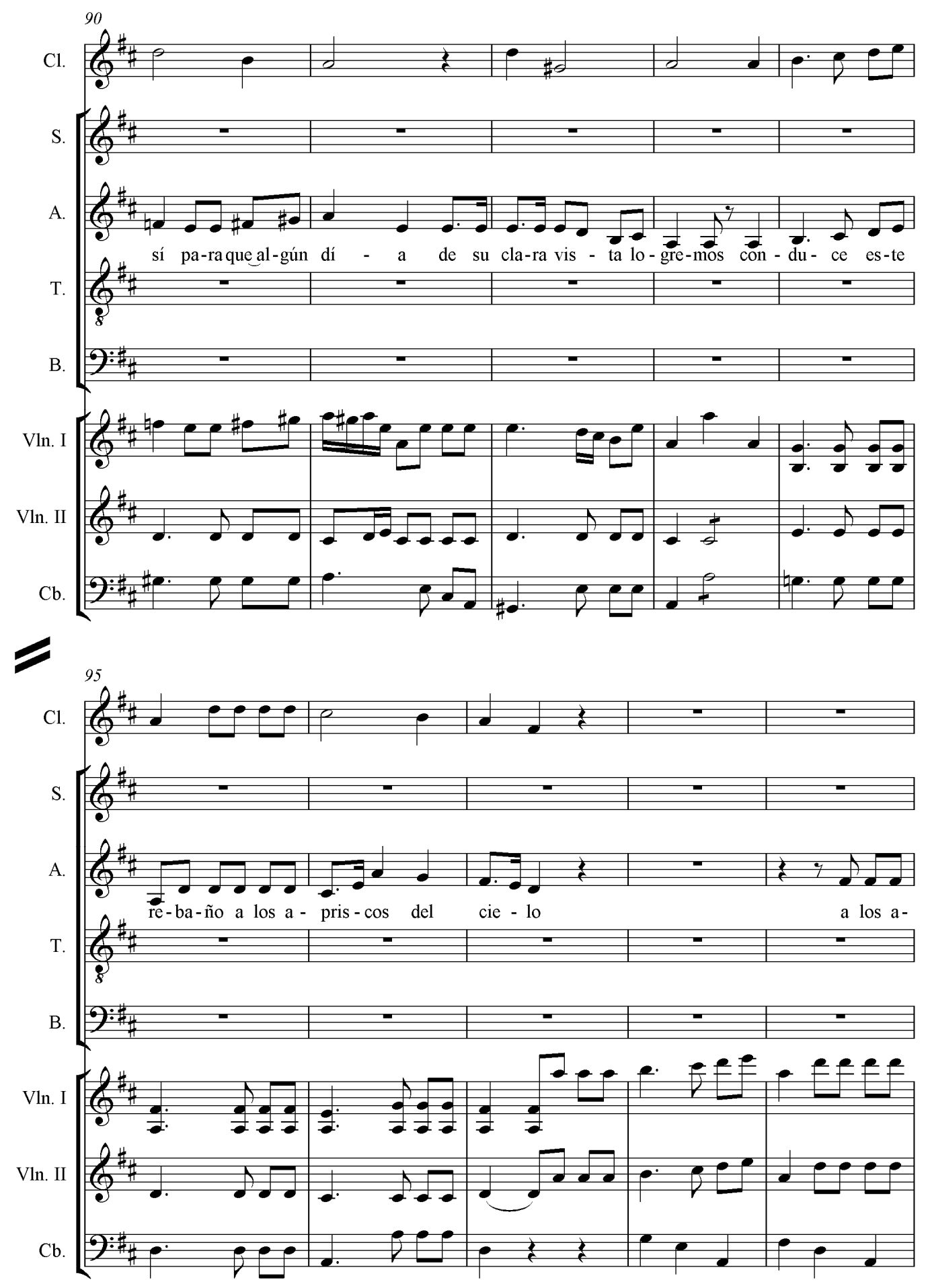




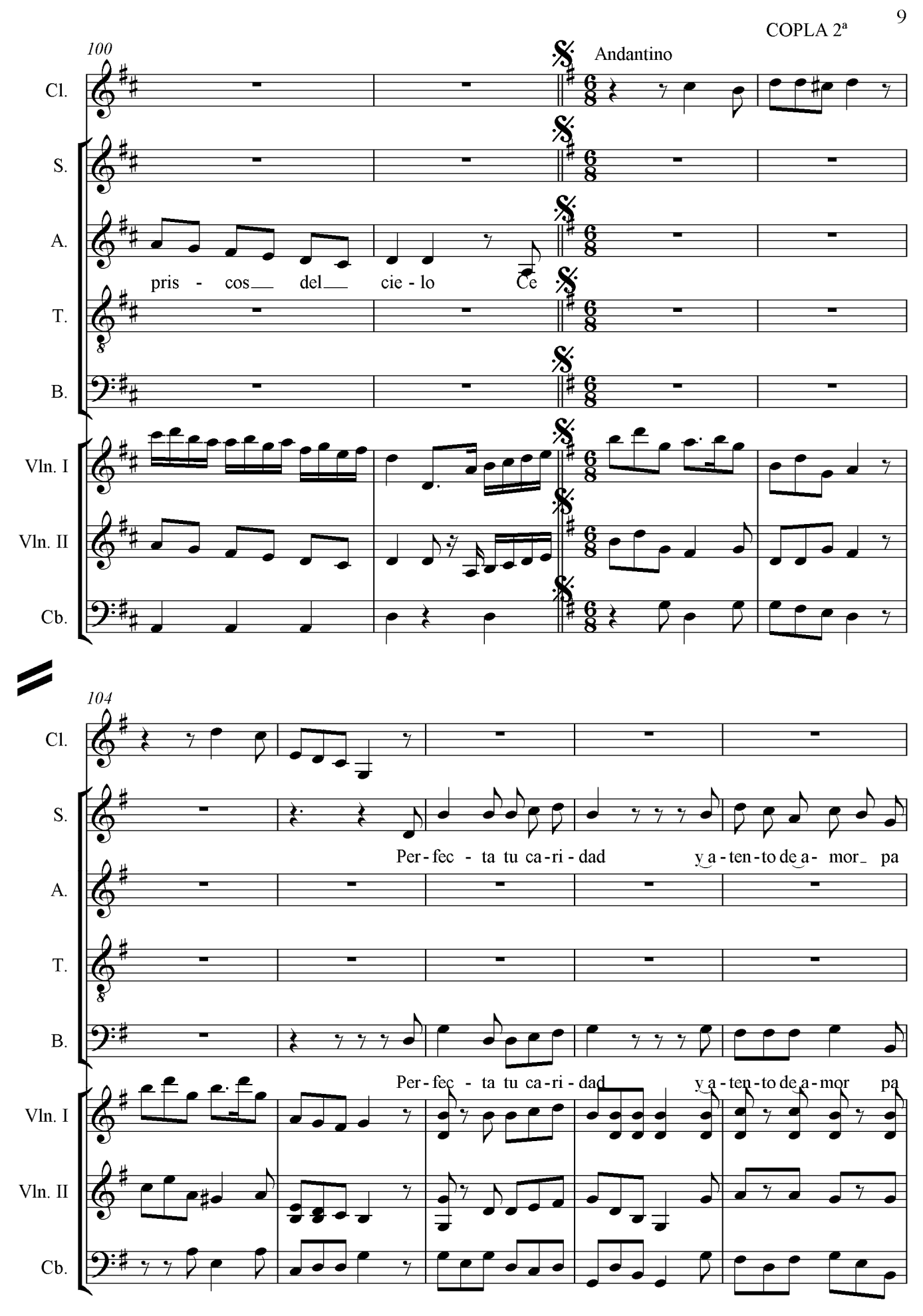




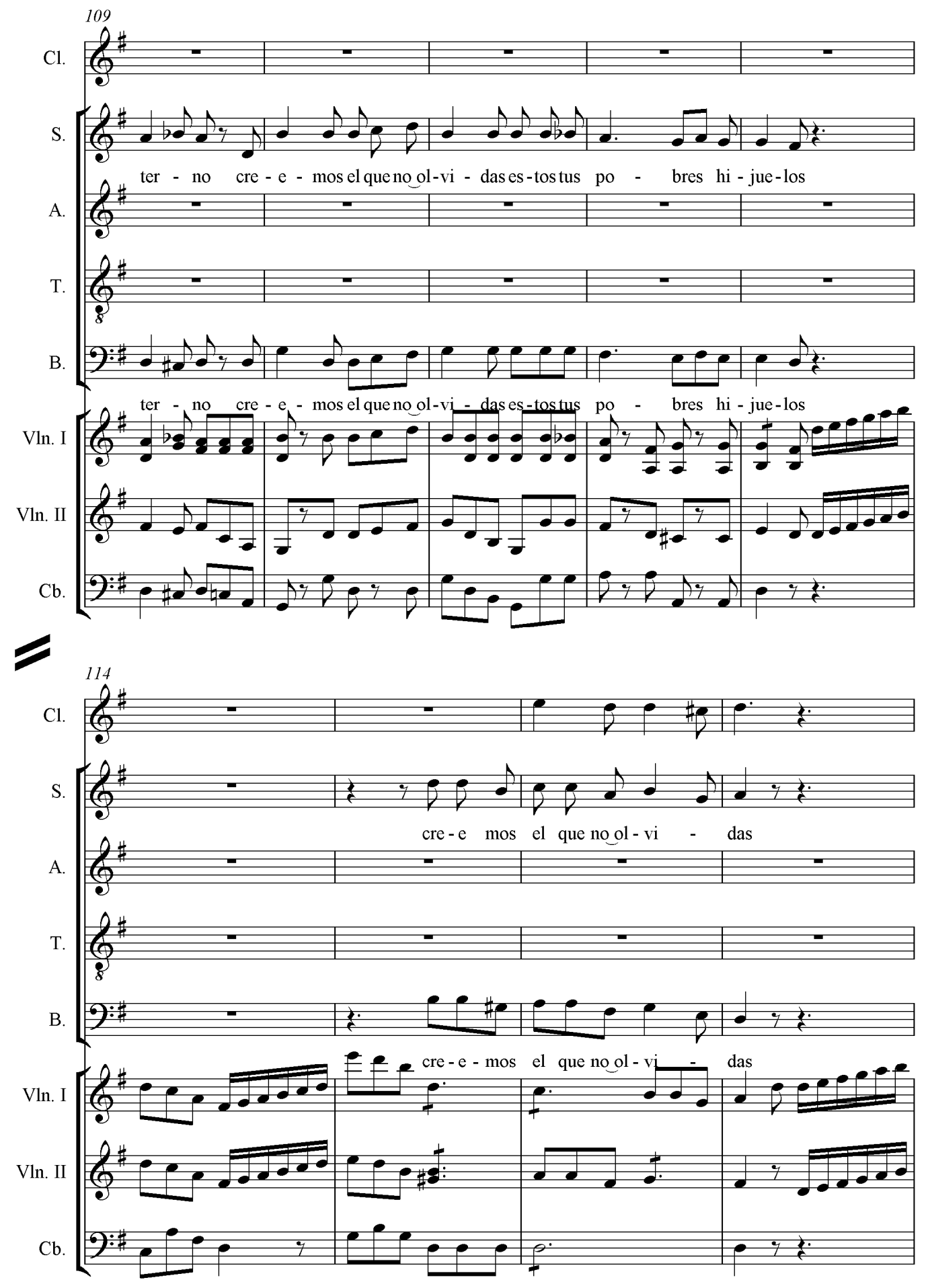



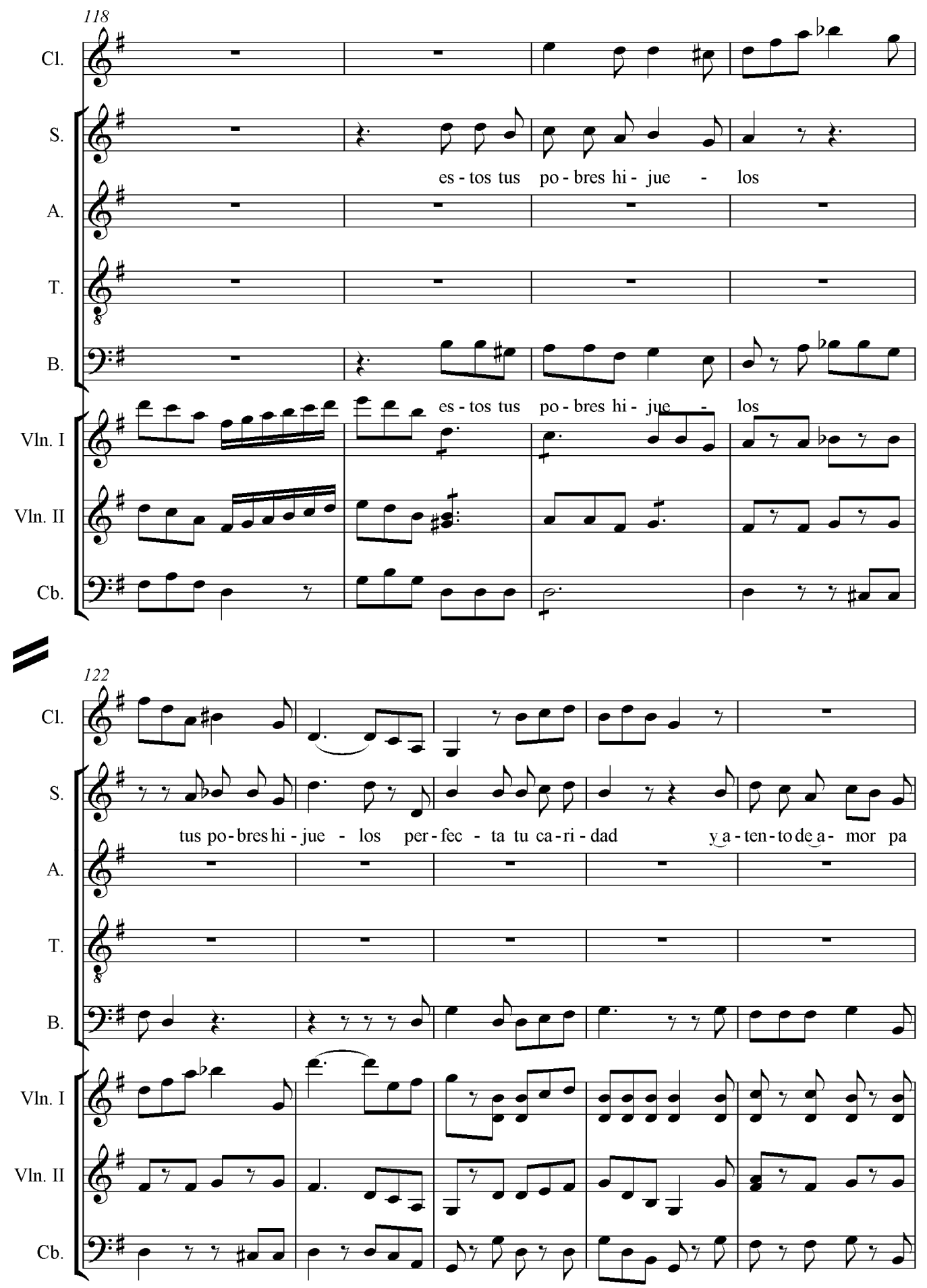


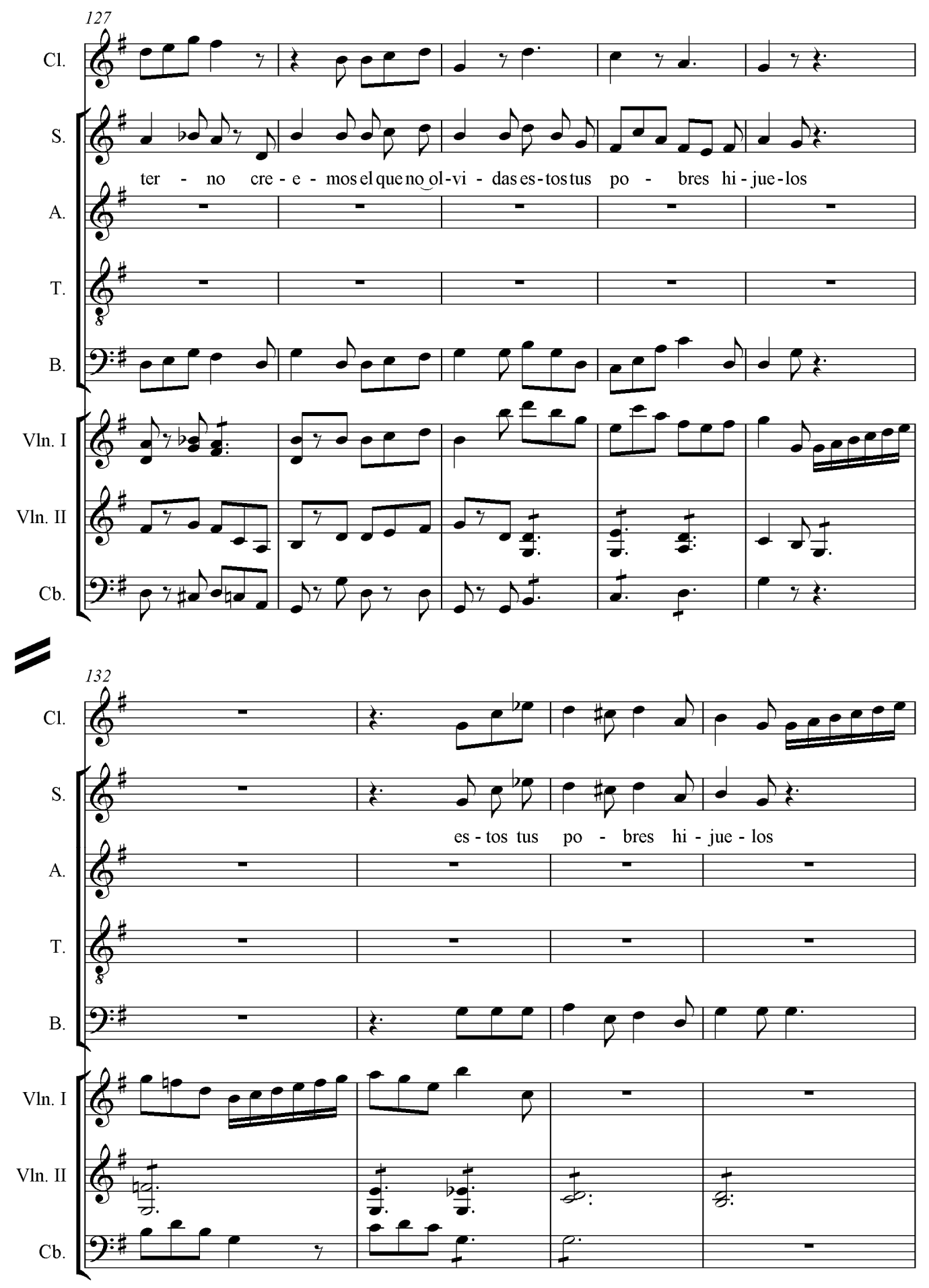




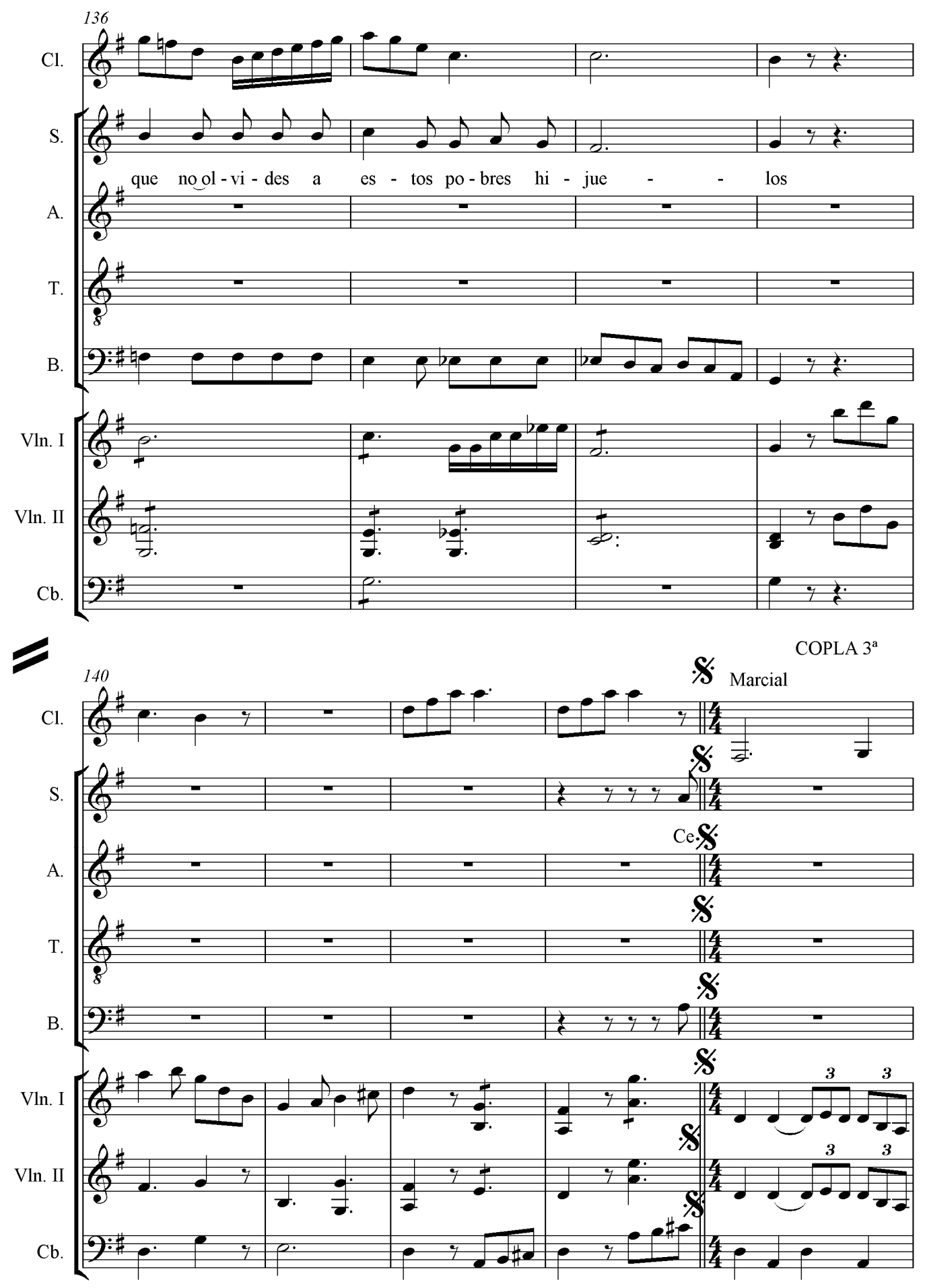




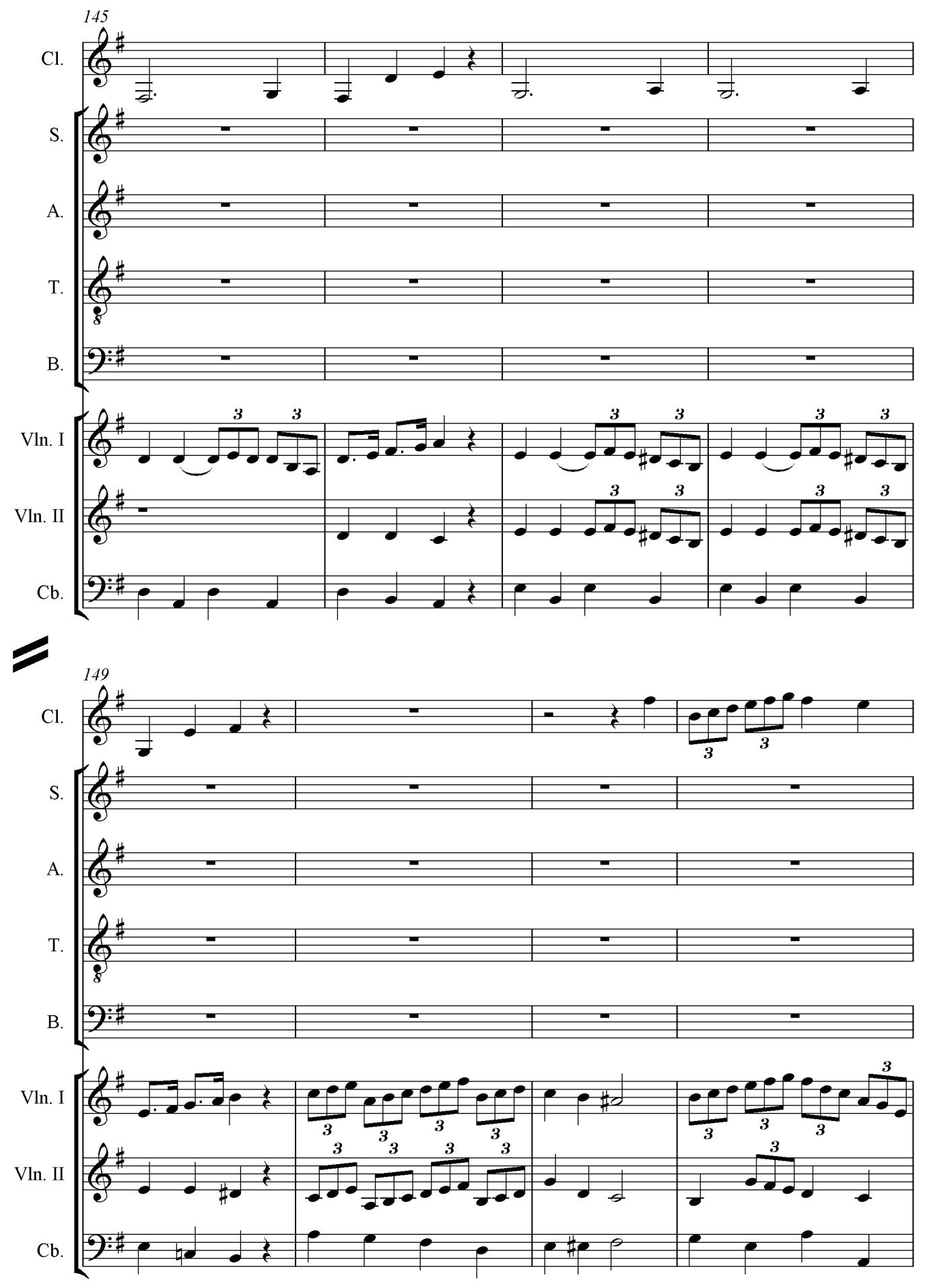




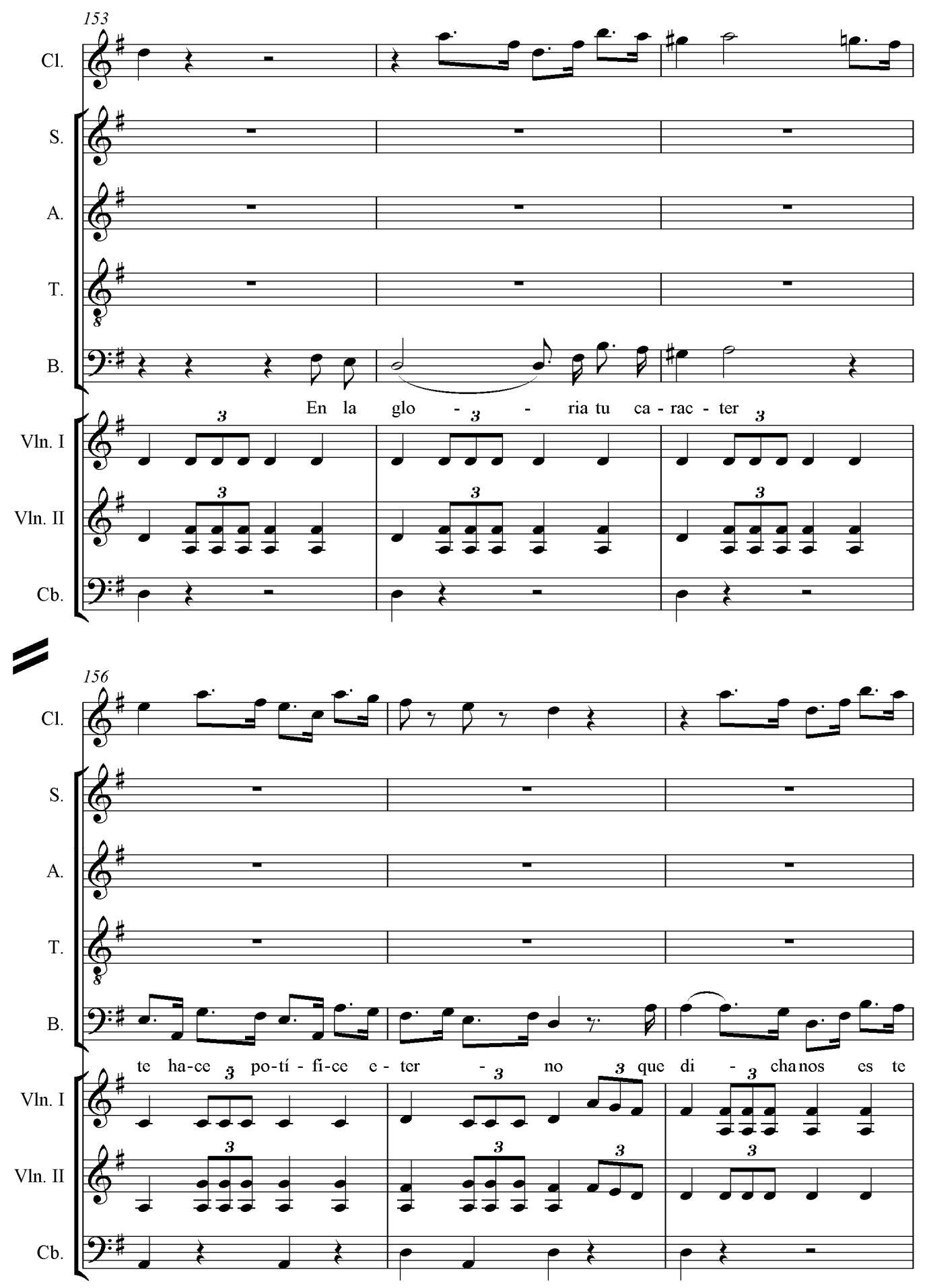



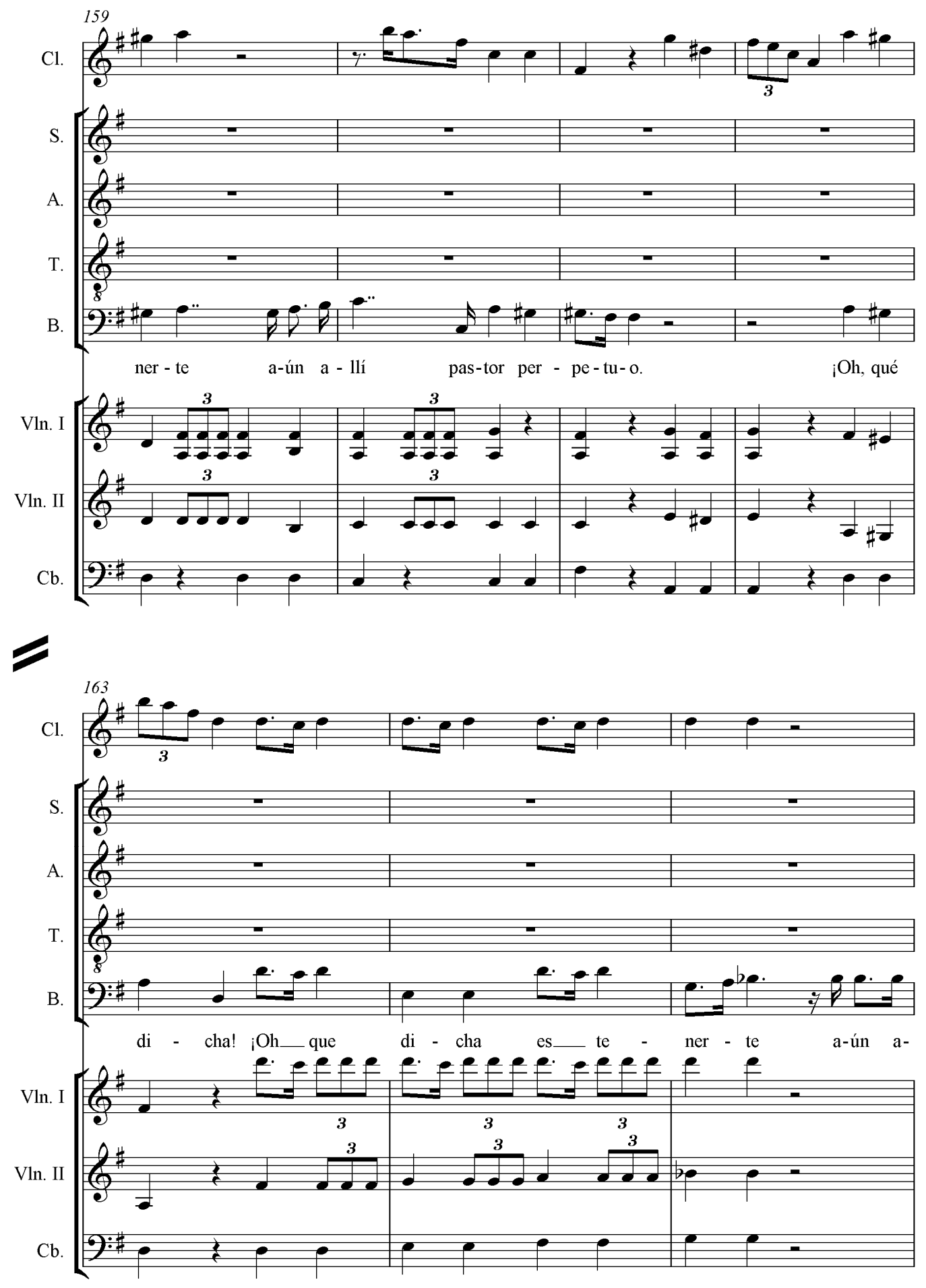


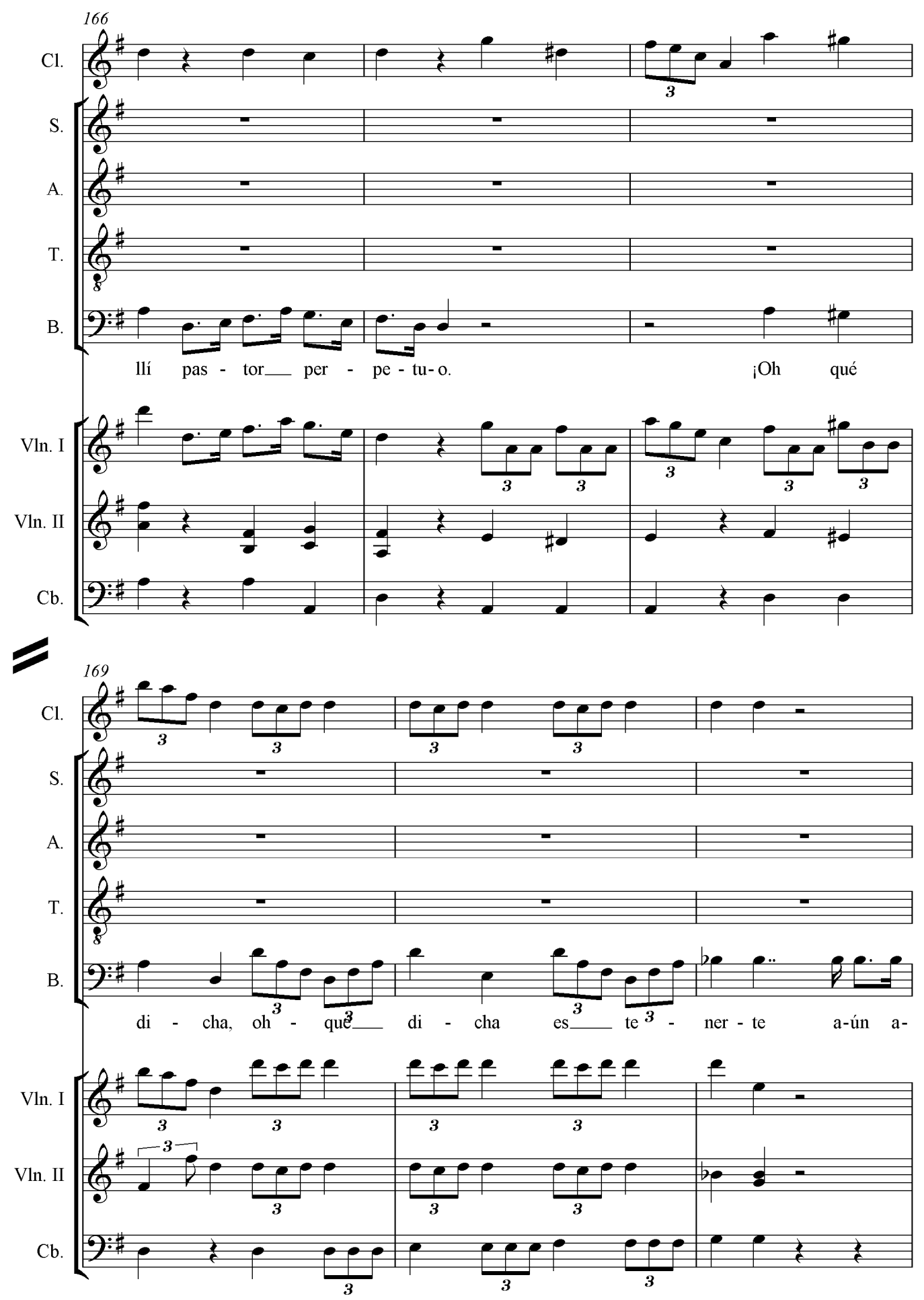



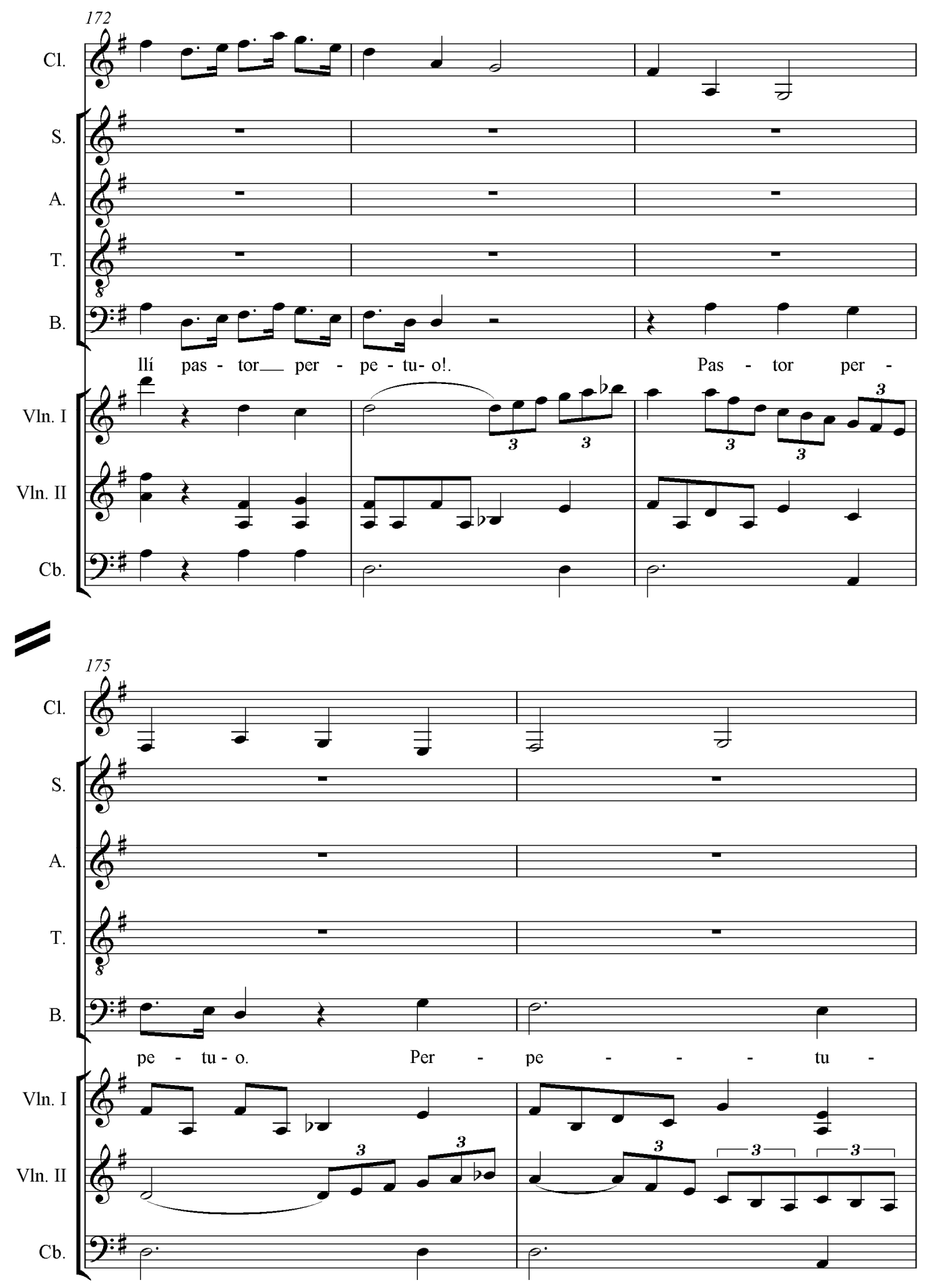


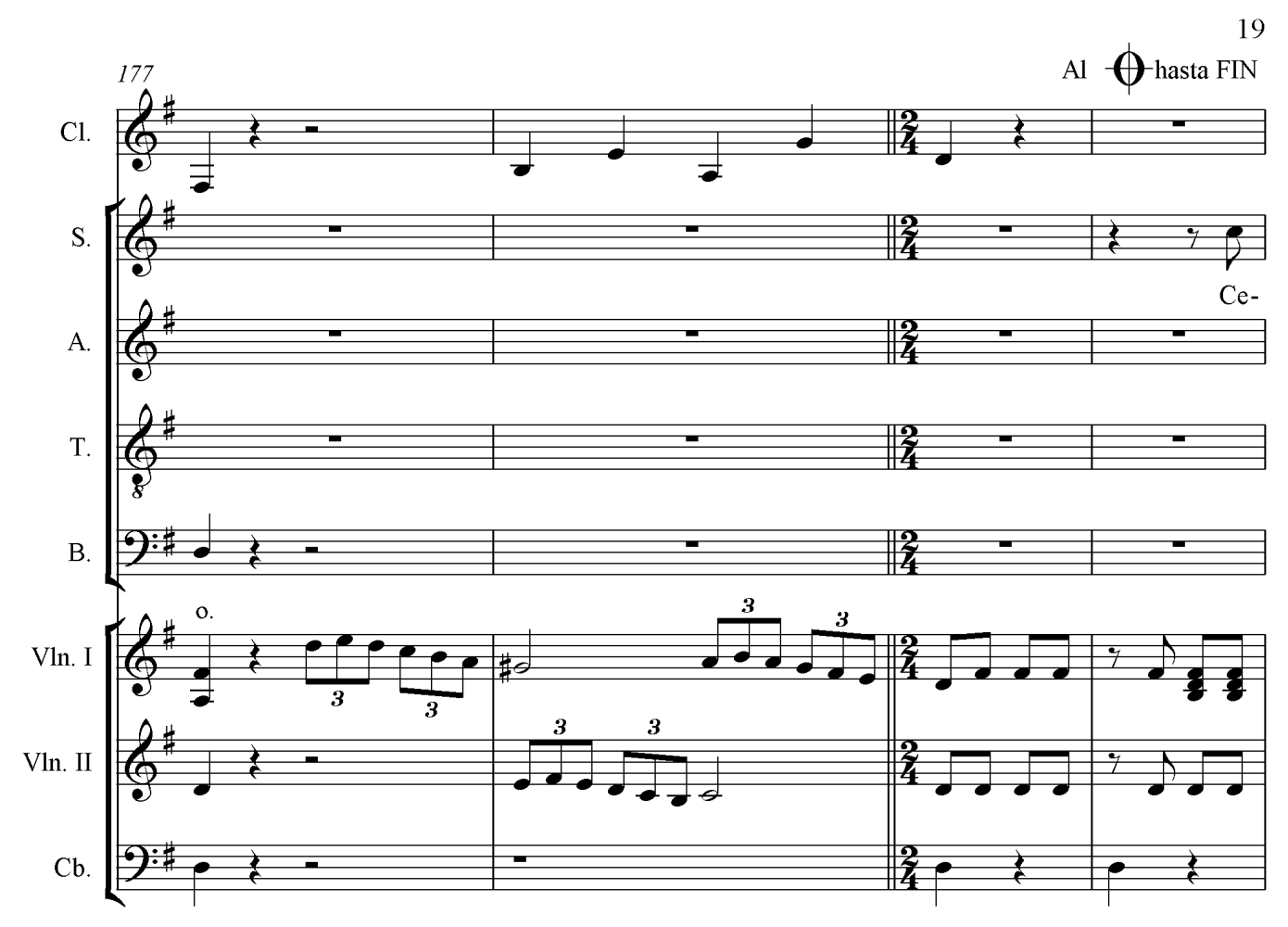



Celestino Vila de Forns (1850-1930)

Transcripción y edición: Mercedes Castillo Ferreira
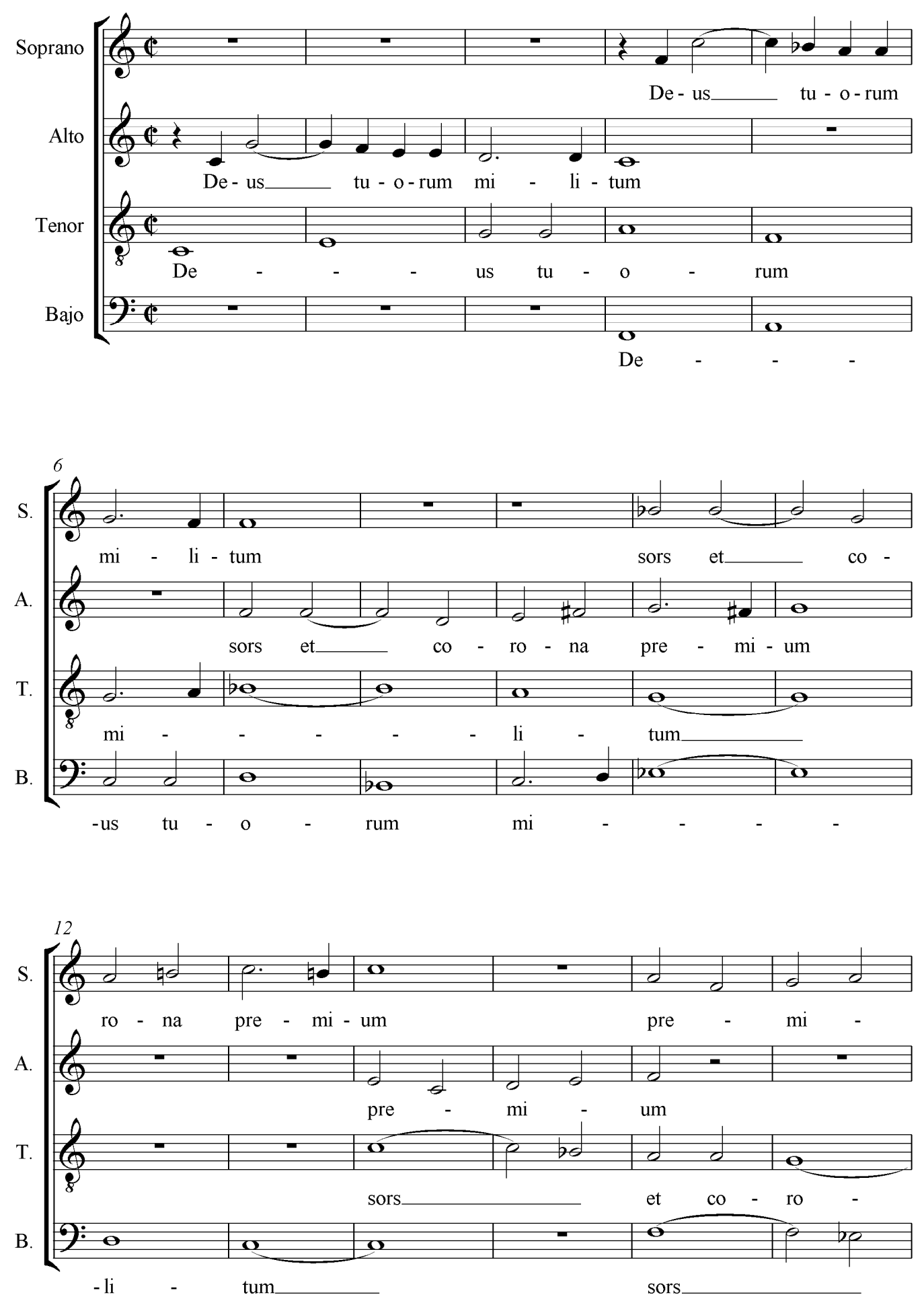

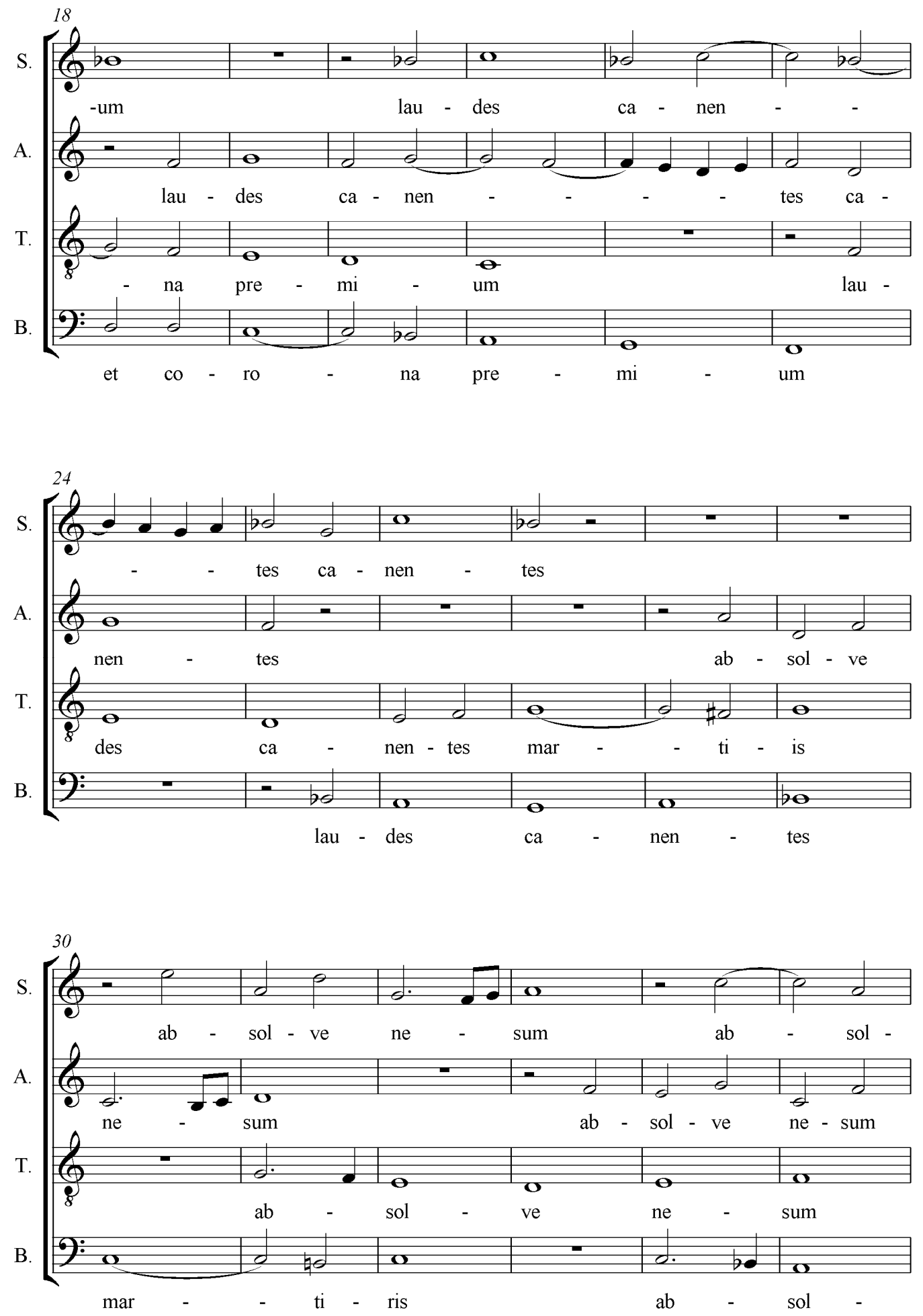


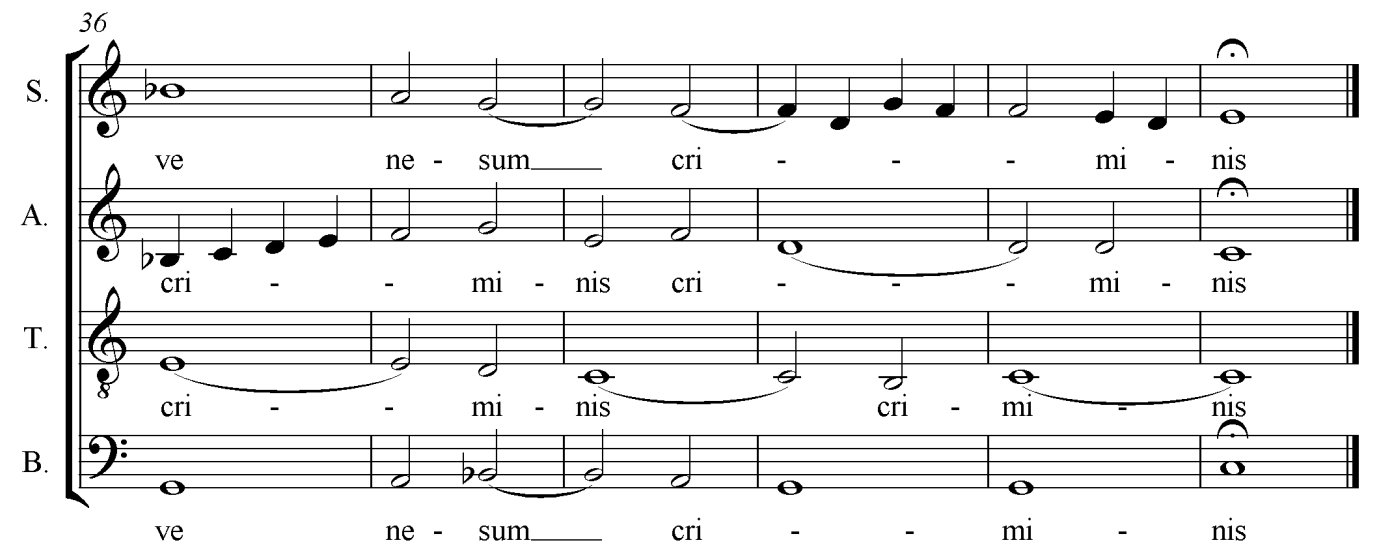

